\title{
INTERNATIONAL GONFERENGE ON EURASIAN ECONOMIES 2013
}




\title{
INTERNATIONAL CONFERENCE ON EURASIAN ECONOMIES 2013
}

\author{
Editors: \\ Selahattin Sarı \\ Alp H. Gencer \\ İlyas Sözen
}

Copyright (C) 2013

Beykent University

\begin{abstract}
ALL RIGHTS RESERVED.
This book contains material protected under International and Federal Copyright Laws and Treaties. Any unauthorized reprint or use of this material is prohibited. No part of this book may be reproduced or transmitted in any form or by any means, electronic or mechanical, including photocopying, recording, or by any information storage and retrieval system without express written permission from the publisher.
\end{abstract}

ISBN: 978-975-6319-21-5

Typesetting: Alp H. Gencer

Printing: Çetin Ozalit 


\section{INTERNATIONAL CONFERENGE ON EURASIAN ECONOMIES 2013}

St. Petersburg - Russia 17-18 September 2013 


\section{FOREWORD}

We are very proud to welcome you to the International Conference on Eurasian Economies 2013, the fourth conference in this series. We want to express our happiness in seeing that this conference became a traditional international academic event with increasing interest and continued support by international institutions, academicians and researchers in Eurasia. Specifically, we want to express our gratitude to you, since most of you have attended all four conferences in the series, and every year we see new faces added to our community.

We are delighted to organize the International Conference on Eurasian Economies 2013 in St. Petersburg, a city that's both beautiful and rich in history. Undoubtedly, Russia has played and continues to play a huge role in Eurasian economics and politics. St. Petersburg has been the capital of imperial Russia for many centuries (1713-1918). Renamed to Leningrad during the Soviet era, St. Petersburg today is one of the major European cultural centers with countless world-class museums, including the Hermitage Museum.

As always, the topics presented at the conference cover a wide variety of subjects with vital impact on the region such as globalization and its impact on Eurasia, integration of Eurasian economies to the world economy, economic growth and development strategies in Eurasian economies, international trade, financial markets, institutions and public policies as well as sector-specific issues such as tourism, energy, natural resources and agriculture. New topics presented this year include entrepreneurship and environment economics.

This year, we received a new record of 228 abstracts and 218 full papers from 20 countries. You will find 142 selected papers in this proceedings book, which have been presented at the conference. We would like to thank the advisory board and the scientific board for their dedicated efforts throughout the paper review process.

We are grateful to the Turkish International Cooperation and Development Agency (TIKA) and to the governors and experts of the Central Bank of Turkey for their continued support in organizing this conference. We also want to thank the Board of Trustees and the administrative personnel of Beykent University.

We are indebted to all the researchers and academicians who participated at the conference by submitting their distinguished work for presentation. We believe that their contributions will be greatly beneficial to the economies of Eurasian countries. We are looking forward to meeting you in another Eurasian country at the International Conference on Eurasian Economies 2014.

\section{Prof. Dr. Selahattin Sarı}

Conference Chair 


\section{ÖNSÖZ}

Sizleri dördüncüsünü organize ettiğimiz Uluslararası Avrasya Ekonomileri Konferans1 2013'te aramızda görmekten gurur duyuyoruz. Konferansın geleneksel bir uluslararası konferansa dönüştügünü, ve Avrasya akademisyenleri, araştırmacıları ve çeşitli kurumlarca artan ilgi ve destekle karşılandığını görmekten duyduğumuz mutluluğu sizlerle paylaşmak istiyoruz. Özellikle, serimizdeki dört konferansın tümüne katılan ve her sene aramıza yeni yüzler kazandıran sizlere sonsuz teşekkürlerimizi sunarız.

Uluslararası Avrasya Ekonomileri Konferansı 2013'ü dünyanın en güzel ve tarihi açıdan en zengin şehirlerinden biri olan St. Petersburg'da organize etmekten mutluluk duyuyoruz. Şüphesiz ki, Rusya tarih boyunca Avrasya ekonomisi ve politikası üzerinde büyük rol oynamış ve günümüzde de bu etkisine devam etmektedir. St. Petersburg, çarlık Rusya'sının yüzyıllarca (1713-1918) başkenti olmuş, Sovyet döneminde ismi Leningrad olarak değiştirilmiş, günümüzde ise sayısız müzeleriyle Avrupa'nın önemli bir kültür merkezi konumuna gelmiştir.

Her zamanki gibi, konferans çerçevesinde sunulan çalışmaların başlıkları geniş bir çeşitliliğe sahip ve bölge açısından hayati önem taşıyan konularda toplanmaktadır: Küreselleşme ve Avrasya ekonomileri üzerine etkileri, Avrasya ekonomilerinin dünya ekonomisine entegrasyonu, Avrasya ekonomileri için iktisadi büyüme ve kalkınma stratejileri, uluslararası ticaret, finans piyasaları, kamu politikaları ve turizm, enerji, tabii kaynaklar ve tarım gibi sektörlerin sorunlarından oluşmaktadır. $\mathrm{Bu}$ sene konferansa dahil edilen yeni konular ise girişimcilik ve çevre ekonomisidir.

2013 konferansına 20 ülkeden yeni bir rekor olan 228 özet ve 218 tam metin gelmiştir. Bu kitapta bunların arasından özenle seçilen ve konferansta sunulmuş olan 142 çalışmanın tam metnini bulacaksınız. Bu bağlamda, danışma kurulunun ve bilim kurulunun değerli üyelerine çalışmaların değerlendirilmesinde gösterdikleri özveri ve verdikleri emek için teşekkürlerimizi sunmak isteriz.

Türkiye İşbirliği ve Kalkınma İdaresi Başkanlığı (TİKA) üye ve bürokratlarına ve Türkiye Cumhuriyeti Merkez Bankası yöneticileri ve uzmanlarına konferansın sponsorluğu ve hazırlanma aşamasında değerli desteklerinin devamı için teşekkürlerimizi sunarız. Beykent Üniversitesi Mütevelli Heyetine ve konferansin düzenlenmesinde ve yürütülmesinde her türlü desteği veren idari personele katkılarından dolayı teşekkür ederiz.

Konferansa ilgi gösteren araştırmacı, akademisyen ve katılımcılara içten teşekkürlerimizi sunarız. Konferansda sunulan değerli bildiri ve çalışmaların Avrasya ülkeleri için yararlı olacağı inancını bir kez daha paylaşmak isteriz. Uluslararası Avrasya Ekonomileri Konferansı 2014 için bir başka Avrasya ülkesinde buluşmak dileğiyle.

\section{Prof. Dr. Selahattin Sarı}

Organizasyon Kurulu Başkanı 


\section{ADVISORY BOARD}

- Prof. Dr. Mehmet Emin Karahan (Rector, Beykent University, Turkey)

- Prof. Dr. Sebahattin Balcı (Rector, Kyrgyzstan-Turkey Manas University, Kyrgyzstan)

- Prof. Dr. Rahman Alshanov (Rector, Turan University, Kazakhstan)

- Prof. Dr. Cevat Gerni (Dean, Faculty of Economics and Administrative Sciences, Beykent University, Turkey)

- Prof. Dr. Jusup Pirimbaev (Chair, Department of Economics, Kyrgyzstan-Turkey Manas University, Kyrgyzstan)

- Prof. Dr. Selahattin Sar1 (Chair, Department of Economics, Beykent University, Turkey)

\section{ORGANIZING COMMITTEE}

- Prof. Dr. Selahattin Sarı (Beykent University, Turkey)

- Assoc. Prof. Dr. Ayşen Hiç Gencer (Istanbul Aydın University, Turkey)

- Asst. Prof. Dr. İlyas Sözen (Beykent University, Turkey)

- Assoc. Prof. Dr. Özgür Ömer Ersin (Beykent University, Turkey)

- Asst. Prof. Dr. Mustafa Ercilasun (Beykent University, Turkey)

- Ph.D. Candidate Bekir Aşık (Beykent University, Turkey)

- Dr. Aynura Turdalieva (Kyrgyzstan-Turkey Manas University, Kyrgyzstan)

- Mrs. Didem Karataş (Beykent University, Turkey)

\section{WEB \& PRINT DESIGN}

- Dr. Alp Gencer 


\section{SCIENTIFIC BOARD}

- Prof. Dr. Faruk Andaç (Çağ University, Turkey)

- Assoc. Prof. Dr. Hakan Ay (Dokuz Eylül University, Turkey)

- Prof. Dr. Ahmet Ay (Selçuk University, Turkey)

- Prof. Dr. Mehmet Balcilar (Eastern Mediterranean University, Cyprus)

- Prof. Dr. Tansu Barker (Brock University, Canada)

- Prof. Dr. Berch Berberoglu (University of Nevada, Reno, United States of America)

- Prof. Dr. Faik Bilgili (Erciyes University, Turkey)

- Prof. Dr. Ersan Bocutoğlu (Karadeniz Technical University, Turkey)

- Prof. Dr. Cumabek Cailov (Kyrgyz Economic Research Center, Kyrgyzstan)

- Prof. Dr. Emin Çarıkçı (Çankaya University, Turkey)

- Prof. Dr. Mustafa Kemal Değer (Karadeniz Technical University, Turkey)

- Prof. Dr. Hüseyin Avni Egeli (Dokuz Eylül University, Turkey)

- Prof. Dr. Ömer Selçuk Emsen (Atatürk University, Turkey)

- Prof. Dr. Ekrem Erdem (Erciyes University, Turkey)

- Prof. Dr. Alpay Filiztekin (Sabancı University, Turkey)

- Prof. Dr. Şaziye Gazioğlu (Middle Eastern Technical University, Turkey)

- Prof. Dr. Ahmet Incekara (Istanbul University, Turkey)

- Prof. Dr. Selezneva Irina (Turan University, Kazakhstan)

- Prof. Dr. Danijela Jacimovic (University of Montenegro, Montenegro)

- Assoc. Prof. Dr. Damira Japarova (Kyrgyzstan-Turkey Manas University, Kyrgyzstan)

- Prof. Dr. Gani Kaliev (Academy of Agricultural Sciences, Kazakhstan)

- Prof. Dr. S. Ridvan Karluk (Anadolu University, Turkey)

- Asst. Prof. Dr. Farrukh Kayani (COMSATS Institute of Information Technology, Pakistan)

- Prof. Dr. Nuriddin Kayumov (Tajikistan Academy of Sciences, Tajikistan)

- Prof. Dr. Recep Kök (Dokuz Eylül University, Turkey)

- Prof. Dr. Turar Koychuev (National Academy of Sciences, Kyrgyzstan)

- Dr. Valentina Orlova (Donetsk National University of Economics and Trade, Ukraine)

- Prof. Dr. Zekai Özdemir (Istanbul University, Turkey)

- Prof. Dr. Ali Özgüven (Kültür University, Turkey)

- Prof. Dr. Jusup Pirimbaev (Kyrgyzstan-Turkey Manas University, Kyrgyzstan)

- Prof. Dr. Tatiana Pyshkina (Academy of Economic Studies of Moldova (ASEM), Moldova)

- Dr. Nataliya Rad (Donetsk National University of Economics and Trade, Ukraine)

- Prof. Dr. Alisher Rasulev (Institute of Economics, Uzbekistan)

- Prof. Dr. Orazaly Sabden (Institute of Economics, Kazakhstan)

- Assoc. Prof. Dr. Mehmet Sarışık (Sakarya University, Turkey)

- Prof. Dr. Asım Şen (Beykent University, Turkey)

- Prof. Dr. Euphrasia Susy Suhendra (Gunadarma University, Indonesia)

- Prof. Dr. Mustafa Topaloğlu (Beykent University, Turkey)

- Dr. Iuri Tsuladze (State Committee for Science and Technologies, Georgia)

- Prof. Dr. Leila Tusupova (Turan University, Kazakhstan)

- Prof. Dr. Khodjamakhmad Umarov (Institute of Economics, Tajikistan)

- Prof. Dr. Bahadir Umurzakov (G.V. Plekhanov Russian University of Economics in Tashkent, Uzbekistan)

- Prof. Dr. Ahmet Yörük (Kadir Has University, Turkey) 


\section{Contents}

\section{OPENING SESSION}

\section{Session Chair: Prof. Dr. Selahattin Sart}

\#834: Yeni Sanayileşen Ülkelerde Sermaye Akımları ve Büyüme: Türkiye Örneği

- Prof. Dr. Ercan Uygur (Turkish Economic Association, Turkey)

\#835: Ценностные Ориентиры Определения Гуманизированной Экономики

- Prof. Dr. Turar Koychuev (National Academy of Sciences, Kyrgyzstan)

\#706: Перспективы создания ЕЭС

- Prof. Dr. Jusup Pirimbaev (Kyrgyzstan-Turkey Manas University, Kyrgyzstan)

- Prof. Dr. Anara Kamalova (Academy of Public Administration, Kyrgyzstan)

\#734: Impact of Globalization on Entrepreneurship in Developing Countries

- Prof. Dr. Ahmet Incekara (Istanbul University, Turkey)

- Ph.D. Candidate Mesut Savrul (Çanakkale Onsekiz Mart University, Turkey)

\#836: Avrasya'da Enerji Ekonomileri Pontansiyeli Üzerine Bir Değerlendirme 22

- Prof. Dr. Recep Kök (Dokuz Eylül University, Turkey)

SESSION 1A: Energy

Session Chair: Prof. Dr. Ahmet Ay

\#657: The Causes of Electricity Theft: An Econometric Analysis for the Case of Turkey

- Asst. Prof. Dr. Çağlar Yurtseven (Bahçeşehir University, Turkey)

\#810: The Relationship between International Oil Prices and Current Account Deficit: The Case of Turkey

- Assoc. Prof. Dr. Mehmet Mucuk (Selçuk University, Turkey)

- Mr. Mustafa Gerçeker (Selçuk University, Turkey)

- Prof. Dr. Ahmet Ay (Selçuk University, Turkey)

\#693: Evolution of Comovement between Commodity Futures: Do Biofuels Matter?

- Ph.D. Candidate Dinçer Dedeoğlu (Bahçeşehir University, Turkey)

\#660: The Relationship between Oil Prices and Exchange Rate: The Case of Romania

- Asst. Prof. Dr. Ahmet Şahbaz (Gaziantep University, Turkey)

- Asst. Prof. Dr. Uğur Adıgüzel (Cumhuriyet University, Turkey)

- Asst. Prof. Dr. Tayfur Bayat (İnönü University, Turkey)

- Asst. Prof. Dr. Selim Kayhan (Bozok University, Turkey)

SESSION 2A: International Trade

Session Chair: Asst. Prof. Dr. Ayşen Hiç Gencer

\#679: Analysis of Competitiveness of Turkey and Commonwealth of Independent States in their Automotive Market ....

- Dr. Emre Güneşer Bozdağ (Gazi University, Turkey)

- Ph.D. Candidate Sıtkıcan Saraçoğlu (Gazi University, Turkey)

\#832: The Role of Economic Integration in Trade Openness: The Black Sea Economic Cooperation Organization Case

- Prof. Dr. Sedat Murat (Istanbul University, Turkey)

- Assoc. Prof. Dr. Sefer Şener (Istanbul University, Turkey)

- Dr. Burcu Kılınç Savrul (Canakkale Onsekiz Mart University, Turkey)

\#623: Burgeoning Sino-Russian Economic Relations and the Russian Far East: Prospects and Challenges

- Asst. Prof. Dr. Çağrı Erdem (Doğuş University, Turkey) 
\#644: Economy and National Security

- Asst. Prof. Dr. Ramazan Kurtoğlu (Istanbul Aydın University, Turkey)

SESSION 3A: Tourism

Session Chair: Prof. Dr. Ayşe Akyol

\#694: Effects of Russia's Economic Growth on Turkey’s Tourism Sector

- Asst. Prof. Dr. Levent Şahin (Çankırı Karatekin University, Turkey)

- Assoc. Prof. Dr. Hasan Akça (Çankırı Karatekin University, Turkey)

\#618: Investigating Existence of Tourism-Led Growth Hypothesis in Cental Asian Republics: A Bootstrap

Panel Causality Analysis

- Prof. Dr. Ekrem Erdem (Erciyes University, Turkey)

- Asst. Prof. Dr. Can Tansel Tuğcu (Nevşehir University, Turkey)

\#830: The Effects of Destination Personality Items on Destination Brand Image

- Ph.D. Candidate Çiğdem Unurlu (Trakya University, Turkey)

- Asst. Prof. Dr. Selin Küçükkancabaş (Trakya University, Turkey)

\#831: The Relationships between Destination Brand Image, Destination Brand Loyalty and Word of Mouth

Behaviour

- Ph.D. Candidate Çiğdem Unurlu (Trakya University, Turkey)

- Prof. Dr. Ayşe Akyol (Trakya University, Turkey)

- Assoc. Prof. Dr. Dilek Altaş (Marmara University, Turkey)

\#826: An Evaluation of Electronic Commerce in Terms of Accounting Information System in the Global Competitive Environment

- Prof. Dr. Naim Ata Atabey (Selçuk University, Turkey)

- Ph.D. Candidate Fatma Özlem Yılmaz (Selçuk University, Turkey)

- Assoc. Prof. Dr. Baki Yılmaz (Selçuk University, Turkey)

SESSION 4A: Growth \& Development

Session Chair: Prof. Dr. Mehmet Balcllar

\#710: Poverty Alleviation and Microfinance in post-Soviet Central Asia .100

- Assoc. Prof. Dr. Heiko Fritz (Linnaeus University Växjö, Sweden)

\#717: Features of Business Cycles across the Middle East and North Africa: A Nonparametric Analysis

- Prof. Dr. Mehmet Balc1lar (Eastern Mediterranean University, Cyprus)

- Dr. Nezahat Küçük (Eastern Mediterranean University, Cyprus)

\#684: On the Source of Macroeconomic Fluctuations in the Middle Eastern and North African Countries: A Structural Vector Autoregression Analysis

- Ph.D. Candidate Evrim Toren (Eastern Mediterranean University, Cyprus)

\#685: A Summary of the Developments Regarding the Economic Regime Implemented in Developed and Developing Countries

- Asst. Prof. Dr. Özlen Hiç Birol (Istanbul University, Turkey)

\#695: Trade Openness, Financial Development, and Economic Growth in Turkey: Linear and Nonlinear Causality Analysis

- Prof. Dr. Muhsin Kar (Necmettin Erbakan University, Turkey)

- Assoc. Prof. Dr. Şaban Nazlıŏlu (Pamukkale University, Turkey)

- Asst. Prof. Dr. Hüseyin Ağır (Sütçü İmam University, Turkey) 
SESSION 5A: Finance I

Session Chair: Prof. Dr. Euphrasia Susy Suhendra

\#597: The Influence of Corporate Governance Mechanism to Earnings Management on Indonesia and China Industrial Banking.....

- Prof. Dr. Euphrasia Susy Suhendra (Gunadarma University, Indonesia)

- Mrs. Dini Tri Wardani (Gunadarma University, Indonesia)

\#645: On the Predictive Power of the Yield Spread for Future Growth and Recession: The Turkish Case

- Asst. Prof. Dr. Hüseyin Kaya (Bahçesehir University, Turkey)

\#728: The Impact of the US Dollar and the Euro on Currencies in Europe and Asia

- Prof. Dr. Malgorzata Doman (Poznan University of Economics, Poland)

- Prof. Dr. Ryszard Doman (Adam Mickiewicz University, Poland)

\#595: Monetary Response to Exchange Rate Dynamics: Regime Switching - Chartists and Fundamentalists Application to Australia

- Ph.D. Candidate Ferry Syarifuddin (Bank Indonesia, Indonesia)

SESSION 6A: Finance II

Session Chair: Prof. Dr. Malgorzata Doman

\#702: Analysis of Capital Flight in Developing Countries: A Study on Turkey between 1980 and 2010 172

- Asst. Prof. Dr. Ali Özer (Erzincan University, Turkey)

- Ph.D. Candidate Aslı Cansın Doker (Erzincan University, Turkey)

- Ph.D. Candidate Adem Türkmen (Erzincan University, Turkey)

\#724: Was the Turkish Financial Crisis in 2001 Caused by External or Internal Factors?

- Ph.D. Candidate Fatih Konak (Hitit University, Turkey)

- Ph.D. Candidate Hakan Turan (Hitit University, Turkey)

\#674: The Effects of Exchange Rates on Macroeconomic Variables: A Study on Selected Emerging

Economies

- Asst. Prof. Dr. Birgül Cambazoğlu (Haliç University, Turkey)

- Assoc. Prof. Dr. Hacer Simay Karaalp (Pamukkale University, Turkey)

- Assoc. Prof. Dr. Konstantinos Vergos (University of Portsmouth, United Kingdom)

\#796: The Applicability of Responsibility Accounting System within the Scope of Increasing Efficiency in Hospital Bussinesses in Turkey

- Prof. Dr. Fehmi Karasioğlu (Selçuk University, Turkey)

- Asst. Prof. Dr. İbrahim Emre Göktürk (Aksaray University, Turkey)

SESSION 7A: Environment \& Regional Economies

Session Chair: Prof. Dr. Aysegül Kaptanoğlu

\#704: Stakeholder-Based Analysis of Sustainability Report: A Case Study on Mining Companies in Indonesia204

- Dr. Ati Harmoni (Gunadarma University, Indonesia)

\#705: Sectoral Decomposition of CO2 Emissions in China and India for the Period 1980-2010

- Ph.D. Candidate Hasan Rüstemoğlu (Eastern Mediterranean University, Cyprus)

- Assoc. Prof. Dr. Sevin Uğural (Eastern Mediterranean University, Cyprus)

\#828: Environmental Accounting and Environmental Costs

- Assoc. Prof. Dr. Baki Yılmaz (Selçuk University, Turkey)

- Ph.D. Candidate Fatma Özlem Yılmaz (Selçuk University, Turkey)

- Prof. Dr. Naim Ata Atabey (Selçuk University, Turkey)

\#677: The Internal Innovation Processes in Kazakhstan

- Ph.D. Candidate Aizhan Samambayeva (Universidade de Santiago de Compostela, Spain)

- Prof. Dr. Manuel Fernandez-Grela (University of Santiago de Compostela, Spain) 
\#629: Allegories and Realities of Innovative China: The Case of Haier

- Asst. Prof. Dr. Farrukh Kayani (COMSATS Institute of Information Technology, Pakistan)

\#630: Opinions on the Political Economy of the New Turkish Healthcare System

- Prof. Dr. Aysegül Kaptanoğlu (Trakya University, Turkey)

SESSION 1B: Büyüme ve Gelişme

Session Chair: Prof. Dr. Recep Kök

\#688: Küreselleşmiş Dünyada Sürdürülebilir Gelişme Açısından İşsizliğin Önemi

- Prof. Dr. Levin Özgen (Abant İzzet Baysal University, Turkey)

\#602: Türkiye'de Sürdürülebilir Kentsel Gelişme Stratejileri: KENTGES Eylem Planı (2010-2023) Örneği ....255

- Assoc. Prof. Dr. Mahmut Güler (Trakya University, Turkey)

- Asst. Prof. Dr. Abdulmenaf Turan (Yüzüncü Y1l University, Turkey)

\#676: Ordu-Üniversite-Sanayi İşbirliğinin Ekonomik Gelişme Üzerindeki Rolü

- Asst. Prof. Dr. Özgür Uysal (Akdeniz University, Turkey)

- Prof. Dr. Recep Kök (Dokuz Eylül University, Turkey)

\#662: Alternatif Bir Ekonomik Model Olarak Halk Sektörü ve Denizli Örneği

- Prof. Dr. Ayşe İrmiş (Pamukkale University, Turkey)

- Mrs. Mehtap Sarıkaya (Pamukkale University, Turkey)

- Mrs. Hatice Çoban (Pamukkale University, Turkey)

\#709: Türkiye'de Hanehalkı Tüketim Harcamaları: Pseudo Panel Veri ile Talep Sisteminin Tahmini

- Prof. Dr. Seda Şengül (Çukurova University, Turkey)

- Ph.D. Candidate Çiler Sigeze (Çukurova University, Turkey)

\#609: Türkiye'de İç Göçün Yoksulluğa ve İstihdama Etkileri

- Asst. Prof. Dr. H. Yunus Taş (Yalova University, Turkey)

- Assoc. Prof. Dr. Selami Özcan (Yalova University, Turkey)

\section{SESSION 2B: Kalkınma}

Session Chair: Asst. Prof. Dr. Zerrin Sungur

\#718: Sağlık Hizmetleri Reformu ve Hane Halkı Refahı: Türkiye'de Sağlıkta Dönüşüm Programı .299

- Dr. Serdal Bahçe (Ankara University, Turkey)

- Ph.D. Candidate Altuğ Murat Köktas (Ankara University, Turkey)

- Ph.D. Candidate Deniz Abukan (Ankara Üniversitesi, Turkey)

\#762: Bir Sosyal Dışlanma Biçimi Olarak Türkiye'de Refah Hizmetlerinden Dışlanma

- Asst. Prof. Dr. Nagihan Durusoy Öztepe (Pamukkale Universty, Turkey)

- Asst. Prof. Dr. Çağla Ünlütürk Ulutaş (Pamukkale University, Turkey)

\#643: Beşeri Sermayeye Yönelik Eğitim ve Sağlık Alt Yapı Yatırım Harcamalarının Bölgesel Gelir Üzerindeki Etkisi: Türkiye Örneği

- Dr. Mehmet Akif Kara (Sütçü İmam University, Turkey)

- Asst. Prof. Dr. Serkan Ada (Selçuk University, Turkey)

- Asst. Prof. Dr. Salih Yeşil (Sütçü İmam University, Turkey)

\#797: Yükseköğretimin Büyümeye Etkisi: Eşbütünleşme Analizi

- Asst. Prof. Dr. Murat Mustafa Kutlutürk (Çankırı Karatekin University, Turkey)

- Assoc. Prof. Dr. Hakan Kasım Akmaz (Çankırı Karatekin University, Turkey)

- Assoc. Prof. Dr. Ahmet Çetin (Çankırı Karatekin University, Turkey)

\#668: Türkiye'de İş Kazaları ve Meslek Hastalıkları ile Sosyal Güvenlik Sistemi İçindeki Yeri .328

- Assoc. Prof. Dr. Dilek Baybora (Anadolu University, Turkey) 
SESSION 3B: Makroekonomi

Session Chair: Prof. Dr. Sedat Murat

\#696: Türkiye'de Enflasyonun Uzun Hafiza Özellikleri ve Enflasyon Sürekliliği Analizi

- Ph.D. Candidate Zühal Kurul (Hacettepe University, Turkey)

- Ph.D. Candidate Pinar Sezer (Hacettepe University, Turkey)

\#619: Enflasyon Hedeflemesi Yaklaşımı: Türkiye'deki Uygulama Sürecinin Değerlendirilmesi

- Assoc. Prof. Dr. Serdar Öztürk (Nevşehir University, Turkey)

- Asst. Prof. Dr. Ali Sözdemir (Cumhuriyet University, Turkey)

- Mrs. Özlem Ülger (Nevşehir University, Turkey)

\#614: Özelleştirmenin Teorik Temelleri ve Türkiye'deki Sonuçları

- Assoc. Prof. Dr. Oğuz Bal (Kocaeli University, Turkey)

\#663: Geçiş Süreci: Rusya ve Ukrayna Örneği

- Ph.D. Candidate Esra Ballı (Çukurova University, Turkey)

- Prof. Dr. Muammer Tekeoğlu (Çukurova University, Turkey)

\#594: Satın Alma Gücü Paritesi Hipotezinin Kazakistan İçin Geçerliliği

- Asst. Prof. Dr. Seymur Ağayev (Recep Tayyip Erdoğan University, Turkey)

\#617: Kadınların Çalışma Yaşamına Katılımlarına Yönelik Tutum Ölçeğinin (KÇYKYTÖ) Bir Yapısal Eşitlik Modeli ile Geçerlik ve Güvenirliğinin İncelenmesi

- Asst. Prof. Dr. Erol Karaca (Anadolu University, Turkey)

SESSION 4B: Orta Asya Ekonomileri

Session Chair: Prof. Dr. Erhan Büyükakıncı

\#823: Kırgızistan ve Avrasya Gümrük Birliği

- Mrs. Aigul Turdubekova (Istanbul University, Turkey)

- Mrs. Elmira Kupsuralieva (Kyrgyzstan-Turkey Manas University, Kyrgyzstan)

\#681: Azerbaycan'ın Piyasa Ekonomisine Geçiş Sürecinde Karşılaştığı Sorunlar ve Çözüm Arayışları

- Prof. Dr. Cihan Bulut (Qafqaz University, Azerbaijan)

- Ph.D. Candidate Elchin Suleymanov (Qafqaz University, Azerbaijan)

- Assoc. Prof. Dr. Fakhri Hasanov (Qafqaz University, Azerbaijan)

\#680: Rus Dış Politikasında Ekonomik Bölgeselleşme: Avrasyacı Bütünleşme Modeli’nden Söz Edilebilir mi?

- Prof. Dr. Erhan Büyükakıncı (Galatasaray University, Turkey)

\#711: Döviz Kuru Oynaklığı, Rezerv Oynaklı̆̆ı ve Reel Faiz Oranlarının Dış Ticaret Üzerindeki Etkileri:

Geçiş Ekonomileri Üzerine Uygulamalar

- Prof. Dr. Cevat Gerni (Beykent University, Turkey)

- Prof. Dr. Selahattin Sarı (Beykent University, Turkey)

- Dr. Dilek Özdemir (Atatürk University, Turkey)

- Prof. Dr. Ömer Selçuk Emsen (Atatürk University, Turkey)

\#697: Kamu Harcamaları ile Bürokrasi Arasındaki İlişki: Avrasya Ekonomileri Örneği

- Asst. Prof. Dr. Gökhan Dökmen (Bülent Ecevit University, Turkey)

- Asst. Prof. Dr. Özcan Sezer (Bülent Ecevit University, Turkey)

\#638: Kadının Ekonomik Yaşamdaki Yeri: Türkiye ve Geçiş Ekonomilerinin Karşılaştırması

- Prof. Dr. Nuray Gökçek Karaca (Anadolu University, Turkey) 
SESSION 5B: Uluslararası Ticaret I

Session Chair: Asst. Prof. Dr. Ramazan Kurtoğlu

\#745: Ekonomik İşbirliği Teşkilatı’nın Bölgesel Entegrasyona Dönüşümünde Engelleyici Faktörler: Bölge İçi

Ticaret Açısından Bir Değerlendirme

- Assoc. Prof. Dr. Hamza Çeştepe (Bülent Ecevit University, Turkey)

- Ph.D. Candidate Tamer Güven (Bülent Ecevit University, Turkey)

\#817: Dünya Ticaret Örgütüne Girişi Sonrasında Rusya ile Türkiye Arasındaki Ticari İlişkilerinin

İncelenmesi

- Asst. Prof. Dr. Burak Kartal (Celal Bayar University, Turkey)

\#661: Türkiye - Karadeniz Ekonomik İşbirliği Örgütü: 1996-2012 Dönemi Dış Ticaret İlişkileri

- Ph.D. Candidate Cemal Ardıl (Istanbul Aydın University, Turkey)

\#647: Kültürün Ekonomik Kalkınmaya Etkisi ve Türkiye-Rusya Ekonomik İlişkisi

- Mrs. Emine Ebru Usta (Ministry of Family and Social Policies, Turkey)

SESSION 6B: Uluslararası Ticaret II

Session Chair: Prof. Dr. Muammer Tekeoğlu

\#774: Türkiye'nin İhracat Performans1: İhracat Hacminin Temel Belirleyicilerinin İncelenmesi (1995-2012) ..469

- Prof. Dr. Mehmet Balcılar (Eastern Mediterranean University, Cyprus)

- Prof. Dr. Harun Bal (Çukurova University, Turkey)

- Assoc. Prof. Dr. Neşe Algan (Çukurova University, Turkey)

- Ph.D. Candidate Mehmet Demiral (Çukurova University, Turkey)

\#783: Türkiye'nin İhracat ve İthalat Talep Fonksiyonlarının Rusya ile Dış Ticareti Bağlamında Analizi .479

- Asst. Prof. Dr. Rüştü Yayar (Gaziosmanpaşa University, Turkey)

- Ph.D. Candidate Yunus Emre Birol (Cumhuriyet Universty, Turkey)

- Ph.D. Candidate Yusuf Demir (Cumhuriyet University, Turkey)

\#827: Avrupa Borç Krizinin Türkiye'nin İhracatı Üzerindeki Etkileri

- Prof. Dr. Bedriye Tunçsiper (Balıkesir University, Turkey)

- Ph.D. Candidate Ömer Faruk Biçen (Balıkesir University, Turkey)

\#658: Firmalarda Süreç Yenileme Yaklaşımının İhracat Üzerine Etkileri

- Asst. Prof. Dr. Ali Riza İnce (Cumhuriyet University, Turkey)

- Asst. Prof. Dr. Yücel Erol (Gaziosmanpaşa University, Turkey)

- Asst. Prof. Dr. Enis Baha Biçer (Cumhuriyet University, Turkey)

\#773: Türkiye ile Komşuları Arasındaki Ticaret Potansiyeli: Çekim Modeli Çerçevesinde Bir İnceleme .500

- Mr. Sezai Ata (Ministry of Development, Turkey)

SESSION 7B: Uluslararas1 Ticaret III

Session Chair: Assoc. Prof. Dr. Serap Durusoy

\#636: Krizin Orta ve Uzun Vadeli Yıkıcı Etkisi: Yükselen Korumacılık .510

- Assoc. Prof. Dr. Serap Durusoy (Izzet Baysal University, Turkey)

\#777: Avrupa Komşuluk Politikası'nın Ülkeler Üzerindeki Ekonomik Etkileri

- Ph.D. Candidate Esra Ballı (Çukurova University, Turkey)

- Mrs. Gülçin Güreşçi Pehlivan (Dokuz Eylül University, Turkey)

\#766: Türkiye ve Avrasya Ekonomik Topluluğu Ülkelerinin Lojistik Performans İndekslerinin

Karşılaştırılması ve Bazı Çıkarımlar .524

- Asst. Prof. Dr. Çiğdem Sofyalıŏlu (Celal Bayar University, Turkey)

- Asst. Prof. Dr. Burak Kartal (Celal Bayar University, Turkey) 
\#740: Avrasya Ülkeleri’nde Gayri Safi Yurtiçi Hasıla Üzerine Doğrudan Yabancı Yatırımlar ve Dış Ticaret'in Etkisi: Panel Eşbütünleşme Analizi .....

- Ph.D. Candidate Mehmet Songur (Tunceli University, Turkey)

- Ph.D. Candidate Demet Yaman (Hacettepe University, Turkey)

\#746: İhracat Ve Ücretler Arasındaki İlişkinin Türkiye Ekonomisi İçin Sınanması .541

- Ph.D. Candidate Gürçem Oransay (Çukurova University, Turkey)

\section{SESSION 1C: Finansal Krizler}

Session Chair: Prof. Dr. Harun Bal

\#652: 2008 Küresel Krizinin Felsefesi

- Mr. Ziya Arpalı (Kyrgyzstan-Turkey Manas University, Kyrgyzstan)

\#714: Küresel Kriz Sürecinde Altın Fiyatlarını Etkileyen Dinamikler

- Ph.D. Candidate Togan Karataş (Marmara University, Turkey)

- Ph.D. Candidate Emre Ürkmez (Marmara University, Turkey)

\#748: 2008 Global Krizinin Geçiş Ekonomilerindeki Etkilerinin Kümeleme Analizi ile İncelenmesi

- Asst. Prof. Dr. Ali Özer (Erzincan University, Turkey)

- Ph.D. Candidate Adem Türkmen (Erzincan University, Turkey)

- Ph.D. Candidate Bülent Diclehan Çadırcı (Erzincan University, Turkey)

\#641: AB Borç Krizi ve Aktarım Mekanizmaları ile Yayılımı: Türkiye’ye Muhtemel Etkileri

- Mr. Mustafa Kemal Topcu (Fibonasi Yönetim Danışmanlık, Turkey)

- Asst. Prof. Dr. Poyraz Gürson (Atılım University, Turkey)

- Prof. Dr. Halil İbrahim Ülker (Atılım University, Turkey)

- Asst. Prof. Dr. Turan Erman Erkan (Atılım University, Turkey)

\section{SESSION 2C: Finans}

\section{Session Chair: Prof. Dr. Ömer Selçuk Emsen}

\#727: Bilanço Düzeltme Sürecinde Gelişmekte Olan Piyasa Ekonomilerinde Ani Duruş Problemine Karşı

Makro Basiretli Politikalar

- Mr. Tolga Dağlaroğlu (Gazi University, Turkey)

- Dr. Baki Demirel (Gaziosmanpaşa University, Turkey)

- Ph.D. Candidate Serdar Varlık (Gazi University, Turkey)

\#725: Bağımsız Düzenleyici Denetleyici Kurumların Bankacılık Sektörünün Yeniden Yapılanmasında Önemi: Türkiye Örneğinden Geçiş Ekonomilerinin Alabileceği Dersler

- Asst. Prof. Dr. Resül Yazıcı (Şeyh Edebali University, Turkey)

- Asst. Prof. Dr. Ayla Yazıcı (Anadolu University, Turkey)

\#715: Türkiye'deki 2001 Krizi Sonrası Bankacılık Sektöründeki Yapısal Değişim: 2001 Öncesi ve 2001 Sonrası Bir Karşılaştırma

- Asst. Prof. Dr. Emine Firat (Aksaray University, Turkey)

\#713: Parametrik Riske Maruz Değer Hesaplamasında Volatilitenin Modellenmesi: Türkiye'de Emeklilik Yatırım Fonları Üzerine Bir Uygulama 608

- Mr. Umut Akduğan (Trakya University, Turkey)

- Asst. Prof. Dr. Yasemin Koldere Akın (Trakya University, Turkey) 
SESSION 3C: Girişimcilik

\section{Session Chair: Prof. Dr. Recep Kök}

\#735: Kırgızistan-Türkiye Manas Üniversitesi Öğrencilerinin Girişimcilik Eğilimlerinin Sosyo-Demografik Özellikler Açısından Değerlendirilmesi

- Assoc. Prof. Dr. Lütfiye Özdemir (Ahmet Yesevi University, Kazakhstan)

\#726: Yerel Ekonomilerin Yeni Aktörü, Bölgesel İnovasyon Stratejileri: RIS Mersin Uygulaması

- Asst. Prof. Dr. Filiz Tutar (Niğde University, Turkey)

- Asst. Prof. Dr. Emine Firat (Aksaray University, Turkey)

- Mrs. Çisil Erkan (Niğde University, Turkey)

- Prof. Dr. Erdinç Tutar (Niğde University, Turkey)

\#754: Girişimcilik ve Spor

- Ph.D. Candidate Yeter Aytül Dağlı Ekmekçi (Pamukkale University, Turkey)

- Prof. Dr. Ayşe İrmiş (Pamukkale University, Turkey)

\#786: Türkiye'nin Sakin Şehirlerindeki Kadın Girişimciliğine Sosyolojik Bir Bakış

- Asst. Prof. Dr. Zerrin Sungur (Anadolu University, Turkey)

\#648: Dünya'ya Kıyasla Türkiye'de Kadın Girişimciliği

- Ph.D. Candidate Gülay Tamer (İstanbul Aydın Üniversitesi, Turkey)

\#803: Yeni Zirve: Girişimcilikte Ahlakın Artan Değeri

- Prof. Dr. Sabahat Bayrak Kök (Pamukkale University, Turkey)

- Mrs. Mehtap Sarıkaya (Pamukkale University, Turkey)

\section{SESSION 4C: Turizm I}

Session Chair: Assoc. Prof. Dr. Kadir Karagöz

\#601: Turist Akımında Oynaklık: Türkiye Örneği

- Assoc. Prof. Dr. Kadir Karagöz (Celal Bayar University, Turkey)

\#765: İnternette Gerilla Pazarlaması ve Turizm Endüstrisindeki Uygulamaları Üzerine Bir Değerlendirme

- Ph.D. Candidate Aysegül Kutluk (Kırklareli University, Turkey)

\#646: Türk-Rus Vize Serbestliği Anlaşmasının Turizm Ekonomisine Katkısı

- Mr. Halil Şimşek (Istanbul Aydın University, Turkey)

\#816: Ülkelerin Turizm İstatistikleri Bakımından Farklı Kümeleme Analizi Metotları ile Sınıflandırılması ve Türkiye'nin Bu Oluşumdaki Yeri

- Asst. Prof. Dr. Selay Giray (Marmara University, Turkey)

\#720: Endüstri Mirasının Ekonomiye Kazandırılması: Toronto Distilery District Dönüşüm Örneği

- Assoc. Prof. Dr. Sülün Evinç Torlak (Pamukkale University, Turkey)

\section{SESSION 5C: Turizm II}

Session Chair: Assoc. Prof. Dr. Sülün Evinç Torlak

\#739: Ülke Kalkınmasında Marmaris Turizm Sektörünün Önemi Ve Rus Turistlerin Marmaris’i Tercih Etme

Nedenleri

- Asst. Prof. Dr. Aziz Bostan (Kyrgyzstan-Turkey Manas University, Kyrgyzstan)

- Ph.D. Candidate Zehra Türk (S1tkı Koçman University, Turkey)

- Ph.D. Candidate Hande Akyurt Kurnaz (Sıtkı Koçman University, Turkey)

\#747: Ulusal Otel Zincirinin Büyüme Başarısına İlişkin Bir Değerlendirme: Rixos Otel Zinciri .721

- Assoc. Prof. Dr. Ufuk Durna (Akdeniz University, Turkey)

- Prof. Dr. Mehmet Emin İnal (Akdeniz University, Turkey)

- Ph.D. Candidate İhsan Kurar (Akdeniz University, Turkey) 
\#741: Stratejik İttifak Oluşumundaki Konaklama Sektöründe İşletmeler Arası İlişkileri Düzenleyici Faktörler ve Bir Model Önerisi

- Ph.D. Candidate Nilüfer Vatansever Toylan (Kırklareli University, Turkey)

- Prof. Dr. Fatih Semerciöz (Istanbul University, Turkey)

\#759: Yabancı Turistlerin Güvenlik Algılarının Analizi:Alanya Örneği

- Asst. Prof. Dr. Muharrem Aksu (Akdeniz University, Turkey)

- Asst. Prof. Dr. Ali Rıza Aktaş (Akdeniz University, Turkey)

- Ph.D. Candidate Onur Oku (Akdeniz University, Turkey)

- Ph.D. Candidate Faruk Kerem Şentürk (Akdeniz University, Turkey)

\#758: Turizm ile Ekonomik Büyüme Arasındaki İlişki: Akdeniz Ülkeleri Üzerine Bir Panel Veri Analizi .755

- Asst. Prof. Dr. Ali Rıza Aktaş (Akdeniz University, Turkey)

- Dr. Fatih Kaplan (Bingöl University, Turkey)

- Ph.D. Candidate Seyfettin Kocaman (Akdeniz University, Turkey)

SESSION 6C: Bölgesel Konular

Session Chair: Prof. Dr. Seda Şengül

\#678: Geçiş Ekonomilerinde Girişimciliğin Ekonomik Büyüme Üzerine Etkileri

- Assoc. Prof. Dr. Mine Gerni (Marmara University, Turkey)

- Prof. Dr. Murat Nişancı (Erzincan University, Turkey)

- Asst. Prof. Dr. Ahmet Alkan Çelik (Beykent University, Turkey)

- Ph.D. Candidate Ziya Çağlar Yurttançıkmaz (Atatürk University, Turkey)

\#820: Türkiye ve Seçilmiş Bazı Bağımsız Devletler Topluluğu Ülkelerinde Sebze ve Meyve Ürün Grubunda Uluslararası Rekabet Gücü Analizi

- Assoc. Prof. Dr. Fahriye Öztürk (Gazi University, Turkey)

- Ph.D. Candidate Sıtkıcan Saraçoğlu (Gazi University, Turkey)

- Ph.D. Candidate Işın Kortan (Hacettepe University, Turkey)

\#729: Tüketim Toplumunun Çevresel Etkileri

- Mrs. Naile Karakehya (Osmangazi University, Turkey)

\#824: Türkiye'de Kayıtdışı İstihdam Konusu Üzerine Teorik ve Ampirik Bir Çalışma .783

- Mrs. Eren Gül Aydın (Beykent University, Turkey)

SESSION 7C: Sektörel Sorunlar

Session Chair: Assoc. Prof. Dr. Selami Özcan

\#767: Bankacılık Sektöründe Personel Güçlendirme Uygulamalarının Örgütsel Bağlılığa Etkisi: Trakya

Bölgesi Bankalarında Araştırma

- Mrs. Gözde Gürbüz (Trakya University, Turkey)

- Asst. Prof. Dr. İlknur Kumkale (Trakya University, Turkey)

- Assoc. Prof. Dr. Adil Oğuzhan (Trakya University, Turkey)

\#642: Katılım Bankası Müşterilerinde Bankacılık Ürün ve Hizmetlerine Yönelik Memnuniyet: Türkiye Örneği

- Asst. Prof. Dr. Bengül Gülümser Kaytancı (Anadolu University, Turkey)

- Dr. Etem Hakan Ergeç (Osmangazi University, Turkey)

- Prof. Dr. Metin Toprak (Istanbul University, Turkey)

\#789: Türk Bankacılığında Rekabet Değerlendirme Yaklaşımları ile Rekabet Dinamiklerinin Ampirik Analizi 812

- Asst. Prof. Dr. Utku Altunöz (Sinop University, Turkey)

\#673: Sağlık Sektöründe Bilgi Asimetrisinin Hasta Memnuniyetine Etkisi: Yalova Ağız Ve Diş Sağlığı

Merkezinde Bir Uygulama

- Assoc. Prof. Dr. Selami Özcan (Yalova University, Turkey)

- Mr. Kerim Baş (Yalova University, Turkey)

- Asst. Prof. Dr. H. Yunus Taş (Yalova University, Turkey) 
- Dr. Mediha Tezcan (Anadolu University, Turkey)

SESSION 1D: Uluslararas1 Sorunlar

\section{Session Chair: Prof. Dr. Ekrem Erdem}

\#698: Post - Sovyet Ülkeler Arasında Bölgeselleşme Eğilimleri

- Prof. Dr. Ekrem Erdem (Erciyes University, Turkey)

- Dr. Halit Mammadov (Erciyes University, Turkey)

\#610: Açık Denizlere Kıyısı Bulunmayan Avrasya Devletlerinin Transit Geçiş Hakkı

- Asst. Prof. Dr. Abbas Karaağaçlı (Giresun Univesity, Turkey)

\#756: Türkiye'nin Yeni Jeopolitiğinin Çevresi

- Asst. Prof. Dr. Hakkı Çiftçi (Çukurova University, Turkey)

- Dr. Murat Koç (Gaziosmanpaşa University, Turkey)

\#794: Uluslararası Emek Göçü Bağlamında Almanya’ya Türk İşgücü Göçü ve Sosyo-Ekonomik Etkileri

- Asst. Prof. Dr. Şenol Yaprak (Kocatepe University, Turkey)

\#635: Rusya'nın Oylama Gücünün Avrasya Ülkeleri Üzerindeki Ekonomi Politiği

- Asst. Prof. Dr. Ceyhun Haydaroğlu (Bilecik Şeyh Edebali University, Turkey)

SESSION 2D: Uluslararası Hukuk

Session Chair: Prof. Dr. Mustafa Topaloğlu

\#807: Türk Hukuk Sisteminde Tahkim Mevzuat1

- Mr. Ahmet Tuncay (Turkish Supreme Court, Turkey)

\#808: Milletlerarası Ticari Tahkim Kuruluşları

- Mr. Uğur Sayın (Turkish Supreme Court, Turkey)

\#805: Tahkimde Kamu Düzenin Etkisi

- Prof. Dr. Mustafa Topaloğlu (Beykent University, Turkey)

\#806: Türkiye'de Yabancı Hakem Kararlarının Tanınması ve Tenfizinde Karşılaşılan Sorunlar

- Assoc. Prof. Dr. Adnan Deynekli (Turkish Supreme Court, Turkey)

\#804: Ceza Hukukunun Tahkime Etkileri

- Assoc. Prof. Dr. Çetin Arslan (Turkish Supreme Court, Turkey)

SESSION 3D: Hukuksal Sorunlar

Session Chair: Prof. Dr. Faruk Andaç

\#690: Türkiye ve Rusya'da Rekabet Politikası ve Rekabet Hukuku

- Asst. Prof. Dr. Hülya Göktepe (Anadolu University, Turkey)

\#780: İnsan Ticaretinin Ekonomik ve Hukuki Boyutları

- Asst. Prof. Dr. Filiz Tepecik (Anadolu University, Turkey)

\#772: Çevrenin Ceza Hukuku Yoluyla Korunması Kapsamında Çevrenin Kirletilmesi Suçları

- Asst. Prof. Dr. Nazmiye Özenbaş (Anadolu University, Turkey)

\#731: Türkiye'de Giderek Artan Hukuka Aykırı Bir Ekonomik Faaliyet Olarak Kredi Kartı Kullanılması

Suretiyle Tefecilik

- Assoc. Prof. Dr. Hakan Karakehya (Anadolu University, Turkey)

\#599: Grev İşçinin Temel Hakkıdır, Engellenemez

- Prof. Dr. Faruk Andaç (Çağ University, Turkey) 


\section{SESSION 4D: Çevre}

Session Chair: Prof. Dr. Müslüme Narin

\#770: Kyoto Protokolü Esneklik Mekanizmas1: Emisyon Ticareti .941

- Prof. Dr. Müslüme Narin (Gazi University, Turkey)

\#603: Türkiye'de Sürdürülebilir Çevre Politikaları: İklim Değişikliği Örneği

- Asst. Prof. Dr. Abdulmenaf Turan (Yüzüncü Y1l University, Turkey)

- Assoc. Prof. Dr. Mahmut Güler (Trakya University, Turkey)

\#822: Küresel İklim Değişikliği Sorununa Çözüm İçin Nasıl Bir Sürdürülebilir Kalkınma Anlayışına İhtiyacimiz Var?

- Dr. Ayşen Satır (Ministry of Environment and Forestry, Turkey)

- Asst. Prof. Dr. Hakan Reyhan (Hitit University, Turkey)

\#596: Karadeniz Havzasında Sınıraşan Çevresel Zararlar ve Bölgesel Sorumluluk Rejimi

- Ph.D. Candidate Arda Özkan (Giresun University, Turkey)

\#600: Ekolojik Çevreye Duyarlı İşletmecilik Yaklaşımı: Unilever Örneği

- Mr. Çetin Kalburan (Pamukkale University, Turkey)

- Assoc. Prof. Dr. Selçuk Burak Haşıloğlu (Pamukkale University, Turkey)

SESSION 5D: Enerji ve Tabii Kaynaklar

Session Chair: Asst. Prof. Dr. İlyas Sözen

\#699: Avrasya Doğal Gaz Boru Hattı Projeleri Özelinde Kafkasya Üzerine Bir Değerlendirme

- Ph.D. Candidate Nuri Gökhan Toprak (Kirklareli University, Turkey)

\#604: Trans-Anadolu Doğal Gaz Boru Hattı Projesi'nden Ekonomik ve Stratejik Beklentiler

- Assoc. Prof. Dr. Osman Nuri Aras (Fatih University, Turkey)

- Ph.D. Candidate Elchin Suleymanov (Qafqaz University, Azerbaijan)

- Assoc. Prof. Dr. Fakhri Hasanov (Qafqaz University, Azerbaijan)

\#723: Avrupa Birliği ve Enerji Arzı Güvenliği Açısından Trans Anadolu Doğalgaz Boru Hattı

- Dr. Nuran Belet (Gazi University, Turkey)

\#691: Geçiş Sürecindeki Orta Asya Cumhuriyetlerinde Enerji Tüketimi ve Büyüme İlişkisi

- Asst. Prof. Dr. Abdullah Özdemir (Adnan Menderes University, Turkey)

- Asst. Prof. Dr. Mehmet Mercan (Hakkari University, Turkey)

- Mr. Erkan Dendeş (Adnan Menderes University, Turkey)

\#701: Elektrikli ve Elektronik Atıkların Geri Dönüşümünde Tüketici Davranışları: İstanbul Örneği

- Ph.D. Candidate Aslı Okay Toprak (Kırklareli University, Turkey)

- Asst. Prof. Dr. Elif Haykır Hobikoğlu (Istanbul University, Turkey)

- Ph.D. Candidate Taha Eğri (Istanbul University, Turkey)

- Prof. Dr. Zekai Özdemir (Istanbul University, Turkey)

\#640: Doğu Akdeniz Enerji Kaynaklarının Güney Kıbrıs Rum Yönetimi Ekonomisine Etkileri 1027

- Prof. Dr. Halil İbrahim Ülker (Atılım University, Turkey)

- Asst. Prof. Dr. Poyraz Gürson (Atılım University, Turkey)

- Mr. Mustafa Kemal Topcu (Fibonasi Yönetim Danışmanlık, Turkey)

- Asst. Prof. Dr. Turan Erman Erkan (Atılım University, Turkey)

SESSION 6D: Экономический рост и развитие

Session Chair: Prof. Dr. Turar Koychuev

\#593: Только Правильная Политика Вернет Доверие

- Prof. Dr. Turar Koychuev (National Academy of Sciences, Kyrgyzstan)

- Prof. Dr. Merim Koichueva (Kyrgyz-Russian Slavic University, Kyrgyzstan) 
\#654: Рыночный фундаментализм и провал экономических реформ в постсоветском пространстве ......1036 - Prof. Dr. Khodjamakhmad Umarov (Institute of Economics, Tajikistan)

\#763: «Структурная лестница» устойчивого экономического роста (на примере Республики Молдова)1041

- Prof. Dr. Tatiana Pyshkina (Academy of Economic Studies of Moldova (ASEM), Moldova)

\#815: Государственный и частный сектор в системе здравоохранения Кыргызстана и перспектива их сотрудничества 1050

- Assoc. Prof. Dr. Damira Japarova (Kyrgyzstan-Turkey Manas University, Kyrgyzstan)

\#613: Налоговая нагрузка как критерий реформы в налоговой системе Кыргызской Республики .1056

- Assoc. Prof. Dr. Khicheza Fynchina (Kyrgyz-Russian Slavic University, Kyrgyzstan)

SESSION 7D: Международная торговля

Session Chair: Prof. Dr. Jusup Pirimbaev

\#624: О влиянии интеграционных процессов на агарный рынок Казахстана 1065

- Prof. Dr. Gani Kaliev (Academy of Agricultural Sciences, Kazakhstan)

- Ph.D. Candidate Nikitina Galina (Kazakh Scientific Research Institute, Kazakhstan)

\#771: Значение географических факторов для положения государств их политики и экономики .1075

- Asst. Prof. Dr. Saadat Demirci (Çankırı Karatekin University, Turkey)

\#682: Водный вопрос Центральной Азии и борьба за региональное лидерство 1079

- Ph.D. Candidate Dina Kurkova (National Research University, HSE, Russia)

\#633: Открытая экономика и экономическая интеграция в рамках Евразии .1086

- Prof. Dr. Omurbek Karatalov (Kyrgyz-Russian Slavic University, Kyrgyzstan) 


\title{
Yeni Sanayileșen Ülkelerde Sermaye Akımları ve Büyüme: Türkiye Örneği
}

\section{Capital Flows and Growth in Emerging Market Economies: The Case of Turkey}

\author{
Prof. Dr. Ercan Uygur (Turkish Economic Association, Turkey)
}

\begin{abstract}
Since May 2013, we have witnessed sudden stops and large reversals in the flow of capital to the emerging market economies (EMEs). What we have witnessed is the reversal of the surge of capital that started in 2009 from the advanced economies to the emerging ones, as has been expected. The episodes of capital surges and retrenchments have been observed repeatedly in the last three decades. In this period, capital flows across countries have increased dramatically, but their fluctuations and volatility have been even more dramatic. Furthermore, these flows have played an increasingly important role in the business cycles of both advanced economies and EMEs and during episodes of crises. Why then, in spite of cycles and crises, there is free flow of capital to EMEs? One answer is that these flows might be used to finance investments and to contribute to the long run growth of the EMEs. The basic aim of this paper is to examine the validity of this assertion. Thus, the paper attempts to establish the effect of capital flows on the growth performance of the EMEs, with special reference to Turkey. After a survey of research on the subject, the paper first provides an account of the recent developments in international capital flows. The paper concentrates more on capital flows to Turkey in terms of categories, namely, foreign direct investment, portfolio investment and credit flows. The paper then empirically investigates the effect of these three categories and total capital inflows on the growth of the EMEs. Policy implications of the findings are also discussed.
\end{abstract}




\title{
Ценностные Ориентиры Определения Гуманизированной Экономики
}

\section{Value Determination Landmarks of Humanized Economy}

\author{
Prof. Dr. Turar Koychuev (National Academy of Sciences, Kyrgyzstan)
}

\begin{abstract}
The report characterized valuable indicators for evaluating the processes of humanization of social development, revealed the interdependence and interaction of processes of socio-economic structure and development of the productive forces of scientific and technological achievements, highlighted the fundamental and crucial stages in their development trends. The humanized society is seen as a special stage of economic development and public relations.
\end{abstract}

Научно-технические и технологические достижения, используемые в экономике, делают экономику более производительной и эффективной, труд становится физически и психологически более облегченным и менее напряженным, умственно и интеллектуально более содержательным, процесс производства - более комфортным и безопасным, как для жизни людей, так и для экологии.

Потребуются и в экономику придут специалисты и работники образованные, высокой квалификации, новых специальностей и профессий в соответствии с новыми требованиями. Новый технический и технологический уровень производства предъявляет требования и духовному развитию, интеллекту, нравственным качествам работников, что важно для создания психологически благоприятной атмосферы в коллективах.

Более техновооруженная, технологично лучшая экономика будет производить продукты и оказывать услуги несравнимо выше по качеству и это в интересах людей.

В связи с цивилизационными изменениями меняются и возвышаются материальные потребности людей и потребности в услугах, что обуславливает отраслевые структурные изменения, ориентированные на удовлетворение запросов населения.

С ростом производительности труда и финансовой самодостаточности повысятся доходы работающих в экономической сфере.

C обеспечением надежности пополнения и устойчивости роста госбюджета за счет экономического динамичного развития государство будет иметь возможность усилить финансирование социальной сферы и целенаправленно формировать полноценный социальноориентированный госбюджет.

С инновационным ростом экономики и соответствующим расширением финансов государство будет в состоянии не просто законодательно регулировать, но и предметно содействовать увеличению доходов малоимущего населения, чтобы постепенно исчезло понятие «малоимущее население». Важно достигнуть такого положения, чтобы не было сильного расслоения населения по доходам и имущественному положению. Это - основа возникновения социальных конфликтов.

Предметом особой заботы сильной экономики должны стать материальная помощь людям преклонного возраста и больным, а также материальная поддержка семьям в воспитании детей. Нужно создавать частные целевые фонды поддержки. Бизнес должен не только «зарабатывать» прибыль, но и оказывать благотворительность. В конце концов, извлечение прибыли и наращивание капитала не конечная цель в бизнесе. Всех денег не унесешь туда, откуда не возвращаются. Много ли надо одному даже со всеми домочадцами. Делать добро не только себе, а окружающим тебя людям, народу - вот такой должна быть конечная цель каждого человека, кем бы он ни был. Кем бы он ни был - он человек, в этом его естественная сущность.

Одним из признаков гуманизации экономики является создание экологически безопасной экономики, чтобы горы не разрушались, почвы не истощались, естественные, биологические ресурсы варварски не уничтожались, ледники «техногенно» не таяли и водные источники не иссыхали, воздух не загрязнялся. Человек должен дышать чистым воздухом, пить чистую воду, жить в незагрязненной, неопустошенной, дышащей и цветущей благодатной природной среде.

Процесс гуманизации экономики не может осуществляться изолированно, не соприкасаясь с внешним миром. Развитые страны, в которых уже проглядываются «черты» гуманизации, объективно передают свой опыт в этом направлении другим странам. Такая тенденция объективно будет расширяться по мере экономического процветания большинства стран мира. Она не будет связана только с извлечением для себя выгоды, а больше будет носить благотворительный, гуманитарный характер. 
Теоретический анализ того, что может быть привнесено в жизнь общества процессом гуманизации экономики, показывает, что гуманизация не как единичное, а целостное явление может быть достигнута только в развитых странах, переживших этапы индустриального, информационного, инновационного развития. На этих этапах возможны проявления отдельных признаков процесса гуманизации, но до проявления всей экономики как гуманизированной еще не дошли. Гуманизация сейчас, когда не дошли до полной гуманизации экономики, может рассматриваться только как процесс идущий, как одно из свойств того или иного, в данном случае скажем инновационного развития, но не отражает сущность этапа, сопровождаемого им.

Когда же гуманизация будет отражать в целостности сущность всей экономики, то это будет ознаменовать наступление нового этапа экономического, шире общественного развития - этапа гуманизации развития. Категория «гуманизация экономики», как и категории «индустриальное общество», «информационное общество», «инновационное общество» будет характеризовать очередной достигнутый переломный этап в цивилизационном развитии.

Цивилизационное развитие можно рассматривать в двух аспектах: 1) выделяя этапы изменения общественно-экономического устройства общества; 2) раскрывая этапы развития и качественных изменений производительных сил, технико-технологических переломных прорывов. Первый аспект блестяще показан К. Марксом, а второй - У. Ростоу и Дж. Гэлбрейтом.

Масштабные и принципиально качественные изменения производительных сил, научно-технические достижения и их использование в экономике объективно приводили к изменениям в общественноэкономических укладах, в экономических, социальных, политических и правовых отношениях.

Общественно-экономические уклады (формации) К. Маркс выделял по формам (частным) собственности, из наличия классов с антагонистическими интересами и власть в государстве рассматривалась как выражение господства имущего класса и защитница ее положения. Он теоретически обосновывал существование в будущем новой общественно-экономической формации (коммунистической) с общественной собственностью на средства производства и с наличием социальных слоев населения без антагонистических противоречий.

На цивилизационном пути человеческого общества, основанные на частной собственности, общественно-экономические уклады менялись в связи с изменениями в положениях классов, когда один имущий господствующий класс «приходит» на смену другому, «оттесняя» от авансцены. Государство как власть, действительно выражало приоритетно интересы господствующего класса.

Советский опыт утверждения общественной формы собственности на средства производства, проделанного, якобы, по марксистскому «рецепту», а на самом деле искаженному догматическим пониманием, не доказал, к сожалению, преимущество коммунистической формации. Сравнительно экономическое отставание от капитализма привело к отказу от «советского опыта».

Классовое общество, основанное на частной собственности на средства производства, последним прообразом которого является капитализм, добилось высокого уровня развития производительных сил. Высокоразвитая экономика не позволила обеспечить высокий уровень жизни всего населения, но социальное расслоение по имущественному положению не резко растет, а сглаживается, сокращается бедность как явление, политическая жизнь все более демократизируется и государство как власть все больше становится исполнительницей воли всего общества. Конечно, нельзя полностью исключить влияние «имущих» на политику, но оно не абсолютно, не ненаказуемо. Политическая демократия «уравняла» участие всех социальных слоев в управлении государством и в выработке социальноэкономической политики.

Общественно-экономические уклады не различаются по формам собственности на средства производства. Они становятся многоукладными, сочетая частную и общественную формы собственности.

«Классовый» формационный подход к общественно-экономическим укладам исчерпал себя. Наступает эра социально солидарного общества. С дальнейшим цивилизационным развитием социальная солидарность должна «укрепляться». Высокий уровень развития производительных сил, жизни населения, научно-технических достижений, демократических принципов в общественной жизни приводят ко все более глубокой гуманизации экономического и всего общественного развития. Вслед за индустриальными, информационными, инновационными развитиями наступит этап гуманизированного общества.

Гуманизированное общество - это: высокий уровень развития производительных сил, способный полноценно удовлетворять потребности людей; высокое качество жизни населения и полноценный уровень потребления; социальная солидарность, высокая духовность и нравственность, пресекающая и исключающая общественные негативные явления, такие как коррупция, насилие, грабеж и т.д.; социально-психологическая комфортная, притягательная атмосфера в человеческих отношениях и общениях, когда «правят балом» теплота и сердечность, любовь и доброта душ; экологическая 
безопасность, позволяющая «развивать» в здоровом теле здоровый дух; технологическая безопасность, когда научно-технический и технологический прогресс прежде всего не нанесет вреда физическому, умственному и психическому здоровью человека.

Гуманизированное общество - это социально солидарное, нравственное и доброизлучающее, сердечное человеческое общество, излучающее ум и добро, тепло и свет! 


\title{
Перспективы Создания ЕЭС Prospects for a Common Economic Union
}

\author{
Prof. Dr. Jusup Pirimbaev (Kyrgyzstan-Turkey Manas University, Kyrgyzstan) \\ Prof. Dr. Anara Kamalova (Academy of Public Administration, Kyrgyzstan)
}

\begin{abstract}
This article discusses the current situation and the future of the integration process of the CIS countries. The main problems include a small number of active participating countries and regional imbalance distribution of productive forces. In this regard, all members of the Eurasian union must understand that the implementation of the idea of "union" is unattainable within the currently existing members only. The main issues in the integration - it is a professional job in order to protect the interests of the majority of the residents of the participating countries that will awaken a general interest in the idea of the Union.
\end{abstract}

\section{1 На повестке дня Кыргызстана}

решение проблемы вхождения в Таможенный союз и дальнейшей интеграции в Евразийский экономический союз, который берет свое начало с 1 января 2015 года. Споры идут нешуточные. Сражаются «не на жизнь, а на смерть». Причин много, о них немало и говорили, и писали, но главной остается одна - отношение к обеспечению суверенитета. Одни считают, что вхождение Кыргызстана в этот интеграционный процесс вызовет потерю суверенитета, другие, наоборот, уверены в его последующем укреплении. Однако никто не задумывается, что термин «суверенитет государства», содержит в себе не только понятие независимости и самостоятельности, но и взаимодействия с другими суверенитетами, без ущемления собственного. Загляните в глубину веков. Исторически кыргызы, где только не расселялись, с кем только вместе не жили, в каких только государственных образованиях не состояли на огромной Евразийской территории. И тем не менее умели сохранять свою исконную самостоятельность, культуру и идентификацию, при этом оставаясь полноценными гражданами тех государственных образований, к которым они относились. И когда кыргызы в результате длительных исторических испытаний получили в 20 веке свое суверенное государство, то говорить о его утрате вследствие наблюдаемых интеграционных процессов - это несомненная глупость. Да, есть другие факторы, вызывающие тревогу о его возможном разрушении, поскольку есть заинтересованные силы, еще не исчезло намерение сильных государств подмять под себя более слабые. Но существуют и факторы, сводящие к минимуму влияние разрушающих сил.

Сегодня нас должны интересовать именно созидающие факторы, способствующие тому, чтобы сделать государство сильным и процветающим, обеспечивающие стабильность, перспективы существования и развития суверенного Кыргызского государства. Безусловно, в этом огромную роль играло и будет играть обеспечение самодостаточной и динамично развивающейся экономики страны.

Экономическую деятельность республики на сегодняшний день трудно тесно связывать с экономической политикой. Ибо экономическая политика связана с выбором стратегической эконономической цели страны и координацией всех сил и ресурсов на достижение конечной цели. Определена ли такая цель на сегодня? Ответ на этот вопрос еще предстоит найти.

Было бы несправедливым считать, что экономическая деятельность государства осталась вне политики и были проявлены радикальные меры в отношении экономики. Республика после получения независимости столкнулась с необходимостью самостоятельно решать экономические проблемы, разрабатывать программы экономических действий. Гиперинфляция на всей территории постсоветского периода, экономический хаос, породивший глубокий кризис, а также неуклонно падающий уровень жизни населения объективно требовали принятия радикальных экономических мер. Нужен был хотя бы механизм сдерживания и контроля неуправляемого экономического процесса. И этим механизмом явилось введение на территории республики национальной валюты. Убеждать высшее руководство страны в необходимости решения таких проблем было непросто, но возможно. Реализация выпуска национальной валюты автоматически поставила вопросы, требовавшие пересмотра в срочном порядке многих экономических задач в контексте твердого укрепления позиции сома на рынке Кыргызстана. И хотя ввод национальной валюты создал кратковременную видимость стабильности экономических отношений, однако он показал, насколько «хрупка» судьба самой валюты в действующей системе хозяйственных отношений. Рыночные отношения, ради которых отказались от социалистического экономического уклада, требовали активных действий, чтобы не создавать атмосферу недееспособности власти.

Осуществили приватизацию, которая не дала желаемого результата, более того, создала больше проблем, что вызывает у многих желание ревизировать результаты приватизации и повернуть «колесо 
истории» вспять. Реформы, проведенные в социальной сфере, больше похожи на «бомбу замедленного действия», нежели на решение проблем. Независимо от уровня экономического развития подобные проблемы существуют почти во всех государствах постсоветского периода. Приведем один пример из экономической истории Кыргызской Республики (см. таблицу).

\begin{tabular}{|l|l|l|l|l|l|}
\hline & 1960 & 1970 & 1980 & 1985 & 1986 \\
\hline Общий объем промышленной продукции & 6,2 & 19 & 37 & 46 & 49 \\
\hline Валовая продукция с/х-ва & 1,8 & 2,9 & 3,7 & 3,9 & 4,3 \\
\hline
\end{tabular}

Таблица 1. Темпы роста экономики Кыргызской Республики за период 1940-1987 г2. $(1940=1)^{2}$, \%

По данным таблицы, темпы роста в двух реальных секторах экономики Кыргызстана являются характерными и для других союзных республик, демонстрируя тенденцию к постоянному росту. За 26 лет хозяйствования в условиях социалистического уклада промышленность республики выросла в 42,8 раза, сельское хозяйство - в 2,5 раза, а капитальные вложения за 15 лет (с 1970 по 1985 г.) - в 1,4 раза и составили 6249 млн. руб. (можно сделать сравнение с 20-летней экономической историей независимого Кыргызстана, борющегося за демократию и лучшую форму общественного развития). Мы взяли этот период Кыргызстана осознанно, ибо именно на него приходится наивысший рост производительных сил в республике (хотя явного несоответствия развития производительных сил уровню и характеру производственных отношений в последующем - до развала Советского Союза - практически нет, по сравнению с более развитыми союзными республиками). Анализ урожайности сельскохозяйственных культур выявил явное отставание показателей, достигнутых за 20 лет существования республики в условиях независимости, от показателей в советского периода.

Это результат тесной экономической интеграции советского периода. Не надо здесь, подобно «Фоме неверующему», отвергать действительное. Развалили все вместе эту экономическую интеграцию, так, давайте, создадим альтернативную, не трогая незыблемости суверенитета каждого. Такая интеграция является объективной экономической необходимостью, требующей от всех трезвого расчета. Здесь не должно быть места для политической спекуляции, проявления политического шарлатанства. Даже в условиях тоталитарного Советского Союза идея обновления экономических взаимоотношений, при условии укрепления самостоятельности и независимости отдельных союзных республик под названием Евразийского союза, постоянно существовала. Реализуй мы эту идею вовремя, была бы совершенно другая действительность постсоветского пространства. А так она оказалась в плену демагогий самостоятельного достижения современного прогресса, игнорирующих идею рационального использования производительных сил огромной территории для созидания общего блага.

Поэтому в середине 90-х годов «евразийство» получило новое распространение с точки зрения создания единого экономического пространства. Активным сторонником такой идеи был Президент РК Нурсултан Назарбаев, который получил неподдельную поддержку со стороны Президента РФ Владимира Путина и Президента Беларуси Александра Лукошенко. Идеологами этого движения были, конечно, философы, экономисты и политологи: Александр Дугин, Александр Панарин, Сергей Глазьев, Сергей Гавров и др. Особую лепту внес в идею Евразийского объединения кыргызский писатель Чингиз Айтматов.

Евразийский экономический союз как интеграционная организация включал три этапа осуществления интеграционного процесса:

Таможенный союз;

Единое экономическое пространство (Евразийская экономическая комиссия);

Евразийский экономический союз.

В 2010 году начал работу Таможенный союз трех стран: Россия, Казахстан и Беларусь. С 1 января 2012 года осуществлен переход ко второму этапу интеграционного процесса, и территория участников Таможенного союза объявлена единым экономическим пространством. Этому предшествовало подписание 18 ноября 2011 года Декларации о Евразийской интеграции лидерами стран Таможенного союза, на основе которой была создана Евразийская экономическая комиссия, контролирующая около 170 функций союза. Встреча лидеров стран Таможенного союза в Астане определила действия Евразийского экономического союза с 1 января 2015 года.

С самого начала реализация этого объединительного процесса носила название Евразийский союз, который охватывал более широкие процессы интеграции, намного превышающие пределы экономической интеграции, включая создание единого Евразийского парламента. Такой подход был очень спорным, поскольку все страны постсоветского периода больше беспокоил вопрос их суверенитета в любых интеграционных процессах, хотя само понятие «суверенитет» больше вызывает риторических вопросов. В данном случае такое беспокойство носит объективный характер из-за болезненного восприятия молодыми суверенными странами исторического опыта взаимодействия центра и отдельных 
республик. Поэтому всегда берет верх категоричность в оценке объединительных процессов, нежели скрупулезный анализ, поиск оптимальных решений взаимодействия.

В этой связи ясна реакция мажилиса Казахстана, который 18 сентября 2012 года отвергал идею создания единого Евразийского парламента. Свое принципиальное несогласие мажилис видит в невозможности создания наднациональной политической структуры, затрагивающей суверенитет страны. В действительности, создание Евразийского союза в начале больше носило декларативный характер и было воспринято большинством как амбициозный политический фарс. Об этом свидетельствуют многочисленные публикации и выступления экспертов не только Казахстана и Беларуси, но и России главного действующего игрока.

Последующие действия лидеров РФ, РК и Беларуси потребовали корректировки понятия «союз». В результате родилась окончательная его трактовка не как Евразийский союз, а как Евразийский экономический союз, что помогло бы очистить понятие «союз» от политической шелухи. И даже такая трактовка вызвала невосприятие со стороны лидеров США. Госсекретарь Хиллари Клинтон заявила о намерении всесторонне помешать созданию «новой версии Советского Союза» под видом экономической интеграции. Налицо факт спорности понимания демократических ценностей в мире, страны-лидеры которого озабочены сохранением незыблемости системы несправедливых экономических взаимоотношений с развивающимися странами. Безусловно, позиция США больше исходит из гегемонических интересов, хотя нас интересует больше позиция экспертов стран-участниц объединительного процесса.

И здесь позиции разные даже среди противников создания подобного союза, которых достаточно в самом союзе: одни «пугают» реанимацией Советского Союза, где главенствующая роль отдается Российской Федерации, другие считают невозможным нормальное функционирование экономики союза при наличии большого разрыва в уровнях экономического развития отдельных стран, третьи опасаются потери самостоятельности национальных экономик, четвертые - возможной неуправляемости цен на рынках, зависимости от принимаемых решений и т.д. Все эти утверждения в условиях глобализации мировой экономики беспочвенны по причине того, что данный союз создается между независимыми странами, а не регионами одного государства, между странами с различным экономическим уровнем развития, что нужно принимать в расчет, а также в условиях наличия высокого уровня трудовой миграции, оказывающей реальное влияние на экономику каждой из стран. И, наконец, создание союза на равных правах, на взаимовыгодных условиях, с приемлемыми обязательствами, отвественностью за нарушение условий союза, делегированием полномочий в различных международных организациях является внутренним делом членов союза. Следует принимать во внимание, что самоизоляция национальной экономики - это самый неперспективный путь развития экономики в современном мире.

Реализация на практике амбициозной идеи Евразийского экономического союза возложена на Евразийский банк развития, созданный в рамках Евразии в 2010 году, где организован Центр интеграционных исследований, который осуществляет СВОП-анализы деятельности всех участников интеграционного процесса и сторон, желающих участвовать в этом процессе. В аспекте этих исследований разработаны условия вхождения в Евразийский экономический союз, которые в какой-то мере отражают основные цели данного союза:

единые тарифы;

единые технические регламенты;

гармонизация трудового законодательства;

гармонизация миграционного законодательства;

единая банковская система;

единая валюта;

укрепление внешних границ.

Конечно, создание полноценного Евразийского экономического союза в пределах трех стран без привлечения объективно интегрированных соседних стран, отвечающих условиям вхождения, маловероятно. Тем более, если учесть перспективу создания большого Евразийского экономического союза, включающего в себя Китай, Индию и Иран. Поэтому в ближайших стратегических планах авторов этой идеи может быть вовлечение в процесс ярых сторонников из бывших соотечественников. Таковыми выступают пока Кыргызстан и Таджикистан. Однако последний саммит в Астане лидеров стран Единого экономического пространства внес свои коррективы, признавая статус наблюдателя со стороны Кыргызстана и Украины. Чем закончится такая перспектива для общего Союза трудно прогнозировать, но бесспорно то, что этот факт широко резонирует по всей территории постсоветского пространства.

В определении перспектив Евразийского экономического союза важно не столько вхождение Кыргызстана, Таджикистана или Украины, сколько признание объективности и необходимости их вхождения в данный союз. Не распространяясь об условиях вхождения наших партнеров, хотелось бы 
показать обоснованность поддержки перспективы создания Евразийского экономического союза со стороны Кыргызской Республики.

Сбрасывая со счетов политический и экономический мотивы данного вопроса в широком смысле, хотелось бы подчеркнуть важность и безальтернативность двух проблем воспроизводства, вынуждающих поддерживать идею интеграции кыргызской экономики. Это:

проблемы текущего воспроизводства, касающиеся сугубо потенциала внутренней экономики;

проблемы перспективного воспроизводства, которые не могут найти своего решения без учета достижений мировой экономики. Кстати, возможность самостоятельного решения обеих проблем воспроизводства в Кыргызстане вызывает глубокие сомнения. Обращаемся к фактам текущего возпроизводства страны: реальный рост ВВП в разрезе отраслей характеризуется данными таблицы.

\begin{tabular}{|l|l|l|l|l|l|l|}
\hline & $\mathbf{2 0 0 7}$ & $\mathbf{2 0 0 8}$ & $\mathbf{2 0 0 9}$ & $\mathbf{2 0 1 0}$ & $\mathbf{2 0 1 1}$ & $\mathbf{2 0 1 2}$ \\
\hline & & & & & & \\
\hline ВВП, всего & 108,5 & 108,4 & 102,9 & 99,5 & 106,0 & 99,1 \\
\hline в том числе: & & & & & & \\
\hline $\begin{array}{l}\text { Сельское хозяйство, охота и лесное } \\
\text { хозяйство }\end{array}$ & 101,6 & 100,9 & 106,7 & 97,4 & 101,8 & 101,2 \\
\hline Рыболовство, рыбоводство & 150,0 & 111,1 & 96,2 & 95,7 & 108,6 & 100,0 \\
\hline Горнодобывающая промышленность & 96,8 & 109,1 & 107,7 & 96,4 & 119,5 & 122,5 \\
\hline Обрабатывающая промышленность & 106,3 & 121,2 & 90,7 & 111,3 & 105,2 & 72,8 \\
\hline $\begin{array}{l}\text { Производство и распределение } \\
\text { электроэнергии, газа и воды }\end{array}$ & 107,5 & 92,6 & 97,4 & 111,2 & 121,9 & 105,2 \\
\hline Строительство & 132,3 & 110,8 & 122,1 & 81,5 & 102,5 & 117,3 \\
\hline $\begin{array}{l}\text { Торговля; ремонт автомобилей, бытовых } \\
\text { изделий и предметов личного } \\
\text { пользования }\end{array}$ & & & & & & \\
\hline Гостиницы и рестораны & 110,9 & 109,6 & 102,3 & 94,4 & 110,2 & 110,5 \\
\hline Транспорт и связь & 113,0 & 113,3 & 104,2 & 90,5 & 116,9 & 111,7 \\
\hline Финансовая деятельность & 144,4 & 131,1 & 105,1 & 104,2 & 109,5 & 108,9 \\
\hline $\begin{array}{l}\text { Операции с недвижимым имуществом, } \\
\text { аренда и предоставление услуг } \\
\text { потребителям }\end{array}$ & 111,0 & 105,5 & 106,0 & 95,1 & 110,9 & 101,0 \\
\hline Государственное управление & 105,0 & 110,2 & 101,1 & 104,9 & 101,6 & 98,1 \\
\hline Образование & 101,8 & 102,9 & 102,5 & 99,7 & 105,2 & 101,8 \\
\hline $\begin{array}{l}\text { Здравоохранение и предоставление } \\
\text { социальных услуг }\end{array}$ & 100,1 & 101,4 & 101,4 & 99,7 & 101,3 & 105,1 \\
\hline $\begin{array}{l}\text { Предоставление коммунальных, } \\
\text { социальных и персональных услуг }\end{array}$ & 101,5 & 99,6 & 99,7 & 101,7 & 100,9 & 102,4 \\
\hline Налоги на продукты & 108,5 & 99,2 & 93,7 & 97,8 & 101,3 & 96,7 \\
\hline
\end{tabular}

Таблица 2. Реальный рост ВВП в разрезе отраслей (в процентах к соответствующему периоду предыдущего года)

Как видно, рост ВВП в общем не характеризуется реальным сектором экономики, за исключением деятельности компании «Кумтор». Это связано со многими факторами: отсутствием бюджетной поддержки со стороны государства, инвестиционных вливаний, конкурентной ревности соседних братских стран, четкой экономической политики государства, иждивенческой позицией в отношении производительных сил и т. д.

Самое слабое положение участников в удовлетворении потребностей текущего воспроизводства наблюдается в Кыргызстане. Оценить вклад регионов КР в решение задач текущего воспроизводства можно по данным рис. 1.

Как видно, даже прогнозные показатели не удовлетворяют запросы Министерства экономики страны. Региональная диспропорция размещения производительных сил, раскритикованная еще во времена СССР, имеет свое продолжение в процессе обретения «независимости». А реальная возможность регионов Кыргызстана отдана на откуп внешним консультантам и внутренним «всезнающим» горлопанам, которые оказывают реальное влияние на общественное сознание в вот уже течение более 20 лет.

В плане перспективного воспроизводства в Кыргызской Республике необходимо стремиться хотя бы приблизиться к показателям стран Таможенного союза, которые представлены на рис. 2. 


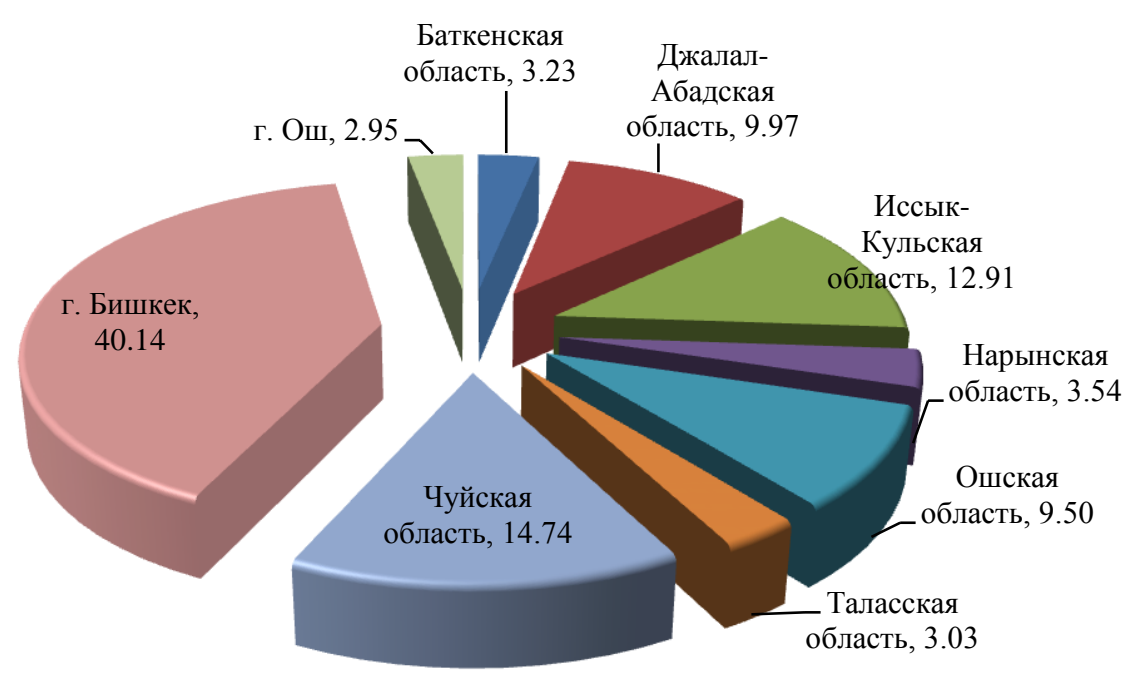

Puc. 1. Вклад регионов в производство ВВП в 2013 г. (прогноз)

\section{Беларусь}

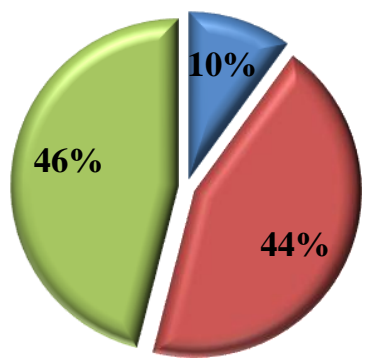

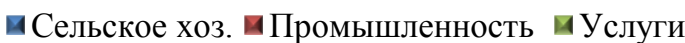

Казахстан

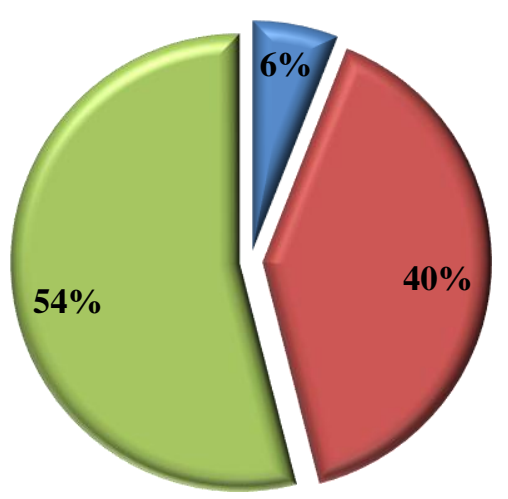

\section{Кыргызстан}

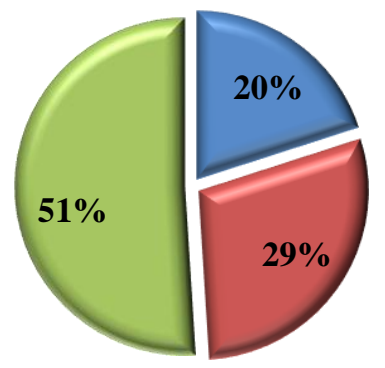

目Сельское хоз. 目Промышленность

目Сельское хоз. 目Промышленность 目Услуги $\square$ Сельское хоз. $\square$ Промышленность $\square$ Услуги 
Данные рис. 2 показывают соответствие структуры ВВП стандарту мировых государств по обеспечению экономического прогресса, поскольку за основу принят реальный сектор экономики. В то же время эти показатели ярко свидетельствуют о том, насколько уязвима оценка реального сектора стран постсоветского периода на соответствие международному стандарту. Конечно, в соответствии с цифрами можно констатировать, что Казахстан ближе к стандарту, но его положение, по оценке казахстанских экспертов, этому не соответствует.
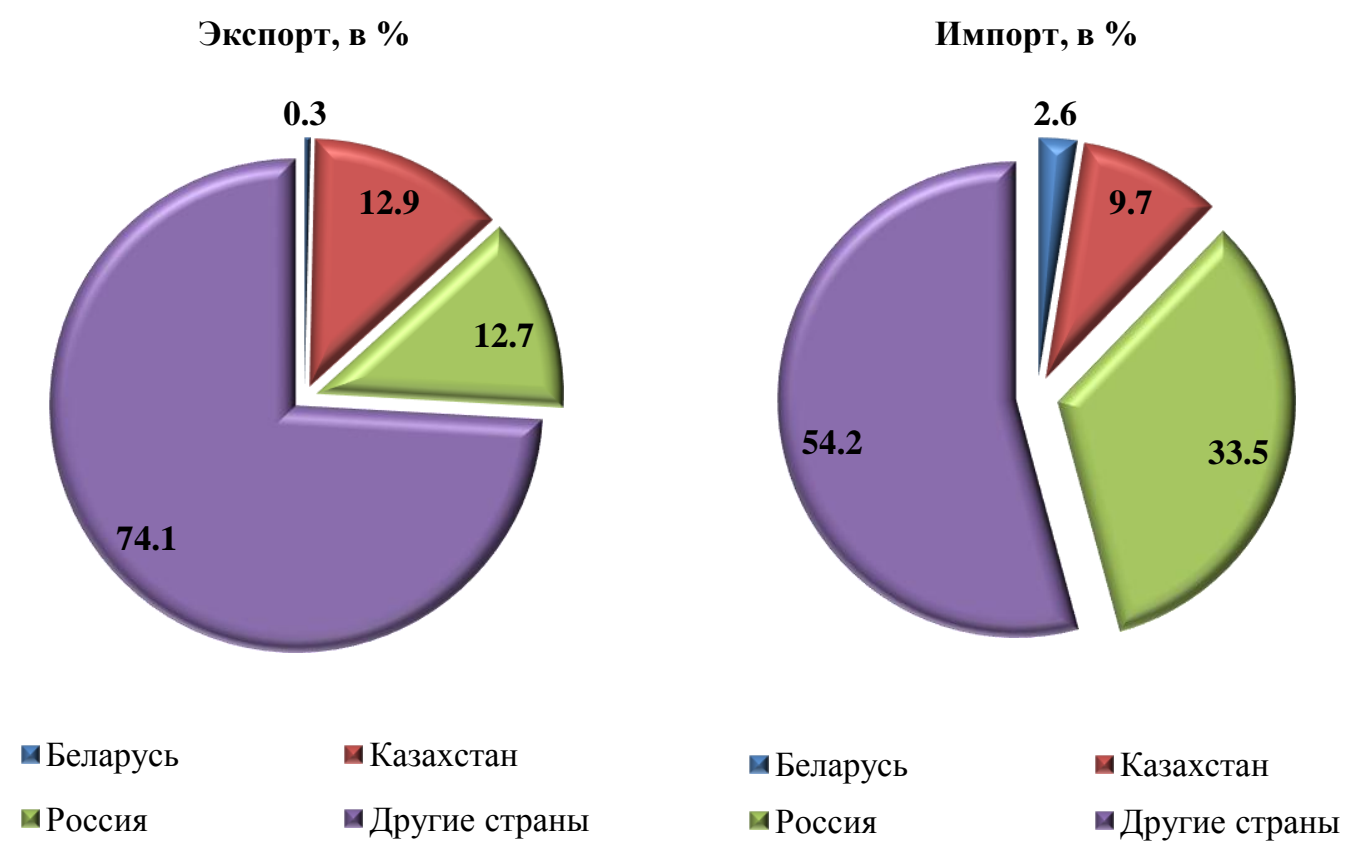

目еларусь

Ф Россия

\begin{abstract}
目 Казахстан
\end{abstract}
曰Другие страны

口 Россия

Рис. 3. Внешняя торговля КР с странами ТС, 2011 г.

Эти данные подтверждают объективность Кыргызстана как молодого суверенного государства интегрироваться со странами, которые определяют его внутреннюю потребность решения насущных экономических проблем. Нужно здесь принять в расчет, что внешняя торговля связана больше с внутренней возможностью технологической реалией, основанной на признании внутри «Союза».

Большой спор в основном происходит в выравнивании таможенных тарифов. Если посмотреть с точки исследования ЦИИ ЕАБР, они выглядят на следующем рисунке и вполне решаемый вопрос.

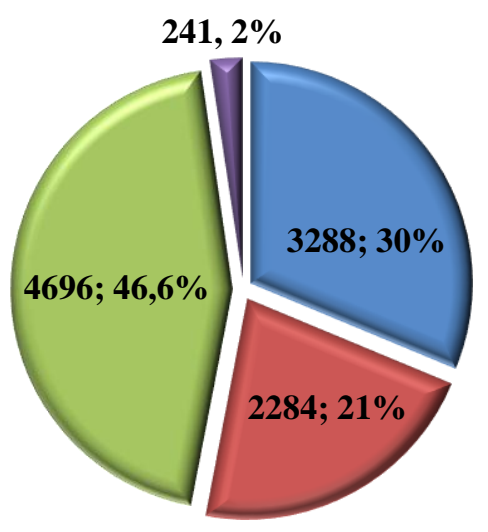

目 Совпадают с ЕТТ ТС

Можно приравнять к ЕTT ТС, не нарушая обязательств перед BTO

口 Не совпадают с ЕТT TC
Несравнимы из-за различных видов ставок

Puc. 4. Сопоставление таможенного тарифа КР и ЕТT ТС 
Для нас важно, чтобы все члены Евразийского объединения вполне осозновали, что реализация идеи «союза» недостижима в пределах только ныне существующих участников. Ведь перспективы создания Евразийского союза сводятся к следующему:

Этот союз создает прецедент в мировой практике появления нового крупного объединения по интересам.

Появляется экспериментальная площадка познания теории действия глобальной экономики.

Создаются условия для проявления противоречий региональных взаимоотношений.

Осуществляется тезис: лучше вместе, чем врозь; поддерживается ценность общечеловеческих отношений.

Главное в интеграционных вопросах - не участие в этом процессе, а осознание, что это не воображение сторонников или не сторонников, а профессиональная работа с целью защиты интересов большинства жителей стран-участниц, что пробудит общий интерес к идее Союза.

\section{Список литературы}

- Исторические переломные этапы развития Кыргызстана: комплексный теоретический анализ / Под науч. рук. акад. Т. Койчуева. - Б.: Илим, 2011. 264 с.

- $\quad$ А.Н. Павлов «Оценка экономического эффекта присоединения Кыргызской Республики к Таможенному союзу»

- Путин: Евразийский союз заработает в 2013 году // Россия 24, 12.07.2011 г.

- Декларация о евразийской экономической интеграции

- К Казахстан блокирует название «Евразийский союз»

- Аждар КУРТОВ: Евразийский экономический союз не угрожает независимости стран Центральной Азии.

- Мария Перова. Евразийство Назарбаева. // Центр Востока и Запада, 9 сентября 2011 г.

- П Путин В. В. Новый интеграционный проект для Евразии - будущее, которое рождается сегодня // «Известия», 03.10.2011 г

- Александр Дугин, Сергей Гавров Национальный лидер Путин: Евразийская интеграция для России // Финам. Инфо 07.11.2011

- Евразийский Союз - перспективный и выгодный проект интеграции евразийских народов. // MOLDINFO 09.08.12

- Грызлов Б. В. Будущее за нами - «Единая Россия» на деле доказала, что способна решать стоящие перед страной задачи // Независимая газета, 15.11.2011 г.

- $\quad$ Микроблог Дмитрия Медведева

- Медведев посулил Кыргызстану членство в Евразийском союзе // ИнтерфаксКазахстан/Tengrinews.kz, 10.12.2010 г.

- Медведев: ЕЭП и Евразийский союз открыты для вступления новых стран // РИА Новости, 09.12.2010 г.

- Владимир Путин: Евразийский союз начнет работу в 2013 году // Российская газета/ ИТАРTACC, 12.07.2011 г.

- Путин хочет создать единую валюту Евразийского союза - Песков // «Финмаркет» информационное агентство/Політико.com.ua15.10.2011 г.

- Киргизию решили принять в Таможенный союз // РБК, 19.10. 2011 г.

- Путин: Евразийский союз можно создать к 2015 году, если действовать так же энергично // «Интерфакс»/Газета.ру, 19.10. 2011 г.

- Казахстан блокирует название «Евразийский союз» 16.11.2011 г.

- $\quad$ Молдова может стать пятым государством в Таможенном союзе // Мир, 24.10.2011 г.

- РиаНовости: РФ, Белоруссия и Казахстан создают ЕЭК - орган управления интеграцией

- Айдос Сарым Нарышкин труд // Журнал «Власть», 20.09.2012 г.

- Казахская элита отвергает идею создания Евразийского парламента // REGNUM, 25.09.2012 г.

- Всероссийский референдум о создании Евразийского союза Заявление оргкомитета // Официальный сайт Евразийского союза молодёжи 
- Объявлено о формировании оргкомитета проведения референдума по вопросу о создании Евразийского союза // Civitas.ru — pесурс гражданского общества, 04.11.2012 г.

- Вес российского рубля в ТС составит 90 \%, — советник президента РФ, 19.12.2012 г.

- Клинтон: «США не допустят воссоздания СССР»

- Алексей Тома Российско-китайский союз против американской «стратегии анаконды» // REGNUM / Геополитика.ру, 08.09.2012 г.

- Вассерман о рынках России и Украины // RUSSIA.RU, 10.03.2009

- $\quad$ Таможенный союз - преимущества вступления // Новости банков, 02.11.2010

- МТРК «МИР». Таможенный союз России, Беларуси и Казахстана может перейти на единую валюту через 10 лет. Москва. 04 мая 2012 г. // Мир, 04.05.2012 г.

- $\quad$ Владимир Путин, Новый интеграционный проект для Евразии - будущее, которое рождается сегодня // «Известия», 03.10.2011.

- Назарбаев Н. Речь Перспективы евразийской интеграции. Астана, 2004 г.

- Назарбаев Н. Речь Проект Евразийского Союза: проблемы и перспективы интеграции. Астана. 2009 г.

- Назарбаев Н. Речь От Евразийского Университета к евразийскому экономическому сообществу. Астана. 2000 г.

- Таможенный союз. Независимое обозрение

- Официальный сайт Таможенного союза

- Сообщество сторонников Евразийского Союза в «Живом Журнале»

- Программа политической партии «Евразия»

- Официальный сайт Евразийского союза молодежи

- 5 причин, почему стоит полюбить Евразийский союз 


\title{
Impact of Globalization on Entrepreneurship in Developing Countries
}

\author{
Prof. Dr. Ahmet Incekara (Istanbul University, Turkey) \\ Ph.D. Candidate Mesut Savrul (Çanakkale Onsekiz Mart University, Turkey)
}

\begin{abstract}
Contemporarily, globalization is regarded as one of the most comprehensive forces that shape the modern world. It led to major increases in worldwide trade and exchanges in an increasingly open, integrated, and borderless international economy. The participation of developing countries in the globalization process created an opportunity for them to better utilize their comparative advantages through entrepreneurs. Entrepreneurship is often associated with job creation, wealth creation, innovation and its related welfare effects. Thus it is generally credited with economic development instrument especially for developing countries. In this regard, impact of globalization on entrepreneurship in developing countries is investigated in the study. Entrepreneurship and globalization data is collected from KOF Index of Globalization and Global Entrepreneurship Monitor. The data of the countries classified by UNDP Country Classification System. Comparison of the data has shown that globalization has a positive impact on entrepreneurial activities and although entrepreneurship levels are rising all over the world it is more effective in developing countries than developed ones and emerging markets in the last decade due to the increase in the globalization process.
\end{abstract}

\section{Introduction}

Globalization is the result of increasing integration of economies around the world, particularly through the movement of goods, services, and capital across borders which also led to the movement of labour and technology across international borders. The term became more common in the 1980s, reflecting technological advances that made it easier and quicker to complete international transactions both trade and financial flows. Globalization refers to an extension beyond national borders of the same market forces that have operated for centuries at all levels of human economic activity, village markets, urban industries, or financial centres.

Globalization is the tendency of investment funds and businesses to move beyond domestic and national markets to other markets around the globe, allowing them to become interconnected with different markets. Accordingly globalization provides organizations a superior competitive position with lower operating costs, to gain greater numbers of products, services and consumers. This approach to competition is gained via diversification of resources, the creation and development of new investment opportunities by opening up additional markets, and accessing new raw materials and resources(İncekara and Savrul, 2012).

Globalization has begun to dismantle the barriers that traditionally segregated local business opportunities and local firms from their international counterparts. Local markets are becoming integral parts of broader, global markets. Consequently, internationally oriented entrepreneurs can now view a much broader range of opportunities and competitive modes, unrestricted by national boundaries. In this integrating global environment, entrepreneurs and emerging businesses face both new opportunities, and formidable new challenges (Etemad and Wright, 2003).

Entrepreneurship is often regarded as an important component in stimulating economic growth, innovation, competitiveness, and alleviating poverty in developing countries. In this framework whether globalization phase has any impacts on level of entrepreneurship come into question.

\section{Globalization}

The advancement of science and technologies has greatly reduced the cost of transportation and communication, making economic globalization possible. Nowadays, ocean shipping cost is only a half of that in the year 1930, the current airfreight one-sixth, and telecommunication cost one percent. The price level of computers in 1990 was only about one percent of that in 1960, and this price level in 1998 reduced again by about eighty percent. This kind of time and space compression effect of technological advancement greatly reduced the cost of international trade and investment, thus making it possible to organize and coordinate global production (Shangquan, 2000:1).

Clearly, globalization has something to do with increased integration of the world society, with an emphasis on increased economic integration. It also involved with businesses changing their reference point thinking globally rather than locally and technological change. However despite the concept's being new none of these elements have existed since, at least the Second World War. The economic integration of world economies has been ongoing over the last fifty years, as countries have worked through GATT and the WTO to reduce trade restrictions. In the 1960s and 1970s there was major discussion of the growth of the multinational corporation as businesses changed their reference point from domestic to international (Colander, 2002:1). 
By the 1980s, the dynamics of globalization can be explained by broader and interacting movements such as innovation and institutional change which are both internal and external to the economies. Since 2000, the arrival of new players has amplified the trends at work and caused them to converge defining a new phase of globalization (Miotti and Sachwald, 2006 :9). Today globalization is seen as one of the most comprehensive force that shape the modern world. The concept is increasing its presence due to the weakening of the economic and national structures of societies. As it is defined by the concepts such as "new economy" and "post-industrial production", globalization created a radical transformation in the world economy by focusing on the production of services rather than goods. This development led qualified human resources to turn into the most important factor of production (İncekara and Savrul, 2011:6). This transformation resulted in globalization to boost its strength and potency in the world.

Globalization led to major increases in worldwide trade and exchanges in an increasingly open, integrated, and borderless international economy. There has been remarkable growth in such trade and exchanges, not only in traditional international trade in goods and services, but also in exchanges of currencies, in capital movements, in technology transfer, in people moving through international travel and migration, and in international flows of information and ideas (Intriligator, 2003:2). Financial and industrial globalization is increasing substantially and is creating new opportunities for both developed and developing countries. However developed and developing countries basically have different expectations in this process. While integration and globalization of the developing countries mean of initiating industrialization, it means increase of the rate of industrialization for the developed countries (İncekara and Savrul, 2012:24). For developing countries, this has led to both positive and negative effects such as increased standard of living, access to new markets, widening disparity in incomes, decreased employment.

The concept of globalization received attention from researchers because of its generally recognized importance as an economic factor, but seemingly also due to of the lack of a generally accepted definition. Although globalization has become a widely used term, equally widespread is its related misconception. An aim for academic research on globalization should be describing the relationship between visible elements and the broad term globalization, as this will lead to awareness (Vinig and Kluijver 2007:6). In this framework, when the economic channels that the globalization penetrate the economy questioned the concepts such as innovation and entrepreneurship come forward.

\section{Entrepreneurship in Globalization Phase}

Although entrepreneurship isn't a new term for the developed countries, economical infrastructure of most of them formed due to it and at least in practice, it can be said to be rather new in developing countries. Due to lack of capital accumulation, qualified human resources and social and political substructure, the term remained a theatrical concept until recently and it can be accepted that globalization phase launched the golden era of entrepreneurship especially in developing countries.

The participation of developing countries in the globalization process created an opportunity for them to better utilize their comparative advantages, introduce advanced technologies, foreign capital and management experience. It is also favourable for eliminating monopolistic behaviours and strengthening market competition (Shangquan, 2000:4-5) and entrepreneurs have played a major role in initiating the process.

\section{Entrepreneurship and Economic Development}

The role of entrepreneurship in economic development is the subject of much interest to academic and policy circles alike. Entrepreneurship is often credited with many positive changes in developing countries. At the very least, it is associated with job creation, wealth creation, innovation and its related welfare effects. A strong small business sector and entrepreneurship are generally linked to a strong economy (Desai, 2009:1). Developing countries are beginning to focus on their business environments and creating an economic space which is conducive to private enterprise, after failed attempts at development through import substitution and infant industry protection programs and somewhat mixed results from export promotion strategies. Indeed, the promotion of entrepreneurship and the promulgation of small and medium sized enterprise policy has become an important development prescription in recent years. Entrepreneurship policy, then, joins a list which includes reforms to countries' macro-economic, exchange rate, trade and industrial policies and improvements in governance (Acs and Virgill, 2009:2-3).

Development economists distinguish three major stages of development in which entrepreneurship play a crucial role (Acs, 2006:99-100). 

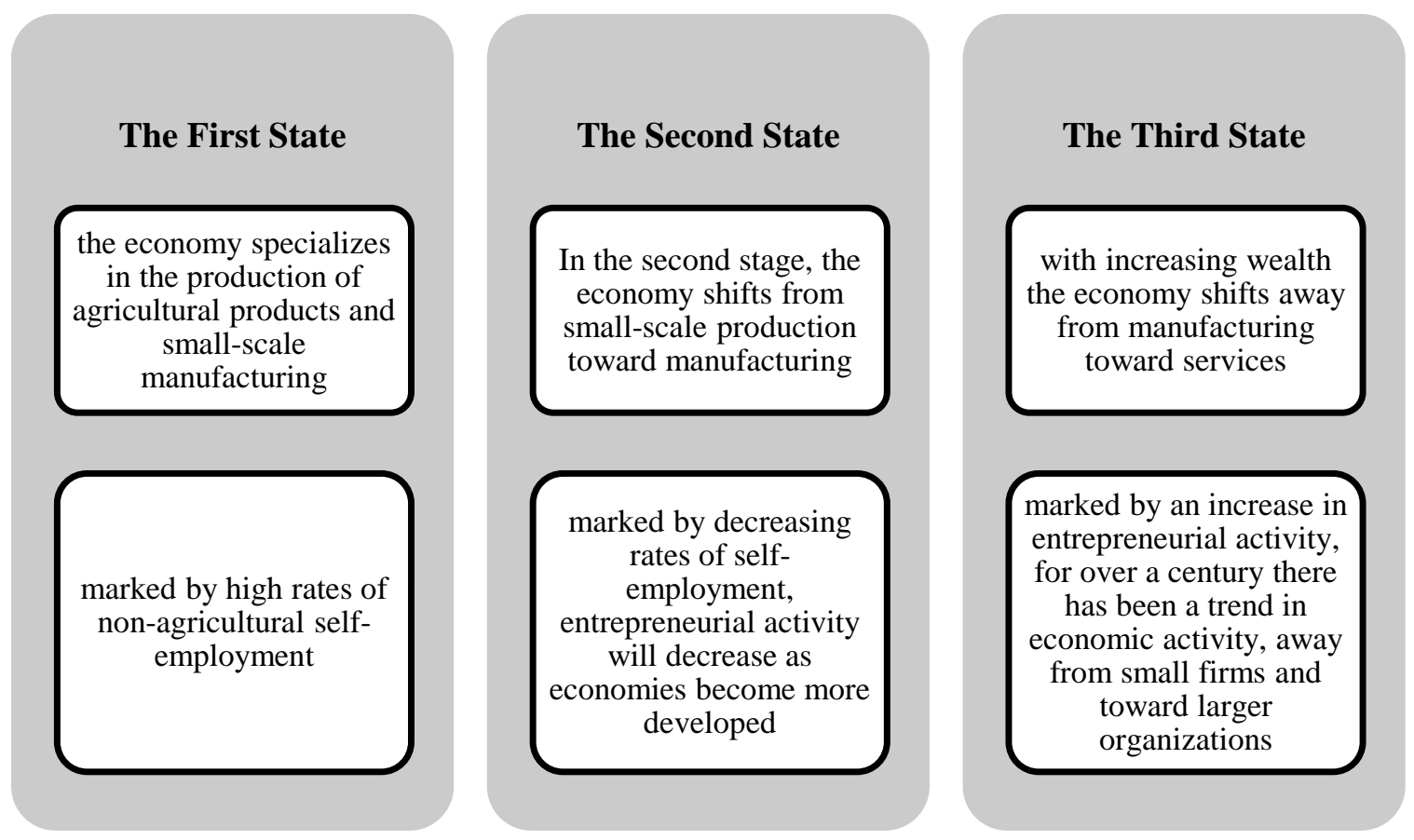

Fostering entrepreneurship is widely perceived to be a critical policy agenda to expand employment and earning opportunities and to reduce poverty. Sound macroeconomic conditions and business environment including infrastructure, regulation, and legal environment have typically been emphasized to increase entrepreneurial activities and create jobs. While these remain relevant, in developing countries, increasing attention is being paid to the role of labour policies that aim to reduce constraints and enhance productivity among the self employed and small scale entrepreneurs. This is particularly pressing in developing countries where wage and salary employment is limited and the majority of jobs are created and operated in self employment (Cho and Honorati 2013:1).

\section{Entrepreneurship in Developing Countries}

While providing more development opportunities for developing countries, the globalization process is also posing enormous risks. Economic globalization has developing countries' risks of being concussed by unfavourable external factors. Under open economic conditions, the conflict between the realization of external economic equilibrium and that of internal economic equilibrium is a great constraint on the macroeconomic policies of developing countries, weakening their capacity of macroeconomic control and regulation (Shangquan, 2000:4-5). In this respect although entrepreneurship is not a precise cure for economic development for developing countries, it can boost economic development when practiced conveniently.

Kirzner (1973) distinguishes his view of entrepreneurship, which he envisions as equilibrating, with Schumpeter's (1934), which he depicts as disequilibrating. Schumpeter's entrepreneur acts to disturb an existing equilibrium situation. The entrepreneur is pictured as initiating change and generating new opportunities. More recent studies have confirmed this result for most developing countries in the 1970 and 1980s. The empirical evidence clearly showed that the firm-size distribution in developed countries began to shift away from larger corporations and toward entrepreneurial activity (Acs, 2006:99-100).

Some distinctive attributes of entrepreneurship in developing countries appear to improve the probability of success for growth-oriented firms, while others appear to hold back these firms (Lingelbach et al, 2005:3-6);

- Opportunity

- Opportunities for entrepreneurs in developing countries are broader in scope than in developed markets, allowing firms to pursue a portfolio approach to strategy that can efficiently manage the higher levels of business and market risk.

- Entrepreneurs in developing countries face a different set of circumstances than their counterparts in developed economies.

- Emerging markets lack a stable of mature markets and the consistency that such markets offer. Consequently, the opportunity for entrepreneurship in emerging markets is pervasive.

- Financial Resources

- While entrepreneurial opportunities are broader and resultant strategies are naturally self-hedging in developing countries, limited personal and family savings and an absence of financial innovation severely limits the growth prospects of promising start-ups in developing countries. 
- Apprenticeship and Human Resources

- Technical, industry-specific training is an important component in the creation of globally competitive firms.

- These firms often form into geographically focused industrial clusters which led to emergence of globally competitive industries in developing countries.

\section{Does Globalization Impact Entrepreneurship?}

The globalization of economies has heightened the importance of entrepreneurial action for creating wealth. Demographic shifts, liberalization of national economies and attendant markets, institutional and state failures, and technological advances have combined to increase the calls for more social consciousness within businesses (Zahra et al, 2008:118). Audretsch (2007) argues that globalization has led to a shift from an industrial to an entrepreneurial model of production. Globalization is interpreted as a level shock in the supply of unskilled labour to the world economy, a decrease in the level of political risk associated with foreign direct investment, and the widespread diffusion of ICT. References to the impact of country's level of globalization on its level of entrepreneurship can be found in based on comparing data measuring entrepreneurship and globalization.

The global business environment is changing dramatically. Traditionally, competition in international markets has been the realm of large companies, while smaller businesses remained local or regional in scope. However, the removal of government-imposed barriers that segregated and protected domestic markets and recent technological advances in manufacturing, transportation and telecommunications allows even the smallest firms access to customers, suppliers and collaborators around the world. Economic growth and innovation, both domestically and internationally, are fuelled increasingly by small companies and/or entrepreneurial enterprises (Etemad and Wright, 2003:3).

Macroeconomical alterations in a country due to globalization are likely to be experienced differently by SMEs than large companies. SMEs have to operate within the macroeconomic environment of domestic and international markets, and as such are affected by changes in this environment. Among others, two socialeconomic results of an increased level of globalization in a country are enlarged inequality enhanced consumer demand for variety. Both of these have been marked as determinants for higher levels of entrepreneurship in a country (Vinig and Kluijver 2007:12).

\subsection{Competitive patterns}

McKinnon (2003) cited Namiki's four competitive patterns illustrate how firms can maintain competitive advantage under globalisation as follows;
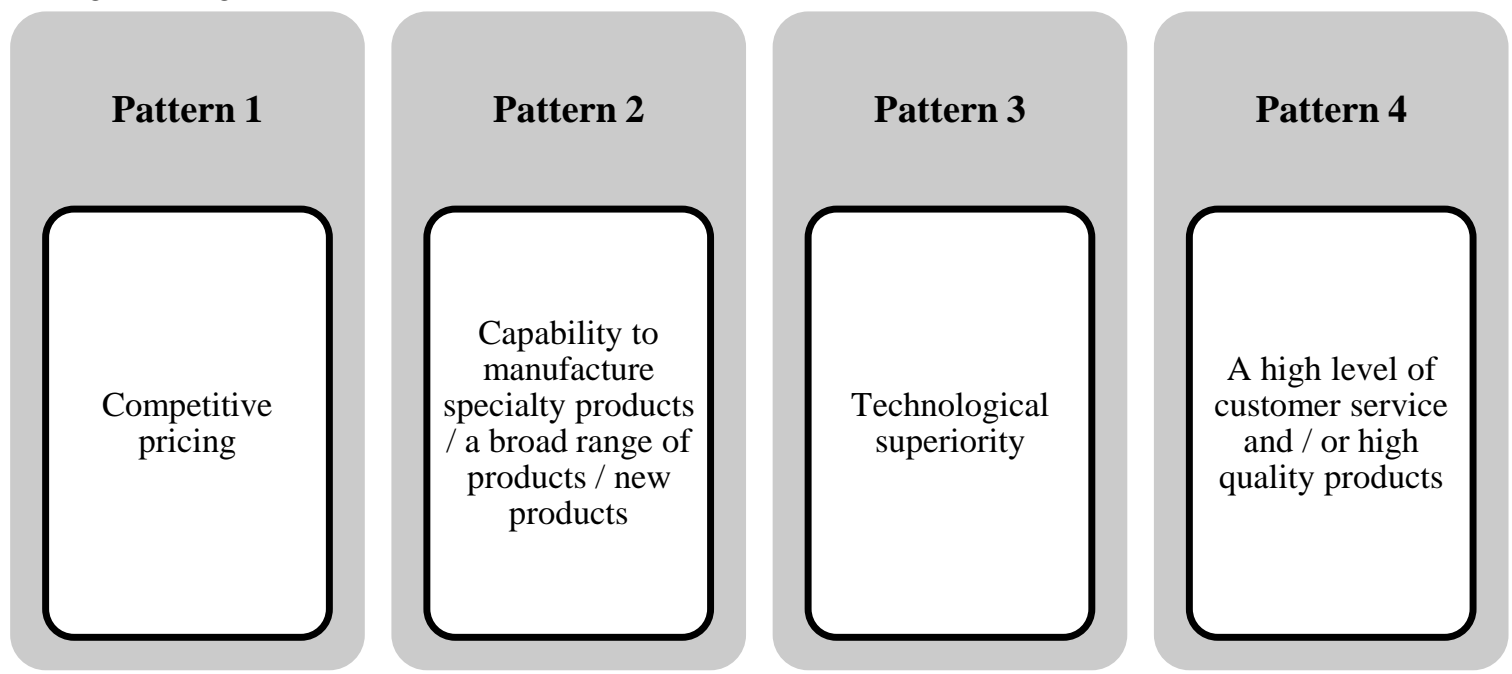

The most important factors in the globalization of entrepreneurs are technology and the falling costs of communications. The success of entrepreneurship is driven by technological changes. These changes have democratized entrepreneurship and entrepreneurs can come from anywhere in the world and can reach customers anywhere from the day they open their doors (Haar, 2012:2). In this regard the patterns can provide insights for the current situation of developing countries. Although developed countries precede in technological superiority and high level of customer service and / or high quality products patterns since most of their production facilities have been settled in developing countries by entrepreneurship and technological spillovers, developed countries gained too much competitive advantage in the last decade. 


\subsection{Development Level Comparison of Globalization and Entrepreneurship}

Before glancing at how globalization affected entrepreneurship levels of the countries, it would be beneficial to check out the comparison of entrepreneurship figures of developed, developing and emerging economies using Global Entrepreneurship Monitor data.

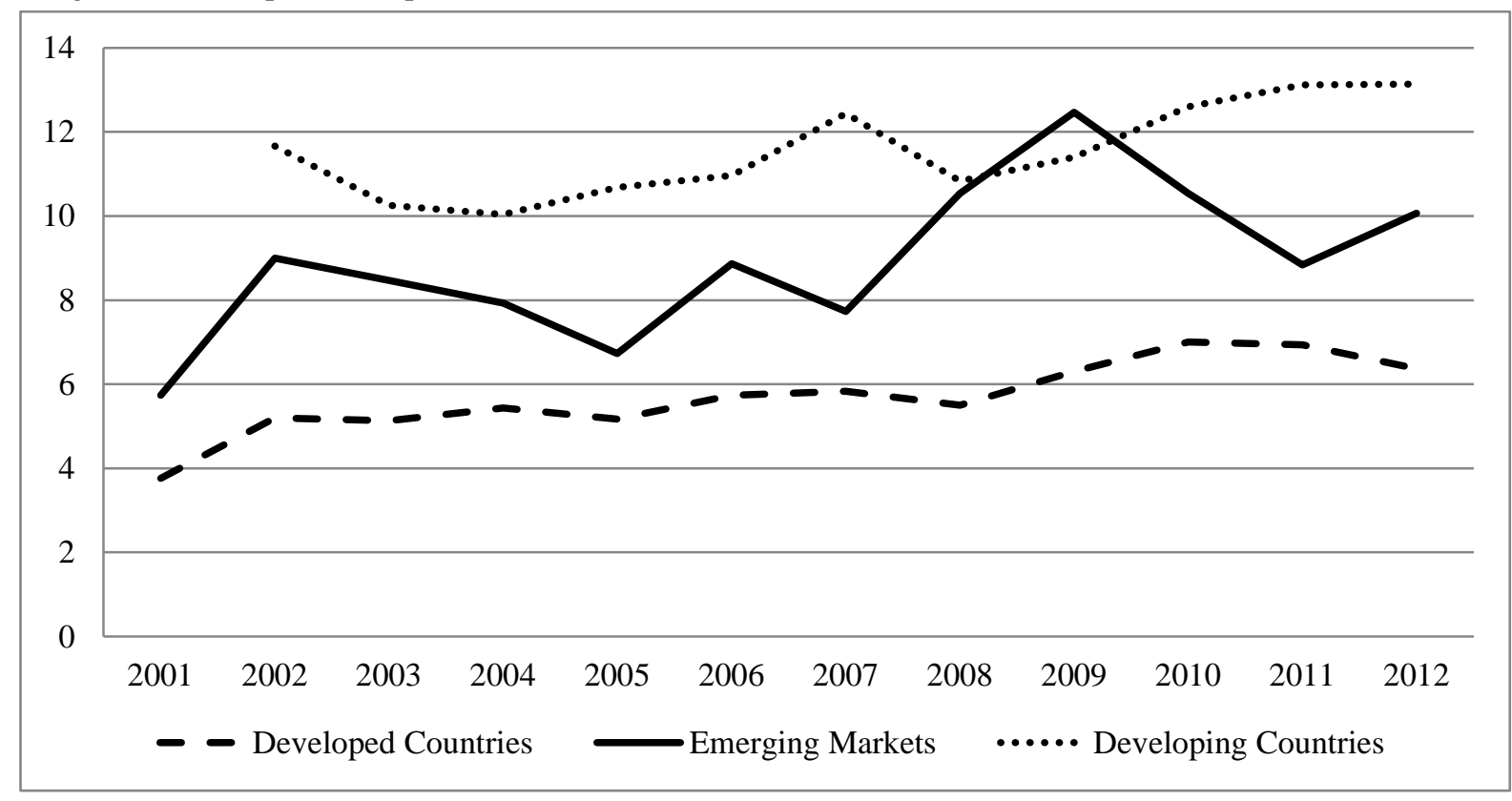

Figure 1. Established Business Ownership 2001-2012 Source: Global Entrepreneurship Research Association (2013), "Global Entrepreneurship Monitor", London Business School, UK.

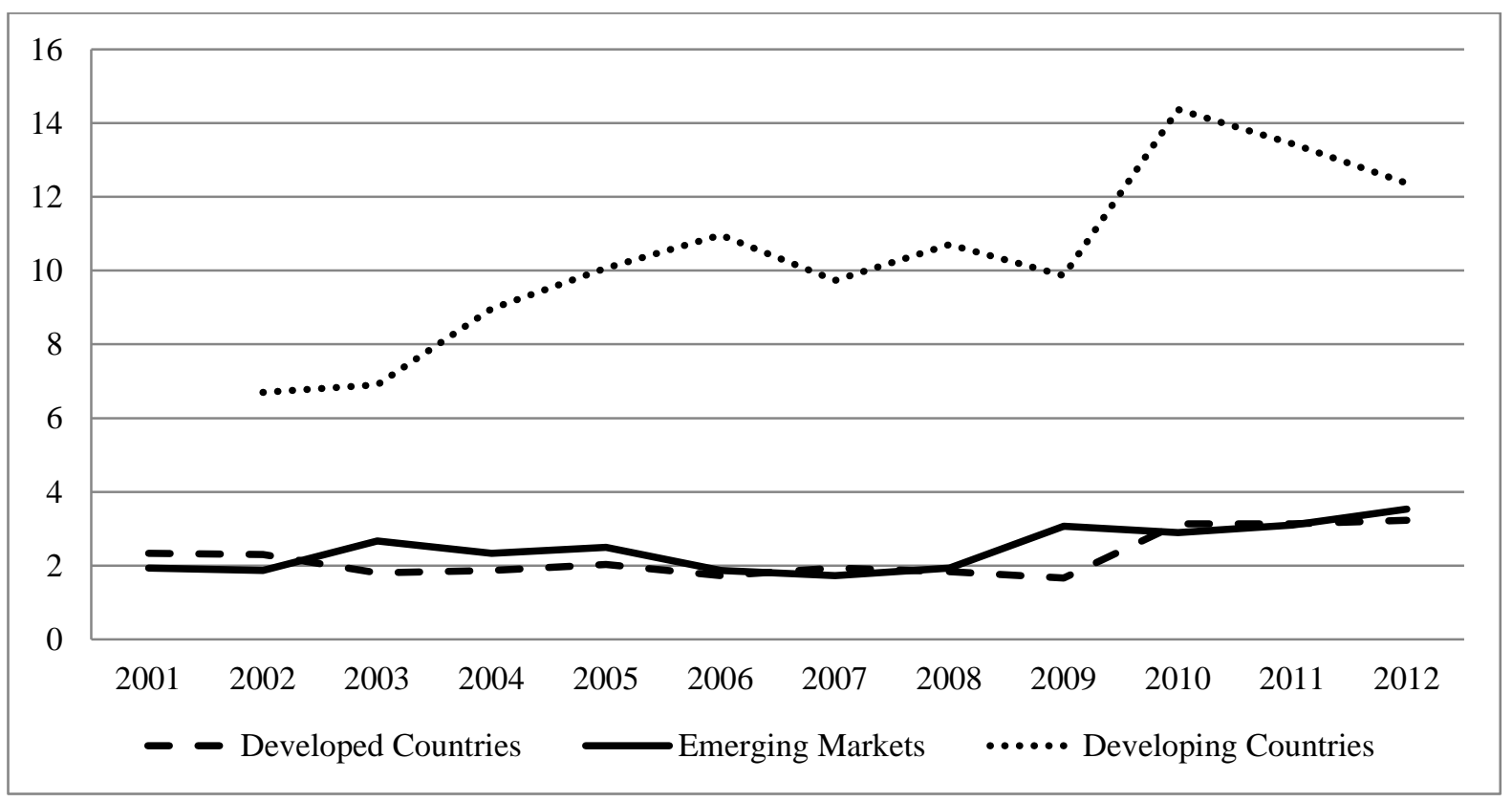

Figure 2. Informal Investors Rate 2001-2012 Source: Global Entrepreneurship Research Association (2013), "Global Entrepreneurship Monitor", London Business School, UK. 


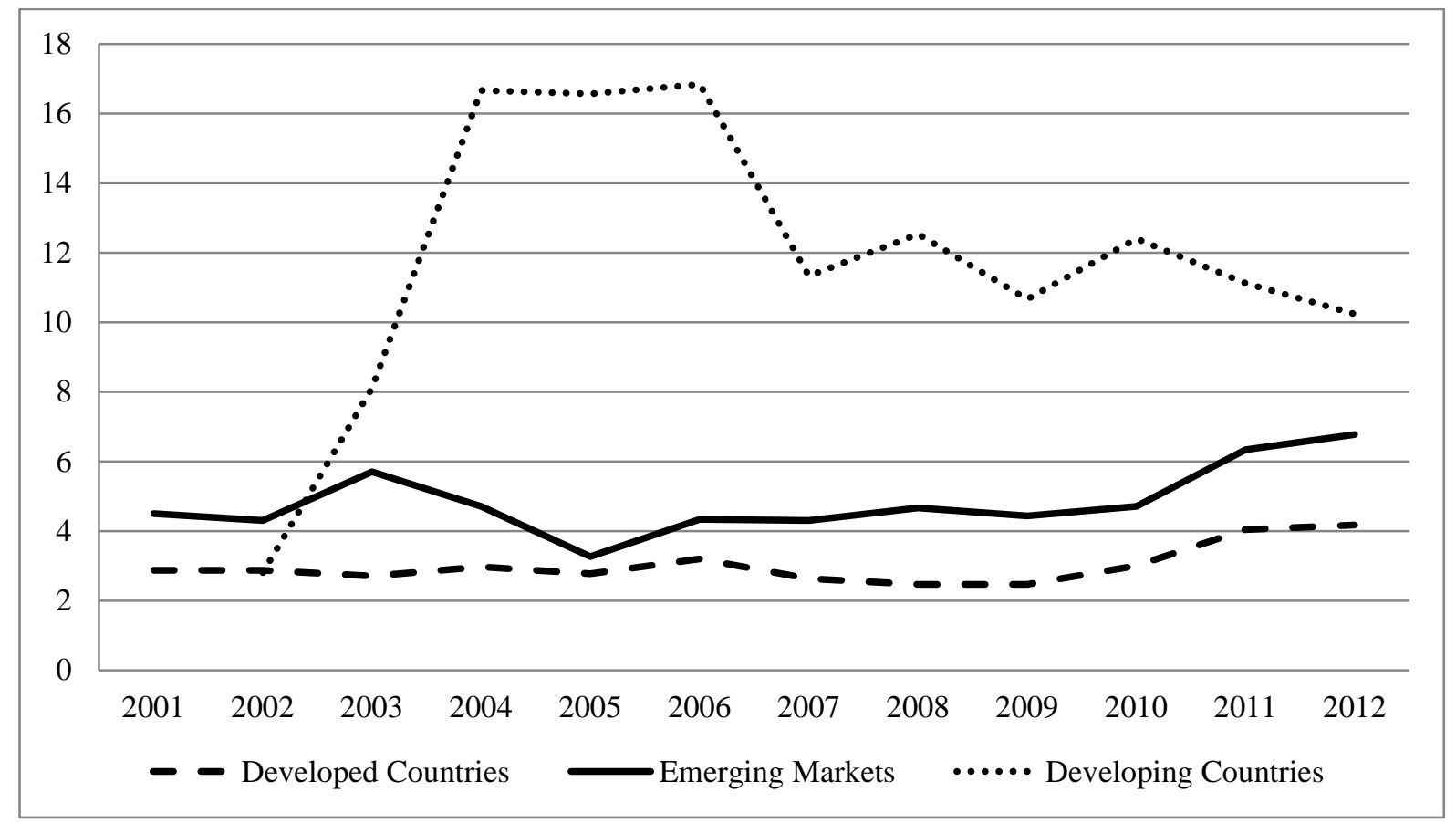

Figure 3. Nascent Entrepreneurship Rate 2001-2012 Source: Global Entrepreneurship Research Association (2013), "Global Entrepreneurship Monitor", London Business School, UK.

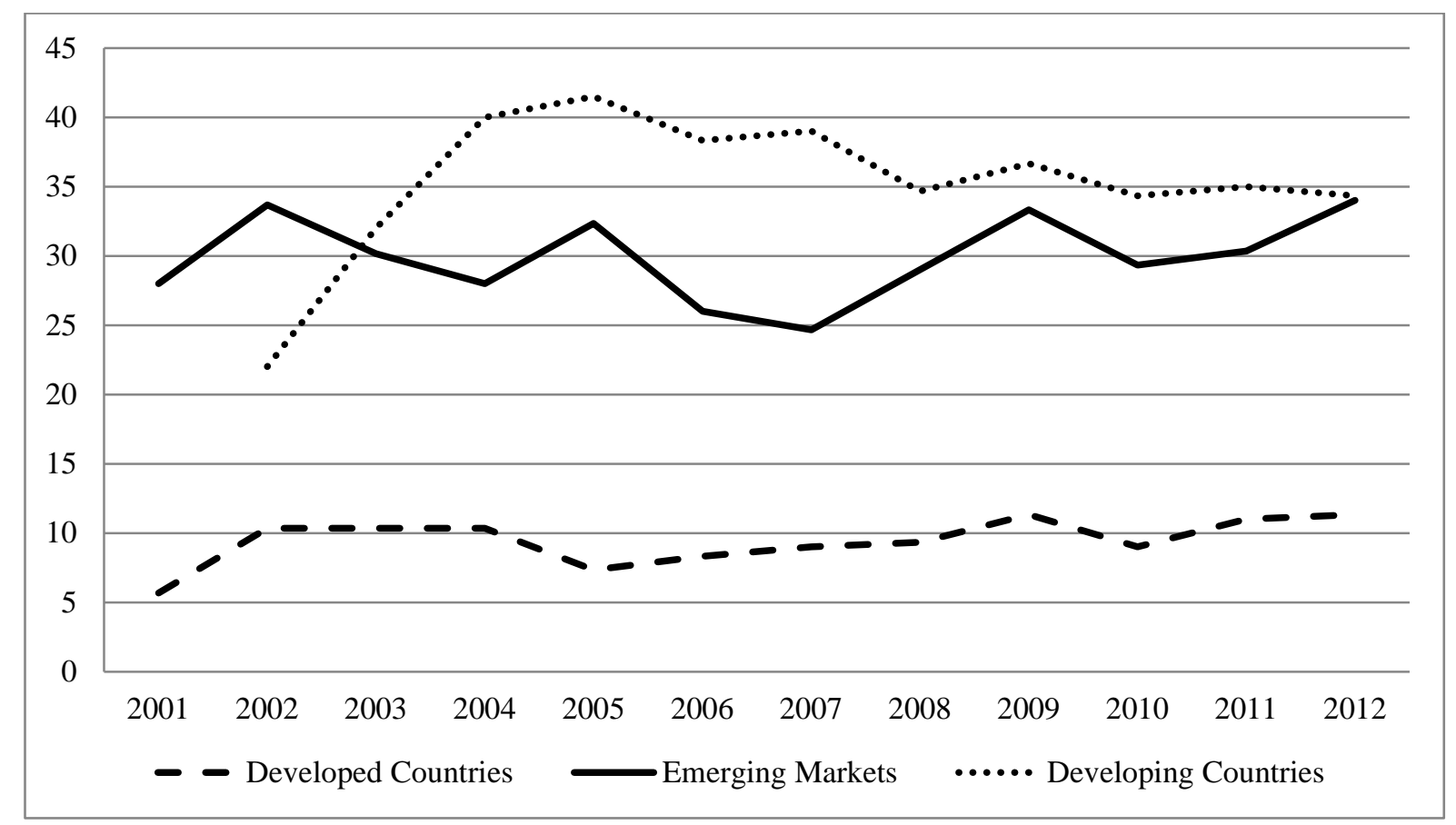

Figure 4. Necessity-Driven Entrepreneurial Activity 2001-2012 Source: Global Entrepreneurship Research Association (2013), "Global Entrepreneurship Monitor", London Business School, UK. 


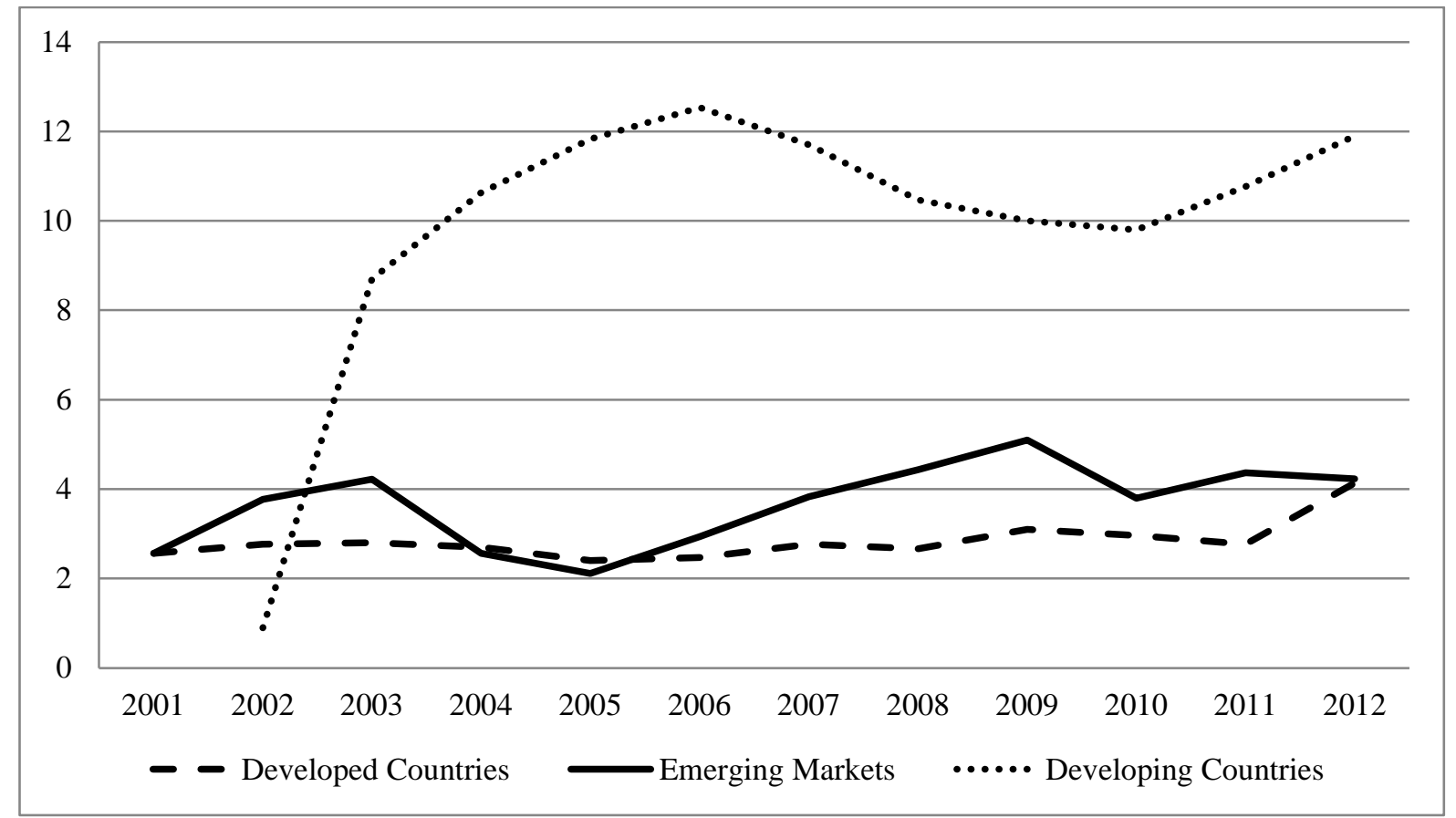

Figure 5. New Business Ownership Rate 2001-2012 Source: Global Entrepreneurship Research Association (2013), "Global Entrepreneurship Monitor", London Business School, UK.

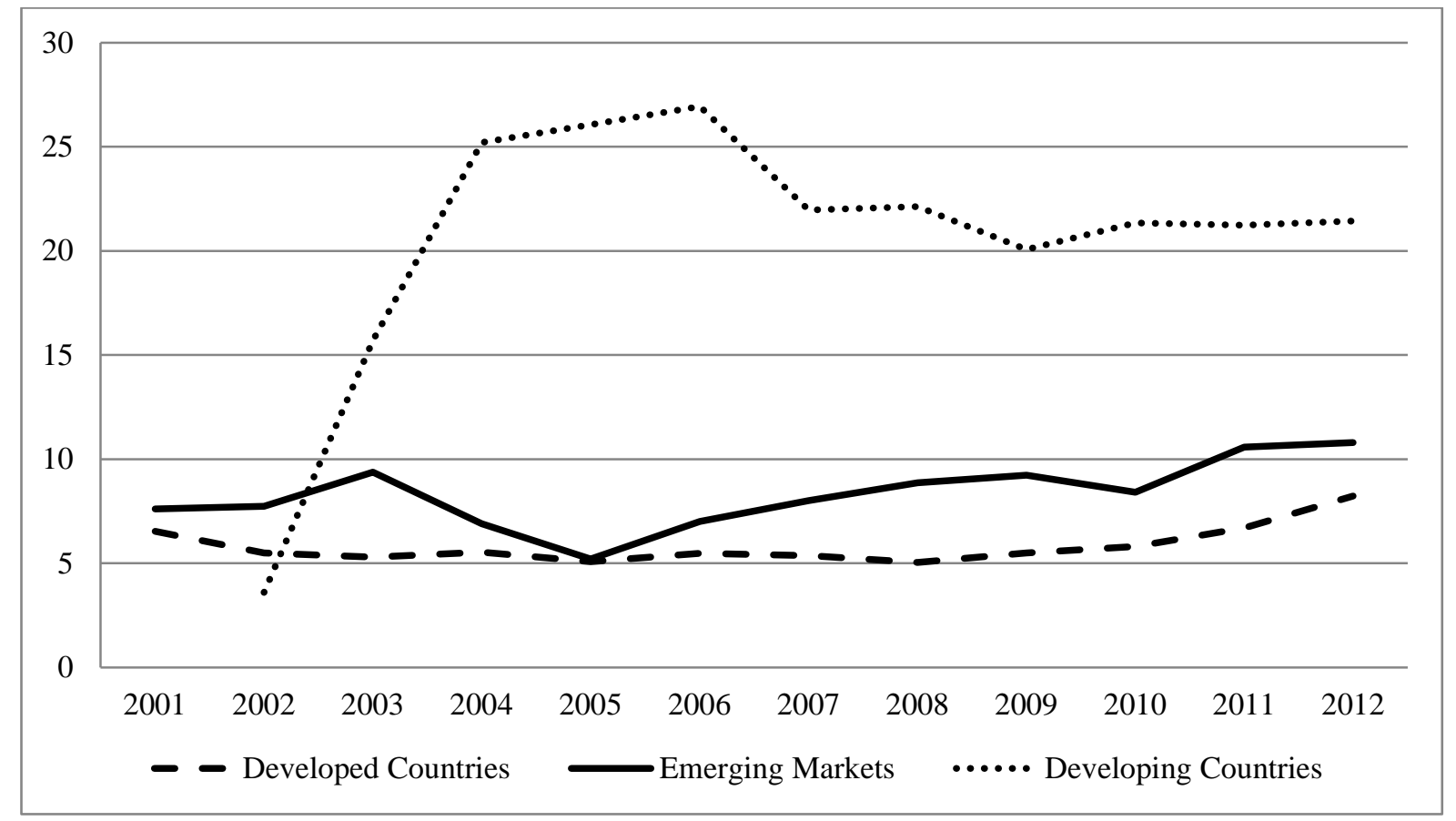

Figure 6. Total Early-Stage Entrepreneurial Activity (TEA) 2001-2012 Source: Global Entrepreneurship Research Association (2013), "Global Entrepreneurship Monitor", London Business School, UK.

The figures visualize that entrepreneurial activities are in a rising trend all over the world. However it is apparent that entrepreneurship levels of developing countries are far more active than both emerging markets and developed countries. Developing countries have established business ownership values more than $200 \%$ of developed ones; they have 500\% more informal investors rate; $600 \%$ more nascent entrepreneurship rate; $350 \%$ more necessity-driven entrepreneurial activity rate; $400 \%$ more new business ownership rate and $400 \%$ more total early-stage entrepreneurial activity on the average. It also can be seen that emerging markets is the second in the list in all of the figures. Another remarkable issue is that the Global Economic Crisis of 2008-2009 had negative impact on entrepreneurial activities of all the countries but the Crisis hit the activities of developing countries worse. 


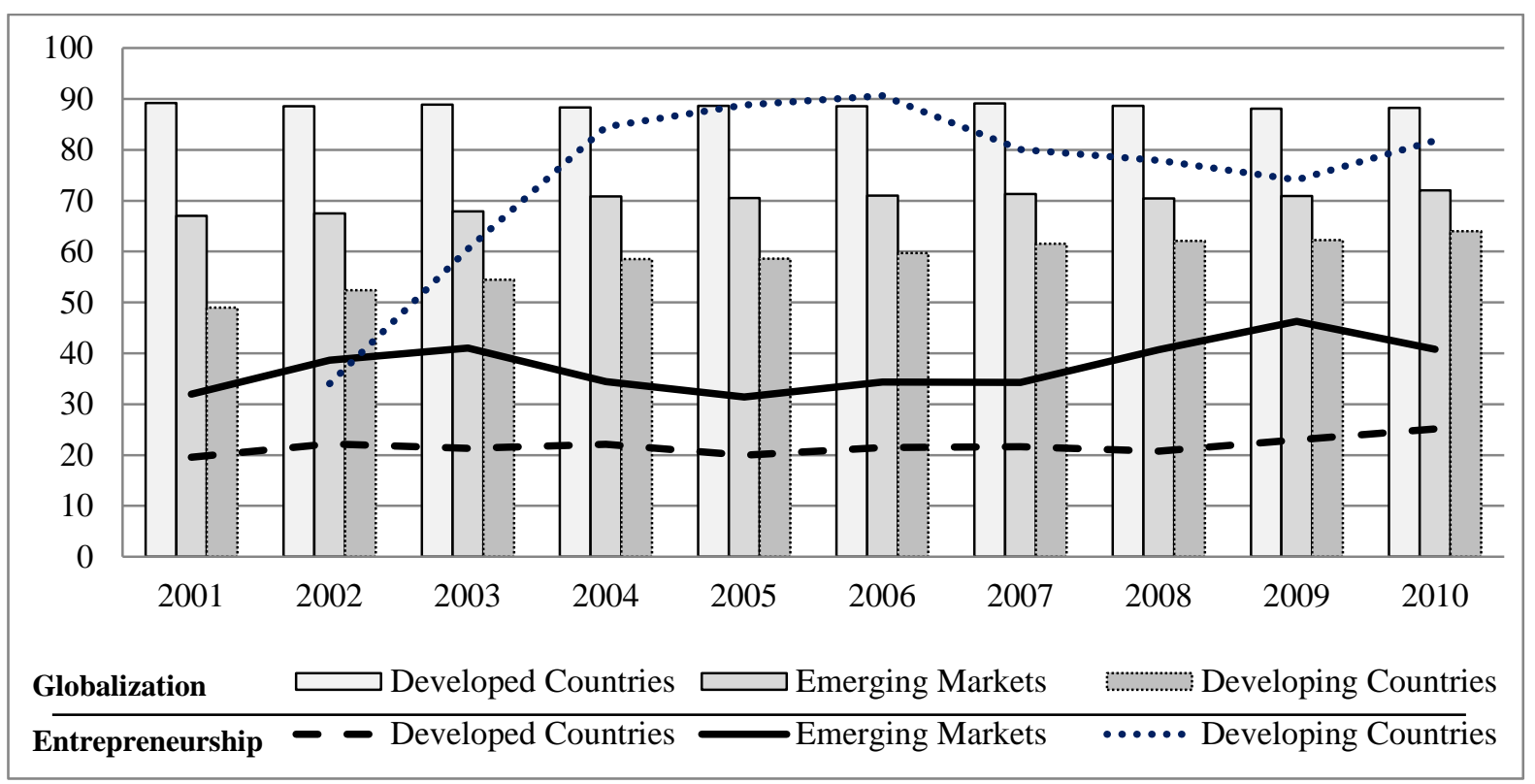

Figure 7. Development Level Comparison of Globalization \& Entrepreneurship 2001-2010 Source: Global Entrepreneurship Research Association (2013), "Global Entrepreneurship Monitor" , London Business School, UK; KOF Swiss Economic Institute, (2013), "KOF Index of Globalization", Zurich.

When overall Global Entrepreneurship Monitor score of the countries compared with the globalization index, it can be said that the values almost overlap. In the last decade globalization index of the developed countries had no change at all and their entrepreneurship level had a little rise. On the other hand emerging markets and particularly developing countries gained too much from globalization phase in terms of entrepreneurship. While their globalization index increased 34\%, their entrepreneurship approximately increased $238 \%$.

\section{Conclusion and Suggestions}

Globalization led to major increases in worldwide trade and exchanges in an increasingly open, integrated, and borderless international economy. Developing countries have left no stone unturned to achieve economic development and growth and globalization process have created an opportunity for them to utilize their comparative advantages, introduce advanced technologies, foreign capital and management experience. It is also favourable for eliminating monopolistic behaviours and strengthening market competition.

With the rise of globalization, entrepreneurial global start-ups have emerged in developing countries which is associated with job creation, wealth creation, innovation and its related welfare effects. Indeed, the promotion of entrepreneurship and the promulgation of small and medium sized enterprise policy has become an important development prescription in recent years in this countries.

In this study we questioned how globalization process diversify the development of entrepreneurship at a development level classification. Global Entrepreneurship Monitor and KOF Index of Globalization data is used to investigate the query. The figures displayed that entrepreneurial activities are for more operative in developing countries than both emerging markets and developed economies. Also a positive relationship between the development of a country's level of globalization and the rate of entrepreneurship.

It can be concluded that the distinctive economic nature of developing countries and developed ones provide broader opportunities for the entrepreneurs and they are currently at the centre of attention for both local and global enterprises. The limitation of the study is the lack of observations about the subject. Since many of the developing countries and even some of developed ones don't have sufficient entrepreneurship information at the moment the study can't be expanded further but it can be broadened with quantitative analyses when sufficient observations are obtained in the future.

\section{References}

- $\quad$ Acs, Z. (2006), "How Is Entrepreneurship Good for Economic Growth?" Mitpress journals, <http://www.mitpressjournals.org/doi/pdf/10.1162/itgg.2006.1.1.97>.

- $\quad$ Acs, Z. J., Preston, L. (1997), "Small and Medium-Sized Enterprises, Technology, and Globalization: Introduction to a Special Issue on Small and Medium-Sized Enterprises in the Global Economy", Small Business Economics, 9, pp. 1-6. 
- $\quad$ Acs, Z. Virgill, N. (2009), "Entrepreneurship in Developing Countries", Jena Economic Research Papers, 023.

- Cho Y., Honorati M. (2013), "Entrepreneurship Programs in Developing Countries: A Meta Regression Analysis", IZA, DP No. 7333.

- Colander, D. (2002), "Globalization and Economics", Middlebury College, Economics Discussion Paper No. 02-35, Middlebury, Vermont.

- Desai, S. (2009), "Measuring Entrepreneurship in Developing Countries", UNU-WIDER, Research Paper No. 2009/10.

- Etemad, H., Wright, R.W. (2003), "Globalization and Entrepreneurship: Policy and Strategy Perspectives", Edward Elgar Publishing, UK.

- Global Entrepreneurship Research Association (2013), "Global Entrepreneurship Monitor" , London Business School, UK.

- Haar, J. (2012), "Globalization and Entrepreneurship in Latin America", The Impact of Globalization on Latin America Task Force, Center For hemispheric Policy, Florida.

- İncekara, A., Savrul, M. (2011), "Küreselleşme, Büyüme ve Ekonomik Entegrasyonlar: Türkiye Açısından Bir Değerlendirme", Iktisat Fakültesi Mecmuası, Cilt: 61, Sayı:2, 3-22.

- İncekara, A., Savrul, M.(2012), "The Effect Of Globalization On Foreign Trade And Investment In Eurasian Countries", International Conference On Eurasian Economies 2012, 23-30, Almaty, KazakistanRepublic (October, 11th-13th 2012).

- $\quad$ Kirzner, I. M. (1973), "Competition and Entrepreneurship", University of Chicago Press, USA.

- $\quad$ KOF Swiss Economic Institute, (2013), "KOF Index of Globalization", Zurich.

- $\quad$ Lingelbach, D.C., De La Vina, L., Asel, P. (2005), "What's Distinctive about Growth-Oriented Entrepreneurship in Developing Countries?", UTSA College of Business Center for Global Entrepreneurship Working Paper No. 1.

- $\quad$ M. D. Intriligator (2003), "Globalization Of The World Economy: Potential Benefits And Costs And A Net Assessment", Policy Brief No:33, Milken Institute, Los Angeles.

- McKinnon A. (2003), "Entrepreneurship and Globalisation, A Literature Review", <http://homepages. inspire.net.nz/ jamckinnon/business/Entrepreneurship\%20and\%20Globalisation\%20$\% 20 \mathrm{~A} \% 20$ Literature\%20Review.pdf>.

- Miotti, L., Sachwald, F. (2006), "Old Economy in the New Globalization Phase", IFRI Reports, Institut Français des Relations Internationales, France.

- Schumpeter, J. A. (1934), "The Theory of Economic Development", Harvard University Press, Cambridge.

- Shangquan, G. (2000), "Economic Globalization: Trends, Risks and Risk Prevention", Economic \&Social Affairs, CDP Background Paper No. 1, ST/ESA/2000/CDP/1.

- Vinig, T., Kluijver, J. de (2007), “Does Globalization Impact Entrepreneurship? Comparative Study of Country Level Indicators”, Sprouts: Working Papers on Information Systems, 7(8). University of Amsterdam, Netherlands.

- Zahra, S.A., Rawhouser H.N., Bhawe, N., Neubaum, D.O., Hayton, J.C. (2008), "Globalization of Social Entrepreneurship Opportunities", Strategic Entrepreneurship Journal, 2: 117-131. 


\title{
Avrasya'da Enerji Ekonomileri Pontansiyeli Üzerine Bir Değerlendirme
}

\section{An Evaluation of the Potential of Energy Economies in Eurasia}

\author{
Prof. Dr. Recep Kök (Dokuz Eylül University, Turkey)
}

\begin{abstract}
The basic hypothesis of this evaluation is how efficient the natural resource-rich countries use rents they can create so much sustainable welfare; how inefficient they use the rents, they will be subject to a welfare loss. When we consider the case of energy profile in the case of Eurasia in the scale of inventory, fossil oil, natural gas, coal and water reserves should be examined primarily. Shortly after, examining the distribution of the natural resource will be beneficial. In fact, it would be possible to develop more efficient policy propositions than the potential situation if we take into account the caring of the transportation/trade infrastructure and the infrastructure that enables a larger scale production through the current production and distribution channels. In this study, the results of different experiences acquaired till today will be elaborated. Some indicators will be given place with reference to the importance of $\mathrm{R} / \mathrm{P}$ ratio. The priority condition for Eurasian countries to catch the contemporary civilization is directly related with the efficiently sustainable and steadily utilization of natural resources. Briefly, the evaluation of all propositions which are parts of the responsibilities of making projections for the future, especially with the historical mission of Turkey, will make contribution to the social peace as well as the welfare of people living in this region.
\end{abstract}




\title{
The Causes of Electricity Theft: An Econometric Analysis for the Case of Turkey
}

\author{
Asst. Prof. Dr. Çağlar Yurtseven (Bahçeşehir University, Turkey)
}

\begin{abstract}
Every year, especially in developing countries, electricity theft causes billions of dollars of loss. Since the consumers who pay their bills legally, bear the burden of this loss, it disturbs the social justice. In addition by affecting the investment decisions, it distorts the economic growth hence the future of the nations as well. Authorities try to prevent electricity theft with different engineering techniques and devices designed especially for detecting purposes. However, there are ways to prevent this behavior before it took place. For this reason, energy theft equation is estimated with different techniques to understand the socio-economic background of this illegal behavior. Education, income and political ideologies are found to be the important electricity theft determinants. Policy suggestions, to prevent this illegal behavior before it took place, are discussed.
\end{abstract}

Full paper not published upon author's request. 


\title{
The Relationship between International Oil Prices and Current Account Deficit: The Case of Turkey
}

\author{
Assoc. Prof. Dr. Mehmet Mucuk (Selçuk University, Turkey) \\ Mr. Mustafa Gerçeker (Selçuk University, Turkey) \\ Prof. Dr. Ahmet Ay (Selçuk University, Turkey)
}

\begin{abstract}
In developing countries such as Turkey, the current account deficit, occuring due to the lack of national savings, is considered to be one of the determinants of economic crisis. At the same time owing to Turkey is dependent on foreign countries for energy resources, current account deficit is highly sensitive to fluctuations in the prices of these resources. This paper, investigates the causal relationship between international oil prices and current account deficit for Turkey using Johansen cointegration and causality tests. The empirical findings show that there is a relationship between two variables in the long term.
\end{abstract}

\section{Introduction}

Economical growth plays a core part for the developing countries to join the developed countries. Because being able to carry out this process successfully depends on use of the income generated as a result of the growth effectively and efficiently in all fields. At the same time, it is required to canalize the said income to such investments that will reduce external dependency. Integrated to the global economical system by the Decisions of January 24, 1980, Turkey also needs a healthy and sustainable growth to achieve the social and economical targets set as soon as possible. In this respect, it is important to reduce external dependency and mobilize domestic resources in economy. However, the current deficit emerging as a result of the fact that national savings are not much enough to cover the investments and the problematic form of the deficit threatens the development course of the country. While the development structure that is based mainly on domestic consumption and external resource input generates income increase at high rate, marked stimulation of importation by the income increase leads to sacrifice on growth from time to time by increasing the current deficit risk. On the other hand, basic determinants of the current deficit include domestic consumption as well as energy importation. As a matter of fact, current account balance is highly vulnerable to the fluctuations in the prices of energy resources as Turkey, with its external dependency by $70 \%$ in energy, procures 93 percent of the oil, 97 of the natural gas needed from outside the country. This study aims to determine the actions to be taken in Turkey particularly in regard to the field of energy in line with the long term targets regarding the changing energy balances and basic macro dimensions by testing impact of the movements in the international oil market on the current account in respect of Turkey's economy deficit using econometric methods. With respect to this aim, first, the present status of international oil prices and the current account deficit in Turkey is addressed, then the association between the said variables is analyzed using VAR technique. In the last section, the measures required to be taken in the field of energy are mentioned of based on the findings attained.

\section{International Oil Prices and Its Economical Impacts}

Oil prices, which have always been a controversial matter, is addressed as an important variable in the process of planning economical activities of a country (Kiani, 2011). However, as formation of the oil prices cannot be explained solely by the supply-demand conditions, they have a very volatile structure compared to other commodity prices. Australian Institute of Petroleum (AIP) lists the key factors determining the international oil prices as in Table 1.

According to US Energy Information Administration (EIA), 7 key factors influencing crude oil price include production, oil discoveries in global scale, financial markets, demand, demand of non-OECD member countries like China, India and Saudi Arabia, and spot markets (Fessler, 2011). Depending on the said factors, oil prices have from time to time exhibited very critical deviations in the historical process. The trend followed by the oil prices from the 1970s to today is shown in Graph 1.

The 1973 Arab oil embargo had a major price impact as Arabian Light prices surged from USD 1.84/barrel in 1972 to USD 10.98 in 1974. The next spike after 1973 came in 1981, in the wake of the Iranian revolution, when prices rose to a high of nearly USD 40. Prices declined gradually after this crisis. They dropped considerably in 1986 when Saudi Arabia increased its oil production substantially. The first Gulf crisis in 1990 brought a new peak. In 1997, crude oil prices started to decline due to the impact of the Asian financial crisis. Prices started to increase again in 1999 with OPEC target reductions and tightening stocks. A dip occurred in 2001 and 2002, but the expectation of war in Iraq raised prices to over USD 30 in the first quarter of 2003. Prices remained high in the latter part of 2003 and in 2004. Crude oil prices increased dramatically in late August 2005 after Hurricane Katrina hit the US coast of the Gulf of Mexico. Prices continued to increase throughout 2006 as the demand for 
oil in emerging economies, especially China, put pressure on the supply/demand balance, averaging 24 per cent higher than the previous year. In 2007, the increase continued with Dubai hitting USD 88.82/barrel at the beginning of November and WTI climbing to USD 96.50/barrel. In early 2008, prices crossed the symbolic USD 100/barrel threshold and reached a new peak just under USD 150/barrel in July 2008; this brought the real price of oil in 2008 to an all time high. At the beginning of 2009, prices fell to USD 40/barrel as the impact of high prices and the onset of the global financial crisis sharply curbed oil demand. Later in the year, prices ranged between USD 70 and 80/barrel. Crude oil prices increased steadily throughout 2010and 2011 with the postrecession demand rebound, tightening stocks and low spare capacity. In 2012, prices continued to increase at the beginning of the year, averaging USD 122.40/barrel in March, before declining to under USD 100/barrel in June. (OECD, 2011).

\begin{tabular}{|l|l|}
\hline $\begin{array}{l}\text { Changes in regional and global supply balances in } \\
\text { both the short \& longer term }\end{array}$ & $\begin{array}{l}\text { Changes in economic conditions/sentiment in both } \\
\text { the short and longer term }\end{array}$ \\
\hline $\begin{array}{l}\text { Major supply disruptions from natural disasters, war, } \\
\text { civil unrest and strikes }\end{array}$ & New oil discoveries \\
\hline Seasonal demand and demand spikes & Investment in new oil production/refining capacity \\
\hline Inventory management & Future global demand and supply balances \\
\hline Shipping availability and freight rates & Global economic growth and conditions \\
\hline Market trading activities and strategies & Costs of oil production and refining \\
\hline $\begin{array}{l}\text { Short term decisions of oil producing countries, } \\
\text { National Oil Companies (NOCs) and nations holding } \\
\text { strategic reserves }\end{array}$ & Technological progress \\
\hline Alternative fuel developments & $\begin{array}{l}\text { Long term policies of NOCs and oil producing } \\
\text { nations }\end{array}$ \\
\hline Population growth & Regulation and government policy \\
\hline
\end{tabular}

Table 1. Key Factors Influencing International Crude Oil Prices. Source: Australian Institute of Petroleum (AIP), "Facts About the International Fuels Market \& Prices", www.aip.com.au 01.02.2013.

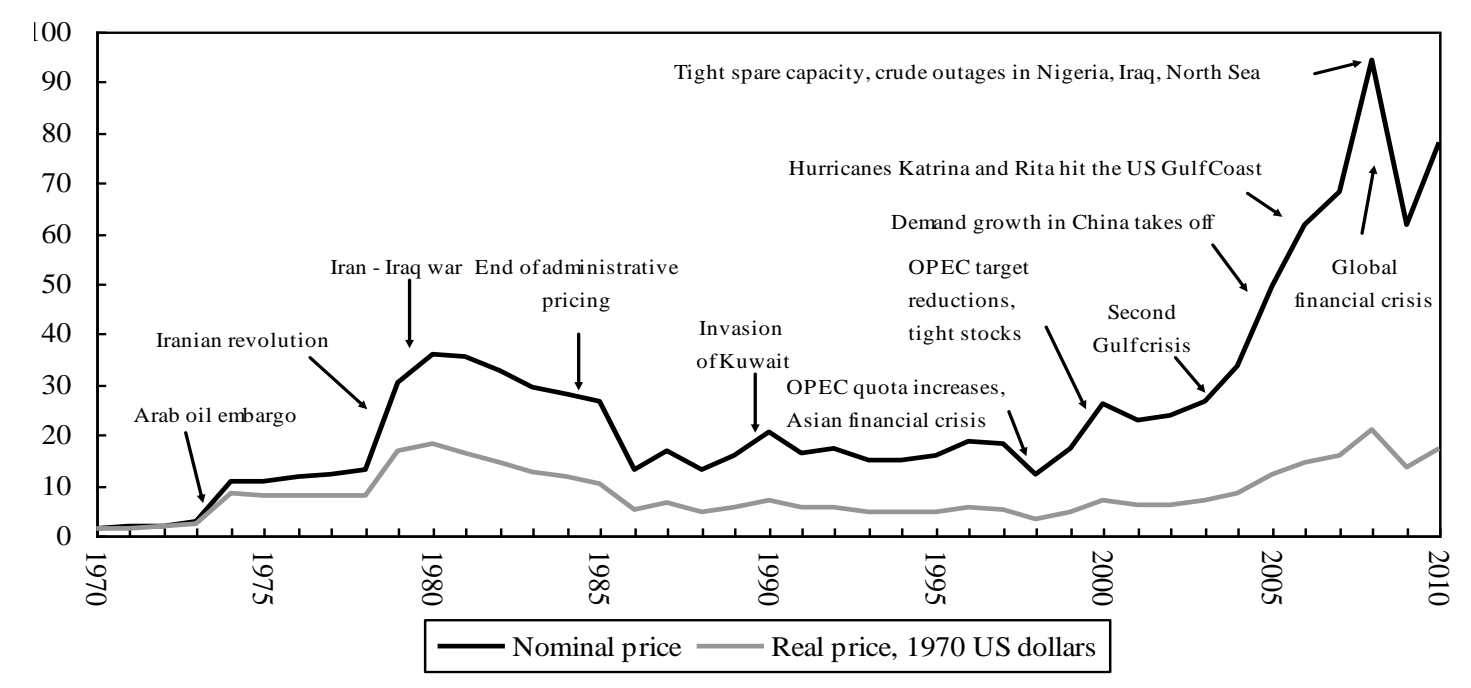

Figure 1. Crude Oil Spot Prices (US dollars per barrel). Source: OECD (2011), OECD Factbook 2011-2012: Economic, Environmental and Social Statistics

Various estimations are made within the framework of Hubbert Curve about the trend to be followed by the oil prices in the upcoming terms. According to the Hubber Curve reflecting the course of production over time for the resources with limited reservoir, once a natural resource is discovered, its production increases rapidly in the beginning and peaks at a certain point of the time. Expressing that price of the old energy resource will stand high for the new energy resource to become more attractive in the regions where production decreases, Ediger (2007) draws the attention to the fact that oil importation cost will increase henceforward. This is expected to be reflected on the energy bills of the countries such as Turkey, which are highly external dependent in respect of basic energy resources, particularly oil.

Along with the economies' beginning to recover following the 2008 global crisis, the balances involving production and consumption also strengthen the expectations that the oil prices may increase. However, when 
considered along with other factors, there is an uncertainty about the exact trend to be followed by the oil prices in the future.

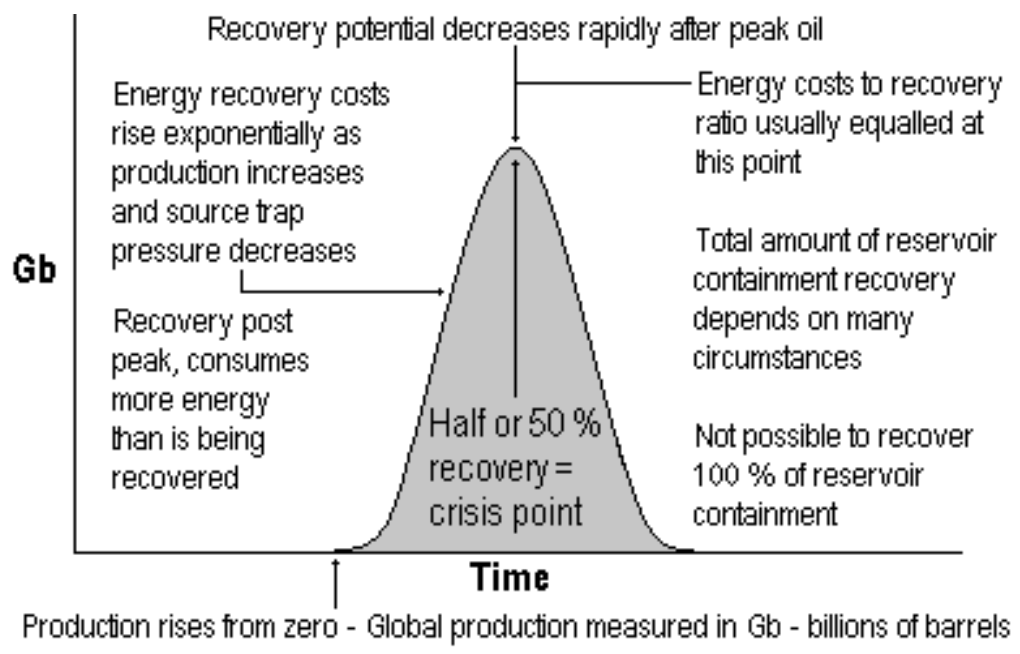

Figure 2. Hubbert Curve. Source: www.hiram-caton.com 05/05/2013; Hubbert, M. King (1956), "Nuclear Energy and The Fossil Fuels", Shell Development Company Exploration and Research Division, Publication 95.

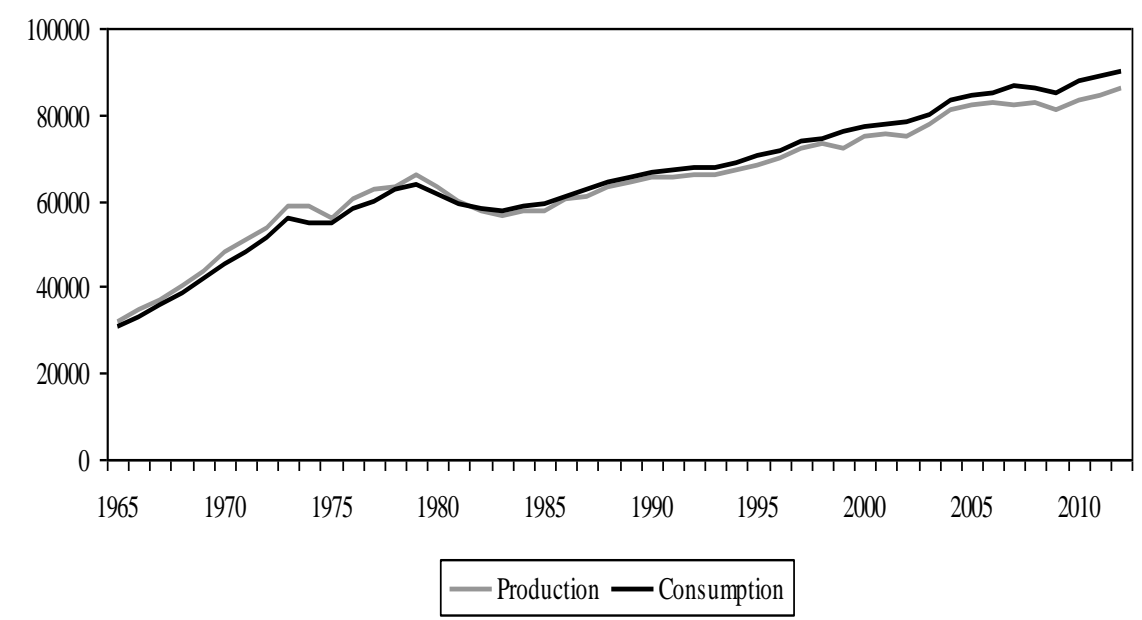

Figure 3. World Oil Production and Consumption(thousands barrels daily) Source: BP Statistical Review of World Energy 2012

Like with other developing countries, as the energy demand of Turkey at production phase is high, the increase in oil prices could lead to cost inflation. On the other hand, persistency and scale of the shock in the oil markets as well as the money and finance policies to be implemented by the central bank and government in this course are of great importance as well. Moreover, the increase in oil prices contribute to growth of the current account deficit by increasing the energy bill (Yetkiner and Berk, 2008). As a matter of fact, the current account deficit of 77 billion dollars, corresponding to 10 percent of the national income in 2011, consisted of energy importation by around 70 percent with 54 billion dollars. In 2012 when oil prices stood high in average, a resource of around 60 billion dollars was allocated for importation of energy resources. This figure amounts to 25 percent of the total importation. Share of the energy importation that stood around 10 percent until 2005 within the total importation raised to over 20 percent recently as a result of increase of the international energy prices and high growth performance (Y1ldirım, 2013). In parallel to this, for struggling with current deficit, increasing the share of the domestic and renewable resources in energy, reducing the dependency on importation by supporting the efforts providing energy efficiency are also presented as a measure in the Medium Term Development Programme for 2013-2015, prepared by the Ministry of Development.

\section{Literature Survey}

Relationship of the energy factor that is among the most important inputs of almost all sectors of the economy with the basic macro dimensions in the external dependent countries particularly in terms of this resource is increasingly gaining importance. As the most consumed energy resource among the fossil fuels is oil, changes in 
the oil prices are closely followed and their impacts are tested econometrically. In this study, it was sought to analyze the relationship between the movements in the oil prices and the current account deficit that poses a great problem for Turkey's economy. Information on the studies conducted previously to test the impact of the oil prices on the current account deficit are given in Table 2.

\begin{tabular}{|l|l|l|l|l|}
\hline Authors & Country & Period & Empirical Method & Results \\
\hline $\begin{array}{l}\text { Baclajanschi et al. } \\
(2006)\end{array}$ & Moldova & $1997-2004$ & $\begin{array}{l}\text { Arithmetic Index } \\
\text { and Geometric } \\
\text { Index }\end{array}$ & $\begin{array}{l}\text { Energy price changes could dampen } \\
\text { economic growth while putting } \\
\text { additional strains on the current } \\
\text { account deficit. }\end{array}$ \\
\hline $\begin{array}{l}\text { Demirbaş et al. } \\
(2009)\end{array}$ & Turkey & $1984-2008$ & $\begin{array}{l}\text { Error Correction } \\
\text { Model }\end{array}$ & $\begin{array}{l}\text { An increase in oil prices would led tor } \\
\text { is in cureent account deficit. }\end{array}$ \\
\hline $\begin{array}{l}\text { Demirci and Er } \\
(2007)\end{array}$ & Turkey & $1991-2006$ & ARMA-VAR & $\begin{array}{l}\text { Turkish economy is getting more } \\
\text { dependent on the prices of crude oil } \\
\text { and natural gas which makes the } \\
\text { current account deficit grow faster. }\end{array}$ \\
\hline $\begin{array}{l}\text { Bildirici et al. } \\
(2010)\end{array}$ & USA & $1968-2008$ & $\begin{array}{l}\text { TVAR and Granger } \\
\text { Causality Analysis }\end{array}$ & $\begin{array}{l}\text { There is a bidirectional relationship } \\
\text { between oil prices and current } \\
\text { acoount deficit. }\end{array}$ \\
\hline $\begin{array}{l}\text { Özlale and } \\
\text { Pekkurnaz (2010) }\end{array}$ & Turkey & $1999-2008$ & Structural VAR & $\begin{array}{l}\text { A significant effect of oil price shocks } \\
\text { on the current account ratio in the } \\
\text { short-run. }\end{array}$ \\
\hline $\begin{array}{l}\text { Anam and Zaman } \\
\text { (2012) }\end{array}$ & Pakistan & $1975-2010$ & ARDL Approach & $\begin{array}{l}\text { There is a unidirectional causality } \\
\text { running from oil prices to trade } \\
\text { imbalance. }\end{array}$ \\
\hline
\end{tabular}

Table 2. Overview of Previous Studies

A substantial portion of the studies conducted both on Turkey's economy and other countries' economies points out presence of a strong correlation between the international oil prices and current account deficit. However, while oil prices reflect positively on the current account balance in the oil exporter countries, exactly opposite results attained in the importer countries.

\section{Data and Methodology}

The monthly current account deficit (CD) data for the period 1992:01-2013.02 as used in the study were obtained from Electronic Data Distribution System of Central Bank of Turkey, and international oil prices (OP) were obtained from official website of BP.

In this study addressing impact of the international oil prices on the current account deficit in the context of Turkey's economy, the correlation between the said variables were analyzed through the following econometric methods:

- Unit Root Test

- Johansen's Cointegration Test

- Vector Error Correction Model

\section{Results}

In this study examining impact of the international oil prices on the current account deficit, first, stability tests of the series were conducted in order to establish significant relationships between the variables. Results of the Expanded Dickey-Fuller (ADF), Phillips-Perron (PP) and Kwiatkowski Phillips Schmidt Shin (KPSS) unit root tests used to test the stability are presented in Table 3.

While assuming that null hypothesis $\left(\mathrm{H}_{0}\right)$ series contain unit root in ADF and PP tests, it is suggested that alternative hypothesis $\left(\mathrm{H}_{1}\right)$ series contain unit root in KPSS test. In this context, ADF, PP and KPSS unit root tests show that current account deficit and international oil prices series are not stable at level, but both become stable at their first difference. As a matter of fact, the t statistics calculated for ADF and PP tests are, as absolute value, smaller than the MacKinnon's critical value at original level. In KPSS test, as LM statistics is bigger than the critical value, not the $\mathrm{H}_{0}$ hypothesis but its alternative is valid. At their first difference, the unit root problem disappears, the series become stable.

The fact that the series are stable at the same level points out that it is probable for the current account deficit and international oil prices to move in parallel in the long term. In order to clearly determine whether there is a long term relationship between the variables, the optimal lag length was selected and VAR model was predicted 
in the first stage. According to the Table 4 containing the LR (Consecutive Modified Likelihood Ratio Test Statistics), FPE (Final Prediction Error), AIC (Akaike Information Criterion) and HQ (Hannan-Quinn Information Criterion), SC and HQ criteria show that the optimal lag length is 2.

\begin{tabular}{|c|c|c|c|c|c|c|}
\hline & \multicolumn{2}{|l|}{ ADF Test } & \multicolumn{2}{|l|}{ PP Test } & \multicolumn{2}{|l|}{ KPSS Test } \\
\hline & t statistics & $\begin{array}{l}\text { Critical } \\
\text { Values }\end{array}$ & t statistics & $\begin{array}{l}\text { Critical } \\
\text { Values }\end{array}$ & LM statistics & $\begin{array}{l}\text { Critical } \\
\text { Values }\end{array}$ \\
\hline \multirow{3}{*}{$\mathrm{CA}$} & \multirow{3}{*}{-1.982859} & -3.457515 & \multirow{3}{*}{-3.162461} & -3.456093 & \multirow{3}{*}{1.558615} & 0.739000 \\
\hline & & -2.873390 & & -2.872765 & & 0.463000 \\
\hline & & -2.573160 & & -2.572826 & & 0.347000 \\
\hline \multirow{3}{*}{$\mathrm{PF}$} & \multirow{3}{*}{-1.792379} & -3.456197 & \multirow{3}{*}{-1.380814} & -3.456093 & \multirow{3}{*}{1.691471} & 0.739000 \\
\hline & & -2.872811 & & -2.872765 & & 0.463000 \\
\hline & & -2.572851 & & -2.572826 & & 0.347000 \\
\hline \multirow{3}{*}{$\Delta \mathrm{CA}$} & \multirow{3}{*}{-3.467575} & -3.457515 & \multirow{3}{*}{-24.36584} & -3.456197 & \multirow{3}{*}{0.039647} & 0.739000 \\
\hline & & -2.873390 & & -2.872811 & & 0.463000 \\
\hline & & -2.573160 & & -2.572851 & & 0.347000 \\
\hline \multirow{3}{*}{$\Delta \mathrm{PF}$} & \multirow{3}{*}{-9.114739} & -3.456197 & \multirow{3}{*}{-9.037412} & -3.456197 & \multirow{3}{*}{0.044839} & 0.739000 \\
\hline & & -2.872811 & & -2.872811 & & 0.463000 \\
\hline & & -2.572851 & & -2.572851 & & 0.347000 \\
\hline
\end{tabular}

Table 3. Unit Root Test Results

\begin{tabular}{|l|l|l|l|l|l|l|}
\hline & LogL & LR & FPE & AIC & SC & HQ \\
\hline 0 & -3203.080 & NA & 1.09 e+09 & 26.48826 & 26.51710 & 26.49988 \\
\hline 1 & -2679.723 & 1033.737 & 14951281 & 22.19606 & 22.28256 & 22.23091 \\
\hline 2 & -2641.465 & 74.93584 & 11264758 & 21.91293 & $22.05710^{*}$ & $21.97101^{*}$ \\
\hline 3 & -2640.195 & 2.465674 & 11522080 & 21.93550 & 22.13734 & 22.01681 \\
\hline 4 & -2638.398 & 3.460190 & 11734214 & 21.95370 & 22.21321 & 22.05824 \\
\hline 5 & -2633.501 & 9.348872 & 11648205 & 21.94629 & 22.26347 & 22.07406 \\
\hline 6 & -2627.886 & 10.62736 & 11494676 & 21.93294 & 22.30779 & 22.08394 \\
\hline 7 & -2620.275 & 14.27838 & 11157954 & 21.90310 & 22.33561 & 22.07733 \\
\hline 8 & -2619.179 & 2.037386 & 11430677 & 21.92710 & 22.41728 & 22.12456 \\
\hline 9 & -2613.534 & 10.40345 & 11278412 & 21.91351 & 22.46136 & 22.13420 \\
\hline 10 & -2608.588 & 9.034141 & 11193099 & 21.90569 & 22.51120 & 22.14961 \\
\hline 11 & -2599.276 & 16.85330 & 10715327 & 21.86179 & 22.52498 & 22.12894 \\
\hline 12 & -2593.591 & $10.19554 *$ & $10570610 *$ & $21.84786^{*}$ & 22.56872 & 22.13825 \\
\hline
\end{tabular}

* Shows the lag length selected by the criterion.

\section{Table 4. VAR Model Lag Length Determination Criterion Results}

Number of cointegrated vectors in the system is required to be found in order to determine the long term relationship between the series seen to be stable at the same level. For this purpose, trace and maximum eigenvalue statistics were used in the study within the scope of Johansen's cointegration test. In maximum eigenvalue test, existence of maximum $\mathrm{r}$ cointegrated vectors is tested against the alternative hypothesis expressing that $\mathrm{r}+1$ cointegrated vectors exist. In trace eigenvalue test, existence of maximum $r$ conintegrated vectors is tested against the alternative hypothesis expressing that minimum $\mathrm{r}+1$ cointegrated vectors exist (Üçdoğruk, 1996).

\begin{tabular}{|c|c|c|c|c|c|c|}
\hline \multirow{2}{*}{$\begin{array}{l}\text { Number of } \\
\text { Assumed } \\
\text { Cointegration } \\
\text { Equalities }\end{array}$} & \multicolumn{3}{|l|}{ Trace Test } & \multicolumn{3}{|c|}{ Maximum Eigenvalue Test } \\
\hline & Eigenvalue & $\begin{array}{l}\text { Trace } \\
\text { Statistics }\end{array}$ & $\begin{array}{l}5 \% \text { Critical } \\
\text { Values }\end{array}$ & Eigenvalue & $\begin{array}{l}\text { Maximum } \\
\text { Eigenvalue } \\
\text { Statistics }\end{array}$ & $\begin{array}{l}5 \% \text { Critica } \\
\text { Values }\end{array}$ \\
\hline 0 & 0.162177 & 46.82078 & 15.49471 & 0.162177 & 44.41400 & 14.26460 \\
\hline Maximum 1 & 0.009543 & 2.406783 & 3.841466 & 0.009543 & 2.406783 & 3.841466 \\
\hline
\end{tabular}

Table 5. Johansen's Cointegration Test Results

According to Table 5, both trace test and maximum eigenvalue test show that 1 cointegrated vector exists among the international oil prices and current account deficit at the significance level of 5\%. Because for the zero hypothesis assuming that cointegrated vector does not exist, maximum eigenvalue was calculated as 44.4 and trace statistics was calculated as 46.2. As the calculated test values were higher than the critical values at $5 \%$ significance level (14.2 for maximum eigenvalue test, 15.4 for trace test), the zero hypothesis suggesting the cointegrated does not exist was rejected by both tests. This result reflecting existence of long term balance 
relationship shows a substantial parallelism with the results of the studies conducted previously for Turkey and other countries.

Existence of a long term relationship between the current account deficit and the international oil prices shows that the behaviors of the variables in the short term may be addressed within the framework of error correction model. Results of the error correction model and Wald test conducted to determine the causal relationship between the variables in the short and long term are presented in Table 6.

\begin{tabular}{|c|c|c|c|c|c|c|c|}
\hline \multirow{2}{*}{$\begin{array}{l}\text { Dependen } \\
\text { t Variable }\end{array}$} & \multicolumn{4}{|l|}{$\mathrm{t}$ test } & $\mathrm{t}$ test & \multirow{2}{*}{\multicolumn{2}{|c|}{ Wald test }} \\
\hline & $\Delta \mathrm{CA}_{\mathrm{t}-1}$ & $\Delta \mathrm{CA}_{\mathrm{t}-2}$ & $\Delta \mathrm{PF}_{\mathrm{t}-1}$ & $\Delta \mathrm{PF}_{\mathrm{t}-2}$ & $\mathrm{ECT}_{-1}$ & & \\
\hline$\Delta \mathrm{CA}$ & $\begin{array}{l}-0.110766 \\
{[-1.49025]}\end{array}$ & $\begin{array}{l}0.058178 \\
{[0.86485]}\end{array}$ & $\begin{array}{l}-6.997350 \\
{[-0.49019]}\end{array}$ & $\begin{array}{l}0.013418 \\
{[0.00094]}\end{array}$ & $\begin{array}{l}-0.287848 \\
{[-4.60101]}\end{array}$ & $\begin{array}{l}\left(\Delta \mathrm{PF}_{\mathrm{t}-1}\right. \\
\left.\mathrm{ECT}_{-1}\right)\end{array}$ & $\begin{array}{c}\chi^{2}(2)= \\
21.82895\end{array}$ \\
\hline
\end{tabular}

Values in [ ] show t statistics.

Table 6. Results of Short and Long Term Causality Relationships

Response to Cholesky One S.D. Innovations \pm 2 S.E.

Response of CA to CA

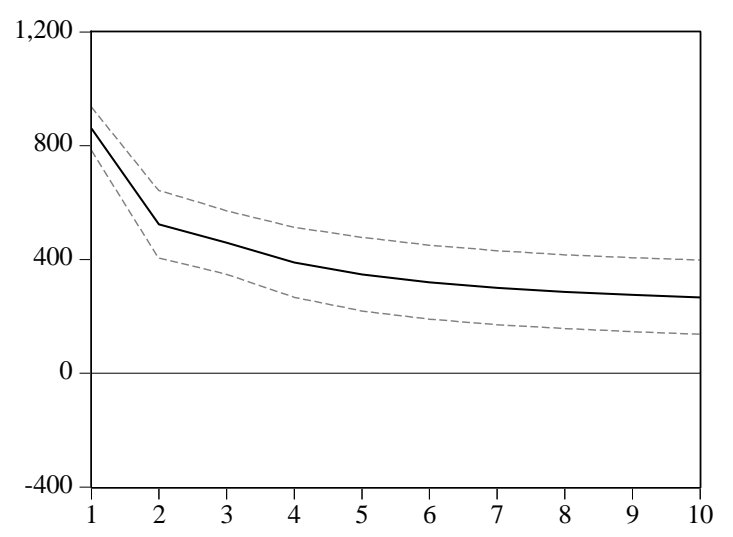

Response of PF to CA

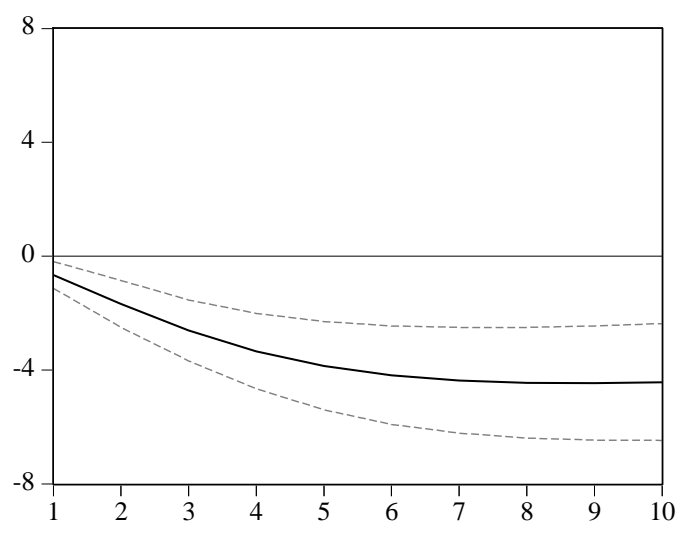

Response of CA to PF

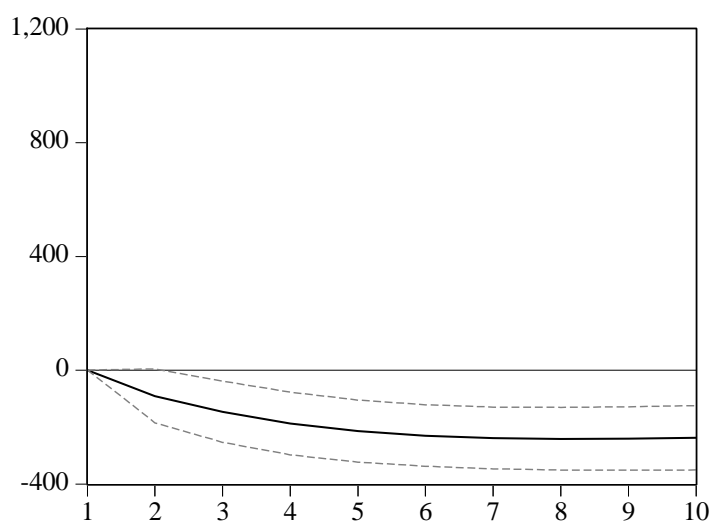

Response of PF to PF

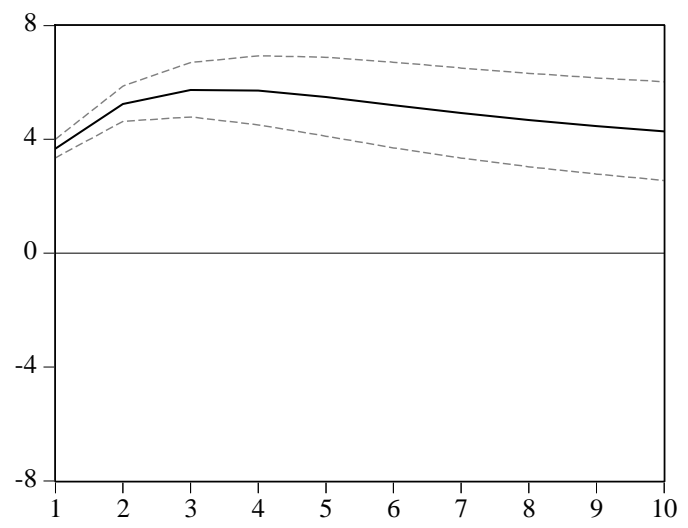

Figure 4. Impulse - Response Functions

While Wald test results confirm that a causality relationship from international oil prices to current account deficit exists in the long term, $t$ test results show that oil prices are not an explanatory variable on the current account deficit in the short term.

Whether any variable is effective on a macroeconomical structure is determined initially with the causality tests used above. Whether the effective variable can be used as a policy instrument is analyzed with the impulseresponse functions (Sar1, 2008). The impulse-response functions reflecting the response given by a variable against the shock applied to another variable in the system was plotted taking into account 10 period. The horizontal axis on the graphs shows duration of the response as monthly periods and vertical axis show the magnitude of the response as standard error. While the continuous lines demonstrate response of the shockdependent variable for 1 standard error occurring in the error terms of the model over time, dashed lines 
represent the confidence intervals attained for \pm 2 standard error. Presence of the dashed lines in the positive and negative area at the same time means that the response is statistically significant (Yamak and Korkmaz, 2005; Erkılıç, 2006).

As shown in the Figure 4 with the straight line, one standard deviation shock to an oil price change results in a decline in the change in current account balance. Therefore, we can say that oil price shocks have the expected impact on the current account deficit.

Another method used for dynamic characteristics of the system is variance decomposition. By variance decomposition, sources of the change in variance of the variables in the models can be decomposed, it can be seen to what extent the change in variance of a variable is attributable to itself and to what extent the same is attributable to the other variable (Pekkaya and Tosuner, 2004).

\begin{tabular}{|l|l|l|l|}
\hline Period & Standard Error & Current Account Deficit (CD) & International Oil Prices (OP) \\
\hline 1 & 860.1016 & 100.0000 & 0.000000 \\
\hline 2 & 1010.861 & 99.19331 & 0.806685 \\
\hline 3 & 1119.928 & 97.63576 & 2.364237 \\
\hline 4 & 1200.355 & 95.49397 & 4.506034 \\
\hline 5 & 1267.971 & 93.10195 & 6.898054 \\
\hline 6 & 1327.690 & 90.69978 & 9.300220 \\
\hline 7 & 1381.890 & 88.43814 & 11.56186 \\
\hline 8 & 1431.678 & 86.38762 & 13.61238 \\
\hline 9 & 1477.684 & 84.56781 & 15.43219 \\
\hline 10 & 1520.327 & 82.97020 & 17.02980 \\
\hline
\end{tabular}

Table 8. Variance Decomposition Results

According to variance decomposition results, the whole change in the current account deficit in the period can be explained by itself. But beginning from the second period, explanatoriness of the international oil prices begin to increase, and in the tenth period, around $17 \%$ of the change in the current account deficit is explained by the international oil prices.

\section{Conclusion and Evaluation}

The international oil prices determined by the supply\&demand conditions as well as social factors can influence the macro dimensions such as current account balance particularly in developing countries that are external dependent in energy. In this study, the relationship between international oil prices and current account deficit was tested with the aid of the monthly data for the period 1992:01-2013:02 for Turkey's economy using VAR analysis. The data obtained showed existence of a causal relationship from international oil prices to current account deficit. Hence, very critical steps are required to be taken in the field of energy in order to reduce to a certain extent the current account deficit that has reached very high levels due to reasons attributable to both domestic demand increase and production structure. In this respect, it is required to support the efforts aimed at determining domestic energy resources and mobilizing the said resources, modernize the existing energy sites, reduce the demand for fossil fuels by supporting the private and public investments in renewable energy resources, and minimize the losses and illicit uses on energy lines.

\section{References}

- Australian Institute of Petroleum (AIP), "Facts About the International Fuels Market \& Prices", http://www.aip.com.au

- Baclajanschi, I. et al. 2006. "The Impact of Energy Price Changes in Moldova", World Bank Policy Research Working Paper, 3960.

- $\quad$ BP Statistical Review of World Energy 2012

- Demirbaş M. et al. 2009. "Petrol Price Developments in the Analysis of the Effects of Turkey's Current Account Deficit”, Süleyman Demirel Üniversitesi İktisadi ve İdari Bilimler Fakültesi Dergisi, 14, p. 289299.

- Demirci E. and Ş. Er 2007. "The Analysis of the Effect of Crude Oil Prices over Turkish Current Account Deficit”, 8. Türkiye Ekonometri ve İstatistik Ulusal Kongresi, İnönü Üniversitesi- Malatya.

- Ediger, V. Ş. 2007. "Yeni Yüzyılın Enerji Güvenliğinde Karşılıklı Bağımlılık Bir Zaruret”, Doğal Gaz Dergisi, 12, p. 30-36.

- Erk1lıç, S. 2006. "The Determinants of Current Account Deficit in Turkey", Türkiye Cumhuriyet Merkez Bankası İstatistik Genel Müdürlügü, Ankara.

- Fessler, D. 2011. "What Really Drives Crude Oil Prices?”, http://www.investmentu.com 
- Hubbert, M. K. 1956. "Nuclear Energy and The Fossil Fuels", Shell Development Company Exploration and Research Division, Publication 95.

- Kiani, A. 2011. "Impact of High Oil Prices on Pakistan's Economic Growth”, International Journal of Business and Social Science, 2, p. 209-216.

- OECD 2011. OECD Factbook 2011-2012: Economic, Environmental and Social Statistics.

- $\quad$ Özlale Ü. and D. Pekkurnaz 2010. "Oil Prices and Current Account: A Structural Analysis for the Turkish Economy", Energy Policy, 38, p. 4489-4496.

- Pekkaya, S. and A. Tosuner 2004. “Türkiye Ekonomisinin Temel Dinamikleri Işı̆̆ında 2000 Yılı Enflasyonu Düşürme Programına Eleştirel Bir Yaklaşım: 1990-99 Dönemine Yönelik Bir VEC (Vector Error Correction: Vektör Hata Düzeltme) Modeli Denemesi”, 2004 Türkiye İktisat Kongresi, İzmir.

- Sar1, A. 2008. "Efficency of How to Solve Balance of Payments Problems Under the Monetary Approach Using Automatic Stabilization Mechanism in Turkey", Cumhuriyet Üniversitesi İktisadi ve İdari Bilimler Fakültesi Dergisi, 9, p. 1-12.

- $\quad$ Üçdoğruk, Ş. 1996. "The Econometric Analysis of the Health Expenditures in Turkey: A Multicointegration Test", Ekonomik Yaklaşım, 7, p. 101-112.

- $\quad$ Yamak, R. and A. Korkmaz 2005. "Reel Döviz Kuru ve Diș Ticaret Dengesi İlișkisi", İstanbul Üniversitesi Iktisat Fakültesi Ekonometri ve Ístatistik Dergisi, 2, p. 16-38.

- $\quad$ Yetkiner, İ. H. and İ. Berk 2008. "The Reasons behind the Rise in Oil Prices and Its Effect", Cumhuriyet Energy Supplement, 8, p. 12-14.

- Yıldırım, A. 2013. "En Yüksek Enerji Faturasını 2012'de Ödedik", http://www.haberturk.com

- http://eia.gov

- $\quad$ http://www.hiram-caton.com 


\title{
Evolution of Comovement between Commodity Futures: Do Biofuels Matter?
}

\author{
Ph.D. Candidate Dinçer Dedeoğlu (Bahçeşehir University, Turkey)
}

\begin{abstract}
In this study we investigate the commodity futures linkages for the period 1988:M1-2012:M4. We use monthly futures prices for nine commodities. We employ wavelet analysis to investigate the comovement of commodity futures. By using wavelet based measure of correlation we investigate correlation between commodity futures in both time and frequency domain. The results indicate that correlations are low for short, medium and long-run. We also find evidence of a tendency towards an increase in correlations after 2008. This can be the result of the global crises which has an effect on feedstock costs and the price of energy inputs by putting front a channel through biofuels that links energy and agricultural commodities by increasing the correlation between these commodities after 2008 .
\end{abstract}

Full paper not published upon author's request. 


\title{
The Relationship between Oil Prices and Exchange Rate: The Case of Romania
}

\author{
Asst. Prof. Dr. Ahmet Şahbaz (Gaziantep University, Turkey) \\ Asst. Prof. Dr. Uğur Adıgüzel (Cumhuriyet University, Turkey) \\ Asst. Prof. Dr. Tayfur Bayat (İnönü University, Turkey) \\ Asst. Prof. Dr. Selim Kayhan (Bozok University, Turkey)
}

\begin{abstract}
This study investigates to causality between crude oil prices and exchange rates in Romania employing monthly data from the beginning of floating exchange regime for November 2004 to December 2011. The study benefits from the recent advance in the time series econometric analysis and carries out non-linear causality and frequency domain causality tests. According to nonlinear causality test results there is no causality between the variables. Results show that frequency domain causality results slightly differentiate from the nonlinear causality analysis and imply that there is a causality running from real exchange rate to real oil price on the mediun and long run.
\end{abstract}

\section{Introduction}

The term of transition economy includes the countries located in Central and Eastern Europe. The common point of these countries is strong change in their economic structure. The defining characteristic of the transition countries is their decision to abandon central planning as the principal mode of organizing their economies and to move to market-oriented economies with significant private ownership of the means of production (IMF, 2000). Romania was included in the list of transition countries in 1989.

The country experienced different stages of development in the period including years between years 1989 and 2011. After the economic decline and recovery periods, Romania participated to European Union in 2007. International Money Fund, World Trade Organization and European Bank for Reconstruction and Development are the other institutions which Romania joined in the last sub-period of the transition process.

By the beginning of transition period in Romania, a number of major reforms were made in the fields of privatization, price liberalization, banking and commercial law and regulations in financial system and financial institutions in order to participate global economic system. Another important reform was made in trade and foreign exchange rate system of Romania. Similar to other transition countries, Romania has started with a fixed exchange rate regime and moved gradually from an intermediate (soft peg) regime to a managed floating regime (Marcu, 2008). The National Bank of Romania started to apply controlled (managed) floating regime in 1999 (Dobrota, 2007). Finally the Bank has started to implement floating regime by the beginning of inflation targeting regime in November 2004. Transition to floating exchange rate regime allows to external factors to induce exchange rate fluctuations.

By the beginning of transition period, the Romanian economy has grown remarkably. The growing economy has induced to increase energy demand. According to Eurostat database, the primary energy demand was 34 million tonnes of oil equivalent (MTOE) in 1999, it was more than 38 MTOE in 2008. Although a contraction occured in energy consumption because of global crisis in 2008, it has increased again by the end of crisis.

Romania meets its energy demand mainly from its own sources. In this regard, its energy import dependency is lower than European Union avarage. On the other hand, a quarter of total primary energy supply is met by oil. Romania is a significant producer of oil. Domestic oil production covers a large percentage of oil needs. Oil dominates the primary energy supply of Romania with gas and solid fuels. Romania imported oil more than 4.8 MTOE, while it produced 6 MTOE in 2004 (EC, 2007). $40 \%$ of imported energy is in the form of crude oil imported mainly from the Russian Federation and Kazakhstan.

In addition to transition to floating exchange rate regime in November 2004, increasing energy demand parallel to economic growth brings to question that "Do oil price fluctuations induce exchange rate fluctuations in Romania?". In the light of these explanations, we examine the causation linkage between real exchange rate and oil price in Romania. We employ monthly data from the beginning of floating exchange rate regime in November 2004 to December 2011. The causal relationship is identified by employing multiple testing approaches. In that respect we employ linear causality test developed by Hatemi-J (2006) and frequency domain causality test developed by Breitung and Candelon (2006).

The contribution of this study is two fold. First, the determination of causation linkage has important policy implications. The fluctuations in exchange rate impairs on economic growth (Rickne, 2009). In this regard, reducing price volatility of oil also proves exchange rate stability and hence economic growth. On the other hand, the information about possible interaction between oil prices and exchange rate plays crucial role in 
making long term energy policies. By determining the causation linkage, policymakers might tend to alternative energy sources in order to reduce oil dependency and oil demand. In the light of results, we also provide information for global investors in investment decisions. By monitoring oil prices, investors may forecast exchange rate movements. Besides, financial market actors and speculators could be able to identify portfolio diversification options in exchange rate markets. Secondly, this study also attempts to compare time domain and frequency domain causality analyses approach which generates test statistics at different frequencies across spectra. By doing so, we examine the existence of causality between variables in different time frequencies. This would give opportunity to test Coudert et al.'s (2008) findings about the differences in price elasticity of oil demand and supply in different time periods.

The rest of paper is organized as follows. The next section devoted to summarize theoretical interpretations about the linkages between variables. The third section summarizes the existing literature investigating the relationship between variables. In the fourth and fifth sections, econometric methodology and the data are described. In the section six, empirical results are presented. We summarize and conclude empirical findings in the last section.

\section{Theoretical Background}

Theoretically there is a number of variables affect exchange rates in floating exchange rate regime. The economists have investigated the effects of possible variables on exchange rates. In this regard, real factors as well as nominal factors are examined. While Branson (1981) attributes an important role to monetarial factors, Dornbusch (1980), Bergstrand (1991), Faruquee (1995), Clarida and Gali (1994), Mark and Choi (1997) find the significant effects of real variables.

On the other hand, Golub (1983) and Krugman (1983a and 1983b) attributes an important role to oil price shocks in definition of exchange rate fluctuations. While Golub (1983) explains the relationship via wealth transfer channels, Krugman (1983a and 1983b) argues that exchange rates differentiate due to import preferences and investment decisions of oil exporting countries in the case of oil price increases.

On the other hand, Coudert et al. (2008) suggest that a shock in U.S. dollar exchange rate also affects oil prices. They explain the relationship as follows: oil pruchases are paid in dollars. Demand depends on the domestic price for consumer countries which changes with the dollar fluctuations. Depreciation in dollar reduces the oil price in domestic currencies for countries with a floating currency (Coudert et al., 2008). This leads to an increase in real income of consumer countries and increases oil demand. So, dollar depreciation increases oil demand and this would increase oil price. Similarly, a U.S. dollar depreciation has effects on oil supply. The depreciation in U.S. dollar can also trigger inflation and reduce the income in oil producer countries, the currencies of which are linked to the dollar. The increase in inflation and the decrease in purchasing power reduce the real disposable income and therefore the income available for drilling, everything else equals (Coudert et al., 2008). As a result, dollar depreciation may result in a reduction in oil supply, henceforth oil price. But the effects of exchange rate shocks on oil demand and supply can be observable on the long run. Because the price elasticity of both demand and supply are inelastic on the short run. So the effect of exchange rate on oil price occurs on the long run.

\section{Literature Review}

In this section we focus on the literature analyzing exchange rate and oil price relation. We classify the literature into four groups. The first group of studies supports evidence of causality running from oil price to exchange rate. Amano and van Norden (1998) for the U.S.A. and Chaudhuri and Daniel (1998) for sixteen OECD countries support evidence for this argument. In latter studies, Aleisa and Dibooglu (2002) for Saudi Arabia, Akram (2004) for Norway, Kutan and Wyzan (2005) for Kazakhstan, Zalduendo (2006) for Venezuela, Issa et al. (2006) for Canada, Olomo and Adejumo (2006) for Nigeria, Chen and Chen (2007) for G7 countries, Coudert et al. (2008) for U.S.A., Narayan et al. (2008) for Fiji Islands, Korhonen and Juurikkala (2009) for nine OPEC countries, Nikbakht (2010) for seven OPEC countries, Hasanov (2010) for Azerbaijan, Dawson (2003) and Mendez-Carbajo (2011) for Dominic Republic and Lizardo and Mollick (2010) for Canada, Mexico, Norway and Russia as oil exporting countries and for Denmark, Japan, Sweden, the United Kingdom and the Euro area countries as exporting countries reach similar results with Amano and van Norden (1998).

Second group of studies implies that real exchange rate shocks induce oil price fluctuations and indicates a causality runing from real exchange rates to oil prices. Indjehagopian et al. (2000) find that variation in exchange rates has an instantaneous impact on the variations in oil prices for Holland, Germany and France. In another study for developed country context, Sadorsky (2000) analyzes U.S.A. and obtains that exchange rate induces crude oil future prices. This view is supported by Schmidbauer and Rösch (2008) and Zhang et al. (2008), Yousefi and Wirjanto (2004) for Indonesia, Iran, Nigeria and Saudi Arabia; Yousefi and Wirjanto (2005) for Iraq, Kuwait and Venezuela. 
The third group of studies finds evidence of two way causality (the feedback relation) between oil price and real exchange rates. In their initial studies Usama and Normee (2009) imply that there is a bi-directional causality between variables in the short run in United Arabic Emirates. Huang and Tseng (2010) investigate the relationship between oil price and nominal exchange rate by using different kind of oil types and find bidirectional causality for U.S.A.Yanagisawa (2010) examines the relationship for U.S.A. and implies that bidirectional casuality is valid previously, but casuality running from exchange rate to oil price dissappears in the last year of analysis. Mohammadi and Jahan-Parvar (2008) find bi-directional causality for Gabon, Indonesia, Nigeria and Saudi Arabia.

The fourth group of studies indicates that there is no causal relationship (the neutrality) between variables, implying that oil price and exchange rates do not provide a predictive power with respect to each other. The empirical evindence on the neutrality between oil prices and exchange rates is supported by Bjorvik et al. (1998), Habib and Kalamova (2007) and Bjornland and Hungnes (2008) for Norway, Habib and Kalamova (2007) for Saudi Arabia, Wu et al. (2011) for U.S.A; Mohammadi and Jahan Parvar (2010) for thirteen oil exporting countries; and Jahan-Parvar and Mohammadi (2008) for Algeria, Bahrain, Kuwait and Mexico.

\section{Econometric Methods}

\subsection{Hatemi-J (2006) Bootstrap Process-Based Toda-Yamamoto (1995) Linear Granger Causality Type}

In a standard Granger causality analysis, zero restrictions based on the Wald principle are imposed on the lagged coefficients obtained from the estimation of Vector Autoregressive (VAR) model. However, the Wald statistic may lead to nonstandard limiting distributions depending upon the co-integration properties of the VAR system that these nonstandard asymptotic properties stem from the singularity of the asymptotic distributions of the estimators (Lütkepohl, 2004). The Toda and Yamamoto (1995) (TY, hereafter) procedure overcomes this singularity problem by augmenting VAR model with the maximum integration degree of the variables. In addition to this advantage, the TY approach does not require testing for co-integration relationships and estimating the vector error correction model and is robust to the unit root and co-integration properties of the series.

The standard Granger (1969) causality analysis requires estimating a VAR $(p)$ model in which $p$ is the optimal lag length(s). In the TY procedure, the following VAR $(p+d)$ model is estimated that $d$ is the maximum integration degree of the variables.

$$
y_{t}=v+A_{1} y_{t-1}+\cdots+A_{p} y_{t-p}+\cdots+A_{p+d} y_{t-(p+d)}+\mu_{t} .
$$

where $y_{t}$ is vector of $k$ variables, $v$ is a vector of intercepts, $\mu_{t}$ is a vector of error terms and $A$ is the matrix of parameters. The null hypothesis of no-Granger causality against the alternative hypothesis of Granger causality is tested by imposing zero restriction on the first $p$ parameters. The so-called modified Wald (MWALD) statistic has asymptotic chi-square distribution with $p$ degrees of freedom irrespective of the number of unit roots and of the co-integration relations.

Hacker and Hatemi-J (2006) investigate the size properties of the MWALD test and find that the statistic with asymptotic distribution poorly performs in small samples. $\otimes$ the Kronecker product, $C=p \times n(1+n(p+d))$ a selector matrix, $S_{U}$ variance-covariance matrix of residuals, $\hat{\beta}=v e c(\hat{D})$ and vec is the column-stacking operator as the MWALD test statistics;

$$
M W A L D=(C \hat{\beta})^{\prime}\left[C\left(\left(Z^{\prime} Z\right)^{-1} \otimes S_{U}\right) C^{\prime}\right]^{-1}(C \hat{\beta}) \square \chi_{p}^{2}
$$

Monte Carlo simulation of Hacker and Hatemi-J (2006) shows that the MWALD test based on the bootstrap distribution has much smaller size distortions than those of the asymptotic distribution. Hacker and Hatemi-J (2006) extends the TY approach based on the bootstrapping method developed by Efron (1979). In this new approach that is so-called the leveraged bootstrap Granger causality test, the MWALD statistic is compared with the bootstrap critical value instead of the asymptotic critical value.

\subsection{Frequency domain causality test}

While conventional time domain causality tests produce a single test statistic for the interaction between variables in concern, frequency domain methodology generates tests statistics at different frequencies across spectra. This is contrary to the implicit assumption of the conventional causality analysis that a single test statistic summarizes the relation between variables, which is expected to be valid at all points in the frequency distribution. Frequency domain approach to causality thereby permits to investigate causality dynamics at different frequencies rather than relying on a single statistics as is the case with the conventional time domain analysis (Ciner, 2011). Hence, it seems to be very meaningful to carry out frequency domain causality to better understand temporary and permanent linkages between oil prices and exchange rates in the Romania. Details of frequency domain approach are given in the appendix A. 


\section{Data}

The exchange rate is defined as the foreign currency price of the U.S. dollar, concluding that the dollar appreciates as the nominal value of exchange rate rises. Real exchange rates (RER) are constructed using consumer price indices. The world price of oil, quoted in U.S. dollars, is chosen as representative of the general movement in oil prices over the period. To obtain the real oil price (ROP), the U.S. dollar price of oil was converted to domestic prices using the U.S. dollar exchange rate and then deflated by the domestic consumer price index. We employ monthly data belonging o period between November 2004 and December 2011. All the data is obtained from the International Financial Statistics published by IMF. The descriptive statistics are reported in table 1 . It seems that data characteristics are slightly different in each series. First of all, as expected, the mean of the real exchange rate is higher than real oil price. According to the standard deviation and coefficient of variation of the real oil price is higher than real exchange rate. However, kurtosis value of real exchange rate is smaller than real oil price.

\begin{tabular}{lllllll}
\hline Time Span & Variable & Mean & Std. Dev. & Coef. of var. & Skewness & Kurtosis \\
\hline November 2004- & RER & 4.665 & 0.057 & 0.012 & -0.062 & 3.675 \\
December 2011 & ROP & 0.538 & 0.202 & 0.375 & -0.28 & 2.737
\end{tabular}

Table 1. Descriptive Statistics Notes: Coefficient of variation is the ratio of standard deviation to mean. Descriptive statistics are for log series. ROP: real oil prices, RER: real exchange rates.

\section{Empirical Findings}

Prior to the identification of possible causality between the real exchange rates and the real oil prices, it is necessary to determine integration degree of variables. In that respect, we employ a battery of the unit root tests developed by Dickey and Fuller (1978 and 1981) (henceforth ADF), Phillips and Perron (1988) (henceforth PP), Elliot et al. (1996) (henceforth DF-GLS), and Kwaitkowski et al. (1992) (henceforth KPSS). The results from the unit root tests in table 2 show that ADF, PP and DF-GLS test do not reject the null of a unit root for the levels of real exchange rate and real oil price. When the ADF, PP and DF-GLS tests are applied to the first differences of the variables, the results indicate that all variables are stationary. Consistent with these results, the KPSS test for the null hypothesis also shows that the variables are stationary in their first differences. The unit root analyses thereby imply that the variables are integrated of order one. Accordingly, the maximum integration order (d) of the variables equal to one in the Toda Yamamoto linear Granger causality analysis.

\begin{tabular}{|l|l|l|l|l|l|}
\hline & & ADF & DF-GLS & PP & KPSS \\
\hline Levels & & & & & \\
\hline \multirow{3}{*}{ Intercept } & RER & $-2.800(1)^{*}$ & $-0.803(1)$ & $-3.205(3)^{* *}$ & $0.223^{*}$ \\
\cline { 2 - 6 } & ROP & $-3.039(2)^{* *}$ & $-2.236(2)^{* *}$ & $-2.247(4)$ & 0.416 \\
\hline \multirow{2}{*}{$\begin{array}{c}\text { Intercept and } \\
\text { Trend }\end{array}$} & RER & $-2.690(1)$ & $-1.340(1)$ & $-2.961(1)$ & 0.222 \\
\cline { 2 - 6 } & ROP & $-3.508(2)^{* *}$ & $-3.489(2)^{* *}$ & $-2.661(4)$ & $0.078^{* *}$ \\
\hline First-differences & & & & & \\
\hline \multirow{3}{*}{$\begin{array}{l}\text { Intercept } \\
\text { Intercept and } \\
\text { Trend }\end{array}$} & RERR & $-6.701(0)^{* * *}$ & $-3.873(0)^{* * *}$ & $-6.618(4)^{* * * *}$ & $0.373^{* * *}$ \\
\cline { 2 - 6 } & ROPR & $-7.557(0)^{* * *}$ & $-2.351(1)^{* * *}$ & $-7.710(3)^{* * *}$ & $0.043^{* * *}$ \\
\cline { 2 - 6 } & RERR & $-6.832(0)^{* * *}$ & $-5.886(0)^{* * *}$ & $-6.741(4)^{* * *}$ & $0.115^{* * *}$ \\
\hline
\end{tabular}

Table 2. Results of the Unit Root Test Notes: For the KPSS test: * The asymptotic critical values of LM statistic for intercept 0.739, 0.463 at the \%1 and \%5 levels, ** the asymptotic critical values of LM statistic for trend and intercept 0.216, 0.146 at the $\% 1$ and $\% 5$ levels.

For the DF-GLS test: *The asymtotic critical values for without trend $-2.591,-1.944$ at the $\% 1$ and $\% 5$ levels. ** The asymtotic critical values for with trend $-3.602,-3.177$ at the $\% 1$ and $\% 5$ levels. The figures in parenthesis denote the number of lags in the tests that ensure white noise residuals. They were estimated through the Schwarz criterion.

For the ADF test: * shows the results of Dickey Fuller test in the case of zero lag length and lag length choosen due to SIC criteria.** For the ADF test, the Mac Kinnon(1996) critical values for with constant -.3.485, -2.885, 2.579 at the $1 \%, 5 \%$ and $10 \%$ levels. The critical values for with constant and trend $-4.035,-3.447$ ve -3.148 at the $1 \%, 5 \%$ and $10 \%$ levels, respectively.

For the PP test: *Values in the paranthesis show bandwiths obtained according to Newey-West using Bartlett Kernel criteria. ** For the PP test Mac Kinnon(1996) critical values for with constant $-3.483,-2.884,-2.579$ at the $1 \%, 5 \%$ and $10 \%$ levels.the critical values for with constant and trend $-4.033,-3.446$ and -3.148 at the $1 \%$ $5 \%$ and $10 \%$ levels, respectively. 
In the first step we employ bootstrap process based Toda Yamamoto (1995) linear causality (TY hereafter) test. Table 2 shows the results of bootstrap process based linear TY Granger type causality test results. As indicated in the table 2 statistics for both tests are higher than critical values obtained by replication for 10.000 times. According to test results, there is a uni-directional causality running from real oil price to real exchange rate.

Real oil prices to real exchange rates

\begin{tabular}{|c|c|c|c|c|}
\hline \multirow{2}{*}{ MWALD } & \multirow[b]{2}{*}{ p-value } & \multicolumn{3}{|c|}{ Bootstrap critical values } \\
\hline & & $1 \%$ & $5 \%$ & $10 \%$ \\
\hline 11.369 & 0.000 & 12.499 & 8.240 & 6.444 \\
\hline \multicolumn{5}{|c|}{ Real exchange rates to real oil prices } \\
\hline \multicolumn{5}{|c|}{ Bootstrap critical values } \\
\hline MWALD & p-value & $1 \%$ & $5 \%$ & $10 \%$ \\
\hline 0.743 & 0.862 & 12.265 & 8.335 & 6.674 \\
\hline
\end{tabular}

Table 3. Results of Linear Granger Causality Test Note: p-value denotes asmptotic chi-sqaure distribution. The AIC was used to determine the optimal lag lengths for $\operatorname{VAR}(p+d)$ models. Numbers in brackets are p-values. The number of replication is 10000.

In the second step, we employ Breitung and Candelon's (2006) analysis which permits to decompose the causality test statistic into different frequencies. We calculate the test statistics at a high frequency of $\omega_{i}=2.5$ and $\omega_{i}=2.0$ to examine short term causality, $\omega_{i}=1.00$ and $\omega_{i}=1.50$ to examine medium term causality and finally $\omega_{i}=$ .01 and $\omega_{i}=.05$ to investigate long term causality. By doing so, we are able to learn both temporary and permanent relations between variables. According to results of frequency domain causality test, we imply that there is no effect of real oil prices on real exchange rate in any time period. Results show that the causal relationship running from real exchange rate to real oil price is valid for long and medium term.

\begin{tabular}{|c|c|c|c|c|c|c|}
\hline \multicolumn{7}{|c|}{ Real exchange rate to real oil price } \\
\hline \multirow[b]{2}{*}{$\omega_{i}$} & \multicolumn{2}{|c|}{ Long Term } & \multicolumn{2}{|c|}{ Medium Term } & \multicolumn{2}{|c|}{ Short Term } \\
\hline & 0.01 & 0.05 & 1.00 & 1.50 & 2.0 & 2.50 \\
\hline \multicolumn{6}{|c|}{ Real oil price to real oil price } & $4.503 *$ \\
\hline & Long T & & Mediu & & Short T & \\
\hline \multirow[t]{2}{*}{$\omega_{i}$} & 0.01 & 0.05 & 1.00 & 1.50 & 2.00 & 2.50 \\
\hline & 1.563 & 3.089 & 0.391 & 0.380 & 1.273 & 0.157 \\
\hline
\end{tabular}

Table 4. Results for frequency domain causality test Notes: The lag lengths for the VAR models are determined by SIC. F-distribution with $(2, T-2 p)$ degrees of freedom equals 5.99.

While linear causality analysis results imply existence of causality running from real oil price to real exchange rate in Romania, frequency domain causality results find evidence the causality running from real exchange rate to real oil price on the longer periods. As can been, both the time domain and frequency domain causality tests imply different results.

\section{Conclusions}

In this study, we examine monthly data belonging November 2004- December 2011 period in order to find whether there is an interaction between oil price fluctuations and exchange rate volatilities in the Romanian economy. In this regard, we employ linear causality test developed by Hatemi-J (2006) and frequency domain causality test developed by Candelon and Breitung (2006).

The results imply that time domain and frequency domain causality approaches imply different results. While time domain causality analysis indicates causality running from real oil price to real exchange rate, frequency domain causality analysis implies reverse causality in all time frequencies.

According to frequency domain causality analysis results, it is clear that oil price shocks do not affect exchange rate in the Romanian economy. This result is consistent with Romanian's energy dependency level. Low energy dependency prevents the effects of oil price shocks. Also relatively low share of oil in total energy consumption helps to explain the absence of the relationship running from oil price to exchange rate. On the other hand, existence of causality running from exchange rate to oil price on the medium and long run supports the Coudert et al.'s (2008) implications about the price elasticity of oil demand and oil supply. The effect of exchange rate fluctuations appears on the longer periods due to inelasticity of oil demand and supply on the short run. 


\section{References}

- $\quad$ Akram, Q. F., 2004. Oil prices and exchange rates: Norwegian evidence. Econometrics Journal 7, 476-504.

- Aleisa, E. A., Dibooglu, S., 2002. Sources of real exchange rate movements in Saudi Arabia. Journal of Economics and Finance 26 (1), 101-110.

- Amano, R. A., van Norden, S., 1998. Oil prices and the rise and fall of the U.S. real exchange rate. Journal of International Money and Finance 17, 299-316.

- $\quad$ Bergstrand, J. H., 1991. Structural determinants of real exchange rates and national price levels: Some empirical evidence. American Economic Review 81 (1), 325-334.

- $\quad$ Bjornland, H. C., Hungnes, H., 2008. The commodity currency puzzle. The IUP Journal of Monetary Economics 0(2), 7-30.

- Branson, W. H., 1981. Macroeconomic determinants of real exchange rates. NBER Working Paper no. 801.

- Breitung, J., Candelon, B., 2006. Testing for short and long-run causality: A frequency domain approach. Journal of Econometrics 12, 363-378.

- Bjørvik, L. M., Mork, K. A., Uppstad, B. H., 1998. Påvirkes kursen på norske kroner av verdensprisen på olje? (Is the exchange rate for the norwegian Krone affectted by the real oil price?), Norsk Økonomisk Tidsskrift 1, 1-33.

- Chaudhuri, K., Daniel, B. C., 1998. Long-run equilibrium real exchange rates and oil prices. Economic Letters 58, 231-238.

- Chen, S. S., Chen, H. C., 2007. Oil prices and real exchange rates. Energy Economics 29, 390-404.

- Ciner, C., 2011. Eurocurrency interest rate linkages: A frequency domain analysis. International Review of Economics and Finance 20, 498-505.

- Clarida, R., Gali, J., 1994. Sources of real exchange rate fluctuations: How important are nominal shocks. Carnegie-Rochester Conference Series on Public Policy 41 (1), 1-56.

- $\quad$ Coudert, V., Mignon, V., Penot, A., 2008. Oil price and the dollar. Energy Studies Review 15 (2).

- Dawson, J. C., 2003. The effect of oil prices on exchange rates: A case study of the Dominician Republic. The Park Place Economist 14, 23-30.

- Dickey, D. A., Fuller, W. A., 1979. Distribution of the estimators for autoregressive time series with a unit root. Journal of the American Statistical Society 75, 427-431.

- Dickey, D. A., Fuller, W. A., 1981. Distribution of the estimators for autoregressive time series with a unit root. Econometrica 49, 1057-1072.

- Dobrota, G., 2007. The foreign currency regime and policy in Romania. MPRA paper no. 11433.

- Dornbusch, R., 1980. Exchange rate economics: Where do we stand?. Brookings Papers on Economic Activity 1, 143-186.

- Elliot, G., Rothenberg, T. J., Stock, J. H., 1996. Efficient tests for an autoregressive unit root. Econometrica 64 (4), 813-836.

- European Commission, 2008. FDI in Romania: from low-wage competition to higher value-added sectors. ECFIN Country Focus 5 (3), 1-6.

- European Commission, 2007. Energy fact sheet Romania.

- Faruqee, H., 1995. Long-run determinants of the real exchange rate: A stock-flow perspective. International Money Fund Staff Papers 42 (1), 80-107.

- Geweke, J., 1982. Measurement of linear dependence and feedback between multiple time series. Journal of the American Statistical Association 77, 304-313.

- Golub, S. S., 1983. Oil price and exchange rates. The Economic Journal 93 (371), 576-593.

- Groen, J. J. J., Pesenti, P. A., 2010. Commodity prices, commodity currencies and global economic developments. NBER Working Papers no. 15743.

- Habib, M. M., Kalamova, M. M., 2007. Are there oil currencies? The real exchange rate of oil exporting countries. European Central Bank Working Paper Series no. 839.

- Hasanov, F., 2010. The impact of real oil price on real effecive exchange rate: The case of Azerbaijan. German Institute for Economic Research Discussion Paper no. 1041.

- Hosoya, Y., 1991. The decomposition and deasurement of the interdependence between second-order stationary process. Probability Theory and Related Fields 88, 429-444. 
- Huang, A.Y., Tseng, Y. H., 2010. Is crude oil price affected by the U.S. dollar exchange rate?. International Research Journal of Finance and Economics 58, 109-120.

- IMF, 2000. World Economic Outlook.

- Indjehagopian, J. P., Lantz, F., Simon, V., 2000. Dynamics of heating oil market prices in Europea. Energy Economics 22, 225-252.

- Issa, R., Lafrance, R., Murray, J., 2006. The turning back tide: Energy prices and the Canadian Dollar. Bank of Canada Working Paper no. 2006-29.

- Jahan-Parvar, M. R., Mohammadi, H., 2008. Oil prices and real exchange rates in oil-exporting countries: A bounds testing approach. University Library of Munich no. 13435.

- Korhonen, I., Juurikkala, T., 2009. Equilibrium exchange rates in oil exporting countries. Journal of Economisc and Finance 33, 71-79.

- Krugman, P., 1983a. Oil and the dollar. NBER Working Paper Series no. 554.

- Krugman, P., 1983b. Oil shocks and exchange rate Dynamics, in Frenkel, J.A. (Eds.) Exchange Rates and International Macroeconomics, University of Chicago Press.

- $\quad$ Kutan, A.M. and Wyzan, M.L., 2005. Explaining the real exchange rate in Kazakhstan, 1996-2003: Is Kazakhstan vulnerable to the Dutch Disease?. Economic Systems 29, 242-255.

- $\quad$ Kwiatkowski, D., Phillips, P.C.B., Schmidt, P., Shin, Y., 1992. Testing the null hypothesis of stationary against the alternative of a unit root. Journal of Econometrics 54, 159-178.

- Linn, J. F., 2003. Transition in Central and South East Europe and the CIS: The energy dimension. The World Bank at Conference on Restructuring the Energy Sector in Transition Countries Lessons Learned and Challenges Ahead, Leipzig, Germany.

- $\quad$ Lizardo, R.A., Mollick, A.V., 2010. Oil price fluctuations and the U.S. dollar exchange rates. Energy Economics 32, 399-408.

- Marcu, N., 2008. Romania's exchange rate policy towards its European Monetary Union membershipprospects and challenges. Romanian Journal of Economic Forecasting 9(1), 175-181.

- Mark, N. C., Choi, D.Y., 1997. Real exchange rate prediction over long horizons. Journal of International Economics 43(1-2), 29-60.

- Mendez-Carbajo, D., 2011. Energy dependence, oil prices and exchange rates: The Dominican economy since 1990. Empirical Economics 40(2), 509-520.

- Mohammadi, H., Jahan-Parvar, M. R., 2010. Oil prices and exchange rates in oil-exporting countries: Evidence from TAR and M-TAR models. Journal of Economics and Finance 23.

- Narayan, P. K., Narayan, S., Prasad, A., 2008. Understanding the oil price-exchange rate nexus for The Fiji Islands. Energy Economics 30, 2686-2696.

- Nikbakht, L., 2010. Oil prices and exchange rates: The case of OPEC. Business Intelligence Journal 3 (1), 83-92.

- $\quad$ Olomola, P. A., Adejumo, A. V., 2006. Oil price shocks and macroeconomic activities in Nigeria. International Research Journal of Finance and Economics 3, 28-34.

- $\quad$ Phillips, P. C. B., Perron, P., 1988. Testing for a unit root in time series regressions. Biometrica 75, 335-346.

- Popa, L. P., 2009. Trends of the Romanian foreign trade in transition period. Ştiinte Economice, 442-457.

- Sadorsky, P., 2000. The empirical relationship between energy futures prices and exchange rates. Energy Economics 22, 253-266.

- $\quad$ Rickne, J., 2009. Oil prices and real exchange rate movements in oil-exporting countries: The role of institutions. Research Institute of Industrial Economics Working Paper Series no. 810.

- Schmidbauer, H., Rösch, A., 2008. Volatility spillovers between crude oil prices and U.S. dollar to Euro exchange rates. Unpublished paper.

- Usama, A. M., Normee, C. S., 2009. The impact of oil prices on the real exchange rate of the dirham: A case study of the United Arab Emirates. MPRA Paper no.23493.

- Wu, C. C., Chung, H., Chang, Y. H., 2012. The economic value of co-movement between oil price and exchange rate using copula-based GARCH models. Energy Economics 34(1), 270-282.

- Yanagisawa, A., 2010. Relationship among crude oil prices, share prices and exchange rate. IEEJ, November.

- Yousefi, A., Wirjanto, T. S., 2004. The empirical role of the exchange rate on the crude oil price formation. Energy Economics 26, 783-799. 
- Yousefi, A., Wirjanto, T. S., 2005. A stylized exchange rate pass-through model of crude oil price formation. OPEC Review September 2005, 177-197.

- Zalduendo, J., 2006. Determinants of Venezuela's equilibrium real exchange rate. IMF Working Paper no. WP/06/74.

- Zhang, Y. J., Fan, Y., Tsai, H. T., 2008. Spill over effect of U.S. dollar exchange rate on oil prices. Journal of Policy Modelling 30, 973-991.

\section{Appendix}

To test for causality based on frequency domain, Geweke (1982) and Hosoya (1991) defined causality;

$$
M_{y \rightarrow x}(\omega)=\log \left[\frac{2 \pi f_{x}(\omega)}{\left|\psi_{11}\left(e^{-i \omega}\right)\right|^{2}}\right]=\log \left[1+\frac{\left|\psi_{12}\left(e^{-i \omega}\right)\right|^{2}}{\left|\psi_{11}\left(e^{-i \omega}\right)\right|^{2}}\right]
$$

if $\left|\psi_{12}\left(e^{-i \omega}\right)\right|^{2}=0$ that $\mathrm{y}$ does not cause $\mathrm{x}$ at frequency $\omega$. If components of $z_{t}$ are $\mathrm{I}(1)$

and cointegrated, $\Theta(L)$ has a unit root. Breitung and Candelon (2006) investigate the causal effect of $M_{y \rightarrow x}(\omega)=0$ if $\left|\psi_{12}\left(e^{-i \omega}\right)\right|^{2}=0$. The null hypothesis is equivalent to a linear restriction on the VAR coefficients. $\psi(L)=\Theta(L)^{-1} G^{-1}$ and $\psi_{12}(L)=-\frac{g^{22} \Theta_{12}(L)}{|\Theta(L)|}$, with $g^{22}$ as the lower diagonal element of $G^{-1}$ and $|\Theta(L)|$ as the determinant of $\Theta(L)$, it follows $y$ does not cause at frequency $\omega$ if

$$
\left|\Theta_{12}\left(e^{-i \omega}\right)\right|=\left|\sum_{k=1}^{p} \theta_{12, k} \cos (k \omega)-\sum_{k=1}^{p} \theta_{12, k} \sin (k \omega) i\right|=0
$$

with $\theta_{12, k}$ denoting the (1,2)-element of $\Theta_{k}$. Thus for $\left|\Theta_{12}\left(e^{-i \omega}\right)\right|=0$,

$$
\begin{aligned}
& \sum_{k=1}^{p} \theta_{12, k} \cos (k \omega)=0 \\
& \sum_{k=1}^{p} \theta_{12, k} \sin (k \omega)=0
\end{aligned}
$$

Breitung and Condelon's (2006) applied to linear restrictions (14) and (15) for $\alpha_{j}=\theta_{11, j}$ and $\beta_{j}=\theta_{12, j}$. Then the VAR equation for $x_{t}$ can be implied as

$x_{t}=\alpha_{1} x_{t-1}+\ldots+\alpha_{p} x_{t-p}+\beta_{1} y_{t-1}+\ldots+\beta_{p} y_{t-p}+\varepsilon_{1 t}$

and the null hypothesis $M_{y \rightarrow x}(\omega)=0$ is equivalent to the linear restriction with $\beta=\left[\beta_{1}, \ldots, \beta_{p}\right]^{\prime}$

$H_{0}: \quad R(\omega) \beta=0$

and

$$
R(\omega)=\left[\begin{array}{cccc}
\cos (\omega) & \cos (2 \omega) & \ldots & \cos (\mathrm{p} \omega) \\
\sin (\omega) & \sin (2 \omega) & \ldots & \sin (\mathrm{p} \omega)
\end{array}\right]
$$

The causality measure for $\omega \in(0, \pi)$ can be tested a Standard F-test for the linear restrictions imposed by Eq.(14) and Eq. (15). The test procedure follows an F- distribution with (2, T-2p) degrees of freedom. 


\title{
Analysis of Competitiveness of Turkey and Commonwealth of Independent States in their Automotive Market
}

\author{
Dr. Emre Güneşer Bozdă̆ (Gazi University, Turkey) \\ Ph.D. Candidate Sitkıcan Saraçoğlu (Gazi University, Turkey)
}

\begin{abstract}
Automotive sector is a driving sector for countries due to forward and backward linkages and employment and value added it creates. Starting from this point, this study aims to analyze the competitiveness of CIS and Turkey automotive sector in their market. The competitiveness of the countries should be assessed with their production potential. The countries subject to the study are thirteen Eurasian countries, Armenia, Azerbaijan, Belarus, Georgia, Kazakhstan, Kyrgyz Republic, Republic of Moldova, Russian Federation, Tajikistan, Turkey, Turkmenistan, Ukraine and Uzbekistan. The data from UNCTAD for 1995-2011 period for these countries and Liesner Index (RCAL), Balassa Index (RCA), Relative Trade Advantage Index (RTA) and Relative Competitiveness Index (RC) are used and the rank correlation between the outcomes are checked via Spearman Rank Correlation coefficient. According to the outcomes, Belarus, Turkey and Uzbekistan have higher comparative advantage compared to the other countries. The cooperation of these countries with Russia and Ukraine on production and trade of automotive sector will enhance their comparative advantage against third countries.
\end{abstract}

\section{Introduction}

After 1980, the acceleration of globalization in line with the changing world order, increased the importance of international competitiveness. Countries taking the opportunities and threats in the global market into consideration, focused on increasing their competitiveness to participate or increase their share in the global market. According to Deppreu and Cerrato (2005), increasing or conserving the competitiveness of a country depends on the competitiveness level of the firm and related industry on the micro level; and competitiveness level of the country on the macro level. The strategies applied by a firm effect the competitiveness initially of the firm and spillover to the industry it belongs, and determine the competitive power of the country in the global markets. Within this context, automotive sector, which had an increasing importance in line with globalization, became a key sector to push competitiveness of a country in the global markets. Automotive sector is a driving sector for both developed, and developing countries due to forward, and backward linkages and employment and value added it creates and its potential for export revenues. For Commonwealth of Independent States (CIS) and Turkey which have the same development path, belong to the same geography and possess a certain level of industrial accumulation, automotive sector supplies the opportunity to earn momentum for economic development with the effect of internalizing technology and upgrading in dynamic comparative advantage. It is important to know whether Eurasian countries as Turkey and CIS countries reached a certain level of trade in this sector, namely their trade potential and competitiveness. This gives some idea about the competitiveness against the other exporting countries in their own markets. Starting from this point, this study aims to analyze the competitiveness of Turkey and CIS countries automotive sector in their market. The competitiveness of the countries should be assessed with their production potential. In the second section of the study, the indices used to measure competitiveness are defined and their characteristics are expressed. In the third section, the literature on the international competitiveness of the automotive sector is briefed. In the fourth section, the foreign trade volumes of the CIS countries and Turkey is analyzed. In the fifth section, the competitiveness of the related countries on the sub groups of automotive sector is analyzed. The outcomes and policy recommendations are given in the conclusion.

\section{Methods of Measuring International Competitiveness}

\subsection{Liesner Index}

In Liesner (1958), the competitiveness of United Kingdom was questioned for 60 products exported to Western Europe for the period 1953-1956. The aim of Liesner was to find out the sectors which United Kingdom was competitive against European Common Market (Liesner, 1958). The formula Liesner developed for this aim is the following (Utkulu and Seymen, 2004):

$$
R C A=\frac{X_{i j}}{X_{n j}}
$$

In the formula, " $X$ " refers to exports; " $i$ " refers to the country subject to the analysis; " $n$ " refers to the competing country and " $\mathrm{j}$ " refers to the product subject to the analysis. 


\subsection{Balassa Index}

In Balassa (1965) the competitiveness of 74 commodities produced by the developed economies such as Canada, France, Italy, Japan, United Kingdom, Germany and United States of America was calculated (Balassa, 1965). The index developed by Balassa is the following (Balassa, 1989):

$$
R C A=\frac{\boldsymbol{X}_{i j}<\boldsymbol{X}_{i}}{\boldsymbol{X}_{w_{i j}} / \sum \boldsymbol{X}_{w}}
$$

In the equation, " $\mathrm{X}_{\mathrm{ij}}$ " refers to the export volume of commodity $\mathrm{j}$ by country $\mathrm{i}$; " $\mathrm{X}_{\mathrm{i}}$ " refers to the total volume of country $\mathrm{i}$; " $\mathrm{X}_{\mathrm{wj}}$ " referes to the total world export of commodity $\mathrm{j}$. The index value is greater than ' 1 ' indicates the comparative advantage and the value is less than ' 1 ' refers to the comparative disadvantage in the related commodity(Aynagöz Çakmak, 2005).

\subsection{Vollrath Index}

According to Vollrath, the competitiveness calculations of Liesner and Balassa were constrained on the country and commodity axes and were concentrated on the commodities produced and on the developed countries. These researches ignored the low or middle income countries and agricultural products. Furthermore the previous indices take into consideration only the exports but not the imports (Vollrath, 1991). Vollrath (1991) developed the Relative Trade Advantage (RTA) index involving export and import volumes and net trade effect. This index was defined as the difference between Relative Export Advantage (RXA) index and Relative Import Penetration (RMP) index.

The Relative Export Advantage (RXA) index was calculated by the export share of a country on a specific commodity in international markets divided by the total export share of that country in all exported commodities. With this formula, the countries and commodities subjected to the analysis were not included in the total volume of the world export in order to avoid double counting and the Relative Export Advantage (RXA) index is defined as below (Frohberg and Hartmann, 1997):

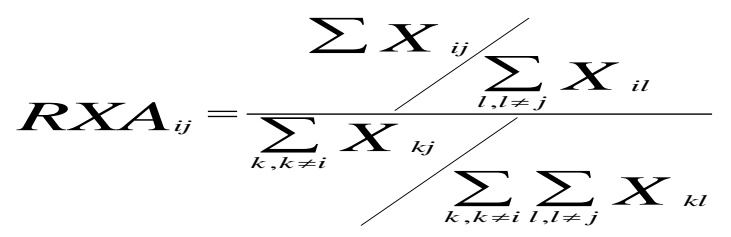

In the formula, "X" refers to the export, " $\mathrm{i}$ " and " $\mathrm{k}$ " refers to the commodity categories, " $\mathrm{j}$ " and "l" refers to the countries subject to the analysis. The index value is greater than ' 1 ' indicates that the country in the related commodity owns the comparative advantage and the index value is less than ' 1 ' indicates comparative disadvantage.

Relative Import Penetration (RMP) index is formulated in a similar way with the relative export advantage, but the main difference is, export is replaced with import and it is interpreted as export's as in an opposite way. Consequently, a value greater than ' 1 ' refers to a relative disadvantage while the value less than ' 1 ' refers to relative advantage. (Aktan and Vural, 2004). Relative Import Penetration (RMP) index is formulated as below (Frohberg and Hartmann, 1997):

$$
\boldsymbol{R M P} \boldsymbol{P}_{i j}=\frac{\sum \boldsymbol{M}^{i j} / \sum_{l, l \neq j} M_{i l}}{\sum_{k, k \neq i} \boldsymbol{M}_{k j} / \sum_{k, k \neq i} \sum_{l, l \neq j} M_{k l}}
$$

Relative Trade Advantage (RTA) index is defined as the difference between Relative Export Advantage (RXA) index and Relative Import Penetration (RMP) index. Because of the Relative Export and Relative Import values being weighted in this index, marginal values of export and import levels do not make an important effect on the index, and the index is formulated as the following (Frohberg and Hartmann, 1997:8):

$$
R T A_{i j}=R X A_{i j}-R M P_{i j}
$$

The positive value of the index refers to comparative advantage, and negative value refers to comparative disadvantage (Aktan and Vural, 2004).

Relative Competitiveness (RC) index is defined as below, and the negative value of RC refers to comparative disadvantage and positive value of RC refers to comparative advantage (Utkulu and Seymen, 2004:11):

$$
R C=\operatorname{In} R X A-\operatorname{In} R M P
$$




\section{Literature Survey}

Utkulu and Seymen (2004), Erlat and Erlat (2005), and Küçükkiremitçi (2006) calculated the competitiveness of Turkey in different sectors and automotive sector was among these sectors. Utkulu and Seymen (2004) calculated the competitiveness of Turkey against European Union (EU) within the international trade and bilateral trade contexts for before and after the customs union agreement between Turkey and EU, using EUROSTAT and Undersecretariat of Foreign Trade statistics via Relative Trade Advantage (RTA) index, Relative Export Advantage (RXA) index and Relative Competitiveness (RC) index. Automotive sector was not competitive in either periods. Erlat and Erlat (2005) calculated the international competitiveness of Turkey and EU-15 for 1990-2000 period using UNCTAD-ITC and OECD statistics via Revealed Comparative Advantage (RCA) index. The Revealed Comparative Advantage (RCA) index for the "road vehicles" was 1.60 for the whole period; 1.39 for the first eight years and 2.15 for the last three years. According to the outcomes, after 1997 an important progress in "road vehicles" was earned. Küçükkiremitçi (2006) calculated the competitiveness in 130 sectors subject to foreign trade was calculated for the period 1995-2005 using Turkey Statistical Institute via Revealed Comparative Advantage (RCA) index. The outcomes indicated that the "Road Vehicles and Motors" sector competitiveness index increased both in the whole period and the last three years.

Bekmez and Komut (2006), Kaya and Altın (2008), Başkol (2011), and Özdamar and Albeni (2011) in their researches calculated the competitiveness of Turkish Automotive Sector. Bekmez and Komut (2006) calculated Turkish Automotive Sector competitiveness against EU-15 for the period 1995-2004 using OECD and WTO data via Revealed Comparative Advantage (RCA) index. For the period 1995-2000, Turkish Automotive Industry was net importer while in 2001 and 2002 the index signaled that Turkey increases her competitiveness against EU-15 countries. Although in 2003 and in 2004 the value of the index decreased, still kept on marginal level. Kaya and Altın (2008) calculated the competitiveness of Turkish Machine and Transportation Equipment sector in EU market and international markets using UN-COMTRADE data and Balassa index for the period 1994-2005. In global markets, the index value for the sub commodity group with SITC code 78 (Road Vehicles) moved from 0.28 in 1994 to 1.55 in 2005 and stayed greater than ' 1 ' after 2003. In EU market, the index value for the mentioned sector moved from 0.25 in 1994 to 1.15 in 2005 and stayed greater than ' 1 ' after 2004. Başkol (2011) calculated the competitiveness of Turkish Automotive Sector in global markets via several indices including Revealed Comparative Advantages (RCA) index for the period 1996-2010 using the data from Chamber of Automotive Manufacturers and Turkish Statistics Institute. According to the index values, automotive sector did not have comparative advantage between 1996 and 1998, and index value increased after 1999 except for 2009 and 2010. For the period 2003-2010 the index value was greater than ' 1 ' and it referred to the comparative advantage. The index value moved from 0.39 in 1996 to 1.77 in 2010. Özdamar and Albeni (2011), calculated the competitiveness of Turkish Automotive Sector in global markets via several indexes developed on the Balassa index and using UN-COMTRADE data for the period 1990-2008. The research included the passenger car sector with 781 code in SITC Rev.3, goods and specialised vehicles with 782 code in SITC Rev.3, and road motor vehicles n.e.s. with 783 code in SITC Rev.3. Turkish Automotive Sector achieved comparative advantage in group 781 after 2002, in group 782 after 2000 and in group 783 after 1994.

Freinkman et al. (2004), Ahrend (2006), Cooper (2006), Shelburne and Pidufala (2006), Garanina (2008), and Khatibi (2008) were among the researches measuring the international competitiveness of different countries and different sectors for the Commonwealth of Independent Countries. Freinkman et al. (2004) calculated the competitiveness of the CIS countries within the CIS market and global market using WITS and COMTRADE data for the year 2000 via Revealed Comparative Advantage (RCA) index. For the "road vehicles", Belarus with 3.1 index value, Uzbekistan with 1.1 index value, and Kyrgyz Republic with 1.0 index value, had comparative advantage against other CIS countries. Russia and Ukraine followed these countries with 0.5 index value. However in the global markets, none of the CIS countries were competitive. Ahrend (2006) calculated the competitiveness of Russia for the period 1997-2004 using UN-COMTRADE data and Revealed Comparative Advantage (RCA) index. The Revealed Comparative Advantage (RCA) index in this study was Balassa Index multiplied by 100 . According to the outcome, in "Road Vehicles" main group Russia did not have comparative advantage with the index value moving from -3.7 in 1997 to -9.6 in 2004 . Furthermore, "Road Vehicles" was among the sectors in which Russia had the highest comparative disadvantage. Cooper (2006), calculated the competitiveness of Russia against the selected countries and in the global markets for the period 2000-2004 using UN-COMTRADE data and Balassa index. For the "the passenger car" sector with SITC 781 code the index values of 2004 were 0.06 for Russia, 0.01 for China, 0.17 for India, 0.48 for USA, 0.66 for Brazil and 1.16 for Turkey. According to these values, Turkey had comparative advantage compared to the other countries. In 2004, index values of Russia in global markets were 0.057 for group 781, 0.313 for group 782 and 0.240 for group 783. The index values for sectors with group 782 and 783 increased compared to their 2000 level $(0.142$ and 0.140 respectively) and the index value for the sector with group 781 decreased compared to the 2000 value (0.070). Shelburne and Pidufala (2006), calculated the comparative advantage of the CIS countries within the CIS market and in global markets using 2004 UN-COMTRADE data and Balassa Index in manufacturing industry. In the group 783 Belarus had comparative advantage with 10.9 index value against CIS countries and 
5.3 in the global markets. Garanina (2008), calculated the comparative advantage of Russia for the 1998-2006 period using UN-COMTRADE data and Revealed Comparative Advantage (RCA) index. Although the index value for "Road Vehicles" main commodity group moved from -0.14 in 1998 to 0.26 in 2006, it indicated that Russia could not have comparative advantage in this commodity group against CIS countries. Khatibi (2008), calculated the comparative advantage of Kazakhstan against EU-27 in several sectors using EUROSTAT data and Revealed Comparative Advantage (RCA) index. The index value for "Road Vehicles" main commodity group moved from 0.01 in 1999 to 0.00 between 2000-2006 and indicated that Kazakhstan did not have comparative advantage in this commodity group against EU-27.

\begin{tabular}{|c|c|c|c|c|c|c|c|c|}
\hline & 781 & 781 & 782 & 782 & 783 & 783 & $\begin{array}{l}\text { Total } \\
(781+ \\
782+783)\end{array}$ & $\begin{array}{l}\text { Total } \\
(781+ \\
782+783)\end{array}$ \\
\hline Country & Average & Growth & Average & Growth & Average & Growth & Average & Growth \\
\hline Armenia & 598 & $24 \%$ & 628 & $15 \%$ & 163 & $14 \%$ & 1,389 & $18 \%$ \\
\hline Azerbaijan & 847 & $1 \%$ & 5,470 & $-8 \%$ & 499 & $18 \%$ & 6,816 & $-7 \%$ \\
\hline Belarus & 13,684 & $15 \%$ & 597,587 & $20 \%$ & 207,259 & $37 \%$ & 818,530 & $22 \%$ \\
\hline Georgia & 48,503 & $108 \%$ & 3,674 & $19 \%$ & 1,026 & $51 \%$ & 53,203 & $42 \%$ \\
\hline Kazakhstan & 6,566 & $6 \%$ & 9,872 & $6 \%$ & 1,635 & $2 \%$ & 18,073 & $6 \%$ \\
\hline Kyrgyzstan & 3,518 & $22 \%$ & 10,585 & $29 \%$ & 2,464 & $1 \%$ & 16,567 & $25 \%$ \\
\hline Moldova & 2,110 & $10 \%$ & 508 & $-4 \%$ & 827 & $16 \%$ & 3,446 & $8 \%$ \\
\hline Russia & 474,946 & $-1 \%$ & 500,960 & $8 \%$ & 123,643 & $9 \%$ & $1,099,548$ & $3 \%$ \\
\hline Tajikistan & 935 & $-7 \%$ & 449 & $-8 \%$ & 412 & $-9 \%$ & 1,796 & $-8 \%$ \\
\hline Turkey & $3,153,722$ & $23 \%$ & $1,762,669$ & $33 \%$ & 686,814 & $14 \%$ & $5,603,204$ & $23 \%$ \\
\hline Turkmenistan & 314 & $15 \%$ & 663 & $26 \%$ & 243 & $15 \%$ & 1,219 & $23 \%$ \\
\hline Ukraine & 123,745 & $21 \%$ & 88,376 & $1 \%$ & 29,879 & $4 \%$ & 242,000 & $8 \%$ \\
\hline Uzbekistan & 441,243 & $64 \%$ & 2,561 & $16 \%$ & 2,837 & $19 \%$ & 446,640 & $60 \%$ \\
\hline Turkey and & & & & & & & & \\
\hline CIS Total & $4,270,731$ & $16 \%$ & $2,984,002$ & $18 \%$ & $1,057,701$ & $15 \%$ & $8,312,434$ & $17 \%$ \\
\hline World & $414,953,193$ & $7 \%$ & $79,654,215$ & $7 \%$ & $26,200,536$ & $7 \%$ & $520,807,944$ & $7 \%$ \\
\hline
\end{tabular}

Table 1. Average and Growth Rate of Automotive Sectors Exports of the Countries to Global Markets in thousand dollars, in the Period of 1995-2011, annually. Source: Calculated by authors from unctadstat.unctad.org.

Filiztekin and Karaata (2010) and Karaalp (2011) calculated the comparative advantage of Turkey against CIS market. Filiztekin and Karaata (2010) calculated comparative advantage of Turkey on different sectors and automotive sector was among these sectors and "Motor road vehicles" commodity group was analyzed through Relative Export Advantage (RXA) index. Turkey and Russia were involved in the analysis. The Relative Export Advantage (RXA) index of Turkey was volatile for 1995-1997 but continuously increased for 1998-2008 and reached over the average of the other countries. The index value of Turkey moved from 0.37 in 1995 to 1.09 in 2003 and to 1.68 in 2008. Namely, Turkey had comparative advantage in "Motor Road Vehicles" commodity group in 2003 and after. The index value of Russia was 0.10 for the period 2004-2008 and this indicated that Russia did not have comparative advantage in this sector. Karaalp (2011), calculated the comparative advantage of Turkey against CIS and in global markets for several sectors using 1996-2008 WTO data and several indices including Balassa Index. The Balassa Index indicating the comparative advantage of Turkish Automotive Industry in the global markets moved from 0.37 in 1996 to 1.76 in 2008. Balassa Index value showed that comparative advantage of Turkish Automotive Industry accelerated from 1999 on and after 2003 this movement was more apparent. Furthermore Turkey was more competitive against CIS. The Balassa index of Turkish Automotive Industry against CIS was greater than 2.00 after 2000.

Automotive Trade between Turkey and Commonwealth of Independent States

For the 1995-2011 period among Turkey and CIS countries exporting group 781 to the global markets, Turkey (\$ 3,153,722 thousand), Russia ( \$ 474, 946 thousand) and Uzbekistan (\$ 441,243 thousand) were the first three countries. Uzbekistan increased its group781 export rapidly. Within the same period, the export of Russia declined. Turkey had a stable increase in export volume (23\%) although not as high as Uzbekistan (64 \%) and Georgia (108\%) (Table 1).

Within the same period, the first three countries exporting group 782 such as trucks and pickups were Turkey (\$ 1,762,669 thousand), Belarus ( $\$ 597,587$ thousand) and Russia (\$ 500,960 thousand) (Table 1).

Turkey had the highest level of increase in group 782 exports within this period (33\%). Kyrgyz Republic (29 $\%)$ and Turkmenistan (26\%) were the second and the third. The export volume growth of Belarus $(20 \%)$ for the group 782 seems to be reasonable but the export volume growth of Russia (8\%) was not satisfactory for such an important producer (Table 1). 
Within the same period, the first three countries exporting group 783 to the global markets were Turkey (\$ 686,814 thousand), Belarus (\$207,259 thousand) and Russia (\$123,643 thousand) as in the group 782 exports. When the growth of exports in group 783 was analyzed, Georgia (51\%), Belarus (37\%) and Uzbekistan (19\%) had highest growth rates. Although Turkey (14\%) and Russia (9\%) increased their volume of exports, were

falling behind the average export growth of the total of Turkey and CIS countries (Table 1).

Within the same period, the first three countries exporting road vehicles $(781+782+783)$ to the global markets were Turkey ( $\$ 5,603,204$ thousand), Russia ( $\$ 1,099,548$ thousand) and Belarus $(\$ 818,530$ thousand). The leading countries in intra industry export volume increased among the mentioned countries in road vehicles $(781+782+783)$ were Uzbekistan $(60 \%)$, Georgia (42 \%) and Kyrgyz Republic (25\%). Turkey (23\%) and Belarus $(22 \%)$ increased their volume of exports above the average of the total of Turkey and CIS countries (15 $\%)$ in road vehicles $(781+782+783)$. Russian export in road vehicles $(781+782+783)$ increased by $(8 \%)$ and this ratio was under the average (Table 1$)$.

For the 1995-2011 period, when the share of the related Turkey and CIS countries' export in total world export to Turkey and CIS countries for the group 781 was analyzed $(781 \mathrm{CXW})$, the first three countries with the highest share were Uzbekistan $(2.7 \%)$, Russia $(2.5 \%)$ and Turkey $(1.3 \%)$. The share of the total exports of Turkey and CIS countries to their market, to the world total exports to their market in group 781 was $7.4 \%$. The first three countries with the highest export volume, the share of their exports to Turkey and CIS countries to their world export in group 781 were, Uzbekistan 99\%, Russia $54 \%$ and Turkey 8\% (Table 2).

Within the same period in group 782 exports, the share of the related Turkey and CIS countries' exports to all Turkey and CIS countries (782 CXW), Belarus (18.3\%), Ukraine $(2.3 \%)$ and Russia $(8.8 \%)$ had the highest shares (Table 2).

Turkey $(1.4 \%)$ was the fourth in group 782 exports within Turkey and CIS countries. The share of group 782 exports among Turkey and CIS countries to the total exports to their countries was $31.7 \%$. For the first four countries with the highest export volume of 782 exports, the shares of their Turkey and CIS countries exports of their total exports were for Belarus $89 \%$, for Ukraine $67 \%$, for Russia $54 \%$ and for Turkey 7\% (Table 2).

Within the same period, in group 783 exports, the share of the related Turkey and CIS countries' exports to all Turkey and CIS countries (783 CXW), Belarus (11.2\%), Russia (4.5\%) and Turkey (3.7 \%) had highest share rates. Ukraine $(1.8 \%)$ was the fourth in group 782 exports in Turkey and CIS countries. The ratio of group 783 exports of Turkey and CIS countries to each other to the world export to Turkey and CIS countries was $21.8 \%$. For the first four countries with the highest export volume of group 783 exports, the shares of their Turkey and CIS countries exports to their total exports were for Belarus $86 \%$, for Russia $63 \%$, for Turkey $13 \%$ and for Ukraine $86 \%$ (Table 2).

\begin{tabular}{|c|c|c|c|c|c|c|c|c|}
\hline Countries & $\begin{array}{l}781 \\
\text { CXW }\end{array}$ & $\begin{array}{l}781 \\
\text { Shares }\end{array}$ & $\begin{array}{l}782 \\
\text { CXW }\end{array}$ & $\begin{array}{l}782 \\
\text { Shares }\end{array}$ & $\begin{array}{l}783 \\
\text { CXW }\end{array}$ & $\begin{array}{l}783 \\
\text { Shares }\end{array}$ & $\begin{array}{l}\text { Total }(781+782+783) \\
\text { CXW }\end{array}$ & $\begin{array}{l}\text { Total }(781+782+783) \\
\text { Shares }\end{array}$ \\
\hline Armenia & 0.00 & $41 \%$ & 0.02 & $58 \%$ & 0.00 & $46 \%$ & 0.01 & $49 \%$ \\
\hline Azerbaijan & 0.01 & $68 \%$ & 0.26 & $90 \%$ & 0.02 & $74 \%$ & 0.07 & $84 \%$ \\
\hline Belarus & 0.18 & $80 \%$ & 18.31 & $89 \%$ & 11.16 & $86 \%$ & 5.13 & $89 \%$ \\
\hline Georgia & 0.16 & $83 \%$ & 0.09 & $86 \%$ & 0.03 & $59 \%$ & 0.14 & $87 \%$ \\
\hline Kazakhstan & 0.06 & $87 \%$ & 0.25 & $70 \%$ & 0.09 & $80 \%$ & 0.10 & $76 \%$ \\
\hline Kyrgyzstan & 0.03 & $89 \%$ & 0.19 & $81 \%$ & 0.21 & $75 \%$ & 0.08 & $79 \%$ \\
\hline Moldova & 0.01 & $63 \%$ & 0.01 & $42 \%$ & 0.02 & $37 \%$ & 0.01 & $53 \%$ \\
\hline Russia & 2.48 & $54 \%$ & 8.82 & $54 \%$ & 4.51 & $63 \%$ & 3.90 & $52 \%$ \\
\hline Tajikistan & 0.00 & $51 \%$ & 0.00 & $54 \%$ & 0.04 & $99 \%$ & 0.01 & $57 \%$ \\
\hline Turkey & 1.27 & $8 \%$ & 1.35 & $7 \%$ & 3.66 & $13 \%$ & 1.61 & $9 \%$ \\
\hline Turkmenistan & 0.00 & $47 \%$ & 0.02 & $79 \%$ & 0.01 & $69 \%$ & 0.01 & $61 \%$ \\
\hline Ukraine & 0.47 & $80 \%$ & 2.34 & $67 \%$ & 1.81 & $86 \%$ & 1.06 & $78 \%$ \\
\hline Uzbekistan & 2.71 & $99 \%$ & 0.07 & $91 \%$ & 0.22 & $86 \%$ & 1.94 & $99 \%$ \\
\hline Turkey and & & & & & & & & \\
\hline CIS Total & 7.38 & $26 \%$ & 31.74 & $46 \%$ & 21.78 & $37 \%$ & 14.05 & $35 \%$ \\
\hline World & 100.00 & $3 \%$ & 100.00 & $4 \%$ & 100.00 & $6 \%$ & 100.00 & $3 \%$ \\
\hline
\end{tabular}

Table 2. Averages Shares of the Countries' Automotive Exports in the World Total Automotive Exports to Turkey and the CIS Countries (CXW) and Shares of the Countries Exports in Turkey and the CIS Countries to the all over the World of Automotive Sectors (Shares) in the Period of 1995-2011, annually. Source: Calculated by authors from unctadstat.unctad.org.

For the 1995-2011 period, in total road vehicles $(781+782+783)$ exports, the share of the related Turkey and CIS countries' exports to all Turkey and CIS countries (780 CXW), Belarus (5.1 \%), Russia (3.9 \%) and Uzbekistan $(1.9 \%)$ had the highest shares. Turkey $(1.6 \%)$ is the fourth after them. The ratio of 783 group exports of Turkey and CIS countries to each other to the world export to themselves was $14.1 \%$. For the first 
four countries with the highest export volume of 783 exports, the shares of their Turkey and CIS countries exports to their total exports were for Belarus $89 \%$, for Russia $52 \%$, for Uzbekistan $99 \%$ and for Turkey $9 \%$. (Table 2).

\begin{tabular}{|c|c|c|c|c|c|c|c|c|c|c|c|c|c|c|c|c|}
\hline \multirow[t]{3}{*}{ Rank } & \multirow{3}{*}{$\begin{array}{l}\text { For } \\
781\end{array}$} & RCA & For & \multirow{3}{*}{$\begin{array}{l}\text { RCAL } \\
\text { Gwt }\end{array}$} & \multirow{3}{*}{$\begin{array}{l}\text { For } \\
781\end{array}$} & \multirow{3}{*}{$\begin{array}{l}\text { RC } \\
\text { A } \\
\text { Avr }\end{array}$} & \multirow{2}{*}{$\begin{array}{l}\text { For } \\
781 \\
\end{array}$} & \multirow{3}{*}{$\begin{array}{l}\text { RC } \\
\text { A } \\
\text { Gwt }\end{array}$} & \multirow{3}{*}{$\begin{array}{l}\text { For } \\
781\end{array}$} & \multirow{3}{*}{$\begin{array}{l}\text { RT } \\
\text { A } \\
\text { Avr }\end{array}$} & \multirow{3}{*}{$\begin{array}{l}\text { For } \\
781 \\
\end{array}$} & RT & For & & For & \\
\hline & & $\mathrm{L}$ & 781 & & & & & & & & & A & 781 & $\mathrm{RC}$ & 781 & $\mathrm{RC}$ \\
\hline & & Avr & & & & & & & & & & Gwt & & Avr & & Gwt \\
\hline 1 & Uzb & 0.0 & Geo & 0.7 & Uzb & 2.7 & Geo & 0.7 & Uzb & 2.3 & Uzb & 1.6 & Uzb & 1.5 & Geo & 1.8 \\
\hline 2 & Rus & 0.0 & Uzb & 0.4 & Geo & 1.1 & Uzb & 0.3 & Geo & 0.9 & Geo & 1.5 & Tur & 1.0 & Uzb & 1.8 \\
\hline 3 & Tur & 0.0 & Tur & 0.0 & Tur & 0.7 & Arm & 0.1 & Tur & 0.2 & Tur & 1.5 & Geo & -0.4 & Tur & 1.6 \\
\hline 4 & Ukr & 0.0 & Krg & 0.0 & Rus & 0.2 & Ukr & 0.0 & Bel & 0.0 & Ukr & 0.1 & Bel & -1.0 & Azr & 0.1 \\
\hline 5 & Bel & 0.0 & Ukr & 0.0 & $\mathrm{Krg}$ & 0.2 & $\mathrm{Krg}$ & 0.0 & Mol & -0.4 & Arm & 0.1 & $\mathrm{Krg}$ & -1.6 & Ukr & 0.0 \\
\hline 6 & Geo & 0.0 & Arm & 0.0 & Ukr & 0.1 & Tur & 0.0 & $\mathrm{Krg}$ & -0.5 & Azr & 0.0 & Rus & -2.4 & Taj & 0.0 \\
\hline 7 & Kzk & 0.0 & Bel & 0.0 & Mol & 0.1 & Mol & 0.0 & Tkm & -0.6 & $\mathrm{Krg}$ & 0.0 & Ukr & -2.5 & Kzk & 0.0 \\
\hline 8 & $\mathrm{Krg}$ & 0.0 & Mol & 0.0 & Bel & 0.1 & Bel & 0.0 & Taj & -0.6 & Kzk & 0.0 & Mol & -2.5 & Arm & 0.0 \\
\hline 9 & Azr & 0.0 & Tkm & -0.1 & Azr & 0.0 & Tkm & 0.0 & Ukr & -0.6 & Mol & -0.1 & Kzk & -4.0 & Tkm & 0.0 \\
\hline 10 & Mol & 0.0 & Rus & -0.1 & Arm & 0.0 & Rus & 0.0 & Kzk & -1.6 & Taj & -0.1 & Taj & -4.5 & $\mathrm{Krg}$ & 0.0 \\
\hline 11 & Arm & 0.0 & Kzk & -0.1 & Kzk & 0.0 & Kzk & -0.1 & Rus & -2.2 & $\mathrm{Tkm}$ & -0.1 & Arm & -5.0 & Mol & 0.0 \\
\hline 12 & Taj & 0.0 & Azr & -0.2 & Taj & 0.0 & Taj & -0.2 & Azr & -2.6 & Bel & -0.6 & Azr & -5.2 & Bel & -0.6 \\
\hline 13 & Tkm & 0.0 & Taj & -0.2 & Tkm & 0.0 & Azr & -0.2 & Arm & -3.7 & Rus & -0.6 & Tkm & -6.3 & Rus & -0.6 \\
\hline Rank & For & RCA & For & & For & $\mathrm{RC}$ & For & $\mathrm{RC}$ & For & $\mathrm{RT}$ & For & RT & For & & For & \\
\hline & 782 & $\mathrm{~L}$ & 782 & RCAL & 782 & A & 782 & A & 782 & A & 782 & A & 782 & $\mathrm{RC}$ & 782 & $\mathrm{RC}$ \\
\hline & & Avr & & Gwt & & Avr & & Gwt & & Avr & & Gwt & & Avr & & Gwt \\
\hline 1 & Bel & 0.3 & Tkm & 0.4 & Bel & 6.3 & Tkm & 0.9 & Bel & 6.6 & $\mathrm{Krg}$ & 1.7 & Bel & 5.4 & $\mathrm{Krg}$ & 1.5 \\
\hline 2 & Rus & 0.1 & Tur & 0.1 & Krg & 0.9 & $\mathrm{Krg}$ & 0.1 & Tur & 0.6 & Tur & 0.1 & Tur & 2.4 & Rus & 0.1 \\
\hline 3 & Ukr & 0.0 & Krg & 0.1 & Azr & 0.9 & Tur & 0.1 & Geo & -0.1 & Rus & 0.1 & Geo & -0.3 & Mol & 0.1 \\
\hline 4 & Tur & 0.0 & Bel & 0.0 & Tur & 0.7 & Bel & 0.0 & $\mathrm{Krg}$ & -0.2 & Arm & 0.0 & $\mathrm{Krg}$ & -0.5 & Ukr & 0.1 \\
\hline 5 & Azr & 0.0 & Geo & 0.0 & Rus & 0.7 & Arm & 0.0 & Mol & -0.3 & Bel & 0.0 & Ukr & -1.0 & Tur & 0.0 \\
\hline 6 & Kzk & 0.0 & Uzb & 0.0 & Geo & 0.6 & Geo & 0.0 & Ukr & -0.8 & $\mathrm{Tkm}$ & 0.0 & Azr & -1.5 & Bel & 0.0 \\
\hline 7 & $\mathrm{Krg}$ & 0.0 & Arm & 0.0 & Ukr & 0.5 & Uzb & 0.0 & Taj & -1.0 & Mol & 0.0 & Rus & -1.7 & Taj & 0.0 \\
\hline 8 & Geo & 0.0 & Kzk & -0.1 & Arm & 0.2 & Rus & -0.1 & Azr & -1.1 & Ukr & 0.0 & Mol & -2.4 & Arm & 0.0 \\
\hline 9 & Uzb & 0.0 & Rus & -0.1 & Kzk & 0.1 & Kzk & -0.1 & Arm & -2.1 & Uzb & -0.1 & Arm & -2.9 & Kzk & 0.0 \\
\hline 10 & Tkm & 0.0 & Ukr & -0.1 & Uzb & 0.1 & Ukr & -0.1 & Uzb & -2.5 & Kzk & -0.1 & Kzk & -3.2 & Uzb & 0.0 \\
\hline 11 & Arm & 0.0 & Taj & -0.2 & Mol & 0.0 & Taj & -0.1 & Kzk & -2.8 & Taj & -0.1 & Taj & -4.1 & Tkm & -0.1 \\
\hline 12 & Mol & 0.0 & Mol & -0.2 & $\mathrm{Tkm}$ & 0.0 & Mol & -0.2 & Rus & -3.1 & Geo & -0.5 & Uzb & -4.3 & Geo & -0.5 \\
\hline 13 & Taj & 0.0 & Azr & -0.2 & Taj & 0.0 & Azr & -0.3 & Tkm & -5.6 & Azr & -0.6 & Tkm & -6.4 & Azr & -0.6 \\
\hline Rank & For & RCA & For & & For & $\mathrm{RC}$ & For & $\mathrm{RC}$ & For & RT & For & RT & For & & For & \\
\hline & 783 & $\begin{array}{l}\mathrm{L} \\
\text { Avr }\end{array}$ & 783 & $\begin{array}{l}\text { RCAL } \\
\text { Gwt }\end{array}$ & 783 & $\begin{array}{l}\text { A } \\
\text { Avr }\end{array}$ & 783 & $\begin{array}{l}\text { A } \\
\text { Gwt }\end{array}$ & 783 & $\begin{array}{l}\text { A } \\
\text { Avr }\end{array}$ & 783 & $\begin{array}{l}\text { A } \\
\text { Gwt }\end{array}$ & 783 & $\begin{array}{l}\text { RC } \\
\text { Avr }\end{array}$ & 783 & $\begin{array}{l}\mathrm{RC} \\
\text { Gwt }\end{array}$ \\
\hline 1 & Bel & 0.1 & Uzb & 0.7 & Bel & 4.0 & Geo & 1.3 & Bel & 3.8 & Bel & 1.6 & Bel & 4.3 & Bel & 1.8 \\
\hline 2 & Rus & 0.1 & Geo & 0.6 & Tur & 2.0 & Uzb & 1.2 & Tur & 1.9 & Taj & 0.2 & Tur & 4.3 & Taj & 0.2 \\
\hline 3 & Tur & 0.0 & Tkm & 0.3 & $\mathrm{Krg}$ & 1.2 & Tkm & 1.1 & $\mathrm{Krg}$ & 0.3 & Geo & 0.1 & $\mathrm{Krg}$ & -0.7 & Ukr & 0.1 \\
\hline 4 & Ukr & 0.0 & Bel & 0.3 & Ukr & 0.4 & Bel & 0.3 & Ukr & -0.5 & Mol & 0.1 & Ukr & -0.8 & Azr & 0.1 \\
\hline 5 & $\mathrm{Krg}$ & 0.0 & Tur & 0.0 & Rus & 0.3 & Arm & 0.0 & Mol & -0.8 & Azr & 0.1 & Taj & -2.3 & Mol & 0.1 \\
\hline 6 & Uzb & 0.0 & Arm & -0.1 & Uzb & 0.2 & Tur & 0.0 & Geo & -0.8 & Ukr & 0.1 & Rus & -2.4 & Tur & 0.0 \\
\hline 7 & Kzk & 0.0 & Rus & -0.1 & Taj & 0.2 & Rus & 0.0 & Taj & -1.0 & Arm & 0.1 & Mol & -2.5 & Kzk & 0.0 \\
\hline 8 & Taj & 0.0 & Ukr & -0.1 & Geo & 0.2 & Ukr & -0.1 & Azr & -1.5 & Rus & 0.0 & Geo & -4.0 & Arm & 0.0 \\
\hline 9 & Geo & 0.0 & Krg & -0.1 & Mol & 0.1 & Mol & -0.1 & Arm & -1.5 & Kzk & 0.0 & Kzk & -4.0 & Rus & 0.0 \\
\hline 10 & Azr & 0.0 & Kzk & -0.1 & Arm & 0.1 & Kzk & -0.1 & Kzk & -2.1 & $\mathrm{Tkm}$ & 0.0 & Arm & -4.0 & $\mathrm{Krg}$ & 0.0 \\
\hline 11 & Mol & 0.0 & Azr & -0.1 & Azr & 0.1 & $\mathrm{Krg}$ & -0.1 & Uzb & -2.2 & Tur & 0.0 & Uzb & -4.1 & Tkm & -0.1 \\
\hline 12 & Tkm & 0.0 & Mol & -0.2 & Kzk & 0.0 & Taj & -0.1 & Tkm & -2.5 & $\mathrm{Krg}$ & -0.1 & Azr & -4.3 & Geo & -0.1 \\
\hline 13 & Arm & 0.0 & Taj & -0.2 & $\mathrm{Tkm}$ & 0.0 & Azr & -0.4 & Rus & -3.1 & $\mathrm{Uzb}$ & -0.2 & Tkm & -6.5 & Uzb & -0.2 \\
\hline Rank & For & RCA & & RCA & & $\mathrm{RC}$ & & $\mathrm{RC}$ & & RT & & RT & & & For & \\
\hline & RV. & $\begin{array}{l}\mathrm{L} \\
\text { Avr }\end{array}$ & For RV & $\begin{array}{l}\text { L } \\
\text { Gwt }\end{array}$ & For RV & $\begin{array}{l}\text { A } \\
\text { Avr }\end{array}$ & For RV & $\begin{array}{l}\text { A } \\
\text { Gwt }\end{array}$ & For RV & $\begin{array}{l}\text { A } \\
\text { Avr }\end{array}$ & For RV & $\begin{array}{l}\text { A } \\
\text { Gwt }\end{array}$ & For RV & $\begin{array}{l}\mathrm{RC} \\
\text { Avr }\end{array}$ & RV & $\begin{array}{l}\text { RC } \\
\text { Gwt }\end{array}$ \\
\hline 1 & Bel & 0.1 & $\overline{\mathrm{Uzb}}$ & 0.4 & Uzb & 1.9 & $\mathrm{Uzb}$ & 0.3 & Bel & 1.7 & Uzb & 1.6 & Bel & 3.7 & $\overline{\mathrm{Uzb}}$ & 1.7 \\
\hline 2 & Rus & 0.0 & Geo & 0.2 & Bel & 1.7 & Tkm & 0.2 & Tur & 0.6 & $\mathrm{Krg}$ & 1.5 & Tur & 1.7 & Geo & 1.5 \\
\hline 3 & Uzb & 0.0 & Tkm & 0.1 & Geo & 1.0 & Geo & 0.2 & Uzb & 0.5 & Geo & 1.5 & Uzb & 0.0 & $\mathrm{Krg}$ & 1.4 \\
\hline 4 & Tur & 0.0 & $\mathrm{Krg}$ & 0.1 & Tur & 0.9 & $\mathrm{Krg}$ & 0.1 & Geo & 0.5 & Rus & 0.1 & Geo & -0.1 & Tur & 0.2 \\
\hline 5 & Ukr & 0.0 & Bel & 0.0 & $\mathrm{Krg}$ & 0.4 & Bel & 0.0 & Mol & -0.4 & Tur & 0.1 & $\mathrm{Krg}$ & -0.9 & Azr & 0.2 \\
\hline 6 & Geo & 0.0 & Tur & 0.0 & Rus & 0.3 & Arm & 0.0 & $\mathrm{Krg}$ & -0.4 & Arm & 0.1 & Ukr & -1.5 & Rus & 0.1 \\
\hline 7 & Kzk & 0.0 & Arm & -0.1 & Ukr & 0.2 & Tur & 0.0 & Ukr & -0.8 & Azr & 0.1 & Mol & -2.3 & Ukr & 0.1 \\
\hline 8 & $\mathrm{Krg}$ & 0.0 & Ukr & -0.1 & Azr & 0.2 & Mol & 0.0 & Taj & -0.8 & Bel & 0.1 & Rus & -2.4 & Taj & 0.0 \\
\hline 9 & Azr & 0.0 & Mol & -0.1 & Arm & 0.1 & Rus & 0.0 & Azr & -2.1 & Ukr & 0.0 & Azr & -3.2 & Bel & 0.0 \\
\hline 10 & Mol & 0.0 & Rus & -0.1 & Mol & 0.1 & Ukr & -0.1 & Kzk & -2.1 & Tkm & 0.0 & Kzk & -3.8 & Kzk & 0.0 \\
\hline 11 & Taj & 0.0 & Kzk & -0.1 & Kzk & 0.1 & Kzk & -0.1 & Tkm & -2.7 & Mol & 0.0 & Taj & -3.9 & Arm & 0.0 \\
\hline 12 & Arm & 0.0 & Taj & -0.2 & Taj & 0.0 & Taj & -0.2 & Rus & -2.8 & Kzk & 0.0 & Arm & -3.9 & Mol & 0.0 \\
\hline 13 & Tkm & 0.0 & Azr & -0.2 & Tkm & 0.0 & Azr & -0.3 & Arm & -2.9 & Taj & -0.1 & Tkm & -6.6 & Tkm & 0.0 \\
\hline
\end{tabular}

Table 3. Average Ranks and Comparative Advantage Indices of Turkey and CIS Countries in the Period of 1995 2011 in Automotive Sector Source: Calculated by authors from unctadstat.unctad.org. 


\section{The Comparative Advantages of Turkey and Commonwealth of Independent States in their Automotive Market}

In order to assess the international competitiveness of Turkey and CIS countries in their automotive market, the four main indices Liesner (RCAL), Balassa (RCA), Relative Trade Advantage Index (RTA) and Relative Competitiveness Index (RC) are calculated. The average (Avr) of these indices for the 1995-2011 period and for the same period the annual average growth rates (Gwt) of these countries are summarized in Table 3. Automotive sector is analyzed in line with the Standard International Trade Code (SITC) Revision 3 with the codes 781, 782, 783 and Road Vehicles $(781+782+783)$. In table 3 the countries are ranked according to their competitiveness in a descending order. The point of focus in the analysis is the share of the countries' exports in Turkey and CIS automotive market. The main automotive manufacturing countries are Russia, Turkey, Belarus, Ukraine, Uzbekistan (Table 3).

In group 781, Uzbekistan has the highest values in all four indices. Georgia follows Uzbekistan. For Georgia, only the RC value is negative but even it increased highly within the period. This continuous increase may take the country to a higher position in RC as well. Turkey is the third country following Georgia in all four indices. The RCAL and RCA values of Russia are high but the RTA and RC values indicate comparative disadvantage. Ukraine has similar values with Russia but all values are increasing which gives an opportunity to increase competitiveness. RCAL and RCA values for Belarus indicate a moderate competitiveness. RTA is high but the decline in RTA indicates a losing comparative advantage (Table 3).

In group 782, Belarus has the highest values in all four indices. Turkey is the second when all four indices are taken into consideration. Russia holds the highest RCAL and RCA values but they are declining and instable. Moreover, Russia has lower values in RTA and RC. Ukraine is parallel with Russia as in 781 group (Table 3).

In group 783, Belarus has the highest values in all four indices. Turkey is the second when all four indices are taken into consideration. Russia has the highest RCAL and RCA values but has comparative disadvantage in RTA and RC. The level of comparative advantage of Ukraine is higher than Russia in group 783. However, RCAL and RCA values of Ukraine are in a decreasing trend (Table 3 ).

In road vehicles $(781+782+783)$, Uzbekistan has the highest values in all four indices. The main reason of this result for Uzbekistan is the highest comparative advantage in group 781. Due to the increasing automotive production, Uzbekistan achieved a high performance in automotive industry between 1995-2011 and became an exporter rapidly while Uzbekistan previously was an importer. Belarus is the second after Uzbekistan. Turkey is close to Belarus in all four indices. Russia has positive values except RTA and has values in the other three indices indicating moderate comparative advantage. Ukraine is parallel with Russia (Table 3).

The relation of four indices with each other, average Spearman rank correlation coefficient is shown in Table 4. The relation rank correlation coefficient averages for all four indices group 781, group 782, group 783 and Road Vehicles $(781+782+783)(\mathrm{RV})$ are as follows:

Under each coefficient, the number of significant coefficients of 17 years for $1 \%$ and $5 \%$ significance levels are indicated. For example in 781 group, the relation between RCA and RCAL is 16 out of 17. As seen in the table, there is high rank correlation between RCAL and RCA for all four groups. Neither RCAL nor RCA has a rank correlation with RTA except for Road Vehicles. RC has a significant and high rank correlation with the three other indices for each sectors.

\begin{tabular}{|c|c|c|c|c|c|c|c|c|c|}
\hline For 781 & RCAL & RCA & RTA & $\mathrm{RC}$ & For 782 & RCAL & RCA & RTA & $\mathrm{RC}$ \\
\hline RCAL & 1,000 & & & & RCAL & 1,000 & & & \\
\hline \multirow[t]{2}{*}{ RCA } & 0,826 & \multirow[t]{2}{*}{1,000} & & & \multirow[t]{2}{*}{ RCA } & 0,825 & \multirow[t]{2}{*}{1,000} & & \\
\hline & $16 / 17$ & & & & & $17 / 17$ & & & \\
\hline \multirow[t]{2}{*}{ RTA } & 0,290 & 0,284 & \multirow[t]{2}{*}{1,000} & & \multirow[t]{2}{*}{ RTA } & 0,319 & 0,513 & 1,000 & \\
\hline & $0 / 17$ & $0 / 17$ & & & & $1 / 17$ & $5 / 17$ & & \\
\hline \multirow[t]{2}{*}{$\mathrm{RC}$} & 0,763 & 0,817 & 0,639 & \multirow[t]{2}{*}{1,000} & \multirow[t]{2}{*}{$\mathrm{RC}$} & 0,689 & 0,834 & 0,808 & \multirow[t]{2}{*}{1,000} \\
\hline & $17 / 17$ & $17 / 17$ & $13 / 17$ & & & $14 / 17$ & $17 / 17$ & $17 / 17$ & \\
\hline For 783 & RCAL & RCA783 & RTA783 & RC783 & For RV & RCAL & RCA & RTA & $\mathrm{RC}$ \\
\hline RCAL & 1,000 & & & & RCAL & 1,000 & & & \\
\hline \multirow[t]{2}{*}{ RCA } & 0,884 & \multirow[t]{2}{*}{1,000} & & & \multirow[t]{2}{*}{$\mathrm{RCA}$} & 0,820 & \multirow[t]{2}{*}{1,000} & & \\
\hline & $17 / 17$ & & & & & $17 / 17$ & & & \\
\hline \multirow[t]{2}{*}{ RTA } & 0,340 & 0,494 & 1,000 & & \multirow[t]{2}{*}{ RTA } & 0,416 & 0,635 & 1,000 & \\
\hline & $1 / 17$ & $5 / 17$ & & & & $3 / 17$ & $12 / 17$ & & \\
\hline \multirow[t]{2}{*}{$\mathrm{RC}$} & 0,762 & 0,902 & 0,726 & \multirow[t]{2}{*}{1,000} & \multirow[t]{2}{*}{$\mathrm{RC}$} & 0,719 & 0,890 & 0,823 & \multirow[t]{2}{*}{1,000} \\
\hline & $14 / 17$ & $17 / 17$ & $17 / 17$ & & & $17 / 17$ & $17 / 17$ & $17 / 17$ & \\
\hline
\end{tabular}

Table 4. Averages of Spearman's Rank Correlation Coefficients for Index of Automotive Sectors in the Period of 1995-2011 Source: Calculated by authors from unctadstat.unctad.org with SPSS V.20.32bit. 


\section{Conclusion}

Commonwealth of Independent States and Turkey have a certain level of industrial potential. The shift of the trade between these economies with the above mentioned industrial potential from the sector of low level technology to high technology leads to increase level of growth in the long term. According to the results of this study which aims to measure the competitiveness of automotive sector, one of the industrial branches to enhance technologic opportunities, Uzbekistan has the most comparative advantage in the passenger cars (group 781). Georgia, Turkey, Belarus, Russia and Ukraine follow Uzbekistan. Belarus has the most comparative advantage in goods and specialised vehicles (group 782) and is followed by Turkey, Ukraine and Russia. Belarus has the most comparative advantage in road motor vehicles n.e.s. (group 783) and is followed by Turkey, Ukraine and Russia. For total road vehicles $(781+782+783)$ sector, competitiveness, Uzbekistan has the most comparative advantage and is followed by Belarus, Turkey, Russia and Ukraine respectively. The relationship between the four comparative advantage indices shows that, there are high rank correlations between Liesner (RCAL), Balassa (RCA) and RC. RTA index is only correlated with RC. According to these outcomes of RCAL, RCA and partially of $\mathrm{RC}$ indices, the countries which have high production potential and competitive advantage are Uzbekistan, Belarus and Turkey. On the other hand, the countries with high production potential but volatile comparative advantage are Ukraine and Russian Federation. To develop a new strategy against the third party exporters to Turkey and CIS countries markets, the cooperation among the three countries with high comparative advantage and two relatively low comparative advantage is important. Either bilateral or multilateral cooperation of these countries on automotive production policies and trade strategies will be an important step for the development of Turkey and CIS countries markets.

\section{References}

- Ahrend, Rudiger, 2006. "Russian Industrial Restructuring: Trends in Productivity, Competitiveness and Comparative Advantage", Post-Communist Economies, Vol.18, No.3, pp.277-295.

- Aktan, Coşkun Can ve Vural, İstiklal Yaşar 2004. Rekabet Gücü ve Rekabet Stratejileri, Rekabet Dizisi:2, Türkiye İşveren Sendikaları Konfederasyonu Yayınları, Ankara.

- Aynagöz Çakmak, Özge, 2005. “Açıklanmış Karşılaştırmalı Üstünlükler ve Rekabet Gücü: Türkiye Tekstil ve Hazır Giyim Endüstrileri Üzerine Bir Uygulama”, Ege Akademik Bakış Dergisi, Cilt:5, Say1:1-2, s.65-76.

- Balassa, Bela, 1965. "Trade Liberalisation and "Revealed" Comparative Advantage", The Manchester School, 33, 99-123.

- Balassa, Bela, 1989. Comparative Advantage, TradePolicy and Economic Development, Harvester Wheatsheaf, New York.

- Başkol, M. Ozan, 2011. "Türk Otomotiv Sektörünün Uluslar arası Rekabet Gücü (1996-2010)", Paradoks Ekonomi, Sosyoloji ve Politika Dergisi, Cilt:7, Say1:2, s. 63-78.

- Bekmez, Selahattin ve Komut, Murat, 2006. "Competitiveness of Turkish Automotive Industry: A Comparison with European Union Countries", in International Conference on Human and Economic Resources Proceedings, pp. 180-189.

- Cooper, Julian, 2006. "Can Russia Compete in the Global Economy?", Eurasian Geography and Economics, 47, No. 4, pp.407-425.

- Depperu, Donatella and Cerrato, Daniele, 2005, “Analyzing International Competitiveness At The Firm Level: Concepts And Measures” Working Paper No. 32, Dipartimento Scienze Sociali - Sezione Economia Aziendale, Universita Cattolica Del Sacro Cuore, Piacenza.

- Erlat, Güzin ve Erlat, Haluk, 2005. "Do Turkish Exports Have a Comparative Advantage with Respect to the European Union Market, 1990-2000", Topics in Middle Eastern and North African Economics, electronic journal,7, pp.1-17.

- Filiztekin, Alpay ve Karaata, Selçuk, 2010. Türkiye'nin Dış Ticarette Rekabet Gücü: Seçilmiş Ülkeler, Sektörler-Mal Grupları ve Endeksler Bazında Karşılaştırmalı Bir Analiz, TÜSİAD-Sabancı Üniversitesi Rekabet Forumu (REF) ve Sektörel Dernekler Federasyonu (SEDEFED), İstanbul.

- Freinkman, Lev, Polyakov, Evgeny and Revenco, Carolina, 2004. "Trade Performance and Regional Integration of the CIS Countries", World Bank Working Paper No.38.

- Frohberg, Klaus and Hartmann, Monika,1997. "Comparing Measures of Competitiveness", Institute of Agricultural Development in Central andEastern Europe DiscussionPaper, No:2.

- Garanina, Olga, 2008. "What beyond oil and gas? Russian trade and specialization in manufacturers", BOFIT Discussion papers, No: 23.

- Karaalp, H. Simay, 2011. "Competitiveness of Turkey in Eurasia: A Comparison with CIS countries", China-USA Business Review, Vol.10, No.9, pp.727-744.

- Kaya, Ayten Ayşe ve Altın, Onur, 2008. "Türkiye Makine ve Ulaştırma Araçları Sektörünün Rekabet Gücü (1994-2005), İktisat, Işletme ve Finans, Cilt:23, Sayı:271, s.29-45. 
- Khatibi, Arastou, 2008. "Kazakhstan's Revealed Comparative Advantage vis-a-vis the EU-27”, European Centre for International Political Economy (ECIPE) Working Paper, No.3.

- Küçükkiremitçi, Oktay, 2006. Dış Ticaretteki Rekabet Gücüne Göre Sanayi Sektörünün Değerlendirilmesi, Türkiye Kalkınma Bankası A.Ş Ekonomik ve Sosyal Araştırmalar Müdürlüğü, Ankara.

- Liesner, Hans, 1958. "The European Common Market and British Industry”, Economic Journal, 68, pp.302316.

- $\quad$ Özdamar, Gökhan ve Albeni, Mesut, 2011. "Türkiye Otomotiv Sanayisi Dış Ticaret Rekabet Gücü Üzerine Bir İnceleme”, Süleyman Demirel Üniversitesi Sosyal Bilimler Enstitüsü Dergisi, Yıl: 2011/1, Say1:13, s.193-216.

- Shelburne, Robert C. and Pidufala, Oksana, 2006. "Evolving Trade Patterns in the CIS: The Role of Manufacturing”, United Nations Economic Commission for Europe Discussion Paper Series, No. 2006.2.

- Utkulu, Utku ve Seymen, Dilek, 2004. "Trade, Competitiveness and Revealed Comparative Advantage: Evidence for Turkey towards the EU", ETSG (European Trade Study Group) Sixth Annual Conference, Nottingham, 9-11 September 2004.

- Vollrath, Thomas L., 1991. "A Theoretical Evaluation of Alternative Trade Intensity Measures of Revealed Comparative Advantage", Weltwirtschafliches Archiv, 127, 265-279. 


\title{
The Role of Economic Integration in Trade Openness: The Black Sea Economic Cooperation Organization Case
}

\author{
Prof. Dr. Sedat Murat (Istanbul University, Turkey) \\ Assoc. Prof. Dr. Sefer Şener (Istanbul University, Turkey) \\ Dr. Burcu Kılınç Savrul (Canakkale Onsekiz Mart University, Turkey)
}

\begin{abstract}
Trade liberalization is one of the greatest economic arguments of the economics and it is claimed that trade openness is a crucial phenomenon for the well-being of nations since Adam Smith. Although various practices have been seen in different parts of the world in the history, from 1980s trade liberalization movements have been the dominant trend. However liberalization of trade in developing countries brought debates in economic literature and it is argued that open trade can have catastrophic effects instead of providing growth and welfare to the practitioner countries. In this study if The Black Sea Economic Cooperation Organization had contributed the member states to liberalize their trade has been investigated. The changes in the rates of inward and outward investment, import, export, population and labour force of the member countries during the establishment period of the Organization has been evaluated. The data is collected from Worldbank National Accounts Database, IMF World Economic Outlook and Balance of Payments Database and UNCTAD. The results of the study has shown that although the establishment of the organization had positive effect on investment and trade flows of the countries, it had no effect on labour flows of the member states.
\end{abstract}

\section{Introduction}

All economies are increasingly open in today's economic environment of globalization. International trade plays a vital role in shaping economic and social performance and prospects of countries around the world, especially those of developing countries. Without trade, the economic and social condition of the country cannot progress. However, the contribution of trade to development depends a great deal with the context in which it works and the objectives it serves. In recent years, many developing countries, have stepped upon unilateral trade liberalization, with very limited results at best in terms of increased growth and development (UNCTAD, 2004).

Although general consensus argue that free trade has benefits, in 1980s many developing country had economic instability and had to struggle with financial and economic crises due to structural unemployment caused by the removal of trade barriers, domestic economic instability from international trade cycles and pressures created by global economic competition. Today the global economic competition continues through economic integrations in commercial sense. In this perspective, these integrations can help developing countries liberalize the trade without facing the issues mentioned above alone.

Although the countries in Black Sea region had strategic advantages such as having mass raw materials and oil resources, being settled on crossroads between Asia and Europe and having relatively young and ample labour force; social and political conflicts, cold war and impact of planned economic system keep the region from bring its strength out. Just as the rest of the developing world many countries of the region gave emphasis on open trade in 1980s and 1990s. In this framework the study investigates whether or how the Black Sea Economic Cooperation established in the same period had affected the member countries opening their trade and investment to global markets.

\section{Trade Openness}

Economic theory propose that international trade improves resource allocation, lowers prices for consumers, and leads to a more efficient production. An open trade regime is also believed to encourage the integration of the economy into the global system and imports of modern technology, which results in productivity improvements (Montalbano, 2011: 1489).

Trying to ease to exchange goods and services, capital, labour, information, and ideas across the borders is known as trade openness. The main goal of these efforts is to integrate economies and societies at global level. Openness is known to help movement of resources from developed to developing economies and contributed to technological advancement. Today economies are reaping fruits of openness due to the diffusion and absorption of technology. Improvement of transportation and communication has helped rediscover the opportunities at global level and identify new international markets for exchange of goods and services. Openness allows foreign direct investment in host country which contributes to economic growth by supplementing domestic capital, redefining the concept of economic efficiency, boosting productivity and bringing the world together (Shahbaz, 2012: 2325). 
Trade openness has emerged as the main argument among economists and policy makers in explaining the growth phenomena in developing countries. Besides, due to continuous interest on the issue, new methods were also proposed. The positive contribution of trade openness towards growth stemmed from the notion that liberalization increases specialization and division of labour thus improving productivity and export capability as well as economic performance (Chandran and Munusamy, 2009: 638). In addition, with greater efficiency as a result of trade openness, many of the developing countries followed suit with the export-led strategies. It is widely recognized that trade openness has a positive effect towards economic growth. It is found that countries with more trade openness relatively outperformed the countries, with less openness (World Bank, 1993). Accordingly the dimensions that trade openness can contribute an economy can be seen in Figure 1.

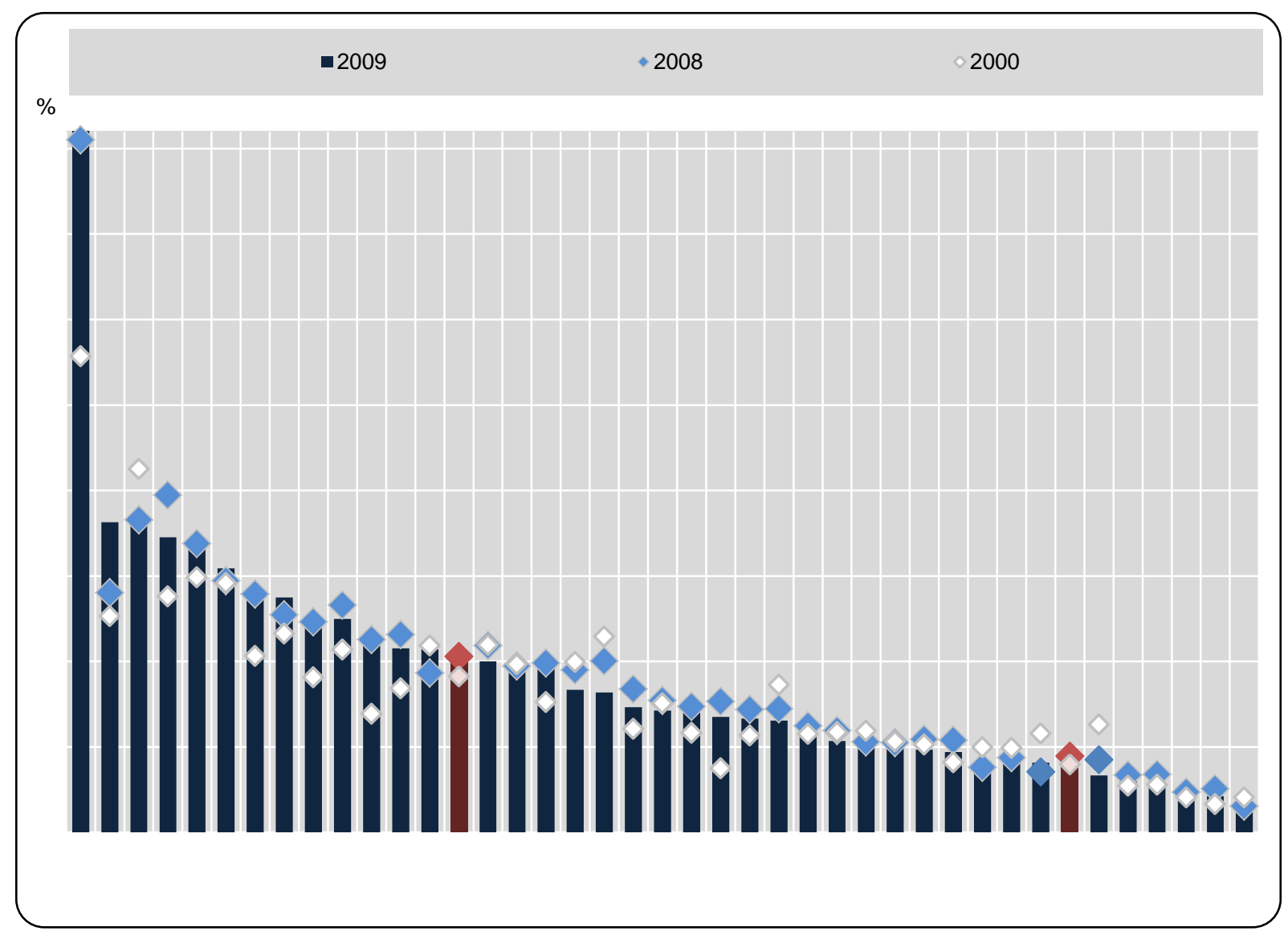

Figure 1: Average of Exports and Imports of Services as a Percentage of GDP, 2000, 2008 and 2009 Source: OECD, National Accounts Database, June 2011; International Monetary Fund, World Economic Outlook and Balance of Payments Databases, May 2011

The OECD and IMF figures displaying trade flows as a percentage of GDP between 2000 and 2009 show that the relative importance of trade. Trade flow of OECD average has increased 10 percent from 2000 to 2008 and more in some countries. After widespread increases in the trade-to-GDP ratio between 2000 and 2008, all OECD countries and the BRIICS (Brazil, the Russian Federation, India, Indonesia, China, South Africa) saw a drop in this ratio between 2008 and 2009, mostly owing to significant drops in trade in goods due to the Economic and Financial Crisis of 2008. In many countries it fell below the ratio recorded at the -beginning of the decade. In 2009 , the average trade-to-GDP ratio of OECD countries was about $41 \%$, nearly double that of the BRIICS. In part, this is because the OECD includes many relatively small economies. Considering the OECD as a single aggregate, with high weights for Japan and the United States, would give a ratio closer to $20 \%$, similar to that of the BRIICS.

Despite significant falls in 2009, trade in goods remains the principal channel for economic integration for many countries. It represents, on average, three times the value of trade in services in OECD countries and more than four times in the BRIICS. However, the crisis had a much smaller impact on trade in services than in goods; few countries experienced significant falls in the ratio of trade in services to GDP.

Free and open markets may influence long-run economic growth in many different specific ways in a dynamic world. One path comes from the expanding the opportunities of firms to realize more fully scale economies and greater efficiency in investment. Increased competition, resulting from reduced barriers for foreign competitors, serves to limit the market power of domestic imperfectly competitive markets, mandates efficiency, and delivers 
a greater variety of both finished products and intermediate inputs to consumers and industry, respectively. A different path for growth through trade liberalization stems from the transfer of ideas and the ability of domestic industries to utilize imported intermediate inputs that benefit from new technologies in the world economy. Repeated and sustained interaction through international trade facilitates the ability of domestic producers to adopt foreign knowledge in their own production (Skipton, 2007).

The economic well being of a country is associated closely to the availability of resources and the productivity of its workforce. Trade operates in a diversify ways to sustain the economic development process. It enhances competition and the linked thrust to innovation and specialization, and it provides a significant channel for international technology transfer (Mazumder, 2008: 9). In this respect, opening up their economies to the global economy has been essential in enabling many developing countries to develop competitive advantages in the manufacture of certain products.

Although general consensus argue that free trade has benefits, there are a number of arguments put forward by lobby groups and protestors who oppose free trade and trade liberalisation. These can be listed as follows (HSC, 1999):

- With the removal of trade barriers, structural unemployment may occur in the short term. This can impact upon large numbers of workers, their families and local economies.

- Increased domestic economic instability from international trade cycles, as economies become dependent on global markets. This means that businesses, employees and consumers are more vulnerable to downturns in the economies of trading partners.

- International markets are not a level playing field as countries with surplus products may dump them on world markets at below cost. Some efficient industries may find it difficult to compete for long periods under such conditions.

- Developing or new industries may find it difficult to become established in a competitive environment with no short-term protection policies by governments, according to the infant industries argument. It is difficult to develop economies of scale in the face of competition from large foreign TNCs.

1980s witnessed many cases that various developing country had economic instability and had to struggle with financial and economic crises after they liberalized their markets before they consolidated their economic system. In this context it is questionable whether instead of confronting global competition alone, accessing an economic integration may protect developing countries from global pressure.

\section{Economic Integrations and Trade Openness}

The elimination of barriers to global trade also meant the removal of barriers to global competition. Although unfavourable impacts of getting into global competition are obvious, inclination towards global trade is questionable. Despite the negative experiences, the reasons countries have a positive look on the global trade can be summed as (Gürak, 2006: 285-286);

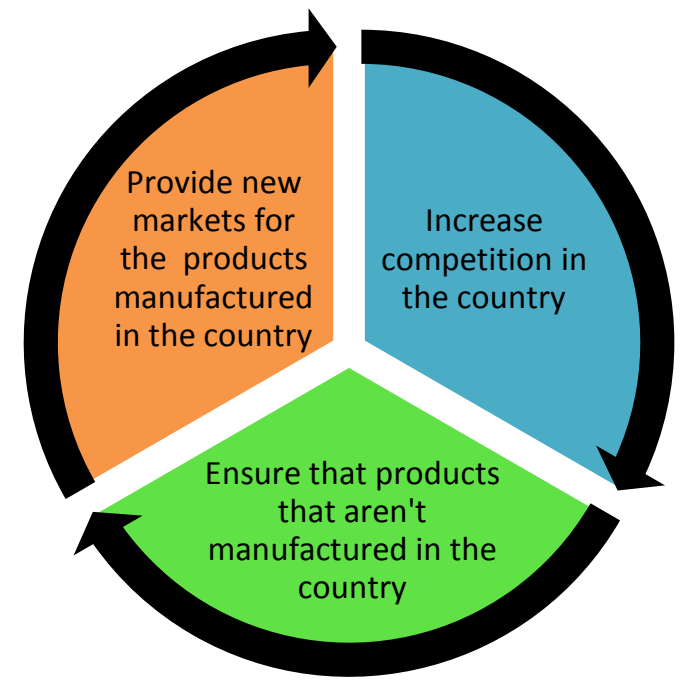

In this respect sooner or later liberalization case came to agenda of any country which seek for economic development and stability. Liberalization of trade has been one of the most important economic arguments of the economics and it has been suggested that free trade would increase the well-being of nations since Adam Smith. In this context, the ultimate goal of developing countries is to outsource. Trade liberalization movements which accelerated through the activities of The General Agreement on Tariffs and Trade (GATT) and the its modern- 
day equivalent World Trade Organization (WTO), continues with the recent activities of accelerating economic integration trend (İncekara and Savrul, 2011: 11-12).

International economic integrations emerge often based on liberalization of trade between the countries in the same geographical area. Although they are discussed at a theoretical level for a long time, after the Second World War, practice opportunities came out for economic integrations and many of them have been established in different areas of the world between both developed and less developed countries (Güran, 1997: 12). The resulting integration of the world economy has raised living standards around the world. Most developing countries have shared in this prosperity; in some, incomes have risen dramatically. As a group, developing countries have become much more important in world trade, they now account for one-third of world trade, up from about a quarter in the early 1970s. Many developing countries have substantially increased their exports of manufactures and services relative to traditional commodity exports: manufactures have risen to 80 percent of developing country exports. Moreover, trade between developing countries has grown rapidly, with 40 percent of their exports now going to other developing countries (IMF, 2001)

In this perspective, since the emergence of the concept of economic integration, the reasons the countries find economic integration movements appealing can be summarized as follows (İncekara, 1995: 266);

- Increasing economic potential of a country by expanding the production capacity of the country, increasing efficiency and consequently maximizing social well-being. These objectives can be reached through joining economic integrations which can expand market volume.

- In recent years developed countries' imparting momentum to free trade has led to an increase in regional trade integrations. Trying to achieve greater competitiveness against non-regional countries or blocks and strategies such as taking part in international policy are the major causes of the emergence of economic integrations.

- Another reason of emergence of economic integrations is to eliminate the potential disputes between the neighbouring countries that have to live together. Instead of having conflicts, countries involved in integration can eliminate potential conflicts and establish political stability by uniting their capabilities.

Economic integrations between developing countries can also stimulate foreign trade by constituting some cross-border investment projects. Starting an industrial joint venture in a country which has the most favourable position in the integration to produce any property can meet the needs of all member states which in result solving the issue of scale (Sabir, 2010) which bring out social cooperation possibilities besides the economic ones which is essential for a sound economic integration.

\section{Organization of the Black Sea Economic Cooperation}

The Black Sea area between the crossroads of Asia and Europe where people of different nationalities, trades, cultures and religions blended to each other, has been the cradle of different civilizations since ancient times. It witnessed periods of peace and tranquillity were followed by protracted conflicts and wars. But even in that climate the Black Sea area was well known for its developed trade relations and contacts. Attempts were undertaken to build bridges of rapprochement. It is sufficient to mention the famous Silk Road which linked the countries of Europe and Asia. A valuable experience of contact among the peoples of the two continents as well as of the cohabitation and mutual enrichment of different cultures has been accumulated (Photius Coutsoukis, 2013).

Only in the last decade of the twentieth century however, when the atmosphere of the cold war, suspicion and mistrust has receded, have the countries of the Black Sea area been able to undertake bold steps in that direction. They could come together and decide how, in the age of the globalization of economies, valuable assets in their possession, such as geographical proximity, common history, cultural bonds and the interdependence of their national economies could be efficiently employed for mutual benefit and prosperity (Lupu, 2006: 134) and decided to start a regular dialogue leading them to launch the Black Sea Economic Co-operation (BSEC) in 1992 in Istanbul. BSEC permanent members are the three EU MS (Bulgaria, Greece and Romania), Black Sea Synergy's countries (Armenia, Azerbaijan, Georgia, Republic of Moldova, Russia, Turkey and Ukraine) plus Albania and Serbia (European Commission, 2013). BSEC received the status of full international organization in 1999. BSEC promotes and coordinates regional cooperation in a wide range of areas - tourism, trade, banking, communications, energy, transport, agriculture, health, environmental protection, combating organized crime and others (Ministry of Economy and Energy of the Republic of Bulgaria, 2013).

BSEC is found as a unique and promising model of multilateral political and economic initiative aimed at fostering interaction and harmony among the Member States, as well as to ensure peace, stability and prosperity encouraging friendly and good-neighbourly relations in the Black Sea region which covers a geography encompassing the territories of the Black Sea littoral States, the Balkans and the Caucasus with an area of nearly 20 million square kilometres. BSEC region is located on two continents and it represents a region of some 350 
million people with a foreign trade capacity of over USD 300 billion annually (Republic of Turkey Ministry of Foreign Affairs, 2011).

The BSEC has undoubtedly succeeded in creating a framework for multilateral co-operation in an area with different geopolitical and economic realities and hence affected by great turmoil. In a region representing not only an area rich in oil and gas, but also a strategic corridor for the passage of raw materials between Asia and Europe, the organisation has especially committed itself to ensuring political stability and promoting the growth of trade. To this end, priority has been given to sectors such as energy, transport and telecommunications. However, acting according to perspectives of sustainable development, special attention has also been given to issues concerning environmental protection and especially the marine ecosystem. The presence within the organisation of EU Member States and candidates has contributed to turning the objectives of good governance, democracy and protection of human rights into topics for debate and exchange of opinions improving the regional political climate (International Democracy Watch, 2013; RhodesMRC, 2010).

\subsection{The Effect of BSEC on Trade Openness of The Member Countries}

A remarkable issue about the BSEC is that its establishment coincide with the economic liberalization movements of developing countries including the BSEC members. In this regard how the establishment of BSEC has affected the liberalization process of the member countries is a subject of matter.

Before looking into the BSEC it would be useful to query in what channels an economic integration basically affect member countries. Although many reasons lie behind the activities of economic integrations, officially recognized key objectives can be summed up as (Schiff and Winters, 2003: 6-10);

- promote domestic and foreign investments,

- $\quad$ increase their competitiveness through access to broader markets

- $\quad$ provide stable access to foreign technology and investments

In this perspective it would be meaningful to compare the changes in trade investment and labour figures of the member countries to evaluate the effect of establishment of BSEC.

\subsection{Trade, Foreign Direct Investment and Labour Force Trends in BSEC}

The advantages enjoyed by countries engaged in mutual free trades can be summarized as follows (EconomyWatch, 2010):

- Considerable reduction in the cost of transportation, especially with the development of containerization with respect to overseas ocean shipments,

- Decrease or abolition of control over capital and the capital market,

- Formation of free zones for carrying out commercial activities, against payment of little or no tariffs at all,

- Decrease, abolition or synchronization of subsidies in domestic trades,

- Decrease or abolition of every kind of tariffs.

Consequently although it isn't the sole goal, mutual free trade is one of the leading purposes of the Cooperation. The changes in the import and export flows of the BSEC is shown in Figure 2.

Goods and Services Trade Openness data show that both import and export volume of BSEC countries were about $20 \%$ of their GDP on the average in 1980s and the figures fell below $15 \%$ in the beginning of 1990s. The period after 1990 they had a sharp increase in their trade volume and the figures doubled in the following ten years. The period after 2000 was a recession period almost for the whole world and the region has been affected from the process. Although the Crisis slightly affected trade in the region in 2008, it quickly recovered and returned to the level of pre-crisis period.

Evaluating the figures although it is hard to say the establishment of the BSEC is the sole reason of the increase in the trade volume of the member countries after 1990, it can be concluded that the organization has contributed development of trade of the member countries and provided a steady increase for a period.

Capital accumulation is regarded as the basic dynamic of economic development by economists. In other words, failure of capital accumulation is the biggest cause of economic lag in some countries. It is apparent that developing countries need too much capital for, transforming their economic structure to be able to reach the level of developed countries (Kar and Tatlısöz, 2008: 437). Another aspect that economic integrations promote member countries is rise in their capital accumulation through foreign investment.

Foreign direct investment helps developing countries to confront the international competition by boosting their economy, increasing productivity and export capacity. For developing countries, one of the most important benefits of foreign investment is the contributions to eliminate deficits. Foreign direct investments reflect positively to one-time balance sheet of the host country. Another positive effect is that they contribute to development of exports of the host country via operations of the companies with foreign investment in foreign markets (Candemir, 2007). The figures of foreign direct investment flows of BSEC countries before and after the establishment of the Organization is as follows; 


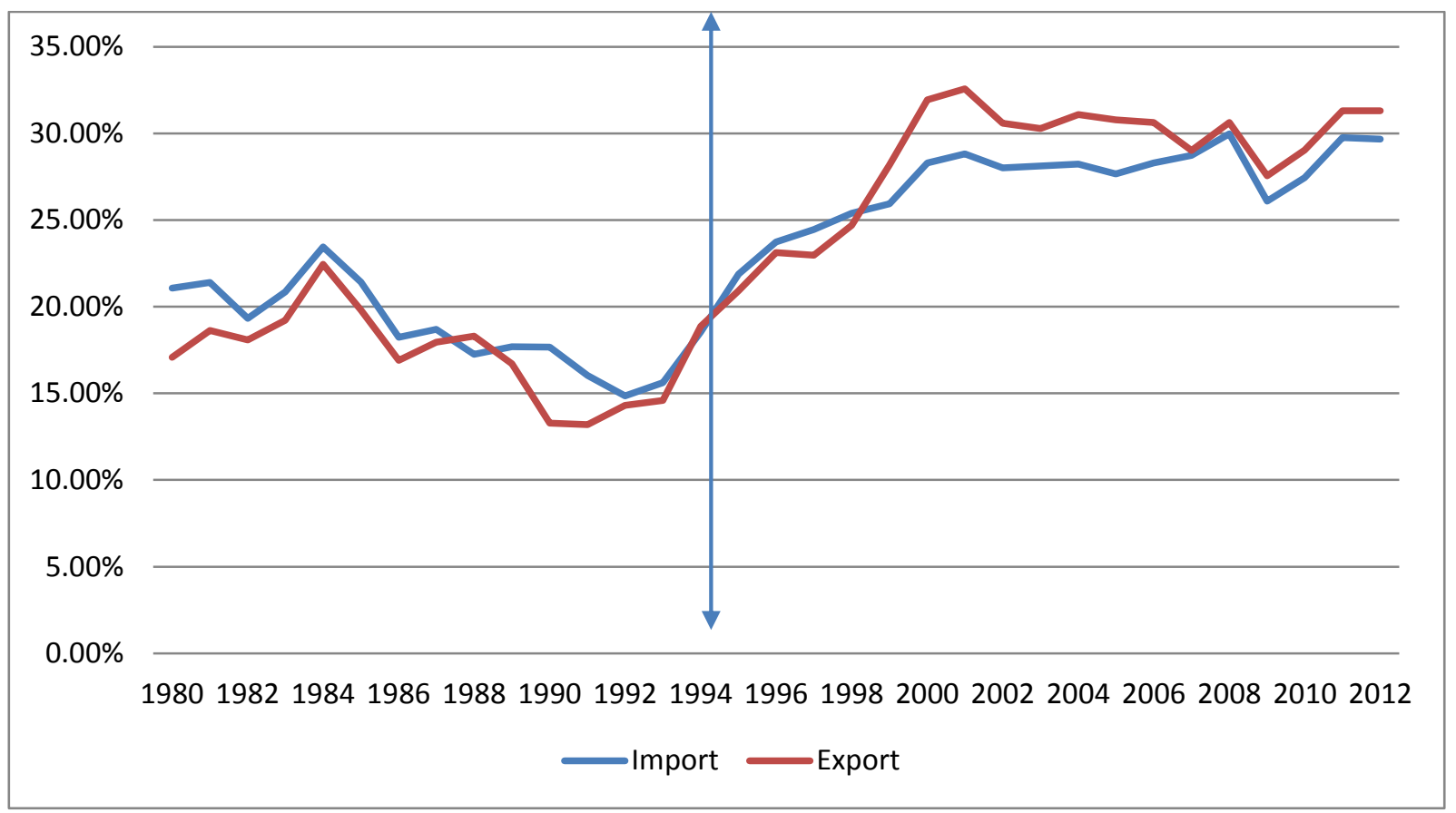

Figure 2: Goods and Services Trade Openness in BSEC, Percentage of Gross Domestic Product, 1980-2012 Source: UNCTAD. (2013), UNCTADstat.

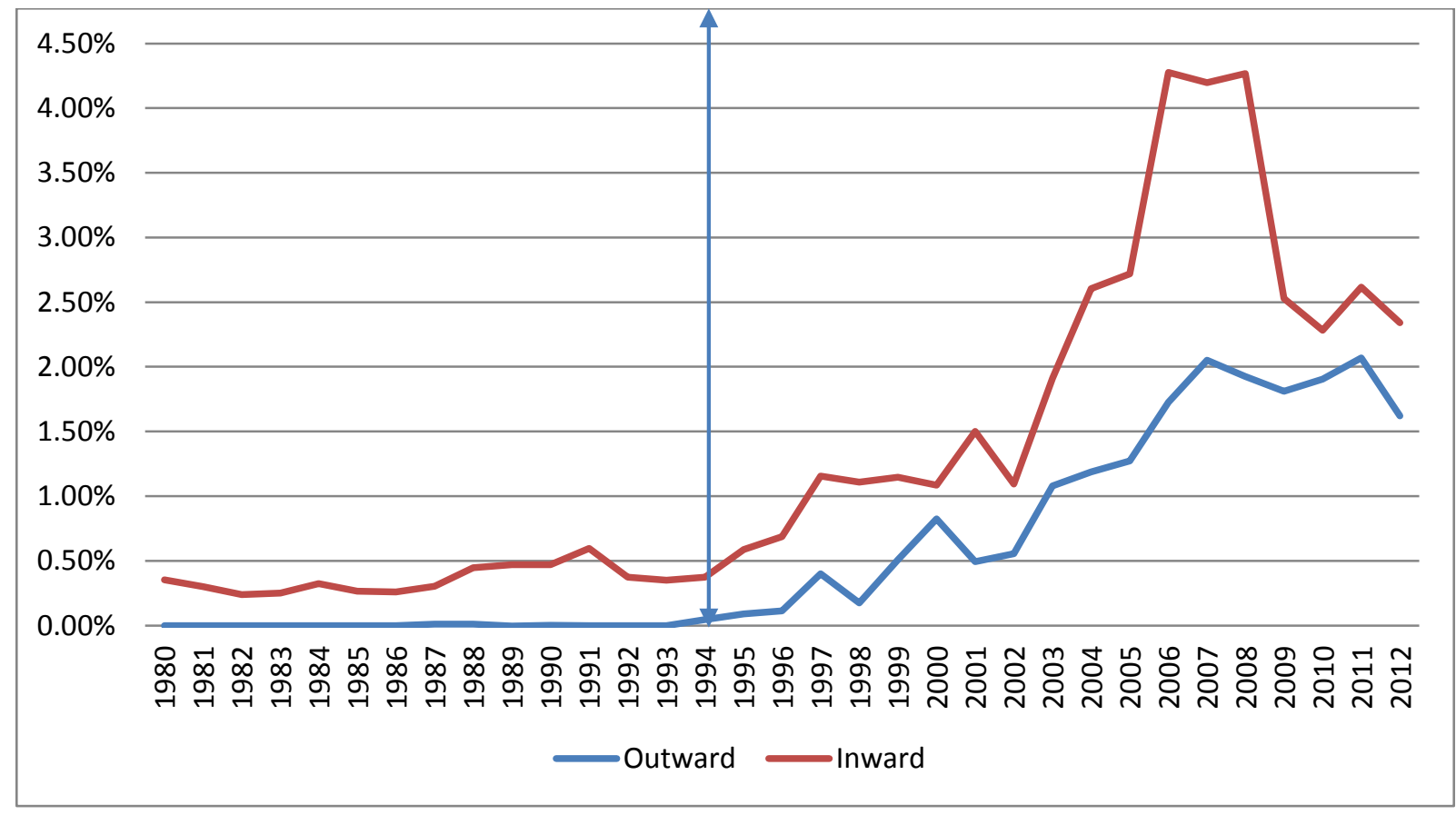

Figure 3: Inward and Outward Foreign Direct Investment Flows in BSEC, \% of GDP, 1980-2012 Source: UNCTAD. (2013), UNCTADstat.

Since the beginning of 1990 the foreign direct investment flows of region were at insignificant levels. Between 1980 and 1990 incoming investment flows were below 0,5\% of GDP and outgoing flows had negative figures. Distinct from trade figures, foreign direct investment figures display that the establishment of BSEC had a direct positive impact on the investment flows the member countries. The establishment of the organization accelerated both incoming and outgoing investment flows. Incoming investment ratio reached to \%1 in 1996, 2,5 in 2003 and went behind $4 \%$ in 2006. Since the BSEC is formed of developing countries the outgoing investment level stayed fairly low compared to the incoming one. However the BSEC contributed the outgoing investment flows in a manner too and the outgoing investment rate changed to positive by the establishment of the organization and reached to \%1 of GDP in 2003 and \%2 in 2006.

It is apparent that the impact of Financial and Economic Crisis of 2008 on direct foreign investment flows of the BSEC has been more severe than trade. The BSEC members lost almost half of their incoming investment 
flows because most of the investors were the western European countries which were badly affected by the crisis. On the other hand the effect of the crisis weren't so intense on outgoing capital flows and it almost maintained the pre-crisis condition.

Integrations are also expected to flourish the member countries with labour flows. When markets are open and are free from all barriers then private investors get better opportunity with reduced uncertainty whereas previous barriers might have restricted their business. Private investment brings intellectual capital and technology, and can also push other aspect of social infrastructure in a positive direction. The change in population and labour force of the BSEC countries is summed up in Figure 4.

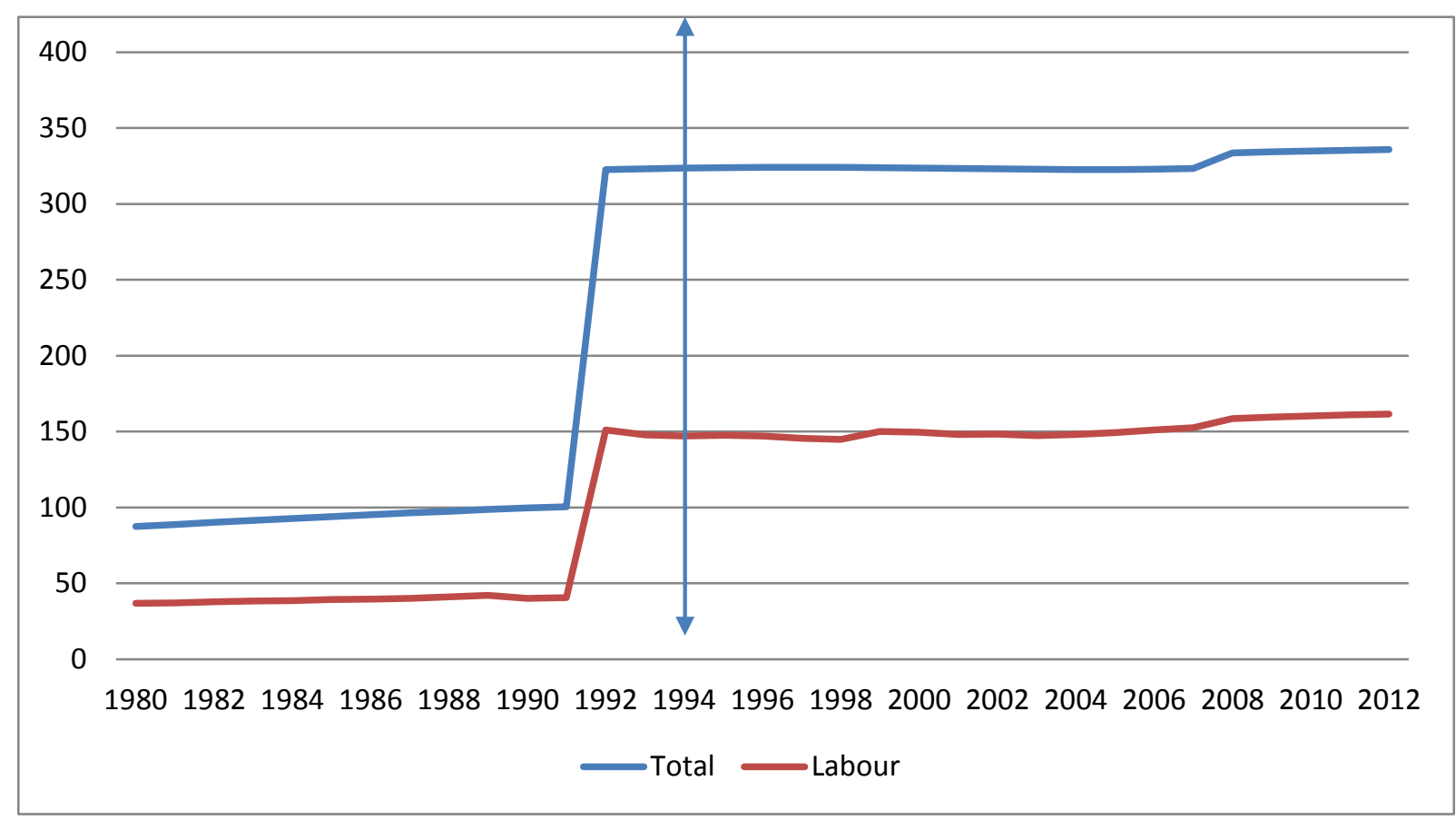

Figure 4: Total Population and Labour Force in BSEC, Million, 1980- 2012 Source: UNCTAD. (2013), UNCTADstat.

Total population of the member states of BSEC has been about 100 million and total labour force has been below 50 million between 1980 and 1991. In 1992 due to the collapse of Soviet Union the population tripled and rose to 322 million people. Same way the labour force exceeded 150 million. The figures increased not insignificantly in the following period and the population reached only 335 million while the total labour force reaching 161 million people. Evaluating the figures it can be said that the establishment of the BSEC had no impact on the increase of population and labour force of the member countries. Since the Organization hasn't reached to level of full economic union, free movement of people within the Organization. As a result establishment of BSEC had no or little influence on labour or population movements. Moreover, although BSEC had helped job creation in the Organization through direct investment flows its extend is away from attracting exterritorial labour to the region.

\section{Conclusion}

The evidences are clear that opening economies to trade and investment with the rest of the world are necessary for sustained economic growth. The experiences has shown that without being open to the rest of the world no country in recent decades has achieved economic success and provided acceptable living standards to its people. In contrast, opening trade and foreign direct investment have been an important element in the economic success of many countries. Integration into the world economy has proven a powerful means for countries to promote economic growth, development, and poverty reduction. Over the past 20 years, the growth of world trade has averaged 6 percent per year, twice as fast as world output. But trade has been an engine of growth for much longer.

Although general consensus argue that free trade has benefits, in 1980s many developing country had economic instability and had to struggle with financial and economic crises due to structural unemployment caused by the removal of trade barriers, domestic economic instability from international trade cycles and pressures created by global economic competition. Today the global economic competition continues through economic integrations in commercial sense. In this perspective, these integrations can help developing countries liberalize the trade without facing the issues mentioned above alone. 
In this study the effect of establishment of the Black Sea Economic Cooperation on trade and investment liberalization process of the member countries has been examined. According as the primary effects of the economic integrations on member countries, changes in import, export, inward and outward foreign direct investment flows and labour force movements of the Organization have been evaluated. The results of the study has shown that although the establishment of the Organization slightly contributed development of trade of the member countries and provided a steady increase for a period, it has been fairly effective in development of foreign direct investment flows in the region however because the Organization doesn't allow free movement of people within the Organization such as EU BSEC had no or little influence on labour or population movements in the region.

\section{References}

- Candemir, Aykan. (2007), "Doğrudan Yabancı Sermaye Yatırımlarının Ekonomık Büyüme ve İstihdam Üzerindeki Etkileri”, İşveren, TISK, May, <http://tiskweb.com/isveren_sayfa.asp?yazi_id=1721 \&id=87>, (29.05.2013).

- Chandran, V.G.R.; Munusamy. (2009), "Trade openness and manufacturing growth in Malaysia", Journal of Policy Modeling, Vol. 31, Issue 5, September-October, 637-647.

- Economy Watch. (2010), "Effects of Globalization", <http://www.economywatch.com/economicstheory/globalization/effects.html> (02.06.2012).

- $\quad$ European Commission. (2013), "Black Sea Economic Cooperation Organisation (BSEC) Ministerial Meeting, Odessa, Ukraine", <

http://ec.europa.eu/information_society/newsroom/cf/mare/itemdetail.cfm?item_id=11179>, (27.05.2013).

- Gürak, Hasan (2006), "Ekonomik Büyüme ve Küresel Ekonomi", Ekin Yayınevi, Bursa.

- $\quad$ HSC. (1999), "Free Trade and Protection: Advantages and Disadvantages of Free Trade", Charles Sturd University, < http://hsc.csu.edu.au/economics/global_economy/tut7/Tutorial7.html>, (27.05.2013).

- Güran, Nevzat; Aktürk, İsmail. (1997), "Uluslararası İktisadi Kuruluşlar", Anadolu Matbaacılık, İzmir.

- İncekara, A., Savrul, M. (2011), "Küreselleşme, Büyüme ve Ekonomik Entegrasyonlar: Türkiye Açısından Bir Değerlendirme", Iktisat Fakültesi Mecmuası, Cilt: 61, Sayı:2, 3-22.

- İ́ncekara, Ahmet. (1995), "Globalleşme ve Bölgeselleşme Sürecinde Nafta ve Etkileri", İstanbul Ticaret Odas1, Yayın No:195-14, İstanbul.

- IMF. (2001), "Global Trade Liberalization and the Developing Countries", <http://www.imf.org/external/np/exr/ib/2001/110801.htm>, (29.05.2013).

- International Democracy Watch. (2013), "Organization of the Black Sea Economic Cooperation", <http://www.internationaldemocracywatch.org/index.php/organization-of-the-black-sea-economiccooperation>, (25.05.2013).

- International Monetary Fund. (2013), "World Economic Outlook and Balance of Payments Databases", May 2011.

- Kar, Muhsin; Tatlısöz, Fatma. (2008), “Türkiye'de Doğrudan Yabanci Sermaye Hareketlerini Belirleyen Faktörlerin Ekonometrik Analizi”, KMU IIBF Dergisi, Year.10, No.14, December.

- Lupu, Gratian. (2006). "EU, BSEC and Energy Co Operation", Sfera Politicii, 125/2006, 134-140.

- Mazumder, Rabin. (2008), "Trade Liberalization \& WTO: Impact on Developing Countries", January 16, < http://ssrn.com/abstract=1084394>, (26.05.2013).

- $\quad$ Ministry of Economy and Energy of the Republic of Bulgaria. (2013), "Black Sea Economic Cooperation Organization (BSEC)", <http://www.mi.government.bg/en/themes/black-sea-economiccooperation-organiz ation-bsec-298-0.html $>$, (24.05.2013).

- Montalbano, Pierluigi, 2011. "Trade Openness and Developing Countries' Vulnerability: Concepts, Misconceptions, and Directions for Research," World Development, Elsevier, Vol. 39(9), 1489-1502, September.

- $\quad$ OECD. (2013), "National Accounts Database", June 2011.

- Photius Coutsoukis. (2013), "Black Sea Economic Cooperation Pact", <http://www.photius.com/bsec/ bsec.html>, (24.05.2013).

- $\quad$ Republic of Turkey Ministry of Foreign Affairs. (2011), "The Black Sea Economic Cooperation Organization (BSEC)", <http://www.mfa.gov.tr/the-black-sea-economic-cooperation-organization_bsec_.en.mfa>, (25.05.2013). 
- RhodesMRC. (2010), Black Sea Economic Co-operation, <http://www.rhodesmrc.org/2010/bsec.php>, (27.05.2013).

- Sabır, Hasan. (2010), "Gelişmekte Olan Ülkeler Arasında Ekonomik Entegrasyon: Mercosur Örneği", DTM <http://www.dtm.gov.tr/dtmadmin/upload/EAD/TanitimKoordinasyonDb/gelismekte.doc〉, (28.12.2010).

- $\quad$ Schiff, Maurice; Winters, L. A. (2003), "Regional Integration and Development", Worldbank and Oxford, Washington.

- Shahbaz, Muhammad. 2012) "Does trade openness affect long run growth? Cointegration, causality and forecast error variance decomposition tests for Pakistan", Economic Modelling, Vol. 29, Issue 6, November, 2325-2339.

- $\quad$ Skipton, Chuck. (2007), "Trade Openness, Investment, and Long-Run Economic Growth", '07- '08 Southern Economics Association (SEA) Meetings, New Orleans, La. November 18-21, 2007.

- UNCTAD. (2013), UNCTADstat.

- UNCTAD. (2004), "The Least Developed Countries Report 2004", United Nations Publications, Switzerland.

- World Bank. (1993), "The East Asian miracle: Economic Growth And Public Policy", Oxford University Press, New York. 


\title{
Burgeoning Sino-Russian Economic Relations and the Russian Far East: Prospects and Challenges
}

\author{
Asst. Prof. Dr. Çağrı Erdem (Doğuş University, Turkey)
}

\begin{abstract}
The colossal economic transformations and political intrusions had been affecting brutally China and the Soviet Union in the final decades of the twentieth century. Currently, Russia is a gigantic power, struggling to rebuild its economic base in an era of globalization. There are a number of significant difficulties of guaranteeing a stable domestic order due to demographic shifts, economic changes, and institutional weaknesses. On the other hand, the economic rise of China has attracted a great deal of attention and labeled as a success story by the Western world. The current growth of the Chinese economy is of immense importance for the global economy. Both nations are part of the world's largest and fastest-growing emerging markets-member of the BRIC. Their respective GDPs are growing at an impressive rate by any global standards. Relations between China and Russia have evolved dramatically throughout the twentieth century. However, it would be fair to argue that during the past decade China and Russia have made a number of efforts to strengthen bilateral ties and improve cooperation on a number of economic/political/diplomatic fronts. The People's Republic of China and the Russian Federation maintain exceptionally close and friendly relations, strong geopolitical and regional cooperation, and significant levels of trade. This paper will explore the burgeoning economic and political relationships between the two nations and place the Russian Far East in the context of Russia's bilateral relations with China in order to examine the political, economic, and security significance of the region for both sides.
\end{abstract}

\section{Introduction}

The Russian Far East (RFE) is considered as a region in crisis due to troubled economic conditions, corrupt governance, and problem-ridden cross-border relations with China, Japan, and both Koreas (Rozman, 2008). Due to the some fears that the Russian Far East might disengage itself from the center and other regional/global powers may end up having a major grip in the region, Moscow started to show some genuine interest in those eastern border provinces.

The region in question covers a large geographical area from Siberia to Russia's Pacific coast, forming the northeastern corner of Asia. Although the Far East constitutes one-third of Russia's total landmass, it has only 6.6 million residents -4.7 percent of the total population. The low population density, just over one person per square kilometer, makes the region one of the most sparsely populated places in the world. The scarcity of residents exists alongside a wealth of natural resources that have attracted the interest of the Russian central government as well as foreign investors. Evidently, Russian politicians, bureaucrats/technocrats are all concerned about the level of socioeconomic development in that region (Troyakova, 2007).

However, it would be fair to assert that the developmental troubles of the RFE partly related to the region's history and location. Moreover, the USSR did also neglect socio-economically the region until its collapse in 1991. After the disintegration of the Union, the RFE, like many other regions, was to a great extent abandoned by the financially struggling central government in Moscow Moscow's extended negligence to the region has left the RFE provinces economically underdeveloped, demographically challenged, and geographically exposed. Yet Moscow has recently begun to focus specifically on revitalizing the RFE, as years of dynamic economic growth and surging global trade in neighboring China have pulled the international community's attention to developments in the Pacific Rim. This change in the international political and economic climate, especially in light of the RFE's rich supplies of natural resources and strategic location in the North Pacific, has brought about a rethinking of Moscow’s policy in Russia’s Far East (Alexeeva, 2008; Blank, 2011).

\section{Historical Background}

For centuries, the territories of the Russian empire located to the east of the Ural Mountains were considered as places of promise and natural resource wealth (Kangas, 2007). Over the last three centuries, imperial Russia expanded both northward and southward across Siberia. After the Treaty of Peking was signed in 1689, Russia directed its energy toward the Sea of Okhotsk, Kamchatka, Chukotka, the Kuril Islands, and Alaska. Russia entered the Amur region in the mid-nineteenth century. In 1856 and 1857, Russia seized Chinese territory north of the Amur River. In 1860, all land east of the Ussuri River was ceded to Russia, thus extending the Russian empire from the Baltic to the Pacific (Troyakova, 2007).

After the disastrous Crimean War of 1854-56, Russia's priorities shifted away from the Northeast Pacific. Alaska was sold to the United States in 1867. The central and northern Kurils were handed over to Japan in exchange for Sakhalin in 1875. Soon a combination of external and internal developments forced the Russian government to upgrade the Far East to accommodate imperial priorities. In 1884 the Transbaikal, Amur, 
Primorye, and Sakhalin districts were united under a new Priamurskii governor-generalship. This established an institutional framework for the regional identity of the Far East (Troyakova, 2007).

As the Trans-Siberian Railroad extended steadily eastward, it brought European and Asian Russia together. Ethnic Russians, Ukrainians, and Tatars moved to the Far East, where they discovered thousands of Chinese, Koreans, and Japanese residing within the Priamurskii governor-generalship. This ethnic mix shaped regional development and added a cosmopolitan shade to Russian life.

From the end of the nineteenth century through the years leading up to World War I, the region played an important economic role in East Asia. It attracted loans and investments that supported its industrialization. Although economic interaction between the region and the rest of Russia was limited, the Far East was open for relations with Asian countries. Labor resources were satisfied by migration not only from the European part of Russia but also from China, Korea, and Japan. In general, the region was seen as a place for agriculture, exile, and a base for the Russian Pacific Fleet at Vladivostok (Bliakher \& Vasil'Eva, 2010).

During the early Soviet period, the region, now known as the Far Eastern Republic, developed as a relatively autonomous economic area. However, in the 1930s Moscow adopted a model of centralized state control and support. The Soviet system imposed a centrally planned economy, limiting the region's economic ties with the outside world. The central government provided substantial economic support because of the geostrategic significance of the region, but it paid little attention to the long-term economic viability of the Far Eastern economy. Moscow stressed the development of mining and defense industries, eventually turning the region into a fortress (Kuhrt, 2012).

The massive Soviet arms buildup in the Far East and the Pacific was a source of considerable concern for China, Japan, and South Korea. By the 1960s, the Sino-Soviet border was closed, and Mao Zedong, the Chinese leader, openly spoke of China's legitimate claim to the southern part of the Far East. This hostile environment was not conductive to economic contacts.

Moscow later eased its grip, however, and the Far East became one of the few regions in the Soviet Union where the central authorities encouraged an export-based development strategy. In the 1970s and 1980s the region was supposed to benefit from expanded trade with Asian countries, particularly through a number of compensation agreements between the Soviet Union and Japan. The region's natural resources were offered in order to finance purchases of machinery and equipment for further resource development. As a result of these agreements, several projects were implemented, including the Vostochnyi port near Nakhodka, and the South Yakutia coal complex. Initial work to develop the oil and gas deposits offshore of Sakhalin Island also began. The region also has reserves of iron, lead, zinc, silver, gold, lumber, farmland, and fish (Sullivan \& Renz, 2010; Zausaev, 2012).

By the mid-1980s the Far East began to reorient from a military outpost to an economic player. The successful development of China's growing economy improved the chances for greater trade and joint projects between the two countries. Indeed, over the past twenty years, Russia and China have sought new points of agreement for broader and more institutionalized cooperation.

In 1986 and again in 1988, Mikhail Gorbachev called for the integration of the Soviet Union into the AsiaPacific region. He stressed that the cold war era was ending and the Soviet government would like to open the Far or adopts a more diversified economic profile.

\section{Economic development}

It would be fair to argue that the Russian Far East has three essential characteristics that make it worthy of attention. Together with eastern and western Siberia, the region is well-endowed with an abundance of variety of natural resources. Particularly, fossil fuels of the region may play a pivotal role vis-à-vis energy hungry countries of East Asia. At the same time, as seen from the European part of the country, the regional bloc qualifies Russia as a rightful member of the Asia-Pacific and Northeast Asia regions, extending its geopolitical influence. Finally, the long coastline and the Amur River boundary of the Russian Far East allow cross-border relations that are a significant component in bilateral ties and key to efforts to establish infrastructure that could jump-start Northeast Asian integration (Rozman, 2008).

\section{Economic challenge}

The developmental troubles of the RFE, which stem in part from the area's history and location, are not new. The legacy of socio-economic neglect of the RFE by the central government in Moscow dates back to the Soviet era. The RFE, like many regions, was to a great extent abandoned by the struggling central government following the 1991 collapse of the Soviet Union. Moscow's prolonged inattention to the region has left the RFE provinces "seriously underdeveloped, demographically challenged, and geographically vulnerable," stated Lee. Yet Moscow has recently begun to focus specifically on revitalizing the RFE, as years of dynamic economic growth and surging global trade in neighboring China have pulled the international community's attention to 
developments in the Pacific Rim. This change in the international political and economic climate, especially in light of the RFE's abundant supplies of natural resources and strategic location in the North Pacific, has brought about a rethinking of Moscow's policy in Russia's Far East.

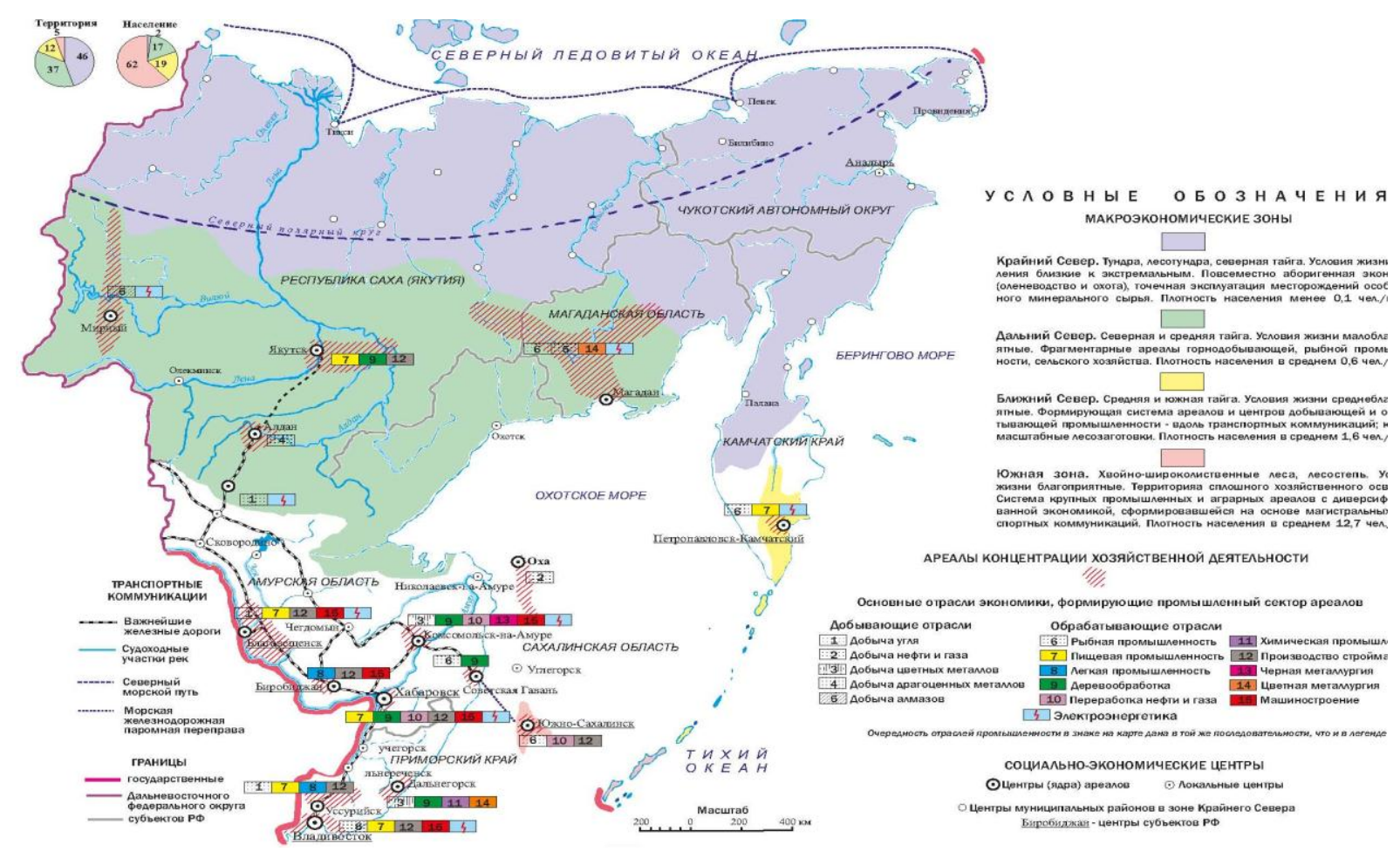

Figure 1. Macroeconomic Zones of the Far East Source: Vishnevskiy, Demyanenko, 2010

\section{China's Role}

From historical point of view, China's role and presence in the region is complex and are linked to energy needs, as well as political, cultural, and historical points of potential tension between itself and Russia. Indeed, the history of the RFE is tightly bound to the history of northern and northeastern China, dating back to the early Russian exploration of the region in the sixteenth and seventeenth centuries. The "unequal treaties" signed by the Russian and Chinese imperial courts in the subsequent centuries formed the basis of relationships mired in mutual suspicion, periodic cooperation, and basic needs. As the Chinese Communist Party began its campaign to defeat the Goumindang, the leadership in Moscow vigorously debated the extent to which they should support these forces under the control of Mao Zedong. Periodically, Stalin opted to not offer substantial support, which created a rift between the sides. Indeed, after the 1949 victory, Mao and his colleagues were repeatedly slighted by the Soviet leadership in bilateral meetings and were unsure as to how deep the relationship would ever be. There was a strong sense that the Soviet leadership condescended to their Chinese counterparts, in sort of an "elder brother-younger brother" relation-ship. This upset Mao and his colleagues, who looked upon their own culture and civilization as being much older and more developed than the Russian/Soviet one (Alexeeva, 2008; Sullivan \& Renz, 2010).

However, currently, China is one of leading trading partners of the Russian Federation. Due to the important economic role played in the global economy by China, Moscow took some important steps to strengthen its political and economic outlook in the Northeast of Asia vis-à-vis China. However, it would be fair to assert that the economic interaction between Russia and China as trading partners is not only resulting from their geographical proximity, but also from an excellent level of bilateral interstate political relations.

\section{Conclusion}

There is no doubt that the Russian Far East has many barriers to economic development. It is very important, for China and Russia, to establish a friendly and mutually beneficial relationship by following the converging interests of the two countries. While discussing long term prospects of cooperation in the Russian Far East with China, it is possible to envisage some scenarios of economic development that may be useful to policymakers. An active involvement of China in the economy of the Russian Far East seems to be the best way to accelerate 
the economic development of the region. It is possible to generate powerful arguments for such a policy regarding the region.

First, the Chinese economy is very dynamic and shows remarkable strength not only in the region but also all over the world. According to some estimations done by the Russian Academy of Sciences, Gross National Product (GNP) of China will be more than twice the size of Japanese economy - another economic giant of the region- by 2015.

Secondly, the length of territorial border between Russia and China in the Russian Far East makes possible the development of joint production facilities by creating "frontier zones" of economic interaction. Thirdly, this economic interaction could make the region more attractive for Chinese labor, which in turn would promote stable/friendly interstate and inter-regional Russian-Chinese relations.

Moreover, the relationship between China and Russia can also be a role model for a new type of relationship between great powers, characterized by mutual security, cooperation and mutual economic development. There is no doubt that those two countries in question have different political/economic systems and social structures. Consequently, there are often misapprehensions regarding a number of issues. But, both sides by getting familiar with these situations may circumvent misreading each other. The strategic partnership between China and Russia should be forged on interests, rationality and rule of law by avoiding the sentiments of fantasizing or idealizing each other. The Russian Far East can present a good opportunity to create that environment where the mutual interests for both sides would come together.

\section{References}

- Alexeeva, O. (2008). Chinese Migration in the Russian Far East. [Article]. China Perspectives, 2008(3), 2032.

- Blank, S. (2011). Russia's Geo-economic Future; The Security Implications of Russia's Political and Economic Structure. [Article]. Journal of Slavic Military Studies, 24(3), 351-395.

- Bliakher, L. E., \& Vasil'Eva, L. A. (2010). The Russian Far East in a State of Suspension. [Article]. Russian Politics \& Law, 48(1), 80-95.

- Kangas, R. (2007). The Changing Face of the Russian Far East: Cooperation and Resource Competition Between Japan, Korea, and China in Northeast Asia. Perspectives on Global Development \& Technology, 6(1-3), 441-460.

- Kuhrt, N. (2012). The Russian Far East in Russia's Asia Policy: Dual Integration or Double Periphery? [Article]. Europe-Asia Studies, 64(3), 471-493.

- Rozman, G. (2008). Strategic Thinking About the Russian Far East: A Resurgent Russia Eyes Its Future in Northeast Asia. [Article]. Problems of Post-Communism, 55(1), 36-48.

- Sullivan, J., \& Renz, B. (2010). Chinese migration: still the major focus of Russian Far East/Chinese North East relations? [Article]. Pacific Review, 23(2), 261-285.

- Troyakova, T. (2007). The Russian Far East: Isolation or Integration? Problems of Post-Communism, 54(2), 61-71.

- Zausaev, V. K. (2012). General Goal of the Strategy for Socioeconomic Development of the Far East and the Baikal Region up to 2025. [Article]. Problems of Economic Transition, 55(4), 45-51. 


\title{
Economy and National Security
}

\author{
Asst. Prof. Dr. Ramazan Kurtoğlu (Istanbul Aydın University, Turkey)
}

\begin{abstract}
After the Great Depression in 1929, “economic security” which was in litterateur after World War II developed and in Cold War period it gained a meaning with neoliberalism which was put into effect with 1978 Washington Consensus. During this period, Soviet Bloc collapsed in early 1990s and a new term emerged in New World Order which is "economic security" equals "national security" or vice versa. Now, these two terms interwined and with a religion - politics philosophy - finance / economics formatted transformation international political economy - mapping and security terms filled.
\end{abstract}

\section{Introduction: The Effect of Economy on Domestic and International Security Perception}

It is known by politics, economics and military that in March 2009, USA did a practice for the Global Finance War with President Obama's permission. Pentagon imposed duty to financial economy experts both from Wall Street and academia during this finance war practice and it is pointed out that the currency wars that started in 2010 will soon turn into a global financial war. It is understood that, the economic national security concept which emerged with the great depression in 1929 and tested in every way with World War II, is becoming more important for today's world. As a matter of fact, Pentagon's economy-finance consultant Rickards's statements are very meaningful: "Upholding U.S. national security interests cannot be done without knowing the dynamics of global capital markets. U.S. dependence on traditional rivalsto finance its debt constrains not only fiscal policy but U.S. national security and military options... The nexus of unrestrained global capital andunstable geopolitics is a beast that has begun to show its claws." At the present time, world economy is at this point.

"Our nation's program of social and economic reform is therefore a part of defense, as basic as armaments themselves.”(Roosevelt 1941:5)

What the president of the US tries to imply with this sentence is that the security of America depends upon the national power, especially the unity of American people. On the other hand, "social and economic security" was the tool of empowering the nation and the President Roosevelt emphasized that the internal and external policies of the US were inseparable and interconnected.

Economical security, as can easily be observed in such departments as social security and especially unemployment, has very important impacts upon external affairs.(Earle 1941: 186-189-193) In this sense, social and economic security is the basis of peace and domestic safety and thus, the programs about this issue are accepted as the first step of national security and national defense. This view first appeared with the Great Depression of 1929 and formed the vision of New Deal program started by President Roosevelt in June 8, 1934. That is to say, national safety is an inseparable part of economic and social security.

President Roosevelt said in his public speech on January 1944 that: "The one supreme objective for the future, which we discussed for each Nation individually, and for all the United Nations, can be summed up in one word: Security. And that means not only physical security which provides safety from attacks by aggressors. It means also economic security, social security, moral security — in a family of Nations.” (Roosevelt 1944)

According to Roosevelt the rights that already existed in American and was brought with the New Deal, the safety of sheltering, education, health and economy all form the domestic security and only this kind of security is the basis of peace. New Deal not only brought economic and social security to the USA, it also was supposed to bring "political security" to the world through the USA as a member of family of nations. Just like New Deal required free (unlimited) expenditure for the great US government's security and progress, international security of post-war also required free expenditure to overcome the chaos created by the war (Schurman 1974:42) . Although we can name this process as imperialism, this world was supposed to become a "liberal world" and was to be formed upon the concept of certain economic order.

Right after the Great Depression, Keynes had proposed a complex, regulated economic New Deal and a reform of public policy that forms a this kind of change all over the world. what he proposed was exactly the system that consists of compromises, controls and balances; which started by Friedman's systemized counterrevolution's state-by-state-refinement. Today, in this respect, Chicago school type of capitalism does not need to have anything in common with the other dangerous ideologies, which means those who believe in the shocking doctrine of neo-liberalism believe that only a great break, disasters, wars or terrorist attacks can create the big, empty plates that they need. 


\section{International Politic Economy-Map and Security}

These theologic-politic-financial "artists" keen on those dangerous opportunities in their hands, start forming a new frame for the world in its most reshapable times/moments when we all can be distorted psychologically and physically disconnected from our roots. The reason why the neo-liberal market economy ideologues assume crises and disasters as appealing is exactly the desire for the holy might for massive creation (Klein 2010: 26) As the issue of fear was forced upon external enemies gradually with neo-liberal globalization, the issue of security began to seem to indicate international dimensions. In other words, the sides of the medallion were economic and national safety. These were the required tools of a political society's security. (Virilio 2005: 170)

According to Robert Pollard, the conception of "economic security" is an economic system idea that is supposed to contribute to the profits of the USA, and that is open and integrated in contrast to a big and systemized army in peace-time. This concept has been powerfully established during the war-time. (Pollard 1985:13)

Actually, the concept of "economic security" is the strategic weapon of liberal capitalism during and postWW2, and as a basic political tool from 1945, is in a close relationship with the security issue. (Pollard 1985:13) In 1943, President Roosevelt was still saying that: “...We must plan for, and help to bring about, an expanded economy which will result in more security" (Roosevelt 1950: 574) Hence, what the Marshall Plan which the US carried out after WW2 was planned on was basically the political purposes (Leffler 1992) Here, it should be emphasized that Marshall Plan was not just a "political intention". It is obvious that this plan is multidimensioned and to separate economic reasons from political reasons prevents us from realizing the fact that economic, political and military reasons are all interconnected. The main idea is that this was a project that is carried out with the ideology of security. In this sense, what forms a basis of security is economic system, in other words capital system.(Neocleous 2012: 72) Marshal Plan and Truman Doctrines are not only a project for "economic security", but also a theological -political intention to re-regulate the global-central capital. This program was of course carried on under the name of national safety. It is quite possible to see this fact in the behind-the-lines of NSC-68. (Etzold, Gaddis 1978:401) To emphasize; the most important document of the US that belongs to the Cold War era is NSC-68. And its basic purpose it still to "shape a world in which US system can survive and grow".

The "New World Order" that has been spoken out since 1990s, and the "Great/Expanded Middle East Project" that has become outspoken especially after $9 / 11$ are nothing but a national security project established with purposes such as "economic security", "political security", "theological security" etc. that seems to "fight against terrorism", frankly "fight with Islamic terrorism". The basic motivation of the project is for Terence Corcoran "untethered neo-liberalism." (Corcoran, 17 Kasim 2006) The economic part of the "government" device, whose theological basis was formed by Messianic Ibn-Meymun (meimonides 1135-1204) and political philosophical basis based on this theological basis was formed by Leo Strauss (1877-1973), has been established by Milton Friedman (- 2006) and his friends in Chicago University Economy and Business Faculty. Friedman advocates that "shock therapy method" is the best model for economy and for this, natural disasters or wars are perfect occasions, just like Meimonides and Strauss. Everything is for the national safety of the state under the control of the "elected".

Hence, according to Yergin, "this new security doctrine of the US is developed to explain America's relationships with the rest of the world." (Yergin 1980: 194) "The historical side of these themes should not be ignored about all the claims about the US's new security assumption.” (Dalby 2002: 7)

Such discourses as the invasion of Afghanistan or Iraq, Wikileaks issue, military attacks against Libya with the mask of "Arabian Spring", civil war in Syria, intentional Turkish plain crash by Syria; the spoken or aliveon-internet war against Iran centered on nuclear power plant, Israel's military attack against Mavi Marmara, the enforcement upon Turkey about "negotiating with PKK" and the rumors about "the change in the maps in the Middle East and North Africa" spoken by secretary of state Rise especially after the invasion of Iraq.

In addition to all, Turkey and its great oil areas on its hinterlands. Boron, thorium, monatomic substance (like gold and platinum) reserves. On the other side, American Evangelist Christian's complete support for Israeli policy because of their belief of Messiah which they were waiting at the first quarter of the 21th century. (Kurtoğlu 2012) Another issue is the politic attractions of Israeli government based on Kabala-Old Testament. The region is like a petrol tank waiting for a spark to blow up.

It is constantly reminded that the borders of the countries, in other words the maps are going to change.

Maps, homogenizes the people on a land through myths about union and artlessness, focuses the political images around the nation state. As an example, a broadcast map which has nothing to do with politics at first sight, bases itself on politic agency. In other words, maps reminds about the collectivism of national area. (Black 1997: 12-17)

Neocleous states that if the governmental and statistic enumeration of population census shows that national population is full of separate subjects, maps first promulgates domestic politic agents, makes these subjects a re- 
united political community and thus builds the national identity. (Neocleous 2003) Second, what maps help is the naturalization of what is possible to happen historically by deleting some important political issues. Every settled order ... tends to produce the naturalization of its own arbitrariness. (Bourdieu 1977: 164)

Now, especially after Iraq's invasion, the USA announced its own map in newspapers, military magazines etc. "by accident" by drawing such maps as "Turkey maps", "Kurdistan maps"; and even Greece announced its own Exclusive Economic Zone in "To Vima" paper, (January, 2013). According to the map, Aegean and Mediterranean Sea have become a Greek lake. If the map were valid, according to it, one seems to transgress the borders of Exclusive Economic Zone and Greek continental shelf if s/he even swims in the sea.

Isn't it obvious that these maps are supposed to contain Turkey in "economic" and "security" manner?

Without maps, the existence of states is under risk. Mapping proposes the expression of "territorial"; to delete a state from a map is to ignore its existence. ... a state without the acknowledgment of the other states is not accepted as a state; it is "out of the map" just like a pirate, mercenary or a terrorist. As a significant political technology of place, maps spontaneously picture the territoriality policy that forms a state and provides it with continuity, but at the same time, masks the ideological and violent nature of the project. By governing the political vision in this way, maps validate the great territoryalization movement thanks to which all the world tends to posses a state. A different form of policy is generally accepted as invalid and out of date. (Neocleous 2012: 282)

The constitution and political/economic regulations in Iraq, as stated by The Economist "the national yard sale" (Economist, 27 September 2003), which is supposed to be performed in the region, especially in Iraq after the invasion, indicates that "military neo-liberalism" and "economic neo-liberalism" match and what is actually being done is nothing but capturing. (Robert 2005: 11, 43, 75)

Winston Churchill, one of the politicians of England and the inventor of Middle East and North Africa at the beginning of the $20^{\text {th }}$ century, says in 1936, in Palestine Royal Commission while talking about the probable Jewish state meant to be established in Palestine: "You all saw the sets on those hills that used to be cultivated but have become deserts with the Arabian government. Those areas should be cultivated and planted for the profit of all the world, Arabians are never going to cultivate, this is unfair." (Gilbert 1978: 176-177) Chaim Weizmann, the chair of World Zionist Organization said for the same issue that: "Palestine rebellion is nothing but a stand of a desert against civilization." ( Gregory 2004: 81-82) Today we call it "Clash of Civilizations" in the Divine Empire or in a more secular discourse "New World Order" project. ( Huntington 2002)

We witness the argument that proposes that "the reason for the destruction of the difference between war and peace is the impact of the war machine upon the daily culture" and "that a long lasting epistemic shift that blurs the old separation of war and peace has occurred" (Debrix 2008:97)

\section{What is Political about "Economic Security" and "Military Security"?}

Carl Schmitt says that "what is political is the most violent and excessive adversity." , and the closer this concrete adversity gets to its peak, which is the separation of friend-enemy, the more political it gets. The nature of friendship lies behind a couple of common values that separates friend from "the other and alien". (Scmitt 1996: 29) When we take a look at the relations between Turkey-US and Turkey-Israel, especially from the $1^{\text {st }}$ Gulf War to today, we see that it exhibits an improvement that proves what Carl Schmitt says. According to Schmitt, the entity of the adversity of friend-enemy is the political one. In this process, what decides this particular adversity is the dominant one." (Schmitt 1985: 5)

At this point, the review of Serdar Turgut is quite significant: "there is this global profound power that prevents governments from breaking the rules that themselves establish to regulate the global world, makes the conflicts fixed up in a safe way and that looks out for the economic benefits of capitalist world system. It is obvious that this profound power is constantly messing with Turkey recently. .. What I see personally is that Turkey is now the target of this profound power. This is also quite normal, expected situation as the keepers of this global system have been dealing with the new geo-strategy that has occurred upon the fall of the Ottoman Empire since the middle of the $20^{\mathrm{th}}$ century. And the question of what Turkey is going to do is the most important issue in these global system-creators. (Turgut, 10 January 2013)

There is more than "economic privatization" that neo-liberalism is dealing with. First, the security fetish has been proposed. Then, "the privatization of security" has come into play under the name of security. In the international market, the income of global security got up to $\$ 56$ billion in 1990, and got more than $\$ 200$ billion in 2000. Now, the stock certificates of security companies are traded.

The conceptual consistency between economic security and the construction of new world order meant that "economic security" can be shown right by putting the economic, thus "humane" needs on an upper place than military needs on neo-liberal base. The global central capital's production process of the New World Order supported by media and Hollywood seemed more humane in this way. This outlook helped taking liberal left into the sub-constructors of neo-liberalism. Of course it also brought such ideas as "individual liberty", "social 
equality" etc. into question by emptying them. As a result it came to the desire for "individual" and "social" security. (Neocleous 2012: 75)

Neo-liberal global power launched the connection between economic and national security as a dependence on capital security. This meant a dependence on national security. For the past 40 years, the US aimed to re-shape the international society by governing the global order according to a security doctrine that has loyalty on capital stock rather than being "reactive" or "against" under the cover of national security. (Neocleous 2012: 76) Rather, economic security became very important for the theory and practice of both social and national security by connecting local with international, domestic with foreign issues, and became the cornerstone of the security project. (Neocleous 2012: 77)

We should also emphasize that the US is the Economic Security Committee that has been on execution since June 1934 with the 6557 act.

It is important to state that today national security operations and/or strategies and (international) politic economies are considered together, because it is quite apparent that there is an obvious connection between national security and economy issues. For these reasons, the main actors of the global politics could never separate security from politic economy. (Neocleous 2012: 52) Already in the 1940s, many important academicians emphasized the supplementary relationship between economy and security. (Hirschman 1945)

Recently, it has been observed that this economic security issue is dealt with more religious discourses, Messiah, Armageddon, Gog and Magog, Apocalypse War, Third World War etc. In this sense, "now, in both East and West religion is more of a political issue... It is getting more and more secular while getting more politic and becoming the main element of every kind of policy.” (Kahraman, 20 June 2010)

\section{Perception of Economic - Political Security in a Theological Format in Turkey and its Hinterland}

The fact that my evaluations and foreseeing In my book named Evangelism are getting true since 2006, scares me in the matter of not only my own country Turkey, but also Turkish people, Islam world and humanity.

"Although in the post-modern world religion seems as poor as a scrappy cottage, it should not be forgotten that whatever is not under the roof of academia is presented to them in the sanctuaries. Prophecy, which is hope, which is miracle... human beings find themselves in sanctuaries. In poverty." (Cündioğlu 2012: 92)

Messiah/Mahdi phenomena can take Turkish/Islam geography into exactly a nuclear, biological and chemical war. For the first time in history, with various belief and estimations; the "messiah that the Jews coming from King David wait for", "Jesus Messiah that especially Evangelist Christians wait for", "Mahdi (Çağlayan 2012), who is the lost $12^{\text {th }}$ imam that Shiite Islamic Muslims headed by Iran wait for" and Mahdi, for whom some of the Sunni Muslim sects or societies wait, and the speculative political attractions and the "strong belief" for the coming of Jesus at the first quarter of the $21^{\text {st }}$ century can all overlap in a surprising level. We do not judge people for what they believe. But what is surprising is that these believers with different beliefs have things in common with one another about the expectation about Messiah. Another desperate and concerning part of this issue is getting more and more serious. The expectation of Messiah/Mahdi that I mentioned above is becoming such a social hysteria that all of the sides "call God for Apocalypse" for the Messiah/Mahdi to come.

The Kabalist celebrity Madonna who is famous for drinking Kabala water knows no bounds about the "cleansing from sins theology" on which the expectation of Jewish Messiah is based. She masturbated in front of thousands and especially her 12-year-old son, during one of her concerts. (Türk, 14 November 2012) The Kabalist celebrity Madonna showed her breasts to the audience in her concert in Istanbul in September, 2012, and in another, her hips. On the other hand, Evangelists, Zionist Israelis and the top directors of Iran, keep on with the "cold war" that announces a probable nuclear, biological or chemical war for the Messiah/Mahdi. Especially in the Western Israel, around the Israel supporters, a doomsday scenario has been composed. According to this, Ahmedinejad who is a member of a secret sect that believes that beyond the classical Shiite Mahdi expectation, Mahdi's return could be fastened with a big war, is planning to attack Israel with the weapons that he would get from the nuclear programs that he keeps and fasten the return of Mahdi." (Çağlayan 2012: 310-311) With a similar plan, an Armageddon War is being foreseen, which is planned to quicken the return of Jewish Messiah from King David's roots and Evangelists' Jesus Messiah. (Hallsell 2003) Similarly, some sects and societies from the Sunni Islamic district publish books, essays and make TV/radio programs with the same view. Besides, Directorate of Religious Affairs of Turkey has placed a fetwa that supports them. According to the fetwa, apocalypse has "small signs" and "big signs". The big signs include: "It has been informed in this hadith that without the ten signs, the doomsday will not come. Coming of Anti-Christ (deccal), return of Jesus Christ, coming of Gog and Magog, coming of Dabbetül Arz,...”(Hürriyet, 16 December 2012) It is quite enough to mention that such a fetwa displays that the council of Directorate of Religious Affairs is full of simple minded and uneducated people, because Qoran says nothing about the return of Jesus Christ. Those sentences that they call "hadith" is nothing but rubbish that is only spoken around. In this matter such a question 
can arouse in minds: "Is the issue of Messiah/Mahdi a phenomena that is achieved through the same center, with a simple saying a phenomena abused for a world war?" we leave it without critique because of the respect for our readers. However, for the Religious Studies Professor Bayraktar Bayrakl,, "All these beliefs (Deccal will come, Jesus will return etc) are pure superstitions." (Bayrakl1, 21 December 2012)

Those legitimate global elites that control the central capital and form the supernational clan canalize with the reward mechanism in fields like spiritual world, business world, politics, arts (especially cinema and music), culture and science through plenty of non-governmental organizations and groups. The two most important ones of these is the Nobel and Oscar awards. It may sound weird but two favorite names of weapon companies, David Trimbel and John Hume were nominated for Nobel Peace Prize in 1999.

English Chatham House, dozens of "international" institutions from Tavistock Enstitute to US Council of Foreign Relations are controlled and canalized from one center. The aim is to establish an esoteric globe state that they named as "Divine Empire" under the Secular definition of New World Order. In fact, it has nothing to do with any of those divinities and religion, they only "appeal to religion" to persuade masses and armies. In conclusion, what they want to achieve is:

A To prove the complete sovereignty of global central capital all around the globe,

A To leave the control of the earth to a bunch of elite under any circumstances,

A To turn celestial religions into one only syntretic religion, thus for this, to melt Islam in the pot of "Abrahamic Religions" by leaving it without Mohammad,

A To impose an elitist, fascist/company socialism model to humanity under the name of "neo-liberal democracy"

The clan of elites can apply to every single way to achieve their aims. This clan, which is called "the Sect of New World Order" (Alatlı 2005) by Alev Alatl1, are preparing for the Third World War by generating regional fixation wars and "global shocks from tiny probabilities". (Kurtoğlu 2012:1) Hence, 9/11 and after, 2008 financial crisis and the process after it, Wikileaks issue, Arabian Spring and worthless attacks against the Islamic prophet Mohammad and Qoran are only some of the operations of the same center.

Mine G. Kirkkanat, in her assay named "From Prophecy to Apocalypse" refers to the Evangelist Messiahs and prophecies about the Armageddon War. (Kırıkkanat, 1 July 2012)

Kurkkanat states in the same essay on September 27, 2002, that she touched upon the same issue with the title "Prophecy of Daniel" and emphasizes that "Daniel Prophecies" have focused on Turkey again.

"the Rumor is quite large and diverse, but Daniel starts the apocalypse that he divides into seven steps from Turkey's basin of Firat River and finishes with the world war that is supposed to take place in Great Palestine (not Today's Palestine), and in the Armageddon region that is a great part of the Middle East. As I understood from Daniel's poetic mysteries, out of seven cavaliers of the great crowd, the sixth one is going to finish. First, the waters of Firat is going to dry, Anatolian lands are going to burn under the burning sun. Then, God knows where(!) an earthquake will take place. The conditions will force the kings (or armies) in the East to come down to Armageddon. And right there, in the Middle East, a war will break out with the Western armies. The reviews about these prophecies also not only show Turkey as the starter of the doomsday, but also they foresee that its borders will get smaller, a disaster will sweep away the Turkish nation, the end of Turkish government on the region and the beginning of armageddon war!

There is for gravestones that are assumed to be Daniel's: Uzbekistan, Iran, Kirkuk and Turkey (Tarsus).

Strangely, in the year 2012, when Turkey sent masses of soldiers to the border of Syria, Daniel prophecies again focused on Turkey in the websites. And there is a new prophecy, says Kirkkanat, no comment... here is the prophecy:

"23/after the sinners conflagrate and their impacts fade out, an insolent and trickster emperor will come out. 24/ his power will grow but it will be someone else's; will give incredible harm, will succeed in his attempts, will cut off the competents and saints. 25/ the abundance and his gains with his tricks will surround his heart with hubris, will ruin many peaceful lives and will fight with the leaders of leaders but will defeat himself without anyone's interventions."

Tom Schelling is an economist with a Nobel prize. His profession and under cover is terrorism, to prepare "counter-attack/anti-terror" scenarios by foreseeing the worst. As a result of the analysis that he come up from the intelligence reports coming from CIA, MOSSAD, NSA and many others, he came up with the idea that now the enemy - especially the "Islamic terrorists" have started considering about using nuclear weapons and from him, every day can be the last day of all humanity. Schelling, the 90-year -old game theory economist, is "renewing" his kitchen in his house in Bethesda Maryland, around Washington DC by spending thousands of dollars. Actually this is what he wants others to know. What he actually does is a nuclear refuge in case of a probable nuclear attack against the US. (Turgut, 25 November 2012) How about this? Hollywood came up with these movies in regular periods: Arlington Road, Under Siege and Swordfish... then here comes the 9/11 attacks in accordance with the scenarios of the movies. Just like in three of these movies, all the criminals were "Muslim 
Arabian terrorists". Remember, now those preparing for a "nuclear attack" in such TV series as "24" are all "Muslim Turkish terrorists". What do you think? Can Turkey be the target this time?

\section{Report of "Global Tendencies" Published by NIC}

The National Intelligence Council (NIC), which is the top intelligence organization of the USA, published the last "search of global tendencies" made every four years on December 10, 2012. The report proposes the "predictions" and dynamics of 2030. the most important "prediction" about Turkey is on "the impact of an independent Kurdistan on Turkey's powers". The report states that Turkey's territorial integrity is in danger and in 18 years, until 2030, a division of land is expected. Matthew Burrows, authority of NIC, states that Turkey will be the first country to be effected from what is going on in Syria by reminding that the war in Syria was the outcome of the expansion.

One of the cases in the "Global Tendencies 2030: Alternative Worlds" report, depicted as "game transformer", are arranged as:

- Global economy open to crisis

- Fondness of governability

- Increasing working potential, both within and international

- Tendency of increase in local inconsistencies

- Effects of the new technology

- Role of the US

While the US is becoming an exporter of gas and petrol, the increase in such important issues as expenses of education to prevent a decrease of quality, and health. According to the report, $60 \%$ of the world population is going to be living in the city centers in 2030 for the first time since 2006 . Another issue is that Asia is going to be the center of world economy. According to this report, which talks about the four great tendencies towards 2030:

- The middle class is to increase in the world population. The world population which is today 7.1 billion, will be 8.3 billion in 2030 .

- Separation of powers, China is to outreach the USA, but will look for a local partner.

- The population will get older especially in Europe, Russia, China and Japan; Pakistan, Afghanistan and Africa will be out of this process.

- Food and water will be harder to reach.

"In short, the NK report has a great significance to read the perspectives of the US deciders about Turkey for the coming period." ( Ergin, 21 December 2012)

Let's get back to the lines of the "Global Tendencies 2030" report concerning Turkey and the region.

Condoleezza Rice, the National Security Consultant and Foreign Affairs Minister during the term of Son Bush said that in 2004, the borders of 22 countries are supposed to change in the Middle East. Rice implied that Turkey can disintegrate referring to Egypt, Iran, Turkey Syria short before the publication of the report. More or less in the same period, American Ambassador of Ankara, Morton Isaac Abromowitz also said that 2014 is a critic year for Turkey. (Abromowitz, 20 September 2012)

The former editor of National Interest magazine and US Marine Forces Academia lecturer Nikolas K. Guasdev stated in February 2012 that "Syria issue" is an understanding that is called "Syria norm", which limits the rights of the state to have counter force for the rebels, and he said that the understanding of government in the international system whose sovereignty rights have been determined with the Montevido Treaty is no more valid. According to the American academic, in a short period, "Syria norm" will make the counter-attacks against PKK in Turkey, FARC in Columbia, Marxist and Islamic rebellions in Philippines more questionable, and as a result, the countries in question will have more restrictions in their sovereignty on certain regions of their own land.

It is obvious that the decision of formation of Turkey and its hinterland on an ethnic and religious sect base since the mid-1970s. and that the project was initiated by American National Security Consultant Henry Kissinger, and that the project carried on successfully in Lebanon.

In June 1978, headed by Bernard Lewis and sponsored by Kissinger, a meeting was held in Princeton University to which well-known experts in concern with Orientals and modern Arabian countries attended. One of the calculations of the meeting was the redrawing of the borders according to the religious sects and beliefs of the $19^{\text {th }}$ century.

Similar perspectives were included in Kivunim (Directions) magazine which was made the media organ of World Zionist Sect by Oded Yinon more clearly. (Yinon, February 1982: 14) 
In his "1980s Strategies for Israel" essay Yinon states that the ethnic and sect structure of all Middle East including Iran and Turkey poses great occasions for Israel. According to him, Iraq should be divided into three, Syria to six different states.

Jewish General Wesley K. Clark who commanded NATO's European Unions (1997-2000) and who carried out the operation that was planned against the David Koresh Sect in Wako Mountain, Texas; which was bloody, had ended up with the death of many women and children; explains the ideas parallel with the ideas above with the name "fight with terrorism" in his book" Winning the Modern Wars-Iraq, Terrorism and American Empire" written after the invasion of Iraq in more detail.

It is clear that the map of the region which includes Turkey, as well, is apt to change. This is not a prophecy, it has already started. Actually the US announced that the maps are to be redrawn in our own region short time ago. Also, Condoleezza Rice, Foreign Affairs Minister of Bush has already emphasized this fact clearly. (Turgut, 27 November 2012)

\section{Geography- Economy-"Fate"}

Robert D. Kaplan is a familiar name for Turkey. The name of his last book is "the Revenge of Geography: What the Map Tells Us about Coming Conflicts and the Battle against Fate"

Kaplan says in his 19 paged essay "On the Coming Anarchy on Our Planet", he asks the question "why should Turkey have built the dams in the Southeast Anatolia Project, which would go out of its possession?" in 1994. (Kaplan, Şubat 1994) This essay was one of the 80 essays written in the Balkans which was the hot spot of Europe, and it was included in his book "Balkan Ghosts", one of the most important 14 books that he wrote. As Serdar Turgut states, "his manner is surprisingly like John Reed, which was the author of the books Ten Days and Insurgent Mexico. He observes and reads the countries that he visits. This kinds of people release the strategic facts that even the secret services cannot."

Kaplan works as the head geo-politic analyst in Straford referred to as open CIA.

Today, to understand the politics that Israel and USA carry on in the Middle East, one should closely examine the prophecies that Kabala+Old and New Testaments say, and study Batıni/esoteric interpretations that especially the Evangelist Christians have out of holy texts. About this issue what Serdar Turgut has to say is that "... Whereas what motivates Israel and their supporters in America is the beliefs and ideas which would sound totally irrational and non-sense. We can explain neither Israel nor America without understanding this situation."

To be able to do this, we should be aware of the secret histories of these countries and esoteric sciences. I, out of curiosity, examined the secret beliefs and superstitions that motivate Israel. So, none of their crime against humanity seems surprising to me. I was expecting these, because they believe that they were fulfilling a great mission that they were assigned by divine beings. Their supporters in Israel and America -Evangelists RKbelieve that fighting is their destiny, moreover these wars were written in their religious sources and they were ordered to do so." (Turgut, 22 November 2012)

According to Serdar Turgut, the people under the control of Israel, which believes that their country is preparing for a war that will bring the end of the world according to the "Israel war calendar", are planning every aspect of their daily life according to the Sabbath calendar. This calendar indicates that Israel's new war is supposed to blow up nowadays. And now guess what! There are many that believe this war is going to be with Turkey. There are also those in Israel and America who believe that this is written in the religious sources about the end of the world. According to this story which is not only told but also believed in, this war with Turkey will not directly lead the world to the final destination, but it will lead it to armageddon, the war that is supposed to directly end up the world. These people believe that the process towards Armageddon must be triggered with some provocations and attacks, because Armageddon is going to take place on the day that Jesus Messiah is supposed to come down to earth. With this belief, the Evangelist Christian communities in the US plump for Israel... Armageddon is going to take place in the Megido Hill on the north of Israel. On the day of Armageddon, it is supposed that some enemy countries will come up to Megido and establish coalitions in this region. This coalition, which would definitely include Turkey and Iran, will go to war with Israel, which would be bloody and include nuclear weapons. (Turgut, 22 November 2012)

On the other hand, the Judeo-Christian perceptions about Turks being a sign of doomsday in the West date back to the ancient times. "thanks to the massive communication devices a famous Turkish enemy outlook was formed using the religion and government war propagandas." (Coşan 2012: 11) For example, as a result of Martin Luther's naming Papacy and Turks as Deccal; this idea was obtained by both Protestantism and Catholic Christianity. (Coşan 2012:161)

During the construction of the New World Order, the last country to be conquered is EDOM. According to Kabala, the holy texts that underlies the Jewish mysticism, "Edom" was the ancient name of Anatolia that covers most of the Turkish land. (Nirun 2006: 9-208) Anatolia is within the promised land. After all, Edom was the name of the country to be conquered with the last victory. We need to say that what we live through now and the 
Middle East paradox is way beyond the surface on which such covers as Saddam, petrol, water and Iran's nuclear power are held as any human being can realize. It is not wrong to think that the world is seriously going towards the Armageddon, which is the last war in the Middle East based on the Apocalyps symbolism. Now we should think more universal and understand why and how one serves the other. We are running out of time and our only solution is Ataturk's worldview and regional policy. God knows, maybe he foresaw all these in Seljuk in 1933 and emphasized today." (Nirun 2006: 208)

The hegemonic aims called New World Order are not only supported by the divine/holy texts. The military expenses of the US -so do Israel- in total is same with the 15 forces' budgets in total that comes after America, and more than twice as much as the EU and NATO expenses in total, and close to Russia's GSMH. Of course the unilateralist policy of the US is not a policy that is started by son George W. Bush, but it has earlier roots (Clinton, as well). (Huntington, Nisan 1999) But this unilateralist policy with Evangelist and neo-con supported Bush caused US' closest supporters to blaze. (Nye, National Interest 2001/2) However, the powerful, rich and strong elites that risk everything for the world hegemony and God Empire both in Israel and in America are still around and "the Islamic terrorists" are remarked with such an observation: "... but if some of them are determined enough to attack you for the sake of their creator, they are probable to succeed. In short, if you want a world hegemony, you should be ready to pay for it." (Isenberg, 30 October 2000)

An example to indicate that they can do very dangerous things to attract the American people and army and "to make global shocks on weak probabilities" (Kurtoğlu 2012) as an indication of the seriousness of the danger that Turkey and Islamic world face: author Christopher Bollyn tracked 9/11 issue for years. In conclusion he published his "Solving 9/11 the Deception that Changed the World". According to the book, Bollyn traced the people whose names were involved in the attacks just like an intelligence agent. He followed the indications to the last and searched if there was a control plan in the 9/11 attacks. What he reached was that behind these attacks there were Jewish/Evangelist Zionists and this business could go even to the corridors of some institutions of the shadow government of the US.

"End of Times", "Armageddon War" are basically American-centered. The belief that Israel was in a holy war and the Armageddon War will show up eventually started within small communities in America, however, it spread throughout the country thanks to some films and book series like "Left Behind", and ultimately the idea reached to a great deal of supporter masses. The novels gathered under the title "End of Times" are written on the basis of the Kabala, Old and New Testament texts, although they seem to be products of science fiction. Americans read these type of novels with a great interest and emotions. This type of literature is called "Apocalyptic Literature" and the most famous author of this genre is Tim La Haye. the civil staff and supporters in the security and intelligence communities in Washington of this idea, especially that of Pentagon are highly abundant. (Turgut, 23 November 2012) For most of these people, Israel is as important as the US and most of them have Israel passport. The power that Israel has to be this reckless is coming from these supports. These powers are determined to get into a holy war with Israel. And they are ready to get rid of any person or power that prevents them from getting into action for their goal. (Turgut, 23 November 2012)

It should not be an overestimation that these irrational stories actually determine the policies of the US Israel. "using nuclear weapons, killing women and kids, sacrificing thousands of people for their non-sense goals is not for rational people; but as these people are the blind captives of the stories told in those holy texts, many people cannot understand the attitudes of America and Israel. (Turgut, 22 November 2012)

The Israeli government has such a faith in this process that the signs of these religious sources can be seen in everything they do. A short time ago Israel secret service sent a computer virus to sabotage Iran's nuclear system. Even in the program texts of these viruses named STUXNET there are references to the part that is about the victory of Jews against the Persians in Torah. These insane people believe that a third Solomon Temple should be built before the return of Messiah. They believe that the Third Solomon Temple is on the sky and that the new temple should be built exactly under the shadow of that temple on the sky. Now, on the spot that this shadow is believed to be, there are two Islam temples, Al-aqsa Mosque and the Dome of the Rock. They say that for the construction of this third temple, those two Islam temples have to be collapsed. (Turgut, 22 November 2012) All these may sound weird, but it is good to remember Italian thinker Umberto Eco's words: "Do not debate over a belief's wrongness and rightness, think about what they could/can challenge for what they believe." It is obvious that "great catastrophes are expected for the world and all the humanity." (Eygi, 27 April 2006) According to the "Alternative Worlds" report that is prepared for the 2030 global tendencies by National Intelligence CouncilNIC, which includes all the intelligence agencies in America, the Islamic parties will be more ECONOMIC, in other words, it will turn into a neo-liberal "market Islam". Again, the report emphasizes that the political Islam is taking over the control in the Sunni Islamic world by showing Turkey, Tunis and Egypt as examples.

Mehmet Şevket Eygi says: "I do not know where, when or how but a great bloody war named Armageddon will break out. I can hear the bells. The bells of the war are not like those of humans. Those who can hear can, and who cannot, cannot... Iran is a big deal. They cannot deal with it by themselves. The best way is to crash them with another Islamic country. Thus, they could do two things at the same time. Iran can disintegrate and become slave, so can those countries with American supports... those Arabian originated and Sefarad Jews in 
Israel are the second-class Jews in America. There is a black panthers movement that fights against racism and Zionism in Israel... on the other hand, there are crypto-Jews in every Islamic country. These people can go to the mosques, pray, fast and go on pilgrimage. They seem to be more or less Muslim from outside, but they still have the Jewish identity in themselves. Bi-identity, bi-religion is acceptable for their religion... just like this, they want to assign seemingly Muslim, actually Jewish governors for the US/Israel and Islamic countries. And they call all these issues the war of good and evil. (Eygi, 27 April 2006)

The 114-paged study "Study on a possible Israeli strike on Iran's nuclear development facilities" carried on by Center for Strategic and International Studies-CSIS, centered in Washington DC indicates that right after such an attack, thousands of people will die, and the radiation clouds will endanger the lives of hundreds of thousands of people in countries such as Bahrain, Qatar, the united Arab Emirates, Turkey, Azerbaijan, Georgia, Armenia and many others. Thus, US president Obama and a group around him are debating over the need for a cyber attack against Iran at first. According to the facts that we obtained from open sources, they have been working on this issue since 2010. And the US passed a document named national cyber policy for the first time in its history and a cyber commander was appointed to National Security Council.

In these "cyber war" plans, it is very significant to collapse the target country's economy. It is frequently mentioned that this system based on the collapse of economic substructure would attack the neighboring countries of Iran and subsequently cause a global financial crisis.

It is known that a successful attack against Iran's nuclear facilities was carried on with a computer virus named STUXNET in 2010-2011 and it could stop the work in the facilities. What is strange is that it is predicted that Israel was supported not only by the US, but also China with this attack. Apparently in a short time, Israel and the US will break out a cyber war that will effect every single country in the territory especially Iran.

The prophecies about the 12.12.12 of Mayans have passed. There was no apocalypse, but it should not be an overestimation that in the coming 30 years, we will have a period in which moral values, religious issues will effect humanity more and at the same time the holy texts will be abused with esoteric/Batıni interpretations.

\section{An Inefficient Economy Theory: Neo-liberalism}

The economic model of neoliberalism which was started officially with Washington Consensus in 1978, collapsed with the financial crisis of 2008. "the financial and debt crisis revealed that economy discipline was in a crisis, as well. The models that the main currency economy has improved are no more efficient to reflect reality and make true analysis. What kind of a solution can be found for financial and debt crisis? Will the inflation disvalue our money? We had never needed the comments and analysis of the economy experts as much as now before. But the thesis that both the main currency economists and Marxist economists have reached have started to be criticized densely. Now nobody believes that the free market can heal itself anymore." (Ulrich 15 September-November 2012)

Prof Thomas Straubhaar, who is the director of the research center named World Economy Institute in Hamburg in Germany says that: "Even the basic rules of the economy discipline must be questioned. Economy discipline does not have such unquestionably valid rules that can be foreseen and followed like in physics. Thus, we should not attempt to come up with standard recipes for extremely complicated issues." But from the middle of 1970s IMF and WB and from the middle of 1990 WTO imposed the standard recipe for the countries all over the world. Fund manager and author Prof. Max Otte is one of the true-predictor of the global financial crisis in 2006. But on the other hand he admits that neither the main currency economy models nor academic economy knowledge is enough for the solution of the crisis. Today's economy can only provoke and increase the crisis. Otte is the first of those who claim that economy is inefficient to explain the current crisis scenarios of the modern economy. While advocating that behavior economy as a new branch of science does not have the deserved interest, Otte continues: "the impact of prejudice and emotions upon behaviors is getting more attention. Thus, the number of those who demand economy to combine with religion, sociology, philosophy, history and even biology is increasing." Because it should not be forgotten that the issue is the human being and its social progress. The importance of imbalance and power distribution and the importance of the distorted knowledge should be considered. There is not only one market that the main currency economists applause and tried to be continued for 20-40 years, there are, instead, many markets.

What has gone bankrupt with the financial crisis of 2008 is not only neo-liberalism but also the "prophecies" that formed the theological basis of neo-liberalism. Here are some of them: a- a one world state-government will be established. (Vahiy 13:7; Daniel 7:23) B- a one world economy management will be established. (Vahiy 13: 16-17), c- a one world-syntretic religion, belief government will be instituted. (Vahiy 13: 3,4,8) When we take a look at the process from the past to the present, Holy Scripture is the basic element of Judeo-Christian consciousness, a basis that cannot be underestimated. Again, from the past to the present, the military and economic gains of the West have always been bloody. So, while searching the policies of TOMORROW of the Judeo-Christian Western world, we should not forget that the things having happened from the past have been "suspended and blessed with the obedience of prophets" as it is not a prophecy to say that tomorrow will be the 
same. We have to see the danger before it happens. The 9/11 "operation", invasion of Afghanistan and Iraq in 2003, financial crisis of 2008, Wikileaks and Arab spring... All these are the operations based on "the global shocks on weak probabilities" (Kurtoğlu 2012) of New World Order project. In this case, the code name of Syria crisis is "Leviathan". (Turgut, 23 July 2012)

Leviathan is an expression with Kabalan roots that is a Jewish mysticism, and a reference to "God Empire" that owns exact power and might. Thomas Hobbes's book published in 1651 named Leviathan, is the code name of the operation against the territory that includes Turkey and its hinterland today.

Turkey's land governs a great area that has boron, thorium that is the new generation nuclear energy fuel, gold and platinum that are the monatomic elements and 453 billion cubic meter of natural gas reserves that are found in East Mediterranean Sea and Cyprus. "today there is a great probability that this struggle carried on secretly for a long time would turn out to be a great war.’(Turgut, 23 July 2012)

The biggest world powers are carrying on military exercises in the Eastern Mediterranean Sea. There is an unusual increase in the number of the Russian war ships passing from Turkish channels arriving at Mediterranean Sea.

"The Israeli submarines loaded with nuclear weapons are running around in the Eastern Mediterranean. It also turned the Greek Islands into military bases. These Greek Islands loaded with weapons have become Israeli airplane carriers. We also need to remember that 100 Israeli airplanes are used in the military exercises carried out in Crete Island and also 2-300 missiles are used, as well.” (Turgut, 23 July 2012) Besides, it is not a hidden information that China also shows its navy East Mediterranean as target.

As academician and columnist Serdar Turgut writes: "some people pushed the button somewhere again and the massacres started in Gaza. It is for sure that the crisis of Mavi Marmara and break of Israel-Turkey relationships are the tools that these "some people that pushes the button" use to create an inconsistency in the region. Getting Turkey into a war is required by the destabilization policies of these power who seeks for the inconsistency. We should consider the fall of our planes and not only exterior, but also interior war calls after the incident in this respect. One of the best ways to fasten the inconsistency is to make a disinformation operation. This kind of operations including cyber attacks war is already being practiced against Lebanon, Iran and Syria. It is quite obvious that they aim at Turkey, as well."

\section{Conclusion}

Turkey now has to practice those short-medium-long term precautions needed more in two occasions, while taking increasing deterrence of Turkish army, which Ozdag calls HARD POWER: (Özdağ 2012: 1) first, as Sait Y1lmaz explains in "Smart Power", "Turkish Armed Forces should establish a cyber war command according to the examples of those in the West for cyber war and information war... the danger in social media should be seen; the national versions of microblogs, facebook and twitter accounts should be promoted and used. Our intelligence system should be encouraged to use social media more." (Y1lmaz 2002: 439) Second thing that should be done is to take lesson from 1838-1914 period of the Ottoman Turkey. As we know in this period, the liberal economy formed of judicial-economic-politic regulations in 1838-1839-1854-1856-1881-1908, has quickened the fall of Muslim Turkish traditional trades lacking an equal competition, and increased the activity of the foreign capital and non-Muslim elements in economic area." (Toprak 2012: 557)

When we compare Republic of Turkey's 1950-80 period in which it practices "Complex Economy-Import Substitution" with the period from January 24, 1980, on which it started to practice neo-liberal policies to today, we unfortunately see that the latter period is more pessimistic than the former and reminds about the 1838-1914 period of Ottoman Turkey.

The progress after the 2008 global financial crisis shows that, the financial sector of economy at the first place especially the strategic sectors' being "national economy" formats is quite important. It is obvious that in the coming period more protective policies will become prominent in the international economy field, which means national economy will never lose its importance in any period.

Turkey should not estimate its national security separate from "economic security" and should take necessary precautions about the "maps" issues without losing time. In other words, Turkey should also be "strengthened with independence and economic independence" as Gazi Paşa says.

The most apparent quality that postmodernism and neo-liberal globalization brought to the present humanity in the last 40 years is "wastage" for Zygmunt Bauman. Just like the weeds being the waste of the garden, "unqualified streets are the waste of city planning, contrasting ideas are against ideological entity, rebelling ideas are waste for orthodoxy and foreignness is the waste of nation state construction" (Bauman 1991: 15)

The most important issue here is that many "common areas" of "nation state" and "national society", time, recovery and solution are all wasted with unnecessary arguments and separations. And Turkey cannot continue this and this kind of luxury any more. 


\section{References}

- Robert, "Afflicted Powers: Capital and Spectacle in a New Age of War", Verso, London, 2005.

- Aktaran, Martin Gilbert, Exile and Return: The Emergence of Jewish Statehood", Weidenfeld and Nicolson, London, 1978.

- Albert Hirschman, "National Power and Structure of Foreign Trade", University of California Press, Berkeley, CA, 1945.

- Alev Alatl1, "Kabus", Everest Yayınları, 16. Bask1, İstanbul, Mayıs 2005.

- Ata Nirun, "Panaya Kapulu-Meryem Ana Evinin Sırrı", Destek Yayınları, Ankara, 2. Baskı, Kasım 2006.

- Ata Nirun, a.g.e, s. 208.

- Bayraktar Bayrakl1, "Kıyamet ne Zaman Kopacak” Haber Türk, 21 Aralık 2012.

- Carl Schmitt, "Political Theology(1922)”, Çev. George Schwab, MIT Press, Camb. MA, 1985.

- Carl Scmitt, "The Concept of the Political" (1932), Çev: George Schwab, University of Chicago Press, Chicago, 1996.

- Daniel Yergin, "Shattered Peace: The Origins of the Cold War", Penguin, Harmondsworth, 1980.

- David Isenberg, "Welcome to the Postmodern Warfare Era", Intellectual Capital.com, Cilt. 5, Sayı. 40, 30 Ekim 2000.

- Derek Gregory, “The Colonial Present", Blackwell, Oxford, 2004.

- Dücane Cündioğlu, "Sinema ve Felsefe", Kapı Yayınları, İstanbul, 2012.

- Edward Mead Earle, "American Security: Its Changing Conditions" Annals of the American Academy of Political and Socience, No. 218, 1941.

- F. D. Roosevelt, "Press Conference", 28 Aralık 1943, The Public Papers and Addresses of Franklin D. Roosevelt içinde, 1943, Harper and Brothers, New York, 1950.

- François Debrix, "Tabloid Terror: War, Culture and Geopolitics”, Routledge, Londra, 2008.

- Franklin D. Roosevelt, "Annual Massage to the Congress", 4 Ocak 1939, Public Papers içinde, Vol. Macmillan, Londra, 1941.

- Franklin D. Roosevelt, "Eleventh State of the Union Address" 11 Ocak 1944, in the Public Papers and Addresses of Franklin D. Roosevelt 1944-1945, Harper and Brothers, New York 1950.

- Franz Schurman, “The Logic of World Power”, Pantheon Books, New York, 1974.

- Grace Halsell, “Tanrı’yı Kıyamete Zorlamak”, Türkçesi: Mustafa Acar-Hüsnü Özmen, 2. Baskı, Kim Yayınları, Ankara, 2003.

- Haber Türk, 14 Kasım 2012.

- Hasan Bülent Kahraman, Pazar Akşam, 20 Haziran 2010.

- Hürriyet, 16 Aralık 2012.

- James Rickards, "Kur Savaşları-Bir Sonraki Küresel Krizin Oluşumu”, Türkçesi: Neşenur Domaniç ve Nusret Avhan, Scala Yayıncılık, İstanbul, 2013.

- Jeremy Black, "Maps and Politics”, Reaktion Books, Londra, 1997.

- Joseph Nye, "Seven Tests: Between Concert and Unilateralism", The National Interest, Sayı. 66, Kış 2001/2.

- Klaus Ulrich, Almanya'nın Sesi radyosu-Turquie Diplomatique 15 Ekim-15 Kasım 2012, Sayı. 45.

- Leyla Coşan, "Kıyamet Alameti Türkler”, Yeditepe yayınları, İstanbul, 2012.

- M. I. Abromowitz, Nationalinterest, 20 Eylül 2012.

- Mark Neocleous, “Güvenlik Şiddet ve Savaş”, Türkçesi: Gül Çorbacıoğlu-Ersin Emkel, Dipnot Yayınları, Ankara, 2012.

- Mark Neocleous, "İmagining the State", -Milton Keynes: Open University Press, 2003.

- Mehmet Şevket Eygi, “İyiler Kötüler”, Milli Gazete, 27 Nisan 2006.

- Mehmet Şevket Eygi, Milli Gazete, 27 Nisan 2006.

- Melvyn P. Leffler, "A Preponderance of Power: National Security, the Truman Administration and the Cold War", Stanford University Press, CA, 1992.

- $\quad$ Mine G. Kirıkanat, Cumhuriyet, 1 Temmuz 2012.

- Naomi Klein, "Şok Doktrini-Felaket Kapitalizmin Yükseliş̧”, Türkçesi: Selim Özgül, Agora Kitaplığı, İstanbul, 2010. 
- $\quad$ NSC-68, 14 Nisan 1950, Thomas H. Etzold and John Lewis Gaddis (Der.), Containment: Documents on American policy and Strategy içinde 1945-1950, Columbia University Press, New York, 1978.

- Oded Yinon, Kivunim, Şubat 1982, Sayı. 14.

- Paul Virilio, "Negative Horizon (1984)”, Çev. Michael Degener, Continuum, Londra, 2005.

- Pierre Bourdieu, "Outline of a Theory of Practice", Çev. Richard Nice, Cambridge University Press, Cambridge, 1977.

- Ramazan Kurtoğlu, “Evanjelizm”, 3. Baskı, Sinemis Yayınları, Ankara, 2012.

- Ramazan Kurtoğlu, “Küresel Ekonomik Kriz ve Yeni Dünya Düzeni”, Sinemis Yayınları, Ankara, 2012.

- Robert A. Pollard, "Economic Security and the Origins of the Cold War 1945-1950", Columbia University Press, New York, 1985.

- $\quad$ Robert D. Kaplan, “On the Coming Ararchy on Our Planet”, The Atlantic Monthly, Şubat 1994.

- Sait Yılmaz, Akıllı Güç, Kum Saati Yayınları, İstanbul, 2002.

- Samuel Huntington, “The Lonely Superpower”, Foreign Affairs, Cilt. 78, Say1. 2, Mart-Nisan 1999.

- Samuel P. Huntington, "Medeniyetler Çatışması ve Dünya Düzeninin Yeniden Kurulması”, Türkçesi: Mehmet Turan-Cem Soydemir, Okuyan Us Yayın, İstanbul, 2002.

- Saule Baycaunova, "Kazakistan Petrol ve Gazının Türk ve Rus Dış Politikalarındaki Yeri ve Önemi”, Avrasya Dosyası, Yaz 2000, Cilt: 6, Say1: 2.

- Sedat Ergin, ABD İstihbaratının Gözünde 2030 Türkiyesi”, Hürriyet, 21.12.2012.

- Selin Çağlayan, “İran-Mehdi’yi Beklerken”, Cinius Yayınları, İstanbul, 2012.

- Serdar Turgut, "Coğrafya”, Haber Türk, 27 Kasım 2012.

- Serdar Turgut, "Herkesi Şaşırtan İhtiyar”, Haber Türk, 25 Kasım 2012.

- Serdar Turgut, “İsrail-Türkiye Savaşı ve Armagedon”, Haber Türk, 22 Kasım 2012.

- Serdar Turgut, Haber Türk, 23 Temmuz 2012.

- Serdar Turgut, Haber Türk, Derin Dünya Türkiye’yle Uğraşıyor, 10 Ocak 2013.

- Simon Dalby, "Environmental Security”, University of Minnesota Press, Minneapolis, 2002.

- Terence Corcoran, "Free Markets Lose Their Last Lion”, National Post Toronto, 17 Kasım 2006.

- The Economist, "Lets All go to the Yard Sale: Iraq's Economic Liberalisation”, 27 September, 2003.

- Ümit Özdağ, -Sait Yılmaz, “Akıllı Güç”, içinde, Kum Saati Yayınları, İstanbul, 2012.

- Vahiy 13: 3,4,8.

- Vahiy 13:16-17.

- Vahiy 13:7; Daniel 7:23.

- Zafer Toprak, “Türkiye'de Milli İktisat 1908-1918” Doğan Kitap, İstanbul, 2012.

- Zygmunt Bauman, “Modernity and Ambivalence”, Polity Press, Cambridge, 1991. 


\title{
Effects of Russia's Economic Growth on Turkey's Tourism Sector
}

\author{
Asst. Prof. Dr. Levent Şahin (Çankırı Karatekin University, Turkey) \\ Assoc. Prof. Dr. Hasan Akça (Çankırı Karatekin University, Turkey)
}

\begin{abstract}
The aim of this study is to analyse whether there is a relation between economic growth in Russia and Turkey's tourism sector or not. Data (GDP in Russia and Russian tourists who prefer Turkey as tourist destination) cover the period 2001-2011. According to results of regression analysis, there is no effect of GDP increase in Russia on number of Russian tourists visiting Turkey. It can be said that most of the Russian tourists visiting Turkey have medium income level. They prefer Turkey due to cheap holiday opportunity (everything inclusive system), closer to Russia and qualitative service. Russian tourists having high income level travel to Far East Countries for holiday.
\end{abstract}

\section{Introduction}

Start of travelling backs to old ages. Human being moved one place to another one due to reasons such as war, migration, trade, etc. Travel started with learning willing of unknown things. For example, in the $19^{\text {th }}$ Century, European Aristocrats having high income organised travel activities towards Greece, Antique Egypt and Italy (Kizılirmak \& Kurtuldu, 2005).

Especially after Second World, tourism activities have extended in Europe. For example, Europeans had visited Mediterranean countries in terms of account cultural values, natural beauties, climate, etc. in second half of 1940s. As parallel to increase opportunity of travelling by plane in 1970s, intercontinental tourism activities started. Today tourism became a sector contributing many countries economy at important level (Öztürk \& Yazıcıŏlu, 2002).

Tourism leads to reduce unemployment due to being a labour-intensive sector, increase foreign Exchange earnings, contribute to balance of payments in positive way, and create new tax areas for governments. In addition, it has significant impacts in the development of many sectors such as construction and food. Adding positive value to economy of the region and country has increased the importance of tourism sector.

Turkey had more than 29.343 million international visitors in 2011, making it the $6^{\text {th }}$ top destination in the world. May 2013 data from the Ministry of Tourism (General directorate of investment and enterprises, Department of research and evaluation) show a substantial increase for the whole year to reach 35.7 million in 2012 (Lanquar, 2013).

Although Russia takes second place in number of international visitors travelling to Turkey, number of studies focusing effects of economic growth in Russia on Turkey's tourism sector is very limited in the literature. Therefore this study has an importance in order to know the level of relation between GDP in Russia and number of Russian visitors travelling to Turkey.

\section{Economic Development of Russian Federation}

Rapid development in the key economic indicators was achieved by Russia as a result of reforms such as restructuring and openness in the last period of Union of Soviet Socialist Republics (USSR) and also liberalization and openness of the country in the period of Russian Federation Russia (Duman \& Samadov, 2003).

After collapse of SSCB, in risk environment Russian economy had face to face economic collapse. In 1992 , Russian Federation made important economic reforms in order to move from centrally planned economic system to market economy. Some of them are as follows (Duman \& Samadov, 2003):

- $\quad$ Left prices free

- Partial abolishment of trade constrains and supports

- Achievement of financial balance

- Open economy

- Privatisation and abolishment of state economic organisations

Between 1992 and 1996, privatisation of small and medium sized state organisations was achieved. In the first stage of the privatisation process, in the period 1992-1995, SMEs in the sectors of industry, service and agriculture were sold to private entrepreneurs, but in second stage (in 1996) big enterprises under control of the state were sold to banks in order to pay credits gotten by government to reduce budget deficit. In the third stage (in 1997), enterprises under control of the state were privatised after some pre working states. Generally it can be 
said that most of the enterprises in the sectors of construction, agriculture, food industry, etc were privatised (Duman \& Samadov, 2003).

According to results of the year 2012, Russia had the highest economic growth ratio with $3.4 \%$ within the Group of Eight. In the reports of comparative economic performance with foreign countries published by Russian State Statistical Organisation, Russia is the leader point of view increase in consumer price with $6.6 \%$. Within the Group of Eight, except for Russia, USA and Japan achieved the highest economic growth with $2.2 \%$ and $1.9 \%$, respectively. In 2011, the highest unemployment ratios were $11.2 \%$ in Italy and $10.6 \%$ in France. The figures were $7.8 \%$ in England and USA, 7.1\% in Canada, 5.3\% in Germany, and $4.2 \%$ in Japan (Rusya'nın sesi radyosu, 2013a).

\section{Russia-Turkey Tourism Sector}

Tourism has an important role in economic relations between Turkey and Russia. After the crisis of 1998 the number of Russian tourists visiting Turkey has experienced a significant decline. However, the number of Russian tourists visiting Turkey has started to rise again as parallel to start of the recovery in the Russian economy and overcoming effects of the economic crisis (Dış Ekonomik İlişkiler Kurulu, 2005). According to data of the Russian Federal Tourism Agency (Rosturizm), 47.813 million Russian citizens went abroad in 2012 and the number of those who went abroad for touristic purposes was 15.332 million (Turizm Güncel, 2013). Turkey is the most preferred country by citizens of Russia. Tourist flow from Russia to Turkey is increasing year by year. It is a fact that 2008 global crisis had very little effect on Turkey's tourism sector. Even there was an increase in the number of tourist arrivals from Lebanon, Kazakhstan and Russia to Turkey. Especially Russian tourists prefer Antalya and Belek resorts located on the Mediterranean coast of Turkey (Hürriyet Daily News, 2012). Therefore, Rostourizm decided to open first abroad agency in Turkey in 2014. About 3.6 million Russian visitors went to Turkey in 2012. This means 3.8\% increase compared to 2011 (Rusya'nın sesi radyosu, 2013b). Russian government has made substantial investments in introducing Russian tourist products in Turkey. The competent authority in the implementation of these investments was determined as Rosturizm. Advantages of the tourism activity in Russia are introduced Turkish people through brochures and advertising films. The purpose of this activity is to provide Turkish tourists visit Russia more intensive manner. Today tourism potential of Russia consist of 12 thousand hotels, 477 historical settlement units, more than 144 thousand historical and cultural monuments, 108 unit park-museums and 142 national parks. Number of active mountain sports centers is 150 (Rusya'nın sesi radyosu, 2013b). Turkey, Egypt, and China are three top tourism destinations in Turkey. In 2012 the biggest jump in the number of Russian tourist and Russian tourism market was experienced by Tunisia. Other countries attracting tourists from Russia are Germany, Greece, Italy, Finland, Thailand and Spain (Turizm Güncel, 2013).

The number of tourists visiting Russia in 2012 was 2.570 million with $10 \%$ increase. The most tourists come from Germany. The number of tourists visiting Russia from the top five countries were 375 thousand from Germany, 136 thousand from England, 101 thousand from Turkey, 100 thousand from France and 86 thousand from Israel in 2012 (Graph 1) (Rusya'nın sesi radyosu, 2013c).

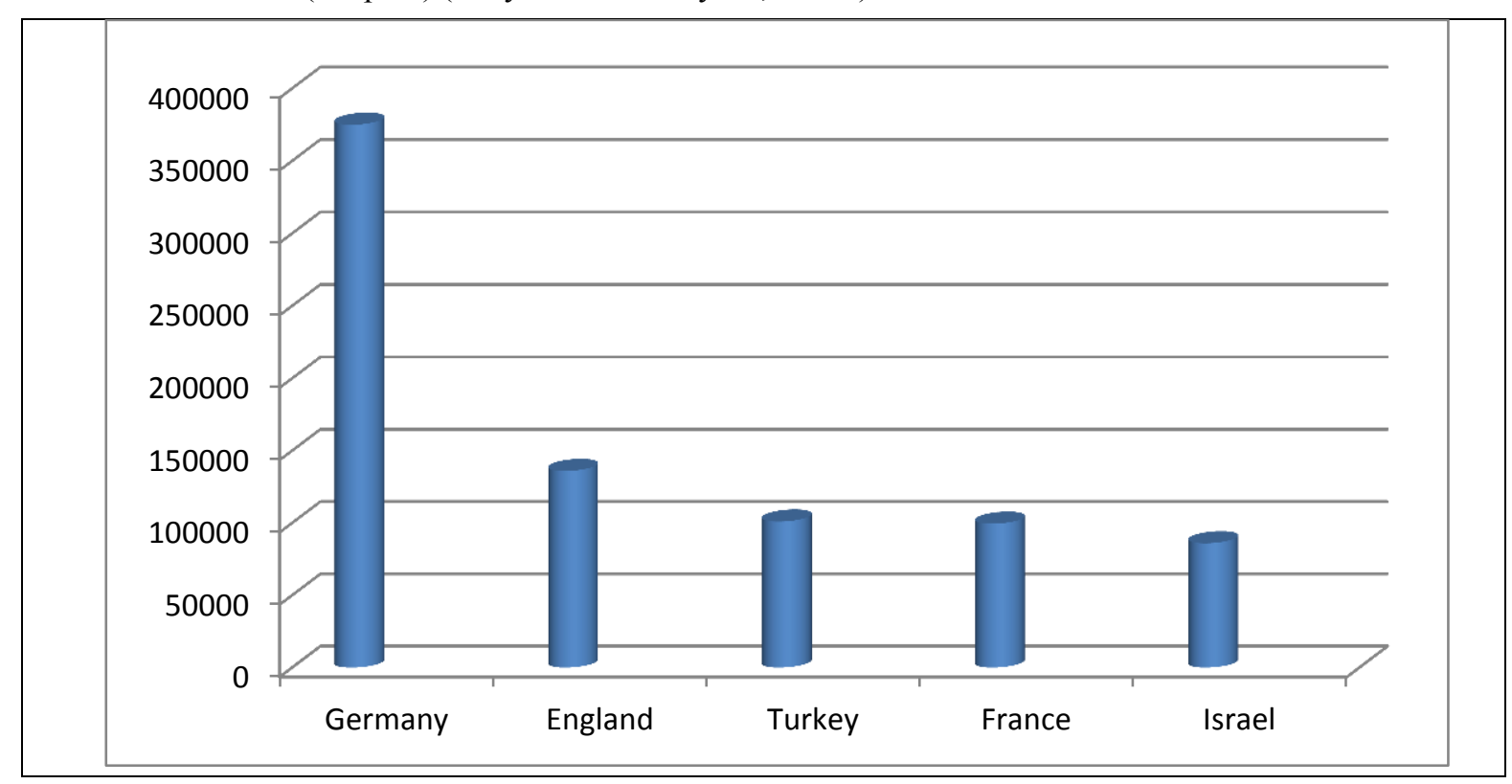

Graph 1: Ratios of First Five Countries Sending Tourists to Russia in 2012 


\section{Analysis of Effect of Economic Growth in Russia on Turkey's Tourism Sector}

The study analyses whether GDP increase in Russia has increased number of Russian tourists visiting Turkey. Due to finding data (GDP in Russia and number of Russian tourists visiting Turkey) easily and more, the year 2001-2011 was determined analysis period. In regression analysis, number of Russian tourists visiting Turkey was used dependent variable, GDP in Russia as independent variable. Results of regression analysis were given in Table 1.

\begin{tabular}{|l|l|l|l|l|}
\hline Variable & Coefficient & Std. Error & t-Statistic & Prob. \\
\hline C & 449943.2 & 132603.7 & 3.393142 & 0.0080 \\
\hline GDP & $1.65 \mathrm{E}-06$ & $1.18 \mathrm{E}-07$ & 13.99888 & 0.0000 \\
\hline R-squared & 0.956091 & & \\
\hline F-statistic & 195.9687 & & \\
\hline Prob (F-statistic) & 0.000000 & & \\
\hline
\end{tabular}

Table 1: Results of Regression Analysis

R-squared is $95 \%$. F statistics was found as 0,00000. Parameters of C constant and GDP in Russia were statistically significant (0,05 significant level). Prob. values of C constant and GDP in Russia were 0,0080 and 0,0000 , respectively.

According to regression analysis, there is no effect of GDP increase in Russia on number of Russian tourists visiting Turkey because GDP value is $1.65 \mathrm{E}-06$. This result shows that one unit increase in GDP of Russia leads to zero unit increase in the number of Russian tourists visiting Turkey. This result is expected because most of the Russian tourists visiting Turkey have medium income level. They prefer Turkey due to cheap holiday opportunity (everything inclusive system), closer to Russia and qualitative service. Russian tourists having high income level travel to Far East Countries for holiday.

\section{Conclusion}

Tourism is all the works done to attract people in order to rest, fun, know each other and a country. Tourism helps people realise beauties in both other countries and outside the region they live in their own countries. Tourists contribute to local people's budget financially as a result of seeing different cultural values, natural beauties, and authentic places. For this reason, Turkey as all countries give importance to tourism sector point of view foreign exchange.

Many people from different countries come to Turkey as tourist every year. Russian Federation is one of the countries sending more tourists to Turkey. Today, tourism is one of the most important economic sectors in the context of Russia-Turkey relations. Contribution of Turkish tourism firms activating in Moscow is very important in this development.

Exchange rate adjustment after financial crisis in Russia in 1998 decreased income level of Russian people. Therefore number of Russian tourist travelling to Turkey decreased at important level. As starting 2005, negative effects of 1998 financial crisis in Russia decreased. This resulted in increase in number of Russian tourists travelling to Turkey again.

As a result of exchange regulation after financial crises in 2001, cost of holiday in Turkey decreased and Turkey became a cheap/suitable holiday country for Russian tourists. Therefore, in 2005 Russian Federation followed Germany point of view number of tourists visiting Turkey.

According to results of regression analyses, economic growth achieved in Russian Federation in the period 2001-2011 has no effect on number of Russian tourists visiting to Turkey. That is number of tourists coming from Russia to Turkey was not affected by one unit increase in GDP of Russia. Number of tourists coming from Russia to Turkey could be increased if following recommendations were taken into practice:

- Collective tour packages should be organised towards different regions in the world.

- Cooperation among firms engaged in tourism sectors in both countries should be developed.

- Cost of holiday in Turkey should be decreased in order to attract Russian tourists or vice versa.

- Tourism enterprises should be supported via tax reduction to present more qualitative service.

- Tourism Year Activities should be organised effectively in Russia and Turkey.

- Tourism centres in Turkey should be introduced in Russia via advertisement on TV channels, newspaper, internet, social media, fair, etc. 


\section{References}

- Dış Ekonomik İlişkiler Kurulu, 2005. “Türkiye-Rusya Ticari ve Ekonomik İlişkileri”, www.deik.org.tr/ bultenler /Rusya-Ekim2005.pdf.

- Duman, Mehmet ve Samadov Nigar, 2003. "Türkiye ile Rusya Federasyonu Arasındaki İktisadi ve Ticari İlişkilerin Yapısı Üzerine Bir İnceleme”,Kocaeli Üniversitesi Sosyal Bilimler Enstitüsü Dergisi, 6(2): 25-47.

- Hürriyet daily news, 2012. "Russian Tourists to Surpass Germans in Turkey Figures", http: //www.hurriyetdaily news.com/russian-tourists-to-surpass-germans-in-turkeyfigures.aspx?pageID=238\&nid=19728.

- K1zılırmak,İsmail ve Kurtuldu Hüseyin, 2005."Kültürel Turizmin Önemi ve TüketiciTercihlerinin Belirlenme- sine Yönelik Bir Çalışma”, Gazi Üniversitesi TicaretveTurizm Fakültesi Dergisi,No. 1, pp.100-120.

- Lanquar, Robert, 2013. Tourism in the Mediterranean:Scenarios up to 2030, MEDPRO Report No. 1/July 2011- (updated May 2013)

- Ö̈türk, Yüksel ve Yazıcıoğlu İrfan, 2002. "Gelişmekte olan Ülkeler İçin Alternatif Turizm Faaliyetleri Üzerine Teorik Bir Çalışma”, Gazi Üniversitesi Ticaret ve Turizm Fakültesi Dergisi, No.2, pp. 183-195.

- Rusya’nın sesi radyosu, 2013a. “Rusya Ekonomik Büyümede G8 Lideri”,http://turkish.ruvr.ru/2013 02_21/Rusya-ekonomik-buyumede-G8-lideri/.

- Rusya’nın sesi radyosu, 2013b. "Rosturizm Türkiye’de Temsilciliğini Açıyor”, http://turkish.ruvr.ru/2013_02_05/Rosturizm-Turkiyede-temsilcigini-aciyor/.

- Rusya’nın sesi radyosu, 2013c. “Türkiye’den Rusya’ya Giden Turist Sayısında Yüzde 25 Artış”,http: //turkish.ruvr.ru/2013_03 04/Turkiyeden-Rusyaya-giden-turist-sayisinda-yuzde-25-artis/.

- Turizm bakanlığı, 2001. "Yabancı Ziyaretçiler ve Vatandaş Anketi 2001", http://www.ktbyatirimisletmeler.gov.tr/TR,9865/yabanci-ziyaretciler-ve-vatandas-arastirmasi.html.

- Turizm güncel haber sitesi, 2013. "Rusya'nın turizm verileri: Türkiye yine zirvede ama yüzde 6,2 kayıp var", http://www.turizmguncel.com/haber/rusyanin-turizm-verileri-turkiye-yine-zirvede-ama-yuzde-62kayip-var-h1 4 215.html. 


\title{
Investigating Existence of Tourism-Led Growth Hypothesis in Cental Asian Republics: A Bootstrap Panel Causality Analysis
}

\author{
Prof. Dr. Ekrem Erdem (Erciyes University, Turkey) \\ Asst. Prof. Dr. Can Tansel Tuğcu (Nevşehir University, Turkey)
}

\begin{abstract}
The contribution of tourism to economic growth can be analyzed under the hypothesis of tourism-led growth. In this sense, this study aims at investigating the existence of the tourism-led growth hypothesis in the Turkic republics for the period 1995-2011. To this end, a bootstrap panel Granger causality analysis which was recently developed by Konya (2006) was employed. Results showed that, in a panel context, the tourism-led growth hypothesis is valid for the Turkic republics. However, the validity of this hypothesis is country specific.
\end{abstract}

\section{Introduction}

Tourism is a sector whichsupplies foreign exchange that can be used for importing capital goods for production, leading in turn to economic growth. In addition, this sector also causes convergence across countries by transferring income from developed nations to developing ones. Thus, the tourism sector can be utilizedby the policy makers either for increasing economic growth performance or reducing welfare inequalities.

The contribution of tourism to economic growth is considered underthe tourism-led growth hypothesis.According to this hypothesis, tourism can promote or cause long-run growth via its effects on the construction, transportation, accommodation, and food/beverage sectors. The tourism-led growth hypothesis is supported, if auni-directional causal relationship existsfrom tourism to economic growth. In this regard, the aim of this study is to test the existence of the tourism-led growth hypothesis in the Turkic republics (i.e. Turkey, Azerbaijan, Kazakhstan, Kyrgyz Republic and Uzbekistan)for the period 1995-2011 by employing a bootstrap panel Granger causality analysis developed by Kónya (2006).

In 2011, total international tourism receipts in the World are 1.3 trillion dollars, and 552.4 billion dollars in Europe and Central Asia. The share of international tourism receipts gained by the Turkic republics to total receipts of the World, and Europe and Central Asia are $2.53 \%$ and $5.77 \%$ respectively. Besides, the ratio of international tourism receipts to trade balance of the Turkic republics in 1995, 2000, 2005 and 2011 are 57.1\%, $131.3 \%, 214.4 \%$ and $953.4 \%$ respectively. These statistics show that tourism is so important for the economic structure of the Turkic republics in terms of income generation and financing international trade.

The rest of the paper is organized as follows: The next section reviews the literature and describes novelty. Section 3 presents the data, methodology and results. Finally, Section 4 concludes.

\section{Literature Review}

It is possible to classify the studies testing the tourism-led growth hypothesisunder two strands. The first strand is composed of the studieswhich investigate the existence of the tourism-led growth hypothesisby employing Granger causality test with time series data. Among these studies, Balaguer and Cantavella-Jorda (2002), Durbarry (2002), Dritsakis (2004), Gunduz and Hatemi-J (2005), Kim et al. (2006), Lee and Chien (2008), Brida et al. (2008), Chen and Chiou-Wei (2009), Akinboade and Braimoh (2010), Belloumi (2010), Tang and Abosedra (2012), Tang and Tan (2013) support the existence of the tourism-led growth hypothesis; whereas Oh (2005), Tang and Jang (2009), Ozturk and Acaravci (2009), and Payne and Mervar (2010)found no evidence for the validity ofthe tourism-led growth hypothesis.

Po and Huang (2008) state that time series data is not capable of reflecting the long-run relationship between tourism and economic growth in terms of coping with some diagnostic problems that arise from business cycles and structural changes, and capturing countries' characteristics. Thus, the second strand of the literature includes studies which test the tourism-led growth hypothesis by using cross-section or panel data. In this sense, Sequeira and Campos (2005), Lee and Chang (2008), Po and Huang (2008), Proenca and Soukiazis (2008), Sequeira and Nunes (2008), Falk (2010), Holzner (2011), and Lee and Brahmasrene (2013) show that there can be confusing results about the existence of the tourism-led growth hypothesisthat are sensitive to the cross-section units in consideration.

The present study as a complement to the second strand of the literature differs from the previous studies in twoaspects. First, in order to consider the possible cross-sectional dependence and heterogeneity of the sample, the panel causality analysis being employed in this study is a bootstrap panel Granger causality test recently developed by Kónya (2006). The second, to the best of our knowledge, validity of the tourism-led growth hypothesisin the Turkic republics has never been analyzed in a panel context before. Thus, the study aims to fulfill this gap and contribute to the empirical literature. 


\section{Data, Methodology and Results}

\subsection{Data}

Data set includes GDP per capita in current US\$ (GDP) and international tourism receipts in current US\$ (RCPT) for the period 1995-2011 in the Turkic republics in consideration. All the panel series were attained from World Bank, World Development Indicators database.

\subsection{Cross-Sectional Dependence}

A possible cross-sectional dependency problem in a panel analysis generally causes inconsistent and upwardbiased estimation results(Bai and Kao, 2006). Thus, it should be tested before the analysis.

This study adopts the Pesaran (2004) methodology in order to investigate the existence of the cross-sectional dependency. Pesaran (2004)proposed a cross-sectional dependency (CD) test, under the null of no cross-sectional dependence, which is asymptotically distributed as standard normal and efficient even in the panels with small sample size. This test statistic can be written in the following manner:

$$
C D=\sqrt{\frac{2 T}{N(N-1)}\left(\sum_{i=1}^{N-1} \sum_{j=i+1}^{N} \hat{p}_{i j}\right)}
$$

where $T$ is time interval, $N$ is the number of cross-section units, and $\hat{p}_{i j}$ is pair-wise correlation between cross-sections.

According to test result presented in Table 1, the null hypothesis is accepted even at $1 \%$ level of significance, indicating no cross-sectional dependence.

\begin{tabular}{|ll|}
\hline Test & Statistic \\
\hline$C D$ & $3.298(0.00)$ \\
\hline
\end{tabular}

Table 1. Cross-sectional dependence test result. (Number in parenthesis is p-value)

\subsection{Causality}

The possibility of cross-sectional dependency and heterogeneity requires a causality analysis which is capable of considering these diagnostic problems. In this regard, this study employs a bootstrap panel Granger causality analysis developed by Kónya (2006) which gives efficient results even in the panels having the cross-sectional dependency and heterogeneity problems. In the light of the tourism-led growth hypothesis, causality analysis is based on a functional relationship which can be simply formulated in the following manner:

\section{Economic Growth $=f($ Tourism $)$}

where economic growth and tourism are proxied by GDP per capita and international tourism receipts (RCPT), respectively.

The causality analysis is built on a system that contains two sets of equations which are presented below (Kónya, 2006: 981):

$$
\begin{aligned}
& y_{1, t}=\alpha_{1,1}+\sum_{l=1}^{m l y_{1}} \beta_{1,1, l} y_{1, t-1}+\sum_{l=1}^{m l x_{1}} \gamma_{1,1, l} x_{1, t-1}+\varepsilon_{1,1, t} \\
& y_{2, t}=\alpha_{1,2}+\sum_{l=1}^{m l y_{1}} \beta_{1,2, l} y_{2, t-1}+\sum_{l=1}^{m l x_{1}} \gamma_{1,2, l} x_{2, t-1}+\varepsilon_{1,2, t} \\
& \vdots \\
& y_{N, t}=\alpha_{1, N}+\sum_{l=1}^{m l y_{1}} \beta_{1, N, l} y_{N, t-1}+\sum_{l=1}^{m l x_{1}} \gamma_{1, N, l} x_{N, t-1}+\varepsilon_{1, N, t}
\end{aligned}
$$

and

$$
\begin{aligned}
& x_{1, t}=\alpha_{2,1}+\sum_{l=1}^{m l y_{2}} \beta_{2,1, l} y_{1, t-1}+\sum_{l=1}^{m l x_{2}} \gamma_{2,1, l} x_{1, t-1}+\varepsilon_{2,1, t} \\
& x_{2, t}=\alpha_{2,2}+\sum_{l=1}^{m l y_{2}} \beta_{2,2, l} y_{2, t-1}+\sum_{l=1}^{m l x_{2}} \gamma_{2,2, l} x_{2, t-1}+\varepsilon_{2,2, t}
\end{aligned}
$$




$$
x_{N, t}=\alpha_{2, N}+\sum_{l=1}^{m l y_{2}} \beta_{2, N, l} y_{N, t-1}+\sum_{l=1}^{m l x_{2}} \gamma_{2, N, l} x_{N, t-1}+\varepsilon_{2, N, t}
$$

where $y$ is real income, $x$ is international tourism receipts, $N$ is the number of cross-section units, $t$ is time interval and $l$ is the lag length. According to Kónya (2006: 981), this specification has two distinctive features. Firstly, each equation in (3), and also in (4), has different predetermined variables. The only possible link among individual regressions is contemporaneous correlation within the systems. Hence, these sets of equations are SUR systems. Secondly, since country specific bootstrap critical values are used, $y_{t}$ and $x_{t}$ are not supposed to be stationary, they denote the levels of economic growth and tourism, irrespectively of the time-series properties of these variables.

In terms of mentioned SUR systems, in country $i$ there is one-way Granger causality running from $x$ to $y$ if in (3) not all $\gamma_{1, i}$ 's are zero but in (4) all $\beta_{2, \mathrm{i}}$ 's are zero, there is one-way Granger causality from $y$ to $x$ if in (3) all $\gamma_{1, i}$ 's are zero but in (4) not all $\beta_{2, \mathrm{i}}$ 's are zero, there is two-way Granger causality between $y$ and $x$ if neither all $\beta_{2, \mathrm{i}}$ 's nor all $\gamma_{1, \mathrm{i}}$ 's are zero, and there is no Granger causality between $y$ and $x$ if all $\beta_{2, \mathrm{i}}$ 's and $\gamma_{1, \mathrm{i}}$ 's are zero (Kónya, 2006: 981).

Konya (2006) states that, since the causality test results rely critically on the lag structure, one should determine the optimal lag length. However, there is no simple rule for this purpose. Thus, as offered by Kónya (2006: 982), the present study allows different maximal lags for $y$ and $x$, but do not allow them to vary across countries. This means that altogether there are four maximal lag parameters. Assuming that their range is 1-4, Eq. (3) and (4) were estimated for each possible pair of $l y_{1}, l x_{1}$ and $l y_{2}, l x_{2}$, respectively, and the combinations which minimize the Akaike Information Criterion (AIC) were chosen.

Table 2 shows the panel causality test results. Accordingly, there exists a uni-directional and/or bi-directional causal relationships between tourism and economic growth in some of the Turkic republics. This means that, although the existence of the tourism-led growth hypothesis is proved in a panel context, it is country specific.

\begin{tabular}{|l|l|l|l|l|}
\hline \multirow{3}{*}{ Cross-Section Units } & \multicolumn{2}{|l|}{ Null hypotheses } & \multicolumn{2}{l|}{$H_{0}:$ EG does not cause RCPT } \\
\cline { 2 - 5 } & $H_{0}:$ RCPT does not cause EG & Wald & Decision \\
\cline { 2 - 5 } & Wald & Decision & 1.800 & Accept \\
\hline Turkey & $* 1.622$ & Reject & $* 11.528$ & Reject \\
\hline Azerbaijan & $* * .358$ & Reject & $* 9.612$ & Reject \\
\hline Kazakhstan & $* * 4.339$ & Reject & 1.550 & Accept \\
\hline Kyrgyz Republic & $* * 5.227$ & Reject & 1.395 & Accept \\
\hline Uzbekistan & 2.478 & Accept & \\
\hline
\end{tabular}

Table 2. Panel causality test results. **,**, and *** indicate rejection of the null hypothesis at the 1, 5, and 10 percent levels of significance, respectively.

\section{Conclusion}

This study investigates the existence of the tourism-led growth hypothesisin the Turkic republics by using annual panel data covering the period 1995-2011. The tourism-led growth hypothesis was tested by a bootstrap panel Granger causality analysis developed by Kónya (2006).

Although findings support evidence for the existence of the tourism-led growth hypothesis, it is clearly seen that the direction of causality between tourism and economic growth is found to be country specific. This result is consistent with Sequeira and Campos (2005), Lee and Chang (2008), Po and Huang (2008), Proenca and Soukiazis (2008), Sequeira and Nunes (2008), Falk (2010), Holzner (2011), and Lee and Brahmasrene (2013) who state that the validity of the tourism-led growth hypothesis is sensitive to the cross-section units in consideration.

Finally, the panel causality test results imply that investing in tourism contributes to economic growth performance of the sample in consideration. In this sense, policy makers should implement policies that subsidize tourism in order to benefit its impact on income growth.

\section{References}

- $\quad$ Akinboade, O.A., L.A. Braimoh, 2010. "International tourism and economic development in South Africa: a Granger causality test”, International Journal of Tourism Research, 12, p. 149-163.

- Bai, J., C. Kao, 2006. On the estimation and inference of a panel cointegration model with crosssectional dependence. In B. H. Baltagi (Ed.), Panel Data Econometrics: Theoretical Contributions and Empirical Applications (p.3-30). Amsterdam: Elsevier. 
- Balaguer, J., M. Cantavella-Jorda, 2002. "Tourism as a long-run economic growth factor: the Spanish case",Applied Economics,34, p. 877-884.

- Belloumi, M., 2010. "The relationship between tourism receipts, real effective exchange rate and economic growth in Tunisia”,International Journal of Tourism Research, 12, p. 550-560.

- $\quad$ Brida, J., E. Carrera, A. Risso, 2008. “Tourism's impact on long-run Mexican economic growth”,Economics Bulletin, 3(21), p. 1-8.

- Chen, C., S.Z. Chiou-Wei, 2009. “Tourism expansion, tourism uncertainty and economic growth: new evidence from Taiwan and Korea",Tourism Management, 30, p. 812-818.

- Dritsakis, N., 2004. Cointegration analysis of German and British tourism demand for Greece",Tourism Management,25, p. 111-119.

- Durbarry, R., 2002. “The economic contribution of tourism in Mauritius”,Annals of Tourism Research, 29, p. 862-865.

- Falk, M., 2010. “A dynamic panel data analysis of snow depth and winter tourism”,Tourism Management, 31(6), p. 912-924.

- Gunduz, L., A. Hatemi-J, 2005. “Is the tourism-led growth hypothesis valid for Turkey?”,Applied Economics Letters, 12(8), p. 499-504.

- Holzner, M., 2011. "Tourism and economic growth: the beach disease?", Tourism Management, 32(4), p. 922-933.

- $\quad$ Kim, H. J., M.H. Chen, S.S. Jang, 2006. "Tourism expansion and economic development: the case of Taiwan",Tourism Management, 27, p. 925-933.

- Kónya, L., 2006. "Exports and growth: Granger causality analysis on OECD countries with a panel data approach”,Economic Modelling,23, p. 978-992.

- Lee, C.C, C.P. Chang, 2008. "Tourism development and economic growth: a closer look at panels",Tourism Management, 29, p. 180-192.

- $\quad$ Lee, C.C., M.S. Chien, 2008. "Structural breaks, tourism development, and economic growth: evidence from Taiwan", Mathematics and Computers in Simulation, 77, p. 358-368.

- Lee, J.W., T. Brahmasrene, 2013. "Investigating the influence of tourism on economic growth and carbon emissions: evidence from panel analysis of the European Union",Tourism Management, 38, p. 69-76.

- $\quad$ Oh, C., 2005. "The contribution of tourism development to economic growth in the Korean economy”,Tourism Management,26(1), p. 39-44.

- Ozturk, I., A. Acaravci, 2009. "On the causality between tourism growth and economic growth: empirical evidence from Turkey”,Transylvanian Review of Administrative Sciences, 25, p. 73-81.

- $\quad$ Payne, J.E., A. Mervar, 2010. "The tourism-growth nexus in Croatia”,Tourism Economics, 19, p. 10891094.

- Pesaran, M.H.,2004. General diagnostic tests for cross section dependence in panels,Cambridge Working Papers in Economics. No: 0435, Faculty of Economics, University of Cambridge.

- Po, W.C., B.N. Huang, 2008. "Tourism development and economic growth-a nonlinear approach",Physica A: Statistical Mechanics and its Applications, 387(22), p. 5535-5542.

- Proença, S., E. Soukiazi, 2008. "Tourism as an economic growth factor: a case study for Southern European Countries",Tourism Economics, 14(4), p. 791-806.

- Sequeira, T., C. Campos,2005. "International tourism and economic growth”,Natural Resources Management, 14, p. 1-25.

- $\quad$ Sequeiraa, T.N., P.M.Nunes, 2008. "Does tourism influence economic growth? a dynamic panel data approach",Applied Economics, 40(18), p. 2431-2441.

- $\quad$ Tang, C.F., A. Abosedra, 2012. "Small sample evidence on the tourism-led growth hypothesis in Lebanon”, Current Issues in Tourism, http://dx.doi.org/10.1080/13683500.2012.732044.

- $\quad$ Tang, C.F., E.C. Tan, 2013. "How stable is the tourism-led growth hypothesis in Malaysia? evidence from disaggregated tourism markets",Tourism Management, 37, p. 52-57.

- $\quad$ Tang, C.H., S.S. Jang, 2009. “The tourism-economy causality in the United States: a sub-industry level examination",Tourism Management, 30, p. 553-558. 


\title{
The Effects of Destination Personality Items on Destination Brand Image
}

\author{
Ph.D. Candidate Çiğdem Unurlu (Trakya University, Turkey) \\ Asst. Prof. Dr. Selin Küçükkancabaş (Trakya University, Turkey)
}

\begin{abstract}
The purpose of this research is to investigate the perceived destination brand personality of Istanbul and to examine the relationships among destination brand personality and destination brand image. A convenience sample of 200 visitors to Istanbul was surveyedvia face-to-face interviews. Initially, a series of exploratory factor analyses (EFA) were conducted for each measurement scales (brand personality and destination brand image) in order to identify the potential underlying factor structure of the data. Then multiple regression analysis was used to investigate the relationship between variables using PASW 18. The findings of this study indicate that destination brand personality has a positive impact on destination brand image. However, the results are not fully represent all personality traits associated with tourism destinations. While four dimensions of the destination brand personality scales (vibrancy, competence, contemporary and sincerity) are found to be significantly related to the destination brand image, sophistication dimension is not significant in predicting destination brand image.
\end{abstract}

\section{Introduction}

It is generally accepted that a brand is a powerful means of differentiation, and that differentiation is a significant competitive marketing strategy (Boo et. al., 2009: 221).Ever since the brand literature commenced in the 1940s, there has been consistent recognition that branding offers organisations a means for differentiation in markets crowded with similar offerings. For destinations, effective differentiation is critical given the increasingly competitive nature of tourism markets, where many places offering similar features are becoming substitutable (Pike, 2009: 861). A tourism destination can also be seen as a product or perceived as a brand since it consists of a bundle of tangible and intangible attributes. Destination branding has become a popular and powerful marketing tool because of increasing competition, product similarity, and substitutability in tourism markets (Uşaklı and Baloğlu, 2011: 117).

As the tourism marketplace is becoming more highly competitive, destination marketers are adopting branding techniques to craft an identity which focuses on the uniqueness of their products, namely destinations. Similar to those marketing consumer products, destination marketers have had to turn to branding to distinguish their destinations to convey a positive message that will motivate tourists to visit them. However, evidence to support the successful implementation of destination branding is mixed. A combination of destination image and destination personality has thus been used as a strategy by destination marketers to differentiate their brands from other competing ones (Chen and Phou, 2013:271).

At the theoretical level, brand image has been defined in terms of brand personality and in some cases, the terms brand image and brand personality have been used interchangeably to gauge consumer perceptions of brands. Past studies have attempted to provide some explanations to the brand image-brand personality relationship debate, but most discussions have remained only theoretical (Hosany et. al., 2006: 640).

\section{Destination Personality}

Personality is viewed as one part of a person's self-concept. In order to grasp the attributes and associations linked to a brand, the concept of brand personality can be employed (Nicola and Sauer, 2011: 1283). In theoretical terms, product/brand personality reflects the "set of human characteristics associated with a brand". It evokes emotional links between brands and consumers, and gives the latter a tangible reference point, which is vivid, alive, and more complete than the sense conveyed by a generic offering. At the practical level, brands can be characterized by personality descriptors, such as youthful, energetic, extrovert, or sophisticated. For example, one may use the word masculine to describe Marlboro cigarettes,rugged to describe Levi's jeans, feminine to describe Chanel perfumes, and intelligent to describe IBM computers. Similarly, destinations can be described 6using human personality traits, such as Europe is traditional and sophisticated; Walesis honest, welcoming, romantic, down to earth; Spain is friendly and family oriented; London is open-minded, unorthodox, vibrant, creative; Paris is romantic. Accordingly, in this paper, destination personality is defined as: "the set of human characteristics associated with a destination" as perceived from a tourist rather than a local resident viewpoint (Ekinci and Hosany, 2006:128).

Destination image and destination personality are different but related concepts, with both being cognitive constructs. Destination image involves subjective knowledge of a destination (i.e., whether it is expensive, exotic, urban, cold, or developed), while destination personality refers to brand personality in the tourism 
context, and uses human personality traits to describe a destination (e.g., whether it is original, interesting, exciting, or friendly) (Chen and Phou, 2013: 272).

Destination brand personality scale developed by Uşaklı and Baloğlu (2011: 119) consisted of five dimensions namely (1) vibrancy, (2) sophisticated, (3) competence, (4) contemporary, (5) sincerity in this study.

\section{Destination Brand Image}

Studies on destination image began in the early 1970s, when Hunt's influential work examined the role of image in tourism development. Since then, destination image has become one of the dominant areas of tourism research (Hosany et. al., 2006: 641).

The image of a destination is a key concept related to understanding tourists' destination selection processes. Destination image can be facilitated by the strengths of a destination in the eyes of potential visitors. Many studies have defined tourism image as an individual's overall perception of a destination and it has been identified as an important element in travel decision-making. Destination image is a key determinant influencing tourists' attitudes toward the destination (Veasna et. al., 2013: 513).

Brand image has been considered as the reasoned or emotional perceptions consumers attach to specific brands. Brand image has also been identified as an important source of brand equity. Blain et al. suggested that destination image should be included in the definition of destination brands (Boo et. al., 2009: 222 ).

Brand image plays a significant role in building brand identity, whereas brand image is also a reflection of brand identity, that is, consumers build a destination image in their minds based on the brand identity projected by the destination marketers. Then, destination marketers establish and enhance brand identity based on their knowledge about consumer's brand image on the particular destination (Qu et. al., 2011: 466).

\section{The Relationship Between Destination Brand Image and Destination Brand Personality}

Brand image and brand personality are key components of brand loyalty and brand positioning (Plummer, 1985). Patterson's review of the branding literature identified 27 definitions of brand image and 12 definitions of brand personality. In some instances, brand image has beendefined in terms of brand personality. The terms brand image and brand personality have also been used interchangeably in the literature (Hosany, Ekinci and Uysal, 2006). Patterson (1999)concluded that most studies fail to distinguish between theconcepts of brand image, brand personality, brand identity anduser image. Kapferer (1997) argues that personality and self-image are antecedents of brand identity. Aaker and Biel (1993) views brand image as a cluster of attributes and associations that a consumer attach to a brand, and brand personality is perceived as the emotional side of brand image. An emergent research strand (Hosany et.al.,2006, 2007 ; Ekinci \& Hosany, 2006; Murphy et al., 2007) has established that the two constructs are distinct,but related concepts, and that an attractive destination personality can effectively leverage the perceived image of a place and thereby influences tourist choice behavior. Since the relationship between brand personality and brand image need further research in order to extend the theoretical link between them the aim of this study is to explore variations in brand perceptions in a different destination namely Istanbul.

\section{Research Model}

Based on the literature review a model on destination brand image is proposed. In this model there are five categories of brand personlity, namely vibrancy, sophistication, competence, contemporary and sincerity. Model predicts that brand personlatiy dimanesions are expected to determine destination brand image. The following hypotheses are developed based on the literature and proposed model.

$\mathrm{H}_{1}$ : Vibrancy is positively related to destination brand image

$\mathrm{H}_{2}$ : Sophistication is positively related to destination brand image

$\mathrm{H}_{3}$ : Competence is positively related to destination brand image

$\mathrm{H}_{4}$ : Contemporary is positively related to destination brand image

$\mathrm{H}_{5}$ : Sincerity is positively related to destination brand image 


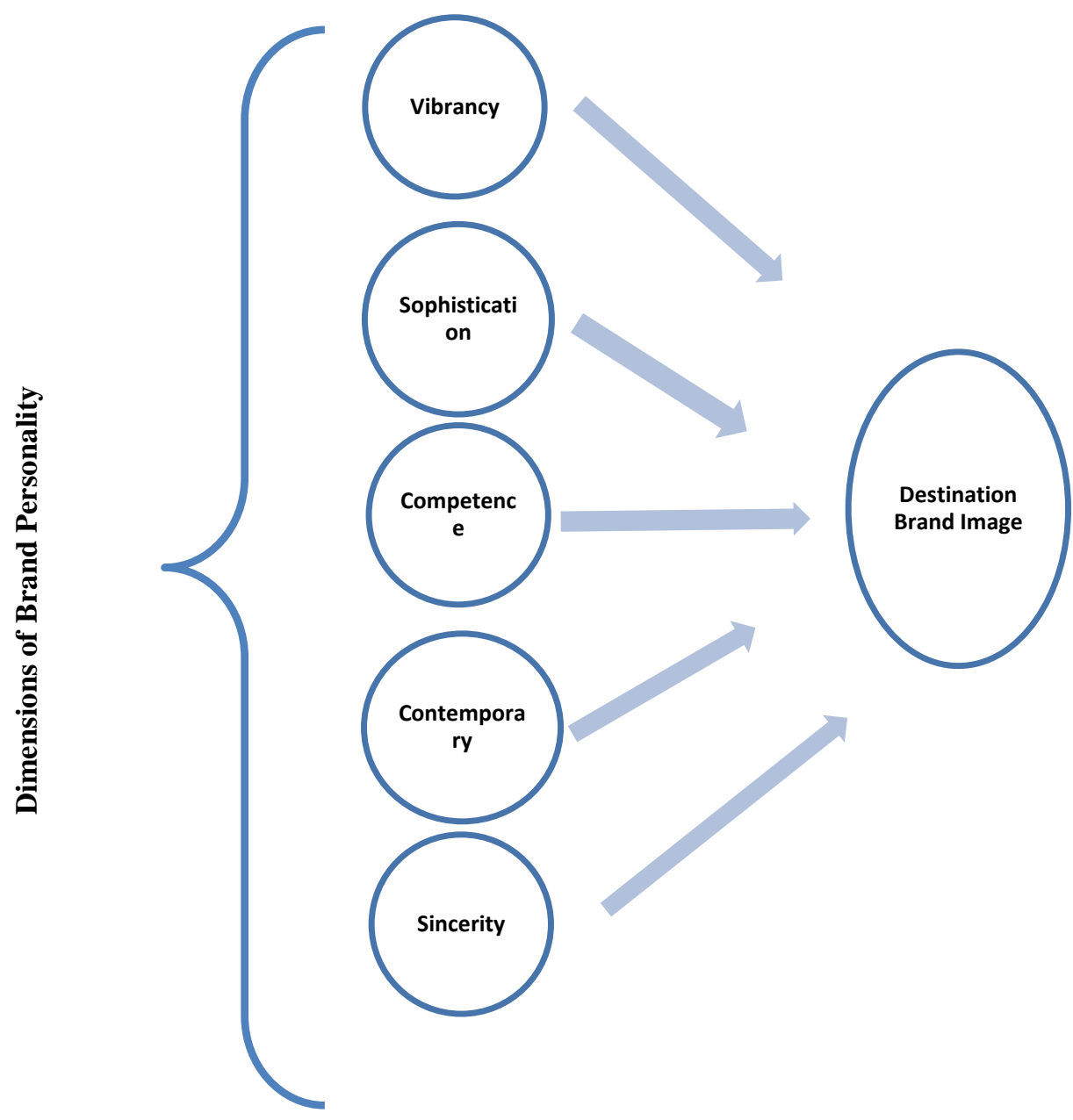

Figure 1: Research Model

\section{Methodology}

This article documents a study of the dimensions of destination brand personality associated with destination brand image. In particular, the research objective is to examine empirically and investigate variations in destination brand image which may be related to destination brand personality.

In order to explore the relationship between destination personality items and destination brand image, descriptive research design was adopted and conducted. Multiple items adopted from Uşaklı and Baloglu (2011) and Boo et all (2009) scales were used to compile the measurement instrument fort his study. Destination brand image was measured using by Boo et. al. (2009)'s four items destination brand image scale.Destination personality was measured using Uşaklı and Baloğlu's destination personality scale which is adapted from Aaker's (1997) five dimensional BPS. The BPS is the most comprehensive instrument for measuring brand/product personality and numerous studies (Siguaw et al., 1999) adopt this scale to capture consumers' perception of brand personality. The multidimensional operationalisation of destination personality items allowed the testing of the relationship between the items of destination personality and destination brand image. The questionnaire items were scored on a 5 point Likert scale, ranging from "strongly disagree" to "strongly agree". Destination brand personality comprimised five dimensions and included 24 items in total. Destination brand image included 4 items.

The data were collected via face-to-face interviews with multiple informants (tourists in Istanbul). To participate in the survey, respondents were approached randomly around touristic places of Istanbul. In general, respondents were responsive and willing to participate, and refusal rates were predominantly low (around 20 percent). A total of 200 usable questionnaires were obtained.A total of 51 percent of the sample is female, the mean age of the sample is less than 29 years, respondents are highly educated (47 per cent holding university degrees), and mainly earning up to 2000-3000 Turkish Lira a month (25 per cent). 


\subsection{Exploratory Factor Analysis}

A series of exploratory factor analyses (EFA) were conducted for each measurement scales (brand personality and destination brand image) used in this study in order to identify the potential underlying factor structure of the data. Factor analyses were conducted without constraining factor which means based on factor's eigenvalue that represents the variance explained by each factor. In EFA 1 (destination personality scale) item loadings less than 0.40 were dropped to enhance reliablity. 8 items were eliminated from destination personality scale. In the first EFA as expected items that loaded higly on the first factor reflected vibrancy, the second factor reflected contemporary, the third factor reflected competence, the fourth factor reflected sincerity and the fifth factor reflected sophistication. A single factor was extracted for destination brand image scale in EFA 2, using an eigenvalue of 1 as the cut-off point (which indicates that the measurement scale used in this study was unidimensional). The Bartlett test of sphericity showed overall significance of the correlation matrix of the 24 items (brand personality) and 4 itmes (destination brand image), indicating the appropriateness for factor analyses. In addition, Kaiser-Meyer-Olkin Measure of Sampling Adequacy was 0.83 for EFA 1 and .79 for EFA 2 , confirming the appropriateness for factor analyses.

The reliability of each scale was examined using Cronbach's coefficient alpha which is the most widely used measure for internal consistency in cross-sectional studies (Netemeyer, Bearden, and Sharma, 2003). Cronbach's alpha coefficients are all higher than .40 (ranging from $\mathrm{X}$ to $\mathrm{Y}$ ) indicating good internal consistency for each factor.

\subsection{Test of Hypotheses}

Multiple regression analysis is used to investigate the relationship between the dependent variable (brand destination image) and the five independent variables (brand personaltiy) (Cohen et al., 2003). The overall model using simultaneous estimation showed statistical significance $(\mathrm{p}<0.05)$, indicating acceptable model fit. The beta coefficient is used to assess each independent variable's relative explanatory power on the dependent variable. The results of multiple regression analysis, including the standardized beta coefficients and the coefficient of determination, are tabulated in Table 1 and Table 2.

Multicollinearity is assessed by the variance inflation factor (VIF) value of each independent variable. As shown in Table 2 each of the independent variables have a variance inflation factor value far less than the suggested threshold of 10, and thus, each one have sufficient variability not explained by the others (Mason and Perreault, 1991; Cohen et al., 2003).

\begin{tabular}{|l|c|l|l|l|l|}
\hline Model & Sum of Squares & df & Mean Square & F & Sig. \\
\hline Regression & 51.460 & 5 & 10.292 & 22.017 & $.000^{\mathrm{a}}$ \\
Residuals & 90.689 & 194 & .467 & & \\
Total & 142.149 & 199 & & & \\
\hline
\end{tabular}

a. Predictors: (Constant), sincerity, competence, vibrancy, contemporary, sophistication,

b. Dependent Variable: destimage

Table 1. Multiple regression analysis results - analysis of variance $e^{b}$

\begin{tabular}{|l|l|l|l|l|}
\hline $\begin{array}{l}\text { Standardized } \\
\text { Coefficients }\end{array}$ & Beta & $\mathrm{t}$ & Significance & VIF \\
\hline Vibrancy & .129 & 1,988 &, 048 & 1.27 \\
\hline Sophistication & .071 &, 946 &, 345 & 1.73 \\
\hline Competence & .208 & 2,917 &, 004 & 1.55 \\
\hline Contemporary & .139 & 1,957 &, 052 & 1.54 \\
\hline Sincerity & .270 & 3,960 &, 000 & 1.41 \\
\hline
\end{tabular}

Table 2. Multiple regression analysis results - independent variables

The brand personality antecedents jointly established an explanatory power (R2) of 36,2 percent for the variance in tourists' evaluation of destination brand image. Results showed that sincerity $(\beta=0.27, \mathrm{p}<0.05)$, competence $(\beta=0.20, \mathrm{p}<0.05)$, contemporary $(\beta=0.13, \mathrm{p}<0.05)$ and vibrancy $(\beta=-0.12, \mathrm{p}<0.05)$. have positive effects on destination brand image, respectively. Therefore, $H 1, H 3, H 4, H 5$ are all supported. However, the nonsignificant beta coefficient indicated that sophistication does not always have a "true" impact on destination brand image. Thus $H 2$ is not supported.

\section{Conclusion}

The purpose of this study is to investigate the perceived destination personality of Istanbul and to empirically examine the relationships among destination brand personality and destination brand image. The results of the present study make important theoretical and practical contributions to the underdstanding of destination brand personality and destination brand image in the context of tourism destinations. 
The findings of this study indicate that destination brand personality has a positive impact on destination brand image, consistent with previous research (Uşaklı and Baloğlu, 2011; Ekinci, Hosany and Uysal, 2006). However, the results are not fully represent all personality traits associated with tourism destinations. The four dimensions of the destination brand personality scales (vibrancy, competence, contemporary and sincerity) are significantly related to the destination brand image. Only the sophistication dimension is not significant in predicting destination brand image.

From a practical standpoint, the findings of the study provide important implications for destination marketers. Today, destinations are faced with increasingly tough competititon than they ever faced before. The findings of this study provide evidence that four dimensions of destination brand personality (vibrancy, competence, contemporary, sincerity) are crucial understanding the complex nature of traveller perception who visited Istanbul. Thus, destination marketers should focus on developing marketing strategies that emphasize the distinctive personality items of their destinations.

The study has also specific practical implications for the destination marketer of Istanbul. Although all the four personality dimensions of Istanbul are found to be significant predictors of destination brand image, the vibrancy is found to be the most influential personality dimension affecting Istanbul's destination brand image. The second and third most influential dimensions on destination brand image are competence and contemporary respectively. The destination marketers of Istanbul should concetrate more on these three dimensions (competence, contemporary and sincerity) in their marketing efforts.

An additional practical implication is that tourist who experience a match between how they see the destination and themself or how they would like to see themselves are more likely to have favorable attitudes toward those destination, resulting in more favorable destination brand image of Istanbul. Therefore, destination marketers should concetrate on developing promotional campaings that emphasize the distinctive personality of tourism destination based on destination brand image. Destination marketers should also capitalize on these findings, be devising an appropriate branding strategy that encompasses these four components in order to create a favourable desination brand image.

Although this study makes important theoritical cantributions to the understanding of the relationship between destination brand personality and destination brand image, it entails several limitations and must be acknowledged. Destination personality is measured using the BPS originally developed for consumer goods. As such, the personality traits used in this study may not fully reflect all the personality characteristics of destination. Furthermore, the sample size is small, and so the findings cannot be generalized to the wider tourist population and to other destinations. Further studies should investigate the nature of this relationship using different destinations across different countries.

\section{References}

- $\quad$ Aaker, D.A. and Biel, A. L., 1993. Brand Equity and Advertising: Advertising's Role in Building Strong Brands, Lawrence Erlbaum Associates, New Jersey.

- Aaker, J. L., 1997. "Dimensions of Brand Personality”, Journal of Marketing Research, 34(3): 347-356.

- Boo, S. et. al., 2009. "A Model of Customer-based Brand Equity and its Application to Multiple Destinations", Journal of Tourism Management, 30(2), 219-231.

- Chen, C. and Phou, S., 2013. "A Closer Look at Destination: Image, Personality, Relationship and Loyalty", Journal of Tourism Management, 36, 269-278.

- Cohen et.al., 2003. "Sociability and Susceptıbility to the Common Cold", Psychological Society, 14(5): 387 395.

- $\quad$ Ekinci, Y. and Hosany, S., 2006. "Destination Personality, An Application of Brand Personality to Tourism Destination", Journal of Travel Research, 45, 127-139.

- Hosany, S. et. al., 2006, "Destination Image and Destination Personality: An application of Branding Theories to Tourism Places", Journal of Business Research, 59(5), 638-642.

- Kapferer, J. N., 1997. Strategic Brand Management: Creating and Sustaining Brand Equity Long Term, Kogan Page Limited, London.

- Mason, C. H. and Perreault, W. D., 2002. The Marketing Game, McGraw-Hill, Newyork.

- Murphy, L., Moscardo, G., and Benckendorff, P., 2007. "Using Brand Personality to Differentiate Regional Tourism Destinations", Journal of Travel Research, 46 (Aug): 5-14.

- Netemeyer, R. G., Bearden, W.O. and Sharma, S., 2003. Scaling Procedures: Issues and Applications, , Sage Publications, California.

- Nicola, E. and Sauer, S., 2011. "The Relevance of Visitors' Nation Brand Embeddedness and Personality Congruence for Nation Brand Identification, Visit Intentions and Advocacy", Journal of Tourism Management, 32(6), 1282-1289. 
- $\quad$ Patterson M., 1999. "Re-Appraising the Concept of Brand Image", Journal of Brand Management, 6(6):409-26.

- Pike, S., 2009. "Destination Brand Positions of a Competitive set of Near-Home Destinations", Journal of Tourism Management, 30,(6), 857-866.

- Plummer, J. T., 1985. "How Personality Makes a Difference", Journal of Advertising Research, 24(6): $27-$ 31.

- Qu, H. et. al., 2011. “Amodel of Destination Branding: Integrating the Concepts of the Branding Destination Image”, Journal of Tourism Management, 32(3), 465-476.

- Uşaklı, A. and Baloğlu, Ş. 2011. "Brand Personality of Tourist Destinations: An Application of Self-cogruity Theory", Journal of Tourism Management, 32(1), 114-127.

- Veasna, S. et. al., 2013. "The Impact of Destination Source Credibility on Destination Satisfaction: The Mediating Effects of Destination Attachment and Destination Image", Journal of Tourism Management, 36, 511-526. 


\title{
The Relationships between Destination Brand Image, Destination Brand Loyalty and Word of Mouth Behaviour
}

\author{
Ph.D. Candidate Çiğdem Unurlu (Trakya University, Turkey) \\ Prof. Dr. Ayşe Akyol (Trakya University, Turkey) \\ Assoc. Prof. Dr. Dilek Altaş (Marmara University, Turkey)
}

\begin{abstract}
This article documents a study and model of the destination brand image, destination brand loyalty and wordof-mouth behaviour (WOM). Therefore, the literature review consists of three parts namely destination brand image, destination brand loyalty and word-of-mouth behaviour. Destination brand image can be defined as the reasoned perceptions consumers attach to specific brands. Destination brand loyalty can be defined as the main source of customer-based brand equity. Brand loyalty was defined as the attachment a customer has to a brand. Lassar et. al. noted that brand equity stems from the grater confidence that consumers place in a brand than they do in its competitors. This confidence translates into consumers' loyalty and their willingness to pay a premium price for the brand. Word of mouth behaviour can be defined as informal communications directed at other consumers about the ownership or characteristic of particular goods and services and/or their sellers. In order to explore the relationship between destination brand image, destination brand loyalty and word-of-mouth behaviour, a two phase research design (exploratory and descriptive) was adopted and conducted. This study was based on the measures of Boo et all (2009), and Kim et all (2011) because their instruments had been developed, tested, refined and yielded reliable results. The questionnaire items were scored on a 5 point Likert scale, ranging from "strongly disagree" to "strongly agree". A cross sectional design was used for the data collection. Data is analysed by using SPSS.
\end{abstract}

\section{Introduction}

The evaluation of destination image has been the subject of much attention in social science literature. Previous studies showed that destination image will influence tourists in the process of choosing a destination, the subsequent evaluation of the trip and in their future intentions. Furthermore, past research across fields has emphasized the importance of understanding the forces, which influence image development. Goodall noted that knowing the factors influencing image would help identify target markets (Jalilvand et. al., 2012:137). Gitelson and Crompton notes that numerous attractions and destination areas, such as beaches or resorts, are heavily reliant on repeat visitation. Petrick finds that loyal visitors were more likely to return in the future, spread positive word of mouth, and hence offer a lower risk and more profitable target market. Thus, many destinations have adopted a business strategy focused on encouraging tourists to become repeat visitors (Liu et. al., 2012: 119).

\section{Destination Brand Image}

The concept of "image" that has been studied for several decades in such disciplines as social and environmental psychology, marketing, and consumer behavior, was introduced into tourism studies in the early 1970s by Hunt, Mayo, and Gunn and has since become one of the most researched topics in the field (Stepchenkova and Morrison, 2008: 549).

Brand image has been considered as the reasoned or emotional perceptions consumers attach to specific brands (Boo et. al., 2009: 221). Destination image is defined as an individual's overall perception or the total set of impressions of a place. It is regarded as the mental portrayal of a destination. A destination's image can be developed based on the estimation or understanding of a region's characteristics (Jalilvand et. al., 2012: 138).

Destination image in tourism research is an overall representation of beliefs, ideas, and impressions of a travel destination (Lee and Locshin, 2011: 11). Destination image can be defined as the expression of all knowledge, impressions, prejudices and emotional thoughts an individual or group has of a particular object or place (Sun et. al., 2013: 13).

Destination image is associated with a subjective interpretation of tourists' feelings and beliefs toward a specific destination. Destination image is a key determinant influencing tourists' attitudes toward the destination (Veasna et. al., 2013: 513).

Destination brand image was measured using by Boo et. al. (2009: 233)'s four items destination brand image scale anchored with strongly disagree (1) and strongly agree (5). 


\section{Destination Brand Loyalty}

Even though the examination of loyalty started in 1923 with Copeland's study of "brand insistence" it is still one of the most frequently examined topics. The concept of brand loyalty has been recognized as a major driving force and one of the most important indicators of success in the marketing and tourism literature (Sun et. al., 2013: 3). Consumer loyalty is defined as the commitment to re-buy a product or service in the future. Scholars have incorporated loyalty into their analyses of tourism/leisure products, destinations (Lee and Shen, 2013: 77).

The concept of brand loyalty has been recognized as a major driving force and one of the most important indicators of success in the marketing and tourism literature. As suggested by Assael, "success depends not on the first purchase but on repurchase. It is unlikely that any brand can survive over time without some degree of loyalty" (Sun et. al., 2013: 3). Brand loyalty is defined as "a deeply held predisposition to re-patronize a preferred brand or service consistently in the future, causing repetitive same brand purchasing, despite situational influences and marketing efforts having the potential to cause switching behavior". Aaker views loyalty as "the attachment that a customer has to a brand" (Pike and Bianchi, 2011: 3).

Repeat purchases or recommendations to other people are most usually referred to as consumer loyalty in the marketing literature. The concept and degree of loyalty is one of the critical indicators used to measure the success of marketing strategy (Yoon and Uysal, 2005: 48).

This study limited brand loyalty to the attitudinal and behavioral elements and proposes a significant relationship between brand value and brand loyalty. Destination brand loyalty was measured using by Boo et. al. (2011)'s four items destination brand loyalty scale anchored with strongly disagree (1) and strongly agree (5).

\section{Word-of-Mouth Behaviour}

Word of mouth (WOM) is informal advice passed between consumers. It is usually interactive, swift, and lacking in commercial bias. WOM is a powerful influence on consumer behavior (East et. al., 2008: 216). Wordof-mouth communications have received extensive attention from both academics and practitioners for decades. Since the early 1950s, researchers have demonstrated that personal conversations and informal exchange of information among acquaintances not only influence consumers' choices and purchase decisions, but also shape consumer expectations, pre-usage attitudes, and even post-usage perceptions of a product or service. Some research has reported WOM influence as greater than print ads, personal selling, and radio advertising (Bruyn and Lilien, 2008: 152).

In marketing, word of mouth (WOM) is normally used to describe advice from other consumers. The interactivity, speed, and lack of commercial bias of WOM make it a very effective source of information about prospective consumer choices, particularly with regard to services for which pre-purchase experience may be limited (East et. al., 2007: 176).

Word-of-mouth behaviour was measured using by Kim et. al. (2011)'s three items positive word-of-mouth scale anchored with strongly disagree (1) and strongly agree (5).

\section{Methodology}

This article documents a study of the destination brand image and destination brand loyalty associated with word of mouth behaviour. In particular, the research objective is to examine empirically and investigate variations in word-of-mouth behaviour which may be related to destination brand image and destination brand loyalty.

In order to explore the relationship between destination brand image, destination brand loyalty and word-ofmouth behaviour, a two phase research design (exploratory and descriptive) was adopted and conducted. To be able to explore the link between destination brand image, destination brand loyalty and word-of-mouth behaviour three measurement instruments were utilised. The questionnaire items were scored on a 5 point Likert scale, ranging from "strongly disagree" to "strongly agree". A cross sectional design was used for the data collection. Data was analysed by using SPSS.

\section{Research Model}

The research objective is to examine empirically and investigate variations in word-of-mouth behaviour which may be related to destination brand image and destination brand loyalty. Therefore, this study was based on the measures of Boo et. al. (2009), and Kim et. al. (2011) because their instruments had been developed, tested, refined and yielded reliable results.

These independant and dependant variables can be seen in the below figure. 


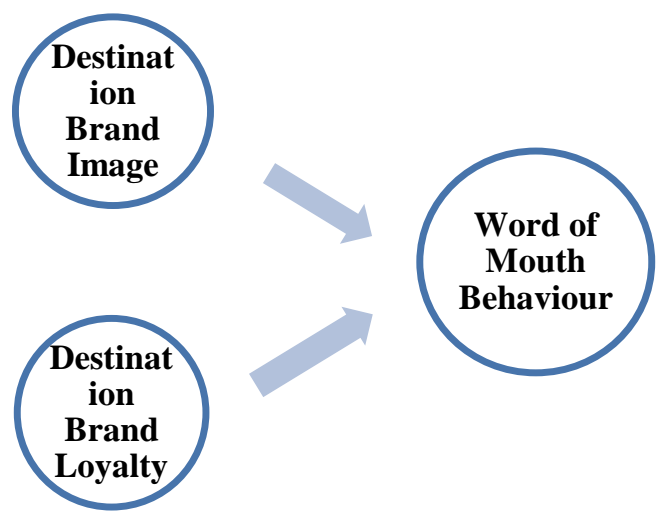

Figure 1: Research Model

Destination brand image included 4 items. Destination brand loyalty included 4 items and word-of-mouth behaviour comprimised 3 items. There were 11 items in total.

$\mathrm{H}_{1}$ The destination brand image and destination brand loyalty are positively related to word of mouth behaviour.

\section{Analysis}

The Multiple Regression Analysis was performed in order to examine the relationship between destination brand image, destination brand loyalty and WOM behaviour.

Main assumptions of Multiple Regression Analysis as error term normality, autocorrelation and multicollinearity was checked before the analysis. Error-term normality was checked by Kolmogorov-Smirnov. Error-term distributed normally (sig.=0,259)

Autocorrelation was checked by Durbin-Watson test. Durbin-Watson (D-W)=1,979. Since it is close to 2 , it can be considered that there is no autocorrelation in model. Multicollinearity was checked by VIF. Since the VIF values are less than 5 , it can be considered that there is no multicollinearity between the independent variables.

The Multiple Regression Analysis results are below:

\begin{tabular}{|c|c|c|c|c|c|c|c|c|c|c|}
\hline \multirow[b]{2}{*}{ Model } & \multirow[b]{2}{*}{$\mathrm{F}$} & \multirow[b]{2}{*}{\begin{tabular}{|l}
$\mathrm{R}$ \\
Square
\end{tabular}} & \multirow[b]{2}{*}{$\begin{array}{l}\text { Adjusted R } \\
\text { Square }\end{array}$} & \multirow[b]{2}{*}{$\begin{array}{l}\text { Std. Error of the } \\
\text { Estimate }\end{array}$} & \multicolumn{5}{|c|}{ Change Statistics } & \multirow[b]{2}{*}{$\begin{array}{l}\text { Durbin- } \\
\text { Watson }\end{array}$} \\
\hline & & & & & $\begin{array}{l}\text { R Square } \\
\text { Change }\end{array}$ & $\begin{array}{l}\mathrm{F} \\
\text { Change }\end{array}$ & df1 & df2 & $\begin{array}{l}\text { Sig. F } \\
\text { Change }\end{array}$ & \\
\hline 1 &, $697^{\mathrm{a}}$ &, 486 &, 481 & 1,83364 &, 486 & 93,052 & 2 & 197 &, 000 & 1,979 \\
\hline
\end{tabular}

a. Predictors: (Constant), destination brand loyalty, destination brand image

b. Dependent Variable: wom behaviour

\section{Table 1: Model Summary ${ }^{b}$}

The $\mathrm{R}^{2}$ is 0,486 , which means WOM can be explained by $\% 48,6$ with destination brand image and destination brand loyalty.

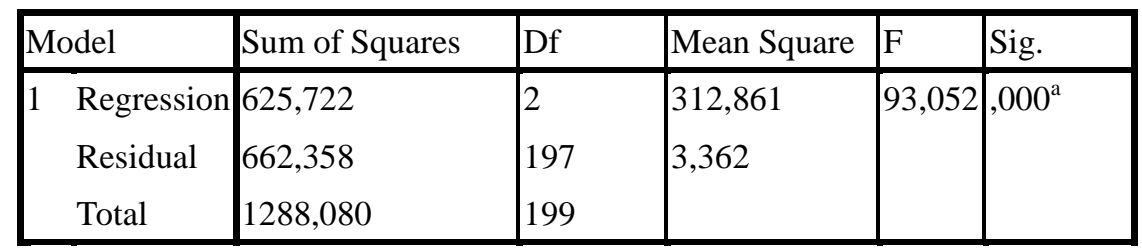

a. Predictors: (Constant), destination brand loyalty, destination brand image

b. Dependent Variable: wom behaviour

Table 2: ANOVA ${ }^{b}$

As can be seen in the above table, Sig. value is 0,00 which shows the model is generally significant. 


\begin{tabular}{|c|c|c|c|c|c|c|c|c|c|c|c|c|}
\hline \multirow[b]{2}{*}{ Model } & \multicolumn{2}{|c|}{$\begin{array}{l}\text { Unstandardized } \\
\text { Coefficients }\end{array}$} & \multirow{2}{*}{$\begin{array}{l}\text { Standardized } \\
\text { Coefficients }\end{array}$} & \multirow[b]{2}{*}{$t_{t}$} & \multirow[b]{2}{*}{ Sig. } & \multicolumn{2}{|c|}{$\begin{array}{l}95,0 \% \\
\text { Confidence } \\
\text { Interval for B }\end{array}$} & \multicolumn{3}{|c|}{ Correlations } & \multicolumn{2}{|c|}{$\begin{array}{l}\text { Collinearity } \\
\text { Statistics }\end{array}$} \\
\hline & B & Std. Error & & & & $\begin{array}{l}\text { Lower } \\
\text { Bound }\end{array}$ & $\begin{array}{l}\text { Upper } \\
\text { Bound }\end{array}$ & $\begin{array}{l}\text { Zero- } \\
\text { order }\end{array}$ & Partial & Part & Tolerance & VIF \\
\hline 1 (Constant) & 3,706 &, 640 & & 5,793 &, 000 & 2,444 & 4,968 & & & & & \\
\hline $\begin{array}{l}\text { destination } \\
\text { brand image }\end{array}$ &, 185 &, 051 &, 246 & 3,592 &, 000 &, 083 &, 286 &, 584 &, 248 &, 184 &, 558 & 1,791 \\
\hline $\begin{array}{l}\text { destination } \\
\text { brand } \\
\text { loyalty }\end{array}$ &, 369 &, 050 &, 509 & 7,447 &, 000 &, 272 &, 467 &, 672 &, 469 &, 380 &, 558 & 1,791 \\
\hline
\end{tabular}

a. Dependent Variable: WOM Behaviour

Table 3: Coefficients ${ }^{a}$

The Multiple Regression Equation is below:

Word of Mouth Behaviour $($ WOM $)=3,706+0,185$ Destination Brand Image + 0,369 Destination Brand Loyalty.

This equation shows that 1 unit increase in image will effect 0,185 unit increase in wom; 1 unit increase in loyalty will effect 0,369 unit increase in wom. Also, significancy of coefficients was examined by t-test. As a result of t- test, sig.values are equivalent to zero. Therefore, coefficients are significant.

\section{Conclusion}

The findings of this study indicate that destination brand image and destination brand loyalty have a positive impact on destination word of mouth behaviour. Therefore, this study has a practical implications for destination and tourism marketers. These managers should try to increase destination brand image and destination brand loyalty to increase word of mouth behaviour.

Although this study makes contributions to the understanding of the relationship between destination brand image, destination brand personality, and word of mouth marketing, it entails several limitations. This presentation is actually a part of a broder research which is in progress. The data is cross sectional in nature. Sample is limited to tourists visited Istanbul, this research will continue using different destinations in Turkey.

\section{References}

- Boo, S. et. al., 2009. "A Model of Customer-Based Brand Equity and its Application to Multiple Destinations”, Journal of Tourism Management, 32(2), 219-231.

- $\quad$ Bruyn, A. and Lilien, G. L., 2008. "A Multi-stage Model of Word-of-mouth Influence Through Viral Marketing”, International Journal of Research in Marketing, 25(3), 151-163.

- $\quad$ East, R. et. al., 2008. "Measuring the Impact of Positive and Negative Word of Mouth on Brand Purchase Probability”, Internetional Journal of Research in Marketing, 25(3), 215-224.

- $\quad$ East, R. et. al., 2007. "The Relative Incidence of Positive and Negative Word-of-mouth: A Multi-category Study", International Journal of Research in Marketing, 24(2), 175-184.

- Jalilvand, M. R. et. al., 2012. "Examining the Structural Relationship of Electronic Wor of Mouth, Destination Image, Tourist Attitude to Toward Destination and Travel Intention: An Integrated Approach", Journal of Destination Marketing \& Management, 1(1), 134-143.

- $\quad$ Kim, D., Magnini, V. P. and Signal, M., 2011. "The Effects of Customers' Perceptions of Brand Personality in Casual Theme Restaurants", International Journal of Hospitality Management, 30: 448-458.

- $\quad$ Lee, R. and Lockshin, L., 2011. "Halo Effects of Tourists' Destination Image on Domestic Product Perceptions", Australasian Marketing Journal, 19(1), 7-13.

- $\quad$ Lee, T. H. and Shen, Y. L., 2013. "The Influence of Leisure Involvement and Place Attachment on Destination Loyalty: Evidence From Recreationists Walking Their Dogs Urban Parks”, Journal of Environmental Psychology, 33, 76-85.

- $\quad$ Liu, C. et. al., 2012. "Relationship Between Self-congruity and Destination Loyalty: Differences Between First-time and Repeat Visitors", Journal of Destination Marketing \& Management, 1(1), 118-123.

- Pike, S. and Bianchi, C., 2011. "Modeling Destination Brand Equity in an Emerging Long Haul Market", Travel \& Tourism Research Association Europan Chapter Conference: 58037. 
- $\quad$ Stepchenkova, S. and Morrison A. M., 2008. "Russia's Destination Image Among American Pleasure Travelers: Revisiting Echtner and Ritchie”, Journal of Tourism Mangement, 29(3), 548-560.

- Sun, X. Et. al., 2013. “Developing Destination Loyalty: The Case of Hainan Island”, Annals of Tourism Research, Available Online.

- Veasna, S. et. al., 2013. "The Impact of Destination Source Credibility on Destination Satisfaction: The Mediating Effects of Destination Attachment and Destination Image", Journal of Tourism Management, 36, 511-526.

- Yoon, Y. and Uysal, M., 2005. “An Examination of the Effects of Motivation and Satisfaction on Destination Loyalty: A Structural Model”, Journal of Tourism Management, 26(1), 45-56. 


\title{
An Evaluation of Electronic Commerce in Terms of Accounting Information System in the Global Competitive Environment
}

\author{
Prof. Dr. Naim Ata Atabey (Selçuk University, Turkey) \\ Ph.D. Candidate Fatma Özlem Y1lmaz (Selçuk University, Turkey) \\ Assoc. Prof. Dr. Baki Yılmaz (Selçuk University, Turkey)
}

\begin{abstract}
The gradually increasing of the competition among the managements that operate in the present-day global competitive environments leads to the speedily and continuously development of the information technologies in the managements. The electronic commerce (e-commerce), which is one of the most dynamic ways of the competition and emerges as a result of the speedily and continuously developments in the information technologies, starts the process of increasing the competition, the flexibility, the quality and the speed among the managements by providing that all sorts of operations, which belong to the commercial activities and interest in both organizations and individuals, are made on the electronic environment. E-commerce makes some changes in the management processes and their operations, and these changes affect on the assets and the sources of the managements, and it causes to incomes and expenses and brings the events and the operations, which had to be explained in the financial tables, into the forefront. E-commerce, therefore, shows itself up as a part of Accounting Information System with its way affecting on the processes and the operations in the managements. E-commerce, in this Study, has been tried to assess by the perspective of Accounting Information System in the global competitive environment.
\end{abstract}

\section{Introduction}

By the passing in the information society, the developments in the information and communication technologies have transformed the world into, with the word of McLuhan, "a big village." This transformation has encountered the managements, which operate across the world, with the new opportunities, particularly. These opportunities have been affected in the structure of economic activities, especially.

The globalization discussions bring with many economical, political, cultural, and social openings. The most important concept coming to the forefront with these discussions is "the phenomenon of competition." Competition is the concept that clearly expresses the change in the present day (Sevim, 2009).

The structure of economic activities in the global competitive environment has been changed radically in parallel to the development process of information technologies. This process of change has increased the use of electronic technologies in the birth of information and in its transferring and producing.

At the present day, by the removal of the usages based on the face-to-face and written recording system and of the trade barriers put forward by the concepts of distance-time, it leaves its place to the process of the electronic/web-based data processing in increasing gradually. By the effect of technological developments, a great number of serious changes, from the forms of production to the forms of distribution and from the forms of usage to the methods of reaching the customers, are lived in the fields that managements operate. E-commerce, in this process, has come to be the form of a new and great trade channel in the commerce by providing a possibility to the trading (buying and selling) of both many imaginary goods and traditional physical goods, especially with the using of Internet in the international commercial operations. The activities of traditional marketing and customer relations almost in all the sectors at the present day have been rearranged as it will be benefitted from some conveniences like marketing, reaching the information, and decreasing the cost that Internet provides (Seyidoglu, 2000).

The electronic commerce has become a powerful instrument of distribution and trade, increasing progressively in the present times. That the distributional and commercial operations are made in an electronic environment leads to the necessity that the electronic commerce is evaluated with the perspective of accounting by affecting especially on the accounting applications together with other managerial processes.

In our Study, firstly it has been given the general information concerning with the electronic commerce and then evaluated the electronic commerce in terms of Accounting Information System.

\section{Electronic Commerce and its Scope}

The technological developments lived by the increasing of global competition and the changing of the understanding structure of information system management of managements have forced the managements to be more innovator, more productive, more flexible, and more dynamic, affecting on them considerably. These developments have made the electronic commerce an important instrument of trade by enabling that information, 
documents, data, and records, which are necessary for commercial activities, are transferred into an electronic environment and that the operations can be made in this environment.

E-commerce, which can be defined as the purchase and sale of goods and services and realized by a medium of exchange between two sides and emerges as a result of being made by an instrument in an electronic environment, can be described in many ways.

Electronic Commerce (WTO, 1998; Carter, 2002; ETicaret 2009);

- World Trade Organization (WTO): "The producing, advertising, selling, and distributing of goods and services by the telecommunication networks."

- Organization for Economic Cooperation and Development (OECD): "All commercial operations, which interest in persons and establishments and base on processing and conveying a written text got numerical, a voice, and an image."

- $\quad$ United Nations Centre for the Facilitation of Procedures and Practices for Administration, Commerce and Transport (UN-CEFACT): "The business information, which is structured and unstructured to be directed the activities of business, management and consumption, is shared on electronic instruments between producers, consumers, public establishments, and other organizations."

- Wurman and et al. have defined the electronic commerce as the unity of activities that uses the electronic communication channels in the stock, exchange, advertisement, distribution, and payment of services and products and as a system that the steps of meeting, agreeing, and realizing among the ones concerned are automatized (Wurman and et al., 1998).

- Electronic commerce is the making of producing, advertising, selling, paying, and distributing of the products by computer networks (Schoop, 2005). By the electronic commerce, trading of goods and services, designing of product, producing, marketing, advertising, presenting, ordering, making an agreement, banking operations, fund transferring, engineering services, public acquisition, coining electronic money (imaginary money), (stock) exchange operations, e-notaryship, transferring of intellectual property rights, and renting operations etc. are made (Bozkurt, 2000).

- The Electronic Commerce Coordination Commission in Turkey has defined the electronic trade as "the whole of the commercial operations, which bases on the processing, conveying, and keeping of the numerical information in the form of writing, voice, and image in the environments of the open network (Internet) of individuals and establishments or the closed-network that can be reached by a limited number of users and which aims at constituting a value" (ETKK, 1998; Parlakkaya, 2005).

- Electronic commerce is to use systematically the developments in the link networks and communication technology to develop the ways of interaction with suppliers, customers, shareholders, investors, and all the concerned persons and people of a company (Alagoz, 2007).

By the development of the concept of 'electronic commerce', computer systems, databases, and various electronic systems have led that the electronic commercial applications have become widespread and that a lot of changes have occurred in these ways by these applications have also contained some cultural, social, and economical fields.

Electronic commerce can be defined as plying a trade with an instrument or as a form of trade in an electronic environment. Any electronic operations resulting commercially are included in the scope of e-commerce. Electronic commerce contains all the activities concerning with the designing, producing, advertising of product, commercial transactions, and the paying on the account by all sorts of computer networks (ETicaret, 2009). Electronic commerce, by its dimension in this point, has a wide scope such the purchasing of goods and services, the instantly distributing of numerical content, the electronic fund transfer, the commerce of electronic share, the electronic bill of lading, the electronic auction, the joint designing and engineering, the instantly presentation from the source, the public acquisitions, the direct marketing to consumer, the services after sale, and the making of payments digitally (Ozbay and Devrim, 2000; Parlakkaya, 2005).

Electronic commerce, in an organizational and individual level, includes the operations related to all commercial activities. All the numerical data produced, processed, and conveyed in this field bases on the processing and conveying of texts, voices, and visual images. Among some important matters in this field, there are protection of consumers; competition; systems of finance and payment; taxation; the intellectual, industrial, and commercial property rights; security; legal regulations; and the mechanism of settling disputes (Canpolat, 2001).

Such every kind of information in electronic commerce is transferred from any place to another place of the world in seconds in an electronic environment is a revolution by itself, it has also a different importance because it has a potential to be able to accelerate other revolutions and to change every dimension of humanity's life fast (Sahin, 2008). 


\section{Instruments and Models of Electronic Commerce}

The instruments, which provide that electronic commerce can be made, can be lined up like this:

- Telephone

- $\operatorname{Fax}$

- Internet

- Television

- Computer

- Electronic (Cashless) Transfer and Money Transfer Systems

- Electronic Data Exchange (Transfer)

- Telecommunications

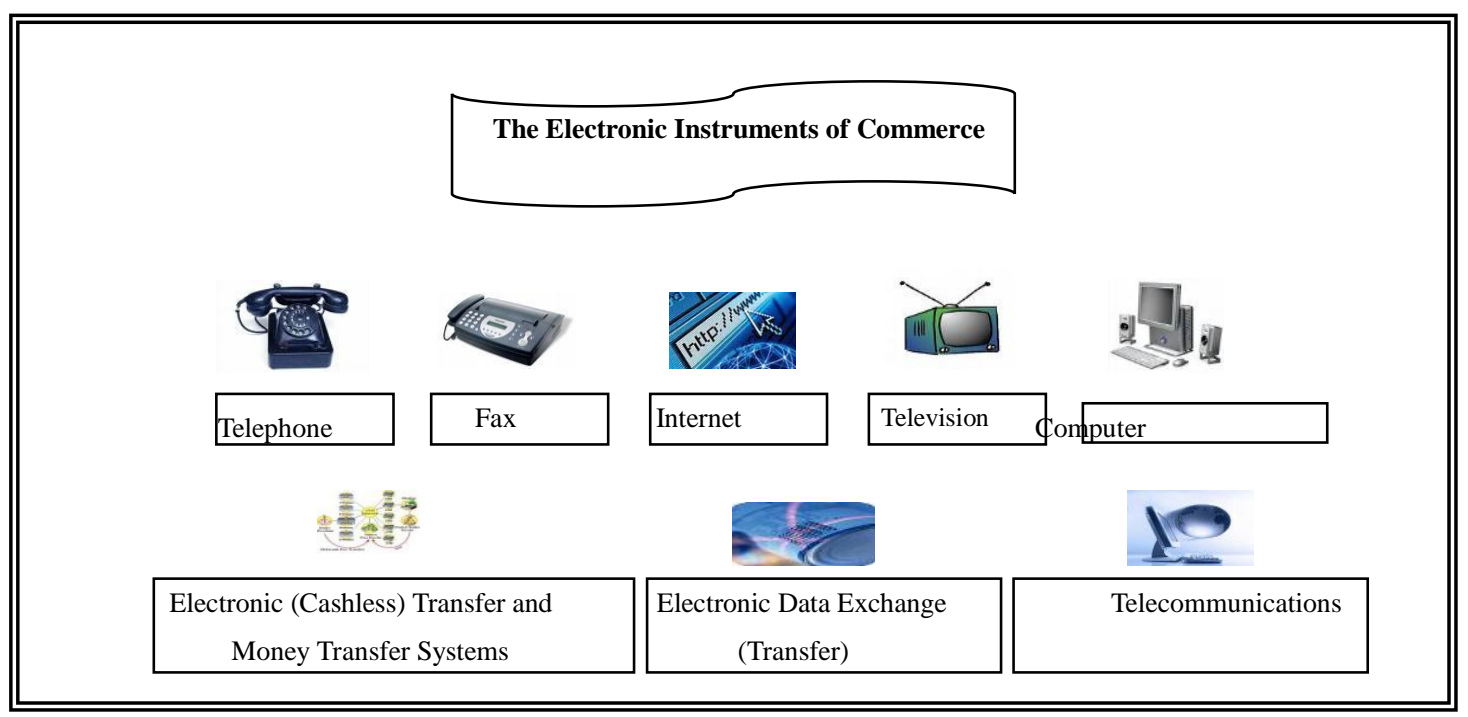

Figure 1. The Electronic Instruments of Commerce

- Telephone, fax, and television are the traditional electronic instruments of commerce. Telephone is used to provide intercom unication between a buyer and a seller; fax to transfer a document; and television to advertise and present the products (Parlakkaya, 2005). By television connects to Internet, the user starts to be able to ply an electronic trade (Ozbay and Akyazı, 2004).

- Because Electronic (cashless) transfer and money transfer systems are used in the electronic commerce, they make the electronic commerce easier significantly and become an inseparable part of it. However, because Automated Teller Machines (ATM) and credit, bank, and smart cards are used only in money transfers, these have a limited function in the trade (Yenigun, 2003).

- Electronic data transfer, as a system that provides documents, information, and data exchange by computer networks between two commercial managements, is one of the instruments of electronic commerce.

- Internet becoming an inseparable and a basic instrument, which develops speedily in the present day, of ecommerce is a commercial instrument providing a multi-directional communication, and the transactions (and operations) can be performed so fast in the computer environment thanks to Internet (Canbolat, 2001).

- Telecommunication setting up the substructure of electronic commerce is one of the classical but important instruments, which raises the information sharing upmost and provide its extensity.

The electronic commercial instruments, which make the transactions of the sides that ply a trade in an electronic environment easier and speedier, are continuously renewed as tied to the development of technology in the present day.

The models of electronic commerce can be lined up like this (Zerenler, 2007):

- Management-to-Management Electronic Commerce

- Customer-to-Customer Electronic Commerce

- Internal Electronic Commerce

- Consumer-to-Consumer Electronic Commerce

- Electronic Commerce from State to Consumer and Management

- Interstate Electronic Commerce

- Electronic Commerce According to the Attribute of a Product 
Management-to-management electronic commerce is a commercial model that is done as an information exchange, which the managements develop on Internet together with buyers, suppliers, and other concerned persons for their buying and selling operations (Trepper, 2000).

Customer-to-customer electronic commerce is a commercial model that contains the operations of directly selling various products to customers by using some electronic instruments.

Internal electronic commerce is a commercial model that is done among management units and that includes a workflow application.

Consumer-to-consumer electronic commerce is a commercial model that consumers buy and sell some their own products among themselves under some conditions and by a management instrument.

Electronic commerce from State to consumer and management is a commercial model that includes the realization of the aim at "reaching" all the relations between public establishments and citizens to "a more management" (Torres and at al., 2005) with information and communication technologies.

Interstate electronic commerce is a commercial model that is done in an electronic environment for importing and exporting between public establishments and other public establishments in other countries.

Electronic commerce according to the attribute of a product can be evaluated in two groups as directly and indirectly (Zerenler, 2007). While the ordering and advertising of a product in the indirect commerce are made in an electronic environment, the delivery of product is done via cargo and post in harmony with traditional ways. As for the delivery of product in the direct commerce is completely realized in an electronic environment.

\section{Accounting Information System and Electronic Commerce}

Accounting Information System is the most important and the oldest of the basic managerial information systems (Surmeli, 1994). Accounting Information System is a system that produces information, which explains the formation of sources of an organization, the form of using of these sources, the increases and the decreases occurring in these sources in consequence of the activities of the organization, and the condition of the organization in terms of finance, and that conveys them to the concerned persons and establishments. This process operates towards the objective of providing on the time the true and reliable information related to assets, sources, and results of activity with the aim of those in the position of decision-making are able to take consistent decisions (Atabey and et al., 2006).

\begin{tabular}{|c||ll|l|}
\hline \multicolumn{1}{|c|}{ INPUT } & PROCESS & \multicolumn{1}{|c|}{ OUTPUT } \\
\hline $\begin{array}{c}\text { Information } \\
\text { and } \\
\text { Documents }\end{array}$ & $\begin{array}{l}\text { Commercial } \\
\text { Books }\end{array}$ & Balances \\
\hline
\end{tabular}

\section{Figure 2. The Flow of Accounting Information-Financial-Qualified Event and Operations Source: Surmeli,
1994.}

As seen in Figure 2, the Flow of Accounting Information that is related to the activities of a management follows the flow of input, process, and output as is in every system.

The financial-qualified events occurring in the managements lead to be lived a change on the structure of assets and sources and on the activity results of the management. In this way, the field of interest of Accounting Information System consists of financial-qualified events and operations that emerge in the management. In Account Information System, that information becomes reliable, well-timed, neutral, understandable, and consistent makes it more useful and beneficial (Karasioglu, 2001).

It is indisputable that Account Information System, which is the most important in terms of managements, has to accord with economical and technological developments. The electronic volume of trade, in the present day, speedily spills over the whole world in the leading of multinational American companies (Karatas and Yilmazsoy, 2001). The firms plying electronic trade use the basic principles and the rules of accounting that the firms trading in traditional ways will use. In this way, the accounting order used in the traditional trade will be valid also for electronic commerce, and it will be used (Semerci, 2007).

The management processes of electronic commerce and the changes that they make in their operations will affect on the accounting systems, inevitably. E-commerce has not only changed the form of trade but also constituted some concepts like electronic billing and electronic archiving that affect on Accounting Information System in the managements (Parlakkaya, 2005). The making of commercial books and the constituting of 
financial statements in the electronic environments enable to be lived a change for things like fastness of business, highness of rate of truthiness, and savings of paper and stationery (Yukcu and Gonen, 2009).

The important problem, which electronic commercial applications lead in terms of Accounting Information System, is that the order of document in the input process of the system is electronic and that some legal regulations concerning with it are not done adequately and that in this way it is seen different applications are done (Y1ldiz and Canbaz, 2008).

By the perspective of Accounting Information System in the managements, it is possible to sum up the effects of electronic commercial applications like this:

- The presentation in digital environments of financial-qualified events and operations, the base of Accounting Information System, will broaden the effects of electronic commercial applications more.

- In a management, in the case of the broadening of electronic commercial applications, managers will be able to obtain the information that they need, at the right time and at will, because all financial information related to a management is more regular and easily accessible.

- In the degree of accuracy and consistency of the decisions on which the future financial informational predictions and managerial plans of managers of managements base, an increase will be lived.

- The financial structures of the managements plying an electronic commerce will be more effective in comparison to other managements.

- Because information is conveyed very speedily, the flow of accounting information will be reached more effectively and fruitfully to the concerned sides.

- The forms of delivery and payment in an electronic commercial operation and the computer programs used in a management will make the applications of Accounting Information System easier.

- Electronic commercial applications will lead to a considerable decrease in the number of accounting documents and in the costs.

- For the order of document(s) and record(s), it will be provided new programs are developed.

- The demand for the accountants using electronic commerce will increase (Akkas, 2000).

- The goal of providing true and reliable information related to assets, sources, and results of activity at the right time will increase the reliability of electronic commerce.

\section{Conclusion}

The dynamic power of globalization is the fast developments in that information and communication technologies. These developments determine the form of trade, the understanding, and the application of the digital era, especially with electronic commercial applications. The phenomenon of competition, together with the phenomenon of globalization lived in the world, increases (its weight) as days pass; the demand periods of products gradually decrease because the products, which are presented in proper to the consumers' personal needs and expectations, are demanded; and the kind of product grows speedily. Managements, as a result of these developments, are in the position of supplying a great variety of products to the market with speed, with a relevant cost and with a level of quality at will, to be able to provide a competitive advantage. The electronic commercial applications providing this state are an important operation instrument of the new models of economy and management. The electronic commercial applications, which continuously renew with information and communication technologies, enable that the good-quality, continuous, simultaneous, and reliable services are provided and presented.

In the global competitive environment, as long as the possibilities of utilization from the information and communication technologies for the applications of Accounting Information System, the function and also the importance of accountancy towards the business managements increase. That Accounting Information System, which provides the production of financial information from the managements, presents the financial-qualified information, which a business management needs in the global competitive environment, inside the digital accounting organization, completely, clearly, timely, and reliably, will enable that the activities of management have a faster, flexible, innovator (reformist), and planned structure.

\section{References}

- $\quad$ Akkaş, Jale, 2000. "Elektronik Ticaret ve Elektronik İş Uygulamaları Muhasebe ve Finansal Raporlamayı Nasıl Etkileyecek ?”, Active Bankacılık ve Finans Dergisi, No:14, Ağustos-Eylül, s.1.

- Alagöz, Ali, 2007. "Web Sitesi Maliyetlerinin Muhasebeleştirilmesi”, Selçuk Üniversitesi Sosyal Bilimler Enstitüsü Dergisi, Sayı:18, s.11.

- Atabey, N.Ata, Parlakkaya, Raif ve Alagöz, Ali, 2006. Genel Muhasebe, Atlas Kitabevi, Konya.

- $\quad$ Bozkurt, Veysel 2000. Elektronik Ticaret, Alfa Yay., Ankara. 
- Canpolat, Ömer. 2001. E-Ticaret ve Türkiye’deki Gelişmeler, T.C. Sanayi ve Ticaret Bakanlığı Tüketicinin ve Rekabetin Korunması Genel Müdürlüğü Yay., Ankara.

- Carter, J., 2002. Developing E-Commerce Systems, Prentice Hall., New Jersey.

- $\quad$ Karataş, N. ve Yılmazsoy, M.,2001. “Sorular ve Cevaplar”, Vergi Dünyası Dergisi, Sayı: 234, ss. $182-183$.

- Karasioğlu, Fehmi, 2001. İnternet Tabanlı Finansal Raporlama, Nobel Yayın Dağıtım, Ankara.

- Özbay, Adem, Devrim, Jan, 2000. E-Ticaret Rehberi, Bilgi Teknolojileri Dizisi 7, Hayat Yayınları, İstanbul.

- Özbay, Sabahat ve Akyazı, Selma, 2004. Elektronik Ticaret, Ankara: Detay Yayıncılık.

- Raif Parlakkaya, 2005. "Elektronik Ticaret ve Muhasebe Uygulamalarına Etkileri”, Selçuk Üniversitesi Karaman İktisadi ve İdari Bilimler Dergisi, Sayı:2, Cilt:5, Aralık. ss.169-170.

- Schoop, Mareike, 2005. "A Language-Action Approach to Electronic Negotiations An International", Journal on Communication, Information Technology and Work, Vol. 1, No. 1, 62-79.

- Semerci, Murat, 2007. Elektronik Ticaretin İşleyişi, Denetimi ve Muhasebeleştirilmesi, Yayınlanmamış Yüksek Lisans Tezi, Sütçü İmam Üniversitesi, Kahramanmaraş.

- $\quad$ Sevim, Adnan, 2009. "Dijital Uygulamaların Muhasebe Eğitimi Üzerine Etkileri, http://www.mu.edu.tr/iibf/tmes24/kitap/2-2.pdf. s.95, 04.01.2009.

- Seyidoğlu, Halil, 20000.Uluslar arası Elektronik Ticaretin Gelişimi, Halil Aksu’ya Armağan Kitabı, İTÜ, İşletme Fak. Yay. İstanbul.

- Şahin, Ali, 2008. Türk Kamu Yönetiminde Yapısal Dönüşüm ve E-Devlet, Çizgi Kitabevi, Konya.

- $\quad$ Torres, Lourdes, Pina, Vicente ve Acerete, Basilio, 2005. "E-goverment Develompent on Delivering Public Services Among EU Cities, Government Information Quarterly, Vol.:22, Issue:2, 217-218.

- $\quad$ Trepper, Charles, 2000. E-Commerce Strategies, Microsoft Pres., Washington.

- WTO(World Trade Organization), 1998. "Study from WTO Secretariat Highlights Potential Trade Gains From Electronic Commerce", http://www.wto.org, 05.01.2004.

- Wurman, P., Walsh, W. ve Wellman, M., 1998. Flexible Double Auctions for Electronic Commerce: Teheory and Implementation, Decision Support Systems.

- Yükçü, Süleyman ve Gönen, Seçkin, 2009. “Türkiye’de Elektronik Ticaretin Muhasebeleştirilmesine İlişkin Uygulama Önerileri”, Atatürk Üniversitesi İktisadi ve İdari Bilimler Dergisi, Cilt: 23, Say1: 2, ss.7-8.

- Yıldız, Fehmi ve Canbaz, Serdar, 2008. “Türkiye’de Elektronik Ticaret Uygulamasında Karşılaşılan Muhasebe Sorunları İle İlgili Bir Araştırma”, Muhasebe ve Finansman Dergisi, Sayı:37, Ocak, s.72.

- Zerenler, Muammer, 2007. Dijital İş Yaşamı: Tüm Boyutlarıyla Elektronik Ticaret, Gazi Kitabevi, Ankara.

- $\quad$ Yenigün, Cüneyt, "Küresel Pazar ve Elektronik Ticaret, 2009. http://www.bilgiyonetimi.org/cm/pages/mkl_gos.php?nt=458, 06.01.2009.

- $\quad$ www.eticaret.org/kavram.htm, 01.04.2009. 


\title{
Poverty Alleviation and Microfinance in post-Soviet Central Asia
}

\author{
Assoc. Prof. Dr. Heiko Fritz (Linnaeus University Växjö, Sweden)
}

\begin{abstract}
Microfinance has played an important role in poverty alleviation throughout the developing world. Though some Central Asian countries are blessed with abundant natural resources, uneven income distribution and poverty are prevalent. Microfinance, however, has not been much in the public discussion in the region. The aim of this paper is to take stock of microfinance in Central Asia; to review recent developments in the context of the global development in the sector; to assess the regulatory and supervisory environment; and to identify untapped potential with respect to the future development of the industry.
\end{abstract}

\section{Introduction}

Microfinance has become a major pillar of strategies for global poverty reduction since Muhammad Yunus pioneered joint liability group lending in the early 1980s in Bangladesh, an innovative institutional setting to reduce transaction cost in small scale lending. In the meantime microfinance has become a mature industry. International donors and commercial investors channel significant funds to microfinance institutions (MFI) in developing countries. The scope of financial services supplied by MFI has broadened beyond microcredit including savings products, microinsurance and leasing. An increasing number of MFI operate profitably. Initially an informal activity, the growth of the industry has brought about a growing body of regulatory and supervisory provisions in many countries often implemented and enforced by the central bank or the banking supervisory authorities. Whilst commercialization allowed raising funds for the growth of microfinance, critiques argue that a mission drift has occurred from the social aim of poverty alleviation to the commercial aim of profit maximization (Armendáriz and Szafarz, 2011).

The causality from microfinance to poverty alleviation is based on the assumption of credit market imperfection. Asymmetric information require lenders to perform costly screening and monitoring of borrowers to reduce the problems of adverse selection and moral hazard. Being fixed cost, these transaction costs of conventional banks are prohibitive in small scale lending. Poor persons, who are likely to demand only small amounts of credit, face rationing in the loan market. Hence, in developing countries characterized by high poverty ratios, the majority of people is excluded from financial services and the financial system suffers low outreach. Microfinance thus can help build a more inclusive financial system. Small scale credit can allow the poor to enhance their earning potential in an environment where self-employment is often the only possibility to be economically active and, ideally, to escape poverty (see Duvendack et al., 2011 for a recent review of the empirical evidence).

Given this backdrop the aim of this paper is to examine the trajectories of microfinance in post-Soviet Central Asia, i.e. Kazakhstan, Kyrgyzstan, Tajikistan and Uzbekistan, henceforth CA4. Turkmenistan will only occasionally be touched upon as the availability of information and data is very limited. Though according to the World Bank only Tajikistan and Kyrgyzstan are classified low income countries, poverty is an issue in the other Central Asian countries as well. The trickle-down effect of revenues from exporting primary products is limited and income inequality is high. Likewise outreach of the formal financial system in all countries is low.

Given the prevalence of both poverty and financial exclusion one should expect Central Asia to be a fertile ground for microfinance. The paper thus continues examining closely the microfinance industry in the region. On the country level, the development of various indicators will be studied on the size of the microfinance sector (number of MFI, number of borrowers, size of the loan portfolio), concentration and market power on the supply side, profitability, the quality of the loan portfolio etc. This allows drawing a detailed picture of microfinance in each country as well as comparing the industry between the countries.

\section{Microfinance in Central Asia}

This chapter provides some general socio-economic information about the Central Asian countries, poverty and simple indicators of financial development. The poverty-financial access nexus is then represented in an international setting to support the case for microfinance as a supplement to the formal financial system. The section then provides an overview of microfinance in Central Asia. The development of microfinance in each of the CA4 is reviewed and some key indicators of the demand and the supply side in the market for microcredit will be provided. Moreover the trajectory of the industry in CA4 is put into the context of global trends in microfinance.

In terms of population size post-Soviet Central Asia comprises three small countries, Kyrgyzstan, Tajikistan and Turkmenistan, and two medium-sized countries, Kazakhstan and Uzbekistan (see table 1). Given that the territory of both Kazakhstan and Uzbekistan is huge the population density in all Central Asia is rather low. A 
large share of the population lives in rural areas with limited access to urban infrastructure. The economies are very heterogenous. Kazakhstan is rich in oil and experienced significant economic growth since independence driven by export revenues of oil, minerals and wheat. Turkmenistan, though otherwise a rather closed economy, strongly benefits from export revenues of natural gas. The smaller countries are less blessed with natural ressources. Uzbekistan is a major exporter of cotton the production of which has required giant irrigation projects that are ecologically not sustainable. Kyrgyzstan and Tajikistan have the production and export structure of developing countries lacking natural resources. About one third of the Tajik GNI is earned abroad and enters the country in the form of remittances.

\begin{tabular}{|l|l|l|l|l|}
\hline & Population & GNI / cap & $\begin{array}{l}\text { Average annual } \\
\text { GDP growth }\end{array}$ & $\begin{array}{l}\text { Poverty } \\
\text { headcount ratio }\end{array}$ \\
\hline & (million) & $($ USD-PPP) & $(\%, 2002-12)$ & $(1.25$ USD/day) \\
\hline Kazakhstan & 16.6 & 11,250 & 7.2 & $0.1^{\mathrm{a}}$ \\
\hline Kyrgyzstan & 5.3 & 2,200 & 4.1 & 5.0 \\
\hline Tajikistan & 6.7 & 2,300 & 7.5 & $6.6^{\mathrm{a}}$ \\
\hline Turkmenistan & 4.9 & 8,690 & 12.2 & $24.8^{\mathrm{b}}$ \\
\hline Uzbekistan & 27.3 & 3,420 & 7.7 & --- \\
\hline
\end{tabular}

Table 1: Selected socio-economic and financial indicators of Central Asia Source: Worldbank-World Development Indicators database. Notes: a 2009; b estimation by the Asian Development Bank; $c$ data from the IMF WEO database, own calculations.

The income distribution in all Central Asian countries is hugely uneven. This is most pronounced in Turkmenistan which has a fairly high average income whereas at the same time one fourth of the population lives in extreme poverty. Extreme poverty seems less of an issue in the other four countries though there is a large share of poor people when the national poverty line is considered. In terms of financial development, Kazakhstan, and there most notably the city of Almaty, is often praised the financial center of the region. Indeed the ratio of bank assets to GDP in Kazakhstan reaches the level of some of the Central and East European EU member states that joined in 2004 and 2007 respectively. However the function of the Kazakh banking system has largely been to channel funds borrowed in international capital markets to sectors in need to finance investment, most notably the oil extraction industry and construction. Accordingly, Kazakh banks faced refinancing problems in 2008-09 when the capital markets dried up in the course of the global financial crisis. This and the drop in oil prices was the main spill-over mechanism of the crisis into Kazakhstan. The banking sector of the other Central Asian countries is only to a limited extent developed. Bank assets to GDP ratios are very low. In Kyrgyzstan and Uzbekistan in particular, Kazakh banks own large stakes in the larger commercial banks.

Given the lopsided development of Kazakh banks, financial outreach in the country has been low. Only slightly more than 40 percent of the adult population own a bank account. In the other Central Asian countries these figures are even dramatically lower. Hence both poverty and low financial outreach are problems in Central Asia and the region can be assumed to be fertile ground for the development of microfinance structures. Drawing on a set of 130 countries figure 1 below confirms the assumed poverty-financial access nexus and highlights the location of Central Asian countries. Note that the headcount poverty ratio in this figure relates to the national poverty line which is significantly above USD 1.25 per day. Hence poverty appears to be more of a problem than the figures in table 1 above suggest.

Figure 1 indeed strongly supports the idea that better outreach of the financial system is associated with lower poverty rates. However, it is subject to discussion in which direction the causality works. Proponents of microfinance argue that building more inclusive financial systems causes poverty to decrease as credit allows the poor to become economically active through self-employment, to increase their earnings and ultimately to escape poverty. However, the causality may well work the other way round. A reduction in poverty may increase demand for financial services so that profit maximizing suppliers of financial services ultimately improve outreach to cater the formerly poor. A third possibility is that there is actually no causal link between financial development and poverty but that both variables are driven by the overall level of economic development. The argument would then be that economic growth stimulates financial development and brings down poverty, for instance through the trickle down effect. 


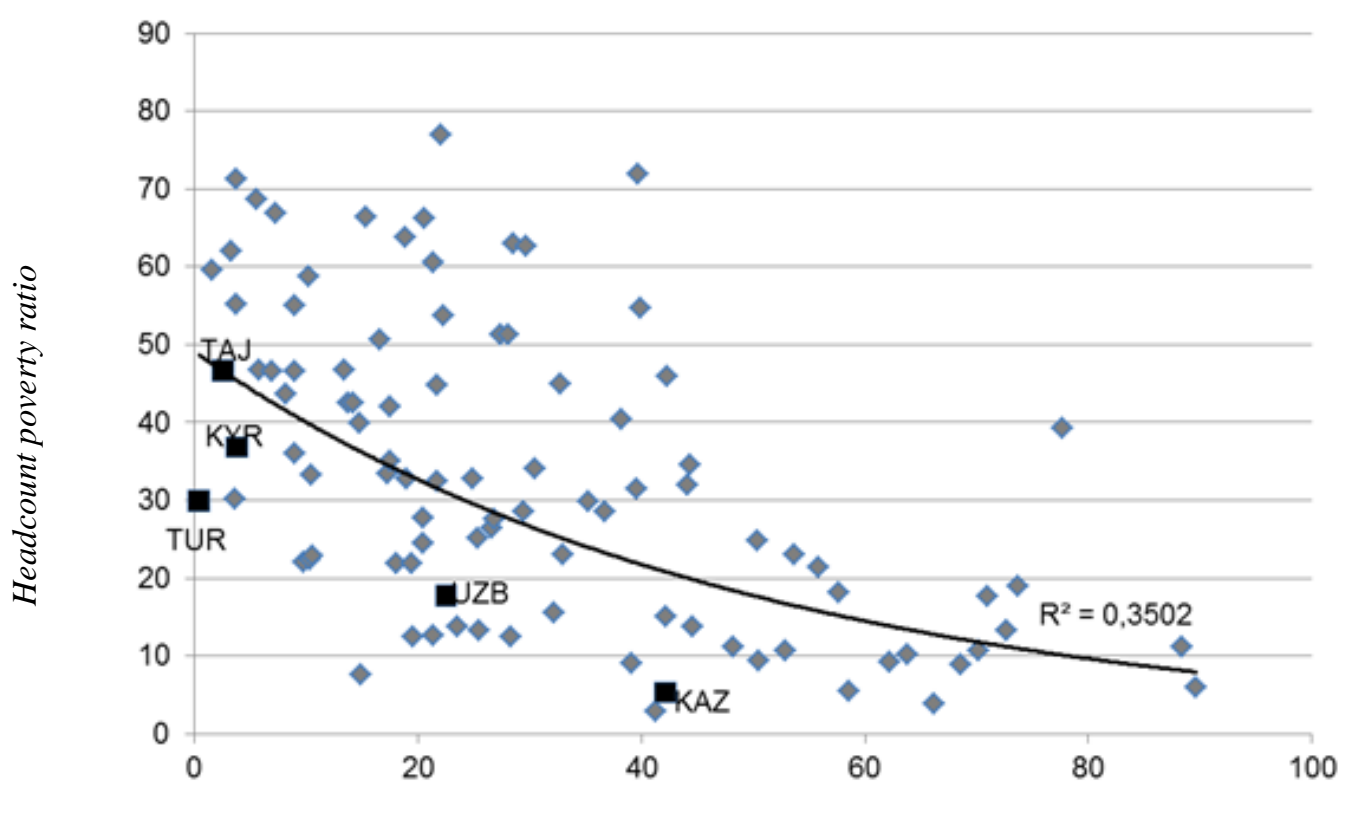

Share of adult population with a bank account (\%)

Figure 1: Poverty and financial inclusion (2011) Source: World Bank - World Development Indicators dataset; Asian Development Bank; CGAP - Global FinDex dataset; own calculations.

Microfinance emerged in Central Asia in the mid-1990s when international donors, most notably the UNDP and USAID, made funds available in the region to finance equity of microfinance institutes.

In Uzbekistan, commercial banks, NGOs and credit unions supply microcredits. More recently pawn shops added to the supply side in the market. Whilst loans extended by commercial banks have the largest share in terms of assets of microcredit providers, credit unions and NGOs account for the largest share of borrowers and thus improve the outreach of the sector. Since its inception in 2006, the state-owned Microcreditbank dominates the sector issuing loans at negative real interest rates.

In Kazakhstan, commercial banks, microlending organisations, NGOs and credit unions offer microloans. Both joint liability group loans and individual loans are supplied. The concentration in the sector is high where the five largest MFIs account for about two third of the aggregate loan portfolio. At the same time there is a relatively large number of registered microcredit suppliers many of which are not operating anymore. When compared to their large populous neighbours, outreach of microfinance in Tajikistan and Kyrgyzstan is much better as indicated by the relatively large numbers of borrowers. These are served by large MFIs and credit unions. Commercial banks play less of a role than in Uzbekistan or Kazakhstan.

\begin{tabular}{|l|l|l|l|l|l|l|l|l|l|}
\hline & \multicolumn{4}{|l}{ Number } & \multicolumn{3}{l|}{ Number of borrowers } & \multicolumn{3}{l|}{ Loan portfolio (mill USD) } \\
\hline & 2007 & 2010 & 2013 & 2007 & 2010 & 2013 & 2007 & 2010 & 2013 \\
\hline Kazakhstan & 745 & 1712 & 1747 & 95,000 & n.a. & n.a. & 291.0 & 369.0 & 502.0 \\
\hline Kyrgyzstan & n.a. & 397 & n.a. & 188,000 & 485,000 & n.a & 112.4 & 195.4 & n.a \\
\hline Tajikistan & n.a. & 123 & 142 & n.a. & 150,000 & 220,000 & 39.0 & 110.0 & 120.0 \\
\hline Uzbekistan & 92 & 209 & n.a. & 21,000 & 104,700 & n.a. & 33.7 & 185.6 & n.a. \\
\hline
\end{tabular}

Table 2: Indicators of microfinance in Central Asia Source: Author's compilation from National Associations of Microfinance Institutes.

In addition to individual countries, the paper looks at microfinance in the entire region as compared to developments in other regions such as South-East Asia, Latin America, and sub-Saharan Africa. A helpful tool to do this is to compare the structure of the aggregate balance sheet of the microfinance industry in Central Asia with other regions. Drawing on a comprehensive database provided by Mixmarket, an international NGO funded by a large number of government bodies and foundations, figure 2 below provides the structure of the aggregate balance sheet of CA4 in 2005 and 2010 respectively.

Assets continue to be dominated by loans. Hence MFI in Central Asia have not diversified into microinsurance. If there are any microinsurance products available, these are supplied through other firms such as insurance companies or state organizations. The structure of the liabilities side changed in the period from 2005 to 2010. In 2010 the leverage of MFI was higher though equity continues to be the most important source of funds. Yet the share of borrowing, largely loans from commercial banks and subsidized loans from international development banks such as the IFC or the KfW, increased to almost 30 percent. Likewise the share 
of deposits tripled although it is still at a meager 10 percent. In particular with respect to the funding structure microfinance in Central Asia differs much from other regions where much of the growth of the sector has been funded by raising additional deposits from microsavers.

2005

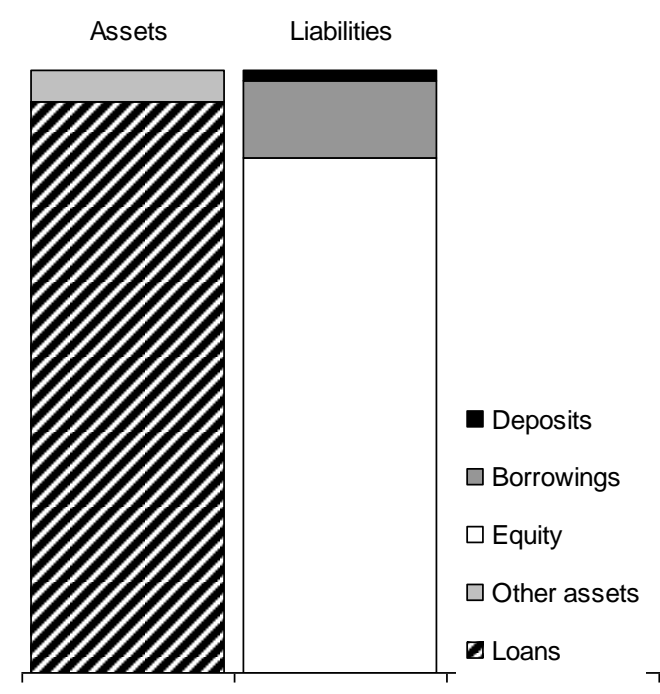

2010

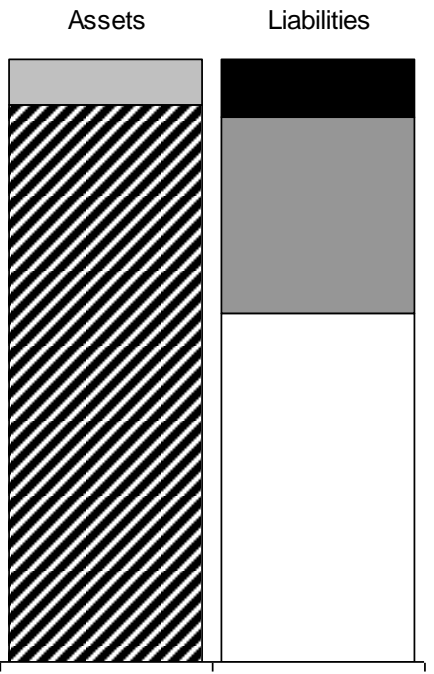

Figure 2: Stylised aggregate balance sheet of MFI in CA4 (2005-2010) Source: Mixmarket; own calculations.

\section{Supervision and regulation of microfinance in Central Asia}

Financial services are among the most strongly regulated industries in the world (Goodhart et al., 1998). The recent global financial crisis sparked a discussion about the quality and the specific nature of the regulatory and supervisory framework (Brunnermeier et al., 2009). As microfinance is an integral yet peculiar part of the financial services industry in developing countries it is reasonable to ask whether the same rationale for regulating MFI applies as for conventional financial intermediaries (see also BSBS, 2010). This section reviews the main arguments for the regulation and supervision of financial services. The rationale behind each argument will be discussed before the transferability to microfinance will be assessed.

Economic arguments for banking regulation and supervision largely rest in market imperfections. Three types of market imperfections are typically emphasized: (i) imperfect competition; (ii) asymmetric or incomplete information; and (iii) externalities.

\subsection{Market power due to imperfect competition}

One of the fundamental insights of welfare economics is that a market in perfect competition maximizes the welfare that accrues from transactions in the market to the society. A deviation from perfect competition and marginal cost pricing is a market imperfection reducing social welfare. Under certain circumstances such as high market entry barriers, the abuse of a dominant position or collusion between different suppliers interventions by a state agency are justified to restore the competitive order or to make the actors in imperfect competition behave as if there were facing competition. In this respect financial markets are not different from goods markets. This is the main argument why it does not require an institutional setting or a specific approach peculiar to the financial services industry. Banks and other intermediaries are subject to the same competition regime as firms operating in other markets. Anti-competitive behaviour is subject to intervention by the authority in charge to implement and enforce competition policy.

In most countries there is an explicit division of power between a banking regulator or supervisor on the one hand and the competition authority on the other hand. While regulators rather tend to restrict competition and to create market entry barriers by means of licensing requirements, competition authorities typically try to remove or reduce this kind of barriers. In general the aim of banking regulation and supervision is to promote financial stability whereas the one of the competition authority is to promote competition. As there may be a trade off between these aims the division of labour between two agencies independent of each other is necessary to avoid a conflict of interest within an agency.

Adverse effects of imperfect competition in microfinance is not an issue. In fact, concentration in the market for microloans is much lower than in the formal financial sector. Severe competition, however, involves risks as well. A recent survey among more than 500 stakeholders in microfinance worldwide identifies challenges from increasing competition among the three major risks the industry is facing (CSFI, 2011). More specifically 
increasing competition may lead to unethical and irresponsible lending practices including usury, deceptive advertising, loan pushing etc. In addition to destabilizing the microfinance industry this puts the main aim of microfinance at risk as the poor could get exploited and overindebted. Indeed, as it will be argued below, concerns related to consumer protection should play a more important role in the regulation of MFI than of commercial banks.

\subsection{Asymmetric information}

In financial transactions at least one party usually possesses information about characteristics of him/herself or of the service provided that are relevant for the transaction and at the same time unknown to the other party. Due to asymmetric information lenders face, first, the problem of adverse selection, i.e. they systematically select borrowers with unfavourable characteristics without getting a fair compensation for the risk associated with those characteristics. Second, asymmetric information may generate moral hazard when the borrower conducts actions that change the risk of the transaction ex post in an undesirable way from the perspective of the lender.

In the loan market the lender is a financial intermediary, say a bank. The bank makes use of a wide array of screening methods to mitigate adverse selection. Moreover collateral, restrictive covenants and other elements of the loan contract aim at aligning the interest of the borrower and the lender. All this obviously incurs transaction costs which financial intermediaries help to reduce due to their expertise, economies of scale and scope. One could even argue that the comparative advantage that financial intermediaries have over markets with respect to transaction costs is the only justification for intermediaries to exist. The crucial aspect here is that neither regulation nor supervision is required to protect the lender from the risks associated with adverse selection and moral hazard.

However, in relation to poor clients conventional mechanisms of screening, monitoring, and contract enforcement fail to bring down transaction costs sufficiently. This is why the poor are considered unbankable. Various mechanisms of microfinance (for details see Armendáriz and Morduch, 2010; Morduch, 1999) provide a more efficient set of institutions in this respect. The most important one is joint liability group lending (JLGL). JLGL has two main effects: (i) it moves, at least partly, transaction costs from the lender to the borrower; and (ii) it reduces transaction costs. Ghatak (2000) shows that JLGL leads to self-selection of borrowers in groups the members of which share similar characteristics with respect to risk. This reduces screening costs of the lender. Stiglitz (1990) demonstrates that JLGL creates incentives for peer monitoring which reduces moral hazard. This reduces monitoring costs of the lender. Besley and Coate (1995) show that peer pressure in JLGL helps enforce the loan contract. This reduces enforcement costs of the lender. The combination of these mechanisms implies that the problems asymmetric information may cause for the lender can be solved without any regulation or supervision. The innovative design of loan contracts provided by microfinance itself is the solution of the problem.

In conventional loan markets the borrower is typically considered the informed party whereas the lender faces the aforementioned problems of adverse selection and moral hazard due to asymmetric information. However, it may be argued that in microfinance there is an additional problem regarding the level of information of the borrower. The vast majority of borrowers in microfinance schemes must be considered financially illiterate largely because of their poor level of education. That means even though information about the nature of the loan or other financial products are available, the borrower does not have sufficient knowledge to fully grasp the implications of the transaction for his or her economic well-being. This makes the poor particularly vulnerable to extortionate behaviour of lenders. Educating the poor to improve their financial literacy would be a measure targeting the roots of the problem most directly. However, there are severe limitations to this when it comes to the practical implementation. This is why a more indirect solution to the problem has been proposed namely the regulation and supervision of MFI to minimize the level of exploitation of the poor (Christen et al., 2003; Davel, 2013).

In the deposit market the individual depositor has imperfect information about the use of his/her funds by the depository institution. However, the rational depositor will not screen and monitor the depository institution for two reasons. First, for small-scale depositors screening and monitoring cost are prohibitive relative to the amount deposited. Second, supervision of the depository institute has the character of a public good for the group of depositors. Other depositors can not be excluded from the discipline imposed on the depository institution due to the supervision of an individual depositor. Thus free riding is rational so that the social level of supervision will be too low. Only a single large depositor could have a sufficiently large incentive to supervise the depository institution individually. In the absence of a single large depositor the government should provide for a regulatory and supervisory framework that makes sure that the depository institution does not engage in excessively risky activities in which the informed depositor would not like to see his funds invested. Accordingly prudential banking regulation largely aims at reducing excessive risk taking and deposit insurance reduces the loss that depositors suffer when the depository institution becomes insolvent.

Indeed one could argue that deposits of the poor require even more protection as they typically constitute the entire wealth of the household which cannot be diversified due to its small size. However, many MFI who accept 
deposits have a dominant depositor typically an international donor such as USAID, KfW etc. These donors have a strong incentive to monitor the behaviour of the MFI. In addition they have the expertise to interpret the information provided by the MFI and the possibility to enforce discipline on the MFI as the donor could threat to withdraw the funds. Thus neither the incentive problem nor the free rider problem of monitoring the depository institution seem to be particularly relevant with respect to MFI.

While the existence of a dominant depositor makes the MFI avoid excessive risk taking it does not set sufficient incentives for the MFI for a sound liquidity management. Once the MFI accepts deposits it is important that the MFI keeps some liquid reserves to make sure smooth conversion of deposits in cash if the depositors wished so. Illiquidity would trigger a domino effect leading to a run of depositors on this bank. Thus the arguments put forward for prudential supervision of banks addressing liquid reserves apply in the same way to MFI.

\subsection{Externalities}

In financial services, it is commonly argued, the failure of an individual institute causes negative externalities on the financial system. If this is true an individual institute tends to accept more risk than desirable from the systemic point of view as part of the cost of failure is external cost to the institute. This would then require some form of regulation which internalizes the external cost. In this respect it is important to think of the spill over mechanism. In which way could the failure of an individual institute be detrimental for other institutes? Generally two spill-over mechanisms are invoked: entanglement of financial intermediaries and demand side network effects. Each of these mechanisms will be briefly described and tested with respect to its transferability to microfinance.

Financial intermediaries operating in the formal financial sector are closely entangled with each other largely via the interbank money market of the economy. Accordingly a critical share of the assets of a bank may be liabilities of another bank. Depending on the size of a bank its insolvency may cause trouble to other banks as well if significant loans in the interbank money market need to be written off. Note that this partly accounts for the too big to fail problem as banks that have a dominant position in the financial system of a country know they will be bailed out by the government because their failure would tear down all the banking system. Thus they tend to accept higher risks than banks that can not count on a bailout.

Obviously this spill over mechanism does not apply to microfinance. First, not being part of the formal financial system MFI do not participate in the interbank money market. And no market exists in the system of microfinance in which liquidity balances are traded. Second, MFI are generally not the counterpart of a claim of any MFI. This is not in line with the underlying idea of microfinance and it is also not common practice.

However, demand side network effects may be a significant source of spill over as some instances of MFI failure proof. Demand side network effects typically root in incomplete information. For instance when a bank faces liquidity or solvency problems, depositors with other banks may be inclined to withdraw their deposits as they do not have sufficient information to assess whether the problem is confined to the individual bank or whether it reflects a problem of the entire banking system. In the worst case this could aggravate to a large scale bank run. There are some arguments for demand side network effects to be particularly severe in microfinance. First, the structure of the balance sheets and the type of risk exposure of different MFI is nearly the same. Hence clients may be even more tempted to interpret trouble in one MFI as a structural problem of the entire sector. This is even more so when MFI do business in the same geographical area where risks of borrowers are closely correlated. For instance a flood or a draught destroying the harvest of farmers in a particular area leads to a surge in loan delinquency or default of all MFI operating in that area. Second, it is reasonable to argue that the assumption of incomplete information applies to clients of MFI even more than to clients of formal banks. Many poor households do not have access to mass media. Depending on the cultural context the main source of information are neighbours, relatives, the assembly of village elders, spiritual leaders of the community etc. This is fruitful ground for rumors to spread.

\subsection{Regulation and supervision of microfinance in Central Asia}

In Uzbekistan, the Law on Credit Unions dates back to mid-2002, the Law on Microfinancing and on Microfinance Organisations to mid-2006 respectively. The Kazakh government of passed the Law on Microlending Organisations in 2006. This law was replaced in December 2012 by the Law on Microfinance Organisations. In Tajikistan the Law on Microfinance Organisations dates back to mid-2012. In Kyrgyzstan the Law on Microfinance Organisations has been in place since 2002. Table 3 below (next page) summarises regulatory and supervisory provisions of the laws and regulations based on these laws that have been in place at the time of writing. 


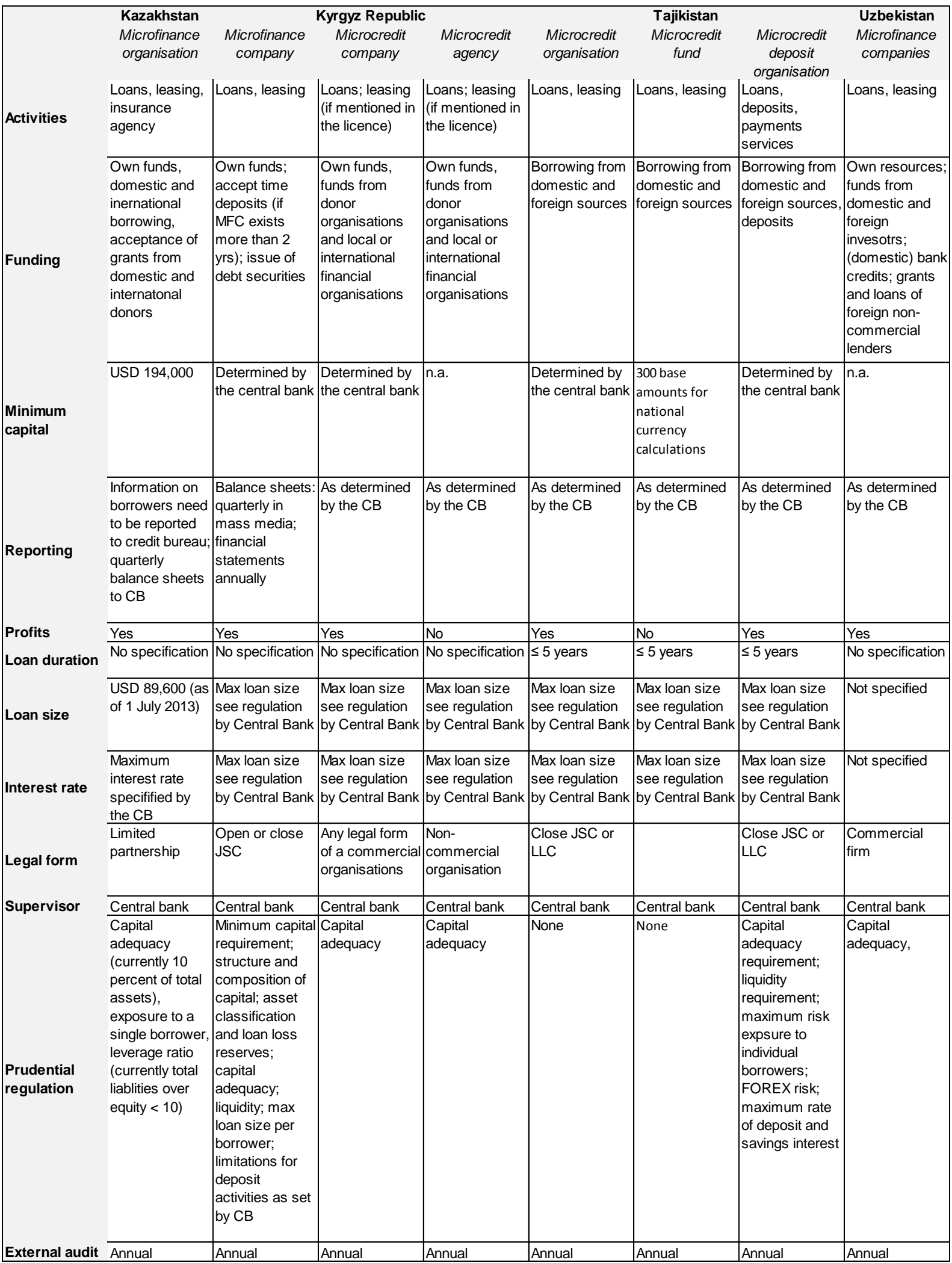

Table 3: Regulation and supervision of MFI in Central Asia Source: Compilation from national laws on microfinance and implementing directives of the central banks of the respective countries.

\section{Non-economic approaches to microfinance in Central Asia}

Whilst poverty is prevalent in Central Asia, though the magnitude of the problem varies regionally, and outreach of the financial system in the region is poor, microfinance does not have the same level of development as in other regions that share the same set of problems. This section briefly discusses three potential non- 
economic reasons for this. These are (i) the political system; (ii) informal institutions; and (iii) religion in Central Asia. Without being exhaustive, the logic behind each factor shall be sketched out below.

\subsection{Autocracy and political economic constraints}

When the Soviet Union demised in 1991, 15 independent and sovereign states emerged. While the Central and East European countries, with the exception of Belarus, adopted democratic political systems characterised by different levels of presidentialism or parliamentiarism, all Central Asian countries ended up being autocratic regimes led by strong presidents (Pomfret, 2006). Arguably the system in Kyrgyzstan is more liberal and more democratic than the other four, not least because the US was more involved in state building. Tajikistan may be considered slightly different either because the way to independence led through a bloody civil war in which different clans battled for control over the state which was at the verge of becoming a failed state during the armed conflict.

Nonetheless in all Central Asian states the presidents managed to install family members, cronies and other loyal persons in nearly all influential positions in politics and business. Political elites and business elites became increasingly congruent. It seems that the main aim of setting policies was to maximize influence and personal wealth of the elites. Constitutional reality has not much limited the possibilities of the political actors to pursue this aim. On the other hand, policies that did not come at the immediate benefit of the elites were procrastinated or not pursued at all. Examples include policies on education, the public system of health care, and social security.

Following this line of reasoning it can be argued that microfinance is less well developed in Central Asia than in most other regions of the world because the ruling elite has not been much interested in developing this sector. Policies to alleviate poverty and to mitigate inequality have not been top of the political agenda. In addition autocratic regimes typically consider the operations international organisations - many of which such as UNDP, GIZ, USAID, are active in providing financial and technical support to MFI - on their territory illegitimate interference with domestic affairs. Likewise non-government organisations are often met with suspicion. Hence, lacking support from the state and from international organisations, grassroot actors were left at their own devices to set up microfinance structures.

\subsection{Peculiar social capital and informal institutions in Central Asia}

Much research on microfinance focuses on the relationship between social capital in a society and microfinance. Two distinct perspectives can be distinguished. On the one hand it has been argued that social capital is an exogenous determinant of the success of microfinance schemes (Karlan, 2007; Karlan et al, 2009). Social capital comes in the form of networks of interpersonal relations generating, for instance, mutual trust. Social capital is a particularly important success factor in joint liability group lending where group members screen and monitor their peers. On the other hand Feigenberg et al. (2010) argue that social capital in endogenous in microfinance as the various institutionalizations of lending schemes foster interpersonal relations and, hence, produce social capital. This argument is occasionally used to justify subsidization of microfinance programs as social capital is a positive externality.

With respect to social capital in Central Asia Collins (2006; 2004) emphasizes the role of clans. Clans are informal organisations based on kinship comprising 500 to 20,000 members. They are often formed on blood relations and ethnity and have a regional core which may or may not branch out. Whilst clan structures are not unique to Central Asia, Collins (2006; 2004) argues that clans gained a particular role in the dynamics of regime change and the formation of new regimes. The benefits of clan membership vary depending on the position in the clan. Clan elites benefit from a loyal network, non-elite members from patronage. In an environment of missing or inefficient formal and informal institutions, the clan potentially fills an institutional vacuum in many areas. With respect to missing or inefficient economic institution, the clans compensate for the missing or malfunctioning labour or capital market. Clans may crowd out alternative political or economic institutions. This crowding out may explain why microfinance is underdeveloped. Even in other countries where clans are not prevalent, research demonstrates that microfinance cannot fully succumb over informal forms of credit allocation such as moneylenders. Clans may have filled the gap of credit allocation in Central Asia impeding the development of alternative, potentially more efficient forms of credit allocation.

\subsection{Islam in Central Asia and microfinance}

Another distinct element of the CA-4 is the distinct role of Islam and religion in general. Microfinance products that are attractive to Muslim believers are still being developed and there seems to be a lack. If this is the case in Central Asia, this may form a demand side constraint for the development of microfinance.

\section{Conclusions}

This paper provided an overview of microfinance in Central Asia. It has been argued that Central Asia, in particular in the southern countries where the outreach of the financial system is low and poverty is a severe problem, is the environment where microfinance can be expected to assume a prominent role. However, a 
detailed overview demonstrated that microfinance in the region has been lagging significantly behind other regions such South Asia or Latin America. Based on a comparative review of the institutional framework, it has been demonstrated that regulatory and supervisory provisions are in place in Central Asia that impede the growth of the sector, whether intended or not. Most notably the prohibition of accepting deposit, microcredit deposit organization in Uzbekistan being the only exception, excludes MFI in Central Asia from a source of funding that developed particularly dynamically in other parts of the developing world. Given the limited scope of financial services that MFI are allowed to supply, reporting requirements and prudential regulation seem overly restrictive in Central Asia. Asking for potential reasons for this, the paper argued that non-economic determinants need to be given particular attention. These may include informal institutions such as the role of clans that can be considered competitors to the development of microfinance structures. Moreover, political economic reasons as well as religious restrictions of Islamic finance have been invoked as potential reasons. More research is needed to substantiate this.

\section{References}

- Armendáriz, Beatriz and Ariane Szafarz. 2011. On Mission Drift in Microfinance Institutions. In: Beatriz Armendáriz and Marc Labie (eds): The Handbook of Microfinance. New York: World Scientific, 341-366.

- Armendáriz, Beatriz and Jonathan Morduch. 2010. The Economics of Microfinance. 2nd ed. Cambridge and London: MIT Press.

- Basel Committee on Banking Supervision (BCBS). 2010. Microfinance Activities and the Core Principles for Effective Banking Supervision. Basel: BIS.

- Besley, Timothy and Stephen Coate. 1995. Group Lending, Repayment Incentives and Social Collateral. American Economic Review, 83(4), 792-810.

- Brunnermeier, Markus K., Andrew Crockett and Charles Goodhart. 2009. The Fundamental Principles of Financial Regulation. London: CEPR.

- Centre for the Study of Financial Innovation (CSFI). 2011. Microfinance Banana Skins 2011 - Losing its Fairy Dust. The CSFI Survey of Microfinance Risk. London and New York: CSFI.

- Christen, Robert Peck, Timothy R. Lyman and Richard Rosenberg. 2003. Microfinance Consensus Guidelines. Guiding Principles on Regulation and Supervision of Microfinance. Washington, DC: CGAP.

- Collins, Kathleen. 2006. Clan Politics and Regime Transition in Central Asia. New York: Cambridge University Press.

- Collins, Kathleen. 2004. The Logic of Clan Politics: Evidence from the Central Asian Trajectories. World Politics, 56(2), 224-261.

- Davel, Gabriel. 2013. Regulatory Options to Curb Debt Stress. CGAP Focus Note 83. Washington, DC: CGAP.

- Duvendack, Maren, Richard Palmer-Jones, James G. Copestake, Lee Hooper, Yoon Loke and Nitya Rao. 2011. What is the Evidence of the Impact of Microfinance on the Well-being of Poor People? London: EPPI-Centre.

- Feigenberg, Benjamin, Erica M. Field and Rohini Pande. 2010. Building Social Capital Through MicroFinance. NBER Working Paper 16018. Washington, DC: NBER.

- Ghatak, Maitreesh. 2000. Screening by the Company You Keep: Joint Liability Lending and the Peer Selection Effect. Economic Journal, 110, 601-631.

- Goodhart, Charles, Philipp Hartmann, David T. Llewellyn, Liliana Rojas-Suarez and Steven Weisbrod. 1998. Financial Regulation: Why, How and Where Now? London: Routledge.

- Karlan, Dean. 2007. Social Connections and Group Banking. Economic Journal, 117 (517), F52-F84.

- Karlan, Dean, M. Mobius, T. Rosenblat and A. Szeidl. 2009. Trust and Social Collateral. Quarterly Journal of Economics, 124, 1307-1361.

- MIX and NAMOCU. 2011. Uzbekistan 2009 Microfinance Analysis and Benchmarking Report. Washington, DC: Microfinance Information Exchange (MIX).

- Morduch, Jonathan. 1999. The Microfinance Promise. Journal of Economic Literature, 37(4), 1569-1614.

- Pomfret, Richard. 2006. The Central Asian Economies Since Independence. Princeton: Princeton University Press.

- Sabi, Manijeh. 2013. Microfinance Institution Activities in Central Asia: A Case Study of Tajikistan and Uzbekistan. Post-Communist Economies, 25(2), 253-266.

- Stiglitz, Joseph E. 1990. Peer Monitoring and Credit Markets. World Bank Economic Review, 4(3), 351366. 


\title{
Features of Business Cycles across the Middle East and North Africa: A Nonparametric Analysis
}

\author{
Prof. Dr. Mehmet Balc1lar (Eastern Mediterranean University, Cyprus) \\ Dr. Nezahat Küçük (Eastern Mediterranean University, Cyprus)
}

\begin{abstract}
In this paper, we provide a compressive analysis of business cycle characteristics across a large set of countries in the MENA region. Contrary to the majority of the papers on business cycles synchronization across the MENA region countries, we concentrate on the appearance of the cycle, not on its synchronization. We use robust methods that are not based on ad hoc filtering or parametric methods. Our findings suggest that important differences exist in the business cycle characteristics of the MENA region economies. We find evidence against a common reference cycle for a group of countries. Although the business cycle characteristics show some similarities among some small number of countries, overall the business cycle characteristics across the MENA countries are dissimilar.
\end{abstract}

\section{Introduction}

Increasing number of countries in the Middle East and North Africa (MENA) region are opting for increased regional economic integration in the future. Increased cross-border trade, partly provided through the lifting of trade barriers within the frameworks of the Gulf Cooperation Council (GCC) and the Greater Arab Free Trade Area (GAFTA), is an important part of the economic integration. A recent UN (2000) report notes that because of the unstable monetary, macroeconomic, and financial environments in certain parts of the MENA region, it is doubtful that macroeconomic policy coordination will benefit the member countries. The UN report examines the implications of policy coordination and, ultimately, the adoption of a common single currency and comments that such adoption is likely to succeed if optimum currency area (OCA) conditions are fulfilled. A key requirement in the OCA theory is the business cycle symmetry among currency union members. The report assesses the degree of business cycle synchronization in the Middle East region and finds that business cycles have not become highly synchronized with one another but the degree of business cycle synchronization is related to trade intensity. Predicting that trade links would increase in the future the UN report suggests that member countries would benefit from macroeconomic policy coordination and formation of an OCR. Hirata et al. (2007) assumes a common synchronized business cycle for MENA and examines the implications of an aggregate dynamic stochastic general equilibrium model. They state that the model captures some important structural characteristics of the MENA economies and is able to replicate the main properties of their common business cycles. However, there has been no study thoroughly examining the characteristics of business cycles in the MENA region. A common MENA business cycle is not demonstrated by empirical evidence rather it is assumed, except the examination of cycle synchronization in UN (2005) and Gallagati et al. (2004), which is limited to a few countries in the MENA. The main objective of this paper is to fill this gap by a through examination of business cycle characteristics using the methods of modern business cycle theory.

The recent growing macroeconomic research interest on the MENA economies concentrated on sources of business cycle and business cycle synchronization. The volatile changes in the MENA region economies during the last three decades created controversies about the relative importance of potential sources of business cycle movements. Several studies attribute a significant role to terms of trade shocks and external linkages (Makdisi et al. 2003; Diboglu and Alesia, 2004; Hirata et al. 2004 and 2007). Mehrara and Oskoui (2007) used a structural vector autoregressive (SVAR) model to examine the sources of business cycle movements in five oil-exporter MENA countries. They found that the oil price shocks are the main source of output fluctuations in Saudi Arabia and Iran, but not in Kuwait and Indonesia. Some other studies pointed out the significant role played by real demand shocks - fiscal imbalances and real exchange rate misalignments - in the MANE region

In this paper we go behind the assumptions made in the previous literature. We use a nonparametric business cycle turning point determination method based on the Bry-Boschan algorithm and estimate business cycle characteristics using the measures proposed in Harding and Pagan (2002). In this way, we analyze the comovements across economies without initially assuming that they should or should not move together. That is we let the "data speak" without imposing any kind of a priori restrictions. Using these robust statistical methods we are able to check which economies are close and which are further away from each other. This approach will also allow us to answer the leading question about the existence of a common MENA region business cycle.

Specifically, the study describes the business cycle characteristics of a group of 22 MENA countries. The business cycle characteristics are examined using the real GDP series. These include average business durations, amplitude, accumulations, and excess (see Harding and Pagan 2002a,2002b, 2003). Rather than calculating pairwise business cycle synchronization indexes between countries, we determine how close are these countries to each other in terms of their business cycle characteristics. In the study, we use quarterly (annual data is used if 
quarterly data is not available for a country in a particular period) over the period 1960-2012 to analyze business cycle movements in the following countries: Algeria, Bahrain, Bangladesh, Egypt, Iran, Iraq, Israel, Kuwait, Lebanon, Libya, Malta, Mauritania, Morocco, Oman, Pakistan, Qatar, Saudi Arabia, Sudan, Syria, Tunisia, Turkey, and United Arab Emirates.

In this study we find statistical evidence in contrast to the existence of a common MENA region business cycle whose characteristics would be shared by all or a group of countries. Although there is some evidence of a group of countries clustering close to each other, once the effect of two outlier observations are taken into account all countries are spread on a single map with one big cluster, which is no grouping at all since the measure of distance between distant countries is too large. But, there is some little evidence of closeness among some countries based on geographic proximity or trade links. Finally, we find that the evidence is not related to sample period we used. We split our data set into two subsets at 1985 . We observe same characteristics in both samples, although there is some evidence that business cycles for the period 1986-2006 are more volatile.

The rest of the paper is organized as follows. In Section 2, se describe the data and present our methodology. Section 3 presents characteristics of the business cycle in the MENA economies based on the empirical analysis. Section 4 concludes the paper.

\section{Data and Methodology}

In any study of business cycle the foremost and most important question is to define and detect cycles. In their classic work, Burns and Mitchell (BM) (1946) define specific cycles in a series $y_{t}, y_{t}=\log \left(\mathrm{GDP}_{t}\right)$ in this study, in terms of turning points in its sample path. This tradition has been central to work at the NBER and other institutions such as the IMF (2002) and OECD. The best-known algorithm for performing these tasks is that associated with the NBER and set out in Bry and Boschan (BB) (1971). An issue for using the BB algorithm for other countries is that there is no widely accepted reference chronology of the classical business cycle for other countries. In order deal with this problem, we use dating algorithm of Harding and Pagan (2002) that isolates the local minima and maxima subject to reasonable constraints on both the length and amplitude of expansions and contractions. The BB algorithm is applied to the level, mostly after taking logarithms, of the series. Mintz (1969, 1972) applied the BB algorithm to the level of economic time of some surging economies, such as the former West Germany, and failed to find turning points. This led researchers to consider detrending the variables and apply the BB algorithm to the detrended series. In this study, we also determine the cycles from the log differenced series resulting in growth cycles. Although differencing may also be considered as a detrending filter it is not subject to the critics directed to filters such as the HP. Such filters, although commonly used, distorts the cyclical properties of the data and leads to biased estimates of turning points. Pagan (1997) showed that removing the stochastic trend with a HP filter resulted in series with cycles that were around 3 years long and, hence, almost half that of the business cycle. Previous studies found growth cycles to be more useful for analyzing business cycle in countries that experience sharp contractions and expansions in growth rates. In a growth cycle, a recession is defined as a phase when output is below its trend. Analogously, an expansion is defines as a phase when output is above its trend.

Recently, amongst the business cycle researchers, the summaries of characteristics of business cycle changed from a graphical orientation towards quantitative measures involving the moments of selected variables (Cooley and Prescott, 1995; Harding and Pagan 2002a, 2002b, 2003). Based on BM study Harding and Pagan (2002a) suggested that there are four characteristics of interest: The duration of the cycle and its phases, the amplitude of the cycle and its phases, any asymmetric behavior of the phases, and cumulative movements within phases.

The duration refers to the length of an expansion or recession. The duration of an expansion corresponds to the time spent from a trough to following peak. Analogously, the duration of a recession is the time from a peak to the following trough. The second classical feature of a business cycle is its amplitude. The amplitude entails some ambiguity. Based on an argument put forward by Moore (1967) that a decline may not be considered as a trough until it reaches certain depth, the concept of amplitude refers to the depth of the decline or rise in the economic activity in terms of gains or losses in production. Therefore, the amplitude is not related to the timing of the cycle in any way. Harding and Pagan (2002a) proposed two measures of the depth of expansions and recessions in cycles, the amplitude and the cumulation of expansions and recessions. For an expansion phase, the amplitude represents the percentage gained in terms of production during the period of expansion relative to the level of output in the first period of the phase, and in case of recessions, the measure may be interpreted as the percentage lost. So the amplitude, in case of an expansion, is the percentage gain for a jump from a through to peak. The cumulation corresponds to the cumulated gain or loss and consists of the sum of the amplitudes for each period of the phase. We can interpret this measure as the loss in wealth in that economy. The cumulation is a measure that combines duration, amplitude and the shape of expansions or recessions. It approximates the effect of the business cycle phase on the wealth. Harding and Pagan (2002a) use a triangle approximation to calculate the cumulation. In practice the actual cumulative movements may differ from the triangular approximation since the actual path through the phase may not be well approximated by a triangle. In order the 
remove move this bias Harding and Pagan (2002a) proposes an index of the excess cumulated movements. The excess is a bias corrected measure of percentage gain or loss per period of a phase.

\section{Empirical Results}

We estimated each of the measures of cycle characteristics for the 22 MENA countries for which the data is available. The data is obtained from the World Development Indicators published by the World Bank and the International Financial Statistics published by the IMF. For several countries quarterly data were not available for the full period and the estimations are obtained using annual data for these periods. Our data sample covers the 1960-2006 period and includes the real GDP series for each country measured in US dollars. In addition to full sample period we consider periods 1960-1985 and 1986-2012 as two distinct sub-periods (Kose et al. 2004 and Hirata et al. 2004 also split their data at 1985). The first period, 1960-1985, corresponds to the fixed exchange rate regime for the major industrial countries during the Bretton Woods (BW). This period also consist of global shocks associated with sharp fluctuations in the price of oil, and it is also a period of contractionary monetary policies in major industrial countries. The second period, 1986-2006 represents a period with dramatic increases in the volume of trade and financial flows (Prasad et al. 2003). We can isolate the impact of globalization by splitting the sample at 1985. Another reason, as pointed out by Hirata et al. (2004), to choose the mid-1980s as the break point is because it corresponds to a "structural policy break" in both the MENA and Asian emerging market economies. During the mid-1980s, the MENA countries undertook comprehensive reform and stabilization policies.

Table 1 gives estimates of four business cycle characteristics for the full sample period 1960-2012. The recessions are designated as peak-to-trough (PT) and expansions as trough-to-peak (TP). With the exception of duration statistics, all measurements are in terms of percentage changes. The cumulation is measured as the percentage of GDP in the first period of phase. The average duration of recessions (displayed in Figure 1) is 1.27 years while the average duration of expansions is 3.82 years. The average duration estimates are close to those observed in developed countries (see the estimates in Harding and Pagan, 2001). However, there are large differences among countries (see Figure 1). The range for the duration of recessions is about one year, while it is about three years for expansions. Algeria, Bahrain, Bangladesh, Egypt, and Morocco stand out with long periods of expansions, while Kuwait, Pakistan, and Turkey are marked with very short periods of expansions. The countries with longer (shorter) periods of expansions are not the countries with longer (shorter) periods of recessions. Iraq and Oman stand out with shortest duration of recessions while Saudi Arabia has the longest recession duration. The reported coefficients of variation indicate that expansions are more variable than recessions.

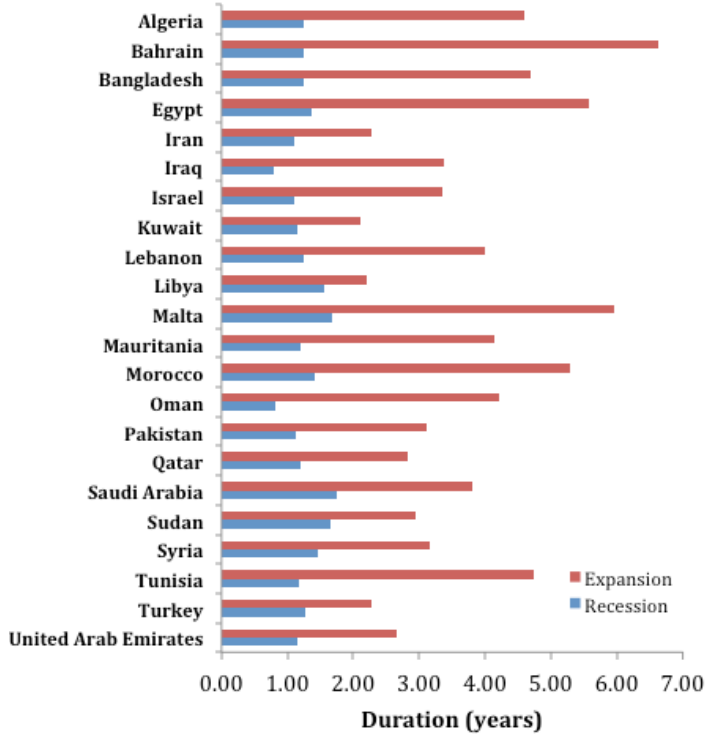

Figure 1. Duration of Expansions and Recessions (Years in recession and expansion)

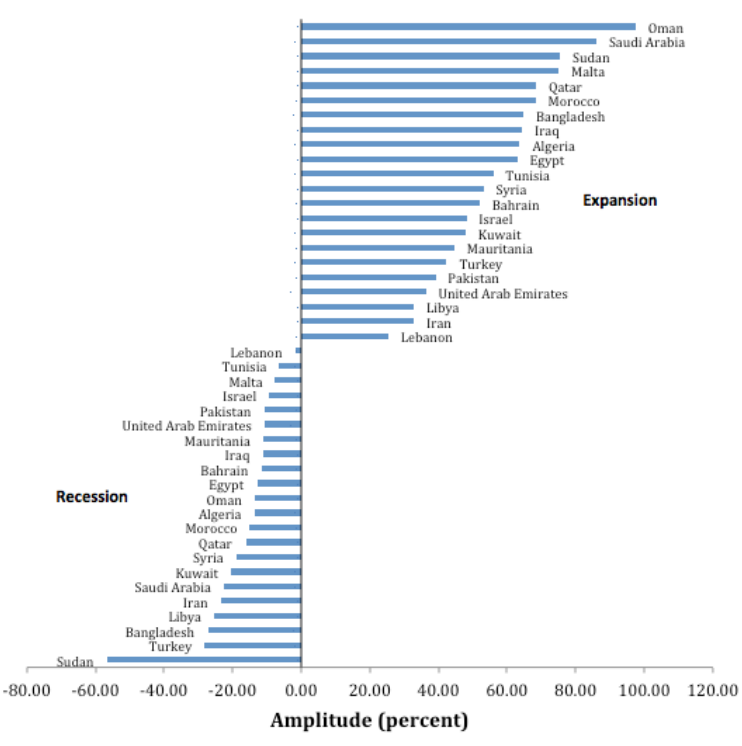

Figure 2. Aplitude of Expansions and Recessions (Percentage of GDP in first year of phase) 


\begin{tabular}{|c|c|c|c|c|c|c|c|c|}
\hline Country & Recession & (peak-to-trs & ugh) & & Expansio & $n$ (trough-to & peak) & \\
\hline & Duration & Amplitude & Cumulation & Excess & Duration & Amplitude & Cumulation & Excess \\
\hline Algeria & 1.25 & -13.72 & -47.19 & -0.25 & 4.58 & 63.60 & 1915.33 & 6.36 \\
\hline Bahrain & 1.25 & -11.43 & -35.44 & 0.48 & 6.63 & 52.02 & 1039.84 & 2.85 \\
\hline Bangladesh & 1.25 & -27.18 & -76.76 & 1.01 & 4.70 & 64.88 & 636.60 & 2.76 \\
\hline Egypt & 1.36 & -12.90 & -48.81 & 0.02 & 5.58 & 63.04 & 905.24 & 1.63 \\
\hline Iran & 1.09 & -23.44 & -69.07 & 0.50 & 2.29 & 32.68 & 301.52 & -0.42 \\
\hline Iraq & 0.79 & -11.24 & -23.98 & 0.43 & 3.38 & 64.44 & 809.92 & 2.70 \\
\hline Israel & 1.10 & -9.39 & -23.33 & 0.25 & 3.36 & 48.20 & 411.33 & 2.29 \\
\hline Kuwait & 1.15 & -20.48 & -60.06 & 1.21 & 2.11 & 47.76 & 307.59 & 3.38 \\
\hline Lebanon & 1.25 & -1.62 & -4.30 & 0.01 & 4.00 & 25.45 & 178.30 & -1.58 \\
\hline Libya & 1.56 & -25.48 & -86.80 & 0.96 & 2.21 & 32.80 & 210.50 & 1.15 \\
\hline Malta & 1.67 & -7.59 & -33.36 & 0.25 & 5.95 & 75.14 & 1280.76 & -1.80 \\
\hline Mauritania & 1.19 & -10.90 & -29.81 & 0.21 & 4.14 & 44.74 & 587.52 & 1.86 \\
\hline Morocco & 1.42 & -15.03 & -47.95 & 0.44 & 5.30 & 68.39 & 1270.43 & -0.85 \\
\hline Oman & 0.81 & -13.50 & -23.63 & 1.00 & 4.21 & 97.51 & 1260.38 & 12.04 \\
\hline \begin{tabular}{|l|} 
Pakistan \\
\end{tabular} & 1.13 & -10.62 & -29.90 & 1.21 & 3.11 & 39.15 & 575.27 & 2.32 \\
\hline Qatar & 1.19 & -16.15 & -44.84 & 0.46 & 2.82 & 68.47 & 453.34 & 1.80 \\
\hline Saudi Arabia & 1.75 & -22.67 & -169.95 & 0.11 & 3.80 & 86.14 & 646.59 & 3.36 \\
\hline Sudan & 1.65 & -56.44 & -218.23 & 3.28 & 2.94 & 75.55 & 683.48 & 4.10 \\
\hline Syria & 1.46 & -19.02 & -110.70 & 0.74 & 3.17 & 53.19 & 478.08 & 3.27 \\
\hline Tunisia & 1.18 & -6.48 & -16.91 & -0.07 & 4.75 & 55.96 & 1084.19 & -2.65 \\
\hline \begin{tabular}{|l|} 
Turkey \\
\end{tabular} & 1.28 & -28.19 & -77.67 & 0.20 & 2.29 & 42.34 & 262.53 & -0.62 \\
\hline United Arab Emirates & 1.14 & -10.79 & -31.57 & 0.07 & 2.67 & 36.41 & 228.26 & -0.01 \\
\hline Mean & 1.27 & -17.01 & -59.56 & 0.57 & 3.82 & 56.27 & 705.77 & 2.00 \\
\hline Max & 1.75 & -1.62 & -4.30 & 3.28 & 6.63 & 97.51 & 1915.33 & 12.04 \\
\hline Min & 0.79 & -56.44 & -218.23 & -0.25 & 2.11 & 25.45 & 178.30 & -2.65 \\
\hline Std. Dev. & 0.25 & 11.26 & 51.00 & 0.74 & 1.29 & 18.38 & 449.21 & 3.13 \\
\hline Coff. of variation & 0.19 & -0.66 & -0.86 & 1.29 & 0.34 & 0.33 & 0.64 & 1.57 \\
\hline
\end{tabular}

Table 1. Business Cycle Statistics for Period: 1960-2012

\begin{tabular}{|c|c|c|c|c|c|c|c|c|}
\hline Country & Recession & (peak-to-t) & ough) & & Expansio & $n$ (trough-to & -peak) & \\
\hline & Duration & Amplitude & Cumulation & Excess & Duration & Amplitude & Cumulation & Excess \\
\hline Algeria & 0.63 & -3.86 & -4.67 & 0.22 & 4.25 & 49.48 & 402.95 & -1.04 \\
\hline Bahrain & 1.50 & -15.51 & -49.76 & 1.03 & 6.63 & 52.02 & 1039.84 & 2.85 \\
\hline Bangladesh & 1.67 & -52.28 & -150.03 & 2.05 & 3.63 & 108.17 & 807.60 & 1.20 \\
\hline Egypt & 1.00 & -10.71 & -25.50 & 0.10 & 4.85 & 55.03 & 658.44 & 0.70 \\
\hline Iran & 1.13 & -34.07 & -96.42 & 0.16 & 8.00 & 107.04 & 1612.78 & -3.12 \\
\hline Iraq & 0.50 & -3.16 & -2.26 & 0.45 & 4.50 & 53.62 & 435.95 & -3.17 \\
\hline Israel & 1.00 & -11.42 & -25.68 & 0.15 & 3.45 & 52.21 & 462.73 & 2.31 \\
\hline Kuwait & 1.15 & -20.48 & -60.06 & 1.21 & 2.11 & 47.76 & 307.59 & 3.38 \\
\hline Lebanon & 1.75 & -1.85 & -6.67 & -0.03 & 4.00 & 25.45 & 178.30 & -1.58 \\
\hline Libya & 1.19 & -14.02 & -43.31 & -0.35 & 1.67 & 38.61 & 185.11 & 1.40 \\
\hline Malta & 2.25 & -9.16 & -53.36 & 0.34 & 8.38 & 110.34 & 2203.79 & -7.87 \\
\hline Mauritania & 0.81 & -4.11 & -6.97 & 0.21 & 4.50 & 53.27 & 721.22 & 3.27 \\
\hline Morocco & 1.58 & -18.65 & -68.57 & 0.46 & 7.38 & 98.37 & 2241.11 & -8.08 \\
\hline Oman & 0.67 & -13.53 & -13.51 & 2.21 & 5.25 & 207.08 & 2825.81 & 37.53 \\
\hline Pakistan & 1.63 & -33.48 & -101.25 & 4.48 & 5.13 & 87.82 & 1734.22 & 7.99 \\
\hline Qatar & 1.17 & -19.34 & -53.71 & 1.20 & 2.92 & 104.61 & 765.18 & 6.95 \\
\hline Saudi Arabia & 0.63 & -15.20 & -15.02 & 1.51 & 3.88 & 164.21 & 1255.93 & 11.45 \\
\hline Sudan & 1.25 & -16.30 & -39.68 & 0.35 & 1.50 & 29.56 & 99.88 & 1.86 \\
\hline Syria & 0.69 & -7.83 & -10.58 & 0.57 & 3.94 & 69.73 & 671.49 & 3.79 \\
\hline Tunisia & 1.42 & -6.08 & -20.51 & -0.19 & 8.25 & 111.91 & 2894.91 & -7.73 \\
\hline Turkey & 1.75 & -41.37 & -125.82 & 0.55 & 1.88 & 56.32 & 305.70 & 2.76 \\
\hline United Arab Emirates & 1.50 & -13.93 & -51.48 & -0.25 & 2.25 & 40.74 & 302.28 & 3.29 \\
\hline Mean & 1.22 & -16.65 & -46.58 & 0.75 & 4.47 & 78.33 & 1005.13 & 2.64 \\
\hline Max & 2.25 & -1.85 & -2.26 & 4.48 & 8.38 & 207.08 & 2894.91 & 37.53 \\
\hline
\end{tabular}




\begin{tabular}{|lllllllll|}
\hline Min & 0.50 & -52.28 & -150.03 & -0.35 & 1.50 & 25.45 & 99.88 & -8.08 \\
\hline Std. Dev. & 0.46 & 13.00 & 40.90 & 1.09 & 2.13 & 45.06 & 868.78 & 9.22 \\
\hline Coff. of variation & 0.38 & -0.78 & -0.88 & 1.45 & 0.48 & 0.58 & 0.86 & 3.49 \\
\hline Notes: See notes to Table & 1. \\
\hline
\end{tabular}

Table 2. Business Cycle Statistics for Period: 1960-1985

\begin{tabular}{|c|c|c|c|c|c|c|c|c|}
\hline Country & Recession & (peak-to-tr & ough) & & Expansio & n(trough-to & -peak) & \\
\hline & Duration & Amplitude & Cumulation & Excess & Duration & Amplitude & Cumulation & Excess \\
\hline \begin{tabular}{|l} 
Algeria \\
\end{tabular} & 1.50 & -17.67 & -64.20 & -0.44 & 1.75 & 16.94 & 72.16 & 1.31 \\
\hline Bahrain & 0.88 & -3.39 & -7.42 & -0.44 & 2.25 & 28.05 & 118.28 & -0.88 \\
\hline Bangladesh & 0.88 & -0.94 & -1.82 & 0.03 & 7.00 & 41.29 & 719.70 & 4.95 \\
\hline Egypt & 2.00 & -21.72 & -95.04 & -0.06 & 5.50 & 64.30 & 1118.96 & 3.81 \\
\hline Iran & 1.14 & -25.92 & -77.55 & 0.60 & 1.33 & 20.29 & 82.98 & 0.03 \\
\hline Iraq & 1.00 & -17.30 & -40.27 & 0.42 & 1.33 & 18.04 & 55.43 & 1.14 \\
\hline Israel & 1.06 & -4.99 & -13.55 & 0.15 & 3.25 & 35.97 & 322.82 & 3.07 \\
\hline Kuwait & 1.31 & -35.08 & -93.34 & 2.58 & 2.92 & 59.98 & 678.25 & 8.10 \\
\hline Lebanon & 1.25 & -1.62 & -4.30 & 0.01 & 4.00 & 25.45 & 178.30 & -1.58 \\
\hline Libya & 2.17 & -37.74 & -146.66 & 2.69 & 3.17 & 34.00 & 299.56 & 1.62 \\
\hline Malta & 1.08 & -6.02 & -13.35 & 0.16 & 2.88 & 24.82 & 127.87 & -0.29 \\
\hline Mauritania & 1.42 & -17.92 & -49.49 & 0.05 & 1.88 & 9.61 & 80.05 & 1.81 \\
\hline Morocco & 1.25 & -11.41 & -27.33 & 0.43 & 2.25 & 29.34 & 138.81 & 0.14 \\
\hline Oman & 0.81 & -6.70 & -13.89 & -0.08 & 2.94 & 33.04 & 191.33 & -1.40 \\
\hline \begin{tabular}{|l|} 
Pakistan \\
\end{tabular} & 1.00 & -3.23 & -6.57 & 0.21 & 1.94 & 18.06 & 98.54 & 0.60 \\
\hline Qatar & 1.00 & -9.86 & -22.06 & -0.52 & 2.75 & 41.37 & 219.46 & -2.07 \\
\hline Saudi Arabia & 1.25 & -8.51 & -22.01 & -0.15 & 3.75 & 34.10 & 240.36 & -2.03 \\
\hline Sudan & 1.92 & -83.20 & -337.27 & 5.23 & 3.13 & 87.70 & 996.35 & 11.53 \\
\hline Syria & 1.00 & -19.71 & -47.32 & 0.37 & 1.63 & 20.11 & 91.26 & 2.23 \\
\hline Tunisia & 1.00 & -6.78 & -14.20 & 0.02 & 2.75 & 30.30 & 191.36 & 0.22 \\
\hline \begin{tabular}{|l} 
Turkey \\
\end{tabular} & 1.00 & -20.28 & -48.79 & -0.01 & 1.44 & 22.02 & 59.07 & -0.04 \\
\hline United Arab Emirates & 0.88 & -4.49 & -9.02 & -0.05 & 2.88 & 34.25 & 191.25 & -1.66 \\
\hline Mean & 1.22 & -16.57 & -52.52 & 0.51 & 2.85 & 33.14 & 285.10 & 1.39 \\
\hline Max & 2.17 & -0.94 & -1.82 & 5.23 & 7.00 & 87.70 & 1118.96 & 11.53 \\
\hline Min & 0.81 & -83.20 & -337.27 & -0.52 & 1.33 & 9.61 & 55.43 & -2.07 \\
\hline Std. Dev. & 0.38 & 18.14 & 73.62 & 1.33 & 1.35 & 17.89 & 306.19 & 3.35 \\
\hline Coff. of variation & 0.31 & -1.10 & -1.40 & 2.62 & 0.48 & 0.54 & 1.07 & 2.41 \\
\hline
\end{tabular}

Table 3. Business Cycle Statistics for Period: 1986-2012

In terms of amplitude, cumulation, and excess we observe even higher differences across countries as seen from (Figure 2, 3, and 4). First of all, these loss measures are much larger than those observed in industrialized countries, when compared with the estimates in Harding and Pagan (2001). The recessions and expansions in MENA countries are deeper than those in industrialized countries, although their durations are comparable. There are countries with tremendous losses occurring. The average cumulation in Sudan reaches an average of -218.23 percent for recessions. Even the amplitude for a recession in Sudan reaches an extreme level of -56.44. The gains as measured by amplitude (Figure 2) and cumulation (Figure 3) are less variable than losses. However, the excess gain is more variable than excess loss across countries (see Figure 4). This points out that the bias in cumulation is more likely to be larger for expansion phases. The cumulation ranges from 178.30 percent (Lebanon) to 1915.33 percent (Algeria). Further, we note that the countries with large losses during recessions do not have large gains during expansions. The coefficients of variation point out that excess vary more than amplitude and cumulation across the countries.

Business cycle characteristics for the sub-samples 1960-1985 and 1986-2012 are given in Table 2 and Table 3, respectively. A general implication from these sub-sample estimates is that the large differences among the countries are preserved in both sub-samples as in the full sample. However, the 1986-2012 period is more volatile than the 1960-1985 period except the duration, which seems equally varying across the countries in both sub-samples. Although the duration of recessions are 1.22 years in both sub-sample the duration of expansions is much shorter in the 1986-2006 period (2.85 years in the 1986-2012 period and 4.47 years in the 1960-1985 period). The coefficients of variation indicate that in general the variability is about 50 percent higher in the 1986-2012 period. 


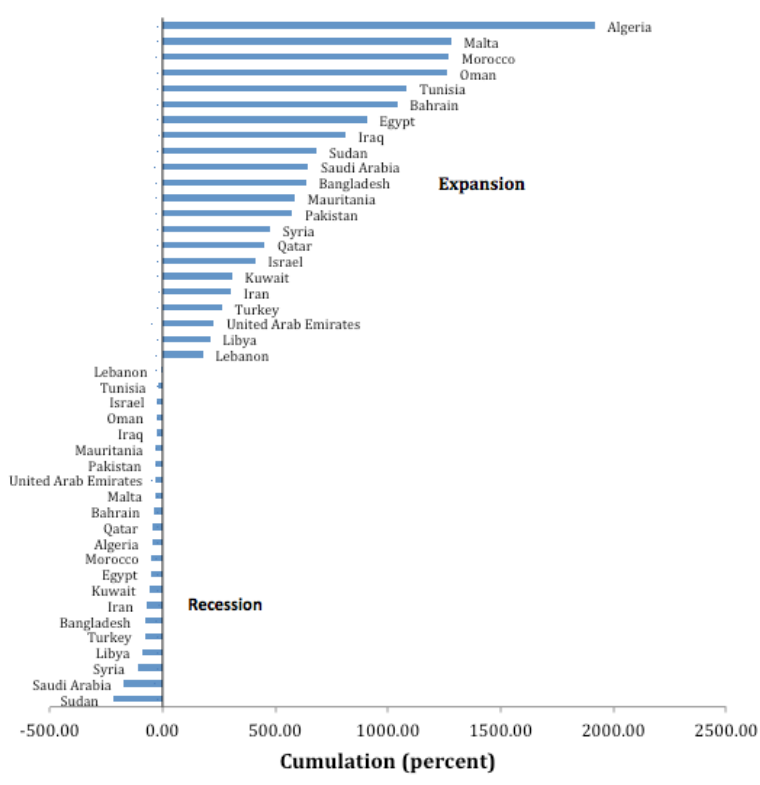

Figure 3. Cumulation during Expansions and Recessions (Percentage of GDP in first year of phase)

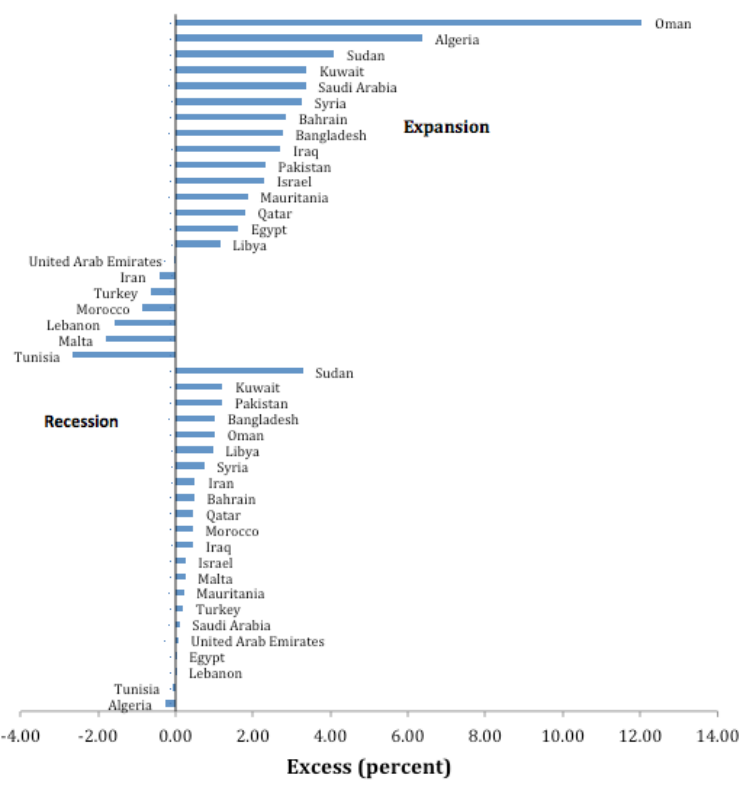

Figure 4. Business Cycle Excess during Expansions and Recessions (Percentage of GDP in first year of phase)

\section{Conclusion}

In this paper, we provided a compressive analysis of business cycle characteristics across a large set of countries in the MENA region. We estimate several numerical measures of their business cycle characteristics. These measures offer a complete description of the cycle. In doing so, we avoided any a priori assumption about the existence of certain business cycle characteristics. The paper also does not assume existence of any common business cycle across some or all countries of the region. We also did not use any parametric model to describe the business cycle movements of individual countries and comovements between pairs (or groups) of countries. These parametric models are extensively used to analyze the business cycle synchronization of major industrialized countries. The results from these models are by now are mixed, inconclusive, and sensitive to various parameterizations. None of the filter-based business cycle synchronizations measures are used either, since the results obtained from this approach are shown to depend on the particular filter used. We adopt robust statistical methods from other scientific disciplines in order to investigate whether some countries can be classified into the same group in terms of their business cycle characteristics. We used multidimensional scaling and cluster analysis to shed some light on the question about the existence of a cycle that might be representative of the MENA region.

Our results bring a different lesson to the previous research that assumed existence of some kind of a common cycle across the MENA region countries. These papers usually attributed this common cycle to increased trade links and/or to similar economic structures. Using the robust classification methods we fail to classify MENA countries into groups based on their business cycle characteristics. We are not able to obtain convincing evidence that there is a common reference cycle for all or groups of countries in the MENA region either. Our findings suggest that the results of those papers assuming a common cycle should be reconsidered.

\section{References}

- Bry, G., Boschan, C., 1971. Cyclical analysis of time series: selected procedures and computer programs. New York, NBER.

- $\quad$ Burns, A.F., Mitchell, W.C., 1946. Measuring business cycles. New York, NBER.

- Cooley, T.F., Prescott, E.C., 1995. Economic growthand business cycles. In: Cooley, T.F., Prescott, E.C. (Eds.), Frontiers of Business Cycle Research. Princeton University Press, Princeton, NJ, pp. 1-38.

- Diboglu, S., Alesia, E., 2004. "Oil prices, terms of trade shocks, and macroeconomic fluctuations in Saudi Arabia”, Contemporary Economic Policy 22, 50-62.

- Harding, D. and Pagan, A. 2001. Extracting, Using and Analysing Cyclical Information, MPRA Paper No. 15.

- Harding, D. and Pagan, A. 2002a. "Dissecting the cycle: a methodological investigation", Journal of Monetary Economics 49: 365-381. 
- Harding, D., and Pagan, A. 2002b. “A comparison of two business cycle dating methods”, Journal of Economic Dynamics and Control 27: 1681-1690.

- Harding D., and Pagan, A. 2003. Synchronization of cycles. Melbourne Institute of Applied Economic and Social Research, mimeo.

- Hirata, H.; Kim, S.H., Kose, M.A., 2004. "Integration and Fluctuations: The Case of MENA”, Emerging Markets Finance and Trade 40, 48-67.

- Hirata, H.; Kim, S.H., Kose, M.A., 2007. "Sources of Fluctuations: The Case of MENA", Emerging Markets Finance and Trade 43, 5-34.

- IMF, 2002. Recessions and Recoveries, IMF World Outlook, April.

- $\quad$ Kose, M.A., Prasad, E.S., Terrones, M.E., 2004. Volatility and Comovement in a Globalized World Economy: An Exploration", forthcoming, in Horst Siebert ed., Macroeconomic Policies in the World Economy, Springer-Verlag.

- $\quad$ Makdisi, S., Fattah, Z., Limam, I., 2003, Determinants of Growth in the MENA Countries. Arab Planning Institute Working Paper 0301.

- Mehrara, M., Oskoui, K.N., 2007. “The Sources of Macroeconomic Fluctuations in Oil Exporting Countries: A Comparative Study", Economic Modelling 24, 365-79.

- Mintz, I. 1969. Dating Postwar Business Cycles: Methods and Their Application to Western Germany, 19501967, Occasional Paper No. 107, National Bureau of Economic Research, New York.

- Mintz, I. 1972. Dating American Growth Cycles, in Zarnowitz, V., ed., The Business Cycle Today, National Bureau of Economic Research, New York.

- Moore, G.H. 1967. "What is a recession?”, The American Statistician 21, 16-19.

- Pagan, A.R., 1997. "Towards an understanding of some business cycle characteristics", Australian Economic Review 30, 1-15.

- $\quad$ Prasad, E.S., Rogoff, K., Wei, S-J., Kose, M.A., 2003. Effects of Financial Globalization on Developing Countries: Some Empirical Evidence, IMF Occasional Paper No. 220.

- UN, 2005. Macroeconomic Policy Analysis for Regional Coordination in the ESCWA Region: Business Cycle Synchronization and Macroeconomic Policy Coordination, New York. 


\title{
On the Source of Macroeconomic Fluctuations in the Middle Eastern and North African Countries: A Structural Vector Autoregression Analysis
}

\author{
Ph.D. Candidate Evrim Toren (Eastern Mediterranean University, Cyprus)
}

\begin{abstract}
This study investigates the relative importance of various shocks in accounting for output fluctuations in the Middle East and North Africa (MENA) countries. The macroeconomic shocks are decomposed into countryspecific, regional, and global sources by using a small open economy structural vector autoregression (SVAR) model. In order to explain output volatility in Middle East and North Africa, the relative importance of each shock in 15 MENA countries is identified in this study. The results show that country-specific factors account for most of the output volatility in the region. For less than half of the countries in the region, global shocks play a significant role in explaining output volatility. Contrary to some findings in the empirical literature, especially on Sub-Saharan Africa, the regional factor does not seem to have a statistically significant impact in any of the countries under consideration. The results are uniform and no statistically significant difference is observed for the countries in the MENA region. Furthermore, oil-exporting and oil-poor countries in the sample do not show any noticeable difference.
\end{abstract}

\section{Introduction}

Until recently, the impact of output fluctuations on economic growth and welfare was generally assumed to be negligible and therefore not a major concern. However, more recent macroeconomic literature, especially following the East Asian crisis of the late 1990s, suggests that high output volatility could have significant adverse effects on long-term growth and welfare (Aizernman and Pinto, 2000; Kose, et al., 2005). The transmission mechanisms between output volatility and long-term economic performance are complex, varied, and not sufficiently understood (Hakura, 2007). One theory argues that, output volatility, by increasing the uncertainty about future returns, could significantly reduce investment and therefore growth. On the other hand, there are those that argue that, volatility could have beneficial effects on growth (Blackburn, 1999; Tornell, et al., 2004).

Output volatility could also adversely affect poverty in developing countries like those in Middle East and North Africa, MENA. Given that fiscal policy is pro-cyclical in most developing countries, this magnifies the negative impact of volatility on poverty especially during crisis. Recent empirical research finds that volatility has significantly negative and causal impact on poverty (Laursen and Mahajan, 2005). The adverse effect of volatility seems to be more pronounced in low-income MENA countries and Sub-Saharan Africa. Periods of extreme volatility have been associated with increased poverty and a concomitant worsening of income distribution in emerging markets. In addition, the poor often lack necessary education and skills, limiting their ability to move across sectors to adjust to changes in economic conditions.

A central concern of this study is whether the source of volatility matters for growth. It is generally recognized in the macroeconomic literature that shocks play a crucial role in predicting national and international business cycles and output volatility. A growing area of research is the relative role played by global, regional, and country specific shocks in accounting for domestic output fluctuations. In recent years, understanding and decomposing the various factors affecting the short and long run behaviour of output volatility in the MENA region has become a rapidly growing area of research. Some studies have focused on the determinants of economic growth (Abed and Davoodi, 2003; Makdisi, et al., 2003, Hakura, 2004; Tamberi, 2005) while others consider how increasing trade and financial linkages affect various economic outcomes in the region (Abed and Davoodi, 2003; Hirata, et al., 2004). More recent studies document the main features of business cycles in the MENA countries (Hirata, et al., 2004; Süssmuth and Woitek, 2004; Lucke, 2004; Al Zoubi and Meghyereh, 2005; Hirata, et al., 2007). Shafik (1998) focuses on the dynamics of economic growth, transitional issues, poverty, and environment in the MENA region. Iqbal (2001) focuses on a range of issues from demographic transition to financial liberalization in the region. The volatile changes in the MENA region during the last three decades have lead to controversies on the relative importance of potential sources of macroeconomic fluctuations. Several studies attribute a significant role to terms of trade shock and external linkages (Makdisi et al., 2003; Diboglu and Alesia, 2004; Hirata et al., 2004, 2007). Using a similar structural vector autoregressive (SVAR) model approach as in this study, Hoffmaisterand Roldos (1997), and Ahmed and Loungani (1998) examine the sources of macroeconomic fluctuations in developing countries and find that terms of trade and world output shocks play a significant role. Mehrara and Oskoui (2007)used a SVAR model to examine the sources of macroeconomic fluctuations in five oil-exporting MENA countries. They found that oil price shocks were the main source of output fluctuations in Saudi Arabia and Iran but not in Kuwait and Indonesia. Some 
other studies point to the significant role played by real demand shocks such as fiscal imbalances and real exchange rate misalignments, in countries of the MENA region (Domac and Shabsigh, 2001; Nashashibi, et al., 2001; Jalali-Naini, 2000).

This study primarily focuses on investigating the sources of output volatility in the MENA region. There is a growing view in the literature that external shocks play a crucial role in accounting for business cycle in the region. Monetary policy is also assumed to have been destabilizing for a long time. Using a small open-economy model appropriate to the MENA region, this study examines the relative importance of external shocks (regional and global) as well as domestic shocks in accounting for output volatility. The rest of the paper is organised as follows. Section 2 outlines the approach used to investigate the sources of output volatility in the MENA countries. Section 3 presents the empirical results derived from the impulse response analysis of shocks and their variance decompositions. Section 4 concludes the discussion.

\section{A SVAR Model of Business Cycle with Global and Regional Shocks}

In order to study the sources of business cycle in the MENA region, this study includes the structural vector autoregression (SVAR) approach proposed by Blanchard and Quah (1989) and extended to open economies by Ahmed et al. (1993), Bjørnland (1998), and Hoffmaister and Roldós (2001). The output volatility is decomposed into three sources, namely; country-specific, regional, and global shocks. Since all variables used in this study are found to be nonstationary, a SVAR model is specified in the first differences. Due to data limitations, 15 countries are included in this study. These include 10 countries (Bahrain, Iran, Israel, Jordan, Kuwait, Libya, Oman, Saudi Arabia, Syria, United Arab Emirates) in the Middle East and 5 countries (Algeria, Egypt, Malta, Morocco, Tunisia) in North Africa. The model incorporates three sources of business cycle: effects of shocks from world output, regional output, and domestic output. To be consistent with the assumption of a small open economy, domestic shocks are not allowed to affect the global and regional variables.

As noted above, the model identifies three structural shocks. The external shocks are the shocks in the global output growth and the regional output growth. Phillips (1991), an extension of Hamilton (1989), gives an example of what can be interpreted as a global shock. Particularly in the Middle East, there might be regional shocks due to past wars. There is a long debate in the literature for an African factor. The African factor may be interpreted as one example of a regional shock. The model identifies one country specific shock, which is productivity shock in the home country. It may be difficult to identify the country specific shocks as either supply or demand shocks. Glick and Rogoff (1995), identify country specific shocks as deviation of Solow residual from world aggregate productivity measure; thus Glick and Rogoff's view is adopted in this study. In the model, country specific shocks include supply shocks possibly including structural reforms such as tariff and trade reforms, relative demand shocks arising from changes in public spending/debt and relative preferences, and aggregate demand shock. The latter captures the effects of nominal variables.

Ordinary least squares (OLS) is used not only to estimate a finite order vector autoregression (VAR) but also to obtain the moving average representation. It is assumed that the global supply and regional shocks have no long run effect on the differential of output level of a country from the world and regional output, respectively. Additionally, the study requires that the global supply shocks have no long-run impact on the deviation of a country's output from the regional output. It is reasonable to assume that in the long-run global shocks will have the same impact across the region. With the just identification of the structural shocks, the SVAR model is used to evaluate the impulse responses and variance decompositions.

\section{Empirical Findings}

In this study, data set contains annual data from 1960 to 2007, but the sample period varies for some countries depending on data availability. Descriptive statistics, sample period and number of observations are given in Table 1. All data, except the crude oil price, were obtained from the World Development Indicators (WDI). The crude oil price data were taken from the British Petroleum Statistical Review of World Energy Workbook. The data set includes 15 countries, 10 countries (Bahrain, Iran, Israil, Jordan, Kuwait, Libya, Oman, Saudi Arabia, Syria, United Arab Emirates) in the Middle East and 5 countries (Algeria, Egypt, Malta, Morocco, Tunisia) in North Africa. The selection of these countries was based on data availability. All variables are measured in a logarithmic scale. The unit root test shows that all the variables are nonstationary in levels and stationary in first differences. Therefore, the SVAR is estimated in first difference form for all countries. For each country, a trivariate SVAR model is estimated as specified in Section 2.

This study determines the appropriate lag length by usingthe reduced form VAR model. The model is estimated by restricting the lag length between one and four. On the basis of the Bayesian (BIC) and the HannanQuinn (HQ) Information Criteria (HQ), the sample evidence for the entire reduced form VAR system suggested a lag length of 1 for all countries, except Malta and Saudi Arabia for which a lag length of 2 is selected. A series of sequential likelihood ratio tests for a shorter lag length versus a longer lag length, suggested also a lag length of 
one. The $p$-value of the Portmanteau test for residual autocorrelation ranges from 0.06 to 0.56 for a lag length of 8 and 0.04 to 0.42 for a lag length of 16 . The normality of the residuals is not rejected using the multivariate normality test of Doornik and Hansen (1994). Given that the evidence for residual autocorrelation is weak and sample sizes were mostly around 48; the VAR models are estimated with a lag length of one for all countries.

Given the potential for structural breaks in the sample, conditional on constant variances, the parameter stability of each equation in the VAR models is tested. When a series of Wald-tests are performed, this study shows that these tests, conditional on constant variances, do not suggest evidence of parameter instability in general. The Chow break point test does not also suggest parameter instability. However, parameter stability is rejected for Libya and Jordan.

In order to show the validity of the structure of the SVAR model, the impulse response functions are estimated (Hamilton, 1994). Each variable in this model is expressed as a combination of current and all past errors. Thedynamic response of domestic real GDP to a one standard deviation innovation is examined in the three structural shocks. The cumulative impulse responses of domestic output to a one-standard-deviation positive innovation in each structural shock are given in Figure 1. The impulse response functions are normalized such that zero represents the steady-state value of the response variable. Several observations are in order. Consider first the impulse response to a positive country-specific shock. A positive country specific productivity shock raises the domestic output permanently in all countries. Responses to country specific shock are relatively much larger than responses to regional and global shocks. In terms of the response to country specific shock there is no difference between the oil-rich and oil-poor countries. It is also observed that the Middle East and North African countries are also analogous.

\begin{tabular}{lllllll}
\hline Country & Period & Mean & Median & Maximum & Minimum & Std. Dev. \\
\hline Algeria & $1960-2007$ & 174 & 193 & 336 & 44.2 & 81.3 \\
Bahrain & $1980-2007$ & 2.39 & 2.3 & 4.57 & 1.29 & 0.96 \\
Egypt & $1960-2007$ & 109 & 97.7 & 275 & 10 & 72.2 \\
Iran & $1965-2007$ & 240000 & 221000 & 482000 & 77000 & 95600 \\
Israel & $1960-2007$ & 281 & 238 & 652 & 52.8 & 173 \\
Jordan & $1975-2007$ & 4.22 & 3.83 & 8.23 & 1.3 & 1.77 \\
Kuwait & $1962-2007$ & 7.35 & 6.86 & 14.3 & 4.64 & 2.24 \\
Libya & $1960-1987$ & 3.71 & 4.09 & 5.94 & 0.65 & 1.5 \\
Malta & $1960-2007$ & 0.32 & 0.28 & 0.68 & 0.06 & 0.21 \\
Morocco & $1960-2007$ & 257 & 231 & 552 & 77.9 & 135 \\
Oman & $1960-2007$ & 2.93 & 2.52 & 7.88 & 0.15 & 2.33 \\
Saudi Arabia & $1968-2007$ & 486 & 484 & 813 & 125 & 172 \\
Syria & $1960-2007$ & 538 & 502 & 1270 & 105 & 338 \\
Tunisia & $1961-2007$ & 9.89 & 8.86 & 24 & 2.36 & 6.05 \\
United Arab Emirates & $1973-2007$ & 155 & 136 & 348 & 53.5 & 74 \\
\hline
\end{tabular}

\begin{tabular}{lllllll}
\hline Country & Period & Skewness & Kurtosis & JB & $\mathrm{p}$ & $\mathrm{n}$ \\
\hline Algeria & $1960-2007$ & 0.1 & 2.05 & 1.87 & 0.39 & 48 \\
Bahrain & $1980-2007$ & 0.69 & 2.42 & 2.6 & 0.27 & 28 \\
Egypt & $1960-2007$ & 0.61 & 2.22 & 4.16 & 0.12 & 48 \\
Iran & $1965-2007$ & 0.61 & 3.09 & 2.69 & 0.26 & 43 \\
Israel & $1960-2007$ & 0.53 & 2.1 & 3.89 & 0.14 & 48 \\
Jordan & $1975-2007$ & 0.52 & 2.64 & 1.65 & 0.44 & 33 \\
Kuwait & $1962-2007$ & 1.34 & 4.55 & 18.34 & 0 & 46 \\
Libya & $1960-1987$ & -0.72 & 2.61 & 2.62 & 0.27 & 28 \\
Malta & $1960-2007$ & 0.32 & 1.71 & 4.17 & 0.12 & 48 \\
Morocco & $1960-2007$ & 0.47 & 2.22 & 2.98 & 0.23 & 48 \\
Oman & $1960-2007$ & 0.48 & 1.97 & 3.97 & 0.14 & 48 \\
Saudi Arabia & $1968-2007$ & -0.36 & 2.85 & 0.92 & 0.63 & 40 \\
Syria & $1960-2007$ & 0.46 & 2.06 & 3.43 & 0.18 & 48 \\
Tunisia & $1961-2007$ & 0.65 & 2.4 & 4.01 & 0.13 & 47 \\
United Arab & $1973-2007$ & 1.01 & 3.36 & 6.14 & 0.05 & 35 \\
Emirates & & & & & & \\
\hline
\end{tabular}

Table 1: Descriptive statistics for real GDP. JB is the Jarque-Berra statistics for normality, $p$ is the $p$ value for the JB test and $n$ is the number of observations. GDP is measured in billions of local currency unit. 

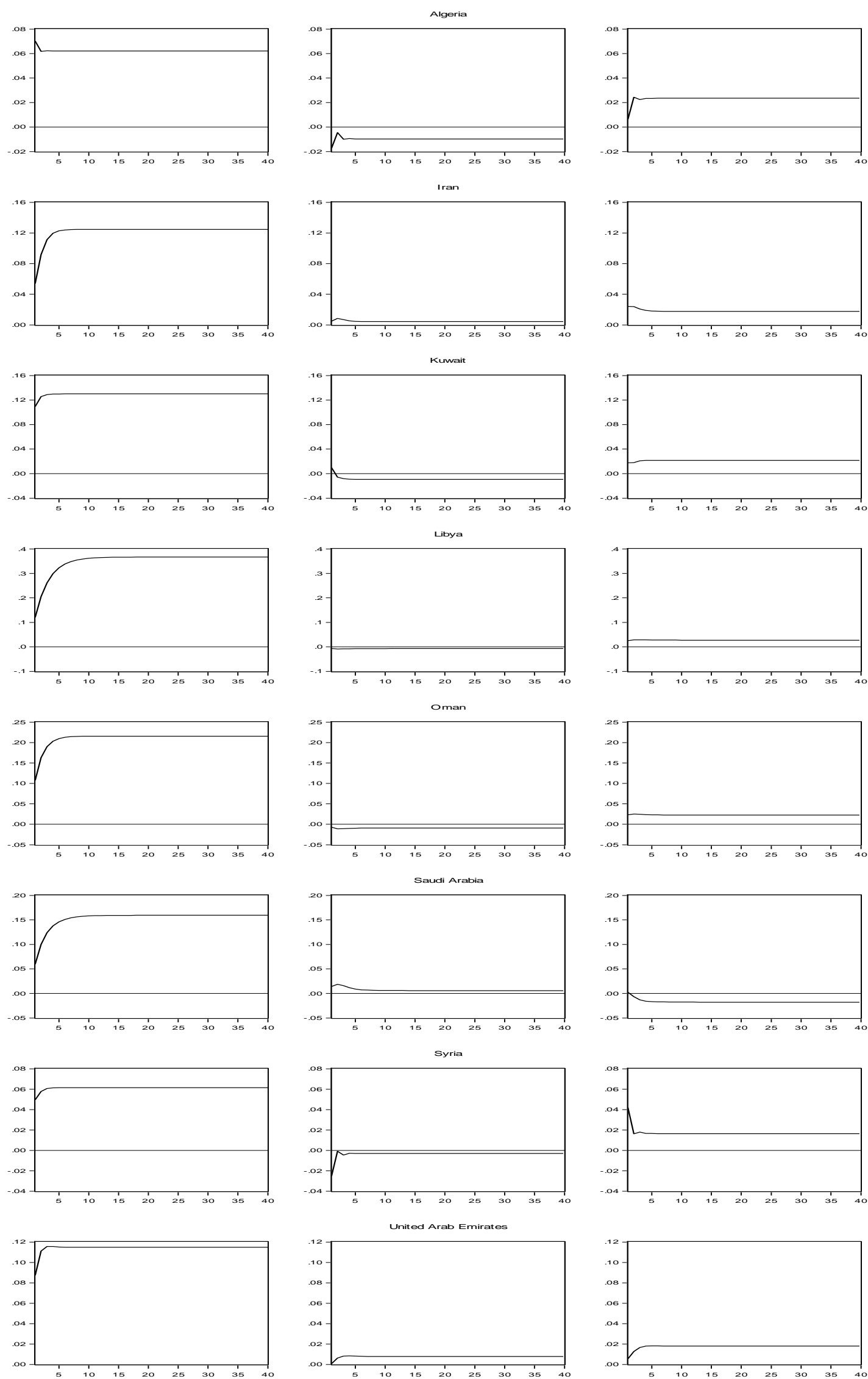

Figure 1. Impulse responses of domestic output: Oil rich countries are represented orderly for country specific shock, regional shock and global shock 

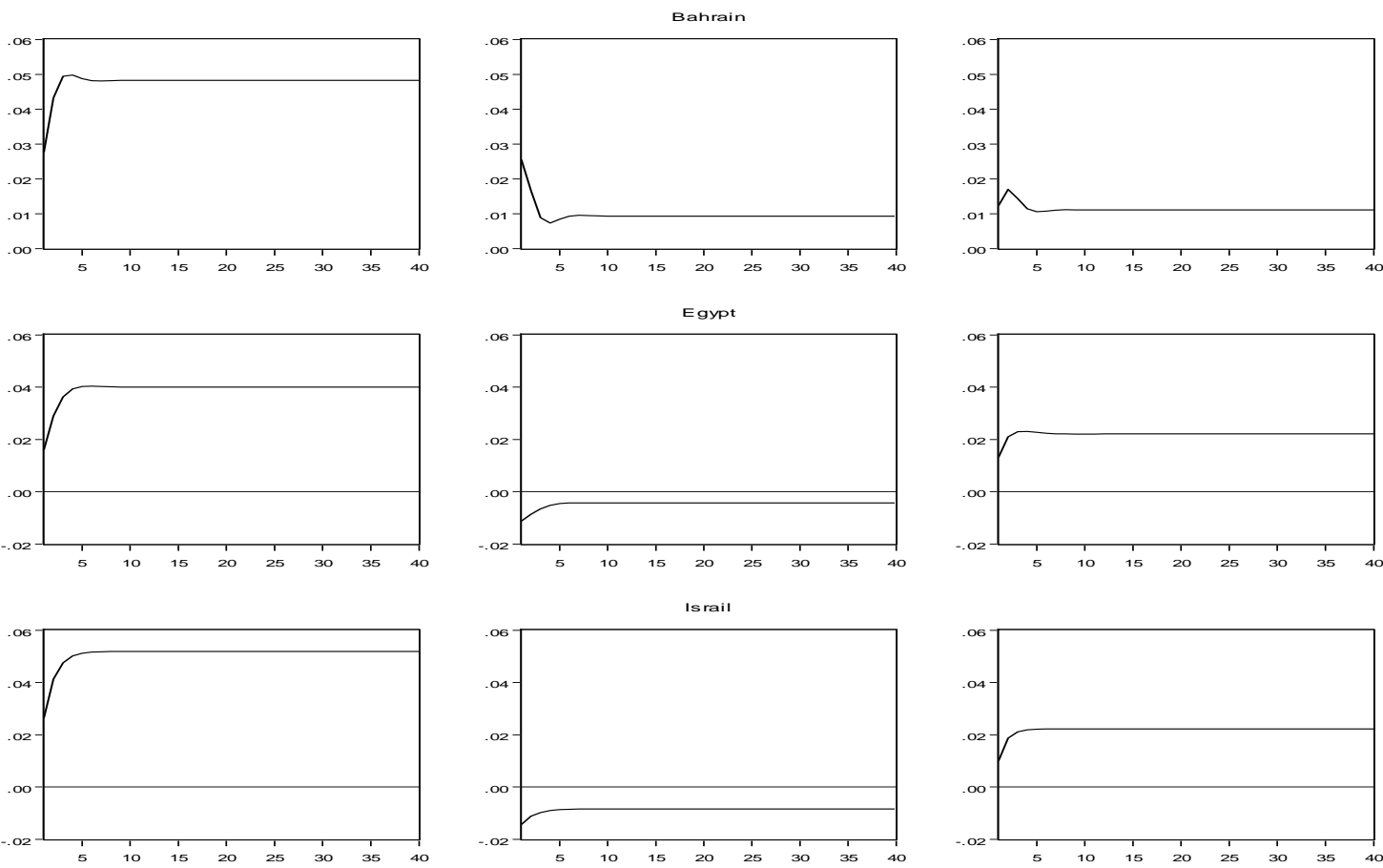

Is rai
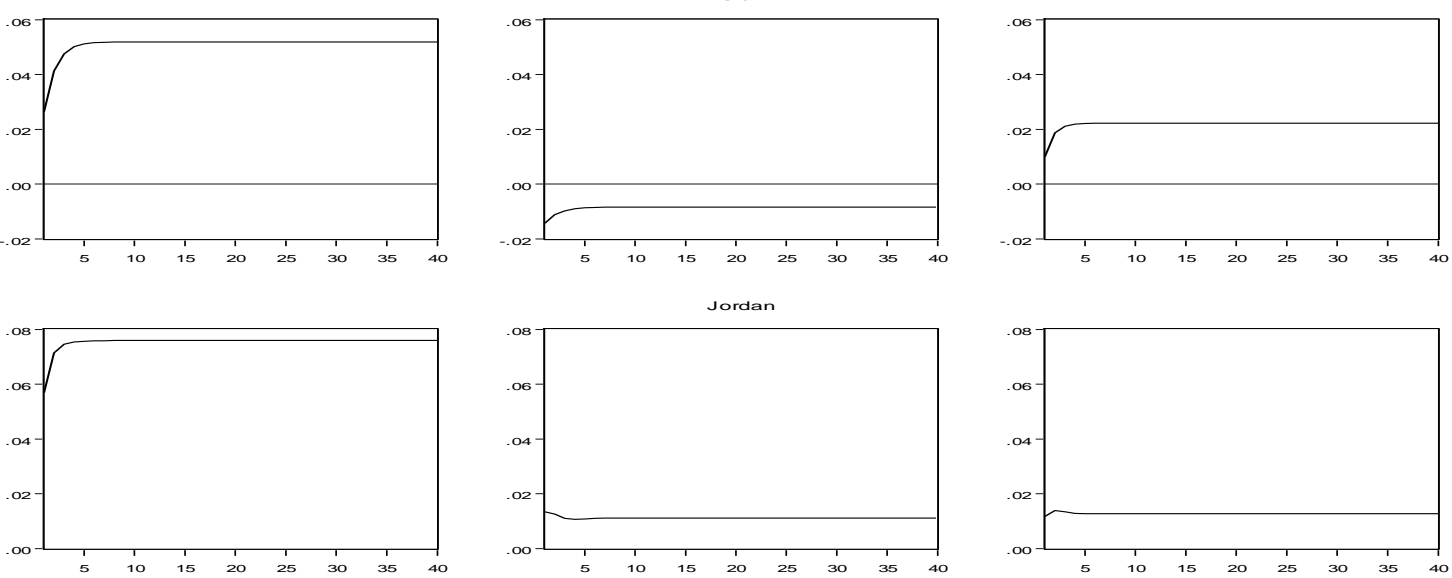

Jordan
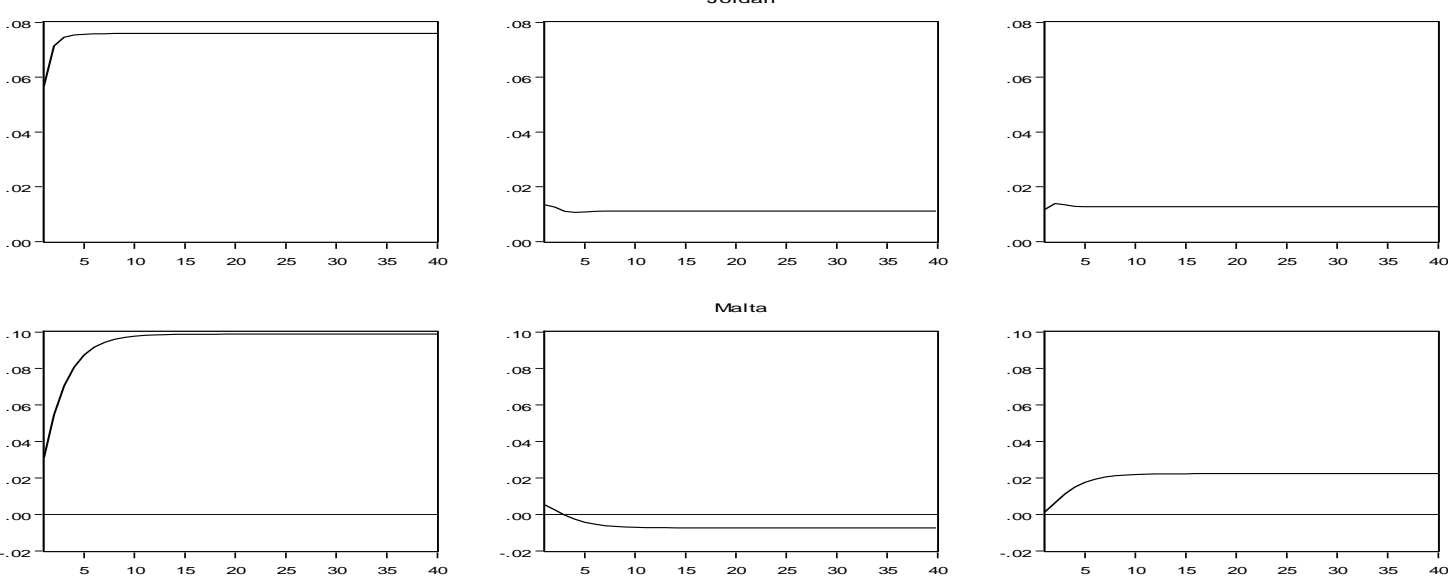

Malta
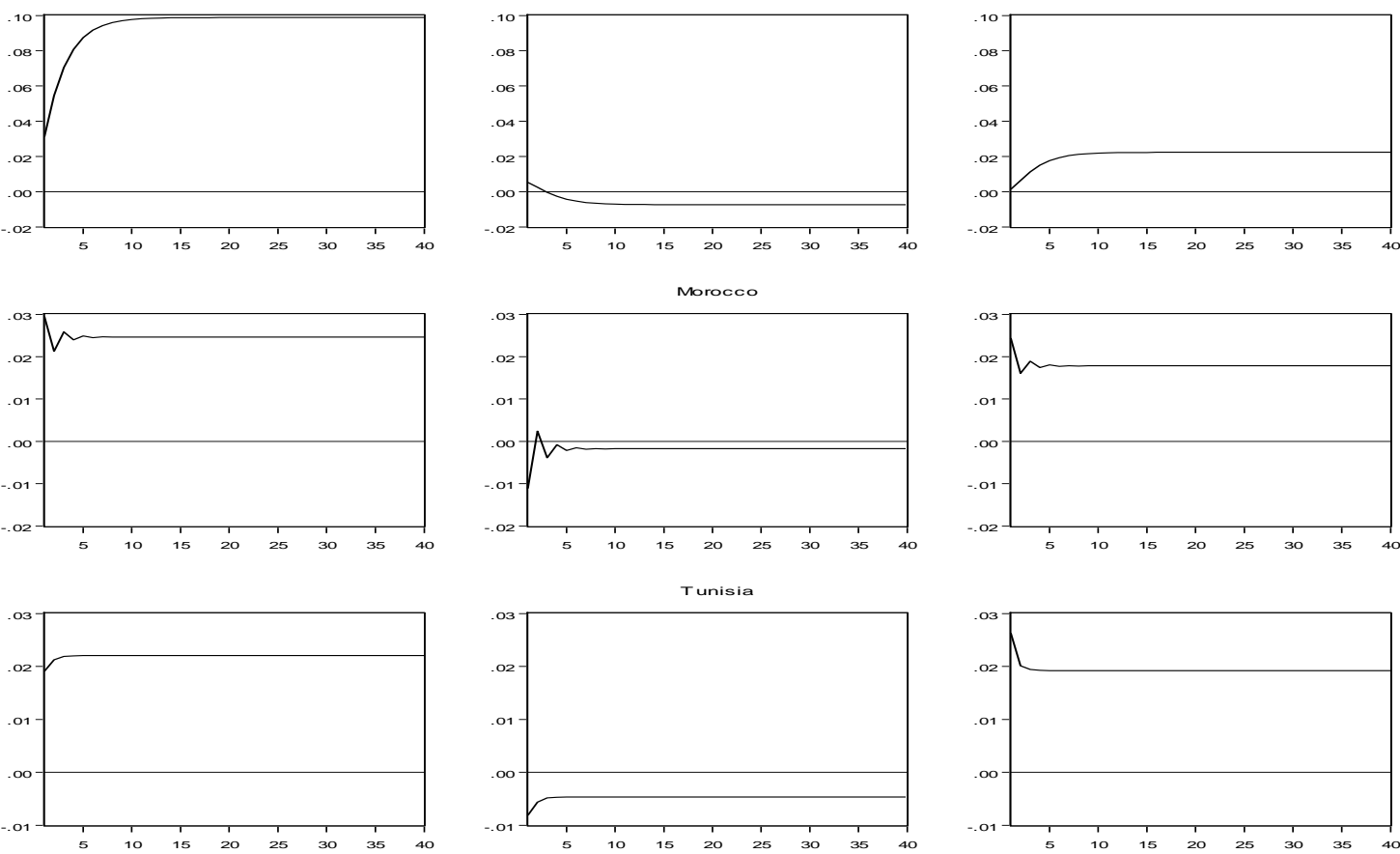

Figure 2. Impulse responses of domestic output: oil poor countries are presented orderly for country specific shock, regional shock and global shock 


\begin{tabular}{|c|c|c|c|c|c|c|c|c|}
\hline $\begin{array}{l}\begin{array}{l}\text { Period } \\
\text { (years) }\end{array} \\
\end{array}$ & s.e. & $\begin{array}{l}\text { Home } \\
\text { Shock }\end{array}$ & $\begin{array}{l}\text { Regional } \\
\text { Shock }\end{array}$ & $\begin{array}{l}\text { Global } \\
\text { Shock }\end{array}$ & s.e. & $\begin{array}{l}\text { Home } \\
\text { Shock }\end{array}$ & $\begin{array}{l}\text { Regional } \\
\text { Shock }\end{array}$ & $\begin{array}{l}\text { Global } \\
\text { Shock }\end{array}$ \\
\hline & \multicolumn{4}{|c|}{ Malta } & \multicolumn{4}{|l|}{ Syria } \\
\hline 1 & 0.04 & 97.12 & 2.70 & 0.18 & 0.07 & 50.44 & 13.02 & 36.54 \\
\hline 2 & 0.04 & 96.25 & 2.12 & 1.63 & 0.09 & 40.67 & 19.71 & 39.62 \\
\hline 3 & 0.05 & 95.02 & 2.25 & 2.73 & 0.09 & 40.65 & 19.84 & 39.51 \\
\hline 4 & 0.05 & 94.34 & 2.39 & 3.28 & 0.09 & 40.62 & 19.87 & 39.51 \\
\hline 5 & 0.05 & 94.02 & 2.46 & 3.52 & 0.09 & 40.62 & 19.87 & 39.51 \\
\hline 6 & 0.05 & 93.88 & 2.49 & 3.63 & 0.09 & 40.62 & 19.87 & 39.51 \\
\hline 10 & 0.05 & 93.79 & 2.51 & 3.70 & 0.09 & 40.62 & 19.87 & 39.51 \\
\hline 20 & 0.05 & 93.79 & 2.51 & 3.70 & 0.09 & 40.62 & 19.87 & 39.51 \\
\hline \multirow[t]{2}{*}{40} & 0.05 & 93.79 & 2.51 & 3.70 & 0.09 & 40.62 & 19.87 & 39.51 \\
\hline & \multicolumn{4}{|c|}{ Morocco } & \multicolumn{4}{|c|}{ Tunisia } \\
\hline 1 & 0.05 & 54.77 & 7.78 & 37.45 & 0.04 & 32.36 & 5.90 & 61.74 \\
\hline 2 & 0.05 & 49.14 & 16.03 & 34.83 & 0.04 & 31.40 & 6.17 & 62.44 \\
\hline 3 & 0.05 & 48.50 & 17.44 & 34.06 & 0.04 & 31.39 & 6.22 & 62.39 \\
\hline 4 & 0.05 & 48.31 & 17.77 & 33.92 & 0.04 & 31.39 & 6.22 & 62.39 \\
\hline 5 & 0.05 & 48.28 & 17.83 & 33.89 & 0.04 & 31.39 & 6.22 & 62.39 \\
\hline 6 & 0.05 & 48.27 & 17.85 & 33.88 & 0.04 & 31.39 & 6.22 & 62.39 \\
\hline 10 & 0.05 & 48.27 & 17.85 & 33.88 & 0.04 & 31.39 & 6.22 & 62.39 \\
\hline 20 & 0.05 & 48.27 & 17.85 & 33.88 & 0.04 & 31.39 & 6.22 & 62.39 \\
\hline \multirow[t]{2}{*}{40} & 0.05 & 48.27 & 17.85 & 33.88 & 0.04 & 31.39 & 6.22 & 62.39 \\
\hline & \multicolumn{4}{|l|}{ Oman } & \multicolumn{4}{|c|}{ United Arab Emirates } \\
\hline 1 & 0.11 & 95.22 & 0.45 & 4.33 & 0.09 & 99.61 & 0.01 & 0.38 \\
\hline 2 & 0.13 & 96.08 & 0.44 & 3.48 & 0.09 & 98.64 & 0.36 & 1.00 \\
\hline 3 & 0.13 & 96.26 & 0.42 & 3.32 & 0.09 & 98.41 & 0.41 & 1.17 \\
\hline 4 & 0.13 & 96.29 & 0.42 & 3.28 & 0.09 & 98.39 & 0.41 & 1.19 \\
\hline 5 & 0.13 & 96.30 & 0.42 & 3.28 & 0.09 & 98.39 & 0.41 & 1.19 \\
\hline 6 & 0.13 & 96.30 & 0.42 & 3.28 & 0.09 & 98.39 & 0.41 & 1.19 \\
\hline 10 & 0.13 & 96.30 & 0.42 & 3.28 & 0.09 & 98.39 & 0.41 & 1.19 \\
\hline 20 & 0.13 & 96.30 & 0.42 & 3.28 & 0.09 & 98.39 & 0.41 & 1.19 \\
\hline \multirow[t]{2}{*}{40} & 0.13 & 96.30 & 0.42 & 3.28 & 0.09 & 98.39 & 0.41 & 1.19 \\
\hline & \multicolumn{4}{|c|}{ Saudi Arabia } & & & & \\
\hline 1 & 0.06 & 94.44 & 5.42 & 0.14 & & & & \\
\hline 2 & 0.07 & 94.40 & 4.11 & 1.50 & & & & \\
\hline 3 & 0.08 & 94.14 & 3.82 & 2.05 & & & & \\
\hline 4 & 0.08 & 93.93 & 3.96 & 2.10 & & & & \\
\hline 5 & 0.08 & 93.87 & 4.04 & 2.09 & & & & \\
\hline 6 & 0.08 & 93.86 & 4.06 & 2.08 & & & & \\
\hline 10 & 0.08 & 93.86 & 4.06 & 2.08 & & & & \\
\hline 20 & 0.08 & 93.86 & 4.06 & 2.08 & & & & \\
\hline 40 & 0.08 & 93.86 & 4.06 & 2.08 & & & & \\
\hline
\end{tabular}

Table 2.Forecast error variance decomposition of domestic real GDP

Cumulative impulse responses to a one standard deviation positive regional shock are given in the second column of Figure 2. The responses to regional shocks are surprisingly small at all horizons uniformly across all countries. Although responses to regional shock are insignificant for all countries some show a little insignificant negative response while others have positive but insignificant response. Thus regional factors seem to play no role in accounting for output volatility in the MENA region. In terms of responses toregional shocks, oil-rich, oil-poor, Middle East, and North Africa countries are highly similar. Our findings indicate that the regional factor play almost no role in explaining macroeconomic volatility in the MENA region. Our result further confirms the findings by Kose et al. (2003) and Berument et al. (2007) for countries from all regions of the world, although their study is based on a different approach. 
Impulse responses to global shocks in the MENA region are shown in the third column of Figure 1. The result indicates that the responses are not significant for most countries. However, the result is not so uniform as in the case of country-specific and regional shocks. Among the oil-rich countries, Algeria, Syria, and United Arab Emirates show some mild positive permanent response to positive global shock. However, these are relatively much smaller than the responses to country-specific shocks. Thus, majority of oil-exporting countries do not show significant response to global shocks. In contrast to oil-rich countries, almost all oil poor countries show significant response to global shocks. Positive global productivity shocks permanently raise the output in these countries. Among these countries Egypt, Israel, Morocco, and Tunisia show quite large responses. The responses in Tunisia are almost as large as the response to country specific shocks. Thus, global shocks seem to play some role for oil poor countries, mostly for those in North Africa. Some of these economies are more integrated to world economies than those who done show significant response.

In order to measure the quantitative importance of the relative contributions of the world, regional, and country-specific factors to variations in output fluctuations in each country are estimated. The variance of domestic output at different horizons is decomposed into the fraction that is due to each of the three factors. The forecast error variance decompositions of domestic output are given in Table 2 along with their standard errors. The forecast error variance decompositions show the variance of domestic output attributable to countryspecific, regional, and global shocks at horizons 1-6, 10, 20, and 40. The variance components add up to 100 percent so that all volatility in domestic output can be attributed to country-specific, regional and global factors.

The variance decompositions show that the country-specific factors play a much larger role in accounting for output dynamics than the world and region factors. The country-specific factors explain more than 70 percent of output fluctuations for 10 countries, and the global shocks account for more than 50 percent of output volatility for 4 countries. The world and regional factors combined account for less than 40 percent of output volatility in 9 countries. For Bahrain, Egypt, Israel, Morocco, and Syria regional factors account for 16 percent of output volatility, while for the corresponding figure for Bahrain is 40 percent. Global shocks account for a significant fraction of output volatility in Egypt (27\%), Israel (13\%), Morocco (34\%), Syria (40\%), and Tunisia (62\%). In summary, the variance decompositions show that that the regional factors play a minor role in explaining output volatility in the MENA region with the exception of Bahrain. Global factors play the second important role after country-specific factors. However, only for one country global shocks dominate the country-specific shocks, which is Tunisia. Overall, country-specific factors account for more than $50 \%$ percent of the output fluctuations at all horizons for 14 countries out of the 15 countries in the region. Further, the results show no significant difference for the Middle East and North Africa. There is also no noticeable difference between oil-rich and oilpoor countries.

\section{Conclusion}

This study attempts to assess the relative importance of country-specific, regional, and global shocks in output fluctuations for the MENA countries. A small open economy SVAR model is used to show that business-cycle fluctuations are driven by country-specific, regional, and global shocks. The model uncovers valuable information about the response of domestic output to country-specific, regional, and global factors. Some of the results contradict the conventional wisdom in the region. In accordance with the small open economy assumption, and to disentangle the effects of external shocks from domestic shocks, it is assumed that the global shocks are not affected by regional and country-specific shocks. Regional shocks are also assumed to be unaffected by country specific shocks. One of the virtues of this approach is that it identifies and measures the effect of different types of shocks in a unified framework.

The research findings show that for all countries under consideration, domestic output volatility is mostly accounted for by country-specific factors. In about one-third of the countries, global shocks play a significant role in output fluctuations. Regional factors do not play a significant role for any of the countries. Although several studies found that regional factors might be an important factor in output volatility, the results found no statistical evidence in support of these studies. Thus, regional business cycles do not play a significant role in explaining output volatility in the MENA region.

\section{References}

- $\quad$ Abed, G.T. and H.R. Davoodi (2003), 'Challenges of Growth and Globalization in the Middle East and North Africa', Washington, DC: International Monetary Fund.

- Aghion, P., G-M Angeletos, A. Banerjee, and K. Manova (2004), 'Volatility and Growth: Financial Development and the Cyclical Composition of Investment', MIT Working Paper, : MIT Press , Cambridge, Massachusetts.

- $\quad$ Ahmed, S., and P.N. Loungani (1998), 'Business Cycles in Asia', Working Paper, Board of Governors of the Federal Reserve System. 
- Aizenman, J., and B. Pinto (2005), Managing Economic Volatility and Crises: A Practitioner's Guide,Cambridge University Press, Cambridge.

- $\quad$ Al Zoubi, H.A. and M. Maghyereh (2005) 'Examining Complex Unit Roots in the MENA Countries Industrial Production Indices', Applied Economics Letters, Vol. 12, pp. 255-259.

- $\quad$ Berument, H., N.B. Ceylan and B. Vural (2007), 'The Effect of World Income on the Economic Performance of African Countries', International Journal of Economic Perspectives, Vol. 1, 183-94.

- Bjørnland, H.C. (1998), 'Economic Fluctuations in a Small Open Economy: Real versus Nominal Shocks', Statistics Norway Discussion Papers, vol. 215, ResearchDepartment of StatisticsNorway, Oslo.

- Blackburn, K. (1999), ‘Can Stabilisation Policy Reduce Long-Run Growth?’,Economic Journal, Vol .109, pp. 67-77.

- Blanchard, O.J. and D. Quah (1989), 'The Dynamic Effects of Aggregate Demand and Supply Disturbances', American Economic Review, Vol. 79, pp. 655-73.

- Diboglu, S. and E. Alesia (2004), 'Oil Prices, Terms of Trade Shocks, and Macroeconomic Fluctuations in Saudi Arabia', Contemporary Economic Policy, Vol. 22, pp. 50-62.

- Domaç, I. and G. Shabsigh (2001), 'Real Exchange Rate Behavior and Economic Growth in the Arab Republic of Egypt, Jordan, Morocco, and Tunisia', in Z. Iqbal (ed), Macroeconomic Issues and Policies in the Middle East and North Africa, : International Monetary Fund, Washington, DC.

- Doornik, J.A. and H. Hansen (1994), ‘A practical test of multivariate normality', unpublished paper, Nuffield College, Oxford.

- Glick, R. K. Rogoff (1995), 'Global versus Country-specific Productivity Shocks and the Current Account', Journal of Monetary Economics, Vol. 35, pp. 159-92.

- Hakura, D.S. (2004), 'Growth in the Middle East and North Africa', International Monetary Fund Working Paper 04, no. 56, : International Monetary Fund, Washington, DC.

- Hakura, D.S. (2007), 'Output Volatility in Emerging and Developing Countries', World Economic Outlook, International Monetary Fund, Washington, DC.

- Hamilton, J.D. (1989), 'A New Approach to the Economic Analysis of Nonstationary Time Series and the Business Cycle’, Econometrica, Vol. 57, pp. 357-84.

- Hamilton, J.D. (1994), Time Series Analysis, Princeton, New Jersey: Princeton University Press.

- Hirata, H., S.H. Kim and M.A. Kose (2004), 'Integration and Fluctuations: The Case of MENA', Emerging Markets Finance and Trade, Vol. 40, pp. 48-67.

- Hirata, H., S.H. Kim and M.A. Kose (2007), 'Sources of Fluctuations: The Case of MENA', Emerging Markets Finance and Trade, Vol. 43, 5-34.

- Hoffmaister, A.W. and J.E. Roldós (1997), 'Are Business Cycles Different in Asia and Latin America, IMFWorking Paper, vol. 97/9, International Monetary Fund, Washington, DC.

- Hoffmaister', A.W. J.E. Roldós (2001) 'The Source of Macroeconomic Fluctuation in Developing Country: Brazil and Korea', Journal of Macroeconomics, 23, pp. 213-39.

- Iqbal, Z., ed. (2001), Macroeconomic Issues and Policies in the Middle East and North Africa, International Monetary Fund, Washington, DC.

- Jalali-Naini, A.R. (2000), 'The Structure and Volatility of Fiscal Revenue in MENA Countries', Paper presented at the Third Mediterranean Development Forum, March 5-7, Cairo.

- $\quad$ Kose, M.A., C. Otrok and E.S. Prasad (2005) Regionalization vs. Globalization: Explaining North-South Business Cycle Dynamics, IMF Working Paper, International Monetary Fund, Washington, DC.

- Kose, M.A., C. Otrok and C. Whiteman (2003), 'International Business Cycles: World, Region, and Country-Specific Factors', American Economic Review, Vol. 93, pp. 1216-39.

- Laursen, T. and S. Mahajan (2005), 'Volatility, Income Distribution, and Poverty', in Managing Economic Volatility and Crises: A Practitioner's Guide, J. Aizenman and B. Pinto (eds), Cambridge University Press, Cambridge.

- $\quad$ Lucke, B. (2004), 'Real Interest Rates and Productivity Shocks: Why Are Business Cycles Negatively Correlated Between the European Union and Jordan?',Emerging Markets Finance and Trade, Vol. 40, pp. 82-94.

- Makdisi, S., Z. Fattah and I. Limam (2003), 'Determinants of Growth in the MENA Countries', Arab Planning Institute Working Paper 0301, Arab Planning Institute, Safat, State of Kuwait. 
- Mehrara, M. and K.N. Oskoui (2007), 'The Sources of Macroeconomic Fluctuations in Oil Exporting Countries: A Comparative Study’, Economic Modelling, Vol. 24, pp. 365-379.

- Nashashibi, K., M. Elhage and A. Fedelino (2001), 'Financial Liberalization in Arab Countries', in Z. Iqbal (ed), Macroeconomic Issues and Policies in the Middle East and North Africa, International Monetary Fund, Washington, DC.

- $\quad$ Phillips, K.L. (1991), 'A two-country Model of Stochastic Output with Changes in Regime', Journal of International Economics, Vol. 31, pp. 121-42.

- Shafik, N. (1998), Prospects for Middle Eastern and North African Economies: From Boom to Bust and Back?, St. Martin's Press, New York.

- Süssmuth, B. and U. Woitek (2004), 'Business Cycles and Comovement in Mediterranean Economies', Emerging Markets Finance and Trade, Vol. 40, pp. 7-27.

- Tamberi, M. (2005), Specialization and Growth Perspectives in the Mediterranean Countries. Paper presented at the Middle East and North African Economies: Past Perspectives and Future Challenges, June 2-23, Free University of Brussels.

- Tornell, A., F. Westermann and L. Martinez (2004), 'Liberalization, Growth and Financial Crisis: Lessons from Mexico and the Developing World', Brookings Papers on Economic Activity, Vol. 2003, 1-112. 


\title{
A Summary of the Developments Regarding the Economic Regime Implemented in Developed and Developing Countries
}

\author{
Asst. Prof. Dr. Özlen Hiç Birol (Istanbul University, Turkey)
}

\begin{abstract}
Since the developments regarding the economic regime in developed countries follow a different path as opposed to those in developing countries, in this article, these two groups of countries will be examined separately. Priority will be given to investigating the economic regime in developed countries due to historical and theoretical reasons. Today, both in developed and developing countries the economic activities basically are taken up by the private sector; nevertheless the government contributes to these activities through intervention, guidance, protectionism, and investment. Still the level of government intervention, protection and public investments in developed countries appears to be at the minimum. The role of government in developing countries, on the other hand, seems to be more significant; the gravity of the government's role depends on the degree of development for the countries concerned. In the countries where the level of development is low, the role of government increases, that is to say, the improvement in development decreases the role government.
\end{abstract}

\section{Outlines of the Economic Regime}

What is meant by the economic regime or the economic system is to identify whether fundamental economic and social activities such as production, allocation of resources, and distribution of income are conducted by the government or the private sector and to what extent. One of the major subjects of the economic regime has to do with the issues of foreign trade and economic relations, and the existence of market economy or government restrictions and protectionism.

As it is well understood by the definition given above, there are two extremes in this topic. First one requires that all economic and social activities are conducted by the private sector through price and market mechanism and profit maximization principle based on the free interaction. In this economic regime, private ownership is essential. Considering their own interests, the owners of land and capital decide which goods to produce and how much to produce, which type of technologies they will use, and how much labor they will employ according to the market conditions, supply and demand, and prices and wages. It is claimed that in the end, the optimal point, in other words, full employment equilibrium and at the same time, balance of payments are reached automatically. Under these circumstances, the government should only carry on its classical functions such as external and internal security, the judiciary and health and education. Although this economic regime, first introduced in the 18th century, is called the "liberal economic regime" as a result of the inspiration from the Marxist publications, it has come to be named as "capitalism".

The second extreme or the opposite end of the spectrum would refer to all economic and social activities that are carried out by government. K. Marx and Marxists call this economic system as "socialism"; but the term generally used and accepted is "communism". In the communist system, the ownership of the land and capital which are the main factors of production is in the hands of the government. The government conducts all economic and social activities by means of central planning.

At this stage, it is necessary to touch upon the interaction between these different economic regimes with the political regime. The political regime which is commensurate with the liberal economic regime seems to be democracy which upholds individual freedoms up to the maximum level. Although in autocracies, private sector also plays an important role in economic activities as it was the case with Hitler and Nationalist Socialism, Mussolini and Fascism, the private sector has to be compliant with government's restraints and directions. Similarly, in the countries where democratic regime is not fully implemented, there again private sector is subjected to various pressures coming from the government. On the other hand, the communist regime essentially emerged as a dictatorship regime; government ownership and central planning hence government conducting all economic and social activities cannot exist side by side with any multi-party system or true "democratic" political system.

At the very outset it should be stated that, these two extreme regimes are not practically enforced. The implementation of private sector conducting all economic activities had begun in the developed countries, yet since they had caused various problems government started to take part in many economic and social activities by means of macroeconomic and social interventions, and government aids. At present this economic regime is identified as "mixed economy" in many standard economics books; here the main point is to emphasize the existence of both the private and the public sector together. Still the term of "mixed economy" would not give away the fact whether the role of government or private enterprise is more important, and it can sometimes even be misleading. That is why both international economic institutions and economics literature mostly make use of the term of "market economy". 
The alternative to it as a second extreme or the opposite end of the spectrum which is government conducting all activities disappeared in practice since the collapse of the Union Of Soviet Socialist Republics (the USSR) and China's transformation into a mixed economy with private enterprise. All these developments will be dealt more thoroughly in the following sections.

\section{Evolution of the Economic Regime in the Developed Countries}

\subsection{The Birth of Liberal Economic Regime}

Before the advent of the science of economics, throughout the $16^{\text {th }}-18^{\text {th }}$ centuries, European countries, in other words, the developed countries at that time, implemented a very heavy interventionist and protectionist economic regime which was dubbed by Adam Smith as "Mercantilism". In Mercantilism each county was cutting down on its imports as much as possible whereas promoting its exports. But these countries could not issue the gold which was entering the country as the result of their foreign trade surpluses into the market as money; the gold was accumulating in the vaults of the Central Bank. The countries believed that this was the only way their countries' wealth would increase. Eventually, Mercantilism was restraining the volume of foreign trade among developed countries on one hand, and on the other hand it was reducing their rate of growth. Additionally, Mercantilism led these countries to colonialism (imperialism). The rational behind possessing a colony was to have cheap raw material and to be able to sell their goods at high prices.

However, the "industrial revolution" brought about significant changes in these countries. With the invention of steam engine, boat and train transportation expanded to a great extent, factories emerged as a result of mechanization of the weaving looms. According to Arnold Toynbee, the industrial revolution evolved through 1760-1840; first started in England and then it spread throughout other European countries. The industrial revolution created rather a large group of entrepreneurs. The most significant of all is the fact that these entrepreneurs started to realize that heavy interventionism and protectionism of the government, in fact, were restraining their economic activities and decreasing their profits. In his work written in 1776, Adam Smith identified this important development; when he was establishing the science of economics, he claimed that through the liberal economic system he developed, the government taking off his hands from all the economic activities would result in the most optimal economic and social outcome for the whole society. Adam Smith assumes that in all markets including the labor market, perfect competition prevails. In an economy under these conditions, the "invisible hand", that is the price mechanism, will solve all economic problems at an optimum point for the whole society. Full employment equilibrium will be reached automatically, and the balance of payments will restore itself so that the trade balance will be reached automatically via the automatic gold standard theorem (Hiç, 1994). In this case, any intervention or protection coming from government would disrupt the equilibrium, and the welfare of the society would decrease. In perfectly competitive markets, the profits of the firms would fall down to their "normal" levels under. However, if monopolies arise, the government should abolish the monopoly. The government should not intervene on wages. However, if labor union (labor monopoly) emerges, the government should intervene again; as the monopolist wage rises of the unions would prevent the economy from reaching the full employment equilibrium automatically.

Free foreign trade based on Adam Smith's absolute advantage theory has gained validity and universality through David Ricardo's (1817) comparative advantage theory; this theory is still valid in our times.

The classical model based on Adam Smith the following classical economists developed further by Alfred Marshall in 1890. For detailed information about the economic model mentioned in the macroeconomic literature as the classical system or the simple classical system (not containing the Keynesian self-correcting features), one can refer to macro economy books such as Hiç (1994), Paya (1997), Ackley (1961), Branson (1989). In this article, though, there is no need to go into the details of the classical system, as for a collective information about classical economists, please refer to Hiç (1974, ps. 1-9)

We can safely assume Adam Smith as the starting point of the science of economics and the implementation of economic policies based on this science. As mentioned before, Smith's system is called "liberal economic regime" or laissez-faire. The very same economic regime had been named by Marx and Marxist writers as "capitalism" or "wild capitalism".

In practice, the implementation of "Laissez-faire" has caused two main problems. Firstly, through its implementation in the early years, the conditions of the workers got worsened, that is the "labor problem" or "social problem". Secondly, economies did not grow at the full employment equilibrium. On the contrary, there had been continuous cyclical fluctuations, and the problem of unemployment in the depression period remained unsolved

\subsection{The Birth of the Communist System}

In 1848, Karl Marx, with F.G. Engels introduced the second extreme regime with their work the "Communist Manifesto" during the first period these serious labor problem and cyclical fluctuations, depression and unemployment encountered by the European countries. Marx, later on, developed his thoughts in Das Kapital (Vol. 1: 1867, Vol. 2: 1885, Vol. 3: 1884 after his death). 
According to Marx, the capitalist system was dynamic but it would give rise to exploitation of workers, monopolies and increased poverty of the workers; the business cycles stem from the nature of the capitalist system, and they are inevitable. Marx argued that the governments in the capitalist system had become the powns (true owners) of the capitalists and could not prevent this doom; on the contrary, the problem will become more serious. In fact, he derided all efforts such as establishing a social security system or wage-legislation. Marx also argued against the religion thought that the religion was there only to calm down and make the workers accept their poor plight.

Marx prophesized that the capitalist system would eventually be destroyed after a severe depression by a "bloody" revolution of workers who had nothing to lose but their chains. After capitalism is destroyed, Marx noted that the production of factors would be owned by the government or the community, free enterprise system would stop and the government would take up all economic activities including investment and production and would implement central planning. According to Marx, in such a system, exploitation of workers and business cycles would be eliminated, and we should have a prosperity, equality, true democracy and full-employment.

The Communist Manifesto had been adopted by all labor unions of the European countries, especially by the German labor unions. However the de facto developments had taken place very differently from Marx's arguments.

\subsection{De Facto Developments, Evolution of Laissez-Faire or Liberal System into the Market Economy}

Contrary to Marx's arguments, the governments of developed countries did not stay indifferent to problems of workers. Affected by the views of intellectuals on one hand and the voting potential of the workers in democracies on the other hand, as well as for humane reasons, almost all governments prioritized the issue of betterment of the conditions of the workers. In these early periods, the workers were given the fundamental rights such as prevention of child labor, limits of the working hours, provision of work safety by regulating working conditions, determination of the minimum wage. Even one more step further, the social security system was institutionalized and at the same time, the labor unions were granted the right to go on strike, the employer was given the right for lockout as opposed to the right to go on strike. By doing this, social objectives were first introduced in the liberal economic regime (laissez-faire) as public policy for the first time, meaning "rightist" standpoint heading towards "center-right". Thus, the conditions of the workers had started getting better.

The business cycles, however, could not be prevented until the Great Depression of 1929-1934. After the Great Depression, Keynes introduced his macroeconomic system through his work (1936) showing that the automatic full-employment equilibrium in the classical system was not a true assumption and that the economy will settle at a less-than-full-employment equilibrium if the government does not increase the level of aggregate demand. According to Keynes' macroeconomic system, in order to ensure the full-employment equilibrium and to prevent unemployment, the total expenditures should be increased up to the level which will bring about full employment; so the government would be implementing monetary policy (money, credit, interest rate) and fiscal policy (government expenditures, taxes). The central banks in charge of determining the amount of money and credit as well the interest rates, later on, have been made independent from governments; obviously, it is always possible for the central bank to consult with the government. The same macro policies would be implemented in the opposite direction to prevent inflationist periods. As for more detailed information about Keynes' macroeconomic system and monetary and fiscal policies, refer to Hiç (1994).

Keynes' ideas and policy recommendations were embraced by all European countries and implemented during the World War II (to decrease inflation) and after the war (to prevent the business cycles). The government interventions in the economy on a macro level (through monetary and fiscal policies) to avoid cyclical fluctuations and to ensure a full-employment has become and inseparable part of the economic regime.

After the Second World War II (1939-1945), the world had split into two parts as the Western World and the Communist Bloc. Since the European governments made again use of trade restrictions and protectionism before the World War I (1914-1915), in order to prevent this tendency, the liberalization of the free foreign trade was initialized through GATT (General Agreement on Tariffs and Trade) signed in 1947. The World Bank established in 1944 (with its first period name and function, IBRD: International Bank for Reconstruction and Development) as well and the IMF provided the implementation of the market economy in the Western World including the developing countries. Instead of liberal economy or laissez-faire, the economic regime comprising of social and Keynesian macroeconomic interventions has started to be called as "market economy".

In the 70s, stagflation aroused as a result of the increase in oil prices by the OPEC, consequently, conservatism in the general public in the US and in Europe increased, and the views against the Keynesian system, namely, Monetarism and Neo-Classical School became widespread. Nevertheless, the implementation of these policies (especially during R. Reagan in the United States through 1980-1988 and M. Thatcher in Britain through 19791988) did not bring about positive results, and on the contrary, unemployment increased. Upon this development, Keynesian macroeconomic system was inclined in the academic circles in the 80s. Alongside with the main Keynesian macroeconomic system, Post-Keynesian and New-Keynesian schools gained some momentum. The 
90s had seen the return to Keynesian macroeconomic policy implementations. As for more detailed information about these new macroeconomic schools, refer to Birol (2001).

The global financial crisis and recession started in September 2008 in the United States, and then spread to the whole world with serious dimensions (for details please refer to Hiç, 2010), resulted in very important outcomes in terms of macroeconomic policies and the market economy. Firstly, especially Reagan in the United States and Thatcher in Britain decreased the size of the government control over the financial sector, and this decrease in oversight was an important factor in the break out of the financial crisis. When the crisis arose, the financial sector was put under severe government control. Thus, the control of the financial sector was accepted as a requirement of the market economy. Secondly, alongside with the financial aid by government against the global crisis, intensive Keynesian macroeconomic policies such as decreasing the interest rates (monetary policy), changes in public investment programs and taxing system (fiscal policy) were implemented. Thus, the requirement for Keynesian macroeconomic policy implementation was confirmed. Thirdly, international cooperation was sought through G-20 instead of G-7, nevertheless though, in the essence, market economy and globalization process which started in the 90s were not abandoned (Hiç, 2010).

The fundamental element in market economy is the private sector; investment and production are delivered by private enterprise. Government, though, invests only in social and productive infra-structure fields; private investment is also allowed in these same areas. The sectoral and regional distribution of income is merely intervened on an exceptional basis. Government interventions are made on the grounds of Keynesian recommendations as well as for social objectives and they are limited only for those areas. Foreign trade is liberalized, restrictions on quotas are eliminated, and customs duties are at their minimum levels. The trade balance is reached by the exchange rates determined in foreign exchange market. Beside the free foreign trade, the entry of foreign private capital is also free. In the process of globalization, international flow of the financial funds plays the most significant role.

The market economy with its guidelines given above is being implemented in the freest fashion in the countries such as United States, Britain, Canada and Germany. On the other hand, in France, government control is traditionally and relatively more intense.

\subsection{Heading towards Social Democracy in Developed Countries}

Marx's Communist Manifesto of 1848 had been published by the German labor unions, and especially in Germany, labor unions in all European countries had embraced communism. Yet, the labor unions noticed the fact that, in time, the governments were dealing with social issues and progressively the conditions of workers were getting better. They also realized that they played an efficient role in these improvements, and eventually they moved away from communism and headed towards democratic socialism or, in short, towards socialism.

When the Marxist-Leninist communist revolution had broken out in Russia in 1917/1918, the majority of the labor unions in the European countries had left communism completely adopting democratic left movement. Only the minority groups had to be faithful to the communist system, and they had supported communist parties.

Following the communist revolution, the USSR had founded "Comintern" (an international association of communist parties) in 1919; however, this organization had been abolished in 1942. After the World War II, this time, the USSR established Cominform, and this organization, too, was disbanded in 1956.

After the World War II, the democratic leftist parties in Europe came together and founded the "Socialist International" in 1951. The Socialist International accepted democracy and market economy as a their principle. Within this framework, the promotion of democracy, human rights and equal opportunities were targeted and acknowledged. The Socialist International supported NATO, opposed the USSR and was pro-disarmament. The British Labor Party, the French Socialist Party and the German Democratic Party took part in the Socialist International as democratic leftist parties.

The developments in the field of social policy starting from the World War II up until today have improved relatively compared to the past. Those improvements including minority rights, women's rights, freedom of the media freedom of justice unemployment insurance health services and tax system taking into account the income distribution are among the fields where social democrats succeeded.

In relatively recent times, the democratic leftist parties headed towards the center-left. The British Labor Party and Tony Blair were the pioneers in this inclination. Today, the conditions of the workers in Europe and certainly in the United States have improved; many of them own their houses and cars, and they go to different countries on holiday.

The fundamental reason for the democracy functioning relatively well in the European countries seems to be the high level of education and the long standing democracy experience. As a result of this fact, the central-right and center-left (social democrat) parties share the majority of the votes whereas the liberals stand in between and in the middle. Both communist parties and anti-workers, racist, radical rightist parties are generally compose the minority. Moreover, the voters may vote differently depending on the time and conditions. This way, the centralleft presents a powerful alternative, and in many occasions, come into power and govern competently. The fact 
that the general principle of the both the central-right and the central-left happens to be democracy and the market economy plays an essential role in this outcome, because the difference between these two parties does not lie in the economic or political regime change, rather in their priorities and focus on the social targets. It should be kept in mind, however, that the economic growth and the employment as the social objectives are their common and most important targets they seek to accomplish.

\subsection{The Expansion and the Collapse of Communism}

According to Marx, to bring about a revolution by the working class and the establishment of socialism (communism) would only be happening in the "mature" industrialized countries; like in England and in Germany at his time. Yet, his expectation never materialized. Later on, the Marxist writers tried to explain this delay. For instance Rosa Luxemburg (1912) claimed that European countries turned to imperialism, and exploiting the colonies alleviated temporarily the exploitation of the workers; for a detailed information about Marxism and communism, refer to Hiç 1974, ps. 44-79.

Contrary to Marx's assumptions, in Tsarist Russia which was relatively less developed in terms of industrialization compared to the European countries at that time, in 1917 a minor militant group, but not the working class, staged a communist revolution taking advantage of the economic and political gap created by the World War II; and thus, Lenin established communism (bolshevism). The second wave of communism had been created, again not as a result of the revolution by the working class, but as an outcome of 1945 Yalta Conference attended by Churchill, Roosevelt and Stalin right after the World War II. In the conference, Northeastern and Balkan countries were left under the influence of the USSR, and eventually the USSR had brought communist dictatorship to these countries. The third important wave was China's becoming a communist country. After a long standing struggle with Chiang Kai-Shek and Japan, Mao Zedong founded People's Republic of China in 1949. Additionally, after serious internal and external problems and wars, North Korea, Cuba and two Indochina countries Vietnam and Laos had chosen the communist regime.

After the World War II, the USSR prioritized to bring communism to the developing countries as part of its expansionist policy, making use of her finances and propaganda towards this goal. Stalin, most probably, saw the fact that, virtually, there was no likelihood for the expansion of communism in the developed Western countries. Developing countries, though, were not yet industrialized, and many of them had a feudal structure. There were new departments established in universities to study and research on how these countries could become communist step by step. As a matter of fact, Şevket Süreyya Aydemir, the leader of cadre movement during Atatürk period, had studied this subject at Moscow University. This propaganda of the USSR, in general, had not been successful, and no country had chosen communism just because of such propagandas. On the other hand, the NEP (The New Economic Policy) implemented during Stalin era, based on the closed economy, importsubstitution, development strategy relying on public investments and central planning created an opinion that these elements were the reasons why the USSR achieved a very high growth rate; hence the NEP was taken as an example by many developing countries. Essentially, although the low level of development in these countries could not be compared to the one in the USSR, these countries generally required an economic regime featuring these strategies. Following this perspective, in India, even a Marxist model (Mahalanobis model) was put into practice; nevertheless, since it failed, in a year's time, it was abolished.

In time, it was realized that the central planning depending solely on public ownership and public enterprise brings about a restriction on the growth rate and technological progress, and public enterprise lacks the dynamism of that of the private enterprise. Eventually, the Soviet system, namely the communism, let alone to provide prosperity for the workers, it transformed into an oppression and police state. The communist regime caused setback to the development and industrialization of Russia and the countries part of the USSR states. The burden of the countries within the USSR on the Russian budget accompanied by the intensive military spending to compete with the United States incurred serious economic problems.

In the years when the communications facilities were limited, the Soviet propaganda was emphasizing freely that the conditions of the workers in Europe were very bad. However, in the following years, as the communications technologies have improved and the difficulty of restricting communications has become a reality, the people in Russia and in other member countries realized that the welfare of the working class in the European countries were much higher contrary what the propaganda was asserting; and that gave rise to discontent. In the end, let alone the claims of the USSR and Krushev to excel over the United States, even the glasnost efforts of Gorbachov did not prove fruitful. In 1990, the Berlin wall fell, and the East Germany broke its ties with Russia and acceded to the West Germany. In 1991 the USSR disintegrated and communism collapsed. Russia and all the now independent countries have chosen democracy and the market economy. Majority of the Northeastern European and Balkan countries have been accepted as a member of the EU (Karluk 2007). The others, though, have established the Commonwealth of Independent States with Russia, and all of them have forsaken communism. Both in Russia and in these countries, problems in the application of democracy and market economy pose a distinct challenge, yet none of them seem to be likely to return again to communism. 
With the collapse of the USSR, there are only five communist countries left in the world: China, Cuba, North Korea, Vietnam and Laos. However, a very significant development in China did occur though. After the death of Mao in 1976 and during the 80s, under the guidance of Deng Xiaoping, rather than following merely the doctrine, China opted for pragmatic economic policy. Being accepted as a member of the World Trade Organization in 2001, Chinese economic policy not only encouraged the private enterprise but started to encourage foreign private investment flow radically as well. At the same time, with this economic strategy based on the foreign private capital, China has occupied an important place in the globalization process of the $90 \mathrm{~s}$. Eventually, with its very high growth rate secured for a long time, in terms of the level of gross national product, she has reached the second position just right after the United States; but the per capita income level is still lagging behind. Today, what China implements as an economic regime is not a central planning which is peculiar to the communist system; the new regime which is open the external world could be considered as a mixed economy model based on encouragement of the private enterprise and private foreign capital. Thus, in practice, there are only four countries left that implement the actual central planning, and therefore they can be called communist countries: Cuba, North Korea, Vietnam and Laos. Cuba and Vietnam could leave communism if appropriate external and domestic opportunities arise, and eventually they may forsake the central planning in terms of economic regime, despite the fact that they may maintain their dictatorship structure. In short, from the point of the economic regime, communism and central planning which represent the second extreme have been dwarfed with no possibility of revival, getting close to the zero point. On the other hand, global economic and political problems are still handful, and new challenges are in the waiting.

\section{Evolution of the Economic Regime in the Developing Countries}

As to the problem of development and economic regime in the developing countries, this issue could be traced back to the aftermath of the World War II. The IMF and the World Bank set up after of the war had advocated the market economy as the economic regime for the developing countries in the Western world. Nevertheless, in the early stages of their development process, in the developing countries there were not enough private enterprises and private investment, and generally speaking, this led to very heavy interventionism, protectionism and public investment based, closed and import-substituted industrialization; the governments intervening the sectoral and regional distribution of income. In fact, the great majority of the economists and economic advisors of the developed countries during those years, actually advocated government interventionism and public investments due to lack of competitiveness in the markets of this countries and the existing price mechanism's not being a good indicator in terms of their productivity. Detailed information can be found in references of Hiç (2001), Toye (1993) and this paper.

As their development progressed, the intensity of the public investments, government interventions and protectionism has decreased gradually as a result of this development. Therefore, developing countries have proceeded in the opposite direction compared to the developed countries. Developed countries had started with laissez-faire, and then, they allowed government interventions to a certain degree. Developing countries, though, have started with statism, after the private sector and the market economy expanded over time, the role of the government diminished; meaning that the developing countries also headed for the market economy; however, they cannot be considered implementing the market economy yet. On the other hand, for these developing countries we can safely state that they prioritize the encouragement of the private enterprise and foreign private capital, and they are open to outward-oriented industrialization, and implement a mixed economic regime with a strong private sector.

In the first stages of their development, developing countries used to employ a closed economy and fixed exchange rate system. However, the governments were increasing their expenditures in order to raise the growth rate and to address the social issues; the necessary finances were provided by the central bank which was not independent from the government. This rise in inflation caused by the increase in the volume of money because the exchange rates were fixed was giving rise to an increase in the volume of imports and decrease in the volume of exports, even though they were trying to restrict imports via high rates of customs and import quotas and encourage exports via export incentives. Eventually, the deficits in their balance of payments were forcing these countries to apply to the IMF. On the other hand, the IMF was stipulating devaluation and stability measures, namely, to eliminate their budget deficits, and additionally, instead of public investments, to encourage the private sector and the flow of foreign private capital. The developing country complied with these recommendations in accordance with the stand-by agreement, after a while, was again pursuing the wrong development strategies, and eventually it had to end up applying to the IMF one more time.

From the very outset, as an exception, Hong Kong, Singapore, Taiwan and South Korea succeeded implementing a development strategy based on the open economy, encouragement of private sector and foreign private capital flow and as export-oriented industrialization. Yet, these countries had different traits compared to other developing countries. Hong Kong, for instance, was an international trade center and Singapore was an international finance center they were both city-states. Taiwan and South Korea on the other hand, were appropriate places in terms of political objectives and from the economic point of view, thus, they benefited 
greatly from the flow of intensive American capital. American companies have been importing the goods they manufacturing in Taiwan and South Korea at very low prices. None of the other developing and newly industrializing country, including Turkey, was never subject to such intense foreign capital flow to this extent. Nevertheless, the economic regime implemented in these countries cannot be defined as a pure "market economy" because of the practice of intensive government interventions and protectionism (Toye, 1993).

In the 70s, many development economists draw the attention to the shortcomings of the closed economy implemented generally in the developing countries, and they advocated development strategies based on open economy and export-oriented industrialization (Hiç, 2001 and Toye, 1993).

In fact, many developing countries which were applying the closed economy model were increasing their public investments and consumption expenditures; they could not collect taxes, eventually ending up with high rates inflation. In some Latin American countries the inflation rate reached over $1000 \%$ s. Due to the fixed exchange policy, the demand for imports was increasing while the exports were falling, and despite the IMF's aid, the deficit in the balance of payments was reducing the growth rate for a long time; resulting in an economic frustration in terms of growth and social welfare. Many of governments of developing countries that became aware of the situation tried maintain the same principles even after the stand-by agreements with the IMF throughout the 70s. That means, they tried to minimize the budget deficit and encourage the private sector and foreign capital flow, and they returned to the market exchange rate system by forsaking the fixed exchange rate system. Since the market exchange rate system will enable the balance of payments equilibrium, it facilitated the liberalization of imports. On the other hand, because the existing state economic enterprises were not profitable and productive, privatization programs were carried out within the framework of the IMF's recommendations. Following a series of unsuccessful and inadequate devaluations in the 70s, Turkey, through 24 January austerity measures, has accomplished a very successful economic policy change in this direction (Hiç, 1980, 2008, ps. 8283). After 1983, serious economic measures were taken in many areas including the implementation of open economy, liberalization of imports, adopting market exchange rate regime, providing incentives for foreign private capital (Hiç, 2008, ps. 21-129). The last significant revision was successfully implemented during the 1999 and 2001 economic crises (Hiç, 2008, ps.191-198; and Yeni Türkiye (2001).

\section{Conclusion}

As it was explained before, the economic regime applied in the developing countries cannot be characterized as "market economy". Since the level of development in these countries are lower compared to the developed countries, there need of the level of government interventions, protections and public investments is higher. For this reason, as we mentioned earlier, what is implemented in these countries is not the market economy but a "mixed economy" heading for the market economy which is based on the encouragement of the private sector and foreign private capital. Moreover, democracies of these countries have some difficulties not allowing the market economy to function properly and effectively; and partisanship, nepotism and level of corruption as well as off-the-record sector are much higher than the developed countries. The whole issue here is to have fewer problems in time as the level of education and economic development rises.

In Latin America, though, a limited number of countries such as Venezuela, Argentina and Bolivia have turned into dictatorship and heavy socialist statism because of many failures. These countries make up a very narrow island on the world map.

On the other hand, many countries, including Turkey, have entered the globalization process started in the 90s. China, India and Brazil have taken much advantage from the globalization by conducting pragmatic and successful economic policies, eventually positioning themselves as economically very powerful BRIC (Brazil, Russia, India and China) countries alongside with the developed countries. Despite the negative impact of the 2008 economic crisis, Turkey has recovered very rapidly and today she is among the "emerging markets" group (Hiç, 2010 b). In conclusion, in spite of the 2008 global economic crisis, heading for the market economy and globalization in general will go on in the majority of the developing countries.

\section{References}

- ACKLEY, Gardner (1961) Macroeconomic Theory, Macmillan Co., New York.

- BİROL, Özlen Hiç (2001) Modern Macroeconomic Schools: A Comparison and Evaluation Essay in terms of Consistency and Validity (published doctoral dissertation), Istanbul University, Department of Economics, Istanbul.

- $\quad$ BRANSON, William (1989) Macroeconomic Theory and Policy 2. ed., Prentice-Hall Inc., New Jersey.

- KANYILMAZ, İbrahim (1995) Macroeconomic Theory and Policy (translation of William Branson's book), Alfa, Istanbul.

- KARLUK, Ridvan (2007) The EU and Turkey, 9th Edition, Beta Printing and Distribution Inc., Istanbul. 
- HİÇ, Mükerrem (1974) Capitalism, Socialism, Mixed Economy and Turkey, 2nd Edition, Sermet Printing., Istanbul.

- _ _ _ (1990) "Last Measures Taken. Erroneous Economic Policies Applied Before and Major Problems Faced”, MEBAN Capital Market Bulletin, May, Istanbul.

- _ _ (1994) Monetary Theory and Policy, Filiz Bookstore, Istanbul.

- —_ (2001) "Development Economics from the 50s to our Times", Istanbul University. Journal of Department of Economics, Vol. 51, Issue 2, Fall 2001.

- — _ (2008) A Survey of Turkey's Economy and Politics, Create-Space, Amazon Co.

- — _ (2010) Global Economic Crisis and Turkey, Beykent University, Istanbul.

- _ _ (2010 b) "Major Current Economic and Political Problems Facing Eurasian Countries", Keynote Speech: International Conference on Eurasian Economics 2010, Beykent University.

- $\quad$ PAYA, MERİH (1997) Macroeconomics, Filiz Bookstore, İstanbul.

- TOYE, John (1993) Dilemmas of Development 2. ed., Oxford UK and Cambridge ABD, Blackwell.

- YENI TÜRKIYYE (2001), Special Issue on Economic Crisis, September-October (Issue 41) and NovemberDecember (Issue. 42), Ankara. 


\title{
Trade Openness, Financial Development, and Economic Growth in Turkey: Linear and Nonlinear Causality Analysis
}

\author{
Prof. Dr. Muhsin Kar (Necmettin Erbakan University, Turkey) \\ Assoc. Prof. Dr. Şaban Nazlıŏlu (Pamukkale University, Turkey) \\ Asst. Prof. Dr. Hüseyin Ağır (Sütçü İmam University, Turkey)
}

\begin{abstract}
This paper aims at empirically investigating the direction of causality among trade liberalization, financial development, and economic growth in Turkey. By employing monthly data for the period January, 1989November, 2007, both linear and nonlinear causality approaches indicate that (i) there is bi-directional causality between economic growth and trade openness, (ii) economic growth causes financial development, and (iii) financial development leads to trade liberalization. Thereby, linear and nonlinear approaches confirm strong causal linkages among financial development, trade openness, and economic growth in Turkey. These results partially imply that economic growth depends upon trade liberalization through external finance in Turkey which has been experiencing capital account liberalization since 1989.
\end{abstract}

\section{Introduction}

It has been theoretically argued that both trade liberalization and financial development may play a crucial role in economic development. Trade liberalization reduces inefficiency in the production process and financial development facilitates the intermediation between savers and investors. Thus, they have a great deal of potential to positively influence economic growth in the developing countries. The theoretical and empirical studies mainly concentrate on either the relationship between trade and growth or the association between finance and growth. However, until recently, the empirical linkages between trade liberalization and financial development have not received sufficient attention in the literature.

Turkey has been implementing trade oriented development strategy since 1980 and has been experiencing financial liberalization process since 1989. Nevertheless, even though Turkey had faced to serious economic turbulences in 1994 and in the early 2000, she has recorded an impressive growth performance during the last decade. These dynamics of the Turkish economy provide us room to examine the nature of causal linkages between trade openness, financial development, and economic growth. To best of our knowledge, there is not any study on this subject for Turkey and thereby identifying the causal linkages among the variables of interest is timely and important to design financial system and trade policies for sustainable development.

The aim of this paper, therefore, is to econometrically investigate direct linkages among trade liberalization, financial development and economic growth for Turkey by employing monthly data for the period January, 1989- November, 2007. In particular, this work tries to empirically find an answer for the question of whether financial development leads trade liberalization or of whether trade liberalization leads financial development in Turkey in a trivariate framework by including economic growth which is interrelated with both trade openness and financial development. In addition to linear causality analysis, we carried out the nonlinear causality test in order to see whether the causal linkages among the variables of interest is sensitive the structural shifts and asymmetries in the series. In brief, we find from both linear and nonlinear approaches that financial development is the cause of trade liberalization and there is bi-directional causality between economic growth and trade openness and between economic growth and financial development. Thereby, linear and nonlinear approaches confirm strong causal linkages among financial development, trade openness, and economic growth in Turkey.

The novelty of this study is three-fold. First, this paper is the first that employs monthly income data in the literature on the finance-growth nexus for Turkey. Second, we conduct the financial development index -that is good able to capture of different dimensions of financial development- by means of principal component analysis. Third, in addition to linear causality analysis, we conduct nonlinear causality tests in order to determine whether there are asymmetric causal linkages between trade openness, financial development, and economic growth in Turkey.

\section{Theoretical Framework and Empirical Evidence}

The impacts of trade liberalization and financial development on economic growth have increasingly obtained a significant attraction in the literature. It is argued that both policy instruments fasten economic growth in the developing economies through various channels. Trade liberalization by allowing the allocation of factors of production across sectors (Grossman and Helpman, 1992; Redding, 1997), by increasing the competition in the domestic economy and hence improving productivity (Greenaway and Milner, 1993; Aghion, Dewatripont and Rey, 1997), by enlarging the market for domestic producers and leading to take advantage of the economies of scale (Taylor, 1994; Grossman and Helpman, 1991), by increasing number of inputs that have no domestic 
substitutes and thus leading to a higher capacity utilization (Nishimizu and Robinson, 1986; Quah and Rauch, 1990; Grossman and Helpman, 1992) and, finally by letting the flow of knowledge across sectors and countries (Feder, 1982; Grossman and Helpman, 1992) might positively influence economic growth.

In fact, the role of financial sector on economic growth has long debated in the literature. Schumpeter (1912), one of the earliest pioneers, emphasized the importance of finance for growth. In the same line, Patrick (1966) introduced two new concepts which highlight the demand and supply side conditions, namely demand-following and supply-leading hypothesis. While the former states that demand in the real sector is the engine for creation of financial services, the latter emphasizes that supply in the financial sector is the driving force behind the development of real sector. Patrick's (1966) argument brought about the discussion whether the direction of causality from finance to growth or vice versa.

The literature moved to highlight the importance of mobilization of domestic resources in the early $1970 \mathrm{~s}$. Specifically, McKinnon (1973) and Shaw (1973) suggested the liberalization in the financial sector in terms of lifting any sort of restrictions in the sector. They argued that lack of saving is a widespread phenomenon rather than lack of investment in the developing countries. Therefore policies should focus on increase in saving through a positive real interest rate policy.

With the emergence of endogenous growth theory (Romer, 1986) in the mid-1980s, it is argued that financial development might be one of the sources for the increase rate of return (Renelt, 1991). Financial development by increasing the possibility of choosing more productive investments through improved management of liquidity risks (Bencivenga and Smith 1991), by collecting information on the efficiency of various investment projects and/or investors' abilities (Greenwood and Jovanovic, 1990; King and Levine 1993) and by diversifying more efficiently investors' portfolios (Levine, 1991; Saint-Paul, 1992) might positively contribute to economic growth (Levine, 1997). These arguments based on endogenous growth theories implicitly assume that financial development promotes economic growth (Hermes, 1994).

The literature, in the 2000s, started to focus on the determinants of financial development. In order to understand the dynamics of the differences in the level of financial development, several factors are proposed for this purpose: Legal origin (La Porta et.al., 1997; Demetriades, 2008), public bank ownership (La Porta et.al., 2002; Andrianova et.al., 2008; Demetriades, 2008), initial conditions and institutional structure (Acemoglu et.al., 2001, 2004; Demetriades, 2008), trade liberalization (Rajan and Zingales, 2003; Do and Levchenko, 2006; Huang, 2006; Demetriades, 2008; Law, 2008, 2009), capital account liberalization (Chinn and Ito, 2002, 2006; Law and Demetriades, 2006; Klein and Olivei, 2008), prudential supervision and effective regulation (Cuadro et.al., 2003; Brownbridge et.al., 2005), deposit insurance (Cull et.al., 2001), required reserves (Di Giorgio, 1999; Arestis et.al., 2002) and macroeconomic policies (i.e. Inflation, exchange rate) (Montiel, 2003; Cuadro et.al., 2003; Bittencourt, 2008; Ben Naceur et.al., 2008).

Although the theoretical literature assumes linkages both between trade liberalization and economic growth and between finance and growth, the multi causal linkages between economic growth, financial development, and international trade has recently attracted attention. Rajan and Zingales (2003) emphasize the role of the supply-side factors and the resistance of incumbent industrialists and domestic financial intermediaries who have a vested interest in a closed financial sector and therefore oppose the developments in the financial market. It is argued that these incentives may be weakened with the opening domestic financial sector to foreign competition and to international flows of capital.

On the contrary, Svaleyrd and Vlachos $(2000,2002)$ highlight the importance of the demand-side factors and the possibility of risk diversification with the trade liberalization which creates new demands for external finance. This external resource for firms is a necessity to overcome short-term cashflow problems and adverse shocks.

In order to fill the theoretical gap for the linkages among trade openness, financial development, and economic growth in a multi causal conceptual framework, Blackburn and Hung (1998) suggest that trade liberalization by leading new product development may contribute to economic growth. Financial development may be resulted from trade liberalization which encourages the number of new producers who need access to finance their activities. Similarly, Feeney (1994) argues that integration in the financial sector may enhance the probability for risk sharing that allows product specialization and, in turn, benefits trade. These studies imply an indirect theoretical link between trade liberalization and financial development via new products.

In sum, the above reviewed studies fall short of establishing direct linkages between trade liberalization and financial development. Ginebri et. al. (2001) emphasize the issue of complementarity between trade and finance and propose a direct relationship between trade liberalization and financial development. In particular, the complementarity is theoretically based upon the fact that trade liberalization enhances entrepreneurial development which in turn increases a need of new instrument from the financial system.

The relationship between trade liberalization and financial development has been a subject matter for a limited number of empirical works which provide evidences for the argument that trade liberalization is a crucial step to enhance financial development and/or vice versa in a single country or a group of countries (Beck, 2002; 
Svaleyrd and Vlachos, 2000, 2002; Rajan and Zingales, 2003; Do and Levchenko, 2004; Huang and Temple, 2005; Hur, Raj and Riyanto, 2006; Bao and Yang, 2007; Law, 2008, 2009; Baltagi et.al., 2009; Das and Rishi, 2010). In contrast, Gries, Kraft and Meierrieks (2009) find a limited support for the finance-led growth and financial deepening and trade openness have swayed economic development rather marginally.

As far as the empirical works for Turkey are concerned, there is not any consensus on the direction of causality not only between trade and growth (Ghatak, Milner and Utkulu, 1995; Bahmani-Oskooee and Domac, 1995; Yiğidim and Köse, 1997; Özmen and Furtun, 1998; Doğanlar and Fisunoğlu, 1999; Özmen et. al, 1999; Hatemi-J ve Irandoust, 2000; Tuncer, 2002; Şimşek, 2003; Bilgin and Şahbaz, 2009) but also between finance and growth (Şıklar, 1992; Akçoraoğlu, 2000; Kar and Pentecost, 2000; Doğan, 2002; Ünalmış, 2002; Aslan and Korap, 2006; Aslan and Küçükaksoy, 2006; Kar and Ağır, 2006; Acaravc1, 2007; Halıcığlu, 2007; Öztürk, 2008; Yücel and Altıntaş, 2009). The results imply that the selection of both variables and the methodology determines the direction of causality between the concerned variables in these empirical works.

There is a limited work which concentrates on the relationship between finance and trade for Turkey. Utkulu ve Kahyaoğlu (2005) examines the impacts of both financial and trade openness on economic growth and find that while financial openness negatively contributes to economic growth, trade liberalization has a positive effect on growth in Turkey. Açıkgöz, Balcılar and Saraçoğlu (2009) also investigate the causal linkages among financial development, financial openness and trade openness by employing bounds test developed by Pesaran et.al. (2001) and Pesaran and Shin (1999) for the period 1989:Q1-2007:Q2 and provide empirical evidence that both financial and trade openness have a positive impact on financial development for Turkey. Kar, Peker and Kaplan (2008) examines a long-run relationship between trade liberalization, financial development and economic growth for the period 1963-2005 in Turkey and concludes that openness and finance has a positive impact on growth in the long-run. Yücel (2009) finds a bi-directional causality between each pair of the variables, namely financial development (measured by the broad money to GDP ratio), trade and economic growth, for the period 1989M1-2007M11 in Turkey. Ağır (2010) provides empirical evidence that trade, among other variables, plays a significant role in explaining financial development in Turkey.

\section{Econometric Methodology}

\subsection{Linear Granger Causality Test}

The standard Granger causality test requires carrying out zero restrictions on coefficients in Vector Autoregressive (VAR) model based on the Wald principle. Wald test for Granger causality may result in nonstandard limiting distributions based on the cointegration properties of the system and possibly on nuisance parameters. These nonstandard asymptotic properties are due to the singularity of the asymptotic distributions of the estimators (Lütkepohl, 2004: 148). Toda and Yamamoto (TY) (1995) developed the modified Wald (MWALD) test for Granger causality which overcomes this singularity problem.

The standard Granger causality analysis is based on estimating a VAR $(p)$ model. In order to correct the singularity problem TY (1995) suggest using a VAR $(p+d)$ model in which $d$ is the maximum integration degree of the variables. The following VAR model is therefore estimated in the TY procedure:

$$
y_{t}=v+A_{1} y_{t-1}+\cdots+A_{p} y_{t-p}+\cdots+A_{p+1} y_{t-p-d}+\mu_{t} .
$$

where $\mathrm{y}_{\mathrm{t}}$ is vector of k variables, $v$ is a vector of intercepts, $\mu_{t}$ is a vector of error terms and $A$ is the matrix of parameters. To test for the null of no-Granger causality against the alternative hypothesis is tested by imposing zero restriction on the first $p$ parameters in equation (1). The MWALD statistic has asymptotic chi-square distribution with $p$ degrees of freedom irrespective of the number of unit roots and the cointegrating properties.

Hacker and Hatemi-J (2006) investigate the size properties of the MWALD test and find that the test statistic with asymptotic distribution poorly performs in small samples. Monte Carlo simulation of Hacker and Hatemi-J (2006) shows that the MWALD test based on the bootstrap distribution has much smaller size distortions than those of the asymptotic distribution. Hacker and Hatemi-J (2006:1492-1493) extends the TY approach based on the bootstrapping method developed by Efron (1997). In this new approach that is so-called the leveraged bootstrap Granger causality test, the MWALD statistic are compared with the bootstrap critical value instead of the asymptotic critical value.

\subsection{Nonlinear Granger Causality Test}

The linear Granger causality test does not account for nonlinear causal relationships among the variables. The Monte Carlo study of Baek and Brock (1992) demonstrates that in the presence of nonlinearity, the forecasting performance of nonlinear approach is better than that of linear modelling. In order to test for the null of nonlinear non-Granger causality, the nonparametric test of Hiemstra and Jones (HJ) (1994) is widely employed. However, the HJ test may over rejects the null hypothesis in the case of increasing sample size, which is stemming from ignoring the possible variations in conditional distributions (Diks and Panchenko, 2005). The nonlinear causality test recently developed by Diks and Panchenko (DP) (2006) overcomes this drawback of the HJ test. 
DP (2006) offer the following statistic to test for nonlinear Granger causality.

$$
T_{n}\left(\varepsilon_{n}\right)=\frac{n-1}{n(n-2)} \sum_{i}\left(\hat{f}_{X, Y, Z}\left(X_{i}, Y_{i}, Z_{i}\right) \hat{f}_{Y}\left(Y_{i}\right)-\hat{f}_{X, Y}\left(X_{i}, Y_{i}\right) \hat{f}_{Y, Z}\left(Y_{i}, Z_{i}\right)\right)
$$

where $\hat{f}_{W}\left(W_{i}\right)$ is a local density estimator of a $\mathrm{d}_{\mathrm{w}}-$ variate random vector $\mathrm{W}$ at $\mathrm{W}_{\mathrm{i}}$ defined by $\hat{f} w\left(W_{i}\right)=\left(2 \varepsilon_{n}\right)^{-d_{W}}(n-1)^{-1} \sum_{j j \neq i} \mathrm{I}_{i j}^{w}$ that $\mathrm{I}_{i j}^{w}=\mathrm{I}\left(\left\|W_{i}-W_{j}\right\|<\varepsilon_{n}\right)$ with the indicator function $\mathrm{I}($.$) and$ the bandwidth $\varepsilon_{n}$. For one lag (i.e. $\left.l x=l y=1\right)$, if $\varepsilon_{n}=C n^{-\beta}\left(C>0, \frac{1}{4}<\beta<\frac{1}{3}\right)$, the test statistic is asymptotically distributed as standard normal. Since the statistic diverges to positive infinity under the alternative hypothesis, the calculated statistic greater than 1.28 implies the rejection of the null hypothesis at 10 percent level of significance.

In the DP test, value of the bandwidth plays an important role in making a decision on nonlinear causality. Since the bandwidth value smaller (larger) than one generally results in larger (smaller) $p$-value (Bekiros and Diks, 2008: 1646), the bandwidth value is equal to one in this study.

\section{Data}

This paper employs monthly observation for the variables for the period 1989:M1-2007:M11 in Turkey. In particular, the Turkish Statistical Institute has provided a quarterly GDP series since 1986 and there is not a monthly data for this variable. The monthly real GDP series used in the analysis is generated by Taşdemir (2008) by utilizing steady-space approach. The time span for income series (monthly real GDP) restricts the range of other series employed in the analysis.

Trade openness (TO) is measured as the ratio of total trade (exports plus imports) to the GDP as a proxy for trade liberalization. Data for trade openness and financial development indicators are respectively collected from the on-line database of TurkStat (Turkish Statistical Institute) and of the Central Bank of Turkish Republic.

Financial development is a multifaceted issue and has not a direct measurement. Instead, a number of proxies to catch up various dimensions of financial development have been used in the literature. This paper develops a financial development index by utilizing principle component analysis that is a statistical tool to transform a number of correlated variables into a smaller number of uncorrelated variables (Creane et al., 2003; Saci and Holden, 2008; Jalli et al., 2010). The financial development index (FD) is constructed from the ratio of M2 to income (M2Y), the ratio of domestic credit to income (DCY), the ratio of private sector credit to income (PSCY), and the market capitalization ratio (MCR). The market capitalization ratio is measured as the ratio of stock market index to income. FD carries information not only about the monetary and credit aggregates but also capital markets.

\begin{tabular}{|c|c|c|c|c|c|}
\hline \multicolumn{6}{|c|}{ Eigenvalues: $($ Sum $=4$, Average $=1)$} \\
\hline & & & & Cumulative & Cumulative \\
\hline Number & Value & Difference & Proportion & Value & Proportion \\
\hline 1 & 2.251237 & 1.205801 & 0.5628 & 2.251237 & 0.5628 \\
\hline 2 & 1.045436 & 0.384093 & 0.2614 & 3.296673 & 0.8242 \\
\hline 3 & 0.661343 & 0.619359 & 0.1653 & 3.958016 & 0.9895 \\
\hline 4 & 0.041984 & --- & 0.0105 & 4.000000 & 1.0000 \\
\hline \multicolumn{6}{|c|}{ Eigenvectors (loadings): } \\
\hline Variable & PC 1 & PC 2 & PC 3 & PC 4 & \\
\hline PCSY & 0.648129 & -0.039295 & 0.214224 & -0.729721 & \\
\hline DCY & 0.557986 & -0.451445 & 0.325603 & 0.615493 & \\
\hline M2Y & 0.464323 & 0.162880 & -0.857189 & 0.151990 & \\
\hline MCR & 0.230184 & 0.876427 & 0.336627 & 0.256074 & \\
\hline
\end{tabular}

Table 1: Results from principal component analysis

Table 1 reports the results from principal component analysis. The eigenvalues for three principal components show that the first principal component (PC1) explains the highest proportion of variance by accounting 56.28 percent of the standardized variance. Accordingly, the financial development index is constructed by using the factor loadings based on the first principal component. 


\section{Empirical Findings}

Before proceeding with the TY and the DP procedures, the maximum integration degree (d) of the variables that are expressed in logarithmic form- are determined by three unit root tests developed by Dickey and Fuller (1979) and Phillips and Perron (1988) which test for the null of a unit root and Kwiatkowski et al. (1992) that tests for the null hypothesis of stationary. The results reported in Table 2 indicate that while the series in loglevels appear to be non-stationary and they are stationary in first-differences. The results accordingly imply that $d$ will be equal to one in the TY procedure, and the series in first-differences will be used in the DP test.

\begin{tabular}{|c|c|c|c|c|c|c|c|}
\hline Levels & & $\mathrm{ADF}$ & & PP & & KPSS & \\
\hline \multirow[t]{3}{*}{ Constant } & FD & -0.68 & & -0.69 & & 0.67 & $* * *$ \\
\hline & TO & -0.91 & & -3.43 & $* *$ & 1.67 & $* * *$ \\
\hline & GDP & -0.63 & & -0.68 & & 1.88 & \\
\hline \multirow{3}{*}{$\begin{array}{l}\text { Constant } \\
\text { And trend }\end{array}$} & FD & -1.54 & & -1.51 & & 0.14 & $*$ \\
\hline & TO & -2.94 & & -8.09 & $* * *$ & 0.10 & \\
\hline & GDP & -3.11 & & -4.99 & $* * *$ & 0.15 & \\
\hline \multicolumn{8}{|c|}{ First Differences } \\
\hline \multirow[t]{3}{*}{ Constant } & FD & -17.76 & $* * *$ & -17.57 & $* * *$ & 0.19 & \\
\hline & TO & -5.06 & $* * *$ & -37.13 & $* * *$ & 0.21 & \\
\hline & GDP & -24.08 & $* * *$ & -31.25 & $* * *$ & 0.28 & \\
\hline \multirow{3}{*}{$\begin{array}{l}\text { Constant } \\
\text { And trend }\end{array}$} & FD & -17.83 & $* * *$ & -17.68 & $* * *$ & 0.07 & \\
\hline & TO & -5.05 & $* * *$ & -37.06 & $* * *$ & 0.21 & \\
\hline & GDP & -24.03 & $* * *$ & -31.73 & $* * *$ & 0.29 & \\
\hline
\end{tabular}

Table 2: Results for unit root tests

The results for linear causality analysis are illustrated in Table 3. Since the TY procedure is based on ordinary least squares estimator, one need to justify the validity of assumption of that estimator. In that respect, we carry out a diagnostic checking procedure. The Breusch-Godfrey's serial correlation test implies that the residual of the estimated models are free from auto correlation problem. The Ramsey's model miss-specification test clearly shows that the functional forms of the models are appropriately specified. The White's heteroscedasticity and Engel's autoregressive conditional heteroscedasticity $(\mathrm{ARCH})$ tests indicate the validity of homoscedasticity assumption.

\begin{tabular}{|l|l|l|l|l|l|}
\hline & & \multicolumn{3}{|l|}{ Critical Value } \\
\hline & MWALD & & $1 \%$ & $5 \%$ & $10 \%$ \\
\hline FD $\neq>$ TO & $\mathbf{1 1 . 9 2}$ & $* * *$ & 9.58 & 6.35 & 4.73 \\
\hline TO $\neq>$ FD & 2.64 & & 9.43 & 6.05 & 4.66 \\
\hline & & & & & \\
\hline FD $\neq>$ GDP & 2.24 & & 9.33 & 6.12 & 4.66 \\
\hline GDP $\neq>$ FD & $\mathbf{2 2 . 6 5}$ & $* * *$ & 9.55 & 6.01 & 4.65 \\
\hline \multicolumn{1}{|l|}{} & & & & 4.67 \\
\hline GDP $\neq>$ TO & $\mathbf{1 6 . 8 9}$ & $* * *$ & 9.54 & 6.08 & 4.76 \\
\hline TO $\neq>$ GDP & $\mathbf{1 0 . 7 8}$ & $* * *$ & 9.57 & 6.31 & \\
\hline $\begin{array}{l}\text { f> implies non Granger causality. The optimal lags in VAR(p) model was determined based on SBC. The bootstrap critical values were } \\
\text { calculated based on 10,000 replications. *** indicates statistical significance at 1 percent.. }\end{array}$ \\
\hline
\end{tabular}

\section{Table 3: Linear causality analysis}

The findings indicate uni-directional causality from trade openness to financial development. With respect to causal linkages between economic growth and financial development, the results show that the causality runs from economic growth to financial development. Thereby, the nature of causation between economic growth and financial development support evidence on the demand-following hypothesis. As regards to causality between trade openness and economic growth, there is bi-directional causality between economic growth and trade openness, which proves support on the feedback hypothesis.

One drawback of linear causality methods is the possibility of overlooking nonlinear relations. It is thereby important to investigate nonlinear causal linkages among the variables of interest. In that respect, we conduct the DP nonlinear causality analysis. The nonlinear Granger causality analysis is carried out in two steps (Bekiros and Diks, 2008). In the first, the DP test is applied to the stationary series to detect nonlinear interrelationships. In the second step, the DP test is reapplied to the filtered VAR residuals to see whether the nature of causation is strictly nonlinear. After removing linear causality with a VAR model, any causal linkage from one residual series 
to another can be considered as nonlinear predictive power (Hiemstra and Jones, 1994: 1648). Note that the results for the DP test are discussed for one lag.

Table 4 present the results from the nonlinear causality test. The DP test on raw data indicates that there is a nonlinear causality from financial development to trade openness, which is consistent with linear causality analysis. Even though the nonlinear causality test implies a nonlinear feedback from financial development to trade openness, the DP test should be reapplied to filtered VAR residuals to see whether this causality is strictly nonlinear in nature (Bekiros and Diks, 2008: 1647). The results for the DP test on the VAR residuals substantiate the findings from raw data. Hence, the nonlinear analysis provides evidence on significant and persistent nonlinear causal linkage from financial development to trade openness in Turkey.

\begin{tabular}{|l|l|l|l|l|l|l|}
\hline & \multicolumn{2}{|l|}{ Raw data $^{\mathrm{a}}$} & \multicolumn{2}{l|}{ VAR residuals } \\
\hline
\end{tabular}

Table 4: Nonlinear causality analysis

When we look at nonlinear causal linkages between economic growth and financial development, it seems that there is bi-directional nonlinear causality from economic growth to financial development. Furthermore, this nonlinear causality appears to be strict due to the fact that the nonlinear causality based on the VAR residuals rejects the null hypothesis of nonlinear non-causality. The finding from nonlinear causality analysis between economic growth and financial development is thereby consistent with that from the linear causality test, implying the demand-following hypothesis. The nonlinear causal linkages between trade openness and economic growth analysis show that there is nonlinear causality from trade openness to economic growth. However, this causal linkage does not seem to be strictly nonlinear since the causality test from the VAR residuals does not show any causal linkage from trade openness to economic growth. Thereby, the nonlinear causality analysis provides weak evidence on the validity of the export-led growth hypothesis. This finding hence is particularly consistent with that from linear causality analysis. On the other hand, the nonlinear causality test supports evidence on the strict nonlinear causal linkage from economic growth to trade openness.

\section{Summary and Discussion}

This paper has empirically tested the causal linkages among trade liberalization, financial development and economic growth for Turkey. To this end, both linear and nonlinear approaches have been employed to detect the direction causality among the concerned variables by employing monthly data for the period January, 1989November, 2007.Empirical findings methodologically show that the nonlinear causality analysis captures all information provided by linear approach and furthermore it provides important information on whether the causal linkages among trade openness, financial development, and economic growth are in nature strictly nonlinear.

The non-linear analysis shows that trade liberalization causes economic growth (export-led growth), economic growth leads to financial development (demand-following) and financial development causes trade liberalization. These results provide empirical support for both the export-led growth and demand-following hypotheses. In addition, there is evidence on that financial development mobilizes resources to meet the need of trade sector. The results from the linear approach indicate that the relationship between trade and economic growth is rather bi-directional. In addition, the causality between both economic growth and financial development and financial development and openness is as in both nonlinear models. Specifically, economic growth causes financial development and financial development leads to trade liberalization.

Furthermore, keeping the analysis period (1989:M1-2007:M11) in mind, these findings partly support the view that economic growth depends upon trade through external finance in Turkey which has been experiencing capital account liberalization since 1989. Financial sector play a key role in this process. Sources of financial deepening may be both domestic as well as external. Whatever the sources, development in the financial markets seems to mobilize resources for the utilization of both import and export. The results imply that economic growth dependent upon trade seems to be sensitive financial development which may resulted from domestic and external sources. Although this paper does not focus on the sources of financial development whether domestic 
or external factors are dominant, it highlights the risk for sustainable economic growth if there is a lack or reverse of capital inflows which expand the domestic credit in Turkey.

\section{References}

- Acaravc1, A. Öztürk, İ. and Acaravc1, S. K., 2007. Finance- Growth Nexus: Evidence from Turkey. International Research Journal of Finance and Economics, 11,pp. 30-40.

- Acemoglu, D. Johnson, S. and Robinson, J. A., 2001. The Colonial Orijins of Comparative Development: An Empirical Investigation. American Economic Review, 91,pp. 1369-1401.

- Acemoglu, D. Johnson, S. and Robinson, J. A., 2004. Institutions as the Fundemental Cause of Long Run Growth. NBER Working Paper, No: 10481.

- Açıkgöz, Ş. Balcılar, M. and Saraçoğlu, B., 2009. Openness and Financial Development: Time Series Evidence From Turkey, Anadolu International Conference in Economics June 17-19, 2009, Eskişehir, Turkey.

- Aghion, P. Dewatripont, M. and Rey, P., 1997. Corporate Governance, Competition Policy and Industrial Policy. European Economic Review, 41,pp. 797-805.

- Ağır, H., 2010. Econometric Analysis of the Relationship Between Financial Liberalization and Financial Development, Banking Supervision and Regulation Agency, No.8., Ankara.

- Akçoraoğlu, A., 2000. Financial Sector and Economic Growth: An Exogeneity Analysis. Ankara University Journal of the Faculty of Political Sciences, 55(1), pp. 1-25.

- Altıntaş, H. and Ayrıçay, Y., 2009. An Analysis of the Relationship Between Financial Development and Economic Growth with the Approach of the Bonds Test: 1987-2007, X. Conference on Econometrics and Statistics, 27-29 May, Atatürk University (in Turkish).

- Andrianova, S. Demetriades, P. and Shortland, A., 2008. Government Ownership of Banks, Institutions and Financial Development, Journal of Development Economics, 85, pp. 218-252.

- Arestis, P. Demetriades, P. Fattouh, B. and Mouratidis, K., 2002. The Impact of Financial Liberalization Policies on Financial Development: Evidence From Developing Economies. International Journal of Finance and Economics, 7(2), pp. 109-121.

- Aslan, Ö. and Korap, H.L., 2006. Relationship Between Financial Development and Economic Growth in Turkey, Muğla University Journal of the Institute of Social Sciences, 17, pp. 1-20 (in Turkish)

- Aslan, Ö. and Küçükaksoy, İ., 2006. Relationship Between Financial Development and Economic Growth: An Econometric Application to the Turkish Economy, İstanbul University, Faculty of Economics, Journal of Econometrics and Statistics, 4, pp. 12-28 (in Turkish).

- Baek, E. and Brock, W., 1992. A General Test for Nonlinear Granger Causality: Bivariate Model. Working Paper. Iowa State University and University of Wisconsin-Madison; 1992.

- Bahmani-Oskooee, M. and Domaç, I.., 1995. Export Growth and Economic Growth in Turkey: Evidence from Cointegration Analysis, METU Studies in Development, 22(1), pp.67-77.

- Baltagi, B, Demetriades, P. and Law, S. H. (2009) Financial Development and Openness: Evidence from Panel Data. Journal of Development Economics, 89, pp. 285 - 296.

- Bao, Q. and Yang, J., 2007. Does Financial Development Promote International Trade? Frontiers of Economics in China, 2(4), pp. 532-557.

- Beck, T., 2002. Financial Development and International Trade Is There a Link? Journal of International Economics, 57, pp. 107-131.

- Bekiros, S.D. and Diks, C.G.H., 2008. The nonlinear dynamic relationship of exchange rates: parametric and nonparametric causality testing, Journal of Macroeconomics, 30, pp. 1641-1650.

- Ben Naceur, S. Boubakri, N. and Ghazouani, S. 2008. Privatization and Financial Market Development: A Comparison Between MENA Countries and Other Regions. Economic Research Forum, Working Paper No. 390.

- Bencivenga, V. and Smith, B., 1991. Financial Intermediation and Endogenous Growth. Review of Economic Studies, 58: 195-209.

- Bilgin, C. and Şahbaz, A., 2009. Causality Relations Between Growth and Export in Turkey, Journal of Social Sciences Gaziantep University, 8(1), pp. 177-198 (in Turkish).

- Bittencourt, M., 2008. Inflation and Financial Development: Evidence from Brazil. United Nations University, Research Paper No: 2008/14. 
- Blackburn, K. and Hung, V.T.Y., 1998. A Theory of Growth, Financial Development and Trade, Economica, 65, pp. 107-124.

- $\quad$ Brownbridge, M. Kirkpatrick, C.H. and Maimbo, S.M., 2005. "Financial Regulation in Developing Countries: Policy and Recent Experience", in C. Green, C. Kirkpatrick and V. Murinde (editors), Finance and Development Surveys of Theory, Evidence and Policy, Cheltenham, UK: Edward Elgar: 154-180.

- Chinn, M. and Ito, H., 2006. What Matters for Financial Development? Capital Controls, Institutions and Interactions. Journal of Development Economics, 81, pp. 163-192.

- Chinn, M.D. and Ito, H., 2002. Capital Account Liberalization, Institutions and Financial Development: Cross Country Evidence. NBER Working Paper Series, No: 8967.

- $\quad$ Creane, S. Goya, R. Mobarak, M. and Sab, R., 2003. Financial development and economic growth in the Middle East and North Africa. Finance and Development, 4(1).

- Cuadro, L. Gallego, S. and Herrero, A.G., 2003. Why Do Countries Develop More Financially than Others? The Role of the Central Bank and Banking Supervision. http://www.cass.city.ac.uk/conferences/emg_finance/Papers/Cuadro_Gallego_Garcia-Herrero.pdf $(12 / 12 / 2008)$.

- $\quad$ Cull, R. Senbet, L.W. and Sorge, M., 2001. Deposit Insurance and Financial Development, Policy Research Working Paper, WPS 2682: 1-61.

- $\quad$ Das, R.U. and Rishi, M., 2010 Are Trade Opennes and Financial Development Complementary? RIS Discussion Papers, 165.

- Demetriades, P.O., 2008. New Perspectives on Finance and Growth. University of Liecester, Working Paper No: 08/14.

- $\quad$ Di Giorgio, D., 1999. Financial Development and Reserve Requirements. Journal of Banking and Finance, 23, pp. 1031-1041.

- Dickey, D. and Fuller, W.A., 1979. Distribution of the Estimates for Autoregressive Time Series with Unit Root, Journal of the American Statistical Association, 74 (June), pp. 427-31.

- Dickey, D.A. and Fuller, W.A., 1979. Distribution of the Estimators for Autoregressive Time Series with a Unit Root. Journal of the American Statistical Society, 75, pp. 427-431.

- $\quad$ Diks, C. and Panchenko, V., 2005. A Note on the Hiemstra-Jones Test for Granger Non-causality. Studies in Nonlinear Dynamics and Econometrics, 9, pp. 1-7.

- $\quad$ Diks, C. and Panchenko V., 2006. A New Statistic and Practical Guidelines for Nonparametric Granger Causality Testing. Journal of Economic Dynamics and Control, 30, pp. 1647-1669.

- Do, Q.T. and Levchenko A.A., 2004. Trade and Financial Development, World Bank Policy Research Working Paper, No. 3347.

- Do, Q.T. and Levchenko, A.A., 2006. Comparative Advantage, Demand for External Finance and Financial Development. World Bank Policy Research Working Paper 3889, WPS 3889.

- Doğan, H., 2008. Relationship Between Finance and Real Economy in Turkey: Was Schumpeter Right?. Iktisat Issletme ve Finans, 23(272), pp. 49-79 (in Turkish).

- Doğanlar, M. and Fisunoğlu, M., 1999. Causality Between Exports and Economic Growth in Asian Countries. Yapı Kredi Economic Review, 10(11), pp. 3-11.

- Efron, B., 1997. Bootstrap Methods: Another Look at the Jackknife. Annals of Statistics, 7, pp.1-26.

- $\quad$ Feder, G., 1982. On Export and Economic Growth. Journal Of Development Economics, 12, pp. 59-73.

- Feeney, J., 1994. Goods and Asset Market Interdependence in a Risky World. International Economic Review 35, pp. 551-563.

- Ghatak, S. Milner, C. and Utkulu, U., 1995. Trade Liberalisation and Endogenous Growth: Some Evidence for Turkey, Economics of Planning, 28(2-3), pp. 147-167.

- Ginebri, S. Petrioli, G. and Sabani, L., 2001. Financial Deepening, Trade Openness and Growth: A Multivariate Cointegrated Analysis of the Complementary Effects, CIDEI Working Paper No. 62, Rome.

- Greenaway, D. and Milner, C., 1993. Trade and Industrial Policy in Developing Countries: A Manual of Policy Analysis, London: Macmillan.

- Greenwood, J. and Jovanovic, B., 1990. Financial Development, Growth and the Distribution of Income. Journal of Political Economy, 98(5), pp. 1076-1107. 
- Gries, T. Kraft, M. and Meierrieks, D., 2009. Linkages Between Financial Deepening, Trade Openness and Economic Development: Causality Evidence from Sub-Saharan Africa, World Development (37)12, pp. 1849-1860.

- Grossman, G. M. and Helpman, E., 1991. Quality Ladders in the Theory of Growth, Review of Economic Studies, 58, pp. 43-61.

- Grossman, G. M. and Helpman, E., 1992. Innovation and Growth in the Global Economy, Cambridge MA: MIT Press.

- Hacker, R. S. and Hatemi-J, A., 2006, Tests for Causality Between Integrated Variables Using Asymptotic and Bootstrap Distributions: Theory and Application. Applied Economics, 38, pp. 14891500 .

- Halıcıoğlu, F., 2007. Financial Development and Economic Growth Nexus For Turkey. MPRA Paper No. 3566, (http://mpra.ub.uni-muenchen.de/3566/, 10.06.2009).

- Hatemi-J, A. and Irandoust, M., 2000. Time-Series Evidence for Balassa's Export-Led Growth Hypothesis. Journal of International Trade and Economic Development, 9(3), pp. 355-365.

- Hermes, N., 1994. Financial Development and Economic Growth: A Survey of the Literature. Internationl Journal of Development Banking, 12(1), pp. 3-22.

- Hiemstra, C. and Jones, J. D., 1994. Testing for Linear and Nonlinear Granger Causality in the Stock Price-Volume Relation. Journal of Finance, 49(5), pp.1639-1664.

- Huang, W., 2006. Emerging Markets Financial Openness and Financial Development. University of Bristol, Discussion Paper No. 06/588. Department of Accounting and Finance, University of Bristol. Bristol.

- Huang, Y. and Temple, J., 2005. Does External Trade Promote Financial Development, University of Bristol, Discussion Paper, 05/575. Department of Economics, University of Bristol, Bristol.

- Hur, J. Raj, M. and Riyanto, Y.E., 2006. Finance and Trade: A Cross-Country Empirical Analysis on the Impact of Financial Development and Asset Tangibility on International Trade. World Development 34(10), pp. 1728-1741.

- Jalil, A. Feridun, M. and Ma, Y., 2010. Finance-Growth Nexus in China Revisited: New Evidence from Principal Components and ARDL Bounds Tests, International Review of Economics and Finance 19, pp. 189-195.

- Kar, M. and Ağır, H., 2006. Capital Markets, Financial Development and Economic Growth: The Turkish Case. İstanbul Üniversitesi, Journal of the Faculty of Economics, 56(1), pp. 13-46 (in Turkish).

- Kar, M. and Pentecost, E., 2000. The Direction of Causality Between Financial Development and Economic Growth in Turkey: Further Evidence. Economic Research Paper, Department of Economics, Loughborough University, No. 00/27. Loughborough.

- $\quad$ Kar, M., O. Peker ve Kaplan, M., 2008. Trade Liberalization and Financial Development and Economic Growth in the Long Run: the Case of Turkey. South East European Journal of Economics and Business, 3(2), pp. 25-38.

- $\quad$ King, R.G. and Levine, R., 1993. Finance and Growth: Schumpeter Might Be Right?. Quarterly Journal of Economics, 108(3), pp. 717-737.

- $\quad$ Klein, M.W. and Olivei, G.P., 2008. Capital Account Liberalization, Financial Depth and Economic Growth. Journal of International Money and Finance, 27, pp. 861-875.

- $\quad$ Kwiatkowski, D. Phillips, P.C.B. Schmidt, P. and Shin Y., 1992 Testing the Null of Stationarity Against the Alternative of a Unit Root: How Sure Are We That Economic Time Series Have a Unit Root?", Journal of Econometrics, 54, pp. 159-178.

- $\quad$ La Porta, R. Lopez-de-Silanes, F. and Shleifer, A., 2002. Government Ownership of Banks. Journal of Finance, 57(1), pp. 265-301.

- $\quad$ La Porta, R. Lopez-de-Silanes, F., Shleifer, A. and Vishny, R.W., 1997. Legal Determinants of External Finance. Journal of Finance, 52, pp. 1131-1150.

- $\quad$ Law, S. H. 2008. Does a Country’s Openness to Trade and Capital Flows Lead to Financial Development? Evidence from Malaysia. Asian Economic Journal, 22(2), pp. 161 - 177.

- $\quad$ Law, S. H. 2009. Trade Openness, Capital Inflows and Financial Development in Developing Countries. International Economic Journal, 23(3), 409 - 426 
- $\quad$ Law, S.H. ve Demetriades, P., 2006. Opennes, Institutions and Financial Development. Wold Economy \& Finance Research Programme Working Paper Series, WEF 0012, Economic \& Social Research Council.

- $\quad$ Levine, R., 1991. Stock Markets, Growth, and Tax Policy. The Journal of Finance; V(XLVI), pp. 14451465.

- $\quad$ Levine, R., 1997. Financial Development and Economic Growth: Views and Agenda. Journal of Economic Literature, 35, pp. 688-726.

- Lütkepohl, H., 2004. "Vector autoregressive and vector error correction models" in Lütkepohl, H. and Kratzig, M. (eds.) Applied Time Series Econometrics, Cambridge University Press: Cambridge.

- $\quad$ McKinnon, R.I., 1973. Money and Capital in Economic Development. Washington, D.C.: The Brooking Institution.

- Montiel, P.J., 2003. Development of Financial Markets and Macroeconomic Policy. Journal of African Economies, 12(2), pp. ii12-ii52.

- Nishimizu, M. and Robinson, A., 1986. "Productivity Growth in Manufacturing in Industrialisation and Growth: A Comparative Study” in H. Chenery, S. Robinson and M. Syrquin (eds.), Industrialisation and Growth, Oxford:Oxford University Press for World Bank.

- Özmen, E. and Furtun, G., 1998. Export-Led Growth Hypothesis and the Turkish Data: An Empirical Investication. METU Studies in Development, 25(3), pp. 491-503.

- Özmen, A, Özer, M. and Türkyılmaz, S., 1999. An Application Experience to the Causal Relations Between Export and Economic Growth. Dedication to Orhan Ŏguz, Marmara University Press, No. 640, pp.379-392.

- $\quad$ Öztürk, İ., 2008. Financial Development and Economic Growth: Evidence from Turkey. Applied Econometrics and International Development, 8(1), pp. 85-98

- $\quad$ Patrick, H. T., 1966. Financial Development and Economic Growth in Underdeveloped Countries. Economic Development and Cultural Change, 14, pp. 174-189.

- $\quad$ Pesaran, M. H. and Shin, Y., 1999. “An Autoregressive Distributed Lag Modeling Approach to Cointegration Analysis" in S. Strom (ed.), Econometrics and Economic Theory in the 20th Century, The Ragnar Frisch Centennial Symposium, Cambridge University Press, Cambridge, pp. 371-413.

- Pesaran, H. Shin, Y. and Smith, R.J., 2001. Bound Testing Approaches to the Analysis of Long Run Relationships. Journal of Applied Econometrics, 16(3), pp. 289-326.

- Phillips, P.C.B. and Peron, P., 1988. Testing for a Unit Root in Time Series Regression. Biomètrika, 75(2), pp. 336-346.

- Quah, D. and Rauch, J.E., 1990. Openness and the Rate of Economic Growth, Working Paper, University of California.

- $\quad$ Rajan, R.G. and Zingales, L., 2003. The Great Reversals: The Politics of Financial Development in the Twentieth Centurt. Journal of Financial Economics, 69, pp. 5-50.

- $\quad$ Redding, S., 1997. Dynamic Comparative Advantage and the Welfare Effects of Trade, Nuffield College Economics Discussion Paper, no. 140.

- Renelt, D., 1991. Economic Growth: A Review of the theoretical and Empirical Literature, Working Papers WPS 678, Washington, D.C.: World Bank.

- Renelt, D., 1991. Economic Growth: A Review of the theoretical and Empirical Literature. Working Papers WPS 678, Washington, D.C.: World Bank.

- $\quad$ Romer, P.M., 1986. Increasing Returns And Long Run Growth. Journal Of Political Economy, 94(5), pp.1002-1037.

- $\quad$ Saint-Paul, G., 1992. Technological Choice, Financial Markets and Economic Development. European Economic Review; 36(4), pp. 763-781.

- $\quad$ Saci, K. and Holden, K., 2008. Evidence on Growth and Financial Development Using Principal Components, Applied Financial Economics, 18(19), pp. 1549 - 1560.

- Schumpeter, J.A., 1912. The Theory of Economic Development, Cambridge: Harvard University Pres.

- Shaw, E.S., 1973. Financial Deepening in Economic Development, New York: Oxford University Pres.

- Şıklar, İ., 1992. Financial Development and Economic Growth in Turkey. Anadolu University Yearbook of Afyon Faculty of Economics and Administrative Sciences, pp.159-182 (in Turkish). 
- Şimşek, M., 2003. An Analysis of the Export-Led Growth Thypothesis with the Data of the Turkish Economy, 1960-2002. Dokuz Eylül University, Journal of the Faculty of Economics and Administrative Sciences, 18(2), pp. 43-63 (in Turkish).

- Svaleryd, H., Vlachos, J., 2002. Markets for Risk and Openness to Trade: How Are They Related? Journal of International Economics, 57, pp. 369-395.

- Svaleyrd, H. and Vlachos, J., 2000. Does Financial Development Lead to Trade Liberalization?, Department of Economics, Research Papers in Economics, No:2000:11, Stockholm University.

- $\quad$ Taşdemir, M., 2008. Estimating Monthly GDP for Turkey by State-Space Approach. International Research Journal of Finance and Economics, 17, pp. 144-151.

- $\quad$ Taylor, M.S., 1994. Once-off and Continuing Gains From Trade, Review of Economic Studies, 61, pp. 589-601.

- $\quad$ Toda, H.Y. and Yamamoto, T., 1995. Statistical Inference in Vector Autoregression with Possibly Integrated Processes. Journal of Econometrics, 66, pp.225-250.

- $\quad$ Tuncer, İ., 2002. Export, Import and Growth in Turkey: Granger Causality Analysis with the TodaYamamoto Approach (1980-2000). Çukurova University Journal of the Institute of Social Sciences, 9(9), pp. 90- 106 (in Turkish).

- Ünalmış, D., 2002. The Causality Between Financial Development and Economic Growth: The Case of Turkey. CBRT Research Department, Working Paper No: 3, Ankara. http://www.tcmb.gov.tr/research/work/wp6.pdf 25.01.2009.

- Utkulu, U. and Kahyaoğlu, H., 2005. To What Direction Did Trade and Financial Opennesses Affect Growth in Turkey?, Turkish Economic Association Discussion Papers 2005/13 (in Turkish).

- Yiğidim, A. and Köse, N., 1997. The Relationship Between Export and Economic Growth, the Effects of Import: The Turkish Case (1980-1996). Ekonomik Yaklaşım, 8(26), pp. 71-85.

- Yücel, F., 2009. Causal Relationships Between Financial Development, Trade Openness and Economic Growth: The Case of Turkey. Journal of Social Sciences 5(1), pp. 33-42. 


\title{
The Influence of Corporate Governance Mechanism to Earnings Management on Indonesia and China Industrial Banking
}

\author{
Prof. Dr. Euphrasia Susy Suhendra (Gunadarma University, Indonesia) \\ Dini Tri Wardani (Gunadarma University, Indonesia)
}

\begin{abstract}
The goal of this research is to evaluate the influence of managerial ownership structure, independent board of commissioners proportion, independent commissioner size, and audit committee size on earnings management in banking industry in China and Indonesia. The data used is secondary data with discretionary accrual as earnings management proxy. Data is processed and analyzed by independent samples t-test and multiple linear regression The results of this research show that there is a difference between earnings management, managerial ownership structure, proportion independent board of commissioners, board of commissioners size in banking industry in Indonesia and China, however there is no difference between Audit Committee size. The variable of managerial ownership structure in Indonesian's banking industry is negatively significant influence on earnings management, whereas in China has no influence. The variable of independent board of commissioners proportion in banking industry in Indonesia has no influence on earnings management, while negatively significant influence on China's. The variable of Board of Commissioners size in Indonesia banking industry positively significant influence on earnings management, while negatively significant influence in China. Then, the variable of Audit Committee size in Indonesia banking industry negatively significant influence on earnings management, whereas positively significant influence in China.
\end{abstract}

\section{Introduction}

Earning management is an intervention conducted by management on financial statement process to external parties, to obtain personal benefit (Rahmawati, 2006). Recently, earning management is a common phenomenon that occurs in several companies. The objective of this practice is to affect the profit rate which can occur legally and illegally. Financial statement scandals occurred in almost all areas including banking area. Financial statement scandals case in Indonesia, for example happenedd in PT Bank Lippo Tbk. The actions of lowering profit in the case of Lippo Bank financial statement double-scandal, proving that the practice of earnings management has begun to enter the banking industry. This makes the banking industry has become interesting to study because the banking industry has more stringent rules than other industries, such as banks must meet the criteria of minimum CAR. Therefore, managers have an incentive to manage earnings so that their companies can meet criteria required by the BI (Setiawati and Na'im, 2001).

Earning management also much happened in China's company. China's economic growth has attracted international investments significantly. In order to protect their investment interests on China's companies, investors institutions apply a transparent and efficient corporate governance system. However, in the past, China received criticism because of corporate governance that is less effective (Shi and Drake, 2002). To respond investor's criticism, China Securities Regulatory Commission (CSRC) has made rules and recommendations for Corporate Governance. CSRC provide conditions for listed companies to deal with Return on Equity (ROE) report on $6 \%$ for three years respectively, and the average of ROE for three years it should be not less than $10 \%$, and the most important criteria for delisted companies is to give the net loss report for three years respectively (Liu and Lu, 2007). Since China joined WTO in 2001, significant steps have been taken to improve corporate governance, especially through the amendment of corporations and securities law. Although China has made improvements to the corporate governance system in recent years, there is still much work to do in order to improve international standards.

Some related research done in China so far has focused on a particular mechanism of corporate governance. For example, Lai and Tam (2005) had researched only on influencing of the Independent Board Commissioners on earning management. Research on the effectiveness of corporate governance in protecting investors in Indonesia has also been a lot done, such as a research which is conducted by Ujiyanto and Pramuka (2007) that evaluate the influence mechanism of corporate governance: the composition of the Independent Board Commissioners, the size of the Board Commissioners and the size of the audit committee on earning management.

\section{Research Objectives}

These paper objective is evaluate the influence mechanism of corporate governance: the composition of the Independent Board Commissioners, the size of the Board Commissioners and the size of the audit committee on earning management. 


\section{Research Methodology}

The population in this research is banking companies in China at 2008-2010 which are listed on the Hong Kong Stock Exchange, and the public banking companies in Indonesia at 2007-2009 periods which is listed in Indonesia Stock Exchange (IDX).

In this research, earnings management measured through the discretionary accruals by disaccording the total accruals (TACC) and nondiscretionary accruals (NDACC). In calculating the DACC, Modified Jones model is used accordance with the results of Dechow et al.'s research (1995).

Following calculation model:

$$
\begin{aligned}
& \mathrm{TACC}_{\text {it }}=\mathrm{NI}_{\mathrm{it}}-\mathrm{OCF}_{\mathrm{it}} \\
& \mathrm{TACC}_{\mathrm{it}} / \mathrm{TA}_{\mathrm{i} . \mathrm{t}-1}=\beta_{1}\left(1 / \mathrm{TA}_{\mathrm{i} . \mathrm{t}-1}\right)+\beta_{2}\left(\Delta \mathrm{REV}_{\mathrm{it}} / \mathrm{TA}_{\mathrm{i} . \mathrm{t}-1}\right)+\beta_{3}\left(\mathrm{PPE}_{\mathrm{it}} / \mathrm{TA}_{\mathrm{i} . \mathrm{t}-1}\right) \text {. }
\end{aligned}
$$

From the regression equation above, NDACC can be calculated by entering the return coefficient $\beta$.

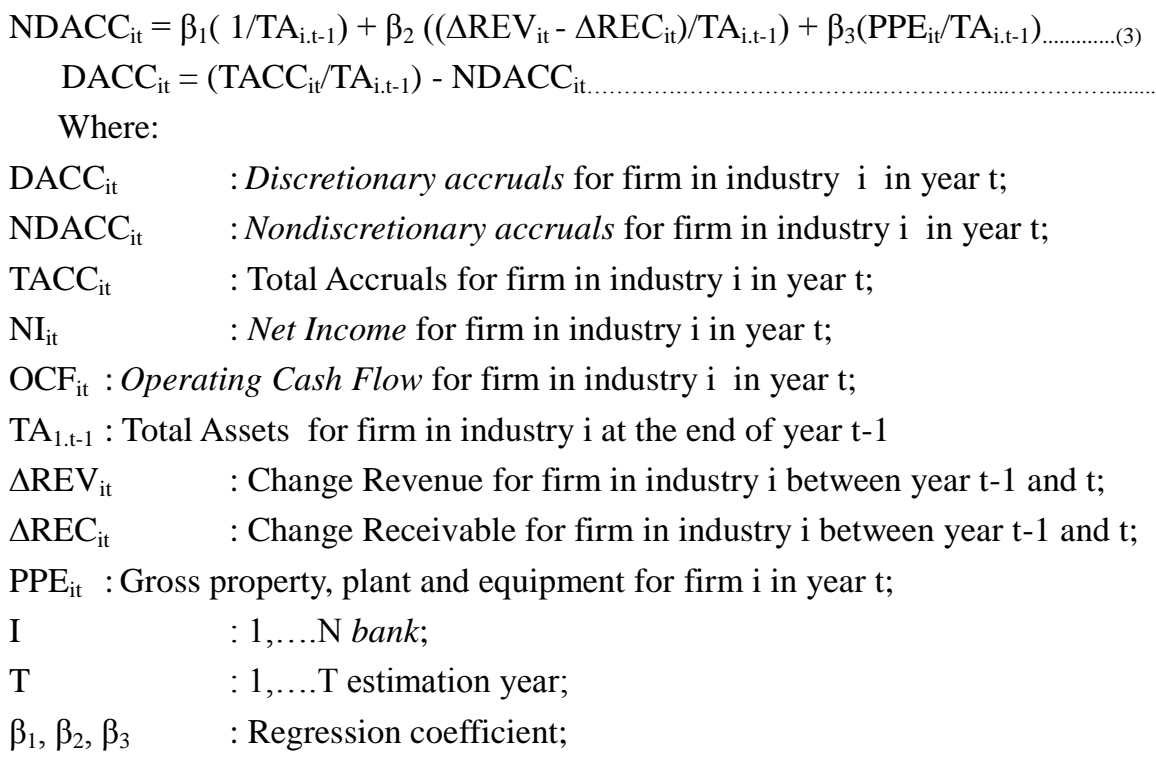

From the formula above, can be found in the absence of earnings management, then the TACC $=$ NDACC, or in other words the number of DACC $=0$.

Indicator that is used to measure the managerial ownership is percentage of the owned shares number by the management of the entire outstanding company's capital stock (Gideon, 2005).

This variable is measured using indicator of the Independent Board of Commissioners number percentage on Board of Commissioners total number of its members which is available in Company's Board of Commissioners structure (Chtourou, 2001).

Board of Commissioners size is measured using indicator of the Board of Commissioners members' number in a company (Ujiyanto \& Pramuka, 2007).

Audit Committee (AC) size is measured using indicator i.e. the total number of audit committee members, both originating from internal and from external companies.

\section{Literature And Theoretical Background}

Scott (2000) divided understanding of the earnings management into two. First, see it as opportunistic behavior of managers to maximize utility in dealing with compensation contracts, debt contracts and political costs (Profit Opportunistic Management). Second, by looking at earnings management from the perspective of efficient contracting (Efficient Profit Management), where earnings management give managers a flexibility to protect themselves and the company in order to anticipate unexpected events for the parties' benefit that get involved in the contract.

According to SFAS No. 1 accrual concept of discretionary and accrual nondiscretionary. Discretionary Accruals (DA) is an accrual that can be controlled or determined by management in which management can freely choose policies in selecting methods and estimates of accounting that will be used. Meanwhile, the NonDiscretionary accruals (NDA) is an accrual that can not be controlled or determined by management, but is determined based on economic conditions.

The separation of ownership by principal and control by agent in a company is inclined because agency conflict between principal and agents (Watts and Zimmerman, 1989). In this such conditions, required a control 
mechanism to align the differentiation between the management and principal's interest. Hence, good corporate governance is considered necessary. Komite Nasional Kebijakan Governance (KNKG, 2006) defines corporate governance as a process and structure that is used by the company in order to give add value to the company on going in the long term for shareholders, while paying attention to the stakeholders interests, based on the legislation rules and norms.

Since China joined the WTO in 2001, significant steps have been taken to improve corporate governance, especially through corporate law amendment and securities. Improvements have also given to minority shareholders positions that have been granted the authorization to organize, make movement and led the shareholders meeting. Significant progress has been done particularly to improve the governance structure in banking and equity markets. Then the hypothesis research as follows:

H1: Earnings Management in banking industry in Indonesia is different with banking industry in China.

One of the corporate governance mechanisms which are used to reduce agency cost is by increasing the ownership by management. The separation of ownership by principal and control by agents in an organization give agency conflicts between principal and agent. To minimize this conflict is by enhancing the managerial ownership in company (Siallagan and Machfoedz, 2006). From the explanation above then the hypothesis research as follows:

H2 : Managerial Ownership Structure in banking industry in Indonesia is different with banking industries' in China.

The Board Commissioners is enterprise component who are responsible collectively monitoring and providing advice to the Board Directors and ensure that enterprises carry out GCG (KNKG, 2006). To implement good corporate governance, registered companies should have mandatory independent Commissioner and the size is proportional to the number of stokes that is not owned by shareholder controller with a provision that Independent Commissioner is at least $30 \%$ of the total number of Commissioner Members. From the explanation above then the hypothesis as follow:

H3: Independent Board Commissioners' proportion in banking industry in Indonesia is different with banking industries' in China.

H4: The size of the Board Commissioners in banking industry in Indonesia is different with banking industries' in China.

The audit committee is one of the essential elements in realizing the implementation of good corporate governance. Based on Circulars IDX, SE-008/BEJ/12-2001, the membership of Audit Committee (AC) at least consists of 3 members including a Chairman of audit committee. On respect to the audit committee functions, indicated that the company that owns the audit committee has intensity of earning management activity lower than in companies that does not have audit committee. From the explanation above then the hypothesis research as follows:

H5: The size of Audit Committee in banking industry in Indonesia is different with banking industries' in China.

A wide research on corporate governance has been done with inconsistent results. One of those is research done by Midiastuty and Machfoedz (2003) the result of this research is managerial ownership and institutional ownership negatively influence on earnings management, whereas the size of Board Directors positively influence on earnings management. The analysis result Ujiyantho and Pramuka (2007) show that only managerial ownership which influence significantly to earnings management. Ding et al. (2004) analyzes show that there is no relationship between ownership shares concentration to the earnings management calculation in private enterprise, but instead in the national enterprise there is significant relationships.

Research Siallagan and Machfoedz (2006) the results prove that managerial ownership positively influence to the earnings quality, Board Commissioners negatively influence to the earnings quality, and audit committee positively influence to the earnings quality. Nasution and Setiawan (2007) was found that the proportion of independent Board Commissioners has negative influence on earnings management, size of the Board Commissioners has positive influence on earnings management, and the existence of audit committee negatively influence on earnings management.

Xie et al. (2003) the results of his research shows that audit committee from outside are able to protect the shareholders' interests from earnings management practice. The study result also found a negative relationship between the proportions of Independent Management Board Commissioner on earnings management and found a positive relationship between sizes of Board Commissioners on earnings management. Beasley (1996) concluded that the proportion of the Board Commissioners from outside can reduce financial statement fraud. The study also shows that the size of Council and characteristic of Independent Commissioner has influence in financial statement fraud. Chtourou et al (2001) found that the Board Commissioners and audit committee are significantly related to earnings management practice. 
From the view of management accounting theory, earnings management highly determined by company's manager motivation. Jensen and Meckling (1976) show that earnings management can be minimalized by enlarging the stock ownership by the company management (managerial ownership). From the explanation above then the hypothesis research as follows.

H6a: Managerial ownership Structure significant influence on earnings management in banking industry in Indonesia.

H6b: Managerial ownership Structure significant influence on earnings management in banking industries' in China.

The Board Commissioners as a top company's internal control system has the role as supervisory activities (Siallagan and Machfoedz, 2006). In general the Board Commissioners was commissioned and given responsibility for monitoring the information quality contained in financial statements. Research Beasley (1996) concluded that the proportion of Independent Board Commissioners can reduce financial statement fraud. From the explanation above then the hypothesis as follows:

H7a: Proportion of Independent Board Commissioners significantly influence on earnings management in banking industry in Indonesia.

H7b: Proportion of Independent Board Commissioners significantly influences on earnings management in banking industry in China.

Board Commissioners size are able to give the influence on company's performance. Yu (2006) found that the size of Board Commissioners has negatively influence on earnings management. This signifies that fewer Board Commissioners then make the earnings management practice higher because of few Board Commissioners. It makes possibility for organizations to be dominated by the management to bring their roles. From the explanation the hypothesis as follows:

H8a: Size of the Board Commissioners significantly influence on earnings management in banking industry in Indonesia.

H8b: Size of the Board Commissioners significantly influence on earnings management in banking industry in China.

The audit committee will be able to reduce the earnings managements practice. Siallagan and Machfoedz (2006) found that the audit committee has positively influence to earnings and value quality of the company. From the explanation above then the hypothesis research as follows:

H9a: Size of audit committee significantly influences on earnings management in banking industry in Indonesia.

H9b: Size of audit committee significantly influences on earnings management in banking industry in China.

\section{Analysis and Discussion}

Based on the discussion of theory, research data, research variables, and previous studies, this research form the regression equation using the following model:

$$
\begin{array}{ll}
\text { Model 1: } & D A C C=\alpha+\beta_{1} M S O+\beta_{2} P B O C+\beta_{3} S B O C+\beta_{4} S A C \\
\text { Model 2: } & D A C C=\alpha+\beta_{1} M S O+\beta_{2} P B O C+\beta_{3} S B O C+\beta_{4} S A C
\end{array}
$$

Based on the analysis $\mathrm{H} 1$ is accepted, i.e. there is differentiation between earnings management in banking industry in Indonesia and China. If it is viewed from average of earnings managements two group, China's banking industry has higher earnings management than banking in Indonesia. The high of earnings management in banking industry in China due to the China Securities Regulatory Commission (CSRC) has made the rules and recommendations on Corporate Governance. CSRC presuppose to companies listed to meet the criteria for Return on Equity (ROE) reported is $6 \%$ for three consecutive years, and the average ROE over the these years must be not less than $10 \%$, and the criteria that are most important to de-listings of registered company is reporting a net loss for three consecutive years (Liu and $\mathrm{Lu}, 2007$ ). It is not an easy thing for Chinese companies to comply the regulation. Therefore, the managers will do everything that is able to avoid a net loss for these three years respectively by doing earnings management. Whereas in Indonesia during the global crisis (observation period), the banking industry is precisely able to increase revenues significantly (Colin, 2009). It has made banking industry in Indonesia do not do earnings management extremely.

$\mathrm{H} 2$ is acceptable where there is difference between managerial ownership structure on banking industry in Indonesia and China. If it is viewed from average of managerial ownership structure two groups, China's banking industry has higher managerial ownership structure than banking in Indonesia.The high of managerial ownership struc ture in China's banking basically is caused of all the companies in China adopt managerial ownership governance. The manager has a large stock in company because of China's Government issued regulations management stock incentive to set rules and encourage companies to provide stock for top management in order to reduce the agency conflict (Andy, 2012). Similarly in Indonesia, managerial ownership 
structure is utilized to reduce the agency conflict, increasing the proportion managerial stock ownership then company performance will be better. Greater stock ownership in economic terms has incentive to monitor management. Theoretically, when managerial ownership is lower, then the incentive on possibility of opportunistic management will increase. Managerial ownership on company's stock can be seen aligning potential interest differentiation between shareholders and management (Ujiyanto \& Pramuka, 2007). But in fact, managerial ownership structure in banking industry is very low so the agency conflict in company is inevitable.

H3 is acceptable where there is difference between Independent Board of Commissioners in banking industry in Indonesia and China. If viewed from the average of two proportion independent Board of Commissioners groups in banking industry in Indonesia is higher than banking in China. This is caused by the existence of independent Commissioner in Indonesia have been regulated in Decree of Jakarta Stock Exchange (JSX) directors, Number: Kep 315/JSE/06-2000 which declare that in order to make a good corporate governance, companies listed on the JSE must have an independent Commissioner which the number of proportion equal to the number of ownership by shareholder that does not have control with concern on total number of Independent Commissioner at least $30 \%$ from total number of Commissioners members.

Meanwhile, the China Securities Regulatory Commission (CSRC) in 2001 issued a regulation that Chinese companies that are listed have at least 2 Board of Commissioners which is independent and must have a basic knowledge in law and regulations in capital market field (Lai et al., 2005). The Independent Board of Commissioners should be honest and responsible, with the experience is more than 5 years working in related fields. However, it is not easy for China's enterprises to get independent Board of Commissioners in accordance with the regulations of the CSRC. Therefore the proportion independent Board of Commissioners in banking industry in Indonesia is higher than banking industry in China.

H4 is acceptable where there is difference between Board of Commissioners size on the banking industry in Indonesia and in China. If viewed from the average of two sizes of the Board of Commissioners groups in banking industry in China is higher than banking in Indonesia. This is caused by number of Board of Commissioners will influence on work efficiency. The number of Board of Commissioners that regulated by law firm in China is 5-7 people. The specific number must be determined within the framework of budget based and should be revised in the shareholders meeting. The number of Board of Commissioners is determined by company size. To be larger of the company the number of Board of Commissioners will be greater (Zhong, 2002). While in Indonesia, the number of Board of Commissioners depend on the industry in which the company will contribute to determine the type of competence that should be owned by the Board of Commissioners as a whole. Therefore the number of Board of Commissioners member is determined by the number of expertise types which is needed in the industry. The number of Board of Commissioners which is too large will make the process of searching an agreement and the process of making decisions becomes difficult (Rony, 2006). This limitation becomes the consideration in determining the number of company's Board of Commissioners members.

H5 is rejected, meaning that there is no difference between Audit Committee size in banking industry in Indonesia and China. If viewed from the average of two groups audit Committee size in banking industry in Indonesia is almost same with banking in China. The size of Audit Committee in a company has a limited effectiveness. The number of audit committee members may not exceed the number of Board of Commissioners, because the optimum effectiveness can be obtained only with a proportional Audit committee number. A small number makes weak monitoring on corporate financial statements conducted by management, while if too large causing weakness in coordinating in the Committee and less effective monitoring. In addition, the audit Committee also has consequences such as, audit opinion, restatements, and earnings management. These will become considerations for Indonesia and China's company to decide the number of audit committee number.

Regression analysis shows that managerial ownership structure in banking industry in Indonesia has negative significantly influence on earnings management, so in this research H6a can be accepted. While in China's banking data, do not influence significantly on earnings management, so in this research H6b can be rejected. Independent Board of Commissioners proportion in banking industry in Indonesia do not significantly influence on earnings management, so in this research $\mathrm{H} 7 \mathrm{a}$ can be rejected. While in China's banking data, negative significantly influence on earnings management, so in this research $\mathrm{H} 7 \mathrm{~b}$ can be accepted. Board of Commissioners size in banking industry in Indonesia positive significantly influence on earnings management, so in this research H8a can be accepted. While in China's banking data, negative significantly influence on earnings management, so in this research $\mathrm{H} 8 \mathrm{~b}$ can be accepted. Audit committee size in banking industry in Indonesia negative significantly influence on earnings management, so in this research H9a can be accepted. While in China's banking data, positive significantly influence on earnings management, so in this research $\mathrm{H} 9 \mathrm{~b}$ can be accepted.

The regression calculation result for banking industry data in Indonesia indicate that managerial ownership structure variables, independent Board of Commissioners, Board of Commissioners size and audit Committee size in banking industry in Indonesia and China simultaneously or together has influence on earnings management. 


\section{Conclusion}

Based on the research results and discussion in previous chapter can be concluded:

There is a difference between earnings management in banking industry in Indonesia and China. The average of earnings management in banking industry in China is higher than in Indonesia.

There is a difference between managerial ownership structure in banking industry in Indonesia and China. The average of managerial ownership structure in banking industry in China is higher than in Indonesia. However, based on hypothesis managerial ownership structure test result in banking in China negative significantly influence on earnings management, while in banking in Indonesia shows that managerial ownership structure has no significantly influence on management.

There is a difference between proportion independent Board of Commissioners in banking industry in Indonesia and China. The average proportion independent Board of Commissioners in banking industry in Indonesia is higher than in China. However, based on the hypothesis test result, showed that the proportion independent Board of Commissioners in banking industry in Indonesia has no significantly influence on earnings management practices, while in China's banking, proportion independent Board of Commissioners variable has negative significantly influence on earnings management.

There is a difference between Board of Commissioners size in banking industry in Indonesia and China. The average of Board of Commissioners size in banking industry in China is higher than in Indonesia. However, based on hypothesis test result is showed that Board of Commissioners size in banking industry in Indonesia is positive significantly influence on earnings management, while in China's banking shows that Board of Commissioners size has negative significantly influence on earnings management.

There is no difference between Audit Committee size in banking industry in Indonesia and China. The average of Audit Committee size in banking industry in Indonesia is almost same with China's banking. Based on hypothesis test result is showed that Audit Committee size in banking industry in Indonesia negative significantly influence on earnings management, while in China's banking data is showed that audit committee size is positive significantly influence on earnings management.

\section{References}

- Andy. 2012. "Correlation Comparison of Managerial Ownership and Company Performance between Before and After Reform of the Shareholder Structure." Economic Paper.

- Beasley, M. 1996. An Empirical Analysis of The Relation Between The Board of Director Compensation and Financial Statement Fraud. The Accounting review, vol. 71, pp. 443-465.

- Capital Market Supervisory Agency. 2004. "Pembentukan dan Pedoman Kerja Komite Audit." Kep29/PM/2004.

- Chen, Xin. and Nan Zhou. 2009. “Audit Committee Effectiveness: Evidence From a Government Inspection in China.” Working paper. University Jiaotong.

- Chtourou, S.M., Bedard, J. and Courteau, L. 2001. Corporate governance and earnings Management. working paper. University of Laval Canada.

- Cornett, et.al. 2006. "Earnings Management, Corporate Governance and True Financial Performance." Working Paper Series.

- $\quad$ Daniel, Wahyu. 2010. Industri Perbankan RI Terus Melaju Pasca Krisis. Detik Finance.Available:http://www.detikfinance.com.

- Dechow, Patricia M., R.G. Sloan and A.P. Sweeney. 1995. "Detecting earnings management." The Accounting Review 70. 193-225.

- $\quad$ Ding Y., Zhang H., Zhang J.X. 2004. “ Ownership Concentration and Earnings Management: A Comparison Between Chines Private and State-Owned Listed Companies”. Research in Accounting Conference. 4-6 July 2004. Singapore.

- Ghozali, Imam. 2006. Aplikasi Analisis Multivariate dengan Program SPSS. Semarang: Badan Penerbit Universitas Diponegoro.

- Gideon. 2005. "Kualitas Laba: Studi Pengaruh Mekanisme Corporate Governance dan Dampak Manajemen Laba dengan Menggunakan Analisis Jalur.” Simposium Nasional Akuntansi 8. Solo.

- Hongkong Stock Exchange. Laporan Keuangan Tahunan Perusahaan Perbankan Go Publik Tahun 2006, 2007, 2008, 2009. Available: http://www. hkex.com. hk.

- Ikatan Akuntan Indonesia. 2002. Statement of Financial Accounting Standard. Salemba Empat. Jakarta. 
- Indonesia Stock Exchange. Laporan Keuangan Tahunan Perusahaan Perbankan Go Publik Tahun 2006, 2007, 2008, dan 2009. Available: http://www.idx.co.id.

- Jennings, M. M. 2005. "Conspicuous Governance Failures: Why Sarbanes-Oxley Is not an Ethics Warranty.” Corporate Finance Review, 9:5 (Maret/April).

- Jensen and Meckling. 1976. "Theory of The Firm: Managerial Behavior, Agency and Ownership Structure." Journal of Financial Economic. Vol. V 3, No.4.

- Komite Nasional Kebijakan Governance. 2006. Pedoman Umum Good Corporate Governance Indonesia. http:/www.google.com, Access: January $22^{\text {th }} 2012$.

- $\quad$ Lai, L. and Tam, H. .2005. "Independent directors and the propensity to smooth earnings: a study of corporate governance in China”, The Business Review, Vol. 7 No. 1, pp. 328-335.

- $\quad$ Liu, Q. and Lu, Z. .2007. “Corporate governance and earnings management in the Chinese listed companies: A tunneling perspective,” Journal of Corporate Finance, Vol. 13 No. 5, pp. 881-906.

- Midiastuti, Pranata P., and M. Machfoedz. 2003. “Analisis Hubungan Mekanisme Corporate Governance dan Indikasi Manajemen Laba." Simposium Nasional Akuntansi (SNA) VI. Surabaya.

- Nasution, Marihot dan Doddy Setiawan. 2007. "Pengaruh Corporate Governance Terhadap Manajemen Laba Di Industri Perbankan”. Simposium Nasional Akuntansi X, IAI, Makasar.

- Nurhayati, Mafizatun. 2006. “Analisis Data Uji Beda T-Test.” Metode Penelitian. Fakultas Ekonomi.Universitas Mercubuana. Jakarta.

- Rahmawati, et al. 2006. "Pengaruh Asimetri Informasi terhadap Praktik Manajemen Laba pada Perusahaan Perbankan Publik yang terdaftar di Bursa Efek Jakarta.” Simposium Nasional Akuntansi IX.

- $\quad$ Rony, Kusuma Muntoro. 2006. “Membangun Dewan Komisaris yang Efektif.” Working Paper Series.

- $\quad$ Scott, William R. 2000. Financial Accounting Theory. $2^{\text {nd }}$ Ed. Prentice Hall Inc. Ontorio. Canada.

- Setiawati, L., and Naim. 2001. "Manajemen Laba.” Jurnal Ekonomi dan Bisnis Indonesia. Vol. 15, No. 4, hal. 424-441.

- Shi, S. and Weisert, Drake. 2002 'Corporate governance with Chinese characteristics', The China Business, 29:12-19.

- $\quad$ Siallagan, H., dan M. Machfoedz. 2006. Mekanisme Corporate Governance, Kualitas Laba dan Nilai Perusahaan. Simposium Nasional Akuntansi (SNA) IX Padang.

- Surya, Indra dan Yustiavandana, Ivan. 2008. Penerapan Good Corporate Governance. Jakarta: Kencana Prenada Media Group.

- Ujiyanto, Moh. Arief and Bambang A Pramuka. 2007. "Mekanisme Corporate Governance, Manajemen Laba dan Kinerja Keuangan.” Simposium Nasional Akuntansi X.

- Watts, R. L., and J.L. Zimmerman. 1989. Positive Accounting Theory. Englewood Cliffs, NJ: PrenticeHall, Inc., 1989.

- Xie, B., Davidson III, W.N. and DaDalt, P.J. 2003. "Earnings Management and Corporate Governance: the Role of the Borad and the Audit Committee", Journal of Corporate Finance, Vol. 9 No. 3, pp. 295-316.

- Yermack, D., 1996. Higher market valuation of companies with a small board of directors. Journal of Financial Economics, 40, 185a. 211.

- Yu, Q., Du, B., and Sun, Q. 2006. "Earnings management at rights issues thresholds - evidence from China", Journal of Banking and Finance, Vol. 30 No. 12, pp. 3453-3468.

- Zhong, Jiyin. 2002. "Board of Director: Composition, Meeting and Committee." Research Fellow Institute of Economics. Chinese Academy of Social Sciences. 


\title{
On the Predictive Power of the Yield Spread for Future Growth and Recession: The Turkish Case
}

\author{
Asst. Prof. Dr. Hüseyin Kaya (Bahçeşehir University, Turkey)
}

\begin{abstract}
This paper investigates the predictive power of the yield spread on future industrial production growth and recession in Turkey. Employing the linear regression model we find that the yield spread has predictive power when forecasting industrial production growth. The results also suggest that in the inflation targeting monetary policy period, predictive power of the yield spread has increased. Furthermore, we investigate whether the yield spread predicts recession by employing a probit model. Since no official recessions are available in Turkey, we determine the recessions using the BBQ methodology. The findings suggest that the yield spread predicts the recessions about one year ahead.
\end{abstract}

Full paper not published upon author's request. 


\title{
The Impact of the US Dollar and the Euro on Currencies in Europe and Asia
}

\author{
Prof. Dr. Malgorzata Doman (Poznan University of Economics, Poland) \\ Prof. Dr. Ryszard Doman (Adam Mickiewicz University, Poland)
}

\begin{abstract}
In this paper, we analyze dependencies between the currencies of chosen emerging countries and the major (global) currencies - the euro and the American dollar. The idea is taken from a paper by Eun and Lai proposing a method to verify an opinion that currencies systematically co-move and the pattern of co-movement is significantly driven by the relative influence of the two global currencies. The observation by Eun and Lai is that in the case when a minor currency XYZ is driven by the US dollar, the exchange rates XYZ/EUR and USD/EUR co-move very closely. In the opposite case, i.e. when the $\mathrm{XYZ}$ is influenced by the euro, the exchange rates $\mathrm{XYZ/USD}$ and EUR/USD show strong interdependence. In our approach, the dynamics of dependencies is modeled by means of 3-regime Markov regime switching copula models, and the considered measures of the strength of the linkages are dynamic Spearman's rho and tail dependence coefficients. Applying the Markov regime switching copula models allows us to capture temporal changes in the impact of the global currencies on the analyzed minor ones. Our results show that the euro area of influence is widening, and that during the considered period some of the analyzed currencies are releasing from the US dollar impact.
\end{abstract}

\section{Introduction}

In the paper, we analyze dependencies between the currencies of chosen emerging countries and the major (global) currencies - the euro and the American dollar. The idea of the investigation is taken from a paper by Eun and Lai (2004) describing the pattern of currency co-movement. The shortage of their approach is that it captures only linear dependencies between the analyzed exchange rates. In our investigation, currency linkages are described by using dynamic copula models. This allows us to apply dependence measures which are better suited to quantify dependence in the case of nonelliptical joint conditional distributions and take into account dependencies between extremes.

Practitioners working in financial markets express very often an opinion that currency co-move and the pattern of this co-movement is significantly driven by the competitive influence of the two global currencies, i.e. the US dollar and the euro. This pattern is a crucial factor of the FX market risk because it determines the possibilities of international portfolio diversification. Moreover, the knowledge about the way in which currencies co-move is very important for understanding many macroeconomic phenomena. The investigation of currency market linkages is more complicated than it is in the capital market case. The reason for this is that the analysis of comovement between two currencies requires the consideration of exchange rates which are always calculated against a third currency. The choice of this third currency certainly influences the results of comparison. Despite this difficulty and the fact that the exchange rate fluctuations are subject to different shocks, it is possible to find some pattern of dependencies suggesting that some currencies can co-move in a predictable manner. A special situation occurs when the third currency involved in the analysis is one of the global currencies: the US dollar or the euro. Eun and Lai (2004) confirm the above mentioned opinion that currency co-movement is significantly driven by the competitive influences of major currencies on minor ones. Their analysis is based on the fact that in the case when a minor currency XYZ is driven by the US dollar, the exchange rates XYZ/EUR and USD/EUR co-move very closely (XYZ/EUR means the price of $1 \mathrm{XYZ}$ in euros). In the opposite case i.e. when the XYZ is influenced by the euro, the exchange rates XYZ/USD and EUR/USD show strong interdependence. Eun and Lai (2004) propose to measure the degree to which a currency is exposed to the influence of a major currency, using the so-called "currency beta". Their idea is obviously taken from the notion of the Sharpe beta. The currency beta is a measure of sensitivity of a currency's exchange rate movements to those of a major currency. The disadvantage of their approach is that it only captures the linear part of dependencies. We propose a different description based on very flexible Markov regime switching copula models that allow for a deeper analysis of the currency market linkages. In this framework, the measure of "normal" dependence is dynamic Spearman's rho. Additionally, we obtain information about the pattern of tail dependencies i.e. the dependencies between extremes.

In the paper, we attempt to discover the nature and dynamics of linkages between the Czech koruna (CZK), Indian rupiah (INR), Polish zloty (PLN), Russian ruble (RUB), Turkish lira (TRY), and the global currencies: the US dollar and the euro. The aim of the investigation is to describe the possible changes in the impact of the two major currencies on the considered currencies of the emerging countries during last 16 years. Our results confirm that CZK and PLN are in the euro area of influence. They also suggest that the currencies INR, RUB and TRY seem to be connected with the US dollar. However, the increasing impact of the euro on those currencies is observed. 


\section{Copulas and Dependence Measures}

The usual Pearson linear correlation still plays a significant role in financial econometrics, yet it should be realized that this tool for measuring dependence between financial returns is appropriate only in the case of elliptical distributions (e.g. multivariate normal or multivariate Student's $t$ distributions). Outside this class of distributions a more adequate measure of dependence is provided by the concept of copula. A bivariate copula can be defined as a mapping $C:[0,1] \times[01] \rightarrow[0,1]$ from the unit square into the unit interval which is a distribution function with standard uniform marginal distributions.

Assume that $(X, Y)$ is a 2-dimensional random vector with joint distribution $H$ and marginal distributions $F$ and $G$. Then by a theorem by Sklar (1959) $H$ can be written as

$$
H(x, y)=C(F(x), G(y)) \text {. }
$$

If $F$ and $G$ are continuous, the function $C$ is unique and is given by

$$
C(u, v)=H\left(F^{\leftarrow}(u), G^{\leftarrow}(v)\right),
$$

for $u, v \in[0,1]$, where $F^{\leftarrow}(u)=\inf \{x: F(x) \geq u\}$. In this case, $C$ is called the copula of $H$ or of $(X, Y)$. Since by means of the copula $C$ the marginals and the dependence structure can be separated, it makes sense to interpret the copula as the dependence structure of the vector $(X, Y)$.

The simplest copula is defined by $C^{\Pi}(u, v)=u v$ and it corresponds to independence of marginal distributions. In the empirical part of this paper we will also use the Gaussian, Joe-Clayton, and rotated Joe-Clayton copulas. They are defined as follows:

$$
\begin{aligned}
& C_{\rho}^{\text {Gauss }}(u, v)=\Phi_{\rho}\left(\Phi^{-1}(u), \Phi^{-1}(v)\right), \\
& C_{\kappa, \gamma}^{J-C}(u, v)=1-\left(1-\left(\left[1-(1-u)^{\kappa}\right]^{-\gamma}+\left[1-(1-v)^{\kappa}\right]^{-\gamma}-1\right)^{-1 / \gamma}\right)^{1 / \kappa}, \\
& C_{\kappa, \gamma}^{J-C_{-} r 90}(u, v)=v-C_{\kappa, \gamma}^{\mathrm{J}-\mathrm{C}}(1-u, v) .
\end{aligned}
$$

In formula (3), $\Phi_{\rho}$ denotes the distribution function of standard 2-dimensional normal vector with the linear correlation coefficient $\rho$, and $\Phi$ stands for the standard normal distribution function. The parameters in the Joe-Clayton copula (4) are assumed to satisfy the conditions: $\kappa \geq 1, \gamma>0$. For $\kappa=1$, the Joe-Clayton copula becomes the Clayton copula $C_{\gamma}^{\text {Clayton }}$. In the limit case $\gamma=0$, the Clayton copula approaches the independent copula $C^{\Pi}$ (Nelsen 2006). The rotated version of the Joe-Clayton copula, $C_{\kappa, \gamma}^{J-C_{-} r 90}$, allows for the modeling of negative dependence, which is not possible using the copula $C_{\kappa, \gamma}^{J-C}$.

The density associated to a copula $C$ is a function $c$ defined by

$$
c(u, v)=\frac{\partial^{2} C(u, v)}{\partial u \partial v} \text {. }
$$

In the case of continuous random vector, the copula density $c$ is related to joint density function $h$ by the following canonical representation:

$$
h(x, y)=c(F(x), G(y)) f(x) g(y),
$$

where $F$ and $G$ are the marginal distribution functions, and $f$ and $g$ are the marginal density functions.

If the joint distribution of a random vector $(X, Y)$ is nonelliptical, measures of dependence, which are more appropriate than the linear correlation coefficient, are copula-based ones. An example of such a measure, used in the empirical part of this paper, is Spearman's rho. It can be defined as

$$
\rho_{S}(X, Y)=\rho(F(X), G(Y)),
$$

where $F$ and $G$ are the distribution functions of the variables $X$ and $Y$, respectively (McNeil et al. 2005). If $(X, Y)$ is a vector of continuous random variables with copula $C$, then

$$
\rho_{S}(X, Y)=\rho_{C}=12 \iint_{[0,1]^{2}} C(u, v) d u d v-3
$$

(Nelsen 2006). For the Gaussian copula, $C_{\rho}^{\text {Gauss }}$, Spearman's rho equals $\frac{6}{\pi} \arcsin \frac{1}{2} \rho$. For the Clayton and JoeClayton copulas, it can be computed numerically using (9). Spearman's rhos for the copula $C_{\kappa, \gamma}^{J-C_{-} r 90}$ and $C_{\kappa, \gamma}^{J-C}$ are equal in magnitude and have opposite signs. 
A very important concept relevant to dependence in extreme values is tail dependence (see Joe 1997). If $X$ and $Y$ are random variables with distribution functions $F$ and $G$ then the coefficient of upper tail dependence is defined as follows

$$
\lambda_{U, U}=\lim _{q \rightarrow 1^{-}} P\left(Y>G^{\leftarrow}(q) \mid X>F^{\leftarrow}(q)\right),
$$

provided a limit $\lambda_{U, U} \in[0,1]$ exists. Analogously, the coefficient of lower tail dependence is defined

$$
\lambda_{L, L}=\lim _{q \rightarrow 0^{+}} P\left(Y \leq G^{\leftarrow}(q) \mid X \leq F^{\leftarrow}(q)\right),
$$

provided that a limit $\lambda_{L, L} \in[0,1]$ exists. If $\lambda_{U, U} \in(0,1] \quad\left(\lambda_{L, L} \in(0,1]\right)$, then $X$ and $Y$ are said to exhibit upper (lower) tail dependence. Upper (lower) tail dependence quantifies the likelihood to observe a large (low) value of $Y$ given a large (low) value of $X$. The coefficients of tail dependence depend only on the copula $C$ of $X$ and $Y$ :

$$
\begin{aligned}
& \lambda_{L, L}=\lim _{q \rightarrow 0^{+}} \frac{C(q, q)}{q}, \\
& \lambda_{U, U}=\lim _{q \rightarrow 0^{+}} \frac{\hat{C}(q, q)}{q} .
\end{aligned}
$$

where $\hat{C}(u, v)=u+v-1+C(1-u, 1-v)$. For the Gaussian copula it holds $\lambda_{U, U}=\lambda_{L, L}=0$ (McNeil et al. 2005), meaning asymptotic independence in the tails. In the case of the Joe-Clayton copula, $\lambda_{U, U}=2-2^{1 / \kappa}$ and $\lambda_{L, L}=2^{-1 / \gamma}$ (Patton 2006). Thus upper and lower tail dependence can change freely of each other.

When the components of the random vector $(X, Y)$ display negative dependence it is convenient to consider negative tail dependence. We define the coefficients of negative tail dependence, $\lambda_{U, L}$ and $\lambda_{L, U}$, as follows

$$
\begin{aligned}
& \lambda_{U, L}=\lim _{q \rightarrow 0^{+}} P\left(Y \leq G^{\leftarrow}(q) \mid X>F^{\leftarrow}(1-q)\right), \\
& \lambda_{L, U}=\lim _{q \rightarrow 1^{-}} P\left(Y>G^{\leftarrow}(q) \mid X \leq F^{\leftarrow}(1-q)\right),
\end{aligned}
$$

provided that the limits exist. It can be directly shown that the coefficients of negative tail dependence are invariants of the copula $C$ of the random vector $(X, Y)$ :

$$
\begin{aligned}
& \lambda_{U, L}=\lim _{q \rightarrow 0^{+}} \frac{q-C(1-q, q)}{q}, \\
& \lambda_{L, U}=\lim _{q \rightarrow 0^{+}} \frac{q-C(q, 1-q)}{q} .
\end{aligned}
$$

It follows from (16) and (17) that for the rotated Joe-Clayton copula $C_{\kappa, \gamma}^{\mathrm{J}-\mathrm{r} \_ \text {r90 }}$ the following holds:

$$
\begin{aligned}
& \lambda_{U, L}\left(C_{\kappa, \gamma}^{J-C_{-} r 90}\right)=\lambda_{L, L}\left(C_{\kappa, \gamma}^{J-C}\right)=2^{-1 / \gamma}, \\
& \lambda_{L, U}\left(C_{\kappa, \gamma}^{J-C_{-} r 90}\right)=\lambda_{U, U}\left(C_{\kappa, \gamma}^{J-C}\right)=2-2^{1 / \kappa} .
\end{aligned}
$$

\section{Markov Regime Switching Copula Models}

We model the joint conditional distributions of bivariate returns using copulas, so the evolution of the conditional copula $C_{t}$ has to be specified. In such approach, usually the functional form of the conditional copula is fixed, but its parameters evolve through time (Patton 2004, 2006). In this paper, however, similarly to we assume that there are three regimes in each of which a fixed copula prevails, and they switch according to some Markov chain. Thus the joint conditional distribution of the vector $r_{t}=\left(r_{1, t}, r_{2, t}\right)$ in the applied Markov regime switching copula model (MRSC model) has the following form

$$
r_{t} \mid \Omega_{t-1} \sim C_{S_{t}}\left(F_{1, t}(\cdot), F_{2, t}(\cdot) \mid \Omega_{t-1}\right)
$$

where $S_{t}$ is a homogeneous Markov chain with state space $\{1,2,3\}$. The parameters of the MRSC model are the parameters of univariate models for marginal distributions (ARMA-GARCH), the parameters of copulas $C_{1}$ ,$C_{2}$ and $C_{3}$, and the transition probabilities, $p_{i j}=P\left(S_{t}=j \mid S_{t-1}=i\right),(i, j) \in\{(1,1),(2,2),(3,3),(1,2),(2,1),(3,2)\}$.

The parameters have been estimated by the maximum likelihood method. The main by-product the estimation are the conditional probabilities $P\left(S_{t}=j \mid \Omega_{t-1}\right)$ and $P\left(S_{t}=j \mid \Omega_{t}\right), j=1,2,3$. They are calculated by means of Hamilton's filter (Hamilton, 1994): 


$$
\begin{aligned}
& P\left(S_{t}=j \mid \Omega_{t-1}\right)=\sum_{i=1}^{3} p_{i j} P\left(S_{t-1}=i \mid \Omega_{t-1}\right), \\
& P\left(S_{t}=j \mid \Omega_{t}\right)=\frac{c_{j}\left(u_{t} \mid S_{t}=j, \Omega_{t-1}\right) P\left(S_{t}=j \mid \Omega_{t-1}\right)}{\sum_{i=1}^{3} c_{i}\left(u_{t} \mid S_{t}=i, \Omega_{t-1}\right) P\left(S_{t}=i \mid \Omega_{t-1}\right)}
\end{aligned}
$$

where $p_{13}=1-p_{11}-p_{12}, p_{23}=1-p_{21}-p_{22}, p_{31}=1-p_{32}-p_{33}, u_{t}=\left(u_{1, t}, u_{2, t}\right)^{\prime}$,

$$
u_{1, t}=F_{1, t}\left(r_{1, t}\right), \quad u_{2, t}=F_{2, t}\left(r_{2, t}\right) \text {, }
$$

and $c_{j}\left(\cdot \mid S_{t}=j, \Omega_{t-1}\right)$ is the density of the conditional copula coupling the conditional marginal distributions in regime $j, j=1,2,3$. The maximized log-likelihood function has of the form

$$
\begin{aligned}
& L=\sum_{t=1}^{T} \ln \left(\sum_{j=1}^{3} c_{j}\left(u_{t} \mid S_{t}=j, \Omega_{t-1} ; \widetilde{\theta}_{j}\right) P\left(S_{t}=j \mid \Omega_{t-1} ; \widetilde{\theta}_{j}\right)\right) \\
& +\sum_{t=1}^{T} \ln \left(f_{1, t}\left(r_{1, t} \mid \Omega_{t-1} ; \theta_{1}\right)\right)+\sum_{t=1}^{T} \ln \left(f_{2, t}\left(r_{2, t} \mid \Omega_{t-1} ; \theta_{2}\right)\right)
\end{aligned}
$$

where $f_{1, t}$ and $f_{2, t}$ are the density functions corresponding to $F_{1, t}$ and $F_{2, t}$, fitted using the AR-GARCH models.

Presenting our empirical results, we use the so-called smoothed probabilities which can be obtained from the predicted and filtered probabilities by using the backward recursion:

$$
P\left(S_{t}=j \mid \Omega_{T}\right)=P\left(S_{t}=j \mid \Omega_{t}\right) \sum_{i=1}^{3} \frac{p_{j i} P\left(S_{t+1}=i \mid \Omega_{T}\right)}{P\left(S_{t+1}=i \mid \Omega_{t}\right)}, \quad t=T-1, \ldots, 1,
$$

where $T$ denotes the length of the sample.

The models are estimated by the two-step maximum likelihood method. First we fit univariate ARMAGARCH models to the return data. The obtained standardized residuals are transformed to uniform variates, using the theoretical cumulative distribution functions. After that copula models are fitted and estimates of dynamic Spearman's rho and the lower and upper tail coefficients and the coefficients of negative tail dependence are calculated using the smoothed probabilities.

\section{The Data, Analysis, and Results}

As it was mentioned before, our investigations follows the idea proposed by Eun and Lai (2004). This idea is that in the case when a minor currency XYZ is driven by the US dollar, the exchange rates XYZ/EUR and USD/EUR co-move very closely. In the opposite case, i.e. when the XYZ is influenced by the euro, the exchange rates XYZ/USD and EUR/USD show strong interdependence. Applying very flexible 3-regime Markov switching copula models, allows us to describe different types of dependence and capture temporal changes in the impact of the global currencies on the analyzed minor ones.

The analysis is based on the percentage daily logarithmic returns of the exchange rates of chosen currencies against the USD and euro. The considered currencies are CZK, TRY, RUB, PLN, INR, and the period under scrutiny is from January 3, 1997 to May 24, 2013 (about 4200 observations). For the period before 1999, exchange rates against the ecu are applied. The exception is the Russian ruble, for which the sample begins from January 3, 2002.

The steps of the presented analysis were as follows. First, to each of the investigated return series we fitted a univariate ARMA-GARCH model. Because the data under scrutiny come from a long period, the fitted models are usually the asymmetric GARCH (EGARCH, APARCH or GJR-GARCH) ones with a Student's $t$ or skewed Student's $t$ distribution for the innovations (Lambert and Laurent 2001). The obtained standardized residuals were routinely examined for the presence of desirable distributional and serial properties. Next, the standardized residuals from the ARMA-GARCH models were transformed by means of the corresponding distribution functions into the series of the form (23), and the MRSC models were fitted by the maximum likelihood method, using the first summand in (24). We tried to apply copulas from various families, and our final choice is the effect of taking into account the obtained values of the information criteria, and the results of the performed likelihood ratio tests where it was applicable. All the calculations were done using G@RCH 6.0 package (Laurent 2009) and the Matlab software. Due to space limit, we do not present here the estimates of univariate models, and focus only on the results concerning estimation of the MRSC models. 
In Tables 1-5 we present the parameter estimates for the fitted MRSC models. The plots in Figures 1-10 show the dynamics of the applied dependence measures. A general observation is that CZK, PLN are in the euro area of influence, whereas INR, RUB and TRY seem to be connected with the USD dollar.

The linkages of the Czech koruna with the euro, measured by means of Spearman's rho, oscillate from 0.6 to 0.9 (Figure 1), what indicates the stable level of dependence. They are described by 2-regime copula model with the Gaussian copula in each regime, what indicates no tail dependence. Dependence between the CZK/EUR and USD/EUR is very weak or even, sometimes, negative (Figures 2, 3).

\begin{tabular}{|c|c|c|c|c|c|c|}
\hline $\begin{array}{l}\text { CZK/USD } \\
\text { EUR/USD }\end{array}$ & Regime 1 & Regime 2 & $\begin{array}{l}\text { CZK/EUR } \\
\text { USD/EUR }\end{array}$ & Regime 1 & Regime 2 & Regime 3 \\
\hline Copula & $C_{\rho}^{\text {Gauss }}$ & $C_{\rho}^{\text {Gauss }}$ & Copula & $C_{\rho}^{\text {Gauss }}$ & $C^{P I}$ & $C_{\kappa, \gamma}^{\text {Joe-Clayto } \theta 0}$ \\
\hline$\rho$ & $\begin{array}{l}0.5927 \\
(0.0197)\end{array}$ & $\begin{array}{l}0.8879 \\
(0.0052)\end{array}$ & $\rho$ & $\begin{array}{l}0.2784 \\
(0.0227)\end{array}$ & & \\
\hline$\kappa$ & & & $\kappa$ & & & $\begin{array}{l}4.0461 \\
(0.0174) \\
\end{array}$ \\
\hline$\gamma$ & & & $\gamma$ & & & $\begin{array}{l}4.8977 \\
(0.0085)\end{array}$ \\
\hline & \multicolumn{2}{|c|}{ Transition probabilities } & & \multicolumn{3}{|c|}{ Transition probabilities } \\
\hline Regime 1 & 0.9689 & 0.0311 & Regime 1 & 0.9989 & 0.0011 & 0.0000 \\
\hline Regime 2 & & 0.9831 & Regime 2 & 0.0001 & 0.9956 & 0.0044 \\
\hline & & & Regime 3 & 0.0051 & 0.0494 & 0.9455 \\
\hline
\end{tabular}

Table 1. CZK. Parameter estimates for MRSC models.

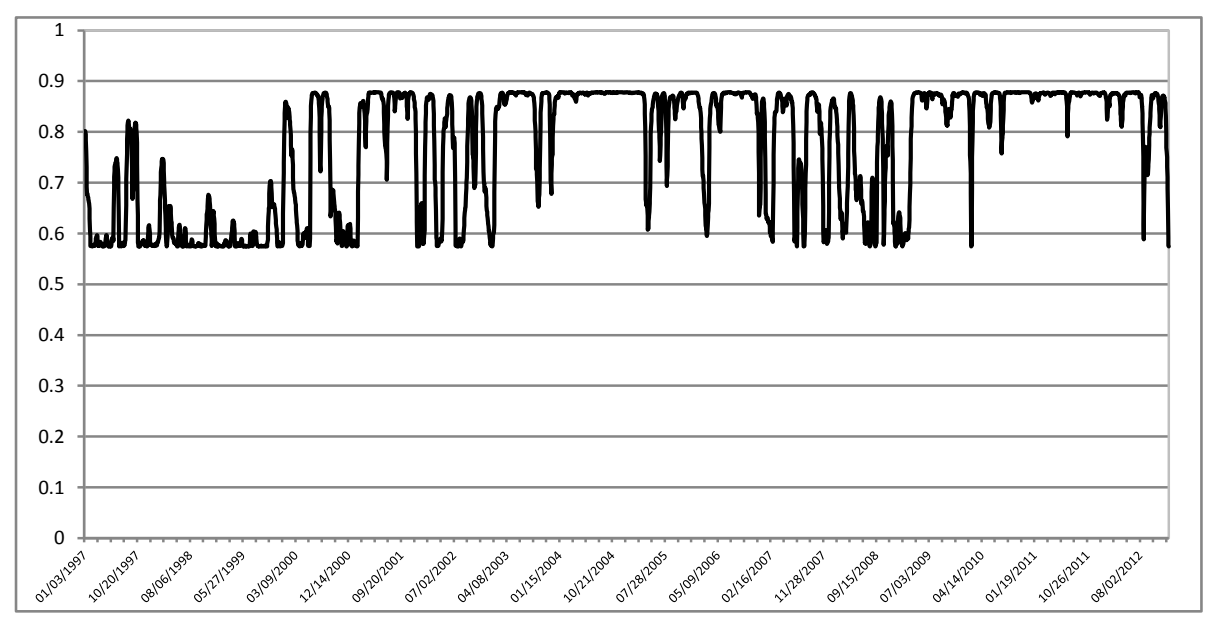

Figure 1. Linkages between CZK and EUR. Spearman's rho for (CZK/USD, EUR/USD)

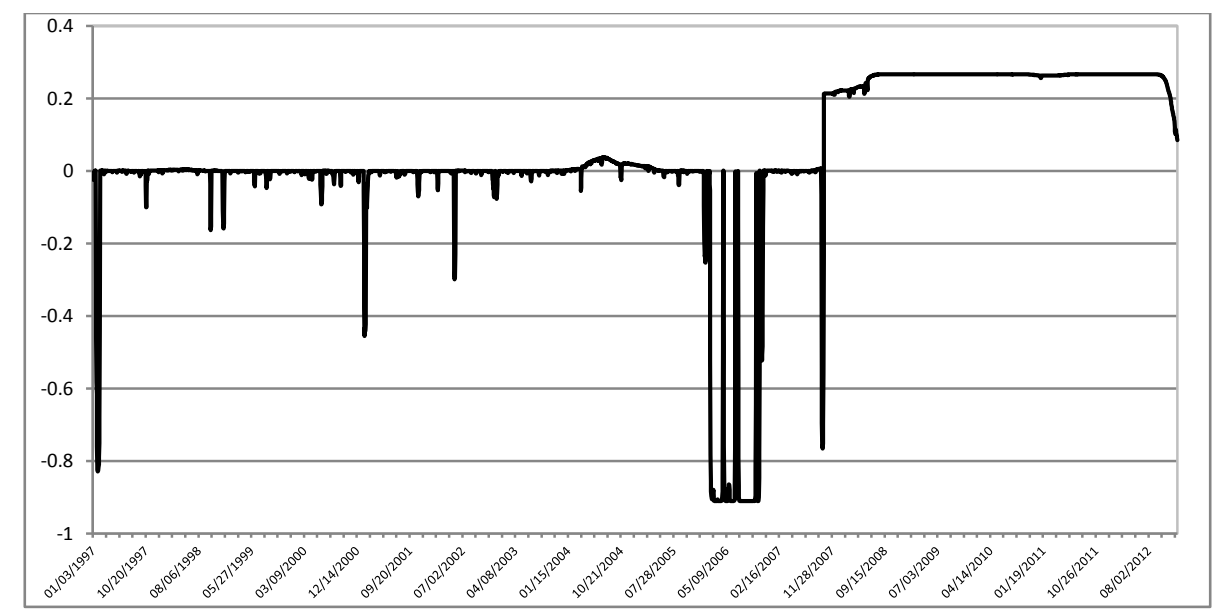

Figure 2. Linkages between CZK and the USD. Spearman's rho for (CZK/EUR, USD/EUR) 


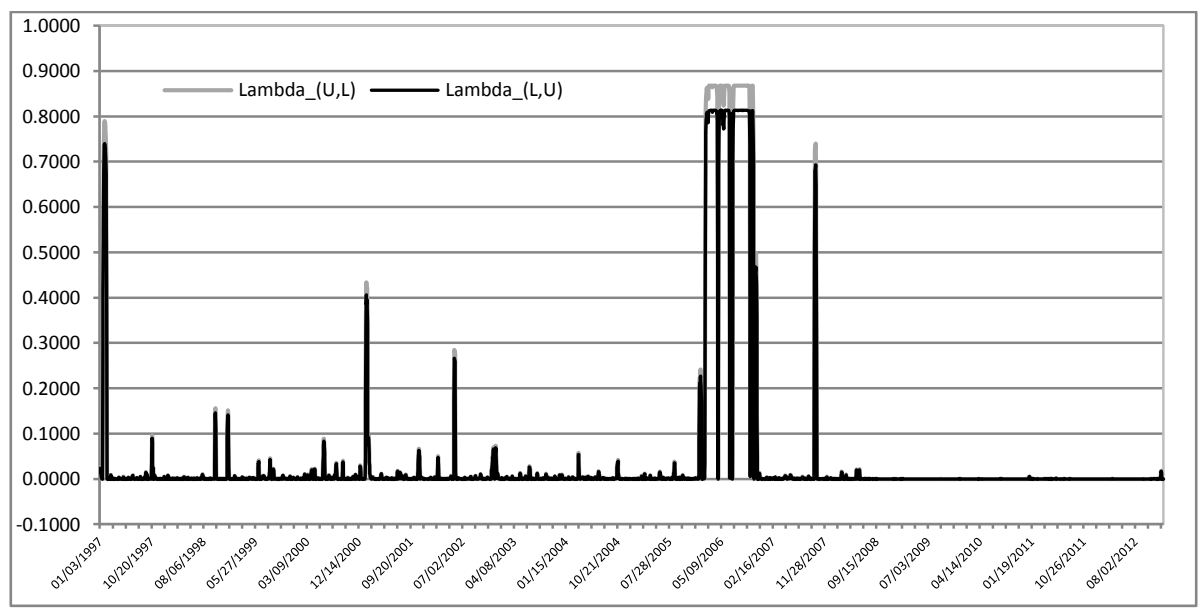

Figure 3. Linkages between CZK and USD. Dependence in tails for (CZK/EUR, USD/EUR)

The dependence between the Indian rupiah and the euro is described by means of 2-regime MRSC model. In regime 1, the Gaussian copula with the correlation coefficient 0.2274 is applied, and in regime 2, the independence copula fits. This means that the dependence between INR and EUR is very weak. Figure 6 shows, however, that the level of dependence jumped in 2004 from negative values to 0.2 . The linkages with the USD are stable with strong dependence in tails (Table 2, Figure 4).

\begin{tabular}{|c|c|c|c|c|c|c|}
\hline $\begin{array}{l}\text { INR/USD } \\
\text { EUR/USD }\end{array}$ & Regime 1 & Regime 2 & $\begin{array}{l}\text { INR/EUR } \\
\text { USD/EUR }\end{array}$ & Regime 1 & Regime 2 & Regime 3 \\
\hline Copula & $C_{\rho}^{\text {Gauss }}$ & $C^{P I}$ & Copula & $C_{\rho}^{\text {Gauss }}$ & $C_{\gamma}^{\text {Clayton }}$ & $C_{k, y}^{\text {Joe-Clayon }}$ \\
\hline$\rho$ & $\begin{array}{l}0.2274 \\
(0.0180)\end{array}$ & & $\rho$ & $\begin{array}{l}0.8538 \\
(0.0160)\end{array}$ & $\begin{array}{l}0.2836 \\
(0.1566) \\
\end{array}$ & \\
\hline$\kappa$ & & & $\kappa$ & & & $\begin{array}{l}4.5441 \\
(0.0001)\end{array}$ \\
\hline$\gamma$ & & & $\gamma$ & & & $\begin{array}{l}5.0000 \\
(0.0003)\end{array}$ \\
\hline & \multicolumn{2}{|c|}{ Transition probabilities } & & \multicolumn{3}{|c|}{ Transition probabilities } \\
\hline Regime 1 & 0.9997 & 0.0003 & Regime 1 & 0.9527 & 0.0337 & 0.0036 \\
\hline Regime 2 & 0.0003 & 0.9997 & Regime 2 & 0.0203 & 0.9797 & 0.0000 \\
\hline & & & Regime 3 & 0.0000 & 0.0045 & 0.9955 \\
\hline
\end{tabular}

Table 2. INR. Parameter estimates for MSC models.

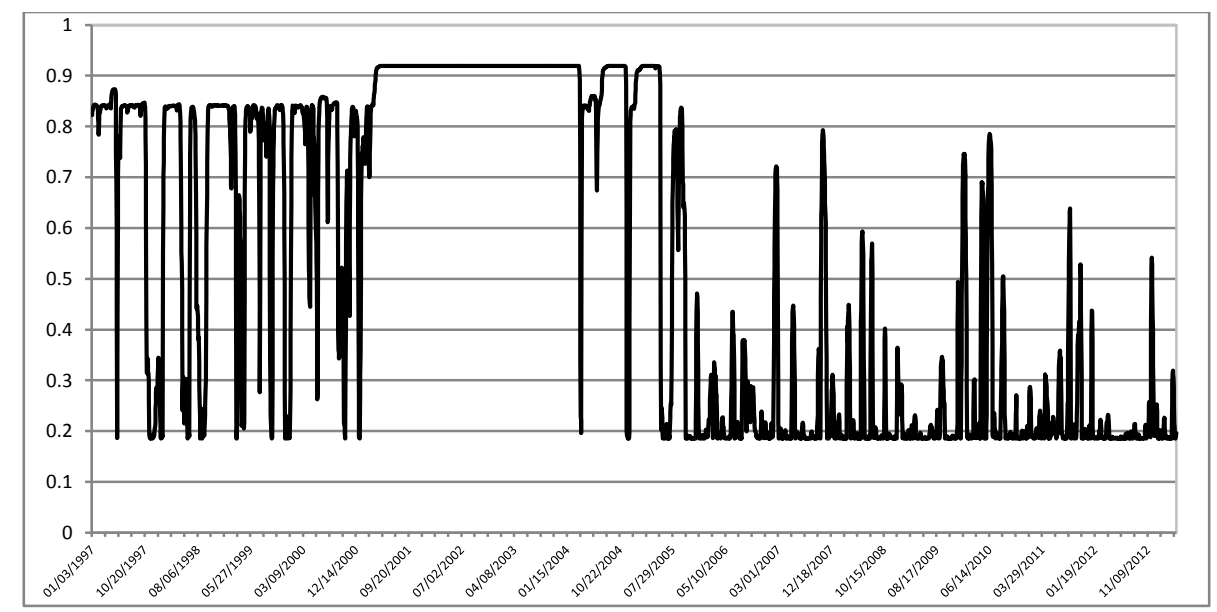

Figure 4. Linkages between INR and USD. Spearman's rho for (INR/EUR, USD/EUR) 


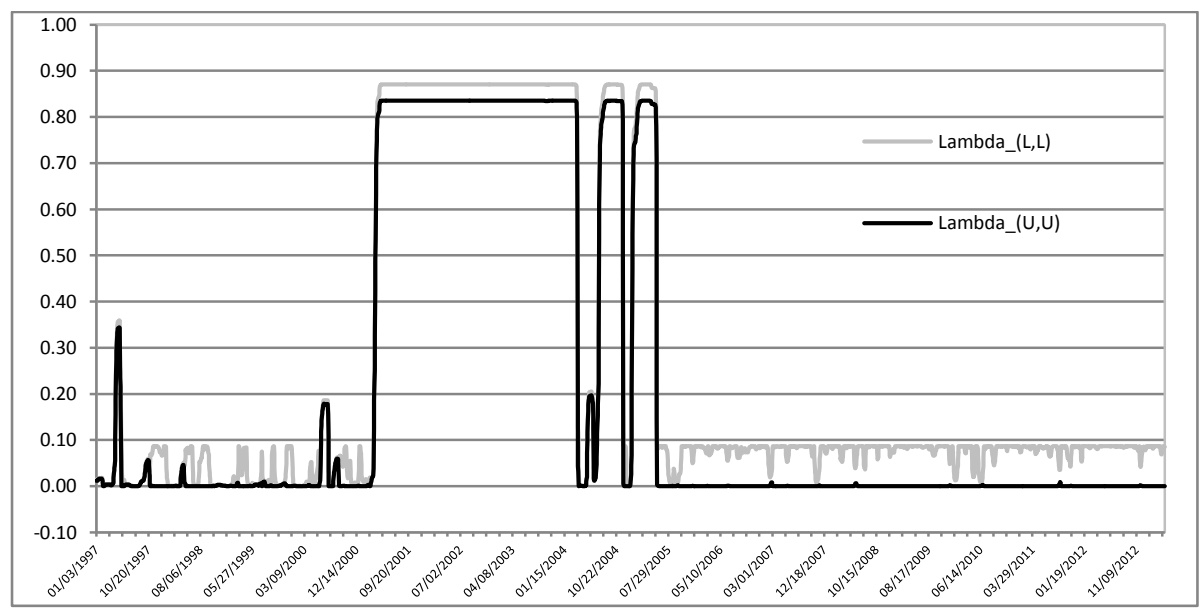

Figure 5. Linkages between INR and the USD. Dependence in tails for (INR /EUR, USD/EUR)

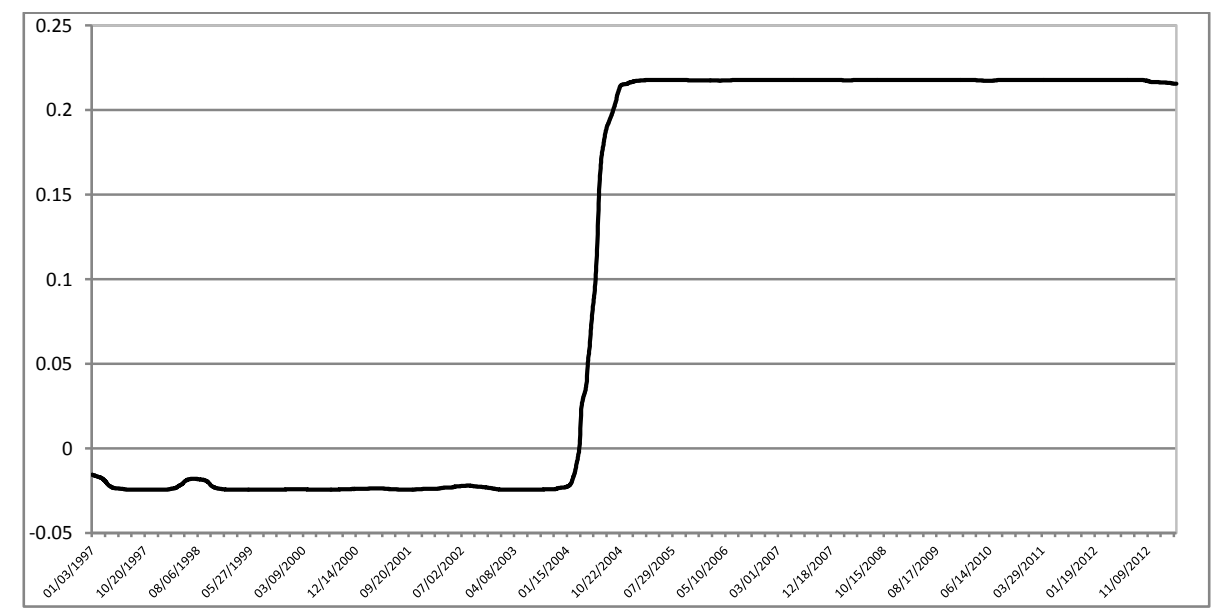

Figure 6. Linkages between INR and EUR. Spearman's rho for (INR/USD, EUR/USD)

In the case of the Polish zloty, we observe a spectacular decrease in the linkages (from 0.4 to negative values, even -0.4) with US dollar after Poland's EU joining in 2004. The connections with the euro are described by means 3- regime MRSC model with the Gaussian copula in regimes 1 and 2, and the Joe-Clayton copula in regime 3 . In the case of the dependence with the US dollar, the applied copulas are the independence, the JoeClayton, and the rotated Joe-Clayton.

\begin{tabular}{|c|c|c|c|c|c|c|c|}
\hline $\begin{array}{l}\text { PLN/USD } \\
\text { EUR/USD }\end{array}$ & Regime 1 & Regime 2 & Regime 3 & $\begin{array}{l}\text { PLN/EUR } \\
\text { USD/EUR }\end{array}$ & Regime 1 & Regime 2 & Regime 3 \\
\hline Copula & $C_{\rho}^{\text {Gauss }}$ & $C_{\rho}^{\text {Gauss }}$ & $C_{\kappa, \gamma}^{\text {Joe-Clayton }}$ & Copula & $C^{P I}$ & $C_{k, \gamma}^{\text {Joe-Clayon }}$ & $C_{\kappa \gamma}^{\text {Joe-Clayton } 90}$ \\
\hline$\rho$ & $\begin{array}{l}0.3409 \\
(0.0219)\end{array}$ & $\begin{array}{l}0.7746 \\
(0.0106)\end{array}$ & & $\rho$ & & & \\
\hline$\kappa$ & & & $\begin{array}{l}1.1751 \\
(0.0708)\end{array}$ & $\kappa$ & & $\begin{array}{l}1.2738 \\
(0.0367)\end{array}$ & $\begin{array}{l}1.1622 \\
(0.0422)\end{array}$ \\
\hline$\gamma$ & & & $\begin{array}{l}0.1693 \\
(0.0893)\end{array}$ & $\gamma$ & & $\begin{array}{l}0.4942 \\
(0.0408)\end{array}$ & $\begin{array}{l}0.5764 \\
(0.0656) \\
\end{array}$ \\
\hline & \multicolumn{3}{|c|}{ Transition probabilities } & & \multicolumn{3}{|c|}{ Transition probabilities } \\
\hline Regime 1 & 0.9990 & 0.0000 & 0.0010 & Regime 1 & 0.9859 & 0.0005 & 0.0136 \\
\hline Regime 2 & 0.0000 & 0.9520 & 0.0480 & Regime 2 & 0.0000 & 0.9997 & 0.0003 \\
\hline Regime 3 & 0.0018 & 0.2053 & 0.7929 & Regime 3 & 0.0127 & 0.0001 & 0.9873 \\
\hline
\end{tabular}

Table 3. PLN. Parameter estimates for MRSC models. 


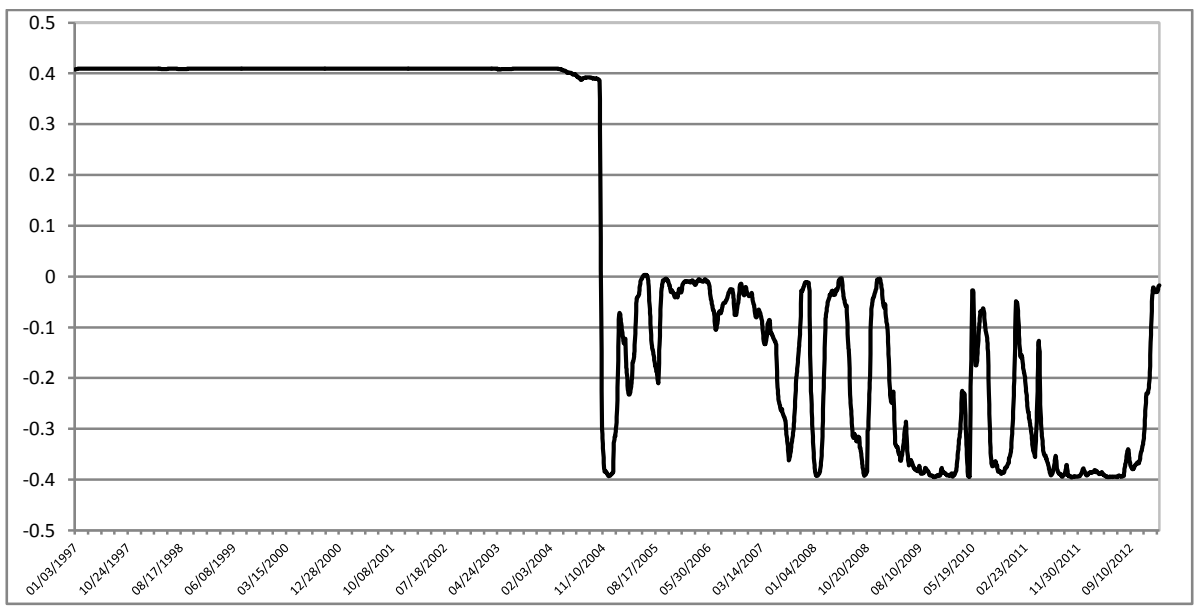

Figure 7. Linkages between PLN and USD. Spearman's rho for (PLN/EUR, USD/EUR)

In the case of the Russian ruble, we analyze shorter time series - from 2002 to 2013. Our results show that during this period the RUB is switching between the areas of influence of the major currencies (Figures 8,9). In the case of linkages with the euro, tail dependence appears (the Joe-Clayton copula in regime 3 ). There is no dependence in tails with the USD against the euro.

\begin{tabular}{|c|c|c|c|c|c|c|c|}
\hline $\begin{array}{l}\text { RUB/USD } \\
\text { EUR/USD }\end{array}$ & Regime 1 & Regime 2 & Regime 3 & $\begin{array}{l}\text { RUB/EUR } \\
\text { USD/EUR }\end{array}$ & Regime 1 & Regime 2 & Regime 3 \\
\hline Copula & $C^{P I}$ & $C_{\rho}^{\text {Gauss }}$ & $C_{\kappa,}^{\text {Joe-Clyyon }}$ & Copula & $C_{\rho}^{\text {Gauss }}$ & $C_{\rho}^{\text {Gauss }}$ & $C^{P I}$ \\
\hline$\rho$ & & $\begin{array}{l}0.5524 \\
(0.0177)\end{array}$ & & $\rho$ & $\begin{array}{l}0.6432 \\
(0.0179)\end{array}$ & $\begin{array}{l}0.9013 \\
(0.0103)\end{array}$ & \\
\hline$\kappa$ & & & $\begin{array}{l}2.0319 \\
(0.1395)\end{array}$ & $\kappa$ & & & \\
\hline$\gamma$ & & & $\begin{array}{l}1.4248 \\
(0.1687)\end{array}$ & $\gamma$ & & & \\
\hline & \multicolumn{3}{|c|}{ Transition probabilities } & & \multicolumn{3}{|c|}{ Transition probabilities } \\
\hline Regime 1 & 0.9977 & 0.0023 & 0.0000 & Regime 1 & 0.9867 & 0.0000 & 0.0133 \\
\hline Regime 2 & 0.0014 & 0.9979 & 0.0007 & Regime 2 & 0.0000 & 0.9891 & 0.0109 \\
\hline Regime 3 & 0.0000 & 0.0026 & 0.009973 & Regime 3 & 0.0372 & 0.0042 & 0.9585 \\
\hline
\end{tabular}

Table 4. RUB. Parameter estimates for MRSC models.

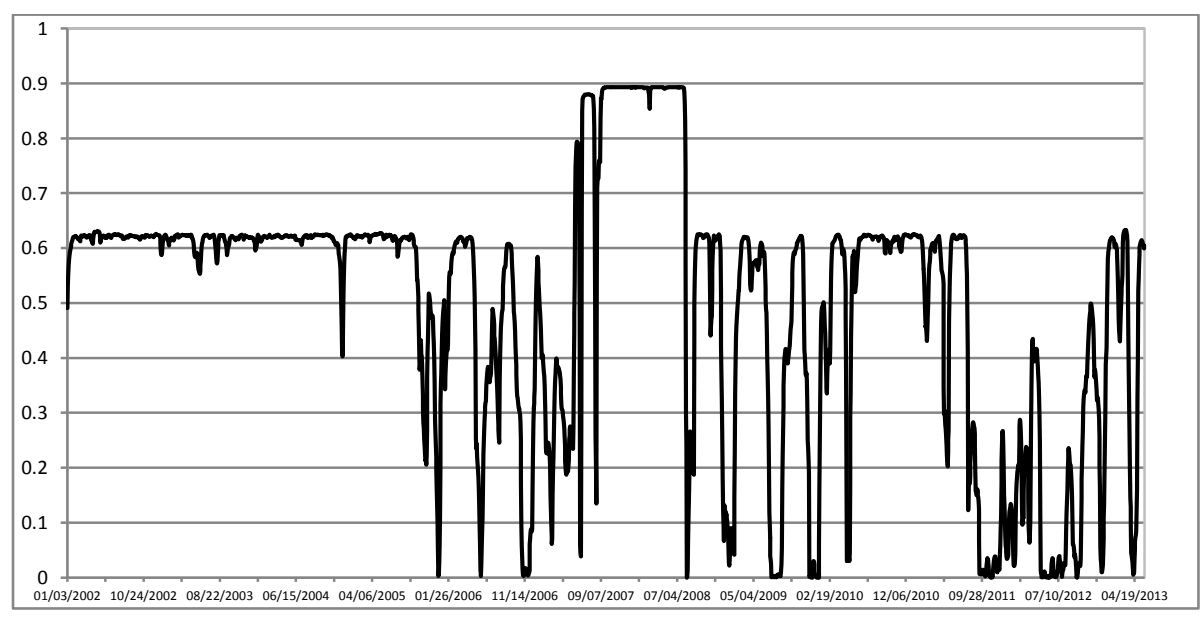

Figure 8. Linkages between RUB and USD. Spearman's rho for (RUB/EUR, USD/EUR) 


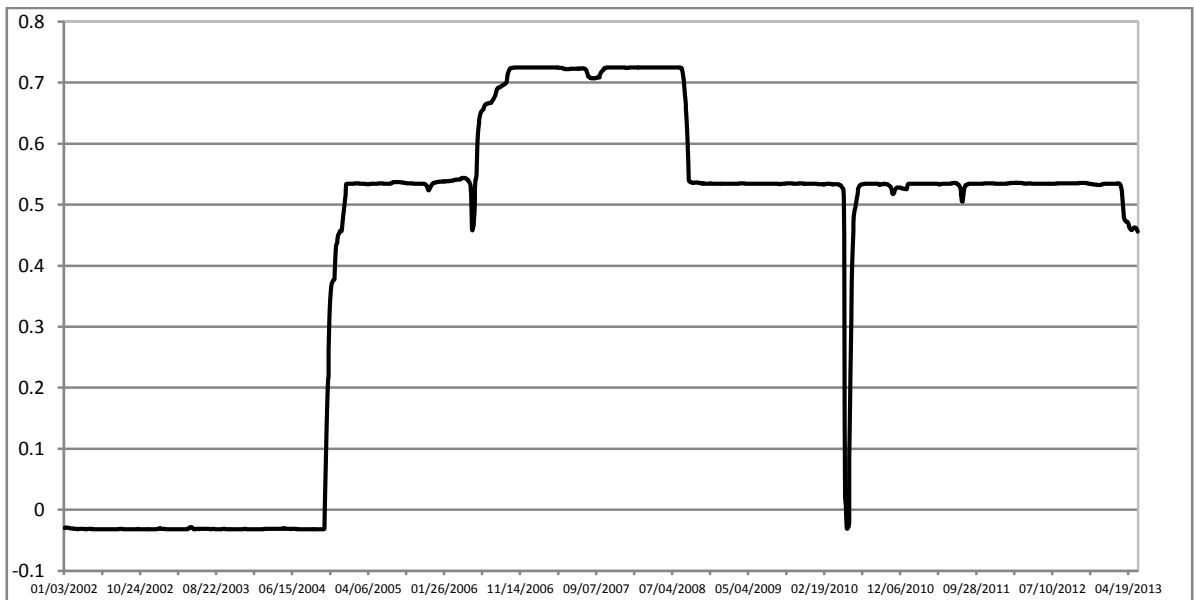

Figure 9. Linkages between the RUB and the EUR. Spearman's rho for (RUB/USD, EUR/USD)

The linkages between the Turkish lira and US dollar, against the euro, oscillate from negative values to even 0.75, exhibiting very strong dynamics (Figure 10). From 2001, the periods with Spearman's rho lower than 0.45 prevail. The fitted MRSC model is 3-regime with the Gaussian, Joe-Clayton and rotated Joe-Clayton copulas (Table 5). A rather surprising result is that the dependence between the TRY and EUR, against the USD, are described by a static Joe-Clayton copula model, showing stable, non sensitive on market situation pattern of dependence. The value of Spearman's rho is 0.3172 and tail dependence coefficients are 0.0915 for lower tail and 0.2490 for upper one. This means that extreme increases of the EUR/USD impacts stronger on the TRY/USD than extreme decreases.

\begin{tabular}{|c|c|c|c|c|c|}
\hline $\begin{array}{l}\text { TRY/USD } \\
\text { EUR/USD }\end{array}$ & Regime 1 & $\begin{array}{l}\text { TRY/EUR } \\
\text { USD/EUR }\end{array}$ & Regime 1 & Regime 2 & Regime 3 \\
\hline Copula & $C_{k y}^{\text {Joe-Clayon }}$ & Copula & $C_{\rho}^{\text {Gauss }}$ & $C_{k, y}^{\text {Joe Clayon }}$ & $C_{\kappa y}^{\text {Joee-Cayton } 90}$ \\
\hline$\rho$ & & $\rho$ & $\begin{array}{l}0.4891 \\
(0.0381)\end{array}$ & & \\
\hline$\kappa$ & 1.2373 & $\kappa$ & & $\begin{array}{l}2.3201 \\
(0.0807)\end{array}$ & $\begin{array}{l}1.0123 \\
(0.0205)\end{array}$ \\
\hline$\gamma$ & 0.2898 & $\gamma$ & & $\begin{array}{l}1.2178 \\
(0.0643)\end{array}$ & $\begin{array}{l}0.0939 \\
(0.0467)\end{array}$ \\
\hline & & Regime 1 & 0.9524 & 0.0054 & 0.0422 \\
\hline & & Regime 2 & 0.0064 & 0.9935 & 0.0000 \\
\hline & & Regime 3 & 0.1203 & 0.0000 & 0.8796 \\
\hline
\end{tabular}

Table 5. TRY. Parameter estimates for MRSC models.

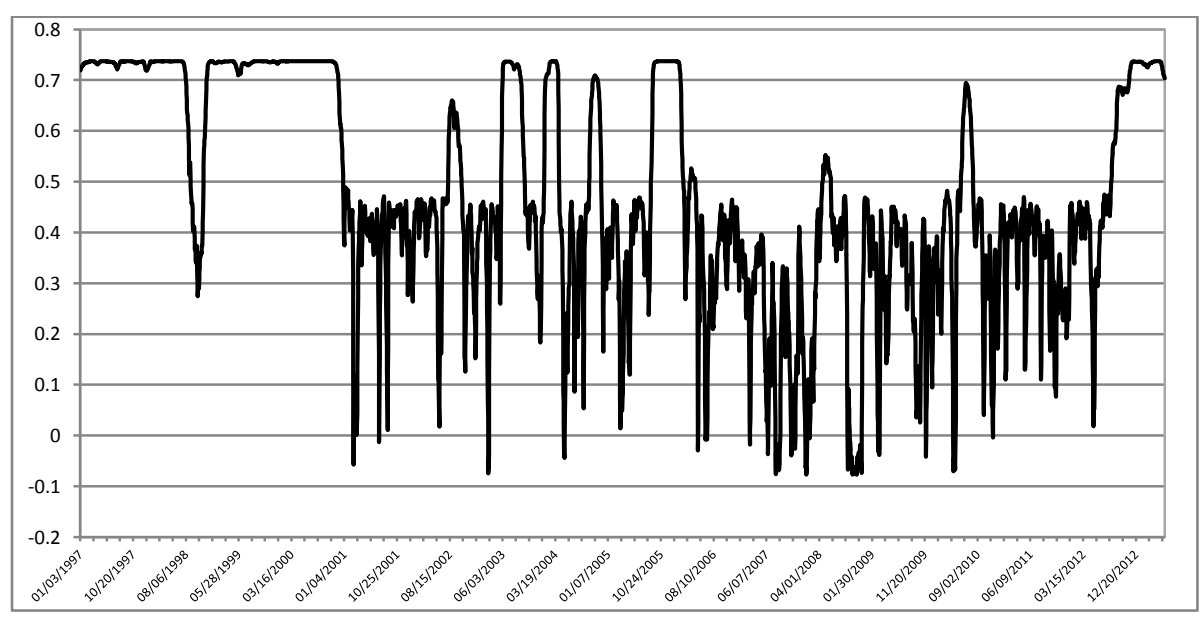

Figure 10. Linkages between the TRY and the USD. Spearman's rho for (TRY/EUR,USD/EUR) 


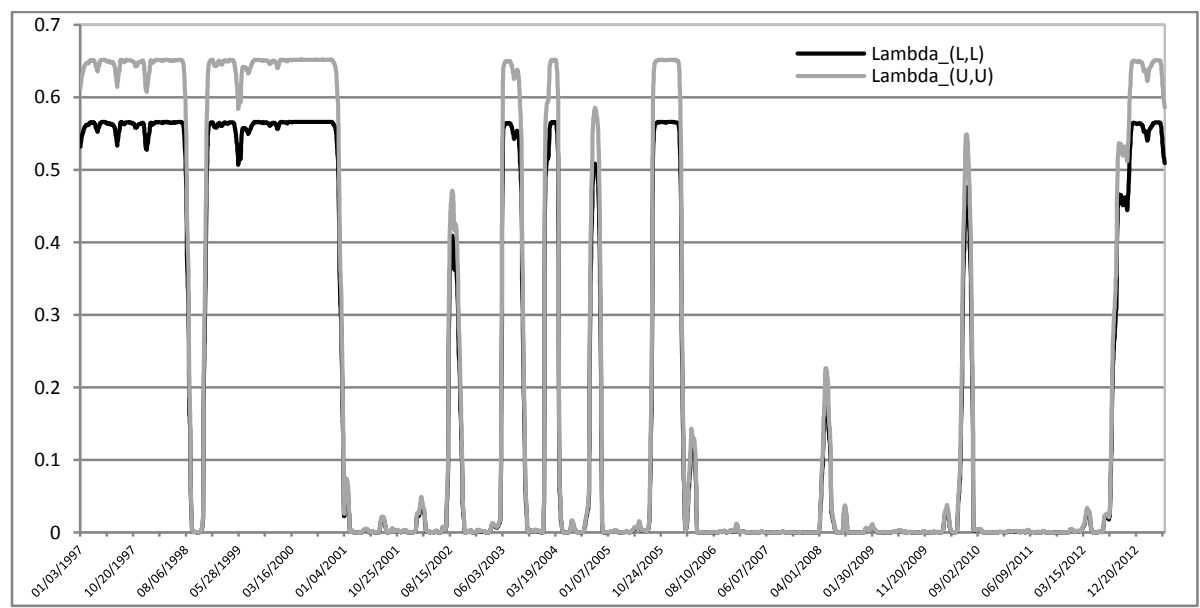

Figure 11. Linkages between the TRY and the USD. Dependence in tails for (TRY /EUR,USD/EUR)

\section{Conclusions}

The aim of the analysis presented in this paper was to describe the pattern of dynamic linkages between the chosen currencies (the Czech koruna, Indian rupiah, Polish zloty, Russian ruble and Turkish lira) and two global currencies - the American dollar and the euro. The applied approach follows the idea by Eun and Lai (2004) that in the case when a minor currency XYZ is driven by the US dollar, the exchange rates XYZ/EUR and USD/EUR co-move very closely. In the opposite case, i.e. when the $\mathrm{XYZ}$ is influenced by the euro, the exchange rates $\mathrm{XYZ/USD}$ and EUR/USD show strong interdependence. To describe the strength and dynamics of dependence between the returns of the analyzed exchange rates we apply very flexible 3-regime Markov switching copula models. The considered dependence measures are dynamic Spearman's rho and dynamic coefficients of dependence tails. A general observation is that the impact of the US dollar and the euro is changing due to globalization process and is sensitive on the market situation. Our results confirm that CZK and PLN are in the euro area of influence. They also indicate that INR, RUB and TRY seem to be connected with the US dollar, even though the increasing impact of the euro on these currencies is observed.

\section{References}

- $\quad$ Eun, C.S., Lai S.-C. S. (2004), “The Currency Co-movement”, Georgia Institute of Technology Working Paper 21.

- Garcia, R., Tsafack, G. (2006), "Dependence Structure and Extreme Comovements in International Equity and Bond Markets", Journal of Banking \& Finance, Vol. 35, pp. 1954-1970.

- Hamilton, J.D. (1994), Time Series Analysis, Princeton University Press, Princeton.

- Joe, H. (1997), Multivariate Models and Dependence Concepts, Chapman and Hall, London.

- $\quad$ Lambert, P., Laurent, S. (2001), "Modelling financial time series using GARCH-type models with a skewed Student distribution for the innovations", Institut de Statistique, Université Catholique de Louvain, Discussion Paper 0125.

- Laurent, S. (2009), Estimating and Forecasting ARCH Models Using G@RCH 6, Timberlake Consultants, London.

- McNeil, A.J., Frey, A., Embrechts, P. (2005), Quantitative Risk Management, Princeton University Press, Princeton.

- Nelsen, R.B. (2006), An Introduction to Copulas, Springer, New York.

- $\quad$ Patton, A.J. (2004), “On the Out-of-Sample Importance of Skewness and Asymmetric Dependence for Asset Allocation”, Journal of Financial Econometrics, Vol. 2, pp.130-168.

- Patton, A.J. (2006), “Modelling Asymmetric Exchange Rate Dependence”, International Economic Review, Vol. 47, pp. 527-556.

- Sklar, A. (1959), "Fonctions de répartition à n dimensions et leurs marges", Publications de l'Institut Statistique de l'Université de Paris, Vol. 8, pp. 229-231. 


\title{
Monetary Response to Exchange Rate Dynamics: Regime Switching - Chartists and Fundamentalists Application to Australia
}

\author{
Ph.D. Candidate Ferry Syarifuddin (Bank Indonesia, Indonesia)
}

\begin{abstract}
In this paper we study the effect of central bank intervention within a heterogeneous expectations exchange rate model. The empirical evidence is conducted by applying a Markov switching approach to daily AUD/USD exchange rate, intervention data of the Reserve Bank of Australia from 2006 to 2012. Our results are supporting both chartists and fundamentalist regimes. It is shown that the two regimes are persistent. However, Reserve Bank of Australia efforts to exert a stabilizing effect of foreign exhange interventions, the result is inconclusive.
\end{abstract}

\section{Introduction}

According with the postulate trilemna, freely floating exchange rate will be adapted by a country which adapts freely foreign exchange system and independent monetary policy. Australia is one of the country that adapts it. By freely floating exchange rate and position as an advanced open economy, Australia's exchange rate movements is strongly influenced by capital flows. Hence, existence of central bank optimal monetary response (i.e.foreign exchange intervention) needed to control the exchange rate for the long-term equilibrium exchange rate.

An intervention (non-sterilized) occurs when a monetary authority buys (sells) foreign exchange. This action will affect the monetary base, interest rates, market expectations and intimately the exchange rate. Intervention is said sterilized if the monetary authority offsets or sterilizes the effect of the foreign exchange operation on the monetary base by selling or buying domestic bonds in order to keep the monetary policy unchanged. The main results in the empirical literature (Almekinders et al., 1996; Frenkel et al., 2004; Ito and Yabu, 2007; Jun, 2008 and in papers of surveys Neely, 2001) suggest that interventions tend to be conducted in order to reduce exchange rate misalignment or to reduce foreign exchange undesired fluctuations.

Relying on the efforts of monetary authorities to maintain exchange rate stability, economic actors usually are actively hedging the exchange rate in order to avoid losses due to exchange rate fluctuations. Rothig, Semmler, and Flaschel (2005) argued that the negative effect of exchange rate on the balance sheet can be removed by the practice of company risk management. Risk management of exchange rate fluctuations will be conducted by hedging. Hedging generally conducts by forward transactions, swaps, NDF etc.

The effectiveness of sterilized interventions was usually evaluated on the basis of traditional macro-economic channels: the portfolio balance channel and the signaling channel. With the emergence of microstructure approach of exchange rate (Lyons, 2006) and the failure of numerous empirical studies (based on the asset market approach of exchange rate) to explain short term movements of exchange rate (Lewis, 1995 and Taylor, 1995) many other studies have used to introduce microstructure based channels and microstructure variables. These studies suggested two new channels through which sterilized intervention may be transmitted: the noise trading channel (Hung, 1997) and the coordination channel (Reitz and Taylor, 2008, Taylor, 2004, 2005). Microstructure specification like order flow, Bid-ask spread, market makers, heterogeneity of traders, was also taken into account for studying the effectiveness of intervention (Beine et al., 2009, Chari, 2007, Scalia, 2008).

The noise trading channel have been pioneered by Hung (1997) and is based on the functioning and the microstructure of the foreign exchange market. This channel assumes two hypotheses: noise traders must prevail the foreign exchange market and the exchange rate is determined by flow market equilibrium. Once these hypotheses are satisfied, the central bank should intervene in highly volatile market periods and keep its interventions secret.

This study contributes to the noise trading channel by allowing intervention to influence the both forecasting rules of chartists and fundamentalists, thereby altering the proportion of the two groups in the foreign exchange market. We define a new criterion for the effectiveness of interventions. To allow for different forecasting strategies, the impact of central bank intervention is investigated applying a heterogeneous expectations exchange rate model. A central bank intervening in the foreign exchange market is considered effective if the exchange rate is driving closer to its fundamental value. Apart from providing the rationale for the application of trading rules, intervention may as well improve the performance of expectations based on fundamentals, especially when central banks try to correct current exchange rate misalignments.

Following Frankel \&Froot (1986), the excess demand for foreign currency is assumed to be a function of the relative success of chartist and fundamentalist forecasting techniques. As is stated above the performance of 
chartist or fundamentalist predictions is expected to be temporarily improved by central bank intervention thereby altering the time series properties of exchange rates.

This article presents a new and improved data series on interventions by RBA in the foreign exchange market. These data allow a documentation of the evolution in the approach to foreign exchange market intervention after the float of the exchange rate. This evolution reflects a recognition that when foreign exchange markets are deep and liquid (and the capital account is open), the effects of intervention on the level of the exchange rate are generally short-lived. Moreover, under these 'normal' circumstances, the practical difficulties involved in determining what the 'fair value' of an exchange rate should be suggest that it is difficult for policymakers to systematically improve on market outcomes, particularly in real time. Nevertheless, in instances of severe market dysfunction, intervention can exert an important stabilising influence on the foreign exchange market.

The article uses the new data to reassess previous empirical assessments of the effectiveness of foreign exchange market intervention. It shows that it is not possible to draw strong conclusions, notwithstanding the use of an improved measure of RBA interventions. The well-known limitations of this type of analysis suggest that the estimates of the effect of intervention on the exchange rate are expected to be understated, and may even be perverse. Moreover, as the goal of intervention has evolved toward addressing instances of extreme market dysfunction, it has become less clear that such specifications are still well-suited for assessing the effectiveness of foreign exchange market intervention.

The empirical examination of the hypothesis is done by applying the Markov regime-switching approach originally proposed by Hamilton (1989) to daily RBA intervention data from 2006 to 2012. Considering the results of Neely and Weller (2001) intervention data is used only to construct a dummy variable distinguishing between intervention and no-intervention periods. Statistically significant estimates of dummy coefficients lead to the conclusion that an impact of central bank intervention on exchange rate expectation cannot be rejected.

Furthermore, we re-examine the effects of intervention on exchange rate volatility, where empirical work has reported quite mixed results. The parameter estimates of the Markov switching model suggest that the inconclusive evidence is due to a regime dependent correlation between the intervention and volatility. Dominguez (1998) estimates $\operatorname{GARCH}(1,1)$ models and shows that overt intervention was able to reduce volatility in certain periods. But in general, intervention seemed to have an increasing effect on the conditional variance of exchange rate changes (Baillie and Osterberg, 1997b).

The remainder of the paper is organized as follow. Section 2 describes the problem formulation, followed by Research Objectives in section3. Research methodology is presented in section 4. Section 5 describe literature and Theoretical Background. Then in section 6 we explain the econometric model used. Our main empirical results concerning intervention effectiveness are reported in Section 7 before the final section (8) concludes.

\section{Problem Formulation}

How to get a model that could explain exchange rate dynamics built by FX traders (fundamentalist and chartist) as well as the relationship between changes in exchange rateand foreign exchange intervention (monetary policy)? How to estimate the volatility of the exchange rate using by the model?

\section{Research Objectives}

These paper objectives are as follow:

- To get a model that could explain exchange rate dynamics built by FX traders (fundamentalist and chartist) in the case of Australia

- To expand the model that could explain the relationship between changes in exchange rate, and foreign exchange intervention (monetary policy)?

- To estimate the volatility of the exchange rate using the model?

\section{Research Methodology}

This study contributes to the noise trading channel by allowing intervention to influence the exchange rate both forecasting rules of chartists and fundamentalists, thereby altering the proportion of the two groups in the foreign exchange market. We define a new criterion for the effectiveness of interventions. A central bank intervening in the foreign exchange market is considered effective if the exchange rate is driving closer to its fundamental value. The models are estimated by maximum likelihood. Estimated parameters obtained by using the BFGS algorithm (Broyden-Fletcher-Goldfarb-Shanno), a method of solving nonlinear optimization problems, and t-statistics which reported by the heteroscedasticity-consistent standard errors based (White, 1982). For data processing, the software used is RATS 6.0 


\section{Literature and Theoretical Background}

In the literature of financial markets, participants are classified in two groups according to different approaches of expectations; the fundamental analysis and the chartist analysis. The classification was introduced by Frankel and Froot (1986, 1990), and has been enhanced among others by Ahrens and Reitz (2004), Reitz (2005), Westerhoff (2003), De Grauwe and Grimaldi (2005), Wieland and Westerhoff (2005).

Beine et al. (2009) investigated the effect of sterilized intervention in a noise trading channel with two states Markov switching model. Using biweekly data, they found that interventions increase the weight of fundamentalists in the foreign exchange market and therefore exert stabilizing influence on the exchange rate. The fundamentalists behavior tends to stabilize the market while the presence of chartists may cause destabilization.

There are many economists are interested to see the effectiveness of exchange rate intervention which conducted by central bank due to stabilize the exchange rate. However, there are also the differences about the view of exchange rate intervention affectivity to stabilize the exchange rate. Taylor (2004) examines the effectiveness of exchange rate intervention by using Markov switching model for the real exchange rates. The probability of switching between stable and unstable regimes depends nonlinearly upon the amount of intervention, the degree of misalignment and the duration of the regime. Taylor applied this to dollar-mark data for the period 1985-98. Markov switching models can have also been used recently to study the effectiveness of intervention (Taylor 2004). In conclusion, Taylor shows that the intervention increase the probability of stability when the rate is misaligned, and that its influence grows with the degree of misalignment. However, intervention within a small neighborhood of equilibrium will result in a greater probability of instability.

Dominguez (1998) tried to analyze whether intervention operations generally increase exchange rate volatility. Dominguez explored the effect of foreign exchange intervention by the G-3 central banks (US, German, and Japanese) on the behavior of exchange rates over the 1977-1994 period. The G-3 central banks have undertaken an unprecedented number of both coordinated and unilateral intervention operations in the last 10 years.

Existing empirical evidence on the effectiveness of intervention is mixed. Dominguez examines the effect of US, German, and Japanese monetary and foreign exchange intervention on dollar-mark and dollar-yen exchange rate volatility over the 1977-1994 period. The results indicate that intervention operations generally increase exchange rate volatility. Besides the effectiveness, economists are also interested to analyze the expectations from the businesses on the exchange rate movements after the existing of exchange intervention by central bank. Cited by Messe (1990) from Vigfusson (1996), models based on economic fundamentals have been poor at explaining the movements in the exchange rate since the early 1980s.

The effectiveness of sterilized interventions was usually evaluated on the basis of traditional macro economic channels:

- The portfolio balance channel

- The signaling channel

With the emergence of microstructure approach of exchange rate (Lyons, 2006) and the failure of numerous empirical studies to explain short term movements of exchange rate (Lewis, 1995 and Taylor, 1995) many other studies have used to introduce microstructure based channels and microstructure variables. These microstructure approach of exchange rate studies suggested two new channels through which sterilized intervention may be transmitted. The noise trading channel (Hung, 1997) is based on the functioning and the microstructure of the foreign exchange market. This channel assumes two hypotheses: noise traders must prevail the foreign exchange market and the exchange rate is determined by flow market equilibrium. Microstructure specification like order flow, Bid-ask spread, market makers, heterogeneity of traders, was also taken into account for studying the effectiveness of intervention (Beine et al., 2009, Chari, 2007, Scalia, 2008).

For example, the high appreciation of dollar (US) in the beginning of 1980-an have been poor at explaining by the fundamental perspective. In response to this problem, Frankel and Froot (1988) developed a model where two approaches are used to forecast the exchange rate, chartist and fundamentalists $(\mathrm{C} \& \mathrm{~F})$. The fundamentalist approach, where the forecast is based upon economic fundamentals, continues to be used. This models innovation is that the chartist approach, where the forecast is based upon the past behavior of the exchange rate, is also used.

Although the model C\&F looks well-satisfied, there's still no direct empirical test. The main problem lies on the relative importance of each market players which has various kind and unobservable. This condition makes the difficultly to estimate this model with the general statistical methods. Vigfusson (1996) tried to solve this problem by using the Markov regime-switching model. Markov switching model explains the C\&F model within two concerns. First, $C \& F$ model has two forecasting equations of both chartist and fundamentalist. Second, $C \& F$ model placed the time-varying weight on each forecasting equations. Vigfusson explains about the response of the financial market players to influence the exchange rates expectation by observe the switching contribution between chartist and fundamentalist. By defining the two groups different methods of forecasting as regimes, 
Vigfusson rewrite the C\&F model as a regime-switching model. This approach is used to test for chartist and fundamentalist behavior in the Canada-US daily exchange rate between 1983 and 1992. Vigfusson found favorable though inconclusive evidence for the $C \& F$ model because the difference of regime variance assessed more important than the other variables. Ideally, this model could aside the switching that caused by the differences of variance and made both of the regime used the ARCH effect. Therefore, he suggest to do the further research.

The further research from Reitz (2002) is about the usage of C\&F model to analyze the exchange rate behavior which connected to the foreign exchange intervention by central bank. Reitz propose a generalization of the noise trader transmission mechanism to examine the impact of central bank intervention on exchange rates. Within a heterogeneous expectations exchange rate model intervention operations are supposed to provide support to either chartist or fundamentalist forecasts, which forces portfolio managers to adjust their foreign currency positions.

The empirical examination of the hypothesis is done by applying a Markov regime-switching approach to daily US-dollar/DEM forward rates and intervention data of the Deutsche Bundesbank and the Federal Reserve from 1979 to 1992. It is shown that the performance of simple chartist trading rules was strong whenever these central banks intervened on the foreign exchange market. Instead, the fundamentalists which used the fundamentalist technique has a worse estimation results.

Jonathan Kearns and Roberto Rigobon (2003) argued that the endogeneity of exchange rates and intervention has long plagued studies of the effectiveness of central banks' actions in foreign exchange markets. Researchers have either excluded contemporaneous intervention so that their explanators are predetermined, or obtained a small, and typically incorrectly signed, coefficient on contemporaneous intervention. Failing to account for the endogeneity, when central banks lean against the wind and trade strategically, will likely result in a large downward bias to the coefficient on contemporaneous intervention - explaining the negative coefficient frequently obtained.

The RBA researchers use an alternative identification assumption - a change in the intervention policy of the Reserve Bank of Australia - that allows them to estimate, using simulated Generalised Method of Moments (GMM), a model that includes the contemporaneous impact of intervention. There are three main results. Their point estimates suggest that central bank intervention has an economically significant contemporaneous effect. A US\$100 million purchase of the domestic currency will appreciate the exchange rate by 1.3 to 1.8 per cent. This estimate is remarkably similar to the calibration conducted by Dominguez and Frankel (1993c), who themselves noted their estimate was larger than previous empirical findings. Secondly, the vast majority of the effect of an intervention on the exchange rate is found to occur during the day in which it is conducted, with only a smaller impact on subsequent days. Finally, they confirm findings that Australian central bank intervention policy can be characterized as leaning against the wind.

The Reserve Bank's approach to foreign exchange market intervention has evolved since the float of the Australian dollar in 1983, as the Australian foreign exchange market has developed and market participants have become better equipped to manage their foreign exchange risk. Over time, foreign exchange market intervention has become much less frequent and more targeted towards addressing periods of market dysfunction. This article presents a new dataset and summarises the key characteristics of major intervention episodes since the late 2000s. Some simple regression analysis is undertaken to gauge the effectiveness of these interventions, but the results mainly illustrate the inherent limitations of such exercises.

\section{The Econometric Model}

In the literature of financial markets, participants are classified in two groups according to different approaches of expectations; the fundamental analysis and the chartist analysis. The classification was introduced by Frankel and Froot (1986, 1990), and has been enhanced among others by Ahrens and Reitz (2004), Reitz (2005), Westerhoff (2003), De Grauwe and Grimaldi (2005), Wieland and Westerhoff (2005). Beine et al. (2009) investigated the effect of sterilized intervention in a noise trading channel with two states Markov switching model. Using biweekly data, they found that interventions increase the weight of fundamentalists in the foreign exchange market and therefore exert stabilizing influence on the exchange rate. The fundamentalists behavior tends to stabilize the market while the presence of chartists may cause destabilization.

\subsection{A Basic Chartist-Fundamentalist Model for The Exchange Rate}

As discussed in the last section, we consider heterogeneous traders in our model: fundamentalists and chartists. Fundamentalists, using fundamentalist rule, base their forecasts on the fundamental exchange rate; they expect that exchange rate converge to its fundamental value. While chartists, using technical analysis rules, explore paste movements of exchange rate in the future. Fundamentalists forecasting rules and chartists forecasting rules can be expressed, respectively, as follow:

$$
r_{f, t}=-\psi\left(e_{t-1}-f_{t-1}\right)+\epsilon_{f, t}
$$




$$
r_{c, t}=C\left(r_{t i}\right)+\epsilon_{c, t} r_{c, t}=C\left(r_{t i}\right)+\epsilon_{c, t}
$$

Fundamentalists consider exchange rate as a reaction function to misalignments of exchange rate level with the fundamental value. $r_{\mathrm{f}, \mathrm{i}}$ is the forecasted value of the exchange rate return $\mathrm{r}_{\mathrm{t}}$ by fundamentalists, $-\psi \psi$ is speed of adjustment parameter , $\mathrm{ft}-1$ is the fundamental exchange rate, $\mathrm{C}_{\mathrm{f}, \mathrm{t}}$ is the error term of fundamentalists. $\mathrm{r}_{\mathrm{c}, \mathrm{t}}$ is the forecasted value of the exchange rate return $r$ by chartists, $C$ the chartists forecasting rule, $\epsilon_{c, t}$ is the error term of chartists.

In order the characterize the exchange rate behavior of exchange rate, we choose the Markov regime-switching model. It was initially introduced by Hamilton (1989) and developed further by, among others, Engel (1994) and Dewachter (1996). In Markov switching model, dynamics of the exchange rate is governed by an unobserved state variable or a latent variable $\mathrm{lt}(\mathrm{lt}=\mathrm{c}$ for chartist regime $\mathrm{lt}=\mathrm{f}$ for fundamentalists one). The indicator regime It is parametrized as a first order Markov process and is driven by first-order transition probabilities. These transitions probabilities, in the case of two regimes, could be expressed as:

$$
\begin{gathered}
p=\operatorname{prob}\left(l_{t}=f \mid l_{t-1}=f\right) \\
q=\operatorname{prob}\left(l_{t}=c \mid l_{t-1}=c\right)
\end{gathered}
$$

These probabilities are constant over time. In this specification, $p$ is the probability of remaining in the fundamentalist regime, and $\mathrm{q}$ for the chartist

$$
\begin{aligned}
& p=1-\left(1-\exp \left(\pi_{0}\right)\right)^{-1} \\
& q=1-1-\left(1-\exp \left(\kappa_{0}\right)\right)^{-1}
\end{aligned}
$$

\subsection{Model Specification}

As used by Reitz (2002), in the standard chartist and fundamentalist (C\&F) model originally suggested by Frankel and Froot (1986) the (log of the) exchange rate $\mathrm{e}_{\mathrm{t}} \widetilde{e_{t}}$ is driven by the decisions of portfolio managers. They buy and sell foreign currency in response to changes in the expected rate of appreciation and a set of contemporaneous variables included in a vector zt. Thus, the exchange rate can be written as:

$$
e_{t}=a E_{t}\left[\Delta e_{t+1}\right]+b z_{t} e_{t}=a E_{t}\left[\Delta e_{t+1}\right]+b z_{t}
$$

Where the vector of elasticities of the contemporaneous variables (b) and the elasticity of exchange rate expectation (a) should be constant overtime. Under the rational expectations hypothesis equation (1) has the well known forward looking solution that et is the weighted sum of current and expected future market fundamentals. In contrast to this, Frankel and Froot (1986) assumed that portfolio managers generate their exchange rate expectations using a mixture of chartist $E_{t}^{c}\left[\left[\boldsymbol{\Delta}_{\boldsymbol{t}+1}\right]\right] E_{t}^{c}\left[\left[\boldsymbol{\Delta}_{\boldsymbol{t}+1}\right]\right]$ and fundamentalist $E_{t}^{c}\left[\left[\boldsymbol{\Delta} \boldsymbol{e}_{t+1}\right]\right]$ forecasts:

$$
\begin{aligned}
& E_{t}^{c}\left[\left[\boldsymbol{\Delta}_{\boldsymbol{t + 1}}\right]\right]=\omega_{t} E_{t}^{f}\left[\boldsymbol{\Delta} \boldsymbol{e}_{\boldsymbol{t + 1}}\right]+(\mathbf{1}-\boldsymbol{\omega}) E_{t}^{c}\left[\boldsymbol{\Delta} \boldsymbol{e}_{\boldsymbol{t + 1}}\right] \\
& E_{t}^{c}\left[\left[\boldsymbol{\Delta}_{\boldsymbol{t + 1}}\right]\right]=\omega_{t} E_{t}^{f}\left[\boldsymbol{\Delta} \boldsymbol{e}_{\boldsymbol{t + 1}}\right]+(\mathbf{1}-\boldsymbol{\omega}) E_{t}^{c}\left[\boldsymbol{\Delta} \boldsymbol{e}_{\boldsymbol{t + 1}}\right]
\end{aligned}
$$

The parameter $\mathrm{E}_{\mathrm{t}}$, denoting the weight given to fundamentalist views at date $\mathrm{t}$, is dynamically updated by the portfolio managers in a rational Bayesian manner:

$$
\Delta \omega_{t}=\delta\left(\omega_{t-1}^{*}-\omega_{t-1}\right) \Delta \omega_{t}=\delta\left(\omega_{t-1}^{*}-\omega_{t-1}\right)
$$

With :

$$
\omega_{t-1}^{*}=\frac{\Delta e_{t}-E_{t}^{c}\left(\Delta e_{t}\right)}{E_{t-1}^{f}\left[\Delta e_{t}\right]-E_{t-1}^{c}\left[\Delta e_{t}\right]} \omega_{t-1}^{*}=\frac{\Delta e_{t}-E_{t}^{c}\left(\Delta e_{t}\right)}{E_{t-1}^{f}\left[\Delta e_{t}\right]-E_{t-1}^{c}\left[\Delta e_{t}\right]}
$$

Where $\omega_{t-1}^{*} \omega_{t-1}^{*}$ is the expost calculated weight that must have been assigned to fundamentalist forecast in order to predict the current exchange rate change accurately. The value of reflects the extent to which portfolio managers enclose new information in this adaptive process and proves responsible for the exchange rate dynamics. Since portfolio managers always maintain a positive weight for both chartist and fundamentalist forecasts, has to be restricted so that stays in the range between 0 and 1 . To makesure that the empirical analysis remain stractable, another feedback rule is introduced. Similar to Lewis(1989), portfolio managers are supposed to optimize the weight assigned to fundamentalist forecasts by means of a Bayesian learning process: 


$$
\begin{aligned}
\omega_{t} & =\frac{\omega_{t-1} \cdot \varphi_{f}\left(\Delta e_{t} \mid E_{t-1}^{f}\left[\Delta e_{t}\right]\right)}{\omega_{t-1} \cdot \varphi_{f}\left(\Delta e_{t} \mid E_{t-1}^{f}\left[\Delta e_{t}\right]\right)+\omega_{t-1} \cdot \varphi_{c}\left(\Delta e_{t} \mid E_{t-1}^{c}\left[\Delta e_{t}\right]\right)} \\
\omega_{t} & =\frac{\omega_{t-1} \cdot \varphi_{f}\left(\Delta e_{t} \mid E_{t-1}^{f}\left[\Delta e_{t}\right]\right)}{\omega_{t-1} \cdot \varphi_{f}\left(\Delta e_{t} \mid E_{t-1}^{f}\left[\Delta e_{t}\right]\right)+\omega_{t-1} \cdot \varphi_{c}\left(\Delta e_{t} \mid E_{t-1}^{c}\left[\Delta e_{t}\right]\right)}
\end{aligned}
$$

Where

$$
\varphi_{c}\left(\Delta e_{t} \mid E_{t-1}^{c}\left[\Delta e_{t}\right]\right) \varphi_{c}\left(\Delta e_{t} \mid E_{t-1}^{c}\left[\Delta e_{t}\right]\right)
$$$$
\varphi_{f}\left(\Delta e_{t} \mid E_{t-1}^{f}\left[\Delta e_{t}\right]\right) \varphi_{f}\left(\Delta e_{t} \mid E_{t-1}^{f}\left[\Delta e_{t}\right]\right)
$$

density function of $\Delta e_{t} \Delta e_{t}$ conditional on conditional on the forecasts of chartists and fundamentalists, respectively.

\subsection{Fundamentalist Rule}

Concerning the expectation formation fundamentalists have in mind some kind of long-run equilibrium , to which the exchange rate reverts with a given speed over time, i.e.:

$$
E_{t}^{f}\left[\Delta e_{t+1}\right]=\theta\left(\widetilde{e_{t}}-e_{t}\right) E_{t}^{f}\left[\Delta e_{t+1}\right]=\theta\left(\widetilde{e_{t}}-e_{t}\right)
$$

This can be explained by the fact that agents have different beliefs about the equilibrium value of the exchange rate, which is certainly not observable. Kilian and Taylor (2001) conclude that the heterogeneity of beliefs will diminish when the exchange rate becomes increasingly overvalued and the supply of foreign exchange should rise. According to (4) fundamentalist expectation can be viewed as distributed symmetrically around . We assume that the fundamental value can be described by purchasing power parity (PPP) or uncovered interest parity (UIP). PPP states that exchange rates between any two currencies will adjust to reflect changes in the price levels of the two countries. The theory of PPP is simply an application of the law of one price to national price levels rather than to individual price. Takagi (1991) provides evidence from survey data that foreign exchange market participants accept PPP as a valid relationship only in the long run implying low values for . This view is recently supported by Taylor and Peel (2000) and Taylor et al. (2001) showing that due to its nonlinear dynamics the exchange rate reverts to the PPP level, but only in the long run. Furthermore, PPP as a measure of the fundamental exchange rate seems to be suitable for the investigation of central bank intervention, because monetary authorities have used it as a target level (Dominguez and Frankel, 1993b). However, in many cases, the Theory of Purchasing Power Parity cannot fully explain exchange rates. The PPP conclusion that exchange rates are determined solely by changes in relative price levels rests on the assumption that all goods are identical in both countries and that transportation costs and trade barriers are very low. When this assumption is true, the law of one price states that the relative prices of all these goods (that is, the relative price level between the two countries) will determine the exchange rate. PPP theory furthermore does not take into account that many goods and services (whose prices are included in a measure of a country's price level) are not traded across borders. Housing, land, and services such as restaurant meals, haircuts, and golf lessons are not traded goods. So even though the prices of these items might rise and lead to a higher price level relative to another country's, there would be little direct effect on the exchange rate. Therefore, we use uncovered interest parity (UIP) as an approach to long-run exchange rate expectation within fundamentalist rule. Within this framework, central bank operations on foreign exchange markets can be called effective, if the adjustment of the exchange rate to its long run equilibrium is accelerated. This implies that the observed reversion of the exchange rate to uncovered interest parity (UIP) condition - denoted by - is driven by both fundamentalist speculation and central bank intervention. Denoting the influence of intervention by , we can formulate as a function of a 0,1 intervention dummy $I_{t} I_{t}$ as follows:

$$
\zeta_{t}=\theta+\delta_{\theta} I_{t}, \quad \theta, \delta_{\theta}>0
$$

\subsection{Chartist Rule}

Chartists are defined as market participants who believe that exchange rate time series exhibit regularities which can be detected by a wide range of so-called technical trading rules. To reduce the impact of data snooping biases brought on by searching for the best performer, we employ a very simple type of trading rule following common practice (Takagi,1991). Excess returns of moving average (MA) trading rules of daily U.S. dollar quotes for the DM, yen, poundsterling and swiss francis reported in Neely(1997) and LeBaron (1999). Leeetal (2001) found MA trading rule profitability for Latin American currencies applying out of sample-tests. These studies show that the length of the short run and long run moving average don't have much influence on the trading rule profitability. To be concrete, chartists are supposed to expect that a future exchange rate increase is predicted by the proportion of the positive difference between the 14 day moving average $\left(\mathrm{ma}_{14}\right)$ and 200 day moving average $\left(\mathrm{ma}_{200}\right)$ and vice versa. Hence, their exchange rate expectation at date $\mathrm{t}$ is: 


$$
E_{t}^{c}\left[\Delta e_{t+1}\right]=\psi\left(m a_{14, t}-m a_{200, t}\right) E_{t}^{c}\left[\Delta e_{t+1}\right]=\psi\left(m a_{14, t}-m a_{200, t}\right)
$$

As is stated in the noise trader hypothesis of intervention (Hung,1997), a leaning against the wind-strategy of central banks may introduce trends into exchange rate dynamics. Subsequent changes in noise trader's positions magnify the initial impact of intervention operations. We assume that this kind of trend establishing intervention can be formalized by means of a moving average specification very similar to speculation based on chartist analysis. This implies that a given trend in the exchange rate () is due to both chartist speculation and central bank intervention. Denoting the influence of intervention by, we can formulate as a function of the intervention dummy It as follows:

$$
\eta_{t}=\psi+\delta_{\psi} I_{t} \quad \psi, \delta_{\psi}>0
$$

Of course, neither the chartists, the fundamentalists, nor the portfolio managers have rational expectations about the future exchange rates. Within the model, agents could do a better job in expected value terms, if they knew the complete model. But as long as market participants try to compensate the lack of a verified exchange rate model with different forecasting techniques, the imposed informational restrictions are a realistic description of the foreign exchange market.

In order to confront the C\&F-model with exchange rate data, the econometric approach should be able to describe the conditional distribution of the exchange rate change by a mixture of (normal) distributions. As is stated in Clarida et al.(2001) the Markov regime- switching model suggested by Engel and Hamilton (1990) and developed further by, among others, Engel (1994), Vigfusson (1997) and Dewachter (2001) is a natural candidate to characterize exchange rate behavior. In our model, the conditional mean $t$ and the conditional variance ht of exchange rate changes et are allowed to follow two different regimes-a chartist and a fundamentalist regimeindicated by an unobservable state variable St. The regime indicator St is parameterized as a first-order Markov process and the switching or transition probabilities $\mathrm{P}$ and $\mathrm{Q}$ have the typical Markov structure:

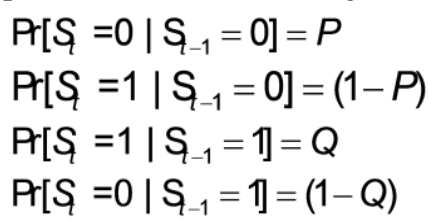

Thus, under conditional normality, an observed realization $\Delta e_{t} \Delta e_{t}$ is presumed to be drawn from a $\mathrm{N}\left(\mu_{0 \mathrm{t}}, \mathrm{h}_{0 \mathrm{t}}\right)$ distribution if $\mathrm{S}_{\mathrm{t}}=0$, whereas $\Delta e_{t} \Delta e_{t}$ is distributed $\mathrm{N}\left(\mu_{1 \mathrm{t}}, \mathrm{h}_{1 \mathrm{t}}\right)$ The evolution of the log first differences of exchange rates can therefore be written as:

$$
\begin{gathered}
\Delta e_{t}=\mu_{0 t}\left(1-S_{t}\right)+\mu_{1 t} S_{t}+\sqrt{h_{0 t}\left(1-S_{t}\right)+h_{1 t} S_{t}} \\
\Delta e_{t}=\mu_{0 t}\left(1-S_{t}\right)+\mu_{1 t} S_{t}+\sqrt{h_{0 t}\left(1-S_{t}\right)+h_{1 t} S_{t}} . \varepsilon_{\mathrm{t}}
\end{gathered}
$$

Where $t$ is an i.i.d. standard normal variable. The parameter estimation of the mean (t) and variance (ht) equation since the regime switching model are derived from maximization of the log-likelihood function

$$
\begin{gathered}
L=\log p_{1 t} \frac{1}{\sqrt{2 \pi h_{1 t}}} \exp \frac{-\left(\Delta e_{t}-\mu_{1 t}\right.}{2 h_{1 t}}+\left(1-p_{1 t}\right) \frac{1}{\sqrt{2 \pi h_{2 t}}} \exp \frac{-\left(\Delta e_{t}-\mu_{1 t}\right.}{2 h_{2 t}} \\
L=\log p_{1 t} \frac{1}{\sqrt{2 \pi h_{1 t}}} \exp \frac{-\left(\Delta e_{t}-\mu_{1 t}\right.}{2 h_{1 t}}+\left(1-p_{1 t}\right) \frac{1}{\sqrt{2 \pi h_{2 t}}} \exp \frac{-\left(\Delta e_{t}-\mu_{1 t}\right.}{2 h_{2 t}}
\end{gathered}
$$

$p_{1 t} p_{1 t}=\operatorname{Pr}\left(\mathrm{S}_{\mathrm{t}}=1 \mid \Phi_{\mathrm{t}-1}\right)$ is the probability that the analyzed process is in regime 1 at time $\mathrm{t}$ and is updated by means of Bayesian inference using information available at time $t-1$. Therefore, $p_{1 t}$ and $\left(1-p_{1 t}\right)$ can be regarded as weights assigned to regime dependent forecasts resulting from a rational learning process as outlined in the theoretical exchange rate model. For comparison purposes, we first specify the mean equations without taking into account foreign exchange market activities of central banks. However, the important results of the study are derived from mean equations that include intervention dummies as it is done in the second specification.

(1)The standard regime-switching-c\&f model: $R S-C F$

The mean equation of the first regime represent the fundamentalist regime including the deviation of the exchange rate from its fundamental value $e_{t}$ describe by Uncovered Interest Parity (UIP) as outlined above. The second regime's mean equation contains chartist expectation, i.e the moving average trading consisting of the differences between $\mathrm{ma}_{14}$ and $\mathrm{ma}_{200}$ :

$$
\mu_{0 t}=\theta\left(p p p_{t-1}-e_{t-1}\right.
$$




$$
\mu_{1 t}=\psi\left(m a_{14, t-1}-m a_{200, t-1}\right)
$$

The variance of et,i.e.the volatility of $\mathrm{e}_{\mathrm{t}}$ is assumed to be constant within regimes, $\mathrm{h}_{0 \mathrm{t}}=\sigma_{F}^{2} \sigma_{F}^{2}$ and $\mathrm{h}_{1 \mathrm{t}}=\sigma_{c}^{2}$ $\sigma_{c}^{2}$ so that the only source of conditional heteroscedasticity is the regime switching behavior.

\section{(2)The intervention augmented regime-switching-c\&f model: RS-CF-Int}

To introduce intervention operations into the regime-switching framework, we define that the dummy variable It $=1$, if the central bank intervenes at time $t$ and $\mathrm{It}=0$, otherwise and rewrite the mean equations of the standard C\&F model as follows:

Fundamentalist Rule without FX intervention Specification

\section{With FX intervention}

\section{Chartist Rule without intervention Specification}

\section{With FX Intervention}

As long as interventions do not occur, i.e. It $=0$, this more general formulation boils down to the standard RSCF model. More interestingly, if the foreign exchange intervention of the central bank had an impact on the forecasting performance of chartists and fundamentalists, a change of coefficients represented by significant estimates of the various s should be observed. By introducing intervention dummies in the specification of second Moments $\mathrm{h}_{0 \mathrm{t}}={ }_{F}^{2}+\delta_{\sigma_{F}^{2}} \sigma_{F}^{2}+\delta_{\sigma_{F}^{2}} . \mathrm{I}_{\mathrm{t}}$ and $\mathrm{h}_{1 \mathrm{t}}=\sigma_{c}^{2}+\delta_{\sigma_{c}^{2}} \sigma_{c}^{2}+\delta_{\sigma_{c}^{2} \text {. It }}$ we are able to re-examine the relationship between central bank intervention and exchange rate volatility, where the existing literature provided mixed evidence (Baillie and Osterberg, 1997b and Dominguez, 1998).

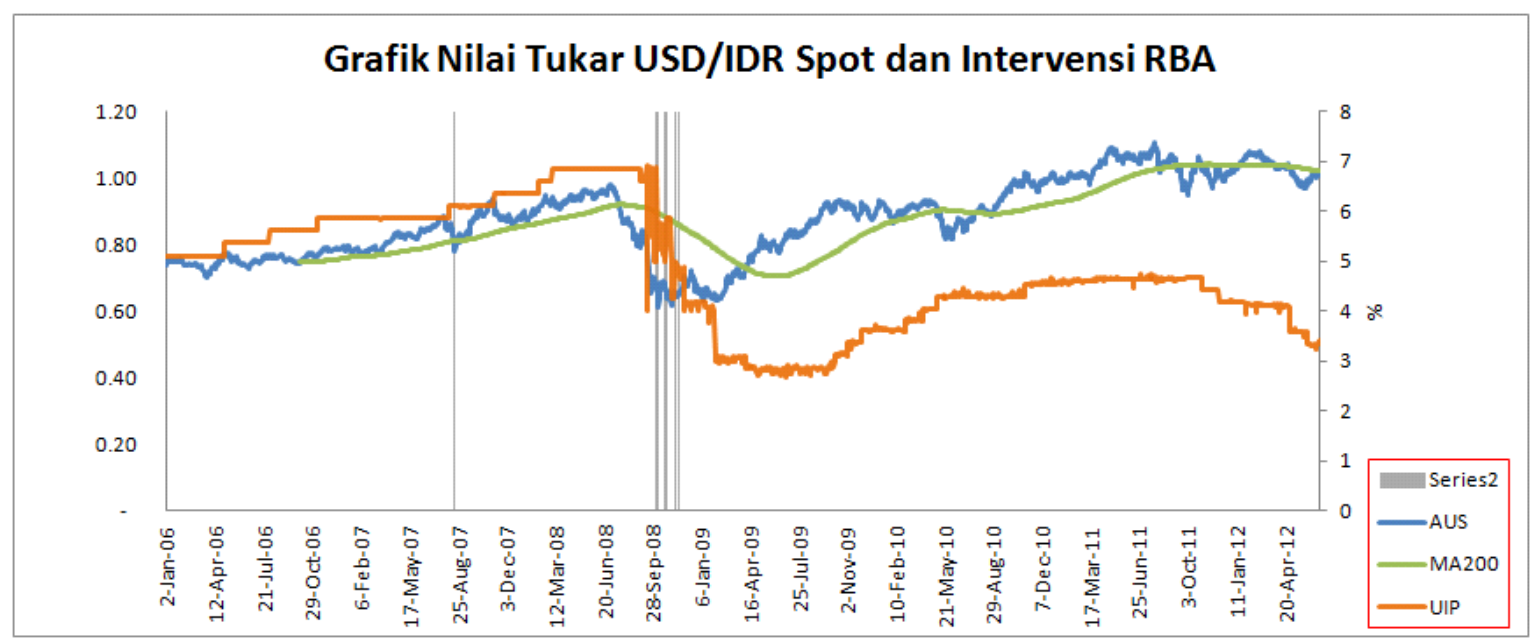

Figure 1. AUD/USD Spot, UIP, MA200 \& the RBA Intervention

\section{Empirical Results}

The models described above were estimated by maximum likelihood. Parameter estimates were obtained using the BFGS algorithm, and the reported t-statistics are based on heteroskedastic-consistent standard errors (White,1982). The estimates are derived from the daily AUD/US-Dollar spot exchange rate series kindly supplied by the RBA. The UIP was constructed using daily O/N Interbank rate of AUD and USD. The intervention dummy series is based on intervention data from the RBA. The foreign exchange intervention series only includes active trades made by the RBA for reasons of influencing foreign exchange rates. Purchases and sales of the RBA are reported whenever they changed their net foreign assets. The sample extends from January 2006 to June 2012. The series of the spot exchange rate, the UIP relation and the 200 day moving average are presented in upper graph, the RBA purchases and sales of Dollars against AUD can be found in the middle graph.

Table 1 contains the estimates of both the RS-CF, and the RS-CF-Int models for Australian Case. As regards the transition probabilities, the models differ slightly at best. P and Q range above 0.95 thereby indicating high persistence of regimes. The unconditional probability of the fundamentalist regimes $\mathrm{P}$ is lower $(0.4)$ than the one assigned to chartist regimes (0.6). This is also reflected in the expected duration of regimes. The (first) fundamentalist regimes are expected to last up to 21 trading days whereas the (second) chartist regimes have a longer duration of at least 32 trading days. Significant estimates of variances point to regime dependent heteroskedasticity capturing periods of high and low volatility: The second moment in the second regimes is 
lower than the variance in the first regimes. The estimates of chartist and fundamentalist coefficients and are statistically significant and of the correct sign

\begin{tabular}{|c|c|c|}
\hline & $\mathrm{RS}-\mathrm{CF}$ & RS-CF-Int \\
\hline$\theta$ & $\begin{array}{l}0,257 \\
(11,74) * * *\end{array}$ & $\begin{array}{l}0,251 \\
(13,02) * * *\end{array}$ \\
\hline$\delta_{\theta}$ & & $\begin{array}{l}0,156 \\
(2,86)^{* * *}\end{array}$ \\
\hline$\omega_{\theta}$ & & \\
\hline$\psi$ & $\begin{array}{l}0,081 \\
(10,68) * * *\end{array}$ & $\begin{array}{l}0,080 \\
(12,90)^{* * *}\end{array}$ \\
\hline $\begin{array}{l}\delta_{\psi} \\
\omega_{\theta}\end{array}$ & & $\begin{array}{l}0,011 \\
(0,16)\end{array}$ \\
\hline$\sigma_{F}^{2}$ & $\begin{array}{l}8,37 \times 10^{-5} \\
(6,33) * * *\end{array}$ & $\begin{array}{l}8,19 \times 10^{-5} \\
(6,41)^{* * *}\end{array}$ \\
\hline$\delta_{\sigma_{F}^{2}}$ & & $\begin{array}{l}0,43 \times 10^{-5} \\
(0,10)^{*}\end{array}$ \\
\hline$\sigma_{C}^{2}$ & $\begin{array}{l}1,74 \times 10^{-5} \\
(6,04) * * *\end{array}$ & $\begin{array}{l}1,71 \times 10^{-5} \\
(7,75)^{* * *}\end{array}$ \\
\hline$\delta_{\sigma_{C}^{2}}$ & & $\begin{array}{l}0,80 \times 10^{-6} \\
(0,1)\end{array}$ \\
\hline $\mathrm{P}$ & $\begin{array}{l}0,953 \\
(33,55) * * *\end{array}$ & $\begin{array}{l}0,954 \\
(42,34) * * *\end{array}$ \\
\hline Q & $\begin{array}{l}0,969 \\
(47,05) * * *\end{array}$ & $\begin{array}{l}0,969 \\
(54,39) * * *\end{array}$ \\
\hline $\bar{P}$ & 0,398 & 0,406 \\
\hline $\bar{Q}$ & 0,602 & 0,594 \\
\hline$(1-P)^{-1}$ & 21,48 & 21,81 \\
\hline$(1-Q)^{-1}$ & 32,54 & 31,94 \\
\hline Log-Likelihood & 5266,31 & 5270,10 \\
\hline LRT & & $7,59 *$ \\
\hline
\end{tabular}

Table 1.Estimation Result

\section{Conclusion}

Although there is evidence that monetary authorities tried to avoid misalignments and counter 'disorderly markets', the impact of central bank intervention on foreign exchange rates repeatedly turned out to be low when assessed by means of conventional single regime approaches. It becomes even more difficult to imagine a rational expectations model capable of explaining these results, when taking into account that intervention seems to increase the profitability of technical trading rules (LeBaron,1999). On the basis of the theoretical heterogeneous expectation framework, a generalization of Hung's (1997) noise trading channel is estimated by means of an intervention augmented two state Markov regime-switching model. We show that the predictive power of sophisticated fundamentalist forecasting techniques approximated by the deviation of the current exchange rate from the UIP level, was enhanced whenever the RBA intervened on the foreign exchange market, whereas simple chartist approach was not strengthened in these periods. However, intervention seems to have small influence on the weight assigned to either forecasting strategy.

If chartist analysis tends to be destabilizing as is widely accepted in the literature, a volatility enhancing impact of central bank intervention on exchange rates, can not be ruled out. However, this is little proof by the finding that the intervention dummy identified periods in which the volatility is a bit increasing especially within fundamentalist rule. Of course, we have to address a serious causality problem. Before quickly concluding that exchange rate volatility is due to intervention operations, 'disorderly markets', i.e. high volatility, may have challenged central bank activities. But as long as this reverse causality is not confirmed, central bank intervention remains an ambiguous policy tool in influencing exchange rates.

\section{References}

- $\quad$ Ahrens et.al, 2003."Heterogeneous Expectations in the Foreign Exchange Market Evidence from the Daily Dollar/DM Exchange Rate”.CFS Working Paper No. 2003/11.German. 
- Baillie, R and Osterberg, W, 1997a."Central Bank Intervention and Risk in the ForwardMarket”, Journal of International Economics, Vol. 43, p.483 - 497.

- $\quad$ Baillie, R and Osterberg, W, 1997b.“Why Do Central Banks Intervene?”,Journal of International Money and Finance, Vol. 16, p. $909-919$.

- Ben Maatoug, et.al, 2010. “Central Bank Intervention within a Chartist-Fundamentalist Exchange Rate Model: Evidence from the RBA Case".

- Clarida et al, 2001."The Out-of-Sample Success of Term Structure Models as Exchange Rate Predictors: A Step Beyond", Mimeo.

- Dewachter, H, 2001.“Can Markov Switching Models Replicate Chartist Profits in the Foreign Exchange Market?”,Journal of International Money and Finance, Vol. 20, p.25-41.

- Dominguez and Kathryn M, 1998.“Central Bank Intervention and Exchange Rate Volatility”.Journal of International Money and Finance, 17(1998) 161-190. USA.

- Engel, Ch, 1994.“Can the Markov Switching Model forecast Exchange Rates?”,Journal of International Economics, Vol. 36, p.151 - 165.

- Engel, Ch and Hamilton, J, 1990.“Long swings in the Dollar: Are they in the data and do markets know it?”,American Economic Review Vol. 80, p.689 - 713.

- Frankel, J.A. andFroot, K.A, 1986, "Understanding the US Dollar in the Eighties: The Expectations of Chartists and Fundamentalists", The Economic Record, 24 - 38.

- $\quad$ Frankel, J.A. and Froot, K.A, 1989. "Chartists, Fundamentalists, and Trading in the Foreign Exchange Market", American Economic Review Papers and Proceedings, vol.80, p.181-5

- Hung, J, 1997.“Intervention Strategies and Exchange Rate Volatility: A Noise Trading Perspective”, Journal of International Money and Finance, Vol. 16, p. 779 - 793.

- $\quad$ Krugman and Paul R, 2000. "Technology, trade and factor prices," Journal of International Economics, Elsevier, vol. 50(1), pages 51-71.

- LeBaron, B, 1999.“Technical Trading Rule Profitability and Foreign Exchange Intervention”, Journal of International Economics, Vol. 49, p.125 - 143.

- Lee, Ch et al, 2001. "Trading rule profits in Latin American currency spot rates", International Review of Fin. Analysis, Vol. 10, p.135 - 156.

- Ma, Guonan et al, 2004.’The Markets for non-deliverable forwards in Asian Currencies”, BIS Quarterly Review

- Neely, C, 1997. “Technical Analysis in the Foreign Exchange Market: A Layman's Guide”, Federal Reserve. Bank of St. Louis Review, Vol. 79:5,p. 23 - 38.

- Neely, C and veller, P, 2001.'Technical Analysis and Central Bank Intervention”, Journal of International Money and Finance, Vol. 20, p.949 - 970.

- Pilbeam K, 1998. "International Finance” $2^{\text {nd }}$ Edition.Palgrave Publishers Ltd. New York, USA.

- $\quad$ Reitz, S, 2002. "Central Bank Intervention and Exchange Rate Expectations - Evidence from the Daily DM/US-Dollar Exchange Rate". Discussion Paper 17/02. Economic Research Centre of the Deutsche Bundesbank.

- $\quad$ Richard TB and William PO, 1998."Central bank intervention and overnight uncovered interest rate parity," Working Paper 9823, Federal Reserve Bank of Cleveland.

- $\quad$ Röthig, et.al ,2005. "Corporate Currency Hedging and Currency Crises," Publications of Darmstadt Technical University, Institute of Economics (VWL) 27194, Darmstadt Technical University, Department of Business Administration, Economics and Law, Institute of Economics (VWL).

- Takagi, S, 1991. "Exchange Rate Expectations, A Survey of Survey Studies”, IMF Staff Papers, Vol. 38 (1)

- Taylor, MP, 2004. “Is Official Exchange Rate Intervention Effective?”.Economica, 71,1-11. The London School of Economics and Political Science.

- Vigfusson, R, 1996. "Switching Between Chartists and Fundamentalists: A Markov RegimeSwitchingApproach”. Working Paper 96-1. Bank of Canada.

- Wang, P, 2009. “The Economics of Foreign Exchange and Global Finance”,Springer-Verlag Berlin Heidelberg

- White, H,1982."Maximum likelihood estimation of misspecified models”, Econometrica, Vol. 50,p. 1 - 25.

- Warjiyo, P, 2004. “Ekonomi KeuanganInternasional: Teori, Model Empiris, dan Kebijakan”. Program Pascasarjana - Universitas Indonesia Program Studi Ilmu Ekonomi. 


\title{
Analysis of Capital Flight in Developing Countries: A Study on Turkey between 1980 and 2010
}

\author{
Asst. Prof. Dr. Ali Özer (Erzincan University, Turkey) \\ Ph.D. Candidate Aslı Cansin Doker (Erzincan University, Turkey) \\ Ph.D. Candidate Adem Türkmen (Erzincan University, Turkey)
}

\begin{abstract}
The aim of this study is to determine whether there is a relationship between Capital flight and some macroeconomic variables by using anual data between 1980 and 2010 in Turkey. Capital flight measured by World Bank (1985) method, was used as dependent variable and external debt, foreign direct investment, uncertainty, real GDP growth, exchange rates, trade balance and consumer price index were used as independent variables. Ordinary Least squares estimation method, Johansen-Jeselius cointegration test, Granger causality test and variance decomposition results produced by VEC model were used in the study. After those econometrics and economics analysis, this paper put forward that there is a long run relationship between some macroeconomic variables and capital flight.The results show external debt, foreign direct investment inflows, and foreign reserves to be the major effector of capital flight.
\end{abstract}

\section{Introduction}

It is suggested to developing countries opening the capital outside for attract capital and finance their investment. These countries adapted to financial liberalazation policies and benefited from large amounts of capital input in accordance with these recommandations. Dependency on foreign capital is generally quite variable and exhibits an unstable structure, has made these countries more vulnerable to the financial crisis. The specified point, has affected developing countiries, including Turkey. These developments have led to discussions about importance capital flight in Turkey and how we could be back this capital from abroad.

There is no generally accepted definition of capital flight, even though its activities have been identified for periods dating back to the seventeenth century.The variety of capital flight definitions (Cuddington 1986; World Bank 1985; Morgan Guaranty Trust Company 1986; Cline 1987; Dooley 1986; Lessard and Williamson 1987) makes it diffucult to separate normal capital out flows and flight capital out flows. Although there is no generally accepted definition of capital flight, the literature has postulated three major reasons for its existence: (1) investment, (2) money laundering, and/or (3) tax evasion (Boyrie 2010).

Although capital flight has been a problem as early as the seventeenth century in Europe and in the early twentieth century in Europe and United States of America (see, e.g., Kindleberger, 1987), the subject matter in the contemporary world latter gained momentum again since the early 1980 s.

Demirgil (2011) examined capital flight and instability for Turkey between 1970 and 2006 with using GARCH and EGARCH analysis and he founded that political instability affects on economic growth negatively and on inflation rate positively, additionally exchange rate does not have long run and strong effect on macroeconomic varibles.(Demirgil H., 2011)

\section{Literature}

There are many of studies and research papers examined the reasons and results/impacts of capital flight in developing countries. Most of them investigated relationship between macroeconomics variables, which can be classified such as foreign direct or indirect investment, infilation, external debt, and capital flights. In addition, there are many of studies related to measurement of capital flight. In this section, those indicators and findings will be discussed in respect of determinants of capital flights, measurements for capital flights and classification diffrences for analysing capital flight.

Ndikumana and Boyce (2003) examined with their seminar paper which way the relationship between capital flight and external borrowing has in African countries between 1970 and 1996. One of important result of their study is that external borrowing effects significant and positively to capital flight. Another important finding from their study is related to persistence of the value of capital flight which was found significant. This result shows that past data of capital flight can cause or effect future data of capital flight.

The impacts of capital flight in Indonesia, Malaysia and Thailand were examined with using the explanation of revolving door mechanism by Beja (2007). He put forward three type of risk as causes or explanaories of capital flights. Moreover, there are very importance finding from this paper such that large capital flows follow revoling door mechanism. This study also shows lost capital in these countries may well return as either foreign investment or debt hence following revolving door mechanism. One of econometric result of this paper is capital flight causes debt and high level of risk. From conclusion of this paper is an adequate amount of international 
reserves and trustworthy indicator of economic growth could well cause decrease of external borrowing and capital flight.

About explation power of external borrowing for capital flight in China is analysed by Ljuingwall and Wall (2008). In their study, balance of payment data between 1993 and 2003 is used. In china external borrowing is significant, in other words external borrowing can be an explanation for capital flights. Another supportive study related to China is about external borrowing fuels findings are similar to Latin America except interest rate and exchange rate significancy which China does not have those indicators. Frank R. Gunter (2003) presented that capital policies in China between 1998 and 1999 did not change level of capital flights with using balance of payment and residuals measurements.

Another important research of capital flight with using portfilo choice model was conducted by Quan Vu Le and Paul J. Zak (2006). The inflences from this paper can be written such that firstly, the political stability is the most crucial factor to return capital flights. Secondly, with using three types of risk, which economic risk, political instability, and policy variability are, explains capital flights statistically significant. In 2011, Yasemin Yalta and A. Talha Yalta examined effects of financial liberalisation on magnitude of capital flight with using panel causality modelling in private sector. Their sample was 21 emerging market economies between 1980 and 2004 time period. This study showed that there is no significant proof of causal relationship and their result is that financial liberalasation could not be useful for reducing capital flight. Furhtermore, Maria E. de Boyrie (2010) examined determinants of capital flight and capital movement through trade missing including African Case between 1990 and 2005. In this study, 21 independent variables were used as a result of this capital flight could not explain all capital flows. Moreover, long-term relationship was found only for a few cases. They also concluded their paper with recommendation for African policymakers such as putting forward stronger and more specified trade policies to decrease capital flight. There is also another paper which is conducted for investigating the causes of capital flight on Zimbabwe between 1980 and 2005. (Makochekanwa A., 2007)

In econometrics aspect, capital flight is subject with several techniques which are causality, cointegration, panel analysis and unit root and simultaneous equations. For instance, Chipakatti and Rishi (2002), they applied utilized simitaneous equations to associate external debt and capital flight in Indian case during 1971-1997 and the study confirmed that this relationship is following same way with revolving door mechanism. Another econometric method was used for capital flight research is coingtegrtion technique which is developed by Pesaran et.al.(2001). The findings from this paper states that income taxes, higher real interest rate diffrentials are significant to identify capital flight. As a result of this findings and research political stability is the most effective factor to prevent from capital flight.(Alam, M, Quazi R., 2003)

\section{Capital Flight Measurement}

There is no concensus measure of capital flight. There are several methods used in the literature to measure capital flight. Some of them are direct, while others are indirect. The Residual measure introduced by the World Bank (1985) is the most popular measure and it relies on the indirect definition of capital flight. The World Bank (1985) estimates the capital flight as the difference between the sources of funds and uses of funds. According to World Bank definition, capital flight can be written as follows:

$$
\mathrm{CFR}=\mathrm{CXB}+\mathrm{NFDI}-\mathrm{CAD}-\mathrm{COF}
$$

Where:

$\mathrm{CFR}=$ Capital Flight (residual measure)

$\mathrm{CXB}=$ Change in external borrowing

NFDI $=$ Net foreign direct investment

$\mathrm{CAD}=$ Current account deficit

COFR $=$ Change in official foreign reserves

Dooley (1986) method distinguished between normal capital flows from abnormal capital flows. Based on this approach, the motive behind capital flight is the individual assumptions about the individuals' motives. Capital flight is therefore measured as the sum of externally held assets of the private sector that does not generate recorded income in the Country's balance of payments. Following Hermes et al $(2002$, p.2), the Dooley method of measuring capital flight can be derived as follows:

$\mathrm{TCO}=\mathrm{FB}+\mathrm{FDI}-\mathrm{CAD}-\Delta \mathrm{FR}-\mathrm{EO}-\Delta \mathrm{WBIMF}$

Where;

TCO is total capital outflows,

FB is foreign borrowing as reported in the balance of payments,

FDI is the net foreign investment inflows,

FR is the stock of official foreign reserves, 
CAD is the current account deficit/surplus,

EO is net errors and omissions (debit entry),

WBIMF is the difference between the change in the stock of external debt and foreign borrowing reported in the balance of payments

Another indirect measure introduced by Morgan Guaranty Trust Company (1986),

$$
\mathrm{CFPC}=\mathrm{CXB}+\mathrm{NFDI}-\mathrm{CAD}-\mathrm{COFR}-\mathrm{CBSFA}
$$

Where,

CFPC $=$ Capital flight (private claim)

CBSFA $=$ Change in short - term banking system foreign assets

The balance of payments measure introduced by Cudington (1986) defines capital flight as short-term capital outflow rather than total outflow of capital by the private sector. Cuddington measure can be calculated as follows:

$\mathrm{CFC}=\mathrm{NBSC}+\mathrm{EO}$

Where,

$\mathrm{CFC}=$ Capital flight (Cuddington)

NBSC $=$ Non-bank short-term capital outflow

$\mathrm{EO}=$ Balance of payments errors and omissions

Ajilore (2010) argues that countries that have strong capital flight proclivities, it is reasonable to assume that trade mis-invoicing may be utilized as a channel for capital flight. Trade mis-invoicing method equations are given as follow:

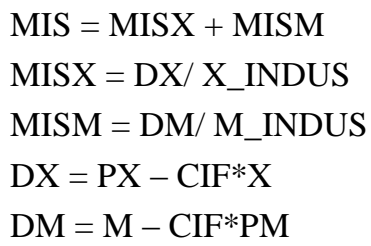

Where;

MIS = total trade mis-invoicing

MISX $=$ trade mis-invoicing from the export

MISM $=$ trade mis-invoicing from the import

$\mathrm{DX}=$ total export discrepancies with trade partners

$\mathrm{DM}=$ total import discrepancies with trade partners

X_INDUS = industrialized-country trading-partners in the country's total import

M_INDUS = industrialized-country trading-partners in the country's total export

$\mathrm{PX}=$ trading partner's import value

$\mathrm{PM}=$ trading partner's export value

$\mathrm{M}=$ reported imports

$\mathrm{X}=$ reported exports

$\mathrm{CIF}=$ cost of freight and insurance adjustment

\section{Methodology}

The theory does not offer a sharp way of determining a priori which independent variables should be included when we examine that factors that affect the variation in the capital flight. Therefore, we follow the literature and examine the most important variables that have been considered.

The following model is employed in the analysis of the determinants of capital flight in Turkey;

$\mathrm{CF}=\alpha_{0}++\alpha_{1} \mathrm{ED}+\alpha_{2} \mathrm{INF}+\alpha_{3} \mathrm{FDI}+\alpha_{4} \mathrm{ER}+\alpha_{5} \mathrm{UNC}+\alpha_{6} \mathrm{TBAL}+\alpha_{7} \mathrm{GR}+\varepsilon_{\mathrm{t}}$

Where,

Capital Flight (CF): We use the World Bank (1985) method .

External Debt (ED): is measured as change in external debt divided by GDP. A positive relationship between the external debt and capital flight is expected

Inflation (INF): is the rate of inflation in the domestic economy. We measure inflation as consumer price index. 
Foreign Direct Investment (FDI): We include this variable in the model in order to see if FDI facilitate or reduce capital flight (see Le and Rishi, 2006)

Exchange Rate (ER): is the yearly average of exchange rate of one US dollar in Turkey.

Uncertainty (UNC): We measure the macroeconomic uncertainty by calculating the deviation of GDP from its three-year moving average.

Trade Balance (TBAL): is the trade balance in million US dollars.

Real GDP Growth (GR): Following Mikkelsen (1991), we use Real GDP growth rate as a measure for real rate of return of the economy. The higher the level of growth in the economy and hence the opportunities for domestic investments, the less the incentives to engage in capital flight. (Ajayi 1992) A negative relationship is expected between capital flight and Real GDP.

$\varepsilon_{\mathrm{t}}$ is the error term.

In the study, determinant of capital flight is investigated with both ordinary least squares and a Vector Error Correction model for mutual relationship between these variables. VEC model is introduced by Engle and Granger (1987) for examining cointegration i.e. for long-run relationship between variables in Vector Autoregression (VAR) model. A VEC model can be expressed as follow.

$$
\Delta \mathrm{x}_{\mathrm{t}}=\alpha+\mathrm{B}(\mathrm{L}) \Delta \mathrm{x}_{\mathrm{t}-1}+\mathrm{d}^{\prime}\left(\mathrm{e}_{\mathrm{t}-1}\right)+\mathrm{y}_{\mathrm{t}}
$$

Where;

$$
\begin{aligned}
& \Delta \mathrm{x}_{\mathrm{t}}=\mathrm{n} \times \mathrm{t} \text { vectors of variables, } \\
& \alpha=\mathrm{n} \times 1 \text { vectors of constants, } \\
& \mathrm{B}(\mathrm{L})=\mathrm{n} \times \mathrm{n} \text { matrices of the polynomial expression in the lag operator, } \\
& \mathrm{d}^{\prime}=\mathrm{n} \times 1 \text { vectors of constants, } \\
& \mathrm{e}_{\mathrm{t}-1}=\mathrm{n} \times \mathrm{t} \text { vectors of error correction terms, } \\
& \mathrm{y}_{\mathrm{t}}=\mathrm{n} \times \mathrm{t} \text { vectors of residuals. }
\end{aligned}
$$

In the study, Granger causality test is applied for investigating direction of relationship between variables. This test is fist applied in the literature by Granger (1969). Then, Hamilton (1994) developed this test. In Granger causality, the direction of relationship is investigated between variables like $\mathrm{x}$ and $\mathrm{y}$. If the current $\mathrm{y}$ value is better estimated with past values of $x$ rather than current value of $x$, we can say that there is Granger causality from $\mathrm{x}$ to $\mathrm{y}$ variable.

The data employed in this study are yearly macroeconomic variables which include, capital flight, interest rate, inflation, external debt stock, exchange rate, foreign direct investment, trade balance, uncertainity and real GDP growth. The sample period is from 1980 through 2010. All data were directly obtained from CBRT (Central Bank of the Republic of Turkey) Electronic Data Delivery System, International Financial Statistics (IFS) issued by International Monetary Fund and World Bank Data. Eviews 7.1 was used for analysis.

\section{Empirical Analysis and Discussion}

The regression of a nonstationary time series on another nonstationary time series may produce a spurious regression. In order to produce a meaningful estimate, it is important to conduct a unit root test. Testing for the existence of unit roots is a principal concern in the study of time series models and co-integration. The presence of a unit root implies that the time series under investigation is non-stationary; while the absence of a unit root shows that the stochastic process is stationary. The Augumented Dickey-Fuller test as presented in Dickey and Fuller (1979) is an important tool for doing this. To test the null hypothesis of a unit root, the t-statistic and the asymptotic critical values were taken from Davidson and MacKinnon (1993). This outcome is presented in Table 1.

\begin{tabular}{|l|l|l|l|}
\hline Variables & Levels & First Difference & Second Difference \\
\hline CF $(0)$ & -2.493982 & $-4.757862^{*}$ & - \\
\hline ED $(0)$ & -2.582605 & $-4.083576^{* *}$ & - \\
\hline INF (1) & -2.564259 & $-4.334224^{*}$ & - \\
\hline FDI (1) & -1.974891 & $-7.354670^{*}$ & - \\
\hline ER (0) & $-5.880260^{*}$ & - & - \\
\hline UNC (2) & -1.595645 & $-12.13160^{*}$ & - \\
\hline TBAL $(0)$ & $-4.498936^{*}$ & - & - \\
\hline GR (3) & -3.149052 & -2.439746 & $-4.145467^{* *}$ \\
\hline
\end{tabular}

Table 1: Result of Stationary Test (Augmented Dickey-Fuller Test) (Note: * significant at 10\%; ** significant at $5 \%$;** significant at $1 \%$ ) 
The table above shows that the stationarity of the variables at different levels of differencing. It could be seen that ER and TBAL are the variables that is stationary at level difference while other variables are stationary at first difference except GR which is stationary at second difference. Below is the presentation of the least square estimation results from the analysis conducted on the model.

\begin{tabular}{|l|l|l|}
\hline Variables & Coefficient & T-Statistic \\
\hline C & 47.42254 & $8.344144^{*}$ \\
\hline ED & 0.00914 & $19.63005^{*}$ \\
\hline INF & -0.163405 & -1.605811 \\
\hline FDI & -0.001770 & $-1.971529^{* * *}$ \\
\hline ER & -27.14612 & $-5.689021^{*}$ \\
\hline GR & $-2.51 \mathrm{E}-08$ & $-0.833179^{*}$ \\
\hline UNC & $1.18 \mathrm{E}-07$ & $1.065974^{*}$ \\
\hline TBAL & 0.002213 & $2.665611^{* *}$ \\
\hline \multicolumn{2}{l}{} \\
\hline $\mathrm{R}^{2}$ & 0.9265 & \\
\hline DW & 1.9361 & \\
\hline F & $124.6686^{*}$ & \\
\hline
\end{tabular}

Table 2: The Least Square Estimation Results (* significant at 10\%; ** significant at 5\%; *** significant at 1\%)

According to regression model we use, the results for independent variables, except INF all the variables are significant which means that only inflation rate has no influence on the capital flight in Turkey during the study period. From the above results, it can be seen that the co-efficient of the constant parameter is positively related with the CF. This indicates that if all explanatory variables are held constant, CF will increase by 47.42254 units. The explanatory power of the model is estimated at 0.9265 which indicates that $92.65 \%$ variations or changes that occurs in the present state of CF is determined by the changes in the values of the independent variables while the remaining $7.35 \%$ is explained by the variation outside the model or captured by the error term. The Ftest statistic of 124.66 , significant at $1 \%$ indicates that conducted model is valid.

The coefficient UNC variable is positive and significant at the $1 \%$ level. Finding from analysis of relationship between uncertainty and capital flight is found positive and significant within 1 per cent level. In other words, uncertainty causes capital flight at per cent significance level. The content and the movement of recent and future public policies are indetermined and also it could well. Economic uncertainty is directly related to increase capital flight because of the characteristic of capital flight. From the theory, it is possible to say, if the economy has high level of uncertainty with using percentage of difference from previous value, this could be magnitude for capital flight. It is clear that policymakers should draw the way of the economy to prevent uncertainty level and relatively capital flight.

The results also indicate that the GR is negatively related to capital flight: higher growth leads to less capital flight. GDP growth rate is statistically significant at the 5\% level. Countries unable to improve economic growth, because of weak macroeconomic policies or inefficient economic sectors, will discourage investors.

The impact of the ED on CF is positive and significant at the $1 \%$ level. In economic theory, one of important indicator for economic instability can be external debt. In this situation, it is had to estimate the position of debtor credit and also it can struggle to use taxes as a preventer for decreasing external debt. As expected from the theory, there is significant and positive relationship between external debt and capital flight at $1 \%$ level.

The impact of the FDI on CF is negative and significant at the $10 \%$ level. Foreign direct investment has sensitivity to economic stability; of course, the econometric results are negative and significant relationship at $1 \%$ level. The meaning of this relationship is to put forward the policies for attracting foreign direct investment can reduce capital flight.

The impact of the TBAL on CF is positive and significant at the 5\% level. The impact of the trade balance is examined and relationship with capital flight is found significant and positive at $\% 5$ level. Increase in trade blance provides boost on exchange for the chosen county in other words the chosen country reaches the exchange surplus position. Consequently, this situation is resulted being exchange deficit position for another county. Based on that information, the foreign county aims to increase their investment rate for eliminating the exchange deficit position as a result of it, capital flight occurs.

The impact of the ER on CF is negative and significant at the $1 \%$ level. Another result from econometric analysis is related to exchange rate and capital flight which is found significant and negative with in $1 \%$. Decrease in exchange rates as a result of foreign portfolio investors who invested in hot money in TL, TL increases in the value of assets denominated in foreign currencies. Wishing to benefit from the increase in the return on the exchange rate difference arising out of the interest of foreign investors, capital flight occurs. Moreover, the decrease in exchange rates of foreign currencies appreciated the owners of capital market orientation shifts towards developing countries. 
There are various approaches to test for cointegration, say, Engle and Granger approach, Johansen approach and Gregory and Hansen approach. The bivariate approach of Engle and Granger is very restrictive because it can be applied only if there is one cointegrating relation. And the most commonly used method is the Johansen cointegration test based on the autoregressive representation discussed by Johansen (1988) and Johansen and Juselius (1990). This test determines the number of cointegrating equations for any normalization used. It provides two different likelihood ratio tests; one is based on the trace statistic and the other on the maximum eigenvalue. At this stage of the study, whether it is a long run relationship between the variables JohansenJuselius cointegration test is investigated. In addition, the Johansen-Juselius cointegration test of bilateral relations with $\mathrm{CF}$ was investigated.

\begin{tabular}{|l|l|l|l|l|l|l|l|l|}
\hline & \multicolumn{9}{|l|}{ Trace Test } & \multicolumn{2}{l|}{ Max-Eigen Test } \\
\hline & $\mathbf{H}_{\mathbf{0}}$ & $\mathbf{H}_{\mathbf{1}}$ & $\begin{array}{l}\text { Trace } \\
\text { Statistic }\end{array}$ & $\begin{array}{l}\mathbf{0 . 0 5 C r i t i c a l} \\
\text { Value }\end{array}$ & $\mathbf{H}_{\mathbf{0}}$ & $\mathbf{H}_{\mathbf{1}}$ & $\begin{array}{l}\text { Max-Eigen } \\
\text { Statistic }\end{array}$ & $\begin{array}{l}\text { 0.05Critical } \\
\text { Value }\end{array}$ \\
\hline None* $^{*}$ & $\mathrm{r}=0$ & $\mathrm{r} \geq 1$ & $388.7022^{*}$ & 187.4701 & $\mathrm{r}=0$ & $\mathrm{r}=1$ & $121.3865^{*}$ & 56.70519 \\
\hline At most 1* & $\mathrm{r}=1$ & $\mathrm{r} \geq 2$ & $267.3157^{*}$ & 150.5585 & $\mathrm{r} \leq 1$ & $\mathrm{r}=2$ & $87.17834^{*}$ & 50.59985 \\
\hline At most 2* & $\mathrm{r}=2$ & $\mathrm{r} \geq 3$ & $180.1374^{*}$ & 117.7082 & $\mathrm{r} \leq 2$ & $\mathrm{r}=3$ & $62.58674^{*}$ & 44.49720 \\
\hline At most 3* & $\mathrm{r}=3$ & $\mathrm{r} \geq 4$ & $117.5506^{*}$ & 88.80380 & $\mathrm{r} \leq 3$ & $\mathrm{r}=4$ & $52.23570^{*}$ & 38.33101 \\
\hline At most 4 & $\mathrm{r}=4$ & $\mathrm{r} \geq 5$ & 62.31494 & 63.87610 & $\mathrm{r} \leq 4$ & $\mathrm{r}=5$ & 25.86353 & 32.11832 \\
\hline At most 5 & $\mathrm{r}=5$ & $\mathrm{r} \geq 6$ & 39.45141 & 42.91525 & $\mathrm{r} \leq 5$ & $\mathrm{r}=6$ & 20.19299 & 25.82321 \\
\hline At most 6 & $\mathrm{r}=6$ & $\mathrm{r} \geq 7$ & 19.25842 & 25.87211 & $\mathrm{r} \leq 6$ & $\mathrm{r}=7$ & 13.32489 & 19.38704 \\
\hline At most 7 & $\mathrm{r}=7$ & $\mathrm{r} \geq 8$ & 5.933532 & 12.51798 & $\mathrm{r} \leq 7$ & $\mathrm{r}=8$ & 5.933532 & 12.51798 \\
\hline
\end{tabular}

Table 3. Johansen Cointegration Test Results (Multivariate)

In Table 3, cointegration of variables expressing whether the hypothesis $\mathrm{H}_{0}(\mathrm{r}=0)$ of the Trace Statistic is calculated 388.7022. This value is obtained from the 5\% significance level, the null hypothesis was rejected because it is larger than the critical value of 187.4701 and cointegrated vector have been identified. Both statistic tests which are Trace and Max-Eigen statistic produced similar results. Either the trace test or the maximum eigenvalue test reveals the presence of a cointegrating vector, implying that there is a long-run equilibrium relationship between the variables. The results show that there is more than one cointegrating vectors whereby there are four cointegrating vectors between the CF and other variables. This gives the conclusion that in the long-term CF moves together with other variables towards equilibrium. In this context about the relationship between long-term stability can be mentioned and cointegration vector estimates obtained from this relationship is shown below.

$$
\mathrm{CF}=-0.001103 \mathrm{ED}+0.324888 \mathrm{INF}+0.005969 \mathrm{FDI}+24.83708 \mathrm{ER}+-1.12 \mathrm{E}-07 \mathrm{GR}
$$
(2.7E-05)
(0.16277)
(0.00048)
(2.77017)
(4.9E-08)

-1.12E-06 UNC-0.003491DTD

\section{(1.5E-07) (0.00089)}

(Note: An estimate of the cointegration vector is normalized according to CF. Standard error in parentheses.)

In this study, we are not discuss more on the interpretation of these number of cointegrating vectors due to the problems of interpretation when dealing more than one cointegrating vector (see Maddala and Kim, 1998: 233242).

\begin{tabular}{|l|l|l|l|l|c|}
\hline & $\mathrm{H}_{0}$ & $\mathrm{H}_{1}$ & Trace Statistic & $\mathbf{0 . 0 5}$ Critical Value & 0.01Critical Value \\
\hline CF-ED & $\mathrm{r}=0$ & $\mathrm{r}=1$ & 16.67821 & 18.39771 & 23.15239 \\
& $\mathrm{r} \leq 1$ & $\mathrm{r}=2$ & $5.966755^{* *}$ & 3.841466 & 6.634897 \\
\hline CF-FDI & $\mathrm{r}=0$ & $\mathrm{r}=1$ & 16.17171 & 18.39771 & 23.15239 \\
& $\mathrm{r} \leq 1$ & $\mathrm{r}=2$ & 2.683073 & 3.841466 & 6.634897 \\
\hline CF-ER & $\mathrm{r}=0$ & $\mathrm{r}=1$ & 14.58948 & 18.39771 & 23.15239 \\
& $\mathrm{r} \leq 1$ & $\mathrm{r}=2$ & $6.163261^{*} *$ & 3.841466 & 6.634897 \\
\hline CF-GR & $\mathrm{r}=0$ & $\mathrm{r}=1$ & $43.74255^{*}$ & 18.39771 & 23.15239 \\
& $\mathrm{r} \leq 1$ & $\mathrm{r}=2$ & 3.348945 & 3.841466 & 6.634897 \\
\hline CF-INF & $\mathrm{r}=0$ & $\mathrm{r}=1$ & 12.65611 & 18.39771 & 23.15239 \\
& $\mathrm{r} \leq 1$ & $\mathrm{r}=2$ & $4.684800^{* *}$ & 3.841466 & 6.634897 \\
\hline CF-UNC & $\mathrm{r}=0$ & $\mathrm{r}=1$ & $48.80179^{*}$ & 18.39771 & 23.15239 \\
& $\mathrm{r} \leq 1$ & $\mathrm{r}=2$ & $6.269029^{* *}$ & 3.841466 & 6.634897 \\
\hline CF-TBAL & $\mathrm{r}=0$ & $\mathrm{r}=1$ & 13.63300 & 18.39771 & 23.15239 \\
& $\mathrm{r} \leq 1$ & $\mathrm{r}=2$ & 2.256511 & 3.841466 & 6.634897 \\
\hline
\end{tabular}

Table 4. Bivariate Johansen's Cointegration Test Results (Note: * significant at 1\%; ** significant at 5\%) 
According to the bivariate cointegration test presented in Table 4, while there is a cointegration relationship between CF and ED, ER, GR, INF and UNC variables, a cointegration relationship can not be observed between $\mathrm{CF}$ and FDI, and TBAL. So, we can say that there is a long run relationship between CF and ED, ER, GR, INF and UNC variables.

It's already known that cointegration implies the existence of Granger causality, but it does not indicate the direction of the causality relationship. So, at least one directional relationship must be expected between variables. Table 5 presents Granger causality test results between CF and the other variables from VEC model.

\begin{tabular}{|l|l|l|l|}
\hline Variables & Direction of Causality & F Statistics & Probability \\
\hline CF-ED & $\rightarrow$ & $2.77274^{* * *}$ & 0.0762 \\
ED-CF & - & 1.90672 & 0.1637 \\
\hline CF-FDI & - & 1.12469 & 0.3362 \\
FDI-CF & - & 1.20145 & 0.3129 \\
\hline CF-ER & - & 0.18041 & 0.8357 \\
ER-CF & - & 2.26982 & 0.1183 \\
\hline CF-GR & $\rightarrow$ & $4.32697^{*}$ & 0.0041 \\
GR-CF & $\rightarrow$ & $11.67002^{*}$ & 0.0000 \\
\hline CF-INF & - & 2.11194 & 0.1362 \\
INF-CF & - & 0.19736 & 0.8218 \\
\hline CF-UNC & - & 0.38232 & 0.6851 \\
UNC-CF & $\rightarrow$ & $10.3067 *$ & 0.0003 \\
\hline CF-TBAL & - & 0.63606 & 0.5354 \\
TBAL-CF & $\rightarrow$ & $3.21583^{* * *}$ & 0.0522 \\
\hline
\end{tabular}

Table 5: Granger Causality Test Results from VECM (Note: * significant at 10\%; ** significant at 5\%; *** significant at 1\%)

According to the test results, there is a bidirectional causality between CF and GR. Also, we found causality from changes in UNC and TBAL to changes in CF. This means uncertainty and trade balance anticipate changes in capital flight and capital flight appear to have no effect on uncertainty and trade balance. There is no causality between $\mathrm{CF}$ and FDI, ER and INF variables.

The variance decomposition measures the proportion of forecast error variance in one variable explained by innovations in itself and the other variables. The results are summarized in Table 6 . The salient results from the variance decomposition technique are as follows: in general, own shock constitutes the predominant source of variations for all the variables in the model. Variance decomposition results from VEC model are given in Table 6.

\begin{tabular}{|l|l|l|l|l|l|l|l|l|}
\hline Periods & CF & ED & INF & FDI & ER & GR & UNC & TBAL \\
\hline 1 & 100.000 & 0.00000 & 0.00000 & 0.00000 & 0.00000 & 0.00000 & 0.00000 & 0.00000 \\
\hline 2 & 85.3166 & 0.82238 & 0.06690 & 0.59299 & 0.98027 & 5.29727 & 0.03896 & 6.88459 \\
\hline 3 & 74.7235 & 1.15919 & 0.05147 & 0.55518 & 1.00143 & 4.79465 & 0.89311 & 16.8213 \\
\hline 4 & 67.3776 & 1.41054 & 0.10891 & 0.60066 & 1.27914 & 3.67521 & 2.89336 & 22.6544 \\
\hline 5 & 62.8371 & 1.53081 & 0.26416 & 1.22525 & 2.33019 & 3.46534 & 4.13864 & 24.2084 \\
\hline 10 & 47.4866 & 4.81941 & 3.65416 & 2.17016 & 2.40722 & 2.96976 & 7.05528 & 29.4373 \\
\hline 15 & 22.2175 & 4.69556 & 13.4248 & 4.45967 & 1.28795 & 10.1928 & 11.0337 & 32.6877 \\
\hline 20 & 18.1492 & 4.19453 & 15.4465 & 4.87064 & 1.00009 & 11.5683 & 11.5719 & 33.1986 \\
\hline 25 & 14.4481 & 3.71537 & 17.5413 & 5.40874 & 0.77755 & 12.8466 & 12.0876 & 33.1746 \\
\hline 30 & 11.2494 & 3.33624 & 19.4385 & 5.86550 & 0.59273 & 14.4343 & 12.4551 & 32.6280 \\
\hline
\end{tabular}

Table 6. Variance Decomposition

According to the variance decomposition results, CF variable is mostly affected by its shocks, and then by variables of trade balance, inflation rate, growth, uncertainty, foreign direct investment, external debt, and exchange rate, respectively. At the beginning of the period, capital flight is determined only by their shocks but at the end of the 30 years, this ratio decreases to $11,2 \%$. So, $88,8 \%$ percentage of change in CF was determined by variables used in the study. Trade balance shows its impact after the fourth year and this ratio rises to $32 \%$ at the end of the period. Inflation affects CF by 2,8\% at the end of the fourth year and this ratio rises to $19 \%$ at the end of the 30th year. The effect of ER is rather small.

\section{Conclusion}

Recently capital flight has been became one of important issue for the developing countries'government and the main question is how it can be measured in orther words which measurement can show real capital flight 
effect on macroeconomic variables. After the financial crisis, develeoping countiries affected mostly including Turkey. Turkish government has been trying to fing a way to get back the capital from abroad. The chosed medhod to calculate capital flight is the residuals method which is used by World Bank. The aim of this study is to investigate the relationship between capital flight and some macroeconomic variables which are GDP per capita, exchange rate direct financial investment, rate of inflation and trade balance. For this aim, OLS method, Johansen- Juselius cointegration method, Granger causality test and VEC model are used. OLS estimation results show that there are significant relationships between capital flight and exchange rate, trade balance, exchange rate, uncertainty, financial direct investment and external debt. However, rate of infilation is insignificant with $10 \%$. There are positive impacts on trade balance, uncertainty and external debt as expected from the economics theory. Additionally, there are negative relationshiops between capital flight and financial direct investment and exchange rate. It is recommended that policymaker should put forward stricted laws to prevent capital flight; this paper shows that capital flight can be a cause of macroeconomic instability and vice verca.

\section{References}

- Ahmed A. (2013). Effects of financial liberalization on financial market development and economic performance of the SSA region: An empirical assessment. Economic Modelling, 30,261-273.

- Ajilore, O.T. (2010). “An Economic Analysis of Capital Flight from Nigeria”, International Journal of Economics and Finance, 2 (4), pp.89-101.

- $\quad$ Alam, M, Quazi R (2003). "Determinants of Capital Flight: An Econometric Case Study Of Bangladesh", International Review of Applied Economics, 17, pp.85-103.

- Beja, E (2007). "Brothers in Distress: Revolving Capital Flows of Indonesia, Malaysia, and Thailand", Journal of Asian Economics, 18, pp.904-914.

- Beja, Jr. L .Edsel. (2006). "Revisiting the Revolving Door: Capital Flight from Southeast Asia”, DESA Working Paper No. 16.ST/ESA/2006/DWP/16.

- $\quad$ Boratav,K. et.al, 1996. Dilemmas of Structural Adjustment and Environmental Policies Under Instability: Post-1980 Turkey .World Development,Volume 24, Issue 2, February 1996, Pages 373-393.

- Boyrie M., (2010). "Determinants of Capital Flight and Capital Movement through Trade Misspricing The African Case", Afican Journal of Accounting Economics, Finance and Banking Research, Vol.6 No.6.

- $\quad$ Boyrie, Maria E., (2010). "Determinants of Capital Flight and Capital Movement Through Trade Mispricing: The African Case", African Journal of Accounting, Economics, Finance and Banking Research, 6(6), pp.1-16.

- Broner F. et al, (2013). "Cross Capital Flows: Dynamics and Crisis”, Journal of Monetary Economics, 60, pp.113-133.

- Chipalkatti, N. and M. Rishi. (2001). "External Debt and Capital Flight in the Indian Economy", Oxford Development Studies, 29(1).

- Cuddington, J T (1986). “Capital Flight: Issues and Explanations”, Princeton Studies in International Finance, 58, Princeton, NJ: Princeton University.

- Davidson, R., \& MacKinnon, J. G. (1993), Estimation of Inference in Econometrics. Oxford University Press.

- Demir, F. (2004).A Failure Story: Politics and Financial Liberalization in Turkey, Revisiting the Revolving Door Hypothesis. World Development Vol. 32, No. 5, pp. 851-869, 2004.

- Demirgil, H. 2011. Political Instability, Uncertainty and Macroeconomics: the Case of Turkey (19702006). Marmara Üniversitesi I.I..B.F. Dergisi, vol 31, issue 2, pp. 123-144.

- Dickey, D. A., \& Fuller, W.A. (1979). Distribution of the Estimators for Autoregressive Time Series with a Unit Root. Journal of the American Statistical Association, 74, 427-437.

- Engle, R. E., C. W. J. Granger, “Cointegration and Error Correction: Representation, Estimation, and Testing”, Econometrica, 55, 1987, pp: 251-276.

- Epstein G. A.,2005. Capital Flight and Capital Controls in Develeoping Countries. Edwad Edgar Publishing, Cheltenham,UK.

- $\quad$ Gunter, F.R.,(2004). Capital Flight from China 1984-2001.China Economic Review, 15, pp: 63-85.

- Johansen, S., (1988). "Statistical Analysis of Cointegration Vectors", Journal of Economic Dynamics and Control, 12, pp.231-254. 
- Johansen, S., Juselius, K., (1990). "Maximum Likelihood Estimation and Inference On Cointegration With Applications to The Demand For Money", Oxford Bulletin of Economics and Statistics, 52, pp.169-209.

- Kindleberger, C. P. (1987). “A Historical Perspective,' in D. R. Lessard, and J. Williamson (eds), Capital Flight and Third World Debt. Washington, DC: Institute for International Economics, pp.7-26.

- Ljungwall C and Wang Z (2008). "Why is capital flowing out of China?”, China Economic Review, 19, pp.359-372.

- Maddala, G.S. and Kim, I-M., (1998). “Unit Roots, Cointegration, And Structural Change”, Cambridge: Cambridge University Press.

- Makochekanwa, A. (2007). “An Empirical Investigation of Capital Flight from Zimbabwe”, Department of Economics University of Pretoria Working Paper Series 2007-11.

- Morgan Guaranty Trust Company (1986). "LDC Capital Flight”, World Financial Markets (March), pp.13-15.

- Ndikumana L. and Boyce J.(2003). Capital Flight from North-Africa Countries. Massachusetts: University of Massachusetts.

- The World Bank (1985). World Development Report. The World Bank, Washington, DC.

- Vu Le,Q. Zak P.(2006). "Political Risk and Capital Flight", Journal of International Money and Finance, 25, pp: 308-329.

- Yalta Y., Yalta T.(2012). "Does Financial Liberalization Decrease Capital Flight? A Panel Causality Analysis”, International Review of Economics and Finance, 22, pp:92-100. 


\title{
Was the Turkish Financial Crisis in 2001 Caused by External or Internal Factors?
}

\author{
Ph.D. Candidate Fatih Konak (Hitit University, Turkey) \\ Ph.D. Candidate Hakan Turan (Hitit Üniversitesi, Turkey)
}

\begin{abstract}
There has been much discussion on the issue of whether financial crisis are caused by external factors or internal factors. This research has attempted to demonstrate what were the real reasons whether internal or external factors, behind the Turkish financial crisis in 2001. The crucial question that demands an answer is 'which one of them overwhelmingly triggered the crisis. It was argued that before the crisis occurred, the Turkey economy had been affected by some unfavourable external shocks such as, rise in crude oil prices which increased the current account deficit; however, it can be seriously solved by employing correct finance technique that using long-term capital and direct investment instead of short-term capital. Therefore, external factors effects on the economy can be eliminated by right monetary policy, which means they were not the key factors. On the other hand, there were many internal factors behind the crisis such as fragile finance and banking system, ruling out dis-inflation negative effects and seasonal factors and so on. It could be advocated that these factors led the Turkish economy into uncertain situation and they had central part in the crisis because, when the last global financial crisis was occurred in 2008, although all unexpected external factors were soared, the Turkish economy was less affected, because the Turkish economy has been become more durable by solving the internal triggering factors.
\end{abstract}

\section{Introduction}

There has been much discussion on the issue of whether financial crisis are caused by external factors or internal factors. In this context, internal factors in economic crisis refer to the financial structure of a country, lack of monetary policy and so on. In addition, it has to be noted that these internal factors can be controlled and altered by the government of the country. In contrast, external factors represent to macroeconomic matters throughout the world which cannot be controlled by the government of the country. In the case of Turkey, on the February 19, 2001, the Turkey economy was hit by massive financial crisis. In that time, overnight interest rates of the Central Bank of Turkey (CB) skyrocketed to 4059 percent in few days (Table 8), CB lost 7,5 billion dollars of reserves and the dollar exchange rate jumped from 685 thousand liras to 958 thousand liras (Fatih and Guven 2002). Therefore, the balance of Turkey economy was devastated and these conditions led the Turkey financial system to bankruptcy. Peter (2001) claimed that this crisis was the bankruptcy of the Turkey economy. Hence, it could be possible to state that it was the biggest financial crisis had been recorded in the Turkey economy history. Some economist blamed the Turkish financial crisis in 2001 was caused by the unfavourable changing in the world economy during the crisis period (Emre, 2001). According to Emre (2001), these external factors, which triggered the crisis, were: "the rise of the interest rates in the United States by 100 basis points, the increase in the international energy prices and the loss in the relative strength of the Euro vis-à-vis the US \$". In addition, it can be added that the Russian economic crisis effects on the Turkey economy as a external factor (Ersan and Kenan, 1999), while other economist argue that the Turkish economy was overwhelmingly affected by internal factors (Emre, 2001). These internal factors behind the crisis namely dis-inflation programme, which was initiated in December 1999 backed and supervised by the International Monetary Fund (IMF), deficiencies and effects on the fragile banking system and financial environment, lack of fiscal discipline and monetary policy, also ruling out of structural reforms such as privatization, and seasonal factors, wrong monetary policy to finance the current account deficit and political crisis as a last shot (Emre,2001, Emre, Hakan and Kamuran, 2001, Ahmet and Erinc, 2002 , Fatih and Guven, 2002 ). This essay argues that this crisis was overwhelmingly caused by internal factors because it could possible to eliminate the external factors effects on the economy with implementing right monetary and it could also possible that if a country's financial system is strong enough, it could protect itself from external attacks. However, some external factors also had an impact. In order to, demonstrate that this essay will first focus on the external factors behind the 2001 Turkish financial crisis. Having done that in the context of Turkey right before the crisis, the internal triggering factors will be presented. Moreover, this essay will endeavour to make contrast both of them with last global economic crisis effects, which boomed in the USA in the year 2008.

\section{Role of External Factors}

External factors behind the 2001 Turkish financial crisis can be examined under four main headings.

First of all, it is obvious that the USA economy is one of the most powerful economies in the world. Thus, other economies throughout the world are affected by tiniest variation in the USA economic indicators. One of 
them is the gradual interest rate (the federal interest rate). It refers to overnight borrowing by banks to maintain their bank reserves in the United States of America (Federal Reserve Bank of New York, 2007). This is an important development because, Eichengreen and Rose (1998) point out that highly significant coefficient between changes in industrial-country such as America, interest rates and liquidity crisis in emerging market. Therefore this indicator should be monitored to determine monetary policy makers in order to avoid its bad effects on the economy by the economic policy makers. In the case of Turkey, during the year before the 2001 liquidity crisis, this rate was increased 125 basis point s (from 4,97\% to 6,24\%) (Figure 1) so as to relieve the US economy by the Board of Governors of the Federal Reserve System (Emre,2001). Meanwhile the Turkish overnight interest rates was affected negatively and continued to go up due to this situation. It was dramatically increased from 45, 6\% to 62, 5. (Figure 2) As a result, it damaged the Turkish economy and triggered the 2001 economic crisis. This clearly shows that external factors are therefore relevant the 2001 crisis.

However, it can be argued that this external factor was not a big player behind the crisis. Because, in contrast, before the 2008 global financial crisis, which was considered to be the worst economic crisis worldwide since "the great depression". There was a considerable fluctuation in the FED Funds rates. For example, it was decreased from $6.24 \%$ to $1.13 \%$ between 2002 and 2004. (Figure 1) Nevertheless, after that it was went up sharply and reached to $5.02 \%$ just before the global financial crisis. In this context the Central Bank of Turkey could achieve to keep the recovery policies, which included financial and banking sector's reforms, after the 2001 crisis period. Thus, at the same period, the overnight interest rate of Turkey was declined from 62, 50\% to $15,75 \%$ apart from small rise at the beginning of 2006 (Figure 2). Consequently, it is clear that FED Funds rates effects could be reduced by keeping the monetary policy. Therefore, it could be possible to state that external factors are not the relevant because their effects can be eliminated.

Secondly, it could be claimed that there was a significant link between rise in crude oil prices and the 2001 financial crisis in Turkey. Emre (2001) has drawn attention to the fact that in the case of Turkey, "crude oil is the most important imported input for production and consumption". It is clear that trade deficit, which refers to the amount by that merchandise imports exceed merchandise exports, could be affected negatively by this variation in crude oil prices. In this case, crude oil prices raised from US\$ 17,8 to US\$ 35 in 2000 (Figure 1). Thus, this exacerbated the problem of the trade deficit of Turkey (Table 2). In addition, the current account balance was affected negatively as well (Table 4). Because, the fact that the current account balance in the Turkey economy is mostly affected by changing energy prices (CB, Bulletin, 2009). Hence, this balance was devastated by this rise. As a result, it prepared a convenient ground for the liquidity crisis in 2001. Therefore, this clearly shows that there is an important relationship between the crisis and external factors.

On the other hand, in order to see the role of rising crude oil prices on the Turkish economy as a triggering factor, ten year period after the 2001 financial crisis should be analyzed. There was a dramatic increase in crude oil price between early 2003 and 2007, and it reached the peak at almost \$100 (Figure 1). It is true that it affected the balance of foreign trade and either trade deficit or the current account deficit soared. However, the Turkish economy could keep the sustainable growth and also could reduce the effects of this augmentation because, monetary policy makers changed the financing the current account system (CB, Bulletin, 2007). In 2001, it was based on short- term capital which is so vulnerable. After that the government started to finance this deficit with long-term capital and direct investment (Figure 2). Therefore, it is clear that rise in crude oil price's effects would be reduced. This clearly shows that external factors are therefore not the most relevant.

Thirdly, unfavourable change in US\$/EURO parity triggered the Turkish liquidity crisis in 2001 because turkey import depends on US\$ while export of Turkey EURO (Emre, 2001). As he points out "imports of raw materials and intermediary inputs are carried out in US\$, whereas export to the EURO zone (54\% of export in 1999, especially to Germany which is very important trade partner) are carried out in EURO”. Therefore, changing in this parity could affect the Turkey economy. In this case, the balance of foreign trade of Turkey was devastated. Moreover, this movement in US\$/EURO parity might have resulted in deterioration of current account deficit. Consequently, it is true that this variation triggered the crisis. This clearly shows that external factors are therefore relevant the 2001 crisis.

However, it has to be noted that the monetary policy makers of Turkey should have taken necessary measures in order to protect economy from unfavourable shock in this parity. Therefore, after the crisis, export and import inputs have been diversified so as to reduce unexpected variation in this parity. In this context, the Turkey government has developed trade relationship with different countries such as eastern, northern and Middle East countries. For example, the foreign trade volume has been increased from 6 billion $\$$ in 1998 to 52 billion $\$$ with countries, which are member of the Back Sea Economic Cooperative, so far. As a result, this external factor's effects have been eliminated.

Finally, the vulnerable financial structure of Turkey economy was affected by the Russian economic crisis, which had been caused by the Asian crisis by reducing the prices of raw materials and by disturbing confidence of foreign investors to Russian emerging capital market (Ersan and Kenan, 1999). As a result of these developments Russia faced a financial crisis in 1998. Ersan and Kenan (1999) claim that this crisis affected Turkish firms engaged in business and exports, luggage trade and tourism, which is the major revenue in the 
Turkey economy. They also note that the total loss of Turkey due to the Russian crisis amount for 3 billion dollars per year. Therefore, it can be claimed that it was the one of the most important external factors behind the 2001 liquidity crisis in Turkey.

In order to understand how the Russian economic crisis affected the Turkey economy, some data should be analyzed. The Turkish export to Russia had gone up from \$1442 million in 1992 to \$ 2057 million in 1997. However, the fall in Russian income due to the crisis, the Turkish export to Russia dropped \$777 million in 1998. Hence, the Turkey economy lost $\$ 1290$ million in a year.(Table 1). Moreover, the Turkey economy's revenue from luggage trade with Russia and the number of tourists in Turkey from Russia dropped sharply from $\$ 8,842$ million and 1,256 (number in thousands) in 1996 to \$3,689 million and 326 (number in thousands) in 1998, respectively (Table 1). As a result, this crisis had raised the vulnerability of the Turkey economy. Therefore, it could be possible to state that Turkey economy affected external factors.

In contrast, in terms of the last global financial crisis (2008), the majority of the governments throughout the world have taken austerity measures in order to preserve themselves from the crisis wave. For example, the USA, the UK and other European countries such as Greece, have been attempting to cut spending to reduce the effects of the crisis (Yenigun, 2010). In this perspective, this movement affected the Turkey foreign trade especially rate of export, it dropped from $\$ 132$ billion in 2008 to approximately $\$ 102$ billion in 2009(Table 2). The total loss of Turkey economy was $\$ 30$ billion. However, the proportion of imports covered by exports rate increased from $65,4 \%$ to $72,5 \%$ at the same period. Consequently, it can be said that although the last global financial crisis was bigger than the Russian crisis, in terms of foreign trade, its effects on the Turkey economy was lower (Table 2). This clearly shows that external factors are therefore not the most relevant.

\section{Role of Internal Factors}

There were some external factors behind the 2001 Turkish liquidity crisis, even though internal factors the most relevant. In this perspective, Fatih and Guven (2002) has drawn attention the fact that the Turkish economy had been struggling the chronic inflation, which is one of the most important internal factors, for 25 years. Therefore, the monetary policy makers had implemented many stabilisation attempts, some of which have failed, in order to solve this problem (Emre, 2001). It is echoed by Ahmet and Erinc (2002), this program "exclusively relied on a nominally pegged exchange rate system for dis-inflation which has been major concern for Turkish policy makers for many years". In this case, before the Turkish liquidity crisis in 2001, Turkey initiated an extensive dis-inflation programme in December 1999 backed and supervised by the International Monetary Fund (IMF) (Ahmet and Erinc, 2002). As outlined in the Turkey letter of intent (1999), this programme aimed at fiscal adjustment, structural reform and privatization in Turkey economy. This letter also included significant measures to reinforce and regulate both the financial environment and banking sector of Turkey. However, this programme had many deficiencies on the implementation. For example, it just focused on reducing interest rate and inflation so that policy makers forgot the banking sector thus, this behaviour increased the vulnerability of the banking sector, and lack of monetary policy, also the Turkish government could not complete privatisation, which was very important in structural reform, and so on. As a result, it could not have been successful to prevent the internal factors effects so they triggered the crisis. Thus, this clearly shows that if the Turkish monetary policy makers had solved the internal problems, the crisis would not have boomed.

Initially, it could be possible to argue that the Turkish monetary policy makers should not have taken essential measures so as to protect economic stabilisation before the crisis. However, Ahmet and Erinc (2002) claim that throughout the first year of the dis-inflation programme, rule of this programme's were followed and the Central Bank of Turkey successfully controlled expansion of monetary base with its net domestic asset position within the programme limits. They also mentioned that "the fiscal operations were in line both the revenue and expenditure targets". Nevertheless, the crisis conditions emerged in does course, primarily as a result of the increase fragility in financial system. According to Ahmet and Erinc (2002) "this fragility, in turn, was generated by the uncontrolled and excessively capital flow with exceedingly speculative component". In other words, this could be explained in this way, the Turkish economy had become more vulnerable to speculative capital flow because of liberalized capital account system which had been applied since 1989 due to this programme's permission to higher level of speculative capital inflow. Hence, this clearly shows that lack of monetary policy increased the economic crisis risk.

Ahmet and Erinc (2002) also claim that, in the context of the Turkish dis-inflation programme, dept financed public deficit and rapid acceleration of private expenditures increased inflow of short-term foreign capital. Therefore, the ratio short-term foreign dept to the Central Bank's reserves rose secularly throughout the programme. In this case, this ratio should have been the value of 60 percent because in terms of international speculation, its critical threshold is 60 percent (see e.g. Kaminsky,Lizondo and Reinhart,1998). It is obvious note that this ratio had never fallen below 100 percent since the liberalization system in Turkey, 1989. It means that the Turkish financial system had been operating consistently under the "danger zone" (Ahmet and Erinc, 2002). During the implementation of the dis-inflation programme, this ratio rose to 112 percent in June 2000 to 
147 percent December 2000 (Table 3). Thus, it can be said that the programme increased the financial fragility and its liquidity creating mechanism did not allow for stabilisation. Therefore, it could be said that internal conditions were the most relevant.

Moreover, in the context of the Turkish banking system before the crisis, the banking sector's profit based on high inflation rates and real interest rate because no one believed that these rates could neither be reduced nor controlled (Emre, Hakan and Kamuran, 2001). Therefore, they organized all working plans to gain profit based on these rates. Demirguc and Huizinga (1999) concluded that in their analysis, the determinant of interest margins and profitability of banking sector, "higher inflation and real interest rates are associated with higher realized interest margins and profitability". They also found that "banking sectors with higher rates of concentration have higher margins and earn more profit". However, after the dis-inflation programme, inflation rate and interest rate started to decrease so that the Turkish banking sector changed their position towards to government debt instrument portfolio. It has to be noted that the quality of the government debt instruments portfolio is directly related to expectation regarding dept sustainability. Hence, Fatih and Guven (2002) argue that this feature increased the vulnerability of the system to concerns about the rollover it the outstanding government debt instruments because they also claimed that this portfolio in commercial bank balance sheets was even greater than loan portfolio. Consequently, this movement triggered the crisis under the uncertain financial environment in Turkey. Therefore, this clearly shows that if the government had realized the banking sector's this perilous movement timely, the crisis could have been prevented.

The other crucial internal factor behind the crisis is mid-sized banks in the banking system. Einchengreen (1998) argues that regarding the banking sector crisis which triggered the 2001 financial crisis, "the problem lied with a number of mid-sized banks". In addition, it ought to be noted that the Turkish govern- ment gave them bailout guarantee which means that when they are in the bankruptcy situation, their deposits and assets will be protected by the government (CB, Financial Stability Report, 2008). In fact, the majority of mid-sized banks were established because they relied on this guarantee (Fatih and Guven, 2002). According to Burnside,Enchenbaum and Rebelo (2001) "economic agents expect that these future deficit due to bailout guarantee, are going to be financed by many creation, which leads to a collapse of fixed exchange rate regime". Hence, it is clear that these banks damaged the Turkish banking system. Therefore, having been given permission to establish these kinds of banks in the Turkish banking sector, and lack of controlling of these banks' financial structure, led the Turkey economy into the crisis.

Furthermore, The Banks Association of Turkey's data showed that before the 2001 crisis, Turkey have 84 banks. However, during the crisis period 37 mid-sized banks were bailout and the number of banks in the Turkish banking sector decreased to 47 (BRSA,2010). Failure of these banks brought massive amount of $\$$ billion financial burden on the Turkey economy. Therefore, this circumstance led the Turkey economy into worse condition. However, it should be noted that after the crisis, Turkish banking sector has grown under the control of the Banking Regulation and Supervision institute which was established in the year 2000(Tevfik,2010). This institute reduced the number of mid-sized banks and controlled the bank's balance sheets in order to keep the sustainable growth. As a result, many banks have bankrupted in the USA after the global crisis. Despite this fact there is no bank has bankrupted. Therefore, this clearly shows that if the banking sector is controlled in right way, in other words, if the fragility of the banking sector is solved, the economy can be protected from the crisis.

On the privatisation front, the Turkish monetary policy makers were planning to make money from privatisation under the control of IMF so as to decrease budget deficit and increase the investments. However, Emre (2001) has drawn attention the fact that "instead of the privatisation receipt target value of US\$7, 5 billion only US\$3, 5 billion was realized throughout 2000". This development showed that the Turkish authority went out of the programme. Therefore, they could not meet the target. As a result, their finance plan was devastated. In contrast, after the crisis, the Republic of Turkey Prime Ministry Privatisation Administration's data indicates that the government has made almost $\$ 25$ billion revenue from privatisation so that they could use this money to protect economy. (Table 7). Hence, following the monetary policy rules is very important. In this perspective, if it is not followed, it could trigger the crisis.

Besides, one of the most important triggering factors behind the crisis is the current account deficit. It reached the peak before the crisis at $-9,92$ in 2000. Therefore, all economic predictions were damaged by this augmentation. However, it could be argued that the problem was not just current account deficit. The real problem was in how to finance it. Current account deficit was overwhelmingly financed with short-term capital in that year (Figure 2). Hence, when the short-term capital float from the country, it could not be financed consequently the problem become bigger. Turkey had same situation in the crisis year. On the other hand, although in the year 2007 the current account deficit was higher than used to be, the Turkey economy was not damaged because it was financed with long-term capital and foreign direct investment which are more durable than short-term capital. it stated in the CB bulletin (March 2009) that "long-term capital and foreign direct investment have significant impact in terms of the financing quality of the current account deficit, and they reduce the degree of vulnerability of the economy". As a result, it can be said that the current account might not be a big problem, if it is financed in right way. (Table 4) 
Another important internal reason in the crisis is lack of monetary policy. For example, monetary policy makers ruled out the seasonal factors such as common in finance literature the so-called "January affect" which refers to outflow of the capital from a country in order for avoiding tax liability. In the case of Turkey, according to Emre (2001) stated that although the Central Bank of Turkey is able to sterilize the effects of this seasonal outflow, it operated like a quasi currency board and ruled out the possibility of unfavourable effects on the fragile finance and banking system structure due to such outflow. As a consequence, it is clear that policy makers always have to prepare themselves to these kinds of effects. Otherwise, financial environment could not be protected like in Turkish crisis case. This clearly shows that lack of monetary policy is therefore the one of the most relevant internal factors behind the crisis.

It could be stated that political stability is one of the most significant indicators for financial environment in order to sustain and keep their position. In this case, on the 19 of February in 2001, after the National Security Council meeting, the Prime Minister Bülent Ecevit declared that there was a deep difference opinion between him and President A.Necdet Sezer. He also added that it was a very important political crisis. This declaration was not estimated in the uncertain financial environment. Therefore, after this announcement, Fatih and Guven (2002) stated that overnight interest rate skyrocketed to 4019 in two days, and the Central Bank lost 7, 5 billion dollars of reserve thus, the CB had to accept the collapse of crawling peg exchange system and the Lira would be going to freely float so that the dollar exchange rate jumped to 958 thousand liras from a level of 685 thousand liras. Consequently, the Turkey economy slid into a massive crisis. This clearly shows that if this political instability had not been occurred, the financial crisis could have been obstructed. Therefore, it was relevant internal factor behind the crisis.

\section{Conclusion}

In conclusion, this essay has attempted to demonstrate what were the real reasons which were divided into two section; internal and external factors that have been already mentioned above, behind the Turkish financial crisis in 2001. The crucial question that demands an answer is 'which one of them overwhelmingly triggered the crisis. On the one hand, it has argued that before the crisis boomed, the Turkey economy had been affected by some unfavourable external shocks such as, rise in crude oil prices which increased the current account deficit; however, it can be seriously solved by employing correct finance technique that using long-term capital and direct investment instead of short-term capital. Therefore, it can be clearly seen that external factors effects on the economy can be eliminated by right monetary policy. On the other hand, it can be stated that there were many internal factors behind the crisis such as fragile finance and banking system, ruling out dis-inflation negative effects and seasonal factors and so on. It could be advocated that these factors led the turkey economy into uncertain situation and they had central part in the crisis because, after the crisis, they had been solved so the Turkey economy had become stronger. Consequently, it was not be affected by the last global financial crisis (2008) which soared the all unexpected external factors. It can be said that if an economy is strong enough, the external factors are not big problems.

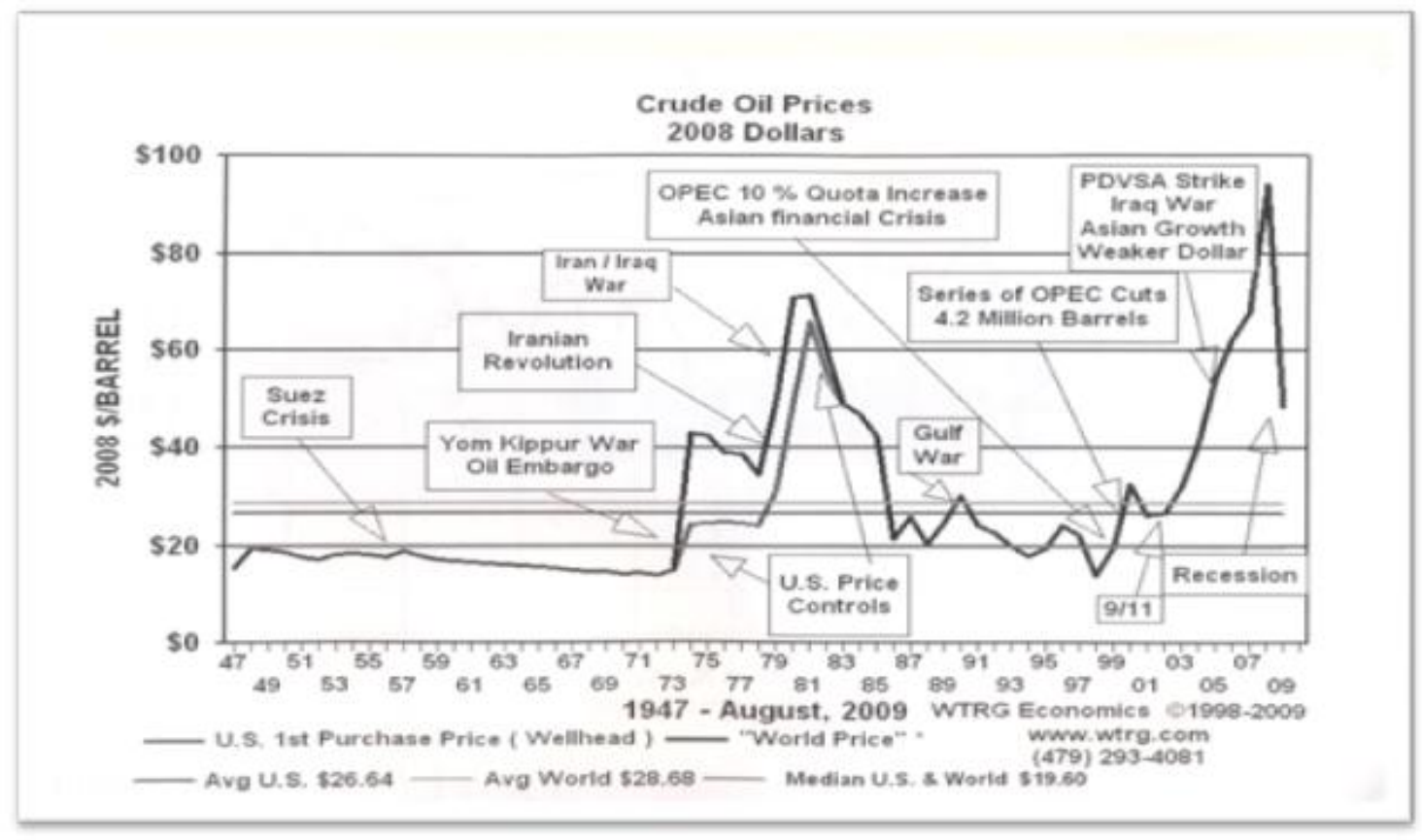

Figure 1: The Trend of Crude Oil Prices 


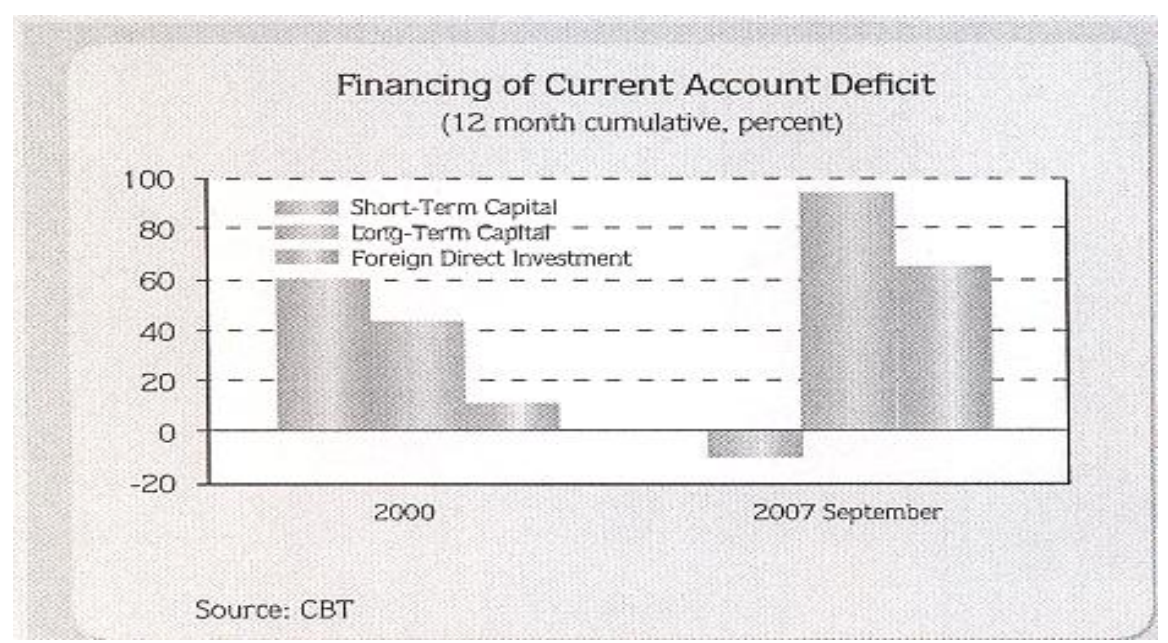

Figure 2: The History of Current Account Deficit in Turkey

\begin{tabular}{|l|l|l|l|l|}
\hline Years & Exports(fob) & Imports & Total & Balance \\
\hline 1992 & 442 & 1036 & 1478 & -594 \\
\hline 1993 & 499 & 1542 & 2041 & -1043 \\
\hline 1994 & 820 & 1046 & 1866 & -226 \\
\hline 1995 & 1232 & 2082 & 3314 & -850 \\
\hline 1996 & 1512 & 1921 & 3433 & -409 \\
\hline 1997 & 2057 & 2174 & 4231 & -117 \\
\hline 1997 & 914 & 1018 & 1932 & -104 \\
\hline 1998 & 777 & 1071 & 1848 & -294 \\
\hline
\end{tabular}

Table 1: Turkish Foreign Trade with Russia (in million dollars) Source: Turkish State Institute of Statistics

\begin{tabular}{|l|l|}
\hline 1996 & 8842 \\
\hline 1997 & 5849 \\
\hline 1998 & 3689 \\
\hline
\end{tabular}

Table 2: Turkish Revenues from The Luggage Goods Trade with Russia (million dollars) Source: Turkish State Planning Organization

\begin{tabular}{|l|l|l|l|l|l|l|}
\hline \multicolumn{2}{|l|}{} & \multicolumn{2}{|l|}{1996} & 1997 & 1998 \\
\hline Countries & $\begin{array}{l}\text { Number in } \\
\text { thousand }\end{array}$ & $\%$ & $\begin{array}{l}\text { Number in } \\
\text { thousand }\end{array}$ & $\%$ & $\begin{array}{l}\text { Number in } \\
\text { thousand }\end{array}$ & $\%$ \\
\hline Russia & 1256 & & 1017 & & 326 & \\
\hline
\end{tabular}

Table 3: The Number of Tourists in Turkey from Russia Source: Central Bank of Turkey 


\begin{tabular}{|c|c|c|c|c|c|c|c|}
\hline \multicolumn{8}{|c|}{ Foreign trade by years } \\
\hline \multirow[b]{3}{*}{ Years } & \multicolumn{2}{|c|}{ Exports } & \multicolumn{2}{|c|}{ Imports } & \multirow{3}{*}{$\begin{array}{c}\begin{array}{c}\text { Balance of } \\
\text { Foreign Trade }\end{array} \\
\text { Value } \\
\text { '000 \$ }\end{array}$} & \multirow{3}{*}{$\begin{array}{c}\begin{array}{c}\text { Volume of } \\
\text { Foreign Trade }\end{array} \\
\text { Value } \\
\text { '000\$ }\end{array}$} & \multirow{3}{*}{$\begin{array}{c}\text { Proportion of } \\
\text { Imports covered } \\
\text { by Exports } \\
\%\end{array}$} \\
\hline & Value & Change & Value & Change & & & \\
\hline & $' 000 \$$ & $\%$ & '000\$ & $\%$ & & & \\
\hline 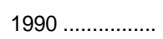 & 12959288 & 11,5 & 22302126 & 41,2 & -9342838 & 35261413 & 58,1 \\
\hline $1991 \ldots \ldots \ldots \ldots$ & 13593462 & 4,9 & 21047014 & $-5,6$ & -7453552 & 34640476 & 64,6 \\
\hline 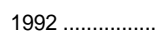 & 14714629 & 8,2 & 22871055 & 8,7 & -8156426 & 37585684 & 64,3 \\
\hline 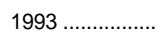 & 15345067 & 4,3 & 29428370 & 28,7 & -14083303 & 44773436 & 52,1 \\
\hline 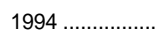 & 18105872 & 18,0 & 23270019 & $-20,9$ & -5164147 & 41375891 & 77,8 \\
\hline $1995 \ldots \ldots \ldots \ldots \ldots$ & 21637041 & 19,5 & 35709011 & 53,5 & -14071970 & 57346052 & 60,6 \\
\hline $1996 \ldots \ldots \ldots \ldots \ldots$ & 23224465 & 7,3 & 43626642 & 22,2 & -20402178 & 66851107 & 53,2 \\
\hline 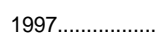 & 26261072 & 13,1 & 48558721 & 11,3 & -22297649 & 74819792 & 54,1 \\
\hline 1998...................... & 26973952 & 2,7 & 45921392 & $-5,4$ & -18947440 & 72895344 & 58,7 \\
\hline 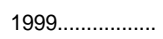 & 26587225 & $-1,4$ & 40671272 & $-11,4$ & -14084047 & 67258497 & 65,4 \\
\hline $2000 \ldots \ldots \ldots \ldots$ & 27774906 & 4,5 & 54502821 & 34,0 & -26727914 & 82277727 & 51,0 \\
\hline $2001 \ldots \ldots \ldots \ldots$ & 31334216 & 12,8 & 41399083 & $-24,0$ & -10064867 & 72733299 & 75,7 \\
\hline $2002 \ldots \ldots \ldots \ldots$ & 36059089 & 15,1 & 51553797 & 24,5 & -15494708 & 87612886 & 69,9 \\
\hline 2003.................... & 47252836 & 31,0 & 69339692 & 34,5 & -22086856 & 116592528 & 68,1 \\
\hline 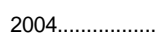 & 63167153 & 33,7 & 97539766 & 40,7 & -34372613 & 160706919 & 64,8 \\
\hline $2005 \ldots \ldots \ldots \ldots \ldots$ & 73476408 & 16,3 & 116774151 & 19,7 & -43297743 & 190250559 & 62,9 \\
\hline $2006 \ldots \ldots \ldots \ldots . . . . . . . .$. & 85534676 & 16,4 & 139576174 & 19,5 & -54041498 & 225110850 & 61,3 \\
\hline $2007 \ldots \ldots \ldots \ldots \ldots \ldots$ & 107271750 & 25,4 & 170062715 & 21,8 & -62790965 & 277334464 & 63,1 \\
\hline $2008 \ldots \ldots \ldots \ldots \ldots$ & 132027196 & 23,1 & 201963574 & 18,8 & -69936378 & 333990770 & 65,4 \\
\hline $2009^{*} \ldots \ldots \ldots \ldots \ldots$ & 102128759 & $-22,6$ & 140926023 & $-30,2$ & -38797264 & 243054782 & 72,5 \\
\hline
\end{tabular}

Table 4: Turkish Foreign Trade by Years

\begin{tabular}{|l|l|l|l|l|l|l|l|l|l|}
\hline 1984 & $-1,4$ & 1989 & 0,9 & 1994 & 2,6 & 1999 & $-0,9$ & 2004 & $-14,4$ \\
\hline 1985 & $-1,0$ & 1990 & $-2,6$ & 1995 & $-2,5$ & 2000 & $-9,9$ & 2005 & $-22,1$ \\
\hline 1986 & $-1,5$ & 1991 & 0,3 & 1996 & $-2,4$ & 2001 & 3,8 & 2006 & $-32,1$ \\
\hline 1987 & $-0,8$ & 1992 & $-1,0$ & 1997 & $-2,6$ & 2002 & $-0,6$ & 2007 & $-38,2$ \\
\hline 1988 & 2,6 & 1993 & $-6,4$ & 1998 & 2,0 & 2003 & $-7,5$ & 2008 & $-41,4$ \\
\hline
\end{tabular}

Table 5: Turkish Current Account Balances by Years (billions USD) Source: CBT

Balance sheet of the Central Bank, interest rates, and exchange rate in the second attack period, February 2001

\begin{tabular}{|c|c|c|c|c|c|c|c|}
\hline & $\begin{array}{l}\text { Net domestic assets } \\
\text { (Trillion Lira) }\end{array}$ & $\begin{array}{l}\text { Net foreign assets } \\
\text { (Trillion Lira) }\end{array}$ & $\begin{array}{l}\text { Base money } \\
\text { (Trillion Lira) }\end{array}$ & $\begin{array}{l}\text { Reserves }^{d} \\
\text { (Million \$) }\end{array}$ & $\begin{array}{l}\text { Overnight rate }{ }^{\theta} \\
(\%)\end{array}$ & $\begin{array}{c}\text { Bond rate } \\
(\%)\end{array}$ & $\begin{array}{c}\text { Exchange rate } \\
\text { (\$/Lira) }\end{array}$ \\
\hline February 15 & -1754 & 6680 & 4927 & 28217 & 39.2 & 61.9 & 682686 \\
\hline 16 & -1547 & 6649 & 5102 & 27943 & 40.3 & 63.4 & 685998 \\
\hline 19 & -1626 & 6708 & 5082 & 28105 & 43.7 & 67.9 & 685039 \\
\hline 20 & -1300 & 5687 & 4387 & 26739 & 2057.7 & 25514.7 & 683074 \\
\hline 21 & 868 & 3417 & 4286 & 23207 & 4018.6 & 150.2 & 688001 \\
\hline 22 & 2070 & 3373 & 5443 & 23267 & 1195.3 & 147.7 & 685391 \\
\hline 23 & 1560 & 4198 & 5758 & 22581 & 568.0 & 195.8 & 957879 \\
\hline 26 & 1205 & 4046 & 5251 & 21988 & 102.1 & 145.3 & 1072988 \\
\hline 27 & 1659 & 3311 & 4970 & 21699 & 100.2 & 168.7 & 946306 \\
\hline 28 & 2156 & 2915 & 5071 & 21432 & 100.1 & 245.3 & 906164 \\
\hline
\end{tabular}

a: Net domestic assets = Credit to public sector + government securities + credit to banking sector - public sector deposits + other

b: Net foreign assets $=$ Foreign assets - foreign exchange liabilities to non-residents - foreign exchange liabilities to banking sector

c: Base money $=$ Net domestic assets + net foreign assets

d: Reserves: International reserves

e: Overnight rate is the weighted average uncompounded rate.

$\mathrm{f}$ : Bond rate is the compounded average secondary market rate.

Source: Central Bank

Table 6: Interests Rates and Exchange Rates on February 2001 


\section{References}

- Alper, C.Emre (2001) "The Turkish Liquidity Crisis of 2000: What Went Wrong..., Forthcoming: Russian and East European Finance and Trade, vol. 37, no. 6, Novvember-December 2001, pp. 51-71

- $\quad$ Alper, C. Emre, Berument, M. Hakan and Malatyali, N.Kamuran (2001) "The Effect of the Disinflation program on the Structure of the Turkish Banking Sector", Russian and East European Finance and Trade, vol. 37, no. 6, Novvember-December 2001, pp. 81-95

- Bilgin Tevfik Head of BRSA (15 February 2010) Available at: http://www.stratejikboyut.com/haber/turkiye-bankacilikta-nereden-nereye--32378.html

- Bocutoglu,Ersan and Celik,Kenan (1999) "The Effects of Russian Economic Crisis on Turkish Economy: A Brief Assessment” Karadeniz Technical University

- $\quad$ Burnside, C., Einchenbaum, M. and S. Rebelo (2001) “Prospective deficits and the Asian Currency Crisis”, Journal of Political Economy, 109(6), 1155-1197

- $\quad$ BRSA (2010) Files of excel about the Turkish Banks Available at: http://www.tbb.org.tr/tr/Banka_ve_Sektor_Bilgileri/Tarihsel_Bilgiler.aspx

- Central Bank of the Republic of Turkey Bulletin March 2009 Issue: 13

- Central Bank of the Republic of Turkey Bulletin December 2007 Issue: 8

- CB Financial Stability Report (November 2008) Available at: http://www.tcmb.gov.tr/

- Demirguc-Kunt, A and H. Huizinga (1999) Determinants of Commercial Bank Interest Margins and Profitability: Some International Evidence" World Bank Economic Review 13, no. 2: 379-408

- Einchengreen, B., and A.Rose(1998) "Staying Afloat When the Wind Shifts: External Factors and Emerging-Market Banking Crisis.” National Bureau of Economic Research, Working Paper No. 6370

- Ertugrul,Ahmet and Yeldan, Erinc “ On the Structural Weaknesses of the Post1999 Turkish Dis-Inflation Program”

- Einchengreen, B., and A.Rose(1998) "Staying Afloat When the Wind Shifts: External Factors and Emerging-Market Banking Crisis.” National Bureau of Economic Research , Working Paper No. 6370

- Federal Reserve Bank of New York (2007) "Fed Point” Available at: http://www.newyorkfed.org/aboutthefed/fedpoint/fed15.html

- Ozatay, Fatih and Guven, Sak (2002) “The 2000-2001 Financial Crisis in Turkey”, Central Bank of Turkey and Ankara University

- Tsagaris, Peter (2001) “Turkey’s Crisis” International Socialist Review

- Yenigun (2010) Available at :http://www.as-add.de/haber/guencel/3839-avrupa-ekonomisinindizginleri-el-aryor-.html

- 1999 “ Turkey Letter of Intent” International Monetary Fund, Washington, DC, www.imf.org/external/np/loi/1999/120999.htm, December 


\title{
The Effects of Exchange Rates on Macroeconomic Variables: A Study on Selected Emerging Economies
}

\author{
Asst. Prof. Dr. Birgül Cambazoğlu (Haliç University, Turkey) \\ Assoc. Prof. Dr. Hacer Simay Karaalp (Pamukkale University, Turkey) \\ Assoc. Prof. Dr. Konstantinos Vergos (University of Portsmouth, United Kingdom)
}

\begin{abstract}
The exchange rate channel of the monetary transmission mechanism has gained importance through widespread use of the floating exchange rate regime with increased globalization. In this context, this study aims to explore the effectiveness of the exchange rate channel on net exports and thereby total output and price level using vector auto-regression (VAR) models. The sample countries are Turkey and Argentina, which have employed a floating exchange rate regime since 22 February 2001 and 11 February 2002, respectively. The monthly data set consists of five macro-economic variables, which are short-term interest rates, the real effective exchange rate, net exports, the consumer price index, and the industrial production index for the period 2003 to 2010. The impulse-response function outcomes indicate that the operation of the exchange rate channel is effective, both in Turkey and in Argentina.
\end{abstract}

\section{Introduction}

Because fiscal policy has lost its luster as a tool to stabilize the aggregate economy, economists and politicians advocate that the stabilization of the real economy should be left to monetary policy. In recent years, central banks in many countries are using monetary policies to provide price stabilization (to cope with inflation) and output. In this context, monetary policy is a powerful tool used by central banks to ensure sustainable growth and low inflation in the economy. However, to be successful in conducting monetary policy (or to determine which monetary policy affects the economy), the monetary authorities must have an accurate assessment of the timing and effect of their policies on the economy.

Furthermore, they must evaluate the stance of monetary policy at a particular point in time (Mishkin 1995, 1996; Boivin, Kiley, and Mishkin 2010). In this context, monetary policy decisions are implied with changes in the money stock or in short-term interest rates. Central banks usually use short-term interest rates as a tool of monetary policy.

The effectiveness of changes in monetary policies on the real economy (output) and prices (inflation) is expressed as the result of monetary transmission mechanisms. These transmission mechanisms, which include interest rate effects, exchange rate effects, and other asset price effects, can be categorized into two basic types: neoclassical channels, in which financial markets are perfect, and non-neoclassical channels, in which financial markets are imperfect (Boivin, Kiley, and Mishkin 2010). According to this classification, neoclassical channels comprise interest rate channel, other asset price channel, and exchange rate channel. Non-neoclassical channels comprise credit channel (credit view). In addition to understanding this classification, it is important to take into account changes in expectations, which affect the relationship between monetary policy and aggregate economic activity. In this context, 'management of expectations' has become an important tool of monetary authorities throughout the world (Boivin, Kiley, and Mishkin 2010).

Therefore, expectations of economic actors' are also included in this classification as expectation channel.

Within this framework, many international studies focus on the effectiveness of the channels of the monetary transmission on the macro economic variables due to evaluate the stance of monetary policy and decide to set the accurate policy instruments for the economy. In this context the main objective of this study is to explore the effectiveness of the exchange rate channel on net exports and thereby on total output and price level using two different vector auto-regression (VAR) models. In this study, Turkey and Argentina are analyzed as the case countries because they are both emerging market countries and because they switched their fixed exchange rate regimes to floating exchange rate regimes in 2001 and 2002, respectively, after an economic crisis. Following a long period of monetary and economic turmoil, both countries have reduced their inflation through exchange rate-based stabilization programs (DTM 2002). The VAR model covers the period of 2003 to 2010, and the monthly data set consists of five macroeconomic variables, which are short-term interest rates, real effective exchange rates, net exports, the consumer price index, and the industrial production index. This study proceeds as follows: following the Introduction, Section 2 provides a theoretical background for the exchange rate channel of monetary transmission mechanisms; Section 3 summarizes recent empirical studies; Section 4 gives brief information about the exchange rate systems of Argentina and Turkey; Section 5 describes variables and discusses the empirical findings of the model and Section 6 presents the Conclusion of the study. 


\section{Monetary Transmission Mechanism Exchange Rate Channel}

With the growing internationalization of economies and the gradual increase in the implementation of floating exchange rate regimes, more attention has been paid to monetary policy transmission, which operates through exchange rates and effects on net exports. Both for developed and developing countries, one of the most important variables that affect the basic economic indicators of open economies has been the changes in exchange rates. In this

context, monetary authorities occasionally attempt the course of exchange rates with monetary policies (short-run interest rates). In this context, the monetary transmission mechanism exchange rate channel is expressed as the changes of real production and general price level, which is the result of the effect of monetary policy on exchange rates and their impact on net exports. The theoretical foundation of the exchange rate channel, which operates in open economies, is based on the Mundell-Fleming model (Bordo and Schwarts 1988; Büyükakın, Cengiz, and Türk 2009). Therefore, the exchange rate channel is more effective in open economies, which adopt floating exchange rate regimes, than it is in closed economies.

Moreover, the exchange rate channel involves interest rate effects, and it reveals the mechanism through the interest rate channel. When domestic real interest rates drop, domestic currency deposits become less attractive relative to deposits denominated in foreign currencies. This situation leads to a drop in the value of the domestic currency and an appreciation of the foreign currency (denoted by $\mathrm{E} \uparrow$ ). The lower value of the domestic currency makes domestic goods less expensive than foreign goods, which causes an increase in net exports (NX $\uparrow$ ) and, hence, in aggregate output $(\mathrm{Y} \uparrow)$.

The operation of the monetary transmission mechanism through the exchange rate channel in a monetary expansionary process is shown in the following schematic representation:

$$
\mathrm{M} \uparrow \Rightarrow \mathrm{i}_{\mathrm{r}} \downarrow \Rightarrow \mathrm{E} \uparrow \Rightarrow \mathrm{NX} \uparrow \Rightarrow \mathrm{Y} \uparrow
$$

Contrary to monetary expansion is the implementation of contractionary monetary policy. When domestic real interest rates rise, foreign capital investors will want to take advantage of this rate rise and will therefore increase capital inflow and thereby, the amount of foreign currency in the country. The rise in the amount of foreign currency leads to a drop in the value of foreign currency $(E \downarrow)$ by force of the law of supply and an appreciation of the domestic currency. Moreover, the higher values of the domestic currency make domestic goods more expensive than foreign goods and cause a decrease in net exports (NX $\downarrow$ ) and hence, a decrease in aggregate output $(\mathrm{Y} \downarrow)$. The operation of the monetary transmission mechanism through the exchange rate channel in a contractionary monetary process is shown in the following schematic representation:

$$
\mathrm{M} \downarrow \Rightarrow \mathrm{i}_{\mathrm{r}} \uparrow \Rightarrow \mathrm{E} \downarrow \Rightarrow \mathrm{NX} \downarrow \Rightarrow \mathrm{Y} \downarrow
$$

Finally, it is shown that two opposite monetary policies can affect both aggregate output and general price level (Mishkin 1995, 1996, 2001, 2007). Therefore, due to the effectiveness of changes in interest rates and exchange rates on the financial and real sectors, on the investment decisions of foreign companies and on consumer spending, it is important to consider interest rates and exchange rates during the constitution of economic policies and to ensure a stable economy and sustainable development.

\section{An Assessment of the Floating Exchange Rate Regime}

The transition from fixed or pegged exchange rates to managed floating or independently floating exchange rates has occurred gradually after the breakdown of the Bretton Woods system in 1973. While many developing countries continue to peg their exchange rates to a single currency, such as the US dollar or French franc or a basket of currencies, they, at first, shifted from single currency pegs to basket pegs in the late 1970s. Following that initiative, many developing countries over the past three decades have shifted from fixed exchange rates (that is, those that peg the domestic currency to one or more foreign currencies) and moved toward more flexible exchange rates (those that determine the external value of a currency more or less by the market supply and demand for it) (Caramazza and Aziz 1998). In floating exchange rate regimes or flexible exchange rate regimes, the currency itself is accepted as a nominal anchor, and central banks do not intervene in determining change rates (Arat 2003). Economists, analysts, and policy makers agree that determining the right exchange rate is crucial for economic stability and growth in developing countries. In this sense, exchange rates have been at the center of policy debates in developing countries for the last three decades. Emerging market economies, which have gradually combined with the increased integration of capital markets around the world, have been adversely affected by the crises in the international capital markets, such as the Mexican crisis of 1994-95, the Asian crisis of 1997-1998, the crises in Russia (May-August 1998), Brazil (from November 1998 to January 1999), and Turkey and Argentina in 2001. Therefore, the need for an appropriate exchange rate regime developed for the emerging economies (Yağcı 2001; Artus, Cartapanis, and Legros 2003; Ardıç and Selçuk 2006).

Although the debates about fixed or floating exchange rate regimes have been continuing, many economies have switched to floating exchange rate regimes since the last decade. Floating exchange rate regimes are an appropriate choice for the countries that are industrializing and for some emerging market countries that are fully 
integrated into global capital markets and have diversified production and trade, whose import and export sectors are relatively small compared to GDP and that have a deep and broad financial sector with strong prudential standards (Yağc1 2001). In this context, Turkey and Argentina are two emerging market countries that switched their fixed exchange rates to flexible exchange rates in 2001 and 2002, respectively.

\subsection{The Floating Exchange Rate Regime in Turkey}

Turkey has switched from a more controlled exchange rate regime to a flexible exchange rate regime over the past 20 years. However, many different exchange rate systems have been implemented throughout that time period. Turkey implemented a fixed but adjustable peg exchange rate regime in 02 February 1947 after it became a member of the International Monetary Funds (IMF) and the World Bank (Arat 2003:37). After the collapse of the fixed exchange rate regime, alternative regimes were adopted in Turkey. The "crawling peg" regime was implemented from 1980 until the 1994 crisis. Then Turkey employed a managed float regime between 1994 and 1999 (Görmez and Yilmaz 2007). In this application, the exchange rate was determined freely in the market, but the Central Bank could intensively intervene in determining the exchange rate. At the beginning of 2000, a 3 year stand-by agreement, signed with the IMF, and a two-term implementation strategy were initiated in the exchange rate regime. From the beginning of 2000 until February of 2001, the first term of the implementation strategy, the exchange rate-based stabilization program implemented in Turkey and the exchange rate system were based on a flexible anchor. The second phase of the program involved the band strategy, which was a gradual shift toward a more flexible exchange rate regime (Ertekin 2003; Kasman and Ayhan 2006; Görmez and Y1lmaz 2007). However, after the financial crisis in February 2001, the program failed, and Turkey started to implement the floating exchange rate regime almost a year earlier than was planned. Turkey is currently implementing a floating exchange rate regime, which started in 2002.

After the first day of the implementation of the floating exchange rate regime, exchange rates in Turkey overdepreciated (overshoot). The Turkish Lira depreciated 28.5\% against US dollar. This depreciation can happen in any country until the exchange rates reach the natural balance value of the market (Arat 2003). However, the Central Bank of Turkey announced the dynamics of the floating exchange rate as follows: exchanges rates are determined by supply and demand conditions in the market, without any exchange rate target from the Central Bank during the implementation of the floating exchange rate regime. The Central Bank also announced that it would intervene in the markets only in cases of excess volatility, without trying to affect the long-run equilibrium level of exchange rates (Görmez and Y1lmaz 2007; Y1lmaz 2008). To increase foreign currency reserves, the Central Bank implemented 'foreign exchange buying auctions to build up reserves' to quell the negative effects of internal and external shocks to Turkey as an emerging economy and to increase confidence in the country. Since April 01, 2002, the Central Bank has implemented foreign currency purchases at foreign exchange auctions, where terms and conditions are pre-announced, to minimize the impact of supply and demand conditions on the foreign exchange market (Görmez and Y1lmaz 2007; Uygur 2010). During the post-floating exchange rate regime, the Central Bank did not intervene in the foreign exchange market unnecessarily. It only intervened when expecting a significant volatility increase in this market, e.g., the volatility in financial markets observed in May and June 2006, in July 2007, and in the 2008 global crisis (October 2008). International conditions are the decisive factors for foreign currency liquidity. The Central Bank intervened in the markets and continued the foreign exchange buying auctions. It resumed the intermediary function in the foreign exchange deposit market and announced other precautions during the high level of uncertainty in the global economy. During the global financial crisis triggered in October 2008, the Central Bank suspended the foreign exchange buying auctions to reduce the financial market problems of Turkey and to strengthen the liquidity of Turkish banks (CBRT 2009). Following the recovery period of 2010, Turkey, along with inflation targeting, has been continuing to implement the floating exchange rate regime started in 2002, without using the exchange rate as a tool and without having any nominal or real target. Moreover, the Central Bank adopted a more flexible method for foreign exchange buying auctions in October 2010 and will continue to implement this method in 2011 to accelerate foreign reserve accumulation. Due to the normalization and recovery period of the global markets, the intermediary function of the Central Bank in the foreign exchange deposit market was abolished on 15 December 2010. However, the Central Bank will continue to monitor developments in the exchange rate market and will intervene through foreign exchange selling or buying auctions in case of unhealthy price formations (CBRT 2010).

\subsection{The Floating Exchange Rate Regime in Argentina}

Latin American countries' choice of an exchange rate regime has been substantially affected by historically specific degrees of freedom or urgency (Frankel and Rapetti 2010:3). After the breakdown of the Bretton Woods system, Latin American countries began to face a different international environment between the late 1960s and the early 1970s, which was the result of the shift in developed countries from fixed to floating exchange rates. Among Latin American countries, Argentina, Chile, and Uruguay had suffered economic and political crises and high inflation during the first half of the 1970s. Moreover, after the liberalization of the domestic financial system, the reduction of taxes on trade and the opening of a capital account for the balance of payments, Argentina, Chile, and Uruguay oriented their exchange rate policies towards stabilizing prices and adopting 
active crawling peg regimes in the second half of the 1970s (Frenkel and Rapetti 2010:4). In the early 1980s, the rise in international interest rates triggered massive balance of payments crises in Argentina, Brazil, Chile, Mexico, Peru, Uruguay, and Venezuela. Therefore, the crawling peg exchange rate regime was not effective, especially in Argentina, Chile, and Uruguay, because it produced current account imbalances and real exchange rate appreciation, which were the cause of slow labor market adjustments and the selection of currency baskets in the crawling peg regime (Obstfeld 1984; Drabek and Brada 1998). Due to that financial crisis, some Latin American countries, including Argentina, Brazil, and Mexico, experienced sharp devaluation and high inflation between 1982 and 1990. These three countries were able to use fixed or near-fixed exchange rates during the 1990s, which was a new period with high international liquidity and credit availability. While the use of fixed exchange rates as a nominal anchor to lower inflation is often successful, some problems started to emerge (Caramazza and Aziz 1998; IMF 2004; Frenkel and Rapetti 2010). In Argentina, the Convertibility Law was sanctioned in March 1991, according to which the currency was fixed at one peso to the dollar, under a currency board. However, this approach caused overvalued real exchange rates (IMF 2004; Frenkel and Rapetti 2007, 2010). The appreciation of the US dollar in 1997, which was the commencement date of the Argentina crisis, reduced the competitiveness of Argentina significantly. Mexican, Asian, and Brazilian crises also negatively affected the competitiveness of Argentina, and the currency board in Argentina prevented adaptation to this new situation. Therefore, from 1998 to 2000, Argentina underwent a series of adverse shocks and consequently, unfavorable economic developments (IMF 2004). Argentina was one of the countries that maintained a hard peg in the 1990s, and in the early 2000s, it announced the implementation of a new exchange rate system for exports, which extended the currency peg to include the Euro as of 15 June 2001. At the end of 2001, Argentina moved to a dual exchange rate system, adopting a preferential exchange rate peg for exports (Spiegel 2002). However, the government abandoned the dual exchange rate system, intended to control capital outflows and stabilize the foreign exchange market, and started to implement a floating exchange rate system in 11 February 2002 (DTM 2002). As a result, the currency board, through which Argentina had a highly dollarized economy, came to an end after the Argentina crisis, which was one of the most severe currency crises (Edwards 2002).

After the implementation of the floating exchange rate regime following the economic crisis, nominal exchange rate increased rapidly, and the Argentinean Central Bank ran out of foreign exchange reserves due to the economic and political uncertainties Then, as the result of the stabilization of the foreign exchange market by the Central Bank, in July 2002, through selling US dollars in the market, nominal and real exchange rates began to appreciate. However, the government started to intervene in the foreign exchange markets in the opposite direction in July 2003 due to Argentina's new exchange rate policy, oriented towards maintaining a stable and competitive real exchange rate to recover output, employment and external and fiscal balances. Although the Central Bank did not make any statement regarding the existence of a real exchange rate target, it stated that its intervention in the foreign exchange market was to protect the economy from international capital market volatility. Therefore, the joint intervention of the Central Bank and the Treasury in the foreign exchange market continued until the beginning of 2007. After the implementation of the floating exchange rate regime, the monetary transmission mechanism interest rate was considered weak and uncertain by the Central Bank authorities. In this case, Argentina started to follow a monetary policy based on broad, quantitative monetary targets, apart from the implementations of other Latin American countries (Frenkel and Rapetti 2010). From 2003, targets were announced at the beginning of every year through the Central Bank's monetary programs. From mid-2002 to mid-2008, the Argentina economy grew at an 8.5\% average annual rate because of the success of this exchange rate regime (Frenkel and Rapetti 2010). Currently, in spite of diminished domestic growth in 2008 and a mild recession in 2009 due to global economic turmoil, the economic downturn was less severe in Argentina than elsewhere. Therefore, Argentina's exchange rate policy is presently based on a managed floating exchange rate (DoS 2011).

\section{Recent Empirical Studies of the Exchange Rate Channel in Turkey and Argentina}

Channels of the monetary transmission mechanism have been examined in many international studies. A vast number of studies analyze the monetary transmission mechanism exchange rate channel in Turkey. However, there appear to be a limited number of studies that analyze the monetary transmission mechanism exchange rate channel in Argentina. In this context, the further contribution of this study is the analysis of the operation of the exchange rate channel in both Turkey and Argentina. Some recent studies that focus on the monetary transmission mechanism exchange rate channel for Turkey are summarized in the following discussion.

Generally, most of the studies that analyze the exchange rate channel for Turkey find that it operates in Turkey (Saraçoğlu and Köse 1999; Gündüz 2001; Öztürkler and Çermikli 2007; Çiçek 2005; Kasapoğlu 2007; Erdoğan and Yıldırım 2008; Örnek 2009; Büyükakın, Cengiz, and Türk 2009). The studies reveal that the exchange rate channel has a significant impact on prices (inflation). Başçı, Özel, and Sarıkaya (2008) reveal that the exchange rate channel is an important transmission channel for Turkey. They also find that in addition to its traditional effect on total demand through foreign trade, the exchange-rate channel has an important impact effective on fundamental variables, such as expectations, the risk premium, the company balance sheet, production costs and 
prices. However, these authors indicate that, after the implementation of the flexible exchange rate system following the economic crisis in 2001, the effectiveness of the exchange rate channel started to decline. They showed that low inflationary environment resulting from the implementation of structural reforms after the 2001 have increased the importance of interest rate and credit channels in Turkey compared with the pre-crisis period, which is consistent with the economic theory about monetary transmission channel. Similarly, Catik and Martin (2012) examined monthly data for the period 1986 to 2011 by using a Threshold VAR (TVAR) model to investigate changes to the macroeconomic transmission mechanism in Turkey following a major reform of monetary policy in 2004. They detected two regimes, with a clear transition between them in 2003-4. The prereform regime is characterized by high inflation and persistent responses to shocks. The post-reform regime is characterized by low inflation, more active monetary policy and less persistent responses to shocks. However, Magud et al (2012) analyzed the impact of exchange rate flexibility on domestic credit to the private sector and volume of capital flows for 12 countries, including Turkey, and found that larger share of capital inflows could be intermediated through the banking system in economies with less flexible exchange regimes, which is not in line with Başçı et al. (2008) and Catik and Martin(2012), whilst also finding that less flexible regimes are associated with a higher share of credit in foreign currency, suggesting that the impact of exchange rate flexibility is economically relevant.

A limited number of studies find varying results for Argentina. Hsing (2004) applies the VAR model to determine how real output in Argentina would react to a shock to real interest rate, the external debt/GDP ratio, real stock prices, real exchange rates, deficit spending, and the lagged output for the period of 1994 to 2003 . He finds that real GDP in Argentina responds negatively to a shock to real interest rate, the external debt ratio, or the real exchange rate and positively to a shock to real stock prices or the lagged real GDP during some of the quarters. Frenkel (2004) discusses the mechanisms by which the real effective exchange rate affects employment performance and finds that the magnitude of the real effective exchange rate effect is important for Argentina, Brazil, Chile, and Mexico. Vargas (2009) examines the relationship between net capital inflows, real exchange rates and economic growth in 20 emerging economies and compares it to a panel of 13 developed countries with a panel model. Twenty emerging economies divided into three regions, Argentina is included in the first group (Latin America and Africa), and Turkey is included in the third group. The results indicate that, unlike the situation in developed countries, credit constraints work through the exchange rate channel as an important driver of the business cycle in emerging economies. Padilla (2010) uses a series of VAR models that incorporate money market mutual funds (MMMFs) as a new endogenous variable to examine the transmission of monetary shocks to real activity, inflation, and money market funds in Argentina. According to the results, the exchange rate model shows that a currency devaluation positively impacts output but later causes inflation. The exchange rate channel is not the only source of monetary transmission to MMMFs. Friori and Amico (2010) examine the comparison of monetary policy and the inflationary process in Argentina and Brazil for the period 1990 to 2010 and find that the exchange rate channel to monetary policy has a critical importance for both Argentina and Brazil.

\section{Data and Empirical Model}

\subsection{Data Selection}

In this study, the relative effect of the monetary transmission mechanism exchange rate channel on macroeconomic variables is tested for Turkey and Argentina. For this purpose, the VAR model is used for the period of January 2003 to August 2010. All variables are internal to the VAR method, which is widely used in the analysis of monetary transmission mechanisms (Sims 1980; Asteriou and Hall 2007).

International empirical studies are taken into consideration during the selection of variables.The VAR models cover the period of January 2003 to August 2010. The data set consists of macroeconomic variables that include the following: short-term interest rates (quarterly term reel deposit interest rates, Muço et al., 2004) $(d r)$, real effective exchange rates (rexc), net exports (nexp), the industrial production index ( $i p)$, and the consumer price index $(c p)$. The symbols ' $t$ ' and ' $a$ ' represent the abbreviations for Turkey and Argentina, respectively. The real effective exchange rate and industrial production index of Argentina are provided by Bloomberg, the real effective exchange rate of Turkey comes from the Central Bank of the Republic of Turkey, and the rest of variables are from the IMF International Financial Statistics (IFS). The theoretical framework is taken into consideration during the ranking of the variables. In this framework, the VAR models used in the analysis of the exchange rate channels for Turkey and Argentina can be written as follows:

$$
\begin{aligned}
& \text { Model I: } t d r_{t} \operatorname{trexc}_{t} \operatorname{tnexp}_{t} \operatorname{tip}_{t} t c p_{t} \\
& \text { Model II: } a d r_{t} \operatorname{arexc}_{t} \operatorname{anexp}_{t} \text { aip }_{t} \operatorname{acp}_{t}
\end{aligned}
$$

\subsection{VAR Estimation}

Initially, all series should be processed for the VAR analysis. As a first step, logarithms of all variables were taken except for ' $t d r$ ', ' $a d r$ ', and 'tnexp' so that they could so that they could become independent of unit values 
(to bring them to the same level). As a second step, all variables were tested as to whether seasonality effects exist. No seasonality effect was found for the variables. In the third step, all variables were tested for whether they were stationary using the augmented Dickey-Fuller (ADF) test because all variables must be stationary in VAR models. The stationarity of all variables in Model I estimated for Turkey was questioned for a significance level at 0.01 , and all variables were found to be stationary in their first difference $I(I)$ except the 'tnexp' variable. The stationarity of all variables in Model II estimated for Argentina was also questioned for a significance level at 0.01 , and all variables were found to be stationary in their first difference $I(I)$.

Before estimating a VAR model, it is essential to determine the optimal lag length of the model. In this context, the Likelihood Ratio (LR), Final Prediction Error (FPE), Akaike Information Criteria (AIC), and Hannan-Quinn (HQ) tests were used to determine the optimal (appropriate) lag length. According to the test results, the optimal lag length was determined to be "one" for both Model I and Model II. The reliability of Model I and Model II, whose lag lengths were determined to be one, was also confirmed on the basis of the 0.05 significance level found in four diagnostic tests: the Breusch-Godfrey Serial Correlation LM, ARCH, White Heteroskedasticity, and Ramsey Reset Tests.

The variance decomposition method was used to overcome the obstacles in the interpretation of the parameters in the VAR model and to determine the source of the changes in the variable. In this context, according to the results of variance decomposition for twenty- five periods obtained from Model I and Model II, the main source of all variables' variance is explained by their own shocks. In Model I, the secondary important source of the variance of the 'trexc', 'tip', and ' $t c p$ ' variables is the ' $t d r$ ' variable, with an average 5.61\%, 1.29\%, and $19.40 \%$, respectively. Moreover, the 'trexc' variable explains the $4.90 \%$ of the forecast error variance in the ' $t c p$ ' variable as the tertiary important source. According to the variance decomposition results of Model II for the long-run and mid-term period, the ' $a d r$ ' and 'arexc' variables are secondary important sources of each other. On the other hand, the 'aip' and ' $a d r$ ' variables explain the 'anexp' variable. Shocks to the 'arexc' variable explain up to $9.42 \%$ of the forecast error variance in the 'aip' variable, and shocks to the 'anexp' variable explain up to $3.14 \%$ of the forecast error variance in the 'aip' variable. The sources of changes in variance of the 'acp' variable for the twenty-five periods are explained by the ' $a d r$ ' variable with $17.45 \%$, the 'arexc' variable with $12 \%$ and the 'aip' variable with $3.21 \%$.

The response of other variables to a shock taking place in one of the variables of the VAR model is analyzed with the impulse-response function (IRF). Therefore, with the IRF, other variables' responses to the shocks that may occur in the future could be estimated.

In this context, the responses of other variables to one standard deviation of 'trexc' shock in Model I is reported in Figure 1. The response of the 'trexc' variable to its own shock was downward from the beginning period to the fourth period. The effect of the shock disappeared after the fourth period. The response of shortterm interest rates to real effective exchange rates was downward from the initial period to the second period. However, after the foreign capital inflow, an upward trend is expected as the first response of short-term interest rates. In this context, the expected response emerged after the end of second period continued to the end of sixth period and then disappeared. The response of net exports to the 'trexc' shock was found to be downward. The reason for this outcome is that the increase in the import ratio exceeds the increase in the export ratio due to the decrease in exchange rates. Due to the drop of the ' $t d r$ ' and 'trexc' variables, industry production increases from the initial period to the end of the second period in Turkey, which has imported input dependency. The response of 'tcp' to the decrease of ' $t d r$ ' which originated from 'trexc', was upward due to the increase in household consumption. The upward tendency of 'tcp' continued to the seventh period.

The response of the short-term interest rate to its own shock was downward from the initial period to the end of the fourth period, as shown in Figure 2. After this period, the response of the ' $t d r$ ' variable to its own shock disappeared. In the process, the expected response of the 'trexc' variable is upward. In other words, the 'trexc' variable, which is acting in line with the monetary transmission mechanism, increases from the initial period to the fifth period. As the result of depreciation of domestic currency deposits against foreign currency, the demand of foreign countries for domestic goods increases and the demand of foreign goods decreases. Therefore, as an outcome of the loss of real value (an increase in the real exchange rate leads to an increase in the export ratio and a decrease in the import ratio), the 'tnexp' variable is affected positively. The response of the 'tnexp' variable continues into the beginning of the second period. That increase in the aggregate demand also affects aggregate output (tip), positively. Finally, the inflation rate increases as the result of responses of the variables in the model, which are in line with the theory. In other words, the 'tcp' variable increases from the initial period to the fifth period because of the recovery effect of the changes in the 'trexc' variable on the aggregate demand, as a response to the monetary shock.

The responses of other variables to one standard deviation 'arexc' shock in Model II are reported in Figure 3. The response of the 'arexc' variable to its own shock is downward from the initial period to the end of the fifth period. The 'arexc' shock creates an upward pressure on short-term interest. In other words, this shock causes an upward response by the ' $a d r$ ' variable from the initial period to the second period. A decrease in exchange rates causes an increase in the demand for imported goods and a decrease in the export quantity. For this reason, the 
net export rate decreased from the initial period to the second period. The changes in the 'adr' variable, which are created by the 'arexc' variable, cause a decrease in the 'aip' and 'acp' variables. Nevertheless, the response of the 'acp' variable continues up to the fourth period.
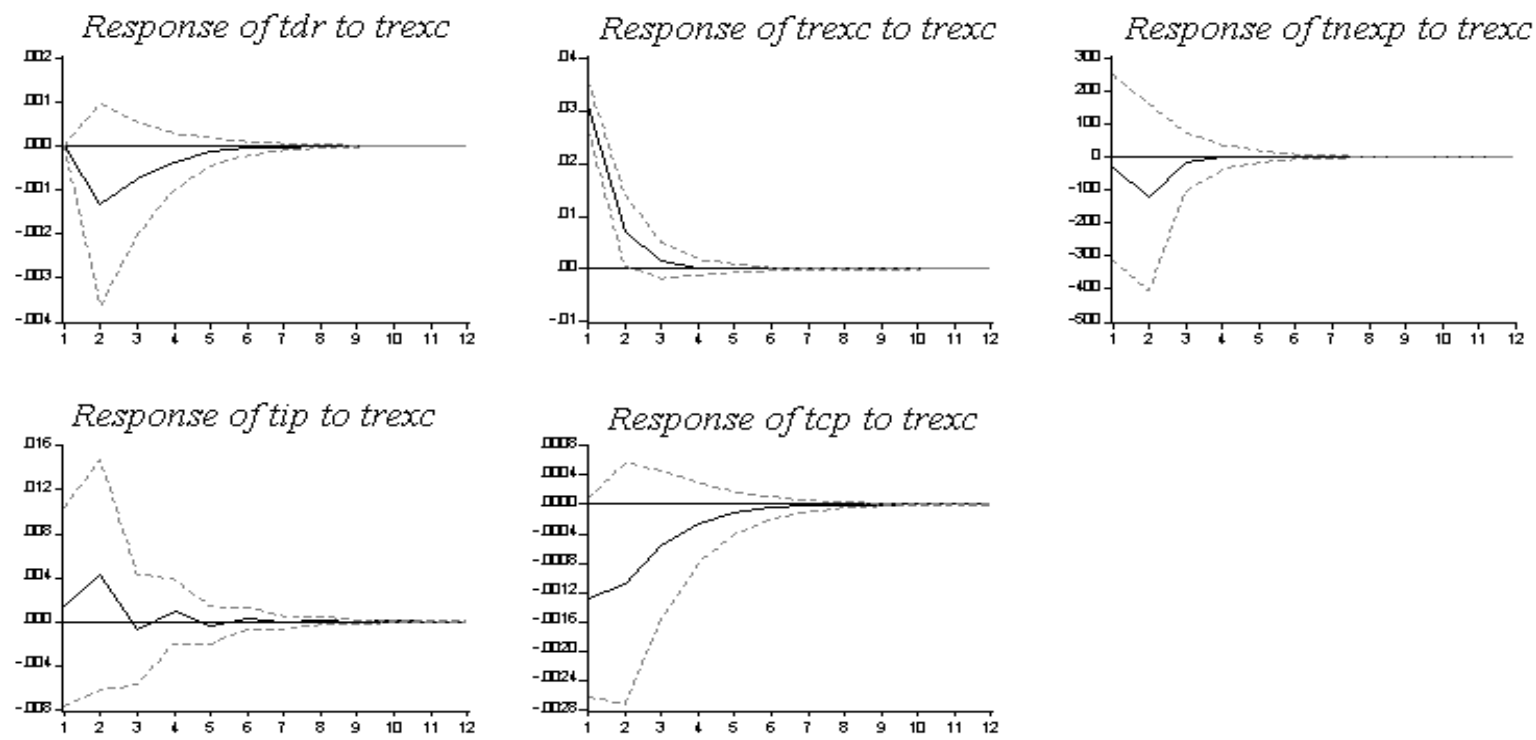

Figure 1: Response of model I variables to 'trexc'variable shock
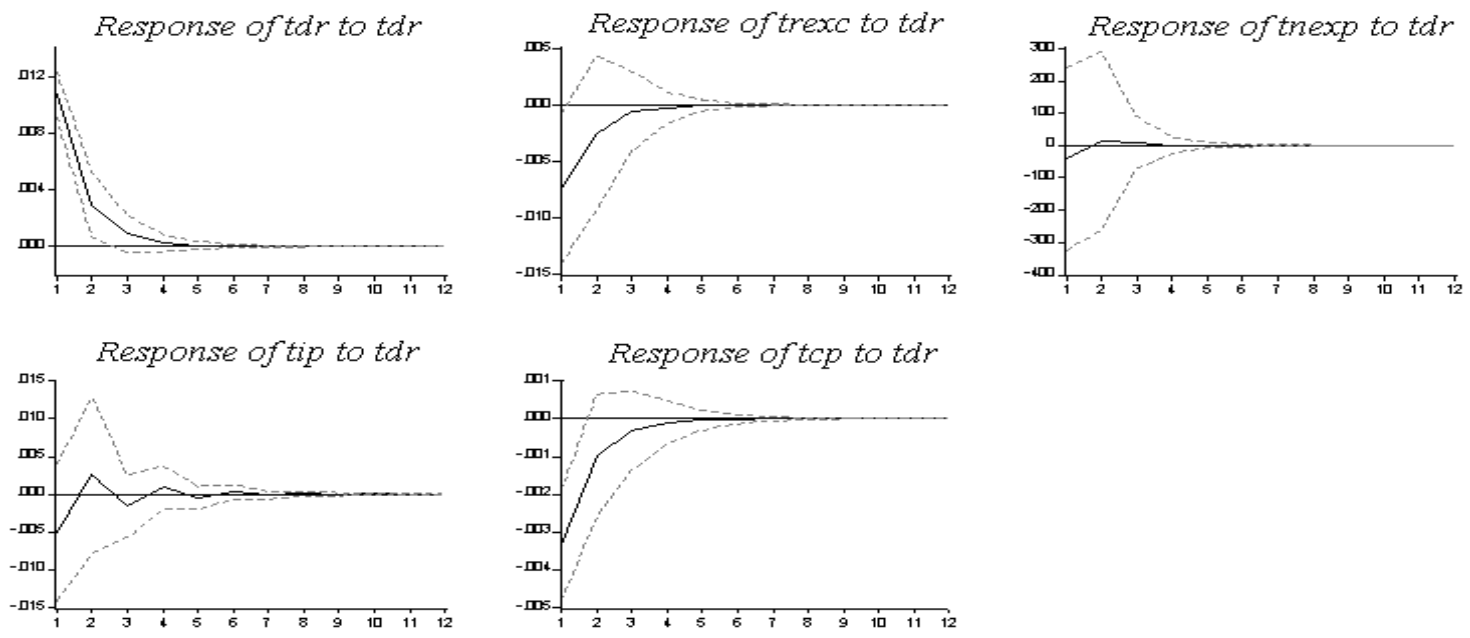

Figure 2: Response of model I variables to 'tdr'variable shock
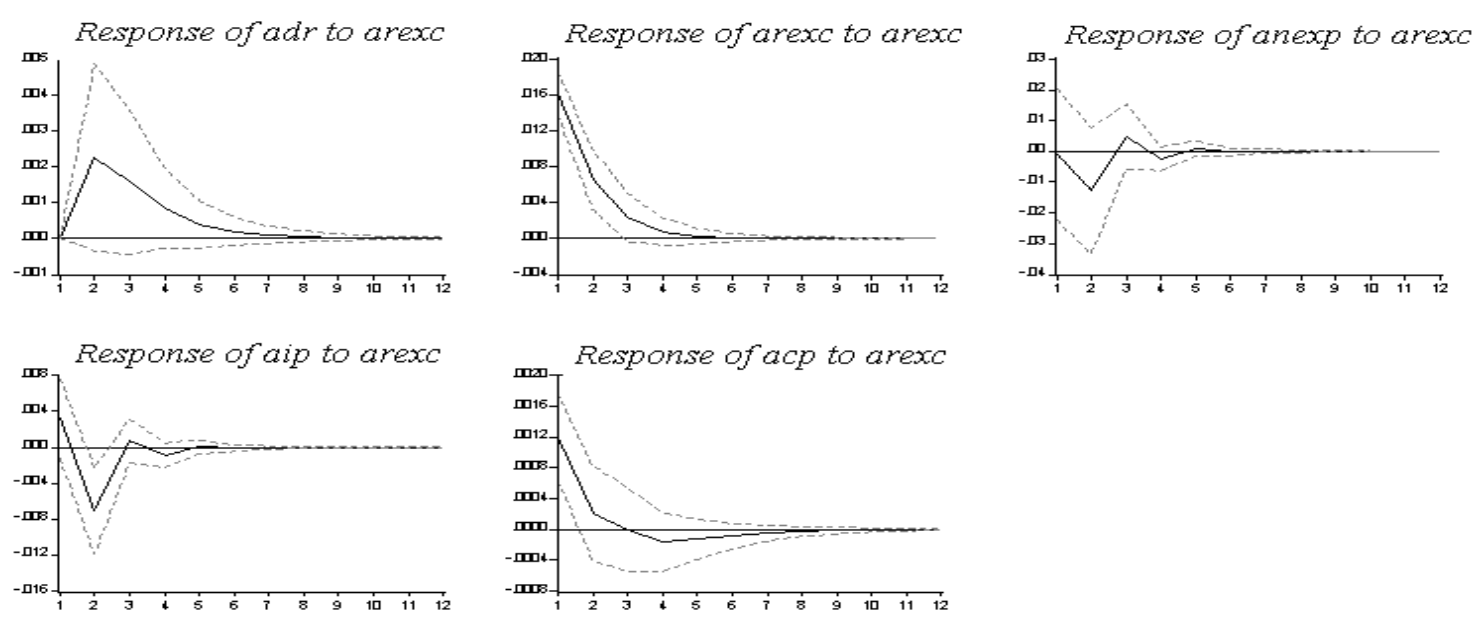

Figure 3: Response of model II variables to 'arexc'variable shock 
The responses of other variables to one standard deviation ' $a d r$ ' shock in Model II are shown in Figure 4. The response of the ' $a d r$ ' variable to its own shock from the beginning period to the fifth period downward. Although the first response of the 'arexc' variable to the 'adr' shock is downward and contradicts expectations, it is in line with expectations from the second period to the fifth period. The 'anexp' variable decreased up to the second period due to the increase in imports relative to exports, which originated from the 'arexc' variable. The effect of the shock on the 'anexp' variable comes to an end after this period.
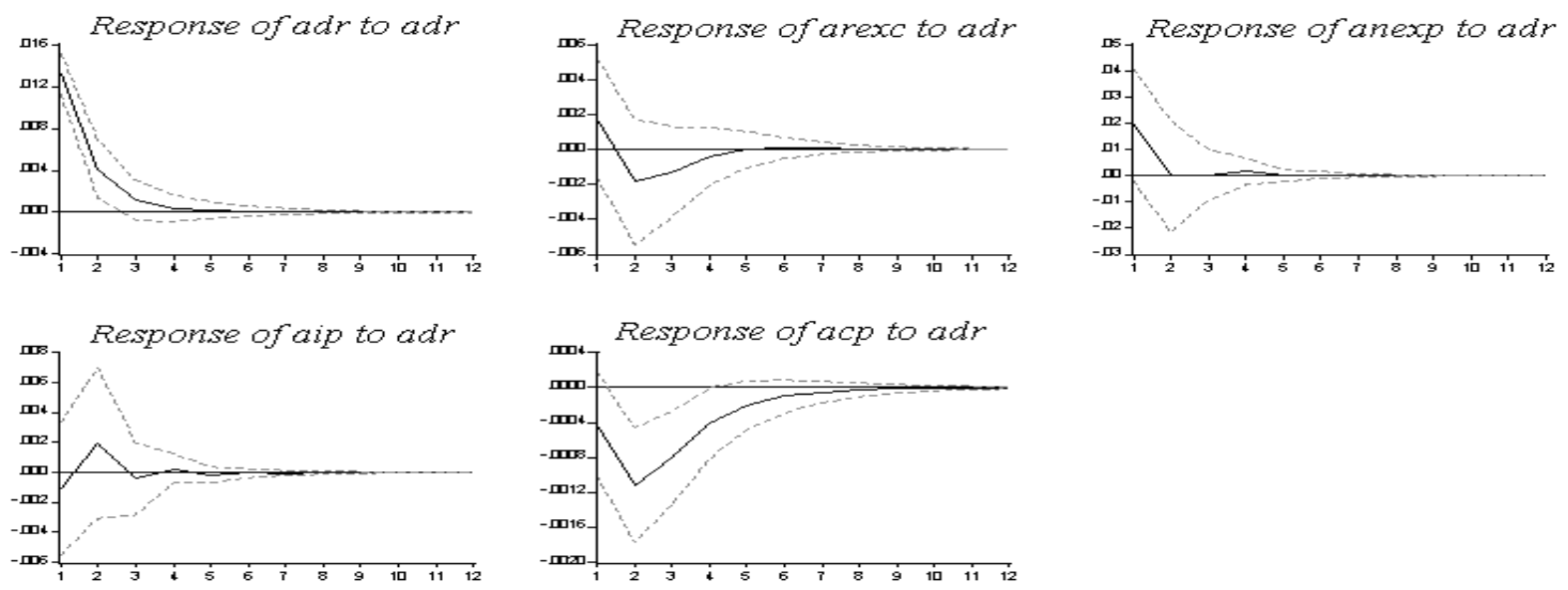

Figure 4: Response of model II variables to 'adr'variable shock

When the first responses are evaluated, it is found that the effect 'adr' shock on the 'aip' variable is positive, but that its effect on the 'acp' variable is negative. However, the expected effect of the shock on the ' $a c p$ ' variable emerged in the second period and continued until the ninth period. In this context, the lagged response of the ' $a c p$ ' variable is accepted as normal in international studies.

\section{Conclusion}

Determination of the magnitude and timing of macroeconomic variables are gaining importance in predicting the effects of shocks to the macroeconomic variables. In this context, the issue of which monetary transmission mechanism channel is more effective arises. It is important to analyze and resolve this issue on a national basis. In this framework, this study examines the effects of the exchange rate channel, which is based on the interest rate channel and is especially effective with regard to net exports, over the period of 2003 to 2010 for Turkey and Argentina, which adopted flexible exchange rate regimes in 2001 and 2002, respectively. According to the results of the impulse-response function, the exchange rate channel is effective for both Turkey and Argentina.

\section{References}

- Arat, K. (2003), “Türkiye'de Optimum Döviz Kuru Rejimi Seçimi ve Döviz Kurlarından Fiyatlara Geçiş Etkisinin İncelenmesi”, Uzmanlık Yeterlilik Tezi, TCMB Dış İlişkiler Genel Müdürlüğü, Temmuz.

- Ardiç, O. P. and F. Selçuk (2006), "The Dynamics of a Newly Floating Exchange Rate: The Turkish Case”, Applied Economics, Vol. 38, No.8, pp.931-941.

- Artus, P., A. Cartapanis and F. Legros (2003), "Towards a Macroeconomics of Exchange Rate Regimes", Revue économique, Vol.54, No. 5, pp. 905-912.

- Asteriou, D. and S.G. Hall (2007), Applied Econometrics: A Modern Approach, New York: Palgrave Macmillian

- Başçı, E., Ö. Özel and Ç. Sarıkaya (2008), "The Monetary Transmission Mechanism in Turkey: New Developments”, Bank for International Settlements (BIS) Papers No. 35, March.

- Boivin, J., M.T. Kiley and F.S. Mishkin (2010), “How Has the Monetary Transmission Mechanism Evolved over Time”, NBER Working Paper, No.15879, April.

- Bordo, M. D. and A. J. Schwartz (1988), "Transmission of Real and Monetary Disturbances under Fixed and Floating Exchange Rates”, Cato Journal, Vol. 8, No. 2, pp.451-475.

- Büyükakın, F., V. Cengiz and A. Türk (2009), "Türkiye'de Para Politikası Aktarım Mekanizması: Döviz Kuru Kanalı Üzerine Bir Değerlendirme”, Dokuz Eylül Üniversitesi İktisadi ve İdari Bilimler Fakültesi Dergisi, Vol. 24, No. 1, pp.171-198.

- Caramazza, F., J. Aziz (1998), "Fixed or Flexible? Getting the Exchange Rate Right in the 1990s", International Monetary Fund, Economic Issues no. 13, April. 
- Catik A., Martin C. (2012), "Macroeconomic Transitions and the Transmission Mechanism: Evidence from Turkey", Economic Modelling, Vol. 29, No.4, pp.440-1449.

- CBRT (Central Bank of the Republic of Turkey) (2009), Monetary and exchange rate policy for 2010, Central Bank of the Republic of Turkey, December, http://www.tcmb.gov.tr/yeni/announce/2010/Mon_Exc_Pol_2010.pdf.

- CBRT (Central Bank of the Republic of Turkey) (2010), Monetary and exchange rate policy for 2011, Central Bank of the Republic of Turkey, December, http://www.tcmb.gov.tr/yeni/announce/2010/Mon_Exc_Pol_2011.pdf.

- Çiçek, M. (2005) “Türkiye'de Parasal Aktarım Mekanizması: Var (vektör otoregregrasyonu) Yaklaşımıyla Bir Analiz", Iktisat Iş̧letme ve Finans, Vol.20, No. 233, pp. 82-105.

- DoS (U.S. Department of State) (2009), Background note: Argentina. Bureau of Western Hemisphere Affairs (July), http://www.state.gov/r/pa/ei/bgn/26516.htm.

- $\quad$ Drabek, Z. and J.C. Brada (1998), "Exchange Rate Regimes and the Stability of Trade Policy in Transition Economies", Journal of Comparative Economics, Vol.26, No. 4, pp.642-668.

- DTM (Dış Ticaret Müsteşarlığı) (2002), Arjantin ve Türkiye Ekonomik Krizleri, Ankara, http://www.foreigntrade.gov.tr/dtmadmin/upload/EAD/KonjokturIzlemeDb/arjantin.doc

- Edwards, S. (2002), “The Great Exchange Rate Debate after Argentina”, NBER Working Paper, No.9257, October.

- Erdoğan, S. and D. Ç.Yıldırım (2008), “Türkiye’de Döviz Kuru Kanalının İşleyişi: VAR Modeli ile Bir Analiz”, İstanbul Üniversitesi Siyasal Bilgiler Fakültesi Dergisi, No 39, pp. 95-108.

- Ertekin, M. (2003), Exchange Regimes and Impacts on Foreign Trade of Turkey. Republic of Turkey Ministry of Economics, http://www.ekonomi.gov.tr/upload/BF09AE98-D8D3-85664520B0D124E5614D/Murat_Ertekin-ingilizce.pdf.

- Frenkel, R. (2004), "Real Exchange Rate and Employment in Argentina, Brazil, Chile and Mexico", Iktisat İsletme ve Finans, Vol.19, No.223, pp.29-52.

- Frenkel, R. and M. Rapetti (2007), “Argentina's Monetary and Exchange Rate Policies after the Convertibility Regime Collapse”, CEPR Reports and Issue Briefs, No. 2007-12, April.

- Frenkel, R. and M. Rapetti (2010), “A Coincise History of Exchange Rate Regimes in Latin America”, CEPR Reports and Issue Briefs, No. 2010-11, Washington DC, April.

- F. Alejandro and F. Amico (2010), "Exchange Rate Policy, Distributive Conflict and Structural Heterogeneity. The Argentinean and Brazilian Cases", International Conference Sraffa's Production of Commodities by Means of Commodities 1960-2010, Roma Tre University, Faculty of Economics, Roma, December 2-4.

- Görmez, Y. and G. Y1lmaz (2007), "The Evolution of Exchange Rate Regime Choices in Turkey", Proceedings of OeNB Workshops No.13, Oesterreichische National Bank, April.

- Gündüz, L. (2001), “Türkiye'de Parasal Aktarım Mekanizması ve Banka Kredi Kanalı”, IMKB Dergisi, Vol.5, No.18, pp. 13-30

- Hsing, Y. (2002), "Responses of Argentine Output to Shocks to Monetary Policy, Fiscal Policy and Exchange Rates: A VAR Model", Applied Econometrics and International Development, Vol. 4, No.1, pp. 21-36.

- IMF (International Monetary Fund) (2004), The IMF and Argentina 1991-2001, The IMF Evaluation Report, http://www.imf.org/external/np/ieo/2004/arg/eng/pdf/report.pdf.

- Kasapoğlu, Ö. (2007), "Parasal Aktarım Mekanizmaları Türkiye için Bir Uygulama”, Uzmanlık Yeterlilik Tezi, TCMB, Piyasalar Genel Müdürlüğü, Şubat.

- Kasman, S., and D. Ayhan (2006), "Macroeconomic Volatility under Alternative Exchange Rate Regimes in Turkey”, Central Bank Review, Vol.6, No.2, pp.37-58.

- Magud N., Reinhart C. and E. Vesperoni (2012), "Capital Inflows, Exchange Rate Flexibility and Credit Booms", IMF Working Paper No.12/41, February.

- Mishkin, F.S. (1995), "Symposium on the Monetary Transmission Mechanism”, The Journal of Economic Perspectives, Vol.9, No.4, pp.3-10.

- Mishkin, F.S. (1996), “The Channels of Monetary Transmission: Lesson for Monetary Policy”, NBER Working Paper No. 5464, February.

- Mishkin, F.S. (2001), "The Transmission Mechanism and the Role of Asset Prices in Monetary Policy", NBER Working Paper No. 8617, December. 
- Mishkin, F.S. (2007), Money, Banking and Financial Markets, Pearson Education Inc: Boston.

- Muço, M., P. Sanfrey and A. Taci (2004), "Inflation, Exchange Rates and the Role of Monetary Policy in Albania”, European Bank Working Paper No. 88, August.

- Obstfeld, M. (1984), “Capital Flows, The Current Account and the Real Exchange Rate: Consequences of Liberalization and Stabilization”, NBER Working Paper No. 1526, April.

- Örnek, İ. 2009. Türkiye'de parasal aktarım mekanizması kanallarının işleyişi. Maliye Dergisi 156: 104-125.

- Öztürkler, H. and A. H. Çermikli (2007), “Türkiye'de Bir Parasal Aktarım Kanalı Olarak Banka Kredileri”, Finans Politik \& Ekonomik Yorumlar, Vol.44, No.514, pp.57-68.

- Padilla, J. L. (2010), "How Does Monetary Transmission Mechanism Impact Output, Inflation and Money Market Funds in Argentina? A VAR Approach”, Working Paper Series, University of Lausanne - School of Economics and Business Administration, February.

- Saraçoğlu, B. and N. Köse (1999), "Vektör Otoregresyon Yaklaşımı ile Enflasyonla Mücadelede Politika Seçimi: Türkiye Örneği 1980-1996”, Iktisat Ísletme ve Finans, Vol.14, No.159, pp.12-27.

- Sims, C.A. (1980), "Macroeconomics and Reality”, Econometrica, Vol. 48, No. 1, pp. 1-48.

- Spiegel, M. M. (2002), “Argentina's Currency Crisis: Lessons for Asia”, FRBSF Economic Letter, No.25, pp. 1-4.

- Uygur, E. (2010), “The Global Crisis and the Turkish Economy”, Turkish Economic Association Discussion Paper No.3, Ankara.

- Vargas, L. C. (2009), "Capital Flows and Real Exchange Rate Depreciation Effects on the Business Cycle in Emerging Markets”, Journal of Business and Policy Research, Vol. 4, No. 2, pp. 72-92.

- Yilmaz, D. (2008), “Turkey's Monetary and Exchange Rate Policy for 2009”, The Central Bank of the Republic of Turkey Research Department Discussion Paper, No. 3/2009, December. 


\title{
The Applicability of Responsibility Accounting System within the Scope of Increasing Efficiency in Hospital Bussinesses in Turkey
}

\author{
Prof. Dr. Fehmi Karasioğlu (Selçuk University, Turkey) \\ Asst. Prof. Dr. İbrahim Emre Göktürk (Aksaray University, Turkey)
}

\begin{abstract}
In order to reduce the waste of resources of health to minimum level, The most important sub-system of the system must take the necessary precautions in hospitals. Improving the quality of services provided in hospitals, ensuring cost control in hospitals, increasing competition, promotion of private initiatives are important elements which help these bussinesses to increase their effectiveness. Because of human health is a matter of priority in health services, the businesses which offer this services should think the economic priorities for second plan. This is a policy based on hospital establishments with income instead of providing added value to the costs without compromising on quality to ensure a minimum to decrease the cost, with the creation of the control system will be possible. The complex and the complex structure of hospitals also complicates the management of these enterprises.With the centrifugal organization structure and the sparation of management in the responsibility fields, management of this complex structure can be provided more efficiently.The most important problems in Turkey, in hospitals, professional management and cost control as a responsibility accounting system is a system that will produce a solution to the problem proposed.
\end{abstract}

\section{Introduction}

The main source of hospitals' fundamental inputs and outputs involves people. The output in hospital enterprises can not be evaluated physically and it is hard to measure against certain standards. (Alpugan, 1995: 140). The output is attempted to be determined through such criteria as the number of patients or patient day. (Kurup, 2010 : 4). However, in this case, the functioning of hospitals becomes harder because different treatments and costs are applied for inpatients and outpatients in hospitals that have complex structures. (Alpugan, $1995: 140$ )

Quality health services can be offered through the formation of qualified enterprises. A high quality approach to running of hospitals needs to be attained in order to be able to offer the best possible health services in health organizations. High quality service requires proper organization of these enterprises in terms of organization and their becoming enterprises operating effectively in such fields as production, marketing, sales and accounting in terms of functioning.

Ensuring the continuity of well-being, one of the fundamental needs of people, who are inputs in such a complicated and complex institution, requires passing through various stages of diagnosis and treatment and attempts are made to eliminate health problems or maintain the state of health. Although health services are the chief services being offered, use of raw materials or semi-finished materials, use of personnel and use of other production costs are also involved during the offering of these services. At the same time, services such as hotel services, catering services, security and transportation services are also provided in hospitals. Therefore, bringing costs under control in these institutions is an important issue but this requires formation of a system, which is a difficult and at the same time an important task.

One of the important benefits that responsibility accounting provides to enterprises is to ensure control over spending, In addition to macro-level measures that will be taken in health expenditures, supervision of unnecessary health expenditures in hospital enterprises, which are one of the most important sources of health expenses, will be possible through cost control. The system of responsibility accounting is one of the methods that can be used for more effective and efficient use of these hospitals to ensure cost control.

\section{Efficiency (Productivity) in Hospital Enterprises}

Increase in the efficiency of hospital enterprises depends on efficient distribution and use of resources, (Jacobs,2011 : 177), offering services in an effective manner, equal treatment in target group's accessing services and the satisfaction that recipients of services feel with the services given to them. An enterprise that has data to yield productivity growth can engage in activities to increase productivity. If productivity is not measured, it will not be appropriate to talk about the concepts of productivity performance and quality. At the same time, productivity is a concept that can be measured only when costs are controlled and cost data are known. (Jacobs,2011: 178)

Today, rising health costs have become an important issue in developed and developing countries alike. In countries that wish to have positive health indicators thanks to health expenditures they make, it is a huge challenge for health institutions to get the worth of their spending. Hospitals are expected to work more 
effectively and productively in the face of this challenge. The most important expectation is for them to bring costs under control and ensure productivity. (Moshiri vd., $2010: 36$ )

Measurement of productivity is a prerequisite for the presence of a well-coordinated health system. At the same time, measurement of productivity is a necessity for a rational distribution (Barutçugil, 1983:202-203) of workforce, capital, technology and materials, which are major components of productivity in hospitals. (O'neil, $2008: 42)$

The most frequently and widely used ratio for the measurement of productivity is

Productivity = Output /Input. (Kavuncubaş1, $2000: 341$ )

The formula given above is usually aimed at explaining productivity in enterprises of production. In hospital enterprises, on the other hand, complex structures and difficulties in the measurement of output make it hard to measure productivity. (Nachum, 1999 : 923)

It is necessary to have healthy data about the output, which is the most important condition in the measurement of productivity, and the input used in the production of output. It is hard to say that hospitals in Turkey posses these data in full. Hospitals can measure their productivity as long as they have healthy data. Two fundamental precautions to have hospitals possess healthy data involve formation of information flow systems and implementation of the responsibility (functional/profitability) accounting system in enterprises. (Alpugan, 1981 : 149)

The information flow system in hospitals can be established within a medical statistics unit. The accuracy of the statistical information that will be obtained in this unit will be guaranteed if the personnel employed in this unit are composed of experts who can measure data accuracy. (Alpugan, 1981:150)

Being able to measure productivity is an important concept for hospital enterprises which aim at profitability to maximize profits and fulfil the goals of enterprises. Measurement of productivity should be performed in not only profit-oriented enterprises but also in non-profit public hospitals. (Craycraft, 1999 : 11). When seen from a larger perspective, return on investments made in the sector will affect development in health indicators such as human development index, which influences states' level of development. Therefore, implementation of responsibility accounting in public hospitals for productivity will be a useful practice.

In order to increase productivity in hospital enterprises and hence raise quality, hospitals' physical, ergonomic and motivational shortcomings should be eliminated, (Y1lmaz, 1995 : 547) personnel's particitation in management should be ensured, personnel productivity should be rewarded, a supervisory mechanism should be established to prevent ill use and unnecessary expenses in the field of heatlh, unnecessary use of medicine and unnecessary tests and operations should be avoided, and new methods that will raise productivity should be implemented in hospital enterprises.

The structure of hospital enterprises should be modernized in order to increase productivity in hospital enterprises in Turkey. The number of hospital beds per 1000 patients in Turkey is below the OECD average with 2.5 beds. It is also seen that ratios of hospital bed occupation, hospital bed turnover range and average duration of stay in hospitals affiliated to the Ministry of Health are below the OECD data. (Hacettepe Üniversitesi, 2005 : 5)

The level of productivity and effectiveness of hospitals is directly related to qualities such as the enthusiasm, effort, hardwork and efficiency of their personnel. Managerial effectiveness and all other achievement criteria are based on the efforts of the human factor. The quality of services offered in hospitals rises in direct proportion to the hospital staff's adoption of the hospital's goals and targets and uniting around these goals and this situation influences the performance and productivity of the employees.(Bilgin and Çıraklı, $2010: 118$ )

A good and high quality health service should be provided by well-trained and specialized health personnel using adequate and fully safe diagnostic devices; necessary tests and treatment should be performed, resources should be used appropriately, duration of tests and treatment and expenses should be kept at a minimum, and nothing should be wasted. (Yilmaz, 1995: 554). Meeting the conditions that are listed above for the organization will be possible through organizations that are formed in a decentralized structure. This structure, which we can also be called centrifugal structure, is at the same time one of the prerequisites of the responsibility accounting.

Increasing competition in the field of heatlh services and rising expectations on the part of individuals to obtain better services from these enterprises require raising quality in this sector. In order to further improve the level of health services in hospital enterprises and effectively use the resources, inputs and outputs should be determined and analyzed.(Tutar and Kılınç, 2007: 39) 


\section{The Importance of Responsibility Accounting in Raising Productivity in Hospital Enterprises}

The responsibility accounting system ensures distribution of responsibility by creating a decentralized structure in hospital enterprises, and in this way aims to improve productivity by activating both administrative control and cost control through establishing centers of responsibility in the enterprise.

The responsibility accounting system, as an aid to management accounting and cost accounting, will create a decentralized management and cost, revenue, profit and investment centers compatible with this system of management in hospitals, the most important sub-systems among health enterprises, where managerial structure is complex, and managerial and cost control is hard due to this complexity. It will enable the emergence of an effective control mechanism within the organization through managers in these, centers, ensure cost control without sacrificing human health, which is the primary goal of hospital enterprises, and thus enable them to be better quality, high performance and productive enterprises.

Hospital enterprises are service organizations that require massive investments and the management and control of these investments are hard to handle. It is seen that in comparison to other enterprises, not enough progress has been made in these enterprises, which have become a billion-dollar sector in today's world, in terms of professional management. Although hospital enterprises are institutions where individuals such as doctors, nurses and laboratory technicians who are experts in their fields are employed, the health system has not attached enough importance to the management of these leading institutions of health as it has done to other professions. (Akwahle, $2006: 1$ )

As of 2012, the concept of hospital manager is used by virtue of a law called public hospital unions in public hospitals in Turkey, which makes the first mention of management by a professional manager. Although it has not been fully implemented yet, it is expected that this concept will contribute significantly to public hospitals' becoming effective enterprises. In the responsibility accounting system, along with the decentralized structure, a more democratic system needs to be formed and individuals spealized in management need to have responsibility in regard to expenses, revenues and even investments in the enterprise and in their relevant units within the enterprise. This gives larger authority to expert managers regarding the decision-making process to ensure that hospital enterprises operate more effectively and efficiently.

The decentralized management style, which is necessary for the implementation of responsibility accounting, requires employment of personnel who are experts in management and in their relevant fields in the responsibility centers within the organization and this will ensure effective running of the system and hence the expected benefits. When the health sectors of developed countries are observed, it is seen that to meet the need for professional managers in hospital enterprises, individuals trained in accordance with the principles of management in health management programs of universities have entered this sector as members of a prestigious profession (Reed, 2008: 39). Raising effectiveness can be achieved by making use of these individuals.

With the implementation of responsibility accounting in hospital enterprises, it will be possible to run hospital enterprises in accordance with the principles of modern management and organization, ensure unity of goal in these organizations, provide equivalency in auhority and responsibility and define division of labor and duties (Özgen, 1993: 38-39) and thus hospital enterprises will be able to operate more effectively and efficiently.

For effective running of the responsibility accounting system, managers of the responsibility centers need to ensure effectiveness within their area of responsiblity, and to provide a rational measurement of performance, they need to have authority over costs and revenues and even decisions of investments that take place in the responsibility center. For this to happen, managers should be given this opportunity through transfer of authority (Newstrom and Davis, 1993 : 247). As long as this is ensured, benefits expected of responsibility accounting will be obtained. (Young, $2003: 241$ )

The task of bringing costs under control within this complex structure of hospital enterprises requires the use of responsibility accounting system. For example, gathering information about daily costs of polyclinic services provided to outpatients, costs of x-rays and laboratory services, costs of doctors and nurses who take care of these patients, or daily costs of inpatients including costs of wards, care, medicine, nursing and similar services, overall calculation of costs and addition of these costs for different service centers necessitate cost accounting and cost control in hospital enterprises (Young, 2003: 241). Responsibility accounting offers significant benefits by allowing managers of enterprises, which it has divided into units through responsibility centers, to collect cost information that has accumulated in these centers, sort it out in the best possible way, check and report it and thus ensure an overall supervision.

In addition to macro-level measures that will be taken regarding health expenses, prevention of unnecessary health spending in hospital enterprises, which are among the most important sources of health expenditures, will also be possible through cost control. The responsibility accounting system is one of the methods that can be used for efficient and effective running of these hospitals for the purpose of controlling costs. 
One of the objectives intended to be achieved for financial development of the health sector in accordance with the 8th five-year development plan as expressed in the "Effectiveness Special Expertise Report" concerns bringing costs of health services under control and using scientific methods and cost accounting systems to this end (DPT, 2001:132-143). As can be seen, the objectives stated in this report are intended to rid health enterprises of their unproductive structure and improve health services. One of the practices that help attain aforementioned goals will be the establishment of the responsibility accounting system in health enterprises. Costs wil be brought under control, necessary expertise will be achieved in terms of management, importance of budget applications will be understood and scientific studies will be adapted to these institutions thanks to the responsibility accounting system.

One of the contributions of the responsibility accounting system to enterprises concerns responsibility (accountability) reports. Accountability reports are those where managers of revenue, profit and investment centers compare and contrast the values arising in the centers of their repsonsibility with the actually occurring values according to the previously budgeted values. Thanks to these reports, the senior mnagement can see the activities that take place in their responsibility center and to what extent the objectives set by the budget values have been attained through deviations; these deviations are separately calculated, their causes are investigated and are used in preparing effective budgets in subsequent years. At the same time, accountability (responsibility) reports enable the senior management to make comparisons between units, conduct controls and checks and measure performances of responsibility centers and their managers.

One of the most important problems in hospital enterprises involves implementation of performance measurements to increase productivity. Productive and efficient hospital enterprises will provide benefits such as improvement in indicators in the health sector, more effective exploitation of health services by society at large and reduction of costs to a minimum. The most prominent obstacle in the way of measuring performance of health enterprises concerns problems encountered in the measurement of the output needed for productivity measurements. Measurement of performance is a phenomenon where increase in productivity will be achieved through responsibility centers and accountability (responsibility) reports.

It will not be possible to talk about concepts of productivity performance and quality if productivity can not be measured. At the same time, productivity is a concept that can be measured through control of costs and knowing cost information. (Jacobs,: 177)

Today, rising health costs have become an important issue in developed and developing countries alike. In countries which wish to have positive health indicators thanks to health expenditures they make, it is a huge challenge for health institutions to get the worth of their spending. Hospitals are expected to work more effectively and productively in the face of this challenge. The most important expectation is for them to bring costs under control and ensure productivity. (Moshiri vd., $2010: 36$ )

Measurement of productivity is necessary for the presence of a well-coordinated health system. Measurement of productivity is also a necessary factor for a rational distribution of workforce, capital, technology and materials (Barutçugil, 1983: 202-203), which are major components of productivity in hospital enterprises (O'neil, 2008 :42). The measurement of these compounents in hospital enterprises which are divided into responsbility centers can be performed on the basis of centers and this may ensure obtainment of more active results.

It will be possible to get better results using the responsibility accounting system in hospital enterprises within the framework of the efforts intended to implement a system known as the diagnosis-related group method (DRG) in international literature for cost control in Turkey. Currently, ICD10-AM (International Classification of Diseases, Australian Modification) is being used in Turkey as an Australian example while A.R. D.R.G. (Australian Refined Diagnosis Related Groups) is being used as T.I.G. algorithm.

For the formation of our own T.I.K. structure in hospital enterprises in Turkey by determining the costs of each unit, the diagnostic and treatment services generated in these units and production of relative values on the basis of costs, first, hospital enterprises should be accomodated to this structure. A system that can be used for this purpose is the responsibility accounting system. When this system is implemented in hospitals, a cost control system where these values can be formed will be created in hospitals.

The responsibility accounting system enables decentralization by dividing hospital enterprises into certain responsibility centers and thus reveals the controllable costs arising in each major center of service production; it can also provide the cost data, which are necessary to be able to form TIK values, in a more reliable manner than the responsibility center where the cost has occurred. Formation of relative values at the stage of determining costs on the basis of responsibility centers, and formation of the accounting system in cost production on the basis of responsibility centers and putting the accounting information system, where this system will be implemented, into use through computers and computer software will save time and procedures and enable obtainment of more realistic results. 


\section{Conclusion}

The process of transformation in health, which began in Turkey in the 2000s, aim at providing more effective and productive services. Increasing productivity in hospital enterprises, which are the keystones of the health system in Turkey, will ensure that health spending is reduced to a minimum, people are treated without losing their health, the level of health is raised and welfare of people is increased. Although an increase in productivity, formation of an effective managerial process and profit motives are secondary, their more active functioning will be possible through effective control on costs without sacrificing health.

To this end, effective systems need to be added to the system in order to put in order the complex and complicated structures of hospital enterprises. The responsibility accounting system should be tried as one of the systems that can activate ponderous nature of hospital entreprises and provide increases in productivity.

\section{References}

- ALPUGAN Oktay (1995). Hastanelerde Verimlik Sorunu ve Kimi Öneriler, Hastane İşletmeciliği Seçme Yazılar, Eskişehir : Anadolu Üniversitesi Yayınları.

- ALPUGAN Oktay (1981). Genel Hastanelerin Kullanımı Türkiye’de Uygulamada Karşılaşılan Kimi Sorunlar Ve Bu Sorunların Çözümlenmesi E.Ü. İşletme Fakültesi Doçentlik Tezi, İzmir.

- $\quad$ AKWAHLE Willis (2006). An Urgent Call to Professionalize Leadership and Management in Health Care Worldwide , Management Sciences for Health, Volume.4.

- ÖZGEN Hüseyin (1993). Çăgdaş hastane yönetim anlayışı ve Türkiye' deki uygulamalar” işletme yönetiminde güncel konular, Adana, Çukurova üniversitesi İIBF, işletme bölümü yayın no:2,

- CRAYCRAFT Catherine (1999). A Review of Statistical Techniques in Measuring Efficiency. Journal of Public Budgeting, Accounting \& Financial Management 19-27.

- KURUP Hari (2010). On the Estimation of Hospital Cost: The Approach, Centre for Development Studies (JNU), 18 May, Kerala, India, MPRA Paper No. 22767.

- JACOBS Rowena, Alternative Methods to Examine Hospital Efficiency: Data Envelopment Analysis and Stochastic Frontier Analysis, Centre For Health Economics, Discussion Paper 177, http: www.york.ac.uk/inst/che/pdf /DP177.pdf E.t. : 30.09.2011.

- MOSHIRI Hossein, ALJUNID, S.Mohammed, AMIN R.Mohd (2010). Hospital Efficiency: Concept, Measurement Techniques And Review Of Hospital Efficiency Studies, Malaysian, Journal of Public Health Medicine, Vol. 10 (2): 35-43.

- BARUTÇUGİL İsmet (1983). Üretim Sistemi ve Yönetim Teknikleri, Bursa : Uludağ Üniversitesi Yayınları.

- KAVUNCUBASI Sahin (2000). Hastane ve Saglık Kurumlarl Yönetimi, Ankara, Siyasal Kitabevi.

- O'NEILL Liam, RAUNER Marion., HEIDENBERGER Kurt, and KRAUS, Markus (2008). Cross-national comparison and taxonomy of DEA-based hospital efficiency studies. Socio-Economic Planning Sciences, :s. 158-189

- NACHUM, Lilach. (1999). Measurement of productivity of professional services. An illustration on Swedish management consulting firms, International Journal of Operations \& Production Management, 19 (9).

- YILMAZ Uğur (1995). Türkiye’ De Sağlık Ve Sigortacılık Sisteminde Görülen Temel Sorunlar Ve Çözüm Yaklaşımları, “1. Ulusal Sağlık Kuruluşları Ve Hastane Yönetim Sempozyumu”, İzmir, Sempozyum Kitabı, Dokuz Eylül Üniversitesi.

- HACETTEPE ÜNIVERSITESİ (2005). “Tanıya Dayalı Hastalık Sinıflandırması Sisteminin Pilot Uygulamasına Yönelik Olarak Pilot Hastanelerin Seçimi Ve Değerlendirilmesi Raporu” Sağllk Hizmetleri Finansman Yapısının Güçlendirilmesi Ve Yeniden Yapılandırılması Için Altyapı Geliştirilmesi Projesi, , Ankara, 21.11.2005, http://www.tig.saglik.gov.tr/ E.t. : 17.06.2010

- BİLGIN Gülhan, ÇIRAKLI, Zeynep (2010). Hastanelerde Kurum Kültürü, II. Uluslar Arası Sağlıkta Performans Ve Kalite Kongresi, Ankara : Bildiriler Kitabi.

- $\quad$ TUTAR Filiz, KILINÇ Nurcan (2007). Türkiye' nin Sağlık Sektöründe ki Ekonomik gelişmişlik ve Farklı Ülke Örnekleriyle Mukayesesi, Afyon Kocatepe Üniversitesi, IIBF. Dergisi, Cilt 9, S 1

- REED Lydia M. (2008). I Healtcare Management - A different Kind of Health Profession, The Advisor, March, ss.38-42 .

- NEWSTROM John W., DAWIS Keith, (1993) Organizational Behavior: Human Behavior at Work, McGraw-Hill, Ninth Edition.

- YOUNG W.David (2003), Management Accounting in Health Care Organizastions, Jossey-Bass, A Wiley Company.

- D.P.T. (Devlet Planlama Teşkilatı) (2001). Sağlık hizmetlerinde Etkinlik Özel İhtisas Komisyonu Raporu Sekizinci Beş Yıllık Kalkınma Planı, Yayın no: DPT:2561 - ÖİK:577, Ankara-2001. 


\title{
Stakeholder-Based Analysis of Sustainability Report: A Case Study on Mining Companies in Indonesia
}

\author{
Dr. Ati Harmoni (Gunadarma University, Indonesia)
}

\begin{abstract}
This paper reviews the experience of the mining companie in Indonesia that publish a sustainability report. By doing such exploratory research, the study aims to contribute to the development of country-specific descriptive non financial disclosure theory by establishing a benchmark understanding of how company interpret their responsible relationship with stakeholders. Based on content analysis of the annual sustainability report, this paper provide a description of current practices current prioritization in terms of social, environmental, and sustainability disclosure themes. The results show that Indonesian mining companies share a wide range of disclosure themes in order to support relationships with their stakeholders.
\end{abstract}

\section{Introduction}

One of the main issues that emerged today is the debate on corporate responsibility to the stakeholder groups that influence their behavior and who in turn have an impact on their success. More than ten years of research by MORI has shown increasing corporate responsibility to various stakeholders, from customers and employees to legislators and investors (Dawkins and Lewis, 2003). This increases the concern that corporate responsibility issues are not confined to the public only. For many stakeholders, corporate responsibility is now the dominant driver opinions.

Corporate responsibility entails a company's recognition of broad responsibilities, that is part of society with consequent obligations, and that it should be concerned with more just profit. Concept which is currently considered to describe corporate responsibility not only in terms of profit alone is corporate social responsibility (CSR). CSR - one of the major aspects of sustainable development business, is a concept whereby companies integrate social and environment concerns into the company's business operations, as well as how they interact with stakeholders on a voluntary basis (CEC, 2001).

Along with the increasing number of companies acknowledging and internalizing the importance of CSR values and practices, a variety of sources have pressured the private sector to go beyond financial measures as all-inclusive indicators of corporate market performance. This operationally process is well represented by the large number of studies on the multiple ways of enacting CSR, which recognize the existence of a sort of parallelism between corporate socially responsible behavior and the aptitude of companies to systematically demonstrate their ability to respond to the social, economic and environmental requests of their stakeholders (Hummels and Timmer, 2004).

For these reasons, in addition to the initial trend, that is, adhering to the CSR paradigm, companies have paid growing attention to the importance of demonstrating CSR commitment through clear and verifiable data and information, similar to more traditional financial documents. Previous studies show that it is difficult for companies investing in CSR activities to maximize their reputation without disclosing information of such activities (Hasseldine et al. 2005). It is generally accepted that companies engaging in CSR activities usually concern the disclosure of related information because of its contribution to financial performance (Orlitzky et al, 2003; Barnett, 2007) or to market value (Mackey et al, 2007).

By now, research on CSR disclosure has referred to different theoretical perspectives - those of legitimacy theory, agency theory and stakeholder theory (Gray et al., 1995; Roberts, 1992). While, however, numerous studies have investigated the disclosure of nonfinancial information, only recently has research considered disclosure in a stakeholder-based setting, and extended the research focus to a more comprehensive CSRreporting framework, based on the triple bottom line approach. In other words, although the content of nonfinancial disclosure has been addressed in an increasing number of studies, the adopted perspective is often partial, impeding the development of a complete CSR portrait (Schwartz and Carroll, 2003) for firms engaged in responsible practices.

Indonesia has become the first nation in the world to introduced mandatory legal requirements for corporations to implement corporate social responsibility (CSR) reporting based on Law No. 40 in 2007 regarding Limited Liability Companies. According to this law, all corporations that operate in Indonesia's natural resources sector or that have business activities related to natural resources must implement CSR, especially in relation to environmental responsibility, called corporate social and environmental responsibility (CSER). All companies are mandated to perform the social and environmental responsibility activities and submit annually the reports of these activities. 
This study attempts to providing an up-to-date description of Indonesian companies' CSR reporting practices, how companies clearly engaged in socially and environmentally responsible practices interpret their CSR relationships with stakeholders. Hence, the remainder of this paper is organized as follows. First, we review the recent empirical evidence about sustainability reporting. Secondly the stakeholder theory and sustainability reporting are outlined with particular reference. Thirdly, the research method and data source are described. Fourthly, the findings from the study of sustainability reports are presented together with the relevant implications and concluding reflection.

\section{Stakeholder Theory and Sustainability Report}

The term 'stakeholder(s)' is broad ranging in scope. It has been defined as meaning all those individuals and groups with a 'critical eye' on corporate actors (Bowmann-Larsen and Wiggen, 2004). Freeman (1984) look at companies' responsibilities as consisting of a two-way responsibility between business and groups of stakeholders in a society. This is the stakeholder theory perspective which postulates that there are various groups in the society that an organization can impact on. These groups have a right on the organization for their interest to be addressed by the organization because of agency relationship. Business operations affect interests of multiple parties having stake in a business. Similarly behavior of multiple parties also affects business interests. Therefore businesses should incorporate stakeholder expectations into their planning and policies.

Stakeholders, acting either formally or informally, individually, or collectively, are a key element in the firm's external environment that can positively or negatively affect the organisation (Murray and Vogel, 1997). The main challenge for businesses is the task of identifying to whom they are responsible and how far that responsibility extends. Underpinning the difficulties of managing the relationship between a business and its stakeholders are issues such as divergent and often conflicting expectations between stakeholders (Brammer and Pavelin, 2004; Fairbrass, 2006); contextual complexities (Daniels and Radebaugh, 2001) that are further complicated by varying interpretations arising out of different geographical regions and cultures (Maignan and Ferrell, 2003); the challenge of identifying what might be considered to be 'best practice' with regard to CSR stakeholder dialogue strategy and then communicating this to stakeholders.

A prevalent way of exploring the roles and responsibilities of companies in today's society has been to look at them as nodes in a network of relationships among different parties that have stakes in their activities (Donaldson and Preston, 1995; Freeman, 1984). According to this theory, a principal function of managers is to handle stakeholders' needs, expectations and demands, and to manage conflicts among them. Different criteria have been suggested on how and why managers should allocate priorities to competing stakeholder views and demands, and the way to find the appropriate level of engagement.

Stakeholder theory is a fundamental element of corporate social responsibility, in the open system in which organizations interact with society; different groups with their own specific sets of needs, expectations and demands personify every interaction. CSR programs are or should be tailored around these needs in a strategic way. The impact of company's corporate responsibility program will depend on its alignment with the expectations of its various stakeholders. A Company's balancing of these several priorities must therefore be informed by its stakeholders of importance. The company must define, consult and engage these stakeholders in its program to ensure that its activity is seen as relevant both to the business and to its stakeholders, and some companies are well advanced in this process of dialogue.

Social, environmental and sustainability reports are placed in the context: 1) they substantially contribute to both formalizing firms' positions on CSR and providing a viable opportunity to assert commitment to good business practices; 2) reporting practices, that is, pulling and collecting information from business units with different priorities, represent not only a step towards evaluating and measuring the overall corporate responsibility performance, but also, and most important, a concrete opportunity to identify strengths and weaknesses across the whole spectrum of corporate responsibility (Nitkin and Brooks, 1998) and stakeholder relationships.

Sustainability reports are a modern concept of interdisciplinary reporting. They indicate the simultaneous integration of economic, environmental and social elements (Quick, 2008). After various attempts in the areas of social and environmental reporting, so-called sustainability reports have emerged in an attempt to respond to demands for interdisciplinary reporting. They reflect a simultaneous integration of economic, environmental and social factors into corporate behavior with the aim of sustaining resources for future generations.

Sustainability reporting can be explained by legitimacy theory (Gray et al., 1995). It assumes an implicit contract between companies and society. By reporting on economic, social and environmental issues a company can demonstrate that it fulfils its part of the contract and that its activities coincide with the value systems of society. This can prevent or mitigate future regulatory requirements that would constrain the strategic options of the company. Thus, the company can maintain its status and reputation in society. Instrumental stakeholder theory regards sustainability reporting as a means to address the demands of a company's stakeholders (Solomon $\&$ Lewis 2002). Following agency theory, voluntary disclosures on economic, social and environmental issues 
can decrease the information asymmetry between management and stakeholders of a company and therefore reduce agency costs. These disclosures can avoid future legislative actions against the company (Gray et al. 2001).

The benefits of sustainability reporting go beyond relating firm financial risk and opportunity to performance along environment, social and governance dimensions and establishing license to operate. Sustainability disclosure can serve as a differentiator in competitive industries and foster investor confidence, trust and employee loyalty. Analysts often consider a company's sustainability disclosures in their assessment of management quality and efficiency, and reporting may provide firms better access to capital.

Beyond the Global 250, thousands of companies around the world issue sustainability reports, and the number of companies reporting grows every year. In 2011, more than 2,200 firms filed reports with the Global Reporting Initiative (GRI), and hundreds more filed GRI-referenced reports. These firms exemplify the principle that reporting is expected of the top companies in our modern business world. Firms continuously seek new ways to improve performance, protect reputational assets, and win shareholder and stakeholder trust.

Companies unanimously state that they are reporting in order to provide information to stakeholders. When asked which stakeholders, specifically shareholders were the group most frequently referred to followed by: government and local authorities; customers; business partners; the general community and NGOs. It is clear that companies in the ASEAN region produce a Sustainability Report to gain a competitive edge when attracting and retaining capital, dealing with global clients and managing relationships with governments.

Sustainability reporting is still a relatively new process for many companies. Unsurprising therefore the collection of data for a report is the key challenge for companies. Nevertheless, companies are able to clearly articulate the benefits of reporting: to improve branding and image; and, to strengthen dialogue with stakeholders who are key to their business. For report writers there is still a huge debate about the future of sustainability reporting. For many companies reporting started as disclosure on environmental issues and has now developed into something much more encompassing. For others it began as a report on philanthropic activities and expanded to address business operations pertinent to the attainment of sustainable development.

The link between CSR strategy and sustainability reporting implies that if companies want to obtain their stakeholders' trust, they must not only communicate, but also give concrete evidence that they are committed to continual, long-term improvement. Therefore, a sustainable and responsible company must identify, measure, monitor and report all social, environmental and economic effects of its operations on society at large, in order to increase both external and internal dialogue with constituencies and improve "managerial awareness of and control over social impact of corporate activity" (Preston, 1981). As a responsible management strategy to communicate with stakeholders, the reporting of CSR is one channel by which an organization discloses how it is addressing the social, environmental and economic issues (SustanAbility/UNEP, 2002).

These points are relevant to our paper because we are interested in modeling how firms translate their perceptions of their context of reference into CSR disclosure practices. If we accept the empirical maxim that firms are what they do (Post, Preston and Sachs, 2002), CSR topics chosen for reporting provide overall insight into a company's current priorities and, particularly, its perspective on nonfinancial reporting practices. This does not imply that the opposite is true and that the absence of reporting corresponds to an absence of action.

\section{Methods}

The data for this study was collected from the sustainability report of a mining company listed in Indonesian Stock Exchange (IDX) for the year 2011, since the required data was available for this particular year. Specifically, the company chosen for the study were quoted in November 2011 - April 2012 in the selective index of the IDX, the Bisnis-27 Index. Only publicly available sustainability reports was eximined in this study. The existence of a sustainability rreport will be determined via a web-site-based survey.

The choice to focus the analysis on an Indonesian sample was based on the firm belief that the country in which the company reports influences the themes of disclosure. In other words, we believe that single elements of organizational practice cannot be considered in isolation, especially when such practices result from the context in which firms operate.

The sustainability report were analyzed using content analysis. Content analysis is appropriate in that this study dwells upon the assumption that sustainability reporting represents the most external and systematic result of company thoughts concerning responsible relationships with stakeholders. We are aware that all forms of data reaching the public domain can be considered as part of the disclosure activity of an organization. However, the choice to focus the analysis solely on sustainability reporting is justified by several reasons already highlighted in previous literature. In particular, sustainability reports help focus on a firm's CSR prioritization because managers commonly use them to signal what is important to stakeholders (Cormier et al. 2004). Even more important, sustainability reports are produced regularly, thus allowing for comparative analysis across time and space. 
The construction of categorization scheme is an essential stage in content analysis research. An interrogation instrument used in this study is adapted from a previous comparative analysis of the standard reporting tools from Tencati, Perrini, and Pogutz (2004) that are available on the market as reporting frameworks for firms who decide to disclose nonfinancial information. The interrogation instrument's categories, constructed based on the comparison among reporting standards, include the dimensions of the disclosure theme, which corresponds to seven categories of stakeholders (human resources, shareholders and the financial community, customers, suppliers, public authorities and institutions, communities and environment), a checklist for each dimension of disclosure theme, and evidence for each sub-theme included in the checklist (qualitative disclosure; quantitative disclosure; both qualitative and quantitative disclosure).

Given the recording instrument and consistent with previous literature on social and environmental reporting, the amount of disclosure per content category consists of recording whether or not a company made a disclosure in the category. At this stage, the quantification of the amount of disclosure per company is excluded.

\section{Stakeholders: Who and What Really Counts?}

The initial results showed that of the 7 companies studied, 5 of them issued sustainability reports. These 5 companies applying Global Reporting Initiatives (GRI) for their sustainability reports. Some companies indicate whether the coverage is fully, partially, or none for each indicator. Of the 5 companies analysed, 2 have $100 \%$ GRI indicator themes coverage. Table 1 breakdown the number of companies in the sample making CSR disclosures in each category themes, by stakeholders.

As shown by Table 1, the result of this empirical study is avarage degree of achievement of 84.8 per cent, which is high. This situation indicates that the companis consider important almost every stakeholder. Table 1 illustrated that the lowest number is the dimension of financial partners that just 20 per cent while other dimensions of more than 70 per cent. Highest results obtained for the environmental dimention and shareholder.

As mentioned above, according to Law No. 40 in 2007 regarding Limited Liability Companies, all corporations that operate in Indonesia's natural resources sector or that have business activities related to natural resources must implement CSR, especially in relation to environmental responsibility. The law also states that the companies must report the CSER in the annual reports and publish them publicly. The emphasis of CSER in on the issues of environmental concern, while CSR is aiming at the social responsibility activities in general. For those corporations whose business activities have a high impact on the environment, they are not only required to be responsible socially, but also environmentally through CSER.

Community concerns and shareholder rights are the most important factors that influence the companies' decision to report. Shareholders have a particularly powerful position from which to hold the company accountable on a variety of issues. The notion of shareholder democracy is a commonly discussed topic in corporate governance. The basic idea behind the term is that a shareholder of a company is entitled to have a say in corporate decisions

Human resources is a category that gets a high score. This is understandable because corporations have a strong influence on the administration of social rights of their employees, including aspects of health and safety, fair wages, education, etc. This is particularly the case in developing countries where governments have proven unwilling or unable to protect such rights, leaving it open to the discretion of corporations.

\section{Conclusion}

Interesting that in each the report are made, each company present the results of its own analysis of who their key stakeholders. In contrast to the reference made to the research instrument, the companies mentions NGO as the important stakeholders. Studies on CSR have shown that there has been increasing public pressure from bodies (such as governmental organisations, non-government organisations (NGOs), academics, trade unions and the media) for corporations to act in a socially and environmentally responsible way (Unerman and O'Dwyer, 2007). Such pressure has to some extent had an impact on CSR, as they have created a 'legitimacy gap', which provide a significant motivation for companies to engage or attempt to engage in responsible business practices in order to acquire or maintain legitimacy (Waddock, 2004). The work of NGOs and other independent pressure groups is crucial in promoting corporate disclosure, transparency and public accountability. NGOs have sought to step into the regulatory gap created by the inadequacy of both national governments and international institutions in demanding for social and environmental accounting and improved public accountability NGOs have played an increasingly significant role globally in challenging government policies and the activities of corporations with regard to abuses of human rights, environmental degradation and social unrest, including in Indonesia.

One of the key findings of this research was that Indonesian mining companies share a systematic approach to sustainability reports that address well-defined categories of stakeholders. The results also show that Indonesian mining companies share a wide range of disclosure themes in order to support relationships with their 
stakeholders in order to support relationships with their social context. Research also shows that the company considers NGOs are stakeholders who should receive attention. This provides an opportunity to conduct advanced research in the future by expanding the dimensions of stakeholders and with a greater number of companies in order to obtain a complete picture of the practice of sustainability reporting in Indonesian context.

\begin{tabular}{|c|c|c|c|}
\hline $\begin{array}{l}\text { Stakeholder } \\
\text { base category }\end{array}$ & CSR Themes & $\begin{array}{l}\text { Number of } \\
\text { companies } \\
\text { having CSR } \\
\text { Disclosure }\end{array}$ & $\begin{array}{l}\text { Percentage of } \\
\text { sample (average) }\end{array}$ \\
\hline $\begin{array}{l}\text { Human } \\
\text { Resources }\end{array}$ & $\begin{array}{l}\text { Staff composition } \\
\text { Turnover } \\
\text { Equality of treatment } \\
\text { Training } \\
\text { Working hours } \\
\text { Schemes of Wages } \\
\text { Absence form Work } \\
\text { Employees' benefits } \\
\text { Industrial relations } \\
\text { In-house communications } \\
\text { Health and safety } \\
\text { Personnel's' satisfaction } \\
\text { Workers rights } \\
\text { Disciplinary measures and litigation }\end{array}$ & $\begin{array}{l}5 \\
2 \\
5 \\
5 \\
2 \\
4 \\
2 \\
5 \\
5 \\
4 \\
5 \\
5 \\
5 \\
5\end{array}$ & 84.3 \\
\hline Shareholders & $\begin{array}{l}\text { Capital stock formation } \\
\text { Shareholders'/ } \\
\text { partners' pay } \\
\text { Rating performance } \\
\text { Corporate governance } \\
\text { Benefits and services } \\
\text { Investor relations }\end{array}$ & $\begin{array}{l}5 \\
3 \\
4 \\
4 \\
5 \\
5 \\
5\end{array}$ & 90.0 \\
\hline Customers & $\begin{array}{l}\text { General characteristics } \\
\text { Market development } \\
\text { Customer satisfaction } \\
\text { Customer loyalty } \\
\text { Product/Services information and labelling } \\
\text { Ethical \& environmental product and services } \\
\text { Promotional policies } \\
\text { Privacy }\end{array}$ & $\begin{array}{l}5 \\
3 \\
5 \\
3 \\
5 \\
3 \\
3 \\
2\end{array}$ & 72.5 \\
\hline Suppliers & $\begin{array}{l}\text { Supplier management policies } \\
\text { Contractual conditions }\end{array}$ & $\begin{array}{l}5 \\
3\end{array}$ & 80.0 \\
\hline $\begin{array}{l}\text { Financial } \\
\text { Partners }\end{array}$ & $\begin{array}{l}\text { Relations with banks } \\
\text { Relations with insurance companies } \\
\text { Relations with financial institutions }\end{array}$ & $\begin{array}{l}1 \\
1 \\
1\end{array}$ & 20.0 \\
\hline $\begin{array}{l}\text { Public } \\
\text { Authorities }\end{array}$ & $\begin{array}{l}\text { Taxes and duties } \\
\text { Relations with local authorities } \\
\text { Codes of conducts and compliance with laws } \\
\text { Contributions, benefits or easy-term financing }\end{array}$ & $\begin{array}{l}2 \\
5 \\
5 \\
4\end{array}$ & 80.0 \\
\hline Community & $\begin{array}{l}\text { Corporate giving } \\
\text { Direct contributions in the different } \\
\text { intervention fields } \\
\text { stakeholder engagement } \\
\text { Relations with the media } \\
\text { Virtual community } \\
\text { Corruption prevention }\end{array}$ & $\begin{array}{l}5 \\
3 \\
4 \\
4 \\
3 \\
3\end{array}$ & 73.3 \\
\hline Environment & $\begin{array}{l}\text { Energy consumption } \\
\text { Materials } \\
\text { Emissions } \\
\text { Environmental strategy and relations with the } \\
\text { community }\end{array}$ & $\begin{array}{l}4 \\
5 \\
5 \\
5\end{array}$ & 95.0 \\
\hline
\end{tabular}

Table 1. Incidence of CSR disclosure by stakeholder catagories and CSR themes 


\section{References}

- $\quad$ Barnett, M.L.: 2007, Stakeholder Influence Capacity and the Variability of Financial Returns to Corporate Social Responsibility, Academy of Management Review, 32(3), 794-816.

- Belkaoui, A. and P.G. Karpik: 1989. Determinants of the corporate decision to disclose social information, Accounting, Auditing \& Accountability Journal 2(1), 36-51.

- Bowmann-Larsen, L. and Wiggen, O. 2004. Responsibility in World Business: Managing Harmful Sideeffects of Corporate Activity, USA: United Nation University Press

- Brammer, S. and Pavelin, S., 2004. Building a good reputation. European Ma-nagement Journal, 22 (6), pp. 704-713.

- Commission of the European Communities: 2001, Green Paper "Promoting a European framework for Corporate Social Responsibility”, Brussels: COM(2001) 366 final.

- Cormier, D., Gordon, I.M. and M. Magnan: 2004, Corporate environmental disclosure: Contrasting management's perceptions with reality, Journal of Business Ethics 49, 143-165.

- Dando, N. and T. Swift: 2003, Transparency and assurance: Minding the credibility gap, Journal of Business Ethics 44, 195-200.

- Daniels, J. and Radebaugh, L. 2001. International Business: Environments and Operations. ${ }^{\text {th }}$ Edition, New Jersey: Prentice Hall Inc

- Dawkins, J. and S. Lewis. 2003. CSR in Stakeholder Expectations: And Their Imphcation for Company Strategy. Journal of Business Ethics 44: 185-193

- Donaldson, T. and L. Preston, 1995, The stakeholder theory of the corporation: concepts, evidence, and implications, Academy of Management Review 20, 65-91.

- Freeman, R.E.: 1984, Strategic management: A stakeholder approach, (Pitman, Boston).

- Gray, R., Kouhy, R. and S. Lavers: 1995, Corporate social and environmental accounting: A review of the literature and a longitudinal study of UK disclosure, Accounting, Auditing \& Accountability Journal 8(2), 47-77.

- Gray R. H., Javad M., Power D. M. \& Sinclair C. D. 2001. Social and environmental disclosure and corporate characteristics: A research note and extension. Journal of Business Finance and Accounting, 28 (3/4), 327-356.

- Hackston, D. and M.J. Milne, 1996, Some determinants of social and environmental disclosures in New Zealand companies, Accounting, Auditing \& Accountability Journal 9(1), 77-108.

- Hummels, H. and D. Timmer: 2004, 'Investors in need of social, ethical, and environmental information', Journal of Business Ethics 52, 73-84.

- Maignan, I. and Ferrell, O.C. 2000. Measuring corporate citizenship in two countries: the case of the United States and France. Journal of Business Ethics, 23, 283-297.

- 2003. Nature of corporate responsibilities: perspectives from American, French, and German consumers. Journal of Business Research, 56, 55

- Nitkin, D. and L.J. Brooks: 1998, 'Sustainability auditing and reporting: The Canadian experience', Journal of Business Ethics 17, 1499-1507.

- Orlitzky M. , Benjamin J.D. 2003. Corporate Social Performance and Firm Risk: a Meta-Analytic Review,

- Business \& Society, vol. 40, n. 4, 2001, pp. 369-396.

- $\quad$ Post, J.E., Preston, L.E. and S. Sachs, 2002, Managing the extended enterprise: The new stakeholder view. California Management Review 45(1), 6-27.

- $\quad$ Preston, L.E.: 1981, 'Research on corporate social reporting: Directions for development', Accounting, Organizations and Society 6(3), 255-262.

- Quick, Reiner. 2008. Voluntary sustainability reporting practices in Germany: a study on reporting quality. Contbilidade a Gestao, No 5

- $\quad$ Roberts, R.W.: 1992, Determinants of corporate social responsibility disclosure: An application of stakeholder theory, Accounting, Organizations and Society 17(6), 595-612.

- Schwartz, M.S. and A.B. Carroll, 2003, Corporate Social Responsibility: A three-domain approach, Business Ethics Quarterly 13(4), 503-530.

- SustanAbility/UNEP, 2002. Trust Us: The 2002 Global Reporters Survey of Corporate Sustainability Reporting. Engaging Stakeholder Series. SustainAbility/UNEP, London 
- Tencati, A., Perrini, F. and S. Pogutz: 2004, New tools to foster corporate socially responsible behaviour Journal of Business Ethics 53, 173-190.

- Unerman J. and B. O’Dwyer. 2007. The Business Case for Regulation of Corporate Social Responsibility and Accountability, Accounting Forum, 31: 332-353

- Waddock, S. A. 2004. Parallel Universes: Companies, Academics, and the Progress of Corporate Citizenship, Business and Society Review, 109(1): 5-42. 


\title{
Sectoral Decomposition of $\mathrm{CO}_{2}$ Emissions in China and India for the Period 1980-2010
}

\author{
Ph.D. Candidate Hasan Rüstemoğlu (Eastern Mediterranean University, Cyprus) \\ Assoc. Prof. Dr. Sevin Uğural (Eastern Mediterranean University, Cyprus)
}

\begin{abstract}
Increasing amount of $\mathrm{CO}_{2}$ emissions and global warming is one of the hottest topics of world's agenda. At the same time there exists a public awareness about this important chapter. A lot of researcher proved that in order to live in a sustainable world, necessary regulations should be done and $\mathrm{CO}_{2}$ emissions should be reduced immediately. For this study our aim is to decompose the $\mathrm{CO}_{2}$ emissions of the world's new super powers, China and India, over 1980-2010. In order to see the accelerating and decelerating factors for $\mathrm{CO}_{2}$ emissions, the Refined Laspeyres Index used as a method. Consistent data gathered from the official web sites of the World Bank and United Nations. Five main sectors, agriculture, manufacturing, construction, transportation and other services are used. Four different impacts, scale effect, composition effect, energy intensity effect and carbon intensity effect have been discussed to see the increasing or decreasing factors of $\mathrm{CO}_{2}$ emissions. The results were interesting. The dominant impacts were the scale effect and energy intensity effect. The minor impacts were composition effect and carbon intensity effect. Fuel switching, efficient energy use and increasing usage of renewable resources are efficient tools to reduce the emissions.
\end{abstract}

\section{Introduction}

During the last thirty years, increasing amount of $\mathrm{CO}_{2}$ emissions and the threat of global warming is one of the most important topics of World's agenda. The biological and economic impacts of global warming are discussed especially by researchers since the beginning of 1990s. The environmental damage certainly increased due to increasing world population, energy consumption and industrial activities. After the industrial revolution the amount of Greenhouse Gas (GHG) emissions started to increase. Six of the main greenhouse gases are namely, carbon dioxide $\left(\mathrm{CO}_{2}\right)$, methane $\left(\mathrm{CH}_{4}\right)$, nitrous dioxide $\left(\mathrm{N}_{2} \mathrm{O}\right)$, Hydrofluorocarbons (HFC), Perfluorocarbons (PFC) and Sulphurhexafluorid $\left(\mathrm{SF}_{6}\right) \cdot \mathrm{CO}_{2}$ emissions have the highest share in $\mathrm{GHG}$ emissions which also referred to as the 'carbon footprint'. The carbon footprint is a measure of the exclusive total amount of $\mathrm{CO}_{2}$ emissions that is directly and indirectly caused by an activity or is accumulated over the life stages of a product. The amount of $\mathrm{CO}_{2}$ concentrations was equivalent to $280 \mathrm{ppm}$ in 1850 and by 2006 this value reached to 384 ppm. $\mathrm{CO}_{2}$ emissions, is the main cause of global warming, which is estimated to increase up to 5.8 degrees of Celsius until the end of $21^{\text {st }}$ century. According to scientists in order to keep the global temperature increase by 2 degrees of Celsius the overall countries should stabilize their total emissions either $400 \mathrm{ppm}$ or $450 \mathrm{ppm}$. Accordingly to obtain a sustainable world, countries should reduce their $\mathrm{CO}_{2}$ emissions by $60 \%$ in 2030 . Furthermore this limitation should be $80 \%$ by 2050 . The main element of $\mathrm{CO}_{2}$ emissions are the fossil fuels that are widely used in all sectors of economics and daily life. Thermal electricity plants, natural gas electricity plants, other fossil fuel electricity plants, transportation (automobiles, buses, trucks, plane), industrial production (cement factories, petrochemical buildings, refineries, iron and steel industry), agriculture and livestock, global trade, tourism, defense industry, domestic electrical devices, deforestation are the main reasons of climate change. According to biological studies the temperature of earth's surface increased by 0.6 degrees of Celsius during the last $20^{\text {th }}$ century (IPCC, 2001a). For Europe this value is equal to 1.2 degrees of Celsius. In the nearest future, because of the global warming and climate change, scientists are expecting extreme droughts and floods for some regions of the world. For example Mediterranean Countries, such as Spain, Greece and Turkey are expected to face a 5 percent average rainfall decline in every next decade. As a result of global warming, especially in summer seasons the ice shelf has been declined by 40 percent and at the same time it has been observed that there exists 10 or $20 \mathrm{~cm}$ increase in sea level of the world (IPCC, 2001a). As a result of climate change, hurricanes, floods and extreme droughts reveal a certain danger of extinction of some animal species and biodiversity. Global warming and climate change creates a certain threat on country's economies as well. They will show their negative impacts mainly on agriculture, industry, tourism and insurance sectors if serious preventions and developments on environmental issues are not taken into consideration. Energy policies and environmental issues have an important relationship with the GHG emission and with regard to this understanding and analyzing the decomposition of $\mathrm{CO}_{2}$ emissions are important. In order to reduce the negative impacts of global warming World Wide Organizations (for example United Nations) organized series of meetings. They firstly came together in 1988 and organized the Intergovernmental Panel on Climate Change. The aim of this panel was evaluating technical, scientific and socio-economic information about impacts of climate change. The IPCC published evaluation reports about the $\mathrm{CO}_{2}$ emissions and global warming regularly. After long discussions, in December 1997 they signed the Kyoto Protocol. The Kyoto Protocol is an agreement under the United Nations Framework Convention on Climate Change (UNFCCC) aims to reduce the amount of 
GHG emissions that are the main reason for global warming. It is the only agreement that targets a certain decline on GHG emissions. The protocol puts some restrictions to developed countries such that they would reduce the amount of GHG concentrations 5.2\% below 1990 level between the years 2008-2012. It has been started to apply in 2005 after the long ratification process of Russian Federation.

Today the Kyoto Protocol considers more than 160 countries and more than $55 \%$ of overall GHG emissions. According to the agreement, there would be a certain decline in GHG emissions between 2008 and 2012 as compared to 1990 levels. The main objectives of Kyoto Protocol are heating with less energy, taking the long way by using less energy, placing less consuming technology systems into the industries, considering the environmentalism as a basic principle for transportation and waste storage, turning to alternative energy sources in order to decrease the amount of $\mathrm{CO}_{2}$ and $\mathrm{CH}_{4}$ emissions. Instead of fossil fuels the usage of biodiesel should be increased. High energy consuming enterprises, such as iron and steel, cement and lime factories should be reorganized according to their waste handling. Less carbon technologies in thermal power plants should be used. Strategies should clear the ways of solar energy. Since the nuclear energy is zero carbon energy, it should be placed at forefront in the world. Countries that are consuming high amount of waste and producing too much carbon should pay higher amount of taxes.

The Kyoto Protocol has three mechanisms, namely, Joint Implementation Mechanism, Clean Development Mechanism and Emission Trading Mechanism. According to the Joint Implementation Mechanism, if one country (that determined an emission target) makes an investment in another country (that also determined an emission target) in order to reduce GHG emissions then it will gain Emission Reduction Units. ERUs will be subtracted from the country's total emission targets. In the case of Clean Development Mechanism, if one country (that determined an emission target) makes an investment to reduce GHG emissions on another country (that did not determine an emission target) then it will gain Certified Emission Reduction Units. CERUs will also be subtracted from the total emission target. According to the third mechanism, Emission Trading, the countries that determined the emission targets can make emission trade between themselves. If a country obtains a higher reduction performance than its determined emission target then it will be able to sell the extra reduced emission units to other country.

The aim of this study is to decompose the $\mathrm{CO}_{2}$ emissions for the most crowded countries China and India between the years 1980 and 2010 according to sectors agriculture, manufacturing, construction, transportation and service sectors. For each sector four effects (scale effect, composition effect, energy intensity effect and carbon intensity effect) are considered. The aim is to determine the accelerating and decelerating effects for $\mathrm{CO}_{2}$ emissions. By using this analysis, it will be possible to apply true policies to reduce the amount of emissions.

\section{Literature Review}

For the concern of decomposition analysis, researchers followed different ways to do their research. Some researchers either did some comparison for decomposition analysis or they evaluated some extensions for available methods in order to reduce the value of residual terms and obtain a better approach. However, in the second category some researchers used the available methods to decompose the $\mathrm{CO}_{2}$ emissions of countries according to sectors.

Ang et al. (2003) analyzed the perfect decomposition techniques for energy and environmental issues. They stated, "as there has been a great deal of interest in decomposition analysis in energy policy studies, we extend the work by Albrecht et al. (Energy Policy 30 (2002) 727) by giving a more complete and up to date overview of perfect decomposition techniques and their role in energy demand and related analysis."

Ang et al. (2004) developed a general Fisher index approach to energy decomposition analysis. By extending the conventional two-factor Fisher index decomposition approach to $\mathrm{n}$ factors, the authors evaluated a complementary approach for the existing methodology. The new approach possesses some desirable properties and may be used for some situations in energy studies. The authors also notice that the new formula is more complex than the other commonly adopted IDA approaches.

Liu (2006) did a comparison analysis for methodologies related with the decomposition approach based on energy consumption. The author considered the size of residual term as a comparison tool and he concluded the adaptive weighting Divisia index method and simple average Divisia index method represent most robust and smallest residual term.

Paul \& Bhattacharya (2003) focused the factors that are increasing or decreasing $\mathrm{CO}_{2}$ emissions emitted from the energy use of India. They did their research for time period 1980-1996. For their study, they used decomposition method and considered four main factors such as, pollution coefficient, energy intensity, structural changes and economic activity to explain the changes in $\mathrm{CO}_{2}$ emissions. The authors applied the decomposition method and hence they proved that economic growth has the largest positive impact on $\mathrm{CO}_{2}$ emissions changes, for all major economic sectors. As a result of the improved energy efficiency and fuel switching, they mentioned for all industrial sectors and transportation there is a decline for $\mathrm{CO}_{2}$ emissions. The authors also underlined the reduction of pollution coefficient and energy intensity for $\mathrm{CO}_{2}$ emissions emitted 
from agriculture can be ignored. They finally concluded that the energy intensity has had a greater impact on energy induced $\mathrm{CO}_{2}$ emissions than the production coefficient.

Comillie\&Fankhauser (2004) decomposed energy data to identify the main factors behind the improvements in energy intensity. For more efficient energy use they concluded energy prices and progress in enterprise restructuring are two important factors. The authors also underlined the economies of Central and Eastern Europe and the former Soviet Union countries have been highly energy intensive. They also stated there is a decrease for energy intensity during the transition but still the transition countries are very energy intensive.

Kawase et al. (2005) discussed the long-term scenarios in other countries and the medium-term scenarios for Japan in order to develop Japan's long term climate stabilization scenario. For their study, the authors decomposed the $\mathrm{CO}_{2}$ emissions by using extended Kaya identity according to following indexes: $\mathrm{CO}_{2}$ capture and storage, carbon intensity, energy efficiency, energy intensity and economic activity. They also constructed a Reduction Balance Table. The authors also calculated the necessary energy intensity improvement and carbon intensity decline to achieve a $60-80 \%$ reduction for $\mathrm{CO}_{2}$ emissions.

Ma \& Stern (2007) examined the factors related with changing energy intensity schedule of China for time period 1980-2003. The authors used logarithmic mean Divisia index (LMDI) techniques to decompose the changes that are accelerating or decelerating energy intensity. They concluded technological change is the dominant factor for decreasing energy intensity. Structural change for industry sector increased the energy intensity during that period. Structural change considers shifts of production between sub-sectors, represent a declining trend for energy intensity. They also reported that increasing energy intensity after 2000 is because of the negative technological progress. Finally, inter-fuel substitution is a small contributor for changes in energy intensity.

Vinuya et al. (2010) decomposed the $\mathrm{CO}_{2}$ emissions growth in US according to states between the years 1990 and 2004. They used the Logarithmic Mean Divisia Index (LMDI) method to decompose the emissions into five effects, namely, emissions per unit of fossil fuel, share of fossil fuel in total energy consumption, energy intensity, gross state product per capita and population. Their analysis showed that, during the 15 years period there is an increase in efficiency for energy use. At the same time, lowering the share of fossil fuels in total energy consumption and lowering the emissions intensity balances the effect of Gross Domestic Product (GDP) per capita and population growth in carbon emissions for US.

Kumbaroğlu (2011) examined $\mathrm{CO}_{2}$ emissions for Turkey for time period 1990-2007 according to sectors agriculture, manufacturing, electricity, residential buildings and transportation. The author considered four main effects (composition effect, scale effect, energy intensity effect and carbon intensity effect) and he used Refined Laspeyres Index Method to decompose the $\mathrm{CO}_{2}$ emissions. He also noted that various interesting results on the underlying effects of sectors emission data are found. He also underlined the valuable insights that are gained into $\mathrm{CO}_{2}$ impacts of sector policies including energy and emission intensities, fuel switching and activity changes.

The aim of this study is analyzing the most dominant effects of $\mathrm{CO}_{2}$ emissions for China and India between 1980 and 2010 according to sectors. 5 different sectors (agriculture, manufacturing industries, construction, transportation and other service sectors) and 4 different effects (scale effect, composition effect, energy intensity effect and carbon intensity effect) will be considered. For decomposition analysis, Refined Laspeyres Index Method and a consistent data that is gathered from World Bank and United Nations will be used.

\section{Overview of China and India}

After the market reforms in 1978, Chinese economy moved from a centrally planned to a market based economy. As a result of this, China obtained a rapid economic and social development. In 1980, the total population of China was 981.235.000. By showing an annual average population growth of 1.02\%, in 2011 its population reached 1.344.130.000. The total GDP of China was $\$ 189.399 .992 .473$ in 1980 and by showing a great and impressive average economic growth performance (equal to 10\%) it reached \$7.318.499.269.769 in 2011. Today China is the second biggest economy of the world, as a result of rapid growth 600 million people have lifted out of poverty. China is an upper middle income country, its GDP per capita was equal to \$193 in 1980 , but after the thirty years significant growth performance, it reached \$5444.79 in 2011. However, according to the World Bank records still more than 170 million people are below the $\$ 1.25$ a day international poverty line.

$\mathrm{CO}_{2}$ emissions of China showed annual $5.99 \%$ growth during the last thirty years. Today, China has the first position in world's $\mathrm{CO}_{2}$ emissions classification. In $1980, \mathrm{CO}_{2}$ emissions per capita were equal to 1.5 metric tons and after thirty years it reached to 5.77 metric tons. During that period the $\mathrm{CO}_{2}$ emissions share schedule from the fuel consumption didn't change significantly. Still more than $73 \%$ of the $\mathrm{CO}_{2}$ emissions are due to solid fuel consumption. Liquid fuel consumption is responsible from $14 \%$ of $\mathrm{CO}_{2}$ emissions. Gaseous fuel consumption is responsible only $2 \%$ of $\mathrm{CO}_{2}$ emissions from whole fuel consumption. These values definitely prove that, China should focus to pollution reduction and it also should set new energy efficiency targets. If one considers 
according to the sectors of Chinese economy, it can be easily seen that the schedule for $\mathrm{CO}_{2}$ emissions completely changed during the three decades. In 1980, the biggest carbon dioxide share was related with the manufacturing industries and construction sectors. Numerically they considered $46.48 \%$ of all $\mathrm{CO}_{2}$ emissions that are obtained from fuel combustion. In that year, second biggest $\mathrm{CO}_{2}$ emissions were obtained from electricity and heat production, equivalently $25.02 \%$ of total fuel combustion. Third biggest share for $\mathrm{CO}_{2}$ emissions was related with residential buildings and commercial and public services. They considered $17.26 \%$ of total fuel combustion in 1980. Transport sector and other service sectors considered small amount of total $\mathrm{CO}_{2}$ emissions. Only $5.71 \%$ and $5.53 \%$ of total fuel combustion, respectively. In 2010 , biggest share for $\mathrm{CO}_{2}$ emissions was obtained from electricity and heat production. Compared to 1980 share, the percentage of emissions doubled. Numerically they considered $53 \%$ of all $\mathrm{CO}_{2}$ emissions. The share of manufacturing industries and construction gradually decreased. By 2010, the numerical value for this sector was equal to $32.25 \%$. Compared by 1980 level the CO2 emissions share of transport sector increased with little amount. Numerically it was equal to $7.04 \%$ in $2010 . \mathrm{CO}_{2}$ emissions share of residential buildings and commercial and public services decreased to $6.08 \%$. Finally the other service sector was responsible only $1.63 \%$ of all $\mathrm{CO}_{2}$ emissions in 2010 .

As the population increased and technology developed, the energy use of Chinese economy also increased rapidly. During the thirty years period annual energy use of China increased by $4.82 \%$. In 2010 , the total energy consumption of China reached $2417125.926 \mathrm{kt}$. For electricity production, the situation of China is quite interesting. In 1980, the share of electricity production from coal sources was equivalent to 54.6\%. During the thirty years the dependence of electricity production to coal sources increased gradually. By 2010, China was getting $77.7 \%$ of its electricity production from coal sources. In 1980, oil was the second biggest source for electricity production of China equivalent to $25.80 \%$ of overall production. Until 2010 , the production from oil resources showed a huge decreasing performance. On average, it decreased by $12.53 \%$ annually. In 2010 , only $0.31 \%$ of electricity production of China depends to oil. There are no big fluctuations in Chinese electricity production from hydroelectric sources. It was equivalent to $19.36 \%$ and $17.16 \%$ in the years 1980 and 2010 , respectively. Electricity production from nuclear sources, natural gas sources and renewable sources has really small shares, respectively $1.75 \%, 1.64 \%$ and $1.14 \%$ according to 2010 records. Those values are proving the idea that rapidly growing Chinese economy didn't show enough responsibility in case of environmental sustainability. Significant policy adjustments are necessary for China to obtain a sustainable growth. Past experiences are proving that it's more difficult to move from middle income to high income than to move from low income to middle.

India is a very crowded country like China and also in the last decade it showed a significant economic growth. According to WB 2011 records India is the $4^{\text {th }}$ largest economy in the world. India is also an active player of global economy now. Recently there exists a slowdown in GDP growth of India. It seems that this will consider because of the tight macroeconomic policies, slow growth in the core OECD countries, weakness of investment and also because of an expectation for a global recession. Between 2004 and 2010 poverty showed a certain decline in India. It was $37.2 \%$ in 2004 and after six years it reduced to $29.8 \%$. The Indian government does some necessary investment in order to bring fundamental services to the poor people. Elementary education, basic health care, health insurance, rural roads and rural connectivity are the examples for the investments that Indian government is doing.

The need for universalizing secondary education has obtained because of the necessary number of children entered to elementary school. A large number of Indian people are not able to access to good quality health care, and progress in improving health indicators is slow. India also has a certain malnutrition problem.

In 1980, the population of India was equal to 700.058.589. However, by showing annual average growth rate of $1.86 \%$ it reached 1.241.491.960 in 2011. During the thirty years, annual GDP growth rate of India was equivalent to $6.24 \%$, as a result of this remarkable success Indian GDP reached to $\$ 1.847 .976 .748 .641$. In 1980, GDP per capita for India was equal to $\$ 270.83$, by showing $4.28 \%$ annual average GDP per capita growth rate performance, in 2011, it reached to $\$ 1488.51$. In case of environmental sustainability, like China, India also must show enough responsibility. According to World Bank records, during the thirty years period, $\mathrm{CO}_{2}$ emissions of India, increased annually by $6.19 \%$ on average. The total amount of $\mathrm{CO}_{2}$ emissions was equal to $1979424.60 \mathrm{kt}$. In $1980, \mathrm{CO}_{2}$ emissions per capita, was equal to 0.5 metric tons and after three decades this value reached to 1.64 metric tons. The $\mathrm{CO}_{2}$ emissions of India are due to solid fuel consumption at most. In 1980, solid fuel consumption accounts $72.54 \%$ of overall $\mathrm{CO}_{2}$ emissions where liquid fuel consumption accounts $23.88 \%$ and gaseous fuel consumption accounts $0.71 \%$. During the three decades, the schedule didn't change too much. In 2009 , solid fuel consumption is responsible from $67 \%$ of overall $\mathrm{CO}_{2}$ emissions, $23.74 \%$ is the share of liquid fuel consumption and $3.99 \%$ is the share of gaseous fuel consumption. If we check the responsibility of $\mathrm{CO}_{2}$ emissions of the main economic sectors it can be see that situation of India, like China is quite interesting. In 1980, electricity and heat production considers $31.39 \%$ of total emissions where manufacturing industries and construction were responsible from $32.16 \%$ of emissions from fuel combustion. In 1980 , for $\mathrm{CO}_{2}$ emissions, transport sector consists $19.97 \%$, residential buildings and commercial and public services consist $12.33 \%$ and 
finally other service sectors considers $4.14 \%$ of overall $\mathrm{CO}_{2}$ emissions from total fuel combustion. During the three decades the schedule completely changed. Responsibility of the electricity and heat production increased to $57.63 \%$. During that period $\mathrm{CO}_{2}$ emissions share of manufacturing industries and construction sectors declined to $24.66 \%$. $\mathrm{CO}_{2}$ emissions from transport, residential buildings and commercial and public services, other service sectors declined to $9.93 \%, 5.49 \%$ and $2.29 \%$ respectively.

Total energy use of India increased gradually during the last three decades. By showing, on average, $4.14 \%$ increase it reached to $692689.009 \mathrm{kt}$ of oil equivalent. In 1980, coal was the main source for electricity production. Numerically $51.53 \%$ of overall electricity production was obtained from coal. In that time, for India, water was also an important source for electricity generation. It considers $39.03 \%$ of overall electricity production. In 1980, electricity production from oil sources consists of $6.38 \%$ of overall electricity generation. Nuclear energy and natural gas sources consist only $2.51 \%$ and $0.52 \%$ of overall electricity production, respectively. When we check 2010 shares, it can be easily seen that electricity production scheme has completely changed during the last three decades. Share of coal sources increased to $68.02 \%$ and of course huge amount of coal dependence is challenging the environmental sustainability. During that period share of natural gas sources for electricity production showed an increasing performance and $2010 \mathrm{WB}$ records show that they consist $12.27 \%$ of overall production. At the same time, hydro sources showed a sharp decline and today they account $11.92 \%$ of total production. Electricity production from oil sources and nuclear sources consider $2.75 \%$ and $2.73 \%$ respectively. India started use renewable sources for electricity generation in 1986. According to 2010 records $2.29 \%$ of electricity needs are obtained from renewable resources.

Because of its growing economy India is a significant consumer of oil and natural gas. According to 2009 energy results, India located at the $4^{\text {th }}$ position in the energy consumption list of world just after US, China and Russia. Even a lot of countries suffered from global recessions the energy need of India will consider to increase. Petroleum demand of transport sector will continue to rise due to the expansion of car ownership.

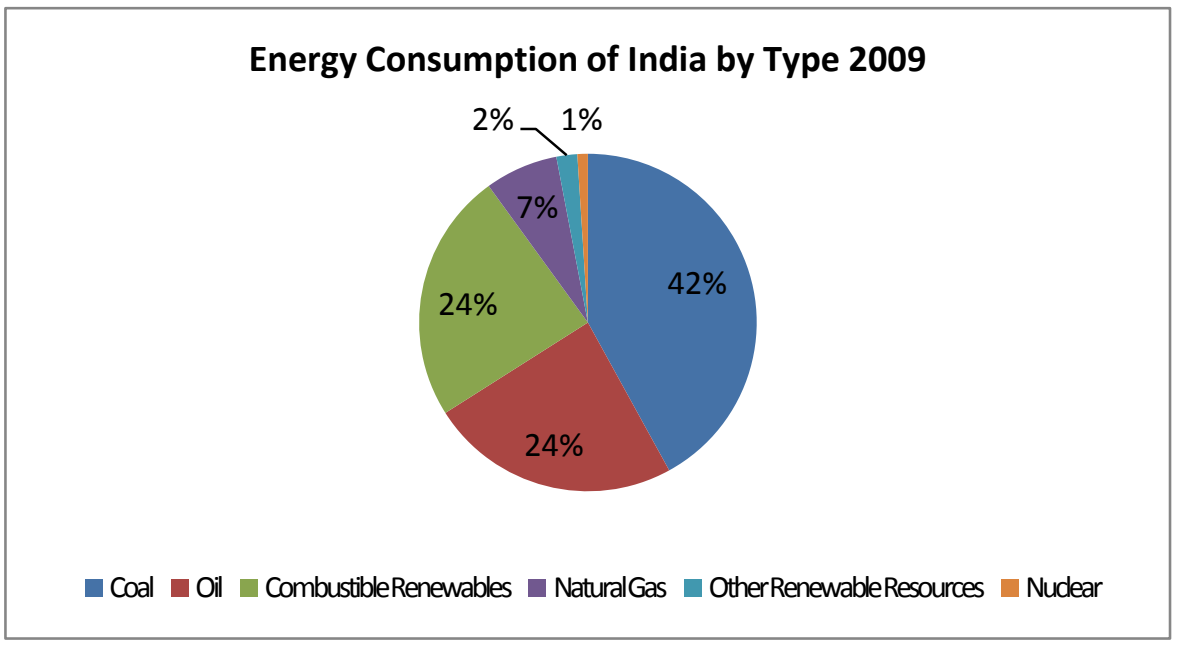

Source: The International Energy Agency

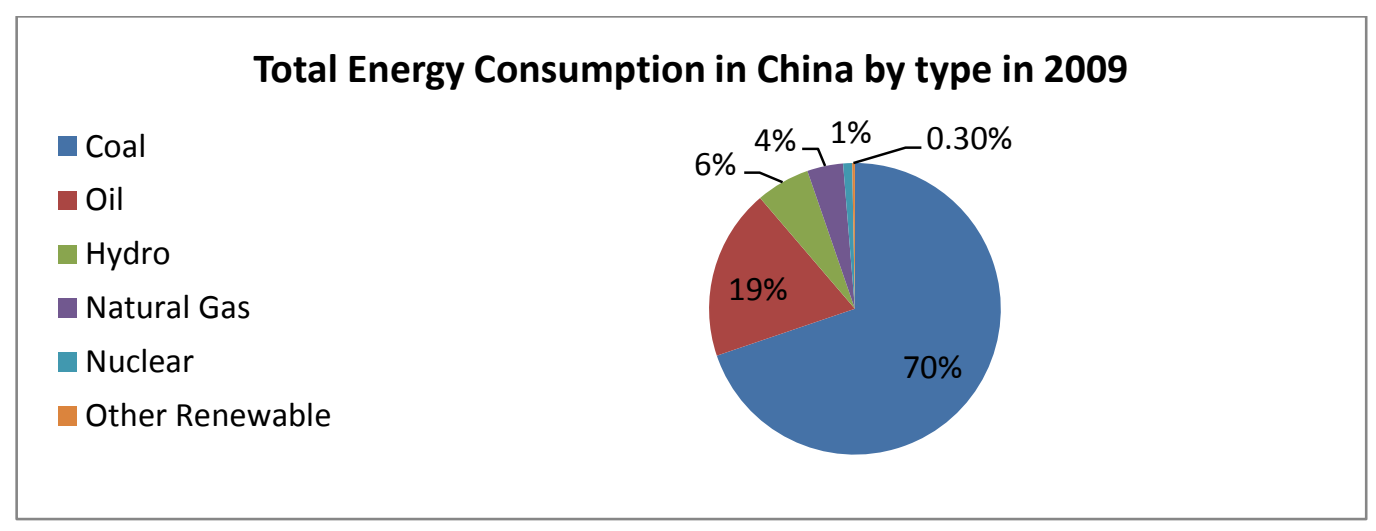

Source: US Energy Information Administration International Statistics.

In 2010, Indian oil production was equivalent to 950 thousand barrels per day (bbl/d) and oil consumption was equivalent to 3.2 million barrels per day (bbl/d). India was the fifth largest oil importer of the world by 2010 . In 2011 China obtained an annual growth performance equivalent to $9.2 \%$ where in the first half of 2012 this value was $7.8 \%$. During the second half of 2012, growth of Chinese economy considers to slow because of global 
financial crisis, decrease in industrial production and exports. According to 2011 energy statistics, China is the second largest oil consumer just behind the US. More interestingly China was a net oil exporter country at the beginning of 1990s and just after two decades it is the second largest oil importer of world. China produced an estimated 4.3 million barrels per day (bbl/d) of total liquids in 2011, of which $95 \%$ was crude oil (EIA). However, at the same year, the total consumption of country was 9.8 million $\mathrm{bbl} / \mathrm{d}$. Net oil import of China was equivalent to 5.5 million $\mathrm{bbl} / \mathrm{d}$.

\section{Methodology}

There exist, mainly two methods for decomposing the indicator changes according to sectors: namely the Structural Decomposition Analysis (SDA) and the Index Decomposition Analysis (IDA). As Kumbaroglu stated, SDA is related with the input output model of quantitative economics and its theoretical foundations and major properties are discussed by Rose and Casler. In literature mostly the IDA methods are used. The main advantage of IDA is it can be easily applied to any data at any level of aggregation. The well-known Laspeyres index method isolates the impact of a variable by letting that specific variable to change between two years while holding other variables constant at their base year values (Kumbaroğlu, 2011). Various methods have been developed and employed under IDA methodology (Kumbaroglu, 2011). In 2000, Ang and Zhang provided a survey of index decomposition analysis in energy and environmental issues. Refined Laspeyres Index (RLI) method is developed from Laspeyres Index Method by Ang and Zhang and it distributes the residual term evenly to each variable. RLI method widely used because, it is easy for calculation and understanding. According to Ang and Zhang, who include a comparison of several IDA methods, the refined Laspeyres Index Method passes all tests (time reversal, factor reversal and zero value robustness) and possesses several desirable properties (Kumbaroğlu, 2011). In this study to decompose Chinese and Indian $\mathrm{CO}_{2}$ emissions, the Refined Laspeyres Index method is used.

The RLI method is based on the extension of Kaya Identity, which it is widely used to analyze the role of different factors, which influence the $\mathrm{CO}_{2}$ emissions. The Kaya Identity explains carbon emissions (C) as a multiplication of four effects: population (POP), carbon intensity of energy use $(\mathrm{C} / \mathrm{E})$, energy intensity of production (E/P) and per capita production (P/POP). Mathematically, it can be shown as,

$$
C=P O P * \frac{C}{E} * \frac{E}{P} * \frac{P}{P O P}
$$

For this study the above given Kaya Identity is expanded to account for impacts at subsectors level. Therefore $\mathrm{CO}_{2}$ emissions are calculated as a multiplication of the subsectoral total of four effects given as

$$
C O_{2 i}^{t}=P_{i}^{t} * \sum_{j} \frac{C O_{2 j}^{t}}{E_{j}^{t}} * \frac{E_{j}^{t}}{P_{j}^{t}} * \frac{P_{j}^{t}}{P_{i}^{t}}
$$

where $\frac{\mathrm{CO}_{2 j}^{t}}{E_{j}^{t}}$ represents the carbon intensity of energy use in subsector $\mathrm{j}$ at time $\mathrm{t}, \frac{E_{j}^{t}}{P_{j}^{t}}$ represents the energy intensity of production in subsector $\mathrm{j}$ at time $\mathrm{t}$, and $\frac{P_{j}^{t}}{P_{i}^{t}}$ is equivalent to share of subsector $\mathrm{j}$ within sector $\mathrm{i}$, at time $\mathrm{t}$ and can denote the carbon intensity by $\mathrm{CI}$, the energy intensity by EI and the sectors share by SS then the previous equation can be written as;

$$
C O_{2 i}^{t}=P_{i}^{t} * \sum_{j} C I_{j}^{t} * E I_{j}^{t} * S S_{j}^{t}
$$

The effect of changes in production activity which is referred to as scale effect, composition effect, energy intensity and carbon intensity can be calculated as:

$$
\begin{aligned}
& \text { Scale Effect }\left(P_{i}^{t}\right) \\
& \begin{array}{l}
=\Delta P(i) \sum_{j}\left\{S S(j) E I(j) C I(j)+\frac{1}{2} *(\Delta S S(j) E I(j) C I(j)+S S(j) \Delta E I(j) C I(j)+S S(j) E I(j) \Delta C I(j))\right\} \\
+\Delta P(i) \sum_{j}\left\{\frac{1}{3} *(\Delta S S(j) \Delta E I(j) C I(j)+\Delta S S(j) E I(j) \Delta C I(j)+S S(j) \Delta E I(j) \Delta C I(j))+1 / 4\right. \\
*(\Delta S S(j) \Delta E I(j) \Delta C I(j))\}
\end{array}
\end{aligned}
$$

First effect is the scale effect and it shows the change in $\mathrm{CO}_{2}$ emissions due to the changing activity levels. According to the scale effect, the increase of activity levels increases the amount of $\mathrm{CO}_{2}$ emissions and the decrease of activity levels reduces the amount of $\mathrm{CO}_{2}$ emissions.

Composition Effect $\left(S S_{j}^{t}\right)$ 


$$
\begin{aligned}
=\sum_{j} \Delta S S(j)\{P(i) & \left.E I(j) C I(j)+\frac{1}{2} *(\Delta P(i) E I(j) C I(j)+P(i) \Delta E I(j) C I(j)+P(i) E I(j) \Delta C I(j))\right\} \\
& +\sum_{j} \Delta S S(j)\left\{\frac{1}{3} *(\Delta P(i) \Delta E I(j) C I(j)+\Delta P(i) E I(j) \Delta C(i)+P(i) \Delta E I(j) \Delta C I(j))+1 / 4\right. \\
& *(\Delta P(i) \Delta E I(j) \Delta C I(j))\}
\end{aligned}
$$

Composition effect represents the change of emissions due to the changes in the composition of sector. A structural change toward less carbon intensive subsectors decreases $\mathrm{CO}_{2}$ emissions and a structural change toward more carbon intensive subsectors increases $\mathrm{CO}_{2}$ emissions.

$$
\begin{aligned}
& \text { Energy Intensity Effect }\left(E I_{j}^{t}\right) \\
& \begin{aligned}
=\sum_{j} \Delta E I(j)\left\{P(i) S S(j) C I(j)+\frac{1}{2} *(\Delta P(i) S S(j) C I(j)+P(i) \Delta S S(j) C I(j)+P(i) S S(j) \Delta C I(j))\right\} \\
\\
\quad+\sum_{j} \Delta E I(j)\left\{\frac{1}{3} *(\Delta P(i) \Delta S S(j) C I(j)+\Delta P(i) S S(j) \Delta C I(j)+P(i) \Delta S S(j) \Delta C I(j))+1 / 4\right. \\
*(\Delta P(i) \Delta S S(j) \Delta C I(j))\}
\end{aligned}
\end{aligned}
$$

Energy intensity effect suggests an indication for efficiency of energy process, conversion technologies and energy conservation. Energy saving activities reducing the use of fossil fuels and use of renewable technologies increases the energy efficiency. As a result of this there will be a decline in $\mathrm{CO}_{2}$ emissions.

Carbon Intensity Effect $\left(C I_{j}^{t}\right)$

$$
\begin{gathered}
=\sum_{j} \Delta C I(j)\left\{P(j) S S(j) E I(j)+\frac{1}{2} *(\Delta P(i) S S(j) E I(j)+P(i) \Delta S S(j) E(j)+P(i) S S(j) \Delta E I(j))\right\}+ \\
\sum_{j} \Delta C I(j)\left\{\frac{1}{3} *(\Delta P(i) \Delta S S(j) E(j)+\Delta P(i) S S(j) \Delta E I(j)+P(i) \Delta S S(j) \Delta E I(j))+\frac{1}{4} *(\Delta P(i) \Delta S S(j) \Delta E I(j))\right\}
\end{gathered}
$$

Carbon intensity effect is used to analyze the effect of fuel substitution on $\mathrm{CO}_{2}$ emissions. For example, if the share of renewable resources increases or if people use natural gas instead of coal, there will be a certain decline in $\mathrm{CO}_{2}$ emissions. The change of $\mathrm{CO}_{2}$ emissions between two time periods is the sum of these four effects.

$$
\begin{gathered}
\mathrm{SCO}_{2}(i)=\text { Scale Effect }(i)+\text { Composition Effect }(i)+\text { Energy Intensity Effect }(i) \\
+ \text { Carbon Intensity Effect }(i)
\end{gathered}
$$

For the detailed analysis about the RLI method one can follow the work of Ang and Zhang, called Methodological Issues in Cross-Country/Region Decomposition of Energy and Environment Indicators.

\section{Empirical Results for China \& India}

\subsection{Agriculture}

For agriculture sector of China, scale effect is one of the most dominant effects for identification of $\mathrm{CO}_{2}$ emissions. Generally scale effect for agriculture shows an increasing trend because the output for agriculture increased during the last three decades despite the decreasing share of agricultural output in GDP. Energy intensity effect for agriculture sector of China shows a negative trend generally. For some years it has an increasing effect on emissions due to modern agricultural production techniques (i.e. for one unit of agricultural output more agricultural machinery has been used) but at the same time agricultural production is decreasing for some years therefore the energy use for this sector is also decreasing. Another reason is that, by time, the agricultural machinery equipment is getting more fuel efficient. Carbon intensity effect is negligibly small for Chinese agricultural production. For GDP decomposition analysis, agriculture is accepted as the primary industry. As it considered as a whole, there is no composition effect for agriculture.

For India, as the agricultural production of India continuously increased during the last three decades, scale effect is one of the most important contributors of $\mathrm{CO}_{2}$ emissions and generally it showed an increasing trend. Despite the share of agriculture gradually decreased, still an important part of the population obtain their income from agriculture, therefore scale effect importance is not a surprising result for Indian carbon emissions. In this study, agriculture considered as the whole of primary industry there is no composition effect for Indian agriculture sector. For energy intensity, during the first half of time period, energy intensity effect showed an increasing performance for agriculture. After that, in the second half, energy intensity generally represents a decreasing trend because of the increasing energy efficiency. Carbon intensity effect is also an important contributor of $\mathrm{CO}_{2}$ emissions. Generally it shows a decreasing trend. 


\subsection{Manufacturing Industries}

Secondary industry for China is considered as the total of manufacturing industries and construction. The major impact for $\mathrm{CO}_{2}$ emissions through manufacturing sector directly comes from the scale effect. As the Chinese economy showed a significant growth performance during the last three decades the results are not surprising. China has a huge manufacturing capacity today ( $40 \%$ of its GDP can be explained by manufacturing industries) and the scale effect for Chinese emissions showed a positive trend. Another major impact for manufacturing industries was the energy intensity effect. After 1990's the energy intensity effect shows a decreasing trend because of the raising energy efficiency. Energy use of the country increased but per unit of industrial output is produced by less energy. Carbon intensity effect for manufacturing industries is negligibly small during the last thirty years. Composition effect is even smaller than carbon intensity effect, because the share of manufacturing industries did not change too much in the same time interval.

The scale effect shows an increasing trend generally due to the raising capacity of manufacturing industries for India. Composition effect is smaller than the other effects for Indian manufacturing industries but it is a positive contributor for carbon emissions since its share in secondary industry increased faster than the share of construction. Energy intensity generally showed a decreasing trend during that period. Most probably it is due to increasing energy efficiency but in some years it represents a sharp increasing performance. This shows that India should do necessary regulations for energy efficiency. Carbon intensity shows a negative trend on average, that means some environmental regulations started to show their positive impacts however more regulations are needed for Indian manufacturing industries.

\subsection{Construction}

The dominant factor for Chinese construction sector for $\mathrm{CO}_{2}$ emissions is the scale effect. As the population growth and country developed, the need for construction sector increased. Therefore scale effect for construction also showed an increasing trend. Composition effect also represents a raising trend especially in the last decade, because the share of construction sector of China is gradually increasing. Consequently the share of construction sector also grows in the overall share of secondary industry. Energy intensity effect for construction sector is also one of the major effects. It shows a negative trend as a result of increasing energy efficiency. Carbon intensity effect is also important for construction sector. For some years it shows a decreasing performance and for some years it represents an increasing performance. On average the impact of carbon intensity is negative on emissions.

As the population of the country increased the scale effect has a positive impact on carbon emissions in India, which is an expected result. Composition effect is negligibly small but generally has a negative trend for emissions. This was also an expected result because the increase of the share of construction sector is slower than the increase of manufacturing industries' share. For reducing the costs of construction, construction companies started to use their energy more efficiently. As a result of this, in the second half of research period, there is a certain decline for energy intensity effect. On average carbon intensity effect is also declining during the 30 years period, implies that construction sector started to be more environmentally efficient.

\subsection{Transportation}

The major determinant for Chinese transportation sector is the scale effect. As the production and use of cars, buses, trucks and other vehicles increased and as the population of China rapidly increased, the scale effect represents a significant impact on $\mathrm{CO}_{2}$ emissions. The composition effect is also important for transport sector and it generally shows a negative trend during the last thirty years. Especially for recent years, composition effect becomes larger on the negative way. The main reason is share of transportation sector becomes smaller in tertiary industry. Energy intensity effect shows generally a decreasing trend for transportation sector because new technological vehicles are consuming less energy, i.e. there is an increase on fuel efficiency. Carbon intensity effect is negligibly small for Chinese transportation. Generally shows a decreasing trend due to alternative energy sources for transportation.

Compared to other sectors scale effect plays a smaller role for Indian transportation sector. There is an unexpected decrease in transportation GDP in 2010 and this decline also reduces the overall impact of scale effect. The composition effect plays also small negative role on the emissions for transportation sector. As the share of transportation grows with a smaller performance than the other service sectors, a negative impact is not surprising. However, this impact can be neglected. For India energy intensity effect represents a negative impact on $\mathrm{CO}_{2}$ emissions. However in the last years of analysis there is a certain increase on this concept. This proves the idea that India needs certain regulations on fuel efficiency. The carbon intensity effect nearly has zero impact on emissions from transportation.

\subsection{Other Service Sectors}

As the output of service sector increased the main determinant factor is the scale effect for other service sectors and it represents an increasing trend during the last three decades. The second determinant factor is the energy intensity effect and generally it shows a decreasing performance. This is, probably, because of the increasing usage of nuclear sources, natural gas sources and renewable sources for electricity and heat 
production for households and other main service sectors. Carbon intensity effect also represents a negative trend during the period. This is again, probably, due to the changing energy schedule for the country. Clean energy share is increasing for China but still country needs many reforms to prevent the air pollution. Finally the smallest impact for other service sectors is due to composition effect. It shows generally an increasing trend because of the increasing share of other service sectors concerning the tertiary industry.

As the population of the India increased very rapidly, a dominant scale effect is not a surprising result for other service sectors. The enormous growth of energy use at 2001 brings a big positive impact on energy intensity effect. The average energy intensity effect is also positive for other service sectors of India. Increasing usage of renewable sources and natural gas resources for residential and commercial buildings may be a true solution for energy intensity damage in the future. Carbon intensity effect is also left some dominant impacts on $\mathrm{CO}_{2}$ emissions on the declining way. By doing necessary modifications this impact can be even smaller.

\section{Conclusion}

For this study, $\mathrm{CO}_{2}$ emissions of the most populous countries, China and India decomposed according to data obtained for time period 1980-2010. Refined Laspeyres Index method has been used and some interesting results and valuable insights obtained. The countries' economies are subdivided into countries namely, agriculture, manufacturing industries, construction, transport and other service sectors. Four important effects considered, scale effect, composition effect, energy intensity effect and carbon intensity effect.

For China, scale effect plays an important role for the agricultural production. It shows an increasing trend during the research period. Energy intensity effect is also important for agricultural production. However it represents a decreasing trend during the research period. This is the result of increasing fuel efficiency. For India, scale effect is also remarkable for agricultural production. This is not a surprising result, because, despite the decreasing share of agriculture in Indian GDP, still agriculture is an important tool of GDP. Energy intensity effect started to show a decreasing trend but our study showed that for India, still energy regulations are necessary in order to reduce the energy intensity. Carbon intensity effect is more important for India in agriculture if we compare with China. In manufacturing sectors for both countries scale effect is dominating the $\mathrm{CO}_{2}$ emissions. For both countries, energy intensity effect is an important tool to explain the emissions due to manufacturing industries and because of the efficient energy use it represents a declining performance. Because of the rapid technological growth the carbon intensity effect shows an increasing trend for manufacturing industries in China. This is not a surprising result, as the economy of the country boomed then the environmental damage is unavoidable. For construction sector of countries, the major effects are scale effect and energy intensity effect. They represent their dominant impacts on positive and negative directions respectively for both countries. As the population of both countries increased, the positive scale effect for construction sector is expected. During the thirty years there are some developments on construction sector for each of the countries. Construction companies are well organized and more efficient for energy use and other materials use, therefore there exists a decreasing trend on energy intensity effect. For composition effect there exist interesting results for both countries. For China there is a positive trend for construction according to composition effect and the opposite is observed for India. This is because of the changing share of construction sectors of countries, in the secondary industry. As mentioned before, secondary industry is classified as manufacturing industries and construction. For this case, carbon intensity effect can be ignored.

For transportation sector some interesting insights observed. For both of the countries, as their population increased, the transportation need also increased. Therefore a positive scale effect occurred during the research period. As the share of transportation in tertiary industry getting smaller then negative composition effect expected and observed. Because of the technological developments, new vehicles are consuming less fuel if one compare with the past. Today, cars, buses, trucks, ships etc... are more energy and economically efficient. As a result of this, energy intensity effect, on average, represents a decreasing trend for both China and India. However, if one compare these two countries, China is much better than India in energy intensity for transport sector. Since the alternative fuels have started to use, there exists a decline for carbon intensity for both countries. But, also for carbon intensity both countries need certain regulations.

Both of the countries were getting more and more crowded during the last three decades. At the same time the number of residential buildings, commercial buildings, hotels, restaurants and other service buildings increased. Therefore scale effect showed its positive dominant impact for both countries for service sectors. Composition effect for service sectors is also positive in India and in China because, the share of service sectors was increasing in tertiary industry. For energy intensity Chinese service sector shows a certain decline as the share of natural gas sources and renewable sources increased for residential and commercial electricity production. For India, energy intensity is generally increasing for service sectors. Probably, it will consider increasing in the near future, because $40 \%$ of the houses still do not have electricity generation according to World Bank.

Our work was interesting, because we also tried to show the similarities and differences of one upper middle income and one lower middle income countries. At the beginning of the research period, China and India had almost the same amount of GDP even in the concept of per capita income India was better than China. Today, of 
course, China is in better conditions compared to India. However both of the countries still need certain regulations for environmental issues. They considered more than 40 percent of total world population. That means well organized economic and energy policies will bring a great success. The dominant scale effect also proves the idea that these two countries need modifications. The modest energy intensity effect is increasing the motivation that environmental success is not away from world. These countries may avoid to apply the policies related with environmental issues, because, they do not want to interrupt their economic growth.

\section{References}

- Ang, B. W., Liu, F., \& Chew, E. (2003). Perfect decomposition techniques in energy and environmental analysis. Energy Policy 31, 1561-1566.

- Ang, B., \& Zhang, F. (2000). A survey of index decomposition analysis in energy and environmental studies. Energy $25,1149-1176$.

- B. W. Ang, F. L.-S. (2004). A generalized Fisher index approach to energy decomposition analysis. Energy Economics $26,757-763$.

- Cornillie, J., \& Fankhauser, S. (2004). The energy intensity of transition countries. Energy Economics , 283295.

- DiFurio, S. V. (2010). A decomposition analysis of CO2 emissions in the United States. Applied Economics Letters , 925-931.

- Dislers, K. L. (2011, June). CO2 Emission Reduction Practices of Road Freight Transportation: which could be implemented by Small and Medium Sized Enterprises in Latvia. Jönköping, Sweden.

- Kawase, R., Matsuoka, Y., \& Fujino, J. (2006). Decomposition Analysis of CO2 emissions in long-term Climate stabilization scenarios. Energy Policy 34, 2113-2122.

- Liu, C.-C. (2006). A Study on Decomposition of Industry Energy Consumption. International Research Journal of Finance and Economics .

- Ma, C., \& Stern, D. I. (2008). China's changing energy intensity trend: A decomposition analysis. Energy Economics $30,1037-1053$.

- Mishina, Y., \& Muromachi, Y. (2011). Revisiting Decomposition Analysis For Carbon Dioxide Emissions From Car Travel: Introduction of Modified Laspeyres Index. Yokohama: TRB 2012 Annual Meeting.

- Paul, S., \& Bhattacharys, R. N. (2004). CO2 emission from energy use in India: a decomposition analysis. Energy Policy 32, 585-593. 


\title{
Environmental Accounting and Environmental Costs
}

\author{
Assoc. Prof. Dr. Baki Yılmaz (Selçuk University, Turkey) \\ Ph.D. Candidate Fatma Özlem Y1lmaz (Selçuk University, Turkey) \\ Prof. Dr. Naim Ata Atabey (Selçuk University, Turkey)
}

\begin{abstract}
The result of economic improvement and growth; rapidly population increase, technologic development, rapid industrialization, extreme water, air and soil pollution bring the enviromental problems. The increase lived in the environmental problems has caused an environmental conscious emerges, roots, and spills. With environmental conscious aganist the environmental problems; in the environmental costs and environmental accounting topics significant developments appear. Environmental Accounting aims at explaining the interaction between economy and environment by the information that it produces. The main approach in understanding of environmental accounting and environmental costs are to include changes in the natural environment into the national/regional accounts or corporate balance sheet. Our this Study serves the goal of the necessity of the subject of Environmental Accounting and Environmental Costs by aiming at providing for evaluating the damages in the natural environment in our world inside the process of globalization, in both a macro and micro level, and in a social, cultural, and economical structure.
\end{abstract}

\section{Introduction}

The managements, which are an indispensible part of the economical life and produce goods and services by the aim of fulfilling the unlimited needs of individual and society, carry out their activities to reach the objectives like maximizing the profit and providing the continuity of managerial activities. Managements, in the performing process of these activities, consume the nature and the natural resources differently and leave their wastes, which are in the base of environmental problems, into the nature by their activities occurring unconsciously and irresponsibly.

The increase lived in the environmental problems has caused an environmental conscious emerges, roots, and spills. Managements, because both the effect of environmental conscious and the laws inclined towards protecting the environment and the customers' reactions, who gradually become self-aware, have been obliged to move more sensitively. Managements have to pay attention not only economical but also the social effects of the activity results that they practice depending on the principle of social responsibility. In this reason, to make investments towards protecting the environment and to develop some technologies concerning with it is a state to which managements definitely have. The determination of the effects of the costs that emerge because of environmental investments and altruisms, which managements will make, and its usability in the decisions of the administration by following it is possible with the approach of Environmental Accounting. That accountancy gains an importance together with the changes occurring in economical and technological fields has brought this profession into an effective position inside the life of society and commerce. In this point, accountancy, due to the concept of 'social responsibility' of accounting, has begun to reveal the damages that managements bring in the nature; by determining its effects, it has started to work by the goal of calculating, classifying, auditing (observing), and reporting of the costs that may come out, and at the end of these works, the concept of "Environmental Accounting" has been on the agenda.

\section{The Environment and the General Principles towards Environment}

Environment is "the general sense of the sources that the livings fulfill their vital needs directly or with operations," (Kabasakal, 1995). Environment, with its one broader definition, is "the whole of the nature and the man-made elements in the nature together with human and all other living beings," (Bulca, 1995). In the second definition concerning with environment, it is mentioned about the two dimensions of the nature: The first of them is the natural environment that, the natural environment is the environment that has not been exposed to humanity's effect and intervention and that the nature constitutes. In the result of humanity's effect and intervention on the nature, the artificial environment, which is the second dimension of the nature, has been emerged. As the artificial environment is a part of the natural environment, it is a state of the natural environment beginning to be destroyed, and it has been emerged in a result of humanity's intervention on the nature (Kirloglu and Can, 1998).

The environment that has a significant influence and a vital importance on all the living beings is an important phenomenon for managements. If we think managements are born, grow and die like all livings as well, we see managements try to function inside an environment that gives opportunities for themselves.

When we define the environment in terms of managements, the environment of managements is the system of the internal and external conditions and the effects that affects on its life of activity and its development as is for all the living beings (Yoruk, 1999). 
We cannot definitely isolate the managements, which produce goods and/or services with the aim of fulfilling the unlimited needs of individuals and society, from the environment; because, managements consume the natural sources in different ways due to their activities and use many natural sources as a raw material. During the using of these sources, the nature is negatively affected, and the hazardous wastes, which bring the environmental problems out, emerge. We can express this state in the following figure:

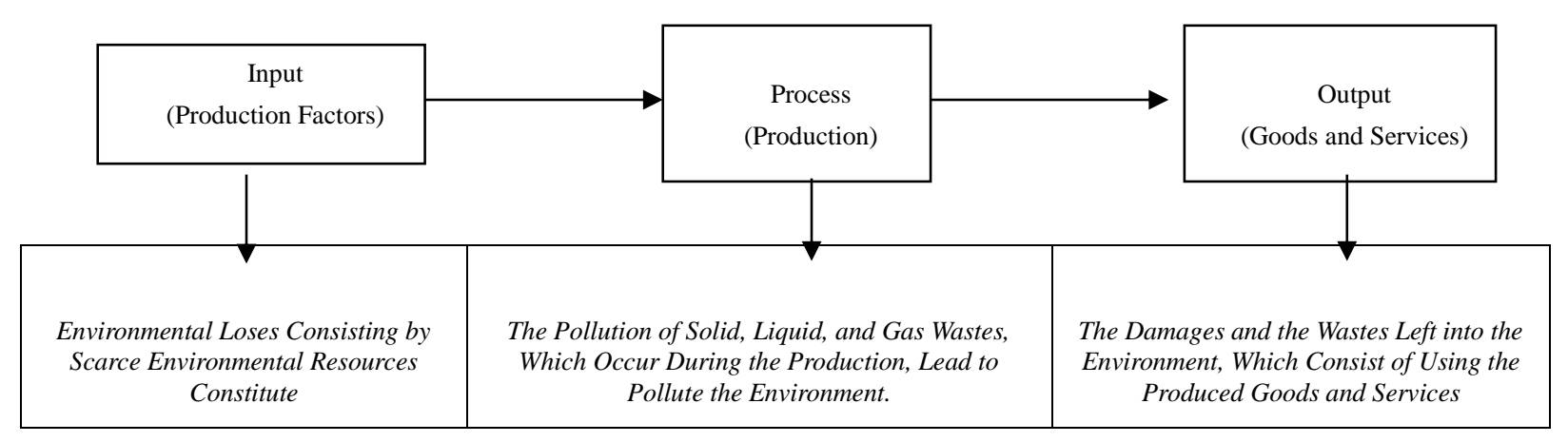

Figure 1: The Role of Managements in the Environmental Problems Source: (Kirlioglu and Can, 1998)

In the figure above, the managements continuously take some inputs from its environment and again give some outputs to its environment. Among these inputs called as production factor, there are many environmental sources, too. In the result that these sources used as an input are scarce, environmental loses emerge, and the sources decrease day by day. In addition, the pollution of solid, liquid, and gas wastes occurring during the production constitutes the base of the environmental problems.

\section{The Concept of Environmental Accounting}

Accounting, which is one of the basic functions of managements, is a science, an art, and an application that observes and determines systematically the financial-qualified events and operations occurring in the managements in the form of unit of currency and that collects and records information and documents concerned with them and that classifies and sums up meaningfully and reports and presents the results to the concerned persons and establishments by interpreting (Atabey and et al., 2001).

Accounting, as an open system, is continuously in an interaction with its environment. Accounting, due to the concept of social responsibility, is in the position of looking after the whole society's interests, not definite persons' and groups'. As an extension of the concept of social responsibility, the concept of social responsibility accounting has been born. Environmental Accounting, which is a subgroup of the social responsibility accounting, as a branch growing with the information demands suitable for the objectives of the concerned groups, stands in front of us as a field of study that includes the matters of documenting, reporting, and auditing of the expenses related to the environment.

"In recent times, as a result of the interaction between the environmental responsibility and the managerial strategies of the managements, it has needed to arise the information system of Environmental Accounting by the goal of getting the information needed in the evaluation of environmental effects and in the various managerial decisions" (Akun, 1999).

Various definitions have been made towards Environmental Accounting that is also called as "Green Accounting" in the literature of the world. Environmental Accounting:

"The definition of negative measurements of environment, and their practicing on the accounting system and its applications" (Güvemli, 1996).

"The indication of the financial-qualified events about the environment in the financial statements by accounting” (Pearce and et al., 1993 ; Aslan, 1995).

"In the accounting systems that are still practiced, especially on the cost and the profit analyses, the planning and the practicing of environmental factors" (Güvemli, 1996).

"As an example of the financial accounting measuring functions, the carefully practicing of the financial reporting and the internal and external environmental factors (related to a management)" (Gray and et al., 1993).

"The accounting of effects that are going to be emerged in the result of the using of environmental sources" (Ozbicerikli and Melek, 2002).

"It is an information system, which produces the information that explains the constituting of environmental sources, the form of using of these sources, the increases and the decreases occurring in these sources in the result of the operations of organizations and the state of the organization in terms of environment, and which conveys them to the concerned persons and establishments" (Kirlioglu and Can, 1998). 
"The recording, classifying, reporting after summing up, and interpreting of the results of the financialqualified environmental operations and events by signing with money" (Ozbicerikli and Melek, 2002).

Environmental Accounting aims at explaining the interaction between economy and environment by the information that it produces. It is seen that Environmental Accounting has the objectives lined up below, such other accounting systems (Kirlioglu and Can, 1998):

"To make up a balance sheet that indicates which level the source inventory stands on, in a definite time, and that gives its profile",

"To determine how much source stock is used, how much source come to the stock, what is added into them, and how much it changes the form in a definite period of time, and to prepare the accounts",

"To provide that the assets getting along with fixed assets become consistent, and in this way, to show it is the adding of the floating asset calculations of this year onto the balance sheet of the previous year, for every balance sheet".

Environmental Accounting has found a meaning generally in a macro level and always has been practicing like that until today. While the national applications of Environmental Accounting have been present in the resources in the literature, it has not been almost possible to meet with a work in the level of the management. The putting into practice of the ISO 9000 Quality Standards and the ISO 14000 Environmental Management and Audit Standards in the process of European Union and International Accounting Standards by the Turkish Standards Institution is an important phase practiced in this process (Kirlioglu and Can, 1998).

\section{The Environmental Costs}

The cost, in a general sense, can be defined as the whole of economical altruisms gone through to reach a goal. "As for the environmental costs are accepted as one of the costs that managements bear to present goods and services for their target groups" (Ozbicerikli, 2000). All the activities done by the managements for the environment lead to emerge the environmental costs.

Business managers, by considering the environmental suitability, will make the product diversifying and pricing, the selection of production inputs, the evaluation of the pollution prevention projects, and the waste management alternatives according to the environmental cost information, in the decisions that they will take in the managerial strategies (Akun, 1999).

Environmental costs may differ according to their shapes of formation. While some environmental costs emerge in result of the activities made for the aim of protecting the environment, some of them may arise because of their using for environmental sources (Kirlioglu and Can, 1998).

Moving from the data above, it is possible to come together the environmental costs in the dimension of environment in the three basic groups as costs of reduction, costs of using, and costs of damage (Aslan, 1995; Lutz and Munasingle, 1991).

Costs of reduction contain the costs that managements bear to prevent and reduce their environmental problems. Costs of using include the costs that a management has to go through in return for using the environmental sources. As for costs of damage, it consists of the costs of the environmental pollution and the environmental damages, which emerge in the result of the managerial activities, will load on the shoulders of managements (Ozbicerikli and Melek, 2002).

Under the light of the classification above, the cost distributions can be made the following:

\begin{tabular}{|l|l|l|}
\hline Costs of Reduction & Costs of Using & Costs of Damage \\
\hline Environmental planning & Cost of air & Air pollution \\
Control of process & Cost of water & Water pollution \\
Emission measurement devices & Cost of soil & Image pollution \\
Environmentally unharmful product-designing & Cost of noise & Punishments and Compensations \\
developing & Cost of image & Environmental Cleaning \\
Recycling designs & Cost of natural gas & Researches of Complain \\
Environmentally unharmful packing developing & Cost of petroleum & Costs of Bail and Guarantee \\
Develop the environment & Cost of coal & Sale Reductions \\
Environmental education & Cost of energy & Other Costs of Damages \\
Services of biologist and chemists & & \\
Services of environmental engineering & & \\
Environmental reports & & \\
Environmental labels & & \\
Environmental reliability & & \\
Environmental management system & & \\
Environmental audit & & \\
\hline
\end{tabular}

Table 1. The Distribution of Environmental Costs Source: (Ozbicerikli and Melek, 2002) 
The costs can be classified, grounding on various criterions. As known, we can classify the costs as fixed cost and variable cost according to the sensitiveness tied to the level of production. Fixed costs are the elements of cost, which are not tied to the level of production and not variable whatever the level of production happens. As for variable costs are the elements of cost, which are variable as tied to the level of production. Besides, it is possible to be able to observe the distribution of environmental costs in this classification.

Costs of reduction, because of its general structure, are the costs that will consist usually by the managements make investments. By a definite investment is made by a management, it is evitable that the management bears the fixed costs related to these investments. Costs of reduction are the fixed costs that managements go through, namely bear to prevent the environmental problems. In this context, here, we can examine environmental planning, environmental education, and other costs of reduction inside the class of the fixed costs. With regard to the costs of using and damaging act usually as tied to the increasing and the decreasing of the level of the management production. In addition, we can treat cost of noise and cost of energy that are of costs of using, and soil pollution, noise pollution and other costs of using and damage that are of costs of damage, inside the class of variable costs.

The environmental costs are accepted as important for a business management in the direction of the reasons below (EPA, 1995; Ozbicerikli, 2000).

"A lot of environmental costs can be considerably reduced or removed in the result of its decisions towards the matters like an investment for a more green process of production, the process of producing/manufacturing and/or the redesigning of the product rather than the short-term changes related to the activities of the business management. Because, an important part of environmental costs can be provide an added-value into the process of production, system, and product."

"Environmental costs can be followed from the general expenses account or perhaps may be ignored."

"Many companies have discovered they can compensate the environmental costs, making an income by getting the license of clean technology or selling the outage byproducts."

"The better managing of environmental costs has a big share to provide significant benefits for human's health and to increase environmental performance as much as the success of management."

"Knowing the environmental costs and the environmental performance related to the process of manufacturing and producing helps for both determining the costs and the prices of the product more truly and designing the manufacture, service, and production processes of the management more preferably in terms of environment."

"The manufacture, service, and production processes, which are more preferably for customers in terms of environment, provide a competitive advantage."

"The accounting of the environmental costs and the environmental performance can support the development of a company and all the activities of the environmental management system."

Managements have to make some self-sacrifice in both legal coercion and thematic pressures for environmental matters (Dales, 1996).

For this, managements can reduce their environmental costs, going to adopt these ways below:

- The true preference of factory location,

- The preference of technologies that pollute the environment less,

- The preference of chemical materials that pollute the environment less,

- The true preference of clean-up system,

- The reduction of the quantity of chemical materials used,

- The reduction of the quantity of wastewater,

- The reusing of waste-water,

- The recycling some materials from wastewater.

In the environmental costs in the world, especially in the sector of energy, the important progresses have been made. Particularly in the energy sector of Brazil, the concepts of social and environmental costs, which are suitable for the characteristic of the sector, have been developed. The characteristic of the environmental costs defined for this sector is the following (Tolmasguim and et al., 2000):

Costs of Audit (Costs of Control): It is the costs, which the efforts of the energy sector that are inclined toward completely or partly preventing the social and environmental effects of an investment

Costs of Reduction: It is the costs, which the energy sector makes for decreasing the results of the social and environmental effects of an investment.

Costs of Compensation: In the case that the repairing (or renovating) is not possible, it is the costs emerged from the efforts directed to balancing the social and environmental effects of an investment.

Costs of Observing: It is the costs that the energy sector makes for evaluating the social and environmental programs of the energy sector. 
Institutional Costs: It is the costs that the energy sector makes while managing the phases of planning, practicing, and managing of the social and environmental works and while preparing the works that the environmental agencies demand and while taking the environmental licenses.

Costs of Decomposition: It is the external costs that the waste social and environmental effects, which remain even after the energy sector makes real the costs of audition (control), reduction and/or compensation, do cause.

In the present day, there are two standards known environmentally. These are ISO 14000 International Environmental Management and Audit System Standards and BS (British Standard) 7750 British Environmental Management System. The Environmental Management System (EMS) is "the serial of management instruments, principles, and procedures that will protect the health of environment and human from the hazardous effects, which can be emerged from the activities, products, and services of the managements," (www.5mworld.com).

The most important advantage in the application of the Environmental Management System on the managements is the reduction that can occur in the costs of management. "The importance showed for prevention of pollution and waste-management (reduction) guides the managers continuously to look for lowercost solutions," (www.5mworld.com).

\section{Conclusion}

In the present day, the increased population, the growing cities, the local and national highways traffics, and the industrialization have exposed people to environmental problems. By the environmental problems have begun to threat the life of humanity and other livings particularly after the Revolution of Industry, the attention of the whole world has started to focus on the environmental problems. It will not be a mistake to express that the levels of humanity's sensitiveness about the environment have increased and reached a significant point today.

By the phenomenon of globalization, all the countries of the world have begun to give a place to the environmental matters in their regulations (and legislation), and they have made some regulations on the environmental regulations in both national and international level.

The environmental issues, in a micro level, have become a matter interested in the managements very closely. The managements, which make investments towards the environment and renovate their present technologies, have to constitute an effective environmental accounting system, determining the environmental costs. Under the light of the environmental costs, the integration of environmental information into the accounting system will be provided by the environmental accounting system. As for this system, it is the adaptation of the functions of the accounting, such the documenting, calculating, classifying, recording, reporting, and auditing (control), on the environmental accounting.

By the aim of being able to evaluate the damages, in micro and macro levels, which are brought into the natural environment, inside the social, cultural, and economical structure of our world in the process of globalization, the necessity of the accounting of the natural sources and of the environmental accounting today emerge. In this point, inside this thinking system, the auditing, reporting, classifying, and interpreting of the environmental investments belonging to the managements and of the cost-profitableness analyses will be surely possible only with the environmental accounting. Besides, the establishing and developing of the environmental accounting system will be tied to the environmental cost information, which will be gotten from the environmental management systems, and to the analyzing of these information.

\section{References}

- $\quad$ Akün, Lerzan, 1999. "Çevre Muhasebesi; Genel Bir Bakış”, Muhasebe Bilim Dünyası Dergisi, Cilt:1, Sayı: 1, Nisan, ss.153-155.

- Aslan, Ümmühan, 1995. Çevre Muhasebesi ve Nuh Çimento A.Ş.'nde Çevre Muhasebesi Üzerine Pilot Bir Çalışma, Yüksek Lisans Tezi, Anadolu Üniversitesi Sosyal Bilimler Enstitüsü, Eskişehir, 1995.

- Atabey, N.Ata-Parlakkaya, Raif-Alagöz, Ali, 2001. Genel Muhasebe, Dizgi Ofset, Konya.

- Bulca, Aydan, 1995. Çevre Sorunları, Cumhuriyet Dönemi Türkiye Ansiklopedisi, İletişim Yayınları, Cilt:2, İstanbul ,s.332-335.

- Dales, J.H; Çevre Sorunlarının Hukuki ve Ekonomik Temelleri, Çeviren: İ.Orhan Türköz,1996. Mobil Yayınları, İstanbul.

- EPA Project, 1995. An Introduction to Environmental Accounting as a Business Management Tool, Washington.

- Gray, Rob-Jean, Bebbington-Walters, Diana, 1993. Accounting for the Environment, Founded by the Chartered Association of Certified Accountannts, London.

- Güvemli, Oktay-Gökdeniz ,Ümit, 1996. “Çevre Muhasebesindeki Gelişmeler”, Muhasebe Bilim Dünyası Dergisi, Cilt:1, Say1:4, 1996.s.24.

- Kabasakal, Öner, 1995. "Ekonomi ve Çevre İlişkisi”, Yeni Türkiye, Mayıs, ss.330-335. 
- Kırlığlu, Hilmi-Can, Ahmet Vecdi, 1998. Çevre Muhasebesi, Değişim Yayınları, Adapazarı.

- Lutz, Ernst-Munasingle, Mohan, 1991. Accounting for the Environment, Finance\&Development, Environment Department Working Papers, World Bank, Washington D.C., March.

- Özbirecikli, Mehmet,2000. “Çevre Muhasebesi Kavramı ve Yönetsel Kararlara Katkıları”, Muhasebe ve Finansman Dergisi, Sayı:7, Temmuz 2000.s.18.

- Özbirecikli, Mehmet-Melek,Zeynep, 2002. “Çevre Muhasebesi ve Çevresel Maliyetlerin Maliyet Muhasebesi Sistemine Etkileri ve Bir Araştırma”, Muhasebe ve Finansman Dergisi, Sayı:14, Nisan, s.85.

- Pearce, David-Markandya, Anil-Barbier, B.Edward,1993. Yeşil Ekonomi İçin Mavi Kitap, Çev: Arslan, B.Kafaoğlu, T., Alan Yayıncılık, İstanbul.

- Tolmasguim, T.Mauricio-Motta, R.Seroa-Rovero, E.Lebre-Barata, M.M.Lima-Monterio, A.Guimares, 2000. Environmental Valuation for Long-Term Strategic Planning Tehe Case of the Brazilian Power Sector,

- Yörük, Nevin, 1999. Çevre Muhasebesi, İktisat, İşletme ve Finans Dergisi, Ocak, s.68.

- http://www.5mworld.com/ekim_2000/Tarih_cevreyonetim.htm 


\title{
The Internal Innovation Processes in Kazakhstan
}

\author{
Ph.D. Candidate Aizhan Samambayeva (Universidade de Santiago de Compostela, Spain) \\ Prof. Dr. Manuel Fernandez-Grela (University of Santiago de Compostela, Spain)
}

\begin{abstract}
To evaluate the internal innovation processes in Kazakhstan, the paper involves two pieces of empirical research. In the first piece, the main drivers of innovation performance are identified based on regression analysis. The literature suggests three factors affecting innovation activities of firms, namely foreign direct investments, research and development investments, and international trade. In order to test this theoretical framework, a probit regression analysis is carried on to estimate the determinants of innovation performance in Kazakhstan. The chapter makes use of firm level data from the Kazakhstan Enterprise Survey 2009, conducted by The World Bank. The results are supplemented by descriptive analysis. The second piece deals with the examination of multi-level relationships between business organizations and innovation. The literature distinguishes between two modes of learning and innovation, based on the distinction between implicit and explicit knowledge. Promotion of R\&D and codification of innovation process are the main features of the Science, Technology, and Innovation mode of innovation. On the other hand, the Doing, Using, and Interacting mode of innovation is based on learning by doing. In order to discern which of these is the main innovation mode adopted by firms within the EKMC, a survey was conducted among them in the period from November 2011 to January 2012.
\end{abstract}

\section{Theoretical Background}

Empirical and theoretical studies highlight three key factors affecting innovation performance: research and development activities, foreign direct investments and international trade.

Knowledge generated by firms' R\&D activities creates an internal stock of scientific knowledge. According to many authors, their own installed knowledge base increases the absorptive capacity of the firms, enabling them to understand externally generated ideas and technologies, and to apply them to commercial ends (Feinberg \& Majumdar, 2001). Therefore, the technological capability of firms depends on their investments in R\&D and in the development of human capital (Aw, Roberts, \& Winston, 2007). Other studies provide empirical evidence of a positive correlation between exporting and R\&D investments. Firms exporting and investing in $R \& D$ at the same time are about 10 to $17 \%$ more efficient than those that only export (Aw, Roberts, \& Winston, 2007).

International trade can be expressed in two activities, as the selling to export market and the importing of intermediate inputs. Exports as a channel of technology spillovers facilitate knowledge diffusion and transfer. Firms learn from information exchanges within foreign markets, directly or through export intermediaries (Liu \& Buck, 2006). There, communication with buyers and suppliers stimulate firms to improve their own technological capacity and to increase the quality and specialisation of their products. Empirical results from Spanish manufacturing firms confirmed that international trade gives firms the opportunity to benefit from knowledge spillovers and learn from exporting and importing (Solomon \& Byungchae, 2008). Firms gain from exposure to the more intense competition present in international markets that forces them to enhance their innovation activities.

Much of the empirical literature considers foreign direct investment (FDI) as an important channel of knowledge spillovers. Branstetter (2006) showed that FDI increased the flows of knowledge spillovers both from and to the firms. In particular, FDI spillovers are much higher in relatively high-technology industries than in relatively low-technology industries (Keller \& Stephen R. Yeaple, 2003). Besides the fact that FDI brings employment and capital inflows, it also leads to technology transfers to domestic firms. Domestic firms gain from the accelerated technological diffusion implied by higher labor turnover. Moreover, foreign firms usually spend more on training programs than domestic firms. Since the early 1980s countries all over the world have liberalized their policies regarding FDI in order to attract foreign multinational enterprises (MNEs), based on the assumption that FDI positively affects human capital stocks, exports, capital formation, and the technological capacity and productivity of domestic firms. The contribution of FDI to knowledge accumulation by domestic firms, as well as to the increased productivity and production of the host country was well described in many articles (Blomstrom \& Kokko, 1998). In them, MNEs are considered as main agents of technology transfer through the movements of skilled staff, the existence of demonstration effects, and the operation of backward linkages facilitating the adoption of new technologies by local firms.

Apart from the drivers of innovation performance there are externalities that have influence on the innovation performance of firms. These can originate from firms' and industry's characteristics such as firm size, age of firms, technological opportunity and foreign presence. Interidustry differences considerably contribute to the explanation of cross-industry variations in innovation performance. 


\subsection{Data and Methodology}

In order to test the theoretical framework, we employed probit regression analysis to estimate the determinants of innovation performance in Kazakhstan. We used firm level data from the Kazakhstan - Enterprise Survey 2009, conducted by The World Bank, collected in Kazakhstan during calendar year 2008/2009. The survey covers firms in the manufacturing and services sectors using stratified random sampling. Three levels of stratification, industry, establishment size, and oblast (region) were used. To obtain unbiased estimates for the whole population, the survey comprises all manufacturing sectors, construction sector, services sector and transport, storage, and communications sector. Some industries are not included: financial intermediation, real estate and renting activities, except the IT subsector which was added to the population under study, and all public or utilities-sectors. To sum up, industry stratification includes 23 manufacturing industries, 2 services industries -retail and IT-, and one residual. Each sector had a target of 177 interviews. Regional stratification was defined in five regions: North, West, East, South, and Central. According to size stratification, the number of employees was defined on the basis of reported permanent full-time workers. The survey covers the entire population of Kazakhstan's firms with more than 5 employees. 544 completed interviews are included in the sample (The world bank, 2009).

\subsection{Dependent Variable}

As an output variable we have the declaration of whether an enterprise has introduced new products or services in the last three years (dummy variable) and the sales share of innovative products introduced in last three years (continuous variable). The use of various indicators of innovation allows us to discover different aspects of the same phenomena and to interpret our results more properly. Firms may differ in their ways of innovating and the ways of turning research efforts into sales. Therefore reliance on the introduction of innovation variable alone might give the false impression of innovation processes in Kazakhstan. Innovation output is not easily measurable and moreover takes several years to be realized (Innovation performance of firms in manufacturing industry: Evidence from Belgium, 2007). Assessing both measures of innovation compensates partly the deficiencies inherent in selecting one measure to the exclusion of the other, like the subjectivity of innovation counts (Salomon \& Shaver, 2005) or the difficulties to gather the information of innovative activities that do not lead to the introduction of actual innovations due to its failure, for instance (Archibugi \& Pianta, 1996). Furthermore, the measures of new product sales throw some light about commercialization processes and the economic benefits of innovation.

In early researches on innovation, patents were used as a measure of innovation output, although technologies are not easily codifiable in from of patents or blueprints. As an alternative, Miresse and Mohnen (2002) suggested using innovative sales instead of the number of patents as a measure of innovativeness. Despite the fact that the sales of innovative products cover only product innovations, there are studies demonstrating that the majority of process innovating firms are also product innovators. The introduction of innovation is a better measure of innovation performance since it is faster than patenting.

\begin{tabular}{|c|c|}
\hline Variables & Description \\
\hline \multicolumn{2}{|l|}{ Dependent variables } \\
\hline The introduction of innovation & $\begin{array}{l}\text { Dichotomous variable taking the value } 1 \text { if the firm introduced an } \\
\text { innovation during the last three years, and the value } 0 \text { otherwise }\end{array}$ \\
\hline $\begin{array}{l}\text { The ratio of new sales product to } \\
\text { total sales product }\end{array}$ & Proportion of total sales represented by new product sales \\
\hline \multicolumn{2}{|l|}{ Independent variables } \\
\hline Domestic import & $\begin{array}{l}\text { Percentage of material inputs and supplies of domestic origin in the last } \\
\text { fiscal year }\end{array}$ \\
\hline Foreign import & $\begin{array}{l}\text { Percentage of material inputs and supplies of foreign origin in the last fiscal } \\
\text { year }\end{array}$ \\
\hline Export & $\begin{array}{l}\text { Dichotomous variable taking the value } 1 \text { if the firm exported in last fiscal } \\
\text { year and the value } 0 \text { otherwise }\end{array}$ \\
\hline R\&D investments & $\begin{array}{l}\text { Dichotomous variable taking the value } 1 \text { if the firm invested in R\&D in the } \\
\text { last three years and the value } 0 \text { otherwise }\end{array}$ \\
\hline \multicolumn{2}{|l|}{ Control variables } \\
\hline Foreign presence & $\begin{array}{l}\text { Percentage of private foreign individuals, companies or organization in } \\
\text { ownership }\end{array}$ \\
\hline Size & The number of permanent full-time employees \\
\hline Technological opportunities & $\begin{array}{l}\text { Dichotomous variable taking the value } 1 \text { if the firm belongs to a } \\
\text { technology-intensive industry and the value } 0 \text { otherwise }\end{array}$ \\
\hline
\end{tabular}

Table 1: Description of Variables 
The first dependent variable $y$ represents the declaration of whether an enterprise has introduced new product or services in the last three years. By the definition of The Agency of Statistics of the Republic of Kazakhstan, "innovation" is the result of scientific and technological activities, been realized in the form of new or improved products (goods and services) or technology (The Agency of Statistics of the Republic of Kazkhstan). The value takes 1 if the firm introduced new products or services in the last three years and 0 otherwise (Table ).

In the second model the innovation performance is measured by the ratio of new product sales to total sales in a given firm. "New product" is classified as a product or service that was introduced in the last three years. The ratio of new product sales to new total sales is a continuous variable expressed in percentage that presents a number of advantages. Firstly, it measures better the economic value and scope of innovation performance. Secondly, focusing on firms' efforts to launch new products more directly assesses innovation provoked by international knowledge spillovers. It can be interpreted then as an indicator of market acceptance and commercialization processes. Thirdly, in contrast to patent measures, the ratio consists of unpatented products that were employed in the production process i.e. "new to the firm" (Wang \& Kafouros, 2009).

\subsection{Independent variables}

According to the theoretical framework, there are three factors that determine the innovation performance of a firm. To measure international trade we included in the model import and export variables. For exports, a dummy variable is used, taking the value 1 if the firm directly or indirectly exported in the last fiscal year, or 0 otherwise. Imports are divided into domestic and foreign imports. The last ones are measured as the percentage of material inputs and supplies of foreign origin in the last fiscal year. Domestic imports imply import of inputs from domestic manufactures. A dummy variable of $R \& D$ expenditure indicates to which extent a firm invest in $R \& D$. R\&D intensity is determined by whether or not the firm has invested in research and development in the last three years, including in-house or outsourced investments.

Unfortunately, the Enterprise Survey does not provide information on foreign direct investments. Therefore, the only way to measure foreign involvement is to take into account the share of foreign ownership in the ownership structure.

\subsection{Control variables}

In order to clarify the effect of explanatory variables, control variables have to be included. We included controls for a number of factors that include firm size, foreign presence and technological opportunity.

Firm size is believed to have a significant effect on innovation performance. Large firms are able to reap economies of scale that motivate them to innovate more (Liu \& Buck, 2006). Size is one of the widely analysed and recognised determinants of innovation performance. We measured the size of firms by the number of permanent full-time employees.

We control for foreign presence, expecting a strong relationship between foreign participation and innovation performance. We measure foreign presence by the percentage of private foreign individuals, companies or organizations in the ownership structure ( $\mathrm{Lu} \& \mathrm{Ng}, 2012$ ).

The literature on innovation considers that there is a significant effect of industry classification on innovation performance. For example, A. Jaffe (1986) argued that firms in a given industry patent more in some classes than in others. The sectorial context relates to the fact that belonging to a particular industry may condition a firm's strategy and performance (Rodriguez \& Rodriguez, 2005). Therefore, all firms were divided according to if they operate in low-technology industries or in high-technology industries, determining these categories according to Kafouros \& Buckley (2008).

\subsection{Methodology}

We apply a probit model to measure whether firms introduced innovations or not. Then, we carried out a regression analysis for the second model, where the ratio of new product sales to total sales is the dependent variable.

\begin{tabular}{|l|l|l|l|}
\hline Variables & Innovator & Non-innovator & Difference \\
\hline Domestic import & 67,51 & 83,9 & $16,39 * * *$ \\
\hline Foreign import & 32,5 & 16,1 & $16,38^{* * *}$ \\
\hline Export & 0,073 & 0,033 & $0,039 * *$ \\
\hline R\&D investments & 0,224 & 0,03 & $0,193^{* * *}$ \\
\hline Foreign presence & 0,09 & 0,04 & $0,05 * *$ \\
\hline Size & 142,8 & 87,4 & $55,4 * * *$ \\
\hline $\begin{array}{l}\text { Manufacturing and } \\
\text { non-manufacturing }\end{array}$ & 0,39 & 0,29 & $0,09 * *$ \\
\hline
\end{tabular}

Table 2: Descriptive Statistics ***Significant at the 0,01 level **Significant at the 0,05 level

Table 2 compares the mean values of innovator and non-innovator firms. As can be seen there are significant differences between both groups of firms. Innovators import and export more intensively than non-innovators. 
Interestingly, their imports are approximately double than those of non-innovators. As it was expected, noninnovators export and invest in R\&D significantly less than innovators. In our dataset there is a distinction between imports of domestic origin and imports of foreign origin. Domestic inputs are inputs from other districts but within the country and foreign origin inputs are inputs imported from abroad.

Figure 1 visually shows the composition of innovative firms by trade orientation. Unsurprisingly, the majority of importers are service sectors. However, they have a very low rate of innovation. The highest rate of innovation is observed in high technology sectors such as chemicals, electronics, machinery and equipment and fabricated metal products. The country exports considerably less than imports. Exporters are mostly represented by manufacturing sectors, for instance electronics, machinery and equipment, fabricate metal products, chemical and non-metallic product.

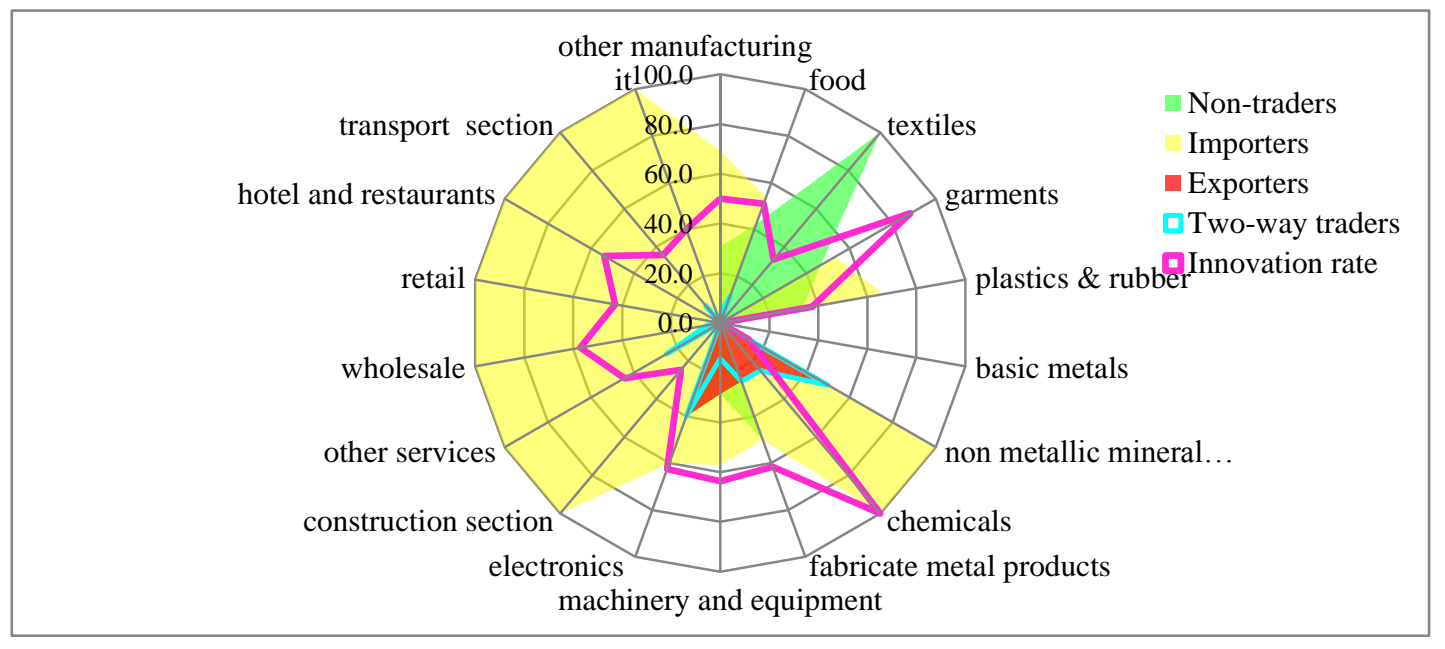

Figure 1: The Composition Of Innovative Firms By Trade Orientation

Table 3 represents the results of the regression analysis of determinants of innovation performance. As can be seen, imports of material inputs and supplies of foreign origin have a positive and highly significant impact on the introduction of innovation. However, domestic imports have a negative and significant effect on innovation performance. Both R\&D investments and the percentage of foreign imports are statistically significant. For each unit increase in foreign imports, the probit index of the predictor (introduction of innovation) increases by 0,007 . Similarly, for one unit increase in R\&D investments, the z-score of the predictor increases by 1,12 .

Although the coefficients of size, export and foreign ownership are positive, they are not important in the decision to introduce innovation. In contrast to theory, technological opportunity does not show a significant effect on innovation performance. Moreover, the coefficient has a negative sign.

\begin{tabular}{|l|l|l|}
\hline & First model & Second model \\
\hline Variable & Coefficient & Coefficient \\
\hline Domestic import & $-0.0071762^{* *}$ & \\
\hline Foreign import & $0.0071726^{* *}$ & 0.00 \\
\hline Export & 0.0434462 & -0.01 \\
\hline R\&D investments & $1.116533^{* *}$ & $1.45^{* * *}$ \\
\hline Foreign presence & 0.2866239 & $0.15^{* *}$ \\
\hline Size & 0.0012847 & $0.18^{* * *}$ \\
\hline Technological opportunity & -0.003 & \\
\hline Foreign technology & & 0.11 \\
\hline Intercept & $-0.3899152^{*}$ & 5.77 \\
\hline Dummy variable for 5 regions & & ------ \\
\hline Dummy variable for 18 sectors & & ------ \\
\hline Number of observations & 172 & 496 \\
\hline Likelihood Ratio & 28.99 & \\
\hline Pseudo $R^{2}$ & 0.1220 & \\
\hline Log Likelihood & -104.30523 & \\
\hline$R^{2}$ & & 0.22 \\
\hline Adj $R^{2}$ & & 0.17 \\
\hline
\end{tabular}

Table 3: Regression's Results 
The results of the second model show that foreign presence, as share in the ownership of company is positively correlated and significant with proportion of new product sales, in contrast to the introduction of innovation. In order to estimate the "pure" effect of explanatory variable on our dependent variable, we control sector and region differences. Until the control of region, the results show positive and significant effect of foreign import on our dependent variable. However, the variable of foreign presence does not change if other explanatory variables are introduced. Unsurprisingly, the variable of R\&D investment is highly significant and the increase of investments by 1 percent leads to the growth of new product sales by 1.5 percent approximately.

The foreign import does not influence on the firm's decision to sale new products, controlling for the East region. In contrast to the results at national level, the size is insignificant to the dependent variable. The foreign presence is positively and statistically significant correlated with the share of new product sales. This can lead to the conclusion that the most of innovative firms are large-size and foreign firms in the East Region.

\section{The Modes of Innovation}

The innovativeness of an organization depends on its prior accumulation of knowledge that makes possible to assimilate and exploit new knowledge. From this point of view, both cognitive and organizational learning play important roles.Two key models of innovation can be distinguished: the STI model and the DUI model. The first one is the Science, Technology and Innovations (STI) mode that relies on codified scientific knowledge. The other is the Doing, Using and Interacting (DUI) mode, based on tacit knowledge and collective knowledge.

All the improvements in machinery, however, have by no means been the inventions of those who had occasion to use the machines" (Smith, 1904). This phrase proves the crucial importance of the STI mode, especially in radical innovations. R\&D departments of big firms serve as key players in the STI mode. Usually, any $R \& D$ project is evoked by a practical problem. However, the primary search for a solution is based on the STI mode due to the availability of explicit knowledge, such as scientific publications or written recommendations. In order to communicate with scientists and scientific institutions it is needed to know their language in codified form. On the other hand, all research results have to be tested, and in this case the results have to be presented in an uncodified tacit form, the language of potential users. Then, it is not sufficient that the single scientist keeps results in his own memory as tacit knowledge ( Jensen, Johnson, Lorenz, \& Lundvall, 2007).

Social interactions, context and organizational environment are important for learning and knowledge creation. What makes the DUI mode crucially important as a key source of innovations? It is empirically proved that the successful innovation process involves interaction between people, departments or organizations. Steven Cohn (1980) has observed strong relationships between technical progressiveness and the openness of the formal interdepartmental communication structure. Since human knowledge is mainly tacit and subjective, it is difficult to codify and transfer it. Therefore, the transfer requires good functioning of social interactions, shared understanding and common interpretive schemes (Polanyi, 1966).

\begin{tabular}{|c|c|c|}
\hline & Indicators & \\
\hline 1 & $\begin{array}{l}\text { DUI-mode } \\
\text { Interdisciplinary } \\
\text { workgroups }\end{array}$ & 1 if the firm makes some use of interdisciplinary workgroups, 0 otherwise \\
\hline 2 & Quality circles & 1 if the firm makes some use of quality circles, 0 otherwise \\
\hline 3 & $\begin{array}{l}\text { System for collecting } \\
\text { proposals }\end{array}$ & $\begin{array}{l}1 \text { if the firm makes some use of system for collecting proposals, } 0 \\
\text { otherwise }\end{array}$ \\
\hline 4 & Autonomous groups & 1 if the firm makes some use of autonomous groups, 0 otherwise \\
\hline 5 & Integrations of functions & 1 if the firm makes some use of integrations of functions, 0 otherwise \\
\hline 6 & Softened demarcations & $\begin{array}{l}1 \text { if demarcation between employee grouping have become more indistinct } \\
\text { or invisible, o if they are unchanged or have become more distinct }\end{array}$ \\
\hline 7 & Cooperation with customers & $\begin{array}{l}1 \text { if the firm has developed closer cooperation with customers to a high } \\
\text { extent, } 0 \text { if to a small or medium extent or not at all }\end{array}$ \\
\hline 1 & $\begin{array}{l}\text { STI-mode } \\
\text { Expenditures on } R \& D \text { as a } \\
\text { share of total revenue }\end{array}$ & 1 if the firm's expenditure on R\&D are positive, 0 otherwise \\
\hline 2 & $\begin{array}{l}\text { Cooperation with } \\
\text { researchers }\end{array}$ & $\begin{array}{l}1 \text { if the firm cooperates with researchers attached to universities or } \\
\text { scientific institutes rarely, occasionally, frequently or always, } 0 \text { if it never } \\
\text { engages in these forms of cooperation }\end{array}$ \\
\hline
\end{tabular}

Table 4: Indicators Of STI And DUI Modes Source: Jensen, Johnson, Lorenz, \& Lundvall (2007)

The DUI model can be described in terms of organizational practice and organizational design. Certain types of organizational design and practice are more likely to yield superior innovative performance in a particular 
environment. They are more adapted to reduce or avoid transaction costs and cope with market failures. In contrast to the STI mode, the DUI mode does not pay a lot of attention to research-based knowledge. It focuses instead on experience and interactions. Employees combining their work experience with their previous education solve problems on the basis of teamwork and trial-and-error exercises. Usually, they rather cooperate with customers and suppliers than with research institutions and universities. Innovations in their majority are just incremental changes in already existing products and processes.

Nevertheless, we have to bear in mind that these two modes of innovation are theoretical concepts that do not exist in pure form in reality. Usually, industries combine in some proportion both models at the same time. The choice of methodology for our empirical analysis is based on that applied on the 2001 Danish DISKO Survey ( Jensen, Johnson, Lorenz, \& Lundvall, 2007). Methodology suggests using 7 and 2 indicators to measure the DUI-mode and STI-mode, respectively. The first six indicators of DUI model distinguish between rigid and bureaucratic organizations and more flexible and decentralized ones. Cooperation with customers reflects to which extent firms learn by interacting. Expenditure on R\&D and cooperation with researchers are the indicators of the STI-mode. Since the evaluation of the DUI-mode is a more complicated and difficult process, more indicators are applied. As it is shown on Table, variable have been coded for further statistical analysis.

Our empirical analysis is based on 419 firms in the East Region, including private and government sectors. The majority of the firms (85\%) present less than 50 employees. Medium size firms, from 51 to 250 employees, account to $9 \%$ of the firm population. Firms with more than 250 employees are the minority (6\%). We identified firms belonging to 11 sectors related to the metallurgical cluster. The half of total firms are classified as engaged in architecture and engineering activities, technical testing and analysis. East Kazakhstan is divided into 4 big cities and 15 administrative districts. The firms belonging to the metallurgical cluster are present in all four big cities and only nine districts. The largest share of firms is concentrated in the cities of Oskemen (54\%) and in Semey $(27 \%)$. At the initial stage, we identified 456 firms as belonging to the metallurgical cluster. During the research preparation stage and after interwieving some firms and specialists in this area, the number of firms was reduced to 388. Some firms were deleted due to being irrelevant to our cluster (34 firms). Twelve firms changed the sector where they operate in. Three firms moved into another district and ten are not active any more.

By 2011, nine firms ceased to exist, but 31 firms were created in the sectors identified as part of the metallurgical cluster. Therefore, we increased number of firms to 419 observations by adding 31 new firms.

We were able to contact only with 70 firms, to which we sent the questionnaire. Of these, we got an answer from 33 (i.e., a response rate of $48 \%$ ).

In order to categorize firms into different innovation modes, we have pursued hierarchical cluster analysis. The goal of cluster analysis is to have observations in the same group to be more alike than observations in the other groups. The hierarchical method of clustering gradually forms groups going from small to large. The process starts out with each observation considered as its own separate "group". Then, the closest two groups are merged into one group and this procedure continues until all observations belong to one group. The cluster tree in Figure 2 allows to visualize the results.

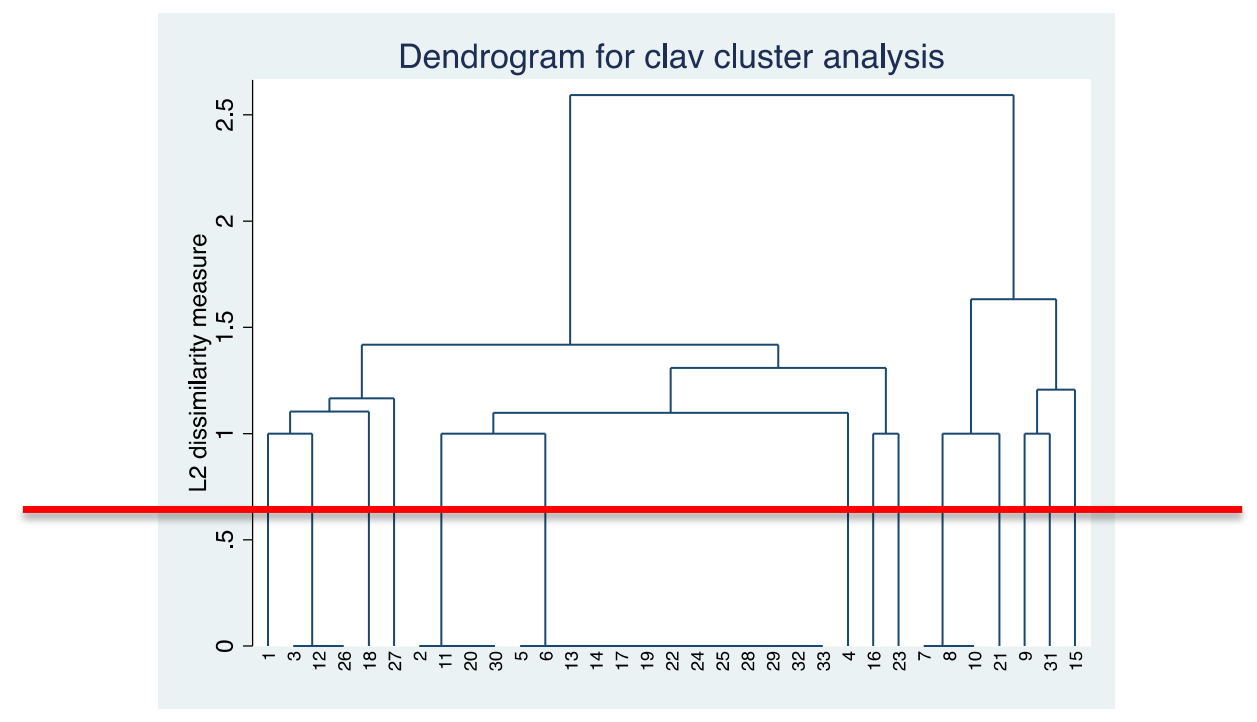

Figure 2: Cluster Tree Diagram

The most appropriate number of clusters is four. The low learning cluster includes 4 firms. This cluster join together firms that are neither have highly developed forms of DUI or STI modes. The group includes 5 firms 
that support DUI-learning and spend on R\&D and cooperate with researchers, so can be considered as tending to a pure DUI mode of innovation, while three other firms tend to a pure STI mode of innovation.

The majority of the firms, $60 \%$ of them, combine both modes of innovation. They use a mixed strategy of informal experience-based learning with activities that indicate a strong capacity to absorb and use codified and scientific knowledge.

\section{Conclusion}

Our analysis has produced some important findings. Firstly, high percentage of material inputs and supplies of foreign origin increases probability to introduce innovations. Nevertheless, the firms, importing domestically produced inputs, are less likely to innovate. According to theory, the import of foreign intermediate inputs is more than simply purchasing foreign goods and passively installing it. Whole process includes the development of technological capabilities to introduce new technologies developed abroad, to absorb and use them efficiently, and to adapt them to local conditions. In Kazakhstan, import facilitates the assimilation of skills and knowledge embodied in goods. As a result it enhance local capabilities, since it requires activities required to adopt, adapt, repair and commercialize new inputs. The results confirm that Kazakhstan innovate mostly absorbing new knowledge and technologies embodied in import. Import may involve the purchases of foreign intermediate inputs as well as the import of machinery and equipment. Therefore, reverse engineering and learning-by-doing may take place.

The second finding is that foreign imports and the presence of foreign ownership increase the ratio of new product sales. The explanation can be that imports are accompanied by the absorption of new knowledge and skills. The introduction of new products always requires some experience and practice in launching new production. Usually, purely or partly foreign ownership is associated with new knowledge and experience embodied in personnel. This significantly contributes to the introduction and commercialization of "new to firm" products. However, foreign presence is critical only to firms' capability to launch new product rather than to introduce innovation. This leads us to conclude that the firms with the high ratio of new product sales are mostly foreign companies.

The comparison of results at regional and national levels showed that imports do not influence firms' decisions to launch new product lines in the East region nor at national level. In both cases, foreign presence increases a firm's probability to introduce new products. Regression results indicated the insignificance of the size variable at the regional level, where most of the firms introducing new products are large.

Exports are only statistically significant in high-technology industries such as chemical, electronics, machinery and equipment, and fabricated metal products. The relationship between industry characteristics and the likelihood to innovate appears to be complex. The extent of technological opportunity, foreign ownership and firm size are not important determinants of innovation. However, a larger number of employees is associated with a higher probability to sell new products. Unsurprisingly, manufacturing industries innovate more than nonmanufacturing ones because they are more involved in international trade. The innovation performance of services industries and construction depends heavily on imports, which is also consistent with theory.

Our finding that firms in the low learning cluster are all firms with less than 50 employees supports the "Schumpeterian hypothesis" of the relative innovative advantage of large firms where markets are characterized by imperfect competition (Schumpeter, 1950). Since the innovation activity is positively correlated with R\&D expenditures, large firms invest and innovate intensively than small and medium size firms. The evidence from our analysis confirms that business $\mathrm{R} \& \mathrm{D}$ expenditure $(88 \%)$ are predominating over the public $\mathrm{R} \& \mathrm{D}$ expenditure.

Our findings are particularly important and relevant for metallurgical cluster. Mining and metallurgical sectors usually requires the large amounts of capital investments for long period of time under conditions of substantial technological, geological and market risk. Therefore, only large firm is able to take large up-front investments with long time of payback possibilities. Almost all firms in the low learning cluster belong to the Casting of other non-ferrous metals sector (code 24540). This can be explained by the technological nature of the sector, which is not technological intensive sector.

The majority of firms with employment higher than 250 employees adopted organizational practice designed to promote scientific and codified knowledge exchange, problem-solving and learning among their employees (DUI/STI modes). The small number of respondents does not give us opportunity to apply regression analysis in order to analyse the effect of learning modes on firm innovative performance, which might be an important topic for future research. Our research raised a number of problems caused by the lack of data and/or the interpretation of the data. For example, there are a large number of pseudo firms that seriously hampers the usefulness of the statistical information available. The high number of firms that do not actually exist may lead to an overestimation of the economic effect of the metallurgical cluster. Because of all this, it is difficult to achieve a meaningful description of the economic processes occurring in the East Region, so we want to conclude this 
paper with a note of caution regarding statistical data in Kazakhstan. They should be treated with care, taking into account the particularities involved in gathering data about transition economies.

\section{References}

- Cuneo, P., \& Mairesse, J. (1984). Productivity and R\&D at the frim level in French manufactruring. En Z. Griliches, $R \& D$, patents, and productivity (págs. 393-416). Chicago, US: University of Chicago Press.

- Jensen, M., Johnson, B., Lorenz, E., \& Lundvall, B. (2007). Forms of knowledge and modes of innovation. Research Policy .

- Şeker, M. (2009). Importing, Exporting and Innovation in Developing Countries. The World Bank. Research Working Paper 5156.

- Aitken, B. J., \& Harrison, A. (1999). Do domestic firms benefit from direct foreign investments? Evidence from Venezuela. The American Economic Review , 89 (3), 605-618.

- Amiti, M., \& Konings, J. (2005). Trade liberalization, intermediate inputs, and productivity: Evidence from Indonesia. IMF Working Paper .

- Archibugi, D., \& Pianta, M. (1996). Measuring technological change through patents and innovation surveys. Technovation, 16 (9), 451-468.

- Aw, B. Y., Roberts, M., \& Winston, T. (2007). Export market participation, investments in R\&D and worker training, and the evolution of firm productivity. The world economy.

- Baldwin, J. R., \& Sabourin, D. (1999). Innovative Activity in Canadian Food Processing Establishments: The Importance of Engineering Practices. International Journal of Technology Management .

- Baldwin, J. R., \& Wulong Gu. (2004). Trade Liberalization: Export-market Participation, Productivity Growth and Innovation. Oxford Review of Economic Policy, 20, 372-92.

- Biesebroeck, J. V. (2005). Exporting raises productivity in sub-Saharan African manufacturing firms. Journal of International Economics , 67, 373-391.

- Blalock, G., \& Gertler, P. (2004). Learning from Exporting Revisited in a Less Developed Setting. Journal of Development Economics , 75, 397-416.

- Blalock, G., \& Veloso, F. (2007). Import, productivity growth, and supply chain learning. World development , 35 (7), 1134-1151.

- Blomstrom, M., \& Kokko, A. (1998). Multinational corporations and spillovers. Journal of economic surveys , 12 (3), 247-277.

- Branstetter, L. (2006). Is foreign direct investment a channel of knowledge spillovers? Evidence from Japan's FDI in the United States. Journal of International Economics , 68, 325-344.

- Burns, T., \& Stalker, G. M. (1961). Management of innovation. London: Tavistock.

- Cheung, K.-y., \& Lin, P. (2004). Spillover effects of FDI on innovation in China: Evidence from the provincial data. China Economic Review , 15 (1), 25-44.

- Cohen, W. M. (2010). Fifty years of empirical studies of innovative activity and performance. In B. H. Hall, \& N. Rosenberg, Handbooks in Economics. Economics of innovation. (p. 131-213). Amsterdam: Elsevier.

- Cohen, W. M., \& Klepper, S. (1996). A reprise of size and R\&D. The Economic Journal , 106 (437), 925951.

- Cohn, S. (1980). Characteristics of technically progressive firms. The National Science Foundation, 8 (4), 441-450.

- Connolly, M. (2003). The dual nature of trade: measuring its impact on imitation and growth. Journal of Development Economics , 72, 31-55.

- Connolly, M., \& Valderrama, D. (2000). North-South Technological Diffusion and Dynamic Gains from Trade. Working Papers No. 99-08

- Doing business . (2013), http://www.doingbusiness.org/data/exploreeconomies/kazakhstan/

- Feinberg, S., \& Majumdar, S. (2001). Technology spillovers from foreign direct investments in the Indian pharmaceutical industry. Journal of international business studies , 32 (2), 421-437.

- Geroski, P. A. (1990). Innovation,technological opportunity, and market structure. Oxford economic papers , $42(3), 586-602$.

- Girma, A. S., Gong , Y., Görg, H., \& Lancheros, S. (2012). Foreign ownership structure, technology upgrading and exports: Evidence from Chinese firms . Kiel Working Paper 1793 
- $\quad$ Griffith, R., Redding, S., \& Reenen, J. (2004). Mapping the Two Faces of R\&D: Productivity Growth in a Panel of OECD Industries. Review of Economics and Statistics , 86 (4).

- Griliches, Z. (1979). Issues in Assessing the Contribution of Research and Development to Productivity Growth. The Bell Journal of Economics , 10 (1), 92-116.

- Grossman, G. M., \& Helpman, E. (1993). Innovation and growth in the global economy. Cambridge, England: The MIT Press.

- Grossman, G., \& Helpman, E. (1990). Trade, knowledge spillover and growth. Working Paper \# 3485

- Hall, B. H., \& Mairesse, J. (1995). Exploring the relationship between R\&D and productivity in French manufacturing firms. Journal of econometrics , 263-293.

- Halpern, L., \& Miklós Koren. (2005). Imports and Productivity. CEPR Discussion Paper No. 5139

- Innovation performance of firms in manufacturing industry: Evidence from Belgium, (2007). Government Institute for economic research, http://www.vatt.fi

- Jaffe, A. (1986). Technological opportunity and spillovers of R\&D: Evidence from firms 'patents, profit, and market value. The American Economic Review , 76 (5), 984-1001.

- Kafouros, M. I. (2008). Industrial innovation and firm performance. The impact of scientific knowledge on multinational corporations. Cheltenham, UK: Edward Elgar.

- $\quad$ Kafouros, M., \& Buckley, P. (2008). Under what conditions do firms benefit from the research efforts of other organisations? Research Policy, 37, 225-239.

- Karlsen, J., \& Isaksen, A. (2010). Different Modes of Innovation and the Challenge of Connecting Universities and Industry: Case Studies of Two Regional Industries in Norway. European Planning Studies , 18 (12).

- Kazkhstan country profile 2009. (2009). The world bank: http://www.enterprisesurveys.org

- Keller, W., \& Stephen R. Yeaple. (2003). Multinational enterprises, intenational trade, and productivity growth: Firm level evidence from the United States. NBER Working Paper 9504

- Klepper, S. (1996). Entry, exit, growth, and innovation over the product life cycle. The American Economic Review , 86 (3), 562-583.

- Klette, T. J. (1996). R\&D, Scope Economies, and Plant Performance. The RAND Journal of Economics, 27 (3).

- $\quad$ Klevorick, A., Levin, R., Nelson, R., \& Winter, S. (1995). On the sources and significance of interindustry defferences in technological opportinities. Research Policy, 24, 185-205.

- Kumar, N., \& Aggarwal, A. (2005). Liberalization, outward orientation and in-house R\&D activity of multinational and local firms: A quantative exploration for Indian manufacturing. Research policy , 34, 441460.

- Lam, A. (2004). “Organisational Innovation”. In Fagerberg, J., Mowery, D. and Nelson, R., Handbook of Innovation (115-148). Oxford University Press, Oxford.

- Laursen, K., \& Foss, N. J. (2003). New human resource management practices, complementarities and the impact on innovation performance. Cambridge Journal of Economics , 27, 243-263.

- Lawler, E. E. (1986). Click on any of the links below to perform a new search. (P. 3. Jossey-Bass Inc., Ed.) San Francisco.

- Lawrence, P., \& Lorsch, , J. (1967). Differentiation and Integration in Complex Organizations. Administrative Science Quarterly, , 10 (5), 519-534.

- Lee, C. (2004). Determinants of innovation in the Malaysian manufacturing sector: An empirical analysis at the firm level. ASEAN Economic Bulletin , 21 (3), 319-329.

- Lee, C., \& Ging, L. (2007). SME innovation in the Malaysian manufacturing sector. Economic bulletin, 12 (30), 1-12.

- Levin, R., \& Reiss, P. (1984). Tests of a Shumpeterian model of R\&D and market structure. In Z. Gliliches, R\&D, patents, and productivity (p. 175-208). Chicago: University of Chicago press.

- $\quad$ Lipsey, R. E., \& Sjoholm. (2005). Host country impacts of inward FDI: Why such different answers? In T. Moran, E. Graham, \& M. Blomstorm, Does foreign direct im;nvestments promote development? (p. 23-42). Wachington: Center for global development.

- Liu, X., \& Buck, T. (2006). Innovation performance and channels for international technology spillovers: Evidence from Chinese high-tech industries. Research Policy, 36, 355-366. 
- $\quad$ Liu, X., \& Buck, T. (2007). Innovation performance and channels for international technology spillovers: Evidence from Chinese high-tech industries. Research policy, 355-366.

- Lu, Y., \& Ng, T. (2012). Do imports spur incremental innovation in the South? China Economic Review , 23 (4), 819-832.

- Lundvall, \& Johnson, B. (1994). The learning economy. Journal of Industry Studies , 1 (2), 23-42.

- MacGravie, M. (2006). Do firms learn from internationall trade? Review of Economics and statistics , 88, 46-60.

- Mairesse, J., \& Mohnen, P. (2002). Accounting for innovation and measuring innovativness: An Illustrative framework and an application. . The economics of technology and innovation. , 92 (2).

- Mansfield, E., \& Romeo, A. (1980). Technology transfer to overseas subsidiaries by U.S.- based firms. The Quarterly Journal of Economics , 95 (4), 737-750.

- Massey, D., Wield, D., \& Quintas, P. (1992). High-Tech Fantasies: Science Parks in Society, Science and Space. London: Routledge.

- Mintzberg, H. (1979). The Structuring of Organizations. Englewood Cliffs, N.J.: Prentice Hall.

- Muuls, M., \& Pisu, M. (2007). Imports and exports at the level of the firm: Evidence from Belgium. National Bank of Belgium, http://.nbb.be

- Nelson, R. (2004). The market economy and the scientific commons. Research Policy, 33, 455-471.

- Nonaka, \& Takeuchi, H. (1995). The Knowledge Creating Company. New York:: Oxford University Press.

- Nonaka, I. (1994). A Dynamic Theory of Organizational Knowledge Creation (Vol. 5). Tokyo: Organization Science.

- Polanyi, M. (1966). The tacit dimension. New York: Anchor Day Books.

- $\quad$ Rhee, Y. W., Ross-Larson, B., \& Pursell, G. (1984). Korea’s Competitive Edge: Managing the Entry into World Markets. Baltimore: World Bank by the Johns Hopkins University Press.

- Rodriguez, J. L., \& Rodriguez, R. G. (2005). Technology and export behaviour: A resource-based view approach. International Business Review , 14, 539-557.

- Running a business in Kazakhstan. (2011). The World Bank, http://www.enterprisesurveys.org

- Saggi, K. (May de 2000). Trade, foreign direct investments, and international technology transfer. Policy research working paper $N 2349$.

- Salomon, R., \& Shaver, M. (2005). Learning by exporting: New insights from examing firm innovation. Journal of economics , 14 (2), 431-460.

- Scherer, F. M. (1965). Firm size, market structure, opportunity, and the output of patented inventions. The American Economic Review , 55 (5), 1097-1125.

- Schumpeter, J. A. (1950). Capitalism, Socialism and Democracy, third edition. New York: Harper and Row.

- Shrieves, R. E. (1978). Market structure and innovation: A new perspective. The journal of industrial economics , 26 (4), 329-347.

- Smeets, R. (2008). Collecting the pieces of the FDI knowldge spillovers puzzle. Research Observer, 23 , 107-138.

- Smith, A. (1904). An Inquiry into the Nature and Causes of the Wealth of Nations,. (E. Cannan, Ed.) London: Methuen and Co., Ltd.,.

- Solomon, R., \& Byungchae, J. (2008). Does knowledge spill to leaders or laggards? Exploring industry heterogenity in learning by exporting. Journal of intrenational business studies (39), 132-150.

- Taalikka, S. (2002). Factors Affecting Innovation Adoption in Organizations: The Case of Corporate Website Adoption. Lappeenranta. Lappeenranta University of Technology Master's Thesis.

- Teece, D. J. (2010). Technological innovation and the theory of the firm: The role of enterprise-level knowledge, complementarities and (dynamic) capabilities. In B. H. Hall, \& N. Rossenberg, Handbooks in economics (p. 679-730). Amsterdam: Elsevier.

- The Agency of Statistics of the Republic of Kazkhstan, http://www.eng.stat.kz

- $\quad$ The World Bank, 2009. Description of Kazakhstan implementation 2009, http://microdata.worldbank.org/index.php/catalog/182

- The World Bank, 2009, http://data.worldbank.org/indicator/GB.XPD.RSDV.GD.ZS

- The World Bank. Global Statistical Strategy, http://data.worldbank.org/about/data-overview/globalstatistical-strategy 
- Vernon, R. (1966). International Investment and International Trade in the Product Cycle. The Quarterly Journal of Economics , 80 (2), 190-207.

- Walsh, J., \& Ungson, G.R. (1991). Organizational Memory (Vol. 16). The Academy of Management Review.

- Walton, R. (1985). From control to commitment in the workplace. Harward Business Review, 632, 77-84.

- Wang, C., \& Kafouros, M. (2009). What factors determine innovation performance in emerging economies? Evidence from China. International business review , 18, 606-616.

- Wood, S., \& Menezes, L. (1998). High commitment management in the UK: evidence from the Workplace Industrial Relations Survey, adn Employers. Human Relations , 51, 485-515. 


\title{
Allegories and Realities of Innovative China: The Case of Haier
}

\author{
Asst. Prof. Dr. Farrukh Kayani (COMSATS Institute of Information Technology, Pakistan)
}

\begin{abstract}
It is well recognized phenomenon that innovations are a strategic weapon for economic growth and they have played an important role in the industrialization of developing countries during the last few decades. Because of the conventional thought that China produces sub-standard goods; the term innovative China sounds like a myth. But in reality China has made tremendous progress in producing innovated goods. To support this view, in this paper, we have thoroughly discussed the case of Haier Company. Haier is one of the very successful stories of Chinese companies which absorbed the foreign technology and climbed up the technological ladder. The innovation target of Haier is very ambitious: two successful intellectual patent applications every work day. By building this firm innovation foundation, Haier was able to aggressively enter and establish a repute in the global appliance market.
\end{abstract}

\section{Introduction}

The Social Economic Zones (SEZs) have gained huge importance in this era of globalization as countries are shifting from import substitution strategies to export promotion policies. SEZs are geographically separate small areas of a country where governments provide special fiscal and financial incentives to foreign and domestic firms for boosting the exports. Developing countries offer various kinds of incentive packages to attract Multinational Corporations (MNCs) from developed and middle-income countries. These incentives are usually divided into "soft" and "hard" ones (Kusago and Tzannatos, 1998). In 1978, the Chinese government decided to move away from Soviet-style economic policies and to gradually reform the economy towards free market principles.

(Wong, 1987) mentioned that countries establish SEZs for employment creation, technology up-grading and foreign exchange earnings. SEZs as a means of attracting foreign investment and technology along with promoting Chinese exports. By granting special investment incentives to foreign investors, it was hoped that an export-oriented industrial base might be created in the SEZs via foreign capital and technology. Many of these privileges were also extended to domestic firms to encourage their participation in the SEZs and thereby increase their contact with foreign technology and managerial skills.

(Aggarwal, 2007) has discussed three aspects of SEZs i.e. employment generation, skill (human capital) formation and technology up gradation. Each aspect exerts two types of effects i.e. direct and indirect. For instance, the employment would be directly generated when the SEZs would hire labor. The indirect employment would be generated through the demand for complementary goods. Similarly, the skill formation effect operates directly when they acquire the skills by working in the SEZs. The spillover effects would take place through the movement of workers to domestic firms. The SEZs would also result into technology transfer to domestic firms.

(Johanson and Vahlne, 1977) stated that with the increasing internationalization, lots of businesses are emerging on the globe. For firms, to survive and to earn a leading role in the fierce competition, unremitting innovations are of immense importance. A number of studies in international business field show that the internationalization of a firm is an incremental process, that is, a firm should gradually increase its international involvement. There are several theories that focus on internationalization process of a firm on "its gradual acquisition, integration and uses of knowledge about foreign markets and operations and on its successively increasing commitment to foreign markets".

Haier is the single most extensive producer of exhaustive family machines in China. It has developed from a minor undertaking to being one of the advancing family apparatuses of China. In 2007, Haier had worldwide sales of worth RMB 118 billion and it employs 50,000 individuals worldwide.

The overall sale pattern of Haier Electronics Company, for the years 2008 to 2012 is provided along with forecasted sale in the same year as well as for the years 2013 and 2014, is provided in Figure 1.

We see an upward trend which shows an increase in sales. The forecast till year 2012 is very close to the actual sale, which shows the accuracy of the forecast sales. For the subsequent years after the year 2012, we expect the same pattern of the Haier's sales..

Haier has been the business guide in the Chinese family electrical machine industry, with a piece of the pie of $21 \%$ for generally speaking apparatuses, $34 \%$ for white merchandise and $14 \%$ for modest electrical machines. 
TOTAL ASSETS

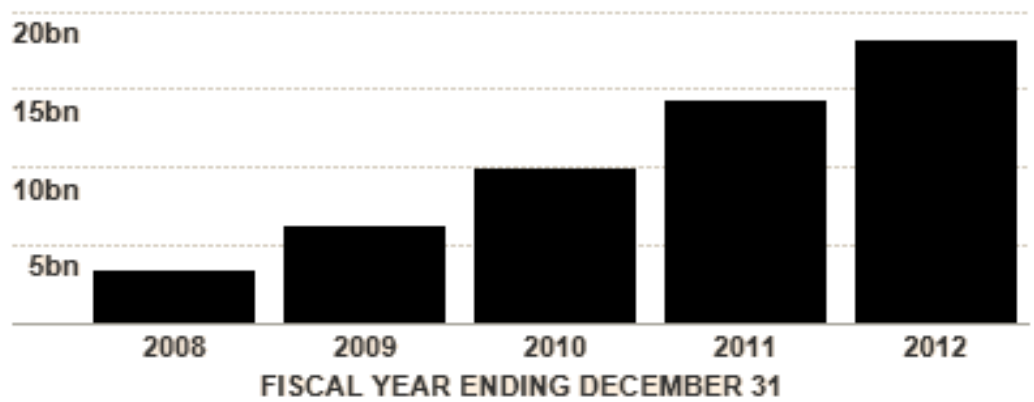

Figure 1: Asset Trends over time (2008-2012) Source: http://markets.ft.com/ TOTAL DEBT

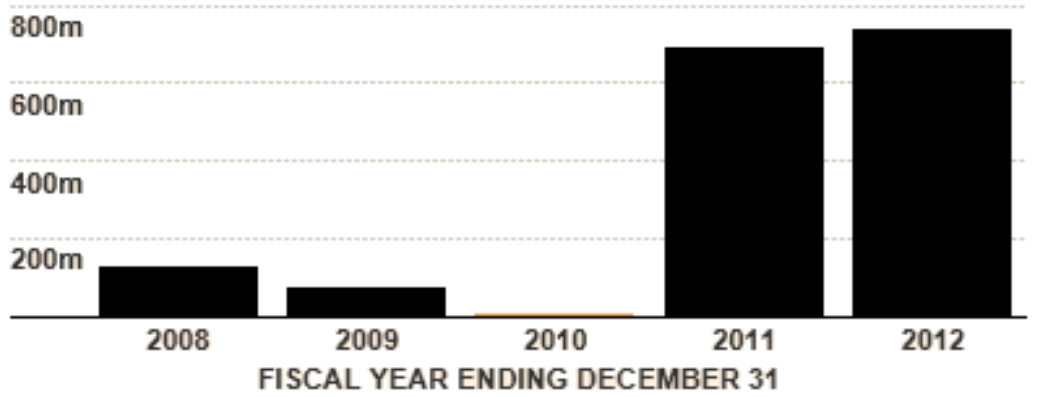

Figure 2: Total Debt Trends over time (2008-2012)

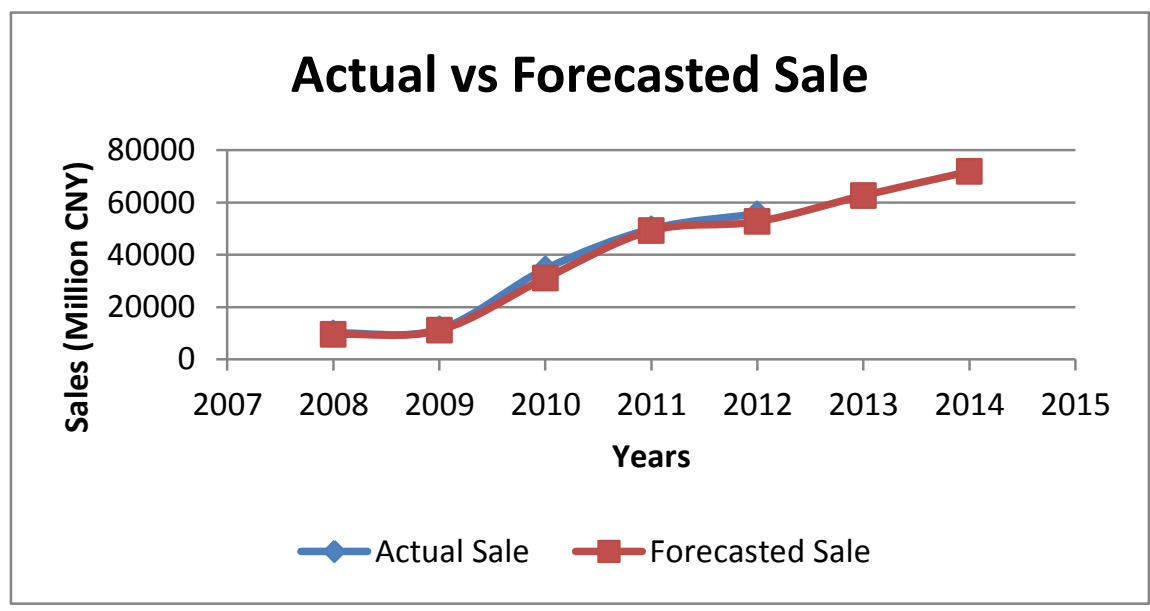

Figure 3: Actual vs Forecasted Annual Sales (2007-2015) Source: http://www.4-traders.com/

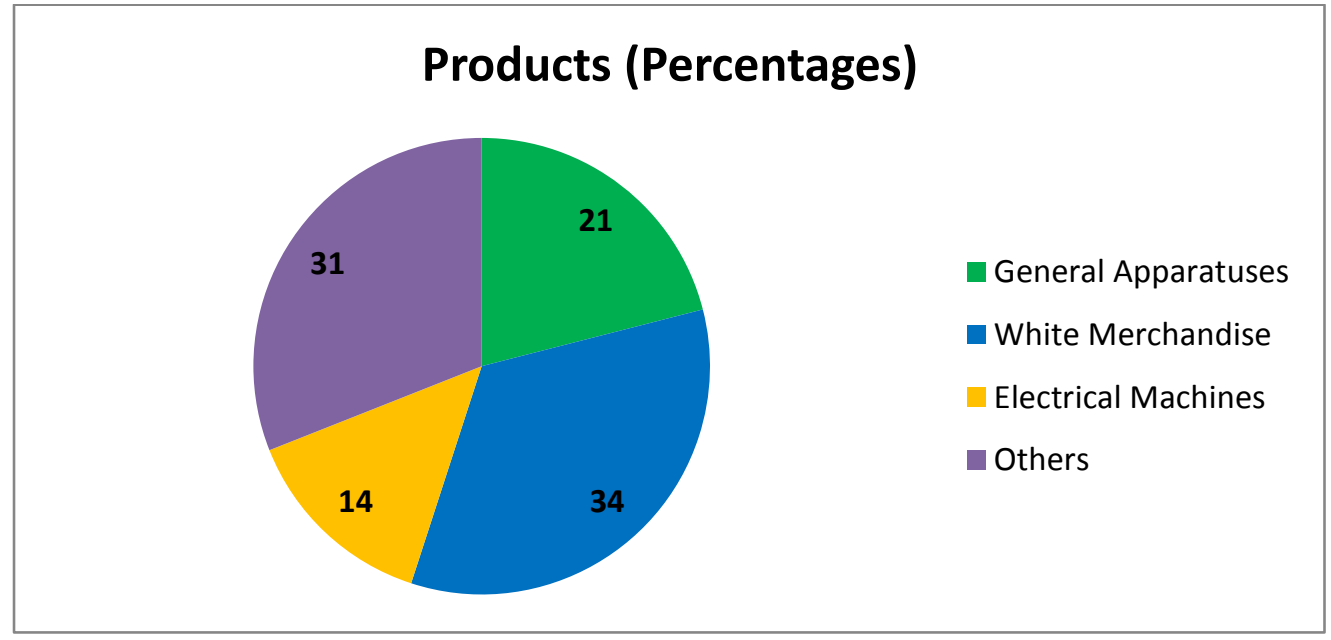


Today it makes about 15,100 feature mixed bags in 96 item lines. Over the period of time, Haier has not just upgraded the value but aid, objective and innovative proficiencies as well. In 1993, nine years following its establishment, Haier was certain enough to start a worldwide IPO. The role of present CEO of Haier in upgrading the quality of products is obvious. His order of destruction of 76 defective refrigerators was a symbolic step of moving towards quality production.

In 2003, the Haier brand topped all Chinese trademarks in a nationwide survey. The Chinese Fortune Magazine (issue 8/2004) appraised Haier the second in their catalogue of most obviously appreciated ensembles in China. In this rating Haier was observed as number one in the fields of administration display, development capacity and social obligation. In 2004, Haier was distinguished as one of the World's 100 Most Recognizable Brands in a worldwide name mark post altered by the World Brand Laboratory 10.

As per 2006 Euro-monitor statistics on outfit bargains, Haier has the most extensive planet business sector mark impart for fridges, and it is the fourth right around the worldwide white merchandise makers. Among 2003 and 2006, Haier ranked first in terms of the most part initiative right around terrain Chinese ensembles in the Wall Street Journal Asia's anniversary study of Asia's 200 Most Admired Companies. In 2008, Haier ranked 13th on Forbes' Reputation Institute Global 200 record. In addition in the same year, Haier ranked first around Chinese endeavors on the Financial Times record of the most exceptionally regarded worldwide teams (Duysters, Jacob, Lemmens and Jintian 2010). This short article thoroughly discusses the historical development, diversification process and globalization strategies of Haier Company in China.

\section{Haier's Historical Development}

Haier group started to work in 1992 by renaming the Qingdao Refrigerator plant which was shaped in 1984. In 1984 an organization together with Liebherr was created following a watchful assessment of 32 potential agreeable confederates. Haier transported in Liebherr's four-star fridge processing innovation and gear to China. Liebherr had 70 years of interaction in generating brilliant fridges. The Chinese features were a few star advances and obsolete-formed with a solidifying ability of - 12 degree Celsius. The solidifying ability of Liebherr's four-star innovation was - 18 degree Celsius. Haier ended up being the just Chinese ensemble to give four-star refrigerator mechanics following the partnership with Liebherr.

Following collusion, Haier sent above and beyond 40 of its beat engineers and managers to Liebherr for developing. Liebherr authenticated to be a truly fruitful teaching establishment for Haier's beat R\&D talents. They concentrated on the growth of four-star refrigerator, and possibly aced the crux innovative aptitudes needed for improving progressed fridges. In 1985, a year following it permitted Liebherr's engineering, Haier was fit to present its first four-star icebox in the Chinese business. This feature immediately secured Haier as the advancing refrigerator maker in China.

\section{The Process of Haier's Diversification}

In 1991, Haier started to diversify. Haier also started to produce air-conditioners and freezers besides refrigerators. Haier took three years to establish repute in these two industries. In 1991, the sales and profits of Haier were RMB 724 million and RMB 31.2 million respectively. Whereas in 1994, Haier's sales and profits had grown to RMB 2.56 billion and to RMB 200 million respectively. Subsequently, Haier developed washing machines, microwave ovens and water heaters. In 1997, Haier entered into the production of black household appliances. Table 1 summarizes the processes of Haier's diversification over the time.

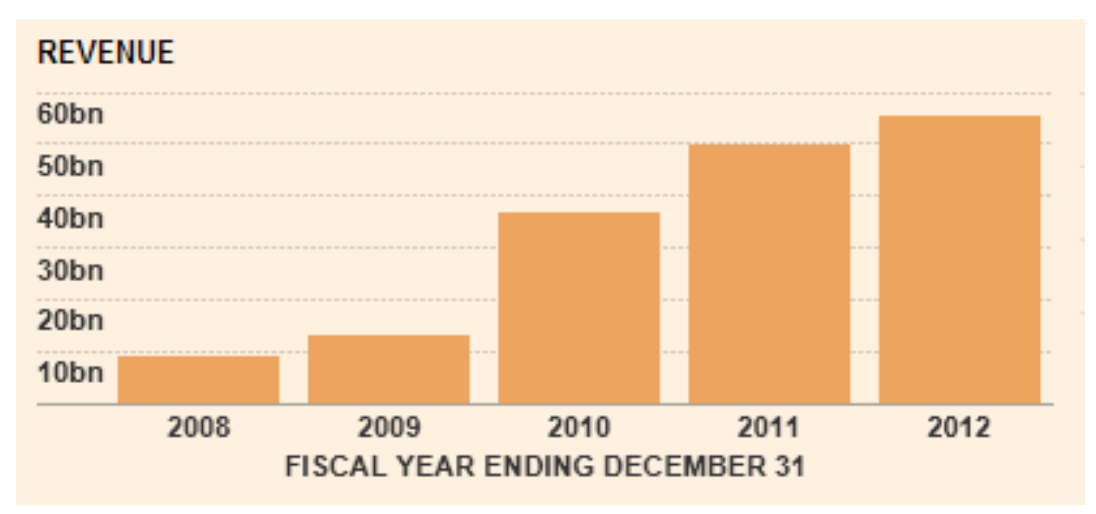

Figure 4: Revenue over the time (2008-2012) Source: http://markets.ft.com/ 


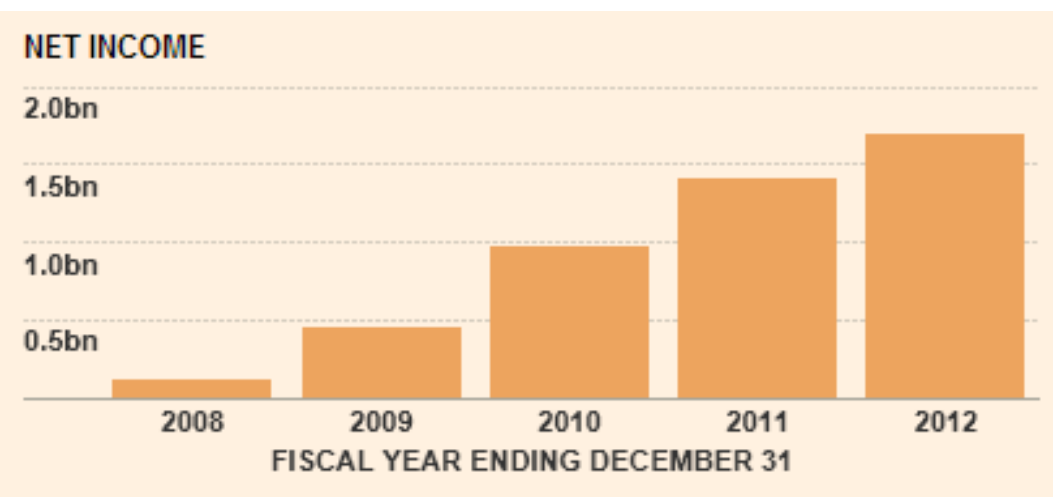

Figure 5: Net Income over the time (2008-2012) Source: http://markets.ft.com/

\begin{tabular}{llll}
\hline Stage & Period & Diversification Area & Procedure \\
\hline 1 & 1984-Dec 1991 & Refrigerators & $\begin{array}{l}\text { Imported refrigerator technology from Liebherr } \\
\text { Company of Germany. }\end{array}$ \\
\hline 2 & Dec. 1991- Jul.1995 & $\begin{array}{l}\text { Freezers } \\
\text { Air-conditioners }\end{array}$ & $\begin{array}{l}\text { Acquired Qingdao Freezer General Plant and } \\
\text { Qingdao Air-conditioner Plant. }\end{array}$ \\
\hline 3 & July.1995-Aug.1995 & $\begin{array}{l}\text { Washing machines } \\
\text { Microwave ovens } \\
\text { Water Heaters }\end{array}$ & $\begin{array}{l}\text { Acquired Red Star Electric Appliance Factory and } \\
\text { established a joint venture with Laiyang of } \\
\text { Shandong Household Appliance General Plant. }\end{array}$ \\
\hline 5 & Sept. 1997 & $\begin{array}{l}\text { Black household } \\
\text { Appliances }\end{array}$ & $\begin{array}{l}\text { Established a joint venture with West Lake of } \\
\text { Hangzhou Electric Group. }\end{array}$ \\
\hline 5 & \multirow{2}{*}{ Knowledge sectors } & $\begin{array}{l}\text { Formed technology cooperation with many external } \\
\text { organizations }\end{array}$ \\
\hline
\end{tabular}

Table 1: The Stages of Haier's Diversification Source: Sun (2002) Yan and Hu (2001) and Duysters, Jacob, Lemmens and Jintian (2010)

\section{Provision of Services by Haier}

With the idea of "customers as the foundation of growth", Haier furnishes a one-stop star aid to its clients. In a joint review directed by the China Consumer Association and the China Enterprise Research Centre of Tsinghua University on China's domesticated sturdy items for 2003 and 2004, eight of Haier's feature classifications were ranked No. 1 for client fulfillment and for the most part fulfillment. Notwithstanding excellent home apparatuses, Haier is additionally centered on offering greatest-of-breed aid answers to its clients. Haier's aid framework runs all through the preparation method from item plan, preparation, assembling, to pre-deal, under deals and following deals fix. Inasmuch as 2002, Haier has efficaciously secured an arrangement of over 5,000 household pro aid suppliers to transport auspicious redid utility.

\begin{tabular}{|l|l|l|l|l|l|}
\hline USA & Europe & South Asia & ASEAN & Middle East & Africa \\
\hline & Germany & India & Thailand & Jordan & Tunisia \\
\hline & Italy & Pakistan & Indonesia & & Nigeria \\
\hline & Holland & Bangladesh & Philippines & & Egypt \\
\hline & Denmark & Sri Lanka & Malaysia & & Algeria \\
\hline & Romania & & & & South Africa \\
\hline & Ukraine & & & & \\
\hline
\end{tabular}

Table 2: Foreign Operations of Haier

\section{Internationalization Strategies}

Haier is the first Chinese firm to buy a fridge production line in the European Household apparatus segment. It made the first European acquisition in 2001 by getting refrigerator manufacturing plant in Italy. The reason for this acquisition is to enhance range and production capacity. Haier has several abroad modern stops in the United 
States, Pakistan and Jordan. In particular, it has 30 abroad plants and 58,800 deals executors worldwide. It sends out its items to more than 130 nations in Europe, Asia, Middle East and North America. The predominant production plant of Haier was in Yugoslavia under a joint wander with a neighborhood community. Haier is transforming coolers, freezers, clothes washers, dishwashers, microwave broilers and modest machines for the European business. European and North American business sectors elucidate about 60 percent of Haier's fares. In Asia, it has engaged in the business sectors of Indonesia, Philippine, Malaysia, United Arab Emirates, Algeria, Bangladesh and Iran through joint ventures.

Haier has received a few guidelines for its globalization policy. Under this guideline, one-third of its features are both handled and sold in its home nation and the other on one-third of the items are handled in home nation but sold abroad, and rest of the items are both handled and sold abroad. Under the worldwide extension procedure, Haier's method is to move from challenge to simplicity i.e. dropping in additional propelled business sectors first. It is vital to drop in the more progressed businesses first with a specific end goal, which is to increase more brand recognition.

In the European Union, Haier entered in the German business sector first. Germany is recognized as a troublesome business sector to enter in. Scrutinize systems possess a foremost place in the development and innovative advancements of any immovable. In this respect Haier has engaged in accommodating scrutinize systems with acclaimed unfamiliar firms. The proposed helpful systems furnish Haier qualified information about global slants in innovation improvement. Haier's worldwide mechanics cooperation compass Tokyo, Los Angeles, Montreal, Lyons, Seoul, Sydney and Amsterdam. The accommodating associates of Haier incorporate Toshiba, Mitsubishi, ESS, Philips, Metz and Lucent.

\section{Haier's Secret of Success}

Haier's success lies in the careful positioning of the products rather than only selling its products at the lowest possible prices. The products that accommodate the local specificities were made along with the identification of the niche markets. They are a lot of examples where Haier's products accommodated the local requirements. In Indonesia, Haier presented power saving adaptable-voltage apparatuses due to nation's capacity deficiencies and voltage variances. Haier presented a fridge with fold-out table in United States so as to target the scholars who are residing in dorms.

In China, Haier advanced a clothes washer that washes both the garments and vegetables. This model is offered to target the people of country territories. In France and Italy, Haier first sold out the iceboxes in light of strategic explanation. As the ventilation system business sector being comparatively a brand new mark was not imperative. The different item lines for example iceboxes and clothes washers were presented later following making its mark. Haier additionally presented brand new classes of products similarly as wine cellar room for American market. At first, Haier confronted weighty challenges in influencing the clients regarding the handiness of this feature. Anyway, now Haier's this item has a stupendous demand in the American businesses.

\section{Conclusion}

The products of Haier are sold in over 100 nations. The sales of Haier's production are about RMB 118 billion and it employees more than 50,000 workers across the world. Haier with its innovation spirit is a pioneer of Chinese enterprises globalization and brand building. Haier has emerged into a hefty multinational corporation, and it keeps on expanding its business in China as well as in abroad, such as North America, Europe, and Asia. Over the passage of time, Haier has advanced a noteworthy international R\&D system. The ambitiousness of Haier's plan is reflected in its innovation target: two successful intellectual patent applications every work day.

\section{References}

- Aggarwal, A, 2007, “Impact of Social Economic Zones on Employment, Poverty and Human Development”'Indian Council for Research on International Economic Relations, Working Paper No 194.

- Duysters, G., Jojo, J., Charmianne, L., and Yu, J., 2010, "Internationalization and Technological Catching up of Emerging Multinationals: A Comparative Case Study of China's Haier Group", Industrial and Corporate Change, 18 (2), 325-349.

- Ernst, D., 2003, "Pathways to Innovation in the Network Global Economy: Asian Upgrading Strategies in the Electronics Industry” East-West Center Working Papers, No. 58.

- Johanson, J. and Vahlne, J. E., 1977, “The Internationalization Process of the Firm: A Model of Knowledge Development and Increasing Foreign Market Commitments", Journal Of International Business Studies, 8 (1), 32-44.

- Johanson, J. and Vahlne, J. E., 2001, “The Mechanism of Internationalization”, International Market Review, 7 (4), 11-24. 
- Johanson, J. and Vahlne, J. E., 2003, "Business Relationship Learning and Commitment in the Internationalization Process", Journal of International Entrepreneurship, 1, 83-101.

- Kusago,T and Tzannatos Z, 1998, "Export Processing Zones: A Review in need of Update” Social Protection Discussion Paper No 9802.

- Paul, D. and Li, J., 2008, "From Made in China to Invented in China" Bain and Company.

- Shah, S. G. W., 2009, "Internationalization and Innovation: The Case of Haier" School of Sustainable Development of Society and Technology MIMA-International Business and Entrepreneurship EFO 705 Master Thesis.

- Sun, J. (2002), The Company Strategy of Haier, The Enterprise Management Press, China: Beijing.

- Swedberg R, ed., 2003, Entrepreneurship. The social science view, Oxford University Press, Oxford.

- Yan, J. and B.Hu (2001), China’s Haier. Hainan of China Press: Haikou. 


\title{
Opinions on the Political Economy of the New Turkish Healthcare System
}

\author{
Prof. Dr. Aysegül Kaptanoğlu (Trakya University, Turkey)
}

\begin{abstract}
Turkish health care system is going on health care transitions nowadays. Fundamental role of government in providing, financing and managing public services, including health care are changed. Health care marketers insist that competition and aggressive management will raise health care productivity. Health economist suggests that health is a public service and has a value. The Health Care System in Turkey is financed by public funds, compulsory insurance premiums and delivered $(90 \%)$ by The Ministry of Health $(\mathrm{MoH})$ that also manages the system. For the sustainability of universal access to health care special insurance programs according the rule of political economy should be built. Poor and severe ill people who cannot work and elderly may not get access to public medical insurance. So, for contributing to the nationwide public health care system rich people could give some extra insurance premium and obtain additional private insurance as well. Referral chain might be established in the country in between primary, secondary and tertiary care.
\end{abstract}

\section{Introduction}

The purpose of this article is to draw up a brief global picture of political health economy in Turkey. In order to understand what is going on Turkish Health care system, there is a need for closer look to the context. Turkish Ministry of Health has initiated the Health Transition Program. "Health Transformation Programme" launched by the Turkish Government in 2003. Structural deficiencies of health care system were universal health insurance, access and quality of healthcare services for all citizens in needs, the strong establishment of the Primary Health Care Network via family practice. By this way the role of the Ministry of Health, change of the legislative environment, autonomy of healthcare facilities, capacity building and health professional training, health information systems as well as drug and medical devices independent control institutions. Turkey has 44 JCI certified hospitals, approximately 100 internationally standardized private hospitals and more than 1000 Turkish Republic Ministry of Health accredited hospitals with 60 university hospitals (Karadeniz. 2012). The Health Care System in Turkey is financed by public funds, compulsory insurance premiums and delivered $(90 \%)$ by The Ministry of Health $(\mathrm{MoH})$ that also manages the system. Healthcare providers are classified as physician, dentist, nurse, health officer, midwife and pharmacist etc. There is not a referral chain in the country yet.

Transformation in Health Care in Turkey has 4 major components. (Sharma, 2013).

1) Prime based general health insurance,

2) Determining the role Ministry of Health as overall planning, coordination and evaluation.

3) Solo practice of primary care by contracted family doctors.

4) Change of payment schedule for health care staff (fee for per capita + fee for service).

Until 2013 health indicators have improved, as observed in Table 1.

\begin{tabular}{|l|l|l|l|l|l|l|}
\hline Indicators & 1960 & 1980 & 1990 & 2000 & 2005 & $2013^{* *}$ \\
\hline Population (million) & 27,7 & 44,7 & 56,4 & 67,8 & 73,2 & 79,0 \\
\hline Infant mortality rate (\%) & $>150$ & 126 & 67 & 28.9 & 23.6 & 18.5 \\
\hline Total fertility rate (births per woman) & $>4$ & 3.41 & 2.65 & 2.27 & 2.19 & 2.07 \\
\hline Life expectancy at birth (year) & $<60$ & 61.9 & 66.3 & 70.4 & 71.3 & 72.3 \\
\hline Population per hospital bed & $>500$ & 451 & 469 & 391 & 374 & 336 \\
\hline Population per physician & 2,799 & 1,631 & 1,109 & 792 & 715 & 658 \\
\hline
\end{tabular}

Table 1. Changes of some selected health indicators Source: Turkish Statistical Institute database and 9th strategic development plan report

Health care is an important component of an economy. Health care technologies have advanced rapidly in the past few decades and the demand for health care continues to grow, health care expenditures have been increasing steadily in industrialized nations (Eatwell, J., Milgate, M. and Newman, P. (eds) 1987). In the Turkey, for example, health care expenditures as a share of the gross national product (GNP) grew from 4.4 percent in 1970 to 6.7 percent in 2009

\section{Definition of Political Economy}

The "political economy is the science of wealth" and "deals with efforts made by man to supply wants and satisfy desires". The political economy of health care has complex procedures (Hart, 2008). 


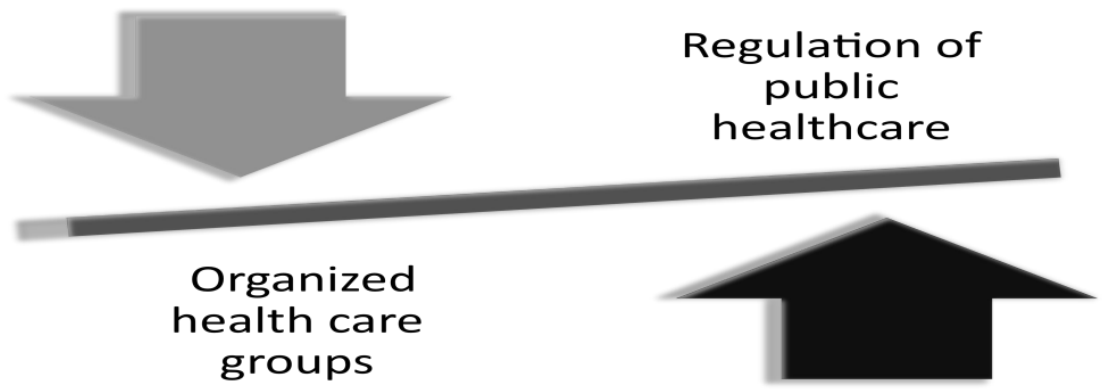

Figure 1. The political economy

Efficiency and equity of heath care services to be the main concern of political economy. Political economy is the study of the role of economic processes in transforming society (Campos, Rafael, 2011). This economy makes extensive and intensive use of important analysis in making sense of society and history. This branch of economy does not deal with the context of political, cultural, and environmental processes, as well as other economic processes (Devi, Ngaire 2013).

\section{Measuring Health Care System}

The health care system gain can be measured by healthier births, lives, and improved patient's health etc. The most important result of the health care system is health gain that can be measured by quality of life (qaly) per year. Qaly is able to combine 'the effects of health interventions on mortality and morbidity into a single index'. This single index might provide a 'common currency' for comparisons across different chronic illness and health intervention. For example Qaly is calculated as follow:

Patient A has a serious, life-threatening condition like Leukemia.

If he continues receiving usual standard treatment A will live for 1 year. The quality of life of A will be 0.5 ( 0 or below $=$ worst possible health, $1=$ best possible health)

If A receives the new drug, A will live for 2 year with a quality of life of 0.7 .

The new treatment is compared with standard care in terms of the Qaly's gained:

Standard treatment: 1 (year's extra life) x $0.5=0.5$ QALY

New treatment: 2 x $0.6=1.2$ Qaly

Therefore, the new treatment leads to 0.7 additional Qaly's (that is: 1.2 -0.5 Qaly $=0.7$ Qaly's).

The cost of the new drug is assumed to be $£ 5,000$, standard treatment costs $£ 2000$.

The treatment costs of leukaemia (£3000) are divided by the Qaly’s gained (1.2) for calculating the cost per Qaly. So the new treatment would cost $£ 2500$ per Qaly. The well-organised political economy for health care system including whole population can help to sustain good mortality.

\section{Political Economy Created by Turkish Health Care System}

In 2003, the health transformation project started to be implemented. One of the main goals of this project was to increase accessibility to health care services. According to the results of this project, health expenditures increased rapidly. It was 3.86 of GDP in 2004. It reached $5.13 \%$ of GDP in 2009. Financing of healthcare led to a decrease in direct out-of-pocket expenditures (OOP) and the private health sector that expand all over the big cities. According to the current official data from the $\mathrm{MoH}$, the level of OOP has fallen to $16.7 \%$. According to the Ministry of Health's review (2012), the total health financing was at $7.4 \%$ levels. This trend shows that public spending and resource allocation on medical costs in relations to income has caused major concerns over the social and economic consequences to an increasingly larger segment of the population. The health service availability has been improved. The population has a big increase in hospital utilization. In times of illness, lowincome families are not trying to find money for needed treatments in case if they paid some amount like 30-90 Turkish Lira monthly. All family member spouse or husband can profit within this amount of money. 


\section{Health Insurance in Turkish Health Care System}

The compulsory health insurance system in Turkey was firstly introduced in 2012 to cover all citizens. Government officials, state employees and staff of large invested companies are paying according to their wages. Their insurance covers all family member like spouse and mother, father. Those considered indigents such as war heroes, war invalids and all children below the age 18 are paid by government funds. Today, about 20 million Turkish who are not poor or disable are uninsured. Those people do not work anywhere else. Expanding insurance coverage is planned to reduce OOP payments, but most studies have found only a modest effect. The design of current insurance schemes has made the poor paying hospital fees for the rich and extracts insurance refunds from poor provinces to wealthier cities. It is state officials and urban elites that are the main beneficiaries of the insurance refunds as insurance coverage and refunds are to cover mainly high-class curative care and inpatient services in urban and centralized hospitals.

The health insurance refund system is facing major challenges in containing costs, involving dysfunctional rules and informal arrangements in which corruption incurs. There is hardly any effective mechanism to record, report or measure service costs and adverse insurance selections. Neither can they control doctors in their prescriptions and consultations involving duplication and falsification of doctors' medical records to claim refunds and medical reimbursements. Furthermore, pharmaceutical companies can lobby, or often pay bribes, to make their drugs included in insurance lists. Once on the lists, they encourage physicians to overprescribe expensive medications and laboratory tests.

\section{Management and Productivity in Primary Care}

Everyone in Turkey has a free access to a family practice center functioning as a personal physician. Currently, there is not a compulsory referral system in Turkey. $\mathrm{MoH}$ points to the inadequate number of primary care physicians for not being able to initiate referral chain obligation. An efficient gatekeeper role is needed for an effective primary care in the country. In 2013, Turkey has 1.7 physicians and 1.4 nurses per 1000 people. There is a serious demand of health staff for primary care health services. Clinical productivity of primary care has not been taken seriously until yet. There have been successive revisions designed to encourage proactive work considered by government likely to raise outputs of health care and to shift responsibilities for ambulant care from hospital outpatient departments back to primary care, particularly for continuing care of chronic health conditions like COPD, diabetes, hypertension etc. MoH of Turkey had been concerned almost exclusively with satisfying users rather than verifiably improving either their health, the health of their communities or their efficiency as gatekeepers to hospital based specialists. Everyone had free access to go secondary and tertiary care for undifferentiated, unprioritised public wants. Therefore, iatrogenic risks could not be avoided. The economic consequences of its loss in Turkey need to be calculated. Hospital based specialists are seen as a good doctor in the form of public opinion. Patients do not trust primary care physicians. They only apply to primary care whenever they need to repeat their prescriptions. Another main reason of application is oblige physician to write false illness report. Media side also report that primary care physician knowledge and health service is insufficient.

\section{Management and Productivity in Hospital Based Care}

Health services create jobs. This is increasingly labor intensive rather than capital intensive. The expansion of this work area depends in large part on further developing the skills of its workforce. If health care expands, it means that everyone wins economically. In recent years, mostly machines replaced agriculture and manufacture sectors instead of human labor. But, productivity labor in health care would still depend on increasingly very sophisticated human skills. Patients act as a co-producers rather than clients. As a result the health sector is expected to grow gradually every year. Health professionals would become relatively more costly to employ. In the very near future spending on health care in hospital would rise. The cost of health care is attributable to wages. If physicians are paid by capitation, they want to keep their patients as customers.

\section{Conclusion}

Healthcare systems are in crisis worldwide with rising rates of diseases and a growing gap between the poor and rich. The modern healthcare systems focus on benefitting individuals rather than communities (Ren, 2013). According to the rule of liberalism private healthcare is supported to provide quality healthcare only to those who can afford it. Budgetary cuts generally come at the expense of the primary determinants of health. Political economic gains are focused on the short-term healthcare system.

Pharmaceutical industry, medical profession unions, World banking institutions and political decision makers, think tank institutions challenged neoliberal assumptions directly to prevent the medical profession, health economists and public health practitioners in some instances (Sarbo, 2013). Financial support for health care would become a predominant consideration in the Turkish health system in near future. Turkey has adopted 
blended payment systems that consist of a salary-like base supplemented by incentive payments with revolving funds. These payment reforms would not lead to the recreation of a "gatekeeper" system. Patients would continue to access to hospital based specialists. For the sustainability of universal access health care special insurance programs according the rule of political economy must be done. Poor people, severe ill people who cannot work and elderly may not get access to public medical insurance. For redistributive reasons, the rich who contribute to the nationwide public health care system could give some extra insurance premium and obtain additional private insurance as well. The aim of Turkish's health reforms is to ensure all citizen s access to general health care in case if they regularly pay the insurance premiums according to their income (especially the informal economy). Tertiary care physicians might select patients who need extra health care services like diseases. Process indicators might audit those physicians. To solve the political health economic insurance problem actions might be taken by health care providers, patients (consumers), policy makers, and health care industry. The important mater is that public health economic source is for health profit of all citizens of nations (Idrissa, 2013). The political economy of health in Turkey faces several challenges. Ageing population has a moderate challenge to long-term financial sustainability. The major challenges is linked to the labor market and weaknesses in resource allocation, purchasing and provider payment. Strengthening health care-financing policy can address many of the inefficiencies in resource allocation and health care utilization that exacerbate cost pressures.

\section{References}

- Campos, SP, Rafael GM, 2011. Estudios Multidisciplinarios sobre Derecho Medico y Organizaciones de la Salud. Uruguay: La Ley Uruguay,

- Devi S., Ngaire W. (2013) Trojan Multilateralism: Global Cooperation on Health, GEG Working Paper 72.

- Eatwell, J., Milgate, M. and Newman, P. (eds) 1987. The New Palgrave. A Dictionary of Economics, London, Macmillan, Vol. IV. 907.

- Forsberg, Le Thanh. 2013. The Political Economy of Healthcare Commercialization in Vietnam. GEG Working Paper 2013/74.

- Gloppen, Siri. 2009. "Litigation as a Strategy to Hold Governments Accountable for Implementing the Right to Health." Health and Human Rights. 10 (2) 21-36.

- Hart JT. 2008. The political economy of health care. A clinical perspective. The policy press. United Kingdom. 256-258.

- Idrissa, A. 2013. Out of the Penkelemes: The ECOWAS Project as Transformation. GEG Working Paper 2013/76.

- Karadeniz O. 2012 Extension of Health Services Coverage for Needy in Turkey: From Social Assistance to General. Health Insurance. Journal of Social Security / 2Idrissa, Abdourahmane. 2013. Divided Commitments: UEMOA, the Franc Zone, and ECOWAS. GEG Working Paper 2013/77.

- Ren, H. 2013. Enterprise Hegemony and Embedded Hierarchy Network: The Political Economy and Process of Global Compact Governance in China. GEG Working Paper 2013/73.

- Sarbo DN. 2013. Reconceptualizing Regional Integration in Africa: The European Model and Africa's Priorities. GEG Working Paper 2013/78.

- Sharma, P. 2013. Role of Rules and Relations in Global Trade Governance. GEG Working Paper 2013/75.

- $\quad$ http://socialcapital.weebly.com/uploads/1/0/5/9/1059736/woolcock_paper.pdf. Last Visited 01.06.2013.

- $\quad$ http://www.sup.org.uy/Boletines/BolNov2011.pdf. Last Visited 01.06.2013

- http://www.shef.ac.uk/polopoly_fs/1.209843!/file/serps_2012020.pdf. Last Visited 01.06.2013.

- http://www.who.int/countryfocus/cooperation_strategy/ccsbrief_tur_en.pdf Last Visited 01.06.2013.

- http://www.oecd.org/els/health-systems/oecdhealthdata2012-frequentlyrequesteddata.htm. Last Visited 01.06.2013.

- http://siteresources.worldbank.org/INTTURKEY/Resources/361616-1173282369589/tr_per_cr.pdf. Last Visited 01.06.2013. 


\title{
Küreselleşmiş Dünyada Sürdürülebilir Gelişme Açısından İşsizliğin Önemi
}

\section{The Importance of Unemployment with respect to Sustainable Development in the Globalized World}

\author{
Prof. Dr. Levin Özgen (Abant İzzet Baysal University, Turkey)
}

\begin{abstract}
Unemployment is in a continious increasing trend during the 2000s in the globalized world. This fact have negative implications in accordance with the sustainable development which is the main development approach in the discourse of the globalized world. Main reasons of the unemployment in the globalized world may be explained throughout the changes and transformations in the labor process and production organization due to changing phiylosophy and regime, process and mechanizms of the capital accumulation of the capitalist system which has been based on the neo-liberal economy policy. A study about unemployment and it's implications may be realized by using the system method and consideretaions on emerging facts and literature. After the brief explanations related to unemployment, globalized world and sustainable development, basing on the some statistical data and literature, changes in the labor process and production organization may be taken in hand. Some implications of the unemployment for sustainable development may be discussed. In this study unemployment and it's sources were taken in hand by considerations on some data and literature. Finally, some solution propositions were tried to set up for unemployment.
\end{abstract}

\section{Giriş}

Bu çalışmada küreselleşmiş dünyada sürekli artma eğiliminde olan işsizliğin sürdürülebilir gelişme açısından önemi üzerinde duruldu. Çünkü önceki dönemin ve Keynesyen ekonomi politikaların önem verdiği ve tam istihdam politikaları içinden çeşitli çözüm uygulamaları ortaya konulabilen işsizlik sorunu, 1980ler sonrasında sürekli artış içinde olmasına karşın benzeri bir önem verişe konu değildir. İşsizliğin özelliklerinin de bu süreçte değiştiği öne sürülebilir. Bu duruma karşın küreselleşmiş dünyanın dayandığı neo-liberal politikaların işsizliğe çözüm önerilerinin yetkinliği de tartışmalıdır.

Çalışmanın sorunsalı 1980ler sonrasında sürekli artan, özelde 2000li yıllarda kalıcılık gösteren işsizlik olgusunun sürdürülebilir gelişme üzerindeki olumsuz etkileri bağlamında özelliklerinin, kaynaklarının ve olası tehlikelerinin irdelenmesidir. Kapsam olarak küreselleşmiş dünyada ve sürdürülebilir gelişme açısından, emek / iş süreci, ulus üstü üretim organizasyonu gibi çerçeveler ele alındı. Çalışmanın zaman ve mekan boyutu 2000 li y1llar ve Avrasya coğrafyasındaki ülkeler özelinden hareketle küreselleşmiş dünyadır.

Çalışmada kullanılan malzeme dünya işsizlik istatistikleri, işsizlik, sürdürülebilir gelişme / kalkınma ve küreselleşmiş dünya üzerine yazın ve tartışmalardır. Yöntem olarak kuramsal irdelemelerden yola çıkan, işsizlik üzerinde irdelemeler yaptıktan sonra yeniden kuramla bağlantıların kurulduğu sistem yöntemi ve karşılaştırma yolu kullanıld1.

Çalışmanın temel savı ve bulgusu küreselleşmiş dünyada sürekli artış kaydeden işsizliğin yapısal olma özellikleriyle kalıcılık dinamizmi taşıdığıdır. Bu durumun ilgili unsurları ve bağlantılarıyla birlikte insanlığın barışı ve huzuru bakımından, özelde ise en azından sürdürülebilir gelişme açısından önemli sorunlar ve engeller yaratacağıdır. Bu bağlamda üzerinde toplumsal uzlaşı sağlanacak rasyonel, uzun soluklu ve kalıcı çözümlerin geliştirilmesinin zorunlu olduğudur.

$\mathrm{Bu}$ yaklaşımlarla çalışmanın metni beş kısım üzerinde kurgulandı. Birinci kısım olan Giriş’te çalışmanın konusu, konunun önemi, ana sorunsalı ve kapsamı, sınırları, kullanılan malzeme ve yöntemi ile temel savı ve bulgusu yerleştirildi. Metnin yapısı açıklandı. İkinci kısımda işsizlik hakkında genel tanımlara, açıklamalara ve tartışmalara yer verildi. Üçüncü kısımda küreselleşmiş dünyadaki gelişme ve kalkınma yaklaşımları bakımından sürdürülebilir gelişme yaklaşımı tanımlandı. Bunun üzerinde işsizliğin etkilerine bakıldı. İşsizlik ile ilgili istatistiksel verilere ve çeşitli yaklaşımlara yer verildi. Küreselleşmiş dünyadaki işsizlik özelliklerine ve olası risklere değinildi. Neo-liberal ekonomi politikaların ve uygulamaların işsizliğe ilişkin çözüm önerileri irdelendi.

Dördüncü kısımda küreselleşmiş dünyadaki işsizliğin kaynaklarına ilişkin yaklaşımlar, emek sürecinde ve üretim organizasyonunda ortaya çıkan değişmeler, sanayi ve hizmet sektörü ile doğrudan yatırım ve mali sermayeler arasında önem bakımından yer değiştirme, hizmet sektörünün sanayi sektörü aleyhine önem kazanması ve genişlemesi gibi olgular irdelendi. Mikro-elektronik teknolojilerindeki gelişmelerin küreselleşmiş dünyaya sağladığı olanaklar yerleştirildi. Ortaya çıkan yeni birikim düzenlemesi üzerinde duruldu.

Beşinci kısım olan Sonuç kısmında çözüm önerileri getirilmeye çalışıldı. 


\section{2 İşsizlik Üzerine Genel Açılımlar}

2000li yıllarda, küreselleşmiş dünyada işsizliğin sürekli artış eğiliminde olduğu yazında sıklıkla dile getirilen bir olgudur (Boratav; 2007, Kepenek; 1990, MÜSİAD; 2012, ILO; 2012). Neo-liberal ekonomi politikalar bakımından bir sorun olarak önemini yitirmiş bir olgu gibi görünse ve yine bu politikalar 1şı̆̆ında çözümler önerilse (Rosas ve Rossignotti; 2010) de işsizlik insanlık açısından önemli bir sorundur. Küreselleşmiş dünyanın temel söylemlerinden ve hedeflerinden biri gibi görünen sürdürülebilir gelişme / kalkınma açısından insan kaynaklarının sürdürülebilir değerlendirilmesi, kullanılması bakımından ise yaşamsal önemdedir.

İşsizlik genel olarak bir kişinin çalışabilir durumda ve çalışmaya istekli olmasına karşın işsiz kalması, bir iş bulamaması şeklinde tanımlanır. Tanımın, işsizliğin, açık, gizli, yapısal, geçici, teknolojik, mevsimlik, konjonktürel, istihdam daralması, isteğe bağlı, istem dışı gibi türleri dikkate alındığında daha geniş açıklamalara taşınabileceği görülür.

Nüfus ve demografik çerçevelerle ilişki kurularak ekonomik aktif işgücü olan kesim içinde işi olmayan, çalışmayan kesimin yarattığı bir olgu olarak da vurgulanabilir. Çalışan ve çalışabilir durumda olan toplam işgücü ve bunlara dönük istihdam kapasitesi arasındaki denge önemlidir. Bunlar ücret / maaş gibi ödemeler karşılığında bir kurum ve işveren hesabına çalışırlar.

Uluslararası Çalışma Örgütünün (ILO) ölçütleri ile 14 - 65 yaş arasındaki nüfus kesimi ekonomik aktif işgücü olarak kabul edildiğinde bu grubun içinde ücret, maaş gibi çalışma karşılığ sağlanan gelirden işsizlik durumunda mahrum kalınır. Bu bağlamda çalışabilir durumda olan nüfus kesimi içinden bir kısmının kendi adına çalışan girişimci, kendi işini kuran olarak kabul edilmesi söz konusudur.

Yine nüfus ve demografik özellikler bakımından değerlendirildiğinde, işsizlik, 0-14 ve 65 yaş üstü yaş gruplarının oluşturduğu bağımlı nüfus miktarı yüksek ise daha yaşamsal bir sorun haline gelir. Daha geniş bir kitlenin karşı karşıya olduğu bir soruna dönüşür. Bu nedenle işsizliğin bir sorun olup olmadığı, sonuçları ve toplumsal barış, gelişme gibi açılardan taşıdığı risklerin, tekil verilerin değerlendirilmesi ile değil, nüfus ve demografik özellikler ile bağlantılı ve aile yapısı, hanehalkı büyüklüğü ve hane reisi gibi verilerle karşılıklı etkileşim içinde ele alınarak değerlendirilmesi gerekir. Aynı yaklaşımla işsizlerin ya da tersi olarak istihdamın nüfus gruplarına göre ayrımlandırılması ve değerlendirilmesi yerinde olacaktır. Örneğin genç kesimin işsizliği, yüksek eğitim mezunlarının işsizliği ya da orta yaş grubunun işsizliği veya kadınların işsizliği gibi çeşitli toplumsal kesimlerin işsizliğinin her birinin geniş bağlamları nedeniyle ayrı bir önemi vardır şeklinde kabul edilmesinde yarar vardır. Her biri için çözüm önerileri politikaları ve uygulamaları farklı olacaktır.

Yazında ve ilgili yasal düzenlemelerde işsizliğin genel nedenleri, bulunan iş türü için uygun olmama, sahip olunan becerinin/işin ilgili olduğu sektörün ekonomik sıkıntıda olması, açık iş sayısının veya istihdam kapasitesinin az olması şeklinde sayılır. İşsizlik yaratıcı nedenler olarak ülkenin ekonomik durumu, dış alımın / rekabetin yarattığı üretim gerilemesi, yeni işyeri açılmasını engellemesi gibi olgular öne sürülür. Yanı sıra işsizliğin ortaya çıkmasında gelişen teknolojinin rolünden, sanayilerin gerilemesinden ve kapanmasından da söz edilebilir.

O halde işsizliğin ülkenin ekonomik yapılanmasında sektörlerin birbirine göre konumu ve hiyerarşik sıralamadaki yerleri, nüfusun kırsal ve kentsel dağılımı, nüfusu kırsal ve kentsel mekanda tutan yatırımlar, bunlara bağlı olarak istihdamın özellikleri ve kapasitesi, istihdama ve emek pazarlarına ilişkin politikalar ve yasal, kurumsal düzenlemeler gibi olguların bir arada etkileşiminin sonucu olduğu öne sürülebilir. Bu yaklaşımla işsizliğe ilişkin çözüm önerilerinin ve uygulamaların bu ana çerçeveler içinden ortaya konması gerekir.

Çeşitli ekonomi politikaların böyle bir tutumu benimseyip benimsemediği, ne ölçüde bunları pratiğe aktardığı da işsizliğin ele alınış şekline ve içeriğine ilişkin ipuçları sunabilir. Bu çerçevede Keynesyen ekonomi politikası bakımından tam istihdam yaklaşımı, dönemin devlet /kamu anlayışlarıyla bütünleşen, sosyal devlet, sosyal refah uygulamaları, sanayileşme, hızlı kentleşme olguları ile denk düşen, onları içselleştiren bir yapı taşır. İşsizlik bu nedenle ciddi bir sorundur. Eksik istihdam pazarın dengesini bozucu bir rol üstlenebilir. Sosyal hukuk devleti yaklaşımı içinde bunun çözümünden kamu sorumludur.

Oysa neo-liberal ekonomi politikalar açısından pazar dinamiklerinin özgürlüğü önemlidir. Buna dışarıdan müdahale edilmemesi gerekir. Pazar kendi içinde denge sağlayacaktır. O halde devletin veya kamunun pazarı dengelemek üzere müdahale etmemesi, öteki deyişle yatırımcı, girişimci, üretimci ne olursa olsun üretim ve istihdam süreçleri içinde yer almaması gerekir. Emek pazarına, istihdam olanaklarına da karışmaması söz konusudur. Sosyal devlet anlayışı, sosyal refah ekonomi politikaları ve uygulamaları, pazarın bu özgür işleyişini zedeleyen, haksız rekabete yol açan bir unsur olarak görev üstlenmiş olacaktır. Oysaki serbest pazar ilişkileri içinde özel sektöre yer açılması, hatta öncelik verilmesi gerekir. Böylece özel sektör verimliliğini, karını en çoğa çıartmak için en uygun emek / iş sürecini ve üretim organizasyonunu kurabilir. Özel sektör, sermaye türleri serbest rekabet ortamı içinde, sektörlerin önem sıralamasındaki ve firma tiplerindeki değişmelere dayalı ciddi bir yapısal dönüşüme de uğrayarak zayıflıklarından kurtulacak güçlü bir yapılanmaya yönelebilecektir.

$\mathrm{Bu}$ olgularla işsizlikle ilgili veriler üzerinde geniş tartışmalar olduğu söylenebilir. Tartışmaların başında 1980ler sonrasında işsizliğin gerçekten artıp artmadığ gelir. Ancak çeşitli istatistikler artışın gerçekliğine ilişkin 
fazlasiyla kanıt ortaya koyar (Aysu ve Dökmen; 2011, Kepenek; 1990, Kongar; 1998, Erarslan; 2010, ILO; 2012, Güney; 2010). Sayısal verilerin artış olmadığını ifade etmeye temel oluşturan yanları olan işsizlik tanımları da tartışmalıdır. Özel olarak ise kayıt dışı ekonomik etkinliklere ilişkin verilerin bulunmayışının da işsizliğin gerçek boyutlarının tam olarak değerlendirilmesini engellediği yolunda yaklaşımlar vardır. İstatistiki veriler ve sektörel analizler üzerine dayalı bir kısım çalışmada ise sürekli artış içinde olan işsizliğin bir histeriye dönüşüp dönüş̧mediği (Onur; 2011) ya da doğal işsizlik olup olmadığı ele alınır. Ancak pek çok bilgi 2000li yıllardaki işsizliğin gerçekten bir histeri oluşturacak denli kabus haline geldiğini doğrular durumdadır.

1980ler sonrasında yüksek boyutlara ulaştı̆ı halde sistem tarafından önemli bir sorun olarak görülmemesinin nedenleri ise yine sistem içinden yanttlanabilir. Bu yaklaşımla 1980ler sonrasında biçimlenen küreselleşmiş dünyanın emek sürecini, üretim organizasyonunu, öteki deyişle anılan dönemdeki sermaye birikim düzenlemelerini, sürdürülebilir gelişme /kalkınma yaklaşımlarını ele almak yerinde olur.

\section{Küreselleşmiş Dünya ve Sürdürülebilir Gelişme}

1980 sonrasında kapitalist sistemin yeniden yapılanma sürecine girdiği, bu sürecin giderek küreselleşme sürecini getirdiği savları, üzerinde farklı yaklaşımlar ve tartışmalar olmakla birlikte genel kabul görür. Küreselleşme sürecinin içinden en azından 2000li yıllarda yeni bir dünya yapılanmasının istikrar kazandığı, küreselleşmiş dünyanın biçimlendiği öne sürülür. Bu kapitalist sistemin yeni bir aşamasıdır. Sistemin temel unsurları, yapısı aynı olmakla birlikte çeşitli düzenlemeleri, sermaye birikim rejimi ve mekanizmaları, bunların içinde yer alan aktörleri değişmiş durumdadır. Bağlı olarak söylemi, ekonomi politikası ve uygulamaları da değişti (Freidman; 2000 ve 2006).

Küreselleşmiş dünyanın biçimlenişinde, dönemin bilişim devrimi olarak da görülmesine ortam yaratan mikroelektronik teknolojilerindeki gelişmeler temel katkıyı sağlayan unsurdur denebilir. Her şeyden önemli olarak zaman ve mekan kısıtlılıklarının aşılmasına ortam yaratan bu gelişmeler, küreselleşmiş dünyanın, ağlar üzerinden işleyen, çevresinde, iletişim ağlarının oluşturduğu sanal bir evren ile kuşatılmış dünya olarak betimlenmesine kaynak oldu.

Bu ağlar üzerinde sermaye, mal, ve hizmetler kesintisiz, engelsiz, hızlı ve sürekli, çok miktarlarda bir akış içindedir. Hareket etmeyen yalnızca emek ve işçilerdir, çalışanlardır. Sermaye üretim yatırımları için ucuz, düşük ücretli ve örgütsüz işgücünün olduğu mekanları yeğlerken, mal ve hizmetler uygun alım gücünün yaratıldığı her yere, talebi de kışkırtarak sorunsuzca girebilir ve en küçük risk karşısında da çıkabilir durumdadır. Sermaye akışlarının çoğu mali sermaye olarak hizmet sektörünün en canlı ve verimli olduğu, düzensiz pazarları yeğleyebilmektedir. İmalat sermayesi ise üçüncü pazarlara yakın coğrafyalarda imalat işlerini tamamlatabilmektedir.

$\mathrm{Bu}$ ana çerçeveler içinden küreselleşmiş dünyada önceki dönemin kalkınma / gelişme söylemi, stratejisi ve siyasaları da dönüşüme uğradı denebilir. Kaldıki bunların çoğu dünyanın geniş bir kesimini oluşturan gelişmemiş, azgelişmiş, gelişmekte olan çoğu ülke için sorunlarla ve yetersizlikler ile doluydu (Chang; 2011, Chang ve Grabel; 2005). Dünyanın geniş bir kesimini oluşturan Avrasya coğrafyasındaki ülkeler ise bağımsızlıklarını küreselleşmiş dünyada ve sürdürülebilir gelişme yaklaşımları ortaya çıktığında kazanmış oldular. Bu ülkelerin sosyalizm deneyimi ve yapılanması ile kapitalist sistemin bu yeni aşaması arasında hemen kavranamayacak önemli yapısal farklar vardı. Yanı sıra bu ülkelerin bağımsız bir bütçelerinin, devlet yapılarının oluşması da zaman gerektiren olgulardı (ILO; 1994). Enerji kaynakları dışındaki sektörlerinin varlığı ve rekabet gücü de sorunluydu. 1989 sonrasında doğrudan küreselleşmiş dünya ve sürdürülebilir gelişme uygulamalarıyla, yabancı sermaye çekme, dünya pazarlarında rekabet gücü sağlayabilme sorunlarıyla yüz yüze kaldılar. Bu arada sürdürülebilir gelişme yaklaşımı ve uluslararası düzenlemeleri tüm dünya ülkelerini bağlayıcı bir düzeye ulaşmıştı.

Sürdürülebilir gelişme, 1990da Birleşmiş Milletlerin Ortak Geleceğimiz ya da Beyaz Kitap adlı çalışmasında, var olan kaynakların gelecek nesillerin kullanımın riske atmaksızın kullanılması olarak tanımlandı. Bu temel çerçeveye bağlı olarak başka tanımlara da rastlanır. Hareket noktası kapitalist ülkelerin eşitsiz gelişme dinamizmi göstermeleri nedeniyle toplumsal ve küresel barışın tehdit altında olması, üretimin gitgide genişleyen kapasitesi nedeniyle insanlığa ait kaynakların tahrip olmasıdır. Bu nedenle ekonomik büyüme tek başına anlamlı değildir. Önemli olan insanlıkça yaratılan zenginliklerin, sahip olduğu kaynakların küresel çapta, dünyanın farklı mekanlarında adaletli dağıtılması ve sürdürülebilir kullanım için korunmasıdır (Kaynak; 2005). Bunlar doğal ve beşeri kaynakların ve değerlerin tümünü kapsar.

Tanımlarda anılan kaynaklar arasında insan kaynaklarının da sürdürülebilir kullanımı önemlidir. İnsan kaynaklarının yönetimi, verimli ve insanca kullanımı sürdürülebilir gelişme bakımından temel vurgulardan biridir. Bu bağlam içinde işsizliğin sürekli artmasına göz yummak sürdürülebilir gelişme açısından yaşamsal bir çelişki oluşturur durumdadır.

İşsizlik, ilgili tanımlar, içeriği ve düzeyi üzerinde tartışmaların genişliği ne olursa olsun, sürdürülebilir insani gelişme ölçütlerine aykırı bir durum oluşturur. İşsizlik, işsiz nüfus kesimleri, gelecek zaman dilimleri, nesiller ve sistem için önemli risk taşıyabilecek bir unsurdur. En azından 2000li yıllarda tüm dünyada yaygın şekilde 
görülen işçi göçleri, buna bağlı olarak gitgide genişleyen insan ticareti ve bunun için örgütlenen küreselleşmiş dünyanın karanlık yanı, işsizlerin ve çevrelerinin yaşadığı insani bakımdan olumsuzluk yaratan intiharlar, moral düşüklüğü, psikolojik bozukluklar, şiddet (Özbek; 2007) görmezden gelinebilecek olgular değildir. Dahası, gelişmiş kapitalist ülkelerin sürdürülebilir gelişme, kaynakların sürdürülebilir kullanımı gibi söylemlerine karşın, insan kaynaklarının verimsiz kullanımı, işsizliğin sürekli artışı gibi olgularla somutlanan aşırı sermaye biriktirme hırsları ve çabaları ilerde dünyanın şiddeti çatışmalara girmesine de yol açabilecektir Attali; 2007).

İşsiz insanların yaşamlarını sürdürmedeki seçenekleri, iş bulamadıkça farklı yönlere gitme potansiyeline sahiptir. Bugün değilse yarın, bu birikimlerin önünde ya farklı yaşam tarzlarını ve yollarını seçmek ya da isyan etmek vardır. Yaşamını çalışmasının karşılığında elde ettiği gelir ve maaş gibi kazançlara dayandıran işçilerin bunlardan mahrum kaldıklarında özel girişimci olabilmeleri, kendi işlerini kurabilmeleri de pek olanaklı değildir. Olanaklı olsa bile işsiz kitlenin içinden pek azı girişimci olabilecek geriye yine de geniş bir işsiz kitlesi kalacaktır.

Bu açıdan işsizlik, ekonomi politikalar neyi önerirlerse önersinler, insani bakımdan, barış ve huzur dolu yaşam açısından, sürdürülebilir gelişme için ve sonuçta sistem için önemli bir risktir. Sistemin her zaman yedek işsizler ordusunu oluşturacağı varsayımı küreselleşmiş dünya için de uygun bir saptamadır. Çünkü zaten işsiz işçiler sermaye birikiminin hem zorunlu bir ürünüdür. Hem de birikimin varlık koşuludur. Her an hazır bir işgücü olarak tümüyle sermayeye aittir. Her türlü sömürüye açık ve razıdır. İstihdam içinde yer alan işçileri çeşitli açılardan baskılamak üzere rahatlıkla sistem tarafından kullanılır. Bu yaklaşımla aslında işsizlik sermaye birikim rejiminin dayandığı egemen birikim felsefesinin ve buna göre kurguladığı emek sürecinin ve üretim organizasyonunun dolaysiz sonucudur (Marx; 1986).

2000li yıllardaki işsizliğin nedenleri, kaynakları ve özellikleri de önceki dönemden farklıdır. Bunun ayrıntılı hale getirilmesi için küreselleşmiş dünyanın sermaye birikim rejimine, mekan üzerindeki yer seçimine, emek süreci ve üretim organizasyonuna bakılması yerinde olacaktır. Çünkü esasen işsizlik kapitalist ekonomik politik sistemin bir zaman diliminde kendini üzerinde var ettiği emek sürecinin içindeki emeğin ve teknolojinin kompozisyonunun, emekçilerin bu süreçteki ve mekandaki konumlanışlarının ve rollerinin, iş örgütlenmesinin ve akışının, ürünün üretim mekanının oluşturduğu organizasyonun sonucu olarak ortaya çıkar.

\section{Küreselleşmiş Dünyada İşsizliğin Kaynakları}

Küreselleşmiş dünyanın ortaya çıkışı, kapitalist ekonomik politik sistemin sorunlarının, 1970li yıllarda krizlerin ortaya çıkmasıyla belirgin hale gelen birikiminin sonucudur. Sistemin doğası gereği belirli bir dönemde egemen durumdaki birikim rejimi ile düzenleme mekanizmalarının uyumlu olması gerekir. Bu bağlamda sistemin karşılaştığı krizlerin bir kısmı, birikim rejiminin süreçlerini ve düzenleme mekanizmalarını, bunlar içinde yer alan aktörleri uyumlandırma krizleridir. Uyumlandırma sonuç vermeyince, yerine sistem, birikim rejimini, süreçlerini, mekanizmalarını ve aktörlerini tümüyle değiştirme yoluna gider. 1970li yılların sonrasında kapitalist sistemin yeniden yapılanma sürecine girmesi bu çapta bir değişmedir.

Sistemin yaşadığı kriz, bazı yaklaşımlarda yer verildiği gibi petrol fiyatlarının ani yükselmesinden kaynaklanmış görünür. Böyle olsa da, bunun da etkisini içererek esasen, işçi sınıfının ekonomik siyasal kazanımlarından, fordist adı verilen önceki dönemin emek süreci ve üretim organizasyonunun katılıklarının yol açtığı sorunlardan, işgücü maliyetlerinin yüksekliğinden, atıl sermayenin fazlalığından ve talebe dönük üretim organizasyonunun verimlilik ve karlılık sorunlarından kaynaklanmış durumdadır. Bu durumda emek sürecinin ve üretim organizasyonunun köklü bir şekilde değiştirilmesi temel ve kesin çözümdü. Mikro-elektronik teknolojilerinin sağladığ 1 zamanın ve mekanın aşılabilmesi olanaklarıyla da yeni bir emek sürecinin ve üretim organizasyonunun inşası, bunun üzerinde yeni bir sermaye birikim rejiminin, süreçlerinin, mekanizmalarının kurulması olanaklı hale geldi.

Böylece kapitalist sistemin yeni bir aşamaya doğru evrilmesi olanaklı olabildi. Yapısal değişmeye denk düşen bu yapılanma aynı zamanda sermaye birikim sürecinin ve mekanizmalarının dünya çapında örgütlenmesini, öteki deyişle üzerinde geniş tartışmalar olan küreselleşmiş dünyayı (Hirst ve Thompson; 1998) ortaya çıkardı.

Önceki dönemin, kitlesel seri üretim, öteki deyişle fordist emek süreci ve üretim organizasyonunda, sermaye birikimi açısından dört temel katılık ya da sorunlu alan vardır. Birincisi, imalat işlerini içeren blokta çok sayıda işçinin bir arada olması, hareketli üretim bandı üzerinde ilerleyen ürünün kalitesi üzerinde işçilerin ne bir sorumluluğunun ne de bir insiyatifinin olmamasıdır. Birarada oluşun örgütlenme ve pazarlık gücünü arttırmaya olanak yaratan bir ortam oluşturmasıdır.

İkinci olarak üretim siparişe/talebe göre yapıldığından üretimin başında envanter stokları olarak geniş bir miktar sermayenin atıl bekletilme zorunluluğudur. Üçüncü olarak kalite kontrolün ancak emek süreci ya da hareketli bant sonunda çıktı olarak çıkan bitmiş üründe yapılabilmesi nedeniyle çok miktarda defolu ürün üretiminin yol açtığı sermaye kaybıdır. Dördüncü olarak, seri, ucuz ve kalitesiz ürünün tüketicisi/pazarı hazır olduğundan pazarlama sonrası yeni talep yaratacak düzenlemelerin olmamasıdır. 
Bu sorunların çözümü öncelikle imalat blokunu emek sürecinin hem mühendislik, tasarım, planlama, yönetim blokundan, öteki deyişle beyin emeğinin yoğunlaştığı kısımdan, hem de pazarlama blokundan koparmakla başladı. Burada bilgisayarlı tasarım ve üretim olanaklarının sağladığı katkı önemli bir rol üstlendi. Çünkü blokların birbirinden kopartılabilmesi yalnızca bir mekan içinde gerçekleşmedi. İmalat işlerini birbirinden kopuk, uzak mekanlarda, coğrafyalarda gerçekleştirilebilir kıldı. Zaman kısıtlılığıını da aşmış oldu. Artık ürünün tasarımı, mühendisliği ana firmanın denetiminde ve bulunduğu ülkede yapılırken, çeşitli üretim işleri başka mekanlarda, coğrafyalarda yapılabilir oldu. Bu olanağın yarattığı felsefe içinde kapitalist üretim sistemi kısa zamanda emek sürecinin de sayısız alt parçalara bölünerek, her bir işin en alt/küçük yüklenicilere/taşeronlara (Özgen; 1994 b) kadar dağıtılabileceğini kavradı.

Bu sürecin eşliğinde bir yandan da talep yaratmaya dönük yapılanma olanağının farkına varan sermayenin hem atıl sermaye bekletmekten kurtulması, hem ucuz, örgütsüz, becerili emeği bulduğu her yerde üretim yapmak üzere ulus üstü üretim yapabilmesi, bu amaçla ortaklıklar, firmalar kurması olanaklı hale geldi. Böylece işgücü maliyetlerinin en aza indirilmesi, işçilerin kitlesel siyasal gücünün yarattığ 1 sorunların yok edilmesi, hem de pazarların küresel çapta genişletilmesi olanağı doğdu. Bu oluşumlarda Japon modelinin (Özgen; 1992) örnek alındığ1 görüldü. Yanı sıra tasarım, mühendislik, planlama blokunda yer alan önceki dönemin yüksek ücretli beyaz yakalı becerili işgücü de sıradanlaştırıldı. Genelde her tür emek kişisel pazarlık gücüne göre istihdam edilir oldu. Bu süreçte pek çok işçinin emek sürecinin dışında ve işsiz kaldığı açıktır.

Bunun da ötesinde kapitalist birikim sisteminin bu yeni aşamasında ortaya çıkan maddi-olmayan emek pratikleri, önceki dönemlerin emeğe ait özelliğine ve vasfina yönelik değerleri, kategorileri bulanıklaştırdı ve parçaladı. Sonuçta maddi-olmayan emek süreçleri çalışanlar üzerinde çalışma yaşamı ile gündelik yaşam/boş zaman arasındaki ayrımı belirsizleştirdi (Emirgil; 2010). Böylece toplumsal üretim ilişkileri de belirsiz, bulanık dizgeler haline dönüştü.

Emek sürecine donanım teknolojilerinin ikamesi becerili emeğe gereksinimi azaltırken bir yandan işsizliği arttırarak bunları emek süreci dışında bıraktı. Bir yandan da becerili emeği becerisiz emek ile ücret, konum, pazarlık gücü gibi açılardan denk hale getirdi, becerisizleştirdi. Bu süreç içinde işçilerin önceki dönemde kazandıkları pazarlık ve örgütlenme gücü, ekonomik sosyal hakları ve ücretleri de önemli ölçüde geriletildi. Bilgisayarların ve internet ağlarının sağladığı olanaklarla, üretim organizasyonu dünyanın her tarafında tamamlanabilen üretim işleri sayesinde ulus üstü özellik kazanırken sermaye birikimi de küresel çapa ulaştı.

Sermayenin tasarımını, üretimini, yatırımını ve pazarlamasını küreselleşmiş bir düzlemde sanal ortamda yapma olanağına sahip olması, ilerleyen dönemlerde ortaya çıkan mali sermayenin yol açtığı krizlerde uluslararası para ve kredi kuruluşları eliyle tüm gelişmemiş ülkelere müdahale yeteneğini geliştirdi. Öteki deyişle dünyadaki gelişme süreçlerinin aklanması ya da karalanması ortak bir cürüm, yeni emek sürecinin ve üretim organizasyonunun üzerinde yükselen yeni sermaye birikimi rejiminin yarattığı işsizlik olgusu da salgın (MÜSİAD; 2012) haline dönüştü.

Yeni emek sürecinde kalite kontrol timleri düzenlemesiyle sermaye verimsizliğinden kurtulurken, bir yandan da pazarlama sonrası hizmet blokunu geliştirdi. Bu yolla talep yaratma, yeni pazarlar/mali sermaye ortaklıkları bulma olanağı sağladı. Hem mali sermaye hem hizmet sektörü bu süreçten sınai sermaye ve sanayi sektörü aleyhine daha fazla önem kazanarak çıktı. İmalat işleri giderek kolaylaştı ve önemsizleşti. Küreselleşmiş dünyanın her yerinde, Amerika firmalarının Çin'de, Kore'de, Avrasya ülkelerinde ya da Hindistan'da yatırım yapması örneklerinde olduğu gibi yayıldı.

Ürünün üretimindeki alt işler her yerde tamamlanabilir hale geldi. Üretim organizasyonu da değişti. Bu sırada ölçek ekonomileri önem yitirirken, bir birim işyerinde üretilen ürünün çeşitlendirilmesinden doğan alan ekonomilerinden (Özgen; 1994 a) yararlanan küçük, atak firmalar önem kazandı. Büyük sanayi kuruluşları bu süreçte işsizlik yaratarak ya kapandı, ya bünyesindeki imalat işlerini küçük firmalara verdi. Bazen bunları kendi kurdu. Bünyesinde stratejik işleri, beyin emeğine dayalı işleri ve mali işleri tuttu. Bunlar arasında pazarlama/sonrası hizmet ve ar -ge birimleri de vardır.

Böylece ağırlıklı olarak hizmet sektörü ve mali sektör firması haline geldiler. Küresel çapta çeşitli sermaye gruplarıyla bütünleşebildiler. Öteki deyişle odak sermaye grupları gelişmemiş /azgelişmiş ülkelerin sermaye gruplarını kendilerine eklemlenmeye yöneltti. Sermaye birikimi ulus üstü mekanda, öteki deyişle ulusal devleti ve sınırları aşarak küresel çapta, en küçük yerel sermaye aktörünü de içererek bütünleşti. Buradan bu tür kuruluşlarda çalışan beyin emekçilerinin düz hizmet sektörü çalışanı haline geldiğini, bireysel iş sözleşmeleri ve çalışma koşullarıyla yüz yüze kaldığını söylemek olanaklıdır.

Ucuz ve örgütsüz emek sunan ülkelerin kalkınma, ekonomik yapılanma yaklaşımları, küreselleşmiş dünyanın sürdürülebilir gelişme düzenlemelerine uyum sağlamak zorunda kald1. Ancak bu uyumun, bu ülkelerin ulusal pazarlarını dışa açmak, ihracata dönük üretim yapmak, bu nedenle sanayi sektörlerinin yapısal bir dönüşüm yapması zorunluluğu ile yüz yüze kalırken, sektördeki çoğu firmanın bu dönüşümü gerçekleştiremediği de oldu. Sürdürülebilir gelişme, bu nedenlerle insan kaynaklarının verimli kullanılmasından çok doğal kaynaklar bakımından zengin Avrasya coğrafyasındakiler gibi ülkelerin gündemine doğal kaynaklarla ilgili düzenlemelerle, 
yabancı firmaların hizmet sektörleri ve mali sermaye yatırımları ile girmiş oldu. Bu ülkelerdeki üretimin ve sektörel yapılanmanın daha baştan dış dinamiklere bağlı olarak biçimlenmeye yöneldiği öne sürülebilir.

Esasen neo-liberal ekonomik yaklaşım ve politika, yukarıda değinilen olguların betimlenmesidir. Neoliberalizmin sonuçlarından biri, ekonomik büyüme ve istihdam artışı arasındaki ilişkiyi zayıflatmasıdır. Sanayi sektörünü önemsizleştirip, mali sermayeye, dolayısıyla hizmet sektörüne önem yüklemesidir. Bir başka deyişle istihdamsız büyüme, istihdamın istikrarsızlaştırılması, güvencesiz ve esnek hale getirilmesi, yasal ve kurumsal düzenlemelerle emek pazarının esnek yapıya yönlendirilmesi, devlet eliyle çalışan kesime yönelik korumanın terk edilmesidir. Kısaca küreselleşmiş dünyadaki işsizlik yapısaldır, kalıcıdır.

Neo-liberal politikaların işsizliğe çözüm önerileri genel olarak yaşanan olgular karşısında kalıcı olmayan, çalışanlara güven vermeyen, sorunu kısmi ve geçici olarak ele alan önerilerdir. Bunların gerçek çözümler olamayacağı çeşitli çalışmalarda dile getirilir. Önemli olan önlemler, işsizlerin de pay alabileceği altyapı yatırımları ve toplumsal yatırımlar (Erdoğdu; 2010) gibi yapısal düzenlemelerdir.

İşsizlik sorununun insanlık açısından ağır sonuçları olabileceği dikkate alınarak; öncelikle iş sürecinin sayısız ölçüde alt parçaya bölünerek kayıt dışı üretimi ve ekonomiyi oluşturan, hiçbir kurala, belirlenmiş çalışma koşuluna ve insani değere sahip olmayan firmalara verilmesinin sınırlandırılması gereklidir. Bununla ilgili çalışma kurallarının konmasında yarar vardır.

Yeni emek sürecine ve üretim organizasyonuna katk1 sağlayan teknolojik gelişmelerin her zaman işsizliğe yol açacağı yaklaşımıyla, buradan sağlanan toplam yarar ve refahın bir kısmının toplumsal, yönetsel ve kültürel düzenlemeler yoluyla çalışanlara ve işsizlere toplumsal barışa katkı sağlayacak şekilde dönmesinin sağlanması yerinde olacaktır.

\section{Sonuç}

2000lerde sürekli artış içinde olan işsizlik, küreselleşmiş dünyanın birikim rejimini oluşturan yeni emek süreci ve üretim organizasyonunun dolaysız sonucudur. Aynı zamanda bilgisayar teknolojilerinin sağladığı olanaklardan doğan felsefesi de işsizliğin yapısal ve kalıcı hale gelmesine katkı yapmaktadır. İşsizlik bir histeriye ve salgına dönüşmüş durumadır. Neo-liberal politikalar ve uygulamalar, işsizlikle ilgili önerileri bir bakıma bunların meşrulaştırılmasıdır.

$\mathrm{Bu}$ nedenle işsizlik 2000li yıllarda gereken önemi görmemektedir. Ancak işsizlik en azından sürdürülebilir gelişme yaklaşımlarının önünde önemli bir engeldir. İşsizliğin oluşturduğu olumsuzluklar geniş kesimleri ilgilendirecek boyuttadır. Kısa sürede ortaya çıkabilecek şekilde, toplumsal barış ve huzur bakımından riskler barındırır durumdadır.

Bu yaklaşımla geçici ve rasyonel olmayan, bireyin yaşamını sürdürmesinde güvence sağlamayan çözümler yerine kalıcı ve uzun soluklu çözümlerin bulunmasında yarar vardır. Böylesi çözümlerin yine işsizliği yaratan emek sürecinin ve üretim organizasyonun bünyesinden çıkartılması yerinde olacaktır. Buna göre işsizlere, emek kesimine toplumsal refahtan daha yüksek payların verilmesi, toplumsal, yönetsel ve kültürel yaşamın, iş̧̧ilerin çalışma ve boş zaman anlayışlarını değiştirecek ve ekonomik olanaklarla da destekli bir şekilde geliştirilmesine yarar vardır.

\section{Kaynakça}

- Attali, J. 2007. Geleceğin Kısa Tarihi. 2. Baskı, İmge Kitabevi, Ankara

- Aysu, A., Dökmen, G. 2011. An Investigation on the Relationship Between Government Size and Unemployment Rate; Evidence From OECD Countries. Sosyoekonomi Dergisi. 2, 179 - 190.

- Boratav, K. 2007. Türkiye İktisat Tarihi; 1908 - 2005. 11. Bask1, İmge Kitabevi, Ankara.

- Chang, Ha - J. 2011. Kalkınma Reçetelerinin Gerçek Yüzü. 5. Baskı, İletişim Yayınevi, İstanbul.

- Chan Ha-J., Grabel, I. 2005. Kalkınma Yeniden - Alternatif İktisat Politikaları El Kitabı. İmge Yayınevi, Ankara.

- Emirgil, B. F., 2010. Yeni Kapitalizmde Emeği Sorunsallaştırmak; Emeğin Maddi-Olmayan Görünümleri. Çalı̧̧⿰㇒⿻二丨冂刂 ve Toplum. 24, 221-238.

- Erarslan, İ. 2010. Küreselleşmiş Dünyada İşsizlik; Türkiye'de İşsizlik Üzerine İnceleme. Abant İzzet Baysal Üniversitesi, Sosyal Bilimler Enstitüsü, Kamu Yönetimi Anabilim Dalı, yayınlanmamı̧̧ Yüksek Lisans Tezi, Bolu.

- Erdoğdu, S. 2010. Küresel Krizin İstihdama Etkileri ve Kriz Karşıtı İşgücü Piyasası Önlemleri. Memleket, Siyaset, Yönetim. 12, $142-167$.

- Freidman, T. 2006. Dünya Düzdür; 21. Yüzyılın Kısa Tarihi. Boyner Yayınları, İstanbul.

- Freidman, T. 2000. Küreselleşmenin Geleceği; Lexus ve Zeytin Ağacı. Boyner Yayınları, İstanbul.

- Güney, A. 2010. Türkiye'de Geliştirilmiş İşsizlik Oranları. Çalışma ve Toplum. 24, 239 - 252 
- Hirst, P., Thompson, G. 1998. Küreselleşme Sorgulanıyor. Çevirenler; Ç. Erdem, E. Yücel. Dost Kitabevi, Ankara.

- $\quad$ Kaynak, M. 2005. Kalkınma İktisadı. Gazi Kitabevi, Ankara.

- Kepenek, Y. 1990. Türkiye Ekonomisi; Gelişimi, Üretim Yapısı ve Sorunlarıyla. 5. Baskı, Verso Yayıncilık, Ankara.

- Kongar, E. 1998. 21. Yüzyılda Türkiye; 2000li Yıllarda Türkiye’nin Toplumsal Yapısı. 2. Basım, Remzi Kitabevi, İstanbul.

- Marx, K. 1986. Kapital, Kapitalist Üretimin Eleştirel Bir Tahlili. Birinci Cilt. Çeviren; A. Bilgi. Üçüncü Bask1, Sol Yayınları, İstanbul.

- Müstakil Sanayici ve İşadamları Derneği. 2012. Küresel Kriz ve İstihdam. Hazırlayan; İ. Öztürk ve B. Tuzcu. MÜSİAD Aratırma Raporları 80. İstanbul.

- Onur, S. 2011. Türkiye Ekonomisinde İşsizlik Histerisi (1992 - 2009). Sosyal Bilimler Metinleri. 4, 1 - 29

- Özbek, F. 2007. Negatif Moral Kültür - Güvensizlik ve İşsizlik Kaygısı İlişkisi Üzerine Bir Araştırma. Işs, Güç; Endüstri İlişkileri ve Insan Kaynakları Dergisi. 9 (3); 40 -60.

- Ö̈zen, L. 1994 a. “Ölçek Ekonomilerinde Değişmeler ve Alan Ekonomileri”. İktisat Dergisi, Y1l. 30, sayı. 353-354, Ekim-Kasim,

- Özgen, L. 1994 b. "Taşeron Üretim ve Taşeron İlişkiler Üzerine”. Birikim. 62. Haziran,

• Ö̈zgen, L. 1992. "Japon Modeli”; İyi mi, Kötü mü?“. Mülkiyeliler Birliği Dergisi. V.XVI, No. 145. Temmuz.

- Rosas, G., Rossignotti, G. 2010. Gençlerin İstihdamıyla İlgili Ulusal Eylem Planlarının Hazırlanmasına Yönelik Kılavuz. Birinci Baskı. Uluslararası Çalışma Örgütü (ILO).

- Uluslararası Çalışma Örgütü (ILO). 2013. Global Employment Trends for Youth 2013; A generation at risk. Rapor.

- Uluslararası Çalışma Örgütü (ILO). 2012. Dünya İşsizlik Oranları.

- Uluslararası Çalışma Örgütü (ILO). 1994. Economic Transformation and Employment in Central Asia. Edited by P. Ronnas, O. Sjöberg. Ankara. 


\title{
Türkiye'de Sürdürülebilir Kentsel Gelişme Stratejileri: KENTGES Eylem Planı (2010-2023) Örneği
}

\section{Development Strategies for Sustainable Urbanization in Turkey: KENTGES Action Plan (2010-2023) Case}

\author{
Assoc. Prof. Dr. Mahmut Güler (Trakya University, Turkey) \\ Asst. Prof. Dr. Abdulmenaf Turan (Yüzüncü Y1l University, Turkey)
}

\begin{abstract}
One of the main characteristics of Turkey which is one of the countries that is becoming urbanized fast is that the majority of population chooses metropolises and accumulates in metropolises rather than medium sized cities. In this sense, there are specific problems such as basic urban services especially in metropolises. Therefore, there is an increasing need for enhancing spatial life quality of urban settlements in turkey, strengthen economic and social structure, restructuring spatial planning system in Turkey. It was projected to prepare "Urban Development Strategy and Action Plan" for this aim. In this sense, "Raising Life Standards of Cities and Enabling Sustainable Development" was determined as the primary policy. Moreover, "Integrated Urban Development Strategy and Action Plan for Sustainable Urban Development" was prepared within scope of Program for Alignment with the EU Acquis. "Integrated Urban Development Strategy and Action Plan 20102023", with its short name Urban Development Strategy (KENTGES), comprises of settlement and urbanization; space, theme and extents of settlement and spatial planning within the principle of sustainability, make relations between spatial sectors within an integrated approach, enable adaptation with national basic policies. KENTGES is a national document which puts forward principles, strategies and actions for solution of structural problems of urbanization and providing healthy, balanced and habitable urban development; determines their practical principles and conveys them to an action program. In this paper, basic principles and practicability of the mentioned action plan which was prepared in order to enable sustainable urbanization in Turkey will be discussed.
\end{abstract}

\section{Giriş}

Dünyanın en hızlı kentleşen ülkelerinden birisi olan Türkiye'nin başlıca özelliklerinden biri nüfusun artan oranlarda büyük kentleri seçmesi, orta büyüklükte kentlerden ziyade anakentlere yığılmasıdır. Bu bağlamda özellikle büyük kentlerde başta işsizlik olmak üzere, güvenlik, temel kentsel hizmetler, kadın ve çocukların korunması gibi bir takım sorunlarla karşı karşıya kalınmaktadır. Bundan dolayı da Türkiye'de kentsel yerleşmelerin mekânsal yaşam kalitesinin artırılmasına, ekonomik ve toplumsal yapının güçlenmesine, mekânsal planlama sisteminin yeniden yapılandırılmasına olan ihtiyaç giderek artmaktadır. Bu ihtiyaçtan hareketle "Kentsel Gelişme Stratejisi ve Eylem Planı" hazırlanması öngörülmüştür. Bu bağlamda "Kentlerin Yaşam Standartlarının Yükseltilmesi ve Sürdürülebilir Gelişmenin Sağlanması” öncelikli politika olarak belirlenmiştir. Ayrıca, Türkiye'nin AB Müktesebatına Uyum Programı kapsamında "Sürdürülebilir Kentsel Gelişme İçin Bütünleştirilmiş Kentsel Gelişme Stratejisi ve Eylem Planı hazırlanmıştır. Kısa adı Kentsel Gelişme Stratejisi (KENTGES) olan "Bütünleşik Kentsel Gelişme Stratejisi ve Eylem Planı", sürdürülebilirlik ilkesi çerçevesinde yerleşme ve kentleşme ile yerleşme ve mekânsal planlamanın alan, tema ve boyutlarını kapsamakta, mekâna ilişkin sektörleri bütünleşik bir yaklaşımla ilişkilendirmekte, temel ulusal politikalarla uyumu sağlamaktadır. KENTGES kentleşmenin yapısal sorunlarının çözümüne, sağlıklı, dengeli ve yaşanabilir kentsel gelişmenin sağlanmasına yönelik ilke, strateji ve eylemleri ortaya koyan ve bunların uygulama esaslarını belirleyen ve bir eylem programına bağlayan ulusal bir dokümandır. Bu yazıda Türkiye'de sürdürülebilir kentleşmenin gerçekleştirilmesi amacıyla hazırlanmış olan söz konusu eylem planının temel hedefleri ve uygulanabilirliği Türkiye'deki kentsel politikalar üzerinden değerlendirilecektir. Ancak öncelikle sürdürülebilirlik, sürdürülebilir gelişme, sürdürülebilir kentsel gelişme gibi kavramlara değinmek gerekmektedir.

\section{Sürdürülebilirlik ve Sürdürülebilir Gelişme Kavramları}

Sürdürülebilir kentsel gelişmeyi anlamak için öncelikle sürdürülebilirlik ve sürdürülebilir gelişme kavramlarına açıklık getirmek gerekmektedir.

Sürdürülebilirlik; bir toplumun, ekosistemin ya da sürekliliği olan herhangi bir sistemin işleyişinin kesintisiz, bozulmadan, aşırı kullanımla tüketilmeden ya da ana kaynaklara aşırı yüklenilmeden sürdürülebilmesi olarak açıklanabilir. Sürdürülebilirliğin temelde ekonomik, çevresel ve toplumsal sürdürülebilirlik olmak üzere üç boyutu olduğu düşünüldüğünde (Uysal, 2002: 46); sürdürülebilir gelişme kavramı da en temel ifadesini ekonomi, çevre ve toplum arasındaki dengede bulmaktadır. 
Nitekim, Birleşmiş Milletler (BM) Çevre ve Kalkınma Komisyonu tarafından 1987 yılında hazırlanan ve komisyon başkanı Gro Harlem Brundtland'ın ismiyle Brundtland Raporu olarak da anılan "Ortak Geleceğimiz" başlıklı raporda sürdürülebilir gelişme kavramını benzer biçimde şu ifadelerle ele almaktadır: "Sürdürülebilir gelişme; temel ekonomik, çevresel ve sosyal hizmetlerin, bu hizmetlerin dayandığı ekolojik ve toplum merkezli sistemlerin varlığını tehdit etmeksizin herkese sunulabildiği gelişme olarak tanımlanabilir. Sürdürülebilir gelişme; yaşayan ve gelecekte yaşayacak olan tüm insanların, mevcut çevresel sınırlar dahilinde, ekonomik ve sosyal gelişmeye adil olarak katılmalarını sağlamak için gerekli olan üretim ve tüketim biçimlerindeki değişimlerle ilgilidir" (Türkiye Çevre Sorunları Vakfı, 1991: 71).

Brundtland Raporu'nda "bugünkü kuşakların, ihtiyaçlarını karşılarken gelecek kuşakların da kendi ihtiyaçlarını karşılama olanaklarını elinden almamasına" dayalı bir felsefe olarak vurgulanmıştır. Brundtland Raporu'ndan sonra yaygınlık kazanan sürdürülebilir gelişme kavramı; 1992 yılında Brezilya'nın Rio de Janerio kentinde gerçekleştirilen ve bu nedenle Rio Konferansı olarak da bilinen ve Rio Bildirgesi, Gündem 21, Orman İlkeleri, İklim Değişikliği Sözleşmesi ve Biyolojik Çeşitlilik Sözleşmesi olmak üzere beş temel belgenin ortaya konduğu BM Çevre ve Kalkınma Konferansı ile birlikte, 21. yüzyılda tüm insanlık için ulaşılması gerekli bir hedef olarak benimsenmiş ve sonraki yıllarda uluslararası düzeyde gerçekleştirilen birçok etkinlik ve ortaya çıkan birçok çalışmada bu şekilde yansıma bulmuştur.

\section{Sürdürülebilir Kentsel Gelişme Konusundaki Temel Düzenlemeler ve Uygulamalar}

Farklı ülkelerin deneyimleri ele alındığında; sürdürülebilir gelişme felsefesi çerçevesinde başvurulan politika ve uygulamaların her ülkenin kendi ekonomik, çevresel ve sosyal yapısına uygun olarak farklılık gösterdiği görülmektedir. Bu noktada, özellikle hızla kentleşen az gelişmiş ve gelişmekte olan ülkeler ve bu ülkelerdeki kentleşme olgusu dikkat çekmektedir.

Gerçekten de, özellikle az gelişmiş ve gelişmekte olan ülkelerde kentleşme, mevcut kent planlama ve yönetim kapasitelerinin önünde seyretmekte ve kaçınılmaz olarak ekonomik etkililiği azaltmakta, güçlükle korunan çevresel değerleri tehdit etmekte ve sosyal adaletin önüne geçmektedir (UN-HABITAT ve UNEP, 2001). İnsanların gerekli tüm ihtiyaçlarını karşılayan canlı sistemler olan kentler, en genel ifadeyle; sürekli gelişme içinde bulunan ve toplumun, yerleşme, barınma, gidiş-geliş, çalışma, dinlenme, eğlenme gibi gereksinmelerinin karşılandığı, pek az kimsenin tarımsal uğraşlarda bulunduğu, köylere oranla nüfus yönünden daha yoğun olan yerleşim birimi olarak tanımlanmaktadır (Keleş, 1998: 75). Bu haliyle doğal kaynakların başlıca tüketicisi ve çevresel zararın başlıca üreticisi olarak değerlendirilebilecek kentlerin, sürdürülebilir gelişme olgusu çerçevesinde ele alınması son derece önemli ve gereklidir. İşte sürdürülebilir kentsel gelişme kavramı da bu noktada önem kazanmaktadır. Bunun yanında, her kentin farklı özelliklere ve kendisine özgü farklı sorunlara sahip olduğu düşünüldüğünde, sürdürülebilir kentsel gelişmenin hassasiyet gerektiren bir konu olduğu daha iyi anlaşılacaktır. Sürdürülebilir kentsel gelişme, küresel düzeyde ortaya çıııp gelişen sürdürülebilir gelişme olgusunun kentsel ya da yerel yansıması olarak değerlendirilebilir.

Sürdürülebilir kentsel gelişme konusunda BM ve AB'nin oldukça önemli bir rolü bulunmaktadır. Sürdürülebilir gelişme kavramının 1987 yılında Bruntland Raporu'nda dile getirilmesi ve 1992 Rio Zirvesi'nde ise küresel düzeyde kabul görmeye başlayan bir ilkeye dönüşmesi ülkelerin iç politikalarına da yansımıştır. Dolayısıyla sürdürülebilir gelişme ilkesinin etkisini artırmasıyla eş zamanlı olarak kentlere ilişkin çeşitli düzenlemelere de yansımıştır. Sözgelimi Gündem 21 ve Yerel Gündem 21, BM HABITAT ve UNEP ortaklığıyla kurulmuş olan Sürdürülebilir Kentler Programı (2001-2007), Avrupa Kentsel Şartı I (1992), Avrupa Kentsel Şartı II (2008), Avrupa Kıtasının Sürdürülebilir Mekânsal Gelişmesi İçin Rehber İlkeler (2000), Avrupa Kentsel Gelişme Politikaları Süreci, Sürdürülebilir Avrupa Kentleri İçin Leipzig Şartı (2007), Sürdürülebilirliğe Doğru Avrupa Kent ve Kasabaları Şartı (Aalbourg Şart1-1994 ve Aalbourg Taahhütleri-2004) sürdürülebilir kentleşme bakımından önem taşıyan toplantı, sözleşme veya şartlar arasında sayılabilir (Mutlu, 2010). Sözkonusu düzenlemelerin tamamı da sürdürülebilir kentsel gelişme konusunda birbirini tamamlayıcı ilkelerin ortaya çıkmasında çok önemli katkılarda bulunmuşlardır. Bu tür düzenlemeleri küreselleşen dünyanın kentlerine ilişkin yasalar olarak değerlendirmek yanlış olmayacaktır. Nitekim 1992 yılında hazırlanan ve Türkiye tarafından da kabul edilmiş olan Avrupa Kentsel Şartı I'in ardından 2008 yılında bu şartın ikincisi de hazırlanmıştır. İlkinde sürdürülebilir kentsel gelişme konusu nisbeten zayıf bir değiniden ibaret iken Avrupa Kentsel Şartı II'nin ise adeta belgenin ruhuna sirayet etmiştir. Öyle ki bu belgede sürdürülebilir kentle ve kasabalar başlığı altında 15 madde sayılmıştır. Bu maddelerin tamamında geleceğin Avrupa'sının kentlerinin ve kasabalarının sürdürülebilir mekânlara dönüştürülmesi isteği ilan edilmiştir. Ne yazık ki Türkiye'de Pendik ve Nilüfer belediyelerinin dışında bu Şart'a imza koyan belediye bulunmamaktadır (Mutlu, 2010). Ancak KENTGES Eylem Planı'nın bu düzenlemeler esas alınarak hazırlanmış olduğunu da belirtelim.

Öte yandan bu anlayışa uygun olarak gerek AB ülkelerinde gerekse de dünyada uygulanan bütünleşik kentsel gelişme projeleri olmuştur (EC, 2013). Avrupa Bölgesel Kalkınma Fonu 2007-2013 Dönemi Final Raporu'nda Bütünleşik Alan Temelli Yaklaşımlar başlığı altında yer alan sekiz örneğin hepsinde uygulanan kentsel yenileme projelerinin bütünleşik bir yaklaşımla yapıldığına referans verilmektedir. Örneğin, Fransız Politique de la Ville, 
dezavantajlı yerleşimlerde eşitsizlikleri azaltma ve ulusal düzeyde Duyarlı Kentsel Bölgeleri artırma hedefiyle Avrupa'da başlatılan ilk ulusal programlardan biridir. Almanya'da, Sosyal Açıdan Bütünleşik Kent Programı da benzer bir yaklaşımla, bütünleşik girişimciliğe ilişkin yasal bir çerçeve ve planlama araçları sağlayarak dezavantajlı bölgelerin bütünleşik yenileme şemasını ulusal düzeyde çizmiştir. İspanya'da Kent İnisiyatifi yönetişim şeması, kentlerin blok fonlara başvurabilecekleri ulusal ve yerel düzey arasında doğrudan ilişki yapısı üzerinde çizilmiştir. Kazinbarcika örneği özellikle ilginçtir, çünkü Macaristan yalnızca AB fonuna dayanan ulusal bir bütünleşik politika çerçevesi hazırlamıştır. Bu ulusal bütünleşik politika çerçevesine göre, kentlerden bir Bütünleşik Kentsel Gelişme Stratejisi hazırlamaları istenmiştir. Asya Kalkınma Bankası ve Nepal Yönetimi Özel Fon kaynakları kullanılarak yürütülen Nepal Bütünleşik Kentsel Gelişme Projesi, Nepal'deki dört belediyede gerçekleştirilmek üzere Eylül 2011'de başlatılmıştır (ADB, 2013). Dünya Bankası tarafından finansal destek sağlanan Yemen Bütünleşik Kentsel Gelişim Projesi’nin amacı Taiz'de seçilen enformel yerleşim alanlarında temel ihtiyaçlara ulaşımı artırmak olarak belirlenmiştir (World Bank, 2013). Bir başka proje Güney Afrika'da gerçekleştirilmektedir. 1997 yılında başlayan bütünleşik Kentsel Gelişme Projesi’nin amacı kent yoksullarının yaşam alanlarının iyileştirilmesine dayanmaktadır (Practical Action, 2013).

Konuya kavramsal açıdan bakmak gerekirse, bu örneklerdeki bütünleşme anlayışının ortak bir anlayış mı yoksa bir niyetin ifadesi veya gerçek bir uygulama mı olduğu sorusu önem kazanmaktadır. Bütünleşme çevresel, sosyal ve ekonomik planlama politikalarının birbirlerine bağımlılığını ifade eder ve kentlilerin ve yönetimlerin gelişen kapasiteleri doğrultusunda kentsel sorunların karmaşıklığı ile mücadele etme niyetidir (EC, 2013).

\section{Türkiye'de Kentsel Politikalar}

2010 yılında KENTGES'in resmi bir belge olmasından önce Türkiye'de uygulanan kentsel politikaları değerlendirmek uygun olacaktır. Öncelikle belirtmek gerekir ki KENTGES Eylem Planı bir kopuşu değil bir sürekliliği arz etmektedir. Çünkü KENTGES’in üzerinde yükselmiş olduğu bir kentsel politikalar demeti, bir kentsel gelişme gerçekliği bulunmaktadır. Bundan ötürü KENTGES’in üzerinde yükselmiş olduğu zeminin analiz edilmesi gerekmektedir. Bu analizi Türkiye'nin kentsel gelişim sürecini kamu yönetimi, dolayısıyla yerel yönetimler alanında gerçekleştirilen reformlar bağlamında ama dahası bu reformların ekonomi-politik yönüne değinmek daha doğru olacaktır.

Türkiye'deki kentsel politikaların gelişim süreci aşağı yukarı birbirine benzeyen dönemlendirmeler şeklinde ele alınmıştır. Örneğin Tarık Şengül (2009), (a) ulus-devletin topraksallaşması (1923-1950), (b) emek gücünün kentleşmesi (1950-1980), (c) sermayenin kentleşmesi (1980 ve sonrası); Ayda Eraydın (2006), (a) Cumhuriyet'ten İkinci Dünya Savaşı sonrasına (yeni bir ulus-devlet yaratma döneminin tartışmaları 1923-1945) ve İkinci Dünya Savaşı'ndan planlı döneme (1945-1960) (b) nüfus artışının ve göçün kentlerde yarattığı sorunların ve gelişmişlik farklarının fazlalaşmasının getirdiği planlı gelişme dürtüsü (planlı dönemin başlangıcı ve sonu 1960-1980), (c) küresel bütünleşmeden beklentiler ve çözülemeyen sorunlar (bunalım sonrası noe-liberal politikaların mekânsal süreçleri tanımladığı dönem 1980 sonrası); Birgül Ayman Güler (1998), (a) yerel ölçekte devletçilik (1930-1945), (b) meclislerde geleneksel kentsel unsurların egemenliği (1946-1960), (c) yerel güçlerin dönüşümü ve gecekondulaşma (1961-1980), (d) sermaye ile küçük üreticiliğin çıkar birliği ve yeni ortaklar (1980'den günümüze). Her üç dönemlendirmede ve gerek kentsel politikalar gerekse de yerel yönetimlere ilişkin diğer çalışmalardaki en önemli temel özellik ilk dönemin ulus-devletin kentleşme süreci üzerindeki hegemonyası şeklinde, 1960 ve sonrası yılların gecekondulaşma ve planlı kalkınma çabalarının birlikte ele alındığı bir süreç şeklinde ve 1980 sonrası dönemin küreselleşme, neo-liberal politikaların uygulanması veya sermayenin egemenliği şeklinde ele alınmakta olmasıdır. Öte yandan 2000'li yıllarda kamu yönetimi alanında gerçekleştirilen düzenlemelerin önemli bir kısmının yerel yönetimlerle ilgili olduğu düşünüldüğünde yerelleşme ve kentsel politikaların yeni dönemin temel stratejileri açısından taşıdığı önem ortaya çıkacaktır. Ancak planlama yetkilerinin merkezileştirilmesi ve büyükşehir belediyeleri kurularak yerelde yeni merkezler oluşturulması yerelleşme politikalarının başka bir biçimde ama yeniden ele alınmasını gerektirmektedir.

Konumuz bakımından ise asıl önemli gelişmeler 1980 sonrasına ilişkin gelişmelerdir. 1980'li yıllar ve sonrası Türkiye açısından bütün dünyada olduğu gibi yeni bir dönemin başlangıcıdır ancak bu durum mekânsal politikalara da yansımıştır. Önceki dönemlere doğrudan değinilemese bile yeni dönem kentleşme sorunlarının önceki dönemlerde birikmiş olan sorunların birer uzantısı olduğu belirtilebilir. Gecekondulaşma, göç, kentsel yoksulluk, kentsel rantlar, kentsel dönüşüm, afet, 2b arazileri, meralar ve tarım topraklarının kullanımı, doğal ve kültürel varlıkların yanlış kullanımı, kıyılardaki yapılaşma yalnızca bugüne özgü değil geçmişten kaynaklanan sorunların tezahürleridir. Nitekim Eraydın (2006) bu dönemi farklılaşan bir dönem olarak nitelerken, süregelen ve çözülemeyen sorunların 1980 sonrası gündemin ana maddeleri olduğunu ifade etmiştir. Erayadın devamla, yeni politikaların mekânda yaratmış olduğu değişimleri şöyle sıralamıştır: Bölgeler arası dengesizliğin ekonomik ve siyasal niteliği ile gündeme gelmesi, kentsel kalitenin yükseltilmesi, gecekondu alanlarındaki dönüşüm, toplu konut alanlarının oluşturulması, küreselleşen ilişkiler ve küresel kentlerin ve yeni sanayi merkezlerinin ortaya çıkması ve yerel siyaset. Yine Bayındırlık ve İskân Bakanlığı tarafından 2007 yılında hazırlanmış olan bir raporda (akt. Mutlu, 2010), Türkiye'de sürdürülebilir kentleşmenin önünde duran sorunlar iki ana kategoride gösterilmiştir: Teknik alanlar ile ekonomik, sosyal ve kurumsal alanlar. KENTGES de bu tür sorunların 
çözülmesi bakımından hazırlanmış olan, Türkiye'yi 2023 yılına taşıyacak yeni kentsel politikaların neler olacağını belirten ve sürdürülebilir kentsel gelişme ilkesini odağına alan bir eylem planıdır.

BM'nin başını çektiği uluslararası örgütlerin öncülüğünde ortaya konup birçok ülke tarafindan sahiplenilen sürdürülebilir kentsel gelişmeye yönelik çalışmalar, Türkiye'de günümüzde merkezi düzeyde özellikle, 2011 yılında kurulan Kalkınma Bakanlığı ve aynı yıl Bayındıllık ve İskân Bakanlığı'nın yerine kurulan Çevre ve Şehircilik Bakanlığı bünyesinde gerçekleştirilmektedir. Bu noktada, 2003 yılında DPT tarafindan gerçekleştirilen ve 2011 yılında Kalkınma Bakanlı̆ğ tarafindan güncellenen Kentlerin ve Bölgelerin Sosyo-Ekonomik Gelişmişlik Sıralaması Araştırması'na (SEGE) değinmek yerinde olacaktır. Kentlerin, sürdürülebilir kentsel gelişmeye yönelik performanslarının; kavramın tüm boyutlarıyla, yani ekonomik, çevresel ve sosyal olarak izlenmesini mümkün kılması hedeflenen bu çalışmada kullanılan sosyo-ekonomik gelişmişlik göstergeleri incelendiğinde, SEGE-2003 çalışmasında 10 alt kategoride kullanılan 58 değişkenin yerini 8 alt kategoride 61 değişkenin aldığı görülmektedir.

\section{KENTGES Eylem Planı (2010-2023)}

Sürdürülebilir Kentsel Gelişme İçin Bütünleşik Kentsel Gelişme Stratejisi ve Eylem Planı Hazırlama Projesi (KENTGES)'in ön hazırlık çalışmaları Çevre ve Şehircilik Bakanlığı tarafindan Nisan 2007'de başlatılmış, ilk aşaması 30 Mayıs 2008 - 4 Mayıs 2009 tarihleri arasında istişare toplantıları, Kentleşme Şurası Komisyonları ve Genel Kurul Çalışmaları ile tamamlanmış ve ikinci aşaması 3 Mart 2010 tarihinde deklare edilerek sonuçlandırılmıştır. Bu projenin sonuç dokümanı; "KENTGES Bütünleşik Kentsel Gelişme Stratejisi ve Eylem Planı (2010-2023)" Yüksek Planlama Kurulu'nun 25.10.2010 tarih ve 2010/34 sayılı kararı ile kabul edilmiş ve 4 Kasım 2010 tarih ve 27749 sayılı Resmi Gazete'de yayımlanmıştır (http://www.kentges.gov.tr., 2013). Özetle KENTGES'in hazırlanmasında; yukarıda anılan Kentleşme Şurası Komisyon Raporları ve Sonuç Bildirgesi, DPT Müsteşarlığınca yürütülen Sürdürülebilir Kalkınmanın Sektörel Politikalara Entegrasyonu Projesinde yer alan Türkiye'de kentleşmeye ilişkin tespit ve değerlendirmeler, kentleşme alanında sürdürülebilirlik çerçevesi, yaklaşım ve modeller, Dokuzuncu Kalkınma Planı, Orta Vadeli Program, Yıllık Programlar, Özel İhtisas Komisyonu Raporları, Ulusal Strateji Belgeleri, BM’nin Habitat, Mekânsal Planlama Rehberi, Gündem-21 ve ilgili strateji ve eylem planları, Avrupa Kentsel Şartı, Avrupa'nın Mekânsal Gelişmesi için Rehber İlkeler, Avrupa Mekânsal Gelişme Perspektifi vd. belgelerin dikkate alınmış olduğu görülmektedir (Kentges Eylem Planı, 2010).

$\mathrm{Bu}$ eylem planında temel amacın, yerleşmelerimizin yaşanabilirlik düzeyinin, mekân ve yaşam kalitesinin yükseltilmesi ile ekonomik, sosyal ve kültürel yapılarının güçlendirilmesine yönelik merkezi ve yerel idareler için yol haritasının oluşturulması olduğu ifade edilmiştir (Kentges Eylem Plan1, 2010). Katılımcı bir süreçle elde edilmiş olan KENTGES için, çalışmaları Mayıs 2008'de başlayan ve 4-7 Mayıs 2009'da Genel Kurul ile sonuçlanan Kentleşme Şurası'nın Komisyon Raporları ve Sonuç Bildirgeleri, önemli bir kaynak oluşturmaktadır (Kentges Eylem Planı, 2010). Kentleşme Şurası ve KENTGES çalışmalarına merkezi ve yerel olmak üzere, 151 farklı kurum ve kuruluştan yaklaşık 500 uzman katkı sağlamıştır (KENTGES, 2013). Şûra Sonuç Bildirgesi'nde bu eylem planının gerekliliğini işaret eden şu ifade yer almaktadır. "Türkiye'de mekânsal planlama alanında bütüncül bir bakış açısının geliştirilmesinin gerekli olduğu belirlenmiştir. Mevcut durumdaki çok parçalı kurumsal yapının ve dağınık planlama yetkilerinin birlikte ele alınması ve çerçeve bir kanun ile yeni bir planlama yaklaşımı ve planlama sisteminin geliştirilmesi gerekmektedir" (Kentleşme Şurası, 2010).

KENTGES; ulaşım, altyapı, konut ve arsa sunumu, afetlere hazırlık, koruma, iklim değişikliği, yaşam kalitesi, sosyal politikalar ve katılım konularında merkezi ve yerel düzeyde yapılacak iş ve işlemleri belirlemektedir (KENTGES, 2013). KENTGES'te yer alan eylemlerin yüzde 28'si yerel yönetimlerin, yüzde 72'si ise merkezi yönetimin sorumluluğundaki eylemlerdir. Bayındırlık ve İskân Bakanlığı ise 37 eylemden sorumlu kılınmıştır (KENTGES, 2013). Belediyeler, KENTGES' in uygulanmasından sorumlu kurumlar içinde eylemlerin büyük bir kısmının yerine getirilmesinden sorumludur. Yerel yönetimlerin sorumlu olduğu eylemler 11 ayrı hedef başlığı altında toplanmıştır (Kentges Eylem Planı, 2010).

1. Yerleşmelerde sürdürülebilir bir mekânsal gelişme sağlamak.

2. Sürdürülebilir kentsel ulaşım sistemini oluşturmak.

3. Kentsel altyapı plan, proje ve yatırımlarını mekânsal planlarla bütünleştirmek.

4. Yerleşmelerde sosyal donatı ve hizmetlerin dengeli dağılımını sağlamak.

5. Sosyal, kültürel ve ekonomik boyutlarıyla bütünleşik bir kentsel yenileme ve dönüşümü sağlamak.

6. Afet ve yerleşme risklerini azaltmak.

7. Kent kimliğini korumak ve geliştirmek.

8. Kentlerde çevre duyarlı bir yaşam ortamı oluşturmak.

9. Kentlerde toplumsal dayanışmayı, bütünleşmeyi ve hoşgörüyü artırmak, muhtaçların ve dezavantajlı grupların kentsel hizmetlerden yararlanabilmesi için gerekli önlemleri almak.

10. Kent kültürünü, kentlilik bilincini, aidiyet duygusunu geliştirmek.

11. Kentli hakları konusunda farkındalık oluşturmak. 
Söz konusu hedeflere ulaşmak için Çevre ve Şehircilik Bakanlığı'nca belirlenen performans hedefleri doğrultusunda belediye eylemlerinin izlenmesi ve raporlanması yapılmaktadır. Bu kapsamda tüm belediyelerin mevcut kurumsal kapasiteleri ile sorun alanlarının ortaya konulması ve KENTGES'i uygulama kapasitesine sahip belediyelerin tespit edilebilmesi amaciyla elektronik ortamda toplam 2954 adet belediyeyi kapsayan KENTGES Belediyeler Anketi hazırlanmıştır. Bu ankete katılım 2130 belediye ile yaklaşık yüzde 80 oranında olmuştur (KENTGES Belediyeler Anketi, 2011). Teknik kapasite, planlama ve arazi kullanımı, yeşil alanlar, ulaşım, altyapı, atık yönetimi, enerji, kentsel dönüşüm, afet, konut, kent kimliği, kültürel miras, kentlilik bilinci, sosyal hizmetler ve katılım konularında yapılan ankette şu sonuçlar ortaya çıkmıştır (KENTGES Belediyeler Anketi, 2011):

Büyükşehir belediyelerinin KENTGES belgesine dayanarak hazırlanan performans hedeflerine teknik kapasite, sosyal hizmetler, kent kimliği, kültürel miras ve kentlilik bilinci konularında yaklaştıkları görülmektedir. Ancak, planlama ve arazi kullanımı, yeşil alanlar, ulaşım, altyapı ve atık yönetimi, yenilenebilir enerji, kentsel dönüşüm, afet ve konut gibi konularda ise önemli ölçüde merkezi idare ile işbirliğine ihtiyaç duydukları ortaya çıkmıştır. Temel konularda il ve ilçe belediyelerine göre daha ileride olan büyükşehir belediyelerinin sakınım planı veya kentsel risk yönetimi, tasarım rehberleri, kent bilgi sistemi, yenilenebilir enerjinin kullanılması, yolculuk süresinin kısaltılması konularında konulan hedeflerin çok gerisinde oldukları ve bunları geliştirmek üzere merkezi yönetim ile bir işbirliğine ihtiyaçlarının olduğu ortaya çıkmıştır. İl belediyeleri, teknik kapasite ve sosyal hizmetler, kent kimliği, kültürel miras ve kentlilik bilinci konuları haricinde büyükşehir belediyeleri ile benzerlik göstermektedir. KENTGES hedeflerini gerçekleştirmek için yeterli teknik kapasite desteği sağlanırsa il belediyeleri ile verimli bir işbirliği ortamında KENTGES hedeflerinin hayata geçirilme potansiyeli yüksektir. İl ve ilçe belediyelerinin de altyapı, ulaşım ana planı, atık yönetimi, enerji, afet zararlarını azaltma, yeşil alanlar, katılım, kent kimliği ve sosyal hizmetler açısından katkı ve desteğe ihtiyaçları olduğu anketten anlaşılmaktadır. Özellikle ilçe belediyeleri yaya bölgesi, kentsel atık depolama ve geri dönüşüm, yenilenebilir enerji, dönüşüm projeleri, risk yönetimi ve kent kimliği konularında birikimleri düşüktür. $\mathrm{Bu}$ ölçekteki sorunun, kapasite artırımı, rehberlik etme, deneyimleri paylaşma ve eğitim gibi yöntemlerle aşılabileceği düşünülmektedir. Burada teknik ve idari kapasitenin artırılmasında önemli rol merkezi idareye düşmektedir.

Genel olarak tüm belediyelerde bina sayısının, yap1 ruhsatlı ve yap1 kullanma izinli bina sayısı, yol uzunlukları, alan büyüklükleri gibi sayısal verilerde tutarsızlıkların ve eksikliklerin bulunduğu, envanter ve istatistik konularında belediyelerde yeterli kapasite ve altyapı bulunmadığı tespit edilmiştir (KENTGES Belediyeler Anketi, 2011).

KENGES Eylem Planında ülkemizde kentleşme ve yerleşmeye ilişkin sorun ve potansiyeller belirli başlıklar altında toplanmıştır. Sorun alanları:

1. Kentsel sorunlar ve kentlerde kontrolsüz büyüme.

2. Kırsal gelişme ve göçler.

3. Kaçak yapılaşma ve gecekondu.

4. Afetlere dayanıksız kentleşme.

5. Kentsel altyapı ve çevre sorunları.

6. Kentsel ulaşım sorunları.

7. Planlama sisteminden kaynaklana sorunlar.

8. Yerel yönetimlerin kapasitelerine ilişkin sorunlar.

9. İklim değişikliği.

10. Kentsel dönüşüm.

11. Sürdürebilir kent formu ve enerji verimliliği.

Ancak asıl olarak kentleşme ve yerleşmeye ilişkin sorunların temelinde etkin mekânsal planlama sisteminin oluşturulamamasının bulunduğu ve Türkiye'de merkezi ve yerel düzeyde kurumlar arasında mekânsal planlama yetki ve uyum sorunlarının devam ettiği ve kent planları ile mekânsal kararlar getiren tematik planların bütünleştirilemediği belirtilmektedir (Kentges Eylem Planı, 2010).

Yukarıda sıralanan sorunların çözümü için ise üç temel strateji geliştirilmiştir:

1. Mekânsal Planlama Sisteminin Yeniden Yapılandırılması.

2. Yerleşmelerin Mekân ve Yaşam Kalitesinin Artırılması.

3. Yerleşmelerin Ekonomik ve Toplumsal Yapılarının Güçlendirilmesi.

\section{Sonuç ve Değerlendirme}

Ertan’ın (2007) belirttiği gibi sürdürülebilir kent, "sömürüye dayanmayan insanlığın hak ettiği, sağlıklı, nitelikli ve dengeli bir çevreyi de içine alan toplumsal eşitlik ilkesine dayanan, tüm toplumsal kesimler için uygun-sağlıklı yaşam koşulları sağlayan, ussal ve bütüncül planlama anlayışına dayalı, demokratik yurttaş 
katılımlı bir kent olmalıdır." Görüldüğü üzere gerek tespit edilen sorunlar gerekse de sorunların çözümü için geliştirilmiş olan stratejilerde doğrudan sürdürülebilir kentsel gelişme kavramı kullanılmamış olsa da sözkonusu ilkenin KENTGES'e sirayet etmiş olduğu söylenebilir. Yalnızca Eylem Planı metnine ve belirlenen sorunlara bakıldığında oldukça faydalı görünen bu proje oluşturulduğu ancak döneme hakim neo-liberal politikalar ve uygulamalar ile ilişkilendirildiğinde kimi çekinceler ortaya çıkmaktadır. Swyngedouw ve arkadaşlarının (2002) $12 \mathrm{AB}$ ülkesinde gerçekleştirilen 13 büyük ölçekli kentsel kalkınma projesinin teorik altyapısını/içyüzünü analiz ettikleri çalışmadan elde edilen sonuçlar düşündürücüdür. Çalışma, küreselleşme ve liberalleşmenin yeni yönetişim biçimleri yoluyla nasıl eklemlendiği/uygulandığı, yönetmenin yeni bir skalar bütünlüğünün oluşturulması ve büyük ölçekli kentsel kalkınma ile kentteki siyasal, sosyal ve ekonomik güç ilişkileri üzerine odaklanmıştır. Çalışmada, büyük ölçekli kentsel gelişme projelerinin planlama ve politika pratiklerinde istisnai ölçütlerin kurulması için bir araç olarak kullanıldığı ve bunun bir neo-liberal "Yeni Kent Politikası" yaklaşımı ve onun seçkinci "orta ve üst sınıf" demokrasisinin parçası olduğu ve bunun dadaha az demokratik daha çok elitist öncelikler tarafından karakterize edilen kentsel girişimlerin "yönetiminin" yeni formlarıyla ilişkili olduğu belirtilmektedir. Yine yerel demokratik katılım mekanizmalarının muteber olmadığı veya elit gücün yeni bir kareografisi ile sonuçlanan son derece "biçimsel" bir şekilde uygulandığı, kentsel gelişim projelerinin nadiren daha geniş ölçekli kentsel süreç ve planlama sistemleri ile azami ölçüde bütünleşmekte olduğu, bu projelerin gayrimenkul piyasası eliyle sosyo-ekonomik kutuplaşmaya neden olduğu belirtilmektedir

Sonuç olarak, Haziran 2013 itibariyle Türkiye gündemini meşgul eden ve uzun bir süre daha meşgul edeceğe benzeyen Gezi Parkı olaylarının ortaya çıkış nedenleri hatırlanacak olduğunda sürdürülebilir kentsel gelişmenin ne denli önem kazandığı anlaşılmaktadır. Sürdürülebilir kentsel gelişmeyi izlemekte birer araç olarak kullanılmalarının yanında; kentsel ve bölgesel düzeyde kamu politikalarının uygulanmasında kıstas görevi gören ve yazıda ele alınan konular özü itibariyle niteliksel bir yaklaşımı gerektiren sürdürülebilir kentsel gelişme anlayışıyla çelişkili görünmektedir. Çünkü bu ilke kuşaklar arası adaleti, sosyal, ekonomik ve çevresel sürdürülebilirliği i i̧ermektedir.

\section{Kaynakça}

- ADB, 2013. http://www.adb.org/sites/default/files/projdocs/2012/42161-012-nep-tacr.pdf.

- Bayındırlık ve İskân Bakanlığı, 2009. Kentleşme Şurası Sonuç Bildirgesi.

- Çevre ve Şehircilik Bakanlığı, 2010. KENTGES Eylem Planı (2010-2023).

- Çevre ve Şehircilik Bakanlığı, 2011. KENTGES Belediyeler Anketi.

- EC, 2013. http://ec.europa.eu.

- Eraydın, Ayda, 2006. "Mekansal Süreçlere Toplu Bakış”, Ayda Eraydın (der.), Değişen Mekan, Dost Kitabevi, Ankara, s. 25-68.

- Ertan, Kıvılcım Akkoyunlu, 2007. “Sürdürülebilir Kent”, Ayşegül Mengi (ed.), Kent ve Politika, İmge Kitabevi, Ankara.

- Keleş, Ruşen, 1998. Kentbilim Terimleri Sözlüğü, 2. Baskı, İmge Kitabevi, Ankara.

- KENTGES, 2013. http://www.kentges.gov.tr.

- Mutlu, Ahmet, 2010. Kentli Hakları ve Türkiye, Çizgi Kitabevi, Konya.

- Practical Action, 2013. http://practicalaction.org/region_southern_africa_iudp.

- Swyngedouw, Erik, Frank Moulaert, Arantxa Rodriguez, 2002. "Neoliberal Urbanization in Europe: LargeScale Urban Development Projects and the New Urban Policy", Antipode, Vol. 34, Iss.3, ss. 542-577, July.

- Şengül, Tarık, 2009. Kentsel Çelişki ve Siyaset, İmge Kitabevi, Ankara.

- Türkiye Çevre Sorunları Vakfi, 1991. Ortak Geleceğimiz, TÇSV Yayınları, Ankara.

- UDP, 2013. http://www.udp-aleppo.org/?id=1.

- UN-HABITAT \& UNEP, 2001. Sustainable Cities Programme Report.

- Uysal, Yıldız, 2002. "Uluslararası Platformda Çevre", Sürdürülebilirlik ve Mimari Dosyası, Mimarist Dergisi, Y11 2, Say1 6, İstanbul.

- World Bank, 2013. http://www.worldbank.org/projects/P107050/ry-integrated-urban-development-projectiudp?lang=en. 


\title{
Ordu-Üniversite-Sanayi İşbirliğinin Ekonomik Gelişme Üzerindeki Rolï
}

\section{The Role of Army-University-Industry Cooperation in Economic Development}

\author{
Asst. Prof. Dr. Özgür Uysal (Akdeniz University, Turkey) \\ Prof. Dr. Recep Kök (Dokuz Eylül University, Turkey)
}

\begin{abstract}
The cooperation between the different institutions in an economic system, is one of the elements that contributes to the development of the economic system. The main purpose of this study is to analyze the main determinants of growth rate of the defense industry based patent production as a concretized indicator of the information economics, in order to determine in which ways the army-university-industry cooperation will contribute to economic development. In this study, generated basic and derivative hypotheses were tested using panel data method on NATO countries and were developed an econometric model to provide and improve the army-university-industry cooperation. The contribution of the army-university-industry cooperation to economic development have been revealed with a model proposal. According to the results of analysis, the basic dynamics that determined the growth rate of patent production resulting from army-university-industry cooperation are the share of technological progress of army on national income received by the army, the share of university $R \& D$ expenditures in total R\&D expenditure and technological gap levels of the countries. It's observed that any reduction in technological gap levels of the countries or any increase in military-oriented technological progress or the share of university $R \& D$ expenditures in total $R \& D$ expenditure increases the growth rate of patent production resulting from the army-university-industry cooperation.
\end{abstract}

\section{Giriș}

Sosyal sistem parçalardan oluşan bir bütündür ve ekonomik sistem de sosyal sistem içerisinde var olan kurumlardan birisidir. Bu nedenle sosyal sistem içerisinde bulunan herhangi bir parçada meydana gelen bir değişiklik bütünün diğer parçaları üzerinde de etkide bulunur. Söz konusu durum, ister ekonomik, ister politik, isterse kültürel olsun bütün olaylar için aynıdır. O halde ekonomik sistemi, daha genel ve tüm sistemleri içerisine alan sosyal sistem içerisinde analiz etmek gerekir. Böylece ekonomik sisteme etki eden birçok faktör analiz dışına itilmemiş olur. Gelişme gibi birden çok faktörden etkilenen toplumsal bir olgunun doğru ve tutarlı bir analizinin yapılabilmesi ekonomiyle birlikte sosyo-kültürel ve psikolojik faktörleri de içinde barındıran bir yöntemle mümkün olabilir. Gelişme araştırmaları ancak bu şekilde tek boyutluluktan ve indirgemecilikten kurtarılıp toplumların problemlerini çözmeye yöneltilebilir.

Sosyal sistem bütününün parçalarından birisi ekonomik gelişmedir. Ekonomik gelişmeye etki eden faktörlerden birisi ise kurumlar arası işbirliğidir. Farklı kurumlar aralarında fikir, bilgi ve ürün paylaşımı yaparak yenilik üretmekte ve bu yolla ekonomik gelişmeye katkı sağlamaktadırlar. Bu işbirlikleri arasında ekonomik gelişmenin itici gücü konumunda olan ve ilerlemeye en yatkın olması beklenen ilişsi üniversite-sanayi işbirlikleridir. İktisat literatüründe üniversite-sanayi işbirliğine yönelik olarak yapılan birçok çalışma mevcuttur. Yapılan bu çalışmalarda üniversite-sanayi işbirliğinin ne şekilde olduğu/olması gerektiği ve üniversitelere, sanayiye ve genel ekonomiye olan katkıları çeşitli boyutlarıyla ele alınmıştır. Bu çalışmada ise ordu, üniversite ve sanayi arasında oluşturulacak işbirliği, ekonomik gelişmeye katkıları bağlamında ortaya konulmuştur. İktisat literatüründe bu anlamda bir çalışma bulunmazken, ekonomilerdeki bazı temel kurumlarının niteliksel yapısı ve işleyişinin geliştirilmesine yönelik bazı öneriler ortaya koyması çalışmanın bir başka önemli yanıdır.

$\mathrm{Bu}$ çalışmanın temel amacı ülkelerin temel kurumları olan ordunun ve üniversitelerinin hem kendi aralarında hem de sanayi sektörü ile işbirliğini geliştirecek bir model önerisi ortaya koymak, nasıl bir ordu-üniversitesanayi işbirliği modellenebileceğini araştırmak ve bilgi ekonomisinin somutlaştırılmış göstergesi olan savunma sanayi temelli patent üretiminin temel belirleyenlerini analiz etmektir. Bu sayede ekonomik gelişmede ordu, üniversiteler ve sanayi arasındaki karşılıklı etkileşimin ve işbirliğinin rolü ortaya konmuş ve bu konuda tarafımızdan kurulmuş hipotezler test edilerek ordu-üniversite-sanayi işbirliğinin geliştirilmesine yönelik politika önerileri geliştirilmiştir. Bu çalışma orduyu da içine alan bir işbirliği modeli ortaya koyarak literatürdeki bu eksikliği gidermeyi amaçlamaktadır.

Çalışmanın uygulama kısmında ordu-üniversite-sanayi işbirliğini sağlamaya ve geliştirmeye yönelik bir takım hipotezler kurulmuştur. Daha sonra ordu-üniversite-sanayi işbirliğine yönelik ilgili değişkenler belirlenerek ekonometrik bir model oluşturulmuş ve NATO ülkeler grubu üzerinden panel veri yöntemiyle çalışmanın hipotezleri test edilmiştir. 
Üniversiteler bilim üreten ve geliştiren kurumlar olması, sanayi ekonominin üretim yapan motoru olması, ordu ise devletin bekasını sağlayan ve savunma hizmetini yürüten kurum olması bakımından ekonomik gelişmede önemli rol oynamaktadır. Ekonomik gelişmeye ayrı ayrı katkıları bulunan bu üç temel dinamiğin işbirliği yapmaları halinde ekonomik gelişmenin niteliğinin ve hızının artacağı ve işbirliğinden doğan sinerjinin ekonomiye daha büyük katma değer yaratacağı düşünülmektedir.

\section{Ekonomik Gelişme}

Gelişme, bir ulusun ekonomik, sosyal (doğum oranı, kentleşme oranı vb.), kültürel (sanat faaliyetleri vb.) ve çevresel yaşamındaki genel ilerlemedir. Ekonomik gelişme, aynı zamanda bir ekonomideki nicel değişmelerin yanında nitel (yaşam standardını iyileştiren, sayı ile ölçülemeyen) değişmeleri de kapsamaktadır.

Ekonomik gelişme süreci ve onun unsurları araştııılırken karmaşık bir yapıyla ve daima iç içe geçmiş olaylarla karşılaşılır. Bu nedenle sermaye ve teknoloji gibi ekonomik faktörlerin, diğer faktörlerin desteği olmaksızın gelişme olgusunu ortaya çıkarması güçtür. Gelişme olgusunun, iktisadın da içerisinde olduğu birden fazla faktörün birbirleriyle karşılıklı ilişki kurularak ortaya çıkması daha muhtemeldir. Genellikle toplumsal olayları ortaya çıkaran unsurlar birbirlerine bağlıdırlar. Bundan ötürü bir tek neden-sonuç ilişkisi anlayışı sosyal olayların incelenmesinde yeterli olamamaktadır. Çünkü bütünün bir değişkenle belirlenmesi değil, değişkenlerin birbirleri üzerindeki karşıllklı etkisi ile toplumsal olguların değişmesi söz konusudur. Gelişme gibi sosyal sistemin değişimini ifade eden ve sosyal sistemin değişikliğine neden olan bir olgunun da tek nedenli ilişki yerine, sosyal olaylar arasındaki karşılıklı ilişki anlayışıyla çözümlenmesi gerekir. Bu anlayış ise bütüncül bir yöntemi gerekli kılmaktadır. Bütüncül (holistik) yöntem; iktisadi, kültürel, politik ve psikolojik faktörlerin birlikte ele alınıp gelişmeye olan etkilerinin karşılıklı etkileşim içerisinde konu edildiği bir araştırma metodunu içermektedir.

Ekonomik gelişme olgusunun anlaşılabilmesi ve gerçekleştirilebilmesi için iktisadi yapı gibi tek bir kurumsal oluşumun ötesinde, birden fazla kurum birlikte ele alınmalıdır. Çünkü siyasal, ekonomik, kültürel ve bireysel faktörler arasında koparılamayacak bir ilişki bulunmaktadır. Bu nedenle, yukarıdaki faktörlerin gelişme olgusu etrafinda birbirleriyle olan bağlantıları kurulmalı ve ilgili değerlerin değişimleri, bir bütünlük içerisinde tanımlanmalıdır (Yavilioğlu, 2002:68).

Bilgi toplumunda ekonomik gelişmenin temelinde, sermaye birikimi değil, bilimsel bilgi birikimi yatmaktadır. Burada üretilen bilimsel bilgi, kuantum düşüncesinin bilimsel yaklaşımları içerisinde üretilen yeni teknolojilere dayanmaktadır. Bilimsel bilginin doğaya ve yaşama uygulanabilir olması teknoloji olarak ortaya çıkmaktadır. Ekonomik gelişme; bilimsel bilgi ve teknolojik yeniliklere dayalı bir süreç olarak devreye girmektedir. Bilgi toplumunun temelindeki bilimsel bilgi ve yenilikler, toplumun; eğitim, öğrenim ve Ar-Ge ile entelektüel sermayesine ve dolayısıyla yetişmiş nitelikli insan gücüne bağlı olarak üretilmektedir.

Ekonomik gelişmeyi açıklamada büyüme teorileri denge analizleri olması ve konulara tek yönlü yaklaşması nedeniyle yetersizdir. Dolayısıyla ekonomik gelişme konusunun daha genel bir çerçevede incelenmesi gerekmektedir. Kuantum düşüncesi ve ağ etkileşim sistemi göz önünde bulundurulduğunda ekonomik gelişmeyi sağlamada farklı kurumlar arasında işbirliğinin sağlanması gerekir. Ordu, üniversite ve sanayi gibi farklı kurumların karşılıklı ilişkisini inceleyecek bir yaklaşımın basit ve tek yönlü mekanik etkileşim modeli ile incelenmesi yerine çok yönlü interaktif etkileşim yaklaşımıyla incelenmesi doğrudur. Yani, kullanılacak yöntem tek yönlü neden sonuç ilişkisinden ziyade çok yönlü interaktif etkileşim ilişkisi olmalıdır. Bu interaktif etkileşim sürekli ve dinamiktir. Bu da ancak kuantum mantığıyla olur. Karşılıklı dönüşüm ve kümülatif etkileşim kuantum mantığına dayanır. Bir toplumu sağlıklı olarak inceleyebilmek adına çok yönlü interaktif etkileşim ilişkisine bağlı kalarak yapılan bir arayışın varacağı yer kurumlar arası etkileşim ve işbirliği olmaktadır. Dolayısıyla, noktasal yaklaşım yerine işbirliği sayesinde daha çok sayıda yenilik üretilir.

\section{3 Üniversite-Sanayi İşbirliği ve Ar-Ge}

Sanayileşmiş ve ekonomik olarak gelişmiş ülkelerde üniversite-sanayi işbirliğinin de oldukça geliştiği görülmektedir. Dura (1995:101)'ya göre üniversite-sanayi işbirliği; üniversitelerin mevcut kaynakları (bilgi, personel, materyal, vb.) ile sanayinin mevcut kaynakları (tecrübe, personel, ekonomik güç, vb.) her iki tarafa ve topluma fayda sağlamak üzere, bir metot ve sistem dâhilinde birleştirilerek yapılan eğitim-öğretim, araştırmageliştirme ve diğer hizmet faaliyetlerinin tümüdür.

Günümüzde bir ülke sanayisinin ya da bir sanayi kuruluşunun uluslararası pazarlardaki rekabet üstünlüğü yarışında ön plana çıkabilmesi, imalat yeteneğine Ar-Ge becerisini de ekleyebilmesine bağlıdır (Rasiah ve Govindaraju, 2009).

Üniversite-sanayi işbirliği sayesinde sanayi ve hizmet sektörlerinin talep ettiği iş gücü ihtiyacını nitelikli bir şekilde arz edilmesi sağlanacaktır. Güler (2000)'e göre, temel anlamda aşağıda belirtilen koşullar işbirliğini zorunlu kılmaktadır: Nitelikli insan yetiştirme zorunluluğu, Üniversitenin mevcut ve potansiyel imkânlarının sanayiye aktarılmasi; Sinerji etkisi yaratmak. 
Gelişen teknoloji ve bilgi çağının getirdikleri, geride kalmayı ya da yerinde sabit bir yapıyı asla kabul etmemektedir. Bu kapsamda yarış, rekabet, hizmetler ya da üretim sektöründe ve her alanda devam etmektedir. Bu yarışta başarılı olmak ve en önde olmak, makro düzeyde her ülkenin, mikro düzeyde her sektör ve işletmenin var oluş amacı ile ayrılmaz bir bütünlük içindedir. İnsan kaynaklarına yapılan yatırım ve entelektüel sermayenin bu yarışta son derece önemli bir yeri vardır. Yetişmiş insan kaynakları ve rekabetin diğer unsurları arasında iyi bir koordine ile amaca yönelik işbirliğinin sağlanması zorunluluğu vardır (Çağlar, 1999).

Ar-Ge, bilimin evrenselliği temelinde bağımsızdır ama evrensel bilime yapılacak bireysel ya da kurumsal katkı, bağlı olunan ulus için de özel bir saygınlık kazandırmaktadır. O nedenle Ar-Ge yetersizliği ya da zayıf ArGe yeteneği, o ülke için bilimsel ve teknolojik bağımlılık, ayrıca da dünya üzerinde saygın bir yerde olamama demektir.

\section{Savunma Sanayi}

Çalışmanın temel amacı ordu-üniversite-sanayi işbirliğinin ekonomik büyümeye katkılarını belirlemek olduğu için bu noktadan itibaren devletin temel kurumlarından olan "ordu" çalışma kapsamına dâhil edilmiştir. Ordu devletin bekasını sağlayan ve savunma hizmetini yürüten kurumu ve devletin silahlı gücüdür. Sanayi sektörünün ordu ve savunma ile ilgili olan kısmı genel olarak savunma sanayi başlığı altına girmektedir. Bu anlamda ekonomik gelişmeye önemli katkılar sağlayan ordu sanayi işbirliği özellikle savunma sanayi ölçeğinde gerçekleşmektedir.

Savunma sanayinin sivil sektörlerin faaliyetlerine benzer yanları olmasına rağmen, ileri teknoloji kullanımı, yüksek kalite standartları, sınırlı sayıda alıcısı olan bir pazar, politik etkilere açık olması ve tek bir ürün için çok büyük miktarlarda Ar-Ge ve yatırım gerektirmesi gibi özellikleri savunma sanayini diğerlerinden ayırmaktadır (SSM, 2004).

Savunma sanayi ülkenin tüm ekonomik yapısı, özellikle üretim endüstrilerinin yatırım faaliyetleri ile sıkı ilişki içerisinde, bir ülkenin silahlı kuvvetleri için, taktik ve stratejik silah sistemleri ile diğer askeri teçhizatı tasarlayan, geliştiren ve üreten kamu ve özel sektör işletmelerinin toplamıdır (Öztürk, 2001: 44). Silah sistemleri yüksek Ar-Ge harcaması ve uzun süren bir üretim süreci gerektirirler. Bu faktörler savunma sanayi işletmelerinin ürün değişim gereklerine reaksiyon göstermelerini zorlaştırır. Bazı hükümetler ise savunma sanayi kapasitesinin belirli bir seviyenin altına düşmesine politik direnç gösterebilirler (Öztürk, 2001:44-48).

Savunma Sanayi sektörü, uluslararası serbest ticaret antlaşmaları dışında tutulan, ticari ilişkilerin politik ilişkilere sıkı bir biçimde bağlı olduğu, uluslararası ticaret hacminin sınırlı ve az sayıdaki ülke tekelinde olduğu, bu nedenle iç pazar ile büyüyen, yatırım ve harcama kararları ekonomik gerekçelerden çok jeostratejik ve siyasi gerekçelerle verilen bir sektördür. Savunma Sanayi sektörünü diğer sektörlerden ayıran bir diğer konu da, bu sektörün, bilim ve teknolojinin en son yeniliklerinden yararlanması, ürünlerin genel olarak en ileri ürün ve üretim teknolojilerinin birer örneği olmasıdır (Cleand ve Gallagher, 1993:23). Dolayısıyla sektör, ülkelerin teknolojik altyapısının gelişimi açısından itici rol oynamaktadır. Bu gücün korunmasıysa, sürekli ve geniş ölçekli bir Ar-Ge faaliyeti yürütülmesi ve nitelikli, yenilikçilik ve yaratıcılık yetenekleri geliştirilmiş bir insan kaynağına yatırım yapılması ile mümkün olmaktadır. $\mathrm{Bu}$ nedenle, bu alanlardaki yatırım kararlarında ülkelerin stratejik hedefleri de önemli bir rol oynamaktadır. Öte yandan, yüksek teknolojiye dayalı tüm sektörlerde görüldüğü gibi, bu sektör; nitelikli, katma değeri yüksek ürünleri hedefleyen, teknoloji üretmek ve karşılıklı bağımlılık ilkesi çerçevesinde dünyayla sıkı entegre olmak zorunda olan, bu nedenle de karmaşık ve ileri düzeydeki Ar-Ge projelerine dayanan, ihtiyaçlardaki değişiklikler nedeniyle kapsamı ve hedefleri sıkça değişen faaliyet ve teknoloji alanlarını kapsayan bir sektördür (Gökpınar, 2003:5).

Son yıllarda ordunun ihtiyacı olan savunma sistemlerinde özgün yurt içi geliştirme modellerine öncelik verilmeye çalışılmıştır. Böylece, teknolojinin satın alınması yerine üretilmesi durumunda tedarik edilen sistemler üzerinde gerekli geliştirmelerin kısıtlamasız olarak yapılması mümkün hale gelmekte ve bu ürünlerin fikri mülkiyet ve kısıtsız kullanım haklarına sahip olunmaktadır. Savunma sanayinde yurtiçi üretim, güçlü bir savunmasının yanı sıra, savunma sanayinin uluslararası rekabette yer alabilmesi ancak teknolojik gelişmelere ayak uydurmak ve ileri teknoloji alanlarına hâkim olmakla mümkün olabilecektir. Bu çerçevede, Ar-Ge çalışmalarına olan ihtiyaç her zamankinden fazla hissedilmektedir.

\section{Ordu-Üniversite-Sanayi İşbirliğine Yönelik Bir Uygulama}

Çalışmanın bu bölümünde, hedeflenen ordu-üniversite-sanayi işbirliğini sağlayacak desteklenebilir bir yapının oluşturulmasına yönelik bir uygulama yapılmıştır. Daha sonra panel veri analizi sonuçları değerlendirilerek politika önerileri ortaya konmuştur. Çalışmanın temel amacı çerçevesinde ordu-üniversite-sanayi işbirliğine yönelik temel ve türev hipotezler kurulmuş ve yukarıda tanımlanan yöntemlerle kurulan model üzerinde test edilmiştir. Temel hipotez aşağıda belirtilmiştir.

Ordu-üniversite-sanayi işbirliğinden doğan patent artış hızı teknolojik yayılma etkisi yaratmaktadır. 
Bu temel hipotezi destekleyecek iki türev hipotez şöyledir:

1) Ordu-üniversite-sanayi işbirliğine bağlı olarak artan katma değer ekonomide itici bir güçtür.

2) Patent artışında üniversite Ar-Ge harcamalarının etkisi yadsınamaz.

\subsection{Uygulamanın Yöntemi}

Temel amaç fonksiyonu olarak öncelikle çalışmanın ilk iki bölümünde aktarılan teorik çerçeveden hareketle ordu-üniversite-sanayi işbirliğine yönelik bir model oluşturulmaya çalışılmıştır. Oluşturulan model için tek bir ülkenin gerekli çoğunlukta veri seti bulunmaması nedeniyle analiz 15 NATO ülkesini kapsayacak şekilde genişletilmiş ve analiz aracı olarak panel veri yöntemi tercih edilmiştir.

Yukarıda belirtilen amaç doğrultusunda bu çalışmada yararlanılan yöntem panel veri yöntemidir. Bu yöntemin kullanılmasının nedeni tek bir ülkeye ait verilerde yaşanan zaman kısıtı nedeniyle analize diğer ülkelerin de dâhil edilmesidir. Veri setinin 1997-2010 dönemi ile sınırlı tutulmasının nedeni, hem savunma sanayi Ar-Ge harcamaları ve üniversite Ar-Ge harcamalarının hem de savunma sanayi sektörüne ait patent sayılarının ayrıntı bilgiler olması ve de gizlilik arz etmesi nedeniyle eski yıllara ait bu tür detaylı verilerin yayınlanmamasıdır. Bu tür verilerin daha ayrıntılı biçimde açıklanması özellikle son 10-15 yılda ortaya çıkan bir gelişme olmuştur. Dolayısıyla bu dar zaman aralığındaki veri seti ile sağlıklı bir ekonometrik uygulama yapmak ve çalışmanın hipotezlerini test edebilmek için tek bir ülke ölçeğinde değil aynı savunma paktında yer alan ülkeler grubu ölçeğinde analiz yapmak gerekir. Bu yüzden model analizinde başvurulan yöntem panel veri yöntemi olmuştur. Panel veri yönteminin standardizasyonunu sağlama açısından kurulan model NATO ülkeleri kapsamında düşünülmüştür. Birçok NATO ülkesi teknolojik yayılma politikalarını yüksek teknoloji üzerine kurmakta ve ulusal verilerini de açık olarak ortaya koymaktadır. Analiz 15 NATO ülkesinin verileri üzerinden analiz yapılmış, diğer NATO ülkelerinin söz konusu yıllara ait yayınlanmış verileri bulunmadığından bu ülkeler analiz dışında tutulmuştur. Örneklem olarak 1997-2010 döneminde 15 NATO ülkesine ait y1llık verilerden oluşan panel veri seti kullanılmıştır. Veri seti Ekonomik İşbirliği ve Kalkınma Teşkilatı (OECD) resmi internet sitesi (http://www.oecd.org/) ve Avrupa Patent Ofisi (EPO) resmi internet sitesinden (http://www.epo.org/) elde edilmiştir. Veri setinde her bir ülkeye ait 4 ayrı veri olmak üzere 14 yıl üzerinden toplam 840 veri kullanılmıştır.

Panel veri analizinde oluşturulan ekonometrik modelin katsayılarını tahmin etmenin yolu olarak Pedroni (1996, 2000) Düzenlenmiş/Geliştirilmiş En Küçük Kareler Yöntemi’ni (Fully Modified Ordinary Least Squares (FMOLS)) önermektedir. Bu yüzden çalışmada araştırma yöntemi olarak Düzenlenmiş/Geliştirilmiş En Küçük Kareler Yöntemi izlenmiş, kurgulanan modellerin spesifikasyonlarında Sabit Etkiler Modeli dikkate alınmıştır. Eğer araştırma yapılacak panel veri seti OECD ülkeleri, NATO ülkeleri, Amerikan Eyaletleri vb. gibi spesifik bir firmalar/ülkeler/eyaletler seti dikkate alınarak ve belirlenen bu set içinden oluşturuluyorsa, Sabit Etkiler Modeli en uygun panel veri spesifikasyonu olarak değerlendirilmektedir.

Sabit, eğim katsayısı ve hata terimi hakkında yapılan varsayımlara bağlı olarak panel veri regresyonu değişik şekillerde tahmin edilebilmektedir. Örneğin eğim katsayısının sabit, buna karşılık sabit katsayısının yatay kesitlerde farklı olduğu varsayılabilmektedir. Her bir yatay kesitin bireyselliklerini dikkate almanın bir yolu, her bir ülke için sabit katsayıların farklı olmasına, buna karşılık eğim katsayılarının aynı olmasına izin vermektir. Bu model literatürde Sabit Etkiler Modeli olarak bilinmektedir (Coşkun, Kök, Yücel, 2010:71). Buradaki sabit etkiler terimi, eğim katsayısının sabit (aynı), ancak sabit katsayısının her bir kesit için farklı olduğu ve her bir kesitin sabitinin zaman boyunca değişmemesi (time invariant) varsayımlarını nitelemektedir. Bu modelde eğim katsayıları hem zaman hem de kesit için aynı olmaktadır (Gujarati, 2004:642). Bu durumda bir veri setine ilişkin olarak ülkelerdeki bireylerin ırkı, cinsiyeti, yetenekleri, ülkelerin yönetsel performansları ve coğrafi konumları gibi gözlenemeyen bireysel etkiler (heterojenite), tahmin edilmesi gereken $\mathrm{N}$ sayıda parametre olarak düşünülmektedir (Greene, 2003:285). Bu çalışmanın veri seti göz önüne alındığında, kurgulanan modellere ilişkin spresifikasyonlarda sabit etkiler modeli dikkate alınmış ve gerçekleştirilen F testi sonuçları da Sabit Etkiler Modelinin seçiminin uygun olduğunu desteklemiştir (ilgili test sonuçları Tablo 1'de gösterilmiştir).

\subsection{Model Analizi}

Burada ordu-üniversite-sanayi işbirliğine yönelik bir model oluşturulmuş, değişkenlerle ilgili veri tanımlaması yapılmıştır. Sağlanacak işbirliği sayesinde ortaya çıkacak olan yenilikler ve buluşların bir göstergesi olarak savunma sanayinin elde ettiği patentler aynı zamanda bilgi ekonomisinin somutlaşmış bir göstergesi kabul edilmiş ve açıklanan değişken olarak modele dâhil edilmiştir. Bunun yanında savunma sanayi Ar-Ge harcamaları, üniversite Ar-Ge harcamaları ile bu verilerin toplam büyüklükler içindeki payları ve ülkelerin teknolojik açık düzeyleri 1997-2010 dönemi verileri halinde elde edilmiş ve panel veri yöntemiyle analiz edilmiştir.

\subsection{Modelin Tanımı ve Temel Değişkenleri}

Çalışmanın amaç kısmında belirtildiği üzere savunma sanayi patent üretimindeki gelişmenin temel dinamiklerini ele alan aşağıdaki değişkenler model ve analizde şu şekilde tanımlanmıştır.

$$
\begin{aligned}
& \mathrm{P}_{\mathrm{i}, \mathrm{t}}=\alpha_{\mathrm{i}, \mathrm{t}}+\beta_{1 \mathrm{i}} \mathrm{M}_{\mathrm{i}, \mathrm{t}}+\beta_{2 \mathrm{i}} \mathrm{U}_{\mathrm{i}, \mathrm{t}}+\beta_{3 \mathrm{i}} \mathrm{T}_{\mathrm{i}, \mathrm{t}}+\varepsilon_{\mathrm{i}, \mathrm{t}} \\
& \mathrm{i}=1, \ldots, 15 \text { ve } \mathrm{t}=1997, \ldots, 2010
\end{aligned}
$$


Bir nitelik değişkeni haline getirilen modelin bağımlı değişkeni $\left(\mathrm{P}_{\mathrm{i}, \mathrm{t}}\right)$ ordu-üniversite-sanayi işbirliği sonucu elde edilen savunma sanayi patent sayılarının bu patentlerin dışında kalan diğer tüm patentlere oranındaki değişism hızıdır. Modeli açıklayan üç temel değiş̧ken ise şunlardır. $\left(\mathrm{M}_{\mathrm{i}, \mathrm{t}}\right)$ ordu Ar-Ge harcamalarının toplam ArGe içindeki payının ordunun milli gelirden aldığı paya oranı ve $\left(\mathrm{U}_{\mathrm{i}, \mathrm{t}}\right)$ üniversite Ar-Ge harcamalarının toplam ArGe harcamaları içindeki payı modelin iki yapısal değişkenidir. $\left(\mathrm{T}_{\mathrm{i}, \mathrm{t}}\right)$ ise araştırma konusu olan her bir ülkenin teknolojik açık düzeylerini ifade etmektedir ve ülkelerin denge durağan durumlarıyla paralel temel bir piyasa değişkenidir. Değişkenler aşağıdaki gibi formüle edilmiştir:

$$
\begin{aligned}
& \begin{aligned}
& P_{i, t}= \frac{\text { Ordu }- \text { Üniversite }- \text { Sanayi İşbir }}{\text { Savunma San }} \\
& M_{i, t}= \frac{\text { Ordu Ar - Ge Harcamaları }}{\text { Toplam Ar - Ge Harcamaları }} \\
& \frac{\text { Ordu Harcamalar } 1}{\text { GSYH }}
\end{aligned} \\
& U_{i, t}=\frac{\text { Üniversite Ar }- \text { Ge Harcamalar } 1}{\text { Toplam Ar - Ge Harcamalar } 1} \\
& T_{i, t}=\frac{\mathrm{GSYH}_{\text {max,t }}-\mathrm{GSYH}_{\mathrm{i}, \mathrm{t}}}{\mathrm{GSYH}_{\mathrm{i}, \mathrm{t}}}
\end{aligned}
$$

Burada, $P_{i, t}$ bağımlı değişkeni ordu-üniversite-sanayi işbirliği sayesinde elde edilen savunma sanayi patentlerinin diğer patentlere oranındaki gelişmeyi göstermektedir.

$\mathrm{M}_{\mathrm{i}, \mathrm{t}}$ oluşturulan modelin birinci bağımsız değişkenidir. Savunma sanayi Ar-Ge harcamalarının toplam Ar-Ge harcamaları içindeki payının ordu toplam harcamalarının GSYİH içinden aldığı paya oranını temsil eder. Başka bir ifadeyle ordu odaklı Ar-Ge paylarının (ordudaki teknolojik ilerlemenin) ordunun milli gelirden aldığı paya oranıdır. $\mathrm{Bu}$ anlamda bakıldığında $\mathrm{M}_{\mathrm{i}, \mathrm{t}}$, kaynak yönlendirme açısından ordu eksenli teknolojik ilerlemeyle ilgili yapısal bir kaynak tahsisi değişkenidir. $\mathrm{M}_{\mathrm{i}, \mathrm{t}}$ değ gşseni ordu odaklı kaynak kullanımının ne tür bir patent artışına neden olduğunu gösterir. Burada değişkenlerin birbirine oranlanması orduya ayrılan kaynakların hangi ölçüde Ar-Ge'ye yönlendirildiği ile ilgilidir ve modelde yapısal bir değişken olarak değerlendirilmiştir. Böylece değişkenler ayrı ayrı modele konmayıp birleştirildiği için çoklu doğrusallık probleminin ortaya çıkma şansı da azalmış olur.

$\mathrm{U}_{\mathrm{i}, \mathrm{t}}$ değişkeni üniversite Ar-Ge harcamalarının ülkedeki toplam Ar-Ge harcamalarına oranını ifade etmektedir. Modelde üniversite Ar-Ge harcamalarının toplam Ar-Ge harcamaları içindeki payı $\left(U_{i, t}\right)$ ile bağımlı değişken $\left(\mathrm{P}_{\mathrm{i}, \mathrm{t}}\right)$ arasında pozitif yönlü bir ilişki beklenmektedir.

$\mathrm{T}_{\mathrm{i}, \mathrm{t}}$ değişkeni modelde ülkelerin teknoloji açığını ifade etmektedir. Teknoloji açığı iki ülkenin teknoloji düzeyleri arasındaki farkı ifade eder (Kök, Açıkgöz Ersoy, 2009:112). Teknoloji açığı; en ileri teknolojiye sahip olan ülkenin kişi başına düşen GSYİH değerini referans alarak referans ülkenin kişi başına düşen GSYH değerinden diğer ülkelerin kişi başına düşen GSYİH verilerini çıkarıp yine aynı ülkenin kişi başına düşen GSYH değerine bölerek hesaplanır. Örneğin modelde referans ülke A.B.D. olduğundan kişi başına terimlerle [(A.B.D. milli geliri - Türkiye Milli Geliri) / Türkiye milli geliri] şeklinde teknolojik açık hesaplanabilir. Böylece ülkeler arası refah farkları da ortaya çıkmış olur. Buna göre Ordu-üniversite-sanayi işbirliğinden doğan patent artış hızının yarattığı teknolojik yayılma etkisi incelenirken ülkelerin teknoloji açığını da dikkate almak gerekmektedir. Modelde bağımlı değişken $\left(\mathrm{P}_{\mathrm{i}, \mathrm{t}}\right)$ ile teknolojik açık değişkeni $\left(\mathrm{T}_{\mathrm{i}, \mathrm{t}}\right)$ arasında negatif bir ilişki beklenmektedir. Çünkü teknolojik açık arttıkça işbirliğinden doğan patent oranının azalması beklenir.

\subsection{Ampirik Bulgular}

Bu kısımda yukarıda belirtilen model, 1997-2010 yılları için panel veri yöntemi yardımıyla modellenmiştir. Veri setine otokorelasyon testi yapılmış ve otokorelasyona rastlanmadığı bunun yanında değişen varyans sorunu ile karşılaşıldığı görülmüştür. Bu sorun da modeli ağırlandırarak (white period metodu ile) çözülmüştür. Spesifikasyon testleri yapılmıştır. Ekonometrik modellerde uzun dönem denge varlığı tespiti ve veri kaybını önlemek amacıyla aynı dereceden durağan değişkenler için geçerli olan Johansen Eşbütünleşme Testi elde edilen verilerin azlığı ve değişkenlerin aynı derecede durağan olmamaları nedeniyle bu çalışmada kullanılmamıştır.

Aşağıda analiz sonuçları tablo halinde verilmiştir.

$$
P_{t}=13,06422+0,249066 * M_{t}+0,359225 * U_{t}-15,25142 * T_{t}+\varepsilon_{i, t}
$$

Model analizi sonuçlarına göre $M_{i, t}$ değişkeni anlamlı ve işareti pozitif, $U_{i, t}$ değişkeni anlamsız ve pozitif işaretli, $T_{i, t}$ değişkeni de anlamlı ve negatif işaretli olarak belirlenmiştir. Üç katsayının da işareti beklendiği gibi çıkmıştır. Buna göre ordu Ar-Ge harcamalarının toplam Ar-Ge içindeki payının ordu harcamalarının milli 
gelirden aldığı paya oranı savunma sanayi patent sayılarıyla doğru orantılıdır. Üniversite Ar-Ge harcamalarındaki artışın toplam Ar-Ge içindeki payı da savunma sanayi patent oranlarıyla doğru orantılıdır. Üniversite Ar-Ge harcamalarındaki artışı toplam Ar-Ge içindeki payı arttıkça savunma sanayi patent oranları da artmaktadır. Buna karşılık teknolojik açık değişkeni ile savunma sanayi patent oranları ise beklendiği üzere ters orantılı çıkmıştır. Yani ülkelerin teknolojik açık düzeyleri azaldıkça savunma sanayi patent oranları artmaktadır.

\begin{tabular}{|c|c|c|c|c|}
\hline Değişken & Katsayı & Standard Hata & t-istatistiği & $\begin{array}{l}\text { Anlamlılık } \\
\text { Düzeyi }\end{array}$ \\
\hline Sabit Katsayl $(\alpha)$ & 13.06422 & 4.761724 & 2.743589 & 0.0067 \\
\hline $\begin{array}{l}\text { Ordu Ar-Ge } \\
\text { Harcamalarl }\left(M_{t}\right)\end{array}$ & 0,249066 & 0.051832 & 4.805227 & 0.0000 \\
\hline $\begin{array}{l}\text { Üniversite Ar-Ge } \\
\text { Harcamalarl }\left(U_{t}\right)\end{array}$ & 0,359225 & 0.837614 & 0.428867 & 0.6685 \\
\hline Teknoloji Açığı $\left(T_{t}\right)$ & $-15,25142$ & 5.228661 & $-2,916888$ & 0.0040 \\
\hline$\overline{\mathrm{R}^{2}}$ & 0.107453 & & Akaike Bilgi $\mathrm{K}$. & 3.304452 \\
\hline Adj- $R^{2}$ & 0.028011 & & Schwarz Kriteri & 3.592309 \\
\hline F İstatistiği & 1.352602 & & Hannan-Quinn K. & 3.420834 \\
\hline Olasıllk (F İstatistiği) & 0.164491 & & Durbin-Watson & 2.614021 \\
\hline
\end{tabular}

Tablo 1: Model Analizi Sonuçları

Bu bulgulara göre $M_{i, t}$ değişkeninin paydası (ordu bütçesinin veya harcamalarının GSYİH içindeki payı) gittikçe azalıyorken, payı (ordu Ar-Ge'sinin toplam içindeki payı) artıyorsa, ekonominin bütününde orduüniversite-sanayi niteliksel işbirliği sayesinde oluşan patentlerin oranı artıyor demektir. Model analizi sonucunda bu durumun doğrulandığı görülmüştür.

Modelde üniversite Ar-Ge harcamalarının toplam Ar-Ge harcamaları içindeki payı $\left(U_{i, t}\right)$ ile bağımlı değişken $\left(P_{i, t}\right)$ arasında pozitif yönlü bir ilişki beklenmektedir. Bu hipoteze göre toplam Ar-Ge harcamaları içinde üniversite Ar-Ge harcamalarının payındaki artış Ordu-Üniversite-Sanayi niteliksel işbirliği sayesinde oluşan patentlerin oranında bir artışa neden oluyor demektir. Model analizi sonucunda bu iliş̧inin pozitif yönlü olduğu ve bu hipotezin doğrulandığı görülmüştür.

Daha önce $P_{i, t}$ ile $T_{i, t}$ arasındaki ilişkinin ise negatif çıkması beklendiği vurgulanmıştı. Model analizi sonucunda bu ilişkinin de beklenildiği üzere negatif çıktığı görülmüştür. Dolayısıyla ülkelerin teknolojik açık düzeyleri azaldıkça işbirliğinden doğan patent artış hızı artmaktadır. Aynı zamanda $P_{i, t}$ ile $M_{i, t}$ arasındaki yapısal gösterge ülkeler arası yapısal teknoloji farklılığıyla $\left(T_{i, t}\right)$ açıklanabilir. Genel olarak zengin ülkelerin Ar-Ge'ye daha fazla kaynak ayırdığı gözlenmektedir. Yüksek teknolojilere kaynak ayırabilmek ise daha çok zenginlik gerektirir. Bu yüzden ekonominin itici gücü kendi içerisinde katma değer yaratabilme gücüdür. Teknolojik açı̆̆ kapatmadan ve ülke içinde zenginlik yaratmadan patent ve teknoloji üretmek çok zordur. Kişi başına milli geliri daha yüksek ülkelerin daha fazla sayıda patent ürettiği görülür. Nurkse (1966)'nin Fakirlik Kısır Döngüsü Teorisi bu konuya 1 şı tutmaktadır. Nurkse azgelişmişliğin nedeni yine azgelişmişlikle açıklar. Teoriye göre, söz konusu ülkelerde düşük gelir düzeyi sonucu ortaya çıkan düşük tasarruf düzeyi ve sermaye birikiminin başlangıç noktası olarak alınması halinde, kısır döngü süreci sırasıyla; düşük gelir düzeyi, düşük tasarruf ve talep düzeyi, düşük yatırım düzeyi, yetersiz sermaye oluşumu, düşük verimlilik ve düşük gelir düzeyi biçiminde ortaya çıkmaktadır. Nurkse'ye göre az gelişmiş ülkeler bu çemberi kendiliğinden kıramaz. Bu nedenle, bu ülkelere dış yardım ya da yabancı sermaye girişi şartıyla kısır döngü aşlabilecektir (Altın, 2003:9). Bu nedenle çalışmada bahsedilen kısır döngüden kurtulmanın yolu olarak kaynakları doğru yönlendirmenin niteliksel bir sıçramaya neden olacağı üzerinde durulmuş ve teknoloji açığı değişkeni $\left(T_{i, t}\right)$ modele dâhil edilmiş̧ir.

Analiz sonuçları değerlendirildiğinde ordu-üniversite-sanayi işbirliğinden doğan patent üretimindeki gelişmeyi belirleyen temel dinamiklerin ordudaki teknolojik ilerlemenin ordunun milli gelirden aldığ 1 paya oranı, üniversite Ar-Ge harcamalarının toplam içindeki payı ve ülkelerin teknolojik açık düzeyleri olduğu anlaşılmıştır. Böylece ordu-üniversite-sanayi işbirliğinden doğan patent üretimindeki gelişmenin temel dinamikleri belirlenmiş olmaktadır.

Model analizi yapılırken ülkeler bazında bireysel etkileri görebilmek için ülke sayısı yıl sayısına göre azaltılarak model daraltılmıştır. Modelin daraltılmasına referans olarak analize giren 15 NATO ülkesine ait açıklanan değişkenin (patent artış hızının) ortalaması hesaplanmış, ortalamanın altında kalan ülkeler analizden çıkarılmış, ortalamanın üzerinde kalan 4 ülke dikkate alınarak bu ülkelerin yanına Türkiye beşinci ülke ve kontrol değişkeni olarak dâhil edilmiştir. Söz konusu 5 ülkenin verileri panel SUR analizi yardımıyla analiz edilmiştir. Panel SUR analizine göre her bir ülkenin teknolojik açık düzeyi sonuçları (değişkenlerin katsayıları ve anlamlılık düzeyleri) daha önce kurulan ana modelle tam olarak örtüşmediği için ve modele yönelik örneklemlerin zaman aralığının darlığından ve örneklemin giderek küçülmesinden doğan bir serbestlik derecesi sorunu ile karşıllaşıldığı için sonuçlar rapor edilmemiştir. 
Çalışmanın temel hipotezi "ordu-üniversite-sanayi işbirliğinden doğan patent artış hızı teknolojik yayılma etkisi yaratmaktadır" ifadesidir. Temel hipoteze bağlı türev hipotezler ise "Ordu-üniversite-sanayi işbirliğine bağlı olarak artan katma değer ekonomide itici bir güçtür" ve "Patent artışında üniversite Ar-Ge harcamalarının etkisi yadsınamaz" hipotezleridir. Temel hipotez olan ordu-üniversite-sanayi işbirliğinden doğan patent artış hızının yarattığı teknolojik yayılma etkisi test edilirken ülkelerin teknoloji açı̆̆ı, ordu odaklı teknolojik ilerleme (ordu Ar-Ge harcamalarının payı) ve üniversite Ar-Ge harcamalarının toplam içindeki payı dikkate alınmıştır. Model sonuçları genel olarak değerlendirildiğinde ülkelerin teknoloji açığındaki azalmaların, ordu odaklı teknolojik ilerlemenin ve toplam Ar-Ge harcamaları içinde üniversitelerin payındaki artışın ordu-üniversitesanayi işbirliğinden doğan patent üretim hızını artırdığı görülmüştür. Diğer bir ifadeyle işbirliğinden doğan patentlerdeki artışlar ordu Ar-Ge ve üniversite Ar-Ge harcamalarındaki artışla, ülkelerdeki teknoloji açığının kapanmasıyla ve dolayısıyla teknolojinin yaygınlaşmasıyla mümkün hale gelmektedir. Bu sonuç çalışmanın temel ve türev hipotezlerini doğrular niteliktedir. Üniversite Ar-Ge harcamalarının patent artışını olumlu yönde etkilediği sonucu çalışmanın türev hipotezlerinden "Patent artışında üniversite Ar-Ge harcamalarının etkisi yadsınamaz" ifadesini de doğrulanmış olmaktadır.

Çalışmada sanayide var olan üretim gücü, üniversitede var olan bilgi ve orduda var olan tahsis yetkisi bir araya getirilerek, üretim, bilgi açığı ile tahsis yetkisi arasındaki bir olgu modellenmiş olmaktadır.

\section{Sonuç}

Sosyal sistem bütünü içerisinde birbirleriyle ilişkili çok sayıda sistem barınmaktadır ve bu sistemlerden birisi olan ekonomik sistemde meydana gelen değişiklikler bütünün parçası olan diğer sistemler üzerinde etkide bulunmaktadır. Ekonomik sistem içerisinde meydana gelen değişiklikler üzerinde inceleme yapılırken toplumsal ve psikolojik faktörlerle birlikte sosyal sistem bütününü oluşturan teknolojik, kültürel ve siyasal sistemleri de göz önüne almak gerekir. Ekonomik gelişme ekonomik sistemin içerisinde meydana gelen en önemli değişikliklerden birisidir. Dolayısıyla toplumsal bir olgu olan ekonomik gelişmeyi sosyal sistem bütünü içerisinde incelemek gerekir.

Farklı kurumlar arasındaki işbirliği nedeniyle oluşan fikir ve bilgi paylaşımı sayesinde ortaya çıkan yenilikler ve yeni teknolojiler ekonomik gelişmeye yol açan faktörlerdendir. Bu yolla ekonomik gelişmeye en çok katkıda bulunan işbirlikleri üniversite- sanayi işbirlikleridir. Bilim ile teknoloji arasındaki dinamik ilişsinin bir bileşeni olan üniversite sanayi işbirliğinin önemli unsurlarından birisini teknoparklar oluşturmaktadır. Üniversite-sanayi işbirliği teknoparkları doğurmuş, teknoparklarda oluşan yenilikler ve bu yeniliklerin ekonomik sistemde yarattığı değişimler de üniversite-sanayi işbirliğinin daha hızlı bir biçimde yayılmasını sağlamıştır.

Çalışmada Ordu-Üniversite-Sanayi İşbirliği’nin ekonomik gelişmeye olası katkılarına yönelik temel hipotez ve türev hipotezler geliştirilmiş, daha sonra bu hipotezler panel veri ve anket yöntemiyle test edilmiştir. Çalışmanın temel hipotezi "Ordu-Üniversite-Sanayi İşbirliğinden doğan patent artış hızı teknolojik yayılma etkisi yaratmaktadır" ifadesidir. Bu temel hipotezi destekleyecek diğer türev hipotezler ise "Ordu-Üniversite-Sanayi İşbirliğine bağlı olarak artan katma değer ekonomide itici bir güçtür" ve "Patent artışında üniversite Ar-Ge harcamalarının etkisi yadsınamaz" ifadeleridir.

Öncelikle Ordu-üniversite-sanayi işbirliğine yönelik özgün bir model geliştirilmiş, model kapsamında NATO ülkelerinin 1997-2010 yıllarına ait verileri bulunarak panel veri yöntemiyle oluşturulan model test edilmiştir. Modelde bir bağımlı değişken $\left(P_{i, t}\right.$, Ordu-Üniversite-Sanayi işbirliği sonucu elde edilen savunma sanayi patent sayılarının bu patentlerin dışında kalan diğer tüm patentlere oranındaki gelişme) üç de bağımsız değişken vardır $\left(M_{i, t}\right.$; ordu Ar-Ge harcamalarının toplam Ar-Ge içindeki payının ordunun milli gelirden aldığ teknoparklardaki üniversite Ar-Ge harcamalarının toplam Ar-Ge harcamaları içindeki payı, $T_{i, t}$; ülkelerin teknolojik açık düzeyleri). Model analizi sonuçları aşağıdaki şekilde oluşmuştur:

$$
P_{t}=13,06422+0,249066 * M_{t}+0,359225 * U_{t}-15,25142 * T_{t}+\varepsilon_{i, t}
$$

Model analizi sonuçlarına göre ordu-üniversite-sanayi işbirliğinden doğan savunma sanayi patentlerinin diğer patentlere oranındaki gelişme ile savunma sanayi Ar-Ge harcamalarının toplam Ar-Ge harcamaları içindeki payının ordunun toplam harcamalarının GSYH içinden aldığı paya oranı arasında anlamlı ve pozitif bir ilişki bulunmuştur. Bunun yanında savunma sanayi patentlerinin diğer patentlere oranındaki gelişme ile üniversite ArGe harcamalarının toplam Ar-Ge harcamalarına oranı arasında pozitif bir ilişki bulunmuştur. Yine savunma sanayi patentlerinin diğer patentlere oranındaki gelişme ile ülkelerin teknoloji açıkları arasında ters yönlü bir ilişki bulunmuştur. Buna göre teknolojik açık azaldıkça savunma sanayi patentlerinin diğer patentlere oranının artış hızı artmaktadır. Bu model sonuçları çalışmanın temel hipotezi ve türev hipotezini doğrular niteliktedir.

Çalışmada yapılan hipotez testleri sonuçları değerlendirildiğinde ordunun ekonominin içerisinde sadece bir güvenlik öğesi olarak yer almadığı, aynı zamanda sanayileşmeyi geliştiren ve sürükleyen, katma değer ve istihdam yaratan bir kuruma dönüştüğü görülmüştür. Ordu istihdam ve katma değer yaratıcı ve ekonomide sürükleyici bir bağımsız güç olarak işlemektedir. Orduya yapılan harcamaların zorunlu güvenlik harcamaları olduğu, bunun yanında ekonomiye dolaylı olarak bir dinamizm kazandırdığı görülmektedir. Dünyanın savunma sanayisi en gelişmiş ülkesi olan Amerika Birleşik Devletleri’nde ordu ve savunma sanayinin Ar-Ge faaliyetleri 
ağ ekonomileri açısından dünya güvenlik sisteminde baskın bir şemsiye ve refah yaratma unsuru olarak öne çıkmaktadır. Ülkelerde yapılan silah karşıtlığı ve güvenlik mallarına yapılan harcamalar karşıtlığı ideolojik bir karşıtlıktır. Askeri harcamaların ülkelere bir sosyal maliyeti bulunmaktadır. Ülkeler bir yandan bu sosyal maliyeti karşılarken diğer yandan bu harcamaları refah yaratma aracı olarak da kullanmaktadır. Dolayısıyla ordunun bu tür maliyetleri sadece sosyal bir maliyet olarak algılanmamalıdır. Askeri harcamalar ve patent sürecinin yaratmış olduğu katma değere bakıldığında ve karşılıklı dışsallık ve içsellik analizleri yapıldığında askeri harcamalardan kaynaklanan sosyal maliyeti kapatan artı bir değer yaratıldığı ve ekonominin sürükleyici bir güce dönüştüğü görülmektedir. Dolayısıyla bu tür harcamalar tek yönlü bir güvenlik aracı olarak görülmemeli, sağladığı ilave kazançlar göz ardı edilmemelidir. Ordu eksenli yapılan harcamaların yalnızca bir sosyal maliyet unsuru olarak görülmesi ya bir ideolojik önyargıya dayanmakta ya da toplumsal bilinç yetersizliklerinden kaynaklanmaktadır. $\mathrm{Bu}$ tür bir algı ekonominin jeopolitiğinin doğurduğu refah yaratma araçlarının ihmal edilmesine veya bazı ayrılıkçı ideolojilerin kasıtlı önyargılarına dayanmaktadır.

\section{Kaynakça}

- Altın, S. 2003. Türkiye Ekonomisinin Gelişimi Açısından Dış Kaynakların Değerlendirilmesi. Süleyman Demirel Üniversitesi. Sosyal bilimler enstitüsü. Yüksek Lisans Tezi. Isparta.

- Cleand, J. M., Gallagher, R. S., 1993. Whitehead. Military Project Handbook, New York: Mc.Graw-Hill Inc.

- Coşkun, E., Kök, D., Yücel, A., 2010. Pazarlama Faaliyetlerinin Firma Değerine Kısa ve Uzun Dönem Etkilerinin İncelenmesi: İMKB Örneği. Finans Politik \& Ekonomik Yorumlar Dergisi. 540: 67-76.

- Çağlar, İ., 1999. Üniversite-Sanayi İşbirliğinin Sistem ve Durumsallık Yaklaşımları Açısından İncelenmesi. Standart Dergisi. Haziran Sayısı.

- $\quad$ Dura, C., 1995. Üniversite Sanayi İşbirliği Üzerine Bir Deneme http://dergiler.ankara.edu.tr/dergiler/42/465/5318.pdf (4 Haziran 2012).

- Gökpınar, E. S., 2003. Ülkemizde Savunma Sanayii Alanında Araştırma ve Geliştirmeye Dayalı Tedarik Süreç Modeli Oluşturulması. Yayınlanmamış Yüksek Lisans Tezi, Ankara: Ankara Üniversitesi Sosyal Bilimler Enstitüsü.

- $\quad$ Greene, W. H., 2003. Econometric Analysis. New Jersey: Prentice Hall.

- Gujarati D., 2004. Econometría. México D.F. McGraw Hill. Interamericana de México.

- Güler, F., 2000. Üniversite-Sanayi İşbirliği Sorunlar Ve Avantajlar Araştırması, Prf. Dr. Yüksel Ülken'e Armağan, İstanbul Üniversitesi İktisat Fakültesi Dergisi. 235-248.

- Kök, R., Açıkgöz Ersoy, B., 2009. Analyses of FDI Determinants in Developing Countries. Emerald Group Publishing Limited Research Paper. 36:105-123.

- Nurkse R. 1966. “Azgelişmiş Ekonomilerde Büyüme”, Çev: Tunca Toskay, İktisadi Büyüme ve Gelişme: Seçme Yazılar. İstanbul Üniversitesi Yayınları. No: 1193. İstanbul.

- $\quad$ Öztürk, T., 2001. Development of Turkish Defense Industry with Technology Transfer. Yayınlanmamış Yüksek Lisans Tezi. Yeditepe Üniversitesi. Sosyal Bilimler Enstitüsü.

- $\quad$ Pedroni, P., 1996. "Fully Modified OLS for Heterogeneous Cointegrated Panels and the Case of Purchasing Power Parity,” Indiana University Working Papers In Economics, No. 96-020.

- Pedroni, P., 2000. "Fully Modified OLS for Heterogeneous Cointegrated Panels", Nonstationary Panels, Panel Cointegration, and Dynamic Panels. Advances in Econometrics, Ed.Badi H. BALTAGI, Amsterdam, New York, Tokyo: Elsevier Science içinde, 93-130.

- Rasiah, R., Govindaraju, C., 2009. University-Industry Colloboration in the Automotive, Biotechnology and Electronics Firms in Malaysia. Seoul Journal of Economics. 22(4): 529-550.

- SSM., 2004. Savunma Sanayi Yeniden Yapılanma Projesi Raporu. Haftalık Haber Bülteni. Ankara: Say1 12.

- Yavilioğlu, C., 2002. Geri Kalmışlık Olgusu Ve Ekonomistik Kalkınma Teorileri (Eleştirel Bir Yaklaşım). C. Ü. Iktisadi ve İdari Bilimler Dergisi. Cilt 3. Sayı 2: 49-70 


\title{
Alternatif Bir Ekonomik Model Olarak Halk Sektörü ve Denizli Örneği
}

\section{People's Sector as an Alternative Economic Model and the Example of Denizli}

\author{
Prof. Dr. Ayşe İrmiş (Pamukkale University, Turkey) \\ Mehtap Sarıkaya (Pamukkale University, Turkey) \\ Hatice Çoban (Pamukkale University, Turkey)
}

\begin{abstract}
People's sector is an establishment of an enterprise result of bringing together production tools take decisions related to the management of this property and create self-employment opportunities with people's own savings. This is the most distinctive feature from the private sector and the public sector. As well as the public sector and the private sector, labor is a part of the production, but in people's sector, employees participate in management, capital and profit. In private sector and public sector there is an up to down organization but in People's Sector, organization settles from down to top. People's Sector resemble to publicly held companies and worker companies in Western Europe and United States but differ from them in the form of establishment and statue of partnership. Because in these companies in the West, government or private sector open shares to public or make workers partner to the shares. In these companies, managerial decisions belong to the person or group that holds most of the shares. Whereas in public sector enterprises, people come together and have equal rights in establishment and management of the enterprise, without any person or group keeping the majority of shares in the hand. Without a precedent in the world, this sector is formed in 1970's with the savings of the workers went from Turkey to Germany and other European countries. In this study, a literature rewiev in the people's sector has been made, then exemplary research was carried out by the founders of the two People's sector companies
\end{abstract}

\section{Halk Sektörünün Tanımı ve Amaçları}

Kepenek’e (1974) göre, Halk Sektörü, köylü, esnaf ve zanaatkâr gibi küçük ölçekli üretim yapan grupların ve işçi-memur gruplarının birikimleri ile emek güçlerini kooperatifler, sosyal yardım kurumları ve diğer toplu girişimler vasıtasıyla, kendilerinin yönetiminde ve bir sektör bütünlüğü içerisinde birleştirmeleri sonucunda oluşan sektördür. Bir başka tanıma göre ise, Halk Sektörü “yaşamlarını kol ve kafa çalışmaları ile sürdüren fakat gelirleri katkılarının gerisinde kalan çok sayıdaki dağınık küçük girişimlerin ve halk yığınlarının örgütüdür. Bu bağlamda, halkın kendi tasarruflarını bir araya getirerek, kendi yönetiminde üretim yapma ve gelir elde etme imkânını sağlayan" sektöre Halk Sektörü denilir (Hamitoğulları, 1974). Halk sektörü ile halk kendi yönetiminde, kendisini üretici durumuna getirir. Her birey, tasarrufa katılma payı ve üretim mülkiyeti oranından bağımsız olarak, Halk Sektörü yönetiminde eşit işe ve eşit etkinliğe sahiptir (Ölçen, 1974).

Halk sektörünü özel sektörden ve kamu sektöründen ayıran en önemli özellik yayılma biçimleriyle ilgilidir. Özel sektör ve kamu sektörü girişimciliğgi, tavandan başlayıp aşağıya doğru giden bir üretim girişimciliğidir. Halk Sektöründe ise durum tam tersi olmakta, tabandan başlayıp, yukarıya doğru meydana gelen bir üretim girişimi gerçekleşmektedir (Ölçen, 1975). Halk Sektörünü diğer sektörlerden ayıran bir diğer özellik de, sosyal amaçlı yatırımların ve maliyet minimizasyonunun beraber sağlanmasıdır. Özel sektörde amaç kârın maksimizasyonun, kamu sektöründe ise maliyet minimizasyonunun ya da katma değer maksimizasyonunun sağlanmasıdır (İlbaş, 1974). Aynı zamanda, özel sektörde yönetim, sermayeyi elinde bulunduran sınırlı sayıdaki kişinin elindedir. $\mathrm{Bu}$ da genellikle işletmenin kurucusudur. Dolayısıyla işletmenin \%51 hissesine kim sahipse, yönetimde söz sahibi olan o kişi veya gruptur (Ölçen, 1974). Kamu sektöründe ise yönetim devlete aittir. Hem özel sektörde hem de devlet sektöründe emek sahipleri sadece "üretimin bir parçasıdır”. Hâlbuki Halk Sektöründe çalışanlar, sermayenin ve kârın sahibi olup, yönetimde de eşit söz hakkına sahiptir. İşçinin, sermayenin ve kârın sahibi olmasının ötesinde üretim faaliyetinin en kutsal parçası olan emeğin sahibi olarak yönetime katılmasıyla da iş yerlerinde demokrasi sağlanmış olacaktır. Ayrıca, üretimin bir parçası olan işçinin, yapıcı, yaratıcı ve uygulayıcı fikirlerini sunma firsatını yakalamış olması üretimin ve kalitenin artmasını sağlayacaktır (Ak, 1976).

1974 yılındaki hükümet programında Halk Sektörünün amaçlarından daha sistematik bahsedilmiştir. Buna göre, Halk Sektörüyle, sanayileşmeye hız kazandırılacak, dağınık tasarruflar değerlendirilecek, kalkınmanın nimetlerinden daha yaygın ve adil faydalanma sağlanacak, halkın girişimcilik gücü harekete geçirilecek, yurt dışındaki işçilerin tasarruflarının ve teknik becerilerinin temel sanayi projelerine yönlendirilmesi sağlanacaktır (Öngün, 1974). S. H. Türk ise Halk Sektörünün amaçlarını ekonomik ve sosyal amaçlar olmak üzere iki grup içerisinde sınıflandırmış daha sonra bu amaçları ayrıntılı hale getirmiştir. Türk’e göre bu amaçlar (Türk, 1975); 
1. Geniş halk topluluklarının küçük tasarruflarını, çağdaş ölçeklere uygun büyük işletmeler kuracak ve işletecek biçimde, bir araya getirerek daha hızlı bir kalkınma için gerekli sermaye birikimini sağlamak (ekonomik),

2. Üretim araçlarının mülkiyetini geniş halk topluluklarına yaymak (sosyal),

3. Halkı ekonomik karar merkezlerinde söz sahibi yaparak demokratik gelişme sürecinin ekonomik boyutunu tamamlamak (sosyal)

4. Toplumda daha adil bir gelir dağılımı sağlamaktır (ekonomik).

Bu amaçların sonucunda ise, milli gelirin artan bölümü, tasarruflara ve yatırıma yöneltilerek, tüketim malları üzerindeki talep fazlalığından kaynaklanan enflasyonist baskı azaltılacak, yatırım malları piyasası genişleyecek, tekelci sermaye karşısında dengeleyici bir güç oluşacaktır. Ayrıca, ekonomik gücü artan geniş halk topluluklarının siyasal alanda da etkinliği artacak, demokratik rejim daha sağlam temellere oturacaktır (Türk, 1975).

Bütün bu amaçlarının ötesinde Halk Sektörünün sosyal, ekonomik ve hatta siyasi bağlamda kendi yapısı itibariyle çok önemli fonksiyonları da yerine getirdiği görülmektedir. Hepsinden öte, Halk Sektörleri kırsal kesimde de örgütlenen sektörlerdir. Böylece, göçlerle köylerin boşalmasına gerek bırakmayan bir sanayileşme, kırsal alanların, kentsel alanlarla denge kuracak şekilde modernleşmesi ve kırsal alanlarda geniş istihdam imkânlarının sağlanması Halk Sektörleriyle mümkün olmuştur (Ölçen, 1974). Sermayenin tamamen tabana yayıldığı ve işçilerin çalıştıkları işletmede aynı zamanda pay sahibi olduğu bu sektörde sermaye payları ne olursa olsun, karar vermede eşit haklara sahip olmaları kendiliğinden öz yönetimi de getirmektedir. Öz yönetimde artı değeri yaratan emek gücü bu değerin nereye kullanılacağı kararında, yürütülmesinde ve denetiminde söz sahibi olmaktadır (Coşkun, 1976). Hatta emek gücünün yarattığı artı değer işletmenin kâra geçmesiyle beraber tekrar işçiye geri dönecektir. Böylece Halk Sektörüyle, Türkiye'de "endüstriyel demokrasi” gerçekleşecektir (Altun ve Akınc1, 1974). İşçinin üretim araçlarına sahip olması, yönetime katılması ve emeğinin yarattığı değere sahip olması onun yabancılaşmasını ve mekanikleşmesini de önleyecektir. Böylece işgücünün dolaylı olarak, yaratıcılığı, etkinliği ve verimliliği de artacaktır (Kepenek, 1974).

\section{Sanayi Kenti Denizli’de Halk Sektörü Örnekleri}

Günümüz Denizli'si Türkiye'nin önemli tekstil merkezlerinden biridir. Bu gelişmenin temeli tarihsel sürece dayalıdır. Türk tarihinde Osmanlı'dan beri bilinen Denizli dokumacılı̆̆ı, bugün tekstilde dünya markası haline gelen, sanayi üretimine dönüşmüştür. Ancak, Denizli'nin bir sanayi kenti haline gelmesinin tek sebebi geleneksel üretime dayalı faaliyet göstermesi değildir. Türk Halkının 1970’li yıllarda Halk Sektörüyle ortaya çıkan girişimcilik vasfının en önemli örneklerinden birini de Denizli vermiştir. Üstelik sadece tekstilde değil, onun yanısıra, gıda, cam, elektronik ve makine sanayinde Türkiye'nin o dönemki şartlarına göre büyük atılımlar ve başarılar elde etmişlerdir. Bu çalışmanın alan araştırması yarı biçimsel mülakat usulüyle yapılmıştır. Denizli'deki Halk Sektörünün oluşumu anlatıldıktan sonra, Halk Sektörüne örnek teşkil eden üç şirketin hikâyesi bizzat kurucularının dilinden aktarılmıştır. Bu çalışmaya üç işletmenin dâhil olmasının sebebi, üçünün de kurucularını hayatta olmasıdır. Mülakata katılan kişilerden mülakat sırasında isimlerini çalışmada açık olarak yazabilmek için izin alınmıştır. Mülakatlara Ayşe İrmiş ve Mehtap Altınkesen Sarıkaya beraber katılmış ve her ikisi de anlatılanları elle yazarak not almıştır. Aynı gün içerisinde yazılanlar birbirleriyle karşılaştırılıp, bilgisayara geçilmiştir. Mülakata katılan kişilere ulaşmak için telefonla randevu alınmış, Uygar Motor'un kurucusu B.A ile 20.03.2013 tarihinde, Bir-Emek kurucusu H.A’yla 26.07.2012 tarihinde kendilerinin şu andaki iş yerlerine gidilerek mülakat yapılmıştır. Mülakat sırasında anlatılanlar elle not alınmıştır. Mülakat müddetince araştırmacılar tarafından mülakatın gidişatına göre az sayıda soru sorulmuş, mülakata cevap veren kişiler tamamen kendi doğal anlatımlarıyla konuyu aktarmışlardır. Araştırmanın ana amacı, halkın girişimci ruhunun ve gücünün, birbirleriyle ve devletle yaptıkları güven esasına dayalı karşılıklı işbirliği neticesinde, sanayiye, üretime ve kâra nasıl dönüştüğünü görebilmektir. İkinci amaç ise gelecekte sermayenin, üretimin ve riskin daha geniş bir tabana yayılacağı yeni işbirlikleri, üretim alanları ve ülkelerin kalkınmasındaki en önemli faktör olan girişimcilik için örnek modeller sunabilmek ve bu modellerin başarı ve başarısızlık sebeplerini irdelemektir. Araştırma sorusu, Denizli’deki Halk Sektörlerinin nasıl oluştuğu ve işleyiş̧lerinin nasıl olduğuyla ilgilidir.

\subsection{Halk Sektörünün Ortaya Çıkışını Sağlayan Sosyo-Ekonomik Alt Yapı}

Türkiye'nin 1950'li yıllarda başlayan sanayileşmesi İstanbul, Ankara, İzmir gibi daha ziyade az sayıdaki büyük kentte ve çoğunlukla devlet destekli özel sektör eliyle gerçekleşmiştir. Henüz özel sektör tecrübesi az olan ülkede tarımsal faaliyetler de nüfusun geçim şartlarını iyileştirmek ve refahını sağlamak için yeterli düzeyde değildir. Bu sebeple bir taraftan özel sektördeki istihdamı gerçekleştirmek için diğer taraftan da köydeki yaşam şartlarından daha iyi yaşam şartlarını sanayileşmiş kentlerde bulabilmek gayesiyle köyden kente önemli miktarda göçler başlamıştır. Ancak, özel sektörün çok kısıtlı gelişmiş olması kırsal kesimde yaşayanların ve köyden kente iş bulma ümidiyle göç edenlerin istihdam beklentisini karşılayabilecek düzeyde değildir. Aynı dönemlerde, sanayileşmeye neredeyse yüz yıl önce başlamış ve çok büyük gelişme kaydetmiş olan başta Federal Almanya olmak üzere batı Avrupa ülkeleri fabrikalarında çalışacak fiziki güce dayalı işgücü talep etmektedir. 1961 yılında Federal Almanya ile imzalanan “Türk-Alman İşçi Mübadele Anlaşması” ve daha sonra diğer Avrupa ülkeleriyle 
yapılan anlaşmalarla Türkiye'den özellikle Almanya'ya giden ve daha ziyade fiziki emek göçüne dayalı büyük miktarda işgücü göçü başlamıştır. Öyle ki, 1973 yılına kadar Türkiye'den Almanya'ya işçi olarak gidenlerin sayısı, 800 yüzbini bulmuştur. Ancak, hem kültürel farklılıklar, hem büyük sanayi ile ilk defa karşllaşmanın sıkıntısı hem de ülkelerinden ve ailelerinden uzak olmanın sıkıntılarıyla ilk dönem, oldukça sancılı geçmiştir. Bu nedenle göç eden işçiler kısa sürede sermaye biriktirip, ülkelerine geri dönmeyi ve tasarruflarını Türkiye'de değerlendirmeyi düşünmüşler, geleceklerini Türkiye'de görmüşlerdir (Akseki, 2007). Halk Sektörlerinin ortaya çıkışıla beraber, tasarruflarının önemli bir kısmıyla Türkiye'deki işçi şirketlerinden pay almışlar ve bu şirketlerin ana sermayesini oluşturmuşlardır.

Türkiye'den yurt dışına en çok işçi gönderen yedinci il Denizli olmuştur. Denizli, 1960'lı yıllara kadar, nüfusunun \%76'sı kırsal kesimde yaşayan, temel iktisadi faaliyetinin tarım ve el tezgâhlarıyla dokumanın olduğu bir kenttir. Türkiye'den Almanya'ya ve diğer batı ülkelerine işgücü göçünün başladığı bu dönemde Denizli'den 35 bin kişi adı geçen ülkelere işgücü olarak göç etmiştir. Göç eden işçilerin çoğunluğu gibi Denizli'den yurt dışına göç eden iş̧̧iler de tasarruflarını Türkiye'de değerlendirmeyi tercih etmişlerdir. Bu sebeple yurt dışındaki işçilerin birikimleriyle, Türkiye'deki vatandaşların birikimlerinin birleşmesiyle, 1970'li yıllarda kurulan Halk Sektörü bağlamındaki, çok ortaklı şirketlerin ve iş̧̧i şirketlerinin 21 tanesi Denizli'de kurulmuş ve önemli başarılar elde etmişlerdir (Akseki, 2007).

\subsection{Halk Sektörü Kapsamında Denizli’deki İşçi Şirketi Örnekleri}

Araştırma yapılırken Denizli'de kurulan bütün işçi şirketlerinin kurucularına ulaşılamamıştır. Bu kurucuların bir kısmı Denizli'den başka şehirlere göç etmiş, bir kısmı yaşlılığı ve hastalıkları sebebiyle mülakat yapmak için uygun şartlarda bulunmamış bir kısmı da vefat etmiştir. Mülakatlar ulaşılabilen ve araştırmaya en iyi örneği teşkil edebilecek iki şirketin önder kurucularıyla yapılmıştır. Bu şirketler Bir-Emek ve Uygar Motor'dur.

\subsection{Uygar Motor Örneği}

Uygar Motor, 1974 yılında Denizli ili Honaz ilçesi Kocabaş beldesinde motor üretmek üzere B.A'nın önderliğinde 10 bin iş̧inin birikimleri ve katılımıyla kurulan fakat daha sonra döküm ve döküm parçaları üreten bir iş̧̧i şirketidir. 1995 'te icra yoluyla 130 milyar Liraya satılan Uygar Motor, Kalkınma Bankası, Sosyal Sigortalar Kurumu, Maliye ve işçilere borçlarını ödedikten sonra kalan 93 milyar Lirayı bankaya yatırmıştır. Uygar Motor, yıllar önce iflas etmiş olmasına rağmen bankaya yatırdığ 93 milyar Lira'nın 2,3 trilyon Lira'ya ulaşmasıyla faiz zengini olmuştur. Bu paranın 307,8 milyar Lira'sı vergi olarak ödenmiş geri kalan kısmı da ortaklara dağıtılmıştır. Böylece iflas etmiş olmasına rağmen vergi rekortmeni olan Uygar Motor vergi tarihine geçmiş, hatta Denizli'de vergi rekortmeni olmuştur.

\section{B.A ile yapılan mülakat}

Soru: Uygar Motor'un nasil kurulduğunu anlatır mısınız?

B.A: 1974 yılında Almanya'da 100 arkadaşla beraber benim önderliğimde şirketi kurduk. Ben o dönem Almanya'daydım. Denizliliyim. 19 yaşında askere gitmeden 1968 yılında Almanya'ya iş̧i olarak gittim. Orada çalışırken bir yandan Almanca öğreniyordum. Tahsilimi tamamladım. Makine Mühendisliği okudum. Kendi başıma iş̧̧i olarak gittim. Hem çalışıp hem okudum. Okurken hamallık bile yaptım. Şirketi kurarken 25 yaşındaydım. O zaman tabii genç, ateşli bir durumdaydık. 1974 yılının Haziran ayında Kıbrıs Harekâtı yapılmıştı. 1974 Aralık ayında böyle bir girişim yaptık. O zamanlar her şey dışarıya bağımlıydı, ülkede bir şey yapılmıyordu, Denizli'de sanayi yoktu. Birkaç tane un fabrikası vardı o kadar. Birtakım arkadaşlar da Avrupa'nın çeşitli yerlerinde birleşerek bir şey meydana getirmek istedik. Takım oluşturduk ve bu şirketi kurduk. O zamanki işçi arkadaşların çoğu vefat etti. Şirketi kurma aşamasındaki ekipte uzman biri yoktu. Yola motor üreteceğiz diye başladık. Ancak bu mümkün olmadı. Daha doğrusu şirketin nasıl işleyeceği, nasıl olacağı konularında bilgimizde yoktu. Çeşitli kitaplar okuyarak araştırma yaparak bilgiler elde etmeye çalıştık. Motor fabrikası derken yani motor üretimi derken amacımız, zirai (su motorları, çeşitli amaçlarla kullanılan motorlar vs.) motorlardan başlayarak değişik motorlar üretmekti. Bu arada hummalı şekilde ortaklarla ilişkimizi ve iletişimimizi sürdürdük. 10.000 hissedarımız oldu. Hissedarlar da maksimum adedi geçmeyecek şekilde sermaye artıım haklarını kullandılar. 100 kişiyle karar almak daha kolaydı ancak bir süre sonra sermayeyi artıramadık. Beş milyara sermayeyi çıkardık ancak sonra artıramadık çünkü ortaklar toplanamıyordu. Ayrıca belirlediğimiz kararla, bir kişi kuruluşta on beş hisseden fazla alamıyordu.

Soru: Neden motor üretimi yapmaya karar vermiştiniz?

B.A: Açıkça söylemek gerekirse motor üretme konusunda aldığımız karar doğru değildi. O heyecanla oldu. 19 yaşında Almanya'ya gitmişim, 19 yaşında bir çocuğun ülke hakkında, ekonomi hakkında ne kadar bilgisi olur? Televizyonun olmadığı, iletişimin olmadığı dönemde yetiştik. Kıbrıs Harekâtından sonra Türkiye'ye ambargo uygulanmıştı. Başkalarının vermediğini biz yaparız diye yola çıktık. Hatta bizim sloganımız vardı "Kendi Motorunu Yapamayan Toplum Sanayileşemez" diye.

Yaptığımız üretimde başarılı olduk. Çünkü üretimde Alman mühendisler falan çalıştı. İyi bir teknoloji geliştirmiş̧ik. Döküm konusunda başarılıydık. Ancak şirketin işleyişi ve hukuksal yapısında bocaladık. Yoksa üretim iyiydi. Hammadde İskenderun'dan geliyordu. Piyasadan hurda topluyorduk. Emsan vardı, onun kırpıntı 
saçlarını ve tuğlalarını alıyorduk. Elektrik enerjisi kullanıyorduk. Üretim makinelerini Almanya'dan aldık. Makineler alırken kendi sermayemizle aldık bütün altyapıyı kendi sermayemizle oluşturduk.

Soru: Biraz önce "Yola motor üreteceğiz diye başladık. Ancak bu mümkün olmadı" dediniz, neden mümkün olmadi?

B.A: Olmamasının en büyük nedeni o dönem yasal düzenlemelerin olmayışıydı. Daha sonraki gelen hükümetlerde bu şirketlere soğuk baktılar. Halk sektörü diye ismi de kondu. O zamanlar komünizm korkusu vardı. Birlik olmaya, birleşmeye, komünistlik gibi bakıldı. Özellikle 1980 sonrası daha soğuk bakıldı.

Soru: Ürettiğiniz şeyleri biraz açar mısınız? Tam olarak ne ürettiniz?

B.A: Madem motor üretemeyeceğiz, motor üretmekle ilgili döküm ve işleme kısmı kurduk, orada kaldık. Sonra döküm parçaları üretmeye başladık. İhracat yaptık.

Soru: Pazarınız neresiydi, nerelere ihracat yaptınız?

B.A: Ana pazar İstanbul'du. İhracatı biz kendimiz doğrudan Almanya ve Irak'a yaptık. Almanya'ya tır parçaları gönderdik. Mesela traktör parçaları falan yaptık. Haddanelerde, had topları döktük. Çeşitli motor ve makine parçaları ürettik. 1993'e kadar üretim devam etti. En büyük problemimiz yasal düzenlemelerin olmayışıydı. Yasal düzenlemeler olmadığı için şirkettin genel kurulu toplanamıyor, gerekli kararlar alamıyor, sermaye artırımını yapamıyorduk. Genel kurulun toplanması için dörtte üç çoğunluk gerekiyordu. 10.000 ortak var. Bunları toplamak imkânsızdı. İlk yıllar genel kurul, ortakların çoğunluğu Almanya'da olduğu için orada yapıldı. 1-2 y1l gittik sonra hepsi burada oldu.

Soru: Diğer pek çok Halk Sektörü bağlamındaki şirketler DESIYAB'dan kredi almış, daha sonra da ödeyemediği için yönetim hakkı DESIYAB'a geçmiş sizinde böyle bir kredi talebiniz oldu mu?

B.A: Biz de DESIYAB'dan kredi aldık. DESIYAB'dan kredi alacağımız zaman, uzmanlar geldi. Biz o zamanki parayla 1,5 milyonluk kredi aldık ve zamanında ödedik. Borcu ödediğimiz için DESiYAB'ın ortaklığına gerek kalmadı. Zaten sahip olunacak hisseyle ilgili sınırlandırma vardı. Şirketi kurarken bir kişinin alacağı hisseyi sınırladık. Şirket kurulup hisseler satıldıktan sonra o ortakları toplayabilmek sorun oldu. Nitekim tasfiye zamanında bile, elimizdeki parayı ortaklara dağıtamadık. 1 trilyon devlete kaldı. Sorun genel kurulun toplanamamasıydı. Ortaklara ulaşmak mümkün olmadığı için dağıtılamadı. Bir kısmının adresleri bile bulunamad. Birçoğu da küçük pay sahibi olduğu için ilgilenmedi. Şunu da söyleyeyim; 1996 yılında şirketin mal varlığı satıldı. Fabrikası, büroları, taşıtları, her şeyi satıldı. O dönem tek Uygar Motor iflas etmemiştir. Diğer şirketler batmıştır, el değiştirmiş̧tir. Uygar Motor batmamıştır, el değiştirmemiştir.

Soru: Çalışanlarınızın işletme sermayesinde payları var mıydı?

B.A: Çalışanların ortak olması gibi bir mecburiyet yoktu ama çalışan ortaklar vardı. Size Yönetim kuruluyla ilgili çok komik bir olay anlatayım. Bir yönetim kurulu üyesi fabrikaya geliyor, fabrikanın bekçisi bana selam vermedi diye, gelip bana şikâyet ediyor. Bu Yönetim Kurulu üyesi köyden biri aslında, düşünün artık. O dönemde bir statü açlığı da var. İşçilikten sermayedarlığa geçme durumu var. Sorunumuz profesyonel kişilerin olmayışıydı. İş çok karmaşık. Hem genel müdür, hem sermayedar hem de yönetim kurulu başkanıydım.

Soru: Çalışanlarınızın ne kadarı hissedardı?

B.A: Tam rakam söyleyemeyeceğim ama \%10’u geçmez. İş̧i şirketinden çok Halk Şirketi olarak çalışıyorduk.

Soru: Fabrikada çalışacak işçiyi bulmakta sorun yaşadınız mı?

B.A: Üretime başladığımız yıllarda sanayi işçisi yoktu, eleman bulmada çok sorun yaşadık. Adamları tarladan getirip dökümcü yaptık. İdari personeli de çeşitli illerden, özellikle İstanbul ve İzmir'den sağladık. Yerimiz Kocabaştaydı. Fizibilite çalışması yapıldı. Fizibilite çalışmasında motor üretimi olamayacağını anladık. $\mathrm{O}$ ara fark ettik, motor üretimi çok büyük sermaye isteyen bir işti, bunu toplayamayacağımızı anladık. Ama motor diye de çıktı yola. Bu nedenle motorun ana unsuru dökümdür, dökümden üretime başladık. Kısmet olursa daha iyisini yaparı dedik.

Soru: Gazetelerde Uygar Motorun kapandıktan yıllar sonra vergi rekortmeni olduğu yazdı. Bu haberlerin aslı nedir?

B.A: Sene 1992. Burada ben bütün milletvekillerini çağırdım, her partiden. Valiyi, belediye başkanlarını çağırdım. Ve bilgilendirme verdim. Şirketin durumu nedir, teknik durumu, mali durumu nedir, ne yapılacak, ne lazım. Bütün bunları açıklayan dosyalar hazırladım. Buraya devlet sahip çıksın, biz yürütemiyoruz dedik. Ancak gerekli ilgiliyi göremedik. Mali açıdan üretimi çeviremediğimiz için üretimini durdurduk. Tasfiye ettik. Malvarlığı satıldı. Elde edilen para bankaya yatıııld. Sonra o da faizle çoğaldı. Vergi rekortmeni olundu ve haberler ondan oldu. Faiz işleyen paranın üçte biri devlete kaldı, üçte ikisini dağıttık. Genel kurul toplarken bulamadığınız ortakları, faiz verirken bulmada zorluklar yaşadık. Bulabildiklerimize dağıttık. Aşağı yukarı üçte ikisine ulaştık. Üçte birini devlete verdik. Dağıtılan gelir, çok sayıda kişiye yayılınca fazla bir önemi olmuyor. 


\subsubsection{BİR-EMEK (Birleşen Emekçiler) Örneği}

Bir-Emek, Elektrik-Elektronik Sanayi ve Ticaret A.Ş. o dönem BM bursuyla Lahey'de eğitim gören H.A'nın öncülüğünde ve Almanya'daki Türk işçilerinin biraraya gelmesiyle Denizli'de kurulan, yaklaşık 16 bin ortağı bulunan bir şirkettir. Şirketin kuruluşundaki ana sözleşme gereği bir kişi en fazla on hisse alabilmektedir. Böylece şirketin hisselerinin birkaç elde toplanması engellenmekte ve tamamen Halk Sektörü özelliği ile kalması sağlanmaktadır. Kuruluşundaki asıl gaye elektrik sarf malzemeleri üretmektir. Telsiz ve haberleşme cihazları üretimiyle ilgili olarak 1974 yılında karar alınmıştır. Kıbrıs Barış Harekâtında Türk ordusunun haberleşmede büyük sorunlar yaşaması ve Kocatepe Muhribinin başka telsizlerden gelen yanlış yönlendirmesi sonucu Türk jetlerince batırılması yerli telsiz üretimi yapmak üzere yola çıkan Bir-Emek'in ortak sayısını hızla artırmıştır. Yurt içi ve yurt dışından ortak olanların bir kısmının gayesi kendilerive yakınları için iş imkânını sağlamakken, bir kısmı da tamamen milliyetçi duygularla ortak olmaktaydılar. Çünkü Türk Silahlı Kuvvetleri teknik ve teknolojik araçlar açısından dışa bağımlılıktan kurtulmak amacıyla yerli şirketlere çeşitli ihtiyaçlarını duyuruyor ve bunların geliştirilmesini istiyordu. Bir-Emek, 1975’te İtalyan firması Larimart lisansıyla Orman Bakanlığının telsiz ihalesini kazanır. Ancak Orman Bakanlı̆ğ kısa süre sonra Türkiye'deki ormanların geliştirilmesi için Finlandiya'dan kredi alır ve ilginç bir şekilde telsiz alımı da Finlandiya'ya verilir. Daha sonra Bir-Emek şirketi Alman firması Rohde Und Schwarz'ın lisansıyla Türk Silahlı Kuvvetlerinin ordular arası iletişimi sağlayacak büyük telsiz üretimi ihalesine katılır. Bir-Emek yerli firma olduğu için tercih sebebidir fakat bu defa da Türkiye Elektronik Sanayii A.Ş. ve Kara Kuvvetlerini Güçlendirme Vakfı tarafından ASELSAN kurulur ve bütün elektronik cihazların ASELSAN tarafından üretilmesine karar verilir. Böylece telsiz üretimi Bir-Emek için sadece bir proje olarak kalır. Bir-Emek mühendisleri Yugoslavya'da Philips lisansı ile üretim yapan bir fabrikadan elektronik parça ithal ederek 31 ekran TV dizayn eder ve üretime başlarlar. Televizyon markası hem şirketin ismi hem de milliyetçi bir anlayışla rakiplerle farkını göstermek için (diğer marka isimleri Türkçe değildir) Bir-Emek olarak belirlenmiş̧tir. Daha sonra Sanayi Bakanlığının Bir-Emek’i yerli bir firmayla lisans anlaşmasına zorlaması üzerine, yönetim Profilo ile Profilo'nun TV 24 olarak bilinen modelini üretmek için anlaşma yapar. 61 ekran siyah-beyaz televizyonun seri üretimine 1979 yılında başlanır. 1982 yllında renkli televizyon da üreten Bir-Emek aynı zamanda telefon ve telefon santralleri de üretmiş̧ir. Türkiye'deki ilk bilgisayar üretimi hatta bu bilgisayarın ana kartı da Bir-Emek tarafından üretilmiştir. Ancak Bir-Emek de diğer işçi şirketleri gibi sürekli finansman sıkıntısı çekmektedir. Büyük çoğunluğunu DESiYAB'dan aldığı borçlarını ödeyemez duruma geldiğinde de Denizli Asliye Hukuk Mahkemesi tarafindan 1986 yılının sonunda Bir-Emek'in iflasına karar verilir (Akseki, 2007).

\section{H.A'yla yapılan mülakat}

Soru: Bir-Emek Şirketini nasıl kurduğunuzu, kurulma sürecini anlatır mısınız?

H.A: 1969 ODTÜ Mimarlık Fakültesi mezunuyum. Mezuniyetten sonra Köy işleri bakanlığı bünyesinde çalışmaya başladım. 1971 yılında Birleşmiş Milletlerin Türk Hükümetine verdiği bursun bana aktarılması sonucu lisansüstü eğitim için Hollanda'ya gittim. Lahey'de Institude of Social Studies okulunda eğitim devam ederken Denizlili bir grup Türk işçisi Denizli'de bir fabrika kurmak istediklerini benim de böyle bir kuruluşa önderlik etmemi söylediler. Kabul ettim. Eğitim bittikten sonra Bir Emek'in (Birleşen emekçiler) kuruluşu için çalışmaya başladım. Türkiye'deki bazı arkadaşlarımla işin teknik boyutunu planladık. Telsiz cihazları ve televizyon üretimine karar verildi. Fizibilite raporlarını endüstri mühendisi Ali Dinçer hazırladı. Denizli'de bir hazine arazisi tahsis edilmesini talep ettik. Ve bu gerçekleşti. O dönemki hükümet zamanında halk sektörü önemliydi. Hatta o hükümet döneminde resmi gazetede yayınlanan hükümet kararına göre Türkiye'de elektronik sanayide imalat yapacak kuruluşlardan sadece halk sektöründe olanlar teşvik edilecektir diye adı belirtilmeden Bir Emek desteklenmişti, elektronik sanayide o dönem sadece bir emek vardı. Dönemin hükümet üyesi Erol Çevikçe biz şirketi kurarken Devlet Planlama Teşkilatında Daire Başkanıydı ve bize büyük destek olmuştu, bakan olduktan sonrada bize desteğini devam ettirdi. Daha sonra fabrika binasını kurduk, laboratuvarda prototip üretime başladık. Ortak sayısı hızla yükseldi. Toplanan sermaye miktarı hızla yükseldi. Yatırımı tamamladık.

Soru: Bir-Emek'in sermaye yapılanması nasıl oldu?

H.A: Bir Emek'in en büyük özelliği sermaye yapılanmasıdır. Kuruluş sermayesi 60 milyon TL idi. Bu sermayenin her biri $2.500 \mathrm{TL}$ değerinde 24 adet hisseden oluşmaktaydı. Ancak bir kişi en fazla $25.000 \mathrm{TL}$ değerinde 10 hisse alabilirdi. Bundan amaç şirketi belirli sermaye gruplarına bırakmamaktı. Daha sonra genel kurulda sermaye 400 milyon TL'ye çıkarıldı. Şirketin, çoğunluğu yurtdışındaki işçilerden oluşan 16.000 ortağı oldu. Çoğunluk Denizli'den olmak kaydıyla Türkiye'nin değişik yerlerinden ortaklar vardı. 1974 Kıbrıs Harekâtında Kocatepe isimli Türk savaş gemisi Türk uçakları tarafından yanlışlıkla batırıldı. Nedeni ise gemi ile uçaklar arasında telsiz bağlantısı kurulamadığı için gemi kendisinin bir Türk gemisi olduğunu ifade edememiş ve Yunan gemisi diye batırılmış. Bu olay telsiz imalatıyla yola çıkan Bir Emek fabrikasına yurt dışındaki işçilerin büyük oranda sempati duyması ve ortak olması sonucunu getirdi. Bizim sloganımız " Türk ordusu yabancıdan telsiz almayacak" cümlesi oldu. Bir Emek'in sermaye yapılanması çok önemli. Hâlbuki Türkiye'deki ekonomik ve ticari yapılanma buna uygun değildi.

Soru:Şirketi kurmaya nasıl karar verdiniz? 
H.A:7-8 kişi kurucu arkadaştık. Şirketi kurduğumuzda ne imal edelim diye konuştuğumuz arkadaşlar bunlar. Teknik eleman ve işçi arkadaşlar vardı. Ben aracı görevi üstlendim. İlk Hollandalı işçilerden böyle bir fikir çıktı. İşçiler toplanıp demişler ki Denizli'de bir fabrika kuralım, kendimize de bir önder bulalım. Dayığlumda onların arasındaymış. Dayığlum, "Lahey'de bir halaoğlum okuyor onunla konuşalım” demiş. Çarşamba telefonla konuştuk, Pazar günü yanıma geldiler durumu anlatılar. Olur dedim, fabrikanın kurulması iyi olur dedim. Başarılar diledim. Dayığlum Hüseyin Cihan tekrar telefon etti. "Pansiyonun yemekhanesini ayarladık, Pazar günü toplantı yapacağız. Almanya'daki arkadaşlara haber gönderdik, seni bekliyoruz” dedi. Bunların kaldığı yer Almanya sınırında. Şu an Denizli'nin kardeş şehri Almelo. Almelonun, Denizli'nin kardeş şehri olmasında da ben öncülük yaptım. Orda çalışanların çoğunluğu Türk işçisiydi. Onların çoğunluğu da Denizliliydi. Pazar günü bindim trene gittim. Hakikaten bunlar bir hazırlık yapmışlar, her taraf Türk bayrağı, 50 kişi toplanır demişlerdi, en az 200 kişi birikmiş. Orada bir konuşma yaptık ve iş orada başladı. İlk topladığımız parayı bankaya yatırmak istedik. Henüz şirket kurulmamış olduğu için banka şirket adına kabul etmedi. 3 kişi adına parayı yatırdık, o şekilde kurulma kararı verildi. Daha sonra Almelo şehrinin stadyumunda bir Türk takımı maçı vardı. O maça gittik, fikri biraz da o stadyumda geliştirdik. Ben Ankara'daki arkadaşlara Türkiye'ye dönünce aktardım. Sonra Ali Dinçer fizibiliteyle, Nazım Kalancı işin teknik kısmıyla görevlendirildi. Yıldırım Becer makine mühendisi vardı Denizli'den. Nordmende'nin laboratuvar şefini getirdik. Beko'dan teknik eleman getirdik. Cihazlar son teknolojinin gerektirdiği cihazlardi.

Soru: İşletmeyi ilk kurduğunuzda kaç çalışanınız vardı.

H.A: Ben çalışıyorken 80 çalışanımız vardı. 1985 'de 400’ü bulmuştu.

Soru: Sermayeyi nasıl topladınız?

H.A: İşçileri toplayıp konuşma yapıyorduk. 8-10 kişilik bir grup, 2-3 kişilik alt gruplara ayrılıp dolaşıyordu. Evlerde toplanıyorduk. Saygı duyulan kişileri arayıp bulmak lazımdı. Türklerin gittiği kahveleri buluyorduk, toplantılar yapıyorduk. Ekipler oluşturup Almanya, Belçika, Avustralya, Fransa ve İsviçre'ye gidildi. Ve yurtdışındaki Türk işçilerin yoğun olduğu yerlerde temsilciler tayin ediyorduk. Zaman zaman biz de hisse satıp sermaye toplamak için yurtdışında dolaşıyorduk. Fabrikanın kurulumuyla ilgili film hazırlamıştık. Filmde bizde oynamıştık, bu filmi gösteriyorduk. Teşvik belgemizi gösterirdik. T.C. Hükümetinin Resmi Gazetede yayınlanan kararı gösterirdik. O dönemin valisi Münir Güney Bey’den özellikle hazine arazinin alınmasında çok yardım gördük. Bakın bir anımı anlatayım. Hollanda'da genel kurul toplantısı yapacağız. Fakat Ticaret Bakanlığı'na başvurmayı unutmuşuz. Erol Bey’e telefon ettim. Zor durumda olduğumuzu söyledim. Ertesi günü hemen Ticaret Bakanı Fehim Adak'a söyledik. Telekse geçecekler, elçilikten temsilci katılacak dedi. 2 gün sonra Elçilikten hükümet temsilcisinin toplantıya katılmasıkonusunda Ticaret Bakanlığı'ndan yazı geldi, biz de genel kurulu yapabildik.

Soru: Bir Emek'in sermaye yapılanmasının Türkiye'nin ekonomik ve ticari yapılanmasına uygun olmadığını söylemiştiniz bunu biraz açar mısınız?

H.A: Türkiye'deki ekonomik ve ticari yapılanma, kredi yapılanması Bir Emek'in yapılanmasına ters düştü ve Bir-Emek'in yapılanması onların yapılanmasına ters düşmüştü. İşçi şirketlerin özelliği yatırım sermayesi tamamlanır, fabrika kurulur, işletme sermayesi gerekir, bunun için bankaya gidersiniz ve kredi talep edersiniz. Şirkette 24.000 hissede 10 hissesi olan birisi milyonlarca dolarlık bir kredinin altına imza atmaz, zaten bankada onu kabul etmez. Bizim avantajımız o günlerde devlet hazinesinde dövizin olmamasıydı. Bizim sermayemizin çoğu da döviz sağliyordu. Fakat bu durum bir avantaj olarak kullanılamadı. Çünkü toplanan döviz Türkiye’ye girdiği zaman TL'ye çevriliyordu. İthalat yapacağımız zaman sıraya giriyorduk, sadece hazinedeki döviz kadar ithalat yapıyorduk. Bir Emek'in diğer işçi şirketlerinden farkı sermaye sınırlamasıydı. Herhangi bir sermaye grubunun şirketi ele geçirmesini istemedik. Hatta Asil Nadir Grubu Manisa'da Vestel'i kurmadan önce Bir Emek'i satın almak, hisseleri toplamak istemiş. Ama ana tüzükteki maddeden dolayı olmadı. Bir Emek kurulduğunda telsiz kullanımı devlet tekelindeydi. Alıcı sadece devletti. Şimdi artık her çocuğun elinde telsiz var. Bir diğer tabloda yurtdışında malzeme ithalinin o dönem büyük izinlere tabi olmasıydı. Şimdi her şeyi ithal edebiliyorsunuz. Bir-Emek ve benzeri şirketler banka kredisi sistemine ve Türk Ticaret Kanunundaki uygulamalara ters düştü. Halk şirketlerinin yapısına uygun gerekli değişiklikler yapılamadı. Bu değişiklikler yapılsayd1, bu şirketler yaşayabilirdi. Kredinin projeye verilmesi ve bu tür ortaklı şirketlerde şahsi kefalet aranmaması gerekiyordu. Mesela kredi alırken banka ipotek için tapu istiyor. Tapu hazinenin, ipotek için bankaya tapuyu veremiyorsunuz. İşçi şirketlerinin başarıya ulaşamamasının sebebi Ticaret Kanununda ve bankalar yasasındaki gerekli uyum değişikliğinin yapılamamasıdır. Bir diğer konu Türkiye'de ekonomiyi yöneten güçlerle ilgilidir. İşçi şirketleri ilk ortaya çıktığı zaman mesela un, irmik, salça, makarna fabrikası yapacağız diye ortaya çıktılar. Bunlar ekonominin yapısının etkilemeyecek küçük çapta yöresel yapılardı. Ekonomik güçler bu fikirleri kolaylıkla destekledi ve hatta önderlik etti. Ne zamanki bu şirketler elektronik, motor ve mekanik sanayinde yatırım yapacağız dediler, ekonomiyi yöneten güçler irkildi ve siyaseti etkiledi. 16.000 ortaklı işçi şirketi Türk Silahlı kuvvetlerinin telsiz ihtiyacını karşılayacak. Nasıl bir güç! Buna izin verilmedi. Biz bu amaçla yola çıktık. Devlet TESTAŞ’ı kurdu ben yapacağım dedi ama yapamadı. Bir-Emek de engellendi. Devletin telsiz ihtiyacı da karşılanmadı. 
Soru: Orman Bakanlığı Telsiz İhalesini almıştınız, neden daha sonra iptal edildi?

H.A: Biz İtalyan firmasıyla işbirliğine gittik. En kaliteli en ucuz teklifi verdik. Bizimki seçildi. Ancak Finlandiya devletinin Türk devletine verdiği orman ıslah çalışmalarıyla ilgili bir kredi söz konusuydu. Hazır Finlandiya'nın ayırdığg kredi var, bu telsizleri o kredinin içinde mütalaa edebiliriz denilmiş. O telsizler bu kredi kapsamında teslim edildi ve ihale iptal edildi. 460 küsur işçi şirketi kurulmuş, bunun 1 tanesi mi başarılı olmaz. Hepsinin mi bir yanlışı vardı. Hiçbiri kalmadı. Devam edenlerde büyük şirketlerin eline geçti. Ecevit 1987'de bu konuya bir takım konuşmalarında değindi ve büyük sermaye güçleri buna izin vermedi dedi. Bir-Emek'te payı olan 1.600 işçiden şimdi arada bir uğrayanlar oluyor, "bizim para ne oldu" diyorlar. "Ben parayı size vermiştim" diyorlar. Bu tür şirketlerde kâra da zarara da ortak olunduğunu düşünmüyorlar.

\section{Değerlendirme}

Girişimcilik, fırsatları görme, onları hayata geçirme, yenilik yapma faaliyetlerinin tamamını kapsayan bir süreçtir. Girişimciliğe başlamadan önceki karar aşamasında girişimi yapan kişi ya da kişilerin istekli olması, amaç ve hedefler belirlemesi, firsat ve tehditleri öngörmesi, gerekli olan kaynakları temin etmesi ve engelleri görüp onlarla baş etme konusunda istekli olması gereklidir. Girişimciliğe başlama aşamasında ise keşfedilen firsatlarla istek ve ihtiyaçlara cevap vermek, amaçları gerçekleştirmek ve uygulamadaki eksiklikleri gidermek üzere harekete geçilir ve stratejiler geliştirilir. Başarı aşamasında, büyüme, yeni yatırımlar gerçekleştirme, satışları ve kârlılığı artırma ve sürdürülebilir rekabet imkânları geliştirme vardır. Girişimin başarısızlığa uğraması veya geriye doğru gitmesi durumunda ise yeni önlemlerin alınması esastır (Yıldırım ve Balaban, 2013). Denizli'de Halk Sektörüyle ilgili yapılan araştırmanın mülakatları girişimcilik sürecinin bu dört aşaması bağlamında değerlendirilecektir:

Karar aşaması:

$\mathrm{Bu}$ aşamada girişimi yapacak olan kişileri harekete geçiren unsurlar ve karara götüren güdüleyici motifler önemlidir. Uygar Motor'un kurulmasında da yine ülkenin ve toplumsal şartların kurucular üzerinde yarattığı motive edici unsur vardır. B.A. ile yapılan mülakatta, "O zamanlar her şey dışarıya bağımlıydı, ülkede bir şey yapılmıyordu, Denizli'de sanayi yoktu. Birkaç tane un fabrikası vardı, o kadar. Birtakım arkadaşlar da Avrupa'nın çeşitli yerlerinde birleşerek bir şey meydana getirmek istedik....... Kıbrı Harekâtından sonra Türkiye'ye ambargo uygulanmıştı. Başkalarının vermediğini biz yaparız diye yola çıktık. Hatta bizim sloganımız vardl "Kendi Motorunu Yapamayan Toplum Sanayileşemez" diye.Bir-Emek'in kurucularından H.A. da işletmenin karar aşamasının “Denizlili bir grup Türk işçisi Denizli’ de bir fabrika kurmak istediklerini, benim de böyle bir kuruluşa önderlik etmemi söylediler” şeklinde ifade edip, sermayenin toplanması sırasında işletmeden pay alanların sayısındaki hızlı artışı şöyle anlatıyor: "1974 Kıbrıs Harekâtında Kocatepe isimli Türk savaş gemisi Türk uçakları tarafindan yanlışlıkla batırıldı. Nedeni ise gemi ile uçaklar arasında telsiz bağlantısı kurulamadığ için gemi kendisinin bir Türk gemisi olduğunu ifade edememiş ve Yunan gemisi diye batırlmış. Bu olay telsiz imalatıyla yola çıkan Bir Emek fabrikasına yurt dışındaki işçilerin büyük oranda sempati duyması ve ortak olması sonucunu getirdi. Bizim sloganımız "Türk ordusu yabancıdan telsiz almayacak". Her iki işletmenin de kuruluş kararında, görüleceği üzere, özellikle yöre halkının itici gücü önemli rol oynamıştır. Bilhassa, Uygar Motor ve Bir-Emek girişimlerinde halkın sermaye oluşumuna verdiği katkının kuvveti milli bir ruhun ve gücün de etkisiyledir. Bu sebeple denilebilir ki, Halk Sektörlerinin oluşumundaki en önemli istek, amaç ve hedef Halkın var olma, birlik olma ve güçlü olma arzusudur. Millet olarak bağımsız ve güçlü olma olgusu Denizli'deki Halk sektörlerinin oluşumunda en önemli güç kaynağıdır. Halk, dışarıya bağımlı olma tehdidi karşısında elindeki kaynakları (kendi tasarruflarını, kendi yörelerindeki eğitimli kişileri ve fikir önderi olarak gördükleri aydın kişileri) firsat olarak görüp, girişime döndürmüşlerdir.

Girişimciliğe başlama ve başarma aşaması:

Halk Sektörlerinde girişimciliğe başlama aşamasının ilk adımı sermayeyi bir araya getirmektir. Uygar Motor'un kurucu önderi B.A ise işletmenin kuruluşunu 100 arkadaşıyla beraber gerçekleştirdiğini ve motor üretmek üzere çok sayıda kitap okuyup araştırma yaptıklarını ifade ediyor. Ancak bu konuda hiçbir bilgileri olmayan B.A ve arkadaşları motor üretme fikrinin yanlış bir karar olduğunu fark ederek döküm üretimine başlamışlardır. B.A. bu kararlarını anlatırken, “......... motor üretme konusunda aldı̆̆ımız karar doğru değildi. O heyecanla oldu..........Madem motor üretemeyeceğiz, motor üretmekle ilgili döküm ve işleme kusmı kurduk, orada kaldık. Sonra döküm parçaları üretmeye başladık" diyor.

Bir-Emek işletmesi ise o döneme kadar Türkiye'de kurulmamış olan elektronik alanında faaliyet göstermek ve bu alandaki ihtiyacı karşılamak amacına sahiptir. Bir-Emek'in kurucularından olan H.A ve arkadaşları ise işletmeyi kurabilmek ve sermayeyi biraraya getirebilmek için 8-10 kişilik bir grup oluşturup Almanya, Belçika, Avusturya, Fransa ve İsviçre'ye gitmiş, kendilerinin de oynadıkları tanıtım filmlerini yapıp, oradaki Türk işçilerine göstermişlerdir. Ayrıca, Bir-Emek'in kurulması için teşvik belgesi alınmış, fizibilite raporu hazırlanmış ve devletten hazine arazisinin tahsisi talep edilmiştir.

Araştırmaya konu olan her iki işletme ve onların girişim önderleri işletmelerin kuruluş ve başarı aşamașında halkın istek ve ihtiyaçlarına cevap vermek üzere kurulma kararı alınan işletmeler için amaçları gerçekleştirmek 
üzere üretim konusunu belirleme, sermayeyi bir araya getirme ve bu konuda bürokratik işlemleri gerçekleştirmek için çaba göstermiş ve de başarılı olmuşlardır. Uygar Motor örneğinde görüldüğü üzere motor üretiminin gerçekleşemeyeceği anlaşılınca, gelecekte motor üretimine firsat oluşturacak şekilde döküm işine karar verilerek önemli bir stratejik adım atılmıştır. Keza, Bir-Emek de bütün çabasına rağmen kuruluş gayesi olan telsiz üretim firsatını yakalayamamış olmasına rağmen, daha sonraki dönemlerde televizyon ve bilgisayar üretimiyle elektronik sanayinde varlığını korumaya çalışmıştır. Ancak işletmelerin başarısının ardında devlet desteğinin varlığını da göz ardı etmemek gereklidir. Özellikle H.A ile yapılan mülakatlarda dönemin Denizli Valisi Münir Güney Denizli'deki Halk Sektörü oluşumunun "kapılarını açan” önemli bir isim olarak görülmektedir. H.A, kendilerine dönemin hükümeti ve bürokrasisi tarafından verilen desteği şöyle dile getirmektedir: “.....o hükümet döneminde resmi gazetede yayınlanan hükümet kararına göre Türkiye'de elektronik sanayide imalat yapacak kuruluşlardan sadece halk sektöründe olanlar teşvik edilecektir diye adı belirtilmeden Bir Emek desteklenmişti, elektronik sanayide o dönem sadece Bir Emek vardl. Dönemin hükümet üyesi Erol Çevikçe biz şirketi kurarken Devlet Planlama Teşkilatında Daire Başkanıyd ve bize büyük destek olmuştu, bakan olduktan sonrada bize desteğini devam ettirdi".

Girişimciliğin başarısızlığa uğraması durumunda alınan önlemler:

Her girişimsel faaliyet bir müddet sonra varlığını korumakta bir takım güçlükler yaşar. Toplumsal, ekonomik, siyasi değişiklikler ya da mevcut kaynaklarda, pazarda, teknolojide vb. alanlarda meydana gelen değişiklikler işletmelerin ilk girişim sebeplerinin ve girişim türlerinin devamlılığında engeller oluşturmaktadır. İşletmelerin girişimlerine devam edebilmeleri bu engellerle baş edebilme becerilerine bağlı olmaktadır. Aksi takdirde işletmeler yaşamlarını devam ettirememektedirler. Denizli'deki çalışmaya konu olan işletmeler açısından da girişimlerin başarısızlığa uğrayıp Halk Sektörü bağlamıyla yaşamlarını devam ettirememelerinin sebeplerini iki grupta ele almak mümkündür. Bunlardan ilki işletmelerin dış çevresinden (toplumsal, ekonomik ve siyasi) kaynaklanan sebepler, ikincisi iç çevresinden kaynaklanan sebeplerdir.

Araştırmaya konu olan işletmelerin yaşamlarını devam ettirememelerindeki en önemli dışsal sebepler enflasyon, yasal düzenlemelerin olmaması ve bankacılık faaliyetlerinin Halk Sektörü özelliklerine uyum sağlayamaması olarak dile getirilmiştir. Bir-Emek'in girişim önderi H.A'ya göre, “Türkiye'deki ekonomik ve ticari yapılanma, kredi yapılanması Bir Emek’in yapılanmasına ters” düşmüştür. H.A. “........ işletme sermayesi gerekir, bunun için bankaya gidersiniz ve kredi talep edersiniz. Şirkette 24000 hissede 10 hissesi olan birisi milyonlarca dolarlik bir kredinin altına imza atmaz, zaten banka da onu kabul etmez" diyerek bankacılıktaki kredi sisteminin Halk Sektöründeki sermaye yapılanmasının gereklerine cevap verecek bir düzenlemeye sahip olmadığını belirtmektedir. H.A’ya göre, telsiz kullanımının sadece devlet elinde olması yani tek pazarın devlet olması, o dönem malzeme ithalinin büyük izinlere tabi olması, ithalat yapılırken sıraya girilmesi, sadece hazinedeki döviz kadar ithalatın yapılabiliyor olması ve Ticaret Kanunu'nda gerekli düzenlemelere gidilememesi işletmenin başarısızlığa sürüklenmesindeki önemli faktörlerdir. Keza B.A'da başarısızlığa gidişteki en önemli dışsal faktör olarak “o dönem yasal düzenlemelerin olmayışı"nı görmektedir.

İşletmelerin başarısızlığına sebep olan içsel faktörlerden en önemlisi profesyonelleşmenin olamamasıdır. İşletmeler kuruluş sermayesini temin etmekle beraber sıra işleyiş sermayesine geldiğinde aynı başarıyı gösterememişlerdir. Uygar Motor'un girişim öncüsü B.A'ya göre motor üretimindeki başarısızlıklarının sebebi üretim konusu ve şirket işleyişleri hakkındaki bilgisizlikleri olurken, döküm yaparken de şirketin işleyişiyle ilgili hukuksal yapıdaki bocalamaları olmuştur. Keza işgören bulurken de profesonelleşme konusunda sıkıntı yaşanmıştır. B.A. “.... İşçilikten sermayedarliğa geçme durumu var. Sorunumuz profesyonel kişilerin olmayışıydı...... Üretime başladı̆̆ımız yıllarda sanayi işçisi yoktu, eleman bulmada çok sorun yaşadık. Adamları tarladan getirip dökümcü yaptık" diyerek yaşanan zorluğu anlatmaktadır.

İkinci içsel sebep ise ortak sayısının binlerle ifade edilen rakamlardan olması ve ortakların önemli bir çoğunluğunun Almanya'da ikamet ediyor olması sebebiyle genel kurulların toplanamamasıdır. Uygar Motor için B.A. benzer bir durumdan bahsediyor ve “.........şirkettin genel kurulu toplanamiyor, gerekli kararlar alamıyor, sermaye artırımını yapamıyorduk. Genel kurulun toplanması için dörtte üç çoğunluk gerekiyordu. 10.000 ortak var" diye ifade ediyor.

Sonuç olarak; ister içsel, isterse dışsal sebeplerden kaynaklansın her şeyden öte önemli bir Milli Sermaye birikimi olan ve üretim faktörleri mülkiyetinin tabana yayıldığı Halk sektörü1980’li yıllarda ülkenin dışa açılmasıyla da beraber tamamen ortadan kalkmıştır. Sektördeki işletmelerin başarısıyla ya da başarısızlığıyla ilgili tecrübeler de fiiliyatta sonraki nesillere aktarılamamıştır.

\section{Sonuç}

Girişimcilik, ülkenin endüstrileşmesine, endüstriyel dağılımın ve endüstriyel çeşitliliğin sağlanmasına, rekabet gücünün seviyesine ve ekonominin karakteristiğine etki ederek sonuçta o ülkenin teknolojisinin gelişmesi ve kalkınmasında ana rolü oynar (Ersoy, 2010). Girişimciliğin yapısında, bir malın ya da hizmetin üretilmesi, bunun için üretim metodunun kurulması ve geliştirilmesi, pazarın oluşturulması, hammadde kaynağının bulunması ve endüstrinin yapılandırılmasıyla genel olarak ülkenin ekonomik, ticari, teknolojik ve sosyal hayatında yenilenme 
sürecine katkı vardır. 1970'li yılların başında yeni bir endüstriyel yapılanma olan Halk Sektörleri ülkenin sanayileşmesinde, teknolojik gelişmesinde, sermayenin bir araya getirilmesinde dünyada emsali çok da görülmemiş önemli bir girişimcilik örneğini temsil etmiştir. Yukarıda, yazına ve alan araştırmasına dayalı olarak aktarılanların satır aralıklarında o yıllara dair, girişimcilikte esas olabilecek çok önemli mesajlar da mevcuttur. Özellikle gelişme çabası içerisindeki ülkelerin girişimcilikle bir bütün olarak kalkınması, milli bir ruhun itici gücüyle hareket kazanabilmektedir. Çünkü girişimcilik stratejik bağlamıyla rekabeti içerisinde barındıran bir olgudur. Türk Halkının yeniden yapılanma, ekonomik ve teknolojik açıdan da bağımsız olma arzusu kimi zaman Halk Sektörü içerisindeki işletmelerin oluşumunda kimi zaman da bu işletmelerin gelişiminde güdüleyici faktör olmuştur. Böyle bir milli ruhun girişime dönüşmesinde ve on binlerce ortağın tasarruflarını bir çatı altında sermayeye dönüştürmesinde ise ana araç halkın birbirine duyduğu güvendir. Ülkelerinden binlerce kilometre uzakta yaşayan insanlar, birbirlerine güvenerek ve kendilerini organize etmek için çaba gösteren girişim ve fikir önderlerine güvenerek ve inanarak tasarruflarını büyük bir heyecanla bir araya getirmişlerdir. Halkın birbirine güveni, henüz sanayileşme tecrübesi çok düşük olan Türk insanının kârı ve zararıyla riske girdikleri işletmelerin kurulmasına ve işlemesine vesile olmuştur.

Yapılan yazın taramasında ve mülakatlarda bir diğer dikkati çeken faktör ise sosyal girişimcilik olgusunun 1970'li yılların Türkiye'sinde bizzat fiiliyatta gerçekleşmiş olmasıdır. Sosyal girişimciler, fark ettikleri ihtiyacı ve bununla ilgili firsatı tespit eden, bu ihtiyacı karşılamaya yönelik girişime hayal gücü ve vizyon katan, söz konusu girişim için diğer insanları bir araya getiren, onları motive eden ve gerekli ağları kuran, ihtiyaç duyulan kaynakları bulan, engellerin ve zorlukların üstesinden gelen ve oluşan risklerle baş eden, girişimi kontrol etmek için uygun sistemler oluşturan kişilerdir (Thompson, 2002). Bu bağlamda araştırmaya konu olan her iki işletmenin de girişim önderleri, Uygar Motor'da B.A ve Bir-Emek'te H.A. gerçekte birer sosyal girişimcilik özelliği de göstermektedirler. Özellikle ihtiyaç boşluklarını görme, gerekli ağları kurma ve insanları bir araya getirme, kaynakları bulma, engellerin üstesinden gelme konularında önemli bir role sahip olmuşlardır.

Halk Sektörü dâhilindeki işletmelerin, yaklaşık on yıllık süreçte başarı göstermelerine rağmen, ekonomik, ticari, siyasi ve sosyal meselelerde gerekli zemine kavuşamamış olması ve halkın girişimcilik ve işletme bağlamında yeterli tecrübeye sahip olmaması gibi dışsal sebeplerle ve girişim öncülerinin ve pay sahiplerinin ticari ve hukuki açıdan yeterli bilgiye ve deneyime sahip olmamaları, profesyonel kişilerin istihdam edilememesi vb. içsel sebeplerle uzun dönemde başarılı olamamışlardır. Ancak bu gün, Türk Halkının elinde yaşanmış ve olabilirliği görülmüş bir Halk Sektörü tecrübesi vardır. Halk Sektörünü diğer sektörlerden ayıran en önemli özellik, sermayenin ve üretim araçları mülkiyetinin bir girişimcilik faaliyeti sürecinde tabana yayılmış olmasıdır. Çok daha önemlisi Halk Sektörü işletmeleriyle halkın, küçük tasarruflarını sermayeye dönüştürmesiyle ekonomik gücünün, kendilerinin sahibi oldukları işletmeye verdikleri fikirlerle zihin gücünün ve bilgi gücünün sinerjisi sağlanmaktadır. Aynı zamanda sahibi oldukları işletmelerde çalışan işgücünün yabancılaşmasına da engel olunabilecektir.

Bugün böyle bir oluşumun yaşanması Türkiye'de veya dünyanın herhangi bir yerinde tekrar mümkün olabilir mi bilinmez. Bununla beraber sürekli tüketim arzusu güdülenen hatta üretmek için önce tüketmesi gerektiği vurgulanan ve kazançları bankacılık sektörüyle alışverişe kanalize edilen insanların tekrar tasarrufa yönlendirilerek birikim yapmalarının sağlanması ve bu tasarrufları sermayeye dönüştürmek üzere Halk Sektörlerinin yeniden canlandırılması ihtimal dâhilindedir. Böylece kaynaklar israf edilmeyeceği gibi, mevcut kaynaklarla daha fazla katma değer yaratılabilecektir. Bunun için önce ülkelerin yöneticilerinin ve fikir önderlerinin gerekli olan ekonomik, hukuki ve ticari düzenlemeleri yapmaları, halkın birbirine ve yöneticilerine güvenlerini pekiştirmeleri gereklidir.

\section{Kaynakça}

- Ak, Mehmet, 1976, Millet Sektörü, Ayyıldız Matbaası A.Ş. Ankara.

- Akseki, Cengiz, 2007, “Denizli’de Türk İşçilerinin Kurduğu Elektronik Fabrikası, BİR-EMEK”, Toplumsal Tarih, Sayı:166, Ekim, s. 68-74.

- Altun, Ahmet ve Şevki, Akınc1, 1974, “Halk Sektörünün Tanımı, Halk Sektörü’nün Isşlenmesinde Devletin Rolü, Halk Sektörünün Kuruluş Başlangıcında Karşılaşılacak Sorunlar ve Çözüm Yolları”, Halk Sektörü Semineri, Köy İşleri ve Kooperatifler Bakanlığı Yayınları, No:224, Ankara, s.93.

- Coşkun, Alev, 1976, “Demokratik Sol’da Kamu İktisadi Teşebbüsleri, Yeni Örgütlenme-Öz Yönetim Uygulaması”, Demokratik Sol Düşünce Formu, Cilt 2, Kalite Matbaas1, Ankara.

- Ersoy, Hüseyin, 2010, “Kültürel Çevrenin Girişimcilik Tercihine Etkisi”, Organizasyon ve Yönetim Bilimleri Dergisi, Cilt:2, Say1:1, s. 72.

- Hamitoğulları, Beşir, 1974, "Halk Sektörünün Anlamı, Doktrini ve Yapısı, Yeni ve Ulusal Bir Kalkınma Modeli Olarak Halk Sektörü”, Halk Sektörü Semineri, Köy İşleri ve Kooperatifler Bakanlığı Yayınları, No:224, Ankara, s.25. 
- İlbaş, Mehmet Hâdi, 1974, Halk Sektörünün Genel Ekonomik Gelişmedeki Yeri, Diğer Sektörlerden Fark1 ve Bunlarla İlişkileri”, Halk Sektörü Semineri, Köy İşleri ve Kooperatifler Bakanlığg Yayınları, No:224, Ankara, s. 223.

- Kepenek, Yakup , 1974, "Halk Sektörünün Tanımı, Devletin Halk Sektörünün İşlemesindeki Rolü, Halk Sektörünün Kuruluşunun Başlangıcında Karşılaşılacak Sorunlar ve Çözüm Yolları”, Halk Sektörü Semineri, Köy İşleri ve Kooperatifler Bakanlığı Yayınları, No:224, Ankara, s. 12.

- Ölçen, Ali Nejat, 1974, Halk Sektörü, Ayyıldız Matbaası A. Ş., Ankara.

- Ölçen, Ali Nejat, 1975, “Halka Açık Anonim Ortaklıklar ve Halk Sektörü”, Banka ve Ticaret Hukuku Araştırma Enstitüsü Yayınları, No: 116, Ankara, s. 81, (1974 yılında Ankara'da yapılan "Halk Sektörü” Açık Oturumundaki bildiri).

- Ö̈ngün, Korkut, 1974, "Yatırımlar ve Halk Sektörü”, Makine Mühendisleri Odası Sanayi Kongresi (adı geçen kongrede sunulan bildiri), http://arsiv.mmo.org.tr/pdf/10549.pdf, Erişim tarihi, 28.04.2013

- Thompson, John L, 2002, “The World of the Social Entrepreneur”, The International Journal of Public Sector Management, Vol:15, No:5, p. 415.

- Türk, Hikmet Sami, 1975, Halk Sektörü Politikası, Sevinç Matbaası, Ankara.

- Yıldırım, Elvan ve Özlem, Balaban, 2013, “Girişimci Kişilik Özelliklerinin Girişimcilik Eğilimi Üzerindeki Etkisi”, 4. Uluslararası Girişimcilik Kongresi, 2-4- Mayıs 2012, Manisa, Türkiye, s. 166.

- 11.05.2002 Tarihli Milliyet Gazetesi, http://www.milliyet.com.tr/Ekonomi/HaberDetay.aspx?aType=HaberDetayArsiv\&KategoriID=3\&ArticleID $=51656 \&$ PAGE $=1$, Erişim Tarihi 02.05.2013 


\title{
Türkiye'de Hanehalkı Tüketim Harcamaları: Pseudo Panel Veri ile Talep Sisteminin Tahmini
}

\section{The Consumption Expenditure of Households in Turkey: Demand System Estimation with Pseudo Panel Data}

\author{
Prof. Dr. Seda Şengül (Çukurova University, Turkey) \\ Ph.D. Candidate Çiler Sigeze (Çukurova University, Turkey)
}

\begin{abstract}
In this study, micro data sets obtained by 2005 and 2009 Household Budget Surveys compiled by Turkish Statistical Institute were used to estimate the parameters of household consumption demand and calculate the income-demand elasticities of consumer goods. Total expenditures of the households in this data set delivered into the following 12 different categories of goods and services. The expenditure share of these different categories of goods and services is the dependent variable of this model. In addition, the total household expenditure, the squared total household expenditure, the household size adjusted in accordance with the OECD equivalence scale and the logarithms of squared household size are the independent variables used in the study. The Seemingly Unrelated Regression Equations (SURE) is used to estimate the Quadratic Almost Ideal Demand System (QAIDS) so as to determine the demand parameters of the main commodity groups. The principal result of the study is that the consumption elasticities of the food and nonalcoholic beverages, housing, water, electricity, fuel, clothing and footwear, furniture and house appliances, communications, alcoholic beverages, cigarette and tobacco expenditure are less than 1 . Therefore, it can be said that these commodity groups are considered to be mandatory goods. On the other hand, the consumption elasticities of the health, transportation, education services, entertainment and culture, restaurants, hotels, patisseries are more than 1 . Thus, these commodity groups are considered to be luxury goods. In this regard, the study concludes that Turkey is considered to be a developing country in terms of the consumption characteristics.
\end{abstract}

\section{Giriş}

Hanelerin kısıtlı gelirlerini harcama grupları arasında nasıl dağıttıkları iktisatçıların ve politika yapıcıların en çok ilgilendiği alanlardan biridir. Bunun en önemli sebeplerinden biri mal ve hizmet tüketiminin büyük bir bölümünün temel gereksinimleri karşılamaya yönelik olmasıdır. Dolayısıyla hanehalkı tüketim harcamaları yaşam standardının önemli bir göstergesidir.

Tüketici davranışlarını belirleyen faktörler arasında gelir, ilgili malların fiyatları, tüketici zevkleri ve tercihleri, farklı sosyo-kültürel yapılar ve yerleşimler sayılabilir. Tüketim harcamaları çalışmalarında, gelir ve fiyat esnekliklerinin belirlenmesi ile tüketim üzerinde gelir ve fiyat gibi önemli faktörlerin etkisi vurgulanmakta ve bu etkilerin büyüklüklerin belirlenmesi ile gelecek piyasa tahminlerinin yapılması ve uygun mali politikaların belirlenmesi sağlanmaktadır.

Tüketiciler tarafından bir mal grubuna yapılan harcama o mal grubunun üreticisi açısından geliri ifade ettiğinden dolayı toplam tüketim harcamalarının mal grupları itibariyle dağılımının ve fiyat ve gelir değişimleri karşısındaki esnekliklerinin belirlenmesi, tüketiciler kadar üreticileri de yakından ilgilendirmektedir. Analiz sonuçları 1şı̆̆ında üreticiler araştırma bölgesindeki tüketicilerin taleplerini hangi mallara yönlendirdiklerini veya fiyatlarda meydana gelecek muhtemel bir değişme karşısında tüketim kalıplarında nasıl bir değişme olacağını tespit etmek suretiyle fiyat, tüketim ve pazarlama politikalarını belirleyecektir (Özer, 2001).

Talep sisteminin tahmini için yapılan ilk çalışmalarda zaman serisi verileri kullanılırken daha sonraki çalışmalara demografik değişkenlerin eklenmesi ile yatay-kesit veriler kullanılmıştır. Son çalışmalarda ise hem zaman hem de kesit boyutunu içeren panel veri analizi kullanılmaya başlanmıştır. Ancak hanehalkı çalışmalarında tekrarlı yatay-kesitlerdeki gözlemlerin aynı olmamasından dolayı Deaton (1985), bireysel gözlemlerden ziyade, aynı özelliklere sahip bireylerin gruplandırılması ile elde edilen verilerin (cohort) ortalamalarını baz alarak ekonomik ilişkileri tahmin etmeyi ve dolayısıyla pseudo panel veri kullanılmasını önermiştir.

Bu çalışmada da 2005 ve 2009 yıllarına ait Türkiye'de hanehalkı tüketim talebine ilişkin parametreleri tahmin ederek; tüketim mallarının gelir-talep esnekliklerini hesaplamak ve hesaplanan gelir-talep esnekliklerinden yararlanarak karar alıcılara, politika yapıcılara, refah düzeyini artırmaya yönelik doğru sosyal politikaların oluşturulmasına yardımcı olacak bilgiler sunmak amaçlanmaktadır. 


\section{Veri ve Değişkenler}

Çalışmada Türkiye İstatistik Kurumu (TÜIKK) tarafından derlenen, 2005 yılı ve 2009 yılı Hanehalkı Bütçe Anketi (HBA) Mikro Veri Seti kullanılmıştır. 2005 yılı 8560 ve 2009 yılı için 10046 hanehalkı örneklemi oluşturmuştur (TÜİK 2005, TÜİK 2009).

TÜİK, Hanehalkı Bütçe Anketlerinde uyguladığı COICOP (classification of individual consumption by purpose) sınıflamasında dikkate aldığı 12 mal ve hizmet grubu bu çalışmada incelenen mal gruplarıdır. Bu mal grupları; 1) gıda ve alkolsüz içecekler, 2) alkollü içecek, sigara ve tütün, 3) giyim ve ayakkabı, 4) konut, su, elektrik ve yakıt 5) mobilya, ev aletleri ve bakım merkezi, 6) sağlık, 7) ulaştırma, 8) haberleşme, 9) kültür, eğlence, 10) eğitim hizmetleri, 11) otel, lokanta, pastane 12) çeşitli mal ve hizmetlerdir.

Bu 12 mal ve hizmet grubunun bütçe paylarının bağımlı değişken olarak kullanıldığı QAIDS (Kuadratik İdeale Yakın Talep Sistemi) modelinin bağımsız değişkenleri ise toplam harcamanın logaritması, toplam harcamanın logaritmasının karesi, OECD eşdeğerli ölçeğine göre düzeltilmiş hane genişliğinin logaritması ve OECD eşdeğerlik ölçeğine göre düzeltilmiş hane genişliğinin karesinin logaritmasıdır.

Çalışmada kullanılan değişkenlerin ortalama değerleri ve standart sapmaları Tablo 1'de sunulmuştur.

\begin{tabular}{|l|l|l|l|}
\hline Değişkenler & Açıklama & 2005 & 2009 \\
\hline w1=G1da & Gida harcamas1/toplam harcama & 0.257 & 0.234 \\
\hline w2=Giyim & Giyim ve ayakkabı harcaması/toplam harcama & 0.063 & 0.053 \\
\hline w3=Konut & Konut, su, elektrik, gaz harcaması /toplam harcama & 0.269 & 0.280 \\
\hline w4=Mobilya & Mobilya ve ev aletleri harcaması/toplam harcama & 0.060 & 0.064 \\
\hline w5=Sağlık & Sağlık harcamas1/ toplam harcama & 0.023 & 0.021 \\
\hline w6=Ulaştırma & Ulaştırma harcaması/toplam harcama & 0.120 & 0.133 \\
\hline w7=Haberleşme & Haberleşme harcamasi/ toplam harcama & 0.042 & 0.042 \\
\hline w8=Eğitim & Eğitim hizmetleri harcaması/toplam harcama & 0.018 & 0.017 \\
\hline w9=Evdış1 & Otel, lokanta, pastane harcaması/toplam harcama & 0.042 & 0.049 \\
\hline w10=Kültür & Kültür, eğlence harcamas1/toplam harcama & 0.025 & 0.026 \\
\hline w11=Diğer & Çeşitli mal ve hizmetlerin harcaması/ toplam harcama & 0.041 & 0.041 \\
\hline w12=Alkol-tütün & Alkollü içecek, sigara, tütün harcaması/toplam harcama & 0.040 & 0.040 \\
\hline LOECD & OECD eşdeğerli ölçeğine göre düzeltilmiş hane genişliğinin logaritmas1 & 0.837 & 0.772 \\
\hline SLOECD & OECD eşdeğerli ölçeğine göre düzeltilmiş hane genişliğinin karesinin log. & 0.701 & 0.605 \\
\hline LHARCAMA & Hanehalk1 aylık toplam harcamasının logaritması & 4,04 & 7,39 \\
\hline SLHARCAMA & Hanehalk1 aylık toplam harcamasının karesinin logaritması & 6,08 & 14,79 \\
\hline
\end{tabular}

Tablo 1: Çalışmada Kullanılan Değişkenler ve Tanımlayıcı İstatistikler

Değişkenlere ait tanımlayıcı istatistiklere baktığımızda 2005 ve 2009 yıllarında hanelerin tükettikleri mal ve hizmet gruplarının bütçe paylarında önemli bir değişiklik olmadığı saptanmıştır. Gıda harcamasının toplam harcama içindeki payı 2005 yılında \%25.7 iken 2009 yılında \%23.4'e düşmüş, otel, lokanta pastane gibi ev dış1 gıda harcamasının toplam harcama içindeki payı ise sözü edilen dönemde $\% 4.2$ 'den \%4.9'a yükselmiştir. OECD eşdeğerlik ölçeğine göre 2005 yılında 2.31 olan hane genişliği 2009 yılında 2.17 'ye düşmüştür.

\section{Yöntem}

Hem gelişmiş hem de gelişmekte olan pek çok ülkede zaman içerisinde hanehalkı bütçe anketleri diğer verilere kıyasla daha sistematik ve düzenli olarak toplanmaktadır. Bu da, tüketim davranışlarının hem bireyler arasında hem de zaman içinde nasıl değiştiğini belirlemeye yönelik çalışmaların yapılmasına, yani panel verilerin kullanılmasına olanak tanımaktadır. Ancak, hanehalkı bütçe anketleri genellikle farklı hanelerden gözlemlenen tekrarlı yatay-kesit anketlerinden oluşmaktadır. Bu şekilde derlenen Hanehalkı Bütçe Anketi verilerinde (tekrarlanan yatay-kesitlerde) bireylerin aynı olmaması nedeniyle; bireysel gözlemlerin gruplandırılması (cohort) ile oluşturulan pseudo panel veri kullanılmaktadır. Bireysel gözlemlerin gruplandırılması bireylerin zamanla değişmeyen ortak özelliklerine (doğum yılı, cinsiyet, eğitim, yerleşim yeri büyüklüğü vb. ) göre yapılmaktadır ve her bir grup pseudo panel verinin cohortlarını oluşturmaktadır. Öyle ki hanedeki referans kişinin (hanehalkı reisi) doğum yılı ya da eğitim düzeyine göre gruplandırma yapılmaktadır (Gardes vd, 2005).

Bu çalışmada, hanedeki referans kişinin (hanehalkı reisinin) doğum yılına (yaşına) ve eğitim düzeyine göre cohortlar oluşturulmuştur. Hanehalkı reisinin yaşına göre oluşturulan beş cohort ve hanehalkı reisinin eğitim düzeyine göre oluşturulan 4 cohort sırasıyla;1) Hanehalkı reisinin yaşının 35'den küçük olduğu haneler,2) Hanehalkı reisinin yaşı 35 ve 44 arasında olan haneler, 3) Hanehalkı reisinin yaşı 45 ve 54 arasında olan haneler, 4) Hanehalkı reisinin yaşı 55 ve 64 arasında olan haneler, 5) Hanehalkı reisinin yaşı 65 ve üstü olan haneler,6) Hanehalkı reisinin okur-yazar olmadığı ya da okur-yazar olup bir okul bitirmediği haneler, 7) Hanehalkı reisinin ilkokul-ilköğretim öğrenim düzeyinde olduğu haneler, 8) Hanehalkı reisinin ortaokul-orta dengi meslek lisesi ya 
da lise-lise ve dengi meslek lisesi öğrenim düzeyinde olduğu haneler ve 9) Hanehalkı reisinin yüksekokulfakülte, yüksek lisans ve doktora öğrenim düzeyinde olduğu hanelerdir.

Uygulamalı talep çalışmalarında özellikle hanehalkı bütçe verileriyle tutarlı bir fonksiyonel biçime sahip olması ve tahmininin de kolay olması nedeniyle AIDS talep sistemi kullanılmaktadır.

AIDS modeli Eşitlik 1'de sunulmuştur.

$$
w_{i}=\alpha_{i}+\sum \alpha_{i} P_{i}+\beta_{i} \log \left(\frac{X}{P}\right) \quad i, j=1,2, \ldots, 12
$$

Burada;

$w_{i}$ : i. malın harcama payını, $\mathrm{X}$ : toplam harcamayı, P: genel fiyat indeksini, $\mathrm{P}_{\mathrm{i}}$ : i. mal grubunun fiyatını göstermektedir.

Eşitlik 1'in parametreler itibariyle doğrusal olmamasından kaynaklanan tahmin güçlüğünü gidermek için model Stone fiyat indeksi kullanılarak (Eşitlik 2) doğrusallaştırılmaktadır. Doğrusallaştırılan bu model, Doğrusal Formda İdeale Yakın Talep Sistemi (Linear Approximated Almost Ideal Demand System-LA/AIDS) olarak adlandırılmaktadır (Deaton \& Muellbauer, 1980b). Ancak, Stone fiyat indeksinin eşanlılık sorununa yol açması nedeniyle ampirik çalışmalarda farklı fiyat indekleri kullanılmıştır. Bu çalışmada kullanılan fiyat indeksi Eşitlik 3 'te verilmiştir (Burton ve Young, 1992).

$$
\begin{aligned}
& \log P=\alpha_{o}+\sum_{i=1}^{n} \alpha_{i} \log P_{i}+\frac{1}{2} \sum_{i=1}^{n} \sum_{j=1}^{n} \gamma_{i j} \log P_{i} \log P_{j} \\
& \log P=\sum_{i=1}^{n} \bar{w}_{i} \log p_{i} \quad i, j=1,2, \ldots, n
\end{aligned}
$$

$\bar{w}_{i}: w_{i}{ }^{\prime}$ nin ortalaması, $\mathrm{P}_{\mathrm{i}}$ : i mal grubunun aylık fiyat indeksidir.

Ancak, her bir mal grubuna ait fiyat verileri sağlanamadığından Eşitlik 1'den fiyat değişkeni çıkarılmıştır. Eşitlik 3’teki fiyat indeksi ise her bir mal grubunun fiyatının göstergesi olarak, bu mal gruplarının her biri için 2005 ve 2009 yillarında TÜIK tarafindan hesaplanan aylık fiyat indeksi (TÜİK, 2009) verileri kullanılarak hesaplanmıştır. Bu durumda, AIDS modeli Eşitlik 4 şeklinde gösterilebilir. Fiyat değişkeni modelde yer almadığından simetri kısıtının da test edilmesine gerek kalmamıştır.

$$
w_{i}=\alpha_{i}+\beta_{i} \log \left(\frac{X}{P}\right) \quad \mathrm{i}=1,2, \ldots, 12
$$

Toplam harcama i. mal grubunun bütçe payı üzerinde her zaman doğrusal olarak artan bir etkiye sahip olmayabilir. Bağımsız değişkenler arasında yer alan toplam harcamanın karesinin modele dahil edilmesi durumunda AIDS modeli, Karesel İdeale Yakın Talep Sistemi'ne (QAIDS) dönüşmektedir. Bu çalışmada da, toplam harcamanın bütçe payı üzerindeki doğrusal olmayan etkisini elde edebilmek için QAIDS modeli kullanılmıştır (Banks vd., 1997).

$\log \left(\frac{X}{P}\right)$ 'in karesi Eşitlik 4 ' te sunulan eşitliğe eklendiğinde Eşitlik 5 'te verilen QAIDS modeli elde edilmiştir.

$$
w_{i}=\alpha_{i}+\beta_{i} \log \left(\frac{X}{P}\right)+\beta_{2} \log \left(\frac{X}{P}\right)^{2}
$$

Çalışmada kullanılan veri setinin özellikleri ele alınarak kullanılan model ise Eşitlik 6' da sunulmuştur. $\mathrm{Bu}$ model pseudo panel veri analizinde, $(\mathrm{C}, \mathrm{t})$ cohortlarında, $(\mathrm{h}, \mathrm{t})$ hanehalklarının gruplandırılması ile ortaya çıkan toplulaştırılmış model, $h \in C$ olmak üzere $\alpha_{h}^{i}=\alpha_{C}^{i}$ hipotezi altında $\gamma_{h t}=\frac{X_{h t}}{\sum_{h \in C} X_{h t}}$ ile $\sum_{h \in H} \gamma_{h t} w_{h t}^{i}=w_{C t}^{i}$ olmak üzere aşağıdaki şekilde elde edilir.

$$
\begin{aligned}
& w_{C t}^{i}=\alpha_{C}^{i}+\beta_{1}\left(\sum_{h} \gamma_{h t} \ln \left(\frac{X_{h t}}{P_{t}}\right)\right)+\beta_{2}\left(\sum_{h} \gamma_{h t} \ln \left(\frac{X_{h t}}{P_{t}}\right)^{2}\right) \\
& +\beta_{3}\left(\sum_{h} \gamma_{h t} \ln \varsigma_{h t}\right)+\beta_{4}\left(\sum_{h} \gamma_{h t} \ln \varsigma_{h t}{ }^{2}\right)+\sum_{h} \gamma_{h t} \varepsilon_{C t}^{i} \\
& \mathrm{i}=1,2, \ldots, 12, \mathrm{C}=1,2, \ldots, 9, \mathrm{t}=1,2, \ldots, 12
\end{aligned}
$$


$X_{h t}: \mathrm{t}$ zamanında, $\mathrm{h}$ hanesinin harcama tutarını, $\gamma_{h t}: \mathrm{t}$ zamanında, $\mathrm{h}$ hanesinin toplam harcamasının, bulunduğu cohorttaki toplam harcamaya oranını, $w_{h t}^{i}: \mathrm{t}$ zamanında, $\mathrm{h}$ hanesinin toplam harcaması içinde $\mathrm{i}$ malının harcama payını, $w_{C t}^{i}: \mathrm{t}$ zamanında cohortta yer alan bütün hanelerin toplam harcamaları içinde i malının harcama paylarının toplamının ağırlıklı değerini, $\ln \varsigma_{h t}: \mathrm{t}$ zamanında, $\mathrm{h}$ hanesinin OECD eşdeğerli ölçeğine göre düzeltilmiş hane genişliğinin logaritmasını, $\ln \varsigma_{h t}{ }^{2}: \mathrm{t}$ zamanında, $\mathrm{h}$ hanesinin OECD eşdeğerli ölçeğine göre düzeltilmiş hane genişliğinin karesinin logaritmasını göstermektedir.

Tam talep sistemi tahminlerinde, sistemi oluşturan eşitlikler arasında korelasyon olma olasılı̆̆ı nedeniyle ve eşitlikler arasındaki kısıtlardan dolayı sistemi oluşturan eşitliklerin birlikte tahmin edilmesi gerekmektedir.Bu nedenle Eşitlik 6'daki sistem Zellner'in (1962) önerdiği görünürde ilişkisiz regresyon (SUR) denklemleri seti olarak ele alınabilir ve SUR tahmin edicisiyle (SUR estimator, SURE) ile tahmin edilebilir. Sistemde hata terimleri arasında korelasyonun olması sebebiyle varyans-kovaryans matrisi tekil olmaktadır. Bu matrisin tekil olması da, mal gruplarının bütçe payları toplamının 1'e eşit olması ve her bir harcama denklemindeki hata terimleri toplamının da sıfıra eşit olması gerektiğinden sistem tahminini imkânsız kılmaktadır. Bu da n sayıdaki denklemden oluşan sistemden herhangi bir denklemin atılması (hangi denklemin modelden atılacağı tahmin sonuçlarını etkilemez) ve n-1 sayıdaki denklemden oluşan sistemin tahmin edilmesiyle çözülebilmektedir.

Sistemden atılan n'inci denklemin parametresi ise toplama şartı $\left(\sum_{i=1}^{t} \beta_{i}=1\right)$ gereğince diğer denklemlerin parametrelerinden kolayca hesaplanabilmektedir (Judge vd., 1988). Ana mal grupları itibariyle AIDS'in tahmininde 12 denklemden oluşan sistemden "çeşitli mal ve hizmetler" mal grubuna ait denklem çıkarılarak 11 denklem tahmin edilmiştir.

Eşitlik 6 'nın gruplandırılmış veriler (ya da cohortlar) üzerinden oluşturulmasından dolayı hata terimi her bir gruptaki hanehalkı sayısına bağlı olarak değişen varyanslıdır. Kakwani (1977), hata terimi varyansının her bir gruptaki (cohorttaki) hanehalkı sayısı ile ters orantılı olduğunu ve bu değişen varyansın Ağırlıklı En Küçük Kareler yöntemiyle düzeltilebileceğini göstermiştir. Bunun için sistemdeki tüm değişkenlere ait gruplandırılmış veriler (sabit terim dahil) her bir gruptaki hanehalkı sayısının karakökü ile çarpılmak suretiyle dönüştürülmüştür.

Panel veriler, birim etkinin sabit yada rassal olmasın göre Sabit etkiler modeli ya da Rassal etkiler modeli olarak ayrılmaktadır. Sabit ve Rassal etkiler modelleri arasındaki en önemli fark, birim etkinin bağımsız değişkenlerle ilişkili olup olmamasıdır. Hausman (1978), yokluk hipotezi $\left(H_{0}=E\left(u_{i t} / X_{i t}\right)=0\right)$ altında her ikisi de tutarlı ve bununla birlikte, yokluk hipotezinin reddedilmesi durumunda farklı olasılık limitlerine sahip olan iki tahmin ediciyi karşılaştırmayı önermiştir. Buna göre, birim etkinin bağımsız değişkenler ile ilişkisiz olduğu rassal etkiler modeli için Between tahmin edicisi $\left(\hat{\beta}_{\text {Between }}\right)$ ve birim etkinin bağımsız değişkenler ile ilişkili olduğu sabit etkiler modeli için Within tahmin edicisi ( $\left.\hat{\beta}_{\text {within }}\right)$ karşılaştırılmıştır (Baltagi, 2005).

Çalışmada Türkiye'deki tüketim mallarının gelir-talep esnekliklerini hesaplamak için kullanılacak AIDS modeli ve QAIDS modelinin gelir-talep esneklik formülleri Eşitlik 7 ve Eşitlik 8'de sırasıyla verilmiştir.

$$
\begin{aligned}
& \varepsilon_{i}^{a}=1+\frac{\beta_{i}}{w_{i}} \quad i=1,2, \ldots 12 \\
& \varepsilon_{i}^{q}=1+\frac{\beta_{i}}{w_{i}}+2 \frac{\lambda_{i}}{w_{i}} \ln \left(\frac{X_{h t}}{P_{t}}\right) \quad i=1,2, \ldots, 12
\end{aligned}
$$

\section{Araştırma Bulguları}

\subsection{Türkiye'de Hanehalkı Tüketim Harcamalarının Cohortlara Göre Dağılımı}

2005 yılında 12 mal grubunun cohortlara göre oratalama harcama paylarının verildiği Tablo 2'ye baktığımızda,2005 yılında \%25.9 olan gıda harcama payı, hanehalk1 reisinin 35 yaşından küçük olduğu hanelerde $\% 22.7$ oranıyla genel ortalamanın altında, 65 yaşından büyük olduğu hanelerde ise $\% 30.6$ oranılla ortalamanın üstündedir.

Benzer şekilde 2005 yılında hanehalkı reisinin okur yazar olmadığı ya da okur-yazar olup bir okul bitirmediği hanelerde gıda harcama payı \%37.3 oranıyla diğer öğrenim düzeyleri için hesaplanan gıda harcama payından yüksek iken, hanehalkı reisinin üniversite öğrenim düzeyinde olduğu hanelerde ise $\% 15$ oranıyla en düşüktür. 2005 yılında giyim- ayakkabı harcama payında cohortlara göre önemli bir farklılık olmadığı gözlenmistir. 


\begin{tabular}{|l|l|l|l|l|l|l|l|l|l|l|l|l|}
\hline Cohort & w1 & w2 & w3 & w4 & w5 & w6 & w7 & w8 & w9 & w10 & w11 & w12 \\
\hline 35yaşından küçük & 0.227 & 0.064 & 0.261 & 0.013 & 0.045 & 0.064 & 0.027 & 0.140 & 0.024 & 0.05 & 0.045 & 0.040 \\
\hline $35-44$ & 0.244 & 0.066 & 0.245 & 0.026 & 0.044 & 0.069 & 0.017 & 0.130 & 0.027 & 0.045 & 0.042 & 0.044 \\
\hline $45-54$ & 0.238 & 0.064 & 0.243 & 0.029 & 0.046 & 0.071 & 0.019 & 0.131 & 0.029 & 0.041 & 0.045 & 0.045 \\
\hline $55-64$ & 0.268 & 0.063 & 0.258 & 0.010 & 0.039 & 0.068 & 0.023 & 0.127 & 0.025 & 0.036 & 0.041 & 0.043 \\
\hline $65+$ & 0.306 & 0.050 & 0.315 & 0.007 & 0.033 & 0.077 & 0.032 & 0.067 & 0.016 & 0.035 & 0.029 & 0.033 \\
\hline Ok-yaz & 0.373 & 0.067 & 0.240 & 0.009 & 0.036 & 0.068 & 0.026 & 0.058 & 0.017 & 0.029 & 0.046 & 0.031 \\
\hline İlkokul İlköğretim & 0.282 & 0.061 & 0.254 & 0.014 & 0.040 & 0.072 & 0.023 & 0.103 & 0.022 & 0.041 & 0.047 & 0.041 \\
\hline ort-ort.den. meslek lisesi & 0.216 & 0.064 & 0.265 & 0.024 & 0.046 & 0.066 & 0.020 & 0.143 & 0.026 & 0.045 & 0.041 & 0.043 \\
\hline $\begin{array}{l}\text { yükokul, fakülte veya } \\
\text { lisansüstü }\end{array}$ & 0.150 & 0.059 & 0.232 & 0.031 & 0.045 & 0.065 & 0.018 & 0.167 & 0.038 & 0.043 & 0.024 & 0.044 \\
\hline
\end{tabular}

Tablo 2: 2005 Yılında Mal Gruplarının Cohortlara Göre Ortalama Harcama Payları

Tablo 3'de ise 2009 yılı için 12 mal grubunun cohortlara göre ortalama harcama payları sunulmuştur, Tablo 3 incelendiğinde 2009 yılının 2005 yılıyla benzerlik gösterdiği saptanmıştır. 2009 yılında \% 23 olan gida harcama payı, hanehalkı reisinin 35 yaşından küçük olduğu hanelerde \% 19.7 oranıyla genel ortalamanın altında, 65 yaşından büyük olduğu hanelerde ise \%29.7 oranıyla ortalamanın üstündedir. Bununla birlikte, 2009 yılında hanehalkı reisinin okur yazar olmadığı ya da okur-yazar olup bir okul bitirmediği hanelerde gida harcama payı \%33.3 oranıyla diğer öğrenim düzeyleri için hesaplanan gıda harcama payından yüksek iken, hanehalkı reisinin üniversite öğrenim düzeyinde olduğu hanelerde ise $\% 16.4$ oranıyla en düşüktür.

2005 ve 2009 yıllarında, konut, su, elektrik ve gaz harcama payı, hanehalkı reisinin 65 yaşından büyük olduğu cohortlarda ortalamadan oldukça yüksek gözlenmiştir. Bu grupta en düşük harcama payı mobilya ve ev aletleri harcama payında gözlenmiştir.

\begin{tabular}{|l|l|l|l|l|l|l|l|l|l|l|l|l|}
\hline Cohort & w1 & w2 & w3 & w4 & w5 & w6 & w7 & w8 & w9 & w10 & w11 & w12 \\
\hline 35 yaşından küçük & 0.197 & 0.055 & 0.288 & 0.038 & 0.042 & 0.063 & 0.019 & 0.156 & 0.026 & 0.064 & 0.042 & 0.043 \\
\hline $35-44$ & 0.231 & 0.058 & 0.274 & 0.029 & 0.043 & 0.065 & 0.016 & 0.144 & 0.029 & 0.053 & 0.042 & 0.042 \\
\hline $45-54$ & 0.232 & 0.055 & 0.266 & 0.025 & 0.047 & 0.066 & 0.017 & 0.149 & 0.028 & 0.049 & 0.045 & 0.043 \\
\hline $55-64$ & 0.258 & 0.050 & 0.280 & 0.023 & 0.042 & 0.064 & 0.020 & 0.125 & 0.026 & 0.043 & 0.043 & 0.046 \\
\hline $65+$ & 0.297 & 0.036 & 0.327 & 0.022 & 0.037 & 0.066 & 0.030 & 0.087 & 0.022 & 0.031 & 0.032 & 0.033 \\
\hline Ok-yaz & 0.333 & 0.048 & 0.281 & 0.014 & 0.037 & 0.062 & 0.025 & 0.081 & 0.018 & 0.031 & 0.046 & 0.037 \\
\hline İlkokul İlköğret. & 0.269 & 0.049 & 0.283 & 0.021 & 0.041 & 0.063 & 0.020 & 0.122 & 0.021 & 0.047 & 0.049 & 0.035 \\
\hline ort-ort.den. meslek lis & 0.210 & 0.055 & 0.287 & 0.036 & 0.046 & 0.064 & 0.017 & 0.148 & 0.029 & 0.054 & 0.041 & 0.046 \\
\hline $\begin{array}{l}\text { yüksekokul, fakülte } \\
\text { veya lisansüstü }\end{array}$ & 0.164 & 0.060 & 0.271 & 0.036 & 0.048 & 0.073 & 0.019 & 0.185 & 0.042 & 0.059 & 0.023 & 0.051 \\
\hline
\end{tabular}

Tablo 3: 2009 Yılında Mal Gruplarının Cohortlara Göre Ortalama Harcama Payları

\subsection{Türkiye'de Hanehalkı Tüketim Harcamalarının Tahmini}

Türkiye'de 2009 yılında hanelerin ana mal gruplarına göre talep parametrelerini bulmak için QAIDS modeli SUR tahmin ediciyle tahmin edilmiştir. Modelin sabit etkili mi rassal etkili olup olmadığını saptamak için Within ve Between tahmin edicileri kullanılmıştır. Bu iki tahmin edicinin hangisinin daha iyi sonuç verdiğini belirlemek için Hausman testi yapılmıştır. Hausman testine göre Within tahmin edicisinin Between tahmin edisicine göre daha iyi sonuç verdiği saptanmıştır. Bu durumda, bu çalışmada kullanılan veri setinin sabit etkiler modeli için daha uygun olduğu söylenebilir. Ayrıca çalışmada kullanılan veri setinin, bireylerin ortak özelliklerine göre gruplandırılması yani cohortların oluşturulması nedeniyle sabit etkili modelin geçerli olması beklenen bir sonuçtur.

Türkiye'de hanehalkı tüketim talebinin QAIDS modeli ile gerçekleştirilen tahmininde toplam harcamanın logaritması ve toplam harcamanın karesinin logaritması değişkenlerinin katsayılarının tamamı 0,05 anlamlılık düzeyinde istatistiksel olarak anlamlı ve iktisadi beklentiyle uyumlu elde edilmiştir.

2005 ve 2009 yılları için Within ve Between tahmin edicilerinden elde edilen parametre tahminleri Tablo 4 ve Tablo 5 `te sunulmustur. Türkiye'de hanehalkı tüketim talebinin QAIDS modeli ile gerçekleştirilen tahmininde toplam harcamanın logaritması ve toplam harcamanın karesinin logaritması değişkenlerinin katsayılarının tamamı incelenen mal ve hizmet grupları için 0,05 anlamlılık düzeyinde istatistiksel olarak anlamlı ve iktisadi beklentiyle uyumlu elde edilmiştir. 2005 yılında gıda ve alkolsüz içecekler, giyim ve ayakkabı, konut, su, elektrik, yakıt, mobilya, ev aletleri, otel, lokanta ve pastane harcama grubunun harcama payı belli bir hanehalkı büyüklüğüne kadar artacak, daha sonra azalış gösterecektir. Eğitim hizmetleri, haberleşme, sağlık, ulaştırma, kültür, eğlence ve alkollü içecek, tütün ve sigara harcaması payı ise ortalama hanehalkı büyüklüğüne kadar azalacak, daha sonra artış eğilimi gösterecektir (Tablo 4). 


\begin{tabular}{|c|c|c|c|c|}
\hline \multirow{2}{*}{$\begin{array}{l}\text { Mal Grupları } \\
\text { G1da ve alkolsüz içecekler }\end{array}$} & \multicolumn{2}{|l|}{ Within } & \multicolumn{2}{|l|}{ Between } \\
\hline & Parametre & $\mathrm{t}$ istatistiği & Parametre & t istatistiği \\
\hline Harcamanın logaritması & -0.120 & -2.29 & -0.109 & -2.08 \\
\hline Harcamanın logaritmasının karesi & 0.021 & 2.56 & 0.025 & 5.42 \\
\hline Hanehalk1 Büyüklüğü & 0.325 & 2.79 & 0.479 & 4.14 \\
\hline Hanehalk1 Büyüklüğünün karesi & -0.215 & -2.23 & -0.253 & -7.01 \\
\hline \multicolumn{5}{|l|}{ Giyim ve ayakkab1 } \\
\hline Harcamanın logaritması & 0.099 & 7.14 & 0.118 & 2.42 \\
\hline Harcamanın logaritmasının karesi & -0.030 & -3.88 & -0.035 & -1.76 \\
\hline Hanehalkı Büyüklüğü & 0.231 & 3.19 & 0.264 & 2.50 \\
\hline Hanehalk1 Büyüklüğünün karesi & -0.138 & -1.62 & -0.142 & -1.35 \\
\hline \multicolumn{5}{|l|}{ Konut, su, elektrik, yakit } \\
\hline Harcamanın logaritması & 0.021 & 3.19 & 0.045 & 4.37 \\
\hline Harcamanın logaritmasının karesi & -0.020 & -1.24 & -0.021 & -3.84 \\
\hline Hanehalk1 Büyüklüğü & 0.278 & 1.06 & 0.082 & 3.25 \\
\hline Hanehalk1 Büyüklüğünün karesi & -0.172 & -2.25 & -0.102 & 2.51 \\
\hline \multicolumn{5}{|l|}{ Eğitim hizmetleri } \\
\hline Harcamanın logaritması & 0.029 & 4.12 & 0.033 & 9.48 \\
\hline Harcamanın logaritmasının karesi & -0.007 & -2.24 & -0.009 & 8.49 \\
\hline Hanehalk1 Büyüklüğü & -0.150 & -0.67 & -0.534 & -3.25 \\
\hline Hanehalk1 Büyüklüğünün karesi & 0.078 & 0.63 & 0.351 & 1.95 \\
\hline \multicolumn{5}{|l|}{ Haberleşme } \\
\hline Harcamanın logaritması & 0.013 & 2.75 & 0.013 & 4.81 \\
\hline Harcamanın logaritmasının karesi & -0.008 & -5.65 & -0.006 & -1.85 \\
\hline Hanehalk1 Büyüklüğü & -0.175 & -3.46 & -0.197 & -2.35 \\
\hline Hanehalkı Büyüklüğünün karesi & 0.119 & 4.37 & 0.128 & 2.56 \\
\hline \multicolumn{5}{|l|}{ Mobilya, ev aletleri } \\
\hline Harcamanın logaritması & -0.041 & -6.91 & -0.016 & -4.42 \\
\hline Harcamanın logaritmasının karesi & 0.009 & 2.30 & 0.004 & 7.13 \\
\hline Hanehalk1 Büyüklüğü & 0.084 & 2.29 & -0.022 & -2.14 \\
\hline Hanehalk1 Büyüklüğünün karesi & -0.053 & -2.28 & 0.009 & 1.99 \\
\hline \multicolumn{5}{|l|}{ Sağlık } \\
\hline Harcamanın logaritması & -0.052 & -2.41 & -0.004 & -2.72 \\
\hline Harcamanın logaritmasının karesi & 0.009 & 1.59 & -0.003 & -2.35 \\
\hline Hanehalk1 Büyüklüğü & -0.164 & -2.36 & -0.195 & -1.91 \\
\hline Hanehalk1 Büyüklüğünün karesi & 0.095 & 4.13 & 0.095 & 5.61 \\
\hline \multicolumn{5}{|l|}{ Ulaştırma } \\
\hline Harcamanın logaritması & -0.179 & -2.34 & 0.013 & 2.12 \\
\hline Harcamanın logaritmasının karesi & 0.055 & 2.65 & -0.006 & -1.76 \\
\hline Hanehalkı Büyüklüğü & -0.312 & -2.72 & -0.272 & -0.85 \\
\hline Hanehalk1 Büyüklüğünün karesi & 0.141 & 8.21 & 0.114 & 0.59 \\
\hline \multicolumn{5}{|l|}{ Kültür, eğlence } \\
\hline Harcamanın logaritması & 0.027 & 3.98 & -0.013 & -7.71 \\
\hline Harcamanın logaritmasının karesi & -0.005 & -3.77 & 0.010 & 6.33 \\
\hline Hanehalkı Büyüklüğü & -0.107 & -4.37 & -0.048 & -4.22 \\
\hline Hanehalk1 Büyüklüğünün karesi & 0.061 & 2.66 & 0.036 & 5.55 \\
\hline \multicolumn{5}{|l|}{ Lokanta, otel, pastane } \\
\hline Harcamanın logaritması & 0.069 & 7.03 & 0.048 & 3.58 \\
\hline Harcamanın logaritmasının karesi & -0.041 & -4.14 & -0.009 & -2.48 \\
\hline Hanehalkı Büyüklüğü & 0.143 & 5.67 & 0.548 & 2.79 \\
\hline Hanehalk1 Büyüklüğünün karesi & -0.042 & -3.34 & -0.027 & -6.55 \\
\hline \multicolumn{5}{|l|}{ Alkollü içecek, sigara ve tütün } \\
\hline Harcamanın logaritması & 0.022 & 2.42 & 0.037 & 2.41 \\
\hline Harcamanın logaritmasının karesi & -0.008 & -2.00 & -0.011 & -2.60 \\
\hline Hanehalkı Büyüklüğü & -0.029 & -2.78 & -0.007 & -3.33 \\
\hline Hanehalk1 Büyüklüğünün karesi & 0.065 & 2.82 & 0.044 & 4.18 \\
\hline
\end{tabular}

Tablo 4 :Türkiye'de 2005 Yılında Hanehalkı Tüketim Harcama Gruplarının Parametre Tahminleri 


\begin{tabular}{|c|c|c|c|c|}
\hline \multirow{2}{*}{$\begin{array}{l}\text { Mal Grupları } \\
\text { Gıda ve alkolsüz içecekler }\end{array}$} & \multicolumn{2}{|l|}{ Within } & \multicolumn{2}{|l|}{ Between } \\
\hline & Parametre & t istatistiğ $i$ & Parametre & $\mathrm{t}$ istatistiği \\
\hline Harcamanın logaritması & $-0,079$ & $-2,90$ & $-0,043$ & $-2,27$ \\
\hline Harcamanın logaritmasının karesi & 0,001 & 2,24 & 0,002 & 1,94 \\
\hline Hanehalkı Büyüklüğü & 0,409 & 7,62 & $-0,352$ & $-3,11$ \\
\hline Hanehalkı Büyüklüğünün karesi & $-0,141$ & $-4,15$ & 0,212 & 2,02 \\
\hline \multicolumn{5}{|l|}{ Giyim ve ayakkab1 } \\
\hline Harcamanın logaritması & $-0,061$ & $-6,41$ & $-0,043$ & $-4,21$ \\
\hline Harcamanın logaritmasının karesi & 0,012 & 3,12 & 0,012 & 2,24 \\
\hline Hanehalkı Büyüklüğü & 0,412 & 4,08 & 0,425 & 4,19 \\
\hline Hanehalkı Büyüklüğünün karesi & $-0,173$ & $-3,01$ & $-0,252$ & $-1,84$ \\
\hline \multicolumn{5}{|l|}{ Konut, su, elektrik, yakıt } \\
\hline Harcamanın logaritması & 0,015 & 4,31 & 0,037 & 1,96 \\
\hline Harcamanın logaritmasının karesi & $-0,020$ & 2,16 & $-0,011$ & $-2,26$ \\
\hline Hanehalk1 Büyüklüğü & 0,512 & 5,90 & 0,119 & 1,96 \\
\hline Hanehalk1 Büyüklüğünün karesi & $-0,073$ & $-3,37$ & $-0,068$ & $-1,74$ \\
\hline \multicolumn{5}{|l|}{ Eğitim hizmetleri } \\
\hline Harcamanın logaritması & 0,017 & 9,11 & 0,028 & 3,13 \\
\hline Harcamanın logaritmasının karesi & $-0,003$ & $-8,43$ & $-0,006$ & 5,03 \\
\hline Hanehalkı Büyüklüğü & $-0,457$ & $-6,46$ & $-0,321$ & $-2,98$ \\
\hline Hanehalkı Büyüklüğünün karesi & 0,236 & 5,47 & 0,063 & 1,21 \\
\hline \multicolumn{5}{|l|}{ Haberleşme } \\
\hline Harcamanın logaritması & 0,004 & 2,23 & $-0,006$ & $-1,20$ \\
\hline Harcamanın logaritmasının karesi & $-0,001$ & $-2,49$ & $-0,001$ & $-1,86$ \\
\hline Hanehalk1 Büyüklüğü & $-0,584$ & $-1,75$ & $-0,196$ & 2,43 \\
\hline Hanehalkı Büyüklüğünün karesi & 0,332 & 1,67 & 0,013 & 1,72 \\
\hline \multicolumn{5}{|l|}{ Mobilya, ev aletleri } \\
\hline Harcamanın logaritması & $-0,023$ & $-3,21$ & $-0,017$ & 2,62 \\
\hline Harcamanın logaritmasının karesi & 0,006 & 3,25 & 0,001 & 3,25 \\
\hline Hanehalkı Büyüklüğü & 0,376 & 2,11 & 0,109 & 8,60 \\
\hline Hanehalkı Büyüklüğünün karesi & $-0,072$ & $-1,96$ & $-0,018$ & $-4,40$ \\
\hline \multicolumn{5}{|l|}{ Sağlık } \\
\hline Harcamanın logaritması & $-0,017$ & $-6,80$ & $-0,023$ & 7,72 \\
\hline Harcamanın logaritmasının karesi & 0,007 & 2,87 & 0,005 & $-3,81$ \\
\hline Hanehalk1 Büyüklüğü & 0,262 & 3,47 & 0,087 & 7,83 \\
\hline Hanehalkı Büyüklüğünün karesi & $-0,015$ & $-2,94$ & $-0,050$ & $-5,34$ \\
\hline \multicolumn{5}{|l|}{ Ulaştırma } \\
\hline Harcamanın logaritması & $-0,043$ & $-2,21$ & $-0,049$ & $-2,26$ \\
\hline Harcamanın logaritmasının karesi & 0,015 & 1,80 & 0,011 & 2,72 \\
\hline Hanehalkı Büyüklüğü & 0,428 & 4,81 & $-0,239$ & $-2,76$ \\
\hline Hanehalk1 Büyüklüğünün karesi & $-0,284$ & $-5,81$ & 0,152 & 2,70 \\
\hline \multicolumn{5}{|l|}{ Kültür, eğlence } \\
\hline Harcamanın logaritması & $-0,031$ & $-9,28$ & $-0,049$ & $-2,74$ \\
\hline Harcamanın logaritmasının karesi & 0,011 & 8,89 & 0,017 & 1,76 \\
\hline Hanehalkı Büyüklüğü & 0,272 & 6,11 & 0,569 & 7,618 \\
\hline Hanehalkı Büyüklüğünün karesi & $-0,021$ & $-1,97$ & $-0,381$ & $-2,30$ \\
\hline \multicolumn{5}{|l|}{ Lokanta, otel, pastane } \\
\hline Harcamanın logaritması & 0,105 & 6,61 & 0,157 & 3,74 \\
\hline Harcamanın logaritmasının karesi & $-0,017$ & $-3,84$ & $-0,016$ & $-5,61$ \\
\hline Hanehalkı Büyüklüğü & 0,367 & 5,81 & $-0,174$ & $-3,01$ \\
\hline Hanehalkı Büyüklüğünün karesi & $-0,249$ & $-5,73$ & 0,008 & 3,21 \\
\hline \multicolumn{5}{|l|}{ Alkollü içecek, sigara ve tütün } \\
\hline Harcamanın logaritması & $-0,019$ & $-5,16$ & $-0,015$ & $-2,68$ \\
\hline Harcamanın logaritmasının karesi & 0,003 & 2,82 & 0,001 & 2,57 \\
\hline Hanehalkı Büyüklüğü & $-0,563$ & $-5,81$ & 0,460 & 1,66 \\
\hline Hanehalkı Büyüklüğünün karesi & 0,031 & 5,48 & $-0,298$ & $-1,65$ \\
\hline
\end{tabular}

Tablo 5 :Türkiye'de 2009 Yılında Hanehalkı Tüketim Harcama Gruplarının Parametre Tahminleri 
2009 yılında ise hanehalkı büyüklüğü artıkça, gıda ve alkolsuz içecekler, giyim ve ayakkabı, konut, su, elektrik, yakıt, mobilya, ev aletleri, sağlık, ulaştırma, kültür, eğlence, otel, lokanta ve pastane harcama grubunun harcama payı önce artış, daha sonra azalış gösterecektir. Eğitim hizmetleri, haberleşme, alkollü içecek, tütün ve sigara harcaması payı ise belli bir büyüklüğe kadar azalacak, daha sonra artış eğilimi gösterecektir

Within ve Between tahmin edicilerinin parametrelerinden hesaplanan gelir-talep esneklikleri Tablo 6'da verilmiş̧ir.

\begin{tabular}{|l|l|l|l|l|}
\hline Mal Grupları & 2005 & \multicolumn{2}{l|}{2009} & \multicolumn{2}{l|}{} \\
\hline & Within & Between & Within & Between \\
\hline G1da ve alkolsüz içecekler & 0.83 & 0.94 & 0.68 & 0.85 \\
\hline Giyim ve ayakkab1 & 0.81 & 0.82 & 0.94 & 1.19 \\
\hline Konut, su, elektrik, yakıt & 0.79 & 0.81 & 0.73 & 0.95 \\
\hline Eğitim hizmetleri & 1.17 & 0.98 & 1.16 & 0.91 \\
\hline Haberleşme & 0.60 & 0.79 & 0.78 & 0.73 \\
\hline Mobilya, ev aletleri & 0.88 & 0.98 & 0.67 & 0.81 \\
\hline Sağlik & 1.15 & 1.31 & 1.64 & 0.98 \\
\hline Ulaştırma & 1.20 & 0.92 & 1.21 & 1.01 \\
\hline Kültür, eğlence & 1.32 & 1.34 & 1.74 & 1.05 \\
\hline Lokanta, otel, pastane & 1.33 & 1.36 & 1.57 & 1.72 \\
\hline Alkollü içecek, sigara ve tütün & 0.81 & 0.91 & 0.87 & 0.74 \\
\hline
\end{tabular}

Tablo 6: Türkiye'de Hanelerin Ana Mal Gruplarına Göre Gelir-Talep Esnekliği

Türkiye geneli için harcama gruplarına bir bütün olarak bakıldığında, 2005 ve 2009 yıllarında gıda ve alkolsüz içecekler, giyim ve ayakkabı, konut, su, elektrik, yakıt, mobilya ve ev aletleri, haberleşme, alkollü içecek, sigara ve tütün gruplarının harcama esneklikleri 1'den küçük hesaplanmıştır. Bu da, Türkiye'de bu mal gruplarının zorunlu mallar sınıfına girdiğini göstermektedir. Aynı zamanda, sağlık, ulaştırma, eğitim hizmetleri, kültür ve eğlence, lokanta, otel ve pastane mal gruplarının harcama esneklikleri 1'den büyük çıktığından bu mal gruplarının da lüks mallar sınıfına girdiği söylenebilir.

Türkiye'de gıda-alkolsüz içecekler harcamasının toplam harcamaya göre esnekliği 2005 yılı için 0.83, 2009 yılı için 0.68 bulunmuştur. İncelenen dönemlerde gida -alkolsüz içecekler harcama esnekliği düşmüştür. Bu da, Türkiye'de hanelerin toplam harcamalarının \%1 oranında artması durumunda toplam harcamalarından gidaalkolsüz içeceklere ayıracakları payın \% 1 oranından daha düşük olacağını, bu oranın 2005 yılı için \%0.83, 2009 y1lı için $\% 0.68$ oranında artacağını göstermektedir

Türkiye'de giyim ve ayakkabı grubunun harcama esnekliği, 2005 y1lında 0.81, 2009 yılında 0.94`tür. Gelişmekte Olan Ülkelerde giyim ve ayakkabı grubu nispeten pahalı mal grubundadır. Ayrıca, 2008 yılında yaşanan finansal krizin etkisiyle 2009 yılı için hesaplanan esneklik değerinin 2005 yllına göre daha yüksek çıktığı söylenebilir.

Türkiye'de konut, su, elektrik ve yakıt grubu harcama esnekliği 2005 ve 2009 yılları için 0.79 ve 0.73 değeriyle zorunlu mal grubundadır. Bu grup içerisinde kira harcamalarının payı yüksektir. Konut harcama esnekliğinin düşük olmasının nedenlerinden biri, son yıllarda düşük faiz oranı ve uzun vadeli borçlandırma yoluyla (mortgage-bu neden, aynı zamanda dünyada ve ülkemizde yaşanan finansal krizin de çıkış nedenlerinden biridir) ev sahibi olanların sayısındaki artıştır. Aynı zamanda, TOKİ aracılığıyla düşük gelirlilerinde ev sahibi olmalarının son yıllarda artması konut esnekliğinin düssmesinin nedenleri arasında gösterilebilir.

Türkiye'de hanehalkı eğitim hizmetleri harcama esnekliği 2005 ve 2009 yılları için 1.17 ve 1.16 değerleriyle benzer büyüklükte elde edilmişlerdir. Kültür ve eğlence grubu harcama esnekliği ise 2005 y1lında $0.92,2009$ yılında ise 1.74 bulunmuştur. Türkiye'de 2009 yılında toplam harcama içinde eğitim harcamasının payı $\% 0.9$ değeriyle, kültür ve eğlence harcama grubunun payı da \%2.1 oranıyla oldukça düşüktür. Türkiye'de en yüksek harcama esnekliği 2009 yılı için 1.74 değeriyle kültür ve eğlence grubu için hesaplanmıştır.

Ulaştırma harcama esneklik degeri her iki yıl içinde 1.2 bulunmuştur. Bu esneklik değeri de hanelerin toplam harcamalarındaki \%1'lik bir artışın, ulaştırma harcamaların da \%1.2 oranında bir artışa sebep olacağını göstermektedir. Lokanta, otel ve pastane harcama esnekliği 2005 yllından 2009 yllına 1.33 'ten 1.57 'e yükselmiştir. Bu da hanelerin toplam harcamalarının \%1 oranında artması durumunda lokanta, otel ve pastane gibi ev dışı gıda harcamalarının \%1 oranından daha fazla artacağını göstermesi bakımından önemlidir.

2005 ve 2009 yılları için Türkiye'de cohortlara göre hesaplanan mal gruplarının gelir-harcama esneklikleri Tablo 7 ve Tablo 8'de sunulmuştur.

2005 yılında hanehalkı reisinin yaşına göre oluşturulan cohortlar incelendiğinde, gıda ve alkolsüz içecekler harcama esnekliği bütün cohortlarda en küçük 0.81 , en büyük 0.86 değeriyle yaklaşık olarak tüm cohortların ortalaması için hesaplanan 0.83 değerine yakın büyüklükte hesaplanmıştır. Ancak, eğitim cohortlarına gore gıda harcama esnekliği incelendiğinde ise en yüksek 0.88 değeriyle hanehalkı reisinin okur-yazar olmadığı veya okur- 
yazar olup diploması olmayan haneler için, en düşük ise 0.80 değeriyle hanehalkı reisinin üniversite öğrenim düzeyine sahip olduğu haneler için hesaplanmıştır.

2009 yılında ise hanehalkı reisinin yaşına göre oluşturulan cohortlar incelendiğinde, gıda ve alkolsüz içecekler harcama esnekliği 0.62 değeriyle en düşük hanehalkı reisinin 35 yaşından küçük olduğu haneler için, en yüksek 0.85 değeriyle hanehalkı reisinin 45-54 yaş grubunda yer aldığı haneler için hesaplanmıştır. Hanehalkı reisinin 35 yaşından küçük olduğu hanelerde çocuk sayının 45-54 yaş grubundaki hanelerden daha az olması, dolayısıyla çocuk sayısının az olduğu, diğer bir ifadeyle hane genişliğinin küçük olduğu hanelerde gıda harcama esnekliğinin düşük, büyük olduğu hanelerde ise yüksek olduğu söylenebilir. Hanehalkı reisinin öğrenim düzeyine göre oluşturulan cohortlara bakıldığında gıda-alkolsüz içecekler harcama esnekliğinin hanehalkı reisinin okur-yazar olmadığ ya da okur- yazar olup bir okul bitirmeyen hanelerde 0.77 değeriyle en yüksek, hanehalkı reisinin üniversite öğrenim düzeyine sahip hanelerde ise 0.54 değeriyle en düşük hesaplanmıştır.

Cohortlara göre hesaplanan giyim-ayakkabı, konut gelir harcama esnekliği tüm cohortların ortalamasına göre hesaplanan esneklik değerinden önemli bir farklılık göstermemiştir.

2009 yılında sağlık harcama esnekliği 1.91 değeriyle en yüksek hanehalkı reisinin 35-44 yaş grubunda yer aldığı haneler için hesaplanmıştır.

\begin{tabular}{|l|l|l|l|l|l|l|l|l|l|l|l|}
\hline Cohortlar & Gıda & Giyim & Konut & ğitim & Sağlık & Haber & Mobilya & Ulaştırma & Eğlence & Lokanta & Alkol \\
\hline $\begin{array}{l}\text { Hanehalk reisinin } \\
\text { yaşı }\end{array}$ & & & & & & & & & & & \\
\hline 35 yaşından küçük & 0.81 & 0.81 & 0.79 & 1.23 & 1.12 & 0.63 & 0.87 & 1.17 & 1.52 & 1.27 & 0.83 \\
\hline $35-44$ & 0.82 & 0.81 & 0.78 & 1.11 & 1.20 & 0.62 & 0.88 & 1.18 & 1.31 & 1.3 & 0.81 \\
\hline $45-54$ & $\mathbf{0 . 8 2}$ & 0.81 & 0.78 & 1.10 & 1.18 & 0.63 & 0.89 & 1.18 & 1.29 & 1.32 & 0.83 \\
\hline $55-64$ & 0.84 & 0.80 & 0.79 & 1.31 & 1.15 & 0.57 & 0.88 & 1.19 & 1.34 & 1.37 & 0.81 \\
\hline $65+$ & 0.86 & 0.76 & 0.83 & 1.44 & 1.10 & 0.49 & 0.9 & 1.36 & 1.53 & 1.38 & 0.73 \\
\hline $\begin{array}{l}\text { Hanehalkı reisinin } \\
\text { eğitim durumu }\end{array}$ & & & & & & & & & & & \\
\hline $\begin{array}{l}\text { Okur-yazar değil, } \\
\text { okur yazar, } \\
\text { diplomas yok }\end{array}$ & $\mathbf{0 . 8 8}$ & 0.82 & 0.77 & 1.34 & 1.13 & 0.53 & 0.88 & 1.42 & 1.5 & 1.46 & 0.83 \\
\hline $\begin{array}{l}\text { İlkokul } \\
\text { Ilköğret. }\end{array}$ & 0.85 & 0.80 & 0.79 & 1.22 & 1.15 & 0.58 & 0.89 & 1.23 & 1.38 & 1.32 & 0.83 \\
\hline $\begin{array}{l}\text { Orta okul ve dengi, } \\
\text { meslek lis. }\end{array}$ & 0.80 & 0.81 & 0.8 & 1.12 & 1.17 & 0.63 & 0.88 & 1.17 & 1.32 & 1.3 & 0.81 \\
\hline $\begin{array}{l}\text { yüksekokul, } \\
\text { fakülte,lisansüstü }\end{array}$ & $\mathbf{0 . 7 1}$ & 0.79 & 0.77 & 1.1 & 1.19 & 0.63 & 0.88 & 1.14 & 1.22 & 1.31 & 0.68 \\
\hline
\end{tabular}

Tablo 7 :Türkiye'de 2005 Yllinda Cohortlara Göre Mal Gruplarınin Gelir Talep Esneklikleri

\begin{tabular}{|l|l|l|l|l|l|l|l|l|l|l|l|}
\hline Cohortlar & Gıda & Giyim & Konut & $\begin{array}{l}\text { Eğiti } \\
\text { m }\end{array}$ & Sağlı & Haber & Mobilya & Ulaştırma & Eğlence & Lokanta & Alkol \\
\hline $\begin{array}{l}\text { Hanehalkı reisinin } \\
\text { yaşı }\end{array}$ & & & & & & & & & & & \\
\hline 35 yaşından küçük & $\mathbf{0 . 6 2}$ & 0.93 & 0.73 & 1.21 & 1.77 & 0.77 & 1.05 & 1.15 & 1.79 & 1.55 & 0.87 \\
\hline $35-44$ & 0.67 & 0.94 & 0.72 & 1.10 & $\mathbf{1 . 9 1}$ & 0.78 & 1.06 & 1.17 & 1.70 & 1.62 & 0.87 \\
\hline $45-54$ & $\mathbf{0 . 8 5}$ & 0.93 & 0.71 & 1.09 & 1.86 & 0.80 & 1.07 & 1.16 & 1.65 & 1.68 & 0.87 \\
\hline $55-64$ & 0.71 & 0.93 & 0.73 & 1.28 & 1.73 & 0.77 & 1.05 & 1.19 & 1.76 & 1.77 & 0.86 \\
\hline $65+$ & 0.74 & 0.90 & 0.77 & 1.40 & 1.48 & 0.74 & 1.07 & 1.28 & 2.19 & 2.02 & 0.81 \\
\hline $\begin{array}{l}\text { Hanehalk reisinin } \\
\text { eğitim durumu }\end{array}$ & $\mathbf{0}$ & & & & & & & & & & \\
\hline $\begin{array}{l}\text { Okur-yazar değil, } \\
\text { kuur yazar, } \\
\text { diplolması yok }\end{array}$ & $\mathbf{0 . 7 7}$ & 0.92 & 0.73 & 1.31 & 1.58 & 0.74 & 1.04 & 1.30 & 2.12 & 1.96 & 0.88 \\
\hline $\begin{array}{l}\text { İlkokul- } \\
\text { Illköğretim }\end{array}$ & 0.72 & 0.92 & 0.73 & 1.20 & 1.73 & 0.77 & 1.05 & 1.20 & 1.86 & 1.68 & 0.88 \\
\hline $\begin{array}{l}\text { Orta okul ve dengi, } \\
\text { meslek lis. }\end{array}$ & 0.64 & 0.93 & 0.73 & 1.11 & 1.86 & 0.79 & 1.05 & 1.16 & 1.73 & 1.62 & 0.86 \\
\hline $\begin{array}{l}\text { yüksekokul, } \\
\text { fakülte,lisansüstü }\end{array}$ & $\mathbf{0 . 5 4}$ & 0.94 & 0.72 & 1.09 & 1.86 & 0.80 & 1.10 & 1.13 & 1.50 & 1.65 & 0.77 \\
\hline
\end{tabular}

Tablo 8:Türkiye'de 2009 Yllında Cohortlara Göre Mal Gruplarının Gelir Talep Esneklikleri 


\section{Sonuç ve Öneriler}

Türkiye genelinde 2005 ve 2009 yıllarında hanelerin tükettikleri mal ve hizmet gruplarının bütçe paylarında önemli bir değişiklik olmadığı saptanmıştır. Gıda harcamasının toplam harcama içindeki payı 2005 yılında \%25.7 iken 2009 yılında \%23.4'e düşmüş, otel, lokanta pastane gibi ev dış1 gıda harcamasının toplam harcama içindeki payı ise sözü edilen dönemde \%4.2'den \%4.9'a yükselmiştir. OECD eşdeğerlik ölçeğine göre 2005 yılında 2.31 olan hane genişliği 2009 yılında 2.17'ye düşmüştür.

Türkiye geneli için harcama gruplarına bir bütün olarak bakıldığında, 2005 ve 2009 yıllarında gıda ve alkolsüz içecekler, giyim ve ayakkabı, konut, su, elektrik, yakıt, mobilya ve ev aletleri, haberleşme, alkollü içecek, sigara ve tütün gruplarının harcama esneklikleri 1'den küçük hesaplanmıştır. Bu da, Türkiye'de bu mal gruplarının zorunlu mallar sınıfına girdiğini göstermektedir. Aynı zamanda, sağlık, ulaştırma, eğitim hizmetleri, kültür ve eğlence, lokanta, otel ve pastane mal gruplarının harcama esneklikleri 1'den büyük çıktığından bu mal gruplarının da lüks mallar sınıfına girdiği söylenebilir.

Bu çalışmada incelenen mal gruplarının büyük bir bölümü gıda, eğitim, konut, ulaştırma, giyim, sağlık vb. temel gereksinimler grubundadır. Bu çalışmanın bulguları, sosyal politikalarının oluşturulmasında ve refah analizlerinde yararlanılacak önemli bilgilerdir. Bu bağlamda, bu çalışma da sunulan, gelir-talep esneklikleri; sosyal politikalarıyla ve refah analizleriyle ilgili politika üretenler için önemli göstergeler olduğu söylenebilir.

\section{Kaynakça}

- Baltagi, B. H. ,2005. Econometric Analysis of Panel Data. John Wiley \& Sons: England

- $\quad$ Banks, J., Blundell, R. \& Lewbel, A (1997).Quadratic Engel Curves and Consumer Demand. The Review of Economics and Statistics. 79(4), November, 1997, pp. 527-539

- Blundell, R. \& Browning, M. (1994). "Consumer Demand and the Life-Cycle Allocation of Household Expenditures”. Review of Economic Studies (1994) 61, 57-80.

- Chung, C. F. ,1994. “A Cross-Section Demand Analysis of Spanish Provincial Food Consumption”. American

- Deaton, A., 1985a. "Panel Data From Time Series of Cross-Sections". Journal of Econometrics, 30 (1985), 109-126. North-Holland.

- Deaton, A. \& Muellbauer, J., 1980b. “An Almost Ideal Demand System”. The American Economics Review. Vol.70, n.3. pp. 312-326.

- Gardes, F., Duncan, G. J., Gaubert P., Gurgand, M. \& Starzec, C. ,2005. "Panel and Pseudo Panel Estimation of Cross-Sectional and Time Series Elasticities of Food Consumption: The Case of American and Polish Data". Journal of Business and Economic Statistics, 23(2): 242-253.

- Judge, G. G., Hill, R. C. , Griffihts, W. E. , Lütkepohl, H. \& Lee, T.- C., 1988. Introduction to the Theory and Practice of Econometrics. 2nd Edition, New York: John Wiley \& Sons.

- Kakwani, N. ,1977. "On the Estimation of Engel Elasticities from Grouped Observations with Application to Indonesion Data”. Journal of Econometrics, 6: 1-19.

- $\quad$ Lyons, S., Mayor, K. \& Tol, R. S. J. ,2007. “Convergence of Consumption Patterns During Macroeconomic Transition: A Model of Demand in Ireland and the OECD"

- Özer, H.,2001. “Türkiye'de Hanehalkı Tüketim Harcamalarının Doğrusal Harcama Sistemi ile Analizi”. T.C. Başbakanlık Devlet İstatistik Enstitüsü, Ankara.

- Hanehalkı Tüketim Harcamalarının Doğrusal Harcama Sistemi ile Analizi. T.C. Başbakanlık Devlet İstatistik Enstitüsü, Ankara.

- Şengül, S., 2004. “Türkiye'de Yoksulluk Profili ve Gelir Gruplarına Göre Gıda Talebi”. T.C. Tarım ve Köyişleri Bakanlı̆̆ Tarımsal Ekonomik Araştırma Enstitüsü, Yayın No.119, Ankara.

- Steward, J. , 1991. Econometrics. Philip Allan, London.

- Tansel, A. ,1986. “An Engel Curve Analysis of Household Expenditure in Turkey 1978- 1979”. Metu Studies in Development, No. 13, pp. 239-257.

- Tatoğlu, F. Y. ,2005. Sermaye Piyasası'nda Riskin Sınırlı Bağımlı Değişkenli Panel Veri Modelleri ile Analizi. Yayınlanmamış doktora tezi, İstanbul Üniversitesi, İstanbul.

- $\quad$ TÜİK, Hanehalkı Bütçe Anketi Mikro Veri Seti, 2005,2009.

- Zellner, A. ,1962. “An Efficient Method of Estimation Seemingly Unrelated Regressions and Tests for Bias”. Journal of the American Statistical Association, vol. 57, No. 298, pp. 348-368. 


\title{
Türkiye’de İç Göçün Yoksulluğa ve İstihdama Etkileri The Effects of Internal Migration on Poverty and Employment in Turkey
}

\author{
Asst. Prof. Dr. H. Yunus Taş (Yalova University, Turkey) \\ Assoc. Prof. Dr. Selami Özcan (Yalova University, Turkey)
}

\begin{abstract}
Migration, which is persons movement to another location geographically, is usually predicated on economic, social and political reasons. Based on economic reasons, because of differences of region or intercity's economic conditions. To put it another way, move from regions, which have underdeveloped economy to developed regions of labor forces. Thus, developed regions about economic terms, are waited become a "center of attraction". It is discussed after a particular rate immigrated to there immigrants can't find the desired conditions employment. In this study, the problems experienced in cities, which are sending immigrants, with internal migrations' structures and ways of Turkey will be examined. For this purpose, migration and its results' social structure of the last 50 years in Turkey will be examined.
\end{abstract}

\section{Giriş}

Göç, yerleşmek amaciyla bir yerleşim yerinden, başka bir yerleşim yerine doğru gerçekleşen mekân değiştirme eylemidir (Keleş, 1998). Ancak bu tanımlama göçün daha çok demografik sürecine vurgu yapmakta, göçün içeriğini anlatmak bakımından sınırlı kalmaktadır. Bu açıdan göç, mekânsal bir yer değiştirme hareketinin yanı sıra, sosyal formasyonların ekonomik, politik ve kültürel yapıların ve bu yapılar içindeki ilişkiler sisteminde yaşanan değişimlerin sonucunda ortaya çıkan, söz konusu yapılar üzerinde de önemli değişim ve dönüşümlere yol açan bir olgudur (Özer, 2004: 11; Kaygalak, 2009: 9).

Tarih boyunca birçok sebepler insanları göçe zorlamıştır. Dünyada her sene milyonlarca insan, ekonomik, sosyal, güvenlik, sağlık, doğal afetler veya daha iyi yaşam şartlarını elde etmek gibi birçok nedenle göç etmektedir. Yaşanan bu göçler, toplumlar arasında farklı bir şekilde bulunan imkânlardan yararlanma isteğinin bir sonucu olabildiği gibi çevreyle ilgili dayatmalar, otoritenin gündeme getirdiği sürgünler, mecburi iskânlar ve savaşlar gibi bir çok nedenle ortaya çıkabilmektedir. Günümüzde göçlere kaynaktarlık eden nedenler arasında, yoksulluk, işsizlik, siyasal koşullar, askeri çatışmalar, tarım alanlarına teknolojik aletlerin girmesi, hızlı nüfus artışı, sosyal ve kültürel imkânlardan yararlanma isteği, gidilecek yerin iş yönünden çekiciliği, haberleşme ve ulaşım imkanlarındaki gelişmeler olarak sıralanabilmektedir

Türkiye'de yaşanan iç göç süreci 1950’li yıllardan itibaren kır ve kent arasındaki farklılıklar, kentlileşme) süreci, gecekondu kültürünün ortaya çıkması göçün yönünün aslında farklı bir yöne doğru olduğunu doğrulamaktadır. Göç sadece var olan yerleşim yerindeki bir değişikliği değil, toplumsal yaşam alanındaki değişikliği de içermektedir. Göç bir yönüyle ülkede var olan imkân ve olumlu şartlardan mümkün olan en yüksek oranda yararlanma isteğinin bir ifadesidir.

Türkiye' de 1950' li yıllardan itibaren başlayan göçlerle kentleşme sürecide hızlanmış ve böylece belli bölge ve şehirlerde nüfus, yoğunlaşmaya başlamıştır. Türkiye' de iç göçlerin, ekonomik yönden geri kalmış doğu bölgelerinden gelişmiş batı bölgeleri doğrultusunda meydana geldiği varsayılmaktadır. Göçe ilişkin veriler, nüfus sayımı verilerinden elde edilebilmektedir. Türkiye' de göçlerdeki artışa paralel olarak, bu durumu inceleyen araştırmalar da artmıştır. İç göçle ilgili araştırmalara bakıldığında, 1960'larda daha fazla olan çalışmaların 1970’ler de azaldığı ve bu azalışın sonraki dönemlerde de devam ettiği görülür.

Yukarıda sayılan bu nedenlerin dışında olan göç türleri de bulunmaktadır. Bu durumu zorunlu göçlerle ifade etmek mümkün olmaktadır. Göçleri bu anlamda öncelikle iki ana kategori ye ayırmak mümkündür. Bu nedenle karar sürecini belirleyen, irade esasına dayalı gönüllü ve zorunlu göç türlerinden söz edilmektedir. Bu iki farklı göç türünün, başlangıcı, süreci, neden ve sonuçları da farklılaşmaktadır. Gönüllü olarak göç edenler, taşınma kararlarını hür iradeleri ile almış, kendi istekleri doğrultusunda çoğu zaman ekonomik nedenler gerekçe gösterilerek, göç edecek yeri ve devamında ne gibi şartlarını kendilerini beklediğini tahmin edebilmektedir. Ayrıca beklenmeyen durumlarda yeniden eski yer ve yurtlarına dönebilme imkânları da bulunmaktadır.

Zorunlu olarak göç edenler ise, taşınma kararını istek ve hür iradeleri dışında kabullenmiş/kabullenmek zorunda kalmış kişilerdir. Bu kişiler için eski yaşam alanlarındaki olumsuz şartlar göçün nedeni olmaktadır. Göçün süreci ve göç edilecek yeri ve sonrasını da önceden tam manasıyla bilemediğinden her açıdan hazırlıksız bir şekilde yeni yaşayacağı yerlere doğru, yaşanacak sorunlardan habersizdir.

Gönüllülük, göç edilecek yerleşim yerinde karşılaşılacak sorunları iradi olarak kabul etmeyi gerektirdiğinden başa gelebilecek muhtemel her türlü sorunla az-çok baş edebilen güçlü birey ve toplulukların hareketini belirler. Ancak zorunlu göç kararı, kişinin iradesi dışında belirlenmektedir. Bu şekilde yola çıkan güçsüz birey ve 
topluluğun, göç sürecinde ve göç sonucunda yaşanan olumsuzluklar nedeniyle aldıkları darbelerle psikolojik olaraktan yaşam alanlarında tanımlanamayan kimlikleriyle, kentte uyum sağlama sorunları yaşayabildiklerinden, enformel sektörün ya da işsizliğin pençesinden kendilerini kurtaramadıkları görülmektedir.

Genellikle az gelişmişlik sorunu olsa da yoksulluk birçok gelişmiş ülkenin de temel sorunlarından biri olabilmektedir . Temel ihtiyaçlardan mahrum, yoksulluk içerisinde yaşayanlar; yeterli biçimde beslenemeyen, sağlıksız koşullarda yaşayan, ortalama yaşam beklentisi düşük olanlardır. Özellikle kentte göç eden, işsiz, çok çocuklu ve yaşamlarını idame ettirecek mal ve gelire sahip olmayan birey ve aileler için yoksulluk, kendilerini içinde buldukları ve kurtulmak için stratejiler geliştirdiklerinde bile kolay kurtulamadıkları acımasız bir gerçeklik olarak varlı̆̆ını kentin göç mekânlarında sürdürdüğü görülmektedir.

Göç, kentteki mekânsal ayrışmaları derinleştiren etkilerde bulunurken yoksulluğun mekânsal olarak yoğunlaşmasına da neden olmaktadır. Göçlerle tekrar tekrar biçimlenen kent alanlarında yoksulluk olgusu, yeni bir yüz edinmiştir. Kente göçen ve kentin eski yoksullarına benzemeyen yeni kent yoksulları, sorunlarıyla yoksulluğun farklı bir yüzü olmuşlardır. Göçlerle gelenler, kent merkezlerinde tutunamadıklarından, kendilerini kent dışındaki az gelişmiş mahallelere atmaktadırlar. Kentlerin kıyısında yaşayanlar için kente yakın olmamak, bir bakıma kentin ekonomik, sosyal, kültürel imkânlarının dışında olmak, kentin üretim sürecine katılamamak anlamına gelmektedir. Bu durumd bulunanların çoğunun düzenli bir işi ve geliri de bulunmamaktadır.

Bu anlamda kentin dış mahallelerinde göçün en önemli sorunlardan biri yoksulluk ve işsizlik olmaktadır . Son yirmi yılda Türkiye'de çok hızlı ve önemli ekonomik ve toplumsal değişmeler meydana gelmiştir. Bu değişmeler kentin yoksullarına benzemeyen, yoğun ve kitlesel göçler sonucu kentlerde biriken başta ekonomik olmak üzere, konut, sağlık, eğitim vb. sorunların yanı sıra yeni bir kültürle karşılaşmanın sebep olduğu sarsıntı ve çatışmaları yaşamak durumunda kalanlar kentin yeni sakinlerinin yanı sıra "kentin yeni yoksulları" olarak anılmışlardır (Bayhan, 1997: 28).

Kent yoksulluğunun dışında kentin yeni yoksullarının toplumsal görünümlerine baktığımızda, her konuda dezavantajlı durumlarıyla, geliştirdikleri yaşam stratejileriyle var olmaya çalışan, talepleri ve sorunlarıyla çoğu zaman yalnız kalan bir kesim görmekteyiz. Bugün Türkiye'nin İstanbul, Ankara, İzmir, Bursa, gibi metropol kentleri başta olmak üzere Mersin, Diyarbakır, Van, Şanlıurfa ve Batman gibi diğer kentlere zorunlu göçün kattığı nüfus, yeni kent yoksulluğunun ağır sonuçlarıyla yaşamak durumda kalmıştır.

\section{Kavramsal Çerçeve}

Bu bölümde göç kavramı, yoksulluk ve istihdam konuları değerlendirilecek göçün ne olduğu, göç tanımlarıyla ilgili tartışmalara, türlerine, neden ve sonuçlarına aynı zamanda Türkiye'de iç göç sürecinin son 60 yıllık sürecini 1990 öncesi ve 1990 sonrası olmak üzere iki ayrı dönem üzerinden bakılarak incelenecektir. Göçün olumsuz neticelerinden biri olan yoksulluk ve yoksulluk türlerinden de bahsedilecektir. Son olarak da yine gö̈cün sonuçlarından biri olan şehirlerdeki hızlı nüfus artı̧̧ı ve işsizlik problemi anlatılmaya çalışılacaktır. Söz konusu dönemlerde yaşanan göç hareketleri arasındaki farklılıklara değinilecektir. Özellikle son 20 yılda Doğu ve Güneydoğu Anadolu Bölgesinde yaşanan "zorunlu göç" üzerinde de durulacaktır.

\subsection{Göç Kavramı}

Göç, neredeyse tüm toplumları etkileyen, insanlık tarihiyle özdeş bir olgu olarak insanlık tarihinin bütün dönemleri boyunca var olmuş ve bugün de varlığını devam ettiren bir gerçektir. Göç kavramı ilk etaptaanlamı belli bir nüfusun bir bölgeden başka bir yere olan hareketi olarak tanımlanır| Bununla birlikte göç, kitlesel yer değiştirmenin ötesinde, sonuçları itibarıyla sosyal, ekonomik, kültürel ve psikolojik birçok konu ve kavramı da içinde bulundurmaktadır. Bu açıdan göç, coğrafi mekân değiş̧irme sürecinin sosyal, ekonomik, kültürel ve siyasi sonuçlarıyla toplum yapısını değiştiren nüfus hareketi olarak tanımlanabilir (Özer, 2004: 11).

Kimi durumlarda göç, yaşanılan yerden, ulaşılmak istenen yere doğru gerçekleşen bir harekettir. Yine göç, bireylerin ya da grupların sembolik veya siyasal sınırların ötesine, yeni yerleşim alanlarına ve toplumlara doğru kalıcı hareketleri olarak tanımlanabilmektedir. Bu tanımlama kalıcı olmayan göç hareketlerini dışarıda tutmaktır. Bir açıdan denebilir ki göç, insanların yaşadıkları yeri terk edip devamlı, geçici ya da belirli bir süre yaşayacakları bir başka yere gitmeleridir. Göçün, idari sınırı geçerek oturma yerini devamlı, uzun süreli ve geçici ya da belirli bir süreliğine değiştirme olayını ifade etmesi, bu değişimin, kıtalararası, uluslararası, bölgelerarası, kırsal kesimlerden şehirlere ya da bugün bazı ülkelerde görüldüğü gibi, kentten kıra doğru bir mekansal hareketlilik olarak ta tanımlanabilmektedir (Tümertekin \& Özgüç, 1998: 308).

\subsection{Göç Türleri}

Göçler belli özelliklerine göre birbirinden ayrılmaktadır. Kimi araştırmacılar göç olgusunu göçün şekline ve süresine, yoğunluğuna göre sınıflandırabilmektedir. Tanımlamaların bazılarında ise göçün yönüne göre bir sınıflamaya gidilirken, diğer tanımlarda göçmenin göç istekliliğine göre bir sınıflama yapılabilineceğini belirtmişlerdir. Böylece göçleri beş başlık alında sınıflandırmak mümkün olmuştur.

Ayrıca buna benzer şekilde yine göçlerin sınıflandırılması mümkündür. Bunlar, zorunlu, ilkel, serbest, büyüklüğ̈̈ ve zorlama olmak üzere, beş kategoriye ayrılmaktadır. Burada zorlama ile zorunlu göç arasında bir 
ayrım yapmak mümkündür.Bu durumda ikisinin arasındaki farkı da şu şekilde açıklamak mümkündür. "Zorunlu göç, insanların içinde yaşadıkları koşullar gereği bir bölgeden ötekine göç etmeleridir. Zorlama göç ise insanların kendi istekleri dışında baskı ile bir yerden ötekine göç ettirilmeleridir. Göçün yönüne göre yapılan sınıflamalara göre ise göçler içgöç ve dışgöç olarak ikiye ayrılmaktadır. "İçgöçler, bir ülkenin milli sınırları içinde, dışgöçler de ülkelerin milli sınırlarını aşarak (her iki yönde de olabilir, milli sınırların içinden dışarıya veya milli sınırların dışından içine doğru) yapılan nüfus hareketleridir” (Sevim, 2000: 58).

İçgöç, "bir ülke içinde bölge, kent, kasaba ve köy gibi yerlerin birinden ötekine yerleşme amacıyla yapılan devinim" olarak tanımlanmaktadır (Keleş, 1998: 63). Tekeli’ye göre ise, içgöç, günümüzde belli bir zaman dilimi içinde belli bir yerleşme alanında yaşayanların kendi iradesiyle yaşam yerlerini söz konusu yerleşme alanının dışına taşıyanların miktarı olarak tanımlanmakta; ancak söz konusu tanımın aynı ülke içindeki irade dışı gerçekleşen göçleri içgöç içinde değerlendirmediği görülmektedir (Keleş, 1998: 7).

Günümüzde içgöç, belli bir zaman dilimi içinde belli bir yerleşme alanında yaşayanların kendi iradesiyle yaşam yerlerini söz konusu yerleşme alanının dışına taşıyanların miktarı olarak tanımlamak Tekeli’ye göre, her toplum için geçerli bir tanım olamamaktadır. Bu tanım daha çok modern sanayi toplumları için geçerliyken, tarım toplumlarında insanların toprağa bağlılıkları dikkate alındığında nüfusun yer değiştirmesi bireyin kendi iradesinden bağımsız olmaktadır. Bu durumda göç zorla yer değiştirmeleri değil sadece gönüllü yer değiştirmelerini kapsayacaksa bu kategorinin var olabilmesi için modern toplumun, ulus devletin ve özgür bireyin oluşmuş olması gerekir. Ayrıca göçün belirli bir zaman dilimi içinde belli bir yerleşme alanından dışarıya çıkan yer değiştirmelerin toplam sayısı olarak tanımlanması, göçün zamanda ve mekânda toplumsallaştırılmış bir değer olmasını da gerektirmektedir (Tekeli, 1998: 9-10)

Diğer pek çok göç sınıflaması ise özellikle göç edenlerin istekli olup olmamaları yönüyle belirleyici olmaktadır. Buna göre göç zorunlu ve gönüllü göç olarak ikiye ayrılmaktadır. Kimi yazarlara göre gönüllü göç her ne kadar göç eden bireyin göç ettiği yerdeki değişiklikten kaynaklansa da, göç kararındaki 'gönüllülük', göç eden bireylerin hem göç ettiği yeni çevreyle, hem de eski çevresiyle ilişki biçimlerini önemli ölçüde etkilemektedir." Zorunlu göç ise göç kararının gönüllü olmayışı ve kendisi dışında oluşan zorlamayla gerçekleşmiş olması, hem göçün kaynaklandığı yerle ilişkilerinin kesintiye uğramasına neden olmakta, hem de göç edilen yeni çevreyle ilişkilerinde, önemli farklılıklar doğurabilmektedir” (Erder, 1997: 144).

\subsection{Göçlerin Nedenleri}

Göç nedenlerine değinirsek, çok sayıda neden tarih boyunca insanoğlunu göçe zorlamıştır. Bunlarında en başında ekonomik nedenler gelmektedir. Yoksulluk ve işsizlik milyonlarca insanı yerinden yurdundan etmeye devam etmekte, gerek siyasal şartlar günümüzde gerekse de geçmişte birçok insanı göçe zorlamıştır. Yine kitlesel göçlere yol açan askeri çatışmalar, çevresel koşullardaki bozulmalar, önemli depremler, su baskınları ve volkanik patlamalar da göçlere neden olmaktadır. Kişilerin gerek ülke içerisinde (iç göç) gerekse de bir ülkeden diğerine (dış göç) göç etme nedenleri oldukça çok ve karmaşıktır. Ancak bu nedenler belli kategoriler altında toplanıp temel nedenlere ilişkin bir şeyler söylemek mümkün olabilir (Tümertekin \& Özgüç, 1998: 312).

İç göçler, kırdan kıra, kırdan kentte, kentten kentte ve kentten kıra doğru gerçekleştirilebilmektedir. Köyden veya kırdan kentlere olan göçlerin sebepleri açıklanırken, ilk olarak kentin çekiciliği ve kırın iticiliği ifadeleri kullanılmaktadır. Kentin çekiciliği, kent hayatının ekonomi, eğitim, sağlık ve refah gibi kişiye sağlayacağı imkân ve firsatların varlığıyla ilgiliyken, kırın iticiliği ise tarımda makineleşme sonucu açığa çıkan işgücü, toprağın aşırı parçalanarak küçülmesi, kan davaları vb. olumsuzluklar bireylerin göç etmelerine neden olmaktadır. Ayrıca itici ve çekici faktörleri de şu şekilde sıralamak mümkündür. Bunlardan ilki olan itici güçler arasında çevresel, demografik, ekonomik ve siyasal baskılar yer alırken, göçmenleri varış yerine çeken çekici göçlerde hayat şartlarını iyileştirmek için ekonomik firsatlar, kişisel güvenlik, özgürlük, ve eğitim firsatları gibi toplumsal imkanları sıralamak mümkündür (Tümertekin \& Özgüç, 1998: 314).

\subsection{Göçlerin Sonuçları}

Göçün, göç eden açısından, yeni bir yaşam biçimi, yararlanacağı fırsatları artırma, mesleki ve sosyal hareketlilik sağlamak gibi olumlu sonuçların yanı sıra maddi durumun elverişsizliği, işsizlik, psikolojik sorunlar gibi çok çeşitli olumsuzlukları da olmaktadır. Göç teorilerinden biri olan "Etnisite Teorileri”, göç sonucunda ortaya çıkan bir gerçeği de göz önüne sermektedir. Farklı ırktan, dilden, dinden ve hayat tarzlarından insanların aynı ortamı paylaşma durumlarını konu etmektedir. Farklı kültürlerin göç sonucunda biraya gelip aynı ortamda bulunmaları etnisite kavramının ve bu konuda söz edilen teorik açıklamaların incelenmesini gerektirmiştir. Ayrıca göç edenlerin yeni yaşam alanlarına uyum sorunları yaşamaktadırlar (Yalçın, 2004: 76-78).

$\mathrm{Bu}$ uyum sorunu ise birbirinden bağımsız birçok değişkene bağlı olarak farklılık arz etmektedir. Göç nedeni, göç eden kişiler, göçün türü, göçle varılan yer ve burada yaşanılanlar değiştikçe göç eden kişilerin karşılaştıkları uyum sorunları da değişmektedir. Örneğin, kırsal bir alandan kentsel bir alana göç eden kişilerin ve ailelerinin konumlarını ele alan birçok çalışma kaçınılmaz olarak göçmenlerin yeni vardıkları alanlara uyum süreçlerini, göç etmiş olanlarla yeni çevreleri arasındaki Kentleşme, kentlileşme süreci, gecekondulaşma ve yoksulluk gibi göçün kaynaklık ettiği toplumsal olgulara değindiğimizde, göçün sonuçlarına da parmak basmış olacağız. Söz konusu olguların iç içe geçtiğini, neden-sonuç ilişkisi açısından da birbirlerine bağlı oldukları görülmektedir. 
Ülkemizde kentleşme olgusu kırdan kentte doğru yaşanan göç hareketleriyle birlikte anıla gelmiştir. Bunun en önemli sebeplerinden birisi iki olgunun birbiriyle olan değişmez bağıdır. Bu bağın kurulduğu mekân olan kentlerde hem kentleşmenin, hem de kırdan kentte göçün sebep olduğu değişimlerin sonuçları, nüfus yoğunluğu ve buna bağlı yasadışı yapılaşma olgusudur. Demografik etmenler arasında yer alan nüfus artışı, insanların dünya üzerindeki paylarını sınırlayan unsurlardan biri olduğundan yoksulluk üzerinde olumsuz etkisi olmaktadır. Hanenin türü, büyüklüğü gibi özellikleri hane halkı içindeki bireylerin yaş ve eğitim durumları yoksulluk oranıyla ilişkili olduğu belirtilmektedir.

\section{Türkiye'de İç Göç Hareketleri}

Kavramsal çerçevenin başından bu yana vurgulandığı gibi, göç bir süreçtir. Bu süreç zaman ve mekân, neden ve sonuç, gibi birçok boyutun içinde barındırdıkları değişkenler, bu değişkenlerin yapısı ve karmaşık etkileşimleri nedeniyle de karşımıza farklı farklı biçimlerde çıkmaktadır. Göç sürecinin bu hareketli yapısı göçle ilgili yapılacak her türlü çalışmanın yanı sıra, sürecin anlaşılmasını ve yorumlanmasını da zorlaştırmaktadır. İçöç süreci de ülkelerin, bölgelerin, köylerin kendi özgün konumlarından beslendiğinden sürecin net açıklamaları bazen mümkün olmayabilir. Göçler, yönü itibariyle iç ve dış göçler olarak iki şekilde ele alınmaktadır.

İç göç, bir ülkenin kendi sınırları içerisinde gerçekleştirilen nüfus hareketiyken, dış göç ülkeler arası bir nüfus hareketi olarak anlaşılmalıdır. Bu çalışmada dış göç olgusundan söz edilmeyecek, içgöç olgusu ve Türkiye'deki sürecine ilişkin açıklamalara yer verilecektir. Ayrıca Türkiye'de gerçekleşen içgöç hareketlerini tarihsel bir ayrıma göre tanımlamak yerine göçün yönü açısından ele alındığında, Türkiye'de ki içgöçleri dört ayrı kategoride incelemek mümkündür. Bunlar; "köyden kentlere basamaklı göç, köyden büyük kentlere sıçramalı göç, kentler arası basamaklı göç, kentlerden büyük kentlere sıçramalı göç” tür (Sezal, 1996: 150).

Bazı yazarlara göre Türkiye'de yaşanan bu karmaşık göç yönünün süreçlerinin tam yaşanmadığı için kentleşmeyi geciktiren unsurlar olarak değerlendirmektedir. Türkiye'de iç göçü açıklamaya yönelik düşünceleri incelediğimizde ise konuyu şu şekilde özetlemek mümkündür (Sezal, 1996: 150).

- Kirsal yapıdaki teknolojik dönüşüm

- Bazı önemli kentlerde sanayinin hızla genişlemesi

- Türkiye'deki hızlı nüfus artışı

- Köyün itici ve kentin çekici nedenleri

- Kırsal kesimdeki kan davaları ve terör olayları olmaktadır (Yalçın, 2004: 115-119).

$\mathrm{Bu}$ temel etkenler sonucu yaşanan iç göçlerin, zamansız ve plansız yapılması ülke içinde önemli problemlere neden olmuştur. İç göçlerde en çok rastlanan özellik ülkelerin gelişmekte olan bölgelerinden gelişmiş bölgelerine doğru olan göçlerdir. Örneğin İtalya'nın Mezzogiorno bölgesinden daha kuzeyindeki sanayi alanlarına, Norveç'in kuzeyinden Oslo ve çevresine, Türkiye'de Doğu ve Güneydoğudan Marmara başta olmak üzere diğer bölgelere yapılan göçler gibi (Tümertekin \& Özgüç, 2002: 335)

Bu çalışmada Türkiye'nin iç göç süreci, nüfusun aynı ülke içinde yeniden yerleşim anlamında, 1990 öncesi ve sonrası olarak ele alınıp değerlendirilecektir. 1990’a kadar ki göçlerin itici, çekici, iletici gibi nedenleri söz konusuyken, 1990 sonrası göçlerin o yıllarda tırmanışa geçen Doğu ve Güneydoğu Anadolu Bölgelerindeki terör olayları, en başta buralarda yaşayan halkı tehdit eder duruma gelmesiyle, köy ve mezralardaki halkın can ve mal güvenliği nedeniyle zorunlu olarak göç ettirilmesidir. 1990 sonrası göç süreci, Türkiye göç tarihine yeni bir göç şekli eklemiştir. Literatüre "zorunlu” ve "zoraki” gibi adlarla geçen bu süreç önceki süreçlerden tamamen farklı ve süreci yaşayanlar açısından travmatik sonuçlar doğurmuştur.

\subsection{Türkiye'de 1990 Öncesi İçgöç Hareketleri}

Türkiye'deki göç hareketlerini içgöç bağlamında üç döneme ayırmak mümkündür. Bu üç dönem ise : “19501960", “1960-1970-1980" ve "1980-1990” şeklinde sinıflandırılabilir. Özellikle 50’li yıllarda başlayan ve hızlanan içgöç daha çok ülkede kırsal alanlardaki dönüşümün hız kazanması, bir anlamda "istenmeyen şekli”, ile açıklanabilirken, 60’lı yılların sonları ile 70’li yıllar ve 80'lerin başına kadar daha çok kentsel alanlardaki dönüşümün belirleyici olduğu, bir anlamda “cazibesi” ile anlatılabilir. 1980’li ve 90'lı y1llar içinde ise, içgöç olgusu ve süreçleri modernleşme temelindeki toplumsal değişim ve dönüşümün yeni iletişim teknolojileri ile daha da yoğunlaşması sonucu ve toplumsal hareketliliğin her anlamda "iletişimciliğii" etkenlerin oldukça artması ile yeni bir döneme girilmiştir.

Göç olgusu, dünyada daha ziyade 1950'li yıllarda Türkiye'de ise ancak 1960'lı yıllardan itibaren ağırlıklı olarak çalışılmaya başlanmıştır. Bu durum göç olgusunun geçmişini daha öte tarihlere dayandırılamaz anlamına gelmeyeceği gibi göçle ilgilenen bilim insanlarının da konuya ilgisiz kalmalarının ötesinde, göçün ülkelerin nüfus hareketleri içerisinde dikkati çeker bir konuma gelmesiyle hız kazanmış olmasıdır (Özcan, 1998: 78).

\subsection{Türkiye’de 1990 ve Sonrası İçöç Hareketleri}

1990 sonrası görülen göçler, siyasal politikalar sonucunda zorunlu olarak ortaya çıkmıştır (Akşit, 1998: 2829). 1990’lı yıllar boyunca köylerini terk etmek zorunda kalan yüz binlerce insanın büyük kentlere ve 
kendilerine yakın kentlere göçmesi sonucunda, bu kentlerde nüfus patlamasıyla birlikte kentlerin gelen nüfusu kaldıramamasının doğurduğu birçok problem gündeme gelmiştir. 1990’lı yıllarda Türkiye'deki iç göçün, son 40 yıldır gözlenen nüfus hareketinden farklı bir yapı arz ettiği görülmüştür.

Ülkenin doğusunda yer alan bölgelerde güvenlik nedeniyle yaşanan göçler, ekonomik nedenli içgöçlerden farklıydı. Başlarda büyük kentlere olan göçlere diğer kentlerde eklenmiştir. Türkiye toplumu söz konusu iç göçlerle en büyük mekânsal değişimi yaşamak durumunda kalmıştır. Önceleri İstanbul, İzmir, Ankara, Bursa, gibi büyük metropollerdeki içgöçle oluşan gecekondu mahallerinin medyaya yansıyan toplumsal görünümlerin benzerleri Adana, Mersin, Diyarbakır, Van, Şanlıurfa gibi illerde de görülmüştür.

Doğu ve Güneydoğu Anadolu'da devletin 'güvenlik nedeniyle' boşalttığı ve yaklaşık olarak 3200 köy ve göçe zorlanan 385.000 köy sakini bulunmaktadır. Zorunlu göç konusunda yapılan araştırmalarda, zorunlu göç edenlerin 1990 sonrasında önemli bir yüzdesinin bölgede can ve mal güvenliklerinin sağlanmaması nedeniyle göç ettiklerini belirtmektedirler, bunun nedeni olarak da PKK ve kolluk kuvvetlerinin baskısını göstermektedirler. Zorunlu göç konusunda yapılan çalışmalarda, göç etmek zorunda kalanların geldikleri yerlerde çok zor koşullarda yaşadıkları, göç edenlerin çoğunun yoksulluk sınırının altında yaşarken, konut, yiyecek, ve sağlık hizmetlerinin yokluğundan kaynaklı sorunlarla uğraşırken bu göçmenlerin çoğu için gündelik hayatın bir yaşamda kalma savaşına dönüştüğüne yönelik açıklamalar yer almaktadır (Çakmak, 2012: 38).

Türkiye Mühendis ve Mimarlar Odalar Birliğinin (TMMOB) İnsan Hakları Komisyonu tarafından yayınlanan 'Zorunlu Göç Raporu'nda: “Türkiye'nin güneydoğusunda 1990’lı y1lların başlarında yoğunlaşan köy boşaltma ve zorla göç ettirme olgusu 1999 yılına kadar devam etmiştir. Bu dönem içerisinde yaklaşık 3700 yerleşim alanından üç milyondan fazla bir nüfus kendi iradeleri dışında yaşadıkları alanları terk etmek zorunda kalmıştır. On altı yıllık çatışma ortamında yalnızca yerleşim alanları yakılıp boşaltılmakla kalmamış, aynı zamanda yaylalara çıkmak yasaklanmış, binlerce dönüm orman yakılmıştır. Boşaltılan, yakılan ve yıkılan yerleşim alanlarında mevcut yol, su, elektrik gibi temel altyapı olanakları da yok olmuştur. Tarlalar kullanılamaz hale gelmiştir. Meyve bahçeleri yok edilmiş, ağaçlar kesilmiştir. Boşaltılan köylerdeki arazi ve mülkler köy korucuları tarafından hem tahrip edilmiş hem de bunlara korucular tarafından el konulmuştur" (TMMOB, 2009).

TMMOB'nin 'Zorunlu Göç Raporu', devletin çeşitli sosyal, ekonomik ve güvenlik vb. konularda aldığ1 kararların yerine getirilmesi aşamasında nüfusta oluşan hareketliliğin zorunlu göçü ifade ettiğini belirtir ve cumhuriyet tarihinin en kitlesel zorunlu göçünün 1980 yılından sonragerçekleştiği ifade edilmiştir. 12 Eylül 1980'den itibaren devam eden sıkıyönetim ve olağanüstü hal uygulamaları, güvenlik nedeniyle köy boşaltma, bölgede yaşanan silahlı çatışmalar, yayla, mera yasağı, kontrollü gıda uygulaması gibi uygulamalar olduğunu ifade etmektedir (TMMOB, 2009).

Bir başka çalışma Başak Kültür ve Sanat Vakfının Aralık 2003’te başlayıp (Kadıköy, Üsküdar, Ümraniye, Beykoz, Maltepe, Kartal, Pendik, Sultanbeyli ve Tuzla) 9 ilçede yürütülmüştür. Dokuz ilçeye yerleşen 500 aile ve 369 çocuk ile görüşülmüştür. Zorunlu göçün çocuk, gençler ve aile üzerindeki etkileri araştırılmıştır. Araştırma sonuçları, 1989-1999 yılları arasında zorunlu göçle gelen ailelerin ekonomik, sosyal-kültürel, demografik sorunlarla boğuştuğunu ortaya çıkardı, özellikle çocukların bu süreçten çok etkilendiğini gözler önüne serdi: Çocukların dil, kültürel uyum konusundaki problemleri, okumayıp çalışmak zorunda kalmaları, sosyal güvenceden yoksun çocukların sağlık hizmetlerinden faydalanamamaları gibi bir çok sorun yaşadıkları görülmüştür.

Yaygın olan işsizlik göç edilen yerlerdeki işsizliğin daha da çok artmasına neden olmuştur. Göç edenlerin bu yerlere ne maddi ne de manevi bir kaynak getirmemeleri buraların oldukça sınırlı olan kaynaklarının daha çok tüketilmesine neden olmuştur. Göçmenlerin emeğini ucuza pazarlaması iş gücü piyasasının düşmesine neden olmaktadır. Emek karşılığı alınan ücretlerin düşmesinin yanı sıra yukarıda sayılan sorunların tamamı buralarda eskiden beri yaşayan insanların bu yeni gelen insanlara karşı düşmanlık ve ön yargı içinde yaklaşmasına neden olmaktadır. Bu tür bir tutum ise yeni gelenler ile eskiler arasında zaten var olan kültürel ve toplumsal uçurumun giderek büyümesine neden olurken, belli kesimlerin bu durumu istismar etmesine yol açmaktadır. (Peker, 1999: 28 ).

\subsection{Türkiye'de İç Göçler Üzerine Genel Bir Değerlendirme}

Türkiye'de esas olarak göçler 1950 li yıllardan sonra nispetten daha fazla artmıştır. Bu durumun bir çok sebeplerinden en önemlisinin sosyal ve ekonomik olduğunu belirtmekte yarar vardır. 1950'li yıllarda Türkiye’nin çok partili sisteme geçişi ve özgürlüklerle birlikte yolların yapılarak ulaşım imkanlarının artması ve köylünün adeta kabuğunu kırıp büyük şehirlere doğru akın ettiği bir dönem olarak tanımlamak mümkündür. Tablo 1 incelendiğinde bu durumu açıç̧a görmek mümkündür.

Tablo 1'e baktığımızda 1927 ile 1950 arası dönemdeki Türkiye nüfusu ve bu nüfusun kent ve kıra göre dağılımının kentli nüfusun \% 0.72 oranında arttığı görülmektedir. Buradan kent nüfusunun bu dönemde sayı bakımından durağan olduğu yani fazla bir göç hareketi görülmemektedir. 1950'li yıllardan önce Türkiye'de artan nüfusla birlikte toprağın bireyler arasında paylaştırıldığı, ölüm ve doğum oranlarının yüksek olduğu, göçün olmadığı geleneksel köy toplumlarında hane ve topluluk düzeyindeki bir hayat sürülmektedir. (Akşit, 1998: 26). 
Türkiye'de 1950'li yılların kalkınma faaliyetleriyle beraber bölgelerarası farklılıklar daha belirgin hale gelmiş, hızlı nüfus artışı ve tarımda makine ve teknolojinin kullanılmaya başlanması nedeniyle içgöç ve dışgöç hareketleri hızlanmıştır. Peker, Türkiye'de 1945-1950 döneminden günümüze kadar olan içgöçleri ve kentleşme olgusunu tipleştirdiğimizde karşımıza çıkacak olan iki örüntünün altını çizmektedir. İlki 1950-1980'de yaşanan kır-kent göçü, ikincisi 1980'den günümüze kent-kent göçü tipidir. Bu iki tipte söz konusu egemen faktör gönüllü göç olgusudur derken ikinci tipte, 1990'larda güvenlik nedeniyle Doğu ve Güneydoğu'da yaşanan göçlerin sosyal sistemde ihmal edilemeyecek boyutlara ulaştığının altını çizerken bu tipin aslında ayrı bir göç tipi olduğunu vurgulamaz.

Devlet İstatistik Enstitüsü (DİE) verilerine göre, Türkiye'nin 1927'den 1990'lara kadar kır nüfus oranı kentlere göre fazlayken, 1990'lı yıllarda kent nüfus oranının kır nüfusunu geride bıraktığı görülmektedir. Ve sonraki yıllarda da kent nüfusunda giderek daha fazla bir artış gözlenmektedir. 1990'da kent nüfus oran1 \%59 kır oranı ise \%41 iken, 2000 yılında ise kent kapsamına giren yerleşim yerlerinin toplam nüfusa oranı daha da artarak \%65' e ulaşmış kırların oranı ise \% 35'lere kadar inmiştir (DİE Türkiye İstatistik Yıllı̆̆ı, 2000: 48). Yaklaşık 30 y1ldan bu yana ülkenin içinde yaşanan ve 1990'larda başlayan zorunlu göçlerin devam ettiğini de göz önünde bulundurduğumuzda kent nüfus oranının 2000'lerde daha da artmış olduğunu aşağıdaki tabloda yer alan TÜİK' verileri desteklemektedir (TUIK, 2007).

\begin{tabular}{|l|l|l|l|l|l|}
\hline Yıllar & Genel Nüfus & Kent Nüfusu & Kent $(\%)$ & Köy Nüfusu & Kur(\%) \\
\hline 1927 & 13.648 .270 & 3.305 .879 & 24.22 & 10.342 .391 & 75.78 \\
\hline 1940 & 16.158 .018 & 3.802 .649 & 23.53 & 12.355 .376 & 76.47 \\
\hline 1945 & 17.820 .950 & 4.346 .249 & 24.38 & 13.474 .701 & 75.62 \\
\hline 1950 & 18.790 .174 & 4.687 .102 & 24.94 & 14.103 .072 & 75.06 \\
\hline 1955 & 20.947 .188 & 5.244 .337 & 25.03 & 15.702 .851 & 74.97 \\
\hline 1960 & 24.064 .763 & 6.927 .343 & 28.78 & 17.137 .420 & 71.22 \\
\hline 1965 & 27.754 .820 & 8.859 .701 & 31.92 & 18.895 .089 & 68.08 \\
\hline 1970 & 31.391 .421 & 10.805 .817 & 34.42 & 20.585 .604 & 65.58 \\
\hline 1975 & 35.605 .176 & 13.691 .101 & 38.45 & 21.914 .075 & 61.55 \\
\hline 1980 & 40.347 .719 & 16.869 .068 & 41.80 & 23.478 .651 & 58.20 \\
\hline 1985 & 44.736 .957 & 19.645 .57 & 53.02 & 23.789 .701 & 46.98 \\
\hline 1995 & 56.473 .035 & 33.326 .351 & 59.01 & 23.146 .684 & 40.99 \\
\hline 2000 & 67.803 .937 & 44.006 .274 & 64.90 & 23.797 .653 & 35.10 \\
\hline 2007 & 70.487 .917 & 49.747 .859 & 70.57 & 20.838 .397 & 29.43 \\
\hline 2008 & 71.517 .100 & 53.611 .723 & 74.96 & 17.905 .377 & 25.04 \\
\hline 2009 & 72.561 .312 & 54.807 .219 & 75.53 & 17.754 .093 & 24.47 \\
\hline 2010 & 73.722 .938 & 56.222 .356 & 76.26 & 17.500 .632 & 23.74 \\
\hline 2011 & 74.724 .269 & 57.385 .706 & 76.8 & 17.338 .53 & 23.20 \\
\hline 2012 & 75.627 .384 & 58.460 .35 & 77.3 & 17.167 .200 & 22.70 \\
\hline
\end{tabular}

Tablo 1: Türkiye'de Sayım Yıllarına Göre Nüfus, Kent ve Kır Nüfusu., Kaynak: (TÜIK, 2011.)

\begin{tabular}{|l|l|l|l|l|l|l|}
\hline Yıllar & Toplam & Şehir & Oranı & Köy & Oranı & Değişim (\%) \\
\hline 1965 & 27.754 .820 & 8.859 .730 & 32 & 18.895 .059 & 68 &,,,, \\
\hline 1975 & 35.605 .176 & 13.631 .101 & 38 & 21.914 .075 & 62 & 9 \\
\hline 1985 & 44.736 .957 & 19.645 .007 & 44 & 25.091 .950 & 56 & 9 \\
\hline 1990 & 56.473 .035 & 33.326 .351 & 59 & 23.146 .684 & 41 & 26,8 \\
\hline 2000 & 67.803 .927 & 44.006 .274 & 65 & 23.797 .653 & 35 & 14,6 \\
\hline 2007 & 70.586 .256 & 49.747 .859 & 70,5 & 20.838 .397 & 29,5 & 14,3 \\
\hline
\end{tabular}

Tablo.2: Çeşitli Dönemlere Göre Türkiye'de Nüfus Hareketleri., Kaynak: TÜIK,1965- 2007 Tarihleri arası nüfus hareketleri.

Türkiye'de 1950'li yıllardan itibaren içgöçü ele alan araştırmalar çoğunlukla kırdan kentte ekonomik göçü 'kentleşme, gecekondulaşma' çerçevesinde irdelerken niteliksiz erkek işgücü üzerinde durulurdu. 1990'larda nüfus hareketlerini etkileyen unsurlara gerek Doğu ve Güneydoğu'dan diğer bölgelere, gerekse bölge içindeki 'zorunlu göç' de dâhil oldu. O günden bugüne mevcut çalışmalar, göç nedenleri, göç sürecine katılım, bu süreç esnasındaki yaşam deneyimleri ve göçün etkileri, göç edenlerin tutumları ve göçün sonuçları üzerinde durulmaktadır (İlkkaracan, 1998: 305-306).

Türkiye söz edilen göç hareketlerinden farklı olarak özellikle 1980'li yılların ortaları ve 1990’lı yıllar boyunca farklı bir göç hareketine tanıklık eder. "75 Yılda Köylerden Şehirlere”, adlı kitapta bu göç hareketi, kırsalın iticiliği, kentin çekiciliği ve iletici etkenlerden görece bağımsız olarak ülkenin Doğu ve Güneydoğu Anadolu 
bölgelerinin kırsal alanlarından bu bölgelerin kent merkezleri ile batıdaki büyük kentlere doğru gerçekleşen bir harekettir. Bu hareket daha önceki göçler gibi ekonomik kökenli değil siyasal kökenlidir. "1984 yılında bölgede başlayan ve giderek yoğunlaşan çatışmalar, bölgedeki kitlesel göç hareketlerinin nedenidir. Terör ortamı, can ve mal güvenliğinin olmaması, geçim kaynaklarının daralması, sivil halkın bölgeden hızlı bir şekilde uzaklaşmasına yol açmıştır.

\section{Yoksulluk Kavramı ve Tanımlar}

Toplumsal bir sorun olarak yoksulluğun yaygınlaşması ve çözüme dönük düzenlemelerin, politikaların başarılı olabilmesi için, yoksulluk kavramına açıklık kazandırılması gerekmektedir. Kavramın tanımına açıklık getirilmesi temelde iki amacı gerçekleştirmek için yapılmaktadır. Bunlardan birincisi bu tanımla yoksulluğun öğelerinin ve nedenlerinin neler olduğunun ortaya konulmasını sağlamak, ikincisi ise yoksulların sayısının hesaplanabilmesine yol göstermektir. Yoksulluğun nasıl tanımlanacağı ve hesaplanacağı konusunda değişik yaklaşımlar öne sürülmektedir. Tanımlar yoksullara bakış açısına göre, toplumdan topluma zaman içinde değişkenlik gösterebilmektedir. Yoksulluk araştırmalarında bazen ekonomik göstergelerin ön plana çıktığı görülürken, bazı yaklaşımlarda ise yoksulluk ile gelir eşitsizliği ilişkisine vurgu yapılmaktadır. Ancak genel olarak yoksulluk iki temel şekilde ölçülebilmektedir.

Bunlar "mutlak yoksulluk" ve "göreli yoksulluk" tur. Mutlak yoksulluk kavramı, fiziksel açıdan sağlıklı bir yaşam sürdürebilmek için gerekli temel koşulları ifade eden geçim düşüncesine dayandırılırken, göreli yoksulluk, her ülkeye göre değişen bir toplumun günlük yaşama katılma maliyetinden hareketle, her bir toplum için geçerli olan, geniş bir yaşam standardı düşüncesine dayanır. Bu yaklaşımlardan ilki evrensel yoksulluk standartlarıyla ölçülebilirken, ikinci yaklaşım ölçülemez; çünkü mutlak olarak yoksul sayılan birey evrensel yaşam standartlarının altına düştüğü zaman dünyanın neresinde olursa olsun yoksul sayılırken, insan ihtiyaçlarının toplumdan topluma farklılık arz etmesi bu ihtiyaçların her yerde aynı olduğunu düşünemeyeceğimiz anlamına gelmektedir. 21. yüzyılda yaşanmakta olan yoksulluk ise sanayi devrimi sürecinde yaşanan yoksulluktan farklı özellikler taşımaktadır. 21. Yüzyılda yoksulluk, üretim alanından dışlanmak, toplumdan dışlanmak, yalıtılmak, yalnızlık ve ihmal anlamına gelmektedir Bektaş \& Yankaya, 2003: 58.

\subsection{Yoksulluğun Nedenleri}

Şenses'in belirttiği gibi yoksulluk tanımı genişledikçe yoksulluğun nedenlerini belirlemek de güçleşmektedir. Yoksulluk nedenleri tek bir başlık altında toplanabilecek kadar basit bir olgu olmadığından değişik türlerine göre, farklı nedenlerden kaynaklanabilmektedir. Aynı zamanda yoksulluk türlerinin bütün ülkelerde ve hatta aynı ülke içinde değişik yerleşim yerlerinde aynı nedenlerle ilişkilendirilmesi bile mümkün değildir. Yoksulluğun nedenlerinin zaman içinde siyasal ve sosyo-ekonomik değişimlere duyarlılık göstererek farklılık göstermesi doğal karşılanmalıdır.

$\mathrm{Bu}$ açıdan yoksulluğun nedenlerine ilişkin görüş ve değerlendirmeler arasında farklılıklar görülebilir. Yoksulluğun nedenlerini, kişilerin yetenekleri, sorumluluk ve disiplin anlayışı, tutumluluk derecesi ve gösterdikleri çaba gibi kişisel özellikleriyle ilişkilendiren ve yoksulların "yoksulluğun hem kurbanı hem de nedeni” olarak gören yaklaşımın yanı sıra yoksulluğu, yoksulların dışında başta ekonomi politikaları olmak üzere düşük ücretler, yetersiz eğitim ve istihdam olanakları ve ayrımcılık gibi yoksulların kendi denetimleri dışındaki "yapısal" nedenler sosyo-ekonomik sistemle ilişkilendiren yaklaşımlar, bir bütün olarak yoksulluğun nedenlerine ilişkin geniş bir yelpaze sunmaktadır.

\subsection{Dünya'da Yoksulluk}

Dünya yoksulluğunu etkileyen en önemli etkenler sıralanırken gida, giyecek, yakacak, vs. gibi malzeme mahrumiyeti, ücretsiz veya ikame edilmiş kamu hizmetlerinden mahrum kalmak, sağlık, eğitim ve yol hizmetlerinden yararlanamama, alt yapı ve ulaşım araçlarından yararlanamama, servet ve gelir düşüklüğü gibi hususlar yer almaktadır (Dumanlı, 1996: 27).

Günümüzde dünya çok önemli bir dönüşüm yaşayarak üretim potansiyelini hızla geliştiriyor. Her geçen gün dünya toplam olarak daha çok katma değer üretiyor. Ama bu üretilen değerlerin dağılımının eşitsizliğini arttırıyor. Dünyada 1960 yılında nüfusun en varlıklı yüzde 20'sinin gelirinin en yoksul yüzde 20'sinin gelirine oranı 30 iken 1991'de aynı oran 61'e yükselmiştir Tekeli, 2000: 55 1970'li yıllarda yoksulluk kavramı yaşanmakta olan toplumsal olguları anlamakta yeterli olurken, günümüzde artık yeterliliğini yitirmektedir. Küreselleşen ve teknolojik olarak yeniden yapılanan dünya ekonomisi içinde uyum sağlayamayan gruplar ve kişiler emek piyasasından, siyasal süreçlerden, toplumsal ilişki ağlarından kolayca dışlanabilmektedir. Sanayi toplumu dünyasında sistemin yoksullara ihtiyacı varken, bilgi toplumuna geçen küreselleşen dünyada bu ihtiyaç azalmakta ve dışlanmalar yaşanmaktadır.

Neo-liberal politikalarla sosyal devlet uygulamalarının sınırlanması kitleleri ekonomik değişmeler karşısında korumasız bırakmış, özelleştirmeler sonrası işsizlik yaygınlaşmıştır. Dünyanın bir bölümünde üretim artışı ve zenginleşme yaşanırken öte yandan yoksulluk artmakta açlık, eğitimsizlik ve bunların uzantısı olan şiddet olayları ve savaşlar dünya gündemini meşgul etmektedir (Gürses, 2007: 61). 


\subsection{Türkiye'de Yoksulluk}

Bireyin, gelişmiş ve gelişmekte olan ülkede yaşaması tüm yaşam çizgisini etkileyen bir unsur olmaktadır. Bireyin sahip olduğu nitelikler ve bunları üretime katabilmesi için sistemin ona sağladığı imkanlar ve ülkenin gelişmesi bir tür karşıllklı bağımlılık oluşturmaktadır. Yoksulluk Türkiye'nin önde gelen sosyolojik bir gerçeğidir. Devlet İstatistik Enstitüsü'nün 2010 verilerine göre, Türkiye'nin \% 30’u yoksuldur. Türkiye insani gelişmişlik bakımından dünya ülkeleri arasında arzu edilen seviyeden oldukça uzak görülmektedir (TÜIK, 2010). 2010 yılında Türkiye İstatistik Enstitüsü, tarafindan yayınlanan bir rapora göre yoksulluk, bir önceki yıla göre azalmıştır. Kırsal ve kentsel nüfusun gelir düzeyinde iyileşme görülmektedir (TÜiK, 2009).

Ülkemiz esas olarak zengin olduğu halde, toplumda yoksul bir kesim yine de mevcuttur. Bu tür yoksulluk, ülkenin genel karakterinden değil, sistemin insan merkezli olmayışından kaynaklanmaktadır ve tamamen gelir dağılımı bozukluğunun sonucudur. Örneğin Türkiye'de yoksulluk ve yoksul kesimlerin giderek artması bu iki nedenden kaynaklanmaktadır. Çünkü Türkiye hem çok az üreten bir ülkedir; hem de ülkemizde yürürlükte olan sistem gelir dağılımını son derece bozan bir yapıya sahiptir.

Sonuç olarak, önemli bir noktanın altını çizmek gerekir. Birçok yoksulluk nedeninin aynı yerleşim yerinde, ülke, bölge, il, ilçe, belde ve mahalle olabilir, birlikte ortaya çıkması bu söz konusu yerleşim yerinin yoksullukla özdeşleştirilmesi, yoksulluğu görünür kılmadığı gibi o yerlerde yoksulluk nedenlerinin birbirini güiçlendirerek büyüttüğ̈̈ ve yoksulluğu sürekli kıldığını unutmamak gerekir.

\section{Sonuç}

1950'li yıllardan bu yana göçün Türkiye'de özellikle kırdan kente doğru artan bir hareketi mevcuttur. Bu göçün en önemli sebeplerden biri önceleri ekonomik sosyal nedenler iken 1980'li y1llar ortalarından itibaren doğu ve güneydoğu illerimizdeki terör olaylarından dolayı kimi zaman zorunluluklardan kimi zaman da devlet eliyle bu bölgelerde yaşayanlar zorla göç ettirilmişlerdir. Bu nedenlerden dolayı Türkiye'de yaşanan iki farklı göç olgusu bulunmaktadır. Bu her iki göçün tabi olarak birbirinden farklı sonuçları olmaktadır. Dolayısı ile her iki göç için farklı önlemler almak gerekmektedir.

Ekonomik nedenlerle göç eden açısından, yeni bir yaşam alanına geçiş, yararlanacağı firsatları artırma, mesleki ve sosyal hareketlilik sağlamak gibi olumlu sonuçların yanı sıra maddi durumun elverişsizliği, işsizlik, psikolojik sorunlar gibi çok çeşitli olumsuzlukları da olmaktadır. Etnisite ve yeni yaşam alanlarına uyum sorunları yaşamaktadırlar. Bu uyum sorunu ise birbirinden bağımsız birçok değişkene bağlı olarak farklılık arz etmektedir. Göç nedeni, göç eden kişiler, göçün türü, göçle varılan yer ve buralarda yaşanılanlar değiştikçe göç eden kişilerin karşılaştıkları uyum sorunları da değişmektedir. Kırsal bir alandan kentsel bir alana göç eden kişilerin ve ailelerinin yeni vardıkları alanlara uyum süreci, kentleşme, kentlileşme süreci, gecekondulaşma ve yoksulluk gibi göçün sebep olduğu toplumsal sorunlar yaşanmaktadır.

Kente göçen ve kentin eski yoksullarına benzemeyen yeni kent yoksulları, sorunlarıyla yoksulluğun farklı bir yüzü olmuşlardır. Göçlerle gelenler, kent merkezlerinde tutunamadıklarından, kendilerini kent dışındaki az gelişmiş mahallelere atmaktadırlar. Kentlerin kıyısında yaşayanlar için kente yakın olmamak, bir bakıma kentin ekonomik, sosyal, kültürel imkânlarının dışında olmak, kentin üretim sürecine katılamamak anlamına gelmektedir. Bu durumda bulunanların çoğunun düzenli bir işi ve geliri de bulunmamaktadır.

$\mathrm{Bu}$ anlamda kentin dış mahallelerinde göçün en önemli sorunlardan biri de yoksulluk ve işsizlik olmaktadır. Son yirmi yılda Türkiye'de çok hızlı ve önemli ekonomik ve toplumsal değişmeler meydana gelmiştir. Bu değişmeler kentin yoksullarına benzemeyen, yoğun ve kitlesel göçler sonucu kentlerde biriken başta ekonomik olmak üzere, konut, sağlık, eğitim vb. sorunların yanı sıra yeni bir kültürle karşılaşmanın sebep olduğu sarsıntı ve çatı̧̧maları yaşamak durumunda kalanlar kentin yeni sakinlerinin yanı sıra "kentin yeni yoksulları" olarak anılmışlardır.

Türkiye'nin 1980 sonrası başlayan zorunlu göç sorunu, etkileri zaman geçtikçe çeşitlenerek artan, sadece zorunlu göç mağdurlarını değil, göç alan ve veren illerin genel nüfusunu, bu illerin sosyo-ekonomik ve kültürel dokusunu ve dolaylı olarak ülkenin bütününü etkileyen birçok önemli konu haline gelmiştir. Göç sonrası ağır bir yoksulluk ve yoksunluk içinde yaşamaya devam eden zorunlu göç mağdurlarının geniş bir yelpaze oluşturan yasal, sosyal, eğitim, siyasi, kültürel, çevreye uyum ve sağlık sorunları bulunmaktadır.

Türkiye'de zorunlu göç, sadece göç veren doğu ve güneydoğu illerini değil, ülkenin bütününü etkileyen toplumsal bir hareketliliktir. Ülkenin batısındaki büyük kentlere doğru gerçekleşen göçler sonucu kentler nüfus olarak büyürken, hayatlarını dayadıkları tarımsal ekonomiden uzak, kentsel ekonomiye katkı yapabilmek için gerekli beceriler ve çalı̧̧ma sisteminden yoksun olan bu gruplar, göçle geldikleri yerde ayakta kalmaya ve yeni çevresi ile uyum sağlamak için verdiği mücadelesinde pek çok problemle karş̧laşabilmektedirler.

$\mathrm{Bu}$ göç gruplar, kentlerin gecekondu mahallelerinde ya da yerleşim alanı olan ilçelerde genellikle tanıdıklarının yanında yaşamlarını sürdürmek ve çoğu zaman geçici işlerde çalışmaktadırlar. Tanıdık, akraba, hemşeri gibi yakın ilişkilerin gücüyle kente uyum sağlama ve kente dahil olma sürecinin sancılarını uzun bir süre çekmektedirler. Söz konusu nüfusun varlığı, kentlerde yaşanmakta olan yoksulluktan farklı yeni yoksulluk 
izahlarını gerektirmektedir. Bu yeni problemlerin en çok hissedilen ve yaşananları ise işsizlik ve kentlerdeki altyapı yetersizliği, suç oranlarının artması gibi sorunların da ortaya çıkmasına neden olduğu belirtilmektedir.

Zorunlu göç sorununun ortaya çıkmasının üzerinden 30 yılı aşkın bir süre geçmiş olmasına rağmen, devletin çözüm ve rehabilitasyona yönelik attığı adımlar son derece geç kalınmış ve yetersiz görülmektedir (2013 yılında başlatılan çözüm süreci hariç). Bu yeni durumun sonuçlarının önümüzdeki yıl ve yıllarda görebileceği tahmin edilmektedir. Ayrıca zorunlu göç mağdurları için geliştirilen, 1999'dan bu yana yürürlükte olan Köye Dönüş ve Rehabilitasyon Projesi (KDRP) gibi projelerin geliştirilerek uygulamaya konulması Türkiye'nin normalleşmesi için önemli görülmektedir.

Hiç şüphe yok ki göçün göçenlere yüklediği en önemli sorunlardan biri olan işsizlik ve istihdam problemidir. Göçle gelen nüfusun büyük çoğunluğu kırsal alandan kent ve kentsel alanlara taşındığı için buralarda öncelikle sahip oldukları tarım ve hayvancılık vasıflarına uygun iş bulma imkanlarının olmaması nedeniyle bir anda işsizler ordusuna katılmaktadırlar. Bu durumda kendileri en büyük mağduriyeti yaşadıkları gibi yeni geldikleri mahalle ve komşularına da olumsuz etkileri kaçınılmaz olmaktadır. Bu nedenle bu tür zorunlu göçle gelenlerin Devlet otoritesi tarafindan belli bir program dahilinde çeşitli eğitim ve rehabilitasyon seminerlerinden yararlandırılması gerektiği düşünülmektedir.

\section{Kaynakça:}

- Akşit, B., 1998. İçgöçlerin Nesnel Ve Öznel Toplumsal Tarihi Üzerine Gözlemler: Köy tarafından Bir Bakış, Türkiye'de İçgöç. Tarih Vakfı Yayınları, İstanbul,

- Aktan, C. Can. 2003. "Yoksulluk Sorunun Nedenleri ve Yoksullukla Mücadele Stratejileri.’”.' Yoksulluk Seтровуити I.cilt.

- Akgür, Z. G., 1997. Türkiye'de Kırsal Kesimden Kentte Göç ve Bölgeler Arası Dengesizlikler (19701993),İl Kültür Bakanlığı Yayınları: Ankara.

- Bayhan, V., 1997. "Türkiye'de İ̧ Göçler ve Anomik Kentleşme”. Toplum ve Göç, DİE. Matbaası, Ankara,

- Çakmak, D., 2012. "Göç ve Kent Yoksulluğunun Toplumsal Görünümleri: Van Bostaniçi Örneği, Van Yüzüncü Yıl Üniversitesi, Sosyal Bilimler Enstitüsü, Sosyoloji Anabilim Dalı, Yayınlanmamış Yüksek Lisans Tezi, Van.

- Dumanl1, R., 1996. Yoksulluk ve Türkiye'deki Boyutları, DTP, Ankara.

- Erder, S., 1996. İstanbul'a Bir Kent Kondu Ümraniye, İletişim Yayınları: İstanbul.

- Erder, S., 1997. Kentsel Gerilim, Uğur Mumcu Vakfı Yayınları: Ankara.

- Ersoy, M., Şengül T., 2002. Kentte Göç ve Yoksulluk Diyarbakır Örneği., ODTÜ Kentsel Politika Planlanması ve Yerel Yönetimler Anabilim Dalı No:6., Ankara.

- $\quad$ Fikret Ş., 2006. Küreselleşmenin Öteki Yüzü Yoksulluk, 4. bs., İstanbul: İletişim Yayınları.

- HÜNEE, 2006. “Türkiye Göç ve Yerinden Olmuş Nüfus Araşttrması (TGYONA)” Ankara, http://www.hips. hacettepe.edu.tr/index.html.

- Özcan Y., Z. 1998. “İçgöçün Tanımı ve Verileri ile İlgili Bazı Sorunlar”. Türkiye’de İçgöç, Tarih Vakfi,İstanbul.

- Kaygalak, S., 2009. Kentin Mültecileri, Dipnot yayınları: Ankara.

- Keleş, R., 1998. Kent bilim Terimleri Sözlüğü, İmge Kitabevi: Ankara.

- Laçiner Ö., 2002. "Bir Süreç ve Durum Olarak Yoksullaşmayl Sorgulamak”, Yoksulluk Hâlleri içinde, ed. Necmi Erdoğan, İstanbul: Demokrasi Kitaplığı Yayınevi.

- Macit R., 2009. Sefaletin Yoksulluğu Kovduğu Bir Dünya (çev. Şule Ünsaldı), Ankara: Özgür Üniversite Yayınları.

- Müderrisoğlu S., 2010. Psikolojik Gelişim, Yoksulluk ve Hak Temelli Yaklaşım: STK Uygulamalarında İlkelerden Yönteme Doğru, İnsan Hakları İhlali Olarak Yoksulluk, ( ed. Pınar Uyan Semerci), (İstanbul: Bilgi Üniversitesi Yayınları.

- Özer, İ., 2004. Kentleşme, Kentlileşme ve Kentsel Değişme, Ekin Kitabevi: Bursa.

- Sevim, Ö., Y. 2000. “Terör Nedeniyle Elazığ’a Göç Edenlerin Sorunları Üzerine Sosyolojik Bir Araştırma”, Yayınlanmamış Doktora Tezi , Elazığ.

- Sezal, İ., 1997. "Göçler ve Kentleşemeyen Kentler”, Toplum ve Göç, DİE. Matbaası: Ankara.

- Şenses, F., 2006. Küreselleşmenin Öteki Yüzü Yoksulluk, İletişi̇m Yayınları: İstanbul.

- Tekeli, İ., 2000. "Kent Yoksulluğu ve Modernite nin Bu Soruya Yaklaşım Seçenekleri Üzerine” Yoksulluk İçinde TESEV Yayınları 21, İstanbul, 
- TESEV., 2008. Zorunlu Göç Mağdurlarına Destek, Hizmet ve Yardım Veren Kişi ve Kuruluşlar İçin Yol Gösterici Kılavuzu, Tesev Yayınları, İstanbul.

- TMMOB., 2009. “Van Kent Sempozyumu”, Van.

- TMMOB, 1998. “Bölge Iç̧i Zorunlu Göçten Kaynaklanan Toplumsal Sorunların Diyarbakır Kenti Ölçeğinde Araştırılması”, Arş. Koordinatörü: Rıfat Dağ, Ankara.

- Tümertekin, E., Özgüç, N., 2004. Beşeri Coğrafya; İnsan, Kültür, Mekan., Çantay Kitapevi: İstanbul, 1998. Yalçın, C., Göç Sosyolojisi, Anı Yayıncılık: Ankara. 


\title{
Sağlık Hizmetleri Reformu ve Hane Halkı Refahı: Türkiye'de Sağlıkta Dönüşüm Programı

Health Care Reform and Household Welfare: Health
Transformation Programme in Turkey

\author{
Dr. Serdal Bahçe (Ankara University, Turkey) \\ Ph.D. Candidate Altuğ Murat Köktas (Ankara University, Turkey) \\ Ph.D. Candidate Deniz Abukan (Ankara Üniversitesi, Turkey)
}

\begin{abstract}
We assessed the health care reform and its effects on household's welfare such as access to health care and household economic burden. We used descriptive analysis on 2002-2011 Ministry of Health and OECD Health Statistics. The main result is about using health care. Access to health care increased after health care reform in Turkey. Number of applications to health care service server and its units rose. On the other hand, financial burden of health care on household's budget decreased number of applications. The main result percentage of not consulting a specialist even needed to consult a specialist but did not during the past 12 months is \%4.9 in 2003 and \%19.9 in 2010. To improve health care access, policy makers should improve public sector provision of health care, increase social security benefit packages and protect poor and vulnerable.
\end{abstract}

\section{Giriş}

Sağlık harcamalarının son yıllarda ekonomik büyümeden daha hızlı artış göstermesi, bu hizmetlerin finansmanında bütçe baskısını beraberinde getirmektedir. Çeşitli yollarla sağlı harcamaları olması gerekenin üzerinde gerçekleşmekte ve bir bakıma da kaynak israfina neden olmaktadır. Dolayısıyla ülkeler, sağlık harcamalarının artışını kontrol altına almaya çalışmakta ve bu yönde politikalar geliştirmektedirler. Söz konusu politikalar, "reform" olarak nitelendirilmekte ve sağlık piyasasının hem arz hem de talep ayağına odaklanmaktadır. Diğer yandan uygulanmasının kolay olması nedeniyle talep yanlı maliyet paylaşımları ağırlıklı olarak tercih edilmektedir. Sağlık hizmetleri finansmanında talep yanlı maliyet paylaşımının katkı ve katılım payı gibi isimlerle ağırlıklı olarak uygulanması, hane halkı tüketim harcamaları içinde sağlık harcamalarının payını artırmakta ve sonuç olarak hane yaşam memnuniyetini etkilemektedir. Bu bağlamda çalışmanın amacı, sağlık reformu uygulamalarının, yaşam memnuniyeti üzerindeki etkilerinin incelenmesidir. Elde edilen sonuçlar itibariyle, Türkiye'de sağlık hizmetlerinden duyulan yaşam memnuniyeti, reform ile birlikte artmıştır. Bunun yanında, sağlık hizmetleri kullanımında ise olumsuz göstergeler bulunmaktadır. Uluslar arası karşılaştırmalarda ise Türkiye, hizmet kullanımında son sıralarda yer almaktadır.

Ülkelerin sağlık harcamalarının sürekli olarak artmasıyla birlikte, harcamaların kamu bütçelerinde baskı oluşturması sağlık harcamalarının kontrol edilmesi üzerine politika önerilerinin doğmasına neden olmuştur. Sağlık reformu olarak isimlendirilen söz konusu politika değişiklikleri, temel olarak sağlık harcamalarının mümkünse kısılması veya kontrol altına alınması ile sağlık hizmetlerinden elde edilen gelirlerin artırılmasına odaklanmaktadır. Bu bağlamda sağlık hizmetlerinde reform çalışmaları birçok ülkenin gündeminde yer almakta ve reform yanlısı uygulamalara gidilmektedir.

Reform kavramının oldukça popüler olmasının yanında, sağlık sektöründe reformu oluşturan unsurların neler olduğuna yönelik evrensel ve tutarlı bir tanım bulunmamaktadır (Saltman ve Figueras, 2004: 2). Buna göre reform, toplum düzeni ve yapısının daha iyi bir konuma getirilebilmesi için gerçekleştirilen köklü değişim ya da düzeltme olarak tanımlanmakta ve hissedilen sorunlar üzerinde meydana gelen pozitif yönlü değişim olarak ifade edilmektedir (Berman ve Bossert, 2000). Bir diğer yaklaşıma göre ise reform, "politika hedeflerine ulaşmak için sürdürülebilir ve yoğun kurumsal ve yapısal değişiklikleri kapsayan bir süreci kapsamaktadır” (Saltman ve Figueras, 2004: 3). Sağlık hizmetlerinde reform ise, "sağlık hizmetleri sisteminin performansını geliştirme yönünde önemli, amaçlı bir çaba” olarak tanımlanmaktadır (Roberts vd., 2009: 9). Bu bağlamda reform, sağlık politikaları ve ilgili kuruluşları bir defaya mahsus olmayıp uzun vadede değiştirmeye yönelik faaliyetlerdir. Dolayısıyla sağlık reformu, önceliklerin belirlenmesi, politikaların geliştirilmesi ve bu politikaların uygulanacağı kurumlarda reform yapılması biçiminde özetlenebilir (Cassels, 1995: 331). Sağlık sektörünün finansman, ödeme sistemi, organizasyon, düzenleme ve tüketici davranışları gibi bir takım "kontrol düğmeleri” yoluyla etkilenmesi ise, reformun odak noktasını oluşturmaktadır (Hsiao, 2000).

Ülkelerin karşı karşıya kaldığı yaşlanma, ileri düzey kronik hastalıklar, yeni tedavi yöntemleri ve ileri teknoloji gibi sorunlar sağlı harcamalarının artması yönünde baskı oluşturarak, reform çalışmalarına zemin hazırlamaktadır (Saltman ve Figueras, 2004: 3). Kıt kaynakların verimsiz kullanımı, bireylerin ihtiyaç duyduğu sağlık hizmetlerine erişememesi ve sağlık hizmetlerinin bireylerin ihtiyaçlarına cevap verememesi ise reform gerekçelerinden bazılarıdır (Cassels, 1995: 330). Bu bağlamda 1980'lerin ikinci yarısından itibaren Batılı 
gelişmiş ekonomilerde görülen sağlı endüstrisinde reform politikaları, ülkelerin en önemli girişimleri arasında yer almaktadır (Flood, 2003: 1; Twaddle, 2002: 3). Doğu Avrupa ülkeleri, sosyal sigorta programlarını genişletmekte, Güney Amerika ülkeleri, sağlık sigorta kapsamını kır ve kentte yaşayan yoksulları kapsayacak biçimde genişletmekte, Afrika'da mali desantralizasyon hastanelere ek kaynak oluşturmak amaciyla kullanılmakta ve verimliliğin artırılması için birçok ülke, yeni geri ödeme sistemleri ve sağlık hizmet sunumu organizasyonunda yeni yöntemler denemektedir (Saltman ve Figueras, 2004).

\section{Türkiye Sağlık Hizmetlerinde Reform Uygulamaları}

3 Mayıs 1920 tarihinde 3 Sayılı Kanun ile kurulan Sağlık Bakanlığı, ülke genelindeki tüm sağlık hizmetlerinin yürütülmesi ile görevlendirilmiştir. Diğer yandan 1921 Anayasasının 11. Maddesinde yer alan "...Medaris, Maarif, Sihhiye, Ikktisat, Ziraat, Nafia ve Muaveneti içtimaiye işlerinin tanzim ve idaresi vilâyet şûralarının salâhiyeti dahilindedir" ifadesi ile sağlık hizmetlerinin yönetimine değinilmiştir. Cumhuriyetin ilanı ile birlikte sağlık hizmetlerine yönelik çalışmalar hız kazanmıştır. Dönemin Sağlık Bakanı Dr. Refik Saydam, 1937 yılına kadar süren bakanlığında, sağlık hizmetlerinin kuruluşu ve gelişiminde önemli bir rol oynamıştır. Bu bağlamda geliştirilen sağlık politikalarının temel amaçları; savaş sonrası problemlerin çözülmesi, sağlık personelinin nicelik ve nitelik bakımından desteklenmesi, merkezden başlayarak köylere kadar ulaşan örgütlenmenin oluşturulması ve koruyucu sağlı hizmetlerinin yaygınlaştırılması olarak belirtilebilir (Sağlık Bakanlığı, 2003: 8). Dolayısıyla tarihsel süreç, sağlık hizmetlerinin yaygınlaştırılması ve hizmet sunumunda kalitenin artırılması için reform çalışmaları hayata geçirilmiştir. Bu bağlamda 1946-1960, 1961-1980, 1980-2002 dönemlerinde yoğun olarak reform uygulamaları gerçekleşmiştir. Bununla birlikte söz konusu reform çalışmalarının en kapsamlısı 3 Kasım 2002 ile gerçekleşen hükümet değişikliği sonucu uygulamaya konulan "Sağlıkta Dönüşüm Programı"dır. Hükümet programında yer alan “Acil Eylem Planı"nda sağlığa yönelik politika değişikliğinin ipucu verilmiş ve kapsamlı bir reform düşüncesi ortaya çıkmıştır. Bahse konu planda belirtilen politika maddeleri şu şekilde sıralanabilir: "Etkin ve kaliteli bir sağllk sistemi oluşturma, herkesin temel sağllk ihtiyacını özel sektörle işbirliği yaparak yerine getirme, ülkemizde sağllk hizmetlerinin yurt düzeyinde dă̆ıllminı dengeli hale getirme hedefleri çerçevesinde; Bir yll içinde; i.) Devlet hastanesi, sigorta hastanesi, kurum hastanesi ayırımın kaldırılmaya dönük çalışmalar başlatılacak, ii.) Hastanelerin idari ve mali yönden özerkliğinin sağlanması çalışmaları başlatılacaktır, iii.) Genel Sağllk Sigortası Sistemi kurulacak, iv.) Aile hekimliği uygulamasına geçilecek ve sağlam bir sevk zinciri oluşturulacak, v.) Koruyucu hekimlik yayginlaşttrilacak, vi.) Özel sektörün sağllk alanına yatırım yapması özendirilecektir. Insanların ayırım gözetilmeksizin, ekonomik ve sosyal bakımdan güvencede yaşamalart ilkesi çerçevesinde yine bir yll içinde; i.) Sosyal güvenlik kuruluşlarında norm ve standart birliği sağlanacak, bütünleştirilmiş bir sosyal güvenlik ağl kurulacaktır, ii.) Bütünleştirilmiş bir sosyal hizmet ve yardım ağının oluşturulabilmesi için dağını durumdaki sosyal hizmet faaliyetleri tek çatı altında toplanacak, iii.) Sosyal Yardımlaşmayı ve Dayanışmayı Teşvik Fonu'nun kaynakları artırlacak, harcama usul ve esasları yeniden belirlenecek ve yönetim yapısı güçlendirilecektir”. Bu bağlamda Acil Eylem Planında yer verilen politika önerileri ile sağlı ve sosyal güvenlik sistemlerinde kapsamlı bir reform düşüncesinin temelleri atılmıştır.

\section{Sağlık Hizmetleri Reformunun, Yaşam Memnuniyeti Üzerindeki Etkileri}

Sağllk hizmetleri reformu, esas itibariyle sosyal güvenlik reformu olarak ifade edilebilir. Reformun temel mantığının, harcamaları kontrol altına almak, ek gelir sağlamak ve hizmet sunumunun sürdürülebilirliğini sağlamak olduğu dikkate alındığında, sosyal güvenlik kapsamında yer alan garanti paketinin boyutu, hizmet kullanımının katkı payı gibi isimlerle finansmanının özel kesime kaydırılması ve sosyal güvenlik kapsamında yer alan nüfusun artırılması gibi uygulamalar, sosyal güvenlik reformunu desteklemektedir. Bu bağlamda söz konusu reform uygulamalarının ulaşmak istediği çeşitli amaçlar bulunmaktadır. Bunlar aşağıdaki gibi sıralanabilir.

1. Ahlaki tehlike nedeniyle oluşan aşırı talebin önlenmesi,

2. Gereksiz tetkik ve tedaviler nedeniyle artan sağlık harcamalarının azaltılması,

3. Ek gelir elde ederek, mali sürdürülebilirliğin sağlanması,

4. Sağlık hizmet sunumuna erişimde hakkaniyetin sağlanması,

5. Hizmet sunucuları tarafından oluşturulan yapay talebin önlenmesi,

6. Hastanın bilinçlendirilerek, harcamaların kontrol altına alınmasıdır.

Sağlık reformu, yukarıdaki hedeflere odaklanmakla birlikte, özellikle maliyet sınırlama düşüncesi çerçevesinde, talep odaklı maliyet paylaşımı unsurlarının (katkı payı, ek sigorta vb.) yoksul kesimin hizmete erişimi üzerinde olumsuz etkiye neden olduğu, literatürde genel kabul görmüş bir yaklaşımdır. Bu bağlamda hanehalkının, sağlık hizmete erişiminde yaşadığı güçlüğün yaşam memnuniyetini etkilediği ileri sürülebilir.

\section{Sağlık Hizmeti Kullanımı Üzerindeki Etki}

Sağlık reformunun temel mantığı, sektördeki aşırı talebi azaltarak sağlık harcamalarını ve bu bağlamda sağlık harcamalarını kontrol altına almak olarak özetlenebilir. Bu bağlamda, reformun etkilemek istediği temel 
çıktılardan biri olan, hekime müracaat sayısında azalış beklenmektedir. Şekil 1, Türkiye'de kurum ve kuruluşlar bazında kişi başına hekime müracaat sayısını göstermektedir.

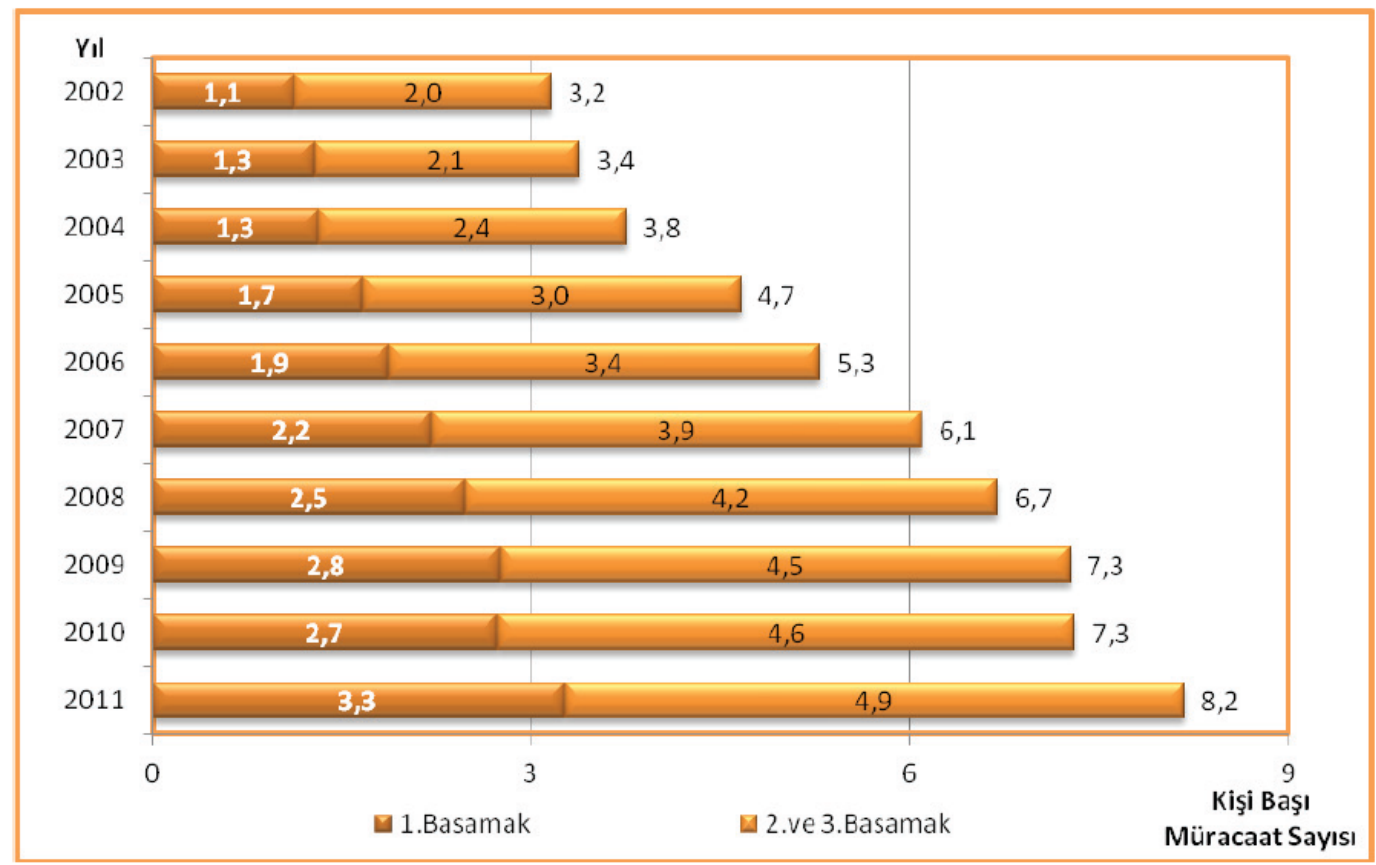

Şekil 1: Să̆lık Hizmet Sunucularına Kiş̧i Başı Hekime Müracaat Sayısı Kaynak: Să̆lık Bakanlı̆̆l 2011 İstatistik Yılliğl.

Şekil 1'de görüldüğü üzere, SDP'nin uygulamaya geçtiği 2003 yılı itibariyle hekim başvuru sayısı düzenli olarak artış göstermiştir. Özellikle kamuda sağlık hizmet sunucularının birleştirilmesi ile birlikte, özel hizmet sunucularına erişimin kolaylaşması bu oranı artıran en önemli faktörlerdendir. Bu bağlamda, söz konusu oranda meydana gelen artış, maliyetleri ve harcamaları da artırdığından, 2009 yılında uygulamaya konulan katkı payı ile, bu oran kontrol altına alınmaya çalışılmıştır. Nitekim 2010 yılında, katkı payı uygulaması etkisini göstermiş ve artmamış fakat izleyen yıl yine artmıştır. Şekil 2 ise yıllar itibariyle müracaat sayısını vermekle birlikte yukarıdaki sonucu desteklemektedir.

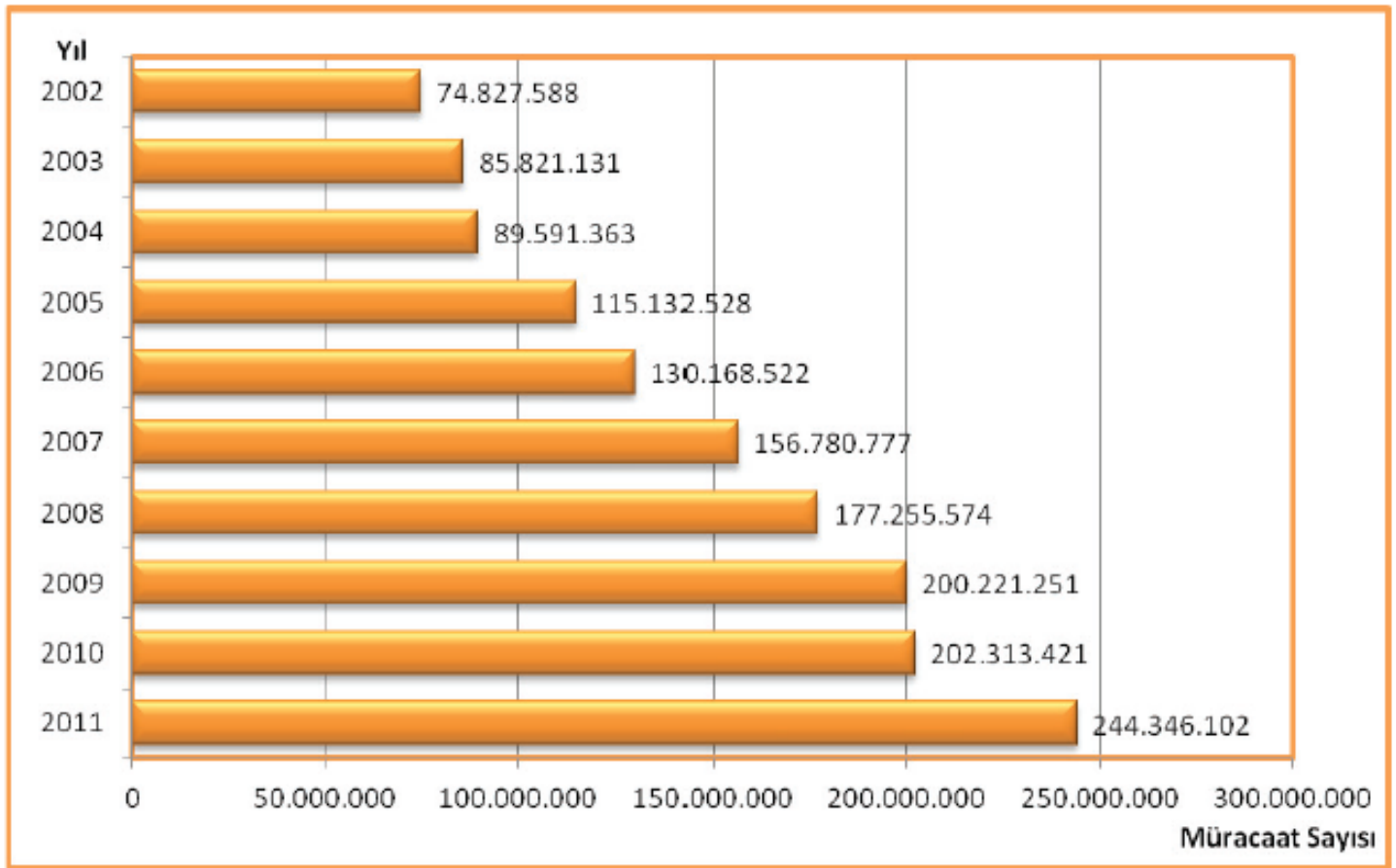

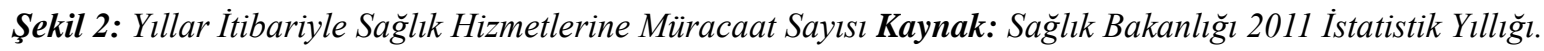

Kişi başı hekime müracaat sayısının uluslar arası karşılaştırmasına ilişkin veriler Şekil 3'te gösterilmektedir. 


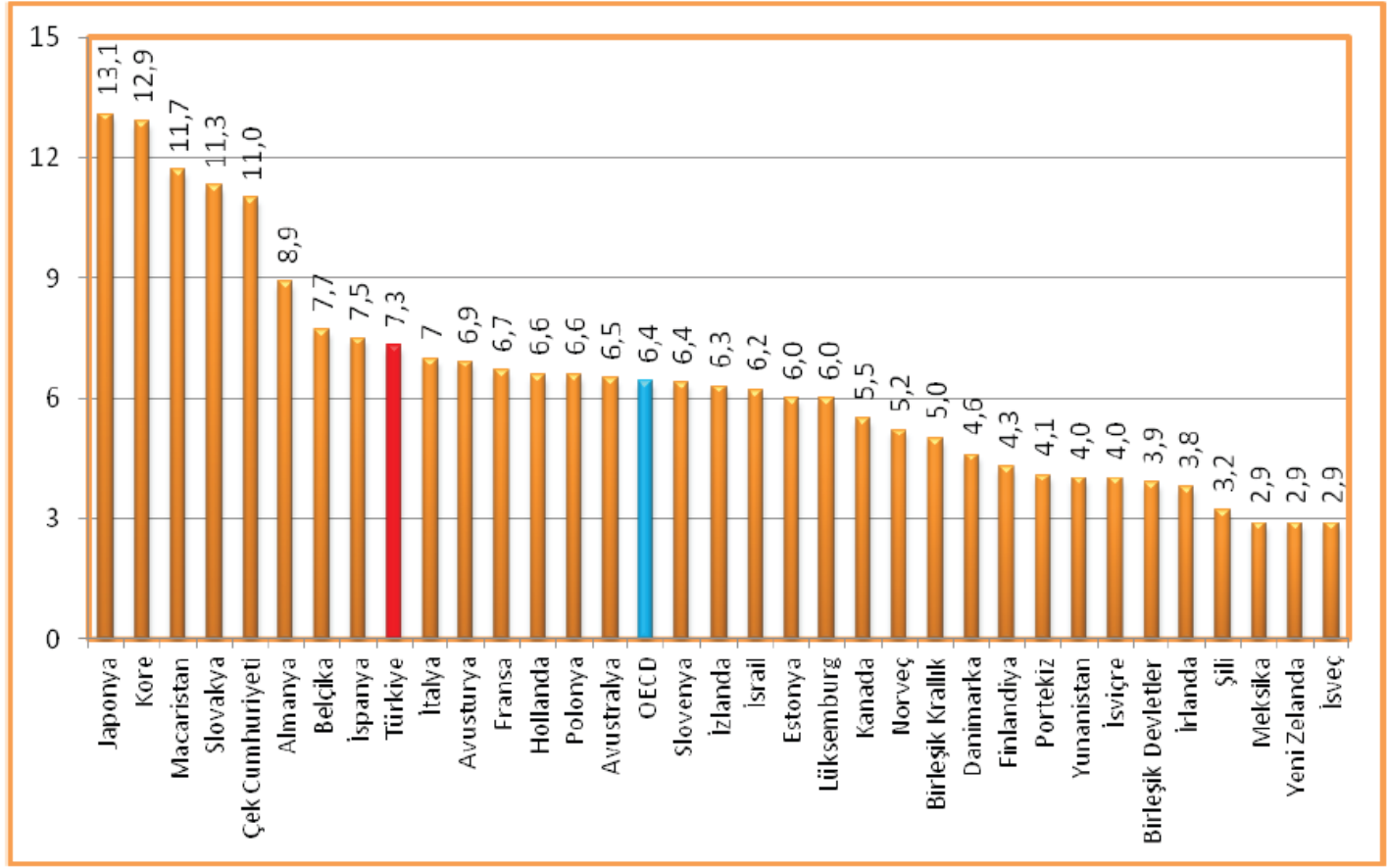

Şekil 3: Seçilmiş Ülkelerde Kişi Başına Hekime Müracaat Saylsı Kaynak: OECD Sağlık İstatistikleri, 2013.

Şekil 3 'te görüldüğü üzere, Türkiye SDP ile birlikte hizmete erişimi kolaylaştırmış ve hekim başvuru sayıları yıllar itibariyle artmıştır. Bu durum kendisini uluslar arası karşılaştırmada da göstermektedir. Buna göre Türkiye 7,3 olan hekime müracaat sayısı ile OECD ortalamasının üzerinde olup, birçok gelişmiş ülkeyi gerisinde bırakmıştır. Dolayısıyla 2009'da uygulamaya geçen maliyet paylaşımı çerçevesinde katkı payının, söz konusu müracaat sayısını azaltma başarısı tartışmalıdır.

Sağlık hizmetlerinde maliyet paylaşımının bir diğer önemli sonucu, tetkik ve tedavilerin daha kısa zamanlarda yapılarak, hastanede yatı̧s süresinin azalmasıdır. Bu bağlamda Şekil 4, Türkiye'de yıllar itibariyle, hastanede ortalama kalış gününü göstermektedir.

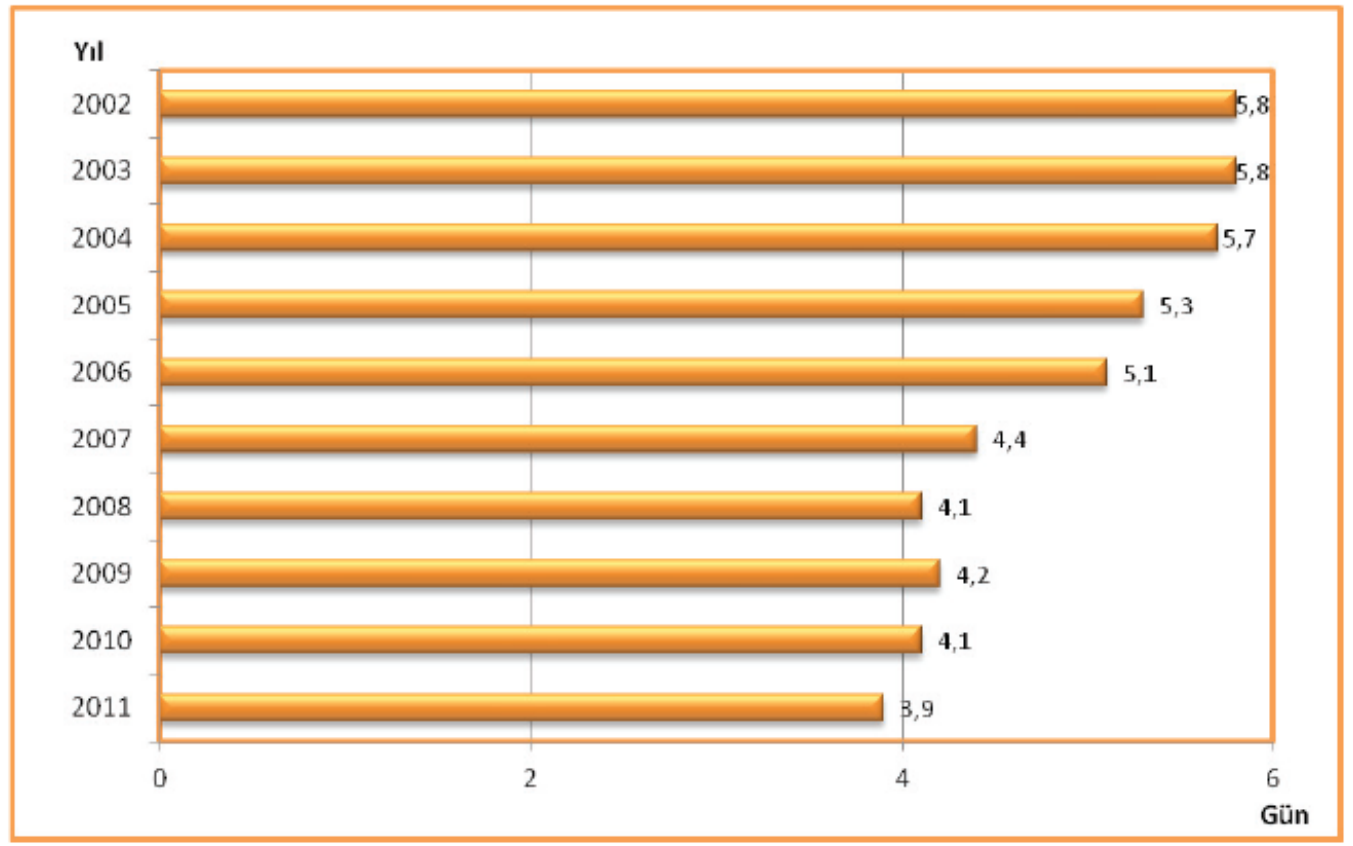

Şekil 4: Yıllar İtibariyle Hastanede Ortalama Kalış Süresi Kaynak: Sağlık Bakanlığı 2011 İstatistik Yıllığı.

2002 yllında ortalama kalış günü 5,8 iken bu oran SDP ile birlikte 2011 yılında 3,9'a düşmüştür. Türkiye'de mevcut veri seti ile, söz konusu azalışın, maliyet paylaşımı ile ilişkisi test edilememektedir. Diğer yandan uluslar arası karşılaş̧ırma, bunun üzerinde fikir oluşturabilir. Şekil 5, OECD ülkelerinde hastanede yatan hastaya ilişkin ortalama yatış gün sayısını göstermektedir. 


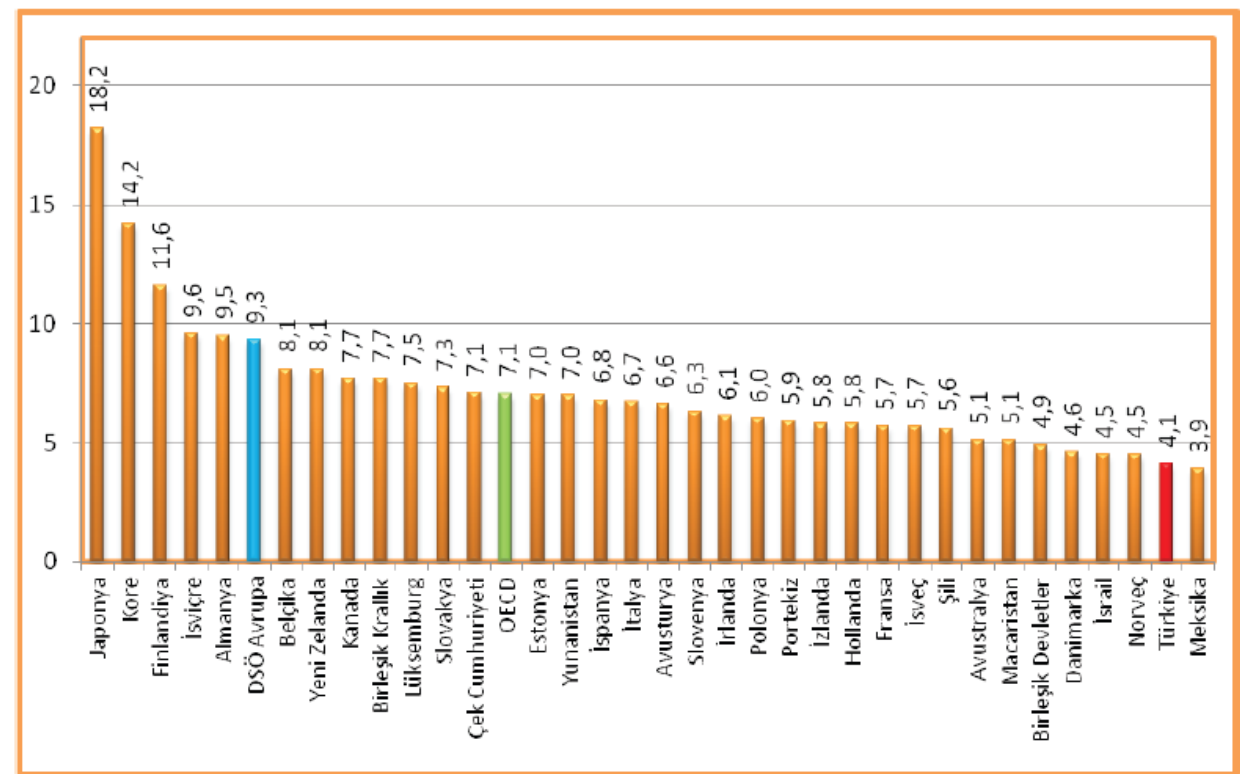

Şekil 5: OECD Ülkelerinde Hastanede Ortalama Kalış Süresi Kaynak: OECD Sağllk İstatistikleri, 2013.

Şekil 5 'te görüldüğü üzere, Türkiye mevcut hastanede ortalama yatış süresi ile Meksika'nın hemen üzerinde ve sondan ikindi durumdadır. OECD ortalamasının 7,1 ve Avrupa bölgesinin 9,3 olduğu uluslar arası göstergelere göre, Türkiye'nin söz konusu göstergesi oldukça kötüdür.

2009 yılında maliyet paylaşımı kapsamında uygulamaya konulan katkı payı türü cepten harcamaların önemli bir etkisi de, hastalar arasında acil kullanımının artmasıdır. Acil servislerde katkı payının bulunmaması nedeniyle, hastalar acil servisleri poliklinik hizmetleri için kullanmaya başlamakta ve bu da acil servislerin iş yoğunluğunu artırmaktadır. Söz konusu düşünce, 2012'de acil servislerde acil olmayan hastalar için getirilen katkı payı ile de desteklenmektedir. Şekil 6 yıllar itibariyle acil servis kullanım düzeyini göstermektedir.

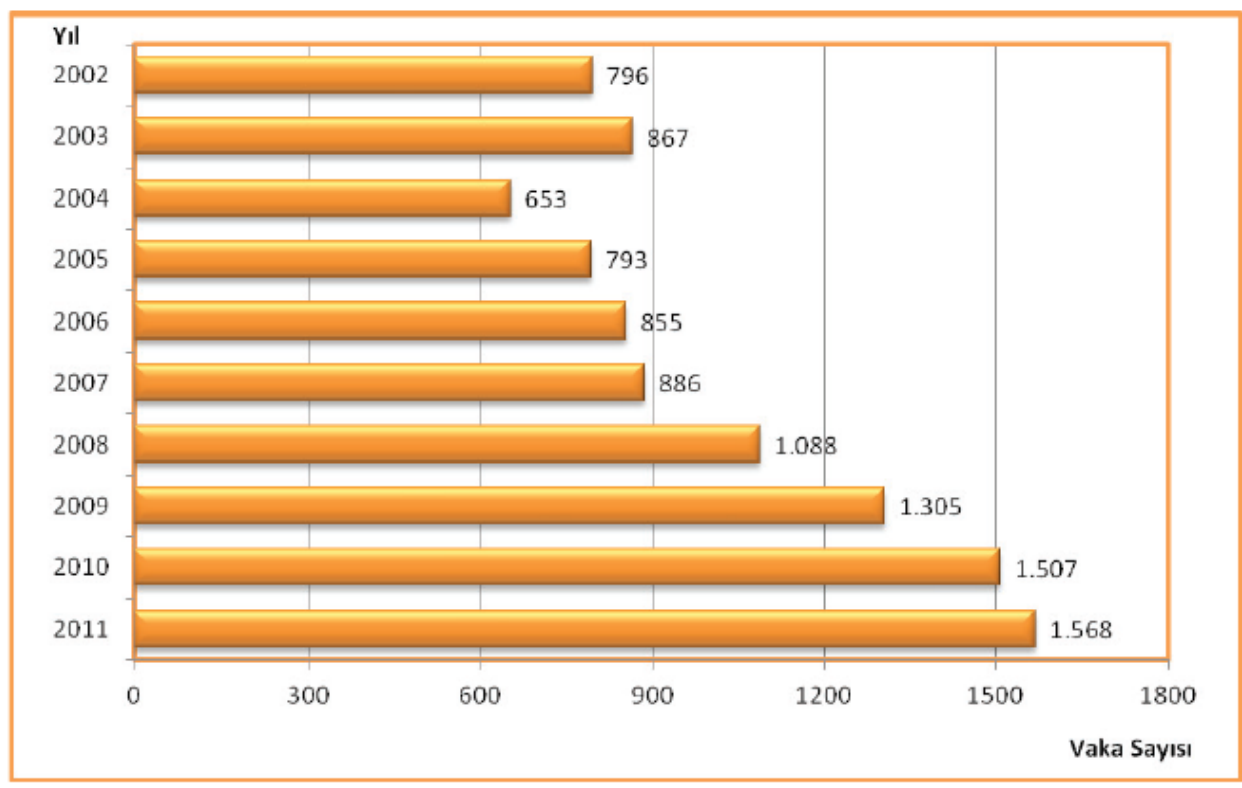

Şekil 6: Yıllar İtibariyle Acil Servis Kullanım Düzeyi Kaynak: Să̆lık Bakanlı̆̆ 2011 İstatistik Yıllı̆̆l.

SDP ile birlikte hizmet sunucularına erişimin artması, hastane ve hekim başvuru sayılarını artmıştır. Diğer yandan 2009 yılında uygulamaya konulan katkı payı ile birlikte Acil servis kullanımında artış görülmektedir. Bu bağlamda 2011 yılı için acil servis istasyonu başına düşen vaka sayısı 1.568 olup, bir önceki y1la göre artış hızı frenlenmiştir. 2012 yılında uygulama konulan acil serviste acil olmayanlara yönelik katkı payı ile bu miktarın düşeceği ileri sürülebilir.

Tablo 1, 2008 ve 2010 yıllarında, son 12 içerisinde bir hekim tarafından yataklı ya da günübirlik tedavi hizmeti önerilmesine rağmen, bu hizmeti alamayanların oranını ve nedenlerini göstermektedir. 


\begin{tabular}{|l|l|l|}
\hline & \multicolumn{1}{|c|}{$\mathbf{2 0 0 8}$} & \multicolumn{1}{c|}{$\mathbf{2 0 1 0}$} \\
\hline Hizmet alamayanlar & 4.9 & 19.9 \\
\hline Ödeme güçlüğ̈̈ (çok pahalı olması ya da sigorta fonu tarafından karşılanmaması) & 44.1 & 44.9 \\
\hline Poliklinikte muayene olma güçlüğ̈ & 6.3 & 6.8 \\
\hline İş, çocuk ya da bakmakla yükümlü olduğu diğer kişilerden dolayı zaman bulamama & 17.4 & 18.3 \\
\hline Hastanenin uzak olması, ulaşım imkanının zorluğu & 3.5 & 4.3 \\
\hline Ameliyat/Tedavi korkusu & 10.3 & 4.1 \\
\hline Kendisini hastaneye götürecek birinin olmaması & 2.4 & 2.7 \\
\hline Ailesinin veya yakınlarının gerek görmemesi & 1.9 & 0.6 \\
\hline Diğer nedenler & 12.4 & 15.7 \\
\hline
\end{tabular}

Tablo 1: Son 12 Ay İçerisinde Bir Hekim Tarafindan Yatakl ya da Günübirlik Tedavi Hizmeti Önerilmesine Rağmen, Bu Hizmeti Alamayanların Oranı (2008, 2010) TÜIK, Sağlık Araştırması, 2008-2010.

Tablo 1'de görüldüğü üzere, 2008 yılında sağlık hizmeti önerilmesine rağmen, bu hizmeti alamayanların oranı \%4.9 iken, bu oran 2010 yılında yaklaş1k olarak \%20'dir. Hizmetten yararlanamama nedeni olarak ise birinci sırada finansal sorunlar belirtilmektedir. Herhangi bir sigorta sahipliğinin bulunmamasıyla birlikte, sigorta kapsamı dışında bulunan hizmetlerin ortaya çıkardığı finansal yük, bireylerin sağlık hizmetlerinden yararlanamamasına neden olmaktadır.

\section{Sağlık Finansmanı Üzerindeki Etki}

Genel olarak herhangi bir sağlık finansman sisteminin üç temel amacı bulunmaktadır. Bunlar, i. Tüketicileri, sağlık harcamalarının finansal riskinden korumak, ii. Sağlık hizmetleri sunumunda etkinlik ve iii. Tüketici ve hizmet sunucu arasında adil olmaktadır (Ellis ve McGuire, 1993: 138). Bu bağlamda, sağlik sisteminin bu hedefler doğrultusunda planlandığı varsayımıyla, hastaları finansal yükten koruyarak, hizmete erişimde hakkaniyetin sağlandığı bir sistem reform çalışmalarının temel dayanağı olarak kabul edilebilir. dolayısıyla, özellikle yoksul, yaşlı ve kronik hastaların sağlık hizmetleri nedeniyle katlanacağı finansal yükün garanti altına alınmasıyla birlikte, sigorta kapsamının genişletilmesi, hizmet çıktılarında hakkaniyeti sağlayabilecektir.

Sağlık harcamalarında meydana gelen olağanüstü artışın, devlet bütçelerinde oluşturduğu finansal baskı ise, ülkeleri iki farklı politikaya yöneltmektedir. Bunlardan birincisi sağlık sistemine ek gelirler sağlamak, ikincisi ise harcamaları kontrol etmektir. Bu bağlamda ek gelir elde etmek adına, sağlık hizmetleri finansmanının daha yoğun olarak özel kesime (hanelere) kaydırılması düşüncesi, söz konusu hedefle uyumluyken, bu kaymanın haneler üzerindeki finansal yükü artırması ise, hizmetten yararlanan kesim üzerinde olumsuz etkiye yol açmakta ve nihayetinde hizmete erişimi engellemektedir. Dolayısıyla sağlık hizmetlerinin finansmanında cepten yapılan harcamaların yüksekliğinin, söz konusu etkiyi daha da şiddetlendireceği ileri sürülebilir. Şekil 7, Türkiye'de yıllar itibariyle sağlık harcamalarının GSYİH içindeki payını, kaynakları kapsamında göstermektedir.

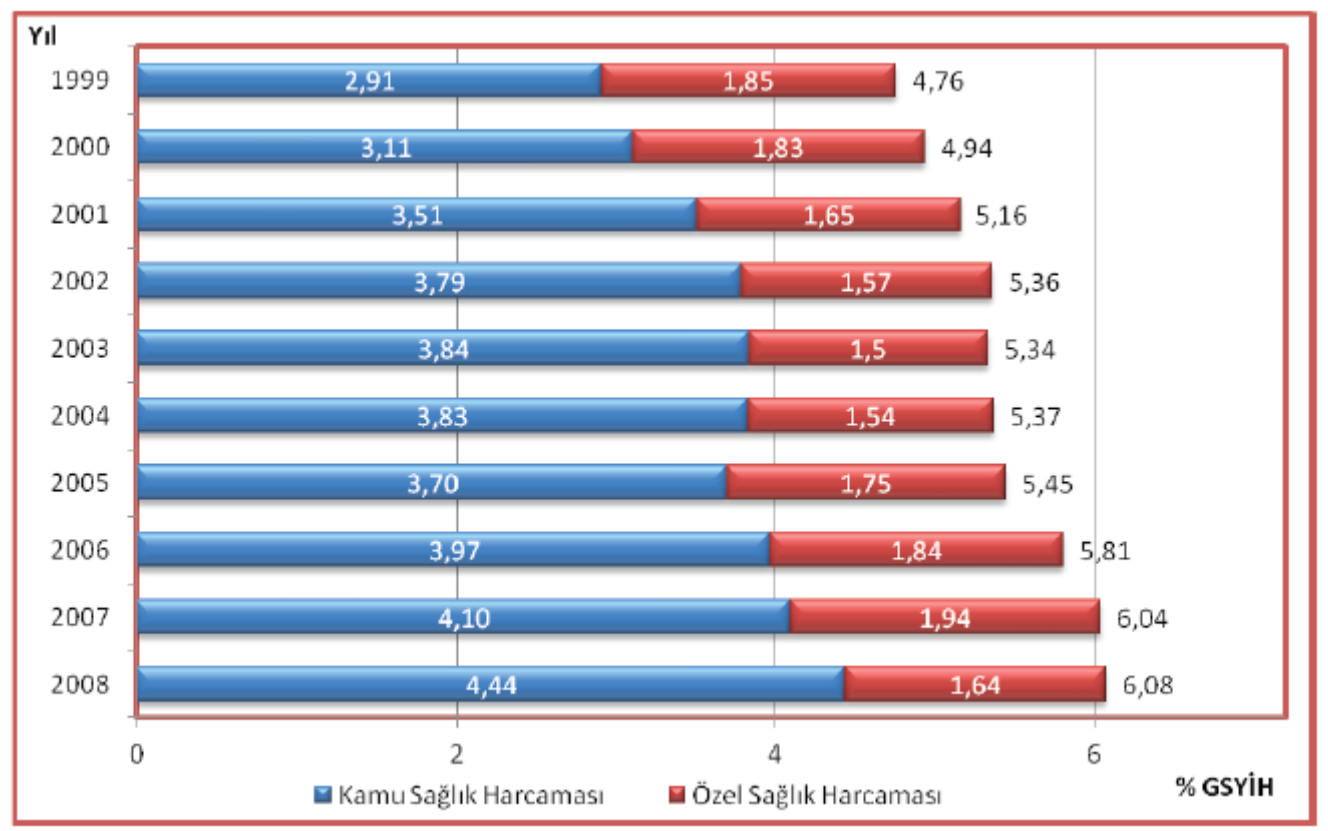

Şekil 7: Yıllar İtibariyle Sağlık Harcamalarının GSYİH İ̧̧indeki Payı Kaynak: Sağglık Bakanlığı 2011 İstatistik Yillı̆̆l. 
Şekil 7'de görüldüğü üzere Türkiye'de sağlık harcamalarının GSYİH'ya oranı yıllar itibariyle artıŞ göstermektedir. Diğer yandan söz konusu veriler 2008 yılına kadar gösterilmektedir. Çünkü TÜİK tarafından, 2008 yılından sonraki harcama istatistikleri halen ilan edilmemiştir. Bu bağlamda 2009 yılı sonlarında yürürlüğe giren maliyet paylaşımının, somut etkileri tespit edilememektedir. Diğer yandan Şekil 8, uluslar arası karşılaştırmaya yönelik verileri göstermektedir.

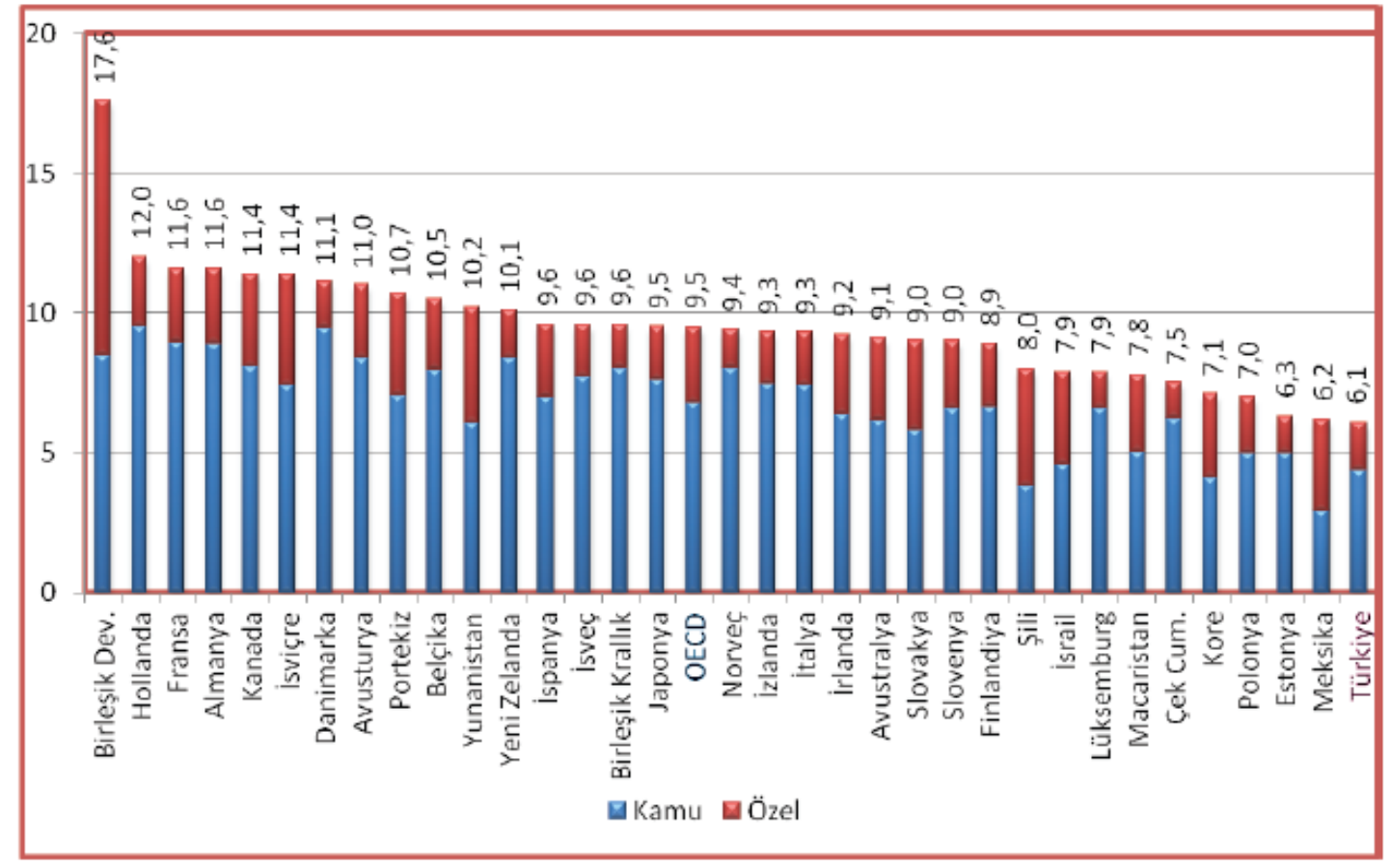

Şekil 8: OECD Ülkelerinde Să̆lık Harcamalarının Kamu-Özel Dăğlımı, 2008 Kaynak: OECD Să̆lık Istatistikleri, 2013.

Şekil 8'de görüldüğü üzere, Türkiye mevcut sağlık harcamaları ile 2008 yılı itibariyle tüm OECD ülkeleri arasında son sırada yer almaktadır. OECD ortalamasının \%9,5 olduğu bu durumda, Türkiye sağlığa ayırdığı kaynak bakımından oldukça gerilerdedir. Benzer biçimde satın alma gücü paritesi kapsamında, kişi başına yapılan sağlık harcamalarında da Türkiye son sıradadır. Şekil 9, ilgili verileri göstermektedir.

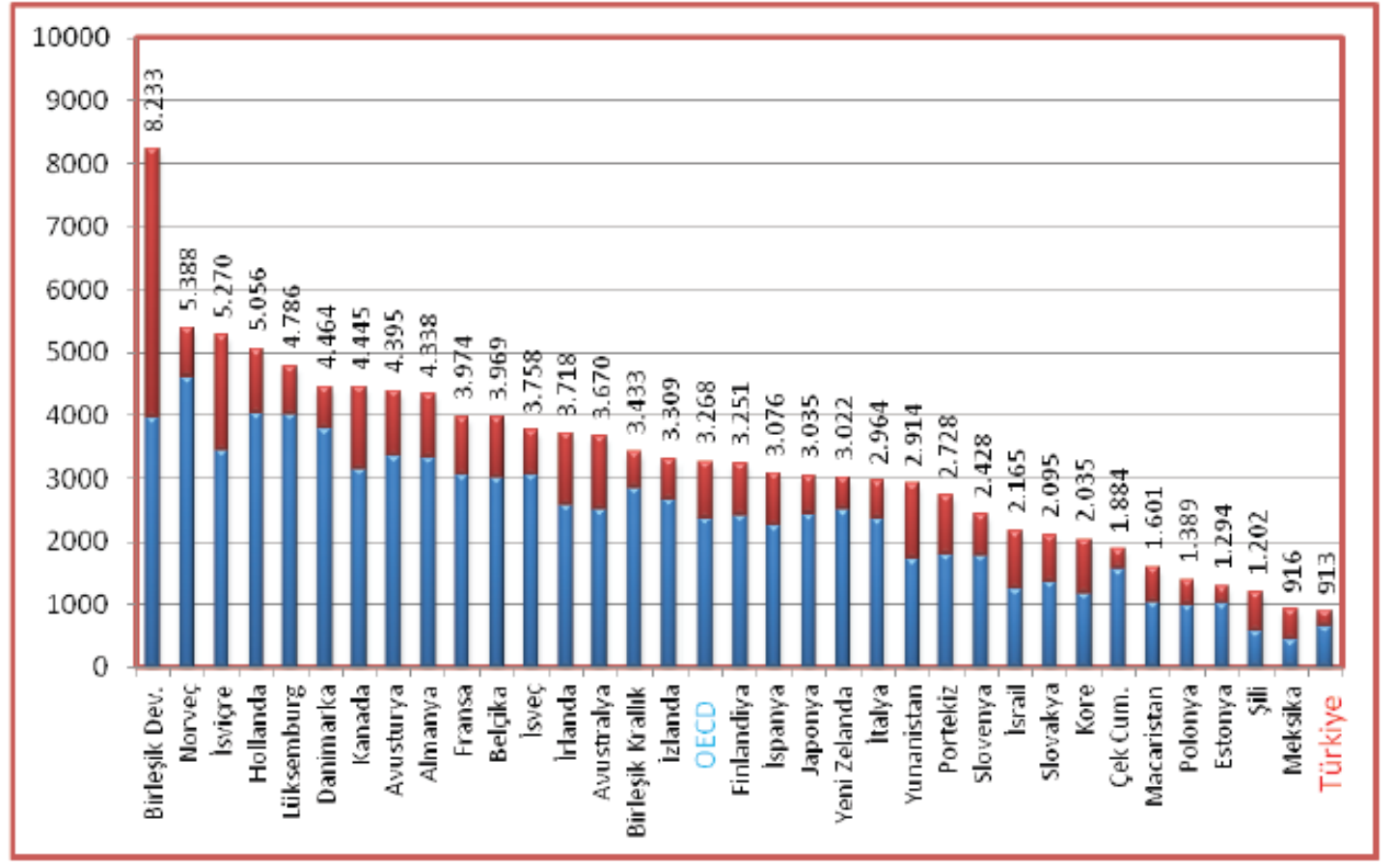

Şekil 9: OECD Ülkelerinde Kişi Başına Sağlık Harcamalarının Dağılımı, 2008 Kaynak: OECD Sağlık Istatistikleri, 2013 
Sağlık harcamalarında oldukça kötü durumda olan Türkiye, hanelerin cepten sağlığa yaptığı harcamalar bakımından farklı bir durumdadır. Şekil 10, söz konusu verileri göstermektedir.

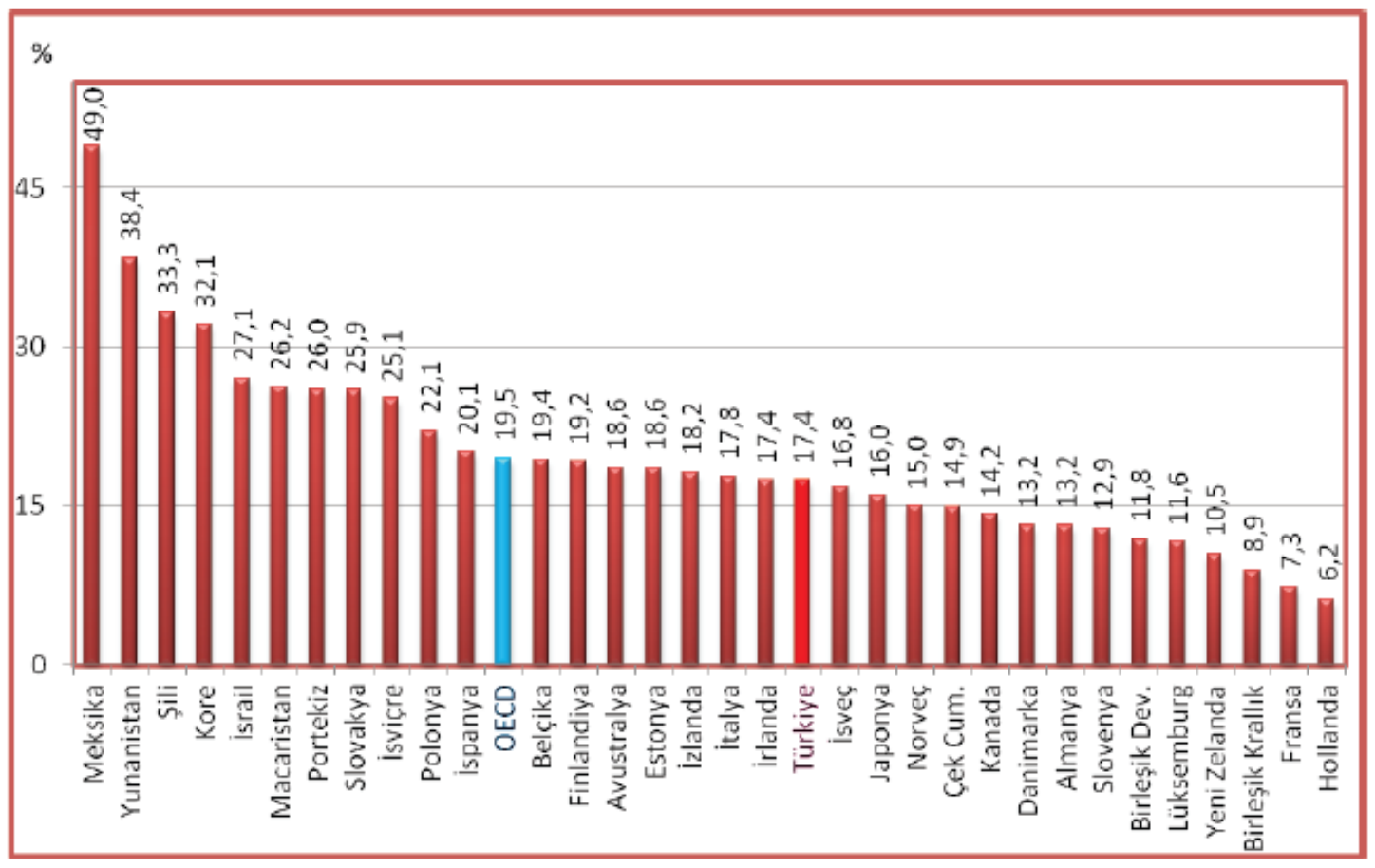

Şekil 10: OECD Ülkelerinde Cepten Yapılan Să̆lık Harcamalarının Dă̆ılımı, 2008 Kaynak: OECD Sağlık Istatistikleri, 2013.

\section{Sonuç}

2003 yılı itibariyle uygulamaya konulan Sağlıkta Dönüşüm Programı ile birlikte, Türkiye'de demografik özellikler itibariyle sağlık göstergelerinde iyileşmeler görülmüş ve OECD ülkelerine yakın sonuçlar elde edilmiştir. Sosyal güvenlik kapsamında yer alan nüfus oranının artması ve güvence kapsamının genişlemesiyle birlikte, sağlık hizmet sunucularına olan erişim kolaylaşmıştır. Bununla birlikte sağlık reformunun temel mantığını oluşturan, sağlık harcamalarının kontrol altına alınması, gereksiz tetkik ve tedavinin önlenmesi ve bu yolla yapay talebin azaltılması, hizmet sunumuna erişimde adaletin sağlanması, sosyal güvenlik sistemi açıklarının azaltılarak bütçe üzerindeki baskının hafifletilmesi ile sosyal güvenlik sisteminin mali sürdürülebilirliğinin garanti altına alınması gibi hedeflenen birçok unsurun gerçekleşmediği görülmektedir. Bu bağlamda sağlık reformu uygulamalarının yakından takibi ve kapsamlı analizi gerekmektedir.

\section{Kaynakça}

- Berman, A., Bossert, T., (2000), A Decade of Health Sector Reform in Developing

- Countries: What Have We Learned?

- http://www.hsph.harvard.edu/ihsg/publications/pdf/closeout.PDF Erişim: 13.02.2012

- Cassels, A. (1995), "Health Sector Reform: Some Key Issues in Less Developed Countries”, Journal of International Development, 7(3): 329-348.

- DPT (2003), 58. Hükümet Acil Eylem Planı, Ankara.

- Ellis, Randall P., McGuire, Thomas G., (1993), "Supply-Side and Demand Side Cost Sharing in Health Care", Journal of Economic Perspectives, Volume 7, Number:4, 135-151.

- Flood, C. (2003), International Health Care Reform: A Legal, Economic and Political Analysis, Routledge Chapman \& Hall.

- Hsiao, W.C. (2000) “Inside the Black Box of Health Systems.” Program on Health

- Care Financing, Harvard School of Public Health, Boston.

- OECD, (2013), Sağlık İstatistikleri.

- Sağlık Bakanlığı, (2011), İstatistik Yıllığı.

- Sağlık Bakanlığı, (2003), Sağlıkta Dönüşüm Programı, Ankara. 
- TBMM (2002), 58. Hükümet Programı, http://www.tbmm.gov.tr/hukumetler/HP59.htm TÜİK (2008) Sağlık Araştırması, Ankara.

- $\quad$ TÜİK (2010) Sağlık Araştırması, Ankara.

- Twaddle, A. (2002), Health Care Reform Around the World, Health Care Reform Around the World.

- WHO (1997), European Health Care Reform Analysis of Current Strategies,

- $\quad$ B. Saltman and Josep Figueras (Ed), WHO Regional Publications, European Series, No: 72. 


\title{
Bir Sosyal Dışlanma Biçimi Olarak Türkiye'de Refah Hizmetlerinden Dışlanma
}

\section{Exclusion from Welfare Services in Turkey as a Social Exclusion Form}

\author{
Asst. Prof. Dr. Nagihan Durusoy Öztepe (Pamukkale Universty, Turkey) \\ Asst. Prof. Dr. Çağla Ünlütürk Ulutaş (Pamukkale University, Turkey)
}

\begin{abstract}
The welfare regime of Turkey is classified in South European Welfare Modal. One of the main characteristics of this regime is lack of the inclusion of entire population. The aim of this presentation is analysing the exclusion of citizens from four main welfare services: health care, education, social security and social assistance. Datas of Turkey Staistics Institution's (TURKSTAT) 2010 Household Budget Survey are used to examine the population excluded from basic welfare services. This study has found that $\% 13,5$ of the population is excluded from health insurance. $\% 8,6$ of the population are not completed any school. Furtheremore, $\% 49,8$ of theemployees are not under the covereage of social security system. \% 3,3 of the population can access to social assistance.
\end{abstract}

\section{Giriş}

18. yüzyılda İngiliz Yoksul Yasaları, 19. Yüzyılda, başta İngiltere olmak üzere, çeşitli ülkelerde zorunlu temel eğitimin hayata geçirilmesi, Fransa ve Almanya'da sosyal ve ekonomik hakların anayasal düzeyde tanınması, Almanya'da Bismark'ın ilk defa sosyal sigorta sistemini kurmaya dönük adımlar atması, refah devletinin de ilk adımları arasında sayılmaktadır. Bununla birlikte refah devletinin gelişimi ve yaygınlaşması 2. Dünya Savaşının ardından gerçekleşmiştir. Savaşı takip eden yeni dönemde Keynesyen ekonomi politikalarının benimsenmesi ve tam istihdam, yüksek büyüme oranları, devletin temel ihtiyaçları sağlamaya ve risklerden korumaya dönük hizmetler sunmasıyla tanımlanan altın çağ ancak 1970'li yıllardaki petrol krizlerine dek sürebilmiştir. Gerek ekonomik krizler, gerek toplumsal risklerin, nüfus ve aile yapısının dönüşümü, tüm ülkelerde refah karmasının bileşimini değiştirmiştir. Özellikle iki kutuplu dünyanın sona erişinin ardından küresel düzeyde hâkim olan neoliberal politikalar, refah devletini tehdit etmekle kalmamış, sosyal dışlanma ve yoksulluk sorununu gerek ulusların, gerek küresel örgütlerin başlıca sorun alanları haline getirmiştir. 1974 yılında Fransa'da sosyal dışlanma kavramını literatüre kazandıran Rene Lenoir, sosyal dışlanmışları devlet tarafından uygulanan refah programlarına erişim olanakları olmayanlar olarak tanımlamıştır ( Zohir vd,2008). Altın çağ olarak adlandırılan savaş sonrası dönemde meta dışına çıkarılmış olan temel refah hizmetlerinin metalaşması, çalışma devleti (workfare state) uygulamaları, sosyal harcamaların kısılması gibi uygulamalar, temel refah hizmetlerine erişemeyen nüfusu genişletmiş, sosyal dışlanmayı yakıcı bir sorun haline getirmiştir. Her ne kadar başta $A B$ olmak üzere uluslararası örgütler, sorununun çözümü için istihdama katılım ile herkesin kaynaklara, haklara, mallara ve hizmetlere erişiminin kolaylaştırılmasını gerekli adımlar içinde formüle etseler de, benimsedikleri piyasayı hâkim kılan ekonomi politikaları çözüm önerilerini işlevsiz kılmaktadır.

Türkiye endüstrileşme sürecini Avrupa'nın gerisinden takip etmiş, dolayısıyla refah devleti uygulamalarının tarihsel süreci Batı Avrupa ülkelerindekinden farklı bir seyir izlemiştir. Her ne kadar Türkiye'de hiçbir tarihsel dönemde evrensel sağlı hizmetleri kurulamamış, refah hizmetlerine tüm nüfusun eşit erişim olanakları sağlanamamış olsa da, sosyal devlet nitelemesinin anayasal olarak tanındığ 1960'lı yıllardan itibaren temel hizmetlerinin meta dışına çıkarılması yönünde bazı önemli adımlar atılmıştır. Uluslararası dönüşümlere paralel biçimde 1980'li yıllardan itibaren özelleştirmeler, işsizlik oranlarındaki artış, ücretlerin baskı altında tutulması yoluyla işgücü maliyetlerinin düşürülmesi gibi uygulamalar yaygınlaşmış ve refah rejimine rengini vermiştir.

Türkiye'de gerek refah hizmetlerine gerek sosyal dişlanmaya ilişkin literatür çok gelişmemiştir ve daha çok batı merkezli kuramsal tartışmalara odaklanmaktadır. Türkiye'deki uygulamaları ele alan refah devleti çalışmaları ise, daha çok sağlık ve sosyal güvenlik reformu ekseninde geliştirilmiştir. Ülkemizdeki mevcut duruma ve uygulamalara odaklanan az sayıdaki sosyal dışlanma çalışmasının ise göçmenler, engelliler gibi farklı dezavantajlı grupların dışlanma pratiklerini ele aldıkları görülmektedir. Bu çalışmada mevcut literatür ışı̆̆ında ülkemizde refah hizmetlerinden dişlanma, nicel verilerle irdelenmeye çalışılacaktır. TÜİK Hane Halkı Bütçe Anketi 2010 verilerinden yararlanılarak gerçekleştirilen hesaplamalarla, temel refah hizmetlerinden dişlanan nüfusun profili çizilecektir. $\mathrm{Bu}$ anlamda, gerek sosyal dışlanma kavramının ekonomik dışlanma boyutuna odaklanarak, refah hizmetlerine erişimi odak noktasına koyması açısından, gerekse nicel veriler 1şı̆̆ında sosyal dışlanmanın boyutlarını ortaya koyması açısından ülkemizdeki ilgili literatürden farklılaşmaktadır.

Çalışmanın ilk bölümünde refah rejimine ilişkin temel kavramlara kısaca değinildikten sonra, sosyal dışlanma kavramı ele alınacaktır. Ardından refah hizmetlerinden dışlanma sağlık, eğitim, sosyal güvenlik ve sosyal yardımlardan dışlanma başlıkları altında değerlendirilecektir. 


\section{Türkiye Refah Rejimi: Kapsayıcı mı Dışlayıcı mı?}

Türkiye refah rejimine ilişkin kısa değerlendirmemize başlamadan önce kısaca refah devleti kavramının sınırlarını çizmeye çalışacağız. Ancak hatırlatmak gerekir ki, refah devleti üzerine son derece geniş bir literatür bulunmaktadır ve kavramsal tartışma henüz son bulmuş değildir. Bu noktada, burada yalnızca çalışmamız açısından anlamlı mevcut tanımlar içinden araçsal bir seçicilikle kavramın ne olduğu ortaya konmaya çalışılacaktır. Refah Devleti kavramı, 1942 yılında yayınlanan ve refah devleti oluşumunda önemli bir basamak olan Beveridge Raporu ile bireysel refah için beşikten mezara kadar devletin sorumluluğunu belirtme amacıyla kullanılmaya başlanmıştır. Refah devletinin dört tanımlayıcı unsuru, yurttaşlığa dayalı kapsamlı ve evrensel refah uygulamaları; kamusal kaynakların bu alanlara tahsisi, geniş tabanlı bir toplumsal ve siyasal konsensüs ve tam istihdam hedefine yönelik makroekonomik politikalar olarak tanımlanabilir (Topak, 2012: 54). Vaat ettiği, sadece toplumsal hastalıkları hafifletmek ve temel risklerin yeniden dağıtımını gerçekleştirmek değil, aynı zamanda devlet ve yurttaş arasındaki sözleşmeyi yeniden yazmaktır (Anderson, 2006: 34). Asa Briggs (1969’dan aktaran Özdemir, 2007)'in ünlü tanımına göre refah devleti, "piyasa güçlerinin rolünü azaltmak amacıyla, bilinçli bir şekilde örgütlü kamu gücünün kullanıldığı bir devlet türüdür” ve üç alanda faal durumdadır:

- $\quad$ Bireylere ve ailelere, minimum gelir garantisi sağlamak;

- $\quad$ Kişilerin, belirli sosyal risklerin (hastalık, yaşlılık, işsizlik vb.) üstesinden gelmelerine yardımcı olmak;

- Sosyal refah hizmetleri aracılığıyla, tüm vatandaşları en iyi yaşam standartlarına eriştirmek.

Bununla birlikte gerek refah devleti tanımları, gerek refah rejimleri, devletin rolü, devlete yüklenen sorumluluklar ve devlet yurttaş ilişkisi açısından büyük bir çeşitlilik göstermektedir. Ortak bir refah tanımında uzlaşma sağlanamamasının gerekçelerinden biri de budur. Esping-Anderson (1990)'ın ünlü tipolojisi, refah rejimlerinin ne denli farklılaştığını gözler önüne sermektedir. Anderson'un refah rejimi modellemesi olan Sosyal Demokrat (İskandinavya), Muhafazakâr- Korporotist (Almanya) ve Liberal (İngiltere) refah rejimi tipolojisi, Türkiye için açıklama gücüne sahip değildir. Söz konusu modelde kendine bir yer bulamayan Türkiye, refah rejimi sınıflandırmalarında Ferrera'nın Güney Avrupa refah rejimi tipolojisi kapsamında ele alınmaktadır. Ferrera (2006) bu modelin temel özelliklerini aşağıdaki biçimde tanımlamıştır:

- $\quad$ Nakit desteği sistemlerinin işteki statüye dayandırılması ve kurumsal parçalılık

- Sosyal korumanın formel/ enformel sektör arasında kutuplaşmış niteliği

- $\quad$ Özel sektör tarafından sağlanan kısmı genişleyen (kısmen) evrensel ulusal sağlık sistemleri

- $\quad$ Tikelci- klientalist refah devleti

Türkiye'de 2006 yılında başlayan sosyal güvenlik ve sağlık reformları, refah rejiminde önemli bir dönüşüme karşılık gelmektedir. İşteki statüye göre farklılaşan sosyal güvenlik kurumlarının tek çatı altında birleşmesiyle kurumsal parçalılığın ortadan kalkması söz konusu olmuştur. Bununla birlikte, hastanelerin SGK çatısı altında birleştirilerek finansmanla hizmet sunumunun ayrılması, sağlığın sosyal güvenlikle ilişkisini zaafa uğratırken sağlığın yeniden metalaşması sürecine ivme kazandırmıştır (Ünlütürk, Ulutaş, 2011).

Diğer Güney Avrupa ülkelerine benzer biçimde aile, refah karması içinde merkezi bir önem sahiptir. Devletin bakım hizmetlerinde boş bıraktığı alan, piyasa tarafından, daha yaygın biçimde ise aile içinde kadınlar arası dayanışma yoluyla doldurulmaktadır. Yakın döneme değin zayıf ve parçalı bir yapı arz eden sosyal yardım hizmetlerinin boşluğu da aynı biçimde aileler tarafından doldurulmuştur. Bununla birlikte bir yandan yeni yoksulluk biçimi, enformel dayanışma ağlarında zayıflamayı ve kent yoksullarının gıda deposu olma işlevi gören kırla ilişkilerinin zayıflamasını beraberinde getirmiştir (Buğra ve Keyder, 2008). Diğer yandan son yıllarda sosyal yardımlar alanında ortaya çıkan kurumsallaşma ve yardım miktarlarındaki yükseliş dikkat çekicidir. Nitekim sosyal yardım ve hizmetlere ayrılan payın GSYH'ye oranı geçtiğimiz 10 yılda \%0,5"ten \%1,43'e erişmiştir. Bununla birlikte halen sosyal yardımların hak statüsünde genelleşmesi söz konusu değildir ve göreli yoksulluk sınırının altındaki nüfusun çok azı sosyal yardımlara erişebilmektedir.

\section{Sosyal Dışlanma Kavramı ve Tarihsel Gelişimi}

En genel tanımıyla, toplumla bütünleşme sağlayacak ekonomik ve sosyal bir takım haklardan ve kaynaklardan yoksun olmak anlamına gelen sosyal dışlanma kavramı, genel olarak yoksulluk ve yoksunluklar üzerine inşa edilmiştir. Bu yoksulluk ve yoksunluk süreçleri bireyden bireye, ülkeden ülkeye hatta ülkelerin kendi içlerinde bile farklılıklar göstermektedir. Bu durum, üzerinde uzlaşılmış, tek ve sabit bir sosyal dışlanma tanımı yapmayı zorlaştırmaktadır.

Küreselleşme ve küreselleşmeye paralel süreçlerle farklı şekillerde ortaya çıkan sosyal dışlanma kavramı bugün üzerinde durulması ve çözüm bulunması gereken başlıca sorun alanlarının başında gelmektedir. Özellikle yoksulluğun derinleşen yüzü sorunun büyüklüğünü bir kez daha ortaya koymaktadır. Bu anlamda başta Avrupa Birliği olmak üzere birçok ülke sosyal dışlanmayla mücadele için kendi ulusal içerme politikalarını hazırlamaya koyulmuşlardır. Ancak liberal ekonomik politikalara insani bir çehre kazandırma amacından yola çıkan bu programların ne kadar etkili ve ihtiyaca dönük olduğu da büyük tartışmalara sahne olmaktadır. 
Marshall (1999; 150)'a göre sosyal dışlanma, bireylerin ya da hanelerin kaynaklardan yada toplumla sosyal bağlar kurmaktan yoksun bırakılması sürecini ifade eder. İlk olarak 1960'larda Fransa'da kullanılmaya başlanan sosyal dışlanma kavramı, 1980'li yılların ekonomik krizi ve yeniden yapılanma sürecinde, refah devletinin krize girmesiyle daha sık kullanılmaya başlanmıştır. 1960'larda toplumda görülen marjinalleşme durumları için kullanılan dışlanma kavramı; 1980'lere gelindiğinde yaşanan yapısal değişimlerle, eşitsizlik ve yoksullukla birlikte ele alınmaya başlanmıştır. Küreselleşme ve küreselleşmeye paralel süreçlerin kavramın gelişiminde ve ele alınmasındaki etkisi hiç kuşkusuz önemlidir.

Kavramla ilgili yazından anlaşılacağı gibi sosyal dışlanma kavramı, genel olarak birbiriyle örtüşen ve birbirini tamamlayan farklı tanımlamalar içinde ele alınmaktadır. Kavramın çok yönlü ve geniş doğası nedeniyle kavrama, ekonomik, sosyal, politik ve kültürel birçok yan anlam ve boyut yüklenmiştir (Silver;1995: 60). Her ne kadar üzerinde uzlaşılmış bir tanım olmasa da sosyal dışlanma kavramının birçok unsuru içerdiği açıktır. Her şeyden önce sosyal dışlanma kavramı, bireylerin ve grupların yaşadığı yoksunluk ve yetersizlik durumunu ifade etmektedir (Sapancal1; 2003: 19). Yoksunluk, kabaca, bir şeye sahip olamama durumudur. Mutlak yoksunluk yiyecek, giyecek, barınma gibi yaşamı sürdürecek temel ihtiyaçların olmaması ya da kaybedilmesini ifade ederken; göreli yoksunluk kavramı, bireyin kendisini başkalarıyla kıyasladığında yoksun olduğu şeyleri ifade eder (Marshall,1999:828). Tanımdan da anlaşıldığı gibi, yoksunluk kavramı hem bir karş̧laştırma içermekte, hem de sübjektif koşullarla belirlenmektedir. Dolayısıyla yoksunluk süreçlerine odaklanan sosyal dışlanma kavramı, farklı bireyler için farklı anlamlar ifade edebileceği gibi, ülkelerin farklı sosyo-ekonomik ve kültürel değerlerine göre de farkl1lıklar gösterebilmektedir.

Sosyal dışlanma kavramı genel olarak, ekonomik alandan dışlanma, sosyal haklardan ve sosyal dayanışma yöntemlerinden dışlanma, kurumsal yapılardan ve hizmetlerden dışlanma olmak üzere farklı tanımlamalar içinde yer almaktadır. Bu bağlamda ekonomik alandan dışlanma işgücü piyasalarından ve dolayısıyla ücretli bir işe sahip olmaktan dışlanmayla birlikte ele alınırken; sosyal haklardan dışlanma temelde yurttaşlık nosyonuyla birlikte ele alınmaktadır.

Bireylerin temel ihtiyaçlarını karşılamak için yeterli gelirden yoksun olması ekonomik dışlanmayı ifade eder. Gelirden yoksunluğun en büyük nedeni işsizliktir. Özellikle uzun süreli işsizler ekonomik dışlanmanın başlıca aktörleridir. İşsizliğin sosyal, psikolojik ve ekonomik sonuçlarını anlamak ancak çalışmanın, birey ve toplum açısından değerini tanımlamakla mümkündür. En genel ve önemli tanımıyla iş, birey ve ailesi için geçim kaynağı olarak düzenli bir gelir anlamı taşır. Bunun yanında iş, bireye sosyal statü ve kimlik sağlar, yaratıcılığını geliştirir, bireye amaç yaratır, kendine saygı ve işe yarama duygusu oluşturur (Savc1; 2002: 48). Dolayısıyla toplumsal düzenin sağlıklı işleyebilmesi için çalışmak önemli bir değer olarak kabul edilir. Ancak işgücü piyasasından ve düzenli gelirden dışlanmak, ekonomik dışlanmanın sadece bir ayağını oluşturmaktadır. Yapılan işin niteliği ve işgücü piyasası içindeki aktörler arasındaki eşitsizlik de ekonomik dışlanmanın önemli bir parçasıdır. Bu bağlamda, iş güvencesinden, sosyal korumadan ve örgütlenme özgürlüğ̈ünden yoksun, düşük ücretle istihdam edilen bireyler insan onuruna yaraşır çalışma koşullarına ve ücretlere erişememek anlamında dışlanmış sayılmaktadır.

Yurttaşlık haklarından dışlanma ise; toplumdaki önemli ekonomik ve toplumsal firsatlara katılmayı sağlayan ve yaşam standartlarını belirleyen temel haklardan yoksun olma ya da bunlara ulaşamama durumudur (Bryne; 1999: 2). Marshall (1999: 833), yurttaşlık haklarının üç bileşeninden bahseder. Bunlar; medeni haklar, siyasal haklar ve sosyal haklardır. Medeni haklar, bireysel özgürlükleri ifade ederken; siyasal haklar, topluluk içinde siyasal gücün kullanımı sürecine katılmayı güvence altına alır. Sosyal haklar ise, düzgün bir yaşam standardına sahip olma hakkıdır ve bu hak genellikle eğitim, sağlık, konut, sosyal hizmetler gibi kavramlar etrafinda değerlendirilir (Marshall ve Bottomore (2000)'den aktaran Sapancal1; 2003: 32). Yurttaşlık hakları içerisinde özellikle sosyal haklar ayrı bir anlam ifade etmektedir. Çünkü diğer hak ve özgürlüklerin gelişmesi ancak sosyal hakların gerçekleşmesi ölçüsünde mümkün olabilmektedir (Koray (2001)' den aktaran Sapancali; 2003: 33) .

Toplumsal bağlardan ve toplumsal dayanışmadan dışlanma ise Durkheimcı görüşe atıfta bulunur ve "anomi" nosyonuyla birlikte anılır. Durkheim dayanışmayı ele alırken, mekanik ve organik olmak üzere iki tür dayanışma modelinden bahseder. Mekanik dayanışma, birincil dereceden, yüz yüze iliş̧iler yaşayan ve birbirine benzeyen bireylerin geliştirdiği dayanışma şeklidir; genellikle geleneksel toplumlarda görülür. Böyle bir dayanışma, bireylerin artık bireysel kimliklerini kaybedip, kolektif bir varlığın parçası oldukları zaman ortaya çıkar (Sapancal1; 2003: 27). Organik dayanışma ise, uzmanlaşma ve işbölümü sonucu farklılaşan toplumlarda ortaya çıkan dayanışma şeklidir. Bu toplumlarda bireyler arasında benzerliklerden ziyade farklılıklar hâkimdir; dolayısıyla ikincil derece ilişkilerin ve daha kurumsallaşmış ilişkilerin hâkim olduğu, modern toplumlara özgü dayanışma türleridir. $\mathrm{Bu}$ bağlamda sosyal dışlanma, organik dayanışmanın zayıflaması ve bu çerçevede pasif güven mekanizmasının gerilemesiyle ilgilidir (Sapancalı: 2003: 30). Başka bir ifadeyle Durkheimcı yaklaşıma göre sosyal dışlanma, sosyal bütünleşmenin anormal çöküşünün bir sonucudur (Levitas;1996:5).

Kurumsal yapılardan ve hizmetlerden dışlanma, tüm bireylere onurlu bir yaşam sağlayacak devlet destekli barınma, eğitim, sağlık hizmetleri ile sosyal sigorta ve sosyal yardım mekanizmalarından dışlanma anlamına gelmektedir. Özellikle eğitimden ve sağlıktan dışlanma azgelişmişliğin ve yoksulluğun bir göstergesi olarak karşımıza çıkmaktadır. Eğitimden dışlanma ile istihdamdan dışlanma ve gelirden dışlanma doğru orantılı olarak 
kabul edilmelidir. Örneğin; iyi eğitim almamış bir birey meslek edinmekten ve dolayısıyla işgücü piyasasından dışlanmaktadır. Bu durum bireyi aynı zamanda gelirden, tüketimden, konuttan ve sosyal güvenlikten dışlamaktadır (Sapancalı;2003:175). Aynı şekilde sağlıktan ve sosyal güvenlikten dışlanma da, dışlanmanın hem nedeni hem de sonucu olarak karşımıza çıkmaktadır. Sosyal dışlanmanın bu çok yönlü doğasına karşın, çalışmamız yalnızca temel refah hizmetleri olan eğitim, sağlık, sosyal güvenlik ve sosyal yardım hizmetlerinden dışlanma ile sınırlandırılmıştır.

\section{Temel Refah Hizmetlerinden Dışlanma}

\subsection{Eğitim Hizmetlerinden Dışlanma}

Eğitim, çocukluktan başlamak üzere, bireyin gelişimini belirleyen önemli bir aşama olduğu gibi, toplumsal bütünleşmeyi sağlayan katılımcı bir süreçtir. Çocukluk döneminde eğitimden dışlanma, ileriki yaşlarda sosyal dışlanmaya zemin hazırlamaktadır. Eğitimden dışlanmanın toplumsal cinsiyet, etnisite, ailenin sınıfsal konumu, ailenin eğitim düzeyi gibi çok sayıda toplumsal gerekçesi olabilmektedir (Sapancalı, 2003: 176) . Kuşkusuz eğitimin ne ölçüde piyasa ilişkilerinden bağışık kılındığı, tüm yurttaşların eğitim hizmetlerine erişiminin en temel belirleyicisidir.

Eğitim hizmetlerinden dışlananların sağlıklı bir şekilde ortaya konulabilmesi amacıyla herhangi bir öğrenim kurumunda okumakta olanlar dişarıda bırakılarak, bitirilen eğitim kurumu cinsiyet bazında ayrıştırılmıştır. Nüfusun \%8,6'sının bir okul bitirmediği görülürken, bir okul bitirmeyenlerin \% 63,6'lık kısmını kadınların oluşturması, kadınların eğitim hizmetlerinden daha çok dışlandığın gözler önüne sermektedir. İlk derece eğitim kurumlarına kadınlarla erkeklerin erişimi eşit düzeyde iken, öğrenim düzeyi yükseldikçe, söz konusu eşitlik kadınlar aleyhine bozulmaktadır. Kadınlar yükseköğrenim ve lisansüstü öğrenim olanaklarına erişim açısından erkeklere göre bir hayli dezavantajlı konumdadırlar. Eğitim hizmetlerine erişimin kolaylı̆̆ı, öğrenim düzeyinin yüksekliği ile kişilerin diğer refah hizmetlerine erişim olanakları arasında da önemli bir ilişki vardır. Örneğin fakülte mezunlarının \%5,9'u sağlık sigortasından dışlanmışken, bu oran herhangi bir okul bitirmeyenlerde $\% 13,7$ 'dir.

\begin{tabular}{|l|l|l|l|}
\hline & Erkek & Kadın & $\begin{array}{l}\text { Ĕgitim Düzeyine } \\
\text { Göre Toplam } \\
\text { Dağılım }\end{array}$ \\
\hline $\begin{array}{l}\text { Okur Yazar Olup Okul } \\
\text { Bitirmeyenler }\end{array}$ & $36,8 \%$ & $63,2 \%$ & $8,6 \%$ \\
\hline İlkokul & $49,8 \%$ & $50,2 \%$ & $46,1 \%$ \\
\hline İlköğretim & $50,0 \%$ & $50,0 \%$ & $7,2 \%$ \\
\hline Orta Okul & $65,9 \%$ & $34,1 \%$ & $8,2 \%$ \\
\hline Orta Dengi Meslek & $56,7 \%$ & $43,3 \%$ &, $2 \%$ \\
\hline Lise & $55,4 \%$ & $44,6 \%$ & $11,1 \%$ \\
\hline Mesleki/ Teknik Lise & $66,2 \%$ & $33,8 \%$ & $7,9 \%$ \\
\hline Yüksekokul & $57,2 \%$ & $42,8 \%$ & $3,4 \%$ \\
\hline Fakülte & $62,3 \%$ & $37,7 \%$ & $6,7 \%$ \\
\hline Yüksek L., Doktora & $66,1 \%$ & $33,9 \%$ &, $7 \%$ \\
\hline
\end{tabular}

Tablo:1 Cinsiyete Göre Bitirilen Ĕ̈itim Kurumu

\subsection{Sağlık Hizmetlerinden Dışlanma}

Dünya Sağlık Örgütü,1946 yılında imzalanan Anayasası'nda sağlığı "sadece hastalık ve sakatlığın olmayışı değil, bedence, ruhça ve sosyal yönden tam iyilik hali” olarak ele almıştır (WHO, 2006). Bu tanım, sağlığın salt bireysel bir sorun olmadığını, toplumsal bir sorun olduğunu evrensel düzeyde ilan etmesi açısından önemlidir. $\mathrm{Bu}$ anlamda, yurttaşların bir bölümünün sağlık hizmetlerinden dışlanması, önemli bir toplumsal sorun alanıdır. Nitekim hasta veya engelli bireylerin yoksulluk ve sosyal dışlanma riski en yüksek gruplar içinde yer aldıkları bilinmektedir. Çünkü fiziksel veya zihinsel hastalık ya da engelle sahip olmak, bireylerin diğer refah hizmetlerine erişimini de önlemektedir.

Genel bütçeden finanse edilen, evrensel bir sağlık sigortası sitemi, tüm nüfusun sağlığa erişimini sağlayan bir refah uygulamasıdır. Bununla birlikte 1980'li yıllardan itibaren evrensel sağlık sistemine sahip İngiltere gibi ülkelerde dahi sağlık reformları eliyle sağlı̆̆ı yeniden metalaştırılması söz konusu olmuştur. Türkiye'de de reform sonrası özel sigortacılık tekniklerine göre örgütlenmiş olan Genel Sağlık Sigortası (GSS) ile temel teminat paketi daraltılmış, cepten ödemeler artırılmıştır. Tüm nüfusun, prime esas kazancın \%12,5'i düzeyindeki GSS primlerini ödeyerek sağlık sigortası kapsamına alınması hedeflenmiştir. Ancak kişi başına geliri asgari ücretin üçte birinden az olanların primleri devlet tarafından ödenmektedir. Prim borcu olanlar GSS'den yararlanamamakta ve kamusal sağlık hizmetlerine erişememektedirler (Ünlütürk, Ulutaş, 2011).

Sağlık reform sürecinde, reformların tüm nüfusu kapsayacağına ilişkin argümana karşın, nüfusun \%13,5'inin herhangi bir sağlık sigortası bulunmamaktadır. \%15,1'i ise yeşil kart kapsamındadır. Kadınların zorunlu sosyal 
güvenliğe \%51,5'lik oranla göreli olarak yüksek erişimi, hanenin erkek bireyleri üzerinden bağımlı sigortalı olmaları ile ilişkilidir.

\begin{tabular}{|l|l|l|l|}
\hline & Erkek & Kadın & $\begin{array}{l}\text { Sigortalılık } \\
\text { Durumuna Göre } \\
\text { Toplam Dağılım }\end{array}$ \\
\hline Zorunlu Sigortalı & $48,5 \%$ & $51,5 \%$ & $70,3 \%$ \\
\hline Diğer (Banka, Vakıf) & $51,9 \%$ & $48,1 \%$ &, $4 \%$ \\
\hline İsteğe Bağlı Sigorta & $50,2 \%$ & $49,8 \%$ &, $8 \%$ \\
\hline Yeşil Kart & $48,6 \%$ & $51,4 \%$ & $15,1 \%$ \\
\hline $\begin{array}{l}\text { Sağlık Sigortası } \\
\text { Olmayan }\end{array}$ & $56,7 \%$ & $43,3 \%$ & $13,5 \%$ \\
\hline
\end{tabular}

Tablo 2: Să̆lık Sigortası Olanların Cinsiyete Göre Dă̆ılımı

\subsection{Sosyal Güvenlikten Dışlanma}

Uluslararası Sosyal Güvenlik Örgütü’ne göre sosyal güvenlik, yaşlılık, iş göremezlik, sakatlık, işsizlik ya da ölüm gibi durumlarla ile karşı karşıya kalındığında, bireylere gelir güvencesi sağlayan, mevzuat ya da başka bir zorunlu düzenleme ile kurulan sosyal koruma programları olarak tanımlanmaktadır. Tanımdan da anlaşılacağ gibi, sosyal güvenlik sosyal risklerle yakından ilgilidir. Bu anlamda, bireylerin karşılaşabileceği her türlü riski önlemek ve bu riskin ortaya çıkarabileceği zararları azaltmak konusunda bireylere ekonomik güvence sağlamak sosyal güvenlik sisteminin görevidir. Sosyal sigortalar ile sosyal yardım ve hizmetler, sosyal güvenliğin sağlandığı ana bileşenlerdir. Bireylerin sosyal güvenlik gereksinimleri hangi bileşenden karşılanırsa karşılansın, sosyal güvenliğin asıl amacı, gelirin yeniden dağılımı ile sosyal adaletin sağlanmasıdır (Ayhan, 2012). Bu anlamda sosyal güvenlik, tüm bireylerin toplumun bir üyesi olarak sahip olması gereken bir haktır. Ancak bugün dünya genelinde insanların sosyal güvenliğe erişimi oldukça kısıtlıdır. Uluslararası Sosyal Güvenlik örgütünün verilerine göre dünya nüfusunun yalnızca \%50'lik kısmı sosyal güvenlik sisteminin çeşitli formlarına ulaşabilmektedir. Bunların yalnızca \%20'si ise sosyal güvenlik sisteminin tüm edimlerinden yararlanmaktadır. $\mathrm{Bu}$ anlamda sosyal güvenlik sisteminden dişlanma, açık olarak sosyal güvenlik sistemine dâhil olmamaktan kaynaklanabileceği gibi, sosyal güvenlik sistemi içerisinde olduğu halde prim ödeme güçlüğü nedeniyle sosyal güvenliğin tüm edimlerinden yararlanamama şeklinde de karşımıza çıkmaktadır.

\begin{tabular}{|l|l|l|l|}
\hline & Erkek & Kadın & $\begin{array}{l}\text { Sosyal Güvenlik Kurumuna Kayıtlılık } \\
\text { Durumuna Göre Toplam Dağılım }\end{array}$ \\
\hline Kayıtlı & $79,5 \%$ & $20,5 \%$ & $50,2 \%$ \\
\hline Kayıtlı Değil & $60,6 \%$ & $39,4 \%$ & $49,8 \%$ \\
\hline Diğer & $55,1 \%$ & $44,9 \%$ &, $1 \%$ \\
\hline
\end{tabular}

Tablo 3: Cinsiyete Göre Sosyal Güvenlik Kurumuna Kayıtlllık Durumu

Tablo 3'de görüldüğü gibi çalışan bireylerin \%49,8'i herhangi bir sosyal güvenlik kuruluşuna kayıtlı değildir. Sosyal güvenlik kurumuna kayıtlılık durumu kadınlarda $(20,5)$ erkeklere oranla $(\% 56,9)$ daha düşüktür. Sosyal güvencesizliğin kadınsılaşması büyük ölçüde kadınların, cinsiyet eşitsizliği nedeniyle çalışma yaşamına girememesinden, güvencesiz işlerde yoğun olarak çalışmasından kaynaklanmaktadır. Bu durum gerek çalışma çağında gerekse emeklilik döneminde sosyal güvenlik açısından kadınların erkeğe bağımlılığını arttırmaktadır.

\subsection{Sosyal Yardımlardan Dışlanma}

Sosyal yardım, toplumun geleceğini güvence altına almak için devletin yoksul kimselere yiyecek, giyecek, yakacak, tedavi ve ilaç yardımı yapmak ve bunları ilgililerin katkısı olmadan işleten bir sosyal güvenlik aracı olarak tanımlanmaktadır (Ayhan, 2012: 47). Başka bir ifade ile sosyal yardımlar temel gereksinimlerini karşılamaya yetecek düzeyde gelire sahip olamayan bireylere devlet tarafından yapılan karşılıksız yardımlardır. $\mathrm{Bu}$ anlamda sosyal yardımlar, karşılık esasına dayanmaz ve kişilerin sosyal ve ekonomik durumlarından dolayı devletin bir görevi olarak ortaya çıkar.

Aşağıdaki tabloda görüldüğü üzere, ülkemizde sosyal yardımlardan yararlanan bireylerin oranı oldukça sınırlıdır. 2010 yılı itibariyle, 2022 sayılı yasaya göre verilen yaşlılık aylığını alan erkeklerin oranı \%1,3, kadınların oranı ise yalnızca \%2'dir. Sosyal yardımlar açısından da durum değişmemektedir. Kadınlar arasında dul ve yetim aylığı alanlar içinde ise erkeklere göre yüksek oranda olması dikkat çekicidir.

\begin{tabular}{|l|l|l|}
\hline & Erkek & Kadın \\
\hline Yaşlıık Aylığı (yoksullar için) & $\% 1,3$ & $\% 2$ \\
\hline Dul ve Yetim Aylığı & $\% 0,4$ & $\% 6,9$ \\
\hline Gazi-Maluliyet Aylı̆̆ı & $\% 1,2$ & $\% 0,8$ \\
\hline Sosyal Yardım (Nakdi) & $\% 1,3$ & $\% 2$ \\
\hline
\end{tabular}

Tablo 4: Yaşlılık Aylı̆̆l, Dul ve Yetim Aylı̆̆l, Malullük Aylı̆̆ı ve Sosyal Yardım Alanların Cinsiyete Göre Dă̆ılımı 


\section{Sonuç}

Küreselleşme ve buna paralel süreçlerle birlikte, refah hizmetlerine erişimin tüm yurttaşları kapsayan "genellik ilkesinden" ayrılıp, çalışanları temel alan yeni devlet-yurttaş ilişkisine dönmesi toplumun birçok kısmını refah hizmetlerinden dışlanmayla yüz yüze bırakmıştır. Bu noktada, eğitim, sağlık, sosyal güvenlik ve sosyal yardım gibi refah hizmetlerinin toplumun tümünü kapsayacak şekilde düzenlenmesi sosyal dışlanmanın toplumsal alandaki görünürlüğünü azaltacak en önemli araçlardır.

Türkiye'de 2010 yılı itibariyle eğitimden dişlanma hala önemli boyutlardadır. Nüfusun \%8,6'sı okuma yazma bilmezken, \%46,1'i ilkokul mezunudur. Yüksekokul ve üzeri eğitim düzeyine sahip bireylerin oranı ise oldukça düşüktür. Sağlık hizmetlerinden dışlanan bireylerin oranı ise toplam nüfusun $\% 13,5$ 'dir. Nüfusun $\% 15,1$ 'i ise yeşil kart kapsamındadır.

Refah hizmetlerinden dışlanmada dikkat çeken diğer bir nokta ise Refah hizmetlerinden dışlanmanın büyük ölçüde cinsiyet eşitsizliği ile paralel gitmesidir. Öğrenim düzeyi yükseldikçe, kadınların yükseköğrenim ve lisansüstü öğrenim olanaklarına erişimi azalmaktadır. Benzer bir durum sosyal güvenlikten dışlanmada da karşımıza çıkmaktadır. Erkeklerde sosyal güvenlik kurumuna kayıtlılık \%56 iken kadınlarda bu oran \%20'lerdedir. Kadınların çalışma yaşamına düşük oranda girmesi, daha çok atipik işlerde istihdam edilmeleri sosyal güvenlik sisteminden dışlanmalarının başlıca nedenidir.

Sosyal güvenlik sisteminden dışlanma, hiç sosyal güvenlik sistemi kapsamına girmemekle ortaya çıabileceği gibi sosyal güvenlik sistemine dâhil olunduğu halde prim yükümlülüklerinin yerine getirilememesi dolayısıyla sosyal güvenlik edimlerinden dışlanma şeklinde de ortaya çıkabilmektedir. Bireylerin sosyal güvenceden yoksun bırakılmaları sağlık ve güvenlik endişelerini de beraberinde getirmektedir. Sosyal yardımlar alanında ise toplumun önemli bir kısmının bu hizmetlerden yararlanamadığı görülmektedir. Sosyal yardımlara erişimin ç̧şitli koşullara bağlanması, bireylerin bu koşullarını bilmemesi ya da sosyal yardımlara erişimde "damgalanma korkusu" sosyal yardımlardan dışlanmanın önemli nedenleridir.

\section{Kaynakça}

- Andersen, G. E. (2006), “Toplumsal Riskler ve Refah Devletleri”, in Sosyal Politika Yazıları, ed. A. Buğra, Ç. Keyder), İletişim Yayınları, İstanbul.

- Andersen, G. E. (1990),Three Worlds of Welfare Capitalism, Polity Press, Cambridge.

- Bryne D., (1999), Social Exclusion, Open University Press, Buckingham.

- Buğra, A., Keyder, Ç. (2006), “Turkish Welfare Regime in Transformation”, Journal of European Social Policy, 16 (3), s.224- 41.

- Ferrera, M. (2006), “Sosyal Avrupa’da Güney Avrupa Refah Modeli”, in Sosyal Politika Yazıları, ed. A. Buğra, Ç. Keyder), İletişim Yayınları, İstanbul.

- http://www.bracresearch.org/publications/Exclusion_and_Poverty\%20.pdf

- http://www.issa.int/Topics/About-social-security

- Levitas R., (2005), “Three Discourses of Social Exclusion”, in The Inclusive Society, New York: Palgrave MacMillan, p.7-48

- Marshall G., (1999), Sosyoloji Sözlüğü, Bilim ve Sanat Yayınları, Ankara.

- Özdemir, S. (2004), Küreselleşme Sürecinde Refah Devleti, İstanbul, İTO Yayınları.

- Sapancalı F., (2003), Sosyal Dışlanma, Dokuz Eylül Üniversitesi, İktisadi ve İdari Bilimler Fakültesi Yayınları, İzmir.

- Savcı İ., (2001), “İşsizliğin Sosyal Psikolojik Boyutları”, in İşsizlik Özel Sayısı, TES-İŞ Yayını, s.47-52.

- Silver H., (1995), "Reconceptualizing social disadvantage: Three paradigms of Social Exclusion”, in Social Exclusion: Rhetoric, Reality, Responses, ed: G. Rodgers vd, International Institute for Labour Studies, Geneva, p.57-80.

- Ünlütürk Ulutaş, Ç. (2011), Sağlık Emek Sürecinin Dönüşümü, Notabene Yayınları, Ankara.

- Zohir, S. vd. (2008), Exclusion and Poverty: An Analytical Approach for Understanding Exclusion and Assessing Programmes Targeting the Very Poor in Bangladesh, BRAC/ Economic Research Group, Dhaka,

- WHO, (2006), Constitution of the World Health Organization, http://www.who.int/governance/eb/who_constitution_en.pdf). 


\title{
Beşeri Sermayeye Yönelik Eğitim ve Sağlık Alt Yapı Yatırım Harcamalarının Bölgesel Gelir Üzzerindeki Etkisi: Türkiye Örneği The Effect of Human Capital Improvments via Educational and Health Care Infrastructure Investments on Regional Income: The Case of Turkey
}

\author{
Dr. Mehmet Akif Kara (Sütçü İmam University, Turkey) \\ Asst. Prof. Dr. Serkan Ada (Selçuk University, Turkey) \\ Asst. Prof. Dr. Salih Yeşil (Sütçü İmam University, Turkey)
}

\begin{abstract}
Public education and health care infrastructure spending positively affect regional economic performance and develop regional competitive position through increasing workforce efficiency. While this type of investment is viewed as investment toward developing human capital, development of human capital stock may determine innovative forms of economies and technological applications, which can also be spilled over via human capital. Because of this, region wide educational and health care infrastructure spending aimed towards development of human capital can provide an increase in regional income and welfare. This study, aiming to identify effect of educational and health care infrastructure spending on development of human capital at regional level in Turkey, used regional data 2004-2008 Level-2. According to results obtained from the panel data fixed effect method, this type of spending can influence regional income. At regional level, the greatest positive effect has been observed in West Marmara region, the smallest effect was realized in Northeast Anatolian Region.
\end{abstract}

\section{Giriş}

Alt yapı yatırımları, kamu politikalarının bölgesel düzeyde, uzun dönem büyüme ve verimliliği etkileyebilme yolu olarak görülür iken Aschaur(1989)'un bu konudaki çalışma sonuçlarından sonra konuya yönelik ilgilinin artığı gözlemlenmektedir. Aschauer (1989) üretim fonksiyonunu kullanarak, A.B.D ekonomisinde 1949-1985 dönemini kapsayan ulusal verilerle, Alt yapı yatırımları şeklindeki kamu sermayesinin çıktı seviyesine olan katkısını belirlemeye çalışmıştır. Uygulama sonuçlarına göre kamu sermaye stoku ile çıktı seviyesi arasında çok güçlü ve pozitif bir ilişki bulmuş, kamu sermaye stokundaki yüzde 1'lik bir artışın çıktıyı dönemsel olarak 0,38 den 0,56'ya kadar artırdığını belirlemiştir. Ayrıca Aschauer (1989) temel altyapı (core infrastructure) olarak nitelendirdiği ulaşım altyapısının, elektrik ve gaz tesislerinin, su ve kanalizasyon sistemlerinin, çıktı artışlarına neden olan verimlilik artışlarının büyük bir kısmını oluşturduğunu ifade etmekte ve aynı zamanda A.B.D ekonomisinde 1970'li yıllardan sonra gündeme gelen verimlilik azalışlarının sebebinin, kamu sermaye yatırımlarındaki azalış olduğunu belirlemektedir. Benzer şekilde Munnell (1990)'da ulusal verilerle yaptığ çalışmasında Aschauer'in çalışmasına yakın sonuçlar bulmuşken, 1970-1986 yılları arası eyalet verileriyle yaptığı çalışmasında kamu sermayesindeki yüzde 1'lik artışın ulusal çıktıyı 0,15 civarında artırdığını bulmuştur. Bulduğu katsayıya bağlı olarak da, kamu sermayesinin marjinal verimliliğinin özel sermayeye yakın olduğunu ifade etmektedir. Holtz-Eakin (1994) ise 1969-1986 arası 48 ABD eyalet verileriyle yaptığ çalışmada alt yap1 yatırımları şeklindeki kamu sermayesinin verimlilik üzerindeki etkisini belirlemeye çalışmıştır. Holtz-Eakin bu konuda daha önce yapılan çalışmalarda kamu sermaye birikimi ile özel sektör verimliliği arasında olumlu anlamda bir ilişkinin varlığının belirlendiği ancak, eyalete özgü gözlenemeyen özelliklerin dikkate alınmadığı, bunun dikkate alınması halinde kamu sermayesinin özel sektör verimliliği üzerinde önemli bir etkisinin bulunmadığını ifade etmektedir. Ulaşılan sonuçlar bu konuda yapılan uygulamalı çalışmaları artırır iken, bu çalışmaların bir kısmı ulusal ekonomileri dikkate almış, bir kısmı ise bölgesel ekonomileri dikkate alarak söz konusu alt yapı yatırımlarının bölgesel ekonomiler üzerindeki etkilerine yoğunlaşmıştır (Seitz ve Licht, 1995; Holtz-Eakin ve Schwartz, 1995; Moomaw v.d, 1995; Lau ve Sin, 1997; Fuente ve Vives, 1995; Pereira ve Sagales, 1999; Kumar, 2002; Nijkamp ve Poot, 2004 Pereira ve Andraz, 2006)

Gramlich(1994) alt yapı yatırımlarını; karayolu, diğer ulaşım imkânları, su ve kanalizasyon hattı, haberleşme sistemi gibi büyük sermaye yoğunluğu gerektiren doğal monopoller olarak tanımlanırken, alternatif tanımlama olarak da, kamu sektörünün sahip olduğu maddi sermaye stokuna odaklanılması gerekliliğini belirlemektedir. Kamunun beşeri sermaye, araştırma ve geliştirme yatırımlarını ise, bu tanımlamanın genişletilmiş şekli olarak ifade etmektedir. Hansen(1965) ve Capello(2007)'da, alt yap1 yatırımlarını, ekonomik alt yap1 ve sosyal alt yap1 yatırımları olarak ikiye ayırmakta ve ulaşım imkânları, yollar, otoyollar, demiryolları, havaalanı ve elektrik üretim merkezleri gibi ekonomik verimliliği daha fazla artıran yatırımları, ekonomik alt yapı olarak tanımlarken, sosyal alt yapı yatırımlarını ise beşeri sermayeyi geliştirici ve sosyal hizmetleri içeren okullar, sağlık tesisleri ve spor tesisleri şeklinde tanımlamaktadırlar. Bu sınıflandırmadan hareketle alt yapı yatırımlarının bölgesel ekonomiler üzerindeki etkisini, ekonomik ve sosyal alt yapı yatırımları açısından değerlendirmek mümkündür. 
Bu çalışmada da literatürdeki bu ayrımdan da yararlanılarak, Türkiye'de kamunun beşeri sermayeyi geliştirmeye yönelik eğitim ve sağlık harcamalarının bölgesel gelir üzerindeki etkisi bir uygulanmayla belirlenmeye çalışılacaktır.

\section{Teorik Çerçeve}

Beşeri sermayenin ekonomideki rolü içsel büyüme modelleriyle gündeme gelirken, bu modellerden biri olan Lucas(1988)'in beşeri sermaye modelinde, sermaye fiziksel ve beşeri sermaye olarak ikiye ayrılmış ve Lucas, beşeri sermayeyi de üretim fonksiyonuna dâhil ederek fiziksel ve beşeri sermaye birikimlerinin etkileşimlerine odaklanmıştır. Bu şekilde belirlenmiş Cobb-Douglass üretim fonksiyonu ise aşağıdaki şekildedir (Faggian ve McCann, 2009 ; Capello, 2008).

$$
Y_{t}=A K_{t}^{\alpha}\left(u_{t} H_{t} L_{t}\right)^{1-\alpha} H_{t}^{\phi}
$$

$\mathrm{Bu}$ eşitlikte $(K)$ fiziksel sermaye $(L)$ fiziksel çalışanların sayısı, $(u)$ her bir çalışanın öğrenmeye yönelik aktivitelerine ayırdığı zaman, $(H)$ ise, beşeri sermayedir ve çalışanların bilgi birikimi ve beceri elde edici çalışmalara ayırdığı zamana bağlı olarak gerçekleşmektedir. Böylelikle beşeri sermayenin gelişimi;

$$
h_{t}=H_{t} \lambda\left(1-u_{t}\right)
$$

Şeklinde ifade edilebilir. Bu eşitlikte $(h)$, zaman içerisinde beşeri sermayenin büyüme oranını, $(H)$ beşeri sermaye stokunu (1-u) eğitime ayrılan zamanı ve $(\lambda)$ ise, öğrenme yeteneğidir ve ulaştığı bilgi düzeyi açısından doğrusal ve pozitif olduğu varsayılabilmektedir. $(u)$ zaman içerisinde sabitse, çıktıdaki büyüme oranı basit bir şekilde, yukarıdaki iki eşitliğin logaritmik yapıya dönüştürülmesiyle elde edilebilecektir (Capello,2008: 243).

$$
y_{t}=\alpha k_{t}+(1-\alpha) l_{t}+(1-\alpha+\phi) h
$$

Bu eşitlikte $y, k, l$ ve $h$ sırasıyla çıktıdaki, fiziksel sermayedeki, işgücü ve beşeri sermayede, $t$ zamanında gerçekleşen büyüme oranını ifade etmektedir. Beşeri sermayedeki büyüme oranını ifade eden eşitliği tekrar bu eşitlikte dikkate alarak, işçi başına çıktıda büyüme ile ifade ettiğimizde;

$$
y_{t}-l_{t}=\alpha\left(k_{t}-l_{t}\right)+(1-\alpha+\phi) \lambda\left(1-u_{t}\right)
$$

Eşitliğini elde ederiz. Durağan durumda burada sermaye ve işgücü büyüme oranları eşitse, $\alpha\left(k_{t}-l_{t}\right)=0$ olacaktır. Bu durumda iki içsel değişken, işçi başına çıktıdaki büyümeye imkân sağlayabilecektir. Bunlar ekonomik sistemin artan getirisini mümkün kılabilen $(\phi)$ parametresiyle vurgulanan kalifiye işgücü piyasalarının dışsallıkları ve içsel olarak beşeri sermaye birikiminin belirleyicisi olan öğrenme yeteneğidir( $\lambda)$ (Capello,2008).

Diğer yandan alt yapı yatırımlarıyla ilgili yapılan sınıflandırmalarda eğitim ve sağlık gibi sosyal alt yapı yatırımları, beşeri sermayeyi geliştirici yatırımlar olarak kabul edilirken (Hansen, 1965 ; Capello, 2007), teorik ve uygulamalı çalışmalarda da beşeri sermaye, yenilikler ve teknoloji uygulama ve birikimlerinin arkasındaki temel faktör olarak görülmektedir (Manca, 2011).

Beşeri sermayenin, üretim sürecine ek bir girdi olarak faktör verimliliğini artırabildiği ve teknolojik yenilikler ve teknolojik yayılıma olan katkısı yoluyla da büyüme üzerinde dinamik bir etkisinin olabileceği belirtilmektedir. Bu doğrultuda beşeri sermayenin ekonomik büyümeyi nasıl etkileyebileceğine yönelik iki temel yaklaşımın varlığı dikkati çekmektedir. İlki beşeri sermaye üretim sürecinde bir girdidir ve ima ettiği şey, beşeri sermaye stokunun artırılması çıktı seviyesini artırabilecektir. Bunun anlamı ise büyüme ve beşeri sermaye değişimi arasında bir korelasyon olabileceğidir. İkinci yaklaşım ise, beşeri sermaye stokunun, ekonominin yenilikçi ya da yeni teknoloji uygulamalarının belirleyicisi olması ve bunun yayılımına olan katkısı nedeniyle verimlilik artışlarının kaynağı olarak görülmektedirler. Diğer yandan teorik yaklaşımlarda, beşeri sermayenin büyüme üzerindeki etkisine yönelik geniş bir destek söz konusu iken, uygulamalı çalışmalardaki sonuçlarda kullanılan verilere ve tahmin yöntemlerine bağlı olarak tam bir netlik oluşmamaktadır (Jimenes, 2003).

Benzer biçimde Sanroma ve Ramos (2007), bu konudaki çalışmaların bir kısmının yerel beşeri sermaye ile ilgili dışsal ekonomilerin varlığına dayandığını, bir kısmının ise çeşitli üretim faktörleri özelliklede beşeri sermaye ve fiziksel sermaye arasındaki tamamlayıcılık ilişkilerinin ön plana çıkarıldığını belirlemektedirler. Beşeri sermayenin dışsal etkisi, resmi ve resmi olmayan etkileşim yoluyla çalışanlar arasında bilgi ve becerinin paylaşımıyla, bilginin büyümesi ve yayılmasıyla gerçekleşebilmektedir. Bilginin bu paylaşımı ve gelişimi ise faktör verimliliğini artırabilecektir (Rauch: 1991). Diğer yandan yüksek beşeri sermayenin seviyesine sahip bölgelere firmaların daha fazla yatırım yapacağına yönelik bir varsayım söz konusudur. Bu yatırımlar yalnızca verimli işgücünün verimliliğini değil, aynı zamanda düşük vasıflı işgücünün verimliliğini artırabilecektir. $\mathrm{Bu}$ süreç bölgenin verimlilik ve ücret seviyesini artırabilirken, bölgenin yaşam yeri olarak tercihini ve okullaşma düzeyine yönelik düşünceleri etkileyebilecektir (Sanroma ve Ramos, 2007). 
Eğitim ve diğer alt yapı yatırımlarının, verimliliği ve özel faktör yerleşim yerlerinin değişkenliğini etkileyebileceğini ifade eden Fuente ve Vives (1995)'da, politikalarla bu faktörlerin desteklenmesinin bölgesel dengesizlikleri azaltmakta kullanılabileceğini belirlemektedirler. Aynı zamanda bölgelerin rekabetçi yapısının büyük ölçüde, işgücünün kalitesine bağlı olduğu, eğitim yapısı ve beşeri sermayenin bölgesel rekabetin önemli bir belirleyicisi olduğu ifade edilmektedir. Bu durum ise bölgelerin işsizlik oranı ve vasıflı işgücü arasında negatif yönlü bir ilişkinin varlığı yoluyla ortaya konulmaktadır. Eğitime erişim ve beşeri sermaye seviyesinin yükseltilmesi yerel, bölgesel ve ulusal düzeyde tüm ekonominin uzun dönem beklentilerinin en önemli belirleyicisi olabilmektedir (Taylor, 2001).

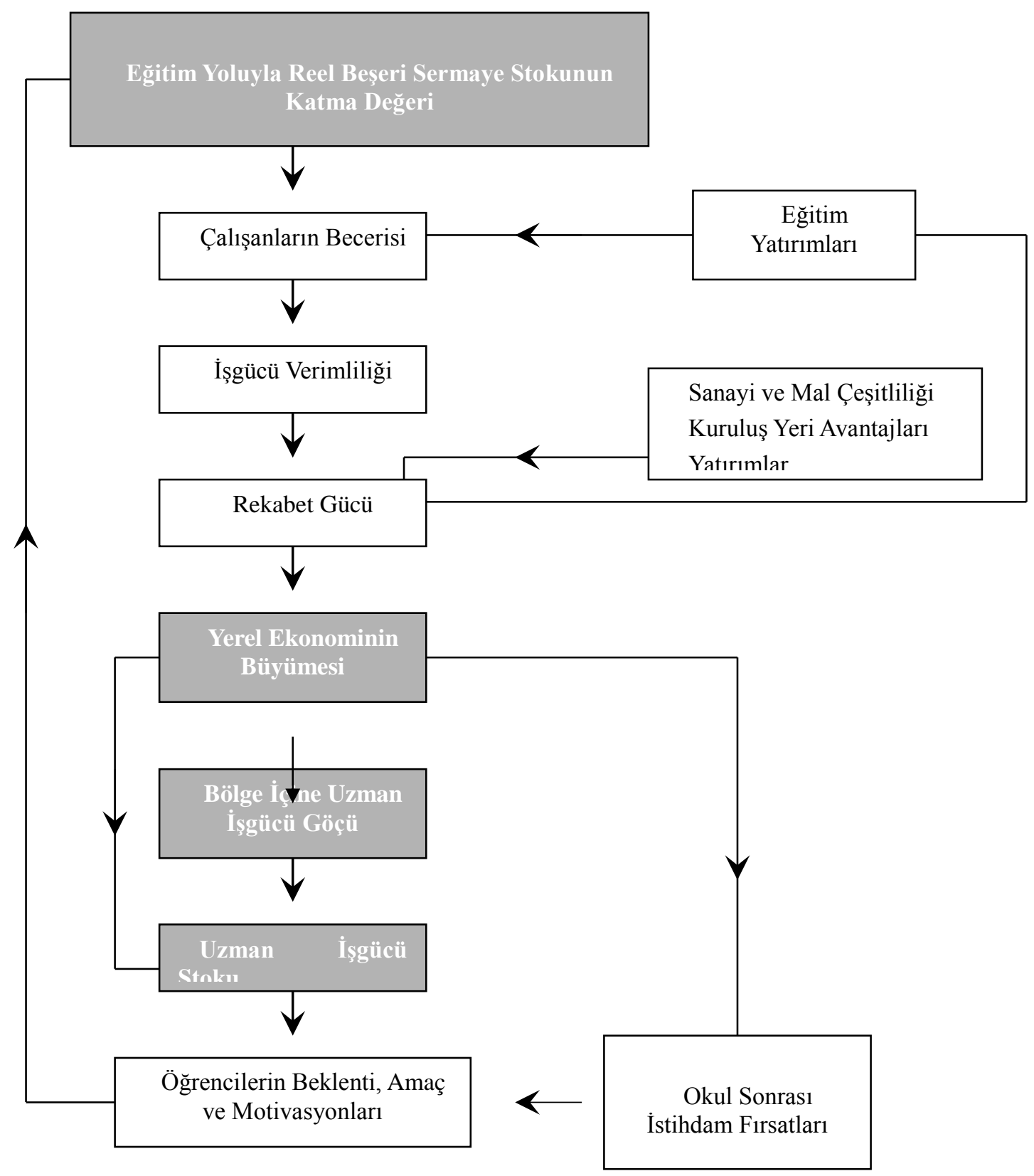

Şekil.1. Beşeri Sermaye Yapısı ve Yerel Ekonomik Performans (Bradley ve Taylor, 1996)

Bradley ve Taylor (1996) ise, Eğitim sistemi ve yerel ekonomi arasındaki etkileşimi inceledikleri çalışmalarında, bu etkileşimi üç değişkeni tanımlayarak modellemektedirler. Bu değişkenler ise, yerel eğitim sisteminin çıktısı, vasıflı işgücü stoku ve yerel ekonomik performanstır. Yerel eğitim sisteminin çıktı düzeyi, yerel ortamın sosyo-ekonomik yapısı, eğitime erişimin istihdam firsatlarını artırabileceğine yönelik düşüncenin varlığı ve okulların kalitesi tarafindan belirlenirken, ekonomik performans üzerinde önemli bir rol oynayan vasıflı işgücünü ise, yerel eğitim sisteminden işgücü piyasasına yeni katılanların beceri seviyesi, yerel piyasalara göç eden işgücünün beceri seviyesi ve işgücünün niteliklerini artırmaya yönelik mesleki eğitimin varlığ belirlemektedir. Yerel ekonomik performansı da onun rekabetçi yapısı belirlerken rekabetçi yapıyı da, göreceli fiyatlar, üretim maliyetleri, faktör verimliliği, ürün bileşimi ve ürün kalitesi belirleyebilmektedir. Dolayısıyla 
yerel eğitim sisteminin ekonomik performans üzerindeki etkisi eğitimin faktör verimliliğine olan katkısıyla gündeme gelebilmektedir. Bu üç değişken arasındaki etkileşimi yukarıdaki şekil.1. yoluyla görmek mümkündür. Bu modele göre alınan, eğitim yerel işgücünün beceri seviyesini uzun dönemde doğrudan etkilemektedir. Bu ise sonuçta yerel rekabet ve buna bağlı olarak ekonomik performansı belirleyerek, yerel piyasaya göç eden işgücünün meslek çeşitliliğini ve hacmini etkilemektedir. Meslek yapısındaki yüksek becerili işgücüne doğru bir kayış ise, eğitimli işgücünün beceri seviyesini daha fazla fayda sağlayıcı biçimde etkileyebilecektir. Ancak eğitim çıktısının yerel ekonomik performans ve işgücü yapısı üzerindeki etkisinde zaman gecikmesi olabilmektedir. Bu etki kısa dönemde küçük olabilir iken, zaman süreci uzadıkça yükselebilmektedir. Benzer şekilde yerel ekonomik performanstaki gelişim, eğitim seviyesini zamanla artırabilecek ve zaman içerisinde yüksek becerili işgücünün bölgeye göçü yoluyla yerel işgücü yapısını etkileyebilecektir. Dolayısıyla uzun dönemde ekonomik performans, eğitim çıktısının kalitesini etkileyebilirken, eğitim çıktısının kalitesi de ekonomik performansı etkileyebilmektedir (Bradley ve Taylor, 1996).

Bradley ve Taylor (1996) yaptıkları çalışma sonuçlarında ise, Birikimli sürece bağlı olarak yerel eğitim sistemi ve sosyo-ekonomik yapının etkileşimlerinin yerel ekonomik performansı belirleyebileceğini ifade ederek, yetersiz sosyo ekonomik alt yapının ve yetersiz ekonomik performansın, yetersiz eğitim sistemiyle açıklanabileceği tespitini yapmaktadırlar. Ekonomik ve sosyal yapıdaki yetersizliklerin ve eğitim sistemindeki eksikliklerin kendi kendini besleyerek, bu yapının sürekliliğini gündeme getirebileceğini, bu sürecin tersine çevrilebilmesi için devlet müdahalesinin gerekliliğini belirlemektedirler. Bu doğrultuda öncelikle mesleki eğitim ve eğitim sisteminin yetersiz olduğu bölgelerde işgücünün kalitesini geliştirebilmek amacıyla daha fazla yatırıma ihtiyaç duyulduğunu, ayrıca bu bölgelerin ekonomik gelişimi için işgücünün beceri seviyesinin yükseltilmesi gerekliliğini ifade etmektedirler.

\section{Ekonometrik Metodoloji}

Türkiye'de bölgesel düzeyde gerçekleştirilen eğitim ve sağlık alt yapı harcamalarının bölgesel gelir üzerindeki etkisini belirlemeyi amaçlayan uygulamada, panel veri analizi kullanılacaktır. Panel veri analizi, zaman serileri ile yatay kesit serilerinin birleştirildiği ekonometrik tahmin yöntemi olarak tanımlanabilecektir (Greene, 2012). Zaman serisi ve yatay kesit regresyonlarından farklı bir panel veri regresyonu aşağıdaki biçimde ifade edilebilecektir (Baltagi, 2005)

$$
Y_{i t}=\alpha+\beta_{k} X_{k i t}+\varepsilon_{i t} \quad i=1 \ldots \ldots . . N ; t=1 \ldots \ldots T
$$

Bu eşitlikte $Y$ bağımlı değişken, $\alpha$ sabit terim, $X_{k}$ gözlenebilen açıklayıcı değişken $i$ yatay kesit birimlerini, $t$ zamanı, $\beta$ ise gözlenebilen açıklayıcı değişkenin tahmin edilen katsayısını gösterir iken, $\varepsilon$ 'de hata terimlerini göstermektedir. Eğer hata terimi;

$$
\varepsilon_{i t}=\mu_{i}+v_{i t}
$$

Şeklinde ise, bu eşitlikte $\mu_{i}$ kesitlerin gözlenemeyen bireysel etkilerini ve $v_{i t}$ de hata teriminin kalan kısmını temsil ediyorsa modelin, tek yönlü hata bileşenine sahip olmasından (Baltagi, 2005:11), eğer hata terimi hem gözlenemeyen bireysel etkileri, hem de gözlenemeyen zaman etkisini içeriyorsa çift yönlü hata bileşenine sahip olmasından söz edilir (Baltagi, 2005). Bu durumda hata terimi;

$$
\varepsilon_{i t}=\mu_{i}+\lambda_{t}+v_{i t}
$$

Şeklinde olacaktır. Bu eşitlikte, $\lambda_{t}$ gözlenemeyen zaman etkisi ifade etmekte ve hata terimine eklenmektedir.

Panel veri regresyonu, farklı varsayımlara bağlı olarak Sabit Etkiler (Fixed Effect) ve Rassal Etkiler (Random Effect) yöntemleriyle tahmin edilebilmektedir. Sabit etkiler yönteminde gözlenemeyen etkiler modele kukla değişkenler yoluyla dahil edilirken, gözlenemeyen etkilerle açıklayıcı değişkenler arasında korelasyon olduğu varsayılmaktadır (Dougherty, 2011).

Panel veriye dayalı uygulamalı çalışmalarda her iki modelin de kullanıldığı görülmekle birlikte, özellikle de yatay kesit birimlerinin büyük ve zaman serisinin küçük olduğu durumlarda her iki yöntemin tahmin sonuçları farklılıklar arz edebilmektedir (Baltagi, 1998). Bu durumda hangi yöntemin kullanılması gerektiği sorusu akla gelmektedir. Genel olarak ifade edilecek olursa, yatay kesit geniş bir popülasyondan geliyorsa ve amacımız popülasyon hakkında çıkarımlar yapmaksa rassal etkiler modeli, eğer amacımız belirli yatay kesit birimleri hakkında çıkarımlar yapmaksa sabit etkiler modeli uygun olacaktır (Atıcı ve Güloğlu, 2006). Ayrıca modelin seçiminde literatürde, gözlenmeyen değişkenlerin, açıklayıcı değişkenlerle arasındaki korelasyonunu belirlemeye yönelik Hausman (1978) testinin kullanıldığı görülmektedir. Bu teste göre;

$$
\begin{gathered}
\mathrm{H}_{0}: \mathrm{E}\left(\varepsilon \mid \mathrm{X}_{\mathrm{it}}\right)=0 \\
\mathrm{H}_{1}:\left(\varepsilon \mid \mathrm{X}_{\mathrm{it}}\right) \neq 0
\end{gathered}
$$


Sıfır hipotezi, gözlenmeyen etkilerle açıklayıcı değişkenler arasında korelasyon olmadığını ifade eder iken sıfır hipotezinin kabul edilmesi Rassal Etkiler modelinin etkin olduğunu, reddedilmesi ise gözlenemeyen etkilerle açıklayıcı değişkenler arasında korelasyon olduğunu ve sabit etkiler modelinin etkin olduğunu ifade etmektedir (Baltagi, 2005 ; Wooldridge, 2002).

Türkiye ekonomisinde, devletin alt yapı yatırımlarının bölgesel gelir üzerindeki etkilerini belirlemeye yönelik oluşturulacak bizim modelimizde, bölgelere göre oluşturulacak yatay kesitlerin geniş bir ana kütleden rastgele seçilmiş örnekler olmaması, bölgelerin tamamının dikkate alınması ve yapılan Hausman test sonuçlarının sıfır hipotezini reddetmesi gibi nedenlerle sabit etkiler yöntemi kullanılacaktır. Ayrıca alt yapı yatırımlarının bölgesel düzeyde etkilerini belirlemeye yönelik yapılan uygulamalı çalışmalarda da, bu yöntemin sıkça kullanıldığı görülmektedir (Percoco, 2004 ; Lall, 2007 ; Sloboda ve Yao, 2008). Diğer yandan sabit etkiler modelinde bireysel etkilerin ve zaman etkisinin olup olmadığına, yani kukla değişkenlerin anlamlılığına yönelik olarak da $\mathrm{F}$ testi yapılmaktadır (Baltagi, 2005 : Greene, 2012). Ancak yatay kesit ya da zaman serisinden bir tanesinin küçük ve diğerinin büyük olması durumunda Greene (2012), modelde daha büyük olan veri seti için, tek yönlü sabit etkilerin, yani kukla değişkenin kullanılabileceğini belirtmektedir. Bizim modelimizde de yatay kesit serisi daha büyük olduğu için, yatay kesit için sabit etkiler kullanılmıştır.

\subsection{Ekonometrik Model ve Veri Seti}

Literatürde alt yapı yatırımlarının bölgesel çıktı veya bölgesel gelir üzerindeki etkisinin belirlenmesinde üretim fonksiyonunun kullanıldığı ve üretim fonksiyonuna sermaye ve emeğe ilave bir girdi olarak alt yapı yatırımları şeklindeki kamu sermayesinin eklendiği görülmektedir (Aschauer, 1989 ; Munnell, 1990 ; Button, 1998 ; Percoco, 2004 ; Rosik, 2006). Bu şekildeki Cobb-Douglas üretim fonksiyonunu aşağıdaki şekilde belirlemek mümkündür.

$$
Y=A K^{\alpha} L^{\beta} G^{\gamma}
$$

Bu fonksiyonda $(Y)$ çıktıyı, $(A)$ teknoloji seviyesi ya da teknolojik değişimi, $(K)$ özel sermaye stokunu, $(L)$ işgücünü ve $(G)$ 'de alt yapı yatırımları şeklindeki kamu sermaye stokunu ifade etmektedir. Bu üretim fonksiyonunu logaritması alındığında aşağıdaki eşitlik elde edilir;

$$
\ln Y_{i t}=\alpha+\beta \ln K_{i t}+\varphi \ln L_{i t}+\gamma \ln G_{i t, \text { sosyal alty. }}+\varepsilon_{i t}
$$

$\mathrm{Bu}$ eşitlikte $\beta, \varphi, \gamma$ sırasıyla çıktının, özel sermayeye, işgücüne ve alt yapı yatırımları şeklindeki kamu sermayesine olan duyarlılığını göstermektedir. Alt yapı yatırımları şeklindeki kamu sermayesi üretim fonksiyonun ek girdisi olarak çıktıyı doğrudan etkileyebilir iken, aynı zamanda işgücü ve sermaye gibi özel girdilerin kullanımını etkileme yoluyla toplam üretimi dolaylı yönden de etkileyebilmektedir (Pereira ve RocaSagales, 2003).

Yukarıdaki (2) nolu model, ulaşılabilen veriler açısından 2004-2008 dönemi itibariyle Türkiye'de Düzey-2 bölgeleri için panel veri sabit etkiler yöntemiyle tahmin edilmiş ve modeldeki alt yapı yatırımları şeklindeki kamu sermayesi için eğitim ve sağlık alt yapı yatırım harcamalarının toplamı kullanılmıştır. Çalışmada 20042008 Düzey-2 bölgesi verileri kullanılmıştır. Bu dönemin verilerinin kullanılma sebebi ise, 2002 yılında yapılan İstatistikî Bölge Birimleri Sınıflamasından (NUTS) sonra yayınlanan Düzey-2 bölgelerinin gelir seviyesinin 2004-2008 dönemiyle sınırlı olmasıdır. Diğer yandan bu model bölgelerle ilgili ortalama değerleri vermektedir ve modelin bölgelere özgü değerlerini bulmak amacıyla da Düzey-2 verileri Düzey-1'e dönüştürülmüş ve bu model ayrı ayrı Düzey-1 Bölgeleri için de oluşturulmuştur. Ancak İstanbul ve Doğu Karadeniz Düzey-1 bölgeleri, tek alt Düzey-2 bölgesine sahip olduğu ve panel veri yönteminde, tek yatay kesitte kullanılamadığı için İstanbul, Batı Marmara bölgesine eklenmiş ve Marmara bölgesi olarak, Doğu Karadeniz ise Batı Karadeniz bölgesine eklenmiş ve Karadeniz bölgesi olarak tahmin edilmeye çalışılmıştır. Modelde kullanılan bölgesel gelir ve işgücü verileri Türkiye İstatistik Kurumunun bölgesel istatistiklerinden alınmıştır. Bölgesel düzeyde özel sermaye verileri bulunmadığı için, sanayi elektrik tüketimi bu veriye yaklaşık bir değer olarak kullanılmıştır. Uygulamalı çalışmalarda özel sermaye stokunun bulunmadığ durumlarda elektrik tüketim verilerinin kullanıldığı görülmektedir (Moody, 1974 ; Schnorbus ve Israilevich, 1987 ; Pirili ve Lenger, 2011). Modeldeki kamunun alt yapı yatırımlarına ilişkin veriler ise DPT’nin yayınladığı kamu yatırımlarının illere göre sektörel dağılım verilerinde yer alan alt yapı harcama türleri, Düzey-2 bölgelerine dönüştürülerek elde edilmiştir. Aynı zamanda bu harcama türleri yine Türkiye İstatistik Kurumunun bölgesel istatistikleri içerisinde yer alan Düzey-2 bölgeleri fiyat indekslerinin kullanılması yoluyla reel harcamalara dönüştürülmüştür. Bölgesel düzeyde kamunun net alt yap1 yatırımları sermaye stokunu hesaplayabilmek amacıyla da, literatürde kullanılması tavsiye edilen sürekli envanter yöntemi(perpetual inventory method) kullanılmıştır. Bu yöntem aşağıdaki şekilde ifade edilmektedir (Jacop vd, 1997).

$$
G_{i t}=(1-\delta) G_{t-1}+g_{i t}
$$

Bu eşitlikte $G_{t}$ net alt yapı kamu sermaye stokunu, $g_{t}$ zaman içerisinde yapılan reel alt yapı yatırımlarını, $\delta$ aşınma payını göstermektedir. Bu yönteme göre kamu sermaye stoku, önceki yılın aşınma payı ile brüt alt yapı 
sermaye stoku arasındaki farkla elde edilen önceki yılın net alt yapı sermaye stokuna mevcut alt yapı şeklindeki kamu yatırımlarının eklenmesiyle hesaplanmaktadır. Ancak modelimizde 2003 yılı alt yapı sermaye stoku olmadığı için 2004 yılı için sermaye stoku aşağıdaki eşitlik yoluyla belirlenebilecektir.

$$
G_{i t}=\sum_{j=0}^{L}(1-d)^{j} g_{i, t-j}
$$

Burada $L$ yatırımların ömrünü gösterir iken, yapılan çalışmalarda bu yatırımların ömrünün yirmi yıl olduğu ve buna göre aşınma payı oranının 0.05 olacağı belirtilmiştir (Pirili ve Lenger, 2011). Oluşturulan modellerde de, alt yapı harcama türleri ile ilgili ifade edilen bu uygulamalar yapılmıştır.

\subsection{Tahmin Sonuçları}

Modellerle ilgili tahminler, E-Views 6 ekonometrik paket programında, panel veri sabit etkiler yöntemiyle yapılmıştır. Oluşturulan modellerle ilgili yapılan Hausman test sonuçlarının sıfır hipotezini reddettiği ve sabit etkileri kabul ettiğini görmekteyiz. Ayrıca yapılan Heteroscedasticty testi LMh ve Otokorelasyon testi LM-stat'a göre de, modelde otokorelasyon ve heteroscedasticty sorunlarının varlığı görülmektedir. Her iki sorunda, Ewiws 6 ekonometrik paket programındaki Cross Section SUR opsiyonuyla giderilmiştir.

Bu çerçevede, eğitim ve sağlık alt yapı harcamalarının toplamının alındı̆̆ı ve sosyal alt yapı harcamaları diye ifade edilen (2) nolu modelin tüm Düzey-2 bölgeleri için tahmin sonuçları ise aşağıdaki tabloda yer almaktadır.

\begin{tabular}{|l|l|l|l|}
\hline \multicolumn{5}{|l|}{ Sosyal Alt Yapı Harcamalarl } \\
\hline Değişkenl. & Katsay1 & Stn.Hata & Ihtimal \\
\hline $\operatorname{lnG}_{\text {sos.altyapı }}$ & 0.24 & 0.0146 & 0.0000 \\
\hline LnK & 0.10 & 0.0685 & 0.1299 \\
\hline $\mathrm{LnL}$ & 0.15 & 0.0628 & 0.0185 \\
\hline Sabit & 22.43 & 1.0073 & 0.0000 \\
\hline $\mathrm{R}^{2}$ & 0.99 & & \\
\hline $\mathrm{N}$ & 26 & & \\
\hline Top.gözlem & 130 & & \\
\hline Testler & İstatistik & İhtimal \\
Hausman & 28.7852 & 0.0000 \\
Heteroscedasticty 50.2401 & 0.0019 \\
Autocorr. LM-Stat 9.4162 & 0.0021 \\
\hline
\end{tabular}

Tablo.1.Sosyal Alt Yapı Harcamalarının Genel Olarak Bölgesel Gelir Üzerindeki Etkisi

Tahmin sonuçlarına göre, kamunun eğitim ve sağlık harcamalarından oluşan sosyal alt yapı yatıımlarının genel olarak bölgesel geliri pozitif etkilediği ve bu sonucunda istatistiki olarak \% 1 seviyesinde anlamlı olduğu görülmektedir. Özel sermaye ve işgücü de bölgesel geliri pozitif etkilerken işgücü katsayısının istatistiki olarak anlamlı özel sermayenin ise anlamsız olduğu belirlenmiştir. Diğer yandan modele bağlı olarak, kamunun sosyal alt yapı harcama türlerinin Düzey-1 bölgeleri için tahmin sonuçları ise aşă̆ıdaki tabloda yer almaktadır.

$\mathrm{Bu}$ tahmin sonuçlarına göre de, beşeri sermayeyi geliștirmeye yönelik sosyal alt yapı harcamalarının tüm Düzey-1 bölgelerinde bölgesel geliri olumlu anlamda etkilediği ve bu sonuçların Batı Anadolu dışında tüm bölgelerde istatistiki olarak anlamlı olduğu görülmektedir. Beşeri sermayeyi artırmaya yönelik alt yapı harcamaları bölgesel gelire en büyük katkıyı Batı Marmara'da sağlarken, Doğu Marmara, Orta Anadolu Akdeniz, Karadeniz, Ege ve Güneydoğu Anadolu bölgelerinde bu harcama türünün bölgesel gelire katkıs1 bölgesel ortalama civarında veya üzerindedir. Bölgesel gelire en düşük katkı ise ülkemizin görece en az gelişmiş bölgelerinden biri olan Kuzeydoğu Anadolu bölgesinde gerçekleşirken, yine görece geri kalmış bir diğer bölge olan Ortadoğu Anadolu bölgesinde de bu katkı bölgesel ortalamanın altında gerçekleşmiştir.

\section{Sonuç}

Bölgesel rekabet kavramının bölgesel ekonomik politikaları şekillendirdiği günümüzde, bu politikalar sadece belirli kaynakları geri kalmış bölgelere yönlendirme ve geri kalmış bölgelerde bazı faaliyetlerin desteklemesinin yanında, bölgelerin rekabet gücünü geliştirmeye yönelik politika araçlarına da ağırlık verildiği görülmektedir. Bu politika araçları içerisinde değerlendirilebilecek beşeri sermayeyi artırmaya yönelik eğitim ve sağlık alt yapı yatıımlarının sağladığı hizmetler, hem özel sermayenin hem de işgücünün verimliliğini artırabilme yoluyla çıktıda ve özel sektör yatırımlarında artı̧ sağlayabilmekte ve firmaların kuruluş yeri tercihinde belirleyici bir faktör olabilmektedir. Ayrıca kamunun beşeri sermayeye yönelik alt yapı yatırım harcamalarındaki artış kısa vadede çoğaltan etkisi, uzun vadede ise verimlilik artışlarının ortaya çıkarabileceği fiyat azalışlarıyla talebi teşvik edebilecek ve talep etkisi de tüm üretimde ve istihdamda artış yaratabilecektir. Aynı zamanda kamunun bu 
alt yapı yatırım türü işgücünün verimliliğini artırabilmesi nedeniyle şehirlerin, bölgelerin ve ulusların rekabetçi yapılarının geliştirilmesine imkân sağlayabilecektir.

$\mathrm{Bu}$ çerçevede eğitim ve sağlık alt yapı harcamalarının Türkiye'de bölgesel gelir üzerindeki etkilerini belirlemeye yönelik, 2004-2008 yılları itibariyle ve panel veri sabit etkiler yöntemiyle yapılan uygulama sonuçlarından da görüldüğü üzere, bu harcama türlerinin bölgesel gelire pozitif katkı sağladığı ve dolayısıyla bir bölgesel ekonomik politika aracı olarak kullanılabileceği söylenebilecektir. Ancak bu harcama türünün en fazla katkıyı, Türkiye'nin görece en gelişmiş bölgeleri olan Batı Marmara ve Doğu Marmara bölgelerine, en az katkıyı ise ülkenin görece en geri kalmış bölgeleri olan Kuzeydoğu Anadolu ve Ortadoğu Anadolu bölgelerine sağladığ1 dikkate alındığında, bazı bölgeler için bölgeler arası ekonomik gelişmişlik farklılığını artırdığı da ifade edilebilecektir. Diğer yandan Karadeniz, Güneydoğu Anadolu gibi yine ülkemizin görece geri kalmış bölgelerinde bu katkının bölge ortalamaları civarında olması nedeniyle, özellikle Kuzeydoğu Anadolu ve Ortadoğu Anadolu Bölgelerinde kamunun yaptığı eğitim ve sağlı alt yapı harcamalarını yeniden gözden geçirme zorunluluğu ortaya çıkmaktadır.

\begin{tabular}{|l|l|}
\hline Bölgeler & Sosyal Alt Yapı Harcamalarl(Katsayl) \\
\hline Batı Marmara & 0.46 \\
& $(0.1120)$ \\
& {$[0.0024]$} \\
\hline Ege & 0.25 \\
& $(0.0569]$ \\
& {$[0.0016]$} \\
\hline Doğu Marmara & 0.41 \\
& $(0.0919)$ \\
& {$[0.0063]$} \\
\hline Batı Anadolu & 0.11 \\
& $(0.1013)$ \\
\hline Akdeniz & {$[0.2946]$} \\
\hline Orta Anadolu & 0.34 \\
& $(0.00408)$ \\
& {$[0.0000]$} \\
\hline Karadeniz & 0.39 \\
& $(0.0313)$ \\
& {$[0.0001]$} \\
\hline Kuzeydoğu Anadolu & 0.28 \\
& $(0.0599)$ \\
& {$[0.0004]$} \\
\hline Ortadoğu Anadolu & 0.12 \\
& $(0.0010)$ \\
& {$[0.0001]$} \\
\hline & 0.22 \\
& $(0.0295)$ \\
& {$[0.0006]$} \\
\hline & 0.25 \\
& $(0.0475)$ \\
& {$[0.0005]$} \\
\hline
\end{tabular}

Tablo.2. Sosyal Alt Yapı Yatırımlarının Her Bir Düzey-1 Bölgesi Geliri Üzerindeki Etkisi Not: Dış bükey parantez değerleri standart hatayl, köşseli parantez değerleri ise anlamlılık değerlerini göstermektedir.

\section{Kaynakça}

- Aschauer, D. A., 1989. “Is Public Expenditure Productive?”, Journal of Monetary Economics, 23(2), pp. 177-200.

- Atıcı, C. ve Güloğlu. B., 2006. “Gravity Model of Turkey’s Fresh and Processed Fruit and Vegetables Export to the EU”. Journal of International Food\&Agribusiness Marketing, 18(3/4), pp.7-21.

- Baltagi, H.B., 1998. "Panel Data Method” Ulah A and Giles D.E.A(eds) Handbook of Applied Economic Statistics. pp. 291-323.

- Baltagi, H.B.,2005. Econometric Analysis of Panel Data, Third Edition, John Wiley- Sons Ltd., Chichester. 
- Bradley, S. and Taylor. J., 1996. "Human Capital Formation and Local Economic Performance", Regional Studies, 30 (1), pp. 1-14.

- Button K., 1998. "Infrastructure Investment, Endogenous Growth and Economic Convergence", The Annals of Regional Science, 32(1), pp.145-162.

- Capello, R.,1999., 2007. Regional Economics, Routledge, London.

- Dougherty, C., 2011. Introduction to Econometrics, Fourth Edition, Oxford Üniversty Press, England.

- Faggian, A. and McCann. P., 2009. "Human Capital and Regional Development” in CAPELLO, R. ve NIJKAMP, P.(eds), Handbook of Regional Growth and Development Theories, Massachusets, Edvard Elgar, pp.133-151.

- $\quad$ Fuente, A. and Vives. E., 1995. "Infrastructure and Education as Instruments of Regional Policy, Evidence from Spain”, Economic Policy, 10(20), pp. 13-51.

- Gramlich, E. M., 1994. "Infrastructure Investment: a Review Essay", Journal of Economic Literature, 32(3), pp. 1176-1196.

- Greene, W. H., 2012. Econometric Analysis, New Jersey: Seventh Edition, Prentice Hall. New York

- Hansen, N. M., 1965. "The Structure and Determinants of Local Public Investment Expenditures" The Review of Economics and Statistics, 47(2), pp.150-162.

- Hausman, J. A., 1978. "Specification Tests in Econometrics”, Econometrica, 43, pp.727-738.

- Holtz-Eakın D., 1994. "Public Sector Capital and the Productivity Puzzle", Review of Economics and Statistics, 76, pp. 12-21.

- Holtz-Eakın, D. and Schwartz. A. E., 1995. "Spatial Productivity Spillovers from Public Infrastructure: Evidence from State Highways", International Tax and Public Finance, 2(3), pp.459-468.

- Jacob, V., Scharma, S. C. and Grabowsk1. R., 1997. "Capital Stock Estimates for Major Sectors and Disaggregated Manufacturing in Selected OECD Countries”, Applied Economics, 29(5), ss. 563-579.

- Jimenez, S. M., 2003. "Efficiency and TFP Growth in the Spanish Regions: The Role of Human and Public Capital", Growth and Change, 34(2), pp. 157-174.

- Kumar, T.R. ,2002. “The Impact of Regional Infrastructure Investment in India”. Regional Studies, 36(2), pp.194-200

- Lall, S. V., 2007. "Infrastructure and Regional Growth, Growth Dynamics and Policy Relevance for India", The Annals of Regional Science, 41(3), pp.581-601.

- $\quad$ Lau, S. P. and Sin. C., 1997. "Public Infrastructure and Economic Growth: Time-Series Properties and Evidence”, The Economic Record, 73(221), pp. 125-135.

- Lucas, R. E., 1988. “On the Mechanics of Economic Development.” Journal of Monetary Economics, 22(1), pp. 3-42

- Manca, F., 2011. "Human Capital Composition and Economic Growth at the Regional Level", Regional Studies, pp.1-22

- Moody, C. E., 1974 “The Measurement of Capital Services by Electrical Energy”, Oxford Bulletin of Economics and Statistics, 36(1), pp. 45-52.

- Moomaw, R. L., Mullen, J. K., and Williams. M., 1995. "The Interregional Impact of Infrastructure Capital”, Southern Economic Journal, 61(3), pp.830-845.

- Munnell A. H., 1990. “How Does Public Infrastructure Affect Regional Economic Performance?” New England Economic Review, Federal Reserve Bank of Boston, pp. 11-32.

- Nijkamp, P., and Poot. J., 2004. "Meta-analysis of the Effect of Fiscal Policies on Long-Run Growth", European Journal of Political Economy, 20(1), pp.91-124.

- Percoco, M., 2004. "Infrastructure and Economic Efficiency in Italian Regions", Networks and Spatial Economics, 4(4), pp. 361-78.

- $\quad$ Pereira, A. M. and Andraz. M. J.,2006. "Public Investment in Transportation Infrastructures and Regional Asymmetries in Portugal", Annals of Regional Science, 40(4), pp. 803-819.

- Pereira, A. M., and Sagales. O. R., 1999. "Public Capital Formation and Regional Development in Spain", Review of Development Economics, 3(3) ss. 281-294.

- $\quad$ Pereira, A. M., and Sagales. O. R., 2003.“Spillover Effects of Public Capital Formation: Evidence from the Spanish Regions”, Journal of Urban Economics, 53(2), pp. 238-256. 
- Pirili, M. ve Lenger. A., 2011. “The Role Of Public Capital İn Regional Economy” International Workshop on Regional Competitiveness and International Factor Movements, Laboratoire d'Economie d'OrleansNetwork for Economic Research-INFER, 17-18 March 2011 France, pp.1-30.

- $\quad$ Rosik, P., 2006. "Public Capital and Regional Economic Growth" Poznan Universty of Economics, 6(1), pp.69-93. http://www.puereview.ue.poznan.pl/2006v6n1/04-rosik.pdf

- Schnorbus, H. R. and Israilevich. R.P., 1987. "The Midwest Manufacturing Index: The Chicago Fed's regional Economic Indicator", FRB-Chicago-Economic Perspectives, 1(5), pp.3-7.

- Seitz, H. and Licht. G., 1995 “The İmpact of Public Infrastructure Capital on Regional Manufacturing Production Cost”, Regional Studies, 29(3) pp.231-240.

- Sloboda, B. W., and Yao. V. W., 2008. "Interstate Spillovers of Private Capital and Public Spending” Annual Regional Science, 42(3), pp.505-518.

- Taylor, J., 2001. “Geographical Income Disparities Within Countries: Is Regional Policy the Answer?, pp.136, http://www.lancs.ac.uk

- Wooldridge, J. M., 2002. Econometric Analysis of Cross Section and Panel Data, MIT Press. London. 


\title{
Yükseköğretimin Büyümeye Etkisi: Eşbütünleşme Analizi The Effect of Higher Education on Growth: A Cointegration Analysis
}

\author{
Asst. Prof. Dr. Murat Mustafa Kutlutürk (Çankırı Karatekin University, Turkey) \\ Assoc. Prof. Dr. Hakan Kasım Akmaz (Çankırı Karatekin University, Turkey) \\ Assoc. Prof. Dr. Ahmet Çetin (Çankırı Karatekin University, Turkey)
}

\begin{abstract}
In this study the relationship between higher education and economic growth was investigated using annual data between 1988 and 2012 for Turkey. To see short and long run effects of higher education on growth the Autoregressive Distributed Lag (ARDL) testing approach was used. In this investigation ratio of higher education graduates in employment was used as an explanatory variable. Zivot and Andrews test was implemented for the variables. The long and short run effects of higher education on growth was found significant. Granger causality test was implemented and one way Granger causality from higher education to growth was determined.
\end{abstract}

\section{Giriş}

İktisadi olgu ve olayların içinde en önemli yeri tutan ekonomik büyüme birçok teorik yaklaşıma konu olmaktadır. Büyümenin önemli faktörlerinden beşeri sermayenin etkisi üzerine mikro ve makro düzlemde araştırmaların önemli bir kısmı eğitim özelinde yoğunlaşmaktadır. Özellikle beşeri sermayenin verimliliğinin arttırılması sürecinde eğitimin doğrudan ve dolaylı etkileri araştırma konusu olarak literatürde önemini korumaktadır. Beşeri sermayedeki iyileşmenin temelde iki farklı etkisinden söz edilebilir. Bu etkiler yeni bilgilerin üretilmesi ve yayılması ile üretim sürecindeki çalışanların yeni teknikleri kullanması şeklinde kendini göstermektedir. Bu bağlamda kamu ve özel eğitim kurumlarındaki her düzeydeki formal eğitim yanında çalışan bireylerin bulundukları iş pozisyonlarına göre yeni geliştirilen teknolojileri kullanmaları için aldıkları eğitimler, hayat boyu öğrenme programları, buluşların genellikle ön plana çıtı̆̆ı lisansüstü programlar bu olgular arasında yerini almaktadır.

Bu çalışmada yükseköğretim ile ekonomik büyüme arasındaki ilişki toplam istihdam içindeki yükseköğretim payı dikkate alınarak incelenmiştir. Bunun için 1988-2012 dönemine ait yükseköğretim mezunlarının istihdam içindeki oranı ile GSYİH değişkenleri kullanılmıştır. Yükseköğretim mezunu olarak istihdam edilen kişi sayısı ve toplam istihdam sayısına ait veriler TÜİK, GSYİH verileri ise Dünya Bankası resmi internet sitesinden alınmıştır.

\section{Literatür Taraması}

Bir ülkenin iktisadi büyümesini etkileyen en önemli unsurlardan birisi insan faktörüdür. Literatürde bu faktör "beşeri sermaye" kavramıla belirtilmiştir. Bu kavram ise bir birey veya topluluğun mal, hizmet veya fikir üretimi sürecinde kullanılmak üzere sahip oldukları bilgi, beceri ve yeteneklerini tanımlamaktadır (OECD, 1998; Westphalen, 1999). Bu tanımlamadan da anlaşıldığı üzere beşeri sermayenin ve dolayısıyla ekonomik büyümenin en önemli etkenlerinden birisi eğitimdir (Mankiw, vd., 1992; Lucas, 1988; Romer, 1990; Nelson ve Phelps 1966). Eğitim ve ekonomik büyüme ilişkisi üzerine yapılan çalışmalar incelendiğinde aralarında pozitif bir ilişki olduğu sonucu ortaya konmuştur (Barro, 1991; Keller, 2006).

Ekonomik kalkınmanın en önemli yollarından birisi de istihdam edilen işgücünün nicelik yanında niteliğinin de arttırılmasıdır. Bu doğrultuda verimlilik düzeyinin yükselmesinde eğitimin rolü büyüktür. Türkiye için eğitimin ekonomik büyüme üzerindeki etkilerine yönelik yapılan çalışmalarda, farklı eğitim seviyelerindeki öğrenci sayıları ve ekonomik büyüme arasındaki ilişki incelenmiştir. 1923-2011 dönemini kapsayan çalışmada (Çalışkan, vd., 2013), eğitimin büyüme üzerindeki etkisi eşbütünleşme analizi ile incelenmiştir. Bu çalışmada, yükseköğretim ve lise seviyesindeki öğrenci sayısındaki artışın ekonomik büyümeyi etkilediği, ilköğretim ve meslek lisesi seviyesindeki öğrenci sayısı artışının büyüme üzerinde etkisi olmadığı tespit edilmiştir. 1923-2005 yıllarını kapsayan çalışmada (Özsoy, 2009), ilköğretim, orta öğretim, yükseköğretim, mesleki ve teknik eğitim olmak üzere farklı eğitim kademelerinin ekonomik büyüme üzerine etkisini incelemiştir. VAR modeli ile gerçekleştirilen eşbütünleşme analizi sonucunda eğitim ile büyüme arasında uzun dönemli bir ilişki bulunmuştur. Özellikle mesleki ve teknik eğitim başta olmak üzere eğitim ile GSYİH arasında nedensellik ilişkisi olduğu saptanmıştır.

$\mathrm{Bu}$ çalışmaların yanı sıra eğitim ve ekonomik büyüme ilişkisi yükseköğretim seviyesi ele alınarak da incelenmiştir. 1970-2008 dönemini kapsayan çalışmada (Erdem ve Tuğcu, 2010), Türkiye ekonomisinde ekonomik büyüme ile yükseköğretim arasında kısa ve uzun dönemli ilişkinin varlığı incelenmiştir. ARDL 
(Autoregressive Distributed Lag) ile Dolado ve Lütkepohl Granger Nedensellik analizinin kullanıldığı bu çalışmada yükseköğretimin ekonomik büyüme ile eşbütünleşik olduğu ve aralarında nedensellik ilişkisi bulunduğu tespit edilmiştir. 1970-2006 yılları arasındaki çalışmada (Özsoy, 2008), VAR modeli kullanılarak ekonomik büyüme ile yükseköğretim arasında uzun dönemli bir bağıntı ve iki değişken arasında nedensellik ilişkisi olduğu belirtilmiştir. 1980-2010 dönemi için yapılan çalışmada (Özşahin ve Karaçor, 2013), yükseköğretime yapılan harcamanın ve yükseköğretim kayıtlarındaki artışın ekonomik büyümeyi olumlu etkilediği bulgusu saptanmıştır. 2002 yılına ait çalışmada (Tekin ve Çiftçi, 2005) yatay veri setiyle kümeleme analizi ve regresyon analizleri kullanılarak farklı eğitim seviyelerine sahip işgücünün kişi başına düşen GSYİH ile ilişkisi OECD ülkeleri için incelenmiştir. İş gücü kalitesinin artması ile kişi başına düşen GSYİH’nın arttı̆̆ tespit edilmiştir. 1968-2006 yıllarını kapsayan çalışmada (Telatar ve Terzi, 2010), Granger nedensellik ve VAR analizi kullanılarak ekonomik büyüme, nüfus ve eğitim arasındaki ilişki incelenmiştir. Çalışma sonucunda kişi başına düşen gelirden yükseköğretim mezun sayısına ve meslek lisesi mezun sayısından kişi başına düşen gelire doğru pozitif bir nedensellik ilişsisi bulunmuştur.

Eğitim ile büyüme arasındaki ilişkiyi inceleyen diğer ülkelere yönelik yapılan çalışmalarda benzer bulgulara ulaşılmıştır. 1970-2003 döneminde Nijerya'ya yönelik çalışmada (Babatunde ve Adefabi, 2005), eğitim ile ekonomik büyüme arasında uzun dönemli bir ilişkinin varlığı araştırılmıştır. Johansen eşbütünleşme tekniği ve Vektör Hata Düzeltme (Vector Error Correction, VEC) modelinin kullanıldığı bu çalışmada iyi eğitimli işgücünün üretim fonksiyonunun önemli bir faktörü olduğu ve toplam faktör verimliliğini artırarak büyüme üzerinde uzun dönem etkisinin olduğu belirlenmiştir. 1965-1999 yıllarına ait verilerle Uganda için yapılan çalışmada (Musila ve Belassi, 2004), çalışan kişi başına düşen eğitim harcamalarının kısa ve uzun dönem ekonomik büyüme üzerinde anlamlı ve pozitif bir etkisinin olduğu bulunmuştur. 1978-2007 yıllarını kapsayan çalışmada (Kreishan ve Hawarin, 2011), VEC modeli kapsamında Ürdün için eğitim ve ekonomik büyüme arasında eşbütünleşme ve nedensellik ilişkisi incelenmiştir. Çalışmada eğitimli çalışanlar ilk, orta, lisans ve lisansüstü mezunu olmak üzere dört kategoriye ayrılmış ve elde edilen bulgular sonucunda yükseköğretimin ekonomik büyüme üzerinde pozitif bir etkisinin olduğu, ilk ve ortaögretimin ise etkisinin olmadığ ortaya konmuştur. 1970-2010 dönemini kapsayan çalışmada (Hussin vd., 2012), Malezya için eğitim ile ekonomik büyüme arasındaki uzun dönem ilişkiye bakılmış, VAR metodu kullanılarak eğitim harcamaları ile ekonomik büyüme arasında eşbütünleşme olduğu belirlenmiştir. 1960-2000 dönemini kapsayan veriler kullanılarak Yunanistan'a yönelik yapılan çalışmada (Tsamadias ve Prontzas, 2012), eğitimin ekonomik büyüme üzerinde pozitif ve anlamlı bir etkisi olduğu saptanmıştır. 1952-1999 döneminde Çin Halk Cumhuriyeti için ARDL metodu kullanılarak yapılan çalışmada (Narayan ve Smyth, 2006), kısa dönemde yükseköğretimin reel gelir üzerinde pozitif bir etkisi olduğu gösterilmiştir.

\section{Model ve Metodoloji}

Çalışmada ekonomik büyümenin göstergesi olarak reel GSYİH (milyar TL) alınmıştır. Yükseköğretimin büyümeye etkisini incelemede kullanılacak açıklayıcı değişken olarak istihdam edilen yükseköğretim mezunu sayısının toplam istihdam sayısına oranı seçilmiştir. Bu oran istihdamın niteliksel anlamda farklılaşmasının bir göstergesi olarak ele alınmıştır. 1988-2012 dönemine ait 25 yıllık veri kullanılmıştır. GSYİH verileri Dünya Bankası, istihdam verileri ise TÜİK resmi internet sitelerinden alınmıştır. Kullanılacak model

$$
Y_{t}=\beta_{0}+\beta_{1} U I O_{t}+\varepsilon_{t}
$$

olarak belirlenmiştir. Burada Y reel GSYİH ve UIO yükseköğretim mezunu olup istihdam edilen kişi sayısının toplam istihdam sayısına oranıdır.

Zaman serisi verilerinin karakteristik özelliklerini ortaya koyabilmek amaciyla geliştirilen Augmented DickeyFuller ve Phillips-Perron testleri yapısal kırılmanın olmadığı varsayımı altında birim kök analizini yapabilmek için kullanılmıştır (Dickey ve Fuller, 1981; Phillips ve Perron, 1988). Bunlara ek olarak yapısal kırılma varsayımı altında uygulanmak üzere geliştirilen Zivot ve Andrews birim kök testi de uygulanmıştır (Zivot ve Andrews, 1992). Yapısal kırılmayı içsel bir olgu olarak irdeleyen Zivot ve Andrews birim kök testi ortalamadaki kırılma, eğimdeki kırılma ve her ikisinin birlikte olduğu üç durumu sınamaktadır. Kırılma yılının tespitinden sonra elde edilen $t$ istatistik değeri ilgili kritik t-değerlerinden küçükse $H_{0}$ : Yapısal kırılmayla birim kök vardır hipotezi reddedilir. UIO ile Y arasındaki eşbütünleşme ilişkisini ARDL yöntemi ile incelemek amacıyla ilk aşamada

$$
\Delta Y_{t}=c_{0}+c_{1} Y_{t-1}+c_{2} U I O_{t-1}+\sum_{i=1}^{m} c_{3 i} \Delta Y_{t-i}+\sum_{i=0}^{m} c_{4 i} \Delta U I O_{t-i}+u_{t}
$$

modeli kullanılarak sınır testi olarak adlandırılan yaklaşım uygulanmıştır. Burada $\Delta$ fark operatörü, $m$ gecikme uzunluğudur. Değişkenler arasında eşbütünleşme olmadığını belirten $H_{0}$ hipotezi $H_{0}: c_{1}=c_{2}=0$ şeklinde 
tanımlanmış olup $H_{1}: c_{1} \neq c_{2} \neq 0$ alternatif hipotezine karşı F-istatistiği kullanılarak test edilmiştir. Elde edilen F-istatistiği değeri, üst kritik değerden yüksek ise değişkenler arasında eşbütünleşme ilişkisi olduğu, alt kritik değerden düşük ise ilişki olmadığı sonucuna ulaşılmaktadır. Hesaplanan F-istatistiği değeri alt ve üst kritik değerlerin arasında ise ilişkinin varlığı hakkında kesin bir sonuca ulaşılamamaktadır. Modelin uygun gecikme sayısının belirlenmesinde AIC ve SIC kriterleri kullanılmıştır.

Sınır testi sonucunda değişkenler arasında eşbütünleşme olduğunun belirlenmesiyle uzun ve kısa dönem ilişkilerin incelenebilmesi için sırasıyla (3) ve (4) nolu ARDL modelleri kurulmuştur.

$Y_{t}=c_{0}+\sum_{i=1}^{m} c_{1 i} Y_{t-i}+\sum_{i=0}^{m} c_{2 i} U I O_{t-i}+u_{t}$

$\Delta Y_{t}=c_{0}+c_{1} E C T_{t-1}+\sum_{i=1}^{m} c_{2 i} \Delta Y_{t-i}+\sum_{i=0}^{m} c_{3 i} \Delta U I O_{t-i}+u_{t}$

Son olarak Granger nedensellik analizi değişkenlerin birbirini hangi yönde etkilediğini test etmek için kullanılmıştır.

\section{Araştırma Bulguları ve Değerlendirme}

Zaman serilerinde verilerin sahte regresyon ihtimaline karşı durağanlıklarından emin olmak için birim kök analizlerinden Augmented Dickey-Fuller (ADF) ve Phillips-Perron (PP) testleri uygulanmış ve sonuçlar Tablo 1 'de özetlenmiştir.

\begin{tabular}{|l|l|l|l|l|}
\hline Değişken & ADF & PP \\
\hline & Sabit & Sabit,trend & Sabit & Sabit,trend \\
\hline $\mathrm{Y}$ & $0.8241[0]$ & $-1.7783[0]$ & $1.1660[3]$ & $-1.8567[1]$ \\
\hline $\mathrm{UIO}$ & $3.7315[0]$ & $-2.0408[2]$ & $9.1750[21]$ & $-0.6484[12]$ \\
\hline$\Delta \mathrm{Y}$ & $-4.6120[0] * * *$ & $-4.7293[0] * * *$ & $-4.6105[2] * * *$ & $-4.7730[3] * * *$ \\
\hline$\Delta \mathrm{UIO}$ & $-1.3785[2]$ & $-5.6421[1]^{* * *}$ & $-2.9092[3] *$ & $-9.4794[22]^{* * *}$ \\
\hline
\end{tabular}

Not: $* * *: \% 1 ; * *: \% 5 ; \quad *: \% 10$ düzeyinde istatistiksel olarak anlamlılı̆̆

Tablo 1: Birim kök testi sonuçları (yapısal kırılma dikkate alınmadan)

Y ve UIO değişkenleri düzeyde durağan çıkmamış ancak birinci farkları alındığında seriler durağan hale gelmiştir. Yapısal kırılma durumunda durağanlığı test etmek için Zivot ve Andrews testi uygulanmıştır ve sonuçlar Tablo 2'de sunulmuştur.

\begin{tabular}{|l|l|l|l|l|l|}
\hline Değişken & Model & Gecikme & t-istatistiği & Kırılma yılı & Sonuç \\
\hline \multirow{4}{*}{ Y } & A & 0 & -2.9291 & 2005 & $\mathrm{I}(1)$ \\
\cline { 2 - 6 } & $\mathrm{B}$ & 0 & -3.3702 & 2002 & $\mathrm{I}(1)$ \\
\cline { 2 - 6 } & $\mathrm{C}$ & 0 & -3.7387 & 2001 & $\mathrm{I}(1)$ \\
\hline \multirow{3}{*}{ UIO } & $\mathrm{A}$ & 2 & -3.1260 & 2002 & $\mathrm{I}(1)$ \\
\cline { 2 - 6 } & $\mathrm{B}$ & 2 & $-4.5651^{*}$ & 2000 & $\mathrm{I}(0)$ \\
\cline { 2 - 6 } & $\mathrm{C}$ & 2 & -4.2703 & 2000 & $\mathrm{I}(1)$ \\
\hline
\end{tabular}

Not: ***: \%1; **:\%5; *:\%10 düzeyinde istatistiksel olarak anlamlılığ $\breve{g}_{1}$ ifade etmektedir.

Tablo 2: Zivot-Andrews yapısal kırılma testi sonuçları

Zivot ve Andrews test sonuçları verilerin yapısal kırılmaların dikkate alınması durumunda Model B haricinde durağan olmadığını göstermektedir. Model farklı yıllar için kesme ve eğim kukla değişkenleri önermekle beraber bu önermelerin hiç biri istatistiki olarak anlamlı çıkmadığı için modele dahil edilmemişlerdir.

\begin{tabular}{|l|l|l|}
\hline Gecikme Say1s1 & AIC & SIC \\
\hline 1 & 5.5026 & 5.8482 \\
\hline 2 & 5.5116 & 5.9579 \\
\hline 3 & 5.3778 & 5.9250 \\
\hline 4 & 5.2421 & 5.8894 \\
\hline
\end{tabular}

Tablo 3: Sınır testi sonuçları

Hesaplanan AIC ve SIC değerlerine göre uygun gecikme uzunluğu 4 olarak hesaplanmıştır. Breusch-Godfrey serisel korelasyon LM testine göre 4 gecikme uzunluğunda otokorelasyon olmadığ 1 belirlenmiştir. Hesaplanan F-istatistiği değeri 7.5023 bulunmuş olup tablo üst kritik sınırı olan 7.30 değerini geçtiği için $H_{0}$ hipotezi reddedilmiştir. Bu da değişkenler arasında eşbütünleşme ilişkisi olduğunu göstermektedir. Değişkenler arasında eşbütünleşme olduğu için ARDL modelleri kullanarak uzun ve kısa dönem ilişkilerin varlığı incelenebilir. 


\subsection{ARDL modeli}

Değişkenler arasındaki uzun dönem ilişkinin araştırılması için oluşturulan ARDL modelinden SIC kriteri kullanılarak uygun gecikme sayısı elde edilmiştir. Burada gecikme sayısı $(1,0)$ olarak belirlenmiş ve elde edilen modelin tahmini ve uzun dönem ilişki değerleri Tablo 4 ve Tablo 5'de özetlenmiştir. Uzun dönem ilişkilere ait katsayı tahminleri beklentilere uygun ve 0.01 anlamlılık düzeyinde istatistiki olarak anlamlı çıkmıştır.

\begin{tabular}{|l|l|l|}
\hline Değişken & Katsay1 & t istatistiği \\
\hline C & 12.6840 & $2.5084^{* *}$ \\
\hline UIO & 2.6224 & $2.7836^{* *}$ \\
\hline Y(-1) & 0.5127 & $2.7040^{* *}$ \\
\hline
\end{tabular}

Tablo 4: Schwarz Bayesian Kriterine göre ARDL(1,0) modeli tahmin sonuçları

\begin{tabular}{|l|l|c|}
\hline Değişken & Katsay1 & t istatistiği \\
\hline C & 26.0314 & $6.9004 * * *$ \\
\hline UIO & 5.3819 & $13.5807 * * *$ \\
\hline
\end{tabular}

Tablo 5: ARDL(1,0) modeli uzun dönem katsayıları

\subsection{Kısa Dönem İlişki}

Uzun dönem ilişkinin bulunmasını takiben hata düzeltme faktörü ile kısa dönem etkileri ARDL yaklaşımının hata düzeltme modeli (ECM) kullanılarak hesaplanmıştır. Hata düzeltme terimi (ECT) ile tahmin edilen modeldeki ECT(-1) katsayısı kısa dönem dengeden sapmaların ne kadarlık kısmının uzun dönemde düzeltildiğini göstermektedir. Bu bağlamda ECT(-1) değeri istatistiki olarak anlamlı ve beklentilere uygun olarak negatif katsayıya sahiptir. Tablo 6'da sunulan sonuçlara göre kısa dönemde gerçekleşen sapmanın uzun dönemde \% 48'lik bir kısmı düzeltilecektir.

\begin{tabular}{|l|l|l|}
\hline Değişken & Katsay1 & t istatistiği \\
\hline$\Delta$ UIO & 2.6224 & $2.7836 * *$ \\
\hline ECT(-1) & -0.4873 & $-2.5696^{* *}$ \\
\hline
\end{tabular}

Tablo 6: ARDL $(1,0)$ hata düzeltme modeli ve kısa dönem ilişki katsayıları

\subsection{Granger Nedensellik}

Değişkenler arasında eşbütünleşme ilişkisinin tespit edilmesi, bu ilişkinin yönünün ne olabileceği konusunda test uygulamamız için olanak sağlamaktadır (Engle ve Granger, 1987) . Granger nedensellik analizi bulguları Tablo 7'de iki farklı gecikme düzeyi için raporlanmıştır.

\begin{tabular}{|l|l|l|}
\hline Gecikme sayısı: 1 & & \\
\hline Boş Hipotez: & F-istatistiğ & Olasılık \\
\hline Y'den UIO'ya Granger nedensellik yoktur. & 1.7425 & 0.2010 \\
\hline UIO'dan Y'ye Granger nedensellik yoktur. & $6.3504 * *$ & 0.0199 \\
\hline Gecikme sayısı: 2 & & \\
\hline Boş Hipotez: & F-istatistiği & Olasılık \\
\hline Y'den UIO'ya Granger nedensellik yoktur. & 0.7613 & 0.4815 \\
\hline UIO'dan Y'ye Granger nedensellik yoktur. & $4.9495 * *$ & 0.0194 \\
\hline
\end{tabular}

Tablo7: Nedensellik Analizi

Sonuçlara göre her iki gecikme için de yükseköğretim mezunu bireylerin istihdam içindeki oranı ile reel GSYİH arasında tek yönlü bir ilişki bulunmuştur. İlişkinin yönünün yükseköğretim istihdam oranından reel GSYİH'ya doğru olduğu tespit edilmiştir. Bu sonuç bize yükseköğretim mezunlarının istihdam içindeki oranının artmasının ekonomik büyümeyi artırıcı bir etkisi olduğunu göstermektedir.

\section{Sonuç}

Bu çalışmada yükseköğretim ile ekonomik büyüme arasındaki eşbütünleşme ve nedensellik ilişkisi 1988-2012 dönemine ait yıllık veriler kullanılarak incelenmiştir. Yükseköğretim için açıklayıcı değişken olarak yükseköğretim mezunlarının istihdama katılım oranı kullanılmıştır. Çalışma sonucunda yükseköğretimin gerek kısa gerekse uzun dönemde büyüme üzerinde olumlu etkisi olduğu sonucuna ulaşılmıştır. Nedensellik testi sonuçlarına göre ise yükseköğretimden büyümeye doğru tek yönlü bir nedensellik ilişkisi olduğu belirlenmiştir. Elde edilen bulgular 1şı̆̆ında yükseköğretim düzeyinde eğitimin hem nicelik hem de nitelik olarak iyileştirilmesinin ekonomik büyüme açısından olumlu olacağı sonucuna ulaşılmıştır.

\section{Kaynakça}

- $\quad$ Babatunde, M. A. ve R. A. Adefabi, 2005. "Long Run Relationship Between Education and Economic Growth in Nigeria: Evidence from the Johansen's Cointegration Approach" Regional Conference on 
Education in West Africa: Constraints and Opportunities”, Dakar, Senegal, November 1st - 2nd, Cornell University (http://www.saga.cornell.edu/saga/educconf/babatunde.pdf).

- Barro, R.J., 1991. "Economic Growth in a Cross Section of Countries", The Quarterly Journal of Economics, 106, 407-443.

- C Çalışkan, Ş., M. Karabacak ve O. Meçik, 2013. “Türkiye’de Eğitim-Ekonomik Büyüme İlişkisi: 1923-2011 (Kantitatif Bir Yaklaşım)”, Yönetim Bilimleri Dergisi, 11, 29-48.

- $\quad$ Dickey, D.A. ve W.A. Fuller, 1981. "Likelihood Ratio Statistics for Autoregressive Time Series with a Unit Root", Econometrica, 49, 1057-1072.

- $\quad$ Engle R.F. ve C.W.J. Granger, 1987. "Co-integration and Error Correction: Representation, Estimation, and Testing”, Econometrica, 55, 251-276.

- $\quad$ Erdem, E. ve C.T. Tuğcu, 2010. "Higher Education And Economic Growth: An Empirical Investigation of Cointegration and Causality for Turkish Economy", Erciyes Üniversitesi İktisadi ve İdari Bilimler Fakültesi Dergisi, 36, 1-14.

- $\quad$ Hussin, M.Y.M., F. Muhammad, M.F.A. Hussin ve A.A. Razak, 2012. "Education Expenditure and Economic Growth: A Causal Analysis for Malaysia", Journal of Economics and Sustainable Development, 3, 71-82.

- $\quad$ Keller, K.R.I., 2006. "Investment in Primary, Secondary, and Higher Education and the Effects on Economic Growth”, Contemporary Economic Policy, 24, 18-34.

- Kreishan, F. M. ve I. M. Al Hawarin, 2011. "Education and Economic Growth in Jordan: Causality Test", International Journal of Economic Perspectives, 5, 45-53.

- Lucas, R. E. 1988. “On the mechanics of economic development”, Journal of Monetary Economics, 22, 342.

- Mankiw, N. G., D. Romer ve D. N. Weil. 1992. "A Contribution to the Empirics of Economic Growth", The Quarterly Journal of Economics, 107, 407-437.

- $\quad$ Musila, J. W. ve W. Belassi, 2004. "The Impact of Education Expenditures on Economic Growth in Uganda: Evidence from Time Series Data", The Journal of Developing Areas, 38, 123-133.

- $\quad$ Narayan P.K. ve R. Smyth, 2006. "Higher Education, Real Income and Real Investment in China: Evidence from Granger Causality Tests", Education Economics, 14, 107-125.

- $\quad$ Nelson, R. R. ve E. S. Phelps. 1966. "Investment in humans, technological diffusion, and economic growth", The American Economic Review, 56, 69-75.

- $\quad$ OECD 1998, Human Capital Investment, Paris.

- Özsoy, C., 2008. “Türk Yükseköğretim Sisteminin Durumu ve İktisadi Büyüme Performansına Katkısı”, Niğde Üniversitesi İktisadi ve İdari Bilimler Fakültesi Dergisi, 1, 31-48.

- Özsoy, C., 2009. "Türkiye'de Eğitim ve İktisadi Büyüme Arasındaki İlişkinin Var Modeli ile Analizi”, The Journal of Knowledge Economy \& Knowledge Management, 4, 71-83.

- $\quad$ Özşahin, Ş. ve Z. Karaçor, 2013. "Ekonomik Büyümenin Belirleyicilerinden Biri Olarak Beşeri Sermaye: Yükseköğrenimin Türkiye Ekonomisi İçin Önemi”, Niğde Üniversitesi İIBF Dergisi, 6, 148-162.

- $\quad$ Phillips, P.C.B. ve P. Perron, 1988. "Testing for a Unit Root in Time Series Regression”, Biometrika, 75, 335-346.

- $\quad$ Romer, P. 1990. "Endogenous technological change”, The Journal of Political Economy, 98, S71-S102.

- $\quad$ Tekin, M. ve M. Çiftçi, 2005. "OECD Deneyimlerinden Hareketle İktisadi Kalkınmada Eğitimli İş Gücünün Önemi ve Türkiye İçin Çıkartılacak Dersler”, İstanbul Üniversitesi İktisat Fakültesi Maliye Araştırma Merkezi Konferansları, 47. Seri.

- $\quad$ Telatar, O. M. ve H. Terzi, 2010. "Nüfus ve Eğitimin Ekonomik Büyümeye Etkisi: Türkiye Üzerine Bir İnceleme”, Atatürk Üniversitesi İktisadi ve İdari Bilimler Dergisi, 24, 197-214.

- Tsamadias, C. ve P. Prontzas, 2012. "The effect of education on economic growth in Greece over the 19602000 period”, Education Economics, 20, 522-537.

- Westphalen, S.A., 1999. "Reporting On Human Capital; Objectives And Trends", International Symposium Measuring and Reporting Intellectual Capital: Experience, Issues, and Prospects, Amsterdam, 9-10 June 1999.

- $\quad$ Zivot, E. ve D.W.K. Andrews, 1992. "Further Evidence on the Great Crash, the Oil-Price Shock, and the Unit-Root Hypothesis”, Journal of Business \& Economic Statistics, 10, 251-270. 


\title{
Türkiye’de İş Kazaları ve Meslek Hastalıkları ve Sosyal Güvenlik Sistemi İçindeki Yeri
}

\section{The Work Accidents and Occupational Diseases in Turkey and Its Place in the Social Security System}

\author{
Assoc. Prof. Dr. Dilek Baybora (Anadolu University, Turkey)
}

\begin{abstract}
The work accidents and occupational diseases are very important especially in the industrializing countries. According to the International Labour Organization (ILO) every 15 seconds, a worker dies from a work-related accident or disease. Every 15 seconds, 160 workers have a work-related accident. Every day, 6.300 people die as a result of occupational accidents or work-related diseases-more than 2,3 million deaths per year. The economic burden of poor occupational safety and health practices is estimated at 4 per cent of global Gross Domestic Product each year. In Turkey, work accidents' figures are very high but occupational diseases' figures are not very high. There are several causes of this condition. In Turkey, the Work Accidents, Occupational Diseases and Maternity Act No. 4772 was accepted in 1945. The Social Security and General Health Insurance Act No.5510 was accepted in 2006. There are regulations about the work accident and occupational disease insurance in the Act. According to the Act, insured and the rights holders can obtain some assistance.
\end{abstract}

\section{Giriș}

Uluslararası Çalışma Örgütü'ne (ILO) göre dünyada, her 15 saniyede 160 iş̧̧i iş kazası geçirmekte olup, her 15 saniyede bir işçi, iş kazası veya meslek hastalığı sonucunda ölmektedir. Dolayısıyla, her gün 6.300 kişi iş̧ kazası veya meslek hastalığı sonucunda ölmektedir ki bu da her yıl 2,3 milyondan daha fazla kişinin ölmesi anlamına gelir. Kötü iş sağlığı ve güvenliği uygulamalarının ekonomik maliyeti ise her yıl dünya gayri safi hasılasının \%4 olduğu tahmin edilmektedir (http://www.ilo.org/global/topics/safety-and-health-at-work/lang-en/index.htm). Türkiye gibi iș kazası rakamlarının yüksek olduğu bir ülke açısından iș kazaları ve meslek hastalıkları büyük önem taşımaktadır. Çünkü iş kazasına uğrayan veya meslek hastalığına yakalanan kişiler açısından ortaya çıkan zararın tazmin edilmesi önem taşımaktadır ki bu noktada da karşımıza iş kazası ve meslek hastalıkları sigortası ve bu sigorta kolundan sağlanan yardımlar çıkmaktadır.

İş kazası ve meslek hastalığı sigortası dünyada ilk kurulan sigorta kollarındandır. Türkiye'de sistemli bir şekilde sosyal güvenlik sisteminin oluşturulması 1945 yılından itibaren gerçekleşmiştir. Türkiye'de de dünyada yaşanan gelişmeye benzer bir gelişme yaşanmış ve1945 yılında 4772 sayılı İş Kazaları, Meslek Hastalıkları ve Analık Sigortası Kanunu kabul edilmiştir (Güzel, vd, 2009; Tuncay ve Ekmekçi, 2011; Gerek, 2002; Alper, 2003). Günümüzde,2006 yılında kabul edilen 5510 sayılı Sosyal Sigortalar ve Genel Sağlık Sigortası Kanunu çerçevesinde "Hizmet Akdiyle veya Kendi Adına ve Hesabına Bă̆ımsız Çalışan Sigortalıların Tabi Olduğu Kısa Vadeli Sigorta Hükümleri” başlığı altında iş kazası ve meslek hastalığı sigorta koluna ilişkin düzenlemeler yer almaktadır.

Bu çalışmamızda, iş kazası ve meslek hastalı̆̆ kavramları üzerinde durduktan sonra Türkiye'de iş kazası ve meslek hastalıklarının boyutları ortaya konacaktır. Daha sonra Türk sosyal güvenlik sistemi içinde iş kazası ve meslek hastalığı sigortası hakkında bilgi verilip Türkiye'de iş kazaları ve meslek hastalıkları konusunda sorunlar ve çözüm önerileri üzerinde durulacaktır. Sonuç kısmında da genel bir değerlendirme yapılacaktır.

\section{2 İş Kazası ve Meslek Hastalığı Kavramları}

\section{1 İș Kazasının Tanımı}

Dünya Sağlık Örgütü (WHO) iş kazasını, "önceden planlanmamış, çoğu zaman yaralanmalara, makine ve teçhizatın zarara uğramasına veya üretimin bir süre durmasına yol açan olay" olarak tanımlamaktadır. Uluslararası Çalışma Örgütü (ILO) ise iş kazasını, "belirli bir zarar veya yaralanmaya yol açan, önceden planlanmamış beklenmedik bir olay" şeklinde tanımlamaktadır (İş Sağlığı ve Güvenliği, 2012).

Doktrinde ise iş kazası, "sigortalının işveren otoritesi altında bulunduğu bir sırada gördüğü iş veya işin gereği dolayısıyla aniden ve dıştan meydana gelen bir etkenle onu bedenen veya ruhça zarara uğratan bir olay" olarak tanımlanmaktadır (Tuncay ve Ekmekçi, 2011).

5510 sayılı Sosyal Sigortalar ve Genel Sağlık Sigortası Kanunu (SSGSSK) m.13'de "İş kazasının tanımı, bildirilmesi ve soruşturulması" başlığı altında iş kazasının tanımı verilmekten çok hangi hal ve durumlarda meydana gelen olayın iş kazası sayılacağı düzenlenmiştir. SSGSSK m.13'e göre, “İş kazası

Sigortalının işyerinde bulunduğu sırada, 
İşveren tarafından yürütülmekte olan iş nedeniyle sigortalı kendi adına ve hesabına bağımsız çalışıyorsa yürütmekte olduğu iş nedeniyle,

a) Bir işverene bağlı olarak çalışan sigortalının, görevli olarak işyeri dışında başka bir yere gönderilmesi nedeniyle asıl işini yapmaksızın geçen zamanlarda,

b) Bu Kanunun 4’üncü maddesinin birinci fikrasının (a) bendi kapsamında emziren kadın sigortalının, iş mevzuatı gereğince çocuğuna süt vermek için ayrılan zamanlarda,

c) Sigortalıların, işverence sağlanan bir taşıtla işin yapıldi ̆̆ yere gidiş gelişi sırasında,

meydana gelen ve sigortalıyı hemen veya sonradan bedenen ya da ruhen engelli hale getiren olaydır".

2012 yılında kabul edilen İş Sağlığı ve Güvenliği Kanunu (İSGK) m.3/g’de iş kazası, "İşyerinde veya işin yürütümü nedeniyle meydana gelen, ölüme sebebiyet veren veya vücut bütünlügünü ruhen ya da bedenen engelli hale getiren olay" olarak tanımlanmıştır.

\subsection{Meslek Hastalı̆̆ının Tanımı}

Doktrinde meslek hastalığı, "belirli bir mesleğin (işin) ifası sonucu o mesleğin (işin) nitelik ve yürütüm şartların doğurduğu bir sakatlık veya hastalık” olarak tanımlanmaktadır (Tuncay ve Ekmekçi, 2011). 5510 sayılı SSGSSK m.14/I'e göre meslek hastalığı, "sigortalının çalıştı̆̆l veya yaptı̆̆ işsin niteliğinden dolayı tekrarlanan bir sebeple veya işin yürütüm şartlarl yüzünden uğradığ geçici veya sürekli hastalık, bedensel veya ruhsal engellilik halleridir". 6331 sayılı ISGK m.3/l'demeslek hastalığı, "mesleki risklere maruziyet sonucu ortaya çıkan hastalık" olarak tanımlanmıştır

Meslek hastalığının tanımından da anlaşıldığı üzere meslek hastalığında tekrarlanan bir durum söz konusudur. Zaten bu durum, iş kazası ile meslek hastalığı arasındaki temel farktır. Çünkü iş kazası aniden, beklenmedik şekilde meydana gelirken meslek hastalığında tekrarlanan bir durum söz konusu olmaktadır (İş Sağlığı ve Güvenliği, 2012). Mesela, inşaatta çalışan işçinin düşmesi sonucunda kolunun kırılmasında aniden, birdenbire meydana gelen bir durum söz konusudur. Ancak, kömür madeninde çalışan işçinin ise sürekli olarak kömür tozu solumasına bağlı olarak solunum yollarıyla ilgili bir hastalığa yakalanmasında ise tekrarlanan bir duruma bağlı olarak ortaya çıkan bir hastalık söz konusudur.

\section{Türkiye'de İș Kazaları ve Meslek Hastalıklarının Boyutları}

Sanayileşme sürecinde bulunan tüm ülkelerde iş kazaları önemli toplumsal sorunların başında yer almaktadır (Güzel, vd, 2009). Ne yazık ki Türkiye'de de iş kazaları önemli boyutlara ulaşmıştır. Sosyal Güvenlik Kurumu (SGK) tarafından iş kazası ve meslek hastalıklarına ilişkin istatistikler her yıl yayınlanmaktadır. SGK tarafından en son yayınlanan istatistikler, 2011 yılı istatistikleridir. Bu nedenle çalışmamızda, en yeni veri olarak 2011 yılı verilerini kullanacağız.

SGK tarafından yayınlanan istatistikleri incelediğimiz zaman bazı çarpıcı sonuçlar karşımıza çıkmaktadır. Yukarıdayer alan tablo 1 ve tablo 2'ye göre 2011 yılında toplam 69.227 iş kazası meydana gelirken meslek hastalığını rakamı toplamda 697'dir. İş kazası ve meslek hastalıkları rakamlarının büyüklügü ülke ekonomisine işgücü, üretim ve kazanç kaybı olarak yansımaktadır (Tuncay ve Ekmekçi, 2011). Tabloları incelediğimiz zaman iş kazaları rakamları ile meslek hastalıkları rakamları arasında büyük bir fark olduğu göze çarpmaktadır. Ancak, bir ülkede iş kazası rakamları bu kadar yüksek iken meslek hastalığı rakamlarının bu kadar düşük olması mümkün değildir.

\begin{tabular}{|l|l|l|l|l|l|l|}
\hline \multirow{2}{*}{ YAŞ GRUPLARI } & \multicolumn{3}{c|}{ 2010 } & \multicolumn{3}{c|}{ 2011 } \\
\cline { 2 - 7 } & ERKEK & \multicolumn{1}{|c|}{ KADIN } & TOPLAM & \multicolumn{1}{|c|}{ ERKEK } & \multicolumn{1}{|c|}{ KADIN } & TOPLAM \\
\hline-14 & 4 & 1 & 5 & 7 & 1 & 8 \\
\hline $15-17$ & 211 & 18 & 229 & 312 & 29 & 341 \\
\hline $18-24$ & 8.422 & 931 & 9.353 & 9.852 & 958 & 10.810 \\
\hline $25-29$ & 14.496 & 845 & 15.341 & 15.100 & 777 & 15.877 \\
\hline $30-34$ & 13.108 & 712 & 13.820 & 14.382 & 818 & 15.200 \\
\hline $35-39$ & 9.818 & 607 & 10.425 & 10.731 & 709 & 11.440 \\
\hline $40-44$ & 7.268 & 424 & 7.692 & 7.714 & 521 & 8.235 \\
\hline $45-49$ & 3.977 & 240 & 4.217 & 4.895 & 245 & 5.140 \\
\hline $50-54$ & 1.240 & 74 & 1.314 & 1.410 & 70 & 1.480 \\
\hline $55-59$ & 329 & 19 & 348 & 495 & 25 & 520 \\
\hline $60-64$ & 83 & 5 & 88 & 104 & 3 & 107 \\
\hline $65+$ & 55 & 16 & 71 & 57 & 12 & 69 \\
\hline TOPLAM & 59.011 & 3.892 & 62.903 & 65.059 & 4.168 & 69.227 \\
\hline AĞIRLIKLI ORT. YAŞ & 33 & 32 & 33 & 33 & 32 & 33 \\
\hline
\end{tabular}

Tablo 1: Iş̧ kazaları vakalarının yaş gruplarına ve cinsiyete göre dağılımı (Kaynak: Sosyal Güvenlik Kurumu Istatistik Ylllı̆̆l, 2011) 


\begin{tabular}{|l|l|l|l|l|l|l|}
\hline \multirow{2}{*}{ YAŞ GRUPLARI } & \multicolumn{3}{c|}{ 2010 } & \multicolumn{4}{c|}{ 2011 } \\
\cline { 2 - 7 } & ERKEK & KADIN & TOPLAM & ERKEK & KADIN & TOPLAM \\
\hline-14 & 2 & 0 & 2 & 11 & 0 & 11 \\
\hline $15-17$ & 0 & 0 & 0 & 0 & 0 & 0 \\
\hline $18-24$ & 22 & 5 & 27 & 36 & 2 & 38 \\
\hline $25-29$ & 55 & 1 & 56 & 88 & 3 & 91 \\
\hline $30-34$ & 87 & 4 & 91 & 104 & 4 & 108 \\
\hline $35-39$ & 104 & 2 & 106 & 105 & 1 & 106 \\
\hline $40-44$ & 87 & 2 & 89 & 124 & 0 & 124 \\
\hline $45-49$ & 78 & 4 & 82 & 83 & 0 & 83 \\
\hline $50-54$ & 27 & 1 & 28 & 45 & 0 & 45 \\
\hline $55-59$ & 20 & 0 & 20 & 15 & 0 & 15 \\
\hline $60-64$ & 12 & 0 & 12 & 19 & 0 & 19 \\
\hline $65+$ & 20 & 0 & 20 & 57 & 0 & 57 \\
\hline TOPLAM & 514 & 19 & 533 & 687 & 10 & 697 \\
\hline AĞIRLIKLI ORT. YAŞ & 40 & 35 & 40 & 40 & 29 & 40 \\
\hline
\end{tabular}

Tablo 2: Meslek Hastalıkları Vakalarının Yaş Gruplarına ve Cinsiyete Göre Dağılımı (Kaynak: Sosyal Güvenlik Kurumu İstatistik Yılliğl, 2011)

Türkiye'de iş kazası ve meslek hastalığı sigorta kolu, ilk kurulan sigorta kollarındandır. Çok sayıda kişinin sigorta yardımlarından yararlanabilmesini sağlamak amacıyla kapsam geniş tutulmuştur. Aşağıda göreceğimiz gibi sigortalının işyerinde bulunduğu sırada başına gelen her olay SSGSSK'ya göre iş kazası sayılmaktadır. Mesela, işçi işyeri bahçesinde öğle tatili sırasında düşer ve kolu kırılırsa bu durum SSGSSK'ya göre iş kazasıdır. Dolayısıyla, iş kazası sayılmaması gereken bazı durumlar Kanun anlamında iş kazası sayılmakta ve istatistiklerde yer almaktadır. Tabi işin bir de diğer yönü bulunmaktadır. Türkiye kayıt dışı çalışma oranının yüksek olmasına bağlı olarak iş kazası sayılması gereken bazı durumlar da SGK'ya iş kazası olarak bildirilmemekte ve buna bağlı olarak istatistiklerde yer almamaktadır.

Meslek hastalığı rakamlarının düşük olmasında ise sigortalıların başlarına gelen hastalığı meslek hastalığ olarak değerlendirmeyip normal bir hastalık olarak tedavi ettirmesinin etkisi görülmektedir. Çünkü meslek hastalığının kişi işte çalışırken ortaya çıkması şart değildir, işten ayrıldıktan belirli bir süre geçtikten sonra da ortaya çıkabilir. Çalışma Gücü ve Meslekte Kazanma Gücü Kaybı Oranı Tespit İşlemleri Yönetmeliği'nde yükümlülük süresi, 2 gün ile 25 yıl arasında düzenlenmiştir.

Verileri incelediğimiz zaman meslek hastalıkları ve özellikle iş kazası rakamlarının erkeklerde kadınlara kıyasla oldukça yüksek olduğu görülmektedir. Kadınların bazı ağır ve tehlikeli işlerde çalıştırılmasının mevzuatla yasaklanmış olması ve kadınların işgücüne katılım oranlarının erkeklere kıyasla daha düşük olmasının bu durumun altında nedenler arasında yer aldığını ifade edebiliriz.

\begin{tabular}{|l|l|l|l|l|l|l|}
\hline \multirow{2}{*}{ FAALIYET GRUPLARI } & \multicolumn{3}{c|}{ IŞ KAZASI SAYISI } & \multicolumn{2}{c|}{ MESLEK HASTALIĞI SAYISI } \\
\cline { 2 - 7 } & ERKEK & KADIN & TOPLAM & ERKEK & KADIN & TOPLAM \\
\hline Kömür ve Linyit Çıkartılması & 9.211 & 6 & 9.217 & 170 & 0 & 170 \\
\hline Bina İnşaatı & 3.792 & 44 & 3.836 & 4 & 0 & 4 \\
\hline Bina Dışı Yapılların İnşaatı & 1.715 & 3 & 1.718 & 2 & 0 & 2 \\
\hline Özel İnşaat Faaliyetleri & 2.167 & 28 & 2.195 & 10 & 0 & 10 \\
\hline Fabrik. Metal Ürün (Mak.Tec.Har) & 7.126 & 142 & 7.268 & 36 & 0 & 36 \\
\hline Ana Metal Sanayi & 5.224 & 46 & 5.272 & 18 & 0 & 18 \\
\hline Metalik Olmayan Ürünler İma. & 4.037 & 203 & 4.240 & 16 & 0 & 16 \\
\hline Tekstil Ürünleri İmalatı & 2.542 & 697 & 3.239 & 2 & 0 & 2 \\
\hline $\begin{array}{l}\text { Kara Taşıma. ve Boru Hattı } \\
\text { Taşıma }\end{array}$ & 2.299 & 64 & 2.363 & 3 & 0 & 3 \\
\hline Gıda Ürünleri İmalatı & 2.037 & 553 & 2.590 & 3 & 0 & 3 \\
\hline $\begin{array}{l}\text { Makine ve Ekipman. Kurulumu ve } \\
\text { On. }\end{array}$ & 1.043 & 12 & 1.055 & 86 & 0 & 86 \\
\hline Metal Cevheri Madenciliği & 449 & 0 & 449 & 257 & 0 & 257 \\
\hline
\end{tabular}

Tablo 3: İ̧s Kazaları ve Meslek HastalıklarınınFaaliyet Gruplarına ve Cinsiyete Göre Dağılımı (Kaynak: Sosyal Güvenlik Kurumu İstatistik Yıllı̆̆ı, 2011) 


\begin{tabular}{|l|l|l|l|l|l|l|}
\hline \multirow{2}{*}{$\begin{array}{c}\text { ISSYERINDE ÇALIŞAN } \\
\text { SIGGRTALI SAYISI }\end{array}$} & \multicolumn{3}{c|}{ 2010 } & \multicolumn{3}{c|}{ 2011 } \\
\cline { 2 - 7 } & ERKEK & \multicolumn{1}{c|}{ KADIN } & TOPLAM & ERKEK & KADIN & TOPLAM \\
\hline $1-3$ & 12.263 & 605 & 12.868 & 10.174 & 543 & 10.717 \\
\hline $4-9$ & 5.941 & 281 & 6.222 & 5.776 & 287 & 6.063 \\
\hline $10-20$ & 7.379 & 459 & 7.838 & 8.700 & 467 & 9.167 \\
\hline $21-49$ & 8.118 & 384 & 8.502 & 9.156 & 480 & 9.636 \\
\hline $50-99$ & 5.547 & 345 & 5.892 & 5.957 & 372 & 6.329 \\
\hline $100-199$ & 6.125 & 476 & 6.601 & 7.657 & 566 & 8.223 \\
\hline $200-249$ & 1.727 & 139 & 1.866 & 2.261 & 190 & 2.451 \\
\hline $250-499$ & 4.354 & 424 & 4.778 & 5.100 & 508 & 5.608 \\
\hline $500-999$ & 2.621 & 396 & 3.017 & 3.841 & 433 & 4.274 \\
\hline $1000+$ & 4.935 & 383 & 5.318 & 6.436 & 322 & 6.758 \\
\hline Bilinmeyen & 1 & 0 & 1 & 1 & 0 & 1 \\
\hline TOPLAM & 59.011 & 3.892 & 62.903 & 65.059 & 4.168 & 69.227 \\
\hline
\end{tabular}

Tablo 4: Işs Kazalarının Issyerinde Çalışan Sigortalı Sayılarına Göre Dă̆ılımı (Kaynak: Sosyal Güvenlik Kurumu Istatistik Yılliğgl, 2011)

\begin{tabular}{|l|l|l|l|l|l|l|}
\hline \multicolumn{1}{c|}{$\begin{array}{c}\text { ISSYERINDDE ÇALIŞAN } \\
\text { SiGORTALI SAYISI }\end{array}$} & \multicolumn{3}{c|}{$\mathbf{2 0 1 0}$} & \multicolumn{3}{c|}{$\mathbf{2 0 1 1}$} \\
\cline { 2 - 7 } & ERKEK & KADIN & TOPLAM & \multicolumn{1}{c|}{ ERKEK } & KADIN & TOPLAM \\
\hline $1-3$ & 178 & 7 & 185 & 31 & 3 & 34 \\
\hline $4-9$ & 12 & 2 & 14 & 7 & 0 & 7 \\
\hline $10-20$ & 30 & 3 & 33 & 28 & 0 & 28 \\
\hline $21-49$ & 32 & 1 & 33 & 25 & 2 & 27 \\
\hline $50-99$ & 72 & 1 & 73 & 103 & 0 & 103 \\
\hline $100-199$ & 74 & 0 & 74 & 353 & 1 & 354 \\
\hline $200-249$ & 18 & 0 & 18 & 15 & 1 & 16 \\
\hline $250-499$ & 59 & 4 & 63 & 73 & 3 & 76 \\
\hline $500-999$ & 13 & 1 & 14 & 41 & 0 & 41 \\
\hline $1000+$ & 26 & 0 & 26 & 11 & 0 & 11 \\
\hline TOPLAM & 514 & 19 & 533 & 687 & 10 & 697 \\
\hline
\end{tabular}

Tablo 5: Meslek Hastalıklarının İsyerinde Çalışan Sigortalı Sayılarına Göre Dağıllımı (Kaynak: Sosyal Güvenlik Kurumu İstatistik Ylllı̆g, 2011)

\begin{tabular}{|l|l|l|l|l|l|l|l|l|l|}
\hline \multirow{2}{*}{ İş Saatleri } & \multicolumn{3}{|c|}{ 2009 } & \multicolumn{3}{c|}{ 2010 } & \multicolumn{3}{c|}{ 2011 } \\
\cline { 2 - 11 } & Erkek & Kadın & Toplam & Erkek & Kadın & Toplam & Erkek & Kadın & Toplam \\
\hline 1. Saat & 8.578 & 565 & 9.143 & 7.179 & 565 & 7.744 & 8.262 & 598 & 8.860 \\
\hline 2. Saat & 8.514 & 459 & 8.973 & 8.384 & 534 & 8.918 & 9.649 & 614 & 10.263 \\
\hline 3. Saat & 8.048 & 402 & 8.450 & 8.187 & 501 & 8.688 & 9.917 & 575 & 10.492 \\
\hline 4. Saat & 7.868 & 433 & 8.301 & 7.685 & 452 & 8.137 & 8.799 & 548 & 9.347 \\
\hline 5. Saat & 6.661 & 451 & 7.112 & 7.173 & 477 & 7.650 & 6.421 & 446 & 6.867 \\
\hline 6. Saat & 5.247 & 284 & 5.531 & 5.498 & 366 & 5.864 & 5.891 & 393 & 6.284 \\
\hline 7. Saat & 7.020 & 410 & 7.430 & 6.876 & 435 & 7.311 & 7.792 & 441 & 8.233 \\
\hline 8. Saat & 8.810 & 558 & 9.368 & 8.026 & 562 & 8.588 & 8.325 & 553 & 8.878 \\
\hline 9. Saat+ & 0 & 0 & 0 & 0 & 0 & 0 & 0 & 0 & 0 \\
\hline Bilinmeyen & 8 & 0 & 8 & 3 & 0 & 3 & 3 & 0 & 3 \\
\hline TOPLAM & 60.754 & 3.562 & 64.316 & 59.011 & 3.892 & 62.903 & 65.059 & 4.168 & 69.227 \\
\hline
\end{tabular}

Tablo 6: İş Kazalarının Meydana Geldiği İşS Saatlerine Göre Dă̆glımı (Kaynak: Sosyal Güvenlik Kurumu Istatistik Yllliğg, 2011)

SGK istatistikleri incelendiğinde en çok iş kazasının kömür ve linyit çıkarılması faaliyet alanında olduğu görülmektedir. İnşaat işleri kendi içinde gruplara ayrılmakla birlikte inşaat işleri toplamına baktığımızda ikinci sırada, fabrika metal ürünlerinin üçüncü sırada olduğu görülmektedir. Meslek hastalıklarında ise metal cevheri madenciliği birinci sırada iken kömür ve linyit çıkarılması işinin ikinci sırada ve makine ve ekipman kurulumunun üçüncü sırada olduğu görülmektedir.

Türkiye'de işyerlerinin büyük ölçüde küçük ve orta ölçekli işyeri olmassına bağlı olarak işyerinde çalışan sigortalı sayısı açısından da bu işyerlerinde iş kazası oranlarının en yüksek olduğu görülmektedir. Çünkü bu işyerleri açısından alınacak önlemler maliyet unsuru olarak görülmekte, işverenler de genellikle sigortalılarla 
birlikte çalışmalarından dolayı önlem almaktan ziyade bir kaza meydana geldiği zaman sonuçlarının giderilmesini düşünmektedirler.

İşyerlerinin büyümesine bağlı olarak çalışan sigortalı sayısı arttıkça işverenler iş kazası ve meslek hastalıklarını önlemek için yapacakları her türlü çalışmanın kendilerine olumlu olarak yansıyacağını düşünmekte ve bu konuda ciddi çalışmalar yapmaktadırlar.

SGK istatistiklerini incelediğimiz zaman geçmiş yıllarda küçük bir farkla iş kazası rakamları 1. saatte daha çok meydana gelmekle birlikte son yıllarda 8 . saatte daha fazla olduğu görülmektedir.

\section{Türk Sosyal Güvenlik Sisteminde İş Kazası ve Meslek Hastalığı Sigortası}

\subsection{Türkiye'de İș Kazası ve Meslek Hastalığı Sigortasının Gelişimi}

Türkiye'de, Cumhuriyet'in ilanından 1945 yılına gelinceye kadar bir sosyal güvenlik sistemi oluşturulamamıştır (Güzel, vd, 2009). 1945 yılında 4772 sayılı İs Kazaları, Meslek Hastalıkları ve Analık Sigortası Kanunu kabul edilmiştir. 09.07.1945 tarihindede İşçi Sigortaları KurumuKanunu çıkarılmıştır.

1961 Anayasası'nda herkesin sosyal güvenlik hakkına sahip olduğu ifade edilmiştir (m.48). Bu çerçevede Türk sosyal güvenlik sistemi karma bir yapıya sahip olarak hem primli sistemi hem de primsiz sistemi kendi içerisinde barındıran bir çerçevede gelişme göstermiştir. Bu kapsamda 17.07.1964 tarihinde kabul edilip 01.03.1965 tarihinde yürürlüğe giren 506 sayllı Sosyal Sigortalar Kanunu ile çeşitli tarihlerde kabul edilmiş bulunan ve dağınık bir görünüm sunan sosyal sigorta kollarının kapsamı genişletilmiş ve bu Kanun bünyesinde toplanmıştır. 506 sayılı Kanunda iş kazası ve meslek hastalığı sigorta kolu yer almaktaydı.

1982 Anayasası'’ndada Türkiye Cumhuriyeti'nin bir sosyal hukuk devleti olduğu ifade edildikten sonra "Herkes sosyal güvenlik hakkına sahiptir. Devlet bu güvenliği sağlayacak gerekli tedbirleri alır ve teşkilatı kurar" (m.60) ifadesi ile 1961 Anayasası'ndaki ilke tekrarlanmıştır.

Türkiye'de sosyal güvenlik sisteminde yaşanan sorunlara bağlı olarak sosyal güvenlik sisteminin revizyonu gündeme gelmiştir. Bu kapsamda önce farklı sosyal güvenlik kurumları, 2006 yılında Sosyal Güvenlik Kurumu Kanunu'nun kabul edilmesiyle Sosyal Güvenlik Kurumu'nun çatısı altında biraraya getirilmiştir. Aynı yıl 5510 sayılı Sosyal Sigortalar ve Genel Sağlık Sigortası Kanunu kabul edilmiştir. Bu şekilde geçmişte çalışma ilişkilerinin hukuki niteliğine bağlı olarak farklı sosyal güvenlik kanunlarına tabi olan tüm çalışanların sosyal güvenliği aynı kanun içerisinde düzenlenmiştir.5510 sayılı Kanunda "Hizmet Akdiyle veya Kendi Adına ve Hesabına Bă̆ımsız Çalışan Sigortalıların Tabi Olduğu Kısa Vadeli Sigorta Hükümleri” başlığı altında iş kazası ve meslek hastalığı sigorta koluna ilişkin düzenlemeler yer almaktadır.

\subsection{0 sayılı Sosyal Sigortalar ve Genel Sağlık Sigortası Kanunu'nda İş Kazası ve Meslek Hastalı̆̆ı} Sigortası

5510 sayılı SSGSSK'da "Hizmet Akdiyle veya Kendi Adına ve Hesabına Bağımsız Çalışan Sigortalıların Tabi Olduğu Kısa Vadeli Sigorta Hükümleri” başlığı altında iş kazası ve meslek hastalığı sigorta koluna ilişkin düzenlemelere yer verilmiştir. 5510 sayılı Kanuna göre kısa vadeli sigorta kolları prim oranı, yapılan işin iş kazası ve meslek hastalı̆̆ı bakımından gösterdiği tehlikenin ağırlığına göre $\% 1$ ila $\% 6,5$ oranları arasındadır. Bu primin tamamını işveren öder $(\mathrm{m} .81 / \mathrm{I}, \mathrm{c})$.

\section{3 İş Kazasının Unsurları}

5510 sayılı SSGSSK, 506 sayılı Sosyal Sigortalar Kanunu m.11'deki düzenlemeyi esas almıştır. 5510 sayılı Kanunda kısa vadeli sigorta kollarına ilişkin hükümler iş sözleşmesiyle çalı̧̧anlar ile bağımsız çalışanlar hakkında uygulanacaktır. Kamu görevlileri hakkında kısa vadeli sigorta kollarına ilişkin hükümlerin uygulanması söz konusu değildir (Güzel, vd, 2009). Bağımsız çalışanlar açısından da aşağıda göreceğimiz gibi sadece yürütmekte olduğu iş nedeniyle kazaya uğraması durumunda meydana gelen olay iş kazası sayılacaktır.

5510 sayılı SSGSSK m.13'de "İş kazasının tanımı, bildirilmesi ve soruşturulması" başlı̆̆ı altında hangi hal ve durumlarda meydana gelen olayın iş kazası sayılacağı düzenlenmiştir. 5510 sayılı Kanunda yer alan hükümden hareketle iş kazasının unsurlarını şu şekilde sıralayabiliriz:

Kazaya uğrayanın 5510 sayılt SSGSSK anlamında sigortalı sayılması: SSGSSK m.4'de tüm sigorta kolları açısından sigortalı sayılanlar, m.5'de bazı sigorta kollarının uygulanacağı kişiler düzenlenmiş̧tir. Kanunda m.6'da ise sigortalı sayılmayanlar sıralanmıştır. Dolayısıyla, SSGSSK'da anlamında bir olayın iş kazası sayılabilmesi için kişinin ya SSGSSK m.4 anlamında tüm sigorta kolları açısından sigortalı sayılanlar arasında yer alması ya da m.5 anlamında iş kazası ve meslek hastalığı sigorta kolunun uygulanacağı kişilerden olması gereklidir.

Sigortalının kazaya uğraması: Sigortalının başına gelen olayın SSGSSK anlamında iş kazası sayılması için Kanunda m.13'de sıralanan hallerden birinde meydana gelmiş olması gereklidir.

Sigortalının işyerinde bulunduğu sırada kazaya uğraması: SSGSSK, sigortalının işyerinde bulunduğu sırada uğradığı kazayı başka hiçbir koşul aramaksızın iş kazası olarak kabul etmiştir. Sigortalının başına gelen kaza olayının mutlaka iş saatleri içinde meydana gelmesi de şart değildir (Güzel, vd, 2009). Örneğin, öğle tatilinde 
sigortalının başka bir işçi veya yabancı bir kişi tarafından öldürülmesi, yaralanması, işyeri bahçesinde koşarken düşmesi, sigortalının sarhoşken işyerinde kendini yaralayıp kan kaybından ölmesi iş kazasıdır (Güzel, vd, 2009; Tuncay ve Ekmekçi, 2011).

a) İşveren tarafından yürütülmekte olan iş nedeniyle sigortalı kendi adına ve hesabına bağımsız çalışıyorsa yürütmekte olduğu iş nedeniyle kazaya uğraması: Sigortalının, başına gelen kaza olayı işyerinde meydana gelmemiş olsa bile sigortalının işverenden aldığı talimat gereğince veya sigortalının işin gereği olarak işyeri dışına çıkması halinde uğradığı kaza iş kazasıdır (Güzel, vd, 2009). Örneğin, mali müşavirin yanında çalışan sigortalının işvereninden aldığı talimat gereğince vergi dairesine giderken trafik kazası geçirmesi sonucunda yaralanması iş kazasıdır.

b) Bir işverene bağlı olarak çalışan sigortalının, görevli olarak işyeri dışında başka bir yere gönderilmesi nedeniyle asıl işini yapmaksızın geçen zamanlarda kazaya uğraması: Sigortalının, işveren tarafından görevli olarak işyeri dışında başka bir yere görevli olarak gönderilmesi durumunda asıl işini yapmaksızın geçen zamanlarda başına gelen her olay iş kazası sayılacaktır. İşveren tarafından sigortalının toplantı için başka bir şehre gönderilmesi halinde boş zamanlarını normal bir yaşantı içinde kalmak içinde koşuluyla sinemaya, kahveye giderek değerlendirmesi ve bu sırada başına gelen olay iş kazası sayılacaktır (Güzel, $\mathrm{vd}, 2009)$.

c) Bu Kanunun 4'üncü maddesinin birinci fikrasının (a) bendi kapsamındaki emziren kadın sigortalının, iş mevzuatı gereğince çocuğuna süt vermek için ayrılan zamanlarda kazaya uğraması: 4857 İş Kanunu m.74/son'a göre, kadın işçilere bir yaşından küçük çocuklarını emzirmeleri için günde toplam bir buçuk saat süt izni verilecektir. Kadın sigortalının emzirme izni süresi içinde başına gelen olay iş kazasıdır. Kadın sigortalının emzirme izni süresi içinde evine giderken kaza geçirip yaralanması iş kazasıdır.

d) Sigortalıların işverence sağlanan bir taşıtla işin yapıldığı yere gidiş gelişi sırasında kazaya uğraması: Sigortalıların, işveren tarafından sağlanan taşıtla işin yapıldığg yere getirilip götürülmeleri sırasında başlarına gelen olay iş kazası sayılacaktır. İşverenin taşıtın sahibi olması şart değildir. Taşıtın işverenin zilyetliği altında bulunması yeterlidir (Güzel, vd, 2009; Tuncay ve Ekmekçi, 2011).

Sigortalının bedensel veya ruhsal bir zarara ŭgraması: Sigortalının başına gelen olayın iş kazası sayılması için sigortalının bedensel veya ruhsal olarak zarara uğraması gerekir. Her türlü yaralanma, sakatlanma, kırık, yanık gibi dış organlarda meydana gelen arızalar olabileceği gibi beyin kanaması, iç kanama gibi iç organlarda meydana gelen arızalar da iş kazası olarak kabul edilecektir. Ayrıca akıl hastalığı, sinir bozukluğu gibi sigortalıyı ruhsal yönden etkileyen olaylar da iş kazası olarak kabul edilecektir (Sosyal Güvenlik Hukuku, 2013).

Kaza olayı ile sigortalının ŭgradı̆̆ı zarar arasında illiyet bağının bulunması: Kaza olayı ile sigortalının uğradığı zarar arasında neden sonuç bağlantısının olması gereklidir. Yani olayların normal akışına ve genel hayat deneyimlerine göre gerçekleşen türden zararlı bir sonucu meydana getirmeye elverişli ya da böyle bir sonucun meydana gelmesini kolaylaştıran nedenin olması gereklidir. Yargıtay tarafindan sigortalının iş kazası sonucunda yaralanıp hastanede tedavi gördükten sonra memleketine giderken trafik kazası geçirmesi sonucunda ölmesi iş kazası sayılmamıştır (Güzel, vd, 2009).

\subsection{Meslek Hastalığının Unsurları}

5510 sayılı SSGSSK'da yer alan düzenlemeden hareketle meslek hastalığının unsurlarını da şu şekilde siralayabiliriz:

Hastalı̆̆a yakalananın 5510 sayılı SSGSSK anlamında sigortalı sayılması: Yukarıda iş kazasının unsurlarını incelerken de ifade ettiğimiz gibi SSGSSK anlamında bir hastalığın meslek hastalığı olarak kabul edilebilmesi için kişinin ya SSGSSK m.4 anlamında tüm sigorta kolları açısından sigortalı sayılanlar arasında yer alması ya da m.5 anlamında iş kazası ve meslek hastalığı sigorta kolunun uygulanacağı sıralananlardan olması gereklidir.

Sigortalının bedensel veya ruhsal bir zarara uğraması: Sigortalının yakalandığı hastalığın iş kazasında olduğu gibi sigortalıda bedensel veya ruhsal bir zarara yol açması gereklidir. Meydana gelen zarar, geçici olabileceği gibi sigortalının sakatlığına neden olabilecek şekilde sürekli de olabilir. Meslek hastalığı sadece vücudun bedensel bütünlüğünde değil ruh ve sinir sisteminde de özür meydana getirebilir (Güzel, vd, 2009).

Hastalık veya sakatlığın yürütülen işin sonucu olması: İş kazasının çalışılan işle ilgisi bulunması şart olmadığı halde meslek hastalığının işin yürütümü sonucunda ortaya çıkması gerekir (Tuncay ve Ekmekçi, 2011). Türkiye'de, meslek hastalığının belirlenmesi konusunda karma bir yöntem benimsenmiştir. Çalışma Gücü ve Meslekte Kazanma Gücü Kaybı Oranı Tespit İşlemleri Yönetmeliği’nde meslek hastalıklarının listesi yer almaktadır. Yönetmeliğe göre, listede yer alan bir hastalığın 2 gün-25 yıl arasında değişen yükümlülük süresi içinde sigortalıda ortaya çıkması halinde bu hastalık meslek hastalığı sayılacaktır. Ancak, listede yer almayan veya yükümlülük süresi geçtikten sonra ortaya çıkan bir hastalığın meslek hastalığı sayılması için Sosyal Sigorta Yüksek Sağlık Kurulu'na başvurulabilir. Taraflar, kurulun kararına karşı İş Mahkemesi’nde dava açabilirler (Sosyal Güvenlik Hukuku, 2013). 


\section{5 İş Kazası ve Meslek Hastalı̆ğ Sigortasından Sağlanan Yardımlar}

İş kazasına uğrayan veya meslek hastalığına yakalanan sigortalıya 5510 sayılı SSGSSK'ya göre iş kazası ve meslek hastalığı sigortası kapsamında sigortalıya veya onun ölümü halinde hak sahiplerine sadece parasal yardımların yapılması düzenlenmiştir. Kanun kapsamında sigortalıya ve hak sahiplerine sağlanacak olan sağlık yardımları, genel sağlık sigortası içinde düzenlenmiştir.

\subsection{Sigortalıya Yapılan Parasal Yardımlar}

Sigortalıya yapılacak parasal yardımlar, geçici işgöremezlik ödeneğinin verilmesi ve sürekli işgöremezlik gelirinin bağlanmasıdır.

Geçici İşgöremezlik Ödeneği: İş kazası veya meslek hastalığı nedeniyle işinde geçici bir süre için çalışamayacağı hekim raporu ile saptanan sigortalıya, çalışamadığı (istirahatli olduğu) her gün için SGK tarafından yapılan parasal yardıma geçici işgöremezlik ödeneği adı verilmektedir. Geçici işgöremezlik ödeneği, iş kazası veya meslek hastalığı nedeniyle çalışamayan sigortalının uğradığı gelir kaybını kısmen telafi etmeye yöneliktir (Güzel, vd, 2009; Tuncay ve Ekmekçi, 2011; Uşan, 2009).

İş kazası geçiren veya meslek hastalığına yakalanan sigortalının geçici işgöremezlik ödeneğinden yararlanabilmesi için belirli süre sigortalı olması ve belirli süre prim ödemiş olması şartı aranmaz. İş kazası veya meslek hastalığı nedeniyle işgöremez duruma düşen sigortalıya Kurum tarafından yetkilendirilen hekim veya sağlık kurullarından istirahat raporu alınmış olması şartıyla her gün için geçici işgöremezlik ödeneği verilir (m.18/I, a). Kendi adına ve hesabına bağımsız çalışan sigortalıların, iş kazası veya meslek hastalığı nedeniyle geçici işgöremezlik ödeneğinden yararlanabilmeleri için genel sağlık sigortası dahil prim ve prime ilişkin her türlü borçlarının ödenmiş olması şarttır (m.18/II).

Geçici işgöremezlik ödeneği, işgöremezliğin ilk gününden itibaren sigortalıya tedavi ve istirahatin devam ettiği süre boyunca verilir. Hastalık sigortasında geçici işgöremezlik ödeneği, hastalığın üçüncü gününden itibaren verilmeye başlanırken iş kazası ve meslek hastalığı sigortasında işgöremezlik ödeneği hastalık sigortasından farklı olarak işgöremezliğin ilk gününden itibaren verilmektedir. 5510 sayılı Kanunda kendi adına ve hesabına bağımsız çalışmaları nedeniyle sigortalı sayılanların iş kazası veya meslek hastalığı halinde geçici işgöremezlik ödeneği, yatarak tedavi süresince veya yatarak tedavi sonrası bu tedavinin gereği olarak istirahat raporu aldıkları sürede ödenecektir (m.18/II).

Geçici işgöremezlik ödeneği, yatarak tedavilerde m.17'ye göre hesaplanacak günlük kazancın yarısı, ayakta tedavilerde ise günlük kazancın 2/3'si tutarındadır (m.18/III).

Sürekli İşgöremezlik Geliri:Sigortalının geçirdiği iş kazası veya yakalandığı meslek hastalığı sonucunda sürekli olarak çalışma hayatından çekilmesi söz konusu olabilir. Bu duruma yönelik olarak 5510 sayılı Kanunda sürekli işgöremezlik geliri düzenlenmiştir. Buna göre, iş kazası veya meslek hastalığı sonucu oluşan hastalık ve engellilik nedeniyle SGK tarafından yetkilendirilen sağlık hizmeti sunucularının sağlık kurulları tarafından verilen raporlara istinaden Kurum Sağlık Kurulu tarafindan meslekte kazanma gücü en az \%10 oranında azalmış bulunduğu tespit edilen sigortalı, sürekli işgöremezlik gelirine hak kazanacaktır (m.19/I). Meslekte kazanma gücü kaybı oranı, Çalışma Gücü ve Meslekte Kazanma Gücü Kaybı Oranı Tespit İşlemleri Yönetmeliği’ndeki cetvellere göre belirlenir.

Sürekli işgöremezlik geliri, sigortalının mesleğinde kazanma gücünün kaybı oranına göre hesaplanır. Sigortalı, meslekte kazanma gücünü \%100 oranında kaybetmişse sürekli tam işgöremezlik, \%10'dan \%100'e kadar olan bir oranda kaybetmişse sürekli kısmi işgöremezlik hali söz konusudur (Tuncay ve Ekmekçi, 2011; Uşan, 2009). Sürekli tam işgöremezlik durumunda sigortalıya m.17'ye göre hesaplanan aylık kazancının \%70'i oranında gelir bağlanır. Sürekli kısmi işgöremezlikte ise sigortalıya bağlanacak gelir, tam işgöremezlik geliri gibi hesaplanarak bunun işgöremezlik derecesi oranındaki tutarı kendisine ödenir. Örneğin, meslekte kazanma gücünü \%30 oranında kaybetmiş olan bir kişiye tam işgöremezlik halinde ödenecek olan \%70'in \%30’u gelir olarak bağlanacaktır. Sigortalının başka birinin sürekli bakımına muhtaç olması durumunda ise gelir bağlama oranı $\% 100$ olarak uygulanır (m.19/III).

Sürekli işgöremezlik geliri, sigortalı iyileşinceye kadar ödenir, sigortalının durumunda iyileşme olmazsa hayatı boyunca verilir (Tuncay-Ekmekçi, 2011).

\subsection{Hak Sahiplerine Yapılan Parasal Yardımlar}

İş kazası veya meslek hastalığı sonucunda sigortalının ölmesi halinde geride kalan hak sahiplerine, 5510 sayılı Kanun çerçevesinde iş kazası ve meslek hastalığı sigortasından gelir bağlanması, cenaze ve evlenme ödeneğinin verilmesi şeklinde parasal yardımlar yapılır. Sağlık yardımları, genel sağlık sigortası kapsamında düzenlenmiştir.

Gelir Bağlanması:5510 sayılı SSGSSKm.3'e göre hak sahibi, "sigortalının veya sürekli işgöremezlik geliri ile malullük, vazife malullüğ̈ veya yaşlılık aylı̆̆ almakta olanların ölümü halinde gelir veya aylık bağlanmasına veya toptan ödeme yapılmasına hak kazanan eş, çocuk, ana ve babasını" ifade etmektedir (m.3/7).

İş kazası veya meslek hastalığı sonucunda ölen sigortalının hak sahiplerine iş kazası ve meslek hastalığı sigortasından gelir bağlanması için ölen sigortalının belirli süre sigortalı olması ve belirli süre prim ödemiş olması şartı aranmamaktadır. Ancak, 5510 sayılı Kanunanlamında kendi adına ve hesabına bağımsız çalışmaları 
kapsamında sigortalı sayılanların hak sahiplerine gelir bağlanabilmesi için kendi sigortalılığından dolayı genel sağlık sigortası dahil prim ve prime ilişkin her türlü borçlarının ödenmiş olması gereklidir (m.20/IV).

İş kazası veya meslek hastalığı nedeniyle ölen sigortalının hak sahiplerine m.17 gereğince belirlenecek aylık kazancının \%70’i Kanundam.55/II'ye göre güncellenerek m.34 hükümlerine göre gelir olarak bağlanır (m.20/I). İş kazası veya meslek hastalığı sonucunda ölen sigortalının dul eşine hesaplanacak gelirin \%50'si gelir olarak bağlanır (m.34/I, a). İş kazası veya meslek hastalığı sonucunda ölen sigortalının çocuklarına hesaplanacak gelirin Kanundam.5/a, b, ehariç 5510 sayılı Kanun kapsamında veya yabancı bir ülke mevzuatı kapsamında çalışmaması veya kendi sigortalılığı nedeniyle gelir veya aylık bağlanmamış çocuklardan 18 yaşını, lise ve dengi eğitim görmesi halinde 20 yaşını, yüksek öğrenim yapması halinde ise 25 yaşını doldurmayanların veya Kurum Sağlık Kurulu kararı ile çalışma gücünü en az \%60 oranında yitirip malul olduğu anlaşılanların veya yaşları ne olursa olsun evli olmayan, evli olmakla beraber sonradan boşanan veya dul kalan kızlarının her birine $\% 25$ oranında gelir bağlanır (m.34/I, c). Hak sahiplerine bağlanacak gelirlerin toplamı sigortalıya ait gelirin tutarını geçemez. Bu sınırın aşılmaması için gerekirse hak sahiplerinin gelirlerinden orantılı indirimler yapılır (m.34/son). Hak sahibi eş ve çocuklardan artan hisse bulunması halinde her türlü kazanç ve irattan elde etmiş olduğu gelirinin asgari ücretin net tutarından daha az olması ve diğer çocuklarından hak kazanılan gelir ve aylıklar hariç olmak üzere gelir ve/veya aylık bağlanmamış olması şartıyla ana ve babaya hesaplanacak gelirin toplam \%25'i oranında gelir bağlanır. Ana ve babanın her birinin hissesi \%25'i geçemez. Ana ve babanın 65 yaşın üstünde olması halinde ise artan hisseye bakılmaksızın ifade ettiğimiz şartlarla toplam \% $\% 2$ 'i oranında gelir bağlanır (m.34/I, d).

Cenaze Ödeneği:İş kazası veya meslek hastalığı sonucu veya sürekli işgöremezlik geliri almakta iken ölen sigortalının hak sahiplerine Kurum Yönetim Kurulu tarafından belirlenen ve Bakanlar Kurulu tarafindan da onaylanan tarife üzerinden cenaze ödeneği ödenir. Cenaze ödeneği, sırasıyla sigortalının eşine yoksa çocuklarına o da yoksa ana babasına o da yoksa kardeşlerine verilir (m.37/III).

Evlenme Ödeneği:Sigortalının ölümü nedeniyle kendisine gelir bağlanmış olan kız çocuklarının evlenmeleri ve talepte bulunmaları halinde almakta oldukları gelirlerinin iki yıllık tutarı bir defaya mahsus olmak üzere evlenme ödeneği olarak peşin verilir. Evlenme ödeneği alan hak sahibinin gelirinin kesildiği tarihten itibaren iki yıl içinde yeniden hak sahibi olması halinde iki yıllık sürenin sonuna kadar gelir bağlanmaz (m.37/I).

\section{Türkiye’de İş Kazaları ve Meslek Hastalıkları Konusunda Sorunlar ve Öneriler}

Türkiye açısından iş kazaları ve meslek hastalıklarının ayrı bir öneminin olduğunu söyleyebiliriz. Çünkü son yıllarda iş kazası rakamlarında biraz düşme olmakla birlikte hala yüksektir. Bunun altında yatan birçok neden bulunmaktadır. Türkiye'de genelde yaygın olan üretimin, küçük ve orta ölçekli işletmelere dayanması etkili bir faktördür. Çünkü bu işyerleri açısından iş kazalarını ve meslek hastalıklarını önlemek için alınacak her türlü önlem, maliyet anlamına gelmekte ve işverenler bu maliyetten kaçınmak istemektedirler. Dolayısıyla Türkiye'de üretim yapısında, büyük ölçekli işyerlerinin sayısının artmasıyla işyerleri iş kazaları ve meslek hastalıklarının önlenmesi konusunda daha fazla çaba harcayacaklardır.

Türkiye'de istatiksel veriler ve araştırma sonuçlarından kaynaklanan bazı sorunlar da bulunmaktadır. Türkiye'de SGK tarafından yayınlanan istatistikler incelendiğinde, iş kazası rakamları ile meslek hastalıkları rakamları arasında uçurum olduğu görülmektedir. 5510 sayılı SSGSSK'da iş kazası olarak kabul edilen durumların kapsamı geniş tutulmuştur. Kayıt dışı çalışmaya bağlı olarak bazı iş kazaları ise istatistiklerde yer almamaktadır. Ayrıca, meslek hastalıklarının her zaman kişi işte çalışırken ortaya çıkmaması nedeniyle normal hastalık olarak tedavi edilmesi ve buna bağlı olarak meslek hastalıklarının istatistiklerinde yer almamasının da etkileri bulunmaktadır.

Türkiye'de iş kazaları ve meslek hastalıkları alanında sorunların çözümünde daha fazla eğitime önem verilmesi, konuyla ilgili herkesin bilinçlendirilmesinin sağlanması önem taşımaktadır. İş kazaları ve meslek hastalıkları konusunda mevzuatın eksikliğini söyleyebilmek mümkün değildir. Ancak, mevzuatın uygulanması konusunda yaşanan sorunlar bulunmaktadır (İş Sağlı̆̆1 ve Güvenliği, 2012).

Sosyal güvenlik sistemi içerisinde iş kazası ve meslek hastalığı sigortasından sağlananlar yardımlar dışında kişilerin karşılanmayan zararları söz konusu ise bu durumda genel hükümler uyarınca dava açılabilir. Ancak, Türkiye'de ne yazık ki davaların çok kısa süre içinde sonuçlandırılması mümkün olamamaktadır. Bu nedenle, iş kazası veya meslek hastalığı sonucunda zarara uğramış olan sigortalının veya onun ölümü halinde hak sahiplerinin bazı gelişmiş ülkelerde olduğu gibi zararlarının tamamının sosyal güvenlik sistemi tarafından karşılanıp daha sonra olayın meydana gelmesinde kusuru olan taraflara rücu edilmesi şeklinde bir yolun izlenmesi daha isabetli olacaktır. Çünkü SGK, zaten her iş kazası veya meslek hastalığı olayında ilgili taraflara olayın meydana gelmesindeki kusurları oranında rücu davası açmaktadır. Bu nedenle, ifade ettiğimiz şekilde bir yolun izlenmesi sonucunda mahkemelerdeki iş yükünün azalmasının yanı sıra zarara uğrayan tarafların zararlarının daha kısa süre içinde giderilmesi söz konusu olacaktır (İş Sağlığı ve Güvenliği, 2006). 


\section{Sonuç}

Sanayileşme sürecinde bulunan bütün ülkelerde, iş kazaları önemli toplumsal sorunların başında yer almaktadır. Çünkü meydana gelen iş kazası veya meslek hastalıklarının işçiler, işverenler ve devlet açısından ortaya çıkan maliyetleri bulunmaktadır. İşçi açısından iş kazası veya meslek hastalığı sonucunda çalışma gücünün veya meslek kazanma gücünün kaybı veya azalması söz konusu olmakta ve buna bağlı olarak gelirin kaybedilmesi veya gelirin azalmasıyla karşılaşılmaktadır. Ayrıca, iş kazasına uğrayan ve meslek hastalığına yakalanan kişide bazı psikolojik ve ruhsal sorunların ortaya çıkması da söz konusu olmaktadır. İşveren açısından iş kazası veya meslek hastalığı sonucunda ortaya çıkan maliyetler tazminat ödenmesi, üretimde yaşanan kayıplar ve cezalar gibi daha çok parasal olmaktadır. Devlet açısından ise ortaya çıkan en önemli maliyet, yetişmiş insan gücünün iş kazası veya meslek hastalığı sonucunda kaybedilmesidir.Ayrıca, devlet açısından ortaya çıkan maliyetler alternatif maliyetler açısından da düşünülebilir. Dolayısıyla iş kazaları ve meslek hastalıkları, çalışma hayatının tüm tarafları açısından önem taşımaktadır

İş kazaları ve meslek hastalıklarının önlenmesi temel amaç olmakla birlikte meydana geldikten sonra ortaya çıkan zararın giderilmesi de büyük önem taşımaktadır. Bu konuda sosyal güvenlik sistemi devreye girmektedir. Nitekim, hem dünyada hem Türkiye'de iş kazası ve meslek hastalığı sigortası kabul edilen ya ilk sigorta olmuş ya da ilkler arasında yer almıştır. Türkiye'de ilk olarak 1947 yılında 4447 sayılı İş Kazaları, Meslek Hastalıkları ve Analık Sigortası Kanunu kabul edilmiştir. Son olarak sosyal güvenlik sisteminin revizyonu kapsamında çalışma ilişkilerinin hukuki niteliğine bağlı olarak farklı sosyal güvenlik kanunlarına tabi olanları tek bir kanunda toplayabilmek amacıyla 2006 yılında 5510 sayılı Sosyal Sigortalar ve Genel Sağlık Sigortası Kanunu kabul edilmiştir. 5510 sayılı Kanunda 2008 yılında yapılan değişiklikle kısa vadeli sigorta hükümlerinden hizmet akdiyle çalışan ve kendi adına ve bağımsız çalışanların yararlanması söz konusu olmuştur. Devlet memurlarının bu hükümlerden yararlanabilmesi mümkün değildir. 5510 sayılı Kanunda "Hizmet Akdiyle veya Kendi Adına ve Hesabına Bă̆ımsız Çalışan Sigortalıların Tabi Olduğu Kısa Vadeli Sigorta Hükümleri” başlığı altında iş kazası ve meslek hastalığı sigortasından sigortalıya ve onun ölümü halinde hak sahiplerine sağlanacak olan para yardımları düzenlenmiştir. Sağlık yardımları, genel sağlık sigortası kapsamında düzenlenmiştir.5510 sayılı Kanunda iş kazası sayılan durumlar düzenlenmiş ve meslek hastalığının tanımı verilmiştir. Bir olayın 5510 sayılı Kanun anlamında iş kazası veya meslek hastalığı sayılması, yapılacak yardımların hangi sigorta kolundan yapılacağının tespit edilebilmesi açısından önem taşımaktadır. Çünkü iş kazası ve meslek hastalığı sigortasından sağlanacak olan yardımlarda, kişilerin belirli süre sigortalı olması veya belirli süre prim ödemiş olması şartı aranmaksızın yardımlar sağlanmaktadır. 5510 sayılı Kanun anlamında sigortalıya sağlanan parasal yardımlar, geçici işgöremezlik ödeneğinin verilmesi ve sürekli işgöremezlik gelirinin bağlanmasıdır. İş kazası veya meslek hastalığı sonucunda sigortalının ölmesi durumunda ise geride kalan hak sahiplerine iş kazası ve meslek hastalığı sigortasından gelir bağlanması, cenaze ve evlenme ödeneğinin verilmesi şeklinde parasal yardımlar yapılmaktadır. Ayrıca, sigorta yardımları ile karşılanmayan zararların tazmini için zarara uğrayan sigortalının veya hak sahiplerinin genel hükümler uyarınca dava açma hakları da bulunmaktadır.

Türkiye açısından ayrı bir önem taşıyan iş kazası ve meslek hastalıklarının önlenebilmesi için ilgili taraflara önemli görevler düşmektedir. Türkiye'de üretim yapısının niteliğinin değişmesinin yanı sıra işverenlerin bu konuda yapacakları çalışmaları maliyet olarak değerlendirmemesi, iş kazaları ve meslek hastalıklarını önleme amacı taşıyan mevzuatın uygulanması veeğitim çalışmalarına her seviyede önem verilmesi yerinde olacaktır. Ayrıca, iş kazası veya meslek hastalığına maruz kalan sigortalının veya onun ölümü halinde hak sahiplerinin zararlarının tamamının SGK tarafından karşılanıp daha sonra kusuru bulunan taraflara rücu edilmesi şeklinde bir yolun izlenmesi hem mahkemelerin iş yükünü azaltacak hem de zarar uğrayanların zararlarının daha kısa süre içerisinde giderilmesini sağlayacaktır.

\section{Kaynakça}

- Alper, 2003. Türkiye'de Sosyal Güvenlik ve Sosyal Sigortalar. B.4, Ekin Kitabevi, Bursa.

- Gerek, 2002. Sosyal Güvenlik Hukuku. Anadolu Üniversitesi, Eskişehir.

- Güzel vd, 2009. Sosyal Güvenlik Hukuku. B.12,Beta Yayınları, İstanbul.

- ILO, 2013. http://www.ilo.org/global/topics/safety-and-health-at-work/lang--en/index.htm.

- İş Sağlığı ve Güvenliği. 2012. Anadolu Üniversitesi, AÖF, Eskişehir.

- İ̧s Sağlığı ve Güvenliği. 2006. Anadolu Üniversitesi, AÖF, Eskişehir.

- Sosyal Güvenlik Hukuku. 2013. Anadolu Üniversitesi, AÖF Yayınları, Eskişehir.

- $\quad$ Sosyal Güvenlik Kurumu, İstatistik Yıllı̆̆1, 2011. http://www.sgk.gov.tr/wps/portal/tr/kurumsal/istatistikler/sgk_istatistik_yilliklari.

- Tuncay ve Ekmekçi, 2011. Sosyal Güvenlik Hukuku Dersleri.B.14, Beta Yayınları, İstanbul.

- Uşan, 2009. Türk Sosyal Güvenlik Hukukunun Temel Esasları. Seçkin Yayıncılık 


\title{
Türkiye’de Enflasyonun Uzun Hafıza Özellikleri ve Enflasyon Sürekliliği Analizi
}

\section{The Long Memory Characteristics of Inflation in Turkey and Analysis of Inflation Persistence}

\author{
Ph.D. Candidate Zühal Kurul (Hacettepe University, Turkey) \\ Ph.D. Candidate P1nar Sezer (Hacettepe University, Turkey)
}

\begin{abstract}
The aim of this paper is to illustrate the long memory characteristics of the Turkish inflation rates and to analyze the potential inflation persistence. Our empirical analysis is carried out for inflation series of Turkey during the period of 1980-2013. We used the Autoregressive Fractionally Integrated Moving Average (ARFIMA) model and find that inflation in Turkey has long memory properties when structural breaks are not taken into account. When structural changes are considered, the long memory properties show different and ambiguous results. The exogenously identified structural changes have altered the dynamic structure of the inflation process and weakened the long memory characteristics of the series.
\end{abstract}

\section{Giriş}

Bir ekonomide politika yapıcılar için politika yapım sürecinde fiyat dinamiklerini anlamak büyük öneme sahiptir. Para otoriteleri, ekonomideki fiyat gelişmelerini dikkate alarak olası enflasyonist baskılara karşı önlemler alma çabası içindedirler. Bu nedenle, günümüzde pek çok gelişmiş ve gelişmekte olan ülke enflasyonla mücadele etmek konusunda enflasyon hedeflemesi rejimini kullanmaktadır. Enflasyonla mücadelede uygulanan politikaların başarısı ise ekonomiyi etkileyen şokların ekonomiyi nasıl ve ne ölçüde etkileyeceğine bağlıdır. Bu tür şokların etkilerinin genellikle süreklilik eğilimi göstermesi temel amacı enflasyonla mücadele etmek olan politika otoritelerini hangi politikaların benimsenmesi konusunda dikkat etmeye zorlamaktadır.

Özellikle enflasyon hedeflemesi rejimi uygulayan ekonomilerde fiyat istikrarının sağlanması ve sürdürülmesi için ekonomide enflasyon sürekliliği olup olmadığının tespit edilmesi ve varlığı halinde büyüklüğünün belirlenmesi uygulanacak politikaların başarısında önemli bir role sahiptir.

Enflasyon sürekliliği, enflasyonun onu etkileyen bir şok sonrası temel düzeyine dönme hızı olarak tanımlanmaktadır (Willis, 2003). Bu anlamda enflasyon sürekliliği, enflasyonun şoka verdiği tepkinin hızıdır. Enflasyon onu etkileyen şoka hızlı tepki veriyorsa süreklilik derecesi yüksek olacaktır.

Enflasyon sürekliliğinin analizi ise enflasyon oranlarının zaman serisi özellikleri incelenerek yapılmaktadır. Uygun bir politika seçimi için enflasyon oranlarının davranışı büyük önem taşımaktadır. Çoğunlukla cari enflasyon oranlarının geçmiş enflasyon oranlarından önemli ölçüde etkilendiği düşünülür. Bir başka deyişle, enflasyonu etkileyen şokların enflasyon üzerinde kalıcı etkileri olduğu varsayılır. $\mathrm{Bu}$ durumun istatistiksel anlamı enflasyon serilerinin genellikle birim köke sahip zaman serilerine sahip olduğuna inanılmasıdır. Optimal politika kurallarının oluşturulmasında durağan olmayan serilerle çalışmak enflasyonla mücadele etmeyi politika yapıcılar için zorlaştırmaktadır.

\section{Literatür}

Enflasyon dinamiklerini inceleyen çalışmalar, Phillips (1958)'den bu yana fiyat ve ücret katılıklarından yola çıkarak yapılmıştır. Fiyat ve ücretlerdeki katılıklarının enflasyona üzerindeki etkilerinin belirlenmesi son dönemde önemli tartışma ve araştırma alanı oluşturmuştur. Bu bağlamda günümüze kadar fiyat oluşumu sürecini oluşturduğu düşünülen pek çok mekanizma öne sürülmüştür. Taylor (1979, 1980) ve Calvo (1983) tarafindan ortaya konan yapışkan fiyat modelleri, iki önemli standart model olarak karşımıza çıkmakta ve uzun bir süre fiyat dinamikleri konusundaki tartışmalarında baskın oldukları gözlemlenmektedir.

Zaman içinde enflasyonun geçmiş enflasyonla olan bağlantısını ve bu anlamda süreklilik gösterip göstermediğini araştıran pek çok çalışma yapılmıştır. Fuhrer ve Moore (1995), Gali ve Gertler (1999), Christiano, Eichenbaum, ve Evans (2001), Gali, Gertler, ve L’opez-Salido (2001), Driscoll ve Holden (2004), Coenen ve Wieland (2005) gibi çalışmalar başlıca örneklerdir. Bu çalışmaların sonuçlarına bakıldığında enflasyon sürekliliğinin nedenleri, derecesi ve istikrarı konusunda tartışmaların ve buna bağlı olarak farklı sonuçların devam ettiği söylenebilir. Gali ve Gertler (1999), enflasyonun gecikmeli değerlerinin dâhil edildiği modellerin başında gelmekte ve Yeni Keynesyen Phillips eğrisinin nihai halini oluşturmaktadır. Modele dâhil olan gecikmeler enflasyonun geçmişe dayalı yapısını gösterirken Gali ve Gertler, çıktı açığı yerine reel marjinal maliyetleri dikkate almaktadır. Aynı konu üzerinde analiz yapan Fuhrer ve Moore (1995) ise enflasyonun geçmişe dayalı yapısını modellerken nispi ücret yapısını ele almaktadır. Bir diğer taraftan para politikasının 
uzun dönemde enflasyon beklentilerini yönetme ve kontrol etme gücü ile enflasyon sürekliliği ilişkisini inceleyen çalışmalar da vardır. Sargent (1999), yüksek derecede enflasyon sürekliliğinin mevcut olması halinde para politikasının etkinliğinin azaldığını öne sürmektedir.

Tüm bu çalışmaların sonuçları enflasyonun yavaş uyarlanmasının ve süreklilik göstermesinin arkasında çeşitli etkenler yer aldığını göstermektedir. Bu etkenlerin en önemlilerinden biri, marjinal maliyetler ya da çıktı açı̆̆ı gibi enflasyonun temel belirleyicilerinden olan değişkenlerde meydana gelen kalıcı dalgalanmalardır. Buna dışsal (extrinsic) süreklilik adı verilmektedir. Bir diğeri ise enflasyonun kendi geçmişine olan bağlılığıdır. Bu duruma da öze bağlı (instrinsic) süreklilik adı verilmektedir. Üçüncü olarak ise enflasyon beklentilerinin oluşumundan kaynaklı bir süreklilik olgusu söz konusudur. Enflasyon sürekliliğine neden olan bu üç kaynak da geleneksel Yeni Keynesyen Philips eğrisine dayandırılabilir. Buna göre cari enflasyon, kendi gecikmelerine, gelecek enflasyon beklentisine, çıktı açığına ve maliyet enflasyonu şoku gibi değişkenlere bağlı olacaktır (Altissimo vd., 2006).

Enflasyon sürekliliği konusundaki ampirik literatür, ABD ve pek çok OECD ülkesinde enflasyonun yüksek derecede süreklilik gösterdiğini ortaya koymaktadır. Pek çok iktisatçı için yükssek enflasyon sürekliliği artık kesin bir olgudur ve yukarıda bahsedilen nedenlerle pek çok ekonomi enflasyon sürekliliği yaşamaktadır. Bu çalışmaların yanında enflasyon sürekliliğinin derecesinin yapısal geçmişten kaynaklanmadığı bunun yerine para politikası rejimlerindeki şeffaflık ve istikrarla birlikte değiştiği yönünde görüşleri öne süren çalışmalar da vardır (Levin ve Pieger, 2002).

Enflasyon dinamiklerinin ampirik olarak incelenmesine gösterilen büyük ilginin nedenleri arasında öncelikle uluslar arası para politikaları ve rejimleri konusunda yaşanan değişiklik ve gelişmeler yer almaktadır. Pek çok ülke enflasyon hedeflemesi rejimi uygulamakta ve para politikalarının temel amacını düşük ve istikrarlı bir enflasyon olarak belirlemektedir. Avrupa'da parasal birliğin kurulması ve pek çok gelişmiş ülkenin antienflasyonist süreçlerden geçmesi bunun belirgin örnekleridir (Gadea ve Mayoral, 2005).

Enflasyonun nasıl modellemesi gerektiği konusunda ortak bir sonuca varılmadı̆̆ı açıktır. Öncelikle enflasyon sürekliliği kesin ve açık bir biçimde nasıl ölçülecektir? Bu sürekliliğin değişip değişmediği nasıl analiz edilecektir? Burada temel alınması gereken konu, enflasyon sürekliliğinin parasal aktarım mekanizmasında ve para politikasının düşük ve istikrarlı enflasyon oranlarını yakalamasında büyük öneme sahip olduğudur.

Tüm teorik ve ampirik tartışmalara karşın literatür, savaş sonrası dönemde sanayileşmiş ülkelerde enflasyon sürekliliğinin yüksek olduğunu ortaya koymaktadır. Örneğin ABD için Pivetta ve Reis (2001); Euro bölgesi için O’Reilly ve Whelan (2004) ise Euro bölgesi için enflasyon oranlarının geçmiş değerlerinden oldukça fazla etkilendiğini ve enflasyonda yüksek derecede süreklilik olduğunu kanıtlamışlardır. Tüm bu sonuçların kullanılan istatistik ve ekonometrik yönteme duyarlı olduğunu belirtmek gerekmektedir. Bunun yanı sıra gözlemlenen enflasyon sürekliliği incelenirken ekonominin yapısı ve geçmişi dikkate alınmalıdır. Beklenmedik yapısal kırılmalar - enflasyon hedeflerinde değişiklik, farklı döviz kuru rejimlerinde değişiklik, temel fiyatları etkileyen şoklar vs.- enflasyon sürekliliğinin derecesini etkilemektedir (Gadea ve Mayoral, 2005).

Cechetti ve Debelle (2006), son dönemde enflasyon sürekliliğinin yavaşladığını öne sürmektedir. Özellikle 1990'lardan sonra enflasyonla mücadele dönemine girilmesi, pek çok gelişmiş ve gelişmekte olan ekonomide enflasyon hedeflemesine geçilmesi, merkez bankalarının güvenilirliğin ve şeffaflığının artması enflasyon sürekliliğinin düşmesine ön ayak olmaktadır.

\section{Türkiye'de Enflasyon}

Türkiye'de 1980-2013 dönemi farklı para politikası uygulamalarını ve enflasyon dinamiklerini içermektedir. 1980’lerin başından itibaren bakıldığında Türkiye ekonomisinin yüksek ve değişken enflasyonla karşı karşıya olduğu görülmektedir. Bu süre içinde pek çok fiyat istikrarını sağlamaya yönelik dezenflasyon politikası uygulanmış ancak enflasyon Türkiye ekonomisinin temel sorunlarından biri olarak kalmaya devam etmiştir (Akyüz ve Boratav, 2003). Şekilden görüleceği üzere 1980'lerin ilk yıllarında enflasyon \%30'lara kadar gerilemiş olsa da 1980'lerin ortasında yeniden artma eğilimine girmiştir. 1994 yılındaki ekonomik krizle birlikte \%120 seviyelerine kadar yükselen enflasyon, ancak bir sonraki yıl \%80’lere kadar gerileyebilmiştir. Bu dönemde enflasyonla mücadele amaçlı birçok geniş çaplı yapısal önlem alınmış ancak yüksek ve sürekli enflasyon Türkiye ekonomisinin temel özelliklerinden biri olarak kalmıştır.

Türkiye'nin 1995 yılı sonrası enflasyon deneyimi, farklı para politikası uygulamalarını ve değişen enflasyon oranlarını yansıtmaktadır. 1995-2001 dönemi ele alınacak olursa, bu dönem parasal hedefleme ve döviz kuru hedeflemesinin uygulandığı dönemdir ve bu dönemde enflasyon yüksek ve istikrarsız olarak değerlendirilebilir. 2000 yılında uygulanmaya başlanan “Enflasyonu Düşürme Programı”, enflasyonu 2000 yılı sonunda \% 39'a kadar geriletmiş olsa da bu durum sürdürebilir olmamıştır. Bunun nedenlerin başında Türkiye ekonomisine özgü yapısal problemlerin giderilmemesi (bankacılık sektöründeki kırılganlıklar, yapısal reformların gerçekleştirilmemesi, artan faiz oranları vs.) gelmektedir. 2000 yılının Kasım ayında ciddi bir likidite sıkışıklığı yaşanmış ancak bu sıkışıklığı aşmak üzere alınan önlemler yetersiz kalmıştır. 2001 yılı başında faiz oranları hedeflenen düzeyin üzerinde gerçekleşmiş ve fon sıkışıklığı devam etmiştir. Siyasi gelişmelerin de etkisiyle aşırı 
döviz talebinin önüne geçilememiştir. Merkez Bankası'nın müdahalesine karşın likidite sıkışıklı̆̆ııın önüne geçilemeyince 22 Şubat 2001 tarihinde döviz kuru hedefinden vazgeçilerek kur dalgalanmaya bırakılmıştır.

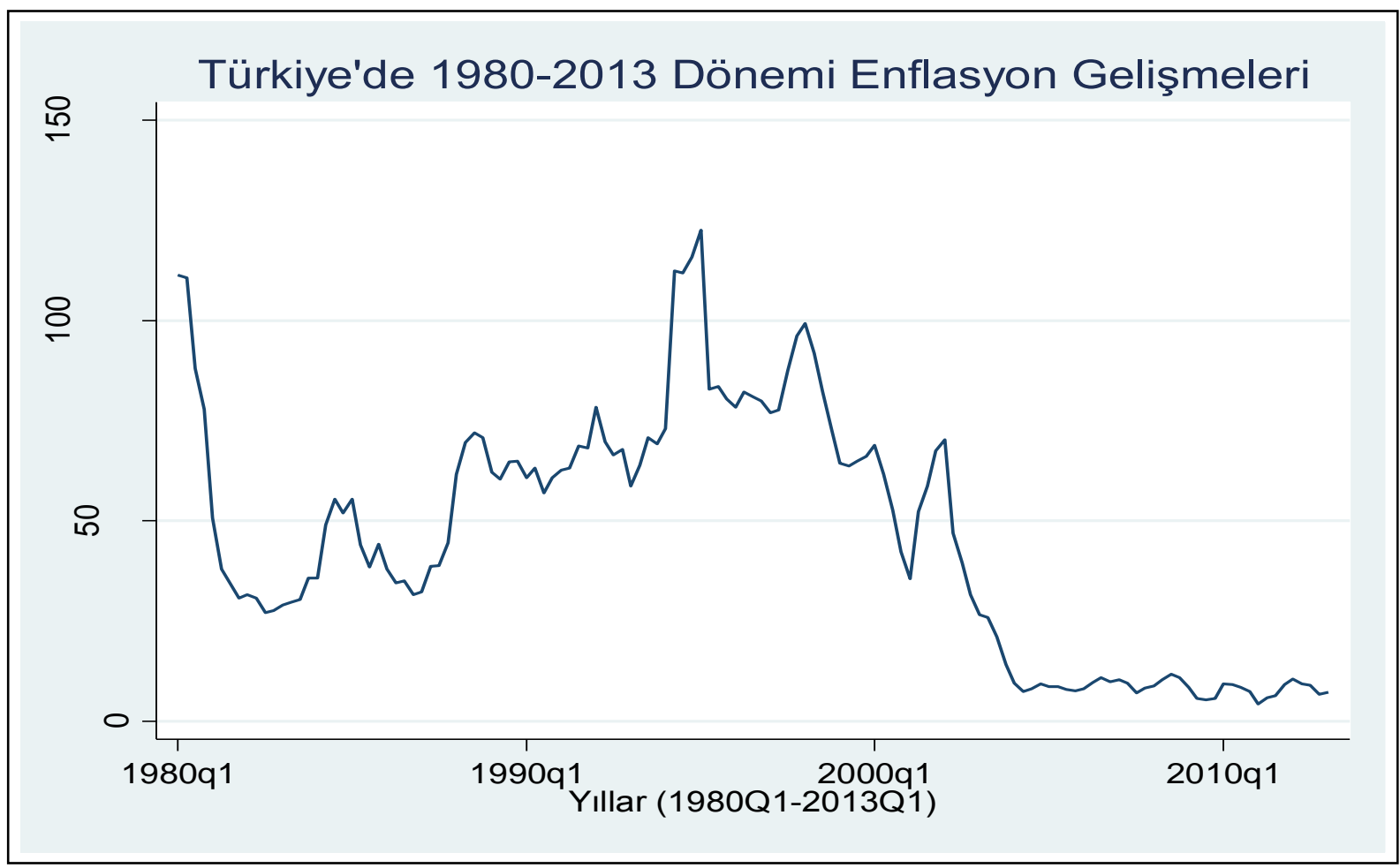

Şekil 1: Türkiye'de Enflasyonun Gelişimi

Yaşanan finansal kriz, ekonominin yapısal olarak daha güçlü olması gerektiğini göstermiştir. Yeniden yapılanma kapsamında bankacılık ve finans sektörü ile reel sektör arasında sağlıklı bir ilişki kurmak, kamu finansman dengesini güçlendirmek üzere değişiklik yapılmasına karar verilmiştir (TCMB, 2001). Kriz sonrası dönemde kriz öncesinde ve sonrasında uygulanan politikaların enflasyonist etkilerinin azaltılması için para tabanı operasyonel bir hedef olarak seçilmiş ve nihai amacın enflasyon hedeflemesi olmasına karar verilmiştir. $\mathrm{Bu}$ çerçevede enflasyon hedeflemesine geçiş için gerekli şartların sağlanması yönünde adımlar atılmıştır. İlk olarak TCMB Kanunu değiştirilmiş ve bu kanunda bankanın temel amacının fiyat istikrarını sağlamak olduğu belirtilmiştir. Banka, bu bağlamda araç bağımsızlığına sahip olmuş ve bankaya şeffaflık ve hesap verebilirlik sorumluluğu yüklenmiştir.

2002 yılından itibaren örtük enflasyon hedeflenmesine geçilmiştir. İlk üç yıl için enflasyon hedefleri sırasıyla $\% 35, \% 20$ ve $\% 12$ olarak açıklanmıştır. Bu hedeflere ulaşılması için seçilen araçlar para tabanı ve kısa vadeli faiz oranları olmuştur. TCMB örtük enflasyon hedeflemesi rejiminde enflasyon beklentilerinin daha iyi yönetilmesini amaçlamış ve kamuoyu ile daha şeffaf bir iletişim kanalı oluşturmaya çalışmıştır. 2003 ve 2004 yılları mali disiplinin sağlanması yönünde önemli gelişmelere tanıklık etmiştir. 2000 yılı itibariyle kamu kesimi borçlanma gereğinin milli gelire oranı \%3,6'ya, kamu borç stoku ise \% 90 seviyesinden \%63,4'e kadar gerilemiştir. Aynı dönemde döviz kurunun enflasyon üzerindeki geçişkenliğinin azaldığı gözlemlenmiştir (Kara ve Öğünç, 2005). Sonuç olarak, 2004 yılında enflasyon 30 yıl sonra ilk defa tek haneli olarak gerçekleşerek uygulanan programa olan güveni arttırmıştır. 2005 yılı bir geçiş yılı olarak düşünülmüş ve merkez bankasının şeffaflığın ve kurumsal alt yapısının geliştirilmesi yönünde çalışmalar yapılııştır. 2006 yılında açık enflasyon hedeflenmesine geçilmiştir. TCMB bu dönemde iletişim araçlarını yeniden düzenlemiş, düzenli olarak Enflasyon Raporu yayınlamaya başlamıştır. Enflasyon raporlarında enflasyonun hedeften sapması halinde bunun nedenleri detaylı olarak açıklanmış ve gelecek enflasyon beklentilerine, uygulanacak para politikasına dair sinyallere yer verilmiştir.

2007-2013 dönemi için genel olarak açık enflasyon hedeflemesi rejiminin çerçevesi ve ilkeleri değişmemiştir. Para politikası aracı olarak kısa vadeli faiz oranları temel alınmıştır. Bu döneme ait enflasyon gelişmeleri dikkate alındığında hedeflemenin uygulandığı ilk üç yılda enflasyon hedeflenen düzeyi aşmıştır. 2006 yılında uluslararası piyasalardaki dalgalanmalar ve petrol fiyatlarındaki artışlar enflasyon üzerinde etkili olmuştur. 2009 yılında enflasyon önceden belirlenen aralık içinde kalmış ancak tam anlamıyla hedeflere ulaşılamamıştır. 2008 yılının son çeyreğinde tüm dünyayı saran küresel krizin etkisiyle TCMB krizin tahribatını azaltmaya yönelik politikalar uygulamaya başlamıştır. TCMB, piyasaya likidite desteğini arttırmış ve hızlı faiz indirimlerine giderek piyasaların işlerliğini korumaya çalışmıştır. İç talebi ve enflasyonu canlandıracak olan bu tedbirle 
birlikte dış kaynaklı ve yukarı yönlü baskılar enflasyonun hedeflenen düzeylerin üzerinde gerçekleşmesine neden olmuştur. Bu süreçte merkez bankası, fiyat istikrarını sağlama sorumluluğunun yanında finansal istikrarı sağlama sorumluluğunu da üstlendiğinden farklı politika araçlarıyla para politikasını sürdürmüştür.

Son dönemde enflasyon, belirlenen hedeflerin üzerinde olmakla birlikte \% 6-8 aralığında hareket etmektedir. Açık enflasyon hedeflemesinin başladığı tarihten günümüze kadar geçen sürede enflasyonun görece düşük ancak hala hedeften yüksek ve belirli bir aralıkta direnç göstermesi tartışmaya açık bir konu olarak karşımızda durmaktadır. Küresel krizle birlikte yeni bir politika bileşimi uygulayan merkez bankasının enflasyon hedefinden ayrılmamakla birlikte döviz kuru ya da krediler ile ilgili birtakım eşik değerler gündeme getirmesi ve gerektiğinde müdahale edileceğine dair sinyaller vermesi yeni politika bileşiminin enflasyonun gelişimi konusunu biraz gölgede bıraktığı izlenimini vermektedir.

\section{Yöntem}

Enflasyon sürekliliğini ölçen modeller başlıca üç grupta toplanabilir. Bunlardan ilki istatistiksel-parametrik ölçülerdir. Bu ölçüler de kendi arasında (i) Sabit ortalamalı otoregresif modeller, (ii) değişken ortalamalı otoregresif modelleri, (iii) ARFIMA modelleri olarak ayrıştırılabilir. İkinci ve üçüncü grup modeller parametrik olmayan ve yapısal enflasyon modelleridir. Bu çalışmanın kapsamında olmadığı için parametrik olmayan ve yapısal modeller detaylı olarak incelenmemiştir. Kısaca değinmek gerekirse yapısal enflasyon modelleri, Yeni Keynesyen Phillips Eğrisine dayanmaktadır. Yapısal yaklaşım, yapısal parametrelerin tahminine dayalı bir enflasyon direnci ölçüsü bulmak için kullanılmaktadır. Çalışmanın bundan sonraki bölümünde çalışmamızın kapsamı gereği sadece parametrik yöntemler tanıtılmaktadır.

\subsection{Sabit ortalamalı otoregresif modeller}

Andrews ve Chen (2004), enflasyon sürekliliğini aşağıdaki denklemle bir AR(p) süreci oluşturarak modellemiştir.

$$
\pi_{t}=\alpha+\sum_{i=1}^{p} \beta_{i} \pi_{t-i}+\eta_{t}
$$

$\mathrm{Bu}$ modelde enflasyon sürekliliği enflasyonun geçmiş değerlerine bağlıdır. Bu modele dayanarak yaygın olarak kullanılan enflasyon sürekliliği ölçüsü denklemdeki otoregresif katsayılar toplamıdır.

$$
\rho=\sum \beta_{i}
$$

Marques (2004)'e göre enflasyon sürekliliği kavramı enflasyonun kendisini etkileyen bir şok sonrası uzun dönem ortalamasına dönme hızı ile de ilişkilidir. Bu nedenle enflasyon için daha uygun bir gösterim (1) denklemini hata düzeltme modeli olarak ortalamadan sapmalarını da gösterecek biçimde yeniden düzenlenmesidir :

$$
\pi_{t}-\mu=\sum_{i=1}^{p-1} \varphi_{i} \Delta\left(\pi_{t-i}-\mu\right)+\rho\left(\pi_{t-1}-\mu\right)+\eta_{t}
$$

Burada $\mu=\frac{\alpha}{1-\rho}$ enflasyonun koşulsuz ortalamasını göstermektedir.

Hata düzeltme modelinde $\rho$ ' nun mutlak değeri arttıkça enflasyon sürekliliğinin derecesi artar. Bir başka deyişle, daha fazla süreklilik gösteren enflasyon, ortalama düzeyine daha yavaş dönmektedir. Burada önemli nokta, sabit ortalama varsayımının yapılıp yapılamayacağına dair makul bir neden bulunmasıdır.

\subsection{Değişken ortalamalı otoregresif modeller}

Levin ve Pieger (2004), enflasyon serisindeki muhtemel kırılmaları dikkate almayan sabit ortalamalı otoregresif modellere dayalı süreklilik ölçüsünün enflasyon sürekliliğini olduğundan yüksek tahmin ettiği sonucuna ulaşmıştır. Bu nedenle ilgili modele yapısal kırılmaların kukla değişken yöntemi kullanarak eklenmesi gerektiğini savunmuşlardır.

Marques (2004), değişken ortalamalı otoregresif modeli ortalamalardan sapmaları da içerek biçimde bir hata düzeltme modeli olarak şu şekilde ifade etmektedir:

$$
\pi_{t}-\mu_{t}=\rho\left(\pi_{t-1}-\mu_{t-1}\right)+\sum_{j=1}^{k-1} \delta_{j} \Delta\left(\pi_{t-j}-\mu_{t-j}\right)+\varepsilon_{t}
$$

\subsection{ARFIMA modelleri}

Enflasyon sürekliliğini göstermek için kullanılan bir diğer parametrik yöntem ARFIMA modelleridir. ARFIMA süreci, kesirli bütünleşme temeline dayanmaktadır. ARFIMA aslen bir otoregresif hareketli ortalama süreciyle temsil edilen bir serinin bütünleşiklik derecesinin tam sayı olmadığı, kesirsel olarak ifade edildiği durumdur. Bir ARFIMA modelinde kesirsel bütünleşme terimi $d$ herhangi bir reel sayı olabilmektedir.

Bir ARIMA modeli tahmin eden araştırmacı, bütünleşme parametresini bir tam sayı olarak seçmekte ve d. derecen farkı alınmış olan bu seriyi durağan bir süreç olarak tanımlamaktadır. Oysaki birim kök testlerinin bir serinin gerçekten durağan olup olmadığı konusundaki sonuçları şüphe uyandırabilmektedir. Geçmişine bağ lılığı 
yüksek olan pek çok zaman serisi, I(1) olmadığı halde I(0) olarak sınıflandırılmaktadır. ARFIMA modeli bu tipteki serileri göstermek için tasarlanmıştır.

Durağan olmayan I(1) bir zaman serisini etkileyen şok kalıcı olmaktadır. Oysa I(0) bir durağan seride söz konusu şok üstel azalma şeklinde etkisini azaltarak ortadan kalkmaktadır. Kesirsel bütünleşme yaklaşımı bu iki durum arasında kalan bir süreci ifade etmektedir. Bir zaman serisi $\mathrm{d}=0$ durumunda kısa hafıza özelliği taşırken d'nin 0 ve 1 arasında değer alması seriyi etkileyen şok sonrasında serinin kendi ortalamasına döneceğini ancak bunun uzun bir süre alacağını göstermektedir. Bir başka deyişle böyle bir seri, uzun hafiza özelliği taşımaktadır. $\mathrm{D}=1$ olması halinde şok kalıcı hale gelmekte ve seri kendi ortalamasına dönmemektedir. Kesirli bütünleşiklik durumu şokun önemli ölçüde kalıcı ancak uzun dönemde kendi ortalamasına döneceğini göstermektedir. AFIMA modelleri ile bu tür bir sürekliliğin daha iyi betimleneceği kabul görmektedir (Franta vd., 2007).

$\operatorname{Bir} \operatorname{ARFIMA}(\mathrm{p}, \mathrm{d}, \mathrm{q})$ modeli şu şekilde gösterilebilir:

$$
\begin{aligned}
& \phi(L)(1-L)^{d}\left(y_{t}-\mu\right)=\theta(L) u_{t} \\
& \phi(L)=1-\sum_{j=1}^{p} \phi_{j} L^{j} \\
& \theta(L)=1+\sum_{j=1}^{p} \theta_{j} L^{j}
\end{aligned}
$$

Burada $\mathrm{p}$ ve $\mathrm{q}$ dereceden polinomların kökleri birim çemberin dışında kalmaktadır ve hata terimi

$$
u_{t} \sim \operatorname{iid}\left(0, \sigma^{2}\right)
$$

Ayrıca kovaryans durağan ve kısa hafizaya sahip bir serinin otokorelasyon fonksiyonu

$\sum_{j=-\infty}^{\infty}|\rho(j)|<\infty$

Şeklindedir ve bu fonksiyon üstel azalma göstermektedir. Eğer $\mathrm{d}>0$ ise otokorelasyon fonksiyonları yavaş ve hiperbolik bir azalma sergileyecektir. Buna göre otokorelasyon fonksiyonu

$$
\sum_{j=-\infty}^{\infty}|\rho(j)|=\infty
$$

Şeklinde olacaktır.

Eğer $0<\mathrm{d}<0.5$ ise seri durağandır, sonlu bir varyansa ve uzun hafizaya sahiptir. Bu seri ortalamasına geri dönecektir. Eğer $0.5<\mathrm{d}<1$ ise seri durağan değildir, sonsuz varyansa ve kalıcı bir hafızaya sahiptir. Bu seri de bir süre sonra ortalamasına geri dönme eğilimindedir fakat artık durağan değildir. $\mathrm{d}=0$ durumunda ise kısa hafızaya sahip durağan ve ARMA modeline dönüştürülebilen bir süreç gözlemlenmiş olur.

Uzun hafizaya ya da sürekliliğe sahip olan bir seri, kısa hafizaya sahip bir ARMA sürecinin geometrik azalan otokorelasyon fonksiyonuna göre daha yavaş ve hiperbolik olarak azalan bir otokorelasyon fonksiyonuna sahiptir.

ARFIMA modeli bu özellikleriyle enflasyonun modellenmesinde yaygın olarak kullanılmaktadır. ARFIMA modelleri ile enflasyon sürekliliğinin yüksek derecede olup olmadığı birim kök olmaksızın tespit edilebilmektedir.

Bir ARFIMA modelinin tahmin edilmesinde ilk aşama kesirli bütünleşme teriminin (d) tahmin edilmesidir. Elde edilen $d$ değeri ile birlikte uygun $\operatorname{ARFIMA}(p, d, q)$ modelinin etki tepki fonksiyonları hesaplanarak enflasyonu etkileyen şokun süreklik gösterip göstermediği ve bunun için ne kadar süre geçmesi gerektiği ortaya konabilir. Sürekliliğin yüksek olduğu d parametresinin 1'e yakın çıkmasından ve etki tepki fonksiyonlarının da 1'e yakın değerler vermesinden anlaşılabilir (Franta vd., 2007).

\section{Veri, Yöntem ve Ampirik Bulgular}

Çalışmanın bu bölümünde Türkiye'de enflasyon sürekliliğini incelemek ve enflasyon serisinin uzun hafıza özelliklerini belirlemek amacıyla yapılan zaman serisi analizleri yer almaktadır. Çalışmada 1980-2013 yıllarını kapsayan çeyrek dönemlik enflasyon verileri kullanılmıştır. Enflasyon verileri $2005=100$ bazlı tüketici fiyat endeksinden elde edilmiştir ve OECD veri tabanından alınmıştır.

Çalışmada ele alınan dönemin en önemli özelliği, Türkiye'de enflasyonun yüksek ve kronik olduğu bir dönemden görece daha düşük ve istikrarlı olduğu bir döneme geçişini yansıtıyor olmasıdır. Bu dönem içinde Türkiye'de iki önemli ekonomik kriz (1994 ve 2001 yılları) meydana gelmiş ve bu krizler enflasyon serisinde belirgin kırılmalara neden olmuştur. Daha önce belirtildiği üzere çalışmanın amacı uzun yıllar yüksek enflasyonla yaşamış olan Türkiye ekonomisinde enflasyonun süreklilik gösterip göstermediğini anlamak ve enflasyona etki eden bir şok sonrasında enflasyonun uzun dönem değerine dönüp dönmediğini ya da bu şokun kalıcı olup olmadığını ARFIMA (Otoregresif Kesirli Bütünleşik Hareketli Ortalama) yöntemi ile test etmektir.

Enflasyon sürekliliğinin derecesini ölçmeye yönelik geleneksel modellerden sabit ortalamalı ve değişken ortalamalı otoregresif modellere bu çalışmada yer verilmemektedir. Bu çalışmada uzun hafiza özelliklerini incelenen enflasyon serisine gerekli test prosedürlerine geçmeden öncelikle serinin durağanlık özellikleri 
incelenmiştir. $\mathrm{Bu}$ nedenle enflasyon serisine uzun hafiza konusunda sinyaller verebilecek olan durağanlık testlerinden geleneksel olan Augmented Dickey Fuller (ADF) ve Phillips-Perron (PP) testleri uygulanmıştır.

\begin{tabular}{||l|l|l|l||}
\hline Değişken & Model & ADF & PP \\
\hline Enflasyon (Düzey) & Sabit & $-2,017(2)$ & $-2,239(4)$ \\
\hline & Sabit ve trend & $-2,354(2)$ & $-2,354(4)$ \\
\hline Enflasyon (1.fark) & Sabit & $-5,430^{* *}(2)$ & $-9,158^{* *}(4)$ \\
\hline & Sabit ve trend & $-5,394^{* *}(2)$ & $-9,145^{* *}(4)$ \\
\hline
\end{tabular}

Tablo 1. Durağanlık Testleri. *\%5 düzeyinde anlamlıllğl, **\%1 düzeyinde anlamlılı̆g göstermektedir.

Parantez içindeki terimler ADF testi için Akaike Bilgi kriterine göre belirlenmiş optimal gecikmeleri, PP testi için Newey West gecikmelerini göstermektedir.

Tablo 1'de yer alan ADF ve PP testlerinin sonuçlarına göre enflasyon serisinin düzey hali her iki model türünde de durağan değildir ve birim köke sahiptir. Serilerin birinci farkları alınarak aynı testler yapıldığında serilerin durağan hale geldikleri gözlemlenmektedir. Dolayısıyla enflasyonu etkileyen bir şok enflasyon üzerinde kalıcı etkiler bırakmaktadır. $\mathrm{Bu}$ sonuçlar enflasyonda süreklilik olgusunun var olduğunu basit anlamda göstermektedir ancak enflasyon serisinin uzun hafiza özelliği taşıyıp taşımadığı konusunda herhangi bir açıklama yapmaya olanak sağlamamaktadır.

Durağanlık testlerinin yanında söz konusu seriye ait otokorelasyon fonksiyonunun incelenmesi de uzun hafızanın varlığına dair sinyaller vermektedir. Grafik 1 enflasyon serisine ait otokorelasyon fonksiyonunu göstermektedir.

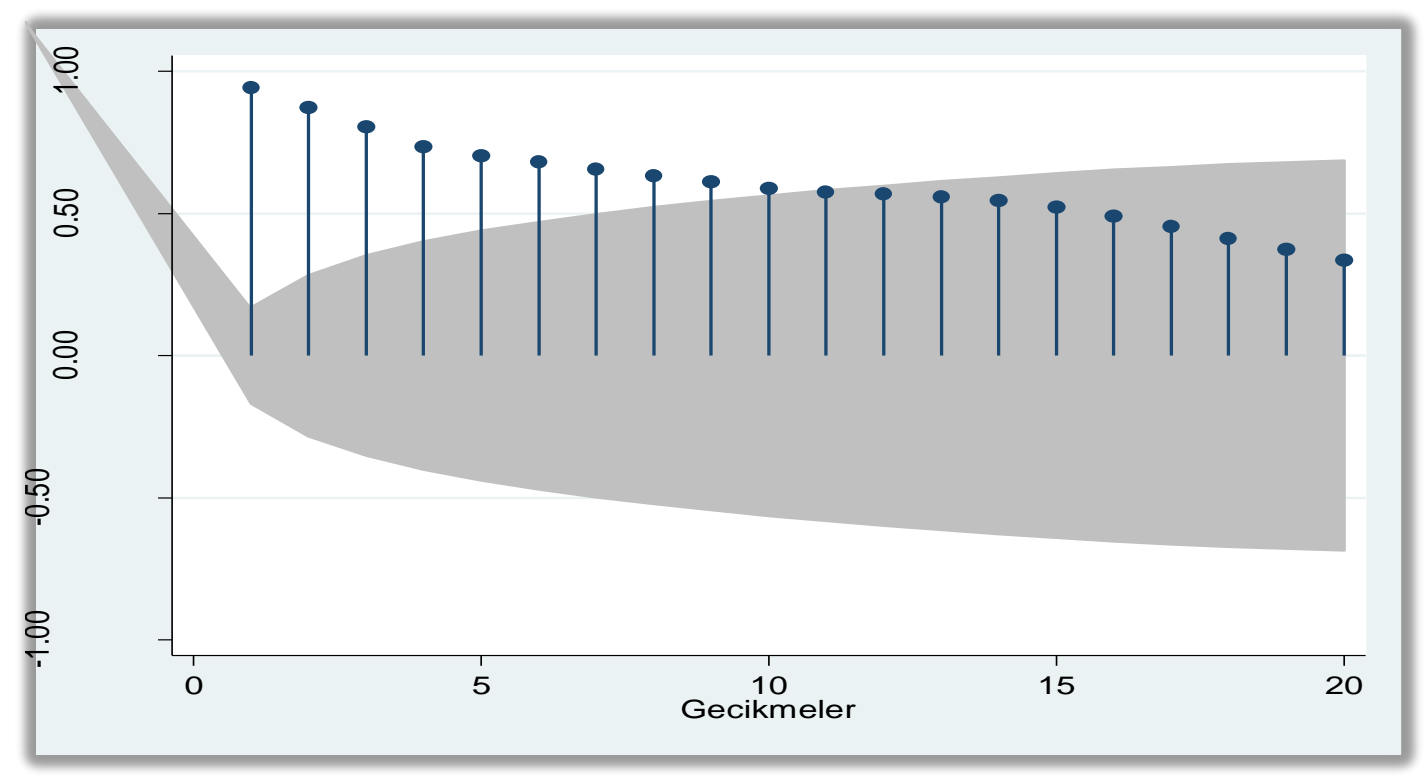

Grafik 1 Enflasyon serisine ait Otokorelasyon Fonksiyonu

Grafik 1'de görüleceği üzere seçilen yirmi gecikme boyunca enflasyon serisine ait otokorelasyonlar yavaş bir azalma göstermektedir. Literatüre göre bu tür bir yavaş azalma seyri gösteren serilerde uzun hafiza özellikleri olmasi muhtemeldir.

Geleneksel birim kök testlerinin enflasyonun birim kökü olduğuna dair kanıtlar sunmasına rağmen bu testlerin açıklama gücünün kesirli bütünleşme (fractional integration) yöntemine nazaran zayıf olduğu düşünülmektedir (Diebold ve Rudebusch, 1991). Bu nedenle enflasyonun ARFIMA (Otoregresif Kesirli Bütünleşik Hareketli Ortalama) yöntemi daha iyi modellenebileceği düşünülerek çalışmaya ARFIMA modelinin tahmini ile devam edilmiştir.

ARFIMA modellerinin tahmininde literatürde yaygın olan en yüksek olabilirlik tahmin yöntemi tercih edilmiştir. Benimsenen tahmin yönteminin yapısı gereği farklı $\operatorname{ARFIMA(p,d,q)~modelleri~denenmiş~ve~bu~}$ modellere göre uzun hafiza parametresi olan " $d$ " tahmin edilmişsir. Bu tahminler arasından istatistiksel olarak en anlamlı modeller seçilerek incelenmiştir.

İlk olarak ARFIMA $(0, \mathrm{~d}, 0)$ modeli tahmin edilmiş ve $d$ parametresi 0,49 olarak bulunmuştur. Parametre tahmini \%1 düzeyinde istatistiksel olarak anlamlıdır. Bulunan $d$ değeri $0<0,49<0,5$ olduğu için seri uzun hafiza özelliği taşımaktadır. Bu durumda enflasyon serisi kovaryans durağandır ve bir süre sonra ortalamasına geri 
dönmektedir. Enflasyonda meydana gelen bir şok ARMA ya da ARIMA modellerine nazaran daha yavaş etkisini kaybetmektedir.

\begin{tabular}{|c|c|c|c|c|}
\hline \multicolumn{5}{|c|}{ Ö̈neklem: 1980Q1-2013Q1 } \\
\hline \multicolumn{5}{|c|}{ Gözlem sayıs1: 133} \\
\hline Değişkenler & Katsayılar & Standart hata & Z testi & $\mathbf{P}>\mathbf{z}$ \\
\hline Sabit & 43,7373 & 84,1800 & 0,52 & 0,603 \\
\hline $\mathrm{d}$ & 0,49714 & 0,00402 & 123,56 & 0,000 \\
\hline \multicolumn{5}{|l|}{ Log olabilirlik: $-515,155$} \\
\hline \multicolumn{5}{|l|}{ Wald Chi2(1): 15266,59} \\
\hline P>Chi2: 0,000 & & & & \\
\hline
\end{tabular}

Tablo 2. ARFIMA $(0, d, 0)$ modeli tahmini

Farklı model tiplerinden istatistiksel olarak anlamlı olan bir diğer model ARFIMA(1,d,0) modelidir. Tablo 3 'de görüldüğü üzere $d$ parametresi bir önceki modele göre düşük olmakla birlikte $0<0,29<0,5$ olduğu için enflasyon serisinin uzun hafıza özellikleri taşıdığını göstermektedir.

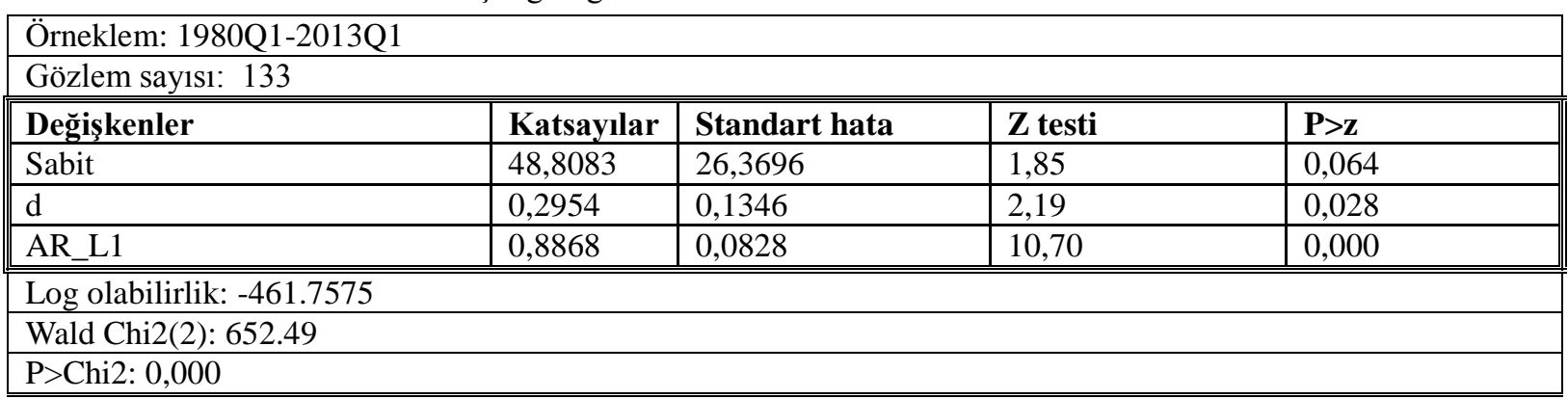

Tablo 3. ARFIMA $(1, d, 0)$ modelinin tahmini

Daha uzun gecikmelerin olduğu olan modeller arasında istatistiksel olarak anlamlılığı yüksek modellerden biri de ARFIMA(1,d,2) modelidir. Tablo 4'te görüleceği üzere, bu model yapısının da uzun hafiza özellikleri taşıyan sonuçlar ortaya koymaktadır. Bu modelin sonuçlarına göre $d$ parametresi 0,42 olarak tahmin edilmiştir. Fark parametresi olan $d$, 0 ve 0,5 arasında yer aldığından enflasyon serisi ARFIMA (1,d,2) modeli için uzun hafiza özelliği taşımakta ve bir süre sonra ortalamasına geri dönmektedir.

\begin{tabular}{|c|c|c|c|c|}
\hline \multicolumn{5}{|c|}{ Örneklem: 1980Q1-2013Q1 } \\
\hline \multicolumn{5}{|l|}{ Gözlem sayısı: 133} \\
\hline Değişkenler & Katsayılar & Standart hata & Z testi & $\mathbf{P}>\mathbf{z}$ \\
\hline Sabit & 45,7719 & 32,8868 & 1,39 & 0,164 \\
\hline $\mathrm{d}$ & 0,4225 & 0,10468 & 4,04 & 0,000 \\
\hline AR_L1 & 0,5841 & 0,1318 & 4,36 & 0,000 \\
\hline MA_L2 & 0,9021 & 0,0442 & 20,37 & 0,000 \\
\hline \multicolumn{5}{|c|}{ Log olabilirlik: $-448,6941$} \\
\hline \multicolumn{5}{|l|}{ Wald Chi2(3): 757,83} \\
\hline P>Chi2: 0,000 & & & & \\
\hline
\end{tabular}

Tablo 4. ARFIMA(1,d,2) modelinin tahmini

Tüm bu sonuçların özetlendiği Tablo 5'e bakılırsa enflasyon serisinin 1980-2013 dönemi için uzun hafiza özelliği taşıdığı, serinin herhangi bir şok sonrası bir süre sonra kendi ortalamasına geri döneceği ancak meydana gelen şokun etkisinin daha yavaş ortadan kalkacağı sonucuna ulaşılmıştır.

\begin{tabular}{||l|l|}
\hline Model ARFIMA $(\mathrm{p}, \mathrm{d}, \mathrm{q})$ & $d$ tahmini \\
\hline ARFIMA $(0, \mathrm{~d}, 0)$ & 0,49 \\
\hline ARFIMA $(1, \mathrm{~d}, 0)$ & 0,29 \\
\hline ARFIMA $(1, \mathrm{~d}, 2)$ & 0,42 \\
\hline
\end{tabular}

Tablo 5. ARFIMA modelleri ve d parametre tahminleri

\subsection{Uzun hafiza ya da yapısal kırılma}

Bir önceki bölümde kesirli bütünleşme parametresini tahmin ettik. Tüm anlamlı ARFIMA (p,d,q) modelleri için $d$ parametresinin, 0 ve 0,5 arasında yer aldığı ve enflasyon serisinin uzun hafiza özelliği taşıdığı görüldü. Ancak serideki olası yapısal kırılmalar dikkate alınmadığı zaman bu sonuçlardan hiçbir zaman emin olamayız. 
$\mathrm{Bu}$ nedenle bundan sonraki amacımız olası yapısal kırılmalar altında enflasyon sersinin gerçekten uzun hafıza özelliği taşıyıp taşımadığının tespit edilmesidir. $\mathrm{Bu}$ çalışmada yapısal kırılmaların varlığı dışsal olarak belirlenmiş ve bu şekilde modele dahil edilmiştir. Olası kırılma tarihleri Chow yapısal kırılma testiyle sınanmış ve 1994 ve 2001 yıllarında serilerde kırılma olduğu sonucu doğrulanmıştır.

Bir zaman serisinin gerçek uzun hafıza özellikleri taşıyabilmesi için yapısal kırılmaların dikkate alınması gerekmektedir. Bunun için her bir alt örneklem ele alınarak $d$ parametresi bu dönemler için ayrı ayrı tahmin edilebilir. Eğer her alt örneklem tüm seri ile aynı istatistiksel özellikleri taşıyorsa seri gerçek uzun hafıza özelliklerine sahip olacaktır.

Aşağıdaki tabloda 1994 ve 2001 yıllarında yaşanan kırılmalarla oluşan üç döneme ait çeşitli ARFIMA modellerine dayanan d parametresi tahminleri yer almaktadır.

\begin{tabular}{||l|l|l|l|l||}
\hline Model & $\begin{array}{l}1980 \mathrm{q} 1-2013 \mathrm{q} l \\
d\end{array}$ & $\begin{array}{l}1980 \mathrm{q} 1-1993 \mathrm{q} 4 \\
d_{1}\end{array}$ & $\begin{array}{l}1994 \mathrm{q} 1-2000 \mathrm{q} 4 \\
d_{2}\end{array}$ & $\begin{array}{l}2001 \mathrm{q} 1-2013 \mathrm{q} 1 \\
d_{3}\end{array}$ \\
\hline ARFIMA(0,d,0) & $0,49^{*}$ & $0,49^{*}$ & $0,46^{*}$ & $0,49^{*}$ \\
\hline ARFIMA(1,d,0) & $0,29^{*}$ & $0,34^{*}$ & 0,12 & 0,40 \\
\hline ARFIMA(1,d,2) & $0,42^{*}$ & $0,20^{*}$ & 0,05 & 0,32 \\
\hline
\end{tabular}

Tablo 6. Yapısal Kırılmalar ve d Tahmini *ilgili katsayının \%5 düzeyinde istatistiksel olarak anlamlı olduğunu göstermektedir.

Tablo 6'de görüleceği üzere yalnızca ARFIMA $(0, d, 0)$ modeli için her bir ayrı alt örneklemde enflasyon uzun hafıza özelliği taşımaktadır. Diğer iki modelde ise yapısal kırılmalar dikkate alındığında $d$ parametre tahmini 1994-2000 ve 2001-2013 dönemlerinde istatistiksel olarak anlamlı değildir ve uzun hafiza özelliği göstermemektedir. Bu sonuçlara göre Türkiye'de enflasyonun yüksek ve kronik olduğu 1980-1994 dönemi enflasyondaki sürekliliğin ve uzun hafızanın belirgin olduğu bir dönemdir. Örneklemin bütünü için geçerli olduğu düşünülen uzun hafıza özellikleri yapısal kırılmaların dikkate alınmasıyla bazı model tipleri için ortadan kaybolmaktadır. Sonuçların model spesifikasyonuna göre değiştiği gözlemlendiğinden bu tür sonuçların dikkatle değerlendirilmesi gerekmektedir. Buradan çıkarılabilecek sonuç, yapısal kırılmaların varlığında enflasyonun ortalamasının değişebileceği ve uzun hafiza özelliklerinin zayıflayabileceğidir. Yapısal kırılmaların içsel olarak sınandığı bir modelde sonuçların daha güvenilir olacağı düşünülmektedir.

\section{Sonuç}

Bu çalışmada Türkiye'deki enflasyonun uzun dönem özelliklerinin ve sürekliliğinin incelenmesi için 19802013 dönemindeki gelişimi ele alınmıştır. Çalışmanın ampirik bulguları öncelikle ekonomideki yapısal kırılmalar dikkate alınmadığında Türkiye'de enflasyonun uzun hafızaya sahip olduğunu göstermektedir. Buna göre enflasyon kendisini etkileyen bir şok karşısında yavaş tepki veren, geçmiş değerlerine uzun dönem bağlılığı olan ancak nihayetinde ortalamasına dönen bir sürece sahiptir. Dışsal olarak seçilen yapısal kırılmalar dikkate alındığında, 1980-1994 dönemi enflasyonda sürekliliğin ve uzun hafızanın olduğuna işaret etmektedir. 19942000 ve 2001-2013 dönemlerinde enflasyon uzun hafıza özelliği taşımamaktadır. Dolayısıyla son dönemde Türkiye'de enflasyon görece düşük ve istikrarlı olmanın yanında büyük ölçüde geçmiş dönem değerlerine bağlılığı zayıf bir yapı sergilemektedir.

\section{Kaynakça}

- $\quad$ Akyüz, Y. Korkut Boratav. "The Making of the Turkish Financial Crisis." World Development 31.9 (2003): 1549-1566.

- Altissimo F., Mojon B. ve Zaffaroni P., 2006. "Sectoral and Aggregate Inflation Dynamicsin the Euro Area", Journal of European Economic Association, 4(2), p. 585-593.

- Andrews D. ve Chen W. K., 2004. “Approximately Median-Unbiased Estimation of Autoregressive Models, Journal of Business and Economic Statistics, 12(2), p. 187-204.

- Calvo G., 1983. "Staggred Prices in a Utility Maximizing Framework", Journal of Monetary Economics, 12(3), p. 383-398.

- Cechetti S. G. Ve ve Debelle G., 2006. "Has the Inflation Process Changed”, Economic Policy, 21(46), p.311-352.

- Christiano L. J., , Eichenbaum M. ve Evans C. L., 2005. Nominal Rigidities and the Dynamic Effects of a Shock to Monetary Policy, Journal of Political Economy, 113(1), p. 1-45.

- Coenen, G. ve Wieland V., 2005. "A Small Estimated Euro Area Model with Rational Expectations and Nominal Rigidities." European Economic Review, 49(5), p. 1081-1104.

- Diebold, F. X. ve Rudebusch G. D.,1991. "On the Power of Dickey-Fuller Tests Against Factional Alternatives." Economics letters 35(2), p.155-160. 
- $\quad$ Driscoll, J. C. ve Holden s., 2004. "Fairness and Inflation Persistence." Journal of the European Economic Association 2.2-3, p. 240-251.

- Franta, M. , Saxa, B., ve Smidkova K., 2007. "Inflation Persistence Euro Area and New Member States", European Central Bank Working Paper, 495.

- Fuhrer J. C. ve Moore G. R., 1995. “Inflation Persistence”, Quarterly Journal of Economics, 110(1), p.127159.

- Gadea, M., ve Mayoral L., 2005. "The Persistence of Inflation in OECD Countries: A Fractionally Integrated Approach." International Journal of Central Banking, 1, 51-104.

- Gali J. ve Gertler M., 1999. “Inflation Dynamics: A Structural Econometric Aalysis”, Journal of Monetary Economics, 44(2), p. 195-222.

- Gali J., Gertler M. ve L’opez-Salido D., 2001. "European Inflation Dynamics” European Economic Review, 45(7), p.1237-1270.

- Kara, H. ve Oğünc F., 2005. "Exchange Rate Pass-Through in Turkey: It is Slow, But is it Really Low?", CBRT Working Paper, 05/10.

- Levin A. ve Pieger J., 2002. "Is Inflation Persistence Instrinsic in Industrial Countries”, The Federal reserve Bank of St. Lois Working Paper, 023E.

- Marques R., 2004. “Inflation Persistence: Facts and Artifacts?”, European Central Bank Working Paper, 371.

- O’Reilly G. ve Whelan K., 2004. Has Euro Area Inflation Persistence Changed Over Time”, Review of Economics and Statistics, 87(4), p.807-820.

- Phillips A. W., 1958. "The Relation Between Unemploymnet and the Rate of Change of Money Wage Rates in United Kingdom", Economica, 25, p. 283-299

- Pivetta F. ve Reis R., 2001. "The Persistence of Inflation in Unites States”, Journal of Economic Dynamics and Control, 31(4), p. 1326-1358.

- Sargent T., 1999. The Conquest of American Inflation. PrincetonUniversity Press, Princeton.

- Taylor J. B., 1980. “Aggregate Dynamics and Stagerred Contracts”, Journal of Political Economy, 88(1), p.1-24.

- $\quad$ TCMB, 2001. Türkiye'nin Güçlü Ekonomiye Geçiş Programı, p.12-13.

- Willis J. L. 2003. "Implications of Structural Changes in the US Econpmy for Pricing Behaviour and Inflation Dynamics”, Economic Review, Federal Reserve of Kansas City, p. 5-24. 


\title{
Enflasyon Hedeflemesi Yaklaşımı: Türkiye'deki Uygulama Sürecinin Değerlendirilmesi
}

\section{Inflation Targeting Approach: An Evaluation of the Application Process in Turkey}

\author{
Assoc. Prof. Dr. Serdar Öztürk (Nevşehir University, Turkey) \\ Asst. Prof. Dr. Ali Sözdemir (Cumhuriyet University, Turkey) \\ Özlem Ülger (Nevşehir University, Turkey)
}

\begin{abstract}
As a result of many countries don't provide the achievement as regards the satisfaction of the price stability between 1970 and 1990, the other targets and the stability programs aimed at these targets were put away and price stability as a point target was put forward in this process. In this context, inflation targeting approach has been formed as providing price stability and the fight against the inflation after 1990s. The first application of inflation targeting approach by the New Zealand in 1990 affected The Central Bank of Republic of Turkey (CBRT), because of positive impacts on many countries such as developing and developed countries. The results of Inflation targeting approach that has been applied by many countries following New Zealand's experience are positive. Thus, CBRT explained to take place inflation targeting of the point target in monetary policy at the beginning of 2002. Because Turkey don't provide with the application set of the preconditions for this approach, CBRT decided to remove the elements that is restricting monetary policy and carried into practice "the implicit inflation targeting" until meeting this conditions. In the process of implicit inflation targeting approach, after the conditions related technical infrastructure was improved a new opinion, The CBRT announced to practice "the explicit inflation targeting" approach by the beginning of 2006.
\end{abstract}

\section{Giriş}

Enflasyon hedeflemesi yaklaşımı, para politikasının performansını arttırmak amacıyla oluşturulmuş operasyonel bir rejimdir. Bu yaklaşımın temel amacı enflasyonla başarılı bir şekilde mücadele etmektir. Merkez bankasına herhangi bir etki altında kalmadan para politikasını oluşturma ve yönlendirme özgürlüğü verildiği için başarı ve başarısızlıkta birinci derecede sorumludur.

Yıllardır yüksek enflasyonla mücadele etmek zorunda kalan Türkiye, bunu başarmak için farklı stratejiler denemiş ancak kalıcı ve istikrarlı çözüm üretememiştir. Yaşanan başarısızlıkların devamındaki yeni arayışlar sonucu Türkiye Enflasyon hedeflemesi yaklaşımına geçme kararı almıştır. Ancak ülkedeki siyasi ve ekonomik istikrarsızlık yanında alt yapının yetersiz oluşu buna imkân vermemiş ve Türkiye 2001-2005 yılları arası bu stratejiye yönelik gerekli koşulları oluşturabilmek amacıyla yoğun bir çaba harcamıştır. 2006 yılından itibaren ise açık enflasyon hedeflemesi yaklaşımına geçtiğini ilan etmiştir.

$\mathrm{Bu}$ bağlamda, bu çalışmada önce enflasyon hedeflemesinin genel çerçevesi sonrasında ise Türkiye'nin enflasyon hedeflemesi yaklaşımına geçiş çabaları ele alınacak ve son olarakta enflasyon hedeflemesinin uygulama süresi ve bu güne kadarki sonuçları incelenecektir.

\section{Enflasyon Hedeflemesi Yaklaşımının Genel Çerçevesi}

Enflasyon, ekonomik, sosyal ve siyasal yapıyı tahrip eden ciddi bir sorundur. Ülkeler tarihsel süreçte, yıllarca bu sorunla mücadele etmeye çalışmışlar ve sürekli farklı yaklaşımlar geliştirmişlerdir (Debelle, vd, 1998). Fiyat istikrarının sağlanmasına yönelik olarak para politikasının yönetilmesinde döviz kuru çapasının veya bazı parasal büyüklüklerin ara hedef olarak kullanılmasındaki zorluklar ve istenilen sonuçların elde edilememesi pek çok gelişmiş ülkenin enflasyon hedeflemesi olarak bilinen bir para politikası yaklaşımını benimsemesine neden olmuştur (Masson, vd, 1997).

Bu yaklaşım, ilk kez 1990 yılında Yeni Zelanda tarafından uygulanmış onu 1991 yılında Kanada ve 1992 yılında da İngiltere takip etmiştir (Gosselin, 2007). İlk başlarda gelişmiş ülkeler tarafından uygulansa da elde edilen başarılar daha sonra gittikçe artan sayıda gelişmekte olan ülkenin de bu yaklaşıma yönelmesine yol açmıştır (Roger, 2009). Enflasyon hedeflemesi yaklaşımının bu kadar geniş kabul görmesinin nedeni doğru zamanda doğru yerde olmasıdır denilebilir (Frankel, 2012).

Enflasyon hedeflemesi yaklaşımında, para politikası kararlarının enflasyonun bazı ölçümleri için sayısal bir hedefin ya da hedef aralığının açık bir şekilde ilan edilmesi ve tüm para politikası araçlarının bu hedefin gerçekleştirilmesine yönelik olarak formüle edilmesi temel prensiptir (Dennis, 2010). Başarılı olabilmek için amaç bağımsızlığı bir zorunluluk değildir. Ancak merkez bankası kullanacağı araç setini oluşturmada özgür olmalıdır (Croce and Khan, 2000). Merkez bankası enflasyonun gelecekteki rotası hakkında tahminlerde 
bulunur; tahmin hedef enflasyon oranıyla karşılaştırılır; tahminle hedef arasındaki fark para politikasının ne şekilde ayarlanması gerektiğini belirler. Bu yaklaşımı uygulayan ülkeler merkez bankasının uyguladığı diğer klasik yöntemlerle karşılaştırıldığı zaman, para politikasının tasarımının ve performansının daha etkili olduğuna inanmaktadırlar (Debelle, 1997). Eğer merkez bankasının gerçekte enflasyonu kontrol edememe olasılığı varsa o zaman enflasyon hedeflemesi yarardan çok zarar verebilir. Bu yaklaşıma geçişte merkez bankasının maliye politikasıyla koordinasyonu sağlayabilmeli ve piyasa eğilimlerini tersine çevirebilecek kabiliyete sahip olmalıdır (Sims, 2003).

Enflasyon hedeflemesi yaklaşımının temel unsurları şu şekilde ifade edilebilir (Mishkin, 1999):

a) Enflasyon için orta vadeli rakamsal hedeflerin halka ilanı

b) Enflasyon hedefinin başarılabilmesi için para politikasının uzun dönem birincil hedefi olarak fiyat istikrarının kurumsal olarak taahhüt edilmesi

c) Para politikası uygulayıcılarının hedefleri ve planları hakkında piyasalar ve halkla iletişim şeffaflığının arttırilmasi

d) Hedeflenen enflasyon oranının başarılmasında Merkez bankasının bağımsızlığının ve sorumluluğunun arttırılmasi

e) Para politikası araçlarının belirlenmesinde pek çok değişkeni kapsayan bilgi içerikli bir strateji oluşturulması

Enflasyon hedeflemesi yaklaşımı özellikle yüksek düzeyde şeffaflık ve hesap verebilirlik düzeyi ile karakterize edilebilir. Merkez bankası, uygulama sürecinde kamuoyunu basın ve yayın araçları yoluyla düzenli olarak bilgilendirmelidir (Svensson, 1998a). Bu merkez bankasının kredibilitesinin arttırılması açısından önemlidir. Aslında, tüm para politikası yaklaşımlarında merkez bankasının kredibilitesinin arttırılması düşüncesi vardır. Ancak bu, enflasyon hedeflemesi yaklaşımının en önemli unsurlarından birisidir (Bleich, vd, 2012).

Sayısal enflasyon hedefi bir nokta hedef şeklinde ya da hedef aralığ ş̧eklinde olabilir. Uygulama sürecinde bazı ülkelerin nokta hedef bazılarının ise hedef aralığı kullandığı görülmektedir (Svensson, 1998b). Aralarında Türkiye'nin de bulunduğu bir takım ülkeler nokta hedef kullanmakta ancak bu hedef etrafinda her iki yönde simetrik olarak belirsizlik aralığı belirlemektedir (Svensson, 2010a). Bu, hedef aralığıyla karıştırılmamalıdır. Belirsizlik aralığ 1 enflasyonun nokta hedeften hangi büyüklükte sapma göstermesi durumunda merkez bankasının hesap verebilirlik mekanizmasının devreye gireceğini gösteren bir sınırdır.

Enflasyon hedeflemesi yaklaşımının, ülkelerin ekonomik performansları üzerine etkileriyle ilgili yapılan ampirik çalışmaların bu yaklaşımı destekler nitelikte sonuçlar ortaya koyabildiği söylenebilir. Ülkelerin enflasyon hedeflemesi yaklaşımına geçtikten sonra, enflasyon düzeyi, enflasyonda oynaklık ve faiz oranlarının düştüğü görülmektedir Mishkin, and Hebbel, 2007). Ancak, buna ilave olarak bu yaklaşımın, istihdam, üretim düzeyi ve gelir dă̆ılımı etkisiyle ilgili gerçek maliyeti hakkında çelişkili tahminler ve farklı görüşlerde vardır (Epstein and Yeldan, 2008).

Para politikası stratejilerinin kural ya da takdir olarak sinıflandırılması para ekonomisinin tarihinde ve bu günkü tartı̧̧malarda önemli bir konudur. Enflasyon hedeflemesi yaklaşımı, bazı iktisatçılar tarafından kurala bağlı bir politika olarak kabul edilip eleştirilse de önemli ölçüde politik takdir unsurları da içerdiği söylenebilir. Dolayısıyla, enflasyon hedeflemesi yaklaşımını "sınırlandırılmış takdir" olarak tanımlamak daha doğru olacaktır (Mishkin, 2001).

Enflasyon hedeflemesi yaklaşımının, 2007 yılında ortaya çıkan küresel finansal krize kadar başarılı bir uygulama süreci yaşadığı görülmektedir. Ancak, kriz sonrasında performansında ciddi yetersizlikler olduğu konusunda ithamlara maruz kalmıştır. Bu eleştiriler doğrultusunda gerçekleştirilen bazı değişiklikler sonrası yaklaşım daha esnek hale getirilmeye çalışılmıştır (Kuttner and Posen, 2011). Esnek enflasyon hedeflemesi olarak isimlendirilen bu yeni yorumda para politikası orta ve uzun dönem fiyat istikrarını gözetirken aynı zamanda reel ekonominin istikrarını da hedeflemektedir (Svensson, 2010b).

\section{Enflasyon Hedeflemesi Yaklaşımının Türkiye'deki Uygulama Süreci}

Ekonomi politikalarının nihai amacı ekonomik refahı arttırabilmektir. Ekonomik refahın arttırılabilmesi için sürdürülebilir istihdam artışıın ve sürdürülebilir büyümenin sağlanabilmesi gerekir. Bunun gerçekleştirilebilmesi ekonomik istikrarın sağlanmasıyla mümkündür. Ekonomik istikrarın ön koşulu ise fiyat istikrarıdır. Fiyat istikrarı paranın alım gücünün korunması ya da ihmal edilebilir düzeyde düşük bir enflasyon oranı olarak tanımlanmaktadır. Türkiye yaklaşık 30 yıllık bir süreçte sürekli yüksek ve kronik enflasyon sorunuyla yani fiyat istikrarsızlığıyla mücadele etmek zorunda kalmış ve bu amaçla pek çok istikrar programı uygulamıştır.

Bu programlardan bir tanesi de 1999 yllında yürürlüğe giren ve IMF tarafindan da desteklenen kur çapasına dayalı istikrar programıdır. Programda döviz kurunun nominal çapa olarak kullanılması planlanmış ve Türk Lirasının 1 ABD Doları ile 0,77 Euro'dan oluşan bir para sepetine endekslenmesi kararlaştırılmıştır. Ancak 2000 yılı Kasım ayında Türkiye'de meydana gelen krizde enflasyondaki inişin beklendiği kadar hızlı olmaması reel kurun değerlenmesine yol açmış ve yapısal önlemlerin hızlı bir şekilde gerçekleştirilememesi, uygulanan sıkı 
para politikalarına karşın programa karşı güven kaybına neden olmuştur (Çelik, vd, 2006). Türkiye Cumhuriyet Merkez Bankası (TCMB), 22 Şubat 2001 tarihinde yapmış olduğu açıklamada programa olan güvenin kaybolmuş olması nedeniyle sürdürülmesinin mümkün olmadığını açıklamıştır (TCMB, 2004).

2001 Şubat dönemi sonunda yürürlüğe konulan ve 2002 yılı başında 2002-2004 dönemini kapsayacak şekilde revize edilen güçlü ekonomiye geçiş programı ile para ve kur politikasına yeni bir çerçeve çizildiği görülmektedir. $\mathrm{Bu}$ bağlamda, ilk önce,14.01.1970 tarihli ve 1211 sayılı TCMB Kanununun 4.maddesi 25.04.2001 tarih ve 4651'nolu kanunla "Bankanın temel amacı fiyat istikrarını sağlamaktır. Banka fiyat istikrarını sağlamak için uygulayacağı para politikasını ve kullanacağı para politikası araçlarını doğrudan kendisi belirler" şeklinde değiştirilerek fiyat istikrarının sağlanması ve sürdürülmesi tek ve öncelikli hedef haline getirilmiştir (HDTM, 2001).

Enflasyon hedeflemesi yaklaşımının gerek gelişmiş gerekse gelişmekte olan ülkelerdeki uygulama sonuçlarının olumlu olması TCMB'yi etkilemiş ve banka 2002 yılı başında para politikasında nihai hedefinin enflasyon hedeflemesine geçmek olduğunu açıklamıştır. Türkiye'de enflasyon hedeflemesi yaklaşımı, enflasyon hedeflemesine geçiş süreci(2002-2005), açık enflasyon hedeflemesine geçiş ve kriz öncesi uygulama süreci (2006 -2008) ve Küresel finansal kriz sonrası enflasyon hedeflemesi yaklaşımının yeniden yapılandırılması (2008 sonrası) olarak üç kısma ayrılabilir.

\subsection{Enflasyon Hedeflemesine Geçiş Süreci: Örtük Enflasyon Hedeflemesi (2002-2005)}

Türkiye 2001 yılında yaşadığı tarihinin en derin krizi sonrası, uzun yıllar kronikleşmiş bir sorun olan enflasyonu çözmek için enflasyon hedeflemesi yaklaşımı uygulama kararı almıştır. Ancak, bu yaklaşıma geçmek için gerekli koşulların Türkiye'de henüz sağlanamamış olması nedeniyle önce mali baskınlık ya da kamu borcu baskınlığı, dolarizasyon ve kurumsal yapının geçiş sürecine ihtiyaç duyması gibi para politikasını kısıtlayan unsurların ortadan kaldırılmasına ve bu sağlanıncaya kadar da “ örtük enflasyon hedeflemesi” uygulanmasına karar vermiştir. Aksi takdirde yaklaşıma olan güvenin sarsılacağı açıktır. Bu doğrultuda, kısa vadeli faiz oranları enflasyonla mücadele de etkin bir araç olarak kullanılırken para tabanı da ek bir çapa olarak belirlenmiş ve bu yolla da enflasyon hedeflerinin güvenirliliğinin arttırılması amaçlanmıştır. 2002 yılı sonunda, emisyon, TL cinsinden zorunlu karşılıklar ve serbest mevduat toplamından oluşan para tabanının nominal milli gelir büyüme hızı kadar artması hedeflenmiştir (TCMB, 2002).

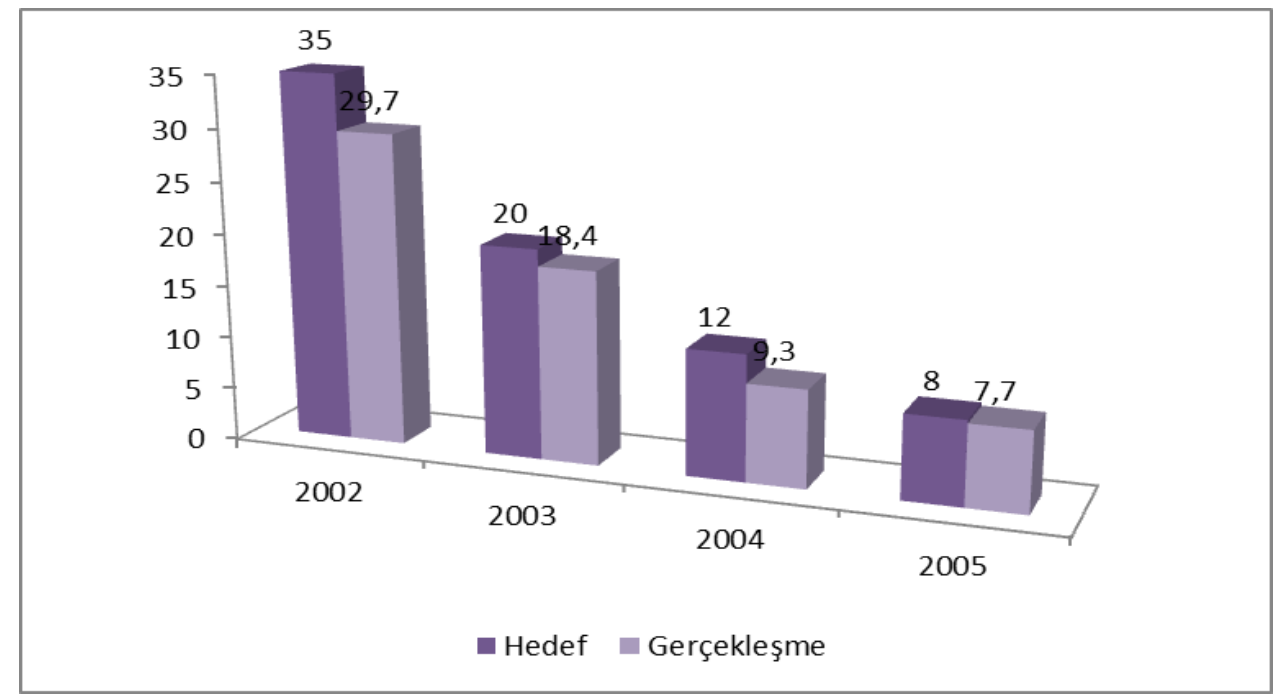

Grafik 1: Hedefler ve Gerçekleşmeler 2002-2005, Kaynak: A. Hakan Kara ve Musa Orak, Enflasyon Hedeflemesi, TCMB, Ekonomik Tartışmalar Konferansı

Bu bağlamda, kolay takip edilmesi, anlaşılması ve günlük yaşam maliyetlerini iyi ölçmesi nedeniyle enflasyon hedefi TÜFE olarak belirlenmiştir. Yılsonu hedefinin, 2003 yılı temel alınarak TÜFE'nin yıllık yüzde değişimi olması kararlaştırılmıştır. Bekleyişleri yönlendirme de etkili olması nedeniyle enflasyon hedefi nokta hedef olarak seçilmiş ve enflasyon hedefi makroekonomik öngörülerle uyumu arttıracağı için üç yıllık patika çerçevesinde TCMB ve hükümet tarafindan birlikte oluşturulmuştur. Ayrıca hedef etrafinda $+1-2$ (\%40) şeklinde bir belirsizlik aralığg belirlenmiştir. Ancak belirsizlik aralığı herhangi bir hedef olarak algılanmamalıdır (TCMB, 2005).

Uygulanan örtük enflasyon hedeflemesi yaklaşımı çerçevesinde 2002-2005 yılları arasında enflasyon belirlenen hedeflerin altında gerçekleşmiştir (Grafik 1). Bu süreçte hedeflerin altında kalınması kamu da enflasyonda ki düşüşün süreceğine dair algılamaları da kuvvetlendirmiştir. Bu süreçte, dalgalı kur rejimine uyum artmış, mali disiplinin sürekliliği konusunda kaygılar hafiflemiş ve finansal piyasaların kırılganlığı azalmıştır. Ayrıca, merkez bankasının bağımsızlığı konusunda da önemli mesafe alınmıştır (TCMB, 2005). 
Ekonomik programın uygulanmasıyla enflasyon dinamiklerinde kalıcı ve belirgin iyileşmeler sağlanmış ve kronik enflasyon süreci son bulmuştur. 2002 yılı başında \%70'lerin üzerinde olan TÜFE 2005 y1lı sonunda \%7.7'ye gerileyerek belirlenen \%8'lik hedefin altında gerçekleşmiştir. Hedeflenen enflasyon ile enflasyon bekleyişleri arasındaki fark olarak ifade edilen güvenirlilik açığının 2002 yılı başında 13.3 puan iken 2005 yılında 0.4 puana gerilediği görülmektedir (Grafik 2).

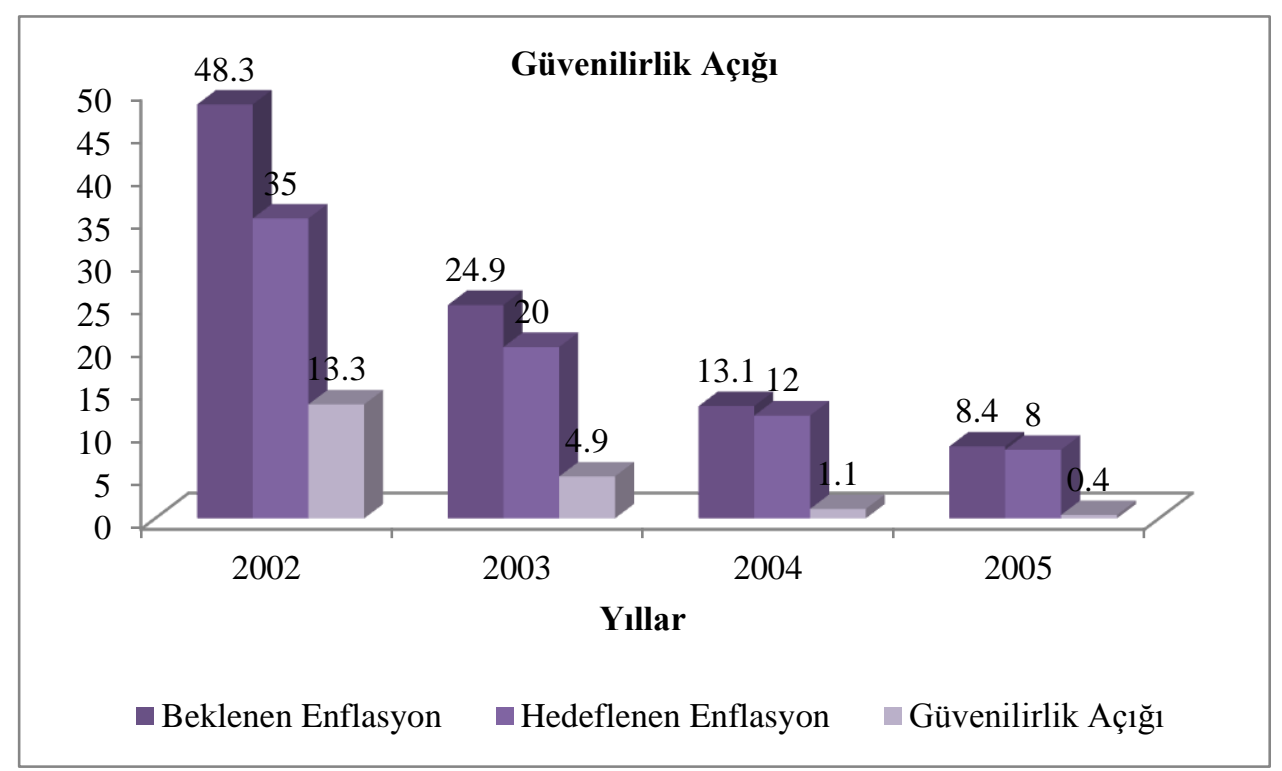

Grafik 2: Güvenirlilik Açı̆̆ı 2002-2005, Kaynak: Erdem Başçı, 74. Hissedarlar Genel Kurul Olağan Toplantısı Açış Konuşması, TCMB

Fiyat istikrarından taviz verilmesi yoluyla sağlanan büyümenin kalıcı olması mümkün değildir. Fiyat istikrarını sağlamak sağlıklı ve kalıcı bir büyümenin önündeki öneli bir engeli kaldırmak anlamına gelmektedir. Enflasyonla mücadelede gösterilen kararlılık ve doğru araçların seçimi 2002-2007 yılları arasında Türkiye’nin dünyada en hızlı büyüyen ülkelerden birisi olmasını sağlamıştır (Tablo 1).

\begin{tabular}{|l|l|l|}
\hline Dönemler & Ortalama Enflasyon & Ortalama Büyüme \\
\hline $1970-2001$ & $\% 74.0$ & $\% 3.0$ \\
\hline $2002-2006$ & $\% 14.9$ & $\% 7.5$ \\
\hline
\end{tabular}

Tablo 1: Türkiye’nin Ortalama Enflasyon ve Ortalama Büyüme Oranları 1970-2006, Kaynak: Erdem Başçı, Merkez Bankası ve Para Politikaları, Karadeniz Teknik Üniversitesi ve Beykent Üniversitesi, TCMB

\subsection{Açık Enflasyon Hedeflemesi Yaklaşımı Uygulama Süreci: (2006-2008)}

Uygulanan örtük enflasyon hedeflemesi yaklaşımı sürecinde altyapıyla ilgili olumsuzlukların ortadan kaldırılması ve elde edilen başarı sonrasında, açı enflasyon hedeflemesi yaklaşımına geçilebilmesi için gerekli koşulların oluştuğu yönünde bir fikir oluşmasını sağlamıştır. Bu doğrultuda, merkez bankası 2006 yılı başından itibaren açık enflasyon hedeflemesi yaklaşımına geçildiğini ilan etmiştir (TCMB, 2006). 5 Aralık 2005 tarihinde yayımlanan politika metninde enflasyon hedeflemesi yaklaşımının genel çerçevesi açıklanmış ve 2006 yılı sonu için yıllık hedef iki puanlık bir belirsizlik bandı içinde \%5, 2007 ve 2008 yılları için \%4 olarak belirlenmiştir (Grafik 3). Açık enflasyon hedeflemesi yaklaşımına geçilmesinden itibaren, enflasyon hedeflerinin, TÜFE'nin 12 aylık değişimi ile hesaplanan yılsonu enflasyon oranları üzerinden 3 yıllık bir dönem için Hükümetle birlikte "nokta hedef" olarak belirlenmesi kararlaştırılmıştır (TCMB, 2008).

Dünya ekonomisinde hızlı değişmelerin ve dalgalanmaların yaşandığı bu dönemde Türkiye Ekonomisi de bir dizi şokla karşılaşmış ve 2006 yılı Mayıs ayından itibaren uluslararası sermaye koşullarında Türkiye'nin de dâhil olduğu gelişmekte olan ülkeler aleyhine önemli değişmeler ortaya çıkmıştır. Bunun yanı sıra YTL'de meydana gelen yaklaşık \%30'luk değer kaybı, gıda fiyatlarında kuraklıktan kaynaklanan sert artışlar ve finansal istikrarsızlıktan kaynaklanan güvensizlik ortamı Türkiye'de fiyatların yükselmesine ve enflasyon beklentilerinin oldukça üzerine çıkmasına neden olmuştur (TCMB, 2008). 


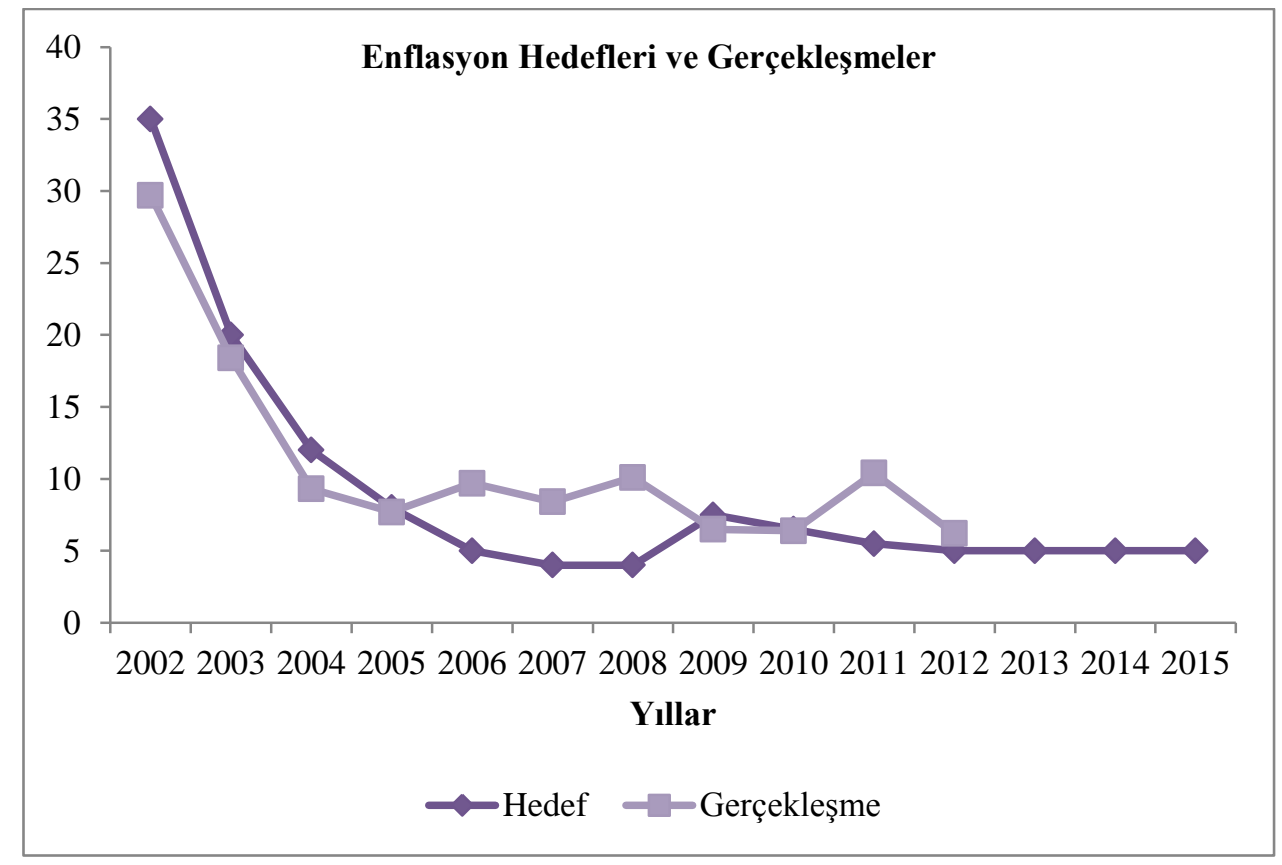

Grafik 3: Enflasyon Hedefleri ve Gerçekleşmeler (2002-2015), Kaynak: TCMB

Önceden ilan edilen bu enflasyon hedeflerinin, yalnızca para politikasının kontrolü dışında ortaya çıkan unsurlara bağlı olarak hedeflerden çok büyük ve uzun süreli sapmalar olabileceğinin belirlenmesi ve orta vadeli hedeflerin anlamsız kalması durumunda değiştirilmesi söz konusudur. Böyle bir durumda yeni hedefler TCMB ve Hükümet tarafından birlikte belirlenecektir. Geçici şoklar, enflasyon hedeflerini değil enflasyon tahminlerini değiştirecektir. Doğru para politikası, fiyat istikrarının sağlanmasında gerekli şarttır, ancak yeterli şart değildir. Fiyat istikrarına ulaşabilmesi için maliye politikalarında disiplinin sağlanması ve sürdürülmesi esastır (TCMB, 2005). Bu bağlamda, Enflasyonun hedefle uyumlu çizginin üzerine çıkması nedeniyle TCMB enflasyonun hedeften sapmasının nedenleri ve tekrar hedefe yönelmesiyle ilgili tedbirler hakkında hükümete yazdığı bir mektupla açıklanmış ve bu sürece ilişkin değerlendirmeler kamuoyuyla paylaşılmıştır. Bütün bu uygulamaların para politikasının iletişimini güçlendirdiği ve beklentilerin şekillenmesinde de önemli rol oynadığı söylenebilir (TCMB, 2005).

TCMB, 2007 yılında da para politikasını enflasyon hedeflemesi yaklaşımı çerçevesinde uygulamaya devam etmiştir. İlk üççeyrekte enflasyon rakamları oluşturulan belirsizlik aralığının içerisinde kalmış, yılın son çeyreğinde de enflasyon ise kuraklık nedeniyle gıda fiyatlarında ortaya çıkan artış ve küresel konjonktürden kaynaklanan nedenlerden olumsuz etkilenmiştir (TCMB, 2007).

\subsection{Küresel Finansal Kriz Sonrası Enflasyon Hedeflemesi Yaklaşımının Yeniden Yapılandırılması (2008 sonrası)}

Dünyada, 2007-2008 döneminde ortaya çıkan finansal dalgalanmanın kaynağı, ABD'de 2007 yılı Ağustos ayında başlayan mortgage krizidir (Tong and Wei, 2008). Bu kriz, Büyük Depresyondan bu güne kadar görülen en büyük şok haline gelmiş, finansal sistemin merkezindeki kurumlar ve piyasalar üzerinde ciddi hasarlara neden olmuştur (IMF, 2008). 2008 yılından itibaren oldukça hızlı bir şekilde yayılan küresel finansal kriz, sert ve sürekli belirsiz bir küresel durgunluğa neden olmuş, başta sanayileşmiş ülkeler olmak üzere birçok ülke resesyona girmiştir (IMF, 2009). Küresel finansal krizin geçmişte yaşanmış krizlerden en önemli farkı, klasik bir finans krizi olmaması karmaşık ve yüksek hacimli türev ürünlerini kapsamasıdır. Türev ürünlerinin yüksek hacimli olması mali destek paketlerinin de daha önce görülmemiş boyutlara çıkarılmasına neden olmuştur (Yılmaz, 2009a). Bu süreç, küresel enflasyonda hızlı bir düşüşe neden olmuştur. Gelişmiş ülkelerin tüketici fiyat enflasyonundaki gerileme eğilimi daha belirgin olmakla birlikte, gelişmekte olan ülkelerde de benzer bir düşüş eğiliminin olduğu dikkat çekmektedir.

Yaşanan bu süreçte, Türkiye'nin de dâhil olduğu gelişmekte olan ülkelerde risk algılaması belirgin bir şekilde bozulduğu için risk primleri yükselmiştir. 2008 yılı süresince, yurtiçi enflasyon oranı yoğun bir şekilde küresel ekonomik gelişmelerden etkilenmiştir (TCMB, 2009). Yaşanan gelişmeler, daha önce ilan edilen enflasyon hedeflerinin değiştirilme gerekliliği ortaya çıarmış ve TCMB 3 Haziran 2008 tarihli açık mektupla Hükümet'e enflasyon hedeflerinin yenilenmesini önermiştir. Bu doğrultuda, 2009-2011 dönemi için yeni enflasyon hedefleri 2009 yılı sonu için \%7.5, 2010 y1lı sonu için \%6.5 olarak değiştirilmiş ve 2011 yılı sonu için ise $\% 5.5$ olarak belirlenmiştir. Enflasyon hedeflerindeki bu değişikliğin parasal sıkılaştırma ile birlikte uygulanmasının sonraki dönemde enflasyon beklentilerinin kontrol edilebilmesine önemli bir katkıda bulunduğu söylenebilir (Yılmaz, 2009b). 
Küresel krizin etkilerinin 2009 yılının üçüncü çeyreğinde azalarak ta olsa devam ettiği görülmektedir. Dış talepte meydana gelen hızlı daralma ve sıkılaşan finansal koşulların etkisiyle iktisadi faaliyette belirgin bir gerilemenin ortaya çıktığı görülmektedir. Bu durum tüm dünya da olduğu gibi Türkiye'de de enflasyon oranları üzerinde aşağı yönlü bir baskı oluşturmuştur (Yılmaz, 2009c).

2010 yılında küresel ekonominin kademeli olarak toparlanmaya devam ettiği, bu sürecin gelişmiş ekonomiler de daha yavaş ve kırılgan bir görünüm arz ederken gelişmekte olan ekonomilerde hızlı ve istikrarlı biçimde gerçekleştiği görülmektedir (TCMB, 2010). Küresel finans krizi sonrasında birçok ülkede para politikası, fiyat istikrarına ilave olarak finansal istikrarı da dikkate almaya başlamıştır. Gelişmiş ülkeler krizle birlikte orta çıkan bilanço sorunlarını çözmeye odaklanırken, gelişmekte olan ülkeler sermaye akımlarını ve bununla ilişkili makro finansal riskleri yönetmeye yönelik olarak daha kapsamlı politika çerçeveleri oluşturmaya çalışmışlardır (TCMB, 2011). Yaşanan küresel kriz sonrasında ortaya çıkan gelişmelerin Merkez Bankalarını yeni politika arayışlarına ittiği söylenebilir. Bu çerçevede TCMB'de 2010 yılının sonlarından itibaren para politikası yaklaşımını yeniden yapılandırmış̧ır. Bu yeni çerçeve dâhilinde fiyat istikrarından ödün vermeden finansal istikrarı da dikkate alan bir yapı söz konusudur (Şekil 1). TCMB, birden fazla amaca yönelik olarak uygulanan para politikasının gerektirdiği araç çeşitliliğini sağlamak amacıyla, politika faizinin yanı sıra likidite yönetimi, gecelik borç alma ve borç verme faizleri arasında oluşan faiz koridorunun ve zorunlu karşılıkların bir arada kullanıldığı bir politika seti oluşturmuştur (Yılmaz, 2011a).

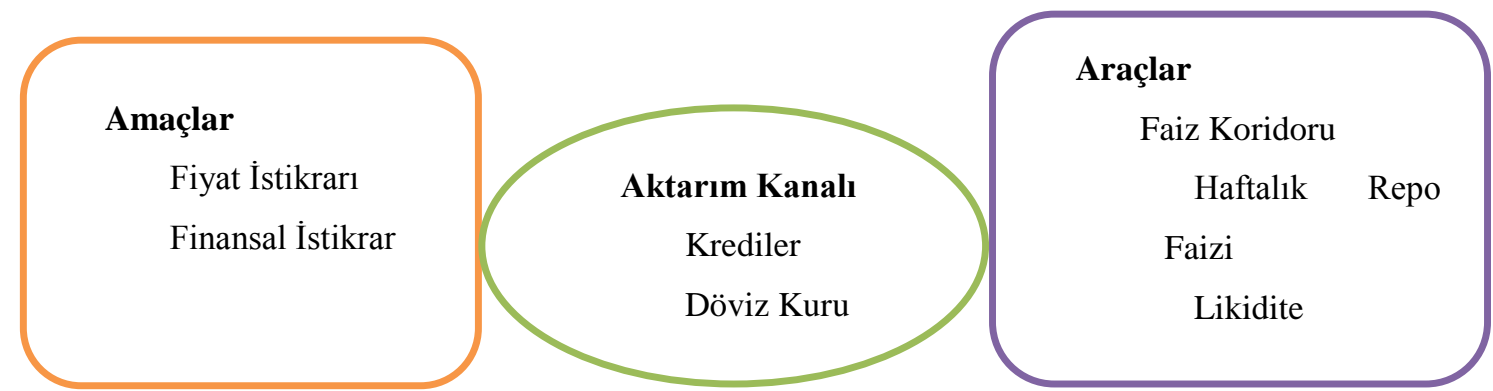

Şekil 1: TCMB'nin Politika Araçları ve Amaçları, Kaynak: A. Hakan Kara, Küresel Kriz Sonrası Para Politikası, Çalışma Tebliği

TCMB, faiz koridoru sisteminin sağladığı esnekliği kullanarak dönem dönem ek parasal sıkılaştırmaya gitmiş̧tir. Bunun nedeni para politikası duruşunun sıkı olmasını sağlamaktır. TCMB bu sıkılaştırma dönemlerinde miktar ihalesi ile yaptığı fonlamayı azaltarak piyasaya sağlanan likiditenin ortalama maliyetini ciddi bir şekilde arttırmıştır (TCMB, 2012).

TCMB enflasyon hedeflemesi yaklaşımında yapmış olduğu yeni düzenleme çerçevesinde TL zorunlu karşılıkların döviz cinsinden tutulabilmesi imkânının üst sınırını \% 40 ’tan \% 45 'e yükseltmiş̧tir. Bu düzenlemeyle TL zorunlu karşılıkların TL veya döviz cinsinden oluşturulmasındaki maliyet farkının azaltılması ve bankaların bunu likidite gereksinimleri doğrultusunda istedikleri şekilde kullanabilmeleri amaçlanmıştır (Başçı, 2012).

Merkez Bankası, 2012 yılında da enflasyon hedeflemesinin yanı sıra dalgalı döviz kuru rejimi uygulamasına devam etmiş̧ir. Merkez Bankasının nominal ya da reel herhangi bir kur hedefi bulunmamaktadır. Diğer taraftan, dalgalı kur rejimi uyguluyor olsalar da ülkemiz gibi gelişmekte olan ekonomilerde güçlü döviz rezerv pozisyonuna sahip olmak karşılaşlabilecek iç ve dış şokların olumsuz etkilerinin giderilmesine ve ülkeye duyulan güvenin arttırılmasına büyük katkı sağlamaktadır. Bu nedenle döviz arzının döviz talebine kıyasla arttığı dönemlerde Merkez Bankası rezerv biriktirme amaçlı döviz alım ihaleleri gerçekleştirmektedir. 2002 yılından itibaren Merkez Bankası toplam 76,2 milyar ABD doları net döviz alımı gerçekleştirmiş̧tir. Söz konusu dönemde Merkez Bankası'nın döviz rezervleri de 73,3 milyar ABD doları artıs göstererek 19,9 milyar ABD dolarından 93,2 milyar ABD dolarına ulaşmıştır (Grafik 4) (TCMB, 2011).

2012 y1lı hem makro finansal risklerin dengelenmesi anlamında hem de fiyat istikrarı konusunda önemli gelişmelerin sağlandığ baskılarının hafiflemesiyle, yıl boyunca aşağı yönlü bir eğilim sergileyerek bir önceki yıla göre 4,3 puan gerilediği görülmektedir. Bu dönemde orta vadeli enflasyon beklentilerinde de ciddi iyileşmeler görülmektedir. Yılsonu itibariyle enflasyon \%6,2 düzeyinde gerçekleşerek \%3-7 arasındaki belirsizlik aralığı içerisinde kalmıştır (Baş̧̧, 2013a). 2013-2014 yılları için olduğu gibi 2015 yılı enflasyon hedefi de Hükümetle koordineli olarak \%5 olarak belirlenmiştir (Grafik 3), belirsiz aralığı önceki yıllarda olduğu gibi her iki yönde +/- 2 olarak korunmuştur (Başç1, 2013b).

Türkiye kriz öncesi döneme göre daha yüksek kredi notu alan birkaç gelişmekte olan ülkelerden biri olmuştur. Farkı yaratan çeşitli etkenlerden bir bileşimi olsa da kilit unsur ülkemizde aşırı borçlanma yaşanmamış olmasıdır (Y1lmaz, 2011b). 


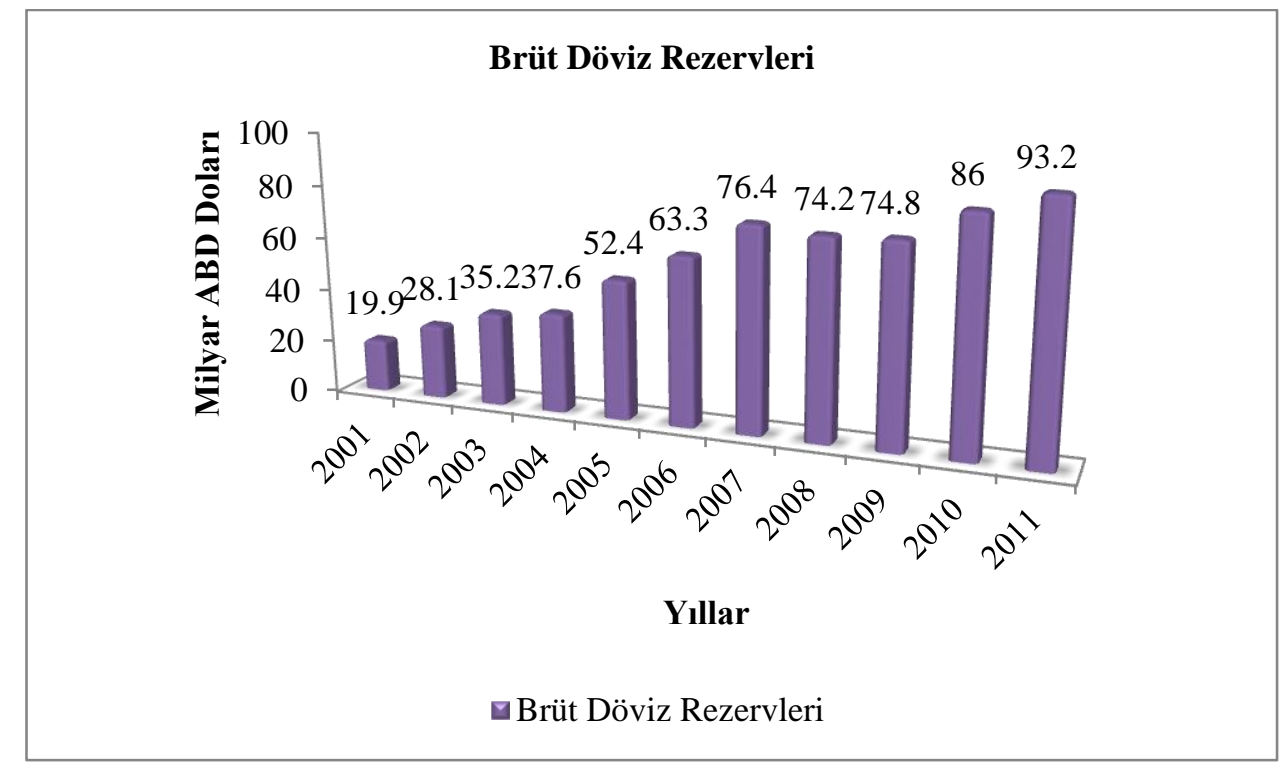

Grafik 4: TCMB Brüt Döviz Rezervleri (Altın Dâhil), Kaynak: TCMB, 2012 Yllında Para ve Kur Politikası

\section{Sonuç}

Tarihsel süreçte, ülkelerin yaşadıkları ekonomik sorunların üstesinden gelebilmek ve istikrarlı bir gelişme çizgisi yakalayabilmek amacıyla kendilerine farklı dönemlerde farklı nihai hedefler belirledikleri ve bu nihai hedeflere ulaşabilmek içinde farklı politika setleri oluşturdukları görülmektedir.

Enflasyon hedeflemesi yaklaşımının, teorik olarak tüm koşullarının aynı anda sağlanabilmesi oldukça zordur. Ayrıca, ülkelerin ekonomik, sosyal ve siyasal yapılarındaki farklılıklar nedeniyle yaklaşıma uyumları, algılanmaları ve tepkileri de farklılıklar göstermektedir. Dolayısıyla, para politikası oluşturulurken tüm bunların dikkate alınması gerekir. Yaklaşım katı kurallar yerine küresel ve ülkelere özgü koşullarla şekillendirilmeli, beklenmedik olaylara tepki verebilecek ve kendisini uyumlaştırabilecek gerekli esnekliğe sahip olmalıdır.

Türkiye'nin 2006 sonrası yaşadığı deneyim enflasyon hedeflemesi yaklaşımına geçişte zamanlamanın büyük önem taşıdığını ortaya koymuştur. Özellikle yüksek enflasyondan düşük enflasyona geçiş sürecinde olan ve iktisat politikaları konusunda henüz yeterince itibar sağlamamış ülkelerde, enflasyon hedeflemesine geçişin ilk yıllarında olumsuz dışsal gelişmelerle karşılaşılması yaklaşımın güvenirliğinin tesis edilmesini geciktirebilmektedir. Karşılaşllan bütün bu güçlüklere rağmen, Türkiye'nin enflasyon hedeflemesi deneyimi, bu yaklaşımın oldukça esnek ve koşullara çabuk uyum sağlayabilen bir para politikası yaklaşımı olduğunu göstermektedir.

\section{Kaynakça}

- Başçı, Erdem (2006), 74. Hissedarlar Genel Kurul Olağan Toplantısı Açış Konuşması, TCMB, 13 Nisan, Ankara, http://www.tcmb.gov.tr/yeni/duyuru/2006/74-2006-genelkurul.pdf

- Başçı, Erdem (2007), Merkez Bankası ve Para Politikaları, Karadeniz Teknik Üniversitesi ve Beykent Üniversitesi, 22 Ekim, TCMB, http://www.tcmb.gov.tr/yeni/iletisimgm/ErdemBasci_Beykent.pdf

- Başçı, Erdem (2012), Küresel Finans Krizi Sonrasında TCMB Para Politikası, TCMB, 30 Mayıs, Ankara, http://www.tcmb.gov.tr

- Baş̧1, Erdem (2013a), 2013 Ocak Enflasyon Raporu Basın Toplantıs1, TCMB, 29 Ocak, Ankara, http://www.tcmb.gov.tr

- Başçı, Erdem (2013b), 81. Olağan Genel Kurul Toplantısı Açış Konuşması, TCMB, 9 Nisan, Ankara, http://www.tcmb.gov.tr

- Bleich, Dirk, Ralf Fendel and Jan-Christoph Rülke (2012), "Inflation Targeting Makes the Difference: Novel Evidence on Inflation Stabilization", Journal of International Money and Finance 31, pp. 1092-1105.

- Croce, Enzo and Mohsin S. Khan (2000), Monetary Regimes and Inflation Targeting, Finance and Development, September, Volume 37, Number 3, http://www.imf.org/external/pubs/ft/fandd/2000/09/croce.htm

- Çelik, Ali, vd. (2006) Türkiye Cumhuriyeti Merkez Bankası Bilançosu Açıklamalar Rasyolar ve Para Politikası Yazışmaları, TCMB, Ankara, 2006.

- Debelle, Guy (1997)Inflation Targeting in Practice, March, WP|97137, http://www.imf.org 
- Dennis, Richard (2010), The Inflation in Inflation Targeting, FRBSF Economic Letter, 2010-17, June 7, http://www.frbsf.org/publications/economics/letter/2010/el2010-17.html

- Debelle, Guy, Paul Masson, Miguel Savastano and Sunil Sharma (1998), Inflation Targeting as a Framework for Monetary Policy, IMF Economic, Issues No.15, October, http://www.imf.org/external/pubs/ft/issues/issues15/

- $\quad$ Epstein, Gerald and A. Erinç Yeldan (2008), "Inflation Targeting Employment Creation and Economic Development: Assessing The Impacts and Policy Altenatives", International Rewiew Of Applied Economics, Vol.22, No.2, pp. 131-144

- Frankel, Jeffrey (2012), The Death of Inflation Targeting, Project Syndicate, 19 May, http://www.projectsyndicate.org/print/the-death-of-inflation-targeting

- Gosselin, Marc_Andre (2010), Central Bank Performance Under Inflatıon Targeting, Working Paper\ Document de Travil, 2007-18, Bank of Canada, http://www.bankofcanada.ca/wpcontent/uploads/2010/03/wp07-18.pdf

- $\quad$ HDTM (2001), Güçlü Ekonomiye Geçiş Programı Politika Metinleri, TCMB Kanununda Değişiklik Yapılmasına Dair Kanun, Ankara, Cilt I, Eylül, s. 220.

- $\quad$ IMF (2008), World Economic Outlook, April, http://www.imf.org

- IMF (2009), The Implications of Global Financial Crisis for Low-Income Countries, March, http://www.imf.org/external/np/pp/eng/2009/092809.pdf

- Kara A. Hakan ve Musa Orak (2008), Enflasyon Hedeflemesi, TCMB, Ekonomik Tartışmalar Konferansı, İstanbul, 10 Ekim, http://www.tcmb.gov.tr

- Kara, A. Hakan (2012), Küresel Kriz Sonrası Para Politikası, Çalışma Tebliği, No:12\17, TCMB, Haziran, http://www.tcmb.gov.tr

- Kuttner, Kenneth N. and Adam S. Posen (2011), How Flexible Can Inflation Targeting be and Still Work?, Peterson Institute for International Economics, Working Paper Series, WP 11-15, September, http://www.iie.com/publications/wp/wp11-15.pdf

- Masson, Paul R., Miguel A. Savastano and Sunil Sharma (1997), The Scope for Inflation Targeting in Developing Countries, IMF Working Paper, October, WP\97\130, http://www.imf.org/external/pubs/ft/wp/wp97130.pdf

- Mishkin, Frederic S. (1999), "International Experiences with Different Monetary Policy Regimes”, Journal of Monetary Economics 43, pp. 579-605

- Mishkin, Frederic S. (2001), From Monetary Targeting to Inflation Targeting: Lessons from the Industrialized Countries, Policy Research Working Paper 2684, The World Bank Financial Sector Strategy and Policy Department, October, http://www-wds.worldbank.org/servlet/WDSContentServer/WDSP/

- Mishkin, Frederic S. and Klaus Schmidt_Hebbel (2007), Does Inflation Targeting Make a Difference?, NBER Working Paper 12876, January, http://www.nber.org \papers\W12876

- Roger, Scott (2009), Inflation Targeting at 20: Achievements and Challenges, IMF Working Paper, October, WP\09\236, http://www.imf.org/external/pubs/ft/wp/2009/wp09236.pdf

- $\quad$ Sims, Christopher A. (2003), Limits to Inflation Targeting, March 17, http://sims.princeton.edu/yftp/Targeting/TargetingFiscalPaper.pdf

- Svensson, Lars E. O. (1998a), Open_Economy Inflation Targeting, Cambridge, May, NBER Working Paper 6545, http://www.nber.orglpapers \W6545

- Svensson, Lars E. O.(1998b) Inflation Targeting as a Monetary Policy Rule, Seminar Paper No. 646, Conference on Monetary Policy Rules, Stockholm, June 12-13, http://ideas.repec.org \plhhsliiesspl0646.html

- Svensson, Lars E. O. (2010a), Inflation Targeting, NBER Working Paper No.16654, December, http://www.nber.org|paperlw16654.pdf

- Svensson, Lars E. O. (2010b), Inflation Targeting After the Financial Crisis, Speech by Prof Lars E. O. Svensson, Deputy Governor of the Sveriges in the Context of Financial Crisis, Mumbai, 12 February, BIS Review 16/2010, http://www.bis.org/review/r100216d.pdf

- TCMB (2002), 2002 Yılında Para ve Kur Politikası ve Muhtemel Gelişmeler, Basın Duyurusu, Sayı: 2002-1, 2 Ocak, http://www.tcmb.gov.tr

- TCMB (2004), 2005 Yılında Para ve Kur Politikası, Sayı: 2004-59, 20 Aralık, http://www.tcmb.gov.tr

- TCMB (2005), Enflasyon Hedeflemesi Rejiminin Genel Çerçevesi ve 2006 Yılında Para ve Kur Politikası, TCMB, Say1:2005-56, 5 Aralık, http://www.tcmb.gov.tr 
- TCMB (2006), 2007 Y1lında Para ve Kur Politikası, 13 Aralık, Ankara, http://www.tcmb.gov.tr

- $\quad$ TCMB (2007), 2008 Yılında Para ve Kur Politikası, 18 Aralık, Ankara, http://www.tcmb.gov.tr

- TCMB (2008), 2009 Yılında Para ve Kur Politikası, 16 Aralık, Ankara, http://www.tcmb.gov.tr

- $\quad$ TCMB (2009), Enflasyon Raporu-I, Ankara, http://www.tcmb.gov.tr

- TCMB (2010), 2011 Yilında Para ve Kur Politikası, 21 Aralık, Ankara, http://www.tcmb.gov.tr

- TCMB (2011), 2012 Y1lında Para ve Kur Politikası, TCMB, 27 Aralık, Ankara, http://www.tcmb.gov.tr

- $\quad$ TCMB (2012), Enflasyon Raporu 2012-II, Ankara, http://www.tcmb.gov.tr

- Tong, Hui and Shang-Jim Wei (2008), Real Effects of Subprime Mortgage Crisis: Is it a Demand or a Finance Shock?, NBER Working Paper 14205, http://www.imf.gov.tr

- Yılmaz, Durmuş (2009a), Küresel Kriz Etkileri ve Para Politikası Uygulamaları, TCMB, 4 Mart, İstanbul, http://www.tcmb.gov.tr

- Yılmaz, Durmuş (2009b), 77. Olağan Genel Kurul Toplantısı Açış Konuşması, TCMB, 14 Nisan, Ankara, http://www.tcmb.gov.tr

- Yılmaz, Durmuş (2009c), 2009 Ekim Enflasyon Raporu Basın Toplantısı, TCMB, 27 Ekim, Ankara, http://www.tcmb.gov.tr

- Yılmaz, Durmuş (2011a), 2011 Ocak Enflasyon Raporu Basın Toplantısı, TCMB, 25 Ocak 2011, Ankara, http://www.tcmb.gov.tr

- Yılmaz, Durmuş (2011b), “Küresel Ekonomide Beklentiler” Değişim Liderleri Zirvesi, TCMB, 15 Mart, İstanbul, http://www.tcmb.gov.tr 


\title{
Özelleştirmenin Teorik Temelleri ve Türkiye'deki Sonuçları Theoretical Foundations of Privatization and Results in Turkey
}

\author{
Assoc. Prof. Dr. Oğuz Bal (Kocaeli University, Turkey)
}

\begin{abstract}
Liberal economic order, businesses efficiency, productivity and profitability, competition for work is present in accordance with the principles defended private property order. As sistematical the main foundations of economic liberalism created by Adam Smith. Then, his prenciples developed by evolving Classic School, continued to the sovereignty until the Great Depression of 1929. I.World War took place in an environment dominated by Classical Ekol During, and after the war, from the principles of Classical School had not doubt. In 1936, John Maynard Keynes, the basic assumptions of the classical school refused. Following the II. World War; the 1950s and 1960s,sounds of the proponents of the liberal principles, was not strong as much as Keynesians. In the 1970s, emerged the world's most developed economy ABD, the high unemployment and inflation. Until 1973, wasn't confronted with a serious crisis. Content of the neo-liberal economic policies between 1975-1980 was adopted. Since the 1980s, heavily affecting the world economy started to implement neoliberal policies. Acceleration of privatization, taxes, discounts for large scale unemployment, increase monetary measures to keep inflation under control was applied. In this article, on eight chapters were created. In the chapters, concept, scope and content, historical background of privatization, investigated material causes that give rise to privatization, the basic bases of privatization, the ideological foundations of privatization. Privatization aims were discussed, and was given examples of countries is characterized by intense privatization. The general results and in Turkey latests cases were discussed.
\end{abstract}

\section{Giriş}

Bütün dünyada "Refah Devleti” olarak kabul edilen 1930-1973 arası dönemde ekonomiler Keynezyen ve PostKeynezyen ekonomi politikalarıyla beslendi. Bu politikalar tamamen veya kısmen mülkiyet ve yönetimi kamuya ait olan Kamu İktisadi Teşebbüslerini oluşturdu. 1973 yılında yaşanan stagflasyon olgusu, mevcut ekonomi politikalarının çözüm yerine çözümsüzlüğe neden olduğunu ortaya koydu. Özelleştirme çözüm olarak sunulmuştu. Başta İngiltere ve ABD özelleştirmeyi uyguladılar. Daha sonra da serbest piyasa ekonomisinin var olduğu tüm ülkelerde uygulanmıştır. Kamunun piyasa koşullarındaki ağırlığının azaltılması ya da tamamen çekilmesi hem gelişmiş hem de gelişmekte olan ekonomilerde yeni problemlerin ortaya çıkmasına neden olmuştur. Sorun hala devam etmektedir. Bu sorunun temelindeki teorik tartışmalar pratiğe de yansımakta ve siyasal, sosyal anlaşmazlıkların da nedeni olmaktadır.

Türkiye ekonomisi dünyada gelişen uygulamalardan ayrı kalmamış, gerek teorik gerekse pratik alanda tartışmaların içerisinde yerini almıştır. Karar verme durumunda olan siyasal odaklar, uygulamaların teorik alt yapısını kavramak ve popülist yaklaşımlardan uzak durmak zorundadır.

Yapılan bu çalışmada öncelikle özelleştirmenin teorik çerçevesi, ekonomik düşünce açısından yeri, tarihsel alt yapısı, gerekçeleri, amaçları ele alındı. Dünyada gelişmiş ve gelişmekte olan ülke örnekleri verildi. Türkiye'deki özelleştirme uygulamalarının kronolojik seyri ve elde edilen kazanımlar ayrıca ele alındı. Çalışmada tümden gelim metodu uygulanmış, kurumsal verilerden ve istatistiklerden, daha önce yapılmış ampirik çalışmaların sonuçlarından yararlanılmıştır.

\subsection{Kavramsal Bakış ve Ekonomik Sorunla İlişkisi}

Özelleştirme kavramı, dayanağını özel mülkiyetten almaktadır. Özel mülkiyet; Kapitalist sistemin temel kavramlarından biridir. Bu kavram, ekonomi bilim dalı bağlamında; iktisâdî, mâlî, sosyal ve siyâsî sebeplerle millî ekonomi içerisinde kamunun iktisâdî faâliyetlerinin sınırlandırılması veya tamâmen ortadan kaldırılmasına yönelik uygulamaların bütünü olarak tanımlanır.

Ana mesele mülkiyeti kimin yöneteceği sorunudur. Bireyler yönetecekse" fayda ve karı maksimum, maliyet ve zararı minimum düzeyde tutma" demek olan rasyonellik ilkesi, baskın bir rol oynamaktadır. Klasik İktisat ekolünde devlet; bireylerin yapamadığı alanlarda söz sahibi olur. Özel mülkiyete dayanan bu sistemde, kamu mülkiyetinin varlığı da güçlüdür. Devlet vergi toplar, tasarruf eder, yatırım yapar, yatırımlar devletin tekelinde gelişir. Sorun burada ortaya çıkar: Devlet; birey veya firma gibi rasyonel davranabilir mi? Devlet kurumunun zararını yine devlet ödemektedir. Bu paraların kaynağı ise vergilerden, ihracat gelirlerinden, iç borçlanma senetlerinden, dış borçlardan oluşmaktadır. Vergilerden ödendiğinde, devletin sağladığı tasarruflara kara delik etkisi etki yapmaktadır. DİBS gelirlerinin kullanılması; iç borçlanmayı artırmaktadır. Dış borçlanma ise dışa bağımlılığı artırmakta ve dış finans kurumlarının kontrolüne girmeye neden olmaktadır. Kamu zararlarını gidermede, KİT lerin toplum ekonomisi için yük olduğu apaçıktır. 


\section{2 Özelleştirmenin Tarihsel Nedenleri}

Kapitalizm, birincisi 1929'da, ikincisi ise 1970'lerin başında Avrupa'da gerileyen verimlilik ile karın düşmesinin sonucu yapısal kriz yaşamıştır. Keynes; 1929 bunalımından şiddetle etkilenen sistemin yeniden inşasında, sistem içi bir çözüm olarak kamu girişimciliği, talep doğurucu kamu harcamalarının arttırılması, devlet müdahalesini kabul ederek de kapitalizmin yaşayabileceğini savunan yeni bir liberalizm modeli önerilerini de, özendirmiştir. Keynes'in ortaya attığı politika önerileri 1929 Buhranı'ndan kurtulmak için birçok ülke tarafından uygulandı ve başarılı sonuçlar elde edildi. İkinci Dünya Savaşı'ndan sonra dünya ekonomisi, kısa dönemde yatırım, ekonomiye satın alma gücü zerk etti, efektif talebi ve dolayısıyla istihdamı artırdı. 20 yıl, Keynesyen politikalar sayesinde ülkelerin finansal yapıları büyük ölçüde güçlenmiş, bankacılık sektöründe iyileşme görülmüş, hükümetin milli hâsıla içindeki payını artmıştır, otomatik istikrar tedbirleri faaliyet hacmini genişletmiştir. Ekonomiyi canlandırmak için bütçe açığı verilmesine göz yumulmuş, altın standardını terk etmiş, enflasyonla mücadele uğruna ücret ve fiyat artışları üzerine getirilen sınırlandırmalar gibi kamu müdahalelerine ve teşviklere geçici bir çözüm olarak bakılmışsa da, ikinci dünya savaşından sonra kamu girişimciliği yine ön plana çıkmıştır. (Berberoğlu;1987)

\subsection{Stagflasyon Sorunu ve Keynesyen Politikalarda Arayışlar}

1970’lerde Keynesyen iktisadın açıklayamadığı stagflasyon olgusu ile karşılaşılmaktadır. (Yay, 1993) Stagflâsyon, büyüme hızının düştüğü, önemli düzeydeki işsizliğe karşın, fiyat ve ücretlerin arttı̆̆ bir ülkenin durumunu tanımliyordu. Bu durum, Keynezyen Ekonomi'nin 1930'lu yıllardan beri süren eden hâkimiyetinin sona ermesine neden olmuştur.

Stagflasyona neden olan olgu; Tekel konumuna sahip ABD'li kapitalistlerin 1960'ların ortalarından itibaren dünya pazarlarında Alman ve Japon rakipleriyle karşılaşmalarıdır. Rekabet sonucu ABD tekel konumunu koruyamadı. Tekel fiyatları ve tekel karlarının uyardığı yatırımlar nedeniyle ortaya çıkan arz fazlaları özellikle ABD kaynaklı malların fiyatlarının düşmesi imalat sanayi mallarında arz fazlası yaratmış ve bu da ABD'de imalat sanayinde fiyatlar ve kar oranlarını aşağı çekmiştir.

İşsizlik sorununu düzeltmek ve talebi canlandırmak için, hükümetler Keynes'çi ekonomiyi denediler. Keynesyen politikalar, resesyon hallerinde para ve maliye politikasının aktif biçimde kullanılmasını, faizlerin düşürülmesini, kamu harcamalarının artırılmasını ve vergilerin indirilmesini içeriyordu. $\mathrm{Bu}$ yolla, talebin yeniden genişlemesi sağlanacak ve tüketim artışından başlayarak üretim artışına ve oradan yatırım artışına, büyümeye ve işsizliğin azalmasına yol açan bir hareketin devreye sokulması amaçlanıyordu. Ancak bu; enflasyonun daha da kötüye gitmesine yol açtı.

\subsection{Keynesyen Politikalardan Çıkış Uygulamaları}

15 Ağustos 1971'de ABD, Bretton Woods Antlaşması'ndan çekildiğini açıkladı. ABD sabit kurdan dalgalı kura geçti hem ABD dolarının hem de diğer para birimlerinin değeri düştü. Petrol fiyatları dolar üzerinden olduğu için petrol üreten ülkeler aynı fiyata daha az net gelir elde eder hale geldi. Bu duruma karşı OPEC yaptığı açıklamayla petrolün fiyatının dolara değil altın değerine göre hesaplanacağını belirtince 1970'lerdeki petrol şoku başlamış oldu. 1970'lerin başlarında yaşanan petrol kriziyle birlikte "Sosyal Devlet" anlayışının terk edilmesi son bulmuştur.

1970'lerde Chicago Ekolü'nce şekillendirilen özelleştirme kavramı, ABD'de Ronald Reagan'ın ve İngiltere'de Margaret Thatcher'in seçilmelerinden sonra teoriden pratiğe geçerek hızlanan muhafazakâr ekonomik teorinin 'Neo-Klasik' versiyonunun egemenliği altına giren iktisat politikaları, devlet denetimlerinin ve düzenlemelerinin kaldırılmasına ve finansal piyasaların küresel bütünleşmesine entelektüel destek sağlamasının yanında, uluslararası ticaretin neredeyse her yerde serbestleştirilmesine yol açtı.

Diğer ülkelerde de Keynes'çi politikalar, ciddi bir biçimde sorgulanmaya başlandı. Klasik iktisadın yeniden yorumlanmasına yönelik düşünce hareketleri gelişmiş, muhafazakâr iktidarların ideolojisini oluşturmuştur. 1989 yılında Berlin duvarının çökmesi, soğuk savaşın sona erişinin ve merkezi planlı ekonomiler ile kamu teşebbüslerinin yerini piyasa ekonomisi ve özel teşebbüse devrettiği yeni bir döneme geçiş sağlanmıştır. Komünist bloktan ayrılan Doğu Avrupa ülkeleri ve gelişmekte olan ülkeler de uygulanmaya başlanmıştır. Verimli ve etkin çalışmayan, ekonomide verimsiz yapılanma modelleri, önemli kamu açıkları, politikanın güdümündeki kamu teşebbüsleri, bunalımın suçlusu olarak görülmüştür.

\section{3 Özelleştirmede Teorik Gerekçeler}

\subsection{Amaçlardaki farklılıklar - Ödül-maliyet sistemindeki farklılıklar}

Kamu statükocudur. Geçmişin izleri ve politikası atılmamaktadır. Özel sektörde şirket politikaları etkendir. Kamuda iktidar; belirli hedeflere göre çalışır. Özel sektör innovasyona dayalı bir politika izler. Kamuda iktidar beklentileri ağırlıktadır ve her şey iktidardan beklenmektedir. Özelde performansı görme ve ödüllendirme imkanı çok daha büyüktür. 
Kamuda işler tepeden inme ve bürokratiktir. Özel sektör her zaman karlılık adına ucuza eleman çalıştırma ister. Kamu sektörü kar gözetmez yalnızca ihtiyacı karşılamaya yönelik üretim sağlar.

Kamu kurumlarındaki düzenin tazelenmesi zaman almakta ve bazen imkânsız hale gelmektedir. Günümüzde özel sektörde birçok şirkette performansa dayalı ücretlendirme özel sektörce kabul görmeye başlamıştır. Uzmanlar aynı sistemin, kamu kesimine taşınmasını tartışmaya başlamıştır. Bir başka sorun da ücretin belirlenmesindeki kriterlerdir.

\subsection{Mülkiyetin devredilebilmesi}

Özel mülkiyet kavramı kapitalist sistemin en temel öğelerinden biridir. Birey, sahibi olduğu mal veya eşyayı; alır, satar, devreder, rehin bırakır, hibe eder, nakleder, şeklini değiştirir ve yok eder. İktisadi bakımdan bu çeşit radikal karar alma hakları tamamen mal veya eşyanın özel mülkiyete konu olmasından kaynaklanmaktadır. Özel mülkiyet hakkı, bireylere kaynakları kullanma ve devretmede büyük bir serbestlik tanımaktadır. Bu hakların sınırlar çerçevesinde kullanılması hukuk sisteminin vaz' edeceği bir husustur. İktisadi açıdan bu sınırları piyasa belirlemektedir. Özel mülkiyete konu olan mal veya eşyaya karşı bireyler daha rasyonel davranma eğilimindedirler. Özel girişimin sahipliği altındaki varlıklarda geliştirme ve servet biriktirme güdüsü, kamuda söz konusu olmadığı için rasyonel davranma da ona göre zayıftır. Daha rasyonel bir düşünce yapısı, kamu sektörü için düşünülmese de olur. Kamuda çalışmaların ve yöneticilerin yegâne kaygısı pozisyonlarını korumak olduğu için, ödül ve ceza sistemde itici bir güç olabilir. Özelde mülkiyette risk alma önemli bir husustur. Bu risk; iflas etme ve ödenmeme şeklinde ortaya çıkmaktadır. Kamuda bu risk sıfıra yakındır.

Politik karar alma sürecinin taraflarının ve özellikle bürokratların davranış kalıplarının, kamu ekonomisinin etkin işlemesi ve kamu çıkarının gözetilmesinde olumsuz bir durum yarattığı düşünülmektedir. Teoriye göre rekabetçi piyasalar, monopolist özellikler taşıyan piyasalara kıyasla çok daha etkin işlemektedir. Rekabetçi piyasalarda kaynakların kullanımı daha dikkatli davranılması ve maliyetlerin minimize edilmesinin zorunluluğu, bu piyasaların daha etkin bir şekilde çalışması sonucunu doğurmaktadır. (Leibenstein;1996)

\subsection{Yönetim - mülkiyet ilişkisi}

İnsanlığın var oluş tarihinden beri mülkiyet kavramı özel ve kamu olarak var olmuştur. Temel sorun, mülkiyeti kim ve nasıl yöneteceği sorunudur. Bir tarafta yönetilen diğer tarafta da yöneten kesim vardır. Yöneticilerin yönetim kabiliyetlerini ortaya çıkaran temel faktörlerden birisi de kişisel farklılıklardır. Kamu yöneticisi gücü, yetkilendirilme yöntemleri, kamu yararının önde tutulması, karar ve denetim mekanizmasının merkeze bağlı olması, risk alma eğiliminin düşük olması, bürokrasinin hâkim olması, başarısızlık sonunda doğan zararın kamu tarafından giderilmesi gibi hususlar, kamu sektörünün özelliklerini içermektedir.

Kurumlar mülkiyet yapısına ve ekonomik-sosyal odaklılık olmak üzere ayrıldığında farklı ilişkiler ağına neden olur. Ekonomik odaklı olma durumunda tamamen bireysel çıkar söz konusu olurken sosyal odaklılık tam tersini içererek, topluma, gruba yönelik eylemler geliştirir. 1980'lerin başından itibaren "devlet" reformuna ilgi yoğun bir şekilde artmış ve günümüzde kamu yönetiminin hantal, çağın ve özellikle de ekonomik hayatın gereklerine cevap veremeyen bir kimliğe büründüğü, halkta uyandırdığı güvenin azaldığı ve giderek toplumun üzerinde bir yük haline geldiğidir (Ateş, 2001).

\subsection{Kamu-Özel ikilemi}

Devlet faaliyetlerinin maliyeti artarken, bunun nedenleri çoğunlukla sorulmaz. Kamu üstündeki kamburların, iktidarların üzerine sürekli yük olarak birbirlerine intikal ettiği göz ardı edilmektedir. Halk çoğu zaman sadece bireysel faydasını düşündüğünden meydana gelen olumsuzluklara karşı tepkinin dozu da kaçmaktadır. Halk iktidarları, iktidarlar da atadıkları kamu yöneticilerini suçlamaktadır. Gerçekler asla sıradan vatandaşın önüne sunulmaz. İktidarlar devamlılıklarını sürdürmek için çeşitli arayışa girerler. Bunun için ya gerçekleri gizleyen muhasebe tekniklerine başvurulur veya açığın kapanması için borçlanma yoluna gidilir. Borcu karşılamak için verimliliği artırıcı yatırımlara girişilir. Özellikle kalkınmakta olan ülkeler yeni yatırımların finansmanı için borçlanırlar. Yenilenen borç sözleşmelerinin bir kısmı eski borçlara tahsis edilerek borcu borç ile ödeme bataklığına girilmiş olur. Verimlilik artışı otomasyon yoluyla gerçekleştiği zaman ortaya teknolojik işsizlik çıkmaktadır. Bu çıkar çatışması kamu- özel ikilemini gündeme getirmektedir. Özelleştirmenin bir seçenek olduğu böylece ortaya çıkar.

\section{4 Özelleştirmenin Teorik Temelleri}

Klasik iktisat teorisi devam ederken oluşan 1929 Buhranı'ndan kurtulma reçetesini sunan Keynes'e göre; ekonomik kriz; doğrudan hükümet müdahalesiyle kırılabilirdi. İş dünyasını canlandırmak için, vergi ve faiz oranlarında indirimler, istihdamı teşvik eden maliye politikaları benimsenmeliydi. Keynes'in yaklaşımları, yeni seçilen ABD başkanı F. Roosevelt'ten büyük destek aldı.(Alçın:2013) Roosevelt, ABD'nin krizden çıkabilmesi için, müdahaleci politikanın gerekliliğini ilan etti. "Keynes'çi" iktisat kuramı, krizden sonraki 40 yıl boyunca ülkelerin temel ekonomik programını oluşturdu. Dünya ekonomisi II. Dünya Savaşı'ndan sonra, 20 yıl büyüme ve refah dönemi yaşamıştır. Ülkelerin finansal yapıları güçlenmiş, bankacılık sektöründe iyileşme görülmüş, hükümetin milli hâsıla içindeki payı artmış, otomatik istikrar tedbirleri faaliyet hacmini genişletmiştir. 
1970'li yıllarla birlikte, Keynes'çi ekonomi politikaları itibarını kaybetti. Neo-liberalizmin yükseldiği yıl 1979'dur.Sağ kanat politikacıları ile eleştirmenler, bu yöntemin Marksizm'in bir uzantısı olduğu ve özgür girişimi engellediğini ileri sürdüler. 1980'lere gelindiğinde ise, sömürge ve bağımlı ülkelere sıçrayan kriz genelleşti. Başbakan Thatcher döneminde özelleştirme ideolojik bir temele oturtulmaya çalışılmıştır. Ona göre; özelleştirmenin gayesi, devletin gücünü azaltmak; bireyin özgürlüğünün, refahının ve mutluluğunun artması demektir. Bu çerçevede "özelleştirme"; uluslararası sermayenin dünya çapında uygulamaya koyduğu bir politika halini aldı. 1980'lerin ortalarına doğru da, paraya dayalı politikalar yok olmaya başladı. Türkiye'de özelleştirme uygulamalarını, dönemin Başbakanı Turgut Özal 1984'te başlattı

Keynes sonrası Klasik iktisadın yeniden yorumlanması ile ortaya çıkan başlıca iktisadi ekoller; Monetarizm, Neo-Liberaller, Arz Yönlü İktisat Teorisi, Yeni Muhafazakârlar, Rasyonel Beklentiler teorisi olarak sıralanabilir. $\mathrm{Bu}$ ekoller farklı yoğunlukta olmalarına rağmen, yaşanan krizi, serbest piyasa mekanizmasını engelleyen müdahalelere bağlamışlar. En büyük engeli de, büyük bir müdahale potansiyeli olan devlet olarak görmüşlerdir. Krizden kurtulmanın reçetesi olarak, serbest piyasa mekanizmasına işlerlik kazandırılması, devletin ekonomik yaşamdaki rolünün daraltılması olduğunu savunmuşlardır.

Serbestleştirme (Deregulation), devletin ekonomideki bütün sektörler üzerindeki hukuki düzenleme ve kısıtlamaların kaldırılması ya da sınırlarını daraltan bir iktisat politikasıdır. Bu metodun ABD'de uygulanmaya başlamasından sonra, ilgili sektörlerde, rekabetin arttı̆̆ı, mal ve hizmet maliyetlerinde önemli düşüşlerin sağlandığı görülmüştür. Türkiye'de 24 Ocak Kararları çerçevesinde, serbestleşme yönünde çeşitli uygulamalar yapılmıştır. Temel mal kavramı kapsamının daraltılması KİT’lerin mal ve hizmet fiyatlarını serbestçe belirleyebilmeleri, kredi ve mevduat faiz oranlarının serbest bırakılması, çay tekelinin kaldırılması, elektrik üretimi, dağıtımı, ticaretiyle eğitim sektöründe özel sektörün teşvik edilmesi bunlara örnek olarak verilebilir.

\section{5 Özelleştirmenin ideolojik dayanağı}

Kapitalist Sistem'de üretim ve tüketim kararları, kar, fiyat, efektif talep gibi piyasa kategorilerine bağlı olarak piyasa mekanizması içinde alınır. Kapitalist sistemde, üretimin asıl hedefi kar maksimizasyonudur. Savaş sonrası kapitalist genişlemenin sonuna ulaşılıp, sistemin yeniden "yapısal krize” girmesiyle, XIX' uncu yüzyılın liberalizmi, neo-liberalizm olarak yeniden sahneye döndü. Neo-liberal akım, üç sloganla yürüyecekti: a. liberalizasyon, b. Deregülasyon ve c. özelleştirme. Bunlardan liberalizasyon, sermayenin ve kapitalistin hareketini sınırlayan engellerin ortadan kaldırılmasını amaçlar. Neoliberal anlayışa göre, sosyal güvenlik 1, bireylerin sorunu olmalıdır. Devletin bu alana müdahalesi engellenmektedir. Devlet bir sanayileşme siyaseti uygulayamaz, bazı sektörleri teşvik edemez, planlama yapamaz. Ancak bu akım; Kapitalizmin doğal gidişinin bir sonucu değil, Keynesyen kapitalizmin 70'lerin ortasında yeni bir krize neden olmasının bir sonucudur. Keynesci model çökmüş, dünya kapitalizmi krize girmişti. Özellikle sosyal tepkilere bir cevap verme gerekiyordu. Verilen cevap eski modellerin yenileştirilmesi biçiminde verilmiştir. Bunun adı, neo liberalizm'dir. Mali sermayenin serbestçe dolaşımı, bütün kamusal alanların tamamen özelleştirilerek kapitalist sisteme dâhil edilmesi, neoliberal ekonominin başlıca özelliklerindendir. Kamusal harcamaların (sağlık, eğitim, barınma, vb.) kaldırılıp özelleşmesinin önü açılmıştır.

\section{6 Özelleştirmenin Amaçları}

Yukarıda kavramsal, teorik, ideolojik, kronolojik incelemelerden sonra özelleştirmenin amaçları aşağıdaki gibi sıralanabilir: 1-Serbest piyasa ekonomisine işlerlik kazandırmak. 2-Kaynak kullanımında ve dağılımında etkinlik sağlamak. 3-Sermaye piyasasını geliştirmek. 4-Devletin ekonomideki etkinliğinin azaltmak. 5-Devlete gelir sağlamak. 6-Daha çok rekabet yaratmak. 7-Ekonomik performansı olumlu etkilemek. 8-Servetin geniş kitlelere yayılmasını sağlamak. 9-Hazine üzerindeki yükleri azaltmak. 10-Yabancı sermaye girişini, teknoloji ve yeni yatırımları özendirmek. 11-Siyasi çıkarlar amacıyla kamuyu şişirmenin önüne geçmek.

\section{Dünyada Özelleştirme Uygulamaları}

\subsection{A.B.D}

Özelleştirme, ABD’de en belirgin biçimiyle genel ve yerel düzeyde revaç bulmuştur. Bütçe fonlarının azalması ve vergilere karşı gelişen hoşnutsuzlukla karşılaşan politikacılar, kamu altyapı yatırımları ve hizmetlerinin özel kesimce gerçekleştirmesi için zorlanmıştır. Federal düzeyde özelleştirme, Başkan Reagan'ın kurduğu Federal Mülkiyeti İnceleme Teşkilatı (Federal Property Review Board) ile 1982 Şubat'ında başlamıştır. ABD'de kamu hizmetlerinin önemli bölümü özelleştirilmiştir. Özellikle belediye, cankurtaran, hapishane, çöp toplama, itfaiye işleri, büyük oranda özel kesimce yürütülmektedir. Böylelikle, yerel yönetimlerde gerçekleşmiş olan büyük çaplı özelleştirmeler sayesinde, 40.000 nüfuslu beldelerde devlet memuru sayısı yaklaşı 55 civarına inmiştir.(Doğan;1993)

Merkezi yönetimde de benzer özelleştirme uygulamaları gerçekleştirilmiştir. ABD ekonomisinde, önemli güce sahip olan haberleşme ve telekomünikasyon hizmetlerinde özelleştirilmeye geçilmiş ve rekabetçi bir piyasa 
yapısı için tamamı özelleştirilmiştir. Hava ve demir yolları, yük taşımacılığı ve otobüs hizmetlerinin yasalkurumsal serbestleşme süreci tamamlanmıştır(Aktan;1993). Gerçekleştirilen özelleştirmeler yararlı sonuçlar vermiş, ilgili sektörlerdeki rekabet ve verimlilik arttırmıştır. Özellikle şehirlerde özelleştirme faaliyetlerine ağırlık verilmektedir. Yönetimleri özelleştirmeye götüren sebep maliyetlerdeki düşüşlerdir.

\section{2 İngiltere}

Dünyada özelleştirme uygulamasının ilk örneği, 80 li yıllarda, İngiltere, Şili, Arjantin ve Meksika'da uygulanmıştır. İngiltere özelleştirme konusunda en başarılı ülkelerden birisidir. Özelleştirmeye taraftar sağlamak için yerel yönetimlere ait evler, kiracılara satılmıştır. En önemli özelleştirme British Telecom'a aittir. İngiltere'de tarım, ulaştırma, PTT, tersaneler, madenler, atom enerjisi, demir ve deniz yolları, çelik üretimi kadar tamamen kamu malı halinde idi. Artan sübvansiyonlar, politik arpalıklar, işçi-devlet münakaşaları, tüketici huzursuzlukları, sürekli bir şekilde zararının hazinece karşılanması ve borçlanma ve ortaya çıkan stagflasyon krizine karşı Keynes'yen çabalar sonuç vermemiştir. (Bilgin;1998) Bu gerekçelerle İngiltere'deki muhafazakâr parti iktidara gelince özelleştirmenin bütün yöntemleri denenmiştir (Öztürk;2005,12). 1991 y1lında kamu sektörünün \%50 den fazlası özelleştirilmiştir. Gerçekleştirilen özelleştirme uygulamaları sonucunda, sadece Margaret Thatcher'in başbakanlığı döneminde 75 milyar Dolar özelleştirme geliri sağlanmıştır.

\subsection{Fransa'daki Özelleștirme}

1979 petrol sokundan Fransa'da ekonomi bunalımlı bir döneme girmiş̧ir. Mauroy Başbakanlığındaki sosyalist hükümet döneminde, tam bir istikrar politikası uygulanamamıştır. Bütçeden KİT şirketlerine yapılacak kaynak aktarımı sağlanamamıştı. 1985 yılına gelindiğinde, artık özelleştirmeden yana olanlar çoğunluğa ulaşmıştı.( Chirac, Mart-1986 ). 800 bin isçinin çalıştığı 65 adet kamu kurulusunun hisselerinin satısı kararlaştırılmış ve bunlardan 12 tanesi 1986- 1987 arasında 5 yıl için bir özelleştirme programı açıklandı 1987 Haziran'ına kadar 13 kuruluş satılmış ve bunlardan 56,8 milyar Frank gelir elde edilmiştir. Fransa'yı ayırt eden noktalardan biri de özelleştirmenin oldukça kapsamlı olmasıdır. Fransa'da tartışılan günlük ekonomik konulardan birisi de millîleştirilen şirket ve bankalardan hangilerinin özelleștirileceğidir. Fransız hükümeti, 33 kamu iktisâdî kuruluşunu özelleştirerek, önemli ölçüde gelir elde etmeyi plânlamaktadır.

\subsection{Almanya'daki Özelleştirme}

Preussag Prusya Mâden ve İzobe Ocakları A.Ş. ve Volkswagen firmaları ilk özelleştirilen şirketler arasında sayılabilir. Almanya'da 1980 yılında rekabet konusunda yapılan bu değişiklikler, bankacılık ve sigortacılık sektöründe yer alan ve rekabet dışında tutulan kurumlar da, rekabet sistemi içerisine alınmıştır. Birleşik Almanya ile dev ve hantal kamu isletmeleri için özelleştirme programı uygulamaya koymuştur. Bu uygulamalar ile 1991 yılı Ekim ayının sonuna kadar, özelleştirilen devlet isletmelerinin sayıs1 4337'yi bulmuştur(Dartan, 1993, s:58). Başarılı bir özelleştirme programı devam etmektedir. Hükümet yıllara yayarak, Telekom, Alman Demir Yolları (Deutsche Bahn), Alman Posta İdaresi (Deutsche Post), Alman Hava Güvenliği, TLG mülkiyet şirketi ve BerlinSchönefeld, Köln-Bonn ile Münih havalimanları gibi devasa devlet tekellerinin özelleştirilmesinin yolunu açmaya çalışıyor. Ülke güvenliği açısından önem taşıyan sektörlerdeki yabancı payını yüzde 25 ile sınırlamaya hazırlaniyor.

\section{5 İspanya'da Özelleştirme}

Diğer Batı Avrupa ülkeleri gibi İspanya ekonomisi de 2. Dünya Savaşı'nın ardından bir dönüşüm sürecine girmiş, bu süreçte tarım sektörü ekonominin hâkim sektörüdür. Ülkenin enerji bakımından ithalata bağımlı olması nedeniyle 1970'lerde yaşanan petrol krizi ekonomik büyümeyi şiddetli biçimde etkilemiştir. 1985 ten beri sanayide kamu payı önemli ölçüde azalmıştır. 1996 yılında petrol, elektrik ve telekomünikasyon iştiraklerini hızla özelleştirmiștir. Son 10 yılda yoğun bir özelleștirme uygulamasıyla her alanda devlet hâkimiyeti azalmıștır. $\mathrm{AB}$ mevzuatına uyum çalışmaları, devlet hâkimiyetinin ve tekellerin kaldırılması sonucunu doğurmuştur. Otoyolların yüzde 90'ını özel şirketler kontrol ediyor. 2000 yılının ortalarında petrol, doğal gaz, elektrik, telekomünikasyon, kitap, farmakotikler, arazi ve taşıt piyasalarında serbestleştirme ver uzun vadeli liberalizasyon önlemleri paketi onaylanmıştır.

\subsection{Kanada}

Diğer gelişmiş ülkeler ile karsılaştırıldığında daha 1lımlı bir kamu sektörüne sahip iken, yapılan özelleştirmeler daha yavaş olmuştur. Kanada'da 1962 yılında sağlık sektöründe özelleştirmeler yapılırken, 1963 yillarında British Colombia ve Quebec’te güç istasyonları özelleştirilmesi yapıldı. Federal, bölgesel ve yerel hükümetler, mali durumlarına göre farklı yöntemler izlediler. Birçok bölgesel kuruluş, doğal tekel sandıkları birçok sanayiyi özelleştirdiler. 1980'lerin ortalarında özelleştirme, halka arz yoluyla satıldı. Özelleştirmelere; BCRIC, The Mulroney Years, Bombardier, Air Canada, The Chretien Years, Navcan örnek verilebilir. Kanada Ulusal Tren yolu işletmesindeki hükümet payı, 1995 yılındaki açık arttırma ile satılma yöntemiyle özelleştirildi.

\section{Türkiye'de Özelleştirme Uygulamaları}

1970 li yıllarda gelişmiş ekonomilerde yaşanan stagflâsyonun esas nedeninin Keynes'in önerdiği politikalar olduğu keşfedilmiştir. Uygulanan politikaların, kamu borçlanmasını artırdığı, kamunun rasyonel davranamadığı 
gerekçeleriyle, özelleştirme politikaları, ABD ve İngiltere'nin denemeleriyle, birkaç ülkenin dışında tüm dünyaya sirayet etmiş Türkiye Ekonomisi de bundan etkilenmişsir.

Türkiye, Cumhuriyetin başından beri serbest piyasa ekonomisi düşüncesine sahipken, sermaye birikiminin azlığı, girişimci sınıfın zayıflığı sebebiyle Sümerbank, Etibank, Şeker Fabrikaları, TMO gibi KİT'ler kurulmuştur. 1960'lara kadar iç dinamikler, 1929 buhranı, Dünya savaşlarının belirlediği dış konjonktürün de etkisiyle devlet tekeli pek çok alanda hâkimdi. Ülkemizde uzun süre uygulanan ithal ikameci politikaların da desteğiyle, devletçi politikalar hantal bir ekonomik yapının oluşmasına neden oldu. Dünyada yaşanan petrol şokları ve ülke ekonomimizin gidişatı sebebiyle kamu sektörünün işleyişinin ve ekonomiye getirdiği sorunların en yoğun tartışıldığı yıllar 70 li yıllardı.ı(Özsoylu;2011).

Özelleştirme için siyasal dönüm noktası 24 Ocak 1980 kararları olmakla beraber, yasal çerçevenin oluşturulması 1984 'de başlamıştır. 1986 yılından itibaren hızlanan ve tamamı kamu malı veya iştiraki olan kuruluşlardaki kamu paylarının özelleştirme kapsamına alınması yoluyla yürütülen program çerçevesinde, İdare tarafindan bugüne kadar 201 kuruluşta hisse senedi veya varlık satı̧̧/devir işlemi yapılmış ve bu kuruluşlardan 191 'inde hiç kamu payı kalmamıştır. 1986 yllından bugüne kadar gerçekleştirilen özelleştirme uygulamalarının toplam tutarı 46,3 milyar \$ düzeyindedir. Bir bölümü vadeli ve döviz cinsinden gerçekleştirilen bu hisse senedi ve varlık satış işlemlerinden Mart 2013 itibariyle 44,7 milyar \$ net giriş sağlanmıştır. Özelleştirme kapsamındaki kuruluşlardan elde edilen 4,5 milyar \$ temettü geliri ve 1,4 milyar \$ diğer kaynaklarla birlikte 1985 - Mart 2013 dönemi toplam kaynakları 50,6 milyar \$ düzeyine ulaşmaktadır.

\subsection{Türkiye şartlarında özelleştirmenin kronolojik seyri ve özelleştirme yöntemleri}

Özelleştirmeye ilişkin ilk yasal düzenleme, 29.2.1984 tarih ve 2983 sayılı Kanun ile yapılmıştır. Bu çerçevede, gelir ortaklı̆ğ senedi, hisse senedi ve işletme hakkı devrinden oluşan özelleştirme yöntemleri tanımlanarak, Toplu Konut ve Kamu Ortaklığı Kurulu, Toplu Konut ve Kamu Ortaklığı İdaresi ve Kamu Ortaklığı Fonu kurulmuştur. Özelleştirmeye ilişkin ikinci yasal düzenleme 8.6.1984 tarih ve 233 sayılı KHK'nin 38'inci maddesi ile yapılmıştır. Diğer taraftan, 1984 yılında, 4.12.1984 tarih ve 3092 sayılı Çay Kanunu ile çay tarımı, üretimi, işlenmesi ve satışı serbest bırakılmış, aynı tarih ve 3096 sayılı Kanun ile de Türkiye Elektrik Kurumu dışında, özel sektörün elektrik üretimi, İletimi, dağıtımı yapabilmesine ilişkin düzenlemeler yapılmıştır.

28.5.1986 tarih ve 3291 sayılı Kanun ile 233 sayılı KHK'nin 38'inci maddesinin uyarınca, özelleștirmenin karar alma ve uygulama aşamalarına ilişkin yeni düzenlemeler yapıldı. 1986 yılında çıkarılan 3291 sayılı kanunda, kamu kuruluşlarının özelleştirme kapsamına alınması ve uygulanmaların yürütülmesine iliş̧kin esaslar belirlendi. Buna göre, 233 sayılı kanun hükmünde kararnamede adı geçen, tamamı devlete ait ve kamu iktisadi teşebbüsü statüsünde faaliyet gösteren kuruluşların özelleştirme kapsamına alınmasına Bakanlar Kurulu, KİT lerin müessese, bağlı ortaklık, işletme ve işletme birimleri, iştirakleri ile iştiraklerindeki payların özelleştirme kapsamına alınmasına da Yüksek Planlama Kurulu yetkili kılındı. Özelleştirme programının yürütülmesi konusunda ise, 2983 sayılı kanunla oluşturulan Toplu Konut ve Kamu Ortaklığı İdaresi görevlendirildi. Bu idare, özelleştirme programının yanı sıra, toplu konut uygulamalarının yürütülmesi, Kamu Ortaklığı Fonu'nun yönetimi ve Çalışanların Tasarruflarını Teşvik Hesabı'nda biriken paraların nemalandırılması gibi görevler de üstlenmişti. 3291 sayılı kanunla, özelleştirme uygulamaları konusundaki karar mercii, Toplu Konut ve Kamu Ortaklığı Kurulu olarak belirlendi.

28.12.1987 tarih ve 304 sayılı KHK ile TKKOK ve EIYKK'na ait olan görev ve yetkiler Yüksek Planlama Kurulu (YPK)'na devredilmiş ve bundan böyle özelleştirme kararları YPK tarafından alınmaya başlanmış, kamu iktisadi teşebbüslerinin özelleştirilmesine ise Bakanlar Kurulu tarafından karar verilmesine devam edilmiştir. 1987 yılında Sümerbank'ın özelleştirilmesi kararı alındı ve banka Kamu Ortaklığı İdaresi'ne devredildi. 1988'de Sümerbank Holding kuruldu. Holdingin bankacılık birimi 1993 de Yüksek Planlama Kurulu kararıly Sümerbank adı altında yeniden yapılandırıldı. 24 Ekim 1995'te Garipoğlu şirketler grubuna 103,4 milyon dolara satılarak özelleştirildi. 1987 yılında Hüsnü M. Özyeğin tarafından kurulan Fiba Grubu bünyesinde yer alan Fina Enerji ve Fina Limancılık, İstanbul Anadolu Yakası Elektrik Dağıtım özelleştirme sürecinde Ortak Girişim Grubu olarak yer alıyor. 1987 yılında özelleştirme kapsamına alınan Petkim'in, İzmit-Yarımca'da bulunan üretim kompleksi, 2001 yılında 60 milyon dolar bedelle satılmış, kalan kısmının özelleştirme ihale süreci ise 20 Ocak 2003 tarihinde başlamıştı. 6 Haziran 2003 tarihinde yapılan ihaleyi ise Standart Kimya Petrol Doğalgaz Sanayi ve Ticaret A.Ş kazanmıştı. 28.12.1987 tarih ve 304 sayılı KHK ile Özelleştirmede tüm yetkiler Yüksek Planlama Kurulu (YPK)'na devredilmiş ve bundan böyle özelleştirme kararları YPK tarafindan alınmaya başlanmıştır. Nisan 1987'de özelleştirme kapsamına alınan Gübre Fabrikaları A.Ş. 1989 yılında kapsamdan çıkarılmıştır. Yine kapsama alınan Boğaziçi Hava Taşımacılığı A.Ş. ise tasfiye edilmiş̧ir.

1988 yılında, sadece YPK'nun 8.7.1988 tarih ve 88/3 sayılı Kararı ile Keskin Kalıp Fabrikası tesisinin özelleştirilmesine karar verilmiştir. Özelleştirme mevzuatında yapılan dördüncü önemli düzenleme 9.4.1990 tarih ve 414 sayılı KHK ile yapılmıştır

20.12.1991 tarihli ve 470 sayılı KHK ile Yüksek Planlama Kurulu'nun görevleri yeniden tanımlanmış, aynı tarih ve 473 sayılı KHK ile Kamu Ortaklığı Yüksek Kurulu oluşturularak özelleştirme ve Kamu Ortaklığı Fonu hakkında karar alma yetkisi bu kurula bırakılmıştır. 
Özelleştirme mevzuatında bazı kuruluşlara ilişkin özel düzenlemeler de yapılmıştır. 20.8.1993 tarihli ve 509 sayılı KHK ile PTT’nin haberleşme hizmetleri ayrılarak yeni bir şirket kurulmuş ve bu şirketin özelleştirilmesine ilişkin hükümler ihdas edilmiştir.

10.6.1994 tarih ve 4000 sayılı Kanun ile PTT'nin posta ve telgraf dışında kalan hizmetlerinin ayrılması ve özelleştirilmesine ilişkin hükümler yeniden düzenlenmiştir. Özelleştirme konusu kapsamında değerlendirilebilecek bir diğer yasal düzenleme ise 8.6.1994 tarih ve 3996 sayılı Kanun ile yapılmıştır. Bu Kanun ile yap-işlet-devret modelinin uygulanabilmesi için yasal dayanak oluşturulmuştur.

1995 yılında özelleştirme kapsamına alınan Hamitabat, Kemerköy, Soma-B ve Yeniköy elektrik santralleri 1997 yılında kapsamdan çıkarılmış ve Enerji Bakanlığı'na iade edilmiştir. 1995 yılından bu yana özelleştirilmeye çalışılan PTT, telekomünikasyon ve posta hizmetlerinin birbirinden ayrılarak, Türk Telekomünikasyon A.Ş.'nin kurulmasıyla özelleştirildi.

Türkiye'nin tek çinko üreticisi ve altın üretim teknolojisine sahip kamu kuruluşu olan Çinko ve Kurşun İşletmesi (Çinkur), İranlı, Kanadalı ve yerli Ekin Madencilik firmalarından oluşan Kayseri Metal Madencilik firmasina, 29 Mart 1996 tarihinde 14 milyon dolar bedelle satıldı.

1997 yılında özelleşen Tekirdağ limanı özelleşen ilk kamu limanıdır.

TEAŞ'ın bazı şirketlerinde iştirak payı olan AKTAŞ, NURTEK, TGT ve SOYTEK Elekt. Sant. Tes. İşl. ve Tic. A.Ş., ETITAŞ Elekt. Teç. İmal. Tesisat A.Ş., MITAŞ Madeni İnş. İşleri A.Ş. ile Kayseri ve Civarı Elekt. T.A.Ş. Mart 1998'de kapsam ve programdan çıkarılmış, eski statülerine iade edilmiştir. Eylül 1997'de kapsama alınan Oyak Sigorta şirketleri Ekim 1998 tarihinde kapsamdan çıkartılarak eski statülerine iade edilmiştir.

Kamunun tekelini kaldırmak amacı ile doğalgaz iç pazarı için ortak kurallar ile ilgili 22 Haziran 1998 tarih ve 98/30/EC sayılı Avrupa Parlamentosu ve Konsey Direktifine karşılık gelen 18 Nisan 2001 tarih ve 4646 sayılı Doğalgaz Piyasası Kanunu 2 Mayıs 2001 tarihinde yürürlüğe girdi.

1998 yılında 98/10552 sayılı Kararname ile Etibank 'ın ETİ HOLDİNG A.Ş. ve yedi adet bağlı ortaklı şirkete dönüştürülmesiyle müessese ETİ KROM A.Ş. Genel Müdürlüğü adını almıştır. ETİ KROM A.Ş. 18.10.2000 tarih ve 24204 sayılı Resmi Gazetede yayınlanan Özelleştirme Yüksek Kurulunun kararı ile özelleştirme kapsam ve programına alındi.

Enerji sektöründe liberalizasyon ve elektrik üretim özelleştirmelerine bakıldığında; Elektrik Enerjisi Sektörü Reformu ve Özelleştirme Strateji belgesinin 10. maddesinde de belirtildiği önceliğe uygun olarak elektrik üretim özelleştirmelerine, dağıtım özelleştirme sürecinin tamamlanmasının ardından başlanması planlandı. Bu kapsamda, şimdiye kadar gerçekleştirilmiş olan tek elektrik üretim özelleştirmesi; yedi hidroelektrik, bir jeotermal ve bir de doğalgaz santralinden oluşan toplamda 140 MW kapasiteye sahip olan Ankara Doğalgaz Üretim Anonim Şirketi (ADÜAŞ) oldu. 5 Mart 2008 tarihinde yapılan ihaleyi 510 Milyon Dolar bedel ile Zorlu Enerji kazanmıştır. Bu çerçevede yapılan özelleştirme kapsamında ihaleyi kazanan Zorlu Enerji; Engil Gaz Türbinleri Santrali(Van, 15 MW), Kuzgun HES (Erzurum, 20,9 MW), Çıldır HES (Kars, 15,4 MW), İkizdere HES (Rize, 18,6 MW), Mercan HES (Tunceli, 19,2MW), Tercan HES (Erzincan, 15 MW), Ataköy HES(Tokat, 5,5 MW), Beyköy HES (Eskişehir, 16,8 MW) ve Denizli'de faaliyet gösteren Türkiye'nin en büyük kapasiteli jeotermal santralinin (15 MW) 30 yıllık işletme hakkına sahip olmuştur.

Et ve Balık Kurumu'nun (EBK) 16 kombinas1, 1995-1999 arasında arsa bedellerinin bile altında kalan fiyatlarla özel sektöre devredildi. YEMSAN' bağlı tüm fabrika ve birimler 1993-1995 yılları arasında özelleştirildi.

1998 yılında da T. İŞ BANKASI'NDAKİ kamu hisseleri ile 2000 yılında TÜPRAŞ hisselerinin büyük bölümünün özelleştirilmesiyle yurtiçi ve yurtdışı piyasalarda bugüne kadar yapılan en büyük halka arz gerçekleştirildi. Etibank A.O. hisselerinin tamamı, 2 Mart 1998 tarihinde toplam 155 milyon 500 bin ABD Doları bedelle Medya - İpek Holding A.Ş.'ye satılarak özelleştirildi.

Özelleştirme Yüksek Kurulu'nun 30 Ocak 1999 tarihli toplantısında almış olduğu karar çerçevesinde, Turban Turizm A.Ş.'ye ait Ürgüp Moteli'nin 3 milyon 100 bin ABD Doları bedelle ODEN İnşaat Turizm ve Ticaret A.Ş.'ye satışı onaylandı.

Özelleştirmede 1985 yılında 28,6 milyon dolar, 1989'da 131,2 milyon dolar, 1990'da 486 milyon dolar, 1991 'de 243,8 milyon dolar, 1992'de 422,9 milyon dolar, 1993'de 565,5 milyon dolar, 1994'de 411.8 milyon dolar, 1995'de 572.2 milyon dolar, 1996'da 292 milyon dolar, 1997'de 465.5 milyon dolar ve 1999'da da 38.3 milyon dolarlık uygulama gerçekleştirildi.

2000 yılı içerisinde POAŞ’’n \% 51 oranındaki hissesinin blok satış yöntemiyle özelleştirilmesi sonucunda bugüne kadar yapılan en önemli özelleştirme uygulamalarından biri gerçekleştirilmiş. 2002 yılında ise kalan kamu hisselerinin İMKB'de satışı sonucunda POAŞ'da bulunan kamu hisselerinin tamamı özelleştirilmişstir. Ayrıca bu süreç içerisinde devletin, turizm, tekstil ve hayvancılık sektörlerindeki işletmelerinin yaklaşık \% 90'1 da özelleştirildi. 
Özelleştirme Yüksek Kurulu'nun 12 Mart 2001 tarihli kararı ile Sümer Holding A.Ş.'ye devredilmiş, 4 kuruluşun özelleştirme işlemleri tamamlandı Öte yandan, Özelleştirme İdaresi 2000 yılı programındaki 30 kuruluşun 25'inde ihaleye çıktı. Bu kuruluşlardan 11'inin özelleştirilmesi tamamlandı. Bazı kuruluşlarda halen ihale prosedürü devam ederken, bu kuruluşların bazılarında ise teklif gelmemesi veya başka nedenlerle ihalesi iptal edildi. ÖİB, 2000 yılında, özelleştirme programında yer alan Deniz Nakliyat, Orüs, Ankara Sigorta, Güven Sigorta, Asil Çelik, KBİ (varlık), Turban (Varlık), Petrol Ofisi, Tüpraş (halka arz), bazı iştiraklerin satışını tamamlad1. Programda bulunan THY, Ebaş, Taksan, TZDAŞ, Etağ, İsdemir, KBİ (Blok), Sümer Holding (varlık), Trabzon limanı, Tügsaş, İgsaş’ta ise ihale prosedürü halen devam ederken, Tümosan ve bazı iştiraklerin ihalesi ise teklif gelmemesi nedeniyle iptal edildi.

2001 yılının ilk çeyreğinde (3 aylık dönemde) Ataköy grubunun hazırlıklarının tamamlanması nedeniyle ihaleye çıkılması, THY'nin ihalesinin tamamlanması, Petkim-Yarımca'da çalışmaların devam ettirilmesi ve İsdemir-Erdemir birleşmesinin gerçekleşmesi bekleniyor.

İGSAŞ İstanbul Gübre San. A.Ş. ise 15 Nisan 2002'de TÜGSAŞ Türkiye Gübre San. A.Ş. bünyesinde birleştirilmiş ve özelleştirildi.

İSDEMİR 31 Ocak 2002 tarihinde imzalanan devir sözleşmesiyle tüm varlıkları ile birlikte ERDEMIR'e devredilmiş ve tüzel kişiliği sona ermiştir. ÇELBOR A.Ş.' de bulunan \%100 oranındaki hisselerin tamamı 31 Mayıs 2002 tarihinde ERDEMİR'e devredilmiştir. T. Gemi Sanayii A.Ş. ise T. Denizcilik İşletmeleri A.Ş. bünyesinde birleştirilerek Mayıs 2002'de tüzel kişiliği sona ermiştir. DİTAŞ Deniz İşletmeciliği A.Ş.'de bulunan \%50.98 oranındaki hisselerin tamamı 21 Kasım 2002 tarihinde TÜPRAŞ' devredilmiştir.

Turban Turizm A.Ş., T. Zirai Donatım A.Ş. ve TÜMOSAN Türk Motor Sanayii A.Ş. 7 Şubat 2003 tarihinde, Türkiye Selüloz ve Kağıt Fabrikaları A.Ş. (SEKA) ile Türkiye Gübre Sanayi A.Ş. (TÜGSAŞ) 19 Eylül 2005 tarihinde SÜMER HOLDİNG A.Ş. bünyesinde birleştirilerek tüzel kişilikleri sona ermiştir.

2004 yılında Esgaz, Eti Bakır, Divhan A.Ş.,Bursa Gaz, Amasya Şeker Fabrikası A.Ş., Eti Gümüş A.Ş., Eti Krom A.Ş.,Çayeli Bakır İşletmeleri A.Ş., BET Kütahya Şeker Fabrikası A.Ş., Eti Elektrometalürji A.Ş. nin blok satış yöntemiyle, Türk Hava Yolları A.O.' nun halka arz yöntemiyle özelleştirilmesi başta olmak üzere gerçekleştirilen tüm özelleştirme uygulamalarından cari yıl satış gelirleri ile geçmiş yıl satış taksitleri toplamı 1.1 milyar ABD Doları gelir elde edildi.

2005 yılının ilk 8 aylık döneminde ise Ataköy Turizm A.Ş. Ataköy Otelcilik A.Ş., Ataköy Marina ve Yat İşletmeleri ve Eti Alüminyum A.Ş.'nin blok satış yöntemiyle özelleştirilmesi başta olmak üzere gerçekleştirilen tüm özelleştirme uygulamalarından cari yıl satış gelirleri ile geçmiş yıl satış taksitleri toplamı 1.4 milyar ABD Doları gelir elde edildi. 2003 yılından önce çeşitli nedenlerle yapılan borçlanmaların tamamı 2004 yılında ödenmiştir. Bu kapsamda 2004 yılında ödenen borçların toplam tutarı 778 milyon ABD Dolarıdır. Ayrıca uzun yıllardan beri ilk kez 2005 yılının ilk 8 ayında 1,3 milyar ABD Doları kaynak Hazineye aktarılmıştır. 2005 yılında gerçekleşen özelleştirmeler: Araç muayene istasyonlarının 20 yıllık kullanım hakkı 613,5 milyon dolara Akfen - Doğuş - TÜV Süd ortak girişim gurubuna devredildi.( Yargıda ) Atatürk Havalimanının 15 yıllık işletmecilik hakkı 3 milyara TAV ‘ a ( Tepe -Akfe Vie ) verildi. Aynı gurup 755 Milyon dolara Mersin Limanını ald1.( Yargida )

TT nin \% 55 hissesi 6 Milyar 550 Milyon Dolara Oger Telecoma verildi. Emekli Sandığına ait İstanbul Hilton Oteli 255,5 Milyon Dolara Doğan Grubuna satıldı. Ankara'da ki Tekel' e ait ikiz kuleler 100 Milyon Dolara TOBB "'e satıldı. Eylül 2005 de TÜPRAŞ ' 1 \% \% 51 lik hissesi 4 Milyar 140 Milyon Dolara Koç - Shell Grubuna satıld1. Erdemir ' in \% 46.12 oranında ki hissesi 4 Ekim 2005 te 2 Milyar 770 Milyon Dolara OYAK ، a satıldı. 2005 Yı1ı özelleştirme gelirleri 16,9 Milyar Dolardır( Bu bölümde ki bilgiler TBMM, Kütüphane, Dokümantasyon ve Tercüme Müdürlüğü, Araştırma Servisinden alındı .

Özellikle 2005 ve 2006 'da Türkiye çok önemli özelleştirme çalışmalarına imza attı ve özelleştirme gelirleri rekor yüksek seviyelere ulaştı. 2005 yılında yapılan özelleştirme işlemleri 8.2 milyar dolara, 2006 yılında ise 8.1 milyar dolara ulaştı. Özelleştirme gelirlerinin en yüksek olduğu yıllar 2005, 2006 ve 2008 yıllarıdır. (bkz Grafik 2)

2007 yılındaki özelleştirme uygulamalarına bakıldığında, dünyada yaşanan ekonomik dalgalanmalara ve ülkemizdeki seçim sürecine rağmen, başta Türkiye Halk Bankası'nın yüzde 24,98'lik bir payının halka arzı olmak üzere, TCDD Mersin Limanı, Türkiye Demir Çelik İşletmesi Deveci Maden Sahasının İşletme Hakkı, Karayolları Genel Müdürlüğü İstanbul Levent arsası, BUMAS A.Ş. ile TEDAŞ ve TEKEL'e ait bazı taşınmazların satış ve devir işlemleri tamamlandı.

2008 yılında özellikle Türk Telekom'un halka arzından 1 Milyar 911 Milyon Dolar, PETKİM'in yüzde 51'lik hissesinin devri ile 2 Milyar 40 Milyon Dolar gelir elde edilmiştir. 2006 Yılı içinde, TÜPRAŞ, ERDEMİR, BAŞAK SİGORTA A.Ş ve BAŞAK EMEKLİLIK A.Ş özelleştirilmeleri gerçekleştirildi.

2008 özelleştirmeleri, Mayıs ayında Türk Telekom'un yüzde 15'inin satılmasıyla 2008 yılı ikinci yarısından itibaren dünyada oluşan mali krize rağmen PETKĐM, Tekel Sigara, Ankara Doğal Elektrik Üretim ve Ticaret A.S.ye ait Elektrik Santralleri, TEDAS ve Tekel'e ait taşınmazların satış ve devir işlemleri ile Türk 
Telekomünikasyon A.S.nin yüzde 15'lik kamu payının ulusal ve uluslararası sermaye piyasalarında birincil halka arz işlemleri tamamlandı. Türk Telekom'un yüzde 15'lik kamu payının halka arz işlemleri, 2008 yılında Türkiye'de yapılmış en büyük halka arz işlemi olduğu gibi, gelişmekte olan ülkeler arasında da en dikkat çekici halka arz işlemi oldu. 29 Ocak 2008 tarihinde ise, Türkiye Demir Çelik İşletmeleri A.Ş., SÜMER HOLDİNG A.Ş. bünyesinde birleştirilerek tüzel kişiliği sona ermiştir. 2009 yılında ise Sümer Halıcılık A.Ş. hisseleri Sümer Holding A.Ş. bünyesinde birleştirilerek tüzel kişiliği sona ermiştir. 2009 yılında Sakarya Elektrik Dağıtım A.Ş, Başkent Elektrik Dağıtım A.Ş ile Tekel, TEDAŞ ve T.Şeker Fabrikalarına ait çeşitli taşımazların özelleştirme çalışmaları tamamlanmıştır.

2010 y1lı itibariyle özelleştirme portföyünde toplam 19 kuruluş bulunmaktadır. Temel politika belgelerinde yer verilen hedefler doğrultusunda özelleştirmelere program döneminde de hızla devam edilecektir. Önde gelen projeler arasında Türkiye Elektrik Dağıtım A.Ş. Elektrik Üretim A.S.,Türk Seker, limanlar, şans oyunları ve otoyollar-köprüler bulunmaktadır. Özelleştirme programında bulunan Türkiye Elektrik Dağıtım A.S.'ye bağlı 18 adet elektrik dağıtım şirketi bulunmaktadır. Bu şirketlerden 7 adedi (Başkent, Sakarya, Meram, Osmangazi, Çamlıbel, Uludağ ve Çoruh Elektrik Dağıtım A.S.) özelleştirilmiş, Aras Elektrik Dağıtım A.S. için yapılan ihaleyle ilgili olarak Danıştay tarafından yürütmeyi durdurma kararı verilmiştir. 7 adedinin (Yeşilırmak, Van, Fırat, Boğaziçi, Dicle, Gediz ve Trakya Elektrik Dağıtım A.S.) sözleşmeleri onay ya da imza aşamasında olup, 3 adedinin (Akdeniz, Istanbul Anadolu Yakası ve Toroslar Elektrik Dağıtım A.S.) özelleştirilmeleri ile ilgili süreç devam etmektedir. 2010 yılının Eylül ayı itibariyle elektrik dağıtım sektörünün \% 75'i serbestleştirilmiş olup, 1986-2010 döneminde ihalesi tamamlanan özelleştirme işlemleriyle birlikte toplam 50 milyar ABD doları rakamına ulaşılmıştır

\section{Grafik 1 : Dünyada Özelleştirme Uygulama Gelirleri}

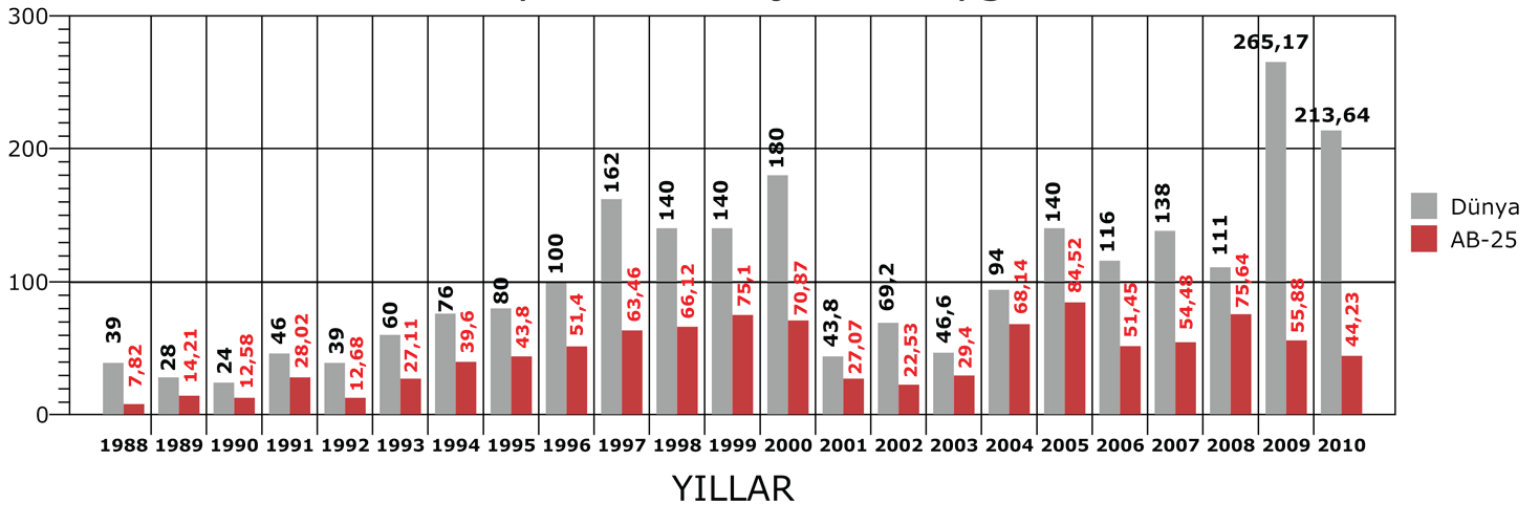

Kaynak: The Privatization Barometer Report, 2010

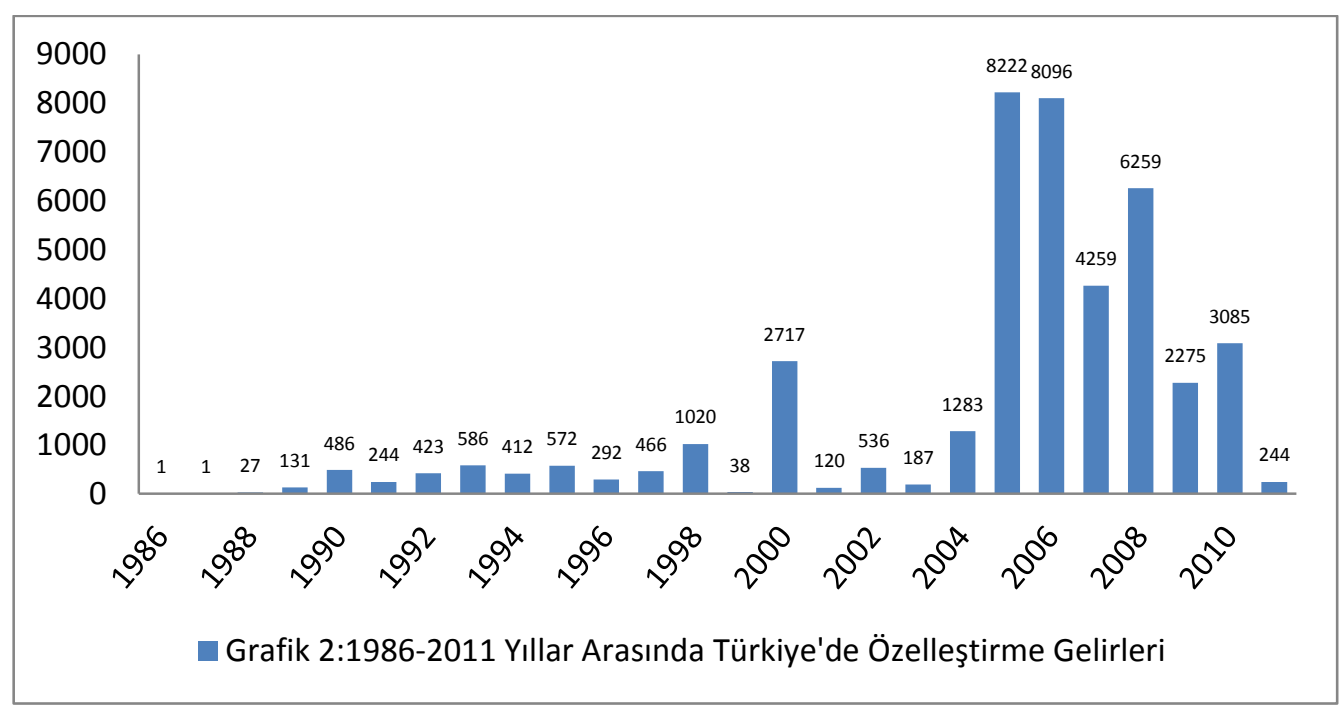

Kaynak: T.C. Başbakanlık Özelleştirme İdaresi Başkanlığ 


\section{Sonuç}

Sunulan bu çalışmanın başlığından anlaşıldığı gibi, önce “özelleştirme” sözcüğünün sözlük, terim anlamı üzerinde duruldu ve tanımlama yapılmıştır. Tanımlamalardan da anlaşılacağı gibi; "özelleştirme” sözcüğü ekonomi bilimi çerçevesinde özel bir anlama sahiptir.

Özelleştime;1970 li yıllarda, başlangıçta ABD ve İngiltere ekonomilerinde, var olan koşullar altında meydana gelmiş olan sorunların, meydan okumasına karşı bir cevap verme çabası olarak gündeme gelmiştir.

1930-1970 yılları arasında Keynesyen-müdahaleci politikalar denenmiş, deney sonucunda da, oluşan sorunların çözüm reçetesi değil, sorunların kaynağı olduğu açıkça ortaya çıkmıştır.

Özelleştime; Kapitalist sistem içerisinde geliştirilen Neo-Liberal teorik temellere dayanan bir uygulamadır.

Kuruluş yıllarından itibaren Karma Ekonomi sistemiyle, ithal ikameci politikalarla, büyük ölçüde devlet tekelinin hâkim olduğu ve Keynezyen Ekonomi Politikalarla da örtüşen Türkiye Ekonomisi için, 24 Ocak 1980 kararları bir dönüm noktası olmuştur.

Türkiye ekonomisi bağlamında özelleştirmeye ilişkin ilk yasal düzenleme, 29.2.1984 tarihinde yapılmıştır. Özelleştirme yöntemleri tanımlanarak, Toplu Konut ve Kamu Ortaklığı Kurulu, Toplu Konut ve Kamu Ortaklığı İdaresi ve Kamu Ortaklığı Fonu kurulmuştur.

Metin içinde ifade edilen özelleştirmenin amaçları, dünya ekonomisin ne ölçüde geçerli ise, Türkiye ekonomisi için de geçerlidir. Türkiye açısından ek bir amaç; kamu görevlilerinin politika ve yönetmelik konularında çalışmalarına izin verilmesi, yabancı yatırımlarla uluslararası ekonomik ve politik bağların kuvvetlendirilmesidir.

Metinden de anlaşılacağı gibi; özelleştirme kronolojisine bakıldığında özelleştirme uygulamaları ile Türkiye ekonomisinin, dünya ekonomisine uyum sağladığı, dışa açık ekonomisiyle yabancı sermayenin çekim merkezlerinden biri haline gelmiştir.

İdare tarafından bugüne kadar 201 kuruluşta hisse senedi veya varlık satış/devir işlemi yapılmış ve bu kuruluşlardan 191'inde hiç kamu payı kalmamıştır. 1986 yılından bugüne kadar gerçekleştirilen özelleştirme uygulamalarının toplam tutarı 46,3 milyar \$ düzeyindedir. Bir bölümü vadeli ve döviz cinsinden gerçekleştirilen bu hisse senedi ve varlık satış işlemlerinden Mart 2013 itibariyle 44,7 milyar \$ net giriş sağlanmıştır. Özelleştirme kapsamındaki kuruluşlardan elde edilen 4,5 milyar \$ temettü geliri ve 1,4 milyar \$ diğer kaynaklarla birlikte 1985/Mart/2013 dönemi toplam kaynakları 50,6 milyar \$ düzeyine ulaşmaktadır.

Türkiye Ekonomisi‘ nin dişa açılma sürecinin 2000-2007 yılları arasında OECD ülkelerinde gerçekleştirilen özelleştirme işlemlerinin büyüklük açısından değerlendirildiği Top-10 listesinde, Türkiye, 5. sıraya yerleştiği anlaşılmaktadır.

\section{Kaynakça}

- $\quad$ AKTAN, Coşkun C. "Posta ve Telekomünikasyon Hizmetlerinde Yeniden Yapılanma ve Özelleştirme Uygulamaları (ABD ve İngiltere Örnekleri), İktisat İşletme ve Finans Dergisi, Yı1:8, Sayı: 92-93, Kasım- Aralık/1993.

- $\quad$ ALÇIN, Sinan; “ Keynes ve Keynescilik nedir?”(ÖZGÜRLÜK DÜNYASI) Say1:197, www.sosyalist forum.net; ulaşım tarihi:24.03.2013

- ATEŞ, Hamza, (2001); “İşletmeci, Girişimci ve Verimli Yeni Bir Kamu Yönetimi ve Devlet Anlayışına Doğru", İ.Ü. Siyasal Bilgiler Fakültesi Dergisi, No:25, ss. 45-60.

- BİLGIN, Vedat,'Dünyada ve Türkiye'de Özelleştirme Uygulamaları", Türkiye Sağlık İşçileri Sendikası Yay. Araştırma dizisi,1998,Ank.:131

- BERBEROĞLU, İbrahim, "Kamu İktisadi Teşebbüslerinin Özelleştirilmesi ve İngiltere Uygulaması", Maliye Yazıları Dergisi, Sayı:6, Nisan-Mayıs/1987, s.16

- $\quad$ DOĞAN, Yahya, Kamu İktisadi Teşebbüsleri ve Özelleştirme, İzmir, Fakülteler Kitapevi, 1993, s.156.

- LEIBENSTEIN, Harvey; (1996), “Allocative Efficiency vs. X-Efficiency”, The American Economic Review, 56 (3), pp. 392-415.

- $\quad$ ÖZSOYLU; Ahmet Fazıl, Türkiye Ekonomisi, Karahan Kitabevi, Adana, 2011, s.159.

- ÖZTÜRK,Nursel;’'Değişen Devlet Anlayışı ve Özelleştirme ’’http://ydk.gov.tr/eğitim notları/özelleştirme.htm(Erişim tarihi:17.04.2013)2005. s:12

- $\quad$ T.C. BAŞBAKANLIK ÖZELLEŞTİRME İDARESİ BAŞKANLIĞI, Yayınlar,2013

- YAY, T. F. A. Hayek’te İktisadi Düşünce, Ezgi Kitapevi, Bursa,1993;S:80.

- YAVİLIOĞLU Cengiz, "Dünyada ve Türkiye'de Özelleştirme Uygulamaları, Teorik ve Tarihsel Bir Perspektif”, ÖİB Yayınları, No.1, Ankara, 2010

- $\quad$ http://www.optimayed.com/Erişim tarihi:(17.04.2013)

- http://www.optimayed.com/Erişim tarihi:(17.04.2013) 


\title{
Geçiş Süreci: Rusya ve Ukrayna Örneği Transition Process: Russia and Ukraine Case
}

\author{
Ph.D. Candidate Esra Ballı (Çukurova University, Turkey) \\ Prof. Dr. Muammer Tekeoğlu (Çukurova University, Turkey)
}

\begin{abstract}
This study analyses how real GDP growth, inflation, employment, foreign direct investment inflow and income equality for Russia and Ukraine changed during the process of economic transition from 1991 to 2011. Most opinions agree that initial conditions and economic situation of a country, natural resources, historical background and institutions affect the process of economic transition. We see that both Russia and Ukraine experienced a transitional recession in the early 1990s at the start of the transition and an increase in the inflation rate. The Gini indexes of Russia and Ukraine have increased dramatically. The unemployment also went up in both countries until 1999s and reached a peak 13\% during the 1998 Russian crisis in Russia. The growth rates of both countries were below $1 \%$ until 1997-1998, although it started to increase, after 2000, it decreased sharply in 2008 because of the Global Economic Crisis experienced the same year.
\end{abstract}

\section{Giriş}

Geçiş süreci sosyal, kültürel, siyasi ve politik yapıyı içine alarak köklü bir şekilde değişime yol açan bir süreç olma özelliği taşımaktadır. Kumanda ekonomilerinden piyasa ekonomisine geçiş sürecinin başlangıcında güvenilir verilere ulaşılamaması ve bunun yanında sistemin kendisinden kaynaklanan zorluklar bu geçiş sürecini anlama ve değerlendirmede büyük zorluklarla karşılaşılmasına sebep olmaktadır. Bunun yanı sıra uluslararası kuruluşların geçiş ekonomilerine ve sürecine yönelik sınırlı tecrübeleri kumanda ekonomilerinin dağılmasıyla birlikte ortaya çıkan problemleri çözmede yeterli olamamışlar, geçiş ekonomilerinin yerel koşulları, tarihsel geçmişleri ve kurumsal yapıları dikkate alınmadan politikalar uygulamaya konulmuştur (Güler, 2012).

Sosyalist modelin gelişiminde merkezi yönetim altında ağır endüstrileşme ve büyük tekel firmalar ön plana çıkmış, uluslararası ticaret piyasa tarafından değil de devletler tarafından yapılan antlaşmalar yoluyla organize edilmiştir (Fisher ve Gelb, 1991). IMF’ye göre, geçiş süreci liberalleşme, makroekonomik istikrar, yeniden yapılandırma, özelleştirme ve yasal ve kurumsal reformlar ile gerçekleşmektedir. Liberalleşme sürecinde, fiyatlar çoğunlukla serbest piyasada belirlenmekte, ticaret engellerinin kaldırılmasına izin verilerek dünya piyasa ekonomilerine entegre olunması gerçekleştirilmeye çalışılmaktadır. Makroekonomik istikrarda öncelikle enflasyonun kontrol altına alınarak düşürülmesi, kredi büyümesinin disiplin altına alınmasının sağlanması amaçlanır. Yeniden yapılandırma ve özelleştirme ise, bu ekonomilerde sağlıklı bir finansal sektör yaratılarak, teşebbüslerin serbest piyasalarda işlem görebilecek mal üretimini yapmalarını sağlamak ve bu teşebbüsleri özel sektöre transfer etmek şeklinde gerçekleşmektedir. Yasal ve kurumsal reformlar ile kastedilen ise bu ekonomilerdeki devletin rolünün yeniden tanımlanmasının gerekliliği, hukuk kuralları ve rekabet politikalarının oluşturulması gerekliliğidir. Donnorummo (2006)'ya göre üç önemli faktör geçiş sürecini etkilemektedir. Bunlar tarihsel geçmiş, 1990'lı yıllardan itibaren ülkelerin yapmış oldukları politikalar ve dış ve/veya iç çatışmaların varlığıdır.

'Şok terapi' olarak da adlandırılan Rusya'nın neoliberal geçiş stratejisine göre liberalizasyon, istikrar ve özelleştirme üç önemli politikadır. Liberalizasyon ile fiyatlar üzerindeki devlet kısıtlamalarının kaldırılması; istikrar ile hükümet harcamalarının azalttırılarak enflasyonun kontrol altına alınması; özelleştirme ile devlete ait teşebbüslerin satılarak özelleştirmesi kastedilmektedir (Kotz, 2000).

Aslund (1999) Rusya’nın ekonomik transformasyonu sürecindeki problemleri incelediği çalışmasında ülkede uygulanan radikal ekonomik reformların başarısız olmasını eski teşebbüs yöneticilerinin rant peşinde koşmasına bağlamaktadır. Aslund'a göre, Sovyetler Birliği’nin dağılmasından sonra Rusya'da ekonomik elitin eksikliği ve ekonomik çarpıklık eski yöneticilerin güçlenmesine yol açmıştır. Eğer demokratik kurumlar hızlı bir şekilde gerçekleştirilseydi ve Batı, 1992'nin başlarından itibaren reformların gerçekleştirilmesi için finansal bakımdan hızlı bir şekilde destek sağlasaydı reformların gerçekleştirilmesi için gerekli takviye sağlanmış olabilecekti. Zaman içinde rantın azalmaya başlamış olmasına rağmen, Rusya'nın sahip olduğu kurumlar yolsuzluklar nedeniyle ciddi zarara uğramışlardır. Rant üzerindeki bu rekabet de Ağustos 1998'de meydana gelen krize sebep olan etmenlerden biri olmuştur. Aslund (1999), aynı zamanda başarılı reformların gerçekleştirilebilmesi için rant düzeyinin sınırlandırılmasının ön şart olduğunu ileri sürmektedir.

Ahrend ve Tompson (2005)'e göre Rusya'nın piyasa dönüşüm süreci incelendiğinde öncelikle Sovyet sisteminin krizlerine, Sovyetler Birliği'nin çöküşüyle birlikte oluşan yeni bağımsız devletler ile girişilen radikal reformlara bakmak gerekir. 1950'lerden itibaren Sovyet Sosyalist Cumhuriyetler Birliği’nin büyüme oranındaki uzun süreli düşüş, Çernobil kazası, 1986 yılında uluslararası petrol fiyatlarındaki düşüş, 1986-1987 yılları arasında dolarda meydana gelen hızlı değer kaybı gibi dış şoklar da Sovyet kumanda ekonomisinin çöküşünü 
hızlandıran etmenlerden olmuşlardır. 1980’lerin sonlarında gerçekleştirilen gevşek ekonomik reformlar, geleneksel yapılar ve kumanda ekonomisi özelliği nedeniyle başarıya ulaşamamıştır. Dąbrowski ve Antczak (1995)'a göre Orta ve Doğu Avrupa ve eski Sovyetler Birliği ülkeleri komünist dönemden kalan ciddi ekonomik problemlerle karşılaştıkları görülmektedir. Bunlar arasında ekonominin hemen hemen tümüyle devletleştirilmesi sonucu özel yatırım için açık yasaklamalar veya ciddi sınırlamalar, monopol piyasa yapısı, yönetim tarafından gerçekleştirilen fiyat düzenlemeleri ve merkezi yatırım kararları nedeniyle yapısal bozuklar, ekonomik gelişme düzeyine oranla sosyal harcama yükümlülüklerinin fazlalığı, iç ve diş makroekonomik dengesizlik sayılabilir.

Kumanda ekonomisine dayalı sosyalist sistemden piyasa ekonomisine geçiş sürecinde sistem değişimi ile karşı karşıya kalan ülkelerin sahip oldukları özellikler ve yaşadıkları süreçler birbirinden farklı olmakla birlikte bu ülkeler "Geçiş Ekonomileri" olarak sınıflandırılmışlardır. Bu ülkeler için geçiş sürecinde serbest piyasa ekonomisine geçiş esas alınmış Uluslararası Para Fonu (IMF)'nin (2000) yapmış olduğu sınıflandırma kullanılmıştır. Buna göre geçiş ekonomileri Avrupa ve eski Sovyet Sosyalist Cumhuriyetler Birliği (SSCB) Geçiş Ekonomileri ile Asya'daki geçiş ekonomileri olmak üzere iki temel grup altında sınıflandırılmaktadır (Güler, 2012).

Bu çalışmada aynı dönemde geçiş sürecine başlayan eski SSCB ülkelerinden Rusya ile Ukrayna'nın kişi başına düşen geliri (KBDG), reel GSYH'daki büyümeleri, yabancı doğrudan yatırım girişi, gelir eşitsizliği, enflasyon ve işsizlik oranlarında yaşanan değişimler, geçiş sürecine başladıkları 1991'den 2011 yılına kadar olan dönem esas alınarak incelenecektir. Bu değişkenler bir ekonominin gerek gelişmişlik düzeylerini gerek de bölüşümün yapısını göstermeleri açısından önem kazanmaktadır. Gini katsayısı, reel GSYH'daki büyüme, enflasyon, işsizlik oranı, yabancı doğrudan yatırım girişi verileri Dünya Bankas Dünya Gelişim Göstergeleri'nden, İnsani Gelişme Endeksi verileri ise Birleşmiş Milletler Kalkınma Programı veri bankasından elde edilmiştir. Çalışmanın ilk bölümünde geçiş sürecine, ikinci bölümde geçiş sürecinde olan ülkeler üzerine yapılmış çalışmalara yer verilmiştir. Üçüncü bölüm verilerin analizi ve dördüncü bölüm ise sonuç bölümünden oluşmaktadır.

\section{Literatür taraması}

Geçiş sürecindeki ekonomiler üzerine yapılmış birçok çalışma bulunmaktadır. Dąbrowski ve Antczak (1995)'ın yapmış olduğu çalışmada, Rusya, Ukrayna ve Beyaz Rusya'nın geçiş sürecinde diğer Baltık ülkeleri ile Merkez ve Doğu Avrupa ülkelerinden neden geride kaldıkları analiz edilmiştir. Araştırmacılar, kullandıkları karşılaştırmalı analizde, bu ülkelerin geride kalmasının nedenleri arasında politik değişim ile ekonomik geçişteki başarı arasında güçlü bir korelasyon bulmuşlardır.

Dünya Bankası Kalkınma Raporu (1996)'ya göre, geçiş sürecine giren ülkelerin farklı başlangıç noktaları ve temel ekonomik reformları bulunmaktadır. Geçiş sürecinde olan ülkelerin başlangıç koşulları her ülkede farklılık gösterebilmektedir. Ülkelerin ekonomik düzeyleri, kumanda ekonomisi ve komünist rejim altında kaldığı süre, ulusal ekonomideki özel sektörün payı, kapitalist ülkelere göre ekonominin açıklı̆̆ı, ticarete konu olabilecek doğal kaynakların varlığı, iç ve dış makroekonomik dengenin düzeyi, komünist rejim yıkılmadan önce ülkelerin politik liberalizasyon ve demokratikleşme düzeyi, geçmişteki anti-komünist ve bağımsızlık hareketlerinin gücü, etnik bakımdan homojenlik veya farklılıklardan oluşan bu faktörler her ülkenin ekonomik ve politik geçiş sürecini farklı kılmaktadır.

De Melo, vd. (1996)'un Orta ve Doğu Avrupa ülkeleri ile eski Sovyetler Birliği ülkelerinin geçiş sürecini inceledikleri çalışmada ülkelerin başlangıç koşullarının farklı olmasına rağmen reform sürecinde aynı aşamada olan ülkelerin ortak özellik gösterdiklerini bulmuşlardır. Araştırmacılar, politik reformlar ile başlangıç koşullarını oluşturdukları liberalizasyon indeksi ile ölçtükleri çalışmada, liberalleşme sonucu sermayenin ve işgücünün endüstriyel sektörlerden hizmet sektörüne kaydığını ve daha önce baskı altında tutulan sektörlerin gerçekleştirilen hızlı reformlar ile birlikte pozitif gelişme sağladığını göstermişlerdir.

Dabrowski (1998) eski Sovyetler Birliği ülkelerindeki ekonomik dönüşüm ile Batı’nın 1990-1994 yılları arasında yapmış olduğu yardım arasındaki ilişkiyi incelediği çalışmasında, dönüşüm sürecinde dönüşümün ilk aşamalarında en önemli yardımın IMF'den geldiğini, IMF tarafından finanse edilen programların dönüşüm sürecindeki her ülke için hayati rol oynadığını ileri sürmektedir. Bunun yanı sıra, Batı ve eski komünist ülkeler IMF veya Dünya Bankası’nın bütçe kısıntıları ve tasarruf konusuna çok önem verdiklerini ileri sürerken IMF veya Dünya Bankası'nın borç verme raporları farklı söylemektedir. IMF ve Dünya Bankası tarafından ileri sürülen şartlar sıklıkla özellikle eski Sovyet Bloğu ülkelerinde makroekonomik istikrar için yanlış yönlendirilmiş tecrit edici yaklaşımların uyarlanmasını teşvik etmiştir. Geçiş ekonomisinde olan ülkelerin tecrübelerine bakıldığında radikal ve kapsamlı bir yaklaşımın istikrar ve ekonomik düzelme sonucunu verdiği görülmektedir. Araştırma sonuçlarında birçok yardım programının yumuşak önlemler içerdiği ve yapılan teknik yardımın kalitesinin de bunu gerçekleştiren kaynağa göre farklı olduğu görülmüştür.

De Melo, vd. (2001)'un Doğu Asya, Orta ve Doğu Avrupa ile eski Sovyetler Birliği’ni içine alan 28 geçiş ülkesi-üzerine yapmış oldukları çalışmada büyüme ile başlangıç koşulları, politik değişim ve reformlar 
incelenmiştir. Çalışma sonucunda, başlangıç koşulları ve liberalizasyon indeksi ile büyüme arasında ilişki olduğunu bulmuşlardır.

Dünya Bankası Kalkınma Raporu (2002)'nun eski Sovyetler Birliği ve Doğu Avrupa ülkelerinin 1991-2000 yılları arasında geçirdiği geçiş sürecini inceleyen raporunda, ülkelerin farklı büyüme performansları gösterdikleri saptanmıştır. Bu rapora göre, ülkelerin özellikleri sözgelimi, kumanda ekonomisi veya kontrol altında tutulan veya diktatörlük rejiminde olup olmaması önemlidir. Piyasa ekonomisine geçiş ve reform sürecinde öncelikle fiyatlar serbest bırakılmalı, fakat fiyat liberalizasyonu sonucu oluşabilecek yüksek enflasyon nedeniyle, politika yapıcılar sıkı para ve maliye politikaları gerçekleştirmelidirler. Sivil toplum kuruluşları reform politikalarının uygulanmasında önemli bir rol oynamaktadırlar. Ayrıca, özelleştirme metodu büyük önem taşımaktadır. Devlet sahipliğinde olan yatırımların verim sağlamayacak şekilde özelleştirilmesi, devlet sahipliğinin devamı şeklinde olabilecek tercihler ve riskler ile politika yapıcıları karşı karşıya kalmaktadırlar. Ekonomik büyümeyi sağlamak için, politika yapıcıları eski teşebbüsleri disipline edecek ve yeni yatırımların yapılmasını teşvik edecek bir ortam oluşturmalıdır. Yasal ve kurumsal yapıların oluşturulması da reformlar açısından büyük önem taşımaktadır.

Avrupa İmar ve Kalkınma Bankası'nın geçiş sürecinde olan ülkelerdeki sektörlerin düzeylerini ölçtüğü ve geçiş göstergelerini 1'den (çok az veya hiç değişiklik göstermemekte) $4^{+}$'e kadar (endüstrileşmiş piyasa ekonomisi standardına sahip olduğunu göstermekte) belirlediği Geçiş raporu 2012'ye göre, Rusya ve Ukrayna tarım ticareti, emlak sektörü, bankacılık $3^{-}$ile gösterilen puanlama ile aynı gelişim skoruna sahiplerdir. Telekomünikasyon, elektrik, demiryolları ile sermaye piyasaları bakımından ise Rusya'nın gelişmişlik düzeyi daha üst siralarda yer almaktadır.

\section{Rusya ve Ukrayna'da Geçiş Süreci}

Bu bölümde, Kişi Başına Düşen Gelir (KBDG), Büyüme Oranı, İşsizlik Oranı, Enflasyon Oranı, İnsani Gelişme Endeksi (İGE) ve Gini Katsayısı verileri incelenerek geçiş sürecinde Rusya ve Ukrayna'daki ekonomik durum ortaya konmuştur.

Rusya ve Ukrayna'nın bazı ekonomik ve sosyal göstergelerin incelenmesi bize bu ülkeler hakkında geçiş sürecinde meydana gelen değişiklikler hakkında bilgi vermesi açısından önem arz etmektedir. Bunlardan birisi olan İnsani Gelişme Endeksi'de (İGE) bu ülkelerin gelişmişlik düzeyleri hakkında bilgi vermesi açısından önemli göstergelerden biri olmaktadır. Bir ülkenin yalnızca kişi başına düşen gelir düzeyine bakılarak o ülkenin gelişmiş bir ülke olduğunu söylemek doğru değildir. Bu değerlendirmeyi yapabilmek için eğitim ve sağlı gibi bazı göstergelere de ihtiyaç duyulmaktadır. Bu ülkelerin İnsani Gelişme Endekslerine bakıldığında, Ukrayna'nın 0.740 ile 187 ülke arasında 78. sırada, Rusya'nın da 0.788 ile 55. sırada olduğu görülmektedir. Avrupa ve Orta Asya bölgesinin İnsani Gelişme Endeksi'lerinin1980'li y1llarda 0.651'den günümüzde 0.771'e çıktığ1 göz önünde alındığında Ukrayna İnsani Gelişme Endeksi'nde bölge ortalamasının altında, Rusya ise ortalamanın üstünde yer almaktadır.

$\mathrm{Bu}$ ülkelerin Gini katsayılarına baktığımızda, Sovyetler Birliği döneminden Ofer and Vinokur (1992) tarafından Sovyet göçmenleri esas alarak yapmış oldukları çalışmada bu katsayı 1973'de 0.77, 1979'da 0.61 olarak gerçekleşmiştir (Aktaran Alexeev, 1999). Rusya'da bu oranın 1993'te 0.48 iken 1999'da 0.37'e düştügünü, 2006'da 0.42, 2009'da 0.40 düzeylerinde gerçekleştiğini görüyoruz. Verilerde de görüldüğü üzere Rusya'da geçiş sürecinin başında gelir eşitsizliğinin daha yüksek olduğu söylenebilmektedir. Bunun temel nedenlerinden birisinin gerçekleştirilen özelleştirmeler yoluyla bölüşümün adil olarak dağıtılamaması olduğu ileri sürülebilir. Ukrayna'da ise Gini katsayısı 1992 'te 0.25 iken 1995 'te 0.39 ile en yüksek değerine ulaşmış ve bu tarihten itibaren azalan bir seyir izlemiş, 2006'da 0.29'a ve 2009'da da 0.26'ya düşmüştür. Ukrayna'da ise gelir eşitsizliği bakımından geçiş süreci boyunca çok büyük farklılıklar yaşanmamıştır.

Rusya ve Ukrayna'nın 1990-2011 döneminde KBDG'i Grafik 1'de gösterilmiştir. Rusya ve Ukrayna'da KBDG 1990-2003 döneminde beraber hareket ederken 2003 yılından sonra bu ülkelerdeki KBDG farkı çok açılmıştır. Bunun temel sebeplerinden birisi Rusya'nın dünyanın en büyük doğal gaz ihracatçısı ve ikinci en büyük petrol ihracatçısı konumunda olmasıdır (EIAa, 2013). 1990'ların başında petrolün varili 18 USD iken, bu rakam 2001'den itibaren yükseliş trendine girmiş, 2003'de 28 USD, 2008 Temmuz'unda en yüksek rakam olan 132.72 USD'ye ulaşmış (EIAb, 2013) ve sonrasında petrol fiyatları düşme eğilimine girmiş ve GSMH'sı doğal kaynak ihracatına bağlı olan Rusya'nın ihracat gelirlerinde azalma meydana gelmiştir. Bu durum, Grafik 1 'de görüldüğü gibi 2008 yılında Rusya’nın KBDG’na yansımış ve 2007 yılında KBDG’i 12000 USD’e yaklaşan Rusya'nın KBDG’i 8000 USD’e düşmüştür. 2008 küresel krizinin etkileri 2009 yılında bu iki ülkede büyük ölçüde hissedilmiştir. Ancak 2010 yılı sonrası petrol ve doğal gaz fiyatlarının artmasına bağlı olarak Rusya’nın KBDG'si tekrar artmaya başlamıştır.

Üretimde keskin düşüşler ve işsizlikte yüksek oranlı artışlarla karakterize edilen geçiş resesyonunun Rusya ve Ukrayna'daki uzunluğu sırasıyla 9 ve 10 yıllık dönemleri kapsamaktadır (Mickiewicz, 2005). Bu durum Grafik 2'de görüldügüü gibi Rusya ve Ukrayna'nın büyüme oranı ile geçiş döneminin başlangıcından itibaren 2000 döneminde kadar negatif bir seyir izleyen her iki ülkenin büyüme oranları ile örtüşmektedir. Üretim düzeyinin en düşük olduğu yıl 1998'de Rusya ‘da \% 45.1 olarak Ukrayna’da ise 1997 yılında \%63.8 olarak gerçekleşmiştir 
(Fischer ve Sahay, 2000). Bunun yanında Ağustos 1998'de yaşanan Rusya Ekonomi krizide Rusya'nın Ukrayna'ya en büyük ihracatçı ülke konumunda olması nedeniyle Ukrayna'nın da bu krizden etkilenmesine yol açmıştır.

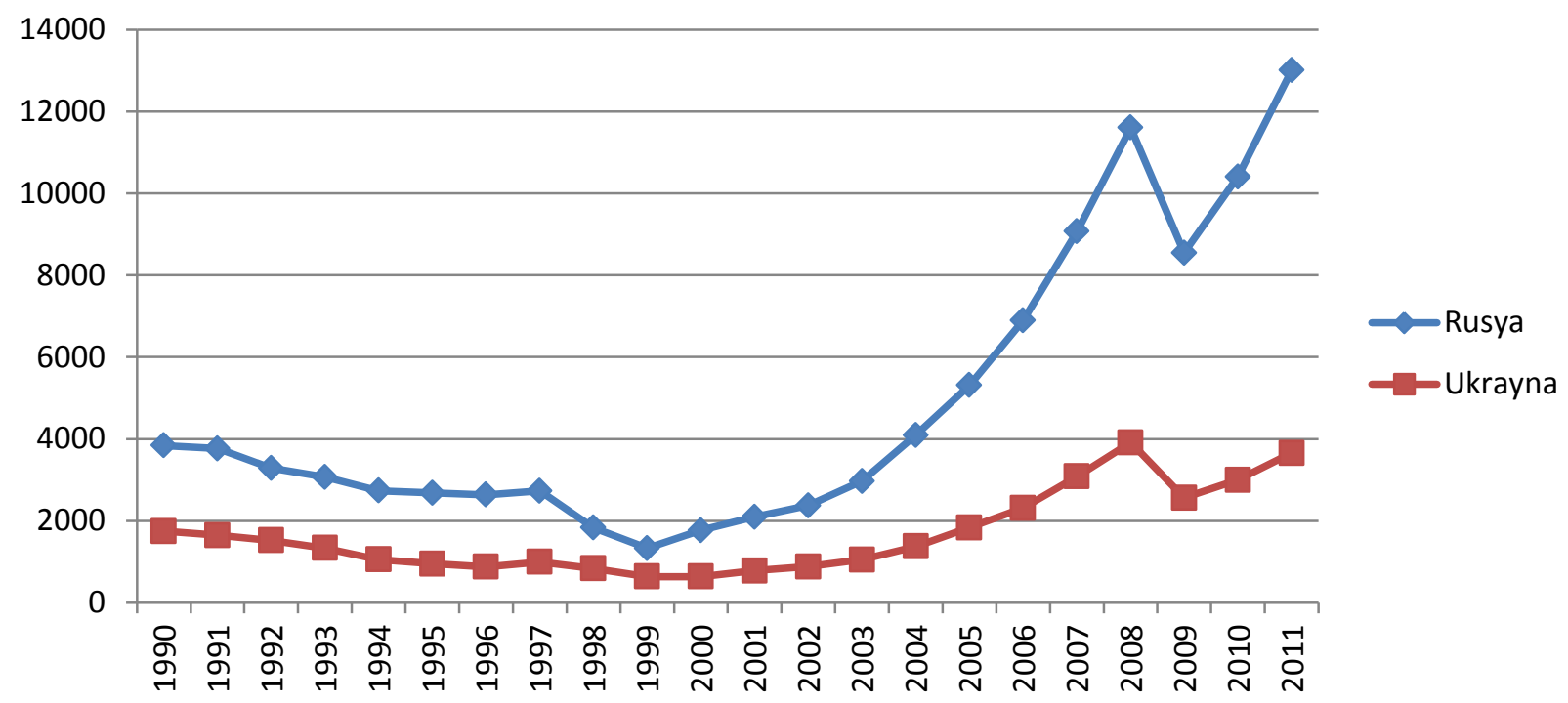

Grafik 1. Kişi Başına Düşen Gelir (Kaynak: Dünya Gelişim Göstergeleri, Dünya Bankası)

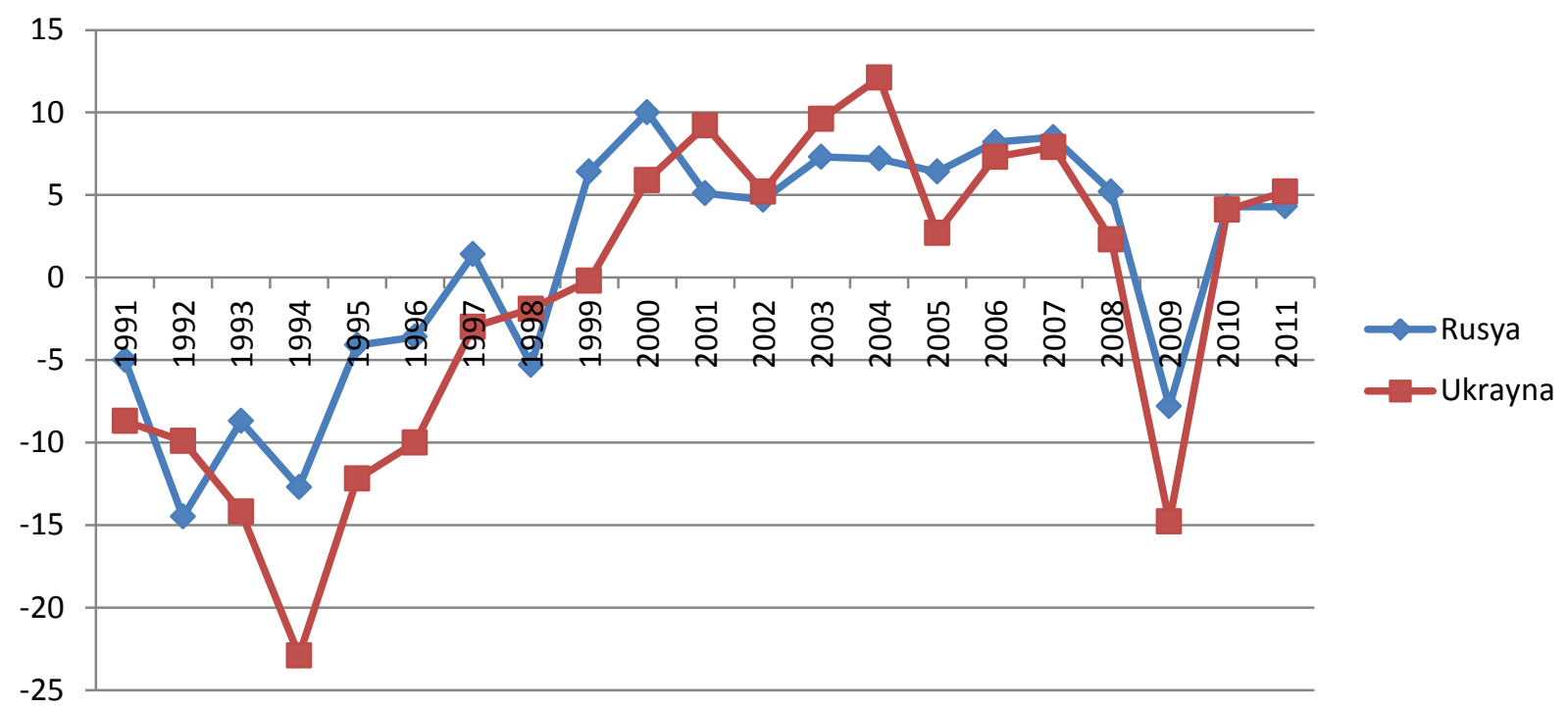

Grafik 2. Büyüme Oranı (\%) (Kaynak: Dünya Gelişim Göstergeleri, Dünya Bankası)

Geçiş süreci sırasındaki resesyon sırasında-yaşanan üretim azalışları işsizlik oranının yükselmesine neden olmuştur. Geçiş süreci ile birlikte hızla ortaya çıkmaya başlayan işsizlik, üretim düşüşlerine paralel bir şekilde firmaların işçi çıkarmalarına bağlı olarak gelişmiştir. Rusya ve Ukrayna'nın işsizlik oranları Grafik 3'te belirtilmiştir. Rusya'nın işsizlik oranı 1998 krizi ile ilişkili olarak \%13 en yüksek düzeye ulaşmıştır. 1999-2008 dönemi sonrasında işsizlik oranı düşme eğilimine girmiştir. Hem Ukrayna hem Rusya 2008 sonrasında Küresel Kriz'den etkilenmişlerdir.

Grafik 4'e baktığımızda Rusya ve Ukrayna'nın geçiş sürecine girdikleri dönemde çok yüksek enflasyon oranlarıyla karşılaştıklarını görmekteyiz. Rusya Sovyet Federe Sosyalist Cumhuriyeti Devlet Bankası olarak anılan banka, 1991'de SSCB Devlet Bankası'nın tasfiye edilmesiyle Rusya Merkez Bankası haline gelmiştir. Ukrayna Merkez Bankası ise 1992 yılında kurulmuştur. Loungani ve Sheets (1997)'nın enflasyon üzerinde Merkez Bankasının etkisini ve enflasyonun ekonomik büyüme üzerindeki etkilerini Rusya ve Ukrayna dahil 12 eski SSCB ülkesini içine alarak inceledikleri çalışmalarında Merkez Bankası'nın bağımsızlığı ile düşük enflasyon oranı arasında ilişki olduğunu bulmuşlardır. Cukierman, Miller ve Neyapti (2002)'nin 26 eski sosyalist ekonomiyi inceledikleri çalışmada, liberalizasyon sürecinin ilk aşamalarında Merkez Bankalarının oluşan enflasyonła ilgisiz olduğu ve merkez bankası bağımsızlığının da başlangıçtaki fiyat kontrolleri üzerindeki güçlü enflasyonist etkiyi durduramadıklarını belirtmişlerdir. Liberalizasyon sürecinin hız kazanması ile birlikte yasal 
olarak Merkez Bankası bağımsızlığı, enflasyon oranının düşüşünde etkili olmuştur. Kurumların eksikliği geçiş süreçlerinin uzamasına, gerekli reformların yapılmasına da engel teşkil eden bir durum olarak karşımıza çıkmıştır.

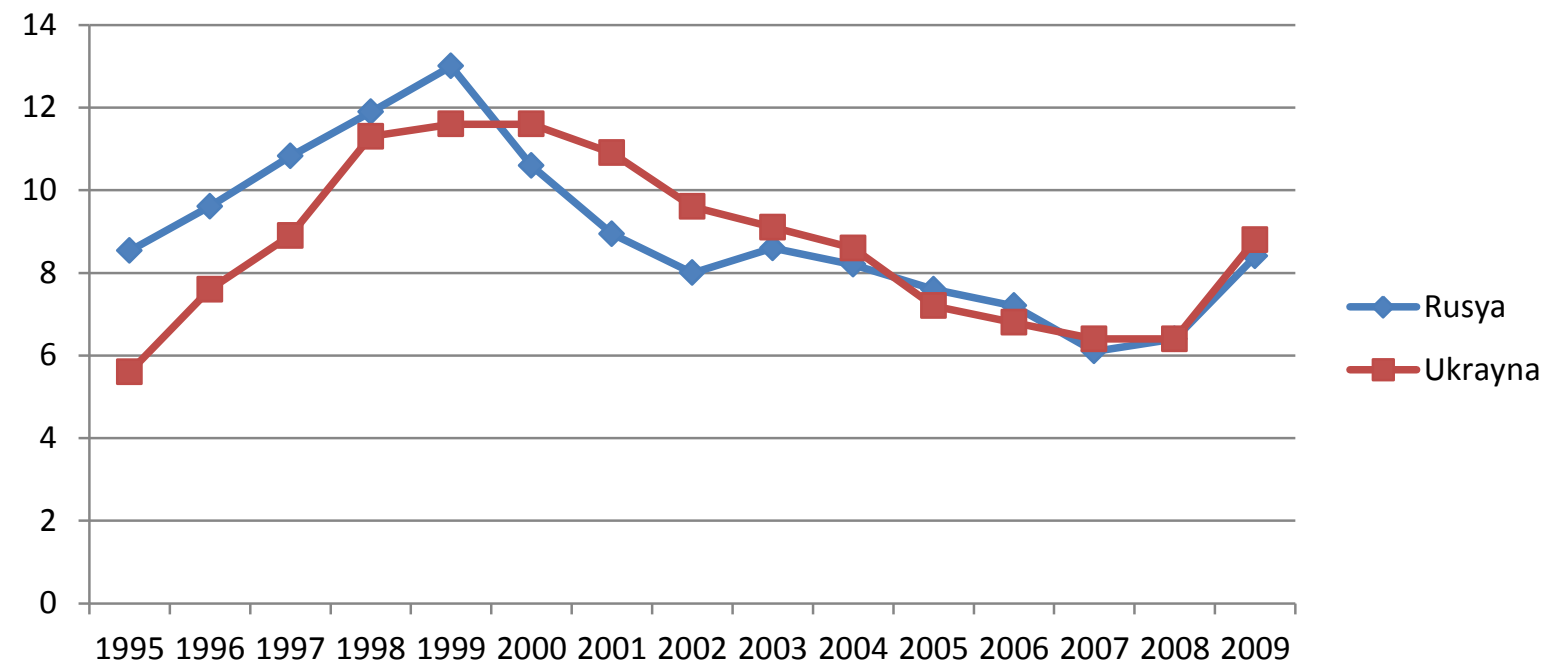

Grafik 3. İssizlik Oranı (Kaynak: Dünya Gelişim Göstergeleri, Dünya Bankası)

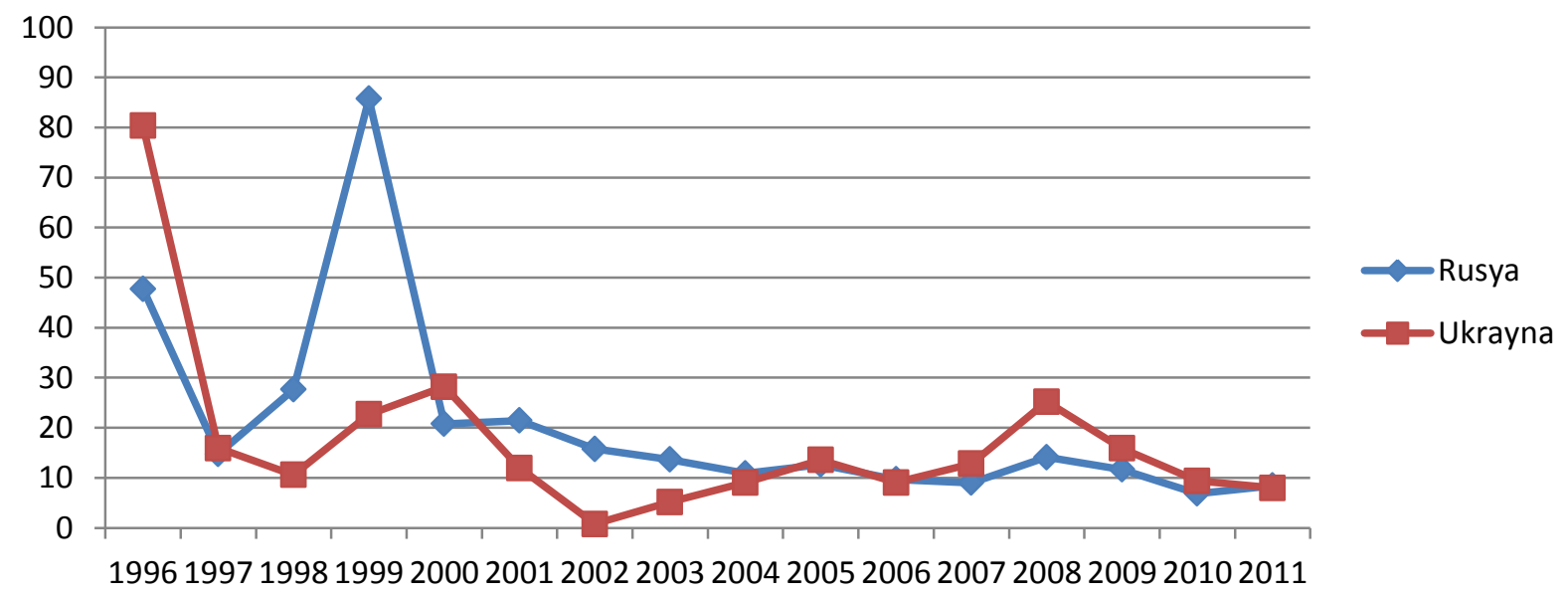

Grafik 4. Enflasyon Oranı (Kaynak: Dünya Gelişim Göstergeleri, Dünya Bankası)

Yabancı doğrudan yatırımların büyüme ve kalkınma hedeflerini gerçekleştirmek isteyen ülke ekonomilerine yararlı olduğu konusunda birçok görüş bulunmaktadır. Bu yatırımlar verimlilik ve hizmetlerin kapsamı yönünden büyük oranda olumlu etkiye sahip olmakta, ülkenin hayat standardını yükseltmekte, yerel firmaları oluşacak rekabet nedeniyle zorlama, birlikte çalıştıkları durumda gerekli bilgi ve teknikleri transfer etme yoluyla yeni teknoloji kullanmaya ve yeni işletme tekniklerini uygulamaya yol açmaktadırlar. Bunun yanı sıra yabancı doğrudan yatırımcılar yatırım yaptıkları ülkede daha istikrarlı ve uzun vadeli bir yaklaşım içinde olduklarından, ülkelerde meydana gelebilecek kriz zamanlarında bu yatırımcılar yabancı kreditörlerin ve portföy yatırımcılarının aksine yatırım yaptıkları ülkede kalma yönünde hareket etmektedirler (Kaymak, 2005). Grafik 5 'te doğrudan yabancı sermaye yatırımlarının milli hâsılaya oranı verilmektedir. 1992-2004 yıllarında doğrudan yabancı sermayenin gelire oranı Rusya ve Ukrayna için birlikte hareket ederken 2004'den sonra yabancı sermaye girişi Ukrayna'da Rusya’ya göre göreceli olarak oldukça fazladır. Miktar olarak baktığımız zaman 2011 yılında Rusya'ya ve Ukrayna’ya gelen yabancı doğrudan yatırımların büyüklüğünün sirasıyla 52 milyar USD ve 7 milyar USD olduğunu görmekteyiz. GSYH'nın yüzdeleri bakımından Ukrayna daha fazla iken, Rusya'nın miktar olarak Ukrayna'ya oranla yılda yaklaşık 7,5 kat daha fazla yabancı doğrudan yatırım çekmektedir. Bevan, Estrin ve Meyer (2004)'ün geçiş döneminde olan Rusya, Ukrayna ve 10 tane Doğu Avrupa ülkesini kapsayan çalışmalarında kurumlar bakımından gelişmiş olan ülkelerin daha fazla yabancı doğrudan yatırım çektiklerini bulmuşlardır. Bununla birlikte özel sektörün büyüklüğü, bankacılık sektörünün gelişmişliği, döviz kuru ve ticaret liberalizasyonu ve yasal kurumların gelişmişliği de yabancı yatırımları pozitif olarak etkilemektedir. Araştırmacıların 1994-1998 yıllarını esas aldıkları çalışmada, Rusya’nın doğrudan yabancı yatırım çekebilmesinin önündeki temel engelin büyük olasılıkla yasaların kapsamı ile etkinliği arasındaki aralıktan 
meydana geldiğini belirtmişlerdir. Çalışmanın da ortaya koyduğu gibi özel sektör büyüdükçe bankacıllk sektörü genişledikçe, döviz kuru ve ticaret liberalizasyonu ve yasal kurumlar daha etkili çalıştıkça Rusya ve Ukrayna'da daha fazla doğrudan yabancı yatırım çekmeye devam edeceklerdir.

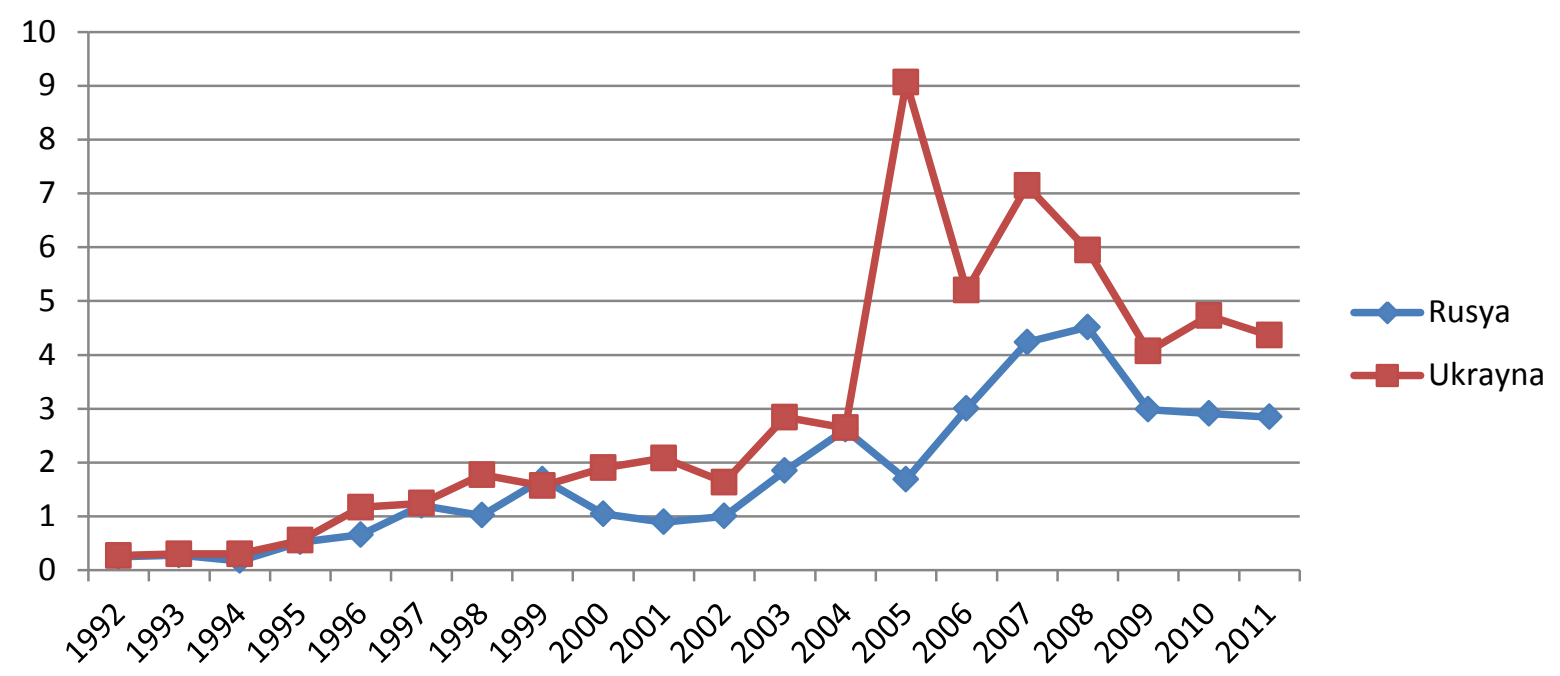

Grafik 5. Doğrudan Yabancı Sermaye Yatırımları (GSYH’nın yüzdesi) (Kaynak: Dünya Gelişim Göstergeleri, Dünya Bankasi)

\section{Sonuç}

Rusya ve Ukrayna sahip oldukları yer altı kaynaklarına, SSCB döneminden kalan güçlü bir sanayi mirası altyapısına ve iyi eğitilmiş insan güçlerine rağmen sosyalist ekonomiden piyasa ekonomisine geçiş süreci sıkıntılarından derin bir şekilde etkilenmişler, reformları hızlı bir şekilde gerçekleştirememişlerdir. Bu ülkelerde meydana gelen geçiş resesyonu Ukrayna'da 10 yıl, doğal kaynak zengini Rusya'da ise 9 yıl sürmüştür. Rusya ve Ukrayna'nın piyasa ekonomisine geçiş süreci sırasında meydana gelen resesyon ile birlikte her iki ülkenin üretim düzeylerinde çok büyük oranlı azalışla birlikte ekonomileri negatif bir ekonomik büyüme seyri izlemiş, işsizlik ve hiper enflasyon durumları ortaya çıkmıştır. Geçiş süreci başında Rusya'da meydana gelen özelleştirmeler zenginliğin bölüşümünde dengesizlik yaratmış, zenginliğin yalnızca bazı ellerde toplanmasına neden olmuş, gelir eşitsizliği yüksek oranlarda artmıştır.

Geçiş sürecinde uygulanması amacıyla eski sosyalist bloğa önerilen politikalar her ülke koşullarına göre uyarlanmadığından ve önerilen politikaları gerçekleştirebilecek kurumsal yapıların bulunmaması, reformların gerçekleştirilebilmesi yönündeki desteklerin yetersizliği geçiş sürecinin zorlu ve sancılı bir şekilde geçmesine neden olan etmenlerden biri olmuştur. Bunların yanı sıra geçiş sürecinde kurumsal bakımdan eksiklik büyük önem taşımaktadır. Kumanda ekonomisinden piyasa ekonomisine geçiş sürecinde geçiş sürecine hazırlayacak olan kurumların eksikliği de geçiş sürecinin uzun ve sancılı geçmesine neden olan temel faktörlerden bir olmuştur.

1999 yılından itibaren reformlarda ilerleme kaydedilmesi ülke ekonomilerine de olumlu yansımış, ekonomik büyümede ve yabancı doğrudan yatırımlarda artış baş göstermiştir. Yabancı doğrudan yatırımların artmasında bankacılık ve özel sektörünün gelişmesi, döviz kuru ve ticaret liberalizasyonu ve yasal kurumların gelişmişliği önemli faktörlerden biri olmaktadır.

Geçen 20 yıl süresince Rusya ve Ukrayna'nın artık başlangıç dönemine göre enflasyon oranının düştüğü, büyüme oranının ve kişi başına düşen milli gelir arttığı, daha çok yabancı yatırım çektikleri görülmektedir. Özel sektör büyüdükçe bankacılık sektörü genişledikçe, döviz kuru ve ticaret liberalizasyonu ve yasal kurumlar daha etkili çalıştıkça her iki ülkenin piyasa ekonomisine geçişi daha az sıkıntılı atlatılabilecektir.

\section{Kaynakça}

- Alexeev, M. 1999. "The effect of privatization on wealth distribution in Russia", Economics of Transition, 7 (2), syf. 449-465

- Ahrend, R. and Tompson, W. 2005. "Fifteen Years of Economic Reform in Russia: What has been achieved? What remains to be done? ", OECD Economics Department Working Paper, No. 430, http://papers.ssrn.com/sol3/papers.cfm?abstract id=881547 (Erişim Tarihi: 10 Nisan 2013)

- Aslund, A. 1999. "Why Has Russia's Economic Transformation Been So Arduous?”, Carnegie Endowment for International Peace 
- $\quad$ Bevan A., Estrin, S. ve Meyer, K. 2004. "Foreign investment location and institutional development in transition economies ", International Business Review, 13, syf. 43-64

- Cukierman, A., Miller G. P. ve Neyapti, B. 2002. "Central bank reform, liberalization and inflation in transition economies -an international perspective", Journal of Monetary Economics 49, syf. 237-264

- Dabrowski, M. ve Antczak, R. 1995. "Economic Transition in Russia, the Ukraine and Belarus in Comparative Perspective", Center for Social and Economic Research (CASE), Warsaw, Poland

- Dabrowski, M. 1998. "Western aid conditionality and the post-communist transition 1990-1994", The Journal of Policy Reform, 2:2, syf.169-193

- De Melo, M., Denizer, C. ve Gelb, A. 1996. "From Plan to Market”, The World Bank Policy Research Department Transiton Economics Division, WP, 1564

- De Melo, M., Denizer, C. ve Gelb, A. ve Tenev, S. 2001. "Circumstance and Choice: The Role of Initial Conditions and Policies in Transition Economies", The World Bank Economic Review, (15), 1, syf.1-31

- Donnorummo, B. 2006. "The Political and Economic Complexities of Transition. Keynotes Address", Zagreb International Review of Economics and Business, Special Conference Issue, syf. 13-27

- Energy Information Administration (EIAa). 2013. Country analysis brief http://www.eia.doe.gov/countries/country-data.cfm?fips=RS (Erişim Tarihi: 3 Haziran 2013)

- $\quad$ Energy Information Administration (EIAb). 2013. (Erişim Tarihi: 5 Temmuz 2013). http://www.eia.gov/dnav/pet/hist/LeafHandler.ashx?n=pet\&s=rbrte\&f=m

- European Bank for Reconstruction and Development (EBRD). 2012. Transition Report

- Fisher, S. ve Gelb, A. 1991. “The Process of Socialist Economic Transformation”, The Journal of Economic Perspectives, 5 (4), syf. 91-105

- Fischer, S ve Sahay R. 2000. “The Transition Economies after Ten Years”, NBER Working Paper Series, 7664

- Güler, E. 2012. “Sosyalizmden Kapitalizme Geçiş Sürecinde Rusya: Nasıl Bir Kapitalizm?”, Business and Economics Research Journal, 3(3), syf. 93-120

- Kaymak, H. 2005. "Yabancı Doğrudan Yatırımları Artırmak İçin Teşvikler Gerekli ve/veya Yeterli Mi?",Maliye Dergisi, 149, syf. 74-104

- Kotz, D. M. 2000. "Lessons from Economic Transition in Russia and China Political Economy and Contemporary Capitalism: Radical Perspectives on Economic Theory and Policy” edited by Ron Baiman, Heather Boushey, and Dawn Saunders, Armonk, NY: M.E. Sharpe, 210-217

- $\quad$ Loungani, P. ve Sheets, N. 1997. “Central Bank Independence, Inflation, and Growth in Transition Economies", Journal of Money, Credit and Banking, 29 (3), syf. 381-399

- Mickiewicz, T.M. 2005. "Post Communist Recessions Re-examined", School Of Slavonic\&East European Studies, WP, (55)

- National Bank of Ukraine. http://www.bank.gov.ua

- The Central Bank of Russian Federation. www.cbr.ru

- World Bank .2013. World Development Indicators. World Bank, Washington, D.C.

- World Bank .2002. "Transition - The First Ten Years: Analysis and Lesson or Eastern Europe and the Former Soviet Union", World Bank, Washington D.C.

- World Bank. 1996. "World Development Report: From Plan to Market”, London, Oxford University Press

- United Nations Development Program. 2013 .International Human Development Indicators 


\title{
Satın Alma Gücü Paritesi Hipotezinin Kazakistan İçin Geçerliliği The Validity of Purchasing Power Parity Hypothesis for Kazakhstan
}

\author{
Asst. Prof. Dr. Seymur Ağayev (Recep Tayyip Erdoğan University, Turkey)
}

\begin{abstract}
The article examines the validity of Purchasing Power Parity (PPP) hypothesis for Kazakhstan by using the data set belonging to the period January 1995 to December 2012. Both linear and nonlinear unit root tests are used to make an econometrical investigation on stationarity characteristics of real exchange rate series of Kazakhstan's Tenge that defined according to different foreign countries or country groups. First of two nonlinear unit root tests that applied in this paper models structural change as a smooth transition and the other nonlinear unit root test takes into account both structural change and asymmetric adjustment characteristics of real exchange rates. Linear unit root test findings support the validity of the PPP hypothesis between Kazakhstan and Commonwealth of Independent States (CIS) countries. In addition to this finding, unit root tests that allow for nonlinear adjustment support evidences on stationarity of Tenge - US dollar real exchange rate, Tenge - Euro real exchange rate and Tenge's non-CIS related real effective exchange rate series. As a whole, findings of this study provide a strong support on the validity of PPP hypothesis for Kazakhstan. Furthermore, it is also shows that the nonlinear adjustment characteristics of real exchange rate should be taken into account, if foreign countries are represented by free market economies.
\end{abstract}

\section{Giriş}

Tek fiyat yasasına dayanan satın alma gücü paritesi (PPP) mutlak yaklaşımı bazı varsayımlar altında, aynı para cinsinden ifade edildiği zaman yurtiçi ve yurtdışı fiyatların eşitleneceğini öngörür. PPP mutlak yaklaşımı şu şekilde ifade edilebilir;

$$
\operatorname{ExP}_{d}=P_{f}
$$

Burada $E$ ulusal para birimi karşılığında satın alınabilen yabancı para miktarı şeklinde ifade edilen döviz kurunu, $P_{d}$ yurtiçi fiyatları ve $P_{f}$ ise yabancı ülke fiyatlarını ifade etmektedir. Bu durumda, döviz kuru yabancı ülke fiyatlarının yurtiçi fiyatlara oranı şeklinde gösterilebilir;

$$
E=P_{f} / P_{d}
$$

PPP mutlak yaklaşımı aynı zamanda ulusal malların yabancı ülke malları cinsinden karşılı̆̆ını ifade eden reel döviz kurunun da bire eşit olmasını ima eder;

$$
R E R=E x P_{d} / P_{f}=1
$$

Taşıma gibi işlem maliyetleri, kotalar ve gümrük tarifeleri gibi dış ticaret kısıtlamaları ve arbitrajı engelleyici tekelleşme PPP mutlak yaklaşımının gerçekleşmemesine neden olabilir. Ayrıca ticarete konu olmayan mallar, başlangıç yatırım sermayesinin büyüklüğü, ülkelerin fiyat endeksi sepetlerine dahil olan malların veya bunların ağırlıklarının farklı olması, fiyat ve döviz kuru müdahaleleri mutlak PPP'den sapmalara neden olabilir. PPP nispi yaklaşımı ise yurtiçi ve yurtdışı fiyatların eşitleneceğini değil, beraber hareket edeceğini öngörür. Sapmaların kalıcı veya geçici özellikler taşıması PPP bakımından önemli sonuçlara yol açar. Ulusal malların yabancı ülke malları cinsinden fiyatını ifade eden reel döviz kurunun uzun dönem denge düzeyine tekrar intibak etmesi sapmaların geçici ve dolayısıyla PPP hipotezinin geçerli olması anlamına gelir. Fakat reel döviz kurunun uzun dönem denge düzeyinden kalııı şekilde uzaklaşması ise sapmaların kalıcı olduğu anlamına gelir. Bu nedenle reel döviz kurunun durağanlık özellikleri incelenerek PPP hipotezinin geçerliliği test edilebilir.

Bu çalışmada, Kazakistan için PPP hipotezinin geçerliliği reel döviz kuru serilerinin durağanlık özellikleri doğrusal ve doğrusal olmayan birim kök testleri kullanılarak incelenmiştir. Bu amaçla, Ocak 1995 - Aralık 2012 dönemine ait aylık veri seti kullanılarak Kazakistan ulusal parası Tenge'nin (KZT) on üç farklı reel kuru farklı özelliklere sahip birim kök testi incelemelerine tabi tutulmuştur. Uygulanan birim kök testlerinden ilki doğrusal genelleştirilmiş Dickey ve Fuller (1979) yaklaşımıdır. Doğrusal olmayan yaklaşımlardan ilki yapısal değişmeyi üstel yumuşak geçiş şeklinde modelleyen Kapetanios, Shin ve Snell (2003) tarafindan önerilen yaklaşımdır. Çalışmada uygulanan diğer doğrusal olmayan birim kök testi ise yapısal değişmenin yanı sıra asimetrik intibaka izin veren Cuestas ve Ordóñez (2012) yöntemidir.

ADF test sonuçları on üç KZT reel kur serilerinden beşinin durağan olmadığını gösterirken, KSS testi bulguları bu sayının iki olduğu şeklindedir. Asimetrik intibaka izin veren CO testinin sonuçları ise KZT'nin Çin Yuanına karşı reel kuru hariç diğer tüm reel kur serilerinin durağan olduklarını gösterir ve PPP hipotezinin Kazakistan için geçerli olduğunu desteklemektedir. 
Çalışmanın devamı şu şekilde düzenlenmiştir. Öncelikle Kazakistan'ın serbest piyasa ekonomisi dönemindeki ekonomik gelişmelere ilişkin öz bilgi verilmiş, döviz kurunun ve fiyatlar genel düzeyinin izlediği seyir değerlendirilmiştir. Ardından Kazakistan'da PPP hipotezinin geçerliliğine ilişkin yapılan çalışmalar değerlendirilmiş, kullanılan yöntem ve alınan sonuçlar ifade edilmiştir. Dördüncü bölümde reel döviz kuru serilerinin durağanlık özelliklerinin incelenmesinde kullanılan birim kök testlerine yer verilmiştir. Beşinci bölümde veri seti tanıtılmış ve test bulguları sunulmuştur. Sonuncu bölümde ise bulgular doğrultusunda değerlendirmelerde bulunulmuştur.

\section{Geçiş Döneminde Kazakistan'da Konuyla İlgili Temel Gelişmeler}

Sovyet sisteminin dağılmasından sonra kısa süre uygulanan Rus Rublesine dayalı parasal birliğin başarısızlıkla sonuçlanmasının ardından Kazakistan 15 Kasım 1993'de ulusal parası olan KZT'yi tedavüle bırakmıştır. Fakat 1990’lı yılların ilk yarısı tüm Bağımsız Devletler Topluluğu (BDT) ülkeleri için olduğu gibi Kazakistan için de ekonomik açıdan oldukça sorunlu bir dönemdir ve genellikle geçiş dönemi durgunluğu şeklinde karakterize edilmektedir. Kazakistan'ın 1991-2012 yıllarına ilişkin reel GSYİH artış hızı, enflasyon ve döviz kuru değişim oranı Tablo 1'de verilmiştir. Tablodan da görüldüğü gibi 1991-1995 y1llarında Kazakistan ekonomisi sürekli küçülmüştür ve bu dönemde reel GSYİH küçülmesi kümülatif olarak \%38.84'tür. Başka bir ifade ile 1995 yılı GSYİH'sı 1990 yılına ait değerinin ancak \%61.16'sına eşit olmuştur. Aynı dönemde fiyatlar genel düzeyindeki yüzde değişim yüksek, hatta bazı yıllarda hiperenflasyon düzeyindedir. 1992-1994 yıllarında Kazakistan'da Aralık ayları itibariyle tüketici fiyatları endeksinde yüzde değişim sırasıyla 2960.8, 2165.0 ve 1158.3 olarak gerçekleşmiştir. Bu oran 1995 ve 1996 yıllarında ise sırasıyla 60.3 ve 28.7 olmuştur. İlk olarak KZT Rubleye sabitlenmiş (1 KZT $=500$ Ruble $)$ şekilde tedavüle bırakılmıştır. Fakat kısa süre sonra ise dalgalanmaya bırakılmış ve ABD Doları karşısında süratli şekilde değer kaybetmiştir. Aralık 1993'de 5.8 olan ABD Doları kuru Aralık 1994'te 53.7 olmuş ve KZT Dolar karşısında yaklaşık olarak \%825.1 oranında değer kaybetmiş̧tir. KZT'nin ABD Doları karşısında değer kaybı Aralık ayları itibariyle 1995 ve 1996 yılında ise sırasıyla \%19.6 ve \%13.4 olmuştur. 1990'ların ortalarından itibaren bütçe açıklarının azaltılması, döviz kuru ve enflasyon için hedeflerin açıklanması fiyat ve döviz kuru istikrarında etkili olmuştur. Sonraki dönemde KZT’nin ABD Doları kuru Rusya'da finansal krizin patlak verdiği Ağustos 1998'a kadar istikrarlı bir seyir izlemiştir.

\begin{tabular}{|l|l|l|l|}
\hline Y1llar & $\begin{array}{l}\text { Reel GSYİH'de \% } \\
\text { değişim }\end{array}$ & $\begin{array}{l}\text { TÜFE'de \% } \\
\text { değişim }\end{array}$ & $\begin{array}{l}\text { Dolar kurunda \% } \\
\text { değişim }\end{array}$ \\
\hline 1991 & -11.0 & - & - \\
\hline 1992 & -5.3 & 2960.8 & - \\
\hline 1993 & -9.2 & 2165.0 & - \\
\hline 1994 & -12.6 & 1158.3 & 825.1 \\
\hline 1995 & -8.2 & 60.3 & 19.6 \\
\hline 1996 & 0.5 & 28.7 & 13.4 \\
\hline 1997 & 1.7 & 11.2 & 4.1 \\
\hline 1998 & -1.9 & 1.9 & 10.3 \\
\hline 1999 & 2.7 & 17.8 & 65.3 \\
\hline 2000 & 9.8 & 9.8 & 4.7 \\
\hline 2001 & 13.5 & 6.4 & 3.8 \\
\hline 2002 & 9.8 & 6.6 & 3.6 \\
\hline 2003 & 9.3 & 6.8 & -6.9 \\
\hline 2004 & 9.6 & 6.7 & -10.3 \\
\hline 2005 & 9.7 & 7.5 & 2.9 \\
\hline 2006 & 10.7 & 8.4 & -4.4 \\
\hline 2007 & 8.9 & 18.8 & -5.5 \\
\hline 2008 & 3.3 & 9.5 & -0.1 \\
\hline 2009 & 1.2 & 6.2 & 23.2 \\
\hline 2010 & 7.3 & 7.8 & -0.8 \\
\hline 2011 & 7.5 & 7.4 & 0.4 \\
\hline 2012 & & 6 & 1.7 \\
\hline & & & \\
\hline
\end{tabular}

Tablo 1: Kazakistan'da Büyüme, Enflasyon ve Döviz Kuru Artış Hızı Kaynak: Kazakistan Merkez Bankası. Not: TÜFE artışı yılsonlarına, kur artışı KZT’nin Aralık ayı değerlerine göre hesaplanmıştır.

Rusya krizi Kazakistan ekonomisini oldukça ciddi bir şekilde etkilemiştir. Uzun bir dönem devam eden sürekli ekonomik küçülmeden sonra 1996 ve 1997 yıllarında artan reel GSYİH 1998 yılında tekrar azalmıştır. 1998 yılında reel GSYİH büyüme oranı eksi işaretle \%1.9'dur. Dünya Bankası verilerine (Global Economic Monitor) göre Rusya Rublesi ABD Doları karşısında Ağustos ve Eylül aylarında sırasıyla \%21.4 ve \%106.9 oranında değer kaybetmiştir. Rublenin ABD Doları karşısındaki değer kaybı düşük oranlarda olsa da Nisan 1999'a kadar 
sürekli devam etmiştir. Ağustos 1998'de 7.6 olan Ruble-ABD Dolar kuru Nisan 1999'da 25.4 olmuştur. Rusya'nın Kazakistan'ın en önemli dış ticaret ortağı olması sebebiyle bu finansal kriz Kazakistan dış ticaretini ciddi şekilde etkilemiştir. Rublenin değer kaybetmesine karşın Kazakistan Nisan 1999'a kadar gözetimli dalgalanma sistemini izlemiş ve KZT'nin aşırı değer kaybetmesine izin vermemiştir. Nihayet durumun sürdürülemezliğini dikkate alan Kazakistan hükümeti ve merkez bankası yönetimi 5 Nisan 1999'da döviz kurunu dalgalanmaya bırakmış, bunun yanı sıra dış ticaret ve döviz kontrolüne yönelik tedbirler almıştır (NBK, 1999). Bunu takiben Nisan, Mayıs ve Haziran aylarında KZT Dolar karşısında \%29.7, 6.1 ve 9.7 oranında değer kaybettikten sonra istikrarlı bir seyir izlemeye devam etmiştir.

Temmuz 1999 itibariyle kur 1Doları=132.5KZT düzeyindedir ve 2002 yılının sonuna kadar KZT ABD Doları karşısında yıllık \%5'in altında değer kaybederek 1Dolar=155.6KZT düzeyine ulaşmıştır. 2002 sonundan ABD menşeli dünya finansal krizinin Kazakistan ekonomisinde etkilerinin hissedilmeye başlandığı 2009 yılı başlarına kadar ise KZT ABD Doları karşısında değer kazanma eğiliminde olmuştur. 2003-2008 yıllarında KZT'nin Dolar karşısında değer kazanma oranı \%22.5'tir. Bahsedilen dönemde Kazakistan'da özellikle doğalgaz, petrol ve tarım ürünleri üretiminin artmasının yanı sıra dünya enerji ve tahıl fiyatlarının yükselmesi ulusal paranın değer kazanmasında etkili olmuştur.

Eylül 2004'de Kazakistan merkez bankası 2007 yılından itibaren enflasyon hedeflemesine geçeceğini ve öncelikli hedefinin fiyat istikrarını sağlamak olacağını duyurmuştur (NBK, 2004). İhracat ve yabancı sermaye girişi şeklinde ülkeye akan yabancı paranın ulusal para değeri üzerinde yarattığı yukarı yönlü baskıya rağmen

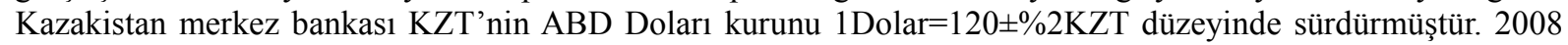
dünya finansal krizi ile birlikte Kazakistan için olumlu koşullar ortadan kalkmıştır. Petrol fiyatlarının süratli şekilde ucuzlaması ve dünyada sermaye akımlarının yok olması ulusal paranın değeri üzerinde aşağı yönlü baskı oluşturmuş ve Kazakistan merkez bankasını uluslararası rezervlerini korumak ve yurtiçi üreticilerin rekabet yapabilirliğini desteklemek amacıyla döviz kuru politikasını değiştirmeye itmiştir. Merkez bankası petrol fiyatlarınızdaki düşüşü, dış ticaret ortağı ülkelerin paralarının ABD Doları karşısında değer kaybetmelerini dikkate alarak ve döviz rezervlerini korumak amacıyla Dolar kuru bandını 1Dolar $=150 \pm \% 3$ veya $\pm \% 5 \mathrm{KZT}$ şeklinde düzeltmiş (NBK, 2009). Bu değişiklikle Şubat ayında KZT'nin Dolar karşısında yaklaşık olarak \%21 oranında değer kaybetmesine izin vermiştir. Kur bandında değişiklik sonrası dönemde Kazakistan'da döviz kuru ve fiyatlar genel düzeyi istikrarı sürdürülmüş, yıllık enflasyon \%10'un altında ve Dolar kurunun da 145.5-150.9 bandında seyrettiği görülmüştür.

\section{Literatür}

Kazakistan için PPP hipotezinin geçerliliğine ilişkin sınırlı sayıda çalışma mevcuttur. Bu çalışmalar araştırma dönemi, reel kur hesaplamasında dikkate alınan yabancı ülke, kullanılan yöntem ve elde edilen sonuç açısından Tablo 2'de özetlenmiştir. Doğrusal panel birim kök testlerini kullanan Solakoglu (2006) geçiş ekonomileri için PPP hipotezinin geçerli olduğunu bulmuştur. Doğrusal koentegrasyon testlerini kullanan Doğanlar (2006) ise Kazakistan için PPP hipotezini destekleyici herhangi bir bulgu elde edememiştir. Doğrusal dişılığı dikkate alan birim kök testlerinin kullanıldığı Telatar ve Hasanov (2009) çalışmasında ise sadece Kapetanios ve diğerleri (2003) testi bulguları KZT’nin reel kurunun durağanlığını desteklemektedir. Liew, Puah, Choong ve Lau (2010) çalışmasında da uygulanan aynı yöntem benzer bulgu sunmamaktadır. Tablo 2'de ifade edilen çalışmalardan Hung ve Weng (2011) hariç diğer tüm çalışmalarda yabancı ülke olarak ABD dikkate alınmıştır. KZT'nin Rusya Rublesi reel kurunu dikkate alındığı Hung ve Weng (2011) çalışmasında kullanılan doğrusal zaman serisi birim kök testleri reel kur serisinin durağanlığını destekleyici bulgu sunmamaktadır. Liew, Chia ve Ling (2010), Liew, Puah, Choong ve Lau (2010) ve Korkmaz, Çevik ve Çevik (2013) de Kazakistan'da PPP hipotezini destekleyici bulgular sunmaktalar.

\section{Yöntem}

Reel döviz kuru serilerinin durağanlık özellikleri PPP hipotezinin geçerliliğine ilişkin bilgi sunmaktadır. Bu nedenle PPP hipotezinin uzun dönem geçerliliği birim kök testleri yardımıyla incelenebilir. Kazakistan için PPP hipotezinin incelendiği bu çalışmada reel döviz kuru serilerinin durağanlık özellikleri genelleştirilmiş Dickey ve Fuller (1979, ADF) ve iki farklı doğrusal olmayan birim kök testi yardımıyla incelenmiştir. Doğrusal olmayan yöntemler yapısal değişmenin üstel yumuşak geçiş şeklinde modellendiği Kapetanios ve diğerleri (2003) testi ile yapısal değişmenin yanı sıra asimetrik intibaka da izin veren Cuestas ve Ordóñez (2012) testidir.

İlgili literatürde yaygın şekilde kullanıldığından ADF birim kök testine ilişsin metodik açıklama burada verilmemiştir. Kapetanios ve diğerleri (2003) tarafından önerilen yöntemde durağan değildir şeklinde ifade edilen boş hipotez küresel olarak durağan (globally stationary) üstel yumuşak geçişli otoregresif süreçlere karş1 test edilir. Yumuşak geçişli otoregresif temel model aşağıdaki gibidir:

$$
\Delta y_{t}=\sum_{j=1}^{p} \rho \Delta y_{t-j}+\gamma y_{t-1}\left\{1-\exp \left(-\theta y_{t-d}^{2}\right)\right\}+\varepsilon_{t}
$$




\begin{tabular}{|c|c|c|c|c|c|}
\hline Çalışma & Ülkeler & Dönem & Y. ülke & Yöntem & Sonuç \\
\hline $\begin{array}{l}\text { Solakoglu } \\
(2006)\end{array}$ & $\begin{array}{l}21 \text { geçiş } \\
\text { ekonomisi }\end{array}$ & $\begin{array}{l}1994- \\
2003 \text { y1llık }\end{array}$ & $\mathrm{ABD}$ & $\begin{array}{l}\text { LLC ve IPS panel birim } \\
\text { kök testleri }\end{array}$ & Kabul \\
\hline $\begin{array}{l}\text { Doğanlar } \\
(2006)\end{array}$ & $\begin{array}{l}\text { Azerbaycan, } \\
\text { Kazakistan ve } \\
\text { Kirgizistan }\end{array}$ & $\begin{array}{l}\text { Ocak } 1995 \\
- \text { Aralık } \\
2002\end{array}$ & $\mathrm{ABD}$ & $\begin{array}{l}\text { Engle-Granger, tam } \\
\text { değiştirilmiş (fully } \\
\text { modified) EKK yaklaşımı, } \\
\text { ARDL yaklaşımı ve } \\
\text { Johansen koentegrasyon } \\
\text { testleri }\end{array}$ & Ret \\
\hline $\begin{array}{l}\text { Telatar ve } \\
\text { Hasanov } \\
(2009)\end{array}$ & $\begin{array}{l}\text { Kazakistan ve } 9 \\
\text { eski Sovyet } \\
\text { cumhuriyeti }\end{array}$ & $\begin{array}{l}\text { Kasim } \\
1993 \text { Eylül } \\
2006\end{array}$ & $\mathrm{ABD}$ & $\begin{array}{l}\text { KSS (2003), Leybourne, } \\
\text { Newbold ve Vougas } \\
\text { (1998) ve Sollis (2004) } \\
\text { birim kök testleri }\end{array}$ & KSS testinde kabul \\
\hline $\begin{array}{l}\text { Liew, Chia } \\
\text { ve Ling } \\
(2010)\end{array}$ & $\begin{array}{l}\text { Azerbaycan, } \\
\text { Kazakistan ve } \\
\text { Kirgizistan }\end{array}$ & $\begin{array}{l}\text { Ocak } 1995 \\
- \text { Aralık } \\
2002\end{array}$ & $\mathrm{ABD}$ & $\begin{array}{l}\text { Breitung (2001) } \\
\text { koentegrasyon rank testi }\end{array}$ & Kabul \\
\hline $\begin{array}{l}\text { Liew, Puah, } \\
\text { Choong ve } \\
\text { Lau (2010) }\end{array}$ & $\begin{array}{l}\text { Azerbaycan, } \\
\text { Kazakistan ve } \\
\text { Kirgizistan }\end{array}$ & $\begin{array}{l}\text { Ocak } 1995 \\
- \text { Aralık } \\
2002\end{array}$ & $\mathrm{ABD}$ & $\begin{array}{l}\text { DF, KSS (2003), panel } \\
\text { durağanlık ve Engle ve } \\
\text { Granger (1998) in eşik } \\
\text { koentegrasyon analizi }\end{array}$ & $\begin{array}{l}\text { Sadece momentum eşik } \\
\text { otoregresif modelde } \\
\text { reel kurun asimetrik } \\
\text { uyumu desteklenmekte }\end{array}$ \\
\hline $\begin{array}{l}\text { Hung ve } \\
\text { Weng (2011) }\end{array}$ & $\begin{array}{l}\text { Azerbaycan, } \\
\text { Kazakistan ve } \\
\text { Kirgizistan }\end{array}$ & $\begin{array}{l}\text { Ocak } 1995 \\
- \text { Mart } \\
2009\end{array}$ & Rusya & $\begin{array}{l}\text { ADF, DF-GLS, PP ve } \\
\text { KPSS zaman serisi birim } \\
\text { kök testleri ile Hadri, LLC, } \\
\text { Harris-Tzavalis, Breitung, } \\
\text { IPS, Taylor-Sarno, Fisher } \\
\text { ve Pesaran panel birim kök } \\
\text { testleri }\end{array}$ & $\begin{array}{l}\text { Zaman serisi için ret, } \\
\text { LLC, Harris-Tzavalis, } \\
\text { Breitung, Fisher ve } \\
\text { Pesaran panel birim } \\
\text { kök testlerde destek }\end{array}$ \\
\hline $\begin{array}{l}\text { Korkmaz, } \\
\text { Çevik ve } \\
\text { Çevik } \\
(2013)\end{array}$ & $\begin{array}{l}\text { Azerbaycan, } \\
\text { Kazakistan ve } \\
\text { Kirgizistan }\end{array}$ & $\begin{array}{l}\text { Ocak } 1995 \\
- \text { Ocak } \\
2009\end{array}$ & $\mathrm{ABD}$ & $\begin{array}{l}\text { ADF, PP, KPSS Zivot- } \\
\text { Andrews, Lee-Strazizich } \\
\text { birim kök testleri ile } \\
\text { Engle-Granger, Gregory- } \\
\text { Hansen ve Hatemi-J } \\
\text { koentegrasyon testleri }\end{array}$ & $\begin{array}{l}\text { KPSS, Zivot-Andrews, } \\
\text { Lee-Strazizich birim } \\
\text { kök testlerinde kabul }\end{array}$ \\
\hline
\end{tabular}

Tablo 2: Kazakistan'da PPP Hipotezinin Geçerliliğine İlişkin Yapılan Çalışmalar

Kapetanios ve diğerleri (2003), boş hipotezde sıfır $(\theta=0)$ ve alternatif hipotezde pozitif olan $(\theta>0)$ ortalamaya geri dönme hızı parametresine odaklanmaktadır. $\gamma$ parametresi boş hipotezde tanıtılmadığından durağanlığı bu şekilde doğrudan test etmek mümkün değil. Bu nedenle Kapetanios ve diğerleri (2003) geçiş değişkeni gecikmesini $d=1$ varsayarak ve sıfır hipotezi çerçevesinde 4 numaralı eşitliğin birinci mertebeden Taylor yaklaşıklığını elde etmektedir:

$$
\Delta y_{t}=\sum_{j=1}^{p} \rho \Delta y_{t-j}+\delta y_{t-1}^{3}+e_{t}
$$

Cuestas ve Ordóñez (2012) tarafindan önerilen doğrusal olmayan test ise doğrusal dışılığın iki kaynağını dikkate almaktadır. Bunlar yapısal geçiş ve asimetrik uyumdur. Deterministik trendin yanı sıra asimetrik uyuma da izin veren Cuestas ve Ordóñez (2012) testi şu şekilde açıklanabilir:

$$
y_{t}=g(t)+\epsilon_{t}
$$

Burada $g(t)$ zamanın sabit olmayan bir fonksiyonudur ve $g(t)=g_{1}+g_{2} t+g_{3} L_{t}(\gamma)+g_{4} t L_{t}(\gamma)$ şeklinde modellenir. $L_{t}(\gamma)$ ise $L_{t}(\gamma)=1 /\left(1+e^{-\gamma t}\right)$ şeklinde tanımlanan bir lojistik yumuşak geçiş fonksiyondur. Yapısal değişim ve asimetrik intibakı dikkate alarak birim kök incelemesinin yapılması için Cuestas ve Ordóñez (2012) 6 numaralı eşitliğin hata terimlerine $\left(\epsilon_{t}\right)$ Kapetanios ve diğerleri (2003) testini uygulamayı önerirler.

\section{Veri Seti ve Bulgular}

Çalışmada kullanılan veri seti Ocak 1995 - Aralık 2012 dönemini kapsamakta olup Kazakistan merkez bankasından alınmış KZT'ye ait on üç reel kur serisinden oluşmaktadır. Reel kur serilerinin araştırma dönemi için zaman yolu Grafik 1'de verilmiştir. Bunlardan yedisi Kazakistan ile en fazla diş ticarete sahip ülkelerin paraları karşısında KZT’nin reel kurlarıdır. Bu paralar ve temel alınarak oluşturulan KZT reel kurlarının grafikteki ve çalınmanın bundan sonraki kısmındaki kısaltmaları şöyledir; Rusya Rublesi (RUB), Euro (EUR), ABD Doları (USD), Çin Yuanı (CNY), Kırgızistan Somu (KGS), Ukrayna Hryvniası (UAH) ve Beyaz Rusya Rublesi (BYR). Diğer altısı ise KZT'nin reel efektif kurlarına ait serileridir. Bunlar tüm ülkeler (ER1), BağımsıZ Devletler Topluluğu (BDT) ülkeleri (ER2), BDT dışındaki ülkeler (ER3), petrol ticareti hariç tüm ülkeler (ER4), 
petrol ticareti hariç BDT ülkeleri (ER5) ve petrol ticareti hariç BDT dışındaki ülkeler (ER6) dikkate alınarak hesaplanan reel kurlardır. Grafikten de görülebildiği üzere ülke grupları için efektif reel kur serilerinin seyirleri petrol ihracatının dahil edildiği ve edilmediği durumlarda oldukça benzerdir. Bunun yanı sıra KZT'nin tüm ülkeler için efektif reel kuru serisi olan ER1'in seyri en fazla RUB şeklinde ifade edilen KZT'nin Rusya Rublesine karşı olan reel kuru serisine benzerdir.

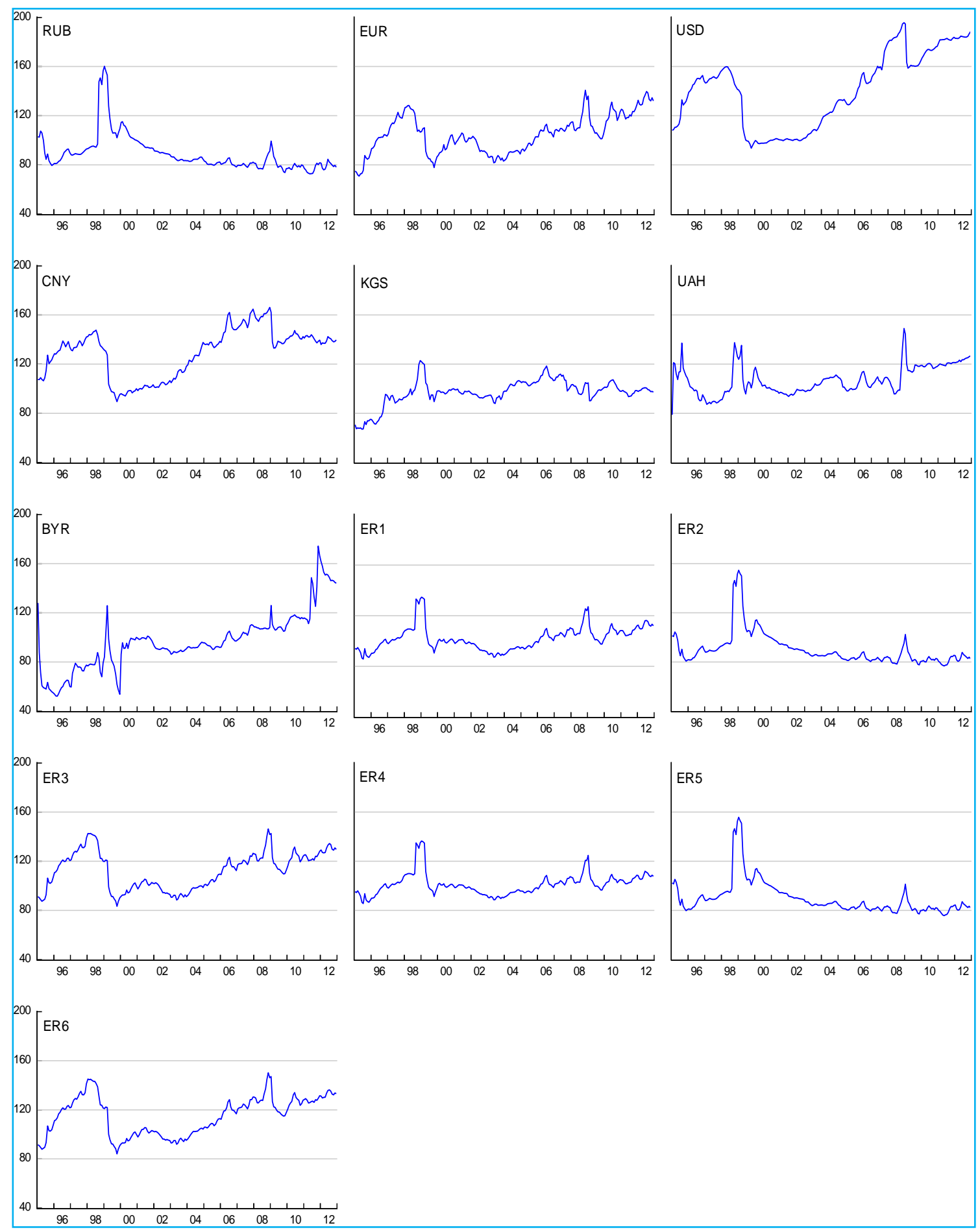

Grafik 1: Kazakistan'a Ait Farklı Reel Kur Serilerinin Zaman Yolu

ADF birim kök testi sonuçları Tablo 3'de sunulmuştur. Trende ilişkin farklı doğrusal varsayımlara sahip ADF testine ait bulguları KZT'ye ait on üç reel kur serisinden beşinin durağan olmadığını, ikisinin en az 0.01 düzeyinde, beşinin en az 0.05 düzeyinde ve birinin de 0.10 düzeyinde durağan olduğunu gösterir. Durağan olmayan reel kur serileri KZT'nin Euro, ABD Doları, Çin Yuanı reel kurları ile BDT dışındaki ülkelere ve petrol ticareti hariç BDT dışındaki ülkelere ait reel efektif kur serileridir. Kazakistan'a iliş̧kin yapılan ve Tablo 2'de ifade edilen çalışmalardan bazılarında ADF testine yer verilmiştir. Bunlardan KZT'nin ABD Doları reel kurunu 
dikkate alan Telatar ve Hasanov (2009) ile Korkmaz ve diğerleri (2013) de ADF testlerinde Kazakistan reel kur serilerinin durağan olmadığını bulmuşlar. KZT'nin Rusya Rublesi reel kurunu dikkate alan Hung ve Weng (2011)'in ADF bulguları ise elde ettiğimiz bulgulardan farklıdır. Şöyle ki, Hung ve Weng (2011)'in ADF testi sonuçları reel kur serisinin durağan olmadı ̆̆ı şeklindedir.

\begin{tabular}{|l|l|l|l|}
\hline Reel kur & Trend durağan & Sabit durağan & Sifir ortalama durağan \\
\hline RUB & $-3.3732(1)^{* * *}$ & $-2.8638(1)^{* * *}$ & $-0.7577(1)$ \\
\hline EUR & $-2.6406(1)$ & $-2.3059(1)$ & $0.5231(1)$ \\
\hline USD & $-1.4030(1)$ & $-0.8874(1)$ & $0.9007(1)$ \\
\hline CNY & $-1.9455(1)$ & $-1.8448(1)$ & $0.2115(1)$ \\
\hline KGS & $-3.2550(1)^{* * *}$ & $-3.3752(1)^{* *}$ & $0.2636(1)$ \\
\hline UAH & $-4.4096(2)^{*}$ & $-3.3389(2)^{* *}$ & $-0.1609(2)$ \\
\hline BYR & $-4.0979(2)^{*}$ & $-1.3678(2)$ & $0.4410(2)$ \\
\hline ER1 & $-3.2553(1)^{* * *}$ & $-3.0579(1)^{* *}$ & $0.0500(1)$ \\
\hline ER2 & $-3.3736(1)^{* * *}$ & $-2.9727(1)^{* *}$ & $-0.4920(7)$ \\
\hline ER3 & $-2.2473(1)$ & $-2.1892(1)$ & $0.3310(1)$ \\
\hline ER4 & $-3.3284(1)^{* * *}$ & $-3.2686(1)^{* *}$ & $-0.0404(1)$ \\
\hline ER5 & $-3.3357(1)^{* * *}$ & $-2.9372(1)^{* *}$ & $-0.4881(7)$ \\
\hline ER6 & $-2.2136(1)$ & $-2.1205(1)$ & $0.3954(1)$ \\
\hline
\end{tabular}

Tablo 3: ADF Birim Kök Testi Sonuçları Not: Parantez içindeki sayllar minimum Schwarz bilgi kriterine (SCI) göre gecikme uzunluklarını, *,**ve *** simgeleri ilgili istatistiğin strastyla \%1, \%5 ve \%10 düzeyinde anlamlı olduğunu gösterir.

Yapısal değişmenin yumuşak geçiş şeklinde modellendiği Kapetanios ve diğerleri (2003) birim kök testi sonuçları Tablo 4'te ifade edilmiştir. Buna göre on üç reel kur serisinden ikisi durağan değildir. Bu serilerden beşi en az 0.01 düzeyinde, diğer beşi ise en az 0.05 düzeyinde durağan bulunmuştur. Durağan olmayan reel kur serileri KZT'nin ABD Doları ve Çin Yuanı reel kurlarına ait serileridir. Kapetanios ve diğerleri (2003) birim kök testi Tablo 2'de ifade edilen iki çalışmada kullanılmıştır. Her iki çalışmada da KZT'nin ABD Dolar reel kuru kullanılmasına karşın sonuçları birbirinden farklıdır. Kapetanios ve diğerleri (2003) testi sonucunda Kazakistan için Telatar ve Hasanov (2009) reel kur serisinin durağan olduğu, Liew, Puah, Choong ve Lau (2010) ise bizim de elde ettiğimiz gibi reel kur serisinin durağan olmadığı yönünde bulgulara ulaşmıştır.

\begin{tabular}{|c|c|c|c|c|}
\hline $\begin{array}{l}\text { Reel } \\
\text { kur }\end{array}$ & Gecikme & $\begin{array}{l}\text { Ortalama, trendden arındırıl- } \\
\text { mış veri için } t \text {-istatistikleri }\end{array}$ & $\begin{array}{l}\text { Ortalamadan arındırılmış } \\
\text { veri için } t \text {-istatistikleri }\end{array}$ & Ham veri için $t$-istatistikleri \\
\hline RUB & 1 & $-3.2151 * * *$ & $-3.2650 * *$ & $-2.0949 * * *$ \\
\hline EUR & 1 & -2.4763 & $-3.3754 * *$ & -0.1855 \\
\hline USD & 1 & -1.5553 & -1.6670 & 0.3668 \\
\hline CNY & 1 & -2.1708 & -2.2404 & -0.3534 \\
\hline KGS & 1 & $-3.1711 * * *$ & -2.5366 & -0.4134 \\
\hline UAH & 2 & $-9.5243 *$ & $-6.7583 *$ & -1.0361 \\
\hline BYR & 2 & $-5.8881 *$ & -2.2281 & -0.3790 \\
\hline ER1 & 1 & $-4.2214 *$ & $-4.7888 *$ & -0.6760 \\
\hline ER2 & 1 & $-3.3558 * * *$ & $-3.3587 * *$ & $-1.9202 * * *$ \\
\hline ER3 & 1 & -2.0536 & $-3.2778 * *$ & -0.2949 \\
\hline ER4 & 1 & $-4.2757 *$ & $-4.5479 *$ & -0.7956 \\
\hline ER5 & 1 & $-3.3480 * *$ & $-3.3567 *$ & $-1.9648 * * *$ \\
\hline ER6 & 1 & -2.0593 & $-3.4644 * *$ & -0.2241 \\
\hline \multirow{3}{*}{$\begin{array}{l}\text { Kritik } \\
\text { değerler }\end{array}$} & $\% 1$ & -3.93 & -3.48 & -2.82 \\
\hline & $\% 5$ & -3.40 & -2.93 & -2.22 \\
\hline & $\% 10$ & -3.13 & -2.66 & -1.92 \\
\hline
\end{tabular}

Tablo 4: Kapetanios ve diğerleri (2003) Birim Kök Testi Sonuçları Not: Kritik değerler Kapetanios ve diğerleri (2003)'ne dayanmaktadır. *, ** ve *** simgeleri ilgili istatistiğin strasıla \%1, \%5 ve \%10 düzeyinde anlamlı olduğunu gösterir. Gecikme uzunlukları SCI'e göre belirlenmiştir.

Yapısal değişmenin yanı sıra asimetrik intibakı da dikkate alan Cuestas ve Ordóñez (2012) birim kök testi sonuçları Tablo 5 'te verilmiştir. Bu testte, 6 numaralı eşitliğin hata terimlerine Kapetanios ve diğerleri (2003) testi uygulanmaktadır. Hata terimlerinin ortalama ve trendden arındırılmış, ortalamadan arındırılmış ve ham şekli birbirinden farklı değildir. Bu nedenle Kapetanios ve diğerleri (2003) testinden farklı olarak Cuestas ve Ordóñez (2012) testi sonuçları her bir reel kur serisine ilişkin bir $t$-istatistiği ile ifade edilmiştir. Cuestas ve Ordóñez (2012) birim kök testi sonucuna göre on üç reel kur serisinden sadece biri; KZT’nin Çin Yuanına karşı reel kuru 
serisi durağan değildir. Durağan bulunan serilerden beşi 0.01 düzeyinde, altısı 0.05 düzeyinde ve biri 0.10 düzeyinde durağan bulunmuştur.

\begin{tabular}{|l|l|l|}
\hline Reel kur & Gecikme & $t$-istatistiği \\
\hline RUB & 1 & $-3.2184^{* * *}$ \\
\hline EUR & 1 & $-4.3852^{*}$ \\
\hline USD & 1 & $-3.4715^{* *}$ \\
\hline CNY & 1 & -2.8261 \\
\hline KGS & 1 & $-3.4434^{* *}$ \\
\hline UAH & 2 & $-8.5364^{*}$ \\
\hline BYR & 2 & $-8.5263^{*}$ \\
\hline ER1 & 1 & $-4.8218^{*}$ \\
\hline ER2 & 1 & $-3.4997^{* *}$ \\
\hline ER3 & 1 & $-3.8722^{* *}$ \\
\hline ER4 & 1 & $-4.8263^{*}$ \\
\hline ER5 & 1 & $-3.4998^{* *}$ \\
\hline ER6 & 1 & $-3.8791^{* *}$ \\
\hline
\end{tabular}

Tablo 3: Cuestas ve Ordóñez (2012) Birim Kök Testi Sonuçları Not: Cuestas ve Ordóñez (2012)'e göre 250 gözlem için \%1, 5 ve 10 anlamlllık düzeyi için kritik değerler sirasiyla $-3.928,-3.386$ ve -3.110 'dur. *, ** ve *** simgeleri ilgili istatistiğin sirasıyla \%1, \%5 ve \%10 düzeyinde anlamlı olduğunu gösterir. Gecikme uzunlukları SCI'e göre belirlenmiştir

\section{Sonuç ve Değerlendirme}

Kazakistan için PPP hipotezinin geçerliliği oldukça sınırlı sayıda çalışmada araştırılmış ve genellikle sadece ABD yabancı ülke olarak dikkate alınmıştır. Bu çalışmada KZT'nin çok sayıda farklı reel döviz kuru serisinin durağanlık özellikleri doğrusal ADF ile doğrusal dışlığı dikkate alan iki farklı birim kök testi çerçevesinde incelenerek PPP hipotezinin Kazakistan için geçerliliği araştırılmıştır. Çalışmada kullanılan doğrusal olmayan yaklaşımlar yapısal değişmeyi üstel yumuşak geçiş şeklinde modelleyen Kapetanios ve diğerleri (2003) testi ile yapısal değişmenin yanı sıra asimetrik intibaka da izin veren Cuestas ve Ordóñez (2012) testidir. Çalışmada, KZT'nin on üç farklı reel kurunun Ocak 1995 - Aralık 2012 dönemine ait aylık verileri kullanılmıştır.

ADF test sonuçları KZT'ye ait on üç reel döviz kuru serisinden beşinin durağan olmadığını gösterirken, Kapetanios ve diğerleri (2003) testi bulguları bu sayının iki olduğu şeklindedir. Asimetrik intibaka izin veren Cuestas ve Ordóñez (2012) testinin sonuçları ise KZT'nin Çin Yuanına karşı reel kuru hariç diğer tüm reel kur serilerinin durağan olduklarını gösterir. Bulgular KZT’nin Euroya karşı reel kur ve BDT dışındaki ülkelere ilişkin efektif reel kur serilerinde (Petrol ticareti dahil ve hariç) doğrusal dışı uyumun, ABD Dolarına karşı reel kur serisinde ise asimetrik intibakın varlı̆̆ını desteklemektedir.

Bunun dışında, Kazakistan gibi önceden merkezi planlamaya dayalı sisteme sahip olan ve serbest piyasa ekonomisine geçiş yapan Rusya, Kırgızistan, Ukrayna, Beyaz Rusya ile BDT ülkelerinin tamamı dikkate alındığında doğrusal ADF testi sonuçları PPP hipotezinin geçerli olduğunu gösterir. Fakat KZT'in ABD Dolarına ve Euroya karşı reel kuru ile BDT dışındaki ülkelere karşı efektif reel kuru dikkate alındığında doğrusal PPP hipotezinin Kazakistan için geçerliliği desteklenmemektedir. Piyasa ekonomisinin hakim olduğu ülkelerle Kazakistan arasında PPP hipotezinin geçerliliğine ilişkin destek doğrusal dışllığın dikkate alınmasıyla elde edilmektedir. Bu sonuç Kazakistan'da piyasa ekonomisine yönelik uygulanan yapısal dönüşüm reformlarının reel döviz kuru intibakı üzerindeki etkisini yansıtmaktadır. Ayrıca Kazakistan ve Çin arasında PPP hipotezinin geçerli olmaması muhtemelen Çin'in önemli derecede dış ticaret fazlasına sahip olmasına rağmen Yuanın aşırı değerlenmesine izin vermemesinden kaynaklanabilir.

\section{Kaynakça}

- Cuestas, J. C. ve Ordóñez, J. 2012. "Smooth Transitions, Asymmetric Adjustment and Unit Roots", Sheffield Economics Research Paper No. 2012012, Department of Economics, University of Sheffield.

- Dickey, D. A. ve Fuller, W. A. 1979. "Distribution of The Estimators for Autoregressive Time Series with a Unit Root", Journal of the American Statistical Association, 74, 427-431.

- Doğanlar, M. 2006. "Long-run Validity of Purchasing Power Parity and Cointegration Analysis for Central Asian Countries", Applied Economics Letters, 13, 457-461.

- Hung, S. H. ve Weng, M. J. 2011. "Panel Unit Root Tests of Purchasing Power Parity for Central Asian Countries", Applied Economics Letters, 18, 585-590.

- Kapetanios, G., Shin, Y. ve Snell, A. 2003. "Testing for a Unit Root in The Nonlinear STAR Framework", Journal of Econometrics, 112, 359-379. 
- $\quad$ NBK, 1999. “Правила Проведения Конвертации Тенговых Депозитов Физических И Юридических Лиц В Банках Второго Уровня В Связи С Переходом К Режиму Свободно Плавающего Обменного Курса Тенге", Правила Национального Банка от 05.04.1999 N 62.

- $\quad$ NBK, 2004. National Bank of Kazakhstan Press Release No: 20, September 14.

- $\quad$ NBK, 2009. National Bank of Kazakhstan Press Release No: 3, February 4.

- Korkmaz, T., Çevik, E. İ. ve Çevik, N. K. 2013. "Satın Alma Gücü Paritesinin Azerbaycan, Kazakistan ve Kırgızistan İçin Geçerliliği: Birim Kök ve Eşbütünleşme Analizi”, bilig, 64, 259-284.

- $\quad$ Liew, V. K.-S., Chia, R. C.-J. ve Ling, T.-H. 2010. "Long-run Validity of Purchasing Power Parity and Rank Tests for Cointegration for Central Asian Countries", Applied Economics Letters, 17, 1073-1077.

- $\quad$ Liew, V. K.-S., Puah, C.-H., Choong, C.-K. ve Lau, E. 2010. "Revisiting Purchasing Power Parity for Central Asian Countries Using Threshold Cointegration Tests", Economics Bulletin, 30, 1283-1292.

- Solakoglu, E. G. 2006. “Testing Purchasing Power Parity Hypothesis for Transition Economies”, Applied Financial Economics, 16, 561-568.

- Telatar, E. ve Hasanov, M. 2009. "Purchasing Power Parity in Transition Economies: Evidence From the Commonwealth of Independent States”, Post-Communist Economies, 21, 157-173. 


\title{
Kadınların Çalışma Yaşamına Katılımlarına Yönelik Tutum Ölçeğinin (KÇYKYTÖ) Bir Yapısal Eşitlik Modeli ile Geçerlik ve Güvenirliğinin İncelenmesi
}

\section{Investigation of the Reliability and Validity of Attitude Scale on Labor Force Participation of Women with a Structral Equation Model}

\author{
Asst. Prof. Dr. Erol Karaca (Anadolu University, Turkey)
}

\begin{abstract}
This study is designed to find out the relationship between labour force participation of women, internal and external factors that limiting to their labour force participation and negatives of working. This research was carried out with 900 women between the ages of 15-64, living in Eskişehir. The data was collected through "Attitude Scale on Labor Force Participation of women" developed by researchers. These data were analyzed with Second Order Confirmatory Factor Analysis by using the statistical package LISREL. The findings from the study revealed that the scale was valid and reliable and that internal factors and external factors that limiting to their labour force participation and negatives of working affect directly labour force participation of women.
\end{abstract}

\section{Giriş}

Türkiye'de kadınların işgücüne katılımı engelleyen nedenlerden olan toplumsal cinsiyet temelli iş yükleri ve bakım hizmetleri, kadınlar için evli olmak, özellikle kentlerde işgücüne katılımı azaltan ciddi bir faktördür. Kadınlar ev dışında çalışma ya da çalışmama kararı alırken evde yapmakta oldukları işlerin aksama olasılığını, çocuklara ve yaşlılara kimler tarafından bakılacağını, iş saatleri dışında evdeki işler için ayırabilecekleri zamanı düşünmek zorunadırlar. Eğitimde toplumsal temelli eşitsizlik ise işgücüne katılımı azaltan bir diğer nedendir. Türkiye'de ekonomi büyümekte, kadın istihdamına aynı oranda yansımamaktadır. Ekonomik büyüme, istihdam, işsizlik işgücüne katılımı etkileyen diğer önemli unsurlardır. Yüksek işsizlik oranları kadınları korkutmakta, bu nedenle kadınlar işgücü piyasalarında iş arama kararı vermekte zorlanmaktadırlar. Ayrıca teknolojik gelişmeler sonucu işlerin beceri gereklerinin yükselmesi, beceri düzeyi yüksek olmayan kadınlar bakımından işgücüne katılımda olumsuz etkide bulunan bir faktör olarak karşımıza çıkmaktadır (TÜSİAD, 2008: 168).

Günümüzde kadınlar diğer alanlara göre en çok ekonomik yaşama katılım konusunda ayırımcılığa maruz kalmaktadır. Kuşkusuz bu durumun en önemli nedenlerinden biri, kadını ekonomide erkeklerle aynı mesleki firsatlardan ve eşit ücret alma hakkından yararlanmaktan alıkoyan sosyo-kültürel engellerin varlığını sürdürmesidir. Gerçekten de kadınların yaptığı işin, aileye destek olmak için yapılan bir çalışma olduğu yolundaki geleneksel anlayış, kadınlara ekonomik büyüme dönemlerinde gereksinim duyulan ve gerileme dönemlerinde bir kenara itilen, yedek işgücü niteliği kazandırmaktadır.

Kalkınmış ülkelerde kadınların işgücüne katılım oranları son yıllarda büyük ölçüde artmaktadır. Buna karşılık Türkiye'de kadınların işgücüne katılma oranlarında azalma eğilimi gözlenmektedir (TÜSİAD, 2008: 10). Bu çalışmanın amacı da, kadınların işgücüne katılma oranlarındaki azalma eğiliminin nedenlerinin ve işgücüne katılıma yönelik tutumlarının saptanabilmesi için bir tutum ölçeği geliştirmektir.

\section{Yöntem}

\subsection{Evren ve Örneklem}

Bu çalışmanın evreni, Eskişehir ilinde, ilçe ve köyler dâhil olmak üzere, yaşayan kadınlar; örneklemini ise Eskişehir il merkezi ile Sarıcakaya ve Seyitgazi ilçesi ve köylerinde ikamet eden 15-64 yaş grubunda yer alan, 900 kadın oluşturmaktadır.

\subsection{Veriler ve Toplanması}

Araştırmanın amaçları, kadınların işgücüne katılma oranlarını etkileyen nedenlerin belirlenmesine yönelik bir ölçme aracının kullanılmasını gerektirmektedir. Sosyal ve ekonomik yaşama katılım konusunda erkek ve kadın arasında eşitliğin sağlanabilmesi ve kadınların işgücüne katılımının artırılabilmesi için önem taşımasına rağmen, Türkiye'de kadınların işgücüne katılma oranlarını etkileyen nedenlerin belirlenmesine yönelik ölçek yoluyla yapılmış çalışmalar çok sınırlıdır. Toplumsal cinsiyet eşitliğinin son derece önem kazandığı günümüz açısından kadınların işgücüne katılma oranlarını etkileyen nedenlerin belirlenmesine dönük bir ölçme aracının geliştirilmemiş olması önemli bir eksikliktir. Bu eksikliğin giderilmesi amacıyla kadınların işgücüne katılma oranlarını etkileyen nedenlerin ve çalışma yaşamına katılımlarına yönelik tutumlarının saptanması amacıyla "Kadınların Çalışma Yaşamına Katılımlarına Yönelik Tutum Ölçeği” (KÇYKYTÖ) geliştirilmiştir. Söz konusu ölçeğin maddeleri oluşturulurken, öncelikle genel olarak işgücü, işgücüne katılım ve kadının işgücüne katılımı 
ile ilgili literatür taranarak, yurtdışında ve yurtiçinde konuyla ilgili yapılan alan araştırmaları ve kadınların çalışma yaşamına katılımları konusunda geliştirilen ölçekler gözden geçirilmiştir. Alana ilişkin yapılan literatür taramaları sonucunda 18 tutum maddesi yazılmıştır. Bu maddelerin yarısının tutum boyutunun olumlu tarafinı, diğer yarısının da tutum boyutunun olumsuz tarafını kapsayan ifadeler olmasına; bilişsel, duyuşsal ve davranışsal ifadeleri içermesine özen gösterilmiştir (Tezbaşaran, 1996). Maddelerin 7'si kadınların işgücüne katılımını etkileyen dışsal faktör ifadelerinden, 5'i kadınların işgücüne katılımını etkileyen içsel faktör ifadelerinden ve 6'sı da kadınlar açısından çalışmanın olumsuzluklarına ilişkin ifadelerden oluşmaktadır.

\subsection{Kadınların Çalışma Yaşamına Katılımlarına Yönelik Tutum Ölçeği’nin Geçerlik ve Güvenirlik Çalışması}

İşücü, işgücüne katılım ve kadının işgücüne katılımı ile ilgili literatürün taranması sonucu hazırlanan tutum ölçeği, dil bakımından bir uzman tarafından incelenmiştir. Kapsam geçerliği açısından ise üniversitelerde görev yapan alan uzmanlarının görüşlerine başvurulmuştur. Alan uzmanlarının görüşleri doğrultusunda, gerekli düzeltmeler yapılarak, kadınların işgücüne katılma oranlarını etkileyen nedenlerin ve çalışma yaşamına katılımlarına yönelik tutumlarının saptanması için geliştirilen veri toplama aracının deneme formu, son şeklini almıştır. Veri toplama aracının geçerlik ve güvenirlik analizinin yapılabilmesi için hazırlanan veri toplama aracı deneme formu, ön deneme grubu olarak çalışma grubu dişında kalan 2010-2011 öğretim yılında Anadolu Üniversitesi İktisadi ve İdari Bilimler Fakültesi’nde okuyan 33 katılımcıya uygulanmıştır.

Araştırmada, tutum maddelerine verilecek tepkiler için 5'li dereceleme tercih edilmiştir. Cevaplayıcılardan ölçekte yer alan her bir tutum ifadesini "kesinlikle katılmıyorum - katılmıyorum - kararsızım - katılıyorum kesinlikle katılıyorum" gibi beş kategoriden biriyle sınıflaması istenmiştir. Her cevaplayıcı için toplam puanın elde edilebilmesi için, en olumlu kategoriye 5 puan, en olumsuz kategoriye 1 puan verilerek toplanan cevaplar 1-5 arasında puanlanmıştır (Turgut, 1977, s.10, 11).

Geliştirilen ölçeği oluşturacak maddelerin belirlenmesi amacıyla söz konusu öğrencilerinden elde edilen veriler üzerinde, her bir maddenin madde-toplam korelâsyonları hesaplanmıştır. Ölçekte yer alacak maddelerin seçiminde madde-toplam korelasyon katsayısının .20 değerinin üzerinde olması ölçütü esas alınmıştır (Tavşancıl ve Keser, 2002, s.87). Ölçekte bulunan maddelerin ayırt ediciliğin değerlendirmek amacıyla yapılan madde analizi sonuçları incelendiğinde; ölçekteki maddelerin 16'sının madde-toplam korelasyonunun .20'nin üzerinde olduğu görülmektedir. Bu bulgu ölçekteki 16 tutum ifadesinin her birinin ayırt edici özelliğe sahip olduğunu göstermektedir. Tüm ölçeğin güvenirlik katsayısı Cronbach $\alpha=.89$ olarak bulunmuştur. Bu değerler, ölçeğin güvenilir olduğunu göstermektedir.

Ön deneme sonucunda maddelerin gayet iyi anlaşıldı $\breve{1}$, ancak çok az sayıda maddenin ifade değişikliği gerektirdiği anlaşılmıştır. İfade değişikliği gerektiren maddeler değiştirilerek veri toplama aracına son şekli verilmiştir.

Ön deneme grubuna uygulanıp son şekli verilen "Kadınların Çalışma Yaşamına Katılımlarına Yönelik Tutum Ölçeği” (KÇYKYTÖ), araştırmaya dâhil edilen Eskişehir il merkezi ile Sarıcakaya ve Seyitgazi ilçesi ve köylerinde ikamet eden 15-64 yaş grubunda yer alan 914 kadına uygulanmıştır. Ancak daha önce değinildiği üzere, 14 anket yönergeye uygun şekilde doldurulmadığından analiz dışında tutulmuştur. Uygulama sonrası, ölçeğin geçerlik ve güvenirliğini test etmek için, analize dâhil edilen 900 kişiden elde edilen veriye veriye üç temel bileşenden oluşan Yapısal Eşitlik Modeli (YEM) uygulanmıştır.

Günümüzde gözlenen değişkenler tarafından ölçülen gizil yapılar arasındaki nedensel ilişkiler ile ilgili olan araştırma problemlerini çözmek için pek çok disiplinde kullanılan YEM'in tarihsel gelişimi incelendiğinde; path (yol) analizi, yapısal model ve ölçüm modellerinin kavramsal sentezi ve genel tahmin süreçleri şeklinde başlıca üç temel bileşeninin bulunduğu görülmektedir (Pek, 1999).

Path analizinin amacı değişkenler arasında varsayılan nedensellik bağlarının önemini ve büyüklüğünü tahmin etmek ve politika çıkarımları yapmaktır. Bu gerekçe ile sonuç ve sebep değişkenleri arasındaki ilişkiler dizisinin belirlenmeye çalışıldığı bu analizde hangi değişkenlerin sebep değişkeni, hangi değişkenin ya da değişkenlerin sonuç değişkeni olarak ele alınması gerektiği önem arz etmektedir (Pek, 1999).

Araştırmanın temel amacı kadınların işgücüne katılımlarını engelleyici dışsal ve içsel faktörler ile çalışmanın kendileri açısından doğurduğu olumsuzluklar gibi değişkenler ile kadınların çalışma yaşamına katılımları arasında nedensel bir ilişki bulunup bulunmadığını araştırmaktır. Bu amaç da, araştırmanın değişkenleri arasında neden-sonuç ilişkisi kurulmasını, başka bir deyişle YEM kurulmasını ve path analizini gerektirmektedir. Bu gerekliliğe uygun olarak açımlayıcı faktör analizi (AFA) çalışmasıyla belirlenen faktör yapıları, ikinci düzey doğrulayıcı faktör analizine (DFA) tabi tutulmuştur.

YEM, iki farklı istatistiksel geleneğin melezi olarak ortaya çıkmıştır. Bu geleneklerden ilki, psikoloji ve psikometri alanlarında gelişen faktör analizidir. Diğer ise, temel olarak ekonometri, daha öncesinde ise genetik alanında eş zamanlı olarak gelişen eşitlik modelidir (Çokluk, Şekercioğlu ve Büyüköztürk, 2010). YEM, gözlenen ve gizil değişkenler arasındaki nedensel ilişkilerin test edilmesinde kullanılan kapsamlı bir istatistiksel tekniktir. Özellikle ekonometri, psikoloji, sosyoloji, pazarlama ve eğitim bilimlerinde değişkenler arasındaki ilişkilerin değerlendirilmesinde ve kuramsal modellerin test edilmesinde kullanılan sistemli bir araçtır. YEM, 
gizil değişkenler seti arasında bir nedensellik yapısının var olduğunu ve gizil değişkenlerin gözlenen değişkenler aracılığıyla ölçülebildiğini varsayar (Yılmaz vd., 2006: 172).

Açımlayıcı Faktör Analizi: AFA, ölçme aracının yapısını aynı yapıyı ya da niteliği ölçen değişkenleri bir araya toplayarak ölçmeyi az sayıda faktör ile açıklamayı amaçlayan bir istatistiksel tekniktir (Büyüköztürk, 2002, s.117). Faktör Analizine çok çeşitli amaçlarla başvurulabilir (Baykul, 2000, s.389). Bu araştırmada Faktör Analizi ölçeğin yapısını belirlemek amacıyla yapılmıştır.

Faktör analizi sonunda elde edilen varyans oranları ne kadar yüksek olursa, ölçeğin faktör yapısı da o kadar güçlü olmaktadır (Gorsuch, 1974; Lee ve Comrey, 1979. Akt. Tavşancıl ve Keser, 2002, s.87). Sosyal bilimlerde \%40 ile \%60 arasında değişen varyans oranları yeterli kabul edilmektedir (Scherer, Wiebe Luther, Adams, 1988. Akt. Tavşancıl ve Keser, 2002, s.87). Aynı yapıyı ölçmeyen maddelerin ayıklanmasında; maddelerin yer aldıkları faktördeki yük değerlerinin yüksek olmasına ve maddelerin tek bir faktörde yüksek, diğer faktörlerde ise düşük yük değerine sahip olmasına dikkat edilerek, maddelerin faktör yüklerinin en az .45 ve tek faktör altında yer alması (maddenin iki ayrı faktör altında yüksek faktör yükü alması durumunda farkın en az .10 olması) ölçütleri (Büyüköztürk, 2002, s.118, 119) esas alınmıştır. Faktör analizinde aynı yapıyı ölçmeyen maddelerin ayıklanmasında; maddelerin yer aldıkları faktördeki yük değerlerinin. 45 ' in üstünde olmasına dikkat edilmiştir. $\mathrm{Bu}$ ölçütlere göre, Temel Bileşenler Analizi Uygulanan 16 maddeden varyansları .40'ın ve faktör yükleri ise .45 'in altında olan 7, 10, 14, 15 ve 16. maddeler ölçekten çıkartılmış ve 11 madde kalmıştır.

Temel Bileşenler Analizi uygulanan 11 madde öz değeri 1.00'dan büyük olan 3 faktör altında toplanmaktadır. Dolayısıyla KÇYKYTÖ en çok 3 faktörlü kabul edilebilir. Üç faktör tarafindan açıklanan toplam varyans \%61.89'dur. Temel Bileşenler Analizine göre birinci faktörün sırasıyla öz değeri 4.52 açıkladığı varyans \%41.04; ikinci faktörün 1.29, \%11.68 ve üçüncü faktörün 1.01, \%9.17'dir. Tablo 7'de görüleceği gibi, maddelerle ilgili olarak tanımlanan üç faktörün ortak varyansları ise, .50 ile .74 arasında değişmektedir. Bu bulgu, analizde önemli faktör olarak belirlenen üç faktörün birlikte maddelerdeki toplam varyansın ve ölçeğe ilişkin varyansın önemli bir kısmını açıkladığını göstermektedir.

Faktör analizinde faktör yük değeri $.45^{\prime}$ 'in üstünde olan maddeler alınmış ve bu ölçüte göre, 11 maddenin birinci faktörde yer aldığı ve birinci faktör yük değerlerinin .45 ile .74 arasında değiştiği gözlenmektedir. Bu durum KÇYKYTÖ’nün genel bir faktöre sahip olduğunu göstermektedir. Temel Bileşenler Analizinde birinci faktörün açıkladığı varyansın \% 41.04 olması da bunun bir göstergesidir.

Ölçekte bulunan maddelerin ayırt ediciliğini değerlendirmek amacıyla yapılan madde analizi sonuçları incelendiğinde madde-toplam korelasyon katsayısı .37 ile .63 arasında değişmektedir. Bu bulgu, 11 tutum ifadesinin her birinin ayırt edici özelliğe sahip olduğunu göstermektedir. Tüm ölçeğin güvenirlik katsayıs1 Cronbach $\alpha=.84$ olarak bulunmuştur. Bu değerler ölçeğin güvenilir olduğunun bir göstergesi olarak yorumlanabilir.

KÇYKYTÖ üç faktörlü olduğu için, faktörlerin kendileriyle yüksek ilişki veren maddeleri bulmaları ve daha kolay yorumlanabilmeleri amacıyla varimax tekniği uygulanarak rotasyon işlemi yapılmıştır (Büyüköztürk, 2002, s.120). KÇYKYTÖ'nün faktör yapılarını incelemek amacıyla uygulanan varimax rotasyon sonucu ölçekteki maddelerin madde-toplam korelasyon katsayıları, temel bileşenler analizi sonuçları ve dört faktördeki yük değerleri Tablo 2'deverilmiştir.

Aynı yapıyı ölçmeyen maddelerin ayıklanmasında; maddelerin yer aldıkları faktördeki yük değerlerinin yüksek olmasına ve maddelerin tek bir faktörde yüksek, diğer faktörlerde ise düşük yük değerine sahip olmasına dikkat edilerek, maddelerin faktör yüklerinin en az .45 ve tek faktör altında yer alması (maddenin iki ayrı faktör altında yüksek faktör yükü alması durumunda farkın en az .10 olması) ölçütleri (Büyüköztürk, 2002, s.118, 119) esas alınmıştır. Ölçekteki tüm maddelerin faktör yüklerinin bu ölçütlere uygun olduğu saptanmış ve ölçekte 11 madde kalmıştır. Ölçekte kalan 11 maddenin faktörlere göre dağlımı Tablo 1'de verilmiştir.

\begin{tabular}{|l|c|}
\hline \multicolumn{1}{|c|}{ Faktörler } & Maddeler \\
\hline 1. Faktör: İşgücüne Katılımı Engelleyici dışsal Faktörler & $4,5,8$ ve 9 \\
\hline 2. Faktör: İşü̈cüne Katılımı Engelleyici İçsel Faktörler & 1,2 ve 3 \\
\hline 3. Faktör: Kadın Açısından Çalışmanın Olumsuzlukları & $6,11,12$ ve 13 \\
\hline
\end{tabular}

Tablo 1. Ölçekte Kalan 11 Maddenin Faktörlere Göre Dă̆llımı

Tablo 2'de görülebileceği üzere, birinci faktörde yer alan dört maddenin faktördeki yük değerleri .65-.78; ikinci faktörde yer alan üç maddenin faktördeki yük değerleri .71-.84; üçüncü faktörde yer alan dört maddenin faktördeki yük değerleri ise .56-.74 arasında değişmektedir. Bu bulgu, ölçeğin birbiriyle yüksek düzeyde ilişkili olan maddelerden oluştuğunu ve kadınların çalışma yaşamına katılımlarına yönelik tutumlar olarak tanımlanan yapıyı ölçtüğünü göstermektedir. Birinci faktör ölçeğe ilişkin toplam varyansın \%41.04'ünü, ikinci faktör \%11.68'ini ve üçüncü faktör ise \%9.17'sini açıklamaktadır. Üç faktör tarafından açıklanan toplam varyans \%61.89'dur. Üç faktörün maddelerde açıkladıkları ortak varyans ise, .47-.74 arasında değişmektedir. Bu bulgular, ölçeğin faktör yapısının güçlü olduğunu göstermektedir. 
Faktörler, maddelerin içerdiği anlamlar dikkate alınarak adlandırılmaya çalışılmıştır. Birinci faktöre, "İşgücüne Katılımı Engelleyici dışsal Faktörler”; ikinci faktöre, "İşgücüne Katılımı Engelleyici içsel Faktörler" ve üçüncü faktöre ise, "Kadın Açısından Çalışmanın Olumsuzlukları" adı verilmiştir.

\begin{tabular}{|c|c|c|c|c|c|c|c|}
\hline \multirow[b]{2}{*}{ 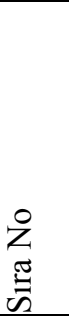 } & \multirow[b]{2}{*}{$\begin{array}{l}0 \\
z \\
0 \\
\frac{0}{0} \\
\sum^{\pi}\end{array}$} & \multirow[b]{2}{*}{ 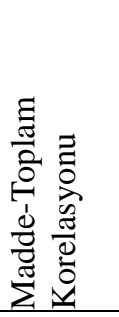 } & \multirow{2}{*}{ 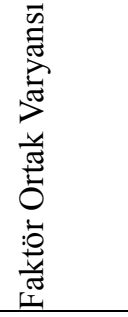 } & \multirow{2}{*}{ 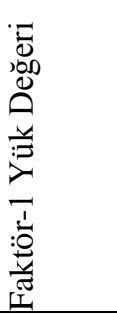 } & \multicolumn{3}{|c|}{ Rotasyon Sonrası Yük Değeri } \\
\hline & & & & & Faktör-1 & Faktör-2 & Faktör-3 \\
\hline 1 & M1 & .53 & 74 & .65 & .21 & .83 & .10 \\
\hline 2 & M2 & .46 & .73 & .59 & .10 & .84 & .10 \\
\hline 3 & M3 & .63 & .67 & .74 & .32 & .71 & .26 \\
\hline 4 & M4 & .55 & .65 & .65 & .76 & .27 & .07 \\
\hline 5 & M5 & .55 & .66 & .65 & .78 & .17 & .13 \\
\hline 6 & M6 & .59 & .53 & .68 & .22 & .41 & .56 \\
\hline 7 & M8 & .60 & .60 & .71 & .65 & .17 & .37 \\
\hline 8 & M9 & .60 & .63 & .70 & .68 & .10 & .40 \\
\hline 9 & M11 & .47 & .51 & .58 & .18 & .14 & .68 \\
\hline 10 & M12 & .55 & .62 & .63 & .14 & .24 & .74 \\
\hline 11 & M13 & .37 & .47 & .45 & .16 & -.04 & .67 \\
\hline
\end{tabular}

Açıklanan Varyans

Toplam $=\% 61.89$

Faktör-1 = \% 41.04

Faktör-2 = \% 11.68

Faktör-3 = \% 9.17

Cronbach $\alpha=.84$

Tablo 2. Varimax Rotasyon Sonucu Ölçekteki Maddelerin Madde-Toplam Korelasyon Katsayılarl, Temel Bileşenler Analizi Sonuçları ve Ü̧̧ Faktördeki Yük Değerleri

Ölçekte bulunan maddelerin ayırt ediciliğini değerlendirmek amacıyla yapılan madde analizi sonuçları incelendiğinde, madde-toplam korelasyonlarının .37 ile .63 arasında yüksek düzeyde olduğu görülmektedir. Bu bulgu, 11 tutum ifadesinin her birinin ayırt edici özelliğe sahip olduğunu göstermektedir. Tüm ölçeğin güvenirlik katsayısı Cronbach $\alpha=.84$ olarak bulunmuştur. "İşgücüne Katılımı Engelleyici Dışsal Faktörler” olarak adlandırılan birinci faktörde bulunan maddelerin ayırt ediciliğini değerlendirmek amacıyla yapılan madde analizi sonuçları incelendiğinde, her madde için hesaplanan madde-toplam korelasyon katsayısı .56-.63 arasında değişmektedir. Birinci faktörün güvenirlik katsayısı Cronbach $\alpha=.79$ 'dur. "İşgücüne Katılımı Engelleyici İçsel Faktörler" olarak adlandırılan ikinci faktörde bulunan maddelerin ayırt ediciliğini değerlendirmek amacıyla yapılan madde analizi sonuçları incelendiğinde ise, her madde için hesaplanan madde-toplam korelasyon katsayısı .63-.67 arasında değişmektedir. İkinci faktörün güvenirlik katsayısı Cronbach $\alpha=.79$ 'dur. "Kadın Açısından Çalışmanın Olumsuzlukları" olarak adlandırılan üçüncü faktörde bulunan maddelerin ayırt ediciliğini değerlendirmek amacıyla yapılan madde analizi sonuçları incelendiğinde, her madde için hesaplanan maddetoplam korelasyon katsayısı .38-.54 arasında değişmektedir. Üçüncü faktörün güvenirlik katsayısı Cronbach $\alpha=.69$ 'dur. Bu değerler ölçeğin güvenilir olduğunun bir göstergesi olarak yorumlanabilir.

Doğrulayıcı Faktör Analizi: Daha önce değinildiği üzere, AFA çalışmasılyla belirlenmiş olan faktör yapılları, DFA'ya tabi tutulmuştur. Ancak DFA uygulamasına geçmeden önce, belirlenen faktör yapıları doğrultusunda, KÇYKYTÖ'nün geçerlik ve güvenirlik analizlerinin yapılabilmesi ve kadınların çalışma yaşamına katılımlarının üç gizil değişkeni ne ölçüde açıkladığının saptanabilmesi için öncelikle bir YEM modeli tanımlanmıştır. Kadınların çalışma yaşamına katılımları ile işgücüne katılımı engelleyici dışsal faktörler, işgücüne katılımı engelleyici içsel faktörler ve kadın açısından çalışmanın olumsuzlukları arasındaki ilişkiyi açıklayan model Şekil 1 'de gösterilmiştir.

Şekil 1'de görülebileceği üzere, önerilen YEM'de değişkenler arasında tek yönlü oklarla gösterilen yollar, aslında araştırmanın hipotezleridir. Buna göre kadınların işgücüne katılımı engelleyici dışsal ve içsel faktörler ile kadın açısından çalışmanın olumsuzlukları gibi değişkenler kadınların çalışma yaşamına katılımını etkiler. Modelde kadınların çalışma yaşamına katılımını etkileyeceği öngörülen söz konusu değişkenler bağımsız gizil değişkenler, kadınların çalışma yaşamına katılımı ise bağımlı gizil değişken olarak tasarlanmıştır.

KÇYKYTÖ’nün geçerlik ve güvenirlik analizlerinin yapılabilmesi ve kadınların çalışma yaşamına katılımlarının üç gizil değişkeni ne ölçüde açıkladığının belirlenebilmesi, başka bir deyişle kadınların çalışma 
yaşamına katılımı ile üç gizil değişken arasındaki ilişkinin incelenebilmesi için veri grubuna ikinci düzey DFA uygulanmış ve KCYKYTÖ ölçeği için yol şeması Şekil 1 'de gösterilmiştir.

KÇYKYTÖ’nün üç boyutlu modeli için gizil değişkenlerin gözlenen değişkenleri açıklama oranlarının anlamlılık düzeyleri ise Şekil 3'te gösterilmiştir. Şekil 2 ve Şekil 3 'te görülebileceği üzere veri grubuna uygulanan DFA sonuçları Tablo 3'te de gösterilmiştir.

Toplanan verilerin LISREL'de ikinci düzey doğrulayıcı faktör analizi sonuçlarına göre, öncelikle gözlenen değişkenlerin $\mathrm{t}$ değerlerinin anlamlılık düzeyi kontrol edilmiştir. $t$ değeri 1.96'dan büyük ise, .05 düzeyinde, 2.56 'dan büyük ise .01 düzeyinde anlamlıdır. DFA sonuçlarına göre, t değerlerinin 2.56'dan büyük olduğu saptanmıştır. Bu sonuca göre, gizil değişkenlerin gözlenen değişkeni açıklama durumlarına ilişkin t değerleri. 01 düzeyinde anlamlı bulunmuştur. DFA sonuçlarına göre, t değerlerinin anlamlı olduğu saptandıktan sonra, ayrıca değişkenlerin hata varyansları da incelenmiştir. Şekil 3'te görülebileceği üzere, değişkenlerin hata varyanslarının düşük düzeyde olduğu saptanmıştır. Dolayısıyla bu modelde tüm maddeler için anlamlı $\mathrm{t}$ değerlerinin elde edilmesi nedeniyle tüm göstergelerin bu model içerisinde yer alması yönünde karar verilmiştir.

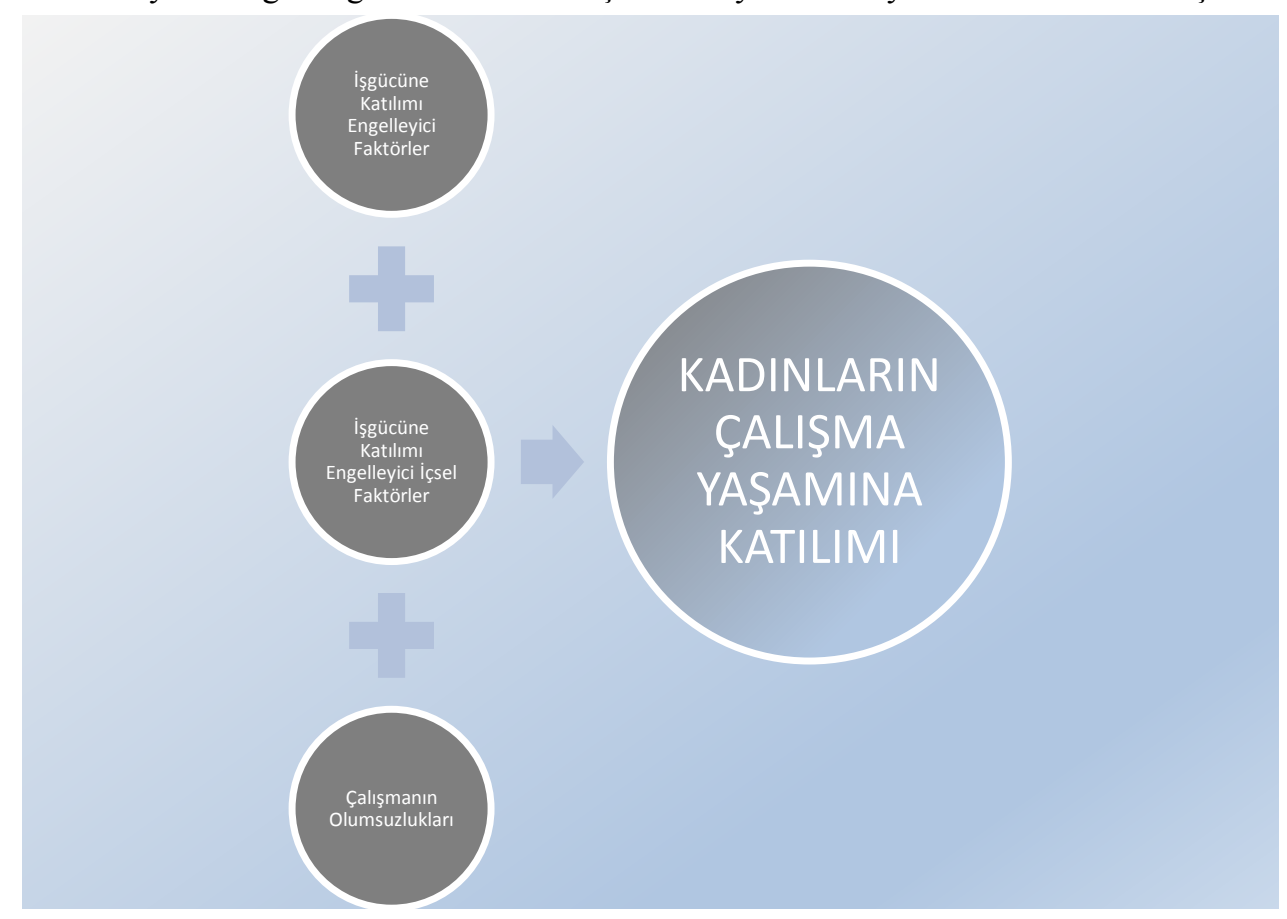

Şekil 1. Önerilen Model

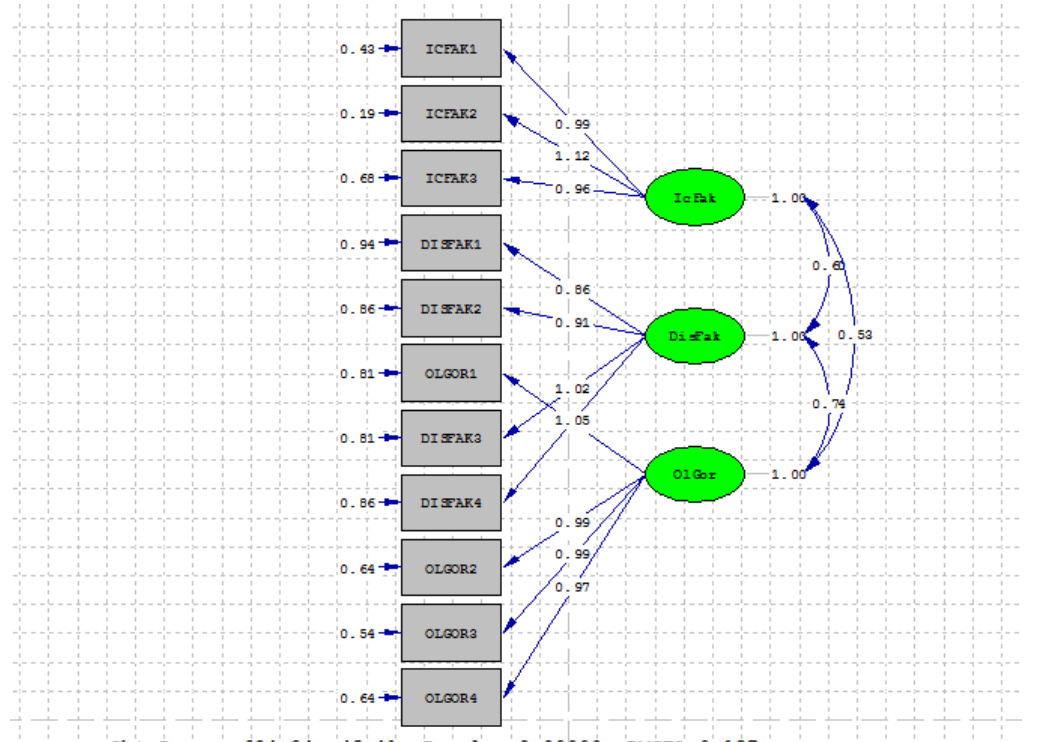

Chi-Square $=634.34, d f=41, \quad \mathrm{p}$-value $=0.00000, \quad$ RMSEA $=0.127$ 


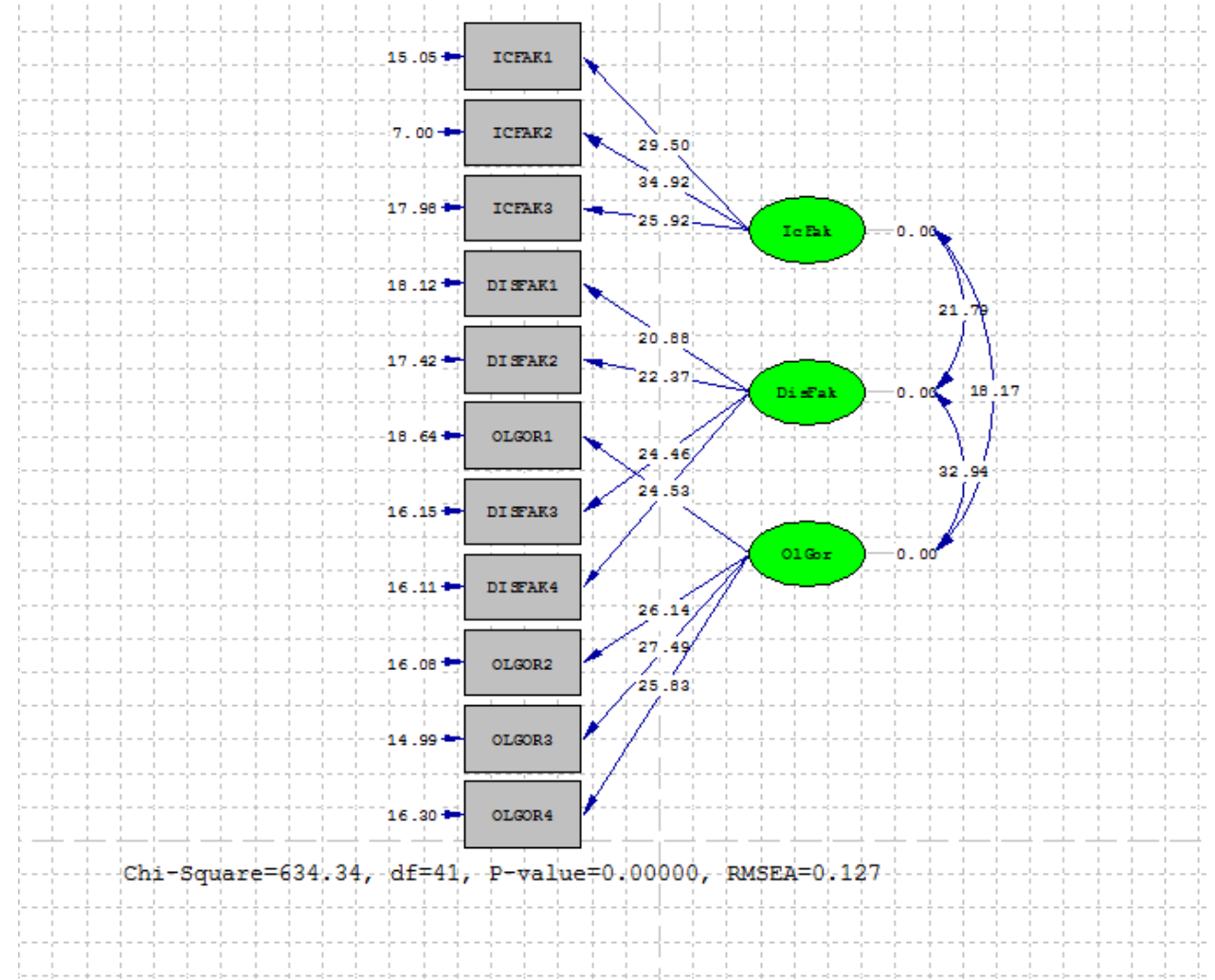

Şekil 3. Ölçeğin Ü̧̧ Boyutlu Modeli İ̧̧in Gizil Değişkenlerin Gözlenen Değişkenleri Açıklama Oranlarının Anlamllllk Düzeyleri

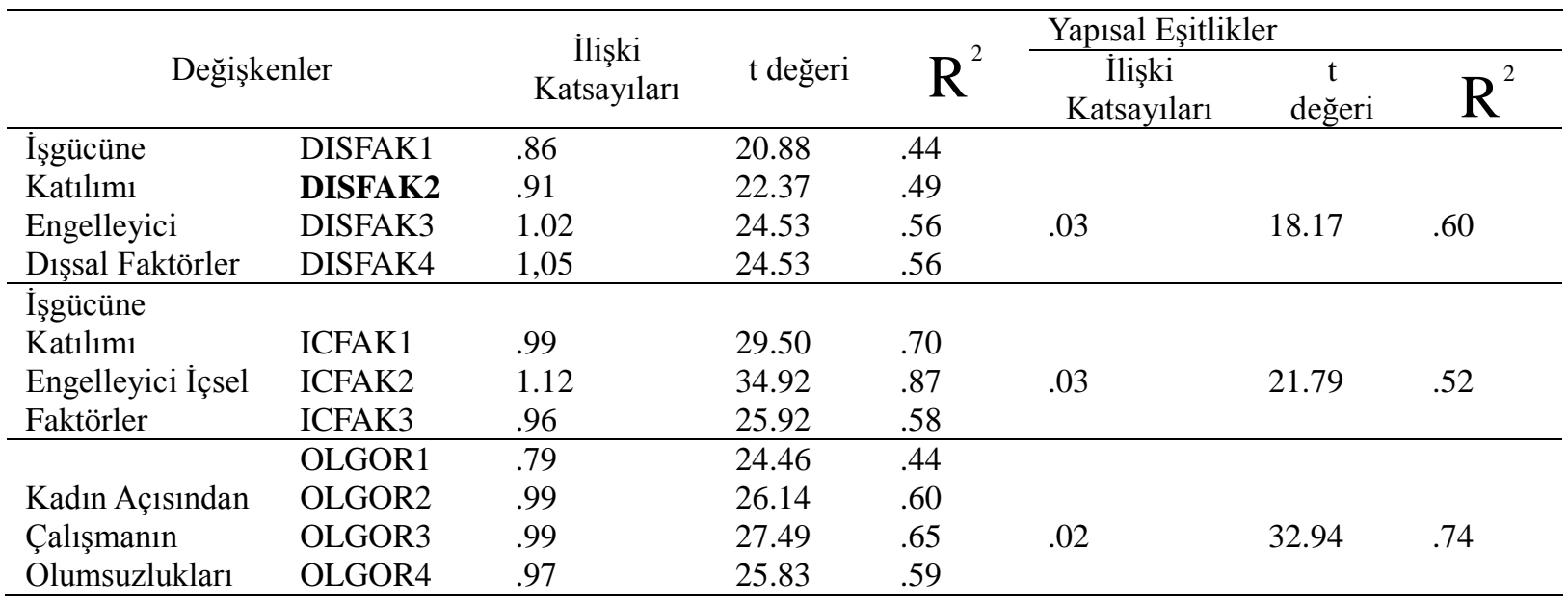

Tablo 3. İkinci Düzey DFA Sonuçları

İkinci düzey doğrulayıcı faktör analizi sonuçlarına göre, hangi göstergelerin tanımlanan model içerisinde yer alması gerektiğine karar verildikten sonra, uyum ölçütleri göz önüne alınarak modelin uygunluğu tartışılmıştır.

Modelin uygunluğu açısından öncelikle p değeri kontrol edilmiştir. $p$ değerinin anlamlı olmaması arzu edilen bir durum olmasına rağmen, Şekil 3’teki gibi doğrulayıcı faktör analizinde örneklemin büyüklüğüne bağgl olarak p değeri anlamlı çıkmaktadır. Bu nedenle alternatif uyum endeksleri değerlendirmeye alınmaktadır. Bu uyum endekslerinden ilki ki-kare istatistiği $\left(\chi^{2}\right)$ 'dir. Ancak $\chi^{2}$, tek başına değerlendirilen bir istatistik değildir. Bu nedenle serbestlik derecesi (sd) ile oranlanarak değerlendirmeye alınır. $\chi^{2} /$ sd oranı 3 'ten küçük ise, uyum mükemmel; 5'in altında ise uyum kabul edilebilir düzeydedir. Buna göre, yapılan analiz için $\chi^{2} /$ sd oranının (634.34 / 41 = 15.46) düşük düzeyde uyum değeri verdiği ifade edilebilir. 


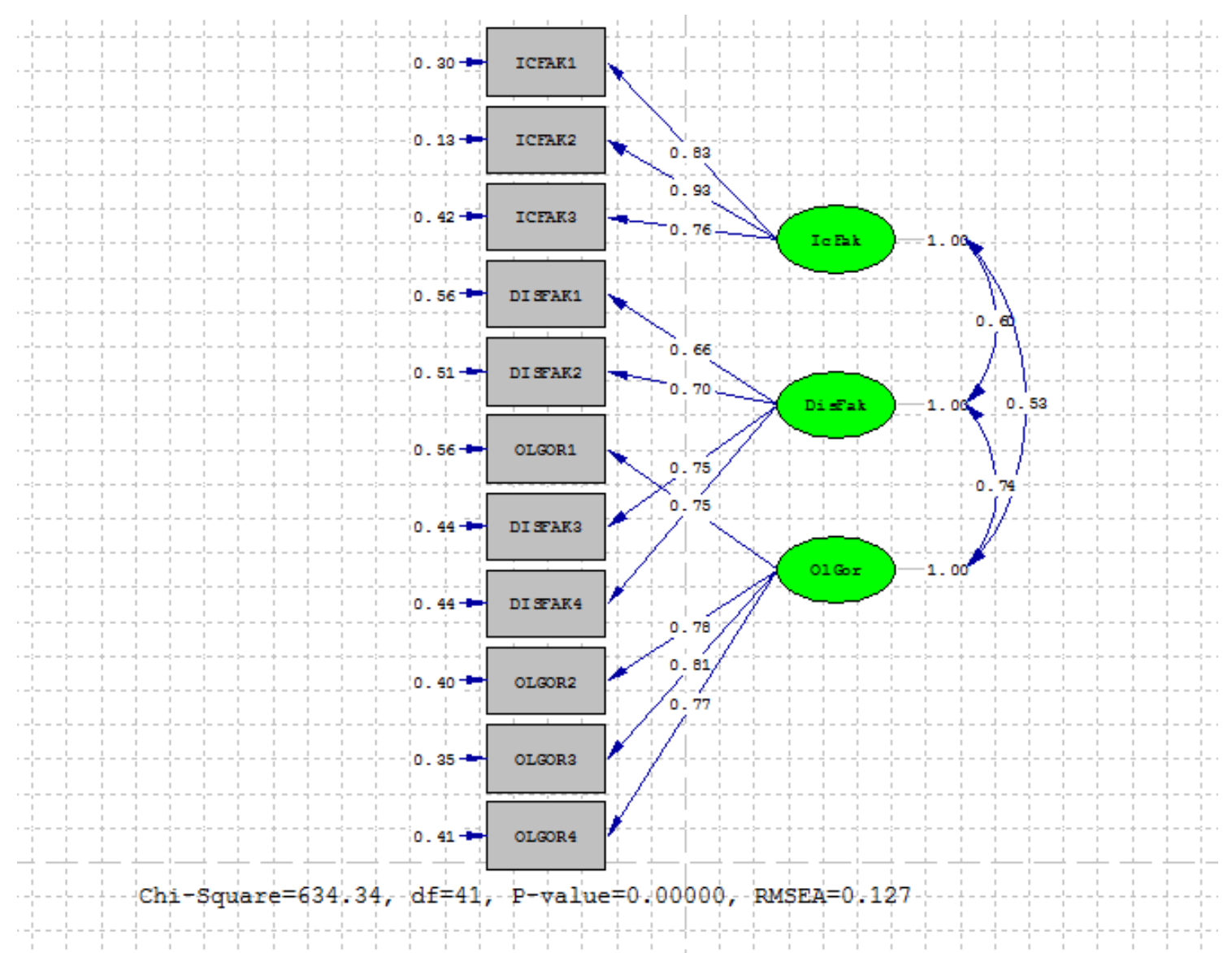

Şekil 4. Yol Şemasında Hata Varyanslarının İncelenmesi

Yaklaşık Hataların Ortalama Karekökü (RMSEA) incelendiğinde ise, .13 düzeyinde bir uyum endeksi elde edildiği görülmektedir. RMSEA'nın aldığı değer 05'e eşit veya daha küçük ise uyum mükemmel, .08 ve altında ise uyum kabul edilebilir ve .10 ve daha büyük ise uyum zayıftır. Buna göre yapılan analiz için elde edilen uyum endeksinin zayıf olduğu söylenebilir.

Uyum endekslerinin incelenmesine devam edildiğinde, İyilik Uyum İndeksi $(\mathrm{GFI})=.89$ ve Düzenlenmiş İyilik Uyum Endeksi (AGFI)'nin .82 olduğu görülmektedir. GFI ve AGFI, 0-1 aralığında değişen değerler alır. GFI ve AGFI değeri .95 ve üzerinde ise uyum mükemmel, .90-.94 arasında ise uyum kabul edilebilirdir (Schumacker ve Lomax 2004; Hooper, Caughlan ve Mullen, 2008). Buna göre, GFI'nın kabul edilebilir düzeye yakın bir uyum değeri verdiği, buna karşın AGFI'nın kabul edilebilir düzeyde uyum değeri vermediği söylenebilir.

Standardize edilmiş Artık Ortalamaların Karekökü (RMR) endeksinin .07 olduğu görülmektedir. RMR ve standardize edilmiş RMR'nin .05'in altında olması mükemmel uyuma, .08'in altında olması iyi uyuma ve .10'un altında olması ise kabul edilebilir uyuma karşılık gelmektedir. Buna göre, yapılan analiz için standardize edilmiş RMR'nin iyi bir uyuma sahip olduğu ifade edilebilir.

Normlaştırılmamış Uyum İndeksi (NNFI) ve Karşılaştırmalı Uyum İndeksi (CFI) incelendiğinde, NNFI'nın .86 ve CFI'ın .90 olduğu görülmektedir. NNFI ve CFI değerleri .95 'in üzerinde ise uyum mükemmel, .90'ın üzerinde ise uyum kabul edilebilirdir (Sümer, 2000). Buna göre, yapılan analiz için NNFI'nın kabul edilebilire yakın düzeyde bir uyum değeri verdiği ve CFI'ın ise kabul edilebilir düzeye yakın bir uyum değeri verdiği söylenebilir.

İkinci düzey doğrulayıcı faktör analizi sonuçlarına göre modelin uygunluğunu ilişkin yapılan değerlendirmelerin ardından modifikasyon önerileri incelenmiştir. Yapılan incelemede yedi modifikasyon önerisi olduğu görülmektedir. Yapılan modifikasyonlar sonucunda 634.34 olan $\chi^{2}$, 120.01'e düşmüştür.

Modifikasyon sonrası $\chi^{2} / \operatorname{sd}(120.01 / 33)$ oranı 3.64 bulunmuştur. Bu oranın 5'in altında olması nedeniyle uyumun kabul edilebilir olduğu ifade edilebilir. Yol şemasındaki RMSEA incelendiğinde ise, .054 düzeyinde bir uyum endeksi elde edilmiştir. RMSE'nın .08'den küçük olması nedeniyle uyum iyi olarak değerlendirilebilir.

Modifikasyondan sonra elde edilen uyum endeksleri incelendiğinde, NFI (.98), NNFI (.97) ve CFI (.98) değerlerinin .95 'in üzerinde olmasının ve standardize edilmiş RMR değerinin ise .05'in altında olmasının mükemmel bir uyuma karşılık geldiği söylenebilir. GFI değerinin .98 olmasının mükemmel bir uyuma ve AGFI değerinin .94 arasında olmasının ise kabul edilebilir bir uyuma karşılık geldiği ifade edilebilir. 


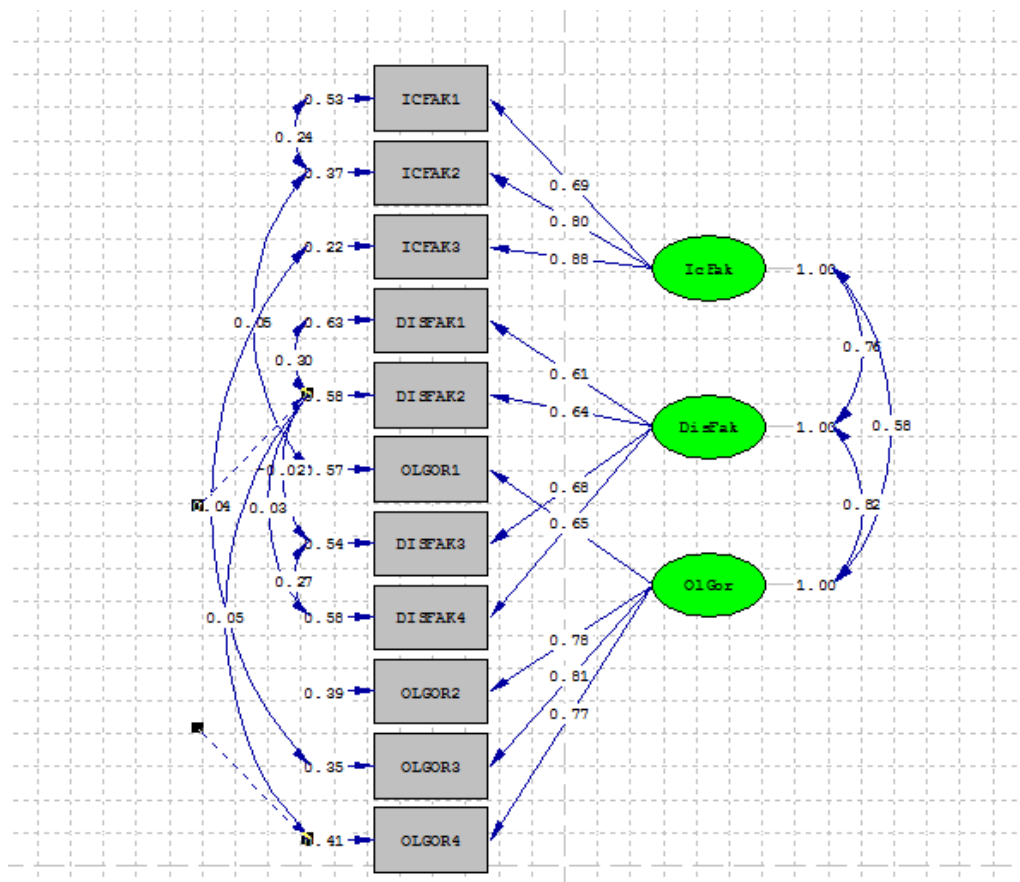

Chi-Square $=120.01, \mathrm{df}=33, \mathrm{P}$-value $=0.00000, \mathrm{RMSEA}=0.054$

Şekil 5. Modifikasyonun Yapılmasının Ardından Elde Edilen Yol Şeması

\section{Sonuç}

Araştırma bulguları, KÇYKYTÖ’nün 11 maddeden oluşan üç faktörlü yapısının bir model olarak doğrulandığını; işgücüne katılımı engelleyen dışsal faktörler, işgücüne katılımı engelleyen içsel faktörler ve çalışmanın olumsuzlukları ile çalışma yaşamına katılım arasındaki ilişkiyi açıklamak için geliştirilen modelin uygunluğunu ortaya koymaktadır. Geliştirilen modelin uyum endeksleri, modelin reddedilmediğini gösterdiğinden güvenirliğin delili olarak sunulabilir. DFA sonuçlarına göre tüm standardize parametre değerleri .50'den büyüktür. Dolayısıyla tüm yapılar birleşme geçerliliğine sahiptir (Chou, Boldy ve Lee, 2002: 52).

Araştırma kapsamında elde edilen sonuçlar, ölçeğin çalışma grubundan elde edilen veriler için geçerli ve güvenilir olduğunu göstermektedir. Bu araştırmanın kapsamadığı, farklı illerde yaşayan kadınlar bakımından güvenirlik ve geçerlik çalışmalarının yinelenmesi ve yapılan analizlerin karşılaștırılması özellikle faktör yapı geçerliğini belirlenebilmesi açısından önemlidir. Bu bakımdan "Kadınların Çalışma Yaşamına Katılımlarına Yönelik Tutum Ölçeği” (KÇYKYTÖ) kullanılarak araştırmalar yapılmalı ve elde edilen sonuçlar bu araştırmanın sonuçları ile karşılaştırılmalıdır.

$\mathrm{Bu}$ araştırmada geliştirilen "Kadınların Çalışma Yaşamına Katılımlarına Yönelik Tutum Ölçeği (KÇYKYTÖ)"nin, kadınlar dışında işgücüne katılım oranlarını etkileyen nedenlerin belirlenmesi amacıyla kullanılabilmesi de mümkündür.

\section{Teşekkür}

Bu çalışma, Anadolu Üniversitesinin 1006E125 nolu BAP projesi için araştırmacı olarak yaptığım bir ölçek geliştirme çalışmasıdır.

\section{Kaynakça}

- $\quad$ Baykul, Y. (2000). Eğitimde ve Psikolojide Ölçme: Klasik Test Teorisi ve Uygulaması, Ankara: ÖSYM Yayınları.

- Büyüköztürk, Şener (2002), Veri Analizi El Kitabı (1. Bask1), Ankara: Pegem A Yayıncılık.

- Chou S. C., Boldy D. P. ve Lee A. H. (2002), Measuring Job Satisfaction in Residential Aged Care, International Journal for Health Care, 14(1), 49-54.

- Çokluk, Ö., Şekercioğlu, G. ve Büyüköztürk, Ş. (2010), Sosyal Bilimler İçin Çok Değişkenli İstatistik SPP ve LISREL Uygulamaları (1. Baskı), Ankara: Pegem A Yayıncılık.

- Doğrul, G.(2008). 2001 Krizi Sonrasında Türkiye’de Kentsel Alanlarda Kadınların İşgücüne Katılımının Belirleyicileri, Dumlupınar Üniversitesi Sosyal Bilimler Dergisi, 22, 1-35.

- $\quad$ Gorsuch, R. L. (1974). Factor Analysis. Philadelphia: Saunders. 
- Hooper, D., Caughlan, J. ve Mullen, M. R. (2008), Structural Equation Modeling: Guidelines for Determining Model Fit, Electronic Journal Of Business Research Methods, 6 (1), 53-60. http://arrow.dit.ie/cgi/viewcontent.cgi?article=1001\&context=buschmanart, (Erişim Tarihi: 08.01.2011).

- Karasar, N., (2000). Bilimsel Araştırma Yöntemi. 10. Baskı. Ankara: Nobel Yayın ve Dağıtım.

- Lee, H. B. ve Comrey, A. L. (1979). Distortions in a commonly used factor analytic procedure, Multivariate Behavioral Research, 14, 301-321.

- $\quad$ Pek, H. (1999). Nedensel Modeller, Ankara: Gazi Üniversitesi Fen Bilimleri Enstitüsü, Yayımlanmamış Yüksek Lisans Tezi.

- $\quad$ Scherer, R. F., Wiebe, F. A., Luther, D. C., ve Adams J. S. (1988), Dimensionality of Coping: Factor Stability Using the Ways of Coping Questionnaire, Psychological Reports, 62, 763-770.

- $\quad$ Schumacker R. E. ve Lomax R G. (2004), A Beginner's Guide to Structural Equation Modeling (second edition), Londra: Lawrence Erlbaum Associates Publishers, 79-122.

- Sümer, N., (2000), Yapısal Eşitlik Modelleri: Temel Kavramlar ve Örnek Uygulama, Türk Psikoloji Yazıları, 3 (6), 49-73.

- Şimşek, M. (2008). Küreselleşen Dünyada Kadının Ekonomik Konumu, Ekin Basın Yayın Dağıtım: Bursa.

- Tansel, A. (2002). İktisadi Kalkınma ve Kadınların İşgücüne Katılımı: Türkiye’den Zaman Serisi Kanıtları ve İllere Göre Yatay Kesit Kestirimleri, ERC Working Papers in Economics, 1-31, 01/057, http://www.erc.metu.edu.tr/menu/series01/0105T.pdf, (Erişim Tarihi: 09.11.2009).

- Tavşancıl, E. ve Keser, H. (2002). İnternet Kullanımına Yönelik Likert Tipi Bir Tutum Ölçeğinin Geliştirilmesi, Eğitim Bilimleri Dergisi, 1(1), 79-100.

- $\quad$ Turgut, M. F. (1977). Tutumların Ölçülmesi, Eğitimde Ölçme Teknikleri Ders Notu. No:7.

- TÜSİAD (2008). Türkiye'de Toplumsal Cinsiyet Eşitsizliği: Sorunlar, Öncelikler ve Çözüm Önerileri, TÜSİAD-T/2008-07/468: İstanbul.

- Y Yılmaz, V. - Çelik, H. E. ve Ekiz, E. H. (2006). Kuruma Bağlılığı Etkileyen Faktörlerin Yapısal Eşitlik Modelleriyle Araştırılması: Özel ve Devlet Bankası Örneği, Anadolu Üniversitesi Sosyal Bilimler Enstitüsü Dergisi, 2, 171-183. 


\title{
Kırgızistan ve Avrasya Gümrük Birliği
}

\section{Kyrgyzstan and Eurasian Customs Union}

\author{
Mrs. Aigul Turdubekova (Istanbul University, Turkey) \\ Mrs. Elmira Kupsuralieva (Kyrgyzstan-Turkey Manas University, Kyrgyzstan)
}

\begin{abstract}
This paper looks at the issue of joining the Eurasian Customs Union for Kyrgyzstan. We first provide a short description of how some former Soviet Union countries attempted to rejuvenate their regional integration followed by the review of the economic, social and political background of Kyrgyzstan in joining the Eurasian Customs Union. The main conditions for and the associated impact of joining the Union on customs tariffs and the international trade of Kyrgyzstan are discussed. By comparing the main development indicators of the Customs Union member countries we try to find any advantages for the Kyrgyz economy from joining the Union. An additional discussion of the potential losses and benefits shows that there are more benefits from joining the Customs Union. In general, we find that since the founders of the Customs Union - Russia and Kazakhstan - are also very important geographical, economic and political partners of our country, joining the Union seems inevitable for Kyrgyzstan.
\end{abstract}

\section{Giriş}

Günümüzdeki dünya ekonomisinin giderek bir bütün haline geldiği koşullarda ülkeler birbirleriyle karşılıklı ilişkiler kurmadan ve entegre olmadan gelişmeleri mümkün değildir. Özellikle de 1990'lardaki Doğu Bloku ve Sovyet Sosyalist Cumhuriyetler Birliğinin dağılıp serbest piyasa ekonimisini benimsemeleri ile dünya ülkeleri arasındaki sıkı ekonomik ve siyasi ilişkiler de hızla artarak küreselleşme ve bölgesel entegrasyon olguları daha da önemli hale gelmiştir.

Yeni dağılan eski sövyet ülkelerinin her biri bağımsız bir ülke olarak kendine en uygun gördüğü yollarla piyasa ekonomisine geçiş sürecini başlatmalarına rağmen birbirleriyle olan önceki bağları bir şekilde koruma eğiliminde bulundular. Böylece başlangıçta Sovyetler Birliğinin dağılmasının kolay ve sorunsuz geçmesi için kurulan Birleşik Devletler Topluluğunun amacı giderek değişerek bölge ülkeleri arasında ekonomik ve siyasi bütünleşme ile dünya arenasında iyi bir konuma sahip olma çabası ön plana çıktı. İşte Rusya Federasyonu, Kazakistan ve Belorusya'nın kurduğu Avrasya Gümrük Birliği de bu eğilimin bir sonucudur.

Günümüzde Kırgızistan da Avrasya Gümrük Birliği'ne üye olma aşamasındadır. Ancak bu konu hem Kırgız hem de Gümrük Birliği araştırmacıları tarafından çok yönlü tartışmalara yol açarak hala sonucunun nasıl olacağı bilinmeyen bir gelişme olarak nitelendirilmektedir. İşte biz de bu çalışmamızda Kırgızistan'ın bu bölgesel entegrasyon süreci içindeki yerini ve rolünü belirtmeye ve Avrasya Gümrük Birliği'ne üye olmasının yararlarını ve kaybedebilecek yönleriyle zararlarını tartışmaya çalışacağız.

\section{Kıgızistan'ın Genel Ekonomik, Siyasi ve Sosyal Durumu}

Kırgızistan 1991'de bağımsızlığını ilan etmesiyle hem demokratik rejime geçmede, hem de refomları uygulamada kararlılık yönünden bölgede en aktif ülkelerden biri oldu. 1998'de ise uluslararsı ilişkileri kurma açısından da bölgede ayrıcalık göstererek Dünya Ticaret Örgütüne(DTÖ) üye olan ilk ülke oldu. Ancak diğer BDT ülkelerinden farklı olarak Kırgızistan yüzölçümünün, nüfusunun ve doğal kaynaklarının çok az olmasının yanında ne yazık ki bağımsızlığını kazandığından beri siyasi açıdan da devrimlerin en çok ve sık yapıldığı istikrarsız bir ülke olarak tanındı.

Eski sovyet dönemindeki üretim ağlarının kopmasıyla büyük fabrikaların kapatılması, tarım sektörünün ön plana çıkması ve sanayi sektörünün gelişimi için sermayenin yetersizliği işsizlik sorununu ön plana çıkardı. 5,6 milyon kişilik nüfusu ve 1158 dolar kişi başına düşen GSYİH'sı ile dünya ülkeleri arasında 149.sırada yer alması da (BDT ülkeleri arasında Tacikistan'dan önceki en son sıradadır) işsizlik sorununu daha da derinleştirerek işgücünün komşu ülkelere (Rusya ve Kazakistan'a) ve bölge dışındaki başka gelişmiş ülkelere göç etmesine sebep oldu. Doğal kaynakları açısından hidroelektrik, altın ve değerli madenler rezervlerine zengin olmasına karşın bunları işletmek ve üretmek için verimli yatırımlara ihtiyacı vardır. Böylece, Sovyetler döneminde tarımsal-endüstriyel olan Kırgızistan günümüzde tarımsal-hizmet ülkesi olarak eskideki ihracatçı ülkeden ithalatçı ülkeye dönüşmüştür. 2012 yılı verilerine baktığımızda ülkenin ticaret yapısında ihracatın payı \%19,5 oran iken, ithalatın payı \%80,5 olarak dış ticaret dengesi açık gösterdiği ve bu açığın Ocak-Nisan ayları aralığında 1287,4 milyon dolar olarak gerçekleştiği bilinmektedir. Ancak bunun yanında belirtmemiz gerekir ki Kırgızistan dışa açık ekonomiye sahiptir ve dış ticaret dengesinin GSYİH’ya oranı \%110 cıvarındadır. Bu yüzden de diş ekonomik partnerlerinin ekonomisindeki herhangi bir değişiklikler hemen ülkenin ekonomisini de doğrudan etkiler. Özellikle komşu BDT ülkelerine (özellikle Rusya ve Kazakistan) olan cografi yakınlık ve 
teknolojik bağımlılığı dolayısıyla bugünlere kadar bu ülkelerle sıkı ilişkilerini sürdürtmektedir. Fakat bunun yanında BDT dışı diğer ülkelerle olan ticari ilişkileri de önemlidir. Dış ticaret açığını kapatmak için ihracatı artırmak ve hammaddeye yönelik üretimden sanayi üretimine geçmek için yabancı sermayeleri çekmek gereklidir. Kırgızistan ekonomisisnin diğer önemli sorunu da dış borçlardır. 2010 yılında 2,62 milyar dolar olan dış borç, 2012 yılında da 3,3 milyar dolara ulaşarak GSYİH’yı \%46 oranında aşmıştır.

\begin{tabular}{|l|l|l|l|l|l|}
\hline & 1991 & 1995 & 2000 & 2005 & 2011 \\
\hline GSYİH (Milyon Som) & 92,6 & 16145,1 & 65357,9 & 100899,2 & 273107,8 \\
\hline GSYİH (milyon dolar) & 1,97 & 343,51 & 1370,59 & 2146,79 & 5810,80 \\
\hline Sanayi Üretimi (milyon dolar) & 1,67 & 158,36 & 881,01 & 1089,71 & 2827,24 \\
\hline Tarım Sektörü Üretimi (milyon dolar) & 1.02 & 216,40 & 911.07 & 1348,5 & 3135,05 \\
\hline Kişi Başına Asgari Geçim (1 ay için dolarla) & $\ldots$ & 7,59 & 26.28 & 39,92 & $74,52^{* *}$ \\
\hline Tüketici Fiyat İndeksi. Yillı Artış1 (\%) & $21.3^{*}$ & 132,1 & 109,6 & 104,9 & $119,2^{* *}$ \\
\hline Kayıtlı İşsiz sayısı (bin kişi) & 0,1 & 50,4 & 58,3 & 68,0 & 61,1 \\
\hline Sabit Sermaye Yatırımları (milyon dolar) & 0,3 & 76,69 & 241,22 & 257,65 & 1019,34 \\
\hline Diş Ticaret (milyon dolar) & $737,4^{*}$ & 934,4 & 1069,0 & 1862,7 & 5576,3 \\
\hline İhracat & $317,0^{*}$ & 412,0 & 510,9 & 674,0 & 1794,6 \\
\hline İthalat & $420,7^{*}$ & 522,4 & 558,1 & 1188,7 & 3781,7 \\
\hline
\end{tabular}

Tablo 1: Kırgızistan Cumhuriyetinin Genel Ekonomik Göstergeleri

Yukarıdaki tablodan görüldüğü gibi eski sovyet dönemindeki üretim ağlarının kopmasıyla büyük fabrikaların kapatılması, tarım sektörünün ön plana çıkması ve sanayi sektörünün gelişimi için sermayenin yetersizliği işsizlik sorununu ön plana çıkarmıştır. Tarımın en önemli can damarı olan sulak arazilerde buğday, pamuk, kenevir, tütün, yağlı tohumlar, şeker pancarı, üzüm, mısır gibi muhtelif meyveler ve sebzeler yetiştirilmesi de önemli bir imkândır. Çalışan nüfusun \%34'ü tarım ve ormancılık alanlarında istihdam edilmektedir. Tarımın iklim ve benzeri etkilere çok açık olması dönemlik dalgalanmaları da beraberinde getirmektedir. Ancak Bağımsılık sonrası Kırgızistan Cumhuriyeti'nin reform politikalarından biri de tarım arazilerini köydeki kayıtlı aile ferlerine bölmesinin doğru bir politika olduğunu da söylemeliyiz. Çünkü günümüzde tarıma dayalı bir ekonomi olarak nitelendirilmesine rağmen tarımın ülke nüfüsunun yarısına yakınını geçindirmesi ve komşu Kazakistan ve Rusya ülkeleri açısından avantaja sahip olmasına sebep olduğunu inkar edemeyiz.

\section{Birleşik Devletler Topluluğu Bölgesinde Bir Entegrasyon Çabası Olarak Avrasya Gümrük Birliği}

1990’lardaki Doğu Blokunun ve Sovyetler Birliğinin dağılması dünya ekonomisinin tarihinde en önemli değişim noktalarından biri olarak nitelendirilebilir. Çünkü eski sovyet ülkelerinin bağımsızlıklarını ilan ederek dışa açılması ve dünya ekonomisi içine sokularak kendi yerlerini aramaya başlamaları tüm dünya ülkelerine yeni yollar açarak ekonomik ve siyasi politikalarını yeniden gözden geçirmeye sebep oldu. Bu yüzden küreselleşme olgusu da çok yönlü gelişmeye başladı. Bu karışık sisteme yeni açılan eski sovyet ülkeleri bir anda eski bağlarını yitirerek ekonomik ve siyasi politikalarını yeniden kurmak zorunda kaldılar.

Tabii ki çalışmamızın başında açıkladığımız gibi bu ülkeler dağılım sürecinin daha kolay ve sorunsuz geçmesi için bir Birleşik Devletler Topluluğu adı altında birlik kurdular. Ancak bu birliğin kurulmasına rağmen sözkonusu ülkelerin yeni kazanan egemenliği kaybetmeme endişeleri ve kendine uygun gödüğ̈ yollarla gelişme arzuları olduğundan ilk başta birliğgin ancak isimi olduğu da bir gerçektir. Daha sonraki yıllarda EurAsEC, SCO, CSTO gibi bütünleşme çabaları ile bölgesel siyasi ve askeri sorunların çözülmesi için entegrasyon çabaları yapılmıştır. Ancak üye ülkelerin genel amaç ve stratejiler konusunda oybirliğinin yokluğu, her memleketin kendi çıkarlarını düşünerek özgür hareket etmesi de bu kurumların etkisini ve önemini azaltmıştır.

Ancak bütün bu bütünleşme çabalarının bir sonucu olarak Avrasya Ekonomik Topluluğu EurAsEC(AET) çerçevesinde Rusya Federasyonu, Kazakistan ve Belorus devletelri arasında bir "Gümrük Birliği” oluşturulmasının kararlaştırılması çok önemli bir gelişme oldu. Dolayısıyla, bu birliğin kurulması ile bölgedeki entegrasyon hızının artmasına şartlar kuruldu diyebiliriz. Günümüzde Kırgızistan, Tajikistan ve Ukrayna'nın Gümrük Birliği'ne girmesi düşünülmektedir. AET'in coğrafi alanında 182,6 milyon kişinin ve dünya GSYİH'nın $\% 4$ 'ü, dünya petrol rezervlerinin $\% 7,5$ 'i, gaz ve kömürün \%20'si, elektrikenerjisinin \%5,5'i ve tahıl üretiminin $\%$ 5,9'una ve altın ve diğer değerli madenler rezervleri açısından dünyada ön sıralara sahip olduğunu hesaba aldığımızda birliğin ekonomik, siyasi stratejik önemi büyük olduğu anlaşılmaktadır.

Ancak, Avraya Gümrük Birliği oluşturma fikrini başlatan ve gelecekte de Avrasya Ekonomik Birliği kurma taraftarları olan Rusya ve Kazakistan ülkelerinin inisiyatifine gelecekte üye olması düşünülen Kırgızistan gibi küçük ülkeler çok dikkatli ve şüpheli bakarak bağımsızlıklarını ve diğer önemli dış ekonomik partnerlerini kaybetmekten kormakta iseler, bazı araştırmacılar bu birliğin eski entegrasyon çabaları gibi başarılı olup olmayacağını tartışmaktadırlar. Öyleyse, çalışmamızın esas amacı olan Kırgızistan Cumhuriyetinin Avrasya 
Gümrük Birliği’ne üye olması nasıl bir sonuçları doğuracak? Bu üyelik hem Kırgızistan hem de Gümrük Birliği için gerekli mi? Kırgızistan açısından birliğe üye olmanın yararları neler ve kaybedecek zararları nelerdir? Bütün kaybedeceklerine rağmen üye olma riskine katlanmanın gereği var mıdır? Bütün bu sorulara biz de cevap aramaya çalışalım.

\section{Kırgızistan ve Avrasya Gümrük Birliği}

Kırgızistan egemenliğini ilan ettikten sonra eski sovyet ülkelerle olan bağlarının kopması ve üretimin durmasıyla elektrik ve elektronik ürünler, otomobil ve aletlerin üretimi, hafif sanayi ve tarım ürünleri pazarını kaybederk ihracatçı ülkeden ithalatçı ülkeye dönüştü. Bu yüzden de ülkeye yabancı yatırımları çekerek üretimi canlandırmak ve dış ticaret hacmini genişletmek amacıyla DTÖ’ne üye oldu. Ancak bunun sonucunda daha etkin ekonomik şartlarda çalışan diş ülkelerin rekabetiyle karşı karşıya kalarak ekonomisinin durumu daha da kötüleşti ve beklenen yabancı sermaye yatırımları patlaması da gerçekleşmedi. Bunun en önemli sebebleri ise, iç pazarın küçüklüğü, siyasi ve ekonomik istikrarsızlık olarak belirlendi. Küçük ve ekonomik açıdan gelişmekte olan ülkenin böylece aşırı derecede dışa açıklığı da ithlataçı ülkeye dönüşerek dış ticaretten negatif etkinin alınmasına yol açtı.

Günümüzde Kırgızistan'ın Avrasya Gümrük Birliği’ne (AGB) üye olması durumunda ise, onun DTÖ’ne üyeliği ve bundan kaynaklanan ticari rejimlerini uyumlaştırma meselesi ortaya çıkmaktadır. Çünkü DTÖ üyesi olarak Kırgızistan ithalat vergileri oranlarını cezalandırma maliyetlerisiz AGB oranlarıyla uyumlaştırması mümkün olmayacaktır. Bunun yanında DTÖ’nün üye ülkeleri ile en çok kayrılan ülke kuralını uygulamakta olan Kırgızistan'ın AGB'ne üye olmasıyla da onun ticari rejimlerinin gümrük birliği ülkelerinin üçüncü ülkelere uyguladığı ticari rejimleriyle uyumlaştırması gereklidir. Bu da Kırgızistan’ın DTÖ yükümlülüklerinin yeniden gözden geçirilmesini gerektirir.

Kırgızistan’ın Gümrük Birliği’ne üye olması durumunda ilk önce gümrük tarifelerini Gümrük Birliği Genel Tarifesine uygun olmalıdır. DTÖ’nde bölegesel birlikleri oluşturmaya izin verildiğinden Kırgızistan bu tarifelerini tekrar gözden geçirme hakkına sahiptir (3 yılda bir kez yapılabilir). Kırgızistan'ın gümrük tarifelerinin \%30'nun gümrük birliği tarifeleriyle uygun olduğu, \%21'inin gümrük birliği tarifeleriyle uyumlaştırılabileceğinin, \%46,6'sının ise gümrük birliği tarifeleriyle uygun olmadığı kalan \%2'sinin de tarife türlerinin farklı olduğundan mükayese edilemeyeceği görülmüştür. Gümrük Birliği’nin ortalama gümrük tarife oranı \%10,5, Kırgızistan'ın ortalama gümrük tarife oranı \%5, Kırgızistan'ın DTÖ karşısındaki yükümlüklerini hesaba kattığımızdaki tahmini ortalama gümrük tarifesi orani ise, \%7,7'dir. Dolayısıyla Kırgızistan'ın gümrük birliği tarifelerini masrafsız kabul etmesi durumunda ülkenin gümrük tarifesinin DTÖ yükümlülüklerini aşan ortalama gümrük tarifesi artışı yaklaşık olarak \%3 olacaktır. Gümrük tarifelerindeki bu değişiklik ilk olarak Kırgızistan'ın Çin Halk Cumhuriyeti ile olan ticari ilişkilerine etki eder.

ÇHC, gümrük birliği üyesi ülkelerinin ve bunların yanındada diğer üçüncü ülkelerin Kırgızistan'ın dış ticaretindeki yerine aşağıdaki şekilden bakabiliriz:

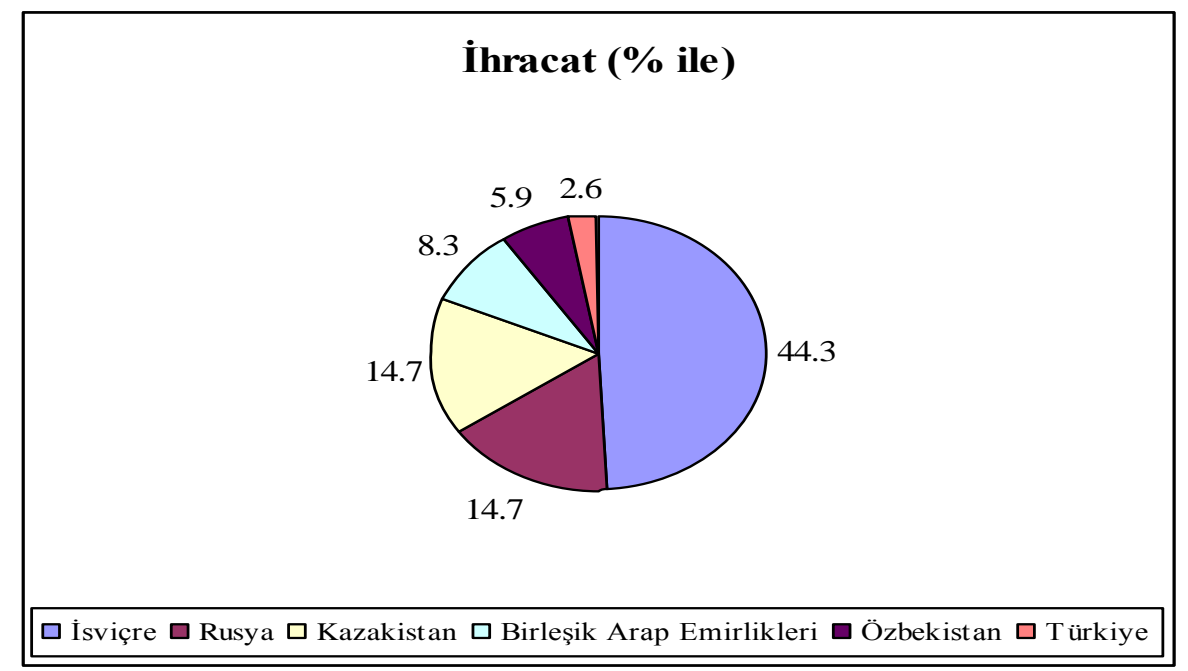

Şekil 1: Kırgızistan'ın İhracatındaki Başlıca Ülkeler (2011)

Şekil 1'den anlaşılacağı üzere, komşu ülkelerden Rusya ve Kazakistan, Kırgızistan'ın en önemli ihracat pazarlarını (tüm ihracatın yaklaşık olarak \%30’unu) oluşturmaktadırlar. İsviçre ise Kumtör altın madeni üretimi işletmesinin sayesinde ihracatın \%40'ına sahiptir. Şekil 2'den anlaşılacağı üzere Kırgızistan'ın ithalat partnerleri içinde ise \%33 oranıyla Rusya en önemli paya sahiptir. Böylece bira, petrol ürünleri, eczacılık ürünleri, lastik, çikolata, karton, kağıt ve kereste ürünlerinin ithalatında Rusya birinci sırada yer almaktadır. Kömür, petrol, 
benzin, dizel yakıtı, buğday, un, tütün, ayçiçek yağı ithalatında Kazakistan Japonyadan sonraki üçüncü önemli partner ülke durumundadır. Çin Halk Cumhuriyeti ise gıda, teksil ürünlerinden başlayarak beyaz eşya gibi her türlü malların ithalatında yaklaşık \%22 orana sahiptir. Bu yüzden uzmanlara göre ÇHC mallarının yeniden ihraç edilmesi de kaçınılmaz olduğundan bu komşu ile ticari ilişkileri korumak gerekir. Bununla birlikte ÇHC'nin ihracatını azaltamak istemeyeceği ve bu yüzden de Kırgızistan toprakları içine yatırım yaparak üretimini kuracağı da tahmin edilmektedir.

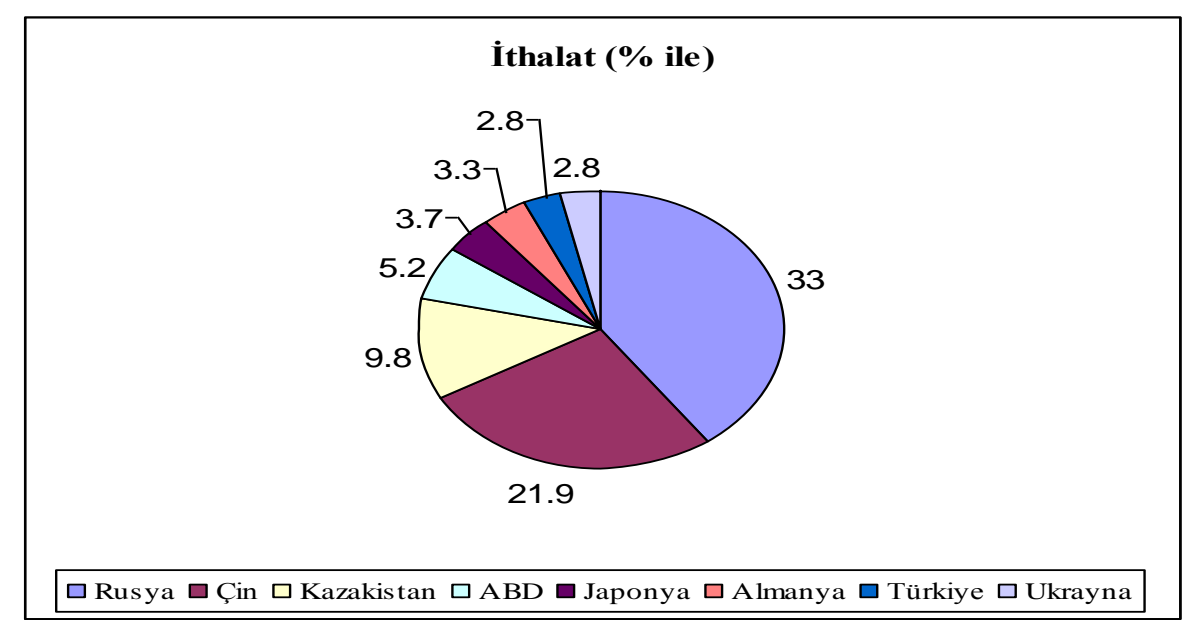

Şekil 2: Kırgızistan'ın İthalatındaki Başlıca Ülkeler (2011)

Kırgızistan'ın ihraç ettiği önemli ürünler ise, kıymetli metaller (altın), giyim ve aksesuarlar, sebzeler, elektrik, kerosin, süt ve süt ürünleri, meyveler, organik olmayan kimyasal maddeler, pamuk lifini sayabiliriz. İthalatındaki önemli ürünlere de petrol ürünleri, ikinci el otomobiller, giyim ve aksesuarlar, ilaçlar, elektrikli iletişim donanım ve cihazları, şeker, et ve et ürünleri, doğalgaz, buğday olarak sıralanabilir.

Diğer bir önemli konu da Kırgızistan’ın üretim kaynaklarının bölgesel dağılımındaki eşitsizliği sorunudur. Ülkenin yedi bölgesinin gelişme oranındaki dengesizlikleri, özellikle güney bölgelerinden kuzeye doğru iç göçün, ondan sonra da nüfusun ülke dışına göç etmeleri ciddi bir sorun haline gelmiştir. Güney bölgelerinde aktif nüfüsün olmaması, komşu ülkelerin nüfüsünün da söz konusu bölgelere taşınmasına imkan sağlamaktadır. Şu anda uzmanların tahminlerine göre 1 milyon kişi yurt dışında çalışmaktadır, bu rakam ise aynı zamanda ülke nüfusunun beşte birini oluşturduğu da üzücü bir gerçektir. Kırgız Cumhuriyeti Ulusal İstatistik Komitesi verilerine göre 2011 yılında Kırgızistan'dan dişa göç edenler 457 bin kişi oldu, onun çoğunluğu - 416 bin işçi yani \% 92 Rusya Federasyonu’nda çalışmaktadır. Bu yüzden Kırgızistan’ın Gümrük Birliğine üye olması göçmenlerin yasal statülerinin ve hukuklarının korunmasının iyileşmesini beraberinde getirmesi de ümit edilmektedir. Ancak böyle bir olumlu tarafiyla birlikte ülkede göç oranının daha da yükselmesi sorununun meydana gelebileceği de unutulmamalıdır. Bu ise ülkedeki ve bölgedeki çözülemeyen en önemli demografik (göçmenleri kabul eden ülkelerde etnik çatışmalara da yol açabilen) sorun olduğundan hangi boyutlara ulaşabileceğine dair henüz bir net cevap bulunamamaktadır.

\begin{tabular}{|l|l|l|l|l|l|l|l|l|}
\hline & $\begin{array}{l}\text { Yüzölçümüi } \\
\text { (bin km }^{2}\end{array}$ & $\begin{array}{l}\text { Nüfusu } \\
\left(\begin{array}{l}\text { kisisi) } \\
\text { kilyon }\end{array}\right.\end{array}$ & GSYİH & $\begin{array}{l}\text { Sanayi } \\
\text { Üretimi }\end{array}$ & $\begin{array}{l}\text { Tarım } \\
\text { Üretimi }\end{array}$ & $\begin{array}{l}\text { Sabit } \\
\text { Varlık } \\
\text { Yatırımları }\end{array}$ & $\begin{array}{l}\text { Perakende } \\
\text { Ticaret }\end{array}$ & $\begin{array}{l}\text { Dış } \\
\text { Ticaret }\end{array}$ \\
\hline Belarusya & 207,6 & 9,5 & 48,9 & 62 & 9,9 & 17,6 & 20,1 & 87,2 \\
\hline Kazakistan & 2724,9 & 16,7 & 188,1 & 109 & 15,6 & 34,2 & 26,4 & 125,1 \\
\hline Kırgızistan & 199,9 & 5,6 & 5,9 & 3,6 & 3,2 & 1,0 & 3,6 & 6,5 \\
\hline Rusya & 17,1 milyon & 143,0 & 1860 & 1147 & 117,6 & 367 & 650,2 & 822,1 \\
\hline
\end{tabular}

Tablo 2: 2011 yılındaki Avrasya Gümrük Birliği Ülkelerinin ve Kırgızistan ’ın Temel Ekonomik ve Sosyal Göstergeleri (milyar dolar olarak)

Günümüzde iç tüketim büyük oranda Gümrük Birliği ülkelerinde, özellikle Rusya ve Kazakıstan'da çalışanların para transferi ile gerçekleşmektedir. Para transferleri 2008 y1lı 1,1 milyar dolar, 2009 y1lı 894 milyon dolar, 2010 yılı yaklaşık 1,2 milyar dolar olarak devletin bütçe gelirleri oranlarıyla kıyaslanabilir. 2011 yılının ilk 6 ayı için Kırgız Cumhuriyeti para transferinin oranı toplam 724 milyon dolar olarak 2010 yılının ilk yarıyılı ile karşılaştırıldığında \% 46'lık bir artış olmuştur. Rusya'dan 2011 yılı için ilk yarıyılında para transferi 676 milyon dolar olarak 2010 yılının aynı dönemine göre 1,5 kat bir artış gerçekleşmiştir.

Yukarıdaki tablodan anlaşılacağı üzere Kırgızistan diğer AGB ülkelerinden coğrafik, sosyal ve ekonomik göstergeler açısından en zayıf ve küçük ülke konumundadır. Bu yüzden Kırgızistan’ın Gümrük Birliğ’e girmesi, 
üye ülkelerin makroekonomik göstergelerine etkisini göstermeyecektir. Ancak Gümrük Birliği için Kırgızistan ve ÇHC gümrüğündeki değişmeler, ucuz ve kalitesiz malların girmesini engelleyerek Gümrük Birliğin hukuki çerçevesi gereğince sağlık ve teknik açıdan daha kaliteli malların ithalatına yol açabilir. Bu da hem Kırgızistan’ın hem de diğer üye ülkelerin üreticilerinin Çin mallarına karşı fiyat rekabetinde avantaj sağlayarak birlik içi üretimin artmasına sebep olabilir.

Bununla birlikte Kırgızistan'ın en küçük ve ekonomik açıdan daha az gelişmiş ülke olarak doğal kaynakları ile üretim olanaklarına zengin olmaması uzmanların şüphe duyduğu konulardandır. Ancak AGB gibi büyük bölgesel ekonomik kuruma entegre olma, ülke içinde üretilen malların daha geniş pazara açılmasına, diğer ülkeler için yatırım açısından çekiciliğine yol açarak GSYİH'nın da artışını sağlayabilir. Bazı uzmanlara göre genel olarak Gümrük Birliğine üye olmak ile ülkenin ihracat potansiyeli \%20-22 cıvarında artabilir. Bunun için Gümrük Birliği’ne üye olma sürecinde makroekonomik ve sektörel analizlerin yapılması, ülkemizden elektrik, tekstil, pamuk lifi, sebze ve meyvelerin (kuru meyve de dahil olmak üzere), süt ve et ürünlerinin ihracatı için indirimlerin ve kolaylıkların sağlanması, bölgelerde dünya standartlarına uygun sertifika verebilecek laboratuvarların kurulması, ülke düzeyinde ortak bir stratejilerin geliştirilmesi gereklidir.

Kırgızistan'ın ekonomik yapısına baktığımızda ise, sanayinin payı yaklaşık \%15 iken, tarım sektörünün oranı daha yüksektir (yaklaşık olarak \%20). Bu ekonominin tarıma dayalı olduğunu gösteriyorsa da, belirli yiyecek pozisyonları için bir net ithalatçı konumunda olduğu da bellidir. Ayrıca GB ülkelerinden yatırımların ülkeye çekilmesiyle tarım sektörünün de gelişmesi öngörülmektedir. Çünkü Kırgızistan AGB'nin güney tarafında yer alan ülkesi olarak suyunun bolluğu, ikliminin elverişliliği ve tarımda çalışanların sayısının çokluğu ile diğer üye ülkelere göre avantaja sahiptir. Bu avantajını iyi kullandığında ülke bölgede önemli tarım üreticisine dönüşebilir.

Sonuç olarak araştırmamızı genel olarak özetlersek Kırgızistan’ın Avrasya Gümrük Birliğine üye olması üye olmamasından daha avantajlı olarak görülmektedir. Gelecekte eğer Gümrük Birliği, ortak stratejileri belirleyerek genel ekonomik politikaları başarılı bir şekilde yürütürse bu üyelik hem Kırgızistan için hem de birlik için yararlı olabilecektir. Aksi halde Kırgızistan'ın Dünya Ticaret Örgütüyle olan etkisiz tecrübesi tekrarlanabilir.

\section{Kaynakça}

- $\quad$ Alatau, интеллектуальный клуб, «Центральная Азия - 2020: Взгляд Изнутри.», Алматы, 2012.

- Афонцев, С.А., «Единое экономическое пространство:предпосылки успеха интеграции.», МЦСЭИ «Леонтьевский центр», 2012

- Ван Шуцунъ и Ванъ Чинсун, «Перспективы Евразийского интеграционного проекта и Китай», http://www.svom.info/entry/315-perspektivy-evrazijskogo-integracionnogo-proekta-i/

- $\quad$ Гриняев С.Н. и Фомин А.Н., «Среднесрочные оценки устойчивости Евразийского союза при различных сценариях развития мировой экономики.», Центр стратегических оценок и прогнозов, Москва, 2012.

- Джоомарт Оторбаев: Надеюсь, вступим в Таможенный союз к 2014 году, http://www.vb.kg/doc/207980_djoomart_otorbaev:_nadeus_vstypim_v_tamojennyy_souz_k_2014_gody.html (Erişim, 22 Haziran, 2013)

- Евразийская Экономическая Комиссия, Годовой Отчет, 2012

- Евразийский Банк Развития, «Оценка экономического эффекта присоединения Кыргызской Республики к Таможенному союзу», Сентябрь 2011

- Касенова Наргис, «Евразийский таможенный союз и его влияние на Центральную Азию», Аналитический форум Центральной Азии, № 4, февраль 2013

- Kırgızistan Ulusal İstatistik Komitesi Verileri

- Международное общественное Движение развития Институт демографии, миграции и регионального развития, «Евразийский Союз -единая цивилизация, много государств», Проектно-аналитический доклад. Версия 1.0, Душанбе-Москва 2012

- Морозова А.Е., «ЕС Как Пример Развития Для Евразийского Союза», Вестник Томского Государственного Университета, №1(17), Томск, 2012

- Мусаева Д.А., и Бровко Н.А., «Сравнительный анализ выгод и рисков вступления Кыргызстана в ТС: динамика товарооборота», Бишкек.

- Павлов, А.Н. «Оценка экономического эффекта присоединения Кыргызской Республики к Таможенному союзу» Евразийская экономическая интеграция, №4(13), ноябрь 2011.

- Ramazanoğlu, Ceybulla ve ACAR, İbrahim Atilla, Bir Geçiş Ekonomisi Örneği Olarak Kırgızistan: Siyasi, Ekonomik ve Toplumsal Yanaşımlar, Review of Social, Economic \& Business Studies, Vol.7/8,

- Секретариат Интеграционного Комитета Евразийского Экономического Сообшества, ЕврАзЭС Сегодня, Москва, 2013

- Ханнес Адомейт, «Евразийский Союз» Путина: Интеграционный Проект России и ее Политика, Neighbourhood Policy Paper, December, 2012. 


\title{
Azerbaycan'ın Piyasa Ekonomisine Geçiş Sürecinde Karşılaştığı Sorunlar ve Çözüm Arayışları \\ Problems Encountered during the Transition to Market Economy in Azerbaijan and Solution Attempts
}

\author{
Prof. Dr. Cihan Bulut (Qafqaz University, Azerbaijan) \\ Ph.D. Candidate Elchin Suleymanov (Qafqaz University, Azerbaijan) \\ Assoc. Prof. Dr. Fakhri Hasanov (Qafqaz University, Azerbaijan)
}

\begin{abstract}
After re-gaining its independence on 18 October 1991, the Republic of Azerbaijan started to transform to the market-based economy and to integrate into the world economy. The country's oil and natural gas reserves have been considered the main source for financing range of government programs for reforms. On the one hand, these reserves had to be used effectively; on the other hand, there was a huge demand for foreign investment for extraction. To this end, Azerbaijan has signed "Contract of the Century" in 1994. Although Azerbaijan has wide oil and natural gas reserves, it has faced a number of difficulties in its transition way. This study analyzes these problems and reforms for solving them. One of the types of the problems were related to the economic structure of the former Soviet Union: disruption of the economic ties between the republics resulted in decline of production, high levels of unemployment and prices and consequently led to an economic recession in all of the republics. Another set of problems was related to lack of sufficient institutional bases to transform to the market economy. Moreover, internal conflicts between the political parties and groups for having authority as well as political chaos in the republic can be considered other serious problems during the transition period. Furthermore, Karabakh war and occupation of 20 percent of the Azerbaijani territory by the Armenian military forces had made the situation extremely complicated. Despite all of these extremes, Azerbaijan transformed to the market-based economy decidedly and even became one of the fast growing countries of the world. Even in 2006, with the GDP growth rate of 34.5 percent, Azerbaijan was a leader among growing economies. In parallel with this significant economic development, there is still a need for some socio-economic and institutional reforms in order to get a well-functioned market-based economy in Azerbaijan.
\end{abstract}

\section{Giriș}

Azerbaycan 18 Ekim 1991 de bağımsızlığını ilan ettikten sonra ekonomisinin liberasyonu ve serbest piyasa ekonomisine geçmek maksadıyla bir çok önemli reformlara imza atmıştır. Ekonomik hedeflerin gerçekleştirilmesinde ülkenin en önemli kaynakları ise hemen hemen hepsi Hazar'da yerleşen petrol ve doğal gaz rezervlerinden oluşan enerji kaynaklarıydı. Bu nedenle ekonomik hedeflere ulaşma adına Hazar enerji kaynaklarının en etkin biçimde kullanılması gerekmekteydi ve öyle de oldu. Zira Azerbaycan, ekonomik, siyasi ve sosyal açılardan yeniden yapılanma, kalkınma, gelişme ve bağımsızlık adına, Hazar enerji kaynaklarından 1994 yılından itibaren faydalanmaya başladı. Enerji kaynaklarının üretim ve dünya piyasalarına ihracına ilişkin çok önemli projelere karar verildi, inşa edildi ve kullanılmaya başlandı.(Suleymanov, Zeynalov,2012) Bağımsızlığını kazanan Hazar Havzası ülkelerinden Kazakistan ve Azerbaycan büyük petrol potansiyellerini, Türkmenistan ise doğal gaz zenginliğini ekonomilerinde değişimi geçekleştirmek için gerekli kaynakları sağlamak ve geçiş döneminin sıkıntılarını hafifletmek amacıyla bir an önce kullanma ihtiyacı duydular. Ancak mevcut boru hatları, Sovyetler Birliği'nin planlı ekonomisi çerçevesinde cumhuriyetler arası işbölümüne göre düzenlenmiş olduğundan, bunların ihraç amaçlı kullanım imkânları sınırlıydı. Sovyetler Birliği'nin dağılmasının ardından Rusya dışındeki üç kıyı devleti; Azerbaycan, Kazakistan ve Türkmenistan'ın bağımsızlıklarını ilan etmesiyle Hazar'ın önemi büyük oranda artmıştır. Bu ülkeler için Hazar enerji kaynaklarının geliştirilmesi ekonomilerini yeniden yapılandırma, kalkınma ve dünya ekonomisine entegre olma açısından önem arz etmektedir. Özellikle kaynakların amaçlar doğrultusunda geliştirilebilmesi için yabancı sermayeye ihtiyaç duyulmaktadır. $\mathrm{Bu}$ bakımdan üç devlet de batılı firmaları bölgede yatırım yapmaya ve enerji kaynaklarını çıkarmaya davet etmiştir. Azerbaycan ve Kazakistan petrol gelirlerinin ülkelerine hızla akmasını istemektedir.(Aras,2005) Dünyanın en önemli enerji kaynaklarından biri olan petrol, diğer enerji kaynaklarına göre daha geniş kullanım sahasına sahiptir. Petrol ürünlerinin maliyeti içerisinde temel yeri petrolün çıkarılması, taşınması ve dağıtılması için yapılan harcamalar önemli yer tutmaktadır. Enerji kaynakları sayesinde sahip olunan gelirlerin verimli şekilde kullanılması metodlarının hazırlanması yolu ile gayri-petrol sektörünün gelişimi, istikrarın, hızlı büyümenin ve reel gelirdeki artışın temini ile petrole dayalı tek yönlü ekonomiden vazgeçilmesi Azerbaycan ve diğer Hazar kıyısı Türk Cumhuriyyetleri için çok önemlidir. Aras,2008) 


\begin{tabular}{|l|l|l|l|l|l|l|}
\hline & 2000 & 2008 & 2009 & 2010 & 2011 & 2012 \\
\hline Nüfus (bin kişi) & 8114.3 & 8897.0 & 8997.6 & 9111.1 & 9235.1 & 9305.1 \\
\hline Toplam GSMH (milyon \$) & 5272.8 & 48852.5 & 44297.0 & 52909.3 & 63402.5 & 64412.5 \\
\hline Kişi Başına GSMH (\$) & 662.9 & 5603.3 & 5018.2 & 5922.0 & 7003.4 & \\
\hline Toplam Yatrım Hacmi (milyon manat) & 967.8 & 9944.2 & 7724.9 & 9905.7 & 12776.4 & 13776.4 \\
\hline Diş Ticaret Hacmi(milyon \$) & 2917.3 & 54926.0 & 20824.5 & 27960.8 & 36326.9 & 36529.9 \\
\hline İhracat (milyon \$) & 1745.2 & 47756.0 & 14701.4 & 21360.2 & 26570.9 & 26670.9 \\
\hline İthalat (milyon \$) & 1172.1 & 7170.0 & 6123.1 & 6600.6 & 9756.0 & 9859.0 \\
\hline Devlet Bütçesinin gelirleri(milyon manat) & 714.6 & 10762.7 & 10325.9 & 11403.0 & 15700.7 & 17360.7 \\
\hline Devlet Bütçesinin harcamaları(milyon manat) & 764 & 10774.2 & 10503.9 & 11765.9 & 15396.2 & 17796.2 \\
\hline Fertlerin gelirleri(milyon manat) & 4047.3 & 20735.4 & 22601.1 & 25607.0 & 30633.5 & 32633.5 \\
\hline Çalışanların ortalama ücreti (milyon manat) & 44.3 & 274.4 & 298 & 331.5 & 363.1 & 423.1 \\
\hline Resmi İşsiz Sayısı & 43739 & 44481 & 41100 & 38966 & 38330 & 37330 \\
\hline TÜFE (önceki y1la oranı) & 101.8 & 120.8 & 101.5 & 105.7 & 107.9 & 105.9 \\
\hline ÜFE (önceki yıla oranı) & 129.7 & 123.4 & 80.6 & 130.5 & 133.5 & 123.5 \\
\hline
\end{tabular}

Tablo-1.Azerbaycanın Temel Sosyo-Ekonomik Göstergeleri Kaynak: ARDSK 2012 verileri

Hazar enerji kaynaklarının harekete geçirici unsur olmasının ardından, yabancı sermaye girişine paralel olarak ülkeye yapılan yardımlar ve uluslar arası mali kurumların açtığı krediler de artmıştır. Sovyetler Birliği’nin son dönemlerinde, dağılışının hayata getirdiği kaos ortamında devlet emlakının ve toplumsal servetin şahsi amaçlar doğrultusunda kullanılması ve dağıtılması sıradanlaşmıştı. Bu açıdan rüşvet ve yolsuzluk, toplumun Sovyet sisteminden miras aldığı ağır toplumsal hastalıklardan biridir. Her ne kadar daha sonra rüşvet ve yolsuzluk belirli şekil değişikliğine uğrasa da, varlığını toplumun genelinde yaygın şekilde hissettirmektedir. Öyle ki ülkede adeta resmi ve gayri resmi olmak üzere iki vergi sistemi mevcuttur. Gayri resmi verginin düzenleyici rolü, resmi verginin düzenleyici rolünden daha büyüktür. (Aras,2005)

\section{Bağımsızlık Sonrası Azerbaycan Ekonomisinin Genel Durumu}

Bağımsızlığını ilan ettikten sonra serbest piyasa ekonomisine geçmek maksadıyla bir çok reformlara imza atan Azerbaycan'ın ekonomik hedeflerin gerçekleştirilmesinde ülkenin en önemli kaynakları Hazar'da yerleşen petrol ve doğal gaz rezervlerinden oluşan petrol ve doğal gaz kaynaklarıydı. 1994 yılından itibaren Azerbaycan'ın uluslararası şirketlerle petrol ve doğal gaz anlaşmaları yapması ve bu çerçevede ortak faaliyetler gerçekleştirmesi, ülkeye gelişmiş modern teknolojilerin getirilmesine, enerji sektörü altyapısının yeniden kurulmasına imkan sağlamıştır. Örneğin, “Asrın Anlaşması”nın ilk aşamasının gerçekleştirilmesi ile hem AzeriÇırak-Güneşli projesinin petrol stoklarını değerlendirme sorunu başarıyla çözülmüş, hem Hazar'da yeni petrol üretime teknolojilerinden yararlanılmış, hem de Hazar petrolünün dünya piyasalarına ihracına ilişkin modern sistem kurulmuştur.Azerbaycan modern teknolojiyi ülkeye transfer ederek, enerji sanayisinin aktiflerini yenileme firsatı bulmuş ve petrol-doğal gaz sanayisinin gelişmesine yardım edebilecek kurum ve kuruluşlar kurmuştur. Böylece modern araştırma, petrol ve doğal gaz çıkarma, işleme ve ulaşım teknolojilerinin ülkeye girmesi mümkün olmuştur. Bu bakımdan, Hazar enerji kaynaklarının üretim ve ihracına ilişkin yapılan anlaşma ve projeler, Azerbaycan'ın enerji sanayisi tarihinde yeni sayfa açmıştır. Günümüzün küresel rekabet ortamında, Azerbaycan'da piyasa ekonomisine geçiş ve ekonomik kalkınmayı gerçekleştirmek amacıyla çeşitli programlarla kalkınma politikaları ve stratejileri belirleyen ülke yönetimi için bilinçli ve sistematik analizler yaparak, ülkenin potansiyel kaynaklarını ve imkanlarını en iyi şekilde kullanabilmesi ve yeni stratejiler geliştirebilmesi için, SWOT Analizi stratejik öneme sahiptir.Farklı sektörlere yatırım yapabilme açısından, ülke ekonomisi hakkında makroekonomik, sektörel ve ekonomi dışı alanlara yönelik ampirik olmayan bir analiz, stratejik ön adım olarak gereklidir(Aras,2005).Azerbaycan ekonomisinin makroekonomik açıdan güçlü yönlerini aşağıdakı gibi siralayabiliriz.

-Başta fiyat istikrarı olmak üzere genel olarak makroekonomik açıdan istikrarlı bir ortamın varlığı: Son 15 yıldır tek rakamlı enflasyon oranı seyredilmektedir.Fiyatların çok istikrarlı şekilde olduğu vurgulanabilir.

-Dış borçların GSMH'ya oranının yüksek olmaması: Ülkede bağımızlığın kazanıldığı ilk yıllarda yaşanan siyasi, ekonomik istikrarsuızlı̆̆ın yanısıra Ermenistan ile Yukarı Karabă̆ savaşı nedeniyle 1995 yılına kadar makroekonomik göstergelerde istikrarsızlık gözlenmiştir. Ancak ülkede sağlanan siyasi istikrar ve ardından uygulamaya başlanan ekonomik politikalar ile birlikte, 1996 yılından itibaren ekonomide istikrarsızlık yerini istikrara bırakmıştır. Dolayısıyla yaklaşık 15 yıldır ülkede makroekonomik göstergelerde olumlu hava hakimdir.(Suleymanov, Zeynalov,2010)

- Döviz kurunun istikrarlı olması: Zaman zaman manat dolar ve euroya göre deger kazansa da genellikle uzun bir dönemdir istikrarlı bir seyir görülmektedir. Azerbaycan 1992 yılında "Ruble Bölgesi”nden çıkarak, milli para birimi olan Manatı tedavüle çıkarmıştır. İlk aşamada Ruble ile birlikte tedavülde olan Manat 1994 yılından 
itibaren ülkede tek resmi para birinmi olmuştur. İthalatın önemli bir kısmının Ruble ile yapılması ve ithalatın yapıldığı ülkelerde, özellikle Rusya'da fiyatların liberalleşmeye paralel olarak yükselmesi sonucunda, Manat 1993'de Ruble karşısında değer kaybetmeye başladı. Öte yandan 1993-94 yıllarında bankacılık sektöründe yaşanan kriz ve Manat'ın değerine ilişsin beklentilerdeki olumsuzluk Manat'ın diğer ülke para birimleri karşısında değer kaybetmesine neden oldu.2000 yılından itibaren manat istikrarlı bir seyir izlemektedir.2006 yılı 10 cak tarihinden Azerbaycanda manatın denominasyonu yapılarak paranın nominal değeri 5000 kat azaldılmış ve 1 Azn yaklaşık 1.2 ABD doları değerinde belirlenmiştir.(Aras,Suleymanov,2010) Yaklaşık yedi yıldır bu kur kısa dalgalanmalar dışında pek değişmemiş ve çok zaman manat dolara gore deger kazanmıştır.

Ülkede sağlanan siyasi ve ardından eknomik istikrar ile birlikte ülkede döviz kurları istikrarlı bir seyir izlemektedir.

-Ucuz işgücünün varlığı: Ülkede işsizlik oranının yüksek olması nedeniyle ücretler düşük seviyededir. Ülkede asgari ücret 93.5 Manat ortalama ücret 2012 yılı verilerine göre 360 manat civarıdır. Üretim faktörü olarak işgücü ödemeleri, toplam maliyetler bakımından avantaj sağlamaktadır. Neticede işgücünün ucuz olması, yatırım yapmayı teşvik eden unsurlardan biri olmaktadır.

Ekonomi Dışı Güçlü Yönler

-Nüfusun eğitim seviyesi: Her ne kadar ekonomik durumdaki gerileme ile birlikte şartların zorlaşmasına rağmen, Sovyet geleneğinin devamı olarak insanların eğitime karşı ilgi gösterdikleri görülmektedir. Ülkede okur-yazar oranı \%98 ve lise-yüksek öğrenimli nüfus oranı \%60 civarındadır. Her bir ülkede, ekonomik kalkınma için öncelikle siyasi istikrar ve bu istikrarı devam ettirecek bir iradenin yöneticilerde olmalıdır. Siyasi istikrar, yürütülen ekonomik programın kesintiye uğramayacağının göstergesi olarak piyasalara güven vermektedir. Azerbaycan'da Haydar Aliyev'in iktidara gelmesinin ardından sağlanan siyasi istikrar ve var olan siyasi istikrarrı devam için gereken irade adına endişeye sevk edici belirsizlikler İlham Aliyev’in Cumhurbaşkanı seçilmesi ile minimum seviyeye çekilerek beklentiler olumlu kılınmıştır.

-Stratejik konumu: Asya ülkelerinin Avrupa'ya geçiş koridorunda yer almasının yanısıra İran'a ve Rusya'ya sınır olması nedeniyle de stratejik konumu itibariyle ABD ve Avrupa ülkeleri için önem taşımaktadır. Asırlar boyunca Doğunun zenginliklerini Batıya taşıyan kervanların geçtiği, beş Türk Cumhuriyeti'nin yanı sıra, Tacikistan, Gürcistan ve Ermenistan'ı da kapsayan, Karadeniz'den Çin'e tarihi İpek Yolu'nun 21. yüzyıla bir iletişim, ulaşım ve enerji koridoru olarak taşınmasını öngören ve 1998'de Bakü'de imzalanan anlaşma ile Azerbaycan global ekonomik ilişkiler zincirine yeni bir halka eklemiştir.

Ülke ekonomisinin zayıf yönleri ise makroekonomik açıdan

-İşsizlik sorunu: Resmi istatistikler Azerbaycan’da işsizlik oranının \%1.5 civarında olduğunu ifade etmesine karşın, uluslararası kuruluşları verdiği bilgilere, yapılan farklı hesaplamalara ve uzmanların kanaatine göre bu oran \% 16-25 arasındadır. Dolayısıyla ülkede işsizlik oranının bir haylı yüksektir.

-Petrol ve petrol gelirlerinin ihracat içindeki payı \%90 civarındadır. Öte yandan bütçe gelirlerinin ise $\% 75^{\prime} i$ petrol ve petrol ile ilgili alanlardan elde edilmektedir. Böylece, bütçenin petrol gelirlerinden, petrol gelirlerinin ise dünya piyasalarındaki konjonktüre bağımlı olması 'Hollanda Hastalığı' tehlikesi ile Azerbaycan'1 karşı karşıya getirmiştir.(Sabiroglu,2001) İşsizlik seviyesinin nedenlerinden birisi, Karabağ’’n Ermeniler tarafından işgalinin ardından 1 milyon civarında insarı mecburi göçe maruz kalmasıdır. Öte yandan değişim sürecinde modern üretim ile rekabet gücünde olmayan işyerlerinin kapanmasının ardından işini kaybedenler de işsizler ordusundaki en önemli oranı oluşturmaktadır. Eğitimli ve kalifiye yurtdışına göçü: İstihdam imkanının yetersizliği nedeniyle eğitimli ve kalifiye işgücünü yurtdışı göç etmiştir. Kalifiye ve eğitimli işgücünün büyük çoğunluğu Rusya, Türkiye, İran gibi komşu ülkelere yönelmişlerdir. Ülkeyi bu şekilde terk edenler arasında gençler ve orta yaşlı insanların oranının daha yüksek olduğu dikkat çekmektedir. "Beyin göçü" olarak ifade edilebilecek olan sözkonusu sürecinin özellikle son yıllarda daha fazla arttığ görülmektedir.

-Büyük işletmelerin özelleştirme sürecinin yavaş işlemesi:

-Bürokrasi ve yolsuzluk her ne kadar da her yıl daha da azalsa da yene de geçiş sürecinin önemli problemi olarak öncül yer tutur.

-İhracatın ve devlet bütçesinin petrol gelirlerine bağımlı olması:

- İşsizlik seviyesinin nedenlerinden birisi, Karabağ’’n Ermeniler tarafından işgalinin ardından 1 milyon civarında insarı mecburi göçe maruz kalmasıdır. Öte yandan değişim sürecinde modern üretim ile rekabet gücünde olmayan işyerlerinin kapanmasının ardından işini kaybedenler de işsizler ordusundaki en önemli oranı oluşturmaktadır. Eğitimli ve kalifiye yurtdışına göçü: İstihdam imkanının yetersizliği nedeniyle eğitimli ve kalifiye işgücünü yurtdışı göç etmiştir. Kalifiye ve eğitimli işgücünün büyük çoğunluğu Rusya, Türkiye, İran gibi komşu ülkelere yönelmişlerdir. Ülkeyi bu şekilde terk edenler arasında gençler ve orta yaşlı insanların oranının daha yüksek olduğu dikkat çekmektedir. "Beyin göçü" olarak ifade edilebilecek olan sözkonusu sürecinin özellikle son yıllarda daha fazla arttığı görülmektedir.

-Büyük işletmelerin özelleştirme sürecinin yavaş işlemesi: 
Öte yandan gelir dağılımında da adaletsizlik vardır. Özellikle petrol ve petrole dayalı sektörlerde çalışanların ekonomik durumları çok iyi iken diğer sektörlerde çalışanların gelir seviyesi çok düşüktür. Bu ise belirli oranda nüfusu lüks tüketime yöneltmektedir. Ülkede orta tabakanın henüz tam oluşmadığı görülmektedir.

-Tekelcilik ve haksız rekabet ortamının olması:

Ülkede işletmecilerin karşılaştığı başlıca problemlerden biri de monopollerin varlığı ya da haksız rekabet ortamının olmasıdır. Belirli alanlarda monopollerin varlığı özel teşebbüsün gelişmesini ve kaynakların verimli kullanımını engellemektedir. Tekellerin varlığı fiyatların zaman zaman kaotik şekilde artmasını da neden olmaktadir.

-Döviz kurunda dalgalanma beklentisi nedeniyle yerli para birimine duyulan güven eksikliği.

Bağımsızlığın ilk yıllarında yaşanan siyasi ve ekonomik krizler ortamında yaşanan enflasyonist süreç ve devalüasyonlarla insanların yerli para birimine karşı itimadı oluşmamıştır.

-Kayıt dışı ekonomi: Ülkede kayıt dışı ekonominin GSMH'ya oranı yüksektir. Hatta Azerbaycan, BDT devletleri ile mukayesede yolsuzluğun seviyesine göre olduğu gibi kayıt dişı ekonominin hacmine göre de ilk siralarda yer almaktadir.

Ekonomide kayıt dışını tercih eden veya tercih etmek zorunda kalan özel sektörün karşısına çıkan temel problem ise rüşvet olmaktadır. Resmi verilere göre kayıt dışı ekonomi GSMH'nın \%18-20'sine tekabül etmektedir. Ancak yapılan bazı değerlendirmelerde, kayıt dışı ekonominin kayıt altına alınan ekonomik faaliyetlerden daha büyük olduğu hesaplanmaktadır. Dünya Bankası uzmanlarına göre kayıt dışı ekonominin hacmi GSMH'nın \%60'ından fazladır. GSMH'nın \%60’ını kayıt dışı olarak kabul edildiğinde bu oran 8-10 milyar dolara tekabül etmektedir. Bazı uzmanlar bu oranın \%80 olduğunu iddia etmektedirler. Rakamlar farklı olmakla birlikte genel anlamda kayıt dışı ekonomik faaliyetlerin yüksek olduğu görülmektedir.

-Altyapı yetersizliği ve eski teknoloji: Tarım ve hayvancılık için gereken sulama v.b. altyapı yetersizdir. Öte yandan tarım ve hayvancılık için gerken teknoloji hem eski hem de yetersizdir. Turizm sektörü içinde gereken yol, ulaşım araçları ve konaklama tesisleri hem yetersiz hem de eskidir. Sanayi sektörüne ilişkin altyapının da yetersiz ve eski teknolojiye sahip olduğu görülmektedir. Bu da günümüz modern teknolojisi ile hem ucuza hem de kaliteli olarak üretilen dünya piyasasında üretim yapmaya imkan vermemektedir. Petrol ve doğal gaz üretimine bağımlı bir ekonomik yapı neden ile diğer sektörlerin gereken ilgiden yoksun olması. Bağımsızlığın ilk yıllarında yaşanan bankacılık krizlerinin ardından finans sektörünün merkezinde yer alan bankacılık sektörü henüz gelişmemiştir. Büyük ölçekli işletmelerin özelleştirmesinin gerçekleştirilememesi menkul kıymetler piyasasının gelişmemesinde en önemli etken olmuştur.

Gelir düzeyinin düşük olması ise sigortacılık sektörünün gelişmesine engel olmuştur.

-Sektörel monopollerin varlığı: Monopollerin bazı sektörlerde varlığı, sözkonusu sektörlede üretilen ürünün kalitesine, fiyatına olumsuz etkide bulunmakta ve üretim kaynaklarının verimli kullanımına engel olmaktadır.

-Hollanda Hastalığı tehlikesi: İhracat, yabancı yatırımların petrol ve doğal gaz üretimine yönelmesi, ihracatın petrol ve doğal gaz ağırlıklı olması, bütçe gelirlerinin yine petrol ve doğal gaza bağımlı olması nedeniyle sektörel açıdan ekonominin petrol ve doğal gaza bağımlı olduğu görülmektedir. 2006 yılından itibaren ise petrol ihracındaki artışla birlikte bu bağımlılık daha da artacaktır.

- Bölgesel kalkınmada dengesizlik:

Öte yandan iktisadi işletmelerin daha çok Bakü ve civarında toplanmış olması ve vergi gelirlerinin Bakü ve civarından elde edilmesi nedeniyle de ülke bölgesel olarak Bakü ve civarına bağımlılık gösteren bir ekonomik yapıya sahiptir. - Bağımsızlık sonrasında daha çok petrol ve doğal gaz üretimine ilişkin olarak enerji sektörü yabancı ve yerli yatırımcı açısından dikkat merkezinde olmuştur. Yine kalifiye işgücü de daha çok bu sektörde iş bulmaya çalışmıştır. Hem yatırım hem de kalifiye işgücünün tek bir sektöre yönelmesi sonucunda diğer sektörlede arz edilen ciddi bir gelişme olmamıştır.

Ekonomi dışı zayıf yönler ise aşağıdakı gibi sıralayabiliriz.

-Bölgelerarası ulaşım engeli: Ermeni işgalinin ardından, Nahçıvan ile ülkenin diğer bölgeleri arasında ulaşıma imkan veren 130 km'lik demir yoluişgal edilmiştir. Dolayısıyla Yukarı Karabağ topraklarının Ermeniler tarafından işgal edilmiş olması nedeniyle, Nahçıvan Özerk Cumhuriyeti ile Azerbaycan'ın diğer bölgeleri arasında kara ve demir yolu ulaşımı yapılamamaktadır.

Günümüzde Nahçıvan'a yolcu ve yük ulaşım imkanı ancak İran üzerinden yapılabilmektedir. -Zihniyet değişimi:Sovyet rejiminden, serbest piyasa ekonomisine ve demokrasiye geçiş sürecinde zihniyet değişimi henüz gerçekleşmemiş, daha doğrusu tamamlanmamıştır. Sovyet sistemine benzer bir bakış açısıyla problemlerin değerlendirilmesi ve çözün önerilerinde bulunulması sözkonusudur. $\mathrm{Bu}$ ise ekonomik açıdan piyasa ekonomisinin ülkede yerleşmesini geciktirmektedir. Elbetteki zihniyet değişimi bir süreçtir, zamana ihtiyaç vardir.

Tehditler

Ekonomik Tehditler 
-Petrol fiyatlarındaki dalgalanmalar. Petrol fiyatlarındaki dalgalanma ekonomik açıdan en önemli tehdittir.

-Yukarı Karabağ probleminin devam etmesi: Yukarı Karabağ henüz Ermeni işgalinden kurtulamamıştır. Bu bölgeye yakın sınırlarda zaman zaman çatışmalar da olmaktadır. Sorunun diyalog ile çözümlenemmesi halinde güç kullanılarak işgal edilen toparkların alınması kararlılığı, ülkenin muhtemel bir savaş ile karşı karşıya olması demektir. Bu problem yabancı yatırımcı açısndan, özellikle petrol dışı sektörlere yatırım yapmada caydırıcı bir etkiye neden olmaktadır.

2012 yılına kadar yapılan toplam 100 milyar dolarlık yatırımların \%70'i yabancı yatırımdır. Yabanc1 yatırımlardan doğrudan yatırımların ise sadece \%30'ü petrol dışı sektörlere plase edilmiştir. Yerli müteşebbislerinde petrol dışı sektörlere ciddi şekilde yatırım yapmadığı görülmektedir.

Sınır ülkelerin konumu: Diğer sınır devletlerinden; Gürcistan'da zaman zaman yaşanan siyasi ve sosyal problemler, Rusya ile sınırda yer alan Dağıstan Özerk Cumhuriyeti'nde Çeçenistan problemi nedeniyle zaman zaman yaşanan hadiseler ve İran'ın siyasi yapısı nedeni ile dış dünya ile hassas ilişki içerisinde olması yabancı ve yerli yatırımcı için olumsuz etki yaratmaktadır. Azerbaycan'a yapılacak olan yatırım, özellikle büyük ölçekli yatırımlar, sadece ülke içi pazar potansiyeli dikkate alınarak yapılmak istenmeyecektir. Yatırımcı bölgedeki diğer ülkeleri de dikkate alarak yapmak isteyecektir. Azerbaycan'ın sınır ülkelerinde zaman zaman yaşanan hadiseler sınırda problemlere neden olmakta, dış ticareti olumsuz şekilde etkilemektedir. Veya hassas ilişkiler içerinide olunması ise dış ticareti olumsuz etkilediğinden yabancı yatırmcıya yine olumsuz şekilde etkide bulunmaktadır.(Aras,2005)

-Hazar'nn statü sorunu: Hazar Denizi'nin statüsünün belirlenememesinden kaynaklanan sorunlar da ülke ekonomisinin kalkınmasına olumsuz etkide bulunmaktadır. Bazı petrol yataklarının tartışmalı olması nedeniyle, petrol şirketleri sözkonusu yataklarda petrol üretimi yapmak istememektedirler. Petrol ve doğal gaz rezervlerinin yanı sıra çok önemli balık ve havyar potansiyeline sahip olan Hazar'ın bu ekonomik imkanları da verimli şekilde kullanılamamaktadır.Öte yandan Hazar'da çevre kirliliği sorunu da zararlı dışsallık olarak ekonomiye olumsuz etkide bulunmaktadır. Statü sorunu Hazar'da deniz ulaşımının gelişmesine de engel olmaktadır.

-Deniz ve okyanus çıkışının olmaması:Ülkenin deniz ve okyanus çıkışııın olmaması ise kıtalararası ulaşımda deniz yolu taşımacılı̆̆ııdan faydalanılamamasına neden olmaktadır.

\section{Azerbaycan'ın Piyasa Ekonomisine Geçişde Karşılaştığı Sorunlar Ve Çözüm Arayışları}

SWOT analizi çerçevesinde Azerbaycan ekonomisinin ülke ekonomik açıdan iç bünyesine bakan yönleriyle güçlü ve zayıf yönlerin yanı sıra dış dünyaya bakan yönleriyle firsat ve tehditler ana hatlarıyla sıralanmıştır.

Yabancı ve yerli yatırımcıların yapacakları yatırımlara ilişkin verecekleri kararlar açısından ilk stratejik adımı, ülke ekonomisinin ülke içi güçlü ve zayıf yanları ve ülke dışına bakan yönleriyle firsat ve tehditleri dikkate alarak atmaları uygun olacaktır. Güçlü yönlerin firsatlarla uyum içinde olduğu alanlara yatırım yapılmasının planlanması uygun olacaktır. Yatırımcılar ancak bu adım sonrasında verecekleri karar doğrultusunda alt sektör, ürün ve bölge bazında karar vermeleri mümkün olacaktır. İlk adım sonrasında hukuki ve diplomatik destek ve güvencenin yanı sıra bireysel ilişkilerin gerekliliğine de ayrıca dikkat çekmek gerekir.

Yukarıdaki analizde dikkat çekilen güçlü ve zayıf yönler ülkenin ekonomik kalkınmasında hangi sektörlere ve ne şekilde, ülkenin firsat ve endişeleri ise hem ekonomik kalkınma hem de dünya ekonomisine entegrasyon açısından siyasi irade tarafından alınacak kararlar, yapılacak programlar, belirlenecek projeler için de önem arz etmektedir.(Aslanl1,2004)

Ülke yönetimi güçlü yönler ile firsatların uyumlaştıracak, bir başka ifadeyle ekonominin güçlü yönlerini firsatlardan yararlanacak şekilde kullanacak kararlar almalı ve uygulamalıdır. Öte yandan zayıf yönleri güçlü yönlere dönüştürecek tehditlerin güçlü yanlar ile bütünleştirilebilecek firsatlara dönüştürüleceği stratejik karar ve politikalar geliştirmelidir. (Bağırzade, 2009)

Ülke yönetiminin gerekli yatıım ikliminin oluşturulmasında daha gerçekçi, kararlı ve güven verici adımları atması, teşvikleri sağlaması, yatırım iklimini olumsuz şekilde etkileyen zayıf yönleri ve tehdit eden unsurları giderici ekonomik, siyasi ve sosyal politikalar belirlemesi ve daha da önemlisi belirlediği politikalar doğrultusunda fiili adımlar atması gerekmektedir.Dış ticarette 150'den fazla ülke ile ekonomik ilişkiye giren Azerbaycan bir çok uluslararası ve bazı bölgesel organizasyonların üyesidir. Yapılan petrol anlaşmaları, petrol anlaşmalarına destek veren ülkeler, ülkelere ait petrol şirketleri ve yapılan yatırımların vermiş olduğu güven ortamı da ülkede mevcuttur.

-Serbest piyasaya geçişte bölgedeki ülkelere göre daha önde olması.

Serbest piyasa ekonomisine geçiş sürecinde, bölgede bağımsızlığını kazanan yeni cumhuriyetler ile mukayese edildiğinde, hukuki ve kurumsal altyapıyı gerçekleştirmede daha önde bulunmaktadır.

-Bağımsızlığını kazanan ülkeler arasında en fazla yabancı yatırımın yapıldı̆̆ı ülke olması: 
Bölgede bağımsızlığını kazanan diğer ülkeler ile mukayese edildiğinde en fazla yabancı yatırımın Azerbaycan'a yapıldığı görülmektedir. Bu ise petrol üretimine başlanmasından sonraki süreçte, diğer sektörlere yatırım yapılmasında, yatırımcı için olumlu bir gösterge olacaktır.

-Petrol ve doğal gaz ihracatçısı ülkeler arasında yer alması.

Petrol yataklarının keşfinin ardından yapılan çalışmalarla, 2005 yılından itibaren petrolün, 2006 yılından itibaren ise doğal gaz ihracatçı ülkeler arasında yer alacak olması, ülkeye yabancı yatırımları çekme ve dünya ekonomisine entegre etmek bakımından en önemli fırsatlardan biridir.

\section{Ekonomi Dışı Fırsatlar}

-Tarihi geçit ve ticari yollar üzerinde olması:

Coğrafi konumu ile Azerbaycan, iki kıtayı ve üç deniz havzasını birbirine bağlayan Yeni İpek Yolu gibi çok önemli tarihi ve ticari yolların geçiş güzergahında yer almaktadır.

-Bölge ülkeleri arasında demokrasiye geçişte aldığı mesafe:

Bölgede bağımsızlığını kazanan yeni ülkeler arasında demokrasiye geçişte daha önde bulunmaktadır. Bu özellik, bölge pazarına yönelik yatırımların Azerbaycan' da yapılmasına imkan vermektedir.

-Bölge ülkeleri arasında istikrarlı ve daha demokratik bir yönetimin varlığı.

Haydar Aliyev'in iktidara gelmesinin ardından ülkede sağlanan siyasi istikrar ve iktidarın demokratik tutumu diğer bölge ülkelerine göre yatırımcının Azerbaycan'ı tercihinde etkin olmaktadır.

Yatırımı İklimindeki Olumsuzluklar

Azerbaycan'da yatırım ikliminin elverişliliği bakımından, vergi oranlarının yüksekliği, rüşvet, yolsuzluk ve monopollerin varlığı, gerekli kanuni düzenlemelerin yetersizliği gibi olumsuzluklar müteşebbisler açısından endişe edilen konuların başında gelmektedir. Geçiş süreci yaşayan ülkelerde rekabet politikası esas unsurlardan biri olarak kabul edilmektedir. Ekonomide aynı şartların olmaması iş adamlarının faaliyetlerini engellemekte, iktisadi gelişmeyi geciktirmektedir. Azerbaycan hükümeti tarafından ekonomide eşitsizlik ortamının giderilmesine ilişkin bazı önlemler alınmaya çalışılmaktadır. Yolsuzluk ile mücadele programının kabulü buna örnek gösterilebilir.Vergi oranlarının yüksek olması nedeniyle, özel sektörün kayıt dışı faaliyete üstünlük verdiği görülmektedir. Özel işletmelerin büyük bir kısmı, istihdam ettiği personeline verdikleri ücretlerin büyük kısmını gayri resmi olarak vermektedirler. Kayıt dışı ekonomi daha çok silah, narkotik maddeler ve pornografik ürünlerin kanunsuz üretimi ve satışı olarak algılanmasına karşın, Azerbaycan'da esas olarak en basit üretim, ticaret ve hizmet alanlarında kayıt dışı ekonomik faaliyetler yürütülmektedir.(Bağırzade, 2007). Yapılan bazı değerlendirmelerde, kayıt dışı ekonominin kayıt altına alınan ekonomik faaliyetlerden daha büyük olduğu hesaplanmaktadır. Azerbaycan'da yapılan yabancı yatırımların \%80'inin petrol sektörüne olduğu görülmektedir. Sektörel yatırımların daha çok petrol sektörüne yapılması ve bu doğrultuda GSMH'nın önemli bir bölümünün petrol gelirlerinden oluşması endişe vericidir. Petrol sektörünün tek taraflı gelişimi nedeniyle dünya piyasalarındaki fiyat değişmeleri GSMH üzerinde de dalgalanmalara neden olmaktadır. Bu durum 1998 Rusya krizinde açıkça görülmüştür. Kısaca Azerbaycan ekonomik açıdan "Hollanda Sendromu" diye ifade edilen, bir bölgenin veya bir sektörün hılı gelişimi karşısında diğer bölgelerin veya sektörlerin çökmesi sonucunu doğuracak bir tehlike ile karşı karşıyadır.

Ekonomik gelişmenin sadece doğal kaynakların ihracı üzerine kurulması halinde ülke rezervlerinin tükenmesi ve sosyal adalet ilkesinin aksine olarak nüfusun yalnız küçük bir grubunun faydalanması, çoğunluğun yaşam düzeyinin düşmesi sonucunu doğurmaktadır. Dolayısıyla ekonomilerini sadece doğal kaynaklara ve tek sektöre dayandıran ülkelerin hem iç hem de dış ilişkilerde bağımsızlıklarını zedeleme durumu olabilecektir. Ekonominin sadece enerji sektörüne bağımlı olması bazı sosyo-ekonomik olumsuz sonuçlar da doğurabilecektir. Enerji sektörüne vasıflı işgücü ve araçların akımı diğer sektörlerin gelişim potansiyelini olumsuz yönde etkileyecektir. Petrol gelirlerinin ithal malları alımında harcanması, özellikle yatırım malları yerine tüketim malları ithal edilmesi durumunda, ülkenin ticaret bilançosu da açık verebilecektir.

Azerbaycan ekonomisine yabancı yatırım akımının güçlendirilmesi ve onların korunması için her türlü şartların yerine getirilmesi, "Hollanda Sendromu"ndan kurtuluş için ekonomi politikalarının temel amaçları arasında yer almaktadır.( Bulut, Suleymanov, 2012) Bu politikaların başında yatırım ikliminin elverişli kılınması gelmektedir. Bunun gerçekleşmesi için; önce ticari olmayan risklerin ortadan kaldırılması, vergi oranları, vergi toplama sistemi ve etiği, yabancı sermayeyi güvenceye alıcı hukuki ve idari düzenlemelerin varlığ ve icraatı, vergi ve gümrük sistemlerinin optimizasyonu ile ilgili düzenlemeler yapılmalıdır.Hollanda Hastalığ dışında Azerbaycan açısından yabancı sermayeden kaynaklanan problemler şunlardır: Ülkenin diş borcunun artması,yabancı sermayeli ve müşterek işletmelerin faaliyetlerinin daha çok erken gelir getiren hammadde yönlü ve hizmet sahalarına yönelmesi,ülkenin üretim sanayisi sahalarına yabancı sermaye yatırımının çok az olması,yatırımların hemen hepsinin Abşeron bölgesinde toplanması sonucu, diğer bölgelerde yabancı sermayenin yok denecek kadar az olmasi, 
Uluslararası finans kuruluşlarından alınan krediler ve finans kuruluşlarının verdikleri tavsiyelerin ülkede makroekonomik istikrarın sağlanmasında büyük rol oynamasına karşın, reel sektörde üretimin seviyesinin ve veriminin yükseltilmesi ve halkın sosyal güvenliğinin artması gibi sosyo-ekonomik problemlerin çözümünde fark edilir bir değişiklikler sağlamamasıdır.Ülkede işletmecilerin karşılaştı̆̆ı başlıca problemlerden biri de tekelcilik eğilimleridir. Bazı şirketlerin, iş adamlarının belirli alanları monopolleştirmesi özel teşebbüsün gelişmesinin karşısına engel koymakta hatta iş yerlerinin kapatılmasına neden olmaktadır. Azerbaycan'da özel teşebbüsün gelişmesine tekelcilik ve haksız rekabet engel olmaktadır. Tekellerin varlığ fiyatların kaotik şekilde artmasını da netice vermektedir.

\section{Sonuç}

Kısaca Azerbaycan ekonomik açıdan "Hollanda Hastalığı" diye ifade edilen ve en genel anlamda; bir sektörün hızlı gelişimi karşısında diğer sektörlerin gelişmemesi sonucunu doğuracak bir tehlike ile karşı karşıyadır. Hatta Azerbaycan'ın bir sektöre bağımlılığın ötesinde bir bölgeye bağımlılık tehlikesi ile de karşı karşıya olduğu görülmektedir.Bağımsızlık sonrası Azerbaycan ekonomisinin gelişimini ana hatlarıyla incelememiz sonucu, 1991-1996 yılları arası dönemde ekonominin neredeyse tüm parametrelerinde önemli gerilemelerin, 1996 yılından başlayarak ise istikrarın sağlanması ve 1998 Rusya ve 2008 dünya ekonomik krizlerinin etkileri dışında pozitif yönde gelişmelerin yaşandığı ortaya çıkmıştır. Özellikle petrol ve doğalgaz sektöründe yaşanan hızlı gelişim süreçlerinin etkisiyle 2000'li yıllarda temel ekonomik parametrelerde çok büyük iyileşmeler kaydedilmiş ve bunun önümüzdeki yıllarda da devam edeceği öngörülmektedir. Böylece bağımsızlık sonrası ekonomide yaşanan tüm olumlu ve olumsuz süreçlere rağmen 1991-2013 yılları arasında GSYİH hacmi (diğer ifadeyle Azerbycan Ekonomisinin büyüklüğü) yaklaşık 120 defa, kişibaşına GSYİH hacmi 400 defa, devlet bütçe harcamaları 280 defa, toplam dış ticaret hacmi 30 defa, ihracat 10 defa, ithalat ise 10 defa artmış ve bugün Azerbaycan ekonominin tüm temel kantitatif parametreleri üzerine Güney Kafkasya'da lider konumdadır. Azerbaycan'ın dış borç miktarı 2013 yılı başı itibariyle 5.688 milyar ABD dolarıdır. Bu miktar GSMH'nın \%13.6'sına tekabül etmektedir. Kişi başına düşen dış borç miktarına göre, BDT ülkeleri ile karşılaştırıldığında sıralamada ortalarda yer almaktadır. Fakat bağımsızlık sonrası yaşanan tüm pozitif gelişmelere ve hükümetler tarafından uygulanan çozüm stratejileri ve politikalarına rağmen, Azerbaycan Ekonomisinde hala belli sorunlar yaşanmaktadır ki, bunlardan da en önemlileri ekonominin önemli ölçüde petrol sektörüne bağımlı hale gelmesi, istihdam dostu ekonomik büyüme modeline geçilememesi, bölgesel dengesizlik, tarım sektörünün verimsizliği, Dağlık Karabağ ve çevre bölgelerinin Ermenistan tarafından işgalinin doğurduğu sosyo-ekonomik sorunlar, yüksek faizler, yüksek vergi yükü, kamu hizmetlerinin yeteri kadar gelişememesi, şirketleşme oranının düşüklüğü, kurumsal yönetim geleneğinin zayıf olması, "nakit ekonomisi”nin yaygın olması, suni tekelcilik, kayıtdışılık, yolsuzluk ve çeşitli altyapı sorunlarıdır. Ekonomide yaşanan mevcut sorunların çözümü konusunda aşağıdaki yönlerde politika önlemlerinin alınması etkili olabilir:

- Sürdürülebilir ekonomik kalkınmanın sağlanması, istihdam düzeyinin yükseltilmesi, yoksulluğun azaltılması, gelir dağılımında adaletsizliyin azaltılması, regionlar arasında farklı gelişim düzeyinin azaltılması, petrol dış1 sektörlerin geliştirilmesi yönündeki hükümetin 2008-2012 ve 2013-2015 programlarının takibi ve bu yönlü hükumet politikların sürekliliyi:

-Serbest Piyasa keçit sürecinde yasaların uygulanabilirliyi ve dünyadakı gelişmiş ülkelerin tecrübesinden yararlanma

-Doğal kaynaklara dayanan ekonomik büyüme modelinden yüksek teknoloji ve verimliliğe dayanan ekonomik büyüme modeline geçilmesi gerekir. Bunun için ülkeye yeni teknoloji transferinin teşviki, teknoparkların kurulması, bilim-ekonomi işbirliğinin en mükemmel modellerinin uygulanması, ekonomide kaynak tahsisi ve kullanımı alanında verimlilik artışına yol açan modern üretim ve yönetim sistemlerinin ve optimal büyüklükteki ekonomik birimlerin oluşturulması, eğitimin, özellikler de teknik eğitimin kalitesinin yükseltilmesi

-Petrol fonunda biriken yaklaşık 50 milyar dolarlık rözervin verimli kullanılması.Bu kaynaktan yatırımcıların etkili kullanabilmesi ve bu kaynakların yurt içinde ve yurt dışında etkili yatırımlarla daha da artırılarak petrol sonrası dönemin sigortalanması ve güvence altına alınması.

-Yoksulluğun ve gelir eşitsizliğinin azaltılması amacıyla, yoksullukla mücadelenin mevcut politika mekanizmalarının geliştirilmesi, gelir eşitsizliğinin azaltılmasında mali politika araçlarının aktif şekilde kullanılması gerekir.

-Enflasyonla mücadelenin devamlılı̆̆ını sağlayacak ve enflasyonun ekonomik sistem üzerindeki olumsuz etkilerini minimize edecek politikaların geliştirilmesi.

-Faiz politikasının kayıtdışı tasarrufları yatırım şeklinde resmi sektöre kazandırma etkisinin yükseltilmesi gerekir. Bu açıdan mevduatlara uygulanan ortalama faiz derecesi ile sermayenin kayıtdışı sektörde ortalama getiri derecesi arasındaki farkın minimize edilmesi, yatırım kredilerine uygulanan faiz derecesinin resmi sektörde yatırım faaliyetlerini özendirecek etkiye kavuşturulması etkili olabilir. 
-Ülkede makroekonomik istikrarın önemli unsuru olan döviz gelirlerinin uzun vadede devamlılı̆̆ının sağlanması açısından ihraç gelirlerinin petrole bağımlılığının azaltılması amacıyla petrol dışı sektörlerin ihrac potansiyelinin artırılması yönünde politika önlemlerinin alınması gerekir

-Bütçe dengesinin devamlılığının ve bütçenin sosyo-ekonomik fonksiyonlarının daha etkin bir şekilde gerçekleştirilmesinin sağlanması amacıyla, onun petrol faktörüne bağımlılığının zamanla azaltılması ve vergiler gibi devamlı gelir kaynakları ile finanse edilme düzeyinin yükseltilmesi gerekir

-Hem ekonomik kalkınmayı hızlandırması, hem de kayıtdışı sektörü sınırlayıcı etkiye sahip olması düşünülerek, petrol dışı sektörde yabancı yatırımları özendirici politikaların geliştirilmesi.

-Girişimciler için devlet teşvik mekanizmalarının geliştirilmesi gerekir. Bu bakımdan yeni girişimciler için teşviklerin genişletilmesi, Girişimciliğe Destek Ulusal Fonu'nun ucuz kredilendirme mekanizmasının geliştirilmesi, tarım sektöründe uygulanan teşvik mekanizmasının etkinliğinin artırılması, girişimcilere devlet tarafından bilimsel ve bilgi edinme desteğinin genişletilmesi, girişimcilerin devlet tarafindan ödüllendirilme mekanizmasının geliştirilmesi önlemleri etkili olacaktır.

-Girişimcilik altyapsının geliştirilmesi gerekir. $\mathrm{Bu}$ bakımdan özellikle sermaye ve sigorta piyasasının geliştirilmesi, organize sanayi bölgelerinin oluşturulması, danışmanlık hizmetleri sektörünün ve fuarcılık altyapısının geliştirilmesi önem arz etmektedir.

- Ülkede girişimcilerin hak ve menfaatlerinin sağlanması düzeyinin daha da yükseltilmesi gerekir. Bu açıdan girişimcilerin organize olma düzeyinin yükseltilmesi, resmi işlemlerdeki gecikmelerin önlenmesi ve fikri mülkiyet veya telif haklarının korunması zorunludur.

- Kayıtdışı ekonomiyle mücadele politikasının geliştirilmesi gerekir. Bu yönde kayıtdışı ekonomiyle mücadele alanında devlet programının hazırlanması, resmi merkezi kurumun oluşturulması, istatistik verilerin geliştirilmesi, cezaların sertleştirilmesi, yasal boşlukların giderilmesi.

\section{Kaynakça}

- Aras, Osman Nuri, Suleymanov, Elchin and Zeynalov, Ayaz, Azerbaycanın Enerji Kaynakları Gelirlerinin Ülke Ekonomisine Etkisi (Azerbaijan's Energy Source Revenues and Their Effect on the Economy of the Country) (December 27, 2012). Available at SSRN: http://ssrn.com/abstract=2194173 or http://dx.doi.org/10.2139/ssrn.2194173

- Bulut, Cihan and Suleymanov, Elchin, Azerbaycanin Hollanda Hastaliği Problemini Önleme Stratejilerinde Türkiye Ile Yapilan Ekonomik Ilişkilerin Önemi (Importance of Economic Collaboration between Azerbaijan and Turkey in Preventing Dutch Disease in Azerbaijan) (October 17, 2012). International Symposium on Regional Cooperation and Development on October 17-20, 2012 (Erzurum, Turkey), səhifə/səhifə aralığ1: 99-117, Okt 2012. Available at SSRN: http://ssrn.com/abstract=2172960 or http://dx.doi.org/10.2139/ssrn.2172960

- Suleymanov, Elchin and Zeynalov, Ayaz, Azerbaycan Ekonomisinin Bagimsizlik Sonrasi Makroekonomik Gostericilerinin Ekonomik Istikrar Acisindan Genel Degerlendirilmesi (The General Assessment of Macroeconomic Indicators of Azerbaijan Economy after Independence from the Economic Stability Point of View) (October 28, 2009). Journal of Qafquaz University, 2009. Available at SSRN: http://ssrn.com/abstract=2167943

- Aras, O. N. (2005). Azerbaycan Ekonomisi ve Yatırım Imkanları. Bakü: TÜSİAB Yayın No: 2005-001.

- $\quad$ AR Merkezi Bank1. (2012). 2011 Illik Hesabat. Bak1.

- Aras Osman Nuri, Azerbaycanın Hazar Ekonomisi ve Stratejisi, Derin Yayınları ,İstanbul, 2008

- Aras Osman Nuri, Elçin Süleymanov “Azerbaycan Ekonomisi” Şark-Garb Matbaası , Bakü, 2010.

- Aslanlı Araz, "Bakü-Tiflis-Ceyhan: Petrolün Ötesinde Önem Taşıyan Hat”, TUSAM Ulusal Güvenlik Stratejileri Araştırma Merkezi, 05.10.2004, http://www.tusam.net/makaleler.asp?id=48\&sayfa=53. (25.12.2007).

- Atakıshıyev Mushfig, New Oil Policiy and Economic Development in Azerbaijan, Aspoligraf, Baku, 2007.

- Bağırzade, E. R. (2007). Kayıtdışı Ekonominin Temel Özendirici Faktörlerinden Biri Gibi Yolsuzluk ve Onunla Mücadelenin Azerbaycan Girişimleri. Akademik Bakış, Uluslararası Hakemli Sosyal Bilimler EDergisi, Ocak, Sayı: 11. 5 Ocak 2011 tarihinde http://www.akademikbakis.org/sayi11/makale/kayitdisi.pdf adresinden erişildi.

- Bağırzade, E. R. (2009). Müstegil Azerbaycanda Reallaşdırllan İktisadi Siyasetin Leqallaşdırma Aspektleri. "Heyder Eliyev Iktisadi Inkişaf Strategiyasının Tentenesi” Mövzusunda Keçirilmiş Elmi-Praktiki Konfransın Tezisleri, Bakı: İktisad Universiteti, 141-145

- Bağırov S., "Azerbaijan Oil: Glimpses of a Long History", Journal of International Affair, June 1996, s.28.

- BP Statistical Review of World Energy 2011, http://www.bp.com/centres/energy, (07.04.2012). 
- Cornell Svante E. - Isma1lzade Fariz, "The Baku-Tbilisi-Ceyhan Pipeline: Implications for Azerbaijan", The Baku-Tbilisi-Ceyhan Pipeline: Oil Window to the West, (Edited by S. Frederick Starr and Svante E. Cornell), 2005, ss.61-84.

- Doing Business in Azerbaijan, Baker\&McKenzie, May 2012.

- Eldaroğlu Ekber, "Neft Fondunun Vesaitleri Hansı İstiqamete Yöneldilmelidir?”, Azerbaycan Milli Demokratiya Fondu, "Azerbaycan" Bülleteni - 25 (145), 21 İyun 2001.

- Sabiroğlu İlkin, "Neft Böhranları ve Holland Sindromu”, Azerbaycan Milli Demokratiya Fondu Azerbaycan Bülleteni, No: 19 (139), 10 May 2001.

- Süleymanov Elçin, Zeynalov Ayaz, "Azarbaycan Respublikasının Xalis Ixxrac Funksiyası va Xarici Ticarət Multipikatoru", Azərbaycan, Qloballaşma Prosesində Qafqaz və Mərkəzi Asya III beynəlxalq Konfrans 15-17 Oktyabr 2010 Qafqaz Universiteti, səhifə/səhifə aralığı: 124-125, Okt 2010 , 


\title{
Rus Dış Politikasında Ekonomik Bölgeselleşme: Avrasyacı Bütünleşme Modeli'nden Söz Edilebilir mi?
}

\section{Economic Regionalisation in the Russian Foreign Policy: Is it Possible to talk about the Eurasianist Model of Integration?}

\author{
Prof. Dr. Erhan Büyükakıncı (Galatasaray University, Turkey)
}

\begin{abstract}
In this paper, we try how the idea of economic regionalism has developed within the framework of the interests of the Russian foreign policy, which adopted a Eurasianist rhetoric for nearly fifteen years. As the trends of globalisation spread over the world after the end of the Cold War period, the regional integration movements also gained speed with different forms and contents. Meanwhile the countries in the post-Soviet geography adopted different political approaches towards regionalisation and globalisation by taking into consideration their own capabilities and interests. At its own side, Russia was in search of integration within the world economy by trying to implement its own regionalist policies both at the level of the CIS area and with the neighbouring countries like China and the EU. The Eurasianist discourse has no doubt such impact on Russian leadership's choices of partners and orientations for economic regionalisation. At this point, we want to discuss if it is possible to talk about some "Eurasianist model of regional integration" as a new idea which can combine, at one side, the institutional integration process within the CIS area and, at the other, the strong regional cooperation with the Asian economic partners like China. This model can be also Russia's answer to embrace both globalism and regionalism by preserving its own hegemonic expectations after the Soviet legacy.
\end{abstract}

\section{Giriș}

Soğuk Savaşın bitişiyle birlikte tüm dünyada bölgeselleşme ve küreselleşme eğilimleri farklı açılardan tekrar tartışılmaya başlanmıştır. İdeolojik blokların ortadan kalkmasıyla, bir yandan tüm dünyada ekonomik ve demokratik yapılarda belirli bir liberalleşme eğilimi gözlenirken, öte yandan da bölgeselleșme yaklaşımlarının hız kazanmasına tanık olduk. Aslında bölgeselleşme-küreselleşme birlikteliğinin "ilk dalga"sı, Soğuk Savaş yıllarında Latin Amerika merkezli olarak karşımıza çıkmışıı; ithal ikameci bir sanayi politikasına yönelik daha korumacı hedefi olan bir bölgeselleşme akımı niteliğindeydi. Bölge ülkeleri arasında hammadde akışılla birlikte küreselleşmenin etkilerinden korunma arzusu söz konusuydu. Ancak 1970'lerden itibaren petrol krizlerinin yanı sıra Soğuk Savaş döneminin tekrar 1sınması ile birlikte küreselleşme-bölgeselleşme tartışmaları etkisini yitirmişti.

Tüm dünyada bunlar yaşanırken SSCB geneline baktığımızda, Gorbaçov'un 1985'te S.B.K.P.'nin genel sekreterliğine gelmesiyle başlayan Perestroyka süreciyle ideolojik tonların hem siyaset, hem ekonomi üzerindeki etkileri hafiflemesi ve sosyal yapılarda belirli bir liberalleşme sürecinin başlaması söz konusuydu. 1980'lerin ikinci yarısından sonra yavaş yavaş tüm dünyaya yayılan bu liberalleşme süreci, "ikinci dalga" olarak hem bölgeselleşme eğilimlerinin kurumsallaşmasını hızlandırmaya başlamıș, hem de küresel düzlemde yeni değerlerin ve kurumların doğuşunu desteklemiştir. Soğuk Savaşın bitişi bu dalganın tüm dünyada kabul görmesini de kolaylaştırmıştı, ancak birçok ülke ulusal kalkınmasını tek ürün-hammadde kültürüne dayandırarak küreselleşmeye ayak uydurmak yönünde politikalar benimsemişti.

Nitekim 1990 yılında imzalanan ve Soğuk Savaşın bitiş belgesi konumundaki Paris Şartı ile birlikte hem insan hakları ve liberal demokrasi konuları artık devletler arasında sınıraşan bir tema haline gelirken, serbest piyasa ekonomisi yaklaşımı tüm dünya çapında genel bir kabul kazanmıştı. Birinci Körfez Krizi ve bunu takiben de SSCB’nin dağıllmasının ardından, dönemin ABD Başkanı George Bush'un "Yeni Uluslararası Düzen" söylemi liberal demokrasi ve serbest piyasa ekonomisinin birlikteliğinin artık dünyada tek geçerli yaklaşım olduğunu ilan etmekteydi. Bu aşamada SSCB'nin dağılması sonucunda ortaya çıkan Rusya Federasyonu'nun bu “yeni dünya düzeni”ndeki konumu neydi ve yeni gelişen liberalleşme süreçlerine bakışı nasıldı?

Soğuk Savaşın bitimiyle birlikte küreselleșme ve bölgeselleșme olgularının birlikte hareket ettiklerini görüyoruz. Avrupa Topluluklarının Avrupa Birliği'ne dönüşmesi ve genişleme ve derinleşme süreçleriyle Avrupa kıtasının büyük bir bölümünde hem siyasal hem de ekonomik bütünleşmenin birlikte geliştiğine tanık oluyoruz. Bu süreç 1990'ların başlarından 2000'lerin ortalarına kadar devam eden bir dönemi kapsamaktadır ve bu çerçevede Avrupa bütünleşmesinde yeni bir yapı ortaya çıkmıștır. Her ne kadar üye devletlerin arasında ortak dış ve savunma politikasının kurumsallaşması yetersiz olmuşsa da, para birliğinin gerçekleşmesi bölgesel bütünleşmenin en önemli aşaması olarak da değerlendirilebilir, çünkü sosyal politikalardan ekonomik yapılara kadar para birliğinin inşa süreci siyasal karar alma mekanizmalarını da doğrudan etkileyen bir etki yaratmaktadır.

Avrupa Birliği'nin yanı sıra NAFTA (Kuzey Amerika Serbest Ticaret Alanı), MERCOSUR (Latin Amerika ülkeleri arasındaki ekonomik bölgesel yapılanma), ASEAN (Güneydoğu Asya), APEC (Asya-Pasifik coğrafyası) 
gibi liberal ekonomi koşulları üzerinde kurumsallaşan, hem kıta içinde hem de kıtalar arasında ekonomik yakınlaşmayı amaçlayan hükümetlerarası yapıların ortaya çıkması, ekonomi-politika evliliğinin en önemli göstergesidir. Aynı zamanda bu kurumsal yapılar, küresel düzlemde liberalleşme yaklaşımın benimsenmesinin de en önemli göstergesiydi.

1990'lardan itibaren ivme kazanan bölgesel bütünleşme süreçlerine baktığımızda bu temel olguları tespit etmekteyiz: a) serbest ticaret alanı ya da gümrük birliği yapılanmalarıyla ekonomik alanda bir bütünleşme çabası; b) lojistik koşullarının kolaylaştırılması ve buna bağlı ülkeler arası ulaşım (karayolları, demiryolları, havayolları) şebekelerinin çeşitlendirilmesi ve güçlendirilmesi; c) toplumlar arası yakınlaşma ve kimlikler arası farklılıkların giderilerek sosyo-kültürel bir uyumlandırma sürecinin yaratılması. Hem materyal hem de sosyokültürel düzlemlerden bakıldığında, bölgesel bütünleşme sürecinin küreselleşmenin yaygınlık kazanmasına da yardımcı olduğunu söylemek mümkündür. $\mathrm{Bu}$ çerçevede küreselleşme-bölgeselleşme ilişkisinde daha önce zikrettiğimiz birinci (korumacı) dalga ile ikincisi (liberalleştirme eksenli) dalgalar arasında dönüşümlerin de olduğunu vurgulamak gerekiyor (Guraziu, 2008). Özellikle 11 Eylül sürecinden sonra iç politika ve güvenlik nedenleriyle küreselleşme etkilerini sınırlandırmak amaçlı devletlerin bölgeselleşme politikalarında belirli korumacı önlemler aldıkları da gözlemlenmektedir ve bu örnekleri özellikle de AB içindeki Anayasa ya da Romanların statüsü tartışmalarında da görmek mümkündür.

$\mathrm{Bu}$ süreçler olurken Avrasya coğrafyasında eski Sovyet mirası sonrasında yaşanılan dönüşüm çerçevesinde hangi bütünleşme tartışmaları yaşanmaktaydı? Rusya'nın bu tartışmalar içerisindeki konumu ve bakışı nedir? Bu çalışmamızda, dış dünyaya açıklık ya da kapalılık arasında giden bir bölgeselleşme olduğu hipotezinden hareketle, Rusya'nın özellikle Putin döneminde izlediği Avrasyacı dış politika çizgisine paralel olarak bölgeselleşmeye bakışının dünyadaki örnekler kadar küreselleşmeyi destekler ve dışa açık bir konumda olup olmadığını tartışmak istiyoruz. Bu çerçevede BDT içi ve dışı coğrafyalarda Rusya'nın ekonomik alandaki bölgeselcilik yaklaşımlarının nasıl şekillendiğini ve bu bağlamda "Avrasyacı bir bütünleşme modeli”nden söz edilip edilemeyeceğini gerekçeleriyle değerlendirmeye çalışacağız. Bu modelin Rusya'nın küreselleşen ekonomi şartlarıyla uyumlanmasına mı yardımcı olacağını, yoksa tam tersi daha korumacı, kendi alanı içinde daha müdahaleci bir zemin mi yaratacağı sorusuna da yanıt aramak istiyoruz.

\section{Rus Dış Politikasında Bölgeselleşme Düşüncesi ve Girişimlerin Başlaması}

Rus dış politikasında bölgeselleşme düşüncesi hangi şartlarda ortaya çıkmıştır sorusunu sorduğumuzda, karşımıza şu faktörler çıkmaktadır: Ekonomik ve altyapısal nedenler, jeopolitik ve tarihsel devamlılık arayışı, siyasal gereksinimler ve toplumsal zorunluluklar.

Sovyetler Birliği'nin dağılması neticesinde ortaya çıkan bağımsız devletlerin arasında BDT'nin kurulması, aslında "eski rejim"in avantajlarının sürdürülmesi çabası olarak değerlendirilebilir. Sovyet döneminin hem sosyo-politik, hem de ekonomik düzeni, bu birliği oluşturan devlet yapıları arasında belirli bir karşılıklı bağımlılık süreci yaratmış ve ekonomi-siyaset etkileşimi yapısal bir bağlayıcılık haline gelmişti. SSCB'nin dağılması, bağımsızlık süreçlerini doğurmuş olsa da, karşılıklı bağımlılığın belirli dezavantajlarını da ortaya koymuştu. Nitekim Sovyet sonrası alanda ortaya çıkan bağımsız devletler, aralarında karşılıklı sınırlar, azınlıklar, göçler gibi sosyo-politik sorunlar yaşarlarken, ekonomik bağımsızlıklarını özellikle mali/parasal alanlardan yeniden üretim şartlarının tanımlanması ve yapılanmalarına kadar oluşturmaya çalışmışlardır. Bu açıdan bakıldığında, iç ve dış politika etkileşimi de bu yeni süreç de kendisini göstermiştir. Rusya ve diğer bağımsız devletler, ekonomik yapılanmalarına paralel olarak dış politika söylemlerinde farklı açılara yönelmişler ve Sovyet sonrası coğrafyada dağınık yaşayan etnik gruplara yönelik özel hassasiyetler geliştirmeye başlamışlardır.

Özellikle 1990’ların başında Rusya açısından bakarsak, Soğuk Savaş döneminin blok liderliği - büyük güç statüsünden bölgesel bir güç konumuna düşmesi farklı siyasal söylemlerin ortaya çıkmasına yol açmıştır. Dönemin Rusya Başbakanı Gaydar'la başlayan ekonomide şok terapi politikası uygulamaları, buna uygun bir dış politika stratejisini zorunlu kılarken Avrupac1-Atlantikçi tonları içeren bir "Batıcılık" yaklaşımı hem Avrupa kurumları (Avrupa Konseyi, Avrupa Birliği) ve uluslararası iktisadi kuruluşlarla (İMF) siyasal ve ekonomik alanlarda yakınlaşma ve bütünleşme çabasını zorunlu kılmaktaydı, hem de NATO, AGİT gibi güvenlik alanlarındaki uluslararası kurumlarla işbirliğini cesaretlendirmekteydi. Bu aşamada liberal dünyanın bir parçası olmak isteyen Rusya'nın ekonomi-siyaset çıkarlarını bir arada gözeterek daha batıcı bir yaklaşımla, BDT alanından uzaklaştığına tanık olduk (Kubicek 2009; Libman 2007). Ancak bu liberalleşme aşaması, Rus iç politikasında en başından itibaren engellerle karşılaşmıştır; Komünistlerin Devlet Duması içerisindeki çoğunlukları karar alma sürecini tıkarken, Sovyet sonrası süreçte devletin ve bürokrasinin dönüşümü iradesi sınırlı kalmıştır. Tabii ki bu aşamada SSCB gibi yetmiş yıllık bir ideolojik yapıdan yepyeni bir liberal düzene geçişin kısa sürede gerçekleşmesi mümkün değildi (Büyükakıncı, 2004).

1990’ların başında Yeltsin yönetimi Batı’yla yakınlaşmanın yanı sıra BDT içi işbirliği araçlarını birçok alanda yaratmaya çalışmıştır; güvenlik işbirliği alanında Taşkent Antlaşması ile Kiev anlaşması, ekonomi alanındaki girişimleri göz önünde bulundurursak, hiç birisinde de yeniden bütünleşme ve Sovyetlerinkine benzeyen bir yapıya geçme iradesi bulunmamaktaydı. Her ne kadar 1990'ların ortalarından itibaren "Avrasyacı”" söylem 
ağırlığını göstermişse, BDT içi karar alma mekanizmalarının derinleştirilmesi, çeşitlendirilmesi ve daimi anlamda kurumsallaştırılması söz konusu değildi (Nikitin, 2008). Bu dönemdeki Birinci Çeçen Savaşı, Rusya Federasyonu devleti kendi içerisindeki yapılanmasına dair sorunları su yüzeyine çıkartırken siyasette oligarklar gibi yeni karar alma aktörleri ortaya çıkıyordu. Bu açılardan bakıldığında 1990'lı yılların karmaşasında Rus dış politikasının kendi yakın çevresine yönelik özel bir bölgesel bütünleşme yaklaşımına girebileceği bir çizginin oluşamadığını söylemek mümkündür (Libman, 2011).

Her ne kadar Karadeniz Ekonomik İşbirliği Bölgesi - KEİB, BDT alanı dışından Türkiye tarafından önerilen bir ekonomik bölgeselleşme hareketi olarak çıkmışsa da, bunun ciddi bir bütünleşme hareketine dönüşemediğini söylemek gerekir (Aelenei, 2013). Öte yandan 1994 yılından itibaren AB-Rusya yakınlaşmasına paralel olarak ortaklık ve işbirliği anlaşmasının oluşturulup işlerlik kazandırılması, TACIS gibi fonların BDT coğrafyası düzleminde devreye sokulması, Kuzey Boyutu gibi alt-bölgesel projelerin ele alınması, daha çok bölgeler arası ilişkilerin stabilizasyonu amacına hizmet etmekteydi (Büyükakıncı, 2003). Bunların yanı sıra, Orta Asya ülkelerinin kendi aralarında CASCO gibi serbest ticaret - gümrük birliği karması bir yapıya ilk adım atmaları, Rusya'nın dışında ortaya çıkan bir oluşumdu (Büyükakıncı, 2000).

Son olarak da 1997 yılında Şanghay Beşlisi olarak başlayan ve daha çok sınır güvenliği konularına odaklanan bir bölgesel işbirliği kurumu oluşumu, Rusya ve Çin'in kendi aralarında başlattıkları özel bir süreç olarak ele alınabilir; Rusya'nın Avrasyacı dış politika çizgisinin BDT dışı girişimleri çerçevesinde, "Şanghay İşbirliği Girişimi”, Y. Primakov'un dışişleri başkanlığının ve Rus dış politikasına getirdiği yeni bakış açısının en önemli meyvası olarak görülebilir. Nitekim bu girişim bölgesel bütünleşme arayışından daha çok stratejik bir ortaklığın ilk aşaması olarak karşımıza çıkmakta (Balzer, 2008; Kerr, 2010).

Rusya'da Putin'in başbakanlık görevine gelmesi ve ardından da İkinci Çeçen Savaşı'nın başlamasıyla tamamen kendisini gösteren Avrasyacı-milliyetçi dış politika söylemi, BDT alanındaki eski kazanımları yeniden değerlendirmek hedefini ortaya koymuştu. Nitekim 2000 yılından itibaren kollektif güvenlik alanındaki Taşkent antlaşmasının yeniden canlandırılması, Avrasya Ekonomik İşbirliği Örgütü EURASEC'in gündeme alınması, Moskova-Minsk yakınlaşmasının başlaması gibi BDT coğrafyasına Rusya’nın geri dönüşü söz konusuydu; güvenlik ve ekonomi alanlarında işbirliğinin kurumsallaştırılması hedefi, Putin'in dış politika çizgisinde mevcuttu (Büyükakınc1, 2004).

11 Eylül süreci ve ardından gündeme gelen Afganistan Savaşı'yla birlikte Rusya'nın Avrasya'daki öncelikleri güvenlik konularında yoğunlaşırken, dünya piyasası fiyatlarıyla doğal gaz ihracına endeksli bir ekonomik kalkınma ve dönüşüm iç politikadaki önceliği olmuştu. 2001-2004 arası dönemde değişen uluslararası konjonktüre uygun olarak Putin yönetimi, Avrasyacı-Atlantikçi yaklaşımların bileşimi bir dış politika söylemi benimsemiştir; Atlantikçi söylem çerçevesinde dünyadaki ekonomik kuruluşlarla yakın ilişkilerin geliştirilmesi yapısal bir farklılık olarak değerlendirilebilir (Sokolov, 2008).

2004'ten itibaren Rusya'nın eski Sovyet döneminden gelen belirli yapısal avantajları ve BDT içi karşılıklı bağımlılık zincirlerini kendi lehine çevirmek istediğini görmeye başlıyoruz; bu aşamada Renkli devrimlerin gündemde olması, Rusya açısından BDT alanı içindeki güvenlik ve ekonomi ilişkisini müdahaleciliğe dönüştürme olanağını da yarattı̆ğını söylememiz gerekiyor (Kubicek, 2009). Buna en güzel örnekler RusyaUkrayna arasında yaşanan doğal gaz krizi ya da 2008 Gürcistan krizi verilebilir. Putin'in başkanlığa gelişinden beri arzuladığı Dünya Ticaret Örgütü - DTÖ’ye üyeliğin uzun süre engellenmesi, BDT alanın içinden Kırgızistan, Ukrayna, Asya'dan Çin gibi ülkelerin kabul edilmesi Avrasya coğrafyasında Rusya'yı yalnızlaştırma durumu yaratmaktaydı. Halbuki 2004'te IMF borçlarının kapatılması ve borç veren ülke statüsüne geçiş, Rusya açısından önemli gelişmelerdi, ancak ulusal ekonominin dönüşümü süreci bu aşamada başlayacaktı.

2008 mali krizi karşısında Rus ekonomisinin sağlam duruşu, BRIC ülkeleri arasında yer alması ve Avrupa kıtasında sorun yaşayan ülkelere kredi açması gibi, Rusya'nın dünya piyasalarında belirli bir rol üstlenmeye başladığını görüyoruz; küresel ekonomik gelişmeleri yönlendirmeye çalışan bir Rusya söz konusu. Bunun en önemli sonucu olarak da 2012 yılı itibariyle DTÖ’ye üyeliğin on dokuz senelik müzakereler sonucunda tamamlanması gösterilebilir. Bunun yanı sıra Şanghay İşbirliği Örgütü içinde Çin'le olan ikili ilişkilerin sıkılaştırılması, İran ve Suriye gibi Ortadoğu'daki önemli devletlerle ilişkilerin güvenlik alanında yoğunlaştırılması açılarından baktığımızda ise, güvenlik alanındaki bölgesel yaklaşımların stratejik temellere dayandığını söyleyebiliriz (Simbar, 2011). AGİT, APEC (Mihoko, 2007) gibi işlevsel alanlarda bölgesel işbirliği kurumlarına daha ağırlık veren Rus yönetimi, özellikle Medvedev’in cumhurbaşkanlığıyla çok-taraflı diplomasi söylemini benimsemeye başlamıştı (Nikitina, 2012).

Rusya'nın bölgeselleşmeye bakış açısını özetlemek gerekirse şu ana hatları sıralamak yeterli olacaktır. Öncelikle Sovyet sonrası dönemde her şeye rağmen Sovyet tarzı bir topraksal bütünlük düşüncesinden hareketle Rusya merkezli bir yapı söz konusudur. Tüm taşıma ve enerji nakil hatları şebekeleri Rus topraklarına bağlantılı durumdadır; dolayısıyla bağımsız devletler olsalar da, tüm bölge aktörleri ekonomik ve alt-yapısal olarak Rusya'nın merkezinde bulunduğu bir karşılıklı bağımlılık ağının içinde yer aldıklarının bilincedirler. Öte yandan bölgeselleşme eğilimleri devlet merkezli politikalarca yönlendirilmekte ve icra edilmektedir. Oligarklar ve 
siloviklerin ağırlıklı oldukları bir ekonomi yönetimi çerçevesinde devlet-dışı aktörlerin yatırımları çok fazla etkili olamamaktadır.

\section{BDT İçi Ekonomik Bütünleşmenin Zeminleri}

BDT üyesi ülkeler arasında ekonomik bölgeselleşme girişimlerine baktığımızda, merkez-çevre ilişkisi dikkatleri çekmektedir; ekonomik işbirliği alanında Rusya hep merkezi konumunu korurken, gerek Avrupa tarafinda, gerekse Orta Asya coğrafyasında belirli ülkeler çevre alanlarda alt-liderler olarak ortaya çıkmaktadırlar (Qoraboyev, 2010). Avrupa tarafinda Beyaz Rusya, Orta Asya cephesinde de Kazakistan ön plana çıkmaktalar. Bunlardan birincisi Rusya-AB ülkeleri arasındaki enerji nakil hatları üzerinde bulunmanın avantajıyla, diğeri ise enerji üreticisi ve dağıtıcısı konumuyla bu avantaja sahipler. Öte yandan Rusya'yla olan ekonomik ilişsileri daha kurumsal bir sürece de yayılmış durumdadır; 2012 yılı itibariyle Rusya, Beyaz Rusya ve Kazakistan arasında kabul edilen Ortak Ekonomik Alan (CES - Common Economic Space) yaratma girişimi ekonomik bütünleşmenin yolunu açmaktadır (Camba, 2012).

Öte yandan Beyaz Rusya ve Kazakistan, EURASEC düzeyinde de en istekli ve Rusya'yla en uyumlu partnerler olarak dikkatleri çekmektedir. Ancak Kazakistan'ın özellikle enerji ürünlerini BDT alanı içine pazarlamak yerine dış piyasalara yönelmesi söz konusudur. Bu noktada Rusya ve Kazakistan'ın hidrokarbon hammaddelerine dayalı ekonomilerinin olması, bunların arasında bölgesel bütünleşmenin gerçekleşmesi açısından bir engel midir sorusunu sorabiliriz; belirli hammaddelere dayalı olarak ekonomik yapıların birbirini tamamlamak yerine rekabete girme riski tartışma konusu olabilir (Movkebaeva, 2013).

Orta Asya coğrafyasından Kırgızistan ve Tacikistan da bu bölgeselleşme sürecinde küçük ölçekli çevre ülkeleri olarak karşımıza çıkmaktadır ve bu ülkeler ekonomik araçlarda dışa bağımlılıkları ve jeostratejik konumlarından ötürü bölge liderleri ya da merkez ülkeyle ittifak yapma zorunluluğunu hissetmekteler (Blank, 2011). Bunların yanında, 2000'li yıllar itibariyle baktığımızda gerek demografik açıdan, gerekse jeopolitik avantajlarıyla altbölge lideri konumuna oynayabilecek Ukrayna'nın ekonomik kapasitelerinin yetersiz ve yeniden yapılanmasını tamamlayamamış olmasından ötürü geri planda kaldığını görmekteyiz. Yanukoviç dönemi Ukrayna'sında Rusya'ya bölgesel bütünleşme girişimlerine dair net bir irade sergilendiğini söylemek mümkün değildir.

BDT içerisindeki en çelişkili aktör konumunda olan Özbekistan birçok açılardan güvensizlik sendromu yaşamaktadır; bölgeselleşme politikaları izlemek yerine uluslararası anlamda daha çok-vektörlü bir politika uygulamakta ve ekonomik ve dış politika alanlarında hiçbir ülkeye bağımlı olmamaya ve özel bir ittifak politikası izlememeye çalışmaktadır. Burada en güzel örnek, Özbekistan'ın GUAM'a 1999 yılında girişi, 2001 'de ise çıkışı ya da EURASEC'e 2006 y1lında üye olup 2011 yılında ayrılması gösterilebilir. Öte yandan, Orta Asya coğrafyasında Özbek-Kazak rekâbeti kapasitelerin karşılaştırılması açısından önem teşkil etmektedir; Rusya'nın bölgedeki varllğının arzulanması bu iki ülke açısından da tercih edilen bir durumdur. Rusya'nın buradaki konumu "düzenleyici, arabulucu ve rol dağıtan aktör" olarak ortaya çıkmaktadır. Özbekistan'ın Orta Asya bağlamındaki bir diğer sorunu da, Ferghana Vadisi ve nüfus dağılımları nedeniyle Tacikistan'dan gelebilecek her türlü güvenlik sorunlarıdır. Gerek dışardan gelebilecek köktendincilik kuşkuları, gerekse Tacik nüfusun ekonomik durumu ve sosyal mobilitesine dair çekinceler (Shkaratan, 2012), Taşkent yönetimini bölgesel süreçlere katılımını sınırlamaktadır. Kerimov yönetimi iktidarda kaldığı sürece bu temkinli dış politika oluşturma süreci devam edecek gibi görünüyor.

BDT alanı içerisinde bölgeselleşmeyi yönlendiren sektörler arasında, taşıma (lojistik), enerji (hammadde) ticareti ve nakil şebekeleri, özellikle Renkli devrimlerde gündeme gelen iletişim, medya ve bilişim, bankacıllk başı çekmektedir. Özellikle yatırım bankacılığı alanında Rus ve Kazak firmaları dikkatleri çekmektedir. Bu sektörlerin özellikle küreselleşme-bölgeselleşme ilişkisini en yapısal anlamda geliştiren alanlar olmaları önemlidir. BDT içi doğrudan yatırımlara baktı̆̆ımızda, doğal gaz ve petrol alanlarıyla bankacılık sektöründe Ruslarla Kazakların yarıştıkları söylenebilir. Telekomünikasyon (GSM) alanında da önemli bir yatırım sahası bulunmaktadır. Ruslar, yatırımlarını yaparlarken daha çok off-shore bankacılık yollarını kullanmakta, Kıbrıs, Hollanda, Avusturya, İsviçre, İngiliz Virgin adaları gibi vergi cenneti olan ülkeler üzerinden para aktarmaktadırlar. BDT içerisinde Çinli yatıımcıların sayısı çok önemli bir düzeyde değildir; özellikle Rus Sibirya'sında ve Orta Asya'da Çinli işçi göçüne yönelik sıkı önlemler söz konusudur (Kerr, 2010).

2000'ler sonu itibariyle BDT içi ticaret hacimlerini karşılaştırdığımız zaman Türkmenistan, Beyaz Rusya, Kırgızistan ve Ukrayna'nın BDT üyesi ülkelerle \% 55-40 aralığında dış ticaret ağırlığına sahip olduğu gözlenirken, bu rakamların Rusya, Kazakistan ve Tacikistan açısından \% 10'larda gezindiğini söylemek mümkün. Öte yandan BDT üyesi ülkelerin Rusya'ya yaptıkları ihracatın oranlarına baktı̆̆ımızda, Beyaz Rusya'nın \% 35, Özbekistan'ın \% 22, Ukrayna, Kırgızistan ve Moldova'nın \% 19-18 aralığında, Kazakistan'ın ise $\% 10$ oranında olduğu görülmektedir. BDT üyesi ülkelerinin kendi aralarında yüksek oranlı bir ticaret hacmi yaratamamalarının en önemli sebebi, yukarda da belirttiğimiz gibi, uluslararası piyasalara hammadde ihracı merkezli bir stratejinin olması ve BDT içi piyasalardaki düşük fiyat standartlarından kaçınılması olarak değerlendirilebilir. 


\section{4 “Avrasyacı Bölgesel Bütünleşme Modeli”nin Çerçevesi ve Tartışılması}

“Avrasyacı bölgeselcilik” yaklaşımı, küreselleşen dünya koşullarında belirli farklılıklar arz eden ve kendi iç dinamikleriyle özgün bir model olarak karşımıza çıkmaktadır. Her ne kadar Avrupa Birliği’nin bölgesel bütünleşme modeli belirli bir tarihsel çekişmelerin aşılması mantığıyla ve jeopolitik bütünlük çerçevesine otursa da, "Avrupa değerleri" dediğimiz ve Greko-Romen ve Hıristiyanlık kültürlerinin mirası üzerine Germenİskandinav kimlik unsurlarının katılımıyla oluşmuş bir normlar yapısına dayanmaktadır. Halbuki Avrasya coğrafyası, hem etnik, hem dinsel, hem de coğrafya anlamında birçok farklılığı barındırmanın yanı sıra, farklı üretim biçimleri ve gelenekleri ve büyük nüfus hacmiyle zor bir alan olarak değerlendirilmelidir (Fischer, 2012). Birçok alt-bölgenin varlığı (Orta Asya, Hindiçin, Güneydoğu Asya gibi), Asya kıtasında kimliklerin ve buna bağlı olarak ekonomik yapıların kendi aralarında kümülasyonunu da doğurmuştur.

Rus dış politikası açısından bakıldığında Asya coğrafyasında ekonomik ortaklıklara girebileceği birçok seçenek bulunmaktadır, ancak bölgesel bütünleşme çerçevesinde daha derin ve yapısal olanakların seçeneği sınırlıdır (Vernygora, 2012). BDT alanının Asya coğrafyasındaki en önemli partnerleri Orta Asya ülkeleridir ve bunlar Rusya’yla birlikte daha sıkı ekonomik ve ticari ilişkiler ağı içerisinde olmayı da hem stratejik tercihler olarak görmektedirler, hem de yapısal belirli zorunluluklardan hareket etmektedirler. Rus dış politikasından bakıldığında, Orta Asya coğrafyası Avrasyacı bir bütünleşme modelinin Asya kıtasındaki merkez alanlarından birisini oluşturmaktadır ve Avrasyacı dış politika söyleminin "yakın çevre” ve "uzak çevre" algılamalarını Mackinder'in iç hilal ve dış hilal açılımlarını çok güzel temsil etmektedir. Eski Sovyet Orta Asya'nın Rusya açısından iç hilal coğrafyası değerlendirmesine bağlı olarak onu çevreleyen Çin, İran gibi dış alanlarla da ekonomik ve ticari ilişkilerin yoğunlaştırılması dış hilal çerçevesine çok iyi oturmaktadır.

Öte yandan Avrasya merkezli bölgeselleşmenin Asya ayağının yanı sıra Avrupa yakasından da eski Sovyet coğrafyası bağlamında başlıca aktör olarak Beyaz Rusya ve Ukrayna en önemli ülkeler olarak görülebilir, ancak bu iki ülkenin de Rusya'ya bakışları farklılaşmaktadır.

“Avrasyacı bölgeselleşme modeli”ni temel özellikleriyle tanımlamak gerekirse şu hususlara dikkatleri çekmek gerekir:

Avrasya alanı içerisinde özellikle eski Sovyet coğrafyası çerçevesinde güvenlik ve ekonomi yapıları arasında doğrudan bir etkileşim söz konusudur. Karar alıcıların gözünde stratejik tercihler sosyal ihtiyaçların tanımlanmasından daha büyük bir önem arz etmektedir (Molchanov, 2009). Bu çerçevede jeopolitik anlamda güvenlik aktörü olarak Rusya'nın Sovyet sonrası toplumların gözündeki değeri hâlâ kayda değerdir. Dolayısıyla eski Sovyet coğrafyasında Rusya’sız bir bölgeselleşme düşüncesi hemen hemen olanaksızdır.

Avrasya bütünleşmesine sahne olacak tüm bölge ülkeleri, devlet merkezli bir ekonomi geleneğine sahiptirler ve devlet-dışı yatırımcıların varlığı oldukça sınırlıdır ya da devletin sıkı kontrolü altındadır. Ekonomilerin gelişimi toplumların ihtiyaçlarına göre değil, devletlerin "realpolitik" çerçevelerine göre yapılanmaktadır. Dolayısıyla Avrasyacı bütünleşme modelinin en önemli ortak paydası, bu coğrafyadaki devlet güdümlü ekonomilerin arasında yaratılacak işlevsel bir zemin oluşumudur; bu mantık, aynı zamanda eski Sovyet mirasını ve merkeziyetçiliğinin de devamını sağlamak açısından önemlidir. Nitekim Sovyet döneminin de planlı ekonomi anlayışı bütünleşme ve füzyon hedeflerini içermekteydi.

Tarihten gelen "güç ilişkileri”, jeopolitik çıkarlarla stratejik davranışların bir arada olmasına yol açmaktadır. Bölgesel bütünleşme modelleri hep ekonomik ortaklıklardan başlarken sonuç itibariyle ulusal güvenlik çıkarlarının devletlerin arasında uzlaştırılmasına da hizmet etmiştir. Avrasyacı modelde strateji-ekonomi birlikteliği, devlet merkezli bölgeselleşmeyi ön plana çıkarmakta, dolayısıyla toplumların refahının yaygınlaştırılması çabası daha çok ikinci planda kalmaktadır. Ancak uluslararası konjonktüre tepkimenin olmadığı aşamalarda kendi toplumlarının lehine düzenlemek yapmak amaçlı girişimlerin yoğunlaştığını da söylemek mümkündür (Mirkasymov, 2007). Örneğin Asya Kalkınma Bankası girişimleriyle bölgesel kalkınma projelerinin uygulanagelmesi, her iki açıdan da bölgeselleşme eğilimlerinin geliştiğini göstermektedir; hem devlet merkezli korumacı siyasetler benimsenirken, hem de liberal anlamda yerel yapıların küreselleşen ilişkilerle refah düzeylerinin arttırılması bir arada gitmektedir.

“Avrasyacı bütünleşme modeli”nde siyaseten otoriter ya da yarı-otoriter hükümet yapılarının yoğunluğu dikkatleri çekmektedir; dolayısıyla iç toplumsal dinamiklerin gelişimi arzulanmamaktadır. Başat lider ya da tek parti yönetimlerinin tüm bölge genelindeki hâkimiyeti, bölgeselleşme ve küreselleşme süreçleri arasındaki bağlantıyı da zayıflatmaktadır. Rusya açısından bakıldığında, küreselleşmenin demokratikleştirme etkisi Renkli Devrimler deneyimiyle olabildiğince sakınılması gereken bir gerçeklik olarak çıkmaktadır. Ekonomik anlamda liberal, ancak yönetim anlamında merkeziyetçi yapının olması, sadece Sovyet sonrası alanda karşımıza çıkan bir özellik değildir; bunu aynı zamanda Çin'de de görmekteyiz (Cheng, 2011).

Otoriter devlet merkezli bir bölgeselleşme modeli ister istemez küreselleşme karşısında kendini koruma amaçlı, muhafazakâr bir tepkime sürecini de yaratmaktadır. Batılı sermaye odaklarının yabancı yatırımcı olarak ulusal piyasalara girmesi belirli bir temkinlilik ve çekince ortamı yaratırken, iç siyaset dengelerinin korunması önceliği de söz konusu. Dolayısıyla küreselleşmenin demokratikleştirme etkisine karşı otoriter yönetimler 
arasında bir dayanışma duygusunu da oluşturmaktadır. Bu çerçeveden bakıldığında, Rusya açısından Çin doğal bir ekonomik partner olarak değerlendirilmelidir (Cheng, 2011). Ancak Çin, Kırgızistan, Ukrayna gibi örneklerden sonra Dünya Ticaret Örgütü - DTÖ’ye kabul edilen Rusya’nın dünyadaki bölgesel ve küresel gelişmeleri kendisine pozitif bir sürece çevirmek arzusu önemlidir ve bu çerçevede sadece Avrasya platformunda değil, hem AB ile ilişkilerini geliştirmek, hem de APEC içerisindeki etkinliklerini arttırmak stratejisi dikkatleri çekmektedir. Bu sürecin 2008 mali krizinden sonra tartışılan yeni yükselen değerler olarak BRIC'in dünya ekonomisi içerisindeki konumuyla başladığı belirtmek gerekiyor.

Rusya açısından bakıldığında, “Avrasyacı bütünleşme modeli”nin Asya’daki merkez alanı, kaçınılmaz olarak Orta Asya coğrafyasıdır. Orta Asya ülkelerinin kendi aralarındaki toprak ve sınır sorunları, dinsel faktörler, siyasal yönetimlerin kendi iktidarlarını sürekli kılma arayışları, enerji şebekeleri, Ferghana vadisi gibi birçok sorun ve birçok avantaj da bu bölgede kendisini göstermektedir. Bu coğrafya üzerinde dış aktörlerin de ilgisi dikkatleri çekmektedir. Ancak Rusya, “Avrasyacı bakış açısı”yla Orta Asya coğrafyasının sürekli merkezî konumda bulunmasını arzu etmemektedir; bunu dengeleyebilmek için Beyaz Rusya, Ukrayna gibi denge faktörü olabilecek ülkelerle de yapısal anlamda karşılıklı bağımlılık süreçlerine dahil etmek ve bu süreci çeşitlendirmek istemektedir (Qoraboyev, 2010). Bu açıdan bakıldığında, AB örneğinden hareketle, Avrasya bölgesel bütünleşmesinin genişleme şansı sınırlı görünmektedir; nitekim bu genişleme mantığının ardında birbirlerine karşı çekinceleri olan bölge ülkelerinin ittifak politikalarına giderek bu yapıları tercih ettiklerini söylemek mümkündür.

Avrasya bölgesel bütünleşmesinin Orta Asya açısından bakıldığında en önemli konularından biri sınır güvenliği sorunudur; bu konu, bölge-dışı güvenlik konularının bölge içi dinamiklerini etkilememesi hedefiyle işlevsel işbirliği zemini gerekli kılmakta ve toplumsal ihtiyaçlara ve siyasal istikrara yönelik bölgesel bütünleşmeyi kolaylaştırmaktadır. Özellikle Afganistan ve Pakistan'ın istikrarsız iç politika yapıları, Orta Asya ülkeleri açısından çok önemli bir güvenlik sorunudur. Yasadışı göçler, uyuşturucu ve silah kaçakçılığı, köktendinci hareketlerin yaygınlaşması gibi sınıraşan güvenlik konuları, bölgeselleşme çerçevesindeki en önemli dayanışma zeminini oluşturmaktadır. Bu açıdan bakıldığında Ferghana Vadisi Orta Asya'nın merkez alanı olarak ön plana çıkmaktadır ve Avrasya bölgeselciliği açısından bir alt-bölge konseptini de doğurmaktadır; bu çerçevede yerel düzeydeki güvenlik sorunlarının çözümlenmesinde ortak diyalog arayışlarının güçlenmesine de etkisi olabilir. Ancak dört ülke arasında bölünmüş olan Ferghana Vadisi gerçeğinden hareketle, ademimerkeziyetçi bir çözüm arayışı mümkün olamamaktadır; Ferghana Vadisi’nde egemen olan ülkeler arasında yerel sorunların çözümlenmesi için ortak bir irade resmi olarak ortaya konamamaktadır. Halbuki yerel anlamda ortaya çıkan sorunlara çözüm yollarının bölgesel düzlemlerde aranması bütünleşme çabaları için de önem arz etmektedir (Allison, 2008). Benzer bir yerel-bölgesel düzeyler arasındaki diyalog eksiliği Aral Gölü konusunda da kendisini göstermektedir; Kazakistan ve Özbekistan arasında sorunun çözümlenememesi bölgesel sorunların uluslararası boyuta taşınması sonucunu da doğurmaktadır.

Avrasyacı bütünleşmenin Avrupa kıtasındaki en önemli ayağını Beyaz Rusya oluşturmaktadır; gerek OrtaDoğu Avrupa ile Baltık coğrafyasına uzanmış olmasının, gerekse Batı Avrupa'ya yönelik doğal gaz boru hatlarının temel güzergâhında bulunmasının avantajıyla Rusya'nın çok-vektörlü bir bölgesel işbirliği arayışı için de fayda sunmaktadır. Her ne kadar bir ekonomik potansiyel olarak Kazakistan kadar firsat sunamasa da, Beyaz Rusya, Moskova'nın gözünde Slav-Ortodoks kimliği ve jeopolitik konumuyla olası bir bölgesel bütünleşme içerisinde farklı avantajlara yaratabilecek firsatlar sunmaktadır. Ortak Ekonomik Alan - CES içerisinde yer alma düşüncesini daha 2000'li yılların başından beri Minsk yönetimi savunmaktaydı; hatta ortak dolaşım alanı ve gümrük birliği gibi düşüncelerle SSCB sonrasında BDT içerisindeki en Rusya'ya yakın pozisyondaki ülkelerin başında gelmekteydi. Bu açıdan bakıldığında Beyaz Rusya ve Kazakistan, Rusya açısından Avrasyacı bütünleşmenin "iç hilal” alanının temel aktörleri olarak tanımlanabilir. Ortak Ekonomik Alan girişimin kısa vadede kurumsallaştığını ve normları, ilkeleri ve kuruluş esaslarıyla "düzenleyici bölgeselleşme" (regulatory regionalism) dediğimiz bir modele dönüştüğünü söylememiz mümkündür (Camba, 2012) EURASEC'in CES'e göre kısa vadede daha gevşek ya da uzun vadede daha kurumsal bir çerçeveye dönüşüp dönüşmeyeceği tartışamaları vardır; gümrük birliği hedefiyle birlikte kurumsal anlamda tam bir ekonomik bütünleşmeye geçiş yapısını gösteren sözleşmeler imzalanmaktadır, ancak uygulamada henüz daha net sonuçlar elde edilmemiştir.

Ekonomik hacim olarak Rusya ve Çin merkezli bir Avrasya bütünleşme modelinde her ne kadar belirli bir siyasal dayanışma olsa da, yönetimlerin uluslararası iktisadi ilişkilerini kendi açılarından farklı yönettiklerini söylemek de mümkün (Mikheev, 2011; Chen, 2012). Çin yönetimi Avrasya genelinde daha çok ikili anlaşmalarla ilişkilerini geliştirmeye çalışırken, Rus yöneticiler bölgeselleşme çerçevesine daha çok önem vermektedir. Çin'in tek başına eski Sovyet piyasalarına nüfuzunu önlemek adına bölgesel bir taktik olarak Ruslar ortaklıkların kurulmasından ve "kurumsal ilişkiler"in oluşturulmasından yana tavır sergilemektedirler (Baizakova, 2013).

Avrasya bölgeselleşmesindeki en önemli ortak paydalardan birisi ise, toplum içi ilişkilerde varolan kollektiflik düşüncesidir. Özellikle doğu toplumlarında gördüğümüz bu değer yapısı, farklı kimlik ve inanç yapıları söz konusu olsa bile, merkezi otoritenin tanımladığı kollektif zihniyetiyle biçimlenmekte ve devletçiliğin ağır bastığı bir düzen anlayışı söz konusu olmaktadır. Bireysel girişimlerin yerine daha korporatif yapıların ön plana çıkması dikkatleri çekmektedir. Gerçi Rus ekonomisinin merkezi planlamalı yapıdan liberal sisteme geçerken, gerek 
özelleştirmelerle, gerekse küresel şartlara adaptasyon arayışlarıyla bir nebze de olsa serbest girişimciliği benimsediğini görmekteyiz; benzer süreç Çin ekonomisinde de gözlemlenmektedir (Mikheev, 2011). Ancak serbest girişimciliğin her halükarda devlet güdümü altında yönlendirildiğini, hatta ekonomik kurum ve kuruluşların stratejik aktörler tarafından yönetildiğini (ekonomide partizanlık, oligarklar-silovikler dengesi gibi) görmekteyiz. Ekonomi yönetimiyle devlet kontrolünün iç içe geçmesi, küreselleşmeci eğilimlerin de sınırlı olmasına ve liberal demokrasi zeminin tam olarak oluşamamasına yol açmaktadır.

Avrasya'daki bölgesel işbirliği hareketlerinin merkezindeki en önemli konulardan biri, enerji güvenliği konusudur. Doğal gaz ve petrol boru hatlarının yaygınlaştırılması, Rusya'nın hem Avrupa, hem de Asya'daki siyasal mevcudiyeti açısından çok önem arz etmektedir. Nitekim Şanghay İşbirliği Örgütü’nün en stratejik tartışma konularından birisi de Orta Asya merkezli bir enerji nakil şebekelerinin güvenliğinin sağlanmasıdır; bunun yanı sıra Rusya'nın Orta Asya'daki nakil şebekelerinin işleyişini kendi ağları içerisinde bağımlı bir biçimde devam ettirmek ve bu ülkelerin uluslararası piyasalara doğrudan irtibatını sınırlandırmak arzusu da bulunmaktadır (Baizakova, 2013). Bu açıdan bakıldığında, Orta Asya coğrafyasında Kazakistan ve Türkmenistan enerji alanında Rusya için en önemli ülkeler konumundadır; nitekim Kazakistan'ın Avrasya bölgeselleşmesi içerisindeki konumu, hem stratejik aktör olarak, hem de jeo-ekonomik açılardan denge politikası izlemesini zorunlu kılmaktadır. Ancak enerji alanında bölge aktörlerinin bütünleşmeci stratejiler izlediklerini söylemek mümkün değildir; tektaraflı ya da ikili anlaşmalara dayanan girişimler söz konusudur. Bu davranış biçimi, bölge ülkelerinden bir bölümünün kendi ulusal ekonomisindeki enerji ürünlerine tek sektörlü olarak bağımlı olmasından da kaynaklanmaktadır (Yiğit, 2013; Demir, 2012).

Avrasyacı modelde, APEC gibi kıta-aşan bir yapıdan daha çok bölge içi kapalılık arayışı dikkatleri çekmektedir. Nitekim Dünya Ticaret Örgütü'ne üyelik zorunluluğundan çok birbirlerini tamamlama ve destekleme mantığı daha ön plana çıkmaktadır (Qoraboyev, 2010). AB’nin kuruluşunda gördüğümüz işlevselci (fonksiyonalist) bakış, bu çerçevede de kendisini göstermekte, ancak küresel ekonomi şartlarının tamamına adaptasyon söz konusu olmamaktadır. Öte yandan 2000'lerin sonları itibariyle Orta Asya merkezli bölge içi ihracat rakamlarına baktığımızda, bölge ülkelerinin birbirleriyle ticaret yapma oranlarının EURASEC genelinde ortalama \% 10'larda, BDT genelinde ise ortalama \% 20'ler civarında olduğu görülmektedir; halbuki bu oran AB ülkeleri için \% 60-70 arasında, NAFTA ülkeleri arasında ise \% 55'ler civarında olduğu saptanmaktadır. Bunun en önemli nedenlerinin başında Orta Asya ülkeleri hammaddelerini kendi aralarında düşük fiyatla satmak yerine, dış dünyaya daha yüksek fiyatlarla pazarlamayı tercih etmeleri gelmektedirler.

\section{Sonuç}

Eski Sovyet geleneğinden ve mirasından geldiği halde değişen dünya koşulları çerçevesinde düzene ayak uydurmak, Rusya'nın en önemli sorunsalı olarak karşımıza çıkmaktadır. Bugünkü Rusya, çok fazla içerik olarak değişmeden değişen uluslararası sisteme katılmak arzusundadır. Ancak ekonomik alandaki küreselleşme süreci, korumacılık ile liberalleşme arasında devletlere bölgeselci politikalar yönünde teşvik etmektedir. Küresel sisteme tam olarak katılmadan önce kendi bölgesiyle işlevsel anlamda bütünleşmek, aslında devamında diğer birçok etkileşiminin başlamasına da öncülük etmektedir. Kapalı toplum geleneklerinden gelip dönüşüm geçiren devlet yapılarında küreselleşmenin siyaseti liberalleştirmesine ve toplumun ve devlet yapısının demokratikleşmesine etkisi kaçınılmazdır; dolayısıyla bu devlet yapılarının ara modellerle kendi koşullarını değerlendirmek istemeleri olağandır.

Rusya gerçekliğinden bakıldığında, Avrasya coğrafyasındaki güç ilişkilerini kendi merkezinde yeniden düzenlemek istemesi tarihsel ve buna bağlı olarak da jeopolitik bir gerçekliktir. Dünyanın en büyük yüzölçümüne sahip bir ülkesinde hem farklı bölgelerle olan ilişkileri nedeniyle, hem de siyasal miras itibariyle çok-vektörlü arayışların olması kaçınılmazdır. "Avrasyacı bütünleşme modeli”, küreselleşme sürecinin kaçınılmaz olduğu bir dönemde korumacılık ve liberalleşmeyi aynı çizgide götürmeye çalışan, devletin güdümünde bir serbest piyasa modeline ağırlık veren, hammadde ihracı merkezli kalkınma politikalarına bağımlı ve bu nedenle de orta ve uzun vadede çok riskler içeren bir içerikle karşımıza çıkmaktadır. Batılı liberal ekonomilerle de yakın ilişkileri nedeniyle belirli sanayi alanlarında (otomotiv, havacılık gibi) üst düzey kalite standartlarını gerçekleştirmiş, bankacılık sektörüyle de dünya ekonomisine uyumlu bir Rusya var karşımızda. Bu çerçevede Rusya'nın gerçek hedefinin ne olduğunu sorgulamamız gerekiyor. Hâlâ kendi coğrafyasında merkezi konumunu sürdürerek bir dünya gücü aşamasına gelebilmek için küresel ekonomi şartlarını mı Rusya kullanmak istiyor, yoksa yapısal anlamda devleti ve Rus toplumunu liberalleştirmek mi istiyor? İşte bu açılardan bakıldığında, Avrasyacı bütünleşme modelinin aslında bir araç olduğunu düşünmek mümkün ve değişen uluslararası konjonktüre göre yeni modellerinde de tartışılması gündeme gelebilir.

\section{Teşekkür}

Bu makale çalışması, Galatasaray Üniversitesi Bilimsel Araştırma Projeleri kapsamında 12.101.003 nolu proje desteğiyle hazırlanmıştır. 


\section{Kaynakça}

- Aelenei, Victor I., 2013. “The Black Sea: History and globalization”, Revista Academiei Fortelor Terestre, 18, No. 1, pp. 5-10.

- Allison, Roy, 2008. "Virtual regionalism, regional structures and regime security in Central Asia", Central Asian Survey, 27/2, pp. 185-202.

- Baizakova, Kuralai I., 2013. "The Shanghai Cooperation Organization's role in countering threats and challenges to Central Asian regional security ", Russian Politics and Law, 51/1, pp. 59-79.

- Balzer, Harley, 2008. "Russia and China in the global economy”, Demokratizatsiya, 16/1, pp. 37-47.

- Blank, Stephen J., 2011. "Challenges to Russia in Central Asia”, American Foreign Policy Interests, 33, pp. 209-221.

- Büyükakınc1, Erhan, 2004. Değişen Dünyada Rusya ve Ukrayna, Phoenix Yay., Ankara, Turkey.

- Büyükakınc1, Erhan, 2003. “Avrupa Birliği-Rusya Federasyonu ilişkilerinde güvenlik sorunsalı”, in B. Dedeoğlu (Derl.), Dünden bugüne Avrupa Birliği, Boyut Yay., İstanbul, Turkey, pp. 329-363.

- Büyükakınc1, Erhan, 2000. "Patterns of integration in Central Asia", Perceptions, 5/1, pp. 161-180.

- Camba ,Alvin A., 2012. "Regulatory regionalism? Russia's common econmic space”, http://www.eir.info/2012/05/30/regulatory-regionalism-russias-common-economic-space.

- Chen, Xiaoqin, 2012. "Central Asian factors in energy relationship between China and Russia”, Asian Social Science Review, 8/7, pp. 33-40.

- Cheng, Joseph Y.S., 2011. "The Shanghai Co-operation Organisation: China's initiative in regional institutional building", Journal of Contemporary Asia, 41/4, pp. 632-656.

- Demir, İdris, 2012. "Strategic importance of crude oil and natural gas pipelines", Australian Journal of Basic and Applied Sciences, 6/3, pp. 87-96.

- Fischer, Sabine, 2012. "The European Union and the Insiders/Outsiders of Europe: Russia and the postSoviet space”, Review of European Studies, 4/3, pp. 32-44.

- Guraziu, Rudi, 2008. "Is regionalism a stumbling block or a stepping stone in the process globalisation?", http://archive.atlantic-community.org/app/webroot/files/articlepdf/Regionalism\%20-\%20a\%20stepping\% 20stone \%20or\%20a\%20stumbling\%20block\%20in\%20the\%20process\%20of\%20globalisation.pdf.

- Kerr, David, 2010. “Central Asian and Russian perspectives on China’s strategic emergence”, International Affairs, 86/1, pp. 127-152.

- Kubicek, Paul, 2009. "The Commonwealth of independent states: an example of failed regionalism?", Review of International Studies, 35, pp. 237-256.

- Libman, Alexander, 2007. "Regionalisation and regionalism in the post-Soviet space: Current status and implications for institutional development”, Europe-Asia Studies, 59/3, pp. 401-430.

- Libman, Alexander, 2011. "Russian federalism and post-Soviet integration: Divergence of development paths", Europe-Asia Studies, 63/8, pp. 1323-1355.

- Libman, Alexander and Vinokurov, Evgeny, 2010. "Is it really different? Patterns of regionalisation in the post-Soviet Central Asia”, Frankfurt School - Working Paper Series, 155, 38 s.

- Mihoko, Kato, 2007. "Russia's multilateral diplomacy in the process of Asia-Pacific regional integration: the significance of ASEAN for Russia”, in Eager Eyes fixed on Eurasia - Russia and its eastern edge, Slavic Research Center, pp. 125-151.

- Mikheev, Vasilii. 2011. "Russia-China”, Russian Politics and Law, 49/6, pp. 74-93.

- Mirkasymov, Bakhtiyar, 2007. "Russian policy to Asian regionalism”, Asia-Pacific Review, 14/2, pp. 82-95.

- Molchanov, Mikhail A., 2009. "Regionalization from above : Russia's Asian Vector and the State-led regionalism in Eurasia", a paper prepared for the conference on "International Political Economy and the New Regulations of Globalization", Poitiers, France, 20 p.

- Movkebaeva, Galiia A., 2013. "Energy cooperation among Kazakhstan, Russia and China within the Shanghai Cooperation Organization”, Russian Politics and Law, 51/1, pp. 80-87.

- Nikitin, Alexander, 2008. "Russian Foreign Policy in the fragmented post-Soviet space", International Journal on World Peace, XXV/2, pp. 7-31.

- Nikitina, Yulia, 2012. "Reflecting on twenty years of post-Soviet experience", Demokratizatsiya, 20/3, pp. 256-261. 
- Qoraboyev, Ikbaljon, 2010. "From Central Asian regional integration to Eurasian integration space? The changing Dynamics of post-Soviet regionalism", Regional Integration and Regionalisation, EDB Eurasian Integration Yearbook, pp. 206-228, http://ssrn.com/abstract=1633563.

- Shkaratan, O.I. and Iastrebov, G.A., 2012. "A comparative analysis of the processes of social mobility in the USSR and in Today's Russia”, Russian Education and Society, 54/5, pp. 24-64.

- Simbar, Reza and Ghorbani Sheikhnehin, Arsalan, 2011. "Iran and Russia: Strategic energy relationship", Journal of US-China Public Administration, 8/11, pp. 1275-1287.

- Sokolov, Dmitrii, 2008. "Russia in the World economy", Russian Politics and Law, 46/6, pp. 47-58.

- Vernygora, Vlad, Chaban, Natalia and Yi, Chae-Deug, 2012. "Mirroring the EU? Functional capacity of integration in Asia”, Trames, 16/1, pp. 47-61.

- Yiğit, Süreyya., 2013. “Eurasian Union = Energy Union?”, Ortadoğu Analiz, 5/51, pp. 55-68. 


\title{
Döviz Kuru Oynaklığı, Rezerv Oynaklığı ve Reel Faiz Oranlarının Dış Ticaret Üzerindeki Etkileri: Geçiş Ekonomileri Üzerine Uygulamalar
}

\section{The Effects of Exchange Rate Volatility, Reserve Volatility and Real Interest Rates on Trade: Applications on Transition Economies}

\author{
Prof. Dr. Cevat Gerni (Beykent University, Turkey) \\ Prof. Dr. Selahattin Sarı (Beykent University, Turkey) \\ Ph.D. Candidate Dilek Özdemir (Atatürk University, Turkey) \\ Prof. Dr. Ömer Selçuk Emsen (Atatürk University, Turkey)
}

\begin{abstract}
On the basis of volatility or sharp fluctuations in macroeconomic variables, especially in the 1970 s, it can be said to play a role in deepening the financial capital deepening. Deepening on volatility forms the basis of not only domestic and but also international economic deviations. With the collapse of the Eastern Bloc, a lot of countries have attempted to liberalize. This situation has caused volatility on mainly rate of exchange then many macroeconomics variables. In this aspect, the multi-relationship between volatility in foreign trade balance and the real interest rate, exchange rate and reserves' volatility are investigated empirically with the appropriate set of data on 11 transition economies for the period 1996-2011. In this study, the effects of the volatility of foreign trade (netxvol) on the exchange rate volatility (kurvol), reserve volatility (rezvol), and real interest rates subjected with using panel data analysis. Moreover to regression analysis, centred on Granger Causality Test the volatility of the foreign trade balance, import and export volatility, exchange rate volatility, volatility of reserves and try to determine the causal relationship between the real interest rate. The findings have light on that the volatility of trade balance was mostly affected to the volatility of the reserve. It may well be said that the volatility of the interest rate and the exchange rate at the independence of the trade predispose to speculative movements.
\end{abstract}

\section{Giriş}

Neo-Klasik iktisatta ekonomik denge ayırımında Marshall'ın kısmi denge ve Walras'ın genel denge analizleri yapılırken; buna benzer şekilde genel olarak iç ekonomik denge ve dış ekonomik denge tanımlamaları da söz konusudur. Klasik iktisatçılar iç dengenin kendiliğinden sağlandığını kabul ettiklerinden iç ekonomiye müdahaleden sakınma ve böylece daha çok dış denge üzerine yoğunlaşmışlardır. Buna karşılık Keynesyen iktisatçılar ise kısa dönemde iç ekonomik dengesizliklerin ekonominin doğası gereği var olduğunu kabul ederek iç dengenin sağlanabilirliğine odaklanmışlar ve iç denge sağlandığında dış dengenin kendiliğinden gerçekleşebileceğini ileri sürmüşlerdir. Ayrıca dünya ekonomilerinde özellikle 1973 yılından itibaren uygulanmaya başlanan dalgalı kur rejimi ile birlikte başta döviz kurları olmak üzere pek çok makroekonomik değişkende dalgalanmalar yaşanırken, bu durum da değişkenlerin oynaklığını artırırken; oynaklıklar arasındaki ilişkiler de pek çok araştırmaya konu olmuştur. Kurlarda dalgalanmaları besleyen asıl unsurlardan olan finans kapitalin giderek beslediği küreselleşme eğilimleri ise dış gelişmelere son derece duyarlı, kırılgan ve çok eklemli bir iktisadi yapıyı beraberinde getirmiştir. Dolayısıyla ilerleyen teknolojik gelişmelerin de etkisiyle daha karmaşık hale gelen iktisadi ilişkiler ağında, değişkenlerin birbiriyle olan etkileşimleri de daha karmaşık hale gelmiştir. Bu çerçevede iktisat literatürde makroekonomik değişkenlerin oynaklığı ve birbiriyle olan ilişkileri arasındaki ilişkiler yaygın bir şekilde araştırılırken, literatürde değişkenler arasında kesin ve sistematik ilişkiler yakalanamamıştır. Ancak, yine de dış ticareti etkileyen değişkenlerin bilinmesi, politika araçlarının seçiminde ve izlenecek politikaların doğru belirlenmesinde kolaylık sağlamaktadır. Bu çerçevede ödemeler bilançosunun en önemli kalemlerinin ithalat ve ihracat olduğu düşünüldügünde, diş dengeyi sağlayan diş ticaret kalemleri para/nominal piyasaların yanında, reel sektörü de etkilemektedir ki, uygun politika araçlarının seçimi hususu, günümüzde global etkilerin ve istikrarsızlıkların arttığı dikkate alınırsa, bu unsurlar bir ekonominin başarısı için temel yapıyı oluşturmaktadır.

Diğer taraftan özellikle gelişmekte olan ülke ekonomileri için reel faizin, döviz kurunda ve rezervlerdeki oynaklık üzerine yarattığı en önemli yansımalardan net ihracata etkisinin bilinmesi makro bazda politika önermesinde bulunabilmek açısından büyük öneme sahiptir. Burada faiz cephesinde meydana gelen ani değişimler, finans sermayesinin uluslararası anlamda mobilite kazanması ve bunun sonucunda bozulan dış dengeden beslenen döviz kuru belirsizliği üzerinden ulusal ekonomilerin makro değişkenlerinin olumsuz etkileneceği görüşü de taraftar bulmaya başlamıştır (Hook ve Boon, 2000) 
Çalışmada reel ekonomik unsurlardan olan dış ticaret değişkenlerinin yarattı̆̆ açık (fazla) unsurunun rezervlerdeki azalışa (artışa) mı, yoksa faiz oranlarında yükselme (düşme) yönünde etkilerle mi dengelendiği tartışmalı konulardandır. Ancak, gerek faiz oranlarındaki değişimlerle, gerekse rezerv hareketlilikleriyle dengelenmeye çalışılan süreçlerdeki gecikmeler ya da açığın (fazlanın) doğurduğu belirsizlik ortamları da kurlar üzerinde yükseliş (düşüş) yönünde baskılar doğurarak kur oynaklığını artırabilmektedir (Makin, 2001). Dolayısıyla iç içe geçmiş dış ticaret ilişkiler yumağına bağlı olarak iç ekonomik dengelerde de önemli değişimler yaşanabilmektedir. Bu doğrultuda çalışmanın amacı, dış ticaret dengesindeki oynaklığın reel faiz ile döviz kuru ve rezerv oynaklığı arasındaki ilişkiyi, uygun veri setine sahip 11 geçiş ekonomisi üzerine 1996-2011 dönemi için ampirik olarak incelemektir. Ele alınan ülkeler Hırvatistan, Çek Cumhuriyeti, Macaristan, Makedonya, Moldovya, Polonya, Romanya, Rusya, Slovakya, Slovenya ve Ukrayna'dan oluşmaktadır. Yapılacak analizlerde reel ekonomik faaliyetlerin bir yansıması olarak ortaya çıkan dış dengesizliklerin yine reel bir ölçüt olan rezervlerle ya da nominal bir ölçüt olan faizlerle dengelenebilirliği ile bu dengeleme çabalarının kur istikrarını ne ölçüde koruyup korumadığı ve bunların da bir bütün olarak ekonomiye etkileri ya da krize duyarlılığı inceleme konusu yapılmıştır. Çalışma giriş bölümü dışında, literatür özeti, ampirik irdeleme ve sonuç bölümlerinden oluşturulmuştur.

\section{Literatür Araştırması}

Genellikle literatürde yapılan çalışmalar, döviz kuru oynaklığının dış ticaret hacmi ya da ihracat ve ithalat üzerine etkilerine odaklanmıştır. Buna karşılık dış ticaret oynaklığının hem sebebi hem de sonucu olan reel kurlar ile rezerv düzeyleri ve reel faiz oranları arasındaki ilişkileri ele alan çalışmalar pek fazla dikkat çekmemektedir. Dolayısıyla daha çok kur oynaklığı ile dış ticaret arasındaki ilişkiler araştırılmaktadır. Dış ticaret ve kur oynaklığı ilişkileri açısından da bir ülke dış ticarette ne kadar fazla açık ise, o ülkenin hem para piyasalarının hem de toplam arz şoklarının daha düşük döviz kuru hareketliliği ürettiği görülmüştür. Hau (2002) tarafından 48 ülkeye ait veriler kullanılarak yapılan araştırmada ülkelerin uluslararası ticaretteki dışa açıklık farklılıklarına göre, reel döviz kuru oynaklığı ile ithalatlarının etkilenme derecesi açısından fark olduğu belirlemesi yapılmıştır.

Baldemir ve Keskiner (2004), devalüasyon, para ve reel gelir değişkenlerinin dış ticaret üzerine etkisini Türkiye özelinde en önemli ticaret partnerleri olan ülkeler açısında ele alarak panel veri analizleri yöntemi ile incelemişlerdir. Çalışmada, Türkiye'nin diş ticaret ilişkisinin en yoğun olduğu ABD, Almanya, Hollanda, İngiltere ve İtalya'nın 1987-2001 dönemini kapsayan verileri ele alınmıştır. Çalışmanın sonucuna göre, bütün ülkelerin GSYİH'ındaki artış, çalışmada ele alınan ülkelerin dış ticaret dengelerini olumsuz yönde etkilediği tespiti yapılmıştır.

Hayakawa ve Kımura (2008), döviz kuru oynaklığı ve uluslararası ticaret arasındaki ilişkiyi 60 ülke için inceleme konusu yapmışlardır. Araştırmada özellikle Doğu Asya ülkelerine odaklanılmış ve geleneksel çekim (gravity) modeli kullanılmıştır. Analizde, reel ihracat hacmi, yurtiçi gelir, yurt dişı gelir, mesafe, dil, döviz kuru oynaklığı, yakınlık ve topluluk değişkenleri alınmıştır. 1992-2005 dönemini kapsayan analizde, aylık veri setleri ile çalışılmış ve döviz kuru oynaklığı da GARCH modeli ile test edilmiştir. Öncelikle, EKK tekniği ile dünyadaki karşılıklı ihracat hacmi için çekim denge modeli tahmin edilmiştir. Daha sonra, iç-Asya ve Asya ticareti ile döviz kuru oynaklığı arasındaki ilişki araştırılmıştır. Elde edilen bulgulara göre, döviz kuru oynaklığının iç Asya'daki ticareti diğer bölgelerden daha fazla etkilediği belirlenmiştir. Uluslararası üretim ağında ara mallar ticareti için önemli bir engel oluşturan döviz kuru oynaklığının Doğu Asya ülkelerinde karşılaştırmalı ticaretin önemli bir unsuru olduğu tespiti yapılmıştır. Oynaklığın yol açtığı negatif etkilerin, tarifelerden ve mesafe farklılı̆̆ından kaynaklanan maliyetlere göre daha yüksek olduğu belirlenmiştir.

Chit vd. (2008), döviz kuru oynaklığının reel ihracat üzerine olan etkilerini, gelişmekte olan beş Asya ülkesi ile 13 sanayileşmiş ülke kapsamında ele alarak incelenmişlerdir. 1982:I-2006:IV dönemini kapsayan çalışmada reel ihracat, yurtiçi gelir, yurtdışı gelir, nispi fiyatlar, döviz kuru oynaklı̆̆ı ve çekim değişkenleri (ülkeler arasındaki uzaklık, ortak sınır ve serbest ticaret alanı) kullanılmıştır. Geleneksel uzun dönem ihracat modeli ve genelleştirilmiş çekim modeli ile panel veri çalışması yapılmıştır. Çalışmada sabit etkiler modeli kullanılırken, döviz kuru oynaklığı GARCH modeli ile modellenmiş ve eş-bütünleşme analizi yapılmıştır. Sonuçta, döviz kuru oynaklığının gelişmekte olan Asya ülkelerinin ihracatı üzerine negatif etkisinin olduğu bulgusuna ulaşılmıştır.

Hall vd. (2010), döviz kuru oynaklığının ihracat üzerine etkilerini incelemişlerdir. Araştırmada, yükselen piyasa ekonomileri ve diğer gelişmekte olan ülkeler ele alınmıştır. Yükselen piyasa ekonomileri için 1980:I2006:IV dönemi ve diğer gelişmekte olan ülkeler için ise 1980:I-2005:IV dönemi incelenmiştir. Genelleştirilmiş Momentler Yöntemi (GMM) ve zamanla değişen katsayı yöntemi (TVC) olmak üzere iki tahmin modeli kullanılmıştır. Araştırmada, ihracat hacmi, reel ulusal gelir, nispi fiyatlar, petrol ihracatı gelirleri ve döviz kuru değişkenliği olmak üzere beş değişken analize tabi tutulmuştur. Elde edilen bulgulara göre, yükselen piyasa ekonomilerinde döviz kuru oynaklığının ihracat üzerine önemli ve negatif bir etkisi olmadığı ve diğer gelişmekte olan ülkelerle kıyaslandığında, döviz kuru dalgalanmalarının ihracat üzerine etkisinin daha az olduğu görülmüştür. 
Omojimite ve Akpokodje (2010), döviz kuru oynaklığının Afrika Parasal Topluluğu ülkeleri ile Topluluk dış1 ülkelerin karşılıklı ihracatı üzerine etkilerini araştırmışlardır. 1986-2006 dönemini kapsayan ve çeyrek verilerin ele alındığı çalışmada ihracat, dış gelir, döviz kuru oynaklığı, ithalat ve reel döviz kuru panel veri setleri kullanılmıştır. Araştırmada, döviz kuru oynaklığı GARCH modeli ile tahmin edilmiştir. Yazarlar EKK, sabit etkiler ve genelleştirilmiş momentler tekniklerini kullanarak yaptıkları analiz sonuçlarına göre, döviz kuru oynaklığının ihracat üzerine negatif etkisinin olduğunu tespit etmişlerdir. Bu sonuç her iki paneldeki ülkeler için de geçerlilik arz etmiş̧ir. Ancak, döviz kuru oynaklığının etkisinin parasal topluluk ülkelerine göre topluluk dış1 ülkelerde daha fazla çıktığı belirlemesi yapılmıştır.

Bayraktutan ve Demirtaş (2011), 19 gelişmekte olan ülkenin 1980-2006 dönemi verilerinden yararlanarak cari işlemler açığının belirleyicilerini panel veri analizi yöntemi ile test etmişlerdir. Çalışmada, cari işlemler açı̆̆ının GSYIH'ya oranı, GSYIH'daki yıllık değişme, Yatırımlar/GSYIH, Nispi Gelir, Kamu harcamaları, Finansal Derinlik, Bütçe açığı/GSYiH, Dıı̧ Borç/GSYIH, Reel Döviz Kuru, Dış Ticaret Hadleri, Dışa Açıklık Oranı, Dünya Büyüme Oranı, Dünya Faiz Oranı ve Yurtiçi Faiz Oranı değişkenleri kullanılmışırı. Elde edilen bulgulara göre, GSYİH'daki yıllık değişme, yatırımlar ve nispi gelirin uzun dönemde cari işlemler açığı üzerinde belirleyici olduğu tespit edilmiştir. Buna göre, büyüme oranı, nispi gelir ve yatırımlardaki artış, cari işlemler açığını artırıcı yönde etkide bulunmaktadır. Dünya faiz oranları ve dünya büyüme oranının da cari işlemler açığı üzerine belirleyici bir rol oynadığı; söz konusu değişkenlerdeki artışın, gelişmekte olan ülkelerde cari işlemler açığını kısıcı etkide bulunduğu görülmüştür. Dış ticaret hadleri ve dışa açıklık oranının da cari işlemler açığı üzerinde etkili değiş̧kenler olduğu tespit edilmiştir.

\section{Veriler ve Ampirik Bulgular}

Çalışmanın verileri 1996-2011 dönemini kapsayan 11 geçiş ekonomisini kapsamaktadır. 1996:01-2011:12 dönemini kapsayan aylık mevsimsel etkilerden arındırılmış seriler kullanılarak hesaplanan standart sapmalar oynaklığı temsil için alınmıştır. Veriler Dünya Bankası'nın Dünya Gelişme Göstergeleri (WDI) ve Dünya Görünüm Ekranı (GEM) adlı veri tabanlarından alınmıştır. İnceleme konusu yapılan 11 geçiş ekonomisi için, ele alınan dönemde dış ticaret dengesindeki oynaklık (netxvol), kur oynaklığı (kurvol), rezerv oynaklığı (rezvol) ve reel faiz ile olan ilişkilerini analiz etmek amacıyla panel veri analizleri yapılmıştır. Ayrıca Granger Nedensellik Testi ile dış ticaret dengesindeki oynaklık, ihracat ve ithalat oynaklığı, kur oynaklığı, rezerv oynaklığı ve reel faiz arasındaki nedensel ilişkilerin yönü belirlenmeye çalışılmıştır. Reel faiz hariç diğer değişkenlerin logaritmaları alınmış ve bu durum söz konusu değişkenin başına "l" simgesi getirilerek belirtilmiştir. Verilerin analizinde Eviews 7.0 ve Stata12 programı kullanılmıştır.

Belirtilen değişkenler arasındaki ilişkileri araştırmak için Tek yönlü Sabit Etkiler Modeli (Fixed Effect Model) ve standart Granger nedensellik (standard Granger causality) testi kullanılmıştır. Bu çerçevede çalışmada dış ticaret dengesini etkileyeceği düşünülen reel efektif döviz kurundaki oynaklık, rezervlerdeki oynaklık ve reel faiz oranı değişkenleri ile oluşturulan model aşağıdaki gibi belirlenmeye çalışılmıştır.

$$
\text { LNETXVOL }_{i t}=\alpha+\text { LKURVOL }_{i t}+\text { LREZVOL }_{i t}+\text { REELFAI } Z_{i t}+\mu_{\mathrm{i}}+\lambda_{t}+\varepsilon_{i t}
$$

Burada $\mathrm{i}=1 \ldots 11$ ile analize tabi tutulacak 11 ülkeyi, $\mathrm{t}=1996 \ldots 2011$ yılları arasındaki konumu ifade edecek şekilde her ülke için 16 yıllık verinin varlığını göstermektedir. Ayrıca $\alpha$; sabiti, $\mu_{\mathrm{i}}$; ülkeye özgü etkiyi, $\lambda_{t}$; zaman etkisini ve $\varepsilon_{i t}$; hata terimini göstermektedir. Değişken tanımlamaları aşağıda belirtilmiştir.

LNETXVOL $L_{i t}$; i ülkesinin t dönemindeki net ihracat (dış denge) oynaklığının doğal logaritmasıdır. Oynaklık sabit fiyatlarla mevsimsel düzeltmesi yapılmış aylık ihracat rakamlarının standart sapması şeklinde hesaplanmıştır.

LKURVOL $L_{i t}$; i ülkesinin t dönemdeki $2005=100$ bazlı reel efektif döviz kurunun aylık serisinin standart sapmasının doğal logaritmasıdır.

REELFAİ $Z_{i t}$; i ülkesinin t dönemdeki reel faiz oranıdır.

Panel veri analizlerinde de zaman serisi gibi zaman boyutu olduğu için öncelikle serilerin durağanlık özelliklerinin belirlenmesi gerekmektedir. Granger ve Newbold (1974), durağan olmayan zaman serileri ile yapılan analizlerin sahte regresyon problemine yol açacağını ileri sürmektedir. Diğer yandan durağanlık test sonuçları çalı̧̧mada kullanılacak olan metodu belirleme açısından da önemlidir. Serilerin durağanlık özelliklerini tespit etmek için kullanılan değişkenlere ait serilerin durağan olup olmadıklarının araştırılmasına yönelik olarak, panel veri analizinde sıkça kullanılan birinci nesil birim kök testleri olarak adlandırılan Levin-Lin ve Chu (LLC), Im-Pesaran ve Shin (IPS), Fisher ADF ve Fisher PP birim kök testleri uygulanmıştır. Elde edilen sonuçlar Tablo 1 'de verilmiştir.

Birinci nesil birim kök testlerinin sonuçlarına göre tüm değişkenlerin seviye değerleri cinsinden durağan olduğu görülmektedir. Diğer taraftan bu değişkenler ile (1) nolu modelde yapılacak tahminlerin yatay kesit bağımlılık içerip içermediğine Breusch-Pagan LM bağımlılık ki-kare $\left(\mathrm{X}^{2}\right)$ testi ile belirlenmeye çalışılmıştır. Zira $\mathrm{CD}_{\mathrm{LM} 1}$ yatay kesit bağımlılığı testi, $\mathrm{T}>\mathrm{N}$ durumunda kullanılan bir testtir. Çalışmadaki 1996-2011 dönemini kapsayan 16 yıl (T) ve 11 geçiş ekonomisi $(\mathrm{N})$ yatay kesit boyutunun zaman boyutundan küçük olması koşulu 
gerçekleşmiştir. Bu durumun analizlerde sorun teşkil edip etmediği $\mathrm{CD}_{\mathrm{LM} 1}$ testi ile belirlenir; yani her ülkenin bireysel zaman etkisinden ayrı şekilde etkilenebildiği varsayımı test edilir. Test, LM istatistiğine bağlı olarak tahminlemede bulunur (Çınar, 2011). (1)'nolu modele göre yatay kesit bağımlılık test sonuçları ve korelasyon matrisi Tablo 2'de verilmiştir.

\begin{tabular}{|l|l|l|l|l|}
\hline Değişkenler & $\begin{array}{l}\text { Levin, Lin \& Chu } \\
\mathrm{t}^{*}\end{array}$ & $\begin{array}{l}\text { Im, Pesaran and } \\
\text { Shin W-stat }\end{array}$ & $\begin{array}{l}\text { ADF - Fisher } \\
\text { Chi-square }\end{array}$ & $\begin{array}{l}\text { PP - Fisher Chi- } \\
\text { square }\end{array}$ \\
\hline LNETXVOL & $-4.392(0.0000)^{\mathrm{a}}$ & $-3.143(0.0008)^{\mathrm{a}}$ & $50.486(0.0005)^{\mathrm{a}}$ & $51.284(0.0004)^{\mathrm{a}}$ \\
\hline LKURVOL & $-5.805(0.0000)^{\mathrm{a}}$ & $-4.921(0.0000)^{\mathrm{a}}$ & $63.0629(0.0000)^{\mathrm{a}}$ & $70.972(0.0000)^{\mathrm{a}}$ \\
\hline LREZVOL & $-4.135(0.0000)^{\mathrm{ad}}$ & $-2.212(0.0135)^{\mathrm{bd}}$ & $37.529(0.0207)^{\mathrm{bd}}$ & $42.945(0.0048)^{\mathrm{a}}$ \\
\hline REELFAIZ & $-7.745(0.0000)^{\mathrm{a}}$ & $-7.708(0.0000)^{\mathrm{a}}$ & $97.622(0.0000)^{\mathrm{a}}$ & $81.357(0.0000)^{\mathrm{a}}$ \\
\hline LXVOL $^{\mathrm{a}}$ & $-4.189(0.0000)^{\mathrm{a}}$ & $2.660(0.0039)^{\mathrm{a}}$ & $41.776(0.0067)^{\mathrm{a}}$ & $45.874(0.0021)^{\mathrm{a}}$ \\
\hline LMVOL & $-4.129(0.0000)^{\mathrm{a}}$ & $-2.674(0.0037)^{\mathrm{a}}$ & $41.152(0.0079)^{\mathrm{a}}$ & $47.727(0.0012)^{\mathrm{a}}$ \\
\hline
\end{tabular}

Tablo 1: Birinci Nesil Birim Kök Testleri Sonuçları Not: Parantez içerisinde olasıllk değerleri verilmiştir. Burada (a) \%1, (b) \%5 ve (c) \%10) önem düzeyinde anlamlllı̆̆ göstermektedir. d sabit terimin ve trend değerinin kullanıldığını göstermektedir. Diğer tahminlerde sadece sabit terim kullanılmıştır. Optimal gecikme uzunlukları SIC kriterine göre 0-2 arasında otomatik seçilmiştir.

\begin{tabular}{|l|l|l|l|l|l|l|l|l|l|l|l|}
\hline & _e1 & e2 & e3 & e4 & e5 & e6 & e 7 & _e8 & e9 & e10 & e11 \\
\hline e1 & 1.0000 & & & & & & & & & & \\
\hline e2 & -0.0248 & 1.0000 & & & & & & & & & \\
\hline e3 & 0.0829 & 0.6489 & 1.0000 & & & & & & & & \\
\hline e4 & -0.2927 & 0.6190 & 0.4326 & 1.0000 & & & & & & & \\
\hline e5 & 0.0271 & -0.1321 & -0.0577 & -0.3773 & 1.0000 & & & & & & \\
\hline e6 & -0.0253 & 0.7574 & 0.8274 & 0.4101 & 0.1342 & 1.0000 & & & & & \\
\hline e7 & -0.3420 & 0.0034 & -0.0617 & -0.0447 & 0.0845 & 0.0669 & 1.0000 & & & & \\
\hline e8 & -0.4520 & -0.0616 & -0.0431 & 0.1186 & 0.1049 & 0.0915 & 0.4518 & 1.0000 & & & \\
\hline e9 & -0.2751 & 0.5858 & 0.6564 & 0.6007 & -0.1563 & 0.6007 & 0.3350 & 0.2192 & 1.0000 & & \\
\hline e10 & -0.0109 & 0.7362 & 0.5835 & 0.4968 & -0.2693 & 0.6971 & -0.0634 & 0.3639 & 0.4758 & 1.0000 & \\
\hline e11 & 0.1796 & -0.0067 & -0.0298 & -0.1931 & -0.0954 & -0.0329 & 0.1455 & -0.0621 & -0.0013 & 0.0776 & 1.0000 \\
\hline
\end{tabular}

Tablo 2: Breusch Pagan LM Test Sonucu ve Korelasyon Matrisi Not: Breusch-Pagan LM . chi2(55)=115.102, $\operatorname{Pr}=0.0000$

Yapılan Breusch-Pagan LM bağımlılık testi sonucuna göre birimler arası korelasyonsuzluğu işaret eden $\mathrm{H}_{0}$ hipotezi reddedilmiş ve yatay kesit bağımlılı̆̆ın ya da birimler arasında korelasyon olduğu sonucuna ulaşılmıştır. Ayrıca korelasyon matrisine göre, bazı ülkelerin kalıntıları arasında yüksek korelasyonların olduğu görülmektedir. Özellikle Çek Cumhuriyeti (2) ile Polonya (6); Çek Cumhuriyeti (2) ile Slovenya (10); Macaristan (3) ile Polonya (6) için regresyon kalıntıları arasında yüksek korelasyonlar dikkat çekmektedir. Modelde yatay kesit bağımlılığın olması ikinci nesil birim kök sınamalarına ihtiyaç bulunduğunu göstermektedir. Yatay kesit artırılmış DF [Cross-section Augmented DF; (CADF)] testi ise Pesaran (2005) tarafından hazırlanmış ve kullanılmıştır. Burada uygulanan test, yatay kesit bağımlılığın kesitsel birimleri arasında tek bir ortak faktörün varlığında arttığı durumlar için uygulanır. CADF testi heterojen bir panelde bütün yatay kesit birimler için bireysel verileri ortalama olarak alır. Bireysel CADF t-istatistikleri OLS (En Küçük Kareler) t oranıyla elde edilir (Ndoricimpa, 2009). Sonuç itibarıyla CADF testi, birinci nesil birim kök testlere göre daha avantajlı birim kök sınamalarında bulunmaya imkân ağlar. Tablo 3'de ikinci nesil birim kök sınama sonuçları verilmiştir.

\begin{tabular}{|l|l|l|l|}
\hline Değişkenler & $\mathrm{t}-\mathrm{bar}$ & $\mathrm{Z}[\mathrm{t}-\mathrm{bar}]$ & $\mathrm{p}$ \\
\hline LNETXVOL (1) & -2.576 & -2.686 & 0.004 \\
\hline LKURVOL (1) & -2.186 & -1.419 & 0.078 \\
\hline LREZVOL(1) & -2.224 & -1.541 & 0.062 \\
\hline REELFAIZ(1) & -3.230 & -4.814 & 0.000 \\
\hline LXVOL(1) & -3.300 & -5.039 & 0.000 \\
\hline LMVOL(1) & -2.717 & -3.144 & 0.001 \\
\hline
\end{tabular}

Tablo 3: İkinci Nesil Birim Kök Test Sonuçları

\begin{tabular}{|l|l|}
\hline $\mathrm{F}$ testi & LR testi \\
\hline $\mathrm{F}_{\text {birim }}(10,162)=48.848(0.0000)^{*}$ & $\operatorname{LR}_{\text {birim }}(10)=244.660(0.0000)^{*}$ \\
\hline $\mathrm{F}_{\text {zaman }}(15,157)=0.339(0.9901)$ & $\operatorname{LR}_{\text {zaman }}(15)=5.619(0.9855)$ \\
\hline $\mathrm{F}_{\text {ikiyönlü }}(25,147)=34.975(0.0000)^{*}$ & $\operatorname{LR}_{\text {ikiyönlü }}(25)=341.172(0.0000)^{*}$ \\
\hline
\end{tabular}

Tablo 4: F ve LR Testi Sonuçlarl Not: *, \%1 düzeyinde anlamlılı̆̆l göstermektedir. Parantezler serbestlik derecelerini ve olasılık değerlerini gösterir. 
İkinci nesil birim kök testi sonuçlarında da tıpkı birinci nesil birim kök sınamalarında olduğu gibi serilerin düzey değerlerde durağan olduğu tespit edilmiştir.

Çalışmada serilerin durağan oldukları belirlendikten sonra zaman ve birim etkilerin var olup olmadıklarının tespitine yönelik olarak sabit etkiler modeli için F testi ve rassal etkiler modeli için ise LR testi uygulanarak araştırılmıştır. Sonuçlar Tablo 4'de gösterilmiştir.

Tablo 4'de görüldüğü üzere hem sabit etkiler hem de rassal etkiler modelleri için birim etkilerin var olduğu; buna karşılık zaman etkilerinin olmadığı, başka bir ifadeyle modelin sadece birim etkilerini içerecek şekilde tek yönlü tahmin edilmesi gerektiği anlaşılmaktadır. Bir sonraki aşamada ise, birim etkisinin sabit mi, yoksa tesadüfi mi olduğuna karar vermek için Hausman testi yapılmaktadır. Rassal etki modelindeki birim etki ile açıklayıcı değişkenler arasındaki korelasyonun sıfır olduğu varsayımı $\left[\mathrm{H}_{0}: \mathrm{E}\left(\alpha_{\mathrm{i},}, \mathrm{X}_{\mathrm{it}}\right)=0\right]$, Hausman (1978) testi ile sınanmıştır. Elde edilen Hausman test istatistiği, söz konusu $\mathrm{H}_{0}$ varsayımının sağlanamadığını ve bu nedenle modelin sabit etkiler tahmincisi ile tahmin edilmesi gerektiğini ortaya koymaktadır.

Modelde yatay kesit bağımlılığın olduğu Breusch-Pagan LM testi ile bilinmekle birlikte, otokorelasyon ve değişen varyans sorununun olup olmadığının da tespit edilmesine ihtiyaç vardır. Hata teriminde otokorelasyonu test etmek üzere Bhargava, Franzini ve Narendranathan'nin (1982) Değiş̧irilmiş Durbin Watson testi ile BaltagiWu (1999) tarafından önerilen Yerel En İyi Değişmez (LBI) testleri kullanılmaktadır. Bu testler için modelde öncelikle AR(1) kalıntıları kullanılarak sabit etkiler varsayımı ile tahmin edilmektedir. Her iki otokorelasyon test istatistiğinin değeri 2'den küçük olup birinci dereceden otokorelasyonun olmadığını belirten sıfır hipotezini reddetmektedir (Baltagi, 2005). Değiştirilmiş Wald Testi ise modelde değişen varyansın varlığına işaret etmektedir. Bu bağlamda model, değişen varyans, otokorelasyon ve birimlerarası korelasyonun varlığında tahmin edilmelidir. Parks-Kmenta, Beck-Katz ve Driscoll-Kray tahmincileri değişen varyans, otokorelasyon ve birimler arası korelasyonun varlığında dirençli tahminciler vermektedir. Driscoll-Kray tahmincisi, $\mathrm{N}>\mathrm{T}$ olduğu durumda da güçlü bir tahminci konumundadır (Tatoğlu, 2012). Çalı̧̧mada $\mathrm{T}>\mathrm{N}$ olduğu için Parks-Kmenta ve Beck-Katz tahmincileri ile tahminde bulunulmuştur. Dolayısıyla çalışmada değişen varyans, otokorelasyon ve birimler arası korelasyonun varlığında dirençli tahmincilerle yapılan tahmin modelinin son hali Tablo 5'de sunulmuştur.

\begin{tabular}{|c|c|c|c|c|c|c|c|c|}
\hline \multirow[b]{2}{*}{ Değişken } & \multicolumn{4}{|c|}{ Parks-Kemanta Tahmincisi } & \multicolumn{4}{|c|}{ Beck-Katz Tahmincisi } \\
\hline & Katsayı & $\begin{array}{l}\text { Standart } \\
\text { Hata }\end{array}$ & $\begin{array}{l}\mathrm{z} \\
\text { istatistiği }\end{array}$ & Olasilık & Katsayı & $\begin{array}{l}\text { Standart } \\
\text { Hata }\end{array}$ & $\begin{array}{l}\mathrm{z} \\
\text { istatistiği }\end{array}$ & Olasilik \\
\hline LKURVOL & 0.13544 & 0.04316 & 3.14 & 0.002 & 0.17306 & 0.072857 & 2.38 & 0.018 \\
\hline LREZVOL & 0.44235 & 0.02989 & 14.80 & 0.000 & 0.49978 & 0.057548 & 8.68 & 0.000 \\
\hline REELFAIZ & -0.00102 & 0.00339 & -0.30 & 0.764 & 0.00187 & 0.005884 & 0.32 & 0.749 \\
\hline $\mathrm{C}$ & 1.95644 & 0.19660 & 9.95 & 0.000 & 1.46533 & 0.375990 & 3.90 & 0.000 \\
\hline $\mathrm{N}$ & \multicolumn{4}{|l|}{176} & \multicolumn{4}{|l|}{176} \\
\hline Wald chi2 (3) & \multirow{2}{*}{\multicolumn{3}{|c|}{\begin{tabular}{|l|}
326.84 \\
18.758
\end{tabular}}} & 0.0000 & \multirow{2}{*}{\multicolumn{3}{|c|}{$\begin{array}{l}107.67 \\
R^{2}=0.8606\end{array}$}} & 0.000 \\
\hline Hausman & & & & 0.0003 & & & & \\
\hline $\begin{array}{l}\text { Değişstirilmiş Wald } \\
\text { Testi }\end{array}$ & \multicolumn{3}{|l|}{109.96} & 0.0000 & \multirow{3}{*}{\multicolumn{4}{|c|}{$\Lambda=0.0000$}} \\
\hline $\begin{array}{l}\text { Bhargava vd. D-W } \\
\text { Testi }\end{array}$ & \multicolumn{4}{|l|}{1.04264} & & & & \\
\hline Baltagi-Wu LBI Testi & \multicolumn{4}{|l|}{1.20396} & & & & \\
\hline
\end{tabular}

Tablo 5: Sabit Etkiler Model Sonuçları (Bağımlı değişken: INETXVOL)

Modelde değişkenlere ilişkin elde edilen sonuçlara bakıldığında, bağımlı değişken olan dış dengeyi temsil eden ihracatın ithalattan çıkarılmasıyla ortaya çıkan dış denge oynaklığı değişkeni üzerine reel efektif döviz kurundaki ve rezervlerdeki oynaklığın pozitif etkili ve aynı zamanda istatistiki açıdan anlamlı olduğu anlaşılmaktadır. Elde edilen sonuç, ödemeler bilançosundaki dengesizliklerin döviz kurunda önemli ölçüde ortaya çıkan sapmalardan kaynaklandığına işaret etmektedir. Ekonomide kur istikrarsızlıklarının yansıması olan dış oynaklıktaki derinleşmelerin yanı sıra uygulanan kur politikalarının dış dengedeki sapmaları derinleştirerek iç dengeye de dolaylı bir şekilde etkilerinin bulunduğu söylenebilir. Benzer şekilde dış oynaklığa yol açan ve istatistiki açıdan da anlamlı olan rezerv oynaklığının cari açığı dengeleme aracı konumundadır. Burada rezervler kurdaki spekülatif hareketleri önleme aracı olarak görülse de müdahaleci kur politikalarının ekonomide belirsizlik ortamı yaratarak spekülatif hareketlere zemin yarattı̆ğ ve bunun da dış dengesizlik doğurucu fonksiyonlar icra edeceği açıktır. Diğer taratan dış denge oynaklığı üzerine reel faiz oranlarının negatif, ancak istatistiki açıdan anlamsız etkiler yarattığı görülmüşsür. Kısa dönemli faiz oranlarının sabit kur rejiminde daha fazla oynaklık göstermesi ise, faiz oranları ile dalgalı kur rejimi arasında herhangi bir ilişki bulunmadığına işaret etmektedir.

Çalışmada değişkenler arasında ilişkilerin yönünü belirlemek amacıyla nedensellik sınaması yapılmış ve nedensellik sınamaları sonuçları özet olarak aşağıdaki şekilde gösterilmiştir. Modelde tahmin edilen dış denge 
oynaklık değişkeni ile birlikte, ayrıca ihracat ve ithalat değerlerindeki oynaklıklar da nedensellik sınamalarına tabi tutulmuştur.

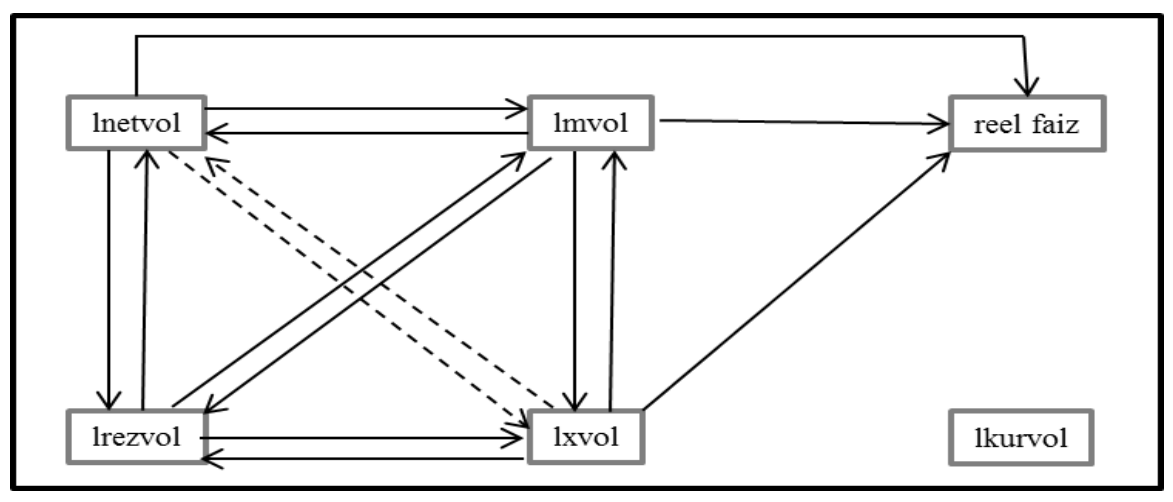

Şekil 1: Nedensellik İlişkilerinin Yönü

Granger nedensellik sınamalarında ele alınan değişkenlerin 1 gecikmeli değerlerinin ilişkileri araştırılmış ve bulunan ilişkiler ise \%1 önem düzeyinde anlamlı bulunmuştur. Nedensellik sınamalarında ilk etapta regresyon analizine koşulan (1) nolu modeldeki değişkenleri arasındaki ilişkiler irdelendiğinde, dış ticaret oynaklığı ile rezerv oynaklığı arasında çift yönlü nedensel ilişkinin olduğu görülmektedir. Diğer taraftan dış ticaret oynaklığı üzerine reel faiz oranlarının herhangi bir etkisinin olmadığı regresyon sonuçlarından farklı olarak bu iki değişken arasında tek yönlü ilişki bulunmuş ve ilişkinin yönü de diş ticaret oynaklığından reel faizlere doğrudur. Nedensellik sınamalarında herhangi bir ilişkinin yakalanamadığı değişken ise döviz kuru oynaklığı değişkenidir.

\begin{tabular}{|c|c|c|c|}
\hline \multirow[b]{2}{*}{ Nedenselliğin Yönü ( $\mathrm{H}_{0}$ Hipotezi) } & \multicolumn{3}{|c|}{ F-testi Sonuçları } \\
\hline & $\begin{array}{l}\text { 1 Gecikme } \\
\text { (165 Gözlem) }\end{array}$ & $\begin{array}{l}2 \text { Gecikme } \\
\text { (165 Gözlem) }\end{array}$ & $\begin{array}{l}3 \text { Gecikme } \\
\text { (143 Gözlem) }\end{array}$ \\
\hline LKURVOL, LNETVOL'un Granger Nedeni Değildir. & 1.21191 & 1.91446 & 1.15883 \\
\hline LNETVOL, LKURVOL'un Granger Nedeni Değildir. & 1.03605 & 1.10656 & 1.56363 \\
\hline LREZVOL, LNETVOL'un Granger Nedeni Değildir. & $7.36765^{(\mathrm{a})}$ & 2.03568 & $\mathbf{3 . 1 7 7 2 8}^{(\mathbf{b})}$ \\
\hline LNETVOL, LREZVOL'un Granger Nedeni Değildir. & $\mathbf{7 . 6 3 7 7 4}^{(\mathrm{a})}$ & 1.42469 & 0.69625 \\
\hline REELFAIZ, LNETVOL'un Granger Nedeni Değildir. & 0.54362 & 0.18625 & 0.08201 \\
\hline LNETVOL, REELFAIZ'in Granger Nedeni Değildir. & $10.1754^{(a)}$ & $4.23467^{(\mathrm{b})}$ & $3.407100^{(b)}$ \\
\hline LXVOL, LNETVOL'un Granger Nedeni Değildir. & $42.47466^{(a)}$ & $13.3324^{(a)}$ & 7.79821 \\
\hline LNETVOL, LXVOL'un Granger Nedeni Değildir. & $17.0617^{(\mathbf{a})}$ & 1.20561 & $2.71690^{(\mathrm{b})}$ \\
\hline LMVOL, LNETVOL'un Granger Nedeni Değildir. & $0.54362^{(a)}$ & $13.3324^{(a)}$ & $6.99609^{(a)}$ \\
\hline LNETVOL, REELFAIZ'in Granger Nedeni Değildir. & $10.1754^{(a)}$ & 1.20561 & $2.99045^{(b)}$ \\
\hline LREZVOL, LKURVOL'un Granger Nedeni Değildir. & 0.66503 & 1.36506 & 1.04192 \\
\hline LKURVOL, LREZVOL'un Granger Nedeni Değildir. & 0.72651 & 0.36497 & 0.95661 \\
\hline REELFAIZ, LKURVOL'un Granger Nedeni Değildir. & 0.05009 & $4.35112^{(b)}$ & $2.78137^{(\mathbf{b})}$ \\
\hline LKURVOL, REELFAIZ'un Granger Nedeni Değildir. & 0.08113 & 0.17836 & 0.64944 \\
\hline LXVOL, LKURVOL'un Granger Nedeni Değildir. & 0.46571 & 0.80006 & 1.13524 \\
\hline LKURVOL, LXVOL'un Granger Nedeni Değildir. & 1.49028 & 0.48217 & 0.37067 \\
\hline LMVOL, LKURVOL'un Granger Nedeni Değildir. & 1.04816 & 0.91292 & 1.60640 \\
\hline LKURVOL, LMVOL'un Granger Nedeni Değildir. & 1.13504 & 0.85649 & 1.30301 \\
\hline REELFAIZ, LREZVOL'un Granger Nedeni Değildir. & 0.86039 & 1.35242 & 1.82745 \\
\hline LREZVOL, REELFAIZ'un Granger Nedeni Değildir. & $14.8195^{(\mathbf{a})}$ & $7.18558^{(\mathbf{b})}$ & $6.02887^{(\mathbf{a})}$ \\
\hline LXVOL, LREZVOL'un Granger Nedeni Değildir. & $\mathbf{8 . 9 3 1 7 8}^{(\mathbf{a})}$ & 2.13762 & 0.81084 \\
\hline LREZVOL, LXVOL'un Granger Nedeni Değildir. & $10.8165^{(\mathbf{a})}$ & 2.28088 & 1.57933 \\
\hline LMVOL, LREZVOL'un Granger Nedeni Değildir. & $\mathbf{6 . 7 2 2 1 8}^{(\mathbf{a})}$ & 1.36059 & 0.80022 \\
\hline LREZVOL, LMVOL'un Granger Nedeni Değildir. & $6.69858^{(a)}$ & $2.39037^{(\mathrm{c})}$ & 1.76724 \\
\hline LXVOL REELFAIZ'un Granger Nedeni Değildir. & $7.99934^{(a)}$ & $\mathbf{4 . 9 3 7 9 3}^{(\mathbf{a})}$ & $3^{2.90785} 5^{(\mathbf{a})}$ \\
\hline REELFAIZ, LXVOL'un Granger Nedeni Değildir. & 0.08360 & 0.45754 & 0.21409 \\
\hline LMVOL, REELFAIZ'un Granger Nedeni Değildir. & $\mathbf{1 0 . 1 4 9 8}^{(\mathbf{a})}$ & $3.76691^{(\mathbf{b})}$ & $4.87581^{(\mathrm{a})}$ \\
\hline REELFAIZ, LMVOL'un Granger Nedeni Değildir. & 0.19780 & 0.32020 & $2.32312^{(\mathrm{c})}$ \\
\hline LMVOL, LXVOL'un Granger Nedeni Değildir. & $\mathbf{1 2 . 1 8 3 8}^{(\mathbf{a})}$ & 1.09260 & 0.48379 \\
\hline LXVOL, LMVOL'un Granger Nedeni Değildir. & $52.6597^{(a)}$ & $\mathbf{1 4 . 6 1 9 3}^{(\mathrm{a})}$ & $6.67365^{(a)}$ \\
\hline
\end{tabular}

Tablo 6: Nedensellik Sinaması Sonuçlart Not: (a), (b) ve (c) sirasıyla \%1, \%5 ve \%10 önem düzeyinde anlamlılığı göstermektedir. 
Nedensellik sınamalarında ihracat ve ithalat oynaklıklarının kendi içerisinde çift yönlü nedensellik bağlarının olduğu görülmektedir. Ayrıca bu iki değişkenin yine çift yönlü nedensellik ilişkileri ile hem rezerv oynaklığına hem de dış ticaret dengesi oynaklığına yol açtığı gözlenirken; ihracat ve ithalat oynaklığından reel faizlere doğru da tek yönlü nedensel ilişkilerin bulunduğu tespit edilmiştir. Genel olarak nedensellik sınamalarında zaman boyutu, yani gecikme uzunluğu artıkça, ilişsilerin de zayıfladığı görülmüştür.

\section{Sonuç}

D1ş ticareti doğrudan ilgilendiren değişkenlerdeki değişmelerin etkileri konusu literatürde tartışma konusudur. Özellikle Klasik ve Neo-Klasik iktisatçıların iç dengenin daima sağlandığına dair görüşleri dikkate alındığında, ekonomi politikalarının da daha çok dış dengeyi sağlamaya yönelik olduğunu ileri sürmektedirler. Bu görüşle taban tabana zit konumunda bulunan Keynesyen ve Neo-Keynesyen düşüncede ise iç dengede kısa dönemli istikrarsızlıklar-dengesizlikler söz konusudur ve dolayısıyla ekonomi politikalarının da iç dengeyi sağlamaya yönelik olması gerektiği; iç ekonomi denge sağlandığında ise dış dengenin de kendiliğinden gerçekleşeceğine dair iddiaları bulunmaktadır. Bu çalışmada planlı ekonomi uygulamalarından piyasa ekonomisi uygulamalarına yönelen eski doğu bloğu ülkelerinden uygun veri setine sahip ekonomilerde cari işlemler bilançosu açığ 1 oynaklığı ile bu oynaklığı etkileyeceği düşünülen reel döviz kuru oynaklığ1 ve döviz rezervleri oynaklığı ile reel faiz oranları arasındaki ilişkilerin araştırılması amaçlanmıştır. Araştırma sonuçlarına göre geçiş sürecindeki ekonomilerde dış denge oynaklığı üzerine reel döviz kuru oynaklığının ve rezervlerdeki oynaklığın etkili olduğu belirlenirken; reel faiz oranlarının etkisinin bulunmadığı tespit edilmiştir. Diğer taraftan nedensellik sınamalarında da dış ticaret oynaklığı ile rezerv oynaklığı arasında çift yönlü nedensel ilişkilerin varlığı tespit edilmiştir.

Her iki sonuç birlikte değerlendirildiğinde, dış ticaret oynaklığının rezerv oynaklığını uyaran etkiler yarattığı belirlenirken; bu durum dış açık karşısında rezerv hareketlerinin hemen devreye girdiğini göstermektedir. Elde edilen sonuç, Merkez Bankalarının özellikle kur istikrarını sağlamayı hedeflediği bir yapının varlığına işaret ederken; kur istikrarının da bir tür iç istikrar unsuru olarak görüldüğü ve bu yönüyle politika uygulamalarının da dış açıklar karşısında doğrudan Klasik iktisat kökenli politikaları devreye soktuğu söylenebilir. Buna karşılık makroekonomik dengeler açısından asıl hedef olarak iç denge üzerine yoğunlaşılarak Keynesyen nitelikli politika uygulamalarına ağırlık verildiği de ileri sürülebilir. Özellikle 1970'lerde batı bloğunda ve 1990'larda da doğu bloğunun çökmesiyle hemen hemen bütün global ekonomilerde uygulamaya konulan esnek kur sistemlerinin hem rezerv birikimine ihtiyaç duyurmayacak hem de ödemeler dengesinde istikrarsızlıklar yaratmayacak şekilde mekanizmalar işletmesi beklenmekteydi. Fakat finans kapitaldeki derinleşmelere paralel olarak sermaye hareketliliğinin artması, kur istikarı arayışlarını ve bunu sağlamak için de rezerv artışını beraberinde getirmiştir. Ancak, bu türden politika uygulamalarının özellikle kısa dönemde sahip olunan rezerv stoku ile alakalı olduğu; uzun dönemde ise reel kur dengelemesini kaçınılmaz kılacağı ileri sürülebilir. Bu durumun nedensellik sınamalarında ihracat ve ithalat değişkenlerinin oynaklıkları arasına çift yönlü nedensel ilişkilerle de teyidi, ihracatın kura dayalı bir rekabet avantajı ile sağlanmadığı ve bunun daha çok ithal girdiye dayalı olduğunu göstermektedir. Sürdürülebilir bir ekonomik büyüme için ithalata dayalı ihracatın görece daha düşük katma değer ve büyüme yarattığı dikkate alınırsa, daha gerçekçi bir kur politikasının hem dış dengeyi hem de iç ekonomik büyümeyi ve istihdamı olumlulaştıracağı açıktır.

\section{Kaynakça}

- $\quad$ Baldemir, E. ve A. Keskiner, (2004), "Devalüasyon, Para, Reel Gelir Değişkenlerinin Dış Ticaret Üzerine Etkisinin Panel Data Yöntemiyle Türkiye İçin İncelenmesi”, Dokuz Eylül Üniversitesi, Sosyal Bilimler Enstitïsü Dergisi, 6 (4): 44-59.

- Baltagi, B. H. (2005), Econometric Analysis of Panel Data, (3rd ed.), England, Jon Wiley\&Sons Ltd.

- $\quad$ Bayraktutan, Y. ve I. Demirtaş (2011), “Gelişmekte Olan Ülkelerde Cari Açığın Belirleyicileri: Panel Veri Analizi”, Kocaeli Üniversitesi Sosyal Bilimler Enstitüsü Dergisi, (22) 2: 1-28.

- Chit, M. M., M. Rizov and D. Willenbockel (2008), "Exchange Rate Volatility and Exports: New Empirical Evidence from the Emerging East Asian Economies", MPRA Paper No: 9014: 1-35.

- Ç̣nar, S. (2011), “Gelir ve CO2 Emisyonu İlişkisi: Panel Birim Kök ve Eşbütünleşme Testi”, Uludăg Üniversitesi İktisadi ve İdari Bilimler Fakültesi Dergisi, XXX (2): 71-83.

- Granger, C. W. and P. Newbold (1974), "Spurious Regressions in Econometrics", Journal of Econometrics, 2 (2): 111-120. http://dx.doi.org/10.1016/0304-4076(74)90034-7

- Hall, S., G. Hondroyiannis, B. Swamy, G. Tavlas and M. Ulan (2010), "Exchange Rate Volatility and Export Performance: Do Emerging Market Economies Resemble Industrial Countries or Other Developing Countries?", ELSEVIER, Economic Modelling, 27: 1514-1521.

- Hau, H. (2002), "Real Exchange Rate Volatility and Economic Openness: Theory and Evidence", Journal of Money, Credit and Banking, 34 (3): 611-630. 
- Hayakawa, K. and F. Kimura (2008), "The Effect of Exchange Rate Volatility on International Trade in East Asia”, ERIA Discussion Paper Series, 03: 1-20.

- Hook, L., S. Tan and H. Boon, (2000), "Exchange Rate Volatility and Malaysian Export to its Major Trading Partners", Working Paper, 6. Universiti Putra Malaysia.

- Makin, A. J. (2001), International Macroeconomics, Prentice Hall.

- $\quad$ Ndoricimpa, A. (2009), Foreign Direct Investments, Exports and Economic Growth in COMESA Countries: A Heterogeneous Panel Causality Approach, Makerere University.

- Omojimite, B. and G. Akpokodje (2010), “A Comparative Analysis of the Effect of Exchange Rate Volatility on Exports in the CFA and Non-CFA Countries of Africa”, J Soc Sci, 24(1): 23-31. 


\title{
Kamu Harcamaları ile Bürokrasi Arasındaki İlişki: Avrasya Ekonomileri Örneği
}

\section{The Relationship between Public Expenditure and Bureaucratic Quality: The Case of Eurasian Economies}

\author{
Asst. Prof. Dr. Gökhan Dökmen (Bülent Ecevit University, Turkey) \\ Asst. Prof. Dr. Özcan Sezer (Bülent Ecevit University, Turkey)
}

\begin{abstract}
One of the controversial issues among researchers in the field of public finance is estimating the determinants of public expenditures. It's argued that public expenditure is determined by economic as well as demographic, social and political variables. One of the important element of political variables is bureaucracy. If bureaucracy, as one of the main actors of political decision making process, works in quality, effectiveness and efficiency would occur in publicly provided goods and services. In parallel with the good quality of bureaucracy, the size of state would become smaller. The purpose of this study is to test empirically between efficient bureaucracy and public expenditure, using dynamic panel data analysis of 6 Eurasian Economic Community countries from 1998 to 2011. This study finds evidence that existence of bureaucratic quality reduces the public expenditures.
\end{abstract}

\section{Giriş}

19. yüzyıl boyunca dünyanın birçok sanayileşmiş ülkesinde, bırakınız yapsınlar bırakınız geçsinler anlayışına dayalı olarak, kamu harcamaları çok düşük düzeyde kalmıştır. Şöyle ki; 1870 yılında kamu harcamalarının gayrisafi yurtiçi hasılaya oranı, 17 sanayileşmiş ülkede, yaklaşık \% 11'ler seviyesinde iken; aynı oran 1913 yılında sadece \% 1'lik bir artışla \% 12 olarak gerçekleşmiştir. Ancak 1. Dünya Savaşı sonrasında yaşanan Büyük Buhran, devletin ekonomik ve sosyal yaşamda daha aktif rol almasını gerektirmiş ve kamu harcamalarının hacmi artmaya başlamıştır. 1937 yılından itibaren, Ekonomik İşbirliği ve Kalkınma Teşkilatı üyesi ülkelerde, kamu harcamalarının gayrisafi yurtiçi hasılaya oranı \% 23'e ulaşmıştır. Kamu harcamalarındaki artış trendi, 1960 ila 1980 yılları arasında en üst seviyeye çıkmıştır. Çeşitli piyasa başarısızlıklarını düzeltmek amacıyla devletin ekonomik yaşama müdahalesi ile şekillenen bu dönemde, kamu harcamalarının milli gelire oranı yaklaşık \% 50 'ler seviyesinde gerçekleşmiştir. 20. yüzyılın son dönemleri ile 21. yüzyılın ilk yıllarında ise neoliberal politikaların etkisiyle kamu harcamalarındaki artış eğilimi azalmaya başlamıştır (Borcherding ve Lee, 2002:2).

Dünya ekonomisinde son dönemde yaşanan kamu harcamalarındaki azalma eğilimine rağmen; kamu harcamalarının hangi unsurlardan etkilendiği ve harcamalarının hacmini etkileyen dinamiklerin neler olduğu, kamu maliyesi literatürünün önemli inceleme konuları arasındaki yerini korumuştur. Bu çalışmada kamu harcamalarındaki değişimi etkileyen dinamikler, Sovyetler Birliği'nin dağılması sonrasında ortaya çıkan bağımsız devletlerin bazılarını da içine alan Avrasya Ekonomik Topluluğu ülkeleri açısından ele alınmıştır. Avrasya ekonomilerinin sosyalist devlet düzeni geçmişi olması nedeniyle konu, bürokrasi özelinde detaylandırılmış ve bürokratik kalitenin kamu harcamalarının hacmini ne ölçüde etkilediği incelenmiştir.

Çalışmanın planı şu şekildedir. İlk kısımda kamu harcamalarının seyri hem gelişmiş hem de gelişmekte olan ülkeler açısından ele alınmıştır. Sonrasında ise Avrasya Ekonomik Topluluğu üyesi ülkelerdeki kamu tüketim harcamaların gelişimi ortaya konulmuştur. İkinci kısımda ise kamu harcamaların hacmini etkileyen unsurlar ele alınmıştır. Bu aşamada bürokratların fayda maksimizasyonunu temel alan davranışları ile kamu harcamaları arasındaki ilişki detaylı bir biçimde incelenmiştir. Son kısımda ise bürokratik kalitenin kamu harcamalarının hacmi üzerindeki etkisi, Avrasya Ekonomik Topluluğu üyesi ülkeler açısından dinamik panel veri analizi yöntemiyle analiz edilmiştir.

\section{Avrasya Ekonomilerinde Kamu Harcamalarına Genel Bir Bakıș}

Devletin ekonomik ve toplumsal yaşamda oynadığı role ilişkin tartışmalar, tarihin farklı dönemlerinde birbirinden farklı açıklamalara konu oluştur. Şöyle ki; Adam Smith öncülüğünde gelişen klasik iktisadi yaklaşımda devletin ekonomik yaşama müdahalesi en düşük düzeyde tutulmuştur. Klasik iktisatçılar, tam kamusal mal ve hizmetlerin sunumu, yasal ve kurumsal altyapının sağlanması ve güvenlik başta olmak üzere oldukça sınırlı bir alanda devlet müdahalesine izin vermiştir. Buna bağlı olarak da devletin ekonomideki büyüklügünü gösteren kamu harcamalarının gayri safi milli hasılaya oranının oldukça düşük düzeyde olması beklenmiştir. $\mathrm{Bu}$ nedenle 19. yüzyılın sonlarından 20. yüzyılın başlarına kadar ki dönemde sanayileşmiş ülkelerin birçoğunda kamu harcamalarının milli gelire oranı yaklaşı \% 10'lar civarında gerçekleşmiştir (Tanzi ve Schuknecht, 1997:165). 
Ekonominin işleyişini bozmayacak bir devlet algısı, 1929 yılında yaşanan büyük buhran dönemine kadar hakim iktisadi anlayışı oluşturmuştur. Ancak büyük buhran sonrasında devletin ekonomik rolüne ilişkin düşünceler yeniden şekillenmeye başlamış ve John Maynard Keynes tarafından 1936 yılında yayımlanan Para, Faiz ve Istihdam: Genel Teori adlı çalışma ile devletin ekonomik rasyonelinin teorik temelleri atılmıştır. Keynesyen yaklaşımla birlikte ekonominin her zaman kendiliğinden dengeye gelemeyeceği ve devlet müdahalesinin gerekliliği kabul edilmeye başlanmıştır. Özellikle talep yönlü maliye politikası uygulamaları ile öne çıkan Keynesyen paradigma ile birlikte gerek gelişmiş gerekse gelişmekte olan ülkelerde kamu harcamalarının milli gelir içerisindeki payı artış eğilimine girmiştir.

1. Dünya Savaşını izleyen dönemden itibaren ise kamu harcamalarındaki artış giderek hızlanmaya başlamıştır. Sanayileşmiş ülkelerde 1960 yılında genel kamu harcamalarının gayrisafi yurtiçi hasılaya oranı ortalama \% 28 iken; aynı oran 1980'de \% 41.9, 1990'da \% 43, 1996'da \% 45 ve 2002 'de \% 43.5 seviyesinde gerçekleşmiştir. Ülke örneklerine bakıldığında ise ortalamadan bazı sapmalar olduğu görülmüştür. Şöyle ki; 1980 yılında Avustralya, Japonya, İsviçre ve Amerika Birleşik Devletleri’nde genel kamu harcamalarının gayrisafi yurtiçi hasılaya oranı \% 35'in altında iken; Avusturya, Fransa, Almanya İrlanda ve İngiltere'de \% 50'ye yakındır. 2000'li yıllarda ise Avusturya, Fransa, Almanya, İtalya, Norveç ve İsveç gayrisafi yurtiçi hasılanın \% 50’ye yakın bir kısmını kamu harcamalarına ayırmıştır (Tanzi, 2005:619).

Kamu harcamalarındaki artış eğilimi sadece gelişmiş ülkeler ile sınırlı değildir. Gelişmekte olan ülkelerde, 1980’ler ve sonrasında kamu harcamalarının büyüklük ve bileşiminde yaşanan değişim oldukça dikkat çekicidir. 1980 yılında, 43 gelişmekte olan ülkenin kamu harcamaları 776 milyar dolar iken; bu rakam 1990 yılında \% 4 artış göstererek 1148 milyar dolara ulaşmıştır. Söz konusu gelişmekte olan ülkelerin kamu harcamaları, 1990 sonrasında da artış kaydederek, 1998 yılında yaklaşık olarak 1789 milyar dolara ulaşmıştır. Kamu harcamalarındaki artışa bölgeler açsından bakıldığında ise en fazla artışın Asya ülkelerinde, ardından ise Afrika ve Latin Amerika ülkelerinde yaşandığı gözlenmiştir ( Kovancılar, Miynat, Bursalıŏlu, 2007:1).

Kamu harcamalarındaki artış eğilimine Avrasya ekonomileri açısından bakıldığında ise diğer ülke ve bölgelerden farklı bir eğilim dikkat çekmektedir. Sovyetler Birliği'nin dağılması sonucu ortaya çıkan Avrasya ekonomileri başta Rusya olmak üzere Beyaz Rusya, Kazakistan, Kırgızistan, Tacikistan, Özbekistan, Moldova, Ukrayna ve Ermenistan'dan oluşmaktadır. Söz konusu ülkelerdeki kamu tüketim harcamalarının gayri safi milli hasılaya oranı, Grafik 1'de gösterilmiştir.

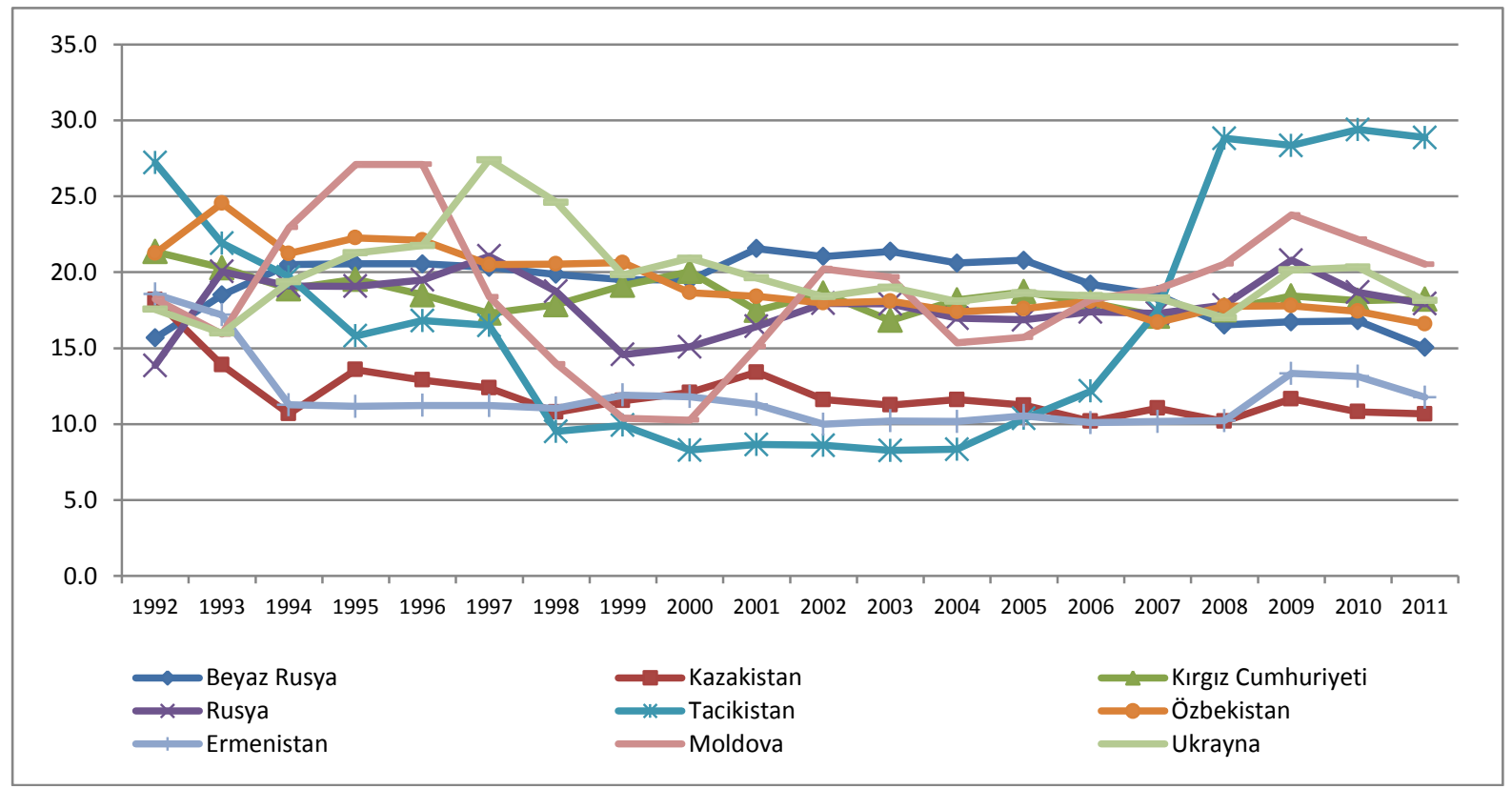

Grafik 1: Avrasya Ekonomilerinde Kamu Harcamalarının Seyri (1990-2011) Kaynak: World Bank(2013), World Development Indicators.

Grafik 1'de görüldüğü üzere, kamu tüketim harcamalarının gayri safi yurtiçi hasılaya oranı dalgalı bir seyir izleyerek, \% 10 ila \% 30 arasında değişen değerler almıştır. Avrasya ekonomileri içinde kamu harcamalarındaki dalgalanmanın en yüksek olduğu ülke ise Tacikistan'dır. Tacikistan'da 1992 yılında \% 27.21 olan kamu tüketim harcamalarının milli gelire oranı, 2000 yılında \% 8.29'a, 2011 yılında ise tekrar eski seviyelerine yaklaşarak \% 28.86 seviyesine ulaşmıştır. Avrasya Ekonomik Topluluğu üyesi diğer ülkelere bakıldığında ise yaklaşık \% 20'ler seviyesi dikkat çekmektedir. Topluluk üyesi ülkelerden kamu harcamalarının en düşük olduğu ülke Kazakistan'dır. Kazakistan’ı sırasıyla Ermenistan, Beyaz Rusya ve Rusya izlemiştir. Kamu harcamalarının en yüksek olduğu ülkeler ise sırasıyla Tacikistan, Moldova, Kırgızistan ve Ukrayna'dır. 


\section{Kamu Harcamaları ile Bürokratik Kalite Arasındaki İlişki}

Kamu harcamalarının hacmini ve bileşimini etkileyen birçok unsur bulunmaktadır. Bu unsurlardan bazıları ekonomik bazıları ise kültürel ve politik dinamiklere dayanmaktadır. Kamu harcamalarının hacmini belirleyen ekonomik faktörler ele alındığında Wagner Kanunu öne çıkmaktadır. Wagner Kanunu'na göre; kamusal mal ve hizmet talebi gelirle bağlantılıdır. Başka bir ifadeyle, gelirdeki artışa paralel olarak bireylerin tam kamusal (güvenlik, adalet gibi) ve yarı kamusal (eğitim, sağlık gibi) nitelikteki mal ve hizmetlere olan taleplerindeki artış, kamu harcamalarının artmasına neden olmaktadır. Bu açıdan bakıldığında kamu harcamalarının gayrisafi yurtiçi hasılaya oranı, kişi başına gelirin artan bir fonksiyonu olarak ele alınmaktadır (Wagner ve Weber, 1977; Ram, 1987; Peacock ve Scott, 2000). Kamu harcamalarının hacmini ve bileşimini etkileyen bir diğer değişken ise demografik yapıdır. Bir ülkenin demografik yapısı içinde esas teşkil eden ölçütlerden birisi nüfus yoğunluğudur. Zira bir ülkedeki nüfus yoğunluğunun artması, kamusal mal ve hizmet talebinin artmasına neden olmaktadır. Bu nedenle kamu harcamaların hacmi, nüfus yoğunluğunun artan bir fonksiyonu olarak ele alınmaktadır (Heller ve Diamond, 1990; Annett, 2000). Küreselleşme sürecinin hız kazandığı günümüz koşullarında ele alınan bir başka değişken ise dışa açıklıktır. Dışa açıklık ile kamu harcamaları arasındaki ilişki, Rodrick (1998)'in çalışmasına dayanmaktadır. Rodrick (1998)'e göre, ekonominin dışa açıklığı arttıkça kamu harcamalarının hacmi de artmaktadır. Başka bir ifadeyle, dışa açıklık ile kamu harcamaları arasında pozitif yönlü bir ilişki bulunmaktadır. Söz konusu ilişki, ekonominin dişa açıklığı arttıkça yaşanabilecek dış şoklar nedeniyle devletin sosyal güvenlik harcamalarına daha fazla pay ayırması ile açıklanmaktadır. Ancak Alesina ve Wacziarg (1998), Garen ve Trask (2005) ve Cavallo (2007) tarafindan yapılan çalışmalarda, artan ekonomik entegrasyon sürecinin kamu harcamalarını olumsuz yönde etkileyebileceğine vurgu yapılarak; dışa açıklık ile kamu harcamaları arasındaki ilişkin çok kesin sınırlar içinde pozitif olmayabileceğinin altı çizilmiştir.

Ekonomik ve demografik faktörlerin yanı sıra politik faktörlerde kamu harcamaların hacmini ve bileşimini etkilemektedir. Kamu harcamalarının hacmini belirleyen politik faktörler ele alındığında siyasal karar alma mekanizmasının aktörleri öne çıkmaktadır. Siyasal karar alma süresince mal ve hizmetlerin üretimine ilişkin kararların alınması aşamasında birçok aktör etkili olmaktadır. Bu aktörler; siyasal partiler, baskı grupları, seçmenler ve bürokratlardır (Buchanan, 1967:7). Kamu harcamalarına ilişkin olarak yürütülen politikaların belirlenmesinde asıl aktör siyasal karar vericiler (politikacılar) olsa da karar verme sürecinde siyaset ve bürokrasinin karşılıklı etkileşim içerisinde olduğu ifade edilebilir. Siyasal elit tarafindan yürütülen politika belirleme süreci ile bürokrasiye ait olması gereken bu politikaları yürütme görevini somut olarak birbirinden ayırt etmek kolay olmamakla birlikte, bürokratik otoritenin kullanılış şekli siyasi otoriteden soyutlanamaz (Şaylan, 1974: 32). Bu nedenle yasal düzenlemelerin ve kararların oluşturulmasında ve alınan kararların uygulanmasında bürokratların belirleyici rolünün olduğunu ifade edilmelidir (Riggs, 2009).

Bürokrasi dünyanın birçok ülkesinde modern yönetimin bir gereği olarak işlemektedir. Gerek devlet yönetiminde gerekse kamu ve özel birçok yönetimin örgüt yapısında bürokrasi mevcuttur. Dolayısıyla günümüzde kamu politikası oluşturma (policy-making) sürecinde bürokrasinin belirleyici rolü olduğu kabul edilmektedir. Kamu harcama politikalarına yön veren, kararların alınmasında belirleyici olan asıl güç noktası bürokrasidir. Bürokrasi ile siyasi iktidar arasında kamu harcama politikalarının oluşturulmasında çelişkiler ortaya çıkabilmektedir. Bazı durumlarda ise ağır ve etkinsiz işleyen bir bürokrasi hatalı kararların alınmasına neden olmakta ve çeşitli yolsuzluk türleri görülmektedir. Politikacılar oy kaygısı ile hareket ettiklerinden hesap verebilirlikleri seçmene karşıdır. Bürokratlar ise oy kaygısı taşımazlar, gelirlerini, prestijlerini, makamlarını ve sahip oldukları imkânları artırma isteğindedirler. Dolayısıyla bürokrasi harcama eğilimli kamu politikalarının oluşturulmasına daha meyillidir.

Bürokratlar, politikacılardan daha baskın çıkarak kararların kendi istedikleri yönde alınmasını sağlamak ve böylece politikacılar üzerinde etkili olmak istemektedir. Bürokratların karar alma sürecindeki davranışlarını şekillendiren bu yapı, kamu tercihi teorisi tarafından ele alınmaktadır. Kamu tercihi teorisi, ekonominin araç ve metotlarıyla politik karar alma sürecini analiz eden bir yaklaşım olarak kabul edilmektedir. Kamu tercihi kuramının arz yönü ile ilgilenen Niskanen, kamu sektöründe üretilen kamusal mal ve hizmetleri arz edenlerin (bürokratların) ve bu mal ve hizmetlerin alıcılarının yani kamusal mal ve hizmetlere seçmenleri adına talepte bulunan politikacıların var olduğunu savunmaktadır. Niskanen modelinin iki karakteristik özelliği bulunmaktadır. Bunlardan birincisi, bürokratların belli talep ve maliyet koşulları altında faydalarını maksimize temek için toplam bütçelerini artırma istekleri; ikincisi ise bürolar ile iktidar partileri arasında bir tür siyasi mübadelenin var olmasıdır (Bakırtaş, 1999: 2).

Özellikle 1990’lı yıllara kadar kamu sektörünün hacminin büyüdüğü ve kamu politikalarının belirlenmesinde bürokratların etkin bir role sahip olduğu ifade edilebilir. Bürokrasi sözü edilen döneme kadar ulus inşasında yönetim ve yönetişimin kurumsallaşmasında belirleyici rol üstlenmiştir. Bürokrasinin bu gücü örgütsel, bilgi ve denetim kapasitesinin yüksekliğinden kaynaklanmaktadır. Aynı zamanda bütçenin kullanımı konusunda hem statükolarını korumak hem de siyasal çıkarlarını genişletmek amacıyla politikacılar üzerinde etkili olmaktadırlar (Farazmand, 2009:10). Kamusal hizmetlere olan talebin artmasıyla birlikte kamu sektörü büyümektedir. Buna paralel siyasal iktidarda yeniden seçilebilmek için bürokrasiden bütçenin hacminin genişletilmesi talebinde 
bulunmaktadır. Bürokrasi, bütçe maksimizasyonu yoluyla kendisine tanınmış olan yüksek mevkii, yüksek maaş, yurt dışı seyahatleri vb. imkânlarını da korumuş olmaktadır (Aktan, 1994: 48).

Bürokrasi ile kamu harcamaları arasındaki ilişki bürokrasinin etkinliği açısından da ele alınabilir. Etkinlik, kamu ve özel bürokrasilerin fayda/maliyet, girdi/çıktı dengesi açısından dikkate alınan en önemli kriter olarak değerlendirilmektedir (Downs ve Larkey, 1986; Blau ve Meyer, 1987; Wilson 1989). Bürokrasinin etkinlik ve etkililiğini artırmada iyi yönetişim (good governance) son yıllarda üzerinde en çok durulan konular arasındadır (Rajkumar ve Swaroop; 2008:96). İyi yönetişim, önemli kamusal gereksinimlerin giderilmesi açısından kamusal kaynakların ve sorunların etkin ve etkili yönetimi anlamına gelmektedir. Devletlerin gittikçe karmaşıklaşan, sayıca çoğalan ve dinamik hale gelen ekonomik ve toplumsal sorunları çözmede yetersiz kalması, yeterli kaynak ve kapasiteye sahip olmaması, ayrıca toplumun sorunlara daha duyarlı hale gelmesi ve katılıma ilişkin taleplerin artması yönetişim yaklaşımının benimsenmesine olanak sağlamıştır (DPT, 2007:1). Son yıllarda devletin kapasitesi ve ulusal ekonomik performans arasındaki bağlantının analizinde yönetişim kalitesinin ölçülmesi çabaları giderek artmaktadır (Polidano, 2000:805).

Kamu harcama politikalarında kararların alınması sürecinde etkin olan bürokratların kendi çıkar maksimizasyonlarına odaklanmaları kamudaki etkinsizliğin en önemli nedenleri arasında sayılmaktadır. $\mathrm{Bu}$ nedenle kamu yönetiminde bürokratların hesap verebilirliğine yönelik olarak iyi yönetişim uygulamalarının uygulamaya geçirilmesi gerekmektedir. Demokrasi ile yönetilen tüm ülkelerde iktidarlar halkı memnun etme adına kamu harcamalarını artırmak isterler. Ancak bu kısa vadede olumlu sonuçlar verse de uzun vadede kamu sektörünün büyümesine, bürokratların gücünün ve etkisinin artmasına ve kamu hizmetlerinde etkisizliğe, yozlaşmalara yol açmaktadır. Bu nedenle, ekonomik istikrar ve sürdürülebilir büyüme hedefleri açısından, hükümetler bütçe politikasını, kısa dönemde ekonomik istikrarı, orta ve uzun dönemde de büyümeyi ve refahı bir arada optimize eden bir vergi ve harcama politikasına göre yürütmek zorundadır (Betam, 2008:12).

\section{Ampirik Uygulama}

Bu kısımda etkin işleyen bir bürokrasinin kamu harcamalarını nasıl ve hangi yönde etkilediğini görmek amacıya ampirik uygulama yapılmaktadır. Bu kapsamda öncelikle çalışmada uygulanan metodolojiye ilişkin olarak teorik açıklamalar yapılacak, sonrasında ise analiz sonuçlarına yer verilecektir.

\subsection{Metodolojiye Yönelik Teorik Açıklamalar}

\section{Birim Kök Testleri}

Bu çalışmada serilerin durağanlığı Levin, Lin ve Chu (LLC) (2002) ve Im, Pesaran ve Shin (IPS) (2003) tarafından geliştirilen panel birim kök testleri ile sınanmıştır. LLC panel birim kök testi, tüm birimlerin aynı otoregresif parametreye sahip olduğunu varsaymaktadır. Bu testteki hipotezler aşağıdaki gibidir:

$\mathrm{H}_{0}$ : Seride genel bir birim kök vardır $\left(\mathrm{H}_{0}: \rho_{\mathrm{i}}=\rho=1\right)$.

$\mathrm{H}_{1}$ : Seride genel bir birim kök yoktur $\left(\mathrm{H}_{0}: \rho_{\mathrm{i}}=\rho<1\right)$.

Bu hipotez testi için sabitsiz, sabitli (birim (sabit) etkiler), sabitli-trendli olmak üzere üç farklı model oluşturulmuştur. Test prosedürünün dayandığı temel model şu şekildedir (Levin, Lin ve Chu, 2002:5):

$$
\Delta y_{i t}=\delta y_{i t-1}+\sum_{L=1}^{P_{i}} \theta_{i L} \Delta y_{i t-L}+\alpha_{m i} d_{m t}+\varepsilon_{i t,} \quad m=1,2,3 .
$$

(1) nolu denklemde $d_{m t}$ deterministik değişkenler vektörünü belirlerken; $\alpha_{m i}$ ise belirli bir model için $(\mathrm{m}=1,2,3)$ katsayılar vektörünü göstermektedir. Modelde $\rho_{i}$ gecikme derecesi bilinmediğinden, LLC testlerini uygulayabilmek için üç adımdan oluşan bir süreç önerilmektedir. Söz konusu adımlardan birincisi, her bir yatay kesit için ayrı ayrı ADF regresyonlarının uygulanmasıdır. İkincisi, uzun dönem standart sapmalardan kısa dönem standart sapmalara doğru bir tahmin yapılarak; birim köklü boş hipotez altında, modelin uzun dönem varyansının tahmin edilmesidir. Üçüncüsü ise panel test istatistiklerinin hesaplanmasıdır (İnal, 2009:23).

Söz konusu panel test istatistikleri, LLC tablo değerleri ile karşılaştırılmakta ve $\mathrm{H}_{0}: \rho_{\mathrm{i}}=\rho=1$ şeklindeki hipotez reddedilirse serinin birim kök içermediğine ve durağan olduğuna karar verilmektedir (Tatoğlu, 2012, 202).

LLC panel birim kök testinin yanı sıra başvurulan bir diğer test ise Im, Peseran ve Shin (IPS) (2003) testidir. IPS testinin en önemli özelliği, verileri birleştirmek yerine tüm birimler için zaman serilerine ayrı ayrı birim kök testi uygulamasıdır ve IPS panel birim kök testi istatistiği, tüm bireysel ADF test istatistiklerinin ortalamasıdır. Test için hipotezler aşağıdaki gibi kurulmaktadır;

$$
\begin{aligned}
& \mathrm{H}_{0}: \rho_{\mathrm{i}}=1 \\
& \mathrm{H}_{1}: \rho_{\mathrm{i}}<1
\end{aligned}
$$

IPS testinde, aşağıdaki modelden hareket edilmektedir: 


$$
\Delta Y_{i t}=\rho_{i} Y_{i t-1}+\sum_{L=1}^{\rho_{i}} \phi_{i L} Y_{i t-L}+\mu_{i}^{\prime} \gamma+v_{i t}
$$

IPS test istatistiği, bireysel ADF istatistiklerinin ortalamasıdır. Şöyle ki;

$$
\bar{t}=\frac{1}{N} \sum_{i=1}^{N} t_{\rho i}
$$

(3) nolu denklemde $t_{\rho i}$, bireysel test istatistiklerini ifade etmektedir. Söz konusu testte hipotezleri sinamak için standart normal t dağılımı yerine, her bir grup için hesaplanan $t$ değerlerinin aritmetik ortalamasının alınması ile elde edilen $\bar{t}$ istatistiği kullanılmaktadır. Standartlaştırılımış $\bar{t}$ istatistiği $W_{-}$olarak adlandırılırsa,

$$
t_{I P S}=W_{t} \frac{\sqrt{N}\left(\frac{1}{N} \sum_{i=1}^{N} t_{i T}\right)-\left(\frac{1}{N} \sum_{i=1}^{N} E\left[t_{i T} \rho_{i}=1\right]\right.}{\sqrt{\frac{1}{N} \sum_{i=1}^{n} \operatorname{var}\left\langle\left[t_{i T} \rho_{i}=1\right]\right\rangle}}
$$

şeklinde ifade edilebilmektedir (Tatoğlu, 2012, 212-213).

\subsection{Sistem GMM Tahmin Yöntemi}

Çalışmada bağımlı değişkenin gecikmeli değerini modele dahil eden dinamik panel veri tahmin yöntemi olan Sistem GMM yöntemi kullanılmıştır. Çalışmanın modelinin dinamik panel veri şeklinde ele alınmasının en temel sebebi, kamu harcamalarının hacminin önceki yıllarla olan organik bağıdır. Başka bir ifadeyle kamu harcamalarının gecikmeli değerinin aynı zamanda modelin bağımsız değişkenleri arasında yer almasının gerekliliği dinamik panel verinin kullanılmasını gerektirmiştir.

Dinamik modellerde bağımlı değişkenin gecikmeli değerlerinin modele eklenmesi, gecikmeli bağımlı değişken ile hata terimi arasındaki ilişki nedeniyle, yapılan tahminlerin sapmalı ve tutarsız olmasına neden olabilmektedir (Baltagi, 2005:135). Bu sorunu gidermek amacıyla dinamik panel tahminlerinde Genelleştirilmiş Momentler Yöntemi'nin (Generalized Method of Moments-GMM) kullanılması önerilmiştir. Dinamik panel veri modellerinde GMM, değişik varsayımlar altında farklı versiyonlarla kullanılmaktadır. Arellano ve Bond (1991), GMM yönetiminin, normal dağılım, değişen varyans ve ölçüm hatalarının olduğu durumlarda diğer yöntemlere göre daha iyi sonuçlar verdiğini vurgulayarak Fark-GMM tahmin yöntemini önermiştir. Daha sonra Arellano ve Bover (1995) ve Blundell ve Bond (1998) tarafindan Sistem-GMM yöntemi geliştirilmiştir. Sistem-GMM yaklaşımı, araç değişkenlerin gecikmeli değerlerini fark denklemlerinde, birinci farklarını ise düzey denklemlerinde kullanmaktadır. Arellano ve Bond (1991) tarafından geliştirilen "Fark GMM" yöntemine oranla Arellano ve Bover (1995) ve Blundell ve Bond (1998) tarafindan önerilen Sistem-GMM'den elde edilen tahmincilerin daha iyi tahminciler olduğu belirtilmektedir (Coşkun ve Kök, 2011:79-80).

Sistem GMM yaklaşımına dayalı olarak çalışmada kullanılan ekonometrik model aşağıda gösterilmiştir.

$$
\text { Khar }_{i t}=\delta \text { Khar }_{i t-1}+\beta_{i t} \mathrm{Z}_{i t}+\eta_{i}+\lambda_{t}+\varepsilon_{i t} \quad t=1 \ldots ., T ; i=1 \ldots \ldots, N
$$

(5) nolu denklemde $Z$ kontrol değişkenler (GDP, Open, Pop ve Bur) vektörünü temsil etmektedir. Modeldeki $\varepsilon_{i t}$ hata terimini; $\eta_{i}$ ile $\lambda_{t}$ ise zamana ve kesite özgü sabit etkileri göstermektedir.

\subsection{Veri Seti ve Değișkenler}

Bu çalışmada kamu harcamaları ile bürokrasi arasındaki ilişki incelenmektedir. Analizde, 1998-2011 yılları arasında Avrasya Ekonomik Topluluğu'nda hem üye olan hem de gözlemci statüsünde yer alan 6 ülkenin verisi kullanılmıştır. Ülkelerden Beyaz Rusya, Kazakistan, Rusya Avrasya Ekonomileri Topluluğu üyesi iken; Ermenistan, Moldova ve Ukrayna Toplulukta gözlemci statüsüne sahiptir.

Kamu harcamalarının hacmini etkileyen unsurlara ilişkin olarak aşağıdaki değişkenler kullanılmıştır.

Kamu Harcamaları (Khar): Kamu tüketim harcamalarının GSYİH içerisindeki yüzde payı ile ölçülmektedir.

Kişi Başıına GYSiH'daki Büyüme Hizı (Gdp): Kişi başı GSYIH düzeyindeki yüzde artışları göstermektedir. Ekonominin içinde bulunduğu durumu göstermek amacıyla modele dahil edilen bu değiş̧kendeki değişim oranı ile kamu harcamaları arasında pozitif bir ilişki beklenmektedir. Başka bir ifadeyle, kişi başına gayrisafi yurtiçi hasılanın değişim oranı arttıkça kamu harcamalarının da artması beklenmektedir.

Dışa Açıklık (Open): Dış ticaret hacminin (ihracat ve ithalat toplamı) GSYIH içerisindeki yüzde payıdır ve ülke ekonomisinin dışa açıklık düzeyini göstermektedir. Dışa açıklık ile kamu harcamaları arasındaki ilişki belirsizdir. Rodrik (1998) başta olmak üzere bir grup iktisatçı kamu harcamaları ile dışa açıklık arasında pozitif 
bir ilişki öngörmekte iken ( Rodrik, 1998; Alesina ve Wacziarg, 1998; Garen ve Trask, 2005; Cavallo 2007); diğer bir grup iktisatçı ise dışa açıklık arttıkça kamu harcamalarının hacminin azalacağını ifade etmektedir (Alesina ve Spolaore, 1997 ve Alesina, Spolaore ve Wacziarg, 1997).

Nüfus Yoğunluğu (Pop): Nüfus yoğunluğu kilometre kare başına düşen kişi sayısı ile ölçülmüştür. Nüfus yoğunluğunun artması kamusal mal ve hizmet talebini arttırmasından dolayı kamu harcamalarının miktarını pozitif yönde etkilemesi beklenmektedir.

Bürokratik Kalite (Bur): Bürokratik kalite endeksi, Uluslararası Şeffaflık Örgütü (Transparency International) tarafından her yıl ülkeler bazında açıklanmaktadır. Bu endekste ülkelere 0 ila 4 arasında bir tam sayı değeri verilmektedir. Yüksek tam sayı değerleri, kamu hizmetlerinin kesintiye uğramaksızın ya da büyük değişiklikler olmaksızın uzmanlığa sahip bürokratlar tarafından yerine getirildiğini göstermektedir. Düşük tamsayı değerleri ise bunun tersini ifade etmektedir.

Analizde kullanılan değişkenlerden kamu harcamaları, kişi başına GSYİH'daki büyüme hızı, dışa açıklık ile nüfus yoğunluğu Dünya Bankası'nın World Development Indicators (WDI) veri tabanından; bürokratik kalite verisi ise Uluslararası Şeffaflık Örgütü’nden alınmıştır.

\subsection{Analiz Sonuçları}

Bürokrasinin kamu harcamaları üzerindeki etkisini incelemeden önce modelde kullanılacak değişkenlerin durağan olup olmadıkları ve eğer durağan iseler hangi seviyede durağan oldukları Levin, Lin ve Chu (LLC) (2002) ile Im, Pesaran ve Shin (IPS) (2003) tarafından geliştirilen panel birim kök testleri ile incelenmiştir. Panel birim kök test sonuçları tüm serilerin düzey değerlerinde durağan olduklarını göstermiştir.

LLC ile IPS panel birim kök test sonuçları, sistem GMM yaklaşımındaki değişkenlerin durağan olması varsayımına uygundur. Modelde kullanılan değişkenlerin durağan olmaları nedeniyle kamu harcamalarına ilişkin model, GMM-Sistem dinamik panel veri yöntemi ile tahmin edilmiştir. Tahmin sonuçları aşağıdaki tabloda gösterilmiştir.

\begin{tabular}{|c|c|c|}
\hline Değişkenler & Katsayı ve Olasılık Değeri & Standart Hata \\
\hline Khar $_{-1}$ & $0.577(0.000)^{*}$ & 0.123 \\
\hline Gdp & $0.127(0.079) * * *$ & 0.098 \\
\hline Open & $-0.009(0.663)$ & 0.022 \\
\hline Pop & $0.028(0.082) * * *$ & 0.016 \\
\hline Bur & $-2.202(0.066) * * *$ & 1.200 \\
\hline Gözlem Sayısı & \multicolumn{2}{|l|}{78} \\
\hline Yatay Kesit Sayısı & \multicolumn{2}{|l|}{6} \\
\hline Wald $\chi^{2}$ (p değeri) & \multicolumn{2}{|c|}{$140.81(0.000)$} \\
\hline $\begin{array}{l}\begin{array}{l}\text { Arellano-Bond } \\
\text { değeri) }\end{array} \\
\text { Test }\end{array}$ & \multicolumn{2}{|c|}{$-1.83(0.068)$} \\
\hline $\begin{array}{l}\begin{array}{l}\text { Arellano-Bond } \\
\text { değeri) }\end{array} \\
\text { Test } \mathrm{AR}(2) \quad(\mathrm{p} \\
\end{array}$ & \multicolumn{2}{|c|}{$-1.42(0.156)$} \\
\hline Sargan Test (p değeri) & \multicolumn{2}{|c|}{$12.148(0.434)$} \\
\hline
\end{tabular}

Tablo 1: Sistem GMM Tahmin Sonuçları Not: *, \% 1 düzeyinde; *** ise \% 10 düzeyinde anlamlı olan değerlerdir.

Sistem GMM tahmin sonuçları genel olarak değerlendirildiğinde, kurulan modelin bir bütün olarak anlamlı olduğu görülmektedir. Wald $\chi^{2}$ değerine göre bağımsız değişkenler \% 1 anlamlılık düzeyinde bağımlı değişken üzerinde anlamlı bir etkiye sahiptir. Sistem GMM tahmincilerinin tutarlılığını test etmek amacıyla yapılan bir diğer test ise Sargan testidir. Sargan testi, modeli tahmin etmek için kullanılan araç değişkenlerin yeterli olup olmadığını ortaya koymaktadır. Test sonuçları, araç değişkenlerin geçerli olduğunu göstermektedir. Araç değişkenlerin geçerliliğinin yanı sıra modelde otokorelasyon olup olmadığının da test edilmesi gerekmektedir. Modelde otokorelasyon sorunu olup olmadı̆̆ Arellano-Bond (AB) testi ile sınanmaktadır. AR(1) istatistiği modelde birinci dereceden otokorelasyon gözlendiğini; $A R(2)$ istatistiği ise ikinci dereceden otokorelasyonun mevcut olmadığını göstermektedir.

Kamu harcamalarını belirleyen dinamiklere ilişkin olarak yapılan bu analizde beklentilere uygun sonuçlar elde edilmiştir. Sistem GMM sonuçlarına göre, cari dönemin kamu harcamaları bir önceki dönemin değerleri ile istatistiksel açıdan anlamlı bir ilişki içindedir. Benzer şekilde, ekonominin içinde bulunduğu konjonktürü gösteren gelir düzeyi ile kamu harcamaları arasında beklentilere uygun bir biçimde pozitif bir ilişki tespit edilmiştir. Bu sonuca göre; kişi başına gayrisafi yurtiçi hasıladaki değişim, kamu harcamalarının bir fonksiyonudur. İstatistiksel açıdan anlamlı bir diğer değişken ise nüfus yoğunluğudur. Analiz sonuçlarına göre kilometre kare başına düşen kişi sayısı ile ölçülen nüfus yoğunluğunun artması sonucu kamusal mal ve hizmet talebi de artmaktadır. Modelde ele alınan bir diğer değişken ise dışa açıklıktır. Yapılan çalışmada dış ticaret 
hacminin gayrisafi yurtiçi hasılaya oranı ile ölçülen dışa açıklık ile kamu harcamaları arasında istatistiksel açıdan anlamlı herhangi bir bulguya ulaşılamamıştır.

Ele alınan bu kontrol değişkenlerin yanı sıra bürokratik kalite ile kamu harcamaları arasındaki ilişkiyi incelediğimizde ise pozitif ve istatistiksel açıdan anlamlı bir ilişki tespit edilmiştir. Bu sonuç, bir ülkedeki bürokratik yapı ile kamusal mal ve hizmet arzı arasındaki bağlantıya işaret etmektedir. Başka bir ifadeyle, kamusal mal ve hizmet üretiminde siyasi otoritenin yanı sıra bürokrasinin oynadığı rol, sistem GMM sonuçları ile ortaya konulmuştur. Bu açıdan bakıldığında, bir ülkedeki bürokrasinin etkin işlemesi durumunda kamu harcamalarının oldukça istikrarlı bir büyüme sürecinde olacağı; aksine eğer bürokrasinin hantal ve ağır işleyen aynı zamanda da kişisel çıkar maksimizasyonunu temel alan bir yapıda olması durumunda ise kamu harcamalarının oldukça dalgalı ve hatta istikrarsız bir gelişme dinamiğinde olabileceği ifade edilebilir.

\section{Sonuç}

Günümüzde devletin yapısı ve işlevlerinde kü̧̈ülme ve etkinleştirmeye dönük olarak önemli değişimler olsa da kamu harcamalarındaki artış devam etmektedir. Kamu harcamalarındaki artış başta ekonomik olmak üzere sosyal ve politik birçok değişkene bağlı olarak açıklanmaktadır. Kamu harcamalarını politik değişkenlere dayalı olarak açıklamaya çalışan yaklaşımlar, bürokrasiyi temel almaktadır. Profesyonellik, daimi ve istikrarlı bir statü, belirli bir kurum ideolojisine sahip olma, planlama ve bütçeleme konusundaki deneyim ve bilgi birikimi bürokratları devlet yönetiminde çok önemli bir aktör haline getirmektedir. Halkın oyu ile iktidara gelen ve yönetimde karar verme gücüne sahip olan siyasi mekanizmanın, devlet yönetiminde profesyonellik ve bilgi birikimi nedeniyle bürokrasi ile uyum içerisinde çalışması gerekmektedir.

Bürokrasi ile kamu harcamaları arasındaki ilişki, bürokratların "bireysel fayda maksimizasyonu" ile açıklanmaktadır. Bu bakış açısında bürokratların kişisel faydalarını maksimize etme çabaları sonucunda kamu harcamaları milli gelirle orantısız bir şekilde arttı̆̆ının altı çizilmektedir. Bürokratlar politikacılar tarafindan alınan kararların uygulayıcısı olarak, fayda maksimizasyonu doğrultusunda hareket ederek kendilerine en uygun avantajları sağlama güdüsü içerisindedirler. $\mathrm{Bu}$ nedenle kamu harcamalarının mümkün olduğunca genişletilmesini isteyeceklerdir. Kamu harcamalarının genişlemesi sosyal ve ekonomik göstergelerde olumlu sonuçlara yol açabilir, ekonomik büyümeyi teşvik edebilir; ancak daha sonra kamu harcamalarındaki ilave artışlar ve bu artı̧ların bürokratlar tarafından bireysel fayda maksimizasyonu doğrultusunda yapılması yolsuzluklara, kamu hizmetlerinde etkinsizliğe, personel sisteminde kayırmacıllğa ve bütçe açığının büyümesi gibi olumsuz sonuçlara yol açabilir. Bu tür olumsuz sonuçlarla karşılaşmamak için bürokrasinin karar verme sürecinde ve uygulama esnasında sınırlarının yasal düzenlemelerle iyi çizilmesi gerekmektedir.

Avrasya Ekonomik Topluluğu üyesi ülkelerdeki bürokratik yapı ile kamu harcamaları arasındaki ilişkinin incelendiği bu çalışmada, kamu harcama politika kararlarını alan politikacılar olsa da bu kararların alınmasında, uygulanmasında ve etkin bir şekilde yürütülmesinde bürokratların oldukça önemli bir rol oynadığı bulgusuna ulaşılmıştır. Bu nedenle söz konusu ülkelerde etkin işleyen, hesap verebilir, iyi yönetişim ilkelerini kurumsal hale getiren bir bürokrasiye gereksinim bulunduğu ifade edilebilir. Dolayısıyla Avrasya ekonomilerindeki etkin işleyen bir bürokrasinin kamu harcamalarının artışını dengeleyeceği ve kamu harcamalarını daha istikrarlı bir hale getireceği söylenebilir.

\section{Kaynakça}

- Aktan, C. Can (1994) "Siyasal Yozlaşmanın Önlenmesine Yönelik Çözüm Önerileri” Politik Yozlaşma ve Şeffaf Yönetim Sempozyumu, İzmir, ss. 45-67.

- Alesina A. and E. Spolaore (1997), "On the Number and Sizes of Nations", Quarterly Journal of Economics, Vol.112, pp.1027-1056.

- Alesina A. and R. Wacziargi (1998), "Openness, Country Size and Government” Journal of Public Economics, Vol.69, pp.305-321.

- Alesina A., E. S Spolaore and R. Wacziargi (1997), "Economic Integration and Political Disintegration" NBER Working Paper 6163.

- Annet, A. (2000), "Social Fractionalization, Political Instability, and The Size Of Government" IMF Working Paper, 00/82.

- Arellano M. and O. Bover (1995), "Another Look at the Instrumental Variable Estimation Of Error Component Models" Journal of Econometrics, Vol.68, pp.29-51.

- Arellano, M. and S. Bond (19910), "Some Tests of Specification for Panel Data: Monte Carlo Evidence and an Application of Employment Equations", Review of Economic Studies, Vol.58, pp.277-297.

- Bakırtaş, İ. (1999), "Kamu Harcamaları Üzerinde Bürokratik Gücün Belirleyici Etkileri”, Dokuz Eylül Üniversitesi İIBF Dergisi, Cilt.14, Sayı.1.

- Baltagi, B. H.(2005), Econometric Analysis of Panel Data, 3. Ed., Wiley, New York. 
- $\quad$ BETAM (2008), Kamu Harcamalarının Bileşiminin Büyüme ve Refah Etkileri, Bahçeşehir Üniversitesi Ekonomik ve Toplumsal Araştırmalar Merkezi, İstanbul.

- $\quad$ Blau, P. and Meyer, M. (1987), Bureaucracy in Modern Society, 3rd., Random Haouse, New York.

- Blundell, R.W. and S.R. Bond (1998), "Initial Conditions and Moment Restrictions in Dynamic Panel Data Models", Journal of Econometrics, Vol. 87, pp.115-143.

- Borcherding, T. E. and D. Lee (2002), "The Growth of The Relative Size Of Government", http://www.claremontmckenna.edu/rdschool/papers/2002-05.pdf, Erişim Tarihi:01.06.2013.

- Buchanan, James M. (1967), Public Finance in Democratic Process, The University of North Carolina Press, Chapell Hill, North Carolina.

- Cavallo, E. (2007) “Openness to Trade and Output Volatility: A Reassessment” IDB Research Department Working Paper 2007.

- Coşkun, E. ve Kök, D. (2011), "Çalışma Sermayesi Politikalarının Karlılık Üzerine Etkisi: Dinamik Panel Uygulaması", Ege Akademik Bakış, Cilt: 11, Özel Sayı, ss. 75-85.

- Downs, G and Larkey, P. (1986) The Search for Government Effiency, Temple University Press, Philadelphia, PA.

- $\quad$ DPT (2007), 9. Kalkınma Planı, Kamuda İyi Yönetişim Özel İhtisas Komisyonu Raporu, Ankara.

- Farazmand, A. (2009), “Bureaucracy, Administration, and Politics: An Introduction” in Farazmand, A. (eds): Bureaucracy and Administration, CRC Prss, USA, pp. 1-15.

- Garen J. and K. Trask (2005), "Do More Open Economies Have Bigger Governments? Another Look", Journal of Development Economics, Vol.77, pp.533-551.

- Heller P. S. and J. Diamond (1990), "International Comparisons of Government Expenditure Revisited: The Developing Countries, 1975-86”, ,IMF Occasional Paper, 69, International Monetary Fund, Washington, D.C.

- Im, K.S. and Pesaran, M.H. (2003), On the Panel Unit Root Tests Using Nonlinear Instrumental Variables, Mimeo, University of Southern California.

- İnal, Ahmet (2009), Durağan Olmayan Paneller ve Bir Uygulama Çukurova Üniversitesi, Sosyal Bilimler Enstitüsü Ekonometri Anabilim Dalı, Yayımlanmamış Yüksek Lisans Tezi, Adana.

- Kovancılar, B., Miynat, M. ve Bursalığlu, S. (2007), Kamu Maliyesinde Küresel Değişimler, Gazi Kitabevi, Ankara.

- Levin, A., Lin, C.F., and Chu., C.S.J. (2002), Unit Root Test in Panel Data: Asymptotic and Finite Sample Properties, Journal of Econometrics, Vol.108, pp.1-24.

- Peacock A. and A. Scortt (2000), “The Curious Attraction Of Wagner's Law”, Public Choice, Vol.102, pp.117.

- Polidano, C. (2000), "Measuring Public Sector Capacity”, World Development, Vol.28, No.5, pp.805-822.

- Rajkumar, A. S. and V. Swaroop (2008), "Public Spending and Outcomes: Does Governance Matter?", Journal of Development Economics, pp. 96-111.

- $\quad$ Ram, R. (1987), “Wagner's Hypothesis in Time-Series and Cross-Section Perspectives: Evidence From Real Data For 115 Countries" The Review of Economics and Statistics, Vol.69, pp.194-204.

- Riggs, Fred W. (2009), "Bureaucratic Links between Administration and Politics" in Farazmand, A. (eds): Bureaucracy and Administration, CRC Press, USA, pp. 85-109.

- Rodrik, D. (1998), “Why Do More Open Economies Have Bigger Governments?”, Journal of Political Economy, 106(5), pp.997-1032.

- Şaylan, Gencay (1974), Türkiye’de Kapitalizm Bürokrasi ve Siyasal İdeoloji, TODAİE Yayınları, Ankara.

- Tanzi, V. and L. Schuknecht (1997), "Reconsidering the Fiscal Role of Government: The International Perspective", The American Economic Review, Vol. 87, No. 2, pp.164-168

- Tanzi, Vito (2005), "The Economic Role of the State in the 21st Century”, Cato Journal, Vol. 25, No. 3, Fall.

- Tatoğlu, Ferda (2012). Panel Veri Ekonometrisi, Beta Yayıncılık, İstanbul.

- Uzay, N. (2002), "Kamu Büyüklüğü ve Ekonomik Büyüme Üzerindeki Etkileri: Türkiye Örneği (19701999)”, Erciyes Üniversitesi IİBF Dergisi, Sayı.19, Temmuz-Aralık, ss.151-172.

- Wagner R. E. and W. E. Weber (1977), "Wagner's Law, Fiscal Institutions and The Growth Of Government”, National Tax Journal, Vol.30, pp.59-68.

- Wilson, J. (1989), Bureaucracies: What Government Agencies Do and Why They Do It, Basic Books, New York.

- World Bank (2013), World Development Indicators, http://data.worldbank.org/data-catalog/worlddevelopment-indicators, Erişim Tarihi:01.06.2013. 


\title{
Kadının Ekonomik Yaşamdaki Yeri: Türkiye ve Geçiş Ekonomilerinin Karşılaştırması
}

\section{The Position of Women in Economic Life: A Comparison between Transition Economies and Turkey}

\author{
Prof. Dr. Nuray Gökçek Karaca (Anadolu University, Turkey)
}

\begin{abstract}
In this study, the participation of women in economic life, in other words their position in economic activity in Turkey was examined in comparison with the Central and Eastern Europe (CEE) countries and the Commonwealth of Independent States (CIS). To examine women's participation in economic life in Turkey in comparison with transition economies, we benefited from the Gender Empowerment Measure (GEM), which was developed by the UNDP the participation of women in economic activity in Turkey is low extremely. The factors that reduce the participation in the workforce by women in Turkey are traditional division of work, economic development, level of education, unpaid family work, informal employment, legal regulation, discrimination, work/non-work preferences. The participation of women in economic activity is also low in transition economies. But transition economies is not homogenous in terms of participation of women in economic activities. Results also indicate that, the participation of women in economic activity in the Central and Eastern Europe (CEE) is higher than the participation of women in economic activity in the Commonwealth of Independent States (CIS).
\end{abstract}

\section{Giriş}

Gelişen feminist hareketin etkisiyle, kadınlar 19. Yüzyılın ikinci yarısından itibaren kendilerini ve isteklerini ifade etmeye başlamışlar, ardından örgütlenerek, istekleri doğrultusunda çeşitli haklar elde etmişlerdir. Bu anlamda kadınların en dikkat çeken sosyal ve siyasal mücadelelerinden birisi, kadınların erkeklerle eşit oy hakkından yararlanabilmek, seçme ve seçilme haklarını kazanmak için verdikleri mücadele olmuştur. Birinci ve İkinci Dünya Savaşları'ndan sonra dünyanın büyük çoğunluğunda kadınlar seçme ve seçilme haklarını elde etmişlerdir. Kadınların seçme ve seçilme haklarını kazanmalarıyla başlayan bu süreç, günümüzde sosyal, siyasal, ekonomik ve kültürel konularda sürdürülen mücadele ile devam etmektedir. İnsan hakları, demokrasi ve eşitlik açısından gerçekleşen gelişmelere rağmen, dünya genelinde hala kadınların seçme ve seçilme haklarından yararlanabildiklerini söylemek olanaklı olmadığı gibi, kadınlara karşı hemen her alanda her tür ayırımcılık da varlığını korumaktadır.

Günümüzde kadınlar diğer alanlara göre en çok ekonomik yaşama katılım konusunda ayırımcılığa maruz kalmaktadır. Kuşkusuz bu durumun en önemli nedenlerinden biri, kadını ekonomide erkeklerle aynı mesleki firsatlardan ve eşit ücretten yararlanmaktan alıkoyan sosyo-kültürel engellerin varlığını korumasıdır. Gerçekten de kadınların yaptığı işin, aileye destek olmak için yapılan bir çalışma olduğu yolundaki geleneksel anlayış, kadınlara ekonomik büyüme dönemlerinde gereksinim duyulan ve gerileme dönemlerinde bir kenara itilen, yedek işgücü niteliği kazandırmaktadır. Bu nedenle kadınlar erkeklerle çalışma hakkına az çok eşit koşullarda sahip olduklarında bile, çocuk yetiştirme ve ev işi hala sadece kadınların sorumluluğu olarak görüldüğünden, ya çifte emek harcamak durumunda kalmakta ya da işgücü piyasasından çekilmek zorunda kalmaktadır. Dolayısıyla kadınlar, ekonomik yaşamın dışına itilmekte ve ekonomik yaşamda yer alsalar bile erkeklerle karşılaştırıldığında pek de varlık gösterememektedirler.

Bu çalışmanın amacı, Türkiye'de kadınların ekonomik yaşama katılım konusunda ayrımcılığa maruz kalıp kalmadıklarının, Birleşmiş Milletler Kalkınma Programı (UNDP) tarafından geliştirilmiş insani gelişmişlik indeksine göre kendisi ile birlikte aynı grupta yer alan geçiş ekonomileri ile karşılaştırmalı bir değerlendirmesini yapmaktır.

\section{Kadınların Ekonomik Yaşama Katılımının Saptanması}

Kadınların ekonomik yaşama katılımı konusunda erkeklere göre ayrımcılığa maruz kalıp kalmadıklarının tespitinde, iki ölçütten yararlanılmaktadır. Bu ölçütler; kadın ve erkeklerin üç ana sektör içindeki istihdam payları ve aile çalışanlarının kadın ve erkek olarak toplam gelirdeki yüzdesel paylarıdır. Bu bağlamda Türkiye'de kadınların erkeklere kıyasla ekonomik yaşama katılım konusunda bir ayrımcıllğa maruz kalıp kalmadıklarının tespitinde, UNDP tarafından geliştirilmiş iki indeksten yararlanılmaktadır. Bu indekslerden ilki, Siyasal ve Ekonomik Yaşama Katılım İndeksi (GEM), diğeri ise Cinsiyetlerle İlgili İnsani Gelişme İndeksi ya da Yaşam Kalitesi İndeksidir (GDI). 
Mesleki ve teknik işgücü içerisinde kadın işgücünün oranı ölçütü dışında, kadının siyasal ve ekonomik yaşama katılımını belirlemek ve bu konuda kadın-erkek arasındaki eşitsizliklerin boyutlarını göstermek amacıyla kullanılan GEM, "parlamentodaki kadın milletvekili sayısı", "yönetici pozisyonunda olan kadın yüzdesi”, ve "toplam kazanılmış gelir içerisinde erkeğin kazancına oranla kadına düşen pay" ölçütleri esas alınarak hesaplanmaktadır. GEM'in de alabileceği en yüksek değer "1", en düşük değer ise "0"dır. Yukarıda değinilen ölçütler çerçevesinde, kadının siyasal ve ekonomik yaşama katılımının yüksek olduğu ve bu konuda kadın-erkek eşitsizliğinin düşük olduğu ülkelerde, GEM değerinin "1"e yaklaştığ 1 , kadının siyasal ve ekonomik katılımının düşük olduğu ve bu konuda kadın-erkek eşitsizliğinin yüksek olduğu ülkelerde ise, söz konusu indeks değerinin “0”a yaklaştığ1 görülmektedir (Karaca ve Kocabaş, 2010: 74).

GDI "sağlık", "eğitim" ve "refah" olmak üzere üç standart ve bu standartları belirleyen dört ayrı ölçüt esas alınarak hesaplanmaktadır. Sağlık standardını belirleyen ölçüt, "ortalama yaşam beklentisi”; eğitim standardını belirleyen ölçüt, "kadın ve erkek okuma-yazma oranı" ve "kadın ve erkek okullaşma oranı"; refah standardını belirleyen ölçüt ise, “ortalama gelir düzeyi” (kazanılan gelir içersinde erkek ve kadının \% payı)'dır.

GDI'nın alabileceği en yüksek değer "1”, en düşük değer ise "0"dır. Yukarıda değinilen standartlar ve bu standartları belirleyen ölçütler çerçevesinde, kadının toplumsal katılımının yüksek olduğu ve bu konuda kadınerkek eşitsizliğinin düşük olduğu ülkelerde, GDI değerinin “1”e yaklaştığı, kadının toplumsal katılımının düşük olduğu ve bu konuda kadın-erkek eşitsizliğinin yüksek olduğu ülkelerde ise, söz konusu indeks değerinin " 0 ” a yaklaştı̆̆ görülmektedir.

\section{Türkiye'de Kadınların Ekonomik Yaşama Katılımı}

\section{1 İstihdam Ölçütüne Göre}

Türkiye'de kadınların ekonomik yaşama katılım konusunda erkeklerle karşılaştırılabilmeleri için yıllar itibariyle sektörler bazında istihdamdaki payları Tablo 1'de gösterilmiştir.

\begin{tabular}{|c|c|c|c|c|c|c|c|c|c|c|c|c|}
\hline & \multirow{2}{*}{\multicolumn{3}{|c|}{$\begin{array}{l}\text { Kadınların Ekonomik } \\
\text { Faaliyeti (15 yaş ve üstü) }\end{array}$}} & \multicolumn{6}{|c|}{$\begin{array}{l}\text { Çalıştığ Ekonomik Faaliyet Alanı } \\
(\%)\end{array}$} & \multirow{2}{*}{\multicolumn{2}{|c|}{$\begin{array}{l}\text { Ücretsiz Aile } \\
\text { İşçiliği }\end{array}$}} & \multirow{3}{*}{$\begin{array}{l}\text { Kadın } \\
\text { Profesyon } \\
\text { el ve } \\
\text { Teknik } \\
\text { Çalışan } \\
\text { Oranı } \\
\text { (Toplamın } \\
\text { \%'si) }\end{array}$} \\
\hline & & & & \multicolumn{2}{|l|}{ Tarım } & \multicolumn{2}{|l|}{ Sanayi } & \multicolumn{2}{|c|}{ Hizmet } & & & \\
\hline Y1llar & $\begin{array}{l}\text { Oran } \\
(\%)\end{array}$ & $\begin{array}{l}\text { İndek } \\
\mathrm{s}\end{array}$ & $\begin{array}{l}\text { Erkeklere } \\
\text { Oran1 } \\
(\%)\end{array}$ & Kadın & Erkek & Kadın & Erkek & Kadın & Erkek & Kadın & Erkek & \\
\hline 2001 & 49.3 & 111 & 60 & 65 & 30 & 13 & 29 & 21 & 40 & - & - & 33.9 \\
\hline 2002 & 49.9 & 114 & 61 & 72 & 34 & 10 & 25 & 18 & 41 & - & - & 36 \\
\hline 2003 & 50.3 & 115 & 62 & 72 & 34 & 10 & 25 & 18 & 41 & 65 & 35 & 36 \\
\hline 2004 & $\begin{array}{l}50.8 \\
\end{array}$ & 116 & 62 & 56 & 32 & 15 & 56 & 29 & 60 & 68 & 32 & 31 \\
\hline 2005 & 51.2 & 117 & 63 & 56 & 24 & 15 & 28 & 29 & 48 & 68 & 32 & 31 \\
\hline 2006 & 27.8 & 81 & 36 & 56 & 24 & 15 & 28 & 29 & 48 & 67 & 33 & 30 \\
\hline $\begin{array}{l}2007- \\
2008\end{array}$ & 27.7 & 81 & 36 & 52 & 22 & 15 & 28 & 33 & 50 & 67 & 33 & 31 \\
\hline
\end{tabular}

Tablo 1: Türkiye'de Ylllar İtibariyle Kadın ve Erkeklerin Üç Ana Sektör İçindeki İstihdam Payları Kaynak: UNDP, 2000-2008, Web: http: http://hdr.undp.org.

Tablo 1'de görülebileceği üzere, Türkiye'de 15 yaş ve üstü kadınların ekonomik faaliyet oranı 2001-2005 yılları arasında 49.3-51.2 arasında değişmekte iken, bu oran 2006-2008 yılları arasında 27.7'ye gerilemiştir. Bu sonuç, Türkiye'de kadınların 2000 yılından itibaren işgücüne katılım oranlarının (İKO) düşmesi ile açıklanabilir. Literatür incelendiğinde, Türkiye'de kadınların İKO'sunu düşüren nedenlerin geleneksel işbölümü, kadınların eğitim düzeylerinin düşüklüğü, kadınların ücretsiz aile işçisi olarak çalıştırılmaları, kayıt dışı istihdam, yasal düzenlemeler ve kadınların ayırımcılıkla karşılaşma risklerinin yüksekliği olduğu görülür (Lordoğlu, 1990; Toksöz, 1999: 60; Törüner-Lordoğlu-Özkaplan, 1999: 44-46; Özer-Biçerli, 2003: 64-66; Minibaş, 2005; Selamoğlu-Lordoğlu, 2006: 197; Karadeniz-Yılmaz, 2007: 35-40; Türk Girişim ve İş Dünyası Konfederasyonu (Türkonfed), 2007: 21, 22; Budak-Özkaya, 2007: 44; T.C. Başbakanlık Kadının Statüsü Genel Müdürlüğü, 2008 : 10).

Tablo 1 incelendiğinde, özellikle 2003 yılından itibaren \%20’lik bir azalma göstermesine rağmen, Türkiye'de kadının tarımdaki istihdam payının hala erkeklerden çok yüksek olduğu, buna karşın kadının sanayi ve hizmet sektöründeki istihdam payının erkeklerden çok düşük olduğu ve bu sektörlerde yıllar itibariyle kadın istihdam payında ciddi bir artış olmadığı görülmektedir. Dolayısıyla Türkiye'de hala tarım, kadınlar için temel istihdam kaynağı olmaya devam etmektedir. Kadınların tarımdan sonra en çok hizmet sektöründe istihdam edilmektedir. İstihdam edilen kadınların önemli bir kısmının ücretsiz aile işçisi statüsünde olduğu görülmektedir.

Tablo 1 incelendiğinde, Türkiye'de mesleki ve teknik işgücü içerisinde kadın işgücünün oranı bakımından kadın ve erkek arasında yıllar itibariyle ciddi bir farklılık olmadığı görülmektedir. 


\subsection{Ortalama Gelir Düzeyi Ölçütüne Göre}

Türkiye'de kadınların ekonomik yaşama katılım konusunda erkeklerle karşılaştırılabilmeleri amacıyla Tablo 2'de yıllar itibariyle "ortalama gelir düzeyi" ölçütü yönünden kadın-erkek eşitliği/eşitsizliğinin boyutları gösterilmiştir.

\begin{tabular}{|l|l|l|l|l|}
\hline & \multicolumn{2}{l}{ GDI } & \multicolumn{2}{l|}{ Tahmini Gelir (Satınalma Gücü Paritesi, ABD Doları) } \\
\hline Y1llar & GDI Sıra & GDI Değeri & Kadın & Erkek \\
\hline 2000 & 69 & 0.726 & 4.703 & 8.104 \\
\hline 2001 & 71 & 0.726 & 3.937 & 8.772 \\
\hline 2002 & 71 & 0.734 & 4.379 & 9.516 \\
\hline 2003 & 81 & 0.726 & 3.717 & 8.028 \\
\hline 2004 & 70 & 0.746 & 4.757 & 7.873 \\
\hline 2005 & 70 & 0.742 & 4.276 & 9.286 \\
\hline 2006 & 71 & 0.745 & 4.038 & 11.408 \\
\hline $2007 / 2008$ & 79 & 0.763 & 4.385 & 12.368 \\
\hline
\end{tabular}

Tablo 2: Türkiye’de Yıllar İtibariyle Ortalama Gelir Düzeyi Yönünden Kadın-Erkek Eşitliği/Eşitsizliğinin Boyutlarl Kaynak: UNDP, 2000-2008.

Tablo 2'de görülebileceği üzere, 2007-2008 y1lları itibariyle erkeklerin ortalama gelirlerinde (12.368\$) diğer yıllara göre ciddi bir artış söz konusu iken, kadınların ortalama gelirlerinde (4.385\$) 2000 ve 2004 (4.703\$ ve 4.757\$) yıllarına göre büyük bir azalma olmuştur. Bu durum, ülkemizdeki kriz sonrası ilk olarak kadınların işten çıkarımının ya da bir kriz ortamında kadınların daha az ücretli işlere razı olduklarının bir göstergesi olarak algılanabilir. Gerçekten de kadınların yaptığı işin, aileye destek olmak için yapılan bir çalışma olduğu yolundaki yaygın görüş, kadınların, ekonomik büyüme dönemlerinde gereksinme duyulan ve gerileme dönemlerinde bir kenara itilen yedek bir işgücü oluşturduğu düşüncesine yol açmaktadır (TİSK, 2002: 30).

\section{Geçiş Ekonomilerinde Kadının Ekonomik Yaşama Katılımı ve Türkiye Karşılaştırması}

\section{1 İstihdam Ölçütüne Göre}

Geçiş ekonomilerinde ve Türkiye'de kadınların ekonomik yaşama katılım konusunda erkeklerle karşılaştırılabilmeleri için yıllar itibariyle sektörler bazında istihdamdaki payları Tablo 3 'te gösterilmiştir.

Tablo 3'te de görülebileceği üzere, kadın-erkek arasındaki eşitliğin/eşitsizliğin boyutları bakımından aralarında farklılıklar olabileceği varsayımı ile geçiş ekonomileri kendi arasında gruplandırılmıştır. Birinci grupta, CEE ülkeleri, ikinci grupta ise CIS ülkeleri yer almaktadır. Ayrıca CEE ülkeleri de kendi içinde AB'ye üye olan, AB'ye üye olmayan ve AB'ye aday ülkeler şeklinde üç gruba ayrılarak incelenmiş, AB'ye aday bir ülke olarak Türkiye'nin özellikle CEE ülkelerinden AB'ye aday olan iki ülke ve CIS ülkeleri ile karşılaştırması yapılmıştır.

Tablo 3 incelendiğinde, kadınların ekonomik faaliyet oranı bakımından CEE ülkelerinden Slovenya, Bosna Hersek ve Hırvatistan'ın ilk üç sırada; Bulgaristan, Letonya ve Polonya'nın son üç sırada yer aldığı görülmektedir. CIS ülkelerinden ise Kazakistan, Azerbaycan ve Özbekistan'ın ilk üç sırada; Ermenistan, Gürcistan ve Ukrayna'nın son üç sırada olduğu görülmektedir. Türkiye'nin ise, kadınların ekonomik faaliyet oranı bakımından son üç sırada yer alan CEE ve CIS ülkelerinden Letonya, Bulgaristan, Ermenistan ve Gürcistan'ın önünde yer almakla birlikte, diğer ülkelerin bir hayli gerisinde olduğu görülmektedir. Aynı şekilde Türkiye AB'ye üye olan CEE ülkelerinden Hırvatistan ve Makedonya'ya göre de, kadının ekonomik faaliyet oranı bakımından düşük indeks değerlerine sahiptir. Kadın ve erkeklerin üç ana sektör içindeki istihdam payları incelendiğinde, kadınların tarımsal istihdamdaki payının en yüksek olduğu üç CEE ülkesi Romanya, Hırvatistan ve Makedonya iken, kadınların tarımsal istihdamdaki payının en düşük olduğu üç CEE ülkesi ise Çek Cumhuriyeti, Slovak Cumhuriyeti ve Macaristan'dır. Kadınların sanayi istihdamındaki payının en yüksek olduğu üç CEE ülkesi Makedonya, Bulgaristan ve Çek Cumhuriyeti iken, kadınların sanayi istihdamındaki payının en düşük olduğu üç CEE ülkesi ise Letonya, Polonya ve Hırvatistan'dır. Kadınların hizmet sektöründeki istihdam payının en yüksek olduğu üç CEE ülkesi Macaristan, Letonya ve Slovakya iken, kadınların hizmet sektöründeki istihdam payının en düşük olduğu üç CEE ülkesi ise Romanya, Hırvatistan ve Bulgaristan'dır.

Kadın ve erkeklerin üç ana sektör içindeki istihdam payları incelendiğinde, yeterli veri olmamasına karşın kadınların tarımsal istihdamdaki payının en yüksek olduğu üç CIS ülkesi Gürcistan, Kırgızistan ve Moldovya iken, kadınların tarımsal istihdamdaki payının en düşük olduğu üç CIS ülkesi ise Rusya, Kazakistan ve Azerbaycan'dır. Kadınların sanayi istihdamındaki payının en yüksek olduğu üç CIS ülkesi Ukrayna, Rusya ve Moldovya iken, kadınların sanayi istihdamındaki payının en düşük olduğu üç CIS ülkesi ise Gürcistan, Kırgızistan ve Kazakistan'dır. Kadınların hizmet sektöründeki istihdam payının en yüksek olduğu üç CIS ülkesi Rusya, Ukrayna ve Kazakistan iken, kadınların hizmet sektöründeki istihdam payının en düşük olduğu üç CIS ülkesi ise Gürcistan, Kırgızistan ve Moldovya'dır. 
Tablo 3'teki verilere dayalı olarak Türkiye'de kadın ve erkeklerin istihdam bakımından sektörel dağılımları incelendiğinde, tarımda çalışan kadınların oranının neredeyse hizmet ve sanayi sektöründe çalışan kadınların oranına eşit olduğu; Türkiye'nin, tarımda kadın istihdamı bakımından Rusya hariç CIS ülkeleri ile benzerlik gösterdiği; CIS ülkeleri ve Türkiye'nin aksine, CEE ülkelerinde kadınların hizmet sektöründeki payının çarpıcı bir şekilde yüksek olduğu görülmektedir. Bu durum Türkiye'nin CEE ülkeleri ile karşılaştırılamayacak boyutta, tarımda kadın istihdamına sahip olduğunu ortaya koymaktadır.

Tablo 3 incelendiğinde, AB'ye yeni üye olan CEE ülkelerinden Bulgaristan, Estonya, Romanya ve Slovakya ile AB'ye aday ülke olan Hırvatistan'da ücretsiz aile işçisi olarak çalıştırılan kadın oranının Türkiye'den yüksek olduğu görülmektedir. Buna karşın aynı oranın Moldovya hariç tüm CIS ülkelerine göre Türkiye'de yüksekliği dikkat çekicidir.

Kadınların ekonomik yaşamdaki statülerini ortaya koyan göstergelerden ikincisi olan mesleki ve teknik işgücü içerisinde kadın işgücünün oranı yönünden bir karşılaştırma yapıldığında, mesleki ve teknik personel içerisinde kadınların oranının Türkiye hariç tüm CEE ve CIS ülkelerinde \%50-70 arasında değiştiği görülmektedir. Türkiye'de ise bu oran \%32'dir. Bu sonuç, CEE ve CIS ülkelerinde kadınların mesleki ve teknik personel içerisindeki oranının erkeklere göre daha yüksek olduğunu, buna karşın Türkiye'de bu oranın kadınlarda erkeklere göre çok daha düşük olduğunu ortaya koymaktadır.

\begin{tabular}{|c|c|c|c|c|c|c|c|c|c|c|c|c|}
\hline & \multirow{2}{*}{\multicolumn{3}{|c|}{$\begin{array}{l}\text { Kadınların Ekonomik } \\
\text { Faaliyeti (15 yaş ve üstü) }\end{array}$}} & \multicolumn{6}{|c|}{ Çalıştığı Ekonomik Faaliyet Alanı (\%) } & \multirow{2}{*}{\multicolumn{2}{|c|}{$\begin{array}{l}\text { Ücretsiz Aile } \\
\text { İşçileri }\end{array}$}} & \multirow{3}{*}{$\begin{array}{l}\text { Kadın } \\
\text { Profesyonel ve } \\
\text { Teknik } \\
\text { Çalışanların } \\
\text { Oranı } \\
\text { (Toplamın \%'si) }\end{array}$} \\
\hline & & & & \multicolumn{2}{|c|}{ Tarım } & \multicolumn{2}{|c|}{ Sanayi } & \multicolumn{2}{|c|}{ Hizmetler } & & & \\
\hline & $\begin{array}{l}\text { Oran } \\
(\%)\end{array}$ & İndex & $\begin{array}{l}\text { Erkekle } \\
\text { re Oranı } \\
(\%)\end{array}$ & $\mathbf{K}$ & $\mathbf{E}$ & $\mathbf{K}$ & $\mathbf{E}$ & $\mathbf{K}$ & $\mathbf{E}$ & $\mathbf{K}$ & $\mathbf{E}$ & \\
\hline \multicolumn{13}{|c|}{ Merkez ve Doğu Avrupa Ülkeleri } \\
\hline Arnavutluk & 49.0 & 84 & 70 & - & - & - & - & - & - & - & - & - \\
\hline $\begin{array}{l}\text { Bosna } \\
\text { Hersek }\end{array}$ & 58.3 & 97 & 86 & - & - & - & - & - & - & - & - & - \\
\hline Bulgaristan & 41.2 & 69 & 78 & 7 & 11 & 29 & 39 & 64 & 50 & 65 & 35 & 60 \\
\hline $\begin{array}{l}\text { Çek } \\
\text { Cumhuriyeti }\end{array}$ & 51.9 & 85 & 77 & 3 & 5 & 27 & 49 & 71 & 46 & 74 & 26 & 52 \\
\hline Estonya & 52.3 & 81 & 80 & 4 & 7 & 24 & 44 & 72 & 49 & 50 & 50 & 70 \\
\hline Hirvatistan & 44.7 & 96 & 74 & 19 & 16 & 18 & 37 & 63 & 47 & 73 & 27 & 50 \\
\hline Macaristan & 42.1 & 91 & 73 & 3 & 7 & 21 & 42 & 76 & 51 & 69 & 31 & 62 \\
\hline Makedonya & 40.8 & 85 & 63 & 19 & 20 & 30 & 34 & 51 & 46 & 54 & 46 & 52 \\
\hline Letonya & 49.0 & 78 & 77 & 8 & 15 & 16 & 35 & 75 & 49 & 43 & 57 & 65 \\
\hline Litvanya & 51.7 & 87 & 82 & 11 & 17 & 21 & 37 & 68 & 46 & 62 & 38 & 67 \\
\hline Polonya & 47.7 & 83 & 78 & 17 & 18 & 17 & 39 & 66 & 43 & 60 & 40 & 61 \\
\hline Romanya & 50.1 & 94 & 80 & 33 & 31 & 25 & 35 & 42 & 34 & 70 & 30 & 57 \\
\hline $\begin{array}{l}\text { Slovak } \\
\text { Cumhuriyeti }\end{array}$ & 51.8 & 87 & 76 & 3 & 6 & 25 & 50 & 72 & 44 & 74 & 26 & 58 \\
\hline Slovenya & 53.6 & 99 & 80 & 9 & 9 & 25 & 47 & 65 & 43 & 58 & 42 & 57 \\
\hline \multicolumn{13}{|c|}{ Bağımsız Devletler Topluluğu Ülkeleri } \\
\hline Azerbeycan & 60.2 & 95 & 82 & 37 & 41 & 9 & 15 & 54 & 44 & - & - & - \\
\hline $\begin{array}{l}\text { Beyaz } \\
\text { Rusya }\end{array}$ & 52.5 & 87 & 82 & - & - & - & - & - & - & - & - & - \\
\hline Ermenistan & 47.9 & 67 & 79 & - & - & - & - & - & - & 38 & 63 & - \\
\hline Gürcistan & 50.1 & 73 & 66 & 57 & 52 & 4 & 14 & 38 & 34 & 65 & 35 & 62 \\
\hline Kazakistan & 65.3 & 106 & 87 & 32 & 35 & 10 & 24 & 58 & 41 & 54 & 46 & 67 \\
\hline Kırgızistan & 55.0 & 94 & 74 & 55 & 51 & 7 & 13 & 38 & 36 & 65 & 35 & 57 \\
\hline Moldavya & 56.6 & 92 & 81 & 40 & 41 & 12 & 21 & 48 & 38 & 75 & 25 & 66 \\
\hline Özbekistan & 56.6 & 95 & 78 & - & - & - & - & - & - & - & - & - \\
\hline Rusya & 54.3 & 90 & 80 & 8 & 12 & 21 & 38 & 71 & 50 & 24 & 76 & 65 \\
\hline Tacikistan & 46.3 & 89 & 74 & - & - & - & - & - & - & - & - & - \\
\hline $\begin{array}{l}\text { Türkmenista } \\
\mathrm{n}\end{array}$ & 60.5 & 94 & 83 & - & - & - & - & - & - & - & - & - \\
\hline Ukrayna & 49.6 & 86 & 79 & 17 & 21 & 21 & 38 & 62 & 41 & 50 & 50 & 64 \\
\hline Türkiye & 27.7 & 81 & 36 & 52 & 22 & 15 & 28 & 33 & 50 & 67 & 33 & 32 \\
\hline
\end{tabular}

Tablo 3: Geçiş Ekonomilerinde ve Türkiye'de Yıllar Itibariyle Kadın ve Erkeklerin Üç Ana Sektör Içindeki Istihdam Paylart Kaynak: UNDP, 2000-2008 


\subsection{Ortalama Gelir Düzeyi Ölçütüne Göre}

Geçiş ekonomileri ve Türkiye'de kadınların ekonomik yaşama katılım konusunda erkeklerle karşılaştırılabilmeleri amacıyla Tablo 4'te 2008 yılı itibariyle "ortalama gelir düzeyi" ölçütü yönünden kadınerkek eşitliği/eşitsizliğinin boyutları gösterilmiştir.

\begin{tabular}{|c|c|c|c|}
\hline & \multicolumn{2}{|c|}{$\begin{array}{l}\text { Tahmini Gelir (Satınalma Gücü } \\
\text { Paritesi, ABD Doları) }\end{array}$} & \multirow[t]{2}{*}{ Tahmini Kadın Erkek Gelir Oran } \\
\hline & Kadın & Erkek & \\
\hline \multicolumn{4}{|c|}{ Merkez ve Doğu Avrupa Ülkeleri } \\
\hline Arnavutluk & 3.728 & 6.930 & 0.54 \\
\hline Bosna Hersek & 2.864 & 4.341 & - \\
\hline Bulgaristan & 7.176 & 11.010 & 0.65 \\
\hline Çek Cumhuriyeti & 13.992 & 27.440 & 0.51 \\
\hline Estonya & 12.112 & 19.430 & 0.62 \\
\hline Hirvatistan & 10.587 & 15.687 & 0.67 \\
\hline Macaristan & 14.058 & 22.098 & 0.64 \\
\hline Makedonya & 4.676 & 9.734 & 0.48 \\
\hline Letonya & 10.951 & 16.842 & 0.65 \\
\hline Litvanya & 12.000 & 17.349 & 0.69 \\
\hline Polonya & 10.414 & 17.493 & 0.60 \\
\hline Romanya & 7.443 & 10.761 & 0.69 \\
\hline Slovak Cumhuriyeti & 11.777 & 22.218 & 0.58 \\
\hline Slovenya & 17.022 & 27.779 & 0.61 \\
\hline \multicolumn{4}{|c|}{ Bağımsız Devletler Topluluğu Ülkeleri } \\
\hline Azerbeycan & 3.960 & 6.137 & 0.65 \\
\hline Beyaz Rusya & 6.236 & 9.835 & 0.63 \\
\hline Ermenistan & 3.893 & 6.150 & 0.63 \\
\hline Gürcistan & 1.731 & 5.188 & 0.33 \\
\hline Kazakistan & 6.141 & 9.723 & 0.63 \\
\hline Kırgızistan & 1.414 & 2.455 & 0.58 \\
\hline Moldavya & 1.634 & 2.608 & 0.63 \\
\hline Özbekistan & 1.547 & 2.585 & 0.60 \\
\hline Rusya & 8.476 & 13.581 & 0.62 \\
\hline Tacikistan & .992 & 1.725 & 0.57 \\
\hline Türkmenistan & 6.108 & 9.596 & 0.64 \\
\hline Ukrayna & 4.970 & 9.067 & 0.55 \\
\hline Türkiye & 4.385 & 12.368 & 0.35 \\
\hline
\end{tabular}

Tablo 4: 2008 Yllı İtibariyle Geçiş Ekonomileri ve Türkiye'de Ortalama Gelir Düzeyi Yönünden Kadın-Erkek Eşitliği/Eşitsizliğinin Boyutları Kaynak: UNDP, 2000-2008.

Türkiye'de kadın-erkek eşitsizliğinin ortalama gelir düzeyi ölçütü yönünden boyutlarını ortaya koymak bakımından geçiş ekonomileri ile bir karşılaştırma yapıldığında ise, Tablo 4'te görülebileceği üzere Slovenya'da tahmini olarak kazanılan gelir içerisinde kadının payının 17.022\$, erkeğin payının ise $27.779 \$$ olduğu; buna karşın Türkiye'de ise tahmini olarak kazanılan gelir içerisinde kadının payının $4.385 \$$, erkeğin payının ise $12.368 \$$ olduğu görülmektedir. Geçiş ekonomileri arasında tahmini olarak kazanılan gelir içerisinde kadının payının en düşük olduğu ülke $992 \$$ ile Tacikistan'dır. Tacikistan'da erkeğin payı 1.725\$'dır. Kırgızistan 1.414 \$, Özbekistan 1.547 ile tahmini olarak kazanılan gelir içerisinde kadının payının düşük olduğu ülkelerdir. Erkeğin payı ele alındığında Kırgızistan'da $2.455 \$$ ve Özbekistan'da da $2.585 \$$ 'dır. CEE ülkelerinde genel olarak ortalama gelir düzeyi bakımından kadın ve erkek arasındaki eşitsizliğin göreli olarak düşük olduğunu, buna karşın söz konusu ölçüt bakımından CIS ülkelerinde kadının payının görece az olduğu söylenebilir. Ancak burada dikkat edilmesi gereken bir durum da genel olarak CIS ülkelerindeki ücret düzeylerinin CEE ülkelerine kıyasla daha düşük düzeyde olduğudur. Türkiye bu tablo içerisinde kadın ve erkek arasındaki eşitsizliğin çok ciddi boyutlarda olduğu ancak CIS ülkeleri de göz önünde bulundurulduğunda orta sıralarda yer aldığını ortaya koymaktadır. İnsani gelişme yönünden kadın ve erkekler arasındaki gelir eşitsizliği, sadece AB ülkeleri ile Türkiye karşılaştırıldığında değil, $\mathrm{AB}$ ile $\mathrm{AB}$ 'ye aday olan diğer iki ülke arasında ve hatta $\mathrm{AB}$ 'ye üye olan ilk 15 ülke ile AB'ye üye olan son 10 ülke arasında da görülmektedir (Karaca ve Kocabaş, 2010).

\section{Sonuç}

Gelişmekte olan ülkeler ile geçiş ekonomilerinde olduğu gibi, Türkiye'de erkeklerle karşılaştırıldığında kadınların ekonomik yaşama katılımının son derece düşük olduğu görülmektedir. Belirtmek gerekir ki, 
kadınların ekonomik yaşama katılımı bakımından geçiş ekonomileri de kendi içlerinde homojen bir yapı göstermediği gibi, CEE ülkeleri ile CIS ülkeleri arasında da ciddi farklılıklar söz konusudur. Hatta bu farklılıklar, iki kategoriye ayrılan geçiş ekonomilerinin kendi içlerinde de söz konusudur. Nitekim araştırma bulguları, toplumsal işbölümü, ekonomik kalkınma, eğitim düzeyi, ücretsiz aile işçiliği, kayıt dışı istihdam, yasal düzenlemeler, ayrımcılıkla karşılaşma risklerinin yüksekliği ve çalışma/çalışmama tercihleri ölçütleri bakımından genel olarak CEE ülkelerinde kadınların ekonomik etkinliğe katılımının CIS ülkelerinden yüksek olduğunu ortaya koymaktadır. Geçiş ekonomilerinde ve özellikle CIS ülkelerinde kadının ekonomik yaşama katılımının yüksek olması, bu ülkelerde kadın-erkek eşitliği politikalarına dayalı planlı ekonomi döneminde oluşturulan altyapı ile açıklanabilir. Burada söz konusu edilen alt yapı kavramının geniş düşünülmesi gerekir. Zira her şeyin bireylerin ekonomik yaşama katılımının en yüksek düzeyde olması düşünülerek planlandığı bir ekonomik düzende, kadınların İKO’larını düşüren nedenlerin varlığından söz edilemez.

Ekonomide, eğitimde, kentleşmede ve iletişimde görülen tüm gelişmelere rağmen, istatistikler kadınların Türkiye'de istihdama giderek daha az katıldığını, istihdamda kısa sürelerle kaldıklarını göstermektedir. Başka bir deyişle, kadınlar çalışma yaşamına ya hiç girmemekte ya da girseler bile ilk firsatta ve kolayca ayrılmaktadırlar. Bu durumun nedeni, kadınların erkeklere göre sigortasız, güvencesiz, örgütsüz, düşük ücretli, çalışma zamanı çoğu zaman belirsiz ve uzun, çalışma koşullar kötü olan kayıt dışı sektörde çalışmalarıdır. Gerçekten de Türkiye'de tarımın gayri safi milli gelir içerisindeki payının hızla küçülmesi ve kırsal yörelerde iş imkanlarının azalması, beraberinde köyden kente göç sürecini hızlandırmıştır. Köyden kente göçle gelen yeni kentli kadının sanayide ve hizmetlerde yaratılan istihdam kapasitesinden yeterince yararlanamaması, onları kayıt dışı istihdama yönelterek İKO'larının düşmesine yol açan önemli bir etken olmuştur.

Kırsal kesimde tarımda ücretsiz aile işçisi olarak çalışan kadın, kente göç ettiğinde nitelikli olmadığ için ya niteliksiz işlerde çalışmakta ya da işgücüne katılmaktan vazgeçmektedir. Bununla beraber eğitimli kadın, işgücü piyasasına girdiğinde, erkeklere göre daha düşük gelir elde etmekte ve işyerinde yükselememektedir. Diğer taraftan mesleki eğitim sisteminden kaynaklanan sorunlar da meslek eğitimi almış kadınların İKO’larını olumsuz yönde etkilemektedir.

Türkiye'de kadınların özellikle ücretsiz aile işçisi olarak tarım sektöründe çalışması ve kadının görünmeyen emek olarak ücretsiz çalışmasının, aile çalışanlarının toplam gelire katkısı hesaplanırken dikkate alınması, diğer ülkelerde olduğu gibi, ülkemizde de kadının toplam gelire katkısının erkekten daha yüksek çıkmasına neden olmaktadır. Sonuç olarak, ekonomik faaliyet oranı ve indeks değerinin oluşturulması ile söz konusu hesaplamaların yapılmasında dikkate alınan ölçütler bakımından kadın-erkek arasındaki eşitsizliğin devam ettiği söylenebilir.

Türkiye'de Kadınların ekonomik yaşama katılımının düşüklüğü formel sektör için geçerlidir. Çünkü kadınların ekonomik etkinliğe katılım oranlarının belirlenmesinde, kadın işgücünün erkeklere göre daha yüksek düzeyde yer aldığı enformel ekonomik faaliyetler göz ardı edilmektedir. Bu nedenle enformel ekonomik faaliyetler kayıt altına alınamadığı sürece, Türkiye'de kadınların ekonomik yaşama katılımının düşüklüğü devam edecektir. Ancak Türkiye'de kadınların ekonomik yaşama katılımının düşüklüğü, sadece kadınların enformel istihdam içinde yer alması ile açıklanamaz. Bu konuda başka nedenlerin olduğu da gözden kaçırılmamalıdır. Nitekim Türkiye'de kadın işçileri korumak amacıyla yapılan kanuni düzenlemeler; işe almada erkeklerin tercih edilmesine, kadınların korunması gereken zayıf cinsiyet imajı vermelerine neden olmakta ve kadınların yüksek ücretli işlere girişlerini engelleyerek özellikle kentli kadınların İKO’larını azaltmaktadır. Ayrıca Türkiye'de kadınların İKO’larının düşmesine neden olan bir diğer faktör ise, yasal düzenlemelerle yasaklanmış olmasına ve yapılması halinde ağır yaptırımlara bağlanmış olunmasına karşın, kadına yönelik yapılan ayrımcılık ve çalışma koşullarındaki olumsuzluktur.

Yapılan açıklamalar bağlamında, sonuç olarak Türkiye'de enformel ekonomik faaliyetler kayıt altına alınsa bile, ücretsiz aile işçiliğinin önlenmesine yönelik politikalar geliştirilmedikçe, kadının ekonomik faaliyetteki konumunun değişmeyeceği söylenilebilir. Bu bakımdan özellikle kadınların işgücüne katılımını özendirici ve yönlendirici -kota sistemi gibi- politikaların gelişmiş Dünya ülkelerinde olduğu gibi, Türkiye'de de hayata geçirilmesi önem arz etmektedir.

\section{Kaynakça}

- Budak, G.-Özkaya, O. M. (2007). Kadının İşü̈cüne Katılımının Artmasını Sağlayacak Eğitim Politikaları, İş Dünyasında Kadın, İstanbul: Türkonfed Ya.

- Bowman, J. M. (1975). Education and Oppurtunity: Some Economic Perspectives, Oxford Review of Education, 1 (1), 73-84.

- Cain, G. G. (1967). Unemployment and the Labor Force Participation of Secondary Workers, Industrial Labor Relations Review, 20(2), 275-297.

- Dedeoğlu, S. Eşitlik mi Ayrımcılık mı? Türkiye'de Sosyal Devlet, Cinsiyet Eşitliği Politikaları ve Kadın İstihdamı, Çalışma ve Toplum, 2009/2, 41-54. 
- Donahoe, D. A. (1999). Measuring Women's Work in Developing Countries, Population and Development Review, 25(3), 543-576.

- Edwards L. N. ve Hendrey E. F. (2002). Home Based Work and Women's Labor, Journal of Labor Economics, 20 (1), 170-200.

- Johnstone E. (1968). Women in Economic Life: Rights and Opportunities, Annals of The American Academy of Political and Social Science, 375, 102-114.

- Karadeniz, O.-Yılmaz, H. (2007). Türkiye'de Kadının İşgücü Piyasası İçindeki Konumu ve İşgücü Piyasasına Katılımını Etkileyen Faktörler, İş Dünyasında Kadın, İstanbul: Türkonfed Ya.

- $\quad$ Lordoğlu, K.(1990). Eve İş Verme Sistemi İçinde Kadın İşgücü Üzerine Bir Alan Araştırması. İstanbul:Frederich Ebert Vakfı Araştırma Sonuçları.

- $\quad$ Lordoğlu, K.-Özkaplan, N.- Törüner, M.(1999). Çalışma İktisadı, 3. Baskı, İstanbul: Beta Ya.No:535.

- Minibaş, T.(2005). Ekonomik Kalkınma ve Kadın İstihdamı, 4. Uluslararası Kadın Yöneticiler Forumu, 7 Temmuz 2005, Retrieved 25.05.2009, Web: http://turkelminibas.net/read.asp?id=23\&tur=makale.

- Mitra A. ve Singh P. (2006). Human Capital Attainment and Female Labor Force Participation- The Kerala Puzzle, Journal of Economic Issues, 40 (3), 779-798.

- Nam S. (1991). Determinants of Female Labor Force Participation: A Study of Seul, South Korea 19701980, Sociological Forum, 6(4), 641-659.

- $\quad$ Nuss, S. ve Majka, L. (1985). Economic Development and Education of Female Population: A CrossNational Investigation, Sociological Perspectives, 28(3), 361-384.

- Ö̈zer, M.-Biçerli, K. (2003). Türkiye’de “Kadın İşgücünün Panel Veri Analizi”, Anadolu Üniversitesi Sosyal Bilimler Dergisi, C.3, No:1, s.55-82.

- Öztürk M. Y. ve Ergüneş N. (2006), Maddeci Feminizm İçin: Kadının Görünmeyen Emeği Tartışmaları, İktisat Dergisi, 469, 14-23.

- Selamoğlu, A.-Lordoğlu, K. (2006). Katılım Sürecinde Avrupa Birliği ve Türkiye’de İşgücü ve İstihdamın Genel Görünümü, Ankara: Belediye-İş Ya., AB’ye Sosyal Uyum Dizisi.

- Sobol M. G. (1973). A Dynamic Analysis of Labor Force Participation of Married Women of Childbearing Age, The Journal of Human Resources, 8(4), 497-505.

- Spencer, B. G. (1973). Determinants of the Labor Force Participation of Married Women: A Micro-Study of Toronto Household, The Canadian Journal of Economics, 6 (2), 222-238.

- Tazeen, F. (2008). Linking Education Policy to Labor Market Outcome, World Bank, retrived 15.09.2010, http://site.ebrary.com/lib/anadolu/docDetail.action?docID=10231538.

- T.C. Başbakanlık Kadının Statüsü Genel Müdürlüğü (2008). Türkiye’de Kadının Durumu, Kadın Statüsü ve Sorunları Genel Müdürlüğü, Ankara.

- Türk Girişim ve İş Dünyası Vakfı Konfederasyonu (Türkonfed) (2007). İş Dünyasında Kadın, İstanbul.

- TİSK (2002). Çağdaş Sanayi Merkezlerinde Kadın İşgücünün Konumu: Bursa Örneği, Ankara: TİSK Ya.No: 219.

- Toksöz, G. (1999). Türkiye’de Kadın İşgücü ve Enformel Sektörde İstihdamı, TíSK Türkiye’de Kadın İşgücü Seminerleri, Ankara: TİSK Ya.No:192.

- UNDP, Human Development Report, 2000-2008, 326-329, Retrieved 05.05.2009, http://hdr.undp.org/en/media/HDR_2000_EN.pdf.

- UNDP, Human Development Report, 2001, 326-329, Retrieved 05.05.2009, http://hdr.undp.org/en/media/completenew1.pdf.

- UNDP, Human Development Report, 2002, 326-329, Retrieved 05.05.2009, http://hdr.undp.org/en/media/HDR_2002_EN_Complete.pdf.

- UNDP, Human Development Report, 2004, 326-329, Retrieved 05.05.2009, http://hdr.undp.org/en/media/hdr04_complete.pdf.

- UNDP, Human Development Report, 2005, 326-329, Retrieved 05.05.2009, http://hdr.undp.org/en/media/HDR05_complete.pdf.

- UNDP, Human Development Report, 2006, 326-329, Retrieved 05.05.2009, http://hdr.undp.org/en/media/HDR06-complete.pdf.

- UNDP, Human Development Report, 2007-2008, 326-329, Retrieved 05.05.2009, http://hdr.undp.org/en/media/HDR_20072008_EN_Complete.pdf. 


\title{
Ekonomik İşbirliği Teşkilatı’nın Bölgesel Entegrasyona Dönüşümünde Engelleyici Faktörler: Bölge İçi Ticaret Açısından Bir Değerlendirme \\ Disincentive Factors for Transformation of the Economic Cooperation Organization to Regional Integration: An Assessment Regarding Intra-regional Trade
}

\author{
Assoc. Prof. Dr. Hamza Çeştepe (Bülent Ecevit University, Turkey) \\ Ph.D. Candidate Tamer Güven (Bülent Ecevit University, Turkey)
}

\begin{abstract}
In this study, the structure and level of intra-regional trade in Economic Cooperation Organization (ECO), which is a movement of regional cooperation founded in the Western and Central Asia region, has been analyzed. In ECO, with a share below its potential at the world trade, intra-regional trade is low relative to other regional integrations such as the European Union. However, the volume of intra-regional trade in the region countries, except a few countries, tend to increase in recent years. In this study, as a result of the evaluation made by the indices calculated, it was found that the region countries is in the position of more complementary economies in context of foreign trade; the countries has generally a high trade intensity with its neighbors; intraindustry trade in the region is at low level. As a result, although the level and structure of intra-regional trade in ECO region seems to be disincentive for the transformation to regional integration as of today, recent developments suggest that this obstacle will gradually diminish in the future. In addition, if some of advantages and potential of the region in terms of regional integration can be valued it does not seem very difficult to reach more advanced stages of integration for this cooperation movement.
\end{abstract}

\section{Giriș}

Günümüz dünya ekonomisinin en önemli gerçekliklerinden ikisi küreselleşme ve bölgeselleşme hareketleridir. Aslında birbirine zıt gibi görünen bu olgular 1980'li yıllardan itibaren birbirini destekler şekilde hız kazanmış, ticaretin küreselleşmesinin temel aracısı konumunda olan GATT 1995'te Dünya Ticaret Örgütü'ne dönüşerek kurumsal yapıya kavuşmasına rağmen, bölgeselleşmeye olan eğilim son yıllarda daha da ivme kazanmıştır.

Genellikle belirli bir coğrafi bölgede yer alan ülkeler arasında dış ticaret ve diğer ekonomik faaliyetleri serbestleştirmeyi ve geliştirmeyi hedefleyen bölgeselleşme eğilimleri, ikinci dünya savaşı sonrasında iki dalga şeklinde gerçekleşmiştir. 1950'lerin sonundan itibaren 1960'lar ve1970'ler boyunca dünya ekonomisinde yer alan "ilk bölgeselleşme" ya da Bhagwati'nin (1992) tabiriyle "eski bölgeselleşme" dalgasında bölgesel entegrasyonlar Kuzey-Kuzey ya da Güney-Güney arasında kurulmuşlardır. Başka bir ifadeyle bölgeselleşmede ağırlıklı olarak ticari hedeflere odaklanılan bu dönemde, gelișmiş ülkeler kendi aralarında gelişmekte olan ülkeler de yine kendi aralarında bölgesel entegrasyonlar oluşturmuşlardır. 1980'lerin sonunda ortaya çıkan ve günümüzde de devam eden ikinci ya da "yeni bölgeselleşme" dalgası ise ilk dalgayla benzer yönleri yanında çok önemli farklılıkları da beraberinde getirmiştir. En önemli farklılıklardan biri, ilkinin aksine yeni dalganın KuzeyGüney birlikteliğine de izin vermesi yani daha kapsayıcı bir nitelik arz etmesidir. Bunun yanında gelişmiş ülkeler kendi aralarında, gelişmekte olan ülkeler de yine kendi aralarında bölgesel entegrasyon oluşturabilmektedir. Temeli 1960'lara dayanan Ekonomik İşbirliği Teşkilatı (Economic Cooperation Organization-ECO) da, benzer amaçlarla Batı ve Orta Asya bölgesindeki gelişmekte olan ülkeler arasında kurulmuş bir entegrasyon hareketidir.

Gelişmekte olan ülkelerin bölgesel entegrasyonlar kurmak ya da bunlara üye olmak istemelerinin siyasi nedenleri de olmakla birlikte ekonomik nedenlerin daha ağır bastığı söylenebilir. Nitekim 1960'larda gelişmekte olan ülkeler arasında kurulan bölgesel entegrasyonlarda gelişmiş ülkelere olan ekonomik bağımlılığı azaltmak ve oluşturulacak tercihli ticaret anlaşmalarıyla ortaya çıkacak ölçek ekonomilerinden yararlanmak düşüncesinin etkin olduğu görülmektedir. Bu ülkeler, entegrasyonlarla genişleyen piyasalarda verimlilik ve rekabet düzeylerini artırarak sanayileşme ve kalkınma düzeylerini geliştirmeyi hedeflemektedirler.

Bölgesel entegrasyonlarda birlik ülkelerinin birbirlerinin ürünlerine yönelik talebinin yüksek düzeyde olması ticaret yaratma etkisinin yüksek düzeyde olmasını sağlar. Başka bir ifadeyle bölge içi ticaret ne kadar fazlaysa bölgesel entegrasyonun başarı şansı da o kadar artmaktadır. Bu çalışmanın amacı, temeli 1960'lara dayanan, üye ülkelerdeki birtakım siyasi gelişmelerden dolayı işbirliğinden öteye gidemeyen, ancak son yıllarda Türkiye'nin çabalarıyla tekrar önem verilmeye başlanılan ECO bölgesinde bölge içi ticaretin düzeyini ve yapısını incelemektir. Şu andaki işbirliğini ileride bir bölgesel entegrasyona götürmeyi amaçlayan ECO'nun bu süreçte avantajları yanında bölge içi ticaretin düşüklüğü gibi bazı dezavantajları da bulunmaktadır. Ancak, bölgesel entegrasyonların amaçlarından biri de bu dezavantajları bu tür birleşmeler yoluyla avantaja dönüştürmektir. 
Konuyla ilgili olarak literatürde yapılan fazla çalışma bulunmamaktadır. Bölgede entegrasyon açsısından fazla bir gelişme olmadığı için ve biraz da veri eksikliği nedeniyle sınırlı sayıda çalışma yapılmıştır. Var olan çalışmalar da genellikle Türkiye ve Türk Cumhuriyetleri arasındaki ekonomik ve ticari ilişkiler üzerine yoğunlaşmıştır.

Çalışmada, bölgesel bir entegrasyona evrilmek isteyen ECO bölgesinde bölge içi ticaretin düzeyi ve yapısı, istatistiksel veriler ve ihracat benzerliği, ticaret yoğunluğu gibi bazı indeksler yoluyla ortaya konulmaya çalışılmıştır. Endeksler hesaplandıktan sonra bölgenin geneli ve bölge ülkeleri açısından yorumlanmış ve değerlendirilmiştir.

Çalışmanın giriş bölümünden sonraki ilk bölümünde ECO bölgesinin ve bölge ülkelerinin ekonomik yapısı ortaya konulmuştur. Ardından bölgenin bölgesel entegrasyon açısından avantaj ve dezavantajları ele alınmıştır. Daha sonraki bölümde, ECO’da bölge içi ticaretin düzeyi ve yapısı çeşitli endekslerden yararlanılarak analiz edilmiştir. Çalışmanın sonunda ise genel sonuçlar yer almaktadır.

\section{ECO Bölgesinin ve Bölge Ülkelerinin Ekonomik Yapısı}

Ekonomik İşbirliği Teşkilatı Türkiye, İran ve Pakistan arasında bölgesel ekonomik, teknik ve kültürel işbirliğini geliştirmek amacıyla 1985 yılında kurulmuştur. Oluşumun temeli aslında 1964 yılında, adı geçen üç ülke arasında daha önce kurulmuş olan Bölgesel Kalkınma İşbirliği Örgütü'ne (Regional Cooperation for Development-RCD) dayanmaktadır. 1977'de İzmir'de yapılan RCD Zirvesi'nde alınan karar doğrultusunda hazırlanan İzmir Anlaşması, Teşkilat'ı kuran temel belge olarak aynı tarihte imzalanarak bir yıl sonra yürürlüğe girmiştir. Ancak, 1979 yılında İran İslam Devrimi'nin gerçekleşmesi İzmir Antlaşması'nın askıya alınmasına yol açmıştır. 1980'li yılların başlarında her üç üye ülkede yaşanan iç sorunların yatışması ve özellikle İran'da yönetimin istikrara kavuşması üzerine 1985 yılında İzmir Antlaşmasında yapılan bir değişiklikle RCD'nin Ekonomik İşbirliği Teşkilatı adı altında yeniden faaliyete geçmesi sağlanmıştır (DPT, 2013).

1992 yılına kadar üç üyesi olan ECO’ya, Sovyet Sosyalist Cumhuriyetler Birliği'nin dağılmasının ardından 1829 Kasım 1992 tarihlerinde İslamabad'da yapılan Bakanlar Konseyi olağanüstü toplantısında Afganistan, Azerbaycan, Kazakistan, Kırgızistan, Tacikistan, Türkmenistan ve Özbekistan üye olmuş, böylece Teşkilat'ın üye sayısı 10'a yükselmiştir. Bunun yanında, aynı yıl Kuzey Kıbrıs Türk Cumhuriyeti'ne gözlemci üye statüsü verilmiştir.

ECO bölgesi toplamda yaklaşık 450 milyonluk nüfusu, 2,5 trilyon dolar büyüklüğünde bir ekonomik büyüklüğü ve 8 milyon kilometrekarelik bir alanı kapsamaktadır. Bu bağlamda, öncelikle nüfus ve coğrafi açıdan ECO'nun önemli bir potansiyele sahip olduğunu belirtmek gerekir. Dünya nüfusunun yaklaşık \%6'sını barındıran bu bölgede nüfus artış hızı $(\% 1,70)$ dünya ortalamasının $(\% 1)$ oldukça üzerindedir. Bölgenin nüfus yapısına bakıldığında özellikle Pakistan, Türkiye ve İran'ın genç nüfus yapısıyla önemli bir işgücü potansiyeline sahip olduğu görülmektedir. ECO bölgesi doğal kaynaklar bakımından da zengin bir potansiyele sahiptir. Bunlar arasında başta petrol (dünyanın \%7,4'ü) ve doğalgaz (dünyanın \%9,2'si) olmak üzere işlenmemiş metaller, hidroelektrik gücü (dünyanın \%3,3) ve pamuk (dünyanın \%40) bölgenin bol olarak sahip olduğu doğal kaynakların en önemlileridir (Shahabi, 2013).

\begin{tabular}{|l|l|l|l|l|l|l|l|}
\hline & Nüfus & $\begin{array}{l}\text { GSYIH } \\
(\text { milyon \$) }\end{array}$ & $\begin{array}{l}\text { Enflasyon } \\
(\%)\end{array}$ & $\begin{array}{l}\text { Isssizlik } \\
(\%)\end{array}$ & $\begin{array}{l}\text { Diş Borç/ } \\
\text { GSMH } \\
(\%)\end{array}$ & $\begin{array}{l}\text { DYY } \\
(\text { bin \$) }\end{array}$ & $\begin{array}{l}\text { IGE }^{\text {b }} \\
(\text { HDI })\end{array}$ \\
\hline Afganistan & 35.320 .445 & 18.315 & 11,8 & v.y. & v.y. & 83.411 & 172 \\
\hline Azerbaycan & 9.168 .000 & 64.819 & 7,8 & 5,42 & 14,94 & 4.485 .120 & 91 \\
\hline İran & 74.798 .599 & 482.433 & 21,50 & 12,31 & v.y. & 4.150 .000 & 88 \\
\hline Kazakistan & 16.558 .459 & 186.199 & 7,4 & 5,39 & 77,91 & 13.227 .193 & 68 \\
\hline Kirgizistan & 5.507 .000 & 5.920 & 16,6 & 2,49 & v.y & 693.528 & 126 \\
\hline Özbekistan & 29.341 .200 & 45.353 & 12,8 & $4,25^{\text {a }}$ & 17,78 & 1.403 .000 & 115 \\
\hline Pakistan & 176.745 .364 & 210.216 & 13,6 & 6,00 & 27,32 & 1.309 & 145 \\
\hline Tacikistan & 6.976 .958 & 6.523 & $-0,5$ & $2,10^{\text {a }}$ & 51,59 & 11.142 & 127 \\
\hline Türkiye & 73.639 .596 & 774.336 & 6,5 & 9,78 & 40,09 & 16.035 .000 & 92 \\
\hline Türkmenistan & 5.105 .301 & 28.062 & 6,1 & v.y. & 2,03 & 3.186 .000 & 102 \\
\hline Toplam/Ort. & 433.160 .922 & 1.822 .176 & 10,3 & & & 44.583 .164 & \\
\hline
\end{tabular}

Tablo 1: ECO Ülkelerinin Sosyoekonomik Göstergeleri (2011). Kaynak: World Bank, 2013, Ecosecretariat, $2013 a ; I M F, 2013$. 
Bölgenin ekonomik büyüklüğüne bakıldığında 2000 yılında 491,2 milyar dolar olan Bölge GSYİH's1 (ki bu miktar o tarihte dünya üretiminin \% 1.56'sını oluşturmaktaydı) Tablo 1'de görüldüğü gibi 2010 yılı itibariyle yaklaşık dört kat artarak 1,6 trilyon dolara ulaşmıştır. Böylece dünya üretiminde ECO bölgesi yaklaşık \%2,5'lik bir paya sahip olmakla birlikle, bölgenin potansiyeli göz önüne alındığında bu payın yetersiz olduğunu söylemek mümkündür. Türkiye, İran, Pakistan ve Kazakistan bölge üretiminde öncü ülkeler olarak ön plana çıkmakta, bölge üretiminin yaklaşık \%45’i Türkiye tarafından gerçekleştirilmektedir. Bölgede kişi başına ortalama gelir yaklaşık 4000 dolar civarında olup 2011 yılı itibariyle en yüksek kişi başına gelire sahip ülke Kazakistan (11.357 dolar), en düşük kişi başına gelire sahip ülke ise Afganistan (518 dolar)'dır.

Bölgenin enflasyon ve işsizlik değerlerine bakıldığında, bölgede 2011 yılı itibariyle ortalama enflasyon oranı \%10,3'dür. Bölgede enflasyon oranının en yüksek olduğu ülkeler İran, Kırgızistan ve Pakistan'dır. Adı geçen üç ülkeden İran ve Kırgızistan'da enflasyon oranı bir önceki yıla göre iki kat artış göstermiştir. İran'da son dönemlerde \%27'lere ulaşan yüksek enflasyon oranının en önemli sebeplerinin başında BM, AB ve ABD'nin bu ülkeye uyguladığı ambargonun geldiği çeşitli kesimler tarafindan ifade edilmektedir. Bölgede en düşük enflasyon oranına sahip Tacikistan'da ise 2011 yılında fiyatlar genel düzeyi \%0,5 azalış kaydetmiştir. Bölgede ortalama işsizlik oranı \%6,5 civarında olup, 2011 y1lı itibariyle işsizliğin en yüksek olduğu ülke İran (\%12,31), en düşük olduğu ülke ise Kırgızistan $(\% 2,49)$ 'dır. Genç bir nüfusa sahip İran'da işsizliğin 15-29 yaş grubunda iki kat daha fazla (\%24) olduğu ifade edilmektedir (Tümhaber, 2013). Bölgede Türk Cumhuriyetlerinde işsizlik oranları nispeten daha düşük düzeyde olup bazılarında işsizlik son dönemlerde düşme eğilimindedir.

Dış borç yükü açısından bölge ülkelerinin genel olarak hafif ağırlıkta dış borç yüküne sahip olduğu görülmektedir. Özellikle bölgedeki Türk Cumhuriyetleri, geçiş sürecinin ilk dönemlerinde uygulamaya konulan yapısal reformların sonucunda ortaya çıkan bütçe açıklarını finanse etmek, ithalatın finansmanına kaynak temin etmek ve ucuz uluslararası finansman kaynaklarından faydalanmak amacıyla dış borcu yoğun olarak kullanmaya başlamışlardır. Diğer taraftan, ülke içinde yeterince özel sermaye yapısının olmaması da, bu ülkeleri dış borçlanmaya itmiş ve borç yükleri artmıştır (Meriç, 2013). Ancak zaman içinde çoğunun dış borçlarının GSYİH'ya oranı düşmüştür. Dış borç/GSYİH kriterine göre en borçlu ülkeler Kazakistan, Tacikistan ve Türkiye'dir.

ECO bölgesine gelen doğrudan yabancı yatırımlar 90’lı yılların ikinci yarısından itibaren artmaya başlamış ve özellikle Türkiye'ye yönelik olarak 2000'li yılların ikinci yarısında daha da hız kazanmıştır. Türkiye dışında Kazakistan, Azerbaycan gibi petrol ve doğal gaz zengini ülkelerle Pakistan, bölgede en fazla doğrudan yatırım çeken ülkeler olarak ön plana çıkmaktadır. Yabancı yatırımlar, Kazakistan ve Azerbaycan'da petrol, doğal gaz ve diğer madencilik sektörlerinde yoğunlaşmıştır. Özbekistan ve Kırgızistan için ise, özellikle altın üretim sahalarında yabancı sermaye akımı yoğunlaşmıştır. Pakistan'da ilaç, kimyasal mamul, polyester iplik, gübre ve batarya üretimi ve otomotiv sanayii gibi alanlarda yoğunlaşmış olan yabancı yatırımlarda ABD, Avrupa ve Japon firmalarının etkin olduğu görülmektedir (Dikkaya ve Üzümcü, 2007). Türkiye'ye özellikle 2005 yılından itibaren yoğun bir şekilde genellikle OECD ülkelerinden gelen doğrudan yabancı yatırımlar ise daha çok hizmet sektörü ve imalat sanayinde yoğunlaşmıştır.

Birleşmiş Milletlerin İnsani Gelişme Raporuna (2011) göre, ECO ülkelerinin çoğu düşük ve orta dereceli insani gelişme gösteren ülkelerdir. İnsani gelişme endeksi (IGE) açısından sıralanan 187 ülke arasında en iyi durumda olan bölge ülkesi okuryazarlık oranın da en yüksek olduğu ülke Kazakistan, en kötü durumdaki ülke ise Afganistan'dır. Bölge ülkelerinin bu endeks sıralamasında üst sıralara tırmanabilmesi için, milli gelirin artışıyla birlikte eğitim, sağlık gibi sosyal hizmetlerin geliştirilmesi gerekmektedir.

\section{ECO Bölgesinin Bölgesel Entegrasyon Açısından Avantaj ve Dezavantajları}

Bölgesel ekonomik entegrasyonların etkileri, daha çok bölgesel entagrasyonun en önemli aşamalarından ya da şekillerinden biri olan gümrük birliği örneğinde ele alınmıştır. Nitekim bu konudaki ilk ve en önemli teorilerden birini ortaya koyan J. Viner (1950) de gümrük birliği üzerinden bölgesel entegrasyonların ekonomik etkilerini statik ve dinamik etkiler şeklinde incelemiştir. Gümrük birliklerinin ya da daha genel bir ifade ile bölgesel ekonomik entegrasyonların başarılı olabilmesi için birtakım şartların olması gerekir. Başka bir ifadeyle bölgenin ve bölge ülkelerinin bazı şartlara sahip olması ya da olmaması bölgesel entagrasyonun başarısını etkilemektedir. $\mathrm{Bu}$ şartları ECO açısından aşağıdaki şekilde değerlendirebiliriz:

Gümrük birliğinin yer aldığı ekonomik alanının büyük olması ve çok sayıda ülkeden oluşması birlik kapsamında daha iyi bir uluslararası işbölümünün ortaya çıkmasını sağlar (Viner, 1950). Böylece ticaret yaratma etkisi daha büyük olacağı için entegrasyonun başarı şansı artar. Şu anda on üyesi bulunan ve geniş bir coğrafyaya ve ekonomik potansiyele sahip olan ECO’nun bu açıdan nispeten iyi durumda olduğu söylenebilir. Tabi, daha ileri entegrasyon aşamalarına ulaşabildiğinde oluşumun üye sayısı daha da artabilir

Birlik ülkeleri coğrafi olarak birbirine ne kadar yakın olursa aralarındaki taşıma giderleri azalacak ve ticaret hacmi artacaktır. Bu nedenle gümrük birliklerinin genellikle komşu ülkeler arasında oluşturulması eğilimi yaygındır (Küçükahmetoğlu, 2008). ECO’ya bakıldığında bölge geniş bir coğrafi alana yayılmakla birlikte ülkelerin genelde Ön Asya ve Orta Asya bölgesinde yer aldıkları ve üye ülkelerin çoğunun birbiriyle komşu 
oldukları görülmektedir. Ayrıca, günümüzde ulaşım araçlarındaki hızlı gelişmeler ülkeler arasındaki uzaklık dezavantajını önemli ölçüde azaltmıştır.

Ekonomik birlik içerisinde yer alan ülkeler arasında ekonomik gelişme seviyesi bakımından önemli ölçüde fark yok ise, entegrasyon daha başarılı olmaktadır. AB ve EFTA bunun örneklerini oluşturmaktadır. Eğer ülkeler arasında gelişmişlik düzeyi farkı çok fazla ise, "Kutuplaşma Teorisi”ne göre sanayisi geri olan ülkelerin gelişmiş sanayi ülkeleri ile rekabet imkanı güçleşecektir. Bölge içi serbest dolaşım sağlandığında işgücü ve sermaye yüksek gelir elde etmek amacıyla gelişmiş ülkelere akacak, böylece farklı gelişme düzeyindeki ülkeler arasında gelişmişlik farkı daha da artacaktır (Karluk, 2002). ECO bölgesinde gelişmişlik düzeyine bakıldığında Türkiye, İran ve Kazakistan gibi gelişmişlik düzeyi nispeten daha iyi ülkeler yanında Afganistan, Tacikistan ve Kırgızistan gibi gelişmişlik düzeyi çok düşük ülkeler yer almaktadır. Bu durum bölgesel entegrasyon önünde en önemli engellerden biri olmakla birlikte muhtemel entegrasyonun pazarın genişlemesi, mali yardımlar, politikaların koordinasyonu gibi gelişmelerle ileriki aşamalarda farkın azalmasını sağlama imkanı bulunmaktadır.

Gümrük birliği ülkelerinin rakip ekonomiler olması durumunda elde edilecek kazanç yüksek düzeyde, tamamlayıcı ekonomiler olması durumunda ise düşük düzeyde olur (Viner, 1950). Bu durumu üretim maliyetleri ve dış ticaret açısından iki şekilde düşünmek mümkündür. Gümrük birliklerinin rakip mallar üreten ülkeler arasında verimi artıran etkisi olduğu, iç üretim yapıları tamamlayıcı nitelikteki ülkeler arasında ise, bu etkinin bulunmadığı kabul edilmektedir. Üretim açısından bakıldığında bölge ülkelerinin çoğunun rakipten ziyade tamamlayıcı ekonomi durumunda oldukları görülmektedir. Buna göre, rekabetin sertleşmesinden sağlanacak yarar beklentisi sınırlı kalmaktadır. Dış ticaret açısından da bölge ülkelerinin durumu ise bir sonraki bölümde sayısal verilerle ortaya konulacaktır.

Gümrük birliği ülkelerinin birlik dışı ülkelerin ürünlerine yönelik talebinin düşük düzeyde, buna karşılık birbirlerinin ürünlerine yönelik talebinin yüksek düzeyde olması ticaret yaratma etkisinin yüksek düzeyde olmasını sağlar. ECO bölgesinde bölge içi ticaret oranı \% 7 civarındadır. Avrupa Birliği'nde \%70 civarındaki bölge içi ticaret oranıyla karşılaştırıldığında bu rakam çok düşük kalmaktadır. ECO ülkeleri birbirlerinden daha çok, bölge dişı ülkelerle ticaret yapmaktadır.

Bölgesel entegrasyonlarda resmi olarak dillendirilmese de ülkelerin ortak kültürel, tarihi, dini ve ahlaki değerlere sahip olması entegrasyonların başarısını etkileyen unsurlardan bir diğeridir. Bu konuda en önemli örnek olan Avrupa Birliği'nde Birliğin ortak görüşü olarak ifade edilmese de bireysel olarak bazı öncü ülke yetkilileri tarafından Türkiye'nin $\mathrm{AB}$ adaylığı konusunda engelleyici faktörlerden birinin bu olduğu çeşitli zamanlarda ve şekillerde dile getirilmiştir. ECO bölgesi bu açıdan avantajlı bir konumdadır. Çünkü bazı mezhep farklılıklarına rağmen ECO ülkelerinin tamamı Müslüman ülkelerden oluşmakta, Türkiye ile Türk Cumhuriyetleri arasında olduğu gibi bölge ülkelerinin birçoğu arasında ortak kültürel ve tarihi bağlar bulunmaktadir.

\section{ECO Bölgesinde Bölge İçi Ticaretin Düzeyi ve Yapısı}

İzmir Anlaşması'nın 2. Maddesinde (Ecosecretariat, 2013b) belirtildiği gibi diğer amaçlarla birlikte ECO, bölge içi ticaretin ve bölgenin dünya ticaretinde oynadığı rolün artırılmasını amaçlamaktadır. ECO bölgesi ülkeleri, gelişmişlik ve ekonomik yapı itibariyle birbirinden farklı ülkelerden oluşmaktadır. Bu durum bölge içi ticaretin düzeyini ve yapısını da önemli ölçüde belirlemektedir. Bölgeye bakıldığında Türkiye dışında bölge ülkelerinin yarıdan fazlasının dünya ekonomisine açılmasının üzerinden fazla zaman geçmediği, bazı ülkelerin ise dünya ekonomisine açılma sürecinin henüz başında oldukları için dış ticaret potansiyellerini tam olarak faaliyete geçiremediği görülmektedir.

ECO bölgesinin diş ticaret hacmi 2000 yılında yaklaşık 175 milyar dolar iken 2011 yılında yaklaşık beş kat artarak 850 milyar dolara çıkmıştır (Ecosecretariat, 2013a). Bu artış önemli olmakla birlikte bölgenin dünya ticaretinde aldığı pay (\%2) düşünüldüğünde bölgenin dış ticaret hacminin, potansiyelinin oldukça altında olduğu söylenebilir. Bölge içinde en büyük ticaret hacmine sahip ülke Türkiye, en küçük ticaret hacmine sahip ülke ise Tacikistan'dır. Bölgede petrol ve doğal gaz gibi doğal kaynaklar bakımından zengin ülkeler dış ticaret fazlası verirken, adı geçen doğal kaynaklarda dışa bağımlı bölge ülkeleri dış açık vermektedir. Pakistan ve Türkiye dışında bölgeden yapılan ihracat başta petrol, doğal gaz olmak üzere maden fiyatlarının dünya piyasasında meydana gelen değişmelerine göre şekillenmektedir. İhracat açısından Türkiye ve Pakistan'ın performansları son dönemlerde dikkat çekmektedir. Bu iki ülke, son 20 yıl içerisinde imalat sanayinde büyük bir gelişim göstermiş, bu gelişme ülkelerin dış ticaret yapılarına da yansımıştır.

ECO bölgesinde bölgesel ticaretin gelişimini etkileyen iki temel faktörün olduğu ifade edilmektedir: Siyasal faktörler ve diş ticaret rejimleriyle tarife dışı engellerin ticarete etkisi (Tekeli ve Acartürk, 2008). Gelişmekte olan ülkelerin çoğunda görülen birbirlerine karşı güvensizlik, istikrarlı yönetimlerin olmaması ve siyasi huzursuzluklar gibi etkenler, bu ülkelerin kurdukları birliklerin başarılı olmasını engellemektedir (Dikkaya, 2002). Bu açıdan bölgede Türkiye dışında bölge ülkelerinin çoğunda demokrasinin ve serbest piyasa sisteminin henüz tam anlamıyla yerleşmemiş olması, bazı bölge ülkeleri arasındaki siyasal gerginlikler ve Rusya, İran gibi ülkelerin bölgedeki etkinliği ya da etkin olma çabası bölge içi ticaretin gelişimini etkilemektedir. Bunun yanında 
bölge ülkelerinin çoğunun dış ticaret açısından kısıtlayıcı ticaret rejimi olmamasına rağmen, özellikle İran ve Özbekistan gibi ülkeler oldukça sıkı dış ticaret rejimine sahiptirler. Tarife oranlarının 0 ile \%30 arasında değiştiği bölgede Özbekistan ve Tacikistan gibi ülkeler nispeten yüksek tarife oranları uygulamakta (Tekeli ve Acartürk, 2008) ve bölgede özellikle tarife dışı engeller bölge içi ticaretin artmasında önemli bir engel teşkil etmektedir.

Dış ticaretin kompozisyonuna gelince, tüm bölge açısından sanayi malları ticaretinin toplam ticaret içerisinde büyük öneme sahip olduğunu söylemek mümkündür. İran, Azerbaycan, Kazakistan ve Türkmenistan için petrol, petrol ürünleri ve doğal gaz gibi doğal kaynakların, Pakistan ve Türkiye için sanayi mallarının toplam ihracatın büyük bir kısmını oluşturduğu görülmektedir. İthalatın kompozisyonu bakımından ise, tüm ülkelerde, başta makine-teçhizat gibi sermaye malları olmak üzere sanayi malları ithalatı en büyük payı almaktadır.

Bölge-içi ticaretin düzeyi, daha önce belirtildiği gibi diğer pek çok bölgesel entegrasyonla karşılaştırıldığında ECO bölgesinde oldukça düşüktür. Bölge içi ticaretin bölgenin toplam ticaretinden aldığı pay sadece $\% 5$ olarak gerçekleşmektedir. Tablo 2'de görüldüğü gibi Türkiye, İran, Pakistan gibi bölgenin en büyük ekonomilerinin diş ticaretleri içerisinde ECO’nun payı oldukça düşüktür. Dış ticareti içinde ECO’nun payının yüksek olduğu Afganistan, Kırgızistan, Özbekistan gibi ülkelerin ise dış ticareti büyük ölçüde bunların komşusu olan bir ya da iki ülkeyle dış ticaretin yoğunlaşmasından kaynaklanmaktadır. Ancak birkaç ülke dışında Türkiye de dahil olmak üzere bölge ülkelerinin bölge içi ticaret hacmi son yıllarda artma eğilimindedir. Türkiye'nin diş ticareti içerisinde ECO'nun payı \% 7 gibi düşük bir orandır.

\begin{tabular}{|c|c|c|c|c|c|c|c|c|}
\hline Ülke & & 2000 & 2003 & 2007 & 2008 & 2009 & 2010 & 2011 \\
\hline \multirow{3}{*}{ Afganistan } & İthalat & 18,0 & 16,8 & 30,9 & 50,8 & 56,2 & 50,7 & 51,9 \\
\hline & İhracat & 38,0 & 73,6 & 73,4 & 56,9 & 64,8 & 66,7 & 59,0 \\
\hline & Toplam & 20,1 & 20,4 & 36,5 & 51,7 & 57,1 & 51,8 & 52,3 \\
\hline \multirow{3}{*}{ Azerbaycan } & İthalat & 22,0 & 22,0 & 17,8 & 16,6 & 17,9 & 18,4 & 17,9 \\
\hline & İhracat & 8,7 & 8,1 & 28,7 & 3,0 & 3,1 & 3,2 & 3,2 \\
\hline & Toplam & 14,0 & 15,1 & 23,4 & 4,8 & 7,4 & 6,8 & 7,2 \\
\hline \multirow{3}{*}{ İran } & İthalat & 5,1 & 4,8 & 5,1 & 5,1 & 6,2 & 7,6 & 6,6 \\
\hline & İhracat & 3,2 & 3,6 & 2,4 & 2,4 & 3,6 & 3,7 & 4,0 \\
\hline & Toplam & 3,9 & 4,1 & 3,3 & 3,4 & 4,6 & 5,1 & 4,7 \\
\hline \multirow{3}{*}{ Kırgizistan } & İthalat & 34,1 & 34,1 & 17,9 & 16,1 & 17,8 & 18,2 & 15,0 \\
\hline & İhracat & 30,4 & 19,9 & 37,5 & 29,8 & 23,5 & 17,2 & 24,3 \\
\hline & Toplam & 32,4 & 27,8 & 24,2 & 20,4 & 19,8 & 17,8 & 18,2 \\
\hline \multirow{3}{*}{ Pakistan } & İthalat & $\ldots$ & 3,3 & 2,2 & 2,2 & 3,4 & 3,8 & 2,5 \\
\hline & İhracat & $\ldots$ & 6,3 & 7,7 & 9,2 & 12,5 & 11,9 & 13,8 \\
\hline & Toplam & $\ldots$ & 4,7 & 4,2 & 4,5 & 6,4 & 6,7 & 6,8 \\
\hline \multirow{3}{*}{ Tacikistan } & İthalat & 26,4 & 24,1 & 20,4 & 18,0 & 17,7 & 50,0 & $\ldots$ \\
\hline & İhracat & 16,0 & 22,6 & 24,1 & 22,9 & 19,6 & 50,0 & $\ldots$ \\
\hline & Toplam & 21,8 & 23,4 & 21,9 & 19,7 & 18,2 & 50,0 & $\ldots$ \\
\hline \multirow{3}{*}{ Türkiye } & İthalat & 2,8 & 3,9 & 5,8 & 6,0 & 4,3 & 6,3 & 7,2 \\
\hline & İhracat & 3,1 & 3,3 & 4,4 & 4,7 & 5,8 & 6,7 & 6,9 \\
\hline & Toplam & 2,9 & 3,7 & 5,2 & 5,5 & 4,9 & 6,4 & 7,1 \\
\hline \multirow{3}{*}{ Özbekistan } & İthalat & $\ldots$ & $\ldots$ & 15,9 & 17,4 & 13,1 & 17,8 & 17,5 \\
\hline & İhracat & $\ldots$ & $\ldots$ & 29,0 & 22,3 & 14,6 & 25,1 & 27,8 \\
\hline & Toplam & $\ldots$ & $\ldots$ & 23,4 & 20,1 & 13,9 & 22,2 & 23,6 \\
\hline
\end{tabular}

Not: Kazakistan ve Türkmenistan'la ilgili veri bulunamamıştır.

Tablo 2: ECO Ülkelerinin Toplam Dış Ticaretleri Içerisinde ECO'nun Payı. Kaynak: Ecosecretariat $2013 a$.

Bir ülkenin uluslararası piyasalarda rakiplerinin hangi ülkeler olduğunu belirlemek amacıyla ihracat benzerlik endeksi kullanılmaktadır. Benzer ürün ve sektörlerin ihracatında yoğunlaşmış iki ülke küresel piyasalarda birbirlerine rakip durumundadır. Ülkeler farklı ürün ve sektörlerde yoğunlaşmışsa bu durum onların rakiplikten çok tamamlayıcılık özelliğine sahip olduğunu gösterir. İhracat benzerlik endeksi Finger ve Kreinin (1979) tarafından şu şekilde formüle edilmiştir:

$\mathrm{ESI}=\sum \min \left[\mathrm{X}_{\mathrm{k}}(\mathrm{jw}), \mathrm{X}_{\mathrm{k}}(\mathrm{mw})\right] \times 100$

Formülde, $X_{k}(j w) \rightarrow j$ ülkesinin dünyaya gerçekleştirdiği $k$ ürün grubu ihracat değerinin, dünyaya yaptığ toplam ihracat içindeki payını, $\mathrm{X}_{\mathrm{k}}(\mathrm{mw}) \rightarrow \mathrm{m}$ ülkesinin dünyaya gerçekleştirdiği $\mathrm{k}$ ürün grubu ihracat değerinin dünyaya yaptığı toplam ihracat içindeki payını göstermektedir.

Endeks 0 ile 100 arasında değerler alır. İki ülke arasında ticari akımlarda uygunluk yoksa yani bir ülkeden diğerine ihraç edilen ve diğeri tarafından ithal edilen ürün yoksa endeks 0 değerini alı (Mikiç, 2005). Bu durum iki ülke arasında rekabetin olmadığı şeklinde yorumlanabilir (Erlat ve Ekmen, 2009). Her iki ülkenin ihracat yapısı tamamen aynı ise endeks 100 değerini alır. 
Azerbaycan’ın ECO ülkeleriyle dış ticarette rakiplik durumuna bakıldığında diğer dört ülke (Veri bulunamadığı için kalan altı ülke için endeks hesaplanamamıştır) içerisinde Azerbaycan'ın en yüksek ihracat benzerliğine sahip olduğu ülke Kazakistan'dır. Petrol ve doğalgaz gibi doğal kaynak bakımından zengin bu iki ülke için böyle bir sonucun ortaya çıkması doğaldır. Aynı şeyi İran için de söylemek mümkündür. Azerbaycan'ın Türkiye ve Kırgızistan'la ihracat benzerliği çok düşüktür.

\begin{tabular}{|l|l|l|l|l|}
\hline Y1llar & Türkiye & Kazakistan & Kirgizistan & İran \\
\hline 2007 & 30.5 & - & - & - \\
\hline 2008 & 41.8 & - & 14.8 & - \\
\hline 2009 & 21.0 & 66.9 & 4.0 & - \\
\hline 2010 & 24.1 & 67.5 & 6.6 & - \\
\hline 2011 & 17.5 & 69.6 & 8.02 & 65.6 \\
\hline
\end{tabular}

Tablo 3. Azerbaycan'ın ECO Ülkeleriyle İhracat Benzerlik Endeksi. Kaynak: UN COMTRADE, 2013 verileri kullanılarak hesaplanmıştır.

Kazakistan'ın dört ECO üyesi ülkeyle ihracat benzerlik endeksine bakıldığında yukarıda ifade edildiği gibi, petrol ve doğal gaz gibi doğal kaynaklar ihracatında yoğunlaşmış bu ülkeyle Azerbaycan'ın küresel piyasalarda birbirinin rakibi olduğu görülmektedir. Tablo 4'da görüldüğü gibi verisi olan 2011 yılına göre İran için de aynı şeyi söylemek mümkündür. Türkiye ve Kırgızistan'la ihracat benzerliği düşük olan Kazakistan bu ülkelerle tamamlayıcı ekonomi durumundadır.

\begin{tabular}{|l|l|l|l|l|}
\hline Y1llar & Azerbaycan & İran & Kirgızistan & Türkiye \\
\hline 2007 & - & - & - & - \\
\hline 2008 & - & - & - & - \\
\hline 2009 & 67.0 & - & 5.9 & 40.2 \\
\hline 2010 & 67.5 & - & 6.7 & 67.5 \\
\hline 2011 & 69.6 & 68.5 & 11.4 & 39.9 \\
\hline
\end{tabular}

Tablo 4: Kazakistan'ın ECO Ülkeleriyle Ihracat Benzerlik Endeksi. Kaynak: COMTRADE (2013) verileri kullanılarak hesaplanmiştır.

Bölgenin en fakir ülkelerinden biri olan Kırgızistan'ın uluslararası piyasalarda rakibi durumundaki en önemli ülke İran (2011 rakamlarına göre)'dır. Kırgızistan'ın diğer üç ülkeyle düşük ihracat benzerlik endeksleri bu ülkenin ihracatındaki rekabet gücü açısından olumlu bir durumdur. Kısaca, Kırgızistan ve dört diğer dört ECO üyesi ülke uluslararası piyasada birbirine rakip değildir.

\begin{tabular}{|l|l|l|l|l|}
\hline Y1llar & Azerbaycan & İran & Kazakistan & Türkiye \\
\hline 2007 & - & - & - & - \\
\hline 2008 & 14.8 & - & - & 20.7 \\
\hline 2009 & 4.0 & - & 5.9 & 17.4 \\
\hline 2010 & 6.6 & - & 9.3 & 22.8 \\
\hline 2011 & 8.0 & 68.5 & 11.4 & 29.9 \\
\hline
\end{tabular}

Tablo 5: Kırglzistan'ın ECO Ülkeleriyle İhracat Benzerlik Endeksi. Kaynak: UN COMTRADE, 2013 verileri kullanılarak hesaplanmıştır.

Bölgenin en gelişmiş ülkesi konumunda olan Türkiye'nin diğer bölge ülkeleriyle ihracat benzerliği düşüktür. Özellikle Türk Cumhuriyetleriyle arasında önemli bir gelişmişlik farkı olan Türkiye'nin bölge ülkeleriyle uluslararası piyasalarda rakip durumunda olmaması beklenen bir sonuçtur. Sadece, petrol ve doğal gaz dişında metal ürünleri, gıda maddeleri gibi ürünler de ihraç eden Kazakistan'la diğer ülkelere nispeten Türkiye'nin ihracat benzerliği biraz daha yüksektir.

\begin{tabular}{|l|l|l|l|l|}
\hline Y1llar & Azerbaycan & İan & Kazakistan & Kirgizistan \\
\hline 2007 & 30.5 & - & - & - \\
\hline 2008 & 41.8 & - & - & 20.7 \\
\hline 2009 & 21.0 & - & 40.2 & 17.4 \\
\hline 2010 & 24.1 & - & 43.3 & 22.8 \\
\hline 2011 & 17.5 & 38.3 & 39.9 & 29.9 \\
\hline
\end{tabular}

Tablo 6: Türkiye’nin ECO Ülkeleriyle Ihracat Benzerlik Endeksi. Kaynak: UN COMTRADE, 2013 verileri kullanılarak hesaplanmıştır.

Sadece 2011 verilerine ulaşabildiğimiz İran'ın uluslararası piyasalarda rakibi durumunda olan ülke Azerbaycan ve Kazakistan'dır. \%9,3'lük oranla Suudi Arabistan, Venezüella ve Kanada'dan sonra dünyanın dördüncü en büyük petrol rezervlerine sahip ülkesi olan İran'ın (Öztürkler, 2012) bu ülkelerle ihracat benzerliğinin yüksek 
çıkması beklenen bir sonuçtur. Türkiye ve Kırgızistan'ın ürün yapısı İran'a dış piyasalarda rakibi olacak benzerlikte görünmemektedir.

\begin{tabular}{|l|l|l|l|l|}
\hline Y1llar & Azerbaycan & Kazakistan & Kırgizistan & Türkiye \\
\hline 2007 & - & - & - & - \\
\hline 2008 & - & - & - & - \\
\hline 2009 & - & - & - & - \\
\hline 2010 & - & - & - & - \\
\hline 2011 & 65.6 & 68.5 & 14.3 & 38.3 \\
\hline
\end{tabular}

Tablo 7: Iran'in ECO Ülkeleriyle Ihracat Benzerlik Endeksi. Kaynak: UN COMTRADE, 2013 verileri kullanılarak hesaplanmıştır.

Ticaret yoğunluğu endeksi iki yanlı ticaret akımlarında değişmeleri ve nispi direnci ölçmek için kullanılır (Bano, 2002). Endeks bir bölgenin belirli bir bölgeye dünyanın geri kalanına yaptığından yüzde olarak daha fazla ihracat yapıp yapmadığını gösterir. Ticaret yoğunluğu endeksinin 1'e eşit olması, bir ülkenin diğerine ticaret ortaklarının satın alma gücüne uygun olarak ihracat yaptığını gösterir (Bano vd., 2013). Ticaret yoğunluğu endeksinin değeri 1'den büyükse, ülke dünya ticaretindeki payına kıyasla partnerine daha fazla ihracat yapıyor demektir. Ticaret yoğunluğunun değeri 1'den küçükse tersi durum ortaya çıkar.

Brown (1947) tarafindan ilk defa ortaya konulan ve Kojima (1964) tarafindan geliştirilen ve popülerleştirilen ticaret yoğunluğu endeksi iki yönden hesaplanabilmektedir. İlk olarak temel ülke açısından ya da başka bir ifadeyle ihracat perspektifinden ticaret yoğunluğu endeksi şu formüle göre hesaplanır:

$$
\mathrm{TII}=\frac{X_{a b}}{X_{a}} / \frac{M_{b}}{\left(M_{w}-M_{a}\right)}
$$

Formülde,

$\mathrm{TII}=\mathrm{a}$ ve $\mathrm{b}$ ülkesi arasında ticaret yoğunluğu endeksi

$\mathrm{Xab}=\mathrm{a}$ ülkesinin $\mathrm{b}$ ülkesine ihracatı

$\mathrm{Xa}=\mathrm{a}$ ülkesinin dünyaya toplam ihracatı

$\mathrm{Ma}=\mathrm{a}$ ülkesinin toplam ithalatı

$\mathrm{Mb}=\mathrm{b}$ ülkesinin toplam ithalatı

$\mathrm{Mw}=$ Toplam dünya ithalatı'dır

Formülde Xab/Xa toplam yerli ihracatın bir yüzdesi olarak yabancı ülkeye gönderilen ihracatın oranıdır. $\mathrm{Mb} /(\mathrm{Mw}-\mathrm{Ma})$ yerli ekonominin ithalatından daha az toplam dünya ithalatının bir yüzdesi olarak yabancı ülkenin toplam ithalatıdır. İhracatlarının çoğunu gönderdikleri aynı ülkeden nispeten yüksek düzeylerde ithalat yapan ülkeler yüksek bir TII'ye sahip olacaktır. Aksine, ithalatı için bir ülkeye bağlı olmayan çeşitli piyasalı bir ülke düşük bir TII'ye sahip olacaktır (Bano, 2002).

İkinci olarak ticaret yoğunluğu endeksi ülkenin ticaret partnerleri perspektifinden de hesaplanmaktadır. Başka bir ifadeyle temel ülke için ithalat perspektifinden ele alınan bu durumda formül aşağıdaki şekilde oluşacaktır:

$$
\mathrm{TTI}=\frac{X_{b a}}{X_{b}} / \frac{M_{a}}{\left(M_{w}-M_{b}\right)}
$$

Burada,

$\mathrm{Xba}=\mathrm{b}$ ülkesinin a ülkesine ihracatı

$\mathrm{Xb}=\mathrm{b}$ ülkesinin dünyaya toplam ihracatı

$\mathrm{Ma}=\mathrm{a}$ ülkesinin toplam ithalatı

$\mathrm{Mb}=\mathrm{b}$ ülkesinin toplam ithalatı

$\mathrm{Mw}=$ toplam dünya ithalatı'dır.

ECO ülkelerinin ticaret yoğunluğu endeksine bakıldığında bölge ülkelerinin genellikle komşularıyla ticaret yoğunluğunun nispeten yüksek olduğu görülmektedir. Örneğin Afganistan'ın ticaret yoğunluğunun en yüksek olduğu ülkeler komşuları başta Pakistan olmak üzere, Tacikistan, İran ve Özbekistan'dır. Afganistan bu ülkelere dünya ticaretindeki payından daha fazla ihracat yapmaktadır. Afganistan Azerbaycan, Kırgızistan ve Kazakistan'a dünya ticaretindeki payından daha az ihracat yapmaktadır. Azerbaycan'ın Pakistan dışında bölge ülkeleriyle ticaret yoğunluğu endeksi pozitif olmakla birlikte tüm ülkelerle ticaret yoğunluğunda azalma görülmektedir. Ticaret yoğunluğu en fazla Afganistan'la olan İran'ın Kazakistan ve Türkiye ile ticaret yoğunluğu negatiftir. Kazakistan'ın dört bölge ülkesiyle (Afganistan, Azerbaycan, İran, Pakistan ve Türkmenistan) ticaret yoğunluğu endeksinin negatif olması bu ülkenin bölge ülkeleriyle ticaretinin dünya ticaretindeki payından düşük 
olduğunu göstermektedir. Kırgızistan ve Özbekistan'ın ticaret yoğunluğu endeksi sadece Pakistan'la negatif, Tacikistan'ın tüm bölge ülkeleriyle ticaret yoğunluğu negatiftir. Sadece iki yıllık verisine ulaşabildiğimiz Türkmenistan'ın Tacikistan ve Pakistan'la ticaret yoğunluğu negatiftir.

Türkiye'ye bakıldığında, Tablo 8'de görüldüğü gibi Türkiye'nin Pakistan dışında bölge ülkeleriyle ticaret yoğunluğu endeksinin pozitif olduğu görülmektedir. Türkiye genel olarak bölge ülkelerine dünya ticaretindeki payından daha fazla ihracat yapmaktadır. Bölge içinde Türkiye'nin ticaret yoğunluğunun en fazla olduğu ülkeler Azerbaycan, Türkmenistan ve özellikle son yıllarda İran olarak sıralanmaktadır.

\begin{tabular}{|c|c|c|c|c|c|c|c|c|c|}
\hline Yillar & 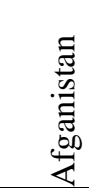 & 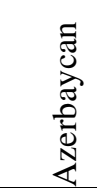 &. & 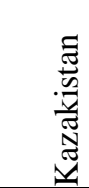 & 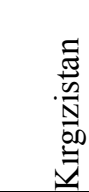 & 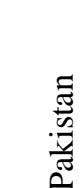 & 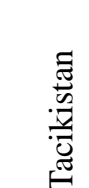 & 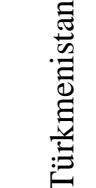 & 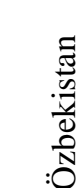 \\
\hline 2007 & 4.77 & 24.17 & 3.92 & 4.35 & 8.57 & 0.68 & 6.11 & 11.39 & 4.42 \\
\hline 2008 & 5.61 & 28.78 & 4.48 & 2.91 & 5.81 & 0.48 & 6.67 & 18.17 & 4.30 \\
\hline 2009 & 8.69 & 28.20 & 4.52 & 2.75 & 5.68 & 0.58 & 6.06 & - & 3.66 \\
\hline 2010 & 6.76 & 31.51 & 6.34 & 3.53 & 5.38 & 0.96 & 7.27 & - & 4.31 \\
\hline 2011 & 5.82 & 28.54 & 7.83 & 3.45 & 5.71 & 0.71 & 7.26 & - & 4.55 \\
\hline
\end{tabular}

Tablo 8: Türkiye'nin ECO Ülkeleriyle İhracat Yoğunluğu. Kaynak: Ecosecretariat, 2013 a verileri kullanılarak hesaplanmiştır.

Diğer bölge ülkeleri perspektifinden bakıldığında ise Kazakistan, Türkmenistan ve İran'ın Türkiye ile ticaret yoğunluğu endeksinin negatif olduğu görülmektedir. Afganistan, Azerbaycan, Kırgızistan, Özbekistan, Tacikistan ve Pakistan dünya ticaretindeki paylarından daha fazla Türkiye'ye ihracat yapmaktadır.

\begin{tabular}{|c|c|c|c|c|c|c|c|c|c|}
\hline Yillar & 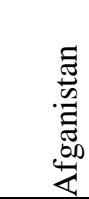 & 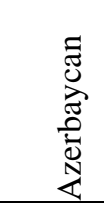 & .ేี & 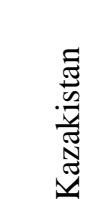 & 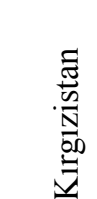 & 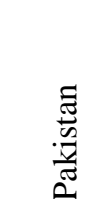 & 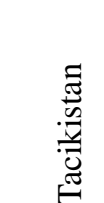 & 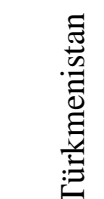 & 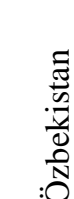 \\
\hline 2007 & 2.15 & 14.67 & 0.49 & 0.00 & 2.74 & 1.91 & 27.37 & 0.00 & 5.52 \\
\hline 2008 & 2.69 & 1.07 & 0.43 & 0.00 & 1.98 & 1.79 & 22.23 & 0.00 & 3.80 \\
\hline 2009 & 3.59 & 0.66 & 0.61 & 0.00 & 1.98 & 2.05 & 13.60 & - & 1.09 \\
\hline 2010 & 2.58 & 0.67 & 0.78 & 0.00 & 1.77 & 2.17 & 26.25 & - & 4.61 \\
\hline 2011 & 2.24 & 1.31 & 0.75 & 0.00 & 1.86 & 2.79 & 33.12 & - & 4.63 \\
\hline
\end{tabular}

Tablo 9: Türkiye'nin ECO Ülkeleriyle İthalat Yoğunluğu. Kaynak: Ecosecretariat, 2013 a verileri kullanılarak hesaplanmiştır.

\begin{tabular}{|l|l|l|l|l|l|l|l|l|l|}
\hline & $\mathbf{2 0 0 1}$ & $\mathbf{2 0 0 2}$ & $\mathbf{2 0 0 3}$ & $\mathbf{2 0 0 4}$ & $\mathbf{2 0 0 5}$ & $\mathbf{2 0 0 6}$ & $\mathbf{2 0 0 7}$ & $\mathbf{2 0 0 8}$ & $\mathbf{2 0 0 9}$ \\
\hline $\mathbf{0 - 4}$ & 0.017 & 0.011 & 0.015 & 0.021 & 0.022 & 0.018 & 0.016 & 0.018 & 0.019 \\
\hline $\mathbf{5 - 8}$ & 0.045 & 0.036 & 0.059 & 0.046 & 0.047 & 0.042 & 0.037 & 0.041 & 0.044 \\
\hline Toplam & 0.062 & 0.047 & 0.074 & 0.067 & 0.069 & 0.060 & 0.053 & 0.059 & 0.063 \\
\hline
\end{tabular}

Tablo 10: Türkiye'nin Türk Cumhuriyetleri ile Endüstriiçi Ticareti. Kaynak: M. Ozan Başkol, 2010.

Faktör girdileri ve tüketim açısından birbirine yakın ikame malların eşanlı ithalat ve ihracatı (Tharakan ve Calfat,1996) şeklinde tanımlanan endüstriiçi ticaret (EITT) ile bölgesel ekonomik entegrasyon arasında yakın bir iliş̧i vardır. Kişi başına gelir düzeyindeki artış, ekonomik gelişmişlik düzeyi, ürünlerin özellikleriyle (farklılaştırılabilme, ölçek ekonomilerinden yararlanılabilme gibi) birlikte EİT üzerinde etkili olan temel faktörlerden biri ekonomik bütünleşmelerdir. Ekonomik bütünleşme, üye ülkeler arasında ticareti engelleyen etkenlerin ortadan kaldırılmasına yol açarak ticaretin genişlemesini sağlar. Bu şekilde bütünleşmeye giden ülkelerde EITT'in artması için gerekli ortam sağlanmış olur (Küçükahmetoğlu, 2008). Bunun yanında bütünleşme üyesi ülkelerin üretim yapıları tamamlayıcılıktan çok rakiplik özelliğine sahipse EİT ticaret artacaktır. ECO ülkelerine bakıldığında bölge ülkelerinin kişi başına gelir düzeyi Türkiye gibi birkaç ülke dışında genel olarak düşüktür. Türkiye, İran ve Pakistan dışındaki ülkelerde gelir ve nüfusun düşüklüguü dolayısıyla Türk Cumhuriyetleri ve Afganistan'ın ölçek ekonomilerinden yararlanmaları sınırlı kalmaktadır (Akal ve Karakaş, 2011). Bu nedenlerle ECO bölgesinde EİT düzeyi düşük kalmaktadır. Nitekim, Başkol (2010) tarafindan hazırlanan çalışmada Türkiye'nin Orta Asya Türk Cumhuriyetleri ile Grubel Lloyd endeksine göre hesaplanan EITT düzeyinin Tablo 10'de görüldüğü gibi oldukça düşük düzeylerde olduğu, başka bir ifadeyle Türkiye'nin bu 
ülkelerle ticaretinin endüstriler arası nitelikte olduğu tespit edilmiştir. Diğer bölge ülkeleri arasındaki ticaretin niteliği de bundan çok farklı değildir.

Tabi ECO henüz işbirliği düzeyinde bir ekonomik entegrasyondur. Bölge ülkeleri arasında zamanla ticaretin artması entegrasyon düzeyinin geliştirilmesinde etkili olacak, entegrasyonun ilerlemesi de bölge içinde ticaretin endüstriiçi ticarete doğru evrilmesine sebep olacaktır.

\section{Sonuç}

$\mathrm{Bu}$ çalışmada, Batı ve Orta Asya ekseninde ileride bir bölgesel entegrasyona dönüşmek üzere kurulmuş bir bölgesel işbirliği oluşumu olan ECO'da bölgesel entegrasyonun önündeki engeller, bölge içi ticaret bağlamında analiz edilmiştir. Şu anda bir tercihli ticaret anlaşmasına sahip olan Teşkilat'ta bazı somut projeler uygulamaya geçmiş olmakla birlikte, serbest ticaret bölgesi olma yolunda henüz bir gelişme olmamıştır.

Dünya ticaretinde potansiyelinin altında bir paya sahip olan ECO'da bölge-içi ticaret, diğer pek çok bölgesel entegrasyonla karşılaştırıldığında oldukça düşüktür. Ancak birkaç ülke dışında, Türkiye de dahil olmak üzere bölge ülkelerinin bölge içi ticaret hacmi son yıllarda artma eğilimindedir. Pakistan ve Türkiye dışında bölgeden yapılan ihracat başta petrol, doğal gaz olmak üzere maden fiyatlarının dünya piyasasında ortaya çıkan değişmelerine göre şekillenmektedir.

Çalışmada bölge içi ticaretin düzeyi ve yapısını belirlemek amacıyla hesaplanan endekslerden ihracatta benzerlik endeksi açısından genel olarak hammadde ve maden ihracatçısı durumundaki bölge ülkelerinin ihracat benzerliklerinin nispeten yüksek olduğu görülmektedir. Bölgenin en sanayileşmiş ülkesi durumundaki Türkiye, Pakistan ve doğal kaynaklar açısından fakir Türk Cumhuriyetleri ile diğer bölge ülkeleri bu bağlamda birbirini tamamlayıcı ekonomiler olarak ortaya çıkmaktadır.

İki yanlı ticaret akımlarında değişmeleri ve nispi direnci ölçmek için kullanılan ticaret yoğunluğu endeksi hesaplamaları sonucunda ECO ülkelerinin genellikle komşularıyla ticaret yoğunluğunun nispeten yüksek olduğu tespit edilmiştir. Türkiye'nin Pakistan dışında bölge ülkeleriyle ticaret yoğunluğu endeksinin pozitif olduğu görülmektedir. Türkiye genel olarak bölge ülkelerine, dünya ticaretindeki payından daha fazla ihracat yapmaktadır. Bölge içinde Türkiye'nin ticaret yoğunluğunun en fazla olduğu ülkeler Azerbaycan, İran ve Türkmenistan olarak sıralanmaktadır.

Bölge ülkelerinin kişi başına gelir düzeyi Türkiye gibi birkaç ülke dışında genel olarak düşüktür. Türkiye, İran ve Pakistan dışındaki ülkelerde gelir ve nüfusun düşüklüğü dolayısıyla Türk Cumhuriyetleri ve Afganistan'ın ölçek ekonomilerinden yararlanmaları sınırlı olmaktadır. Bu nedenlerle ECO bölgesinde EİT düzeyi düşük kalmaktadır.

Özetle, bir bölgesel entegrasyonun başarılı olabilmesi için önemli faktörlerden olan bölge içi ticaret düzeyinin yüksekliği ve ülkelerin dış ticaret yapılarının rekabetçiliği açısından, ampirik hesaplamaların ortaya koyduğu gibi ECO bölgesinin biraz dezavantajlı olduğu görülmektedir. Ancak son zamanlarda Türkiye gibi ülkelerin toplam dış ticaretleri içinde ECO'nun payının artması ve Türk Cumhuriyetlerinin dışa açılma sürecinin nispeten hızlanmış olması bu dezavantajın ileriki zamanlarda azalacağı sinyalini vermektedir.

\section{Kaynakça}

- Akal, M. ve A. Karakaş, 2011. "Türk Cumhuriyetlerinin Üretim Yapılarındaki Dönüşüm ve Türkiye ile Ticari İlişkileri: 1996-2005”, Bilig, Yaz 2011, Sayı: 58, s. 5

- Bano, S., 2002. "Intra-Industry Trade and Trade Intensities: Evidence from New Zeland", Working Paper in Economics, 5/02, University of Waikato, New Zealand.

- Bano, S., Y. Takahashi and F. Scrimgeour, 2013. "ASEAN-New Zealand Trade Relations and Trade Potential: Evidence and Analysis", Journal of Economic Integration, Vol. 28 No.1, March 2013, p. 155.

- Başkol, M., 2010. “Türkiye ile Orta Asya Türk Cumhuriyetleri Arasındaki Endüstri-İçi Ticaretin Analizi”, in Proceedings of International Conference on Euroasian Economies 2010, 4-5 November 2010, İstanbul/Turkey, p. 389

- Bhagwati, J., 1992. "Regionalism versus Multilateralism", The World Economy, Vol. 15, No. 5, p. 538

- Brown, A.J. 1947, Applied Economics, George Allen \& Unwin, London.

- Dartan M., E. Hatipoğlu ve M. Dikkaya, 2002. ECO Bölgesi: Uluslararası Aktörlerin Rolü ve Türkiye, İstanbul: Marmara Üniversitesi, A.T. Enstitüsü Yayınları.

- Dikkaya, M. ve A. Üzümcü, 2007. “Ekonomik İşbirliği Örgütü’nün (ECO) Gelişimi, Potansiyeli ve Dinamikleri”, Stratejik Öngörü, Sayı:11, s. 23.

- DPT, 2013. Ekonomik İşbirliği Teşkilatı http://www.dpt.gov.tr/PortalDesign/PortalControls/WebContentGosterim.aspx?Enc=51C9D1B02086EAFB DE8CAC519B124ADB. 
- Ecosecretariat, 2013a. ECO Key Statistical Indicators (ECOKSI) 2011, http://www.ecosecretariat.org/.

- Ecosecretariat, 2013b. Treaty of Izmir, http://www.ecosecretariat.org/ftproot/Documents/Basics/Treaty_of_Izmir.doc.

- $\quad$ Erlat, G. and S. Ekmen, 2009. "Export Similarity And Competitiveness: The Case Of Turkey in The EU Market Paper", Presented at EconAnadolu 2009: Anadolu International Conference in Economics, June 1719, 2009, Eskişehir, Turkey, p. 4

- $\quad$ Finger, J.M. and M.E. Kreinin, 1979. “A Measure of Export Similarity and Its Possible Uses”, The Economic Journal, 89, pp. 905-912.

- IMF, 2013. International Financial Statistics, http://elibrarydata.imf.org/DataReport.aspx?c=1449311\&d=33061\&e=169393.

- Karluk, R. S., 2002. Uluslararası Ekonomik Mali ve Siyasal Kuruluşlar, Turhan Kitabevi, Ankara.

- Kojima K., 1964. "The Pattern of Trade Among Advanced Countries”, Hitotsubashi Journal of Economics, Vol. 5, No. 1, pp. 16-36

- Küçükahmetoğlu, O., 2008. Küçükahmetoğlu, Osman (2005), “Reel Entegrasyon Teorisi”, içinde O. Küçükahmetoğlu, Ş. Tüylüoğlu ve H. Çeştepe (Ed.), Ekonomik Entegrasyon Küresel ve Bölgesel Yaklaşım, Ekin Kitabevi, Bursa, s. 51

• Meriç, M., 2013. “Geçiş Sürecinde Türk Cumhuriyetleri’nde IMF”nin Rolü”, web.deu.edu.tr/ab/MAKALE/deu\%20MAK/0001.doc.

- Mikiç, M., 2005. “Commonly Used Trade Indicators: A Note”, ARTNet Capacity Building Workshop on Trade Research, UNESCAP, p. 16.

- Ö̈ztürkler, H., 2012. "İran Ekonomisinin Genel Özellikleri”, Ortadoğu Analiz, Cilt: 4, Sayı: 40, Nisan, s. 92.

- Shahabi, S., 2013. "Ekonomik İşbirliği Örgütü (ECO)”, Çev: Emre Yıldırım, http://www.tasam.org/trTR/Icerik/3403/ekonomik_isbirligi_orgutu_eco.

- $\quad$ Tekeli, R. ve E. Acartürk, 2008. “Ortadoğu ve Orta Asya Ekseninde Bölgesel Entegrasyon: Ekonomik İşbirliği Teşkilatı”, içinde O. Küçükahmetoğlu, Ş. Tüylüoğlu ve H. Çeştepe (Ed.), Ekonomik Entegrasyon Küresel ve Bölgesel Yaklaşım, Ekin Kitabevi, Bursa, s. 434

- Tharakan, P.K.M and G. Calfat, 1996. "Empirical Analyses of International Trade Flows", in D. Greenaway (Ed.), Current Issues in International Trade, Mac Millan, pp. 59-81.

- Tümhaber, 2013. "İran'da İşsizlik Rakamları”, http://www.tumhaber.com.tr/HaberOku.php?haber_id=66164.

- UN COMTRADE, 2013. United Nations Commodity Trade Statistics Database, http://comtrade.un.org/db/mr/rfCommoditiesList.aspx?px=S3\&cc=.

- UNDP, 2011. Human Development Report 2011, http://hdr.undp.org/en/media/HDR_2011_EN_Summary.pdf.

- Viner, J., 1950. The Customs Union Issue, Carnegie Endowment for International Peace, London.

- World Bank, 2013. World Development Indicators, http://data.worldbank.org/. 


\title{
Dünya Ticaret Örgütüne Girişi Sonrasında Rusya ile Türkiye Arasındaki Ticari İlişkilerinin İncelenmesi \\ Examining the Turkish-Russian Trade Relations after Russia's World Trade Organization Accession
}

\author{
Asst. Prof. Dr. Burak Kartal (Celal Bayar University, Turkey)
}

\begin{abstract}
Turkey and the Russian Federation (RF) have deep historical political and economic relations. The trade between the two countries have been growing since late 1980s when Turkey began to procure natural gas from Russia. The dissolution of USSR and the revival of Russian economy offered new opportunities for Turkish businessmen. During the last decade, Russia became one of the few major markets for Turkish construction and contractor companies whereas Turkey has been a favorable touristic destination for Russians. The agreements regarding Akkuyu nuclear power plant and natural gas pipelines have strengthened the ties between the two countries. In 2012, Russia became the 156th member of the WTO. Russia's WTO accession, along with the country's other economic cooperation and integration moves provide foreign companies interested in Russia with a better investment climate and business environment. Having competitive advantage in many goods and services categories needed by Russia, Turkish companies should benefit the new developments in RF and increase their business volumes in that country. This paper examines the current trade relations between RF and Turkey in detail considering the potential effects of RF's WTO membership.
\end{abstract}

\section{Giriş}

Rusya Federasyonu (RF), 2012 Dünya Yatırım Raporuna göre yatırım yapılacak en iyi 8 ülkeden birisidir (Yaraman, 2013). Bunun nedenlerini daha iyi anlayabilmek için ülkeyi biraz daha yakından tanımakta fayda var. 17 milyon kilometrekare ile coğrafi alan olarak dünyanın en büyük ülkesi olan RF, büyük çoğunluğu ülkenin batısında yaşayan 142,8 milyon kişiden oluşmaktadır. Ancak hem Dünya Bankası hem de Birleşmiş Miletlerin çalışmalarına göre, nüfusun 2050 yılında ciddi biçimde (\%30'a varan oranlarda) azalması beklenmektedir. Diğer yandan dünya üzerindeki işlenmiş toprakların yüzde $15-20$ 'si ve tropik ormanların \%40'ı bu ülkededir. RF, zengin doğal gaz ve petrol kaynaklarına, kömür, alüminyum, bakır, demir, elmas, altın, platin, nikel, uranyum, gümüş maden kaynakları ve ormancıllk ürünlerine sahiptir. Dünyadaki hammadde, enerji ve biyolojik kaynakların yüzde 35'inin ve alüminyum, platin, nikel, uranyum gibi stratejik hammaddelerdeki dünya rezervinin yarısının RF'da olduğu söylenmektedir. Bu nedenle enerji ve hammadde ihracatında dünyanın önde gelen ülkelerinden birisidir. Dünya çapında petrolün yüzde 13'ü, gazın yüzde 32'si, kömürün yüzde 11 'i, demirin yüzde 26 'sı, kurşunun yüzde 10 'u ve çinkonun yüzde 15 'i RF'na aittir. Ülkenin dünya enerji ihracatındaki payı ise \%7'dir. Doğal olarak, ağır sanayisi gelişen ve ihracatının üçte ikisi petrol, petrol ürünleri ve gaza dayanan ülkenin ihracatında metaller, motor ve teçhizat ile kimyasal ürünler de önemli yer işgal etmektedir. Ülkenin ithalatında öne çıkan ürün grupları ise makine ve ekipman, tüketim malları, ilaçlar, et, şeker ve yarı işlenmiş metal ürünleridir. RF'nun 2012 yılında \%3,4 büyüyen GSYIH's1 2 trilyon \$'a ulaşmıştır ve orta vadede benzer oranlarda büyümesi beklenmektedir. İleri teknoloji ürünleri ile tüketim mallarının üretimi, ekonomi içinde küçük bir paya sahip olduğu gibi, benzer şekilde küçük ölçekli işletmeler de gelişmiş ve gelişmekte olan çok sayıda ülkenin aksine büyük ölçekli işletmelerin hakimiyetindeki ekonominin \%15'ini geçememektedir (Benli Özbaş, 2013; Özilhan ve Göçer, 2013). 2012 yılında 335 milyar \$ ithalatına karşılık 531 milyar \$ ihracat gerçekleștiren RF, 196 milyar \$ civarında dış ticaret fazlası vermiştir (TC Ekonomi Bakanlığı İhracat Bilgi Platformu ${ }^{\text {f }}$, 2013). İhracatın en önemli ürün kalemlerinden birisi olan petrol üretimi 2012 yılı Kasım ayında 1,5 milyon varil ile son dönemlerin en yüksek seviyesine çıkmıştır. Bununla birlikte, RF'nin çıkarılması kolay ve ucuz petrolü giderek azalmaktadır (TC Ekonomi Bakanlığı İhracat Bilgi Platformu ${ }^{g}$, 2013). Doğrudan yabancı yatırım girişi ise 2012 yılında 45 milyar \$ olarak gerçekleşmiş (Benli Özbaş, 2013), 2008 krizi sonrasındaki hemen hemen yatay seyrine devam etmektedir.

\section{Rusya-Türkiye İlişkileri}

Türkiye ve Rusya arasındaki ilişkiler çok köklüdür ve yüzyıllar öncesine dayanmaktadır. Tarih boyunca kimi zaman barış kimi zaman çatışma içinde olan iki ülke, özellikle soğuk savaşın sona ermesinden sonra birbirlerine daha fazla yakınlaşmış, özellikle ekonomik ve ticari açıdan ilişkilerini güçlendirmiş̧lerdir. Ara sıra yaşanan ufak siyasi sorunlar bile söz konusu güçlenen ilişkilerin gölgesinde büyüme firsatı bulamamaktadır.

Her iki ülkenin liderleri de iki ülke arasındaki ekonomik, siyasi, askeri ve kültürel bağların çeşitlenip, gelişerek geleceğe yönelik umut verdiğini belirtmektedir (Dış Ekonomik İlişkiler Kurulu, 2013). RF'da iş yapan Türk iş adamları da Türklere yönelik herhangi bir olumsuzluk yaşamadıklarını ifade etmekte (Özilhan, 2013), Avrupa'da 
yaşanan sorunların iki ülkeyi birbirine daha da yakınlaştırdığını belirtmektedirler. Mersin-Akkuyu nükleer enerji santrali, petrol boru hattı gibi dev projeler (Ön, 2013) iki ülke arasındaki ilişkilere atılan sağlam dikişler haline gelmektedir. Soğuk savaş döneminde Türkiye'deki askeri okullarda Rusça öğretilirken, günümüzde Avrasya ülkelerinde iş yapmak isteyen gençlerimize çeşitli kurslarla Rusça öğretilmekte, soğuk savaş döneminin korkulan teknolojisi olan nükleer enerji konusunda Türk uzmanlar bizzat RF tarafından Rusya'da eğitilmektedir.

\section{Rusya - Türkiye Dış Ticareti}

Rusya ve Türkiye arasındaki ticari ilişkiler 15. yüzyıl sonlarına kadar gitmektedir; ancak 1991'de SSCB dağıldıktan sonra müteahhitlik, doğal gaz, deri, kürk ve bavul ticaretiyle gelişmeye başlamıştır. 1987 yılından itibaren başlayan doğal gaz alımı iki ülke arasındaki ilişkilerde önemli bir dönüm noktası olmuştur. 1998 yılında RF'unda yaşanan ekonomik krizden sonra bavul ticaretinin önemi azalıp mevcut pazar potansiyeli BAE, Çin, Polonya ve Yunanistan'a kaysa da (Özilhan ve Göçer, 2013), ilişkiler farklı alanlarda güçlenmeye devam etmiştir. İlişkilerdeki bu gelişmelerin tek nedeni coğrafi yakınlık değil aynı zamanda ekonomilerin birbirini tamamlamasıdır (İnce vd., 2013). Bunun başlıca nedeni, Türkiye ve RF'nun uluslararası pazarlara sattıkları temel ürünlerin birbirinden oldukça farklı olmasıdır (Kalayc1, 2013).

Türkiye İhracatçılar Meclisi (TIM) Başkanı Mehmet Büyükekşi, Türkiye ve RF’nun hem yatırım hem de ticarette çok güçlü iki ortak ülke olduğunu söyleyip, ortaklığın gelişmesi ve derinleşmesi için iş adamlarına da büyük bir sorumluluk düştüğünü ifade etmektedir. Büyükekşi, RF'nun, Türkiye'ye en çok turist gönderen ikinci ülke, Türklerin en çok yatırım yaptığı birinci, Türkiye'nin en önemli müteahhitlik hizmeti verdiği bir ülke olduğunu belirtmektedir (Dış Ekonomik İlişkiler Kurulu, 2013). Ekonomi Bakanlığı dış ticaret verilerine baktığımızda ise (Tablo 1), 2012 yılında RF, 26.62 milyar \$ ile Türkiye'nin en fazla ithalat yaptığı birinci, 6.68 milyar \$ ile en fazla ihracat yaptığı altıncı ülke olarak gözükmektedir. RF'na yönelik ihracat, Türkiye'nin toplam ihracatının \%4.68'ini, ithalat ise Türkiye'nin toplam ithalatının \%11.26'sını oluşturmaktadır.

\begin{tabular}{|c|c|c|c|c|c|c|c|c|c|c|c|c|c|c|c|}
\hline \multirow{2}{*}{$\begin{array}{l}\text { ÜLKE } \\
\text { SIRASI }\end{array}$} & \multirow[b]{2}{*}{ ÜLKELER } & \multicolumn{4}{|c|}{ IHRACAT } & & \multirow[b]{2}{*}{ (\%) } & \multicolumn{5}{|c|}{ ITHALAT } & \multirow[b]{2}{*}{$(\%)$} & \multirow[b]{2}{*}{ ÜLKELER } & \multirow{2}{*}{$\begin{array}{l}\text { ÜLKE } \\
\text { SIRASI }\end{array}$} \\
\hline & & 2008 & 2009 & 2010 & 2011 & 2012 & & 2008 & 2009 & 2010 & 2011 & 2012 & & & \\
\hline 1 & Almanya & 12.952 & 9.793 & 11.479 & 13.951 & 13.125 & $8,61 \%$ & 31.364 & 19.450 & 21.601 & 23.953 & 26.625 & $11,26 \%$ & Rusya Federasyonu & 1 \\
\hline 2 & Irak & 3.917 & 5.123 & 6.036 & 8.310 & 10.823 & $7,10 \%$ & 18.687 & 14.097 & 17.549 & 22.986 & 21.401 & $9,05 \%$ & Almanya & 2 \\
\hline 3 & iran & 2.030 & 2.025 & 3.044 & 3.590 & 9.922 & $6,51 \%$ & 15.658 & 12.677 & 17.181 & 21.693 & 21.295 & $9,00 \%$ & Çin & 3 \\
\hline 4 & ingiltere & 8.159 & 5.938 & 7.236 & 8.151 & 8.694 & $5,70 \%$ & 11.976 & 8.576 & 12.319 & 16.034 & 14.131 & $5,97 \%$ & $A B D$ & 4 \\
\hline 5 & BAE & 7.975 & 2.897 & 3.333 & 3.707 & 8.175 & $5,36 \%$ & 10.682 & 7.595 & 10.140 & 13.450 & 13.344 & $5,64 \%$ & italya & 5 \\
\hline 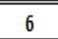 & Rusya Federasyonu & 6.483 & 3.190 & \begin{tabular}{l|l|}
4.628 \\
\end{tabular} & 5.993 & 6.681 & $4,38 \%$ & 8.200 & 3.406 & 7.645 & 12.462 & 11.965 & $5,06 \%$ & iran & 6 \\
\hline 7 & italya & 7.819 & 5.889 & 6.505 & 7.851 & 6.374 & $4,18 \%$ & 9.022 & 7.092 & 8.177 & 9.230 & 8.590 & $3,63 \%$ & Fransa & 7 \\
\hline 8 & Fransa & 6.618 & 6.211 & 6.054 & 6.806 & 6.199 & $4,07 \%$ & 4.548 & 3.777 & 4.840 & 6.196 & 6.024 & $2,55 \%$ & ispanya & 8 \\
\hline 9 & $A B D$ & 4.300 & 3.241 & 3.763 & 4.584 & 5.604 & $3,68 \%$ & 2.458 & 1.903 & 3.410 & 6.499 & 5.844 & $2,47 \%$ & Hindistan & 9 \\
\hline 10 & ispanya & 4.047 & 2.818 & 3.536 & 3.918 & 3.718 & $2,44 \%$ & 4.092 & 3.118 & 4.764 & 6.298 & 5.660 & $2,39 \%$ & Güney Kore & 10 \\
\hline & TOPLAM & 132.027 & 102.143 & 113.883 & 134.907 & 152.469 & & 201.964 & 140.928 & 185.544 & 240.842 & 236.545 & & & \\
\hline
\end{tabular}

Tablo 1: 2008-2012 Yılları Arasında Türkiye'nin Dış Ticaretindeki İlk 10 Ülke (Milyon ABD Dolarl) Kaynak: T.C. Ekonomi Bakanlığı Dış Ticaret İstatistiklerinden yararlanılarak hazırlanmıştır.

RF Ekonomik Kalkınma Bakanlığı Yatırım Politikası ve Kamu-Özel Sektör Ortaklığı Geliştirme Bölümü Müdürü Igor Koval (2013), Türkiye'nin en büyük dış ticaret ortakları listesinde RF'nın ikinci sırada, Türkiye'nin ise RF'nın diş ticaret ortakları arasında yedinci sırada olduğunu belirtmektedir. İki ülke arasındaki mevcut 35 milyar \$ civarındaki dış ticaret hacminin 2015 yılında 100 milyar \$'a çıkması her iki tarafça da hedeflenmektedir (Dış Ekonomik İlişskiler Kurulu, 2013; Kazaklı, 2013). Söz konusu olumlu hava iş adamları arasında da hakimdir. Örneğin, RF'da ciddi yatırımları olan Colin's firmasının Rusya Genel Müdürü Önder Ön, siyasi alandaki gelişmelerin iş dünyasına olumlu yansıdığını ve son 5 yılda, 50 yılda alınandan daha fazla yol alındığını söylemektedir (Ön, 2013).

RF ile ticaretin iyileşme beklentisinin bir nedeni de RF’nun girdiği işbirlikleri, entegrasyonlar ve DTÖ üyeliğidir. DTÖ üyeliği ileride daha detaylı ele alınacağı için burada kısaca işbirlikleri ve entegrasyonlara ilişkin bilgi verilmektedir. RF'nun Beyaz Rusya, Kazakistan, Kırgızistan ve Tacikistan ile Gümrük Birliği Anlaşması, Bağımsız Devletler Topluluğu (BDT) ülkeleri ile Serbest Ticaret Anlaşması bulunmaktadır (Benli Özbaş, 2013). Ayrıca Rusya ve Türkiye Karadeniz Ekonomik İşbirliği Örgütü içinde de aralarındaki ikili ve çok taraflı ekonomik, teknolojik ve sosyal ilişkilerini geliştirmeye çalışmaktadır (Devlet Planlama Teşkilatı, 2013).

Türkiye'nin, 2000'li yılların başından itibaren dış ticaret açığının önemli bir kısmı RF ile gerçekleştirdiği ticaretten kaynaklanmaktadır. (Kalaycı, 2013). Bunun başlıca nedeni, Türkiye'nin enerji açısından oldukça dışa bağımlı olması ve son dönemde tedarik kaynağı olarak tercihini daha çok RF'dan yana kullanmasıdır. İran'ın üzerinde yoğunlaşan uluslararası baskı, bu yönelimi son zamanlarda daha da artırmaktadır (Dombey ve Clover, 2013). 
Türkiye 2002 yılından itibaren özellikle Mavi Akım Projesi kapsamında RF'ndan ciddi miktarda doğalgaz ithal etmeye başlamıştır. Bu alımların yanı sıra enerji fiyatlarındaki artış da RF'ndan yapılan doğalgaz ithalatının tutar olarak büyük ölçüde artmasına neden olmuştur.

Türkiye-Avrupa Birliği (AB) arasında oluşturulan gümrük birliği gereğince $\mathrm{AB}$ dışı ülkelere karşı Ortak Gümrük Tarifesi (OGT) uygulamaya başlaması da Türkiye'nin koruma düzeyini eskiye oranla azaltmış, diğer $\mathrm{AB}$ dışı ülkelere karşı olduğu gibi Rusya Federasyonu'na da bu kapsamda eskiye oranla daha düşük gümrük tarifeleri uygulanmış ve iki ülke arasındaki ticarette, dış ticaret hadlerinin Türkiye aleyhine gelişmesine yol açmıştır (Kalaycı, 2013).

Şekil 1'de Türkiye ve RF arasındaki ticaretin gelişimi 2001 yılından itibaren gözlenebilir. 2009 yılında küresel krize bağlı olarak yaşanan ciddi düşüş dışında hem ihracat hem de ithalatın düzenli bir artış içerisinde olduğu ve 2012 yılında, 2001 yılındaki değerleri üzerinden hem ihracat hem de ithalatın 7 kattan daha fazla artış gösterdikleri görülebilir. Türkiye'nin yakın gelecekte enerji kaynaklarında köklü bir değişim yapması beklenmediği için RF'dan ithalatın artarak süreceği beklenebilir.

Diğer yandan, RF'nun ithalatında tüketim mallarının ağırlığı devam ettiği sürece Türkiye menşeli tüketim mallarına yönelik talebin de sürmesi beklenebilir. Türk ürünleri RF pazarında hem fiyat ve kalite olarak hem de coğrafi yakınlık açısından rakiplerine göre avantajlı konumdadır (Benli Özbaş, 2013).

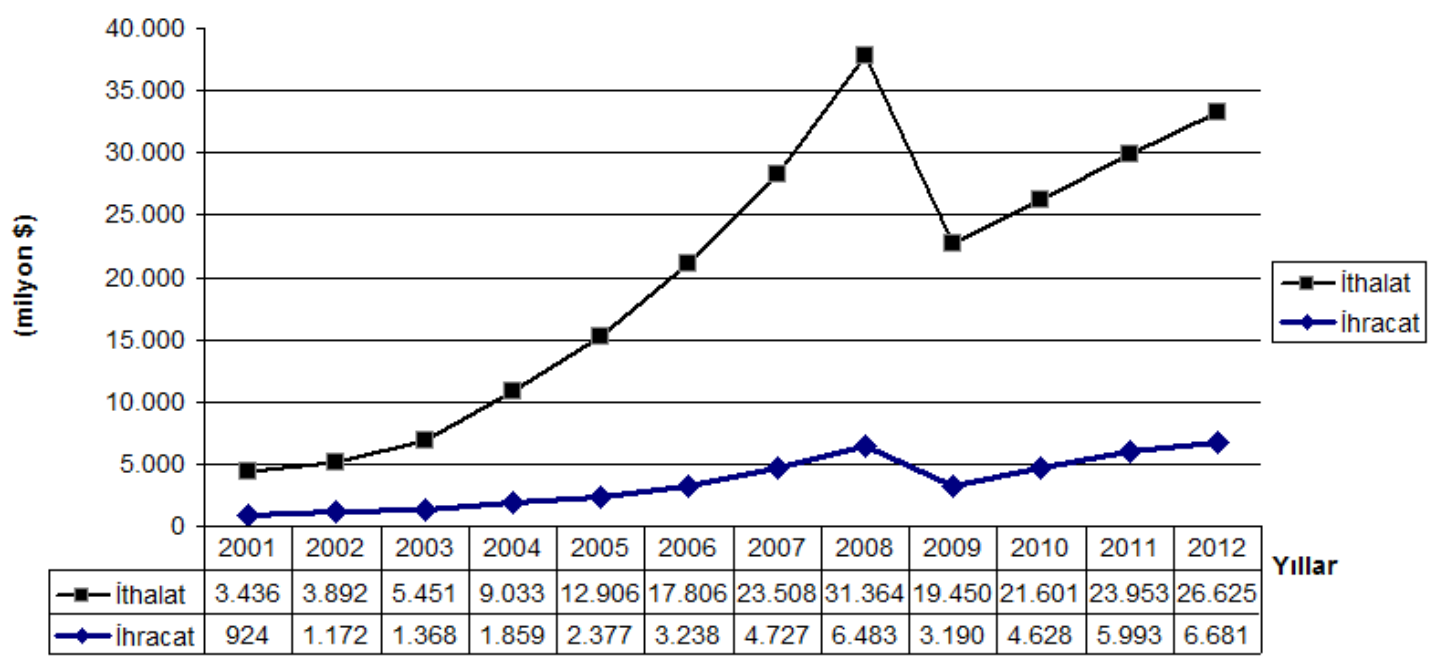

Şekil 1: Türkiye ve Rusya Arasındaki Dış Ticaretin Gelişimi Kaynak: T.C. Ekonomi Bakanlı̆̆ Dış Ticaret Istatistiklerinden yararlanılarak hazırlanmıştır.

Türkiye ile RF arasındaki dış ticaret ilişkilerini sektörler itibariyle incelersek, 2010 yılı verilerine gore, RF'na yapılan ihracatın büyük bir kısmınının başlıca sınıflara ayrılmış işlenmiş mallar ile makine ve ulaştırma araçları olduğu gözükmektedir. Diğer yandan RF'ndan yapılan toplam ithalat içinde ise en fazla payın mineral yakıtlar, yağlar vb. damıtılmasından elde edilen ürünler olduğu gözükmektedir (Kalayc1, 2013). İki ülke arasındaki ticaretin ürün gruplarına göre durumu Tablo 2'de incelenebilir.

\section{Rusya - Türkiye Dış Ticaretinin Sektörel ve Bölgesel Açıdan İncelenmesi}

RF Ekonomik Kalkınma Bakanlığı Yatırım Politikası ve Kamu-Özel Sektör Ortaklığı Geliştirme Bölümü Müdürü Igor Koval (2013), "Rusya'daki Türk yatırımların tekstil, gıda, ve kimya endüstrilerine odaklandığını ve Türk işletmelerinin Rusya’nın Güney Federal Bölgesi’ne yönelik yatırımlara daha fazla önem verdiğini ifade etmektedir. RF'nun Türkiye Ticaret Temsilcisi Tofik Melikov ise bu üç temel sektöre ek olarak ağaç işleme sanayi, elektronik ve teknik sanayi, inşaat malzemeleri, hizmet alanını (ticaret, turizm, banka sektörü) da saymaktadır. Ayrıca Melikov da Türk yatırımcıların artık Rusya'nın büyük şehirlerine değil daha çok Smolensk, Vladimir, Ryazan gibi güney ve özel bölgelere yöneldiğini belirtmektedir. Melikov (2013), her iki ülkede bölgeler arasında yapılacak ekonomik temasların artmasının önemine de dikkat çekmektedir.

Moskova'da düzenlenen Türk - Rus İş Forumunda konuşan Başbakan Recep Tayyip Erdoğan sektörel gelişmelerle ilgili olarak şunları söyledi: “Enerji makineleri üretimi, otomotiv sanayi, kimya sanayi, gemi inşa sanayi, sağlık sanayi, havacılık sanayi, inşaat malzemeleri sanayinde işbirliğinin geliştirilmesi mutabakatına varlld. Rusya Federasyonu'ndaki Özel Ekonomik Bölgeler ve ülkemizdeki Serbest Bölgelerde işbirliği de yine mutabakata varılan konular arasında. Bunlar, işadamlarımız için, özel sektörümüz için gerçekten önemli 
gelişsmeler. Özel sektörümüzün, açılan bu yoldan güvenle ilerlemelerini arzu ediyorum." (Dış Ekonomik İlişkiler Kurulu, 2013)

RF ile dış ticaretimizde önem arz eden ürünleri üç grupta ele almakta fayda var: Sanayi ürünleri, tarım ve gıda ürünleri ile hizmet sektörleri.

RF'na ihracatımızda öne çıkan sanayi ürünleri şunlardır: Çimento, demir-çelik inşaat ve aksamı, demir-çelik radyatörler, demir-çelikten sağlığı koruyucu eşya, tuvalet eşyası ve aksamı, inşaat boyaları, plastik inşaat malzemeleri, işlenmiş doğal taşlar (kayagan hariç), seramik inşaat malzemeleri, prefabrik yapılar, düz cam, aydınlatma cihazları, mobilya, inşaat ve maden makineleri, maden ve mineraller, petrol ürünleri ve yağları, tekstil ve hazır giyim, deri ve kürklü giyim eşyaları, ayakkabılar, otomotiv ana ve yan sanayi, televizyonlar, beyaz eşya, kozmetik ve kişisel bakım ürünleri, sabunlar, ambalaj ürünleri, hijyenik kağıt ürünleri, gezinti ve spor amaçlı deniz taşıtları, takım tezgahları, metal şekillendirme-kesme makine ve presler, elektrik jeneratörleri ve statik konvertörler, kablo ve teller, plastik mutfak eşyaları ve tıbbi alet ve cihazlar (Benli Özbaş, 2013).

Rusya'da umut vaat eden sektörlerden birisi otomotivdir. Rusya, 2012 y1lında Avrupa'da Almanya'dan sonra ikinci büyük otomobil pazarı olmuştur (TC Ekonomi Bakanlığı İhracat Bilgi Platformu g , 2013). 40 milyar dolarlık pazar için mevcut 8 Türk firmasına (1. Nobel Automotive, 2. Coşkunöz, 3. Trakya Cam, 4. Tirsan Kardan, 5. Teklas, 6. Canel Otomotiv, 7. Pilot Koltuk, 8. Tirsan/Kaessbohrer) ek olarak, 20-25 Türk şirketi daha Rusya'da yatırım yapmak için teşebbüste bulunmuştur. Bu şirketlerin daha çok Japon, Kore, Çin ve Avrupalı devlerle rekabet etmesi beklenmektedir. Otomobil İhracatçıları Birliği Başkanı Orhan Sabuncu’ya (2013) göre, Rusya'da belirlenen yeni teşvik sistemiyle otomotiv ana sanayisi 36 ay içinde en az 300 bin araçlık kapasite oluşturacak ve 4 yıl içinde de üretilen araçların motorlarının yüzde 30'u Rusya'da imal edilecek. Son yıllarda özellikle St. Petersburg, otomotiv sanayinde bir üretim merkezine dönüşmektedir. Hyundai,Toyota, General Motors, Nissan ve Scania gibi dünyanın önde gelen otomotiv üreticilerinin bölgede yatırımları olduğu gibi otomotivin yanı sıra ilaç, gemi inşaat, bilgi teknolojileri, radyoloji, elektronik de bölgede öncelikli üretim alanları ve kümelenmelerdir (Bektaşoğlu ve Benli Özbaş, 2013).

Tarım ve gıda da yine Türk iş adamlarının önem verdiği sektörlerden birisidir. RF'na yönelik ihracatta önem arz eden tarım ve gıda ürünleri şunlardır: Su ürünleri, kanatlı eti, tütün, yaş meyve ve sebze (portakal, elma, limon, domates), şekerli ve çikolatalı mamuller, kesme çiçek, çay, meyve suyu, dondurulmuş meyve-sebze, sert kabuklu meyveler, makarna, kuru üzüm, kuru kayısı, gofretler, maya ve organik tarım ürünleri (Benli Özbaş, 2013).

RF 2012 yılında toplamda 5,7 milyar \$ yaş meyve ithalatı gerçekleşmiş̧ir. Türkiye pazarda Ekvador'dan sonra ikinci büyük tedarikçi ülkedir. RF yaş meyve pazarının yaklaşı \% $\% 5$ 'sinin ithal meyveden oluştuğu tahmin edilmektedir. RF'nun ithal ettiği en önemli ürünler muz, elma, mandalina, üzüm, armut, portakal, şeftali ve limondur. Ülkenin yaş sebze ithalatı da 2,3 milyar \$’ı bulmaktadır. Türkiye pazardaki en büyük tedarikçi ülkedir. $\mathrm{Bu}$ alanda başlıca ürünler sırasıyla domates, diğer sebzeler (biber, patlıcan, mantar v.b.), hıyarlar ve kornişonlar, soğan ve şalotlar, havuç ve lahanadır. Türkiye, RF'na 2012 yllında toplam 804 milyon $\$$ değerinde 1.172 bin ton yaş meyve ve sebze ihracatı gerçekleştirmiştir. Türkiye'nin RF'na ihracatından en fazla pay alan ürün grupları sırası ile narenciye ürünleri, domates, üzümler, kayısı, kiraz, vişne ve şeftaliler, diğer meyveler (çilek), hıyarlar ve kornişonlar, diğer sebzeler (kabak, biber, patlıcan), incir, soğan ve şalotlar, elma, armut olmuştur (Bektaşoğlu ve Benli Özbaş, 2013).

Devlet Bakanı Zafer Çağlayan (2013), Rusya Tarım Ürünleri Denetleme Kurumu'nun (Rosselhoznadzor) 1 Şubat 2010 tarihinden itibaren Türkiye'den kümes hayvanları ve kümes hayvanları ürünlerine ilişkin ithalat yasağını kaldırmasıyla, Türk beyaz et ihracatçılarının Rusya Federasyonu'nun en büyük beyaz et tedarikçisi olmasının mümkün hale geldiğini ifade etmiştir. Kişi başı beyaz et tüketiminin yılda 24 kilo olduğu RF'da en büyük beyaz et tedarikçileri sırasıyla $A B D$ ve Brezilya'dır. Türkiye'nin üretim kapasitesinin yüzde 40'ını bu ülkeye satma şansına sahip olduğu da Çağlayan (2013) tarafından ifade edilmiştir.

Perakende sektörü de Türk yatırımcıların eskiden beri içinde bulunduğu sektörlerden birisidir. RF perakende pazarı küresel krizden kurtuldukça yeniden büyüme trendine girdi ve bu büyüme 2010 yılında yeniden çift haneli rakamlara ulaştı ve sektörün 2013 yılında 800 milyar \$'lık büyüklüğe ulaşması bekleniyor. Pazardaki en önemli firmalar X5 Perakende Grubu (Pyaterochka, Perekryostok, Karusel markalarının sahibi) Tander ve Fransız Auchan (TC Ekonomi Bakanlığı İhracat Bilgi Platformu ${ }^{\text {, }}$, 2013).

Hizmetlerde belki de RF ve Türkiye arasında en çok adı geçen sektör ise müteahhitlik hizmetleridir. Rusya'daki 500 büyük Türk yatırımcının 150 tanesi müteahhitlik firmasıdır (Türk, 2013). Dünyadaki en büyük 225 uluslararası müteahhit içinde 32 tane ile Çin'den sonra ikinci sırada olan Türk müteahhitlerinin, 2007 ile 2012 yılları arasında 101 ülkede üstlendikleri 7116 projenin \%44'ü Avrasya'dadır. RF ise \%17,1'lik pay ile tüm ülkeler arasında birinci sırada yer almaktadır. Bu süre zarfında 1423 proje ile toplamda 41 milyar \$'a yakın iş gerçekleştirilmiştir. RF, 2012 yılında ise Türk müteahhitler için yaklaşık olarak 3,8 milyar \$ iş hacmi ile Türkmenistan ve Irak'1 takip etmektedir. (Yenigün, 2013; Özilhan, 2013) RF özellikle Libya'daki iç karışıklıklar sonucu işlerin askıya alınmasından sonra Türk müteahhitlerin önde gelen inşaat pazarı haline gelmiştir. RF'da 
inşaat şirketlerine lisans veren Moskova'daki bir ajansın başkanı olan Dracheva Yulia ülkede inşaat alanının 2015 'te 90 milyon metrekareye, 2020 yılında ise 140 milyon metrekareye ve inşaat yatırımlarının da 120 milyar dolara ulaşmasını beklediklerini söylemiştir. Rusya İnşaatçılar Birliği Başkanı Yardımcısı Kischel Konstantin ise Türk firmalarının işlerini şimdiki gibi kaliteli ve zamanında yaptıkları sürece gelecekte işleri ve kazançlarını iki katına çıkarabileceklerini ifade etmiştir (Emlak En Son Haber, 2013). Bunun yanında, TOBB/DEİK Başkanı Rıfat Hisarcıklığlu da Türk müteahhitlik şirketlerine hem 2014 Soçi Kış Olimpiyatları hem de 2018 yılında Rusya'da yapılacak dünya futbol şampiyonasına hazırlıklar kapsamında projelerde daha aktif rol verilmesini RF tarafından istemektedir (Dış Ekonomik İlişkiler Kurulu, 2013) Önümüzdeki yıllarda RF ekonomisindeki gelişime paralel olarak çeşitli uzmanlarca da belirtildiği gibi müteahhitlik hizmetlerine talep artacak ve başta büyük ölçekli işletmeler olmak üzere Türk firmalarının RF'daki yatırımları artabilecektir (Türk, 2013).

İki ülkeyi yakınlaştıran bir başka alan ise turizmdir. Hisarcıklığlu ve Özilhan'ın verdiği bilgilere gore Türkiye'ye yaklaşık 3-3,5 milyon civarı Rus turist gelmekte ve vizelerin kalkması da Rusya'ya yönelik Türk turist sayısında artışa yol açmaktadır. Gelen Rus turistlerin önemli kısmı ise Antalya bölgesini tercih etmektedir (Dış Ekonomik İlişkiler Kurulu, 2013; Özilhan, 2013).

IHRACAT

\begin{tabular}{|c|c|c|c|c|c|c|}
\hline & 1995 & Pay & 2000 & Pay & 2005 Pay & 2010 Pay \\
\hline OCanl' hayvanlar ve gida maddeleri & 202 & 0.16 & 108 & 0.17 & 3660.15 & 9420.20 \\
\hline 1 İçkiler ve tütūn & 20 & 0.02 & 26 & 0.04 & 220.01 & 160.00 \\
\hline 2 Akaryakit hariç yenilmeyen hammadde & 12 & 0.01 & 27 & 0.04 & $40 \quad 0.02$ & 1080.02 \\
\hline 3 Mineral yakitlar, yağlar vb. damitılmasından elde edilen ürünler & 1 & 0.00 & 0.4 & 0.00 & 10.00 & 1340.03 \\
\hline 4 Hayvansal, bitkisel katı ve sıvı yağlar, mumlar & 39 & 0.03 & 3 & 0.00 & 10.00 & 10.00 \\
\hline 5 Başka yerde belirtilmeyen kimya sanayi ve buna bağlı sanayi ürūnleri & 71 & 0.06 & 73 & 0.11 & 2440.10 & 4150.09 \\
\hline 6 Başlıca sınfflara ayrilan işlenmiş mallar & 200 & 0.16 & 113 & 0.18 & 7490.32 & 13110.28 \\
\hline 7 Makine ve ulaştırma araçlan & 129 & 0.10 & 95 & 0.15 & 6040.25 & 10860.23 \\
\hline 8 Çeşitli mamūl eşya & 564 & 0.46 & 198 & 0.31 & 3420.14 & 6090.13 \\
\hline 9 SITC'da sınfflandırılmamış eşyalar & 0.0 & 0.00 & 0.0 & 0.01 & 90.00 & 110.00 \\
\hline \multirow[t]{2}{*}{ TOPLAM } & 1238 & 1.00 & 644 & 3.69 & 23771.00 & 46331.00 \\
\hline & \multicolumn{6}{|c|}{ ITHALAT } \\
\hline 0 Canlı hayvanlar ve gida maddeleri & 9 & 0.00 & 15 & 0.00 & 420.00 & 4820.02 \\
\hline 1 i çkiler ve tütūn & 0.0 & 0.00 & 0.0 & 0.00 & 40.00 & 30.00 \\
\hline 2 Akaryakit hariç yenilmeyen hammadde & 252 & 0.12 & 419 & 0.11 & 12120.09 & 8090.04 \\
\hline 3 Mineral yakitlar, yağlar vb. damıtılmasından elde edilen ürünler & 804 & 0.39 & 2194 & 0.56 & 88020.68 & 159480.74 \\
\hline 4 Hayvansal, bitkisel katı ve sıvı yağlar, mumlar & 2 & 0.00 & 8 & 0.00 & 360.00 & 910.00 \\
\hline 5 Başka yerde belirtilmeyen kimya sanayi ve buna bağlı sanayi ürūnleri & 183 & 0.09 & 182 & 0.05 & $476 \quad 0.04$ & 6780.03 \\
\hline 6 Başııca sınıflara ayrilan işlenmiş mallar & 707 & 0.34 & 999 & 0.26 & $2256 \quad 0.17$ & 34650.16 \\
\hline 7 Makine ve ulaştırma araçlan & 113 & 0.05 & 65 & 0.02 & 640.00 & 630.00 \\
\hline 8 Çeşitli mamūl eşya & 14 & 0.01 & 5 & 0.00 & 50.00 & 550.00 \\
\hline 9 SITC'da sınfflandırılmamış eşyalar & 0.0 & 0.00 & 0 & 0.00 & 90.00 & 00.00 \\
\hline \multirow[t]{3}{*}{ TOPLAM } & 2082 & 1.00 & 3887 & 3.32 & 129061.00 & 215961.00 \\
\hline & \multicolumn{6}{|c|}{ DIŞ TICARET DENGESI } \\
\hline & & 1995 & & 2000 & 2005 & 2010 \\
\hline 0 Canli hayvanlar ve gida maddeleri & & 194 & & 93 & 324 & 460 \\
\hline 1 iç̧kiler ve tütūn & & 20 & & 26 & 19 & 13 \\
\hline 2 Akaryakıt hariç yenilmeyen hammadde & & -239 & & -392 & -1172 & -701 \\
\hline 3 Mineral yakitlar, yağlar vb. damıtılmasından elde edilen ürünler & & -803 & & -2193 & -8801 & -15814 \\
\hline 4 Hayvansal, bitkisel katı ve sivı yağlar, mumlar & & 38 & & -5 & -36 & -90 \\
\hline 5 Bașka yerde belirtilmeyen kimya sanayi ve buna bağlı sanayi ürūnleri & & -112 & & -109 & -232 & -264 \\
\hline 6 Başııca sınıflara ayrılan işlenmiş mallar & & -507 & & -886 & -1507 & -2154 \\
\hline 7 Makine ve ulaştırma araçlan & & 16 & & 31 & 539 & 1023 \\
\hline 8 Çeşitli mamūl eşya & & 550 & & 192 & 338 & 553 \\
\hline 9 SITC'da sınflandırumamış eşyalar & & 0.0 & & 0.0 & 0.0 & 11 \\
\hline TOPLAM & & -844 & & -3243 & -10529 & -16963 \\
\hline
\end{tabular}

Tablo 2: Türkiye - Rusya Arasındaki Dış Ticaretin Ürün Gruplarına Göre Dağılımı (Milyon ABD Doları) Kaynak: www.tuik.gov.tr'den uyarlayan Kalaycı, 2013.

\section{Rusya'da Faaliyet Gösteren Türk Şirketleri}

Rusya'da çeşitli sektörlerde 3 bin dolayında Türk şirketi faaliyet gösteriyor; bunlar arasından 5 milyon \$'ın üstünde yatırımı olan Türk şirketlerinin sayısı 500'ün üstünde ve Türk şirketlerinin Rusya'da yaptığı doğrudan 
yatırım miktarının 8 milyar \$'a ulaştığı tahmin ediliyor. Bunlar içinde sadece 5 milyon \$ üzerinde büyüklüğe sahip Türk yatırımlarının toplamının 6 milyar \$'a yaklaştığı söyleniyor (Özilhan, 2013; Türk, 2013).

Resmi verilere göre ise, 2011 y1lı itibarıyla yurtdışındaki 3 bin 641 Türk şirketinin 265'i Rusya'da bulunuyor ve yurtdı̧̧ındaki Türk şirketi sayısı bakımından Rusya, KKTC (406) ve Almanya'dan (301) sonra dünyada üçüncü sırada geliyor. Ancak rakamların Türk şirketlerinin Rusya'daki gerçek büyüklüğü doğrudan yansıtmadığı söyleniyor. Bu ülkeye yönlendirilmiş yatırımların Hollanda veya vergi cenneti olarak nitelenen başka bir ülke üzerinden yapıldığı iddiası var (Rusya Online Haber ve Yorum Sitesi, 2013).

Ülkede büyük sanayi tesisleri kuran Şişecam grubunun yanı sıra, Anadolu Efes, Ruscam, Enka, Ramenka, Eczacıbaşı, Koç grubu, Zorlu grubu, Adopen, Merinos Halı gibi büyük şirketlerin de doğrudan yatırımları bulunuyor (Özilhan, 2013; Orta Karadeniz Kalkınma Ajans1, 2013). Sadece Şişecam'ın ülkede sürekli artmakta olan 1 milyar \$'a yaklaşan yatırımı, 13 adet büyük fırını ve 3500 kişiden oluşan istihdam hacmi bulunmakta; cam ambalaj gibi bazı ürünlerinde ise üretim kapasitesi Türkiye'nin de üzerine çıkmaktadır (Yaraman, 2013).

Rusya'daki bazı spesifik Türk girişim ve yatırımları ise şunlardır:

2010'da Rusya'da faaliyet gösteren 6 Türk bankası vardı: Yapı Kredi, Moskova, Garanti Bankası, Denizbank, Finansbank ve Ziraat Bankası (İnce vd., 2013; Ilıcak, 2013). Ayrıca, Fiba Grubu Rusya’nın en büyük bankalarından Credit Europe Bank'ı satın aldı (Özilhan, 2013). RF'da giyim alanındaki başarı hikayelerinden birisi de Colin's. Colin's Rusya'da her iki kişiden birine markasını satmayı başarmış. 2011 sonu itibari ile Rusya genelinde 180 mağazası olan Colin's'in hedefi her Rus'a iki Colin's ürünü giydirmek. Şirketin, 2012 yılı hedefleri 200 mağazaya ulaşmak, 1500 kişiye istihdam sağlamak, en az 6,5 milyon adet ürün satarak perakende cirsounu da 225 milyon \$'a çıkarmak (Ön, 2013). RF'da dikkat çeken bir başka şirket ise Efes'dir. Alkollü içecek sektöründe Efes, SABMiller ile gerçekleştireceği işbirliği ile Rusya'da dördüncü sıradan ikinci sıraya yükselmiştir (Rus Türk İşadamları Birliği, 2013).

\section{Rusya ve Dünya Ticaret Örgütü}

RF'nun DTÖ üyeliği, 2001'deki Çin'in üyeliğinden sonraki dünya ticaretindeki en önemli gelişme olarak görülebilir. (Yaraman, 2012). Rusya, DTÖ’ne girmek için ilk olarak 1993 yılında başvuruda bulundu. 1995 yılında çok sayıda ülkenin katılımıyla oluşturulan çalışma grubunun çalışmaları, 22 Ağustos 2012 tarihinde Rusya'nın Örgüte üye olmasıyla sonuçlandı. (Volchkova, 2013; TC Ekonomi Bakanlığı İhracat Bilgi Platformu ${ }^{\mathrm{d}}$, 2013)

Rusya Ekonomik Kalkınma Bakanlığı Ticaret Müzakereleri Bölümü Direktörü ve Rusya’nın DTÖ’ye Katılım Başmüzakerecisi Maxim Medvedkov DTÖ`nün kurallarını uygulamakta kararlı olduklarını söyledi (Türkiye Ekonomi Politikaları Araştırma Vakfi, 2013). Söz konusu üyelik, sadece gümrük vergisi oranlarında düşüş ve pazara giriş kolaylığı değil, çok sayıda yasal düzenlemenin DTÖ ilkeleriyle uyumlu hale getirilmesini de gerektirmektedir. Sadece ticaretin ötesinde tüm iş çevresini etkilemesi söz konusu olan bu değişikliklerden bazıları şunlardır: Dış ticaret düzenlemeleri, anti damping gibi bazı korumacılık araçlarını düzenlemek, rekabetin korunması, ticari sırlar ve teknik düzenlemeler, döviz kurlarıyla ilgili düzenlemeler, fikri mülkiyet hakları ve kamu alımlarıyla ilgili düzenlemeler. Örneğin, 11 hizmet sektöründe yabancı sermaye ve rekabete kademeli olarak kolaylık sağlanmaktadır. DTÖ’nün vergi oranlarındaki etkisine bakılacak olura, ortalama gümrük vergisi oranları 2011 yılında \%10 iken geçiş sürecinde \%7.8'e düşmüştür. Düşüşler geçiş süreci boyunca sürmektedir. Bazı ürünlerde (domuz eti, otomobil gibi) geçiş süresi 7-8 yıla kadar uzamaktadır (Volchkova, 2013; TC Ekonomi Bakanlığı İhracat Bilgi Platformu d, 2013). Rusya Federasyonu'nun Türkiye Ticaret Temsilcisi Tofik Melikov (2013), katılım prosedürleri tamamen uygulandıktan sonraki düşüşleri şöyle ifade etmiştir: "Rusya' ya ithal edilen malların vergi oranı \%3'e düşecek. Sanayi ürünlerinde düşüş \%3, tarım ürünlerinde \%4, otomotiv ve uçak sanayi ürünlerinde ise \%10-15 olacak". Yapılacak olan toplam gümrük indirimin AB ihracatçıları için yıllık 2,5 Milyar Euro tutarında tasarrufa yol açacağı düşünülmektedir. Bununla birlikte, düşürülen vergilerin Rusya'ya yıllık olarak yapılan AB ihracatına fazladan 3,9 Milyar Euro eklemesi beklenmektedir (TC Ekonomi Bakanlığ İhracat Bilgi Platformu ${ }^{\text {d }}$, 2013).

DTÖ üyeliğinin çok sayıda faydası bulunmaktadır. Öncelikle, DTÖ üyesi olmayan bir ülkenin dış ticaret alanında işinin çok zor olduğu açıktır. Hem ciddi tarife ve tarife dışı ticari engellerle karşılaşır hem de yabancı fonlar için daha az cazibe taşır (Yaraman, 2013). RF üyelikle bu zorlukları aşmayı başarmıştır. Faydalara daha yakından bakacak olursak, gerçekleştirilen analizlere göre, Rusya'daki pazarların liberalleşmesi doğrudan diş yatırımları artıracak ve ilgili sektörlerde verimliliği artırıp, maliyet ve fiyatları düşürecek, sonuç olarak tüketicilerin refahını artıracaktır. Yapılacak iyileştirmelerin aynı zamanda diğer ülkelerin ve bu ülkelerdeki şirketlerin de Rusya'ya karşı olumlu bir tavır sergilemesine neden olması beklenmektedir. Standartlar da yükselecek ve diğer etkenlerle birlikte zamanla tüketici refahına olumlu yansıyacaktır. Melikov'a gore RF'nun DTÖ’ye katılımının en büyük avantajı mevzuatın ve idari prosedürlerin şeffaflaşması, dış piyasalarda çalışmaların istikrarı, ticarette bariyerlerin azalması ve Rusya’nın genel ticaret kuralların oluşumuna katılması olacaktır. Rusya'daki sektörlerin DTÖ üyeliğinden nasıl etkileneceğine bakılırsa, demir ve demir dışı metaller, 
kimya endüstrisi, iletişim ve finans sektörleri karlı çıkabilecek; buna karşın gıda, aydınlatma, mühendislik ve inşaat materyalleri üretimi düşebilecektir. (Volchkova, 2013; Melikov, 2013)

Ancak Melikov'a (2013) göre DTÖ herşeyi kısıtlamamaktadır. Örneğin, RF’nun kırmızı ve beyaz et gibi bazı ürünlerin ithalatında kota uygulamaya devam edeceğini söylemektedir.

Sonuç olarak, Rusya DTÖ'ne girmesi sayesinde ekonomik gelişmesini ve etkinlik artışını hızlandıracaktır. Bu süreçte olumsuz etkileri azaltmak için sosyal politika ve önlemler alınması, bunun yanı sıra iş ortamının iyileştirilmesi ve idari engellerin azaltılması faydalı olacaktır. (Volchkova, 2013; Ön, 2013)

RF’nun DTÖ üyeliğinin Türkiye'ye de oldukça faydası olacağı beklenmektedir. Örneğin, DTÖ üyeliği sayesinde, müteahhitlik sektöründe makine, inşaat malzemesi ihracatı kolaylaşacak, maliyetler düşecek ve Türk şirketleri rekabette daha avantajlı hale gelecektir. Bunun yanında gümrük işlemleri daha standart hale gelecek, firmalar düzenlemeleri daha kolay anlayacak, canlanan Rusya Federasyonu ekonomisi firmalara yeni firsatlar sunacaktır (Yenigün, 2013).

\section{Sonuç}

RF ile Türkiye arasında yüzyıllardır süren siyasi ve ekonomik ilişkiler son yıllarda giderek güçlenmiş ve dünyanın coğrafi olarak en büyük ve yatırıma en uygun ülkelerinden birisi olan RF, Türk iş adamları için giderek artan bir öneme sahip olmuştur. Türkiye'nin enerji açısından oldukça dışa bağımlı olması, komşusu RF'nun ise dünyanın önemli enerji ihracatçılarından birisi olması, iki ülke arasındaki dış ticaret açığının 2000li yıllardan itibaren hızla artmasına yol açmıştır. Bununla beraber Rusya'nın büyük bir tüketim toplumu olması ve ihtiyaç duyduğu mal ve hizmetlerin birçoğunda Türkiye'nin rekabet avantajına sahip olması, söz konusu diş ticaret açığını biraz olsun sınırlandırmıştır. Günümüzde 35 milyar \$ dış ticaret hacmine ulaşmış olan iki ülke arasındaki ticari ilişkilerin yakın geçmişine baktığımızda, 1987 yılında başlayan doğal gaz alımı ve 1991 yılında SSCB'nin dağılmasıly başlayan bavul ticaretinin önemli dönüm noktaları olduğu söylenebilir. Zaman içinde ticari ilişkiler farklı alan ve sektörlere yayılmış, siyasi gelişmelerle birbirlerini etkileyerek, iki ülkeyi birbirleri için vazgeçilmez bir hale getirme yolunda ilerlemiştir. Artık Türkiye, Ruslar için önemli bir turistik destinasyon, Rusya ise Türk iş adamları ve müteahhitler için önemli bir hedef pazar haline gelmiştir. İki ülke arasındaki ilişkiler nükleer enerji ve boru hatları gibi devletler arası anlaşmalar ile geleceğe yönelik olarak daha sağlam ve uzun vadeli hale gelmiştir. Türkiye ve RF'nun ekonomilerinin birbirini tamamlaması ve coğrafi yakınlıkları dışında, RF'nun girdiği işbirliği ve entegrasyonlar, özellikle de DTÖ üyeliği ile dış ticaret ve dış yatırımlara daha açık hale gelmesi, iki ülke arasındaki ticari ilişkilerin daha da artmasına yol açabilecektir. DTÖ üyesi RF, gümrük oranlarını belirli süreler içinde düşürerek, korumacılık araçlarını DTÖ ilkeleri çerçevesinde düzenleyerek, rekabet ve fikri mülkiyet hakları gibi konularda yasal düzenlemelerinde değişikliklere gidecek; bu gibi çabaları sayesinde daha rekabete açık, bürokrasinin azaldığı, rahat iş yapılan, çok sayıda sektöründe maliyet ve fiyatların düşüp, rekabetin arttığı, standartların yükseldiği bir ülke haline gelecektir. Bütün bunların sonucunda tüketici refahı, kişibaşı geliri ve gelişmişlik göstergeleri iyileşmiş bir ülke haline gelecektir. Bu süreç boyunca, Türkiye RF ile ticari ilişkilerini daha da artırma imkanı bulacaktır. Birbirlerine yakın durmak, birbirlerinin kaynak ve uzmanlıklarından yararlanmak, her iki ülkenin de gelişiminde hızlandırıcı bir etkide bulunacaktır.

\section{Kaynakça}

- Bektaşoğlu, Songül ve Özbaş Benli, A. Oya, (2013). "Rusya Federasyonu St. Petersburg Perakende Sektörü ve Potansiyel Hızlı Tüketim Maddeleri Yerinde Pazar Araştırnası”, Ülke Masaları -II Dairesi, T.C. Ekonomi Bakanlığı İhracat Genel Müdürlüğü

- Çağlayan, Zafer, 2010. Devlet Bakanı Zafer Çağlayan Rusya ya 500 Bin Ton Beyaz Et İhraç Edilebileceğini Açıkladı, http://www.ibp.gov.tr/haber-goster.cfm?haberkodu=1000063.

- Devlet Planlama Teşkilatı (DPT), 2013. “Karadeniz Ekonomik İşbirliği (KEI)”, http://www2.dpt.gov.tr /dei/kei/kei.htm, 18.06.2013.

- Dış Ekonomik İlişkiler Kurulu (DEIKK), 2013. Rusya ile 100 Milyar Dolarlık Ticaret Hedefine Ulaşmak İçin Ulaştırma ve Bankacılık Altyapısı Geliştirilmeli, http://www.deik.org.tr.

- Dombey, Daniel and Clover, Charles, 2012. Russia and Turkey focus on economic ties, http://www.ft.com/cms/s /0/6ed0bba8-3d7c-11e2-b8b2-00144feabdc0.html\#axzz2WHOgPiI4.

- Emlak En Son Haber, 2012. Türk şirketlerin Rusya'daki inşaat işleri 2 katına çıkabilir, http://emlak.ensonhaber. com/turk-sirketlerin-rusyadaki-insaat-isleri-2-katina-cikabilir-2012-06-09.html.

- Ilıcak, Erman (2012), Türklere pozitif ayrımc1lı yapılıyor. http://www.rtib.com/component/content/ article/42-frontpage/584-erman-ilicak.html.

- İ̀ce, Ezgi, Kızıldaş, Esra, Dalgalan, Gülsen, Yüzbaşıŏlu, Ferit ve Çetinsay, İsmail Oğuz, 2013. Türkiye ve Rusya Dış Ticaret İlişkileri, http://prezi.com/tx0yvcjxfdig/turkiye-ve-rusya-ds-ticaret- 


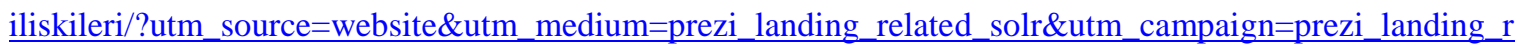
elated author.

- Kalayc1, Cemalettin, (2013), “Rusya Federasyonu ile Ticarette Türkiye'nin Açmazları”, Eskişehir Osmangazi Universitesi IIIBF Dergisi, 8(1), ss. 37-57.

- Kazaklı, Fulya, 2013. Türkiye-Rusya ilişkilerinde en derin dönemi yaşıyoruz, http://www.dunya.com/ turkiye-rusya-iliskilerinde-en-derin-donemi-yasiyoruz-192484h.html.

- Koval, İgor, 2013. Rusya'nın dış ticaret ortakları arasında Türkiye yedinci sırada, http://turkish.ruvr.ru/ 2013_03_21/Rusyanin-dis-ticaret-ortaklari-arasinda-Turkiye-yedinci-sirada

- Melikov, Tofik, 2013. Türk-Rus ticari ilişkilerinde son durum nasıll, http://www.gazete5.com/haber/turkrus-ticari-iliskilerinde-son-durum-nasil-294493.

- Orta Karadeniz Kalkınma Ajans1, 2013. Rusya Ülke Raporu, http://www.oka.org.tr/ContentDownload/Rusya_Ulke_Raporu.pdf.

- Ön, Önder (2012), Rusya'da İki Kişiden Biri Colin's Giyiyor. http://www.rtib.com/explore/492-colinsin buyuk-basarisi-moskova-rusya.html.

- Özbaş Benli, A. Rusya Ülke Raporu, http://www.ibp.gov.tr/pg/section-pg-ulke.cfm?id=Rusya\%20 Federasyonu.

- Özilhan, Elvan ve Göçer, Cihan, 2013. Rusya'nın Dünya Ticaretindeki Yeri ve Türkiye ile İkili Ticari İlişkileri, www.baskent.edu.tr/ sozeri/12.1.ppt

- Özilhan, Tuncay, 2012. Türkiye ve Rusya Birbirine Mecbur. http://www.rtib.com/component/content larticle/42-frontpage/1206-tuerkiye-ve-rusya-birbirine-mecbur.html.

- Rus Türk İşadamları Birliği (RTİB), 2012. Efes Rusya'da zirveye koşuyor!, http://www.rtib.com /component/content/article/42-frontpage/1065-efes-rusyada-zirveye-kouyor.html.

- Rusya Online Haber ve Yorum Sitesi (Rusya.Ru), 2012. Rusya'da 265 Türk şirketi var, http://www.rusya.ru/ Content/17756-Rusya_da+265+T\%C3\%BCrk+\%C5\%9Firketi+var.

- Sabuncu, Orhan, 2013. 25 Türk firması Rusya'da yatırıma hazırlanıyor, http://www.sabah.com.tr/Otomobil/2013/03/18/25-turk-firmasi-rusyada-yatirima-hazirlaniyor.

- TC Ekonomi Bakanlığı İhracat Bilgi Platformu e , 2012. Rusya'nın Petrol Üretimi Arttı, http://www.ibp.gov.tr/pg/section-pg-hab.cfm?haberkodu=1201173

- TC Ekonomi Bakanlığı İhracat Bilgi Platformu a , 2010. Rusya Federasyonu, Beyaz Rusya ve Kazakistan Gümrük Birliği, http://www.ibp.gov.tr/haber-goster.cfm?haberkodu=1000055

- TC Ekonomi Bakanlığı İhracat Bilgi Platformu b, 2011. Rus Perakende Pazarında Büyüme Bekleniyor, http://www.ibp.gov.tr/haber-goster.cfm?haberkodu=1101661, Kaynak: http://www.fructidor.com

- TC Ekonomi Bakanlığı İhracat Bilgi Platformu c , 2012. İnşaat halindeki AVM'ler bakımından Moskova ve St. Petersburg Doğu Avrupa'da lider durumda , http://www.ibp.gov.tr/pg/section-pg-hab.cfm?haberkodu= $\underline{1201173}$

- TC Ekonomi Bakanlığı İhracat Bilgi Platformu ${ }^{d}$, 2012. Rusya Dünya Ticaret Örgütü'nde, http:// www.ibp.gov.tr/haber-goster.cfm?haberkodu=1201024, Kaynak: Avrupa Komisyonu tarafindan hazırlanan EU Trade News adlı haber bülteninden çeviri yapılmıştır.

- TC Ekonomi Bakanlığı İhracat Bilgi Platformu f , 2013. Rusya Federasyonu 2012 Yılı Dış Ticaret Göstergeleri, http://www.ibp.gov.tr/pg/section-pg-hab.cfm?haberkodu=1300053

- TC Ekonomi Bakanlığı İhracat Bilgi Platformu ${ }^{g}, 2013$. Rusya'da Otomobil Satışları 2012 Yılında Rekor Seviyeye Ulaştı, http://www.ibp.gov.tr/pg/section-pg-hab.cfm?haberkodu=1201247

- Türk, Eylem, 2007. 500 firma yatırım yaptı aşçı giden patron oldu, http://www.milliyet.com.tr/2007/09/07 lekonomi/aeko.html eylül.

- Volchkova, Natalya, 2013. An Assessment of the Implications of Russia's Entry into the WTO., Rusya Federasyonu'nun DTÖ Üyeliği: Türkiye-Rusya Ticari ve Ekonomik İlişkilerine Etkileri Uluslararası Konferans1, 11 Haziran, www.tepav.org.tr.

- Yaraman, Alev, 2012. Rusya'nın DTÖ Üyeliğinin Türk-Rus Ticari İlişkilerine Olası Etkileri. TEPAV Rusya Merkezi, Rusya Federasyonu’nun DTÖ Üyeliği: Türkiye-Rusya Ticari ve Ekonomik İlişkilerine Etkileri, Uluslararası Konferans, 1 Haziran, www.tepav.org.tr.

- Yenigün, Mithat, 2013. İnşaat Sektörünün Yurt D1şı Açılımı ve Rusya’da Türk Müteahhitleri, Rusya Federasyonun DTÖ Üyeliği: Türkiye-Rusya Ticari ve Ekonomik İlişkilerine Etkileri Uluslararası Konferans1, 1 Haziran, www.tepav.org.tr. 


\title{
Türkiye - Karadeniz Ekonomik İşbirliği Örgütü: 1996-2012 Dönemi Dış Ticaret İlişkileri
}

\section{Turkey - Black Sea Economic Cooperation Organization: Foreign Trade Relations during the 1996-2012 Period}

\author{
Ph.D. Candidate Cemal Ardıl (Istanbul Aydın University, Turkey)
}

\begin{abstract}
This paper presents the regional economic relations between Turkey and Black See Economic Cooperation Organization (BSEC). The Heads of State and Government of eleven countries: Albania, Armenia, Azerbaijan, Bulgaria, Georgia, Greece, Moldova, Romania, Russia, Turkey and Ukraine signed the Summit Declaration and the Bosphorus Statement giving birth to the Black Sea Economic Cooperation on 25 June 1992, in Istanbul. On 5 June 1998, the Heads of State or Government signed the BSEC Charter, came into force on 1 May 1999 BSEC has evolved into an international regional organization for economic cooperation. The organization has 12 members since Serbia joining the organization in 2004. It came into existence as a unique and promising model of multilateral political and economic initiative aimed at fostering interaction and harmony among the Member States, as well as to ensure peace, stability and prosperity encouraging friendly and good-neighbourly relations in the Black Sea region. Countries bordering the Black Sea, Balkan and Caucasus formed the BSEC countries cover an area of approximately 20 million square kilometer and represent more than 350 million people. The region with the foreign trade volume of U.S. \$ 300 billion per year draws attention to the rich natural resources; and is the main European energy and transport corridor transfer. The Black Sea region is a contested neighbourhood and the subject of intense debates and conflicts in the globe. Also, this reflects the changing dynamics of the Black Sea region, its complex realities, the interests of outsiders and the region's relations with the rest of the globe. Moreover, its strategic position, linking north to south and east to west, as well as its oil, gas, transport and trade routes are all important reasons for its increasing relevance. Turkey's foreign trade volume with BSEC member countries is steadily increasing as per the findings over the period of 1996-2012.
\end{abstract}

\section{Giriș}

Günümüzde ülkeler hızlı küresel rekabet karşısında uluslararası ilişkilerinde örgütlenerek siyasi ve ekonomik yararlar kazanmak istemektedirler. Ülkeler, bu uluslaralarası ilişkilerin uzun vadeli çıkarları arasında ortak refah, ortak barış ve ortak istikrar düşünceleri ekseninde birlikte kalkınmayı hedeflemektedirler.

Yüzyıllardan beri Karadeniz bölgesi, çeşitli uygarlıkların beşiği olmuş, Asya ile Avrupa arasında değişik uluslar, kültürler ve dinlerden gelen insanların birbirleriyle kaynaştığı Doğu ve Güney Doğu Avrupa coğrafyasıdır (Kalaycı, 1993). Karadeniz bölgesinde, bugünkü kültürel, sosyal ve siyasi ekonomik işbirliği dönemine ulaşmak hiçbir zaman kolay bir süreç olmamış, barış ve huzur dönemlerini uzun çatışma ve savaşlar izlemiştir. Bu ortamda bile, İstanbul ve Çanakkale boğazları sayesinde Marmara, Ege ve Akdeniz bölgelerine açılan Karadeniz, gelişmiş siyasi ve ekonomik ilişkileri ve bağlantılarıyla büyük önem kazanmıştır (Karaman, 2009).

Bölgedeki ülkeler arasında barıș ve huzur köprülerinin kurulmasında Avrupa ve Asya'yı birleștiren meşhur İpek Yolu'nun büyük bir etkisi olmuştur. İpek Yolu sayesinde iki kıtanın halkları arasında ilişki kurulması, farklı kültürlerin yanyana yaşaması ve karşılıklı olarak zenginleşmesi şeklinde çok değerli deneyimler kazanılmıştır.

Doğal hammadde ve enerji kaynakları yönünden çok zengin olan eski Sovyetler Birliği'nde savunma ve uzay sanayii gibi alanlara yatırım yapılmış, buna karşılık başta tüketim malları olmak üzere insana yönelik yatırımlar ihmal edilirken Türkiye de eski Sovyetler Birliği'nin çok fazla ihtiyaç duyduğu ve Batı ülkelerinde pazarlamada güçlük çekebileceği gıda ve tüketim mallarına sahip bulunmaktadır. Sanayileşmede önemli bir aşama kaydeden ve yeni bir atılıma hazırlanan Türkiye yanıbaşındaki bu doğal hammadde ve enerji kaynaklarına, eski Sovyetler Birliği ise gıda ve tüketim mallarına ihtiyaç duymaktadır (Şengül, 2009).

Üstelik Sovyetler Birliği'nde birçok Türk Cumhuriyeti'nin bulunması, ilişkilerin geliştirilmesine imkan sunmuştur.

Değinilen tüm bu gelişmeler, Türkiye ile Karadeniz'e kıyısı olan ülkeler arasında ekonomik işbirliği ve bölgesel bütünleşme girişimi için uygun bir ortam oluşturmuştur. Karadeniz Ekonomik İşbirliği (KEİ) fikri böyle bir ortamda ortaya atılmıștır (Gökalp, 1993).

KEİ, dünyada küreselleşme ve bölgesel düzeyde uluslararası bütünleşme yönünde, siyasal ve ekonomik alanda yeniden yapılanma sürecinin bir ürünüdür (Erol, 2006). Doğu ve Güney Doğu Avrupa'da, ekonomik boyutta serbest piyasa ekonomisine ve siyasal boyutta çoğulcu demokrasiye geçiş sürecinin yarattığ ortamda, konumunu ve zamanlamasını bulan KEİ fikri, öncülüğ̈nnü Türkiye'nin yaptığı bir bölgesel ekonomik işbirliği girişimidir. 
Karadeniz Ekonomik İşbirliği Örğütü, 1980'li yılların sonunda Doğu Avrupa Ülkeleri ve Sovyetler Birliği'ndeki "Perestroika" (yeniden yapılanma) ve "Glasnost" (açıklık) değişim sürecinin hızlandığı bir dönemde doğmuştur (Kolos, 2012).

Başlangıçta KEİ'nin amacının Karadeniz'e kıyısı olan ülkeler arasında aşamalı olarak bir "serbest ticaret bölgesi" kurulması olduğu belirtilmiş, ancak daha sonra yapılan toplantılarda bu girişimin "ekonomik işbirliği" çerçevesinde değerlendirilmesi gerektiği belirtilmiştir. KEİ, üyesi ülkelerin potansiyellerinden, coğrafi yakınlıklarından ve ekonomilerinin birbirlerini tamamlayıcı özelliklerinden yararlanarak aralarındaki ikili ve çok taraflı ekonomik, teknolojik ve sosyal ilişkileri çeşitlendirmeleri ve daha da geliştirmeleri, böylelikle Karadeniz havzasının bir barış, istikrar ve refah bölgesi olması amaçlamaktadır. Bu amaca ulaşmak için seçilen araç ise ekonomik işbirliğidir.

KEİ'nin kuruluş sürecini başlatan ülkeler Karadeniz'e kıyısı olan Türkiye, eski Sovyetler Birliği, Romanya ve Bulgaristan'dır. Sovyetler Birliği'nin dağılması üzerine, Bağımsız Devletler Topluluğu olarak Rusya Federasyonu, Ukrayna, Azerbaycan, Moldova, Gürcistan ve Ermenistan kurucu üye sıfatıyla katılmışlardır. Daha sonra Karadeniz'de kıyısı olmayan Yunanistan ve Arnavutluk kurucu üye olarak katılmışıtır.

İşbirliğine ilişkin ilk somut toplantı Türkiye'nin evsahipliğinde 19 Aralık 1990'da Ankara'da yapılmıştır. Toplantıda, Azerbaycan, Gürcistan, Moldova ve Ermenistan temsilcilerinin de dâhil olduğu eski Sovyetler Birliği heyeti ile Romanya ve Bulgaristan temsilcileri yer almışlardır. Toplantı sonucunda işbirliğinin temel prensipleri üzerinde uzlaşıya varılmış, "Karadeniz Ekonomik İşbirliği"nin kurulması hususunda anlaşma sağlandığı resmen açıklanmıştır. 12-13 Mart 1991 tarihlerinde Bükreş'te, 23-24 Nisan 1991 tarihlerinde Sofya'da uzman düzeyinde toplantılar yapılmıştır. Bu toplantılarda KEİ'nin amaçları ve ilkeleri üzerinde ortak bir anlaşmaya varılmıştır. 3 Şubat 1992 tarihinde Türkiye'nin ev sahipliğinde gerçekleştirilen toplantıda, Türkiye, Rusya Federasyonu, Romanya, Azerbaycan, Ermenistan, Gürcistan, Moldova, Ukrayna ve Bulgaristan KEİ ile ilgili temel belgeyi parafe etmişlerdir. Anılan belge, 25 Haziran 1992 tarihinde İstanbul'da düzenlenen ve yukarıda ismi geçen dokuz üye ülkenin yanı sıra, Yunanistan ile Arnavutluk'un da kurucu üye olarak katıldığı Zirve toplantısında on bir ülkenin devlet veya hükümet başkanları tarafından imzalanarak, "İstanbul Zirvesi Bildirisi" adı altında resmen işlerlik kazanmıştır.

Yalta'da 5 Haziran 1998 tarihinde Devlet veya Hükümet Başkanları tarafından imzalanan KEİ Şartı'nın 1 Mayıs 1999 tarihi itibarıyla yürürlüğe girmesiyle KEİ uluslararası bölgesel bir ekonomik işbirliği örgütüne dönüşmüş̧ür. 2004 yılında Sırbistan'ın da katılmasından bu yana örgütün 12 üyesi bulunmaktadır.

KEİ, bundan böyle hükümetler boyutunun yanı sıra, parlamenterler, özel sektörler, belediyeler ve hatta hükümet dışı kuruluşlar boyutuyla; çalışma organları, usulleri ve yöntemleriyle; bankası, İstatistik Veri ve Ekonomik Bilgi Değişimi Koordinasyon Merkezi'yle somut projeleri sonuçlandırabilecek temel öğelere sahip olmuş bulunmaktadır (Dışişleri Bakanlığı, 2013).

KEİ Şartı'nın hukuki hükümleri kapsamında, anlaşmazlıkların halli için başvurulacak merci açık olarak belirtilmiştir. Bu hukuki hükümlere göre, iki veya daha fazla üye devlet arasında KEİ Şartı'nın yorumlanması veya uygulanmasıyla ilgili bir anlaşmazlığın olması halinde taraflar istişarede bulunacaklar ve gerekirse anlaşmazlığın incelenmesi ve sonuçlandırılması için Dışişleri Bakanları Konseyi'ne sunacaklardır.

\section{Türkiye'nin Karadeniz Ekonomik İşbirliği Örgütü ile İlişkileri}

Coğrafi konumunun kendisine verdiği esşiz stratejik üstünlüklere sahip olan Türkiye, Türklerin 1354 yılında Anadolu' dan (Asya) Çanakkale Boğazı'nı Gelibolu (Avrupa) üzerinden Balkan yarımadasına geçerek 1361 yılında Edirne'yi ve 1453 yılında İstanbul'u fethettikleri tarihten itibaren, askeri, sosyal, kültürel, siyasi ve ekonomik gelişmesini Batıya yönelerek sağlamakta ve 1959 yılından bu yana da sabırla ucu açık müzakereler kapsamında Avrupa Birliği (AB) ile bütünleşme sürecini tamamlayarak tam üyesi olmaya çalışmaktadır. Türkiye koşut siyasi ve ekonomik ilişkilerini çeşitlendirmeye yönelik arayışlar sürecinde, AB'nin yanısıra diğer uluslararası ve bölgesel bütünleşme hareketlerine aktif üye veya gözlemci olarak katılmaktadır.

Türkiye, Rusya Federasyonu, Romanya, Azerbaycan, Ermenistan, Gürcistan, Moldova, Ukrayna ve Bulgaristan tarafindan 1992 yılında Karadeniz Ekonomik İşbirliği olarak kurulan ve daha sonra Yunanistan, ve Arvavutluk'un katılımıyla 1998 yılında Karadeniz Ekonomik İşbirliği Örgütü (Black See Economic Cooperation Organization, BSEC) adını alan ve Sırbistan'ın da üye olmasıyla 19.240.267 km² yüzölçümüyle (Dünya yüzölçümünün (148.940.000 $\mathrm{km}^{2}$ kara) \%13’ ü;) zengin doğal kaynaklara (uranyum, petrol, altın, doğalgaz, vb.) ve 350.000 milyon nüfusuyla dünya nüfusunun yaklaşık yirmide birine sahiptir (Black See Economic Cooperation Organization, 2013).

Türkiye'nin öncelikli stratejik bölgelerinden olan Kafkaslar ve Balkanlar arasında bir köprü niteliği taşıyan Karadeniz Bölgesi, tarihten günümüze kadar çevre ülkeler için sürekli olarak yüksek önem taşımaktadır. Zengin doğal hammadde ve enerji kaynaklarına sahip bulunmasıyla birlikte Avrupa, Kafkasya, Asya Ulaşım Koridoru (TRACECA,Transport Corridor Europe-Caucasus-Asia) olması nedeniyle, Karadeniz Bölgesi'ne duyulan uluslararası ilgi günümüzde de sürekli artmaktadır. 
Türkiye, Karadeniz Havzasındaki işbirliği olanaklarının değerlendirildiğinde bölgenin en kapsayıcı ve tam teşekküllü ekonomik örgütü olan KEİ'nin kuruluşunda önemli rol almış olup, o zamandan beri faaliyetlerine aktif katılım sağlamakta ve Sekretarya’sına ev sahipliği yapmaktadır. Ayrıca, uluslararası toplumun Karadeniz'e artan ilgisinden yararlanarak, KEİ çerçevesinde somut işbirliği projelerinin hayata geçirilmesi için çalışmakta ve Örgüt'ün etkinliğinin daha da arttırılması için yoğun çaba sarfetmektedir.

Bölgede ekonomik işbirliğini tesis etme amacı güden KEİ'nin temel özelliklerinden birisi, işbirliğine ve diş dünyaya açık yapısıdır. Avusturya, Hırvatistan, Çek Cumhuriyeti, Mısır, Fransa, Almanya, Belarus, İsrail, İtalya, Polonya, Slovakya, Tunus, ABD, AB Komisyonu, Karadeniz Komisyonu, Uluslararası Karadeniz Kulübü ve Enerji Şartı Sekretaryası, KEİ toplantılarında gözlemci olarak bulunmaktadırlar. Macaristan, İngiltere, İran, Karadağ, Ürdün, Japonya, Kore ve Slovenya ise Sektörel Diyalog Ortağı Statüsünde toplantılara katılmaktadırlar.

KEI'nin tek karar organı, yılda iki defa toplanan ve oydaşma ile karar alan Dışişleri Bakanları Konseyi'dir. Üye ülkelerin Dışişleri Bakanlarını temsil eden ve onlar adına hareket eden Yüksek Düzeyli Memurlar Komitesinin ise temel görevi Konseyin aldığı karar ve tavsiyelerin uygulanmasını sağlamak ve Konseye tavsiyelerde bulunmaktır.

KEİ bünyesinde; ticaret ve ekonomi, ulaştırma, enerji, haberleşme, bilim ve teknoloji başta olmak üzere çeşitli konularla ilgili 18 adet çalışma grubu yardımcı organ olarak faaliyet göstermektedir. Dışişleri Bakanları Konseyi'nin kararı ile kurulan ve KEİ çerçevesinde gelişen işbirliğinin temelini oluşturan Çalışma Grupları, Konseye faaliyetleri hakkında raporlar sunmakta ve tavsiyelerde bulunabilmektedirler. Bir projenin, anlaşmanın veya herhangi bir işbirliği girişiminin ilk etapta tartışıldığı organ olan Çalışma Grupları uzmanlar düzeyinde toplanmaktadır. Çalışma grubu faaliyetlerine etkinlik ve ivme kazandırılmasını teminen her üye ülke belirli alanlarda iki yıllık dönemler halinde "koordinatör ülke" görevini üstlenmektedir. Koordinatör ülke bir eylem planı hazırlayarak sözkonusu alandaki işbirliğinin önceliklerini belirlemek ve koordinatörlüğü boyunca en az iki toplantı düzenlemekle yükümlüdür. Türkiye halen Gümrük Çalışma Grubu, Çevre Koruma Çalışma Grubu, Kurumsal Yapılanma ve İyi Yönetişim Çalışma Grubu, KOBİ Çalışma Grubu ile Bilim ve Teknoloji Çalışma Grubu'nun koordinatörlüğünü yürütmektedir.

KEİnin, Karadeniz Ekonomik İş Birliği Parlamenter Asamblesi (KEİPA), İş Konseyi, Ticaret ve Kalkınma Bankası ve Karadeniz Etütleri Uluslararası Merkezi olmak üzere dört bağlı kuruluşu mevcuttur. Sözkonusu kuruluşların yönetimlerinde Türkiye'nin temsilcileri bulunmaktadır.

Son yıllarda KEİ çerçevesinde gerçekleştirilen işbirliği yeni boyutlar kazanmaya başlamıştır. KEİ faaliyet alanlarında kamu kurumları ve özel sektör tarafından geliştirilecek projelerin ön-fizibilite çalışmalarının finansmanı amacıyla oluşturulan bir Proje Geliştirme Fonu (Project Development Fund-PDF) bulunmaktadır. 2002 yılında kurulan bu Fonun amacı bölgesel işbirliğini olumlu etkileyecek, bölgeye yararlı olabilecek fikirleri destekleyerek projenin oluşturulmasına katkıda bulunmaktır.

PDF kurallarına göre bir proje başvurusu için en az üç KEİ ülkesinden birer proje ortağı bulunması gerekmekte ve bir projeye en fazla 30.000 Euro fon sağlanabilmektedir. Projenin süresi genelde 12 ayla sınırlı tutulmakta olup, KEİye üye olmayan ülkelerden de katılım desteklenmektedir; fakat bu ortakların kendi aktivitelerini finanse etmeleri gerekmektedir. Projeleri değerlendirmek ve bu yöndeki çalışmaları yönlendirmek amacıyla üye ülke temsilcilerinden oluşan bir Yönlendirme Komitesi kurulmuştur.

Ulaştırma konusu, KEİ kapsamında önemli bir işbirliği başlığını oluşturmaktadır. Bu bağlamda KEİ ülkeleri arasında etkin bir ulaşım ağı oluşturmak suretiyle ekonomik işbirliğinin gelişimine katkıda bulunmayı amaçlayan "Karadeniz Çevre Ulaştırma Koridoru/Black Sea Ring Corridor" projesi önem taşımaktadır. Proje, üye ülkeleri birbirine bağlayan ulaştırma altyapısının geliştirilmesi, bu konudaki ulusal düzenlemelerin uyumlaştırılması, çevrenin korunması, uluslararası projelerin izlenmesi için bir veri tabanı oluşturularak bir harita hazırlanmasını amaçlamaktadır. Bu çerçevede, 19 Nisan 2007 tarihinde Belgrad'da yapılan KEİ Dışişleri Bakanları Konseyi 16. Toplantısı'nda "Karadeniz Çevre Otoyolunun Eşgüdümlü Olarak Geliştirilmesine Dair Mutabakat Zaptı (Memorandum of Understanding for the Coordinated Development of the Black Sea Ring Highway) - MoU" imzalanmış ve 1 Kasım 2008'de yürürlüğe girmiştir.

Sözkonusu Mutabakat Zaptı uyarınca, “KEİ Çevre Otoyolu Ortak Daimi Teknik Sekretaryası” Selanik’te faaliyete geçmiştir. Bununla, bölgedeki karayolu altyapısının ve Karadeniz'de kombine ve çok modlu taşımacılığın geliştirilmesi amaçlanmaktadır.

Buna ilaveten, Karadeniz'de deniz ulaşımından gereğince istifadeyle, karayolu ve demiryolu ağları üzerindeki yükün hafifletilmesi ve daha etkin bir ulaştırma modeline yönelinmesi amacıyla, "KEİ Bölgesinde Deniz Otoyollarının Geliştirilmesi Anlayış Muhtırası (Memorandum of Understanding on the Development of the Motorways of the Sea at the BSEC Region)", 19 Nisan 2007 tarihinde Belgrad'da yapılan KEİ Dışişleri Bakanları Konseyi 16. toplantısında imzalanmış, 1 Aralık 2008'de yürürlüğe girmiştir.

Karadeniz Ekonomik İşbirliği Örgütü (KEİ) Deniz Otoyolları Geçici Çalışma Grubu'nun son toplantısı, KEİ Dönem Başkanı Rusya'nın ev sahipliğinde, 6-7 Ekim 2011 tarihlerinde, Novorossisk'de düzenlenmiş, toplantıda KEİ Deniz Otoyollarının Geliştirilmesi Ortak Daimi Teknik Sekretaryasına hangi ülkenin ev sahipliği yapacağı 
konusu ele alınmış, ancak tarafların ikili danışma talepleri nedeniyle bir sonraki toplantıda ele alınmak üzere ertelenmiştir. Türkiye de (Ulaştırma Bakanlığı) sözkonusu Sekretarya'ya ev sahipliği yapmak üzere talip olmuştur.

KEİ Bölgesi’nde Karayolu Eşya Taşımacılı̆̆ı'nın Kolaylaştırılmasına Yönelik Anlayış Muhtırası 20 Temmuz 2006 tarihinde yürürlüğe girmiştir. Sözkonusu Anlayış Muhtırası, KEİ üyesi ülkeler arasında uluslararası karayolu taşımacılığında aşamalı bir serbestleştirmeyi öngörmekte ve buna yönelik olarak ülkelerin somut adımlar atmasını salık vermektedir. Bu hedef doğrultusunda Türkiye'nin öncülügünde başlatılan girişimler çerçevesinde, eşya taşımacılığında kullanılan ticari araçların bir gidiş-dönüş seferinin arzu eden KEİ ülkeleri arasında transit olarak yapılabilmesine izin veren KEİ Geçiş Belgesi oluşturulup deneme amaçlı olarak 1 yıl süreyle uygulanmıştır. Sözkonusu uygulamaya Türkiye, Arnavutluk, Ermenistan, Gürcistan, Moldova, Romanya ve Sirbistan tarafindan destek verilmektedir.

Bölge ülkeleri arasındaki ulaştırma ve ticaret alanında işbirliğini amaçlayan bir alan da KEI üyesi ülkelerin profesyonel sürücülerinin ve işadamlarının vize işlemlerinin kolaylaştırılması anlaşmalarıdır. "KEİ üyesi ülkelerin işadamları için vize işlemlerinin kolaylaştırılması anlaşması" ile "KEİ üyesi ülkelerin profesyonel sürücüleri için vize işlemlerinin kolaylaştırılması anlaşması” Tiran’da, 23 Ekim 2008 tarihinde düzenlenen 19. KEİ Dışişleri Bakanları Konseyi Toplantısında ele alınmış, Türkiye'nin yanı sıra Arnavutluk, Ermenistan ve Moldova tarafindan da imzalanmıştır.

Türkiye, KEİ ile AB arasında gelişmekte olan ilişkileri ve her iki örgüt arasında kurumsal işbirliği tesis edilmesini desteklemektedir. AB Komisyonu 2007 Haziran ayından bu yana KEİ nezdinde gözlemcilik statüsüne sahiptir. AB'nin Karadeniz Sinerjisi'ne görünürlük ve uyum kazandırmayı hedeflediği ilk üst düzey siyasi etkinlik 14 Şubat 2008 tarihinde Ukrayna'nın KEİ Dönem Başkanlığı sırasında, Kiev’de “Karadeniz Bölgesi Ülkeleri ve AB Dışişleri Bakanları Toplantısı” başlığı altında gerçekleştirilmiştir. Sözkonusu toplantıya esas itibariyle KEİ ve AB Dışişleri Bakanları katılmıştır. Toplantı, KEİ ile AB arasında Bakan düzeyinde yapılan ilk toplantı olması bakımından önem taşımıştır. Kiev'de yapılan toplantı sonunda, "Geniş Karadeniz Bölgesi Ülkeleri ve AB Dışişleri Bakanları Toplantısı Ortak Açıklaması” yayınlanmıştır. AB ile tamamı KEİ üyesi olan Geniş Karadeniz Bölgesi ülkeleri arasında ulaştırma, enerji, örgütlü suçla mücadele ve ticaret gibi alanlarda proje bazında işbirliği geliştirilmesine yönelik siyasi irade sergilenmiş ve sözkonusu alanlarda işbirliğinin temeli atılmıştır (TC Dışişleri Bakanlığı, 2013).

Türkiye, KEİ başkanlığını 15 Aralık 2012 de Ukrayna'ya devretmiş, böylece Ukrayna'nın 1 Ocak'tan 30 Haziran 2013'e kadar sürecek olan Karadeniz Ekonomik İşbirliği Örgütü dönem başkanlığı resmen başlamıştır. Eşzamanlı olarak Ukrayna, 2013 yılında Avrupa Güvenlik ve İşbirliği Teşkilatı (AGİT) dönem başkanlığını da yapacaktır. Ukrayna yönetimi, AGİT başkanlığı süresinde insan ticaretine karşı mücadele vaadinde bulunmuştur.

\begin{tabular}{|l|l|l|l|l|}
\hline Siralama & Ülke & $2011($ Milyar \$) & Ülke & $2012($ Milyar \$) \\
\hline 1 & ABD & $15.075,5$ & ABD & $15.684,8$ \\
\hline 2 & Çin & $7.322,0$ & Çin & $8.227,0$ \\
\hline 3 & Japonya & $5.897,0$ & Japonya & $5.964,0$ \\
\hline 4 & Almanya & $3.607,4$ & Almanya & $3.400,6$ \\
\hline 5 & Fransa & $2.778,1$ & Fransa & $2.608,7$ \\
\hline 6 & Brezilya & $2.492,9$ & İngiltere & $2.440,5$ \\
\hline 7 & İngiltere & 2.431 .5 & Brezilya & $2.396,0$ \\
\hline 8 & İtalya & $2.196,3$ & Rusya & $2.022,0$ \\
\hline 9 & Rusya & $1.899,1$ & İtalya & $2.014,1$ \\
\hline 10 & Hindistan & $1.838,2$ & Hindistan & 1.824 .8 \\
\hline 11 & Kanada & $1.781,1$ & Kanada & $1.819,1$ \\
\hline 12 & Avustralya & $1.490,5$ & Avustralya & $1.541,8$ \\
\hline 13 & İspanya & $1.479,6$ & İspanya & $1.352,1$ \\
\hline 14 & Meksika & $1.158,3$ & Meksika & $1.177,1$ \\
\hline 15 & G. Kore & $1.116,2$ & G. Kore & $1.155,9$ \\
\hline 16 & Endonezya & 837,6 & Endonezya & 878,2 \\
\hline 17 & Hollanda & 837,6 & Türkiye & 786,3 \\
\hline 18 & Türkiye & 774,0 & Hollanda & 773,1 \\
\hline 19 & S.Arabistan & 669,5 & S.Arabistan & 727,3 \\
\hline 20 & İsviçre & 660,8 & İsviçre & 632,4 \\
\hline
\end{tabular}

Tablo 1. En büyük 20 küresel ekonomi. (Cari fiyatlarla GSYH; Milyar \$; Kaynak IMF ve TÜIK) 


\section{Türkiye’nin Karadeniz Ekonomik İşbirliği Örgütü ile Dış Ticaret İlişkileri}

\subsection{Türkiye'nin Dıș Ticaret İlișkileri}

Küresel pazarda birçok sektörde önde gelen üretici ve ihracatçı ülkeler arasına girmeyi başaran Türkiye, Avrupa'nın 6. büyük ekonomisi olmayı başarmıştır (Avrupa Birliği Bakanlığı, 2013). Türkiye, 2012 yılında cari fiyatlarla 786.3 milyar dolarlık GSYH'si ile dünya sıralamasında 17. olmuştur. 2012 yılında milli geliri hızla küçülen Hollanda'nın bir basamak düşerek 18'inciliğe inmesi, Türkiye'yi bir basamak yukarı çıkartmıştır.

2012 IMF verilerine bakıldığında GSYH büyüklüğü baz alındığında ilk 20 küresel ekonomi sıralamasında Türkiye ve Hollanda dışındaki ülkelerin sıralamasında değişiklik olmamıştır (Tablo 1). 2012'deki bir basamaklık yükselişle Türkiye, 2023 hedefine biraz daha yaklaşmıştır. Türkiye, Cumhuriyetin Kuruluşu' nun (29 Ekim 1923) 100 'üncü yılı olan 2023'te gayri safi yurt içi hasılasını (GSYH) 2 trilyon 64 milyar dolara çıkararak en büyük ilk 10 küresel ekonomi arasına girmeyi, kişi başına düşen milli gelirini de 25 bin 76 dolara çıkarmayı hedeflemektedir.

\subsection{Türkiye- KEİ Dış Ticaret İlişskileri}

KEI'in AB, EFTA'ya göre sadece ekonomik işbirliği özelliği taşıması, KEI'ye üye ülkelerin ekonomik düzeyleri arasındaki farklılık, üye ülkeler arasında ticaret hacminin genişlemesinde başlıca olumsuz etmen olduğu görülmektedir (Gençler, 1994). Türkiye açısından KEİ sürecinin en önemli amacı dış ticaret ilişkilerinin geliştirilmesidir. Bölgelerarası ticaretin arttırılması ve dış ticarette engellerin kaldırılması KEİ'nin öncelikli hedefleri arasındadır. Bölgesel dış ticaretin geliştirilmesinin yanı sıra, doğrudan dış yatırımlar ve teknoloji transferi de üye ülkelerde ekonomik gelişmeyi hızlandıran etkenler olarak KEİ'nin eylem alanı içinde yer almaktadır. Sınır ve kıyı ticareti, ticaretin serbestleştirilmesi, KOBİ'lerin teşviki, malların ve kişilerin sınır ötesi hareketlerinin kolaylaştırılması, iş seyahatlerinde vize kurallarının yumuşatılması halen üzerinde çalışılmakta olan konular olarak KEİ gündeminde bulunmaktadır (TC Ekonomi Bakanlığı, 2013).

Türkiye'nin KEİ ülkeleri ile olan diş ticareti incelendiğinde, 1991 yılına kadar Sovyet Sosyalist Cumhuriyetler Birliği (SSCB), 1991 yılında SSCB'nin dağılmasından sonra Rusya Federasyonu dışında, diğer KEİ ülkeleri ile gerçekleşen dış ticareti oldukça düşük olduğu görülürken, KEİ süreciyle birlikte Türkiye açısından büyük bir pazar potansiyeline sahip bu ülkeler ile zamanla diş ticaret ilişkilerinin yoğunluğunun arttığı, diş ticaret hacminin de genişlediği görülmektedir.

Tablo 2 ve 3' deki verilerin analizinden Türkiye'nin 1996-2012 döneminde KEİ ülkelerine yaptı̆̆ toplam ihracat değeri sürekli olarak artmıştır. Bununla birlikte, 1996 yılında Türkiye'den bu ülkelere yapılan toplam ihracat değeri \$ 2.926.481.835 milyar dolar iken, toplam ihracattaki payı yüzde 12.6' dır, 2012 yılında toplam ihracat \$ 18.789.983.573 milyar dolar olarak gerçekleşmiş olup, Türkiye'nin toplam ihracat içindeki payı yüzde 12,3'tür. 1996 yılında Türkiye'nin bu ülkelerden yapmış olduğu toplam ithalatı \$ 3.896.559.666 milyar dolar iken, toplam ithalattaki payı yüzde 8,9 dur, 2012 yılında toplam ithalatı \$ 41.509.682.946 milyar dolar olarak gerçekleşmiş olup, toplam ithalattaki payı 17,5'tir. 2008 küresel ekonomik krizi, 2008 yılının son aylarında ortaya çıkan ve dünyanın birçok ülkelerini olumsuz yönde etkileyen ekonomik gelişmelerdir. 1929 Dünya Ekonomik Bunalımıyla kıyaslanan bu kriz özellikle Eylül ayında gözle görülür hale gelmiştir. Tablo 2 ve 3 ile Şekil 1 ve 2 birlikte incelendiğinde, Türkiye'nin diş ticareti 1996'dan beri sürekli olarak artarken, 2008 krizi nedeniyle 2009 yılında önemli miktarda düşüş kaydetmekle beraber 2012 yılındaki dış ticaret performansı olumlu bir gelişme trendine işaret etmektedir.

Türkiye'nin KEİ ülkeleri ile olan 1996-2012 dönemi dış ticareti aşağıdaki Şekil 1 ve 2 ile Tablo 2 ve 3'de verilmiştir (TC Türkiye İstatistik Kurumu, 2013).

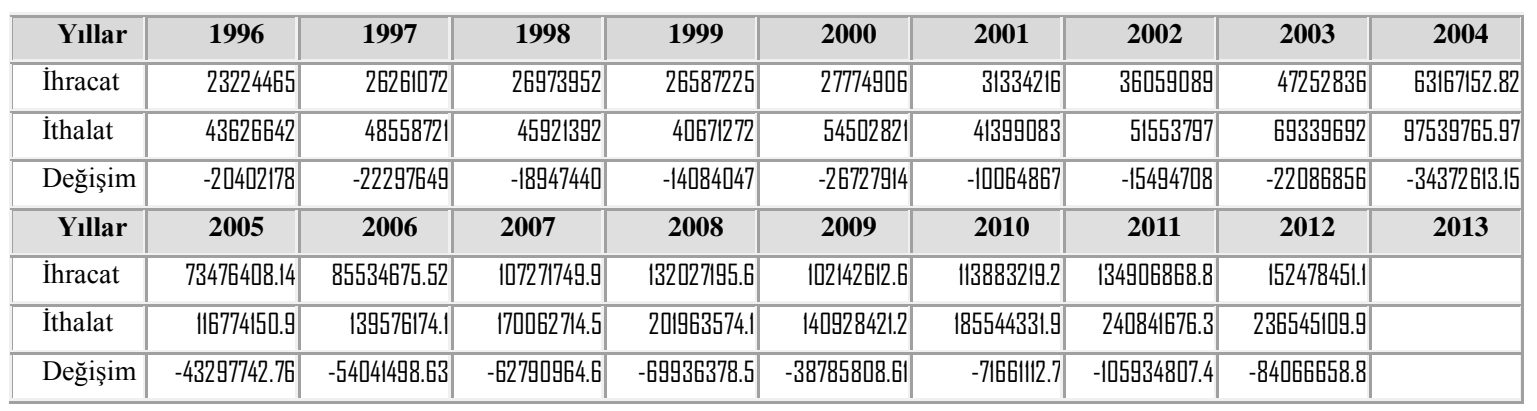

Tablo 2. Türkiye ’nin Dış Ticaret İlişkileri: 1996-2012 Dönemi (Değer 000 \$ ABD Dolarl) 


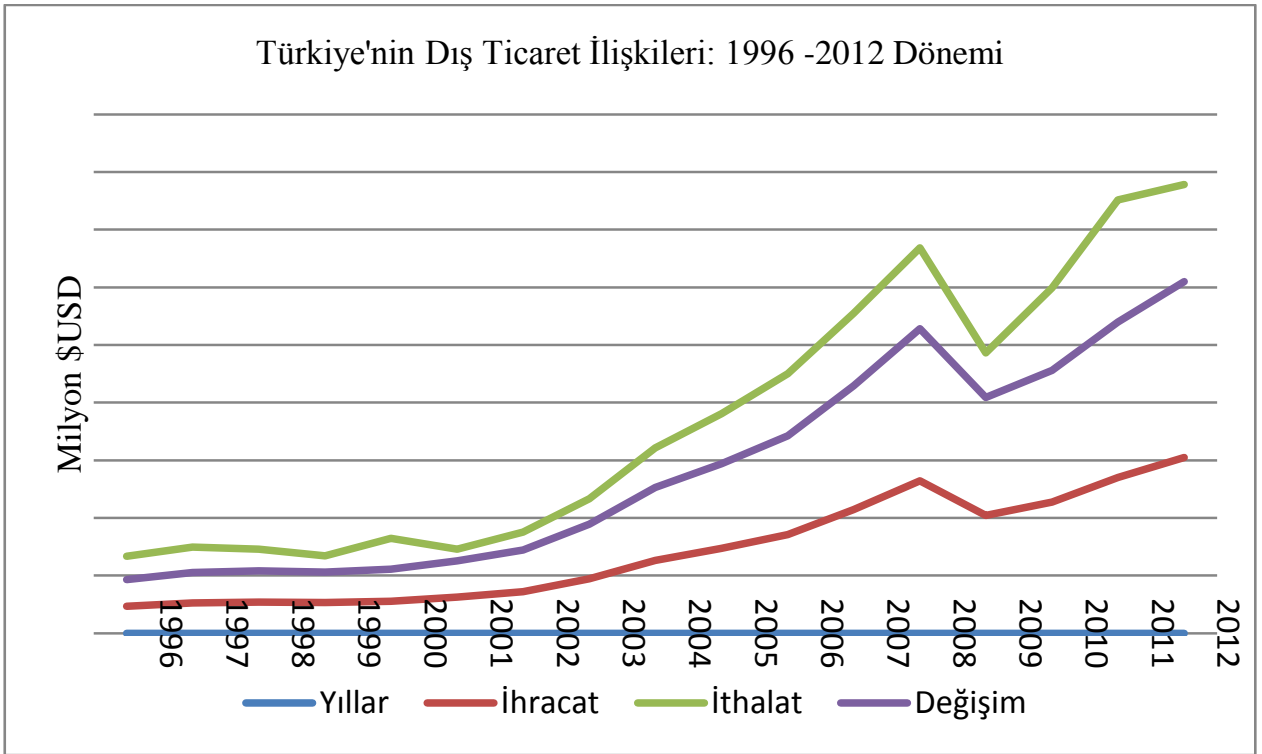

Şekil 1. Tablo 2'e göre Türkiye 'nin diş ticaret iliş̧kileri.

\begin{tabular}{|c|c|c|c|c|c|c|c|c|c|}
\hline Yillar & 1996 & 1997 & 1998 & 1999 & 2000 & 2001 & 2002 & 2003 & 2004 \\
\hline İhracat & 2926481.835 & 3824985.681 & 3290239.496 & 2232283.976 & 2466866.605 & 2932470.833 & 3598969.497 & 5044444.227 & 6778994.638 \\
\hline İthalat & 3896559.666 & 4495436.693 & 4357566.778 & 4307605.622 & 6746470.891 & 5553205.822 & 6587757.351 & 9292339.401 & $15361750.521 \mid$ \\
\hline Değişim & -970077.831 & -670451.012 & -1067327.282 & -2075325.646 & -4279604.286 & -2620734.989 & -2988787.854 & -4247895.174 & -8582755.883 \\
\hline Yillar & 2005 & 2006 & 2007 & 2008 & 2009 & 2010 & 2011 & 2012 & \\
\hline İhracat & 8619515.537 & 11583697.315 & 16784102.479 & 20867276.831 & 12272590.785 & 14456173.474 & 17767963.696 & 18789983.573 & \\
\hline İthalat & 20403091.349 & 26977554.812 & 34664724.186 & 45066638.708 & 27686922.98 & 32979705.109 & 38770164.504 & 41509682.946 & \\
\hline Değişim & -11783575.81 & -15393857.5 & -17880621.71 & -24199361.88 & -15414332.2 & -18523531.64 & -21002200.81 & -22719699.37 & \\
\hline
\end{tabular}

Tablo 3. Türkiye KEI Ülkeleri Diş Ticaret İlişkileri (Değer 000 \$ ABD Doları)

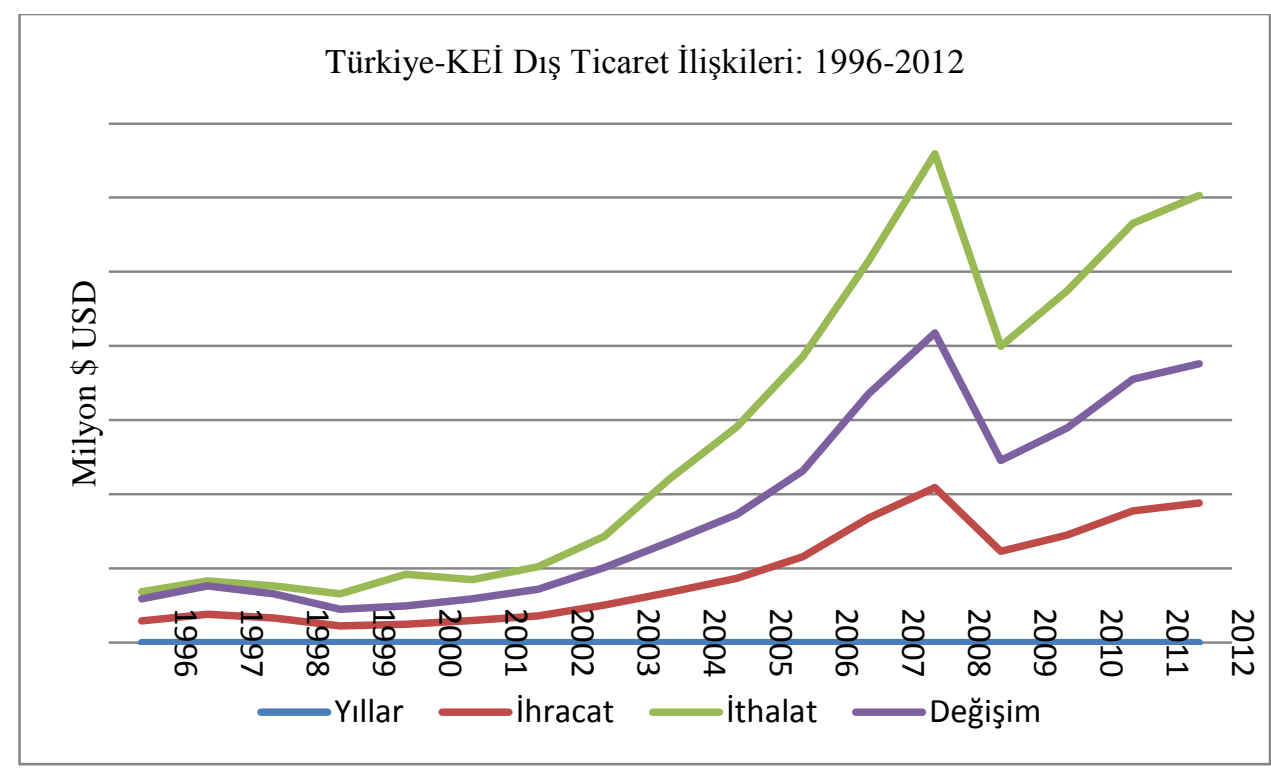

Şekil 2. Tablo 3'e göre Türkiye - KEİ diş ticaret ilişkileri.

\section{Sonuç ve Tartışma}

Türkiye'nin KEİ ülkeleri ile olan diş ticareti incelendiğinde, 1991 yılına kadar SSCB'nin, 1991 yllından sonra Rusya Federasyonu'nun en büyük dış ticaret partneri olduğu, diğer KEİ ülkeleri ile gerçekleşen diş ticaretin ise oldukça düşük olduğu görülmektedir. Büyük ve gelişen bir pazar potansiyeline sahip bu ülkeler ile son yıllarda Türkiye'nin dış ticari ilişkilerinin arttığı, ticaret hacminin de genişlediği göze çarpmaktadır. Türkiye'nin mevcut 
imkan ve potansiyeli ile daha nitelikli, teknoloji seviyesi yüksek ve sofistike ürünlerin ihracatına ağırlık vermesi durumunda, KEİ bölgesine yönelik dış ticaretin arttırılabileceği görülmektedir.

Türkiye'nin KEİ içindeki öncü rolü ve bu işbirliğinden beklentileri dikkate alındığında, Türkiye ile diğer KEI üyesi ülkeler arasındaki ekonomik ilişkilerin geliştirilmesinde kullanılan araçların çeşitlendirilmesi önem taşımaktadır. Türkiye son yıllarda izlediği barış̧̧ıl ve dışa açık politika paralelinde dış ekonomik ilişkilerinde de çeşitlilik aramaktadır. Bu arayış Türkiye'nin dış ticaret verilerinde ve yöneticilerinin sözlerinde kendisini açıkça göstermektedir.

Türkiye, KEI’nin birlikte kalkınma ülküsü etrafında, uluslarası örgütler ve bölgesel ülkelerle birlikte hareket ederek ortak refah, barış ve istikrar sağlamaktadır. KEİ, öncelikli olarak ekonomik ilişkilerin geliştirilmesine dayalı bölgesel bütünleşme biçimi olduğundan, $\mathrm{AB}$ bütünleşmesine alternatif olmamış, buna karşılık, her iki yönde de açılmak isteyen ülkeler için bir köprü olma işlevini hedeflemiş̧ir.

KEİ örgütünün ortaya çıkış nedenleri arasında SSCB'nin dağılması, yeni dünya düzeninde açık ekonomi ve dış ticaretten beklenen büyük ve önemli yararlar, bölgede yeni bağımsız devletlerin ortaya çıkması, AB'nin siyasi bütünleşmesini sağlaması, ayrıca Kafkaslar ve Balkanlarda sıcak çatışmaların değişik boyutlarda sürmesi sayılabilir.

Bölgede meydana gelen bütün bu olay ve gelişmeler, Karadeniz havzasında bulunan istikrar boşluğunu doldurmak ve 20 milyon $\mathrm{km}^{2}$ 'lik büyük bir coğrafi alan üzerinde 350 milyondan fazla bir tüketici pazarı kurmak, siyasi, ekonomik ve kültürel ilişkileri ilerletmek, dostluk ve işbirliğini geliştimek imkanı vermiş̧ir.

Türkiye‘nin KEİ'deki öncülüğü incelendiğinde, model ülke olma sorunu bulunmadığı, ancak bunun yerine 2023 küresel ekonomik hedeflere ulaşmada sorunları bulunduğu gözlemlenmektedir. Türkiye 2023 referans senaryo çerçevesinde; teknolojik gelişim ve altyapı olarak vizyoner, yüksek katma değer elde eden, araştırmageliştime-inovasyon ve tasarım yapan, etkin ve verimli bir yapıyı hedeflemektedir. Ülke konumlanması açısından pazarı set eden, tüketici odaklı, küresel markalar çıkarmış, iş yapış şekli açısından stratejik düşünen ve uzun vadeli planlar yapan, paydaşlar arasında eşgüdümü en üst düzeye taşıyarak, sinerji üreten bir ülke olmayı amaçlamaktadır. Türkiye'nin 2023 yılında 500 milyar dolar ihracat hedefine ulaşmasi için, küresel ticaretten 2013 yılında \%1, 2018 y1lında \%1,25 ve 2023 yılında \%1,5 pay alması gerekmektedir. Ancak, mevcut en büyük ilk 10 küresel ekonomi listesi incelendiğinde, sıralamada ABD, Çin, Japonya, Almanya, Fransa, Brezilya, İngiltere, İtalya, Rusya ve Hindistan yeralmaktadır. Türkiye'nin 2023 hedefleri açısından bakıldığında, yukarıda bahsi geçen sıralamadaki son beş ülkenin, İngiltere (\$2.440,5 milyar dolar), Brezilya (\$2.396,0 milyar dolar), Rusya (\$ 2.022,0 milyar dolar), İtalya (\$ 2.014,1 milyar dolar), ve Hindistan (\$1.824.8 milyar dolar), gelecekteki dinamik performsları dikkate alındığında, Türkiye'yi çok çetin bir küresel rekabet ve üstünlük yarışı beklemektedir.

Bölgede Bulgaristan, Romanya ve Yunanistan'nın AB üyesi olması diğer KEİ ülkelerinin Avrupa Birliği Müktesebatı kapsamında iç bütünleşmelerini, kurumsal yapılanmalarını ve siyasetlerini uyumlaştırmaları için açık firsat ve imkan sağlamaktadır. Bununla birlikte, KEİ, kendisi dışında kalan ülkelere ve diğer bütünleşmelere zarar vermekten kaçınmalı, aksine yararlı diyalog ve işbirliklerine açık olmalıdır. Başta insan ve üretim faktörlerinin serbest dolaşımı sağlanarak, ortak kalkınma ve gelişme sağlanmalıdır. Bu kapsamda, bölgedeki turizm teşvik edilmeli, doğal, tarihi ve kültürel varlıklar korunma altına alınarak geleceğe miras bırakılması sağlanmalıdır.

\section{Kaynakça}

- Black See Economic Cooperation Organization, 2013. http://www.bsec-organization.org

- Erol, Semra, 2006.” Uluslararasi İktisat Bölüm Dali Eski ve Yeni Bölgesellesme Sürecinde Türkiye”, Marmara Üniversitesi, Sosyal Bölümler Enstitüsü, İktisat Anabilim Dalı YL Tezi.

- Gençler, Ayhan, 1994.”Karadeniz Ekonomik İşbirliği: Analitik bir yaklaşım”, İstanbul Üniversitesi, Sosyal Bilimler Enstitüsü, Çalışma Ekonomisi ve Endüstri İlişkileri Anabilim Dalı YL Tezi.

- Gökalp, M. Faysal,1993. "Karadeniz Ekonomik İşbirliği Bölgesi çerçevesinde Türk deniz ticaret sektörünün gelişme olanakları", Dokuz Eylül Üniversitesi / Sosyal Bilimler Enstitüsü / İktisat Anabilim Dalı YL Tezi.

- International Monetary Fund, 2013. http://www.imf.org

- Kalaycı, İrfan, 1993. "Karadeniz Ekonomik İşbirliği Bölgesi'nin ekonomik entegrasyona geçiş problemleri ve başarısında Türkiye'nin rolü”, İnönü Üniversitesi, Sosyal Bilimler Enstitüsü, İktisat Anabilim Dalı, YL Tezi.

- Karaman, Tülin. 2009. “Karadeniz’in Güvenliği ve Karadeniz Ekonomik İşbirliği”, Beykent Üniversitesi, Sosyal Bilimler Enstitüsü, Uluslararasi İlişkiler Anabilim Dali YL tezi.

- Kolos, Valeria, 2012.” Karadeniz Ekonomik İşbirliği Örgütü seçili ülkeleri olan Rusya, Türkiye ve Ukrayna'da idari reformlar dönemi", Fatih Üniversitesi, Sosyal Bilimler Enstitüsü, Siyaset Bilimi ve Kamu Yönetimi Anabilim Dalı YL Tezi. 
- Özay, Seda, 2009.” Türkiye’nin Üyesi Olduğu Bölgesel Ekonomik Entegrasyonlarla Diş Ticaretinin Analizi”, Kahramanmaraş Sütçü İmam Üniversitesi, Sosyal Bilimler Enstitüsü, İktisat Ana Bilim Dalı YL Tezi.

- Şengül, Cemail, 2009.” Karadeniz Ekonomik İşbirliği ve Birliğin Türkiye Üzerindeki Beklenen Etkileri”, Marmara Üniversitesi, Sosyal Bilimler Enstitüsü, İktisat Anabilim Dali YL Tezi.

- TC Avrupa Birliği Bakanlığ1, 2013. http://www.abgs.gov.tr

- TC Dişişleri Bakanlığı, 2013. http://www.mfa.gov.tr

- $\quad$ TC Ekonomi Bakanlığı, 2013. http://www.ekonomi.gov.tr

- $\quad$ TC Türkiye İstatistik Kurumu, 2013. http://www.tuik.gov.tr 


\title{
Kültürün Ekonomik Kalkınmaya Etkisi ve Türkiye-Rusya Ekonomik İlişskisi
}

\section{The Effect of Culture on Economic Development and Turkey- Russia Economic Relations}

\author{
Emine Ebru Usta (Ministry of Family and Social Policies, Turkey)
}

\begin{abstract}
Globalization is worldwide integration of economical ,cultural,political,religious and social system.The incremental competitive conditions of nowadays make the firms not only analysis the other countries economic or political system but also cultural,religious and social systems. In this respect for globalization world, it is sure that culture and economy get the crucial role at the inter state relations.At the base of turkey and Russia also lays this dialog.For this reason in this study it is aimed that with current parameters tried to explain after diagnosis in general means the effects of culture on economical developments especially after 2001 economic recession- lives important regulation period in which known power transition world economy -Turkey,takes place in the developing countries, with Russia Federation ,important member of ascending market economy.
\end{abstract}

\section{Giriş}

Sosyal bir kavram olarak "kültür" kavramının kaynaklarda üzerine hemfikir olunmuş ortak bir tanımına rastlanmamaktadır. Nitekim Trifonovich'e göre kültür kavramının 450'den fazla tanımını yapmak olasıdır (Aydın, 2003). Genel bir tanımlama yapacak olursak kültür, "bir toplumun sahip olduğu bilgi, inanç, sanat, ahlak, gelenek ile her türlü beceri ve alışkanlıklar toplamını ifade eden karmaşık bir bütün" olarak düşünülebilir.

Küreselleşen dünyada kültür ve ekonomik faaliyetlerin ülkelerarası ikili ilişkilerini ilerletmede ve devamını sağlamada önemli bir faktör olduğu bir gerçektir. Fukuyama, herhangi bir ülkede işlerin nasıl yürütülmesi gerektiği konusunda kültürel değerin temel alınması gerektiğini iddia etmektedir. Bu görüş 1şı̆̆ı altında uluslararası ticari görüşmelerin başarısızlığının büyük bir kısmının ürün dışında kalan sosyo-kültürel unsurlardan kaynaklandığı açıklanmaktadır.

Bu çalışmada öncelikle kültürün genel bir tanımı yapıldıktan sonra, ekonomik yapı ile sosyal ve kültürel yapı iliş̧isine değinilecek ve sonraki bölümde Türk ve Rus ortak kültürel yapısı kısaca özetlenecektir. Son bölümde ise iki ülke arasındaki uzun yıllardır süre gelen derin ve çok boyutlu ilişki incelenecek, özellikle 2001 krizi sonrası büyüyen ekonomisiyle ön plana çıkan Türkiye ile yükselen piyasa ekonomilerinin önemli bir ülkesi olan $\mathrm{RF}$ ile giderek artan ekonomik iliş̧kileri güncel verilerle gösterilecektir.

\section{Kültürün Tanımı}

Kültür sözcügünün Latince ekip ürün almak, üretmek anlamına gelen "cultura" sözcüğünden geldiğini ve birçok dünya dilinde aynı sözcüğün kullanıldığı bilinmektedir. Kültür sözcüğü zaman içerisinde değişimlerin gelişimlerin ışığında öylesine zengin anlamlara bürünmüştür ki bu da şaşırtıcı değildir, çünkü "üretim" insanlık tarihinde sadece tarımsal düzlemde değil, düşüncelerin evrimi, teknik ve teknolojinin gelişimi düzeyinde de gerçekleşen bir olgudur. Ve bu tür değişimlerin hayat tarzlarından düşünme biçimlerine ve inançlara dek etkili olmaması olanaksızdır.

Tarihsel bilgiler bize kültürün tüm toplumlarda mutlaka bir birikime dayandığını göstermektedir. Bu birikim, kültür tarihçilerine göre (enerji, tarım, madencilik, metalürji, av ve balıkçlık hep işlemeyle gelişmiştir), zanaat (tüketim eşyalarını ve bununla ilgili teknik sorunların çözümüne yardımcı olacak mekanik nesneleri üretme), dönüştürme (maddeyi fiziksel, kimyasal, teknolojik olanaklarla başka bir nesneye dönüştürme, örneğin sentetik nesneler gibi) ve nihayet yaşam alanını yani mekanı değiştirme (inşaat, mimari, ulaşım için yollar, çevre düzenlemesi) eylemleriyle oluşur. Bütün bu eylemlerin farklı coğrafi alanlarda farklı topluluklar tarafindan oluşturulması aslında dünya kültürünün özünü oluşturmaktadır ve bütün toplulukların er yada geç karşıllıklı ilişkileri ve haliyle karşı1lıklı etkileşimi kaçınılmazdır.

Bilim adamları kültür kavramını tüm toplumsal grupları düzenleyen organik kuralları, düşünsel eğilimleri ve sanatları, gelenek, görenek, inanç ve adetleri, aletleri ve tüketim maddelerini, ahlak kuralları, insanların gerçekleştirdiği yetenek ve alışkanlıkları içine alan bütünsel bir olgu olarak tanımlar. Bu çerçevede, insanlar, kültürün değişik durumlarıyla, özellikleriyle sık sık karşı karşıya kalırlar: sanat etkileri, yemek kültürü, dünya kültür mirası gibi. Bu kısa adlandırmadan kültürün insanların hayatında hem maddi hem manevi öğeleri barındırdığını, hem geçmişten gelen hem günümüzde oluşan birikimleri içerdiğini, kısacası hayatımıza biçim anlam veren her şey olabileceğini düşünmemiz gerekiyor. 
Hem insan hem toplum hem de çevreyi içine alan böylesine geniş içerikli olgunu aynı zamanda birçok bilim dalının da araştırma konusu olması şaşırtıcı değildir elbette. Kültür olgusunun devlet, politika, kamu alanını inceleyen sosyoloji, siyaset ve ekonomi bilimleriyle, ahlak, inanç, gelenek, özgürlük, muhafazakarlık gibi konuların ele alındığı felsefeyle, güzel duyunun ifadesi olan sanat ve sanat tarihini inceleyen arkeoloji, sanat tarihi, estetik bilimleriyle, ilkel toplumlardan günümüze, kültürün inanç ve ibadet dünyasında, ruhsal dünyamızda ve bilinç altı dünyamızda işgal ettiği yeri inceleyen ilahiyat, antropoloji, psikoloji ve psikanalizle bağlantısı çok güçlüdür (Gülmez, 2013). Yani görülen odur ki kültür hayatımızın her alanıyla ilgilidir. Artan rekabet koşullarında işletmeleri sadece diğer ülkelerin ekonomik ve siyasi sistemlerini değil aynı zamanda kültürel, dini ve sosyal sistemlerini de analiz etmeleri gerekmektedir.

Klasik yönetim anlayışının aksine modern yönetim anlayışının insana atfedildiği değer örgütlerin beşeri yönünü ön plana çıkartmaktadır. Bununla birlikte insan ve insancıl değerlerin önem kazanması, işletmeler açısından uluslararası faaliyetlerde kültürün yönetim açısından önemini arttırmaktadır (Öğüt, Kocabacak, 2007).

İşletmelerin küresel rekabette başarılı olabilmeleri yerel değerleri yani kültürü göz ardı etmemelerine bağlıdır. Bu konuda İranlı bir sosyologun bahsettiği olay dikkate değerdir. Sosyolog, Fransa'da öğrenci iken bir otomobil fabrikasının sosyolog ve psikolog aradığını duymuş, başvuruda bulunmuş, ancak bir otomobil fabrikasının neden bir sosyolog ve psikolog aradığına bir türlü anlam veremeyip sorunca, müdürden şu yanıtı almış: "Biz A,B,C ülkelerine çok iyi araba sattığımız halde D,E,F ülkelerine hiç satamıyoruz. Bunun nedenini mühendisler açıklayamıyorlar ve bunu sizden öğrenmek istiyoruz" der. Olaydan da anlaşılacağı üzere işletmeler özellikle yeni dünya düzeni olarak adlandırılan küreselleşen ekonomik sistemin rekabet ortamında büyüyebilmek için diğer ülkelerin kültürel ve sosyal yapılarını da araştırmaları gerekmektedir.

\subsection{Ekonomik Yapı ve Sosyo-Kültürel Yapı Arasındaki Etkileşim}

Ekonomik yapı ile sosyal ve kültürel yapı ilişkisi ekonomik gelişmelerin değerlendirilmesiyle önem kazanmıştır. Çünkü ekonomik gelişmenin yalnızca ekonomik terimlerle analizi mümkün olmamakla birlikte, ekonomik gelişme analizleri yapılırken oluşturulan şemaların insan unsuruna ve tepkilerine yer verilmedikçe sonuç alınamayacağı görülmektedir.

Ekonomik büyümenin analizindeki gelişmeler, elle tutulur ve sayılabilir unsurlardan, ele gelemez ve sayılamaz olgulara doğrudur; ekonominin bir yüzü madde ve servete dönükse, diğer yüzü insan davranışına dönüktür. Nerede ve hangi zamanda olursa olsun, ekonomik hayatın arkasında insan gerçeği ve onun yaşayış normları ile zihniyeti vardır.

Ekonomik unsurlar ve sosyal unsurlar bir bütün olarak ele alınmalıdır. Ekonomik faaliyet, toplumsal bir yapının içinde meydana gelmiş, gelişmiş ve sosyal yapı içerisinde sosyallik kazanmıştır. Ekonomik tedbir ve politikaların soyut bir durumdan somut bir zemine geçişi, sosyal ve kültürel yapı gerçeklerine kaydırılmasıyla mümkündür.

Gelişme, ekonomik işleyişin alışılmış yörüngesinden ayrılarak daha üst seviyede yeni bir denge alanına sıçraması olarak değerlendirilmektedir. Yeni denge durumunda aksama olamaması için, ekonomik gelişme ve büyümenin sosyal bütünleşme politikalarıyla desteklenmesi zorunludur.

Ekonomik yapının ve sosyal kültürel yapının etkileşimi konusunda Karl Marx determinist bir yaklaşım sergilemiş ancak Max Weber ona karşı çıkmıştır. Weber, ekonomik yapının sosyal-kültürel yapıya etkilerini kabul etmekte, ancak o konunun determinist ve tek etkenli bir yaklaşımla ele alınmasına karşı çıkmıştır. Weber'e göre, ekonomik, siyasal veya dinsel tek bir öğeyle ve tek yanlı olarak belirlenmesi mümkün olmayan bir bütün olan toplumun nedensel ilişkileri kısmi ve olası niteliktedir (Aron, 1986).

Weber, kültür ve ekonomik faaliyet arasındaki ilişkiyi incelerken, kültürün ekonomik faaliyetleri şekillendirdiğini ortaya koymuştur. Weber'e göre her toplumun bir kültürü vardır ve toplum kendi inanç ve değerler sistemini kültür yoluyla sahip olmaktadır.

Marx'a göre ise, üretim ilişkilerinin tümü, toplumun ekonomik yapısını oluşturur; bu belirli toplumsal bilinç biçimlerin karşılık olduğu ve üstünde yasal ve siyasal üst yapıların yükseldiği gerçek temeldir (Bottomore, Nisbet,1990). Marx, her toplumda alt yapı ve üst yapının ayırt edilmesi gerektiğini savunur. Ona göre, alt yap1 ekonomik temellidir. Alt yapı üretim güçleri ve üretim ilişkilerinden meydana gelir. Üst yapıda yasal ve siyasal kurumlar, düşünce biçimleri, hayatın, toplumsal, yasal ve manevi süreçlerinin genel niteliğini belirler (Aron, 1986). Üst yapı kurumu olan dünya görüşlerinin ve ahlak anlayışlarının görevi, alt yapıda yer alan üretim araçları sahiplerinin çıkarlarını, gerçeğin kendisiymiş gibi göstermektir (Ülgener, 1983).

Ekonomik yapı ve sosyal-kültürel yapının etkileşimini konu alan diğer düşünürler ise; Schumpeter, ekonomik gelişimin, pür ekonomik terimlerle tahlilinin mümkün olmadığını belirtir. Keynes'e göre, iktisadi gelişme analizlerini, soyut şemalar arkasındaki insan unsurlarına ve onun tepkilerine kadar götürmedikçe sonuç alınamaz, Örnek olarak yatırım kararı, insanın iç dünyasında şekillenen bir oluşum sürecinin bir ürünüdür. Hirschman, ekonomik büyümenin analizindeki gelişmelerin, objektif, elle tutulur ve sayılabilir unsurlardan, ele gelemez ve sayılamaz olgulara doğru olduğunu savunur. Marshall'a göre, ekonominin bir yüzü madde ve servete dönükse, diğer yüzü insan davranışlarına dönüktür (Ülgener, 1983). İki farklı ülkedeki, sektörü, teknolojisi, 
girdileri sayı ve kalite olarak aynı olan iki işletmenin yıl sonu karlılık ve verimlilik oranlarının farklı olması insan unsurunun kültürel farklarından kaynaklanmaktadır.

Ekonomik yapı ile sosyal-kültürel yapı arasındaki ilişki pek çok düşünür tarafindan çok yönlü olarak değerlendirilmiştir. Tüm bu değerlendirmelerin ışığında ikisi arasında ilişki yadsınamaz bir gerçekliktir. Gerçeğin bir öğesinin, gerçeğin öteki yönlerinin onlardan etkilenmeden değerlendirilmesi mümkün değildir. Her toplumda ekonomik gelişme, ekonominin dişında kalan unsurlarla yani toplumun dini, estetik, kültürel ve sosyal değerleri ile örülü bir yapı halindedir. Sermaye birikimi, yatırım hareketleri, üretim, tüketim, satın alma kararları gibi her türlü ekonomik faaliyet derinlemesine incelendiğinde söz konusu faaliyetlerin arkasındaki insan olgusunun iç dünyasına götürür ve bu iç dünya; insanın dış çevresi ile yani sosyal ve kültürel çevresiyle şekillenmiştir.

\subsection{Ekonomik Büyüme ve Sosyo-Kültürel Etki}

İktisadi analiz yapılırken insan olgusunu görmezlikten gelmek değil, insandan başlamak yoluyla yapılmalıdır. Ekonomik unsurlarla toplumsal unsurlar bir bütündür. Beşeri hayatın iktisadi bir çaba ile başlaması, iktisadi faaliyetin bir topluluğun içinde ortaya çıktığını göstermektedir.

Kendiliğinden sosyolojik niteliğe sahip olmayan bir ekonomi birliği, bir sosyal düzen içerisinde toplumsallık kazanmaktadır. Sosyolojik bakımdan iktisadi faaliyetin yerinin tayin edilmesi önem taşımaktadır; bir işletmeye ekonomik nitelik kazandıran sadece teknik özellikleri değil, taşıdığı amaçtır. Biri kazanç dileği, diğeri ihtiyaç giderme zarureti olmak üzere iki esasa dayanan ekonomik fiil ile ilgili denge, bu iki kutup arasındaki çekişmenin sonucuna bağlıdır. Ekonomik konuların sosyolojik incelemesi, ekonominin bir topluluk ve onun düzeni içinde cereyan eden bir olay olduğunun ve bir fiil ekonomik olabilmesi için böyle bir amaca dönük olarak oluşması gerektiğini ortaya koymuştur (Çağatay, 1975).

En basitinden en gelişmiş şekillerine kadar çeşitli tiplerdeki beşeri teşkilatlanmalar içinde ve bir sosyal zeminde ortaya çıkan iktisadi hayat, toplumun bütünlüğüne eğilen sosyolojinin kapsamında yer almaktadır. Üretim, tüketim, mübadele, kıymet, iş bölümü ve dağılımı gibi iktisadi olaylar aynı zamanda toplumsal olaylardır ve bunlar insanları bir sosyal düzen içinde bulunmaya yöneltir (Erkal, 1990). Toplumdaki nüfusun maddi göstergeleri onun iktisadi refahını, sosyal ve kültürel seviyesi ise sosyal gelişmesini gösterir (Erkal, 1990). "Büyüme" sayı ve hacimdeki değişikliği, "gelişme" ise mahiyet ve nitelikteki farklılaşmayı ortaya çıkarır. Nüfusun çoğalması, iş gücünün fazlalaşması, üretim araçlarının artması büyüme kapsamındaki değişikliklerdir. Bünye ve çatıdaki farklılaşma ise, gelişme kapsamında yer alır (Ülgener, 1983). İktisadi büyüme ölçülebilir mahiyettedir; ancak bu durum onu rakamlara sı̆̆dırılabileceği anlamına gelmez. Büyümenin arkasında rakamlarla ifade edilemeyen davranışlar ve kurumlar vardır. Bu davranış ve kurumlar, siyasal düzen, eğitim sistemi, halkın yenilikleri benimseme derecesi, çalışmayı uyaran etkenler ve teşvik edici faktörlerdir (Ülgener, 1983).

Büyüme modellerinin uygulamadaki geçerliliklerine şekil verecek olan her ülkenin kendine has ekonomi dış1 sosyal ve kültürel unsurlardır (Erkal, 1990). Esasen her türlü ekonomik tedbir ve politikaların soyut bir durumdan somut bir zemine geçişi, sosyal ve kültürel yapı gerçeklerine kaydırılmasıyla mümkün olur (Erkal, 1990). Bu konuda pek çok örnek verilebilir. Sözgelişi, israfi yasaklayan bir değer hükmüne sahip İslamiyet'in hakim olduğu ülkelerde iktisadi hayat bu değer hükmü tarafından şekillendirilmektedir; bu alandaki sapmalar, kültürel yap1 ile sosyal yapı arasındaki farkın sonucudur. Hindistan'da inek kesiminin yasak olması, Müslüman ülkelerde domuz etinin haram olması, ekonomik malların dini ve kültürel değerlerden etkilendiğini göstermektedir. Mübadelenin Müslüman ülkelerdeki uygulamaları, onun ekonomik olduğu kadar sosyolojik taraflarının bulunduğunu ortaya koymaktadır. Mübadele, gerek evlilik, sünnet ve doğum hediyeleri gibi, gerekse zekat, fitre, kurban, vakıf gibi konularda sosyal niteliği ağır basan bir dayanışma şekli olarak ortaya çıkmakta, temeli itibariyle her zaman iktisadi-rasyonel/akılcı bir düşünceye de dayanmamaktadır. Geleneksel toplumlarda kişinin tasarrufundan ayrılmak istememesi, onun yatırıma dönüştürerek rizikoya girmekten kaçınması, gelirdeki artışın tasarruftan daha çok tüketimi harekete geçirmesi, sosyal gerçeklerin ekonomik bir mahiyet taşıyan tasarruftaki rolünü göstermektedir (Erkal, 1990).

Günümüzde ekonomik ve sosyolojik unsurlar içi içe geçmiş durumdadır. Bunu en belirgin şekilde ekonomik gelişme ve büyümenin toplumda yarattığı değişikliklerin sosyal bütünleşme ile desteklenmesine olan ihtiyaçta görmek mümkündür.

Schumpeter gelişmeyi, ekonomik akımın alışılmış yörüngesinden ayrılarak daha üst seviyede yeni bir denge alanına sıçraması şeklinde yorumlar. Karmaşık modern toplumlar, bir yeni dengeye giriş kanallarını açmak zorundadırlar. Buradaki aksama, sosyal bütünleşme bakımından sorunlara yol açar. Sosyal bütünleşme ile desteklenmeyen gelişme ve büyüme, sistemi aksatabilmektedir. Toplumdaki fert ve sosyal gruplar maddi tatmine kavuşmalarına rağmen bunalım ortay çıkmaktadır (Erkal, 1990).

Halkın ekonomik planlama ve politika konusunda ikna olması, söz konusu plan ve politikalara destek olmasının ilk koşuludur, çünkü halk nelere katlanacağının ve sonucunda neler elde edeceğini bilmesi uyum sağlamasını sağlar. Ekonomik büyüme hedefleri için planlar oluştururken toplumun davranışları ve o davranışları oluşturan sosyo-kültürel yapısı göz ardı edilemez durumdadır. Rakamları, formülleri, matematik bağlantıları 
canlandıracak olan insan olgusudur. Ekonomik sayılar insanın arzu, istek ve tercihlerinin hacim ve miktara dönüşümleridir.

\section{Rusya Federasyonu ile Türkiye Arasında Kültürel Benzerliklere ve Ekonomik- Ticari İlişkilere Genel Bir Bakış}

\subsection{Türk-Rus İliş̧kilerinin Tarihsel Boyutu ve Kültürel Karşılaştırması}

Osmanlı-Rus ilişkileri, 16. yüzyıldan 20. yüzyılın başına kadar savaşlar ve güç mücadeleleri tarihi olarak gelişmiştir. Bu çatı̧̧macı sürecin ana nedenleri arasında, Rusya'nın güneye doğru yayılma arayışının Osmanlı İmparatorluğu'nun çıkarlarıyla sürekli çatışma halinde olması yer almaktadır. Öte yandan, bölgedeki birçok nüfus rekabeti de bu iki gücün sürekli çatışmasına neden olmaktaydı. Birinci Dünya Savaşı sonrasında her iki ülkede de ortaya çıkan yönetim değişiklikleri iki ulus arasında yakınlaşma ve işbirliği sürecinin de başlangıcı olmuştur (Sönmez, 2004).

1928-29 yıllarından itibaren uluslararası sistemdeki rekabetin yayılmaya başlamasıyla Türk-Rus ilişkilerinde belirli değişim rüzgarları esmeye başlamıştır. II. Dünya Savaşı sonrasındaki yeni dünya düzeni iki kutuplu bir yapıya bürünmüş farklı kutuplarda yer alan iki ülkenin ilişkileri de zaman zaman gerginleşmiş̧ir. Ancak işlevselci okulun ikili ilişkiler bağlamında ekonomik işbirliği olanaklarının geliştirilmesinin, dış politikada siyasal sorunların çözümünü kolaylaştırdığı söylemi açısından ele alacak olursak Soğuk Savaş döneminden itibaren Türk-Rus ilişkilerinde artan bir gelişme seyri olduğu söylenebilir. Söz konusu süreçte ekonomik ilişkiler sürekli devam etmiş ve Türkiye'deki birçok ağır sanayi yatırımı Sovyet döneminde Rusya tarafından yapılmıştır.

Soğuk savaş sonrasında da, iki ülkenin özellikle ekonomik, ticari ve kültürel olarak birbirine yakınlaştı̆g 1 saptanmakta ve ikili ilişkilerinin en iyi seviyeye ulaştı̆̆ ve şu an Türk-Rus ilişkileri stratejik ortaklık boyutuna geldiği görülmektedir.

Yüzyıllardır yan yana yaşamış, iki ülke arasında yaşanan savaşları, gerginlikleri, yakınlaşmaları içeren süreç, sosyo-kültürel alış verişine neden olmuş ve ortak yönleri giderek artmıştır. Ruslar, Avrupalılarla karşılaştırıldığında Türklere daha yakın görünmektedir. Belki de bunun en önemli nedeni her iki ülke içinde geçerli olan ne tam doğulu, ne tam batılı olmaktır. Söz konusu yapı iki ülkenin demokratik gelişimi üzerinde de etkili olmuş ve iki ülkede de demokrasi aşağıdan değil tepeden kurulmuştur. Her iki ülkede de vatandaş devleti "baba" gözüyle görmektedir.

Rus halkının sosyal dünyasını yönlendiren ilici güç, rus kültürüdür. Rusların büyük çoğunluğu için uyum ve sadakat en yüksek kültür değerleridir. Bu nedenle de tarih boyunca pek çok Rus egolarını baskı altında tutmaya, kendilerini tamamen ülkelerine adamaya gönüllü olmuşlardır. Sıradan Rus vatandaşları arasında gözlenen olağanüstü derecede tek düzelik ve düzene itaat, sistematik olarak, sürekli devlete itaat etmenin en büyük şeref olduğu düşüncesinin tarih boyunca aş1lanması sonucu oluşmuştur (Onay, 2008). İsmail Hakkı Küpçü'nün "Türklerin Medeniyetleri" adlı makalesinde Tüklerin kültürel özelliklerinden bahsederken "üste kesin itaat"ten söz etmektedir. Her iki milletinde devletlerini algılama biçimi Batılı ülkeler gibi değildir, "koşulsuz vatanseverlik" milli karakterlerinin temel özellikleridir.

Bütünüyle Bizans'a ait motiflerle dolu Ortodoks Hıristiyanlığının kabulüyle Rusya statik Bizans medeniyeti çevresine girmiş̧tir. İşte bu nokta, Rusya'nın Roma Katolik ya da bir başka ifadeyle batı Avrupa Kavimlerinden ilk ve kesin olarak ayrılışının başlangıcını oluşturmaktadır. Bu gelişme Rus tarihinin bütün evrelerine damgasını vurmuş ve Rusya'nın tarih boyunca kendisini sürekli Avrupa ile onun oluşturduğu medeniyet ve kültürden farklı hissetmesine neden olmuştur (Onay, 2002).

Dinde yaşanan bu gelişmeden en önemli etkilenen Rus alfabesidir. Latin alfabesinden bütünüyle farkl1lık gösteren Bizans alfabesi esas alınmış ve bu yazı dili Rusları giderek Avrupalı kavimlerden ayırmıştır. Tıpkı Osmanlı döneminde de Avrupa ile benzer yazı dili sorunu yaşanmıştır ve gelişmelerin gerisinde kalınmıştır. Ayrıca her iki kültüründe ortak diğer bir özelliği olan gözü peklik özellikle ekonomik anlamda atılım yapmış ve ilişkilerini giderek gelişmesini sağlamıştır.

\subsection{Türk-Rus İlişkisini Ekonomik ve Ticari Boyuttan İnceleme}

Kültürler arası yakınlaşma ile son süreçte dostane bir yapıya bürünen Türkiye ile Rusya Federasyonu'nun ekonomik ilişkileri giderek artan bir seyir halindedir, IMF'nin 2009 yılına ilişkin, ülkeler arasında satın alma gücüne göre yaptığı sıralamada, 2,1 trilyon doları geçen gayri safi yurtiçi hasılası (GSYH) ile 6'ıncı sırada Rusya Federasyonu yer alırken, Türkiye aynı sıralamada 880,1 milyar dolar GSYH ile 16. sırada yer almıştır.

$\mathrm{Bu}$ iki ülkenin son süreçte yaşadığı ticari ilişkinin önemli noktalarını maddeler halinde sıralayacak olursak:

- 2008 yılında 38 milyar dolara ulaşan ticaret hacmi ile Rusya Federasyonu (RF) Türkiye'nin bir numaralı ticaret ortağı haline gelmiştir. İki ülke ekonomisinin rekabetçi olmaktan çok tamamlayıcı yapıya sahip olması ticari ve ekonomik alanda bir çok işbirliği imkanı bulunduğunu göstermektedir.

- 2008 yılının sonundan itibaren etkisini göstermeye başlayan global ekonomik kriz nedeniyle, 2009 yılında ikili ticaret 23 milyar dolara gerilemiş̧ir. 
- Öte yandan, bu gerilemenin, iki ülkenin karşılıklı ticari potansiyelinin gerilemesi anlamına gelmediği 2010 yılının sonu itibariyle ortaya çıkmış ve 2009 yılında yaşanan global ekonomik krizden ve 2009 yılı Ağustos ayına kadar ülkemiz ürünlerine Rus makamlarınca uygulanan önlemlerden kaynaklanan sıkıntıların da aşılması ile 2010 yılında ticaret hacmi 26 milyar dolara yükselmiştir.

- Özellikle, 2009 yılı Ağustos ayından itibaren, iki ülke arasında giderek hızlanan bir şekilde gelişen siyasi ilişkiler de, ticari ve ekonomik ilişkilerin 2013 yılı ile birlikte daha da hızla gelişeceğinin ve 2008 yılında yakalanan rekorların aşılacağının önemli bir göstergesi olmuştur.

- İkili ticaret 2011 yılında 30 milyar dolara yükselmiş ve karşılıklı yatırımlarda da iki ülkenin birbirine olan ilgisi sürekli artmıştır.

- RF'nin 1990'larda yaşadığı büyük gelişme, dünya enerji kaynaklarının önemli bir bölümünü elinde bulunduran Rus ekonomisinin cazip bir pazar olmasını da beraberinde getirmiştir.

- Türk işadamlarının, hemen hemen her sektörde, yoğun bir şekilde bulunduğu ülkelerin başında Rusya Federasyonu (RF) gelmektedir. Özellikle 1990 yılların başından itibaren öncelikle inşaat ve müteahhitlik firmaları RF pazarına giriş yapmış olup, ilerleyen yıllarda, tekstil ve konfeksiyon başta olmak üzere Türkiye ihracatı açısından önem taşıyan sektörlerde işadamları RF'de yerleşik bir şekilde iş yapmaya başlamıştır.

- Halihazırda, RF'de bilişim sektöründen gıda sektörüne, hukuk-danışmanlık sektöründen lojistik sektörüne, hemen hemen her sektörde yerleşik Türk işadamı bulunmakta olup, Moskova, Kazan (Tataristan) ve Güney Rusya Federal Bölgesi (Rostov, Krasnodar, Soçi, Novorossisk) başta olmak üzere, ülkenin önemli ticaret merkezlerinde (Novosibirsk, Yekaterinburg, Samara, St. Petersburg, Astrahan, vs.) yerleşik konumdadır.

- RF'de yerleşik olma ve ticari faaliyetlerini buradan takip etme, Türk firmalarına önemli avantajlar sağlamakta olup, esasen kar marjlarının yüksek olduğu RF pazarına daha hızlı giriş yapmalarını sağlamaktadır. Ayrıca, birçok Türk firmasının RF'de yerleşik konumda bulunması, Türkiye'nin RF'ye yönelik ihracatının artması açısından da yarar sağlamaktadır.

- 1992 yılında Sovyetler Birliği’nin dağılması ile birlikte Rusya Federasyonu ile ilk önce ticari ilişkiler gelişmeye başlamış, ardından ticari ilişkiler kadar olmasa da Türk yatırımlarında artış kaydedilmiştir. Türk özel sektörü 1990'ların sonlarına doğru yatırımlarına hız vermiştir.

- Enka, Koç, Zorlu Grubu (Vestel, Taç, Zorlu Enerji), Efes, Şişecam, Kale Grubu, Eczacıbaşı gibi büyük firmaların yanında küçük ve orta ölçekli firmaların üretim tesisleri kurmak suretiyle pazara olan ilgileri her geçen gün artmıştır.

- Rus özel sektörünün son yıllarda Türkiye'deki özelleştirme ihalelerine olan ilgisi ve yatırım kararları Türkiye'nin Rusya için cazip bir yatırım üssü olduğunu kanıtlamıştır. Turizm, hizmetler, petrol/gaz işleme ve depolama alanında yoğunlaşan Rus yatırım ilgisinin gelecek yıllarda artarak süreceği tahmin edilmektedir. 2011 yılı sonu itibariyle Türkiye'deki Rus yatırımlarının 9 milyar doları aştığı belirtilmektedir.

- 2000 yılında ihracatımızda 9'uncu sirada yer alan Rusya Federasyonu 2004 ve 2005 yıllarında 8'inci sıraya yükselmiş, 2006 yılında tekrar 9'uncu, 2007 yılında 7'nci sıraya yerleşmiştir. 2008 yılında ise Türkiye'deki ihracat sıralamasında 5'inci en büyük ülke konumuna yükselen RF, 2009 yılında 6'ınc1, 2010 yılında da 8'inci siradadır.

- Türkiye'deki ithalar siralamasında ise 2000 yılında 4'üncü sırada iken 2004 ve 2005 yılında 2'nci sıraya 2006 ve 2007 yıllarında ise ilk sıraya yükselmiş 2008 yılından itibaren de bu konumunu sürdürmüştür.

- İkili ticaret, 2000 yılındaki 4,5 milyar dolar tutarındaki seviyeden 2008 yılında 37,8 milyon dolar seviyesine yükselmiştir. Aynı dönemde, Türkiye Rusya Federasyonuna ihracatı da 640 milyon dolar seviyesinden 6,5 milyar dolara ulaşmıştır.

- Diğer taraftan, gerek 2008 y1lı sonundan itibaren yaşanan küresel krizin global ticaretteki olumsuz etkileri, gerek Türkiye ile Rusya Federasyonu arasında son dönemde ikili ticari ve ekonomik ilişkilerde yaşanan sıkıntılar nedeniyle, 2009 yılında ikili ticarette yüksek oranlı bir düşüş kaydedilmiştir. İkili ticaret 2009 yılında 22,9 milyar düzeyine gerilerken, ihracatımız da 3,2 milyar dolar olarak kaydedilmiştir.

- 2010 yılında krizin etkilerinin biraz daha aşılması neticesinde, RF ile Türkiye'deki ticaret hacmi bir önceki yıla göre \%15,8 oranında artarak 26,2 milyar dolar olarak kaydedilmiştir. Ülkedeki ihracat ise, $\% 44,7$ oranında bir artışla 4,6 milyar dolara yükselmiştir. 
- 2011 yılında ise, her ne kadar Türkiye'deki ticaret hacmi 2008 y1lı seviyesine yaklaşsa da, beklenen rekor kırılamamıştır. 2011 yılında ikili ticaret hacmi, bir önceki yıla göre \%14,2 oranında bir artışla 30 milyar dolar olarak kaydedilmiştir. İhracat \%29,5 oranında artışla 6 milyar dolar, ithalat ise, \%10,9 oranında bir artış ile 24 milyar olarak kaydedilmiştir.

- 2011 yılında RF'ye ihracat artış oranı (\%29,5), Türkiye'nin toplam ihracatının genel artış oranından $(\% 18,5)$ iki kat fazla bir oranda artmış, RF'den ithalat artış oranı $(\% 10,9)$ ise, Türkiye'nin toplam ithalatının genel artış oranından $(\% 29,8)$ iki kattan fazla bir oranda az artış göstermiştir.

- İki ülke arasındaki ticarete konu olan ürünler her geçen yıl çeşitlenmektedir. Rusya başlangıçta Türkiye'den çoğunlukla gıda maddeleri alırken daha sonra tekstil ve konfeksiyon ürünleri, deri, kürk, makina ve teçhizat, otomobil almaya başlamıştır. Türkiye ise enerji kaynakları (petrol, doğal gaz, kömür) başta olmak üzere makina aksam ve parçaları, demir çelik, kimyasallar ve gübre ithal etmektedir.

- Türkiye'den Rusya Federasyonu'na ihraç edilen malların 2011 yılı verileriyle kompozisyonu incelendiğinde, dokumacılık ürünlerinin $\% 18,2$, g1da ürünlerinin $\% 17,8$, otomotiv sanayi ürünlerinin $\% 13,8$, diğer elektriksiz makinelerin $\% 7,9$ ve kimyasalların $\% 7,8$ paya sahip olduğu görülmektedir.

- Türkiye'nin Rusya pazarına yönelik ihracatını ağırlıklı olarak fiyat elastikiyetleri yüksek tüketim malları oluşturmaktadır.

- 2011 yılı verilerine göre, Türkiye'nin Rusya'dan ithalatının kompozisyonunda petrol gazlarıdoğalgazların $\% 45,5$, petrol ürünlerinin $\% 18,7$, demir çeliğin $\% 8,6$, demir dışı metallerin $\% 6,7$ ve kömürün \%6,1 oranında payının bulunduğu görülmektedir.

- Türkiye, 2011 yılı verilerine göre Rusya Federasyonunun dış ticaret hacminde 7., ithalatında 13., ihracatında ise 6. sırayı almaktadır.

Son siyasi gelişmelerin iki ülke arasındaki ticari ilişkileri daha da arttıracağı düşünülmektedir. RF ile Türkiye arasında özellikle 2009 yılı Ağustos ayından itibaren siyasi ilişkilerde yaşanan önemli gelişmeler ve bu gelişmelerin iki ülke arasındaki ilişkileri "stratejik ortaklık” boyutuna yükselterek, ikili üst düzey ziyaretleri arttırması sonucunda, siyasi ilişkilerde yaşanan bahar havasının, ticari ve ekonomik ilişkilere yansıtılması hedefi daha da önem kazanmıştır.

Konuyla ilgili güncel istatistikler tablolar halinde aşağıda verilmiştir;

Özellikle, iki ülke siyasi iradelerinin en son Türkiye Cumhuriyeti Başbakanı Tayip ERDOĞAN'nın RF'ye yönelik 12-13 Ocak 2010 ziyareti, RF Devlet Başkanı Medvedev’in Türkiye’ye 11-12 Mayıs 2010 tarihleri arasında gerçekleştirdiği ziyaret, Putin'in 8 Haziran 2010 tarihinde Türkiye'ye düzenlediği ziyaret ve son olarak Başbakan Erdoğan'nın 15-17 Mart 2011 tarihleri arasındaki ziyareti sırasında da vurgulandığı üzere, ikili ilişkilerin stratejik ortaklık boyutuna çıkması ve bu hedefin realizasyonuna yönelik somut adımlar atılması, bu adımların ticari ve ekonomik çalışmalar da taçlandırılması gereğini ortaya çıkarmaktadır.

\begin{tabular}{|c|c|c|c|c|c|c|c|c|c|c|c|}
\hline & \multicolumn{10}{|c|}{ YILLAR } & \multirow{2}{*}{$\begin{array}{l}\text { 2012- } \\
2011 \% \\
\text { Değişim }\end{array}$} \\
\hline & 2003 & 2004 & 2005 & 2006 & 2007 & 2008 & 2009 & 2010 & 2011 & 2012 & \\
\hline İhracat & 1.368 & 1.859 & 2.371 & 3.238 & 4.727 & 6.482 & 3.202 & 4.628 & 5.993 & 6.683 & 11,5 \\
\hline İthalat & 5.451 & 9.033 & 12.818 & 17.806 & 23.508 & 31.365 & 19.450 & 21.601 & 23.953 & 26.620 & 11,1 \\
\hline Ticaret Hacmi & 6.819 & 10.892 & \begin{tabular}{|l|}
15.189 \\
\end{tabular} & 21.044 & 28.235 & \begin{tabular}{|l|}
37.847 \\
\end{tabular} & 22.652 & \begin{tabular}{|l|}
26.229 \\
\end{tabular} & 29.946 & 33.303 & 11,2 \\
\hline Ticaret Açı̆̆ 1 & -4.083 & -7.174 & -10.447 & -14.568 & -18.781 & -24.883 & -16.248 & -16.973 & -17.960 & \begin{tabular}{|l|}
-19.937 \\
\end{tabular} & 11,0 \\
\hline $\begin{array}{l}\text { İhracatta Payı } \\
(\%)\end{array}$ & 2,9 & 2,9 & 3,2 & 3,8 & 4,4 & 4,9 & 3,1 & 4,1 & 4,4 & 4,4 & $-1,4$ \\
\hline İhracatta Sıras1 & 6 & 8 & 8 & 9 & 7 & 5 & 6 & 6 & 6 & 6 & 0,0 \\
\hline $\begin{array}{l}\text { İthalatta Pay1 } \\
(\%)\end{array}$ & 7,9 & 9,3 & 11,0 & 12,8 & 13,8 & 15,5 & 13,8 & 11,6 & 9,9 & 11,3 & 13,2 \\
\hline İthalatta S1rası & 3 & 3 & 2 & 2 & 1 & 1 & 1 & 1 & 1 & 1 & 0,0 \\
\hline
\end{tabular}

Tablo 1. Türkiye-Rusya Federasyonu (Rf) Dış Ticareti(mil. \$)

\begin{tabular}{|l|l|l|l|l|}
\hline 2012 & İhracat & $\%$ Pay & İthalat & $\%$ Pay \\
\hline Yatırım Malları & 627 & 9,4 & 30 & 0,1 \\
\hline Ara Mallar & 3.418 & 51,1 & 25.841 & 97,1 \\
\hline Tüketim Malları & 2.628 & 39,3 & 748 & 2,8 \\
\hline Diğer & 10 & 0,1 & 1 & 0,0 \\
\hline Toplam & 6.683 & 100,0 & 26.620 & 100,0 \\
\hline
\end{tabular}

Tablo 2. Türkiye-RfDış Ticaretinin Yapısı* (mil. \$) 


\begin{tabular}{|c|c|c|c|c|c|}
\hline \multicolumn{3}{|l|}{ İhracat } & \multicolumn{3}{|l|}{ İthalat } \\
\hline 2012 & mil. \$ & $\%$ Pay & 2012 & mil. \$ & $\%$ Pay \\
\hline Dokumacıllk ürünleri & 1.256 & 18,8 & Petrol gazlar1-doğal gaz & 12.272 & 46,1 \\
\hline Gıda ürünleri & 1.028 & 15,4 & Petrol ve ürünleri & 5.068 & 19,0 \\
\hline $\begin{array}{l}\text { Otomotiv sanayi } \\
\text { ürünleri }\end{array}$ & 791 & 11,8 & Gıda ürünleri & 2.034 & 7,6 \\
\hline Diğer yarı mamüller & 597 & 8,9 & Demir-çelik & 1.709 & 6,4 \\
\hline Kimyasallar & 547 & 8,2 & Kömür & 1.669 & 6,3 \\
\hline Diğer tüketim ürünleri & 518 & 7,8 & Demir dışı metallar & 1.359 & 5,1 \\
\hline $\begin{array}{l}\text { Diğer elektriksiz } \\
\text { makineler }\end{array}$ & 477 & 7,1 & $\begin{array}{l}\text { Maden cevherleri ve } \\
\text { döküntüleri }\end{array}$ & 1.067 & 4,0 \\
\hline Hazır giyim & 409 & 6,1 & Kimyasallar & 868 & 3,3 \\
\hline $\begin{array}{l}\text { Elektrikli makine ve } \\
\text { cihazlar }\end{array}$ & 352 & 5,3 & Diğer yarı mamüller & 341 & 1,3 \\
\hline Madencilik ürünleri & 285 & 4,3 & Tarımsal hammaddeler & 164 & 0,6 \\
\hline DİĞER & 423 & 6,3 & DİĞER & 69 & 0,3 \\
\hline GENEL TOPLAM & 6.683 & 100,0 & GENEL TOPLAM & 26.620 & 100,0 \\
\hline
\end{tabular}

Tablo 3. Türkiye-Rf Dlş Ticaretinde İlk 10 Madde/Madde Grubu*

\begin{tabular}{|l|l|l|}
\hline Y1lar & Hacim (mil. \$) & Prj. Ad. \\
\hline $1989-1999$ & 9.694 & 587 \\
\hline 2000 & 165 & 19 \\
\hline 2001 & 343 & 38 \\
\hline 2002 & 428 & 40 \\
\hline 2003 & 1.033 & 70 \\
\hline 2004 & 746 & 56 \\
\hline 2005 & 2.468 & 70 \\
\hline 2006 & 2.738 & 61 \\
\hline $2007 * *$ & 5.922 & 101 \\
\hline 2008 & 2.778 & 43 \\
\hline 2009 & 1.809 & 21 \\
\hline 2010 & 1.277 & 34 \\
\hline 2011 & 2.487 & 74 \\
\hline $2012 * *$ & 2.914 & 69 \\
\hline 2013 (Ocak) & 455 & 9 \\
\hline TOPLAM & 35.257 & 1.292 \\
\hline$* *$ Duymar & & \\
\hline
\end{tabular}

**Duyumlar dahil

Tablo 4. Müteahhitlik Hizmetleri (İş alındı belgelerine göre)

\begin{tabular}{|l|c|c|c|c|c|l|l|}
\cline { 2 - 8 } \multicolumn{1}{c|}{} & 2008 & 2009 & 2010 & 2011 & 2012 & $\begin{array}{c}\text { 2012-2011 } \\
\text { \% Değişim }\end{array}$ & $\begin{array}{c}\text { Türkiye'nin } \\
\text { Sirası (2012) }\end{array}$ \\
\hline İhracat & 468.073 & 301.652 & 397.068 & 516.718 & 524.727 & 1,5 & 5 \\
\hline İthalat & 266.918 & 167.371 & 228.912 & 305.760 & 312.567 & 2,2 & 13 \\
\hline Diş Ticaret Hacmi & 734.991 & 469.023 & 625.980 & 822.478 & 837.294 & 1,8 & 7 \\
\hline Diş Ticaret Fazlası & 201.155 & 134.281 & 168.156 & 210.958 & 212.160 & 0,6 & 2 \\
\hline
\end{tabular}

Tablo 5. Rf'nin Toplam Dış Ticareti (mil. \$)

\begin{tabular}{|l|c|c|c|c|c|c|c|c|c|c|c|}
\hline & \multicolumn{10}{|c|}{ YILLAR } & $\begin{array}{l}2012-2011 \\
\text { \%Değişim }\end{array}$ \\
\cline { 2 - 14 } & $\mathbf{2 0 0 3}$ & $\mathbf{2 0 0 4}$ & $\mathbf{2 0 0 5}$ & $\mathbf{2 0 0 6}$ & $\mathbf{2 0 0 7}$ & $\mathbf{2 0 0 8}$ & $\mathbf{2 0 0 9}$ & $\mathbf{2 0 1 0}$ & $\mathbf{2 0 1 1}$ & $\mathbf{2 0 1 2}$ & 13,1 \\
\hline İhracat & 47.253 & 63.167 & 73.476 & 85.535 & 107.272 & 132.003 & 102.143 & 113.883 & 134.907 & 152.561 & 13.9 \\
\hline İthalat & 69.340 & 97.540 & 116.774 & 139.576 & 170.063 & 201.961 & 140.928 & 185.544 & 240.842 & 236.537 & $-1,8$ \\
\hline $\begin{array}{l}\text { Diş Ticaret } \\
\text { Hacmi }\end{array}$ & 116.593 & 160.707 & 190.250 & 225.111 & 277.335 & 333.964 & 243.071 & 299.427 & 375.749 & 389.098 & 3,6 \\
\hline $\begin{array}{l}\text { Diş Ticaret } \\
\text { Açığ1 }\end{array}$ & -22.087 & -34.373 & -43.298 & -54.041 & -62.791 & -69.958 & -38.785 & -71.661 & -105.935 & -83.976 & $-20,7$ \\
\hline $\begin{array}{l}\text { İhracat } \\
\text { İthalat }\end{array}$ & 68,1 & 64,8 & 62,9 & 61,3 & 63,1 & 65,4 & 72,5 & 61,4 & 56,0 & 64,5 & 15,1 \\
\hline
\end{tabular}

Tablo 6. Türkiye'nin Toplam Dış Ticareti (mil. \$) Kaynak: Ekonomi Bakanlı̆̆l, Moskova Ticaret Müşavirliği, RF Federal Gümrük Servisi, TÜIK 


\section{Sonuç ve Değerlendirme}

Yenidünya düzeni olarak adlandırılan küreselleşme ülkeler arası sınırları giderek ortadan kaldırmış ve ekonomik sistemi tam bir rekabet ortamına dönüştürmüştür. İşletmeler bu rekabet ortamında varlıklarını devam ettirebilmek için birçok çaba ve yeni yaklaşımlar sergilemektedir.

Klasik yönetim anlayışı bu süreçte etkisini kaybetmiş, insani değerlerin ön plana çıktığı modern yönetim anlayışına yerini bırakmıştır. Bu bağlamda işletmelerin küresel rekabette başarılı olabilmeleri yerel değeri yani kültürü göz ardı etmemelerine bağlıdır. İşletmeler söz konusu rekabet ortamında büyüyebilmek için diğer ülkelerin sadece siyasi ve ekonomik sistemlerini değil kültürel, dini ve sosyal sistemlerini de araştırmaları gerekir.

Üretim, tüketim, satın alma, yatırım kararları gibi her türlü ekonomik faaliyetlerin ardında hep insan davranışı söz konusudur. İnsanın düşüncesini ve kararlarını davranışa dönüştüren iç dünyasıdır ve bu iç dünyayı şekillendiren insanın dış çevresi yani sosyal ve kültürel çevresi yer almaktadır. Buradan da, kültürün ekonomik faaliyetleri şekillendirdiği ortaya çıkmaktadır.

Son yaşanan süreçte ekonomik ve sosyolojik unsurlar iç içe geçmiş durumdadır. Ekonomik büyüme analizi, objektif, elle tutulur ve sayılabilir unsurlardan, ele gelemez ve sayılamaz olgulara doğru kaydığı, bu olguları da insan unsurları ve onun tepkileri olduğu görülmektedir. Ekonomik analiz yapılırken insan olgusunu görmezlikten gelmek değil insandan başlamak gerektiği ortaya çıkmaktadır.

Bu bağlamda, kültürel diyalogun ön plana çıktığı Türküye-Rusya ilişkisine son süreçte baktığımızda; Türkiye ve Rusya arasında siyasi, kültürel ve ekonomik alanda ilişkilerin son yüz yılın en iyi seviyede olduğu söylenebilir. Kültürel yönden ortak noktalarda buluşan iki ülke son süreçte bu durumu ekonomilerine yansıtarak ekonomik ve stratejik ortak konumuna gelmiştir. Rusya'nın özellikle ihracat, turizm ve müteahhitlik alanında Türkiye için önemli bir ülke olduğu ayrıca Türkiye'nin ilk nükleer santralini Rusya'nın inşa edecek olması da iki ülke arasında karşılıklı güvenin teyidi niteliktedir. Ayrıca iki ülke arasında kültürel etkileşim için 2007 yılında Türkiye'de "Rus Kültür Yılı”, 2008 yılında Rusya'da “Türk Kültür Yılı” kutlanmış olması ekonomik ilişkileri de canlandırmıştır ve gelecek yıl Rusya'da düzenlenecek olan “Türk Kültür Festivali” de söz konusu yakınlaşmanın pekişmesinde önemli bir göstergesidir.

Hem insan hem toplum hem de çevreyi içine alan kültürün, küreselleşen dünyada ülkeler arası ekonomik ilişkilerin ilerletilmesinde ve devamının sağlamasında önemli bir faktör olduğu şüphe götürmez bir gerçektir. 20. Yüzyılın başlarına kadar savaşlar ve güç mücadelelerine tanık olmuş Türk-Rus ilişkisi her iki ülkede ortaya çıkan ve aynı süreci yaşayan yönetim değişikliği ile iki ulus arasında yakınlaşmaya neden olmuştur. Özellikle ekonomik, ticari ve kültürel anlamda ortaya çıkan yakınlaşma elde edilen veriler ışığında ikili ilişkilerinin en iyi seviyeye ulaştığını göstermektedir.

\section{Kaynakça}

- $\quad$ AYDIN Kenan, "Uluslararası İlişkiler ve Kültürel Pazarlamada Kültürel Etkiler", Nobel Yayınları, Ankara, 2003

- ÖĞÜT Adem, KOCABACAK Ayşe, "Küreselleşme sürecinde Türk İş Kültüründe Yaşanan Dönüşümün Boyutları", Türkiyat Araştırmaları Dergisi, Sayı:145, Konya, 2007

- GÜLMEZ Bahadır, "Kültür Tarihi", Anadolu Üniversitesi Yayınları", Yayın No:2299, Ankara, 2013

- $\quad$ ARON Raymond, Çev:ALEMDAR Korkmaz, "Sosyolojik Düşüncenin Evreleri", Ankara, 1986

- $\quad$ BOTTOMORE Tom, NISBET Robert, Çev:TUNCAY Mete, "Sosyolojik Çözümlemen Tarihi", Ankara, 1990

- $\quad$ ÜLGENER Sabri, "Zihniyet, Aydınlar ve İzmler", Ankara, 1983

- ÇAĞATAY Tahir, "Kapitalist İctimai Nizam ve Bugünkü Durumu", İstanbul, 1975

- $\quad$ ERKAL E.Mustafa, "İktisadi Kalkınmanın Kültür Temelleri", Ankara, 1990

- $\quad$ ERKAL E.Mustafa, "Bölge Açısından Azgelişmişlik, 101 soru, 101 Cevap", İstanbul, 1990

- ONAY Yaşar, "Batıya Direnen Devlet Rusya", Yeniyüzyıl Yayınları, İstanbul, 2008

- ONAY Yaşar, "Rusya ve Değişim", Nobel Yayınları, Ankara, 2002

- SÖNMEZOĞLU Faruk, "Türk Dış Politikasının Analizi", Der Yayınları, İstanbul, 2004

- http://www.peryod.com.tr/images/pdf/uluslararasi.pdf (Erişim Tarihi: 31.05.2013)

- http://ekutup.dtp.gov.tr/planlama/42nciyil/saritam.pdf (Erişim Tarihi: 31.05.2013)

- http://milliyet.com.tr/turkiye-rusya-karsilastirmasi/ekonomi/sondakika (Erişim Tarihi: 31.05.2013)

- http://www.turkrus.com/60930-turkler-ve-ruslar-ve-yollar-xh.aspx (Erişim Tarihi: 31.05.2013)

- http://www.ihkupcu.com/makale/medeniyet.htm (Erişim Tarihi: 31.05.2013)

- http://www.ekonomi.gov.tr (Erişim Tarihi: 31.05.2013)

- http://www.musavirlikler.gov.tr (Erişim Tarihi: 31.05.2013) 


\title{
Türkiye'nin İhracat Performansı: İhracat Hacminin Temel Belirleyicilerinin İncelenmesi (1995-2012)
}

\section{Turkey's Export Performance: Examining the Main Determinants of Export Volume (1995-2012)}

\author{
Prof. Dr. Mehmet Balc1lar (Eastern Mediterranean University, Cyprus) \\ Prof. Dr. Harun Bal (Çukurova University, Turkey) \\ Assoc. Prof. Dr. Neşe Algan (Çukurova University, Turkey) \\ Ph.D. Candidate Mehmet Demiral (Çukurova University, Turkey)
}

\begin{abstract}
The main objective of this study is to investigate the short and the long run relationships between export performance proxied by export volume index and real effective exchange rate changes in Turkey using the aggregated quarterly data sets covering the period of 1995-2012. The other factors that are expected to affect export performance such as wage, foreign income, productivity, trend GDP and exchange rate volatility are also added to the model. The ARDL bounds testing approach to cointegration is performed in the estimation process. The causalities among the variables in the model are determined based on the estimated ARDL models. The empirical results reveal that the variables of interest are cointegrated. Real effective exchange rate coefficient is significantly positive in the short run whereas negative in the long run and exchange rate volatility has no significant effect on export performance in contrast with theoretical expectations. Other evidences indicate that the recent export boom in Turkey can be explained by wages, productivity and world demand, rather than exchange rate changes. Consequently, findings suggest that policies that depressing wages and stimulating high productivity can help export sectors increase their export volume and competitiveness in Turkey.
\end{abstract}

\section{Giriş}

Dünya ekonomisi özellikle 1960'lardan sonra, iletişim ve taşıma teknolojilerindeki gelişmelerin de etkisiyle hızlı bir ticari küreselleşme sürecine girmiştir. Gelişmiş ülkeler özellikle kendi aralarında olmak üzere ekonomilerini daha önce uluslararası rekabete açmışlardır. Onları takip eden birçok gelişmekte olan ülke (GOÜ) için ise Doğu Asya ülkelerinin ihracat artışlarına dayalı ve istikrarlı ekonomik büyüme başarıları teşvik edici olmuştur. 1980'lerde gelişen bu süreçte ithal ikameci politikalar uygulayan Latin Amerika ülkeleri ile ihracata yönelik politikalar uygulayan ve istikrarlı bir şekilde büyüyen Doğu Asya ülkeleri arasında ekonomik performans farklılıkları dikkat çekmiştir.

Türkiye bu gelişmelere 24 Ocak 1980'de aldığı ekonomik kararlar gereğince, daha önce uyguladı̆̆ içe dönük ithal ikameci politikalardan, dış rekabete açılan ihracata yönelik politikalara geçerek uyum sağlamaya çalışmıştır. Bunu 1995'te Dünya Ticaret Örgütü üyeliği ve 1996 yılında Avrupa Birliği (AB) ile başlayan Gümrük Birliği (GB) süreci izlemiştir. Uygulanan bu dışa açılma politikaları ile hem ihracat hem de ithalat önemli ölçüde artmıştır.

Yaşanan ticari liberalizasyon süreci ile GOÜ’lerin dünya ticaretinde artan payı, beraberinde finansal liberalizasyonu getirmiştir. Bu süreçte birçok GOÜ, sermaye hareketleri üzerindeki kontrollerini azaltmış ve 1973 'te Bretton Woods sisteminin yıkılmasının da etkisiyle sabit döviz kuru uygulamalarından vazgeçerek, yönetimli ya da serbest dalgalı kur sistemine geçmişlerdir. Türkiye ise daha önceden yapılan devalüasyonların ticaret açıklarını gidermede yetersiz kalması ve 24 Ocak 1980'de alınan ihracatı teşvik kararlarının bir gereği olarak daha esnek ve gerçekçi bir döviz kuru politikası uygulamaya başlamıştır. Sonrasında ise 1989 yılında sermaye hareketlerinin serbest bırakılmasıyla döviz kurları dış ticarette daha belirleyici bir politika aracı haline gelmiştir. 1990'lı yıllarda döviz kurlarına müdahaleler artmış ve yapılan devalüasyonlarla ihracat hacmi artırılmaya çalışılmıştır. 2001 krizinden sonra döviz kurlarının serbest dalgalanmaya bırakılmasıyla döviz kurlarında meydana gelen dalgalanmalar artmış ve bu oynaklıkların genel ekonomi, dış ticaret ve spesifik olarak ta ihracat üzerine etkilerini araştıran çalışmaların sayısı gün geçtikçe artmıştır.

Bir ülkenin ihracat performansı, yurtiçi firmaların uluslararası piyasalarda rekabet edebilme ölçüsünü göstermekte ve çok sayıda faktör tarafından farklı biçimlerde etkilenmektedir. Bu çalışmada, Türkiye ekonomisi için reel efektif döviz kuru değişmeleri ve oynaklığı başta olmak üzere ücret, yurtdışı gelir, verimlilik ve GSYH trendi gibi faktörlerin ihracat performansı üzerine etkileri araştırılmaktadır. İlk olarak, 1990 sonrası yapılan ampirik çalışmalardan seçilenlerin sonuçları doğrultusunda özet bir literatür incelemesi sunulmaktadır. Sonra, genel olarak ihracat performansının belirleyicilerine yönelik teorik açıklamalar ile ampirik model ve analiz yöntemleri hakkında bilgiler verilmektedir. Veri seti ve model tanıtımı yapılarak elde edilen analiz sonuçları ortaya konulduktan sonra çalışma, ulaşılan bulgular çerçevesinde yapılan yorumlar ve değerlendirmeler ile tamamlanmaktadır. 


\section{Literatür Sunumu}

Türkiye'nin ihracat performansının döviz kuru başta olmak üzere temel belirleyicileri üzerine olan mevcut literatürde kapsam, yöntem ve elde edilen sonuçlar bakımından farklılıklar görülmektedir. Abuşoğlu (1990), 1980-88 dönemi için döviz kuru politikaları ile ihracat arasında anlamlı bir ilişki olmadığını ve Türk Lirası (TL)'nın yabancı paralar karşısında değer kaybetmesinin ihracatı çok az etkilediğini ortaya koymuştur. Arslan ve Van Wijnbergen (1993), 1980-87 dönemini kapsayan çalışmalarında reel döviz kuru (RER) yükselişlerinin ve ihracat teşviklerinin Türkiye'nin ihracatını artırdığını ortaya koymuşlardır. Barlow ve Şenses (1995), Türkiye'de 1980'lerde görülen ihracat artışlarını uygulanan politikalara ve diğer ülkelerin geliri, yaşanan krizler ve savaşlar gibi dış faktörlere bağlamışlardır. Uygur (1997), 1970'lerden 1990'ların ortalarına kadar Türkiye'de uygulanan yurtiçi talep, döviz kuru ve farklı ihracat politikalarının kısa dönemde pozitif, uzun dönemde ise negatif etkilerinin olduğunu ortaya koymuştur. Şahinbeyoğlu ve Ulaşan (1999), 1987-1998 dönemine ilişkin olarak hata düzeltme modeli $(E C M)$ kullanarak arz ve talep fonksiyonlarının fiyat ve gelir esnekliklerinin inelastik olduğu sonucuna ulaşmışlardır. Sivri ve Usta (2001) tarafından yapılan VAR analizinde, RER'den ithalat veya ihracata doğru bir nedensellik bulunmamıştır. Zengin (2001), 1994-2000 dönemine ilişkin olarak, ihracat ve ithalat fiyat endeksleri ile RER değişkenlerinin karşılıklı nedensellik ilişkisini araştırmıştır. Sonuçlar, bu değişkenler arasında uzun dönemli bir eşbütünleşme ilişkisinin varlığını ve döviz kurlarının ithalat fiyat endeksine doğrudan etkisinin olduğunu ancak ihracat fiyat endeksine etkisinin olmadığını göstermiştir. Karagöz ve Doğan (2005), RER'in dış ticaret üzerinde uzun dönemli bir nedensellik etkisinin bulunmadığını ortaya koymuşlardır. Bununla birlikte kısa dönemde ilişkinin bulunduğu ve devalüasyon etkisinin anlamlı olduğu sonucuna ulaşmışlardır. Türkiye'nin AB ile GB sürecinin ticaret etkilerini araştıran çalışmalarında Nowak-Lehmann vd. (2007), 1988-2002 dönemi için yerçekimi modeli yardımıyla AB korumacılığı, fiyat rekabeti ve taşıma maliyetlerinin etkilerini incelemişlerdir. Elde edilen sonuçlar Türkiye'nin ihracatını, taşıma maliyetlerinin negatif ve RER yükselişlerinin pozitif yönde etkilediğini ortaya koymuştur.

Toplulaştırılmış makro verilerin kullanıldığı bu çalışmaların yanında sektörel olarak yapılan analizlerin sayısı da gün geçtikçe artmaktadır. Lall (2000), Türkiye'nin imalat sanayi ihracatının teknolojik yapısını incelemiştir. Lall, 1980’li ve 1990’lı yıllar için ihracatın düşük teknoloji ürünlerinden oluştuğunu, Türkiye’nin yüksek ücretli bir ekonomi olduğunu ve düşük ücretli ülkeler ile düşük teknolojik mallarıyla rekabet etmek durumunda olduğunu belirtmiştir. Ayrıca Lall, ihracat artışlarında, küresel rekabet gücünden çok AB ile yapılan serbest ticaret anlaşmalarından sağlanan imtiyazlara dikkat çekmektedir. Özçelik ve Taymaz (2002), 1995-97 dönemi için, 4000 firmayı kapsayan ankete dayalı verilerle ihracat performansının belirleyicilerini araştırmışlardır. Yazarlar, imalat sanayi firmalarının taklit üretimden vazgeçerek, inovasyon ve AR-GE faaliyetleri ile rekabet etmeleri gerektiği sonucuna ulaşmışlardır. Buna göre Türkiye'nin rekabet gücünün artırılması için teknoloji geliştirme politikalarının önemini ortaya koymuşlardır. Keyder vd. (2004), Türk imalat sanayii ve 15 ticaret ortağına ilişkin 1994-2003 dönemini kapsayan çalışmalarında, uluslararası rekabet gücünün ölçümünde reel kur ile birlikte nispi maliyetlere dayalı bir rekabet gücü endeksinin kullanılmasının yararını belirtmişlerdir. 19992003 döneminde TL'nin yabancı paralar karsısında değerlenmesine karşın ihracatta görülen yüksek ivmeyi, nispi verimlilik artışı ve dolar bazında birim ücret maliyetlerinin ticaret ortaklarından düşük olması ile açıklamışlardır. Yaşar ve Nelson (2004), 1990-96 dönemi için, giyim eşyası ile motorlu araçlar ve aksamları endüstrileri için ihracat ve verimlilik ilişkisini araştırmışlardır. Elde edilen sonuçlara göre, üretim birimlerinin önceki market deneyimleri şimdiki verimliliklerini etkilemektedir ve öğrenme etkisinin geçerli bir faktördür. Hata düzeltme modeli ile elde edilen sonuçlara göre ise, kısa ve uzun dönemde ihracat ve verimlilik arasında iki yönlü ilişkiler bulunmuştur. Elde edilen bir diğer önemli sonuç verimliliğin ihracat üzerine etkisinin, ihracatın verimlilik üzerine etkisinden daha fazla olduğudur. Yükseler ve Türkan (2006), Türk imalat sanayiinin 1996'dan 2005 'e 10 yılda geçirdiği dönüşümü 'ithalatlaşma', 'uluslararasılaşma' ve 'Asyalılaşma' eğilimleri şeklinde özetlemiştir. Bu eğilimlerin etkisiyle imalat sanayiinde önemli ölçekte bir dış ticaret hacmi yaratıldığı, ancak bu ticaret hacminin katma değer ve istihdam üzerindeki yansımalarının kısıtlı olduğu görülmüştür. Yine Aysan ve Hacıhasanoğlu (2007), 1996-2006 dönemi için dinamik panel verilerini kullanarak Türkiye'nin imalat sanayiinde görülen artışların nedenlerini araştırmışlardır. Elde edilen sonuçlar özellikle 2000'lerden sonra verimlilik artışlarının ihracatı artırdığını, bunun yanında ücretlerin ihracatı negatif etkilediğini ortaya koymuşlardır. Özler, Taymaz ve Yılmaz (2007), imalat sanayiine ilişkin olarak mikro düzeydeki verilere dayanarak hazırladıkları çalışmada, ihracat kararının, firma büyüklüğü, toplam çalışanlar içinde yönetim kademesinin ve kadınların ağırlığı ile teknoloji ve makine/teçhizat donanımı tarafından belirlendiğini ortaya koymuşlardır. Son olarak Çelik ve Kaya (2010), 1985-2006 dönemi için Türkiye'nin toplam dış ticaretinin yaklaşık \%60'nı oluşturan 7 ülke ile olan ikili ticaretini incelemişlerdir. RER yükselişlerinin uzun dönemde Almanya, Japonya ve İngiltere ile ikili ticaretinde Türkiye'nin ticaret dengesini iyileştirirken Fransa, Hollanda, İtalya ve ABD için böyle bir bulgu elde etmemişlerdir. Yazarlar, genel olarak kısa dönemde fiyatların yapışkan olmadığını ve böylece J-eğrisi gibi etkilerin görülmediğini ortaya koymuşlardır.

Görüldüğü gibi konuyla ilgili yapılan ampirik çalışmalara ilişkin elde edilen farklı sonuçlar başka faktörlerin de birlikte incelenmesi gerektiğini ortaya koymaktadır. Bu çalışma Türkiye ile ilgili literatüre katkı sağlamayı ve 
global düzeyde değişen ticaret yapıları kapsamında Türkiye'nin ihracat performansını etkileyen başka faktörlere de dikkat çekmeyi amaçlamaktadır.

\section{Teorik ve Ampirik Çerçeve}

Türkiye İstatistik Kurumu (TÜİK) dış ticaret istatistiklerine göre Türkiye'nin ihracatı 1980 yılından itibaren, bazı istisna yıllar dışında, sürekli artmış ve günümüzde en yüksek seviyelerine ulaşmıştır. Bu gelişmelerin belli dönemlerde düşük seyreden döviz kurları ile birlikte yaşanması akademik ilgiyi değerli hale gelen TL sonucunda ucuzlayan ithal girdilere çekmiştir. Aşağıda Tablo 1'de, Birleşmiş Milletler (UN) Standart Uluslararası Ticaret Sınıflandırması (SITC), 3. revizyon 2-basamaklı endüstri sınıflamasına göre, Türkiye'nin hem 1990-2000 döneminde hem de 2001-2012 döneminde, petrol gibi yoğun enerji girdisi kullanan temel ihracat sektörleri için $(78,67,33)$ ihracatın ithal içeriğinin yüksek olduğu ve bazı sektörler için $(65,77,05,69)$ bu payın dönemler itibariyle arttığı görülmektedir.

\begin{tabular}{|c|c|c|c|}
\hline İlk 10 sektör (1990-2000) & $\begin{array}{l}\text { İthal içeriği } \\
(1998)^{* *}\end{array}$ & İlk 10 sektör (2001-2012) & $\begin{array}{l}\text { İthal içeriği } \\
(2002)^{* *}\end{array}$ \\
\hline 84. Giyim eşyası ve aksesuarları & 0,18 & $\begin{array}{l}\text { 78. Motorlu kara taşıtları, bisiklet/ } \\
\text { motosikletler ve aksam/parçaları }\end{array}$ & 0,36 \\
\hline $\begin{array}{l}\text { 77. Elektrikli makine, cihaz ve aletler } \\
\text { vb. ile aksam ve parçaları }\end{array}$ & 0,25 & 84. Giyim eşyası ve aksesuarları & 0,28 \\
\hline 05. Meyve ve sebzeler & 0,05 & 67. Demir ve Çelik & 0,38 \\
\hline $\begin{array}{l}\text { 65. Tekstil ürünleri (iplik, kumaş, yer } \\
\text { kaplamaları, hazır eşya) }\end{array}$ & 0,19 & $\begin{array}{l}\text { 65. Tekstil ürünleri (iplik, kumaş, } \\
\text { yer kaplamaları, hazır eşya) }\end{array}$ & 0,28 \\
\hline $\begin{array}{l}\text { 69. Demir, çelik, bakır, nikel, } \\
\text { alüminyum gibi adi metal eşyaları }\end{array}$ & 0,29 & $\begin{array}{l}\text { 77. Elektrikli makine, cihaz ve } \\
\text { aletler vb. ile bunların aksam ve } \\
\text { parçaları }\end{array}$ & 0,33 \\
\hline 82. Mobilya, yatak ve bileşenleri & 0,21 & 05. Meyve ve sebzeler & 0,07 \\
\hline $\begin{array}{l}\text { 57. İlk şekillerde plastikler, döküntü } \\
\text { ve hurdalar }\end{array}$ & 0,30 & $\begin{array}{l}\text { 66. Taş, alçı, çimento, amyant, cam, } \\
\text { seramik vb. maddelerden eşyalar }\end{array}$ & 0,21 \\
\hline $\begin{array}{l}\text { 61. Başka yerde belirtilmeyen } \\
\text { İşlenmiş deri ve köseleler }\end{array}$ & 0,18 & $\begin{array}{l}\text { 69. Demir, çelik, bakır, nikel, } \\
\text { alüminyum gibi adi metal eşyaları }\end{array}$ & 0,36 \\
\hline 12. Tütün ve tütün mamulleri & 0,05 & $\begin{array}{l}\text { 33. Petrol, petrolden elde edilen } \\
\text { ürünler }\end{array}$ & 0,73 \\
\hline $\begin{array}{l}\text { 27. Hayvansal ve bitkisel gübreler, } \\
\text { tuz, kükürt alçı vb. mineral maddeler }\end{array}$ & 0,12 & $\begin{array}{l}\text { 89. Başka yerde belirtilmeyen } \\
\text { çeşitli mamül eşyalar }\end{array}$ & 0,41 \\
\hline
\end{tabular}

*ilk 10 sektör 1990-2000 dönemi için, USD olarak, toplam ihracatın yaklaşık \%60'nı, 2001-2012 dönemi için ise yaklaşık $\% 65$ 'ini oluşturmaktadır.

** Ihracatın ithal içeriği değerleri, $\mathrm{aN}^{\mathrm{m}}\left(\mathrm{I}-\mathrm{N}^{\mathrm{d}}\right)^{-1} \mathrm{EX} / \Sigma \mathrm{EX}$ formülüyle hesaplanmıştır. Burada, a ele alınan ithalat kalemlerinde içeriği 1'e eşit olan her bir $1 x n$ vektörünü, $\mathrm{N}^{\mathrm{m}}$ ve $\mathrm{N}^{\mathrm{d}}$ sırasıyla ithalat ve ihracat işlemleri için girdi-çıktı katsayı matrislerini; I köşegen özdeş matrisi ve EX ihracat vektörünü göstermektedir. Elde edilen değer aynı zamanda toplam ihracatta 'dikey uzmanlaşma' seviyesini göstermektedir (Hummels vd., 2001).

Tablo 1: Farklı Dönemler İçin 10 Temel İhracat Sektörü ve İthal İçeriği Kaynak: Ticaret verileri, UNCOMTRADE; Girdi-Çıktı Tabloları, TÜIKK-Ulusal Hesaplar'dan elde edilmiştir.

Froyen (1999), uluslararası ticarette kaynak etkinliğini ve uzmanlaşmayı artırdığı için artan ithalatın ülke ekonomilerine zarar vermediğine dikkat çekmektedir. Bunun yanında yatay uzmanlaşma ile şekillenen uluslararası ticaret yapısında köklü değişmeler gözlenmiş ve üretimde dikey uzmanlaşma süreci belirleyici hale gelmiştir. Dış kaynak kullanımı, dikey bütünleşme, dikey doğrudan yabancı yatırımlar ve montaj ticareti gibi genel olarak çok uluslu şirketlerin faaliyetleri tarafindan şekillenen dikey uzmanlaşma, hem ihracat hem de ithalat yönlü tüm üretim faaliyetlerinde ülkelerin birbirlerine bağımlılığını artırmıştır (Hummels vd., 1998).

Gelişen bu ilişkilerin etkisinde, Türkiye'nin ihracat hacmi ile temel belirleyicileri arasındaki uzun dönemli ilişkiyi gösteren regresyon modeli şu şekilde oluşturulmuştur:

$$
\begin{aligned}
& X_{i t}=\beta_{0}+\beta_{1} R_{t}+\beta_{2} Y_{t}^{*}+\beta_{3} C_{t}+\beta_{4} K_{t}+\beta_{5} G_{t}+\beta_{6} H_{t}+\varepsilon_{t} \\
& i=1,2, \ldots, 6 ; \quad t=1995.1, \ldots, 2012.4
\end{aligned}
$$

Burada, $X_{t}$ ihracat hacmini, $R_{t}$ reel efektif döviz kurunu, $Y_{t}^{*}$ yurtdışı reel geliri, $C_{t}$ ücret ile ifade edilen ifade eden nominal değişken maliyeti, $K_{t}$ çıktı seviyesi trendini, $G_{t}$ verimliliği, $H_{t}$ döviz kuru oynaklığını, $\varepsilon_{t}$ rastsal hata terimini ve $t$ zaman ya da trend değişkenini simgelemektedir. Bünyesinde ihracat arz ve talep yapılarını barındıran bu teorik model, temelde Goldstein ve Kahn (1985) tarafindan ortaya konulan ve daha sonra Edwards ve Wilcox (2003) tarafından geliştirilen zayıf ikame modeline dayanmaktadır. Yani model yurtiçi mallar ile ihraç malları fiyatlarının farklı olmasına olanak tanımaktadır. İhracat fiyatlarındaki bir artış ihracat arzını artırırken, 
yurtiçi fiyat seviyesinde ve ücret bakımından ölçülen maliyetlerdeki bir artış ihracat arzını azaltmaktadır. Yine ihracat fiyatlarındaki bir artış ihracat talebini azaltırken, rekabet edilen yurtdışı malların fiyatındaki ve yurtdışı gelirdeki bir artış ise ihracat talebini artıracaktır. Hem ithalat hem de ihracat fiyatlarını etkileyen döviz kurundaki bir yükselmenin ise ihracat talebini artırması beklenmektedir. Teknolojik gelişmenin sağladığı verimlilik artışı üretim maliyetini düşüreceğinden ihracat arzını pozitif yönde etkileyecektir. GOÜ’ler için döviz kuru oynaklığının ihracat üzerine negatif etkilerinin olduğu bilinmekle birlikte (Hall vd., 2010), Türkiye için de benzer bulgulara ulaşıldığı görülmektedir (Doğanlar, 2002; Rey, 2006; Tarı ve Yıldırım, 2009; Hall vd., 2010). Frey (2005)'e göre, döviz kuru dalgalanmalarının ortaya çıkardığı risk firmaların ticaret kararı almasını etkilemektedir. Firmalar kur dalgalanmalarını tahmin edemediklerinden ödeme güçlükleri ortaya çıkabilmekte ve ticaret engellenmektedir. Artan ekonomik faaliyetlerin sağladığı ve fiyat dışı rekabette belirleyici olan, toplam faktör verimliliği, ihracat arz ağları, yaparak öğrenme ve kapasite gibi faktörler gelir trendi tarafından temsil edilmektedir.

Teorik açıklamalara uygun olarak $\beta_{2}$ ve $\beta_{5}$ 'in pozitif, $\beta_{3}$ ve $\beta_{6}$ 'nın ise negatif işaretli olması beklenmektedir. Çok sayıda faktörün etkilerini barındıran gelir trendi değişkenine ilişsin $\beta_{4}$ parametresinin işareti belirsiz olmaktadır. Normal koşullar altında $\beta_{1}$ 'in pozitif olması beklenirken, ihracat içindeki ithal girdi payı ve montaj ticareti arttıkça $R E R$ 'in ihracat arzı üzerine olan pozitif etkisi ortadan kalkabilmekte böylece $\beta_{l}$ parametre tahmini negatif ya da anlamsız olabilmektedir (Arndt ve Huemer, 2004; Freund vd., 2012).

Ayrıca döviz kurlarında meydana gelen değişmelerin gecikmeli etkileri de farklı olabilmektedir. Literatürde yaygın bir biçimde incelenen J-eğrisi etkisi bu faktörlerden biridir (Bahmani-Oskooee ve Ratha, 2004). J-eğrisi etkisi, ARDL gibi bir dinamik modelleme ile görülebilmektedir. Bu nedenle çalışmada kısa ve uzun dönem ilişkilerinin belirlenebilmesi için son yıllarda yaygın olarak kullanılan Pesaran ve Shin (1999) ile Pesaran vd. (2001) tarafından geliştirilen gecikmesi dağıtılmış otoregresif modellere dayanan ARDL (autoregressive distrubuted lag) sınır testi yaklaşımı uygulanmıştır. Klasik eşbütünleşme yöntemlerine göre bazı avantajlar sağlayan bu yaklaşımda, değişkenlerin sıfırıncı dereceden I(0) veya birinci dereceden I(1) bütünleşik olmalarına bakılmaksızın, değişkenler arasındaki eşbütünleşme ilişkisi belirlenebilmektedir. Ayrıca sınır testi, bizim çalışmamızda olduğu gibi sınırlı gözlem sayılarında da kesin sonuçlar ortaya koyabilmekte ve yeterli sayıda gecikme uzunluğun belirlenmesine olanak tanımaktadır. ARDL yaklaşımı kullanılarak modelin kısa dönem dinamikleri ile uzun dönem bileşenleri, uzun dönem bilgi kaybı olmadan tahmin edilebilmektedir (Banerjee vd.,1993).

ARDL sınır testi yaklaşımı iki aşamadan oluşmaktadır. İlk olarak Pesaran ve Shin (1999) sınır testi ile uzun dönemli ilişkilerin varlığı belirlenmektedir. Değişkenler arasındaki ilişkinin yönü konusunda herhangi bir ön bilgi olmadığı durumda sınır testi yaklaşımında kısıtsız koşullu hata düzeltme modeli (unrestricted conditional error-correction model-UECM) tahmin edilmektedir. Bu yapılırken her bir değişken sırasıyla bağımlı değişken olarak alınmaktadır. $X$ bağımsız değişken olduğunda, $U E C M$ şu biçimde olacaktır:

$$
\Delta X_{t}=c_{0}+c_{1} t+\lambda_{1} X_{t-1}+\sum_{i=1}^{6} \phi_{i} V_{i t-1}+\sum_{j=1}^{p} \gamma_{j} \Delta X_{t-j}+\sum_{i=1}^{6} \sum_{j=0}^{p} \omega_{i j} \Delta V_{i t-j}+\psi^{\prime} D_{t}+\varepsilon_{t}
$$

Denklemde $V_{t}, V_{t}=\left(R_{t}, Y_{t}^{*}, C_{t}, K_{t}, G_{t}, H_{t}\right)$ biçiminde tanımlanan bir vektördür. $D_{t}$ ise yapısal değişme kuklaları gibi dışsal değişkenlerden oluşan bir vektördür. Burada Wald kısıt testine göre, sıfir hipotezi eşbütünleşme olmadığ $\left(\mathrm{H}_{0}: \lambda_{1}=\phi_{1}=\phi_{2}=\cdots=\phi_{6}=0\right)$, alternatif hipotezi ise uzun dönem ilişki olduğu $\left(\mathrm{H}_{1}: \lambda_{1} \neq \phi_{1} \neq \phi_{2} \neq \cdots \neq\right.$ $\left.\phi_{6} \neq 0\right)$ yönünde kurulmaktadır. Seçilen bilgi kriterleri ile optimum gecikme uzunluğunun $(p)$ belirlenmesinden sonra en küçük kareler $(O L S)$ yöntemi ile Denklem (1) tahmin edilmektedir. Serilerin kısmen ya da tamamen eşbütünleşik olması durumlarına ilişkin asimptotik kritik değer setleri Pesaran vd. (2001)'nin çalışmalarından elde edilmektedir. Burada ilk set değişkenlerin tümünün I(0) (alt sınır), ikinci set ise tüm değişkenlerin I(1) olduğunu (üst sınır) varsaymaktadır. Eğer hesaplanan $F$ istatistiği kritik değer üst sınırını aşarsa sıfır hipotezi ret edilerek değiş̧kenler arasından uzun dönemli bir ilişki olduğu sonucuna ulaşılmaktadır. Tersi durumda, hesaplanan $F$-istatistiği alt kritik değerden küçük ise değişkenler arasında uzun dönemli bir ilişki olmadığına karar verilmekte ve alt ve üst sınırlar arasında kalırsa, ilişkinin varlığı belirsiz olmaktadır.

Uzun dönemli bir ilişki belirlendikten sonra ikinci aşamada Pesaran ve Shin (1999)'in $A R D L$ yaklaşımı ile uzun dönem ilişkisinin tahmin edilmesi söz konusudur. $A R D L$ prosedüründe $X$ değişkeni için şu biçimde bir uzun dönem koşullu ARDL $\left(p_{1}, q_{i}\right)$ modeli tahmin edilmektedir:

$$
X_{t}=c_{0}+\sum_{j=1}^{p_{1}} \eta_{j} X_{t-j}+\sum_{i=1}^{6} \sum_{j=0}^{q_{i}} \theta_{i j} V_{i t-j}+\psi^{\prime} D_{t}+u_{t} \quad(i=1,2, \ldots, 6)
$$

Burada tüm değişkenler yukarıda tanımlandığı gibidir. Modelde yer alan değişkenlere ilişkin gecikme uzunluğu Akaike (AIC) ya da Schwarz Bayesian Bilgi Kriteri (SBC) kullanılarak seçilebilmektedir. ARDL prosedüründe ikinci olarak ECM tahmin edilmektedir. Koşullu ECM şu biçimde ifade edilmektedir: 


$$
\Delta X_{t}=\mu+\sum_{j=1}^{p} \gamma_{j} \Delta X_{t-j}+\sum_{i=1}^{6} \sum_{j=0}^{p} \omega_{i j} \Delta V_{i t-j}+\vartheta E C M_{t-1}+\psi^{\prime} D_{t}+\varepsilon_{t}
$$

Burada $\gamma_{j}$ ve $\omega_{i j}$ kısa dönem parametreleri iken $\vartheta$ modelin dengeye gelme hızını göstermektedir. Hata düzeltme terimi $\left(E C M_{t}\right)$ ise şu biçimde tanımlanmaktadır:

$$
E C M_{t}=X_{t}-\hat{\beta}_{0}-\hat{\beta}_{1} R_{t}-\hat{\beta}_{2} Y_{t}^{*}-\hat{\beta}_{3} C_{t}-\hat{\beta}_{4} K_{t}-\hat{\beta}_{5} G_{t}-\hat{\beta}_{6} H_{t}
$$

Denklem (5)'de görülen uzun dönem parametreleri ( $\left.\hat{\beta}_{0}, \hat{\beta}_{1}, \ldots, \hat{\beta}_{6}\right)$, denklem (3)'teki koşullu $A R D L$ modelinin $O L S$ tahminlerinden, parametrelere ilişkin standart hatalar Delta $(\Delta)$ yöntemi kullanılarak elde edilmektedir.

Bir başka önemli durum değişkenler arasındaki neden-sonuç ilişkisi ve nedenselliğin yönünden ileri gelmektedir. Örneğin kur yükselişi ihracat performansını artırırken aynı zamanda ihracat artışı da döviz kurunu düşürücü etkiler ortaya çıkarabilmektedir (geri bildirim). Çalışmada ayrıca ihracat hacmi ve onun belirleyicileri arasındaki nedensellik ilişkilerinin belirlenmesi de analiz amaçları arasındadır. Engle ve Granger (1987) eğer iki I(1) serisi arasında uzun dönemli bir ilişki varsa en azından tek yönlü bir nedensellik ilişkisinin olduğuna işaret etmektedir. Nedenselliğin yönü koşullu ECM kullanılarak belirlenebilmektedir. Bizim çalışmamızda Granger nedensellik testi şu denklemler aracılığıyla yapılmıştır.

$$
\begin{aligned}
& \Delta X_{t}= \pi_{10}+\sum_{j=1}^{p} \pi_{11, j} \Delta X_{t-j}+\sum_{i=1}^{6} \sum_{j=0}^{p} \pi_{1 i, j} \Delta V_{i t-j}+\varphi_{0} E C M_{t-1}+u_{1 t} \\
& \Delta V_{i t}=\pi_{i 0}+\sum_{j=0}^{p} \pi_{i 1, j} \Delta X_{t-j}+\sum_{j=1}^{p} \pi_{i i, j} \Delta V_{t-j}^{i}+\sum_{k=1}^{6} \sum_{j=0}^{p} \pi_{k i, j} \Delta V_{t-j}^{k}+\varphi_{0} E C M_{t-1}+u_{i t}
\end{aligned}
$$

Burada, $V_{t}^{i}, V_{t}$ 'nin $i$ 'inci elemanıdır $(i=1,2, \ldots, 6) . V_{t}^{k}$ ise $V_{t}$ nin $k$ 'nncı elemanının dışarıda bırakılmasıyla elde edilen vektördür. $\pi$ ler tahmin edilecek parametreler iken $u_{1 t}$ ve $u_{\mathrm{i} t}$ ilişkisiz hata terimleridir. $E C M_{t}$ denklem (5)'den tahmin edilecek hata terimidir. Hata düzeltme modellerindeki gecikmeli açıklayıcı değişkenlere ilişkin $F$ istatistikleri, kısa dönem nedensellik etkilerinin, $t$-istatistikleri ise gecikmeli ECM deki $\phi_{i}$ ya ilişkin $(i=0,1, \ldots, 6$ ) olarak uzun dönem nedensellik etkisinin anlamlı olup olmadığını göstermektedir.

\section{Veri Seti ve Ampirik Bulgular}

Çalışmada, 1995-2012 dönemine ilişkin üçer aylık veriler kullanılmıştır. Dönem seçiminde Türkiye'nin 1980 sonrası ihracata yönelik politika uygulamalarının ardından 1989 sermaye hesabı liberalizasyonu politikalarının olgunlaştığı dönem olmasına dikkat edilmiştir. Ayrıca bu politikaların ilk büyük kriz deneyimi olan ve büyük bir devalüasyonun yaşandığı 1994 krizi analiz dışında bırakılmıştır. Yine AB ile başlayan GB sürecinde ihracat performansını etkileyen gümrük tarifeleri ve tarife dışı engellerin olmadığı dönem kapsama alınmıştır. Çalışmada kullanılan değişkenlere ilişkin bilgiler aşağıda Tablo 2'de sunulmuştur. ERVOL dışında tüm değişkenler logaritmik formdadır. EXPORT, RWAGE, PROD ve RGDPUS serilerinde anlamlı mevsimsel değişmeler görülmüş ve X-12 yöntemiyle mevsimsel etkilerden arındırılmıştır.

\begin{tabular}{|l|l|l|l|}
\hline Zaman Serisi & Değişken & Açılama & Kaynak \\
\hline İhracat & LEXPORT & İhracat hacim (volume) endeksi. & IMF-IFS \\
\hline $\begin{array}{l}\text { Reel Efektif } \\
\text { Döviz Kuru }\end{array}$ & LREER & $\begin{array}{l}\text { Türkiye'nin ticaretinde en fazla paya sahip 13 } \\
\text { ticaret ortağının ulusal paraları dikkate alınarak ve } \\
\text { TÜFE bazlı olarak hesaplanmıştır. }\end{array}$ & TCMB \\
\hline Reel Ücret & LRWAGE & Reel ücret endeksi. & TÜİK \\
\hline Yurtdışı Gelir & LRGDPUS & ABD'nin Reel GSYH endeksi. & IMF-IFS \\
\hline Verimlilik & LPROD. & Saat başına çıtı miktarı & TÜİK \\
\hline GSYH Trendi & LTRENDGDP & $\begin{array}{l}\text { Reel GSYH'dan Hodrick-Prescott }(H-P) \text { filtreleme } \\
\text { yöntemi kullanılarak elde edilmiştir. }\end{array}$ & $\begin{array}{l}\text { Reel GSYH: } \\
\text { TÜİK }\end{array}$ \\
\hline $\begin{array}{l}\text { Döviz Kuru } \\
\text { Oynaklığı }\end{array}$ & ERVOL & $\begin{array}{l}\text { GARCH (1,1) modellemesi koşullu varyans } \\
\text { tahminleri ile elde edilmiştir. }\end{array}$ & -- \\
\hline
\end{tabular}

Tablo 2: Kullanılan Değişkenlerin Açıklamaları ve Veri Kaynakları

İhracat performansının ölçülmesi için ihracat hacmi, ihracatın GSYH içindeki ya da dünya ihracatındaki payı ile bu payın ticaret ortaklarına kıyasla büyüklüğü gibi göstergeler kullanılmaktadır. Bizim çalışmamızda ise ihracat performansının ölçüsü olarak ihracat hacmi değişkeni kullanılmıştır. Kapasite kısıtı ve daha önce bahsedilen fiyat dışı rekabet gelişmelerinin etkilerini ortaya koymak amacıyla modele GSYH trendi de eklenmiştir. İhracatçıların risk algısı ve riskten kaçınma eğilimlerine bağlı olarak ihracat performansını etkileyen döviz kuru oynaklığı, Engle (1982)'in Otoregresif Koşullu Değişen Varyans (autoregressive conditional 
heteroscedasticity-ARCH) modeli ve Bollerslev (1986) tarafindan genişletilmiş biçimi GARCH (Generalized ARCH) modelleriyle tahmin edilmiştir. Burada Bollerslev (1986) tarafından geliştirilen ve yaygın olarak kullanılan GARCH $(1,1)$ modeli kullanılmıştır. Parantez içindeki ilk rakam denklemde 1 tane otoregresif gecikme olduğunu, ikinci rakam ise değişken hareketli ortalama içeriğine 1 tane gecikme sayısı eklendiğini göstermektedir. TÜFE ve ÜFE bazlı REER değişmeleri ve GARCH $(1,1)$ modellemesi koşullu varyans tahminleri ile elde edilen döviz kuru oynaklığı aşağıda Grafik 1'de sunulmuştur.

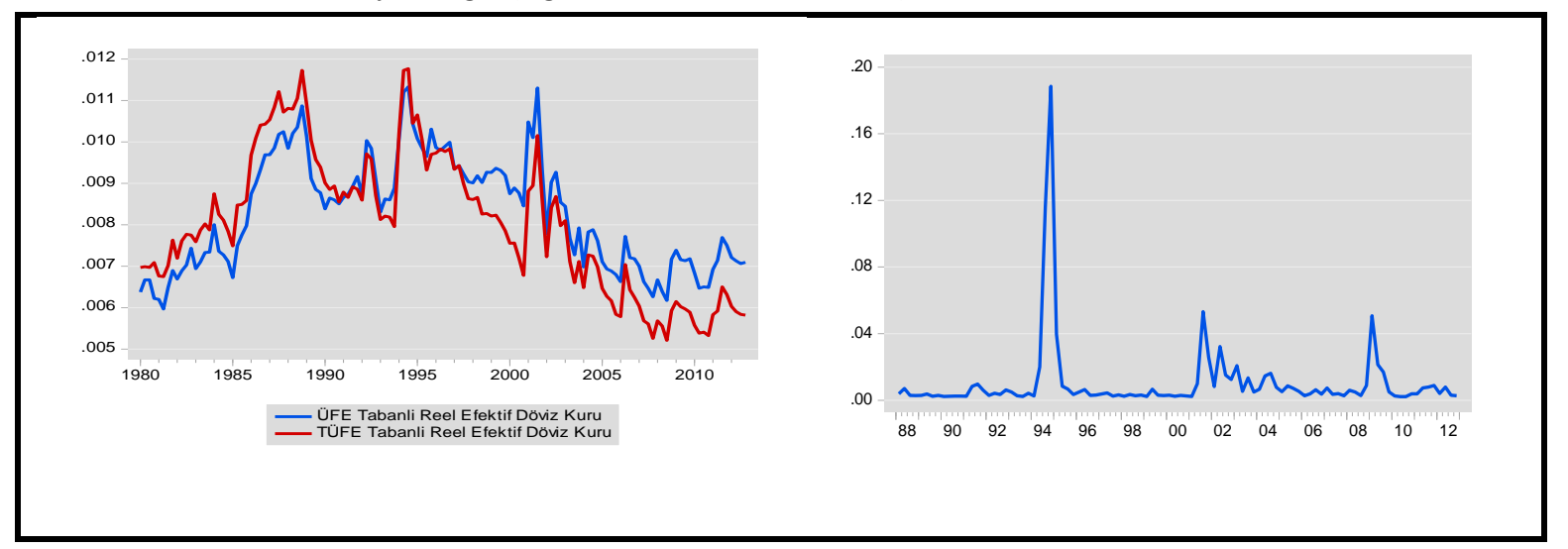

Grafik 1: Reel Efektif Döviz Kuru ve Oynaklik Tahminleri

Çalışmada öncelikle serilerin dağılımlarının normalliği kontrol edilmiştir. Serilerde en büyük çarpıklık değeri $(0,87)$ LEXPORT ve basıklık değeri $(2,44)$ ise LREER değişkeni dağılımında gözlenmiş ve Jarque-Bera normallik testine göre $\% 5$ anlam düzeyinde LREER dışındaki tüm değişkenlerin seviyede normal dağılmadığı, ancak logaritmalarının normal dağıldığı görülmüştür. Logaritmik formda ifade edilen değişkenler arasında statik ilişkileri veren Pearson korelasyon katsayıları incelenmiş, ihracat hacmi ile yurtdışı gelir, verimlilik ve GSYH trendi arasında pozitif güçlü ve REER ile arasında negatif güçlü korelasyonlar belirlenmiştir. Bu ön bilgilerden sonra serilerin durağanlığ $A D F$ birim kök testi ile incelenmiş ve tüm serilerin birinci dereceden durağan olduğu (I(1)) belirlenmiştir (Tanımlayıcı istatistikler ve birim kök testi sonuçlarının tamamı, istenmesi durumunda yazarlardan temin edilebilir). Tüm serilerin I(1) olmasına rağmen yukarıda değinilen avantajlarından dolayı analiz prosedürü $A R D L$ sınır testi yaklaşımında izlenmiştir.

$A R D L$ sınır testi yaklaşımında ilk olarak, değişkenler arasında uzun dönemli bir ilişsi $O L S$ ile tahmin edilmiş̧ir. Teorik beklentiler gereği çalışmanın amacına uygun olarak sadece LEXPORT bağımlı değişken olarak belirlenmiştir. ECM modelinde ise modelin tahmin gücünü artırmak amacıyla her bir model deterministik trend içerip içermemesi durumları için ayrı ayrı tahmin edilmiş̧ir. Kullanılan yöntemin gecikme sayısına hassas olması nedeniyle öncelikle optimum gecikme sayısı belirlenmiştir. Bunun için hata karelerindeki sıralı korelasyon sorununu elimine eden ve kalıntıların karelerine ilişkin minimum değeri veren $A I C$ ve $S B C$ baz alınmıştır. Ayrıca, her bir gecikme uzunluğu için 1. ve 4. sıra kalıntılara otokorelasyon testi uygulanmıştır. Bunun için bağımlı değişkenin gecikmeli değeri de modelde yer aldığından Breusch-Pagan Lagrange Çarpanı (LM) istatistiği kullanılmıştır. Sonuç olarak $A I C$ ve $S B C$ tarafindan optimal gecikme uzunluğu 7 olarak belirlenmiştir. $\mathrm{Bu}$ gecikme uzunluğunda otokorelasyon sorununa rastlanmamıştır. Yine 1. ve 4. sıra kalıntıları için $L M$ istatistikleri otokorelasyon sorunu olmadığını göstermiştir.

Aşağıda Tablo 3'te LEXPORT değişkeni bağımlı değişken olarak alındığında yapılan sınır testi sonuçları görülmektedir. $A I C$ ve $S B C$ tarafindan seçilen 7 gecikme uzunluğunun yanı sıra, 2. 4. ve 6. gecikme için test istatistikleri sunulmuştur. Optimal gecikme uzunluğunda (7), hesaplanan $F$-istatistiklerine göre $F$-iii, $F$-iv ve $F$ $v$ 'den elde edilen değerler doğrultusunda \%5 anlam seviyesinde değişkenler arasında ilişki olmadığı yönündeki sıfir hipotezi ret edilmiştir. Tabloda değişkenler arasında bir eşbütünleşme ilişkisinin olduğu görülmektedir.

\begin{tabular}{|l|l|l|l|l|l|l|}
\hline & Deterministik Trendsiz Modeller & \multicolumn{4}{l|}{ Deterministik Trendli Modeller } \\
\hline $\boldsymbol{L}$ & $\boldsymbol{F}$-iii & $\boldsymbol{P}$ & $\boldsymbol{F}$-iv & $\boldsymbol{p}$ & $\boldsymbol{F}$-v & $\boldsymbol{p}$ \\
\hline 7 & $5,6471^{*}$ & 0,0131 & $5,0554^{*}$ & 0,0230 & $5,6784^{*}$ & 0,0178 \\
\hline 6 & $5,4563^{*}$ & 0,0474 & $4,9099^{*}$ & 0,0213 & $4,0645^{*}$ & 0,0197 \\
\hline 4 & $4,611^{*}$ & 0,0042 & $4,5814^{*}$ & 0,0005 & $5,2105^{*}$ & 0,0003 \\
\hline 2 & $4,5142^{*}$ & 0,0034 & $4,1555^{*}$ & 0,0052 & $4,5996^{*}$ & 0,0029 \\
\hline
\end{tabular}

Not: k, modeldeki bağımsız değişken sayısıdır. $\mathrm{k}=6$ için $5 \%$ kritik değer sınırları: F-iii tablosunda [2,45; 3,61], F-iv tablosunda $[2,63 ; 3,62]$; F-v tablosunda $[2,87 ; 4,00]$ dir (Pesaran vd., 2001). *, Hesaplanan test istatistiğinin, \%5 üst sınırın üstünde olduğunu göstermektedir.

Tablo 3: Sınır Testi Sonuçlarl: Eşbütünleşme İlişkisinin Belirlenmesi 
Denklem (2), deterministik trend içeren ve içermeyen durumlar için 7 gecikmeli koşullu ECM ile tahmin edilmiş ve deterministik trend içeren sınır testi denklemleri için anlamlı katsayılar elde edilmemiştir (test sonuçlarının tamamı, istenmesi durumunda yazarlardan temin edilebilir). Trend içermeyen denklem tahminlerine ilişkin anlamlı olan katsayılar aşağıda tabloda sunulmuştur.

\begin{tabular}{|l|l|l|l|l|l|l|}
\hline Deterministik Trend İçermeyen Sinır Testi Denklemleri & \multicolumn{2}{l|}{ Tanısal Test İstatistikleri } \\
\hline Bağımsız Değ. & Katsay1 & Std. hata & $t$-ist. & $p$ & $R^{2}$ & 0,9832 \\
\hline DLREER(-5) & 0,5916 & 0,2518 & 2,3493 & 0,0467 & Düzeltilmiş $R^{2}$ & 0,8413 \\
\hline DLRWAGE & $-0,5106$ & 0,1983 & $-2,5740$ & 0,0329 & Regresyon Std. Hatasl & 0,0190 \\
\hline DLPROD (-1) & 11,934 & 4,0031 & 2,9812 & 0,0176 & F-istatistiği & 6,9253 \\
\hline DLPROD (-2) & 10,650 & 3,2925 & 3,2348 & 0,0120 & F-ist. için - değeri & 0,0033 \\
\hline DLPROD (-3) & 8,1695 & 2,3682 & 3,4495 & 0,0087 & AIC & $-5,5560$ \\
\hline DLPROD (-4) & 4,9245 & 1,5094 & 3,2624 & 0,0115 & SIC & $-3,4557$ \\
\hline DLPROD (-5) & 2,6788 & 0,9271 & 2,8895 & 0,0202 & Durbin-Watson ist. & 3,1562 \\
\hline ECM(-1) & $-0,3994$ & 0,0872 & $-4,5815$ & 0,0000 & & \\
\hline
\end{tabular}

Tablo 4: ARDL Yaklaşımına Dayalı Hata Düzeltme Modeli Tahmin Sonuçları

Sonuçlar, kısa dönemde ihracat potansiyelinin temel belirleyicisinin verimlilik olduğunu ortaya koymaktadır. Verimlilik arttıkça ihracat hacminin arttığı ancak dönem gecikmesi arttıkça bu pozitif ilişkinin azalma eğiliminde olduğu görülmektedir. LREER'in pozitif işaretli olması, kur yükselişlerinin kısa dönemde ihracat hacmini artırdığı ve j-eğrisi gibi gecikmeli bir etkinin ortaya çıkmadığı biçiminde yorumlanabilecektir. Beklendiği gibi ücrete ilişkin elde edilen negatif katsayı ücret maliyetinin ihracat performansını kısa dönemde olumsuz etkilediğini göstermektedir. Modelde hata düzeltme terimi (ECM(-1)) katsayısı -0,3994 olarak negatif ve anlamlı olarak elde edilmiştir. Bu katsayı kısa dönemdeki dengesizliğin yüzde 40'ının uzun dönemde düzeltileceğini göstermektedir. Bu sonuçlara dayanarak uzun dönem katsayılarını veren seviye ilişkilerini belirlemek için 7 gecikme uzunluğunda denklem (3) tahmin edilmiş ve sonuçlar Tablo 5 'te sunulmuştur.

\begin{tabular}{|l|l|l|l|l|}
\hline Parametreler & Katsay1 & Standart Hata & $t$-istatistiği & $p$ \\
\hline$C$ & $-17,2004$ & $3,7578^{* * *}$ & $-4,5772$ & 0,0000 \\
\hline LREER & $-0,3644$ & $0,0882^{* * *}$ & $-4,1284$ & 0,0001 \\
\hline LRWAGE & $-0,5844$ & $0,0695^{* * *}$ & $-8,4029$ & 0,0000 \\
\hline LRGDPUS & 2,4565 & $0,6566^{* * *}$ & 3,7410 & 0,0003 \\
\hline LPROD & 1,1461 & $0,1435^{* *}$ & 7,9858 & 0,0000 \\
\hline LTRENDGDP & 0,8515 & $0,3792^{*}$ & 2,2455 & 0,0276 \\
\hline ERVOL & 0,5809 & 0,4271 & 1,3600 & 0,1777 \\
\hline
\end{tabular}

Not: Standart hatalar delta $(\Delta)$ yöntemi kullanılarak hesaplanmıştır.

*, ** sırasıyla \%5 ve \%1 seviyesinde anlamlılığı göstermektedir.

Tablo 5: ARDL Modeli Tahmin Sonuçları: İhracat Hacmine İlişkin Uzun Dönem Katsayılar

Tablo 5'te görülen sonuçlar 1şı̆̆ında $L E R V O L$ dışında tüm değişkenlerin katsayılarının anlamlı olduğu görülmektedir. Bu kapsamda özellikle 2001 yılından sonra kurların serbest dalgalanmaya bırakılmasıyla birlikte, ticari ortakların para birimlerine kıyasla TL'nin değeri oldukça oynak olsa da bu durumun ihracatı anlamlı bir biçimde etkilemediği sonucuna ulaşılmıştır. Beklenildiği gibi $\operatorname{LRGDPUS}(2,46), \operatorname{LPROD}(1,15)$ ve LTRENDGDP $(0,85)$ değişkenlerinin işaretlerinin pozitif olduğu görülmektedir. $\mathrm{Bu}$ durum Türkiye ekonomisinde son zamanlarda görülen ihracat artışlarının yurtdışı gelirin uyardığı dış talep ve verimlilik artış1 tarafından belirlendiğini ortaya koymaktadır. Yine artan ekonomik faaliyetlerle gelişen ve modelde gelir trendinin kapsadığ 1 altyapı, toplam faktör verimliliği, ihracat arz ağları, yaparak öğrenme ve uzmanlaşma gibi fiyat dışı rekabet gelişmelerinin ihracat hacmini anlamlı bir şekilde etkilediği anlaşılmaktadır. LREER değişkeninin negatif işaretli olması, reel efektif döviz kurunun yükselerek TL'nin değer kaybetmesinin ihracat hacmini azalttığını ifade etmektedir. Bu durum kısa dönem katsayıları ile birlikte değerlendirildiğinde ters-J eğrisi etkisine benzer gelişmeleri ortaya koymaktadır. Yine LRWAGE değişkenine ilişkin elde edilen negatif katsayı, beklendiği gibi ücret seviyesindeki reel artışların birim emek maliyetini artırarak ihracat performansını olumsuz etkilediğini göstermektedir.

$\mathrm{Bu}$ ilişkilerin daha net ortaya konulabilmesi için değişkenler arasındaki nedensellik ilişkisi ve yönünün belirlenmesi önemli olmaktadır. Bu kapsamda son olarak koşullu Granger nedensellik testi uygulanmış ve nedensellik ilişkisi belirlenen değişkenlere ilişkin sonuçlar aşağıda Tabloda sunulmuştur (Nedensellik testi sonuçların tamamı, istenmesi durumunda yazarlardan temin edilebilir).

Granger nedensellik test sonuçlarına göre anlamlı olan tek nedensellik LPROD değişkeninden LEXPORT'a doğru bulunmuştur. Yani kısa dönemde sadece verimlilik ihracatın bir Granger nedenidir. Elde edilen katsayılar 
ile birlikte değerlendirdiğinde verimliliğin ihracat artışlarının bir nedeni olduğu anlaşılmaktadır. İhracattan verimliliğe doğru bir nedensellik ilişkisi olmaması geribildirim olmadığını göstermektedir.

\begin{tabular}{|l|l|l|l|l|}
\hline Bağımlı değişken & Bağımsız değişken & Ki-kare & s.d. & $p$ \\
\hline D(LEXPORT) & D(LREER) & 0,5013 & 3 & 0,9186 \\
\hline & D(LRWAGE) & 1,0563 & 3 & 0,7876 \\
\hline & D(LRGDPUS) & 1,0389 & 3 & 0,7918 \\
\hline & D(LPROD) & 13,506 & 3 & $0,0037^{* * *}$ \\
\hline & D(LTRENDGDP) & 0,1122 & 3 & 0,9903 \\
\hline & D(LERVOL) & 3,2037 & 3 & 0,3613 \\
\hline D(LRWAGE) & D(LEXPORT) & 11,127 & 3 & $0,0111^{*}$ \\
\hline D(LREER) & D(LEXPORT) & $0,0493^{*}$ \\
\hline
\end{tabular}

Tablo 6: Granger Nedensellik Testi Sonuçlarl

\section{Sonuç ve Değerlendirmeler}

Çalışmada, Türkiye'nin ihracat hacmi ile ifade edilen ihracat performansını belirleyen temel faktörlerden reel efektif döviz kuru ele alınmakla birlikte, literatürde genel olarak ayrı ayrı etkileri incelenen reel ücret, verimlilik, yurtdışı reel gelir, döviz kuru oynaklığı ve GSYH-trendi gibi diğer faktörler de analize dahil edilmiştir. 19952012 dönemi üçer aylık veriler kullanılarak değişkenler arasındaki kısa ve uzun dönem dinamik ilişsiler ARDL sınır testi yaklaşımı ile analiz edilmiştir. Tahmin edilen ARDL modelleri kapsamında değişkenler arasındaki nedensellik ilişkileri incelenmiştir. Analiz sonuçlarından elde edilen temel bulgular ve yorumları şu şekildedir.

i). İhracat performansının reel efektif döviz kuru katsayısı, kısa dönemde pozitif, uzun dönemde negatiftir. Dolayısıyla son yıllarda ticari partnerlerinin paralarına kıyasla değerli seyreden TL (düşük seyreden kur), uzun dönemde ihracatı olumlu etkilemektedir. Bu durum ihracatındaki ithal girdi içeriğinin yüksek olduğu Türkiye için beklenen bir durumdur. Kaynak tasarrufu ya da verimliliğini ve alternatif enerji girdilerinin kullanılmasını teşvik edici politikalar ihracat potansiyelini daha da artıracaktır. Buna karşın döviz kuru oynaklığı ihracat performansını anlamlı bir şekilde etkilememektedir. ii) Verimlilik hem kısa hem de uzun dönemde ihracat performansının temel belirleyicisi durumundadır. Ayrıca ihracat performansı üzerine anlamlı olan tek nedensellik etkisi verimliliğe aittir. Ancak ihracatın verimlilik üzerine anlamlı bir etkisi bulunmamaktadır. Dolayısıyla ihracatın aynı zamanda verimliliği artıracağı argümanı bizim çalışmamızda desteklenmemektedir. iii) Reel ücret seviyesindeki bir artış hem kısa hem de uzun dönemde ihracat performansını olumsuz etkilemektedir. Bu nedenle özellikle 2001 krizi sonrası daha fazla uygulanan ve ücretleri baskı altına almaya yönelik politikalar ihracat hacmini artırmaktadır. Türkiye'nin, benzer ihracat sanayilerine sahip Çin ile uluslararası alanda rekabet edebilmesi için ücretin belirlediği birim emek maliyetinin düşürülmesi gerekliliği kendini göstermektedir. Bu kapsamda ihracat sektörlerinde sınırlı ücret artışlarını öngören politika uygulamaları ihracat hacmini artıracaktır. iv). Uzun dönemde Türkiye'nin ihracat performansının en önemli belirleyicisi ABD reel GSYH ile temsil edilen yurtdışı gelir ve bu yurtdışı gelirin uyardığı dış taleptir. Bu kapsamda Türkiye'nin ihracat performansının yurtdış1 talep koşullarındaki değişmelere bağlı olduğu ve böylece ihraç edilebilir mallar üreten yurtiçi firmaların dişa açılmasıyla ihracat hacminin de artacağı görülmektedir.

Hem sektörel hem de ticaret ortaklarına ilişkin toplulaştırılmış verilerin analiz edildiği bu çalışma makro düzeyde sonuçlar ortaya koymaktadır. Ancak her bir sektör, ele alınan faktörler tarafından farklı şekilde etkilenebilmektedir. Bu nedenle faktör yoğunluklarına ya da ithal girdilere bağlılık durumlarına göre yapılacak sektörel analizler, daha spesifik sonuçlar ortaya koyabilecektir. Yine Türkiye'nin ticari ortaklarıyla ikili ticaretinin incelenmesi bu çalışmada ele alınan faktörlerin ülkeden ülkeye değişebileceği gerçeğinden hareketle daha kesin sonuçlar ortaya koyabilecektir.

\section{Kaynakça}

- Abuşoğlu, Ö. (1990). Döviz Kuru ve İhracat Üzerine Etkisi. Ankara: TOBB Yayınları.

- Arndt, S. W. \& Huemer, A. (2004). "Trade, Production Networks and The Exchange Rate”. http://ssrn.com/abstract=900416.

- $\quad$ Arslan, I. \& Van Wijnbergen, S. (1993). "Export Incentives, Exchange Rate Policy and Export Growth in Turkey". The Review of Economics and Statistics, Vol. 75, No.1, pp.128-133.

- Aysan, A. F. \& Hacıhasanoğlu, Y. S. (2007). "Investigation Into The Determinants of Turkish Export-Boom in The 2000s". The Journal of International Trade and Diplomacy, Vol. 1, No. 2, pp.159-202.

- Bahmani-Oskooee, M. \& A. Ratha (2004). "The J Curve: A Literature Review". Applied Economics, Vol. 36, No. 13, pp.1377-1398. 
- Barlow, R. \& Şenses, F. (1995). “The Turkish Export Boom: Just Reward or Just Lucky?”. Journal of Development Economies, Vol. 48, No. 1, pp.111-133.

- $\quad$ Banerjee, A., Galbraith, J. \& Hendry, D. (1993), Cointegration, Error Correction and Econometric Analysis of Non-stationary Data. Oxford: Oxford University Press.

- $\quad$ Banerjee, A., Dolado, J. \& Mestre, R. (1998). "Error-correction Mechanism Tests for Cointegration in a Single Equation Framework”. Journal of Times Series Analysis, Vol. 19, No. 3, pp.267-283.

- Bollerslev, T. (1986). “Generalized Autoregressive Conditional Heteroskedasticity”. Journal of Econometrics, Vol. 31, No. 3, pp.307-327.

- $\quad$ Bushe, D. M., Kravis I. B. \& Lipsey, R. E. (1986). "Prices, Activity and Machinery Exports: An Analysis Based on New Price Data." Review of Economics and Statistics, Vol. 68, No. 2, pp.248-55.

- Cushman, D. O. (1983). “The Effects of Real Exchange Rate Risk on International Trade”. Journal of International Economics, Vol. 15, No. 1, pp.45-63.

- Çelik, S. \& Kaya, H. (2010). Real exchange Rates and Bilateral Trade Dynamics of Turkey: Panel Cointegration Approach. Applied Economics Letters, No.17, pp.791-795.

- Doğanlar, M. (2002). "Estimating The Impact of Exchange Rate Volatility on Exports: Evidence from Asian Countries". Applied Economics Letters, Vol. 9, pp.859-863.

- $\quad$ Edwards, L. \& Wilcox, O. (2003). "Exchange Rate Depreciation and The Trade Balance in South Africa. http://www.commerce.uct.ac.za/Economics/staff/ledwards/2008/

- $\quad$ Engle, R. F. (1982). “Autoregressive Conditional Heteroscedasticity with Estimates of the Variance of United Kingdom Inflation”. Econometrica, Vol. 50, No. 4, pp.987-1007.

- $\quad$ Engle, R. F. \& Granger, C. W. J. (1987). “Cointegration and Error Correction Representation: Estimation and Testing”. Econometrica, Vol. 55, No. 2, pp.251-276.

- $\quad$ Freund, C., Hong, C. \& Wei, S. J. (2012). "China's Trade Response to Exchange Rate”. AEA Annual Meeting Papers.

- $\quad$ Froyen, R. T. (1999). Macroeconomics Theories and Policies. 5th Edition, New Jersey: Prentice Hall International Editions.

- Goldstein, M. \& Khan, M. S. (1985). “Income And Price Effects In Foreign Trade”. R. Jones \& P. Kenen (Eds), Handbook of International Economics, Vol. II, Amsterdam: North Holland, pp.1041-1105.

- Hall, S., Hondroyiannis, G., Swamy, P.A.V.B., Tavlas, G. \& Ulan, M. (2010). "Exchange-Rate Volatility and Export Performance: Do Emerging Market Economies Resemble Industrial Countries or Other Developing Countries?”. Economic Modelling, Vol. 27, pp.1514-1521.

- Hummels, D., Rapoport, D. \& Yi, K. (1998). "Vertical Specialization and the Changing Nature of World Trade". FRBNY Economic Policy Review, pp.79-99.

- Hummels, D., Ishii, J. \& Yi, K. (2001). "The Nature and Growth of Vertical Specialization in World Trade". Journal of International Economics, Vol. 54, pp.75-96.

- Karagöz, M. \& Doğan, Ç. (2005). “Döviz Kuru Diş Ticaret İlişkisi: Türkiye Örneği”. Fırat Üniversitesi Sosyal Bilimler Dergisi, Vol. 15, No. 2, pp.219-228.

- $\quad$ Keyder, N., Sağlam, Y. \& Öztürk, M. K. (2004). "International Competitiveness and the Unit Labor Cost Based Competitiveness Index". METU Studies in Development, Vol. 31, pp.43-70.

- Lall, S. (2000). "Turkish Performance in Exporting Manufactures: A Comparative Structural Analysis". QEH Working Paper Series, No. 47.

- $\quad$ Nowak-Lehmann, D., Herzer, D., Martinez-Zarzoso, I. \& Vollmer, S. (2007). "The Impact of a Customs Union between Turkey and the EU on Turkey's Exports to the EU'. Journal of Common Market Studies, Vol. 45, No. 3, pp.719-743.

- Özçelik, E. \& Taymaz, E. (2002). “Does Innovativeness Matter for International Competitiveness in Developing Countries? The Case of Turkish Manufacturing Industries.” Research Policy, Vol. 33, No. 3, pp.409-424.

- $\quad$ Özler Ş., Taymaz, E. \& Y1lmaz, K. (2007). "History Matters for the Export Decision: Plant Level Evidence from Turkish Manufacturing Industry”. TUSIAD-Koç University Economic Research Forum Working Paper Series, No. 0706.

- $\quad$ Pesaran, M. H. \& Shin, Y. (1999). “An Autoregressive Distributed Lag Modeling Approach to Cointegration Analysis". Strom, S. (Ed.). Econometrics and Economic Theory in the 20th Century. Cambridge: Cambridge University Press, pp. 371-413. 
- $\quad$ Pesaran, M. H., Shin, Y. \& Smith, R. (2001). "Bounds Testing Approaches to the Analysis of Level Relationships". Journal of Applied Econometrics, Vol. 16, No. 3, pp.289-326.

- Rey, S. (2006). "Effective Exchange Rate Volatility and MENA Countries' Exports to the EU". Journal of Economic Development, Vol. 31, No. 2, pp. 23-54.

- Sivri, U. \& Usta, C. (2001). Reel Döviz Kuru, İhracat ve İthalat Arasındaki İlişki”. Uludağ Üniversitesi Íktisadi ve İdari Bilimler Fakültesi Dergisi, Cilt. 19, No. 4, ss.1-9.

- Şahinbeyoğlu, G. \& Ulaşan, B. (1999), “An Empirical Examination of the Structural Stability of Export Function: The Case of Turkey". The Central Bank of the Republic of Turkey, Research Department Discussion Paper No. 9907.

- Tarı, R. \& Yıldırım, D. Ç. (2009). "Döviz Kuru Belirsizliğinin İhracata Etkisi: Türkiye İçin Bir Uygulama”, C.B.Ü. Yönetim ve Ekonomi Dergisi, Cilt 16, No. 2, ss.95-105.

- Uygur, E. (1997), "Export Policies and Export Performance: The Case of Turkey”. The Economic Research Forum (ERF), Working Paper Series, No. 7.

- Yaşar, M. \& Nelson, C. H. (2004), "The Relationship between Exports and Productivity at the Plant level in the Turkish Apparel and Motor Vehicle Parts Industries". North American Summer Meetings from Econometric Society, No 138.

- Yükseler Z. \& Türkan, E. (2006). “Türkiye’nin Üretim ve Dış Ticaret Yapısında Dönüşüm: Küresel Yönelimler Ve Yansımalar”. Ekonomik Araştırma Forumu Çalışma Raporları Serisi.

- Zengin, A. (2001). "Reel Döviz Kuru Hareketleri ve Dış Ticaret Fiyatları: Türkiye Ekonomisi Üzerine Ampirik Bulgular”. Cumhuriyet Üniv. Íktisadi ve İdari Birimler Dergisi, Cilt 2, No. 2, ss.27-41.

- $\quad$ TÜİK. Dış Ticaret Istatistikleri-Girdi-Çıktı Tabloları. (http://www.tuik.gov.tr/)

- UN. Commodity Trade Statistics Database (COMTRADE). (http://comtrade.un.org/) 


\title{
Türkiye'nin İhracat ve İthalat Talep Fonksiyonlarının Rusya ile Dış Ticareti Bağlamında Analizi
}

\section{Analysis of Turkey's Export and Import Demand Functions within the Context of Foreign Trade with Russia}

\author{
Asst. Prof. Dr. Rüştü Yayar (Gaziosmanpaşa University, Turkey) \\ Ph.D. Candidate Yunus Emre Birol (Cumhuriyet Universty, Turkey) \\ Ph.D. Candidate Yusuf Demir (Cumhuriyet University, Turkey)
}

\begin{abstract}
The main purpose of this study is to analyze the foreign trade of Russia and Turkey. Considering the foreign trade volume between the two countries, an experimental study was carried out to determine export and import demand functions of Turkey. The Russian Federation has been one of the countries having an important part in export of Turkey. Whereas textile products have taken the first place within the export of Turkey, petroleum gas and natural gas have taken the first place in import. The data used in the study covered the period between 1995 and 2010 quarterly. The data were obtained from Turkish Republic Central Bank, International Money Fund, Russian Central Bank and Russian Federal Statistics Service databases. According to obtained results, export of Turkey to Russia has affected more from the income of Russia rather than the relative prices, and import of Turkey from Russia has affected more from the income of Turkey rather than the relative prices. When income and price elasticity of export and import demands were analyzed, income and price elasticity of the export demand was noticed as being greater than the income and price elasticity of the import demand.
\end{abstract}

\section{Giriş}

Temelleri İkinci Dünya Savaşı'nın sona ermesi ile birlikte uluslararası kuruluşların ve kutuplaşmaların ortaya çıkması sonucu atılan küreselleşme 1980'li yıllarda piyasa ekonomisi ve liberalleşmeye geçişle birlikte uygulama alanı bulmuş ve bu amaçla mal, hizmet ve sermayenin serbest dolaşımına ilişkin adımlar atılarak, ülke piyasalarını dünya piyasaları ile bütünleştirme eğilimi ortaya çıkmıştır. 1990'lı yıllarda ise, Sovyetler Birliği’nin dağılması üzerine yeni ulusların ortaya çıkması ve bu ülkelerin piyasa ekonomisini benimsemeleri üzerine süreç daha da hızlanmıştır.

Küreselleşmeyle beraber, uluslararası ticarette artış ve yapısal değişim meydana gelmiştir. Bu hızlı artış ve yapısal değişim ekonomik faktörler başta olmak üzere bir dizi değişken tarafından belirlenmektedir. Bu faktörlerin tespiti ve etki mekanizmalarının analizi uluslararası ticaret analizlerinin en önemli ayrıntılarındandır. Çünkü ihracatın ve ithalatın uygulanacak döviz kuru politikasına, dış ticaret politikasına veya değişen dünya şartlarına nasıl bir tepki göstereceğinin anlaşılması için ihracatın ve ithalatın göreli fiyatlardaki ve yurt dışı-içi talepteki değişmelere olan duyarlılığının bilinmesi önemli bir ön koşuldur. Bu nedenle, uluslararası iktisat literatüründe dış ticaret talep fonksiyonlarının tahminine yönelmiş çalışmalara sıkça rastlanmaktadır (Doğanlar vd., 2006: 51).

1990 yıllarda SSCB'nin dağılmasıyla onu oluşturan 15 ülke bu süreçte bağımsızlıklarını kazanmış ve kendi başlarına çeşitli ülkelerle ekonomik ve siyasi ilişkiler kurmaya başlamışlardır. Bu dağılmanın ardından ortaya çıkan kaos ortamında Rusya'da ekonomik sorunlar söz konusu olmuştur. Bunun ardından 1992 yılında, Rusya Federasyonu merkezi planlı sistemden piyasa ekonomisine geçebilmek için önemli ekonomik reformlar gerçekleştirmiştir. Fiyatlar serbest bırakılmış, mali denge sağlanmaya çalışılmış, ticari engeller ve teşvikler kısmen de olsa kaldırılmış, ülke ekonomisinin dışa açık hale gelmesi amaçlanmıştır. Ayrıca monopollerin kaldırılması ve geniş çaplı bir özelleştirme söz konusu olmuştur (Duman ve Samadov, 2003: 25-26). Bu çalıșmanın temel amacı Türkiye'nin kuzey komşusu olan Rusya ile Türkiye'nin dıș ticaretinin analiz edilmesidir. $\mathrm{Bu}$ bağlamda iki ülke arasındaki dış ticaret hacmi dikkate alınarak Türkiye'nin ihracat ve ithalat talep fonksiyonlarının belirlenmesine yönelik ampirik bir çalışma yapılacaktır.

\section{Türkiye ile Rusya Arasındaki Ekonomik ve Siyasi İlişkilerin Gelişimi}

Komünizm sonrası dönemde ekonomik anlamda ciddi bir çöküntü ile karşı karşıya kalan Rusya'da reel GSYİH 1991 yılında yaklaşık \%12 oranında gerilemiş, bütçe açı̆̆ı GSYİH'nın \%26'sına kadar çıkmıştır. Komünist ekonominin çökmesi ile birlikte enflasyon üç haneli rakamlara yükselmiştir. Bu çöküntünün altında belli başlı yapısal sorunlar bulunmaktadır. Eski Doğu Avrupa pazarlarının Doğu Bloku’nun dağılması ile birlikte çözülmesi ve bunun sonucunda arz zincirinin bozulması, mali yardımların kesilmesi nedeni ile tarım sektöründe ortaya çıkan kriz, kumanda ekonomisi kurallarının, pazar ekonomisi kuralları uygulanmaya başlanmadan terk 
edilmesi v.b. hususlar bu sorunlardan önemli olanları olarak ifade edilebilir (T.C. Moskova Büyükelçiliği Ticaret Müşavirliği, Temmuz 2011 Raporu).

Rusya'da mülkiyet ilişkilerinin dönüşümü temel olarak üç aşamada incelenebilir: 1987-1991 döneminde devlet işletmelerinin mali özerkliğinin artışına bağlı olarak ticari sermayenin geliştiği, spontane özelleştirme (spontaneous privatization process) süreci olarak adlandırılan dönem, mülkiyet ilişkilerinin dönüşümünde ilk adımı oluşturmaktadır. Perestroykanın başlangıç yıllarını oluşturan bu dönemde, işletme özerkliğinin artmasına bağlı olarak kaynak dağılım mekanizması giderek merkezi planlamadan uzaklaşmıştır. Dolayısıyla bu dönemde devlet işletmelerinin mali özerkliğinin artması, merkezi planlamaya dayalı üretim ilişkilerinin gayri resmi olarak piyasa ilişkilerine doğru kaymasına neden olmuştur. Bu süreç, özel parasal sermayenin birikimi olarak değerlendirilebilir. 1992-1994 dönemi, Rusya'nın neo-liberal politikalar eşliğinde kapitalist sistemle entegrasyonunun başladığı dönemi tanımlamaktadır. 1992 programında yer alan önlemler çerçevesinde bu dönemde blok özelleştirmeler ile mülkiyet ilişkilerinin dönüşümü gerçekleştirilmiştir. Blok özelleştirmeler sonrasında mülkiyetin yeniden dağılımı üçüncü aşamayı oluşturmaktadır. Bu aşamada; blok satış paylarının ikincil piyasalarda eski yönetici grup, parti eliti ve organize suç örgütleri tarafindan, yatırım kurumları, bankalar ve elinde özelleştirme kuponları bulunan çalışanlardan satın alınmasıyla mülkiyetin yeniden dağılımı gerçekleşmiştir (Radygin, 2000: 7).

1994 yılında Merkez Bankası tarafından IMF desteği ile sıkı para politikası uygulaması başlatılmış ve enflasyonla mücadeleye dönük bir bütçe kabul edilmiştir. Üç haneli enflasyonla uzun yıllar süren mücadele sonunda Rusya, 1995 yılında belirli ölçüde bir makroekonomik istikrar sağlamış olup, bunu 1998 yılı ortalarına dek sürdürmeyi başarmıştır. 1997-98 döneminde Rusya'nın başlıca ihraç mallarının fiyatlarındaki düşüş ve Asya krizinin sonucunda yatırımcıların gelişen pazarlara yatırımlarda çekimser kalmaları Rus ekonomisi üzerinde güçlü bir dış şok etkisi yaratmıştır. Söz konusu dışsal şok, hızla artan borçlardan ve mikro düzeyde yapısal değişikliklerin eksikliğinden kaynaklanan ekonomik sorunları daha da şiddetlendirmiştir. Sonuç olarak Ruble'nin devalüasyonu ve iç borçların ödenememesi ile karşı karşıya kalınmışıı. Ağustos 1998'de çok ciddi bir ekonomik kriz başlamıştır. Kriz öncesinde 1 \$: 6,3 Ruble iken, kriz sonrasında 1 \$: 20 Ruble'ye ulaşmıştır. Enflasyon belirgin şekilde yükselmiş, 1998 yılı sonu itibarı ile \%85'e ulaşmıştır. 1998 yılında ayarlanabilir sabit kurdan, dalgalı döviz kuru sistemine geçilmiş̧ir (İGEME, 2008: 3)

Kriz sonrasında alınan önlemlere izleyen dönemlerde değişen hükümetler de bağlı kalmıştır. İhracattan elde edilen gelirler Ruble'nin değerinin düşmesi neticesinde artış göstermiş ve pek çok sektör devalüasyonun sağladığı bu avantajdan yararlanarak ihracata yönelmiştir. 2000 yılı sonu itibarı ile enflasyon \%20'ye gerilemiştir. Enflasyondaki düşüş eğilimi izleyen yıllarda da devam etmiş olup, 2007 yılı başı itibarı ile \%7'nin biraz üzerinde gerçekleşmiştir. Ancak bundan sonraki dönemde aşırı yüksek düzeyde seyreden enerji fiyatları, para arzındaki artı̧̧ ve küresel gıda fiyatlarından dolayı enflasyonda yeniden bir yükseliş baş göstermiştir. Kriz sonrasında kamu maliyesi de dikkate değer bir gelişme göstermiştir. Bu gelişme, petrol sektöründen elde edilen beklenenin üzerinde kazancı yansıtmakla birlikte aynı zamanda toplanan vergilerde artış olduğunu ve harcamaların daha iyi denetlendiğini göstermektedir (İGEME, 2008: 4).

Türk-Rus ilişkilerinin tarihine baktığımızda bugün, ilk göze çarpan özellik, tarih içinde Rus Çarlı̆̆ı ve daha sonra Sovyetler Birliği lehine olan güç dengesinin nispeten düzelmiş olmasıdır. Rusya Federasyonun, yaşamakta olduğu siyasi, sosyal, ekonomik ve askeri alanlardaki bunalım ve yaklaşık 300 yıl önceki sınırlarına geri çekilmiş olması nedeniyle, Türkiye karşısında, tarihte alışılagelen askeri ve siyasi ağırlığına artık sahip değildir. Sovyetler Birliği'nin dağılması sonucunda oluşan bu ortam içinde, iki-kutuplu uluslararası ilişkiler sistemi ve bu sistemin Türkiye ve Sovyetler Birliği’nin dış politikalarını şekillendiren kalıplarının da ortadan kalkmasıyla iki ülke, kendi ulusal çıkarlarına dayanan politikalar izlemeye başlamıştır. Türk-Rus ilişkilerinde Sovyetler Birliği'nin 1991 yılında dağılmasıyla yeni bir dönem başlamıştır. Tarih içinde çeşitli siyasi mücadelelere ve pek çok savaşa tanıklık eden bu ilişkilerde her iki ülkenin de kuruluş yılları olan 1920'lerde belirli bir yakınlaşma yaşanmıştır. II. Dünya Savaşı'nın sonunda Sovyetler Birliği'nin Türkiye'den toprak talebinde bulunması sonucunda güvenlik endişelerini gidermek amacıyla Türkiye, NATO'ya katılarak Batı ittifakının bir üyesi olmuştur. 1945 sonrası Soğuk Savaş döneminde, Türkiye-SSCB ilişkileri, iki kutuplu dünyanın izin verdiği çerçevede şekillenmiştir. 1960'larda Kıbrıs krizi sonrasında özellikle ekonomik konularda bir yakınlaşma başlamış, Sovyet lideri Mihail Gorbaçov'un 1980 ortalarında izlediği Perestroyka siyasetine kadar iki ülke mesafeli, ancak işbirliğine de yer veren bir yaklaşım içinde olmuştur (Kudrov ve Ekonomika, 1999: 85; Aktaran: İsmailov, 2003: 35-36).

Siyasi alandaki bu denge politikasının izlerini ekonomik alanda da görmek mümkündür. Nitekim Cumhuriyetin ilanı ile sağlanan siyasi bağımsızlığın ardından aynı zamanda bir ekonomik bağımsızlık mücadelesine de girişen 1930'ların genç Türkiye'sindeki sanayileşme hamlesinde Sovyet ekonomik yardımlarının ve SSCB desteğiyle kurulan ilk sanayi tesislerinin rolü şüphesiz yadsınamaz. Bu çerçevede özellikle Cumhuriyet Türkiye'sinde modern tekstilin, metalürjinin, cam sanayiinin ve kimya sanayiinin temelleri bu ikili işbirliği sayesinde atılmıştır. Ayrıca kuzey komsusu, Soğuk Savaş yıllarında dahi, Türkiye'nin özellikle $\mathrm{ABD}$ ve Batı dünyası ile siyasi ilişkilerde sorunların yaşandığı çeşitli dönemlerde Batı'ya karşı bir alternatif işbirliği merkezi haline gelebilmiştir. 1960 sonrasında özellikle Kıbrıs sorunu ile bağlantılı olarak Batı dünyası ile ilişkilerin krize dönüştüğü bir dönemde Türk ekonomisinin ihtiyaç duyduğu ve Batı dünyasından temin 
edilemeyen çeşitli teknik ve teknolojik imkânların Sovyetler Birliği'nden sağlanması yoluna gidilmiştir. Bu açıdan Cumhuriyetin ağır sanayileşme döneminde, 1970'lerden başlayan Sovyetler Birliği'nin kurduğu dev sanayi kompleksleri, metalürji, kimya ve petrol rafinerileri Türk ekonomik ve sosyal hayatının önemli kilometre tasları olmuştur. Ancak Soğuk Savaş döneminde siyasi gelişmelere paralel olarak çeşitli dönemlerde gerilen siyasi ilişkilerden karşılıklı ekonomik işbirliği süreci de nasibini almıştır. Esasen sadece siyasi alanda değil, ekonomik alanda da Türkiye'nin Rusya'ya yönelik belli stratejiler temelinde sürdürülen istikrarlı bir dış politikasının olduğunu söylemek güçtür. Rusya daha çok Batı ile siyasi ya da ekonomik alanlarda ilişkilerin sıkıntılı devam ettiği ya da krize dönüştüğü kimi dönemlerde bir çeşit denge unsuru olarak değerlendirilmiş, krizlerin asılması ve Batı ile ilişskilerin tekrar rayına girmesi ile tekrar Türk dış politikasındaki alışılagelmiş konumuna dönmüştür (Şen, 2003).

İki ülke arasındaki ticari ve ekonomik ilişkilerin dönüm noktasını; 1967 tarihinde imzalanan ve SSCB tarafından bazı sanayi tesislerin inşası amacıyla Türkiye'ye yaklaşık 200 milyon dolar tutarında kredi açılması ve anılan krediye ait yıllık taksit ve faizlerin geri ödemelerinin ülkemiz menşeli mallarla yapılması esasına dayanan anlaşma oluşturmuştur. Türk ihraç mallarının SSCB piyasasına girmesinde ve iki ülke arasındaki ticaret hacminin geliştirilmesinde büyük bir rol oynayan ve "Özel Hesap" olarak bilinen, 1995 yılı sonu itibariyle de tasfiye edilen bu düzenleme çerçevesinde ülkemiz açısından o tarihlerde büyük önem arz eden İskenderun Demir Çelik Fabrikası, Seydişehir Alüminyum Tesisleri, Aliağa Petrol Rafinerisi, Orhaneli Termik Santrali gibi önemli sanayi kuruluşlarımızın tesisi için finansman sağlanmıştır (İsmailov, 2003: 36)

Rusya ve Türkiye'nin toplam dış ticareti sırasıyla Tablo 1 ve Tablo 2'de verilmiştir. Tablolar incelendiğinde, Rusya Türkiye'nin aksine yıllar itibariyle hep dış ticaret fazlası vermektedir. 2012 yılı itibariyle Rusya'nın toplam dış ticaret hacmi Türkiye'nin dış ticaret hacminin iki katından daha fazla olduğu tespit edilmiştir.

\begin{tabular}{llllll}
\hline & $\mathbf{2 0 0 8}$ & $\mathbf{2 0 0 9}$ & $\mathbf{2 0 1 0}$ & $\mathbf{2 0 1 1}$ & $\mathbf{2 0 1 2}$ \\
\hline \hline İhracat & 468.073 & 301.652 & 397.068 & 516.718 & 524.727 \\
\hline İthalat & 266.918 & 167.371 & 228.912 & 305.760 & 312.567 \\
\hline Dıș Ticaret Hacmi & 734.991 & 469.023 & 625.980 & 822.478 & 837.294 \\
\hline Dış Ticaret Fazlası & 201.155 & 134.281 & 168.156 & 210.958 & 212.160 \\
\hline \hline
\end{tabular}

Tablo 1: Rusya'nın toplam dlş ticareti (milyon dolar). Kaynak: Ekonomi Bakanlı̆̆l, Moskova Ticaret Müşavirliği, Rusya Federasyonu Federal Gümrük Servisi, TÜIK.

\begin{tabular}{llllll}
\hline & İhracat & İthalat & $\begin{array}{l}\text { Dış Ticaret } \\
\text { Hacmi }\end{array}$ & $\begin{array}{l}\text { Dış Ticaret } \\
\text { Açığ }\end{array}$ & $\begin{array}{l}\text { İhracat/ } \\
\text { Ithalat }\end{array}$ \\
\hline \hline $\mathbf{2 0 0 3}$ & 47.253 & 69.340 & 116.593 & -22.087 & 68,1 \\
\hline $\mathbf{2 0 0 4}$ & 63.167 & 97.540 & 160.707 & -34.373 & 64,8 \\
\hline $\mathbf{2 0 0 5}$ & 73.476 & 116.774 & 190.250 & -43.298 & 62,9 \\
\hline $\mathbf{2 0 0 6}$ & 85.535 & 139.576 & 225.111 & -54.041 & 61,3 \\
\hline $\mathbf{2 0 0 7}$ & 107.272 & 170.063 & 277.335 & -62.791 & 63,1 \\
\hline $\mathbf{2 0 0 8}$ & 132.003 & 201.961 & 333.964 & -69.958 & 65,4 \\
\hline $\mathbf{2 0 0 9}$ & 102.143 & 140.928 & 243.071 & -38.785 & 72,5 \\
\hline $\mathbf{2 0 1 0}$ & 113.883 & 185.544 & 299.427 & -71.661 & 61,4 \\
\hline $\mathbf{2 0 1 1}$ & 134.907 & 240.842 & 375.749 & -105.935 & 56,0 \\
\hline $\mathbf{2 0 1 2}$ & 152.561 & 236.537 & 389.098 & -83.976 & 64,5 \\
\hline \hline
\end{tabular}

Tablo 2: Türkiye'nin toplam diş ticareti (milyon dolar). Kaynak: Ekonomi Bakanlığl, Moskova Ticaret Müşavirliği, Rusya Federasyonu Federal Gümrük Servisi, TüIK.

\begin{tabular}{lllll}
\hline & İhracat & $\%$ Pay & İthalat & $\%$ Pay \\
\hline \hline Yatırım Malları & 627 & 9,4 & 30 & 0,1 \\
\hline Ara Mallar & 3.418 & 51,1 & 25.841 & 97,1 \\
\hline Tüketim Malları & 2.628 & 39,3 & 748 & 2,8 \\
\hline Diğer & 10 & 0,1 & 1 & 0,0 \\
\hline Toplam & 6.683 & 100,0 & 26.62 & 100,0 \\
\hline \hline
\end{tabular}

Tablo 3: Türkiye-Rusya Federasyonu dış ticaretinin yapısı (2012) (milyon dolar). Kaynak: TUIK.

İki ülke ihracat ve ithalat açısından karşılaştırıldığında, Rusya’nın ihracat ve ithalatının yıllar itibariyle Türkiye'nin ihracat ve ithalatından fazla olduğu görülmektedir. 2012 yılı itibariyle Rusya'nın toplam ihracatı 524.727 milyon dolar iken Türkiye'nin toplam ihracatı sadece 152.561 milyon dolardır.

Türkiye'nin Rusya ile olan dış ticaret verileri Tablo 3'de verilmiştir. Tablo incelendiğinde, Yıllar itibariyle iki ülke arasındaki ticaret hacmini arttığı görülmektedir. Türkiye'nin Rusya'dan satın aldığı mal ve hizmet değeri 
daha fazla iken sattığı mal ve hizmet değeri daha azdır. Türkiye son yıllarda en fazla ithalatını Rusya'dan yapmaktadır.

Türkiye, Rusya'dan çoğunlukla ara malları ithal ederken (\%97,1), Rusya'ya ara malları ihracatı yapmaktadır $(\% 51,1)$ (Tablo 4).

\begin{tabular}{lll|lll}
\hline İhracat & & & Ithalat & & \\
\hline 2012 & Mil. \$ & $\%$ Pay & 2012 & Mil. \$ & $\%$ Pay \\
\hline \hline Dokumacıllk ürünleri & 1.256 & 18,8 & Petrol gazları-doğal gaz & 12.272 & 46,1 \\
\hline Gida ürünleri & 1.028 & 15,4 & Petrol ve ürünleri & 5.068 & 19,0 \\
\hline Otomotiv sanayi ürünleri & 791 & 11,8 & Gida ürünleri & 2.034 & 7,6 \\
\hline Diğer yarı mamuller & 597 & 8,9 & Demir-çelik & 1.709 & 6,4 \\
\hline Kimyasallar & 547 & 8,2 & Kömür & 1.669 & 6,3 \\
\hline Diğer tüketim ürünleri & 518 & 7,8 & Demir dışı metaller & 1.359 & 5,1 \\
\hline Diğer elektriksiz makineler & 477 & 7,1 & Maden cevherleri & 1.067 & 4,0 \\
\hline Hazır giyim & 409 & 6,1 & Kimyasallar & 868 & 3,3 \\
\hline Elektrikli makine ve cihazlar & 352 & 5,3 & Diğer yarı mamuller & 341 & 1,3 \\
\hline Madencilik ürünleri & 285 & 4,3 & Tarımsal hammaddeler & 164 & 0,6 \\
\hline Diğer & 423 & 6,3 & Diğer & 69 & 0,3 \\
\hline GENEL TOPLAM & 6.683 & 100,0 & GENEL TOPLAM & 26.620 & 100,0 \\
\hline \hline
\end{tabular}

Tablo 4: Türkiye-Rusya Federasyonu dış ticaretinde öne çıkan madde grupları. Kaynak: TUIK

2012 yılı itibariyle Türkiye Rusya'dan 26.620 milyon dolar ithalat yaparken, 6.683 milyon dolar ihracat yaptı̆ğ Tablo 5'de görülmektedir. Rusya'dan yapılan ithalat içerisindeki en büyük payı petrol gazları-doğal gaz $(\% 46,1)$ alırken bunu sırasıyla petrol ve ürünleri $(\% 19,0)$, gida ürünleri $(\% 7,6)$ ve demir-çelik $(\% 6,4)$ izlemektedir. Rusya'ya yapılan ihracatta ise ilk sırayı dokumacılık ürünleri $(\% 18,8)$ alırken, bunu sirasıyla gıda ürünleri $(\% 15,4)$, otomotiv yan sanayi $(\% 11,8)$, diğer yarı mamuller $(\% 8,9)$ ve kimyasallar $(\% 8,2)$ izlemektedir.

\section{Ekonometrik Metodoloji}

Türkiye'nin Rusya ile dış ticaretini dikkate alarak oluşturulan ihracat ve ithalat talep fonksiyonlarının modellenmesinde Houthakker ve Magee (1969), Leamer ve Stern (1970), Stern, Francis ve Schumacher (1976) ve Mayes (1981) gibi araştırmacıların çalışmalarında kullandıkları modeller dikkate alınmıştır (Doğanlar vd., 2006: 57). Bu kapsamda Türkiye'nin Rusya ile dış ticareti üzerinden ihracat ve ithalat talep fonksiyonları aşağıdaki gibi oluşturulmuştur.

$$
\begin{aligned}
\ln X_{t} & =\beta_{0}+\beta_{1} \ln R F G D P_{t}+\beta_{2} \ln P X_{t}+u_{t} \\
\ln M_{t} & =\alpha_{0}+\alpha_{1} \ln T R G D P_{t}+\alpha_{2} \ln P M_{t}+u_{t}
\end{aligned}
$$

Çalışmada kullanılan bütün değişkenlerin logaritmaları alınmıştır. $X$ değişkeni Türkiye'nin Rusya'ya yaptığı ihracatı milyon $\mathrm{ABD}$ doları olarak göstermekte olup, nominal ihracat değerlerinin ihracat fiyat endeksi kullanılarak reel hale getirilmesiyle oluşturulmuştur. RFGDP değişkeni Rusya'nın reel GSYİH'nı, PX değişkeni ise göreli fiyatları yani Türkiye'nin ihracat fiyat endeksinin Rusya'nın tüketici fiyat endeksine oranını göstermektedir. $\mathrm{M}$ değişkeni Türkiye'nin Rusya'dan yaptığı ithalatı milyon ABD doları olarak göstermekte olup, nominal ithalat değerlerinin ithalat fiyat endeksi kullanılarak reel hale getirilmesiyle oluşturulmuş̧ur. TRGDP değişkeni Türkiye'nin reel GSYIH'nı, PM değişkeni ise göreli fiyatlar olan Türkiye'nin ithalat fiyat endeksinin Türkiye'nin tüketici fiyat endeksine oranını göstermektedir.

İhracat talep fonksiyonu yabancı talebin (gelirin) ve göreli fiyatların (yurtiçi ihracat fiyat endeksinin yurtdışı fiyatlara oranının) bir fonksiyonudur. İthalat talep fonksiyonu ise yurtiçi talebin (milli gelirin) ve göreli fiyatların (yurtiçi ithalat fiyat endeksinin yurtiçi fiyatlara oranının) bir fonksiyonudur. İhracat ve ithalat talep fonksiyonlarındaki katsayılar talebin gelir ve fiyat esnekliklerini vermektedir. $\beta_{1}$ ve $\beta_{2}$ katsayıları sırasıyla ihracat talebinin gelir ve fiyat esnekliklerini, $\alpha_{1}$ ve $\alpha_{2}$ katsayıları ise sırasıyla ithalat talebinin gelir ve fiyat esnekliklerini vermektedir.

İhraç ürünlerinin fiyatlarında meydana gelen bir düşüş, söz konusu ürünlerin uluslararası rekabetini artıracağı için yabancı talebin o ürünlere yönelerek ihracatı artırması beklenir. Yabancı ülkelerin reel gelirlerinde meydana gelen bir artış bu ülkelerin yabancı mallara olan taleplerinde bir artışa neden olacağından, yabancı ülkelerin reel geliri ile reel ihracat arasında pozitif bir ilişkinin olması beklenmektedir (Doğanlar vd., 2006: 57). Ayrıca bir ülkenin ihracat talebinin fiyat ve gelir esnekliklerinin büyük olması da önemlidir. İhracat talebinin gelir esnekliği ne kadar yüksek olursa ekonomik büyümede ihracat o kadar önemli rol oynayacaktır. Aynı zamanda fiyat esnekliğinin yüksek olması da bir ülkenin uluslararası piyasalarda ihracatının rekabet gücünün yüksek olmasına yol açacaktır. Yani bu söz konusu esnekliklerin büyük olması ihracat gelirlerinin artırılmasında devalüasyon politikalarının etkinliğini artıracaktır (Şimşek ve Kadılar, 2005: 145). İthal ürünlerinin fiyatlarında meydana gelen bir artış ithalat talebini düşüreceğinden ters yönlü bir ilişki beklenmektedir. Bununla beraber reel milli 
gelirde meydana gelen bir artış ithal ürünlerine olan talebi artıracağından reel milli gelir ile reel ithalat arasında pozitif yönü bir ilişki beklenmektedir (Doğanlar vd., 2006: 57). Teorideki beklentiye uygun olarak çalışmada ihracat ve ithalat talebinin gelir esnekliklerinin pozitif, fiyat esnekliklerinin negatif olması öngörülmektedir.

Çalışmada 1995Q1-2010Q4 dönemini kapsayan üçer aylık veriler kullanılmış olup, veriler Türkiye Cumhuriyet Merkez Bankası, IMF, Rusya Merkez Bankası ve Rusya Federal İstatistik Servisi veri tabanlarından elde edilmiştir. İlgili dönemlerin belirlenmesinde birbiriyle uyumlu verilerin analize dâhil edilmesi belirleyici olmuştur.

Durağan olmayan serilerde sahte ilişki söz konusu olabileceğinden çalışmada öncelikle kullanılan serilerin durağanlığının araştırılması amacıyla birim kök testi uygulanacaktır. Daha sonra regresyon analiz yapılarak esneklik katsayıları en küçük kareler yöntemi ile tahmin edilmeye çalışılmıştır.

İthalat talebinin fiyat esnekliği ile ihracat talebinin fiyat esnekliği toplamının mutlak değer içerisinde birden büyük olması Marshall-Lerner koşulunun geçerli olduğu anlamına gelmektedir (Ünsal, 2003: 357).

$$
\left|\beta_{2}+\alpha_{2}\right|>1
$$

Marshall-Lerner koşulunun geçerli olması devalüasyonun net ihracatı artırmada yani dış ticaret açıklarının kapatılmasında etkili olduğu anlamına gelmektedir (Ünsal, 2003: 358). Ancak bu koşulun sağlanması diş ticaret dengesizliklerinin giderilmesinde yeterli değildir. Dengesizliğin giderilmesinde üretimin ve ihracatın artırılması da büyük öneme sahiptir (Şimşek ve Kadılar, 2004: 33).

Çalışmada elde edilen ihracat ve ithalat taleplerinin fiyat esnekliği katsayıları ile Türkiye'nin Rusya ile ticaretinin devalüasyon sonucu dış dengesizliklerin giderilmesine katkı sağlayıp sağlamadığı değerlendirilecektir.

\section{Ampirik Bulgular}

Zaman serilerinde durağanlık, korelogram ve birim kök (unit root) testleriyle analiz edilmektedir (Tarı, 2005: 388). Literatürde çeşitli birim kök testleri bulunmakla beraber, en çok kullanılan testler; Dickey-Fuller (DF), Genişletilmiş Dickey-Fuller (ADF) ve Phillips-Perron (PP) birim kök testleridir. Bu çalışmada kullanılan serilerin durağanlığının tespit edilmesi amacıyla ADF birim kök testi kullanılmıştır. Serilerin durağanlığının araştırılması amacıyla yapılan ADF birim kök testi sonucu elde edilen bulgular aşağıdaki tabloda ortaya koyulmuştur.

\begin{tabular}{|c|c|c|c|c|}
\hline & \multicolumn{2}{|l|}{ Düzey } & \multicolumn{2}{|l|}{ 1. Fark } \\
\hline & t-ist. & prob. & t-ist. & prob. \\
\hline$\overline{\ln X}$ & -2.422 & 0.3651 & "-5.817 & "0.0000 \\
\hline $\ln M$ & -1.506 & 0.8170 & -9.345 & 0.0000 \\
\hline $\ln R F G D P$ & -3.047 & 0.1286 & -6.443 & 0.0000 \\
\hline $\operatorname{lnTRGDP}$ & -1.761 & 0.7107 & -4.396 & 0.0046 \\
\hline $\ln P X$ & -1.506 & 0.8170 & -4.801 & 0.0013 \\
\hline $\ln P M$ & -2.257 & 0.4504 & -4.418 & 0.0042 \\
\hline
\end{tabular}

Tablo 5: ADF birim kök testi sonuçlart

Tabloda serilerin, düzey değerlerinde ADF test istatistiklerinin mutlak değerinin, MacKinnon kritik değerlerinden küçük olduğu, yani serilerin birim köke sahip olduğu sonucu ortaya çıktığı için, serilerin farklarının alınması gerekmektedir. Serilerin birinci derece farklarının alınması ile elde edilen sonuçlar, serilerin birinci derecede durağan olduklarını ortaya koymaktadır.

Aşağıda birbirine izleyen iki tabloda Rusya ile dış ticareti bağlamında Türkiye'nin ihracat ve ithalat talep fonksiyonlarının katsayılarının tahmini yapılmıştır.

\begin{tabular}{lllll}
\hline Değişkenler & Katsayılar & Std. Hata & t-ist. & prob. \\
\hline \hline Sabit & -7.823082 & 3.764888 & -2.077906 & 0.0421 \\
$\ln R F G D P$ & 3.117854 & 0.423831 & 7.356367 & 0.0000 \\
$\ln P X$ & 0.691521 & 0.163024 & 4.241823 & 0.0001 \\
\hline$R^{2}: 0.92, F$-ist.:234.058, Durbin Watson ist.:1.823045 & \\
\hline \hline
\end{tabular}

Tablo 6: Ihracat talep fonksiyonu tahmin sonuçlarl

Analizi yapılan modellerin açıklama gücünü gösteren $R^{2}$ değeri her iki modelde de yüksek düzeyde gerçekleşmiştir. Durbin Watson istatistik değerleri tablo değerleri ile karşılaştırıldığında otokorelasyon olmayan bölgeye düştüğü görülmektedir. Her iki modelde de tahmin edilen katsayılar istatistiki olarak anlamlı yani yorumlanabilir düzeydedir. 


\begin{tabular}{lllll}
\hline Değişkenler & Katsayılar & Std. Hata & t-ist. & prob. \\
\hline \hline Sabit & 8.818955 & 5.122368 & 1.721656 & 0.0905 \\
lnTRGDP & 1.678197 & 0.497521 & 3.373117 & 0.0013 \\
lnPM & -0.430916 & 0.178541 & 2.413540 & 0.0190 \\
\hline$R^{2}: 0.99, F$-ist.:1067.509, Durbin Watson ist.:1.984107 & \\
\hline \hline
\end{tabular}

Tablo 7: Ithalat talep fonksiyonu tahmin sonuçları

1995-2010 dönemi çeyrek verileri kullanılarak yapılan analiz sonucu tahmin edilen modeller aşağıdaki gibi yazılabilir.

\begin{tabular}{|l|l|}
\hline İhracat Talep Fonksiyonu & $\ln \mathrm{X}=-7.823+3.118 \ln R F G D P-0.692 \ln \mathrm{PX}$ \\
\hline İthalat Talep Fonksiyonu & $\ln \mathrm{M}=8.819+1.678 \ln$ TRGDP-0.431lnPM \\
\hline
\end{tabular}

Tablo 8: Tahmin edilen modeller

İhracat talebinin gelir ve fiyat esneklikleri sırasıyla 3,118 ve -0,692 olarak hesaplanmıştır. İhracat talebinin gelir esnekliğinin pozitif, fiyat esnekliğinin ise negatif işarete sahip olması teorik beklentiye uygundur. İhracat talebinin gelir esnekliğinin pozitif olması Rusya'nın milli gelirindeki artışın Türkiye’nin Rusya'ya ihracatını attırıcı etkiye yol açacağını, ihracat talebinin fiyat esnekliğinin negatif olması ise Türkiye'nin ulusal parasındaki değer kaybının da yine Türkiye'nin Rusya'ya ihracatını arttırıcı etkiye yol açacağını ifade etmektedir. Elde edilen bu sonuçlar Türkiye'nin Rusya'ya ihracatının nispi fiyatlardan çok Rusya'nın gelirinden etkilendiğini göstermektedir.

İthalat talebinin gelir ve fiyat esneklikleri sırasıyla 1,678 ve $-0,431$ olarak hesaplanmıştır. İthalat talebinin gelir esnekliğinin pozitif, fiyat esnekliğinin ise negatif işarete sahip olması teorik beklentiye uygundur. İthalat talebinin gelir esnekliğinin pozitif olması Türkiye'nin milli gelirindeki artışın Türkiye'nin Rusya'dan ithalatını attırıcı etkiye yol açacağını, ithalat talebinin fiyat esnekliğinin negatif olması ise Rusya'nın ulusal parasındaki değer kaybının da yine Türkiye'nin Rusya'dan ithalatını arttırıcı etkiye yol açacağını ifade etmektedir. Elde edilen bu sonuçlar Türkiye'nin Rusya'dan ithalatı nispi fiyatlardan çok Türkiye'nin gelirinden etkilendiğini göstermektedir.

İhracat ve ithalat taleplerinin gelir ve fiyat esneklikleri incelendiğinde ihracat talebinin gelir ve fiyat esnekliklerinin ithalat talebinin gelir ve fiyat esnekliklerinden büyük olduğu görülmektedir. Bu durum Türkiye'nin Rusya'ya ihracatı ve Rusya'dan ithalatı ile alakalı olması mümkündür. Türkiye'nin Rusya'ya ihracatında tekstil ürünleri ön plana çıkarken ithalatında enerji belirleyici konumdadır. Bu nedenle ithalat talebinin gelir ve fiyat esnekliklerinin ihracat esnekliklerine göre katı olması muhtemeldir.

İhracat ve ithalat taleplerinin fiyat esnekliklerinin toplamı 1.123 olarak gerçekleşmiştir. Marshall-Lerner koşulunun sağlanması nedeniyle Türkiye'nin Rusya ile dış ticaretinin kur değişimlerinden etkilendiği yani nispi fiyatların iki ülke arasındaki dış ticaret akışında belirleyici olduğu ifade edilebilir. Bu nedenle devalüasyon politikalarının Türkiye'nin dış dengesizliğinin Rusya ile ticareti üzerinden giderilmesinde etkili olacağını söylemek mümkündür.

\section{Sonuç ve Değerlendirme}

1990’lı yıllarda SSCB’nin dağılmasıyla on beş farklı ülke bu süreçte bağımsızlıklarını kazanmış ve kendi başlarına çeşitli ülkelerle ekonomik ve siyasi ilişkiler kurmaya başlamışlardır. Bu bağımsızlık hareketinden sonra Rusya'da ekonomik sorunlar yaşanmaya başlanmıştır. 1992 yılında, Rusya Federasyonu merkezi planlı sistemden piyasa ekonomisine geçebilmek için bir dizi ekonomik reformlar yapmıştır. Bu çalışmada Rusya ile Türkiye arasındaki dış ticaret hacmi dikkate alınarak Türkiye'nin ihracat ve ithalat talep fonksiyonları farklı değişkenlere göre belirlenmiştir.

Yıllar itibariyle Rusya ile Türkiye arasındaki ticaret hacmini gittikçe artış göstermiştir. Türkiye'nin Rusya'dan ithalatı daha fazla iken ihracatı daha azdır. Son yıllarda Türkiye en fazla ithalatını Rusya'dan yapmaktadır. Türkiye, Rusya'dan çoğunlukla ara malları ithal ederken $(\% 97,1)$, yine aynı şekilde en çok ara malları ihracatı yapmaktadır $(\% 51,1)$. Rusya'dan yapılan ithalat içerisindeki en büyük payı petrol gazları-doğal gaz $(\% 46,1)$ alırken bunu sırasıyla petrol ve ürünleri $(\% 19,0)$, gıda ürünleri $(\% 7,6)$ ve demir-çelik $(\% 6,4)$ takip etmektedir. Rusya'ya yapılan ihracatta ise ilk sırayı dokumacılık ürünleri $(\% 18,8)$ alırken, bunu sırasıyla gida ürünleri $(\% 15,4)$, otomotiv yan sanayi $(\% 11,8)$, diğer yarı mamuller $(\% 8,9)$ ve kimyasallar $(\% 8,2)$ izlemektedir.

1995-2010 dönemi çeyrek verileri kullanılarak regresyon analizi yapılmış ithalat ve ihracat modelleri elde edilmiştir. İhracat modeline ilişkin gelir ve fiyat esneklikleri teoriye uygun olup sırasıyla pozitif ve negatif bulunmuştur. Elde edilen bulgulara göre, Türkiye'nin Rusya'ya ihracatının nispi fiyatlardan çok Rusya'nın gelirinden etkilendiğini açıklamaktadır. İthalat talebinin gelir ve fiyat esneklikleri sirasıyla 1,678 ve $-0,431$ 
olarak bulunmuş olup, teorik beklentiye uygundur. Bu sonuçlara göre, Türkiye'nin Rusya'dan ithalatı nispi fiyatlardan çok Türkiye'nin gelirinden etkilendiğini göstermektedir.

İhracat ve ithalat taleplerinin fiyat esnekliklerinin toplamı 1,123 olarak hesaplanmıştır. Marshall-Lerner koşulunun sağlanması nedeniyle Türkiye'nin Rusya ile dış ticaretinin kur değişimlerinden etkilendiği ifade edilebilir. Bu sebeple Türkiye'nin dış ticaret dengesizliğinin Rusya ile ticareti üzerinden giderilmesinde devalüasyon politikalarının etkili olacağı söylenebilir.

\section{Kaynakça}

- Doğanlar, M., Bal, H., Özmen, M. (2006), “Türkiye ile Almanya Arasındaki Dış Ticaretin Ekonometrik Analizi ve Gümrük Birliği Sonrası Karşılaştırma”, İktisat İ̧̧letme ve Finans, 21(248), Kasım, 50-65.

- Duman, M., Samadov, N. (2003), "Türkiye ile Rusya Federasyonu Arasındaki İktisadi ve Ticari İlişkilerin Yapısı Üzerine Bir İnceleme”, Kocaeli Üniversitesi Sosyal Bilimler Enstitüsü Dergisi, 6(2), 25-47.

- Houthakker, H.S. and Magee, S.P. (1969), "Income and Price Elasticities in World Trade", Review of Economics and Statistics, 51, 111-125.

- İGEME Ülke Raporu, (2008), T.C. Başbakanlık Dış Ticaret Müsteşarlığı İhracatı Geliştirme Etüt Merkezi, Rusya Ülke Profili, http://www.uekibb.org/raporlar/Rusya_394696556.pdf , Erişim tarihi: 21.05.2013

- İsmailov, R. (2003), Rusya'nın Dış Ticareti ve Rusya Dış Ticaretinde Türkiye'nin Yeri, T.C Marmara Üniversitesi Sosyal Bilimler Enstitüsü İktisat Anabilim Dalı Uluslararası İktisat Bilim Dalı Yüksek Lisans Tezi, İstanbul.

- Kudrov, V. ve Ekonomika, M. (1999), Aktaran: Rövşen İsmailov (2003), Rusya'nın Dış Tícareti ve Rusya Dış Ticaretinde Türkiye'nin Yeri, T.C Marmara Üniversitesi Sosyal Bilimler Enstitüsü İktisat Anabilim Dalı Uluslararası İktisat Bilim Dalı Yüksek Lisans Tezi, İstanbul.

- Leamer, E.E., Stern, R.M. (1970), Quantitive International Economics, Allyn and Bacon, Boston.

- Mayes, D.G. (1981), Applications of Econometrics, Prentice Hall, New Jersey.

- Radygin, A. (2000), "The Redistribution of Property Rights in Post Privatizatin Russia”, Problems of Economic Transition, 42(11), March, 6-34.

- Stern, R.M., Francis, J. Ve Schumacher, B., (1976), Price Elasticies in International Trade: An Annotated Bibliography, The MacMillan Press, London.

- Şen, C.G. (2003), "Türk-Rus Ekonomik İlişkileri: Mevcut Durum, Sorunlar ve Perspektifler”, Aylk Strateji ve Analiz E-Dergi, Ağustos 2003, Say1:7. http://www.stradigma.com/turkce/agustos2003/08 2003 01.pdf, Erişim tarihi: 05.08.2013.

- Şimşek, M., Kadılar, C. (2004), “Türkiye'nin İthalat Talebi Fonksiyonunun Sınır Testi Yöntemi ile Eşbütünleşme Analizi: 1970-2002”, Doğuş Üniversitesi Dergisi, 5(1), 27-34.

- Şimşek, M., Kadılar, C. (2005), “Türkiye'nin İhracat Talebi Fonksiyonunun Sınır Testi Yöntemi ile Eşbütünleşme Analizi”, Doğuş Üniversitesi Dergisi, 6(1), 144-152.

- $\quad$ TÜİK, -----, Ekonomi Bakanlığı, Moskova Ticaret Müşavirliği, Rusya Federasyonu Federal Gümrük Servisi.

- T.C. Moskova Büyükelçiliği Ticaret Müşavirliği, Temmuz 2011 Raporu, (2011), http://www.musavirlikler.gov.tr/upload/RF/temmuz\%202011.DOC, Erişim tarihi: 10.05.2013.

- $\quad$ Tar1, R. (2005), Ekonometri, 3. Bask1, Kocaeli Üniversitesi Yayın No: 172, İzmit.

- Ünsal, E. (2003), Makro İktisat, 5. Bask1, Turhan Kitabevi, Ankara. 


\title{
Avrupa Borç Krizinin Türkiye’nin İhracatı Üzerindeki Etkileri The Effects of European Debt Crisis on Turkey's Exports
}

\author{
Prof. Dr. Bedriye Tunçsiper (Balıkesir University, Turkey) \\ Ph.D. Candidate Ömer Faruk Biçen (Balıkesir University, Turkey)
}

\begin{abstract}
The crisis that arose in Greece at the last quarter of 2009 affected the countries that have heavily government debt like Spain, Portugal, Italy and Ireland as soon as 2008 Global Financial Crisis originating from USA Mortgage Markets affect European Union (EU) countries under heavily debt burden. The effects of that crisis in the short run are demand shrinking and decrease in export. Turkey, which has important economic relations with EU countries in the last fifty years, is the primary country that can be negatively affected from demand shrinking in Europe. Turkey that indirectly experience 2008 global financial crisis because of the decrease in export volume in Europe also seem fatefully affected in this crisis. This article aims to determine the effects of the crisis to Turkey's export ampirically in the EU countries that have the lion's share in the Turkey's export markets. As well, it is trying to explain whether this crisis affects over-all Europe or not.
\end{abstract}

\section{Giriş}

2008 yılında Amerika Birleşik Devletleri’nde ortaya çıkan Mortgage Piyasası odaklı Küresel Finans Krizinin etkilediği ve Avrupa Birliği’ne üye ülkelerden Yunanistan'da başlayıp, İspanya, Portekiz, İtalya ve İrlanda'ya da yayılan kriz 2013 yılı içerisinde de etkisini sürdürmektedir. Kriz, her bir ülkede farklı karaktere ve farklı temele sahip olsa da bu ülkelerdeki krizi tanımlayan ortak görüş, krizin bir kamu borç krizi olduğudur. 2009 yılının son çeyreğinde başlayan kriz hızla zayıf mali ve makroekonomik koşullar altında bulunan ülkelere yayılmıştır (Neri and Ropele, 2013).

Krizin ortaya çıkmasında 2008 Küresel Finans Krizi önemli rol oynasa da Avrupa Birliği’nde Avro’ya geçiş süreciyle birlikte ortaya çıkan yapısal sorunların sürdürülebilir olmaktan çıkması krizi açıklayan ana unsur olarak kabul edilmektedir. Jan Kregel (2012)'e göre; Avro Bölgesinde yaşanan borç krizinden çıkarılabilecek bazı dersler bulunmaktadır. Buna göre; Avrupa'daki parasal birlik ödemeler dengesinde var olan problemleri (dengesizlikleri) çözememiş, Avrupa'daki rekabet, enflasyonu düşürmüş fakat büyümeye ve yakınsamaya yol açmamış ve ortak para birimi Avro'ya geçiş içeriden müdahaleye ihtiyacı ortadan kaldırmamıştır.

Mevcut kriz Türkiye'den de dikkatle izlenmektedir. Türkiye'nin Avrupa Birliği ülkeleriyle uzun yıllardır süren yakın ekonomik ilişkileri nedeniyle Avrupa'da ortaya çıkacak bir ekonomik kriz, Türkiye'yi önemli ölçüde etkileme potansiyeline sahiptir. Avrupa Birliği ülkelerinde ortaya çıkacak kriz Türkiye'yi öncelikle yabancı sermaye girişlerinde azalma ve ihracat düzeyinde bir düşme şeklinde etkileyecektir. Türkiye, önemli ölçüde cari açık veren bir ülke konumunda olduğundan yabancı sermaye'ye şiddetle ihtiyaç duymaktadır. Öte yandan, ihracattaki bir azalma da cari açığı daha da arttıracaktır. Bunun anlamı, Avrupa Birliği ülkelerindeki krizin önümüzdeki dönemde de devam etmesi ve diğer Avrupa Birliği ülkelerine yayılması, kaçınılmaz olarak Türkiye'nin de krize girmesine yol açabilecektir.

Çalışma, Avrupa Birliği ülkelerinde yaşanmakta olan borç krizinin Türkiye'nin ihracatını kısa ve uzun dönemde ne ölçüde etkileyeceğini ARDL (Autoregressive Distributes Lag) eşbütünleşme yaklaşımıyla test etmeyi ve bu kapsamda öneriler sunmayı amaçlamaktadır.

Çalışmanın giriş bölümünü takip eden ikinci bölüm, Avrupa borç krizinin ortaya çıkış nedenleri ve krizin gelişimi üzerinde durmaktadır. Üçüncü bölümde, borç krizinin yaşandığı ülkeler bazında krizin farklı sebepleri, krize yönelik alınan önlemler ve krizi yaşayan ülkelerdeki yüksek kamu borçlarının sürdürülebilirliği 2014 perspektifinde değerlendirilmiştir. Dördüncü bölümde, krizin Türkiye ekonomine yönelik olası etkileri incelenmiştir. Beşinci ve son bölümde ise, ampirik olarak Türkiye'nin ihracat düzeyi ile Avrupa Birliği ülkelerinin Gayrisafi Yurtiçin Hasıla düzeyleri arasında bir ilişki kurulmuştur. Bu ilişkiden ARDL eşbütünleşme yaklaşımıyla krizin Türkiye'nin ihracatı üzerindeki etkileri kısa ve uzun dönemli olarak belirlenmiştir.

Daha önce de bahsedildiği gibi, Avrupa Birliği ülkelerinden Yunanistan'da başlayan kriz daha sonra İspanya, Portekiz, İtalya ve İrlanda'ya yayılmıştır. Bu ülkeler, kriz sürecini inceleyen literatürde çoğunlukla borç krizine giren beş ülkenin baş harflerinden oluşan PIIGS (Portugal, Ireland, Italy, Greece, Spain) ülkeleri olarak adlandırılmaktadırlar. Çalışmamızda da, Yunanistan, İspanya, Portekiz, İtalya ve İrlanda'dan oluşan bu ülkeler PIIGS ülkeleri olarak adlandırılmaktadır.

\section{Avrupa Borç Krizinin Ortaya Çıkış Nedenleri ve Krizin Gelişimi}

Avrupa Birliği ülkelerinden Yunanistan'da 2009 yılının son çeyreğinde ortaya çıkan kriz, birliğe üye diğer ülkelerden İspanya, Portekiz, İtalya ve İrlanda'ya da kısa sürede yayılmıştır. Avrupa Birliği ülkelerinde ortaya 
çıkan krizin temel sebebi olarak (birlik içerisindeki yapısal nedenler bir kenara bırakıldığında) 2008 yılının son çeyreğinde Amerika Birleşik Devletlerinde başlayan Mortgage Piyasası kaynaklı küresel finans krizi olduğu üzerinde bir görüş birliği bulunmaktadır.

Kibritçioğlu (2011)'na göre de, Avrupa'da ortaya çıkan kamu kesimi eksenli borç krizi küresel ekonomik/finansal krizin en önemli bileşenlerinden birisidir. Küresel finans krizi başladıktan sonra, kısa bir süre içerisinde Avrupa ülkelerini de etkileyerek, bu ülkelerin makro ekonomik göstergelerinin kötüleşmesine yol açmıştır. Avrupa ülkelerinde küresel finans krizine karşı uygulanan ekonomiyi canlandırma paketleri, bankalar aracılığı ile özel kesim borçlarının kamulaştırılması, büyüme düzeyindeki düşüşler sonucu vergi gelirlerinin azalması ve tasarruf açıkları, cari açığı yüksek olan bazı Avrupa Birliği ülkelerinde kamu borç yükünü arttırmıştır (Kılıç ve Bayar, 2012).

Aslında, 2008 yılının son çeyreğinden itibaren tüm dünyayı ve bununla birlikte Avrupa'yı da etkileyen Küresel Finans Krizi, Avrupa Birliği içerisindeki bilinen, fakat görmezden gelinen yapısal sorunların artık sürdürülemez olduğu gerçeğini bir anlamda kabul ettirmiştir. Avrupa Birliği ülkelerindeki krize ilişkin olarak en belirgin sebep, tek para birimi Euro'ya geçişle birlikte borçlanma maliyetlerindeki azalmalar sonucu göreceli olarak ekonomik açıdan zayıf olan ülkelerin aşırı borçlanması ve bu borçların büyümeyi sağlayacak, ekonominin rekabet gücünü arttıracak üretken alanlara yönlendirilmesi yerine, tüketim harcamalarının finansmanında kullanılmasıdır. $\mathrm{Bu}$ durum, her seferinde yeni borçlanmayı beraberinde getirmektedir.

Avrupa Birliği ülkelerinde ortaya çıkan borç krizinin yapısal sebepleri aşağıda dört grupta toplanabilir (Öztürk ve Aras, 2011):

İlk olarak, Avrupa'da ortak bir ekonomik alanın oluşturulması sürecinde, para politikası bir üst otorite olan Avrupa Merkez Bankasına devredilirken, maliye ve vergi politikalarının uygulama yetkisi hükümetlerin kendisinde kalmıştır. Bu durum mali disiplinden uzaklaşıımasına, bütçe açıkları ve artan borç yüklerinin ortaya çıkmasına yol açmıştır.

İkinci olarak, AB’nin birleşme sürecinde karşılaşılan önemli bir sorun da bölgesel gelişmişlik farkları ve bölgesel gelişmişlik farklarının giderilmesinde görece geri kalmış bölgelere yapılan maddi yardımlardır. 2004 yılında birlik tarihinin en büyük genişlemesinin yaşanması sonucunda birliğe yeni üyelerin dahil olması, fonların yetersiz kalmasına yol açmıştır.

Üçüncü olarak, Birliğe yeni katılan üyelerin Almanya, Fransa gibi birlik üyeleriyle rekabet edebilecek potansiyellerinin söz konusu olmaması, yeni üyelerin imalat sanayilerinin görece gerilemeye başlamasına yol açmıştır (Bagus, 2010).

Son olarak, Euro'ya katılan ülkelerde faiz oranlarının düşmesi, bu ülkelerin borçlanma imkanlarının arttırmıştır. Bunun yanında, Avrupa Merkez Bankası da Portekiz, Yunanistan, İtalya, İspanya ve İrlanda'ya ait kamu borç faiz oranlarını düşük tutarak bu ülkeleri aşırı harcama yapma konusunda bir anlamda teşvik edici rol oynamıştır (Kılıç ve Bayar, 2012).

Görüldüğü gibi, Avrupa Birliği ülkelerindeki borç krizinin arkasında yapısal nedenler ile Avrupa Merkez Bankası ile ulusal hükümetler arasındaki anlaşmazlıklar şeklinde ortaya çıkan ekonomik politikaların koordinasyonundaki sorunlar bulunmaktadır (Kılıç ve Bayar, 2012). Yapısal nitelikteki sorunların ve koordinasyon sorunlarının hızlı biçimde çözüme kavuşturulması, Avrupa Birliği ülkelerinde yaşanan kamu borç krizinin de hızlı biçimde atlatılmasına yol açacaktır.

\section{Borç Krizinin Yaşandığı Ülkelerde Krize Yönelik Alınan Önlemler ve Yüksek Kamu Borçlarının Sürdürülebilirliği}

2008 Küresel Finans Krizi sonrasında Avrupa'da ortaya çıkan durgunluk karşısında çok sayıda Avrupa Birliği ülkesi durgunluğu aşmak için parasal genişlemeyle birlikte geniş ölçekli ekonomik destek paketleri yürürlüğe koymuştur. Bu ekonomik destek paketlerine ek olarak ekonomilerdeki daralmanın vergi gelirlerinde yol açtığ azalma ve artan kamu borç stoku ve faiz oranları Avrupa Birliği genelinde kamu harcamalarının ve açıklarının artmasına yol açmıştır (SDE Analiz, 2012). Bu sebeple Avrupa Borç krizinin öncelikle etkilediği ülkeler olan Yunanistan, İspanya, Portekiz, İtalya ve İrlanda'da kamu borçlarının sürdürülebilirliği sorunu ön plana çıkmıştır.

Kamu borçlarının sürdürülebilirliğinin bazı temel belirleyicileri söz konusudur. Bu temel belirleyiciler arasında (Bryson, 2011);

Borcun değeri,

Hükümet tarafindan ödenmesi gereken faiz oran1,

Faiz dışı bütçe dengesi,

Gayrisafi yurt içi hasıla büyüme oranı bulunmaktadır.

Dolayısıyla, yüksek kamu kesimi borcu, yüksek faiz oranı, büyük bütçe açıkları ve düşük büyüme hızının yaşandığı ülkelerde borçların sürdürülebilirliği sorunu ortaya çıkmaktadır (Kibritçioğlu, 2011). 


\begin{tabular}{|c|c|c|c|c|c|c|c|}
\hline \multirow[b]{2}{*}{ Ülke } & \multirow{2}{*}{$\begin{array}{l}\text { Krizin Ortaya Çıkış } \\
\text { Sebebi }\end{array}$} & \multirow[b]{2}{*}{ Yil } & \multirow{2}{*}{$\begin{array}{l}\text { Kamu Net } \\
\text { Borç Stoku / } \\
\text { GSYİH (\%) }\end{array}$} & \multirow{2}{*}{$\begin{array}{l}\text { Yapısal Açık / } \\
\text { GSYİH (\%) }\end{array}$} & \multirow{2}{*}{$\begin{array}{l}\text { GSYİH } \\
\text { Büyüme } \\
\text { Oranı }(\%)\end{array}$} & \multicolumn{2}{|c|}{ Faiz Oranları (\%) } \\
\hline & & & & & & $\begin{array}{l}2012 \\
\text { Nisan }\end{array}$ & $\begin{array}{l}2013 \\
\text { Nisan }\end{array}$ \\
\hline \multirow[b]{3}{*}{ Yunanistan } & \multirow{3}{*}{$\begin{array}{l}\text { Yüksek bütçe } \\
\text { açıkları ve cari } \\
\text { açılar sonucu büyük } \\
\text { ölçüde artan kamu } \\
\text { borç stoku }\end{array}$} & 2012 & 155,38 & $-3,74$ & $-6,4$ & \multirow[b]{3}{*}{21,48} & \multirow[b]{3}{*}{11,58} \\
\hline & & 2013 & 176,12 & $-0,42$ & $-4,2$ & & \\
\hline & & 2014 & 172,21 & 0,61 & 0,6 & & \\
\hline \multirow{3}{*}{ İspanya } & \multirow{3}{*}{\begin{tabular}{|l} 
Bankacılık \\
sektöründeki hızlı \\
kredi artışları ve \\
konut fiyat balonu
\end{tabular}} & 2012 & 71,93 & $-5,70$ & $-1,4$ & \multirow{3}{*}{5,79} & \multirow{3}{*}{4,59} \\
\hline & & 2013 & 79,13 & $-4,54$ & $-1,6$ & & \\
\hline & & 2014 & 84,66 & $-5,08$ & 0,7 & & \\
\hline \multirow{3}{*}{ Portekiz } & \multirow{3}{*}{$\begin{array}{l}\text { Son on yılda AB } \\
\text { ülkelerinin gerisinde } \\
\text { kalan düşük büyüme } \\
\text { oranı }\end{array}$} & 2012 & 111,55 & $-4,02$ & $-3,2$ & \multirow{3}{*}{12,01} & \multirow{3}{*}{6,15} \\
\hline & & 2013 & 114,99 & $-2,90$ & $-2,3$ & & \\
\hline & & 2014 & 116,52 & $-1,65$ & 0,6 & & \\
\hline \multirow{3}{*}{ İtalya } & \multirow{3}{*}{$\begin{array}{l}\text { Borç stoku düzeyinin } \\
\text { yüksekliği ve düşük } \\
\text { büyüme beklentileri }\end{array}$} & 2012 & 103,20 & $-1,29$ & $-2,4$ & \multirow{3}{*}{5,68} & \multirow{3}{*}{4,28} \\
\hline & & 2013 & 105,75 & $-0,19$ & $-1,5$ & & \\
\hline & & 2014 & 106,04 & $-0,30$ & 0,5 & & \\
\hline \multirow{3}{*}{ İrlanda } & \multirow{3}{*}{$\begin{array}{l}2000 \text { 'lerin başındaki } \\
\text { konut fiyat balonu } \\
\text { sonucu bankacilık } \\
\text { kesimindeki sorunlar }\end{array}$} & 2012 & 102,32 & $-5,98$ & 0,9 & \multirow{3}{*}{6,88} & \multirow{3}{*}{3,78} \\
\hline & & 2013 & 106,15 & $-5,47$ & 1,1 & & \\
\hline & & 2014 & 107,53 & $-3,66$ & 2,2 & & \\
\hline
\end{tabular}

Tablo 1: PIIGS Ülkelerindeki Borç Krizinin Ortaya Çıkış Sebebi ve Kamusal Borçların Sürdürülebilirliğine İlişkin Göstergeler Kaynaklar: Kibritçioğlu, (2011); IMF, World Economic Outlook, 2013; IMF, World Economic Outlook Database; ECB Eurosystem, Long-Term Interest Rate Statistics for EU Member State.

Tablo 1, borç krizine giren Avrupa Birliği ülkelerindeki krizin ortaya çıkış sebepleri ve kamu kesimi borcunun sürdürülebilirliğine yönelik bazı veriler sunmaktadır. Tablo'da da görüldüğü gibi, Yunanistan, İspanya, Portekiz, İtalya ve İrlanda'da yaşanan kriz, kamu kesiminin yüksek borç yükümlülüğünden kaynaklanan bir kriz olmasına rağmen, krizin ortaya çıkış nedenleri ülkeler arasında heterojenlik göstermektedir. Borç krizinin sürdürülebilirliği noktasında önemli olan veriler 2012 için gerçekleşen, 2013 ve 2014 yılları için beklenen veriler olarak gösterilmiştir. Borç krizine giren tüm ülkelerde, 2014 yılına kadar kamu kesimi net borç stokunun gayrisafi yurt içi hasılaya oranında artış beklenmektedir. Bu durumun ortaya çıkışında en önemli etken ise, altıncı sütunda yer alan gerçekleşen ve beklenen büyüme oranlarının düşük düzeylerde olmasıdır. Hatta, İrlanda haricindeki ülkelerin hepsi 2012 yılında küçülmüştür. 2013 yılında da bu ülkelerin negatif büyüme oranlarına sahip olacağ1 beklenmektedir. İrlanda ise, 2012 yılında \% 0,9 oranında büyürken, 2013 ve 2014 yıllarında beklenen büyüme oranı sırasıyla \% 1,1 ve \% 2,2'dir. Yüksek kamu kesimi borç stoklarının yaşanan düşük büyüme oranlarıyla kısa vadede azaltılması güç görünmektedir. Ülkelerde var olan yapısal bütçe açıkları da borçların kontrol altına alınmasını güçleştirmektedir.

Kriz sürecinde öncelikle Yunanistan Avrupalı ortaklarından ve Uluslararası Para Fonu'ndan (IMF) yardım istemiş, Avrupa Birliği ve IMF tarafından kredi havuzu mekanizması kapsamında 110 milyar Euro tutarında kredi sağlanmıştır (Trabelsi, 2012). Yunanistan gibi krize karşı alınan önlemler kapsamında kurulan fonlarla diğer üye ülkelerin de ödeme güçlükleri giderilmeye çalışılmıştır. Bu kapsamda, ödemeler dengesi fonu, kredi havuzu mekanizması, Avrupa finansal istikrar mekanizması, Avrupa finansal istikrar fonu kurulmuş olup, Avrupa finansal istikrar mekanizması ve Avrupa finansal istikrar fonu 2013 yılı itibariyle yerini Avrupa istikrar mekanizmasına bırakmıştır (Öztürk ve Aras, 2011).

Borç krizini yaşayan Avrupa Birliği ülkelerinin krizden çıkış sürecinin uzun olacağı belirtilmektedir. Bu durumun en belirgin etkisi ise, finansal piyasalarda istikrarsızlık ve dalgalanmalara yol açması ve Euro'nun diğer para birimleri karşısında bir süre zayıf kalmasıdır (Oliver, 2011; Öztürk ve Aras, 2011).

Ülkelerin borç krizini atlatmalarında yukarıda da bahsedilen önlemlerin yanında daha uzun vadede krizin atlatılması açısından, öncelikle borçların konsolide edilmesi ve uygun bir vadeye yayılması, ülkelerdeki mali disiplinin sağlanması ve kararlı bir şekilde yürütülmesi, daha uzun vade de ise ülkelerin Almanya ve Fransa gibi ülkeler karşısında rekabet gücünün yükseltilmesi ve bunun içinde imalat sanayinin canlandırılması gerekmektedir. Ayrıca, Avrupa Birliği’ndeki yapısal karakterli sorunlar çözülmediği sürece krize karşı alınan ve alınacak olan kısa ve uzun vadeli önlemlerin başarı şansları çok fazla gözükmemektedir.

İçinde bulunduğumuz yıla ilişkin beklentiler de krizin süreceğine yönelik kanıtlar sunmaktadır. 2013 yılında küresel ölçekte "ikinci dip” olasılığı düşük görülmekle birlikte, Avro Bölgesi’nde hükümetler mali ve siyasi birliğe doğru gidecek politikaları hızla hayata geçirmedikleri takdirde durgunluk daha da derinleşebilecektir. IMF'nin Avro bölgesine yönelik büyüme tahmini 2013 yılında negatif (- \% 0,3) olup, Avro bölgesindeki 
gelişmelerin küresel ekonomiye ilişkin beklentileri önemli ölçüde şekillendireceği ifade edilmektedir (T.C. Kalkınma Bakanlığı, Dünya Ekonomisindeki Son Gelişmeler Bülteni, Ocak ve Mayıs 2013).

\section{Türkiye - Avrupa Birliği Ekonomik İlişkileri Çerçevesinde Krizin Türkiye’ye Etkileri}

Avrupa Birliği ülkelerinde yaşanan borç krizinin bir diğer boyutu da, krizin Türkiye’ye etkileri veya potansiyel etkileridir. Türkiye'nin özellikle tarihsel olarak Avrupa ile ekonomik anlamda sürdürdüğü güçlü bağlar dolayısıyla, Avrupa'da yaşanan gelişmelerin direkt olarak Türkiye’yi de etkileyeceği beklentilerini gündeme getirmektedir.

2008 Küresel Finans Krizi’nde de Avrupa'daki ekonomik durgunluk süreci Türkiye ekonomisinin krizi dolaylı olarak yaşamasına yol açmıştır. Avrupa Birliği ülkelerine yönelik ihracat düzeyinde meydana gelen azalma, Türkiye'nin GSYİH'sının 2009 yılında \% 4,8 oranında küçülmesine yol açmıştır. Ancak petrol fiyatlarındaki düşme ve küresel ölçekte hızlı toparlanma 2010 yılında Türkiye ekonomisinin \% 9,2 oranında büyümesini beraberinde getirmiştir.

2008 Krizinin tetiklediği Avrupa Borç Krizinin de, Türkiye’yi ne ölçüde etkileyeceği merak edilen bir husustur. Avrupa Borç Krizinin Türkiye'yi üç ayrı kanaldan etkilemesi beklenmektedir (Doğru, 2011; Doğru, 2012). Bu üç kanal;

Beklentilerin kötüleşmesi,

Finansal sermaye girişlerinde azalma ve

İhracatın azalmasıdır.

Türkiye'ye yönelik finansal sermaye girişlerine bakıldığında, 2004-2009 yılları arasında Avrupa Birliği ülkelerinden Türkiye'ye gelen doğrudan yabancı sermaye yatırımlarının toplam yabancı sermaye yatırımlarının \% 75'ini kapsadığı görülmektedir (Elitok and Straubhaar, 2010).

\begin{tabular}{|l|l|l|l|l|l|}
\hline Y1llar & AB & ABD & Asya & Ortadoğu & Dünya \\
\hline 2007 & 67,80 & 22,01 & 7,34 & 1,63 & 100 \\
\hline 2008 & 77,08 & 5,89 & 15,90 & 13,31 & 100 \\
\hline 2009 & 83,72 & 4,16 & 10,76 & 3,34 & 100 \\
\hline 2010 & 78,87 & 5,18 & 14,88 & 6,22 & 100 \\
\hline 2011 & 78,16 & 8,73 & 12,54 & 1,21 & 100 \\
\hline 2012 & 76,91 & 4,32 & 18,20 & 5,12 & 100 \\
\hline $2013 /$ Mart & 58,31 & 8,35 & 32,81 & 3,13 & 100 \\
\hline
\end{tabular}

Tablo 2: 2007-2013 Döneminde Türkiye'ye Gelen Doğrudan Yabancı Sermeye Yatırımlarının GSYIH'ye Oranı Kaynak: TCMB, Yurtdışında Yerleşik Kişilerin Türkiye'deki Doğrudan Yatırımlarının Ülkelere Göre Dağılımı.

Tablo 2, 2004-2009 yılları arasındaki durumu doğrular kanıtları 2007-2013 dönemi için sunmaktadır. Türkiye Cumhuriyet Merkez Bankası verilerine göre, bazı ülke ve ülke gruplarının 2007-2013 yılları arasında Türkiye'ye gelen doğrudan yatırımlardaki payını göstermektedir. Tablo'dan da görüleceği gibi, Türkiye'ye gelen doğrudan yabancı yatırımlarda en büyük pay Avrupa Birliği ülkelerine aittir. Coğrafi yakınlığı olmasına rağmen Ortadoğu ülkelerinin Türkiye'ye gelen doğrudan yatırımlar içindeki payı düşüktür. Avrupa Birliği ülkelerinin payı ise 2007 yılında \% 67 olup, 2009 yılına kadar sürekli artarak \% 83,72 seviyesine ulaşmıştır. Daha sonrasında ise, 2012 yılına kadar sürekli azalma yaşanmış ve 2012 yılının sonunda \% 76,91 olarak gerçekleşmiştir. 2013 yılı verileri Mart ayına kadar olan dönemi kapsamaktadır. 2013 yılının ilk çeyreğinde Avrupa Birliği’nin payı \% 58 olarak gerçekleşmiştir. Oransal olarak azalma çok fazla gözükmemekle birlikte, değer olarak Avrupa Birliği'nden Türkiye'ye gelen doğrudan yabancı yatırımlar önemli ölçüde azalmıştır. 2007 yılında Avrupa Birliği ülkelerinden Türkiye'ye gelen doğrudan yatırım tutarı 12974 milyon \$ iken, 2008 yılında 11367 milyon \$'a, 2009 yılında 5234 milyon \$'a, 2010 yılında da 4920 milyon \$'a düşmüştür. 2011 yılında tekrar yükselişe geçen doğrudan yatırımlar (12549 milyon \$), 2012 yılında ise 7796 milyon \$’a gerilemiştir (Yurtdışında Yerleşik Kişilerin Türkiye'deki Doğrudan Yatırımlarının Ülkelere Göre Dağılımı).

\begin{tabular}{|l|l|l|l|}
\hline Y1lar & İhracat $(000 \$)$ & Y1llar & İhracat $(000$ \$) \\
\hline 2000 & 15.664 .421 & 2007 & 60.398 .502 \\
\hline 2001 & 17.545 .567 & 2008 & 63.390 .419 \\
\hline 2002 & 20.415 .034 & 2009 & 47.013 .415 \\
\hline 2003 & 27.393 .762 & 2010 & 52.685 .304 \\
\hline 2004 & 36.580 .859 & 2011 & 62.347 .441 \\
\hline 2005 & 41.364 .962 & 2012 & 59.204 .167 \\
\hline 2006 & 47.934 .746 & $2013 /$ Mart & 15.271 .087 \\
\hline
\end{tabular}

Tablo 3: 2000-2013 Döneminde Türkiye’nin Avrupa Birliği Ülkelerine İhracatı (\$) Kaynak: TÜIK 
Krizin Türkiye’ye yönelik etkilerinin bir diğer kaynağı ise, Türkiye'nin Avrupa Birliği ülkelerine yapmış olduğu ihracatta meydana gelen azalmadır. Tablo 3 incelendiğinde, 2000 yılından 2008 yılında kadar Türkiye'nin Avrupa Birliği ülkelerine yapmış olduğu ihracat sürekli olarak artış göstermiştir. 2000 yılında 15,6 milyar \$ olarak gerçekleşen ihracat, 2008 yılında yaklaşık dört kat artarak 63,3 milyar \$'a yükselmiştir. Fakat, 2008 küresel finans krizinin etkileri ve Avrupa Birliği ülkelerinde yaşanan borç krizi dolayısıyla 2009 yılında 47,0 milyar \$'a düşen ihracat hacmi, 2010 ve 2011 yıllarında artsa da 2008 yılındaki tarihsel olarak en yüksek seviyeye ulaşamamıştır. 2012 yılında ise 59,2 milyar \$ olarak gerçekleşmiştir. 2013 yılının ilk çeyreğinde 15,2 milyar \$ olarak gerçekleşen ihracat hacminin 60,0 milyar \$’1 aşması beklenmektedir.

Yukarıdaki tespitler karşısında, krizin Türkiye’ye yönelik etkilerine ilişkin görüşler farklılaşmaktadır. Bazı görüşlere göre Türkiye, Avro bölgesinin dişında olduğundan krizden direkt olarak etkilenmeyecektir. Bir diğer görüş ise, uzun vadede Avrupa Birliği ülkelerindeki borç krizinin Türkiye ekonomisini olumsuz yönde etkileyeceğini belirtmektedir (Elitok and Straubhaar, 2010).

Türkiye'deki yüksek cari açık düzeyi devam ettiğinde ve Avrupa'daki kriz sonucunda Türkiye'ye yönelik sermaye akımları azaldığında, Türkiye'de de kriz kaçınılmaz görünmektedir. Fakat, Türkiye 2008 Küresel Finans Krizinde olduğu gibi halihazırdaki Avrupa Borç Krizi'nde de cari açık düzeyindeki bir miktar azalma ve gelişmiş ülkelerdeki parasal genişlemeler neticesinde, gelişmekte olan ülkelere ve Türkiye'ye yönelik sermaye akımlarını artması (TCMB, Finansal İstikrar Raporu, Mayıs 2013) sonucunda mevcut açıkların sürdürülebilirliği, Türkiye'yi krizin etkilerinden içinde bulunduğumuz döneme kadar korunmuş gözükmektedir.

\section{Ekonometrik Model ve Veri Seti}

Çalışmada, Avrupa Birliği ülkelerindeki borç krizinin gelişimi, krizin geleceği ve mevcut krizin Türkiye ekonomisine yönelik olası yansımaları değerlendirildikten sonra, krizin Türkiye ekonomisini üç ayrı kanaldan etkileyebileceği belirlenmiştir. Çalışmanın ampirik kısmında, bu üç kanaldan yalnızca bir tanesi olan ihracat düzeyine yönelik etkiler üzerinde durulmaktadır. Ekonometrik model aşağıda gösterilmiştir.

$$
\text { TREXP }_{\mathrm{t}}=\beta_{1}+\beta_{2} \text { EUGDP }_{\mathrm{t}}+\mu_{\mathrm{t}}(1)
$$

Yukarıdaki (1) nolu denklemde, Türkiye'nin ihracat büyüklüğü (TREXP) ile Avrupa Birliği ülkelerinin Gayrisafi Yurtiçi Hasıla düzeyleri (EUGDP) arasında bir ilişki kurulmuştur. Türkiye'nin ihracat pazarlarının \% 50'sine yakın bir bölümünü oluşturan Avrupa Birliği ülkelerinde yaşanan bir krizin, Avrupa Birliği ülkelerinde ekonomik daralmaya yol açarak Türkiye'nin ihracatının azalmasına yol açması beklenmektedir. Dolayısıyla, 2008 Küresel Finans Krizini de aynı mekanizma yoluyla dolaylı olarak yaşayan Türkiye, Avrupa Birliği ülkeleriyle yakın ekonomik ilişkileri sebebiyle Avrupa Birliği ülkelerinin geneline yayılma potansiyeli gösterebilecek bir krizin dolaylı etkilerine bir kez daha maruz kalabilecektir.

Modelde kullanılacak veriler ABD Doları cinsinden olup, 1960-2012 dönemini kapsayan y1llık verilerden oluşmaktadır. Türkiye'nin ihracat verileri Türkiye İstatistik Kurumu veritabanından elde edilirken, Avrupa Birliği ülkelerinin Gayrisafi Yurtiçi Hasıla verileri ise Dünya Bankası veri tabanından elde edilmiştir. Ekonometrik analizlerde Eviews 5 paket programı kullanılmıştır.

Ekonometrik analizin kapsamını denklem 1'de verilen iki seri arasındaki uzunlu dönemli ilişkinin belirlenmesi, yani eşbütünleşme ilişkisinin belirlenmesi oluşturmaktadır. Eşbütünleşme ilişkisini analiz etmeden önce ise serilerin durağan olup olmadıklarının belirlenmesi gerekmektedir. Bu amaçla, aşağıda öncelikle serilerin durağan olup olmadıkları ya da hangi düzeyde durağan oldukları belirlendikten sonra, koentegrasyon analizinin yapılıp yapılamayacağına karar verilecektir.

\subsection{Birim Kök Testi Yardımıyla Verilerin Durağanlığının Tespit Edilmesi}

Ekonometrik zaman serilerinin kullanımında karşılaşılan sorunlardan bir tanesi, serilerin durağan olmamalarıdır. Durağan dışı serilerle çalışmak Granger ve Newbold (1974)'a göre; "düzmece regresyon" sorununu ortaya çıkarmaktadır.’Düzmece regresyon” durumunda $\mathrm{R}^{2}$ yüksek olup, t-istatistikleri de anlamlıdır. Fakat elde edilen tahminler iktisadi çıkarsamalar açısından anlamsız olmaktadır (Gujarati, 2006; Sevüktekin ve Nargeleçekenler, 2010).

Ekonometrik zaman serilerinin durağanlığının belirlenmesinde çoğunlukla birim kök testleri kullanılmaktadır. Uygulamada Dickey-Fuller (DF), Genişletilmiş Dickey-Fuller (ADF) birim kök testleri yanında; ADF-GLS birim kök testi, KPSS (Kwiatkowski-Phillips-Schmidt-Shin) birim kök testi, Phillips-Perron (PP) birim kök testi ve Ng-Perron birim kök testi de kullanılmaktadır. Çalışmamızda da, modeli oluşturan serilerin durağanlığının belirlenmesinde literatürde yaygın olarak başvurulan ADF Birim Kök testi kullanılacaktır.

Dickey-Fuller (DF) birim kök testleri ekonometrik zaman serilerinin durağan olup olmadıklarının belirlenmesinde kullanılmasına rağmen, bu testlerin uygulanmasında ortaya çıkabilecek olası bir serisel korelasyonun DF test sürecini geçersiz kılması, serisel korelasyonun ortadan kaldırılması amacıyla sürece serinin gecikmeli değerlerinin eklenmesi gereğini ortaya koymaktadır. Serinin gecikmeli değerlerinin de dahil edilerek uygulandığı bu testlere Genişletilmiş Dickey-Fuller (ADF) birim kök testleri adı verilmektedir. 
ADF birim kök testleri, denklemlerin sabitsiz ve trendsiz, sabitli ve trendsiz ve sabitli ve trendli olmalarına göre üç farklı şekilde yapılabilmektedir. Bu denklemler aşağıdaki (1), (2) ve (3) nolu denklemlerde sırasıyla gösterilmişlerdir.

$$
\begin{aligned}
& \Delta Y_{t}=\delta Y_{t-1}+\sum_{j=1}^{p} \delta_{i} \Delta Y_{t-j}+\varepsilon_{t}(2) \\
& \Delta Y_{t}=\mu+\delta Y_{t-1}+\sum_{j=1}^{p} \delta_{i} \Delta Y_{t-j}+\varepsilon_{t}(3) \\
& \Delta Y_{t}=\mu+\beta t+\delta Y_{t-1}+\sum_{j=1}^{p} \delta_{i} \Delta Y_{t-j}+\varepsilon_{t}(4)
\end{aligned}
$$

Yukarıdaki denklemlerde yer alan $\mu$ sabit değeri (kesim noktası), t trendi, p gecikme sayısını ve $\varepsilon_{\mathrm{t}}$ ise hata terimini göstermektedir. $\varepsilon_{\mathrm{t}} \sim \operatorname{IID}\left(0, \sigma^{2}\right)$ olduğu varsayılır.

p gecikme sayısının belirlenmesi için uygulamada genellikle Akaike Bilgi Kriteri (AIC) ve Schwarz Bilgi Kriteri (SIC) kullanılmaktadır (Sevüktekin ve Nargeleçekenler, 2010). Gecikme uzunluğu, mümkün olduğu kadar az olmalıdır ve Akaike ve Schwarz Bilgi Kriterlerini minimum yapan p, uygun gecikme uzunluğu olarak seçilmelidir.

Uygun gecikme uzunluğunun belirlenmesinin ardından birim kök testi uygulanır. Birim kök testinin uygulanmasında $\mathrm{H}_{0}: \delta=0$ ve $\mathrm{H}_{1}: \delta<1$ hipotezleri kurulur. $\delta$ parametresinin mutlak t-istatistiği değeri anlamlı ise, sıfır hipotezi reddedilir ve seri durağandır (birik kök içermemektedir), sıfır hipotezinin reddedilemediği durumda ise seri durağan değildir (birim kök içermektedir). t-istatistiğinin anlamlı olup olmadı̆̆ı ise, Mac Kinnon (1996) kritik değerleri ile karşılaştırılarak belirlenir.

\begin{tabular}{|l|l|l|l|l|l|l|}
\hline \multirow{4}{*}{ Değişkenler } & \multicolumn{2}{|l|}{ I(0) } & \multicolumn{2}{l|}{ I(1) } \\
\cline { 2 - 7 } & $\begin{array}{l}\text { Sabitsiz ve } \\
\text { Trendsiz }\end{array}$ & $\begin{array}{l}\text { Sabitli ve } \\
\text { Trendsiz }\end{array}$ & $\begin{array}{l}\text { Sabitli ve } \\
\text { Trendli }\end{array}$ & $\begin{array}{l}\text { Sabitsiz ve } \\
\text { Trendsiz }\end{array}$ & $\begin{array}{l}\text { Sabitli ve } \\
\text { Trendsiz }\end{array}$ & $\begin{array}{l}\text { Sabitli ve } \\
\text { Trendli }\end{array}$ \\
\hline \multirow{2}{*}{ TREXP } & $4,94(6)$ & $4,38(6)$ & $2,87(6)$ & $1,02(8)$ & $-0,50(7)$ & $-4,92(5)$ \\
& {$[-1,9481]$} & {$[-2,9266]$} & {$[-3,5107]$} & {$[-1,9486]$} & {$[-2,9297]$} & {$[-3,5107]$} \\
\hline \multirow{2}{*}{ EUGDP } & $0,10(5)$ & $-0,69(5)$ & $-4,07(4)$ & - & - & - \\
\hline
\end{tabular}

Not: 1- Parantez içindeki değerler AIC Kriterine göre seçilen gecikme sayılarını göstermektedir.

2- Köşeli parantez içindeki değerler \% 5 güven aralığında Mac Kinnon (1996) kritik değerleridir.

\section{Tablo 4: ADF Birim Kök Testi Sonuçları}

Tablo 4, ADF Birim Kök testi sonuçlarını göstermektedir. Üç modelden de elde edilen sonuçlara göre; Türkiye'nin ihracat serisi (TREXP), birinci farkında ( I(1) ) durağan, Avrupa Birliği ülkelerinin Gayrisafi Yurtiçi Hasıla serisi (EUGDP) ise düzeyde ( I(0) ) durağandır.

\subsection{Eşbütünleşme Analizi}

Literatürde serilerin arasındaki uzun dönemli birlikteliği ortaya koyan farklı yöntemler olmasına rağmen, her birinin birbirine karşı üstün ve zayıf olduğu noktalar söz konusudur. Uygulamada Engle ve Granger (1987), Johansen (1988), Johansen-Juselius (1990) ve Peseran, Smith ve Shin (2001) tarafından geliştirilmiş eşbütünleşme testleri bulunmaktadır. Ancak, Engle ve Granger (1987), Johansen (1988) ve Johansen-Juselius (1990) yaklaşımlarının uygulanabilmeleri için serilerin düzeyde durağan olmamaları ve aynı derecede farkı alındığında durağan hale gelmeleri gerekmektedir (Karagöl vd, 2007). Peseran, Smith ve Shin (2001) tarafindan geliştirilen ARDL (Autoregressive Distributes Lag) yaklaşımında ise, serilerin bütünleşme derecelerine bakılmaksızın seriler arasında eşbütünleşmenin olup olmadığı araştırılabilmektedir. Ayrıca Narayan (2005)'a göre; ARDL yaklaşımı az sayıda gözleme sahip çalışmalarda da sağlam ve etkin sonuçlar vermektedir.

Çalışmamızda da, gözlem sayısı sınırlı ve seriler farklı derecelerde durağan olduklarından, diğer eşbütünleşme yöntemlerinin yerine ARDL yöntemi tercih edilmiştir. bu yöntemin uygulanabilmesi için öncelikle "kısıtlanmamış hata düzeltme modeli" (unrestricted error correction model) tahmin edilmesi gerekmektedir. Kısıtlanmamış hata düzeltme modelinin çalışmamıza uyarlanmış hali denklem 5 'te gösterilmiştir.

$$
\begin{aligned}
& \triangle T R E X P_{t}=\beta_{0}+\sum_{i=1}^{m} \beta_{1} \Delta T R E X P_{t-i}+\sum_{i=0}^{m} \beta_{2} \Delta E U G D P_{t-i}+\beta_{3} \operatorname{TREXP}_{t-1} \\
& +\beta_{4} \text { EUGDP }_{t-1}+\varepsilon_{t} \text { (5) }
\end{aligned}
$$

Modelde yer alan iki seri arasındaki eşbütünleşme ilişkisinin varlığının tespit edilmesinde tahmin edilecek denklemdeki uygun gecikme sayısının (m) belirlenmesi gerekmektedir. Akaike Bilgi Kriterini (AIC) en küçük 
yapan $\mathrm{m}$ değeri uygun gecikme sayısı olarak belirlenir. Fakat, AIC değerini en küçük yapan m değerinin bulunduğu denklem tahmin edildiğinde serisel korelasyon sorununun bulunmadığına da dikkat edilmelidir.

\begin{tabular}{|l|l|l|}
\hline $\mathrm{m}$ & AIC & $X^{2 \text { BG }}$ \\
\hline 1 & 48,207 & 11,475 \\
\hline 2 & 48,116 & 3,812 \\
\hline 3 & 47,848 & 11,892 \\
\hline 4 & 47,698 & 19,680 \\
\hline 5 & 47,354 & 14,496 \\
\hline
\end{tabular}

Not: $\mathrm{X}^{2 \mathrm{BG}}$ Breusch-Godfrey serisel korelasyon test istatistiğidir.

Tablo 5: Gecikme Sayısının Belirlenmesi

Serilerin çok uzun bir dönemi kapsamaması nedeniyle gecikme uzunluğu maksimum 5 olarak alınmıştır. Tablo 5'te de görüldüğü gibi, diğer gecikme uzunluklarının serisel korelasyon problemi içermelerinden dolayı uygun gecikme uzunluğu (m) 2 olarak tespit edilmiştir. Uygun gecikme uzunluğu (m) belirlendikten sonra seriler arasında eşbütünleşme ilişkisinin belirlenmesine geçilebilir.

\begin{tabular}{|l|l|l|l|}
\hline \multirow{2}{*}{$\mathrm{k}$} & \multirow{3}{*}{ F İstatistiği } & \multicolumn{2}{|c|}{$\begin{array}{l}\text { \% 5 Anlamlılık Düzeyindeki } \\
\text { Kritik Alt ve Üst Sinırlar }\end{array}$} \\
\cline { 3 - 4 } & & Alt Sınır & Üst Sınır \\
\hline 1 & 9,8693 & 6,56 & 7,30 \\
\hline
\end{tabular}

Not: k, 5 numaralı denklemdeki bağımsız değişken sayısını göstermektedir. Kritik alt ve üst sınır değerleri, Peseran, Smith ve Shin (2001: 300) Tablo CI(V)'ten alınmıştır.

\section{Tablo 6: Sınır Testi Sonuçları}

2 gecikme uzunluğuna göre denklem 5 tahmin edildikten sonra $\mathrm{H}_{0}: \beta_{3}=\beta_{4}=0$ ve $\mathrm{H}_{1}: \beta_{3} \neq \beta_{4} \neq 0$ hipotezlerinin test edilmesi gerekmektedir. Yapılan Wald testi sonucuna göre elde edilen F istatistik değeri kullanılarak seriler arasında eşbütünleşme olup olmadığına karar verilmektedir. Wald testi sonucunda hesaplanan F istatistik değeri Peseran, Smith ve Shin (2001)'de verilen kritik alt sınır ve üst sınır değerleriyle karşılaştırılması gerekmektedir. Eğer hesaplanan F istatistiği, Alt Sınır değerinden küçükse seriler arasında eşbütünleşme ilişkisi yoktur. F istatistiği Alt Sınır ve Üst Sınır değerleri arasında ise seriler arasında eşbütünleşme olup olmadığına karar verilememektedir. Seriler arasında eşbütünleşme ilişkisinin var olabilmesi için hesaplanan F istatistik değerinin Tablo 6'da verilen Üst Sınır değerini aşması gerekmektedir. Çalışmamızda da, 2 gecikme uzunluğuna göre hesaplanan denklem 5 'ten elde edilen $\beta_{3}$ ve $\beta_{4}$ katsayılarına uygulanan Wald testi sonucunda hesaplanan $\mathrm{F}$ istatistik değeri Üst Sınırı aştığı için seriler arasında eşbütünleşme ilişkisinin bulunduğu sonucuna varılmıştır. Bunun sonucu olarak seriler arasında uzun ve kısa dönem ilişkileri belirlemek üzere ARDL modeli kurulabilir.

\subsection{Uzun Dönem İlişki}

Seriler arasındaki uzun dönemli ilişkiyi ortaya koyan ARDL modelinin çalışmamıza uyarlanmış şekli aşağıda gösterilmektedir.

$$
\operatorname{TREXP}_{t}=\alpha_{\mathrm{o}}+\alpha_{1} \operatorname{TREND}+\sum_{i=1}^{m} \alpha_{2 i} \operatorname{TREXP}_{t-i}+\sum_{i=0}^{n} \alpha_{3 i} E U G D P_{t-i}+\mu_{t}(6)
$$

\begin{tabular}{|l|l|c|}
\hline Bağımlı Değişken: TREXP & Katsayılar & T-İstatistiği \\
\hline Değişkenler & 0,010716 & $2,2956 * *$ \\
\hline EUGDP & $-1776905258,43$ & $-1,5227$ \\
\hline TREND & 11361010520,10 & 0,9129 \\
\hline C & 0,99 \\
\hline Tanımlayıc1 İstatistikler & 0,98 \\
\hline $\mathrm{R}^{2}$ & $221,95(0,000)$ \\
\hline Adj $\mathrm{R}^{2}$ & 1,52 \\
\hline F-İst & $1,8447(0,1638)$ \\
\hline DW & $42,9123(0,0596)$ \\
\hline $\begin{array}{l}\text { Serisel Korelasyon } \\
\text { (Breusch-Godfrey LM) }\end{array}$ & $1,7660(0,4135)$ \\
\hline $\begin{array}{l}\text { Değişen Varyans } \\
\text { (White) }\end{array}$ & $\begin{array}{l}\text { Normallik } \\
\text { (JB) }\end{array}$ \\
*\% 1, **\% 5 ve ***\%10 düzeyinde anlamlılı̆̆1 göstermektedir. \\
\hline
\end{tabular}

Tablo 7: ARDL $(5,8)$ Modeli İçin Uzun Dönem Tahmin Sonuçlart 
Tablo 7, ARDL $(5,8)$ modelinin tahmin sonuçlarına göre hesaplanan uzun dönem katsayılarını göstermektedir. Tablodaki sonuçlara göre, yalnızca EUGDP katsayısı \% 5 düzeyinde istatistiksel olarak anlamlıdır. Buna göre, TREXP ve EUGDP serileri arasında uzun dönemli pozitif bir ilişki olup, Avrupa Birliği ülkelerinin Gayrisafi Yurtiçi Hasıla düzeylerinde meydana gelecek 100 \$ düzeyindeki bir değişme, Türkiye'nin ihracatını uzun dönemde aynı yönde 1 \$ düzeyinde değiştirecektir.

\subsection{Kısa Dönem İlişki}

Yukarıdaki uzun dönem ilişkiden elde edilen hata terimleri serisi kullanılarak oluşturulan ARDL yaklaşımına dayalı "hata düzeltme modeli”nin çalışmamıza uyarlanmış şekli aşağıda gösterilmektedir. Denklemdeki HDT değişkeni uzun dönem ilişkisinden elde edilen hata terimleri serisini göstermektedir. Hata terimleri serisi, hata düzeltme modelinde bir dönem gecikmeli olarak kullanılmıştır.

$$
\Delta \operatorname{TREXP}_{t}=\alpha_{0}+\alpha_{1} \operatorname{TREND}+\alpha_{2} H D T_{t-1}+\sum_{i=1}^{m} \alpha_{3 i} \Delta T R E X P_{t-i}+\sum_{i=0}^{n} \alpha_{4 i} \Delta E U G D P_{t-i}+\mu_{t}(7)
$$

\begin{tabular}{|c|c|c|}
\hline \multicolumn{3}{|c|}{ Bağımlı Değişken: TREXP } \\
\hline Değişkenler & Katsayılar & T-İstatistiği \\
\hline DEUGDP & 0,001238 & 0,1818 \\
\hline Trend & 149092463,07 & 1,1505 \\
\hline $\mathrm{C}$ & $-2903051860,82$ & $-1,1336$ \\
\hline HDT & \multicolumn{2}{|c|}{$-0,3597$ (prob. 0,4737) } \\
\hline \multicolumn{3}{|l|}{ Tanımlayıcı İstatistikler } \\
\hline $\mathrm{R}^{2}$ & \multicolumn{2}{|l|}{0,82} \\
\hline $\operatorname{Adj} R^{2}$ & \multicolumn{2}{|l|}{0,71} \\
\hline F-İst & \multicolumn{2}{|l|}{$7,85(0,000)$} \\
\hline DW & \multicolumn{2}{|l|}{2,11} \\
\hline $\begin{array}{l}\text { Serisel Korelasyon } \\
\text { (Breusch-Godfrey LM) }\end{array}$ & \multicolumn{2}{|l|}{$0,3078(0,7378)$} \\
\hline $\begin{array}{l}\text { Değişen Varyans } \\
\text { (White) }\end{array}$ & \multicolumn{2}{|l|}{$42,9680(0,0932)$} \\
\hline $\begin{array}{l}\text { Normallik } \\
\text { (JB) }\end{array}$ & \multicolumn{2}{|l|}{$3,2438(0,1975)$} \\
\hline
\end{tabular}

Tablo 8: ARDL (5,8) Modeline Dayalı Hata Düzeltme Modeli Tahmin Sonuçları

Tablo 8, ARDL modeline dayalı hata düzeltme modeli sonuçlarını göstermektedir. DEUGDP değişkeninin katsayısı beklenildiği gibi pozitif, fakat istatistiki olarak anlamsız çıkmıştır. Buna göre, kısa dönemde Avrupa Birliği ülkelerinin Gayrisafi Yurtiçi Hasıla düzeyindeki azalma Türkiye'nin ihracatını etkilememektedir.

Denklemde yer alan hata düzeltme terimi (HDT), kısa dönemdeki dengesizliklerin ne kadarının uzun dönemde dengeye geleceğini göstermektedir. Teorik olarak hata düzeltme teriminin negatif, anlamlı ve -1 ile 0 arasında olması beklenmektedir. Hata düzeltme terimi -1'e eşitse son dönemdeki dengesizliklerin tamamı ortadan kaldırılmaktadır. Eğer -1 ile 0 arasında ise, son dönem dengesizliklerin sadece bir kısmının ortadan kaldırıldığ 1 sonucuna ulaşılır (Düzgün, 2010).

Tablo 8'de de gösterildiği gibi, hata düzeltme terimi -1 ile 0 arasında, negatif ve anlamlı çıkmıştır. Buna göre, uzun dönem dengeden sapmaların bir dönem sonrasında yaklaşı \% 36 'sı giderilmektedir.

\section{Sonuç}

Küresel ekonomide önemli bir aktör olmasına rağmen ekonomik birlikten siyasi birliğe doğru yönelen Avrupa Birliği, geçmişinden gelen yapısal sorunlarının 2008 Küresel Finans Krizi sonucu sürdürülemez bir boyuta ulaşması dolayısıyla üç yıla yakın bir süredir ekonomik kriz içerisindedir. Ekonomik kriz başlangıcından günümüze kadar yalnızca PIIGS grubunu etkilemiş gözükmektedir. Krizin temel sebepleri her bir ülkede farklılık gösterirken, krizin tanımlanmasında kamu kesimi borçlarının yüksekliği ön plana çıkmaktadır.

Merak edilen sorulardan en önemlisi, krizin tüm Avrupa Birliği ülkelerini etkileyip etkilemeyeceği sorusudur. Aslında, PIIGS ülkelerinin yaşadığı borç sorunlarının tüm Avrupa'nın ortak bir sorun haline gelmiş olduğuna dair görüşler vardır. Belirli açılardan bu durum geçerli olabilmektedir. Örneğin, krizin temel nedeni olarak mali birliğin gerçekleşmemiş olması olarak görülüyorsa bu durum Avrupa'nın ortak bir sorunu olduğu için krizin de tüm Avrupa'nın ortak bir sorunu olduğu algısı oluşabilmektedir. Ancak, krizin yalnızca PIIGS ülkelerini kapsayan bir kriz olması da, krizin tüm Avrupa’ya yayılmasının beklenmesine rağmen yine de tüm Avrupa'nın ortak bir sorunu olması konusunda temkinli yaklaşılması gerekmektedir. Mevcut kriz şu an için dar bir alana 
yayılmış gözükmektedir. Alınan önlemler krizin etkilerini azaltmış gözükmektedir. Fakat uygulanacak "kemer sıkma" politikaları, vergi artışları ve harcama kısıntılarını içerdiğinden kısa dönemde resesyonist etkileri beraberinde getirmekte ve ağırlaşan kamu borçlarının sürdürülebilirliğini tehlikeye düşürmektedir. Çalışmada da belirtildiği gibi, 2014 yılını da kapsayacak şekilde ülkelerin ekonomik büyüme düzeyleri ya negatif olarak gerçekleşecek ya da çok düşük düzeylerde kalacaktır. Bu durum, krizin etkilerinin kısa vadede ortadan kalkmayacağına bir işarettir.

Avrupa ülkelerindeki kamu borç krizi aynı zamanda Türkiye ekonomisini de etkileme potansiyeline sahiptir. Avrupa Birliği ülkeleriyle tarihsel anlamda yakın ilişkileri bulunan Türkiye, Avrupa'dan Türkiye'ye yönelen yabancı sermaye yatırımlarındaki azalma ve Avrupa ülkelerine yönelik ihracatın azalması dolayısıyla olası bir ekonomik krize yakalanma potansiyeline sahiptir.

Çalışmamızda, Türkiye'nin Avrupa Birliği ülkelerine yönelik ihracat potansiyeli ampirik olarak değerlendirilmeye çalışılmıştır. Uygulanan ARDL yaklaşımı sonucunda Türkiye'nin ihracat düzeyi ile Avrupa Birliği ülkelerinin Gayrisafi Yurtiçi Hasıla düzeyleri arasında uzun dönemli bir eşbütünleşme ilişkisine rastlanılmıştır.

Elde edilen sonuçlara göre, uzun dönemde Avrupa Birliği ülkelerinin Gayrisafi Yurtiçi Hasıla (EUGDP) değişkeninin katsayısı pozitif ve anlamlı çıkmıştır. Buna göre, uzun dönemde Avrupa Birliği ülkelerindeki ekonomik büyüme veya ekonomik daralma Türkiye'nin ihracatını aynı yönde etkileyecektir. Kısa dönemde ise değişkenlerin katsayıları istatistiki olarak anlamsız çıkmıştır.

Buna göre, Türkiye ile Avrupa Birliği ülkeleri arasındaki yakın ekonomik ilişkiler ya da "tek taraflı bağımlılık”, Avrupa Birliği’nde ortaya çıkacak ekonomik bir olumsuzluğun uzun dönemde Türkiye’yi de kaçınılmaz olarak etkileyeceğini ortaya koymaktadır. Çalışmada da belirtildiği gibi, cari açık düzeyindeki bir miktar azalma ve gelişmiş ülkelerdeki parasal genişlemeler neticesinde, gelişmekte olan ülkelere ve Türkiye'ye yönelik sermaye akımlarını artması sonucunda mevcut açıkların sürdürülebilirliği, Türkiye'yi krizin etkilerinden içinde bulunduğumuz döneme kadar korunmuş gözükmektedir. $\mathrm{Bu}$ durum kısa dönemli ampirik bulguları desteklemektedir. Ancak uzun dönemde, Türkiye'nin Avrupa Birliği ülkelerindeki olumsuz ekonomik gelişmelerin etkilerinden korunabilmesi için mutlaka dış ticaret pazarlarını çeşitlendirmesi ve Avrupa Birliği ülkelerinin toplam dış ticaret hacmi içerisindeki payını azaltması gerekmektedir.

\section{Kaynakça}

- $\quad$ Bagus, P. (2010), The Tragedy of Euro, Ludwig Von Mises Institute, http://mises.org/books/bagus_tragedy_of_euro.pdf, 20.06.2013.

- Bryson, J.H. (2011), “European Debt Crisis: What's Next?”, http://mediaserver.fxstreet.com, 20.05.2013.

- Doğru, B. (2012), “ABD ve AB Bölgesindeki Bir Finansal Krizin Türkiye’ye Etkileri: Cari Açık Üzerine Bir Uygulama”, Dumlupınar Üniversitesi Sosyal Bilimler Dergisi, Sayı: 33, ss. 113-128.

- Düzgün, R. (2010), “Türkiye Ekonomisi’nde Para ve Maliye Politikalarının Etkinliği”, Uluslar arası Sosyal Araştırmalar Dergisi, 3(11), ss. 230-237.

- $\quad$ ECB Eurosystem, Long-Term Interest Rate Statistics for EU Member State, www.ecb.int, (17.05.2013).

- Elitok, S.P. and T. Straubhaar (2010), “The Turkish Economy: A Winner of The Euro Crisis?”, HWWI Policy Paper, No: 3-14.

- Gujarati, D. (2006), Temel Ekonometri, Çev. Ümit Şenesen ve Gülay Günlük Şenesen, 4. Basım, Literatür Yayıncılık: İstanbul.

- Hondur, M. (2012), “Maliye Politikaları ve Bütçe Uygulamaları”, SDE Analiz: AB Krizi ve Türkiye’ye Olası Yansımaları içinde, Editör: Kıvılcım METIN ÖZCAN, ss. 21-31.

- IMF, World Economic Outlook, April 2013, www.imf.org, (17.05.2013).

- IMF, World Economic Outlook Database, www.imf.org, (17.05.2013).

- Karagöl, E., E. Erbaykal ve H.M. Ertuğrul (2007), “Türkiye’de Ekonomik Büyüme ile Elektrik Tüketimi İlişkisi: Sınır Testi Yaklaşımı”, Doğuş Üniversitesi Dergisi, 8(1), ss. 72-80.

- Kılıç, C. ve Y. Bayar (2012), “Euro Bölgesi Borç Krizinin Türkiye Ekonomisi’ne Olası Yansımaları Üzerine Bir Değerlendirme”, Ekonomi ve Yönetim Araştırmaları Dergisi, Cilt: 1, Sayı: 2, ss. 53-70.

- Kibritçioğlu, A. (2011), “Avrupa Bölgesi Ülkelerindeki Güncel Borç Krizi”, İktisat ve Toplum Dergisi, Sayı: 10 , ss. 30-41.

- Kregel, J. (2012), "Six Lessons From The Euro Crisis", Levy Economics Institute of Bard College Policy Note, pp. 1-4.

- Narayan, P.K. (2005), “The Saving and Investment Nexus For China: Evidence From Cointegration Tests”, Applied Economics, 37(17), pp. 1979-1990. 
- $\quad$ Neri S. and T. Ropele (2013), "The Macroeconomic Effects of The Sovereign Debt Crisis in The Euro Area", http://www.bde.es/investigador/papers/sie1303.pdf, 05.06.2013.

- Öztürk, M. ve O.N. Aras (2011), “Euro ve Kriz Sonrası Dönemde Parasal İstikrar”, Ekonomi Bilimleri Dergisi, Cilt: 3, No: 2, ss. 143-155.

- $\quad$ Peseran, M.H., R. J. Smith and Y. Shin (2001), "Bounds Testing Approaches to the Analysis of Level Relationships", Journal of Applied Econometrics, 16, pp. 289-326.

- Sevüktekin, M. ve M. Nargeleçekenler (2010), Ekonometrik Zaman Serileri Analizi: EViews Uygulamalı, 3. Basım, Nobel Yayın Dağıtım: Ankara.

- $\quad$ T.C. Kalkınma Bakanlığı, Dünya Ekonomisindeki Son Gelişmeler Bülteni, Sayı: 1, Ocak 2013, www.dpt.gov.tr, 05.06.2013.

- T.C. Kalkınma Bakanlığı, Dünya Ekonomisindeki Son Gelişmeler Bülteni, Sayı: 5, Mayıs 2013, www.dpt.gov.tr, 05.06.2013.

- $\quad$ TCMB, Finansal İstikrar Raporu, Mayıs 2013, www.tcmb.gov.tr, 05.06.2013.

- TCMB, Yurtdışında Yerleşik Kişilerin Türkiye'deki Doğrudan Yatırımlarının Ülkelere Göre Dağılımı, www.tcmb.gov.tr, 20.05.2013.

- Trabelsi, M.A. (2012), “The Impact of The Sovereign Debt Crisis on The Eurozone Countries”, ProcediaSocial and Behavioral Sciences, 62, pp.424-430.

- $\quad$ TÜİK, Ülke Gruplarına Göre İhracat, www.tuik.gov.tr, 20.05.2013. 


\title{
Firmalarda Süreç Yenileme Yaklaşımının İhracat Üzerine Etkileri Renewal Process Approach to Companies Effects of Exports
}

\author{
Asst. Prof. Dr. Ali Riza İnce (Cumhuriyet University, Turkey) \\ Asst. Prof. Dr. Yücel Erol (Gaziosmanpaşa University, Turkey) \\ Asst. Prof. Dr. Enis Baha Biçer (Cumhuriyet University, Turkey)
}

\begin{abstract}
In this study, it has been discussed that whether the results of the reengineering is limited and remarkable or not. In this respect, it has been questioned whether there is a significant increase in the amount of exports of a furniture company before and after carrying out the reengineering project. It has been follow-up the same sixmonth periods of company's situation and the export amount before and after the reengineering project. The Wilcoxon Signed Ranks Test was applied on the data obtained. It has been concluded that reengineering was an important tool not only in increasing the amount of the production but also increase the amount of exports and profitability dramatically.
\end{abstract}

\section{Giriş}

İşletmelerde radikal bir değişim aracı olarak düşülen süreç yenileme yaklaşımının faydalarının fazlaca abartıldığı, etkisinin sadece üretim miktarını artırmakla sınırlı olduğu, bu konuda yapılan çalışmaların sağduyu ve deneyimler bir kenara bırakılarak konunun spekülatif olarak ele alındığı literatürde sıklıkla tartışılmaktadır. Süreç yenileme yaklaşımın sonuçlarının sadece üretimle sınırlı ve ifade edildiği şekli ile 'radikal' ve 'çarpıcı' olup olmadığını pratik alanda gözlemlemek adına bu çalışma gerçekleştirilmiştir. Bu doğrultuda süreç yenileme projesi yürüten bir mobilya firmasının süreç yenileme öncesinde ve sonrasında ihracat miktarında anlamlı bir artış olup olmadığı sorgulanmak istenmiştir. Söz konusu firmanın süreç yenileme öncesindeki altı aylık durumu ve ihracat miktarları ile yine aynı döneme ait süreç yenileme sonrası altı aylık miktarları takip edilmiştir. Elde edilen veriler Wilcoxon ilişkili örneklem testine tabi tutularak, oluşturulan hipotez doğrulanmaya çalışılmıştır.

\section{Süreç Yenileme}

Süreç yenilemenin daha geniş bir kapsamı olması gerektiğini belirten Grant (2002: 87), süreç yenileme faaliyetlerinde sadece süreçler üzerine odaklanmanın değil teknoloji ile birlikte iletişim, insan ve yapı gibi faktörlerin de dikkate alınması gerektiğini, bu faktörlerden süreç yenileme çalışmalarında hiç birinin diğerine veya diğerlerine rağmen ele alınamayacağı aksi halde süreç yenileme çalışmalarının tamamının başarısızlıkla sonuçlanacağını ifade etmektedir.Kapsamı konusunda farklı yaklaşımlar ve düşüncelere rağmen süreç yenilemenin amaçları konusunda kimi yazarlar ortak görüş bildirmektedirler (Garrison, Noreen ve Brewer, 2006: 15). Süreç yenilemenin amac1;

Çalışma biçimini ve çalışma aletlerini değiştirerek performansta radikal değişimler gerçekleştirmek

Müşteri ihtiyaçlarını belirleyerek bu konular üzerine odaklanmak

Karar verme için gerekli olan bilgi doğrultusunda işleri uygun şekilde yaparak hız kazanmak

Müşteri ihtiyaçlarını karşılamak için ürün ve hizmetlerin kalitesini geliştirerek kalite hedeflerini yakalamak

Gereksiz süreçleri elimine ederek ve değer üreten süreçler üzerine odaklanmak ve maliyetleri düşürmek ve organizasyona yardımcı olarak rakiplerle eş düzeyde mücadele etmek şeklindedir.

Süreç yenileme, TKY ve otomasyon gibi programlardan oldukça farklıdır. Otomasyon bilgi teknolojileri dâhil mevcut prosedürlerin uygunluğunu veya doğruluğunu sorgulamaksızın otomatik hale getirilmesi ile teknolojinin uygulanmasını ifade eder. Oysaki süreç yenileme eskiyi sorgular. Her ne kadar TKY süreçlere odaklansa da aşağıdan yukarı bir katılımla genellikle fonksiyonel açıdan mevcut faaliyetlerdeki iş tasarımında küçük iyileştirmelerle sonuçlanan sürekli gelişmeleri içerir. Oysaki süreç yenileme yukarıdan aşağıya doğru gerçekleşir, geniş ve çapraz fonksiyonel süreçler üzerine odaklanır mevcut iş tasarımının varlığını sorgular ve de kuantum bir sıçramayı hedefleyen tek seferlik bir girişimdir. Bununla birlikte bilgi teknolojileri TKY için çok fazla önem arz etmezken süreç yenilemenin çok önemli bir mümkün kılıcısı ve aracıdır (Grover ve Malhotra, 1997: 199). Bilgi teknolojileri süreç yenilemenin temel katalizörlerinden biridir ve göz ardı edilemeyecek bir öneme sahiptir (Hammer ve Champy, 1993: 92). Ayrıca Davenport and Short (1990: 15)'a göre bilgi teknolojileri süreç yenileme projelerinde maliyet avantajı sağlayan ve zaman kazandıran çözümler sunabilir. Küçük gelişmeleri içeren evrimsel değişmelerle büyük ilerlemeleri konu alan devrimsel değişimlerin bir arada uygulanamayacağını savunan yazarlarla benzer savı öne süren Grover ve Malhotra (1997: 199)'ya göre TKY, ancak sonraki süreç yenileme çabaları için bir yapı taşı olarak hizmet edebilir.Organizasyon yapısını da kapsayan süreçler üzerindeki değişimler çarpıcı sonuçlar elde etmeyi sağlayabilir ancak bu durum beraberinde belirli bir riski de getirecektir. 
Hammer ve Champy, işletmelerin iş yapma şekillerini değiştirerek üst seviyede gelişme sağlayabileceklerini belirtmekle birlikte bunun risksiz olmadığına da değinmektedirler. Onlara göre süreç yenilemeyi deneyen firmaların \% 50- 70 gibi bir oranının başarısız olmaktadırlar (Chan ve Peel, 1996: 44).Başarısızlık genel olarak süreç yenileme yaklaşımını anlamadaki eksikliklerden ve ifade etmedeki yetersizliklerden (Chan ve Choi, 1997: 222; Attaran ve Wood, 1999: 754), planlama sorunlarından (Grover, Jeong ve Teng, 1998: 3) ya da stratejik düşüncenin bir ikamesi olarak değerlendirilmesinden kaynaklanmaktadır (O’neill ve Sohal, 1999: 573). Bütün bunların dışında süreç yenilemeyi mümkün kılan bilgi teknolojilerinin göz ardı edilmesinden, insan kaynaklarının önemini kavrayamamaktan, liderlik eksikliğinden ve gerçekçi hedefler belirleyememekten de kaynaklanmaktadır (Attaran ve Wood, 1999: 755-756; Attaran, 2004: 594; Ray, Fray ve Khasnabish, 1999: 106). Organizasyon altyapısının esnek olmaması organizasyonel iletişim eksikliği ve çalışanların dirençlerini yönetmede başarısızlık da başarılı uygulamaları engellemektedir (Attaran, 2000: 795-796). Kültürün değişmediği sürece süreç yenilemenin de başarısız olacağını belirten yazarlar olmuştur (Hope ve Hope, 1997: 218)

\subsection{Süreç Yenileme Başarı Faktörleri ve Sonuçları}

Başarılı bir süreç yenileme faaliyeti için göz önünde bulundurulması gereken faktörleri şu şekilde sıralamak mümkündür (Hall, Rosenthal ve Wade, 1993: 128);

Saldırgan bir süreç yenileme performans hedefi belirlenmeli ve bu hedef bütün iş birimlerini kapsamalıdır.

Yönetici zamanının \% 20 ile \% 50’lik bir kısmını süreç yenileme projesine ayırmalıdır. Başlangıçta bu süre \% 20 olabilir ancak uygulama aşamasında \% 50 kadar çıkabilmelidir.

Müşteri istekleri, ekonomik kaldıraç noktaları ve pazar trendleri kapsamlı bir şekilde gözden geçirilmelidir.

Uygulamadan sorumlu olacak bir üst kademe yöneticisi özellikle süreç yenileme projesi için görevlendirilmelidir. Bu yönetici kritik uygulamalarda zamanının büyük bir kısmını projeye ayırabilmelidir.

Yeni tasarımın geniş kapsamlı bir pilot uygulaması yapılmalıdır. Pilot uygulama sürecin uygulaması kadar sonuçlarını da test edebilmelidir. Bununla birlikte nihai uygulama için heyecan oluşturabilmelidir.

Birçok riski beraberinde getiren süreç yenilemeyi başarı ile uygulayan firmalar, yüksek verimlilik, kalitede artış, pazara hızla cevap verme, taşıma ve hizmetlerde büyük oranda maliyet etkinliği, kısaltılmış iş çevrim süreleri, toplamda yüksek bir kar (Attaran ve Wood, 1999: 752) daha iyi müşteri hizmeti, hiyerarşik yapıda daha az kademe (Scott, 1995: 57) gibi avantajları elde ettiklerini ifade etmişlerdir.

\section{Araștırmanın Amacı ve Kapsamı}

Araştırmanın amacı bir mobilya firmasının koltuk ve kanepe fabrikasında yürütülen süreç yenileme çalışmalarının firmanın ihracatına olan etkisinin ortaya konmasıdır. Bu kapsamda süreç yenileme sonrasında elde edilen ihracat verileri mevsimsel dalgalanmalardan etkilenmemek için aynı dönemlere ait süreç yenileme öncesi ihracat verileri ile karşılaştırılmıştır. Sonuçların süreç yenileme faaliyetinden beklenen radikal gelişmeleri sağlayıp sağlamadığı konusu istatistiksel olarak ortaya konmaya çalışılmıştır.

\subsection{Araștırmanın Yöntemi ve Kullanılan İstatistik Teknikler}

Araştırmanın amacına ulaşabilmek için aynı dönemlere ait ihracat verileri toplanmış, araştırma sonucunda süreç yenileme öncesi ve sonrasındaki veriler arasındaki farkın istatistiksel olarak anlamlı olup olmadığını anlamak için SPSS paket programı yardımı ile veriler değerlendirilmiştir. Altışar aylık verilerin karşılaştırmasında karar değişkenleri arasında fark olup olmadığını ortaya koymaya yarayan bir test olan Wilcoxon ilişkili iki örneklem testi kullanılmıştır.

\subsection{Araştırmanın Hipotezleri}

Araştırma hipotezlerinde süreç yenileme öncesi ve sonrası ihracat miktarı arasında anlamlı bir farkın olup olmadığını ortaya konmak istenmiş ve hipotezler şu şekilde oluşturulmuştur.

H0: Mobilya firmasının süreç yenileme projesi öncesi ihracat miktarı ve süreç yenileme sonrası ihracat miktarı arasında anlamlı bir fark yoktur.

H1: Mobilya firmasının süreç yenileme projesi öncesi ihracat miktarı ve süreç yenileme sonrası ihracat miktarı arasında anlamlı bir fark vardır.

\section{Süreç Yenileme Faaliyeti Öncesi ve Sonrası Verilerin Karşılaştırılması}

Yurt dışı satışlarının, yurt içi satışlarının düştüğü dönemde artması sebebi ile dönemsel dalgalanmalardan en alt düzeyde etkilenmek açısından dış ticaret firmalar için oldukça önemli olarak kabul edilmektedir. İhracatta kalite ile birlikte termin yani teslimat süresi ön plana çıkmaktadır. Süreç yenileme öncesinde firmanın teslimat sürelerini çoğunlukla aştığı ve ceza ödediği tespit edilmiştir.Firma açısından yurt içinde geçici olarak kısmen tolere edilebilen termin, kalite ve şatışlara cevap verememe sorunları ihracatta büyük problemler doğurduğu ve firmanın problemleri ancak büyük maliyetler ödeyerek çözebildiği gözlenmiştir. Sonuç olarak firma yurt dış1 pazarını genişletmek bir yana bu satışlardan kar elde edemez bir hale geldiği ve ihracatı durdurma konusunun 
düşünülmeye başlandığı bir duruma gelmiştir. Bu noktada yapılan süreç yenileme çalışmaları sonrasında üretim miktarında, teslimat süreleri ve kalite konusunda ilerlemeler kaydedildiği görülmüştür. Böylelikle ihracat miktarında artış olmakla birlikte diğer problemler de büyük oranda çözülmüş ve firma ihracattan kâr yapar bir duruma gelmiştir. İhraç edilen ürün miktarında ise ortalama \% 11,8'lik bir artış gerçekleşmiştir. Aylar itibari ile gerçekleşen ihracat miktarları Tablo 1'de görüldüğü gibidir.

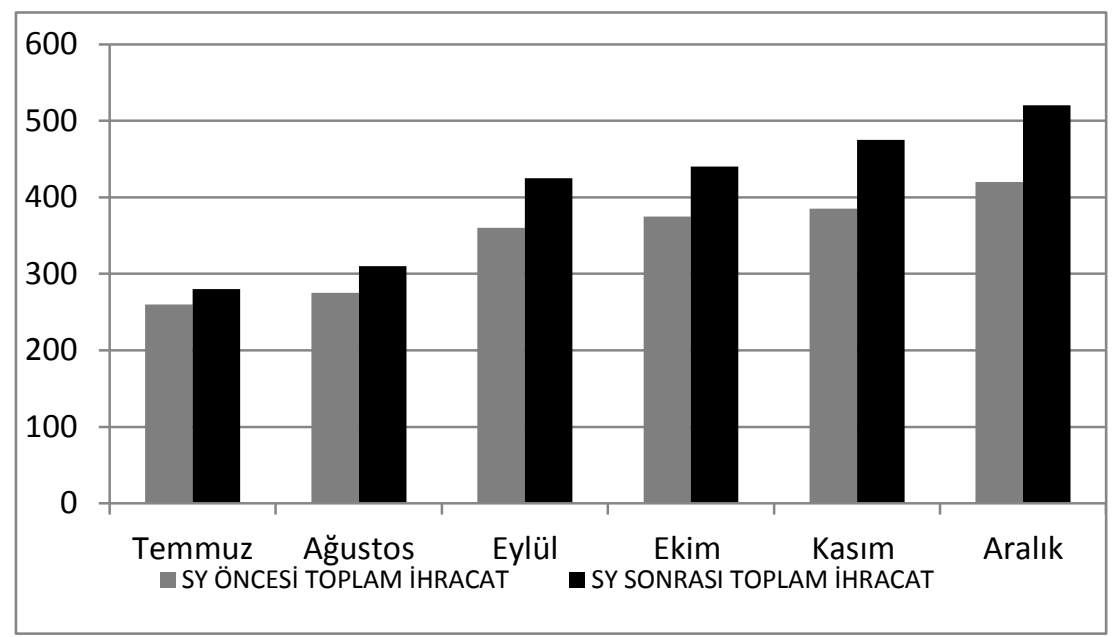

Grafik 1. Aylar İtibari ile Süreç Yenileme Öncesi ve Sonrası İhracat Miktarları

Elde edilen süreç yenileme öncesi ve sonrası ihracat rakamları Wilcoxon ilişkili iki örneklem testine tabi tutulumuş ve aşağıdaki sonuçlar elde edilmiştir.

\begin{tabular}{|ll|l|l|l|}
\hline S1ra Değerleri & N & Ortalama Sıra Değeri & Toplam Sira Değeri \\
\hline S.Y.Sonras1.Toplam.İhracat Negatif Sıra Değeri & $0(\mathrm{a})$ & 0,00 & 0,00 \\
S.Y.Oncesi Toplam.İhracat & Pozitif Sıra Değeri & $6(\mathrm{~b})$ & 3,50 & 21,00 \\
& Eşit & $0(\mathrm{c})$ & & \\
& Toplam & 6 & & \\
\hline
\end{tabular}

Tablo 2. Wilcoxon İlişkili İki Örneklem Testi

a. S.Y. Sonras1.Toplam.İhracat $<$ S.Y.Öncesi.Toplam.İhracat

b. S.Y. Sonrası.Toplam.İhracat $>$ S.Y.Öncesi.Toplam.İhracat

c. S.Y. Sonrası.Toplam.İhracat = S.Y.Öncesi.Toplam.İhracat

\begin{tabular}{|l|l|}
\hline Test İstatistiği(b) & S.Y.Sonras1.Toplam.Ihracat - \\
& S.Y.Onces1.Toplam.Ihracat \\
\hline Z & $-2,207(\mathrm{a})$ \\
Asymp. Sig. (2-tailed) & 0,027 \\
\hline
\end{tabular}

a. Based on negative ranks.

b. Wilcoxon Signed Ranks Test

İhracat rakamlarının süreç yenileme öncesi ve sonrası arasında anlamlı bir fark olup olmadığı araştırıldığında, Asymp. Sig. satırındaki değerin 0,027 olduğu görülmüştür. Söz konusu değer anlamlılık derecesi olan 0,05'den küçük olduğu için, süreç yenileme öncesi ve sonrası ihracat rakamları arasında istatistiksel olarak anlamlı farkın olduğu; buradan hareketle ihracat rakamlarına ait $\mathbf{H}_{\mathbf{0}}$ hipotezi reddedildiği söylenebilir.

\section{Sonuç}

Süreç yenileme, işletmelerde 'temelden', 'radikal' değişimleri konu alan; 'çarpıcı' sonuçları hedefleyen bir değişim aracı olarak değerlendirilmektedir. Sonuçlarının abartıldığı, etkisinin sınırlı olduğu konusunun sıklıkla tartş̧ılması bu çalışmanın yapılmasında önemli bir motivasyon unsuru olmuştur. Bu doğrultuda süreç yenileme projesi yürüten firmanın proje öncesinde ve sonrasında ihracat verileri takip edilmiş; elde edilen veriler 
değişkenler arası farkın anlamlı olup olmadığını değerlendiren Wilcoxon ilişkili iki örneklem testine tabi tutulmuştur. Test sonucuna göre firmanın süreç yenileme öncesi ve sonrası ihracat miktarları arasında istatistiksel olarak anlamlı bir farkın bulunduğu tespit edilmiştir. Süreç yenileme yaklaşımın sadece üretim miktarını artırmak konusunda değil aynı zamanda ihracat miktarını ve karlığını çarpıcı bir şekilde artırmak konusunda da önemli bir araç olduğu sonucuna ulaşılmıştır.

\section{Kaynakça}

- Attaran, M., ve Wood, G. G,1999. 'How to succeed at reengineering', Management Decision, 37(10).

- Attaran, M, 2000. 'Why does reengineering fail? A practical guide for successful implementation', Journal of Management Development, 19(9).

- Attaran, M,2004. 'Exploring the relationship between information technology and business process reengineering', Information \& Management, 41, 585-596.

- Chan, L. S. ve Choi, C. F,1997. 'A Conceptual and analytical framework for business process reengineering’, Int. J. Production, 50, 211-223.

- Chan, P. S. ve Peel, D,1996. 'Causes And Impact Of Reengineering', Business Process Management Journal, 4(1).

- Davenport, T.H. ve Short, J.E,1990.'The new industrial engineering: Information technology and businessprocess redesign', Sloan Management Review, 31(4).

- Garrison, R., Noreen, E. W ve Brewer, P. C,2006. Managerial Accounting, 11thEdition, McGraw-Hill, Irwin.

- Grant, D., (2002) ‘A Wider View of Business Process Reengineering’ Communıcations of the Acm, 45(1).

- Grover, V. ve Malhotra, M. K,1997.'Business process reengineering: A tutorial on the concept, evolution, method, technology and application', Journal of Operations Management, 15, 193-213.

- Grover, V.; Jeong, S. R. ve Teng, J. T. C,1998. ‘Survey of Reengineering Challenges', Information Systems Management, 15(2).

- Hall, G.; Rosenthal, J. ve Wade,J,1993.'How to make reengineering really work’, Harvard business reiew, November December.

- Hammer, M. ve Champy, J,1993.Reengineering the Corporation: A Manifesto for Business Revolution, HarperBusiness, New York, NY.

- Hope, J. ve Hope,T,1997.Competing in the Third Wave, The Ten Key Management Issues of the Information Age, Harvard Business School Press, Boston.

- O’Neill, P.ve Sohal, A. S,1999.'Business Process Reengineering A review of recent literature’ Technovation, 19, 571-581.

- $\quad$ Ray, P.; Fray, M. ve Khasnabish, B,1999.'A Re-engineering, Methodology for Coorporative Management of Enterprise Network’, Journal of Network and System Management, 7(1).

- Scott, G. M,1995. 'Downsizing, Business Process Reengineering, And Quality Improvement Plans:How Are They Related?', Information Strategy:The Executive's Journal, 11(3). 


\title{
Türkiye ile Komşuları Arasındaki Ticaret Potansiyeli: Çekim Modeli Çerçevesinde Bir İnceleme
}

\section{Turkey's Trade with Neigbor Countries:A Gravity Model Analysis}

\author{
Sezai Ata (Ministry of Development, Turkey)
}

\begin{abstract}
With the ever-increasing level of integration in world economy, neighborhood relations become much more important for two-fold reasons. Firstly, neighbor countries are most important trade partners in general and secondly they form a bridge with the other countries. So, while good relations with neigbors have positive externalities for the trade with other countries, bad relations with neigbors mean reduced trade with other countries of a specific region. The main purpose of this study is to analyze Turkey's export potential with the neighbor countries with the help of the gravity model. For this purpose, first a gravity model has been set up using panel data which consists of bilateral data for 68 countries for the period 1980-2009, and then Turkey's exports potential to 10 neigbor countries is analyzed. One important finding of the study is that Turkey's exports to neighbor countries in general is below potential and there is a further room for increasing exports. While the short distance, one of the two most important indicator of trade in a gravity model (the other is GDP), is one of the main drivers of high trade among countries, its full effect depends on the geographical conditons of two countries. Our analysis shows that, high levels of untapped export potential exists for the majority of neighboring countries.
\end{abstract}

\section{Giriş}

Uluslararası ticaret literatüründe yapılan önemli ayrımlardan bir tanesi derinlik (intensive) ile genişlik (extensive) arasında olandır. Bir ülke ile yapılan ticaretin yüksek seviyede olması o ülke ile ticaretin derinliğini gösterirken, ciddi miktarda ticaret yapılan ülke sayısının çokluğu ticaret yapısının genişliğine işaret eder. Her ülke için arzu edilen durum belirli ürün ve belirli ülke grubu çerçevesine sıkışan ihracat yerine hem derinliğe hem de genişliğe sahip olan bir ticaret yapısıdır.

Türkiye'nin dış ticaretine bu açıdan baktığımızda, geçmişten beri ticaret yaptığımız ülkelerle ticareti daha da geliştirmek önemli iken daha önceden ticaret yapmadığımız ülkelerle ticarete başlamak daha da önemli olabilir.

Gelişmiş ülkelerin yakın çevresi ile ticaretine baktığımızda, komşu ve çevre ülkelerle ticaretin toplam ticaret hacmi içerisinde önemli bir paya sahip olduğunu görmekteyiz. Örneğin, 2009 yılı itibarıyla ekonomik entegrasyonları yüksek olan AB-27 ülkeleri, ihracatlarının yüzde 66,7'lik kısmını diğer AB-27 ülkelerine yaparken ithalatlarının da yüzde 64'lük kısmını yine diğer AB-27 ülkelerinden yapmaktadırlar. Asya ülkelerinde ve Kuzey Amerika bölgesinde ise, bölge içi ticaret yüzde 40’lar seviyesinde bulunmaktadır. Dünyadaki diğer pek çok gelişmiş ülkenin dış ticaretinde de bölgelerindeki ülkelerin payının önemli yer tuttuğu görülmektedir. Türkiye'nin ise, toplam ithalatları 2008 yılında yaklaşık 540 milyar dolar olan komşu ülkelerle ticari ilişkileri yeterli düzeyde bulunmamaktadır. Komşu ülkelerin Türkiye'nin toplam ihracatı içindeki payları, 2000 yılında yüzde 7,6 iken bu oran 2008 yılında ancak yüzde 15,7'ye yükselebilmiştir.

Türkiye'nin komşuları ile ticaretinde son dönemde yaşanan kısmi artışların önemli sebeplerinden birisi 2000 yılında ülkemiz tarafından yürürlüğe konulan 'Komşu ve Çevre Ülkelerle Ticareti Geliştirme Stratejisi'dir. Bu strateji çerçevesinde, Ortadoğu, Güneydoğu Avrupa, Karadeniz ülkeleri, Kafkasya ve Orta Asya ülkeleri ile ticaretin geliştirilmesine yönelik bir takım önlemler alınmıştır.

$\mathrm{Bu}$ stratejiye göre, Türkiye ile arasında geçiş zorluğu olmayan ve başka bir ülke üzerinden geçmeksizin doğrudan kara veya yakın deniz bağlantısı vasıtasıyla Türkiye ile ortak sınıra sahip ülkeler komşu ülke olarak tanımlanmaktadır. Bu gruba giren ülkeler Azerbaycan, Gürcistan, İran, Irak, Suriye, KKTC, Yunanistan, Bulgaristan, Romanya, Ukrayna, Rusya Federasyonu ve Ermenistan'dır.

Türkiye ile ortak bir sınıra sahip olmamalarına rağmen Türkiye ile coğrafi, kültürel ve tarihsel yakınlığı bulunan ve ekonomik potansiyeli olan ülkeler çevre ülkeler olarak tanımlanmakta ve bu gruba giren ülkeler de Türkmenistan, Kazakistan, Özbekistan, Kırgızistan, Tacikistan, İsrail, Suudi Arabistan, Ürdün, Lübnan, Mısır, Arnavutluk, Moldova ve Makedonya olarak belirtilmektedir.

Komşu ve çevre ülkeler stratejisi 2003 yılında genişletilmiş ve strateji kapsamına; Macaristan, Slovenya, Hirvatistan, Bosna-Hersek, Yugoslavya Federal Cumhuriyeti, Fas, Cezayir, Tunus, Libya, Sudan, Etiyopya, Eritre, Cibuti, Somali, Gazze, Kuveyt, Bahreyn, Katar, Birleşik Arap Emirlikleri, Umman, Yemen, Afganistan, Pakistan ve Beyaz Rusya da dahil edilmiştir.

Komşu ve çevre ülkeler stratejisi kapsamındaki 52 ülkeye ihracat 2000 yılındaki 6,9 milyar dolar seviyesinden 2008 yılı itibarıyla 56,7 milyar dolara yükselmiştir. Aynı dönemde, bu ülkelerden ithalat ise 13 milyar dolardan 73,5 milyar dolara yükselmiştir. Bölge ülkelerinin toplam ihracat içerisindeki payı 2000-2008 döneminde yüzde 
24,7'den yüzde 43'e yükselmiştir. Suriye, Libya, Lübnan gibi ülkelere vizenin kaldırılması bu ülkelerle ticareti olumlu etkilenmiştir. 2009 yılı itibarıyla bir önceki yıla oranla Mısır'a olan ihracat yüzde 84, Afganistan'a yüzde 71, Libya'ya yüzde 67, Filistin ve Türkmenistan'a yüzde 43, Etiyopya'ya yüzde 40 ve Suriye'ye yüzde 28 oranında artmıştır. Irak'a olan ihracat ise aynı dönemde yüzde 31 oranında artmıştır. Irak ihracat içindeki yüzde 5'lik pazar payıyla 2009 yılında en çok ihracat yapılan ülkeler sıralamasında 5. sıraya yükselmiştir.

\begin{tabular}{|c|c|c|c|c|c|c|c|c|c|c|c|c|}
\hline & \multicolumn{2}{|c|}{$\begin{array}{l}\text { Türkiye'nin } \\
\text { İhracatı }\end{array}$} & \multicolumn{2}{|c|}{$\begin{array}{l}\text { Türkiye'nin } \\
\text { Ithalatı }\end{array}$} & \multicolumn{2}{|c|}{$\begin{array}{l}\text { Ülkenin } \\
\text { Toplam } \\
\text { İhracatı }\end{array}$} & \multicolumn{2}{|c|}{$\begin{array}{l}\text { Ülkenin } \\
\text { Toplam } \\
\text { Itthalatı }\end{array}$} & \multicolumn{2}{|c|}{$\begin{array}{l}\text { Türkiye'nin } \\
\text { Net Ticareti }\end{array}$} & \multicolumn{2}{|c|}{ GSYH } \\
\hline & 2000 & 2008 & 2000 & 2008 & 2000 & 2008 & 2000 & 2008 & 2000 & 2008 & 2000 & 2008 \\
\hline Irak & 0,0 & 3,9 & 0,0 & 1,3 & 14,9 & 54,4 & 3,4 & 21,4 & 0,0 & 2,6 & 26 & 87 \\
\hline İran & 0,2 & 2,0 & 0,8 & 8,2 & 27,0 & 116,9 & 14,3 & 70,1 & $-0,6$ & $-6,2$ & 96 & 333 \\
\hline Suriye & 0,2 & 1,1 & 0,5 & 0,6 & 4,8 & 16,4 & 5,4 & 27,4 & $-0,4$ & 0,5 & 20 & 54 \\
\hline Azerbaycan & 0,2 & 1,7 & 0,1 & 0,9 & 1,7 & 47,8 & 1,2 & 7,2 & 0,1 & 0,7 & 5 & 46 \\
\hline Ermenistan & 0,0 & 0,0 & 0,0 & 0,0 & 0,3 & 1,1 & 0,9 & 4,4 & 0,0 & 0,0 & 2 & 12 \\
\hline Gürcistan & 0,1 & 1,0 & 0,2 & 0,5 & 0,3 & 1,5 & 0,7 & 6,3 & 0,0 & 0,5 & 3 & 13 \\
\hline Rusya & 0,6 & 6,5 & 3,9 & 31,4 & 103,0 & 459,8 & 33,9 & 267,0 & $-3,2$ & $-24,9$ & 260 & 1660 \\
\hline Bulgaristan & 0,3 & 2,2 & 0,5 & 1,8 & 4,8 & 22,5 & 6,4 & 37,0 & $-0,2$ & 0,3 & 13 & 50 \\
\hline Yunanistan & 0,4 & 2,4 & 0,4 & 1,2 & 11,0 & 25,8 & 28,3 & 90,2 & 0,0 & 1,3 & 128 & 352 \\
\hline
\end{tabular}

Tablo 1: Komşu Ülkelerle Ticaret (Cari, Milyar \$) Kaynak: IMF IFS, IMF DOT

Türkiye'nin komşuları ile ticaretine ilişkin genel bilgilerin verildiği Tablo 1'e bakıldığında, bazı ülkeler ile ticaret fazlası verilirken bazı ülkelerle olan ticaret açığının önemli oranda arttığı görülmektedir. 2009 yılının kriz yılı olması ve dış ticaretin önemli ölçüde düşmesinden dolayı karşılaştırma için 2008 yılı verileri kullanılmıştır. 2000 yılında dört ülke ile dış ticaret açığı verirken 2008 yılı itibarıyla dış ticaret açığı verdiğimiz sadece iki komşu ülke kalmıştır. İran ve Rusya ile büyük oranda açık vermemizin sebebi enerji hammadde ihtiyacımızın önemli bir kısmını bu ülkelerden sağlamamızdır.

Türkiye'nin komşuları ile oluşturduğu bölgede 20. yüzyıl boyunca savaşlar, anlaşmazlıklar, siyasi istikrarsızlıklarçok yoğun olarak yaşanmış, 21. yüzyılın ilk yıllarında da yaşanmaya devam etmiştir.

Son döneme kadar ülkemiz gündemini sürekli meşgul eden ve bazıları hala da meşgul etmeye devam eden Kıbrıs, Suriye vb. sorunlar Türkiye'nin komşuları ile ilişkilerinde bir belirsizlik kaynağı olmuşlardır, bu da ülkeler arası ticari ilişkilerin yeterince gelişmemesine sebep olmuştur. Bu bölümün devamında komşu ülkelerle olan ihracat performansımız çekim modelinden hesaplanan ihracat potansiyeline göre değerlendirilecektir.

\section{2 Çekim Modelinin Yapısı}

Sosyal bilimlerde ilk olarak Walter Isard (1954), Linder (1961 ve Tinbergen (1962) tarafindan kullanılmaya başlanan çekim modelleri günümüzde uluslararası ticareti analizde en çok kullanılan modeller haline gelmişlerdir. Modelin fen bilimlerindeki kaynağı Newton'un ünlü çekim yasasıdır. Fizikte iki cisim arasındaki çekim kuvveti $\left(F_{i j}\right)$ cisimlerin kütlelerinin $\left(M_{i}, M_{j}\right)$ çarpımı ile doğru orantılı, aralarındaki uzaklığın $\left(R_{i j}\right)$ karesi ile ters orantilidir.

$$
F_{i j}=c * \frac{M_{i} * M_{j}}{R_{i j}^{2}}
$$

$\mathrm{Bu}$ denklemin uluslararası ticaret akımlarına uygulanmış şekli ise;

- $\mathrm{T}_{\mathrm{ij}}$ : i ve j ülkeleri arasındaki ticaret,

- $\mathrm{GSYH}_{\mathrm{i}}$ ve GSYH : i ve j ülkelerinin GSYH'ları,

- $\mathrm{R}_{\mathrm{ij}}$ : iki ülke arası mesafe,

- C: sabit,

olmak üzere;

$$
T_{i j}=c * \frac{G S Y H_{i} * G S Y H_{j}}{R_{i j}}
$$

halini alır. Denklemde iki tarafın da logaritması alındığında ise aşağıdaki denklemi elde ederiz.

$$
\log \left(T_{i j}\right)=\log (c)+\log \left(G S Y H_{i}\right)+\log \left(G S Y H_{j}\right)-\log \left(R_{i j}\right)
$$

Denklem (1), çekim modelini en basit ve yalın haliyle temsil etmektedir. Denkleme göre iki ülke arasındaki ticaret hacmi, ülkelerin büyüklüklerinin artan, aralarındaki uzaklıkların ise azalan bir fonksiyonudur.

Bir çekim modelinde, i ve j ülkeleri arasındaki ticaret en genel haliyle;

$$
\log \left(X_{i j t}\right)=\alpha_{0}+\alpha_{t}+\alpha_{i j}+\beta_{i j t} Z_{i j t}+\varepsilon_{i j t}, t=1, \ldots, T
$$


denklemiyle ifade edilebilir. Burada, $\mathrm{X}_{\mathrm{ijt}} \mathrm{i}$ ve $\mathrm{j}$ ülkeleri arasında t yılında gerçekleşen ticareti temsil etmektedir. Sabit katsayı üç bölümden oluşmaktadır. Birincisi bütün yıllar ve ülke ikilileri için ortak kısım olan $\alpha_{0}$, ikincisi t y1lına özgü bütün ülke ikilileri için ortak olan $\alpha_{t}$, üçüncüsü ise her bir ülke ikilisine özgü bütün y1llar için ortak olan $\alpha_{\mathrm{ij}}{ }^{\prime}$ dır. Diğer bütün değişkenler $Z_{\mathrm{ijt}}$ vektörüyle, katsayıları ise $\beta_{\mathrm{ijt}}$ ile temsil edilmektedir.

Denklem (2)'de verilen standart çekim modeli denklemini tahmin edebilmek için katsayılar üzerinde bazı kısıtlamalara gitmek zorunludur. Literatürde sıkça rastlanan toplu yatay kesit modellerinde konulan k1sıtlar $\alpha_{\mathrm{ij}}=$

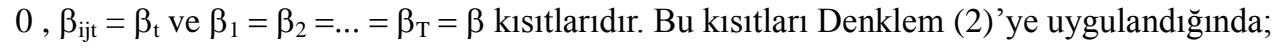

$\log (X i j t)=a 0+a t+\beta^{\prime} Z i j t+e i j t, t=1, \ldots, T$

denklemi elde edilir ve bu denklem standart olarak en küçük kareler (EKK) yöntemiyle tahmin edilir.

Ekonometrik açıdan önemli bir nokta, çekim modeline giren değişkenlerin bazılarında birim köke (unit root) rastlanması durumudur. Böyle bir durumda, panel veri analizi yerine kointegrasyon analizi yapmak gerekmektedir. Bussiere at al (2005: 16), standart çekim modellerinin ticaret akımları ve GSYH gibi durağan olmayan değişkenler içermesine rağmen, sabit etki modelleri ile durağan olmayan etkileri içeren dinamik EKK modellerinin çok benzer oldukları sonucuna varmıştır.

Panel veri analizinde önemli bir diğer nokta sabit etkiler veya rassal etkiler tahmini arasında bir seçim yapmaktır. Sabit etkiler modeli panel gruplarına ait zamana bağlı olmayan bazı özelliklerin açıklayıcı değişkenleri etkilediğini ve aralarında korelasyon olduğunu varsayar. Sabit etkiler modeli, bu zamana bağlı olmayan etkileri gidererek sadece açıklayıcı değişkenlerin etkilerinin görülmesini sağlar. Rassal etkiler modeli ise panel grupları arasındaki varyasyonun rassal ve açıklayıcı değişkenler ile arasında korelasyon olmadığını varsayar. İki metodun hangisinin daha uygun olduğuna kadar vermek için standart olarak Hausman Testi uygulanır.

\section{Türkiye ve Dünya İçin Çekim Modeli}

\subsection{Tahmin Yöntemi}

Bu çalışmadaki modeller panel veri yöntemi kullanılarak tahmin edilmiştir. 1980-2009 dönemine ait olan veriler kesintisiz olduğu için veriler dengeli panel (balanced panel) şeklinde oluşturulmuş ve analizlerde dengeli panel özellikleri kullanılmıştır.

Panel veri analizinde önemli bir nokta sabit etkiler veya rassal etkiler tahmini arasında bir seçim yapmaktır. Sabit etkiler modeli panel gruplarına ait zamana bağlı olmayan bazı özelliklerin açıklayıcı değişkenleri etkilediğini ve aralarında korelasyon olduğunu varsayar ve bu zamana bağlı olmayan etkileri gidererek sadece açıklayıcı değişkenlerin etkilerinin görülmesini sağlar. Rassal etkiler modeli ise panel grupları arasındaki varyasyonun rassal olduğunu ve açıklayıcı değişkenler ile arasında korelasyon olmadığını varsayar. İki metodun hangisinin daha uygun olduğuna karar vermek için standart olarak Hausman Testi uygulanır. Çekim modelimizde uygulanan Hausman Testi sonucu sabit etki modelinin daha uygun olduğu görülmüştür.

Fakat sabit etki modelinde her ülke ikilisi için kukla değişken gerekmesinden dolayı bu modelin tam olarak uygulanabilmesi için 4556 adet kukla değişken kullanılması gerekmekte ve şu an kullanılan istatistik yazılımının buna kapasitesi yetmemektedir. İki tahmin yöntemi sonucunda elde edilen katsayıların ișaretleri aynı ve büyüklükleri bir birine çok yakın olduğu için ve sabit etkiler tahmin yönteminde yıllara göre değişmeyen değişkenler (mesafe, ortak dil, komşuluk) dışlandığı için çalışmada rassal etkiler tahmin yöntemi kullanılmıştır. Böylece, incelenen ülkeler arasındaki mesafe, ortak dil kullanılması ve komşuluğu gibi kukla değişkenlerinin ticareti nasıl etkilediği görülebilecektir.

\subsection{Model}

Tüm ülke grupları için tahmin edilecek denklemin en genel hali şu şekilde ifade edilebilir;

$\log \left(X_{i j}\right)=\alpha+\beta_{1} \log \left(Y_{i}\right)+\beta_{2} \log \left(Y_{j}\right)+\beta_{3} \log \left(d_{i j}\right)+\beta_{4} \operatorname{Contig}_{i j}+\beta_{5} \operatorname{Lang}_{i j}+$ $\beta_{6}$ Colony $_{i j}+\beta_{7}$ Landlock $_{i j}+\beta_{8}$ Pop $_{i}+\beta_{9}$ Pop $_{j}+\beta_{9}$ Rer $_{i j}+e_{i j}$

Yukarıdaki denklemde;

$\boldsymbol{\alpha}$ sabit katsayı1,

$\mathrm{X}_{\mathrm{ij}}$ i ülkesinden $\mathrm{j}$ ülkesine reel ihracatı,

$Y_{\mathrm{i}} \mathrm{i}$ ülkesinin reel GSYH's1,

- $\quad Y_{j}$ j ülkesinin reel GSYH'sını,

- $\quad \mathrm{d}_{\mathrm{ij}} \mathrm{i}$ ve j ülkesi arasındaki uzaklığg,

- $\quad$ Contig $_{i j}$ i ve j ülkelerinin komşu olup olmadığını,

- $\quad$ Lang $_{i j}$ i ve j ülkelerinin aynı dili konuşup konuşmadığını,

- $\quad$ Colony $_{i j}$ i ve j ülkelerinin geçmişte kolonyal bir bağ içinde olup olmadığını,

- $\quad$ Landlock $_{i j}$ i ve j ülkelerinin kaç tanesinin kara ile çevrili olduğunu, 
- $\quad$ Pop $_{\mathrm{i}}$ i ülkesinin nüfusunu,

- $\quad$ Pop $_{\mathrm{j}} \mathrm{j}$ ülkesinin nüfusunu,

- $\operatorname{Rer}_{\mathrm{ij}}$ i ve j ülke para birimleri arasındaki reel kur endeksini,

- $\quad \mathrm{e}_{\mathrm{ij}}$ hata terimini, belirten değişkenlerdir. Kukla değişkenler dışındaki tüm değişkenlerin logaritmaları kullanılmıştır.

\subsection{Model Sonuçları}

Her bir ülke ile ticaret potansiyeli hesaplanırken dört farklı potansiyel hesaplanmıştır. Bunlar; bütün ülkeler, OECD ülkeleri, Euro bölgesi ülkeleri ve AB-27 ülkeleri kriterlerine göredir. Bütün ülkeler kriterine göre Türkiye'nin potansiyel ihracatı hesaplanırken, öncelikle bütün veri yani 68 ülkenin her birinin diğer 67 ülkeye olan ihracatı modellenmekte ve regresyon yapılmaktadır.

Sonrasında ise, bu regresyondan elde edilen denklemde Türkiye'nin her bir yıl için her bir ülkeyle ilgili açıklayıcı değişkenleri yerine konulmakta ve böylece potansiyel ticaret hesaplanmış olmaktadır. Diğger kriterlere göre potansiyel ihracat seviyesi benzer şekilde hesaplanmaktadır. Örneğin, OECD kriterine göre potansiyel hesaplanırken, öncelikle sadece OECD üyesi ülkelerden diğer OECD üyesi ülkelere ihracat modellenmekte ve regresyon yapılarak denklemin katsayıları tahmin edilmektedir. Sonrasında bu denklemde Türkiye ile ihracat yaptığı ülkenin açıklayıcı değişken bilgileri yerine konularak bağımlı değişken olan potansiyel ihracat seviyesi tahmin edilmektedir.

\begin{tabular}{llll}
\hline & $\mathrm{A}$ & $\mathrm{P}$ & $\mathrm{P}-\mathrm{A}$ \\
\hline Komşu Ülkeler & & & \\
\hline Azerbaycan & 1667 & 2089 & 421 \\
Bulgaristan & 2152 & 3620 & 1469 \\
Ermenistan & 0 & 504 & 504 \\
Gürcistan & 998 & 758 & 0 \\
Irak & 3917 & 3461 & 0 \\
İran & 2030 & 3511 & 1482 \\
Kibris R.Y. & 11 & 3242 & 3231 \\
Rusya & 6483 & 8091 & 1608 \\
Suriye & 1115 & 4292 & 3177 \\
Yunanistan & 2430 & 11891 & 9461 \\
\hline Toplam & 20802 & 41460 & 21353 \\
\hline
\end{tabular}

Tablo 3: Komşu Ülkelerle Gerçekleşen \& Potansiyel İhracat (2008, Cari, Milyon \$) Not: A: gerçekleşen ihracat, P: potansiyel ihracat, P-A: kullanılmayan potansiyel ihracatı göstermektedir. Potansiyelin gerçekleşmeden küçük olduğu durumlarda kullanılmayan potansiyel 0 olarak alınmıştır.

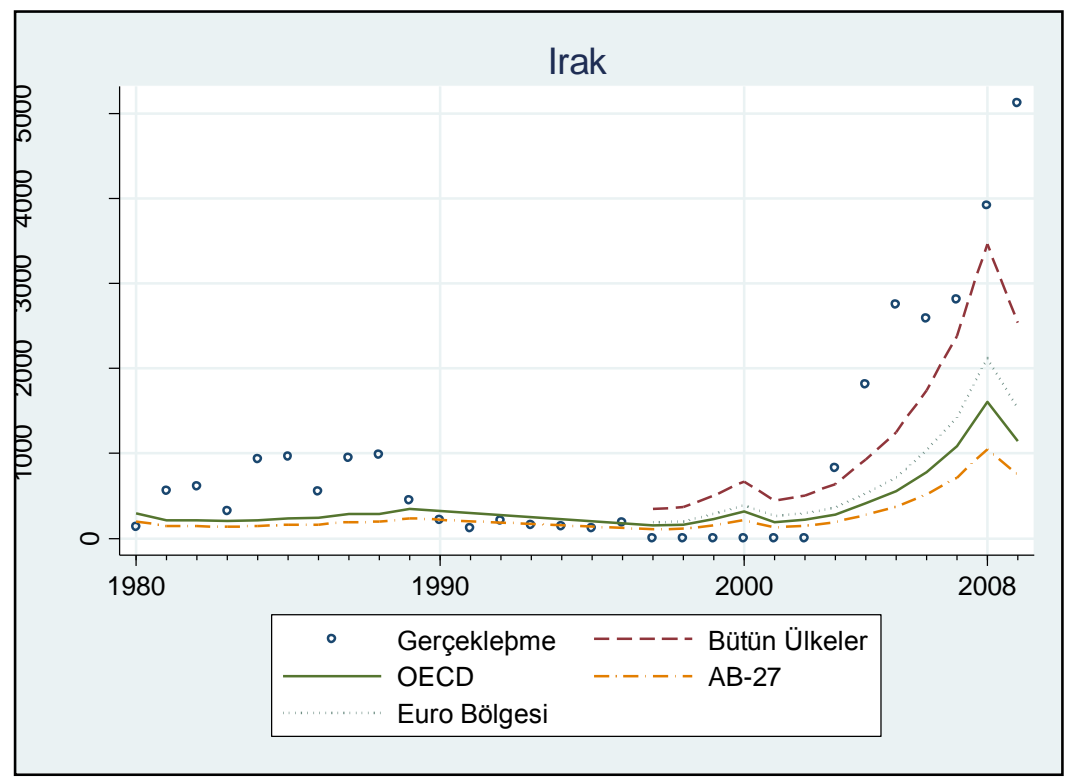

Grafik 1: Türkiye'nin Değişik Kriterlere Göre Potansiyel İhracatı - Irak Kaynak: Bu ve bundan sonraki bütün ülke grafikleri yazar tarafindan oluşturulmuştur. 


\section{Komşu Ülkelerle Ticaret}

\subsection{Irak}

Irak komşularımız arasında en fazla ticaret fazlası verdiğimiz ülkedir. 1990'lı yıllarda yaşanan birinci Körfez Savaşı öncesine kadar Irak Almanya'dan sonra en fazla ticaret yaptığımız ikinci ülke olarak Türkiye'nin en önemli ticari ortaklarından biriydi. Aynı dönemde petrol ihtiyacının önemli bir kısmı bu ülkeden karşılanmasına karşın, Irak aynı zamanda en yüksek ticaret fazlası verdiğimiz ülkeler arasındaydı. Ancak, Körfez Savaşı'nın patlak vermesiyle beraber Irak'a uygulanan ambargo dolayısıyla Türkiye'nin bu ülkeyle dış ticareti uzun yıllar bitme noktasına gelmiş̧ir.

ABD'nin Irak'1 işgaliyle sonuçlanan savaş sonrasında Irak ekonomisi henüz tam anlamıyla düzlüğe çıkamamış ve kayda değer petrol üretimine başlamamış olmasına rağmen Türkiye'nin Irak'la dış ticareti son dönemde yeniden hızla artmaya başladı. Resmi veriler baz alındığında 1997-2002 döneminde hiç ihracat yapmadığımız Irak'a 2006 yılında yaklaşık 2,5 milyar dolar, 2008 yılında yaklaşık 4 milyar dolar ihracat yapılmıştır. Küresel krizden dolayı diğer ülkelere ihracatın önemli ölçüde düştüğü 2009 yılında ise bu artış hız kesmemiş ve Irak’a ihracat 5,1 milyar dolara yükselmiştir. Böylelikle Irak 2010 yılı itibarıyla en çok ihracat yaptığımız 5. ülke konumuna yükselmiş̧ir.

Çalışmada elde ettiğimiz sonuçlara göre, son dönemde önemli oranda artırdığımız ticaretle beraber, Irak'a ihracat potansiyel seviyesini de aşmış, Türkiye için çok önemli bir pazar haline gelmiştir. (Bkz. Grafik 1) 2008 yılında Irak'a ihracat 3,9 milyar dolar iken potansiyel ihracat yaklaşık 3,5 milyar dolar seviyesindedir.

\section{2 İran}

İmparatorluklar döneminde sürekli savaş halinde olduğumuz fakat Kasrı Şirin anlaşmasından beri 400 yıldan uzun süredir barış halinde olduğumuz İran'la ekonomik ilişkilerimiz, bazı dönemlerde iyiyken bazı dönemlerde kesilme noktasına gelmiştir. 1990 yılında en çok ihracat yaptı̆ı̆ımız altıncı ülke olan İran, 2000 yllında yirmi üçüncülüğe gerilemiş, 2009 yılında ise on altıncılığa yükselmiştir. Özellikle 1980-1988 yıllarında Irak-İran savaşı ve ertesinde ABD-İran arasındaki sorunlar İran ile ticaretimizi olumsuz etkilemiştir.

Dışa kapalı ekonomik yapısı, uyguladığı dış ticaret kontrolleri, yüksek gümrük tarifeleri, tarife dışı engeller, bankacılık ve ödemeye ilişkin sorunlar, iki ülke arasındaki ulaşım ağlarının yetersizliği ve sınır kapılarında karşılaşılan sorunlar gibi engeller nedeniyle 2003 yılına dek İran ile ticari ilişkilerimizin boyutu istenen düzeyde gerçekleşmemiştir. Son dönemde ise, İran'ın izlediği dışa açılma politikaları ve Dünya Ticaret Örgütü (DTÖ) 'ne üyelik hedefi doğrultusunda birçok ürünün ithalatında uygulanan tarife dışı engellerin kaldırılması ve birçok yasaklı ürünün ithalatına izin verilmesi gibi iyileşmeler ve son dönemdeki yüksek oranlı büyüme oranları nedeniyle İran Türkiye için önemli bir ticaret pazarı haline gelmiştir.

İran ile 1996 yılında 1 milyar dolar civarında olan diş ticaret hacmimiz, 2008 yılı itibarıyla 10 milyar doları aşmıştır. Türkiye aleyhinde seyreden dış ticaret açığı, İran'dan doğal gaz ithalatı ile birlikte son yıllarda daha da artmış ve 2008 yılı itibarıyla 6 milyar doların üzerinde gerçekleşmiştir.

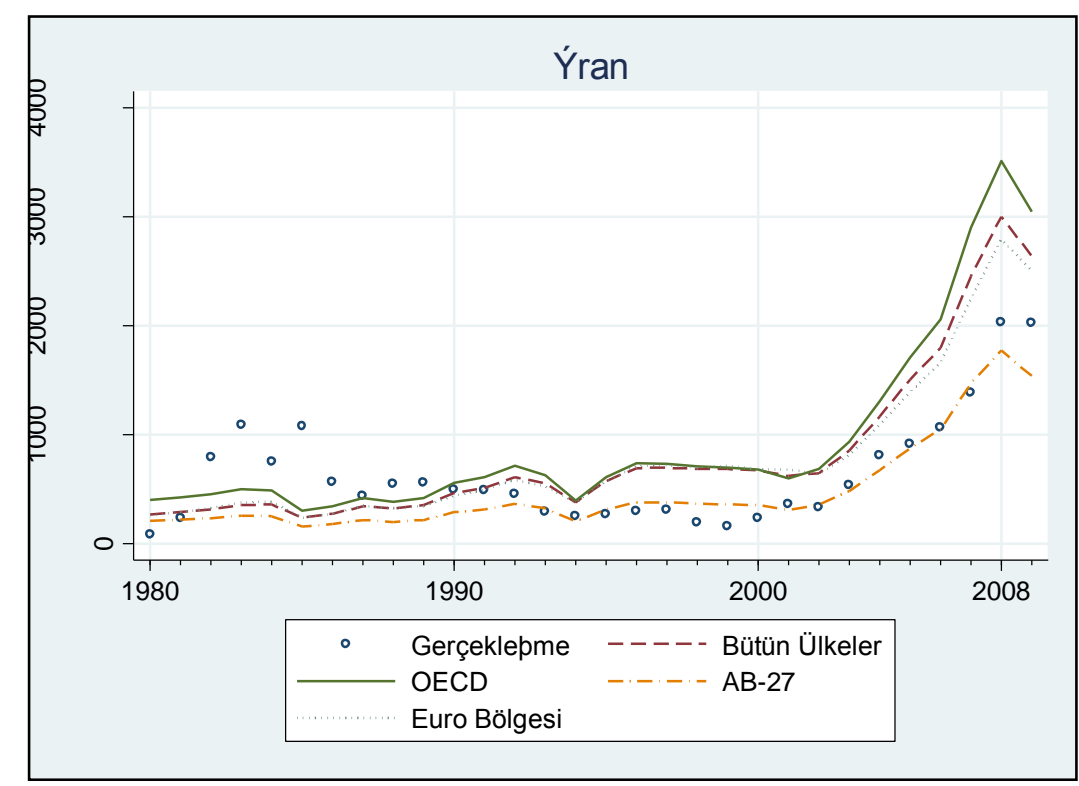

Grafik 2: Türkiye'nin Değişik Kriterlere Göre Potansiyel İhracatı - İran

Çalışmada elde edilen sonuçlara göre, ülkemiz İran ile ticarette önemli bir potansiyele sahiptir. (Bkz. Grafik 2) 2008 yilında İran'a ihracat 2 milyar dolar iken potansiyel ihracat 2,8-3,5 milyar dolar seviyesindedir. Yani, yaklaşık 1,5 milyar dolarlık kullanılmayan bir potansiyel vardır. 
Burada değinilmesi gereken bir nokta, Rusya örneğinde olduğu gibi İran ile Türkiye arasındaki mesafenin görece yüksek olmasıdır. İki ülke arasındaki mesafe bu çalışmada 1676 km olarak alınmıştır. Ancak Türkiye ile İran'ın komşu olduğu ve ticaretin özellikle sınır bölgelerinde yoğun olduğu düşünülürse, gerçek potansiyelin bu çalışma sonuçlarından daha yüksek seviyede olması muhtemeldir.

\subsection{Suriye}

Dışa açıklık konusunda en zayıf komşularımızdan birisi olan Suriye ile ticaretimiz son yıllarda önemli oranda artmıştır. Bu gelişmede, eskiden beri devam eden siyasi problemlerin büyük oranda çözülmüş olması ve son dönemde iki ülke arasındaki vizelerin kaldırılması önemli bir etken olmuştur.

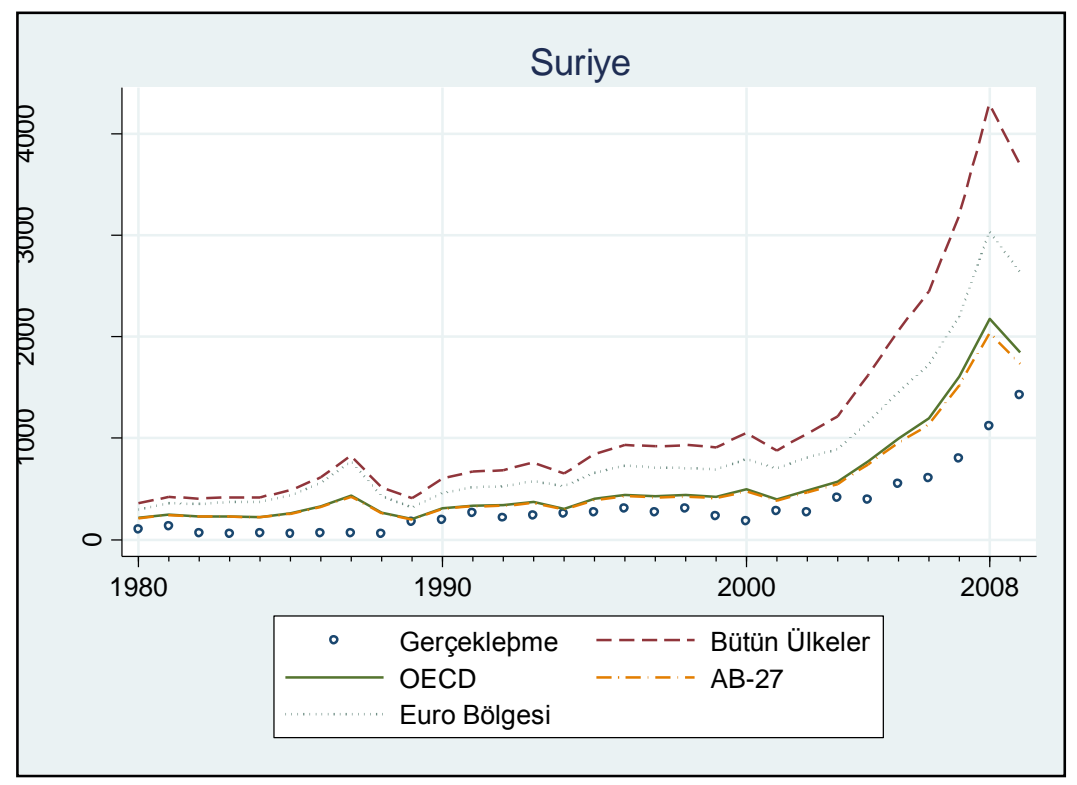

Grafik 3: Türkiye’nin Değişik Kriterlere Göre Potansiyel İhracatı - Suriye

Suriye ile olan dış ticaretimiz, uzun yıllar iki ülke arasında yaşanan siyasi gerginlikten olumsuz etkilenmesine rağmen, Türkiye'nin Suriye'ye ihracatında son yıllarda önemli artışlar kaydedilmiştir. 2007 yılında yürürlüğe giren Serbest Ticaret Anlaşması'nın olumlu etkileri hem 2007 hem de 2008 yılı verilerine yansımıştır.

Çalışmada elde edilen sonuçlara göre, Suriye ihracatta en çok potansiyel vaad eden ülkelerden birisidir. 2008 yılı itibarı ile ihracat 1,1 milyar dolar iken potansiyel 2,1-4,3 milyar dolar aralığındadır. (Bkz.Grafik 3)

\subsection{Azerbaycan}

Önemli bir petrol ve doğal gaz ihracatçısı konumuna yükselmekte olan Azerbaycan'ın milli geliri yükseldikçe buna paralel olarak dış ticaretinde de bir artış olması beklenmektedir. Türkiye son dönemde Azerbaycan'a olan ihracatını önemli oranda artırmıştır.

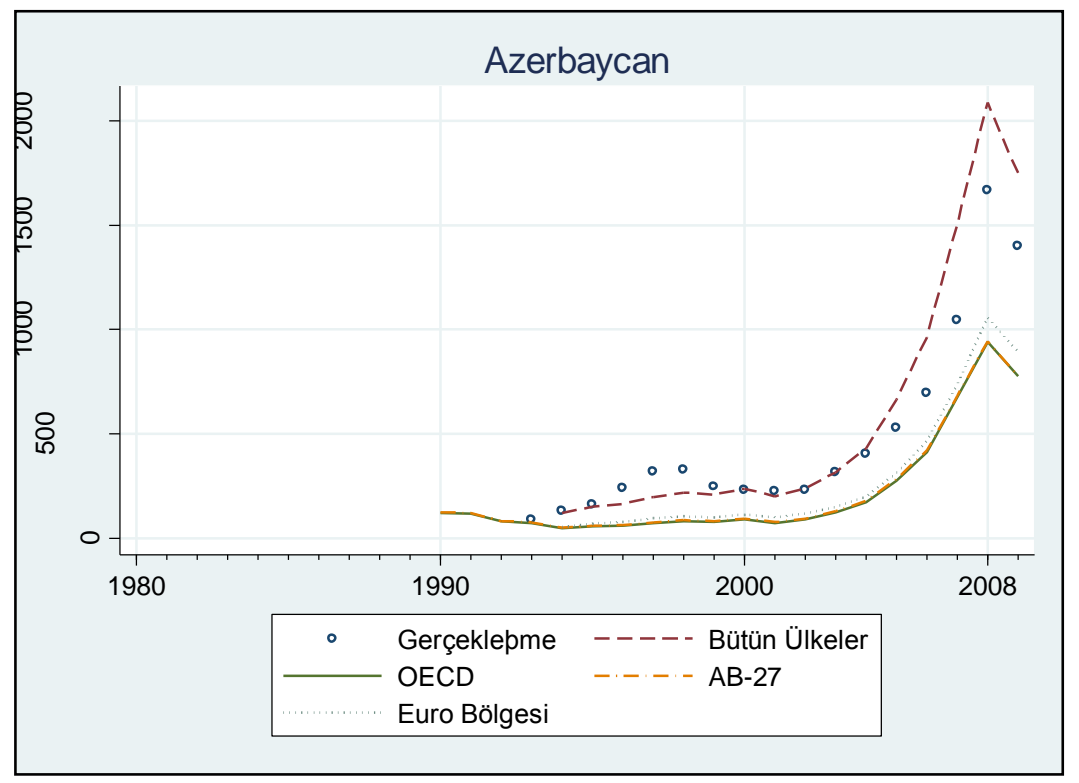

Grafik 4: Türkiye’nin Değişik Kriterlere Göre Potansiyel İhracatı - Azerbaycan 
Özellikle 1990’lı yıllarda Azerbaycan'a ihracat potansiyel düzeyin üzerine çıkarken, bu çalışmada elde edilen sonuçlara göre, son dönemde Azerbaycan'a ihracat potansiyel civarında gerçekleşmektedir. 2008 yılında Azerbaycan'a ihracat 1,7 milyar dolar düzeyinde iken, bu düzeyin 2 milyar dolara kadar çıkması mümkün görünmektedir. (Bkz.Grafik 4)

\subsection{Ermenistan}

Siyasi problemlerden dolayı sınırların kapalı olduğu Türkiye ile Ermenistan arasında resmi olarak ticaret gerçekleşmemektedir.

Ermenistan, doğu ve batı sınırları kapalı olan ve denize komşu olmayan bir ülke olarak, dünyanın geri kalan kısmına uzun kara yollarının kullanılmasıyla ulaşabilmektedir. Türkiye ve Ermenistan arasındaki bağlantı, Gürcistan ve İran üzerinden sağlanmaktadır. Ancak, Türkiye topraklarının kullanılması durumunda Ermenistan'ın bundan sağlayacağı önemli avantajlar bulunmaktadır. Türkiye dışındaki yolların kullanılmasının taşıma maliyetlerini yaklaşık \% 23 oranında artırdı̆̆ı tahmin edilmektedir.

Türkiye-Ermenistan sınırın kapalı olması, Ermenistan'ın Türkiye'nin sınır bölgeleriyle direkt olarak ticaret yapmasını engellemektedir. Ermenistan-Azerbaycan sınırının da kapalı olması, Ermenistan'ın dış dünya ile ticaretini olumsuz etkilemektedir. Bu nedenlerden dolaylı, Ermenistan'ın dış dünyaya açılımında Türkiye'nin karayolu, demiryolu ve deniz yolu bağlantıları büyük bir öneme sahiptir.

Çalışmadan elde edilen sonuçlara göre Ermenistan'a ihracatta 2008 y1lı itibarıyla yaklaşık 500 milyon dolarlık bir potansiyel olduğu tahmin edilmektedir. (Bkz. Grafik 5)

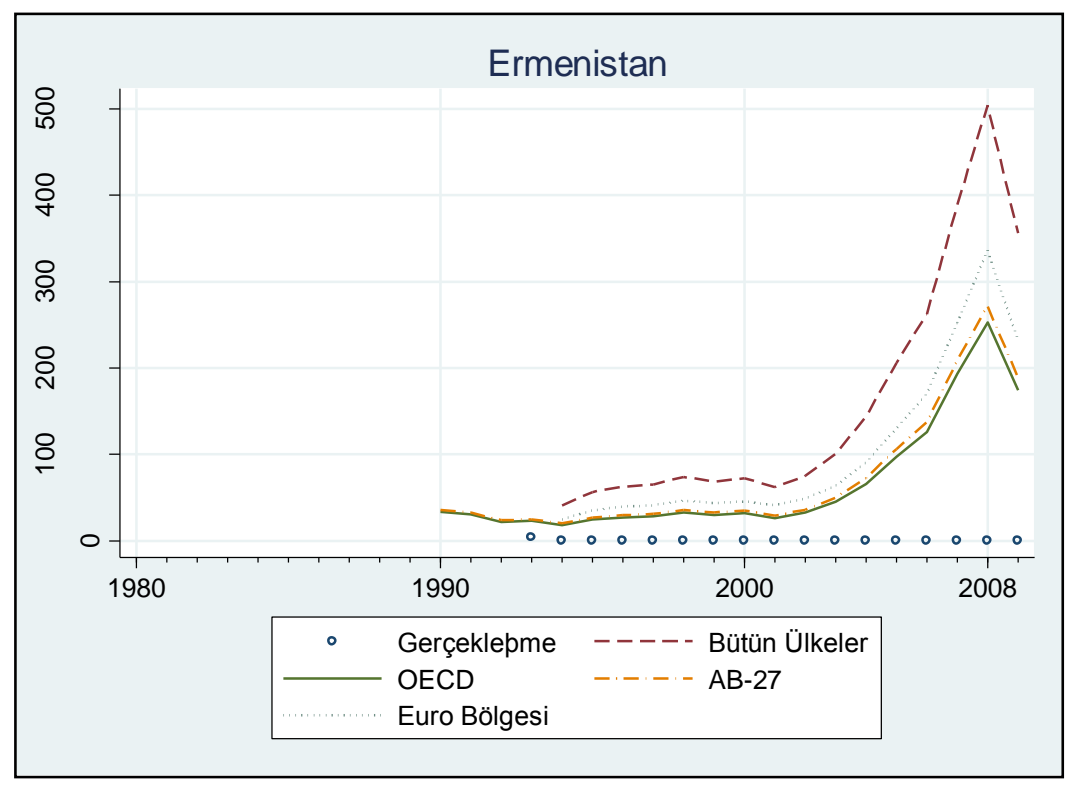

Grafik 5: Türkiye'nin Değişik Kriterlere Göre Potansiyel İhracatı - Ermenistan

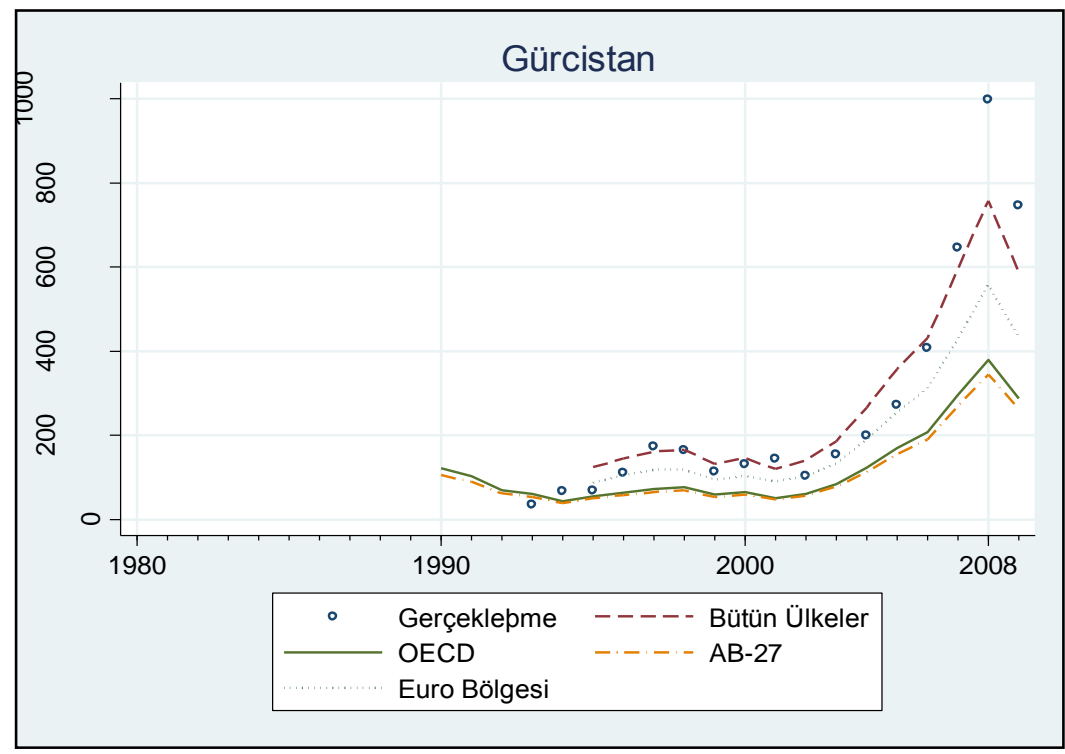

Grafik 6: Türkiye'nin Değişik Kriterlere Göre Potansiyel İhracatı - Gürcistan 


\subsection{Gürcistan}

Son dönemde yüzünü batıya çeviren ve Rusya ile ilişkileri bitme noktasına gelen Gürcistan Türkiye için önemli bir pazar olma yolunda ilerlemektedir. Gürcistan ayrıca Kafkas bölgesine açılan bir kapı olmasından dolayı Türkiye için önem arz etmektedir.

2000 yılında Dünya Ticaret Örgütüne üye olan Gürcistan, Bağımsız Devletler Topluluğu (BDT) dışındaki ülkelerle ticari ilişkilerini geliştirmeye çalışmaktadır.

Çalışmada elde edilen sonuçlara göre, Gürcistan'a ihracat potansiyel seviyeler civarındadır. (Bkz. Grafik 6) 2008 yilında Gürcistan'a ihracat yaklaşık 1 milyar dolar iken potansiyel ihracat yaklaşık 800 milyon dolar seviyesindedir.

\subsection{Bulgaristan}

Bulgaristan Dünya Ticaret Örgütüne 1996 yılında üye olmuştur. DTÖ’ye üyelik Bulgaristan pazarının liberalleşmesinde önemli rol oynamıştır.

Türkiye'nin Bulgaristan'a ihracatı, Bulgaristan'da yaşayan önemli bir Türk nüfusu bulunmasına ve iki ülkenin komşu olmasına rağmen yeteri düzeyde gelişmemiştir.

Çalışmada elde edilen sonuçlara göre, son dönemde önemli oranda artırdığımız ticaretle beraber Bulgaristan'a ihracat potansiyel seviyelere yaklaşmış, 2008 yılında Bulgaristan'a 2,2 milyar dolar ihracat yapılmıştır. Ancak, ihracatın 3 - 3,5 milyar dolar düzeyine taşınması mümkün görünmektedir. (Bkz. Grafik 3.7)

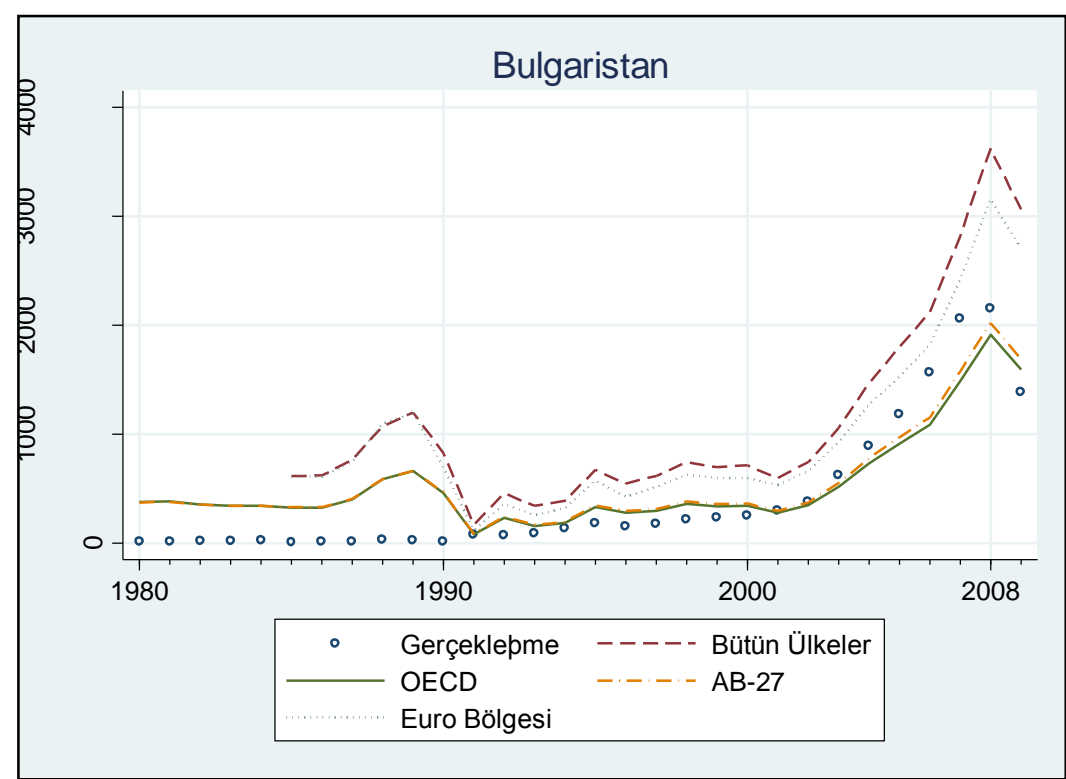

Grafik 7: Türkiye’nin Değişik Kriterlere Göre Potansiyel İhracatı - Bulgaristan

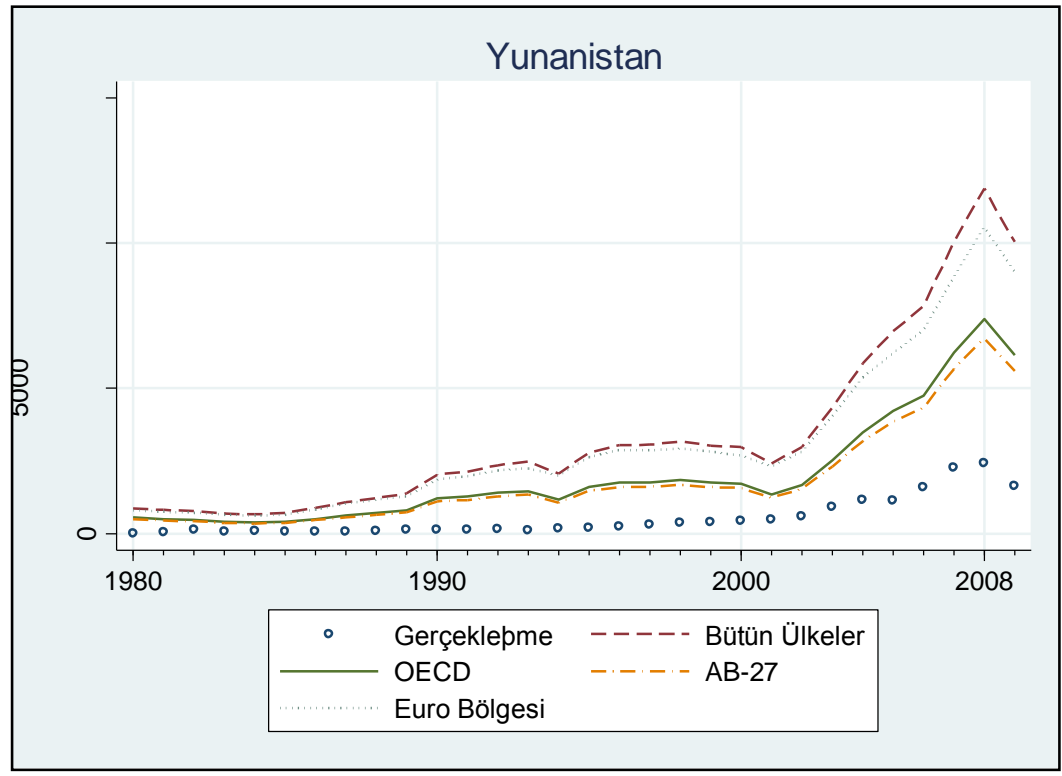

Grafik 8: Türkiye’nin Değişik Kriterlere Göre Potansiyel İhracatı - Yunanistan 


\subsection{Yunanistan}

Çekim modeli sonuçlarına göre ihracatı en fazla artırma imkanımız olan ülke Yunanistan'dır. 2008 yılı itibarıly Yunanistan'a ihracat 2,4 milyar dolar olarak gerçekleşirken, potansiyel ihracat miktarımız 6-12 milyar dolar olarak tahmin edilmiştir.

Potansiyelin bu kadar fazla olmasının sebeplerini araştırdığımızda karşımıza iki basit ve temel neden çıkmaktadır. Çekim modelinin iki önemli değişkeni olan GSYH ve uzaklık açısından Yunanistan'ın yüksek potansiyeline şaşırmamak gerekir. Çünkü 2008 yılı itibarıyla, 352 milyar dolarlık GSYH'sı ile Yunanistan İran'dan daha yüksek gelire sahiptir. Öte yandan Yunanistan'ın Türkiye'ye olan ağırlıklandırılmış uzaklığı 655 km. iken İran'a olan uzaklık 1676 km'dir.

Türkiye ile Yunanistan arasındaki potansiyel ticaret seviyelerine iki ülke arasında yaşanan siyasi sorunlar nedeniyle ulaşılamamıştır. Son dönemde gelişen ilişkilerle beraber artmaya başlayan Yunanistan-Türkiye ticaretinin önümüzdeki dönemde artarak devam etmesi beklenmektedir. (Bkz. Grafik 8)

\subsection{Rusya}

Petrol, doğal gaz, kömür ve çok sayıda değerli madeni kapsayan doğal kaynak rezervi bulunan Rusya ülkemiz ihracatı açısından önemli bir pazardır. Türkiye, 2009 yılı itibarıyla Rusya'nın ihracatında 6., ithalatında ise 16. sirada yer almaktadır.

SSCB döneminde Türkiye'nin önemli bir ticari ortağı olan Rusya ile ticaretimiz SSCB'nin dağıldığı 1992 yılından sonra da devam etmiş özellikle bavul ticaretinin etkisiyle büyük miktarlara ulaşmıştır. 1998 yllında Rusya'da yaşanan ekonomik kriz sebebiyle Türkiye-Rusya ticareti önemli ölçüde daralmış ve kriz öncesindeki ihracat seviyesine ancak 2005 yılında ulaşılabilmiştir. Rusya ile ticaretimizde önemli bir nokta, ticaret açığının 1997 yllından beri sürekli artıyor olmasıdır. Bunun önemli sebeplerinden bir tanesi 1984 yllında SSCB ile imzalanan doğal gaz karşılığı mal ihracı anlaşmasının sonraki süreçte uygulanmamasıdır.

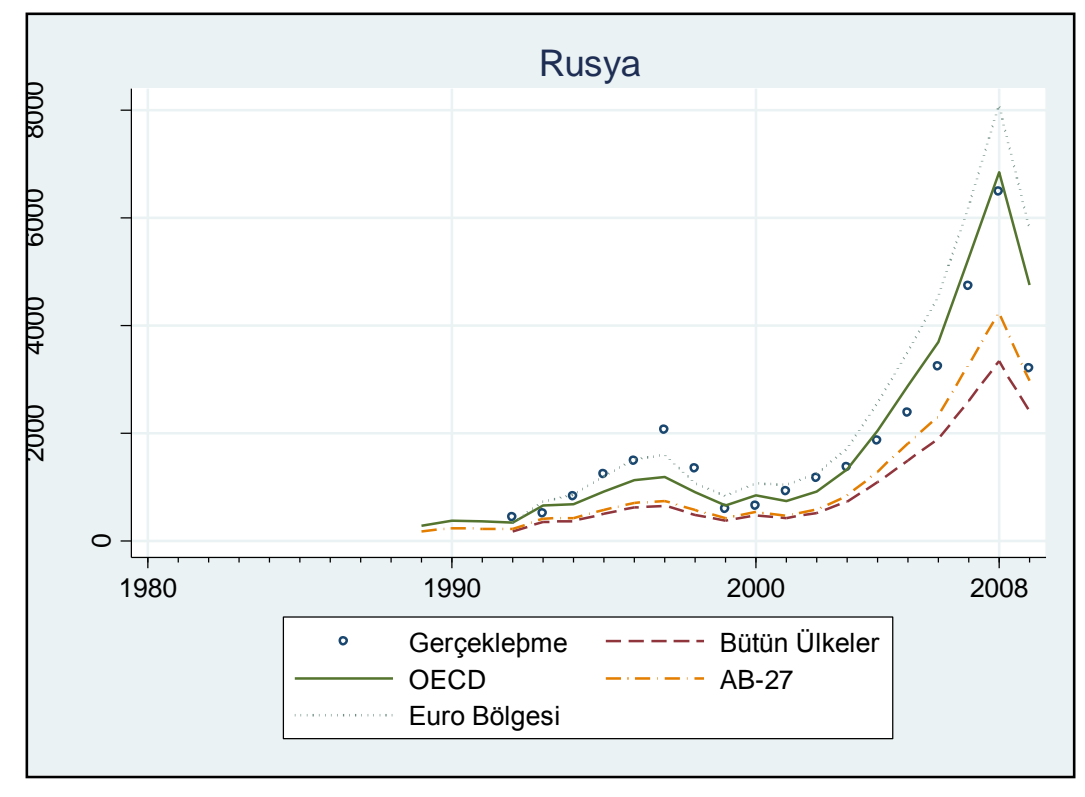

Grafik 9: Türkiye'nin Değişik Kriterlere Göre Potansiyel İhracat - Rusya

Son dönemde özellikle değerli maden, petrol ve gaz rezervleri nedeniyle yüksek büyüme sürecinde olan Rusya'ya ihracat potansiyel civarında seyretmektedir. (Bkz.Grafik 9) Ancak burada değinilmesi gereken bir nokta, Rusya ile Türkiye arası mesafenin kullandığımız kaynaklarda $2009 \mathrm{~km}$ olarak hesaplanması ancak bunun günümüz şartlarında iki ülke arasındaki mesafeyi tam olarak yansıtmamasıdır. Moskova ile Ankara arası mesafe yaklaşık $1800 \mathrm{~km}$ olmasına rağmen iki liman kenti Trabzon ile Soçi arasındaki mesafe yaklaşık 300 km'dir. Bu çalışmada tahmin ettiğimiz logaritmik denklemlerde ihracatın mesafeye bağlı esnekliği yaklaşık -1'dir. Buna göre, Türkiye ile Rusya arasındaki mesafe $2000 \mathrm{~km}$ yerine kabaca $1000 \mathrm{~km}$ olarak alındığında bile, çalışma sonuçlarına göre hesaplanan ihracat potansiyeli yaklaşık yüzde 100 artmakta ve yaklaşık 7 milyar dolardan 1415 milyar dolar seviyesine yükselmektedir.

\section{Sonuç}

$\mathrm{Bu}$ çalışmadan elde edilen en temel sonuç, Türkiye'nin bir çok komşu ülke ile gerçekleştirdiği ihracatın potansiyelin altında olduğu ve geliştirilmeye müsait olduğudur.

Modelin tahmin sonuçlarına göre Türkiye'nin dış ticareti, ticaret ortağı ülkenin ekonomik büyüklüğünden olumlu, nüfus büyüklüğü ve aradaki uzaklıktan olumsuz yönde etkilenmektedir. Ortak ülkenin geçmişte Türkiye 
ile birlikte aynı devletin parçası olması da ticareti olumlu yönde etkileyen faktörlerdir. Dünya genelinde komşuluk ticareti artırıcı bir faktörken Türkiye için bunun tam tersi bir sonuç ortaya çıktığı görülmektedir. Bu da Türkiye'nin komşu ve çevre ülkelerle ticaretinde büyük bir potansiyel olduğunu göstermektedir.

2008 yılı verilerine göre komşu ülkelere gerçekleşen toplam ihracat 20.8 milyar dolar iken model sonuçlarına göre bu ülkelere yönelik potansiyel ihracatımız 41.5 milyar dolar seviyesindedir. $\mathrm{Bu}$ da komşu ülkelerle ticarette yaklaşık yüzde 103 oranında potansiyel artış mümkün görünmektedir. 10 komşu ülkenin 8 tanesi ile ticaretimiz potansiyelin altında iken sadece Gürcistan ve Irak ile ticaretimiz potansiyelin üzerindedir. En çok potansiyel vaad eden komşu ülkeler Yunanistan K.R. Yönetimi ve Suriye'dir.

Rusya ve İran gibi büyük yüzölçümüne sahip koşularımızla ticarette mesafe potansiyel ticareti azaltıcı bir rol oynarken, küçük yüzölçümüne sahip ve nüfus yoğunluğu daha fazla olan Yunanistan gibi ülkelerle ticarette mesafe potansiyeli artırıcı bir rol oynamaktadır.

Son dönemde Suriye'de devam eden gelişmeler sosyal ve siyasal olumsuzlukların ticarete olan olumsuz etkisini bir kez daha göstermiştir. Komşu ülkelerle ticarette sahip olunan potansiyel ancak bütün ülkelerde sağlanacak sosyal, siyasal ve ekonomik istikrar ile beraber kullanılabilecektir.

\section{Kaynakça}

- Anderson, James, 1979. “A Theoretical Foundation for the Gravity Equation”, The American Economic Review, Vol. 69, pp. 106-16.

- Brun Jean-Francois, et. Al,2002. "Has Distance Died? Evidence from a Panel Gravity Model”, The World Bank Economic Review, Vol. 19, No. 1, pp. 99-120.

- Deardorff, Alan, 1998. "Determinants of Bilateral Trade: Does Gravity Work in a Neoclassical World", NBER Working Paper, No. 5377.

- Egger, Peter, 2002. “An Econometric View on the Estimation of Gravity Models and the Calculation of Trade Potentials", The World Economy, Vol. 25, pp. 297-312.

- Egger, Peter, 2008. “On the Role of Distance for Bilateral Trade”, The World Economy, Vol. 31, Issue 5, pp. 653-662.

- Feenstra, Robert, et. Al, 2001. "Using the Gravity Equation to Differentiate Among Alternative Theories of Trade", Canadian Economics Association, Vol. 34, No. 2, pp. 430-447.

- Fidrmuc, Jarko, 2009. “Gravity Models In Integrated Panels”, Empirical Economics, Vol. 37, pp. 435-446.

- Fidrmuc, Jarko, et. Al, 2005. "Trade Integration of Central and Eastern European Countries Lessons From a Gravity Model”, European Central Bank Working Paper Series, No. 545.

- $\quad$ Gencer, Ayşen Hiç ve Öngel, Volkan, "Serbest Ticaret Bölgesi Çerçevesinde Türkiye ile Suriye, Ürdün ve Lübnan Arasındaki Potansiyel Dış Ticaret Hacminin Uluslararası Çekim Modeli Yoluyla Tahmini”, Trakya Üniversitesi Sosyal Bilimler Dergisi, Cilt: 13, Sayı:1, Haziran 2011, ss. 71-94.

- Golovko, Anna, 2009. "Çekim Modeli: Avrasya Ülkelerinin Dış Ticareti", Anadolu Uluslararası İktisat Kongresi'nde sunulmuş tebliğ Eskişehir, Türkiye.

- Hiç, Mükerrem ve Gencer, Ayşen Hiç, "Dış Ticaret Alanındaki Ampirik Araştırmaların Seçilmiş ve Analitik Bir Envanteri”, Marmara Üniversitesi İ.İ.B.F. Dergisi, Cilt 19, Sayı 1, 2004.

- Isard, Walter, 1954. "Location Theory and Trade Theory: Short-Run Analysis", The Quarterly Journal of Economics, Vol. 68, No. 2, pp. 305-320.

- Tinbergen, Jan, 1962. "Shaping the World Economy: Suggestions for an International Economic Policy", The Twentieth Century Fund, New York. 


\title{
Krizin Orta ve Uzun Vadeli Yıkıcı Etkisi: Yükselen Korumacılık Destructive mid- and long-term Side Effect of the Crisis: Rising Protectionism
}

\author{
Assoc. Prof. Dr. Serap Durusoy (Izzet Baysal University, Turkey)
}

\begin{abstract}
Finance based crisis with its effect felt in the second quarter of 2007 has acquired global characteristics, and taken held of many countries. Global crisis not only has worn down constructive opinions regarding global capitalism, which played an important role in shaping the 20 th, but it has also discredited market economies. Thus, in many countries, including the United States of America, public rescue package implementations have lead to more desirable state interventions. On the other hand, economic activities in the global arena following the crisis slowed down and it became more difficult for financial structures to exist, and reduction in global trade movements were observed.This situation has lead for countries to include protective policies against the crisis as well. In study, protective studies will be addresssed, which wear down the globalization acting as a descriptive property of both experimental and normative reality in the definition of the process we are currently experiencing. As the economic problems gradually increase, the kind of shapes trade constrictions and protective instincts illustrate themselves and possible results of this will be examined on a country basis (EURASİAN, USA, EU, OECD). Expecially, it will be examined whether protectionism is the right solition policy against the crisis on not, and then the degree of the effect of this policy in the drop experienced in the recent months in international trade will be addressed. Lastly, the type of measurements taken in the international arena regarding protectionism and suficiently of the measurements will be assessed.
\end{abstract}

\section{Giriş}

Yaşanan küresel krizlerle birlikte 20. yüzyılın ekonomik, sosyal ve siyasal olarak şekillenmesinde etkili olan ekonomide serbestleşmeyi ve rekabeti özendirme çabasını barındıran küreselleşmede bir zemin kayması yaşanmaktadır. Öyle ki dünya ekonomisinin, altmış yılı aşkın bir süredir, ticaretin kolaylaştırılması ve serbestleştirilmesine yönelik çabaları kriz sonrası aşınmaya başlamıştır. Küresel finansal krizin ülke ekonomileri üzerinde yarattığı yıkıcı etkinin olumsuzluklarını elimine etmek için çözüm dış ticarette aranmaktadır. Dolayısıyla bugünkü uluslararası sistemi açıklamakta kullanılan ve kapitalizmin en yüksek aşaması olarak tanımlanan küreselleşmenin ülkeleri organik bir bütün haline getirmesi krizin bütün dünyaya yayılmasına neden olmakla kalmamış kriz sonrası uygulanan korumacı politikalarda da etkili olmuştur. Şekli ve derecesi ne olursa olsun korumacılık, rekabet sürecini, dolayısıyla, toplumsal refahı ve kaynakların etkin kullanımını, çok yönlü ve çok güçlü bir biçimde etkileyen bir uygulamadır. Mevcut serbest ticaret modelinden korumacı uygulamalara geçiş ise aslında dünya ekonomik düzeninin değişmesi anlamına gelmektedir ve çok daha kapsamlı ve sarsıcı etkileri olabilecektir. Buevrilme ile birlikte yani dış rekabetin kontrolüne yönelik politikaların benimsenmesi sonucunda küreselleşme yandaşlarının dahi küresel ekonominin temel ilkelerine olan inançları sarsılmakta, küresel kapitalizmin erdemleri ve kötülükleri çevresinde dönen hararetli tartışmalar çoğalmaktadır. Yani artık kapitalist ilişkilerin dünya ölçeğinde belirleyici bir aşaması olan küresel kapitalizm ve içerisindeki ilişki ağı tartışmalarda başat rolü oluşturmaktadır.

\section{Küresel Kriz Sonrası Küresel Eğilim: Korumacılık}

Bilindiği üzere korumacılık (protectionism), bir ülkenin yerli üreticilerini, her türlü yıkıcı nitelikteki dış rekabet karşısında korunmasını savunan görüşlere dayanan dış ticaret politikasıdır. Klasik koruma araçları arasında akla ilk gelen tarife araçları ve bu kapsamda gümrük vergileridir. Ülkeler, bu tür maliye politikası araçlarını kullanarak birtakım iktisadi amaçlarını gerçekleştirmeye çalışmakta ve bu çerçevede bazı ticari engeller ortaya çıkmaktadır. Gümrük vergisinin konulmasındaki temel amaç, ülkenin iç piyasasını muhafaza etmektir. Ancak bu yönde alınan bazı tedbirler, ticari ilişkide bulunulan ülkelerce de misilleme amaçlı olarak uygulandığında, ticari dengelerin bozulması ve sonuçta dünya ticaretinin bundan olumsuz şekilde etkilenmesi söz konusudur.

Ülkeler ulusal güvenlik-savunma tezi, bebek-çocuk sanayi tezi, hakça ticaret politikası, stratejik ticaret politikası, koşulların eşitsizliği nedeniyle yeni ve daha derin bir kriz yaşamamak için korumacı politikalara başvurur ( Efere, 2002, Robert, 2001).

İşte 2007' de ABD' de ortaya çıkan ve küresel niteliğe dönüşen krizin de Büyük Bunalım gibi derinleşerek uzun yıllar süreceğine dair görüş korumacılığa yönelik endişeleri beraberinde getirmiştir. Öyle ki IMF'nin Dünya Ekonomik Görünümü Raporları'nda ekonomik büyüme oranlarını aşağı seviyeye çekmesi (2012 için 3.5 2013 için ise 3.9 oranın da bir büyüme öngörülmüştür) bu endişenin kanıtıdır. 
Kuşkusuz küresel alanda ekonomik faaliyetler yavaşladıkça finansal yapının varlığını sürdürmesi zorlaşmış ve dünya ticaret akımlarında düşüş gözlenmiştir. Nitekim küresel krizin derinleşmesi ile birlikte küresel boyutta yaşanan durgunluk, etkisini uluslararası ticaret alanında da göstermiş ve birçok sanayileşmiş ülkenin dış ticaret hacmi, bir önceki yıla göre \%20'lerin üzerinde daralmıştır. 2008 yılında başlayan bu düşüş, bütün büyük ekonomileri derinden etkilemiştir. Bu bağlamda gerek söz konusu endişeler, gerekse ekonomik belirsizlik ortamı küresel krize çözüm arayışları içerisinde pek çok ülkede reel sektöre destek sağlayarak istihdam yaratan büyük firmaların ayakta kalmasına yönelik önlem paketleri uygulamaya konulmuştur. Kriz sonrası ekonomik göstergelerin daha da kötüleşmesi ve bunun etkilerinin ekonomik aktörler tarafından iyice hissedilmeye başlanmasıyla birlikte, uluslararası anlaşmaları ve serbest piyasa ekonomisinin temel mantığını zedeleyen korumacı ve içe kapanma gibi tedbirlerin uzun vadede pek çok ülke için bir kurtuluş reçetesi olacağı inancı yaygınlık kazanmıştır. Bu yaygın inançla birlikte korumacı uygulamalar gündeme gelmiştir. Yani küresel finansal ve ekonomik krizin derinleşmesine paralel olarak krizden büyük zarar gören sektörlerde ve işsizlik oranının yükselmesi ile işçi kesiminde serbest ticaret karşıtı ve korumacılık taraftarı baskılar doğal olarak güç kazanmıştır (TÜRMOB, 2009).

Nitekim Dünya Ticaret Alarmı ( GTA) adlı girişimin hazırladığı raporda 2008 yılından beri küçük ve büyük çaplı 192 ayrı korumacılık adımı atıldığı ve bunun başını Çin 'in oluşturduğu belirtilmiştir. Bu uygulamalarla hükümetlerin Dünya Ticaret Örgütü ve çok taraflı ticaret rejimine yönelik taahhütlerden vazgeçtiğini söylemek mümkündür ( Rodrik, 2009). Dolayısıyla günümüzde uluslararası ticaretin çoklu ticaret sistemine bağlı bir şekilde yürüdüğünü ileri süren (Chen, 2009) düşünce bağlamında irdelendiğinde, serbest mübadeleye izin verilmemesini, sınır ötesi ticarete engeller konmasını ve yerli üreticinin dış rekabete karşı korunmasını öngören, korumacılık anlayışının (Bhagwati, 2009), tehlikeli bir virüs olduğu çelişkisi görülmektedir (Kalaycı, 2011).

Aslında serbest ticaret ile korumacılık arasındaki mücadelenin geçmişi modern iktisat tarihi kadar, hatta daha da gerilere götürülebilir. Yani serbest ticaret ve korumacılık tartışmaları Merkantilist (16.-17.yüzyıl) ve Fizyokrat (18.yüzyıl) görüşlerin yaygın olduğu dönemlere kadar geriye gider ( Adda, 2002). Zaman ilerlese, teknoloji gelişse ve dünya küreselleşme sayesinde küçük bir köye dönüşse de bu tartışma bitmemiş; serbest ticaretkorumacılık çatışması her devirde gündemdeki yerini koruyan, kısmen biçim değiştirse de özü itibariyle varlığını sürdüren bir sorunsala dönüşmüştür (Acar, 2012).

Ancak son yıllarda korumacı politikaların tekrar önem kazanmasına yol açan iki olumsuz gelişmenin etkili olduğu söylenebilir.

1- Uluslararası boyutta serbest ticaretin daha da genişlemesi için harcanan çabaların son yıllarda zayıflamasıdır. 1990'lı yıllara kadar özellikle sanayi ürünleri ticaretinde hem gelişmiş hem de gelişmekte olan ülkelerde serbestliğin tesis edilmesi açısından büyük başarılara imza atan dünya ticaret görüşmeleri, 1994'de anlaşmaya bağlanan Uruguay Turu'nun ardından tıkanma noktasına gelmiştir. 2001'de başlayan Doha Kalkınma Turu görüşmelerinin aradan geçen yedi yıldan uzun süreye rağmen hâlâ başarıyla sonuçlandırılamamış olması, kriz öncesinde dünya ticareti açısından oldukça karamsar bir tablo ortaya çıkarmaktadır.

2- 1990'lardan günümüze devam eden küreselleşme sürecinin sonucu olarak gelir dağılımında büyük bozulmanın gerçekleşmiş olmasıdır. Küreselleşme ile birlikte gelir dağılımındaki bozulmaya rağmen ciddi boyutta sosyal tepkiler doğmamıştır. Sonuçta, pasta büyüdükçe orta ve düşük gelirli ailelerin bu pastadan aldığı pay, zengin ailelerin aldığı paya göre azalmış olsa da, bu ailelerin reel gelirleri zaman içinde yavaş da olsa arttığı için küreselleşmeye olan tepkileri kısıtlı oldu. Ancak, küresel çapta ekonomik bunalım tehlikesinin $\operatorname{arttığ1}$ günümüzde bu tepkilerin hızla artmış ve sosyal patlamalara yol açmıştır (Yılmaz, 2009).

İşte kriz sonrası uygulanan paketlerin liberal ekonomiye karşı bir seçenek olmayıp orta vadede etkili olması beklenirken, 1929 Büyük Bunalımından ders alınmamış korumacılık ve gümrük duvarlarını yükseltilmiştir. Yani bunalımın uzun sürmesinin en önemli nedenlerinden olduğunu göz ardı eden birçok ülke korumacılığa başvurarak krizin sosyal etkilerini kısa vadede yok etme çabası içine girmiştir. Bu bağlamda piyasa ekonomisinin mucidi konumunda olan bir çok ülkede korumacı bir takım tedbirlerin yeniden gündeme gelmiş olması küreselleşme ve kriz diyalektiğinin yaşanmasına neden olmaktadır. Görüldüğü üzere ticaret savaşlarından hiç kimsenin kazanmadığını ileri süren düşüncelere rağmen (Stiglitz, 2010) korumacılık ticaret savaşlarında bir silah haline dönüşmüştür.

Nitekim krizden kurtulmanın palyatif çözümü olduğu temelinden hareketle dikkati çeken ilk çıkışı, krizden hemen sonra ABD yapmıştır. ABD Şubat ayında Başkan Obama tarafından imzalanan ekonomik destek paketine Senato'daki görüşme aşamasında bazı maddeler eklemiştir. Bu maddelerde, ekonomik destek paketi çerçevesinde yapılacak demir ve çelik alımlarında sadece ABD'de üretilen demir ve çeliğin satın alınması kısıtlaması getirilmiş̧tir. Her ne kadar daha sonra yumuşatılmışsa da bu maddeler Obama tarafindan imzalanan ve yürürlüğe giren yasada da yer almıştır. Yani ABD açılan 800 milyarlık destek paketi ile Keynesyen politikaları benimsemiş ve bir anlamda ticaret savaşını başlatmıştır. Korumacılık eğiliminin artışa geçtiğine ilişkin diğer bir belirti, İngiltere'de bir petrol projesinde görev alacak bir İtalyan şirketin sadece İtalyan işçi ve mühendislerini çalıştıracağının ortaya çıkması üzerine bu kararın bazı İngiliz sendikalar tarafından gösteri ve grevlerle protesto edilmiştir. Sendikaların İngiltere'de yabancı işçilerin çalışamayacağı konusunu özellikle 
vurgulaması artan korumacılık eğiliminin bir göstergesidir. Son olarak, Fransa Cumhurbaşkanı Nicolas Sarkozy'nin Fransız otomotiv şirketlerine hükümetin vereceği mali destek karşılığında bu şirketlerin başka ülkelerdeki ve özellikle de Orta ve Doğu Avrupa'daki fabrikalarını kapatıp Fransa'ya taşımalarını şart koşması da korumacılık eğiliminin bir başka şekilde kendisini göstermiştir. Bu zihniyetle atılan adımların uzun vadede sadece korumacılıktan ibaret kalmadığı ve $A B$ projesi için de bir tehdit unsuru olduğunu $A B$ ülkelerinde yaşanmakta olan kriz de görmek mümkündür. Bu uygulamalar siyasetçiler ve çıkar çevrelerinde hakim olan korumacılık içgüdüsünün ekonomik sorunlar arttıkça kendisini hangi biçimlerde göstereceğinin örnekleri olarak önem taşımaktadır ( Yılmaz, 2009).Kuşkusuz bu örnekler çoğaltılabilir. Gelişmekte olan ve endüstrileşmiş ülkeler, yerli endüstrilerini korumak için farklı taktikler uygulamaktadır. Aşağıda Tablo 1'de görüldüğü üzere gelişmiş ülkeler daha çok sübvansiyonları kullanmakta ve yerli şirketlere finansal destek sağlamaktadır. Buna karşılık gelişmekte olan ülkelerin, hem sübvansiyonların maliyetini karşılayacak güçte bütçeleri ve hem de birçok endüstrileşmiş ülkelerin yaptığı gibi yerli şirketlerin borçlarını karşılayacak fonları bulunmamaktadır. Bu yüzden gelişmekte olan ülkeler tarifeleri artırmak ve diğer mali olmayan koruma önlemlerini hayata geçirmek eğilimindedir (Dadush,2009).

\begin{tabular}{|l|l|}
\hline GOÜ'in Uyguladığı Önlemler & Gelişmiş Ülkelerin Uyguladı̆̆ Önlemler \\
\hline İthalat Vergisi \%49 & Sübvansiyonlar ve Diğger Destek Paketleri\%100 \\
\hline Sübvansiyonlar - Diğer destek Paketleri \%31 & \\
\hline Tarife Dışı Engeller \%11 & \\
\hline İthalat Yasağı \%9 & \\
\hline
\end{tabular}

Tablo1: Gelişmiş ve Gelişmekte Olan Ülkelerin Uyguladığı Önlemler. Kaynak: Gamberoni Elisa and Newfarmer Richard ( 2009)

Dünyanın ticaret kuralları, zaten ulusların ithalat girdilerinde yaşanan ani bir kesinti yerel firmaları sıkıntıya soktuğunda gümrük vergileri şeklinde tedbirlere başvurmalarına izin verir. Öte yandan WTO'ya yapılan taahhütler nedeniyle gümrük tarifelerini belli bir düzeyin üstüne yükseltmek mümkün olamazken, ülkeler tarife dışı sınırlamalar, ithalat kotaları ve ihracatın çeşitli şekillerde sübvanse edilmesi gibi tedbirlere de başvurulmaktadır. Tarife dişı engeller, tarifelerden farklı olarak kesinlik taşımadığı ve geniş ölçüde idari kararlara bağlı olduğundan zaman içinde büyük değişiklikler gösterebilir. Bu tür engellerle WTO kuralları da ihlal edilebilmekte (Rodrik, 2011) ve ithalat - ihracat üzerinde artan bir risk ve belirsizlik oluşturmaktadır.Öte yandan kriz sonrası gelişmiş ülkelerce uygulanan korumacılık önlemleri çeşitlilik gösterirken gelişmekte olan ülkelerin uygulamaya başladıkları yeni korumacılık önlemlerinin ise daha çok ithalata ve ticarete yönelik korumalardan oluştuğu söylenebilir.

\begin{tabular}{|l|l|l|l|}
\hline & $\mathbf{2 0 0 7}$ & $\mathbf{2 0 0 8}$ & Değişim 2007/2008 \\
\hline Yeni Antidamping & 143 & 188 & $31.5 \%$ \\
\hline Gelişmekte Olan Ülkeler & 85 & 188 & $62.4 \%$ \\
\hline Oran & $59.4 \%$ & $73.4 \%$ & \\
\hline Gelişmiş Ülkeler & 58 & 50 & $13.8 \%$ \\
\hline Oran & $40.6 \%$ & $26.6 \%$ & \\
\hline $\begin{array}{l}\text { Yeni Antidamping } \\
\text { Uygulamaları }\end{array}$ & 100 & 120 & $20.0 \%$ \\
\hline Gelişmekte Olan Ülkeler & 77 & & $14.3 \%$ \\
\hline Oran & $77.0 \%$ & 66 & \\
\hline Gelişmiş Ülkeler & 23 & $55.0 \%$ & $13.8 \%$ \\
\hline Oran & 23.0 & 54 & \\
\hline
\end{tabular}

Tablo2: Gelişmiş ve GOÜ deki Antidamping Soruşturmalarl. Kaynak: Hufbauer, Gary Clyde and Stephenson Jensen \& Sherry (2009)

Nitekim AB Komisyonu tarafından yapılan araştırmalarda 2008'den bu yana G-20 ülkeleri tarafindan uluslararası ticarete karşı getirilen tedbirlerin sayısının 424 olduğu ifade edilmiştir. Bu gelişme, ekonomiyi, uzun sürmesi olası bir daralma riskine sürüklemiştir. 2009 yılının ilk çeyreğinde 111 adet yeni ticaret kısıtlaması ve 2009 yılının ikinci ve üçüncü çeyreğinde de aynı miktarda yeni korumacılık önlemleri uygulanmıştır (Evenett, 2010a). Ayrıca, 2010 yılında dünya ticareti iyileşmeye başlamasına rağmen, 2009 yılından Kasım 2010’a kadar

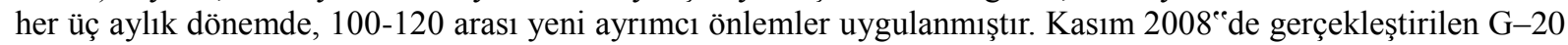
zirvesinden, Ocak 2010 a kadar uygulanan önlemlerin toplam sayısı 493 olarak gerçekleşmiştir (Evenett, 2010b).

Öte yandan Avrasya ekonomileri içerisinde de toplam korumacı uygulama sayısı en fazla Kazakistan'da görülürken en az ise Özbekistan ve Azerbaycan da görülmektedir. 


\begin{tabular}{|l|l|}
\hline Ülke & Uygulanan Korumacı Önlem Sayısı \\
\hline Kazakistan & 96 \\
\hline Kırgizistan & 10 \\
\hline Özbekistan & 11 \\
\hline Ermenistan & 2 \\
\hline Azerbaycan & 2 \\
\hline
\end{tabular}

Tablo 4: Uygulanan Toplam Korumacı Önlem Sayısl. Kaynak: Global Trade Alert, 2013.

Ayrıca Kırgizistan ve Moldovya WTO’nun üyesidir ve Rusya Kazakistan ve Gürcistan'dan daha düşük gümrük tarifesi uygulamaktadır. Özellikle Gürcistan en yüksek tarifeyi un ,şeker ve sigaraya karş1 uygulamaktadır. Ayrıca Rusya,Beyaz Rusya ,Kazakistan tarafindan uygulanan en yüksek koruma seviyesi morotorlu taşıtlar sektöründe görülmektedir ( Cusolito Hollweg, 2013).

Korumacılık önlemlerinde ortaya çıkan hızlı artış, gelişmiş ve gelişmekte olan ülkeler açısından oldukça önemlidir. Çünkü bu önlemler eğer belli bir ölçü dâhilinde alınmamışsa adaletsiz endüstri politikaları olarak nitelendirilmektedir (Spilimbergo vd :2008). Bu bağlamda WTO kurallarını da hiçe saymamak ve gümrük duvarlarının yükseltilmesinin olanaklı olmadığı günümüzde ithal ürünlere karşı en çok başvurulan yöntem tarife dışı engellerden oluşmaktadır (Hufbauer and Stephenson, 2009). Yerli malı kullanımını teşvik edebilmek için 'yerli malı' kampanyalarının düzenlenmesi buna bir örnek olarak gösterilebilir. Global krizle birlikte daha da belirginleşmeye başlayan tarife dışı engeller, ihracatçının karşısına da birçok şekilde çıkmaktadır. Örneğin ABD'de yeni ve oldukça tartışmalı bir yasa olan 12 kasım 2008 de yürürlüğe giren ABD Tüketici Ürünleri Güvenliğini Geliştirme Kanunu (CPSIA) da bu tür düzenlemelerden birisidir (TURKAK, 2012).

Küresel ekonominin giderek artan bir şekilde bütünleşmesi ve artan tüketici talebi nedeniyle ABD'nin tüketici ürünleri ithalatı son 10 yıllık dönemde iki kattan fazla artış göstererek 2007 yılında 639 milyar dolar olarak kaydedilmiştir. $\mathrm{Bu}$ rakam $\mathrm{ABD}$ içinde satılan tüketici ürünlerinin yaklaşı \%44'üne tekabül etmektedir. ABD hükümeti tüketici ürünleri ithalatındaki bu artış karşısında güvenli olmayan ithal ürünlerinin gümrüklerde tespit edilerek girişinin durdurulmasına odaklı olan eski sistem yerine, ithalat işlemlerinin başlangıcından itibaren sürekli izleme yolu ile önlem alınmasına odaklı yeni bir sisteme yönelmiştir. Bu sistem güvenlik açısından risk taşıyan ürünlerin ABD sınırlarına ulaşmadan önlem alınmasını hedeflemektedir. Yasa, özellikle ithal edilen çocuk kıyafetlerindeki kurşun ve kimyasalların miktarına sınırlandırma getirerek bu tür ürünlerin ülkeye girişine vize vermemeyi içermiştir. Bunun yanında yine birçok ülke, anti-damping soruşturmaları ve kurduğu takip sistemleri ile yerli sanayiyi ithal mallara karşı korumaya almıştır (TURKAK, 2012).

Nitekim Tablo 3'de görüldüğü üzere Avrasya ülkelerinden özellikle Rusya ve Ukrayna'nın AB' liğine yönelik antidamping soruşturmalarının yüksekliği dikkati çekmektedir. Buna rağmen Çin Japonya ve AB'inden bölgeye karşı telafi edici uygulama söz konusu değildir (Cusolito and Hollweg, 2013).

\begin{tabular}{|l|l|l|l|l|l|l|}
\hline Ülke & Çin & Hindistan & Japonya & Kore & Malezya & Avrupa Birliği \\
\hline Ermenistan & 0 & 0 & 0 & 0 & 0 & 1 \\
\hline Azerbaycan & 0 & 0 & 0 & 0 & 0 & 0 \\
\hline Beyaz Rusya & 0 & 0 & 0 & 0 & 0 & 9 \\
\hline Kazakistan & 0 & 0 & 0 & 0 & 0 & 6 \\
\hline Kirgizistan & 0 & 0 & 0 & 0 & 0 & 1 \\
\hline Moldovya & 0 & 0 & 0 & 1 & 0 & 1 \\
\hline Rusya & 0 & 3 & 0 & 5 & 0 & 32 \\
\hline Tacikistan & 0 & 0 & 0 & 0 & 0 & 0 \\
\hline Türkmenistan & 0 & 0 & 0 & 0 & 0 & 1 \\
\hline Ukrayna & 0 & 2 & 0 & 0 & 0 & 21 \\
\hline Özbekistan & 0 & 0 & 0 & 1 & 0 & 2 \\
\hline
\end{tabular}

Tablo3: Avrasya Ülkelerinde Antidamping Soruşturmalarl. Kaynak: World Bank's 2012 Global Antidumping Database, Data Available Up to 2011

Öte yandan ABD dışında da birçok gelişmiş ülke ekonomilerini canlandırma yönünde açıkladıkları paketlerde yerli malı kullanımı şartı getirmiştir. Ülke kaynaklarının ve tasarruflarının ilk önce o ülke vatandaşlarının krizden aldıkları darbenin azaltılması için kullanılması iç politika dinamikleri açısından alınması ve anlatılması kolay bir politika tedbiridir. Kısa vadede olumlu politik etkileri olsa bile uzun vadede korumacılığın refah arttırıcı bir politika olmadığı içinde bulunduğumuz liberal ekonominin ve küreselleşmenin en önemli kurallarından biridir. Eğer sistemsel risklerin önlenmesi için veya bazı kritik önemdeki sektörlerin çöküşünü önlemek için hükümetlerin müdahalesi söz konusu ise bu müdahaleler piyasaların işlerliği ve sürdürülebilirliğini bozmayacak, 
aksine destekleyecek şekilde gerçekleşmelidir. Çünkü günümüzde rekor seviyelere ulaşan uluslararası doğrudan yatırımlar ve bunun sonucu olarak gelişen küresel yapı dünya üretimini son derece uluslararası hale getirmiş durumdadır. Bunun sonucu olarak birçok yerli şirket için korumacılık kabul edilemez bir olgu haline gelmiştir. Çünkü ilgili firmaların uluslararası piyasalarda yaptıkları gibi rakipleri de ülke içinde yerel iş gücü ve yerel girdilerle üretim/ihracat yapmaktadır.

Kriz sonrasında korumacılık eğilimi sadece mal piyasasında değil sermaye ve iş gücü piyasalarında da güçlenmiştir. Gelişmekte olan ekonomilere akan fonlar 2007 yılından itibaren hızla geri çekilmeye başlamıştır. Fransa ve İngiltere, sermaye veya kredi desteği almış bankaların bu fonları yurtiçine tahsis etmesi veya ancak ulusal şirketlerin yurtdışı operasyonlarında kullanılmalarını şart koşmuştur. İsviçre ise bazı sermaye rasyolarında yerli şirketlere verilmiş olan kredileri hesaba dahil etmeyip dolaylı faydalar sağlamaya çalışmıştır. Diğger Avrupa ülkelerinde benzer tepkiler görülmüştür. Daha çok yerleşik olmayan (non-resident) çalışanlar işten çıkarılmakta, yeni işe alımlarda yabancı çalışanlar yerine yerleşikler tercih edilmektedir (Hufbauer and Stephenson, 2009). Bu konu TARP (ABD Hükümeti tarafindan 2008'de uygulamaya konulan finansal kurumlara yönelik kriz programı Troubled Asset Relief Program) fonu kullanan bankalar için bir ön şart haline getirilmiştir.

Korumacılık modelleri arasında en tehlikelisi kuşkusuz finansal korumacılıktır. Hükümet yardımlarının ardından daha ulusal bir yaklaşım içine giren pek çok banka, özellikle Newyork, Londra, Frankfurt, Tokyodaki büyük ve önemli bankalar kendi ülkelerine geri dönmüştür. Özellikle bazı bankalar, hükümetleri tarafindan kendi ülkelerinde yatırım yapmaya zorlanmıştır. Benzeri olarak Hollanda da Hollandalı işadamlarına ve tüketicilerine kredilerini yükseltmeleri karşılığında Ing Bank mali destek verilerek kurtarılmıştır ( Hufbauer and Stephenson,2009). Uluslararası bankaların yabancı ülkelerdeki faaliyetlerini durdurmaları, kredi krizine neden olurken, fon bulmakta zorlanan reel sektörlere yönelik kurtarma planlarının da gündeme gelmesine neden olmuştur. Bu bağlamda finansal korumacılığın yaratacağı sonuçların özellikle AB için siyasi, ekonomik ve yasal açıdan önemli bir test niteliği taşıyacağı söylenirken, bankacılık sektöründe entegrasyonun sağlanamamış olmasının AB'ye büyük zarar vereceğine dikkat edilmelidir. Korumacılık baskılarının AB ve özellikle Euro bölgesi için ciddi bir tehdit olduğu Avrupa Merkez Bankası tarafından da çok kez ifade edilmiştir. Bu noktada şu soru dikkate alınmalıdır: "Gerçekten finansal korumacılık mı yaşıoruz, yoksa bankalar kredilerini mi sınırlıyorlar?" Avrupa Uluslararası Ekonomi Politikaları Merkezi Başkan yardımcısı Razeen Sally her iki durumunda söz konusu olduğunu belirtmiştir. Sally’e göre bazı bankaların finans krizinden yararlanarak finansal korumacılık yapmaktadır. Finansal korumacılığın yarattığı bir diğer tehdit ise, devlet yardımlarının bankacılık dışındaki sektörlere yönelmesi. İsveç'in otomotiv sektörüne yönelik hazırladığı kurtarma paketi; Fransa'nın otomobil üreticilerine 6 milyar Euro destek sağlaması ve bunun karşılığında istihdam ve üretimlerini dışarı taşımamalarını istemesi; İtalya'nın zarar eden havayolu şirketi Alitalia'yı yabancılara kaptırmaması; İspanyol hükümetinin vatandaşlarını İspanyol malı tüketmeye davet etmesi; İngiltere'nin yabancı işçilerin istihdamına tepki göstermeye başlaması korumacılık uygulamalarından bazılarıdır ( EURACTIV, 2012a).

Bu bağlamda finansal korumacılık tehdidinin en fazla yaşandığı bölge ise doğu ve güney Avrupa ülkeleridir. $\mathrm{Bu}$ ülkelerde yaşanan en büyük endişe bankaların sermayelerini geri çekebilecek olmalarıdır. Özellikle eski komünist ülkeler bu endişenin en yoğun yaşandığı yerler olarak dikkati çekmektedir. Öyle ki Uluslararası bankalara fonlarını kaçırmamaları için yerel yardımların dahi yapıldığı tespitleri vardır.

Öte yandan küresel finansal krizin ekonomiler üzerinde yarattığı makro ekonomik göstergelerin bozulmasını minimize etmek için ulusal paralarının değerini piyasalarda oluşan değerden farklılaştırmak amacıyla MB'ları kurlara müdahale etmektedir. Serbest piyasa ekonomisi koşullarının geçerliği olduğu küresel finans piyasalarında merkez bankalarının müdahaleleri piyasa mekanizmasının aksamasına haksız kazanç ve karlara yol açmakta olup küresel platformda tartışmalara yol açmaktadır. Bu tartışmaların başlığı Kur Savaşlarıdır. Dolayısıyla kur savaşları küresel ekonomide ülkelerin ihracatta ve yatırımda daha çekici hale gelmek için para birimlerini diğer güçlü kurlar karşısında düşük seviyede tutmaya yönelik aldıkları politika kararlarıyla başlamıştır. Aslında durgunluktan kurtulmak için, ticareti artırmanın ve/veya dünya ticaret içinde payını yükseltmenin yolu değersizleşmiş kurla beraber ülkelerin gelir düzeylerindeki ve/veya istihdamdaki artışla olası olduğudur.

Küresel finansal krizin ülke ekonomileri üzerinde yarattığı sarsıcı ve yıkıcı etkinin olumsuzluklarını elimine etmek için çözümü dış ticaret (dış talep) gören dünya ekonomileri ticaretteki pazarın paylaşımında pay almanın en kolay yolunun ulusal paranın diğer paralar karşısındaki değer kaybıyla olabileceği düşüncesindedir. Ve bu durumda büyük döviz rezervlerine sahip ülke ekonomileri bu avantajlarını sonuna kadar kullanacaktır(Çin'in yaptığı gibi). Kur savaşları korumacı önlemlerin, küresel ticaret hacminde yeni daralma dalgalarının öncüsü niteliğindedir. Getiriler hızla azalırken risklerin büyümesi, riskten kaçınma dalgalarının daha uzun süreli olmasını engellemenin zorlaşması bu süreci hızlandırmaktadır.

\section{Korumacılığın Olası Sonuçları ve Korumacılığa İlişsin Alınan Önlemler}

Küresel resesyon durumunda, bütün hükümetlerce, "komşunu fakirleştir" ticaret politikasını aynı anda uygulanma riski söz konusudur. GATT gibi uluslararası kuruluşların buna izin vermemesine rağmen, bir ülkede korumacılık önlemlerinin artması, diğer ülkelerin misilleme yapmasına yol açmaktadır. Bu durumda kriz 
döneminde korumacılığın derinleşmesi ve uygulanan önlemlerin süresi uzamasına bağlı olarak, küresel refahın azalması ve ekonomik durumun daha da kötüleşmesi söz konusudur. Baldwin “in çalışmasına göre finansal krizin yaşandığı 2008 ie in ilk yarısında, WTO üyelerince yapılan anti-damping uygulamalarında \%40 artış görülmüştür ( Baldwin, 2008). Dolayısıyla bu rakam, küresel resesyon koşullarında ortaya çıkan ortak hareketin bir göstergesi olarak da kabul edilebilir (WTO, 2009:34).

$\mathrm{Bu}$ bağlamda artan korumacılık eğilimine karşı dünyanın çeşitli ülkelerinden oldukça önemli tepkiler de yükselmektedir. 2008'de patlak veren küresel krizden sonra yapılan G-20 toplantılarında üye ülkeler, resesyonun 1930'lardakine benzer bir depresyona dönüşmemesi için uluslararası ticaretin önündeki engellerin kaldırılması gerektiği görüşünü dillendirdiler. Bu görüşte içgüdüsel şekilde gündeme gelen korumacılık söylemlerine karş1 tepkilerin ortaya çıkmasının ardında 1929 Büyük Buhranı deneyimi yatmaktadır. 1930'larda ABD'de başlayan ve dilimize 'komşunun canı çıksın' şeklinde çevirebileceğimiz 'beggar thy neighbor' deyimiyle özetlenen korumacı politikalar daha sonra Avrupa ülkelerine de sıçramış ve Büyük Buhran'ın daha da derinleşmesine neden olmuştur. Krizle mücadelenin ülkeler arası dayanışma yerine her ülkenin kendi duvarları arkasına çekilerek yapılması, önce bir ekonomik yıkıma sonra da savaşa yol açmıştır (Yılmaz, 2009).

İşte gerek 1929 krizi deneyimi, gerekse AB'nin komşuluk politikasıyla hedeflenen ekonomik entegrasyonunun dahi, kriz yüzünden tehlikeye girmesi dünya ekonomisinin deglobalizasyon' denilen yeni bir döneme doğru ilerlediğini göstermiş bu nedenle korumacılığa karşı AB 'nde de seslerin yükselmesine yol açmıştır Bu gelişmeler üzerine Avrupa Komisyonu Başkanı Jose Manuel Barroso ise 2008 yılının son AB zirvesinin ardından, küresel ekonomik krize yönelik "Ya birlikte yüzeceğiz ya birlikte batacağız" yorumunu yapmış ve yaşanan krizin korumacılık politikasının yeniden ortaya çıkmasına mazeret olmaması gerektiğini belirtmiştir (EURACTIV, 2012b).

Benzeri olarak OECD, Mart 2000’da hazırladığı raporunda (OECD, 2009) korumacılığın, küresel krizi daha da kötüleştireceği konusunda uyarılarda bulunmuştur. Rapor, altı gelişmekte olan ülkeyi analiz etmiş ve pazarlarını dünya ticaretine açtıktan sonra ekonomilerinin nasıl canlandığını göstermiştir. OECD, ticaret korumacılığının, mevcut ekonomik krizden kurtulmanın tek yolu olmadığını vurgulamıştır. Rapora göre, korumacı önlemlere karşı koymak siyasi olarak doğru olmasa da, dünyayı yaşadığı finansal sıkıntılardan kurtarmak için ekonomik olarak doğrudur ( OECD,2009).

Küresel kriz sonrasında ortaya çıkan ulusalcı yaklaşımlar ve korumacılık önlemleri 2009 yılında Davos’ta gerçekleşen Dünya Ekonomik Forumu'nun da gündem maddelerinden birini oluşturmuştur. Liderler korumacılığın tehlikelerini gündeme getirseler de, uygulamalar şu an için bu yönde ilerlememekte her hükümet öncelikle kendi ekonomisini, kendi şirketlerini ve kendi işçilerini korumayı tercih etmektedir.

Nitekim 14 Haziran 2012'de yayımlanan korumacılık raporunda ,Kasım 2008'den bu yana alınan korumacı önlemlerin (gerek kamusal gerekse özel sektör kaynaklı), çok büyük bir bölümünden bizzat G20 ülkeleri sorumlu olduğu tespiti yapılmıştır. Bu nedenle, G20 ülkelerinin, korumacılığın geriletilmesi için (G20 dışındaki WTO üyelerinin atacağı adımları kesinlikle beklemeden) acilen ortak kararlar alması gerektiği açıkça ortadadır.

Bu bağlamda 18-19 Haziran 2012'de Los Cabos'da yapılan Liderler Zirvesi'nde, önceki y1llarda oluşturulan genel gündem kataloğundan Meksika'nın tercih önceliklerine göre oluşturulan gündeme göre, iktisadi büyümeyi teşvik için finansal sistemin güçlendirilmesi ve finansal erişimin teşvikine ilişkin uluslararası taahhütler ortaya koyulmuştur.

Tüm bu taahhütlere rağmen özellikle 15 Kasım 2008 'de Washington'da yapılan G-20 zirvesinde liderler, en az 12 ay boyunca korumacı önlemlerden kaçınma sözü verirken, gümrük tarifelerini indirecek ve küresel ekonomiye en az 100 milyar dolarlık katkı yapacak olan Dünya Ticaret Anlaşması'nı da tamamlama vaadinde bulunulmasına rağmen verilen bu sözler tutulmamıştır. Hindistan, bu zirveden yalnızca 3 gün sonra kendi çiftçilerini korumak amacıyla soya fasulyesi yağı ithalatında uygulanan vergiyi yüzde 20 artırmıştır. Küresel ekonominin korumacılık ve ticaretin kısıtlanması ile kısır döngüye sürüklenmesi konusunda özellikle Çin ve ABD'nin belirleyici olacağı çok açıktır.

\section{Sonuç}

1980’lerden sonra başat bir söylem haline gelen küreselleşme ile birlikte uluslararası alanda serbest ticaret artmıştır. Ancak küresel finans krizi küreselleşmeyi yavaşlatmış gelinen noktada, son 25-30 yıla damgasını vuran küresel düzenin bozulmasında etkin olmuştur. Bazı gelişmiş ülkelerin başını çektiği ve serbest piyasa ekonomisinin mantığına uymayan "korumacı" eğilimler küresel süreci aşındırmaktadır. Bu politikanın daha ne kadar devam edeceğini ve ne kadar etkili olacağını bugünden kestirmek güçtür. Ancak ekonomik durgunluk derinleştikçe korumacılık çağrılarının daha da yoğunlaşacağını şimdiden görmemiz gerekmektedir. Bu tür eğilimlerin yaygınlaşması küreselleşme sürecinde bir U dönüşüne yol açmasa dahi bir kırılma noktası yaratma potansiyeline sahiptir. Kuşkusuz yaşanan sorunların altında yatan en önemli neden, ilgili ülkelerdeki ekonomik zaafiyet ve bunlara kalıcı ve etkili bir çıkış yolunun bulunamamasıdır. Dolayısıyla korumacı girişimlerin derinliğini ve etkisini bu ülkelerdeki ekonomik gelişmeler belirleyecektir. Korumacılığa karşı en etken silah ülkelerin tek tek sektörlere seçilmiş destek vermesi yerine (yani seçilmiş bazı sektörlere mikro destek değil), 
genel iç talebi artıracak yaygın makroekonomik destek paketleri uygulamayı seçmeleridir. Ancak gelişen ülkelerin çoğunun makroekonomik desteği vermeleri (kamu harcamasını artıracağı için ) oldukça zor olmaktadır. Bu ülkelerde, ekonomik göstergelerin daha da kötüleşmesi ve bunun etkilerinin ekonomik aktörler tarafindan iyice hissedilmeye başlanmasıyla birlikte, uluslararası anlaşmaları ve serbest piyasa ekonomisinin temel mantığını sakatlayan başka, yeni bir takım tartışmalı adımlar da gündeme gelebilecektir. Kuşkusuz bu tür tedbirler, kısa vadede gündelik sorunların çözümüne katkı sağlayabilir, ancak uzun dönemde dünya gerçeklerine uygun bir piyasa oluşturmaktan başka çare görünmemektedir. Bu da, gelişmiş ülkelerin belli oranda refahtan vazgeçmesi anlamına gelmektedir. Dolayısıyla korumacı girişimlerinin derinliğini ve etkisini bu ülkelerdeki ekonomik gelişmeler belirleyecektir.

Görüldüğü üzere kriz gelişmekte olan ülkeleri, gelişmiş ülkelere göre daha fazla etkilemesine rağmen korumacı tedbirlere başvurarak ticaret savaşını ilk başlatan ülkeler daha çok gelişmiş ülkelerdir. Oysaki bu ülkeler oluşturdukları kapitalizmin kalesi niteliğindeki kuruluşların politikaları aracılı̆̆ıla kriz zamanları dışında gelişmekte olan ülkeler üzerinde korumacı politikalara gitmemeleri yönünde baskı yapmış ve kendilerine yeni pazarlar açmıştır. Kriz koşullarında ise en önde kendileri korumacı politikalara başvurarak gelişmekte olan ülkelerin sanayilerinin mal satma imkânlarını sınırlamaktadır. Bu durum gelişmekte olan ülke sanayilerinin krizle birlikte batmasına ve işsizlik sorununun daha büyük boyutlara ulaşmasına yol açmaktadır. Tüm bunlar göstermektedir ki gelişmekte olan ülkeler kriz koşullarını dahi kendi faydalarına çevirebilme imkânı bulmaktadır. Yani korumacılık politikaları gerçekte gelişmiş ülkeleri korumaktadır.

\section{Kaynakça}

- Adda, Jadques. 2002. Ekonominin Küreselleşmesi, Çev.İneci S, İletişim Yayınları, İstanbul

- Acar Mustafa . 2010. "İktisadın Ezeli Sorunsalı: Serbest Ticaret mi? Korumacılık mı?”, http://www.muhasebetr.com/makaleler/007/, 07.010.2010.

- Baldwin, Richard. 2008. “The Crisis and Protectionism: History Doesn’t Repeat İtself, But Sometimes it Rhymes”, Richard B., Evenett S.,(edts.), What World Leaders Do to Halt the Spread of Protectionism, VoxEU.org Publishing (31-33) .

- Cusolito, Ana.Paula and Hollweg Claire H.2013. Trade Policy Barriers :An Obstacle to Export Diversification in Eurasia, WB, Policy Research Working Paper, 6434,May

- Dadush, Uri, 2009. "Resurgent Protectionism: Risks and Possible Remedies", Carnegie Endowment for International Peace - Policy Outlook, March . http://carnegieendowment.org/files/Resurgent_Protectionism.pdf

- Efere Price. 2002. “Trade \& Protectionism”, International Business, Trans-Atlantic College, London, http://www.bayelsa.org.uk/pdf/bsup-international-businesstrade-and-protec tionism.pdf .

- Evenett, See. 2010a. Section 1: Global Overview and Perspectives on the Gulf Region Will Stabilisation Limit Protectionism? The 4th GTA Report - A Focus on the Gulf Region, CEPR Publishing.

- Evenett, See. 2010b. The Global Overview: Has Stabilisation Affected The Landscape of Crisis-Era Protectionism, Evenett S.,(edt.), Will Stabilisation Limit Protectionism? The 4th GTA Report - A Focus on the Gulf Region, (17-30), CEPR Publishing.17-23

- Gamberoni Elisa. and Newfarmer Richard. 2009. Trade Protection: Incipient but Worrisome Trends, World Bank International Trade Department Trade Notes, 37, March .

- Global Trade Alert, 2013. http://www.globaltradealert.org

- Hufbauer, Gary Clyde. and Stephenson Jensen \& Sherry 2009, "Trade Policy in a time of Crisis Suggestion, for Development Countries" CEPR Policy İnsight,33, May,p.1

- IMF, 2009. World Economic Outlook October 2009 - Sustaining the Recovery, Washington, DC: IMF Publishing.

- IMF, 2011. World Economic Outlook -April 2011 - Tensions from the Two-Speed Recovery Unemployment, Commodities, and Capital Flows, Washington, DC: IMF Publishing.

- Kalaycı, irfanİ. 2011. "2008 Küresel Finans Krizi Sonrasında Dış Ticarette Korumacılık: Paradigma”, Maliye Dergisi, 161, Temmuz -Aralık 2011Kayması (mı?)

- OECD, 2009. OECD Economic Outlook Interim Report, France, March.

- Robert, Russell D. 2001. The Choice: A Fable of Free Trade and Protectionism. 2nded. New Jersey: Prentice Hall.

- Rodrik,Dani 2009. "Yükselen Korumacilık Efsanesi”, Radikal Gazetesi, http://www.radikal.com.tr/yazarlar/dani_rodrik/yukselen_korumacilik_efsanesi-964534

- Rodrik,Dani.2011. Akılı Küreselleşme,Efil Yayınları Ankara. 
- Stiglitz, Joseph. 2010, "No Time for a Trade War", June 4, http://www. projectsyndicate.org/commentary/stiglitz124/English.

- Spilimbergo Antonio and Smansky Steve, Blanchard Oliver,Cottarelli Carlo 2008. Fiscal Policy For The Crisis, IMF, SPN 08/01

- TÜRMOB 2009. "Korumacılık Eğilimleri Krizi Derinleştiriyor”, Bilanço,149, Mart 2009, s.14-17.

- World Bank 2012. Global Antidumping Database. Data Available Up To 2011.

- WTO. (2009), World Trade Report 2009 - Trade Policy Commitment sand Contingency Measures, Geneva: WTO Publishing.

- YILMAZ, K.(2009), “Küresel Kriz, Durgunluk ve Artan Korumacılık Eğilimi”, EAF Politika Notu 09-01 Mart.

- $\quad$ TURKAK, 2012.www.turkak.org.tr/TURKAKSITE/DuyuruListe.aspx,

- $\quad$ EURACTIV, 2012a. www.euractiv.com.tr/ticaret-ve-sanayi/link-dossier/ab-ve-korumacilik-000067.

- EURACTIV, 2012b.www.euractiv.com.tr/finansal-hizmetler/link-dossier/ab-ve-korumacilik-000067. 


\title{
Avrupa Komşuluk Politikası’nın Ülkeler Üzerindeki Ekonomik Etkileri
}

\section{Economic Effects of European Neighborhood Policy on Countries}

\author{
Ph.D. Candidate Esra Ballı (Çukurova University, Turkey) \\ Gülçin Güreşçi Pehlivan (Dokuz Eylül University, Turkey
}

\begin{abstract}
After the fifth enlargement of European Union in 2004 and with the expansion of European Unions borders and new neighbors, it became one of the important policies to provide security, stability and prosperity, and develop relationship between neighborhood countries. Although, enlargement process provide some opportunities to the member states of European Union, it brings about some difficulties. The differences at the life standards, environment, public health, prevention and combating organized crime between European Union and neighbor countries caused to create new policies. European Neighborhood Policy was launched in 2004, and consists of 16 countries, namely: Israel, Jordan, Moldova, Morocco, The Palestinian Authority, Tunisia, Ukraine, Armenia, Azerbaijan, Egypt, Georgia, Lebanon, Algeria, Syria, Libya and Belarus. European Union and the partner country sign the Partnership and Cooperation Agreements or Association Agreements, and then the Agreement Action Plans are mutually adapted. Action Plans include privileged relationship, mutual commitment to common values, democracy and human rights, legal and market economy principles, good governance, sustainable development, energy and transportation policies. Within the framework of European Neighborhood Policy, the main aim is to arrange the relationship between the neighbors of European Union. In this study, economic effects of the European Neighborhood Policy will be examined for the relevant countries.
\end{abstract}

\section{Giriş}

AB'nin 2004 yılında Litvanya, Slovenya, Macaristan, Çek Cumhuriyeti, Polonya, Estonya, Letonya, Malta ve Kıbrıs'ın katılımıyla gerçekleşen son genişleme dalgası değişik firsat ve tehditler içeren bir coğrafya ile karşılaşması, Birliği farklı politika arayışlarına itmiştir.. Soğuk Savaş sonrasında AB'nin doğusunda meydana gelen gelişmeler ve özellikle bölge ülkeleri arasında artan iktisadi ve ticari faaliyetler, $\mathrm{AB}$ açısından memnuniyet verici olmuştur ancak son genişleme dalgasıyla birlikte yeni negatif etkiler ortaya çıkmaya başlamıştır. Primatarova'ya göre $\mathrm{AB}$ ülkeleri ve $\mathrm{AB}$ ülkeleri dışında kalan diğer ülkeler arasında yeni bir 'Demir Perde'nin oluşma ihtimali, yakın gelecekte karşılaşılması muhtemel sorunlardan biri olacaktır. 2004 yılında Hollanda'da Dışişleri Bakanı görevini yürüten Bernard Bot, bu durumu şöyle açıklamaktadır: "AB genişlemesi ile oluşan yeni sınırlar ile birlikte sınırın dışında kalan halkların dışlanmışlık hissi ve sınırın dışında kalan insanların gelişmiş yaşam standartlarından uzak olmaları nedeniyle AB'ye yasal olmayan yollardan girmeye çalışmaları sebebiyle oluşacak sınır güvenliği ve göçmen kontrolleri yeni bir Demir Perde yaratmamalıdır. Bunun yanında yeni metaforlar da oluşmuştur: ‘Avrupa Kalesi', 'Schengen Duvarı', ‘Avrupa ile Büyük Duvar' v.b.” (Aktaran Primatorava, 2005). Christopher Hill’e göre genişlemenin AB diş politikasında neden olduğu en önemli sonuç, sınırların ulaştığı boyuttur. AB Komisyonu genişlemeyle beraber sınırın her iki yakasında oluşacak olan farklılıkların nasıl bir problem oluşturacağını sorgulamaya başlamıştır. (Aktaran Sönmez, 2010).Bu söz konusu firsat ve zorluklara yönelik projeler geliştirilmiş ve bunlar üzerinde çalışmalar yapılmıştır. Yapılan çalışmalar sonucunda Avrupa Komisyonu'nun dış ilişkilerden sorumlu üyesi Benita Ferrero-Waldner 2004'te başlayan Avrupa Komşuluk Politikası (AKP-European Neighbourhood Policy) ile ilgili yaptıkları çalışmaları 3 Nisan 2004 'te açıklamıştır. Ardından 12 Mayıs 2004 tarihinde ise Komşuluk Politikasının temel belgesi niteliğinde olan “Avrupa Komşuluk Politikası Strateji Belgesi” yayımlamıştır. Avrupa Komşuluk Politikası 16 Avrupa komşu ülkesinde siyasi ve ekonomik reformları desteklemektedir.

AB’nin Komşuluk Politikası, AB’nin aday ülke statüsünde olmayan yakın komşuları olan İsrail, Ürdün, Moldavya, Fas, Tunus, Filistin, Ukrayna, Ermenistan, Azerbaycan, Mısır, Gürcistan, Lübnan, Cezayir, Suriye, Libya ve Belarus olmak üzere toplam on altı ülkeyi kapsamaktadır. Söz konusu ülkeler ile Ortaklık Antlaşmaları imzalanmakta, daha sonra da bu antlaşma çerçevesinde Eylem Planları hazırlanmaktadır. Eylem Planları'nın temel unsurları ise ortak değerlere bağlılık, daha etkili siyasi diyalog, ekonomik ve sosyal kalkınma politikası, ticaret ve iç pazar, enerji ve ulaşımdır.Eylem Planları çerçevesinde ortak değerlere bağlılık ile demokrasi, hukukun üstünlüğü, insan haklarına ve temel özgürlüklere saygı gibi ortak değerler kastedilmekte ve bu konulardaki ülkelerin bağlılık seviyeleri göz önünde bulundurulmaktadır. Ortak Güvenlik Politikası ile de bağlantılı olarak, daha etkili siyasi diyalogun yaratılması hususu da Eylem Planlarına eklenmiştir. Bu çerçevede, dış politika ve güvenlik konuları kapsamında, özellikle bölgesel ve uluslararası krizlerin önlenmesi, kriz yönetimi ve ortak güvenlik tehditleri gibi konularda anlaşmalar öngörülmektedir. Bir diğer unsur olan ekonomik ve sosyal kalkınma politikası ile ticaret ilişkilerinin yanı sıra, mali ve teknik yardımların arttırılmasını içeren ekonomik hususlar yer almaktadır. Bu süreçte elde edilen ekonomik faydalar ise doğrudan ve dolaylı faydalar 
olmak üzere ikiye ayrılmaktadır. Tarifelerin ve tarife dışı engellerin kaldırılması ve piyasa bütünleşmesi sağlanması gibi hususlar doğrudan faydalar kapsamına girmektedir. Ekonomik uygulamaların AB'nin ortak politikalarına yaklaştırılması suretiyle bu ülkelerdeki yatırım ortamının iyileştirilmesi ve özel sektörün gelişimi açısından daha saydam ve istikrarlı bir ortam oluşturulması gibi komşu ülkelere daha fazla ekonomik katkı sağlayacak hususlar ise dolaylı faydalar kapsamındadır. Ticaret ve iç pazar konusundaki politikalar, ticaretin serbestleşmesini ve bölgesel bütünleşmeyi sağlayacak çeşitli araçları içermektedir. Bu bağlamda, Dünya Ticaret Örgütüne üyelik Avrupa Komşuluk Politikası kapsamındaki öncelikler arasında yer almaktadır. Enerji temininin güvenliği konusunda komşu ülkelerle ortaklık hayati bir önem taşımaktadır. Zengin petrol ve doğalgaz kaynaklarıyla (Rusya, Hazar Havzası, Orta Doğu ve Kuzey Afrika) çevrelenmiş olan AB, dünyanın en büyük enerji ithalatçısı ve ikinci büyük enerji tüketicisi konumunda bulunmaktadır. Bu nedenle, Eylem Planları enerji konusunda işbirliği ve diyalogu arttırmak üzere somut adımlar içermektedir. Ayrıca, AB ve komşu ülkeler arasındaki ticaret ve turizm faaliyetlerinin artması için daha etkili ve istikrarlı ulaşım sistemlerinin kurulması gerekmektedir.

\section{2 Üyelik Perspektifi Olmayan Avrupa Komşuluk Politikası}

AB'nin, neden AKP'ye ihtiyaç duyduğunun sorgulanması son derece önemlidir. Casas-Cortes, vd, (2012)'e göre AKP ile Avrupa'nın çevresinde AB'ye üyelik perspektifi içermeyen fakat komşu ülkelerle ekonomik uyum ve göçmen kontrolü sağlamaya yönelik iki amaç bulunmaktadır. AKP ile ekonomik açıdan refah ve yasal göç akımlarının düzene konulması amaçlanılmaktadır. AKP, AB sınırlarında barışın ve istikrarın sağlaması amacıyla dizayn edilmiştir. AB bu ülkelere AKP çerçevesinde anlaşma yapılan ülkelere karşı bir taraftan 'Avrupa Kalesi' davranışı sergilerken diğer taraftan yasa dışı göçle, uluslararası suçlarla ve insan kaçakçılığıyla mücadele edebilmek için çözüm yolları üretmeye çalışmıştır. Birlik, AB'ye aday ülkelere AB'nin iç pazarına katılma gibi ekonomik kazançlar sağlama sözü vererek ülkelerin ekonomik ve politik sistemlerini AB üyesi ülkelere göre düzenlemelerini sağlayabilmektedir. Böylece aday ülkeler ileride gerçekleşebilecek tam üyelik nedeniyle, kendi ülkeleri içinde gerekli reformları gerçekleştirmektedirler. Bu noktada göze çarpan ise geçmiş dönemlerde güdülen genişleme politikasının bu sefer gerçekleştirilemeyeceğiydi. Geçmişte, komşulara sunulan tam üyelik şansı bu sefer bulunmamaktadır. Ayrıca söz konusu komşuların gerekli reformları gerçekleştirebilmeleri için ihtiyaç duydukları motivasyon da mevcut değildi. Daha önce bu motivasyon tam üyelik şansı aracılığıyla sağlanmaktaydı (Comelli, 2005).

AKP, dış politik bir araç olarak kullanılarak güvenliğin, AB çevresine yayılmasını amaçlamaktadır. Daha geniş Avrupa, AB dış politikasının önemli bir açılımı haline gelmiştir. Kısacası AKP, AB'nin güvenlik alanındaki rolünü, genişlemenin ötesine taşımak için önemli bir adımdır. Söz konusu politika, çevre ile iyi komşuluk ilişkileri oluşturacak ve genişlemenin tamamlayıcısı olmasının yanı sıra genişleme seçeneğinin yerine de kullanılacaktır. AKP ekonomi ve güvenlik araçlarını kullanan ve iyi yönetimle, hukukun üstünlügünü çevrede geliştirmeyi amaçlayan bir dış politika sistemi olacaktır. Argümanları, genişlemeyle aynı olmakla beraber daima genişlemenin bir adım gerisinde olacaktır. (Arıkbuka, 2006).

AKP, Kuzey Afrika, Akdeniz, Güney Kafkasya ve Doğu Avrupa ülkelerine finansal ve teknik yardımların yanı sıra Ortak Pazara giriş imkânı sunarken bunun karşılığında bu ülkelerin AB'ne üye ülkelerin ekonomik ve politik yapılarına yapacakları reformlarla benzemelerini istemektedir. Bu özellikleri ile AKP, 1995 yılında oluşturulan Barselona Süreci'nin daha ilerisine gitmektedir. Barselona Süreci, Akdeniz ülkelerine üyelik perspektifi vermeden; teknik yardım, ekonomik ve siyasi reformlarda destekte bulunulması konularını kapsamaktadır. Bu kapsamda 2006 yılı sonunda 9 milyar euro tutarında harcama yapmasına rağmen geri dönüşüm çok az olmuştur. Ayrıca o bölgede ekonomik durgunluk oluşmuş ve politik reformlar gerçekleşmemiştir. Toplumsal trendlerde de radikal İslama doğru kayışlar endişe verici boyutlara ulaşmıştır. Bu sonuçlara benzer şekilde AKP, eğer Doğu Avrupa'daki ve Güney Kafkasya'daki ülkelere hemen hemen Barselona Süreci'nin Güney Akdeniz ülkelerine sunduğu aynı imkanları sunarsa aynı şekilde olumlu olmayan sonuçların alınması tehlikesi ile karşı karşıya olunacaktır (Cottrell, 2005). Bu nedenle AKP oluşturulurken geçmiş deneyimler ve uluslararası mevcut ilişkiler iyi değerlendirilmelidir. Bunun yanısıra AKP dahilindeki ülkelere uzak gelecekte olsa bile üyelik perspektifinin sunulmaması nedeniyle ülkelerin komşuluk politikası ile yetinip yetinmeyeceği de ayrı bir sorundur. Bu bağlamda, Ukrayna gibi bir gün AB'ye tam üyeliği amaçlayan ülkelerin komşuluk politikasını benimsememeleri ve gerekli önemi vermemeleri de söz konusu olabilecektir. Pardo (2004)'e göre AKP çerçevesinde farklı ülkelere aynı firsatların sunulup ve her birinden aynı davranışın beklenmesi anlamlı değildir. AKP'de ülkeler arasındaki farklılıklara vurgu yapacak farklı politikalar güdülmelidir. AKP'nin ana amaçlarına ulaşabilmesi için koşullarda ve gerekli zaman hususunda gerekli düzenlemeler yapılmalıdır Tüm bu unsurlar sağlandıktan sonra ancak AKP'nin başarılı olması beklenebilir.

Avrupa Birliği'nin Ortadoğu ve Kuzey Afrika ülkeleri üzerine diş politika yapımı ile ilgili çalışmalara bakıldığına sıklıkla söz edilen durum AB'nin bu bölgelerde demokrasinin geliştirilmesi yönünde karşılaşmış olduğu başarısızlık ön plana çıkmaktadır. AB'nin bu hususta başarısızlığı farklı bilim adamları tarafından AB'nin kurumsal eksikliği veya AB'nin politikaları gereğince kendi realist ihtiyaçları ve çıkarları doğrultusuna hareket ettiği şeklinde açıklanmaktadır. Bununla birlikte, AB'nin demokrasinin yüceltilmesi konusunda isteğinin 
sahici olduğunu ve bu bölge ülkelerdeki rejimler tarafından bu durumun başarısızlığa uğradığı savı dile getirilmektedir. Lübnan'a bakıldığı zaman diğer Arap ülkelerindeki aynı otoriter kurumlara ve karakterlere sahip olmamasının yanı sıra ilke olarak Lübnan yönetiminin de daha yenilikçi olduğu göz önüne alındığında AB'nin stratejisini geliştirmede daha başarılı olması beklenmektedir (Seeberg, 2009). AB - Lübnan Eylem Planı'nda Lübnan'da demokrasinin gelişmesi yönünde $\mathrm{AB}$ 'nin isteği bulunmakta olmasına rağmen bu başarının elde edilememesinin Seeberg'e göre temel iki nedeni bulunmaktadır. Bunlardan birincisi, Lübnan siyasi elitinin 1989 yılında imzalanmış olan Taif Anlaşması'nın uygulanması konusunda yaşamış olduğu sıkıntılar, ikinci olarak da Lübnan siyasi elitinin sahip olduğu bir taraftan o dönemin Başbakanı Fouad Siniora diğer taraftan muhalefetteki Hizbullah nedeniyle 'iki başlıllk' sorunudur.

AKP ile ilgili yapılanan başlıca çalışmaların aşağıdaki sonuçlara ulaştıkları görülmektedir: Freyburg, vd, (2011)'nin AKP çerçevesinde yer alan Ürdün, Moldova, Fas ve Ukrayna'nın demokratik yönetim için AB ile olan fonksiyonel sektörel ortaklık koşullarını rekabet, çevre ve göçmen politikası açısından inceledikleri çalışmada, siyasi liberalizasyon, üyelik isteği ve coğrafik olarak ülkelerin konumunun demokratik yönetimi açıklamadığını, demokratik yönetim kurallarının düzenlenmesi, fonksiyonel işbirliğinin kurumsallaşması gibi sektörel şartlar demokratik yönetimi desteklediğini göstermişlerdir. Browning ve Christou (2010)'nin Ukrayna ve Belarus'un $\mathrm{AKP}$ üzerinden $\mathrm{AB}$ ile olan ilişkileri incelediği çalışmada AKP'nin etkililiğinin $\mathrm{AKP}$ çerçevesinde olan ülkenin konumu ve o ülkenin kendileri nerede konumlandırdığı ve bunun yanında o ülkelerin amaçlarına ulaşmak için uygulayacakları stratejiler olmak üzere iki faktöre bağlı olduğunu ileri sürmektedir. Gavrich vd (2010) AKP-Ukrayna eylem planının etkiliğini ölçmek amacıyla yapmış oldukları çalışmada AKP'nin üç boyutu olan demokrasiyi yüceltme, ekonomik işbirliği, adalet ve içişleri ele alınmıştır. Bu çerçevede bağımsız değişken olarak bu üç değişkenin bağlı olduğu $A B$ 'nin taleplerinin içeriği ve açıklığı, teşvik ve ödül, direkt finansal destek, bağlantının düzeyi ve formu ve yerel düzeyde talep ve ödüllere karşı algı ve bağımlı değişken olarak Avrupalaştırılmış Komşuluk (Neighbourhood Europeanization) kullanılmıştır. Yeni kurumsalcılık yaklaşımın rasyonel seçim ve inşacı bakışı altında yapılan uygulama sonucunda $A B$ ve Ukrayna arasındaki işbirliğinin önceliklerinde, özellikle enerji işbirliği ve yukardan aşağıya demokratikleşme konusunda çok önemli uyumsuzluklar olduğu görülmüştür. En iyi ödül üyelikten sonra vizesiz rejim olarak kapsamlı Serbest Ticaret Bölgesi’nin önünde yer almaktadırlar. Yerel algı açısından ise aşağıdan yukarıya demokratikleşme ve ekonomik işbirliği ön plana çıkmaktadır. Analize göre, Ukrayna'da üyelik perspektifinin olmaması sebebiyle oluşan düş kırıklığına rağmen, üyelik sorunu çözülene kadar daha derin entegrasyon için motive edecek unsur bulunmaktadır.

\section{AKP'nin Komşu Ülkelerin Ekonomileri Üzerindeki Etkileri}

AKP kapsamındaki ülkelerdeki bazı ekonomik ve sosyal göstergelerin incelenmesi bize bu ülkeler ve AKP sonrası meydana gelen değişiklikler hakkında bilgi vermesi açısından önem arz etmektedir. İnsani Gelişme Endeksi (İGE) ülkelerin gelişmişlik düzeyleri hakkında bilgi vermesi açısından önemlidir. İGE'nin üç temel bileşeni vardır. Bunlar sağlık, eğitim ve hayat standartlarıdır. Bir ülkenin yalnızca kişi başına düşen gelir düzeyine bakılarak o ülkenin gelişmiş bir ülke olduğunu söylemek doğru değildir. Bu değerlendirmeyi yapabilmek için eğitim ve sağlık gibi bazı göstergelere de ihtiyaç duyulmaktadır. Çünkü bir ülke, kişi başına düssen gelir düzeyi açısından ilk sıralarda yer alabilir; ancak, diğer faktörler de hesaplamaya dahil edildiğinde aslında o ülkenin insani gelişme düzeyinin düşük olduğu görülebilir. Aşağıdaki tabloda AKP kapsamındaki ülkelerin $\mathrm{AB}$ ile bu bağlamdaki ilişkilerinin başladığı 2005 yılı ve de verilerin elde edilebildiği en yeni tarih olan 2012 yılı İGE verileri görülmektedir.

\begin{tabular}{|l|l|l|}
\hline Ülke & 2005 İGE & 2012 İGE \\
Azerbaycan & - & 0.734 \\
Beyaz & & \\
Rusya & 0.730 & 0.793 \\
Fas & 0.558 & 0.591 \\
Filistin & - & 0.670 \\
Gürcistan & 0.713 & 0.745 \\
İsrail & 0.885 & 0.900 \\
Libya & 0.746 & 0.769 \\
Lübnan & 0.714 & 0.745 \\
Misir & 0.625 & 0.662 \\
Mordavya & 0.636 & 0.660 \\
Suriye & 0.618 & 0.648 \\
Tunus & 0.679 & 0.712 \\
Ukrayna & 0.718 & 0.74 \\
Ürdün & 0.684 & 0.700 \\
\hline
\end{tabular}

Tablo 1: Insani Gelişme Indeksi (Kaynak: Uluslar arası Para Fonu, Dünya Ekonomik Gelişme Veritabanı) 
Bu ülkeler içinde en yüksek İGE'ye sahip olan ülkeler sırasıyla İsrail, Beyaz Rusya ve Libya'dır. En düşük İGE'ye sahip ülkeler ise sırasıyla Fas, Suriye ve Mısır'dır. 2005 yılında dünya ortalaması 0.666 iken 2012 yılında 0.694'tür. AKP kapsamındaki ülkelerin beşinin İGE'si ise hem 2005 yılında hem de 2012 y1lında dünya ortalamasının gerisinde kalmıştır. Ancak Tablo 1'deki tüm ülkelerde AKP'nin başladığı 2005 yılından sonra İGE'lerde gözlenen artış, bu ülkelerde hayat standartları anlamında AKP'nin olumlu etkiler doğurduğunu göstermesi açından önem taşımaktadır.

AKP kapsamında komşu ülkelerle ekonomik ilişkilerin geliştirilmesi amacına yönelik olarak bu ülkelerde doğrudan yabancı yatırımların AKP öncesi ve sonrası durumlarına bakılması önem taşımaktadır. Uluslararası Para Fonu, Dünya Ekonomik Gelişmişlik Veritabanı verilerine göre AKP kapsamındaki ülkelerde doğrudan yabancı yatırımları 2005 yılından 2012 yılına kadar olan süreçte en çok artan ülkeler sırasıyla Beyaz Rusya, Ermenistan, İsrail, Suriye, Gürcistan, Cezayir ve Libya olmuşken, bazı ülkelerde ise önemli düşüşler görülmüştür. Bu ülkeler ise sırasıyla Mısır, Lübnan, Azerbaycan, Ürdün, Tunus, Moldavya ve Ukrayna'dır. Bu veriler sadece $\mathrm{AB}$ ülkelerinden bu ülkelere olan doğrudan yabancı yatırım miktarını göstermemekle beraber, yine de bu ülkelerin AKP kapsamında AB ile olan ilişkilerinin geliştirilmesinin olumlu etkileri sonucu doğrudan yabancı yatırımlarında önemli artışların gerçekleştiği bilinmektedir. Düşüş yaşanan ülkelerde ise güvenlik problemleri, siyasi istikrarsızlıklar ve 2008 dünya ekonomik krizinin olumsuz etkileri söz konusu olmuştur.

AKP'nin komşu ülkeler üzerindeki ekonomik etkilerini görebilmek için komşu ülkelerin AB ülkelerine olan ihracatının 2005 yılından 2010 yılına kadar olan dönemdeki büyüme oranlarını hesaplamak faydalı olacaktır. Aşağıdaki tabloda Uluslararası Para Fonu, Dünya Ekonomik Gelişmişlik Veritabanı verilerine göre bu dönemdeki ilgili ülkelerin $\mathrm{AB}$ ülkelerine olan ihracatlarının büyüme oranları hesaplanmıştır.

\begin{tabular}{|l|l|}
\hline Ülke & İhracat Büyüme Oranı \\
\hline Cezayir & 2.080716518 \\
\hline Misır & 106.466228 \\
\hline Fas & 20.10252168 \\
\hline Tunus & 34.14234454 \\
\hline İsrail & 34.0852276 \\
\hline Ürdün & 32.32776491 \\
\hline Lübnan & 238.8326941 \\
\hline Filistin & -19.83388418 \\
\hline Suriye & 21.95895109 \\
\hline Beyaz Rusya & 95.95487821 \\
\hline Moldavya & 57.83297965 \\
\hline Ukrayna & 57.79475826 \\
\hline Ermenistan & 109.8084066 \\
\hline Azerbaycan & 47.00674163 \\
\hline Gürcistan & 92.03661419 \\
\hline
\end{tabular}

Tablo 2: Ihracat Büyüme Oranlarl

\begin{tabular}{|l|l|}
\hline Ülke & İthalat Büyüme Oranı \\
\hline Cezayir & 70.87406099 \\
\hline Misır & 222.5853683 \\
\hline Fas & 47.79027168 \\
\hline Tunus & 38.52757546 \\
\hline İsrail & 53.5648437 \\
\hline Ürdün & 16.15452153 \\
\hline Lübnan & 60.9249749 \\
\hline Filistin & 36.44942963 \\
\hline Suriye & 261.8616063 \\
\hline Beyaz Rusya & 95.95487821 \\
\hline Moldavya & 57.83297965 \\
\hline Ukrayna & 57.79475826 \\
\hline Ermenistan & 109.8084066 \\
\hline Azerbaycan & 47.00674163 \\
\hline Gürcistan & 92.03661419 \\
\hline
\end{tabular}

Tablo 3: Ithalat Büyüme Oranlarl

Tablo 2'deki ihracat büyüme oranlarına bakıldığında AKP kapsamındaki ülkelerin Komşuluk Politikasının başladığı 2005 yılından sonraki dönemde AB ülkelerine olan ihracatlarında önemli ölçüde artış gözlemlenmiştir. 
$\mathrm{Bu}$ ülkelerden sadece Filistin'in AB ülkelerine ihracatında yüzde 19'luk bir düşüş söz konusudur. Bu veriler AKP'nin komşu ülkelerin ekonomileri üzerindeki olumlu etkilerini göstermesi açısından çok önemlidir. 2005 yılı sonrası komşu ülkelerin $\mathrm{AB}$ ülkelerine ihracatı artış göstermiştir. $\mathrm{Bu}$ artış $\mathrm{AB}$ ülkeleri ile ticari ilişkileri geliştirmesi açısından önemli etkiler doğurmuştur. Aşağıdaki tabloda ise komşu ülkelerin AB ülkelerine olan ithalat büyüme oranları görülmektedir.

Tablo 2 ve 3 karşılaştırıldığında sadece Ürdün ve Lübnan'da ithalat artışının ihracat artışından daha yüksek olduğu görülmektedir. $\mathrm{Bu}$ durum tüm komşu ülkelerin $\mathrm{AB}$ ülkelerinden ithalatının arttığını ancak bu artışın Ürdün ve Lübnan'da ihracat artışının gerisinde kaldığını göstermektedir. Buna göre bu iki ülkenin AB ülkeleri ile dış ticareti pozitif etki doğurmakta, yani ülkelerine giren yabancı para miktarını arttırmaktadır. Bu iki tablodan da görüldüğü gibi AKP'nin etkisiyle AB ülkeleri ve komşu ülkeler arasındaki dış ticaret önemli ölçüde artmıştır.

\begin{tabular}{|c|c|c|c|c|c|}
\hline $\begin{array}{l}\text { AKP Ortak } \\
\text { Ülke }\end{array}$ & $\begin{array}{l}\text { Sözleşme İlişkisinin } \\
\text { başladığı tarih }\end{array}$ & $\begin{array}{l}\text { AKP Ülke } \\
\text { Raporu }\end{array}$ & $\begin{array}{l}\text { AKP Eylem } \\
\text { Planı }\end{array}$ & $\begin{array}{l}\text { AB Tarafindan } \\
\text { Benimsenmesi }\end{array}$ & $\begin{array}{l}\text { Ortak Ülke Tarafından } \\
\text { Benimsenmesi }\end{array}$ \\
\hline Azerbaycan & $\begin{array}{l}\text { Ortaklık ve İşbirliği } \\
\text { Anlaşması-1999 }\end{array}$ & Mart 2005 & 2006 Sonbahar & 13.11 .2006 & 14.11.2006 \\
\hline Beyaz Rusya & - & - & -- & -- & - \\
\hline Cezayir & $\begin{array}{l}\text { Ortaklık Anlaşmas1- Eylül } \\
2005\end{array}$ & 1 & - & - & -- \\
\hline Ermenistan & $\begin{array}{l}\text { Ortaklık ve İşbirliği } \\
\text { Anlaşması-1999 }\end{array}$ & Mart 2005 & 2006 Sonbahar & 13.11 .2006 & 14.11.2006 \\
\hline Fas & $\begin{array}{l}\text { Ortaklık Anlaşması- Mart } \\
2000\end{array}$ & May1s 2004 & 2004 sonu & 21.02.2005 & 27.07.2005 \\
\hline Filistin & $\begin{array}{l}\text { Ara Dönem Ortaklık } \\
\text { Anlaşması-Temmuz } 1997\end{array}$ & Mayıs 2004 & 2004 sonu & 21.02 .2005 & 04.05 .2005 \\
\hline Gürcistan & $\begin{array}{l}\text { Ortaklık ve İşbirliği } \\
\text { Anlaşması-1999 }\end{array}$ & Mart 2005 & 2006 Sonbahar & 13.11.2006 & 14.11.2006 \\
\hline İsrail & $\begin{array}{l}\text { Ortaklık Anlaşması- } \\
\text { Haziran } 2000\end{array}$ & May1s 2004 & 2004 sonu & 21.2.2005 & 11.04 .1005 \\
\hline Libya & - & - & -- & -- & -- \\
\hline Lübnan & $\begin{array}{l}\text { Ortaklık Anlaşması-Nisan } \\
2006\end{array}$ & Mart 2005 & 2006 Sonbahar & 17.10.2006 & Askıda \\
\hline Misir & $\begin{array}{l}\text { Ortaklık Anlaşması- } \\
\text { Haziran } 2004\end{array}$ & Mart 2005 & $\begin{array}{l}2006 \text { Sonbahar } \\
\text { (büyük } \\
\text { çoğunlukla) }\end{array}$ & -- & -- \\
\hline Moldavya & $\begin{array}{l}\text { Ortaklık ve İşbirliği } \\
\text { Anlaşması Temmuz-1998 }\end{array}$ & May1s 2004 & 2004 sonu & 21.02.2005 & 22.02 .2005 \\
\hline Suriye & - & - & -- & -- & -- \\
\hline Tunus & $\begin{array}{l}\text { Ortaklık Anlaşması-Mart } \\
1998\end{array}$ & Mayıs 2004 & 2004 sonu & 21.02 .2005 & 04.07 .2005 \\
\hline Ukrayna & $\begin{array}{l}\text { Ortaklık ve İşbirliği } \\
\text { Anlaşması-Mart } 1998\end{array}$ & Mayıs 2004 & 2004 sonu & 21.02 .2005 & 21.02 .2005 \\
\hline Ürdün & $\begin{array}{l}\text { Ortaklık Anlaşması- } \\
\text { Mayıs } 2002\end{array}$ & Mayıs 2004 & 2004 sonu & 21.02.2005 & $\begin{array}{l}11.01 .2005 \\
02.06 .2005\end{array}$ \\
\hline
\end{tabular}

Tablo 4: Avrupa Komşuluk Politikası Eylem Planlarında Mevcut Durum

\section{Sonuç}

AB'nin genişleyen sınırları çerçevesinde komşularla ilişkileri geliştirebilmek amacıyla oluşturmuş olduğu Komşuluk Politikası yeni bir dış politika aracı olarak karşımıza çıkmaktadır. Genişlemeyle birlikte sınırların iki yakasında kalan ülkeler arasındaki hayat standartları arasındaki farklılıklar, ekonomik açıdan geri kalmışlık, demokrasi, insan haklarının gelişimi gibi faktörlerdeki eşitsizlikler, yasal olmayan yollarla göç, insan kaçakçılığı, organize suçlar olarak AB içerisinde problem yaratabilmektedir.

AKP'nin başarı şansı AB'ye üye olan ülkelerin siyasi durumu ile Komşuluk politikasına dahil olan ülkelerin yapısal, ekonomik ve sosyal faktörlere bağlıdır. Farklı rejimlere sahip ülkelerde Komşuluk Politikası farklı algılanmakta ve AB'nin tehdit algısı ile komşuluk ilişkileri içerisinde bulunan ülkenin tehdit algısı farklı 
olabilmektedir. Bu durumda Avrupa Komşuluk Politikası çerçevesinde ülkelerle yürütülen politikaların ülke gerçeklerini yansıtan, ülke ihtiyaçlarına cevap verebilen, iki taraflı bir plan etrafında hazırlanması Komşuluk Politikası'nın başarıya ulaşabilmesi açısından önem arz etmektedir.

AKP'ye getirilen eleştirilerin başında AB'ye tam üyelik perspektifi olmadan Komşuluk Politikası anlaşmaları yapılan ülkelerin gerekli reformları gerçekleştirme hususunda yeterli motivasyona sahip olmayacakları yönündedir. Doğu Avrupa genişlemesinde o ülkelerde reformların gerçekleştirilmesinde AB'ye tam üyelik perspektifi itici güç olmuştur. Bunun yanı sıra AKP dahilindeki ülkelerin diğer ülkelerle aynı koşullar altında komşuluk politikasına tabi olmak istememesi sorunu da önemli bir problem olmaktadır. Bazı ülkelerin ilerde tam üyelik beklentileri olduğu gibi diğer ülkelerin böyle bir talebi olmayabilmektedir.

AKP'nin komşu ülkelerin ekonomileri üzerindeki etkilerine bakıldığında önemli sonuçlar görülmüştür. Önemli bir gelişmişlik göstergesi olan İGE verilerine göre komşu ülkelerde antlaşmaların yürürlüğe girdiği 2005 yılından 2012 yılına kadar olan süreçte bu ülkelerin İGE'lerinin yükseldiği görülmektedir. Bu da gerek kişi başına düşen gelir gerekse de eğitim ve sağlık alanlarında bu ülkelerde iyi yönde gelişmelerin yaşandığını göstermektedir. Aynı şekilde bu dönemde komşu ülkelerin bir çoğunda doğrudan yabancı yatırımlar artmış; AB ülkeleri ile olan ihracat ve ithalat düzeyleri yüksek oranlarda gerçekleşmiştir. Bu da göstermektedir ki AKP, komşu ülkeler ile $\mathrm{AB}$ ülkelerinin ekonomik ilişkilerini geliştirmekte ve bu ülkeleri hem ekonomik alanda hem de yaşam kalitesi bağlamında daha yüksek bir seviyeye gitmektedir.

\section{Kaynakça}

- Aliboni, R. 2005. “The Geopolitical Implications of the European Neighbourhood Policy”. European Foreign Affairs Review. 10(1), pp.1-16.

- Arıkbuka M. 2006. “Avrupa Birliği’nin Son Genişlemesinin Birlik Dış Politikası’na Etkileri” Yayınlanmış Yüksek Lisans Tezi, Ankara Üniversitesi Sosyal Bilimler Enstitüsü Avrupa Toplulukları Anabilim Dalı

- Bot, B. 2004. "Great Game or European Fair Play? The European Union and the World in the 21th Century”. Speech at the European Studies Centre, St Antony’s College, University of Oxford. http://www.sant.ox.ac.uk/esc/docs/Bernard_Bot.pdf (Erişim tarihi: 05.03.2013)

- Browning, C.S. and Christou, G. 2010. "The constitutive power of outsiders: The European Neighbourhood Policy and The Eastern Dimension”, Political Geography ,29, pp. 109-118

- Casas-Cortes, M., Cobarrubias, S. and Pickles, J. 2012. "Re-bordering The Neighbourhood: Europe's Emerging Geographies of Non-accession Integration”, European Urban and Regional Studies, 20(1), pp. 37- 58

- Comelli, M. 2004. "The Challenges of the European Neighbourhood Policy". The International Spectator. 39(3), pp. 97-110

- Cottrell, R. 2005. "Survey: Meet the Neighbour". The Economist. http://www.economist.com/node/4100576 (Erişim tarihi:06.03.2013 )

- Gawrich, A., Melnykovska, I. And Schweickert, R. 2010. “ Neighbourhood Europeanization through ENP: The Case of Ukraine", JCMS, 48 (5), pp. 1209-1235

- $\quad$ Freyburg, T., Lavenex, S., Schimmelfennig, F., Skripka, T. and Wetzel, A. 2011. "Democracy Promotion through Functional Cooperation? The case of the European Neighbourhood Policy”, Democratization, 18:4, pp. 1026-1054

- Pardo, S. 2004. “Europe of Many Circles: European Neighbourhood Policy”. Geopolitics. 9(3), pp. 731-737.

- Primatarova, A. 2005. "In Search of Two Distinct Tracks for Non-EU Europe and the European Neighbourhood", in Nicolas Hayez et al. (eds), Enlarged EU-Enlarged Neighbourhood: Perspectives of the European Neighbourhood Policy, Bern: Peter Lang, pp. 19-47.

- Seeberg, P. 2009. "The EU as a Realist Actor in Normative Clothes: EU Democracy Promotion in Lebanon and the European Neighbourhood Policy”. Democratization. 16 (1), pp. 81-99.

- $\quad$ Senyücel, S., Güner S., Faath, S. and Matters, H. 2006. "Factors and Perceptions Influencing the Implementation of the European Neighbourhood Policy in Selected Southern Mediterranean Partner Countries". http://www.euromesco.net/euromesco/images/49_eng.pdf (Erişim tarihi:05.03.2013)

- Smith, K. (2005). “The Outsiders: the European Neighbourhood Policy”. International Affairs. 81, pp. 757773.

- Sönmez, S. 2010. “Avrupa Birliğgi’nin Komşu Bölgelere Yönelik Siyasi Açılımı: Avrupa Komşuluk Politikası”. Mustafa Kemal Üniversitesi. Sosyal Bilimler Enstitüsü Dergisi 7 (14), pp.113-122

- T.C. Ekonomi Bakanlığı (2013). www.ekonomi.gov.tr. (Erişim tarihi:05.03.2013).

- Tocci, N. (2005). “Does ENP Respond to the EU's Post Enlargement Challenges?”. The International Spectator. 15(1), pp. 21-32. 


\title{
Türkiye ve Avrasya Ekonomik Topluluğu Ülkelerinin Lojistik Performans İndekslerinin Karşılaştırılması ve Bazı Çıkarımlar A Comparison and some Suggestions for Turkey's and Eurasian
Economic Community Countries' Logistic Performance Index
Scores
}

\author{
Asst. Prof. Dr. Çiğdem Sofyalığlu (Celal Bayar University, Turkey) \\ Asst. Prof. Dr. Burak Kartal (Celal Bayar University, Turkey)
}

\begin{abstract}
Turkey is a bridge between Asia and Europe and this fact provides an opportunity for Turkey, whose exports mostly go to Europe, to diversify its export markets. In this geography, cooperation and integration are needed to sustain and to flourish economic activities. In that sense, Eurasian Economic Community (EurAsEc) is one of the most important economic integrations in the world considering the initiatives of becoming a Customs Union. EurAsEc includes five member and three observer countries while some other Eurasian countries are expected to join this community in the years to come due to its potential advantages. The members of are positive towards a cooperation with Turkey which has a strategic role in many important transport corridors within the Western Europe-Asia transit transport framework. Anyway, the development of international trade depends on logistic performance, logistic infrastructure and effectiveness of logistic sectors of the countries in this region. Therefore, Turkey and EurAsEc countries need to cooperate in overcoming logistics problems to develop international trade. Bearing that in mind, we compared logistic performance indexes of Turkey and EurAsEc countries in our study and we discussed what can be done to improve logistic activities in the region within the framework of mutual cooperation. The findings indicate that a better logistics infrastructure should be available throughout the EurAsEC countries and it is essential to adopt transit pass by EurAsEc countries and to improve the information technology infrastructure to accelerate customs transition.
\end{abstract}

\section{Giriş}

Türkiye'nin 2012 yılı dış ilişkiler gündeminde Avrupa Birliği'ndeki ekonomik sarsıntılar önemli bir paya sahip olmuştur. Türkiye'nin en büyük ekonomik ortağı AB ülkelerinin uzun süredir borç sorunları yaşaması, bu ülkelerdeki dış talebin azalıp, Türkiye'nin bölgeye yaptığı ihracatın da düşmesine neden olmuştur. Bu durum, geçmişte uyguladığı yanlış ihracat politikalarının (ihracatta coğrafi ve sektörel çarpıklıklar) farkında olan Türkiye'yi, (Bilgin, 2005) farklı pazarlara ağırlık verip ihracat pazarlarını çeşitlendirmeye zorlamıştır.

Nitekim 2008 yılında ekonomik krizin baş göstermesiyle birlikte ihracatında daralma yaşayan Türkiye, 2012 yılı itibarıyla ihracatını rekor bir seviyeye getirerek 150 milyar doların üzerine taşımış; bununla birlikte toplam ihracatında AB'nin payı \% 46,2'den \% 38,8'e gerilemiştir (Küresel Stratejik Araştırma ve Takip Portalı ,2013). $\mathrm{Bu}$ durumda söz konusu ülkelerde azalan pazar payının yeni ihraç pazarlarına kaydığını söylemek mümkündür. Bu bağlamda 2002 yılında ihracatımızdaki payı \% 10 olan Ortadoğu'nun 2011 yılındaki payı \% 21, 2012 yılındaki payı ise \% 17.8 olarak gerçekleşmiştir. En önemli ticari ortağımız olan AB ülkelerinde etkisinin halen devam ettiği ekonomik krizin yanında Ortadoğu'da yaşanan siyasi karışıklıklar ve istikrarlı bir seyir izlemeyen petrol fiyatları dünya ekonomisinde belirsizlikleri de beraberinde getirmektedir. Ortaya çıkan bu istikrarsız sürecin Türkiye ihracatına olumsuz bir etkide bulunması muhtemeldir.

Bunun yanında Türkiye, Asya ve Avrupa'yı birbirine bağlayan bir köprü görevi görmekte ve iki farklı kıtayı birleştirerek önemli bir avantaja sahip bulunmaktadır. Bu avantaj, bir yandan Türkiye üzerinden gelişmiş batılı ekonomilere ulaşılabilmesini sağlarken, diğer taraftan eski Sovyet coğrafyasına erişilebilmesini ve bu sayede Türkiye'nin dış pazarını çeşitlendirmesine fırsat vermektedir. (Resmi Gazete, 2013). Sovyetler Birliği döneminde merkezi planlama ile yürütülen ekonomik faaliyetlerin, dağılma sonrasında ortaya çıkan bağımsız devletlerde, yüksek enflasyon ve siyasi/ekonomik istikrarsızlık nedeniyle imkansız hale gelmesi etkin bir iktisadi işbirliği ihtiyacını doğurmuş ve bu dönemde çeşitli ekonomik işbirliği entegrasyonları ortaya çıkmıştır. 10 Ekim 2000 yılında kurulan Avrasya Ekonomik Topluluğu (AvET) en önemli entegrasyon girişimlerinden biridir. Rusya Federasyonu, Beyaz Rusya, Kazakistan, Kırgızistan ve Tacikistan Avrasya Ekonomik Topluluğunun üye, Moldova, Ukrayna ve Ermenistan ise gözlemci statüsündeki ülkeleridir. 2006 yılında Rusya ve Kazakistan öncülüğünde kurulmuş olan Avrasya Kalkınma Bankası ve 1 Ocak 2010 yılından itibaren Rusya Federasyonu, Beyaz Rusya ve Kazakistan arasında yürürlüğe giren Gümrük Birliği anlaşmaları da Merkez Asya ülkeleri arasında ekonomik işbirliğinin sağlanmasında, üye ve gözlemci ülkelere ihtiyaç duydukları desteğin verilmesinde önemli bir girişim olmuştur (Öngel, 2010). Gümrük Birliği üçüncü ülkeler ile yapılan ticareti de kapsamaya başlamıştır. Dünya ekonomisi ve uluslararası ticaret sistemine entegrasyonu kolaylaştırmayı amaçlayan bu işbirliğinin diğer hedefleri; ortak döviz politikası belirlemek, ortak ulaştırma ve altyapı sistemi 
kurmak, mal ve hizmet ticaretine yönelik ortak politikalar belirlemek, yabancı sermaye yatırımları için eşit şartlar sağlamak, üye ülkelerin hukuk sistemleri arasında işbirliğini geliştirmek, eğitim ve sağlı hizmetleri açısından topluluk içinde standardizasyon sağlamak, üye ülkelerin üretim seviyelerini birbirine yakınlaştırmak ve ortak enerji piyasası kurmak şeklinde sıralanabilir (Şanlı, 2010)

Ekonomik entegrasyonlara dahil olmanın dış ticaret ilişkilerini geliştireceği yadsınamaz bir gerçektir. Jeopolitik ve jeostratejik önemi nedeniyle Kazakistan ve Rusya devlet başkanları yaptığı açıklamalarda Avrasya Birliği projesine Türkiye'nin de dahil olmasını istediklerini belirtmişler, bunun gerçekleşmesi durumunda çok büyük bir güce ulaşacaklarının altını çizmişlerdir. Bunda Türkiye'nin Batı Avrupa-Asya transit ulaşım çerçevesinde birçok önemli ulaştırma koridorunun içinde yer almasının önemli bir payı bulunmaktadır. Son yıllarda uluslararası ticaret çerçevesinde Asya Kıtası'nın öneminin artması nedeniyle Avrupa ile Asya arasındaki ulaşım koridorlarının, özellikle demiryolu koridorlarının, kritik bir rol oynayacağı düşünülmektedir. Türkiye'nin bu gelişmelerin içerisinde yer alması kaçınılmazdır (Çekerol ve Kurnaz, 2011).

Türkiye'de bugün Batı yanlısı bir görüş hakim olmakla birlikte, Avrupa ülkelerinin ekonomik krizde olmalarına karşılık Avrasya ülkelerinin gelişmekte olduğu gerçeği birlikte Türkiye Avrasya’ya yönelmeye başlamıştır (Deutche Welle, 2013). Gümrük Birliği anlaşması imzaladığı AB ile bütünleşme sürecinin devam ettiği bir dönemde, Türkiye'yi dışarıda bırakan bir Avrasya Ekonomik Birliğinin kurulması, bölgede Türk ihracatçısının rekabet gücünü zayıflatacak ve bu durum ihracatın Avrupa pazarlarına sıkışması anlamına gelecektir. Bu yapıda, Avrasya girişiminin Avrupa'nın alternatifi değil, tamamlayıcısı olduğu unutulmamalı; bu süreçte başta Rusya, Ukrayna, Kazakistan ve Beyaz Rusya olmak üzere diğer ülkelerle de bölgesel işbirliklerinin arttırılması gerekmektedir (Bilgin, 2005).

Bu yaklaşıma paralel olarak çalışmamızda Türkiye'nin dış ticaret pazarlarını farklılaştırması açısından diğer işbirliği entegrasyonları arasında daha iyi bir işlerliğe sahip olduğu düşünülen Avrasya Ekonomik Topluluğu ele alınmıştır.

Tablo 1'de 2012 y1lı itibari ile Türkiye'nin AvET üye ve gözlemci statüsünde yer alan ülkeleri ile gerçekleştirdiği dış ticaret rakamlarına yer verilmiştir.

\begin{tabular}{|c|c|c|c|}
\hline Ülke Adı & $\begin{array}{c}\text { İracat } \\
\text { (milyon \$) }\end{array}$ & Ülke Adı & $\begin{array}{c}\text { Ithalat } \\
\text { (milyon \$) }\end{array}$ \\
\hline Rusya Federasyonu & 6681 & Rusya Federasyonu & 26625 \\
\hline Kazakistan & 1069 & Kazakistan & 2056 \\
\hline Kırgızistan & 257 & Kırgizistan & 45 \\
\hline Tacikistan & 235 & Tacikistan & 345 \\
\hline Beyaz Rusya & 264 & Beyaz Rusya & 190 \\
\hline Ukrayna & 1829 & Ukrayna & 4394 \\
\hline Moldovya & 225 & Moldovya & 135 \\
\hline Ermenistan & 0 & Ermenistan & 0 \\
\hline Genel Toplam & $\mathbf{1 0 5 6 0}$ & Genel Toplam & $\mathbf{3 3 7 9 0}$ \\
\hline Türkiye toplam ihracat & $\mathbf{1 5 2 4 7 8}$ & Türkiye toplam ithalat & $\mathbf{2 3 6 5 4 5}$ \\
\hline
\end{tabular}

Tablo 1. 2012 Yı1ı İtibarıyla Türkiye’nin AvET Üye ve Gözlemci Statüsündeki Ülkelerle Gerçekleştirdiği Dış

Ticaret Rakamları. Kaynak: Türkiye İhracatçılar Meclisi, 2013.

Tablo 1'de görüldüğü gibi Türkiye'nin bölge ülkeleri ile 2012 y1lındaki ticaret hacmi 44,35 milyar \$ civarındadır. Ancak bu rakamın sadece 10,560 milyar \$’lık kısmı bölge ülkelerine ihracat, 33,790 milyar \$’lık kısmı ise bölge ülkelerinden ithalat şeklinde gerçekleşmiştir. Bölge ülkelerinden en önemli ithalat kalemleri ise petrol ve doğalgaz ve diğer doğal kaynaklar olmuştur. Topluluk içinde diş ticaret hacmi nispeten yüksek olan ülkeler sırasıyla Rusya Federasyonu, Kazakistan ve Ukrayna'dır. T.C Ekonomi Bakanlığı bünyesindeki çalışmalar sonrasında 2012-2013 dönemi için belirlenen 17 hedef ülkenin içinde Rusya, Kazakistan ve Ukrayna'nın da bulunması tesadüf değildir. 2023 Türkiye İhracat Stratejisi ve Eylem Planında Türkiye'nin uzun dönemli vizyonu “Orta ve yüksek teknolojili ürünlerde Avrasya'nın üretim üssü olmak”, genel amacı ise "Türk sanayisinin rekabet edebilirliğinin ve verimliliğinin yükseltilerek, dünya ihracatından daha fazla pay alan, ağırlıklı olarak yüksek katma değerli ve ileri teknolojili ürünlerin üretildiği, nitelikli işgücüne sahip ve aynı zamanda çevreye ve topluma duyarlı bir sanayi yapısına dönüşümünü hızlandırmak" olarak belirlenmiştir. (TC Ekonomi Bakanlığı, 2013). Tüm bu gelişmeler paralelinde Türkiye’nin uzun dönem hedeflerine ulaşmak üzere ihracat pazarlarını farklılaştırmasında Avrasya Ekonomik Topluluğu'nun önemi yadsınamaz. 


\section{Türkiye'nin Lojistik Performans Endeksinin Değerlendirilmesi}

İhracat pazarlarının farklılaştırılmasında Avrasya ülkeleri yükselen bir pazar olması nedeniyle sadece Türkiye'nin değil, diğer tüm Batı ülkelerinin de dikkatini çekmektedir. Batı ekonomisinin başta enerji olmak üzere yeni kaynaklara ulaşabilmesinde ve başka potansiyel pazarlar bulabilmesinde Avrasya bir cazibe merkezi haline gelmiştir (Yazıcı, 2003). Ancak Avrasya bölgesinin lojistik yapısı incelendiğinde, açık denizlere kıyısının olmaması ve ulaştırma alt yapısı sorunları bölgenin entegrasyonu açısından olumsuz bir etki yaratmaktadır (Şanl1, 2010). Hammadde ve malzemelerin tedariğinden ürün/hizmetin teslimatına kadar geçen süreçte katlanılan maliyetler ve süreler firmaların dış pazarlarda rekabet gücünü etkileyen önemli faktörler arasında sayılabilir. Firmaların lojistik performansları ve dış ticaret işlemlerinde katlandıkları maliyetler kuşkusuz ülkenin lojistik alt yapısına ve lojistik sektörünün etkinliğine bağlıdır (Ulu ve Aracı, 2012). Dolayısıyla karşılıklı dış ticaretimizin gelişebilmesi, sadece Türkiye'nin değil söz konusu Avrasya ülkelerinin de lojistik alanda karşılaşılan sorunların üstesinden gelebilmek için gerekli iyileştirmeleri yapabilmelerine bağlıdır.

Rekabetçi bir çevrede lojistik kalitesi firmaların hangi ülkelerde konumlanacağı, hangi tedarikçilerden satın alacağı ve hangi pazarlara gireceği ile ilgili kararlarda önemli bir etkiye sahiptir. Yüksek lojistik maliyetleri ve düşük lojistik hizmet düzeyi ticaret, doğrudan yabancı yatırımlar ve dolayısıyla ekonomik büyüme önünde bir engel teşkil etmektedir. Bu nedenlerden dolayı lojistik performansın iyileştirilmesi önemli bir kalkınma politikası hedefi haline gelmiştir. Dünya bankası ülkelerin ticaret yeteneği ve rekabet gücünü arttırmada lojistik reform programları geliştirmesine yardımcı olmak amacıyla lojistik performans indeksini (LPI) geliştirmiştir (Arvis vd., 2008). Bu endeks sayesinde ülkeler uluslararası lojistik faaliyetleri açısından kendilerini diğer ülkelerle karşılaştırma imkânı bulmakta, önlerindeki firsat ve engelleri görmektedirler. Endeks bu açıdan 155 kadar ülkeye performanslarını geliştirmek için hangi temel alanlara yönelmeleri gerektiği hususunda da bir takım işaretler vermektedir (Çevik ve Gülcan, 2011). Lojistik Performans İndeksi (LPI) ilk olarak 2007 yılında, sonra sırasıyla 2010 ve 2012 yıllarında yayınlanmıştır.

LPI, ülkelerin özellikle öne çıkan aşağıdaki altı performans boyutu açısından değerlendirilmeleri ve bunların istatistiksel olarak birleştirilmeleri ile elde edilmektedir:

Gümrüklerin ve diğer sınır işlemlerinin etkinliği

Ticaret ve ulaştırma altyapısının lojistik açıdan kalitesi

Uluslararası sevkiyatların düzenlenmesinin kolaylığı ve maliyeti

Lojistik hizmetlerin kalitesi ve lojistik yetkinlik

Sevkiyatların takibi ve izlenebilmesi

Sevkiyatların alıcıya zamanında ulaşması

Tablo 2'de Türkiye'nin her üç yıl boyunca almış olduğu genel LPI ve alt bileşenlerine ait puanları ve dünya ülkeleri arasındaki sıralaması yer almaktadır. Endeks genel değerlendirmesinde Türkiye, 2007 yılında 34. sırada yer almış, 2010 yılında 39. sıraya gerilemiş ve en son 2012 y1lı endeksinde ise gözlemlenen olumlu yönde değişiklik ile sıralamada 27. sıraya yükselmiştir. Bu gelişmede LPI alt bileşenlerindeki performans gelişmelerinin etkisi olduğu söylenebilir. $\mathrm{Bu}$ iyileşmeyle birlikte Lojistik performans indeksinin alt bileşenlerinde sürekli iyileştirme çabaları kuşkusuz önümüzdeki yıllarda Türkiye’yi endeks sıralamasında daha da üst sıralara taşıyacaktır. Bu kapsamda aşağıdaki bölümde Türkiye'nin her bir alt bileşende mevcut durumu, sorunları incelenecek ve çözüm önerileri getirilmeye çalışılacaktır.

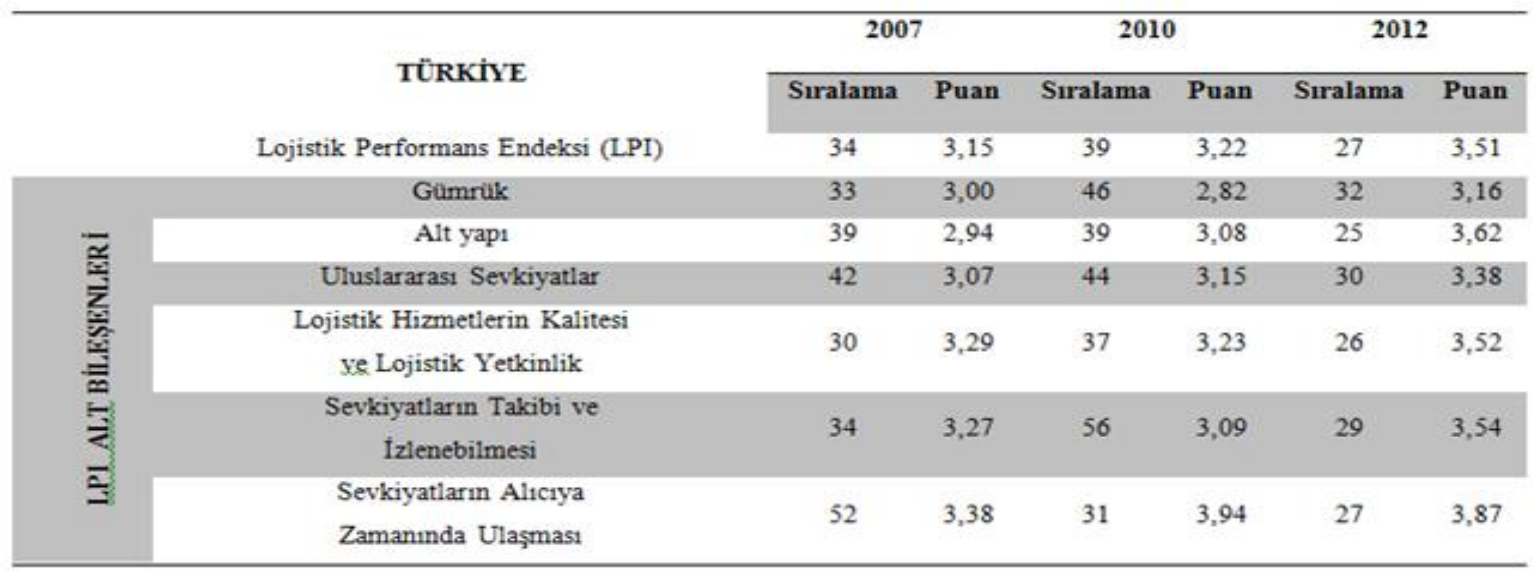

Tablo 2. Türkiye'nin 2007, 2010 ve 2012 Y1lları İtibarıla Genel LPI ve Alt Bileşenlerine Ait Puan ve Siralamaları. Kaynak: World Bank, 2013. 
Tablo 2 incelendiğinde Gümrük işlemlerinin etkinliği açısından her ne kadar Türkiye önceki yıllara göre önemli bir gelişme kat etmiş olsa da, ele alınması gereken en önemli kriterin gümrük işlemlerinin hızı ve etkinliği olduğu görülmektedir. Bu alanda yaşanan sorunları gümrük işlemlerinin yapıldığı alanlardaki fiziki alt yapı yetersizliği ve gümrük BELGE otomasyon sisteminde zaman zaman yaşanan teknik alt yapı arızalarına bağlı sorunlar nedeniyle iş akışının yavaşlaması olarak saymak mümkündür. Ayrıca gümrüklerin ihracat ve ithalat işlemlerinde son nokta olarak yer alması, tüm mevzuatları uygulayıcı kurum olması, ilgili diğer kurumların yaptığ 1 işlemler ve bu kurumlarla ilgili yasal yükümlülüklerin takibinin de gümrüklerde yapılması nedeniyle tüm sorunların gümrüklerden kaynaklandığı algısı artmaktadır (Koban, 2013).

Gümrük işlemlerinin hız ve etkinliğini arttırmak amacıyla Gümrük ve Ticaret Bakanlığının bazı yeni uygulamaları söz konusudur. Bunlar "yetkilendirilmiş yükümlü statüsü”, “ihracatta yerinde gümrükleme” ve "izinli gönderici” uygulamalarıdır.

"Yetkilendirilmiş yükümlü"; kurallara uyan, kayıtları düzenli ve izlenebilir olan, kendi öz denetimini yapabilen, mali yeterliliğe ve yeterli güvenlik standartlarına sahip firmalar ile gümrük idaresi arasında stratejik bir işbirliği girişimidir. Yetkilendirilmiş yükümlü statüsünü alan firma güvenilir olduğunu ispatlamıştır. "Yerinde Gümrükleme" ve "İzinli Gönderici” haklarından sadece yetkilendirilmiş yükümlüler faydalanırlar. Uygulama ile güvenilir firmaların malları gümrüğe gelmeyecek ve gümrüklerde sadece güvenilir olup olmadığı tam olarak bilinmeyen firmaların malları incelenecektir. "Yerinde gümrükleme" ile güvenilir firmalar gümrük işlemlerini yapmak için gümrüğe gitmeyecek, kendi tesislerini gümrükleme mekanı olarak kullanabilecektir (Uluslararası Taşımacılık ve Lojistik Hizmet Üretenler Derneği, 2013). "İzinli Gönderici”; güvenilir olduğu onaylanmış taşıyıcı firmaların işlemlerinin kolaylaştırıldığı ve ihraç edilecek ürünlerin gerekli kontrollerinin taşıyıcı firmalar tarafından yapıldığı bir uygulamadır. "izinli gönderici” haklarından sadece "yetkilendirilmiş yükümlü” belgesine sahip ve uygulamaya ilişkin ilgili ek koşul veya koşulları sağlayan kurumlar yararlanabilmektedir. İzinli gönderici, eşyanın transit işlemlerini kendi tesislerinde basitleştirilmiş usuller çerçevesinde yapmak suretiyle, eşyayı hareket gümrük idaresine sunmaksızın doğrudan çıkış gümrük idaresine sevk etme yetkisine sahip olacaktır.

Ayrıca Türkiye 1 Aralık 2012 itibarıyla "Ortak Transit Sözleşmesi”ne de taraf olmuştur. Ortak Transit Sisteminin amacı bir $\mathrm{AB}$ üyesi ülkede açılan transit beyannamesinin, verilen teminatın ve tanınan basitleştirmelerin AB'ye üye olmayan ancak Ortak Transit Rejimine taraf olan bir ülkede de geçerli olması ve bu ülkeye girişte ayrıca bir transit beyanında bulunulmasına gerek kalmadan ortak transit işleminin kesintisiz bir şekilde tamamlanmasıdır. Aynı durum bir EFTA ülkesinde başlatılan her ortak transit işlemi için de söz konusudur. Ortak transit uygulamasıyla, gerek Türk gümrük idarelerinde gerek AB gümrük geçişlerinde daha az bürokrasi ile zamandan tasarruf sağlanacaktır (İktisadi Kalkınma Vakfi, 2013).

Tablo 2'de Lojistik Performans Endeksi'nin iyileştirilmesi gereken diğer bir kriterinin de uluslararası sevkiyatların kolaylığı ve maliyeti olduğu görülmektedir. Türkiye uluslararası sevkiyatların düzenlenmesiyle ilgili olarak 2012 yılında performansını iyileştirerek 3,38 puanla 30. sıraya yükselmiştir. Dış ticaretinin önemli bir kısmının karayolu üzerinden yapılması nedeniyle, bu alanda zaman zaman meydana gelen tıkanmalar Türkiye'nin dış ticaretini olumsuz yönde etkileyebilmektedir. Türkiye'nin yurt dışı taşımalarda yer alan belli başlı güzergahları Avrupa ve Kuzeye yönelik güzergahlar (Batı kapıları), Doğuya yönelik güzergahlar (Doğu kapıları) ve Güneye yönelik güzergahlar olmak üzere üç grup altında toplanmaktadır. Söz konusu güzergahlarda gerçekleşen taşımalarda taşıyıcıların karşılaştıkları başlıca sorunlar vize sorunları, geçiş belgesi sorunları, geçilen ülkenin gümrük ve yerel mevzuatıyla ilgili sorunlar olarak sıralanabilir. Türkiye uluslararası planda taşımacılığ kolaylaştıran 16 önemli konvansiyondan sadece yedisine taraftır. Bu alanda diğer dokuz anlaşmaya da taraf olunması taşımacılara önemli kolaylıklar getirecektir (Keçeci, 2006).

Türkiye lojistik hizmet kalitesi ve yeterlilik alt bileşeninde de performansını geliştirerek 3,52 puanla 26. sıraya yükselmiştir (Tablo 2). Günümüz küresel ve bölgesel pazarlarında varlık gösterebilmek için düşük üretim maliyetleri ile mal ve hizmet kalitesi firmalar açısından bir zorunluluk haline gelmiş, teslim hızı ve teslim güvenirliği rekabette ayırt edici bir özellik olmuştur. Firmaların lojistik hizmet kalitesini geliştirebilmesi ülkenin lojistik ve bilgi teknolojisi alt yapısı ile sektörde kalifiye elemanların varlığına bağlıdır. Dolayısıyla bilgi işlem teknolojisi kullanımının yaygınlaştırılması, lojistik eğitim niteliğinin arttırılması, lojistik meslek standartlarının oluşturulması, meslek içi eğitimin teşvik edilmesi, sektörde güven ortamı sağlamak için kurumsallaşma ve profesyonelleşmenin sağlanması, lojisik şirketlerin akreditasyonu, lojistik çalışanların sertifikasyonu, yeşil ve tersine lojistik faaliyetlerinin yaygınlaştırılması çalışmalarına odaklanmalı ve destek verilmelidir (Müstakil sanayici ve İşadamları Derneği, 2013). Türk lojistik sektörüne son yıllarda giren yabancı firmaların sayısının artması hem sektörde sunulan lojistik hizmetlerinin kalitesini, hem de sektörde yer alan diğer firmalarla kalite temelindeki rekabeti arttırmaya başlamıştır. Lojistik firmalarının hizmet kalitelerini iyileştirmesi için belirli bir ürün lojistiğinde uzmanlaşması, seçtiği ürün bazında hizmet çeşitliliğini geliştirmesi, insan kaynağına, eğitime ve bilgi teknolojilerine önem vermesi, kurumsallaşması ve profesyonel yönetime geçmesi, kalite yönetim standartlarına sahip olması, firsat ve tehditleri iyi izlemesi gerekir (İhracat, Ticaret ve Ekonomi Sitesi, 2013).

Tablo 2'de Türkiye'nin sevkiyatların takibi ve izlenebilirliği kriterinde 2012 yılında ise 29. sıraya yerleştiği görülmektedir (3,54/5 puan). Bu performans artışında bilişim alt yapısındaki iyileştirmelerin önemli payı 
bulunmaktadır. Günümüzün giderek karmaşıklaşan lojistik ve tedarik zinciri sistemleri "sevkiyatların sürekli olarak izlenmesi ve yönetilmesini” gerektirmektedir. Son yıllarda meydana gelen teknolojik gelişmeler şirketlerin mallarını tüm yaşam döngüleri boyunca izleyebilmesini ve tedarik zincirlerini yönetebilmelerini sağlamaktadır. Otomatik tanımlama teknolojileri (akıllı taşıma sistemleri, ITS teknolojileri) lojistik zincirinde malzeme akışının izlenmesinde yaygın olarak kullanılmaktadır (Shamsuzzoha vd., 2013). Bu sistemler işletmelerin giderek artan mobil operasyonlarını daha iyi yönetmelerine olanak sağlamaktadır. Takip ve izleme sistemleri birçok işletme için en yaygın kullanılan bilişim teknolojisine dayalı iş uygulamalarından birisi olmuştur. Bu sistemler maliyet düşürücü, müşteri memnuniyetini sağlayan katma değerli uygulama alanları yaratmaktadır (Pagani, 2005). Takip ve izleme sistemlerinin avantajlarını aşă̆ı̆da olduğu gibi sıralamak mümkündür (Ünlü, 2007).

Haberleşme giderlerinin azalması,

Rekabet avantajinın artmasi,

Etkin filo yönetimi,

Araçların hızlarının, rotalarının anlık olarak takip edilebilmesi,

Müşterilerin bilgilendirilmesiyle müşteri memnuniyetinde artı̧s sağlanması,

Araçlardaki yüklerin takibi ve yeni yüklerin sipariş anında en yakınındaki araçlara yönlendirilmesiyle esneklik sağlanması,

Güvenliğin arttırılabilmesi,

Ürünlerin talep edilen noktalara varış sürelerinin belirlenebilmesi

Sevkiyatların takibi ve izlenebilme performansının daha da iyileştirilebilmesi için internet altyapısı sürekli geliştirilmeli, e-devlet, e-belge uygulamaları (e-vergi, e-tescil, e-sözleşme, e-imza, e-beyanname vd.) ve e-ticaret uygulamaları yaygınlaştırılmalı, lojistik bilişim ve iletişim standartları oluşturulmalı, BT yatırımları Tedarik Zinciri Yönetimi kapsamında gerçekleştirilmeli, araç, yük, taşıma kabı ve doküman izlenebilirliği (uydu haberleşmesi, akıllı ulaştırma sistemleri vd.) artırılmalı ve son olarak lojistik merkezler arasında iletişim, planlama, koordinasyon ve izlenebilirliğin sağlanmasına yönelik bir yapılanma gerçekleştirilmelidir (Tanyaş, 2010)

Türkiye'nin "ticaret ve taşımacılık ile bağlantılı alt yapı kalitesinde" ciddi bir artış olduğu ve bu konuda dünya ülkeleri arasında 25. siraya yükseldiği (3,62/5 puan) görülmektedir. Ancak yine de lojistikle ilgili alt yapısında ivedilikle çözülmesi gereken sorunlar bulunmaktadır. Türkiye'de demiryolu ve denizyolu işletmelerindeki alt yapı eksikliği karayolu taşımacıllğ̆ına daha da yük binmesine neden olmuştur. Bu durumun önüne geçmek üzere ulaşım sektörünün demir, deniz ve karayolları arasında daha dengeli bir biçimde dağılması konusunda çözüm arayışları üzerinde durulmaktadır. Bu kapsamda yük taşımacılığında karayolu taşımacılığı ile işbirliği halinde demiryolu ve denizyolu taşımacılığının daha da yaygınlaştırılmasının yanı sıra, birden fazla modu içeren kombine yük taşımacılığının da özendirilmeye başlaması dikkat çekicidir Keçeci, 2006 ; Kutlu ve Amil Gür, 2008; Kaya 2008).

Türkiye'nin puanını yükselten ve iyileşen bir diğer kriter de, “zamanında teslim” olup, üç dönemde de yükselme görülmüş, 2012 yılında ise 3,87 puanla 27. sıraya yerleşmiştir. Zamanında teslim performansının iyileştirilmesi diğer kriterlerin performansıyla yakından ilişkilidir. Dolayısıyla bu kriterlerin iyileştirilmesi uluslararası lojistikte zamanında teslim kriterini daha da geliştirecektir.

\section{Türkiye İle Avrasya Ekonomik Topluluğu Ülkelerinin Lojistik Performans Endekslerinin Karşılaştırılması}

Daha önce de değindiğimiz gibi genel olarak Avrasya bölgesinde özelde ise AvET ülkeleri ile dış ticaretin geliştirilmesi, her iki tarafında lojistik alt yapısıyla ilgili sorunları çözme çabalarına ve bu yönde karşılıklı işbirliğine bağlıdır. Tek yönlü çabalar sorunun çözümüne yeterli katkı sağlamayacaktır. $\mathrm{Bu}$ kapsamda Türkiye'nin ve $A v E T$ ülkelerinin Dünya bankası tarafından geliştirilen lojistik performans endekslerini karşılaştırmak yararlı olacaktır.

Türkiye ve diğer $A v E T$ üye ve gözlemci ülkelerinin 2012 lojistik performans indeksleri ve bu indeksin hesaplanmasında dikkate alınan kriterlerdeki performans ve sıralamaları Tablo 3'de yer almaktadır. Tablo 3 incelendiğinde Türkiye 'nin 2012 yılı itibarıyla LPI sıralamasında 155 ülke arasında 27. sırada yer aldığı (3,51/5,00 puanla), AvET ülkeleri arasında da gerek LPI gerekse LPI kriterleri bakımından açık ara ilk sırada yer aldığı görülmektedir. AvET üye ve gözlemci statüsündeki ülkelere bakıldığında ise hiçbir ülkenin üst üçte birlik dilime giremediği, Ermenistan, Kırgızistan, Moldovya ve Tacikistan'ın ise en alt üçte birlik dilimde yer aldığı söylenebilir. Bu dört ülke ekonomilerinin iyi gelişmemiş olması bölge içi ticaretin düşük olmasının temel nedeni olarak görülebilir (Primpayev ve Ganiyev, 2010 ). Bunun dışında kara ve demiryollarının etkin ve iyi durumda olmaması, gümrük prosedürlerinin çok zaman alması, gümrük kontrol ve ülke içi mal kontrollerinin uyumlu yürütülmemesi, bilgi (enformasyon) değişiminde etkin sistemin olmayışı, transit vergilerin yüksek olması, resmi 
olmayan ödemeler ve altyapının iyi gelişmemiş olması, uluslararası ödeme sisteminin olmaması AvET ülkelerinin LPI endeksi sıralamasında alt sıralarda yer almalarının temel nedeni olarak görülebilir.

\begin{tabular}{|c|c|c|c|c|c|c|c|c|c|c|c|c|c|c|}
\hline \multirow[t]{2}{*}{ ÜLKELER } & \multirow[t]{2}{*}{ Srralama } & \multirow{2}{*}{$\begin{array}{c}\text { LPI } \\
\text { Puanı }\end{array}$} & \multicolumn{2}{|c|}{ Gümrük } & \multicolumn{2}{|c|}{ Altyap1 } & \multicolumn{2}{|c|}{$\begin{array}{l}\text { Uluslararası } \\
\text { Tașımacllk }\end{array}$} & \multicolumn{2}{|c|}{$\begin{array}{c}\text { Lojistik Kalitesi ve } \\
\text { Yeterlilik }\end{array}$} & \multicolumn{2}{|c|}{$\begin{array}{c}\text { Serkiyatlarn } \\
\text { Takibi }\end{array}$} & \multicolumn{2}{|c|}{$\begin{array}{l}\text { Serkiyatlarn Ahcrya } \\
\text { Zamaninda Ulașması }\end{array}$} \\
\hline & & & Siralama & Puan & Suralama & Puan & Srralama & Puan & Siralama & Puan & Suralama & Puan & Suralama & Puan \\
\hline Türkiye & 27 & 3,51 & 32 & 3,16 & 25 & 3,62 & 30 & 3,38 & 26 & 3,52 & 29 & 3,54 & 27 & 3,87 \\
\hline Ukrayna & 66 & 2,85 & 88 & 2,41 & 70 & 2,69 & 83 & 2,72 & 61 & 2,85 & 50 & 3,15 & 68 & 3,31 \\
\hline Kazakistan & 86 & 2,69 & 73 & 2,58 & 79 & 2,60 & 92 & 2,67 & 74 & 2,75 & 70 & 2,83 & 132 & 2,73 \\
\hline Beyaz Rusya & 91 & 2,61 & 121 & 2,24 & 65 & 2,78 & 107 & 2,58 & 89 & 2,65 & 98 & 2,58 & 114 & 2,87 \\
\hline Rusya Federasyonu & 95 & 2,58 & 138 & 2,04 & 97 & 2,45 & 106 & 2,59 & 92 & 2,65 & 79 & 2,76 & 94 & 3,02 \\
\hline Emenistan & 100 & 2,56 & 116 & 2,27 & 110 & 2,38 & 96 & 2,65 & 115 & 2,40 & 99 & 2,57 & 92 & 3,07 \\
\hline Kurguzistan & 130 & 2,35 & 84 & 2,45 & 90 & 2,49 & 147 & 2,00 & 129 & 2,25 & 132 & 2,31 & 135 & 2,69 \\
\hline Moldorya & 132 & 2,33 & 129 & 2,17 & 98 & 2,44 & 145 & 2,08 & 142 & 2,15 & 116 & 2,44 & 126 & 2,74 \\
\hline Tacikistan & 136 & 2,28 & 85 & 2,43 & 138 & 2,03 & 135 & 2,33 & 130 & 2,22 & 143 & 2,13 & 146 & 2,51 \\
\hline
\end{tabular}

Tablo 3. Türkiye ve AvET Üye ve Gözlemci Statüsün deki Ülkelerin LPI ve Alt Kriterlerine Ait Puan ve Siralamaları. Kaynak: World Bank, 2013

Diğer önemli bir sorun da, ülkeler arası bilgi değişim sisteminin yokluğu ve istatistikî verilerdeki hata ve noksanlar, yani ülkeler arasında istatistiki verilerin uyumsuz olmasıdır. Bunun nedeninin yolsuzluk olduğu öne sürülmektedir (Primpayev ve Ganiyev, 2010). Bölgede söz konusu ülkelerle diş ticareti daha da geliştirebilmek için lojistik ve ulaştırma alanında sağlanacak işbirliği de çok önemlidir. Bölgedeki ulaştırma ilişkilerinin, mevcut sorunları ortadan kaldırma ve bütün taraflara avantaj sağlamaya yönelik bir işbirliği yaklaşımıyla ele alınması gerekmektedir. Ulaştırma alanında bölge ülkeleri arasında;

Karayolu kullanımında, ortak ücret ve tarife politikasının uygulamaya konulması,

Gümrük altyapısında rehabilitasyon çalışmalarına hız kazandırılması,

Avrupa ülkeleri arasında uygulanmakta olan, belirli bir kota sistemine göre, serbest ve sorunsuz geçiş imkânı sağlayan sistemin benzerinin oluşturulması,

Bazı ülkelerde uygulanan yüksek geçiş ücretlerinin düşürülmesi,

Eşit rekabet şartları içinde, ortak kara taşımacılığ 1 şirketleri kurulmasının teşvik edilmesiyle,

büyük faydalar temin edilecektir (TOBB, 2006).

Ayrıca Orta Asya ekonomilerinde, özellikle hizmet ve lojistik sektörlerinde, bölgesel entegrasyonun ve rekabetin gelişmesini sağlamak için, tarihsel İpek Yolu'nun canlandırılması ulaştırma alanındaki sorunların çözümüne katkı sağlayacaktır. Avrasya Bölgesinde Kuzey, Orta ve Güney olmak üzere Doğu ve Batı'yı birbirine bağlayan üç tane koridor bulunmaktadır. Bu koridorlardan Orta ve Güney koridoru Türkiye üzerinden Avrupa'ya bağlanmaktadır. Orta koridorunda demir ve denizyolu ile etkin bir taşımacılığın yapılabilmesi için öncelikle Hazar Denizi limanlarında gerekli alt yapı yatırımlarının tamamlanması, ülkeler arası transit anlaşmaların imzalanması ve demiryolu ağındaki teknik eksikliklerin giderilmesi gerekmektedir. Güney koridoru üzerinde ise demiryolu ve karayolunu kullanarak konteynır taşımacılığı yapılabilmesi için demiryolu alt yapısının tamamlanması, güvenlik sorunlarının aşılması ve ülkeler arası anlaşmalara gerek duyulmaktadır. Modern İpek yolunun bu sayede hayata geçirilmesi mümkün olabilecektir (Kulaklıkaya, 2013). Bu bağlamda Türkiye’ nin artık sona yaklaşan Kars-Tiflis demiryolu projesini hızlı bir biçimde tamamlanması, İstanbul-Almaata konteynır demiryolu hattının etkin kullanımını sağlaması, Gümrük Birliğine olan sorumluluklarını unutmadan karşılıklı gümrük tarifesi ve kota muafiyetlerini sağlayabilmesi dış ticarette lehine bir durum olacaktır (Öngel, 2010). Türkiye'nin Gümrük Birliğine olan sorumluluklarını unutmadan karşılıklı gümrük tarifesi ve kota muafiyetlerini sağlayabilmesi dış ticarette lehine bir durum olacaktır (Öngel, 2010).

Ayrıca Türkiye'nin gerek kendi gerek Avrasya coğrafyasında stratejik noktalarda lojistik üslerin kurulması ve kombine taşımacılığın yaygınlaştırılabilmesi için gerekli yatırımları yapabilmesi lojistik maliyetlerin azalmasına katkı sağlayacaktır.

\section{Sonuc}

Dış ticaret hacmini arttırmak için alternatif ihracat pazarları bulmanın önemini fark eden Türkiye, Avrupa ve Asya kıtalarını birbirine bağlayan bir köprü olması nedeniyle bu avantajı bir üstünlüğe dönüştürmek üzere Avrasya bölgesi için Avrupa ülkeleriyle rekabet edebilecek ekonomik bir yapıya, karayolu, demiryolu, denizyolu ve boru hatlarından oluşan uygun bir ulaşım ve lojistik alt yapısına sahip olmak zorundadır. Dünya Bankası 
tarafından hazırlanan lojistik performans endeksinde Türkiye 2012 yılı itibarıyla 155 ülke arasında 27. sıraya yükselmiştir. Lojistik alanda Türkiye'nin sürekli iyileştirme çabaları yanında endeks sıralamasında oldukça alt sıralarda yer alan AvET ülkeleriyle karşılıklı işbirliği çabalarının da büyük önem taşıdığı unutulmamalıdır. Türkiye AvET ülkelerine ve diğer ülkelere en uygun taşımacılık sistemini kullanarak bağlanmak zorundadır. Bu bakımdan Orta ve Güney koridorları, üzerinde çalışılması gereken bağlantılardır (Kaynak, 2004). Bu bağlantıların iyileştirilmesi, Türkiye'nin bölgesel lojistik güç olma potansiyelini güçlendirmiş olacaktır. AvET ülkeleriyle ticari faaliyetlerini arttırmaya çalışan Türkiye, özellikle Rusya ile denizyolu taşımacılığını güçlendirmek durumundadır. Ayrıca topluluğa gelecekte üye olması muhtemel Azerbaycan limanlarının iyileştirilmesi de; Türkiye açısından söz konusu bölgeye önemli bir yatırım firsatı sunmaktadır. Orta ve Güney koridorlarında etkin bir kombine taşımacılığın desteklenebilmesi için mevcut demiryolu altyapısının modernize edilmesi, projelerin hızlı bir biçimde tamamlanması gerektiği unutulmamalıdır. Doğu-Batı ticaretinde Türkiye'yi transit geçiş noktası yapacak olan Kars-Tiflis-Bakü demiryolu hattının bitirilmesiyle bu hattan her yıl 3 milyon ton yük akışı hedeflenmektedir.

Sonuç olarak AvET ülkeleriyle dış ticareti geliştirebilmek için gerekli şartların oluşturulması önem taşımaktadır. Karayolları ve demir yollarında söz konusu ülkelerde fiziki standartlar geliştirilmelidir. Fiziksel altyapı standartlarının ülke bazında iyileştirilmesi yeterli olmamaktadır. Standartların uluslararası düzeyde, güzergâh bütününde geçerli hale getirilmesi gereklidir. Ayrıca bu ülkelerde gümrük geçişlerinin hızlandırılması için gerekli bilgi teknolojisi alt yapısının iyileştirilmesi, gümrükle ilgili transit geçiş belgelerinin de topluluğa üye ülkelerce uyumlu hale getirilmesi gerekmektedir.

\section{Kaynakça}

- $\quad$ Arvis, J.F., Mustra, M. A., Panzer, J., Ojala, L. and Naula, T. (2008), “Connecting to Compete:Trade Logistics in the Global Economy”, The Global Enabling Trade Report 2008, 2008 World Economic Forum

- Bilgin, Mert (2005): “Türkiye’nin İhracata Yönelik Ekonomi Politikalarında Avrasya'nın Stratejik Önemi”, Uluslararasi İlişkiler, 2(7), ss. 87-124.

- CÇekerol, Gülşen S. ve Kurnaz, Niyazi (2011): "Küresel Kriz Ekseninde Lojistik Sektörü ve Rekabet Analizi”, Selçuk Üniversitesi Sosyal Bilimler Enstitüsü Dergisi, 25, ss. 48-59.

- CCevik, Osman ve Gülcan, Bayezid (2011), "Lojistik Faaliyetlerin Çevresel Sürdürülebilirliği ve Marco Polo Programı”, KMÜ Sosyal ve Ekonomik Araştırmalar Dergisi, 13(20), ss. 35-44

- $\quad$ Deutche Welle, 2013. Rusya Şangay Çıkışını Nasıl Yorumluyor?, http://www.dw.de/rusya$\% \mathrm{C} 5 \% 9$ Fanghay-\%C3\%A7\%C4\%B1k\%C4\%B1\%C5\%9F\%C4\%B1n\%C4\%B1-nas\%C4\%B11yorumluyor/a-16624248

- İhracat, Ticaret ve Ekonomi Sitesi, 2012. Lojistikte Pazar Büyüklügü̈ 120 Milyar Dolar, http://www.ihracat.info.tr/lojistikte-pazar-buyuklugu-120-milyar-dolar-1235h

- İktisadi Kalkınma Vakfi, 2013. Ortak Transit Yönetmeliği Yenilendi, http://www.ikv.org.tr/icerik.asp?konu=haberler\&baslik=ORTAK\%20TRANS\%DDT\%20Y\%D6NETMEL $\%$ DD\%D0\%DD\%20YEN\%DDLEND\%DD\&id=3009

- Kaya, Sait (2008), “Türkiye'de Ulaştırma Sektörünün Genel Görünümü ve Sorunları”, Ar\&Ge Bülten, Şubat, ss. 31-38

- $\quad$ Kaynak, Muhteşem, A. (2004), “Uluslararası Taşımacılık ve Lojistik Bağlamında Avrasya Ulaştırma Koridorlarında Bölgesel Rekabet ve Türkiye”, Ekonomik Yaklaşım, 15(52-53), ss. 3-33

- Keçeci, Adnan (2006), “Türkiye'de Karayolu Taşımacılığı”, Uluslararası Ekonomik Sorunlar Dergisi, 20, Şubat, http://www.mfa.gov.tr/turkiye_de-karayolu-tasimaciligi-.tr.mfa

- Koban, Emine (2012), “Gümrük-Lojistik Aşkı”, Transport Dergisi, Sayı: 100, http://www.transport.com.tr/akt4,100@2200.html

- Kulaklıkaya, Ömercan (2013), “Modern İpekyolu: Orta Asya’nın Küresel Ekonomiye Açılan Kapısı”, Türkiye Ekonomi Politikaları Araştırma Vakfi, Şubat, ss. 1-7

- Kutlu, Serap ve Amil Gür, Furkan (2008), "Lojistik Master Planı ve Bir Lojistik Üs Olarak Türkiye”, Mevzuat Dergisi, 11(129), ISSN 1306-0767, http://www.mevzuatdergisi.com/2008/09a/02.htm

- Küresel Stratejik Araştırma ve Takip Portalı, 2013. Türkiye'nin 2012 Ekonomik Performansı Üzerine Bir Değerlendirme", http://www.straturk.com/2013/05/09/turkiyenin-2012-ekonomik-performansi-uzerine-birdegerlendirme/

- Müstakil Sanayici ve İşadamları Derneği, 2010. Lojistik Sektörü Raporu 2010, http://www.musiad.org.tr/img/arastirmalaryayin/pdf/arastirma_raporlari_70.pdf 
- Öngel, Volkan (2010), "Türkiye İçin Alternatif Bir Dış Ticaret Pazarı: Avrasya Ekonomik Topluluğu”, International Conference on Eurasian Economies, ss. 86-91, 4-5 Kasım, İstanbul

- $\quad$ Pagani, Margherita (2005), Mobile and Wireless Systems Beyond 3G: ManagingNew Business Opprtunities, IRM Press, Italy

- $\quad$ Pirimpayev, Cusup ve Ganiyev, Cunus (2010), “Avrasya Ekonomik Topluluğu: Bir İktisadi İşbirliği Alternatifi”, International Conference on Eurasian Conference on Eurasian Economies, ss. 82-85, 4-5 Kasım, İstanbul.

- $\quad$ Resmi Gazete, 2012. 2023 Türkiye İhracat Stratejisi ve Eylem Planı, http://www.resmigazete.gov.tr/eskiler /2012/06/20120613-31-1.pdf

- Şanlı, Bahar(2010), “Ekonomik Entegrasyon Teorisi Çerçevesinde Avrasya Birliğinin Olabilirliği”, edergi.atauni.edu.tr/index.php/IIBD/article/view/3756/3585, ss.13-29

- Tanyaş, Mehmet (2010), “Türkiye Lojistik Sektörünün Sorunları ve Çözüm Önerileri”, YAEM, 1 Temmuz, Sabancı Üniversitesi, İstanbul

- TC Ekonomi Bakanlığı, 2012. 2023 Türkiye İhracat Stratejisi ve Eylem Planı, http://www.sasad.org.tr/uploaded//2023_ihracat(3).pdf

- $\quad$ TOBB, 2011. Türkiye Ulaştırma ve Lojistik Meclisi Sektör Raporu, http://www.karid.org.tr/upload/data/Image/TOBB_ulastirma_kitap_2012.pdf

- Türkiye İhracatçılar Meclisi, 2013. “31.12.2012” Tarihi İtibariyle Ülke Bazında Aylık İhracat Rakamları, http://www.tim.org.tr/tr/ihracat-ihracat-rakamlari-tablolar.html

- Ulu, Cenk ve Aracı, Cem (2012), Türkiye'de Dış Ticaret Lojistik Süreçleri: Maliyet ve Rekabet Unsurları, Yayın No: TÜSİAD-T/2012-03/526, ISBN: 978-994-405-80-5, İstanbul

- Uluslararası Taşımacılık ve Lojistik Hizmet Üretenler Derneği, 2013. Yerinde Gümrükleme ile Her Tesis Gümrük Haline Geliyor, http://www.utikad.org.tr/haberler/?id=10921

- $\quad$ Ünlü, Zehra Filiz (2007), Tedarik Zinciri Yönetimi, Lojistik ve Taşımacılıkta Bilişim Teknolojileri ve Uygulamaları, Yayınlanmamış YL Tezi, İTÜ FBE, İstanbul

- $\quad$ World Bank, 2007. LPI Full Report 2007, http://siteresources.worldbank.org/INTTLF/Resources/lpireport.pdf

- World Bank, 2010. LPI Full Report 2010, http://siteresources.worldbank.org/INTTLF/Resources/LPI2010 for_web.pdf

- World Bank, 2012. LPI Full Report 2012, http://siteresources.worldbank.org/TRADE/Resources/2390701336654966193/LPI_2012_final.pdf

- $\quad$ TOBB, 2006. Avrasya Odaları Zirvesi, http://www.tobb.org.tr/Documents/Konusmalar/Avrasya \%20Odalari\%20Zirvesi.doc.

- Y Yazıcı, Erdinç (2003), “Yirmi birinci Yüzyılın Başında Avrasya ve Türkiye’nin Avrasya Vizyonu”, Kamuİş, 7(2), ss. 1-12. 


\title{
Avrasya Ülkeleri’nde Gayri Safi Yurtiçi Hasıla Üzerine Doğrudan Yabancı Yatırımlar ve Dış Ticaret'in Etkisi: Panel Eşbütünleşme Analizi
}

\section{The Effect of Foreign Direct Investment and Foreign Trade on Gross Domestic Product in Eurasian Countries: Panel Cointegration Analysis}

\author{
Ph.D. Candidate Mehmet Songur (Tunceli University, Turkey) \\ Ph.D. Candidate Demet Yaman (Hacettepe University, Turkey)
}

\begin{abstract}
In recent years, with the phenomenon of globalization, both foreign trade and foreign direct investment have become important factors that impact on economic growth. The effect of foreign trade and foreign direct investment on economic growth has been an important research area for many economists. For this purpose, this study investigates the effects of foreign direct invesment and foreign trade on economic growth, with the help of Pedroni Panel Cointegration Analysis,for 9 Eurasian countries using annual data for the period 1995-2011.The results show that in analyzed countries, there has been a long-term relationship between the variables. The results of cointegration coeffficients show that, import and export has a negative impact but foreign direct invesment has a positive impact on GDP. From these results, Eurasian economies on one hand should develop policies to increase the effeciency of foreign direct invesment and increase foreign trade. On the other hand Eurasian economies should improve policies to increase the economic and human infrastructure.
\end{abstract}

\section{Giriş}

Mal ve hizmet üretim sınırındaki genişleme şeklinde tanımlanan ekonomik büyümenin nasıl sürdürülebilir ve iyileştirilebilir olması gerektiği tartışması iktisatçılar tarafından en çok araştırılan konuların başında gelmektedir. Özellikle gelişmiş ve gelişmekte olan ülkeler arasındaki ekonomik büyüme farklılıkları ve bu farklılıkların nasıl giderileceği birçok iktisat teorisinin inceleme konusu olmuştur. Klasik, Neoklasik ve hatta İçsel Büyüme Teorilerine göre ülkeler arasındaki ekonomik büyüme farklılıklarının temel kaynağı arz yönlü faktörlerdir. Diğer taraftan Keynesyen temelli ekonomik büyüme modelleri her ne kadar ekonomik büyüme üzerine spesifik olarak çalışmamış olsalar da ülkeler arasındaki ekonomik büyüme farklılıklarını açıklarken ekonomik büyümenin kaynağı olarak talep yönlü faktörleri dikkate almışlardır. Post Keynesyen İktisadi düşüncenin ortaya çıkışı ile birlikte Keynes'in çizgisinden ilerleyen iktisatçılar ekonomik büyüme üzerinde daha fazla durmaya başlamışlar ve özellikle 20. Yüzyılın ikinci yarısının ilk çeyreğinde ekonomik büyüme üzerinde sadece iç talebin değil aynı zamanda dış talebinde etkili olabileceğini belirterek diş ticareti ekonomik büyüme modellerine dahil etmişlerdir.

Post Keynesyen İktisat içerisinde yer alan Kaldor (1970) ihracatın toplam talebin temel unsuru olduğu gerçeğini dikkate alan ve kümülatif nedensellik üzerine temellendirdiği bir ihracata dayalı büyüme modeli geliştirmiştir. Thirlwall (1979) Kaldor'un modelinde ithalatın olmamasını bir eksiklik olarak görmüş ve ithalatın büyüme üzerinde kısıtlayıcı yani negatif bir etki yaratacağını belirtmiştir.

Dünya üzerinde küreselleşme olgusunun artması ile birlikte dış ticaretin yanı sıra doğrudan yabancı sermaye yatırımları da ekonomik büyüme üzerinde etki yaratan en önemli değişkenlerden biri olmaya başlamıştır. Özellikle gelişmekte olan ülkeler ekonomik büyüme performanslarını iyileştirmek için doğrudan yabancı yatırımların ülkeye girişini desteklemektedirler. Bu ülkelerde doğrudan yabancı yatırımların kalkınma ve büyüme için gerekli olan tasarruf ve yatırımı sağlaması, teknoloji transferini ve beşeri sermaye birikimini arttırması beklenmektedir.

$\mathrm{Bu}$ çalışmada, doğrudan yabancı yatırımların ve dış ticaretin ekonomik büyüme üzerindeki etkileri incelenmeye çalışılmıştır. Çalışmanın literatürde yer alan çalışmalardan temel farkı Avrasya Ekonomileri’nin seçilmiş olmasıdır. Avrasya Ekonomileri genel olarak 1991 yılında Sovyet Sosyalist Cumhuriyetler Birliği'nin dağılması ile birlikte bağımsızlığını elde eden ülkeler olarak tanımlanmakta olup toplamda 12 ülkeyi kapsamaktadır (Belarus, Ermenistan, Gürcistan, Kazakistan, Kırgızistan, Moldova, Özbekistan, Rusya, Tacikistan, Türkmenistan, Ukrayna, Azerbaycan). Ancak çalışmamızda kullanılan ilgili verilere ulaşılamadı $\breve{g}_{1}$ için analize Gürcistan, Özbekistan ve Türkmenistan dahil edilmemiştir. Bu çerçevede çalışmanın amacı, ele alınan 9 Avrasya Ekonomisi'nde doğrudan yabancı yatırımların ve dış ticaretin ekonomik büyüme üzerindeki etkilerini Pedroni (1999) Panel Eşbütünleşme çerçevesinde incelemektir. Bu doğrultuda çalışmanın ikinci bölümünde ilgili literatür incelenecektir. Üçüncü bölümde çalışmada kullanılan veri seti ve ekonometrik yöntem hakkında bilgi verildikten sonra, dördüncü bölümde ekonometrik analizden elde edilen bulgulara yer verilmektedir. Sonuç bölümünde ise, çalışmadan elde edilen bulgulara ilişkin değerlendirme yapılmaktadır. 


\section{Ampirik Literatür}

İktisat Teorisi'nde genel kanı doğrudan yabancı yatırımların ve dış ticaretin ekonomik büyüme üzerinde pozitif etki yaratacağı yönündedir. Ancak ampirik literatüre baktığımızda bu durum teori ile daima paralellik arz etmeyebilir. Bu çerçevede doğrudan yabancı yatırımlarım ekonomik büyüme üzerine etkilerini uygulamalı olarak inceleyen çalışmaları doğrudan yabancı yatırımların ekonomik büyümeyi pozitif, negatif ve aralarındaki ilişkinin anlamsız olduğunu ifade eden çalışmalar olarak üçe ayırmak mümkündür.

Bu bağlamda Borensztein, Gregorio ve Lee (1995), Bosworth ve Collins (1999), Djankov ve Hoekman (2000), Ericsson ve Irandoust (2001), Campos ve Kinoshita (2002), Yang (2002), Cuadros, Orts ve Alguacil (2004), Fedderke ve Romm (2004), Razin (2004), Yao ve Wei (2007), Vu ve Noy (2009) çalışmalarında doğrudan yabancı yatırımların ekonomik büyümeyi pozitif yönde etkilediği sonucuna ulaşmışlardır. Diğer taraftan, Herzer, Klasen ve Lehmann (2008), Yang (2008) çalışmalarında doğrudan yabancı yatırımların ekonomik büyümeyi negatif yönde etkilediği, Xu (2000), Hermes ve Lensink (2003), Katerina, Papanastasiou ve Athanasios (2004) ise doğrudan yabancı yatırımlar ile ekonomik büyüme arasında ilişki olmadığı sonucuna ulaşmışlardır.

Doğrudan yabancı sermaye yatırımlarının yanı sıra dış ticareti temsil eden en önemli iki kalem olan mal ve hizmet ithalatı ile ihracatı da ekonomik büyüme üzerinde önemli etki göstermektedir. İhracat değişkeninin ekonomik büyümeyi pozitif etkileyeceği konusunda teorik olarak bir genel kanı oluşmasına rağmen, ithalat değişkeninin ekonomik büyüme üzerinde yaratacağı etki konusunda genel bir uyum sağlanamamıştır. Bu çerçevede kimi iktisatçılara göre ithalat ekonomik büyümeyi pozitif etkilerken, kimi iktisatçllar ithalatın ekonomik büyüme üzerinde kısıt oluşturacağını yani negatif bir etki yaratacağını ifade etmişlerdir.

Ampirik literatüre baktığımızda ise, ihracatın ekonomik büyüme üzerinde pozitif etki yaratacağını ifade eden çalışmaların yanı sıra aralarında anlamlı bir ilişki olmadığını ifade eden çalışmalarda bulunmaktadır. Bu çerçevede Balassa (1978), Williamson (1978), Feder (1982), Balassa (1985), Ram (1985), Chow (1987), Sengupta (1991), Bahmani-Oskooee ve Alse (1993), Konya (2006) ihracatın ekonomik büyüme üzerinde pozitif etki yarattığı sonucuna ulaşmışlardır. Diğer taraftan, ampirik literatürde ithalatın büyüme üzerinde pozitif etki yarattığı sonucuna ulaşan çalışmalara da rastlanmakta olup, Levine ve Renelt (1992), Marwah ve Tavakoli (2004), Shirazi ve Manap (2005), Mahadevan ve Suardi (2007) çalışmalarında ithalatın ekonomik büyümeyi pozitif etkilediği sonucuna ulaşmışlardır.

Tüm bunların yanı sıra dış ticaret ile ekonomik büyüme arasında herhangi bir anlamlı ilişki olmadığını ifade eden çalışmalar olmakla bunlar Darrat (1987), Colombatto (1990), Afxentiou ve Serletis (1991), Kugler (1991), Ramos (2001), Jin (2006)'in çalışmalarıdır.

\section{Veri Seti ve Yöntem}

Bu çalışmada 9 Avrasya Ekonomisi’nde doğrudan yabancı yatırımların ve dış ticaretin ekonomik büyüme üzerindeki etkileri incelenmektedir. Bu amaçla analizde 9 ülkeye ait 1995-2011 dönemine ait yıllık veriler kullanılmış olup, ilgili veri seti Dünya Bankası tarafından yayınlanan Dünya Kalkınma Göstergeleri'nden (World Development Indicators) elde edilmiştir. Öte yandan modellerin tahmininde E-views 6.0 Beta, WinRATS Pro 7.0 ve Gauss 9.0 paket programlarından yararlanılmıştır.

Çalışmada kullanılan en geniş model 1 numaralı denklemde verilmiş olup, lnGDP; Gayrisafi Yurtiçi Hasıla Düzeyini, $\operatorname{lnX}$; mal ve hizmet ihracatını, $\operatorname{lnM}$; mal ve hizmet ithalatını, lnFDI; doğrudan yabancı yatırım düzeyini ifade etmektedir. Tüm değişkenler 2000 yılı baz alınarak reel hale getirilmiş ve logaritması alınarak analize dahil edilmiştir.

$$
\ln G D P_{i, t}=\beta_{0}+\beta_{1} \ln X_{i, t}+\beta_{2} \ln M_{i, t}+\beta_{3} \ln F D I_{i, t}+\varepsilon_{i, t}
$$

Çalışmada panel eşbütünleşme yöntemi kullanılmış olup, panel eşbütünleşme analiz yönteminde ele alınan serilere ait birim kök özellikleri büyük önem arz etmektedir. Ancak hem panel birim kök testleri hem de panel eşbütünleşme testleri, panel veri setini oluşturan gruplar arasında yatay kesit bağımlılığının var olduğu ve olmadığı duruma göre varsayımlarını oluşturmuşlardır. Bu bağlamda, birinci nesil panel birim kök testleri yatay kesit bağımlılığının varlığını dikkate almaz iken, ikinci nesil panel birim kök testleri yatay kesit bağımlılığının varlığını dikkate almaktadırlar. Bu çerçevede öncelikle ele alınan serilerde yatay kesit bağımlılığının varlığı araştırılmalıdır.

Panel veri analizlerinde yatay kesit bağımlılığını test etmek için genellikle 3 test kullanılmaktadır. Birincisi, Breusch-Pagan (1980) tarafından geliştirilen $C D_{B P}$ testidir. Bu test $N$ sabit ve $T$ sonsuza giderken $(T \rightarrow \infty)$ yani $T>N$ iken geçerli olup (2) numaralı denklem ile hesaplanmaktadır. Burada $\hat{\rho}$ bireysel en küçük kareler (EKK) tahminlerinden elde edilen artıklar arasındaki yatay kesit korelasyonlarının tahminlerini göstermektedir. "Yatay kesit bağımlılığı yoktur" sıfır hipotezi altında geliştirilen $C D_{B P}$ testi $N(N-1) / 2$ serbestlik derecesi ile $\chi^{2}$ dağılımına sahiptir. 


$$
C D_{B P}=T \sum_{i=1}^{N-1} \sum_{j=i+1}^{N} \hat{\rho}_{i, j}^{2}
$$

Yatay kesit bağımlılığı testlerinden ikincisi, Pesaran (2004) tarafından geliştirilen $C D_{L M}$ testidir. Bu test $T$ ve $N$ 'in büyük olması durumunda $(N \rightarrow \infty$ ve $T \rightarrow \infty$ 'a giderken) geçerlidir. "Yatay kesit bağımlılığı yoktur" sıfır hipotezi altında standart normal dağılıma sahip olan $C D_{L M}$ testi (3) numaralı denklem yardımıyla hesaplanmaktadır:

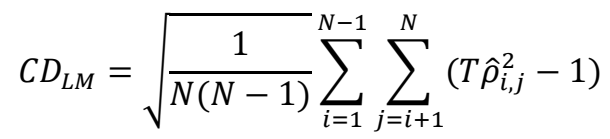

Yatay kesit bağımlılı̆̆ı testlerinden üçüncüsü ve sonuncusu, Pesaran (2004) tarafından geliştirilen $C D$ testidir. "Yatay kesit bağımlılı̆̆ı yoktur" sıfır hipotezi altında, standart normal dağılıma sahip olan bu test, $T$ sabit ve $N$ sonsuza giderken $(N \rightarrow \infty)$ yani $N>T$ iken geçerli olup, (4) numaralı denklem ile hesaplanmaktadır:

$$
C D=\sqrt{\frac{2 T}{N(N-1)}}\left(\sum_{i=1}^{N-1} \sum_{J=i+1}^{N} \hat{\rho}_{i, j}\right)
$$

Panel eşbütünleşme testinde kullanılacak tekniğin seçiminde değişkenlerin birim kök özellikleri önemlidir. Bu çalışmada değişkenlere ait birim kök özellikleri, birinci nesil panel birim kök testlerinden Levin, Lin, ,Chu (LLC, 2002), Im, Pesaran, Shin (IPS, 2003) ve Hadri (2000) birim kök testleri ile ve ikinci nesil panel birim kök testlerinden ise Pesaran (2007) tarafından geliştirilen, Yatay Kesit Açısından Geliştirilmiş Dickey-Fuller (CrossSectionally Augmented Dickey Fuller (CADF)) testi ile incelenmiştir.

LLC (2002) panel birim kök testi bütün yatay kesitlerin homojen olduğu varsayımına dayanarak ortak birim kökün varlığına dair boş hipotez test edilmektedir. IPS (2003) panel birim kök testinde ise bütün yatay kesitlerin homojen olması varsayımının LLC panel birim kök testinin zayıf yönü olduğunu belirterek, bütün yatay kesitlerin heterojen olduğu varsayımından hareketle bireysel birim kökün varlığına dair boş hipotez test edilmektedir. Hadri (2000) ise ortak birim kökün olmamasını boş hipotezde test etmektedir.

Çalışmanın güvenilirliğini arttırmak amacıyla birinci nesil panel birim kök testlerinden LLC, IPS ve Hadri panel birim kök testlerinin yanı sıra panel veri setinde yer alan gruplar arasında yatay kesit bağımlılığını dikkate alan ikinci nesil panel birim kök testlerine de yer verilmiş olup, Pesaran (2007) tarafından geliştirilen, Yatay Kesit Açısından Geliştirilmiş Dickey-Fuller (Cross-Sectionally Augmented Dickey Fuller (CADF)) testi olarak adlandırılan panel birim kök testi bu çalışmada kullanılmıştır. CADF panel birim kök testi, (5) numaralı eşitlikte yer alan regresyon modeli sinamasina dayanmaktadır.

$$
\begin{aligned}
& \Delta y_{i, t}=a_{i}+b_{i} y_{i, t-1}+c_{i} \bar{y}_{t-1}+d_{i} \Delta \bar{y}_{t}+\varepsilon_{i, t} \\
& \bar{y}_{t}=N^{-1} \sum_{j=1}^{N} y_{j t} \\
& \Delta \bar{y}_{t}=N^{-1} \sum_{j=1}^{N} \Delta y_{j t}
\end{aligned}
$$

Bu modelde $\bar{y}_{t}(6)$ numaralı eşitlikteki gibi, $\Delta \bar{y}_{t}$ ise (7) numaralı eşitlikteki gibi bulunurken, $\varepsilon_{i, t}$ hata terimini ifade etmektedir. Regresyon modelinde yer alan yatay kesit ortalaması $\bar{y}_{t}$, onun gecikmeli değerleri $\left(\bar{y}_{t-1}, \bar{y}_{t-2}\right.$, ...) ve $\Delta \bar{y}_{t}$; genel bir faktör yapısına bağlı olarak yatay kesit bağımlılığının dikkate alınmasını sağlayan bir kukla (Proxy) olarak regresyon modeline dahil edilmiştir (Pesaran, 2007: 269).

Pesaran (2007)'ın CADF panel birim kök testinde sıfır hipotezi, “paneli oluşturan her bir yatay kesite ait serinin birim kök içerdiği" önermesini $\left(H_{0}: b_{i}=0\right.$ bütün yatay kesitler için); alternatif hipotez ise "paneli oluşturan yatay kesitlerin belirli bir bölümünün birim kök içermediği $\left(H_{1}: b_{i}<0\left(i=1,2, \ldots, N_{l}\right), b_{i}=0\left(i=N_{l}+1\right.\right.$, $N_{l}+2, \ldots, N$ ) önermesini sinamaktadır (Pesaran, 2007: 267-269).

CADF testinde bulunan $b_{i}$ katsayıları CADF istatistiği olup, bunlara ait t-istatistikleri mevcut kritik değerlerle karşılaştırılarak her bir yatay kesite ait serinin birim kök içerip içermediğine karar verilir. Panel veri setinin durağan olup olmadığını test etmek için CADF istatistiklerinin ortalaması alınarak kesit açısından genişletilmiş IPS (cross-sectionally augmented IPS (CIPS)) test istatistiği (8)'da ki gibi elde edilir.

$$
C I P S=N^{-1} \sum_{i=1}^{N} C A D F_{i} \sim N(0,1)
$$

Son olarak panel veri setinin birim kök içerip içermediğini tespit etmek için Pesaran (2007: 279-280-281)'da verilmiş olan CIPS için kritik değerlerle karşılaştırılarak karar verilir. 
$\mathrm{Bu}$ çalışmada, değişkenler arasındaki uzun dönemli eşbütünleşme ilişkisini tespit etmek için panel eşbütünleşme analizleri içerisinde sıklıkla kullanılan Pedroni (1999) panel eşbütünleşme testi kullanılmıştır. Pedroni panel eşbütünleşme testi durağanlık sınamasında serilerin I(1) yani birinci mertebeden durağan olduğu durumda geçerlilik arz etmektedir. Pedroni testinde ilk aşamada aşağıdaki model EKK yöntemi ile tahmin edilmektedir:

$$
Y_{i, t}=\alpha_{i}+\delta_{i} t+\beta_{i} X_{i, t}^{\prime}+e_{i, t}
$$

$\mathrm{Bu}$ denklemde, $Y$ ve $X$ birinci farkları alındığında durağan olan değişkenler olup, $\alpha_{i}$ sabit etkileri, $t$ trendi göstermektedir. Tahmin edilen modelden $\left(e_{i, t}\right)$ hata terimleri elde edilir ve ikinci aşamada, (9) numaralı modelin EKK tahmininden $\left(\eta_{i, t}\right)$ hata terimi elde edilir.

$$
\Delta Y_{i, t}=\beta_{i} \Delta X_{i, t}^{\prime}+\eta_{i, t}
$$

Üçüncü aşamada, Newey-West (1987) tahmincisi kullanılarak $\left(\eta_{i, t}\right)$ hata teriminin uzun dönem varyansı $\left(L_{11 i}^{2}\right)$ hesaplanır. Dördüncü aşamada, parametrik olmayan testler için ve parametrik testler için ayrı ayrı tahminlerden hata terimleri varyansı elde edilir. Parametrik olmayan testler için (10) numaralı model tahmin edilir ve $\left(\hat{u}_{i, t}\right)$ hata terimlerinin varyansı $\left(\hat{S}_{i}^{2}\right)$, uzun dönem varyansı $\left(\hat{\sigma}_{i}^{2}\right)$ elde edilir.

$\hat{e}_{i, t}=\hat{\gamma}_{i} \hat{e}_{i, t-1}+\hat{u}_{i, t}$

Daha sonra, $\left(\hat{\lambda}_{i, t}\right)$ terimi $\hat{\lambda}_{i, t}=1 / 2\left(\hat{\sigma}_{i}^{2}-\hat{s}_{i}^{2}\right)$ denklemi kullanılarak elde edilir. Parametrik testler için (11) numaralı model tahmin edilir ve $\left(\hat{u}_{i, t}^{*}\right)$ hata terimlerinin varyansı $\left(\hat{s}_{i}^{* 2}\right)$ elde edilir.

$$
\hat{e}_{i, t}=\hat{\gamma}_{i} \hat{e}_{i, t-1} \sum_{k=1}^{K_{i}} \hat{\gamma}_{i, k} \Delta \hat{e}_{i, t-k}+\hat{u}_{i, t}^{*}
$$

Beşinci ve son aşamada ise, Pedroni (1999) tarafından geliştirilen, ilk dördü kesit içi, son üçü kesitler arası olmak üzere yedi panel eşbütünleşme testi aşağıdaki denklemler yardımı ile hesaplanır:

Kesit içi panel eşbütünleşme testleri:

$$
\begin{aligned}
& T^{2} N^{3 / 2} Z_{\widehat{v}_{N, T}} \equiv T^{2} N^{3 / 2}\left(\sum_{i=1}^{N} \sum_{t=1}^{T} \hat{L}_{11 i}^{-2} \hat{e}_{i, t-1}^{2}\right)^{-1} \\
& T \sqrt{N} Z_{\widehat{\rho} N, T^{-1}} \equiv T \sqrt{N}\left(\sum_{i=1}^{N} \sum_{t=1}^{T} \hat{L}_{11 i}^{-2} \hat{e}_{i, t-1}^{2}\right)^{-1} \sum_{i=1}^{N} \sum_{t=1}^{T} \hat{L}_{11 i}^{-2}\left(\hat{e}_{i, t-1} \Delta \hat{e}_{i, t}-\hat{\lambda}_{i}\right) \\
& Z_{t_{N, T}} \equiv\left(\tilde{\sigma}_{N, T}^{2} \sum_{i=1}^{N} \sum_{t=1}^{T} \hat{L}_{11 i}^{-2} \hat{e}_{i, t-1}^{2}\right)^{-1 / 2} \sum_{i=1}^{N} \sum_{t=1}^{T} \hat{L}_{11 i}^{-2}\left(\hat{e}_{i, t-1} \Delta \hat{e}_{i, t}-\hat{\lambda}_{i}\right) \\
& Z_{t_{N, T}}^{*} \equiv\left(\tilde{s}_{N, T}^{* 2} \sum_{i=1}^{N} \sum_{t=1}^{T} \hat{L}_{11 i}^{-2} \hat{e}_{i, t-1}^{* 2}\right)^{-1 / 2} \sum_{i=1}^{N} \sum_{t=1}^{T} \hat{L}_{11 i}^{-2} \hat{\mathrm{e}}_{\mathrm{i}, \mathrm{t}-1}^{*} \Delta \hat{\mathrm{e}}_{\mathrm{i}, \mathrm{t}}^{*}
\end{aligned}
$$

Kesit içi panel eşbütünleşme testleri:

5. Grup

$\rho$-istatistiği:

$$
T N^{-1 / 2} \tilde{Z}_{\hat{\rho} N, T^{-1}} \equiv T N^{-1 / 2} \sum_{i=1}^{N}\left(\sum_{t=1}^{T} \hat{e}_{i, t-1}^{2}\right)^{-1} \sum_{t=1}^{T}\left(\hat{e}_{i, t-1} \Delta \hat{e}_{i, t}-\hat{\lambda}_{i}\right)
$$

6. Grup

t-istatistiği:

(Parametrik

olmayan)

7. Grup

t-istatistiği:

(Parametrik)

$$
N^{-1 / 2} \tilde{Z}_{t_{N, T}} \equiv N^{-1 / 2} \sum_{i=1}^{N}\left(\hat{\sigma}_{i}^{2} \sum_{t=1}^{T} \hat{e}_{i, t-1}^{2}\right)^{-1 / 2} \sum_{t=1}^{T}\left(\hat{e}_{i, t-1} \Delta \hat{e}_{i, t}-\hat{\lambda}_{i}\right)
$$

Pedroni (1999) eşbütünleşme testinde sıfir hipotezi, "bütün yatay kesitler için eşbütünleşme ilişkisi yoktur", alternatif hipotez ise, "bütün yatay kesitler için eşbütünleşme ilişkisi vardır" savını sınamaktadır. Bu testler standart normal dağılıma sahip olmakla beraber panel v-istatistiği sağ kuyruk dağılımı, diğerleri sol kuyruk dağılımı göstermektedir.

Değişkenler arasında eşbütünleşme ilişkisi olduğu sonucuna ulaşılırsa, değişkenlere ait uzun dönem katsayılarının nasıl elde edileceği önem taşımakta olup çalışmada Pedroni (2001) tarafından geliştirilen Panel DOLS (Panel Dynamic Ordinary Least Squares) tahmincileri kullanılmıştır. Panel DOLS tahmincileri bağımsız değişkenler ve hata terimleri arasında içsellik ve hata terimlerinin kendine bağlaşımlılık sorununun 
giderilmesinde Panel OLS tahmincisine kıyasla daha etkindir. Pedroni (2001) tarafından önerilen Panel DOLS tahmincisi (19) numaralı regresyon tahmini ile gerçekleştirilir:

$$
y_{i, t}=\alpha_{i}+\beta_{i} x_{i, t}^{\prime}+\sum_{k=-K_{i}}^{K_{i}} \gamma_{i, k} \Delta \beta_{i, t-k}+\mu_{i, t}^{*}
$$

(19) numaralı denklemde $\left(-K_{i}\right)$ ve $\left(K_{i}\right)$ öncül ve gecikme sayılarını ifade etmektedir. Panel DOLS'da paneli oluşturan yatay kesitlerin yatay kesit bağımlılığı içermediği varsayılmaktadır. Panel DOLS'da birinci aşamada panel eşbütünleşme vektörünü elde edebilmek için (19) numaralı denklem her bir yatay kesit için tahmin edilir. İkinci aşamada, her bir yatay kesite ait bu tahminlerin aritmetik ortalaması (20) numaralı denklemdeki gibi alınarak, panel eşbütünleşme katsayıları elde edilmektedir:

$$
\hat{\beta}_{G D}^{*}=N^{-1} \sum_{i=1}^{N} \beta_{D, i}^{*}
$$

(20) numaralı eşitlikte yer alan $\left(\beta_{D, i}^{*}\right)$ her bir yatay kesite ait DOLS tahmininden elde edilen eşbütünleşme katsayılarını ifade etmektedir. Panel DOLS tahmincilerinin anlamlılıkları t-istatistikleri ile belirlenmekte olup, $t$ istatistikleri (21) numaralı denklemdeki gibi ifade edilmektedir.

$$
t_{\widehat{\beta}_{D}^{*}}=N^{-1 / 2} \sum_{i=1}^{N} t_{\widehat{\beta}_{D, i}^{*}}
$$

(21) numaralı denklemde $\left(t_{\widehat{\beta}_{D, i}^{*}}\right)$ her bir yatay kesit için DOLS tahmininden elde edilen eşbütünleşme katsayısına ilişkin t-istatistiğini göstermektedir.

\section{Bulgular}

Panel eşbütünleşme analizleri yapılırken, panel veri setinde yatay kesitler arasında ilişki olup olmadı ğı önem arz etmektedir. Çalışmada kullanılan değişkenlere ait yatay kesitler arasında ilişki olup olmadığını tespit ettiğimiz test sonuçları Tablo 1'de verilmiştir. Sonuçlar baktığımızda lnGDP CD testinde yatay kesit bağımlılığının varlığ $1 \% 10$ anlamlılık düzeyinde kabul edilmiş ve lnFDI değişkeni için yine CD testinde yatay kesit bağımlılığının varlığı reddedilmiş olmasına rağmen diğer testlerde yatay kesit bağımlılığının varlığı kabul edilmiştir. Bu bağlamda test sonuçlarına göre tüm değişkenlere ait yatay kesitler arasında ilişki olduğu yani değişkenlerin yatay kesit bağımlılı̆̆ı içerdiği sonucuna ulaşılmıştır.

\begin{tabular}{|l|l|l|l|}
\hline & $\mathrm{CD}_{\mathrm{BP}}$ & $\mathrm{CD}_{\mathrm{LM}}$ & $\mathrm{CD}$ \\
\hline $\ln \mathrm{GDP}$ & $52,939(0,034)^{* *}$ & $1,996(0,023)^{* *}$ & $-1,369(0,086)^{*}$ \\
\hline $\ln \mathrm{X}$ & $57,367(0,013)^{* *}$ & $2,518(0,006)^{* * *}$ & $-2,097(0,018)^{* *}$ \\
\hline $\ln \mathrm{M}$ & $53,252(0,032)^{* *}$ & $2,033(0,021)^{* *}$ & $-2,061(0,020)^{* *}$ \\
\hline $\ln \mathrm{FDI}$ & $69,651(0,001)^{* * *}$ & $3,966(0,000)^{* * *}$ & $-1,004(0,158)$ \\
\hline
\end{tabular}

Not: Parantez içerisindeki değerler olasılık değerlerini göstermektedir. ***, ** ve * sırasıyla \%1, \%5 ve \%10 anlamlılık düzeylerini ifade etmektedir.

\section{Tablo 1: Yatay Kesit Bă̆ımlılı̆̆ Test Sonuçları}

Serilerde yatay kesit bağımlılığı olduğundan serilere ait birim kök özellikleri hem birinci nesil panel birim kök testleri hem de ikinci nesil panel birim kök testleri ile araştırılmıştır. Ele alınan seriler panel birim kök testlerinde serilerin panel birim kök testlerinde düzey durumunda tam bir tutarlılık göstermemekle birlikte birince dereceden farkı alındığında tüm serilerin durağan hale geldikleri gözlemlenmiştir. Dolayısıyla çalışmada ele alınan serilerin tamamı I(1) olduğu sonucuna ulaşılmıştır.

\begin{tabular}{|l|l|l|l|l|}
\hline & LLC & IPS & Hadri & CIPS \\
\hline $\ln \mathrm{GDP}$ & $-1,209(0,113)$ & $3,147(0,999)$ & $7,037(0,000)$ & $-2,566^{* *}$ \\
\hline $\ln \mathrm{X}$ & $-0,779(0,218)$ & $2,278(0,988)$ & $6,968(0,000)$ & $-2,054$ \\
\hline $\ln \mathrm{N}$ & $0,473(0,682)$ & $2,900(0,998)$ & $6,862(0,000)$ & $-2,268^{*}$ \\
\hline $\ln \mathrm{FDI}$ & $-2,242(0,013)^{* *}$ & $-1,260(0,104)$ & $4,821(0,000)$ & $-2,369^{*}$ \\
\hline$\Delta \operatorname{lnGDP}$ & $-6,886(0,000)^{* * *}$ & $-5,812(0,000)^{* * *}$ & $0,876(0,190)^{* * *}$ & $3,272^{* * *}$ \\
\hline$\Delta \ln \mathrm{x}$ & $-7,493(0,000)^{* * *}$ & $-5,539(0,000)^{* * *}$ & $-0,114(0,545)^{* * *}$ & $-2,942^{* * *}$ \\
\hline$\Delta \ln \mathrm{M}$ & $-8,639(0,000)^{* * *}$ & $-6,992(0,000)^{* * *}$ & $0,099(0,461)^{* * *}$ & $-3,739^{* * *}$ \\
\hline$\Delta \operatorname{lnFDI}$ & $-11,740(0,000)^{* * *}$ & $-10,961(0,000)^{* * *}$ & $-0,079(0,532)^{* * *}$ & $-3,302^{* * *}$ \\
\hline
\end{tabular}

Tablo 2: LLC, IPS, Hadri ve CIPS Birim Kök Sınaması Sonuçları 
Not: Testlerde tahmin edilen modeller sadece sabit terim içermektedir. Gecikme uzunlukları Modifiye Edilmiş Schwarz Bilgi Kriterine göre belirlenmiş olup, tüm testlerde maksimum 3 olarak alınmıștır. Parantez içerisindeki değerler olasılık değerlerini göstermektedir. ***, ** ve * sırasıyla \%1, \%5 ve \%10 anlamlılık düzeylerini ifade etmektedir. CIPS testi için kritik değerler Pesaran (2007) sayfa 280'dan alınmış olup $\% 1, \% 5$ ve $\% 10$ anlamlılık düzeyleri için sırası ile $-2,66 ;-2,37$ ve $-2,22$ 'dir.

Modele ait Pedroni (1999) panel eşbütünleşme testi sonuçları Tablo 3’te verilmiştir. Tablo 3 'te görüldüğü gibi 7 testten 4'ü en az $\% 5$ anlamlılık düzeyinde istatistiksel olarak anlamlı bulunmuştur. Bu durumda ele alınan model için panel veri setinde eşbütünleşme ilişkisi yoktur sıfır hipotezi reddedilmektedir. Yani ekonomik büyüme, ihracat, ithalat ve doğrudan yabancı yatırımlar arasında uzun dönemli bir ilişki olduğu tespit edilmiştir.

\begin{tabular}{|l|l|}
\hline Test İstatistikleri & \\
\hline Panel v istatistiği & 0,681 \\
\hline Panel $\rho$ istatistiği & 0,433 \\
\hline Panel t istatistiği (Parametrik Olmayan) & $-1,841^{* *}$ \\
\hline Panel t istatistiği (Parametrik) & $-2,145^{* *}$ \\
\hline Grup $\rho$ istatistiği & 1,616 \\
\hline Grup t istatistiği (Parametrik Olmayan) & $-1,670^{* *}$ \\
\hline Grup t istatistiği (Parametrik) & $-3,150^{* * *}$ \\
\hline
\end{tabular}

Not: Eşbütünleşme testinde maksimum gecikme uzunluğu 3 olarak alınmıştır. ***, ** ve * sırası ile \%1 $(2,326), \% 5(1,645)$ ve \%10 $(1,282)$ anlamlılık düzeylerinde ait oldukları istatistiklerin sıfır hipotezini reddettiklerini göstermektedir.

Tablo 3: Pedroni (1999) Panel Eşbütünleşme Testi Sonuçları

\begin{tabular}{|c|c|c|c|}
\hline Ülke & Değişken & Katsayı & t-istatistiği \\
\hline \multirow{3}{*}{ Belarus } & $\ln X$ & 0,427 & $288,484 * * *$ \\
\hline & $\ln M$ & $-0,340$ & $-99,804 * * *$ \\
\hline & $\operatorname{lnFDI}$ & 0,178 & $91,112 * * *$ \\
\hline \multirow{3}{*}{ Ermenistan } & $\ln X$ & 0,923 & $5,987 * * *$ \\
\hline & $\ln M$ & $-0,509$ & $-1,894 * *$ \\
\hline & $\operatorname{lnFDI}$ & 0,175 & $1,644 *$ \\
\hline \multirow{3}{*}{ Kazakistan } & $\ln \mathrm{X}$ & 0,490 & $48,321 * * *$ \\
\hline & $\ln M$ & 0,047 & $3,458 * * *$ \\
\hline & $\operatorname{lnFDI}$ & $-0,047$ & $-20,806 * * *$ \\
\hline \multirow{3}{*}{ Kırgızistan } & $\ln X$ & $-0,296$ & $-6,894 * * *$ \\
\hline & $\ln M$ & $-0,023$ & $-1,620^{*}$ \\
\hline & $\operatorname{lnFDI}$ & $-0,024$ & $-3,640 * * *$ \\
\hline \multirow{3}{*}{ Moldova } & $\ln X$ & 0,979 & 370,426 *** \\
\hline & $\ln M$ & $-0,687$ & $-109,430$ *** \\
\hline & $\operatorname{lnFDI}$ & $-0,006$ & $-16,732 * * *$ \\
\hline \multirow{3}{*}{ Rusya } & $\ln \mathrm{X}$ & $-3,182$ & $-381,953 * * *$ \\
\hline & $\ln M$ & 2,149 & $221,152 * * *$ \\
\hline & $\operatorname{lnFDI}$ & $-0,479$ & $-245,855 * * *$ \\
\hline \multirow{3}{*}{ Tacikistan } & $\ln X$ & 0,179 & $1,756 * *$ \\
\hline & $\ln M$ & $-0,292$ & $-13,053 * * *$ \\
\hline & $\operatorname{lnFDI}$ & $-0,172$ & $-14,255 * * *$ \\
\hline \multirow{3}{*}{ Ukrayna } & $\ln X$ & $-0,367$ & $-167,293 * * *$ \\
\hline & $\ln M$ & 1,547 & $266,085 * * *$ \\
\hline & $\operatorname{lnFDI}$ & $-0,070$ & $-138,611 * * *$ \\
\hline \multirow{3}{*}{ Azerbaycan } & $\ln X$ & 0,945 & $53,016 * * *$ \\
\hline & $\ln M$ & $-0,633$ & $-22,208 * * *$ \\
\hline & $\operatorname{lnFDI}$ & $-0,060$ & $-10,691 * * *$ \\
\hline \multirow{3}{*}{ Grup } & $\ln \mathrm{X}$ & 0,011 & $70,616 * * *$ \\
\hline & $\ln M$ & 0,014 & $80,895 * * *$ \\
\hline & $\operatorname{lnFDI}$ & $-0,056$ & $-119,279 * * *$ \\
\hline
\end{tabular}

Tablo 4: Panel DOLS Sonuçlarl

Son olarak, değişkenler arasında eşbütünleşme ilişkisi tespit edildiğinden değişkenlere ait uzun dönem katsayıları Panel DOLS tahmincisi kullanılarak tespit edilmiştir. Tablo 4'de yer alan panel grup istatistiği sonuçlarına göre ihracatta meydana gelen \%1'lik bir artı̧̧ GSYİH’yı \%1,1 ithalatta meydana gelen \%1'lik bir artış GSYİH'yı \%1,4 arttırmaktadır. Diğer taraftan doğrudan yabancı yatırımlarda meydana gelen \%1'lik bir artış GSYİH’yı \%5,6 azaltmaktadır. Bireysel ülke sonuçlarına baktığımızda ise, Belarus, Ermenistan, Kazakistan, 
Moldova, Tacikistan ve Azerbaycan'da ihracatın GSYIH üzerine etkisi pozitif iken, Kırgızistan, Rusya ve Ukrayna'da etki negatif olarak gerçekleşmiştir. Diğer taraftan, Kazakistan, Rusya, ve Ukrayna'da ithalatı'ın GSYIH üzerine etkisi pozitif iken, diğer ülkelerde negatif olarak gerçekleşmiştir. Son olarak doğrudan yabancı yatırımlar GSYIH üzerinde sadece Belarus ve Ermenistan'da pozitif iken, diğer tüm ekonomilerde negatif olarak gerçekleşmiştir.

\section{Sonuç}

Bu çalışmada, 1991 yılında Sovyet Sosyalist Cumhuriyetler Birliği’nin dağılması ile birlikte bağımsızlığını elde eden ülkeler olarak tanımlanmakta olan Avrasya ekonomilerinde dış ticaret ve doğrudan yabancı yatırımların gayrisafi yurt içi hasıla üzerine etkisi incelenmiş̧ir. 1995-2011 dönemine ait verilerden yararlanılmış ve analiz Pedroni (1999) tarafindan geliştirilen Panel Eşbütünleşme testi ile gerçekleştirilmiştir. Analizden elde edilen sonuçlar değiş̧kenler arasında uzun dönemli bir eşbütünleşme ilişkisi olduğunu göstermekle birlikte, her bir ülke için Panel DOLS sonuçlarına bakıldığında her ne kadar ülkeler arasında farklılık göstermiş olsa da ele alınan ülkelerde Panel Grubuna ait sonuçlara bakıldığında ithalat ve ihracatın GSYİH'yı pozitif yönde, doğrudan yabancı yatırımların ise negatif yönde etkilediğini göstermektedir.

Çalışmadan elde edilen sonuçlar ele alınan Avrasya Ekonomileri'nde dış ticaretin ekonomik büyümeyi arttırıcı yönde desteklediğini göstermektedir. Gerçektende çalışma verileri incelendiğinde ele alınan Avrasya Ekonomileri'nde genel eğilim dış ticaretin arttığı yıllarda ekonomik büyümenin de artmış olmasıdır. 1995-2000 arasında ekonomilerdeki genel eğilim hem büyüme hem de dış ticaret bağlamında durgunlukla geçerken, 2000'li yıllarda hem dış ticaret hacmi artmış hemde ekonomik büyüme hızlanmıştır. 1995-2000 döneminde var olan durgunluğun temel sebebi ise Rusya kaynaklı Orta Asya Krizi'dir.

Diğer taraftan, doğrudan yabancı yatırımların ekonomik büyümeyi azaltıcı etkisi literatürde yer alan Herzer, Klasen ve Lehmann (2008), Yang (2008)'ın çalışmaları ile benzerlik göstermektedir. Bu durumun temel nedeni ele alına Avrasya ekonomilerinin temel yapısından kaynaklı olduğu düşünülebilir. Çok yakın zamanda bağımsızlığını ilan eden bu ekonomilerin hemen Orta Asya Krizi ile karşı karşıya kalmaları küreselleşme sürecini olumsuz yönde etkilemiş ve yeterli doğrudan yabancı yatırımların aktarılamamış olmasına neden olmuş olabilir. Ayrıca doğrudan yabancı yatırımların gidecekleri ülkelerde sürekli ve kalıcı olmaları ve gidilen ülke ekonomisinin doğrudan yabancı yatırımları destekleyecek hem ekonomik hem de beşeri altyapının varlığı ekonomik büyüme üzerinde olumlu etki yaratabilir. Diğer taraftan doğrudan yabancı yatırımlar gidilecek ülkede hem ekonomik hem de siyasi istikrarın var olmasını isterler. Avrasya ekonomilerinde hem ekonomik hem siyasi istikrarın var olması, ayrıca doğrudan yabancı yatırımların sürekli ve kalıcı olmasını sağlayacak ekonomik ve beşeri altyapının varlığı ancak 2000'li yıllarda gözlemlenmeye başlandığı söylenebilir.

Sonuç olarak, ele alınan Avrasya ekonomilerinde dış ticaretin ekonomik büyüme üzerinde var olan pozitif etkisi devam ettirilmelidir. Ancak bu amaca yönelik politikalar geliştirilirken politika uygulayıcılar ithalat ile ihracat arasındaki makasın ithalat lehine açılmasını önlemeye yönelik politikalar geliştirmelidirler. Diğer taraftan doğrudan yabancı yatırımların ekonomik büyüme üzerindeki negatif etkisini pozitife dönüştürmek için ekonomik ve siyasi istikrarın sağlanması ya da devam ettirilmesi, doğrudan yabancı yatırımların ülke ekonomisine girişini arttırmak ve kalıcı olmasını sağlamak için gerekli olan ekonomik ve beşeri altyapının sağlanması gerekmektedir. $\mathrm{Bu}$ çerçevede doğrudan yabancı yatırımların kalıcı olacak ve uzun vadede ekonomik büyüme üzerinde pozitif etkisi görülecektir.

\section{Kaynakça}

- Afxentiou, P. C., ve Serletis, A. 1991. "Exports and GNP Causality in the Industrial Countries: 1950-1985", Kyklos, 44(2), pp. 167-79.

- Balassa, B., 1978. "Exports and Economic Growth: Further Evidence", Journal of Development Economics 5(2), pp. 181-189.

- Balassa, B., 1985. "Exports, Policy Choices, and Economic Growth in Developing Countries After the 1973 Oil Shock", Journal of Development Economics, 4(1), pp. 23-35.

- Bahmani-Oskooee, M., ve Alse, J. 1993. "Export Growth and Economic Growth: an Application of Cointegration and Error-Correction Modelling", The Journal of Developing Areas, 27, pp. 535-542.

- Borensztein, E., De Gregorio J ve Lee, J-W. 1998. "How Does Foreign Direct Investment Affect Economic Growth”, Journal of International Economics, 45, pp. 115-135.

- Bosworth, B. ve Collins, S. M., 1999. “Capital Inflows, Investment, and Growth”, Tokyo Clup Papers, 12, pp. 55-74.

- Breusch, T. S. ve Pagan, A. R., 1980. "The Lagrange Multiplier Test and its Applications to Model Spesification in Econometrics" The Review of Economic Studies, 47(1), pp. 239-253. 
- Campos, N. F. ve Kinoshita, Y., 2002. Foreign Direct Investment as Technology Transferred: Some Panel Evidence from the Transition Economies", http://deepblue.lib.umich.edu/bitstream/handle/2027.42/39822/wp438.pdf;jsessionid=D972ACA54F2A32E AB08861AD54DFD057? sequence=3.

- Chow, P.C.Y., 1987. “Causality Between Export Growth and Industrial Development: Empirical Evidence from the NICs”, Journal of Development Economics, 26(1), pp. 55-63.

- Colombatto, E., 1990. “An Analysis of Exports and Growth”, Kyklos, 43(4), pp. 579-97.

- Cuadros, A., Orts V., ve Alguacil, M. 2004. “Openness and Growth: Re-examining Foreign Direct Investment, Trade and Output Linkages in Latin America”, Journal of Development Studies, 26, pp. 167-92.

- Darrat, A.F. 1987. “Are Exports an Engine of Growth? Another Look at the Evidence”, Applied Economics 19(2), pp. 277-283.

- Djankov, S. ve Hoekman, B., 2000. "Foreign Investment and Productivity Growth in Czech Enterprises", The World Bank Economic Review, 14(1), pp. 49-64.

- $\quad$ Ericsson, J. ve Irandoust, M. 2001. “On the Causality Between Foreign Direct Investment and Output: A Comparative Study”, The International Trade Journal, 15(1), pp. 1-26.

- $\quad$ Fedderke, J.W., ve Romm A. T., 2006. "Growth Impact and Determinants of Foreign Direct Investment Into South Africa, 1956-2003”, Economic Modelling 23, pp. 738-760.

- $\quad$ Feder, G., 1982. “On Exports and Economic Growth”. Journal of Development Economics, 12(2), pp. 59-73.

- Hadri, K. 2000. “Testing for Stationarity in Heterogeneous Panel Data”, Econometrics Journal, 3, pp. 148161.

- Hermes, N., ve Lensink, R., 2003. "Foreign Direct Investment, Financial Development and Economic Growth", http://www.rug.nl/staff/c.l.m.hermes/fdi_and_financial_development.pdf

- Herzer, D., Klasen, S. ve Nowak-Lehmann D., 2008. "In Search of FDI-led Growth in Developing Countries: The Way Forward”, Economic Modelling, 25, pp. 793-810.

- Im, K. S., Pesaran, M. H., ve Shin, Y. 2003. "Testing For Unit Roots in Heterogeneous Panels", Journal of Econometrics, 115, pp. 53-74.

- Jin, Jang C., 2006. “Openness, Growth, and Inflation: Evidence from South Korea Before the Economic Crisis", Journal of Asian Economics, 17, pp. 738-757.

- Kaldor, N., 1970. “The Case for Regional Policies”, Scottish Journal of Political Economy, 17(3), pp. 337348.

- $\quad$ Katerina, L., John, P. ve Athanasios, V., 2004. "Foreign Direct Investment and Economic Growth in Transition Economies", South Eastern Europe Journal of Economies, 1, pp. 97-110.

- Konya, L., 2006. "Exports and Growth: Granger Causality Analysis on OECD Countries with a Panel Data Approach”, Economic Modelling , 23, pp. 978-992.

- Kugler, P., 1991. "Growth, Exports and Cointegration: an Empirical Investigation”, Weltwirtschaffliches Archiv, 127(1), pp. 73-82.

- $\quad$ Levin, A., Lin, C. ve Chu, C. J. 2001. "Unit Root Tests in Panel Data: Asymptotic and Finite-Sample Properties" Journal of Econometrics, 108, pp. 1-24.

- Levine, R., ve Renelt, D. 1992. “A Sensitivity Analysis of Cross-Country Growth Regressions”, American Economic Review 82(4), pp. 942-963.

- Mahadevan, R. ve Suardi, S. 2008. “A Dynamic Analysis of the Impact of Uncertainty on Import-and/or Export-led Growth: the Experience of Japan and the Asian Tigers" Japan and the World Economy, 20(2), pp. 155-174.

- Marwah, K., ve Tavakoli, A. 2004. "The Effect of Foreign Capital and Imports on Economic Growth: Further Evidence from Four Asian Countries (1970-1998)" Journal of Asian Economics, 15, pp. 399-413.

- Pedroni, P., 1999. "Critical Values for Cointegration Tests in Heterogeneous Panels With Multiple Regressors”, Oxford Bullettin of Economics and Statistics, Special Issue, pp. 653-670.

- Pedroni, P., 2001. "Purchasing Power Parity Tests in Cointegrated Panels", Review of Economics and Statistics, 83, pp. 727-931.

- Pesaran, M. H., 2004. "General Diagnostic Tests for Cross Section Dependence in Panels" http://www.dspace.cam.ac.uk/bitstream/1810/446/1/cwpe0435.pdf.

- Pesaran, H. M., 2007. "A Simple Panel Unit Root Test in the Presence of Cross-Section Dependence”, Journal of Applied Econometrics, 22, pp. 265-312. 
- $\quad$ Ram, R., 1985. "Exports and Economic Growth: Some Additional Evidence", Economic Development and Cultural Change, 33(2), pp. 415-25.

- $\quad$ Ramos, F.F.R., 2001. "Exports, Imports, and Economic Growth in Portugal: Evidence from Causality and Cointegration Analysis", Economic Modelling, 18, pp. 613-623.

- Razin, A. 2002. "FDI Contribution to Capital Flows and Intestment in Capacity", http://www.nber.org/papers/w9204.pdf?new_window=1.

- Sengupta J. K., 1991. "Rapid Growth in NICs in Asia: Tests of New Growth Theory for Korea", Kyklos, 44(4), pp. 561-579.

- $\quad$ Shirazi, N.S., ve Abdul Manap, T. A. 2005. "Export-led Growth Hypothesis: Further Econometric Evidence from South Asia", The Developing Economies, 18(4), 472-488.

- Thirlwall, A. P., 1979. "The Balance of Payments Constraint as an Explanation of International Growth rate Differances” Banco Nazionale del Lavoro Quarterly Review, 1, pp. 45-53.

- Vu, T.B. ve Noy I. 2008. "Sectoral Analysis of Foreign Direct Investment and Growth in the Developed Countries", Journal of International Financial Merkets, 19(2), 402-413.

- Willamson, R., 1978. "The Role of Exports and Foreign Capital in Latin American Economic Growth" Southern Economic Journal, 45(2), pp. 410-20.

- Xu, B., 2000. "Multinational Enterprises, Technology Diffusion, and Host Country Productivity Growth", Journal of Development Economics, 62, pp. 477-493.

- Yang, B., 2008. "FDI and Growth: a Varying Relationship Across Regions and Over Time", Applied Economics Letters, 15, pp. 105-108.

- Yang, J. 2002. "Direct and Financial Foreign Investment: How Do They Differ in Benefits to Developing Countries?”, http://home.gwu.edu/ jwyang/FFI\%20and\%20FDI.pdf

- $\quad$ Yao, S. ve Wei, K., 2007. "Economic Growth in the Presence of FDI: The Perspective of Newly Industrialising Economies", Journal of Comparative Economics, 35, pp. 211-234. 


\title{
İhracat Ve Ücretler Arasındaki İlişkinin Türkiye Ekonomisi İçin Sinanması
}

\section{An Examination of the Relationship between Exports and Wages for Turkey}

\author{
Ph.D. Candidate Gürçem Oransay (Çukurova University, Turkey)
}

\begin{abstract}
In this study the together with increasing foregin trade after trade liberalization, affects of changing income distribution on wages has been discussed. Assuming wages as an issue of income distribution, it continues with foregin trade theories which are related to foreign trade and affect of export on wages in particular. The developments such as effective markets after trade liberalization, high efficiency and removal of barriers in front of international trade increase cost competitiveness and wage levels change. It is still discussed whether foreign trade has positive or negative affects on wages but it can be claimed that differences of opinion vary depending on economical structures and trade volumes of countries. Using a model which has been supplied from both theoretical and practical literature, this research will try to find out affects of export and openness on wages using unit root test, cointegration techniques and error correction mechanism on Turkish economy during the period of 1988:Q1-2010:Q4. Affects of both export and openness on wages has been studied seperately for sub sectors of Turkish Manufacturing Industry. Although there is not a full compliance in all sectors which are studied in all models within periods examined, it has been found out that export and openness create a negative affect on wages.
\end{abstract}

\section{Giriş}

Son 30 yılda gelişmekte olan ülkeler ve Türkiye de dahil olmak üzere dünya ülkelerinin büyük bir kısmı uluslararası ticaretinin serbestleşmesi doğrultusunda ithal ikamesine dayalı büyüme stratejisini bırakıp, ihracata dayalı büyümeyi benimsemiş ve bu doğrultuda ihracat ve ithalat oranlarını arttırmışladır. Bu değişim büyüme oranlarında olumlu sonuçlar doğururken, yurtiçi gelir dağılımı ve ücretler üzerine olumsuz etkileri ise giderek artmıştır. Sebebi ise kısa dönemde artan rekabet baskısı ile baş edememe ve işgücünün ticareti yapılan ve yapılmayan mal sektörleri arasında yeniden dağılımının zorlaşması olup, uzun dönemde ise ülke kaynaklarının daha etkin kullanılarak büyüme oranlarında artış elde edileceğidir.

Ticari liberalizasyon ve yurtiçi gelir dağılımı arasındaki ilişkiler, teorik düzeyde ilk olarak geleneksel ticaret teorisinde ele alınmış, konu ile ilgili tartışmalar günümüze de farklı kollardan ilerlemeye devam etmiştir. Aşağıda bu konuda yapılan çalışmalarla ilgili literatürden bazı çalışmalara kısaca değinilecektir.

Beyer, Rojas ve Vergara (1999), Şili’de ticari liberalizasyon ve ücret eşitsizliği arasındaki ilişkiyi inceledikleri ampirik çalışmalarında Şili'deki son 20 yılda yaşanan liberalizasyon gelişmeleri ile işgücü yoğun ürünlerdeki göreceli fiyat düşüşünün ücret adaletsizliğindeki artışı açıklamaya yardımcı olduğunu ortaya koymuşlardır. Haouas, Yagoubi ve Heshmati (2002)'nin Tunus ekonomisinde 1980'lerden sonra artan ticari liberalizasyon üzerine, bu sürecin ihracat ve ithalat sektörlerine etkilerini uzun dönem ve kısa dönemler için ayrı ayrı incelemiştir ve sonucunda ihracat sektöründe kısa dönemde istihdam ve ücret artışları gözlenmiştir. Uzun dönem içinde ise yaparak öğrenmenin pozitif etkilerinin yanında üretkenlikte ve kapasitede gelişmeler ortaya çıtığı için düşüşler yaşandı̆̆ı görülmüştür.

Kim ve Thompson (2006) 1964-1997 yılları arasında Birleşik Devletler üzerine yaptığı çalışmalarında tarifelerde yapılan indirimlerin ücretleri düşürdüğünü ve bununla birlikte satın alma gücünü de arttırdığını ortaya koymuşlardır. 1986-1990 yılları arası veriler kullanarak tarife indirimleri ve ithalat izinlerinde \% 50'nin üzerine çıkan kısıtlama oranlarının Meksika'da ücretlere etkisini araştıran Feliciano (2001), ticaret yapılan sektörlerin ticaret yapılmayan sektörlere oranla daha fazla ücret düşüşleri ile karşı karşıya kaldığını bulmuştur.

Milner ve Wright (1998), sanayi açısından kalkınmakta olan ülkelerin işgücü piyasalarının liberalizasyondan etkilenip etkilenmediğini gösteren çalışmalarında ticaret politikası reformları ile Morityus'da ücretlerin seyrini incelemiş, 1972-1991 yılları arasında ticaret liberalizasyonu ile birlikte uzun dönemde ücretlerde artış gözlemlemiş, ancak kısa dönemde ücretlerde aşağı yönlü bir hareket belirlemişlerdir.

Greenway, Hine ve Wright (1999)'in yaptıkları çalışmada Birleşik Krallık’ın 1979-1991 yılları arasındaki 167 adet imalat sanayi alt sektörleri verileri ile ticaret yoğunluğunun ücretlere etkisini incelemişlerdir. İthalat ve ihracat yapılan sektörlerde ticaret yoğunluğu arttığında işgücüne talebi azaltarak, yurtiçi ücretleri arttırmaktadır.

Robbins (1996), çalışmasında 1976-1995 yılları arası farklı periyotlarda Arjantin, Şili, Kosta-Rika, Kolombiya, Malezya, Meksika, Filipinler, Çin ve Uruguay üzerine yaptığı çalışmada az gelişmiş ülkelerde ticaret liberalizasyonunun göreceli ücret farklarını düşürdüğünü göstermiştir. 
Oyvat (2011) Türkiye üzerine yaptığı çalışmada, küreselleşmenin işgücü esnekliği ve işgücü pazarlık gücündeki düşüş sonucu özellikle de ticari malların üretildiği sektörlerde ücretleri düşürücü etkisinin olup olmadığı sorusuna yanıt aramış ve ticaret liberalizasyonunun takip ettiği düşük ücret durumunda rekabetin, imalat sanayinde ücret paylarını düşürdügünü ortaya koymuştur.

Feenstra ve Hanson (1997) Meksika üzerine yaptıkları çalışmada gelişmekte olan ülkelerde 1980’lerle birlikte başlayan dış kaynaklı sermaye birikimi sürecinin, nitelikli işgücü talebini ve bu işgücünün talebinin de reel ücretleri arttırdığını bulmuştur. Bu reel ücretlerdeki artış aynı zamanda gelir eşitsizliğinin artmasına da yol açmıştır.

Gökalp, Baldemir ve Akgün (2011) Türkiye üzerine yaptığı incelemede, dışa açılma sürecinin ücretlere etkisini üç sektör grubunda incelemiştir. Bu sürecin emek yoğun sektörlerde çalışanların (niteliksiz işgücünün) ücretlerini, sermaye ve araştırma yoğun sektörlere nazaran arttırmadığı bulunmuştur. Teoremin aksine gelir dağılımının emek yoğun sektörde çalışanların lehine değişmediği, nitelikli işgücünün gelirlerinde daha yüksek düzeyde artış olduğu ve gelir dağılımının bozulduğu ortaya çıkmaktadır.

Avalos ve Savvides (2003), Latin Amerika ve Batı Asya üzerine yaptıkları çalışmada dış ticaret ve ücret eşitsizlikleri arasındaki ilişkiyi incelemişlerdir. Ticarette açıklık ücret farklarını her iki ülkede de azaltmaktadır. Revenga (1997), Meksika üzerine yaptığı çalışmasında kar paylarının ücret belirlemede önemli olduğunu ve ticarette korumacılığın ücret primlerini absorbe ettiğini vurgulamıştır. Ticari reformlar ücretleri baskılamaktadır ve kazanılabilecek karları azaltmaktadır. Onaran (2007) Kore, Meksika ve Türkiye için yaptı̆̆ı incelemede, küreselleşmeyi uluslararası ticaret ve yabancı sermaye yatırımları ile bağdaştırarak, ücret değişimleri üzerindeki rolünü araştırmıştır. Kriz dönemlerinde ulusal paranın değer kaybı ve ekonomik resesyon görülen dönemlerde ücretlerin nasıl değiştiğini de incelediği çalışmasında, açıklığın ve endüstriyel politika altyapısının ticaret derinliğinin de etkili olduğunu belirtmiştir. İhracat yoğunluğunun artması, Türkiye ve Meksika imalat sanayi ücretlerinin düşmesine yol açarken, Kore için aynı etki söz konusu değildir. Yabancı sermaye yatırımlarının pozitif etki beklentisi ise üç ülke için de geçerli değildir.

Emirhan ve Konyalı (2010), 1983-2000 yılları arası Türkiye üzerine yaptıkları çalışmada imalat sanayisini tüm sektörler, ticarete tabi olan ve olmayan ve teknoloji yoğun olan ve olmayan sektörler olarak üçe bölmüşlerdir. Genel sonuç dışa açıklığın ücretler üzerine negatif etkisi olduğudur. İhracatın yüksek olduğu sektörlerde ücretler düşük, ithalatın yüksek olduğu sektörlerde ise ücretler yüksektir. İhracatın ücretlerle ters ilişkide olmasına açıklama getiren çalışmaya göre, ihracat yoğun sektörlerde uluslararası piyasalarla rekabet ve artan üretim maliyetlerinin karlılığı azaltmaması için ücretleri baskıladığıdır. Genel sonuç ise dış ticaretin Türkiye ekonomisinde beklendiği gibi üretkenliği arttırmayıp, rekabet için ücretlerde düşüşlere yönelindiğidir.

Abrache, Dickerson ve Green (2004) çalışmalarında ticari liberalizasyonun ücret düşüşlerine yol açtığını ve dışa açıklığın en yüksek olduğu sektörlerde en yüksek ücret düşüşlerine rastlandığını gözlemlemiştir.

\section{Bir Gelir Bölüşümü Problemi Olarak Ücret Ve Ücreti Belirleyen Unsurlar}

Ekonomideki önemli konulardan biri üretim süreci sonunda ortaya çıkan ürünün üretim faktörleri arasında nasıl paylaşılacağına karar verilmesidir. Bu karar teknik, ekonomik, toplumsal ve siyasal boyutları olan çok yönlü ve karmaşık bir olgudur (Öztürk, 2010). Bölüşüm problemi ve bu konuyla alakalı olarak ücret kuramları günümüze kadar iktisatçılar tarafından farklı şekillerde ele alınmış ve iktisadi olayların etkileri bu tanımlarla ifade edilmeye çalışılmıştır. Bölüşüm problemlerinin artan dış ticaretle birlikte daha da arttığı düşünülecek olursa, konuyu uluslararası ticaretle ilgili derli toplu görüşlere ilk olarak rastlanan merkantilist dönemden, dış ticaretin en yüksek seviyelere ulaştığı günümüze kadar incelemede fayda vardır. Dış ticaret ile ücretler arasındaki ilişkiye yönelik çıkarımlar da bu kuramlardan yola çıkarak elde edilebilir.

\section{Neoklasik İktisatta Gelir Bölüşüm Problemi}

Neoklasiklere göre işgücü piyasası; talebin marjinal verimlilik teorisine göre karını maksimum kılmak isteyen işverene ve arz teorisi ise faydasını maksimum kılmak isteyen işçiye bağlı olduğu bir piyasadan ibarettir (Leontaridi, 1998). Neoklasiklerde hem fiyatlar hem de miktarlar arz ve talep tarafindan belirlenmektedir. Faktör piyasalarında arz-talep dengesi işgücünün tam istihdam durumunda olması olup, işgücü arzı ve talebini eşitleyen bir fiyata yani "ücrete" ulaşıldığı anda tam istihdam da sağlanmış olacaktır (Akyüz, 2009).

Neo klasik iktisatçıların varsayımları altında, emek talebi fonksiyonu $D_{L}=f(W / P, K), f_{l}<0$ ve emek arzı fonksiyonu $S_{L}=f(W / P, K), f_{2}>0$ iken işgücü piyasası dengesi $D_{L}=S_{L}$ olarak ifade edilir. $\left(\mathrm{D}_{\mathrm{L}}\right)$ reel ücretle ters yönlü ilişki içindedir, çünkü kısa dönemde tek değişken girdi emek olduğu için ( $\mathrm{MR}=\mathrm{MC}) \mathrm{koşulu}$ $\left(\mathrm{W} / \mathrm{P}=\mathrm{MP}_{\mathrm{L}}\right)$ 'ye dönüşecektir ve daha düşük reel ücret ile işgücü maliyeti düşecek, bunun sonucunda daha fazla işgücü istihdam edilecektir. $\mathrm{S}_{\mathrm{L}}$ 'nin reel ücretlerle doğru yönlü ilişki içinde oluşu ise; emek sahibinin arz edeceği emek miktarını belirlerken çalışmanın marjinal zahmeti ile ücretin sağlayacağı marjinal tatmin arasındaki dengeyi göz önüne aldığı söylenebilir (Savaş, 2007). 
Ücret, işçinin geliri olduğu için yaşam standartlarını belirleyen bir unsur, ekonomik açıdan maliyet unsuru ve ulusal gelirin gelir grupları arasında paylaşımının göstergesi olduğu için ise sosyal adaleti temsil eden bir unsurdur (Ar, 2007). Ancak bu derece önemli bir kavram olan ücret, liberal devletlerde yukarıda belirtildiği gibi ideal bir iş piyasasında değil, rekabetin eksik ve aksak olduğu tabii iş piyasalarında oluşmaktadır (Zaim, 1986). Ücret oluşumunda etkili arz ve talep koşullarının yanında, işgücü piyasasına etki eden yaşam maliyeti ve işgücü verimliliğindeki değişimler, işverenin ödeme gücü, diğer endüstri veya firmalarda ödenen ücretler, fiyatlar genel düzeyindeki sürekli artışlar, iktisadi konjonktürün seyri, mal piyasalarının özellikleri, seçilen istihdam politikaları ve ücretin istihdam üzerindeki sözde etkisi gibi birçok unsur ücret seviyesi üzerinde söz sahibidir (Shultz ve Coleman, 1959). Gelir; fiyatların bir fonksiyonu olup, fiyatlarda görülen değişimler ücretlerde değişimlere neden olmaktadır. Bunun dışında işçi ve işverenin piyasaya dair bilgilerinin tam olmayışı da işgücü piyasasında emek arz-talep dengelerinde olumsuz etkiler yaratmaktadır

Beşeri sermaye farklılıkları da ücret seviyeleri arasında farklılıklara yol açmaktadır. Yüksek beşeri sermaye stoku yüksek ücret gerektirdiği için, aynı iş kollarında farklı firmalarla çalışan iki işçinin ücretleri beşeri sermaye farklılıklarından dolayı birbirinden ayrılabilir. Bu durum iki işçinin çıktı düzeylerinin farklılaşmasına neden olabilir ve sonucunda çıktı düzeylerinin farklılaşması ücret farklılaşmasını gerektirebilir (Akyıldız ve Karabıçak, 2002).

\section{Dış Ticaret ve Ücret İlişkisinin Uluslararası İktisattaki Yeri}

Dış ticaretin ücretler üzerindeki etkisini açıklayabilmek için izlenecek yol, uluslararası ticaretin ortaya çıkışından günümüze kadar gelişerek gelen ve tartışmalara rağmen halen geçerliliğini koruyan uluslar arası iktisat teorilerine başvurmaktır. Dış ticaretin ücretlerle ilişkisini uluslararası düzeyde ortaya koyan teorilerden biri olan "Faktör Fiyatları Teoremi"ne göre aynı teknolojiye fakat farklı faktör donatımına sahip iki ülkenin ticarete açılmasıyla birlikte, eğer söz konusu iki ülke iki mal üretiyor ve faktör yoğunluklarında tersine dönme gerçekleşmiyorsa, faktör fiyatları eşitlenme eğilimi gösterir (Feenstra, 2004).

Ticarat liberalizasyonunun artışı ile yurtiçi gelir dağılımını teorik olarak ilişkilendiren ilk geleneksel ticaret teorisi olan Stolper-Samuelson gelir dağılımı teoremine göre, ülkeler ticarete daha çok açıldıkça ülkenin karşılaştırmalı olarak üstünlüğünün bulunduğu ihraç endüstrilerinde kullanılan bol faktörlere olan talep artar, ithalata rakip endüstrilerde kullanılan kıt faktörlere olan talep ise azalır. Bu nedenle işgücü ve sermaye gibi iki üretim faktörünü ele alan geleneksel modelde, artan dış ticaretin gelişmekte olan ülkelerin bol üretim faktörü olan işgücünün geliri olan ücretleri arttırması beklenmektedir (Litwin, 1998).

Yeni-Ricardocu görüşlerin geliştirdiği şekliyle ise; tarıma ilginin azaldığı sanayileşmiş dünyada zengin ülkeler yüksek katma değerli yani az emekli bol sermayeli malların üretiminde daha fazla rekabet gücüne sahip olup, tam tersi durumun görüldüğü fakir ülkeler ise az sermayeli ve bol emekli malların üretiminde daha fazla rekabet gücüne sahiptirler. Bu iki zıt özelliğe sahip ülkeler ticaret yapmalarıyla birlikte piyasalarda dengesizlikler görülmeye başlar. İthalat pek çok iş alanının ortadan kalkmasına yol açtığı için, genel sonuç emek aleyhine ve sermaye lehine işlemektedir. İthalat sonucu işlerini kaybeden işçiler yeni iş bulmak zorunda bırakılırken, bu durumu fark eden işverenler ücretleri aşağı çekecek, sermayedarlar kar marjlarını yükseltmek için bu fırsatı değerlendireceklerdir. İhracat sektörlerinde daha fazla kullanılan sermaye kıt hale geldikçe, sermayedarların karları daha da artacak ve küreselleşmeden karlı çıkan tek bir taraf olmuş olacaktır (Cohen, 2009). Ticaret liberalizasyonu ücretler konusunda bir nevi beklentileri boşa çıkarmıştır. İthal ikamesinden ihraç yanlısı politikalara kayma gelişmekte olan ülkelerde işgücü yoğun endüstrilerin genişleyerek işgücü talebinde artışa ve uzun dönemde ücret artışlarına neden olması beklenmiştir. Oysaki ticaret liberalizasyonu ile birlikte artan dış rekabet ücretlerde beklenen etkiye izin vermemektedir (Milner ve Wright, 1998).

\section{Türkiye’de İmalat Sanayinde Yaşanan Gelişmeler Paralelinde Ücretlerin Gelişimi}

Dış ticarette dönüşümün, 24 Ocak Kararlarıyla başladığı Türkiye'de mal piyasalarının dış pazarlara açılması ve ticaret kotalarının korumasındaki ithalat rejimi serbestleştirmesi 1980-83 döneminde başlamış, 1989-90'da sermaye hareketliliği ile devam etmiş, 1996'da AB ve Gümrük Birliği üyelikleri ile tamamlanmıştır. Döviz kuru yüksek bir devalüasyonla esnekleştirilmiş, teşviklerle ihracata yönelim sağlanmaya çalışılmıştır. 1980 öncesi korumacı ve ithal ikamesine dayalı içe dönük sanayileşme benimsenmiş, daha sonrasında ihracata dayalı büyümeyi benimseyerek 1990'lı yıllarda tamamen dışa açılmıştır (Yeldan, 2010). Türkiye ekonomisinde kar, faiz ve rant sahipleri lehine yaşanan dönüşümlerde reel ücretlerin azalan bir seyir izlemesinin veya düşük ücret politikasının nedenleri üç başlıkta özetlenebilir. Birincisi; tüketim harcamalarında kısıtlamalarla enflasyonu kontrol etme arzusu ve iç piyasaya olan talebi düşürerek, iç piyasada alıcı bulamayan malların yurt dışına satılma olanağının arttırılmasıdır. İkinci beklenti ise; istihdamın arttırılması amaçlı düşük ücret avantajıyla emek-yoğun yatırımların artacağıdır. Üçüncü önemli neden ise; üretim maliyetinde azalmanın bir yolu olarak görülen düşük ücretlerle, ihracat faaliyetinde dış dünya ile rekabet gücünün artacağıdır (Özkaplan, 1994).

1980 sonrası dış ticarette liberalleşme ve ekonomi politikaları ile ücretlerin seyri izlendiği zaman birebir örtüş̧üğü söylenebilir. İhracatı artırmaya yönelik politikaların emek-yoğun sanayilere dayandığı ve kısa 
dönemde düşük maliyet temelinde rekabet gücü sağlamayı hedeflediği için ücretlerin düşürülmesini amaçladığı görülmektedir. Askeri yönetim yılları olan 1980-83 arası ve sendikaların baskılandığı 1981-87 arası reel ücret düşüşleri yılda \% 3,3 oranındadır (Şenses ve Taymaz, 2003). 1988 sonrası dönemde ise reel ücretler 1993 yılına kadar artmıştır. En büyük sıçramanın 1991 yılında olmasının sebebi, bir önceki yılın sabit sermaye yatııımlarının \%14 artmasına, büyüme oranının son yirmi yıldaki en yüksek büyüme oranı oluşuna, 1989 yerel seçim sonrası sendikal hakların kullanımının yaygınlaşmasına ve 1991 yılının genel seçim yılı olmasına bağlanmaktadır. 1994 krizi sonucunda düşen ücretler bu etkileri yok etmiş, 1994 yllından sonra yükselme eğiliminde olsa da ücretlerde ortalama artış 1993-2000 dönemi arası \% 1,6 rakamıyla sınırlı kalmıştır (Kepenek ve Yentürk, 2003).

Sektörlerin faktör yoğunlukları açısından değerlendirilecek olursa ise 1980-1988 yılları arası emek ve sermaye yoğun sektörlerdeki değişim yüzdeleri benzer yapıda ilerlemekte olup, 1989-1993 yılları arası ise sermaye yoğun sektörlerdeki reel ücretler emek yoğun sektörlerdeki ücretlere kıyasla oldukça artış göstermiştir. 1994 kriz yılı her iki sektöre de aynı etkiyi bırakmış, 1996 sonrası sermaye yoğun sektörlerde artış emek yoğun sektörlerde ise azalış devam etmiştir (Gökalp vd., 2011).

\section{Türkiye'de Ücret İhracat İlişkisinin Sınanması}

Çalışmanın amacına yönelik olarak modelde çıktı düzeyinin, istihdam seviyesinin, ihracatın ve ithalatın ücret belirlemede rol oynadığı varsayımı ve kısıtları altında, ücretlerle ihracat düzeyi arasındaki ilişkiye bakılacaktır. Çalı̧̧mada 1988:Q1-2011:Q4 döneminde, Türkiye İstatistik Kurumu (TUIK) tarafindan hesaplanan, 20 ve daha fazla çalışanı olan tüm kamu ve özel sektör işletmelerini kapsayan, Türk İmalat Sanayi alt sektörleri bazında ücret, istihdam, üretim (yayınlanmamış istatistikler), ithalat ve ihracat verileri kullanılmıștır. Ücret verilerinin 1988Q1-2006Q4 dönemleri arası “İstihdam ve Ücret İstatistikleri” veri tabanından dönemler itibariyle imalat sanayi üretimde çalışan saat başına reel ücret endeksi olarak alınmıştır. 2007:Q1-2011Q4 dönemleri aras1 nominal ücretlerin enflasyondan arındırılıp, reelleştirilmesi için ise TÜFE(2005=100) verileri TÜiK’ten temin edilmiştir.

Sektör tanımlaması Uluslararası Standart Sanayi Sınıflandırılması Rev.3'e göre olup, 2 basamakta 7 sanayi kolunu kapsamaktadır. Bu 7 sanayi kolunun belirlenmesinde, üretimin \% 70'ine sahip 7 sektör olan Gıda ürünleri ve içecek imalatı (15), Tekstil ürünleri imalatı (17), Giyim eşyası imalatı, kürkün işlenmesi ve boyanması (18), Kok kömürü, rafine edilmiş petrol ürünleri ve nükleer yakıt imalatı (23), Kimyasal madde ve ürünlerin imalatı (27), Başka yerde sınıflandırılmamış makine ve teçhizat imalatı (29) ve Motorlu kara taşıtı, römork ve yarırömork imalatı (34) seçilmiştir.

Analiz E-Views 6.0 Beta ekonometri paket programında çoklu regresyon modeli ile uygulama gerçekleştirilmiştir. Bu modelin tahmini için ise "En Küçük Kareler (EKK)" yöntemi kullanılmıştır.

ADF ve KPSS birim kök testi sonuçlarına göre değişkenlerin düzeyde durağan olmadıkları ve birinci farkları alındığında durağan hale geldikleri için bütünleşme dereceleri I(1)'dir. Tüm değişkenlerin birinci dereceden entegre olması eşbütünleşme testini uygulayabilmemize imkan vermektedir. Değişkenler arasında eşbütünleşme var ise uzun dönemli ilişki olduğunu, eğer eşbütünleşme yok ise uzun dönemli ilişki olmadığını söyleyebilmekteyiz. Birim kök testleri yapılan verilere, çok değişkenli eşbütünleşmenin test edilmesine yarayan Johansen-Juselius (1990) eşbütünleşme testi yapılmış ve analiz sonuçları her bir sektör için değerlendirilmiş̧ir ve normalize edilmiş eşbütünleşme vektörleri ile beraber sunulmuştur.

Tüm sektörlerin kısıtsız eşbütünleşme rank testi sonuçlarına göre İz test istatistiği \% 5 önem düzeyinde değişkenler arasında bir eşbütünleşme vektörünün varlığına işaret ederken maksimum özdeğer istatistiği \% 5 önem düzeyinde değişkenler arasında uzun dönem denge ilişkisinin bulunmadığını göstermektedir. Bu bağlamda İz test istatistiği dikkate alınarak değişkenler arasında bir eşbütünleşme vektörünün varlığı kabul edilmiştir. Söz konusu eşbütünleşme vektörü bağımlı değişken ücrete göre normalize edilerek değişkenler arasındaki uzun dönemli ilişkiyi gösteren denklemlere de her bir sektör için verilen analiz değerlerinin altında belirtilmiş̧ir.

Gıda ürünleri ve içecek imalatı, Motorlu Kara Taşıtı, Römork ve Yarı-Römork İmalatı ve Kok Kömürü, Rafine Edilmiş Petrol Ürünleri ve Nükleer Yakıt İmalatı sektörüne ait bulgulara göre ihracatın ücret üzerinde pozitif etkisi vardır. Buna göre üretim ve istihdam düzeyindeki \% 1'lik bir artış uzun dönemde ücretlerde sırasıyla $\% 0.47$ ve \%1.27'lik bir artışa yol açarken, dışa açıklığı temsil eden net ihracatın milli gelire oranındaki bir birimlik artış ücretlerde $0.0203^{\prime}$ lük bir azalmaya neden olmaktadır. Motorlu Kara Taşıtı, Römork ve YarıRömork İmalatı sektöründe üretim düzeyindeki \% 1'lik bir artış uzun dönemde ücretlerde $\% 0.22^{\prime}$ lik bir azalışa yol açarken istihdamdaki \%1'lik bir artış uzun dönemde ücretler üzerinde \%0.14'lük bir artışa yol açmaktadır. İhracatın milli gelire oranındaki bir birimlik artış ise ücretlerde $0.0155^{\prime}$ 'lik bir artışa neden olmaktadır. Kok Kömürü, Rafine Edilmiş Petrol Ürünleri ve Nükleer Yakıt İmalatı üretim ve istihdam düzeyindeki \% 1'lik bir artış uzun dönemde ücretlerde sırasıyla $\% 0.68$ ve $\% 080$ 'lik bir azalışa yol açarken, ihracatın milli gelire oranındaki bir birimlik artış ise ücretlerde $0.0772^{\prime}$ lik bir artışa neden olmaktadır. 


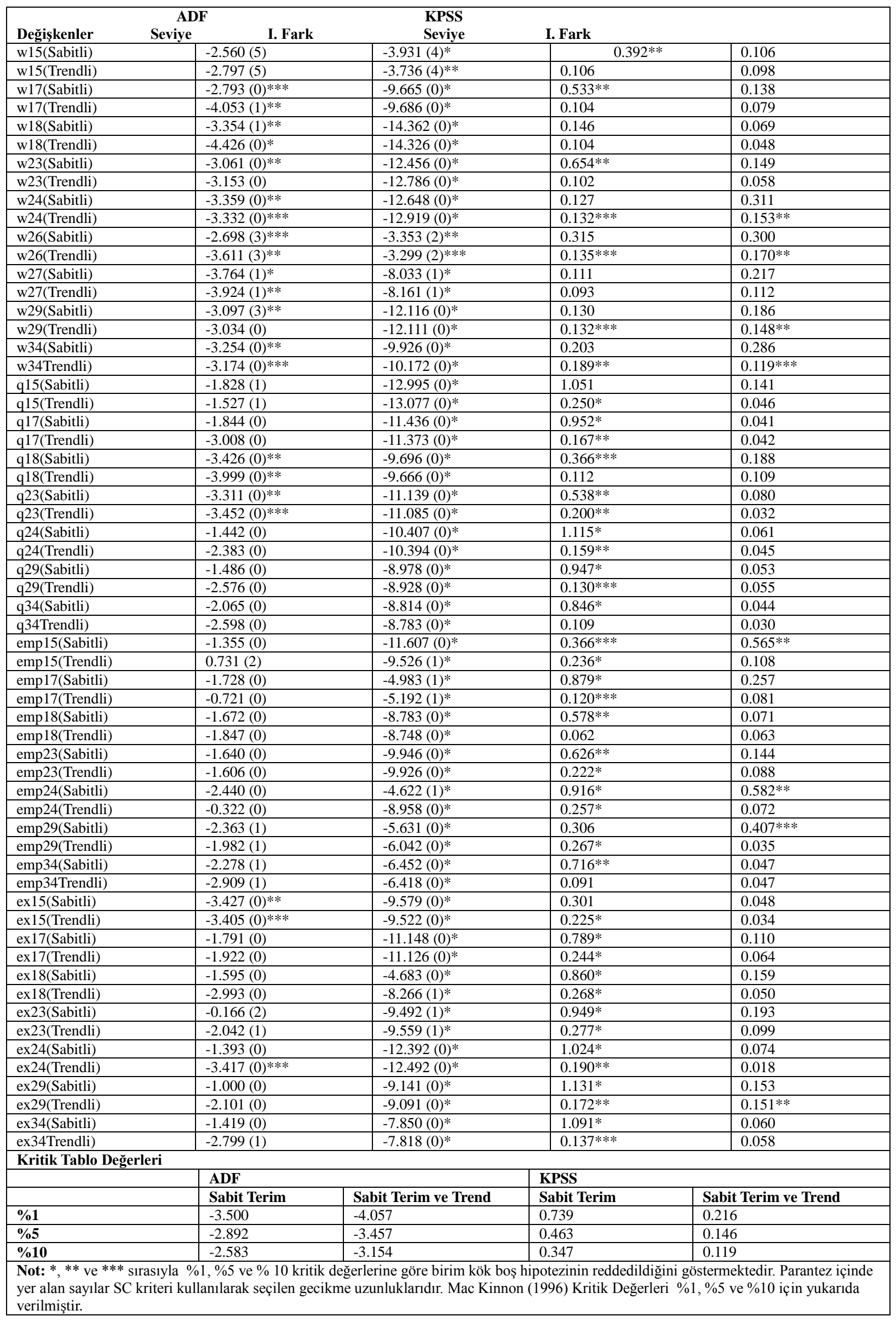




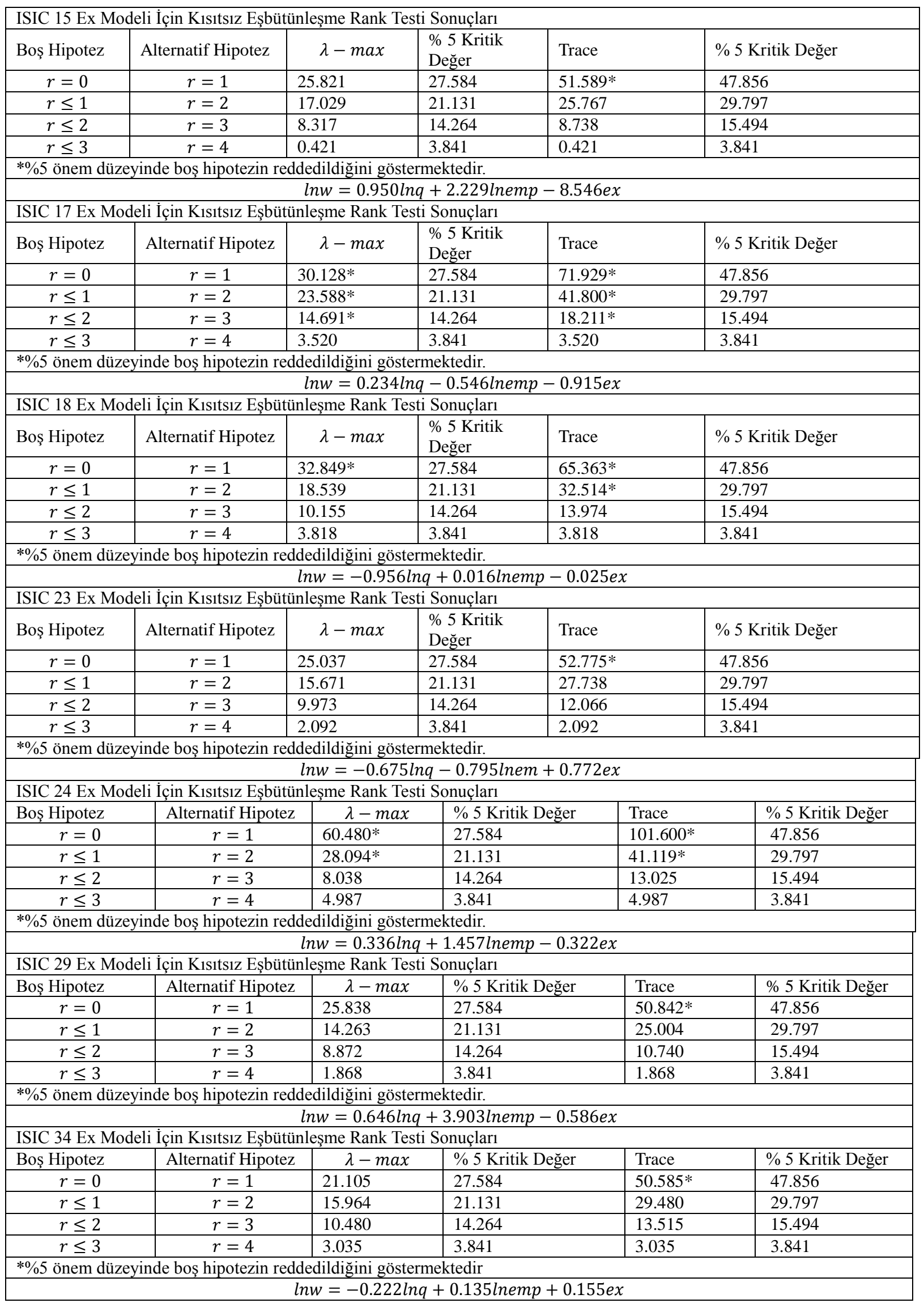

Tablo 2. Eşbütünleşme Analizi Sonuçları 
Başka Yerde Sınıflandırılmamış Makine Ve Teçhizat İmalatı, Tekstil ürünleri imalatı, Giyim eşyası imalatı, Kimyasal Madde Ve Ürünlerin İmalatı sektörlerine ait verilerden elde edilen sonuçlara göre ihracattaki değişimlerin ücretler üzerinde negatif bir etkiye sahip olduğu gözlenmektedir. Buna göre üretim ve istihdam düzeyindeki \% 1'lik bir artış uzun dönemde ücretlerde sırasıyla \%0.65 ve \%3.90'lık bir artışa yol açarken, ihracatın milli gelire oranındaki bir birimlik artış ücretlerde 0.0586'lık bir azalmaya neden olmaktadır. Tekstil ürünleri imalatı sektöründe üretim düzeyindeki \% 1'lik bir artış uzun dönemde ücretlerde \% 0.23 'lük bir artışa yol açarken, istihdamdaki \%1'lik bir artış uzun dönemde ücretler üzerinde \%0.55 azalışa yol açmaktadır. İhracatın milli gelire oranındaki bir birimlik artış ise ücretlerde 0.0915 'lik bir azalmaya neden olmaktadır. Giyim eşyası imalatı sektöründe üretimdeki \% 1'lik bir artış uzun dönemde ücretlerde \%0.96'lık bir azalışa yol açarken istihdamdaki \%1'lik bir artış uzun dönemde ücretler üzerinde \%0.02'lik bir artışa yol açmaktadır. İhracatın milli gelire oranındaki bir birimlik artış ise ücretlerde $0.0025^{\prime}$ lik bir azalmaya neden olmaktadır. Kimyasal Madde Ve Ürünlerin İmalatı sektöründe üretim ve istihdam düzeyindeki \% 1'lik bir artış uzun dönemde ücretlerde sırasıyla $\% 0.34$ ve \%1.46'lık bir artışa yol açarken, ihracatın milli gelire oranındaki bir birimlik artış ise ücretlerde 0.0322 'lik bir azalmaya neden olmaktadır.

\section{Sonuç}

Dünya genelinde serbestleşme temeline dayalı neo liberal politikalarla dışa açıklık temelli küresel bir yapı ortaya çıkmış, üretken sermaye verimlilik ve kar oranlarını arttırmak amacıyla artan dış ticaret ve rekabet olgusu ekonominin her alanında olduğu gibi ücretler üzerinde de etkili olmuştur. Son otuz yıl içerisinde dünya ekonomisinin hızla bütünleşmesi, dikkatleri bu bütünleşmenin ücretler üzerindeki etkilerinin incelenmesine çekmiştir.

Buna göre; 15. sektör olan gıda ürünleri ve içecek imalatı, 17. sektör olan tekstil ürünleri imalatı, 18. sektör olan giyim eşyası imalatı, kürkün işlenmesi ve boyanması, 24. sektör olan kimyasal madde ve ürünlerin imalatı, 29. sektör olan başka yerde sınıflandırılmamış makine ve teçhizat imalatı ve 34. sektör olan motorlu kara taşıtı, römork ve yarı-römork imalatında ihracatın ücretler üzerine negatif etkisi söz konusudur. Başka bir deyişle, bu sektörlerde ihracat oranlarında herhangi bir artış ücretlerde azalışa neden olmaktadır. Bu negatif etkinin en yüksek olduğu sektör gıda ürünleri ve içecek imalatı olurken, ikinci en yüksek negatif etkiye kimyasal madde ve ürünlerin imalatı sahiptir. Dışa açıklığın etkilerine bakılacak olursa da ücretler üzerinde en büyük negatif etkiye plastik ve kauçuk ürünleri imalatının sahip olduğunu söyleyebiliriz.

Motorlu kara taşıtı, römork ve yarı-römork imalatına ait analiz sonuçlarına göre ücretlerin ve dışa açıklığın etkisinin negatif ancak oldukça düşük olduğu görülmektedir. Bu sonuç bize bu sektörde rakebet gücünün yüksekliğini işaret etmektedir. Sektörün özellikleri incelenecek olursa, gelişmiş teknolojilerin ülke içine transfer yaratması ve bu teknolojiye adapte olabilecek nitelikli işgücü arzında yaşanan sıkıntılar ücretlerde bir miktar düşüşler yaşanmasını kaçınılmaz kılmaktadır. Sektörel özellikler, sendikalaşma oranları, rejim değişiklikleri, yasalar ve birçok yerleşik sosyal yapı gibi kurumsal etkiler emeğin karşılığı olan ücretin belirlenmesinin çok boyutlu olmasına neden olmakla birlikte ana akım uluslar arası ticaret kuramının da desteklediği gibi, ihracatın genişlemesinin işgücü bakımından zengin olan Türkiye'de talebi arttırarak ücretlerde pozitif etki yaratacağıdır. Sonuçlara baktığımızda ise durumun pek de kuramla tutarlı olmadığını görmekteyiz.

Sonuç olarak, gelirin kâr ve ücretler olarak belirlendiği bir ortamda kâr ve ücretleri belirleyen etkenlerin birikimli 'bir neden-sonuç ilişkisi' içinde birbirlerini şekillendirmesi kaçınılmazdır. Tam liberalleşme süreciyle ihracata dayalı büyüme politikası yeni rekabet koşullarıyla birleşince uygun rekabet koşullarında kâr oranlarında yaşanan herhangi bir düşüşün, fiyat artışları ile telafi edilebilirliği geçerli olmamıştır. Artan rekabet ile kar oranlarında yaşanan düşüşlerde maliyeti kısmak için ilk başvurulan da ücretler olmuştur. Ücretlerin esnekliğinin yüksek oluşu ve aynı zamanda ithalata bağımlı ihracat yapısına sahip sektörlerde firmaların girdi maliyet fiyatlarında söz sahibi olamamalarının bu durumda büyük rolü vardır. Bu etkiyi yok edebilmenin yolu ise daha verimli bir üretim teknolojisine geçiştir ancak gelişmekte olan ülke sınıfında yer alan Türkiye'de bu da pek mümkün olamamaktadır. Sürekli rekabet süreci ve teknolojik değişmelerin yarattığı farklı üretim koşullarına adaptasyonda zorluk ve nitelikli işgücünün kıt oluşu, üretimde verimlilik sağlanamayışı ve işsizler ordusundan kaynaklı esnek ücret yapısı ücretlerde düşüşlere neden olmaktadır. Ayrıca imalat sanayi anketlerinin kapsadığı firmaların tam rekabet varsayımına uymaması durumu daha da kötüleştirmektedir.

\section{Kaynakça}

- $\quad$ Abrache, J. S., Dickerson, A. \& Green, F. (2004). Trade Liberalisation and Wages in Developing Countries. The Economic Journal, 114, 73-96.

- Akyıldız, H. \& Karabıçak, M. (2002). Verimlilik Ücret İlişkisinin Analizi. Süleyman Demirel Üniversitesi İ̈BF Dergisi, c.7, s.2, 57-76.

- $\quad$ Akyüz, Y. (2009). Sermaye, Bölüşüm, Büyüme. Eflatun Yayınevi, Yayın No:7, 3.Baskı, Ankara.

- $\quad$ Ar, K. N. (2007). Küreselleşme sürecinde Türkiye'de Ücretlerin Gelişimi, Ankara. 
- $\quad$ Avalos, A.\& Savvides, F. A. (2003). On the Determinants of the Wage Differential in Latin America and East Asia: Opennes, Technology Transfer and Labor Supply. Latin America/Caribbean and Asia/Pasific Economics and Business Association Annual Meeting, Working Paper No:19.

- $\quad$ Beyer, H., Rojas, P. \& Vergara, R. (1999). Trade Liberalization and Wage Inequality. Journal of Development Economics, Vol:59, 103-123.

- Cohen, D. (2009). Dünyanın Zenginliği, Ulusların Fakirliği, 2. Baskı, Çeviri: Dilek Hattatoğlu, İletişim Yayınları, İstanbul.

- $\quad$ Emirhan, P. N. \& Konyalı, G. (2010). Türkiye'de Dış Ticaretin Ücretlere Etkisi: İmalat Sanayi İçin Bir Uygulama. İktisat, İşletme ve Finans Dergisi, 25(288), 29-50.

- $\quad$ Feenstra, R. C. \& Hanson, G. H. (1997). Foreign Direct Investment and Relative Wages: Evidence from Mexico's Maquiladoras. Journal of International Economics, 42, 371-393.

- $\quad$ Feenstra, R.C. (2004). Advanced International Trade: Theory and Evidence. Princeton and Oxford: Princeton University Press.

- Feliciano, Z. M. (2001). Workers and Trade Liberalization: The Impact of Trade Reforms in Mexico on Wages and Employment, Industrial and Labor Relations Review, Vol. 55(1), 95-115.

- Gökalp, M. F., Baldemir, E. \& Akgün, G. (2011). Türkiye Ekonomisinde Dışa Açılma ve Gelir Eşitsizlikleri İlişkisi. Yönetim ve Ekonomi, c:18, s:1, 87-104.

- Greenway, D., Hine, R. C. \& Wright, P. (1999). An Empirical Assessment of the Impact of Trade on Employment in the United Kingdom. European Journal Of Political Economy, Vol.15, 485-500.

- Haouas, I., Yagoubi, M. \& Heshmati, A. (2002), The Impact Of Trade Liberalization On Employment and Wages in Tunisian Industries. WIDER Discussion Papers World Institute for Development Economics (UNU-WIDER), No.102, 1-30.

- Kepenek, Y. \& Yentürk, N. (2003). Türkiye Ekonomisi. 14. Basım, Remzi Kitabevi, İstanbul.

- $\quad$ Kim, H. \& Thompson, H. (2009). Factor Proportions Wages in a Structural Vector Autoregression. MPRA Paper No. 17798, 1-20.

- Leontaridi M. R. (1998). Segmented Labor Markets: Theory and Evidence. Journal of Economic Surveys, c. 12, s.1, 63-101.

- Litwin, C. (1998). Trade and Income Distribution in Developing Countries. Working Papers in Economics No: 9.

- $\quad$ Milner, C. \& Wright, P. (1998). Modelling Labour Market Adjustment to Trade Liberalization in an Industtrialising Economy. The Economic Journal, 108, 509-528.

- Onaran, Ö. (2007). Wage Share, Globalization, and Crisis: The Case of the Manufacturing Industry in Korea, Mexico and Turkey. PERI Working Paper Series, No:132.

- Oyvat, C. (2011). Globalization, Wage Shares and Income Distribution in Turkey. Cambridge Journal of Regions, Economy and Society, 4, 123-138.

- Özkaplan, N. (1994). Çalışma Ekonomisi. Kavram Yayınları, 2. Basım, İstanbul.

- Öztürk, N. (2010). Klasik ve Neoklasik İktisatta Gelir Bölüşümü. Çalışma ve Toplum, s:1, 59-89.

- Revenga, A. (1997). Employment and Wage Effects of Trade Liberalization: The Case of Mexican Manufacturing. Journal of Labor Economics, Vol. 15, No. 53, 520-543.

- $\quad$ Robbins, D. J. (1996). Evidence on Trade and Wages in the Developing World. OECD Development Centre Working Paper No:119.

- Savaş, V. F. (2007). Keynezyen İktisat Yıkılırken. Nobel Basımevi, 3. Baskı, Ankara.

- Shultz, G. P. \& Coleman, J. R. (1959). Labor Problems: Cases And Readings (İkinci Basım). McGraw-Hill Book Company: London.

- Şenses, F. \& Taymaz, E. (2003). Unutulan Bir Toplumsal Amaç: Sanayileşme Ne Oluyor? Ne Olmalı?. ERC Working Papers in Economics, 03/01.

- Yeldan, E. (2010). Küreselleşme Sürecinde Türkiye Ekonomisi. 13. Basım, İletişim Yayınları, Ankara.

- Zaim, S. (1986). Çalışma Ekonomisi. Filiz Kitabevi, 7. Baskı, İstanbul. 


\title{
2008 Küresel Krizinin Felsefesi Philosophy of the 2008 Global Crisis
}

\author{
Ziya Arpalı (Kyrgyzstan-Turkey Manas University, Kyrgyzstan)
}

\begin{abstract}
The crisis in late 2007 and early 2008, re-questioning of capitalism and re-evaluating institutional structures have arisen. Developed countries which directing of the world economy started a process along with the comments that developed countries maintain their existence. By Western economists led to criticism of the crisis inform of "today's form of capitalism, can't establish compliance with the changing world". The economic model based on the Balance of Imbalance is scheduled to sleep period in future years of the world management system. The sleeping process has been completed by the broken Balance of Imbalance. The process of planning in the field of application and the name given is crisis. This process should have a philosophy that mobilizing the internal dynamics of the economy. At the same time this crisis shown that money-driven economy conversion process is necessity in capitalism. The process of falling asleep economic model, in other words, the output from the crisis, not the money lead the economy but the economy lead the money. Transformation process will be realized at some point. In this study, it is introduced the philosophy of the crisis, in order to put into action the inner dynamics of capitalism's legal infrastructure, the political preferences of the founders of the political game and to pass system into sleeping process the necessity of the transformation an economic model to the upper structure have been identified.
\end{abstract}

\section{Giriş}

Kriz tanımı üzerinde ortak tanım olmasa da, varılan ortak bir kavram bulunmaktadır. Dengenin bozulması. Bozulma makro düzeyde ekonomik büyüklükler, mikro düzeyde bilançoların bozulması, bilanço içerisindeki kalemlerden kredi kalitesinin bozulması, mevduat içerisinde vade uyumunun bozulması. Bir denge; kontrolden çıkan büyüme, dengeye dışarıdan bir müdahale olması ya da dengenin tarafları arasında dengenin birisi lehine tekrar denge oluşturulmaya çalışması durumunda bozulabilir. Bu bağlamda krizi tanımlarken: Kriz, dengesizliğin dengesinin bozulması sonucu ekonomik olayların önceden bilinmesi ama katlanılmak istenmeyen maliyet nedeniyle aniden beklenmeyen olaylar olarak tanımlanan yeni ekonomik olayların tepkiye dönüşmesi sonucu ekonomik yönetimlerin mazeret ileri sürmeleri nedeniyle ortaya çıkan yönetim boşluğunun yönetilme sürecinden başka bir şey değildir.

Dengesizliğin dengesinin bozulmasında araçlar farklı olabilir, ancak süreç ve zamanlama ile ilgili politikalar, varlıkların el değişimi ve paylaşımına yönelik müdahaleye neden olan sonuçlar doğurmaktadır. Düşük faiz, kalitesi düşürülmüş kredi kullanım fursatlarını sağlayan politikalar, teknolojideki gelişmelerin sonucu sanal ortamda kontrolden çıkmış büyük fonların piyasalara anlık giriş çıkışları, ekonomiyi sanal ekonomiye dönüştüren kağıtların kar yumağı mülkiyetten yoksun el değiştirmesi gibi türev piyasaların karmaşıklığı, yatırımcıların risk iştahını artırarak faize dayalı sistemin değerle ifade edilmeyen balona dönüşerek büyüyen ekonomin spekülatif hareketlerle dengesizliğin dengesinin taraflarından birinin lehine tekrar dengeye getirebilmek için siyasi bir karar olarak dünya kamu oyunu meşgul eden, vergi mükelleflerinin maliyetine katlanacağı kriz, ekonomik modelin uykudan uyanacağı süreç, üçüncü dünya paylaşımından başka bir şey değildir.

Bu çalışmada krizin bizatihi ekonomik modelin özünde var olduğunu, dünya servetindeki el değiştirmelere ihtiyaç duyulması sonucu yeniden paylaşımı sağlamaya yönelik amacın aracı olduğunu ortaya koymak. Krizin, dengesizliğin dengesinin bozulması sonucu, ortaya çıkan yönetim boşluğunun yönetilme süreci olduğu belirtilerek, uygulanan neo-liberal politikalarının etkisiz kaldığı ve kriz maliyetinin vergi mükellefleri üzerinde kalacağı tespiti yapılmıştır.

\section{Küresel Krizi Farklılaștıran ve Krizin Ortaya Çıkıș Nedenleri}

Katma değeri en yüksek olan teknoloji üretimi yapan gelişmiş ülkelerle, bilgi teknolojisini gerçekleştiren ülkelerin aleyhine süreç hızlanırken bilim teknolojisi üreten, dünya yönetimini üstlenen küresel sermayenin, tüzel kişiliğe sahip devlet olma yönünde firsata dönüştürmeye çalıştığ kriz, siyasi bir tercih olarak spekülatif hareketler sonucu ortaya çıkmıştır.

1990’lı yıllarda, dünyada finansal piyasalardaki küreselleşme ve şeffaflaşma süreci ile birlikte bilgi teknolojisinde yaşanan buluş ve yeniliklerin finansal tekniklerde ve araçlarda sağladığı gelişim, yaşanan krizlere farklı boyutlar katmıştır. Yaşanan teknolojik gelişme sermaye akımlarının hızlanmasını kolaylaştırmış ve aynı zamanda yaşanan krizleri yaygınlaştırma ve algılamada da hızlandırıcı bir rol üslenmiştir. 
2008 yılında yaşanmaya başlanan, birçok iktisatçı tarafindan mortgage krizi, krizin başlangıcı olarak ifade edilse de, yaşanan süreç içerisinde karşılanması talep edilen likiditenin sistem içerisinde hareket kabiliyetinin etkisizleştirilmesi nedeniyle likidite krizine dönüşmüş̧ür.

Krizin nedenleri olarak;

1. Likidite bolluğu sonucunda verilen kalitesi düşük krediler,

2. Aşırı menkul kıymetleştirme,

3. Saydamlık eksikliği,

4. Kurumsal yapı olan derecelendirme kurumlarının denetleme ve düzenlemedeki kabiliyetinin etkisizleştirilmesi ve kurumların müdahalede gecikmeleri (Alantar, 2009).

5. Spekülatif sermayenin hareketlerinin kontrol dışı kalmasıdır.

Netice olarak nedenlerin ortaya çıkmasını sağlayan; alınan politik kararlar ve siyasi tercihlerdir. Bu karar ve tercihlerin sonucu sanal ekonominin büyümesi ve nihaiyi olarak sanal ortamda oluşan finansal kriz reel ekonomiyi etkilemiştir.

2000-2007 yılları arası dönemde piyasalarda likiditenin tavan yaptığı, ekonomilerin akılcılıktan uzaklaştığı ve aşırı risk iştahının da finansal krize hız kazandırdığı söylenebilir.

Harvard Üniversitesi öğretim üyesi Dani Rodrik, Forum İstanbul'da yaptığı konuşmada küresel krizin ortaya çıkardığı zafiyetleri üç ana grupta toplamaktadır:

1. Mali kesimde yapılan düzenlemelerin, yenilikler karşısında yetersiz kalışı.

2. ektörde alınan risklerin anlaşılamamasıdır.

3. Aşırı kaldıraç kullanılmasına izin verilirken; ahlaki zafiyetler, yöneticilerin yanlış teşvikleri vs. küçümseniyor (Dani, 2010) olmasıdır.

Bu sınıflamada bile hukuki düzenleme zafiyeti, kontrol dışına çıkan ve akıl tutulması olarak ifade edilebilecek olan risk karmaşıklığı ile yönetimdeki ahlak bozulmasına vurgu yapılmaktadır.

Uluslararası finansal kriz tartışmalarında iktisatçılar balon ve köpük kavramları üzerinde fikir birliğine varırken, balon ve köpük oluşumunu etkinleştiren spekülatif sermayenin damarlarında dolaşan kapitalist sistemin genlerinde var olan faiz üzerinde durmamaktadırlar.

Faiz toplumsal değer yargılarının adeta kültürel dokusuyla uyumlaşmıştır. Ticari hayatta vade farklarının belirlenmesinde etken olan, spot piyasalarda, kontratlarda rol alan, piyasaya yön veren, büyük rakamlara ulaşmış olan borçlarda bir puanlık değişimin sonucu bakiye üzerinde etkili olan, üretim ve toplumsal adaletsizliğe neden olan faiz, göz ardı edilemeyecek kadar etkili faktördür. Dolayısıyla faizin ekonomi üzerindeki bu tahribatı göz ardi edilmektedir.

Ekonomideki dengesizliğin dengesinin kalıcı olmaması: Krizin bizatihi sistemin kendi yapısında var olması ve kapitalist sistemin DNA'sında var olan faizden kaynaklanmaktadır. Dengenin bozulmasının temelinde faiz etkili olmaktadır. Bu nedenle;

1. Küresel düzeyde reel dengesizliklerin oluşuyor olması, başta ABD-Çin ilişkileriyle ortaya çıkan dış ticaret dengesizliği ve üzerine rezervlerdeki hızlı artı̧larında eklenmesi neticesinde küresel likidite patlamıştır.

2. Gerekli mekanizmalar olmadığı için, finansal krize küresel düzeyde tepki verilemiyor. Krizin derinliğine rağmen finansal kesimin düzenlenmesi, canlandırma paketleri ve küresel likidite konularında bir türlü koordinasyon sağlanamıyor olması. Faiz sistemine bağlı paylaşımın optimum noktada dengeyi sağlayamamasıdır.

\section{Küresel Krizi Tetikleyen Sürecin İşleyişi}

1990 y1lı sonrası ABD ekonomisini hareket kabiliyetini koruya bilmek için düşük faiz bol para siyaseti benimsemiştir (Ertuna, 2009: 26). 2000 yılının başlarından itibaren ise dünya ekonomisinin kazandığı büyüme yönündeki ivme neticesi, parasal genişleme ve iyimserlik piyasalarda özellikle mal piyasasında hızlı fiyat yükselişine ve bu piyasalarda bir balon oluşmasına yol açmıştır (Akgüç, 2009:7). Haziran 2003 de mortgage faiz oranları 45 yılın en düşük seviyelerine inmiştir. Faizlerin gayrimenkul fiyat artışının altına düşmesi, borçlanarak gayrimenkule yatırım yapmayı kazançlı hale getirmiştir. ABD taşınmaz mal piyasasında fiyatlar kısa bir sürede ikiye katlanmış, 650 bin dolayında taşınmaz mal stoku oluşmuştur. Yalnız konut sahibi olmak isteyenler değil, yatırımcılar, vurguncular, karlı bir alan olarak gördükleri için gayrimenkul piyasasına yönelmişlerdir. Bankalar bilinçli olarak muhtemelen aldıkları kredilerin geri ödemelerinin tamamını ödeyecek kişilere vermişlerdir. $\mathrm{Bu}$ davranışlarının arkasındaki esas neden, ev fiyatları arttıkça kazançlarının garanti olacağını bilmeleridir. Bankalar ev fiyatları artmaya devam ederse kazançlarını artıracak, kredi alanlar geri ödeme yapmaz duruma gelseler bile, evlerini ellerinden alıp verdikleri kredilerden daha yüksek bir fiyatla satacaklar yani her iki durumda da kazançlı çıkacaklar. Daha doğrusu bankalar kredilerin ödenememe riskinin bir kısmını türev araçları yoluyla menkulü kıymetleştirerek diğer bankalara, finans kurumlarına ve fonlara dağıtmışlar ve bu şekilde kendilerini 
korumuşlardır. İpotek karşılı̆̆ı krediler için çıkarılan varlığa dayalı menkul kıymetler Lehman Brothers ve diğer büyük finansal kurumlar tarafından piyasaya sürülmüş, bu menkul kıymetlerin önemli bir bölümü yatırım bankaları/ticaret bankacılığının yatırım bankacılığı yapan bölümlerince satın alınmıştır (Akgüç, 2009:7).

Gözden kaçan ya da gözden kaçırılmak isten ise, gayrimenkul kredilerinden elde edilen yüksek riskli menkul kıymetlerin tahsil edilebilirlikleri düşüktür. Bu yüzden çok fazla riskli kredi veren bir finansal kuruluş batar ya da yükümlülüklerini yerine getiremezse bu durum diğer finansal kurumlar arasına da yayılırsa, bankalar birbirlerine para vermeyi kesecekler ve daha çok finansal kurum likidite darlığı yaşayacak olmasıdır (Pressacco and Seravalli, 2009:792-793).

Dünya ekonomisini etkisi altına alan 2007- 2008 finansal krizi ve sonunda gerçekleşen inişli çıkışlı süreç aslında varlıkların el değiştirme mücadelesidir. Piyasa yapıcısı aktörler, araçlar, ürünler ve birimler arasında hareket alanını kısıtlama süreci yaşanmaktadır. Bu durum krize neden olan süreç değil dengesizliğin dengesinin bozulmasının doğal sonucudur. Finans sektöründe artan sorunlar krizi tetikleyen en önemli nedenler haline dönüştürülmüştür.

Geri dönmeyen krediler ne kadar artar ise bilançodaki vade uyumsuzluğu o denli çoğalır. Likidite riski yüksek, dövizde aşırı pozisyon açığı ile çalışan, özkaynakları yetersiz olan bir bankacılık sisteminin varlığı, kuşkusuz ekonomik kriz için uygun bir ortam yaratır (Akgüç, 2001). Bu bağlamda krize giden yolu açan nedenleri siralamak istersek:

1. Rezerv paranın (ABD doları) tahtına yönelik Euro bölgesinden gelen tehdit,

2. Kontrolden çıkan enerji kaynaklarına sahip diktatörlerden gelen tehdit,

3. BRIC (Yükselen Ekonomiler) dünya üretim hacmindeki paylarının artması nedeniyle ortaya çıkan durumun tehdit olarak algilanması,

4. Stoklardaki ekonomik ömrü tamamlanmış silah, mühimmat, araç ve gereçlerin yüksek maliyetinden kurtulma isteği,

5. Üçüncü dünya paylaşımının küresel sermaye lehine yeniden tasarım sürecinin başlatılmasına duyulan gereksinim,

6. Dünya üretim hacminin genişlemesi için gerek duyulan yeni icatların gerçekleşememiş olması,ya da üretim tarihinin ötelenmesi,

7. Azalan oranda küresel sermayenin artı-değerdeki payının azalması,

8. Tek kutuplu dünyada dengesizliğin dengesinde istikrarlı büyümenin durmuş olması,

9. Emeğin üretiminin sermayeye dönüşüm sürecinin uzaması,

10. Sistemin devamlılığını sürdürebilmek için kriz süreçlerinin zaman dilimini 10 yıl Aralığından 5 yıl, son zamanlarda 19 ay gibi bir zaman aralığına çekmiş olması, bir başka ifadeyle sistem tıkanıklığının küçük çaplı operasyonlarla aşılamayacağı noktaya gelmiş olması,

11. Sermayenin kendini yenileme maliyetlerinin artması, 1929-1933 krizinden sonra rafa kaldırılmış olan kriz senaryosu 2007 yilında dünya ekonomisinin gündemine küresel sermayenin siyasi tercihi olarak oturtulmuş olmas1,

12. Krizin esas nedeni dolar merkezli dünya para sistemidir.

13. ABD’nin düşük dolar strateji ile dış ticaret açığını kapatma düşüncesi, Kapitalist sistemin gelecekte de öncelikli sorunlarından olan, dünya liderlik sorunu su yüzüne çıkmamış ve politikalarının sürdürülebilirliği tartışılır hale gelmiş olması, küresel ekonomide dengesizliğin dengesinin bozulmasında bir başka belirleyici etken olmuştur.

Akat'a göre kriz, para sistemindeki zafiyetin kanıtıdır (Akat, 2009). Aynı zamanda paranın ekonomiye yön verdiği nihaiyi dönemin sonuna yaklaşırken, ekonominin paraya yön vereceği aşamaya gelinmiş olmasıdır.

\section{Siyasi Tercih Olarak Krizin Hukuki Altyapısı}

ABD'de hukuki düzenleme 90'lı yılların başında krizin yolunu açan 'SEC 144 A yasası' ile olmuştur. Bu düzenleme tahvil piyasasının yabancılara açılmasını sağlamıştır. Aynı yıllarda 65 sayılı yasanın yürürlükten kaldırılmasıyla Japonya finansal piyasalarına yabancıların girme serbestliği sağlanmıştır. Ayrıca AB'de ülkelerinin tüm sınırları kaldırma girişimlerinin finansal piyasaları da kapsıyor olması teknolojik gelişimle paralel gelişen sermayenin yeni coğrafyaları hızla etki alanına almasıyla artarak genişleyen dünya ticaret hacminin yaratmış olduğu katma değerin paylaşılması finansal piyasalarla ilgili bir takım zorlukları da beraberinde getirmiştir.

$\mathrm{Bu}$ gelişme süreci küreselleşen finansal sistemde ikili bir yapı ortaya çıkarmıştır. Birincisi üretilmiş mal ve ticaretin yapıldığı yapı, ikincisi para tüccarlarıyla vurguncuların yer aldığı paradan para kazanan üretken olmayan bir kültürel bir yapı. Krizi bu iki yapının mücadelesi olarak da görmekte mümkün. Yani kriz kültürel yapının doğal sonucu olarak dışarıdan ekonomiye müdahale edilebilirlik üzerinden geliştirilmiş bir oğludur 
Bu kültürel yapı bütün dünyada finansal sektörün, sanayinin; rantiyecilerin de yatırımcıların önüne geçmesine neden olmuştur. Ayrıca, bu yapı finansal sektörün tek başına krizi belirleyen unsur olarak düşünülmesine neden olan algılama hatasına yol açmıştır. Çünkü sistem faize odaklı büyümektedir. Faizin hareket kabiliyeti kazandığı kurumsal yapılar ise finans sektör içerisinde ağırlıklı olarak yer alan aynı zamanda ekonomi üzerinde etkin rol alan bankalardır. Bankalar ekonominin DNA'sına enjekte edilen faizlerden beslen bir yapısal özelliğe sahiptir. Bu yapısal özelliğinden dolayı da ekonominin kırılganlığı üzerinde temel belirleyici faktör olmaktadır.

\section{Ticari Bankaların Kriz Sürecine Katkısı Ve Önemi}

Küresel bankacılığın 2000-2008 yılları arasında büyümesi krize sürükleyen nedenlerin gizlenmesinde de etkili olmuştur. Özellikle ABD ve AB'de ticari bankacılık bu dönemde hızlı ivme kazanmıştır. ABD'de 2000 yılların başında 7 trilyon dolar seviyesindeki aktif büyüklüğe sahip olan ticari bankacılık, 2008 yılında yaklaşık 15 trilyon dolar seviyesine ulaşmıştır. AB'de ise, 30 trilyon dolardan 60 trilyon seviyesine ulaşmıştır (IFSL, Banking 2010). Bu gelişme reel bir finans olmaktan çok, sorunları bünyesinde taşıyan sanal bir büyüme şeklindedir. Bünyede taşınan sorun; ters seçim ve ahlaki tehdit sorununun bir niteliği şeklinde ortaya çıkmaktadır. Dolayısıyla emlak kredilerinin dağıtımda teminatsız kredilerin dağıtımıyla başlayan süreç (ters seçim) krizin ilk unsurudur. Bu krediyi dağıtan finans kurumunun kurtarılması gerektiği şeklindeki beklentisi de ahlaki tehdidi olarak açıklanmaktadır (Mishkin, 1992;115-130). Ticari bankacılık bünyesinde yatırım bankacılığına hareket kabiliyeti kazandıran hukuki düzenlemeler, yöneticilere verilen yüksek prim ve imtiyazlı hisse senelerinin yönetim kurulu üyelerine dağıtılması, krizin önemli nedenleri arasında sayılmaktadır ( Gorton,2008). Bu durum geleneksel bankacılığın devletler tarafından desteklenmesi nedeniyle, krizden kaynaklanan sorunları artırmıştır. İkinci dünya savaşıyla rafa kaldırılan, 1929 krizinden sonra, 90’lı yıllarda yürürlükten kaldırılan ticari bankaların yatırım bankacılığı yapmalarını yasaklayan Glass Stegall Kanunu, krize yol açan hukuki temel sebeplerden biridir.

Finansal piyasalarda çok önemli role sahip olan bankaların, finansal aracılık ve borç verme işlemlerindeki gücünün azalması, yatırımlarda ve ekonomik faaliyetlerde düşüşe neden olacaktır (Mishkin, 1997: 67). Banka bilânçolarında bozulmanın temel nedeni ise, yetersiz düzenleme ve denetleme sonucu aşırı risk üstlenilmiş olmasıdır. Faiz oranlarındaki artış, hisse senedi fiyatlarında hızlı düşüş ve para biriminde beklenmeyen değer kaybı gibi olumsuz şoklara neden olunmuştur. Böyle bir durumda finansal kurumlar ekonomik faaliyetleri yavaşlatma pahasına kredi verme işlemlerini kısmak ya da sermaye artırımına gitmek. Finansal kurumların kredi verme işlemlerinin önündeki en büyük engel ise, asimetrik bilgi sorunlarının artmasından kaynaklanan bilânçolardaki bozulmalardır ki, bu da finansal krizlerin etki alanlarının genişlemesinin temel faktördür (Mishkin, 1999a: 2-3).

Bu bağlamda bankacılık sektörünün; ABD gibi, gelişmiş türev piyasalarının işlerlik kazandığı, sermaye piyasalarınca yönlendirilen ve sermaye odaklı ekonomilerde geniş ekonomik alanı etkileyen kriz öncesine kadar göreli önemi azalmamıştı. Ancak özellikle banka merkezli finansal sisteme sahip gelişmekte olan ülkelerde bankacılık sektörü ' özel’ olma niteliğini, ekonominin parayı yönetme kabiliyeti gerçekleşene kadar koruyacaktır. Netice de paranın ekonomiyi yönlendirdiği kriz aşamasında nakit pozisyonda olanlar, kurtarma paketleriyle gerçekleştirilen varlıkların el değiştirilmesi ve yaklaşık iki trilyon doların buharlaşma sürecinde karlı çıkmışlardır. Bu nedenle bankalar aracı kurum olarak yeni bir dönüşüm süreci gerçekleşene kadar "özel” olma konumlarını sürdürmede ısrarlı olacaklardır.

IMF'nin eski başkan yardımcılarından Joseph E. Stiglitz'e göre, "Diğer ülkelerde finans sektörüne ve onun gücüne gösterilen saygı çoğunlukla $\mathrm{ABD}$ 'de olduğundan daha büyüktür. Finans sektörünün görüşleri ve politikaları yönlendirebilir ve hatta seçim sonuçlarını etkileyebilir" (Korkmaz, 2013). Günümüzde olduğu gibi, dünya coğrafyasında sınırlar yeniden çizilirken yönetimleri de geleceğe yönelik kurdukları modele uygun olarak tasarlanmaktadır. Süreç içerisinde tasarıların uygulanabilirliği bankaların “özel” olma konumlarının sürdürülebilirliğine bağlıdır. Ayrıca süreç yaşanırken yeni kullanılabilecek kavramlara ihtiyaç duyulmaktadır.

2008 Uluslararası Finansal Krizin ekonomik dönüşüm sürecinde kullanılmaya başlanan kavramlar ise;

1. Batmayacak kadar büyük,

2. Batmayacak kadar iyi bağlantılı,

3. Batmayacak kadar politik olmak.

İfadeleri ile kullanılan bu kavramlar, ölçeğin yarattı̆̆ı risklerin ekonomik ve politik yönlerine vurgu yapmaktadır. Aynı zamanda bilinen iktisat yöntemleriyle sorunun çözülemeyeceğini de ortaya koymaktadır.

Netice olarak günümüzde, kredi sisteminin makro ekonomik faaliyetler açısından önemi, uluslararası finansal krizle birlikte ticari bankaların en önemli rakipleri arasında yer alan yatırım bankalarının faaliyetleri büyük ölçüde sekteye uğramıştır. Bankaların finans sektöründe büyük paya sahip olmaları ve para kanallarındaki hareket kabiliyetlerindeki rolleri nedeniyle ve ekonomiye yön vermeleri neticesinde hala sistemik krize neden olma riski taşımaktalar. Bu nedenle bankalar halen 'özel' olma konumuna sahip ve uluslararası finansal kriz sürecinde yaşanan banka kurtarmaları bankaların hala fazlasıyla “özel” olduğunu göstermektedir. 


\section{Sistemde Bir Düzeltme Hareketi Olarak Finansal Kriz}

Soğuk savaş sonrası; üretim ve finans sermayesi küreselleşirken beklenti ve kriz tetikleyicilerde küreselleşmiştir. Krizi kapitalist sistemde bir düzeltme hareketi olarak düşünmekse, özelleştirilen karın maliyetinin toplumun geniş kesimine ödettirilirken, krizden kurtulma operasyonları adı altında varlıkların el değiştirme sürecinde küresel sermayenin yeniden yapılandırılma zorunluluğunun ortaya çıkmasının sonucudur.

Krizin ortaya koyduğu sonuçlardan biri de faize dayalı sistem tıkanmıştır. T1kanıklığı aşabilmek için yeni bir patlamaya ihtiyaç duyulmaktadır. Patlama ise spekülatif sermaye ile gerçekleşebilmiştir. Çünkü spekülatif sermaye hem küresel sermayeye hem de iktidarlara yön vermektedir. Aynı zamanda spekülatif sermaye aklın yönettiği merkezin ikna aracıdır.

Doların rezerv para olma özelliğinin tartışılması ve kriz olarak ifade edilen ekonomik dengesizliğin koşulları, aklın yönettiği spekülatif sermaye tarafından hazırlanması, yaşanan olayların tamamen aklın yönettiği merkezce alınmış siyasi bir karar ifadesini kullanmamızda sanırım yanlış olmaz. Çünkü küreselleşen dünya ekonomisinde, uluslararası para ticareti uluslararası mal ticaretinin 40 katını aşan bir seviyeye ulaşmıştır. Bu rakam bile sanal dünya ekonomisinde yaratılan reel ekonomi üzerinde yarattığı krizin derinliğini anlamak için yeterlidir.

Küreselleşen dünya ekonomisinin büyüyen sermayesine, gelişmiş ve körfez ülkelerin tasarruf fazlaları kadar uluslararası kayıt dışı ekonominin artan hacmi de katkı sağlamaktadır. Bu Parasal döngü bize krizin hangi yapı içerisinde mücadeleye dönüştüğünü anlamamız için yeterlidir.

Küresel sermayenin kısa vadeli karlara odaklanması bütün mali piyasaları hedef haline getirmektedir. Hareket halindeki büyük miktarlı fonların piyasalara anlık giriş ve çıkışları finansal krizleri tetiklemektedir. Spekülasyonun ve açıktan sermaye hareketlerinin yol açtığı dalgalanmalar, bütünüyle dünya ekonomisini etkileyerek sosyo-ekonomik sonuçlar doğurabilmektedir.

Faiz odaklı dünyanın ekonomik-sosyal yapısı, tıkanıklı̆̆ı düzeltme hareketiyle aşmak isterken yeniden yapılanmaya da ihtiyaç duymaktadır. Netice olarak dünya ekonomik düzeninde hiçbir oluşum beklenmedik, tesadüf, rastlantılar ve finans kuruluşlarının bilançolarındaki bozulmalarla açıklanamaz.

\section{Krizi Firsata Dönüşstürenler}

2007-2008 uluslararası finansal krizde finansal kurumların risklerini dağıtmış olmaları finansal sistemin yetersiz sermayeden kaynaklanan sorunları engelleyememiştir.2008 yılındaki finansal kriz paranın ekonomiye yön verdiği bir yapıda mevduat toplayamayan yatırım bankalarının bilançolardaki bozulma, makro düzeyde ekonomideki iniş çıkışları önemli ölçüde etkilemiştir.

Standard and Poor's Sanayi Endeksli Şirketlerin 1998 yılında 200 milyar dolar olan, toplam nakit büyüklügüunün 2008/ Şubat ayında 600 milyar doları aştığına dikkat çekmektedir. 1980-2006 döneminde ABD şirketlerinin nakit varlıklarının önemli ölçüde arttığını belirtmekte Bates, Kahle ve Stulz (2007:32).Bu gelişim süreci ABD’nin dünya ekonomisi üzerindeki ağırlığı nedeniyle, sanal ekonomisi sayesinde işler iyi giderken dahi nakit oranının artması; temelde faiz sisteminin tıkanması. Sonuç olarak paranın hareket edeceği karlı bir üretim sahası bulamaması ile ilişkilidir. Bu bağlamda, kriz ile birlikte, paranın kaliteye yönelerek güvenli limanlara sı ğınması, kısa vadede küresel ölçek de durgunluk ve işsizlik beklenen bir sonuçtur. Ancak küresel sermayesinin karlılığı düşen reel ekonomiye aktarılmasındaki güçlüklerin; ekonomide hareket kabiliyetini kısıtlaması, spekülatif sermayenin küresel sermayeye yön vermesinde etkili olmuştur.

Küreselleşen dünya ekonomisinde uluslararası para ticaretinin, uluslar arası mal ticaretinin yaklaşık 40 katına ulaştığı ve ekonomik krizlerin sıklaşmasının, dolardaki, altındaki ve sermaye piyasalarındaki dalgalanmaların dünyayı spekülatif bir pazara çeviren küresel yaklaşımın sonucudur. Bu bağlamda likidite fazlalığının, karlı yeni bir alanlara aktarılamaması, sistemin gelişimini engellemiştir.

\section{Krize Giden Yolda Dünya Ekonomisindeki Gelişmeler Ve Krizin Derinliği}

Krizin dünya ekonomisine bağlı nedeni; 1973 birinci petrol şoku, 1975 durgunluk, özellikle FED tarafından uygulanan sıkı para politikası neticesinde dolar faiz oranının yükselmesi olarak öncelikle belirtebiliriz. Faiz oranlarının yükseltilmesiyle, değişken faiz haddinden alınan eski borçların faiz yükünü artırmıştır. Ulusal parayla ifade edilen borç yükü artarken, borç erteleme anlaşmaları yeni faiz oranı üzerinden yapılmıştır. Uzun vadeli kredi sağlanması güçleşmiş ve maliyet artmıştır. Aynı dönemlerde dikkat çeken bir diğer husus ise kısa vadeli sermaye hareketlerinin kazandığı hızdır. Bir başka neden Amerikan ticari bankalarının yabancı devletlerin risklerinin analiz ve değerlendirmelerindeki hatalarıdır. Amerikan bankalarının \%75'inin gelişmekte olan ülke hükümetlerine kredi açtığı ve bu kredilerin risk analizindeki hatalarda düşünülürse krizin dünya ekonomisindeki etkisinin ve sonuçlarının siyasi karar alan aktörler tarafından belirleneceğini ifade etmek yanıltıcı olmaz kanaatindeyim.

Ticari bankaların geri ödeme sorunu olan ülkelere nakit akışı sağlayan kredi kanallarını etkisizleştirmeleri, bu ülkelere sermaye piyasalarının açılmasının dayatılması da bu ülkelerin sermaye piyasalarına hareketlilik 
kazandırmıştır. Gelişen piyasaların büyümesinin bu piyasalara yönelik portföy yatırımlarındaki artışa neden olurken, diğer bir nedeni de uluslararası sermaye piyasalarının kısa ve uzun vadeli faiz oranlarında büyük düşüşlerin yaşanmasıdır. Bu gelişme ağılıklı olarak ABD kaynaklı olmak üzere uluslararası fonların kısa vadede işlem yapan vurguncuların söz konusu piyasalara yönelmesini sağlamıştır. Bu süreç dünya'nın yer altı yerüstü zenginliklerinin hangi yöntemlerle el değiştirdiğini göstermektedir.

Aklın ikna aracı olan spekülatif sermaye yoluyla devletin ekonomideki ağırlığının azaltılmasını, devletin etkisizleştirilmesini öneren neo-liberal özelleştirme politikaları, krizin şiddetini artıran diğer bir neden olmuştur. Bu nedenle küresel ekonomik kriz, sadece finansal sektörle sınırlı bir kriz değildir dersek, "Kapitalizmin bizatihi hastalığıdır" diyen iktisatçıların görüşlerini desteklemiş oluruz.

"Büyük buhran hiç sona ermedi, savaş ekonomisi içinde kayboldu" diyen Kenneth Galbraith gibi ABD'nin gerçekte 1929-1933 krizinden çıkmadığı, sıcak ve soğuk savaşların, bölgesel savaşların krizden çıkış görüntüsü verdiğini savunan ekonomistlerde bulunmaktadır. Sadece, bozulan dengesizliğin dengesi, küreselleșen sermayenin lehine olacak şekilde kurumsal yapıları ve araçları tekrar dengeye getirecektir. Bu nedenle sistem Birleşmiş Milletler, NATO ve Dünya Bankası gibi kurumlarla yapılandırarak kendisini güncelleştirmektedir.

\section{Gelişmekte Olan Ülkelerde Kapitalizmin Değişen Yüzü ve Kriz}

Gelişmiş ülkelerde başlayan kriz küresel piyasalarda olan ilişkinin boyutuna bağlı olarak hızla gelişmekte olan ekonomileri de etkisi altına almıştır. Krizin gelişmekte olan ülkelere ulaşması hem arz hem de talep yanlı farklı kanallarla olmuştur. Bu kanallar:

1. Birinci olarak, finansal piyasalar aracıllğıyla krizin gelişmekte olan ülkelere ulaşmasıdır. Amerika ve Avrupa'nın para akışını durdurması gelişmekte olan ülkeleri olumsuz etkilemiş̧ir.

2. İkinci olarak, Menkul değerler piyasası. Emtia fiyatlarının düşmesiyle menkul kıymetlerin fiyatları hızla ve önemli ölçüde gerilemiştir.

3. Üçüncü olarak ihracattaki değişim. Mallara olan talebin düşmesi, gelişmiş ülkelerde üretimi azaltmışsır.

$\mathrm{Bu}$ gün dünya ekonomisinin temel sorunu, küreselleşmenin kriz aralığını daraltmış olmasıdır. Bu nedenle Dünya sürekli kriz içerisindedir.

Finansal liberalizasyon süreci ile birlikte gelişmekte olan ülkelerde yüksek reel faiz oranından yabancı sermaye girişi hareketleri teşvik edilmiştir. Sermaye girişi hareketleri, ulusal paralarını dolara sabitleyerek sabit döviz kuru sistemini uygulayan hükümet politikalarıyla da desteklenmiştir. Finansal liberalizasyona bağlı olarak gelişen yüksek reel faiz oranları, gelişmekte olan ülkelerde finansal sektörün likidite krizlerinin temel belirleyici nedenlerini oluşturmaktadır (Mishkin, 1999a:10).

Gelişen ülkeler 1990'lı yıllardan itibaren dış kaynağa büyümekteydiler Bu siyasi tercih aynı zamanda sermaye hareketlerinin özendirilmesi anlamına gelmektedir. Dolayısıyla ülkelerin bağımsız para veya maliye politikası uygulama şansıda ortadan kalkmaktadır. Çünkü yukarıda açıklandığı üzere ülkeler, uzlaşmaz üçlü faktörlerden (sermaye-faiz ve döviz kuru) sadece birisini kontrol edebilmektedir (Eren ve Süslü, 2001:664).

Sermaye girişleri ekonomide makro ekonomik ısınma veya "balon etkisi" de denilen yapay bir genişleme etkisi doğurmaktadır. Böylece ulusal para arzı artmakta, borsa spekülatif biçimde yükselmekte, ulusal para aşırı değer kazanmakta ve sonuçta ihracat gerilerken ithalat artmaktadır. Ekonomik, siyasal veya doğal bir olay ya da gelişme, geleceğe ait bekleyişleri aniden olumsuzluğa dönüştürebilmekte ve yabancı sermayenin kitleler halinde ana ülkelerine geriye dönmesi için ilk kıvılcımı oluşturmaktadır (Adelman, 1999:8). Yakın geçmişteki finansal krizlerin çoğunda buna benzer bir gelişme gözlemlenmektedir. Bu nedenle Türkiye ekonomisi gelecekte önemli bir ekonomik sahada fay kırılmasıyla karşı karşıya kalabilir.

Gelişmekte olan ülkelerdeki finansal krizlerin dinamiklerini, Türkiye örneğindeki gibi üç aşama ile açıklamak mümkün;

1. Birinci aşamada, finansal serbestleşmenin ardından, sermaye girişleri ile sağlanan banka borçlarındaki aşırı artış, büyük ölçüde batak kredilere dönüşmesi ve bankalar başta olmak üzere, finans ve finans dış1 kurumların açık pozisyon durumları bilânçolarında bozulmaya neden olmaktadır.

2. İkinci aşamada, piyasalarda ulusal para biriminin daha fazla korunamayacağı düşüncesinin egemenken ulusal para biriminin değerini korumak amacıyla Merkez Bankasının faiz oranlarını yükseltmesi neticesinde sermaye yapısı zayıf olan sektördeki bankaların bilânçoları daha da bozulmakta ve sürü psikolojisinin de etkisiyle, finansal kriz ortaya çıkmakta. 1994 Türkiye da yaşanan kriz gibi.

3. Üçüncü aşamada ise, ulusal para biriminin spekülatif saldırıların yoğunlaşmasıyla, değer yitirmesi ve yabancı para birimine bağlı olarak, kısa vadeli borçların, yani (bilânçodaki yükümlülüklerin) artması ve bu borçların genellikle çok kısa vadeli olması nedeniyle, nakit sorunlarının ortaya çıkışı. 2001 Türkiye örneğinde yaşanan, batık bankaların tasfiyesiyle sonuçlanan ve küresel sermaye tarafindan yeniden dizayn edilerek dengesizliğin dengesi üzerine kurulan ve spekülatif sermaye tarafindan yönlendirilen ekonomi ile yeniden dengeler kurulmaya çalışılmıştır. 
Sonuçta bilânçolar, hem varlık hem de yükümlülük kalemleriyle, her iki yönden sıkışmış olmaktadır. Bozulan bilânçolar ile zayıf sermaye tabanının varlığı, bankaların borç vermesini zorlaştırmakta, böylece son aşamada, tam anlamıyla bir finansal kriz ortaya çıkarken sistem kendi kendini yeniliye bilmek için zayıf halkaların tasfiyesi ile büyük balığın küçük balığı yutması gibi şirket evlilikleri yoluyla varlıkların el değiştirmesi süreci yaşanmaktadır.

Bu gün dünya ekonomisinin temel sorunu, küreselleşmenin kriz aralığını daraltmış olmasıdır. Bu daralma aynı zamanda sistemin varlığını sürdürebilirliğinin sonuna yaklaşıldığını göstermektedir. Çünkü dünya sürekli kriz içerisindedir. Bu kriz ABD de finansal sorun Avrupa Birliği'nde ekonomik durgunluk, Türkiye'de enflasyon ve cari açık Kırgızistan da ise sermaye yetersizliği ve yatırıma yönelecek kaynak maliyetinin yüksek olması nedeniyle üretimin yetersiz oluşu paranın üretimle ilişkilendirilmeyip faizle ilişkilendirilen yapı olarak ortaya çıkmaktadır. Bu yapı adaletsiz paylaşıma neden olan sanal ekonomi ve faize bağlı sistemdir. Bu sistem dengesizlik üzerine kurulu bir dengesel yapıdır. Bu yapının zayıflaması krizin oluşmasına neden olmaktadır. Bu süreç ise, sistemin uykudan uyanma sürecidir.

Dünya da ekonomik krizlerin şekli değişmiştir. Çünkü küreselleşmeyle birlikte yalnızca sermaye ve spekülatif fonlara dolaşım imkanı getirilmiş, emek gibi üretim faktörlerinde küreselleşme olmamıştır. Mal hareketlerinde de sınırlar tamamen kalkmamıştır. Bu nedenle de dünyada, sektörel ve faktörel dengeler bozulmuştur (Korkmaz, 2012). Krizin temel nedeni, ekonominin dinamiklerindeki bu dengesizliğin dengesinin bozulmasıdır.

Shwab, "kapitalizm bu günkü haliyle, değişen dünyaya uyum sağlayamıyor ve bu nedenle küresel bir sorumluluk anlayışıyla yeniden tasarlanması gerekiyor" diyor. Burada ilginç olan gelinen noktada küresel kapitalizmin faize bağlı dünya sisteminin işleyiş biçiminin sorgulanması talebinin batılılardan geliyor olmasıdır.

Kriz bir başka gerçeği daha ortaya koymuştur. Kaldıraçlı araçların ve risk azaltıcı mekanizmaların ABD'den başlayarak kontrol altına alınma eğilimi, küresel ölçüde yaratılmış olan büyük kaydi paranın giderek ve süratle azalması sonucunu doğurmuştur. Bu ortam ABD odaklı olarak başlayan küresel krizin ABD merkez bankası (FED) politikaları ile çözülebilmesini olanaksız hale getirmiştir. Kısacası FED ne kadar para basarsa bassın, bastığı paranın üretim faaliyetlerini geliştirme etkisi sınırlı kalmaktadır. Anlaşılan o ki, iktisat ilminin bilinen bütün klasik kuralları değişecektir (Törüner, 2012). Asıl değişimi zorunlu kılan faize dayalı ekonomilerde sağlanan istikrarın kalıcı olmayışıdır.

$\mathrm{Bu}$ aşamada, ABD ekonomi yönetimi ve FED ne yaparsa yapsın AB gibi bölgesel yapının sorunları çözülmedikçe küresel sermayenin gelişim sürecindeki kriz de sona ermeyecektir. Bir süreliğine sorunun çözümünü sağlayacak karar merkezi, birinci ve ikinci dünya paylaşımının aktörü olan ve üçüncü dünya paylaşımının da oyun kurucusu olmak isteyen Almanya'nın elinde olacak gibidir. Çünkü patinaj yapan ekonominin tekerlerinin dönebilmesi Avrupa Birliğinin kendi içerisindeki, dengesizliğin dengesinin dengede olması gerekmektedir. Çünkü bölgesel yapıda;

1. Ürettiği kadar ya da ürettiğinden az tüketip, tasarruf sağlayan

2. Tükettiğinden daha az üretip tasarruf sağlayamayan,

3. Yaşlı nüfusun akıl tutulmasını yaşadığı bir ekonomik saha söz konusudur.

$\mathrm{Bu}$ yapıdaki birliktelik ise, ortak Merkez Bankası ve ortak para politikasıdır. Bu ortaklık ülkeler arasındaki farklılı̆̆ı ortadan kaldıramamıştır. Aksine Üretmeden tüketen ülkelerin kontrolsüz borçlanmaları ve ticari bankaların birbirlerine olan borçları nedeniyle, finansal krizin derinleşmesine neden olmuştur. Bu bölgesel yapı bile faize dayalı sistemin sorunlarıyla ilgili kendi içerisinde istikrarlı gelişime katkı sağlayamamıştır. Dünya ekonomisinde istikrarlı büyüme bölgesel yapıda kurulan dengesizliğin dengesinin, yeni bir denge üzerine kurulmasıyla mümkün olabilecektir.

\section{Sonuç ve Değerlendirme}

Sonuç olarak Uluslararası Finansal Krizin Felsefesini kısaca özetlemeye çalışırsak; Sermayenin kendini yenileme maliyetinin artması, bir başka ifadeyle ödenmemiş belirli miktarda emeğin üzerindeki tasarrufun azalması krizin çıkış noktasıdır. Her türlü artı-değer sonrasında (kar, faiz rant gibi) karşılığı ödenmemiş emeğin maddeleşmesidir. Sermayenin kendisini yenileme sırrı da buradadır. Mevcut sermaye, biriktirilmiş ya da sermayeleşmiş faizdir. Faiz sistemine bağlı ekonomik yönetim biçimi gelir dağılımındaki eşitsizliğe neden olan dengesizliğin dengesini kuran istikrarsızlığın temel kaynağıdır. Kapitalist üretim biçimi yalnız bir zevkler dünyası oluşturmakla kalmaz, spekülasyon ve kredi sistemi ile dengesizliğin dengesini sürdürmeye çalışırken varlığını sürdürebilmek için kendi iktidarlarını ve sistemi koruyan küresel sermaye, faize dayalı sistemde yeni bir dengesizlik üzerine kurulan dengede, savunma iç güdüsüyle sistemi yeniden dizayn eder.

Küreselleşen sermaye, başkalarının emek gücünü baskı altına alarak, geniş halk kitlelerini yaşamın zevklerinden yoksun bırakmaya zorladığı ölçüde zenginleşir. Zenginleşmeye giden yol faiz sistemi. Faizi emeğin tasarrufundaki paya el koymada, el konan tasarrufun sermayenin kendisini yenilemesine katkı sağlaması, sermaye için faiz ve emeğin tasarrufunda ki azalma, krizin sessizliğini bozduğu anın kırılma noktasıdır. 
Küresel Sermaye için ne kadar çok üretilirse o kadar çok tüketilir ve dolayısıyla o kadar fazla ürün, üretim araçlarına çevrilir. $\mathrm{Bu}$ süreç, emeğin üretim araçları ve onunla birlikte kendi ürünü ve geçim araçları, onun karşısına sermaye biçiminde çıkmadığı sürece, kendisini sermaye birikimi ya da kapitalistin bir işlevi olarak ortaya koymaz.

Ulusal sanayi gücünde ortaya çıkan güçlü bir ilerleme olduğu zaman, karlar, birikim kaynağı olarak küresel sermaye için büyük bir anlam ifade eder. Çünkü gelişmekte olan ülkelerde bir yıl içinde biriktirilen toplam servet, gelişmiş ülkelerin toplam servetine katkı yaptığı sürece sanayisi ivme kazanmakta ve küresel sermaye adına gelişmiş ülkelere Milli Gelirlerinden transfer edildiği sürece dengesizliğin dengesinde istikrar sağlanmaktadır. Çevre ülkelerden merkez ülkelere küresel sermaye adına transferlerin azalarak artmaya başlaması uluslararası krizin ayak seslerinin duyulması demektir. Bir başka ifadeyle üretimin genişlemesinin durduğu nokta dengesizliğin dengesinin kırılma noktasıdır.

Kapitalist sistemde ekonominin istikrarı sağlaması, sistemin düzeltme hareketinden önce, tasarlamış olduğu modele uygun rol verilecek ekonomik güçler belirlendikten sonra, dengesizlik üzerine kurulan dengeyle birlikte dünya ekonomisinde istikrar sağlanabilir.

Dünya nüfusunun geniş kitleleri fakirleşirken, oransal olarak sayıları azalan varlıklı kesim, yeni kurulan dengesizlik üzerine dengede, yeni bir sürece kadar krizi sessizliğe gömer. Netice olarak kriz faiz sistemini beslemekte, faiz adaletsizliği yaygınlaştırarak gelir dağılımını bozmakta, bozulan servet dağılımındaki adaletsizlik, dengesizliğin dengesini bozmaktadır.

Sonuç olarak sistem krizle birlikte var olmaktadır. Adil olmayan paylaşımı ortadan kaldıran model olmadıkça, kriz ekonomik gelişmelerle yerinden oynayan taşları yeniden yerine koyarak dengesizliğin dengesini dengeye getiren sonucun başlangıcını ifade etmektedir. Çünkü kapitalist sistemin DNA'sında faiz var. Faiz ise, adaletsiz paylaşım ve ekonomik kargaşa demektir. Ekonomik kargaşa ise geniş kitlelerin fakirleşmesi demektir. Fakirleşen geniş kitleler ise, nesillerinin bu günden geleceklerini ipotek altına koymaları demektir. Bu nedenle sistemin krize, krizin fakirleştireceği kitlelere ihtiyacı vardır. Bu nedenle geniş kitlelerin ekonomideki faiz halkasını ortadan kaldırması gerekir.

\section{Kaynakça}

- Akat A. S., Http://Haber.Gazetevatan.Com/Dolarin_Sonu_Mu/243359/4/Haber 20.02.2013

- Rodrik, Dani, Forum İstanbul 2009http://Arsiv.Salom.Com.Tr/News/Print/11971-Prof-Dr-Dani-Rodrik-DisBorc-Bagimliliginin-Azalmasi-Sart.Aspx

- Alantar Doğan, "Küresel Finansal Kriz: Nedenleri Ve Sonuçları Üzerine Bir Değerlendirme"http://denizegitimdanismanlik.com/FileUpload/ks212629/File/dogan_alantar_kuresel_finans al_kriz_nedenleri_sonuclari_mfy81.pdf

- Ertuna Özer, (2009), "Dünya Ekonomik Krizi ve Türkiye'nin Durumu”, Muhasebe ve Finansman Dergisi, 41.

- Öztin A., “Bankacılık Kesimi Kriz Nedeni Mi?”, İktisat Dergisi, Şubat-Mart 2001, s.32.

- Öztin A.,(2009) “Kriz Nedeni ve Çıkış Yolları” http://journal.mufad.org.tr/attachments/article/239/1.pdf $\underline{31.12 .2011}$

- Pressacco, Flavio and Seravalli Gilberto, (2009), "The Real Origins of the Global Crisis", Transition Studies Review, 16.

- IFSL, (2010) Ltd Has Informed Bse about the Financial Results for the Quarter Ended December 31, www.Moneycontrol.Com/Stocks/Stock_Market/Corp_Notices.Php?Autono=404506

- Mishkin, (1992) Hyman P. "The Financial Instability Hypothesis” The Jerome Levy Economics Institute Of Bard College Working Paper No. 74.

- Mishkin, F., (1991) “Anatomy Of Financial Crisis", Nber Working Paper Series, No: 3924, December. (1992) "The Financial Instability Hypothesis", Working Paper No. 74 May, The Jerome Levy Economics Institute Of Bard College. pp. 115-130.

- Gorton, G., "The panic of 2007” Federal Reserve Bank of Kansas City, Jackson Hole Conference, August 2008.

- Mishkin, Inflation Targeting: A New Framework For Monetary Policy Journal Of Economic PerspectivesVolume 1, Number 2 - Spring 1997 - Pages 97-67.

- Mishkin, Frederic S, (1999) "Global Financial Instability: Framework, Events, Issues," Journal Of Economic Perspective, Vol 13(4), pp. 2-3.

- Bates, Kathleen and Stulz "Why Do U.S. Firms Hold So Much More Cash Than They Used To?” The Journal Of Finance, Vol. LXIV, No. 5 October 2009 
- Galbraith, John Kenneth, Büyük Kriz 1929, Çev. Elif Nihan Akbaş, İstanbul, Pegasus Yayınları, 2009, s. 185-194.

- Mishkin, Frederic S. (1999a), pp. 3-20.

- Korkmaz Esfender, (2013), http://www.yg.yenicaggazetesi.com.tr/yazargoster.php?haber=26228 27.3.2013 erişim tarihi

- $\quad$ Eren, Aslan ve Bora Süslü, (2001), "Finansal Kriz Teorileri Işığında Türkiye'de Yaşanan Krizlerin Genel Bir Değerlendirmesi", Yeni Türkiye, Sayı: 41, Y1l: 7, Eylül-Ekim, s. 662-674.

- Adelman, I., (1999), "Financial Crises - Causes, Consequences And Remedies", Department Of Agricultural And Resource Economics And Policy, Division Of California At Berkeley, May, s. 8.

- Korkmaz Esfender, (2012), http://www.esfenderkorkmaz.com/yenicag/davosta-canlar-kimin-icincaliyor.html 27.01.2012

- Shwab Http://Www.Dw.De/Davosta-Kapitalizm-Ele\%C5\%9ftirisi/A-15692470 30.01.2012

- Törüner Yaman, (2012) http://ekonomi.milliyet.com.tr/dunya-krizi-golgesinde-merkez-bankalaripolitikasi/ekonomi/ekonomiyazardetay/10.10.2011/1448869/default.htm28.12.2012 


\title{
Küresel Kriz Sürecinde Altın Fiyatlarını Etkileyen Dinamikler Dynamics Affecting Gold Prices in the Global Crisis
}

\author{
Ph.D. Candidate Togan Karataş (Marmara University, Turkey) \\ Ph.D. Candidate Emre Ürkmez (Marmara University, Turkey)
}

\begin{abstract}
Gold prices have been one of the most observed financial indicators in the global economy. Various macro dynamics that historically determine the price of gold, as a precious metal have been initiated. In this scope, gold price fluctuations are closely linked to the global economic conjuncture. In this study, the role of gold in the global economy and historical gold prices are examined briefly, and in the course of global finance crisis, the elements Dow- Jones Index, petrol prices and silver prices as assigning gold prices are dealt with. An economic and econometric analysis is carried out for these indicators since it is regarded that they are crucially instrumental in gold prices. Study period is determined monthly and covers between 2007:01 and 2013:02. Johansen co-integration test, VECM and impulse response analyses are used in the econometric analysis. According to VECM analysis, it has been found out that the indicators do not act in unison in the short term, but the results of co-integration analysis reveal that gold prices are associated with the related economic indicators in the long term. As a result of impulse response analysis, it is seen that gold prices are more influenced by the fluctuations in petrol prices than other indicators. Within the frame of findings, it has been revealed that gold prices unsurprisingly increase during the crisis periods and are influenced by the indicators stated above.
\end{abstract}

\section{Giriş}

$\mathrm{Bu}$ çalışmada dünya ekonomik konjonktürüne bağlı olarak fiyatı dalgalanmalar gösteren altının son finansal krize karşı verdiği tepkinin altında yatan dinamikler incelenmeye çalışılmıştır. Bu çerçevede değerli bir metal ve emtia olan altının dünya ekonomisindeki rolü, altın fiyatının gösterdiği değişkenliklerin tarihçesi ve nedenleri ile küresel kriz dönemindeki altın fiyatlarının değişimleri incelenmeye çalışılmıştır.

Çalışmanın birinci bölümünde, altının fiyatının nesnel şartlarını oluşturan, altının para sistemleri ile olan ilişskisi ele alınmıştır. İkinci bölümde, alın fiyatlarının tarihçesi incelenmiş ve altın fiyatlarına dair yapılan bazı çalışmalar ele alınmıştır. Bu çerçevede altın fiyatını belirleyen temel makroekonomik göstergeler ortaya koyulmuştur. Çalışmanın üçüncü bölümünde ise, küresel kriz sürecinde (2007'den günümüze) altın fiyatını belirleyen bazı kritik makroekonomik göstergeler, ilgili dönem içinde, aylık verilerle ve çeşitli testler aracılığıyla ekonometrik olarak analiz edilmiştir.

\section{Para Sistemleri ve Değerli Bir Metal Olarak Altın}

Günümüzde kullanılan para sistemi kâğıt para sistemidir. Bu sistemde paranın kendisinin bir değeri olmasa da paraya atfedilmiş bir itibari değer vardır. Bu çerçevede değerli metallerin para olarak kullanıldığı dönemlere göre para sistemi ciddi şekilde farklılaşmış durumdadır. Tarihsel olarak itibari paranın değerli metal cinsinden (altın) dönem dönem karşılığının olması, altının iktisadi ve politik olarak sahip olduğu konumun önemli bir göstergesi niteliğindedir. Çünkü itibari paranın değerinin emtia cinsinden ölçülmesinde dönemsel olarak en çok tercih edilen değerli metal altın olmuştur ve egemen para sistemi ile altının girdiği etkileşim altın fiyatlarını etkileyebilmektedir.

19. yüzyıldan günümüze uluslararası para sistemlerinin, değeri kendinden menkul olan altına bağlanması ya da altından ayrışması, altının dolar cinsinden fiyatı için karşılıklı etkileşimler yaratmıştır. 19. yüzyıldan 1. Dünya Savaşı'na kadar olan sürede belli kesintiler olsa da paranın bir değerli metal karşılı̆̆ olmuştur. Bu dönemde uygulanan sistem "klasik altın standardı" sistemidir. Ardından dünya savaşlarının da etkisi ile kısa süreli bir sistemsizlikten sonra 1944-1971 arası uygulanan "Bretton Woods" sisteminde, dünya altın rezervlerinin önemli bir kısmına sahip olan ABD’nin ulusal parası olan dolar, altına bağlanmıştır ve diğer para birimleri de dolara bağlanmıştır. Bu periyotta 1ons altın = 35 dolar olacak şekilde dolar için değerli bir metal üzerinden sabit kur uygulaması söz konusu olmuştur. Bu bağlamda o dönemde kurlar altın üzerinden sabitlendiğinden, altının fiyatı da sabitlenmiştir. Ancak ABD’nin Vietnam Savaşında yaptığı emisyon kaynaklı yaptığı yüksek harcamalar, dünyadaki ödemeler dengesi sorunları gibi nedenler ile doların değeri reel olarak düşmeye başlamış ve nominal seviyeyi zorlayarak, sabit kur uygulamasından 1971'de vazgeçilmesine neden olmuştur.

Altın fiyatındaki uzun dönemli istikrarın bozulması da hem ABD’nin sabit kur uygulamasından vazgeçmesine hem de 1973 'te petrol krizi olarak şekillenen sermaye birikim krizi ile aynı döneme denk gelmiştir. Bu dönemden sonra dünya para piyasalarında bu türden bir sabit kur uygulamasından genel olarak vazgeçilmesiyle birlikte, madalyonun diğer tarafında yer alan altın için de fiyat dalgalanmasına yol açacak bir dinamik ortaya çıkmıştır. $\mathrm{O}$ süreçten sonra altın fiyatları da dalgalanmaya başlamıştır. $\mathrm{Bu}$ durum altının fiyatlarının 
dalgalanmasına neden olan nesnel durumu oluşturmuştur. Küresel krize uzanan süreçteki para sistemi ise 2 . Bretton Woods olarak adlandırılmıştır (Dooley vd.2004). Dünya ekonomisinde yeni sistem arayışına yol açacak olan her iktisadi gelişmede olduğu gibi yeni finansal krizin de uzun vadede yeni bir para sistemine yönelişi cezbetme olasılığı söz konusudur (3. Bretton Woods analizi için bkz: Şişman 2009). Olası bir değişim, tarihte olduğu gibi gelecekte de altın fiyatını etkileyebilecek niteliktedir.

\section{Altın Fiyatlarının Tarihçesi: Fiyatları Hangi Göstergeler Belirliyor?}

Altın fiyatları tarihsel olarak incelendiğinde, dünya ekonomisinin genişleme dönemlerinde altın fiyatlarının hareketinin genelde istikrarlı veya aşağıya doğru olduğu, kriz dönemlerinde ise yukarıya doğru olduğu görülmektedir. Enflasyonist etkilerden arındırılma durumunda dahi, gerek 1929, gerek 1973, gerekse 2007 kriz sürecinde altın fiyatı önceki dönemlere göre ciddi bir şekilde artmıştır. Bu da altının değerli metal olma özelliğinin kriz dönemlerinde daha net ortaya çıktığının tarihsel göstergesi niteliğindedir:

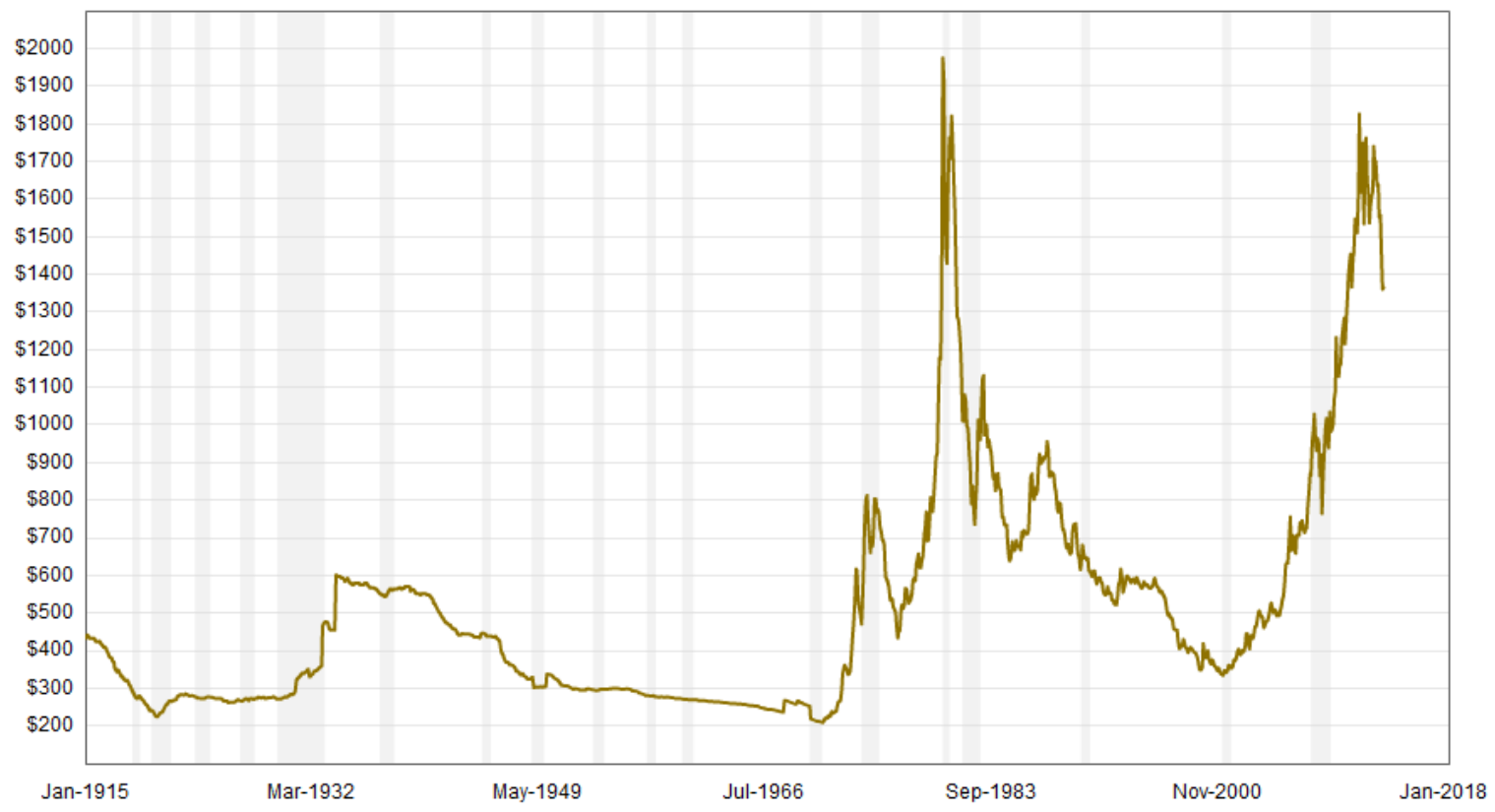

Grafik 1 Altın Fiyatları 1915-2013 (Enflasyondan Arındırılmış - Ons Olarak Dolar Bazında) Kaynak: Macrotrends (2013).

Altın fiyatının oluşmasında dünya ekonomisinin reel ve finansal konjonktürünün oldukça etkili olduğu Grafik 1 'den kolayca okunabilmektedir. Bu çerçevede her ne kadar bir iktisadi göstergenin fiyat dinamiklerini tümüyle belirlemek mümkün olmasa da dünya altın piyasasında oluşan fiyatlar, çeşitli göstergelerden etkilenmektedir. Piyasalarda fiyat; finansal, reel ve siyasal birçok dinamiğin bütüncül etkisi sonucu oluşmaktadır. Zira ekonomilerde hemen hemen her gösterge birbiriyle ilişki içerisindedir. Bu bağlamda altın fiyatının belirleyenleri olarak birçok değişken ortaya çıkmaktadır.

Bu konuda yapılan bazı çalışmalara göz atmak gerekirse; Abken'e göre (1980) altın fiyatları iktisadi ve siyasal dengenin bir göstergesi olmasının yanı sıra bu makroekonomik ilişki karşılıklı ve karmaşık bir yapıya sahiptir. Vural'ın çalışmasına göre (2003), 1990-2003 dönemi için altın fiyatının; gümüş, petrol ve bakır fiyatı ile aynı yönde, Dow-Jones Endeksi ile ise ters yönde hareket ettiği sonucu söz konusudur. Levin vd. yaptığı çalışmaya göre (2006), ABD için uzun dönemde altın fiyatları ile enflasyon oranları, kurlar ve kredi riski arasında ilişki söz konusudur. Zaiyong ve Shuguang'ın yaptığı çalışmaya göre (2008), altın fiyatlarının uzun dönemli belirleyenleri olarak ABD'deki enflasyon oranları, dolar kuru, faiz oranları, altın stoğu ve Dow-Jones Endeksi ele alınmıştır. Simakova'ya göre (2011), altın ve petrol arasındaki ilişki son yıllarda biraz zayıflamış olsa da uzun dönemde bu iki gösterge arasında güçlü bir ilişki söz konusu olmuştur. Aksoy ve Topçu'nun (2013) 2003-2011 dönemi için yaptığı çalışmaya göre ise, altın getirisi ile hisse senetleri arasında ters yönlü bir ilişki söz konusudur. Görüldüğü üzere altın fiyatlarının belirleyicisi olarak birçok dinamik söz konusu olabilmektedir. Tüm değişkenleri birlikte incelemek zor olmakla birlikte, fiyat dinamiği olarak hem finans sektöründen hem de reel sektörden en azından bir değişkenin ele alınması yerinde olacaktır. 


\section{Küresel Kriz Sürecinde Altın Fiyatları ve Ekonometrik Analiz}

2007'de etkileri ortaya çıkmaya başlayan ve halen tam olarak aşıldığı söylenemeyecek olan finans krizi ile birlikte altın fiyatları da artmaya başlamıştır. Kriz dönemlerinde, iktisadi aktörlerin altını "güvenli liman" olarak algılanması gayet doğal ve rasyoneldir. Zira altın, değeri kendinden menkul bir yatırım aracıdır. İnsanların tasarruflarını değerlendirme biçimlerinin konjonktürel olarak değişmesinin bir yansıması olarak altın kriz dönemlerinin yatırım aracı olma özelliğini bu dönemde de taşımıştır ve bunun bir sonucu olarak da 2007 sonrası altın fiyatlarında ciddi artışlar olmuştur.

Küresel kriz sürecinde altın fiyatının belirleyicileri olarak Dow-Jones Endeksi, kriz konjonktürlerinde fiyatları değişkenlik gösteren petrol ve temel iki değerli madenden biri olarak görülen gümüş fiyatındaki değişimlerle altın fiyatları arasındaki kısa ve uzun dönem ilişkisi incelenmiştir. İktisadi olarak altının diğer emtialar ile birlikte hareket etmesi, Dow-Jones Endeksi ile ters yönlü hareket etmesi beklenir. Çünkü kriz sürecinde menkul kıymetler piyasası düşüşe geçerken altın fiyatları ve diğer emtia fiyatları artma eğilimi gösterir. Bu çerçevede model şu şekilde oluşturulmuştur:

\subsection{Metodoloji ve Model}

Nominal altın fiyatları ile Dow-Jones hisse senedi Endeksi(DJI), West Texas Intermediate tanımlı petrol fiyatları(PE) ve gümüş fiyatları arasındaki uzun dönem ilişkiyi araştırmak için Johansen eşbütünleşme analizi kullanılmaktadır. Analize başlamadan önce, her bir değişkenin zaman serisi özellikleri araştırılmalıdır. Diğer bir ifadeyle serilerin bütünleme mertebeleri belirlenmelidir. Bu da birim kök testleri yardımıyla yapılmaktadır.

Bir zaman serisinde birim kökün varlığını araştıran ve literatürde en çok kabul edilen ilk test Dickey-Fuller birim kök testidir. Dickey-Fuller testi hata teriminin gaussyan saf hata özelliklerini yani ortalamasının sıfır, varyansının sabit ve normal dağıldığını varsayar. Ancak bu varsayım çoğunlukla geçerli değildir. Eğer hata terimlerinde otokorelasyon varsa, bu otokorelasyonu ortadan kaldırmak için bağımlı değişkenin gecikmeli değerleri modele dahil edilerek Dickey-Fuller birim kök testi yeniden uygulanır. Bu yeni test Genişletilmiş Dickey-Duller(ADF) testi olarak adlandırılır ve model şu şekilde sunulur:

$$
\Delta y_{t}=\alpha+\beta T+\rho y_{t-1}+\sum_{j=1}^{k} \theta_{j} \Delta y_{t-j}+\varepsilon_{t}
$$

Burada $\varepsilon_{t} \sim$ iid $\left(0, \sigma^{2}\right)$ olduğu varsayılır ve modele eklenmesi gereken gecikmenin cimrilik prensibi gereği seçilmesi gerekmektedir. Modele eklenmesi gereken gecikme uzunluğu k’nın Akaike Bilgi Kriteri(AIC), Schwarz Bilgi Kriteri(SIC) ve Hannan Quin gibi bilgi kriterleri yardımılla belirlenmesi gerekmektedir.

Diğer alternatif birim kök testi hata teriminin $\varepsilon_{t} \sim$ iid $\left(0, \sigma^{2}\right)$ olduğu varsayımı dikkate almamaktadır. Phillips-Perron(1988) çalışmalarında Dickey-Fuller tarafindan ileri sürülen birim kök testini genelleştirerek parametrik olmayan bir yaklaşımla yeni bir birim kök testi geliştirmişlerdir. Ancak bu yaklaşımda hata teriminin otokorelasyonları yüksek dereceden negatif olduklarında Phillips-Perron testi hata teriminin örneklem hatası ile karşılaşmaktadır. Ancak bu düzeltme yapıldığında Phillips-Perron testi ADF testine göre daha güçlüdür.

Eğer ilgili seriler, birim kök testleri sonucunda aynı mertebeden(özellikle birinci mertebeden, I(1)), bütünleşik ise değişkenler arasındaki uzun dönem ilişkisini araştırmak için eşbütünleşme testleri uygulanabilir. Johansen testi, iktisadi zaman serileri arasındaki uzun dönem ilişkilerini ortaya koyarken VAR modelini temel alır. Johansen testi eşbütünleşme vektör sayısını belirlemek için iz(trace) ve maksimum(max) testlerini kullanmaktadır. Ayrıca bu yaklaşım m boyutlu VAR modelinin hata düzeltme modeli(VECM) olarak yazılmasına da imkân vermektedir.

$$
\Delta y_{t}=\Gamma_{0}+\sum_{i=1}^{k-1} \Gamma_{i} \Delta y_{t-i}+\prod y_{t-k}+\varepsilon_{t}
$$

Burada $\Gamma_{0}$ vektörü serilerde olması mümkün olan deterministik yığılmayı göstermektedir. $\prod$ matrisi değişkenler arasındaki uzun dönem bilgiyi içermektedir ve $\Pi=\alpha \beta^{\prime}$ olarak tanımlanmaktadır. $\alpha$ ayarlama katsayısı ve $\beta^{\prime}$ eşbütünleşme vektörünü göstermektedir. $\prod$ matrisinin $\operatorname{rank} 10<\operatorname{rank}\left(\prod\right)=\mathrm{r}<\mathrm{m}$ olduğunda değişkenler arasında bir uzun dönem ilişkisinden bahsedilebilir. Denklem(2) verilen modelde gecikme uzunluğu(k)'nun doğru bir şekilde belirlenmesi oldukça önemlidir. VAR modelindeki gecikme uzunluğunun(k) belirlenmesi için kullanılan en yaygın bilgi kriterleri; AIC ve SIC'dır. Bu bilgi kriterlerinin yanında özellikle paket programlar tarafindan sunulan; Olabilirlik oranı(LR), Nihai öngörü hatası(FPE) ve Hannan-Quinn bilgi kriteri(HQ)'de yer almaktadır. 


\subsection{Veri ve Ampirik Bulgular}

Nominal altın fiyatları ile Dow-Jones hisse senedi endeksi(DJI), West Texas Intermediate tanımlı petrol fiyatları(PE) ve gümüş fiyatları arasındaki uzun dönem ilişkiyi araştırmak için Johansen eşbütünleşme analizi kullanılmaktadır. Çalışma 2007:01-2013:02 dönemini kapsayan aylık veriler kullanılarak yapılmıştır. Çalışmada kullanılan zaman serilerinin yapılarını görmek için Grafik 2'de serilere ilişkin zaman serisi grafikleri bir arada verilmiştir.

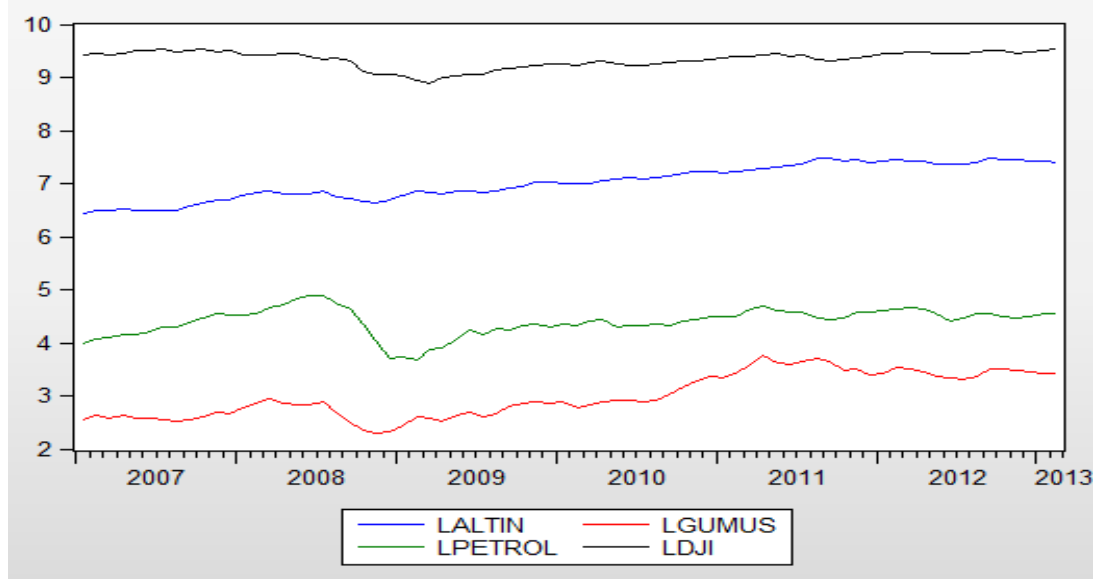

Grafik 2 Altın - Petrol - Gümüş - Dow Jones Zaman Serisi Grafikleri

Grafik 2 incelendiğinde, dört serinin de belirli bir ortalamaya sahip olmadığ hatta zaman ile birlikte hareket ettiği zaman serisi grafikleri yardımıyla görülmektedir. Ayrıca Grafik 2'de dört serinin de benzer davranışlar sergilemesi, bu dört seri arasında bir uzun dönemli ilişki olabileceğinin sinyalini vermektedir. Zaman serisi grafikleri her ne kadar serilerin durağanlığ hakkında önsel bir bilgi verse de, durağanlığın belirlenmesinde sadece zaman serisi grafiklerinin kullanılması yeterli değildir. Bu nedenle birim kök testlerine başvurulmaktadır.

\subsubsection{Birim Kök Testleri}

Çalışmada kullanılan serilerin bütünleme mertebelerini analiz etmek için uygulanan Genişletilmiş DickeyFuller ve Phillips-Perron birim kök testleri sonuçları Tablo 1'de gösterilmiştir.

\begin{tabular}{|l|l|l|l|l|l|l|l|l|}
\hline & \multicolumn{3}{|l|}{ DÜZEYLER CINSİNDEN } & \multicolumn{3}{l|}{ BİRINCÍ FARKLAR CINSINNDEN } \\
\hline $\begin{array}{l}\text { Birim Kök } \\
\text { Testleri }\end{array}$ & LALTIN & $\begin{array}{l}\text { LGUMU } \\
\text { S }\end{array}$ & $\begin{array}{l}\text { LPETRO } \\
\text { L }\end{array}$ & LDJI & $\begin{array}{l}\text { LALTI } \\
\text { N }\end{array}$ & $\begin{array}{l}\text { LGUMU } \\
\text { S }\end{array}$ & $\begin{array}{l}\text { LPETRO } \\
\text { L }\end{array}$ & LDJI \\
\hline ADF & -1.8036 & -2.3451 & -3.8207 & -1.4816 & -7.1841 & -6.3266 & -5.3981 & -6.3706 \\
\hline Phillips-Perron & -1.8036 & -1.8772 & -2.6220 & -1.3231 & -7.1572 & -6.2615 & -5.4624 & -6.3706 \\
\hline
\end{tabular}

*Serilerin birinci farkları alındığında, 0.05 anlam düzeyinde Ho hipotezi reddedilir.

*Tablo Kritik değerleri $\tau$ tablosundan düzeyler cinsinden sabit+trend için -3.45(\%5), birinci farklar cinsinden ise sabit için -

$2.89(\% 5)$ olarak alınmıştır.

\section{Tablo 1 Birim Kök Testleri Sonuçları}

Tablo 1 incelendiğinde ilk olarak LALTIN serisi için sabit ve trendli model kalıbına göre birim kök testlerinin uygulandığ1 görülmektedir. Genişletilmiş Dickey-Fuller(ADF) birim kök testi uygulanırken tahmin edilen modele dâhil edilen gecikme sayısı Akaike(AIC) ve Schwarz(SIC) bilgi kriterleri ile Lagrange Çarpanları(LM) testi yardımıyla belirlenmiştir. Her üç değerlendirme kriteri de kullanılarak modele iki gecikme eklendiğinde artıklardaki serisel korelasyonun ortadan kalktığı görülmüştür. ADF testinde seri için birim kök testi uygulandığında ALTIN serisinin birim köke sahip olduğu sonucuna ulaşılmaktadır. Dolayısıyla ALTIN serisinin birinci farkı alınarak yeniden birim kök testi uygulandıktan sonra serinin durağanlaştığı veya birim kök olmadığ 1 sonucuna ulaşılmıştır. Yani ALTIN serisinin birinci mertebeden bütünleşik, I(1) olduğu söylenebilir. Benzer biçimde LGUMUS, LPETROL ve LDJI serileri için de aynı işlemler yapılmıştır. Bu testlerin sonucunda, bu üç serinin de birinci mertebeden bütünleşik seriler olduğu sonucuna ulaşılmıştır.

Phillips-Perron testi, zaman serisinde dikkate alınmayan hareketli ortalama yapısını da dikkate alarak birim köktesti yapmaktadır. Tablo 1 incelendiğinde ALTIN serisi için sıfır hipotezi red edilememektedir. Yani ALTIN serisinin birim kök içerdiği veya durağan olmadığı sonucuna ulaşılır. ALTIN serisinin birinci farkı alındıktan sonra uygulanan test sonucunda serinin durağanlaştığı görülmektedir. Benzer sonuçlar LGUMUS, LPETROL ve LDJI serileri içinde söylenebilir.

\subsubsection{Eşbütünleşme Testleri}

LALTIN, LGUMUS, LPETROL ve LDJI serilerinin birinci mertebeden bütünleşik I(1) oldukları belirlendikten sonra, bu seriler arasında uzun dönem ilişkilerini ortaya koymak için eşbütünleşik olup olmadıkları 
araştırılmaktadır. Eğer bu seriler arasında eşbütünleşme ilişkisi bulunursa, bu serilerin uzun dönem ilişkisine sahip olduğu söylenebilir. Ancak seriler eşbütünleşik olmadıklarında ise bu seriler arasında uzun dönemli bir ilişkiden bahsedilemez.

Eşbütünleme analizi için birçok test söz konusudur. Dolayısıyla farklı testler kullanılarak farklı sonuçlara ulaşılabileceğinden, burada LALTIN, LGUMUS, LPETROL ve LDJI serileri arasındaki uzun dönem ilişsisini ortaya koymak için iki tane eşbütünleşme testi uygulanmıştır.

Johansen testi için Tablo 2'de verilen karakteristik kökler Johansen'in olabilirlik fonksiyonundan hesaplanmaktadır. Olabilirlik oranı testi $\left(\lambda_{\text {trace }}\right)$ ve maksimum karakteristik kök testi $\left(\lambda_{\max }\right)$ için boş hipotez kointegrasyonun olmadığıdır. $\lambda_{\text {trace }}$ ve $\lambda_{\max }$ için kritik değerler ise Osterwald-Lenum'den alınmıştır. Engle ve Granger kointegrasyon testinde hesaplanan $\tau_{\gamma}$ için kritik değerler Patterson ve MacKinnon tepki yüzeyi fonksiyonundan bulunmuştur. Tablo 2 aynı zamanda eşbütünleşme için Johansen test sonuçlarını yansıtmaktadır. Johansen testi uygulanmadan önce VAR modeli için uygun gecikmenin belirli kriterlere göre belirlenmesi gerekmektedir. Çalışmada uygun gecikme uzunluğu Olabilirlik oranı (Likelihood Ratio, LR), Hannan-Quinn ve SIC'ye göre bulunmuştur. Buna göre uygun gecikmeli model VAR(4) olarak alınmıştır. Tablo 2 incelendiğinde Trace testi ve max-eigenvalue testi iki seri arasında bir uzun dönem ilişkisi olduğunu göstermektedir. Son olarak Engle-Granger (1987) tarafından ileri sürülen ve EKK artıklarına dayanan eşbütünleşme regresyon tahmin edilmiştir. Eşbütünleşme regresyon denklemi tahmin edildikten sonra kalıntılarına ADF testi uygulanmıştır. Ancak artıklarda serisel korelasyon söz konusu olduğundan AIC, SIC ve LM testi kullanılarak modele eklenmesi gereken gecikme uzunluğu belirlenmiştir. Buna göre artıkların 6 gecikmesi modele eklendiğinde serisel korelasyonun ortadan kalktığı belirlenmiştir. Sonuçta LALTIN ve LGUMUS, LPETROL ve LDJI serileri arasında uzun dönemli ilişki olmadığını ileri süren boş hipotez reddedilmiştir.

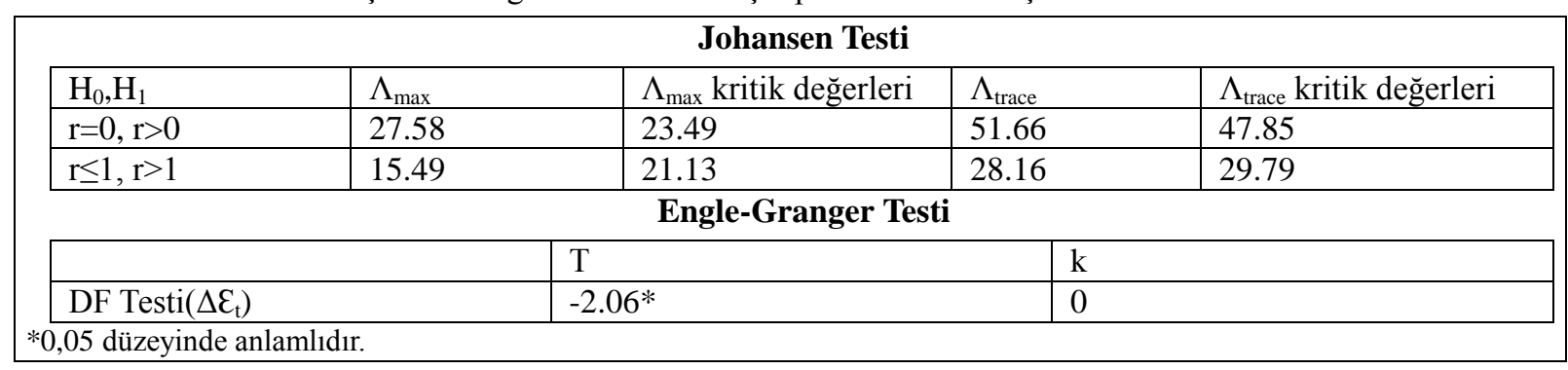

Tablo 2 Eşbütünleşme Testi Sonuçlarl

Uygulanan iki eşbütünleşme testi de aynı sonucu vermiştir. Yani LALTIN ve LGUMUS, LPETROL ve LDJI serileri arasında uzun dönemli bir ilişki olduğu sonucuna ulaşılmaktadır. Dolayısıyla LALTIN ve LGUMUS, LPETROL ve LDJI serileri arasında bulunan uzun dönemli ilişki en azından bir dolaylı nedensel ilişkinin varlığını yansıtmaktadır. Bu uzun dönemli ilişki normalleştirilmiş eşbütünleşme vektör tahminleri yardımıyla daha kolay yorumlanabilir. Tahmin edilen vektör, LALTIN katsayısının ters işaretiyle çarpılması sonucu normalleştirilir. Normalleştirilen katsayılar aynı zamanda uzun dönem elastikiyetleri de gösterirler. Bulunan sonuçlar Tablo 3 'te sunulmaktadır.

\begin{tabular}{|c|c|c|c|}
\hline \multicolumn{4}{|c|}{ Normalized cointegrating coefficients (standard error in parentheses) } \\
\hline LALTIN & LOIL & LDJI & LSILVER \\
\hline 1.000000 & $\begin{array}{r}-0.298855 \\
(0.04664)\end{array}$ & $\begin{array}{l}0.318658 \\
(0.05397)\end{array}$ & $\begin{array}{r}-0.244548 \\
(0.04295)\end{array}$ \\
\hline
\end{tabular}

Tablo 3 Eşbütünleşme Denklemi ${ }^{a} 0.05$ düzeyinde anlamlıdır, ${ }^{b} 0.01$ düzeyinde anlamlıdır.

$$
\text { LALTIN }_{t}=0.29 \text { LPETROL }_{t}-0.31 \text { LDJI }_{t}+0.24 L G U M U S_{t}
$$

Denklem (3) incelendiğinde LALTIN serisinin, LGUMUS, LPETROL ve LDJI serileri üzerine uygulanan regresyondan tahmin edilen PETROL ve GUMUS uzun dönem parametreleri pozitif ve anlamlı bulunmuştur. Bu sonuç ALTIN fiyatları ile PETROL ve GUMUS fiyatları arasında doğru yönlü, DJI Endeksi ile ters yönlü bir ilişki olduğu sonucuna ulaşılmıştır.

Engle ve Granger(1987) çalışmalarında değişkenler arasında uzun dönemli bir ilişki olması halinde hata düzeltme mekanizmasının yazılabileceğini göstermişlerdir. Yani uzun dönem dengesinde oluşacak bir sapmanın düzeltilebileceği ortaya konulmaktadır. Eşbütünleşme regresyon denklemindeki sapmaların düzeltilmesi hata düzeltme terimi (ECT) ile sunulmaktadır. Tablo 4 vektör hata düzeltme model (VECM) tahmin sonuçlarını göstermektedir. 


\begin{tabular}{|crrrr|}
\hline Error Correction: & D(LALTIN) & D(LOIL) & D(LSILVER) & D(LDJI) \\
\hline \hline CointEq1 & -0.009241 & 0.102508 & 0.039472 & 0.081946 \\
& $(0.01792)$ & $(0.03432)$ & $(0.03731)$ & $(0.01557)$ \\
& {$[-0.51583]$} & {$[2.98718]$} & {$[1.05802]$} & {$[5.26233]$} \\
\hline
\end{tabular}

Tablo 4 Vektör Hata Düzeltme Modeli Sonuçları

Tablo 4 incelendiğinde ALTIN modeli için elde edilen tahmin sonuçları kısa dönemde diğer serilerde bir değişme olması altın fiyatlarını ters yönde etkilediği görülmektedir. Fakat ALTIN modeli için tahmin edilen kısa dönem parametresi istatistiksel olarak anlamsızdır. Yani bu seriler arasında kısa dönem denge ilişkisi söz konusu değildir.

\subsubsection{Etki-tepki(Impulse-response, IR) Analizi}

Etki-tepki fonksiyonları, hata terimlerinden birindeki bir standart sapmalık şokun, içsel değişkenlerin şimdiki ve gelecekteki değerlerine olan etkisini yansıtır. Başka bir ifadeyle, etki-tepki analizi bir değişkende meydana gelecek bir şokun sistemdeki diğer değişkenler üzerindeki etkisini analiz etmekte ve bu bakımdan ekonomik politikalara yön vermede önemli bir işlev görmektedir. Hareketli ortalama vektörü(VMA) gösterimi Sims(1980)'in yönteminde şokların VAR sisteminin içerdiği değişkenler üzerindeki etkilerinin zaman serisi grafiğinin çizilmesine imkân verir:
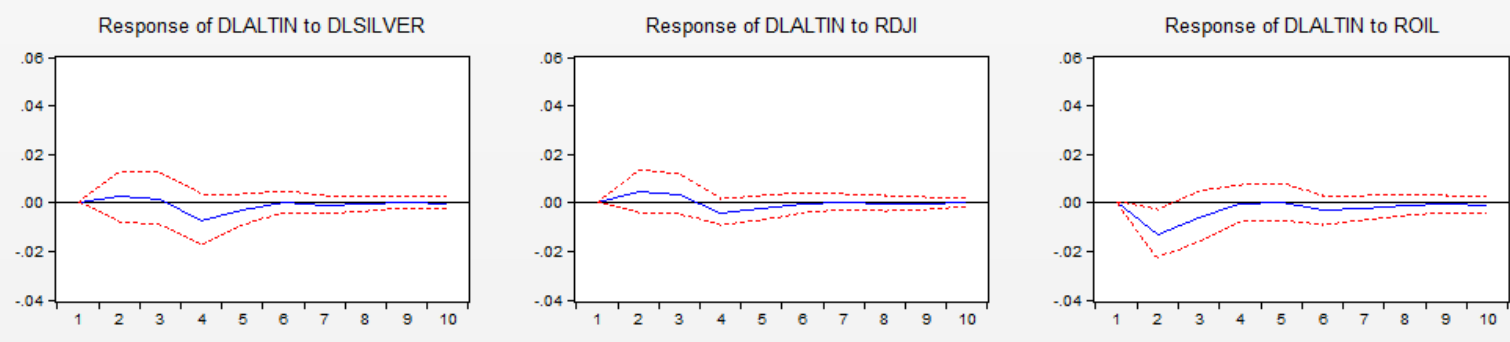

Grafik 3 Etki-Tepki Analizi Sonuçlart

Grafik 3'te gösterilen sonuçları incelemek gerekirse, gümüş fiyatlarında 1 standart sapmalık şok meydana geldiğinde, altın fiyatları 3. döneme kadar yatay yönde, 4. dönemde azalış yönünde, 6. döneme kadar artış yönünde hareket eder ve daha sonra eski sürecine geri döner. DJI Endeksinde 1 standart sapmalık şok meydana geldiğinde, altın fiyatları 2. döneme kadar hafifçe artış yönünde, 4. döneme kadar azalma yönünde, 5. döneme kadar artış yönünde hareket eder ve sonra eski sürecine geri döner. Petrol fiyatlarında 1 standart sapmalık şok meydana geldiğinde altın fiyatları 2. döneme kadar azalır, 4. döneme kadar artar ve sonra eski uzun denge değerine geri döner.

\section{Sonuç}

Piyasalarda fiyatı en çok izlenen göstergelerden biri olan altın fiyatları tarihsel olarak başta dünya ekonomik konjonktürü olmak üzere birçok dinamikten etkilenmiştir. Son küresel finans krizi sürecinde de altın fiyatları dalgalanmıştır. Çalışmada küresel finans krizi sürecinde altın fiyatlarını belirleyen unsurlar olarak Dow-Jones Endeksi, petrol fiyatları ve gümüş fiyatları ele alınmıştır. Elde edilen bulgular çerçevesinde, altın fiyatının beklendiği gibi kriz dönemlerinde arttığı ve yukarıda adı geçen göstergelerden uzun dönemde etkilendiği ortaya çıkmıştır. Yapılan eşbütünleşme testi, VECM analizi ve etki tepki analizlerinin sonuçlarını spesifik olarak belirtmek gerekirse, VECM sonuçlarına göre kısa dönemde göstergelerin birlikte hareket etmediği ancak eşbütünleşme analizinin sonuçlarına göre uzun dönemde birlikte hareket söz konusu olduğu saptanmıştır. Ayrıca etki-tepki analizi sonucuna göre de petrol fiyatlarındaki oynaklığın, diğer göstergelere göre altın fiyatlarını daha çok etkilediği ortaya çıkmıştır. Bu çerçevede uzun dönemde altın fiyatlarının petrol ve gümüş fiyatları ile aynı yönde, Dow-Jones Endeksi ile ters yönde hareket ettiği görülmüştür. Bu durum hem altının diğer emtialar ile aynı yönde ilişkili olduğunun, hem de finansal krizin bir göstergesi niteliği olarak ele alınabilecek olan DowJones'daki düşüşlerle ters yönde ilişkili olduğunu göstermiştir.

Öte yandan her ne kadar altın, değerli maden özelliği taşıması dolayısıyla herhangi bir türev ürüne göre daha az spekülasyona açık olsa da, büyük yatırımcıların hareketlerinden ve siyasi değişimlerden - tercihlerden de fiyat bazında etkilenmektedir. Bir başka deyişle, altın fiyatının uluslararası piyasadaki büyük oyuncular tarafından speküle edilebileceği ve siyasal gelişmelerden etkilenebileceği unutulmamalıdır. Bu bağlamda, son küresel krizde genel eğilimlerle birlikte başka bir sorun daha ortaya çıkmıştır. Krizin Avrupa'ya yayılması ile AB ülkelerinde merkez bankalarının altın stoklarının satışı gündeme gelmiştir. Böylece hem siyasal etkilerle hem de uluslararası arenada büyük oyuncuların - spekülatörlerin de etkisi ile 2013 yılında altın fiyatlarının artışı yavaşlamış hatta altın fiyatları düşüşe geçmiştir (bu konuda bkz: Guardian 2013 ve Soros 2013). Bu çerçevede, 
altın fiyatlarının keskin bir şekilde yükselmesi krizin bir sonucu olarak ele alınabilecek nitelikte olsa da son aylarda altın fiyatlarındaki düşüşü, krizden çıkıldığına dair net bir gösterge olarak algılamak doğru olmayacaktır. Günümüzdeki küresel kriz için yukarıda bahsedilen bazı özel durumların yol açtığı riskler ve belirsizlikler söz konusu olsa da altın kriz dönemlerinin kritik yatırım araçları arasında halen yerini korumaktadır.

\section{Kaynakça}

- Abken, Peter A, 1980. "The Economics of Gold Price Movements" http://www.richmondfed.org/publications/research/economic review/1980/pdf/er660201.pdf

- Aksoy, Mine, Nuraydın Topçu, 2013. "Altın İle Hisse Senetleri ve Enflasyon Arasındaki İlişki”. Atatürk Üniversitesi I.I.I.B.F. Dergisi, Cilt: 27, Say1:1, s.59-78.

- Data 360, 2013. Petrol Fiyat İstatistikleri (West Texas Intermediate bazında): http://www.data360.org/dsg.aspx?Data_Set_Group_Id=279\&count=all

- Dooley, Michael P., David Folkerts-Landau ve Peter Garber, 2004. "The Revived Bretton Woods System: The Effects of Periphery Intervention and Reserve Management on Interest Rates and Exchange Rates in Center Countries." NBER Working Paper No:10332. http://www.nber.org/papers/w10332

- Enders, Walter, 2010. Applied Econometric Time Series. 3. Basım. Alabama: Wiley Yayıncilık.

- Engle, Robert F. ve Granger, C. W. J. 1987. "Co-integration and Error Correction: Representation, Estimation, and Testing", Econometrica, Vol:55, No:2, p.251-276.

- Fred Economic Data 2013. (Dow-Jones Endeksi İstatistikleri): http://research.stlouisfed.org/fred2/series/DJIA/downloaddata

- Granger, C.W.J. ve Paul Newbold,1986. Forecasting Economic Time Series, Economic Theory, Econometrics and Mathemathical Economics. Second Edition, New York, Harcourt Brace Jovanovich.

- Guardian, 2013. Cyprus sell-off fears send gold price tumbling: http://www.guardian.co.uk/business/2013/apr/12/gold-selloff-cyprus-eurozone-crisis

- Gujarati Damodar N. ve Dawn C. Porter, 2012. Temel Ekonometri. 5. Basım. İstanbul: Literatür Yayınları.

- Index Mundi, 2013. Gümüş Fiyat İstatistikleri (Ons bazında): http://www.indexmundi.com/commodities/?commodity=silver\&months $=120$

- Levin, E.J. and Montagnoli, A. and Wright, R.E. 2006. Short-run and long-run determinants of the price of gold. http://strathprints.strath.ac.uk/7215/1/strathprints007215.pdf

- Macrotrends, 2013. Altın Fiyat İstatistikleri (Enflasyondan arındırılmış - ons bazında): http://www.macrotrends.net/1333/gold-and-silver-prices-100-year-historical-chart

- Phillips, Peter, Pierre Perron, 1988. "Testing for a Unit Root in a Time Series wih a Changing Mean" Journal of Business \& Ecoonomic Statistics, Vol.8, No.2, p.153-162.

- Sevüktekin Mustafa ve Mehmet Nargeleçekenler, 2010. Ekonometrik Zaman Serileri Analizi. 3. Basım. Ankara: Nobel Yayınevi.

- Simakova, Jana, 2011. Analysis of the Relationship between Oil and Gold Prices. 13th International Conference on Finance and Banking, Czech Republic. http://www.opf.slu.cz/kfi/icfb/proc2011/pdf/58_Simakova.pdf

- Sims, Christopher A. 1980. "Macroeconomics and Reality". Econometrica. Vol:48, No:1, p.1-48.

- Soros G. 2013. Altın Güvenli Liman Olarak Yok Edildi: http://www.bloomberght.com/haberler/haber/1335079-soros-altin-guvenli-liman-olarak-yok-edildi

- Şişman, Mehmet 2009. "On Crisis and Third Bretton Woods Debate" SSRN. http://papers.ssrn.com/sol3/papers.cfm?abstract_id=1508036

- TCMB, 2013. Nominal Altın Fiyat İstatistikleri (Ons bazında): http://evds.tcmb.gov.tr/

- Vural, M. Göknil, 2003. Altın Piyasası ve Altın Fiyatlarını Etkileyen Faktörler. TCMB Uzmanlık Yeterlilik Tezi. http://www.tcmb.gov.tr/kutuphane/TURKCE/tezler/goknilvural.pdf

- Zaiyong, Hu ve Liu Shuguang, 2008. "An Analysis The Stability of Long-Run Determinants of the Gold Price" http://en.cnki.com.cn/Article_en/CJFDTOTAL-JING200802009.htm 


\title{
2008 Global Krizinin Geçiş Ekonomilerindeki Etkilerinin Kümeleme Analizi ile İncelenmesi
}

\section{An Analysis of the Effects of 2008 Global Crises on Transition Economies using Cluster Analysis}

\author{
Asst. Prof. Dr. Ali Özer (Erzincan University, Turkey) \\ Ph.D. Candidate Adem Türkmen (Erzincan University, Turkey) \\ Ph.D. Candidate Bülent Diclehan Çadırcı (Erzincan University, Turkey)
}

\begin{abstract}
In 2008 the global financial crisis on economic conjuncture had affected on not only developed and developing countries but also remarkably on transition economies. Effects of financial crisis in 2008 showed up impacts on developed countries in 2008, on the other hand, it is known that the reflection of crisis has emerged in 2009. In this study, it is examined that transition economies has moved different depends on time, additionally the phenomenon of facing crisis has followed heterogeneous patterns transition economies in 2009 the while transition economies has seemed as showing homogenous economic performances/movements on either specification or previously their structure. It is analysed in three cluster using classification of chosen countries. Among chosen countries, taking place in same cluster Belarus, Cambodia, Kazakhstan, Lao, Latonia, Lithuania, Romania and Russia between 2007 and 2010 have responded similar to both input and output of crisis. Moreover, the cluster for Kirgizstan, Macedonia and Moldova is determined as the most moving group between clusters and this group, which moved homogeneously within cluster, is affected on crisis differed from other countries. The cluster analysis has been investigated with 20 transition economies has appropriate data and it is determined that the relatively low level of current account economies has weak impact on the crisis contagion; while the exit from crisis is created stronger effects in the relatively high level of domestic savings economies.
\end{abstract}

\section{Giriș}

Geride bıraktığımız yüzyılın en önemli olaylarından birisi şüphesiz ki, 1989 yılının sonlarında Berlin Duvarı'nın yıkılması ve hemen ardından 1991 yılında Sovyet Sosyalist Cumhuriyetler Birliği'nin (SSCB) dağılmasıdır. Yıllarca sosyalizme dayalı merkezi planlama sistemiyle idare edilen ülkelerin serbest piyasa ekonomisine geçtiklerinin resmen ilan edildiği bu süreçte, böylesi bir düzen değişikliğine maruz kalan tüm ülkeler için "Geçiş Ekonomisi" (Transition Economies) tanımlaması kullanılmaktadır. Her ne kadar bu guruba dahil ülkelerin özellikleri ve yaşadıkları süreçler birbirinden çok farklı da olsa, ortak noktaları merkezi planlamadan serbest piyasa ekonomisine geçmek olduğundan, tamamı "geçiş ekonomisi" kavramı içine dahil edilmişlerdir.

1990'larda doğuda bu türden bir geçiş yaşanırken; batıda ve özellikle Amerika'da 2000'li yıllar boyunca uygulanan düşük faizler, düşük gelirli aileler için konut kredilerinin yolunu açarken, kredi baloncuklarının oluşmasını da beraberinde getirmiştir. Dolayısıyla risk primi yüksek olan bu konut kredilerinde 2006 yılında başlayan geri ödeme aksaklıkları ipotekli konutların satışı ile konut fiyatlarında düşüşlere neden olmuş ve 2007 yılının sonunda yüksek faizli ve yüksek riskli kredi (subprime mortgage) denen kredi sistemi çökmüştür. Bankaların ellerindeki değerinden fazla ipotek konulmuş konutların kredi akitlerini yatırım bankalarına tahvil olarak satması 2008 yılında Amerikan finans sistemi içinde büyük bir finansal krizin domino etkisiyle yayılmasını beraberinde getirmiştir. 2008'in son çeyreği itibariyle küresel bir likidite ve kredi krizine dönüşerek piyasalardaki güven unsuruna zarar vermiştir. Ayrıca 2008'de dev finans şirketlerinin iflası ile bankacılık ve finans alanlarında da yeni bir kriz olarak ortaya çıkmış, borsalarda dramatik düşüşler ve kurlarda ciddi yükselişler görülmüştür.

2008 krizi ABD’de ve tüm Dünya'da serbest piyasa olgusu ile ilgili tüm düşünceleri tıpkı 1929 Büyük Bunalımı'nda olduğu gibi sarsmıştır. Piyasaların kendi kendine iyi işleyebileceği inancı sarsılsa da; kapitalizmin tamamen ortadan kalkıp yerine daha farklı bir alternatif sistemin gelmesini beklemek pek mümkün görünmemektedir. Önümüzdeki yıllarda da liberal iktisadi düşüncenin ana hatları ile devam edeceği; ancak aksayan yönlerini de yeniden şekillendirerek bir tür evrim geçireceği söylenebilir. Bu nedenle 2008 krizi sonrasında tüm Dünya piyasalarındaki regülâsyonların; bir başka deyişle kısmi müdahalelerin ön planda olacağı açıkça anlaşılmaktadır. Dolayısıyla kapitalizmin gerektiğinde piyasaların düzenlenmesini öneren yeni yorumu veya yeni şekli için "düzenleyici kapitalizm” (regulatory capitalism) kavramı ifade edilmeye ve kullanılmaya başlanmıştır. $\mathrm{Bu}$ nedenle planlı ekonomik sistemden kapitalizme geçiş yapan ve ekonomik sistem ortaklığ dışında herhangi bir ortaklığı bulunmayan Geçiş Ekonomilerinin kriz karşısında nasıl gruplandığını görmek önem arz etmektedir. 
Buraya kadar yapılan açıklamalardan anlaşıldığı gibi, bu kriz ilk sinyallerini 2006 yılında vermesine karşın bunun globalleşmesi biraz zaman almıştır. Bu nedenle çalışmada veri aralığ 2007-2010 olarak belirlenmiş ve son krizin, geçiş ekonomileri üzerindeki etkileri kümeleme analizi yardımıyla ortaya konulmaya çalışılmıştır.

\section{Literatür}

Hutchison ve Ilan (2005), Dell'Ariccia vd., (2008) Reinhart ve Rogoff's (2009) gibi çalışmalar krizlerin ekonomiler üzerindeki etkilerini incelemiş ve gelişmekte olan ülkelerde krizin etkisini gelişmiş ülkelere göre daha büyük ve kalıcı olduğunu iddia etmiştirler.

Aras (2010), 2008 krizinin Türkiye'ye etkilerini araştırdığı çalışmasında, Türkiye ekonomisinin 2008 krizinden temelde dört farklı kanaldan etkilendiğini; bu kanalların ise dış talepte azalma, dış kredi azalması, iç kredi daralması ve ekonomiye duyulan güvenin azalması olduğunu vurgulamıştır. Krizin Türkiye'ye makro ekonomik açıdan olumsuz etkilerinin ise 1994 ve 2001 kriz tecrübeleri ve alınan önlemler dolayısıyla daha çok reel sektörle sınırlı kaldığını ifade etmiştir.

Çakmak ve Sarıdoğan (2010), küresel iktisadi kriz, genelde dünya ve özelde ise Türkiye ekonomisi ve sanayisini, beklentilerdeki ve talep koşullarındaki bozulmaya bağlı olarak üretimi, istihdamı, kârlılıklarıkazançları ve dolayısıyla toplumsal refahı olumsuz etkilediğini tespit etmiştir. İmalat sanayi ve alt sektörlerin krizden etkilenme düzeyi farklı olmakla birlikte, özellikle dış finansmana, dış talebe ve yüksek gelir esnekliğine bağlı olan sektörlerde daha fazla kayıpların ortaya çıktığını ileri sürmüşlerdir.

Yıldırım (2010), çalışmasında 2008 krizinin Türkiye üzerindeki etkisinin finansal piyasalara olduğunu iddia etmiştir. Çalışmaya göre; küresel ekonomik kriz önce borsada ortaya çıkmakta ve daha sonra da reel ekonomide kendini göstermektedir. Türkiye ekonomisinde 2007 yılından itibaren tarım, sanayi ve hizmetler sektöründe büyüme hızları düşmüş, buna bağlı olarak da GSYIHH'da azalma meydana gelmiştir. 2007 yılı sonunda $\% 4,7$ olan GSYIH büyüme hızı 2008 yılı ağustos ayı sonunda \%0,9'a düşmüştür. İşletmelerin talep yetersizliği nedeniyle kapasite kullanım oranlarında da azalışlar görülmüştür.

Berberoğlu (2011), 2008 krizinin Avrupa Birliği ülkelerindeki etkisini kümeleme analiziyle araştırmıştır. Analiz sonuçlarına göre 2006 yılı için Almanya, Fransa, İtalya ve İngiltere bir kümede; İspanya ve Hollanda bir diğer kümede ve Türkiye ile diğer $\mathrm{AB}$ ülkeleri ise bir başka kümede yer almıştır. 2007 yılı sonuçlarına göre aynı kümelenme durumunun devam ettiği tespiti yapılmıştır. Başka bir deyişle sözü edilen ülkelerden oluşan kümelerde bir değişiklik görülmemektedir. Ancak, 2008 yllına gelindiğinde; İngiltere'nin önceden bulunduğu küme olan Almanya, Fransa ve İtalya'dan ayrılarak İspanya ile bir küme oluşturduğu görülmüştür. Hollanda'nın da 2008 yılında İspanya ile aynı kümede yer almayıp Türkiye ve diğer AB ülkelerinin bulunduğu kümeye geçtiği tespit edilmiştir.

Kantar vd. (2011) 50 büyük Türk firmasının 2006-2010 yılları arasındaki verileriyle 2008 küresel krizinin firma bazındaki etkilerini hiyerarşik kümeleme metodu ile incelemişlerdir. Çalışma sonuçlarına göre, firmalar 4 ayrı kümeye ayrılmaktadır. Bankacılık ve finans kuruluşlarından oluşan kümenin, güçlü küme içi ilişkileri ile kriz döneminde sektörel artış yaşadığı ve bu kümenin Türkiye ekonomisi açısından önemli ve baskın nitelikte olduğu da belirtilmektedir. Genel olarak çalışmada 2008 finansal krizinin firma bazında Türkiye ekonomisi üzerinde etkinliğinin zayıf olduğu tespit edilmiştir.

Furceri ve Zdzienicka (2011), 11 Avrupa geçiş ekonomisi üzerinde 2008 krizinin etkilerini araştırmış ve bu ülkeler üzerinde anlamlı ve kalıcı etkisinden bahsetmiştir. Özelliklede finansal dengesizliklere karşı bankacılık sistemi duyarlı olan küçük ülkelerin daha fazla etkilendiğini iddia etmiştir. Ayrıca maliye politikalrının krizle mücadelede para politikalrından daha etkili olduğunu ileri sürmüştür.

Mazurek (2011), 2008 küresel krizinin Çek Cumhuriyeti'ndeki bölgesel etkilerini kümeleme analizi ile araştırmış̧ır. Araştırma sonuçlarına göre Ústecký, Moravskoslezský, Prague, Jihočeský, Jihomoravský, Liberecký bölgeleri krizden az etkilenen bölgeler olarak belirlenirken, Středočeský, Plzeňský, Karlovarský, Královéhradecký, Pardubický, Vysočina, Olomoucký, Zlínský krizden çok etkilenen bölgeler olarak tespit edilmiştir. Ayrıca çalışmada; krizden etkilenme oranlarına göre bölgelerde uygulanan politikaların incelenmesi sonucu, krizin etkilerinin hafifletilmesini sağlayabilecek politika önermelerine de vurgu yapılmıştır

Göçer (2012), 2008 küresel ekonomi krizinin genel olarak dünya ekonomisini ve özelde de ABD ile beş Avrupa ülkesi ve Türkiye ekonomisi için inceleme konusu yapmıştır. Krizin ekonomik büyüme üzerindeki etkilerinin dünya genelinde ve ülke özelinde en çok özel tüketim harcamaları yoluyla etkilediğini ortaya koymuştur. Doğrudan yabancı yatırımların genel olarak olumlu, fakat bazı ülkelerde ekonomik büyümeyi olumsuz yönde etkilediği görülmüştür. Kamu harcamalarının ise dünya genelinde ve ele alınan ülkelerde ekonomik büyüme üzerinde önemli bir etkisinin olmadığı tespiti yapılmış; ancak İtalya ve Yunanistan'daki etkileri anlamlı ve pozitif bulunmuştur. İspanya'daki etkisi ise negatiftir. İhracat, beklentilere uygun olarak ekonomik büyümeyi pozitif etkilerken, ithalat negatif etkilemiştir. Krizin bütün ülke ekonomilerine etkisi negatif olup, etki düzeyi ve etkinin anlamlılık derecesi farklılıklar göstermiştir. Krizden en çok etkilenen ülkelerin de sırasıyla; ABD, İtalya ve Yunanistan olduğu görülmüsstür. 


\section{Yöntem ve Uygulama}

Bu araştırmanın amacı, 2007-2010 yılları arasında küresel krizin geçiş ekonomileri üzerindeki etkisini analiz etmektir. Dolayısıyla kriz öncesi, kriz esnası ve kriz sonrasında geçiş ekonomilerinin birbiri ile olan ilişkilerini belirlemek amacıyla hiyerarşik kümeleme analizi kullanılmıştır. Hiyerarşik kümeleme analizi tipik olarak sayısı 250 'den az olan küçük örneklem gruplarının analizinde etkin olarak kullanılan bir yöntemdir (Everitt ve Landau, 2001). Veriler Dünya Bankası ve ilgili ülkeler Merkez Bankaları internet sitelerinden elde edilmiş ve verilerin analizinde SPSS 21.0 paket programı kullanılmıştır. Ulaşılabilir verilere sahip ülkeler üzerine yapılacak geçiş ekonomileri de Tablo 1'de sunulmuştur.

\begin{tabular}{|l|l|l|l|}
\hline $\begin{array}{l}\text { Alfabetik } \\
\text { Siralaması }\end{array}$ & Ülkeler & $\begin{array}{l}\text { Alfabetik } \\
\text { Sıralaması }\end{array}$ & Ülkeler \\
\hline 1 & Arnavutluk & 11 & Lao \\
\hline 2 & Beyaz Rusya & 12 & Letonya \\
\hline 3 & Bulgaristan & 13 & Litvanya \\
\hline 4 & Kambocya & 14 & Makedonya \\
\hline 5 & Hirvatistan & 15 & Moldova \\
\hline 6 & Çek Cum. & 16 & Polonya \\
\hline 7 & Estonya & 17 & Romanya \\
\hline 8 & Macaristan & 18 & Rusya \\
\hline 9 & Kazakistan & 19 & Slovenya \\
\hline 10 & Kirgizistan & 20 & Ukrayna \\
\hline
\end{tabular}

Tablo 1: Çalışmada Kullanılan Geçiş Ekonomileri

Çalışmada, literatürde krizin etkisi çalışmalarında sıkça kullanıldığı tespit edilen 6 değişken çalışmaya dahil edilmiştir. Kullanılan değişkenler ve kısaltmaları Tablo 2'deki gibidir.

\begin{tabular}{|l|l|}
\hline Kısaltımı & Değişkenin Tanımı \\
\hline CAB & Cari İşlemler Dengesi (\% GSYİH) \\
\hline FE & Nihai Tüketim Harcamaları (\% GSYİH) \\
\hline GCE & Kamu Nihai Tüketim Harcamaları (\% GSYİH) \\
\hline GDS & Brüt Yurtiçi Tasarruflar (\% GSYİH) \\
\hline M2 & M2 Para arzı (\% GSYİH) \\
\hline GDPPC & Kişi Başı Gayri Safi Yurtiçi Hasıla Büyümesi (Yıllık \%) \\
\hline
\end{tabular}

Tablo 2: Çalışmada Kullanılan Değişkenler ve Kısaltmaları

Çalışmanın bu kısmında birbirine en çok benzeyen ülkeleri belirlemek amacıyla hiyerarşik kümeleme analizi uygulanmıştır. Kümeleme sürecinin başlangıç aşamasında her gözlem bir küme konumundadır. Süreç sonunda ise tüm gözlemler bir kümede toplanmaktadır. Bu yöntem aşağıdaki algoritma ile ifade edilebilmektedir(Tatlıdil, 2002).

1. Adım: $\mathrm{n}$ tane gözlem, $\mathrm{n}$ tane küme olarak işleme başlanır.

2. Adım: En yakın iki küme (uzaklık değerleri en küçük olan) birleştirilir.

3. Adım: Küme sayısı bir indirgenerek yinelenmiş uzaklıklar matrisi bulunur.

4. Adım: 2 ve 3 nolu adımlar n-1 kez tekrarlanır.

$\mathrm{Bu}$ algoritmaya dayalı; tek bağıntılı, tam bağıntılı, grup ortalama, merkezi, ortanca ve minimum varyans yöntemlerinden (Ward yöntemi) söz edilebilmektedir. Çalışmada bu yöntemlerden hiyerarşik kümeleme analizlerinde sıklıkla tercih edilen Ward yöntemi kullanılmıştır. Bu yöntem iki küme arasındaki benzerlik tüm değişkenler dikkate alınarak en küçük kareler toplamının bulunması ile ölçülür. Amaç küme içinde homojenliği, kümeler arasında heterojenliği maksimum yapacak şekilde kümeler oluşturmaktır (Sharma, 1996). Bu yöntemle elde edilen aglomeratif tablolar yardımıyla 2007- 2010 yılında çalışmada kullanılan değişkenlere bağlı olarak birbirine en çok benzeyen ve birbirine en az benzeyen ülkeler tespit edilmiştir. Daha sonrada dendrogram yardımıyla 0-25 ölçek arasında ülkelerin kümelenmesine göre oluşan kümeler ve kümelerdeki ülkeler verilmiştir.

2007 y1lı için aglomeratif tabloya bakıldığında, en çok benzeyen ülkelerin 1.basamakta Çek Cumhuriyeti ve Slovenya'nın ve birbirine en az benzeyen ülkelerin ise Arnavutluk ve Beyaz Rusya'nın olduğu görülmektedir. Diğer çok benzeşen ülkeler ise Polonya-Ukrayna ve Letonya-Litvanya'dır.

2008 yılı için aglomeratif tabloya bakıldığında, en çok benzeyen ülkelerin 1.basamakta Polonya ve Ukrayna olduğu ve birbirine en az benzeyen ülkelerin ise Arnavutluk ve Beyaz Rusya olduğu görülmektedir. Diğer çok benzeşen ülkeler ise Estonya-Macaristan ve Kamboçya-Romanya'dır 


\begin{tabular}{|c|c|c|c|c|c|c|}
\hline \multirow[b]{2}{*}{ Stage } & \multicolumn{2}{|c|}{ Cluster Combined } & \multirow[b]{2}{*}{$\begin{array}{l}\text { Coefficie } \\
\text { nts }\end{array}$} & \multicolumn{2}{|c|}{$\begin{array}{l}\text { Stage Cluster First } \\
\text { Appears }\end{array}$} & \multirow[b]{2}{*}{ Next Stage } \\
\hline & $\begin{array}{c}\text { Cluster } \\
1\end{array}$ & $\begin{array}{c}\text { Cluster } \\
2\end{array}$ & & $\begin{array}{c}\text { Cluster } \\
1\end{array}$ & Cluster 2 & \\
\hline 1 & 6 & 19 & 1,705 & 0 & 0 & 14 \\
\hline 2 & 16 & 20 & 5,729 & 0 & 0 & 8 \\
\hline 3 & 12 & 13 & 10,513 & 0 & 0 & 12 \\
\hline 4 & 4 & 17 & 15,999 & 0 & 0 & 12 \\
\hline 5 & 5 & 8 & 22,000 & 0 & 0 & 7 \\
\hline 6 & 2 & 11 & 29,502 & 0 & 0 & 15 \\
\hline 7 & 5 & 7 & 38,678 & 5 & 0 & 8 \\
\hline 8 & 5 & 16 & 48,893 & 7 & 2 & 14 \\
\hline 9 & 9 & 18 & 59,129 & 0 & 0 & 15 \\
\hline 10 & 10 & 14 & 71,244 & 0 & 0 & 13 \\
\hline 11 & 1 & 3 & 83,532 & 0 & 0 & 17 \\
\hline 12 & 4 & 12 & 96,788 & 4 & 3 & 16 \\
\hline 13 & 10 & 15 & 110,137 & 10 & 0 & 17 \\
\hline 14 & 5 & 6 & 124,493 & 8 & 1 & 18 \\
\hline 15 & 2 & 9 & 142,267 & 6 & 9 & 16 \\
\hline 16 & 2 & 4 & 171,603 & 15 & 12 & 18 \\
\hline 17 & 1 & 10 & 202,331 & 11 & 13 & 19 \\
\hline 18 & 2 & 5 & 253,345 & 16 & 14 & 19 \\
\hline 19 & 1 & 2 & 319,324 & 17 & 18 & 0 \\
\hline
\end{tabular}

Tablo3: 2007 Yılı Geçiş Ekonomileri İçin Aglomeratif Tablo

\begin{tabular}{|c|c|c|c|c|c|c|}
\hline & \multicolumn{2}{|c|}{ Cluster Combined } & & \multicolumn{2}{c|}{$\begin{array}{c}\text { Stage Cluster First } \\
\text { Appears }\end{array}$} \\
Stage & Cluster & Cluster & Coefficie & Cluster & Cluster & \\
& 1 & 2 & nts & 1 & 2 & Next Stage \\
\hline 1 & 16 & 20 & 1,988 & 0 & 0 & 9 \\
2 & 7 & 8 & 5,431 & 0 & 0 & 6 \\
3 & 4 & 17 & 9,220 & 0 & 0 & 7 \\
4 & 6 & 19 & 13,306 & 0 & 0 & 13 \\
5 & 12 & 13 & 17,828 & 0 & 0 & 15 \\
6 & 5 & 7 & 23,389 & 0 & 2 & 9 \\
7 & 4 & 11 & 31,655 & 3 & 0 & 12 \\
8 & 9 & 18 & 40,942 & 0 & 0 & 17 \\
9 & 5 & 16 & 50,581 & 6 & 1 & 13 \\
10 & 1 & 3 & 60,696 & 0 & 0 & 16 \\
11 & 14 & 15 & 71,834 & 0 & 0 & 14 \\
12 & 2 & 4 & 83,518 & 0 & 7 & 15 \\
13 & 5 & 6 & 97,725 & 9 & 4 & 16 \\
14 & 10 & 14 & 112,107 & 0 & 11 & 18 \\
15 & 2 & 12 & 129,066 & 12 & 5 & 17 \\
16 & 1 & 5 & 156,684 & 10 & 13 & 19 \\
17 & 2 & 9 & 194,028 & 15 & 8 & 18 \\
18 & 2 & 10 & 260,167 & 17 & 14 & 19 \\
19 & 1 & 2 & 336,537 & 16 & 18 & 0 \\
\hline
\end{tabular}

Tablo 4: 2008 Yllı Geçiş Ekonomileri İçin Aglomeratif Tablo

2009 yılı için aglomeratif tabloya bakıldığında, en çok benzeyen ülkelerin 1.basamakta Hırvatistan ve Macaristan olduğu ve birbirine en az benzeyen ülkelerin ise Arnavutluk ve Bulgaristan olduğu görülmektedir. Diğer çok benzeşen ülkeler ise Çek Cumhuriyeti-Slovenya ve Kamboçya-Romanya 'dır.

2010 yılı için aglomeratif tabloya bakıldığında, en çok benzeyen ülkelerin 1.basamakta Estonya ve Macaristan; birbirine en az benzeyen ülkelerin ise Arnavutluk ve Beyaz Rusya olduğu görülmektedir. Diğer çok benzeşen ülkeler ise Polonya-Ukrayna ve Bulgaristan-Hırvatistan'dır. 


\begin{tabular}{|c|c|c|c|c|c|c|}
\hline \multirow[b]{2}{*}{ Stage } & \multicolumn{2}{|c|}{ Cluster Combined } & \multirow[b]{2}{*}{$\begin{array}{l}\text { Coefficie } \\
\text { nts }\end{array}$} & \multicolumn{2}{|c|}{$\begin{array}{l}\text { Stage Cluster First } \\
\text { Appears }\end{array}$} & \multirow[b]{2}{*}{$\begin{array}{l}\text { Next } \\
\text { Stage }\end{array}$} \\
\hline & $\begin{array}{c}\text { Cluster } \\
1\end{array}$ & $\begin{array}{c}\text { Cluster } \\
2\end{array}$ & & $\begin{array}{c}\text { Cluster } \\
1\end{array}$ & $\begin{array}{c}\text { Cluster } \\
2\end{array}$ & \\
\hline 1 & 5 & 8 & 3,870 & 0 & 0 & 5 \\
\hline 2 & 6 & 19 & 8,144 & 0 & 0 & 9 \\
\hline 3 & 4 & 17 & 12,934 & 0 & 0 & 11 \\
\hline 4 & 13 & 20 & 18,859 & 0 & 0 & 8 \\
\hline 5 & 3 & 5 & 24,840 & 0 & 1 & 9 \\
\hline 6 & 2 & 11 & 32,250 & 0 & 0 & 11 \\
\hline 7 & 7 & 18 & 40,198 & 0 & 0 & 10 \\
\hline 8 & 12 & 13 & 48,348 & 0 & 4 & 16 \\
\hline 9 & 3 & 6 & 56,608 & 5 & 2 & 19 \\
\hline 10 & 7 & 16 & 66,086 & 7 & 0 & 13 \\
\hline 11 & 2 & 4 & 76,817 & 6 & 3 & 17 \\
\hline 12 & 10 & 14 & 88,828 & 0 & 0 & 14 \\
\hline 13 & 7 & 9 & 103,779 & 10 & 0 & 16 \\
\hline 14 & 10 & 15 & 120,725 & 12 & 0 & 15 \\
\hline 15 & 1 & 10 & 141,511 & 0 & 14 & 18 \\
\hline 16 & 7 & 12 & 162,888 & 13 & 8 & 17 \\
\hline 17 & 2 & 7 & 195,553 & 11 & 16 & 18 \\
\hline 18 & 1 & 2 & 246,133 & 15 & 17 & 19 \\
\hline 19 & 1 & 3 & 302,329 & 18 & 9 & 0 \\
\hline
\end{tabular}

Tablo 5: 2009 Yllı Geçiş Ekonomileri İçin Aglomeratif Tablo

\begin{tabular}{|c|c|c|c|c|c|c|}
\hline \multirow[b]{2}{*}{ Stage } & \multicolumn{2}{|c|}{ Cluster Combined } & \multirow[b]{2}{*}{$\begin{array}{l}\text { Coefficie } \\
\text { nts }\end{array}$} & \multicolumn{2}{|c|}{$\begin{array}{l}\text { Stage Cluster First } \\
\text { Appears }\end{array}$} & \multirow[b]{2}{*}{$\begin{array}{l}\text { Next } \\
\text { Stage }\end{array}$} \\
\hline & $\begin{array}{c}\text { Cluster } \\
1\end{array}$ & $\begin{array}{c}\text { Cluster } \\
2\end{array}$ & & $\begin{array}{c}\text { Cluster } \\
1\end{array}$ & $\begin{array}{c}\text { Cluster } \\
2\end{array}$ & \\
\hline 1 & $\overline{7}$ & $\overline{8}$ & 2,590 & $\overline{0}$ & $\overline{0}$ & $\overline{10}$ \\
\hline 2 & 16 & 20 & 5,210 & 0 & 0 & 4 \\
\hline 3 & 3 & 5 & 8,974 & 0 & 0 & 7 \\
\hline 4 & 13 & 16 & 13,140 & 0 & 2 & 6 \\
\hline 5 & 11 & 17 & 18,468 & 0 & 0 & 9 \\
\hline 6 & 12 & 13 & 24,256 & 0 & 4 & 11 \\
\hline 7 & 3 & 6 & 30,337 & 3 & 0 & 8 \\
\hline 8 & 3 & 19 & 36,982 & 7 & 0 & 15 \\
\hline 9 & 4 & 11 & 45,321 & 0 & 5 & 12 \\
\hline 10 & 7 & 18 & 54,138 & 1 & 0 & 14 \\
\hline 11 & 12 & 14 & 65,086 & 6 & 0 & 16 \\
\hline 12 & 2 & 4 & 77,795 & 0 & 9 & 17 \\
\hline 13 & 10 & 15 & 92,725 & 0 & 0 & 18 \\
\hline 14 & 7 & 9 & 110,466 & 10 & 0 & 16 \\
\hline 15 & 1 & 3 & 132,052 & 0 & 8 & 19 \\
\hline 16 & 7 & 12 & 159,473 & 14 & 11 & 17 \\
\hline 17 & 2 & 7 & 190,056 & 12 & 16 & 18 \\
\hline 18 & 2 & 10 & 243,119 & 17 & 13 & 19 \\
\hline 19 & 1 & 2 & 299,619 & 15 & 18 & 0 \\
\hline
\end{tabular}

Tablo 6: 2010 Yllı Geçiş Ekonomileri İçin Aglomeratif Tablo

Hiyerarşik kümeleme analizi sonuçlarını göstermede dendrogram yöntemi de kullanılmıştır. Dendrogram’da ülkeler soldan sağa 0-25 birim olarak ölçeklendirilmiştir. Burada birimler arasındaki mesafeler eşittir. Dendrogramdaki yatay çizgiler mesafeyi, dikey çizgiler ise birleşen kümeleri göstermektedir. Ölçek üzerinde kümelerin birleşme noktaları, hangi grupların oluştuğunu gösterdiği gibi aynı zamanda aralarındaki mesafeyi de göstermektedir. Araştırmada bu yöntemin uygulanması sonucunda ülkeler 0-25 birim arasındaki ölçeklendirilmiş mesafelerde gruplandırılmıştır.

Dendrogram incelendiğinde ise kullanılan veriler bakımından birbirlerine en çok benzeyen ülkeler 1 birimlik mesafede grup oluştururken, birbirlerine en az benzeyen ülkeler 25 birimlik mesafede bir araya gelmektedir. 
Dendogram incelendiğinde, 10 birimlik mesafede hem ülkelerde kümelenme fazla hem de ölçekte benzeşmenin düşmeden yakalandığı bir nokta olduğu için referans alınmış ve ülkeler 10 birimlik mesafeye göre gruplanmıştır, bu kümeleri oluşturan ülkeler Tablo-7'de gösterilmiştir. Ayrıca k küme sayısını bulabilmek için kullanılan en pratik yöntemlerden biri yaklaşık olarak $\mathrm{k}=(\mathrm{n} / 2)^{1 / 2}$ formülünden de küme sayısı 3,17 bulunmakta ve bu değer çalışmada temel alınan küme sayısını desteklemektedir.

\begin{tabular}{|c|c|c|c|c|c|}
\hline \multicolumn{3}{|c|}{2007 Yılı Kümeleri } & \multicolumn{3}{|c|}{2008 Yılı Kümeleri } \\
\hline 1 & 2 & 3 & 1 & 2 & 3 \\
\hline $\begin{array}{c}\text { Arnavutluk } \\
\text { Bulgaristan } \\
\text { Kirgizistan } \\
\text { Makedonya } \\
\text { Moldova }\end{array}$ & $\begin{array}{c}\text { Beyaz Rusya } \\
\text { Kamboçya } \\
\text { Kazakistan } \\
\text { Lao } \\
\text { Letonya } \\
\text { Litvanya } \\
\text { Romanya } \\
\text { Rusya }\end{array}$ & $\begin{array}{c}\text { Hirvatistan } \\
\text { Çek Cum. } \\
\text { Estonya } \\
\text { Macaristan } \\
\text { Polonya } \\
\text { Slovenya } \\
\text { Ukrayna }\end{array}$ & $\begin{array}{c}\text { Arnavutluk } \\
\text { Bulgaristan } \\
\text { Hirvatistan } \\
\text { Çek Cum. } \\
\text { Estonya } \\
\text { Macaristan } \\
\text { Polonya } \\
\text { Slovenya } \\
\text { Ukrayna }\end{array}$ & $\begin{array}{c}\text { Beyaz Rusya } \\
\text { Kamboçya } \\
\text { Kazakistan } \\
\text { Lao } \\
\text { Letonya } \\
\text { Litvanya } \\
\text { Romanya } \\
\text { Rusya }\end{array}$ & $\begin{array}{c}\text { Kirgizistan } \\
\text { Makedonya } \\
\text { Moldova }\end{array}$ \\
\hline \multicolumn{3}{|c|}{2009 Yılı Kümeleri } & \multicolumn{3}{|c|}{2010 Yılı Kümeleri } \\
\hline 1 & 2 & 3 & 1 & 2 & 3 \\
\hline $\begin{array}{c}\text { Arnavutluk } \\
\text { Kirgızistan } \\
\text { Makedonya } \\
\text { Moldova }\end{array}$ & $\begin{array}{c}\text { Beyaz Rusya } \\
\text { Kamboçya } \\
\text { Estonya } \\
\text { Kazakistan } \\
\text { Lao } \\
\text { Letonya } \\
\text { Litvanya } \\
\text { Polonya } \\
\text { Romanya } \\
\text { Rusya } \\
\text { Ukrayna }\end{array}$ & $\begin{array}{c}\text { Bulgaristan } \\
\text { Hirvatistan } \\
\text { Çek Cum. } \\
\text { Macaristan } \\
\text { Slovenya }\end{array}$ & $\begin{array}{c}\text { Arnavutluk } \\
\text { Bulgaristan } \\
\text { Hırvatistan } \\
\text { Çek Cum. } \\
\text { Slovenya }\end{array}$ & $\begin{array}{c}\text { Beyaz Rusya } \\
\text { Kamboçya } \\
\text { Estonya } \\
\text { Macaristan } \\
\text { Kazakistan } \\
\text { Lao } \\
\text { Letonya } \\
\text { Litvanya } \\
\text { Makedonya } \\
\text { Polonya } \\
\text { Romanya } \\
\text { Rusya } \\
\text { Ukrayna }\end{array}$ & $\begin{array}{c}\text { Kirgizistan } \\
\text { Moldova }\end{array}$ \\
\hline
\end{tabular}

Tablo 7: 2007-2010 Yılları Arasında Geçiş Ekonomileri Iç̧in Hiyerarşik Kümeleme Analizi Dendrogram (Ăgaç Grafiği)'ne Göre Oluşan Kümeler

Tablo 7 incelendiğinde, 2007 yılında 1. kümede Arnavutluk, Bulgaristan, Kırgızistan, Makedonya ve Moldova yer almakta; 2. kümede Beyaz Rusya, Kamboçya, Kazakistan, Lao, Letonya, Litvanya, Romanya, Rusya ve 3. kümede Hırvatistan, Çek Cumhuriyeti, Estonya, Macaristan, Polonya, Slovenya, Ukrayna ülkeleri yer almaktadir.

2008 yılında, 2. Kümede herhangi bir değişiklik olmazken; 2007 yılında 1. kümede yer alan Kırgızistan, Makedonya ve Moldova bu kümeden ayrılarak 3. kümeyi oluşturmakta; 2007 yılında 3. kümede yer alan tüm ülkeler 2008 yılında 1. kümede yer almaktadır.

2009 yllında, krizin etkisi tüm ülkeler ve tüm değişkenler üzerine farklı boyutlarda göstermesi, kümelerde ciddi değişikler ortaya çıkarmıştır. Kırgızistan, Makedonya ve Moldova birinci kümeye geçerken, Bulgaristan, Hırvatistan, Çek Cumhuriyeti, Macaristan ve Slovenya 3. kümeye geçmekte; Ukrayna, Estonya ve Polonya ise 2. Kümeye geçmekte; 2. kümede yer alan diğer ülkelerde ise 2007'den itibaren herhangi bir değişiklik olmadığı gözlenmektedir.

2010 yılında, Bulgaristan, Hırvatistan, Çek Cumcumhuriyeti ve Slovenya 3. Kümeden 1. kümeye geçmekte; Macaristan 2. kümeye geçmekte, 2009 da 1. kümede yer alan Kırgızistan ve Moldova 1. kümeden 3. kümeye geçerken, Makedonya 2. kümeye geçmektedir.

Tablo 8'de görülen betimleyici istatistikler dikkate alındığında; 2007 yılında 1. kümede yer alan ülke grubu için, tüm ülke grubu ortalamasının üstünde cari açık, para arzı ve tüketim harcamaları söz konusu iken, ortalamanın (çok) altında yurtiçi tasarruf ve kişi başı GSYİH büyümesi söz konusudur. 2. ve 3. kümede yer alan ülkeleri ayıran temel noktalar ise 2. kümede ortalamanın altında kamu harcaması ve para arzı ile ortalamanın üstünde kişi başı GSYİH büyümesi söz konusudur.

2008 yılında, 2007 yılına göre bütün ülke grubu ortalamalarında çok büyük değişiklikler gözlenmezken, kişi başı GSYİH'da da \%38'lik bir düşüş gözlenmektedir. 1. kümede yer alan ülke grubu ortalamanın üstünde cari açık, kamu tüketim harcaması, yurtiçi tasarruf ve para arzına sahiptir. 2. kümede yer alan ülke grubu, yurtiçi tasarruf dışında tüm değişkenlerde ülke grubu ortalamasının altında yer almaktadır. 3. kümede yer alan ülkeler 
açısından dikkat çeken değişkenler; çok yüksek tüketim harcamaları, negatif tasarruf (borçlanma) ve ortalamanın üstünde bir büyüme oranıdır.

\begin{tabular}{|c|c|c|c|c|c|c|c|}
\hline 2007 & \multicolumn{2}{|l|}{ 1. Küme } & \multicolumn{2}{|l|}{ 2. Küme } & \multicolumn{2}{|l|}{ 3. Küme } & \multirow{2}{*}{\begin{tabular}{|l|} 
Toplam \\
Ortalama
\end{tabular}} \\
\hline Değişkenler & Ortalama & \begin{tabular}{|l} 
Std. \\
Sapma \\
\end{tabular} & Ortalama & \begin{tabular}{|l|} 
Std. \\
Sapma \\
\end{tabular} & Ortalama & $\begin{array}{l}\text { Std. } \\
\text { Sapma }\end{array}$ & \\
\hline $\mathrm{CAB}$ & $-13,31$ & 8,52 & $-7,59$ & 9,36 & $-7,10$ & 4,14 & $-8,85$ \\
\hline $\mathrm{FE}$ & 98,41 & 10,00 & 76,02 & 9,63 & 74,24 & 4,76 & 81,00 \\
\hline GCE & 14,05 & 2,60 & 10,62 & 3,76 & 17,43 & 1,96 & 13,86 \\
\hline GDS & 1,59 & 10,00 & 23,98 & 9,63 & 25,76 & 4,76 & 19,00 \\
\hline M2 & 55,77 & 18,82 & 35,48 & 7,93 & 59,29 & 7,15 & 48,89 \\
\hline GDPPC & 5,83 & 1,62 & 8,47 & 1,74 & 5,69 & 2,70 & 6,84 \\
\hline 2008 & \multicolumn{2}{|l|}{ 1. Küme } & \multicolumn{2}{|l|}{ 2. Küme } & \multicolumn{2}{|l|}{ 3. Küme } & Toplam \\
\hline Değişkenler & Ortalama & \begin{tabular}{|l|} 
Std. \\
Sapma
\end{tabular} & Ortalama & \begin{tabular}{|l|} 
Std. \\
Sapma
\end{tabular} & Ortalama & $\begin{array}{l}\text { Std. } \\
\text { Sapma }\end{array}$ & Ortalama \\
\hline $\mathrm{CAB}$ & $-9,52$ & 6,15 & $-5,25$ & 8,14 & $-14,13$ & 1,78 & $-8,50$ \\
\hline $\mathrm{FE}$ & 78,33 & 7,55 & 75,10 & 11,55 & 107,37 & 7,89 & 81,39 \\
\hline GCE & 16,57 & 2,70 & 10,72 & 4,03 & 14,77 & 1,92 & 13,96 \\
\hline GDS & 21,67 & 7,55 & 24,90 & 11,55 & $-7,37$ & 7,89 & 18,61 \\
\hline M2 & 62,72 & 7,55 & 33,21 & 6,77 & 41,27 & 13,95 & 47,70 \\
\hline GDPPC & 4,00 & 3,80 & 3,18 & 3,58 & 7,61 & 2,67 & 4,21 \\
\hline 2009 & \multicolumn{2}{|l|}{ 1. Küme } & \multicolumn{2}{|l|}{ 2. Küme } & \multicolumn{2}{|l|}{ 3. Küme } & Toplam \\
\hline Değişkenler & Ortalama & $\begin{array}{l}\text { Std. } \\
\text { Sapma }\end{array}$ & Ortalama & $\begin{array}{l}\text { Std. } \\
\text { Sapma }\end{array}$ & Ortalama & $\begin{array}{l}\text { Std. } \\
\text { Sapma }\end{array}$ & Ortalama \\
\hline $\mathrm{CAB}$ & $-8,06$ & 5,44 & $-1,27$ & 6,05 & $-3,39$ & 3,53 & $-3,16$ \\
\hline $\mathrm{FE}$ & 100,51 & 8,66 & 78,81 & 7,48 & 76,69 & 2,87 & 82,62 \\
\hline GCE & 13,66 & 2,98 & 13,71 & 4,58 & 18,92 & 2,83 & 15,00 \\
\hline GDS & $-0,51$ & 8,66 & 21,19 & 7,48 & 23,31 & 2,87 & 17,38 \\
\hline M2 & 52,15 & 19,62 & 44,43 & 10,19 & 70,11 & 5,05 & 52,40 \\
\hline GDPPC & $-0,60$ & 3,90 & $-6,28$ & 7,91 & $-6,49$ & 1,56 & $-5,20$ \\
\hline 2010 & \multicolumn{2}{|l|}{ 1. Küme } & \multicolumn{2}{|l|}{ 2. Küme } & \multicolumn{2}{|l|}{ 3. Küme } & Toplam \\
\hline Değişkenler & Ortalama & \begin{tabular}{|l} 
Std. \\
Sapma
\end{tabular} & Ortalama & $\begin{array}{l}\text { Std. } \\
\text { Sapma }\end{array}$ & Ortalama & $\begin{array}{l}\text { Std. } \\
\text { Sapma }\end{array}$ & Ortalama \\
\hline $\mathrm{CAB}$ & $-3,80$ & 4,41 & $-1,69$ & 5,28 & $-7,48$ & 0,34 & $-2,80$ \\
\hline $\mathrm{FE}$ & 80,45 & 8,97 & 78,15 & 8,59 & 109,26 & 9,24 & 81,83 \\
\hline GCE & 16,57 & 4,98 & 13,82 & 4,59 & 13,33 & 1,36 & 14,46 \\
\hline GDS & 19,55 & 8,97 & 21,85 & 8,59 & $-9,26$ & 9,24 & 18,17 \\
\hline M2 & 75,76 & 5,01 & 48,33 & 10,03 & 40,73 & 15,29 & 54,43 \\
\hline GDPPC & 1,23 & 1,61 & 3,63 & 2,57 & 2,77 & 6,26 & 2,95 \\
\hline
\end{tabular}

Tablo 8: Kümelere Ait Betimleyici Ístatistikler

2009 yılında, 2008 yılına göre cari açıkta ve kişi başı GSYİH'da ciddi bir azalmaya karşılık, para arzında ve kamu harcamalarında artış gözlenmektedir. Tüm değişimler krizin etkisini 2009'da güçlü olarak gösterdiğini ve geçiş ekonomilerinin kamunun harcamalarını ve para arzını arttırarak, yani genişlemeci politikalarla krizin etkilerini azaltmayı amaçladıkları söylenebilir. Kümeler incelendiğindeyse, 1. kümede yer alan ülkeler için yüksek cari açık ve tüketim harcamalarına ilaveten çok düşük yurt içi tasarruf görülmekte ve buna karşın kişi başı GSYİH büyümesinde krizin etkisinin düşük olduğu söylenebilmektedir. 2. kümede yer alan ülkeler için ortalamanın üstünde tasarruf varken, diğer değişkenlerin tamamının grup ortalamasının altında olduğu görülmektedir. 3. kümede yer alan ülkelerde ise kamu harcaması, yurtiçi tasarruf ve para arzının ortalamanın üstünde olduğu; ayrıca tüm kümeler içinde bu kümenin en düşük kişi başı GSYİH değerine sahip küme olduğu da dikkat çekmektedir.

2010 yılında, cari açığın 2007'de başlayan azalmasına devam ettiği, 2009'da düşen yurtiçi tasarrufların yeniden artmaya başladığını, para arzının artmaya devam ettiğini ve kişi başı GSYİH büyümesinin pozitif değer alması ise krizin daralma etkisinin ortadan yavaş yavaş kalktığını göstermektedir. 1. kümede yer alan ülkeler için kamu harcaması ve para arzının ortalamanın üstünde olduğu ve kişi başı büyümenin ortalamanın altında olduğu görülmektedir. 2. kümede yer alan ülkeler için ise yüksek tasarruf oranı ve düşük cari açık ile kümeler içinde en yüksek büyüme ortalaması söz konusudur. 3. kümede yer alan ülkeler için ise yüksek cari açık ve tüketim harcamaları ile negatif tasarruf söz konusudur. 


\section{Sonuç}

Planlı ekonomiden piyasa ekonomisine geçen geçiş ekonomilerinde 2008 küresel ekonomik krizinin ortak noktaları ve farklılaşan boyutlarını gözlemlemek üzere yapılan istatistiki çalışmada, kullanılan değişkenler itibariyle, bazı ülkelerin kriz öncesi durumlarını kriz sonrasında koruyamadıkları tespit edilmiştir. Buna karşılık, bazı ülkelerinse 2007-2010 yılları arasında aynı kümede yer alarak kriz öncesi ve sonrası grup olarak birbirine yakınsayan etkilere sahip olduğu belirlenmiştir.

Elde edilen bulgularda, 20 Geçiş Ekonomisi için 2009 yllında krizin etkisinin güçlü bir şekilde kendini gösterdiği görülmekte ve kümeler arası ülke geçişlerinin 2009 itibariyle arttığı tespit edilmiştir. Genel olarak 2. kümede yer alan Beyaz Rusya, Kamboçya, Kazakistan, Lao, Letonya, Litvanya, Romanya ve Rusya'nın 20072010 arasında bu kümeden hiç ayrılmadığı ve bu kümenin yıllar itibariyle incelenmesi sonucu sürekli yüksek tasarruf miktarına sahip ülkelerden oluştuğu görülmektedir. Burada 2. kümenin krizden orta düzeyde etkilenen ülke grubu olduğu görülmekte ve 2010 yılında da krizden çıkışı en iyi olan ülke grubu olduğu söylenebilmektedir. Krizden orta düzeyde etkilenen, ancak krizden en hızlı bir şekilde çıkan bu ülkelerin krizden çıkışta ortak olan özelliğinin ortalamanın üzerinde yüksek tasarruf oranlarının yanı sıra ortalamanın çok altında cari açık rakamının etkili olduğu söylenebilir. Diğer bir ifadeyle ikiz açık olgusuna düşmeme bu ülkelerde krizin bir tür panzehri konumundadır.

İstisna olarak kabul edilebilecek olan Arnavutluk, yüksek cari açık, tüketim harcamaları ve para arzı ile düşük tasarruf düzeyi rakamlarına sahip olmasına rağmen, kriz öncesinde de düşük büyüme oranlarına sahip oluşu ile krizden en az etkilenen küme içinde yer almaktadır. Kümeler arasında en çok hareket eden Kırgızistan Makedonya ve Moldova 2009 yılında, kriz öncesinde ortalamanın üzerinde yer alan cari açılarında ve tüketim harcamalarında ciddi düşüş yaşamaktadırlar. 2009 yılında yurtiçi tasarruf ve para arzında artışlar yaşanan Kırgızistan ve Moldova'nın tasarruflarını 2010 yılında düşürdüğü, Makedonya'nın ise 2010'da da tasarruf artışının devam ettiği görülmekte; bu yüzden üçlü 2010 yılında farklı kümelerde yer almaktadır.

Birlikte hareket eden bir diğer grubun ise Bulgaristan, Hırvatistan, Çek Cumhuriyeti ve Slovenya olduğu görülmektedir. $\mathrm{Bu}$ gurubun kriz öncesi ve sonrasında genel durumuna bakıldığında, krizle birlikte cari açıklarında ciddi düşüşler yaşandığı, para arzında artışın gerçekleştiği ve büyüme oranlarının ciddi bir şekilde düştüğü istatistiki verilerinden görülmektedir. Krizden en fazla etkilenen kümede yer alan bu ülkeler kriz sonrasında krizin etkilerinden çabuk sıyrılarak 1. kümeye geçmektedirler.

Genel olarak çalışmadan elde edilen sonuçlar, seçilen ülke gurupları ve kullanılan değişkenlere bağlı olarak farklılık göstermesine rağmen, ülke guruplarının kriz karşısında ekonomik durumlarındaki benzeşmelere paralel olarak birbirine yakınsayan nitelikte, krizden etkilenme ve krizden kurtulma seyri gösterdiğini söylemek mümkündür. Çalışmada dikkat çeken önemli bir konu yurtiçi tasarrufların yüksek oluşunun krizden etkilenmeyi azaltıcı etkisinin yüksek olmamasına rağmen, bu göstergenin seçili ülke grubunda krizden çıkış etkisi açısından önemli bir gösterge niteliği taşıdığı ileri sürülebilir.

\section{Kaynakça}

- Aras, Osman Nuri, (2010),“ Türkiye’ye Makro Ekonomik Etkileri Bakımından 2008 Küresel Krizi”, Finans, Politik ve Ekonomik Yorumlar Dergisi, Cilt:47, Say1:550.

- Berberoğlu, Bahar, (2011), “2008 Global Krizinin Türkiye ve Avrupa Birliği’ndeki Etkilerinin Kümeleme Analizi İle İncelenmesi”, Anadolu Üniversitesi Sosyal Bilimler Dergisi, Cilt: 11, Sayı: 1, ss. 105-130.

- Çakmak, Nesrin Sungur ve Sarıdoğan, Ercan, (2010), "Küresel İktisadi Krizin Türk İmalat Sanayine Etkileri”, Marmara Üniversitesi İI. B.F. Dergisi, Cilt:XXIX, Sayı: II, ss. 23-45.

- Dell'Ariccia, G., Detragiache, E., Rajan, R. (2008). 'The real effect of banking crises', Journal of Financial Intermediation, 17(1), pp. 89-112.

- Everitt, Brian ve Landau, Sabine (2001), Cluster Analysis, Hodder Arnold Publication, London.

- $\quad$ Furceri, Davide ve Zdzienicka, Aleksandra, (2011), "The Real Effect of Financial Crises in the European Transition Economies", Economics of Transition, Vol: 19, Issue:1, pp. 1-25.

- Göçer, İsmet, (2012), “2008 Küresel Ekonomik Krizin Nedenleri Ve Seçilmiş Ülke Ekonomilerine Etkileri: Ekonometrik Bir Analiz”, Yönetim ve Ekonomi Araştırmaları Dergisi, Sayı:17, ss.18-37.

- Hutchison, M., Ilan, N., (2005), "How Bad Are Twins? Output Costs of Currency and Banking Crises", Journal of Money, Credit and Banking, 37(4), pp. 725-752.

- Kantar, Ersin, Keskin, Mustafa, Deviren, Bayram (2012), "Analysis of the effects of the global financial crisis on the Turkish economy, using hierarchical methods", Physica A: Statistical Mechanics and its Applications, Volume 391, Issue 7, April 1.

- Mazurek, Jiří (2011), "Comparison of impacts of the financial crisis on the Czech Republic regions by cluster analysis", 13 th International Conference on Finance and Banking, Silesian University, Czech Republic, October $2-13$. 
- $\quad$ Reinhart, C., Rogoff, K. (2009), “The Aftermath of Financial Crises”, NBER Working Paper, 14656.

- Sharma, Subhash (1996), Applied Multivariate Techniques, J.Wiley and Sons Inc., USA.

- Tatlıdil, H. (2002). Uygulamalı Çok Değişkenli İstatistiksel Analiz, Ankara, Akademi Matbaası.

- Y Y1lırım, Süreyya (2010), “2008 Y11ı Küresel Ekonomi Krizinin Dünya ve Türkiye Ekonomisine Etkileri”, KMÜ Sosyal ve Ekonomik Araştırmalar Dergisi, 12 (18): 47-55. 


\title{
AB Borç Krizi ve Aktarım Mekanizmaları ile Yayılımı: Türkiye'ye Muhtemel Etkileri \\ EU Debt Crisis and Contagious Effect via Transmission Mechanisms: Possible Effects on Turkey
}

\author{
Mustafa Kemal Topcu (Fibonasi Yönetim Danışmanlık, Turkey) \\ Asst. Prof. Dr. Poyraz Gürson (At1lım University, Turkey) \\ Prof. Dr. Halil İbrahim Ülker (Atılım University, Turkey) \\ Asst. Prof. Dr. Turan Erman Erkan (At1lım University, Turkey)
}

\begin{abstract}
The common features of the crises, which are resulted from global crisis rooted from the US and emerged in Euro Zone sequentially, are the rate of public debt and budget deficit of GNP far from reflecting Maastricht criteria. Beginning in Greece in 2009, it has been seen in Ireland, Italy, Portugal, and Spain in a recent time. Although money union is established, leaving financial policies to country's own initiative resulted in unsolved problems. Seeking solutions with IMF led to some sustainability programs. However, expectations show that debts will not be overcome for a long period. Towards this end, it is possible for Turkey to be affected since European Union is her biggest trade partner. There is a general consensus on that trade and credit channel of transmission mechanisms would affect Turkey. Export preserves its level at 55\%. Likewise, a large part of foreign debt of Turkey is to European banks. Furthermore, sustainment of the recent growth trend of Turkey requires new funds. In case European banks strengthen their capital by means of downsizing their balance sheets as a restructuring, Turkey may be in a challenging position.
\end{abstract}

\section{Avrupa Birliği Borç Krizi}

ABD kaynaklı başlayan 2008 küresel kriz etkisini özellikle Avrupa'da sürdürmeye devam etmiştir. Krizin olumsuz etkileri sonucunda avro bölgesi 2009 yılında \% 4,1 oranında küçülerek tarihindeki en büyük daralmayı yaşamıştır. Yaşanan küresel kriz, AB ülkelerinde kamu açıkları ve borç stoklarının ciddi boyutlarda artmasına ve birçok üye ülkede kamu maliyesinin sürdürülebilirliğinin tehlikeye girmesine neden olmuştur. Tablo-1'de istatistikleri bulunan Avro bölgesi üye ülkeler borç krizi ve artan cari açık sorunu ile mücadelede yetersiz kalmış, Avrupa Merkez Bankası (AMB) uyguladığı para politikaları ile bir nebze yavaşlama sağlayabilmiştir. Ancak AMB tarafından ortak bir para politikası uygulanmasına karşın mali politikaların uygulanması ülkelere bırakılmıştır (Kouretas ve Vlmais, 2010, s.396). AB müktesebatında üye devletler için ulusal bütçelerinin yapısına ilişkin hiçbir gereklilik veya standart bulunmamakta ve bütçe sisteminde belirli bir model öngörülmemektedir (Köse ve Karabacak, 2011, s.300). Bu durum da hem krizin etkisinin daha çabuk yayılmasını sağlamış hem de çözüme kavuşma sürecini uzatmıştır.

\begin{tabular}{|l|l|l|l|l|l|l|}
\hline Ülke & $\begin{array}{l}\text { Borç/GSMH } \\
\text { Oranı (\%) }\end{array}$ & $\begin{array}{l}\text { Bütçe } \\
\text { Aç1ğı/GSMH } \\
\text { Oran1 (\%) }\end{array}$ & $\begin{array}{l}\text { İşsizlik } \\
\text { Oran1 }\end{array}$ & $\begin{array}{l}\text { Cari } \\
\text { Aç1k/GSMH } \\
\text { Oran1 }\end{array}$ & $\begin{array}{l}\text { S\&P } \\
\text { Derecelendirmesi }\end{array}$ & $\begin{array}{l}10 \text { Y1ll1k } \\
\text { Bono }\end{array}$ \\
\hline Portekiz & 106 & $-1,9$ & 12 & $-8,9$ & BB & 11,6 \\
\hline İtalya & 121 & 0,5 & 8 & $-3,9$ & BBB+ & 6,7 \\
\hline İlanda & 109 & $-6,8$ & 14 & 0,8 & BBB+ & 8,2 \\
\hline Yunanistan & 166 & $-1,3$ & 17 & $-10,2$ & CCC & 28,4 \\
\hline İspanya & 67 & $-4,4$ & 23 & $-4,3$ & BBB+ & 5,9 \\
\hline Türkiye* & 39.4 & $-2,80$ & 10,1 & $-9,7$ & BB & 8,7 \\
\hline
\end{tabular}

Tablo 1 Ülke Genel Bilgileri Kaynak: Wind, 2011, Chartsbin, 2013. *Araştırmacılar tarafindan 2012 yılı değeri olarak ilave edilmiştir.

AB'nin merkez-çevre ülkeler arasındaki dengesizliği giderebilmek için tek para birliği alanını yaratması ile çoğunlukla küçük ve orta ölçekli işletmelerden kurulu olan Yunanistan ve Portekiz gibi çevre ülkelerin finansman sorunu çözülmüş ve sınırsız kaynak kullanımı sağlanmıştır (Stratfor, 2011). Ancak bu iyi niyetli çabalar ülkelerdeki iyi olmayan yönetim uygulamaları sonucunda borç krizine ve cari açık sorununa dönüşmüştür. Aşağıdaki şekilde yolsuzluk durumu ile bütçe açığı ilişkilendirilmektedir. Buradaki bilgilerin 1şığında Yunanistan, İtalya, Portekiz ve İspanya'da yolsuzluk ile bütçe açığı arasındaki pozitif korelasyon dikkati çekmektedir.

Genel sorunların içerisinde yer alan diğer bir husus da; Maastricht Antlaşması'nın tasarımında, bir kriz mekanizmasına yer verilmeyişidir. Üye devlet ekonomilerinin, ekonomik ve parasal birliğe geçmeden önce, bu 
kriterler çerçevesinde, birbirine yakınlaştırılması hedeflenmiştir. Üye devletlerin bütçe açıklarının gayrisafi yurtiçi hasılaya (GSYH) oranının \%3'ü aşmaması ve kamu borç stoklarının GSYH'ye oranının \%60'ı geçmemesi gerekmektedir. Ancak Tablo-2'den de anlaşılacağı üzere kamu borçlarının oranı Yunanistan ve İtalya’nın 1999 yılından itibaren, diğer üç ülkenin de son yıllarda kriterin üzerinde gerçekleşmiştir.

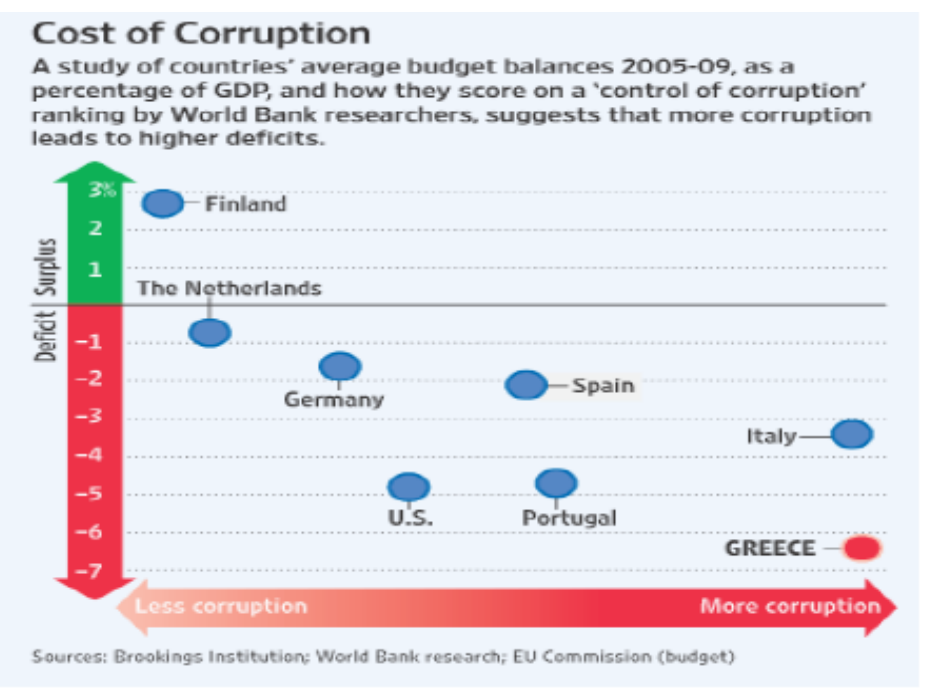

Şekil 1 Yolsuzluk ve Bütçe Açığı İlişkisi Kaynak: Akram ve ark., 2011, s.128.

\begin{tabular}{|l|l|l|l|l|l|l|}
\hline & Portekiz & İlanda & İtalya & Yunanistan & İspanya & Türkiye \\
\hline 1999 & 49,6 & 48,5 & 113,7 & 94,0 & 62,3 & \\
\hline 2000 & 48,5 & 37,8 & 109,2 & 103,4 & 59,3 & \\
\hline 2001 & 51,2 & 35,6 & 108,8 & 103,7 & 55,5 & \\
\hline 2002 & 53,8 & 32,1 & 105,7 & 101,7 & 52,5 & \\
\hline 2003 & 55,9 & 30,9 & 104,4 & 97,4 & 48,7 & \\
\hline 2004 & 57,6 & 29,6 & 103,9 & 98,6 & 46,2 & 67,7 \\
\hline 2005 & 62,8 & 27,4 & 105,9 & 100,0 & 43,0 & 59,6 \\
\hline 2006 & 63,9 & 24,8 & 106,6 & 106,1 & 39,6 & 52,7 \\
\hline 2007 & 68,3 & 25,0 & 103,6 & 105,4 & 36,1 & 46,5 \\
\hline 2008 & 71,6 & 44,4 & 106,3 & 110,7 & 39,8 & 39,9 \\
\hline 2009 & 83,0 & 65,6 & 116,1 & 127,1 & 53,3 & 40,0 \\
\hline 2010 & 93,0 & 96,2 & 119,0 & 142,8 & 60,1 & 46,1 \\
\hline 2011 & 101,7 & 112,0 & 120,3 & 157,7 & 68,1 & 42,2 \\
\hline 2012 & 107,4 & 117,9 & 119,8 & 166,1 & 71,0 & 39,4 \\
\hline
\end{tabular}

Tablo 2 Kamu Borçlarının GSYH'ya Oranı (\%, Brüt) Kaynak: Eurostat ve Avrupa Komisyonu

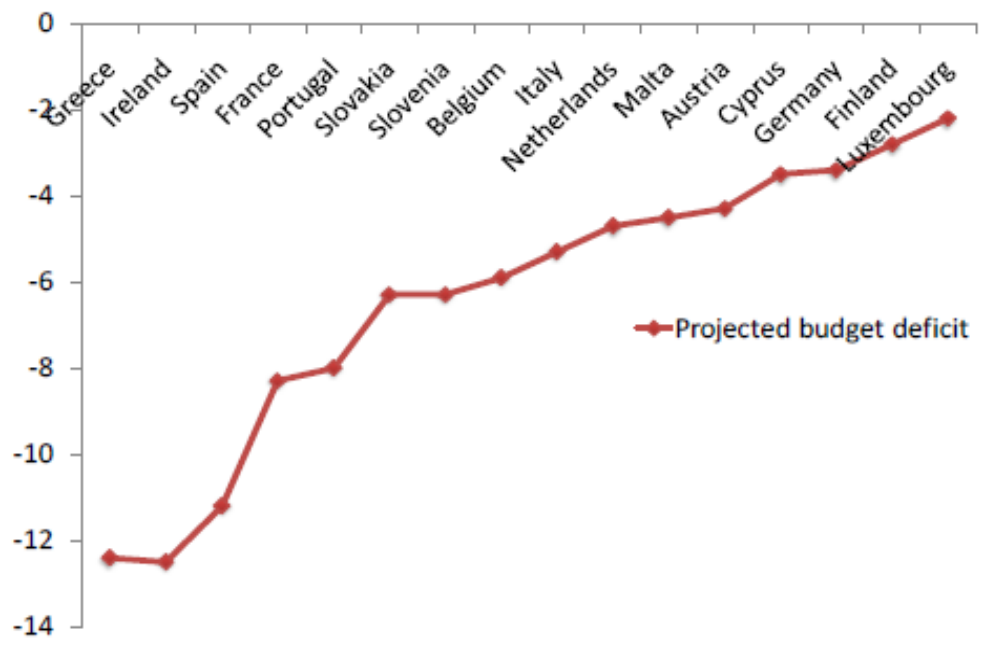

Şekil 2 Bütçe Açılkarı (\%/GSYH) Kaynak: Akram ve ark., 2011, s.122. 
2009 yılında Yunanistan ile başlayan borç krizi, Portekiz ve İrlanda'ya sirayet etmiş, 2011 yılı sonunda İtalya'nın yardım çağrısı ile genişlemiş, 2012 yılında İspanya'nın da aralarına katılması ile gündemde kalmayı sürdürmüştür. Bu yayılmanın dış ticaret, faiz oranları ve döviz kuru olmak üzere üç ana yoldan meydana geldiği belirtilmektedir (akt. Köse ve Karabacak, 2011, s.300). Yunanistan'ın kamu borcunun büyük kısmının yabancı kreditörlere ait olması bu yayılma etkisini güçlendirmektedir. Diğer yandan, ortak faiz oranı ve döviz kuru kanalları ile krizin yayılabilmesi $\mathrm{AB}$ avro bölgesine üye olmakla ilişkili bir risk olarak görünmektedir.

Yunanistan'daki krizin ABD kaynaklı küresel krizden kaynaklanmadığı bilinmektedir (Kouretas ve Vlmais, 2010). Yunanistan krizinin temel nedenleri arasında, ekonomik gerilemeden ve reel GSYH'de beklenenden daha büyük bir düşüş̧ten kaynaklanan "ekonomik döngü" etkisi, gelir toplama mekanizmalarının gevşekliğinden ve harcamaların yüksekliğinden kaynaklanan "seçim veya politik döngü" etkisi ve vergileri toplama, harcamaları kontrol etme ve verileri kaydetmeye ilişkin yaygın yapısal yetersizliklerden ve eksikliklerden kaynaklanan "yapısal" etki yer almaktadır (akt. Köse ve Karabacak, 2011, s.295). Yine de küresel krizden etkilenen özel sektörün borçlarının devlet tarafindan üstlenilmesi de kamu borç stokunun artmasına neden olmuştur (Kouretas ve Vlmais, 2010, s.391). Bunlarla birlikte sosyal güvenlik reformu gibi yapısal reformların yapılmaması, ulusal rekabet gücünün kaybı ve finansal kaynaklara kolay erişim de krizin derinleşmesinde etken olmuştur (Akram ve ark., 2011, s.123). 2010 yılı Mayıs ayı içerisinde IMF destekli 110 milyar avro değerinde üç yıl sürecek bir kurtarma paketi onaylanmıştır.

İtalya'da kamu maliyesinin zayıf durumu bu ülke ekonomilerini kırılgan hale getirmiştir. AMB'nin hükümetlere yardım etmenin söz konusu olmadığını belirtmesi, istikrarın sağlanmasının önüne geçmiştir. AMB'nin bağımsızlık kriterlerinden biri de kamuyu destekleyemeyecek olmasıdır. Ancak 9 Aralık 2011'de AMB'nin politika değişikliği ile bankalara üç yıllık vade ile sınırsız kredi verilmesinin önü açılmıştır.

İrlanda'nın pozisyonu diğer üye ülkelerden farklı olarak ABD'de yaşanan krize benzemektedir. İrlanda krizinin etkenleri; kürsel krizle birlikte gayrimenkulde yaşanan değer kayıpları, sıkı politikaların doğurduğu panik havası ve yoğun işten çıkarmalar olmuştur. İrlanda halkında refahın süreceğine inançla birlikte yatırımlar inşaat sektörüne yapılmış, ancak krizle birlikte \%50’lere varan değer kayıpları ile reel sektör zor durumda kalmıştır. İrlanda, Yunanistan ve Portekiz gibi küresel krizde ekonomik istikrarı sağlayabilmek için bankacılık sektörüne yüklü miktarda kaynak aktarmıştır (Kouretas ve Vlmais, 2010, s.392). Sonuç olarak bütçe açığı tahminlerin üzerinde gerçekleşmiştir. İrlanda için 85 milyar avro kadar mali yardım kapsamında kredi IMF, İngiltere, İsveç ve Danimarka tarafindan sağlanmıştır.

Portekiz'de cari açığın oldukça yüksek seviyelerde olması ve bankacılık sektörüne ilişkin riskler krizi tetiklemiştir. Portekiz ekonomisinde uzun zamandır yaşanmakta olan durgunluk, kamu maliyesinin iyileştirilmesini daha da zor hale getirmiştir. Portekiz AB ve IMF ile 78 milyar avro finansman desteği için anlaşma sağlamıştır.

İspanya'da ise yetersiz iç ve dış talep nedeniyle iktisadi faaliyetin kriz öncesi düzeye kıyasla oldukça düşük seviyelerde seyretmesi ve işsizlik oranının \% 20’leri aşması kırılganlığı artırmıştır. Cari açık Yunanistan'da kamudan kaynaklanırken, İspanya'da özel sektör rol oynamıştır (Üçer, 2011, s.4).

\section{Aktarım Mekanizması Kavramı Üzerine Tartışmalar}

Parasal aktarım mekanizması, para politikası-reel ekonomi arasındaki etkileşimin, toplam talep ve üretimi hangi yollarla ve ne ölçüde etkilediğini gösteren mekanizmadır (Kasapoğlu, 2007). Para politikaları reel piyasayı ve enflasyon oranını parasal hacmi veya faiz oranlarını değiştirerek etkilemektedir. Her iki durumda da farklı kanallar kullanılarak bu hedef gerçekleştirilmektedir. Aktarım kanalları veya mekanizmaları geleneksel olarak tasnif edilirken üçe ayrılmaktadır; faiz oranları, kur oranları ve diğer varlık fiyatları (Mishkin, 1995). Yakın zamanda kredi kanalı da bir aktarım mekanizması olarak kabul edilmektedir.

Ana mekanizma olan faiz oranlarındaki değişiklik yatırım ve dolayısıyla tüketim harcamalarında bir değişikliğe sebep olmaktadır. Para arzındaki artış, tahvillere olan talebi artırmakta, yükselen tahvil fiyatları faiz oranlarını düşürmektedir. Faiz oranlarındaki düşüş ile birlikte sermaye maliyeti azalınca, yatırım harcamaları artmakta ve böylelikle üretim miktarı artmaktadır.

Varlık fiyatlarındaki değişim, bono, menkul kıymetlerin değerlerinde yapılacak oynamalar suretiyle veyahut hanehalkı refahını artırılarak yapılmaktadır. Varlık fiyatları kanalı döviz kuru veya hisse senedi kanalı ile gerçekleşebilmektedir. Uygulanan kur rejimi döviz kuru mekanizmasının işleyişinin belirleyicisidir. Sabit döviz kur rejimi uygulanan ülkelerde faiz oranları dünya faiz oranlarına endeksli olduğu için bu kanalın kullanım imkanları da kısıtlanmaktadır.

Kredi kanalı bankalar aracılığıyla yapılabileceği gibi bilançolardaki oynamalarla da gerçekleştirilebilmektedir. Daraltıcı bir para politikası kredilerde azalmaya neden olarak yatırım harcamalarında da azalmaya sebep olacaktır.

Örnek olarak AB'de yaşanan borç krizinin ABD'ye olan etkisinin ticaret, kredi ve güven kanallarından olduğu belirtilmektedir (BBVA, 2012, s.12). Bunların haricinde varlık fiyatlarındaki değişmeler, belirsizlikler ve kürsel 
kredi daralması aracılığıyla da dolaylı etkiler söz konusu olabilir. Massa ve arkadaşlarına (2011) göre AB krizi gelişmekte olan ülkelere üç aktarım mekanizması vasıtasıyla etki edebilmektedir. Bunlar sırasıyla, finansal (aracı kurumlar ve menkul kıymet borsaları), kurtarma paketleri nedeniyle oluşan işsizlik ve döviz kuru hareketleridir.

Türkiye gibi serbestleştirilmiş sermaye hesabına sahip ve sermaye akımlarının yurtiçinde büyük etkisi bulunan bir ekonomide, politika büyüklükleri fiyat istikrarı ve dış dengenin sağlanması gibi ana hedefler üzerinde farklı etkiler meydana getirebilmektedir (Aslan ve Korap, 2007).

\section{Sonuç ve Öneriler}

$\mathrm{AB}$ bölgesi ekonomilerinin yaşadığı borç sorunları sürdüğü için, Türkiye'nin ihracatının yaklaşık olarak yarısının gerçekleştiği bu ülkeler ile ilgili endişeler gündemde kalmaya devam etmektedir. Reel faiz oranları kriz yaşanan ülkeler açısından yatırımcılar için cazibesini kaybetmekte, böylelikle sermaye çıkışı görülmektedir. Kriz yaşanan AB üyesi ülkelere ait reel faiz oranlarını gösterir grafik Şekil-3’te yer almaktadır.

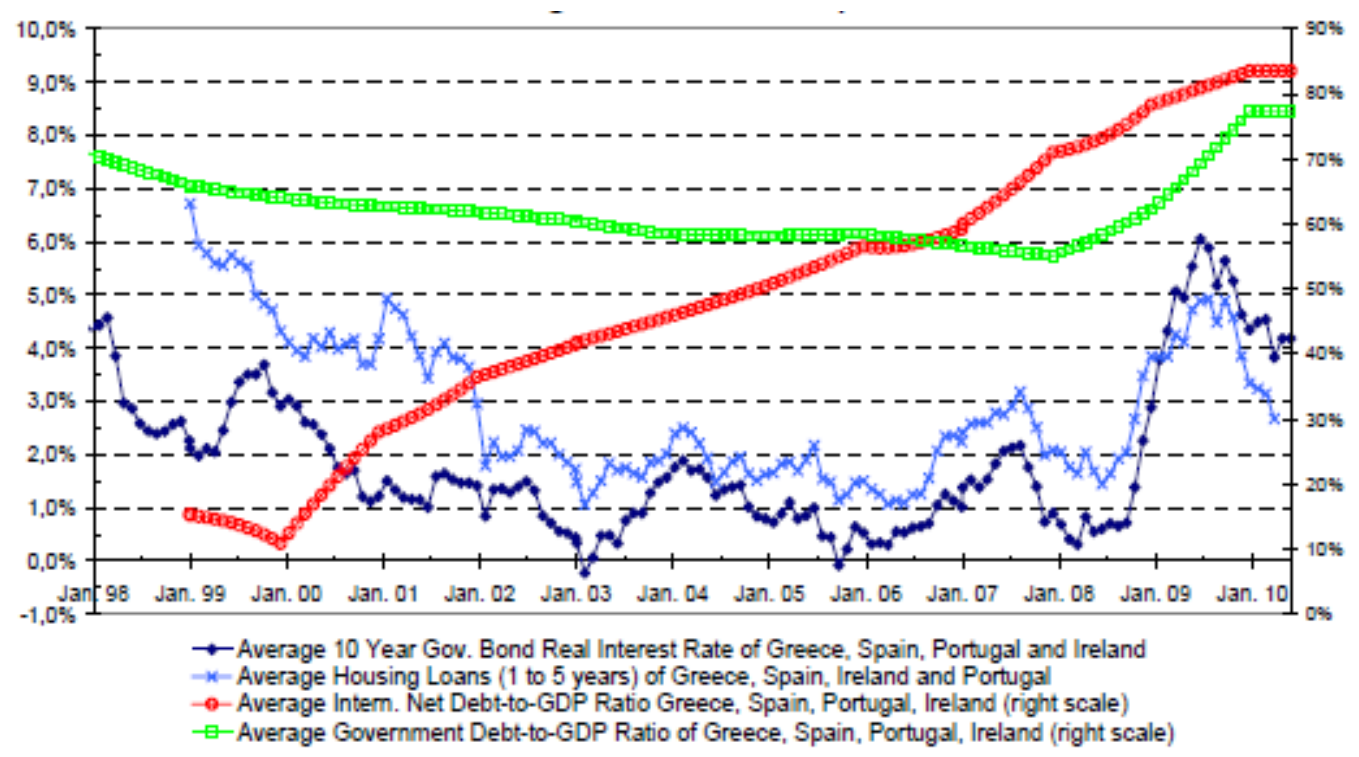

Şekil 3 Uzun Dönem Reel Faiz Oranlarl (Yunanistan, Portekiz, Irlanda ve İspanya) Kaynak: Maurer, 2010.

Türkiye açısından transfer mekanizmalarının işleyişlerini değerlendiren çalışmalar ulusal yazında kısmen yer almaktadır. Örneğin; Aslan ve Korap (2007) tarafından Türkiye örnekleminde yapılan görgül araştırma sonucunda, reel faiz yapısının para politikası gelişmelerine oldukça duyarlı olduğu bulgusuna ulaşılmış ve kısa süreli sermaye akımlarının etkisinden bahsedilmiştir. Benzer şekilde, Kasapoğlu (2007)'nun araştırmasında faiz oranı kanalının Türkiye için işlediği sonucuna varılmıştır. Bununla birlikte araştırmacı döviz kurunun fiyatlar genel seviyesini önemli oranda etkilediğini belirtmiştir. Ayrıca, hisse senedi ve kredi kanalının bir etkisi olmadığı da araştırmada ortaya konmuştur. Öte taraftan Üçer (2011, s.11) Türkiye'nin AB borç krizinden en çok ticaret ve kredi kanalıyla etkileneceğini öngörmektedir. Dünya ekonomisi büyüme oranı Türkiye'nin ihracatı arasında pozitif ilişki olduğundan dolayı cari işlemler açı̆̆ının olumsuz etkileneceği belirtilmektedir.

Sonuç olarak AB krizinin Türkiye'ye transferi için ticaret ve kredi kanallarının aktarım işlevini yerine getirebileceği görülmektedir. Türkiye'nin krizlerden etkilenmemesi için ihracatın ithalata olan bağımlılığını düşürmek, ara malı ve yatırım mallarında yurtiçi üretim kapasitesini artırmak uygun bir çözüm yolu olarak gözükmektedir. Ayrıca, Türk lirası avro karşısında değer kaybetmeye başlayınca, yurtiçinde üretilen malların değeri yabancı mallardan daha ucuz hale gelmektedir. Net ihracat ve toplam talep artarak, ithal malların fiyatlarının lira cinsinden artmasına ve enflasyonun da yükselmesine sebep olmaktadır.

Ayrıca, dış borcun büyük bir kısmının Avrupa bankalarına olması sebebiyle (Özel sektörün 125 milyar dolarlık orta ve uzun vadeli borcunun 90 milyar dolara yakını Avrupa bankalarınadır.), finansal yapılanma söz konusu olur ise kredilerde bir daralma yaşanabileceği tahmin edilmektedir.

\section{Kaynakça}

- Akram, Muhammad, Sajjad, Humna, Fatima, Tooba, Mukhtar, Sidra ve Alam, Hassan Mobeen (2011). "Contagious Effects of Greece Crisis on Euro-Zone States," International Journal of Business and Social Science, Vol. 2 No. 12, ss.120-129.

- Aslan, Özgür ve Korap, H.Levent (2007). "Monetary Transmission Mechanism In An Open Economy Framework: The Case Of Turkey," İstanbul Üniversitesi İktisat Fakültesi Ekonometri ve İstatistik Dergisi, Say1:5, ss.41-66. 
- BBVA (2012). Global Economic Outlook: First Quarter 2012.

- Chatsbin (2013). Standard \& Poor's Credit Rating for each country. http://chartsbin.com/view/1177 (Erişim Tarihi: 30 Temmuz 2013)

- Kasapoğlu, Özgür (2007). "Parasal Aktarım Mekanizmaları: Türkiye için Uygulama,” Uzmanlık Yeterlilik Tezi, Türkiye Cumhuriyet Merkez Bankası Piyasalar Genel Müdürlüğü, Ankara.

- Köse, Yaşar ve Karabacak, Hakan (2011). "Yunanistan Ekonomik Krizi: Nedenleri, Etkileri ve Alınan Tedbirlere İlişkin Bir Değerlendirme,” Maliye Dergisi, Sayı 160, ss.289-306.

- Kouretas, Georgios P. ve Vlamis, Prodromos (2010). The Greek Crisis: Causes and Implications," Panoeconomicus, 4, ss.391-404.

- Massa, Isabella, Keane, Jodie ve Kennan, Jane (2011). “The Euro Zone Crisis: Risks for Developing Countries," Background Note, İngiltere: Overseas Development Institute.

- Maurer, Rainer Willi (2010). "The eurozone debt crisis - A simple theory, some not so pleasant empirical calculations and an unconventional proposal," Discussion Paper, Pforzheim University.

- Üçer, Murat (2011). 2012'ye girerken...20 soruda dünya ve Türkiye ekonomisinde son gelişmeler. Deloitte Yayınlar1.

- Wind, Serge L. (2011). Eurozone Sovereign Debt Crisis. Ders Notlar1, Keller Graduate School of Business, Devry University. 


\title{
Bilanço Düzeltme Sürecinde Gelişmekte Olan Piyasa Ekonomilerinde Ani Duruş Problemine Karşı Makro Basiretli Politikalar
}

\section{De-Leveraging and Mitigating Pro-Cyclicality of Capital Flows in Emerging Market Economies: Role of Macro-Prudential Policies}

\author{
Tolga Dağlaroğlu (Gazi University, Turkey) \\ Dr. Baki Demirel (Gaziosmanpaşa University, Turkey) \\ Ph.D. Candidate Serdar Varlık (Gazi University, Turkey)
}

\begin{abstract}
International capital flows have been on an unprecedented roller-coaster ride in recent years. Capital flows to emerging market economies have been strongly correlated with changes in global financing conditions, rising sharply during periods with relatively low global interest rates and low VIX (called risk-on) and shrinking afterward. In open emerging market economies, interest rate increases can attract excessive capital inflows appreciating the exchange rate, and leading to excessive borrowing in foreign currency, and encouraging leverage. A well-designed macro prudential policy prevents credit -driven bubble and mitigating pro-cyclicality of capital flows.
\end{abstract}

\section{Giriş}

Gelişmekte olan piyasa ekonomilerine yönelik sermaye akımlarında görülen bu artış bu ekonomilerde çıtı açığının azaldığı ve enflasyonun yükseldiği dönemler olarak karşımıza çıkmaktadır. Sermaye akımlarında bu ortamda görülen bu artış sıkı para politikası yoluyla yurtiçi talebin kontrol edilmesini imkansız hale getirmektedir. Tam tersine sıkı para politikası yurtiçi faizlerin yüksek kalması nedeniyle yeni sermaye girişlerini teşvik etmektedir. Buna ek olarak sermaye akımlarında meydana gelen bu artı̧ yurtiçi ekonomik dengelerin bozulmasına neden olarak finansal istikrarsızlığa ve kırılganlığa neden olmaktadır. Bu akımları absorbe etmeye yönelik yurtiçi tahvil, bono ve hisse senedi halka arzları aynı zamanda varlık fiyatları üzerindeki baskının azalmasına yol açmaktadır. Fakat başka bir problem kaldıraçlı işlemlerin artmasına neden olmaktadır.

Finansal piyasaların görece daha sakin olduğu dönemlerde bir başka ifade ile yatırımcıların riske açık (risk-on) sanayileşmiş ekonomilerdeki yatırımcılar kaldıraçlı işlemler ile ve/veya portföy yatırımları ile gelişmekte olan piyasa ekonomilerine yönelik yatırımlarını artırmakta bunun sonucunda gelişmekte olan piyasa ekonomilerinin merkez bankaları kurun değer kazanımının önüne geçebilmek için yerli para karşılığında dolar almakta ve hiç istemedikleri bir biçimde rezerv para birimi cinsinden orta vadeli menkul kıymetlere yatırım yapmaktadırlar. Bu süreçte gelişmekte olan piyasa ekonomileri yurtiçi yatırımcıyla yerli para birimi cinsinden menkul kıymet ihraç ederek buna cevap vermektedir. Böylece görece finansal piyasaların sakin olduğu dönemlerde gelişmekte olan piyasa ekonomilerinde kaldıraçlı işlemler sonucunda yapılan yatırımlar asimetrik varlık swap neden olmaktadır bu işlem rezerv para birimi cinsinden finansal varlık yerine riskli olarak görülen gelişmekte olan piyasa ekonomisine ilişkin finansal varlıklara yatırım olarak ifade edilmektedir.Gelişmekte olan piyasa ekonomilerine yönelik sermaye akımlarının azaldığı ve finansal piyasalarda oynaklığın arttığı dönemlerde kısacası yatıımcıların risk almaya istekli olmadığı kısaca kapalı olduğu (risk-off) durumda ülkeden sermaye çıkışı olmakta bunun sonucunda merkez bankasının uluslararası döviz rezervleri önemli ölçüde azalmaktadır bir başka ifade ile gelişmekte olan piyasa ekonomisine ait merkez bankası uluslararası yatırımcıya güvenli finansal varlık arz etmektedir.Bu noktada makro basiretli politikalar hatta bazı durumlarda ise sermaye kontrolleri bu akımların ve etkilerinin yönetilmesinde önemli birer araç olmaktadır. Çalışmamız beş bölümden oluşmaktadır. İlk bölüm giriş bölümüdür. Giriş bölümünü takip eden birinci bölümde konu hakkındaki literatür üzerinde durulmuştur. İkinci bölüm çalışmada kullanılan verilerin ve yöntemin tanıtıldığı bölümdür. Bu bölümü takip eden üçüncü bölümde ise yapılan ekonometrik uygulama sonucu elde edilen bulgulara yer verilmiş̧ir. Sonuç bölümü çalışmada elde edilen bulguların değerlendirildiği ve yorumlandığı nihai bölümdür.

\section{Literatür Sorgulaması}

Küresel kriz ile birlikte merkez bankacıllğında ve para politikasının çerçevesinde önemli değişimler görülmüştür. İktisat yazınında küresel kriz ile birlikte para politikasının çerçevesinde ve merkez bankacılığında meydana gelen değişmeler ise üç başlık altında toplanabilir (Blanchard, Dell'Ariccia ve Mauro, 2010 ve 2013).

İlki, artık merkez bankalarının sadece fiyat istikrarı hedefine odaklı bir para politikası yürütmemesi gerektiği aynı zamanda açı bir biçimde ekonomik büyümeyi de göz önünde bulunduracak bir para politikası izlemesinin gerekli olduğudur (Blanchard, Dell'Ariccia ve Mauro, 2010 ve 2013). Küresel krizden önce makroekonomi 
yönetiminde hakim görüş; fiyat istikrarının ve para politikasının tek aracı olarak kısa vadeli politika faiz oranlarının ön plana çıkartılmasıdır. Çünkü fiyat istikrarının sağlanması durumunda çıktı açığını oluşmayacağı ve böylece finansal istikrarın kendiliğinden sağlanacağı varsayılmaktadır. Bunu sağlayacak temel aracın ise kısa vadeli politika faiz oranı olduğudur (Blanchard, Dell'Ariccia ve Mauro, 2010 ve 2013). Fakat merkez bankasının yalnızca fiyat istikrarı hedefine odaklanması durumunda çıktının potansiyel düzeyine yakın bir seviyede oluşacağı bu durumun kendiliğinden finansal istikrarı sağlayacağı düşüncesinin kriz ile birlikte geçerli olmadığı görülmüştür. Küresel kriz ile birlikte para politikasında ve merkez bankacılığında ortaya çıkan değişmelerden ikincisi ise, merkez bankalarının finansal istikrarı gözeten ve sağlayan bir para politikası uygulamasıdır. Kısacası merkez bankalarının finansal istikrara ilişkin farkındalıklarının artmasıdır (Blanchard, Dell'Ariccia ve Mauro, 2010 ve 2013). Krizden önce savunulan temel görüş bir ekonomide fiyat istikrarının sağlanması ve çıktının istikrarlı olması aynı zamanda finansal istikrarı da sağlayacağıdır. Bunu sağlayacak temel aracın ise politika faiz oranı olduğudur. $\mathrm{Bu}$ görüşün hakim olduğu krizden önce büyük 1lımlılık dönemi (Great Moderation) olarak adlandırılan makro ekonomik değişkenlerdeki oynaklığın azaldığı dönemde hem akademik yazında hem de politika uygulayıcılar arasında makro ekonomiyi ve finansal sistemi istikrara kavuşturmak için merkez bankasının sadece fiyat istikrarı hedefine odaklanması gerektiği ve politika faizinin krizlere neden olacak dengesizlikleri ortadan kaldırması için ideal bir araç olduğu görüşünün hakim olduğu görülmektedir. Böylece büyük 1 lımlık dönemi bu anlamda merkez bankalarının finansal sistemde yaşanabilecek riskleri göz ardı etmelerine yol açmıştır.

Krizden önceki dönemde finansal istikrarın sağlanmasına yönelik yaygın görüşlerden bir diğeri de politika faizine ek olarak mikro basiretli (micro-prudential) politika araçlarının finansal istikrarı sağlamak için yeterli olacağının düşünülmesidir. Buna göre merkez bankaları sadece para politikasının yürütülmesinden sorumlu olmalıdırlar. Finansal sistemde uygulanan politikalar ve politika araçları tek bir finansal kurum için değil tüm finansal sistemi kapsayacak şekilde uygulanmalıdır. Böylece tüm sistemi kapsayacak şekilde uygulanacak basiretli düzenlemeler ve denetlemeler bankaların aşırı risk almasının önüne geçerek finansal istikrara önemli katkıda bulunacaktır. Kısacası merkez bankaları tarafından savunulan hakim görüş para politikası ve finansal istikrara yönelik politikalar arasındaki dikotomidir (Eichengreen et al., 2011 ve Hahm et al., 2012). Fakat yaşanan kriz, para politikası ve finansal istikrara yönelik politikalar arasındaki dikotominin geçersizliğini göstermiştir. Bir başka ifade ile sadece finansal kurumlara yönelik mikro basiretli düzenlemeler ve denetlemeler sistemin tümünden kaynaklanan riskleri ortadan kaldırmakta yetersizdir (Unsal, 2011).

Dolaysıyla yaşanan bu kriz bu dikotominin geçersiz olduğunu göstermesi açısından son derece güzel bir örnektir. Ağustos 2008 yılında Amerika Birleşik Devletlerindeki konut kredileri piyasalarında ortaya çıkan kriz, ABD sermaye piyasalarının çok küçük bir kısmını oluşturmaktaydı. Başlangıçta bu piyasada önemli kayıplar görülmesine rağmen politika yapıcıları bu kayıpları yönetilebilir olduğunu düşünmekteydiler. 2008 yılının yaz aylarında başta ABD Merkez Bankası ve diğer merkez bankaları bütün dikkatlerini artan enflasyona çevirmişlerdi. Fakat bu dönemde peş peşe yaşanan şoklar finansal sistem ve ekonomi arasındaki uçurumun artmasına neden olmuştur. 15 Eylül 2008 tarihinde Lehman Brothers'ın ve 16 Eylül'de AIG iflası aynı gün ABD'de repo piyasalarında (Reserve Primary Fund) yaşan hücüm ve daha sonra ABD Kongresinin Sorunlu Varlıkları Alım Programı (TARP) onaylaması ile ABD finansal piyasalarında yaşanan şok global bir krize dönüşmüştür. Başta $\mathrm{ABD}$ olmak üzere Dünya'da ekonomik büyüme önemli ölçüde daralmış ve işsizlik başta ABD olmak üzere sanayileşmiş ekonomilerde yüzde 10'ların üzerine çıkmıştır. Dünya genelinde finansal kriz nedeniyle yaşanan resesyon $1930^{\prime}$ lardan sonra dünyada yaşanan en ciddi resesyona neden olmuştur. Sonuç olarak yaşanan kriz para politikası ile finansal istikrarı sağlamaya yönelik politikalar arasındaki uyumun önemine dikkat çekmesi açısından önemlidir. Çünkü finansal sistemde yaşanan bu gelişmelerin ekonomiye etkisi düşünülenden daha fazla olmaktadır. Ayrıca finansal krizler sonrasında ortaya çıkan maliyette düşünülenden daha fazladır. Kriz ile birlikte artık finansal piyasalardaki gelişmelerin makro ekonomik analizlerin merkezinde yer alması gerektiğinin önemi anlaşılmıştır (Hahm et al., 2012: 10). Para politikası ve finansal istikrarı sağlamaya yönelik politikalar arasındaki bu dikotomi büyük 1lımlılk döneminde sektörel dengesizliklerin oluşmasına yardımcı olmuş ve bu dengesizlikleri büyüterek global bir krize neden olmuştur. Bu anlamda global finansal kriz krizden önce temel politika araçları olarak görülen politika faiz oranına ve mikro ihtiyatı politikalara olan güveni derinden etkilemiştir (Hahm et al., 2012: 10).Yaşanan bu kriz merkez bankalarına sistemik finansal istikrarı sağlama konusunda iki önemli ders çıkartmalarına neden olmuştur (IMF, 2012). İlki, fiyat istikrarının sağlanması ve çıktının istikrarlı olmasının bir ekonomi açısından önemli olduğu fakat bu faktörlerin tek başına sürdürülebilir makro ekonomik istikrarı sağlayamadığıdır. Bunun için merkez bankaları para politikası uygularken makro basiretli politikalar ile finansal istikrarı da göz önünde bulundurmalarının gerekli olduğudur (Unsal, 2011). Çünkü finansal sektörde yaşanan gelişmelerin ekonomik faaliyetlere olan etkisi geçmiş dönemler ile kıyaslandığında daha büyüktür (IMF, 2010 ve Hahm et al., 2012).

Bunun için merkez bankaları sistemik riski büyütecek döngüsel hareketlerin (pro-cyclicality) önüne geçmeli ve yapısal kııılganlıkların oluşmasını engellemelidir. Kısacası bir ülkede merkez bankası ister ana düzenleyici rolü üstlenen olsun isterse bu rol başka bir denetleyici, düzenleyici başka bir kurumun olsun merkez bankalarının makro ihtiyati düzenleyici çerçevenin içerisinde bulunması mutlaka gerekmektedir. Bunu için açık bir biçimde 
opearsyonel araçların, yönetişim ve kurumsal ilkelerin göz önünde bulundurulduğu makro basiretli politikaların çerçevesi oluşturulması gerekmektedir (IMF, 2012).

İkincisi ise, merkez bankaları enflasyonla mücadelede kazanmış oldukları kredibiliteyi zarar vermeden para politikasının oluşturulmasında (formülasyonunda), yürütülmesinde ve uygulamasında finansal sistemdeki riskleri ve gelişmelere yer vermesi gerekmektedir (Unsal, 2011 ve IMF, 2012). Bu noktada iktisat yazınında ortaya çıkan temel tartışma konusu merkez bankalarının finansal istikrarı sağlamak amacıyla varlık piyasalarda oluşan balonlara nasıl tepki vereceğidir (IMF, 2010). Çünkü, varlık fiyatları para politikasının aktarım mekanizması kanalı içerisinde çok önemli bir role sahiptir. Optimal bir para politikası uygulaması çerçevesinde merkez bankasının varlık fiyatlarına tepki vermesi çıtı ve enflasyon açısından istenilen sonuçlara ulaşılabilmesi açısından önemlidir (IMF, 2010). İktisat yazınında, merkez bankalarının varlık fiyatlarındaki balonlara (hareketlere) nasıl tepki vermesi gerektiği ile ilgili görüşler iki grupta toplanmaktadır. Bir başka ifade ile para politikasının yürütülmesinde varlık balonları ile ilgili temel tartışma, merkez bankası para politikası ile varlık fiyatlarında meydana gelen balonun patlaması halinde ekonomiye olan etkilerini sınırlayabilmek için balonu oluşmadan ortadan kaldırmalı mı (patlatmalı mı) yoksa balon patladıktan sonra ortalığı temizlemeli mi?

İlki, merkez bankalarının varlık fiyatlarında oluşan balonlara karşı durması (lean against wind) savunmaktadır (Blanchard, 2000; Borio ve White, 2003). İkincisi ise, merkez bankalarının varlık fiyatlarına doğrudan tepki vermemesi bunun yerine varlık balonu patladıktan sonra çıktıyı ve enflasyonu istikrarlı hale getirmeye çalışmasıdır. İktisat yazınında bu sonuncusuna merkez bankasının varlık balonu patladıktan sonra bunun temizlemesi (clean) denilmektedir (Bernanke ve Gertler, 1999 ve 2001). Merkez bankasının varlık fiyatlarına müdahale etmemesini savunanlar iktisat yazınında Greenspan doktrini olarak da bilinen görüş savunmaktadırlar. $\mathrm{Bu}$ görüşe göre para politikasının yürütülmesinde varlık fiyatları önemlidir. Bundan dolayı, varlık fiyatları enflasyon ve istihdam üzerinde tahmin edilebilir etkilere sahip olmaktadır. Bundan dolayı merkez bankaları ile varlık balonlarının önüne geçmek yerine varlık balonu patladıktan sonra çıktı ve enflasyonu istikrarlı hale getirmeye çalışmalıdır. Para politikasının yürütülmesinde Greenspan doktirine bağlı kalınmasını savunanların bu konudaki savları beş başlık altında toplanmaktadır. İlki, varlık balonlarının belirlenmesi son derece zordur. İkincisi, faiz oranları varlık balonun oluşmasını engellemek konusunda etkin bir araç olmayabilir. Çünkü merkez bankası varlık balonunu engellemek amacıyla faiz oranlarını arttırdığında piyasa katılımcıları balonun oluştuğu varlıklardan daha fazla getiri elde etmeyi bekleyeceklerdir. Üçüncüsü ise, piyasalarda bir çok varlık bulunmaktadır. Dolaysıyla oluşan balon sadece varlıkların belirli bir kısmını temsil etmektedir. Böylece para politikası eylemleri sadece balonun oluştuğu varlıkları değil tüm varlıkların fiyatlarını etkileyebilir. Dördüncüsü ise, merkez bankasının faiz oranlarını arttırması varlık fiyatlarının ivmelendirici rolünü azaltmaktadır. Kısacası merkez bankasının varlık balonunu ortadan kaldırmak amacıyla faiz oranlarını arttırması sonucu varlık balonun patlamasının ekonomiye olan etkisi tahminlerden daha büyük olabilir (Mishkin, 2010: 20-21). Bu anlamda Mishkin (2010) ve Claessens ve Kose (2013)'ye göre varlık balonlarının hepsi aynı olmamaktadır. Özellikle 1990'ların sonunda Asya'da görülen kredi artışı nedeniyle varlık fiyatlarında oluşan balon (credit-driven bubble) ekonomiler açısından en tehlikeli olanıdır. Bir ekonomide artan kredi hacmi ile varlık fiyatlarında ortaya balon şu şekilde çıkmaktadır. Ekonomiye ilişkin aşırı iyimser beklentiler veya finansal piyasalarda yaşanan yapısal değişism kredilerde artışa neden olmaktadır. Kredi hacminde meydana gelen artış varlık talebinin ve fiyatlarının artmasına neden olmaktadır. Varlık fiyatında meydana gelen artışlar bu kredilerin alınması sırasında kullanılan teminatların değerini artırmaktadır. Teminatların değerinde meydana gelen artış borçlanma imkanını kolaylaştırmakta bunun sonucunda tekrar varlık talebi ve fiyatları artmaktadır. Varlık balonu bu şekilde oluşmakta patladığında ise, varlık fiyatlarında önemli düşüşler meydana gelmekte bunun sonucunda teminatların değeri azalmakta teminatların değerinde meydana gelen azalış sonucunda kredi koşullarında daha fazla sıkılaştırmaya neden olmakta böyle kredileri geri çağrılmasına neden olmaktadır. Böylece varlık talebi, fiyatları ile birlikte kredi arzı da daralmaktadır. Geri dönmeyen krediler ve varlık fiyatlarında meydana gelen azalışlar finansal kurumlarının bilançolarını olumsuz etkilemekte bunun sonucunda tüm varlıkları ve kesimleri kapsayacak bir şekilde krediler ve yatırımlar azalmaktadır. Bu durum ise ekonomik birimlerin yatırım ve tüketim kararlarını olumsuz etkilemekte bunun sonucunda ekonomik küçülmeye bağlı olarak kredi piyasalarında makroekonomik risk artmaktadır.Sonuç olarak finansal kurumların aşırı risk alma güdüsü, örneğin aşırı kaldıraçlı işlemler yapmaları, ellerinde tutmuş oldukları riskli finansal varlıklar nedeniyle taşımış oldukları risk ve kırılgan bir yükümlülük yapısının bulunması kısa dönemde döngüsel olarak balonların oluşmasını ve sonrasında ortaya çıkan ekonomik maliyetin şiddetini arttırabilmektedir. Dolaysıyla son yaşanan kriz finansal sistemden kaynaklanan sorunların mevcut olduğu bir ekonomide refahın sadece fiyat istikrarı ile sağlanamadığını ortaya koymuştur. Ekonomik refahın maksimizasyonu için finansal istikrarın ek faaliyet hedefi olarak kullanıldığı makro basiretli politikalara ihtiyaç duyulmaktadır (IMF, 2013). Böylece makro basiretli politikaların kullanılması potansiyel finansal kırılganlıkların oluşmasını engelleyecektir. $\mathrm{Bu}$ dönemde özellikle gelişmekte olan ülkelerin merkez bankalarının finansal istikrarı sağlama konusunda karşılaşmış oldukları bir diğer önemli sorunda bu ekonomilere yönelik büyük çaplı ve oynaklığı yüksek sermaye akımlarında meydana artıştır. Türkiye gibi gelişmekte olan piyasa ekonomilerinde politika faiz oranlarındaki farklılık ülkeye yönelik carry-trade türünden sermaye akımlarını hızlandırmaktadır. Bu durum bankacılık sektörü aracılığı kredi artışına ve kaldıraçlı işlemlerin artmasına neden olarak finansal istikrarı tehdit etmektedir. Ülkeler arasındaki bu yüksek faiz 
farklılıkları bankacılık sektörü aracılığı ile ülkeye yönelik sermaye akımlarının hızlanmasına neden olmakta bunun sonucunda yerli para değer kazanmakta ve ekonomide aşırı 1sınmaktadır. Enflasyon hedeflemesi uygulayan birçok ülke bu duruma tepki olarak politika faiz oranlarını arttırmış fakat bu durum tam ters etki yaparak tekrar sermaye girişlerinin hızlanmasına neden olmuştur (IMF, 2013: 25-26). Bu durum gelişmekte olan piyasa ekonomilerinde sistemik riski büyütecek döngüsel hareketlerin (pro-cyclicality) oluşmasına yol açarak yapısal kırılganlıkların ortaya çıkmasına neden olmaktadır.Özellikle 2010 yılında G-4 merkez bankalarının (İngiltere Merkez Bankası, Japonya Merkez Bankası, Avrupa Merkez Bankası ve ABD Merkez Bankası) uygulamış oldukları niceliksel gevşeme politikasının sonucu aylık bazda Türkiye gibi gelişmekte olan ülkelere yönelik kısa vadeli sermaye girişlerinin hızlandığını göstermesi açısından önemlidir (IMF, 2010).2010 yılının ilk üç çeyreğinde gelişmekte olan piyasa ekonomilerine yönelik sermaye akımları 2004-2007 yılları arasındaki dönem ortalamasının üzerinde gerçekleşmiştir. Bu sermaye akımlarının bir diğer önemli özelliği gelişmiş ülkeler ile karşılaştırıldığında bu akımların oynaklığının (volatilitesinin) son derece yüksek olmasıdır IMF (2013c). Oynaklığının yüksek olmasından kastedilen bu sermaye akımlarının özellikle dışsal ekonomik gelişmelere son derece çabuk tepki verebilmesidir. Örneğin, IMF (2013b: 38) 2008-2012 yılları arasında gelişmekte olan piyasa ekonomilerinin bu dönemde risklilik düzeyini etkileyen faktörlerin neler olduğun araştırmıştır. Bu dönemde gelişmekte olan ülkelerinin risklilik düzeyinin göstergesi olarak kullanılan risk primleri ortalama olarak 400 baz puan düşmüştür. $\mathrm{Bu}$ dönemde ülkelerinin risklilik düzeyinin iyileşmesine yurtdışı faktörler önemli katkıda bulunmuştur. Bu faktörlerden ilki ABD S\&P borsa endeksinin oynaklığını gösteren VIX endeksinin azalması gelişmekte olan piyasa ekonomilerinin risk primlerinde önemli düşüşe neden olmuştur. Bu endeksin azalması önümüzdeki dönemde borsa endeksinin oynaklığının azalacağını göstermesi açısından önemli olduğu gibi ayrıca günümüzde riski fiyatlamanın alternatif bir ölçüsü olarak ve küresel anlamda yatırımcının risk iştahının göstergesi olarak kullanılmaktadır (Rozada ve Levy Yeyati, 2006:14-15 ve Özatay, Özmen ve Şahinbeyoğlu, 2008b).

Gelişmekte olan piyasa ekonomilerinin risk primlerinde azalışa neden olan dişsal faktörlerden ikincisi ABD Merkez Bankasının uygulamış olduğu aşırı gevşek para politikasıdır. Risk primlerindeki azalışın arkasında yatan temel faktör, özellikle başta ABD olmak üzere sanayileşmiş ülkelerin merkez bankasının izlemiş olduğu gevşek para politikası faiz oranlarının düşmesidir. Faiz oranlarındaki bu azalış sanayileşmiş ülkelerdeki yatırımcıların ellerinde ihtiyaç amacıyla daha az nakit tutmak istemelerine neden olmuştur. Böylece getiri aramak amacıyla yatırımcıların riskli varlıklara yönelik talepleri artmış ve bunun sonucunda risk primleri düşmüştür. Sonuç olarak bu dönemde ABD izlenen aşırı gevşek para politikasının risk primlerindeki azalışa katkısı ise 85 baz puan olmuştur (IMF, 2013b: 38). Aynı zamanda gelişmiş ülkelerdeki düşük faiz oranları bu ülkelerdeki yatırımcıları getiri elde etmek amaciyla (search for yield) risk alma konusunda teşvik etmektedir (Rajan, 2005; 2010 ve Hoenig, 2010). Gelişmiş ülkelerdeki gevşek para politikasına ek olarak kriz, risk ve getiri arasındaki algılamanın da değişmesine neden olmuştur. Bu açıdan gelişmekte olan piyasa ekonomilerinin kamu borç dinamikleri çoğu gelişmiş ülkelerin borç dinamikleri ile karşılaştırıldığında daha iyi olması gelişmekte olan ülkelerin finansal varlıklarına olan talebin artmasına neden olan bir diğer faktör olarak karşımıza çıkmaktadır (IMF, 2010). Risk iştahındaki bu oynaklık risk primlerinin en önemli belirleyicisi olduğu gibi gelişmekte olan ülkelere yönelik sermaye akımlarının da etkileyen en önemli faktördür. VIX endeksinin düşük olduğu dönemlerde yatırımcıların risk alma iştahının arttığı ve Türkiye gibi ülkelere yönelik portföy şeklinde sermaye akımlarının hızlandığ görülmektedir. Tam tersine VIX endeksinin yüksek olduğu dönemlerde portföy biçimindeki sermaye akımlarının azaldığı görülmektedir. Aşağıdaki şekil Dünya ekonomisinde risk algılamasının düşük olduğu (VIX endeksinin düşük) dönemler süresince özellikle hisse senetlerine ve borçlanma enstrümanlarına yönelik sermaye akımlarının arttığını göstermektedir. Küresel kriz sonrasında Türkiye Cumhuriyet Merkez Bankası ve diğer gelişmekte olan piyasa ekonomilerinin yeni bir para politikası çerçevesine ihtiyaç duymasının nedeni uluslararası ekonomik konjonktürün yukarıda belirttiğimiz yapısından kaynaklanmaktadır. Sonuç olarak global hisse senedi piyasalarında nispeten risk algılamasının düşük olduğu dönemlerde Türkiye gibi gelişmekte olan piyasa ekonomilerine yönelik sermaye akımların ve bu ülkelerin çıkartmış olduğu finansal varlıklara olan talep artmakta ve ülkelerin risk primlerinde önemli azalışlar görülmektedir. Bu duruma iktisat yazınında sermaye akımlarının risklere açık (risk-on) olduğu dönem olarak adlandırılmaktadır. Tam tersine global anlamda hisse senedi piyasalarında oynaklığın arttığı dönemlerde yatırımcıların gelişmekte olan ülke finansal varlıklarına olan talebi azalmaktadır. İktisat yazının da bu duruma yatırımcıların risklere kapalı olunduğu (risk-off) durum denilmektedir (McCauley, 2012). Sermaye akımlarındaki bu oynaklık sanayileşmiş ekonomiler açısından çok büyük problemlere neden olmamaktadır. Fakat finansal piyasaların görece daha sı̆̆ olduğu, dış ticarette açıklık derecesinin yüksek olduğu, yabancı para birimi cinsinden finansal varlıklara olan ihtiyacın büyük olduğu ve reel sektörün üretim anlamında fazla bir çeşitlenme gösteremediği gelişmekte olan piyasa ekonomilerini makro ekonomik istikrarı ve finansal istikrarı iki açıdan tehdit etmekte ve uygulanan politikaları karmaşıklaştırmaktadır. İlki doğrudan cari işlemler açığı ve toplam talep üzerinde meydana getirmiş olduğu etkilerdir. Sermaye akımlarının hızlandığı dönemlerde gelişmekte olan piyasa ekonomilerinde çıktı açığı azalırken enflasyon yükselmekte ve reel döviz kuru orta vadeli denge değerinden sapmaktadır. Bu durum ekonomi açısından oldukça maliyetli olmaktadır. Karşılaşılan ilk maliyet enflasyon olurken, ikincisi dış ticarette ülkenin rekabetçiliğini kaybetmesidir. Bu durum karşısında merkez bankası yurtiçi talebi dengeleyebilmek ve enflasyonu kontrol altında 
tutabilmek amacıyla faiz oranlarını arttırmak durumunda kaldığında bu durum ülkeye yönelik sermaye akımlarının tekrar artmasına neden olmakta ve tekrar başa dönülmektedir. Böylece bu ekonomilerde sermaye akımları yurtiçi makro ekonomik dengeleri bozmaktadır. Sermaye akımlarının ekonomi üzerinde ikinci etkisi kredi genişlemesine dayalı varlık balonlarının oluşmasına zemin hazırlayarak ülkeyi ani duruş problemine karşı finansal olarak istikrarsız hale getirmektedir. Özellikle sermaye akımlarının hızlandığı dönemlerde bankalar kredi koşullarını esnetmekte bu durumda hızlı kredi genişlemesine neden olmakta bunun sonucunda varlık fiyatları hızlı bir biçimde artmaktadır. Ayrıca sermaye akımlarının hızlandığı dönemlerde yurtiçi finansal varlıklara olan talebin artması yerel menkul kıymet (tahvil, bono ve hisse senedi) ihraçlarının hızlanmasına neden olmakta bu ihraçlar sermaye akımlarını absorbe edip varlık fiyatları üzerindeki baskının hafiflemesine neden olmakta fakat kaldıraç oranlarının (borç / öz kaynak) artmasına yol açmakta bu durum ülkenin net yurtdışı yükümlülüklerinin artmasına neden olarak ani duruş problemine karşı ülkeyi kırılgan hale getirmektedir (IMF, 2011 ve Claessens ve Kose , 2013:9).

\section{Materyal ve Yöntem}

Çalışmanın bu bölümünde yurt içine gelen kısa vadeli sermaye akımlarını (sıcak para) üzerinde hangi yurt içi ve yurt dışı faktörlerin etkili olduğu araştırılmak istenmiştir. Sıcak para üzerinde etkili olduğu düşünülen değişkenlerin belirlenmesi bir bölüm önce verilen literatürden yararlanılmıştır. Çalışama da kullanılacak regresyon denklemi kurulurken Adler ve Tovar (2012) çalışmaları referans alınmıştır. Temele regresyon denklemi şu biçimdedir:

$$
\operatorname{swap}_{i t}=\beta+\alpha X_{i t}+\varepsilon_{i t}
$$

Burada swap sıcak parayı beta kesişim değerini $X$ ise sıcak parayı etkileyen değişkenler matrisini, $\varepsilon$, ise hata terimini simgelemektedir. Buradaki X matrisinide yer alan değişkenleri de kapsayacak biçimde model bir fonksiyon olarak aşağıdaki gibi yazılabilir

$$
\operatorname{swap}_{t}=f\left(C D S_{t}, E M B I_{t_{t}}, F F_{t}, V I X_{t}, L E V_{t}, R E E R_{t}, T C M B_{t}\right)
$$

Burada CDS hazine bonosu spreadlerini, EMBI, JP Morgan gelişmekte olan ülke piyasa bona endeksini, FF, FED funds'u, VIX, global riski, LEV kaldıraç oranlarını, REER reel döviz kurunu ve TCMB merkez bankası politika faiz oranını $\left(\mathrm{i}_{\mathrm{TR}}\right)$ simgelemektedir.

\subsection{Materyal}

Çalışma 2008-2012 dönemini kapsamaktadır ve yukarıda açıklanan her bir değişkene ait aylık zaman serileri kullanılmıştır. Kullanılan zaman serilerini Thomson data stream ve IMF (IFS) veri tabanlarından elde edilmiştir.

\subsection{Yöntem}

Eşbütünleşme analizi varsayımlarımdan birisi de durağanlıkla ilgili olduğundan değişkenlerin durağanlığının sınanmalıdır. Değişkenlerin durağanlığının sınanmasında ADF, PP ve KPSS gibi birim kök testleri kullanılabilmektedir. Bu testler de bir zaman serisi birim kök içermiyorsa durağan kabul edilmektedir. Bu çalışmada, Genelleştirilmiş Dickey-Fuler (ADF) (Dickey ve Fuller, 1979) kök testleri kullanılmıştır. Birim kök testlerinin sonuçları, Tablo 1'de sunulmuştur

\begin{tabular}{lll}
\hline \hline ADF TESTI & & \\
SERILIER & DÜZEY & BİRİNCI SIRA FARKLAR \\
Swap & 0.7496 & $-8.7198^{* * *}$ \\
EMBI & -1.4704 & $-5.9332 * * *$ \\
FF & -4.5683 & $-6.5027 * * *$ \\
VIX & $-2.8485^{*}$ & $-5.8096 * * *$ \\
REER & -1.0472 & $-6.4835^{* * *}$ \\
LEV & -2.2715 & $-2.7749 *$ \\
TCMB & $-3.7295^{* *}$ & $-5.0149 * * *$ \\
CDS & -2.3368 & $-5.7555^{* * *}$ \\
\hline \hline
\end{tabular}

Not: ADF testine göre serilerin durağanlığı sınanmış, buna göre *** olan yerlerde $1 \%$ anlamlılık düzeyine göre, ** olan yerlerde $5 \%$ anlamlılık düzeyinde ve * olan yerlerde $\% 10$ anlamlılık düzeyine göre null hipotezi reddedilerek serilerin durağan olduğunu öngören alternatif hipotez kabul edilmiştir. ADF testi için kullanılan gecikme sayısını Eviews 5.1 ekonometrik paket programının otomatik olarak seçtiği değer kabul edilmiştir.

\section{Tablo 1. Çalışmanın Değiş̧kenlerine Ait Durağanlık Testleri}

Tablo 1 de görüldüğü gibi analizde ele alınan, Swap, faiz, JP Morgan MB, , FED faiz oranı, reel döviz kuru, kaldıraç oranı ve CDS serilerinin düzeyde durağan olmadı̆̆ı, MB politika faiz oranın düzeyde durağan, VIX ise düzeyde zayıf durağan olduğu bulgularına uyarlanmıştır. Diğer yandan (2) numaralı tahmin denkleminde yer 
alan tüm değişkenlerin birinci sıra farklarının durağan olduğu yani birim kök olmadıkları bulgusuna erişilmiştir. Ancak kaldıraç oranlarının zayıf durağanlığa sahip olduğu görülmektedir. Bu sonuçlarla birlikte analizimiz bir sonraki aşamaya geçmeye olanak kazanmıştır. Birinci sıra farkları durağan olan seriler arasında uzun dönem ilişkinin olup olmadığı eş bütünleşme analizi ile belirlenmektedir. Bu çalışmada değişkenler arasında eş bütünleşmenin varlığ Johansen testi kullanılarak araştırılmıştır.

Johansen ve Juselius (1990), eş bütünleşme hipotezini test etmek için en çok benzerlik yöntemi (Maximum Likelihood Estimation) ve Likehood Ratio testlerini geliştirmişlerdir. Johansen testi birinci farkların ECM (Error Corection Model) formu şöyledir;

$$
\begin{aligned}
& \Delta \mathrm{X}_{1=} \Gamma_{\mathrm{t}} \Delta \mathrm{X}_{\mathrm{t}-1}+\ldots+\Gamma_{\mathrm{k}+1} \Delta \mathrm{X}_{\mathrm{t}-\mathrm{k}}+\Pi \mathrm{X}_{\mathrm{t}-\mathrm{k}}+\mu+\varepsilon_{\mathrm{t}} \mathrm{ve} \varepsilon_{\mathrm{t}} \sim \mathrm{N}(0, \Lambda) \mathrm{t}=1, \ldots, \mathrm{T} . \\
& \mathrm{H}_{1}(\mathrm{r}): \Pi=\alpha \beta \mathrm{d} \mathrm{r} \mathrm{r}
\end{aligned}
$$

Burada $\alpha \beta(\mathrm{nXn})$ boyutundaki matrislerdir $\Pi$ ve $\Gamma$ katsayı matrisleridir. $\Delta$ fark denklemini $\mathrm{k}$ ise gecikme uzunluğunu, $\mu$ (nX1) vektör sabit değeri, $\varepsilon_{\mathrm{t}}$ hata terimi vektörü ve $\Lambda(\mathrm{nXn})$ kovaryans matrisini göstermektedir. $\mathrm{H}_{1}$ (r) belli koşullar altında $\Delta \mathrm{X}_{1}$ sürecinin durağan olduğunu varsaymaktadır. Yani eşitlikte I (0) olduğundan sağ tarafın durağan olması ancak $\Pi \mathrm{X}_{\mathrm{t}-\mathrm{k}}$ ' nın durağan olmasıyla gerçekleşir. Eş bütünleşme testinde Johansen yaklaşımı Likelihood Ratio testine dayalıdır ve Trace ve max statistic testi olmak üzere iki ayrı test kullanılmaktadır.

$\Lambda_{\max }=-\boldsymbol{T} \Sigma_{i=r+1} \ln \left(1-\Lambda_{i}\right), r=0, \ldots, n-1$. Burada $\Lambda_{i}$ en yüksek eigenvalue değeridir. Max statistic testi ise $\Lambda_{\text {max }}=-\boldsymbol{T} \ln \left(1-\boldsymbol{\Lambda}_{i}\right)$ şeklindedir.

Aşağıdaki Tablo 2, tahmin denklemimizde yer alan değişkenler için yapılan Johansen Eş Bütünleşme test sonuçlarını göstermektedir.

\begin{tabular}{llll}
\hline \hline Null Hipotez & Trace Test & Null Hipotez & Maximum Eigenvalue Test \\
$\mathrm{r} \leq 0$ & $309.1989 * * *$ & $\mathrm{r}=0$ & $107.3405 * * *$ \\
$\mathrm{r} \leq 1$ & $201.8584 * * *$ & $\mathrm{r}=1$ & $59.61641 * * *$ \\
$\mathrm{r} \leq 2$ & $142.2420 * * *$ & $\mathrm{r}=2$ & $40.91777 * *$ \\
$\mathrm{r} \leq 3$ & $101.3242 * * *$ & $\mathrm{r}=3$ & 29.94335 \\
$\mathrm{r} \leq 4$ & $71.38087 * * *$ & $\mathrm{r}=4$ & $28.85046 * *$ \\
$\mathrm{r} \leq 5$ & $42.53041 * * *$ & $\mathrm{r}=5$ & 17.37649 \\
$\mathrm{r} \leq 6$ & $\mathrm{r}=6$ & $14.66283 * *$ \\
$\mathrm{r} \leq 7$ & $25.15392 * * *$ & $\mathrm{r}=7$ & $10.49109 * * *$ \\
\hline
\end{tabular}

Not: $r$, eş bütünleşme vektör sayısını göstermektedir. ***, ** ve * sırasıyla $\% 1, \% 5$ ve $\% 10$ anlamlılık düzeyinde null hipotezini (seriler arasında eş bütünleşme yoktur) reddedildiğini gösterir. Kullanılan kritik değerler varsayımlara göre (örneğin: doğrusal trend, sabit değer) farklılık göstermektedir. Johansen öncesi VAR gecikme sayısı 3 alınmıştır.

\section{Tablo 2. Johansen Eş Bütünleşme Testi Sonuçları}

Tablo 2‘de sunulan Johansen eş bütünleşme analizi, trace ve makximum eigenvalue test sonuçlarını yansıtmaktadır. Çalışmada, her iki testten elde edilen sonuçlara göre "Türkiye'de sıcak parayı etkilediğini düşündüğümüz değişkenler arasında eş bütünleşme ilişkisi aranmıştır. Trace (İz) testinden elde edilen bulgular, veri değişkenler arasında en az yedi eş bütünleşme ilişkisi olduğunu göstermektedir. Maksimum Eigenvalue testinde ise üç eş bütünleşme ilişkisinin olduğu bulgusuna erişilmiştir. Her iki testen elde edilen bulgular seçilmiş değişkenler arasında eş bütünleşme ilişkisinin olduğunu işaret etmektedir.

\section{Bulgular}

\subsection{Hata Düzeltme Modeli}

Eş Bütünleşme" analizi sonucu elde edilen bulgular bütün değişkenlerle sıcak para değişkeni (swap) oranı arasında bir eş bütünleşme ilişkisinin varlığına işaret etmektedir. Bu durum aralarında eş bütünleşme ilişkisi bulunan seçilmiş değişkenlerle swap arasında uzun dönemli bir ilişkinin varlığını göstermektedir. Aralarında uzun dönem bir nedensellik saptanan değişkenlerde görülebilecek kısa dönem sapmaların tekrar dengeye ulaşıp ulaşmayacağının saptanmasında "Hata Düzeltme Modelinden" yararlanılmaktadır. Dolayısıyla bu çalışmada da aralarında eş bütünleşme ilişkisi saptanan değişkenler arasında Hata Düzeltme Modelini Kullanmamızın gerektiği ortaya çıkmıştır. Daha açık bir ifadeyle Eşitlik (1) elde edilen hata teriminin bir gecikme değerini Eşitlik (3) de bağımsız değişken olarak katmamıza ihtiyaç olduğu görülmektedir.

$$
\begin{aligned}
& \Delta \operatorname{swap}_{t}=\beta_{0}+\beta_{1} \Delta M S C I_{t}+\beta_{2} \Delta F F_{t}+\beta_{3} \Delta V I X_{t}+\beta_{4} \Delta R E E R_{t}+\beta_{5} \Delta L E V_{t}+\beta_{6} \Delta i_{t}+ \\
& \beta_{7} \Delta C D S_{t}+\beta_{8} e c m_{t-1}+v_{t}
\end{aligned}
$$

Burada, $\Delta$ fark denklemini, $\beta_{0} \ldots \beta_{8}$ parametre değerlerini, ecm, hata düzeltme model terimini, $v$ ise hata terimini göstermektedir. Eş bütünleşme analizleri değişkenler arasındaki uzun dönemli denge ilişkisini 
göstermektedir. Ancak eş bütünleşme analizi eş bütünleşme ilişkisinin yönünü vermemektedir. ECM dayalı nedensellik testi bu ilişkinin yönünü vermektedir. Hata Düzeltme Modeli (VEC-Vector Error Correction), Granger(1987) çalışmasında geliştirilmiş bir modeldir ve zaman serileri arasındaki kısa ve uzun dönem dengesizliğinin giderilmesi için kullanılmaktadır. Daha açık bir ifade ile hata düzeltme modeli kısa ve uzun dönem arasında ayrım yapılmasına ve kısa dönem dinamiklerinin belirlenmesine olanak sağlamaktadır. Bu modelde hata terimi $(\mathrm{ecm})$ değişkenlerin kısa dönem davranışlarını uzun dönem davranışlarına bağlamak için kullanılmaktadır. Aşağıdaki Tablo 4 hata düzeltme modeli (ECM) bulgularını yansıtmaktadır.

\begin{tabular}{|c|c|c|c|}
\hline Değişkenler & Katsayı & Standart Sapma & Olasılık \\
\hline Kesişim*** & 7592.026 & 1334.017 & 0.0000 \\
\hline$\Delta \operatorname{MSCI}(-1)^{* *}$ & -203.8871 & 76.23900 & 0.0135 \\
\hline$\Delta \mathrm{FF}(-3)^{*}$ & -88198.45 & 50053.44 & 0.0913 \\
\hline$\Delta \operatorname{VIX}(-2) * *$ & -1089.250 & 396.9530 & 0.0116 \\
\hline$\Delta \operatorname{REER}(-2) * *$ & 185047.8 & 78686.67 & 0.0276 \\
\hline$\Delta \operatorname{Lev}(-1) * *$ & 32971.65 & 11744.20 & 0.0100 \\
\hline$\Delta \dot{\mathbf{I}}_{\mathrm{TR}}(-8) *$ & 2586.188 & 1269.601 & 0.0533 \\
\hline$\Delta \operatorname{CDS}(-1) * *$ & -216.6085 & 84.10049 & 0.0169 \\
\hline $\operatorname{ecm}(-1)^{* *}$ & -0.348517 & 0.132417 & 0.0149 \\
\hline $\operatorname{AR}(1)^{* *}$ & -0.460724 & 0.206780 & 0.0359 \\
\hline $\mathbf{R}^{2}$ & $\operatorname{Adj} \mathbf{R}^{2}$ & DW & Prob \\
\hline 0.78 & 0.64 & 2.0235 & 0.000115 \\
\hline
\end{tabular}

Not: * **, *** işaretleri sırasıyla $\% 10, \% 5$ ve $\% 1$ anlamlılık düzeylerini göstermektedir.

\section{Tablo 3. ECM Regresyon Analizi Sonuçları}

Tablo 3'de görülen hata düzeltme modeli sonuçları ele alınan değişkenler ile swap değişkeni arasındaki kısa dönem ilişkisi üzerinde bazı değerlendirmeler yapabilme olanağı sağlamaktadır. Tabloda yer alan tüm değişkenler ile swap arasında istatistiki olarak anlamlı bir ilişkisi olduğu bulgusuna ulaşılmıştır. Bu ilişkinin yönü MSCI, FF (FED Funds), VIX ve CDS için negatif $i_{T R}$ (TCMB politika faiz oranı), ve LEV (Kaldıraç oranı) için ise pozitif olarak saptanmıştır. Değişkenler arası ilişkilerin yönü beklendiği gibi çıkmıştır ve ekonomik kurama uygundur.

Bu çerçevede küresel riski yansıtan VIX değerinin yükselmesi, küresel risk iştahının azalmasına ve Türkiye gibi gelişen piyasa ekonomilerine doğru küresel sermaye akışının düşmesine yol açabilecektir. Benzer biçimde ülke riskini yansıtan CDS değerinin yükselmesi de ülkeye yönelik yabancı sermaye akımlarını azaltabilecektir. Ayrıca FED'in faiz artırımına gitmesi küresel sermaye akışının ABD’ye yönelmesine neden olacağı için Türkiye gibi ülkelerden sermaye kaçışları olabilecektir. Dolaysısı ile bu üç değişkenle Türkiye’ye yönelik sıcak para hareketleri arasında negatif bir ilişki olması beklenir ve nitekim bulgular beklendiği gibidir. Kaldıraçlı işlemlerin (LEV artan) yüksek olduğu dönemlerde Türkiye'ye gelen sermaye akımlarının da yüksek olması beklenir açıkçası sıcak para akımlarının yüksek olduğu dönemlerde bankacılık sektörü başta olmak üzere özel sektörün daha yüksek kaldıraç oranları ile çalıştığı ve riski arttırdığı görülmektedir. Buna karşılık sermaye akımlarının tersine dönmesi durumunda (sudden stop) banka ve özel sektörün yüksek kaldıraçlı işlemlerinin tersine döndüğü görülmektedir. Bu çerçevede kaldıraç oranları ve sıcak para ilişkisinin yönünün pozitif olduğunu söyleyebiliriz. TCMB politika faiz oranını yükseltmesi Türk lirası cinsinden yatırımların cazibesini arttıracağından sıcak para için cezp edici olacaktır bu bağlamda iTR ile swap arasındaki ilişkinin yönü pozitif olmalıdır. Reel döviz kuru ise ülke parasının değer kazanması ile birlikte pozitif bir görünüme sahip olacaktır buda sıcak para akışını arttıracaktır. Örneğin Türk lirasının dolar karşısında değer kazanması ucuz dolar cinsinden borçlanma imkanını ve ülkeye giren kısa vadeli yabancı sermayeyi arttıracaktır. Dolayısı ile Swap ve REER arasındaki ilişkinin yönün de pozitif olması beklenmektedir.

Eldeki bulgular gerek TCMB gerekse FED faiz politikalarının Türkiye'ye yönelik sıcak para hareketleri üzerinde zayıf ve daha uzun süreli etkiye sahip olduklarını göstermektedir. Zira FED politika karar değişikliğinin swap üzerindeki etkisi üç gecikme (üç ay) olurken TCMB politika faiz oranın sekiz gecikmedir (sekiz ay). Diğer yandan VIX, MSCI, CDS gibi riski yansıtan değişkenlerin Swap üzerindeki etkilerinin daha yüksek bir istatistiki anlam içerdiği ve gecikme sürelerinin daha kısa olduğu görülmektedir. Bu durum sıcak paranın lokal veya global riske daha duyarlı olduğu biçimde yorumlanabilir.

Uygulama sonucunda, hata düzeltme teriminin $\left(\mathrm{ecm}_{-1}\right)$ beklendiği gibi negatif ve istatistiki olarak anlaml olduğu görülmüştür. Bu durum bize değişkenlerde görülen kısa dönem sapmalara karşın modelin uzun dönem değerlerine yaklaştığını göstermektedir. Modele eklenen AR(1) (Auto Regression) katsayısının anlamlı değer almasından dolayı sistemde bir oto korelasyon probleminin olmadığını söyleyebiliriz.

\subsection{Varyans Ayrıştırması (Variance Decompozition)}

$\mathrm{Bu}$ çalışmada seçilmiş değişkenler arasında bir eş bütünleşme ilişkisinin olup olmamasının sorgulanması kadar, bu değişkenlerin swap değişkenindeki değişmelerini etkileme dereceleri de önemlidir. Dolayısıyla çalışmada bu yönde bulgulara ulaşılmasına imkan tanıyan VAR modelinden hareketle "varyans ayrıştırması" 
hesaplamaları yapılmıştır. Varyans ayrıştırması işleminin yapılabilmesi için ele alınan serilerin durağan olması önemlidir. Aksi takdirde durağan olmayan serilerle yapılan hipotez testleri kuşkulu hale gelmektedir. Bu yüzden çalışma içerisinde varyans ayrıştırma hesaplaması yaparken ele alınan serilerin birinci sıra farkları dikkate alınmıştır. Varyans ayrıştırması ile ilgili yapılan hesaplar aşağıdaki Tablo 4'da gösterilmektedir.

\begin{tabular}{|c|c|c|c|c|c|c|c|c|}
\hline $\begin{array}{l}\text { Dönem/ } \\
\text { Değișken }\end{array}$ & $\Delta$ Swap & $\Delta \mathrm{MSCI}$ & $\Delta F F$ & $\Delta V I X$ & $\triangle R E E R$ & $\Delta$ Lev & $\Delta \dot{\mathbf{I}}_{\mathrm{TR}}$ & $\Delta \mathrm{CDS}$ \\
\hline Q1 & 1000000 & 0.000000 & 0.000000 & 0.000000 & 0.000000 & 0.000000 & 0.000000 & 0.000000 \\
\hline Q2 & 64.03799 & 2.857800 & 9.189844 & 15.89902 & 6.238852 & 1.142504 & 0.453183 & 0.180808 \\
\hline Q4 & 55.54342 & 2.922473 & 14.98223 & 14.15484 & 8.461983 & 2.354681 & 1.403792 & 0.176585 \\
\hline Q6 & 46.50714 & 3.468034 & 16.73069 & 14.59487 & 13.28834 & 3.652419 & 1.550939 & 0.207568 \\
\hline Q8 & 51.83980 & 6.383366 & 12.81656 & 12.57672 & 10.89144 & 2.910456 & 2.365493 & 0.216164 \\
\hline Q10 & 48.05717 & 9.139675 & 15.44988 & 10.69084 & 10.94619 & 2.696890 & 2.769890 & 0.249461 \\
\hline Q12 & 46.63027 & 8.804066 & 14.45301 & 14.19208 & 10.16210 & 2.850187 & 2.665632 & 0.242649 \\
\hline Q14 & 46.07739 & 8.223417 & 15.19780 & 14.14034 & 9.855596 & 2.856094 & 3.415359 & 0.234012 \\
\hline Q16 & 44.64685 & 9.258239 & 15.67193 & 13.68248 & 10.00374 & 2.803849 & 3.705598 & 0.227308 \\
\hline Q18 & 44.15672 & 9.553646 & 15.28875 & 14.13737 & 9.776832 & 3.207857 & 3.648062 & 0.230769 \\
\hline Q20 & 43.73604 & 9.890643 & 15.18484 & 13.67317 & 9.853618 & 3.309531 & 4.118913 & 0.233241 \\
\hline Q22 & 42.85105 & 9.662190 & 14.67394 & 15.44858 & 9.648748 & 3.379006 & 4.106988 & 0.229490 \\
\hline Q24 & 42.47168 & 10.41700 & 14.52998 & 15.20191 & 9.666660 & 3.415888 & 4.046683 & 0.250193 \\
\hline
\end{tabular}

Tablo 4 Varyans Ayrıştırma Hesaplamasının Sonuçları

Tablo 4'de gösterilen varyans hesaplamasından elde edilen bulgular Türkiye'ye yönelik sıcak para akımının büyük ölçüde hata düzeltme modeli ile uyumludur. . Elde edilen bulgulara göre sicak parada meydana gelen değişimi açıklama gücü en yüksek değişkenler, MSCI, VIX ve FF(FED Funds) olarak karşımıza çıkmaktadır. Bu bağlamda sıcak paradaki değişimin açıklanmasında yurt dışı veya küresel faktörlerin daha belirgin bir paya sahip olduğunu söyleyebiliriz. Değişkenlere ilişkin bir başka önemli bulgu CDS'ler hariç tüm değişkenlerin zaman periyodu içerisinde sıcak para akımlarındaki değişimleri açıklama güçlerinin yüksek olmasıdır. Yurt dişı değişkenler kadar reel döviz kurunun da sıcak para akımlarındaki değişmeyi açıklama gücünün yüksek olduğu ve bu açıklama gücünün zaman periyotları içerisinde artış gösterdiği görülmektedir. Diğer yandan kaldıraç oranlarının da en az para politikası faiz oranı kadar sıcak para değişmelerini açıklama gücü olması dikkat çekici bir başka bulgudur. CDS oranlarının açıklama gücünün düşük çıkması ise ülke riski açısından umut verici bir bilgi olabilir.

\section{Sonuç}

Bu çalışma küresel finansal kriz sonrası Türkiye’ye gelen sıcak parayı etkileyen yurt içi ve yurt dışı faktörlerin belirlenmesini amaçlamıştır. Bu bağlamda değişkenler arasında uzun dönem ilişkinin varlığını test etmek için Johansen eş bütünleşme testinden, kısa dönem dinamiklerinin belirlenmesinde ise hata düzeltme modelinden yaralanılmıştır. Eldekii bulgular uzun dönemde veri setini oluşturan bütün değişkenlerle sıcak para arasında uzun dönemli ilişkinin varlığına işaret etmektedir. Kısa dönem etkilerine baktığımızda, sıcak paranın reel döviz kuru, TCMB politika faiz oranı ve kaldıraç oranı ile pozitif yönlü ve istatistiki olarak anlamlı bir ilişkisi olduğu anlaşılmıştır Yani merkez bankası politika faiz oranı ile sıcak para hareketlerine yön verebilmektedir. Ayrıca ülke para biriminin reel olarak değerlenmesi sıcak para için girişte ve çıkışta olmak üzere iki kere kazanç sağlayacağ için cezp edici olmaktadır. Bunlara ilaveten kaldıraçlı işlemlerin arttığı dönemlerde sıcak para akışının da arttığı ve aralarında kısa dönem ilişki olduğu bulgularca desteklenmektedir. Sıcak parayı etkileyen dişsal faktörler ise sıcak para arasında negatif bir ilişki vardır. Bu ilişki VIV, MSCI ve CDS'ler gibi küresel ve ülke riskini yansıtan değişkenlerde istatistiki olarak anlamlı çıkması sıcak paranın risk iştahına bağlı olarak hareket ettiği kanıtlamaktadır. Bu bağlamda küresel veya ülkeye özgü risklerin artması ani duruş (sudden stop) problemine yol açmakta ve ülke kırılganlığını arttırmaktadır diyebiliriz. Diğer yandan FED’in politika faiz oranı üzerinde yaptığı değişikliklerin Türkiye ekonomisine yönelik sıcak para hareketleri ile negatif ancak istatistiki olarak düşük anlamlılığa sahip olduğunun anlaşılması da FED faiz politikasının doğrudan değil dolaylı olarak sıcak para hareketine yön verdiği biçimde yorumlanabilir.

Çalışmada son olarak seçilmiş değişkenlerin sıcak para hareketlerinde meydana gelen değişmeyi açıklama güçlerine bakılmıştır. Bulgular sıcak parada meydana gelen değişmelerin en fazla kürsel değişkenler tarafından açıklandığına işaret etmektedir. Bu durum Türkiye’ye yönelik sıcak para hareketlerinde kürsel risk algılamalarının büyük etkisi olduğu biçimde ifade edilebilir. Ancak reel döviz kurundaki değişmelerde sıcak para hareketini açıklama gücü yüksek değişkenler arasında yer alması Türkiye’ye yönelik sıcak paranın kur değişimlerini dikkate almaya devam ettiği şeklinde yorumlanabilir.

Son olarak elde edilen bulgular Türkiye'ye yönelik sıcak para akımlarının risk on ve risk off uygun hareket gösterdiğini desteklemektedir. Ayrıca kaldıraç oranları ile sıcak para hareketi arasında hem uzun hem de kısa dönem ilişkisinin varlığı dikkate alındığında sıcak paranın ülke ekonomisinde yaratabileceği olumsuzluklar 
karşısında makro ihtiyati politikaların önemi ortaya çıkmaktadır. Diğer yandan reel döviz kuru değişmelerinin sıcak para hareketini etkilediği düşünüldüğünde, döviz kuru ile enflasyon arasından doğrudan ve dolaylı ilişki ihmal edilmemeli ve finansal istikrar yanında fiyat istikrarı hedefinden de vazgeçilmemelidir. Zira fiyat istikrarı hedefinden sapma sıcak para hareketlerinin risk algılamalarında olumsuzluk yaratabilir ve ülke ekonomisinin kırılganlıkları artabilir.

\section{Kaynakça}

- Bernanke, S. Ben., Mark Gertler., (1999) “Monetary Policy and Asset Price Volatility,” In New Challenges for Monetary Policy: Proceedings of the Federal Reserve Bank of Kansas City Economic Symposium at Jackson Hole, 1999 (Kansas City: Federal Reserve Bank).

- Bernanke, S. Ben., Mark Gertler., (2001), "Should Central Banks Respond to Movements in Asset Prices?", American Economic Review, 91 (May), pp. 253-57.

- Bernanke, S.Ben.,(2004), "International Monetary Reform and Capital Freedom” conference remarks at Cato Institute, 22nd Annual Monetary Conference,October 14,2004, pp.1-12 (Washington:Cato Institute) available at http://www.federalreserve.gov/boarddocs/speeches/2004

- Blanchard, Olivier, (2000), “Bubbles, Liquidity Traps, and Monetary Policy,” in: Japan's Financial Crisis and its Parallels to the US Experience, Ryoichi Mikitani and Adam Posen (eds.), Institute for International Economics Special Report 13 (Washington DC: Peterson Institute for International Economics)

- Blanchard, Olivier, (2000), “Bubbles, Liquidity Traps, and Monetary Policy,” in: Japan's Financial Crisis and its Parallels to the US Experience, Ryoichi Mikitani and Adam Posen (eds.), Institute for International Economics Special Report 13 (Washington DC: Peterson Institute for International Economics)

- Blanchard, Olivier., Giovanni Dell'Ariccia ve Paolo Mauro, (2010), "Rethinking Macroeconomic Policy", IMF Staff Position Note SPN /10/03, February 12, 2010.(Washington DC: International Monetary Fund, February 2010).

- Blanchard, Olivier., Giovanni Dell'Ariccia ve Paolo Mauro, (2013), "Rethinking Macro Policy II: Getting Granular", IMF Staff Discussion Note SDN 13/03, April 15, 2013 (Washington DC: International Monetary Fund, April 2013).

- Blanchard, Olivier., John Simon., (2001), "The Long and Large Decline in U.S. Output Volatility" Brookings Papers on Economic Activity, Vol. 2001, No. 1. (2001), pp. 135-164.

- Borio, Claudio,, William White., (2003), "Whither Monetary and Financial Stability? The Implications of Evolving Policy Regimes," in Monetary Policy and Uncertainty: Adapting to a Changing Economy: Proceedings of Federal Reserve Bank of Kansas City Economic Symposium at Jackson Hole, 2003 (Kansas City: Federal Reserve Bank).

- Catão, A. Luis., , Gian Maria Milesi-Ferretti., (2013), "External Liabilities and Crises” IMF Working Paper No.13/113 May, 2013 (Washington DC: International Monetary Fund, May, 2013).

- Claessens, Stijn., M. Ayhan Kose., (2013), "Financial Crises: Explanations, Types, and Implications” IMF Working Paper, WP/13/28, January, 2013 (Washington DC: International Monetary Fund, January 2013).

- Eichengreen, Barry.,Mohamed El-Erian., Arminio Fraga.,Takatoshi Ito.,Jean Pisani-Ferry., Eswar Prasad., Raghuram Rajan.,Maria Ramos.,Carmen Reinhart.,Hélène Rey., Dani Rodrik.,Kenneth Rogoff., Hyun Song Shin.,Andrés Velasco.,Beatrice Weder di Mauro., Yongding Yu., (2011), "Rethinking Central Banking” Committee on International Economic Policy and Reform Brookings Institution, September 2011

- Galati, Gabriele., Alexandra Heath., Patrick McGuire., (2007), "Evidence of Carry Trade Activity” BIS Quarterly Review International Banking and Financial Market Developments in Special Features, September 2007,pp.27-41 (Basel: Bank for International Settlements, September 2007).

- Hahm, Joon-Ho., Frederic S. Mishkin, Hyun Song Shin, Kwanho Shin., (2012), "Macroprudential Policies in Open Emerging Economies" NBER Working Paper No. 17780, January 2012 (Cambridge, Massachusetts: National Bureau of Economic Research)

- Hoenig, Thomas., (2010), “The High Cost of Exceptionally Low Rates,” speech given at Bartlesville Federal Reserve Forum, Bartlesville, Oklahoma (June 3) http://www.kansascityfed.org/SpeechBio/HoenigPDF/Bartlesville.06.03.10.pdf

- International Monetary Fund, (2004), “Global Financial Stability Report Market Developments and Issues in Chapter IV. Global Financial Market Developments, Appendix I: Determinants of the Rally in Emerging Market Debt_Liquidity and Fundamentals", April 2004 (Washington DC: International Monetary Fund, April 2004).

- International Monetary Fund (2010), “Central Banking Lessons from the Crisis” Prepared by the Monetary and Capital Markets Department (Washington DC: International Monetary Fund, May 27, 2010). 
- International Monetary Fund, (2011), "World Economic and Financial Surveys World Economic Outlook: Tensions from the Two-Speed Recovery: Unemployment, Commodities, and Capital Flows in Chapter 4. International Capital Flows: Reliable or Fickle?” April 2011, pp.125-163(Washington: International Monetary Fund, April 2011)

- International Monetary Fund, (2012), "World Economic and Financial Surveys: Global Financial Stability Report: The Quest for Lasting Stability, Chapter 2. Sovereigns, Banks, and Emerging Markets: Detailed Analysis \& Policies" April 2012 pp.35-51 (Washington DC: International Monetary Fund, April 2012).

- International Monetary Fund,(2013a), “The Interaction of Monetary and Macroprudential Policies" January 29, 2013 (Washington DC: International Monetary Fund, January 2013)

- International Monetary Fund,(2013b), "World Economic and Financial Surveys :Global Financial Stability Report: Old Risks, New Challenges” (Washington DC: International Monetary Fund, April 2013)

- $\quad$ Lane, R. Philip., Gian Maria, Milesi-Ferretti., (2006), “The External Wealth of Nations Mark II: Revised and Extended Estimates of Foreign Asset and Liabilities, 1970-2004” IMF Working Paper No.06/69 March, 2006 (Washington DC: International Monetary Fund, March, 2006).

- McCauley, Robert N., (2012), "Risk-On/risk-Off, Capital Flows, Leverage and Safe Assets" Economies BIS Working Papers No 382, July 2012., (Basel: Bank for International Settlements, July, 2012).

- Mishkin S. Frederic., (2010), “Monetary Policy Strategy: Lessons from the Crisis” Prepared for the ECB Central Banking Conference, "Monetary Policy Revisited: Lessons from the Crisis," Frankfurt, November 18-19, 2010

- Ostry, Jonathan D., Atish R. Ghosh, Marcos Chamon.,(2012), "Two Targets, Two Instruments: Monetary and Exchange Rate Policies in Emerging Market Economies” IMF Staff Position Note SPN/12/01 February 29, 2012 (Washington DC: International Monetary Fund, February 2012).

- Özatay, Fatih., Erdal Özmen.,Gülbin Şahinbeyoğlu.,(2008b), "Does Globalization Undermine the Efficiency of Inflation Targeting” Economic Research Forum 15th Annual Conference 23rd-25th November 2008 Cairo, Egypt.

- Rajan, G. Rhaguram., (2005), “Has Financial Development Made the World Riskier?” NBER Working Paper No. 11728, November 2005 (Cambridge, Massachusetts: National Bureau of Economic Research)

- $\quad$ Rajan, G. Rhaguram., (2010), "Bernanke Must End Era of Ultra-Low Rates," Financial Times (July 28), http://www.ft.com/cms/s/0/2a19a706-9a7a-11df-87fd-00144feab49a.html

- Rozada, Martín González., Eduardo Levy Yeyati., (2006), "Global Factors and Emerging Market Spreads" Inter-American Development Bank Research Department Working Paper No.552, May, 2006 (Washington DC: Inter-American Development Bank).

- Unsal, D. Filiz., (2011) “Capital Flows and Financial Stability: Monetary Policy and Macroprudential Responses", IMF Reserach Bulletin, Volume 12, Number 3. (Washington DC: International Monetary Fund, September 2011). 


\title{
Bağımsız Düzenleyici Denetleyici Kurumların Bankacılık Sektörünün Yeniden Yapılanmasında Önemi: Türkiye Örneğinden Geçiş Ekonomilerinin Alabileceği Dersler
}

\section{The Importance of Independent Regulatory and Supervisory Agencies in Restructuring of the Banking Sector: Lessons for Transition Economies from the Case of Turkey}

\author{
Asst. Prof. Dr. Resül Yazıcı (Şeyh Edebali University, Turkey) \\ Asst. Prof. Dr. Ayla Yazıc1 (Anadolu University, Turkey)
}

\begin{abstract}
For countries, who did not know whence and how to start the quest for reform, that has come into question because of crises and downfalls, the solution process extends and the cost increases. In countries that are in the process of restructuring, the most important reform to alleviate these adversities will be the establishment of independent regulatory and supervisory agencies. The financial sector which is acting as an intermediary in the development of market economies should be at most subject to regulation and supervision. However, if these regulations and supervisions are supragovernmental the success of the transition to market economies will improve quickly. In this study the causes of the banking crises experienced in Turkey in 2001, and the means of solution to overcome them, are discussed. Owing to the creation of independent regulatory and supervisory agencies, the Turkish banking sector has qualitatively and quantitatively grown and has transfered positive externalities to the economy. Especially due to the efficient functioning of the regulatory and supervisiory agencies in the banking sector, Turkey has so far successfully managed the global financial crises. In this context with this study, it is aimed to present for transition economies in the process of restructuring, that the services of resource utilization to the private sector, which is the main function of banking, will develop and, like Turkey, these countries can achieve the same outcomes. This means that, these economies can benefit from Turkey's experiences.
\end{abstract}

\section{Giriş}

Geçiş ekonomisi ifadesi (ki çalışmada da bu amaçla kullanılan kavram), ilgili ülkedeki bütün ekonomik yapının, kural ve kurumları ile zorlu süreçlerden geçerek kabuk değiştirmesi anlamına gelmektedir. İktisadi sistemlerdeki değişim olarak bakıldığında ise: "Geçiş Ekonomisi, piyasa ekonomisinin alternatifleri olan sosyalist veya karma ekonomilerin; küreselleşme çağında ve açık ekonomi koşullarında, kendilerini piyasa ekonomisine uyarlamaları sürecine verilen addır” (Akalın, 2003). Özellikle Sovyetler Birliği’nin dağılmasından sonra, kendi içlerinde planlı ekonomiden liberal ekonomiye geçmekte olan ekonomiler için kullanılan kavram; aynı zamanda onların küreselleşme sürecine de uyumları için yapmak zorunda oldukları reformları da ifade etmektedir.

Çünkü bu uyarlanma süreci kaçınılmaz olmaktadır. Yani "sosyalist veya karma ekonomiler piyasa ekonomisine kendi istekleriyle geçmemektedirler. Küresel ekonominin rekabetçi yapısına ve piyasa güçlerinin işleyişine ayak uyduramayan piyasa ekonomisinin alternatiflerini benimsemiş ülkeler, ekonomik kriz denilen bir çöküntü ile karşılaşmaktadırlar” (Akalın, 2003).

Ekonomilerinde yaşadıkları çöküntü sonrasında gündeme gelen değişim, çözüm arayışları, nereden başlanacağı gibi kararsılıklar bu ülkelerdeki gerekli reformlar için hayati kararlar alınmasını ve uygulanmasını zorlaştırmaktadır. Çünkü bu süreçte başarılı olma hızı ülkeden ülkeye farklılık gösteren yapısal özelliklere ve bunları değiştirme isteğine bağlıdır. Tabii ki bu değişime her yönüyle hazır olan, reformları en kısa sürede hayata geçiren ülkeler, geçişi daha az maliyetle ve kısa sürede gerçekleştirir.

Bu reformlardan en önemlileri, devletin düzenleyici rolünü üstlenen, denetim ve gözetim işlevlerini hakkıyla yerine getirebileceği yapılar; üst kurullar, bağımsız düzenleyici kurumlar olarak adlandırılmaktadır.

Bağımsız düzenleyici, denetleyici kurumların, öncelikle finans sektöründe oluşturulması gerekmektedir. Çünkü geçiş ekonomisi sürecinde olan ülkelerin temel sorunları; yetersiz sermaye birikimine ve piyasa aksaklıklarına sahip olmalarıdır. Bu sektör sayesinde işleyecek olan aktarım mekanizmaları sayesinde diğer kesimlerin yeniden yapılanması daha kolay olacaktır.

Zaten piyasa ekonomilerinin gelişiminde önemli bir aracılık görevini yerine getiren finans sektörü ve onun önemli bir parçası olan bankalar, en fazla düzenleme ve denetlemeye tabi olan kurumlar arasındadır. Fakat bu düzenlemelerin ve denetlemelerin hükümetler üstü olması; hem bu kurumların hem de ekonomilerin piyasa ekonomisine geçişlerinin başarısını artıracaktır. 
Düzenleyici, denetleyici kurumların gelişmiş ekonomilerde oluşturulmuş fakat işletilmemiş; bağımsızlığının verilmemiş olmasının sonuçları; etkileri devam eden 2008 küresel finans krizinde görülmektedir.

Krizin temeli bilindiği gibi kısaca: ABD'deki ipotekli konut kredisi sisteminde, kaynak yaratılması sürecinde; bilanço dışı işlemler, türev ürünler ve verilen kredilerin yönetilememesiyle finans krizi olarak ortaya çıkmıştır. İpotekli konut finans sisteminde kaynak yaratılması sürecinde, finansman işlemlerinin uluslararası finans sisteminden de desteklenmesiyle uygulamalar küreselleşmiştir. Bu kredi işlemlerindeki küreselleşme sonrasında; likiditesi daralan küresel finans sisteminden borçlanan ülkelerin, borçlarını çevirememesiyle; kriz, bulaşıcı etkileriyle yaygınlaşmaya başlamıştır. Çoğu ülkelerde bu süreç, kamu borç krizine dönüşmüsstür.

Gereğinden fazla liberal uygulamaların yol açtığı bu krizlerden alınması gereken temel dersler; ekonomideki finansal tarafların aşırı kazanma hırslarının kendi haline bırakılamayacă̆ı; finansal sistemlerin, kurumların ve araçların çok hızlı büyümesini sağlayan serbestleştirme sürecine hazırlıksız girilemeyeceğidir. Çünkü finansal sistemdeki gerekli teknik altyapının düzenlenmesi ve denetlenmesi mekanizmasının kurulmamasıyla oluşturulan ekonomik yapılanmalar büyük riskler taşımaktadır.

Bu riskleri ve hükümetlerin popülist müdahalelerini azaltmak için, bağımsız düzenleyici, denetleyici yapıların oluşturulmuş ve işletilmiş olmasının ne kadar önemli olduğu, 2008 küresel finans krizini genel olarak başarıyla yönetebilen Türkiye tecrübesinde görülmüştür.

Bu çalışmada da, geçiş ekonomilerinin ders alabileceği Türkiye tecrübelerine yer verilmiştir. Özellikle 2001 yılında en sert bankacılık krizini yaşayan Türkiye'nin, bankacılık krizinin nedenleri ve bunları aşmada uygulamaya koyduğu çözüm araçları incelenmiştir. Türk Bankacılık Sektörü’nde, yeniden yapılanma ile oluşturulan bağımsız düzenleyici, denetleyici kurumlar sayesinde sektör niteliksel ve niceliksel olarak gelişmiştir. Bu gelişimin sonuçları sektör rakamlarına olumlu yansımışıı ve küresel finans krizini şimdiye kadar başarıyla yönetebilmiştir. Türkiye'nin bu tecrübesiyle; geçiş ekonomilerinin bankacılık sisteminde; uzun süreli istikrarı sağlayabilmek için oluşturulması gereken bağımsız düzenleyici, denetleyici yapıların meydana getirilmesinin ve işletilmesinin ne kadar önemli olduğu gösterilmektedir.

Zira geçiş süreci o kadar kolay değildir. Değişimde her ne kadar acele edilse de başarılı olunması şansa bağlıdır. Çünkü "bu paradigma kapsamında uygulanan reform stratejilerinin öncelikli amacı bir an evvel serbestleşme (liberalizasyon) sürecinin başlatılması ve özel mülkiyete dayalı bir piyasa ekonomisinin inşa edilmesidir. Dolayısıyla neoklasik iktisat politikaları; ekonomik faaliyetler üzerindeki kısıtlamaların kaldırılması (deregülasyon), liberalizasyon, minimal bir devlet, ekonominin dışa açılması gibi birçok alanda, ilgili ülkenin başlangıç koşulları, büyüklüğü, kaynak rezervi, sosyal yapısı, kurumları, uluslararası ilişkileri ve tarihsel gelişimi dikkate alınmaksızın devreye sokulmuştur. Oysa bir yanda piyasa ekonomisi ile taban tabana zıt eski sistemin mirası, diğer tarafta tüm kurum ve kuruluşlarıyla tamamen yeni bir düzenin inşası, geçiş sürecinin en zor ve karmaşık sorunu olagelmiştir. Burada özellikle belirtilmesi gereken nokta geçişin her şeyden önce kurumsal bir değişim olması"nı sağlamaya yönelik olmalıdır. Bunun başarılabilmesi için, bu düzenlemelerin, hükümetler üstü olması gerekmektedir. Böylece hem bu kurumların hem de geçiş ekonomilerinin piyasa ekonomisine hızla eklemlenmede başarılı olma şansı artacaktır (Güler, 2012).

\section{Yeniden Yapılanmada Bağımsız Düzenleyici Denetleyici Kurumların Önemi}

Piyasa ekonomisine geçiş sürecinde olan ekonomilerde, kamu mülkiyetinde olan işletmelerde, etkin olmayan yönetimlerle ortaya çıkan zararların sürdürülemez hale gelmesi veya "bağımsız olamayan seçilmiş ve atanmış kamu görevlilerinin, kamu malının yönetilmesinde özel sektör yöneticileri kadar etkin olamamaları; kamu sektörünün özel sektöre göre başarısızlık nedenlerinin temellerini oluşturmaktadır. Seçilmiş ve atanmışların, kamusal kaynakları yönetirken, bunları toplum yararına ve yasalara göre idare ettikleri konusunda hesap vermeye ve bireylerin de bu hususları sorgulamaya uygun bir yapılanma süreci ülkelerin geleceği için gereklidir (Şimşek ve Yazıcı, 2008, 399).” Bu yapılanmada bağımsız düzenleyici, denetleyici kurumların oluşturulmasının ne kadar önemli olduğu ortaya çıkan finansal krizlerle teyit edilmiş̧ir.

Kriz dönemleri yanında normal dönemlerde de: Piyasa aksaklıklarının ortadan kaldırılmasıyla, kaynak tahsisinde etkinliği sağlayabilecek; ekonomik sistemi rasyonelleştirebilecek; piyasaların kamu müdahalesinden kurtarılmasını ve mali baskınlık sonucu özel yatırımlar üzerindeki kamu harcamalarının sınırlayıcı, haksız rekabet yaratıcı etkilerinin ortadan kaldırılmasını sağlayacak; oyunun kurallarını koyan ve denetleyen disipline edilmiş bir piyasa; Bağımsız Düzenleyici ve Denetleyici Kurumlar ile sağlanabilecektir.

Bu gerçekleri özellikle, kamunun bütçe açıklarının finansmanını ve borç yönetimini başarıyla uygulayabilmek için mali disiplin dışında gerekli olan; çeşitli politikaların ve kurumların eş zamanlı çalışmasını sağlamaktır. Bu da; otoritenin, yönetimsel hatalarını azaltmak için uygulamaya aktarılan minimal devlet yaklaşımlarıyla; yani, hükümetlerin ekonomideki karışmacı rolünün en aza indirilmesiyle; bağımsız düzenleyici - denetleyici yapıların oluşturulmasıyla sağlanabilmektedir (Yazıcı, 2012, 259).

Devletin ekonomiye müdahalesinin haklı gerekçelerine karşın; uygulama sonuçlarının da aynı şekilde başarılı olmadığı günümüz gerçeklerinde görülmektedir. Yani bir dönem gerekli olan kamu müdahaleleri-kamu 
işletmeciliği günümüzde gerekmemekte veya müdahale şekli değişmektedir: Piyasa ve devlet birbirini dışlamamalı yani müdahaleler sınırsız olmamalı fakat doğru zamanda, tam yerinde ve uygun bir şekilde yapılmalıdır. Mali disiplini sağlayıcı şeffaflık uygulamaları, kamu gelirlerini artırıcı politikalar, profesyonel yönetimin olmadığı kamu işletmelerinde özelleştirme, piyasa ekonomisinin olmazsa olmazı hukuksal ve kurumsal altyapının oluşturulması; birileri (IMF) istediği için değil ülke geleceği için yapılmalıdır. Çünkü artan kamu açıklarının sı ̆̆ mali piyasalarda yarattığı yüksek faiz oranlarıyla; bütçe içinde faiz harcamaları artmakta, crowding-out etkisiyle özel sektör mali piyasalardan dışlandığından kaynaklar sadece kamuya-etkin olmayan kullanıma akmaktadır (Yazıcı, 2004,163-164).

$\mathrm{Bu}$ şekildeki ekonomilerde, yönetimden kaynaklanan olumsuzlukların, kötü alışkanlıkların kısa sürede giderilebilmesi mümkün değildir. $\mathrm{Bu}$ şartlanmış davranışların değiştirilmesi, radikal reformlarla, politikalarla mümkün olabilecektir. "Bu politikalar çerçevesinde, çoğu gelişen ülke ekonomisinde diş ticaret, mali piyasalar ve kamu maliyesinde etkinliği artırmak amacıyla önemli reformlar yapılmıştır. Rekabetçi ve tek bir döviz kuru uygulaması, faiz hadlerinin serbestleştirilmesi, ticari serbestleşme, özelleştirme, vergi gelirlerinin artırılması ve kamu harcamalarının disipline edilmesine yönelik düzenlemeler bu reformların önemli araçları olmuştur. Ancak birinci nesil reformlar olarak da adlandırılan ve makroekonomik istikrarı sağlamanın yanı sıra devletin ekonomideki rolünü en aza indirmeyi amaçlayan bu tür reformlar piyasaların nasıl gelişeceğinden daha çok nasıl işleyeceği üzerinde yoğunlaşmıştır” (Emek ve Diğerleri 2002, 42).

Devlet yönetimindeki klasik bürokrasinin müdahale şekli ve ölçüsü, ortaya çıkan krizlerle; kamu ekonomisinin başarısızlıklarıyla tartışılmaktadır. Kamunun yönetimdeki, denetimdeki yerinin, siyasal sistemden bağımsız, saydam ve hesap verebilen kurumlara verilmesinin önemi, bunların kriz dönemlerindeki başarılarında görülmektedir. Çünkü popülist anlayışın olmadığı yapılarda hatalar daha az ve telafisi daha kolaydır. Bu nedenle bağımsız düzenleyici ve denetleyici kurumlara, ülkelerin yeniden yapılanmasında; kurumsallaşma ilkelerinin uygulanmasında önemli görevler düşecektir.

Özellikle tüketicilerin egemen olduğu piyasa ekonomisine geçişin başarılabilmesi için; düzenleyici, denetleyici kurumların oluşturulması ve hükümetler üstü olabilmesi için de, bağımsızlığının sağlanması gerekir. Piyasa ekonomisine geçiş uygulamalarındaki başarıda, küreselleşme sürecine uyum derecesi de önemlidir. Çünkü piyasa ekonomilerini, dünya ölçeğinde - serbest piyasa koşullarında oluşan fiyatlar yönlendirir.

Küreselleşme sürecinde, ulusal rekabet gücünün yaratılabilmesi için de; üretimden tüketime, üretim süreçlerini düzenleyen ve denetleyen kalite sistemlerinin kurulmasını, mülkiyet haklarının tanınmasını ve korunmasını da bağımsız düzenleyici otoriteler sağlayacaktır.

Tüketici refahını olumlu yönde etkileyecek tüm “özelleştirme uygulamalarının başarısı için özelleştirme yöntemleriyle birlikte piyasa ekonomisinin müesseseleri de önem taşımaktadır. Piyasa ekonomisinin müesseselerinden olan ve kaynak dağılımını yeniden sağlamaya aracılık eden sermaye piyasaları, iflas müessesesi ve iyi düzenlenmiş bir ticaret kanunu olmadan ve bölgesel gelişmişlik farkları dikkate alınmadan, özelleştirmeden beklenen faydaları olan rekabet, kaynak dağılımında etkinlik ve firma yönetiminde verimlilik hedeflerine ulaşılması mümkün değildir” (Yaşar, 2007, 174-175).

\section{Türk Bankacılık Sektöründeki 2001 Krizi Sonrasında Yeniden Yapılanma ve Bağımsız Düzenleyici Denetleyici Kurumların Oluşturulma Sürecine Genel Bakış}

Türk Bankacılık sektöründe krizler; sektörü yöneten ve denetleyenlerdeki düşük risk anlayışının şekillendirdiği yanlış uygulamaların, ekonomik yapının ve onları şekillendiren popülist politikalardaki hataların birikiminin bir sonucudur. Yani makro ekonomik dengesizliklerin olduğu, tutarlı politikaların sürdürülebilir olmadığı bir yapıda bankacılık sektörünün de istikrarlı olmasını beklemek yanlıştır.

Bu yanlışlara ilave olarak; artan borç stoku nedeniyle kamunun; hem bankacılık sisteminin en önemli müşterisi olması hem de sistemi düzenleyen ve denetleyen görevlerini başarıyla yerine getirmesi beklenemez. O dönemde bağımsız olmayan - olamayan düzenleyici, denetleyici otoritelerin başarısız olmasının sebepleri aşağıdaki şekilde özetlenebilir (Yazıc1, 2012, 253-254):

- Siyasi otoritenin, popülist, programsız, yanlış politika seçimi ve uygulamalarıyla; Türkiye ekonomisinin serbestleştirme, dişa açılma sürecinin yönetilememesi.

- $\quad$ Kamunun kötü performansının ve artan bütçe açıklarının neden olduğu çevrilemeyen borç stoku.

- $\quad$ Artan kamu borç stokunun, mali baskınlığa yol açması.

- $\quad$ Mali baskınlığın etkilediği temel fiyatların; kur ve faizi dolayısıyla enflasyonist bekleyişleri artırması.

- $\quad$ Enflasyonist sürecin; güçsüz, denetimsiz bankacılık sektörünün risk yönetimini zayıflatmasıyla aktarım mekanizmasında etkinliğin azalması ve dışlama etkisinin ortaya çıkması.

Böylece hem enflasyonu besleyen bir süreç hem de yetersiz tasarrufların kamuya akışının ortaya çıkardığı kur ve faiz kanalıyla (özel ve kamu) bankacılık sektörünün; menkul kıymet yatırımlarının, mevduatlarının, kredilerinin ve kârlarının kamu tarafından şekillendirildiği bir süreç yaşanmıştır. 
Kamu bankaları üzerindeki baskılar nedeniyle de ortaya çıkan görev zararlarının ve kullandırılan kredilerin geri dönüşünde sorunlar olması, üretime aktarılamaması; hem reel sektörde büyümeyi olumsuz etkileyen

hem de finans sektörünün krize sürüklenmesini artıran bir durum yaratmıştır.

Türkiye ekonomisindeki krizlerin temel nedenleri olarak özetlenebilecek bu durumların artık daha fazla sürdürülemez hale gelmesiyle ortaya çıkan 2001 krizi; maliyetleri çok yüksek olmasına rağmen ve/veya başka çare kalmadığından; yeniden yapılanmanın sağlanabilmesi için heteredoks istikrar programlarının uygulandığı bir dönemi başlatmıştır. Makro anlamdaki önlemleri içeren bu istikrar programları, bankacılık sektöründe IMF'nin direktifleriyle sert bir şekilde uygulanmıştır.

Türk bankacılık sektöründe o dönemde acı faturalara katlanmanın temel amacı; bankacılık sektörünün gelecekteki etkinliğini artırmaktır. $\mathrm{Bu}$ hedefe ulaşılabilmesinde çeşitli araç ve teknikler kullanılmış ve günümüzde de kullanılmaya devam edilmektedir. "Yeniden yapılandırma programlarında kullanılan enstrüman ve teknikler aşağıda sıralanmıştır" (Çolak, 2005, 152):

- Devletten bankalara sermaye aktarımı,

- Sorunlu krediler problemleri ile ilgilenecek aktif yönetim (asset management) şirketlerinin kurulması,

- $\quad$ Merkez bankalarından likidite desteği,

- $\quad$ Kamu bankalarının özelleştirilmesi,

- $\quad$ Sorunlu kredilerin devlet tahvili ile değiştirilmesi,

- Bankalar tarafından yeni hisse senedi ihracı ve senetlerin bir kısmının veya tamamının (geçici olarak) devlet tarafindan satın alınması,

- Banka birleşmeleri,

- Yabanci bankalara devirler,

- $\quad$ İflas etmiş bankaları kapatmak veya idaresini kapanma işlemleri sonuçlanana kadar programı yürüten kurumun kontrolüne alınması,

- Sorunlu bankanın faaliyetlerinin bazı bankacılık ürünlerinden ve alanlarından çekilmesi veya düzenlemeler yapılması ile yeniden şekillendirilmesi (splits), (Bu düzenlemeler genellikle yabancı bankalarla birlikte yapilmaktadir).

- Sorunlu bankalara dişarıdan gerek teknik gerekse danışmanlık gibi destekler vererek bankacılık operasyonları ve faaliyetlerinde daha iyi bir düzeye ulaşılması, (twinning)

- $\quad$ Banka sahipliği ve yöneticiliğine bazı düzenlemeler getirilmesi.

2001 krizi sonrasında yukarıda sıralanan enstrüman ve tekniklerin çoğunu kullanan BDDK'nın (Bankacılık Düzenleme ve Denetleme Kurumu) ve TMSF'nin (Tasarruf Mevduatı Sigorta Fonu) hedefi şu şekilde özetlenebilir: Türk bankacılık sektöründeki kamu bankalarının, görev zararı şeklindeki uygulamalarına son vererek; özerkliğini artırarak etkinliğini artırmak. El konulan TMSF bünyesindeki bankaların sorunlarını en kısa sürede çözüme kavuşturarak finansal sistemi rahatlatmak. Ayakta kalan özel bankaların da sağlıklı bir yapıya kavuşmalarını sağlayacak düzenlemeleri hayata geçirmektir. Bu düzenlemelerin temelini oluşturan "Güçlü Ekonomiye Geçiş Programı” ile Türkiye ekonomisinde özellikle finans sektöründe, aşağıdaki yapısal reformlar gerçekleştirilmiştir.

\subsection{Maliye Politikası Reformlarının Para Politikası ile Uyumluluğunun Sağlanması}

Yeniden yapılanan veya geçiş sürecindeki ekonomilerin makro dengesizliklerinin temel nedeni, kamu açıkları ve bunların sürdürülemez hale gelmesidir. Kamu kesimindeki finansman dengesizliklerinin giderilebilmesi için yapılması gereken temel düzenleme mali disiplini sağlamaya yönelik yeniden yapılandırma reformlarını içermelidir.

$\mathrm{Bu}$ yapısal önlemler özelleştirmeden, bankacılık sisteminin yeniden yapılandırılmasına, şeffaflıktan, kamu kesiminde çalışanların etik kurallarına kadar çok geniş bir yelpazeye yayıldı. Buna paralel olarak kamuoyu ve medyada da yapısal reform adeta sihirli bir kavram haline geldi. "Yapısal reformları cesaretle yapacak hükümetler", "kararlılıkla sürdürülen yapısal reformlar", "yapısal reformlar tamamlanamadığı için patlayan krizler” gibi ifadeler yaygın bir biçimde kullanılmaya başlandı. 1980'lerde 1990'lı yılların başında yapısal reformlar deyince genellikle özelleştirme ve piyasa mekanizması önündeki engellerin kaldırılması yani serbestleşme akla gelirken, son zamanlarda bu kavramın içeriğinin geniş̧lediği gözlenmektedir (Esen, 2002, 1).

Türkiye'de kamu bütçesindeki dengesizliklerin, bankacılık sektörü üzerindeki olumsuz sonuçlarını azaltabilmek için 2001 krizi sonrası uygulanan maliye politikası reformları şu şekilde özetlenebilir (bk.:BDDK, 2009, 9-10):

- Gelir artırıcı, harcama azaltıcı önlemlerle; faiz dışı fazla verilmesinin hedeflenmesi ve çeşitli dolaylı vergilerin artırılması gibi tedbirler.

- $\quad$ Kamu personelinin ve tarımsal destekleme harcamalarının azaltılması. 
Kamu iç ve dış borcunun etkin bir şekilde yönetilebilmesini amaçlayan, Kamu Finansmanı ve Borç Yönetiminin Düzenlenmesi Hakkında Kanun'un 28 Mart 2002'de çıkarılması.

- $\quad$ Kamunun iç piyasadan borçlanmasını kolaylaştırmak amacıyla, kamu borçlanma araçlarının (DİBS) iç piyasada derinleşmesini ve katılımcı bankaların yükümlülüklerini yerine getirmelerini sağlayan bir piyasa yapıcılığı sistemi Eylül 2002'de hayata geçirilmiştir.

- $\quad 1$ Ocak 2003 tarihinde Kamu İhale Kanunu'nun yürürlüğe girmesi.

- $\quad$ Kamuda, kamu mali yönetim ve denetimini düzenleyen Kamu Mali Yönetim ve Kontrol Kanunuyla, bütçe kurumlarının gruplamaları değiştirilerek, analitik bütçeleme tekniği ve denetçiler için performans denetim anlayışı başta olmak üzere yeni uygulamalar getirilmesi.

- $\quad$ Memurlar ve Kamu Yöneticileri İçin Ahlaki Görev ve Uygulama Esaslarına İlişkin Kanun’un, 25 Mayıs 2004'de yürürlüğe girmesi.

\subsection{Para Politikası Otoritesine Bağımsızlığının Kazandırılması}

Türkiye gibi gelişmekte veya geçiş ekonomisi aşamasında olan ekonomilerin (ki 2008 finans krizinin Euro bölgesi bazı ülkelerde maliye ve para politikası uyumsuzluğu gibi) sorunlarının temelinde; genişletici maliye politikası uygulamalarıyla ortaya çıkan bütçe açıkları ve onların finansmanı için artan kamu borç stokunun sürdürülemez hale gelmesidir. Özellikle merkez bankası kaynaklarıyla yaratılan parasallaşma ve iç borçlanmanın ortaya çıkardığı mali baskınlık sonucunda; araç bağımsızlığına sahip olamayan merkez bankaları ve Türkiye Cumhuriyet Merkez Bankası (TCMB) para politikalarında başarılı olamamıştır. Bu başarısılıkları ortadan kaldırıcı düzenlemelerin temelinde para politikası otoritesine, bağımsızlığının yasa ile verilmesi yatmaktadır.

Günümüzde TCMB modern merkez bankacılığı ile uyumlu yasal düzenlemelerle, para politikası araçlarına ve araç bağımsızlığına sahip hale gelmiştir. Diğer yandan, günümüz ekonomisinde dolaylı para politikası araçlarının kullanılabilmesinin ve dolayısıyla para politikasının etkin olarak yürütülmesinin ön şartlarından ilk ikisi mali baskınlığın bulunmaması ve merkez bankalarının bilançolarına hâkim olabilmesiyse, üçüncüsü de etkin çalışan bir para piyasasının bulunmasıdır. Türkiye'de para piyasaları TCMB'nin 1987'den bu yana katkıları ile birlikte gerek teknik alt yapı ve gerekse işleyiş açısından gelişmiş ülkelerle karşılaştırılabilir düzeydedir. Bu nedenle, güvenli bir şekilde Türkiye'deki finansal alt yapının, modern dolaylı para politikası araçlarının etkin olarak kullanımına uygun olduğunu söyleyebiliriz. Ayrıca, TCMB'nin para politikası araçları ve likidite yönetiminin gelişmiş ülke uygulamaları ile aynı teknik özelliklere sahip olduğunu görmekteyiz. Bu çerçevede, geçmişte olduğu gibi gelecekte de makroekonomik istikrar ve para politikalarının başarısı bütçe disiplinine ve yapısal reform sürecine bağlı olacaktır. Bu nedenle, siyasi otoritelerin Türkiye’deki merkez bankacılığının geçmişte yaşadığı olumsuz tecrübeleri her zaman göz önünde bulundurması faydalı olacaktır (Önder, 2005, 287).

\subsection{Bağımsız Düzenleyici - Denetleyici Yapıların Oluşturulmasına Yönelik Reformlar}

Aşırı liberalist uygulamaların finans sektöründe ortaya çıkardığı 2008 küresel finans kriziyle gündeme gelen daha çok müdahale politikaları; önceki dönemlerdeki serbestleştirme politikalarının yerini almaktadır. Türkiye ekonomisinde 2001 krizi sonrası, IMF destekli, bankacılık sektörünün yeniden yapılandırılmasına yönelik program 15 Mayıs 2001'de açıklanmıştır. Bankacılık Sektörü Yeniden Yapılandırma Programı adıyla açıklanan program: İç ve dış şoklara dayanıklı; etkin aracılık fonksiyonuna odaklanmış ve uluslararası ölçekte rekabet edebilir bir bankacılık sektörüne geçişi amaçlayan; yasal ve kurumsal düzenlemelerin en iyi uygulamalarının oluşturulmasını ele almaktadır.

En iyi uluslararası uygulamalara paralel olarak bağımsız düzenleyici kurulların iyi işleyen bir piyasa ekonomisi için gerekli olduğundan hareketle Sermaye Piyasası Kurulu ve Bankacılık Denetleme ve Düzenleme Kurumu'na ilaveten Rekabet Kurumu, Telekomünikasyon Kurumu, Enerji Piyasası Düzenleme Kurumu, Tütün Kurulu ve Kamu İhale Kurulu oluşturulmuştur. Bu kurullar, ekonomi yönetiminin siyasetten arındırılmasına yardım etmiş, kamu harcama yönetiminin iyileşmesine ve daha etkin bir devlet yapısı oluşmasına katkıda bulunmuştur (BDDK, 2009, 10).

Geçiş ekonomilerinin yeniden yapılandırma programlarında yer verilmesi gereken ulusal ve uluslararası ölçekteki bağımsız düzenleyici, denetleyici kurumların önemi, 2008 küresel finans krizinde de ortaya çıkmıştır. $\mathrm{Bu}$ yüzden "bankacılık sisteminin mali ve operasyonel yapısının güçlendirilmesine yönelik uygulamalar ile bankacılık sektöründe gözetim ve denetimin etkinliğini artıracak, sektörü daha etkin ve rekabetçi bir yapıya kavuşturacak yasal ve kurumsal düzenlemeler" devam ederse Türk bankacılık sisteminde dolayısıyla ekonomisinde istikrar devamlı olabilecektir (BDDK, 2001, 13).

\section{Türk Bankacılık Sektöründe Bağımsız Düzenleyici Denetleyici Kurumların Oluşturulması Sonrasındaki Gelișimin Önemli Rakamlara Yansıması}

Türk Bankacılık Sektöründe en sert yaşanan 2001 krizi sonrası uygulanan radikal reformlara; bağımsız düzenleyici denetleyici para politikası uygulamalarına; kamu maliyesinin de destek vermesiyle sağlanan başarı sayesinde, bankacılık sektörünün finansal aracılık işlemlerinde etkinliğin artışı rakamlara olumlu yansımaktadır. 
Mali disiplin, para politikalarının etkinliği ve bankacılık sektörünün istikrarı açısından hayati öneme sahiptir. Küresel kriz öncesinde bütçe dengesi gelişmeleri sıkı mali disiplinin bir göstergesi niteliğinde olmuş, faiz dış1 dengedeki olumlu tablo, finansal istikrarın güçlenmesine katkı yapmıştır (BDDK, 2013).

Bankacılık sektöründeki bağımsız düzenleyici, denetleyici kurumlara destek veren mali disiplin sonucunda, kamunun borçlanma ihtiyacının azalmasıyla; mali baskınlığın eski gücünü kaybetmesiyle; bankacılığın asli fonksiyonu olan özel sektöre kaynak kullandırma hizmetlerinin gelişmesi mümkün olmuştur. Bu gelişmeler:

- 2001-2012 döneminde Kredi/Mevduat Oranında yükseliş ve MDP (Menkul Değerler Portföyü) / Mevduat Oranında azalış şeklindedir. Kredi/Mevduat Oranında yükseliş mali baskınlığın azalmasının, özel sektörün dışlanmasının (crowding-out) önlenmesine işaret eden önemli bir orandır.

- MDP (Menkul Değerler Portföyü) / Mevduat Oranında azalış da bunu desteklemektedir. Yani kamunun borçlanma talebi azaldığı için ihraç ettiği DİBS’ler (Devlet İç Borçlanma Senedi) azalmaktadır. Bu da bankaların, sadece kamuya değil özel sektörü de finanse etmeye yönelmelerine yol açmıştır. Böylece crowding-out etkisiyle özel sektörün mali piyasalardan dışlandığı durum; kaynakların sadece kamuya, etkin olmayan alanlara aktığı konum; kısacası mali baskınlık azalmaktadır.

\begin{tabular}{|l|l|l|l|l|l|l|l|l|l|l|l|l|}
\hline & $\mathbf{2 0 0 1}$ & $\mathbf{2 0 0 2}$ & $\mathbf{2 0 0 3}$ & $\mathbf{2 0 0 4}$ & $\mathbf{2 0 0 5}$ & $\mathbf{2 0 0 6}$ & $\mathbf{2 0 0 7}$ & $\mathbf{2 0 0 8}$ & $\mathbf{2 0 0 9}$ & $\mathbf{2 0 1 0}$ & $\mathbf{2 0 1 1}$ & $\mathbf{2 0 1 2}$ \\
\hline $\begin{array}{l}\text { Kredi / Mevduat } \\
\text { Oranı \% }\end{array}$ & 34 & 36 & 43 & 52 & 62 & 71 & 80 & 81 & 76 & 85 & 98 & 103 \\
\hline $\begin{array}{l}\text { MDP / Mevduat } \\
\text { Oranı \% }\end{array}$ & 54 & 62 & 69 & 65 & 56 & 52 & 46 & 43 & 51 & 47 & 41 & 35 \\
\hline
\end{tabular}

Tablo 1: Türk Bankacılık Sektöründe Mali Baskınlı̆̆ın Değişimi Kaynak: BDDK (2010-2013) verilerinden hesaplanmiştır.

Türk Bankacılık Sektörünün 2001 yılı sonrasında gerçekleştirmiş olduğu reformların sonuçları küresel finans krizinde test edilmiştir. Küresel krizin ülkelerdeki olumsuz etkileri; toparlanmak için mücadeleleri devam ederken Türkiye Ekonomisi, bu reformlar sonucunda göreceli olarak daha iyidir. Ekonomideki bu olumlu sürecin önemli bir göstergesi de, "kredi hacminin milli gelire oranı, hem finansal derinleşmenin hem de kredi genişlemesinin bir göstergesi olarak kabul edilmektedir. Toplam kredi hacminin milli gelir (GSYH) içindeki payı, 2002 yılı sonunda \%14 iken, 2012 üçüncü çeyrek itibarıyla \%54'e ulaşmıştır. Küresel krize rağmen artış eğilimi devam etmiştir. Finansal istikrar ve ekonomik büyüme ile eşanlı giden kredi büyümesi, reel kesim ve tüketici kredilerinin artmasıyla söz konusu ivmeyi kazanmıştır (BDDK, 2013).

\section{Bankacılık Sektörünün Düzenlenmesindeki Türkiye Örneğinden Geçiş Ekonomilerinin Alabileceği Dersler}

Ülkelerin ekonomik yapılarının zorlu süreçlerden geçerek kabuk değiştirmesi anlamına gelen geçiş ekonomisi kavramı, özellikle sosyalist veya karma ekonomilerin, piyasa ekonomisine dolayısıyla küresel ekonomik sisteme uyarlanmaları süreci olarak ifade edilebilir.

Geçiş ekonomilerinde, "geçişin üç sacayağı üzerine inşa edildiği, yani siyasal anlamda otoriter-totaliter devlet anlayışından demokratik sisteme; ekonomik anlamda merkezi planlamacılıktan piyasa ekonomisine ve sosyokültürel anlamda da tek tip-homojen anlayıştan heterojen yapıya yönelimler söz konusudur (Gerni vd. 2011: 253)". "Reformlar açısından ilk etabı fiyat ve ticari liberalizasyon ile küçük ölçekli özelleştirme oluştururken; ikinci etap ise kurumsal yönetim, rekabet politikası ve finansal kurumlar gibi daha ileri kurumsal reformlardır (Gerni vd. 2011: 255)".

Acemoğlu da (2012), bir ulusun yeteneğini en iyi şekilde göstermesini sağlayacak, eşit şartlar sağlayabilecek kurumları "kapsayıcı ekonomik kurumlar" olarak adlandırmaktadır. Bununla birlikte, kapsayıcı ekonomik kurumları, kural değil istisna olarak görmektedir. Bu durumun tüm dünyada tarih boyunca olduğu gibi bugün de geçerli olduğunu ifade etmektedir. Yazar, geçmişte olduğu gibi bugün de pek çok milletin, mülkiyet haklarını koruyamayan, asayiş ve düzeni sağlayamayan, anlaşmazlıkları çözüme kavuşturamayan ya da yenilikçiliği ödüllendirmeyen dışlayıcı kurumlara sahip olduğunu, bu kurumların kesinlikle eşit şartlar sağlayamayacağını ve bu nedenle sürdürülebilir ekonomik büyümeyi teşvik edemeyeceğini belirtmektedir.

$\mathrm{Bu}$ olumsuzlukların ortadan kaldırılabilmesinde; ekonomik düzenin kurulmasında ve etkin işleyişininin sağlanmasında bağımsız düzenleyici, denetleyici kurumların önemi büyüktür. Çünkü kurumsallaşmış, hesap verebilen, profesyonel anlayışa sahip bu yapılar sayesinde; popülist anlayışın olmadığı, günü birlik kararların alınıp verilmediği politikalar uygulanabilir. Bu yönetim tarzında; mülkiyeti garanti eden hukuksal düzenlemeler uygulamada egemen olur; piyasalarda rekabetçi yapılar oluşturulup işletilebilir. Böylece ekonomik gelişme açısından önemli mesafeler alınabilir.

Türkiye ekonomisinde 2001sonrası bankacılık sektöründe oluşturulan bu yapıların, kurulması ve işletilmesi süreçlerini üçüncü alt başlıkta vermiştik. Bu kurumlar sayesinde elde edilen olumlu kazanımları da sonraki başlıkta özetlemiştik. Türk Bankacılık Sektöründeki bu başarılı yeniden yapılanmanın geliştirilmesi ve 
ekonomideki diğer sektörlere de yaygınlaştırılması gerekmektedir. Çünkü bankacılık sektöründe bazen bu kurumların bağımsızlığına müdahale edilmesi şeklindeki günlük yanlış uygulamalarla (örneğin: TCMB'na, politika faizlerini indirmesi şeklindeki beyanlarıyla siyasilerin yaptığı baskı); katlanılmak zorunda kalınan sosyal, ekonomik maliyetler artmaktadır.

Türkiye ekonomisi gibi geçiş ekonomileri de, ülkeden ülkeye dozu değişebilecek bu yapıları kurabilirse aşağıdaki kazanımları elde edebilirler:

- Bağımsız merkez bankalarının, yerel paranın iç ve dış değerini korumada kısacası fiyat istikrarını sağlamada başarısı artar. Parasının dış değeri yani döviz kurunda istikrarı sağlayabilecek bağımsız politika ve araçlarına para politikası otoritesi sahip alacağı için; portföy yatırımlarının (sıcak para) ülkeye hızlı giriş ve çıkışlarında yaratacağı olumsuzlukları azaltabilir.

- Para politikası otoritesine ve ilgili diğer düzenleyici, denetleyici kurumlara bağımsızlığın verilmesine yönelik düzenlemeler ile maliye politikasının da para politikasına destek vermesi şeklindeki uygulamalarla, kamunun borçlanma talebi dolayısıyla finansal sistemde mali baskınlık, özel sektörü dişlama etkisi azalır.

- Böylece finansal sistemin kaynak aktarma yani aracılık işlemleri etkinleşir ki, geçiş ekonomisi sürecinde olan ülkelerin en temel sorunları; (hem yetersiz sermaye birikimine sahip olmaları hem de bunun reel sektöre aktarılacağı etkin piyasalara sahip olamamaları) çözüme kavuşur.

- Aynı zamanda finansal sektörün özellikle bankacılığın öncelikle yapılanması sonucunda, etkin işleyecek olan aktarım mekanizmaları sayesinde diğer sektörlerin yeniden yapılanması daha kolay olacaktır.

- Çünkü bağımsız bankacılık düzenleme denetleme kurumu aracılığıyla, bankacılık sektörünün düzenlenmesi ve denetlenmesinde parçalı bir yapı ortadan kalkar. Sektöre ilişkin tek bir bağımsız düzenleyici ve denetleyici bir kurum sayesinde, düzenleme ve denetlemede etkinlik artar. Zor durumdaki bankalara zamanında yapılacak müdahale ile olumsuz dişsallıklar ortadan kaldırılabilir.

- $\quad$ Proaktif bir yaklaşıma sahip olmak zorunda olan bağımsız düzenleyici, denetleyici kurumların bu yönetim tarzı sonucunda bankalar, en fazla düzenleme ve denetlemeye tabi olmaktadır. Yukarıdan aşağıya sıkı bir şekilde denetlenen bankalar bu disiplini müşterilerine de yansitır. Çünkü banka yönetimlerinin yapacakları hatalarının, batıracakları paranın hesabının sorumluluğu yüksektir. Bu sorumluluğun gereği bankalar, kredi kullandırım süreçlerine, kredi geri dönüşlerini takip etme sistemlerine hassasiyet gösterecektir.

- $\quad$ Bu yüzden bankalar, kredi kullandıracakları müşterilerinin ve projelerinin seçiminde, geri dönüşü yüksek olacak talepleri seçeceklerdir. Riski yüksek projelerden yüksek faiz, düşük riskli projelerden düşük faiz talep ederek portföylerinde müşteri farklılaştırması yapacaklardır. Böylece hem müşterilerini hem de piyasaları, kayıt içinde çalışan, verimli projelere yatırım yapmaya yönelten bir misyona yöneleceklerdir.

- Kayıt dışı ekonominin kayıt altına alınması için de bankacılık sektörü ödeme sistemlerini geliştirecektir. $\mathrm{Bu}$ amaçla kullanılacak elektronik ödeme sistemlerinin yaygınlaştırılması, zorunlu tutulması; hem kayıt dışı hem de yasa dışı ekonomik faaliyetleri azaltabilecektir.

- Kayıt dışı ekonomik faaliyetlerin azalmasıyla, kamu gelirlerinin temeli olan vergi gelirleri dolayısıyla bütçe açıkları ve faiz giderleri azalacaktır.

- Nihayetinde geçiş ekonomileri, bankacılık sistemindeki bu bağımsız düzenleyici, denetleyici kurumları oluşturmuş yapılanmasıyla, ekonomilerinde uzun süreli istikrarı sağlayabileceklerdir.

\section{Sonuç}

Geçiş ekonomisi sürecinde olan ülkelerin, reform arayışlarına nereden, nasıl başlayacağını bilememesiyle; acele edilmesiyle; çözüm süreci uzamakta ve maliyeti artmaktadır. Bu olumsuzlukların hafifletilebilmesindeki reformlardan en önemlileri, devletin düzenleyici ve denetleyici rolünü üstlenen, bağımsız düzenleyici, denetleyici kurumların oluşturulmasıdır. Çünkü geçişi kolaylaştıracak olan, her şeyden önce kurumsal bir yapılanmanın sağlanmış olmasıdır. Böylece hem bu kurumların hem de geçiş ekonomilerinin piyasa ekonomisine hızla eklemlenmesinde başarısı artacaktır.

Bağımsız düzenleyici, denetleyici kurumların, öncelikle bankacılık sektöründe oluşturulması da önemlidir. Çünkü geçiş ekonomisi sürecinde olan ülkelerin en temel sorunları; hem yetersiz sermaye birikimine sahip olmaları hem de bunun reel sektöre aktarılacağı etkin piyasalara sahip olamamalarıdır. Bankacılığın yapılanması sonucunda etkin işleyecek olan aktarım mekanizmaları sayesinde diğer kesimlerin yeniden yapılanması daha kolay olacaktır. Çünkü finans sektörü ve onun önemli bir parçası olan bankalar, en fazla düzenleme ve denetlemeye tabi olmak zorundadır. Fakat bu düzenlemelerin ve denetlemelerin hükümetler üstü olması; hem bu kurumların hem de ekonomilerinin piyasa ekonomisine geçişlerinin başarısını artıracaktır.

Düzenleyici, denetleyici kurumların gelişmiş ekonomilerde oluşturulmuş fakat işletilmemiş; bağımsızlığının verilmemiş olmasının kötü sonuçlarını, etkileri devam eden 2008 küresel finans krizi de göstermektedir. 
Gereğinden fazla liberal uygulamanın yol açtığı bu krizden alınması gereken temel dersler veya yeniden yapılanmada bağımsız düzenleyici, denetleyici kurumlar neden öncelikle finans sektöründe oluşturulmalıdır. Çünkü: Ekonomideki finansal tarafların aşırı kazanma hırsları kendi haline bırakılamaz; finansal sistemlerin, kurumların ve araçların çok hızlı büyümesini sağlayan serbestleştirme sürecine düzenleyici, denetleyici kurumlar olmadan girilemez. Çünkü finansal sistemdeki gerekli düzenlemenin ve denetlemenin kurulmamasıyla oluşturulan yapılanmalar büyük riskler taşır.

$\mathrm{Bu}$ riskleri ve hükümetlerin popülist müdahalelerini azaltmak için, bağımsız düzenleyici, denetleyici yapıların oluşturulmuş ve işletilmiş olmasının ne kadar önemli olduğu, 2008 küresel finans krizini genel olarak başarıyla yönetebilen Türkiye tecrübesinde görülmüştür. 2001 yılında en ağır bankacılık krizini yaşayan Türkiye, kurup işletebildiği bağımsız düzenleyici, denetleyici kurumlar sayesinde, bankacılık sektörünün hızla yeniden yapılanmasını tamamlamış ve olumlu dışsallıklarını da ekonomiye aktarabilmiştir.

Türk Bankacıllk Sektöründe yeniden yapılanma ile oluşturulan bağımsız düzenleyici, denetleyici kurumlar sayesinde sektör niteliksel ve niceliksel olarak büyümüştür. Bu gelişimin sonuçları sektör rakamlarına olumlu yansımıştır ve küresel finans krizi şimdiye kadar başarıyla yönetilebilmiştir. Türkiye'nin bu tecrübesi, geçiş ekonomilerinin bankacılık sisteminde dolayısıyla ekonomilerinde, uzun süreli istikrarı sağlayabilmek için oluşturulması gereken bağımsız düzenleyici, denetleyici yapıların meydana getirilmesinin ve işletilmesinin ne kadar önemli olduğunu göstermektedir.

Piyasa ekonomisine geçiş uygulamalarıyla birlikte küreselleşme sürecine uyum da gerçekleştirilmelidir. Çünkü küresel piyasalara mal ve hizmet satabilmek, ulusal rekabet gücünü yaratılabilmek gerekir. Bunun için de, üretimden tüketime, üretim süreçlerini düzenleyen ve denetleyen kalite sistemlerinin kurulmasını, mülkiyet haklarının tanınmasını ve korunmasını da üst kurullar; bağımsız düzenleyici otoriteler sağlayacaktır.

Günümüz devlet yönetiminde, siyasal sistemden bağımsız; saydam ve hesap verebilen; oyunun kurallarını koyan ve denetleyen bağımsız düzenleyici ve denetleyici kurumlar: Ülkelerin yeniden yapılanmasında; kurumsallaşma ilkelerinin uygulanmasında; piyasa aksaklıklarının ortadan kaldırılmasında; kayıt dışı, yasa dışı ekonomik faaliyetlerin ortadan kaldırılmasında; ekonomik sistemin rasyonelleştirilebilmesinde; piyasaların popülist hükümet müdahalelerinden kurtarılabilmesinde önemli görevleri yerine getirmektedir ve getirecektir.

\section{Kaynakça}

- Acemoğlu, Daron, 2012. "Bazı Milletler Neden Başarısız Olur?”, Türkiye Ekonomi Politikaları Araştırma Vakfi, 2. Merih Celasun’a Saygı Günü, 20.06.2012.

- Akalın, Güneri, 2003. “Piyasa Ekonomisinin Neresindeyiz?” TİSK-İşveren Dergisi, Eylül 2003, http://tiskweb.com/isveren_yazdir.asp?yazi_id=791\&id=47\&baslik_id=\&yapi=\&gecerli_sayfa=

- BDDK, 2001. Bankacılık Sektörü Yeniden Yapılandırma Programı.

- BDDK, 2009. Krizden İstikrara Türkiye Tecrübesi (Çalışma Tebliği Gözden Geçirilmiş İkinci Baskı).

- BDDK, 2010. Finansal Piyasalar Raporu-Aralık 2010-Say1 20.

- BDDK, 2011. Finansal Piyasalar Raporu-Mart 2011-Say1 21.

- BDDK, 2012. Finansal Piyasalar Raporu-Aralık 2011-Say1 24.

- BDDK, 2013. Finansal Piyasalar Raporu-Aralık 2012-Sayı 28.

- Çolak, Ömer Faruk, 2005. "IMF Yönlendirmeli Bankacılık Yeniden Yapılandırma Programı: Türkiye Örneği”, Finansal Piyasalar ve Para Politikası, Nobel Yayını No:226, 4.Bask1, Ankara.

- Emek, Uğur ve Diğerleri, 2002. Bağımsız Düzenleyici Kurumlar ve Türkiye Uygulaması, Türk Sanayicileri ve İşadamları Derneği (TÜSİAD) Yayın No. TÜSİAD-T/2002-12/349, İstanbul.

- Esen, Oğuz, 2002. “Türkiye'de Uygulanan IMF-Destekli Yapısal Programlar”, Kriz ve İMF Politikaları, Editör: Ömer Faruk ÇOLAK, Alkım Yayınevi, İstanbul.

- Gerni, Cevat, Sarı, Selahattin, Değer M. Kemal, Emsen Selçuk, 2011. "Geçiş Ekonomilerinde Liberalizm ve Büyüme İlişkileri”, Uluslararası Avrasya Ekonomileri Konferansı 12-14 Ekim 2011 - Bişkek, Kurgizistan.

- Güler, Esra, 2012. “Geçiş Ekonomileri ve Yeni Kurumsal İktisat'ın Yeniden Yükselişi”, Doğuş Üniversitesi Dergisi, 13 (1) 2012, 52-68.

- Önder, Timur, 2005. Para Politikası: Araçları, Amaçları ve Türkiye Uygulaması (Uzmanlık Yeterlilik Tezi), Piyasalar Genel Müdürlüğü, Ankara

- Yaşar, Süleyman, 2007. Türkiye'de Kullanılan Özelleştirme Yöntemlerinin Analizi, Beta Yayınları, İstanbul. 
- Yazıcı, Resül, 2004. 'Türkiye’ de Faiz Dışı Fazlayı Artırmak ve Kamunun Finansman Açı̆̆ını Azaltmak İçin Borçlanmanın İzlenmesi ve Vergi Kaçağının Önlenmesi Hususunda Alınması Gereken Önlemler”, Afyon Kocatepe Üniversitesi İ.İ.B.F.Dergisi, Cilt: VI, Sayı1, 145-165.

- S Şimşek Mevlüdiye, Yazıcı, Resül, 2008. “Türkiye'de Piyasa Ekonomisine Geçiş Sürecinde KİT’lerin Özelleştirme Faaliyetlerine Bakış ve Çimento Sektöründe Özelleştirme Öncesi ve Sonrası Durum Analizi”, Proceedings Of The International Congress Integration And Economic Development In Transition Economies, Kyrgyz-Turkish Manas University Publication: 106, Conference Series: 14.

- Yazıcı, Resül, 2012. “Türk Bankacılık Sektöründeki Yapısal Değişimlerin Hanehalkının Finansman Yapısına Etkilerinin İncelenmesi”, Civilacademy Journal of Social Sciences, Fatih University, Spring 2012, 249-277. 


\title{
Türkiye’deki 2001 Krizi Sonrası Bankacılık Sektöründeki Yapısal Değişim: 2001 Öncesi ve 2001 Sonrası Bir Karşılaştırma Structural Changes in the Banking Sector in Turkey after 2001
Crisis: A Comparasion between before 2001 and after 2001
}

\author{
Asst. Prof. Dr. Emine Frrat (Aksaray University, Turkey)
}

\begin{abstract}
Globalization movements around the word caused countries to be faced with crisises successive. The financial sector has seen major losses from economic crises. Developments in the aftermath of the economic crisis has led to some changes especially in the banking sector, furthermore leading to the growth of the financial sector. In recent years, after the international economic, financial, technological and social developments, activities of banks have increased. Banks, in line with improving economic conditions and changing customer demands have been restructured in order to provide the best service to customers. First, banks increased product, service, quality, variety, technological advances, demand for advertising expenditures, customer satisfaction and efforts on risk management. After 1980, the Turkish banking sector entered a rapid change period in technology, by taking advantage of the facilities to be brought. However, when crises in November 2000 and February 2001 have been added to the previous problems in the banking system, sector has become more fragile. After the 2001 crisis the banking sector has entered the configuration process. The aim of this study is to investigate in detail the process of rapid change after the 2001 crisis, by comparing with the pre-crisis and after the crisis of Turkish banking sector in 2001. In this study, banks in the market will be examined within the framework of a lot of different topics. The changing face of the banking sector after the 2001 crisis in Turkey will form the basis of the study.
\end{abstract}

\section{Giriş}

Küreselleşmenin hız kazanmasıyla gelişen finansal yapı değişimleri deberaberinde getirmiştir. 1980 ve 1990 arasındaki on yıl içerisinde bankacılık sektörü, demografik değişiklikler, bankaların konsolidasyonu, düzenleyici reformlar, gelişen teknolojilerin bankacılık sektöründe kullanılması ve değişen müşteri istekleri gibi nedenlerden dolayı hızlı bir değişim ve gelişim süreci içine girmiştir. Küreselleşen dünya düzeni bankaların yapıları hatta ülkeler sürekli değiştirmiştir.Küreselleşmeden etkilenme düzeyleri yükselen bankalar kendilerini gittikçe şiddetlenen bir rekabet ortamı içerisinde bulmuştur.Bankalar meydana gelen değişimlere ayak uydurarak faaliyetlerini sürdürülebilmek ve rekabetçi avantajlarını artırabilmek için çeşitli yeniliklere gerek duymuşlardır.Türkiye'de 1980 sonrası yaşanan üç büyük krizin ardından bankalar büyük zarar görmüş, bankacılık ve finans sektörü güvenilirlik açısından sarsılmıştır. Dünya ekonomilerinde 1990'lı yıllara kadar ödemeler bilançosu krizleri yaşanırken, 1990'lardan sonra bankacıllk sektöründeki krizler ve döviz krizleri belirleyici olmuştur.

1990’lı yıllarda bankac1lık sisteminde yaşanan krizler genellikle gelişmekte olan ülkelerde görülmüştür.Çünkü geçiş ekonomilerinde bankacılık sistemi henüz gelişmemiş, mevduat devlet güvencesinin kötü kullanıma açıktır.Yaşanan krizlerde banka sahiplerinin topladıkları fonları kendi şirketlerine aktardığı ve banka müşterilerine olan yükümlülüklerini yerine getiremediği görülmüştür. Ayrıca bankacılık sisteminde kamuya ait bankaların görev zararlarının devlete olan maliyetinde gözlenen sürekli artışlar dikkat çekmiştir.Bu durum merkez bankalarının da sağlıklı çalışmasını engellemiş̧tir (Yentürk, Çimenoğlu, 2003). Bu süreci yaşamış ülkelerden biri de Türkiye ekonomisidir.Yaşanan krizler bankaların zayıf yapısını ve kötü kurumsal yönetim uygulamalarının sonuçlarını gözönüne sermiştir.Türkiye'de yaşanan 2001 Krizi finans ve bankacıllk sektörünün önemini daha iyi ortaya çıkarmıştır.

Dünya ekonomik konjonktüründe yaşanan hızlı dalgalanmalar, sermaye hareketlerini arttırarak bankacıllk sektöründe krizlere yol açmıştır.Özellikle son yıllarda yaşanan küresel krizin ardından bankacılık sektöründe zor günler yaşanmıştır.Bankacılık krizleri bankaların iflas etmesine ve skandalların yaşanmasına neden olmuş, ülke ekonomileri zarar görmüştür.Krizlerin ardından bankacılık sektörünün sarsılan güvenilirlikleri ve zarar gören imajlarını sağlamlaştırma çabaları artmıştır.

Bankacılık sektörü ekonomik ve sosyal bütün değişimlerden çok çabuk etkilenmektedir.Türkiye'de yaşanan krizlerin ardından uygulanmaya çalışılan yeniden yapılandırma programlarında bankacılık sektörü ve özel sektör ayrı bir öneme sahiptir.Bankalar uygulanan yeniden yapılandırma programlarına ayak uydurmak için teknolojik yeniliklere dayalı, bilgi ve rekabet avantajı sağlayacak bir yapıyı benimsemek zorunda kalmışlardır.Bu nedenle bankalar 2001 Krizi sonrasında hızlı bir değişim sürecine girerek, salt kar ve büyümeye dayanan bir bankacılık anlayışı yerine; insana verilen önemin arttığı, büyüme ve kar elde etmenin kurumsal bir anlayış zeminine oturtulduğu bir yapı geliştirmişlerdir. Çünkü bankalar 2001 Krizi'nden sonra rakipleriyle sadece işlem yönünden 
değil; ürün ve hizmet kalitesi, fiyat, pazarlama, reklam, liderlik, kendini geliştirme, yeniliklere uyum sağlayabilme sosyal sorumluluk gibi farklı faktörler konusunda da rekabet etmek zorunda kalmışladır. Bu amaçla bankacılık ve finans sektöründeki işletmelerin, sarsılan güveni geri kazanabilmek ve rekabetçi avantaj sağlayabilmek konularında kurumsal yapılarını değiştirdikleri ve bu konuda Türk Bankacılık sektörünün başarılı oldukları sonucuna varılmıştır.

\section{Sonrasında Türk Bankacılık Sektörünün Gelişimi}

Türkiye ekonomisi 24 Ocak 1980 tarihinde alınan kararlar ile küreselleşme, finansal liberalizasyon, özelleştirme, devletin küçülmesi, döviz kuru, faiz oranları ve sermaye hareketlerinin serbestleşme sürecine başlamıştır (Karaçor, 2006).

1980'li yıllardan sonra finansal entegrasyon ile birlikte uluslararası sermaye hareketlerinin serbestleşmesi ve bankaların özelleştirilmesi hızlanmış, faiz oranlarındaki üst limitin kaldırılması ve zorunlu rezerv oranlarının azaltılması gibi uygulamalara geçilmiştir (Sürek, 1999).Piyasa ekonomisiyle başlayan süreçte bankacılık sektörü de hızlı bir değişim sürecine girmiştir.Ancak 1980 sonrası ülkedeki makroekonomik dengelerin bozulması bankalardaki yaşanan olumlu gelişmelerin duraklamasına neden olmuştur. Bankacılık krizleri Türkiye'nin de yaşamış olduğu ve gelişmekte olan ülkelerin çoğunun deneyim sahibi olduğu krizler olmuştur. Finansal entegrasyon sürecine geçiş aşamasının sancılı olduğu ülkemiz bankacılık krizlerine hazırlıksız yakalanmıştır.

1990’larda yaşanılan krizler “finansal” kelimesinin önemi üzerine yoğunlaşmasına neden olmuştur. Finansal krizlerde aniden ortaya çıkan likidite darlığı, faiz stokları ve ağır devalüasyonlar, mali kurumların ve şirket sektörünün bilançolarını bozarak, büyük zararlara ve güven kaybına neden olmuş, üretimde ve istikrarda büyük kayıplara yol açmıştır. Bu süreçte finansal kesim-reel kesim tartışması ön plana çıkmıştır. 1990'lar da gözlemlenen başlica finansal krizler, sermaye hareketlerinin serbest olduğu ortamda gerçekleşmiştir (Celasun, 2001). Türkiye'de 1990'lı yıllarda yüksek enflasyon ve artan faizler, döviz kurundaki değişmelerin yanı sıra bankacılık sektörü de kırılgan bir hale gelmeye başlamıştır. Bankaların hızla çoğalması, bankalardaki denetimin zayıflığı, bankacılık kesiminin risklerinin artması gibi finansal belirsizlikler bankacılık sektörünü olumsuz yönde etkilemiştir (Seyidoğlu, 2003).1990 yılında TCMB yeni bir para politikası uygulamasına geçerek, bankacılık sistemini güçlendirmeye çalışmıştır.Türkiye'deki bankacılık sektörünün 1990-1993 arasında hızlı büyümesine rağmen, piyasalardaki tedirginlik ve makroekonomik göstergelerdeki belirsizlik krizlere davetiye çıkarmıştır. 1994 yılında ülkedeki mali kriz, piyasalarda tedirginlik yaratmış, ülkede güven ortamını ortadan kaldırmıştır.

1994 yılında bankalar yurtdışına yönelmiş, Hazine açık piyasa işlemlerine başvurarak borçlanmış, piyasadaki belirsizlik dövize yönelmeyi arttırmış, kurlar yükselmiştir (Seyidoğlu, 2003).Bankaların açık pozisyonları artarak özkaynakları azalmış, piyasadaki belirsizlik güvensizlik ortamına dönüşmüştür (Karaçam, 2006: 137). Bu kriz ortamında dedikoduların artmasıyla Marmarabank, TYT Bank ve Impexbank ile üç aracı kurum; Türk Invest, Çarmen ve Pasifik iflas etmiştir (Günal, 2001). 5 Nisan Kararları sonrasında devalüasyon ve dalgalı kur uygulamasına geçilmiş, kısa sürede para ve döviz piyasaları hızla istikrar kazanmış, döviz kuru kontrol altına alınmış, TL'ye güven sağlanmıştır.Devalüasyon sonrası cari işlemler açığı fazlaya dönmüş, bütçe açıkları azaltılmış, enflasyon hızı yavaşlatılmış belli bir süre bankacılık sektörü rahatlamıştır.

Türkiye 1997-1998 Asya ve Rusya Krizlerinden olumsuz etkilenmiş, Asya Krizinin nedenleri arasında sayılan bankacılık sisteminin zayıf olması durumu, krizin boyutlarını arttırmış, genel olarak yüksek faizler ve bankacılık sektöründeki artan sorunlu krediler bankaların karlılığını düşürmüştür (Stubbs, 2005). Latin Amerika özellikle Arjantin'de 1998'den itibaren yaşanan krizlere ekonomik olarak işsizlik, küçülme ve sermaye çıkışları damgasını vurmuş toplumsal olaylar ve yoksulluk krizleri derinleştirmiştir (Pion-Berlin ve Trinkulas, 2005). 2000 yıl1 başında uygulamaya konulan Enflasyonla Mücadele Programı sonrasında bankacılık sektörünün yapılanmasıyla ilgili olumlu gelişmeler yaşanmıştır. Ancak artan cari açık, kamu bankalarının görev zararları ve yönetim zafiyetleri, bankaların açık pozisyonlarının çok yüksek olması, kısa vadeli paranın ülkeye hızlı giriş-çıkışı, iç ve dış borçlanmanın artması, finansal temel sorunların başında gelmiştir.

Kasım 2000 krizi öncesinde enflasyon dizginlenememiş, faizler düşürülememiş, açık pozisyonları olan bankaların sıkıntıları artmış, bono satışına yönelen bankalar, Kasım 2000 Krizi’nin baş aktörleri olmuştur. Bu güvensiz ortamda bankalar paniğe kapılmış, faizler şaşırtıcı bir şekilde yükselmiş, yabancı yatırımcılar bu kriz ortamından kaçmış, borsada bu hareketlerden olumsuz etkilenmiştir (Gülcan vd., 2001). Bankaların denetimsiz yapısı, banka yönetimlerinin yanlış kararlar alması, TMSF bünyesindeki bazı bankaların holdingleşme sonucu mevduatlarını şirketlerine usulsüzce aktarması, bankaların kamu kesimini finanse etmesi gibi nedenler bankaların borçlanmasını arttırmıştır (Ateş, 2004). 2000 yılında IMF ile imzalanan stand-by anlaşması sonrasında uygulanan kur çıpası uygulaması sırasında programa aşırı güven kur riskini arttırmış, döviz kuru ve faiz oranlarındaki hızlı artışlar, kamu borç stokunun hızlanmasına neden olmuştur (Akyüz, Boratav, 2002). Kasım krizinin nedenleri arasında cari açığın büyümesi, döviz kurunun hedefinden sapması, yabancı sermaye giriş çıkışın düzensiz olması makro ekonomik göstergelerin yanında bankacılık sektörünün zayıflaması, kamu bankalarının satılamaması, rekabetin ölçüsüz bir şekilde artması örneğin Demirbank'ın zor durumda bırakılması gibi nedenlerde sayılmıştır (Boratav, 2001). 
Kriz sonrası Bankacılık kesiminin içinde bulunduğu durgunluk, ekonomik küçülmeye yol açmış, bankaların zayıf yapısı istikrarsız bir ortama doğru sürüklenmiştir. 2000 yılında Tasarruf Mevduatı Sigorta Fonu'na toplam 11 banka aktarılmıştır. Kasım 2000 kriziyle TMSF'ye devredilen bankaların sayısı 18 olmuş, bu bankaların 12'si birleştirilmiş, 5'i satılmış, 1'i tasfiye edilmiştir (Kazgan, 2005).Kasım Krizi sonrasında para politikasında değişiklikler yapılmış, Aralık ayında IMF'den Türkiye'ye yönelik olumlu destek gelmiştir. Ancak kısa süreli de olsa bu iyileşme Şubat 2001'de son bulmuş, Kasım 2000'de yaşanan finansal kriz sonrası uygulanan ekonomik programa güvensizlik arttığından, faiz riski kur riskine dönüşerek, dövize yönelim başlamış, Şubat 2001 krizi karşımıza çıkmıştır. Şubat ayında Hazine'nin ihalesi öncesi siyasi gerginlikler de uygulanan programa olan güveni tamamen ortadan kaldırmış piyasalar altüst olmuştur.

Şubat 2001 krizi sonucunda dövizde sabit kurdan vazgeçilmesi ve bankacılık sektöründe yüksek faizler, maliyet artışlarına sebep olmuştur.Bankaların ellerinde bulunan kâğıtların piyasa değerlerindeki düşüş, geri dönmeyen krediler, kambiyo zararlarının artması, TMSF'deki ve kamu bankalarının görev zararlarının Hazine'ye yüklenmesi, kamu borçlanmasının artması bankacılık krizini devam ettirmiştir (Erdoğan, 2002).Finansal krizler yaşanırken yüksek enflasyon ve faiz oranları spekülatif sermaye hareketlerini hızlandırmış, bütçe açıklarını arttırmıştır. Firmaların yüksek faizler sonucu kredi alma imkânının kısıtlanması, işten çıkarmalara hatta şirket iflaslarına kadar giderek üretim daralmasına sebep olmuş, reel sektörü de olumsuz etkilemiştir (Göktaş, 2000). 22 Kasım 2000 tarihinde bankacılık sektöründe başlayan kriz 19 Şubat 2001 tarihinde döviz krizine dönüşerek ikiz kriz (twin crisses) karakterine bürünen krizlerden sonra yapılacak uygulamaların başında enflasyon ve yüksek faizler ile mücadele yer almış, yıllarca uğraşılmıştır.

Yaşanan bu ikiz krizler sonrasında ekonomi yüzde 8.5-9 oranında daralmış, ulusal gelir 51 milyar dolar azalmış, kişi başına gelir 725 dolar gerilemiş, 19 banka kapanmış, 1.5 milyon kişi işsiz kalmış, yüzde 30'lara düşen enflasyonyüzde 70'i aşmış, hazinenin faiz ödemeleri yüzde 101 artmış, iç borç stoku 2000 yllının 4 katına ulaşmıştır (Karluk, 2005). Bankacılık sisteminde yeninden yapılandırma süreci 1999 yılı sonunda uygulanmaya konulan enflasyonla mücadele programı ile başlatılmıştır.2001 yılında kapsamlı "Bankacılık Yeninden Yapılandırma Programı" açıklanmıştır. İlk dönme yapılanlar büyük ölçüde düzenlemelerin uluslararası standartlara ve uygulamlara yaklaştırılması yönünde olmuştur.Bankalar kanunda kapsamlı değişiklikler yapılmıştır. Bankacılık alanında idari ve mali özerkliğe sahip düzenleyici ve denetleyici bir otorite olan BDDK'ya geçmiştir. Bankacılık sektöründe yeninde yapılandırma süreci ; (i) TMSF bünyesindeki bankaların en kısa sürede çözüme kavuşturulması; (ii) Kamu bankalarının finansal ve operasyonel açıdan yeniden yapılandırılması, (iii) yaşanan krizlerden olumsuz yönde etkilenen özel bankaların sağlıklı bir yapıya kavuşturulması ve (iv) bankacıllk sektöründe gözetinm ve denetim etkinliğini arttıracak, sektörü daha etkin ve rekabetçi bir yapıya kavuşturacak yasal ve kurumsal düzenlemelerin gerçekleştirilmesi olmak üzere dört temel unsura dayandırılmıştır. Bankacılık sistemi önemli bir yeniden yapılandırma süreci yaşamıştır. Özel bankalar 2001 krizinden sonra önemli ölçüde kaybettikleri sermayelerini güçlendirmiştir.Bunu yapamayan bankalar birleşmiş ve TMSF ye alınmıştır.Kamı bankları yeniden yapılandırılmış, ortak bir yönetim altına alınmıştır. Kamu bankalarında görev zararları Devlet iç borçlanma senetleri karşıllı̆ı tasfiye edilerek, bankaların mali bünyeleri güçlendirilmiştir. Bankacılık sektörünün takipteki alacaklarının bir kısmı için "Finansal Yeniden Yapılandırma Programı" (FYYP- İstanbul Yaklaşımı) uygulanmıştır. Bankalardaki risk yönetimi anlayışı, kamusal gözetim ve denetim otoritesinde risk bazlı denetim anlayışı güçlenmiştir. Kamusal gözetim ve denetim işlevi özerk bir yapıya kavuşturulmuştur. Bankaların faaliyetini düzenleyen mevzuat 2005yılında yenilenerek, uluslararası genel kabul görmüş prensiplere ve uygulamalara önemli ölçüde yaklaştırılmıştır (TBB, 2008).

2001 öncesi özellikle işadamlarına çok kolay bir şekilde bankacılık ruhsatı vermişlerdir. 2001 yılından sonra bankaların risk yönetimi uygulamalarının yönetim boyutu ve teknik yeterlilikleri konusunda önemli çalışmalar yapılmıştır. Bankacılık sektöründe geleneksel denetim yaklaşımından risk odaklı yaklaşıma geçilmesi ile birlikte düzenlemelere dayalı denetim yanında piyasa denetimi de önem kazanmıştır. Yatırımcılar ve kamuoyu tarafindan bankaların faaliyetlerinin daha kolay izlenilmesi ve değerlendirilmesi amacıyla muhasebe standartları, raporlama ve kamuoyuna bilgi verilmesine yönelik uygulamalar daha çok daha etkin hale getirilmiştir. Bankacılık kanundaki risk yönetimi konusunda uluslararası gelişmeler ve yönetim sistemleri kurma yolunda önemli adımalar atmışlardır (http://www.ekodialog.com).

Kamu bankalarının yüksek görev zararları ve BDDK' nın bazı özel bankalara ek koymak zorunda kalması bu sektörde ciddi bir denetim eksikliği sorunu olduğunu göstermektedir. Genel kabul görmüş muhasebe prensiplerinin uygulanmaması ve mali tabloların bağımsız dış denetim firmalarınca denetlenmemesi sektörde yayınlanan mali tablolar arasında önemli farklar olmaktadır (Toprak ve Demir, 2001) Bu programda sağlam bankacılık sektörünün piyasada etkin bir rol oynaması için başta kamu ve TMSF bünyesindeki bankalar olmak üzere, hızlı ve kapsamlı bir yeniden yapılandırma çalışmalarına başlanmışıtır. Bu programda istikrarlı ekonomik büyüme, yatırım ve istihdamı artırarak refah düzeyini yükseltme toplumsal refahı sağlama genel stratejiler olmuştur (HM, 2001). Yani 2001 Krizi sonrasında düzenleyici otorite bankaların denetimi ve işleyişinde yeknesaklık sağlamış olup, BDDK ve TMSF kısaca rehabilite edilmiştir.

$\mathrm{Bu}$ çalışmalar sonucunda Türk bankacılık sektöründe risk yönetimi konusunda çok büyük gelişmeler sağlanmış, açık pozisyonları kapatılmış, sermaye rasyosu hedefi artmış, banka yapısı teknolojik uygulamalar ve 
enstrumanlar ile güçlendirilmiş, kredi kartına ilişkin düzenlemeler yapılmıştır.Bankaların yapısı güçlendirilmiş, sistemi bozan kamu bankalarının yapısı değiştirilmiştir. TCMB Kanunu'nda değişiklikler yapılmış, BDDK'nın yaptığı denetimler sayesinde sistemin şeffaflığı sağlanmış, bankaların uluslararası rekabet güçlerinin artması için gerekli devir ve birleşmeler yapılmıştır (Pazarbaşığlu, 2003). Bankaların mali tablolarının muhasebeleştirilmesi konusunda Muhasebe Uygulama Yönetmeliği'nin çıkarılmasına, repo işlemlerinin bilanço kapsamına alınmasına, enflasyon muhasebesi uygulama zorunluluğunun getirilmesine karar verilmiştir (Erdönmez, 2001). Bu süreç içerisinde Türkiye ekonomisi para ve fiyat dengesi için Merkez Bankası'nın özerk olması, dalgalı kur rejimi uygulaması içerisinde enflasyonla mücadele edilmesi, mali ve finansal sistemin yeniden yapılandırılması, denetleyici ve düzenleyici kurumların etkin hale getirilmesi, toplumsal uzlaşmanın sağlanması, etkin ve verimli bir devlet ve güçlü ama şeffaf bir kamu finansmanı, rasyonellik, bilgiyi kullanma, kurum ve kuruluşların etkinliği, güvenilir, riski ve belirsizliği yönetmeyi sağlayacak yapısal reformlar gerçekleştirmeye çalışmıştır. Ekonomide kalıcı ve sürekli istikrarı sağlamayı hedeflemiştir (Karaçor, 2006).

ABD'de mortgage piyasalarında başlayan kriz, ABD de konut kredilerinde başlayan sıkıntılar, Freddie Mac ve Fannie Mae'nin devlet gözetime geçmesi, yatırım bankası Lehman Brothers'ın kendini iflasın ortasında bulması, Merrill Lynch çok düşük bir bedelle Bank of Amerika'ya satılması ve AIG sigorta şirketinin hayatını devam ettirebilmesi için FED’den(ABD Merkez Bankası) büyük miktarda kredi kullanmak durumunda kalması küresel bir krizin işareti olarak finansal piyasalar aracılığıyla önce Avrupa ve hemen ardından tüm dünyaya yayılmıştır (Alantar, 2008). Ülkemizin yaşadığı Kasım 2000- Şubat 2001 krizlerinden sonra bankacılık sistemi çok büyük zarar görmüştür.Türkiye'nin yaşadığı krizlerin ardından uygulamaya koyduğu Güçlü Ekonomiye Geçiş Programının uygulamasında ilerlemeler kaydedilmiş ancak artan finansal piyasalar, yeni finansal araçlar, kur riskleri ve ortaya çıkan küresel kriz sonucu program riskli ve uzun bir sürece yayılmıştır.Güçlü Ekonomiye Geçiş Programı sonrasında sermaye yeterliliği açısından güçlü bir yapıya sahip olan Türk bankacılık sektörü global krizden etkilenmiştir. Ancak Türk bankacılık sektöründe o dönemlerde mortgage kredilerinin verilmemesi ve bu krizin global bir kriz olması Türk bankaları'nın 2001 Krizi’ndeki kadar riske girmesini engelemiştir.Küresel kriz süresinde kredi verme konusunda başarılı bir performans sağlayan bankalar kredi bulma konusunda zorlanmışlardır.Banka ve şirket bilançolarının küçülmesi, Türkiye’yi de diğer ülkeler gibi bir takım önlemler almaya zorlamıştır.Özellikle son yıllarda bankalar zor dönemler geçirmiş, hızlı bir değişim sürecine girmiştir.

Günümüzde bankaların yapısındaki gelişmelerin özellikle ekonomi üzerinde olumlu etkileri de söz konusudur. Örneğin 2001 Krizi’nden dersini alan Türk Bankaları 2008 krizinden sağlam bir kurumsal yapı sayesinde fazla etkilenmemiştir. Kriz karşısında bankaların kırılganlığı azaltılmış, sermaye rasyoları yükseltilmiş, sağlıklı bir yapıya kavuşturulması için birbirleriyle rekabet savaşına girmişlerdir.

\section{Türk Bankacılık Sektöründeki Yapısal Gelişmeler}

Bankacılık krizleri, teknolojinin hızlı gelişimi, bankacılık sektörünün küreselleşmesi ve bankaların ekonomik gelişmedeki rolü, bankaların yasal denetim ve gözetimlerini giderek daha önemli hale getirmektedir (Ungureanu, 2008: 1).Bankaların ülke ekonomisindeki rolü dikkate alındığında, kurumsal yönetim uygulamalarının önemi daha da artmaktadır. Bankalariyi yönetildiklerinde, sermayeyi verimli bir şekilde dağıtacak ve kendilerinin kredi vererek fon sağladığı firmaların üzerinde daha etkili olabileceklerdir. Bankalar kaynak aktarım sürecinde talep edebilecekleri norm ve standartlar aracılığıyla reel sektörün yönetim anlayışını değiştirebilirler Diğer taraftan banka yöneticilerikendi kişisel çıkarlarını ön plana almak yerine hissedarların ve mevduat sahiplerinin çıkarlarını gözetmelidir.Böyle bir durumda, bankalar toplumun tasarruflarını verimli bir şekilde değerlendirecek ve firmalara kurumsal yönetim konusunda örnek olacaklardır.Bankacılıkta kredi kalitesini belirlemek çok kolay değildir.Daha önce aldıkları kredileri geri ödeyemeyen müşterilere tekrar kredi vererek problemleri gizleyebilirler. Bankaların ekonomideki önemi ile banka varlık ve faaliyetlerinin şeffaflı̆̆ının az olmasından dolayı, hükümetler bankaları yasa ve yönetmeliklerle kontrol altında tutmaya çalışmaktadırlar. Diğer sektörlerde devlet müdahalesinin az olduğu ülkeler bile, bankacılık sektörüyle ilgili çok sayıda yasal düzenleme getirmişlerdir. Bankaların kurumsal yönetiminin değişimi önemli bir konu haline gelmiştir. (Saygıl1, 2003:47).

Bankacılık sektörü 2001 Krizi sonrasında sistem değişikliklerine gitmiş ve bu süreç sonunda bilgi ve deneyim kazanmışlardır.Krizler sonrasında Bankacılık düzenleme kuralları değişmiş ve bu da bankacılık anlayışını etkilemiştir. Basel II, yasal düzenlemeler ve denetleme kurumlarının getirmiş olduğu kurallar, bankaların sunduğu hizmetleri fiyatlamasında ve uygulamasında değişikliklere neden olmaktadır. Bankalar sosyal gelişimle beraber teknolojik anlamda da gelişmeler yaparak yeni ürün ve sistemler veya mevcut ürünlerinde sistem gelişimine gitmektedirler.

Bankacılık sisteminin sağlıklı bir yapıya kavuşturulması ve istikrarlı işleyişinin sağlanması olan Basel Bankacılık Denetim Komitesi'nin çalışmaları bankalarda kurumsal yapının dünyada ve Türkiye'de yaygınlaşmasına önemli katkılar sağlamaktadır. Basel Bankacılık Denetim Komitesi, sağlam kurumsal yönetim uygulamalarının üye ülkelerdeki bankalar tarafından benimsenmesini sağlamaları konusunda bankacılık otoritelerine yardımcı olmak için 1999 yılında yayımlanan rehber yeniden gözden geçirilerek 2005'te tekrar görüşe sunulmuş ve 2006'da yayınlanmıştır (BIS, 2006a). 
2001 Krizi sonrasında bankaların kurumsal yapısı değiştirilmiştir. Örneğin, 2001 Krizi öncesi Şube Müdürü 'nün daha falza yetkisi var iken şimdi ise şube müdürünün yetkileri yok denecek kadar az seviyeye indirilmiştir. Bankalar segmentasyona gitmektedirler. Eskiden kurumsal, ticari bireysel şubeler gibi bir ayırım yokken şimdi herkes her işi yapmamaktadır. Operasyon işlemleri eskiden şubeden yapılmakta iken şimdi merkezileştirilmektedir.2001 Krizi'nden sonra banka adedi şube adedi insan kaynağı adedi açısında küçülme dönemi yaşanmaktadır. Pazarlama/satış ekipleri ve operasyon ekipleri ayrı ayrı merkezileştirilmektedir.

Bankalar sanayinin gelişiminde, kritik önem taşımaktadır.Türkiye'nin özel sektöründeki şirketlerinin büyük bir bölümünü “Küçük ve Orta Büyüklükteki İşletmeler” kısaca KOBİ’ler oluşturmaktadır. Günümüzde ülkemizdeki işletmelerin \%99,8'i KOBİ durumundadır. Ekonominin lokomotifi olan KOBİ’leri ülkeyi küresel rekabete bankalar hazırlamaktadır.KOBİ'lerin diş pazarlarla tanışmaları, üretim kalitelerini yükseltmeleri, markalaşmaları, çağdaş finans kaynaklarını kullanmaları ve işlerini geliştirmek için araştırma geliştirme, inovasyon gibi alanlarda yatırım yapabilmeleri için sağlam bir bankacılık yapısının var olması gerekmektedir. Bu nedenle KOBİ'lere daha çok kaynak sağlanması ve onların hem yurt içinde hem de yurt dışında küresel rekabette daha başarılı olmaları için KOBİ'leri teşvik projelerinin arttırılması bankaların en önemli konuları arasındadır(Özdemir, 2008;15-17). 2001 Krizi öncesinde sipariş bankacılığ́1 söz konusu iken artık KOBI’lerin ayağına kadar gidilmekte kredi kolaylıkları sağlanmaktadır. Pazarlama ekipleri ürün odaklı yaklaşarak KOBİ'lere çeşitli ürünler ve firsatlar sunmaktadır.

Türk bankalarının yüksek performansında 2001 Krizi sonrasında yabancı ortak ve satın almaların etkili olduğu söylenebilir.2001 Krizi'nden önce piyasada yabancı sermayeli banka yokken, 2001 Krizi sonrası yabanc1 sermaye yavaş yavaş sektöre girmeye ve satın almalara başlamıştır. 2004 den sonra sektör yabancı sermaye ağırlıklı olarak görülmektedir. Örneğin bankacılık sektöründe BNP Paribas, Rabobank, Fortis, UniCredito gibi finans devleri ile General Electric'in finans kolu Türk Bankalarına kayıtsız kalmamıştır.Satın almalar, bankaların piyasa değerine de etki etmiştir. Örneğin Finansbank'1n 2001 krizinde 84 milyon dolara kadar düşen değeri 5 yılda müthiş bir performansla 3.069 milyar dolara çıkmıştır. Yapı Kredi ise \% 200'le değerini en az artıran banka olmuştur.

Türk bankacılık sistemi 2001 krizinin ağır yaralarını en hızlı saran, değerini de en fazla katlayan sektör olmuştur. 2001 krizinde halka açık 10 bankanın toplam piyasa değeri 4.6 milyar dolara kadar gerilemişti. Yani 2001 kriz yılında bu parayı cebine koyan bir yabancı yatırımcı mevduat ve kredi kartı pazarında Türk bankacılık sisteminin yüzde 60'lık bölümüne hükmeden bu 10 bankayı satın alabilirdi.Oysa bugün sözkonusu bankalara sahip olabilmek için 43.7 milyar dolar gerekiyor.Yani 10 bankanın piyasa değeri 5 yılda yüzde 848 oranında artmıştır. Örneğin bu süreçte halka açık banka statüsüne Denizbank'ın da dahil olduğu, Denizbank'ın piyasa değerinin toplama 1.8 milyar dolar katkı yaptığı dikkati çekmektedir. Rabobank'ın ortak olduğu Şekerbank'ın piyasa değeri sadece 20 milyon dolar iken,dünyanın en büyüklerinden BNP Paribas'ın ortak geldiği Türk Ekonomi Bankası'nın (TEB) piyasa değeri de ancak 42 milyon dolar seviyesindeydi.Bugün ise TEB'in toplam piyasa değeri 714 milyon doları geçmiştir.Yani kriz yılına göre yüzde 1601'lık artış göstermiştir.Şekerbank'ın piyasa değerindeki artış ise yüzde 1705'i bulmuştur ( http://www.ekodialog.com).

Sosyal sorumluluk temelde mesuliyet bilincine dayanır.Bireylerin ye da kurumların kendi amaçlarını gerçekleştirmek için gösterdikleri çabalarda, topluma zarar verecek ya da zarar vermesi olası eylemlerden kaçınmaları anlamına gelmektedir.İşletme bilimi açısından bakıldığında sosyal sorumluluk; işletmelerin faaliyetlerini sürdürürken çevre ve toplum konularında duyarlı davranmaları olarak açıklanabilir. Bu duyarlılık sadece yasal düzenlemelere uymakla sınırlı kalmamakta; yasal düzenlemelerde boşluklar olsa bile etik ve ahlaki değerler çerçevesinde gelişen bir bilinç olarak ele alınmaktadır (Lazol vd., 2008: 63).Ülkemizde Sermaye Piyasası Kurulu'na göre, bankalar eşitlik, şeffaflık, hesap verebilirlik, sürdürülebilirlik ve sorumluluk ilkeleri doğrultusunda bankacılık faaliyetlerini devam ettirmelidir (SPK, 2005: 3). Bankaların sosyal sorumluluğa bakışı ilk önceleri hayırseverlik ve yardımseverlik düzeylerinde başlamış, sonraları etik düzeyine yükselmiş ve daha sonra da firma itibarı üzerinden rekabetçi avantaj sağladığı tespit edilince bir iş stratejisi olarak ele alınır olmuştur (Yönet, 2005: 245). 2001 Krizi öncesinde Türk Bankacılığının kurumsal sosyal sorumluluk faaliyetlerinin temeli karlılı̆̆ını arttırma ve büyümeye odaklıyken 2001 Krizi sonrasında kurumsal bir strateji olarak karşımıza çıkmıştır.2001 Krizi öncesinde bankaların başarılarının değerlendirilmesinde sadece kâr payları, büyüme vb. finansal kriterler dikkate alınmaktaydı.Günümüz yaklaşımlarında işletmelerin performansı ölçülürken finansal kriterlerin yanında; değer yaratma, memnuniyet sağlama, toplumsal konulara katkı vb kriterlere de büyük önem verilmektedir.Dolayısıyla kurumsal sosyal sorumluluk düzeyleri işletmelerin başarıları üzerinde etki sahibi olan önemli bir faktör olarak karşımıza çıkmaktadır (Kaygusuz, 2005: 230).Dünyadaki finansal entegrasyon ve küreselleşme hareketlerinin ardından kriz yaşayan toplumlarda görülen makro ekonomik problemler birtakım sosyal ve ahlaki bozulmaları da beraberinde getirmiştir.Kriz yaşayan ülkelerde bazen etik ikilem denilen kargaşanın yaşandığı görülmüştür.Kriz yaşayan işletmelerde ve ülkelerde uygulanan politikalar krizi çözme hedefli olacağından bazı bankalar bazı şirketlerin kayrılması, çıkarcı uygulamalar, sahte belgeler ve etik olmayan bir ikilemlere yönelmiştir.Küreselleşen dünyamızda global krizlerin sonrasında yaşanan gelişmeler etiğin ve sosyal sorumluluk kavramlarının üzerinde durulması gereken kavramlar olduğu gerçeğini ortaya çıkarmıştır.Bu kavramlar günümüz toplumunda ekonomik gelişmelerinde etkisiyle daha detaylı araştırılmaya 
başlanmış son zamanlarda bankacılık hayatında sıkça karşılaştığımız bir gelişme olmuştur.

Yaşanan skandallar ve krizlerin sebeplerini ortadan kaldırarak tekrarlanmalarının önüne geçebilmek amacıyla küresel çapta bazı çabaların gösterildiği söylenebilir.Pek çok ülke yasal düzenlemelerdeki değişikliklerle finansal raporların güvenilirliklerini artırarak özellikle denetim konusunda ilerlemeler kaydetmişlerdir (Arı, 2008: 133). 2008 yılının ardından yine yenilenen yasal düzenlemelerle finansal raporlamanın sarsılan güvenilirlik düzeyinin artırılması amaçlanmıştır. Bu bağlamda ülkemizde de UFRS, TFRS ve TMS konularında çalışmalar yapılarak önemli aşamalar kaydedilmiştir.Türk Ticaret Kanunu'nda yapılan ve 2013 yılı itibariyle yürürlüğe giren düzenlemelerde özellikle kamuyu aydınlatma üzerine vurgu yapılarak şeffaflık ve kurumsal yönetim anlayışının benimsendiği görülmektedir (Güneş, 2012: 243).Ancak krizlerde batan işletmelerin çoğunun büyük ölçekli, kurumsallaşma dereceleri yüksek ve kurumsal yönetim anlayışını benimsemiş olmaları; etik ve ahlak konusundaki eksikliklere işaret etmektedir (Gökgöz, 2012: 329).

Buradan hareketle 2001 Krizi sonrasında bankacılık sektöründe kurumsal sosyal sorumluluk kavramının ön plana geçtiği fark edilmektedir.Bankaların hızla değişen hizmet yapılarının yanı sıra son zamanlarda toplumsal değer yargıların önemsenerek, sosyal sorumluluk projelerine önem verdiği görülmektedir. Bankacılık sektörü içinde bulunduğu topluma ve dünyaya karşı sorumluluğunun farkında olarak var olan değerlerine sahip çıkmak ve yaşatmak adına önemli sosyal sorumluluk projelerine destek vermektedir. Sosyal sorumluluk ve sponsorluk çalışmalarında özel bankalar dikkat çekmektedir.Bankaların en büyük desteği eğitim, spor ve çevre ile ilgili projelere ve etkinliklere verdiği görülmektedir.Son yıllarda bankaların tümü sosyal sorumluluk alanında çeşitli projeler üretip, başarılara imza atmıştır.Bankacılık sektörü dünyadaki yeniliklere açık, değişmeler karşısında daima dinamik, yenilikçi, yaratıcı olmakla birlikte sosyal sorumluluk bilincine etik ve ahlak kurallara da sahip çıkmalıdır.

Pek çok çalışmada belirtildiği gibi 1990'lı yıllar ve 2008'de yaşanan krizlerin sebepleri içerisinde finansal raporlama temelli nedenler önde gelmektedir. Yeterince şeffaf olmayan finansal raporlar, üst düzey yöneticilerinin teşvik edildiği sistemler nedeniyle iyice yanıltıcı hale getirilerek tarafsızlık ve dürüstlük ilkelerinden sapmalara ve belirli bazı grupların kayırılmasına neden olmuştur. Muhasebenin sosyal sorumluluk kavramı ve meslek etiğine tamamen zıt olan bu tür olaylar, finansal raporların güvenilirliklerini iyice sarsarak işletmelerin itibar kaybetmesine yol açmıştır. Bu skandallar ve krizlerin ardından pek çok ülkede finansal raporlamanın güvenilirliğini artırmak, başta yatırımcılar olmak üzere tüm paydaşların haklarını korumak ve iç ve dış denetim konusundaki eksiklikleri giderebilmek için yeni yasal düzenlemelere gidilmiştir. Ancak finansal raporlamanın güvenilirliğinin sağlanması konusunda belirli bir bilinç düzeyine ulaşan bazı işletmelerin, yasal düzenlemeler zorlamasa da kurumsal sosyal sorumluluk anlayışına geçmeye başladıkları da görülmüştür (Arı, 2008: 51-170, Gökgöz, 2012: 315).Bankacılık açısından bakıldığında, kurumsal sosyal sorumluluk ve finansal raporlama arasındaki bağıntının önemi daha da belirginleşmektedir.Çünkü bankaların faaliyet alanı finansal raporlamanın ölçü birimi olan paradır. Kurumsal sosyal sorumluluk gereğince bankaların güvenilir finansal raporlar üreterek bunları iç ve dış kullanıcılarla paylaşmaları; hesap verilebilirlik, şeffaflık, tarafsızlık ve dürüstlük açılarından bir gerekliliktir. Ayrıca bankalar tarafından sürdürülen sosyal sorumluluk projeleri toplumun kendilerine duyduğu sempatiyi etkilemektedir.Bu da işletme itibarı ve marka değeri açılarından rekabetçi avantajlar sağlayarak tercih edilmeleri konusunda önemli katkılar ortaya koymaktadır (Çalışkan ve İçke, 2009: 142).

\section{Alternatif Dağıtım Kanalları}

2001 Krizi’nden önce hizmet kalitesinin kavramına önem verilse de banka ürünlerindeki satışın arttırılması öne çıkmış, müşteriye sunulan hizmetin, hem müşteri istekleri doğrultusunda olması hem de kaliteli sunulması bankaların işini zorlaştırmıştır.Teknolojinin hızla gelişmesi bankaları teknoloji üzerine yatırım yapmaya zorlamıştır.Geçmişte yeni müşteri kazanmanın ve müşteriyi elde tutmanın daha kolay olduğu, ancak günümüzde, daha değişken, endüstrileşmiş ve karmaşık bir müşteri topluluğundan dolayı, bunun giderek zorlaştığı, bu yüzden satışlardan ziyade, özellikle satış sonrası hizmet ve müşterilerle olan ilişkinin önem kazandığı görülmektedir. (Kuveyt Türk, 2012). Son yıllarda Türk bankalarının ileri teknoloji kullanımları artmış, Türk bankacıları ülkeler tarafından aranılan elemanlar haline gelmişlerdir.

Bankalar, bu değişim sürecinde uyum içerisinde çalışan ve entegre olmuş alternatif dağıtım kanallarıyla birlikte derin bir müşteri deneyimi oluşturmayı tercih etmektedir.Bankalar teknolojik gelişmelerden faydalanarak bunu karlarına ve maliyetlerine yansıtan en önemli kurumlardır.Bankaların maliyeti düşürmek için tercih ettikleri yöntem genellikle yeni bir dağıtım kanalı kullanma olmaktadır.Kârı artırmak için ise çapraz satış fırsatlarından yararlanılmaktadır.Müşteri sayısını korumak ve artırmak için müşteri ihtiyaçları yeni ürünlerle karşılanmaya çalışılmaktadır.Bu anlamda Bankalar müşterilerine 7/24 hizmet veren alternatif dağıtım kanalları ürünleri sunmaktadir.

$\mathrm{Bu}$ kanalların çeşitliliği ise bankalara farklılık ve müşteriyle daha derin ilişkiler kazandırmaktadır.Direkt kanallar olarak telefonun, internet ve mobil şubenin, yüz yüze iletişimin ve son olarak da ATM ve maillerin bankacılık hizmetlerindeki önemi özellikle son yıllarda katlanarak artmıştır.ATM, telefon ve maillerin satış ve 
hizmetteki gelişmelerin yanı sıra şubeler de, bankacılık işlemlerinin merkezi durumundadır.Bu kanallar müşteriyle yüz yüze veya çağrı merkezi ile ilişkiyi artırmıltır. 1980’lerde henüz bankacılıkta kullanılmayan internet günümüzde hem işlem sayısı hem verdiği hizmetlerle ATM'ler kadar kullanılmaktadır. Son yıllarda telefon bankacılığında Mobil Bankacılıkta yapılan işlemlerin arttı̆̆ı görülmektedir.Günümüzde bankacılık kanallarının dağılımı konusunda müşteri ile yüz yüze diyaloğun önemli bir yere sahip olması için çalışmalar hızlanmıştır (Bireysel ve İşletme Bankacılığı Ürün Geliştirme Müdürlüğü ADK Birimi, Araştırma Bülteni, 2013).

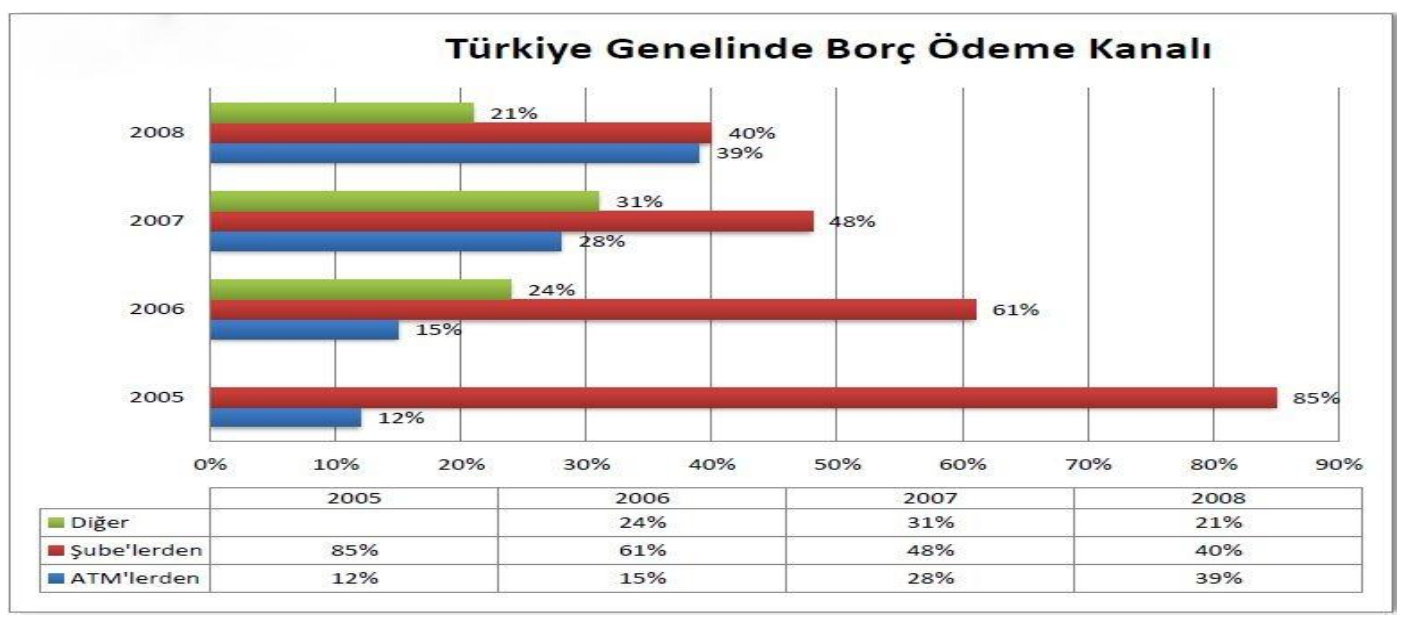

Tablo1: Türkiye Genelinde Borç Ödeme Kanalı

\subsection{ATM ( OtomatikVezne Makineleri)}

Otomatik Vezne Makineleri (ATM), günde 24 saat aralıksız hizmet vererek müşterilerin bankacılık işlemlerini yerine getiren elektronik cihazlardır. ATM'ler, üzerlerindeki bilgisayar ve bu bilgisayarı çalıştıran işletim sistemi aracılığı ile bankanın ana bilgisayarı ile iletişim kurarak müşterilerin bankacılık sistemindeki hesaplarına ulaşmalarını ve bu hesapları üzerinden standart bankacılık işlemlerini kendi kendilerine yapmalarını sağlamaktadır. Ülkemizde ATM makinesinin ilk kullanımı 1987 yılının Aralık ayında gerçekleşmiştir ATM'ler ilk olarak İş Bankası tarafından kullanıma sokulduğu için bu bankanın ATM'lere verdiği özel isim olan Bankamatik ismi zamanla tüm bankaların ATM'leri için benimsenmiş ve bu makinelerde kullanılan tüm kartlara halk arasında bankamatik kartı denilmiştir.Plastik kartların hemen hepsi ATM'lerden para çekmek için kullanılabilmektedir. Aynı zamanda ATM kullanılarak kredi ve banka kartlarının şifrelerinin değiştirilmesi, virman, havale yapılması, ekstre bilgilerinin alınması, bakiye öğrenilmesi, para yatırılması, fon, hisse senedi veya döviz ile ilgili yatırım benzeri pek çok işlemin yapılabilmesi mümkündür. 2001 Krizi öncesinde ATM'lerin sayısı ve kullanımı çok az iken özellikle son yıllarda ATM'ler şubeler kadar hizmet veren kanallar olarak dikkati çekmektedir. Elektronik ödeme makineleri (ATM), satış noktası terminalleri (POS) ve başta kredi kartları olmak üzere chipli kartlar yaygınlığı konusunda Avrupa'da ve Dünya'da saygın bir konuma gelmiştir.ATM'lerin işlem sayısı ve hizmetteki yoğunluğu önemli derecede artmıştır(Banka ve Para Teknolojileri, 1999:24).Tablo 1'e göre 1985-1990 döneminde hazine gelirleri artmaya başlamaktadır.1991-2000 döneminde hazine gelirlerinin zirveye ulaştığı görülmektedir.2001'den sonra ADK'nın (ATM, Çağrı Merkezi, Internet) ağırlığı artmaktadır (Finansbank Eğitim Notlar1, 2008).

\begin{tabular}{|l|l|l|l|l|l|}
\hline \multicolumn{1}{|c|}{ Dönem } & Bireysel & Ticari & Hazine & ADK & Kurumsal \\
\hline $1985-90$ & 45 & - & 40 & - & 15 \\
\hline $1991-2000$ & 30 & 5 & 50 & 5 & 10 \\
\hline 2001 Sonras1 & 30 & 30 & 20 & 10 & 10 \\
\hline
\end{tabular}

Tablo 2: Türk Bankacılık Sektöründe Gelir Merkezlerinin Dă̆ılımı \%

\section{2 İnternet Bankacılığı}

2000'li yıllarda Türk bankalarında ortaya çıkan konsolidasyon eğilimi 2001 Krizi'nden sonra artarak bankaların yeni yapısı üzerinde de belirleyici olmuştur.Müşterilerin talepleri dikkate alınarak, kurumsal yapı içinde; ticari bankacılık, yatırım bankacılığı, sigortacılık ve diğer tüm finansal aracılık hizmetlerinin bir arada verilmiştir.Burada görevler ayrılığı ilkesine dikkat edilerek hareket edilmiştir. Banka müşterilerinin artan iş hacminin getirdiği gereksinimler yeni ödeme sistemlerini doğurmuştur. Bu durum Internet başta olmak üzere elektronik ortam kullanılarak yapılan ödemelerin artmasını, yeni iletişim teknolojilerinden yararlanma ve bu alanda yatırım yapma zorunluluğunu ortaya çıkarmıştır.

Alternatif Dağıtım Kanalları'nın gelişimine baktığımızda elektronik kanalların gelişmesiyle birlikte aynı zamanlarda yol aldığı görülmektedir.İnternet bağlantılarının ADK için önemi büyüktür. İnternet bankacılığının yapısını, müşterinin bilgisayarında çalışan bir internet gezgini programı ile bankanın ana bilgisayarı ile 
bağlantıyı sağlayan bir bankainternet sunucu bilgisayarı oluşturmaktadır.Internet bankacılığı ile, hesap bakiyesi ve takibi, para transferleri, ödemeler, kredi kartı, döviz alım/satım, yatırım işlemleri, hisse senedi, hesap açma ve talimat verme işlemleri gibi 200'e yakın işlem yapılabilmektedir.İnternet hizmetlerinin ve İnternet üzerinden yapılan ticari faaliyetlerin yoğunlaşmasıyla, İnternet bankacılığı uygulamaları hız ve etkinlik kazanmıştır.Türkiye'de uygulama alanı bulan alternatif dağıtım kanalı ürünlerinin başında Elektronik Fon Transfer Sistemi (EFT) başta gelmektedir.1980'lerde henüz bankacılıkta kullanılmayan internet günümüzde hem işlem sayısı hem verdiği hizmetlerle ATM'ler kadar kullanılmaktadır. Şubelerdeki işlem sayısı ise düşerken satış ve hizmet noktasında hala yoğun olmaktadır.Telefon Bankacılığında yapılan işlemler satışlar ve verilen hizmet artışından çok daha fazladır.Maillerle yapılan satışların ve verilen hizmetlerin yoğunluğu azalmış, işlem sayısı ise aynı kalmıştır. Örneğin müşteriler bankacılık hizmetlerini \% 70 oranında şubelerden alıyorken 2010 itibariyle bu oran \%30' a kadar düşmüş durumdadır. Şubelerin hizmet sayısı azalırken diğer kanalların yükselişi devam etmektedir. Web ve ATM, şubeler kadar hizmet veren kanallar olarak dikkat çekmektedir (Tekfenbank Eğitim Notlar1, 2008).

\begin{tabular}{|l|l|l|}
\hline Türkiye Geneli Müşteri Adedi & Kayıtlı (En az bir defa) & Aktif (Son 3 ay) \\
\hline Bireysel & 18,1 milyon & 7,8 milyon \\
\hline Kurumsal & 1,8 milyon & 803 bin \\
\hline $\begin{array}{l}\text { Türkiye Geneli İnternet Şubesi } \\
\text { İlemleri }\end{array}$ & Adedi & Tutar \\
\hline Finansal Olan (Yatırım ișlemleri Hariçtir) & 330 milyon & 1.1 katrilyon TL. \\
\hline Finansal Olmayan & 537 milyon & - \\
\hline
\end{tabular}

Tablo 3: 2011 Yllı Türkiye Geneli Müşteri Adedi ve Türkiye Geneli İnternet Şubesi Işslemleri

SMS onay uygulaması İnternet Şube'sine girişlerde ya da İnternet Şubesi’ndeki işlemlerinde kişiye özel şifrenin banka tarafında kayıtlı olan cep telefonuna giriş esnasında üretilip iletilmesi işlemidir. Bu uygulama için müşterinin İnternet Şubesi hesabı ve sistemde kayıtlı cep telefonu bilgisi olmak zorundadır.Önemli Alternatif Dağıtım Kanalları'ndan biri olan SMS kanalı finans sektörü başta olmak üzere bir çok kurumun başlıca iletişim kanallarından biridir.Bankalar SMS kanalını reklam içerikli, risk takip ve SMS amaçlı kullanmaktadır.Grafik 1'de görüldüğü gibi Türkiye'deki operatörlerin SMS gönderim adetlerine baktığımızda Mart-Haziran 2010 arasında 36, 3 milyar SMS yollandığ1 görülmektedir (Kuveytürk ADK Birimi Araştırma Bülteni 2012).

Parolamatik, İnternet Şubesi'ne girişte ve telefon bankacılığında kullanabilen bir parola üretme cihazıdır. Tek kullanımlık şifre üreten Parolamatik her kullanımda özel bir şifre üretmektedir.Parolamatik herkesin kullanabileceği kullanım kolaylığıyla birlikte özellikle güvenliğe önem veren kurumsal müşterilerde önemli bir tercih nedenidir. Cihazın hafif ve taşınabilir olması ergonomik sunumu yine ürünün başarılı taraflarındandır.Mobil imza, 5070 sayılı Elektronik İmza Kanunu’na göre elektronik ortamlarda 1slak imzaya eş değer kimlik doğrulayan bir servistir. Elektronik posta (e-posta), pazarlamada, markanın tanıtımında ve müşteri ile iletişim kurmada kullanılan pazarlama araçlarından biridir. E-posta kullanımının yaygınlaşması, birçok kişiye bilgisayar aracılığıyla haberleşme alışkanlığı kazandırmasının yanısıra, bilgi aktarımı hız kazandırmıştır. E-posta haberleşme sistemiyle hareketli, sesli ve görüntülü iletilerin gönderilebilmesi, mümkün olup, müşterilerin cevap verme oranı süresi kısadır. Elektronik postada \% 15-\% 30 arasında değişen cevap verme oranı geleneksel posta yönteminde \% 3-\% 4 arasında değişmektedir. Yine yapılan araştırmalarda, pazarlama amaçlı gönderilen elektronik postaların \%99'unun müşteriler tarafından açıldığı, müşterilerin yaklaşık \% 65'inin elektronik posta içerisinde yer alan linklere ulaştığı ve \%8'ininde elektronik postayı aktif olarak yanıt verdiği belirlenmiştir. (infomag.com.tr). Mobil Şube Akıllı Cep Telefonlardan 7/24 bankacılık işlemi yapılan bir mobil uygulamadır. Kiosk müşteri ilişkilerinin interaktif bir şekilde yürütülmesini sağlayan bir bilgi merkezi şeklindeki bilgisayarlara verilen genel sistemdir. Yapılan bir başka araştırma ADK içinde en az kullanılan kanalın Kiosk olduğunu da göstermektedir.

Deloitte, "Deloitte Center forBanking Solutions" raporunda bankaların şubesiz bankacılık kanallarını geliştirirken karşılaşabilecekleri sorunları açıklamıştır.Bunlar müşterilerin alternatif dağıtım kanallarına yönelmesinin şube kaynaklı kar büyümesini zorlaştırması,bankacılık işlemlerin birçoğunun uzaktan yapılabilmesinin bankasüreçleri ve müşteri servislerini her geçen gün şubeden bağımsız hale getirmesi, günümüz teknolojilerini kullanan müşterilerin iyi bir iletişim ve çok kanallı bankacılık hizmeti almak istemeleri,kitle etnik gruplarının özel hizmet tercihleri olarak sıralanmaktadır.

\section{Sonuç ve Değerlendirme}

Türkiye'de yaşanan finansal krizler bankacılık ve finans sisteminin güçlü, güvenilir ve etkin nitelikte olması gerektiğini göstermiştir. Türkiye'de yaşanan Kasım 2000 ve Şubat 2001 krizlerinden sonra, uygulamaya konan Güçlü Ekonomiye Geçiş Programında, bankacılık sektörüne ayrıca önem verilmiş, bankacılık sektörünün zedelenmiş imajını düzeltmek ve uluslararası rekabette söz sahibi yapmak üzere yeni kararlar alınmıştır. 
Çoğunluğu yapısal veya denetim eksikliklerden kaynaklanan Türkiye'deki banka iflasları ve tasfiyeleri sonucunda sektörün imajı zedelenmiş, hortumlanan bankalardan ülke ekonomisi büyük zarar görmüştür. 2000'li yıllarda patlak veren bu finansal krizler bankaların özellikle yapısalanlamda uluslararası standartlara uygun hareket etme, denetim ve bankacılık anlayışının değişmesine vesile olmuştur.Bu süreç içerisinde bankacıllk sektörü hızla gelişmiş, sermaye yapıları ve karlılıkları artmış ve bankacılık anlayışları değiş̧iştir.Dolayısıyla bankacılık anlayışının değişmesi, sosyal sorumluluk kavramına uygun hareket edilmesi daha gerçekçi ve güvenilir finansal raporların oluşturulmasına neden olmuştur.Bankacılık sektörü ve reel sektör yeniden yapılandırma süreci içerisinde birlikte hareket etmiş, marka değeri ve itibarı üzerinde rekabetçi avantaj elde etmiş,makroekonomik dengelerin düzeltilmesinde büyük rol oynamışlardır.

Ülkemizde yaşanan finansal krizler, bir yandan bankacıllk sektörünü zayıflatırken diğer taraftan da son yıllarda bankaların yeni firsatlarla karşılaşmasına imkân tanımıştır.Bankalar mevcut hizmet kalitesini sürdürürken alternatif dağıtım kanallarını da arttırmışlardır.Bir yandan finansal sorumluluklarını bilerek karlılıklarını arttırmışlar diğer yandan da sosyal sorumluluk projeleriyle yeni bir bankacılık anlayışı getirmişlerdir.Bankalar artan rekabet şartları arasında müşterinin tercihi olma yarışına girmişlerdir.Buradan hareketle, bankaların müşteriye yönelik çalışmalarının arttırılarak, müşteri memnuniyetinin sağlanması rekabet açısından faydalı olacaktır.Ayrıca bankacılık işlemlerinin maliyetinin azaltılması için alternatif dağıtım kanallarının zenginleştirilmesi karlılık açısından faydalı olacaktır. Bankacılıkta kalite, Uluslararası Standartları'na sahip çağdaş bir bankacılık sistemi ile sağlanabilir. Bu yüzden alternatif dağıtım kanallarının zenginleştirilmesi, İnternet, web,mobil ve ATM kanallarının etkinliğinin artttırılması, maliyetlerin düşürülmesi, şube işlemlerinin müşterinin ayağına götürülmesi,müsşerilere özel bankacılık hizmetlerinin arttırılarak tercih edilme konusunda bir adım öne geçilmesi, ve diğer ülkelerde kullanılan tüm bankacılık ürünlerinin ve yeni teknolojilerin transfer edilmesi gerekmektedir. Ancak günümüzde artan rekabet şartları, ürün hedefli yaklaşım, bireysel hedef geçekleştirmeleri, azalan marjlar neticesinde daralar karlar, daha çok satış baskısı bankaları zorlamaktadır. $\mathrm{Bu}$ bakımdan bankacılık sektörü sürekli olarak değişikliklere ve yeniliklere açık olmalı ve önümüzdeki günlerdeki yaşayacağı sorunları önceden görerek bu sürece daha hazırlıklı olmalıdır.

\section{Kaynakça}

- Ar1, M., 2008. Finansal Raporlamada Güvenilirlik, Ekin Yayınevi, Bursa, s. 51,133, 170

- Ateş, K., 2004. "Finansal Krizlerden Bankacllık Krizlerine Bir Değerlendirme”, Piyasa Dergisi, Yaz, Sayı: 11, s.195-215.

- Akyüz, Y., Boratav, K., 2002. “Türkiye'de Finansal Krizin Oluşumu”, İktisat İşletme ve Finans Dergisi, Sayı 197.s. 16-17.

- Alantar, D., 2008, “Küresel Finansal Kriz: Nedenleri ve Sonuçları Üzerine Bir Değerlendirme”, Maliye Bakanlığı Bütçe ve Mali Kontrol Genel Müdürlüğü Daire Başkanı, http://www.finanskulup.org.tr/assets/maliyefinans/81/ Dogan_Alantar_Kuresel_Finansal_Kriz_Nedenleri_Sonuclari_MFY81.pdf, 10 Mart 2013.

- Boratav, K., "2001. 2000-2001 Krizinde Sermaye Hareketleri”, Mülkiye Dergisi, Cilt XXV, Sayı 230, s.213215. Banka ve Para Teknolojileri, Alternatif Dağıtım Kanalları, 1999, s.24.

- Bireysel ve İşletme Bankacıllğı̆ Ürün Geliştirme Müdürlüğü ADK Birimi, Araştırma Bülteni, 2013, s.1-3.

- Celasun, M., "Gelişen Ekonomilerin Dlş Kaynak Kullanımı, Finansal Krizler ve Türkiye Örneği”, 2001, Doğu-Batı, Yı1: 4, Sayı: 12, Kasım, Aralık, Ocak 2001-02, s.161-181.

- Çalışkan, E. N. ve İçke, B. T., 2009. "Kurumsal Yönetim Uygulamalarının Türk Bankacıllk Sektöründeki Durumu”, İstanbul Üniversitesi İktisat Fakültesi Mecmuası, Cilt 59, Sayı 2, s. 121,142.

- Deloitte Center for Banking Solutions, Mayıs 2008 Bülteni, 2008.

- Erdoğan, N., 2002. Dünya'da ve Türkiye'de Finansal Krizler, Türk Bankacılık Seköründe Yeniden Yapılandırma Uygulamaları- Kamu Bankaları Deneyimi, Yaklaşım Yayınları, İstanbul, s.133.

- Erdönmez, P. Ataman, 2001, Sistematik Banka Yeniden Yapılandırmasında Teorik Yaklaşım, TBB, Bankacılık Araştırma Grubu Çalışma Raporu, Haziran, s. 1, 19.

- Finansbank, 2008. Bankacılık Eğitimi Notları, Finansbank Genel Müdürlük Baskısı, İstanbul, s. 15.

- Günal M., 2001. Türk Bankacıllk Sektörünün Sorunlart ve Gelecegi, A.T.O Yayınları, Ankara,s. 64.

- Gülcan, Y., Kuştepeli, Y., Ayhan, D., Emirhan, P., Gökmen, H., Halaç, U. ve Konyalı ,G.,"2001. 2000-2001 Ekonomi Programları Üzerine Değerlendirmeler”, Dokuz Eylül Üniversitesi İşletme Fakültesi Dergisi, Cilt 2, Sayı 2, s. 7.

- Göktaş, A., 2000. Küresel Kriz ve Türkiye, Özen Yayımc1lık, Ankara, s. 272.

- Gökgöz, A., 2012. "Küresel Finansal Krizin Muhasebe Temelli Nedenleri Bağlaminda Kurumsal Yönetim ve Muhasebe Meslek Etiğinin Önemi”, Atatürk Üniversitesi İ.İ.B.F. Dergisi, Cilt 26, Sayı 3-4, s. 313,315,331. 
- Hazine İstatistikleri, 2001. Hazine Müsteşarlığı Ekonomik Araştırmalar Genel Müdürlüğü, 1980-2003, Ankara, s. 1-10.

- Güneş, R., “Muhasebe Uygulamalarının Sosyal Sorumluluk Anlayışı Üzerine Bir Araştırma”, Muhasebe Bilim Dünyası Dergisi, Cilt:5, Sayı:2, 2003, s. 243.

- Karaçor, Z. 2006, “Öğrenen Ekonomi Türkiye: Kasım 2000-Şubat 2001 Krizinin Öğrettikleri’’Selçuk Üniversitesi Dergisi, ISSN1302-1796 Sayı: 16, s. 379.

- Karaçam, B., 2006. Orası Yapı Kredi Fark Oradaydı, Yapı Kredi Yayınları, 1. Baskı, İstanbul, s.137.

- $\quad$ Kazgan, G., 2005. Türkiye Ekonomisinde Krizler (1929- 2001) Ekonomik Politik Açıdan Bir Irdeleme, Bilgi Yayınları, İstanbul, s. 249-253.

- Karluk, R. 2005. Cumhuriyetin İlanından Günümüze Türkiye Ekonomisinde Yapısal Dönüşüm, Beta Yayınlar1, İstanbul, s. 428.

- Kaygusuz, S.Y., 2005. “İşletmelerde Strateji Tabanlı Sorumluluk Muhasebesi Sistemi”, Anadolu Üniversitesi Sosyal Bilimler Dergisi, Cilt 5, Sayı 1, s.230,

- Kuveyttürk, 2012. ADK Araştırma Bülteni, Genel Müdürlük, İstanbul, s. 10, 13, 20, 25, $27,33$.

- $\quad$ Lazol, İ., Muğal, E. ve Yücel, Y., 2008. “Sürdürülebilir Bir Çevre İçin Çevre Muhasebesi ve KOBI'lere Yönelik Bir Araştırma”, MUFAD Muhasebe ve Finansman Dergisi, Sayı 38, s. 63.

- Özdemir, S. 2008. Üretim ve Pazarlamada Yenilikçi 40 Patron, 1. Bask1, Macro Micro, İstanbul, s. 15-17.

- $\quad$ Pion-Berlin D.P. and Trinkulas, H., 2005."Democratization, Social Crisis and the Impact of Military Domestic Rules in Latin America”, Political and Military Sociology, Vol: 33, No. 1, s.14.

- Pazarbaşığlu, C., 2003. Yeniden Yapılandırma Programına Genel Bakış, BDDK, Ankara, s. 17-18.

- Seyidoğlu, H., 2003. “Uluslararası Mali Krizler IMF Politikaları Azgelişmiş Ülkeler Türkiye ve Dönüşüm Ekonomileri”, Doğuş Üniversitesi Dergisi, Cilt 4,Sayı 2, s. 147,148.

- Stubbs, R., 2005. “Rethinking Asia’s Economic Miracle”, Palgrave Macmillan, New York, s. 199.

- Sürek, İ., 1999. “Finansal Liberalizasyon ve Bankacılık Krizi”, Türkiye Cumhuriyeti Merkez Bankası Lira Dergisi, Sayı:10, Ankara, s. 24.

- Saygılı, Ş., 2003. “Finans Kesiminde Yeni Ĕ̈ilimler ve Kurumsal girket Yönetimi”, TCMB Kurumsal Şirket Yönetimi Konferansı Kitabı, Ankara, s. 47.

- Türkiye Bankalar Birliği, 50. yılında Türkiye Bankalar Birliği ve Türk Bankacılık sistemi, 2008, s. $20,41$.

- Türkiye Bankalar Birliği, 2012, 2011 Aralık- 2011 Yılına Ait Toplam Veriler.

- Toprak, M., Demir O., 2001, “Türk Bankacılık Sektörü: Sorunlar, Krizler ve Araylşlar”, Çukurova Üniversitesi İ.İ.B.Dergisi, Cilt:2, Sayı: 2, Adana s. 11.

- Tekfenbank, 2005. Bankacılık Eğitim Notları, Tekfenbank Genel Müdürlüğü, İstanbul.

- Yentürk, N., Çimenoğlu A, Uluslararası Sermaye Hareketlerinin Gelişimi ve Türkiye Ekonomisinin Krizleri Üzerindeki Etkisinin Modellemesi, Körlerin Yürüyüşü, Türkiye Ekonomisi ve 1990 Sonrası Krizler, İstanbul Üniversitesi Yayınları, 1.Baskı, İstanbul, Aralık 2003.

- Yönet, E., 2005. “Kurumsal Sosyal Sorumluluk Anlayışında Son Dönemeç Stratejik Sorumluluk”, Balıkesir Üniversitesi SBE Dergisi, Cilt 8, Sayı 13, s. 245.

- http://www.ekodialog.com/Makaleler/bankacilik-sektorunde-yeniden-yapilanma.html. Erişim Tarihi:10.05.2013

- $\quad$ infomag.com.tr. Erişim Tarihi: 10.05.2013. 


\title{
Parametrik Riske Maruz Değer Hesaplamasında Volatilitenin Modellenmesi: Türkiye'de Emeklilik Yatırım Fonları Üzerine Bir Uygulama
}

\section{Volatility Modelling in Parametric Value at Risk Calculation: An Application on Pension Funds in Turkey}

\author{
Umut Akduğan (Trakya University, Turkey) \\ Asst. Prof. Dr. Yasemin Koldere Akın (Trakya University, Turkey)
}

\begin{abstract}
Risk management has strategic importance with deepness and globalization of financial markets. Financial markets are faced with systematic or non-systematic risk factors. Risk management has a great importance for banks, as well as other financial institutions and investors.In this context, "Value at Risk (VaR)" is recommended as one of the methods to measure market risk by international organizations and Turkish Banking Regulation and Supervision Agency (BRSA). The parametric method (Variance-Covariance Method), one of the methods used in VaR calculation, used in pension funds which have reached large numbers and established by the Turkish pension companies. Moreover, this method is applied in two different ways based on the assumption of constant variance and based on the basis of conditional heteroscedasticity, and the results were compared. The accuracy of the calculations have been tested by backtesting method. For this purpose, daily returns company's growth equity fund between 03/01/2011 - 04/30/2013 is used for the four pension companies which is the maximum size of the fund and operating in Turkey.
\end{abstract}

\section{Giriş}

Bireysel emeklilik sistemi dünyada uzun yıllardır uygulanmakta, bireysel emeklilik sisteminin gelişimiyle beraber hızla büyüyen emeklilik yatırım fonları da finansal piyasaların temel unsurlarından bir halini almaktadır. Gelişmiş ülkelerde bireysel tasarrufların yöneldiği alanların başında bireysel emeklilik sistemi gelmektedir. OECD ülkelerinde emeklilik fonu varlıklarının GSYİH'ya oranının ağırlıklı ortalaması 2009 yılında \%67,1 iken 2011 yılında \%72,4 olarak gerçekleşmiştir. Emeklilik fonu varlıklarının GSYİH'ya oranı dikkate alındığında, 2011 yılında Hollanda'da bu oran \%138, İzlanda'da \%129, İsviçre'de \%111 olarak gerçekleşmiş, yani emeklilik fonu varlıkları ülkelerin GSYİH'sını aşmıştır (EGM, 2012).

Türkiye'de ise 2003 yılında başlayan bireysel emeklilik sistemi 2012 yılı sonu itibarı ile 20.352.242.626 TL net varlık değerine ulaşmıştır. 2011 yılına göre 2012 yılında \% 42 büyüyen emeklilik yatırım fonlarına bakıldığında, 2012 yılı sonu itibarı ile halka arz edilmiş fon adedi 173'e yükselmiştir (EGM, 2012). Ancak 2011 yılında Türkiye'de emeklilik fonu varlıklarının GSYİH'ya oranının \% 2,2 düzeyinde gerçekleştiği düşünüldüğünde, dünyadaki diğer ülkelere bakarak Türkiye'de bireysel emeklilik sistemindeki gelişmelerin yetersiz kaldığ 1 görülmektedir. Fakat 2012 yılı bireysel emeklilik sisteminin gelişimine önemli oranda katk1 sağlayacak düzenlemelerin yapıldığ́ ve sistemle ilgili pek çok olumlu gelişmelerin yaşandığı bir yıl olmuştur. Yapılan bu düzenlemeler ile sisteme getirilen yenilikler sayesinde 2013 yılının ilk 4 ayında, önceki yılın aynı dönemine göre sisteme katılanların sayısı 3,5 kata yakın düzeyde artmıştır.

Son yıllarda büyük ilerlemeler sağlayan ve gittikçe büyüyen Türkiye'deki bireysel emeklilik sistemi ve emeklilik yatırım fonları, finansal piyasaların da en önemli parçası haline gelmiştir. Bu bağlamda araştırma kapsamında Türkiye'deki emeklilik şirketlerinin kurduğu bazı emeklilik yatırım fonlarının risk analizi yapılmıştır. Ancak çalışma kapsamında asıl üzerinde durulan nokta Riske Maruz Değer (RMD) hesaplamasında kullanılan tekniklerin doğru seçilmesi ve gerçeğe yakın sonuçların elde edilmesidir.

Risk yönetimi kavramı, 1970’lerin ilk yarısında doğup gelişen bir kavramdır. Zamanla finansal piyasaların derinleşmesi ve işlem hacminin çok büyük boyutlara ulaşmasıyla harekete geçen Basel Komitesi, 1996 yılında son halini alan Basel Sözleşmesi’nin piyasa riskini de içerecek şekilde düzenlenmesini sağlamışlardır. Riske Maruz Değer (RMD) kavramı ise 1990'ların başında karşılaşılan finansal skandallar sonrasında ortaya çıkmış, ilk olarak JP Morgan RiskMetrics ve gerekli veri setini Kasım 1994’te yayınlamaya başlamıştır.

RMD, belli bir zaman aralığında ve bir olasılık dahilinde finansal varlıklardan oluşan bir portföyün değerinde gerçekleşebilecek maksimum değişimi ifade eder. Yani belli bir elde tutma süresi içinde ve belli bir olasılıkla portföy en fazla ne kadar kaybeder sorusunun yanıtını verir. RMD hesaplamasında kullanılan 3 temel yöntem vardır. Bunlar, Parametrik Yöntem (Varyans-Kovaryans Yöntemi), Tarihsel Simülasyon Yöntemi ve Monte Carlo Simülasyonu Yöntemi'dir. Ayrıca RMD hesaplamasında dikkate alınan etkenlerden biri de standart sapma, yani volatilitedir. Dolayısıyla bir zaman serisinin volatilitesinin doğru hesaplanması ve modellenmesi oldukça 
önemlidir. Normal dağılıma uymayan zaman serileri ile RMD hesaplarken normal dağılım varsayımı altında hesaplama yapılırsa gerçeği yansıtmayan sonuçlar elde edilecektir.

Buradan yola çıkarak bu çalışmada seçilen emeklilik yatırım fonlarına ait getiri serileri kullanılarak ve iki farklı yöntemle standart sapma bulunarak RMD hesaplaması yapılmış ve elde edilen sonuçlar karşılaştırılmıştır. Çalışmada verilerin analizi sürecinde MS-Excel 2007 ve E-views 5.0 paket programlarından yararlanılmıştır.

\section{Riske Maruz Değer (RMD)}

RMD, piyasa riskinin belirlenmesinde son yıllarda sıklıkla kullanılan ve istatistiki temeli olan bir yöntemdir. Teorik olarak bir portföyün belirli bir olasılıkla belirli bir zaman aralığında gerçekleşebilecek maksimum zarar miktarını ölçer (Bams, Lehert ve Wolff, 2001). İstatistiki olarak ise, bir örneklem üzerinde hesaplanan portföy zarar dağılımı olarak ifade edilmektedir (Henriks, 1996).

RMD, temel olarak finansal piyasa fiyatlarının değişimi sonucu oluşan piyasa riskini ölçmek için kullanılan bir yöntemdir (Kaplanski ve Kroll, 2001). Bu bağlamda, risk raporlaması, risk limitlerinin belirlenmesi, sermaye uygulamaları, sermayenin iç dağılımının belirlenmesi, performans ölçümü gibi her türlü risk yönetimi ihtiyac1 için kullanılmaktadır (Çelik ve Kaya, 2010).

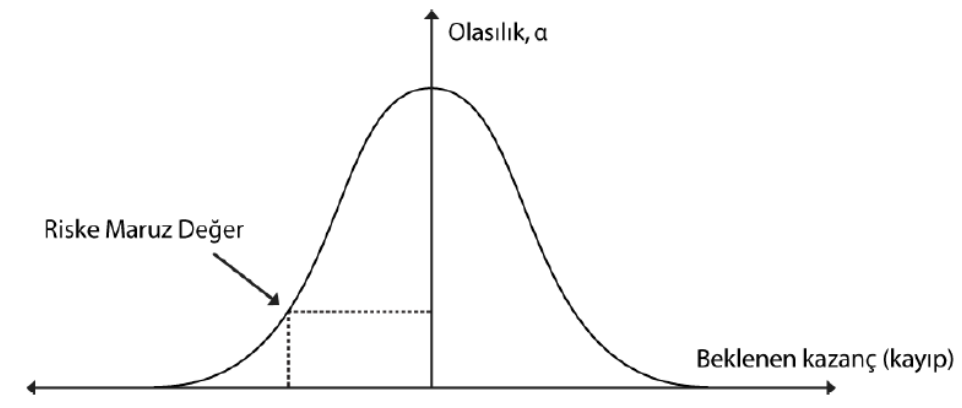

Grafik 1: Riske Maruz Değer (Kaynak: Albanese ve Campolieti, 2006)

RMD modellerinde temel parametrelerin önceden belirlenmesi gerekir. Bu parametreler, elde tutma süresi, örnekleme periyodu, güven aralığının belirlenmesi ve risk faktörleri arasındaki korelasyonun belirlenmesidir. RMD'in hesaplanmasında kullanılan yöntemleri iki başlık altında değerlendirmek mümkündür. Bunlardan birincisi, "Parametrik Yöntemler" olarak bilinir. Varyans-Kovaryans ya da Parametrik RMD olarak adlandırılan yöntemde, taşınan alım-satım portföyünün değerini etkileyen parametreler belirlenmekte ve bunlarda belirli bir olasılık dahilinde meydana gelebilecek dalgalanmalardan yola çıkılarak portföydeki değer kaybı hesaplanmaktadır. İkinci grup ise, simülasyon teknikleridir. Geleceğe ilişkin piyasa fiyatlarının belirlenmesi ve buna bağlı olarak portföyün piyasa değeri dağılımının hesaplanmasına dayanmaktadır. Bu gruptaki yöntemler “Tarihi Simülasyon Yöntemi” ve "Monte Carlo Simülasyonu Yöntemi” dir (Linsmeier ve Pearson, 1996).

Bu çalışmada RMD hesaplamasında Varyans-Kovaryans Metodu, yani parametrik yöntem kullanılmıştır.

\subsection{Varyans Kovaryans Yöntemi}

$\mathrm{Bu}$ yöntemde, geçmiş verilerden elde edilen fiyat ve oranların volatilite ile korelasyonları kullanılarak gelecekteki risk faktörlerinin davranışları hesaplanmaktadır. Bu tahmini volatilite ve korelasyonlar, bir pozisyonun değerindeki beklenen değişimleri hesaplamak için kullanılır (Bolgün ve Akçay, 2009).

Parametrik yaklaşım olarak da adlandırılan bu yaklaşımda, getirilerin normal dağılıma uyduğu varsayımı yapılmaktadır. Bu bağlamda RMD hesaplamasındaki parametreler normal dağılım özelliklerinden faydalanılarak tahmin edilir ve hesaplanır. Normal dağılıma sahip değişkenlerin lineer toplamı da normal dağılıma sahip olduğundan tek yatırım aracı için hesaplanan RMD, normal dağılım özelliklerinden faydalanılarak aynı şekilde hesaplanabilmektedir. Varyans-Kovaryans Yöntemi’nde temel olarak aşağıdaki formül ile RMD hesaplanır:

$$
R M D=P V \times \alpha \times \sigma \times \sqrt{t}
$$

Formülde; PV = Portföyün bugünkü değeri, $\alpha=$ Güven düzeyi, $\sigma=$ Portföyün volatilitesi, $\mathrm{t}=$ Elde tutma süresini belirtmektedir.

Portföyün standart sapması (volatilite) aşağıdaki formülle hesaplanmaktadır.

$$
\sigma_{p}=\sqrt{\left[\begin{array}{llll}
w_{1} & w_{2} & \ldots & \ldots \\
w_{n}
\end{array}\right] * \Sigma *\left[\begin{array}{c}
w_{1} \\
w_{2} \\
\ldots \\
w_{n}
\end{array}\right]}
$$




$$
\sigma_{p}=\sqrt{\left[\begin{array}{llll}
w_{1} & w_{2} & \ldots & \ldots \\
& w_{n}
\end{array}\right] *\left\{\left[\begin{array}{cccc}
\sigma_{1} & 0 & \ldots & 0 \\
0 & \sigma_{2} & \ldots & 0 \\
\ldots & \ldots & \ldots & \ldots \\
0 & 0 & \ldots & \sigma_{n}
\end{array}\right] *\left[\begin{array}{cccc}
\rho_{1,1} & \rho_{1,2} & \ldots & \rho_{1, n} \\
\rho_{2,1} & \rho_{2,2} & \ldots & \rho_{2, n} \\
\ldots & \ldots & \ldots & \ldots \\
\rho_{n, 1} & \rho_{n, 2} & \ldots & \rho_{n, n}
\end{array}\right] *\left[\begin{array}{cccc}
\sigma_{1} & 0 & \ldots & 0 \\
0 & \sigma_{2} & \ldots & 0 \\
\ldots & \ldots & \ldots & \ldots \\
0 & 0 & \ldots & \sigma_{n}
\end{array}\right]\right\} *\left[\begin{array}{c}
w_{1} \\
w_{2} \\
\ldots \\
w_{n}
\end{array}\right]}
$$

$\sigma_{p}=$ Portföyün standart sapmas1

$\Sigma=$ Varyans - Kovaryans Matrisi

$w_{i}=$ Portföyü oluşturan pozisyonların ağırlıkları

$\rho_{i, j}=$ Risk faktörlerinin korelasyon katsayıları

Tek yatırım aracı için parametrik yöntemle yapılan RMD hesaplamasında, koşullu değişen varyans esasına dayanarak elde edilen standart sapma değerlerinin kullanılması daha tutarlı sonuçlar vermektedir (Ural, 2010). Bu çalışmada Parametrik RMD'in hesaplaması, normal dağılım esasına dayanarak elde edilen standart sapma ve koşullu değişen varyans esasına dayanarak "Üstel Ağırlıklı Hareketli Ortalama Yöntemi”" ile elde edilen standart sapma değerleri kullanılarak yapılmıştır.

\section{2 Üstel Ağırlıkı Hareketli Ortalama (EWMA)}

Üstel Ağırlıklı Hareketli Ortalama Yöntemi, varlık getirilerinin simetrik ve bağımsız olarak dağıldığı prensibi üzerine kurulmuş olup, zamana bağlı olarak değişen bir volatilite varsayımına dayanmaktadır (Akçay ve Bolgün, 2009). Bu yöntemde oynaklık tahmin edilirken, hesaplama yapılacak döneme yakın olan fiyat değişimlerine daha fazla ağırlık verilemektedir. $\mathrm{t}$ zamanındaki tahmini varyans, geçmiş tahminlerin $\lambda$ ağırlıklı ortalamasıdır. $\mathrm{Bu}$ yöntemde standart sapma aşağıdaki formülle hesaplanır (Çelik ve Kaya, 2010).

$$
\hat{\sigma}=\sqrt{(1-\lambda) \sum_{i=1}^{t} \lambda^{t-1}\left(r_{t-1}\right)^{2}}
$$

Yukarıdaki eşitlikte;

$r_{t}$ : Yatırım aracının t zamanındaki getirisini,

$r_{t-1}$ : Yatırım aracının t-1 zamanındaki getirisini,

$\lambda$ : Sabit bir sayıyı (RiskMetrics tarafından kabul edilen değeri 0,94’tür) ifade etmektedir.

\section{Uygulama}

Bu çalışmada, Türkiye'de kurulan emeklilik şirketlerinden fon büyüklüğüne göre sıralandığında ilk dördünün kurduğu büyüme amaçlı hisse senedi emeklilik yatırım fonlarının günlük birim pay değerlerine ait veriler kullanılmıştır. Anadolu Hayat Emeklilik A.Ş. Büyüme Amaçı Hisse Senedi Emeklilik Yatırım Fonu, Avivasa Emeklilik ve Hayat A.Ş. Büyüme Amaçı Hisse Senedi Emeklilik Yatııım Fonu, Garanti Emeklilik ve Hayat A.Ş. Büyüme Amaçlı Hisse Senedi Emeklilik Yatırım Fonu ile Yapı Kredi Emeklilik A.Ş. Büyüme Amaçlı Hisse Senedi Emeklilik Yatırım Fonu'na ait birim pay değerleri kullanılarak, iki farklı volatilite modellemesiyle parametrik RMD hesaplanmıştır.

Analizde kullanılan zaman serilerine ilişkin değişkenler aşağıdaki sembollerle gösterilmiştir.

DLNAH: Anadolu Hayat Emeklilik A.Ş. Büyüme Amaçlı Hisse Senedi Emeklilik Yatırım Fonu

DLNAVI: Avivasa Emeklilik ve Hayat A.Ş. Büyüme Amaçılı Hisse Senedi Emeklilik Yatırım Fonu

DLNGRN: Garanti Emeklilik ve Hayat A.Ş. Büyüme Amaçı Hisse Senedi Emeklilik Yatırım Fonu

DLNYKR: Yapı Kredi Emeklilik A.Ş. Büyüme Amaçlı Hisse Senedi Emeklilik Yatırım Fonu

Öncelikle belirtilen fonların 01.03.2011 - 30.04.2013 tarihleri arasındaki kapanış fiyatları alınmış ve bu fiyatların logaritmik getirileri hesaplanmışıı $\left(\ln \left(p_{t} / p_{t-1}\right)\right.$. RMD’nin hesaplanmasıyla ilgili yapılan uygulamalarda ağırlıklı olarak logaritmik getiriler kullanılmaktadır. Çünkü finansal piyasalarda yatırım araçlarının getirileri genellikle lognormal dağılıma uyar (Bolgün ve Akçay, 2009).

Finansal verilerin değerleri genelde birbirine bağımlı değerlerdir ve bu birim kök sorununu, yani durağan olmama sorununu doğurur. Bir serinin durağan olması demek, o serinin ortalamasının ve varyansının sabit, kovaryansının ise zamana değil, gecikme uzunluğuna bağlı olması demektir. Daha teknik bir tanımla, ortalamasıyla varyansı zaman içinde değişmeyen ve iki dönem arasındaki ortak varyansı bu ortak varyansın hesaplandığı döneme değil de yalnızca iki dönem arasındaki uzaklığa bağlı olan olasılıklı bir süreç için durağandır denir (Gujarati, 2006). Yani durağanlık analizi, zaman serileri analizinde bir anakütleyi temsil eden gözlem kümesinden hesaplanacak değerlerin, gelecekteki değerleri tahmin edebilme etkinliğini test etmek için kullanılır. Bir zaman serisi durağan ise gelecekte de benzer eğilimde hareket edecek ve benzer özelliklere sahip 
olacaktır. Tersi durumda ise serinin özellikleri sadece ilgili dönemi içereceği ve geleceğe dair sağlıklı tahminler yapılamayacağı sonucu ortaya çıkmaktadır.

Bu çalışmada serilerin durağan olup olmadıklarını test etmek için "Augmented Dickey Fuller (ADF)" birim kök testi, yani "Genelleştirilmiş Dickey Fuller" birim kök testi kullanılmıştır. ADF birim kök testinin uygulama aşamasında aşağıdaki regresyon denklemleri kullanılmaktadır.

$$
\begin{gathered}
\Delta Y_{t}=\delta Y_{t-1}+\gamma_{i} \sum_{i=1}^{m} \Delta Y_{t-i}+\varepsilon_{t} \\
\Delta Y_{t}=\alpha+\delta Y_{t-1}+\gamma_{i} \sum_{i=1}^{m} \Delta Y_{t-i}+\varepsilon_{t} \\
\Delta Y_{t}=\alpha+\beta t+\delta Y_{t-1}+\gamma_{i} \sum_{i=1}^{m} \Delta Y_{t-i}+\varepsilon_{t}
\end{gathered}
$$

ADF birim kök testinde, deterministik bileşenlerin (trend ve sabit) olup olmamasına göre üç farklı regresyon modeli kullanılmaktadır. Yukarıdaki denklemlerde incelenen seride birim kökün var olduğu kabul edilen hipotez $\left(\mathrm{H}_{0}: \delta=0\right)$, Mc Kinnon kritik değerleri ile test edilir. Hesaplanan test istatistiğinin mutlak değeri, tablo değerinden küçükse sıfir hipotezi kabul edilir. Bu durumda incelenen seri durağan değildir. Tersi durumda ise sıfir hipotezi reddedilerek incelenen serinin durağan olduğu kabul edilir.

Getirilerin logaritmik getiri yöntemiyle hesaplanması, durağan olmama sorununu ortadan kaldırmaktadır. Tablo-1'de analizde kullanılan değişkenlere ait getiri serilerine uygulanan ADF birim kök testi sonuçları yer almaktadır.

\begin{tabular}{|l|l|l|l|}
\hline & \multirow{2}{*}{ ADF } & \multicolumn{2}{|l|}{ McKinnon Kritik Değerleri } \\
\cline { 3 - 4 } & & $\% 5$ & $\% 10$ \\
\hline DLNAH & $-18,8204$ & $-1,9414$ & $-1,6163$ \\
\hline DLNAVI & $-19,1888$ & $-1,9414$ & $-1,6163$ \\
\hline DLNGRN & $-19,7883$ & $-1,9414$ & $-1,6163$ \\
\hline DLNYKR & $-18,9985$ & $-1,9414$ & $-1,6163$ \\
\hline
\end{tabular}

Tablo 1: ADF Birim Kök Testi Sonuçları

Bütün serilere ait ADF test istatistiği, kritik değerlerden daha negatif olduğu için, serilerin birim kök içerdiği temel hipotez reddedilmektedir. Yani analizde kullanılan değişkenlere ait logaritmik getiri serileri hem $\% 5$, hem de \% 10 anlam düzeyinde durağandır. Bu getiri serilerinin tanımlayıcı istatistikleri Şekil-1'de verilmiştir.
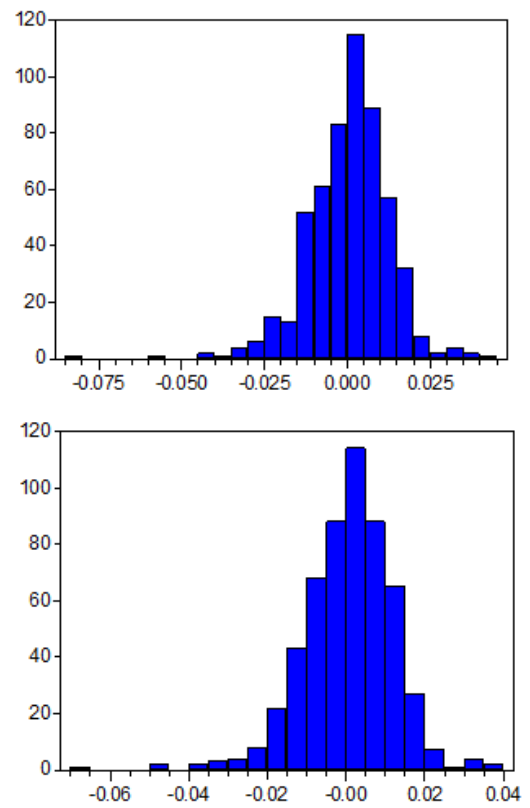
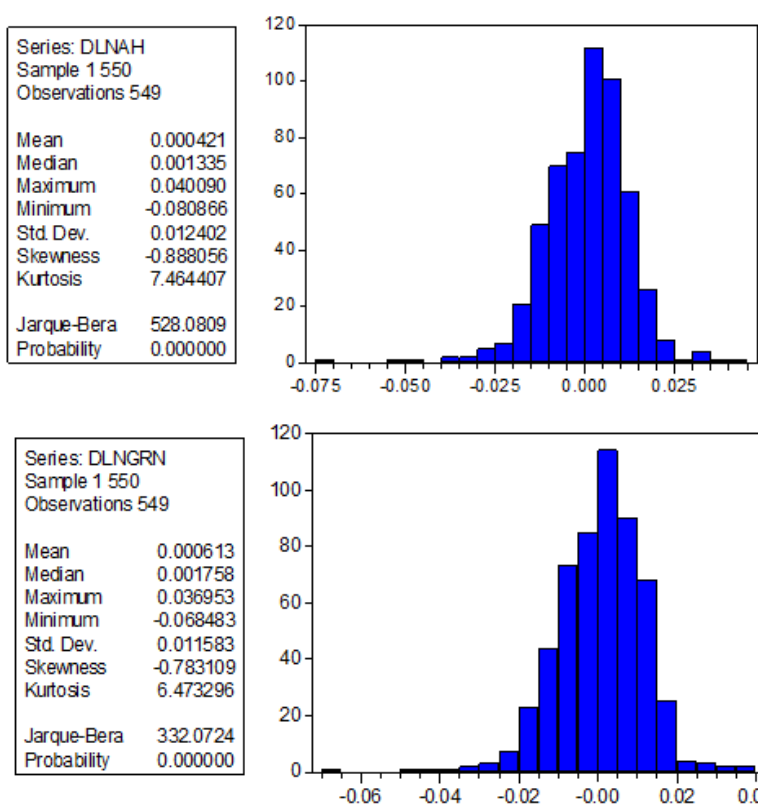
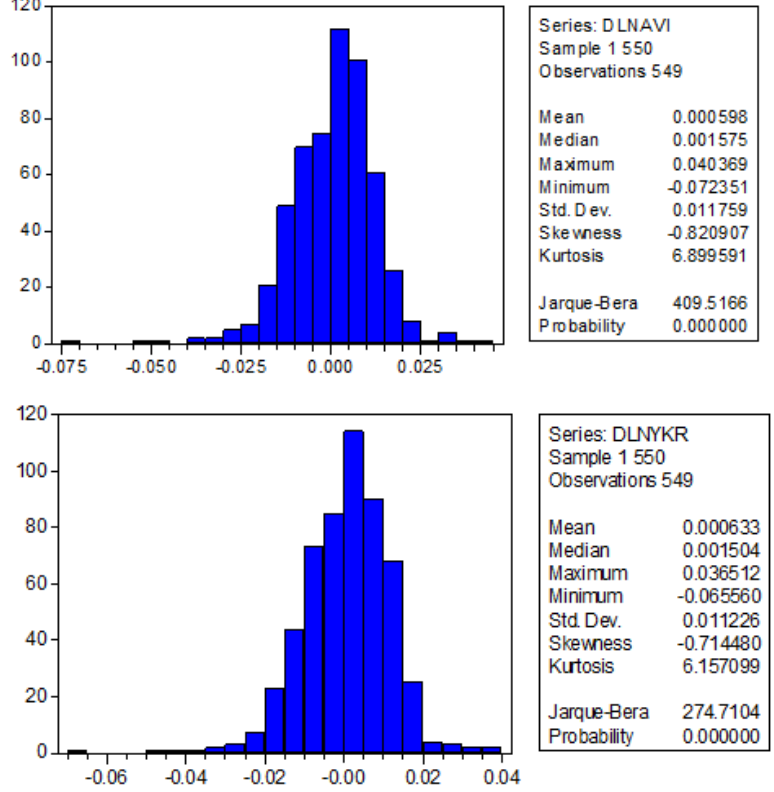

Şekil 1: Değişkenlere Ait Histogram ve Betimleyici İstatistikler 
Getiri serilerinin histogramlarına ve tanımlayıcı istatistiklerine bakıldığında serilerin normal dağılıma uymadığı açıkça görülmektedir. Normal dağılım hipotezi her dört seride de Jarque-Bera istatistiğine bakarak reddedilmektedir. Her dört seri için de basıklık değeri (kurtosis) kritik değer olan 3'ün üzerinde hesaplanmıştır. $\mathrm{Bu}$ da dağılımların ortalamadan aşırı sivrilik gösterdiğini ve şişman kuyruk özelliklerine sahip olduğunu göstermektedir. Bu sonuç ta dağılımların normal dağılıma uymadığğının bir kanıtıdır.

Varyans - Kovaryans yönteminin en önemli ön koşullarından birisi zaman serilerinin normal dağılıma uyduğu, yani standart sapmanın zamandan bağımsız olduğu varsayımıdır. Ancak finansal zaman serileri incelendiğinde genellikle standart sapmasının zaman içinde değiştiği görülmektedir. Bu durumda sabit varyans varsayımı ile hesaplanacak RMD gerçek riski yansıtmayacağından volatilitenin tahmin edilmesinde farklı yöntemlerin kullanılması gerekmektedir. Riskmetrics tarafından da kullanılan Üstel Ağırlıklı Hareketli Ortalama (Exponentially Weighted Moving Average - EWMA) yöntemi, uygulamacilar tarafindan yaygın olarak kullanılan bir yöntemdir.

Araştırma kapsamında seçilen emeklilik yatırım fonlarına ilişkin getiri serilerinin standart sapması hem sabit varyans, hem de koşullu değişen varyans varsayımı altında hesaplanmış ve RMD analizine dahil edilmişstir. Tablo-2'de her iki şekilde hesaplanan standart sapma değerleri verilmiştir.

\begin{tabular}{|l|l|l|}
\hline & $\begin{array}{l}\text { Sabit Varyans } \\
\text { Varsayımı Altında } \\
\text { Hesaplanan Standart } \\
\text { Sapma }\end{array}$ & $\begin{array}{l}\text { Koşullu Değişen Varyans } \\
\text { Varsayımı Altında EWMA } \\
\text { Yöntemiyle Hesaplanan } \\
\text { Standart Sapma }\end{array}$ \\
\hline DLNAH & 0,012402 & 0,014966093 \\
\hline DLNAVI & 0,011759 & 0,01259754 \\
\hline DLNGRN & 0,011583 & 0,012384281 \\
\hline DLNYKR & 0,011226 & 0,01178905 \\
\hline
\end{tabular}

Tablo 2: Getiri Serilerinin Standart Sapma Değerleri

Çalışmada RMD hesaplamalarında varyans - kovaryans yöntemi kullanılmıştır. Yapılan hesaplamalarda seçilen dört ayrı emeklilik yatırım fonunun her birine 10.000 TL yatıran bir yatırımcının \% 99 güven düzeyinde ve 550 gün ile 1 gün elde tutma sürelerinde her bir fon için karşılaşabileceği maksimum kayıp miktarları bulunmuştur. Emeklilik Gözetim Merkezi (EGM)'nin yayınladığı "BES 2012 Gelişim Raporu” na göre emeklilik yatırım fonları ortalama vadeleri 2012 yılı içinde 510 - 740 gün aralığında bir seyir izlemiştir. Bu nedenle yapılan RMD hesaplamalarından birincisinde elde tutma süresi 550 gün olarak alınmıştır. Bunun yanında geriye dönük test sürecinde kullanılmak üzere elde tutma süresi 1 gün alınarak da RMD değerleri hesaplanmıştır. Ayrıca sabit standart sapma ve EWMA yöntemiyle hesaplanan standart sapma değerleri normal dağılım için \% 1 anlamlılık düzeyine karş1lık gelen 2,33 değeriyle çarpılarak RMD hesaplanmıştır.

Elde tutma süresi 550 gün alınarak hesaplanan RMD değerleri aşağıdaki tabloda gösterilmiştir.

\begin{tabular}{|l|l|l|}
\hline & $\begin{array}{l}\text { Sabit Standart Sapma } \\
\text { Kullanılarak Hesaplanan } \\
\text { RMD }\end{array}$ & $\begin{array}{l}\text { EWMA Yöntemi İle Bulunan } \\
\text { Standart Sapma Kullanılarak } \\
\text { Hesaplanan RMD }\end{array}$ \\
\hline DLNAH & 6776,87 & 8177,97 \\
\hline DLNAVI & 6425,51 & 6883,72 \\
\hline DLNGRN & 6329,33 & 6767,19 \\
\hline DLNYKR & 6134,26 & 6441,93 \\
\hline
\end{tabular}

Tablo 3: Elde Tutma süresi 550 gün Alınarak Hesaplanan RMD Değerleri

Sabit standart sapma kullanılarak hesaplanan RMD sonuçlarına göre;

- Anadolu Hayat Emeklilik A.Ş. Büyüme Amaçlı Hisse Senedi Emeklilik Yatırım Fonu (DLNAH)'na 10.000 TL tutarında, 550 günlük bir yatırım yapılması durumunda karşılaşılabilecek kayıp \% 1 olasılıkla 6.776,87 TL'yi aşacaktır.

- Avivasa Emeklilik ve Hayat A.Ş. Büyüme Amaçlı Hisse Senedi Emeklilik Yatırım Fonu (DLNAVI)’na 10.000 TL tutarında, 550 günlük bir yatırım yapılması durumunda karşılaşılabilecek kayıp \% 1 olasılıkla $6.425,51$ TL’yi aşacaktır.

- Garanti Emeklilik ve Hayat A.Ş. Büyüme Amaçlı Hisse Senedi Emeklilik Yatırım Fonu (DLNGRN)'na 10.000 TL tutarında, 550 günlük bir yatırım yapılması durumunda karşılaşılabilecek kayıp \% 1 olasılıkla 6.329,33 TL'yi aşacaktır.

- Yapı Kredi Emeklilik A.Ş. Büyüme Amaçlı Hisse Senedi Emeklilik Yatırım Fonu (DLNYKR)'na 10.000 TL tutarında, 550 günlük bir yatırım yapılması durumunda karşılaşılabilecek kayıp \% 1 olasılıkla 6.134,26 TL'yi aşacaktır.

EWMA yöntemi ile bulunan standart sapma kullanılarak hesaplanan RMD sonuçlarına göre; 
- Anadolu Hayat Emeklilik A.Ş. Büyüme Amaçlı Hisse Senedi Emeklilik Yatırım Fonu (DLNAH)’na 10.000 TL tutarında, 550 günlük bir yatırım yapılması durumunda karşılaşılabilecek kayıp \% 1 olasılıkla 8.177,97 TL'yi aşacaktır.

- $\quad$ Avivasa Emeklilik ve Hayat A.Ş. Büyüme Amaçlı Hisse Senedi Emeklilik Yatırım Fonu (DLNAVI)'na 10.000 TL tutarında, 550 günlük bir yatırım yapılması durumunda karşılaşılabilecek kayıp \% 1 olasılıkla 6.883,72 TL'yi aşacaktır.

- Garanti Emeklilik ve Hayat A.Ş. Büyüme Amaçlı Hisse Senedi Emeklilik Yatırım Fonu (DLNGRN)'na 10.000 TL tutarında, 550 günlük bir yatırım yapılması durumunda karşılaşılabilecek kayıp \% 1 olasılıkla 6.767,19 TL'yi aşacaktır.

- Yapı Kredi Emeklilik A.Ș. Büyüme Amaçlı Hisse Senedi Emeklilik Yatırım Fonu (DLNYKR)'na 10.000 TL tutarında, 550 günlük bir yatırım yapılması durumunda karşılaşılabilecek kayıp \% 1 olasılıkla 6.441,93 TL'yi aşacaktır.

Yapılan RMD hesaplamalarının doğruluklarını test etmek için geriye dönük test uygulanmıştır. Geriye dönük test sürecinde kullanılmak üzere elde tutma süresi 1 gün alınarak RMD değerleri hesaplanmış, bulunan sonuçlar Tablo 4'te gösterilmiştir.

\begin{tabular}{|l|l|l|}
\hline & $\begin{array}{l}\text { Sabit Standart Sapma } \\
\text { Kullanlarak Hesaplanan } \\
\text { RMD }\end{array}$ & $\begin{array}{l}\text { EWMA Yöntemi İle } \\
\text { Hesaplanan Standart Sapma } \\
\text { Kullanılarak Hesaplanan RMD }\end{array}$ \\
\hline DLNAH & 288,97 & 348,71 \\
\hline DLNAVI & 273,98 & 293,52 \\
\hline DLNGRN & 269,89 & 288,55 \\
\hline DLNYKR & 261,57 & 274,68 \\
\hline
\end{tabular}

Tablo 4: Elde Tutma süresi 1 gün Alınarak Hesaplanan RMD Değerleri

Geriye dönük test için en doğru yol önceden belirlenmiş RMD’e karşı günlük kar/zararı işaretlemek ve önceden belirlenen RMD limitine göre oluşan aşım sayılarını veya güven bandı aşımlarını göstermektir (Aksel, 2001). RMD yöntemlerinin performansları ölçülürken belirli bir gündeki pozisyonun ertesi gün gerçekleşen piyasa fiyatları ile piyasa değeri yeniden hesaplanmaktadır. Bulunan bu yeni piyasa değeri ile pozisyonun gerçek piyasa değeri arasındaki fark RMD ile karşılaştırılmaktadır. Bu fark, RMD'den yüksekse, yöntemin o gün itibariyle maksimum kaybı tahmin etmekte başarısız olduğu anlamına gelmektedir (Sezgin ve Tüzün, 2001). Günlük zararın, modelin RMD tahminini aşma sayısı, sapma sayısı (number of exceptions) olarak adlandırılır ve kullanılan modelin uygun olması için sapma sayısının beklenen sapma sayısına yakın olması arzu edilir (Şahin, 2004). Aşağıdaki tabloda değişik gözlem sayılarında, belirli güven aralıkları için kabul edilebilir sapma sayıları verilmiştir.

\begin{tabular}{|l|l|l|l|}
\hline \multirow{2}{*}{ Güven Aralı̆̆ } & \multicolumn{3}{|l|}{ Kabul Edilebilir Sapma Say1s1 } \\
\cline { 2 - 4 } & $\mathrm{T}=255$ Gün & $\mathrm{T}=510$ Gün & $\mathrm{T}=1000$ Gün \\
\hline$\% 99$ & $\mathrm{~N}<7$ & $1<\mathrm{N}<11$ & $4<\mathrm{N}<17$ \\
\hline$\% 97,5$ & $2<\mathrm{N}<12$ & $6<\mathrm{N}<21$ & $15<\mathrm{N}<36$ \\
\hline$\% 95$ & $6<\mathrm{N}<21$ & $16<\mathrm{N}<36$ & $37<\mathrm{N}<65$ \\
\hline$\% 92,5$ & $11<\mathrm{N}<28$ & $27<\mathrm{N}<51$ & $59<\mathrm{N}<92$ \\
\hline$\% 90$ & $16<\mathrm{N}<36$ & $38<\mathrm{N}<65$ & $81<\mathrm{N}<120$ \\
\hline
\end{tabular}

Tablo 5: Kabul Edilebilir Sapma Sayllarl (Kaynak: Jorion, 2002)

Çalışmada geriye dönük test sürecinde, dört ayrı fon için 550 günlük veriler kullanılarak günlük kar/zarar hesaplanmış ve elde tutma süresi 1 gün alınarak hesaplanan RMD değerleri ile RMD bantları oluşturularak sapma sayıları incelenmiştir. $\mathrm{Bu}$ amaçla oluşturulan grafikler aşağıda verilmiştir. $\mathrm{Bu}$ grafikler çalışma kapsamındaki dört ayrı fon için sabit standart sapma kullanılarak ve EWMA yöntemiyle bulunan standart sapma kullanılarak hesaplanan RMD değerlerini ayrı ayrı göstermektedir.

\begin{tabular}{|l|l|l|}
\hline & $\begin{array}{l}\text { Sabit Standart Sapma Kullanılarak } \\
\text { Hesaplanan RMD Sinırlarına Göre Sapma } \\
\text { Sayısı }\end{array}$ & $\begin{array}{l}\text { EWMA Yöntemi İle Hesaplanan Standart } \\
\text { Sapma Kullanılarak Hesaplanan RMD } \\
\text { Sinırlarına Göre Sapma Sayısı }\end{array}$ \\
\hline DLNAH & 7 & 3 \\
\hline DLNAVI & 10 & 6 \\
\hline DLNGRN & 8 & 7 \\
\hline DLNYKR & 8 & 8 \\
\hline GÖZLEM SAYISI: T $=550$ gün \\
\hline GÜVEN ARALIĞI : $\%$ 99
\end{tabular}

Tablo 6: Geriye Dönük Test Sonuçlarına Göre Sapma Sayıları 


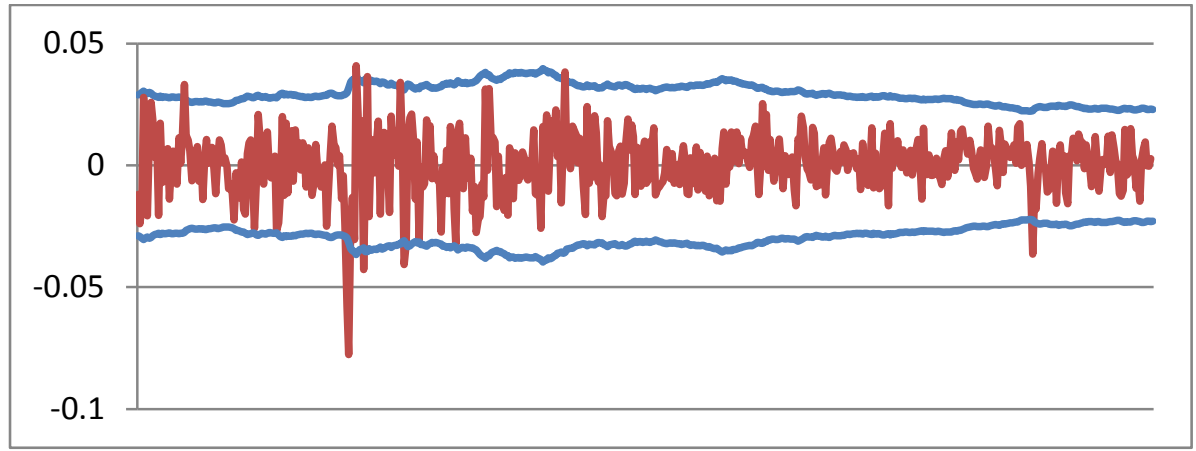

Grafik 2: DLNAH Için Günlük Getiri ve Sabit Standart Sapma İle Elde Edilen RMD Bantları

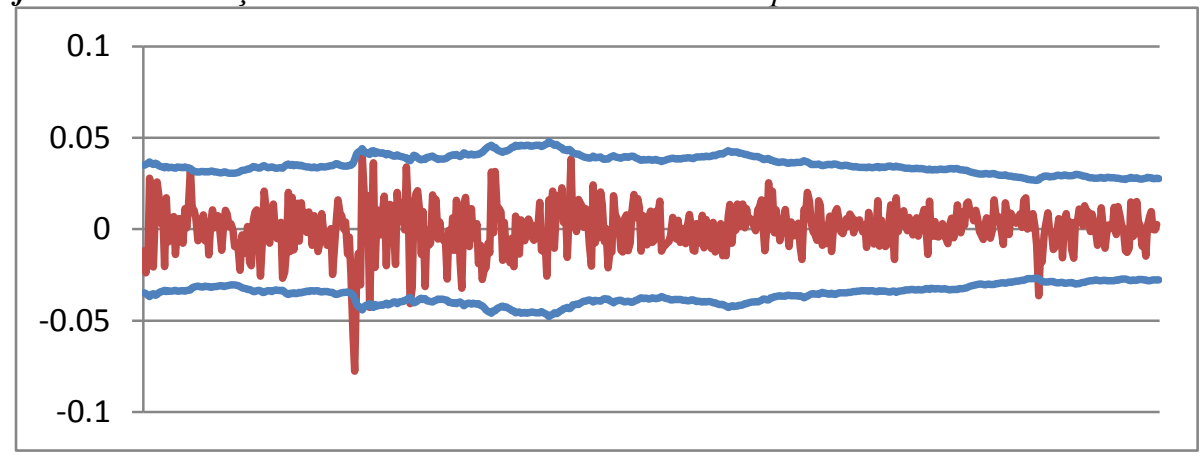

Grafik 3: DLNAH İçin Günlük Getiri ve EWMA Yöntemi İle Elde Edilen RMD Bantları

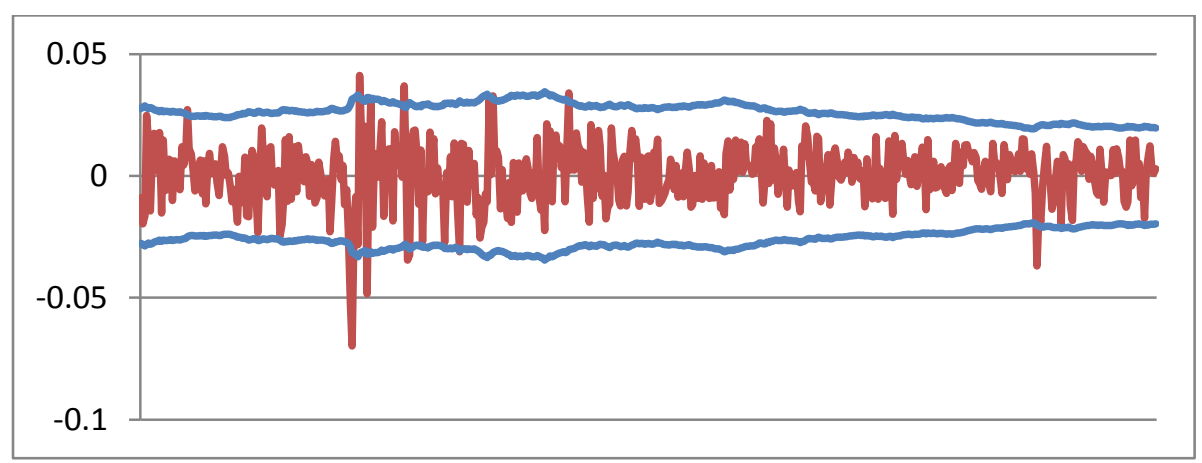

Grafik 4: DLNAVI Için Günlük Getiri ve Sabit Standart Sapma İle Elde Edilen RMD Bantları

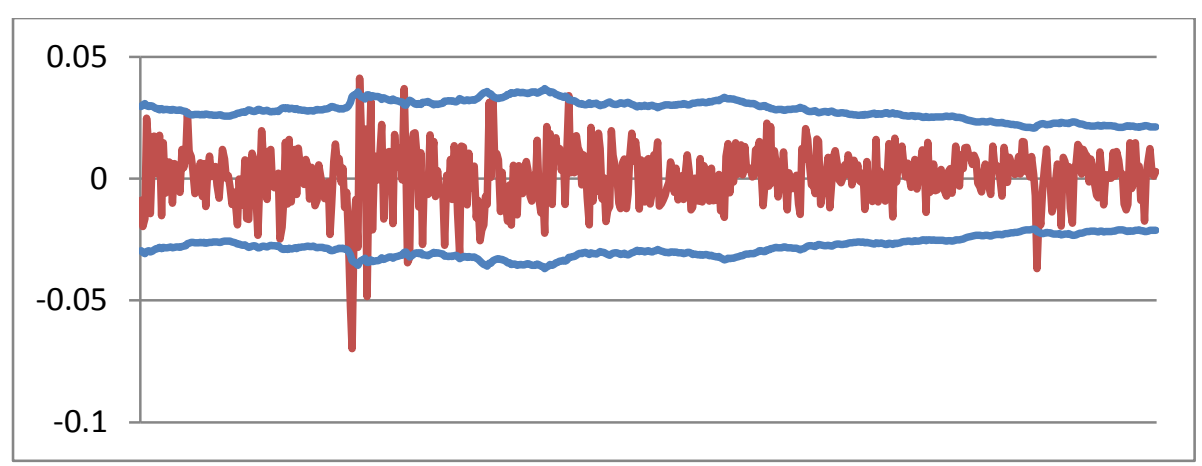

Grafik 5: DLNAVI İçin Günlük Getiri ve EWMA Yöntemi İle Elde Edilen RMD Bantları 


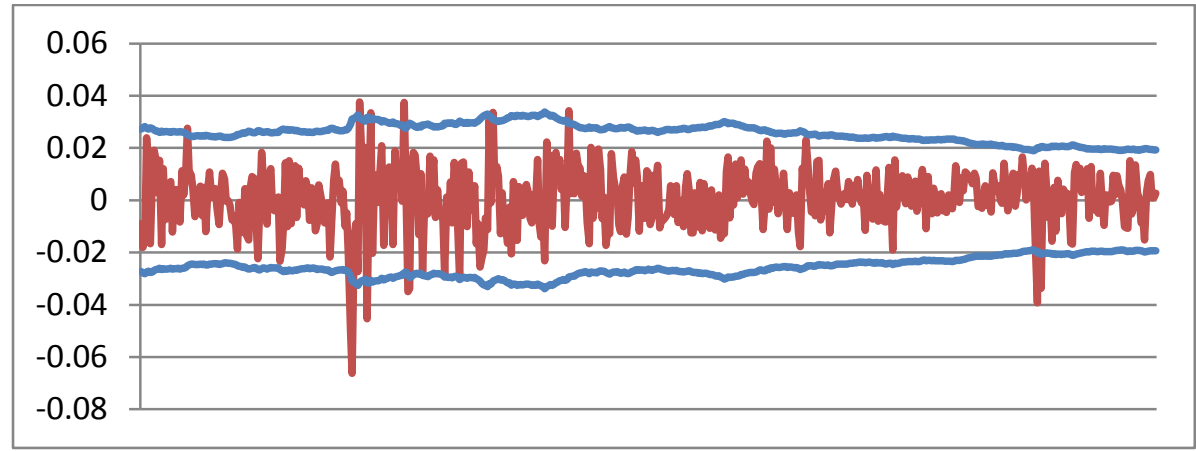

Grafik 6: DLNGRN Için Günlük Getiri ve Sabit Standart Sapma İle Elde Edilen RMD Bantlart

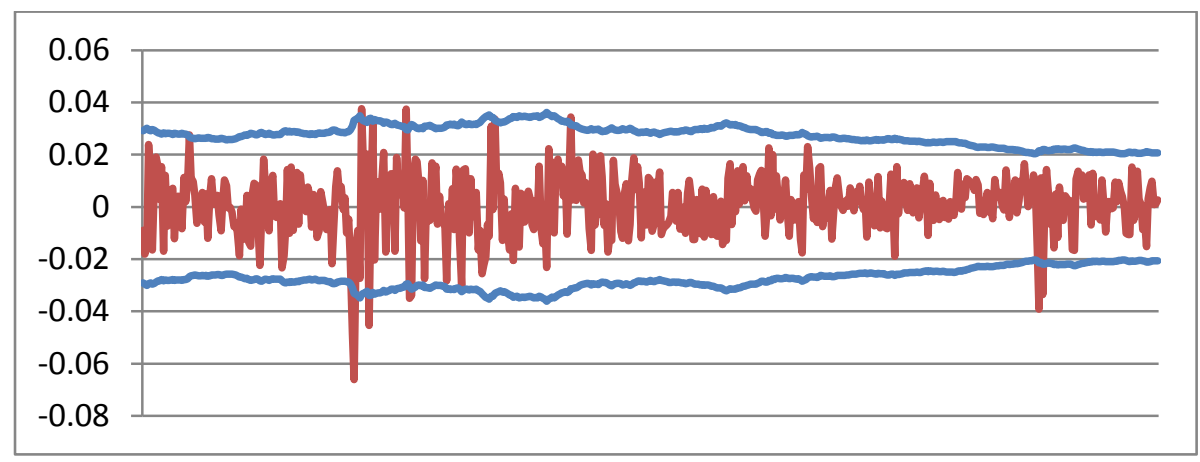

Grafik 7: DLNGRN İçin Günlük Getiri ve EWMA Yöntemi İle Elde Edilen RMD Bantları

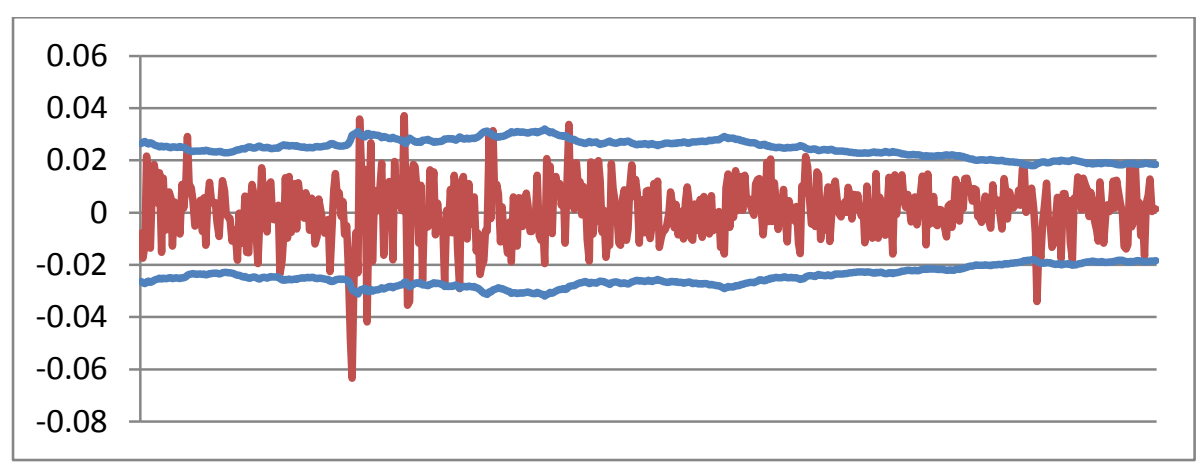

Grafik 8: DLNYKR Iç̧in Günlük Getiri ve Sabit Standart Sapma İle Elde Edilen RMD Bantları

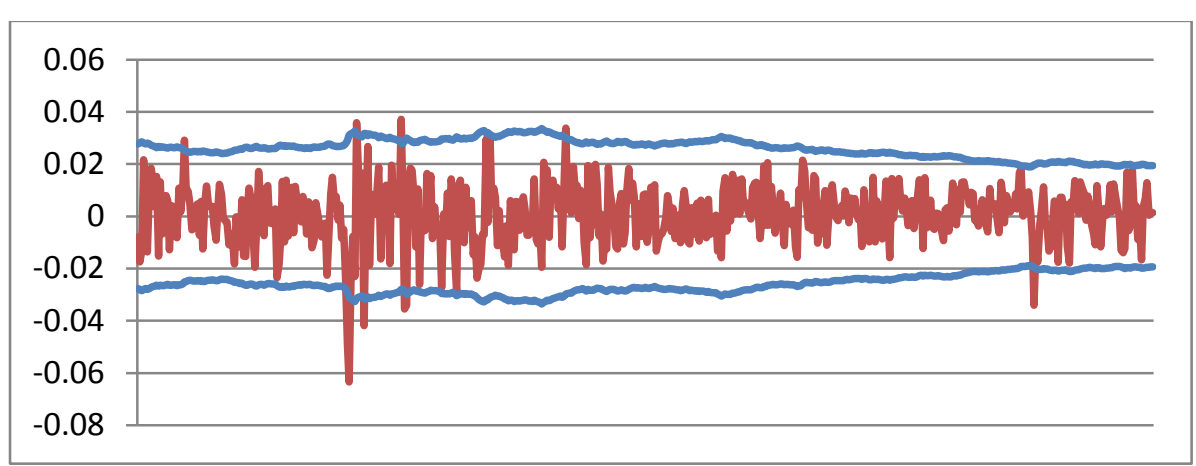

Grafik 9: DLNYKR Iç̧in Günlük Getiri ve EWMA Yöntemi İle Elde Edilen RMD BantlarlSonuç

Türkiye'de özelikle son zamanlarda yapılan düzenlemelerle birlikte Bireysel Emeklilik Sistemi büyük ilerleme kaydetmiş, emeklilik yatırım fonlarının varlıkları da aynı oranda büyümüştür. Çalışmada, Riske Maruz Değer hesaplamak üzere Türk emeklilik şirketlerinin kurduğu emeklilik yatırım fonlarından net varlık değeri en fazla olan dört tane büyüme amaçlı hisse senedi emeklilik yatırım fonunun getirileri kullanılmıştır. Çeşitli fon tiplerinin içinden büyüme amaçlı hisse senedi emeklilik yatırım fonlarının seçilmesinin nedeni, bu fonların riskli fonlar grubunda yer alması ve dolayısıyla bu fonlarla ilgili hesaplanan risk değerlerinin daha yorumlanabilir olmasıdır. Gerçekleştirilen Riske Maruz Değer hesaplamalarında Parametrik Yöntem (Varyans-Kovaryans Yöntemi) kullanılmıştır. Bu yöntemin parametrelerinden biri de standart sapma, yani volatilitedir. Çalışmanın 
asıl amacı ise RMD hesaplamalarında doğru volatilite modellemesi yaparak gerçeğe yakın sonuçlar elde etmektir. Bu bağlamda yapılan RMD hesaplamaları "Geriye Dönük Test (Backtesting)" süreci ile test edilerek elde edilen sonuçlar karşılaştırılmıştır.

Geriye Dönük Test sonuçlarına göre her iki standart sapma modellemesi kullanılarak hesaplanan RMD değerlerinin tutarlı olduğu, yani sapma sayılarının belirtilen güven aralığında kabul edilebilir sınırlar içinde olduğu görülmektedir. Ancak bu iki yöntem karşılaş̧ırıldığında EWMA yöntemi, sabit standart sapma yöntemine göre daha yükse risk tahminine ulaşmıştır. EWMA yöntemi son dönemlere daha çok ağıllık verdiği için daha yüksek risk değerlerine ulaşmış, sabit standart sapma yöntemi normal dağılım varsayımından dolayı daha düşük risk tahmininde bulunmuştur. Bu doğrultuda da geriye dönük test sonuçlarındaki sapma sayıları, EWMA yönteminde daha azdır. Yani EWMA yöntemi ile elde edilen RMD değerleri gerçeğe daha yakındır.

Risk yönetiminde RMD modeli seçimi ve volatilite modeli seçimi portföy yapısı ve ekonomik koşullara göre farklılıklar göstermektedir. Tarihsel hesaplamalara dayalı modeller, yeni yöntemlerin geliştirilmesiyle yerini zaman içerisinde değişen varyans modellerinin ağırlık kazandığ EWMA, ARCH ve GARCH gibi volatilite tahmin yöntemlerine bırakmıştır. Geçmişte yapılan bir çok araştırma portföyde yer alan finansal varlıkların korelasyon ve varyanslarının zaman içinde değiştiğini göstermektedir. Buradan hareketle bu çalışmada, RiskMetrics tarafından geliştirilen risk yöneticilerinin de sıklıkla kullandığı EWMA modeli kullanılarak volatilite tahminleri yapılmış, sabit varyans varsayımı altında yapılan hesaplamalara göre daha tutarlı sonuçlar elde edilmiştir. Çünkü EWMA modelinin temeli olan üstel ağılılıklandırma sonucunda, model piyasadaki büyük değişimlere anında tepki vermektedir. Her veriye aynı ağırlık verildiğinde, olağan dışı durumların etkileri görülememektedir.

Sonuç olarak doğru volatilite tahminleri geleceğe dair öngörülerde en önemli etkenlerin başında gelmektedir. Bu çalışmanın bulgularına ve Basel II'nin de önerilerine göre, en az 252 gün gibi uzun bir dönem ve \% 99 güven seviyesi için volatilitedeki değişimlere daha hızlı tepki verebilen, yani değişen varyansı da hesaba katan EWMA gibi modellerin kullanılmasının daha doğru sonuçlar vereceği düşünülmektedir.

\section{Kaynakça}

- Aksel, Kaan H. (2001). "Riske Maruz Değerin Özellikleri”, Active Bankacılık Dergisi, Mart-Nisan 2001

- Albanese, Claudio ve Campolieti, Giuseppe, (2006). Advanced Derivatives Pricing and Risk Management, Elsevier inc., Londra

- Bams, D., Lehert, T. ve Wolff, C.C.P., (2001). “An Evaluation Framework For Alternative Var Models”. http://arno.unimaas.nl/show.cgi?fid=10654, (10.04.2013).

- Bolgün, K. Evren ve Akçay, Barış, (2009). Risk Yönetimi, 3. Baskı, Scala Yayıncılık, İstanbul

- CCelik, Nuri ve Kaya, Mehmet Fedai, (2010). "Uç Değerler Yöntemi İle Riske maruz Değer'in Tahmini ve İstanbul Menkul Kıymetler Borsası Üzerine Bir Uygulama”, Bankacılık ve Sigortacılık Araştırmaları Dergisi, Cilt 1, Say1 1, ss. 19-32

- EGM, (2012). Bireysel Emeklilik Sistemi Gelişim Raporu

- Gujarati, Damodar N. (2006). Temel Ekonometri, Çev. Ümit Şenesen - Gülay Günlük Şenesen, 4. Baskı, Literatür Yayınc1lık, İstanbul

- Hendricks, Darryll, (1996). "Evaluation of Value-at-Risk Models Using Historical Data”, FRBNY Economic Policy Review, April 1996, pp. 39-70

- Jorion, Philippe, (2002). Value at Risk, Second Edition, Singapore, McGraw Hill Companies

- Kaplanski, G. ve Kroll, Y., (2001). "VaR Risk Measures Versus Traditional Risk Measures: An Analysis And Survey", Journal of Risk, 4, 3.

- Linsmeier Thomas J.ve Pearson Neil D., "Risk Measurement: An Introduction to Value at Risk", 1996, http://www.exinfm.com/training/pdfiles/valueatrisk.pdf (03.10.2011)

- Sezgin, Cüneyt ve Tüzün, Yasemin, (2001). “Dünyada ve Türkiye'de Piyasa Riski Yönetimi Uygulamaları”, Active, Sayı 17, Mart-Nisan 2001

- Şahin, Hasan, (2004). Riske Maruz Değer Hesaplama Yöntemleri, Turhan Kitabevi, Ankara

- Ural, Mert, (2010). Yatırım Fonlarının Performans ve Risk Analizi, Detay Yayıncılık, Ankara 


\title{
Kırgızistan-Türkiye Manas Üniversitesi Öğrencilerinin Girişimcilik Eğilimlerinin Sosyo-Demografik Özellikler Açısından Değerlendirilmesi
}

\section{Assessment of Kyrgyzstan-Turkey Manas University Students' Entrepreneurship Orientations by Socio-Demographic Characteristics}

\author{
Assoc. Prof. Dr. Lütfiye Özdemir (Ahmet Yesevi University, Kazakhstan)
}

\begin{abstract}
The purpose of this research is to determine the effects of socio-demographic characteristics on the entrepreneurship orientation. The research was carried out 581 undergraduates on the Kyrgyzstan-Turkey Manas University. The data was collected with questionnaire. Reliability of measurement tool (Cronbach's Alpha) is 73 $\%$. Frequency analysis, T-test, and one-way ANOVA analysis were used in research. As a result, it was found that the socio-demographic characteristics affected aggressive competitiveness, innovation, proactive behavior, risktaking, autonomy, self-efficacy, need for achievement, internal control focus, and creativity.
\end{abstract}

\section{Giriş}

Çağdaş uygarlığın gelişmesinde önemli bir yere sahip olan girişimcilik, neredeyse hemen her dönem için stratejik değerini korumaktadır. Çünkü girişimcilik geçmişte olduğu gibi günümüzde de ekonomik kalkınmanın, istihdam yaratmanın ve sosyal gelişmenin itici gücüdür. Girişimcilik, aynı zamanda ulusal sorunların çözümü açısından da önem arz etmektedir. Çünkü ülkelerin içinde bulundukları krizlerin ve işsizlik sorunun çözümlenebilmesi, girişimsel çabalarla sağlanabilmektedir.

İçinde bulunduğumuz bilgi çağında girişimciliğin önemi ve etkisi daha da artmaktadır. Çünkü bu çağda ekonomik değerler yaratma kaynağı ve yeteneği, fiziki güçten uzaklaşıp tamamen bilgi gücüne geçmektedir. $\mathrm{Bu}$ dönemde bilim ve teknoloji alanında yaşanan hızlı gelişmeler, toplumların yapısını hızla değiştirirken girişimciliğin ekonomik değerini ve önemini artırmaktadır. Bu bağlamda kişisel yeteneğe ve bilgiye dayalı girişimcilik faaliyeti ön plana çıkmaktadır.

Girişimcilik geçiş ekonomilerinde özellikle önemli olan bir konudur (Chelariu vd., 2008). Çünkü devletçi ekonomiden piyasa ekonomisine geçildiğinde karşılaşılan sorunlar olarak; yoksulluğun ortadan kaldırılabilmesi, ekonominin canlandırılabilmesi girişimciliğin harekete geçirilmesine bağlıdır. Bu bağlamda bilgi donanımlı genç girişimcilere duyulan ihtiyaç ortadadır. Işse bu araştırmayı yapmaktaki amaç, potansiyel girişimci adayları olarak genç girişimcilerin ortaya çıkmasına katkıda bulunabilmektir. Bu nedenle üniversiteye adımını atan her öğrenciye bir girişimci gözü ile bakmak ve onlara içinde yaşadıkları çevrenin çeşitli konulardaki potansiyellerinin farkına varabilecekleri bilgi ve becerilerle donatmak, yaratıcıllğ̆ bastırılmayıp özendirilmiş insanlar olarak yetişmelerini sağlamak büyük önem arz etmektedir. Bu bağlamda söz konusu araştırmada Kırgızistan-Türkiye Manas Üniversitesi öğrencilerinin girişimcilik eğilimlerini sosyo-demografik özellikler açısından irdelemeyi ve böylece öğrencilerin kişisel ve ailesel özelliklerinin, demografik niteliklerinin ve alınan girişimcilik eğitiminin girişimcilik eğilimi üzerinde bir etkisinin olup/olmadığını saptamayı amaçladık.

Girişimcilik eğiliminde yaygın olarak araştırılan boyutlar; risk alma ve yenilikçiliktir. $\mathrm{Bu}$ araştırma, girişimcilik eğilimini daha kapsamlı olarak ele alıp önceki araştırmalarda tam olarak irdelenmeyen proaktiflik, özerklik, öz yeterlilik, içsel denetim odağı, dışsal denetim odağ ile birlikte yenilikçilik, risk alma ve yaratıcılık boyutlarını sosyo-demografik özellikler açısından irdelemiştir. Diğer araştırmalardan farklı olan başka bir yönü de araştırmanın bir uluslararası üniversite niteliği taşıyan Kırgızistan-Türkiye Manas Üniversitesi'nde Kırgızca ve Türkçe olarak uygulanmış olmasıdır. Araştırmada sosyo-demografik özelliklerin girişimcilik eğilimi üzerinde etkisinin olup olmadığ saptanmaya çalışılmıştır. Bu bağlamda istatistiki olarak Cronbach's Alpha, frekans dağılımları, t-testi ve ANOVA analizi kullanılmıştır. Araştırmada öncelikle teorik bilgi olarak girişimcilik, girişimcilik eğilimi (GE) ve girişimcilik eğiliminin boyutlarını ele alınmış daha sonra araştırmanın amacı, yöntemi ve hipotezleri hakkında bilgi verilerek ulaşılan bulgulara değinilmiş ve son olarak bu bulgulara dayanarak sonuç açıklanmıştır.

\section{Girişimcilik Süreci}

Son on yıldır girişimcilik konusuna duyulan ilgi giderek artmaktadır. Ulusal düzeyde girişimcilik ekonomik büyümenin, yeni iş alanları açmanın ve yeniliğin önemli bir lokomotifi olarak görülebilir. Ekonomi alanında ilk kez 18. yüzyılda Fransız ekonomist Richard Cantillon tarafından kullanılan girişimcilik kavramına ilişkin 
literatürde genel kabul görmüş bir tanım yoktur. Buna karşın, girişimcilik esas olarak risk taşıyan ve değer yaratan kişisel firsatçı bir faaliyeti ifade eder ve girişimcilik önemli bileşenlerin biri olan yenilikle güçlü bir şekilde ilişkilendirilir. Girişimcilik, kaynakları yeni kombinasyonlarda birleştirme ya da yenilik yapma, firsatların peşinden koşma, gerekli kaynakları bir araya getirme, risk alma, kar peşinde koşma ve değer yaratmayla ilgili bir kavramdır. Bütün bunlar yeni kurulan bir firmada yapılabileceği gibi kurulu bir organizasyonda da gerçekleştirilebilir. Sık atıfta bulunulan bir girişimcilik tanımı da; firsatlardan yararlanabilmek amacıyla kaynakları tek bir havuzda bir araya getirerek değer yaratma sürecidir. Kişiler, kurulu bir firmada girişimsel davranışlarda bulunarak değer yaratabilirler. Bu durumda, girişimcilik, başarının, büyümenin ve sürdürülebilir rekabetçi üstünlüğün bir itici gücü olarak düşünülebilir (Kraus, 2013; Ercan ve Gökdeniz, 2009). Latince'de "intare" kökünden türüyen girişimci kavramı, İngilizce'de enter (giriş) ve pre (ilk) kelime köklerinden gelmekte ve entrepreneur yani ilk girişen, başlayan anlamını taşımaktadır (Korkmaz, 2000: 163). Bu bağlamda Bozkurt (2000: 12) da girişimciliği yaşadığımız çevrenin yarattığı firsatları sezme, o sezgilerden düşler üretme, düşleri projelere dönüştürme, projeleri yaşama taşıma ve zenginlik üreterek, insan yaşamını kolaylaştırma becerisine sahip olma olarak vurgulamaktadır (Okay ve Karahan, 2010). Girişimcilik konusu sanayi toplumundan bilgi toplumuna geçildiğinde daha fazla önem kazanmıştır. Çünkü bilgi toplumuna geçildiğinde, insanın fiziki gücünün ekonomik değeri azalmış ve düşünce üstünlüğü, bilgi üretmek kısaca beşeri sermayenin ekonomik değeri büyük bir hızla artmıştır (Müftüoğlu, 1997: 2).

\section{Girişimcilik Eğilimi (GE)}

Firmaların yaşları, büyüklükleri ve faaliyet gösterdikleri sektörler her ne olursa olsun bugün GE neredeyse tüm firmalar için önemi giderek artan bir konu olmuştur. Çünkü GE, ekonomik büyümenin ve firma başarısının en önemli itici güçlerden biridir (Kraus, 2013). Ekonomik gelişimi teşvik eden GE (Knight, 1997), özellikle ekonomik koşulları zayıf olan ülkelerde daha büyük önem arz etmektedir. Çünkü GE, firmaların performans gösterebilmelerini sağlamaktadır. Bu nedenle GE'nin örgütsel büyüme üzerinde de önemli bir etkisi vardır (Chen ve Hsu, 2013).

GE'ni kavramsal olarak incelediğimizde, eğilim kelimesi TDK'nun sözlüğünde bir şeyi sevmeye, istemeye veya yapmaya içten yönelme olarak açıklanmaktadır. (TDK, 2013). GE ise kişinin yeni bir girişimde bulunma yönündeki yatkınlığını ifade eder (Chelariu vd., 2008). İşletmeler açısından ele alındığında, GE üst kademedeki yönetimin hesaplı riskler üstenebilme, yenilik yapabilme ve proaktif davranışlar sergileyebilme yatkınlığını gösterir (Todorovic vd., 2011). Bu nedenle GE genelde yenilikçilik, proaktiflik ve risk alma konusunda üst yönetimin stratejisine gönderme yapar (Poon vd., 2006). GE üniversite öğrencileri açısından düşünüldüğünde ise potansiyel girişimci kavramı ile karşılaşırız. Potansiyel girişimci kişilerin kendilerini girişimsel davranışa sevk edebilecek özelliklere, becerilere ve isteklere sahip olmasını tanımlamak için kullanılmaktadır (Chelariu vd., 2008).

Çocukluktan başlayarak, yetişkinlik döneminin sonuna kadar kişinin gelişimi üzerinde etkili olan faktörlerin her biri girişimcilikte de etkilidir. Girişimciliği etkileyen ve kişilerin girişimci olma ya da olmama kararlarını belirleyen bu faktörler; aile desteği, finansman olanakları, devlet destekleri, yetiştirme ve eğitim (Arıkan, 2002) gibi psikolojik, sosyal ve ekonomik etkenler olarak ifade edilebilir. Hatta doğru bir girişimci ruhunun nasıl ortaya çıktığını araştıran çalışmalar; iş, dini geçmiş, olgunlaşma ile ırk, eğitim ve cinsiyet gibi sosyo-biyolojik etkenlerin girişimciliğin ortaya çıkmasında etkin olduğunu ortaya koymuştur. Bu bağlamda eğitimin de özellikle üniversitelerde verilen eğitimin gençlerin girişimciliğe bakış açılarını etkilemede önemli olduğu düşünülmektedir (Börü, 2006: 13).

GE'nin çok sayıda boyutları olmasına karşın, pek çok araştırma, genellikle en önemlileri olarak kabul edilen yenilikçilik, proaktiflik ve risk alma boyutlarına odaklanmaktadırlar (Chen and Hsu, 2013; Chelariu vd., 2008; Kraus, 2013; Covin ve Slevin, 1991; Poon vd., 2006). Daha tutarlı sonuçlara ulaşabilmek amaciyla çalışmamızda bu boyutlara ek olarak saldırgan rekabetçilik, özerklik, başarma ihtiyacı, denetim odağı ve yaratıcılık boyutlarına da değinilmektedir.

\section{Girişimcilik Ĕğiliminin Öğeleri}

Girişimcilik eğilimi dokuz alt boyut açısından irdelenmektedir.

\subsection{Yenilikçilik}

Yenilik, yeni bir düşünceyi pazarlanabilir bir değere dönüştürebilecek yapının kurulmasını ve bu yapının sürdürülmesini (Zahra, 1995; 1998) ifade etmektedir. Literatürde girişimcilik eğilimi çoğunlukla yenilikçilikle ilişkilendirilir (Covin ve Slevin, 1991; Knight, 1997; Zahra 1995). Brenkert (2009) de yeniliği firmanın yeni ürün ve hizmet geliştirmeyi amaçlayan yeni düşünceleri desteklemesi ve yaratıcı süreçleri teşvik etmesi olarak tanımlamaktadır. Firma yeni ürün ve hizmet geliştirdiğinde ve bunları pazara sunduğunda, kolayca rekabet üstünlüğü sağlayabilmektedir. Yenilik yeni ürün ve hizmet getirebilmek amacıyla firmayı yeni teknolojiyi kullanma yönünde harekete geçirebilmektedir (Chen ve Hsu, 2013). Firmalar yeni ürün ve hizmet getirme yönünde çaba harcadıklarında, deneyimle meşgul olma ve yaratıcı düşünebilme eğilimleri gelişmektedir (Chen 
ve Hsu, 2013). Son olarak yenilikçilik sürecinde yaratıcılığın sonucunda ortaya çıkan yeni ya da iyileştirilmiş ürünlerin, hizmetlerin ve süreçlerin ticareti gerçekleştirilmektedir. Bu bağlamda yenilikçilik süreci girişimsel davranış ile birleştiği zaman uzunca bir zaman süresine gereksinim duyulmaktadır (Kraus, 2013). Görüldüğü gibi, yenilikçilik girişimciliğin temelini oluşturan en önemli araçlarından biridir. Girişimcinin yarattığ 1 yenilik ya da yeni düşünceler rekabet ortamında firmayı başarıya taşımaktadır. Bunun farkında olan girişimci, gerekliliklerini mutlaka yerine getirerek, yeni yönetim biçimi, yeni düşünceler, yeni teoriler veya yeni icatları uygulamaya koymaktadır. Sonuç olarak yenilik, yaratıcı düşünlerin başarılı bir şekilde uygulanması ve sonuçlandırılmasıdır (Çetin, 2011).

\subsection{Proaktiflik}

Reaktifliğin karşıtı (Knight, 1997) olarak proaktiflik, geleceği ön görerek ve yeni iş firsatlarını teşvik ederek inisiyatif almadır (Brenkert, 2009). Proaktiflik, rakipleri geçebilmek amacıyla rekabetçi önceliklerin ve amaçların peşinde koşarak atılgan olma anlamına da gelmektedir (Zahra, 2008). Bu nedenle proaktif davranışlar gösterildiğinde, rekabet üstünlüğü elde edebilmek amacıyla müşterilerin gelecekteki ihtiyaçlarıyla ilgili yeni firsatlar arama üzerine odaklaş1lır (Chen ve Hsu, 2013). Örgütsel açıdan değerlendirildiğinde, proaktiflik firmaların müşterilerinin gelecekle ilgili gereksinimlerini önceden tahmin etmeleri ve rakiplerine karşı üstünlük sağlayabilecek yeni mal ve hizmetler üretmeleridir. Proaktif firmalar, rekabet yeteneklerini zenginleştirebilmek amacıyla ortaya çıkan firsatları kullanırlar (Chen ve Hsu, 2013). Girişimci kişilerin proaktif olması; fırsatlara odaklanmaları, olayları henüz tatmin edilmemiş gereksinimler olarak görebilmeleri, pazarı ve pazardaki boşlukları görüp hangi yeni ürün konseptlerini geliştirilebileceklerini kararlaştırmaları ve tüm bunları sürdürülebilir rekabet üstünlüğü yaratabilmek için kullanmaları şeklinde açıklanabilir (Çetin, 2011). Sonuç olarak, proaktiflik, gelecekteki talebi öngörerek rekabette önde kalabilmek için firsat arama davranışını ifade eder (Kraus, 2013).

\subsection{Saldırgan Rekabetçilik}

Saldırgan rekabetçilik, kişilerin rakiplerine karşı daha üstün bir konuma gelebilmek (Brenkert, 2009) ve onlara egemenliklerini kabul ettirebilmek amacıyla bilinçli olarak alışılmadık yöntemlerle "rakibi yok etme" istek ve eğilimine işaret eder. Bu eğilimin temelinde; rakiplerin alt edilmek istenmesi, onların düşman olarak görülmesi ve onlarla barışçıl bir ortamda yaşanmak istenmemesi istekleri vardır. Girişimcilik eğilimi açısından incelendiğinde, saldırgan rekabetçilik potansiyel girişimci adayları olarak öğrencilerin kendilerini değerlendirebilmek amacıyla rekabetten hoşlanmalarına ve başarılı olmak için gayret göstermelerine bağlanabilir.

Saldırgan rekabetçilik firmalar açısından değerlendirildiğinde, girişimci firmaların dinamik pazarlarda değişen müşteri isteklerini ve beklentilerini karşılayabilmek amacıyla pazardaki tehditlerin üstesinden gelerek eylem ve varlıklarını sürdürebilmek adına oldukça gözü pek rekabetçi davranışlar sergilemeleridir (Covin ve Slevin, 1991). Söz konusu rekabetçi davranışlar sıklıkla, rakiplerin eylemlerine doğrudan karşılık verecek biçimde saldırgan fiyat rekabeti, yeni ve üstün bir sunumla pazara giriş, bir rakibi hızlı bir biçimde kopyalayarak izleme, hızlı bir biçimde müşteri farkındalığı yaratmak amacıyla yüksek reklam maliyetlerine katlanma ve kâr marjlarından fedakârlık etme ve alışılmadık sürpriz taktikler geliştirme veya finansman, satış sonrası hizmet, garanti, fiyat, ürün kalitesi ve benzeri rekabet unsurlarına odaklanma biçimindedir. Özetle, rekabetçi davranışların özünde, firmaların kendilerini rakipleri ile karşılaştırarak kaynaklarını hızlı bir biçimde harekete geçirmesi ve rakibe saldırı amacıyla rakibin zayıf yönleri hakkında bilgi biriktirmesi vardır.

\subsection{Risk Alma}

Tüm örgütsel faaliyetlerde birtakım etkileri bulunan risk ve risk alma kavramları, girişimcilik sürecinin temelini oluşturmaktadır. Kraus'a (2013) göre, risk alma gerek kişisel gerekse örgütsel düzeyde hem büyük firsatlar hem de büyük başarısızlıklar getirebilecek faaliyetleri ele alır. Girişimsel yapı içinde risk alma, tedbirsizce değil hesaplı ve kontrollüdür. Risk alma eğilimi ise kişinin riskli durumlarla karşı karşıya kaldığında riski göze almak yönünde davranış gösterme eğilimidir (Keleç vd., 2012). Risk girişimcilik sonucu girişimcinin istediği sonuçları elde edebileceği gibi hayal kırıklığı yaşama durumuyla da karşılaşabileceğini ifade eder. Girişimci bu durumu ortadan kaldıramaz. Önemli olan hesaplanabilir ve kabul edilebilir bir düzeyde risk almaktır (Kraus, 2013). Çünkü girişimciliğin doğasında kazanmak ya da kaybetmek vardır. Kuşkusuz hiçbir girişimci kaybetmek için bir işte başlangıç yapmaz. Ancak kazanmak için, kaybetme olasılığı da dikkate alınmalıdır (Akdemir, 1996: 86). Risk alma eğilimi olan girişimciler firmanın önemli kaynaklarını sonuçları bilinmeyen belirsiz endüstrilere yatırım yapmak isteyebilirler ve hatta firmayı bu yönde teşvik ederler (Chen ve Hsu, 2013).

\subsection{Bağımsızlık}

Özerklik, kişilerin önemli kararları vermede ve firsatların peşine düşmede bağımsız olarak hareket edebilme serbestliğidir (Brenkert, 2009). Özerk olan bir kişi bir düşünceyi ya da vizyonu ortaya koymada ve uygulamada bağımsız olarak hareket edebilir. Genel olarak firsatları kovalamada kendi kendini yönlendirme anlamı taşıyan özerklik kavramı, dar anlamda, iş tasarımı çerçevesinde iş özelliğinin ve iş metotlarının seçilmesi ile iş programı üzerindeki kişisel kontrol derecesini göstermektedir (Kurt vd., 2006). 


\section{6 Öz Yeterlilik}

Luszczynska ve arkadaşları (2005) öz yeterliliği, “zor ve belirsiz görevleri yapabilme ve özel gereksinimleri olan zorluklarla baş edebilme konusunda kişinin kendi yetkinliklerine olan inancı" ş̧eklinde tanımlamaktadır. Diğer yandan öz yeterlilik, "kişinin belli görevleri ve davranışları yapabileceğine olan inancı" olarak tanımlanmaktadır (Salas ve Cannon-Bowers, 2001). Öz yeterlilik algısı kişilerin girişimcilik süreçlerinde göstermeleri gereken yüksek performansın bir açıklayıcı faktörü olarak görülebilir. Öz yeterlilik algısı yüksek kişiler, meydan okuyucu amaçlar planlama eğilimde olan, zor ve stresli koşullar altında dahi amaçlarına ulaşma konusunda istikrarlı olan, başarısızlıkla karşılaştıklarında, hızlı bir şekilde toparlanabilen (Hmieleski ve Corbett, 2008), daha yüksek düzeylerde kişisel inisiyatif gösterebilen (Speier ve Frese, 1997) ve daha uzun dönemli bakış açılarıyla hareket edebilen kişilerdir (Heckhausen ve Schulz, 1995). Karşıt olarak öz yeterlilik algııı düşük olan insanlar, kişisel inisiyatif alamamakta, meydan okuyucu durumlardan kaçma eğilimine girmekte ve engellerle karşılaştıklarında hızlı bir şekilde çekilmektedirler (Speier ve Frese, 1997). Ayrıca yapılan bazı çalışmalarda öz yeterlilik algısının artması ile girişimcilik davranışları arasında aynı yönlü ilişkiler elde edilmiştir (Poon vd., 2006; Hmieleski ve Corbett, 2008). Bu bakımdan kişisel başarıyla yakın ilişkisi bulunan öz yeterlilik algısı, kişilerin girişimcilik süreçlerindeki davranışlarında rolü olduğu değerlendirilen önemli bir kişilik özelliği olarak karşımıza çıkmaktadır.

\subsection{Başarma İhtiyacı}

Girişimcilik eğilimini etkileyen önemli bir faktör olarak başarma ihtiyacı, kişisel başarıya ulaşabilmek için daha iyisini yapma isteğini ifade eder. Başarma ihtiyacı yüksek olan kişilerin başarıya ulaşabilme yönünde daha istekli olmaları, onların girişimcilik eğilimlerinin daha yüksek olmasına neden olmaktadır (Poon vd., 2006). Dolayısıyla yüksek başarma ihtiyacı kişileri bir girişimsel faaliyette bulunmaya sevk etmekte ve bu faaliyetin sonucunun başarılı bir şekilde son bulması için uğraş vermektedirler (İşcan ve Kaygın, 2011). Çünkü başarma ihtiyacı, başarı ve mükemmelliğe ulaşmak için kişiyi mücadeleci olmaya iten güçtür. Sonuç olarak, başarma ihtiyac1; insanları girişimciliğe sevk etmekte, kontrollü riskleri üstlenmeye yöneltmekte, sorun çözme becerisini geliştirmekte ve amaçların belirlenmesine katkıda bulunmaktadır.

\subsection{Denetim Odağı}

Denetim odağı kavramı bilim adamları tarafından içsel ve dışsal denetim odağı şeklinde sınıflandırılmıştır. Bu sınıflandırmaya göre, kişiler başlarına gelen iyi veya kötü olayların sebeplerini algılama bakımından farklılaşmaktadırlar. Kişilerin, yaşadığı olayları nelerin kontrol ettiğine dair inancını ifade eden (Strauser vd., 2002) bu kavrama göre, eğer kişiler başlarına gelen olayların ve sonuçların kendilerinin değil, kader, şans ve talih gibi dışsal ve çevresel olayların belirleyebileceğine inanıyorlarsa (Chelariu vd., 2008), bu algılama dışsal denetim odağına işaret etmektedir. Buna karşılık eğer kişiler başlarına gelen olayları ve durumları kendi davranışlarının bir sonucu olarak algılıyorlarsa, kişinin sahip olduğu bu inanç içsel denetim odağı olarak belirtilmektedir (Solmuş, 2004). İçsel denetim odağına sahip kişiler, çevresel koşulları değiştirme konusunda daha fazla adım atmakta, yeteneklerine, başarı ya da başarısızlıklarına daha fazla önem vermektedirler. Girişimcilik süreçlerinde bu kişilik özelliklerinin etkisi olduğu belirtilmektedir. Özellikle içsel denetim odağına sahip kişiler, elde ettikleri ödüllerin ve başarıların, kendi davranışlarının bir sonucu olduğuna inanmaktadırlar. Bu bağlamda içsel denetim odaklı kişiler, girişimcilik süreçlerinde daha azimli olmakta ve arzu edilen sonuçlara ulaşma yönünde daha fazla çaba sarf edebilmektedirler. Bunun aksine dışsal denetim odaklı kişiler ise, pasif tutumlar takınarak elde edecekleri sonuçlarda kendi tutumlarının ve davranışlarının bir rol oynayabileceğine inanmayarak; bu süreçlerde başarısız olabileceklerdir. İçsel denetim odağı yüksek olan kişilerle düşük olanlar karşılaştırıldığında, içsel denetim odağı yüksek olan kişiler, değerli sonuçları elde edebilme yönünde daha fazla çaba harcamakta ve bu konuda daha istikrarlı davranmaktadırlar; çünkü onlar sonuçları denetleyebileceklerini hissetmektedirler. Gösterilen büyük çaba ve sabır, genellikle bu kişileri daha önemli başarılara götürebilmektedir (Poon vd., 2006). Bu doğrultuda yapılan araştırmalar girişimcilik davranışları ile denetim odağı arasında benzer bir ilişkiyi ortaya çıkarmıştır. Buna göre, içsel denetim odaklı kişilerin girişimcilik süreçlerinde daha başarılı oldukları; dışsal denetim odaklıların ise bu başarıyı yakalayamadıkları belirlenmiştir. Aynı biçimde Chelariu ve arkadaşları (2008) da öğrenciler üzerine yaptıkları bir araştırmada, içsel denetim odağı inancının girişimcilik eğiliminin artmasında önemli bir açıklayıcı olduğunu ortaya çıkarmışlardır. Ayrıca bu araştırmacılar, içsel denetim odağı ile girişimcilik eğilimi arasında pozitif bir ilişki olduğu bulmuşlardır.

\subsection{Yaratıcılık}

Bağımsız bir güç olarak yaratıcılık ve yeni düşüncelere yürekten bağlılık; yeni ya da mevcut ürün ve hizmetlerle yeni veya kurulu piyasalara girebilmek için önemli bir güçtür (Brenkert, 2009). Yaratıcılık kavramının en kabul görmüş tanımlarından biri, her alanda yeni ve yararlı düşüncelerin üretilmesi sürecidir (Amabile vd., 1996: 1154). Bu süreç, ya önceden var olan düşüncelerin geliştirilmesi ya da özgün bir bileşiminin sağlanması şeklinde gerçekleşir (Eren, 1982: 17). Her yeniliğin ve icadın kökeninde yaratıcılıkla elde edilmiş düşünceler vardır. Ancak yaratıcılık sonucu elde edilen düşünceler her zaman sorunların çözümünde uygulanabilirlik niteliği taşımayabilir (Eren, 1982: 17). 


\section{Araştırmanın Amacı, Yöntemi ve Hipotezleri}

\subsection{Araştırmanın Amacı}

$\mathrm{Bu}$ araştırma, Kırgızistan-Türkiye Manas Üniversitesi Öğrencilerinin girişimcilik eğilimlerini saptamak amacıyla yapılmıştır. Ayrıca bu çalışmada potansiyel girişimci olarak tanımlanan üniversite öğrencilerinin "vatandaşı oldukları ülkenin, büyüdükleri yerin, anne/babalarının eğitimlerinin, kardeş sayısının, ailenin kaçıncı çocuğu olduklarının, aile gelirinin, ailede girişimci olup olmadığının, cinsiyetin, okudukları fakültenin/yüksekokulun, kaçıncı sınıfta olduklarının, akademik not ortalamalarının ve girişimcilik dersi alıp almamalarının" girişimcilik eğilimi üzerinde bir etkisinin olup olmadığı ortaya çıkarılmaya çalışılmaktadır.

\subsection{Araștırmanın Yöntemi ve Örneklem Kümesinin Seçimi}

Araştırmada veri toplama aracı olarak yüz yüze anket yöntemi kullanılmıştır. Anket 2013 yılında KırgızistanTürkiye Manas Üniversitesi öğrencilerine uygulanmıştır. Üniversitenin güncel Web sitesinden alınan bilgiye göre, 2013 yılında Manas Üniversitesi'nde toplam olarak 4.026 öğrenci eğitim görmektedir. Bu ana kütleden kolayda örneklem yöntemi ile seçilen 800 öğrenciye uygulanan anketten, analize uygun 581 tanesi değerlendirmeye alınmıştır. Çalışmada öğrencilerin girişimcilik eğilimlerini ölçmek amacıyla Johnson'un (2011) “Girişimcilik Eğilimi Ölçeği”” kullanılmıştır.

Araştırmada kullanılan anket formu; iki bölümden, 57 sorudan oluşmaktadır. Anket formunun birinci bölümünde literatür taraması sonucunda oluşturulan 15 tane sosyo-demografik özelliklerle ilgili soru yer almaktadır. İkinci bölümde öğrencilerin girişimcilik eğilimlerini ölçmeye yönelik 42 tane Likert Ölçeği ifadesi bulunmaktadır. Bu sorular, girişimcilik eğiliminin öğeleri olarak yenilikçilik, proaktiflik, saldırgan rekabetçilik, risk alma, bağımsızlık, öz yeterlilik, başarma ihtiyacı, denetim odağı ve yaratıcılık boyutlarını ölçmeye yöneliktir. Anket Kırgızca ve Türkçe hazırlanmış olup öğrencilerin arzularına göre istedikleri dilden form verilmiştir. Öğrencilerden anketi "1=hiç katılmıyorum-5=tamamen katılıyorum" şeklinde 5'Likert ölçeğine göre doldurmaları istenmiştir. Olumsuz olan onbeş ifadenin veri girişi tersten kodlanmıştır. Toplanan veriler SPSS 16 programına girilmiş ve ölçeğin güvenilir olup/olmadığını ölçen Cronbach's Alpha değerinin .73 olduğu saptanmıştır.

\subsection{Araștırmanın Kısıtları}

Araştırmanın en önemli kısıtları şunlardır:

1. Araştırmayla ilgili olarak toplanan verilerin, girişimcilik eğilimi ölçeğiyle sınırlı olması

2. Verilerin tek bir üniversiteden toplanmış olması

3. Anket tekniğinin dışında diğer veri toplama yöntemlerinin kullanılamamış olması

4. Araştırmanın sonuçlarının örneklemin nitelikleri ile sınırlı olması

5. Zamanın dar olması nedeniyle tüm fakültelere ve meslek yüksekokullarına ulaşılamaması

\subsection{Araştırmanın Varsayımları}

Araştırmanın varsayımları üç madde altında toplanmaktadır:

1. Araştırma için seçilen örneklemin evreni temsil ettiği,

2. Öğrencilerin anketteki soruları doğru anladıkları ve soruları samimi bir şekilde cevapladıkları,

3. Sosyo-demografik değişkenlerin girişimcilik eğilimini etkilediği.

\section{Araştırmanın Hipotezleri, Bulguları ve Analizi}

Uluslararası bir nitelik taşıyan Manas Üniversitesi'nin öğrencilerinin \%86.2'si Kırgız, \%11'i de Türk vatandaşıdır. 269'u (\%46.3) şehirde yetişmiş olan bu öğrencilerin 220'si (\%37.9) köylerde, geri kalan 92 (\%15.8) öğrenci de kasabada büyümüşlerdir. Bu öğrencilerin anne-babalarının eğitim düzeylerinin yüksek olması dikkat çekicidir. Çünkü 396 (\%68.2) anne, üniversite ve lisansüstü eğitim grubundadır. Üniversite ve lisansüstü eğitim düzeyindeki babaların oranı (\%73.2) ise daha yüksektir. Yüksek eğitimli anne ve babaların gelir düzeylerinin düşük olduğu söylenebilir. Çünkü 426 (\%73.2) ailenin geliri $\geq 200-650$ dolar arasında değişmektedir. Düşük gelir düzeyine rağmen ailelerdeki çocuk sayısının fazla olduğu görülebilir. Çünkü tek çocuklu aile sayısı 24 (\%4.1) iken 305 (\%52.5) aile, 4 veya daha fazla çocuk sahibidir. Öğrencilerin \%35.6'sı (207) ailenin en büyük çocuğu durumunda, \%27.6's1 (160) ise en küçük çocuktur.

Öğrencilerin \%48'i (279) İİBF'de, \%23.8'i (138) İletişim Fakültesi'nde, \%9'u (52) Mühendislik Fakültesi'nde, \%9.6'sı (56) meslek yüksekokullarında, \%7.9'u Edebiyat Fakültesi'nde ve en düşük oran olan \%1.7'si (10) de Veterinerlik Fakültesi'nde okumaktadırlar. Farklı bölümlerde okuyan bu öğrencilerin \%42.7'si (248) üçüncü ve dördüncü sınıfta iken \%57.1'i (332) de birinci ve ikinci sınıftadır. İki dilde (Kırgızca ve Türkçe) eğitim vermekte olan Manas Üniversitesi'nin 428 (\%73.6) öğrencisi üç veya daha fazla sayıda yabancı dil bilmektedirler. Bu öğrencilerin çoğunun bildiği dil; Rusça, Kırgızca ve Türkçedir. Öğrencilerin \%69.2'si (402) girişimcilik dersi almadıklarını ve aynı şekilde \%67.3'ü (391) ailelerinde bir girişimcinin olmadığını belirtmişlerdir.

"H1: Öğrencilerin girişimcilik eğilimleri vatandaşı oldukları ülkelere göre anlamlı bir farklılık göstermektedir" hipotezini test edebilmek için t-testi yapılmıştır. T testi sonucunda $(0,05$ anlamlılık düzeyinde) öğrencilerin 
vatandaşı oldukları ülkelerin saldırgan rekabetçilik ve içsel denetim boyutlarına bakış açıları üzerinde anlamlı bir etkisinin olduğu, yenilikçilik, proaktiflik, risk alma, bağımsızlık, öz yeterlilik, başarma ihtiyacı, dışsal denetim odağı ve yaratıcılık boyutları üzerinde ise anlamlı bir etkisinin olmadığı belirlenmiştir. Bu sonuca göre Kırgız ve Türk öğrencilerinin saldırgan rekabetçilik ve içsel denetim boyutlarını farklı algıladıkları görülmektedir. Buna göre Türk öğrencilerinin Kırgız öğrencilere göre daha saldırgan rekabetçi eğilim içinde oldukları buna karşılık Kırgı̈ öğrencilerinin Türk öğrencilerine göre daha büyük bir içsel denetime sahip oldukları görülmektedir. Bu farklılıkların temel kaynağının Kırgız ve Türk öğrencilerinin büyüdükleri ve içinde bulundukları kültüre ilişkin olduğu söylenebilir. Sonuç olarak H1, saldırgan rekabetçilik ve içsel denetim odağı boyutları açısından kabul edilirken, diğer boyutlar açısından reddedilmektedir.

"H2: Öğrencilerin girişimcilik eğilimleri yetiştikleri yerlere göre anlamlı bir farklılık göstermektedir" hipotezinin testi için Anova testi yapılmıştır. Anova testinin sonuçlarına göre $(0,05$ anlamlılık düzeyinde) öğrencilerin yetiştikleri yerin sadece saldırgan rekabetçilik boyutuna bakış açıları üzerinde anlamlı bir etkisinin olduğu belirlenirken, yenilikçilik, proaktiflik, risk alma, bağımsızlık, öz yeterlilik, başarma ihtiyacı, içsel denetim odağı, dışsal denetim odağı ve yaratıcılık boyutlarına bakış açıları üzerinde ise anlamlı bir etkisinin olmadığı görülmektedir. Anova testine ek olarak yapılan Tukey testine göre ise; öğrencilerin saldırgan rekabetçilik faktörünü algılamaları açısından köyde yaşayanlarla şehirde yaşayanlar arasında önemli bir fark olduğu tespit edilmiştir. Sonuç olarak H2, sadece saldırgan rekabetçilik boyutu açısından kabul edilmekte, diğer boyutlar açısından reddedilmektedir.

"H3: Öğrencilerin girişimcilik eğilimleri annelerinin eğitimine göre anlamlı bir farklılık göstermektedir" hipotezinin testi için yapılan Anova sonucuna göre (0,05 anlamlılık düzeyinde), demografik özelliklerden annenin eğitim durumu; yenilikçilik, proaktiflik, saldırgan rekabetçilik, risk alma, bağımsızlık, öz yeterlilik, başarma ihtiyacı, içsel denetim, dışsal denetim ve yaratıcılık boyutlarına bakış açıları üzerinde anlamlı bir etkisinin olmadığı görülmektedir. Sonuç olarak H3, GE'nin tüm boyutları için reddedilmektedir.

"H4: Öğrencilerin girişimcilik eğilimleri babalarının eğitimine göre anlamlı bir farklılık göstermektedir" hipotezinin testi için yapılan Anova sonucuna göre ( 0,05 anlamlılık düzeyinde), demografik özelliklerden babanın eğitim durumu; yenilikçilik, proaktiflik, saldırgan rakabetçilik, risk alma, bağımsızlık, öz yeterlilik, başarma güdüsü, içsel denetim, dışsal denetim ve yaratıcılık boyutlarına bakış açıları üzerinde anlamlı bir etkisinin olmadığı görülmüştür. Sonuç olarak H4, girişimcilik eğiliminin tüm boyutları açısından reddedilmektedir.

“H5: Öğrencilerin girişimcilik eğilimleri kardeş sayısına göre anlamlı bir farklılık göstermektedir” hipotezinin testi için yapılan Anova sonucuna göre (0,05 anlamlılık düzeyinde) ailevi özelliklerden öğrencinin kendisi dahil toplam kardeş sayısının; sadece saldırgan rekabetçilik boyutuna bakış açıları üzerinde anlamlı bir etkisinin olduğu görülürken, yenilikçilik, proaktiflik, risk alma, bağımsızlık, öz yeterlilik, başarma ihtiyacı, içsel denetim odağı, dışsal denetim odağı ve yaratıcılık boyutlarına bakış açıları üzerinde ise anlamlı bir etkisinin olmadığı görülmektedir. Anova testine ek olarak yapılan Tukey testine göre ise; öğrencilerin saldırgan rekabetçilik faktörünü algılamaları açısından 2 kardeşli öğrenciler ile 5 ya da daha fazla kardeşli öğrenciler arasında önemli bir fark olduğu tespit edilmiştir. Sonuç olarak H5, sadece saldırgan rekabetçilik boyutu açısından kabul edilmektedir..

"H6: Öğrencilerin girişimcilik eğilimleri kaçıncı çocuk olduklarına göre anlamlı bir farklılık göstermektedir" hipotezini test etmek amaciyla yapılan Anova sonucuna göre (0,05 anlamlılık düzeyinde), öğrencilerin ailelerinin kaçıncı çocuğu olduklarının; yenilikçilik, proaktiflik, saldırgan rekabetçilik, risk alma, bağımsızlık, öz yeterlilik, başarma ihtiyacı, içsel denetim odağı, dışsal denetim odağı ve yaratıcılık boyutlarına bakış açıları üzerinde anlamlı bir etkisinin olmadığı görülmektedir. Sonuç olarak H6, GE'nin tüm boyutları açısından reddedilmektedir.

"H7: Öğrencilerin girişimcilik eğilimleri aile gelirine göre anlamlı bir farklılık göstermektedir" hipotezi için yapılan Anova testi sonucuna göre (0,05 anlamlılık düzeyinde), demografik özelliklerden öğrencilerin aile gelirinin; yenilikçilik, saldırgan rekabetçilik, öz yeterlilik ve içsel denetim odağı boyutlarına bakış açıları üzerinde anlamlı bir etkisinin olduğu belirlenirken, proaktiflik, risk alma, bağımsızlık, başarma ihtiyacı, dışsal denetim odağı ve yaratıcılık boyutlarına bakış açıları üzerinde ise anlamlı bir etkisinin olmadığ görülmektedir. Anova testine ek olarak yapılan Tukey testine göre ise; öğrencilerin yenilikçilik faktörünü algılamaları açısından aile geliri 200 dolar veya daha az olan grupla geliri 351-500 dolar olan grup arasında önemli bir fark vardır. Öğrencilerin saldırgan rekabetçilik faktörünü algılamaları açısından ise aile geliri 200 dolar veya daha az olan grup ile 651 veya üstünde olan ve ayrıca geliri 201-350 dolar olan grup ile de 651 veya üstü doları olan grup arasında önemli bir fark bulunmuştur.

Öğrencilerin öz yeterlilik faktörünü algılamalarında geliri 501-650 dolar olan grupla 651 veya üstü dolar olan grup arasında istatistiki olarak anlamlı bir fark saptanmıştır. Son olarak öğrencilerin içsel denetim faktörünü algılamalarında geliri 200 dolar veya daha az olan grupla 501-650 gelir grubunda bulunanlar arasında önemli bir fark bulunmuştur. Sonuç olarak H7, yenilikçilik, saldırgan rekabetçilik, öz yeterlilik ve içsel denetim odağı boyutları açısından kabul edilirken, diğer boyutlar açısından reddedilmektedir. 
"H8: Öğrencilerin girişimcilik eğilimleri ailede girişimci olup/olmamasına göre anlamlı bir farklılık göstermektedir" hipotezi için yapılan t testi sonucunda ( 0,05 anlamlılık düzeyinde), ailede girişimcinin olup olmama durumunun; yenilikçilik, proaktiflik, saldırgan rekabetçilik, risk alma, bağımsızlık, öz yeterlilik, başarma ihtiyacı, içsel denetim odağı, dışsal denetim odağı ve yaratıcılık boyutları üzerinde anlamlı bir etkisinin olmadığı görülmektedir. Sonuç olarak H8, GE'nin tüm boyutları açısından reddedilmektedir.

"H9: Öğrencilerin girişimcilik eğilimleri cinsiyetlerine göre anlamlı bir farklılık göstermektedir" hipotezi için yapılan t-testi sonucunda ( 0,05 anlamlılık düzeyinde), demografik niteliklerden cinsiyetin; saldırgan rekabetçilik, bağımsızlık, içsel denetim ve yaratıcılık boyutlarına bakış açılarının anlamlı bir etkisinin olduğu, yenilikçilik, proaktiflik, risk alma, öz yeterlilik, başarma ihtiyacı ve dışsal denetim odağı boyutları üzerinde ise anlamlı bir etkisinin olmadığı belirlenmiştir. Bu sonuca göre kız ve erkek öğrencilerin saldırgan rekabetçilik, bağımsızlık, içsel denetim ve yaratıcılık boyutlarını farklı algıladıkları görülmektedir. Erkek öğrenciler, kız öğrencilerden daha fazla saldırgan rekabetçilik eğilimde iken buna karşılık kız öğrenciler erkek öğrencilere göre daha bağımsız olma, daha yüksek içsel denetim odağına sahip ve daha fazla yaratıcılık eğilimde oldukları söylenebilir. Sonuç olarak H9, saldırgan rekabetçilik, bağımsızlık, içsel denetim odağı ve yaratıcılık boyutları açısından kabul edilirken, diğer boyutlar açısından reddedilmektedir.

"H10: Öğrencilerin girişimcilik eğilimleri bağlı oldukları fakülteye/yüksekokula göre anlamlı bir farklılık göstermektedir" hipotezi ile ilgili olan Anova testi sonucuna göre (0,05 anlamlılık düzeyinde), öğrencilerin fakültelerinin/yüksekokullarının; saldırgan rekabetçilik, öz yeterlilik, başarma ihtiyacı, içsel denetim ve yaratıcılık boyutlarına bakış açıları üzerinde anlamlı bir etkisinin olduğu belirlenirken, yenilikçilik, proaktiflik, risk alma, bağımsızlık ve dışsal denetim odağı boyutlarına bakış açıları üzerinde ise anlamlı bir etkisinin olmadığı görülmüştür. Anova testine ek olarak yapılan Tukey testine göre ise; öğrencilerin saldırgan rekabetçilik ve içsel denetim odağı faktörlerini algılamaları açısından Mühendislik Fakültesi ile İİB arasında önemli bir fark olduğu tespit edilmiştir. İletişim Fakültesi ve Edebiyat Fakültesi öğrencilerinin de öz yeterlilik algılamalarında anlamlı bir fark görülmüştür. Son olarak başarma ihtiyacıyla ilgili algılamalarda İletişim Fakültesi ve Meslek Yüksekokulları arasında anlamlı bir fark varken yaratıcılık boyutunu algılama açısından da İletişim Fakültesi ve Mühendislik Fakültesi arasında önemli bir fark saptanmıştır. Sonuç olarak H10, saldırgan rekabetçilik, öz yeterlilik, başarma ihtiyacı, içsel denetim odağı ve yaratıcılık boyutları açısından kabul edilirken, diğer boyutlar açısından reddedilmektedir.

"H11: Öğrencilerin girişimcilik eğilimleri kaçıncı sınıfta olduklarına göre anlamlı bir farklılık göstermektedir" hipotezi için Anova testi sonucuna göre (0,05 anlamlılık düzeyinde), öğrencilerin sınıflarının; yenilikçilik, proaktiflik, saldırgan rekabetçilik, risk alma, bağımsızlık, öz yeterlilik, başarma ihtiyacı, içsel denetim odağı, dışsal denetim odağı ve yaratıcılık boyutlarına bakış açıları üzerinde anlamlı bir etkisinin olmadığı görülmüştür. Sonuç olarak H11, GE'nin tüm boyutları açısından reddedilmektedir.

"H12: Öğrencilerin girişimcilik eğilimleri akademik not ortalamalarına göre anlamlı bir farklılık göstermektedir" hipotezinin Anova testi sonucuna göre (0,05 anlamlılık düzeyinde), öğrencilerin genel akademik not ortalamasının; risk alma, bağımsızlık, öz yeterlilik ve başarma ihtiyacı boyutlarına bakış açıları üzerinde anlamlı bir etkisinin olduğu belirlenirken, yenilikçilik, proaktiflik, saldırgan rekabetçilik, içsel denetim odağı, dışsal denetim odağı ve yaratıcılık boyutlarına bakış açıları üzerinde ise anlamlı bir etkisinin olmadığı görülmüştür. Anova testine ek olarak yapılan Tukey testine göre ise; öğrencilerin risk alma ve öz yeterlilik faktörlerini algılamalarında şu gruplar arasında fark saptanmıştır; not ortalaması 2.51-3 arasında olan grup ile 3.01-3.50 arasında olan grup. Öğrencilerin bağımsızlık faktörünü algılamalarında ise şu iki grup (2.01-2.50 arası not) (3.01-3.50 arası not) arasında fark saptanmıştır. Son olarak öğrencilerin başarma ihtiyacı faktörünü algılamalarında en düşük not ortalaması olan grup (1-2 aras1) ile en yüksek not ortalaması (3.51-4 arası) grubu arasında önemli bir fark olduğu tespit edilmiştir. Sonuç olarak H12, risk alma, bağımsızlık, öz yeterlilik ve başarma ihtiyacı boyutları açısından kabul edilirken, diğer boyutlar açısından reddedilmektedir.

"H13: Öğrencilerin girişimcilik eğilimleri bildikleri yabancı dil sayısına göre anlamlı bir farklılık göstermektedir" hipotezini test etmek üzere yapılan Anova sonucuna göre $(0,05$ anlamlılık düzeyinde), öğrencilerin ana dillerinin dışında bildikleri dillerin; proaktiflik, risk alma ve bağımsızlık boyutlarına bakış açıları üzerinde anlamlı bir etkisinin olduğu belirlenirken, yenilikçilik, saldırgan rekabetçilik, öz yeterlilik, başarma ihtiyacı, içsel denetim odağı, dışsal denetim odağı ve yaratıcılık boyutlarına bakış açıları üzerinde ise anlamlı bir etkisinin olmadığı görülmüştür. Anova testine ek olarak yapılan Tukey testine göre ise; öğrencilerin proaktiflik ve risk alma faktörlerini algılamaları açısından 2 dil bilenlerle 5 veya daha fazla dil bilenler arasında önemli bir fark olduğu tespit edilmiştir. Ayrıca, 2 dil bilenlerle 4 dil bilenler arasında bağımsızlık faktörünün algılanmasında önemli bir fark olduğu saptanmıştır. Sonuç olarak H13, proaktiflik, risk alma ve bağımsızlık boyutları açısından kabul edilirken, diğer boyutlar açısından reddedilmektedir.

Son olarak "H14: Öğrencilerin girişimcilik eğilimleri girişimcilik dersi alıp/almamalarına göre anlamlı bir farklılık göstermektedir" hipotezine ilişkin t testi sonucunda (0,05 anlamlılık düzeyinde), eğitim esnasında girişimcilik dersi alıp almama durumunun; yenilikçilik, proaktiflik, saldırgan rekabetçilik, risk alma, bağımsızlık, öz yeterlilik, başarma ihtiyacı, içsel denetim odağı, dışsal denetim odağı ve yaratıcılık boyutları 
üzerinde anlamlı bir etkisinin olmadığı belirlenmiştir. Sonuç olarak H14, GE'nin tüm boyutlar açısından reddedilmektedir.

\section{Sonuç}

Girişimcilik, geçiş ekonomilerinde gerek ulusal gerekse bölgesel gelişmenin sağlanabilmesi, rekabetin canlanması ve istihdamın artması açısından büyük önem taşımaktadır. Ancak küresel değişme ve gelişmelere bağlı olarak girişimciliğin niteliğinin de değiştiğini söyleyebiliriz. Çünkü içinde bulunduğumuz bilgi çağında fiziki gücün yerini bilgi gücü almaktadır. Bu çağda sadece para veya sermaye sahibi olmak, girişimci olmaya yetmemektedir. Çünkü girişimci, kendi bilgi ve yetenekleri ile birlikte emek, sermaye, doğal kaynaklar ve hammaddeyi bir araya getirerek üretim ve dağıtım süreçlerini gerçekleştirip yöneten kişidir.

Girişimciliğin ve girişimci kişilerin varlığının geçiş ekonomilerinde ve dolayısıyla Kırgızistan'da yadsınamaz değere sahip olduğu bilinen bir gerçektir. $\mathrm{Bu}$ açıdan potansiyel girişimcileri belirlemek ve onları pazara çıkarmanın yollarını bulabilmek açısından üniversite öğrencilerinin girişimcilik eğilimlerinin saptanması önem arz etmektedir. $\mathrm{Bu}$ amaçla Kırgızistan-Türkiye Manas Üniversitesi öğrencileri üzerinde kapsamlı bir anket çalışması yapılmış ve öğrencilerin sosyo-demografik özelliklerinin girişimcilik eğilimleri üzerindeki etkisi araştırılmıştır. Araştırmanın sonucunda şu bulgulara ulaşıllmıştır:

Uluslararası niteliğe sahip olan Manas Üniversitesi öğrencilerinin çoğunluğunu Türkler ve Kırgızlar oluşturduğu için bu iki grup, vatandaşı oldukları ülkelere göre karşılaştırılmıştır. Türk ve Kırgız öğrencilerinin GE'nin saldırgan rekabetçilik ve içsel denetim boyutları açısından farklılık gösterdiği saptanmıştır. Buna göre Türk öğrencilerin saldırgan rekabetçilik eğiliminin Kırgız öğrencilerden daha fazla olduğu bulunmuştur. Böyle bir bulguya ulaşılmasının sebebi, Kırgız öğrencilerin henüz tam olarak devletçi yapının etkisinden kurtulamamış olmasından kaynaklanıyor olabilir. İçsel denetim boyutu açısında bakıldığında, Kırgız öğrencilerinin içsel denetim odağının Türk öğrencilerden daha yüksek olduğu görülmüştür; -ki bu bulgu, Kırgız kültürünü etkileyen SSCB'nin (Sovyet Sosyalist Cumhuriyetler Birliği) kültürüyle -özellikle dini inançlarıyla- ilgili olabilir. Çünkü Kırgız halkı Müslüman olmasına karşın, bu inançlarını henüz tam olarak gereği gibi yerine getirememektedirler. Türk öğrenciler ise dini inançları gereği kadere daha fazla inanmaktadırlar.

1. Manas Üniversitesi öğrencileri yetiştikleri yer açısından değerlendirildiğinde, köyde, kasabada ve şehirde yetişenler arasında saldırgan rekabetçilik boyutu açısından anlamlı bir farklılık bulunmuştur. Buna göre şehirde yetişen öğrenciler köyde yetişenlere göre daha büyük bir saldırgan rekabetçilik eğilimi sergilemektedirler.

2. Çocukların büyümesinde çok önemli bir etkiye sahip olduğu düşüncesiyle anne ve babaların eğitim düzeylerinin yüksek olup olmamasının GE üzerindeki etkisine bakıldığında, anne baba eğitiminin GE'nin hiç bir boyutunu etkilemediği görülmüştür.

3. Toplam kardeş sayısının GE üzerindeki etkisine bakıldığında, sadece saldırgan rekabetçilik boyutu açısından anlamlı bir farklılık bulunmuştur. Bu bağlamda iki kardeşli olan öğrencilerin beş ya da daha fazla kardeşli olan öğrencilere göre saldırgan rekabetçi eğiliminin yüksek olduğu saptanmıştır. Türkiye'de yapılan araştırmalarda girişimcilerin genelde birinci ve ortanca çocuklardan çıktığı bulgusu elde edilmiştir. Bu bağlamda, Kırgızistan'da kardeş sırasının GE'nin hiç bir boyutu üzerinde etkili olmadığı sonucuna ulaşılmıştır.

4. Aile gelirlerinin öğrencilerin GE üzerinde etkisi değerlendirildiğinde, gelir düzeyinin saldırgan rekabetçilik, öz yeterlilik ve içsel denetim eğilimlerini etkilediği saptanmıştır. Saldırgan rekabetçiliğin en düşük gelir grubu ( $200 \leq$ dolar) ile en yüksek gelir grubu (651 $\geq$ dolar) arasında olduğu bulunmuştur. Ayrıca aile geliri

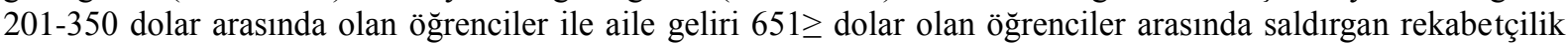
açısından farklılık vardır. Bu bağlamda yüksek gelirli aile çocuklarının daha düşük gelirli aile çocuklarından daha büyük saldırgan rekabetçilik eğiliminin olduğunu söyleyebiliriz. Aile geliri 501-650 dolar arasında olan öğrenciler ile $650 \geq$ dolar olan öğrenciler arasında da öz yeterlilik açısından önemli bir farklılık saptanmıştır. Yüksek gelirin öğrencilerin öz yeterliliği üzerinde etkisi olduğunu belirtebiliriz. Son olarak aile geliri $200 \leq$ dolar olan öğrencilerle 501-650 dolar olan öğrenciler arasından içsel denetim odağ açısından önemli bir farklılık bulunmuştur. Gelir düzeyi yüksek öğrencilerin içsel denetim odağı daha yüksek çıkmıştır.

5. Ailede bir girişimcinin olmasının öğrencileri girişimciliğe yönlendirebileceği düşüncesiyle hareket edilerek yöneltilen soru bağlamında, ailesinde girişimci olan öğrenci grubuyla olmayan grup arasında anlamlı bir farklılık bulunmamıştır. Bu bağlamda Kırgızistan'da ailede girişimcinin olup olmamasının GE üzerinde hiç bir etkisinin olmadığı görülmüştür.

6. Cinsiyet açısından değerlendirildiğinde, saldırgan rekabetçilik, bağımsızlık, içsel denetim odağı ve yaratıcılık boyutları açısından erkek ve kız öğrenciler arasında önemli bir farklılığa rastlanmıştır. Buna göre erkek öğrencilerin saldırgan rekabetçilik eğilimi kız öğrencilerden daha yüksek çıkmıştır. Bu, beklenen bir sonuçtu. Çünkü Hofstede'in de yaptığı bilimsel çalışmalarda ortaya konduğu gibi, eril özelliği bir girişimcilik niteliğidir. Karşıt olarak anlamlı farklılıkların bulunduğu bağımsızlık, içsel denetim odağı ve yaratıcılık eğilimleri açısından da kızlar erkeklere göre daha yüksek ortalamalara sahiptir. Kırgızistan'da kadınların iş yaşamında neredeyse her alanda çok önemli roller üstlendiklerini düşündüğümüzde, böyle bir sonucun çıkması şaşırtıcı olmamıştır. 
7. Fakültelere göre öğrencilerin girişimcilik eğilimleri karşılaştırıldığında, Mühendislik Fakültesi ile İIBBF öğrencileri arasında saldırgan rekabetçilik açısından anlamlı bir farklılık bulunmuş olup, İIBF öğrencilerinin daha fazla saldırgan rekabetçi eğiliminde oldukları görülmüştür. Öz yeterlilik açından ise İletişim Fakültesi ile Edebiyat Fakültesi öğrencileri arasında önemli bir farklılık bulunmuştur. Buna göre Edebiyat Fakültesi İletişim Fakültesi öğrencilerine göre daha yüksek öz yeterliliğe sahiptir. Başarma ihtiyacı açısından anlamlı farklılık gösteren İletişim Fakültesi ile MYO öğrencileri değerlendirildiğinde, MYO öğrencilerinin başarma ihtiyaçlarının İletişim Fakültesi öğrencilerine göre daha büyük olduğu çıkmıştır. Son olarak İletişim Fakültesi ile Mühendislik Fakültesi öğrencileri arasında yaratıcılık eğilimi açısından önemli bir farklılık bulunmuştur. İletişim Fakültesi öğrencilerinin yaratıcılık eğilimlerinin Mühendislik Fakültesi öğrencilerine göre daha yüksek olduğu saptanmiştır.

8. Sınıfa göre öğrencilerin GE'nin farklılaşacağı hipotezi değerlendirildiğinde, birinci sınıfta okuyan öğrencilerle son sınıfta olan öğrencilerin GE'lerinde hiçbir farkın olmadığı görülmüştür.

9. Öğrencilerin genel akademik not ortalamaları değerlendirildiğinde, risk alma, bağımsızlık, öz yeterlilik ve başarma ihtiyacı açısından anlamlı farklılıklar bulunmuştur. Risk alma not ortalaması 2.51-3.00 arasında olan öğrencilerle akademik ortalaması 3.01-3.50 arasında değişen öğrenci gruplarında fark olduğu görülmüştür. Akademik ortalaması yüksek olan grup düşük olan gruba göre daha büyük riskler alma eğilimdedir. Bağımsızlık eğilimi şu iki grup (2.01-2.50 arası) (3.01-3.50 arası) arasında farklılaşmakta olup, not ortalaması yüksek olan grup düşük olan gruba göre daha fazla bağımsız olma eğilimindedir. Öz yeterlilik açısından ise şu iki grup (2.513.00 arası) (3.01-3.50 arası) arasında önemli bir farklılık bulunmuştur. Not ortalaması yüksek olan grubun düşük olan gruba göre daha fazla öz yeterlilik algısına sahip olduğu görülmüştür. Son olarak başarma ihtiyacı, şu iki grupta (1.00-2.00 arası) (3.51-4.00 arası) anlamlı bir farklılık göstermiştir. Not ortalaması en düşük olan grup yüksek olan gruba göre daha fazla başarma ihtiyacı olduğu inancındadır.

10. Yabancı dil bilmenin girişimcilik ve yurt dışına açılabilme açısından önemli olduğu düşünülmüş ve GE üzerindeki etkisi araştırılmıştır. Ana dilin dışında bilinen toplam yabancı dil sayısı değerlendirildiğinde, proaktiflik, risk alma ve bağımsızlık boyutları açısından anlamlı farklılıklara rastlanmıştır. Proaktiflik açısından iki dil bilenle beş ya da daha fazla dil bilen grup arasında fark vardır. iki dil bilen öğrenciler beş ya da daha fazla dil bilen öğrencilere göre daha proaktif davranışlar sergilemektedirler. Ayni şekilde iki dil bilen öğrenciler beş ya da daha fazla dil bilenlere göre daha büyük bir risk alma eğilimindedirler. Son olarak iki dil bilen grupla dört dil bilen grup arasında bağımsızlık açısından görülen fark, dört dil bilenin daha büyük bağımsızlık eğilimde olması şeklindedir.

11. Son olarak eğitim esnasında alınan girişimcilik dersinin GE üzerinde bir etkisinin olmadığı bulunmuştur.

\section{Kaynakça}

- $\quad$ Akdemir, Ali, 1996. Girişimcilik Kültürü “Para ile Mutlu Olunur mu?”. Kütahya.

- Amabile, Teresa M.,Regina Conti, Heather Coon, Jeffrey Lazenby, \& Michael Herron, 1996. "Assessing The Work Environment For Creativity", Academey of Management Journal 39(5), pp. 1169-1184.

- Arıkan, Semra, 2002. Girişimcilik Temel Kavramlar ve Bazı Güncel Konular, Siyasal Kitabevi, Ankara.

- Bozkurt, Rüştü, 2000. “Girişimci ve Rol Bilinci”, İş̧ Fikirleri Dergisi, 12.

- Börü, Deniz, 2006. Girişimcilik Eğilimi: Marmara Üniversitesi İşletme Bölümü Öğrencileri Üzerine Bir Araştırma. Marmara Üniversitesi Yayını, İstanbul.

- Brenkert, George G., 2009. "Innovation, Rule Breaking and Ethics of Entrepreneurship", Journal of Business Venturing, 24, pp. 448-464.

- Chelariu, Cristian, Thomas G. Brashear, Talai Osmonbekov, \& Adriana Zait, 2008. "Entrepreneurial Propensity in a Transition Economy: Exploring Micro-Level and Meso-Level Cultural Antecedents", Journal of Business \& Industrial Marketing, 23(6), pp. 405-415.

- Chen, Hsiang Ling ve Chun-Hui Hsu, 2013. "Entrepreneurial Orientation and Firm Performance in NonProfit Service Organizations: Contingent Effect of Market Orientationa", The Service Industries Journal, 33(5), pp. 445-466.

- Covin, Jeffrey G., \& Dennis P. Slevin, 1991. "A Conceptual Model of Entrepreneurship as Firm Behavior", Entrepreneurship Theory and Practice, Fall, pp. 7-25.

- Çetin, Fatih, 2011. "Örgüt İçi Girişimcilikte Öz Yeterlilik Algısı ve Kontrol Odağının Rolü", Business and Economics Research Journal, 2(3), ss. 69-85.

- $\quad$ Ercan, Salih ve İsmail Gökdeniz, 2009. "Girişimciliğin Gelişim Süreci ve Girişimcilik Açısından Kazakistan", Bilig, 49, ss. 59-82.

- $\quad$ Eren, Erol, 1982. İşletmelerde Yenilik Politikası. Fakülteler Matbaası, İstanbul.

- Heckhausen, J. \& Schulz, R., 1995. "A Life-Span Theory of Control", Psychological Review, 102, pp. 284304. 
- Hmieleski, Keith M., \& Andrew C. Corbett, 2008. "The Contrasting Interaction Effects of Improvisational Behavior with Entrepreneurial Self-Efficacy on New Venture Performance and Entrepreneur Work Satisfaction", Journal of Business Venturing, 23, pp. 482-496.

- $\quad$ İşcan, Ömer Faruk ve Erdoğan Kaygın, 2011. "Üniversite Öğrencilerinin Girişimcilik Eğilimlerini Belirlemeye Yönelik Bir Araştırma", Atatürk Üniversitesi Sosyal Bilimler Enstitüsü Dergisi, 15 (2), ss. 443 462.

- Johnson, Johanna E., 2011. Why Some Leaders Can Build New Organizations: Leadership, Individual Differences, and Gender in Entrepreneurship. The Pennsylvania State University, Unpublished Ph.D Thesis.

- Keleç, Hatice Necla, Tuğba Kıral Özkan ve Ali Ender Altunoğlu, 2012. "Önlisans Öğrencilerinin Girişimcilik Düzeylerini Belirlemeye Yönelik Bir Araştırma", Uluslararası İktisadi ve İdari İncelemeler Dergisi, 5(9), ss. 107-118.

- Knight, Gary A. 1997. "Cross-Cultural Reliability and Validity of a Scale to Measure Firm Entrepreneurial Orientation", Journal of Business Venturing, 12, pp. 213-225.

- Korkmaz, Sezer, 2000. “Girişimcilik ve Üniversite Öğrencilerinin Girişimcilik Özelliklerinin Belirlenmesine Yönelik Bir Araştırma”, Hacettepe Üniversitesi İ̈BF Dergisi, 18(1), ss. 163-169.

- $\quad$ Kraus, Sascha, 2013. "The Role of Entrepreneurial Orientation in Service Firms: Empirical Evidence from Austria", The Service Industries Journal, 33(5), pp. 427-444.

- Kurt, Mustafa, Veysel Ağca ve Saffet Erdoğan, 2006. “Afyonkarahisar İli Girişimcilik Performansının Coğrafi Bilgi Sistemleri ile Analizi”, Afyon Kocatepe Üniversitesi İ̈BF Dergisi, 8(2), ss. 97-114.

- Luszczynska, Aleksandra, Urte Scholz, \& Ralf Schwarzer, 2005. "The General Self-Efficacy Scale: Multicultural Validation Studies", The Journal of Psychology, 139(5), pp. 439-457.

- Müftüoğlu, Tamer, 1997. Girişimcilik, Anadolu Üniversitesi Web-Ofset Tesisleri, Eskişehir.

- Okay, Şenol ve Mehmet Karahan, 2010. "Küçük Ölçekli İşletmelerin Girişimcilik Özelliklerinin Belirlenmesi Üzerine Bir Alan Araştırması: Denizli İli Örneği", Türkiye Sosyal Araştırmalar Dergisi, 14, ss. 291-304.

- $\quad$ Poon, June M.L., Raja Azimah Ainuddin, \& Sa'odah Haj1 Junit, 2006. "Effects of Self-Concept Traits and Entrepreneurial Orientation on Firm Performance", International Small Business Journal, 24(1), pp. 61-82.

- Salas, Eduardo, Janis A. Cannon-Bowers, 2001. "The Science of Training: A Decade of Progress", Annual Review of Psychology, 52, pp. 471-499.

- $\quad$ Solmuş, Tarık, 2004. "İş Yaşamı, Denetim Odağ1 ve Beş Faktörlük Kişilik Modeli", Türk Psikoloji Bülteni, 10, ss. 196-205.

- $\quad$ Speier, Christa, \& Michael Frese, 1997. "Generalized Sel-Efficacy As a Mediator and Moderator Between Control and Complexity at Work and Personel Initiative: A Longitudinal Field Study in East Germany", Human Performance, 10(2), pp. 171-192.

- $\quad$ Strauser, D. R., Ketz, K. \& Keim, J., 2002. "The Relationship Between Self-Efficacy, Locus of Control and Work Personality", Journal of Rehabilitation, 68, pp. 20-26.

- $\quad$ TDK, 2013. http://tdkterim.gov.tr/bts/?kategori=verilst\&kelime=e\%F0ilim\&ayn=tam, (ET: 30.04.2013).

- $\quad$ Todorovic, Zelimir William, Rod B. McNaughton, \& Paul Guild, 2011. "ENTRE-U: An Entrepreneurial Orientation Scale For Universities", Technovatin, 31, pp. 128-137.

- Zahra, Shaker A., 1995. "Corporate Entrepreneurship and Financial Performance: The Case of Management Leveraged Buyouts", Journal of Business Venturing, 10, pp. 225-247.

- Zahra, Shaker A., 2008, "Being Entrepreneurial and Market Driven: Implication for Company Performance", Journal of Strategy and Management, 1(2), pp. 125-142. 


\title{
Yerel Ekonomilerin Yeni Aktörü, Bölgesel İnovasyon Stratejileri: RIS Mersin Uygulaması
}

\section{New Actor of the Local Economies, Regional Innovation Strategies: RIS Mersin Application}

\author{
Asst. Prof. Dr. Filiz Tutar (Niğde University, Turkey) \\ Asst. Prof. Dr. Emine Frrat (Aksaray University, Turkey) \\ Mrs. Çisil Erkan (Niğde University, Turkey) \\ Prof. Dr. Erdinç Tutar (Niğde University, Turkey)
}

\begin{abstract}
Innovation is in a key position of competition and development in our globalizing world.Regional innovation system can be defined to minimize interzonal imbalances, to take the skilled labor and policies and strategies implemented to enhance the competitiveness of firms.In this connection, regional innovation strategy plays an important role in terms of increasing the regions innovation. Mersin which is an important port city in the eastern coast of the Mediterranean, is not at the place it deserves in socio-ecenomic sense either in turkey or in the world. In general to promote regional innovation systems in order to increase of the region's innovation potential and competitiveness and in particular put forth of Mersin's regional innovation strategy's strengths and weaknesses and opportunities and threats is form of the purpose of the study.
\end{abstract}

\section{Giriş}

Günümüzde ulusların Dünya ile rekabet edebilmesinin tek yolu ülkelerin/bölgelerin ne kadar yenilik yani inovasyon yaptığıdır. Bölgesel inovasyon stratejilerinin ana hedefi ise bölgedeki firmalar ekseninde rekabetçiliği ve inovasyonu desteklemektir. Mersin inovasyon stratejisinin vizyonu; Mersin'in yüksek yaşam kalitesi, bilgi ve inovasyona dayalı sürdürülebilir bir ekonomiye sahip bir dünya kenti haline gelmesi, hedefi ise, Mersindeki işletmelerin inovasyon yeteneğinin geliştirilmesidir.

Mersin inovasyon stratejisinin başarısı için kilit önem taşıyan aktörler (Örneğin; işletmeler, hükümet organları, finansman sağlayan kurumlar, üniversiteler ve diğer bilgi üreticileri) arasında bağlantı, etkinlik ve etkileşimin kalitesi ve yoğunluğu çok önemlidir. Bu da inovasyonun sadece teknolojik değil, aynı zamanda sosyal bir süreç olduğunu gösterir. İşte Mersin'de ki işletmelerin inovasyon yeteneğini geliştirmeyi hedefleyen bu strateji, aynı zamanda ilde yaşam kalitesinin arttırılımasına, istihdam yaratılmasına ve sürdürülebilir bir bölgesel ekonomi oluşturulmasına katkı sağlayacaktır. Çalışmamızda öncelikle yerel kalkınma bölgesel inovasyon ilişkisine teorik olarak değinildikten sonra bölgesel inovasyon sistemi ve performans belirleyicileri hakkında bilgi verilmiştir. Çalışmamızın ana konusunu oluşturan Mersin RIS'de tüm detaylarıyla anlatılmıştır.

\section{Yerel Ekonomik Kalkınma - Bölgesel İnovasyon İlişkisi}

Günümüzde kentler arası rekabetin ortaya çıkmasıyla beraber yerel ekonomik kalkınma giderek önemi artan bir kalkınma politikası olmuştur. ILO’ya göre yerel ekonomik kalkınma; yerel kaynakları ve rekabet avantajını kullanarak belirli bir bölgede kamu ve özel sektör aktörleri arasında ortaklık ve işbirliği faaliyetlerini destekleyen, genel bir kalkınma stratejisinin ortak şekilde oluşumu ve uygulamasına imkan tanıyan, uygun bir iş ortamının yaratılması ve ekonomik aktivitelerin desteklenmesi gibi önemli hedefleri olan katılımcı bir kalkınma sürecidir (Boekel ve Logtestijn, 2002). Bu kalkınma sürecinde rol oynayan yerel ekonomik kalkınmanın aktörlerini sıraladığımızda,valilikler, belediyeler, sivil toplum kuruluşları, iş dünyası, üniversiteler ve medya başta gelmektedir. Bunlara ek olarak son yıllarda teknolojinin gelişmesi, kurumlar arası iletişimin artması ve bilginin artan önemiyle beraber inovasyon sistemi kavramı ortaya çıkmıştır.

Başlangıçta ulusal düzeyde tanımlanmış olan inovasyon sistemi kavramı, sonraları bölgesel, sektörel ve yerel düzeye de uyarlanmıştır. Bölgesel düzeyde ele alındığında, işletmeler, üniversiteler ve eğitim kurumları, araştırma kuruluşları, kamu kurumları, finansman kuruluşları, aracı kuruluşlar (inovasyon ve iş destek merkezleri, teknoloji transfer ofisleri, vb.), sivil toplum kuruluşları, inovasyon ve teknoloji altyapısını destekleyen kuruluşlar (teknoparklar, kuluçka merkezleri, vb.) gibi çok çeşitli aktörün ve bunlar arasındaki etkileşimin oluşturduğu bir ortamdır (Elçi, vd, 2008).

İnovasyon sistemi içerisinde; yerel nitelikte ki ekonomik kalkınma araçları/kuruluşları özel bir yer tutarlar. Bunlar (Arıkan, 2004);

- Inovasyon Merkezleri; merkezle firmalar arasında ağyapı kurarak yaratıcı fikir ticareti konusunda danışmanlık hizmetleri sunar ve girişimciye işe başlaması için destek verir. 
- Kuluçkalıklar; başlangıç aşamasındaki yaratıcı girişimciye ucuz mekan, ortak tesisler ve uzman desteği sağlar.

- Araştırma Parkı; endüstriyel araştırma faaliyeti ile akademik araştırma arasındaki bağı kurarak endüstriyel araştırma faaliyetini araştırma enstitülerine yaklaştırır.

- Bilim Parkı; üniversite araştırması ile ticari faaliyet arasında ilişki kurar, üniversite merkezli ve kamu destekli bir ortam sağlar.

- Teknoloji Parkı; endüstriyel gelişme amacı ile teknoloji tabanlı imalatçılara çekim alanı yaratır, onlara destek avantaj sunar.

- $\quad$ Işbirliği Parkl; yapılarla sınırlı olarak tesis kullanımı sağlar.

- Girişimci Bölgesi; belirli iş faaliyetlerinin, özel fon destekleri ile tanımlı alanlara çekilmesini kolaylaştırır.

- Bilim Kenti; imalat bağı bulunmayan bilimsel komplekslerdir. İnovasyon ortamının sinerjisinden bilimsel mükemmeliyet oluşturmak için kurulmuştur.

- Teknokent; teknoloji - sanayi çevresinin bütünüyle bir kent olarak tasarlandığı ve bölgesel kalkınma amaçlı araçlardır.

- Kümeler; bölgesel olarak birbirine yakın ve birbiri ile ilişki içinde olan işletmelerin rekabet içinde işbirliği yapmasidir.

Temel olarak inovasyon sistemleri; mikro, mezo ve makro olmak üzere üç düzeyde ele alınabilir. Mikro düzeyde firmalarda ki inovasyon süreçlerine odaklanılırken, mezo düzeyde endüstriyel/sektörel inovasyon sistemlerine (kümelenmelere) odaklanılmaktadır. Makro seviyede ise inovasyon sistemi ulusal düzeyde ele alınmaktadır. Ancak bu noktada ulusal, bölgesel ve sektörel inovasyon sistemi düzeylerinin birbirlerinin yerine geçebilecek alternatifler olarak düşünülmemesi gerektiği de belirtilmelidir. Aksine tüm inovasyon sitemi düzeyleri, Birbirlerinin tamamlayıcıları niteliğindedir. Çünkü ulus-altı yapılanmalar, böylesine riskli bir faaliyet alanına yatırım yapmak için ihtiyaç duyulan yasal ve finansal kaynaklara sahip değildir. Bu nedenle ulusal bir yaklaşım olmaksızın bilim, teknoloji ve inovasyon için bölgesel bir politika yürütmek mümkün olmamaktadır. Ancak, ulusal bir yaklaşım gerekli olmakla birlikte, böyle bir yaklaşım inovasyonu teşvik edememektedir. Çünkü beşeri sermayenin belli bölgelerde birikmesi, yoğunlaşması ve diğer bölgelerde ki eksiklikler nedeniyle, ulusal inovasyon politikaları bazı bölgelerden yararlanma imkanına kavuşmaktadır. Dolayısıyla ulusal inovasyon sisteminin inşasını bölgesel kurumların oluşturulması ve bölgesel inovasyon sistemi takip etmelidir (Niosi, 2010).

\section{Bölgesel İnovasyon Sistemi}

İnovasyon, bugün artık sadece ulusal düzeyde değil, bölgesel düzeyde de gelişme, kalkınma ve rekabetçiliği mümkün kılan en önemli unsurların başında gelmektedir. Bu gerçekten hareketle yaklaşık 20 yıldır dünyanın pek çok ülkesinde bölgesel inovasyon sistemleri tasarlanmakta ve uygulanmaktadır (OKA, 2012). Günümüzde gelişmiş ve gelişmekte olan ülkelerde bölgesel inovasyon sistemleri ekonomik büyümenin tetikleyicisi olarak görülmeye ve ekonomik politikalarda önemli yer tutmaya başladı.

Bölgesel inovasyon sistemi; bölgeler arasındaki dengesizlikleri en aza indirmek, inovasyona dayalı firmaları ve nitelikli işgücünü çekmek ve firmaların rekabet gücünü artırmak için uygulanan politika ve stratejiler olarak tanımlanmaktadır. Bir bölgenin inovasyona bağlı olarak gelişmesi ve refah seviyesinin yükseltilebilmesi için bölgenin sahip olduğu fiziksel, toplumsal, beşeri ve finansal sermayeye yatırım yapılması gerekir (Işık ve Kılınç, 2011).

Bölgesel İnovasyon Merkezlerinin vizyonu, bulundukları bölgelerin kalkınmasına katkıda bulunmak üzere bölge için kritik sektörlerin inovasyona dayalı sürdürülebilir rekabet gücü kazanmasını mümkün kılacak lider kurumlar olmaktır.

Bölgesel İnovasyon Merkezlerinin misyonu, odaklandıkları sektörlerde faaliyet gösteren firmaların küresel düzeyde rekabet gücüne sahip; daha hızlı ve sağlıklı büyüyen, daha çok değer ve daha fazla istihdam yaratan firmalara dönüşmelerini sağlamak için inovasyona dayalı ihtiyaçlarını karşılamak ve inovasyon için işbirliklerini oluşturmaktır.

Bölgesel İnovasyon Merkezlerinin Amaçları, Yukarıdaki vizyon ve misyon doğrultusunda bölgede odaklanılan sektörlerin küresel düzeyde rekabet edebilir hale gelmesi için inovasyona ilişkin firsatları yaratmak ve bu amaçla bölgedeki inovasyon potansiyelini harekete geçirmektir.

Bu çerçevede belirlenen özel amaçlar şunlardır:

- Odaklanılan sektörlerdeki tüm bölgesel paydaşları (büyük firmalar, KOBİ’ler, üniversiteler, araştırma merkezleri, kamu kurumları, sivil toplum kuruluşları) sektörün inovasyon performansının artması için işbirliği yapma konusunda cesaretlendirmek ve yönlendirmek,

- Odaklanılan sektörlerdeki firmaların inovasyon yapma yeteneğini artırmak, sektörde inovasyona dayalı yeni firmaların kurulmasını sağlamak, 
- Odaklanılan sektörlerin inovasyon faaliyetlerinin etkinliğini artırmak için gerekli altyapı ve imkanların oluşmasını, mevcut ve kurulacak olan altyapıların etkin kullanılmasını sağlamak.

Bölgesel inovasyon sistemi, kendisini oluşturan aktörler (bölgedeki işletmeler, kamu kurumları, finansman sağlayıcılar, üniversiteler, sivil toplum kuruluşları, araştırma kuruluşları ve diğer ilişkili kuruluşlar) arasındaki işbirlikleriyle hayat bulur. Bir bölgesel inovasyon sisteminin etkinliği, bu aktörler arasındaki ilişkilerin kalitesi ve yoğunluğuna bağlıdır.

Bölgesel inovasyon sistemi, bir bölgenin üretim yapısı içerisindeki inovasyonu destekleyen kurumsal altyapı olarak düşünülebilir. Bölgeler, bölgesel (mezo) düzeydeki iktisadi koordinasyonun önemli bir dayanağıdır: Bölge, inovasyonun; inovatif bölgesel ağlar, yerel kümeler ve araştırma enstitülerinin verimli etkileri aracılığıyla üretildiği yerdir (Asheim ve Gertler, 2005).

Bölgesel inovasyon sistemi yaklaşımının önemli olmasının iki ana nedeni vardır: Bölgelerde üretilen güçlü inovasyon dinamikleri ulusal inovasyon politikası hedeflerine ulaşmak için önemlidir ve inovasyon performansı firmaların verimliliğini artırarak bölgelerin genel ekonomik rekabet edebilirliğine katkı sağlarlar. Bölgesel inovasyon politikasının hedefleri bölgesel kalkınma ve bilim ve teknoloji alanlarındaki politika yapıcıları ile ilgilidir (OECD, 2008).

\subsection{Bölgesel İnovasyon Stratejisi}

Bölgesel inovasyon stratejisi bölgelerin yenilikçiliğini arttırması açısından strateji geliştirme noktasında önemlibir rol üstlenmektedir.

Bölgesel İnovasyon stratejisini oluşturan ana kavramlar; Avrupa Yenilikçi Bölgeler Ağı (IRE), Bölgesel İnovasyon Stratejileri (RIS) ve İnovasyon Aktarım Merkezleri (IRC) şeklindedir. Avrupa Komisyonu tarafından desteklenen IRE (Avrupa Yenilikçi Bölgeler Ağı), işbirliğinin sağlanması ve bölgesel yenilikçilik stratejilerinin uygulanması veya gelişmekte olan bölgelerin deneyimlerinin paylaşımı amacıyla yapılanmıştır. IRC (İnovasyon Aktarım Merkezleri) ise Avrupa genelinde kurulan, uluslararası teknoloji transferine destek sağlama konusunda uzmanlaşmış teknoloji aracı kuruluşlarıdır (Gök, 2006).

RIS (Bölgesel İnovasyon Stratejileri); yenilikçiliğin teşvik edilmesine yönelik denenmiş ve sınanmış yaklaşımları işletmelere taşıyarak bu işletmelerin rekabet edebilir düzeye gelmelerini sağlamaktır. RIS, bölgelerin yenilikçiliği arttırmaları adına stratejiler üretmesi, inovasyon politikaları ile birlikte mevcut altyapının en iyi şekilde kullanılması ve geliştirilmesi üzerine çizilen bir yol haritasıdır. Bu, beş aşamalı bir sürecin takip edilmesi ile ortaya çıkmaktadır. Bu aşamaları şu şekilde sıralayabiliriz;

- Bölgesel diyaloğun başlatılması,

- İlgili bütün organizasyonların inovasyon politikasının oluşturulması sürecine doğrudan katkıda bulunması,

- Güçlü ve zayıf yanların,tehdit ve firsatların belirlenmesi,

- İnovasyonun teşviki için önceliklerin belirlenmesi,

- Uygulama ve stratejilerin eyleme dökülmesi (Rekabet Forumu, 2006) Bölgesel inovasyon stratejileri bu aşamaların takip edilmesi sonucu ortaya çıkmaktadır.

Bölgesel inovasyon stratejilerinin oluşturulmasında şu noktaların özellikle altı çizilmektedir.;

- Arzu edilen kalkınma yörüngesinin tanımlanması, ayrıca değişimin ana etkenlerinin belirlenmesi,

- Bu özellikler ışı̆̆ında inovasyon politikasının tasarımı,

- Diğer ulusal fonlarla birlikte yapısal fonların uyarlanması,

- Koordinasyon ve bölgesel karar sistemleri ile merkezi yönetim arasındaki dengenin sağlanması ve sürdürülmesi için kurumsal düzeyde çalışmaların yapılması,

- Kurumlar, organizasyonlar arasındaki etkileşimin en azından mali kaynaklar kadar büyük öneme sahip olduğunun kabul edilmesi,

- Başarı örneklerinin paylaşılması (Rekabet Forumu, 2006).

\subsection{Bölgelerin İnovasyon Sistemi Performans Belirleyicileri}

Bir bölgenin inovasyona bağlı olarak gelişmesi, rekabet gücünün artması ve yaşam kalitesinin yükseltilmesi için, o bölgenin sahip olduğu dört sermaye faktörüne (fiziksel sermaye, toplumsal sermaye, insan sermayesi ve finansal sermaye) yatırım yapılması gerekir. Bu faktörlerin varlığı ve etkin kullanımı, bölgesel verimlilik, istihdam ve yüksek yaşam standartını beraberinde getirir. Bu faktörler;

Fiziksel sermaye, insan sermayesi ve toplumsal sermayenin gelişimi için şarttır.

Toplumsal Sermaye, bireyler arasındaki bağlantıları ifade eder. İnovasyonda başarının ana şartlarından biri işbirliğidir. $\mathrm{Bu}$ nedenle toplumsal sermayenin gücü bölgenin inovasyona dayalı kalkınmasının belirleyici unsurlarındandır.

Insan sermayesi, bireylerin beceri, eğitim ve bilgilerini; bölgenin sahip olduğu insan kaynaklarının niteliğini ve miktarını ifade eder. İnsan sermayesi, diğer sermayelerle yakından ilişkilidir: Nitelikli insan kaynağı toplumsal sermayenin güçlenip gelişmesini sağlar. Güçlü bir fiziksel sermaye nitelikli insan kaynaklarının 
bölgeye çekilmesini mümkün kılar. Zengin insan sermayesi, finansal sermayenin artmasını sağlar (örneğin yabancı yatırım çekilir).

Finansal sermaye, bir bölgede inovasyonun gelişmesi için varolan ve bölgeye çekilen (yerli ve yabancı) finansal kaynakları ifade eder (Elçi, 2006).

Bölgeler arasındaki dengesizliklerin ortadan kaldırılması için, her bölgenin özelliğine göre inovasyon politika ve stratejilerinin oluşturulması gerekir. Bu politikaların tasarlanması ve uygulanmasında bölgenin tüm paydaşlarının etkin rol alması çok önemlidir.

\subsection{Dünya ve AB Ekseninde Bölgesel İnovasyon Stratejileri Uygulamaları}

Dünya'nın çeşitli ülkelerinde değişik şekillerde bölgesel inovasyon stratejileri uygulanmıştır. Bunlara örnek verecek olursak;

Amerika Birleşik Devletleri'nde İnovasyon stratejileri; hükümet aracıllğı ile desteklenmiştir. İnovasyonun önemli araçlarında olan ilk teknopark 1952 yılında ABD Kuzey Kaliforniya Resarch Park'tır. ABD'de 150 teknopark vardır. Bunlardan en önemlilerinden bir tanesi Dell Bilgisayarlarının kurulduğu 1750 teknoloji şirketi ile Teksastaki Austin teknoparkıdır. Bu bölgede spor ve eğlence teknoloji ile kaynaştı̆ı için eğlence programlarının yazılım merkezi olmuştur. Bostondaki Massachusett teknoloji parkında ise 3600 ileri teknoloji şirketi faaliyet göstermektedir. Bölgede 65 kolej ve üniversite vardır. En bilinen şirket Lotus'tur ve IBM'i gerçekleştirmiştir. Bölgedeki zengin kişilerin oluşturduğu iki melek grubu yeni şirketlerin fikir aşamasındaki oluşumlarına finansal destek sağlayarak ilerlemelerini sağlamaktadır. Salt Lake City'de ise savunma sanayinin gelişimi 1960'l yıllardan itibaren araştırma geliştirme faaliyetlerine önemi artırmıştır. 1980 ve 1990'l yıllarda bilgisayar yazılım hizmetlerinde gelişim yaşanmıştır. Bölgede 2120 teknoloji şirketi faaliyet göstermektedir ve yerel araştırma merkezi Utah Üniversitesidir. Novell, Imega, Evans Sutherland ve yeni kurulan yerel şirketler için dört yıllık data depolama yazılımları yapan Power Quest'dir. Washington'da Seattle'da Windows programının başarısı ile yazılım şirketlerinin sayısı 25000'e ulaşmıştır. Microsoft ve Amazon.com bölgedeki teknoloji yetenekleri havuzundan yararlanmışlardır. Silikon Vadisinde ise 8000 şirket bulunmaktadır ve 400.000'e yakın kişi istihdam edilmektedir. Silikon Vadisi Standfod üniversitesi ile bağlantılı çalışmaktadır ve dünyanın en büyük teknokentlerindendir (Taymaz, 2001).

Japonya'da bölgesel inovasyon stratejileri; Japonya'da 1957 yılında teknoloji politikalarının ilk hamlesi olan Elektronik Endüstri Teşvik Yasası çıkarılmıştır. Hükümet yasa çerçevesinde yerel firmaların işbirliğini ve anahtar teknolojilerin geliştirilmesi için gerekli özgür ortamın yaratılmasını desteklemektedir. Japonya'da Uluslararası Ticaret ve Sanayi Bakanlığı MITI inovasyon sürecinde etkin rol oynamaktadır. Japonya'da kurum içi bireyler arası işbirliği ve dayanışma için "Keiretsu" adı verilen örgütler Dış Ticaret ve Sanayi Bakanlığı ile işbirliği sağlayarak rekabette dayanışmayı sağlamışlardır (Ertuna, 2000). Japonya'da bilim ve teknoloji politikaları tek bir kuruma dayalı merkezi bir yapı içerisinde olmamasına rağmen kurumlar arası sistemli ve iyi işler bir eşgüdüm sağlanabilmiş̧ir. Japonya'da inovasyon politikaları açısından etkin olan kurumlar Bilim ve Teknoloji Konseyi (CST), Bilim ve Teknoloji Ajansı( STA), Uluslararası Ticaret ve Sanayi Bakanlığı (MITI), Japon Araştırmaları Geliştirme Kurumu (JRDC), Eğitim Bilim ve Kültür Bakanlığı (MESC)'dir (TÜBİTAK, 1996). Ekonomik Plan Ajansı (EPA) 2010 Yılı Komite Raporunu hazırlayarak inovasyon konusunda çalışmalar yapmakta bilim ve teknoloji hedeflerini ortaya koymaktadır.

Hindistan'da bölgesel inovasyon stratejileri; Bangalore Bölgesel inovasyonun önemli merkezlerindendir. 250 ileri teknoloji şirketi Hindistan Bilim Enstitüsü ile çalışmalar yürütmektedir. Hindistanın teknoloji başkenti olan Bangalor'da 1881 'de 2.4 milyon olan kent nüfusu, son yıllarda 5 milyona çıkmıştır. Dünyada en çok program yazılımcısı yetiştiren Hindistan, yazılım ürünlerinin tümünü uydu aracıllığı ile ihraç edebilmektedir (Harmancı ve Önen, 1999).

AB'nde bölgesel inovasyon stratejileri; 1986 yılında uluslararası rekabet yeteneğinin artırılması amacı ile tek Avrupa pazarını geliştirmeye yönelik Avrupa Tek senedi projesi başlatılmıştır. Bölgenin inovasyon düzeyini artırmak amacı ile Enformasyon Teknolojisi Avrupa Stratejik Programı ESPRIT, Avrupa ülkelerinin dünya pazarında rekabet gücünü artırmak amacı ve Ar-Ge faaliyetlerine öncelik vermek için Avrupa Teknolojik İşbirliği Ajansı-EUREKA, AB ülkelerinin inovasyon politikaları arasında bütünlüğü sağlamak amacı ile Avrupa Çerçeve Programları $\mathrm{AB}$ inovasyon politikaları çerçevesinde oluşturulmuştur. Girişimcilik Genel Müdürlüğü $\mathrm{AB}$ inovasyon politikasının yapılandırılması açısından önemlidir. 1994 yılında büyüme, rekabet ve istihdam konulu Beyaz Rapor yayınlanmıştır. Ar- fonlarının artırılması yönünde sonuç bildiren raporda AB'nin İnovasyon politikaları irdelenmiştir. 2000 yılı AB Lizbon stratejisi kapsamında dünyanın en rekabetçi ekonomisi olma yolunda adımını atmıştır. Rapora göre 2005 yılında ABD'nin inovasyon performansı AB'den \% 40 daha iyi bir gelişme gösterimiş, 2008 yılında fark \% 28 olmuştur. 1997 yılında inovasyon bazlı işletmelerin geliştirilmesi için Avrupa İnovasyon Eylem Planı ve İnovasyon Eğilim Haritası oluşturulmuştur. 2008 Avrupa İnovasyon Göstergeleri son beş yıldır $\mathrm{AB}$ ‘de inovasyon performansı artışının 2.3 oranında olduğunu göstermektedir. $\mathrm{AB}$ 'nin güçlü olduğu alanlar genç eğitimi, kamu kesimine ait Ar-Ge harcamaları, bilgi teknolojileri harcamaları, bilgi yoğun hizmetler ve ileri teknoloji ürün ithalatıdır. Rapora göre AB'nin güçsüz olduğu göstergeler ise hayat boyu eğitim ve KOBI'ler arası inovatif işbirliği performansıdır. AB ülkelerinden Finlandiya, Almanya, Danimarka ve 
İngiltere grup içinde inovasyon lideri olarak değerlendirilirken, İnovasyon liderleri arasında da en yavaş ülke Danimarka iken en hızlı ülke Almanya'dır. Avusturya, İrlanda, Lüksemburg, Belçika, Fransa, Hollanda AB ortalamasının üstünde fakat Finlandiya Almanya Danimarka ve İngiltere'nin altında bir grafik sergilemektedir. Kıbrıs, Estonya, Lüksemburg, Slovenya, Çek Cumhuriyeti, İspanya, Portekiz, Yunanistan ve İtalya AB ortalamasının altında bir seyir izlemektedir. 2008 AB inovasyon göstergesi, inovasyon konusunda Avrupa Birliği'nin, uluslararası patentler, kamu özel sektör bağlantıları, araştırmacı sayısı ve iş dünyasının Ar-Ge harcamaları konusunda $\mathrm{ABD}$ ve Japonya'dan geri olduğunu göstermektedir. AB üyesi olan İtalya'da da inovasyon çalışmaları yapmak amacı ile Technopolis Novus Ortus İnovasyon Parkı, Trieste' deki temel uygulama araştırma merkezi Area ve Torinodaki Tecnocity projesi, ülkenin ilk çalışmalarını oluşturmaktadır. Torino ülkedeki Ar-Ge harcamalarının \%28'nin yapıldığı ve dışsal ekonomilerin yaratıldığı bir bölgedir. 1981 yılında Padoa üniversitesinden güç alınarak kurulan Venedik Araştırma Merkezi'de bölgenin diğer önemli inovasyon merkezidir (Güleç, 1994).

\subsection{Türkiye'de Bölgesel İnovasyon Sistemi Kronolojisi}

Türkiye'de inovasyon politikalarının ilk tohumu 1963 senesinde Türkiye Bilimsel Araştırma Kurumu'nun (TÜBİTAK) kurulmasıyla atılmıştır. 'Türk Bilim Politikası 1983- 2003' adlı ilk politika belgesi devlet tarafından 1983 yılında yayımlanarak Ar-Ge faaliyetlerini artırmayı ve öncelikli teknoloji alanlarını tanımlamayı hedeflenmiştir. Önemli bir diğer kilometre taşı ise yine 1983 yılında 'Bilim ve Teknoloji Yüksek Kurulu'nun (BTYK) kurulmasıdır. 1993 yılında oluşturulan ikinci politika dokumanı ise, 'Türk Bilim ve Teknoloji Politikası: 1993-2003' adı verilen çalışma olmuştur. Söz konusu politika dokümanlarının amacına bakıldığında; bir ulusal inovasyon sistemini kurmak, bu sistemin tüm kurumları ve diğer mekanizmalarının yine sistematik bir uyum içerisinde bilimsel ve teknolojik Ar-Ge aktivitelerini geliştirmesini sağlamak ve tüm faaliyetlerin sonuçlarını ekonomik ve sosyal fayda sağlamaya dönüştürmek olarak ortaya konduğu görülür.

1997 Ağustos’unda BTYK, '1996-1998 yılları için Bilim ve Teknoloji Politikası Gündemi’ başlıklı raporu onaylamıştır. Rapor, ulusal bilim ve teknoloji politikasının ana temalarından biri olan ulusal inovasyon sisteminin oluşturulması amacıyla gerek duyulan hazırlıkları tanımlamaktadır. BTYK'nın bu kararı inovasyon kavramı çevresinde şekillenmiş, bölgesel inovasyon sistemleri üzerinde araştırma; inovasyon kavramı üzerinde bir bilinç yaratma; teknoloji yönetimi, inovasyon ve kalite yönetimi tekniklerini yaygınlaştırma; inovasyon geliştirme faaliyetlerini hızlandırma ve son olarak da KOBİ'lerin inovasyon geliştirme etkinliklerini destekleme alanlarına değinmiştir.

BTYK’nın 1999, 2000 ve 2001 yıllarındaki toplantılarının ardından yayımladığı kararları, benimsenmiş inovasyon politikalarını ve stratejilerini koruyacak biçimde şekillenmiştir. TÜBİTAK'ın koordinasyonu ve BTYK'nın takip eden kararı ile 2002 yılında başlayan 'Vizyon 2023 Projesi' ile geçmişteki Türk bilim ve teknoloji politikasına yönelik çabalar devam etmiştir. Proje genel olarak, farklı sosyo-ekonomik alanda 11 adet panelle beraber bir ulusal teknoloji öngörüsü çalışmasını, kamu, özel sektör ve sivil toplum kuruluşları ile yapılacak olan bir araştırmayı kapsamaktadır.

2001 ile 2005 yılları arasındaki dönemi kapsayan 8. Beş Yıllık Kalkınma Planı teknolojik inovasyon üretme konusundaki ihtiyaçlara odaklanmaktadır. Sekizinci Beş Yıllık Kalkınma Planı'nın hazırlanması aşamasında, 'Bilim ve Teknoloji Özel İhtisas Komisyonu' inovasyon politikalarının sürdürülmesi alanında bir öneri dokumanı hazırlamıştır (Ulusoy vd., 2006).

Tüm bu raporların kalkınma planlarında bahsedilen inovasyon ile ilgili konular üzerinde birer yapıtaşı oluşturduğunu söylemek mümkündür. 2007-2013 yılları arasındaki dönemi ele alan son kalkınma planı olan 9. Plan'da ulusal düzeyde rekabet gücü kazanılabilmesi için inovasyona özel bir önem verildiği görülür.

Türkiye'de son yıllarda çeşitli bölgelerde bölgesel inovasyon stratejileri uygulanmakta ve projeler hazırlanarak yürürlüğe konmaktadır. Bunlara örnek verecek olursak,

ESINKAP adı altında Eskişehir ili inovasyon stratejileri için kapasite oluşturma projesi gerçekleştirilmiştir. Bu projede, Bölgesel İnovasyon Sistemi ile ilgili ana hatlar sunulmuş ve Eskişehir Bölgesi için teknolojik inovasyon ve çevre ağırlıklı bir bölgesel inovasyon çalışması için gerek duyulabilecek ve bölgenin ATGİ yeteneklerinin gelişimine destek olabilecek bazı faaliyetler önerilmiştir.

Gaziantep İlinde Gaziantep Sanayi Odası öncülüğünde, firmaların inovasyona yönlendirilmesini sağlamak, inovasyon bilincini oluşturmak, belirlenen amaçlar ve uygulama planı dahilinde özel sektör- üniversite ve projeye katkı sağlayacak diğer önemli paydaşların etkileşimini arttırmak; Gaziantep yoluyla hedeflenen ve hayata geçirilen gelişmelerin sonucu olarak ortaya çıkan verileri bölgesel, ulusal ve uluslar arası platforma taşıyarak birer başarı, gösterge ve motivasyon öğesi haline getirmek amacıyla 2006 yılında inovasyon vadisi Gaziantep projesi yürütülmeye başlanmıştır ve başarılı olması sonucunda Türkiye Halkla İlişkiler Derneği tarafından sektördeki hizmet kalitesini yükseltmek ve mesleki gelişimi desteklemek amacıyla her yıl düzenlenen “Altın Pusula Halkla İlişkiler Ödülleri” nde 1.lik kazanmıştır.

2011 yılında Orta Karadeniz Kalkınma Ajansı (OKA) tarafından Technopolis Group'un danışmanlığında 'Orta Karadeniz İnovasyon Stratejisi ve Eylem Planı Geliştirme Projesi’ ortaya sürülmüştür. Bölgenin inovasyon potansiyelinin harekete geçirilmesi ve eksiklerinin giderilmesi için bir yol haritası niteliğinde olan ve bölgenin 
geleceğine yön verecek 'Bölgesel İnovasyon Stratejisi ve Eylem Planı'nın hazırlı̆̆ına ilişkin çalışmayı Kasım 2011'de başlatmıştır. Orta Karadeniz Bölgesel İnovasyon Stratejisi, "akıllı uzmanlaşma" ("smart specialisation") yaklaşımı dahil olmak üzere, yeni nesil bölgesel inovasyon stratejilerinin öngördüğü kavram ve unsurlar esas alınarak hazırlanmıştır. Buna göre, bölgenin ulusal ve uluslararası rekabet avantajı kazandıracak az sayıda önceliğe odaklanması ve stratejiyi, dörtlü sarmal olarak nitelendirilen özel sektör, kamu, üniversite ve toplum arasında sağlanacak etkin bir işbirliğiyle hayata geçirmesi öngörülmektedir. Orta Karadeniz Bölgesi inovasyon vizyonu şu şekildedir: Orta Karadeniz Bölgesi, 2023 yılında rekabetçi sektörleri ile inovasyon ve girişimcilik kültürü yüksek toplumu sayesinde ulusal ve uluslararası düzeyde kalkınmada öncü bir bölge halini alacaktır (Orta Karadeniz Eylem Planı, 2012).

Mersin RIS projesi Türkiye'de gerçekleştirilmiş olan en geniş çaplı bölgesel inovasyon projesidir.

\section{Mersin RIS Örneği}

Doğu Akdeniz sahilinde, önemli bir liman kenti olan Mersin'de, RIS-Mersin Projesi, Haziran 2005-Ocak 2008 tarihleri arasında Mersin Valiliğgi başkanlığı ve ODTÜ Teknopark A.Ş. koordinasyon'unda, Mersin Üniversitesi, Mersin Ticaret ve Sanayi Odası, Mersin Tarsus Organize Sanayi Bölgesi ve Yunanistan'dan Epirus Bölgesi İşletmeler için İnovasyon Merkezi (Business Innovation Center) ortaklığında yürütülmüştür.

Avrupa'da yaklaşı 150 bölgede Avrupa Komisyonunun katkılarıyla yürütülen Bölgesel İnovasyon Stratejileri Projeleri "KOBİ odaklı olmak üzere bölgelerin yenilikçilik potansiyelini artırmaya yönelik stratejiler üretilmesini, inovasyon politikaları ile mevcut kaynakların ve altyapının en iyi şekilde kullanılmasını ve geliştirilmesini" amaçlamaktadır.

Proje sonucunda Türkiye'nin ilk bölgesel inovasyon stratejisi çalışması olan "2016 Mersin İnovasyon Stratejisi” ve "2008-2009 Eylem Planı" oluşturulmuştur

Mersin İnovasyon Stratejisi kapsamında Mersin'in vizyonu; "yüksek yaşam kalitesine, bilgi ve inovasyona dayalı sürdürülebilir ekonomiye sahip bir bölge haline gelmek" olarak belirlenmiştir.Mevcut durum analizine dayanarak, Mersin'in bu vizyona ulaşabilmesi için Mersin İnovasyon Stratejisi aşağıdaki hedefler etrafinda şekillendirilmiştir.

Ana stratejik hedefler:

- Mersin'in inovasyon sisteminin iyileştirilmesi,

- Mevcut firmalardaki inovasyon faaliyetlerinin arttırılması ve inovasyona dayalı girişimciliğin teşvik edilmesi,

- Kilit önem taşıyan sektörlerde (Tarım-Gıda, Lojistik ve Turizm) bölgesel potansiyelin kullanılması,

- Bilgi üreticilerinin geliştirilmesidir.

Ortamı iyileştirici yatay hedefler:

- İnovasyon sistemi aktörleri arasında inovasyon kültürü ve inovasyona dayalı kalkınma konusunda fikir birliği ve güven oluşturulması,

- İdari ve hukuksal ortamın iyileştirilmesi ve altyapının neden olduğu engellerin kaldırılması,

- Bölge için çekici bir imaj oluşturulması,

- İnsan sermayesinin geliştirilmesine yatırım yapılmasıdır.

Mersin İnovasyon Stratejisi, 2008-2009 Eylem Plan'ında yer alan projelerin hayata geçirilmesi için Proje Müdürlüğü tarafindan çeşitli fon imkanları araştırılmış ve 2008 yılı içinde bu kapsamda sekiz adet proje teklifi hazırlanmış ve bunlardan altı adedi sözleşmeye bağlanmıştır. İl'de ki diğer kurum ve kuruluşların proje hazırlama kapasitelerini geliştirmek ve farklı finansal araçlar hakkında bilgilenmelerini sağlamak için destek faaliyetleri yürütülmüştür.

Mersin İnovasyon Stratejisi'nin hayata geçirilmesi için en önemli destekleyici kuruluş olan Çukurova Kalkınma Ajansınca yürütülecek hibe programının, 2008-2009 Eylem Planının hayata geçirilmesine imkan verecek kapsamda hazırlanması için lobi faaliyetleri gerçekleştirilmiştir. Mersin İnovasyon Stratejisi ve Eylem Planı'nın uygulanmasını temin ve takip etmek, İl çapında paydaşları temsil etmek ve koordinasyonu sağlamak amaciyla 26 Şubat 2008 tarihinde Mersin İnovasyon Kurulu kurulmuştur.

Proje 4 aşamadan oluşmuştur. Bunlar;

- Aşama:İnovasyon kavramının tanıtılması ve bölge aktörlerinin bilinçlendirilmesi

- Aşama:İl çapında düzenlenen SWOT toplantıları, anket çalışmaları ve firma ziyaretleri yolu ile mevcut durumun saptanması, ihtiyaçların tespiti, taslak stratejinin oluşturulması

- Aşama:Pilot uygulamalar ve taslak stratejinin sinanması (AR-GE 33, GİRIŞiMCİ 33, EXPO 33, MERSIN I. İNOVASYON YARIŞMASI)

- Ocak 2008:Mersin İnovasyon Stratejisi'nin tamamlanmas1

Mersin'de, 2007 yılının başından itibaren taslak Mersin İnovasyon Stratejisi ile uyumlu olarak dört pilot proje uygulanmıştır. Mersin ilinde yenilikçi genç girişimciler yetiştirilmesini amaçlayan eğitim projesi Girişimci 33, 
KOBİ'leri dış ticaret konusunda atağa geçirecek kalifikasyona sahip uzmanların yetiştirilmesini amaçlayan İhracat 33, Üniversite firma işbirliğini kolaylaştırıcı etkinlikler içeren ve ortak proje sayısını artırmayı hedefleyen Ar-Ge 33 adlı projeler başarı ile tamamlanmıştır. Ayrıca firmalar arasında İnovasyon kültürünü yaygınlaştırmayı hedefleyen ve Mersin'de gelenekselleştirilmesi düşünülen 1. İnovasyon Yarışması düzenlenmiştir.

Tarım-Gıda, Lojistik ve Turizm Sektörleri Mersin'de İnovasyon potansiyeli taşıyan ve birbirini bütünleyen üç kilit sektör olarak belirlenmiştir. Bu sektörlerin seçilmesinde kullanılan kriterler ise;

- Sektörlerin coğrafi konum, liman, iklim avantajı, tarihi ve kültürel değerler gibi sürdürülebilir güçlü öz kaynaklara dayanıyor olması,

- Sektörlerin nüfusun geniş kesimini kavraması,

- İnovasyon ve Ar-ge yolu ile bu geleneksel sektörlerde katma değerin yükseltilmesi imkanı,

- İstatistiki sonuçlara göre; firma sayıları, KOSGEB kümeleme analizi, dış ticaret yapan firmaların profili,

- Araştırma altyapısının bu sektörleri destekliyor oluşu,

- $\quad$ Bu sektörlerde kurumsal altyapı ve temsil-karar alma mekanizmalarının güçlü olmasıdır.

İnovasyon potansiyeli taşıyan Tarım-Gıda, Lojistik ve Turizm Sektörleri için; Üç sektörde kümeleşmenin teşvik edilmesi ve ihtiyaç analiz çalışmalarının yapılması, Ulusal ve uluslararası ağların tespit edilmesi ve Mersin'deki sektörel platformların bu ağlara dahil edilmesi ve Eko-inovasyon faaliyetlerinin gerçekleştirilebileceği alanların tespiti gerekmiştir.

\section{Mersin RIS Projesinin SWOT Analizi}

SWOT analizi yapılırken Mersin Bölgesel Inovasyon Stratejisi 2006-2016 1. Taslaktan yararlanılmış, bölgedeki fiziksel, sosyal ve ekonomik sermayenin inovasyon açısından güçlü ve zayıf yönlerinin, firsatlarının ve tehditlerinin anlaşılması amaçlanmıştır.

Güçlü yanlar; kamu-özel sektör uzlaşması, İşbirlikçi kültüre sahip olunması, Mersin’in Ortadoğu ve Akdeniz'e açılan bir kapı olması sebebiyle stratejik konumu, gelişmiş altyapı (liman, karayolları, demiryolları, havayolları, bilgi ve iletişim teknolojilerinde geniş bant bağlant, serbest bölge, organize sanayi bölgesi, teknoloji geliştirme bölgesi, iş geliştirme merkezleri v.b.), girişimci insanların varlığı, verimli topraklara sahip olması, doğal ve tarihi güzelliklerin çokluğu, üniversite ve araştırma enstitülerinin varlığı, Yurtdışından ve yurt içinden diğer bölgelerden yatırımların varlığı, kültürel çeşitlilik, genç nüfusun çok olması, güneş, rüzgar ve su gibi yenilenebilir enerji kaynaklarının kullanılması, KOSGEB benzeri kamu kurumlarının varlığı.

Zayıf yanlar; çevre problemleri, hızlı göç ve plansız kentleşme sonucu oluşan kirlilik, firmaların yenilenebilir enerji kaynaklarının kullanımı için yüksek enerji maliyetlerine katlanması), fiziksel altyapının geliştirilmesine duyulan ihtiyaç, kalifiye insan kaynaklarının Mersin dışına, vasıfsız insan kaynaklarının ise Mersin'e göçü, paydaşların inovasyon konusunda düşük farkındalık düzeyleri (özellikle firmalar ve halk arasında), inovasyona destek veren kuruluşların sayısının ve hizmet çeşitliliğinin artırılması ihtiyacı, inovasyon ve AR-GE yatırımlarının düşük düzeyde olması, üniversitenin kapasitesinin zayıf olması, kent yönetiminin çeşitli nedenlerle projeye katılamamas1.

Fırsatlar; uluslararası düzeyde bir prestij aracı olarak kullanılması, kiși ve firmaları heyecanlandırıp hareketlendiren inovasyon yarıșmalarının bașlamıș olması, bir șehrin gelișmesi için AR-GE faaliyetlerinin gerekliliği ve önemi, girișimci ve ișadamlarının inovatif ürün ve süreç kavramı ile tanıșması ve dıș dünyada rekabet için mücadelenin farkına varması, meslek odaları ve sivil toplum kurulușlarının kent gelișmesinde kendilerini sorumlu bir paydaș olarak görmeleri. (Gök, 2009), Bursa, Eskişehir, Kütahya, Kırşehir, Samsun ve Gaziantep gibi illere örnek olması., 2008 yılında 122 proje arasında en başarılı "yerel kalkınma projesi” seçilmiş olması, Çukurova havaalanının yapılıyor olması, Akdeniz oyunlarının Mersin'de yapılıyor olması, bölgesel inovasyon stratejisinin oluşturulması ve başarılı şekilde uygulanması, Mersin kentsel dönüşüm planının başarılı şekilde uygulanması, araştırma ve inovasyon alanında AB programlarına ve ulusal programlara aktif katılım, İnovasyon konusunda çevre bölgelerle ve diğer ülkelerle işbirliğinde artış, hükümetin bölgesel politikaların geliştirilmesi ve bölgesel kalkınma ajansının kurulması konusundaki kararlılığı, hükümetin Ar-Ge ve inovasyon alanında artan çalışmaları, "Mersin” markasının oluşturulmasında ve Mersin imajının ulusal ve uluslararası ortamda tanıtılmasına yönelik faaliyetler, Türkiye'nin AB'ne entegrasyonu.

Tehditler; bölgede planlanan stratejilerin gerçekleştirilmesi konusunda eksiklik, makroekonomik ve siyasi istikrarsızlık, devam eden göç, kayıtdışı ekonomiden kaynaklanan sorunların devam etmesi, ulusal düzeyde hazırlanan bölge planlarının başarısız şekilde uygulanması, Ortadoğudaki gerginlik ve istikrarsızlık ortamı

\section{Sonuç}

İsviçre'de 2003 yılında OECD üst düzey toplantısı sonuç bildirgesine gore "hem küresel ekonomik büyüme, hemde sosyal uyum özellikle potansiyelin en yüksek olduğu alanlarda bölgelerin rekabet gücünün arttırılmasını zorunlu kılmaktadır. Inovasyon ve yatırımı yönlendiren göreli avantajlar, bölgesel olduğu kadar ulusal 
özelliklerdir. Başarılı olabilmek için bölgeler, küresel piyasada rekabet edebilmek ve kullanılmayan potansiyellerini geliştirmek amacıyla kendi varlık, beceri ve fikir girişimlerinden yararlanmalıdır”.

Çalışmamızın ana eksenini oluşturan Mersin, Türkiye'de eşsiz kaynaklara (turizm, tarım, lojistik) sahip olmasına rağmen içinde barındırdığı büyük potansiyeli yeterince kullanamamış ve ekonomik performansı kendisiyle aynı özelliklere sahip (örneğin, Antalya) illerin gerisinde kalmıştır. Bu strateji ile Mersin'in bir sloganı da olmuştur. "Mersin'in karakterinde Dünyalı olmak ve evrensel olmak vardır". İște Mersin, bu devamedegelen kaderine değiştirmeye katkıda bulunan, Avrupa'dan 20 yılı aşkın süredir yüzlerce bölgede devam eden uygulamalardan ve IRE Network (İnnovating Region in Europe) aracilığıyla paylaşılan metodolojinin uygulandığ1 " bölgesel inovasyon stratejisi" ile kısır döngüden çıkmayı başarabilmiş ve bugün tüm dünyaya (17. Akdeniz Oyunları vb.) sesini duyurabilmiştir. Türkiye'nin ilk inovasyon stratejisi “ RIS Mersin Projesi” ile Mersin ili 2016 yllına kadar belirlenen üç kilit sektörde (turizm, tarım ve lojistik) dünya ve Türkiye ekseninde hakettiği konuma ulaşması beklenmektedir. Mersin inovasyon stratejisi 4 ana stratejik hedef üzerine kurgulanmıştır;

- Mersin'de inovasyon sisteminin ve kültürünün iyileştirilmesi

- Inovasyona yatırım yapılmasının teşvik edilmesi

- Kilit önem taşıyan sektörlerde bölgesel potansiyelin kullanılması

- Bilgi üreticilerinin yetiştirilmesidir.

Bu bağlamda, geliştirilen bu stratejiyle Mersin'de öncelikle ekonomik büyüme, teknolojik rekabet edebilirlik ve ildeki istihdam oranlarına pozitif bir katkı yaptığını söyleyebiliriz.

\section{Kaynakça}

- Arıkan, Cemil, 2004, “İnovasyon ve Girişimcilik",www.tusiadgirisimcilik.org/sunular/Cemil\%20Arikan.ppt.

- Asheim, Bjorn ve Gertler, Mark, 2005, Innovation Processes, New York, Oxford University Press.

- Elçi, Şirin, Karataylı, İ. Ve Karaata, S., 2008, "Bölgesel İnovasyon Merkezleri: Türkiye İçin Bir Model Önerisi”, TÜSİAD, http://www.tusiad.org/filearchive/bimrapor.pdf,

- Ertuna, Özer, 2000, Yönetim Ekonomisi, Kampüs A.Ş Mikado, Ocak, İstanbul.

- Gök, Tamer, 2009, "RIS Mersin Projesi Üzerine Bir Özet Değerlendirme”, TMMOB Şehir Plancllarl Odası Dergisi, 47, p. 3-4.

- Güleç, Kemal, 1994, Türkiye'de ve Dünyada Teknolojik Gelişmeler, DPT Yayınları, Nisan.

- Harmanc1, Mehmet ve Önen, Oğuzhan, 1999, Dünyada ve Türkiye'de Teknopark ve Teknokent Uygulamaları, Türkiye Kalkınma Bankası As Araştırma Müdürlüğü, Mart, Ankara.

- Işık, Nihat ve Kılınç, Efe C., 2011, "Bölgesel Kalkınma'da Ar-Ge veİnovasyonun Önemi:Karşılaştırmalı Bir Analiz”, Eskişehir Osmangazi Üniversitesi İibf Dergisi, Ekim 2011, 2, p. 6.

- Niosi, Jorge, 2010, Building National ve regional İnnovation Sytsems: İnstitutions for Economic Development, UK: Edward Elgar Publishing.

- OECD, 2008, Reviews of Regional Innovation, North of England, UK.

- OKA, 2012, Orta Karadeniz (Amasya-Çorum-Samsun-Tokat) Bölgesel İnovasyon Stratejisi ve Eylem Planı (2012-2023), http://www.oka.org.tr/ContentDownload/BOLGESEL\%20INOVASYON\%20STRATEJISI\%20TASLAK.pf

- REF, 2006, Rekabet Forumu, "Lizbon stratejisi, Bilgi ekonomisi ve Türkiye", http://ref.advancity.net/newsletters/2006agustos/lizbon_stratejisi.html.

- Taymaz, Erol, 2001, Ulusal Yenilik Sistemi: Türkiye İmalat Sanayinde Teknolojik Değişim ve Yenilik Süreci, TÜBITAK/TTGV/DIE, Ankara.

- T-BIM, Bölgesel İnovasyon Merkezleri Stratejisi, http://www.t-bim.org/?q=tr/node/21

- TÜBİTAK, 1996, Bilim ve Teknoloji Yönetim Sistemleri: Ülke Örnekleri ve Türkiye, Mayıs, Ankara.

- Ulusoy, Gündüz ve Diğerleri, 2006, Küresel Rekabet Raporu 2006, TÜSİADREF, İstanbul.

- Boekel, Van G. ve Logtestijn, Van M., 2002, Applying the Comprehensive LED Approach: The Case of Mozambique, Cooperative Branch International Labour Office, Geneva:Switzerland. 


\title{
Girişimcilik ve Spor Entrepreneurship and Sport
}

\author{
Ph.D. Candidate Yeter Aytül Dağlı Ekmekçi (Pamukkale University, Turkey) \\ Prof. Dr. Ayşe İrmiş (Pamukkale University, Turkey)
}

\begin{abstract}
Underlined the contributions of entrepreneurship to countries' economies and development in today's researches, sports entrepreneurship studies referred to in recent times. With this study, emphasized that the sports industry is an economically emerging sector in our developing country and in addition to this economic size many opportunities have been aimed at creating new emphasis. In our country, we have a young population and have the structure of an open society for development and innovation, thus the sports industry is growing rapidly in our country compared with the world. That sports industry is associated with many of the other sectors is a key element to improve the variety of activities. Sports entrepreneurship studies have increased in recent years in the world. However, in our country, this area hosts many opportunities for sports entrepreneurship, almost no work have been encountered, has made it necessary to carry out this study. That sport is managed as professional, it requires the study of sports entrepreneurship. Sports entrepreneurship has needed studied. This study is a first step of building the relations between sport and entrepreneurship at Turkish literature.
\end{abstract}

\section{Giriş}

Girişimcilik hem işsizlik sorununa önemli bir çözüm olanağı sunmakta hem de ekonomik büyümeyi sağlamaktadır. Girişimci, ekonomik kaynakların düşük üretkenlik alanlarından yüksek alanlara aktarılma sürecinde baş aktördür, çünkü üretim kaynaklarını yeni bir tarzda birleştirerek kullanılmayan üretim faktörlerinin kullanılmasını sağlar, ama daha önemlisi kullanılmakta olan üretim araçlarının ve mevcut girdilerinin değişik şekillerde kullanımı ile üretimi artırır. Yeni düşünceler girişimciler sayesinde yaratılır, yayılır ve uygulanması hızlanır. Yeni endüstrilerin doğmasıyla ekonomik büyüme hızlanır (TÜSİAD, 2003, 2). Ayrıca girişimciliğin artması, yeni fikirler ve yeni yatırım alanları, kaynakların farklı şekillerde bir araya getirilmesi rekabet ortamını da etkileyecektir. Örgütler daha etkin olabilmenin yollarını arayacaklar, böylece girişimciliğin temel özellikleri olan yenilik yaratma, kaynakları farklı şekillerde kullanma boyutu yeniden ön plana çıkacaktır. Yani bu durum girişimciliğin daha üst boyutlara geçmesi için itici bir güç yaratacaktır.

Girişimciliğin kalkınma açısından faydaları arasında istihdam sağlanması, ekonomik büyüme ve toplumsal yapıya değişimci/yenilikçi bir anlayış kazandırılması ön planda gelmektedir. Bu faydaları sağlamak açısından bireyin içinde bulunduğu sosyo-ekonomik ve kültürel yapı, aile, toplumsal davranış örüntüleri, eğitimin kalitesi, düzeyi, genel ekonomik koşullar ile devletin girişimciliğin gelişmesine ilişkin teşvik edici tutum ve uygulamaları önem kazanmaktadır. Bu sayede girişimcilik potansiyeline sahip kişiler harekete geçebilecek ve dış kaynaklı büyüme yerine ulusal kaynaklı büyüme sağlanabilecektir (Çetinkaya Bozkurt vd., 2012, 230). Özellikle bu açıdan bakıldığında dünyada çok büyük bir sektör olarak bilinen spor sektöründe de yerel girişimciliğin önemi artmaktadır. Bununla beraber, bir bilim alanı olarak spor, psikoloji, sosyoloji, felsefe, yönetim, pazarlama gibi birçok disiplin tarafından çalışıldığı halde kendisini başlı başına bir disiplin olarak henüz tanımlayan spor girişimciliğine odaklanılmış çalışmalarda önemli eksiklikler bulunmaktadır. Hâlbuki spor pazarlamacıları, girişimciliğe odaklanarak organizasyonlarını ve müşterilerini daha değerli hale getirebilirler. Ayrıca spor örgütlerinin büyümesinde spor girişimciliğinin önemi kendini daha fazla göstermektedir (Ratten, 2011, 57-58).

\section{Girişimciliğin ve Girişimcinin Tanımı}

Girişimci kelimesi, “entre” (girmek) ve "prendre” (almak, üstlenmek) sözcüklerinden oluşmaktadır. Ekonomik açıdan ilk kez 1730'larda Fransız Richard Cantillon tarafından kullanılmış, 19. Yüzyılda da İngilizler tarafından kullanılmaya başlamıştır (Çetindamar, 2002, 33).Cantillon girişimcinin sosyal statüsüne değil, ekonomideki işlevline değinmiştir. Daha sonraki dönemlerde Schumpeter, Kirzner ve Knight Cantillon'un bu tanımını daha geniş çerçevede ele almış ve girişimcinin yenilikçi, kâr firsatlarını fark eden ve risk üstlenen yönlerine değinmişlerdir (Işık vd, 2011, 150-151).

Girişimcilik tanımının modern çağa uyarlanmasında en bilinen isim Schumpeter'dir. Schumpeter'in (1934), tanımıyla bir taraftan girişimciliğin yeni kombinasyonlarından biri olarak, yeni bir pazar oluşturma ifade edilirken (Ibeh, 2004, 96), diğer taraftan da günümüz bilgi toplumunda ekonominin itici gücü olacak ve küresel anlamda başarı elde edebilecek, iyi yetişmiş ve gerçek anlamda girişimcilik ruhuna sahip bireylerin varlığının gerekliliği ortaya çıkmaktadır (Ercan ve Gökdeniz, 2009, 59). Ana unsurları algılayış, riski göze alma ve faaliyete geçme olan girişimcilikte hem mevcut durumda ortaya çıkan firsatları değerlendirmek hem de yeni firsatlar yaratmak önemlidir. Girişimci ise, piyasadaki eksik enformasyon durumunda tam olmasa da diğerlerinden fazla enformasyona sahip olarak hareket eden kişidir (Işık vd., 2011, 153). 
Schumpeter'in girişimcilik tanımının ana unsuru mevcut kaynakların yeni bir bileşimi şeklinde tanımlanan yenilik olgusudur. Bu tanıma göre girişimci davranışı beş çeşittir (Aktaran Çetindamar, 2002, 35):

- Yeni bir malın ya da servisin üretimi

- Yeni bir üretim metodunun geliştirilmesi

- Yeni bir pazarın oluşturulması

- Yeni bir hammadde kaynağının bulunması

- Endüstrinin yeniden yapılandırılması

Tüm bu anlatılanlardan çıkan ortak sonuç; yaratıcı fikir sahibi olmanın sonucunda yeni yatırım olanaklarının bulunması, kar firsatlarının yakalanması ve bu sayede istihdam ve verimliliğin artması yoluyla ekonomik büyümeye katkı sağlanmasında girişimciliğin önemli bir rolü vardır.

\section{Girişimciliğin Ülke Ekonomisi Açısından Önemi}

Girişimci, ekonomi biliminin temelini atan Adam Smith tarafından yönetici olarak düşünülmüştür. Bu fikir; 20. yüzyılın başından Joseph Schumpeter'in bir sistem olan ekonomide değişimlerin dışarıdan değil içeriden geldiğini ve bu değişimi de bizzat girişimcinin sağladığını söylemesine kadar neo-klasikler tarafından da aynı şekilde sürdürülmüştür (Çetindamar, 2002, 35). Schumpeter'le beraber yenilik yapma, üretme, risk alma, firsatları görme ve uygulamaya geçme faaliyetlerinin geneli olarak tanımlanan girişimciliğin davranışsal göstergeleri pazara yeni bir ürün/hizmet sunmak, üretimde yeni bir yöntem geliştirmek, henüz keşfedilmemiş bir talep boşluğu yakalamak ve bir sanayi dalında yeni bir firma kurmak şeklinde aktarılmıştır (Ercan ve Gökdeniz, 2009, 67).

Açıktır ki, girişimcinin yüklendiği yeni faaliyetler yeni kâr firsatlarının oluşmasına alt yapı hazırlamaktadır. Bu firsatlar verimlilik artışının bir nedeni veya sonucu olabilir. Başka bir deyişle girişimcilik ile iktisadi büyüme (Schumpeter'e göre iktisadi gelişme) arasında her ikisini de artıran pozitif yönlü ilişki bulunmaktadır ve bu sistem kendi kendini beslemektedir (Işık vd., 2011,156). Çetinkaya Bozkurt ve arkadaşları (2012, 233-234) girişimciliğin ekonomik ve sosyal yönden önemini birçok yazar tarafından belirtilen görüşleri derleyerek şu şekilde açıklamışlardır. Ekonomik yönden; istihdam hacminin genişletilerek işsizliğin önlenmesinde, ekonomik büyümenin hızlandırılmasında, yeni endüstrilerin doğmasında, refah düzeyinin yükseltilerek geniş bir toplumsal tabana yaygınlaştırılmasında ve orta sınıfın güçlendirilmesinde, bölgesel gelişmişlik farklarının ortadan kaldırılmasında ya da azaltılmasında işlevseldir. Sosyal yönden; birçok teknolojik buluşun toplumun yararı için yenilikçi ürün ya da hizmetlere dönüştürülmesinde, değer yaratmada, toplumsal yapıda değişimci/yenilikçi bir sürecin başlatılmasında, girişimciliğin risk üstlenme, yenilikçi ve öncü olma niteliğinden dolayı tüm toplumların değişim ve gelişim süreçlerinde işlevseldir.

\section{ŞEKIL 1. Girişimcilik Sürecindeki Temel Faktörler}

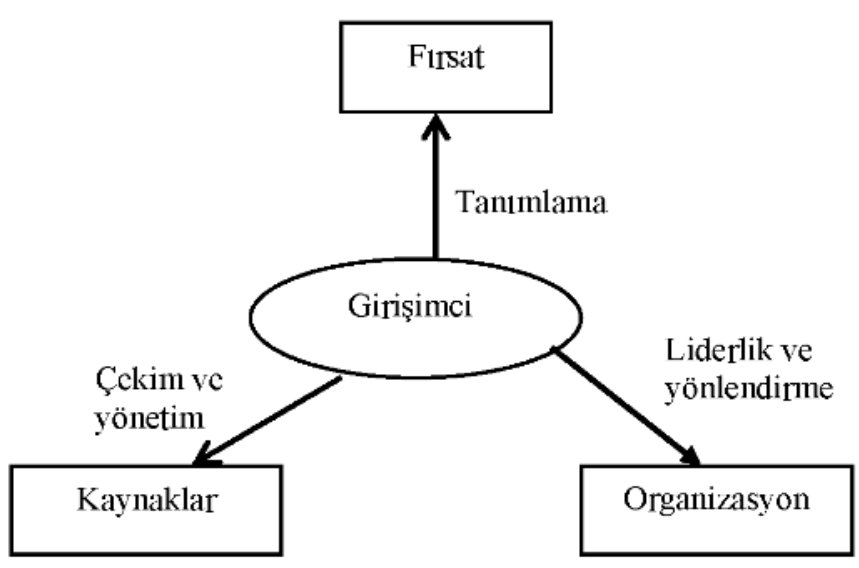

Kaynak: Wickham, 2001: 37.

(Aktaran Karabey ve Bingöl, 2010,12)

Karabey ve Bingöl $(2010,10)$ 'e göre girişimcilik sürecinde her türlü değer yaratma faaliyetinden bahsedildiği için karmaşık bir yapı söz konusudur. Bu karmaşık yapı nedeni ile de girişimciliğin doğası, girişimcinin özellikleri ve davranışları hakkında net açıklamalar yapmak ve ekonomiye katkısını kesin olarak belirlemek zorlaşmaktadır. Yukarıda da belirtildiği gibi girişimcilik "bir firsatın tanımlanması, değerlendirilmesi ve bu firsattan yararlanmak amacıyla faaliyete geçilmesini kapsayan bir süreç” olarak tanımlanmaktadır (Şekil 1). Bu durumda girişimci kaynakları bulan ve bir araya getiren, organizasyonu kuran ve bu organizasyonda liderlik ve 
yönlendirme yapan, firsatları görerek ve/veya firsatları oluşturarak değer yaratan kişidir. Bu özelliğiyle girişimci ülke ekonomisine üründe, üretimde, teknolojide yenilikler yaparak veya mevcut durumun devamlılığını sağlayarak, istihdam imkânları oluşturarak, sermayenin tabana yayılmasına vesile olarak ve bütün bunlar sonucunda değer yaratarak katkıda bulunmaktadır. Aynı zamanda girişimciler küreselleşmeyle beraber, dünya üzerinde geniş pazarlarda yer alarak, üretim iş birliklerini dünyadaki diğer işletmelerle birleştirerek ve endüstrisinde yenilikler yapıp, endüstriler arası yeni organizasyonlar kurarak dünya ekonomisine de katk1 vermektedirler.

\section{Türkiye'de Girişimciliğin Tarihçesi}

Türk kültüründe girişimciliğin en bilinen hali Ahi örgütlerine uzanmaktadır. Ahi örgütlerinin önemli özelliği sadece üretim ve ticaret anlayışına dayanmaması aynı zamanda toplumdaki ekonomik, siyasi, sosyal, askeri ve kültürel yapıda da etkin olmasıdır. Daha kapalı bir sitem içerisinde üretimin ve ticaretin yapıldığı Ahi örgütleri kapitülasyonlar neticesinde kısmen de olsa ekonomide dışa açılma politikasıyla kitle üretimine ve yenilik anlayışına ayak uyduramayarak etkinliğini ve verimliliğini kaybetmiş̧tir. Cumhuriyetin kuruluşundan sonraki ilk dönemlerde alınan karma ekonomik model kararlarıyla Türk Halkının girişimcilik vasıflarının geliştirilmesi ve sanayi kültürünün oluşturulması amacıyla, devletin ve özel sektörün girişimcilik olgusuna beraber katıldıkları bir dönem yaşanmıştır.

1950’li yıllardan itibaren daha ziyade devlet desteğiyle kendini göstermeye başlayan özel sektör girişimciliğinin atak yaptığı dönem 1960'lı yılların sonu ile 1970-1980 arası olmuştur. Halk Sektörü adı altında kurulan çok ortaklı şirketler Türkiye'deki o döneme mahsus bütün imkânsızlıklara rağmen gıda sanayiden, elektronik sanayiye kadar çok geniş bir yelpazede girişimlerde bulunmuşlardır. Bu dönem aynı zamanda milli sermayenin halk eliyle yatırıma dönüştüğü ve yaratılan sinerjiyle kat-kat arttığı dönemdir. Dünya ekonomisinde 1970'lerdeki piyasa istikrarsızlıkları nedeniyle kitlesel üretim yerini esnek üretim sistemlerine bırakmış, 1980'lerden sonra gelişmiş ülkelerde küçük işletmelerin toplam işletmelere oranla paylarının artmış ve batı ülkelerinde işsizlik sorununun makro iktisadi politikalarla çözülememesi küçük ve yeni işletmelere olan ilgiyi artırmıştır. Bu durum da girişimcilik olgusunu özellikle KOBİ niteliğindeki işletmelerde ön plana çıarmıştır (Iş̧k vd., 2011, 149). Ayrıca Batı Avrupa ve Amerika'daki pek çok işletme artan üretim ve çevre maliyetlerinden dolayı, ivme kazanan küreselleşme süreciyle yaratılan bir firsat olarak, üretimlerini gelişme arzusunda olan az gelişmiş ve gelişmekte olan ülkelere kaydırmaya başlamışlardır. Gelişmiş bölge işletmeleri üretimlerini bir taraftan az gelişmiş ve gelişmekte olan bölgelerde yabancı sermayeli yatırımlar yaparak diğer taraftan da o bölgelerdeki KOBİ niteliğinde bulunan işletmelere kendi markaları adına fason üretim yaptırarak gerçekleştirmeye başlamışlardır.

Türkiye'de ise 1980 sonrası dışa açık politikaların uygulanmasıyla Türk ekonomisi ve yatırım alanları dışarıya açılmıştır. İthal ikameci politikalardan dışa açılmaya yönelik ihracatı artırma politikalarıyla uluslar arası sermaye ile tanışan Türk girişimcileri özellikle Anadolu kentlerinde fason üretim yapmaya yönelik girişime teşvik edilmişlerdir. Aradan geçen onlarca yıla rağmen, ulusal piyasalar haricinde, uluslar arası piyasalarda hâlâ gerçek anlamda kendi markasını geliştirememiş olan ülke girişimciliğimizin, üretim girişimciliği açısından kısmen daha çok yol kat etmiş olmasına rağmen mamulü sunma, pazar yaratma, marka oluşturma vb. pazarlama girişimciliği açısından yeterli bir gelişme gösteremediği görülmektedir.

\section{Sporun Tanımı ve Spor Kulüplerinin Şirketleşmesi}

Spor, "belirli ölçüde fiziksel güç ve beceri gerektiren yarışmalı ve eğlenceli etkinlikler", "fiziksel kondisyonu iyileştirmeyi amaçlayan, oyun, yarışma ve mücadele anlayışıyla yapılan fiziksel etkinlikler" ya da çok çeşitli amaç ve araçlarla yapılan, önceden belirlenmiş ve benimsenmiş kurallara farklı derecelerde de olsa uymayı gerektiren, performansı artıııı bedensel etkinlikler" olarak tanımlanmıştır. Spor hem kültür, hem fiziksel aktivite hem de yarışmadır (Kılcıgil, 1998, 8). Bir başka tanıma göre ise spor ferdin tabii çevresini beşeri çevre haline getirirken elde ettiği kabiliyetleri geliştiren, belirli kurallar altında araçlı veya araçsız, ferdi veya toplu olarak serbest zaman faaliyeti olarak veya tam zamanını alacak şekilde meslekleştirerek yaptığı sosyalleştirici, toplumla bütünleştirici, ruh ve fiziği geliştiren rekabetçi, dayanışmacı, kültürel bir olgudur (Erkal, 1982, 119).

Bireyleri doğrudan ya da dolaylı olarak kendisine bağımlı kılan spor her zaman toplumun ilgisini canlı tutmayı başarmış sosyal bir olgudur. Bu olgu toplumun ihtiyaçlarını karşılayarak büyük bir toplumsal kurum olduğunu dünyaya kabul ettirmiş, toplumu yakından ilgilendiren davranış, düşünce, inanç ve simgeler geliştirmiştir. Her toplumsal kurumda olduğu gibi spor da diğer toplumsal kurumlarla ilişki halindedir ve o toplumun hukukundan, siyasetinden, ekonomisinden, demografik, kültürel, coğrafi yapısından ve çevresinden etkilenmektedir (Kılcıgil, 1998, 9). Ayrıca spor; insanlı̆ğın varoluşunda temel ihtiyaçlar için kullanılırken, günümüzde bir sosyal katılım ve sağlık kazanma aracı, bir iş veya bir eğlence olarak görülmektedir (Basım ve Argan, 2009, 4).

Spor, Türkiye'de yıllar içerisinde farklı kurumlar tarafından yönetilmiştir. Ancak genel olarak değişmeyen kısım, spor federasyonlarının özerkliğe kavuşmuş olmasına rağmen dünyada birçok ülkede görüldüğü üzere, tam bağımsız bir yönetimden bahsedilememesi ve işleyişin merkezden güdümlü olması yönündedir. Bununla beraber 
Türkiye'de bazı spor işletmeleri halka açılmıştır. Bunlar; Beşiktaş Futbol Yatırım, Fenerbahçe Futbol, Galatasaray Sportif, Trabzonspor Sportif'tir.

Spor kulüpleri dernek ve şirket olmak üzere iki farklı tüzel kişiliğe sahiptir. Derneklerin amacı kâr değildir ancak şirketler tamamen kâr amacına yöneliktir. Avrupa'da ve Türkiye'de özellikle futbol kulüpleri olmak üzere pek çok spor kulübü şirketleşmek ve borsada işlem görmek (halka arz) üzere birçok metodu kullanmakta ve çalışmalar yapmaktadırlar. Bu gün özellikle Avrupa'daki futbol kulüpleri şirketleşerek veya hizmetlerinin bir kısmını şirketlere devrederek gelirlerini artırma yönünde faaliyet göstermektedirler. Hâlihazırda Avrupa'da çok sayıda halka açık futbol kulübü bulunmaktadır. Bu konudaki öncülüğü İngiliz kulüpleri yapmış ve elde ettikleri başarıyla da diğer Avrupa ülkelerindeki kulüplere model olmuşlardır. Bununla beraber belirtmek gerekir ki, spor kulüpleri için halka açılma, şirketleşmenin bir sonucu değil, sadece şirketleştikten sonra Genel Kurulca onay verilmesi durumunda uygulanabilecek alternatif bir finansman aracıdır (Devecioğlu ve Çoban, 2003, 4).

Türkiye'de spor kulüplerinin şirketleşmesi konusu ilk olarak 1986 yılında Tük Ticaret Kanunu hükümlerince düzenlenmiştir. $\mathrm{Bu}$ düzenlemeden sonra Türkiye'deki büyük kulüpler ve diğer birkaç kulüp şirketleşme çalışmalarına başlamış ve gelirlerini artırmada Avrupa ülkeleri örneklerini benimsemişlerdir. Türkiye'deki ilk Halka arz işlemini başlatan spor kulüpleri ise Beşiktaş Jimnastik kulübü ve Galatasaray Spor kulübüdür. Bu kulüpler, kurmuş oldukları şirketlerle halka arzı gerçekleştirmişlerdir (Devecioğlu ve Çoban, 2003, 5-6).

\section{Spor ve Girişimcilik}

Ratten (2010) spor tabanlı girişimcilik teorisi geliştirmeyi amaçladığı çalışmasında tüketicilerin günden güne değişen istekleri ve girişimciliğin en önemli özelliklerinden biri olan yenilik yapmanın göz önünde bulundurulduğunda sporun girişimcilik açısından önemli bir sektör yarattığını belirtmektedir. Spor bağlamında, kısa vadeli kazançların uzun vadeli kazançlar elde etme umuduyla feda edildiği bir karşılıklılıktan kaynaklanan, sosyal sermayenin mümkün kıldığı girişimcilik söz konusudur. Sosyal sermayeye sahip spor organizasyonları diğer organizasyonların da aynı şekilde cevap vermeleri umuduyla güven ve risk alma isteğine vurgu yapmaya çalışmaktadırlar. Girişimcilik birbiri ardına devam eden sosyal ilişki ağlarından doğar ve spor; takımları, işletmeleri ve tüketicileri ile yeni firsatlar belirlemek için girişimcilikle işbirliği içerisindedir. Dünya çapındaki spor organizasyonları, girişimciliğin gelişmesine, strateji geliştirilmesi için sosyal ağları kapasite oluşturma şeklinde kullanarak yardım etmektedir (Ratten, 2010, 559).

Profesyonel spor liglerinin, programlarını çeşitlendirmelerini sağlayacak eşsiz gelir kaynakları bulunmaktadır. Bunlar bilet bağışları, imza organizasyonları, tesisler (stadyum, arena gibi), müsabakalar/organizasyonlar, medya ilişkileri, locaların tutulması (Amerika'da localardan maç izleyebilmek için öncelikle büyük meblağlarda bağışların yapıldığı spor kulüpleri bulunmaktadır), tedarikçiler, sponsorlar ve profesyonel yöneticiler (sahipler, avukatlar, koçlar, muhasebeciler...)'dir. Profesyonel spor ligleri gişe gelirlerinden, bağışlardan, reklamlardan ve üyelik aidatlarından doğan farklı gelir akışlarına sahiptirler (Sheth\&Babiak, 2010, 436). Hardy (1996)'ye göre spor finansal güdülerle yönetilmezse ve topluluklar ve devlet tarafından sübvanse edilirse, yenilik tüketicilere değer katmanın bir yolu olarak giderek daha önemli hale gelmektedir (Ratten, 2010, 560).

Girişimcilik araştırmaları genel olarak artan bir yapı göstermesine rağmen, spor endüstrisine özellikle spor faaliyetlerinin yer aldığı benzersiz yapıya dikkat son yıllarda çekilmektedir. Ayrıca girişimciliğin sporla ilişkili örgütlerdeki rolü diğer endüstrilerden farklıdır. Girişimcilikle ilgili spora özgü faktörler kitle iletişim gücü, sosyal etkileşim ve spora olan genel taleptir (general appeal). Sporda girişimcilik, daha ileri çalışmaların yapılmasını sağlamak ve girişimcilik literatürüne girişimciliğin incelenme yolunu anlamak ve girişimciliğin örgütlerde/organizasyonlarda nasıl deneyimlendiğini görmek açısından katkıda bulunabilir. Genel performanslarını artırmak için sporla ilgili örgütler tarafından girişimciliğe; işbirlikçi, toplum odaklı ve stratejik bir şekilde yaklaşılmaktadır. Girişimciliğin iç ve dış paydaşları içeren yararlanıcıları sporcular, taraftarlar, müşteriler, hükümetler, sponsorlar, topluluklar ve çalışanlardır. Spor tabanlı girişimcilik, girişimciliğin ekonomik gelişme için umut verici bir strateji sunan bir kategorisidir. The Sports Journal'ın tanımına göre; bir spor tabanlı girişimci, örgütleyen, yöneten ve bu iş girişimi için riski kabul eden kişidir (Ratten, 2010, 560).

Sporla ilgili ürün ve hizmetlerin sunulmasıyla, girişimciliğin bir özelliği olan risk almak belli bir ölçüde oluşmuştur. Gatorade (bir içecek) daha sonra sporcular ve sporla ilgili olmayan kişiler tarafindan küresel olarak kabul edilmiş olan, Florida State Üniversitesi'nin futbol takımı tarafından geliştirilen bir yeniliktir. Cheetah Lower Limb protezleri, çift ampute para olimpik koşucuların, vücudu sağlam koşucularla yarışmasını olanaklı kılmıştır. Sportsvision, Ulusal Futbol Ligi'nde belirlenen alan çizgilerini, Major Beyzbol Ligi'nde atışları ve NASCAR yarışlarında arabaları izlemek için sadece televizyon izleyicisinin görebildiği sarı çizgiler gösteren bir grafik sistemi geliştirmiştir. Spor bilimlerinde, protezlerde ve yapay malzemelerde sporda yeniliklere neden olmaya devam edecek hızlı bir ilerleme olmuştur (Ratten, 2010, 561).

Sporda kurumsal girişimcilik kurumlar tarafından yeni aktivitelerin yaratılmasını içermektedir. MajorLeague Baseball (Amerika ve Kanada Ligi)'da kurumsal girişimcilik standartlaştııılmış uyuşturucu testini, belirlenmiş oyuncuların tanıtımını ve yenilikçi beysbol üniformalarını içermektedir (Ratten, 2010, 562). 
Çetindamar (2002, 33)’’n girişimcilikle ilgili verdiği örnekte; bir lokanta ya da bakkal açan kişinin risk aldığ ancak bir yenilik yapmadığı belirtilmektedir. Yüzyıllardır bilinen ve birçok yerde satılan bir ürün olan Kahramanmaraş dondurmasını bir marka haline getirmek, bunun üretimini standartlaştırmak ve farklı ürünlerle tüketimini sağlamak, özel dağıtım kanalları yoluyla satışa sunmak yenilik yapmak olarak belirtilmektedir.

Bu bağlamda düşünüldüğünde; spor kulüplerinin farklı birçok marka adı altında sunulan sportif ürünleri kendi kulüplerini markalaştırmak üzere; kulüplerinin renkleri ile satmaları, sportif ürünlerin yanı sıra kişisel kullanımı da içeren birçok ürünü üretmeleri (kalem, şampuan, bardak, havlu, dekorasyon ürünleri, atkı, bere vb.) gerçek anlamda girişimcilik tanımına uyan, bir yenilik yapma, risk alma ve bulunan kaynakları farklı şekillerde kullanma özelliklerine uymaktadır. Diğer taraftan spor kulüplerinin kar elde etmek için kurdukları şirketlerin halka arz edilmeleri, diğer sektörlerde de olduğu gibi alternatif bir finansman kaynağı olarak düşünülebilir. Zaten var olan halka açılma yöntemini spor kulüplerinin şirketlerinin hisse denetlerini satmak yoluyla uygulamaları girişimcilikten ziyade, henüz spor sektöründe yer almayan bir uygulamanın başlatılması olarak ele alınabilir.

Spor yöneticiliğinden mezun olan birçok öğrencinin spor endüstrisindeki geleneksel spor alanlarına yönelmek yerine kendi spor işlerini kurmaya başlamaları nedeniyle bazı spor yöneticiliği programları girişimcilik derslerini müfredatlarına koymaya başlamışlardır. Spor yöneticiliği programları girişimcilik programları gibi artmaya devam etmektedir (Borgese, 2007, 1-2).

Girişimcilik ve küçük işletme sahipliği Amerikan ekonomisinin büyük bir payını oluşturmaktadır. "Amerikan Rüyası” olarak bilinen bir işletme sahibi olma ve yürütme fikri hala birçok insan için geçerlidir. Amerika'da yılda yaklaşık 600,000 adet küçük işletme kurulmaktadır ve buna ek olarak \%75inin çalışanı olmayan 23 milyon küçük işletmenin varlığından söz edilmektedir. Bu sonuçlar da her geçen yıl daha çok öğrencinin girişimciliğe bir akademik disiplin olarak ilgi duyduğunu göstermektedir (Borgese, 2007, 2).

Spor muazzam büyüklüğü ve ekonomiye katkısına rağmen henüz USA'da resmi bir sektör olarak değerlendirilmemektedir. Sanat, eğlence ve rekreasyonla aynı grupta değerlendirilmektedir. Ancak spor bu bireysel sektörü aşmakta ve aslında diğer birçok sektörlere de dahil edilebilir. Konaklama ve yiyecek hizmetleri sektörü spor turizmi ve spor alanlarındaki tüketimle beraber değerlendirilmemesi gerekken ayrı bir sektördür. Howard and Crompton (2004) spor ürünleri ve hizmetleri ile ilgili üretim ve tüketim harcamalarının yıllık yaklaşık 213 milyar dolar olduğunu tahmin etmektedirler (Borgese, 2007, 2).

Spor girişimcileri sadece profesyonel spor kurumları sahiplerinden oluşmamaktadır. Spor endüstrisi büyük ve küçük ölçüde alt işletmelerin çeşitliliğini gerektirmektedir. Örneğin sağlık kulübü sahipleri, spor salonlarının ve tesislerinin işletmecileri, lig sahipleri/işletmecileri, sportif ürün mağazalarının sahipleri, bilet acentaları ve fizik tedavi uzmanları bunlardan sadece birkaçıdır. Borgese $(2007,3)$ de girişimcilikle ilgili yapılan araştırmaların bolluğuna rağmen spor girişimciliğiyle ilgili araştırmaların eksikliğine dikkat çekmektedir. Amerika'da online girişimcilik organizasyonlarından Kansas City Royals Major League Baseball takımını alarak hayırseverlik yapan Ewing Marion Kauffman Vakfı web sitesi ve Birleşik Devletler Küçük İşletmeler ve Girişimcilik Derneği (United States Association for Small Business and Entrepreneurship - USASBE) web sitesi spor girişimciliği konusunda daha fazla araştırma yapılmasına gerek duyulduğunu belirtmektedir. Spor işletmeciliği küçük işletme sektörünün büyüyen bir parçasıdır ve bu nedenle bu alanda daha fazla araştırma yapılmasının gerekmektedir.

\section{Sonuç}

Girişimciliğin ekonomiye, kalkınmaya ve ülke refahına katkısının öneminin fark edildiği günümüzde, buna paralel olarak spor sektörünün yeme-içme, eğlence, konaklama, performans ürünleri açısından teknolojik gelişmeler ve sportif ürünler açısından üretim hacmini de içine alarak hızla büyüyen yapısı dikkat çekmektedir. Yenilik yapma, üretme, risk alma, fırsatları görme ve uygulamaya geçme faaliyetlerinin geneli olarak tanımlanan girişimciliğin davranışsal göstergeleri pazara yeni bir ürün/hizmet sunmak, üretimde yeni bir yöntem geliştirmek, henüz keşfedilmemiş bir talep boşluğu yakalamak ve bir sanayi dalında yeni bir firma kurmak şeklinde belirtilmektedir. Ülke ekonomisine üründe, üretimde, teknolojide yenilikler yaparak veya mevcut durumun devamlılığını sağlayarak, istihdam imkânları oluşturarak, sermayeyi tabana yayarak ve bütün bunlar sonucunda değer yaratarak katkıda bulunmaktadır. Bu katkıların sağlanmasında sporun rolü ise, küreselleşen dünyada sosyal ağlar yaratması, özellikle büyük çaplı uluslar arası organizasyonlara aracı olması, kitleleri peşinden sürüklemesi ve birçok disiplinle ilişkili olmasıdır. Bu nedenlerle girişimcilik özelliklerinin gelişmesi ve girişimciliğin beklenen faydalarının sağlanmasında sporun rolü ve önemi göz ardı edilmemelidir.

Dünyada 100'ü aşkın spor dalının bulunması ve bunların yaş, cinsiyet, sağlık durumu, profesyonellik ve katılım düzeyi, bölge gibi ölçütlerle değerlendirilmesi sportif faaliyetlerin çeşitliliğini artırmaktadır. Bu çeşitlilik de girişimcilik açısından üretilebilecek fikirleri artırmaktadır.

Spor sektörünün her geçen gün büyüyen yapısı, sporun yönetiminde profesyonellik ve kurumsallaşmayı da beraberinde getirmekte, spor örgütleri de bu açıdan diğer örgütlerle rekabet edebilir konuma gelmektedir. 
Tüm bu anlatılan nedenlerden dolayı spor girişimciliği son y1llarda bir bilim olarak değerlendirmeye başlanmıştır. Spor yöneticiliği alanında eğitim veren kurumlar spor girişimciliğini ders olarak vermekte ve bu alanda bilimsel çalışmaların sayısı zamanla artmaktadır.

$\mathrm{Bu}$ araştırma sonucunda Amerika ve Avrupa ülkelerinin spor sektörünün büyüklügüunden ve çeşitliliğinden yararlanarak girişimcilik örneği olarak gösterilebilecek birçok faaliyetler gerçekleştirdiği görülmüştür. Aynı şekilde gelişmekte olan ülkelerin spor girişimciliğine örnek uygulamalarına pek rastlanmamıştır. Bu nedenle gelişmekte olan ülkelerin ekonomik kalkınmalarına katkı sağlaması açısından spor sektörünün büyüklügünnü ve çeşitliliğini göz ardı etmemeleri gerekmektedir.

Henüz Türkçe alanyazında rastlanmayan spor girişimciliği konusunun, yoğun genç nüfusa ve buna bağlı olarak sporda yoğun talebe sahip olan ülkemize sağlayacağı katkıların daha net ortaya konulmasını sağlayacak araştırmalara ihtiyaç duyulmaktadır.

\section{Kaynakça}

- Basım, Nejat ve Metin Argan, 2009. Spor Yönetimi, Detay Yayıncılık, Ankara

- $\quad$ Borgese Anthony, 2007. Standarts in Sports Entrepreneurship Education, (Doktora Tezi) United States Sports Academy, Brooklyn, New York, USA

- Çetindamar Dilek, 2002 Türkiye'de Girişimcilik Aralık 2002 (Yayın No. TÜSİAD-T/2002-12/340)

- Çetinkaya Bozkurt Ö. Vd, 2012. “Türkiye’de Girişimciliğin Gelişimi: Girişimciler Üzerinde Nitel Bir Araştırma” Süleyman Demirel Üniversitesi Sosyal Bilimler Enstitüsü Dergisi Yıl: 2012/1, Sayı:15, s: 229247

- Devecioğlu Sebahattin ve Bilal Çoban, 2003. "Türkiye’de Spor Kulüplerinin Halka Arzı” Standart Ekonomik ve Teknik Dergisi T.S.E., yıl 42, Say1 493, Ocak 2003 s.1-11

- Ercan Salih ve İsmail Gökdeniz, 2009. “Girişimciliğin Gelişim Süreci ve Girişimcilik Açısından Kazakistan” Bilig Bahar / 2009 sayı 49: 59-82 Ahmet Yesevi Üniversitesi Mütevelli Heyet Başkanlığı

- $\quad$ Erkal, Mustafa E., 1982. Sosyolojik Açıdan Spor, Filiz Kitabevi, İstanbul

• Işı1k Nihat. vd., 2011.” İktisadi Büyümede Girişimciliğin Rolü” Girişimcilik ve Kalkınma Dergisi (6:1) 2011 Journal of Entrepreneurship and Development s. 148-178

- Ibeh Kevin I.N., 2004. "Furthering Export Participation in Less Performing Developing Countries, the Effects of Entrepreneurial Orientation and Managerial Capacity Factors” International Journal of Social Economics Vol. 31 No. 1/2, pp. 94-110

- Karabey Canan Nur ve Dursun Bingöl, 2010 “Girişimciliğin Başlangıcı Olarak Fırsat Tanımlama” Yönetim, Yıl: 21, Say1:67 Ekim 2010 s.9-31

- Kılcıgil Ertan, 1998. Spor ve Sosyal Çevre, Bağırgan Yayınevi, Ankara

- Ratten, Vanessa, 2010. "Developing a Theory of Sport-based Entrepreneurship" Journal of Management and Organization, Vol. 16, pp. 557-565

- Ratten, Vanessa, 2011. "Sport-based Entrepreneurship: Towards a New Theory of Entrepreneurship and Sport Management” International Entrepreneurship Management Journal, Vol. 7, pp. 57-69

- Ratten, Vanessa, 2012. "Sport Entrepreneurship: Challenges and Directions for Future Research" International Journal of Entrepreneurial Venturing, Vol. 4, No. 1, pp. 65-76

- Sheth Hela ve Babiak Kathy. M., 2010. "Beyond the Game: Perceptions and Practices of Corporate Social Responsibility in the Professional Sport Industry" Journal of Business Ethics (2010) 91:433-450 DOI 10.1007/s10551-009-0094-0

• TÜSİAD, 2003. “Türkiye'de Girişimcilik” Özet Bulgular 27 Şubat 2003 TS/BAS/03-018 


\title{
Türkiye’nin Sakin Şehirlerindeki Kadın Girişimciliğine Sosyolojik Bir Bakış \\ Women Entrepreneurship in Slow Cities of Turkey from a Sociological Perspective
}

\author{
Asst. Prof. Dr. Zerrin Sungur (Anadolu University, Turkey)
}

\begin{abstract}
Cittàslow movement was established in Italy in 1999. The Slow City movement incorporates a philosophy and a commitment to maintain the cultural heritage and quality of life of their membership towns. A slow city aims to improve the quality of life of its citizens and its visitors. Member towns are obliged to pursue local projects protecting local cultures, contributing to a relaxed pace of life, creating conviviality and hospitality and promoting a unique sense of place and local distinctiveness. There are nine slow cities in Turkey in 2013. This study examines the women entrepreneurship in slow cities of Turkey from a sociological perspective. Slow cities offer many opportunities in the meaning of local development especially for women in Turkey. They can engage with small business, hand-crafts, and organic farming in slow cities. But training of women, certification of the quality of artisan products and awareness of the citizens of slow cities are the critical issues in the sustainable local development process. Therefore, it is possible to increase income level of women living in slow cities in Turkey and also to preserve local tastes.
\end{abstract}

\section{Giriş}

Yaşam temposunun hızının giderek arttığı ve yaşam tarzlarının giderek birbirine benzediği gerçeği dikkate alındığında diğer taraftan da yeni yaşam felsefeleri de buna tepki olarak gelişmiştir. Yavaş yemek ve daha sonra ortaya çıkan sakin şehir hareketi bunlardan başlıcalarıdır. Bu hareketlerin 1970'ler sonrası post-Fordist dönemde üretimde de yeni anlayışlara sahne olan İtalya'da ortaya çıkması tesadüf olmasa gerektir. Sakin şehir, modernle geleneksel, küresel ve yerel arasında insan ilişkilerini ve çevreye duyarlılı̆̆ etmektedir. Ortaya çıkardığı dinamikler açısından bakıldığında bir tür yerel kalkınma modeli olarak da ele alınabilecek sakin şehir, özellikle kadınlar açısından istihdam olanakları zengin bir yelpaze sunmaktadır.

\section{Yavaş Beslenme ve Sakin Şehir Hareketi}

İtalyanca Città (şehir) ve İngilizce slow (yavaş) kelimelerinden oluşan Cittàslow, "sakin şehir" anlamına gelmektedir. 1986 yılında hızlı yiyecek (fast food) zincirine karşı çıkılarak, İtalya'nın Barolo kentinde "Yavaş Beslenme Birliği" oluşturulmuştur. Cittàslow Ağı, küreselleşmenin şehirlerin dokusunu, sakinlerini ve yaşam tarzını standartlaştırmasını ve yerel özelliklerini ortadan kaldırmasını engellemek için Slow Food (yavaş beslenme) hareketinden ortaya çıkmış bir kentler birliğidir. Küreselleşmenin yarattı̆̆ homojen mekanlardan biri olmak istemeyen, yerel kimliğini ve özelliklerini koruyarak dünya sahnesinde yer almak isteyen kasabaların ve kentlerin katıldı̆̆ı bir birliktir (http://www.cittaslowturkiye.org/). 1989'da Paris'te uluslararası boyut alan birliğin bugün 100 'den fazla ülke temsilcisinden oluşan 100 binden fazla üyesi bulunmaktadır (http://www.cittaslowturkiye.org/; http://www.habitat.org.tr/sakin-sehirler/727-sakin-sehir-seferihisar.html). Sakin Şehir Hareketi kendisine logo olarak modern ve tarihi binaları taşıyan turuncu renkli bir salyangoz (Sekil 1) tasarımını belirlemiştir (Sırım, 2012; Slow Magazine, 2012). Yavaş, temkinli, fakat kararlı bir biçimde yol alan salyangoz, cüssesinden beklenmedik mesafeler katetmekte; bunu yaparken de geçtiği yerlerde ince bir iz bırakmaktadır (Sırım, 2012; Kavas ve Kavas, 2012).

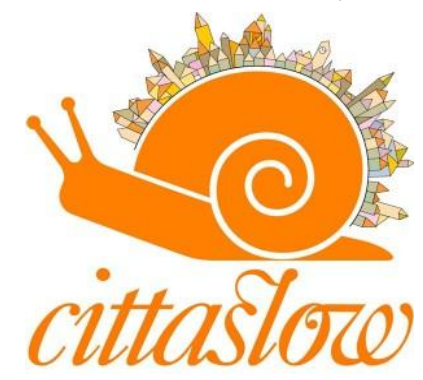

Şekil 1: Cittàslow logosu

Yavaş yiyecek kavramından esinlenen "Sakin Şehir Hareketi”nin temeli, İtalya'nın Toskana bölgesindeki 13 bin nüfuslu Greve in Chianti'nin belediye eski başkanı Paolo Saturnini’nin girişimleri sonucunda 1999 yılında atılmışıır. Saturnini, fikirlerini Bra, Orvieto ve Positano belediye başkanlarıyla da paylaşarak yaşam kalitesini 
artırmaya dayalı olan ve gelişmeyi farklı bir biçimde ele alan bu anlayışın öncüsü olmuştur (http://cittaslow.org/section/association). İlk bildirgede küreselleşmenin insanlar arasındaki iletişimi, kaynaşmayı ve değişimi kolaylaştırmasına karşılık farklılıkların törpülenerek, tek tip bir insan modeline doğru gidildiğini ve sonunda sıradanlığın hakim olacağı bir düzenin yaratılacağı konusundaki endişeler dile getirilmiştir. Bu olası sonuçların engellenmesi, yerel değerlere sahip çıkılması, bu değerlerin korunması ve geliştirilmesi sakin şehir kavramı çerçevesinde bir ağ oluşturulmuştur (http://habitat.org.tr/sakin-sehirler/727-sakin-sehir-seferihisar.html).

Cittàslow, nüfusu 50.000'nin altında olan kentlerin üye olabildiği, kentlerin kendi gelenek, göreneklerini, yemeklerini, tarihsel kimliklerini korumalarını öngören bir birliktir. Cittàslow felsefesi kentlerin hangi alanlarda güçlü ve zayıf olduklarını analiz etmelerini ve sahip oldukları şartlar çerçevesinde bir strateji geliştirmelerini teşvik etmektedir (http://www.cittaslowturkiye.org/). Citttàslow Birliği’ne üye olmak için birliğin tespit ettiği ölçütleri gerçekleştirmek için projeler geliştirmek ve uygulamak gerekmektedir. Kentlerin ölçütler çerçevesinde yaptığı çalışmalar puanlanmakta ve bir kentin üye olması için 50 ve üzerinde puan alması gerekmektedir. 1999 yılında birliğin belirlediği ölçütler, birliğin sadece İtalya veya Avrupa'da değil bütün dünyada yayılması sonucu daha evrensel bir hale getirilmeye çalış1lmıştır (http://www.cittaslowturkiye.org/index.php?option=com_ content\&view=article\&id=131\&Itemid=529). Harekete dahil olan kentlerde insan daha düşük tempoda yaşarken, daha az enerji tüketerek ve vahşi bir gıda tüketimi yerine az ama öz beslenme ile yaşıyabilmektedir. Kendisine, ailesine ve çevresine daha çok zaman ayırabilmektedir. Bu değişim bir anlamda insanın çevresi ve doğa ile sağlıklı bir ilişki içinde olmasının, sağlıklı bir beden ve ruh için en önemli adım olduğunun onaylanmasıdır (Şahinkaya, 2010).

Bir sakin şehrin yaşamına yön veren prensipler, şehir insanlarının ve ziyaretçilerinin yaşam kalitesinin yükseltilmesi, birliğe dahil olan şehirler arasında ulusal ve uluslararası ölçekte bilgi, fikir ve deneyimlerin paylaşılması üzerine kuruludur (Fullagar, Markwell ve Wilson, 2012). Sakin şehir hareketi toplumun "McDonaldlaşması"na (Ritzer, 2004) karşı bir duruşu temsil ederken, yaşamın artan temposuna karşı bir direnişi ve "mekansızlığı" ifade etmektedir (Mayer ve Knox, 2009). Yerli kültürle çok az ilişki kuracakları yabancı ülkelere gitmek için insanlar önemli miktarda harcama ve çaba içine girmektedirler (Ritzer, 2011). Paket turlar genellikle turizm açısından herşeyin öncesinde belirli ve öngörülebilir olduğu, daha çok Batılı bir anlayışı temsil etmektedir.Tatil tercihlerini bu türde yapan kimseler de yerel halkla, oranın yerel kültürüyle hiç karşılaşmadan izole bir ortamda yaşamaktadır. Oysaki sakin şehirlerde birkaç gününü geçiren kimseler çok farklı deneyimleri yaşama şansına sahip olmaktadırlar.

Sakin şehir hareketine yöneltilebilecek eleştiriler ele alınırsa bunlardan biri bu hareketin kolaylıkla moralsiz, geriye dönük ve soyutlanmış topluluklar ortaya çıkarabilmesi üzerindedir. Acaba sakin şehirler hızlı dünyanın hararetli maddeciliğinin yerini sakinliğin tutuculuğuna bıraktığı ortamlar mıdır? Diğer taraftan sakin şehirler çeşitliliğin olmadığı, akşamları gençlere yönelik faaliyetlerin olmadığı, hareketsiz aptallaştırıcı mekanlar olmayı da istememektedir. Sakin şehirler işletmeciliğe, yenilik ya da teknolojiye karşı durma gibi bir niyetleri de yoktur. Yavaşlığın öngördüğü tehlikelerin farkında olarak, sakin şehir hareketli çiftçi pazarları, festivaller ve cazip kamusal alanların yaratılması ile canlılı̆̆ yaygınlaştırmayı hedeflemektedir. Bu anlamda çevreye duyarlı, bölgesel olarak otantik işletmeler yoluyla gastronomi odaklı bir turizmi teşvik etmektedir. Bir diğer tehlike paradoksal bir biçimde sakin şehir etiketinin miras endüstrisi içinde bir tür marka farkındalığına dönüşmesidir. Sakin şehirler nüfusları 50 binin altında olması dolayısıyla zamanla turizm yoluyla kolayca cazibe merkezleri haline gelebilirler. $\mathrm{Bu}$ şehirler sakin tempolarını gösteriş konusu haline getirirken, hızlı bir değişime uğrayabilirler. Bu senaryoda dükkan kiralarının artması, kafelerin özgünlüğünü yitirerek bozulmasına neden olabilir. Dışarıdan gelen zengin ziyaretçiler sakin şehirleri ikinci evleri olarak seçebilirler. Bu durumda ev kiraları yükselecek, yoksullar ve gençler dışlanabilecektir. Bu tehdit karşısındaki en iyi savunma, hareketin propagandasını yapmaktır. Ne kadar yerel kalınırsa, o kadar az özel üyelik statüsü olacak, bunlar daha az ilgi çekecektir. Bu bağlamda herşey ilk uyum sağlayanların başarılarına ve becerilerini daha geniş bir üyelik için zemin oluşturmada kullanma kabiliyetlerine bağlıdır (Knox, 2005).

\subsection{Sakin Şehir Olma Ölçütleri}

Belirli bir çevre politikasını uygulayan, teknolojiyi çevrenin kalitesini geliştirme yönünde kullanan, doğal ürünlerin kullanımını destekleyen şehirler, sakin şehir olarak adlandırılmakta ve bu şehirler, sakin şehir ölçütlerini hayata geçirdikleri takdirde CittàSlow ağına katılabilmektedir (Miele, 2008). Rönesans döneminin temel düşünceleri arasında yer alan "festina lente", hızlı yaşarken, dikkatli olmak; gerektiğinde hızlanıp, gerektiğinde yavaşlayarak, arada denge kurmak anlamına gelmektedir. Sakin şehir olabilmenin 60 ölçütü, "festina lente" prensibine dayandırılmıştır (Çiner, 2011; Bilgi, 2013).

Sakin şehir olma ölçütleri çevre, alt yap1, kentsel kalite için teknoloji ve tesisler, yerel üretimin korunması, misafirperverlik, farkındalık, sakin şehir kimliği ve ilgili projeler başlıkları altında incelenebilir. Bu ölçütlerin detaylı gerekleri ise çevre politikaları bağlamında hava, su ve toprağın kalitesinin, yasa tarafından belirtilen parametrelerde olduğunun belgelenmesi; kentsel çöp ve özel atıkların ayrıştırılarak toplanmasının teşvik edilmesi ve yaygınlaştırılmasına yönelik projelerin uygulanması; endüstriyel ve evsel kompostlamanın teşvik edilmesi ve yaygınlaştırılması; kentsel ya da toplu kanalizasyon için, atık su arıtma tesisinin bulunması; RSU ve biyokütlelerden 1sı üretilmesi ve özellikle alternatif enerji kaynaklarının (yenilenebilir enerji, yeşil hidrojen, mini 
hidroelektrik santral) kullanılması yoluyla enerji tasarrufu yapılmasına yönelik belediyenin planı olması; genetiği değiştirilmiş ürünlerin (GDO) tarımda kullanımının yasaklanması; reklam tabelaların ve trafik işaretlerinin düzenlenmesine dair belediyenin planının olması; elektromanyetik kirliliğin kontrolü için sistemler geliştirilmesi; gürültü kirliliğinin azaltılması ve kontrolü için program yapılması; 1şık kirliliğinin kontrolü için sistemler ve programlar oluşturulması; çevre yönetimi sistemlerinin benimsenmesi (EMAS ve ECOLABEL ya da ISO 9001; ISO 14000, SA 8000 ve Gündem 21 projelerine katılım) olarak sıralanabilir.

Altyapı politikaları bağlamında ise tarihi merkezlerin ıslahı ve iyileştirilmesi için planlar ve/veya kültürel ve tarihi değerler üzerine çalışmalar yapılması; güvenli ulaşım ve trafik için planlar yapılması; okullar ve kamu binalarına bağlanan bisiklet yollarının yapılması; özel taşıtlar yerine uygun alternatif taşıma ve trafiğin toplu taşım araçları ve yaya alanları ile bütünleştirilmesi için (toplu taşımla bağlantılı ilave kentsel araba park alanları, yürüyen merdivenler, yürüyen bantlar, teleferik, bisiklet yolları, okullar, işyerleri ve benzerlerine erişim sağlayan yaya güzergâhları) planlar yapılması; kamusal ve kamuyla ilgisi olan alanların engelliler için erişilebilir olması, mimari engellerin kaldırılması ve teknolojilere erişimin sağlanmasını garanti altına almak üzere altyapıların teşvik edilmesi; aile yaşantısına ve yerel aktivitelere (eğlence, spor aktiviteleri, okul ve aile arasında bă̆ oluşturmayı amaçlayan aktiviteler, yaşlılar ve kronik hastalar için evde yardımı da kapsayan yardım çalışmaları, sosyal tesisler, belediye çalışma saatlerinin düzenlenmesi, umumi tuvaletler) yardımcı olacak programların teşvik edilmesi; tıbbi yardım merkezinin bulunması; vasıflı yeşil alanların ve hizmet altyapılarının (yeşil alanların birbiriyle bağlantıları, oyun sahaları, vb.) bulunması; ticari malların dağıtımı ve "doğal ürünler için ticari merkezler" oluşturulması için plan hazırlanması; mağaza sahipleriyle, zor durumda olan vatandaşlarla ilgilenme ve yardım etme üzerine mutabakat sağlanması: "dost mağazalar"; bozulmakta olan kentsel alanların ve şehrin yeniden kullanılmasına yönelik projelerin iyileştirilmesi; kent tarzının yeniden yapılandırılması ve iyileştirmesi için bir program; kentin tanıtımında kullanılan bilgilendirme ofislerinin, U.R.P. (kentsel yenilenme programı) işlevlerinin Cittàslow tanıtım/bilgi ofisiyle bütünleştirilmesi sayılabilir.

Sakin şehir olma ölçütleri arasında kentsel kalite için teknolojiler ve tesisler bağlamında ise biyomimari için büro ve biyomimarinin teşvik edilmesi yönündeki bilgilendirme projesi için görevlendirilen personelin eğitilmesi; şehrin, fiber optik kablolar ve kablosuz sistemler için teçhiz edilmesi; elektromanyetik alanları izleme sistemlerinin benimsenmesi; kentin çevresi ve peyzajıyla uyumlu çöp tenekeleri bulundurulması ve çöplerin belirli zamanlarda toplanması; kamu ve özel alanların çevreyle uyumlu bitkilerle, tercihen bahçe peyzajı ölçütlerine uygun yerel bitkilerle, bitkilendirilmesi için teşvik edilmesi ve programlar oluşturulması; vatandaşlara götürülen hizmetler (belediye hizmetlerinin internet vb. üzerinden duyurulması, vatandaşlar için internet tabanlı bir belediye ağı oluşturulması ve vatandaşların bu ağı kullanmaları yönünde eğitilmeleri) için planlar yapılması; özellikle gürültülü alanlarda gürültünün kontrol edilmesi için plan yapılması; kentte kullanılan renklerle ilgili plan hazırlanması; elektronik evden çalışmanın (telework) teşvik edilmesi sıralanabilir.

Yerel üretimi koruma başlığında ise organik tarımcılığın geliştirilmesi için projelerin üretilmesi; esnaf ve zanaatkârlar tarafından üretilen ürünler, eşyalar ve el sanatlarının kalitesinin belgelendirilmesi; yok olma tehlikesiyle karşı karşıya olan esnaf ve zanaatkârların ve/veya el işi ürünlerinin korunması ve himayesine yönelik programlar yapılması; yok olma riskiyle karşı karşıya olan geleneksel çalışma ve meslek yöntemlerinin himayesi; organik ürünlerin ve/veya yerli ürünlerin kullanılması ve restoranlar, okul kafeteryaları ve korunan yapılarda yerel geleneklerin muhafaza edilmesi; Slow Food hareketiyle işbirliği içerisinde okullarda tat ve beslenme konusunda eğitim programlarının hazırlanması; yok olma riski altında olan şarap ve gastronomik yavaş yemek çeşitleri için aktivitelere destek olunması; yöreye özgü ürünlerin tespit edilmesi ve bu ürünlerin ticarileşmesi için destek olunması (pazarların ve marketlerin yerel ürünlerin satışı için düzenlenmesi, uygun mekanların oluşturulması); şehirdeki ağaçların sayımının yapılması ve büyük ya da "tarihi ağaçların" değerinin arttırılması; yerel kültürel etkinliklerin korunması ve teşvik edilmesi; kent ve okul bahçelerinde geleneksel yöntemlerle yerel ekinler yetiştirilmesi için teşvik edilmesi yer almaktadır.

Misafirperverlik bağlamında ise turist bilgisi ve nitelikli misafirperverlik için eğitim kurslarının açılması; turistik güzergâhlarıyla tarihi merkezlerin ve turistik yerlerin işaretlenmesinde uluslararası işaretlerin kullanılması; ziyaretçilerin özellikle takvimlendirilmiş etkinlikler için şehre yaklaşımlarını ve bilgi ve hizmetlere erişimlerini kolaylaştırıcı resepsiyon yönergelerinin ve planların hazırlanması (otopark, resmi kurumların çalışma saatlerinin uzatılması/esnetilmesi, vb.); şehrin "yavaş” güzergâhlarının düzenlenmesi (broşürler, internet siteleri, ana sayfalar vb.); turistik işletmeciler ve mağaza sahiplerinin, ücret şeffaflı̆̆ ve fiyatların müessesenin dışında sergilenmesi gerekliliği konusunda bilinçlendirilmesi sakin şehir olma ölçütleri arasındaki yerini almaktadır.

Farkındalık bağlamında bakıldığında yerel yönetimin Cittàslow olma niyetini açıklamadan önce vatandaşların Cittàslow'un ne olduğu, amaçları ve prosedürü hakkında bilgilendirilmesi amacıyla kampanyalar düzenlenmesi; "Yavaş" felsefesini kazanmada ve Cittàslow projelerinin uygulanmasında sosyal yapıların dâhil edilmesi için programlar hazırlanması, özellikle; eğitsel bahçe ve parklar, okuma mekanları, tohum bankası projesine katılım; Slow City ve Slow Food faaliyetlerinin yaygınlaştırılması için programlar hazırlanması ifade edilebilir.

Olağanüstü gereklilikler bağlamında ise kentte Cittàslow kimliğini vurgulayacak kampanyalar düzenlenmesi ve Cittàslow tarafından lanse edilen şartların karşılanması (zorunlu); Yavaş Yemek Komitesinin oluşturulması ve 
desteklenmesi (liyakat notu); üye şehirlerin antetli kağıtlarına Cittàslow logosunu eklemeleri ve web sitelerine "yavaş" felsefesi hakkında içerik koymaları gerekmektedir.

Slow Food Faaliyetlerine ve Projelerine Destek çerçevesinde yerel bir Slow Food Convivium'unun oluşturulması; Slow Food ile işbirliği yaparak zorunlu ve orta öğretimde tat ve beslenme üzerine eğitim programları hazırlanması; Slow Food ile işbirliği yaparak okul sebze bahçelerinin kurulması; Arca veya Slow Food Merkezlerinin, yok olma riski altında olan türlere veya ürünler için bir veya daha çok projelerinin uygulanması; Slow Food tarafindan himaye edilen yerel ürünlerin kullanılması ve beslenme geleneklerinin, gıda eğitim programlarıyla birlikte, toplu gıda hizmetleri, korunan yapılar ve okul kantinleri içerisinde muhafaza edilmesi; Slow Food ile işbirliği içerisinde "Mercati della Terra" uygulamasıyla özgün yerli ürün elde edilmesinin desteklenmesi; "Terra Madre” projesinin ve yemek cemiyetlerinin ortak eşleştirme ile desteklenmesi istenmektedir.

\section{Dünyada ve Türkiye'de Sakin Şehir Profili}

Nisan 2013'te güncellenen listeye göre tüm dünyadan 27 ülkeden toplam 176 şehir Sakin Şehir hareketine katılmış bulunmaktadır. Sakin şehirlerin bulunduğu ülkeler ve bu ülkelerdeki sakin şehir sayıları ise şöyledir: Avustralya (3), Avusturya (3), Belçika (5), Kanada (2), Çin (1), Danimarka (2), Finlandiya (1), Fransa (8), Almanya (12), Büyük Britanya (5), Hollanda (5), Macaristan (1), İzlanda (1), İrlanda (1), İtalya (72), Japonya (1), Yeni Zelanda (1), Norveç (3), Polonya (10), Portekiz (6), Güney Afrika (1), Güney Kore (12), İspanya (6), İsveç (1), İsviçre (1), Türkiye (9) ve Amerika Birleşik Devletleri (3).

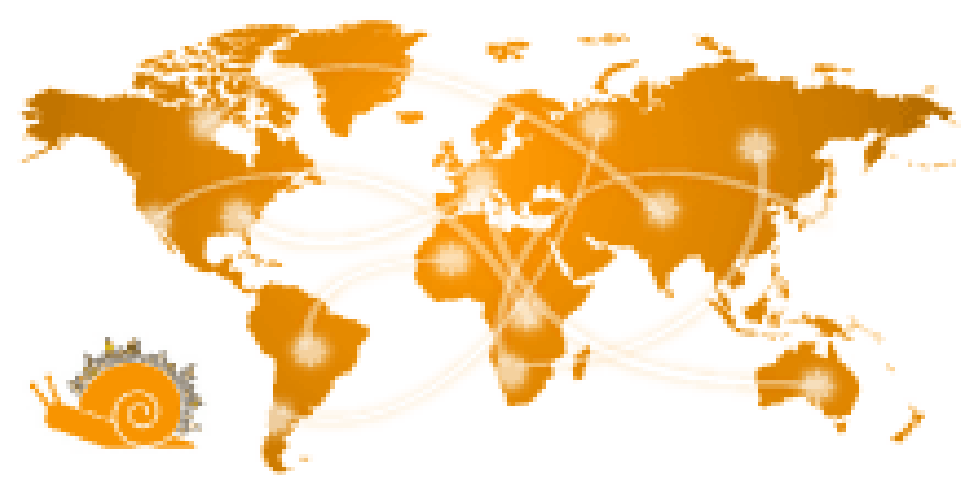

Şekil 2: Cittàslow Uluslararası Ă̆g

Türkiye'de 2013 yılında sakin şehirlerin sayısı 9'a çıkmıştır. Bu belde ve ilçelerin bağlı bulundukları iller ise şöyledir; Seferihisar (İzmir), Gökçeada (Çanakkale), Akyaka Beldesi (Ula İlçesi- Muğla), Taraklı (Sakarya), Yenipazar (Aydın), Yalvaç (Isparta), Vize (Kırklareli), Perşembe (Ordu), Halfeti (Şanlıurfa)'dir. Bunlardan Seferihisar, Türkiye'de ilk sakin şehir olma unvanını kazanarak 2009 yılında Cittàslow ağına dahil olmuştur. Daha sonra 2011 yılında ise Taraklı, Gökçeada, Yenipazar ilçeleri ve Akyaka Beldesi ile birlikte Türkiye'de sakin şehir sayısı beşe çıkmıştır (Sırım, 2012).

Akyaka Özel Çevre Koruma Bölgesi olması ve biyoçeşitliliğiyle, Taraklı karakteristik mimari yapısı ve restore edilen çok sayıda binasıyla, Yenipazar'ın Türkiye çapında ünlü pidesi başta olmak üzere yerel yemekleriyle, Gökçeada ise adada organik üretim yapılmasıyla ve Slow Food etkinlikleri sayesinde kendi özelliklerine sahip çıkan kentlerdir denilebilir. Yeni üyelerle birlikte Ulusal Birliği'ni kurarak İcra Kurulu'na giren Seferihisar, Cittàslow'ların geleceğiyle ilgili karar verme yetkisini kazanmıştır. Ulusal Birliği’ni kuran Türkiye 2013 yılı Cittàslow Genel Kurulu'na ev sahipliği yapma hakkını elde etmiştir. Birliğin en büyük organizasyonu "Cittàslow Genel Kurulu” 2013 yılı Haziran ayında Türkiye’de, İzmir'de, Seferihisar'da yapılmıştır.

\section{Yerel Bir Kalkınma Modeli Olarak Türkiye’de Sakin Şehir}

Sakin şehir hareketinin yerel bir kalkınma modeli olduğuna ilişkin tespitler öncelikle Türkiye'de sakin şehirin ilk örneği olan Seferihisar örneği üzerinden yapılabilir. Seferihisar Belediyesi'ni sakin şehir ağına taşıyan faaliyetler arasında şunlar sıralanabilir:

Köylülerin ürettikleri yerel ürünleri satabilecekleri ve hem yerel kalkınma hem çevre açısından önemli kazanımlar sağlayan pazarlar oluşturulmuştur. Seferihisar'ın Sığacık mahallesinde yerel ürünlerin ve el işlerinin sergilendirdiği "Sığacık Üretici Pazarı" kurulmuştur. Yeni çıkan tohum yasasına göre yerli tohumların satışının yasak olması nedeniyle üreticiler takas yöntemiyle istedikleri tohumları tohum takas şenliğinde elde etmişlerdir. Tarladan Sofraya İyi Tarım Projesi kapsamında 140 üretici, sürdürülebilir üretim yöntemlerinden birisi olan İyi 
Tarım Uygulamaları ile tanışmış bu konuda geniş bilgi edinmiştir. Ulamış mahallesi ve Doğanbey köyünde Seferihisar Belediyesi "Kadın Emeği Evleri” açılmıştır. Bu evler kadın emeğinin değerlendirilmesine, kadınların meslek edinmelerine veya gelir getirici faaliyetlerde bulunmalarına imkan sağlamıştır. Seferihisar'da unutulan ve unutulmaya yüz tutan geleneklerin ve kültürel etkinliklerin tespit edilmesi için "75 Yaş Yemeği" düzenlenerek bu etkinlik kapsamında Seferihisar ilçesinde yaşayan yaşlılarla röportajlar yapılmıştır. Seferihisar'ın yerel değerlerinden biri olan hayvancılık sektörünün korunması ve geliştirilmesi amacıyla Damızlık Koyun-Keçi Panayırı düzenlenmiştir. "Okullarda Sebze Bahçeleri” projesi çerçevesinde öğrenciler sebze yetiştirmeye başlamıştır. Sadece yöresel yemeklerin satıldığı "Sefertası Lokantası”, Sakin Şehir örgütlenmesinin en önemli ölçütlerinden biri olan Yavaş Beslenme (Slow Food) ve yöresel lezzetlerin ön plana çıkarılması amacına hizmet etmektedir. Bunlar arasında sakızlı tarhana, nohutlu mantı, samsades, ekmek dolması, balıklama, piroh, Armola, kuzu dolması, loklok ve yuvalaça gibi yöresel tatların temsil ettiği mutfak mirası sayılabilir. Bunların yanında Seferihisar Sözlü Tarihi çalışmaları, aracısız satış yapılan köy pazarı, tiyatronun kaynağı antik Teos kenti, Mavi Bayraklı plajları, CittàSlow Üniversitesi Projesi ve UNICEF bünyesinde oluşturulan Çocuk Dostu Kentlerin Türkiye'deki ilk örneği olması, Seferihisar'ı özel kılmaktadır (Bilgi, 2013).

Seferihisar'da bisiklet kullanımını yaygınlaştırmak ve günlük kullanılabilecek bir ulaşım aracı olduğunu vurgulamak için Seferihisar Belediyesi hizmet binasında ve Sığacık’ta iki adet bisiklet garajı oluşturulmuştur. Atatürk Caddesi ve çevresi başta olmak üzere Seferihisar şehir merkezindeki trafiğin azaltılması ve yayalaştırılması için trafiğge kapatılması uygulaması başlatılmıştır. Kentsel çöp ve özel atıklarının ayrıştırılarak toplanmasına yönelik projeler hayata geçirilmiştir. 50.000 kişilik bir biyolojik atık su arıtma tesisi kurulmuştur. Şehirde farklı boylarda ve tarzlarda ilan ve reklam panoları yerine Belediye yetkilileri tarafindan belirlenen standart boyda ve tarzda ilan ve reklam panoları kullanılmaya başlanmıştır. Bu çalışmalar için Seferihisar Atatürk Caddesi ve Sığacık-Merkez pilot uygulama alanları olarak seçilmiştir. Bu bölgelerde dükkânların tabelaları yeni tabelalarla değiştirilmiştir. Çeşitli binalarda mimari iyileştirmeler gerçekleştirilerek uydu antenleri merkezi sistemle çatıya alınmıştır. Belediye serasında yetiştirilen sardunyaların kullanıldığı saksılar balkonlara yerleştirilmiştir. Sakin Şehir olmanın amaçları, prosedürleri, bu ağa katılmanın Seferihisar'a katacakları hakkında kamuoyunu bilgilendirici programlar düzenlenmiştir. Seferihisar'ın sakin şehir olma sürecinde planlama ilkeleri ve yaklaşımı doğaya, çevreye ve insana daha saygılı olma anlamında bir bakış açısı değişikliği yaratmıştır (Öztürk, 2012).

Sakin şehirlerin bir diğer hedefi de doğayı koruyarak teknolojiyi en üst düzeyde kullanmaktır (Şarman, 2011). $\mathrm{Bu}$ bağlamda güneş, rüzgâr ve jeotermal gibi alternatif enerjilerden yararlanmak çok önemli bir hedeftir. Güneş enerji panelli aydınlatma elemanlarının kullanılmaya başlandığı Seferihisar’da amaç, bu enerji kaynağının kullanımının yaygınlaştırılmasıdır. Yılın üç yüz gününü güneşli geçiren Seferihisar, aynı zamanda kaplıcalar ve termal enerji kaynakları açısından verimli bir coğrafyaya ve güçlü rüzgâr koridorlarına sahiptir. Bu çerçevede şehrin 1sınmasında jeotermal enerji kullanımı planlanmakta; rüzgâr enerjisi kullanan aydınlatma üniteleri projelendirilmektedir (Bilgi, 2013).

Türkiye'de sakin şehir unvanına sahip bir başka şehir olan Gökçeada'nın da içinde bulunduğu Kuzey Ege Adaları, günümüze kadar ulaşan kültürel miras değerleri ile köklü bir uygarlık sentezinin izlerini taşımaktadır. Sanatın birçok dalının ve ticaretin geliştiği bu adalarda yaşayan uygarlıklar, günümüzde de birçok insanı etkilemeye devam etmektedir (Yurtseven, 2007). Bir Kuzey Ege adası olarak Gökçeada; rüzgârı, tatlı su kaynakları, Rum köylerindeki taş evleri, TÜDAV'a tahsis edilen Yıldız koyundaki Türkiye'nin ilk Su Altı Milli Parkı, sakızlı muhallebi, paştiço, kouka, cicirya, feta, koliva, dibek kahvesi, nar likörü, cipuna, şarap, keçi dolma gibi Slow Food kaynaklarının temsil ettiği mutfak mirası, organik tarımı, gastronomi eğitimi ve kendine özgü günlük yaşam kültürüyle özel bir destinasyondur (Bilgi, 2013).

Gökova Körfezi ağzında bulunan sakin şehir Akyaka, günümüzde Ege ve Akdeniz'deki kıyı yerleşimlerinin plansız yapılaşmayla birlikte yüzleşmek zorunda kaldığı kaçınılmaz sondan uzak kalmayı başaran bir tür örnek şehir denemesidir. Özel Çevre Koruma Statüsü’nün yanı sıra doğal SİT Alanı içinde olması, kuzeyinde 1000 metreye yükselen Sakar Dağı, doğusunda Kadın ve Akçapınar azmakları, azmaklar arasında uzanan verimli ova ve Gökova Körfezi'ne açılan ıssız koylar, Nail Çakırhan tarafından tipik Muğla-Ula mimarisinin stilize edildiği, geleneksel çizgiler taşıyan ahşap evleri Akyaka coğrafyasını özel kılmaktadır. Akyaka’nın ünlü Mavi Bayraklı plajının yanı sıra, coğrafyasına can veren iki akarsudan biri olan Kadın Azmağı, sualtı bitki popülasyonu ile dalış meraklıları için cazip bir doğal akvaryum sunmaktadır. Yıl boyu yüksek debisini ve sıcaklığını koruyan bu sodalı akarsuda eskiden yöre kadınlarının çamaşırlarını yıkamasından dolayı, akarsu halk arasında Kadın Azmağı olarak anılmaktadır. Akyaka'nın diğer akarsuyu Akçapınar, denize yaklaştığı noktadan itibaren denizle arasında uzun bir kıyı şeridi oluşturmaktadır. Doğal SİT Alanı olan Akçapınar Azmağı ile Kadın Azmağı arasında kano, uçurtma kayağı (kite surf) ve çift kişilik yamaç paraşütü gibi (tandem), motorlu su sporlarına alternatif doğa sporları ilgi görmektedir (Tuvi, 2010). Küçük piyade tekneleriyle azmak turu yapmak, Akyaka'nın mimari dokusunun yaratıcısı Nail Çakırhan'ın adının verildiği sokakta dolaşmak ve Azmak kıyısında Akya buğulamayı ve Akyaka balı ile susamın pişirilmesiyle yapılan Çitirmek'i tatmak, Akyaka yerel mutfağı örnekleri arasında bulunmaktadır (Bilgi, 2013). 
Yenipazar'ın 2011 yılında sakin şehir unvanını alması yerel kalkınma modelinin lokomotifi olmuştur. Bu bağlamda, kasabada aracısız köy pazarı ve kadın kooperatifleri kurulmuş, yaya alanları artırılmış, sivil mimari örnekleri koruma altına alınmış ve bisiklet istasyonları projelendirilmiştir. Bisiklet kullanımının alternatif bir ulaşım aracı olarak yaygınlaştırılması amacıyla her yıl Bisiklet Şenlikleri organize edilmektedir. Yerel mutfağı temsil eden en önemli Slow Food kaynakları Yenipazar pidesi, cızdırma, yavru kavurması, hurma ve pırasalı ekmektir. Batı Anadolu'nun kültür mirası olan Geleneksel Yörük Şenlikleri, yirmi altı yıldır Yenipazar'da düzenlenmeye devam ettirilmektedir (Bilgi, 2013).

19. yüzyılda, İstanbul'dan Anadolu'ya uzanan İpekyolu üzerinde bir konaklama merkezi olan Taraklı, o dönemde ipek böcekçiliği, şimşir tarak ve kaşıklarıyla önem kazanırken, 1950'li yıllardan sonra E5 karayolunun ve TEM'in dışında kalarak büyük şehirlerin hızlı yaşam tarzından uzaklaşmıştır. Taraklı evlerinin kendine özgü genel karakteristiği, 19. yüzyıl Osmanlı şehir mimarisini yansıtan üç katlı ahşap karkas evlerden oluşmasıdır. Korunarak günümüze ulaşanlar arasında bulunan Küçükhan, Kale Han, Çakırlar, Orhangazi Çarşısı ve Hacırıfatlar gibi birçok tarihi konağın restorasyonu tamamlanarak bu yapılara butik otel fonksiyonu kazandırılmıştır. Cittàslow üyeliğinin bir özdenetim mekanizması olarak fonksiyonellik kazandığı Taraklı'da, jeotermal enerji potansiyelinin gelecek beş yıllık dönemde rasyonel anlamda değerlendirilebilmesi amacıyla, iki yüz elli bin kişiden oluşan bir nüfus kitlesine hizmet vermeyi hedefleyen kaplıca tesisleri projelendirilmektedir (Bilgi, 2013).

Türkiye'de sakin şehir kavramı belediyelerin yol haritası haline gelirken şehirlerin geleceğini korumaktadır. Yavaş şehir kavramı plansız kentleşme, para kazanma ve küreselleşmenin bir parçası olma gibi kentsel değerleri devam ettirirken, daha hızlı ve modern olma adına insanların gelenek ve göreneklerini unutmalarının önüne geçmektedir (Karabağ ve diğerleri, 2012).

\section{Türkiye'de Sakin Şehirlerde Kadın Girişimciliği}

Türkiye'de istihdam ve işgücüne katılımda kadın ve erkekler arasında büyük farklar bulunurken, kadınların işgücüne katılım oranlarının giderek düşme eğilimi içinde olması, onun diğer gelişmekte olan ülkelerden ayırt edici özelliği olarak ortaya çıkmaktadır. Uluslararası Çalışma Örgütü'nün Kadınlar için Küresel İstihdam Eğilimleri Raporu'na göre gelişmekte olan ülkelerde son on yıl içinde kadınların istidama katılım oranlarının arttı̆ı gözlenmektedir. Türkiye'de ise 1950 sonrası dönemde eğilim, milli gelirde ve istihdamda tarım sektörünün payının azalmasına koşut olarak kadınların işgücüne ve istihdama katılım oranlarının gerilemesi yönündedir (Toksöz, 2011). Türkiye'nin 1970'lerin sonuna kadar izlediği ithal ikameci sanayi modeline dayalı kalkınma stratejisi içinde kadınlar için asıl istihdam alanı tarım olmuş, sınai istihdam içindeki payları çok sınırlı kalmıştır. 1980'lerde yeni kalkınma stratejisi olarak ihraç yönelimli sanayileşme modeli içinde kadınların payı düşük düzeyde artmıştır. Tarımda uygulanan makro ekonomik politikalar sonucu olarak üretimin ve istihdamın gerilemesi hem erkek hem de kadın işgücü açığa çıkmış, fakat tarım dışı istihdamdaki büyüme özellikle kadınlar açısından bu gerilemeyi karşılayacak boyutta bir işgücü talebi yaratmamıştır. Bu durumdan en fazla etkilenen kesim, eğitim düzeyi düşük kadınlar olmuştur (Toksöz, 2011). Kandiyoti, cinsiyete dayalı işbölülümündeki değişimlerin niteliğini anlamak için hem cinsiyetler arasında önceden var olan ilişkilerin niteliğine, hem de sermayenin kırsal alanlara giriş biçimlerine bakmak gerektiğini ifade eder. Toprakta mülkiyet yapılarına, hanelerin tarımsal tabakalaşmadaki konumuna, tarımda mekanizasyonun derecesine, üretilen ürünün cinsine ve niteliğine ve üretim sürecinde emeğe duyulan ihtiyaca bağlı olarak kadın emeğinin kullanım yoğunluğu değişmektedir. Büyük toprak sahibi ailelerde ücretli işçi kullanma ve yeni teknolojilerden yararlanma imkanı ölçüsünde kadınlar üretim sürecinden çekilmekte olup, bu durum özellikle makinayla tahıl üretiminin yapıldığı Orta Anadolu bölgesinde gözlenmiştir. Diğer taraftan pamuk, tütün gibi emek yoğun ürünlerin piyasa için üretimine geçişle beraber Batı Anadolu'da görüldüğü gibi küçük topraklı veya topraksız köylü ailelerinde kadınlar ürün toplama ve çapalama aşamalarında daha yoğun emek harcarken, erkekler makine kullanımı ve ticari faaliyetlerde yoğunlaşmışlardır (Kandiyoti, 1997).

Türkiye'de kadın girişimciliği üzerine yapılmış akademik çalışmalar incelendiğinde olumlu bir tablo karşımıza çıkmaktadır. Çelebi ve Sallan (1994) kadın girişimcilerin cinsiyet rollerini araştırmış ve onların eşdeğer değerlere sahip olduklarını saptarlarken, kadınların ekonomik ve toplumsal değişimlere kolayca uyum sağladıklarını tespit etmişlerdir. Bircan (1998) kadın girişimciliğinin desteklenmesinin kadınlar arasındaki yüksek işsizlik oranlarının düşmesinde etkili olacağını ifade etmektedir. Bircan'a göre kadın girişimciliği bir taraftan yeni istihdam alanları yaratırken diğer taraftan da ürün çeşitliliğini ve ihracatı artırarak, yerel kaynakların harekete geçmesine yardımcı olabilecektir. Çelebi (1997) turizm sektöründeki küçük işyerlerinde kadın girişimciler üzerine yaptığ araştırmayı hedeflemiştir. Araştırmanın sonuçları kadınların beklenenden daha güçlü bir biçimde eşitlikçi tutum sergilediklerini göstermektedir. Özar (2002) Türkiye'de kadınların mikro ve küçük girişimcilik başarılarının önündeki engelleri dokuz kent kapsamında odak grup görüşmesiyle araştırmaktadır. Bu araştırmada kadınların girişimlerine başlarken gösterdikleri motivasyonları, neden benzer faaliyetlere yöneldiklerini, kültürel, sosyal, çevresel ve ekonomik engelleri analiz etmektedir. Ufuk ve Özgen (2001) ise Ankara'da 220 kadınla yüzyüze yaptıkları görüş̧melerle kadın girişimcilerin bir profilini çıkarmayı hedeflemişlerdir. Türkiye'de 2013 yılı 
itibarıyla 9 sakin şehir mevcuttur. Tüm bu şehirlerde özellikle yerel girişimlere yapılan vurgu kadınların bu sürece yapacakları katkının önemini bir kat daha artırmaktadır. Kadın girişimciliğin bu ve benzeri kentlerdeki örnekleri diğer kadınlara da cesaret vermektedir. Ev pansiyonculuğu, halıcılık, lokantacılık, çay ve kahvaltı salonu işletmeciliği, deri ve keçeden üretilen el sanatları, geleneksel lezzetler üzerine mekan işletmeciliği, konserve, tarhana, reçel, kurutulmuş sebze vb. üretme, organik tarım, hayvancılık gibi işlerin çoğu kadınların ev içi rollerinin yada becerilerinin devamı niteliğinde karşımıza çıkmaktadır. Kadınlar girşimcilik eğitimi almaları doğrultusunda kendilerini hem geliştirme fursatı bulurken, girişimci faaliyetlerde bulunmak isteyen diğer kadınlarla biraraya gelip güç birliği de yapabilmekte, bu girişimleri kooperatiflere dönüşebilmektedir. Çağımızın iletişim ve ulaşım olanaklarının çok geliştiği dikkate alınırsa kadın girişımcilerin özellikle ürün ve hizmetlerini pazarlamaları aşamasında bu olanaklardan daha etkin yararlanması etkiyi artıracaktır.

Sakin şehir olma ölçütleri arasında özellikle yerel üretimi koruma başlığında ele alındığı üzere organik tarımcılığın geliştirilmesi ve bölgede üretilen eşya ve el sanatlarının kalitesinin belgelendirilmesi önem kazanmaktadır. Kadın girişimciler bu alanda çalışmaları durumunda bu ön aşamanın gerçekleşmesi başarıyı da beraberinde getirecektir. Bunun yanında yöreye özgü ürünlerin, lezzetlerin tespit edilmesi önem taşımaktadır. Geleneksel tatların hem korunması hem de bunların piyasada talep edilir hale gelebilmesi için uygun mekanların oluşturulması anlamında teşvikler yapılmalıdır. Sakin şehirlerde kadın girişimciliğinin geliştirilmesi için misafirperverlik konusunda turist bilgisi ve nitelikli misafirperverlik için eğitimler verilmelidir. Girişimcilerin ücret şeffaflığı ve fiyatların müessese dışında sergilenmesi gerekliliği konusunda bilinçlendirilmesi gerekmektedir. Tüm bunların yanında önce sakin şehirlerde yaşayan vatandaşlar farkındalığı ve bu anlayışın sürdürülebilirliği anlamında bilinçlendirme önem taşımaktadır.

\section{Sonuç}

Bir taraftan küreselle yerel, modernle geleneksel olanı sentezleyerek insan ilişkilerini ve çevreyi öne çıkararak, birliktelik anlayışına dayanan sakin şehir modeli aynı zamanda yerel bir kalkınma modeli de sunmaktadır. Dünyada ilk örneklerinin İtalya'da görüldüğü sakin şehir hareketi ülkemiz açısından değerlendirildiğinde Türkiye'nin büyük bir potansiyele sahip olduğu açıktır. Uluslararası boyutta giderek önem kazanan ve Seferihisar'ın öncülük ettiği sakin şehirlerin Türkiye'de sayıca artması önümüzdeki yıllarda olasıdır. Bu süreçte hem girişimci olarak hem de karar mekanizmalarında söz sahibi kişiler olarak kadınların daha aktif roller üstlenmesi gerekmektedir. Böylelikle kadın emeğinin daha görünür hale gelmesi, kadının ekonomik ve sosyal statüsünün gelişmesi mümkün hale gelecektir. Girişimcilik ve turist bilgisi konularında kadınların eğitilmesi ve desteklenmesi öncelik taşımaktadır.

\section{Kaynakça}

- http://cittaslow.org/section/association.

- http://www.cittaslow.org/download/DocumentiUfficiali/CITTASLOW_LIST_4_2013.pdf.

- http://www.cittaslowturkiye.org/index.php?option=com_content\&view=article\&id=75\&Itemid =486.

- http://www.habitat.org.tr/sakin-sehirler/727-sakin-sehir-seferihisar.html.

- http://www.cittaslowturkiye.org/.

- http://www.cittaslowseferihisar.org/.

- $\quad$ Bilgi, Merve Görkem, 2013. “Türkiye'nin Sakin Şehirlerinde Permakültürel Koruma, Planlama, Yönetim ve Eğitim Pratikleri”, Selçuk Üniversitesi Sosyal Bilimler Enstitüsü Dergisi, 29, ss. 45-59.

- Bircan, İsmail, 1998. “Türkiye’de İş Gücü Piyasasında Kadın ve Kadın Girşimciliği” içinde O. Çitci (Ed.), 20. Yüzyılın Sonunda Kadınlar ve Gelecek Konferansı Bildirileri, TODAİE Yayınları, Ankara.

- $\quad$ Çelebi, Nilgün ve Sallan, Songül, 1994. Turizm Sektöründeki Küçük Işyerlerinde Kadın Girişimciler, Kadının Kalkınmaya Katılımını Güçlendirme Ulusal Programı Proje Raporu, Ankara.

- Çelebi, Nilgün, 1997. Turizm Sektöründeki Küçük İşyerlerinde Kadın Girişimciler, T.C. Başbakanlık, KSSGM, Ankara.

- Çiner, C. U., 2011. “CittàSlow Hareketi ve Türkiye'deki Uygulamaları”, Memleket Mevzuat, (71): 12-23.

- Eskicioğlu, Hakkı, 2009. "Modern Yaşam ile Geleneksel Yaşam Arasında Kaliteli Bir Yaşam Biçimi-Yavaş Şehirler," http://www.izmirdesanat.org/yavas-sehirler, (erişim: 03.06.2013).

- Fullagar, Simone, Markwell, Kevin and Wilson, Erica, 2012. Slow Tourism: Experiences and Mobilities, UK: Short Run Press Ltd.

- Kandiyoti, Deniz, 1997. "Kadınlar ve Haneiçi Üretim: Türkiye’de Kırsal Dönüşümün Etkileri” içinde Kandiyoti, Deniz, Cariyeler, Bacılar, Yurttaşlar, Metis Yayınları, İstanbul.

- Karabağ, Özgür, Yücel, Fatih, İnal, Emin, M., 2012. Cittaslow Movement: An Opportunity for Branding Small Towns and Economic Development in Turkey, International Joural of Economic Research, v3i3, 6475.

- Kavas, Gökhan ve Kavas, Nazan, 2012. "Slow Food (Yavaş Yemek) ve Cittàslow (Yavaş Şehir)”, Dünya

- $\quad$ Glda, Say1: 74, http://www.dunyagida.com.tr/yazar.php?id=11\&nid=2849, (erişim: 03.06.2013). 
- Knox, Paul, K., 2005. "Creating Ordinary Places: Slow Cities in a Fast World”, Journal of Urban Design, 10:1, 1-11.

- Mayer, Heike, Knox, Paul, 2009. "Pace of Life and Quality of Life: A Slow City Charter”, M. J. Sirgy et al. (eds.), Community Quality-of-Life Indicators: Best Cases III, Community Quality-of-Life Indicators: Best Cases Series, 1. Springer Science+Business Media B.V.

- Miele, Mara, 2008. "CittàSlow: Producing Slowness against the Fast Life", Space and Polity, 12 (1): 135 156.

- Özar, Şemsa, 2002. "Barriers to Women's Micro and Small Enterprise Success in Turkey”, Draft Research Paper, Center for Policy Studies, Central European University and Open Society Institute.

- Öztürk, Songül, 2012. "Small Towns Reshaping Their Urban Planning Policies Joining in the Cittaslow International Network: The Case of Seferihisar”, M.S., METU; Urban Policy Planning and Local Governments.

- Ritzer, George, 2011. Toplumun McDonaldlaştırılması- Çağdaş Toplum Yaşamının Değişen Karakteri Üzerine Bir İnceleme, 2. Baskı, (Çev. Şen Süer Kaya), Ayrıntı Yayınları, İstanbul.

- $\quad$ Ritzer, George, 2004. McDonaldization of Society, Thousand Oaks: Pine Sciences Press.

- Sırım, Veli, 2012. 'Çevreyle Bütünleşmiş Bir Yerel Yönetim Örneği Olarak 'Sakin Şehir' Hareketi ve Türkiye'nin Potansiyeli”, Türk Tarih ve Sanat Araştırmaları Dergisi, Vol. 1, No. 4, ss. 119-131.

- Slow Magazine, http://cittaslownews.files.wordpress.com/2009/08/newcharter.pdf. (24.05.2013).

- Şahinkaya, Serdar, 2010. "Bir Yerel Kalkınma Modeli: Cittaslow ve Seferihisar Üzerine Değerlendirmeler”, http://www.bagimsizsosyalbilimciler.org/Yazilar_Uye/SahinTem10.pdf (erişim: 04.06.2013).

- Şarman, Çağnur, 2011. "Seferihisar: Yavaş Şehir”, Atlas, 222 (9), 71-86.

- Toksöz, Gülay, 2011. Kalkınmada Kadın Emeği, Varlık Yayınları, İstanbul.

- Tuvi, Reyan, 2010. Mavi Tatil, Doğuş Yayın Grubu, İstanbul.

- Ufuk, Hatun ve Özgen, Özlen, 2001. "The Profile of Women Entrepreneurs: A Sample from Turkey”, International Journal of Consumer Studies, 25, 299-308.

- Yurtseven, H. Rıdvan, 2007. Slow Food ve Gökçeada: Yönetsel Bir Yaklaşım, Detay Yayıncılık, Ankara. 


\title{
Dünya'ya Kıyasla Türkiye'de Kadın Girişimciliği Women's Entrepreneurship in Turkey Compared to the World
}

\author{
Ph.D. Candidate Gülay Tamer (Medislim Health Center, Turkey)
}

\begin{abstract}
In recent years, it is strategically important for developing economies that women contribute into working areas and entrepreneurship activities because the way to create new job areas and activate unused potential in business is attached to encouragement of the women entrepreneurship. Giving priority to the policies and strategies that help women exist in business contributes to the economic and social development significantly. However, women encounter important obstacles within the entrepreneurship activities.Entrepreneurship has been speeding up in today's world and this project aims at comparing the women entrepreneurship between Turkey and the world, the obstacles women come across in entrepreneurship and the opportunities created by women in theoretical framework.
\end{abstract}

\section{Giriș}

Küreselleşme, işletmelerin ve girişimcilerin daha şiddetli bir rekabet ortamında çalışmaları sonucunu doğurmuştur. Çünkü kapalı ekonomi döneminin dış rekabete karşı devletçe korunan işletmecilik anlayışı yerini müşteri odaklı, sürekli kendini yenileyen, esnek ve hızlı üretim ve yönetim anlayışına bırakmıştır. Bu anlayışı tüm ekonomik hayata uygulayabilmenin yolu ise etkin girişimcilik faaliyetinden geçmektedir. Özellikle dünyadaki gelir dağılımındaki adaletsizlik, ekonomik gelişmişlik açısından bölgesel farklar, giderek artan işsizlik, yoksullaşma, yeterince büyüyememe ve etkin bir rekabet ortamının oluşturulamaması girişimcilik faktörüne günümüz dünyasında hayati bir önem kazandırmıştır. Bu bağlamda girişimcilik ile üretim ve dağıtım faaliyetleri gerçekleştirilerek bölge ve ülke kalkınmasında ekonomik bir temel yaratılır. Bunun yanında girişimciliğin, bilim ve piyasa arasındaki boşluğu kapatmanın, yeni iş yaratmanın ve piyasaya yeni mal ve hizmet sunmanın en etkili yolu olduğu söylenebilir. Gelişmiş ve gelişmekte olan ülkelerde girişimciliğin özendirilmesine özel bir önem verilmektedir. Avrupa Birliği’nde küçük işletmelerin geliştirilmesi, rekabet gücünün arttırılması, uluslararası ve girişimcililiğin özendirilmesi amacıyla bir dizi destekleme programları geliştirilmiştir. Aynı şekilde Türkiye'de de son yıllarda girişimcilik kültürünün gerek bireysel bazda gerekse kurumsal ölçekte geliştiği, yaygınlaştığ 1 ve teşvik edildiği bilinmektedir. Son teknolojik gelişmeler ve ekonomik beklentiler sayesinde girişimciliğin daha da güç kazandığı söylenebilir. Özellikle 1980'lerden itibaren hızlı bir gelişme gösteren girişimcilik anlayışı, erkekler kadar kadınlarında ilgi alanı içerisine girmiştir. Son yıllarda dünyada çalışanların demografik yapısında görülen birçok değişiklik kadınları da etkileyerek onları iş yaşamının vazgeçilmez aktörleri haline getirmiştir. Sanayi Devrimi'ne kadar kadınların görevleri çok belirgin bir şekilde ev veya el işi olarak belirlenmişken, sonraki dönemlerde kadınların toplumdaki yerinde anlamlı değişimler olmuştur. İşgücüne katılan kadınlar çoğalmış, çalışan karı-koca sayısında yükselme meydana gelmiş ve ailenin geçimini tek başına sağlayan anneler daha sık görülmeye başlanmıştır. Uluslararası rakamlara bakıldığında, kayıtlı ekonomi içindeki şirketlerin yüzde 25-33'ünün sahiplerinin kadın olduğu görülmektedir. Yine Dünya Bankası'nın yedi Orta Doğu ülkesinde yapmış olduğu bir çalışmada, toplam 4000 şirketin sahiplerinin \%13'ünün kadın olduğu belirlenmiştir. Araştırmalar, global kadın işgücündeki en yüksek artışın endüstrileşmiş ülkeler olduğunu gösterirken, en düşük artışı sergileyenlerin ise zaten işgüçlerinde büyük sayıda kadın bulunan Doğu Avrupa Ülkeleri olduğunu belirtmektedir. Böylece yalnızca profesyonel anlamda çalışan kadınlarda değil, kadın girişimciliğinde de artışların olduğu söylenebilir. Bu durum Türkiye açısından değerlendirildiğinde, 1995-2009 arasındaki dönemde kadınların kırsal alanda işgücüne katılım oranı, \%49.3’ten \%35.7'ye düşerken, kentlerde \%17.1'den \%21.3'e çıkmıştır (TÜİK, 2007; TÜİK, 2009). Yani çalışmak isteyen kadın sayısının özellikle kentlerde görevli olarak hızla arttığı söylenebilir. Bu durum, kadınların tarımsal faaliyetlerden çok ticari ve ekonomik arenada daha bilinçli girişimcilik faaliyetlerine yöneldiğini göstermesi açısından önemlidir (Bedük, 2005). Yine toplam 42 ülkede yapılan Küresel Girişimcilik Araştırması'nda (2007), Türkiye'deki kadınların işgücüne katılımı 2006 yılında \%30 iken 2007 yılında bu oranın \%24'e gerilediği ve Türkiye'deki erkeklerin kadınlardan üç kattan daha fazla girişimci olduğu belirlenmiştir. Her ne kadar kadınların erkeklere göre işgücüne katılımı ve girişimcilik faaliyetleri konusunda istenen seviyede olamadığı bir gerçek olsa da, kadınların her geçen gün ekonomik hayatta daha etkin hale gelmeye başladığı bilinen bir gerçektir. Ülkemizde; ekonomik büyütmede, istihdamı arttırmada ve kalıcı bir üretim ve pazarlama anlayışı ile dünya ölçeğinde faaliyet gösteren işletmeler yaratmada, kadın girişimcilerin önemli bir rol oynayabileceği dikkate alınmalıdır. Türk iş dünyasında zengin olmanın, kullanılmayan potansiyeli etkin hale getirmenin ve yeni iş sahaları oluşturmanın yolunun, kadınların girişimciliğinin teşvik edilmesinden geçtiğini ifade edebiliriz. Kadınların, ekonomik ve sosyal yaşamdaki potansiyellerini harekete geçirecek gücü kendilerinde görmeleri gerekmektedir. Ancak bu düşüncelerin başarılı olabilmesi için kadın girişimcilerin karşılaştıkları engelleri, çalışma koşullarını, yönetim biçimlerini, işlerini kurma ve geliştirme stratejilerini, gelecek yönelimlerini ve örgütsel ve çevresel firsatları 
değerlendirme potansiyellerini ortaya koyan kapsamlı araştırmalara gerek vardır. Bu çalışmada, girişimciliğin hız kazandığı günümüz dünyasında, kadınların Türkiye perspektifinden, girişimcilik faaliyetlerinde karşılaştıkları engelleri ve yaratacakları firsatları kuramsal bir çerçevede ele almak amaçlanmıştır.

Bu Proje Kadın Girişimciliğinin Dünya'da ve Türkiye'deki durumunun İncelenmesi ve Değerlendirilmesi amacıyla hazırlanmıştır (Özçelik, 2008).

\section{Dünya'da ve Türkiye'de Kadın Girişimciliği}

\subsection{Kadın Girişimciliği ve Mikro İșletmecilik Kavramı}

Ev dışı bir mekanda, kendi adına kurduğu bir işletmesi olan, bir işletmede tek başına veya çalıştırdığı diğer kişilerle birilikte çalışan veya sahibi olması sıfatıyla ortaklık kuran, iş ile ilgili olarak çeşitli kamu ve özel kuruluşlarla temaslara geçen, işletmenin geleceği ile ilgili planlar yapan, işletmeden elde ettiği kazancı, yatırım ve kullanım alanları üzerinde söz sahibi olan, işletmesi adına tüm riski üstlenen kadındır. Bu bağlamda kendi mesleğini icra eden kadınlar eğitimini gördükleri alanlarda herhangi bir riske girmeden çalıştıkları için girişimci olarak kabul edilmemektedirler. Yapılan çalışmalarda kadın girişimcileri tanımlayan kişisel karakteristikler; dinamik, bağımsız, özgüvenli, rekabetçi ve amaç yönelimli olmalarıdır. Ayrıca girişimcilik faaliyetini sürdüren kadınlar hırslı olma, risk alma, kendi işini kontrol etme gibi özellikler çerçevesinde de betimlenmektedir. Küreselleşme, işletmelerin ve girişimcilerin daha şiddetli bir rekabet ortamında çalşsmaları sonucunu doğurmuştur. Çünkü kapalı ekonomi döneminin diş rekabete karşı devletçe korunan işletmecilik anlayışı, yerini müşteri odaklı, sürekli kendini yenileyen, esnek ve hızlı üretim ve yönetim anlayışına bırakmıştır. Bu anlayışı tüm ekonomik hayata uygulayabilmenin yolu ise etkin girişimcilik faaliyetinden geçmektedir. Özellikle dünyadaki gelir dağılımındaki adaletsizlik, ekonomik gelişmişlik açısından bölgesel farklar, giderek artan işsizlik ve yoksullaşma, yeterince büyüyememe ve etkin bir rekabet ortamının oluşturulamaması girişimcilik faktörüne günümüz dünyasında hayati bir önem kazandırmıştır. Bu bağlamda girişimcilik ile üretim ve dağıtım faaliyetleri gerçekleştirilerek bölge ve ülke kalkınmasında ekonomik bir temel yaratılır. Bunun yanında girişimciliğin, bilim ve piyasa arasındaki boşluğu kapatmanın, yeni iş yaratmanın ve piyasaya yeni mal ve hizmet sunmanın en etkili yolu olduğu söylenebilir. Gelişmiş ve gelişmekte olan ülkelerde girişimciliğin özendirilmesine özel bir önem verilmektedir. Avrupa Birliği'nde küçük işletmelerin geliştirilmesi, rekabet gücünün arttırılması, uluslar arası ve girişimcililiğin özendirilmesi amacıyla bir dizi destekleme programları geliştirilmiştir. Aynı şekilde Türkiye'de de son yıllarda girişimcilik kültürünün gerek bireysel bazda gerekse kurumsal ölçekte geliştiği, yaygınlaştığı ve teşvik edildiği bilinmektedir. Son teknolojik gelişmeler ve ekonomik beklentiler sayesinde girişimciliğin daha da güç kazandığı söylenebilir Özellikle 1980'lerden itibaren hızlı bir gelişme gösteren girişimcilik anlayışı, erkekler kadar kadınlarında ilgi alanı içerisine girmiştir. Son yıllarda dünyada çalışanların demografik yapısında görülen birçok değişiklik kadınları da etkileyerek onları iş yaşamının vazgeçilmez aktörleri haline getirmiştir. Sanayi Devrimi'ne kadar kadınların görevleri çok belirgin bir şekilde ev veya el işi olarak belirlenmişken, sonraki dönemlerde kadınların toplumdaki yerinde anlamlı değişimler olmuştur. İşgücüne katılan kadınlar çoğalmış, çalışan karı-koca sayısında yükselme meydana gelmiş ve ailenin geçimini tek başına sağlayan anneler daha sık görülmeye başlanmıştır. Uluslararası rakamlara bakıldığında, kayıtlı ekonomi içindeki şirketlerin yüzde 2533'ünün sahiplerinin kadın olduğu görülmektedir. Yine Dünya Bankası'nın yedi Orta Doğu ülkesinde yapmış olduğu bir çalışmada, toplam 4000 şirketin sahiplerinin \%13'ünün kadın olduğu belirlenmiştir. Araştırmalar, global kadın işgücündeki en yüksek artışın endüstrileşmiş ülkeler olduğunu gösterirken, en düşük artış1 sergileyenlerin ise zaten işgüçlerinde büyük sayıda kadın bulunan Doğu Avrupa Ülkeleri olduğunu belirtmektedir. Dolayısıyla yalnızca profesyonel anlamda çalışan kadınlarda değil, kadın girişimciliğinde de artışların olduğu söylenebilir.

\subsection{Kadınları Girişimci Olmaya İten Nedenler}

Kadınların iş kurma nedenlerine bakıldı̆̆ında "itme ve çekme" faktörlerinin önemli rol oynadığı söylenebilir. Buna göre kadınları iş kurmaya iten faktörler arasında; ülkenin ekonomik koşullarından kaynaklanan işsizlik sorunları, kadınlara uygun olmayan iş koşulları ve kadınların özellikle ücretli işlerde cinsiyet ayrımcılığına uğramaları sayılabilmektedir. Bağımsızlık isteği, kendini gerçekleştirme isteği, kendi işinin patronu olma, aile ve iş sorumluluğu arasındaki dengeyi kurma isteği gibi çekme faktörleri de kadınları iş kurmaya yönelten faktörler arasında sayılabilmektedir. Buna göre kadını girişimci olmaya hem iten hem de çeken farklı faktörlerin olduğu söylenebilir. Kadınları girişimci olmaya iten nedenleri şu şekilde sıralamışıı. Sosyo-kültürel yapıdaki değişim sonucu öğrenim düzeyi yükselen kadının daha fazla sayıda işgücüne katılması, şirketlerin orta yönetim kadrolarında yer alan kadınların, çalışıkları işletmelerin personel azaltma politikalarından etkilenebilecekleri Türkiye'de Kadın Girişimciler: Engeller ve Fırsatlar Bağlamında Bir Değerlendirme düşüncesiyle, kendi işlerini kurarak kendi kendilerinin patronları olmayı yeğlemeleri, her geçen gün başarılı kadın girişimci sayısının artması ile kadınların kendilerine rol modeli olarak aldıkları kişi sayısının çoğalması ve işlerini kaybetmeyecek kadar şanslı olan kadınların bir süre sonra şirket hiyerarşisinde daha üst kademelere çıkmalarının önüne set çeken, sırf cinsiyetlerinden ötürü daha sorumlu pozisyonlara gelmelerini engelleyen "cam tavan" etkisi nedeniyle yükselme olanakları kalmayan kadınların, her şeye karşın potansiyellerini ortaya koyma, kendilerini gerçekleştirmek ve başarılarını kanıtlamak için kendi işletmelerini kurma ve geliştirme çabaları. Kadınları girişimci olmaya iten bir 
diğer neden ise hükümetler tarafından kadınların yerel ekonomiyi kalkındırmada önemli bir aktör olarak görülmesi politikasıdır. Bu politikada özellikle yerel aktörler içersinde yer alan potansiyel kadın girişimcilerin yönlendirilmesi, teşvik edilmesi ve güçlendirilmesi öngörülmektedir. Böylece özellikle kırsal alanda ekonomik faaliyetlerde yeterince yer alamayan kadınların mikro finansman yöntemi ile gelir elde etmelerinin sağlanması amaçlanmıştır. Çünkü iş hayatında erkeklere göre kadınların yeterli öz sermayeye sahip olmadığı veya başlangıç için gerekli finansmana ulaşamadığı bir gerçektir. Mersin'de kadın girişimciler üzerinde yapılan araştırmada, kadınların \%70'inin kuruluş aşamasında güvensizlik, prosedürlerin zorluğu gibi nedenlerle banka kredisine başvurmadıkları ve \%60'ının ise işletmelerinde sermaye sıkıntısı çektikleri belirlenmiştir. Bu durum dikkate alındığında mikro finansman sisteminin işletmenin gerek kuruluş aşamasında ve gerekse faaliyet döneminde ne kadar önemli olduğu ortaya çıkmaktadır. Dünya nüfusunun \%20'sini oluşturan yaklaşık 1.2 milyar insanın günde 1 dolarlık mutlak yoksulluk sınırının altında http://siteresources.worldbank.org) yaşamaya çalıştı̆̆ı günümüzde, "mikro finansman sistemi”" özellikle kırsal alanda yoksulluğu azaltmak, geliri arttırmak ve istihdamı desteklemek üzere tasarlanmış birçok müdahale stratejilerinden biri olarak görülmektedir.Böylece zamanla yoksul kişilerin ve özelliklede kadınların kendi işine başlaması için mikro finansman bir seçenek olarak da değerlendirilmektedir.Kadınların iş kurma nedenleri ile ilgili Mersin'de 160 girişimci kadın üzerinde yapılmış araştırmada; kazanç elde etmek, bağımsız çalışma ve sosyal yaşam sürme istekleri gibi faktörlerin ön plana çıktığı belirlenmiştir. Kocanın ölmesi, kendini ispat etme ve geçmiş mesleki tecrübelerin ticari hayata aktarılması gibi faktörlerin etkili olduğu tespit edilmiştir (Özdevecioğlu ve Çelik, 2001).

\subsection{Türkiye'de Kadın Girișimciliği ve Mikro ișletmecilik}

Türkiye'de kadın girişimci çalışmalarının yapılmasında, gelişmiş ülkelerden başlayarak artış gösteren kadın girişimci sayısı ve $\mathrm{AB}$, $\mathrm{OECD}$, $\mathrm{BM}$ gibi uluslararası kuruluşların kadın girişimciliğini destekleyici ve yaygınlaştırıcı politikalar izlemesi etkili olmuştur. Fakat buna rağmen ülkemizde, Batı'lı ülkelerde olduğu kadar kadın girişimciliğinde önemli gelişmeler olmamış veya oldukça yavaş olmuştur. Türkiye'de ancak 1980'li yıllardan itibaren kadınların işgücüne katılımı konusunda yapılan çalışmalar yoğunluk kazanmış ve 1990' 1 ı yıllarda da bu çalışmalar belli bir düzeye ulaşmış̧ır. Son yıllarda medyanın da yardımıyla kadın girişimcilere olan ilgi artmıştır. Kadın girişimciliğgine yönelik olan bu ilgi, özellikle gelişmekte olan ülkelerde benimsenen ihracata yönelik kalkınma stratejileri ile yakından ilişkilidir. Gelişmekte olan ülkelerin ithal ikamesi politikasında yaşanan sorunlar, yurt içi kaynak kullanarak küresel pazarla bütünleşme yollarının aranmasına neden olurken, kullanılan girdiler açısından ithalata bağımlı olmayan emek yoğun sektörlerin ve bu sektörlerde istihdam edilen "kadın emeğinin önemini artırmıştır". Yukarıda da belirtildiği gibi Türkiye gibi gelişmekte olan ülkelerde kadın girişimciliği üzerine yapılan çalışmaların oldukça sınırlı olması bu tür ülkelerde kadın girişimcilerin rolünün ve etkinliğinin ne oranda olduğunu anlamada sorun oluşturabilmektedir. Bununla birlikte Türkiye'de kadınların ekonomik faaliyetlere katılımlarının sınırlı olması genellikle; aile içindeki rol, bu role bağlı tercihler ve aile içindeki ataerkil ilişkilerle açıklanmaya çalışılmıştır. Kadınların Türkiye'de girişimcilik faaliyetleri temelde yapısal uyum politikalarının etkisiyle azalan hane gelirlerine yönelik geliştirilen "kadınların kendi başlarına kü̧̧ük işyeri kurma girişimlerine" dayanmaktadır. Kadınların gerek haneye ek gelir sağlamak ve gerekse ücretli işlerde çalı̧̧ma çabalarının artması onların ekonomik faaliyetlere girişini hızlandırmıştır. Fakat Türkiye'de özellikle başvurulan işlere uygun eğitim ve becerisi olmayan kadınların iş bulma şanslarının son derece zayıf olması, zorunlu olarak kadınları kendi işinde çalışmaya sevk etmiş̧ir. Türkiye'de kadınları girişimci olmaya iten nedenlerin, kadınların daha özgürlükçü ve eşitlikçi değerlere sahip olmaya başladıkları ayrıca; Türkiye'de Kadın Girişimciler; engeller ve firsatlar bağlamında bir değerlendirme, güvendikleri çeşitlenen mal ve hizmet piyasasında kendilerine daha uygun işler bulabildikleri gibi faktörler olmadığı aksine ülkenin makro ekonomik koşullarının hane halkı geliri üzerinde yarattığı olumsuz etkileri azaltmanın bir çabası olduğu ifade edilebilir. Kadınların işlerini daha çok yalnız başlarına kurdukları, işlerini büyük ölçüde sevdikleri için yaptıkları, büyük bir bölümünün herhangi bir ticari ve iş deneyimine sahip olmadan işlerini kurdukları, başlangıç sermayelerini ise daha çok aile ve akrabalardan temin ettikleri tespit edilmiştir. Kadınların mücadeleci, hırslı, evine iş götüren ve kendileri için erişilmesi zor hedefler belirleyen yapıda oldukları bulgularına ulaşılmıştır. Türkiye'de 1990'lı yıllardan itibaren kadın çalışanlar ile ilgili yapılan çalışmalar özetlenecek olursa; iş kadınlarının yarısından fazlasının ticaret sektöründe girişimci olduğu, genellikle 30-39 yaş diliminde yer aldığı ve yarısına yakınının eğitim düzeyinin sadece lise eğitimi düzeyinde kaldığı ve genellikle kentli oldukları belirlenmiştir. Türkiye'de girişimci kadınları belirleyen temel karakteristikler ise; kendine güvenli, cesaretli ve sabırlı olmasıdır. Kadınlar, erkek girişimcilerle karşılaştırıldığında kârdan çok sosyal itibara önem vermekte, risk almada erkek girişimcilere oranla daha temkinli hareket etmekte ve daha az özgüvenli bulunmaktadırlar. Bu bağlamda Türkiye'de işverenler içerisinde kendi işini kuran ve girişimcilik faaliyetleri içerisinde olan kadınların oranı $\% 13$ olarak belirlenmiştir. Türkiye'de kadınları girişimci yapmaya yönelik çalışmaların oldukça çeşitli olduğu söylenebilir. Kadın girişimciliğini destekleme ve geliştirme kapsamında dönemini kapsayan Dokuzuncu Kalkınma Planı'nda kadın girişimciliğinin desteklenmesi amacıyla birtakım tedbirler alınmıştır. Kadın girişimciliğinin desteklenmesi amacıyla bankalar kredi programlarını daha etkin hale getirmişlerdir. Yukarıda da ismi geçen kamu kuruluşları, meslek örgütleri ve sivil toplum kuruluşları tarafından kadın girişimciliğini arttırmaya yönelik uygulamaya aktarılan ve yürütülen projeler de bu kapsamda ifade edilebilir (Gürol ve Marşap, 2007). 


\title{
3 Dünya'da ve Türkiye'de Kadın Girişimciliğinin Kıyaslı Değerlendirilmesi
}

\author{
"Toplumdaki başarısızlı̆̆ın nedeni, kadınlarımıza karşı gösterdiğimiz ihmal ve kusurdan doğmaktadır” \\ (Mustafa Kemal Atatürk, 1923).
}

Kadın Girişimciliği: Türkiye açısından değerlendirildiğinde, 1995-2009 arasındaki dönemde kadınların kırsal alanda işgücüne katılım oranı, \%49.3'ten \%35.7'ye düşerken, kentlerde \%17.1'den \%21.3'e çıkmıştır. Yani çalışmak isteyen kadın sayısının özellikle kentlerde göreli olarak hızla arttığı söylenebilir. Bu durum, kadınların tarımsal faaliyetlerden çok ticari ve ekonomik arenada daha bilinçli girişimcilik faaliyetlerine yöneldiğini göstermesi açısından önemlidir. Yine toplam 42 ülkede yapılan Küresel Girişimcilik Araştırması'nda Türkiye'deki kadınların işgücüne katılımı 2006 yılında \%30 iken 2007 yılında bu oranın \%24'e gerilediği ve Türkiye'deki erkeklerin kadınlardan üç kattan daha fazla girişimci olduğu bulgulanmıştır. Her ne kadar kadınların erkeklere göre işgücüne katılımı ve girişimcilik faaliyetleri konusunda istenen seviyede olamadığı bir gerçek olsa da, kadınların her geçen gün ekonomik hayatta daha etkin hale gelmeye başladığı ise bilinen bir gerçektir. Özellikle kırılgan bir ekonomiye sahip olan ülkemizde, ekonomiyi büyütmede, istihdamı arttırmada ve kalıcı bir üretim ve pazarlama anlayışı ile dünya ölçeğinde faaliyet gösteren işletmeler yaratmada, kadın girişimcilerin önemli bir rol oynayabileceği dikkate alınmalıdır. Nitekim Türk iş dünyasında zengin olmanın, kullanılmayan potansiyelin etkin hale getirmenin ve yeni iş sahaları oluşturmanın yolunun açılması gereklidir. Bu bağlamda, kadınların da üretim yaşamı içine katılımını arttırmak için kadın girişimcileri destekleyen politika ve programların ön plana çıkması, kadınların, ekonomik ve sosyal yaşamdaki potansiyellerini harekete geçirecek gücü kendilerinde görmeleri gerekmektedir. Ancak bu program ve düşüncelerin başarılı olabilmesi için kadın girişimcilerin karşılaştıkları engelleri, çalışma koşullarını, yönetim biçimlerini, işlerini kurma ve geliştirme stratejilerini, gelecek yönelimlerini ve örgütsel ve çevresel firsatları değerlendirme potansiyellerini ortaya koyan kapsamlı araştırmalara gerek vardır. Bu çalışmada, girişimciliğin hız kazandığı günümüz dünyasında, kadınların Türkiye perspektifinden, girişimcilik faaliyetlerinde karşılaştıkları engelleri ve yaratacakları firsatları kuramsal bir çerçevede ele almak Kadınların Özellikle 1980’lerden itibaren hızlı bir gelişme gösteren girișimcilik anlayışı, erkekler kadar kadınlarında ilgi alanı içerisine girmiştir. Son yıllarda dünyada çalışanların demografik yapısında görülen birçok değişiklik kadınları da etkileyerek onları iş yaşamının vazgeçilmez aktörleri haline getirmiştir. Sanayi Devrimi’ne kadar kadınların görevleri çok belirgin bir şekilde ev veya el işi olarak belirlenmişken, sonraki dönemlerde kadınların toplumdaki yerinde anlamlı değişimler olmuştur. İşgücüne katılan kadınlar çoğalmış, çalışan karı-koca sayısında yükselme meydana gelmiş ve ailenin geçimini tek başına sağlayan anneler daha sık görülmeye başlanmıştır. Uluslararası rakamlara bakıldığında, kayıtlı ekonomi içindeki şirketlerin yüzde 25-33'ünün sahiplerinin kadın olduğu görülmektedir. Yine Dünya Bankası'nın yedi Orta Doğu ülkesinde yapmış olduğu bir çalışmada, toplam 4000 şirketin sahiplerinin \%13'ünün kadın olduğu belirlenmiştir. Araştırmalar, global kadın işgücündeki en yüksek artışın endüstrileşmiş ülkeler olduğunu gösterirken, en düşük artış1 sergileyenlerin ise zaten işgüçlerinde büyük sayıda kadın bulunan Doğu Avrupa Ülkeleri olduğunu belirtmektedir. Dolayısıyla yalnızca profesyonel anlamda çalışan kadınlarda değil, kadın girişimciliğinde de artışların olduğu söylenebilir. . Yani çalışmak isteyen kadın sayısının özellikle kentlerde göreli olarak hızla arttığı söylenebilir. Bu durum, kadınların tarımsal faaliyetlerden çok ticari ve ekonomik arenada daha bilinçli girişimcilik faaliyetlerine yöneldiğini göstermesi açısından önemlidir. Toplam 42 ülkede yapılan Küresel Girişimcilik Araştırması'nda Türkiye'deki kadınların işgücüne katılımı 2006 yılında \%30 iken 2007 yılında bu oranın \%24'e gerilediği ve Türkiye'deki erkeklerin kadınlardan üç kattan daha fazla girişimci olduğu bulgulanmıştır. Her ne kadar kadınların erkeklere göre işgücüne katılımı ve girişimcilik faaliyetleri konusunda istenen seviyede olamadığı bir gerçek olsa da, kadınların her geçen gün ekonomik hayatta daha etkin hale gelmeye başladığı ise bilinen bir gerçektir. Özellikle kırılgan bir ekonomiye sahip olan ülkemizde, ekonomiyi büyütmede, istihdamı arttırmada ve kalıcı bir üretim ve pazarlama anlayışı ile dünya ölçeğinde faaliyet gösteren işletmeler yaratmada, kadın girişimcilerin önemli bir rol oynayabileceği dikkate alınmalıdır. Türk iş dünyasında zengin olmanın, kullanılmayan potansiyelin etkin hale getirmenin ve yeni iş sahaları oluşturmanın yolunun, kadınların girişimciliğinin teşvik edilmesinden geçtiği ifade edilmektedir. Bu bağlamda, kadınların da üretim yaşamı içine katılımını arttırmak için kadın girişimcileri destekleyen politika ve programların ön plana çıkması ve kadınların, ekonomik ve sosyal yaşamdaki potansiyellerini harekete geçirecek gücü kendilerinde görmeleri gerekmektedir. Ancak bu program ve düşüncelerin başarılı olabilmesi için kadın girişimcilerin karşılaştıkları engelleri, çalışma koşullarını, yönetim biçimlerini, işlerini kurma ve geliştirme stratejilerini, gelecek yönelimlerini ve örgütsel ve çevresel firsatları değerlendirme potansiyellerini ortaya koyan kapsamlı araştırmalara gerek vardır. Bu çalışmada, girişimciliğin hız kazandığı günümüz dünyasında, kadınların Türkiye perspektifinden, girişimcilik faaliyetlerinde karşılaştıkları engelleri ve yaratacakları firsatları kurumsal bir çerçevede ele almak amaçlanmıştır (Nayır, 2008).

\subsection{Ekonomik Kalkınmada Kadın Girişimciliğinin Stratejik Etkisi}

Kadınlar tarih boyunca hemen hemen her dönemde içinde yaşadıkları toplumun özelliklerine göre değişen şartlarda ekonomik faaliyetlere katılmışlardır. Özellikle sanayileşme ile bu sürecin hızlandığ söylenebilir. Gerçekten, 21. yüzyıla doğru hızla ilerlerken her alanda kendini gösteren değişim ve gelişmeler çerçevesinde kadınların bir zamanlar sadece erkeklere açık olan iş dünyasına girdikleri ve bu dünyada güç, yetki, mevkii elde 
etmek için yoğun bir mücadele verdikleri gözlenmektedir. Çalışma yaşamında küreselleşme çerçevesinde yaşanılan değişimler ve yeni değerler, iş dünyasında erkek hakimiyetinin kırılarak kadının güçlenmesine neden olmuştur. Özellikle küreselleşme ile beraber artan rekabet işletmeleri bir taraftan kalite ve fiyat açısından malları ve hizmetleri daha etkin bir biçimde tüketiciye yönlendirmeye, diğer taraftan da mevcut kurumsal yapı ve uygulamalarını insan kaynaklarının geliştirilmesi doğrultusunda "çalışma hayatının kalitesinin iyileştirilmesi", "işin insanileştirilmesi "esneklik" vb. uygulamalarıyla çevrelenmiş yeni işgücü yapısı ve davranış biçimine uygun Abdullah Soysal Türkiye'de Kadın Girişimciler: Engeller ve Fırsatlar Bağlamında Bir Değerlendirme haline getirmeye mecbur kılmaktadır. Bu anlayış doğrultusunda iş hayatında katılımı yetersiz olan, bilgi, beceri ve yeteneğinden yeteri kadar yararlanılmayan kadınların iş hayatına büyük oranda katılması ve daha etkin rol alması gelişen ekonomiler için bir "stratejik" zorunluluk halini almıştır. Özellikle Batılı ülkelerde ve gelişen Uzak Doğu'da kadınların ekonomiye katılımlarını arttırmak için hükümetlerin yasal düzenlemeler yapma, teşvik programları hazırlama ve kurumsal değişiklikleri gerçekleştirme konusunda büyük adımlar ataması bu gelişmelerle ilgilidir. $\mathrm{Bu}$ kapsamda günümüzde yaşanan ekonomik, sosyal ve teknolojik gelişmeler bütün dünyada olduğu gibi Türkiye'de de kadınların gittikçe daha fazla aktif olarak çalışma hayatına katılmalarına yol açmıştır. Bununla birlikte kadınların kişisel çabalarıyla birlikte hükümetlerin ve diğer sivil toplum örgütlerinin de kadınların iş hayatında daha etkin hale getirilmesine yönelik karar ve uygulamalar içerine girmesi gerekmektedir. Çünkü kadınlar dünya ve Türkiye nüfusunun yarısını oluşturmasına karşın aynı oranda temsil edilmemektedir. İnsan kaynakları kullanımı açısından potansiyel işgücünü oluşturan bu nüfusun bilgi, yetenek ve tecrübelerinden yeteri kadar yararlanmamak ciddi bir kayıptır. Bu bağlamda kadınların ekonomik hayatta erkeklerin yanında gerek iş̧̧i statüsünde ve gerekse kendi işinde yer almalarının sağlanması ile onları ekonomik gelişmeye önemli katkılar sağlayan potansiyel güç haline getirmek mümkündür. Böylece kadınların iş hayatında temsili ve başarısının sağlanması her şeyden çok ülke ve toplumların ekonomik ve sosyal gelişimi açısından önem taşımaktadır. Geçmişte kadınların; okuma yazma ve iş yaşamına katılım oranlarının düşüklüğü, finansmana erişim olanaklarının yetersizliği gibi nedenlerle girişimci olmaları daha düşük düzeyde kalırken, son yıllarda yapılan çalışmalarda, kadınların iş yaşamında, karşı cinse göre, daha başarılı oldukları gözlemlenmiştir..Bunun nedeni ise önceden erkeklere özgü olduğuna inanılan işlerde başarılı olmaları, erkeklerle aralarındaki girişimcilik konusundaki bilgi ve deneyim farkının giderek azalması, çok daha iyi örgütlenir hale gelmeleri ve doğaları gereği olaylara karşı daha duyarlı, daha sakin, daha yoğun insan ilişkilerine sahip olmalarıdır. Diğer taraftan gelişmiş ya da gelişmekte olan hemen hemen tüm ülkelerde cinsler arası eşitsizliğe karşı birtakım önlemler alınmaya başlanmış olması da kadınları girişimciliğe teşvik etmede önemli bir politika açılımı olarak algılanabilir. Günümüzde küreselleşmenin birlikte getirdiği hızlı değişim ve rekabet, yeni teknoloji ve anında iletişim karşısında geleneksel yöntemler etkin olamamakta ve bunun üstesinden gelebilmek için "yeni düşünce ve uygulama tarzlarına, bir anlamda "kadına has liderlik stili, kapasite ve niteliklere gereksinim duyulmaktadır. Yani yapısal değişim, değerler sisteminde de değişimi beraberinde getirmektedir. Örgütlerde değişim "değişen değerler sistemi ekonomik gereklilikle birlikte sergilendiğinde" daha belirgin bir şekilde göze çarpacaktır. $\mathrm{Bu}$ bağlamda işyerinde yönetim tarzları ve yaklaşımlarının kadının kendine has değerleri bastırmasından çok tam tersine, firsatını bulduğunda onun potansiyelini açığa vurduğu zaman daha etkin olabilecektir. Bu bağlamda, kadın girişimciliğinin ekonomik ve toplumsal hayata önemli yarar ve firsatlar sunduğu bir gerçektir. Kanıtlar göstermektedir ki, girişimcilik, ekonomik gelişme ve iş yaratımına değişik yollar sağlamaktadır. Kadınlar kendi ülke ekonomilerini geliştirmede potansiyel girişimcilik faaliyetleri ile önemli bir kaldıraç kuvveti oluşturmaktadırlar. Yani kadın girişimciler, ekonomik gelişmenin önemli bir kaynağını temsil etmektedirler. Avrupa'da (Avrupa Birliği ve diğer ülkeler), tahminler göstermektedir ki, yaklaşık 16 milyon işverenden, kendi işinde çalışan kadın sayısı 10 milyondan fazladır ve Amerika'da 9.2 milyon insan için istihdam sağlayanların 6.4 milyonu kendi işinde çalışan kadınlardan oluşmaktadır. OECD kaynaklı bir araştırmada da belirtildiği gibi, kadınların firsatlara nispeten yenilikçi bir tarzda yaklaşımları, iş yaşamının "yaşam kalitesi yanında yeni ekonomik çevrenin gelişimine de katkı sağlayacak niteliktedir. Kadının kendine has karakteristiklerinden biri olan yenilikçilik (innovative impulse) bunda rolü olduğu düşünülebilir. Bernstein'ın yaklaşımı çerçevesinde erkek girişimcinin genelde otoriter yönetim tarzına yatkın olmasına karşın, kadın girişimci, yönetim olgusuna daha "bütüncül" yaklaşmakta, araştırma sonuçlarına göre personel eğitimi, takım çalışması, işletme yapısında hiyerarşinin azaltılması ve kalite konularında ve başarı olgusunu erkeklerden farklı değerlendirmesi sonucu çalışanların kariyerlerinde gelişimlerinin sağlanması ve müşterilerin beklentileri konularında daha duyarlı olmaktadır. Kutanis ve Alparslan'ın (2006) "girişimci kadınların profilleri” ile ilgili yapmış oldukları araştırmada, girişimci kadınlar; kendilerine güvenen, güçlü önsezilere sahip, sabırlı ve dayanıklı olan, riski üstlenebilen, ikna kabiliyeti kuvvetli ve inisiyatif kullanan bireyler olarak bulgulanmıştır. Aynı araştırmada girişimci kadın olmanın, kadına çalışma yaşamında diğer çalışma biçimlerine kıyasla daha fazla özerklik imkanı verdiği, kadının işine yönelik kısa ve uzun vadeli planlar yapma, kaynakları optimum kullanma, beşeri ilişkiler kurma ve sürdürme, işinde edindiği deneyimleri verimli kanallara aktarma gibi önemli kazanımlar sağladığı belirlenmiştir Türkiye'de Kadın Girişimciler: Engeller ve Firsatlar Bağlamında Bir Değerlendirme de Dünya Bankası'nın Orta Doğu ülkelerinde ki şirketlerle ilgili yapmış olduğu bir araştırmada, bu ülkedeki işletme sahibi olan kadınların Afrika ve Asya'daki diğer kadın girişimcilere oranla işletmelerini daha fazla büyütme eğiliminde oldukları ve bir çok engelle karşılaşmalarına rağmen, erkek girişimcilere göre 
işletmelerinde daha fazla sayıda işçi çalıştırdıkları belirlenmiştir. Yine yapılan bir diğer araştırma sonucuna göre ise, kadın girişimcileri "yönetsel becerilerine ilişkin” öz değerlendirmelerinde yeni fikirler ve yeni ürün geliştirme konularında kendi becerilerini "mükemmel” olarak tanımlamışlardır. Aynı araştırmada, insan ilişkileri, yönetim, geliştirme ve eğitim ile pazarlama, pazarlama araştırması alanında "çok iyi", envanter, üretim gibi işe yönelik teknik alanlarda "iyi" oldukları ortaya konulmuştur. İngiltere'de yapılan bir araştırmada, "Çalışanların patronlarını tanımlamaları ve nasıl bir patron istediklerini tarif etmeleri” istenmiştir. Yapılan araştırmanın sonucuna göre çalışanların, kadın patronla çalışmak istedikleri ortaya çıkmıştır. Çalışanların daha çok kadın patron tercih etmelerindeki sebepler ise şöyle sıralanmaktadır:

- Kadınlar, bir iş için erkekten daha fazla çaba gösteriyorlar ve daha dikkatliler.

- Kadınlar, çalışanlarına gerekli eğitimi daha iyi verebiliyorlar.

- Kadınların öğreticilik yanı erkeklere oranla daha gelişkin.

- Kadınlar yeni durumlara ve değişimlere daha rahat uyum sağlayabiliyorlar.

- Kadınların, yanlarında çalışanları iş konusunda heveslendirme ve teşvik etme yetenekleri erkeklere oranla daha gelişkin.

- Kadınlar yeni fikirlere daha açıktır. Ayrıca kadınların yaratıcılıkları da iş yaşamında başarının kapısını araliyor.

- Kadınlar gözlem yeteneklerini iş yaşamında başarılı bir biçimde kullanabiliyor.

- Çalışanlarıyla iletişim kurarken kadının sağladığı başarı iyi bir yönetici olmasında olumlu bir etki yapiyor.

- Kadının problem çözebilmedeki başarısı, bir yönetici olarak erkekten daha başarılı olmasını sağlıyor.

- Kadınlar özel yaşamlarında olduğu gibi iş yaşamında da açık bir stratejiye sahipler.

- Kadınlar iş yaşamında erkeklere oranla daha neşeli ve eğlenceli olabiliyor.

Tahminlerin aksine kadınlar, iş yaşamında kararlarını kolay verebiliyorlar ve kararları konusunda daha ısrarcıdır. Yukarıda belirtilen araştırma ve değerlendirmeler göz önünde tutulduğunda; kadın girişimcilerin ekonomik ve sosyal anlamda ülkeye getirdiği kazanımlarının daha gerçekçi ve geleceğe yönelik olarak değerlendirilmesi gerekmektedir. Bu bağlamda kadın girişimcilerin, hem kendileri hem de istihdam ettikleri kişiler için iş yaratmaları ve çalışma yaşamında daha etkin ve aktif olmaları; onların toplumdaki konumlarını güçlendirmesine, toplumların gelişmişlik düzeyini etkilemesine ve gelir dağılımındaki adaletsizliği de önlemeye önemli katkılar sağlamaktadır, dolayısıyla Türkiye'nin sosyal ve ekonomik gelişmesine katkıda bulunmak ve sürdürülebilir kalkınmayı gerçekleştirebilmek için ekonomik değer yaratan kadın girişimci sayısını arttırmak, var olan kadın girişimcileri güçlendirmek ve onları dünya ile bütünleştirmek gerekmektedir (Can ve Karataş, 2007).

\section{Kişisel Yorum}

Ticari yaşamla birlikte kadınlar, kimlik arayışı içine girmişleridir. Yaşadığımız dönemin beraberinde getirdiği değişen yaşam standartları ve tüketim ihtiyaçları kadınların bilinen evinin kadını, çocuğunun annesi olmanın artık yeterli olmadığ sahip oldukları eğitim, gerekse el becerisi gibi yetenekleriyle çalışma hayatında var olma ihtiyacı doğmuştur. Bu noktada Girişimci Kadınlara çalışma hayatına başlayabilmeleri için bir takım maddi imkanlar veya destek verebilecek kaynaklar sağlanması gerekmektedir, Günümüzde artık birçok kanaldan girişimciliği destekleyecek krediler devreye girmiştir. Kadınlar kendilerini bulundukları ortama kabul ayrı bir kimlik oluşturarak farklılaşma yoluna gitmişlerdir. Başarılarının sürekliliğini sağlayabildiklerinde kurumsal kimlik oluşturma başarısına ulaşabilmektedirler. İşletmelerine küresel bakabilen, rekabetçi avantaj ve katma değer yaratabilen, söyleneni ve düşünülebileni yapabilen hayal kurabilen, sürekli öğrenmeye çalışabilen, kaybetmeyi göze olabilecek kadar stratejik düşünme yeteneği olan girişimciler ekonominin gelişmesine katkıda bulunma, iş imkanı sağlama, işletmesini geliştirerek yeni işkollarının oluşturulması konularında her daim başarılı olmaktadırlar. Son yıllarda yapılan çalışmalarda kadın girişimcilerin kişisel karakteristikleri; dinamik, bağımsız, özgüvenli, rekabetçi ve amaç yönelimli olarak tanımlanmaktadır. Bu bağlamda kadınların ekonomik hayatta erkeklerin yanında yer almalarını sağlayacak politika ve projelere öncelik verilmesi ile onları ekonomik ve sosyal gelişmeye önemli katkılar sağlayan potansiyel güç haline getirmek mümkündür. Bununla birlikte kadınların, girişimcilik faaliyetlerinde önemli engellerle karşılaştıkları ve oldukça zorlandıkları ifade edilebilir. Bu çalışma, girişimciliğin hız kazandığı günümüz dünyasında, Türkiye perspektifinden, kadınların girişimcilik faaliyetlerinde karşılaştıkları engelleri ve yaratacakları fırsatları kuramsal bir çerçevede ele almayı amaçlamaktadır.

\section{Sonuç ve Beklentiler}

Son yıllarda, kadınların, çalışma hayatına büyük oranda katılması ve daha aktif rol alarak girişimcilik faaliyetlerinde bulunmaları, gelişen ekonomiler için "stratejik" bir öneme sahiptir. Çünkü iş dünyasında zengin olmanın, kullanılmayan potansiyeli etkin hale getirmenin ve yeni iş sahaları oluşturmanın yolunun, kadınların girişimciliğinin teşvik edilmesinden geçtiği gerek akademik çevrede, gerekse iş dünyasında ifade edilmektedir. Yapılan çalışmalarda kadın girişimcilerin kişisel karakteristikleri; dinamik, bağımsız, özgüvenli, rekabetçi ve 
amaç yönelimli olarak tanımlanmaktadır. Bu bağlamda kadınların ekonomik hayatta erkeklerin yanında yer almalarını sağlayacak politika ve projelere öncelik verilmesi ile onları ekonomik ve sosyal gelişmeye önemli katkılar sağlayan potansiyel güç haline getirmek mümkündür. Bununla birlikte kadınların, girişimcilik faaliyetlerinde önemli engellerle karşılaştıkları ve oldukça zorlandıkları ifade edilebilir. Bu çalışma, girişimciliğin hız kazandığı günümüz dünyasında, Türkiye perspektifinden, kadınların girişimcilik faaliyetlerinde karşılaştıkları engelleri ve yaratacakları fırsatları kuramsal bir çerçevede ele almayı amaçlamaktadır. Günümüzde kadının çalışma yaşamında, her geçen gün etkinliğini arttırması, hem kendisi hem de toplum açısından oldukça önemli görülmektedir. Özellikle kadının daha eğitimli, azimli, hırslı ve kararlı duruşu onu, erkeğe bağımlı olmaktan kurtararak ekonomik anlamda bağımsızlığını ve toplumdaki konumunu güçlendirmesine olanak sağlamaktadır. Kadına bu gücü sağlayan en önemli olgu ise onun girişimcilik özelliğidir. Girişimcilik faaliyeti ile kadın, bir taraftan maddi ve manevi kazanımlar elde ederken, diğer taraftan bağımsızlık, finansal firsatlar, toplumsal hizmet, iş güvenliği, aile istihdamı ve meydan okuyuculuk gibi özellikler ile de cinsiyet ayrımcılığına yönelik yargıları kadınlar lehine çevirebilme fırsatını da elde etmiş olmaktadır.

Kadının girişimci olarak çalışma yaşamına katılmasının, kadın açısından getirdiği zorluklar ve engellerin de bu süreçte dikkate alınarak değerlendirilmesi daha gerçekçi olacaktır. Çünkü kadın, gerek kadın olmanın, gerekse iş ve toplumsal yaşamın erkek egemen kurgulanmış düzenin de oldukça güç şartlar içerisinde girişimcilik faaliyetini sürdürme çabası içerisindedir. Fakat kadının çalışma yaşamında varlığını kısıtlayan bu düşünce ve uygulamaların, kadını ekonomik hayatta pasifleştirme anlayışına ittiğini söylemek çok da doğru olmayacaktır. Çünkü son yıllarda, kadınların iş yaşamında, karşı cinse göre, daha başarılı oldukları gözlemlenmektedir. Bunun nedeni ise; önceden erkeklere özgü olduğuna inanılan işlerde başarılı olmaları, erkeklerle aralarındaki girişimcilik konusundaki bilgi ve deneyim farkının oluşmasından kaynaklanmaktadır. Türkiye'de Kadın Girişimciler: Engeller ve Fırsatlar Bağlamında Bir Değerlendirme giderek azalması, çok daha iyi örgütlenir hale gelmeleri ve doğaları gereği olaylara karşı daha duyarlı, daha sakin, daha yoğun insan ilişkilerine sahip olmalarıdır. Bu kapsamda ekonomik hayatta girişimci olarak önemli roller oynayan kadının; işine yönelik kısa ve uzun vadeli planlar yapma, kaynakları optimum kullanma, beşeri ilişkiler kurma ve sürdürme, işinde edindiği deneyimleri verimli kanallara aktarma gibi bir etkiye sahip olduğu söylenebilir. Kadınların, örgütün başarısını zora sokan yıkıcı çatışmaların ve şiddetin ortaya çıkmasında veya büyümesinde de engelleyici bir rol üstlendiği ifade edilebilir. Bunun yanında kadınların ekonomik anlamda güçlü olmaları, ortaya çıkabilecek rüşvet, yanlış yönetim, şiddet ve yıkıcı çatışmaların azaltılmasında da etken olabilecektir. Bu bağlamda, kadın girişimciliği, ekonomik ve toplumsal hayatta önemli yarar ve firsatlar yaratarak, kendi ülke ekonomilerini geliştirmede ve iş yaratımında önemli katkılar sağlamaktadırlar. Yani kadınların, potansiyel girişimcilik faaliyetleri ile ekonomik ve toplumsal yaşamın “erkek egemen” cinsiyetler arası adaletsizliğini “insani” boyuta dönüştürerek, çalışma yaşamını daha etkin hale getirdiğini söylemek olasıdır.

\section{Kaynakça}

- AKDEMIR, Ali (2008), Vizyon Yönetimi.

- BAYRAK, S.ve YÜCEL, A. (2000), “Kadın Cinsiyeti, Yöneticilik ve Güç Bir Paradoks Mu?” 11. Yönetim ve Organizasyon Kongresi Bildiriler Kitabı (Nevşehir).

- BEDÜK, Aykut (2005), "Türkiye'de Çalışan Kadın ve Kadın Girişimciliği”.

- CAN, Y.ve KARATAȘ, A. (2007), "Yerel Ekonomilerde Kalkınmanın İtici Gücü Olarak Kadın Girişimcilerin Rolü ve Mikro Finansman: Muğla İli Örneği,” Selçuk Üniversitesi Karaman İ.İ.B.F.Dergisi Yerel Ekonomiler Özel Sayısı: 251-261.

- ÇAKICI, Ayşehan (2003), “Mersin'deki Kadın Girişimcilerin İş Kurma Öyküsü ve İş Kuracak Kadınlara Öneriler," 11. Yönetim ve Organizasyon Kongresi, Bildiriler Kitabı (Afyon).

- ÇELIK, A.ve Akgemci, T. (2007), Girişimcilik Kültürü ve KOBİ’ler (Ankara: Gazi Kitabevi, 2.b.).

- ÇELIK, C. ve ÖZDEVECIOĞLU, M. (2001), "Kadın Girişimcilerin Demografik Özellikleri ve Karşılaşıtıkları sorunlara İlişkin Nevşehir İlinde Bir Araştırma," 1.Orta Anadolu Kongresi (Nevşehir).

- DINÇER .Ö Stratejik Yönetim ve İşletme Politikası.

- DELMAR, F. (2000), "The Psychology of the Entrepreneur,

- CARTER, S .and JONES-EVANS, D. , Enterprise and Small Business: Principles, Practice and Policy (Harlow-England: Pearson Education Ltd.).

- DELMAR, F. (2003), "Women Entrepreneurship: Assessing Data Availability and Future Needs," Workshop on Improving Statitics on SMEs and Entrepreneurship to be held at OECD Headquarters, Paris.

- ECEVIT, Yıldız (2007), Türkiye'de Kadın Girişimciliğine Eleştirel Bir Yaklaşım (Ankara: UluslararasıÇalışma Ofisi (ILO),1.baskı. 
- ECEVİT, Yıldız (1993), Kadın Girişimciliğin Yaygınlaşmasına Yönelik Bir Model Önerisi”, Kadın Girişimciliğe Özendirme ve Destekleme Paneli Bildiriler ve Tartışmalar (Devlet Bakanlığı Kadın ve Sosyal Hizmetler Müsteşarlığı Kadının Statüsü ve Genel Sorunları.

- GÜROL, M .ve MARŞAP Ali ve A., (2007), “Geçmişte ve Günümüz Yaşamında Ücretsiz ve Ücretli İşgücü Olarak Kadın,” Bilig, 4: 95-109.

- $\quad$ HELMS, Brigit (2005), "Mikro Kredi: Birçok Müdahale Stratejisinden Bir Tanesi, Uluslararası Mikro Girişimcilik Finans Konferansı” (İstanbul).

- $\quad$ HISRICH Robert D. and PETERS Michael P. (2002), Enterpreneurship (USA: Mc.Graw-Hill Irwin).

- HISRICH Robert D and BRUSH C.G. (1989), The Women Entrepreneur. Starting, Financing and Managing a Successful Business (USA: Lexington Books).

- KAPU, Hüsnü (2004), “Anadolu Girişimcilerinin Girişimcilik Değerleri”, 12. Ulusal Yönetim ve Organizasyon Kongresi Bildiriler Kitabı (Bursa).

- KUTANIS R. Özen ve ALPARSLAN S., (2006), “Girişimci ve Yönetici Kadınların Profilleri Farklı Mıdır?”, Afyon Kocatepe Üniversitesi İ.İ.B.F. Dergisi, 8/2: 139-153.

- KUTANiS, R. Özen (2003), “Girişimcilikte Cinsiyet Faktörü: Kadın Girişimciler,” 11. Yönetim ve Organizasyon Kongresi Bildiriler Kitabı (Afyon).

- $\quad$ MINNITI M. and ARENIUS P., 2003, "Women In Entrepreneurship, The Entrepreneurial Advantage Of Nations: First Annual Global Entrepreneurship Symposium (United Nations Headquarters).

- NAYIR D,. Zamantılı (2008), "İşi ve Ailesi Arasındaki Kadın: Tekstil ve Bilgi İşlem Girişimcilerinin Rol Çatışmasına Getirdikleri Çözüm Stratejileri,” Ege Akademik Bakış, 8 /2: 631-650.

- ÖZÇELIKK Burcu (2008), "Küresel Girişimcilik Araştırması 2007”.

- ÖRÜCÜ, E. vd KILIÇ R., KILIÇ T. (2007), “Cam Tavan Sendromu ve Kadınların Üst Düzey Yönetici Pozisyonuna Yükselmelerindeki Engeller: Balıkesir İli Örneği,” Celal Bayar Üniversitesi İ.̇̇.B.F. Yönetim ve Ekonomi Dergisi, 14 /2: 117-135.

- $\quad$ PALENO, D. and KLEINER B.H. (2000), “An Entrepreneurial Decision Proces Model Describing Opportunity Recognition,” European, Journal of Innovation Management, 9/1: 61-78.

- $\quad$ SCHINDEHUTTE M. atac MORRIS M., LORD M., BRENNAN C. (2003), Entrepreneurs and Motherhood: Impacts onTheir Children in South Africa and The United States, Journal of Small Business Management, 41/1: 94-107.

- $\quad$ STARCHER D.C. (2001), Women Entrepreneurs Catalysts for Transformation(http//www. ebbf.org/woman.htm) (12.10.2008).

- TAN, F.Z.S. (2006), “Tarihi Akış İçinde Kastamonu Kadın Girişimciliği,” 14. Ulusal Yönetim ve Organizasyon Kongresi Bildiriler Kitabı (Erzurum).

- TÜSİAD (2002), Türkiye'de Girişimcilik Ankara: TÜSİAD Yayınları). ULAŞ, D. (2006), “Franchising Sisteminin Girişimcilik Açısından Değerlendirilmesi,” G.Ü.İ.I.B.F. Dergisi, 8/ 3: 133-151.

- TOKSÖZ, Gülay (2007), “İşü̈cü Piyasasının Toplumsal Cinsiyet Perspektifinden Analizi ve Bölgeler Arası Dengesizlikler," Çalışma ve Toplum.

- ZHAO, F. (2005), “Exploring the Synergy Between Entrepreneurship and Innovation,” International Journal of Entrepreneurial Behaviour\&Research. 


\title{
Yeni Zirve: Girişimcilikte Ahlakın Artan Değeri New Summit: Increasing Value of Morality in Entrepreneurship
}

\author{
Prof. Dr. Sabahat Bayrak Kök (Pamukkale University, Turkey) \\ Mrs. Mehtap Sarıkaya (Pamukkale University, Turkey)
}

\begin{abstract}
The history of entrepreneurship is a history of market economy. Thus, entrepreneurship means to take risks, to catch the novelty, to score the opportunities and it is a process to make all them real. In this sense, entrepreneurship is the basic power to move the economy as the main actor of development. On the other hand, the run riot nature of entrepreneurship in terms of profit maximization since $19^{\text {th }}$ century necessitates some level of ethics in business life. Infringements of consumer rights, bribery, tax evading and the presence of institutional scandals worldwide necessitate to evaluate that entrepreneurship should have both economic and socio-cultural values. This paper aims to discuss a notion that entrepreneurship should be run based on ethics.
\end{abstract}

\section{Giriş}

Ekonomik hayat, hangi yüzyılda ve nerede olursa olsun sadece dış faktörlerin bir araya gelmesinden oluşan bir madde dünyası olarak görülemez. Bütün olay ve olgularda olduğu gibi, ekonomik olay ve olguların arkasında kendine has bir değerler kümesi vardır. Başka bir deyişle, her çağ ve toplumda iktisadi ve sosyal hayat, sadece dış kalıplar ve maddi unsurlarla değil, ahlaki değerlerle de varlık bulmuştur. Ancak, 20. yüzyılın son çeyreği bu bağll1ık ve derinliğin görmezlikten gelindiği ahlaki yozlaşma ve kirliliğin zemin bulduğu zamanlar olarak ifade edilmiştir. 1970'li yıllardan bugüne kadar küresel çapta birbiri ardına ortaya çıkan Enron, Tyco, WorldCom, Adelphia, Ahold, Parmalat gibi şirketlerin hileli finansal raporlama yapmaları, Ford, General Motors, Nestle, Johnson\& Johnson, Union Carbide gibi şirketlerin ciddi sonuçlar doğuran ahlaki olmayan tutumları girişimcilikte ahlaki bir yaklaşımın kaçınılmazlığına işaret etmiştir. Sonuçta yaşanılan çok yönlü kirlilik örnekleri, ahlaka geri dönüş sürecini başlatırken, ekonomik hayatın ahlakı dışarıda bırakan bir faaliyet alanı olmayacağını göstermiştir. Bildiri, bu bakış açısıyla temel olarak ahlaka verilen önem ve artan değeri ve girişimcilikte ahlaka aykırı davranışın neden olabileceği kayıpları değerlendirecektir.

\section{Girișimcilik ve İs Ahlakı}

Girişimcilik, hızla küreselleşen dünyamızda her geçen gün önemi giderek artan bir kavramdır. 1980’li yıllardan sonra dünyada ve Türkiye'de önemli gelişmeler kaydedilmiş, şartlar değişmiş ve yepyeni bir girişimcilik anlayışı ortaya çıkmıştır. Özellikle girişimci, ekonomik mal ve hizmet yaratma sürecinde, artan ulusal ve uluslararası iş firsatları ile birlikte tanınma ve prestij elde etme ve bütün toplum katmanlarında ön plana çıkan kişi olmuştur. Ancak, ekonomik değer yaratma konusunda yüksek başarı güdüleriyle ve iş başarılarıyla dikkat çeken girişimciler, belirsizlik ve riskin arttığı küresel rekabet şartlarında ahlaki değerler konusunda aynı derecede başarılı olamamışlardır. Rollerini, girişimsel başarı ve kişisel yüksek kazançlara yönelten girişimciler, belirsizlik ve risk şartlarında karar vermenin ekonomik yanı ile ilgilenip, kar firsatlarını değerlendirmeye odaklanırken, karar vermenin ahlaki ya da ruhsal yönü ile ilgilenmemiş ve girişimciliğin kişisel ve toplumsal sorumluluk çerçevesini göz ardı etmişlerdir.

Günümüzün son derece değişken ve rekabetçi iş yaşamında girişimciler kar elde etme ve varlık sürdürme ya da rakiplerinden bir adım önde olmak için ahlaki olmayan birtakım tutum ve davranışlar sergilemekte ve ahlak dışı çözümler üretmektedirler. Özellikle piyasa koşulları ve artan küresel rekabet baskıları nedeniyle 1980'li yıllarda rüşvet, çalışanlar arasında ayrımcılık yapma, tüketiciyi yanıltıcı reklamlar, işçi sağlığı ve iş güvenliğinde büyük istismarların varlığı, ekonomideki ahlaki bozuklukların "süte su katmak"tan ya da "elmayı eksik tartmak"tan çok daha ötelere gittiğine dikkat çekmektedir.

Kapitalist zihniyetin hakim olduğu 1980'li yıllar dünyada ve Türkiye'de girişimcilerin para kazanmayı tek amaç haline getirdiği ve bunun için her yolu meşru gördüğü, başkaları tarafından yaratılan ekonomik değerlerin kendi taraflarına aktarıldığı "iş adamı” statüsünü kazanmış girişimcilerin yılları olmuştur. Beş kıtada işlenen insan hakları ihlalleri, yoksulluk, ayrımcılık, sömürü, suistimal ve her türlü kötülüğün kaynağı olarak da kar maksimizasyonuna odaklı girişimcilik anlayışı görülmüştür. Köşe dönmeyi, bencilliği, aç güzlülüğü ilke haline getiren girişimcilik anlayışının cezalandırılmaması ise, bu dejenere girişimciliğin yaygınlaşmasında ve toplumsal değer yargılarının bozulmasında yüksek bir etkiye sahiptir. Alman sosyologu Von Götze'nin, "Marjinal Moral Teorisi" bu noktaya dikkat çekmesi açısından önemlidir. Götze'ye göre, "bir toplumda geçerli olan hukuki ve ahlaki kurallarının en alt sınırında oynayanlar kazançlı çıkarsa, uzun vadede bu alt sınırda oynayanların sayısı artmaktadır. Alt sınır bu ağırlığı taşıyamadığından hukuki ve ahlaki kurallar gevşetilerek sınır daha aşağıya çekilmektedir. Yine kuralların tekrar gevşetilmesi gerekmektedir. Bu sürecin devamı ise kuralların dejenerasyonu ve neticede toplumun bozulmasıyla sonuçlanmaktadır” (Müftüoğlu ve Durukan, 2004). 
Bu noktadan yaklaşıldığında girişimciliğin ne pahasına olursa olsun para kazanmak olmadığı ve girişimciliğin ekonomik olduğu kadar ahlaki bir yönünün de olması gerekliliği anlaşılmaktadır. Elbette piyasa koşulları, artan rekabet baskısı ve mevcut firma dinamiklerinin yanına ahlaki yaklaşımı almak kolay değildir. Ancak önemli olan ekonomik hayatın ahlakı dışarıda bırakan bir faaliyet alanı olmayacağını anlamaktır. Çünkü, insanoğlunun çalışmasının ve üretmesinin temel amacı, mutlu ve refahlı bir yaşamdır. Mutluluk ise hazların doyurulması ile değil, ancak erdem ile ulaşılabilecek bir duygudur. Yani, mutluluk erdemsiz yakalanabilecek bir şey değildir (Bayrak, 2001).

Küreselleşmenin tüm boyutlarıyla yaşanmaya başlandığı günümüzde, girişimlerin varlıklarını devam ettirebilmeleri, çevre ile kurdukları ilişkideki başarıya ve katma değer yaratma potansiyellerine bağlıdır. Dinamik ve çoğulcu bir toplumda girişimcilerin rolü, teknoloji, sosyal değişim ve yönetsel tutum açısından, "sosyal sorumluluk" ve "iş ahlakı" kavramlarını içerecek şekilde yerine getirilmelidir. Bu nedenle günümüzde girişimciler, önceki yılların tersine, kıt kaynakları etkin kullanmayı, çevre kirliliğini önlemeyi, verimliliği artıracak şekilde üretim yapmayı, çalışanların moral ve motivasyonunu artıracak şekilde önlemler almayı, müşteri beklentilerine uygun mal ve hizmet üretme ve toplumda iyi bir imaj oluşturacak şekilde toplumun sorunlarını çözme ve topluma katkıda bulunmayı önemsemelidirler. Amerikalı düşünür Brezinski'nin dediği gibi, "ortak paydaları olmayan ve herkesin kendi ihtiyaçlarını karşılamayı düşündüğü bir toplum, sonunda yok olmaya mahkumdur".

Dürüstlük, güven, sorumluluk kişiler açısından olduğu kadar kurumlar için de önemlidir. Girişimciler iş ahlakına uygun davranıldığı ölçüde, güvensizlik, korku yaşamayacak ve risk almaktan çekinmeyeceklerdir. Piyasalarda ve firmalarda oluşacak güven işbirliğini artıracak, kişiler arası ve kurumlar arası ilişkilerde açıklık ve davranış rahatlığı getirecektir. Bu nedenle, iş ahlakı düzeyi yüksek olan toplumlarda faaliyetler büyük ölçüde belirli olduğundan düzenleme yapma ve politika tespit etmenin maliyeti oldukça düşük olmaktadır. Bu konu son yıllarda "sosyal sermaye" kavramıyla dile getirilmeye çalışılmakta hatta sosyal sermaye kavramına olan ilginin onun yokluğunun ekonomik gelişmede önemli engellerden birini oluşturmasına bağlanmaktadır. Bu nedenle, Woolcook (1998), Coleman (1990), Putnam (1993), geniş bir yelpazede yer alan sosyal sermayenin -karşılıklı ilişkilerde olan güven, bağlılık, dayanışma, norm ve sosyal ağlar- azlığının ya da yokluğunun ülkelerin ve kurumların üretkenliğinde temel sorun olabileceği üzerinde durmaktadırlar (Durlauf ve Fafchamps, 2004).

Değerler sisteminden kök alan bir iş ahlakı günümüzde bütün girişimcilerin ilgi göstermesi gereken bir alandır. Çünkü, karşı karşıya kalınan ahlaki istismar ve ihmallerin bedelinin küresel çerçevede daha fazla arttığ görülmektedir. Diğer taraftan gelişen bir bilinçlenme ile giderek ahlaki yaklaşımlara ve ahlaki tavır ve davranışlara bir ilgi artışına da tanık olunmaktadır. Bu noktada bir takım yanlış inançları düzeltmek anlamında iş ahlakının artan önemi üzerinde durmak girişimcilere yeni bir perspektif sunmak yararlı olacaktır.

\section{1 İş Ahlakı Kavramı}

Madsen'in deyişiyle, iş ahlakını tanımlamak, “çiviyi taş duvara mıhlamak” gibi zor bir sorundur. Çünkü bu kavramla neyin ifade edildiği konusunda genel kabul görmüş bir görüş yoktur. Aynı şekilde, iş ahlakının belirli ve sınırları çizilmiş bir alanını da göstermek oldukça zordur. Hatta "nerede olmadığını” söylemek bile güçtür. Bu durumda iş ahlakı alanının tanımlanmasını, bazı önemli unsurları dışarıda tutarak daraltmak ya da bütünüyle kuşatıcı ve oldukça geniş bir alanı kapsayacak şekilde genişletmek mümkündür (Madsen ve Shafritz, 1990).

Çoğu insan için, tanımlanması ve anlaşılması zor olan iş ahlakı, genel olarak, "ekonomik faaliyetleri yürütürken dürüstlük, güven, sayg1, adaletli davranmayı ilke edinmek ve topluma destek olacak şekilde hareket etmektir" (McHugh, 1991) şeklinde tanımlanabilir. Başka bir tanımda, iş ahlakı, iş dünyasına yol gösteren ahlaki ilke ve standartlar olarak ifade edilmektedir.

İş ahlakı toplum tarafindan görüş birliğine varılmış prensipler, normlar ve standartlar ile tutarlı şekilde işletmecilik uygulaması davranışıdır. İşletmenin; hissedarlarına, müşterilerine, tedarikçilerine, çalışanlarına, içinde faaliyet gösterdiği topluma ve genel olarak küreselleşen dünya ile birlikte ilişkide bulunduğu bütün toplumlara nasıl davrandığına bakılarak bir işletmenin iş ahlakının ne olduğu anlaşılabilir. Eğer işletmeler, işlevlerini yerine getirirken, bir bütün olarak kendileri ve üyeleri için yasal sorumlulukların ötesinde toplumsal sorumluluk da üstlenen ilkeler ile tutarlı davranıorlarsa, işletmenin ahlaklı davrandığı söylenebilir (İlhan, 1990).

\section{2 İș Ahlakının Artan Önemi}

Son otuz yılda iş ahlakının çeşitli nedenlere bağlı olarak önem kazandığı görülmektedir. Nedenlerden ilki, girişimcilerin ahlaki olarak iş yapmaları konusunda artan kamuoyu baskısı ve gelişen sosyal sorumluluk anlayışıdır. Bilindiği gibi ekonomik hayatta, klasik anlayışın hakim olduğu dönemde, işletmeler için, yegane sorumluluk olarak “karı artırmak” öngörülmüştür (Ferrel vd., 1994). Özellikle Milton Fridman'1n öncülük ettiği bu görüşe göre girişimcilerin tek sorumluluğu, açık ve serbest rekabet şartlarında, oyunun kuralları içinde kalarak, kaynaklarını ve enerjilerini, karlarını artıracak şekilde düzenlenmiş faaliyetlerinde kullanmaktır (Carroll, 1991). Milton Freidman (1970) "The Social Responsibility of Business is to Increate Profits" başlıklı yazısında işletmelerin ve yöneticilerin yegane sorumluluğunun yasalar içinde ve açık bir rekabet ortamında ortaklarahissedarlara yönelik olarak kar etmek olduğunu savunmuş, bunun ötesindeki girişimlerin daha karmaşık iktisadi, siyasi ve toplumsal sorunlara yol açacağını ileri sürmüştür. Bu görüşe göre yönetici, hissedar ve ortakların 
görevlendirdiği kişidir ve dolayısıyla topluma değil, hissedara ve ortaklara karşı sorumludur. Yöneticinin kar maksimizasyonu dışında bir amaç peşinde koşması görevini yerine getirmediği anlamına gelmektedir. Sosyal sorumluluk adına yapılan harcamalar ya çalışanların ücretlerinin ya da kalitenin düşürülmesi veya maliyetlerin müşterilere yansıtılmasına neden olacak, her durumda şirket rekabetçi konumdan uzaklaşacaktır. Ayrıca, sosyal sorumluluk ekonomik verimliliği düşürmenin ötesinde yöneticinin iş yükünü artıracaktır. Bu bağlamda, sosyal sorumluğun şirketlerin değil, devletin ve kamunun işi olduğunu, iş dünyasının bu konuda ne yetki nede gerekli beceri ve donanıma sahip olduğu savunulmaktadır (TÜSİAD, 2009).

Kar dürtüsü ve serbest piyasa sisteminin getirdiği yararlarla ilgili kazanımlar kimi girişimciler için hala meşru ya da en geçerli savunumlar olabilir. Ancak kabul edelim ki bu durum geniş bir kesim için de kaygı doğuran en önemli alanlardan biridir. Çünkü yukarıda ifade edilen görüşler doğrultusunda girişimciler çok uzun yıllar karı maksimize etme ve rasyonelliği gerçekleştirme ile ilgilenmiş ve bunlara ulaşmada birer engel olarak gördükleri ahlaki değer ve ilkeleri ya iş hayatının dışında bırakmış ya da kendi istekleri doğrultusunda bu değer ve normlar üstünde yontma yapmışlardır. Böylece, kazanç elde etme, servet biriktirme, statü ve ün kazanma isteğinin önüne serilen imkanlarda, önceki yıllardan daha fazla bir çeşitlilik görülmüş ve geleneksel değerlerdeki çözülmenin etkisiyle bütün toplumlarda bir "ölçüsüzlük" korkusu her yeri sarmıştır. Ancak, bugün gelinen noktada, ticaretin amacının para kazanmak değil, topluma hizmet olduğunun altı çizilmekte ve karın bu hizmetin bir ödülü olduğu, tek başına bir amaç olamayacağı belirtilmektedir. "İşletmeleri zengin eden karları değil, değerleridir” (Quigley, 1993) sözü günümüzde her çerçevede büyük oranda kabul görmektedir.

İş ahlakı kavramının önem kazanmasının ikinci bir nedeni, "good ethics=good business" söyleminin sloganlaşmasıdır (Grace ve Cohen, 2005). "İyi bir işin, iyi ahlak ile özdeş” olduğunun farkına varılmış ve iyi bir iş tanımı için yasal sınırların yeterli olmadığının altı çizilmiştir. Ahlaki olarak faaliyetlerde karar verme, sorunların iyi çözümlenmesi ve etkili stratejilerin tespitinde oldukça önemlidir (Dean, 1997). Bir kişi yasalara aykırı olmasa da müşterilerine zarar verebilecek bir faaliyeti yapabilir mi? Bu soruya günümüzde daha net bir cevap verilerek, "hayır" denilebilmektedir. Ancak bundan öncesine bakıldığında durumun bu kadar açık olduğunu söylemek mümkün değildir. Örneğin, bir İngiliz firması, yasallığı ahlaki davranış açısından yeterli sınır sayarak, Üçüncü Dünya ülkelerine, oranın arazi şartlarına uygun olmayan oto kaplama lastiklerini satmış, trafik kurallarının yeterince iyi düzenlenmediği bu ülkelerde pek çok kazaya neden olmuştur (McHugh, 1991). Aynı şekilde, bir diş hekiminin hastasına gerekmeyen bir tedaviyi sırf daha fazla ücret almak için yapması durumu da yasal olmakla beraber ahlaki değildir. Çünkü hekim, yasal olarak belirlenmiş ücret listesine uygun ücret almaktadır, ancak bu ücret, müşteriye gerekmeyen bir tedavi sonucu oluşmaktadır. Görüldüğü gibi yasalar ve kurallar, bir işletmenin ya da bir kişinin ahlaken ne yapacağını tam olarak hiçbir zaman ifade etmezler. Onlar yapılacaklar konusunda minimum standartları ortaya koyarlar. Bu nedenle yasal zorlamalarla insan davranışlarını düzenlemek en pahalı yoldur (Report and Recommendation to President, 1981).

İş ahlakının önem kazanmasında üçüncü bir neden ise, girişimciler açısından iş ahlakının ve ahlaki tartışmaların, bir tehdit ve zayıflık olarak görülmesi yerine, mükemmellik ve kaliteye ulaşmanın doğal uzantısı ve uzun ömürlü olmanın temel şartı olarak görülmeye başlanmasıdır. Klasik anlayışın tersine, modern anlayışı benimseyen girişimciler, iş dünyasının iş ahlakıyla iç içe geçme zorunluluğuna bir tehdit olarak değil bir firsat olarak bakmakta, kalite ve mükemmelliği iş dünyasının; ahlakı ise, kalite ve mükemmelliğin ayrılmaz parçaları olarak değerlendirmektedirler (Tierney, 1997). Bu çerçevede Surroca, Tribo ve Waddock (2009) bu durumu, sosyal sorumluluk çerçevesinde ahlaki sosyal performansın finansal performansı artırdığı bir "döngü” şeklinde değerlendirmişlerdir. Yazarlara göre başarılı şirketler ahlaki konularda duyarlı sosyal projelere aktif katılan şirketlerdir (Surroca vd., 2009). Dolayısıyla girişimcilikte ahlaki yaklaşım, sürdürülebilir başarının mihenk taşı olarak değerlendirilmektedir.

Rekabetin şiddetinin artması ve niteliğinin değişmesi, iş ahlakına yönelimde etkili bir başka husustur. Küreselleşme sürecinin hız kazanmasıyla şiddeti ve hızı artan rekabette Amerikalı ve Avrupalı işletmelerin iş ahlakının güçlü olduğu Japonya gibi ülkelerin işletmeleri karşısında başarısız olmaları, ahlaki değerler yönünden çözülmüş kitleleri, güçlü ahlaki bağlarla birleştirmenin yollarının aranmasına neden olmuştur. Çünkü yapılan çalışmalar iyi ahlak ve güçlü sorumluluk duygusunun şiddetlenen rekabette stratejik bir önem kazandığını göstermiştir. İşletme sayısının hızla artması, üretilen malların önceden olduğu gibi kolay satılamaması buna karşılık müşterilerin sürekli güçlü ve nazlı hale gelmesi ahlaki yaklaşımın önemini daha da artırmıştır. Bu güçlü ve bilinçli müşteriye ilkeli yaklaşarak güven vermek ve bu konuda sorumlulukları gönüllü olarak üstlenmek bir zorunluluk haline gelmiştir. Aynı şekilde işin yapısındaki değişim bu anlayışı gerektirmektedir. Mikro teknolojilerin kullanılması ve bilgi işçilerinin varlığı ahlaki ilke ve değerlere bağlılığın önemini arttırmıştır.

İş ahlakı kavramının önem kazanmasının diğer bir nedeni de, daha sınırlı değişkenlerin ve daha dar bir ekonomik yaşam alanına göre üretilmiş iş ahlakı anlayışının, günümüzdeki iş ilişkilerini kavramaya ve düzenlemeye yeterli gelmemeye başlamasıdır. 2000'li yıllarda yukarıda da belirtildiği gibi geleneksel toplumlarda egemen olan, daha dar bir kontrol alanına sahip, sosyal baskı ve kanun baskısına dayalı bir ahlaki anlayışın günümüzde yeterli olmadığıdır. Dolayısıyla önceki nesillerden farklı olarak bu nesil sadece maddi unsurlarda değil, moral unsurlarda da hassasiyet kazanmalıdır. Çünkü tarım toplumundan sanayi toplumuna geçişi yaşayanlar, hızlı bir teknolojik yenilenme yaşarken o zamanın gerekli kıldığı moral değerleri üretememiş, 
tam tersine bir önceki neslin ürettiği "antropolojik ahlakın” kendilerine uymayan yönlerini yontmak yoluyla alıp bir süre tüketmiş̧lerdir. Ancak yaşanan hızlı değişim, bu boşluğu istenmeyen ve toplumlarda ahlaki kriz yaratan davranışlarla doldurarak, üretimi bugünkü nesillerin bir sorunu olarak karşımıza çıkarmıştır. Her çağ, her devir nasıl kendi ekonomik, sosyal, siyasi ve kültürel gerçeğini yakalıyorsa, ahlaki gerçeğini de yakalamalıdır. Bu çerçevede günümüz girişimci yöneticileri, yönetim süreçlerinde başkalarını yakından ilgilendiren ve etkileyen kararları ahlaki karar verme mekanizması çerçevesinde alma, bunları tüm paydaşların yararına olacak şekilde uygulama, şirketin yarattığı finansal değeri hak ve sorumluluklar çerçevesinde toplumla adil olarak paylaşma arayışlarını sürdürmektedirler. Böylece yaşanılan dünyaya değerleri yozlaştıran değil, değer katan bilinçli bir benlik sahibi girişimcilik anlayışı yaşanılacaktır. Bu haliyle iyi yaşam ideali ve ahlaki kusursuzluk şeklindeki erdemli var oluşa insanın kendini yeniden keşfetmesi ve gerçekleştirmesi yönüyle yeni nesil girişimciliği katkı sağlayabilecektir.

Toplumdaki genel ahlakın ve iş dünyasındaki ahlaki ilkelerin dejenerasyonu ya da yetersizliği nedeniyle, yaşamın "değerler" alanındaki bozukluğunun, bir anlamda "ahlaksızlığın" sonuçlarının ve maliyetlerinin gittikçe yükseliyor olması, iş ahlakının önem kazanmasının başka bir nedeni olarak görülmektedir. İnsanlık ve iş dünyası, "ahlaki ilkeler" konusundaki duyarsızlığın bedellerini o kadar yüksek faturalarla ödemektedir ki ahlaklı olmayı ve ahlaki tavır ve davranışta bulunmayı bir tür "koruyucu hekimlik" gibi değerlendirmektedir. Ahlaklı olmak, ahlaki davranmamanın neden olduğu sorunlarla uğraşmak zorunda kalmamanın ve bunun için ilave kaynak kullanma durumundan kurtulmanın daha avantajlı olduğu gerçeği, tüm dünyanın deneysel olarak bizzat yaşayıp öğrendiği pahalı bilgiler arasına girmiştir.

Bilindiği gibi, her çağda, her devirde bir takım ekonomik, sosyal ve fikri değerler, diğer değerleri etrafinda toplamaktadır. Öyle görünüyor ki günümüzde de "ahlak ve sosyal sorumluluk" kavramları, diğer kavram ve olguları etrafında toplayacaktır. Merkeziyetçi toplumların çözüldüğü, ulus devletin sınırlarının tam olarak çizilemediği, toplumsal farklılaşmanın arttığı, müşterinin son derece kırılgan ve nazlı hale geldiği, ikili ilişki ve ortaklıkların arttığı 2000'li yıllarda iş ahlakına yönelik değişimin doğru algılanması büyük değer taşımaktadır.

\subsection{Ahlaki Yönetim İlkelerinin Tesis Edilmesi}

Ahlak yönetimi girişimcilikte bir süreç olarak kabul edilebilir. Ahlak yönetiminin temel amacı işyerinde istenilen davranışları teşvik etmektir. Ahlak yönetimini diğer yönetim uygulamalarıyla bütünleştirmek ve görevlerini yerine getirirken çalışanların katılım ve bağlılı̆̆ını sağlamak, yapılacak işlerde yol gösterici bir takım ilkelerin varlığını gerektirmektedir. Bu ilkeler, yapılacak işlerde belirlenen standartlar olarak, "kabul edilebilir davranışların” asgari özelliklerini ortaya koyarlar. Bu ilkelerin varlığı; toplumsal faydayı gerçekleştirmede, halkın güvenini sağlamada ve bir takım şüpheleri gidermede önemli rol oynarlar.

Yönetici ve çalışanlara problemli ahlaki konularda kılavuzluk edecek şekilde davranış ilkeleri oluşturmak ilk anda alışılmadık bir gelenek olsa da, bu ideal dünya genelinde pek çok şirkette olumlu sonuç vermektedir. ABD girişimcilerinin yaşadıkları deneyimler, bu tür ahlaki kılavuzların varlığının çalışanların bağlılıklarını artırdığını ve müşterilerle ilişkileri geliştirdiğini kanıtlamaktadır. Örneğin Johnson \& Johnson'ın elli yıldır uygulanmakta olan ve "Credo" olarak bilinen değerler bildirisinin 1982 ve 1986'da Tylenol'le yaşanan krizlerde şirkete kılavuzluk ettiği (Naisbitt, 1994) güven yaratacak şekilde denge kurduğu görüş ağırlık kazanmaktadır.

İngiltere'deki İş Ahlakı Enstitüsü’nün yaptığı bir araştırma, büyük şirketlerin \%30'unda bir ahlak ilkesi olduğunu ve pek çok Avrupa şirketlerinin davranış standartları hazırlamayı planladığını gösteriyor. National Westminister Bank (NatWest) diğer büyük şirketlerin de kabul edebileceği bir standart oluşturmaya çalışmaktadır. Bu doğrultuda 90.000 NatWest elemanı, bir İngiliz şirketinin hazırladığı en hırslı davranış ilkelerinin ayrıntılarını içeren on sayfalık bir döküman almış ve bu kitapçık şirketin öncelikleri konusunda çalışanları bilgilendirmeye yönelik hazırlanmıştır. Özellikle, anlaşmalarda bütünlük, müşteri tatmininin sağlanması, çalışanlar için firsatlar yaratılması, çıkar çatışmaları, suç oluşturan faaliyetler vb. konular üzerinde durulmuştur (Naisbitt, 1994).

Avrupa, ahlak dışı davranışların çalışanlarda hissedarlarda ve müşterilerde yarattığı etkinin giderek farkına varmakta ve çalışmalarını giderek yoğunlaştırmaktadır. İspanya'da Banoo Bilbao Vizcaya (BBV) adlı şirketin davranış ilkeleri hazırlaması bir İspanyol şirketi için alışılmadık olarak tanımlanmış olsa da bu ilkeler, hükümetle kurulduğu iddia edilen yozlaşmış ilişkiler karşısında iyileştirici bir adım olarak destek bulmuştur. Bu davranış ilkeleri ile şirket üst düzey yöneticilerinden dolaylı ya da dolaysız özel çıkarlarının olabileceği bankalarla faaliyetten kaçınmalarını istemiştir. İsveç’te konu daha ileri boyutlara varmış ve iş dünyasının temsilcilerinden oluşan bir grupla kurulan Yozlaşma Karşıtı Enstitüsü (1923) şirketleri uygulama ilkeleri ve yasal değişiklikler konusunda bilgilendirerek, ahlakla uzun süreli bir uğraş vermişlerdir. Aynı şekilde, Alman girişimcileri ve politikacılar arasında var olan uygun olmayan ittifaklara ve ülkesindeki "ahlaki krize" dikkat çekerek ulusal bir tartışma başlatmıştır. Fransa, rüşvet olayları karşısında daha etkili yaptırımlar için çalışmalar başlatarak, ahlaki davranış ilkelerini gerektiren durumlara dikkat çekmeye çalışmıştır (Naisbitt, 1994).

Günümüzde dünya ekonomisinin "çokuluslu”, "küresel”, ya da "ulus ötesi” olarak nitelendirilen y1llık ciroları 22-484 milyar doları aşan dev şirketlerin varlığı (money.cnn.com, 2013), ahlaki ilkelerin gerekliliği konusunda daha ciddi sinyaller vererek dünya genelinde arayışları başlatmıştır. Kurt Mirow ile Hary Maurer'in Webs of 
Power (İktidar Ağları) kitabında dikkat çektikleri gibi bu şirketler yasadışı sayılmakla birlikte karteller kurarak öteden beri işbirliğine gitmişlerdir. "Av Alanı” anlaşmalarıyla rekabeti azaltıp, karı artıran bu şirketler son yıllarda olağanüstü boyutlara ulaşan güçlerini daha farklı kullanarak, politika alanına kadar güçlerini uzatmışlardır. Bilindiği gibi, politik gündemi belirlemek ve kendi lehlerine siyasal sonuçlar sağlamak için sık sık olağanüstü lobi güçlerini kullanarak politik ağırlıklarını ön plana çıkarmışlardır. Bu durumda, ev sahibi devletler üzerinde büyük çapta nüfuz uygulayabilecek bir konumda olan küresel şirketler, doğrudan ve bazen yasadiş1 biçimde siyasal sürece etki ederek ekonomik gibi gözükse de, politik ve ideolojik bir tutum içerisine girmişlerdir. Klasik ve bilinen örnek ITT'nin, 1970'de Marksist devlet başkanı Salvador Allende'nin seçilmesini önlemek için entrikalar çevirerek Şili'nin içişlerine karışmasıdır. CIA ile birlikte gizli düzenlemelere girişen ITT, Şili içinde ekonomik kaos yaratmaya ve böylece askeri darbeye zemin hazırlamaya çalışmış ve bu arada Allende'nin iktidara gelmesinin önüne geçmesi için Beyaz Saray’a “yedi haneli bir rakam”a varan bir katkıda bulunmayı önermiştir (Morgan,1998).

Küresel şirketlerin yeni dünya düzeninin temel aktörleri olduğu açıktır. Şirketlerin sahip olduğu mutlak güç, beraberlerinde getirdikleri kartel ve ittifakları, onları tutan, iç içe geçmiş mülkiyet ve kontrol kalıpları, hep birlikte kuruluşların egemen olduğu bir dünya ekonomisine, karlılığa, büyümeye ve stratejik gelişmeye yönelik şirket çıkarlarının bir bütün olarak öncelik oluşturup, yerel toplulukların ve ülke çıkarlarının ikinci sırada yer almasının kabul edilebilir olarak görülmesinin mümkün olmadığına dikkat çeken gelişmelere sahne olmaktadır. Özellikle küresel şirketlerin Üçüncü Dünya üzerinde etkilerinin, “doğal ve öteki kaynakları sömüren modern yağmacılar" olarak değerlendirmelere varması, değişime işaret etmektedir. Dünyanın bütünüyle kalkınması için, Birleşmiş Milletlerin tehlikeli atık ürünleri boşaltma konusunda ILO’nun iyi şirket yurttaşlığg konusunda ortaya koyduğu kurallar tarzında, yapıcı bir çerçeve yaratmak için davranış ve sorumlulukla ilgili kural (Morgan,1998) ve ilkeleri acil olarak geliştirmek gerekiyor.

Bütün kötümserlik ve eleştirilere rağmen sevindirici gelişmeleri göz ardı etmemek gerekiyor. Günümüzdeki iletişim firsatları en önemli gerçek. Çünkü geçmişte ahlaka aykırı davranışlar olduğunda (etnik ayrımcılık, rüşvet, sahtekarlık ve skandallar vb.) sadece zarar gören topluluk ya da toplum vatandaşları yaptırımlar uygularken, bugün olayları anında izleme firsatlarının olması, ahlak ve ahlaki standartların ihlal edildiği durumları göz ardı etmenin kolay olmadığını göstermektedir. Sosyolog James Q. Wilson "The Moral Sense" adlı kitabında evrensel öneme sahip ahlaki niteliklerin yerel ilişki ve uygulamalardan türeyerek, küresel ilişki ve uygulamalara kadar varacağına işaret etmektedir. Dolayısıyla büyüyen küresel ekonomik düzen yeni kurallar yaratırken, bir kez daha dünyanın en küçük oyuncaklarından yararlanmak durumunda kalabilecektir (Naisbitt, 1994).

\subsection{Ahlaki Yönetim Anlayışı}

Girişimciliğin ahlaki boyutunu oluşturmak çok önemlidir ve bu nedenle de girişimcilerin ahlaki davranışları ya da karşılaştıkları ahlaki problemler daha fazla ilgi çekmeye başlamıştır. Her ne kadar, girişimci tanımı gereği kendisine ait sermayeyi riske eden kişi olarak kabul edilse de, bir girişimin başarısızlıkla sonuçlanması ya da ahlaki olmayan uygulamalar nedeniyle müşteri ve prestij kaybetmesi sadece girişimcinin kişisel sermayesi değil, fakat aynı zamanda toplumun kıt kaynaklarının da israfı anlamına gelecektir.

Günümüzde örgütler devlete olan vergilerini ödemek, fabrikalarında çevre kirliliğini önlemek amacıyla yatırım yapmak, toplumda muhtaçlara, kadınlara ya da özürlülere istihdam imkanı sağlamak, kültür-sanat faaliyetlerini desteklemek şeklinde örneklendirilebilecek uygulamaların karlarını azaltacağını düşünerek, bu tür faaliyetlere pek de sıcak bakmamaktadırlar. Ancak hatırdan çıkmaması gereken bir gerçek, ahlaki ve toplumsal sorumluluklarını yerine getirmekten kaçınan işletmelerin, kısa dönemde yüksek karlılığa ulaşsalar bile, uzun vadede daha ciddi maliyetlere katlanmak durumunda olacaklarıdır. Her ne kadar kar, bir işletme için bir başarı göstergesi ya da prestij kaynağı ise de, unutulmamalıdır ki, toplumsal sorumluluklarından kaçınmayan girişimciler ya da yöneticiler halkın daha fazla takdirini kazanacaklardır. Bu nedenle ahlaki yönetim, bir işletme için değer yaratan faydalı bir yönetsel tarzı ifade etmektedir.

Ahlaki bir yönetimin faydalarını şu şekilde ifade etmek mümkündür (Arıkan, 2002):

1. Ahlaki kurallara uygun olarak yönetilen bir işletme, her şeyden önce, ahlak-dışı uygulamalarla yönetilen bir işletmenin sahip olduğu kötü ünün zararlarından korunmuş olacaktır. İşletmenin ahlaka aykırı davranışlar sergileyerek karlılığını artırması sadece kısa vadede bir fayda sağlayacaktır. Ancak işletme uzun vadede bu tür uygulamalardan zarar görecektir.

2. Ahlaki anlamda temeli sağlam bir biçimde oluşturulmuş işletmelerin farklı taleplere cevap vermesi çok daha kolay olacaktır.

3. Ahlaki yönetimin söz konusu olduğu işletmeler iki önemli grubun yani müşterilerin ve işgörenlerin saygısını kazanacaktır.

Son olarak, ahlaki davranışları keşfeden işletmeler, yukarıda ifade edilen çelişkinin aksine, kazançlarını artırma şansı yakalayacaklardır. Literatürde yapılan pek çok çalışma da ahlaki bir çalışma tarzı ile yüksek karlılık arasında yakın ilişkiler bulunmuştur. Örneğin, Alfred Marcus tarafından yapılan çalışmada, ahlaki ve sosyal 
sorumluluk davranışları ile yüksek karlılık arasında olumlu yönde bir korelasyon bulunduğu sonucuna ulaşılmıştır.

\section{3 İş Ahlakına Aykırı Davranmanın Neden Olduğu Kayıplar}

Ahlaki değerler, yumuşak ve soyut olarak algılanabilir. Ancak sonunda ahlaka aykırılık, somut ve ölçülebilir çıkarlara, işin özüne, parasal getirilere zarar verebilir. Dahası ahlakı göz ardı etmek, şirketlerin imajını, ismini ve kariyerini mahvedebilir. Union Carbide, BCCI, Exxon Valdez, Michael Miliken, Robert Maxwell, Barlos Clowes Borings Bank, Nestle vb. gibi dünyanın ünlü firmaları iş yaşamında bulanık, belirsiz yasalarla tamamen düzenlenmemiş alanlardaki uygulamaları nedeniyle dünya kamuoyuna konu oldular. Bu firmalar ürün ve hizmet kalitesi ile değil, ne yazık ki sorumsuzca ve ahlaki olmayan kararları ve uygulamaları yüzünden kamuoyunda yer almanın zorluğunu yaşadılar.

Bunlar "Yakalanmayı Başaranlar"dır. Ancak bu firmalar dışında, hiçbir gazete ve haberde yer almayan kişi ve kuruluşlar olduğu da bilinmektedir. Yıllarca hileli işler yapıp hiçbir zaman yakalanmayan bu kişilerin insanlara, hayvanlara ve çevreye verdiği zararlar tespit edildiğinde, bir gün mutlaka düşecekleri durumun olumsuzluğunu göz önüne getirmek dahi istemiyoruz. Bu kişi ve firmaların bu duruma düşmelerinin iki nedeni vardır: Birincisi, ahlaka aykırı davranmanın sonuçlarını görememeleri, ikincisi de ahlaka aykırı davranışların bedelini anlayamamalarıdır.

Dürüst davranmadıkları halde işlerini yürütebilmiş, ahlaka aykırı davranmada bir sakınca görmeyip bu tür uygulamalar ile para kazanan girişimcilerin yakalanmasalar da iyi durumda olduklarını söylemek mümkün değildir. Çünkü, bu kişilerin içine düştükleri yabancılaşma durumları en büyük cezadır. Özellikle nerede, nasıl ve ne şekilde hareket edeceklerini belirleyecek ahlaki norm ve kuralların saygınlık ve etkinliklerini azaltmak ya da ahlaki normlara bağlılıklarını zayıflatmak sonucunda yaşadıkları "anomi", ahlaki norm ve kuralları reddetme ve onlara karşı çıkma şeklinde ortaya koydukları "kuralsızlık ve sapma" sonucunda içine düştükleri başıbozukluk, kararsızlık, karamsarlık ve "hiç"lik duygusu en ağır cezadır. Vicdanını yok sayan bu kişiler, verdiği kararlara güvenme cesaretini gösterememekte, kendilerine inanmamakta, kendilerini güçsüz görmekte ve güçsüzlüklerinden dolayı da küçük görmektedirler (Fromm, 1994). Böylece bu kişilerin kendi varlıkları ile ahlak (moral) anlamındaki varlıkları arasındaki mesafe açılmakta ve bunlar "kendi kendilerine yabancılaşmak"tadırlar (Tolan, 1980).

Anlaşılacağı gibi ahlaka aykırı davranışların bir bedeli vardır, hatta bu bedel oldukça ağırdır. Ahlaka aykırı davranışın neden olduğu kayıplar, güvenin kaybedilmesi, grup çalışmalarının etkinliğinin kaybedilmesi, iletişimin zarar görmesi, bağlılık duygusunun yok olması, imajın zarar görmesi şeklinde sıralanabilir (Tierney, 1997).

\subsection{Güvenin Kaybedilmesi}

Güven duygusu, tarihin başlangıcından itibaren kişisel ve örgütsel ilişkilerin vazgeçilmez unsurları arasında yer alan ve bulunmadığı ilişkilerin sürdürülemez olarak kabul edildiği son derece önemli bir kavramdır. Bu nedenle güven kavramı, insan motivasyonunun en yüksek biçimi olarak kabul edilmekte, kişisel ve mesleki ilişkilerde önemli tek faktör olarak değerlendirilmektedir. Güven bir insanın kontrolü dışındaki olaylardan zarar görmesini önleyen ve olumsuz etkileri azaltan bir süreçtir. Korkunun yeni korkuları beslemesi gibi güven duygusu da güveni artırır. Korku ve güvensizlik bir tehlikenin olduğundan daha büyük algılanmasına neden olur ve gerginliği artırır. İnsanı yalnızlığa, mutsuzluğa, içe kapanmaya götürür. Diğer taraftan, güven ise insanı denge ve kontrol noktasına getirir. İletişim ve ilişki süreçlerinin işlemesini kolaylaştırır. Korku olumsuz düşünce ve duyguları, güven ise olumlu duyguları, sağlıklı ilişkileri ve huzurlu bir ortamı besler.

Örgütsel güven ise, çoğu kişinin zannettiğinden çok daha önemlidir. Çünkü güven, örgütsel verimlilikte kilit sözcüklerden biridir. Günümüzde örgütlerde:

Yaratıcı ortamların geliştirilmesi

Çalışanların düşünce ve fikirlerinin ortaya çıkarılması

Çalışanların sürekli öğrenmesi

Tüm yönlere açık iletişimin yapılabilmesi güvene dayalı ilişkilerin tesis edilmesini gerektirmektedir. Güvenin kaybedilmesi, iletişimin zarar görmesi, öz saygının kaybolması, bağlılık duygusunun kaybolması, sadakatin yitirilmesi, istifa ve benzeri olumsuz sonuçların doğması demektir. Bu durumda güven yaratılmadan başarı beklemek, büyük bir hayalcilik olacaktır. Çünkü Berry'nin de ifade ettiği gibi, "iş ilişkileri ancak ve ancak güven temeli üzerine kurulabilir" (Blois, 1999).

Literatürde, güvenin örgütsel başarı için gerekli olduğu, ancak kısa vadede yaratılamadığı, uzun ve özverili çabalar gerektirdiği konusunda fikir birliğine varılmıştır. Bu nedenle, örgüt üyeleri tarafından paylaşılan değerler, inançlar ve vizyon yaratmak ancak örgütsel güvenle mümkündür. Dolayısıyla işteki başarı için, güvenin tesis edilmesi ve onu zedeleyecek düşünce, davranış ve uygulamalardan uzak kalınması gerekmektedir. 


\subsection{Grup Çalıșmalarının Etkinliğinin Kaybedilmesi}

Günümüzde işletmeler daha etkin ve verimli bir şekilde rekabet edebilmek, kendilerini sürekli yenileyebilmek ve çalışanların yeteneklerinden en iyi şekilde yararlanmak için ekip çalışmasını kullanmaya başlamışlardır. Ancak ekip çalışmasının başarısı bir takım şartların varlığını gerektirir. Bunların başında güven ilişkisi gelmektedir. Güven ilişkisi olmadığında; hedefler, görevler veya projeler bütünüyle zarar görebilir. Çünkü kişiler muhtemelen böyle bir ortamda risk almaz, yaratıcı çözümler bulmak için gayret göstermez ve kendilerini geri çekerler. Çünkü pek çok araştırmanın da ortaya koyduğu gibi (Bourgeois ve Eisenhardt, 1988; Eisenhardt, 1989; Woolridge ve Ployd, 1990) günümüz şartları "grup konsensusunu" gerektiren kararlara dayanmaktadır. Bu da ancak liderin ve grup üyelerinin birbirine güveni ile ancak bir grup ya da ekipte yaratılabilir (Korsgaard vd., 1995). Güven, adeta insanları bir arada tutan bir yapıştırıcıdır.

Örgütlerde güvene dayalı ilişkilerin kurulması, çalışanların arkadaşlarına ve liderlerine güven duyması, örgütlerine duygusal açıdan bağlı, işlerinden tatmin olan ve kurumlarından ayrılmayı istemeyen çalışanlar yaratabilmekte ve ekip çalışmalarının temel dayanağını oluşturmaktadır.

\section{3 İletişimin Zarar Görmesi}

İş dünyasındaki karşılıklı ilişkilerde ahlaki ilke ve kurallar hemen her zaman varlıklarını hissettirmişlerdir. Üst üste baskı yapan bestseller kitaplarından "The 100 Best Companies To Work for in America" eserinin yazarı Robert Levering, bir kuruluşta ahlaki kuralların çiğnenmesi kadar çalışanların moralini bozabilecek pek az durumun söz konusu olduğunu ve kendi kitabına konu olan pek çok kuruluşun en hassas davrandıkları hususların da dürüstlük, güvenilirlik ve adil olma olduğunu (Gürlek ve Gürol, 1993) belirterek girişimcilikte ahlaki davranmamanın ciddi kayıplar yarattığına dikkat çekmiştir.

Ahlaki bir tavrın ciddiye alınmamasının getirdiği en büyük zarar, açıklık ve dürüstlüğün yok olmasıdır. Açıklık ve dürüstlüğün yok olması, güven ortamının kaybolması ve iletişimin zarar görmesi demektir. Bu nedenle güvenin en önemli belirleyicilerinden biri, taraflar arasındaki iletişimin açıklığı kabul edilmektedir (Carnavalle ve Sharp, 1993; Gabarro, 1978; Lambert, 1995).

Gerçekten kişiler arası sağlıklı ilişkilerin kurulabilmesi için kişilerin duygu ve düşüncelerini açabilme güvencesinin olması gerekir. Bir kişinin kendini tanıtma ve kendini açma ölçüsüyle o kişiyle olan yakınlık, samimiyet ve güven derecesi arasında yakın bir bağ vardır. Kendini açmak ancak güven duyulan kişiye yapılabilir. Bir insanın karşısındakine güven duyması ise zaman içinde gerçekleşir. Kendini açan kişi karşısındakine güven verir ve karşılığı da güven duyulan kişinin kendini açmasıdır. Böylece derin ve yakın bir ilişki ortaya çıkar. İnsan kendini kapadıkça, karşısındakini de kendini kapamaya zorlayan bir fasid daire oluşturur. Kuşkusuz açık olmanın riskleri de vardır. Ancak unutmamak gerekir ki hayattaki bütün başarılar, az çok riskli davranışlara dayanır.

Günümüzde yaşanılan rekabette Japon işletmelerinin karşılarındaki rakiplerine üstün gelmelerinde en büyük faktörün, Japon yöneticilerin üstlerine, astlarına ve tüm çalışanlara duydukları güven olduğu belirtilmektedir (Premaux vd., 1991). Diğer taraftan bu güven halka doğru bilgilendirme ve gerçek bilgiye dayalı iletişim aracılığıyla kurumsal girişimciliğinin sürdürülebilirliğini sağlamaktadır. Gerçekten yapılan çalışmalar, ahlaki davranmamanın ve kendi menfaatini düşünmenin iletişimde güvene yönelik bir şüphe ortaya koyduğunu, bunun ise iletişimlerin en büyük engeli olarak gösterildiğinin altını çizmektedir.

\subsection{Bağlılık Duygusunun Yok Olması}

Bir örgütte çalışanların işletmeye ve birbirlerine güvenlerinin kaybolması, iletişimleri bozduğundan doğal olarak aralarındaki bağlılık duygularını da olumsuz etkileyecek ve bağlılık duygusu yok olacaktır (Tierney, 1997). Bağlılık kavramı örgütsel ve mesleki bağlılık olarak ayrılmaktadır. Örgütsel bağlılık, bir çalışanın örgütün amaçlarını, değerlerini kabul etmeye olan inanç ve örgütün yararı için çaba göstermeye olan isteklilik olarak düşünülmektedir (Camp, 1991). Araştırmalara göre, çalışanlar işyerlerinde tatmin oluyorlarsa, üstlerinin destekleyici ve duyarlı olduklarını algılıyorlarsa ve adaletli davranıldığına inanıorlarsa çalışanların örgüte duyduğu bağlılık ve yakınlık artmakta ve çalışanlar örgüt ile kendilerini özdeşleştirmektedirler (Sloat, 1999). Bu bilgi, örgüte bağlı çalışanlara sahip olmanın sağladığı avantajlarla (Meyer ve Allen, 1997) yan yana getirildiğinde, konunun gerçekte ne denli önemli olduğu daha iyi anlaşılacaktır. Bu durumda ahlaki yaklaşım içerisinde olan bir örgüt, günümüzde en zor kazanılan konu olarak karşımıza çıkan çalışanının bağlılık ve sadakatini sağlamış olacaktır. Aksi bir durumda ise, katlanılan maliyetler oldukça yüksek olacaktır. Örneğin, bir işletmede bağlılık duygusu yok olduğunda, başarılı olmaya çalışmanın, sorunlara yenilikçi çözümler bulmanın, işi yoğun bir arkadaşa yardım etmek için gece geç saatlere kadar çalışmanın bir gereği olmayacaktır. Pek çok araştırmanın ortaya koyduğu gibi (Deutsch, 1957-Guth ve MacMillan, 1986; Hitt ve Tyler, 1991), çalışanlar arasında bağlılığın zayıflaması, bilgi paylaşımının azalmasına, motivasyonun kaybolmasına, yabancılaşmaya ve işten ciddi oranlarda ayrılmalara ayrılmalara yol açmaktadır (Campion' ${ }^{1991)}$.

\section{5 İmajın Zarar Görmesi}

Ahlaka aykırı davranışların ve uygulamaların sonucunda güvenin yitirilmesi dışında ödenecek bir başka bedel, o güne kadar oluşturulmuş işletme imajıdır. Müşterilerine verdiği sözleri tutmayan, hesaplarında oynamalar yapan, bir takım meşru olmayan ve bulanık işlere adları karışan işletmeler, olumlu bir imajı anında kötü bir 
imaja çevirebilirler. Toplumda imaj yaratma kaygısı, modern girişimcilerin mal ve hizmet kalitesi kadar önem verdikleri bir konudur. Çünkü günümüzde mal ve hizmeti, saygın imajın daha kolay sattırdığı inkar edilemez bir gerçektir (Aldemir vd., 1996). Bu nedenle, markalar güçlerini milyarlık reklamlarla yarattıkları imajların üzerine kuruyor ve bu konuda çok hassaslar. Şayet şirketler kendilerini özellikle, sosyal, sağlıklı, modern, çocuk sever, kadın, aile ve çevre dostu olarak tanımlıyorlarsa onları kendi koydukları bu değerler üzerinden değerlendirmek çok meşru. Örneğin, İtalyan moda milyarderi Benetton, Aids hastaları, savaş kurbanları, yeni doğmuş bebekleri kullanarak yaptığı kışkırtıcı reklamlarda sosyal konularla ilgilendiğini göstermiş oldu. Oysa 1998 yılında şirketin giyim eşyalarının Türkiye'de 12 yaşında çocuklar tarafından üretildiği kulaktan kulağa dolaşıyordu (Werner ve Weiss, 2002).

Akla günümüzde şu soru geliyor? Niçin şirketler reklamlara ayrılan paraları ödemekten kurtulmak istemiyorlar bizi kurtarmıyor ve ürünlerini usandırıcı marka reklamlarıyla dünyayı bunaltmadan satamıyorlar? Amerikalı ekonomist ve yazar Jeremy Rifkin, şirketlerin reklamla verdiği mesajların, modern iletişim tekniklerinin yardımıyla, okul, dini kurumlar, sosyal topluluklar ve kültürel kuruluşlar gibi geleneksel duyarlılıklar yaratanların rollerini üstlendiğini belirterek, şöyle diyor: "Bir markayı satın almış olmak, alıcıyı hayali bir dünyaya götürür, tasarımcıların aktardıkları değerleri ve anlamları gerçekten başka insanlarla paylaştıkları hissine kapılırlar (Werner ve Weiss, 2002)". Nike işte bu nedenle sadece spor ayakkabı değill, "ortak bir sağlık" duygusu üzerine çalışır. IBM sadece bilgisayar değil sorunlara çözüm üretir. Bu şekilde, ürünün kendisiyle birlikte, ayakkabıların, bilgisayar parçalarının insanı öldürmeyecek kadar yaşatacak ücretlerle üretildiği gerçeği de arka plana atılmış olur. Gazeteci Naomi Klein'in "No Logo!" adlı kitabında yazdığ gibi tam da o anda "markaların göz kamaştıran cephesindeki çatlaklar ve gedikler ortaya çıkıyor..." (Werner ve Weiss, 2002).

Oysa marka değerinin, değerler krizi yaratarak oluşturulduğu servetlerin yıkımı saniyeler sürebilir. Çünkü giderek daha fazla insanın bu göz kamaştıran cepheyi yıkmak için buluştuğu ve pazarın en hızlı silahını "interneti" kullanarak karşıt bir cephe oluşturdukları dikkat çekmektedir. Bu durumda işletmelerin sık sik telaffuz ettiği, ancak uygulamalarında tam tersi sonuçlar sergilediği iş ahlakına çok daha fazla önem vermeleri gerektiğini anlamaları (Hoffman ve Frederick, 1995), modern iş dünyasının temel şartlarından biri olarak görülmektedir.

\section{Sonuç}

"Çağımız bir geçiş dönemi içerisinde bulunmaktadır. Orta Çağ 15. yüzyılda bitmemiş, Yeni Çağ ise hemen ondan sonra başlamamıştır. Son ve başlangıç dört yüz yıl süren bir süreci gerektirmiştir - bu dört yüz yılı kendi ömrümüzle değil de, tarihsel gelişme açısından ölçecek olursak, bunun gerçekten de çok kısa bir zaman olduğunu görürüz. Bizim çağımız da hem bir sondur, hem de imkanlarla yüklü bir başlangıçtır”.

İnsan tarihsel dönemlerin ve sosyo-kültürel coğrafyaların farklılıklarına rağmen genel geçer ahlaki ilkelere işaret etme ve değer ve normlar üretmeye çalışmıştır. Yaşamını ahlaki ilke ve değerlere dayamaya çalışmıştır. Ancak 20. yüz yılın son yarısında yaşanılan büyük değişim ve dönüşümler inşa edilen değerlerin altını üstüne getirmiş ve bu durum dünyanın hemen her köşesinde ortaya çıan ahlaki yozlaşma ve kirlilikle sosyal, siyasi, kültürel ve ekonomik tüm alanları kapsamıştır. Yaşanılan son elli yıl, kapitalist zihniyete dayalı bu kirliliğin yayılım ve çeşitlenme süreci olurken, bu sürecin baş aktörlerini ise girişimciler oluşturmuşlardır.

Kapitalist zihniyetin kendisine amaç kıldığı maksimum kazanç anlayışı, geniş bir rant tabanı yaratmış bu taban üstünde ahlak kendisine yer bulamamıştır. Kendini her türlü ahlaki sınırlamanın üstünde gören aşırı kazanma hırsıyla beslenen girişimcilik kültürü, "her koşulda ve her zaman kar elde etmek" anlayışıyla, insana, topluma ve doğaya ciddi zararlar vermiştir. Böylece, girişimcilerin kar maksimizasyonu amacıyla tüketmiş olduğu maddi kaynaklar yanında, önceki tarihsel süreçte insanlığın ürettiği manevi kaynakların da yok edilmesiyle birlikte ortaya çıkan "ahlaki boşluk" tüm dünyada insanlık için yaşanılan savaşlardan sonra en önemli acı ve sancının kaynağı olmuştur. Zedelenen güven, bozulan iş disiplini, kısa ve uzun vadeye yayılan ekonomik, sosyal, siyasi ve hukuki dezavantajlar ya da ahlaki krizler krizden çıkış yoları aranmasını zorunlu kılmıştır. Dolayısıyla ahlaki kaybettiğimiz zemin ahlaki aynı zamanda inşa zeminimizdir. Ahlaka ilgi ve ahlaki davranışa yönelik artan değer İnsanlık için yeni zirvenin ahlaka odaklılık ve ahlaki bir yönetim yaklaşımı olduğunu belirtmektedir. Ahlak tarihsel olarak yaşanılan bir olgu olarak yeni değer inşasını, ekonomik sahada ahlaki meşruiyet içerisinde kendisine kazanç arayan yeni nesil girişimcileri aracıllğıyla yapacaktır. Yeni nesil girişimciliğin sorumluluğu, maddi temele oturmuş bir dünyada, maddi idrakla alınmış kararlardaki ekonomik faaliyetin "değer körü" olduğunu ve bunun sonucunda elimizde kalan değersizliğin sancı ve acılarını, sömürü, suistimal ve ihlallerini değer üreten girişimci anlayışıyla refah ve barışa çevirmesidir.

Biliyoruz ki, "iyilik de, kötülük de kendi başına ya da bir alın yazısına bağlı olarak gerçekleşen şeyler değillerdir, Karar, insana bırakılmıştır. Bu karar insanın kendisini, kendi hayatını ve mutluluğunu ciddi bir biçimde ele alma yeteneğine bağlıdır; kendisinin ve içinde yaşadığı toplumun ahlaki problemi ile yüz yüze gelme isteğine bağlıdır. "Kendisi”" olma ve "kendisi için" olma cesaretini göstermesine bağlıdır". 


\section{Kaynakça}

- Aldemir M. C., vd, 1996, Personel Yönetimi, Barış Yayınları.

- Arıkan S., 2002, Girişimcilik: Temel Kavramlar ve Bazı Güncel Konular, Siyasal Kitapevi, Ankara.

- Bayrak S., 2001, İş Ahlakı ve Sosyal Sorumluluk, Beta Basım A. Ş., İstanbul.

- Blois K. J., 1999, "Trust in Business to Business Relationships: An Evaluation of Its Status", Journal of Management Studies, 36 (2), p.197

- Camp S. D., 1991, "Assessing The Effects of Organizational Commitment and Job Satisfaction on Turnover, Comparison of Alternative Measures and Recommendations for Research, Journal of Applied Psychology, 76, pp.199-212

- Campion M. A., 1991, "Meaning and Measurement of Turnover: Comparison of Alternetive Measures and Recommendations for Research, Journal of Applied Psychlogy, 76, pp.199-212

- Carroll, A. B., 1991, "The Pyramid of Corporate Social Responsibility Toward the Management of Organizational Stakeholders", Business Horizons, July-August.

- CNN Money, Global 500, http://money.cnn.com/magazines/fortune/global500/2012/full_list/401_500.html, Erişim tarihi:21.06.2013

- Dean P. J., 1997, "Examining The Profession and the Practice of Business Ethics", Journal of Business Ethics, 16, pp.137-148

- Durlauf S. N. and Fafchamps M., 2004, "Social Capital”, The Centre for the Study of African Economies Working Paper Series Paper No:214, pp.1-4, http//www.bepress.com/cgi/viewcontent cgi?article=1214\&context=csa, 2006

- Ferrell O.C., vd, 1994, Business Ethics: Ethical Decision Making and Cases, Second Edition, Houghton Mifflin Company, Boston.

- Fromm E., 1994, Erdem ve Mutluluk, Çev. Ayda Yörükan, İş Bankası Kültür Yayınları, Ankara.

- Grace D. and Cohen S., 2005, Business Ethics: Problems and Cases, 3rd Edition, Oxford University Press.

- Gürlek B. ve Gürol M. A., 1993, "Kaliteye Giden Yolda Etik Yapının Rolü", Dokuz Eylül Üniversitesi I.I.B.F. Dergisi, 8 (1), s.193

- Handy C. B., 1976, Understanding Organizations, Penquin Books Ltd.

- Hoffman M. W. and Frederick R. E., 1995, Business Ethics: Reading and Cases in Conporate Morality, McGraw-Hill Book.

- İlhan İ, 1990, Turizmde İş Ahlakı, Yayınlanmamış Ders Notları, Nevşehir Turizm İşletmeciliği ve Otelcilik Yüksekokulu, Nevşehir.

- İs Etiği Raporu, 2009, TÜSİAD, İstanbul.

- Korsgaard M. A. and et al., 1995, "Building Commitment, Attachment and Trust in Strategic Decision Making Teams: The Role of Procedural Justice" Academy of Management Journal, 38 (1), p.60

- Madsen P. and Shafritz J. M., 1990, Essential of Business Ethics, Penguin Books Inc., New York.

- McHugh F. P., 1991, İş Ahlakı, TÜSİAD Yayınları, İstanbul.

- Meyer J. P. and Allen N. J., 1997, Commitment in the Workplace: Theory, Research and Application, Sage Publication.

- Müftüoğlu T. ve Durukan T., 2004, Girişimcilik ve KOBİ’ler, Gazi Kitabevi, Ankara.

- Morgan G, 1998, Metafor, MESS Yayınları, Ankara.

- Naisbitt J, 1994, Global Paradoks, Çev. S. Gül, Sabah Kitapları, İstanbul.

- Premaux S. R.,vd., 1991, Management and Organizational Behavior, Richard D. Irwin Inc., Homewood Illinois.

- Quigley J. V., 1993, Vizyon: Oluşturulması, Geliştirilmesi ve Korunması, Çev. B. Çelik, Epsilon Yayıncilik, İstanbul.

- Sloat K., 1999, Organizational Citizenship, Professional Safety, 44, pp.20-23

- Tierney E. P., 1997, İş Ahlakı, Rota Yayınları, Çev. Günhan Günay, İstanbul.

- Tolan B., 1980, Çağdaş Toplumun Bunalımı: Anomi ve Yabancılaşma, AİTİA Toplum Bilimleri Araştırma Enstitüsü Yayınları, Ankara.

- USA Government Printing Office, 1981, "The President's Comission on Federal Ethics Law Reform, to Serve with Honor" Report and Recommendation to President, Washington, p.1

- Werner K. ve Weiss H., 2002, Markaların Kara Kitabı, MediaCat Kitapları, Çev. Dilman Muradoğlu, İstanbul. 


\title{
Turist Akımında Oynaklık: Türkiye Örneği Volatility in Tourist Inflows: Evidence from Turkey
}

\author{
Assoc. Prof. Dr. Kadir Karagöz (Celal Bayar University, Turkey)
}

\begin{abstract}
Tourism sector, like most of the other countries of the world, has also gained importance in Turkey in last few decades. Global tourist flows and tourism income have a steady increase. Hence, as an effective tool for sustainable economic development and welfare, importance of tourism sector is rising. Tourism is a considerable source of an additional income, exchange, employment and tax revenue for most countries. Turkey is one of the prominent tourism destinations for the world tourist flows. Turkish tourism industry began to grow in 1980s with the incentive macroeconomic policies. The industry has been growing in terms of international tourist arrivals and tourism receipts despite some discouraging events, such as economics crisis in the source countries, changing concerns, political incidents etc. For a sustainably growing and productive tourism sector it is essential to reduce the volatility in tourist arrivals. A less volatile tourist inflow may help to policy and decision makers. So, understanding the volatility of demand can reduce the uncertainty and help to develop appropriate policies. This paper aims to conduct such an analysis for Turkey's inbound tourist flow, using the monthly data for 19962011 period. Exploiting alternative modeling techniques to measure and investigate the volatility in international tourist arrivals, the study concluded that the volatility of tourist arrivals to Turkey is asymmetric: positive shocks have a differential impact on future volatility than negative shocks.
\end{abstract}

\section{Giriş}

Turizm, dünyada en hızlı gelişen sektörlerden biridir. Küresel turist akımı ve turizmden elde edilen gelir son yıllarda istikrarlı bir artış göstermektedir. Bunun sonucunda, turizmin ekonomik büyüme ve kalkınmada etkili bir araç olarak önemi de artmaktadır. Birçok ülke için turizm önemli bir ilave gelir, döviz, istihdam ve vergi geliri kaynağıdır. 2010 itibariyle küresel turist akımı 940 milyon kişiye, turizm gelirleri ise 733 milyar \$'a ulaşmıştır. Bu değerlerin 2020 yılında 1,36 milyar kişi ve 2 trilyon \$'a çıkacağı tahmin edilmektedir (UNWTO, 2012).

Turizm, kendine özgü doğal, kültürel ve tarihî zenginliklere sahip olan Türkiye ekonomisi için gittikçe önem kazanan sektörlerden biridir. Sektörün önemi, istihdam yaratma kapasitesi, ekonomik büyümeye katkısı, hükümet için kayda değer bir döviz ve gelir kaynağı olmasından kaynaklanmaktadır. Turizm sektörü, güçlü ileri ve geri bağlantıları nedeniyle ekonominin neredeyse tümünü etkileme potansiyeline sahiptir. Turizm, ödemeler dengesi üzerinde önemli etkileri bulunan görünmeyen bir ihracat kalemi olarak değerlendirilebilir. Otomasyon ve mekanizasyon kabiliyeti oldukça düşük olan sektörde istihdam/yatırım oranı da genel olarak yüksektir. Turizm, yarattığı uyarıcı etkiler nedeniyle de dolaylı olarak diğer birçok sektörde üretim, istihdam ve gelir artışına neden olmaktadır. Turizm sektörünün sahip olduğu mikro ve makro dışsallıklar ve büyüme potansiyeli birçok ülkeyi bu pastadan daha fazla pay almak için kıyasıya bir yarışa sevk etmektedir.

Turizm sektörünün yukarıda belirtilen yararları sektörün önemini artırmaktadır. $\mathrm{Bu}$ nedenle, sektörün gelişmesine yönelik önlem ve politikaların belirlenmesi kadar, turist akımının karakteristiklerinin incelenmesi de önem arz etmektedir. Bir ülkeye gelen turist akımının şoklar karşısında aşırı ve kalıcı oynaklık göstermesi, geleceğe yönelik belirsizliği artıracağından sektörden beklenen yararın tam olarak sağlanamamasına yol açacaktır. Bu nedenle Türkiye'ye yönelik turizm akımının oynaklığının ortaya çıkarılması ve buna uygun politikaların izlenmesi sektörün daha plânlı ve kontrollü olarak geliştirilmesi bakımından önem taşımaktadır.

Bu çalışmanın amacı, önemli bir turist destinasyonu olan Türkiye'ye gelen turist akımının oynaklığını çeşitli ölçütler kullanarak test etmektir. Çalışmanın izleyen bölümünde Türkiye'nin turizm potansiyeli ve Türkiye ekonomisi içinde turizmin yerine ilişkin kısaca bilgi verilmektedir. 3. Bölümde turist akımlarındaki oynaklığın sonuçları ve oynaklığın ölçülmesinin önemine değinilmekte, konu ile ilgili önceki çalışmalardan bahsedilmektedir. 4. Bölümde oynaklığın ölçülmesi ve modellenmesi konusunda başvurulan çeşitli ampirik ölçütler tanıtılmaktadır. 5. Bölüm, aylar itibariyle Türkiye'ye gelen turist sayısındaki oynaklığın bahsedilen ölçütlerle araştırıldığı analiz sonuçlarına ayrılmıştır. Çalışma, Sonuç bölümüyle nihayet bulmaktadır.

\section{Türkiye'de Turizm Sektörü}

Dünya turizm akımlarındaki gelişmeye paralel olarak Türkiye’ye gelen turist sayısı ve turizm gelirlerinde de son yıllarda dikkat çekici gelişmeler gözlenmektedir. Özellikle 1980'lerden itibaren, hem devlet destekli arz yanlı atılımlar hem iç ve dış turizm akımlarındaki genişlemeden kaynaklanan talep yanlı gelişmeler nedeniyle Türk turizm sektörü çok büyük bir gelişme göstermiştir.

Türkiye'de ekonomi politikalarının geniş bir perspektifle tartışılmaya başlandığı 1960'lı yıllar, turizmin öneminin de kavranmaya başladığı yılları ifade etmektedir (Çımat ve Bahar, 2003). Türkiye'de kutsal yerler, 
sağlık ve yaz tatili amaçlı yurt-içi turizmin geçmişi eskilere dayansa da, ülkenin uluslararası turizm piyasasına açılması 1980'lerin sonlarına rastlamaktadır (Yıldırım ve Öcal, 2004). 1980'lerin başlarında başlayan dışa açılma ve liberalleşme politikaları ile birlikte uluslararası mal ve hizmet ticareti gibi turizm de önem verilen konulardan biri haline gelmiş, bu yöndeki yatırımlar da devlet tarafından desteklenmiştir. Turizmin gelişmesinde 1982 tarihli Turizmi Teşvik Kanunu ile sektöre sağlanan yatırım teşvikleri ve mali desteğin çok önemli etkisi olduğu söylenebilir (Bahar, 2006;138). Bu destekleyici politikalar sayesinde, 1980 yılında GSYH içinde \% 0,6 olan turizmin payı 2006 yılında \% 13,5'e çıkmıştır. Ödemeler dengesi açı̆̆ını kapatmada da turizm gelirleri en önemli kaynaklardan biridir (Kar vd., 2004). Günümüzde turizm sektörü, imalat sanayisinden sonra en önemli döviz ve istihdam kaynağı durumundadır. Diğer taraftan turizm büyüme, istihdam ve verimlilik artışı açısından da uygun bir araç olarak değerlendirilmektedir. Uzun dönemde turizm sektörünün Türkiye'nin ekonomik büyümesi üzerinde olumlu etkide bulunduğuna dair ampirik bulgular mevcuttur (Bahar, 2006; Gündüz ve Hatemi-J, 2005; Yıldırım ve Öcal, 2004). Girdi - çıktı analizleri, Türkiye'de turizm sektörünün diğer sektörler üzerinde kayda değer bir etkiye sahip olduğunu ortaya koymaktadır (Çakır ve Bostan, 2000; Dilber, 2007; Canlı ve Kaya, 2012).

Bununla birlikte, son yıllarda gelen turist sayısı artarken turist başına harcama miktarındaki azalmaya bağlı olarak turizm gelirlerinde nisbî bir gerileme görülmektedir (Ünlüönen ve Kılıçlar, 2004). 2011 y1lı Dünya Turizm Örgütü verilerine göre, gelen turist sayısı açısından Türkiye dünyada 6. sırada iken, turizm geliri bakımından ne yazık ki ilk 10'a girememektedir (bkz Tablo 1).

UNWTO verilerine göre, 2006 yılı itibariyle Türkiye'nin turizm gelirleri GSYH'sinin \% 13,53'ü kadardır. Türkiye, 2006 yılında turizmden elde ettiği 16,9 milyar \$’lık gelirle dünyada turizmden en fazla gelir elde eden ilk on ülke arasında (9. sırada) yer almaktadır. Ancak yine de, Türkiye'nin sahip olduğu coğrafî ve tarihsel zenginliklerinden kaynaklanan turizm potansiyelini tam olarak değerlendirdiği söylenemez. Türkiye gibi bir Akdeniz ülkesi olan İspanya'nın 2011 yılında turizmden elde ettiği gelir 59,9 milyar \$, İtalya'nın ise 43,0 milyar \$'dir (UNWTO, 2012).

\begin{tabular}{lllll|lllll}
\multicolumn{3}{l}{ Gelen Turist Sayıs1 (Milyon kişi) } & \multicolumn{7}{l}{ Turizm Geliri (Milyar ABD \$) } \\
\hline Sira & Ülke & 2010 & 2011 & \% Değ. & Sira & Ülke & 2010 & 2011 & \% Değ. \\
\hline 1 & Fransa & 77,1 & 79,5 & 3,0 & 1 & A.B.D. & 103,5 & 116,3 & 12,3 \\
2 & A.B.D. & 59,8 & 62,3 & 4,2 & 2 & İspanya & 52,5 & 59,9 & 14,0 \\
3 & Çin & 55,7 & 57,6 & 3,4 & 3 & Fransa & 46,6 & 53,8 & 15,6 \\
4 & İspanya & 52,7 & 56,7 & 7,6 & 4 & Çin & 45,8 & 48,5 & 5,8 \\
5 & İtalya & 43,6 & 46,1 & 5,7 & 5 & İtalya & 38,8 & 43,0 & 10,9 \\
6 & Türkiye & 27,0 & 29,3 & 8,7 & 6 & Almanya & 34,7 & 38,8 & 12,0 \\
7 & İngiltere & 28,3 & 29,2 & 3,2 & 7 & İngiltere & 32,4 & 35,9 & 10,9 \\
8 & Almanya & 26,9 & 28,4 & 5,5 & 8 & Avustralya & 29,8 & 31,4 & 5,5 \\
9 & Malezya & 24,6 & 24,7 & 0,6 & 9 & Makao (Çin) & 27,8 & - & - \\
10 & Meksika & 23,3 & 23,4 & 0,5 & 10 & Hong Kong (Çin) & 22,2 & 27,7 & 24,7 \\
\hline
\end{tabular}

Tablo 1. Turist saylsı ve turizm gelirleri açısından önde gelen ülkeler. Kaynak: (UNWTO, 2012)

\section{Turizm Akımlarında Oynaklık}

Turist akımları içsel ve dışsal faktörlere karşı oldukça duyarlıdır. Turist gönderen ülkelerin ekonomik durumları, doğal afetler, etnik çatışmalar, asayiş sorunları, terörist faaliyetler bir ülkeye gelen turist akımını olumsuz etkileyebilmekte ve dönemsel olarak dalgalanmalara yol açmaktadır. Turizm talebindeki bu dalgalanmalar, özellikle rekabet ve ödeme güçlüğü çeken küçük oteller üzerinde baskı yaratmakta ve sektörün istihdam düzeyi ve genel olarak faaliyetlerini etkilemektedir (Lorde ve Moore, 2008). Diğer taraftan, turizm akımının oynak olması gelirlerde belirsizlik yaratacağından oynaklığın derecesi hükümetler ve yatırım kararları açısından önem arz etmektedir.

Ampirik literatürde turizm hareketleri birçok açıdan incelenmekle birlikte turist akımlarındaki oynaklığın yeterince ele alınmadığı, bununla birlikte son yıllarda konuya olan ilginin arttığı görülmektedir. Chan vd. (2005), 1975 - 2000 dönemi içinde dört büyük kaynak ülkeden (Japonya, Yeni Zelanda, İngiltere ve ABD) Avustralya'ya gelen turist sayısının koşullu ortalama ve varyansını üç farklı GARCH modeli kullanarak incelemişlerdir. Ulaştıkları bulgular, dört ülkenin koşullu varyansları arasında karşılıklı bağımlılık bulunduğunu, iki ülkenin (Japonya ve Yeni Zelanda) ise şoklardan asimetrik olarak etkilendiğini ortaya koymaktadır. Negatif şoklar bu iki ülkeden turist akımının oynaklığını pozitif şoklara oranla daha fazla etkilemektedir.

Lorde ve Moore (2008), 1977 - 2005 dönemine ait aylık verilerle, küçük bir ada ülkesi olan Barbados'a gelen turist miktarının oynaklığını çok sayıda farklı ölçüt kullanarak analiz etmişlerdir. Kullanılan ARCH ve GARCH modelleri Barbados'a gelen turist sayısının kısa dönemde kalıcı (persistent) ve asimetrik bir oynaklığa sahip olduğunu göstermektedir. Gelen turist miktarındaki oynaklığın pozitif şoklardan daha fazla etkilendiği belirlenmiştir. 
Daniel ve Rodriges (2010), Portekiz'e en fazla turist gönderen altı Avrupa ülkesinden gelen turist akımının mevsimsellik ve oynaklığını araştırmışlar ve şokların bu ülkelerden gelen turist akımı üzerinde uzun vadeli etkide bulundukları sonucuna varmışlardır.

Coşkun ve Özer (2011) dört ülkeden Türkiye’ye yönelik turizm talebinin oynaklığını modellemişlerdir. 1985 2009 dönemini kapsayan analiz sonucunda, dört ülkenin turizm talebinin hem etkileme hem de etkilenme açısından birbirleriyle ilişkili oldukları bulgusuna ulaşılmıştır. Çalışma, genel ve ülkelere göre turizm akımlarının iç ve dış şoklar karşısındaki asimetrik tepkisi konusunda herhangi bir ipucu vermemektedir.

\section{Zaman Serilerinde Oynaklığın Ölçülmesi}

Her ne kadar turizm araştırmalarında son zamanlarda kullanılmaya başlamışsa da, oynaklık modelleri 1990'ların başından beri finansal ve makroekonomik araştırmalarda yaygın olarak kullanılmaktadır. Zaman serilerindeki oynaklığın modellenmesine yönelik yöntemler Engle (1982) ve Bollerslev (1986) in çalışmalarıyla başlamış, zaman içinde çeşitlenerek gelişmiştir.

Tüm oynaklık modelleri, hata terimi içeren bir ARIMA veya regresyon modeli biçimindeki bir ortalama denklemi ile işe başlamaktadır. Oynaklığın modellenmesinde koşullu (stokastik) ve koşulsuz (sabit) hatalar arasında bir ayrım yapılmaktadır. Hata terimlerinin $\sigma_{t}^{2}$ ile gösterilen koşullu varyans zaman içinde değişmektedir. Oynaklık modelinde, başlangıştaki ortalama denklemine bir varyans denklemi eklenerek bu koşullu varyans modellenmeye çalışılır (Coshall, 2009).

Bu modellerden biri RiskMetrics (1996) tarafından geliştirilen risk ölçüsüdür. Oldukça basit bir yapıya sahip olan ve fazla gözlem gerektirmeyen bu ölçü aşağıdaki şekilde hesaplanmaktadır:

$$
\sigma_{t}^{2}=(1-b) r_{t}^{2}+b \sigma_{t-1}^{2}
$$

Burada; $\sigma_{t}^{2}, t$ dönemindeki oynaklığ $; r_{t}^{2}, t$ dönemindeki getirinin (bir aydan diğerine gelen turist sayısındaki değişimin) karesini göstermektedir. $b$ ise risk parametresi olarak adlandırılmaktadır ve RiskMetrics tarafindan aylık veriler için 0,97 olarak belirlenmiştir (RiskMetrics, 1996). RiskMetrics ölçütü, aslında daha genel bir ölçüt olan GARCH (generalised autoregressive conditional heteroskedasticity) modelinin özel bir halidir.

Bollerslev (1986) tarafından geliştirilen GARCH modelinde koşullu varyans aşağıdaki gibi modellenmektedir:

$$
\sigma_{t}^{2}=\alpha_{0}+\sum_{i=1}^{q} \alpha_{i} \varepsilon_{t-i}^{2}+\sum_{j=1}^{p} \beta_{j} \sigma_{t-j}^{2}
$$

Burada, varyansın negatif olmasını engellemek için $\alpha_{0}>0$ ve $\alpha_{i}$ ve $\beta_{j} \geq 0$ dır. Bu model yapısına göre, koşullu varyans geçmişe ait bilgi ile, yani ortalama denkleminden elde edilen hata terimlerinin karesinden oluşan kısa dönem şokları $\left(\varepsilon_{i}^{2}\right)$ ve daha uzun dönem koşullu varyanslar $\left(\sigma_{j}^{2}\right)$ ile ilişkilendirilmektedir. Denklem 2'deki genel yapı GARCH(p, q) süreci olarak nitelendirilmektedir. GARCH modellerinde, durağanlık koşulunun sağlanabilmesi için $\sum \alpha_{i}+\sum \beta_{j}<1$ olması gerekmektedir. Bütün $\beta_{j}$ ler sıfır olursa, Denklem $2 \mathrm{ARCH}(\mathrm{p})$ sürecine dönüşür. Uygulamada sürecin derecesi fazla yüksek olmamakta, genellikle aşağıdaki $\operatorname{GARCH}(1,1)$ modeli yeterli olmaktadır (Coshall, 2009; 496).

$$
\sigma_{t}^{2}=\alpha_{0}+\alpha_{1} \varepsilon_{t-1}^{2}+\beta_{1} \sigma_{t-1}^{2}
$$

Denklem 2'nin gerisinde yatan varsayım, pozitif ve negatif şokların etkisinin simetrik olduğudur. Oysa çoğu zaman serisinde negatif ve pozitif şokların etkisi farklılaşabilmektedir. Örneğin, turizm serilerinde negatif bir şokun oynaklık üzerindeki etkisi, aynı büyüklükteki pozitif bir şoktan daha fazla olmaktadır. Bu durum, eşik GARCH (TGARCH) ve üssel GARCH (EGARCH) gibi asimetrik oynaklık modellerinin geliştirilmesine yol açmıştır.

Eşik GARCH modeli, olası asimetrileri hesaba katmak için yukarıdaki GARCH denklemine ilave terim(ler) eklenmektedir. GARCH(p,q) modelinin eşiksel biçimi şöyledir.

$$
\sigma_{t}^{2}=\alpha_{0}+\sum_{i=1}^{q}\left(\alpha_{i} \varepsilon_{t-i}^{2}+\phi_{i} \varepsilon_{t-i}^{2} I_{t-i}^{-}\right)+\sum_{j=1}^{p} \beta_{j} \sigma_{t-j}^{2}
$$

Burada, $I_{t-i}^{-}$kukla değişkendir. $\varepsilon_{t-i}<0$ ise 1 'e, $\varepsilon_{t-i}>0$ ise 0 'a eşittir. Eğer, Denklem 3 'de $\phi_{i}>0$ ise negatif bir şok oynaklığı artıracaktır.

$\operatorname{EGARCH}(\mathrm{p}, \mathrm{q})$ modelinde ise koşullu varyans, asimetriyi de hesaba katarak;

$$
\log _{\varepsilon} \sigma_{t}^{2}=\alpha_{0}+\sum_{i=1}^{q}\left(\alpha_{i}\left|\frac{\varepsilon_{t-i}}{\sigma_{t-i}}\right|+\phi_{i} \frac{\varepsilon_{t-i}}{\sigma_{t-i}}\right)+\sum_{j=1}^{p} \beta_{j} \log _{\varepsilon} \sigma_{t-j}^{2}
$$

şeklinde modellenmektedir. Bu modelde asimetri etkisinin $\phi_{i}$ parametresi yansıtmaktadır. Eğer $\phi_{i}<0$ ise negatif şoklar oynaklığı artıracaktır.

Oynaklığın ölçümü, varyans yerine standart sapmanın modellenmesiyle de yapılabilir. Böylelikle elde edilen Power GARCH modelinde, standart sapmanın güç parametresi $(\delta)$ önceden belirlenmek yerine tahmin edilmektedir. Asimetrik etkiyi hesaba katmak için de bir $\gamma$ parametresi modele eklenmektedir.

$$
\sigma_{t}^{\delta}=\alpha_{0}+\sum_{j=1}^{p} \beta_{j} \sigma_{t-j}^{\delta}+\sum_{i=1}^{p} \alpha_{i}\left(\left|\varepsilon_{t-i}\right|-\gamma_{i} \varepsilon_{t-i}\right)^{\delta}
$$


Burada, $\delta>0, i=1,2, \ldots, r$ için $\left|\gamma_{i}\right| \leq 1, i>r$ için $\gamma_{i}=0$ ve $r \leq p$ dir. $\gamma \neq 0$ ise asimetrik etki söz konusudur.

GARCH(1,1) modelinde benimsenen koşullu varyans yapısı gereği, ortalamaya dönüşün zaman içinde sabit olduğu kabul edilmektedir. Component GARCH modeli, bu varsayımın gevşetilmesine, ortalamaya dönüş hızının $\left(m_{t}\right)$ zaman içinde değişebilmesine imkân vermektedir:

$$
\begin{aligned}
\sigma_{t}^{2}-m_{t} & =\alpha\left(\varepsilon_{t-1}^{2}-m_{t-1}\right)+\beta\left(\sigma_{t-1}^{2}-m_{t-1}\right) \\
m_{t} & =\alpha_{0}+\rho\left(m_{t-1}-\alpha_{0}\right)+\varphi\left(\varepsilon_{t-1}^{2}-\sigma_{t-1}^{2}\right)
\end{aligned}
$$

Burada, $\sigma_{t}^{2}$ yine oynaklığı göstermekte, $m_{t}$ ise zaman içinde değişen uzun dönemli oynaklı̆̆ temsil etmektedir. Birinci denklem, $\left(\sigma_{t}^{2}-m_{t}\right),(\alpha+\beta)$ kuvvetiyle sıfıra doğru yaklaşan geçici bileşeni göstermektedir. İkinci denklem ise, $\rho$ kuvvetiyle $\alpha_{0}$ 'a yaklaşan uzun dönem bileşenini vermektedir.

\section{Ampirik Analiz}

Çalışmada 1996 Ocak - 2011 Aralık dönemine ait giriş yapan yabancı turist rakamları kullanılmıştır. Aylık veriler Türkiye İstatistik Kurumu (TÜİK) elektronik veri tabanından elde edilmiştir. Düzey değerlerindeki olası bir değişen varyans sorununu hafifletmek için seriye logaritmik dönüşüm uygulanmıştır. Zaman serilerinde oynaklığın modellenebilmesi için sürecin durağan olması gerektiğinden önsel olarak, mevsimsellikten arındırılmış logaritmik seriye ADF ve PP birim-kök testleri uygulanmış ve serinin düzey değerleri itibariyle durağan olduğu anlaşılmıştır. Diğer tanımlayıcı istatistiklerle birlikte birim-kök testi istatistikleri de Tablo 2'de verilmiştir. Tablodaki değerlerden, Türkiye'ye gelen yabancı turist miktarı $(Y T)$ serisinin dağılımının sola çarpık ve normalden basık (platicurtic) olduğu görülmektedir. Jarque - Bera istatistiği de serinin normal dağıldı̆̆ yönündeki hipotezin reddedilebildiğine işaret etmektedir.

\begin{tabular}{lr}
\hline Ortalama & 13,951 \\
Medyan & 13,977 \\
En büyük değer & 14,758 \\
En küçük değer & 13,034 \\
Standart sapma & 0,461 \\
Çarpıklık & $-0,021$ \\
Basıklık & 1,584 \\
\hline Jarque-Bera & 16,052 \\
değeri & $(0,0003)$ \\
ARCH & 24,211 \\
& $(0,0000)$ \\
\hline ADF test & - \\
istatistiği & $(0,0465)$ \\
PP test istatistiği & - \\
\hline Gözlem sayısı & \multicolumn{2}{c}{4,262} \\
\hline
\end{tabular}

Tablo 2. Turizm serisine ait tanımlayıcı istatistikler

Gelen turist akımına ilişkin zaman serisi grafiği Şekil 1'de verilmiştir. Grafik incelendiğinde, seride pozitif bir trend ve katı bir mevsimsellik bulunduğu görülmektedir. Türkiye’ye gelen turist sayısında, 1999 yılındaki siyasî ve ekonomik kargaşadan dolayı negatif bir şokun etkili olduğu gözlenmektedir.

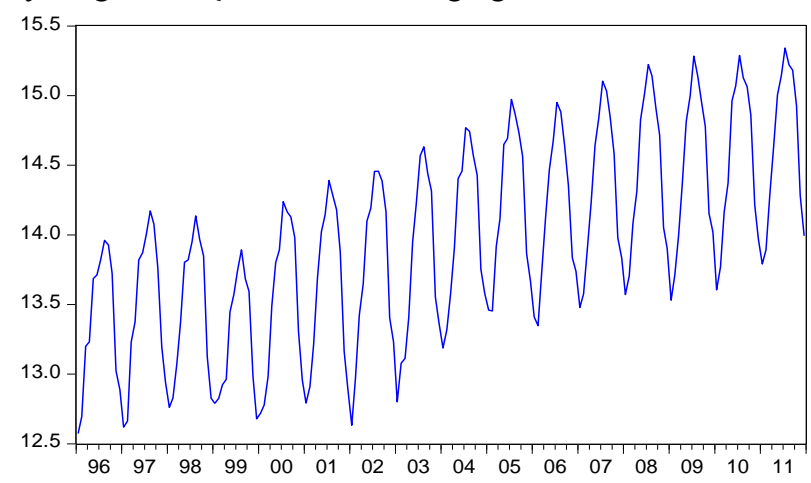

Şekil 1. Gelen turist sayılarının zaman içindeki değişimi (1996-2011) 
Serinin, mevsimsel dalgalanmaların etkisi Census-X12 yöntemiyle giderildikten sonraki seyri Şekil 2'de verilmiştir. 1999 yılındaki şokun gelen turist sayıları üzerindeki etkisi ve pozitif eğimli trend bu grafikte daha net olarak görülmektedir.

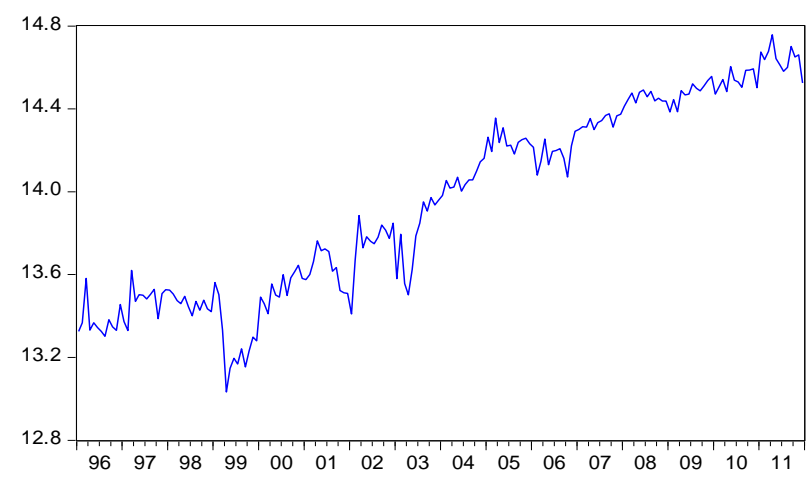

Şekil 2. Mevsimsellikten arındırılmış serilerin zaman içindeki değişimi

Chan, Lim ve McAleer (2005) e benzer şekilde, bir ARMA sürecinden elde edilen hata terimleri tahminlerinin karesi alınarak turizm serisinin oynaklığı hesaplanmıştır. Serinin korelogramı incelendiğinde AR(1) sürecinin uygun olduğu görülmüştür. Birim-kök testi sonucunda da AR(1) sürecinin kalıntılarının durağan olduğu bulunmuştur. Buna göre tahmin edilen oynaklık modeli şöyledir:

$$
\begin{aligned}
& \operatorname{lnTUR} R_{t}=\alpha+\beta t+A R(1)+\varepsilon_{t} \\
& \operatorname{vol}\left(\varepsilon_{t}\right)=\varepsilon_{t}^{2}
\end{aligned}
$$

Burada $t$ trend değişkenini göstermektedir $(t=1,2, \ldots, 192)$. Elde edilen oynaklık serisi aşağıda Şekil 3 'te verilmiştir. Şekil incelendiğinde gelen turist serisinde bir ölçüde oynaklık kümelenmesi olduğu söylenebilir. 1996-2005 döneminde genellikle aşırı oynaklık görülürken, 2005 sonrasındaki dönemde oynaklığın nisbî olarak düşük kaldığı görülmektedir. Bu durum, kısmen Türkiye'deki iç siyasî ve ekonomik istikrarsızlıkların 2005 öncesi dönemde turist akımı üzerinde neden olduğu negatif şoklarla, kısmen de Butler (1980) tarafindan geliştirilen yaşam döngüsü modeli ile açılanabilir. Butler (1980), bir turizm destinasyonunun yaşam döngüsünün ilk dönemlerinde büyümenin genel olarak pozitif fakat çok oynak olacağını ileri sürmektedir.

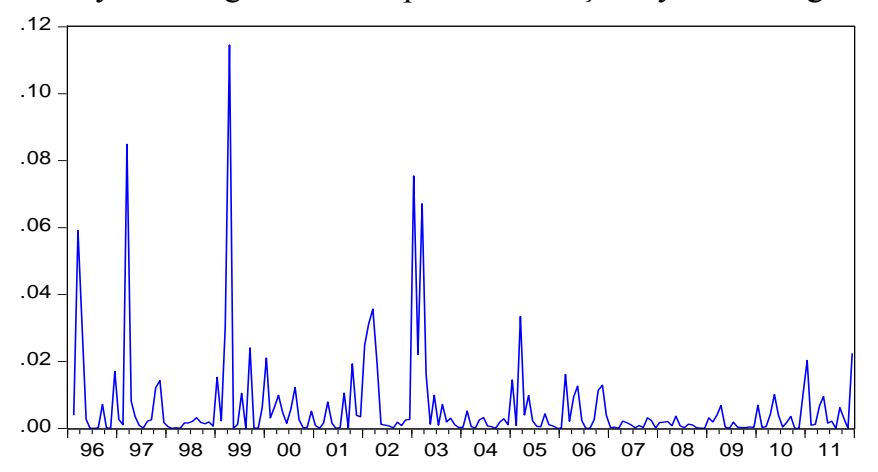

Şekil 3. Mevsimsellikten arındırılmış turizm serisinin oynaklı̆̆

Çalışmada turizm akımında oynaklığı araştırmak üzere farklı oynaklık modelleri kullanılmıştır. Tahmin edilen oynaklık modeline göre tahmin sonuçları Tablo 3'te verilmiştir. İlk olarak gelen turist miktarı serisine ARCH modeli uygulanmıştır. SBC kriteri ARCH (4) modelinin uygun olduğunu göstermiştir. Kalıntılara uygulanan ARCH-LM testi de, dört ARCH teriminin modele dâhil edilmesinin ARCH etkisini gidermek için yeterli olduğuna işaret etmektedir. $\mathrm{ARCH}(4)$ modelinin tahminine göre, üçüncü terim dışında diğer terimler anlamlı etkiye sahiptir. Buna göre cari bir ayda, turist gelişleri üzerindeki bir şok sonraki dört ay boyunca gelen turist sayısının oynaklığını etkilemektedir. Ancak bu etki giderek azalmaktadır.

GARCH(1,1) modelinin tüm katsayıları pozitiftir ve \%1 düzeyinde anlamlıdırlar. $(\alpha+\beta)$ nın tahminî değerinin 0,71 olması kalıntıların durağan olduğunu göstermektedir. Bu değerin 1'e çok yakın olmaması oynaklıktaki kalıcılığın (persistence) uzun dönemli olmadığını ifade etmektedir. ARCH-LM testi GARCH(1,1) sürecinin ARCH etkisini gidermekte yeterli olduğunu ortaya koymaktadır.

Negatif ve pozitif şokların asimetrik etkisini ortaya koyabilmek için buna uygun EGARCH, TGARCH ve PGARCH modelleri de tahmin edilmiştir. Her bir modelde de GARCH terimi $\left(\sigma_{t-1}^{2}\right)$ istatistiksel olarak anlamlı bulunmuştur. Elde edilen bulgular, aylık turist gelişlerindeki oynaklığın şoklara asimetrik olarak tepki verdiğini göstermektedir. EGARCH $(1,1,1)$ modelinde asimetri parametresi negatiftir $(-0,2809)$ ki bu, negatif şokların oynaklık üzerinde aynı büyüklükteki pozitif şoklardan daha fazla etkili olduklarını ifade eder. Diğer taraftan 
TGARCH(1,1,1) sürecine ilişkin tahminlerde ise asimetri terimi yine anlamlı ancak pozitif $(0,4718)$ çıkmıştır. Buna göre pozitif şoklar, aynı büyüklükteki negatif şoklara kıyasla oynaklığa daha fazla etki etmektedir. PGARCH $(1,1,1)$ modelinden elde edilen asimetri tahmini de TGARCH modelini destekler şekilde pozitiftir. Buna göre, Türkiye'de, pozitif şokların yabancı turist gelişlerine ilişkin oynaklık üzerinde negatif şoklardan daha etkili olduğu sonucuna varılabilir.

Tahmin edilen son oynaklık modeli, farklı oynaklık derecelerinde ortalamaya dönüşü araştıran CGARCH sürecidir. $0<\rho<1$ olması koşullu varyansı etkileyen şokların üssel olarak azaldığını ve sürecin ortalamaya dönme eğilimi gösterdiğine işaret etmektedir. $\rho$ katsayısının 0,9797 çıkması bu dönüşün oldukça hızlı olduğunu ifade etmektedir.

\begin{tabular}{|c|c|c|c|c|c|c|}
\hline & $\begin{array}{c}\text { ARCH } \\
(4)\end{array}$ & $\begin{array}{c}\text { GARCH } \\
(\mathbf{1}, \mathbf{1})\end{array}$ & $\begin{array}{c}\text { EGARCH } \\
(1,1,1) \\
\end{array}$ & $\begin{array}{c}\text { TGARCH } \\
(1,1,1)\end{array}$ & $\begin{array}{c}\text { PGARCH } \\
(1,1,1) \\
\end{array}$ & $\begin{array}{c}\text { CGARCH } \\
(1,1) \\
\end{array}$ \\
\hline$\alpha_{0}$ & $\begin{array}{l}0,0046 \\
(0,0000)\end{array}$ & $\begin{array}{l}0,0020 \\
(0,0015)\end{array}$ & $\begin{array}{l}-1,6595 \\
(0,0009)\end{array}$ & $\begin{array}{l}0,0016 \\
(0,0005)\end{array}$ & $\begin{array}{l}0,0484 \\
(0,3390)\end{array}$ & $\begin{array}{l}0,0029 \\
(0,0000)\end{array}$ \\
\hline$\varepsilon_{t-1}^{2}$ & $\begin{array}{l}0,1789 \\
(0,0362)\end{array}$ & $\begin{array}{l}0,3511 \\
(0,0010)\end{array}$ & & $\begin{array}{c}-0,0330 \\
(0,2672)\end{array}$ & & \\
\hline$\varepsilon_{t-2}^{2}$ & $\begin{array}{l}0,2798 \\
(0,0558)\end{array}$ & & & & & \\
\hline$\varepsilon_{t-3}^{2}$ & $\begin{array}{l}0,1042 \\
(0,1787)\end{array}$ & & & & & \\
\hline$\varepsilon_{t-4}^{2}$ & $\begin{array}{l}-0,0850 \\
(0,0000)\end{array}$ & & & & & \\
\hline$\sigma_{t-1}^{2}$ & & $\begin{array}{l}0,3585 \\
(0,0066)\end{array}$ & $\begin{array}{l}0,7313 \\
(0,0000)\end{array}$ & $\begin{array}{l}0,5232 \\
(0,0000)\end{array}$ & $\begin{array}{l}0,5650 \\
(0,0000)\end{array}$ & \\
\hline$\left|\frac{\varepsilon_{t-i}}{\sigma_{t-i}}\right|$ & & & $\begin{array}{l}0,3162 \\
(0,0023)\end{array}$ & & & \\
\hline$\frac{\varepsilon_{t-i}}{\sigma_{t-i}}$ & & & $\begin{array}{r}-0,2809 \\
(0,0000)\end{array}$ & & & \\
\hline$\varepsilon_{t-i}^{2} I_{t-i}^{-}$ & & & & $\begin{array}{l}0,4718 \\
(0,0001)\end{array}$ & & \\
\hline$\delta$ & & & & & $\begin{array}{l}0,6606 \\
(0,1024)\end{array}$ & \\
\hline$\left|\varepsilon_{t-1}\right|$ & & & & & $\begin{array}{l}0,2279 \\
(0,0004)\end{array}$ & \\
\hline$\varepsilon_{t-1}$ & & & & & $\begin{array}{l}0,6506 \\
(0,0101)\end{array}$ & \\
\hline $\begin{array}{l}\left(\varepsilon_{t-1}^{2}\right. \\
-\omega)\end{array}$ & & & & & & $\begin{array}{l}0,2108 \\
(0,0535)\end{array}$ \\
\hline $\begin{array}{l}\left(\sigma_{t-1}^{2}\right. \\
-\omega)\end{array}$ & & & & & & $\begin{array}{l}0,4016 \\
(0,1221)\end{array}$ \\
\hline$\rho$ & & & & & & $\begin{array}{l}0,9797 \\
(0,0000)\end{array}$ \\
\hline$\varphi$ & & & & & & $\begin{array}{l}-0,0495 \\
(0,0255)\end{array}$ \\
\hline $\begin{array}{l}\text { ARCH- } \\
\text { LM }\end{array}$ & $\begin{array}{l}0,1139 \\
(0,7362)\end{array}$ & $\begin{array}{l}0,0287 \\
(0,8657)\end{array}$ & $\begin{array}{l}0,0103 \\
(0,9192)\end{array}$ & $\begin{array}{l}0,0963 \\
(0,7566)\end{array}$ & $\begin{array}{l}0,0061 \\
(0,9378)\end{array}$ & $\begin{array}{l}0,1298 \\
(0,7191)\end{array}$ \\
\hline
\end{tabular}

Tablo 3. Logaritmik turizm serisi için oynaklı modelleri tahminleri Not: \% 10 veya daha yüksek düzeyde anlamlı olan tahminler koyu olarak belirtilmiştir. Olasılık (p) değerleri parantez içinde verilmiştir.

\section{Sonuç}

Turizm sektörü, diğer birçok gelişmekte olan ülke gibi Türkiye için de sürdürülebilir kalkınma ve istihdam için önemli bir alternatif teşkil etmektedir. Bu imkânın gerektiği gibi değerlendirilebilmesi için, sektörün altyapısının iyileştirilmesi kadar Türkiye'ye yönelik turist akımının iyi bir şekilde analiz edilmesi de önem taşımaktadır. Böylelikle daha etkin politikaların ve daha verimli yatırımların önü açılabilecektir.

Bu çalışmada, Türkiye'ye gelen yabancı turist miktarındaki oynaklık modellenmeye çalışmış ve pozitif ve negatif şokların gelen turist miktarının değişkenliği (oynaklığı) üzerinde asimetrik etkide bulunup bulunmadı̆̆ GARCH sınıfı modeller kullanılarak araştırılmıştır. 
ARCH ve GARCH modellerinin tahminleri, Türkiye’ye gelen turist miktarındaki oynaklığın kısa dönemli denebilecek bir kalıcılık sergilediğini göstermektedir. CGARCH modelinin tahmininden elde edilen uyarlanma parametresi tahmininin 1'e yakın olması da turizm sektörünün şokların etkisinden hızlı bir şekilde çıktığına işaret etmektedir. EGARCH, TGARCH ve PGARCH modellerinden elde edilen bulgular ise gelen turist miktarındaki oynaklığın asimetrik karakterli olduğunu, yani pozitif şokların negatif şoklara nazaran oynaklık üzerinde daha etkili olduğunu ortaya koymaktadır.

\section{Kaynakça}

- Bahar, 2006. “Turizm Sektörünün Türkiye’nin Ekonomik Büyümesi Üzerindeki Etkisi: VAR Analizi Yaklaşımı”, Yönetim ve Ekonomi, 13 (2), s. 137

- Bollerslev, 1986. "Generalized Autoregressive Conditional Heteroskedasticity”, Journal of Econometrics, 31, s. 307

- Butler, 1980. "The Concept of a Tourism Area Cycle of Evolution: Implications for Management Resources", The Canadian Geographer, 24, s. 5

• Canlı ve Kaya, 2012. "Türk Turizm Sektörünün Ekonomik Etkilerinin Girdi Çıktı Yaklaşımıyla Ölçülmesi”, Anadolu Üniversitesi Sosyal Bilimler Dergisi, 12 (1), s. 1

- Chan vd., 2005. "Modelling Multivariate International Tourism Demand and Volatility", Tourism Management, 26, s. 459

- Coshall, 2009. "Combining Volatility and Smoothing Forecasts of UK Demand for International Tourism”, Tourism Management, 30, s. 495

- Coşkun ve Özer, 2011. "MGARCH Modeling of Inbound Tourism Demand Volatility in Turkey”, MIBES Transactions, 5 (1), s. 24

- Çakır ve Bostan, 2000. "Turizm Sektörünün Ekonominin Diğer Sektörleriyle Bağlantılarının Girdi-Çıktı Analizi ile Değerlendirilmesi”, Anatolia: Turizm Araştırmaları Dergisi, 11, Özel Sayı, s. 35

- Çımat ve Bahar, 2003. "Turizm Sektörünün Türkiye Ekonomisi İçindeki Yeri ve Önemi Üzerine Bir Değerlendirme”, Akdeniz İ.I.B.F. Dergisi, 6, s. 1

- Daniel ve Rodriges, 2010. "Volatility and Seasonality of Tourism Demand in Portugal", Economic Bulletin, Banco de Portugal, Spring 2010, s. 87

- Dilber, 2007. "Turizm Sektörünün Türkiye Ekonomisi Üzerindeki Etkisinin Girdi-Çıktı Tablosu Yardımıyla Değerlendirilmesi”, Yönetim ve Ekonomi, 14 (2), s. 205

- Engle, 1982. “Autoregressive Conditional Heteroskedasticity with Estimates of the Variance of UK Inflation", Econometrica, 55, s. 391

- Gündüz ve Hatemi-J, 2005. "Is the Tourism-led Growth Hypothesis Valid for Turkey?", Applied Economics Letters, 12, s. 499

- $\quad$ Kar vd., 2004. "Turizmin Ekonomiye Katkısı Üzerine Ampirik Bir Değerlendirme”, Akdeniz I.I.B.F. Dergisi, 8, s. 87

- Lorde ve Moore, 2008. "Modelling the Volatility of Long-stay Tourist Arrivals to Barbados", Paper presented at the 27th Annual Review Seminar, Central Bank of Barbados.

- $\quad$ RiskMetrics, 1996. RiskMetrics - Technical Document, Fourth Edition, RiskMetrics Group, New York.

- UNWTO (United Nations - World Tourism Organisation) (2012) Tourism Highlights - 2012 Edition.

- Ünlüönen ve Kılıçlar, 2004. "Ekonomik Yansımalarıyla Türk Turizminin Seksen Yılı”, Ticaret ve Turizm Eğitim Fakültesi Dergisi, Gazi Üniversitesi, Sayı: 1.

- Yıldırım ve Öcal, 2004. "Tourism and Economic Growth in Turkey”, Ekonomik Yaklaşım, 15, s. 131 


\title{
İnternette Gerilla Pazarlaması ve Turizm Endüstrisindeki Uygulamaları Üzerine Bir Değerlendirme
}

\section{Guerilla Marketing on the Internet and an Evaluation on the Tourism Industry}

\author{
Ph.D. Candidate Aysegül Kutluk (Kırklareli University, Turkey)
}

\begin{abstract}
At the present time, managements which can see and use alterations, they can remain stand and strive with their competitors. Changes are in managements only able to possible by using new strategies, that can make a management comperior under the competition clause. These strategies are: last trends, fun promotions, flash mobbings, guerrilla advertising and even the viral applications that can make people unwittingly a marketer. On the other hand, at the first times, while guerilla marketing was a method that small scale enterprise can struggle against the big bussiness, nowadays it is a very simple method which every management can apply easily. The aim of guerilla marketing is to make more sales, like traditional marketing. But, the methods that used, are different from eachother. This method try to find with very low budget some works, that will take place more higher from other traditional marketing methods' effects. This works have to be effective, different, enjoyable and unforgetable. That is possible to see them in out,on ethernet and somewhere of our life. Especially, these activities are organized contemplated by advertising agencies; diversified according to the imagination of the creators. Guerilla marketing and the other similar marketings are done especially online network in tourism sector of Turkey. The purpose of this study; is increasing the awareness of guerilla marketing as an alternative method in academic and sectorel context, that can increase the sales of tourism managements and at the same time can provide quickly and easily reach to their target group.
\end{abstract}

\section{Giriş}

Günümüzde değişimi görebilen ve değişimi kullanabilen işletmeler ayakta kalabilmekte ve rakipleriyle mücadele edebilmektedir. İşletmelerde değişim sadece; rekabet şartlarında kendini üstün k1labilecek yeni stratejiler kullanma ile mümkündür. Bu stratejiler; en son trendler, eğlenceli tanıtımlar, flash mobbingler, gerilla reklamlar ve hatta insanları da farkında olmadan bir anda pazarlamacı konumuna getiren viral uygulamalar vb. farklı fikirlerdir. Gerilla pazarlama ise, ilk zamanlar küçük işletmelerin büyük işletmelere karşı kafa tutabileceği bir yöntem iken günümüzde her işletme için kolaylıkla uygulanabilen bir yöntemdir. Gerilla Pazarlama'nın amacı geleneksel pazarlama ile aynıdır; daha çok satış yaptırmak. Sadece kullandığı yöntem klasik pazarlama yöntemlerinden biraz farklıdır. Bu yöntem, en düşük bütçe ile klasik pazarlama araçlarının sonuçlarının da üstüne çıkabilecek etki oluşturan araçlar bulmaya çalışmaktadır. Bu uygulamalar, çarpıcı, farklı, eğlenceli, unutulmaz olmalıdır. Gerilla pazarlama örneklerine açık alanda, internette veya yaşamın herhangi bir alanında rastlamak mümkündür. Özellikle reklam ajansları tarafından düşünülüp organize edilen bu çalışmalar yaratıcılarının hayal gücü doğrultusunda farklılık göstermektedir. Türkiye'nin turizm sektöründe gerilla pazarlama ve benzeri pazarlamalar özellikle internet üzerinden daha rahat yapılmaktadır. Bu çalışmanın amacı; turizm işletmelerinin satışlarını arttıracak aynı zamanda hedef kitlelerine kolay ve hızlıca ulaşabilmelerini sağlayacak alternatif bir yöntem olan gerilla pazarlama yönteminin akademik alanda ve sektörde bilinirliğini ve bu yöntemin uygulanmasını arttırmayı sağlamaktır.

\section{2 İnternetin Pazarlamada Keşfedilişi ve Gerilla Pazarlamacılığa Geçiş}

Teknolojiyle birlikte internet, turizm endüstrisinde stratejik bir silah ve rekabet avantajı olarak düşünülmektedir. Güncel bilgi ve müşteri hizmetlerini an ve an sağlayan internet; bugünkü iş dünyasının da temel taş1 konumundadır (Schegg, Murphy ve Leuenberger, 2003: 100).Çünkü internet; mesafe ve zaman kavramını ortadan kaldırarak insanlığa yeni bir iletişim, dayanışma, paylaşım ve ortak çalışma alanı oluşturmaktadır. Bilgi teknolojilerinde yaşanan hızlı gelişmeler ve internetin gün geçtikçe daha çok önemsenmesi, bu teknolojilerden yararlanan kişi sayısının da hızlı bir şekilde artmasına neden olmaktadır (Boz, 2006: 38).

İnternet kullanan her kitleye hitap edebilen çevrimiçi pazarlama yani internetten pazarlama yöntemleri; hedeflenen grupla daha kolay ve etkileşimli bir ilişki kurar. Aynı zamanda maliyeti kitlesel pazarlamaya göre daha düşüktür. Dolayısıyla işletmenin verimliliği artarken, pazarlama faaliyetlerindeki etkileşimli iletişim de işletmenin üstünlüğünü arttırmaktadır (Korkmaz, 2006: 19). Diğer yandan ürün ve hizmetlerin günümüzde çok çeşitli ve alternatiflerinin kolayca bulunabileceği düşünülürse, ürünlerin tanıtımıyla ilgili bir bolluk ve ciddi bir pazarlama kirliliği yaratacağı da beklenilen bir sonuç olmaktadır. Çoğu insan televizyonda on binlerce dolar harcanarak yayınlanan reklamları artık seyretmemektedir. Çünkü bugünlerde satın alma kararında en etkin 
yöntem, tanıdığımız, inandığımız, çevremizdeki insanların deneyimleri ve tavsiyeleridir. Özellikle bu yayılmaların internetteki uygulamaları geleneksel pazarlama yöntemlerinden çok daha fazla etkili olduğu görülmektedir(Taşpınar, 2012). Baruh ve Kırgız, 2009; internetin etkili olmasının temel iki sebebini şöyle açıklamaktadır;

- Çift yönlü bilgi akışının (üreticiden-tüketiciye ve tüketiciden-üreticiye) mümkün olması,

- Bir sistem kullanıcısının o sistemi nasıl kullandığı hakkında her bilgi parçasının içerik sahibi ve servis sunucusu tarafından gerçek zamanda takibi ve depolanabilme kabiliyetinin olmasıdır.

Dünyamızın interaktifleşmeye başlamasıyla birlikte, internet en önemli iletişim mecralarından biri olmuştur. İnternet sayfaları, e-postalar, çevrimiçi satış kanalları, sanal günceler, çevrimiçi sosyal ortamlar, sanal oyun dünyaları gibi birçok yeni kavramı ve anlayışı hayatımıza sokan ve zaman-mekân anlayışımızı tamamen değiştiren internetin, sanal dünyası genel anlamda pazarlamanın da ufkunu genişletmeye ve yeni reklam formları yaratmaktadır (Dahan ve Levi, 2012: 42). Her ne kadar tutundurma için firmaların ayırdığ toplam bütçe içerisinde, "internetten pazarlama" ya ayrılan pay az da olsa, mevcut potansiyelin zamanla farkına varılacaktır. İnternetten yapılan pazarlamaların amacı; tüm iletişim kanallarıyla entegre biçimde çalışılabilen, doğru ve etkili dijital reklam ve pazarlama yöntemlerini kullanabilmek ve mecralardaki faaliyetleri en iyi biçimde yönetebilmektir. Bunun için internetten pazarlama, iletişim ve reklam kavramlarını iyi anlamak, bu kapsamda silah olarak kullanılacak araç ve yöntemlerin neler olduğunu bilmek ve dijital projeleri bütünsel pazarlama çalışmaları içinde doğru bir yerde konumlayabilmek zorundadır(Şahin, 2009: 86). İnternetin göz ardı edilemeyecek yararları sayesinde, turizm endüstrisinde faaliyet gösteren işletmeler internet üzerinden pazarlamaya yönelmektedir. Mesela; Rynaair bilet rezervasyonlarının \%93'ünü, Easyjet ise \%90'ını web siteleri üzerinden almaktadır. Amerika Seyahat Sektörü Birliği'nin (TIA-Travel Industry Association of Amerika) internet üzerinden yapılan seyahat satışları ile ilgili araştırmalar, ABD'li seyahatçilerin büyük bir kısmının uçak biletleri ve konaklama ile ilgili rezervasyonlarını internet üzerinden yaptığını ortaya koymuştur. ABD'de, 2000 yılında yaklaşık 16 milyon kişi internet üzerinden seyahat rezervasyonu yaptırmıştır. Rezervasyon yapanların \%47'si havayollarının işlettiği sitelerden alışveriş yapmış, \%37'si ise hem bağımsız online sitelerinden hem de havayollarından satın alma işlemi gerçekleştirirken, \%18'i online seyahat acentelerine başvurmuştur (Boz, 2006: 40). Turizm endüstrisinde yer alan seyahat acenteleri, tur operatörleri, havayolu şirketleri, konaklama işletmeleri ve diğer turizm işletmeleri, internetin sağladığ 1 yararlara tepkisiz kalmayarak, internet üzerinden faaliyet göstermeye başlamaktadırlar(Boz, 2006: 39) Bu faaliyetlerden biriside gerilla tipi hareketlerden doğan "Gerilla Pazarlama"cilıktır.

Uluslararası sözlükte Gerilla terimi ("Guerilla” İspanyolca Guerra, savaş anlamına gelir) ilk defa Napolyon sayesinde savaş zamanında kullanılmıştır. Zamanında Napolyon, İspanya kral ailesini tahtından mahrum edip kendi ağabeyine iktidarı vermiş fakat İspanya milleti buna isyan ederek silahlı isyancı kitleler oluşturmuştur. İsyan edenler Napolyon askerleriyle olan meydan savaşında başarılı olmuş ve bu az sayıdaki kitleye "gerillagerillalar" adı verilmiştir(İleri ve Shamuratova, 2007: 3). Gerilla kelimesinin işaret ettiği önemli bir teknik bilgi ise "orantısız güçlerde karşı karşıya gelmiş iki silahlı grup"tur. Bu tarz durumlarda zayıf olan tarafın tek çaresi saklanmak ve vur-kaç taktiği ile büyük orduyu taciz etmektir( Yılmaz, 2007 ). Gerilla pazarlama; yer ve zaman temelli pazarlama türlerinden biri olup, alışılmışın dışındaki taktiklerle ve beklenmeyen yerlerde, beklenmeyen zamanlarda ekseriya mahalli yasa ve kurallara meydan okurcasına yürütülen bütün pazarlama kampanyalarıdır (Kaya, 2010; 157). Gerilla pazarlamada önemli olan; inanç, felsefe, enerji ve hayal gücüdür. Geleneksel pazarlamanın soğuk ve mesafeli tavrına karşı gerilla pazarlama, tüketicilerle çok daha yakın temas kurmakta, sıcak ve samimi ilişki içine girmektedir. Geleneksel pazarlamada herkesin ezbere bildiği yöntemler kullanırken gerilla pazarlama, yaratıcılık üzerine kurulu, inovatif ve esnek taktikler kullanılan bir pazarlama türü olma yolunda ilerlemektedir. Uygulamalarının çoğunda tüketicilerin de katılımı sağlanmaktadır. Gerilla pazarlama, içinde barındırdığı yaratıcılık ve müşteriye yakınlık sayesinde, markalara bir aura (hale) ve gençlik katmaktadır. Ayrıca gösterdikleri cesaret ve romantizm ile markaları daha çekici kılmaktadır (Aksoy, 2011). Gerilla pazarlamasının anlaşılabilmesi için üç önemli öğe vardır. Bu öğeler gerilla hareketlerinin neden daha sık kullanılması ile ilgili olup, aşağıdaki gibi sıralanmaktadır (Levinson, 2013);

- Yerelleşme mantığının yayılması, devletin yasal düzenlemelerindeki değişiklikler, teknolojinin her şeyi uygun hale getirmesi, insanların çok daha fazla bilinçlenmesi nedeniyle dünyadaki insanları küçük işletmelere çekmekte ve büyük işletmelerin de küçülmeye gitmesine neden olmaktadır.

- Küçük işletmelerin pazarlama alanında ki başarısızlı̆ğ pazarlamayı anlayamamalarıdır. Gerilla pazarlamanın dünya çapındaki bütün küçük işletmelerde geçerli olması onun basit, anlaşılır ve ucuz olmasından kaynaklanmaktadır.

- Gerilla pazarlama, yüksek fiyatlı ekonomi dünyasında ve pazarlama karmalarıyla karışan rekabetçi pazarlama dünyasında küçük işletmelere, küçük işlerinde biraz adil olmayan avantajlar elde etmeyi öğreten bir yöntemdir. 


\section{Online Gerilla Pazarlama Hareketleri}

İnternet sayesinde küçük işletmeler, multimilyar dolarlık bir pazar payına sahip olarak global markaların önüne geçebilme şansına erişmiştir. Bu nedenle internet gerilla uygulamalar için uygun bir mecra olarak kabul görmektedir. İnternet sayfaları, e-posta, çevrimiçi satış kanalları, sanal günceler, çevrimiçi sosyal ortamlar, sanal oyun dünyaları gibi birçok yeni kavramı ve anlayışı hayatımıza sokan ve zaman-mekân anlayışımızı tamamen değiştiren internetin sanal dünyası genel anlamda pazarlamanın da ufkunu genişletmeye ve yeni reklam formları yaratmaya devam etmektedir (Dahan ve Levi, 2012: 41-42). Bu kadar geniş bir mecrada gerilla pazarlamasını kullanmamak pazarlama alanında geride kalmayı, satışların olası düşüşlerine razı olmak demektir. İnternet kullanımında tüketicilerin sayısının her geçen gün arttığını inkâr edilemez bir gerçektir ve Tablo 1. de de bu artış rakamlarla istatistiksel olarak gösterilmektedir;

\begin{tabular}{|l|l|l|l|l|l|l|}
\hline Bölgeler & $\begin{array}{l}\text { Nüfus } \\
(2012)\end{array}$ & $\begin{array}{l}\text { Internet } \\
\text { Kullanıc1 } \\
\text { Say1s1 } \\
\text { Dec. 31, 2000 }\end{array}$ & $\begin{array}{l}\text { Internet } \\
\text { Kullanic1 } \\
\text { Say1s1 } \\
\text { Son Veriler } \\
(2012)\end{array}$ & $\begin{array}{l}\text { Penetrasyon } \\
\text { Yüzdesi } \\
(2012)\end{array}$ & $\begin{array}{l}\text { Büyüme } \\
2000-2012\end{array}$ & $\begin{array}{l}\text { Dü1 } \\
\text { Däna }\end{array}$ \\
\hline Afrika & $1,073,380,925$ & $4,514,400$ & $167,335,676$ & $15.6 \%$ & $3,606.7 \%$ & $7.0 \%$ \\
\hline Asya & $3,922,066,987$ & $114,304,000$ & $1,076,681,059$ & $27.5 \%$ & $841.9 \%$ & $44.8 \%$ \\
\hline Avrupa & $820,918,446$ & $105,096,093$ & $518,512,109$ & $63.2 \%$ & $393.4 \%$ & $21.5 \%$ \\
\hline Ortadoğu & $223,608,203$ & $3,284,800$ & $90,000,455$ & $40.2 \%$ & $2,639.9 \%$ & $3.7 \%$ \\
\hline Kuzey Amerika & $348,280,154$ & $108,096,800$ & $273,785,413$ & $78.6 \%$ & $153.3 \%$ & $11.4 \%$ \\
\hline $\begin{array}{l}\text { Latin Amerika / } \\
\text { Karayipler }\end{array}$ & $593,688,638$ & $18,068,919$ & $254,915,745$ & $42.9 \%$ & $1,310.8 \%$ & $10.6 \%$ \\
\hline $\begin{array}{l}\text { Okyanusya / } \\
\text { Avusturalya }\end{array}$ & $35,903,569$ & $7,620,480$ & $24,287,919$ & $67.6 \%$ & $218.7 \%$ & $1.0 \%$ \\
\hline DÜNYA TOPLAM & $7,017,846,922$ & $360,985,492$ & $2,405,518,376$ & $34.3 \%$ & $566.4 \%$ & $100 \%$ \\
\hline
\end{tabular}

Tablo 1: Dünyada İnternet Kullanımı ve Nüfus İstatistikleri

Tabloda görüldüğü gibi internetin dünyada 2 milyonu aşkın kullanıcısı vardır. Bu sayının her geçen gün artacağını söylemek yanlış olmayacaktır.

Gerilla uygulamaları; fiyat farklılaştırmaları, yoğun tanıtım faaliyetleri, ürün çeşitlerini arttırmak, yeni ürünler sunmak, maliyetleri düşürmek ve satış sonrası hizmetlere ağırlık vermek şeklindeyken buna ek olarak; yeni müşterileri yakalamaya ve etkilemeye yönelik geliştirilen ağızdan ağıza duyurum taktiği vardır (Uysal, 2011: 71). Müşterilerin bir firma, bir ürün veya hizmet hakkında olumlu ya da olumsuz yorum yaparak o firmayı, ürünü ya da hizmeti yakın çevresine tavsiye etmesi ve ürün hakkındaki deneyimlerini resmi olmayan bir şekilde başka alıcılarla paylaşmasına ağızdan ağıza duyurum denir (Derbaix ve Vanhamme, 2003: 2). İnternette gerilla pazarlama; viral pazarlama ve ağızdan ağıza pazarlama gibi farklı pazarlama karmaları yoluyla, daha fazla farkındalık yaratmaktadır (Drüing ve Fahrenholz, 2008: 7). İnternetin son zamanlarda gerilla pazarlama dünyasına kattığı uygulamalardan biri de "advergaming" reklam-oyunlarıdır. Çeşitli oyunlara ürün yerleştirmesi veya belli bir marka için özel olarak hazırlanması suretiyle oluşturulup kullanılan reklam-oyunları (Sanje \& Şenol, 2010: 307) sanal bir ortamda gerçekleşmelerine rağmen gerçek kişilerce oynanmaları ve bünyelerinde gerçek markaları barındırmaları sebebiyle gerçek bir gerilla pazarlama uygulaması olarak görülmektedir (Dahan ve Levi, 2012: 42). Web sitelerinde kullanılan diğer çevrimiçi oyunlar sayesinde ise hedef kitlenin konunun içine çekilmesi sağlanır. Hedef kitle oyuna katılımı nedeniyle ilgili sitede uzun süre kaldığından gerilla reklam mesajları ile yoğun olarak karşılaşmaktadır (Tosun, 2009: 41).

Herhangi basit bir şeyin internette görülür görülmez değişme olasılığ̣ çok yüksektir. Çünkü sanal ortamda değişim çok çabuk gerçekleşmektedir. İletişim teknolojisinin dünden bugüne gelişimi ve bugünden sonraki gelişimleri sürekli devam edecektir. Gerilla pazarlamanın bu konudaki avantajı da; değişime tepki vermesi ve o doğrultuda ilerlemesidir ( Levinson ve Lautenslager, 2006; 262).

Gerilla pazarlamanın internetteki işleyişini kavrayabilmek için alt yapısında dikkat edilmesi gereken temel öğeleri bilmek gerekir. Bu öğeler sayesinde gerilla pazarlamanın niteliği daha çok artacaktır. Bu temel öğeler şöyledir (Levinson ve Lautenslager, 2006: 262-263);

Trafik; internette, bir web sitesinin ziyaretçi sayısını yükseltmektir. Değer/Enformasyon; çevrimiçi değer genellikle enformasyon ağırlıklı bilgilerin hepsidir. Ne kadar bilgi sunulursa o kadar çok değer yükseltilir. Kaynak; müşteriler için bir kaynak konumuna gelmek gerilla pazarlamada önemlidir. Kaynak ağı oluşturmak pazarlamanın ve müşterilerle ilişkilerin iyi olmasını sağlar. AIDA; Günümüzde hiçbir zaman olmadığı kadar fazla internet pazarlama mesajı bulunmaktadır. Bunların arasından sıyrılabilmek için dikkat çekmek, ilgi uyandırmak, istek yaratmak ve müşterileri harekete geçirtebilecek olayların kurgulanmasını sağlar. 
İnternette pazarlama sistemini işletmesine oturtmuş rakiplerin uzun süredir hizmet veriyor olması, geniş bir veri tabana sahip ve fiyatlara hükmedebileceğini düşünülmektedir ki çoğu zaman durum bu şekildedir. Bu tarz rakiplerle uğraşabilmenin en akılcı yolu gerilla pazarlamalardır. Çünkü her gerilla saldırısı ile rakip firmadan bir parça kopartıldığı ve dikkatinin dağıtıldığı düşünülmektedir. Kotler bu tip saldırıyı "Marketing" kitabında aşağıda ki gibi göstermiştir (Odabaşı ve Odabaş1, 2007: 49-50);

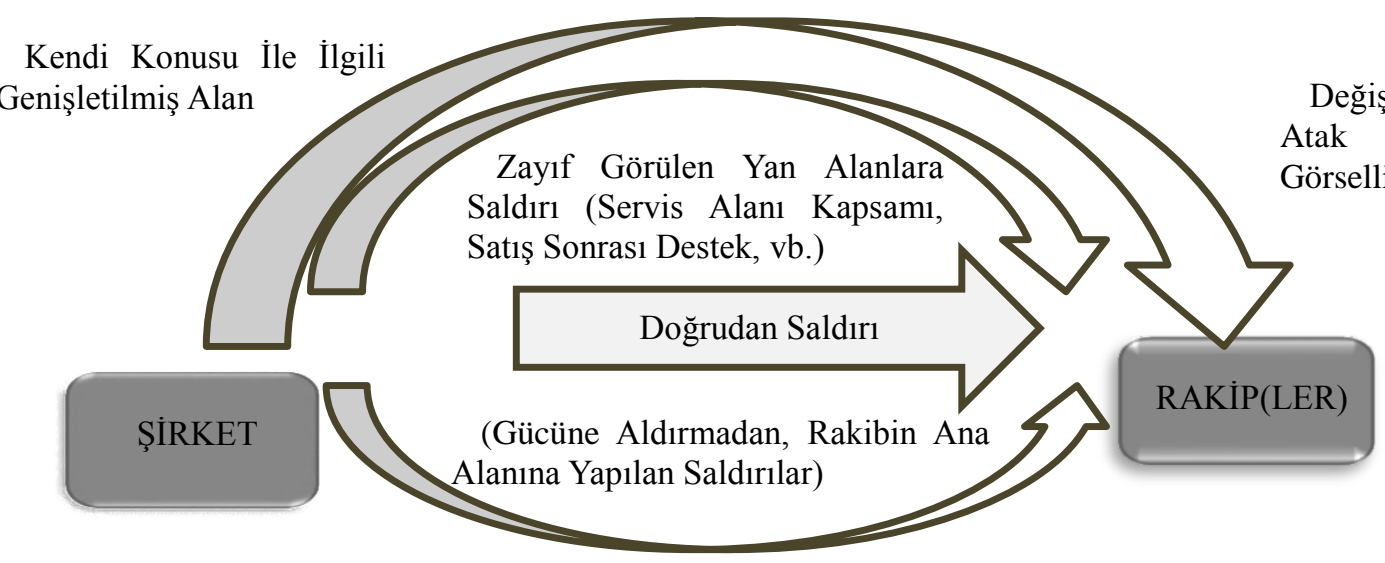

Şekil 1. Rakiplerden Pay Çalmak/ Kotler' in Gerilla Yaklaşımı

Gerilla pazarlamada işletmeciler, müşterilere beklediklerinden ya da ödediklerinden daha fazlasını vererek ya da her zaman orijinal tahmini fiyattan daha az bir bedel isteyerek ve her müşteriyi ödüllendirerek sadık bir müşteri tabanı oluştururlar (Levinson, vd., 2009: 36) Modern gerilla pazarlamasında, müşterilerle sürekli irtibat sağlanır. Müşterilerin satın alma kararları için gerekli bilgiler, 1şık hızında onlara verebilmek için internet, sesli posta, e-posta, web siteleri gibi iletişim sistemleri kullanmaktadır (Levinson, vd., 2009: 21).

İyi bir gerilla pazarlama oluşumu için öncelikle bir plan hazırlanması gerekir ve bu planın içerisinde yer alması gereken öğeler Tablo 2.de online gerilla pazarlama taktikleri uygulanırken dikkat edilmesi gereken hususlar şeklinde gösterilmiştir;

\begin{tabular}{|l|l|}
\hline $\begin{array}{l}\text { Tahmin Edilemeyen } \\
\text { Olaylar/Sürprizler: }\end{array}$ & $\begin{array}{l}\text { Tamamen beklenmeyen olaylar ve kampanyalardır. Amaç; Şaşırtılan müşterilerin } \\
\text { dikkatini çekmek ve internette daha fazla etki yaratmaktır. }\end{array}$ \\
\hline Radikal Öğeler: & $\begin{array}{l}\text { Etkili ve çarpıcı öğeler seçerek küçük bir pazarlama bütçesiyle, büyük hedef } \\
\text { kitlelere ulaşmayı amaçlar. Kullanılacak öğelerin dikkat ve ilgi çekici olması } \\
\text { muhtemeldir. Aynı zamanda kişisel değerlere ters düşebilme riski oldukça fazladır. }\end{array}$ \\
\hline Komik Öğeler/Mizah: & $\begin{array}{l}\text { Mizah, alıcı ile satıcı arasında bariyerleri kaldıran bir öğedir. Pazarlamada } \\
\text { eğlenmek, müşteri potansiyelini arttırıcı ve rakiplerinden ayırt edilebilme özelliğine } \\
\text { sahiptir. Özellikle internette viral pazarlama türünde etkilidir. }\end{array}$ \\
\hline $\begin{array}{l}\text { Tek Atışta İsabet } \\
\text { Edilebilirlik/ Oyunlar: }\end{array}$ & $\begin{array}{l}\text { Gerilla uygulamaları/kampanyaları genelde bir defaya mahsus ve kısa süreli yapılır. } \\
\text { Fakat interaktif araçlar ve ileri teknolojiye dayalı alternatif uygulamalarla uzun } \\
\text { vadeli gerilla kampanyaları yapıllabilmesi mümkündür. }\end{array}$ \\
\hline Ucuzluk: & $\begin{array}{l}\text { Gerilla pazarlamanın işletmeler için çekiciliği aşikârdır. Hedef kitlede söylenti, } \\
\text { vizıltı etkisi, ağızdan ağıza yayılım yaratmak için işletmelerin sıkı bir bütçeye } \\
\text { gereksinimi vardır. Fakat internet üzerinde daha az maliyetle daha fazla yaratıcıllkla } \\
\text { gerilla etkisi yaratmak mümkündür. }\end{array}$ \\
\hline İyi Niyet: & $\begin{array}{l}\text { Merhamet ve kibarlığa doğru ve bununla birlikte güçlü bir marka ve rekabetçi } \\
\text { fayda sağlayabilecek özel eğilimlerdir. }\end{array}$ \\
\hline
\end{tabular}

Tablo 2: Online Gerilla Pazarlama Planının Temel Öğeleri

Yaygın bir yanlış anlama, internet sitelerinde ücretsiz reklamlar yayınlayıp tüm dünyadan insanların, şirketlerin ürün ve hizmetlerine talepleri arttırması gerektiği düşünülüp beklenmektedir ki bu siber uzayda bir internet sitesi yayımlayıp başka hiçbir şey yapmadan milyonlarca internet sörfçüsünün ürün veya hizmetler için sıraya girmesini beklemek ile eşdeğerdir. İnternette başarılı olabilmek bu tarz beklentileri es geçip etkili bir gerilla pazarlama planı hazırlanmalı ve tablo 2'de gösterilen öğelerden mutlaka yararlanılmalıdır. Levinson, (2009)'a göre ise gerilla pazarlama planlarının başarılı olabilmesi için dikkat edilmesi gereken hususlar şunlardır;

1. E-postalar; inandırıcı, kibar ve insanlara yardımcı olabilecek şekilde hazırlanmalıdır.

2. E-postalara müşterilerin alabileceği kadar ücretsiz bilgiler eklenebilir. 
3. Satışları optimize etmek için internet sitesinin tasarımının nasıl olacağı ve ziyaretçilerin tekrar tekrar siteye ulaşmasını sağlamak için yaratıcı fikirler geliştirmek gereklidir.

4. Sitenin görünürlüğü çok önemlidir. Gerçek hayatta vitrin ne kadar önemliyse internet alanında da işletmelerin web site görünüşü müşteriyi kendine çekebilecek kapasitede ve dizaynda olmalıdır. Ayrıca düşük maliyete site görünürlügüünü arttırmak için sitenin nereye yerleştirileceği, siteyi kimin ne şekilde hazırlayacağı da üzerinde durulması gereken konulardan biridir.

5. İnternette haber grupları, internet siteleri ve forumlar gibi birçoğu bedava olan ve sektör ile ilgili reklamlar, basın açıklamaları ve diğer faydalı bilgileri göndermeye izin veren özel alanlar mevcuttur. Bunlardan faydalanılması gereklidir.

6. Bir başka strateji alakalı ve rakip olmayan internet siteleriyle bağlantı değişimi yapmaktır. (Bu siteler Yahoo!, Google gibi büyük arama motorlarından bulunabilir.)

7. İnternette işletmeler kendi firmalarını çok iyi tanımak zorunda ve diğer rakip siteleri, internetteki güncel değişimleri, modaları ve trendleri sürekli takip etmeli ve ona göre güncellemelerini yapmalıdır.

İnternet kullanımı ve teknolojinin sürekli artması rekabet kavramını da doğru orantılı bir şekilde etkilemektedir. Günümüz rekabet koşulları arasında, gerilla pazarlamanın kullanılacağı sektörleri daraltmak doğru değildir. Çünkü bu pazarlama türünün kullanımı, sektördeki firmaların ne kadar yaratıcı olabileceği ile alakalıdır. Tüm sektörler için rahatlıkla entegre edilebilecek bir pazarlama çözümü olan gerilla pazarlama bugüne kadar Türkiye'de aktif olarak alkollü içecekler, ilaç ve otomotiv sektöründe uygulanmıştır (Kaya, 2013). Gerilla pazarlama artık, turizm sektöründe ve internetten e-turizm alanında da uygulanabilir bir stratejik pazarlamadır.

\section{Turizm Sektöründe Gerilla Pazarlama ve Uygulama Örnekleri}

Turizm işletmelerinde en uygun gerilla pazarlama uygulaması, rakiplerin durulduğu, en az miktarda pazarlama yatırımıyla çok büyük payın alınacağı zamanda yapılması gerekir. İşletmenin faaliyet gösterdiği döneme göre rakiplerin pazarlamada en durgun aylar kabul ettiği dönemde gerilla pazarlamanın yapılmasında fayda vardır (Çeltek ve Bozdoğan, 2012: 4809).Bu dönemin turizm sektörü için Aralık ayından itibaren Şubat sonu/Mart başına kadar olabileceği düşünülmektedir.

Turizm sektöründe işletmeler tarafından uygulanan en yaygın gerilla pazarlama taktiği; web sitelerinin kullanımıdır. İşletmelerin web sitelerini hazırlamaları, bu sitelere müşteriler için yararlı bilgiler koymaları, bu bilgileri sürekli güncel tutmaları müşterileri çekme yöntemlerinden biridir (Arslan, 2009, 74). Turizm işletmelerinde gerilla pazarlamanın verimli bir şekilde uygulanabilmesi için gerilla planlaması yapılması gerekmektedir. Bu planlamada; turizm işletmesinin öncelikle iç ve diş çevresiyle ilgili olabildiğince detaylı ve doğru bilgilere dayanan bir veri tabanı oluşturulur, işletmenin ve faaliyet gösterdiği pazarın olası tehdit, fırsat ve üstünlüklerini göz önüne alınarak bir SWOT analizi yapılır. İşletmenin sahip olduğu üstün yönü belirlendikten sonra bu üstünlüğüne uygun bir pazarlama aracı seçilir, daha sonra pazarlama odaklı bir gerilla pazarlama takvimi oluşturulur ve bu takvime olabildiğince sadık kalmaya çalışılır. Rakiplerden gelebilecek tepkilere karşı hazırlıklı olunarak bu tepkiler ve işletmelerin ihtiyaçları doğrultusunda gerilla pazarlama planı güncellenmek zorundadır (Çeltek ve Bozdoğan, 2012: 4792). Ayrıca işletmelerin mevcut kaynaklarını yeni firsatlara hızlı ve en etkin bir şekilde yönlendirebilmeleri ve piyasalarda oluşabilecek her türlü durumu önceden tahmin etmeleri ve yoğun rekabet ortamında ayakta kalabilmek için içinde bulundukları durumu iyi analiz etmeleri gerekmektedir (Kaya, 2011: 29).

Turizm işletmeleri için gerilla pazarlamanın birçok avantajın yanı sıra bazı dezavantajları da bulunmaktadır. $\mathrm{Bu}$ dezavantajlar, pazarlama çalışmalarından kesin sonuçlar alınamaması, gerilla mesajının olabildiğince kişiye ulaşamaması ve kaynakların etkin bir şekilde yönlendirilememesinden kaynaklanmaktadır (Çeltek ve Bozdoğan, 2012: 4792). Bu dezavantajların oluşmasını engellemek için ise gerilla pazarlama uygulamalarının online yani internet alanında gerçekleştirilmesi ya da gerçek hayatta sürdürülen etkinliklerin mutlaka sosyal medyada duyurulması gerekmektedir. Bu sayede daha fazla kişiye ulaşılması sağlanırken aynı zamanda bütçeden de tasarruf edilmesi sağlanır. Gerilla pazarlamanın avantajları ise aşağıdaki gibidir (Çeltek ve Bozdoğan, 2012: 4791);

- Gerilla pazarlamada kullanılan 100 pazarlama metodu vardır ve bunların 62 tanesi ücretsizdir,

- Turizm işletmelerinde daha az maliyetle pazarlama yapma imkânı sunar,

- Sektörde faaliyet gösteren rakiplerle daha iyi mücadele imkânı verir,

- İşletmelere minimum maliyetle maksimum karı elde etme imkânı sunar,

- İşletmelerin kaynaklarının yeni firsatlara hızlı ve en etkin bir şekilde yönlendirebilmesine olanak sunma açısından turizm işletmelerine avantaj sağlamaktadır.

Çalışma kapsamında; 2012 Kasım ayından itibaren internette yer alan gerilla faaliyetleri incelenmiş ve bu faaliyetlerden turizm ile ilgili olanlarına örnek teşkil edecek uygulamalara değinilmiştir. Bu örnekler şöyledir;

“Carpuzz", İstanbul'da "Rent a Car” tarzı hizmet veren işletmelerden birisidir. Bu işletmeyi diğerlerinden ayıran en büyük özelliği, sunduğu hizmetlerin ucuzluğu ve iş yapma anlayışındaki farklılıktır. Şirket çok uygun fiyatlarla araba kiralamayı mümkün hale getirmiştir. Bu kadar uygun fiyata araba kiralamasını mümkün kılan 
uygulama ise gerilla pazarlama taktiğinde gizlidir. Şirket, arabaların üzerine reklamlar alarak, hem arabayı kiralayan tüketiciden hem de arabaya reklam veren işletmeden kazanç elde etmektedir. Müşteriler otomobili çok düşük bir bedelle kiralarken reklam veren işletmenin reklamı da farklı coğrafik bölgelerde kendini gösterme firsatı elde etmektedir. Ayrıca bu işletme reklam verenlerine global positioning system (GPS) yardımıyla reklamlarının nerelerde dolaştığını gösterebilmektedir. Reklam mecrasına son derece etkin bir şeffaflık kazandıran bu uygulama araçların daimi şekilde trafikte olduğunu izlenebilir hale getirmektedir (Nardalı, 2009: 116).

Mirage Tur, bir seyahat acentesi olup, tropik seyahat turların yeni ve farklı bir mecra ile tanıtma fikriyle insanların bir an olsun şehir yaşantısının stresinden uzaklaşarak yapacağı bu tatilin nasıl bir hissiyat sağlayacağını empoze etmek istemiş̧ir. Bunun için işlek sokaklarda, plazaların önündeki ağaçların aralarına hamaklar kurulmuş ve evine giderken trafiğe takılan, işine giderken günün getireceği sıkıntıları düşünen insanların, tatil planlarına egzotik bir turda onları nelerin beklediğini düşlemeleri hedeflenmiştir. Bu gerilla çalışmasının sonucunda ise; turlara ve broşür talebinde artış, rezervasyon sayılarında dramatik bir yükseliş görülmüştür (http://adsoftheworld.com)

Tourism British Columbia'nın "100 BC Anısı" adındaki pazarlama hareketi de son zamanların en dikkat gerilla pazarlama uygulamalarındandır. San Francisco'da Justin Herman Plaza önüne yerleştirilen 14 metre uzunluğunda ve 10 metre genişliğindeki dev bir otomattan tatil ile ilgili (bisiklet, deniz botu, tatil rehberi, can simidi... vs) birçok ürün tedarik edilebilmektedir. Tourism British Columbia eğlenceli ve şaşırtıcı bir teknikle insanları tatile çıkma konusunda etkileyebilmeyi başarmıştır (Anonim, 2012a).

American Airlines, 2010 yılının Aralık ayında, toplu taşıma araçlarından en fazla kullanılan metro istasyonunun iç kısmını seyahat destinasyonlarının dev posterleri ile kaplamışıtır. Yeraltı treni içinde yolculuk yapan kitlenin o an tatile çıkma isteğini ve potansiyelini arttırmaya çalışması dikkat çeken gerilla pazarlama uygulamalarından biri niteliğindedir (Pembecioğlu, 2011).

Brezilya kökenli havayolu şirketi olan "Gol" gerilla pazarlama kapsamında; facebook sayfasından bir kampanya başlatacağını duyurmakta ve bir uçağın koltuk planının ait olan görseli parçalara ayırarak herhangi bir uyarı olmadan gün içinde yayınlayacağını söylemektedir. Yayınlanan resimdeki boş koltuğu gören ve altına koltuk numarasını yazan ilk kişilere şirketin gitmiş olduğu şehirlerden istedikleri birine uçak bileti hediye edeceğini vaat etmektedir. Ücretsiz bilet kazanmak isteyen kullanıcılar bileti kaçırmamak için sürekli olarak sayfayı yenilemek zorunda kalmakta ve firma " Sayfayı yenilemeye devam edin birazdan yeni koltuklar yayında olacak " mesajıyla kullanıcıların sayfayı yenilemesini sağlayarak, sayfanın sürekli olarak ziyaret edilmesi sağlanmaktadır. Kampanya sayesinde büyük bir başarıya imza atan şirket kullanıcı başına ortalama 90 sayfa yenileme rakamıla kampanya öncesinde 13.000 olan Facebook hayran sayısını kampanya sonunda $200.000^{\prime} \mathrm{e}$ çıkartarak rakibi olan diğer Brezilya kökenli havayolu şirketlerini de geride bırakmıştır (Şenkaya, 2012).

Danimarka'daki Kilroy isimli turizm-seyahat firması için hazırlanan afişlerde Antarktika'da ki buzullarının her geçen gün eridiğini göstermektedir. Afiş̧teki diğer destinasyonların da "geç olmadan git ve gör" mesajına uyması başarılı bir gerilla uygulamasıdır (Çeltek ve Bozdoğan, 2012).

Türkiye' de ise her yıl birbirinden ilginç promosyonlarla yerli ve yabancı turistlere kapılarını açan Sheraton Çeşme oteli bir ay boyunca junior süit odalarında konaklayacak müşterilerine Lufthansa havayolları işbirliğiyle Londra, Frankfurt, New York, Miami, Bahamalar, Rio De Janeiro, Buenos Aires, Los Angeles, Hawai, Auckland, Sydney, Singapur ve Hong Kong gibi görülesi şehirlerin bulunduğu, iki yıl içinde istedikleri dönemde çıkabilecekleri 20 günlük dünya turu hediye etmektedir. Birbirinden prestijli markaların, müşterilerine alışveriş karşıllı̆ı konaklama sağladığı Sheraton Çeşme'nin yönetim kadrosu bu noktaya gelişlerini, satış ve pazarlamada gerilla usulü çalıştıklarını, agresif satı̧s ve pazarlama çalışmalarına bağlamaktadır (Milliyet,2012).

2008 yılında Mirage Park Resort Hotel ise Türk gecesinin yapıldığı her cumartesi günü havuz kenarında müşterilerine ücretsiz yemek kursu verme uygulaması başlatmış ve usta aşçllar tarafindan ücretsiz yemek kursu almak isteyen müşterilere onlar farkında olmadan gerilla taktiği uygulanmıştır (Arslan, 2009: 98).

İnternette dijital butik ajans olarak firmaların çevrimiçi gelirlerini maksimum düzeye çekmeye odaklanan Web Girişim ajansı, turizm sektöründeki kurum ve kuruluşların yüksek satış devrimi yakalayabilmeleri hatta daha ileriye götürmeleri için oteller ve seyahat acenteleri için özgün modeller geliştirmeye çalışmaktadır. Örnek bir çalışma olarak yürütülen Wizard İstanbul projesi, Web Girişim 'in çevrimiçi turizm pazarlaması üzerine çalışmalar yürütürken, hayata geçirdiği yenilikçi bir destinasyon pazarlama girişimidir. Wizard İstanbul projesiyle, turistlerin 7/24 Twitter, Facebook ve Wizardistanbul.com üzerinden İstanbul ile ilgili gelen sorular dakikalar içerisinde cevaplanarak yalnızca 1,5 ay gibi kısa bir sürede sadece ağızdan ağıza pazarlama yöntemiyle $20^{\prime}$ den fazla turistin İstanbul'a gelmesi ikna edilmiş, 6000' den fazla turiste bilgi verilmiş ve $1100^{\prime}$ den fazla doğrudan turist sorusu cevaplanmıştır (Kutluk, 2012).

"Gönüller 1 Olsun Diye, 1 Bilet Onur Air' den Hediye!" kampanyası ile Onur Air' in 12 Şubat ve 13 Şubat 2013 tarihlerinde Facebook sayfasında kampanya başvuru formunu doğru ve eksiksiz dolduran ve sayfada sorulan soruyu doğru cevaplayan herkes, kendisi ve sevdiği 1kişi için Onur Air' den \% 50 indirim kodu kazanmıştır (Anonim,2013a). 
Türk Hava Yolları'nın “inanılmaz evlenme teklifi” adlı viral videosu ilk iki gün içinde 150.000 kişi tarafından izlenmiştir. Video, romantik sevgilinin dünyanın çeşitli ülkelerine giderek bir evlenme teklifi videosu hazırlamasını konu almaktadır. "Havada 432 bin mil uçtum ve bunların çoğu bedavaya geldi." cümlesi, videoda birçok karede görünen THY kartları, THY’ nın eğlenceli bir gerilla pazarlama taktiğidir (Anonim,2013b).

İnsanlar tatil planını yapmadan önce Travelocity, Tripadvisor gibi sitelere girip, kullanıcıların o ülke ya da bölge hakkındaki yorumlarını okumakta veya Facebook, My Space gibi sosyal arkadaşlık sitelerindeki gruplar aracılığı ile o bölgeler hakkında bilgi alışverişinde bulunmaktadır. Yani, bu davranış biçimleri günümüzün geçerli tanıtım stratejisinin, bu kanallar aracılığı ile uygulanan gerilla pazarlama yöntemleri olduğunu göstermektedir (Yücel, 2008). İnternetin karşılıklı etkileşime olanak veren iki yönlü bilgi alışverişi sayesinde insanlar diğer insanların tatil bilgilerine çok çabuk ulaşabilmektedir. Üstelik milyonlarca kişinin yaptığı gibi turistler deneyimlerini bloglarında yazmakta, gezdikleri ve fotoğrafladıkları yerleri flicker'a yüklemekte, çektikleri videoları Youtube gibi dünyanın ikinci büyük arama motoru olan video izleme ve paylaşma sitesinde yayınlamaktadır. $\mathrm{Bu}$ mecralar, bir topluluk oluşturmuş insanlardan ve onların yüzlerce arkadaşı, yakınından oluşmaktadır. Hem fotoğraf, hem video, hem yazı içeriği paylaşıp bu içeriklere birçok yorum alınabilirken, bu bilgileri şu anda dünyanın 1 numaralı paylaşım ağı olan ve 860 milyondan fazla üyesi bulunan Facebook'ta insanlar günde en az 1 saatini ayırarak sürekli takip edip, güncellemektedirler. Google'da uçak bileti arama motor Skyscanner'in hazırladığı Travel-Trends benzeri onlarca seyahat alışkanlık raporu ve ya anketine rastlanmaktadır. Travel Trends ve bir çok diğer raporlara ve araştırmalara bakıldığında her 10 kişiden 8'inin facebook, twitter, ve bloglardaki görüşlere anlamlı bir ölçüde önem verdiği ve rezervasyonların çoğunun sosyal veya mobil ağlar kullanılarak yapıldığı görülmektedir (Anonim, 2012b). Seyahat ile ilgili aramaların 2008'den bu yana yılda ortalama yüzde 30 artış gösterdiği, 2011 yılında bu artışın ortalamanın üzerine çıkıp yüzde 36 civarında gerçekleştiğini belirten Google Türkiye Turizm Sektör Yöneticisi Sencer Kutluğ, erken rezervasyon uygulamasının, seyahat alışkanlıklarında değişime neden olduğunu yapılan aramalara bakıldığında seyahat planları yapma zamanlamaları gitgide öne çekildiğini bundan birkaç yıl önce nisan, mayıs gibi dönemlerde artış gösteren seyahat aramalarının artık aralık ayında başlayarak, şubat ayı itibari ile hızlı bir yükselme gösterdiğini belirtmektedir. Çok açık ortaya çıkan, insanların artık yoğun bir şekilde internet üzerinden tatil planlarını yaptığı, interneti bilgi almak, alternatifleri karşılaştırmak, nihai karar verip, satın almada kullandığı yönündedir (Sabah, 2012).

\begin{tabular}{|c|c|}
\hline Güçlü Yönler & Zayıf Yönler \\
\hline $\begin{array}{l}\text { 1)Küçük ve Orta ölçekli konaklama işletmelerinin ve } \\
\text { seyahat acentelerinin kolaylıkla kullanabileceği bir } \\
\text { yöntemdir. } \\
\text { 2)Çarpıcı, etkileyici ve sıra dışıdır. } \\
\text { 3)Geniş pazar kitlesi yerine sınırlı bir pazar (niş) odak } \\
\text { alınarak da gerçekleştirilebilir. } \\
\text { 4)İşletmelerde eski müşterilerle iletişimin iyi } \\
\text { tutulmasını sağlanıp, müşteriler aracılığı ile yeni } \\
\text { müşteriler kazandıran bir yöntemdir. } \\
\text { 5)Gerilla pazarlamada uygulanabilecek yöntemler } \\
\text { genelde maliyetsizdir. } \\
\text { 6)Viral gerilla yöntemleriyle çok çabuk ve kolay bir } \\
\text { şekilde verilmek istenen mesaj yayılır. } \\
\text { 7) İnternette kısıtlı bir alanı yoktur, yayılması istenilen } \\
\text { mesaj veya bir tatil fikrinin herhangi bir sanal ortama } \\
\text { bırakılması yeterlidir. }\end{array}$ & $\begin{array}{l}\text { 1)Sadece uygulandığı dönemde başarılı olmakta } \\
\text { zamanla etkisini yitirmektedir. } \\
\text { 2)Her gerilla uygulaması turizm işletmesine uygun } \\
\text { olamamaktadır. } \\
\text { 3) İnternette bazı gerilla uygulamalarının internet } \\
\text { kullanıcıları tarafından doğru bir şekilde algılanmaması } \\
\text { veya spam olarak algılanması. } \\
\text { 4)Sadece karlılığı hedef almaktadır. } \\
\text { 5)Uygulamadaki bilgi eksiklikleri ve gerilla isminin } \\
\text { negatifliği. } \\
\text { 6)Zaman kaybı olarak görülmesi ve geleneksel } \\
\text { pazarlama yöntemleri ile henüz yarışır konuma } \\
\text { gelememesi. }\end{array}$ \\
\hline Firsatlar & Tehditler \\
\hline $\begin{array}{l}\text { 1)Sadece hizmetin pazarlanması için değil, halkla } \\
\text { ilişkiler ve tanıtım çalışmaları çerçevesinde de } \\
\text { kullanılması mümkündür. } \\
\text { 2)Pazar alanındaki firsatların farkına varma ve } \\
\text { onlardan ne zaman ve nasıl yararlanılacağını anlama } \\
\text { imkânı tanımaktadır. } \\
\text { 3)Rakipler arasından daha kolay sıyrılmayı } \\
\text { kolaylaştırır. } \\
\text { 4)Gelecekte bile bahsedilen ve turistlerin } \\
\text { hafızalarında kalan bir tanıtım/pazarlama ile şaşırtıcı } \\
\text { ve etkili bir imaj oluşturabilir. }\end{array}$ & $\begin{array}{l}\text { 1)Turizm sektöründe gerilla pazarlama uygulamaları } \\
\text { tam olarak bilinmediğinden yanlışlıkla fazla maliyetlere } \\
\text { sebep olabilir. } \\
\text { 2)Turizm ürünün tanıtımında hayal gücü gerektiren sıra } \\
\text { dışı tanıtımlardan kaçınılmaktadır. } \\
\text { 3)Gerilla pazarlamanın yanlış algılanması ve bu } \\
\text { yöntemden kaçınılması } \\
\text { 4)Sıra dışı olmak ve rakipleri elemek için etik olmayan } \\
\text { unsurların kullanılması. }\end{array}$ \\
\hline
\end{tabular}

Tablo 3: Turizm İşletmeleri Açısından Internette Gerilla Pazarlamanın SWOT Analizi 


\section{Sonuç}

İnternetin yaygın kullanımı, turizm endüstrisine ekstra bir canlılık kazandırmasına ve hatta yepyeni bir sektör oluşumuna yol açmıştır. Tatil acentelerinin, hava yollarının ve çeşitli otellerin SMS yöntemiyle müşterilere ulaşması, internet reklamları ve internet kampanyaları internetin etkin gücünün kullanılmasıyla gerçekleşmektedir. Turizm işletmelerinin geleneksel pazarlama yöntemlerinden vazgeçmesi, onları farklı arayışlara itmektedir. Bu aşamada alternatif bir yöntem olarak internette gerilla pazarlama uygulanabilir. Çünkü artık ürün ve hizmetlerin "lovemark" aşamasına geçebilmesi için kampanyalarında ve tüketiciye sunduklarında basit bir "satın al " mesajının ötesine geçmesi gerekmektedir. "Satın al" mesaj içerikli kampanyalar sadece tüketiciyle ticari bir ilişki doğurmakta, onların zihnine hitap etmektedir. Yoğun pazarlama programlarında eksik olan şeyler yaratıcılık, dikkat çekmek ve duygulara hitap edememektir. Gerilla pazarlama her yerde her zaman, müşteriler farkında olmadan bir anda karşılarına çıkabilen ve duyguları etkileyebilen bir pazarlama hareketi olduğu için etkilidir. Gerilla pazarlama uygulamaları için İnternette faaliyet alanları oldukça fazladır ve çok çabuk yayılabilmesi büyük bir firsattır. Ayrıca gerilla pazarlamanın internette çeşitlenen türleri sayesinde etkili bir hedef kitle oluşturabilmek çok kolaydır. Turizm sektöründe "gerilla pazarlama" anlayışı henüz çok yaygın olmadığından özellikle Türkiye literatüründe, örnek gösterilecek uygulama sayısı bakımından sınırlı kalmaktadır. Ancak zamanla gerilla pazarlamanın daha fazla kullanılacağı düşünülmektedir. Çünkü diğer ülkelerde genel olarak turizm sektöründe internet üzerinden yapılan gerilla hareketlerine bakıldığında; özellikle seyahat acentelerinin ve havayolları firmalarının aktif bir şekilde çalışmalarının devam ettiği görülmektedir. Seyahat acentelerinin uygulamalarında, bir "seyahat acentesini pazarlamak" yerine, "tatile çıkma fikri" ni müşterilerin zihninde oluşturmanın amaçlandığı, havayolu firmalarının daha fazla satış yapılmak ve rakiplerin önüne geçmek amacıyla gerilla pazarlama kampanyaları yaptıkları fark edilmektedir. Konaklama işletmelerinin ise pazarlamada bilinen klasik yöntemlerden pek kolay kolay vazgeçemediği ve internette gerilla hareketlerini pek kullanmadiğ görülmektedir. Tablo 3.de turizm işletmeleri için yapılan SWOT analizi şu şekildedir;

Gün ve gün gelişen faklı yöntemler, internetin etkileşim sağladığı alanlarda bilgilerin yayılma hızı ve birçok kişinin bu bilgileri anında görebilme avantajı, turizm işletmelerinin ise sadece kendilerine ait bir web sitesinin olması, işletmelerin pazarlamada gerçekten eksik olduklarını gösterir. Bu çalışma bağlamında; farklı, yaratıcı ve sıra dışı fikirleri kullanmaları ve müşterileri etkilemek zorunda oldukları bir dünyanın ve rekabetin içinde olan turizm işletmelerine aşağıdaki uygulamalar önerilmektedir;

- "Gerilla pazarlamacılık" alanında uzmanlaşmış reklam ajanslarından, bu alanda uzmanlaşmış kişilerden yardım alması sağlanmalı ve mutlaka etkili bir pazarlama planı yapılmalıdır.

- Turizm işletmeleri adına sosyal paylaşım sitelerinde özel hesaplar ve bloglar oluşturmaları ve bu hesapların aktif bir şekilde kullanılması sağlanmalıdır.

- Turizm işletmelerini "erken rezervasyon" kampanyalarını sosyal paylaşım sitelerinin reklam bölümlerine vermeleri hatta advergaming yöntemi kullanılarak müşterilerin eğlenceli bir şekilde tatil planı yapmaları sağlanmalıdır.

- Turizm işletmeleri, kendi fikirlerini de gerilla pazarlama alanında fazla bir maliyet sarf etmeden de bulup uygulayabilirler. Mesela işletmenin logosunun yer aldığı bir aracı şehir içinde dolaştırması, yine az bir bütçeyle 50-60 kişilik bir turist grubunun kiralanarak, bu grubun gittiği her mekânda ve sosyal bir topluluk içerisinde gidilen bir otel ya da tatil satın alınan bir seyahat acentesi hakkında olumlu ağıdan ağıza duyurum yapılması sağlanabilir.

- Turistlerin olmazsa olmazları olan cep telefonlarına çeşitli tatil firsatları içerikli mesajların ve MMS' lerin gönderilmesi sağlanabilir.

- Dans gösterileri, küçük şenlikler düzenlenerek hatta tiyatral oyunlarla "turizm" konusunun sokaklarda işlenmesi ve etkilerinin sosyal medyada duyurulması sağlanabilir.

- Tatile özendirecek renkli afişler veya tatili anımsatacak her türlü öğenin pazarlama amaçlı kullanılması sağlanabilir. Mesela, iş çıkışlarında oldukça yoğun olan metro istasyonlarında insanlara herhangi bir seyahat acentesinin üzerinde reklamı olan deniz kabuklarının dağıtılması gibi farklı projeler düşünülebilir.

Gerilla pazarlama, turizm sektöründe net bir şekilde bilinmeyen ve uygulamalarından kaçınılan bir yöntem olduğu için, çalışmada öncelikle internetin kullanım gerekliliği, pazarlama dünyasında farklı yöntemlere mutlaka gerek duyulduğu ve gerilla pazarlamanın ise diğer klasik yöntemlerden aykırı, kolay ve eğlenceli olduğundan bahsedilmiştir. Bu açıdan gerilla pazarlama ile ilgili yapılacak diğer çalışmalara yol göstermesi ve kaynak oluşturması beklenmektedir. Diğer çalışmalarda, turizm işletmelerinin yöneticileri ile gerilla pazarlama hakkında birebir görüşülerek, konu hakkındaki görüşler alınabilir, ya da satış veya tanıtım için gerilla pazarlama yöntemlerinden birini uygulayan bir turizm işletmesinde anket çalışması yapılarak gerilla pazarlamadan beklentiler ve elde edinilen sonuçlar daha net karşılaştırılabilir. 


\section{Kaynakça}

- Aksoy, T. 2011, Gerilla Pazarlama Yaratıcı Olmak Zorundadır!, http://www.temelaksoy.com/yazilar/marka/Gerilla-Pazarlama-Yaratici-Olmak-Zorundadir.aspx, Erişim Tarihi: 11.11.2012

- $\quad$ Arslan, S. 2009, "Turizm Sektöründe Alternatif Bir Pazarlama Stratejisi Olarak Gerilla Pazarlamasının Kullanılması:" Konaklama İşletmeleri Üzerinde Bir Araştırma. Yayınlanmamış Yüksek Lisans Tezi, Ankara: Gazi Üniversitesi Eğitim Bilimleri Enstitüsü, Turizm İşletmeciliği Eğitimi Anabilim Dalı.

- Anonim, 2012a, Kocaman Tatil Otomat1!, http://guerillamarketinginturkey.com/category/flynews/nontraditional-marketing/creative-outdoor-advertising/, Erişim Tarihi: 25.11.2012

- Anonim, 2012b, Turizm Sektörü ve Sosyal Medya, http://www.kamra.com.tr/turizm-sektoru-ve-sosyalmedya/, Erişim Tarihi: 25.11.2012

- Anonim, 2013a, “Gönüller 1 Olsun Diye, 1 Bilet Onur Arr'den Hediye!” http://www.onurair.com.tr/sevgililer-gunu-kampanyasi-2013.aspx, Erişim Tarihi: 02.07.2013

- Anonim, 2013b, "İnanılmaz Evlenme Teklifi / THY Viral Reklam" http://www.dijitalmarketing.net/2011/04/19/inanilmaz-evlenme-teklifi-thy-viral-reklam/, Erişim Tarihi: 03.07.2013.

- Boz, C. 2006. "Dünya'da Turizm Endüstrisinde İstihdam ve Çalışma Şartları", Yayınlanmış Yüksek Lisans Tezi, İstanbul: Marmara Üniversitesi Sosyal Bilimler Enstitüsü, Çalışma Ekonomisi ve Endüstri İlişkileri Anabilim Dalı

- C Çeltek, E., Bozdoğan, M. 2012. "Alternatif Pazarlama İletişimi Aracı Olarak Gerilla Pazarlama:" Uygulanmış Gerilla Pazarlama Reklam Örneklerinin İncelenmesi ve Turizm Sektörü İçin Model Önerileri, Journal of Yasar University 2012 28(7) s.4788 - 4812.

- Dahan Sanje, Gresi ve Levi, Eser, 2012. "Reklam Ajanslarının Gerilla Pazarlama Uygulamaları: Türkiye Örneklemi Üzerinden Bir İnceleme". İletişim Fakültesi Dergisi, s:42, 37-47.

- Derbaix, C., Vanhamme, J. 2003. "Inducing word-of-mouth by eliciting surprise - a pilot investigation". Journal of Economic Psychology, 24(1), 99-116.

- Drüing, A., Fahrenholz, K., 2008. "Guerilla Marketing", Master Thesis, Saxion University, Netherland.

- Kaya, S. 2011. "Pazarlamada Yeni Bir Çı̆̆ır Açılıyor: "Bütçesi Küçük Hayalleri Büyük Girişimciler İçin” Gerilla Pazarlama", İzmir Ticaret Odası, Ar\&Ge Bülten 2011 Ağustos - Kurumsal, s.27-34.

- Kaya, E., 2013, Gerilla Pazarlama, http://www.pazarlamadunyasi.com/Default.aspx?tabid=5408\&ItemI

- $\mathrm{d}=422$, Erişim Tarihi: 20.12.2012

- Kaya, İ. 2010. "Pazarlama Bi! Tanedir!", Birinci Basım, İstanbul: Babıali Kültür Yayıncılığı.

- $\quad$ Korkmaz, E.,V. 2006. "Tüketicilerin Elektronik Bankacılığa Duyduğu Güven Düzeyinin Kullanıma Etkisi Üzerine Bir Araştırma", Mustafa Kemal Üniversitesi Sosyal Bilimler Enstitüsü, Yayımlanmış Yüksek Lisans Tezi, Hatay.

- Kutluk, A. 2012. " Hizmet Sektöründe Ağızdan Ağıza Pazarlamanın Müşterilerin Satın Alma Karar Sürecine Etkisi: Seyahat Acentesi Müşterileri Üzerinde Bir Uygulama (İstanbul Örneği)", Balıkesir Üniversitesi Sosyal Bilimler Enstitüsü, Yayımlanmış Yüksek Lisans Tezi, Balıkesir.

- Levinson, J., C, Smith, Mark S., A. ve Wilson, O., R, 2009. "Gerilla Telesatış", İstanbul: MediCat Kitapları.

- Levinson, J., C., Lautenslager, A., 2006. "30 Günde Gerilla Pazarlama", İstanbul: MediaCat Kitapları.

- Odabaşı, K., Odabaşı, A. K., (2007). İnternet’te Pazarlama Stratejileri 2007, Birinci Bask1, s.50, İstanbul: Cinius Yayınları.

- Levinson, 2013. What Is Guerrilla Marketing?, http://www.gmarketing.com/articles/4-what-is-guerrillamarketing, Erişim Tarihi: 10.11.2012

- Milliyet, 2012 , ‘Turizm Gerillası' Devriâlem Yaptıracak', http://ekonomi.milliyet.com.tr/-turizm-gerillasidevrialem-yaptiracak/ekonomi/ekonomidetay/12.03.2012/1514170/default.htm?ref= OtherNews. Erişim Tarihi: 02.11.2012

- Pembecioğlu, Y. 2011, American Airlines'dan Metro İçinde Giydirme Uygulamas1, http://bigumigu.com/haber/2013/01/07/american-airlines-dan-metro-icinde-giydirme-uygulamasi, Erişim Tarihi: 23.11.2012

- $\quad$ Schegg, R., Murphy, J. ve Leuenberger, R. 2003. Five Star Treatment E-mail Customer Service by International Luxury Hotels, Information Technology \& Tourism 6, ss. 99-112. 
- S Şahin, F. 2009. "Değişen İletişim Ortamında Etkileşimli Pazarlama", (İçinde; "Yeni Nesil Pazarlamanın Anatomisi”), Editörler: L. Baruh ve M. Yüksel, Doğan Yayıncılık, İstanbul, s.85-103.

- Şenkaya, A., 2012, GOL - Valentine's Flight, http://www.pazarlamasyon.com/2012/03/gol-valentinesflight/, Erişim Tarihi: 05.01.2013

- Taşpınar, Özgür, 2012. "Pazarlamada Gerilla Taktiği-Vur, Kaç, Etkisi Kulaktan Kulağa Yayılsın", http://business.cnbce.com/0912/konuid=10.asp, Erişim Tarihi: 25.11.2012

- Tosun, N., B. 2009. "Değişen İletişim Ortamında Etkileşimli Pazarlama", (İçinde; "Etkileşim Boyutuyla Yeni Medya"), Editörler: L. Baruh ve M. Yüksel), Doğan Yayıncılık, İstanbul, s.3-52.

- Yilmaz, Mehmet, 2007. "PKK... Ters giden nedir? Bundan sonra nereye?", http://www.derindusunce.org/2007/09/16/pkk-ters-giden-nedir-bundan-sonra-nereye/, Erişim Tarihi: 25.11.2012

- Yücel, Emrah, 2008. "Turizm Sektöründe Türkiye'nin Markalaşması", http://www.selimtuncerblog.com/BLOG/Turizm_Sektorunde_Turkiye'nin_Markalasmasi.pdf, Erişim Tarihi: 03.12.2012

- Internet World Statistic 2012, http://www.internetworldstats.com/stats.htm, Erişim Tarihi: 23.11.2012

- http://www.selimtuncerblog.com/BLOG/Turizm_Sektorunde_Turkiye'nin_Markalasmasi.pdf, Erişim Tarihi: 02.01.2013

- http://www.guerrillaonline.com/cs/Guerrilla-Marketing-Principles-54.htm, Erişim Tarihi: 15.11.2012

- http://adsoftheworld.com/media/ambient/mirage_travel_tours_hammock?size=original, Erişim Tarihi: 22.12.2012

- http://www.sciencedirect.com/science/article/pii/S0167487002001575, Erişim Tarihi: 05.01.2013

- http://www.internetworldstats.com/stats.htm, Erişim Tarihi: 02.01.2013

- http://www.guerrillaonline.com/cs/Guerrilla-Marketing-Principles-54.htm, Erişim Tarihi: 18.12.2012

- http://www.sabah.com.tr/Turizm/2012/02/17/tatil-plani-internetten-yapiliyor, Erişim Tarihi: 02.07.2013 


\title{
Türk-Rus Vize Serbestliği Anlaşmasının Turizm Ekonomisine Katkısı
}

\section{The Contribution of Turkey-Russia Liberty of Visa Treaty to the Tourism Economy}

\author{
Mr. Halil Şimşek (Istanbul Aydın University, Turkey)
}

\begin{abstract}
Tourism which is one of the fastest developing sector in the world is an economic source which has a great importance espically for the developing countries. In most countries which have tourism demand, both the balance of the current account deficit and a significant part of employement are met with the revenues which are provided from this sector. So the contribution of tourism to the economies of the countries is increasing day by day. The importance of tourism in Turkey in recent years has been recognized and focused on development efforts but it has not yet been reached the desired level. There is no doubt that as a result of a number of economic and political measures and arrangements taken, Turkey which is almost a tourism paradise will carry its place in $12^{\text {th }}$ ranking in the world today, to the higher ranks. In this context, first of all the importance of tourism and then the contribution of tourism to the economies of countries and Turkish economy were mentioned. Also in this part, tourism datas taken from the official sources were displayed and evaluated in the form of tables and graphs. In the last part, Turkey-Russia tourism economy relations were examined from past to present and the results of the agreement on Visa Liberalization signed in 2011 were evaluated.
\end{abstract}

\section{Giriş}

Turizm bir yeri gezip görmek, öğrenmek, dinlenmek, eğlenmek ve o yerin güzelliklerini tatmak için yapılan seyahattir. (Türk Dil Kurumu) Deniz, sağlık, kongre, "incentive" (ödüllendirme ve motivasyon), yat, spor, av, tarih, inanç gibi daha sayamadığımız bir çok farklı nitelikteki faaliyeti içerir. Ekonomik perspektiften bakıldığında tam anlamıyla bir sanayi çeșidi olduğu söylenemez ancak çok sık kullanılan bir tabir olan "bacasız sanayi" şeklinde ifade edilmektedir. Kısacası turizm, "bir yere yapılan amaçlı ve süreli bir yolculuktur" denilebilir.

Günümüzde milyonlarca insan her yıl çeşitli turistik amaçlarla seyahat etmekte ve gittikleri yerlerde yaptıkları harcamalarla kendilerine turistik mal ve hizmet sağlayan ülke ve bölgeler için gelir kaynağı yaratmaktadırlar. Ülkeler turizmin önemini kavrayarak bu sektörün sürdürülebilirliğine ve kalkınmasına yönelik çalışmalarına ağırlık verdikleri oranda sektörden sağladıkları gelirlerini arttırabileceklerdir. Bunun yanı sıra kendilerine turist sağlayan ülkelerle olan ilişkileri de önemli bir noktadır.

Türkiye'ye yıllardan beri en çok turist gönderen ülkelerin başında Almanya'dan sonra Rusya gelmektedir. Rusya'dan enerji ithalatı turizm geliriyle kıyaslandığında çok daha yüksektir. Ancak Türkiye açısından bakıldığında turizmden elde edilen gelir de bir hayli önemlidir. Özellikle son y1llarda hükümet, turizmin ülkeye olan ekonomik katkılarının farkındadır ve bununla ilgili sürdürülen uluslararası ilişkilere gereken önemi vermektedir. Başta Rusya olmak üzere daha birçok ülke ile gerçekleştirilen vize serbestliğinin de gerek ülkeye sağladığı döviz girdisi, gerek istihdama etkisi ve gerekse de uluslararası platformdaki olumlu izlenim ve neticesindeki ekonomik atılımlar bu anlamda yapılan çalışmaları destekler niteliktedir.

\section{Turizmin Ülkeler ve Türkiye Ekonomisindeki Yeri}

Bugün dünya gayri safi milli hasılasının önemli bir bölümünü oluşturan turizm sektörü dünyada en hızlı gelişen sektörlerin başında gelmektedir. Harcanabilir kişisel gelirlerden turizm ve tatile ayrılan payın artması, iletişim ve ulaşım sektöründeki gelişmeler ve bu faktörlerdeki değişimlere bağlı olarak insanların şimdiye kadar görmedikleri yeni yerleri görmek istemeleri turizme olan ilginin de artmasına neden olmuştur (Dilber, 2007).

İnsanların birbirlerini karşılıklı olarak tanımalarını sağlamanın yanında doğal, sosyal ve kültürel çevrenin korunmasına ve değerlendirilmesine de katkı sunan bir faaliyet olması turizmin sosyal yönünü ortaya koymaktadır. Ekonomik yönden ise üretici ve tüketici olarak milyonlarca insanı ilgilendirir. Ekonomik gelişmenin itici ve sürükleyici bir elemanı olan turizm her şeyden önce, mal ve hizmetlerin tüketimini sağlar. Dolayısıyla bunları üretenler içinde bir gelir kaynağı demektir. İhtiyaçların artmasıyla turizm, daha çok mal ve hizmet üretme zorunluluğunu, yatırımları ve nihayet gelirleri artırır (Dilber, 2007).

\subsection{Turizmin Ülke Ekonomilerindeki Yeri}

Başta gelişmekte olan ülkeler olmak üzere günümüzde birçok ülke ekonomik gelişmeye dolayısıyla refah düzeyindeki artışa yapacağı pozitif katkılar nedeniyle turizmin ekonomi içindeki konumunu geliştirme 
çabasındadır. Özellikle II. Dünya Savaşı'nın ardından değişen dünya düzeni turizmin de gelişimine ivme kazandırmıştır. Şöyle ki teknolojinin gelişmesiyle birlikte küreselleşme ve buna bağlı olarak sınırların ortadan kalkması, ulaşımdaki kolaylık, gelir ve boş zaman artışıyla turizm sektöründe hızlı bir büyüme kaydedilmiştir.

Ödemeler dengesine katkısı, istihdam ve gelir yaratması, katma değerinin çok yüksek olması, altyapı ve üstyapı olumlu etkileri ve diğer sektörlere olan etkisi nedeniyle turizm özellikle gelişmekte olan ülkeler açısından önemli bir sektör durumundadır (Özkök, 2006).

Ödemeler dengesi, bir ülkenin ekonomik durumunu en iyi ve en açık şekilde gösteren ölçüdür. Belli bir dönemde tüm yabancı ülkelerle olan ekonomik ilişkileri tablo şeklinde gösterir. Uluslararası turizmin neden olduğu döviz hareketleri, turist gönderen ülkenin döviz talebini, turist kabul eden ülkenin de döviz arzını artıcı bir rol oynadığından ülkelerin ödemeler dengesini etkiler. Döviz arz ve talebi açısından mal ithal ve ihracı ile turistik faaliyetler arasında ortaya çıkan sonuçlar açısından fark yoktur. Ülkeye gelen turistlere bazı mal ve hizmetlerin satılması, mal ihracında olduğu gibi döviz arzı, buna karşılık ülke vatandaşlarının gittikleri ülkede mal ve hizmetleri satın almaları, sektörel üretim için gerekli mal ve hizmet ithali ise ürün ithalatında olduğu gibi döviz talebi yaratır. Dış turizm bilançosundan yararlanılarak döviz arz ve talebi arasındaki fark ele alınır. Bu etkinin olumlu olması ölçüsünde ödemeler bilançosu açıkları kapatılır (Sarı, 2013).

İstihdam geniş anlamda bütün üretim faktörlerinin, dar anlamda ise yalnızca emek faktörünün üretime katılmasıdır. Turizm, gelişimine ve talebin yoğunluğuna bağlı olarak ekonomide istihdam etkisi yaratır. Turistik talebin yoğunlaştığı dönemlerde işgücü talebi de artar ve bu da istihdam yoğunluğunu etkiler. Artan istihdamla sağlanan gelir harcandıkça ekonomide sağlanan canlılık olumlu gelişmeleri de beraberinde getirecektir. Gelir etkisiyle ilgili olarak ise birinci aşamada direkt harcamalar göze çarpar. Bunlar turistlerin yaptığı harcamalardır. $\mathrm{Bu}$ harcamalar, ekonomide konaklama tesisleri, restoranlar, ulaştırma işletmeleri gibi kuruluşlar için direkt gelir etkisi yaratır. Sağlanan bu direkt gelirleri elde eden birimlerin yaptıkları harcamalar ise endirekt gelirlerdir. Turizm işletmelerinin istihdam ettikleri insanlara ödedikleri ücretler ve stok teşkili için yaptıkları alımlar ek bir talep yaratacaktır. Bu ek talebin karşılanması için istihdamın arttırılması ya da ücretlerin yükseltilmesi gerekecek, bu da kişisel gelirlerde bir artış sağlayacaktır. Kişisel gelirlerdeki yükselişe paralel olarak da artan tüketim harcamaları ekonomide uyarılmış etkiler yaratarak bir canlanmaya neden olacaktır. Turizmin gelir etkisinin bir başka yönü de katma değere olan etkisidir. Katma değer, satışa sunulan malın fiyatından, bu malı üretmek üzere daha önce başka kişiler veya kuruşlar tarafından yapılmış ara tüketim harcamaları çıkarıldığında kalan farktır. Ülkede bütün ekonomik birimlerin mal ve hizmet üretiminde yarattıkları katma değer toplam milli hasılayı verir. Turistik mal ve hizmet üretiminin milli gelir üzerinde yarattığı katma değer etkisi diğer sektörel üretimlerden daha yüksek olduğu için önem kazanmaktadır (Sarı, 2013).

Turist çeken bölgelerde, mevcut turizm gelirlerini arttırabilecek potansiyele sahip su, yol, elektrik, ulaşım gibi alt yapı yatırımları önem kazanmaktadır. Konaklama, eğlence, alışveriş tesisleri gibi üst yapı ile ilgili faktörler de alt yapı eksikleri tamamlandığı taktirde yatırım için ön plana çıkmaktadır. Alt ve üst yapı yatırımları turizm gelirlerinin de artmasını sağlayacaktır. Turizm bölgelerinde havalimanları pist ve tesislerine yapılan yatırım ve yenileştirmeler bu yatırım türüne örnek olarak verilebilir.

Gelişmekte olan birçok ülke açısından turizmin çekici yönlerinden en önemlisi, az zamanda yapılan yatırımların ekonomik geri dönüşlerini daha kısa sürede gösterebilmesidir. Turizm, başarılı bir tanıtım kampanyasından ortalama 1-2 yıl sonra büyük gereksinim duyulan döviz girdisini sağlayabilen, gelir ve istihdam artışı yaratabilen bir sektördür. Özellikle gelişmekte olan ülkelerin ekonomik kalkınmalarını gerçekleştirmede karşılaştıkları en büyük sorun olan döviz darboğazlarının aşılmasında, turizm sayesinde elde edilen dövizler bir çıkış yolu olabilmektedir (Shoyunchap, 2008).

Dünya Turizm Örgütü, hizmet verdiği kişi sayısı, yarattı̆̆ı istihdam, gelir ve katma değerle turizmin, dünyanın en büyük sektörü konumuna geldiğini ifade etmektedir. Bu bağlamda, tüm dünya ülkeleri vatandaşlarını turizme bir şekilde, üretici veya tüketici olarak katılmaları konusunda desteklemektedir (Önal vd., 2008). Dünya Turizm Örgütü tarafindan yayımlanan son turizm raporunda 2012 yılı sonu itibariye uluslararası turizm hareketi tüm detaylarıyla aşağıdaki tablo ve grafiklerde sunulmuştur. 
International Tourism Receipts (US\$ billion)

\begin{tabular}{|c|c|c|c|c|c|c|c|c|c|c|}
\hline \multirow{2}{*}{\multicolumn{2}{|c|}{ Rank }} & & \multicolumn{5}{|l|}{ US\$ } & \multirow{3}{*}{ Series } & \multicolumn{2}{|c|}{$\begin{array}{l}\text { ocal currencies, } \\
\text { current prices }\end{array}$} \\
\hline & & & \multirow{2}{*}{2000} & \multirow{2}{*}{2005} & \multirow{2}{*}{2010} & \multirow{2}{*}{$\frac{2011}{(k}$} & \multirow{2}{*}{$\frac{2012^{*}}{\text { billion) }}$} & & $11 / 10$ & $12 * / 11$ \\
\hline 12 & 11 & & & & & & & & \multicolumn{2}{|c|}{ (change, \%) } \\
\hline & & World & 475 & 680 & 930 & 1,042 & 1,075 & & & \\
\hline 1 & 1 & United States & 82.9 & 82.2 & 103.5 & 116.1 & 128.6 & & 12.2 & 10.7 \\
\hline 2 & 2 & Spain & 30.0 & 48.0 & 52.5 & 59.9 & 55.9 & & 8.6 & 1.2 \\
\hline 3 & 3 & France & 33.0 & 44.0 & 46.9 & 54.5 & 53.7 & & 10.7 & 6.7 \\
\hline 4 & 4 & China & 16.2 & 29.3 & 45.8 & 48.5 & 50.0 & $\$$ & 5.8 & 3.2 \\
\hline 5 & 5 & Italy & 27.5 & 35.4 & 38.8 & 43.0 & 41.2 & & 5.6 & 3.8 \\
\hline 6 & 7 & Macao (China) & 3.2 & 7.9 & 27.8 & 38.5 & .. & & 38.6 & .. \\
\hline 7 & 6 & Germany & 18.7 & 29.2 & 34.7 & 38.9 & 38.1 & & 6.7 & 6.2 \\
\hline 8 & 8 & United Kingdom & 21.9 & 30.7 & 32.4 & 35.1 & 36.4 & & 4.4 & 5.2 \\
\hline 9 & 10 & Hong Kong (China) & 5.9 & 10.3 & 22.2 & 27.7 & 31.7 & & 24.9 & 14.1 \\
\hline 10 & 9 & Australia & 9.3 & 16.8 & 29.1 & 31.5 & 31.5 & & -3.8 & -0.2 \\
\hline 11 & 11 & Thailand & 7.5 & 9.6 & 20.1 & 27.2 & 30.1 & & 30.5 & 25.3 \\
\hline 12 & 12 & Turkey & 7.6 & 19.2 & 22.6 & 25.1 & 25.7 & $\$$ & 10.9 & 2.4 \\
\hline 13 & 14 & Malaysia & 5.0 & 8.8 & 18.3 & 19.6 & 19.7 & & 1.9 & 1.5 \\
\hline 14 & 15 & Singapore & 5.1 & 6.2 & 14.2 & 18.1 & 19.3 & & 17.7 & 5.8 \\
\hline 15 & 13 & Austria & 9.8 & 16.1 & 18.6 & 19.9 & 18.9 & & 1.7 & 3.1 \\
\hline 16 & 16 & India & 3.5 & 7.5 & 14.5 & 17.7 & 18.0 & & 19.6 & 21.8 \\
\hline 17 & 18 & Canada & 10.8 & 13.8 & 15.8 & 16.8 & 17.4 & & 2.4 & 4.4 \\
\hline 18 & 17 & Switzerland & 6.6 & 10.0 & 14.9 & 17.5 & 16.6 & & 0.2 & -0.2 \\
\hline 19 & 21 & Sweden & 4.1 & 6.8 & 11.0 & 13.8 & 15.4 & & 12.3 & 17.0 \\
\hline 20 & 28 & Japan & 3.4 & 6.6 & 13.2 & 11.0 & 14.6 & & -24.5 & 32.9 \\
\hline 21 & 22 & Korea, Republic of & 6.8 & 5.8 & 10.4 & 12.5 & 142 & $\$$ & 20.9 & 13.6 \\
\hline 22 & 20 & Netherlands & 7.2 & 10.5 & 12.9 & 14.3 & 13.9 & & 6.1 & 4.9 \\
\hline 23 & 19 & Greece & 9.2 & 13.3 & 12.7 & 14.6 & 12.9 & & 9.3 & -4.6 \\
\hline 24 & 23 & Mexico & 8.3 & 11.8 & 12.0 & 11.9 & 12.7 & $\$$ & -1.0 & 7.2 \\
\hline 25 & 27 & Taivwan (pr. of China) & 3.7 & 5.0 & 8.7 & 11.1 & 11.7 & $\$$ & 26.9 & 5.8 \\
\hline 26 & 24 & Belgium & 6.6 & 9.9 & 10.4 & 11.7 & 11.4 & & 7.0 & 5.8 \\
\hline 27 & 26 & Russian Federation & 3.4 & 5.9 & 8.8 & 11.3 & 11.2 & $\$$ & 28.3 & -1.2 \\
\hline 28 & 25 & Portugal & 5.2 & 7.7 & 10.1 & 11.3 & 11.1 & & 7.2 & 5.6 \\
\hline 29 & 29 & Poland & 5.7 & 6.3 & 9.5 & 10.7 & 10.9 & & 9.1 & 13.4 \\
\hline 30 & 30 & South Africa & 2.7 & 7.5 & 9.1 & 9.5 & 10.0 & & 4.4 & 18.4 \\
\hline 31 & 32 & Untd Arab Emirates & 1.1 & 3.2 & 8.6 & 9.2 & .. & & 7.3 & .. \\
\hline 32 & 33 & Egypt & 4.3 & 6.9 & 12.5 & 8.7 & 9.9 & $\$$ & -30.5 & 14.2 \\
\hline 33 & 31 & Croatia & 2.8 & 7.4 & 8.3 & 9.2 & 8.8 & $€$ & 6.2 & 3.2 \\
\hline 34 & 35 & Indonesia & 5.0 & 4.5 & 7.0 & 8.0 & 8.3 & $\$$ & 15.0 & 4.3 \\
\hline 35 & 34 & Saudi Arabia & .. & 4.6 & 6.7 & 8.5 & 7.4 & & 26.0 & -12.1 \\
\hline 36 & 36 & Czech Rep & 3.0 & 4.8 & 7.1 & 7.6 & 7.0 & & -0.7 & 2.1 \\
\hline 37 & 37 & Morocco & 2.0 & 4.6 & 6.7 & 7.3 & 6.7 & & 4.4 & -1.7 \\
\hline 38 & 38 & Lebanon & .. & 5.5 & 8.1 & 6.9 & $\ldots$ & $\$$ & -14.8 & .. \\
\hline 39 & 40 & Brazil & 1.8 & 3.9 & 5.7 & 6.6 & 6.6 & $\$$ & 15.0 & 1.4 \\
\hline 40 & 41 & Vietnam & .. & 2.3 & 4.5 & 5.6 & 6.6 & $\$$ & 26.3 & 18.0 \\
\hline 41 & 39 & Denmark & 3.7 & 5.3 & 5.9 & 6.6 & 6.2 & & 7.3 & 1.o \\
\hline 42 & 43 & New Zealand & 2.3 & 5.2 & 4.9 & 5.6 & 5.5 & & 3.7 & -4.7 \\
\hline 43 & 45 & Norway & 2.2 & 3.5 & 4.7 & 5.2 & 5.3 & & 3.1 & 5.1 \\
\hline 44 & 46 & Israel & 4.1 & 2.9 & 4.7 & 4.9 & 5.1 & $\$$ & 2.8 & 5.6 \\
\hline 45 & 44 & Argentina & 2.9 & 2.7 & 4.9 & 5.4 & 4.9 & $\$$ & 8.3 & -8.6 \\
\hline 46 & 42 & Hungary & 3.8 & 4.1 & 5.4 & 5.6 & 4.8 & & 0.3 & -2.8 \\
\hline 47 & 49 & Ukraine & 0.4 & 3.1 & 3.8 & 4.3 & 4.8 & $\$$ & 13.4 & 12.8 \\
\hline 48 & 48 & Dominican Rp & 2.9 & 3.5 & 4.2 & 4.4 & 4.5 & $\$$ & 3.4 & 4.5 \\
\hline 49 & 47 & Luxembourg & 1.8 & 3.6 & 4. 1 & 4.8 & 4.5 & & 11.5 & 1.1 \\
\hline 50 & 51 & Finland & 1.4 & 2.2 & 3.1 & 3.8 & 4.1 & & 19.3 & 16.4 \\
\hline
\end{tabular}

Tablo1. Yıllara Göre Uluslararası Turizm Gelirleri Kaynak: Dünya Turizm Örgütü (Erişim Tarihi: 25.04.2013) 
International Tourism by (Sub)region

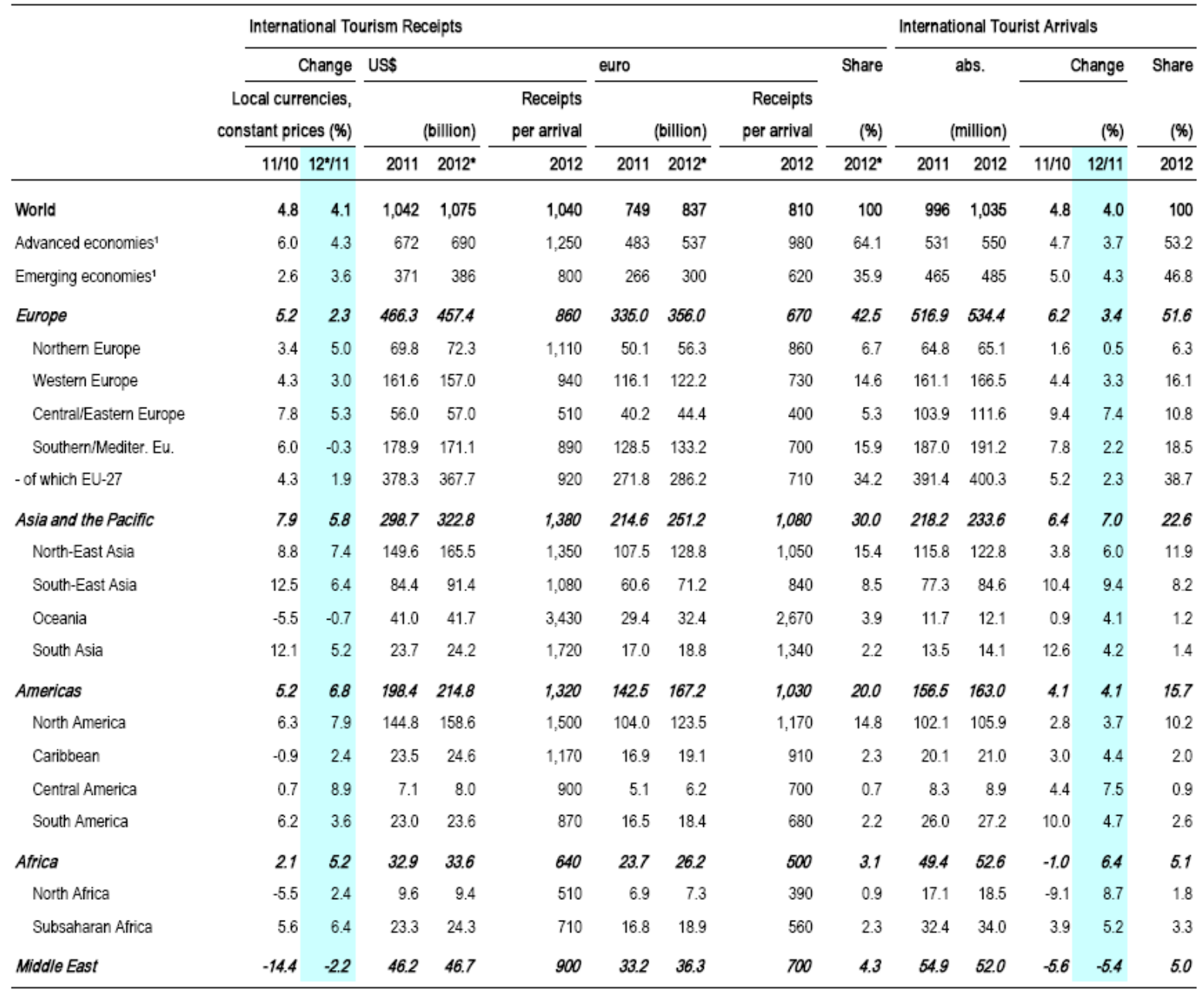

Tablo 2. Yıllara Göre Bölgelerin Turizm Gelirleri ve Turist Rakamları Kaynak: Dünya Turizm Örgütü

\section{Inbound tourism: World}

\section{International tourist arrivals, 1995-2012* (million)}

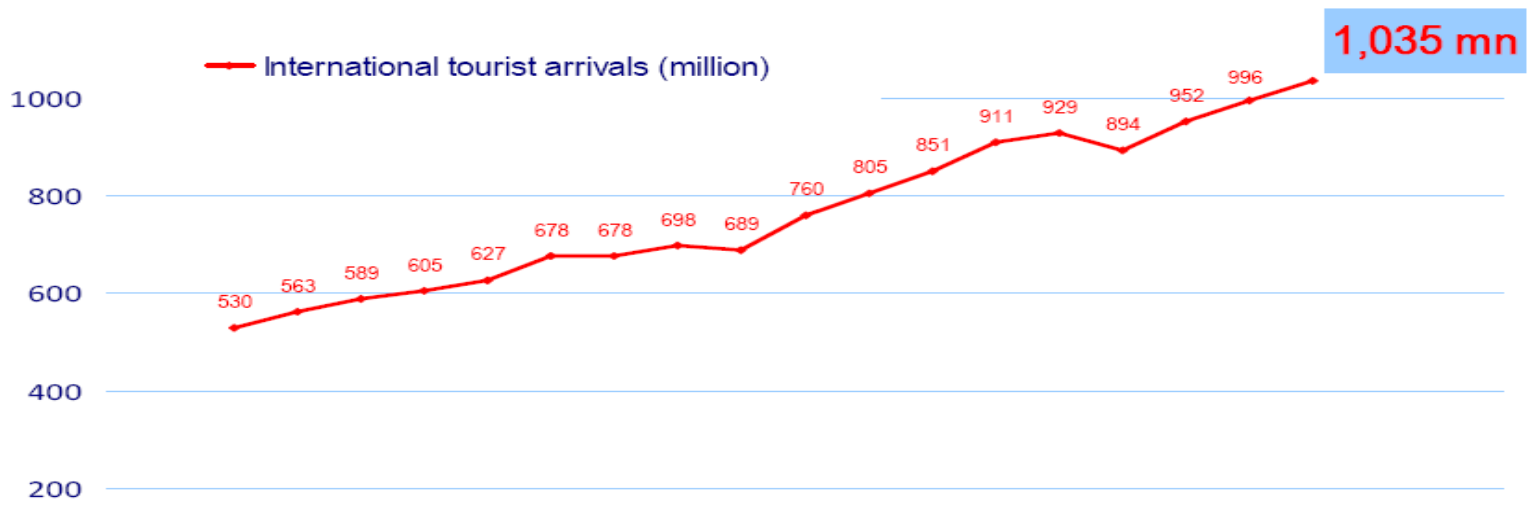

$199519961997199819992000200120022003200420052006200720082009201020112012^{*}$

Grafik 1. Ylllara Göre Uluslararası Turist Rakamları Kaynak: Dünya Turizm Örgütü 


\section{$(((1)))$}
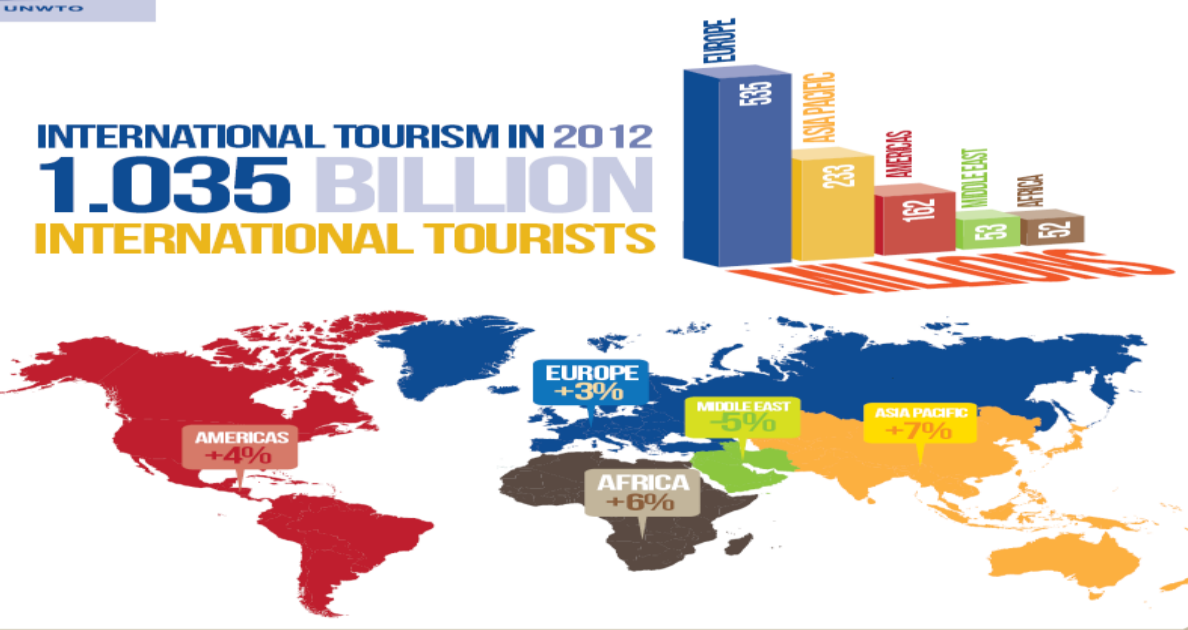

\section{WORLD +4\%}

Grafik 2. 2012 Yılı Bölgesel Turist Artış Oranı Kaynak: Dünya Turizm Örgütü

\section{Absolute numbers 2012 by region}

World Inbound Tourism: International Tourist Arrivals, 2012

(million)

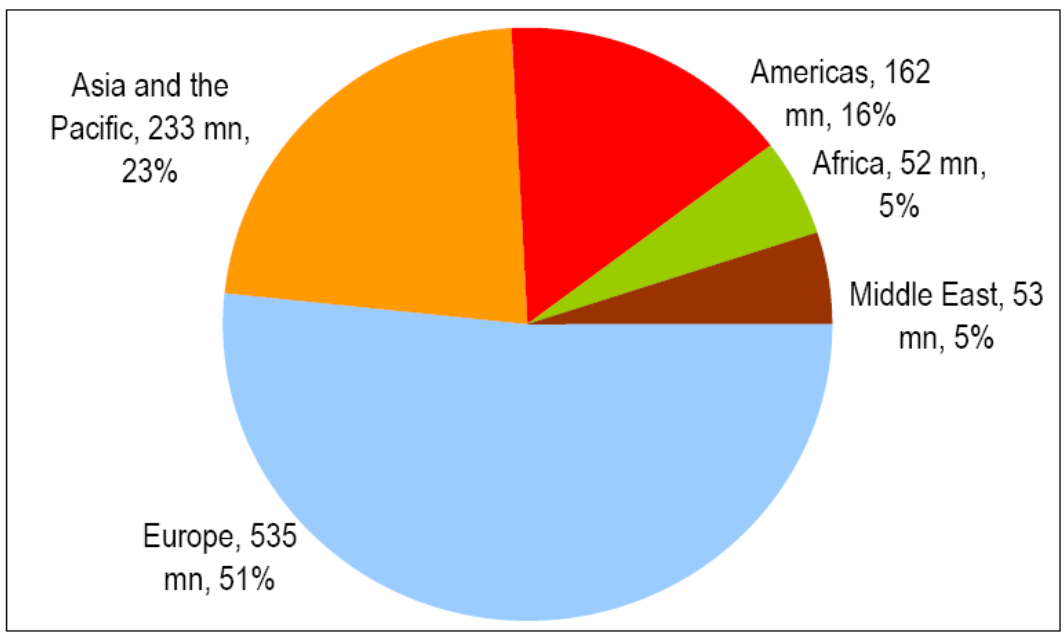

Grafik 3. 2012 Yılı Bölgesel Turist Artış Oranı Kaynak: Dünya Turizm Örgütü International tourism: projection full year 2013

\begin{tabular}{|l|c|c|}
\hline & $\mathbf{2 0 1 2}$ & Projection 2013 \\
\hline World & $+3.8 \%$ & $+3 \%$ to $+4 \%$ \\
\hline Europe & $+3.4 \%$ & $+2 \%$ to $+3 \%$ \\
\hline Asia and the Pacific & $+6.8 \%$ & $+5 \%$ to $+6 \%$ \\
\hline Americas & $+3.7 \%$ & $+3 \%$ to $+4 \%$ \\
\hline Africa & $+6.0 \%$ & $+4 \%$ to $+6 \%$ \\
\hline Middle East & $-4.9 \%$ & $+0 \%$ to $+5 \%$ \\
\hline
\end{tabular}

Tablo 3. 2013 Yllı Turist Artış Projeksiyonu Kaynak: Dünya Turizm Örgütü 


\title{
International tourism maintains strength
}

\author{
International Tourist Arrivals, monthly evolution
}

World (million)

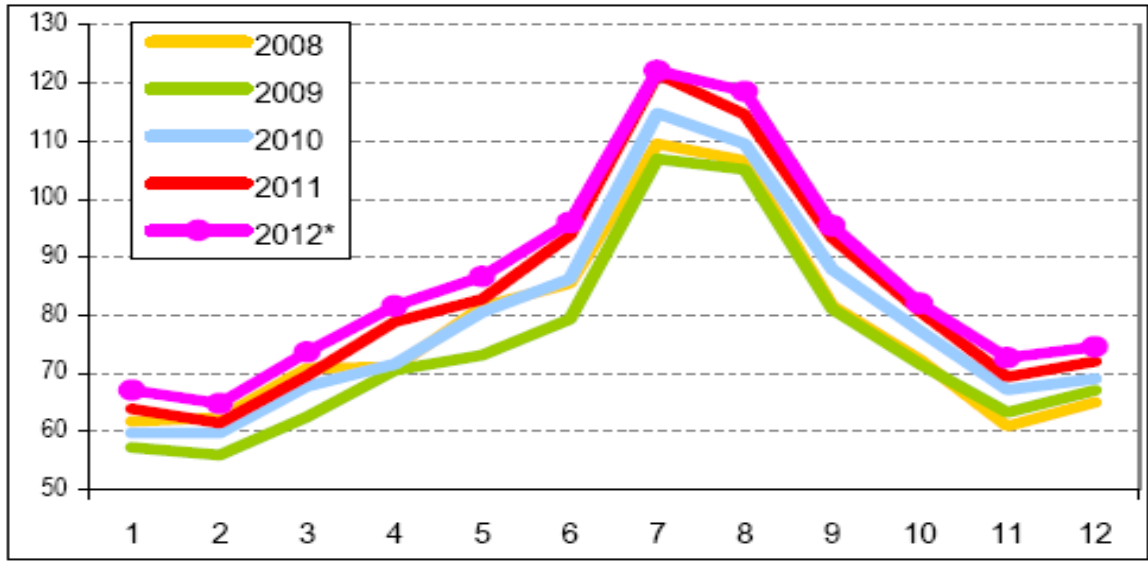

Grafik 4. Aylık Uluslararası Turist Dağılımları Kaynak: Dünya Turizm Örgütü

Yukarıdaki tablo ve grafikler incelediğinde 2012 yılında dünya turizm hareketlerinde bir yıl öncesine oranla yüzde 4'lük bir artış olduğu ve buna bağlı olarak turizm gelirlerinin 1 trilyon 75 milyar dolara çıktığ1 görülmektedir. Ayrıca çarpıcı noktalardan bir tanesi de uluslararası seyahat gerçekleştiren kişi sayısının 2012 yılında ilk defa 1 milyar sınırını aşarak 1 milyar 35 milyona ulaşmasıdır. Gelişmekte olan ülkeler yüzde 4.1'lik büyüme oranı ile gelişmiş ülkelerin (yüzde 3.6) büyüme hızlarını geride bırakmıştır. Birleşmiş Milletler Dünya Turizm Örgütü (UNWTO) Genel Sekreteri Taleb Rifai'nin de ifade ettiği gibi 2012'de küresel boyutta bir ekonomik dalgalanma yaşanmasına rağmen uluslararası turizm rotasından çıkmamış, yolunda ilerlemeye devam etmiştir. 2012'de 2011'e nazaran 39 milyon daha fazla kişi turizm amaçlı seyahat ederken, en fazla büyüme yüzde 7 ile Asya ve Pasifik bölgelerinde görülmüştür. Avrupa 535 milyon kişi ile en fazla turist çeken bölge olmuş ve yüzde 3'lük bir büyüme kaydedilmiştir. Savaşların ve istikrarsızlıkların gölgesindeki Ortadoğu'da bile 2011 yılı turist sayısındaki yüzde 7'lik azalma, 2012 yılında yalnızca yüzde 2 oranında düşerek yüzde 5'e gerilemiştir. Kuzey Afrika ülkelerinde Arap Baharıyla yaşanan halk hareketlerinden dolayı 2011 yılında yüzde 1'lik düşüş yaşayan Afrika kıtası 2012'de yüzde 6 büyümüştür. Amerika Kıtası'da 2012'de yüzde 4'lük artışla toplam 162 milyon turiste ev sahipliği yapmıştır. 2012'de Avrupa merkezli tüm dünyada yaşanan ekonomik kriz ve yıllardır Ortadoğu'da süregelen savaş ortamına rağmen turizmin ekonomiye olan katkısı daima pozitif yönde olmuştur. Dünya Ticaret Örgütü'ne göre 2013 yılında da turizmin ekonomideki payı, dolayısıyla ülke ekonomilerine olan katkısı bu veriler ışığında devam edecektir.

\subsection{Turizmin Türkiye Ekonomisindeki Yeri}

Tarihi medeniyetlerin buluştuğu bir ülke olmasının yanı sıra Türkiye, rakiplerine göre son derece temiz plaj ve koylara sahiptir. Ayrıca dört mevsimin bir arada yaşanması nedeniyle de adeta bir turizm cenneti görünümündedir. Sahip olduğu bu değerleri turizm amaçlı kullanması, ülkemizin içinde bulunduğu işsizlik sorununun giderilmesinde çok önemli rol oynayacaktır.

Turizm sektörüne gereken önem ancak 1980 yılından itibaren verilmeye başlanmış, bu kapsamda gerekli yatırım ve tanıtım faaliyetlerine ağırlık verilmiştir. Ülkemizde özellikle son yıllarda turizm teşvik edilerek özellikle dış turizm gelirlerini artırma ve böylelikle ödemeler dengesi açılarını kapatma politikası benimsenmiştir. Ödemeler dengesi açıklarını kapatan önemli alanlardan birisinin turizm olduğu net bir şeklide hissedilmektedir. İçinde bulunduğumuz kriz dönemlerinde dahi istihdama katkısı en üst düzeyde olan sektör yine turizm sektörüdür. İthalat ihracat dengesizliğine dayanan bütçe açığı artan turizm gelirleriyle kapatılmaya çalışılmaktadır. Ülkemiz, yılın her mevsimde çeşitli turizm etkinliklerine imkan sağlayan ılıman iklimi, zengin kültürel ve doğal değerleri ile seyahat endüstrisinde popülerliği artan bir turizm merkezi haline gelmektedir.

Kültür ve Turizm Bakanlığı tarafından yayımlanan "Türkiye Turizm Stratejisi 2023" konulu eylem planında sektör ile ilgili belirlenen vizyon şöyle ifade edilmiştir: "Sürdürülebilir turizm yaklaşımı benimsenerek istihdamın arttırılmasında ve bölgesel gelişmede turizmin öncü bir sektör konumuna ulaştırılması ve Türkiye'nin 2023 yılına kadar, uluslararası pazarda turist sayısı ve turizm geliri bakımından ilk beş ülke arasında önemli bir varış noktası ve uluslararası bir marka haline getirilmesinin sağlanmasıdır." Bu kapsamda; alt yapı ve üst yapı çalışmaları, turist profilini geliştirmeye yönelik çalışmalar, turizm pastasından alınacak payı büyütmeye dönük uluslararası ilişkiler ile sürdürülen ve planlanan ekonomi politikaları gibi konuyla ilgili birçok faaliyet hızla ve artarak devam etmektedir. Dünya genelindeki turizm hareketliliği ve buna bağlı olarak uluslararası turizm gelirlerindeki artış gözlendiğinde turizmin Türkiye ekonomisi için ne derece önemli olduğu ortaya çıkmaktadır. 


$\begin{array}{rrrrrrr}\text { Yillar } & 2007 & 2008 & 2009 & 2010 & 2011 & 2012 \\ \text { Adet } & 23.340 .911 & 26.336 .677 & 27.077 .114 & 28.632 .204 & 31.456 .076 & 31.782 .832\end{array}$

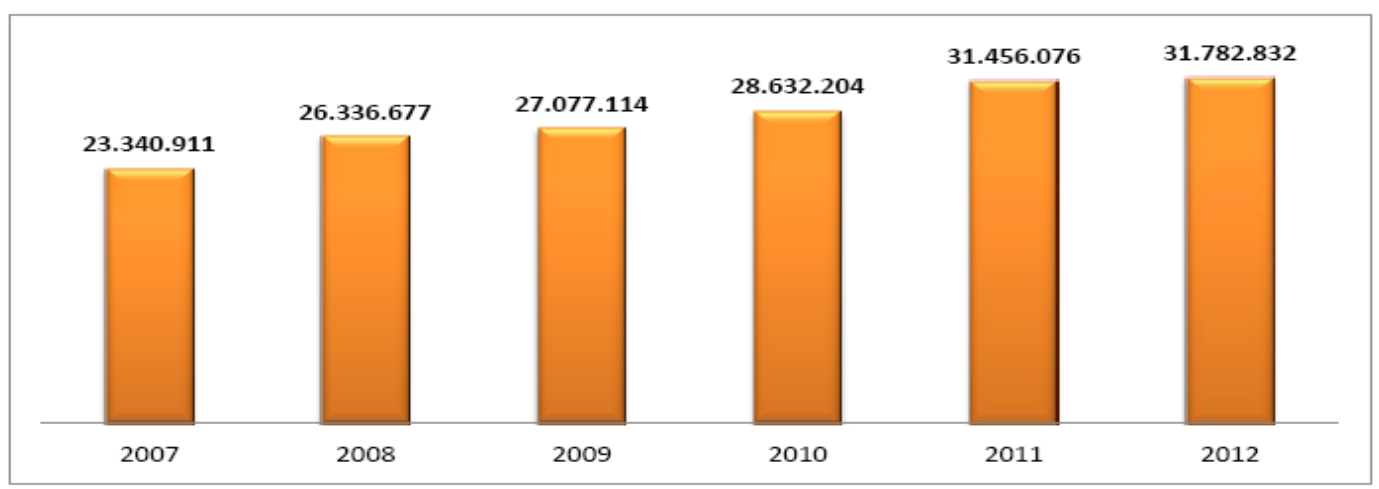

Grafik 5. Yıllara Göre Türkiye’ye Gelen Yabancı Ziyaretçi Sayıları Kaynak: Kültür ve Turizm Bakanlı̆̆ı
Yıllar
20072008
2009
2010
2011
2012

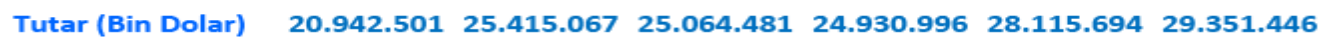

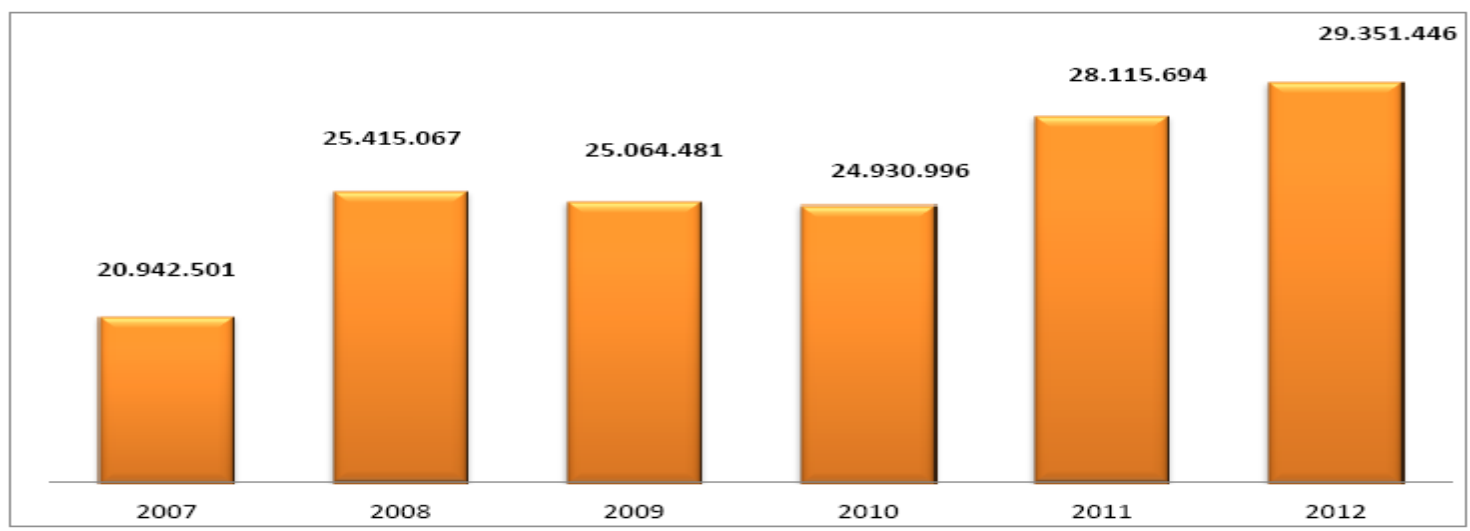

Grafik 6. Yıllara Göre Türkiye Turizm Gelirleri Kaynak: Kültür ve Turizm Bakanlı̆̆

1980’lerden başlayarak son 30 yıl içinde Türkiye'nin turizme verdiği önem giderek artmış, böylelikle sektörün gelişimi ve ülkeye olan katkısı birçok dünya ülkesini geride bırakmıştır. Yukarıdaki grafikler 1şığında Türkiye açısından bakıldığında 2008 yılında başlayarak günümüze kadar devam eden ve tüm dünyayı etkisi altında bırakan ekonomik krize rağmen ülkeye gelen yabancı ziyaretçi sayısı azalan oranlarda da olsa artmaya devam etmiştir. Yine turizm gelirinin de krizle birlikte yıllar içinde inişli çıkışlı bir takım dalgalanmalara rağmen arttığı görülmektedir. Krizin başladığı 2008 yılında bir önceki yıla göre ortalama 3 milyon kişi ve 4.5 milyar dolarlık bir artış gerçekleşmiştir. Grafiklerdeki en dikkat çekici nokta ise 2010 yılında turist sayısındaki artışa rağmen turizm gelirlerinde kaydedilen gerilemedir. Bunun nedeni turist başına gelirin düşmesidir. Daima eleştirilere konu olan kızgın rekabet anlayışı ve küresel krizin özellikle Avrupa'da yarattığı talep düşüşü turizm sektöründe de kendisini göstermiştir. Talepte meydana gelen bu düşüş neticesinde özellikle 2010 yılında turistik tesisler belli doluluk oranlarını koruyabilmek maksadıyla fiyatları indirerek karlarından feragat etmişlerdir. Bu esnada turizm giderleri standart artışını sürdürmüş ve dolayısıyla aradaki fark net turizm gelirlerine negatif oranda yansımıştır.

Günümüzde turizm pastasından pay alabilmek için ülkeler arasında kıyasıya bir rekabet olduğu görülmektedir. $\mathrm{Bu}$ yarışta, birçok medeniyete ev sahipliği yapmış, dünyanın hiçbir yerinde olmayan doğal ve kültürel zenginliklere sahip, dört mevsimin tüm güzellikleriyle yaşandığı ve kıtaları birbirine bağlayan konumuyla adeta bir cennet görünümündeki Türkiye bu avantajını daha iyi bir şekilde kullanmalıdır. Turizme ayrılan kaynakların arttırılması ve turizm faaliyetlerinin çeşitlendirilerek tüm ülke çapında yayılmasıyla birlikte Türkiye yaşanacak her türlü krize rağmen turist çeken bir ülke olma özelliğini koruyacaktır. 


\begin{tabular}{|l|l|l|l|l|l|}
\hline \multicolumn{6}{|l|}{ TÜRKIYE'YE GELEN YABANCI ZIYARETÇILERIN YILLARA VE AYLARA GÖRE DAĞILIMI } \\
\hline & \multicolumn{1}{|l|}{ YILLAR } & \multicolumn{1}{l|}{ \% DEĞIȘiM ORANI } & \\
\hline AYLAR & 2010 & 2011 & 2012 & $2011 / 2010$ & $2012 / 2011$ \\
\hline OCAK & 809974 & 975723 & 981611 & 20,46 & 0,60 \\
\hline ŞUBAT & 953848 & 1079505 & 997571 & 13,17 & $-7,59$ \\
\hline MART & 1414616 & 1617782 & 1460563 & 14,36 & $-9,72$ \\
\hline NISAN & 1744628 & 2290722 & 2168715 & 31,30 & $-5,33$ \\
\hline MAYIS & 3148337 & 3283125 & 3232926 & 4,28 & $-1,53$ \\
\hline HAZIRAN & 3500024 & 3780637 & 3882592 & 8,02 & 2,70 \\
\hline TEMMUZ & 4358275 & 4597475 & 4571389 & 5,49 & $-0,57$ \\
\hline AĞUSTOS & 3719180 & 4076783 & 4470202 & 9,62 & 9,65 \\
\hline EYLÜL & 3486319 & 3923546 & 3991415 & 12,54 & 1,73 \\
\hline EKIM & 2840095 & 3039754 & 3050981 & 7,03 & 0,37 \\
\hline KASIM & 1491005 & 1596295 & 1631647 & 7,06 & 2,21 \\
\hline ARALIK & 1165903 & 1194729 & 1343220 & 2,47 & 12,43 \\
\hline TOPLAM & 28632204 & 31456076 & 31782832 & 9,86 & 1,04 \\
\hline
\end{tabular}

Tablo 4. Türkiye'ye Gelen Yabancı Ziyaretçilerin Yıllara ve Aylara Göre Dă̆̊lımı Kaynak: Kültür ve Turizm Bakanlı̆

\begin{tabular}{|c|c|c|c|c|c|c|}
\hline \multicolumn{7}{|c|}{$\begin{array}{l}\text { 2010-2012 YILLARI OCAK-ARALIK DÖNEMINDE TÜRKIYE'YE GELEN } \\
\text { YABANCILARIN MILLLIYETLERE GÖRE DAĞILIMI - İLK10 ÜLKE }\end{array}$} \\
\hline ÜLKELER & 2012 & MİL.PAY\% & 2011 & MIL.PAY\% & 2010 & MİL.PAY\% \\
\hline ALMANYA & 5028745 & 15,82 & 4826315 & 15,34 & 4385263 & 15,32 \\
\hline RUSYA FED. & 3599925 & 11,33 & 3468214 & 11,03 & 3107043 & 10,85 \\
\hline İNGILTERE & 2456519 & 7,73 & 2582054 & 8,21 & 2673605 & 9,34 \\
\hline BULGARISTAN & 1492073 & 4,69 & 1491561 & 4,74 & 1433970 & 5,01 \\
\hline GÜRCİSTAN & 1404882 & 4,42 & 1152661 & 3,66 & 1112193 & 3,88 \\
\hline HOLLANDA & 1273593 & 4,01 & 1222823 & 3,89 & 1073064 & 3,75 \\
\hline İRAN & 1186343 & 3,73 & 1879304 & 5,97 & 1885097 & 6,58 \\
\hline FRANSA & 1032565 & 3,25 & 1140459 & 3,63 & 928376 & 3,24 \\
\hline A.B.D. & 771837 & 2,43 & 757143 & 2,41 & 642768 & 2,24 \\
\hline SURIYYE & 730039 & 2,30 & 974054 & 3,10 & 899494 & 3,14 \\
\hline DİĞER & 12806311 & 40,29 & 11961488 & 38,03 & $\begin{array}{l}10491 \\
331\end{array}$ & 36,64 \\
\hline GENEL TOPLAM & 31782832 & 100,00 & 31456076 & 100,00 & $\begin{array}{l}28632 \\
204\end{array}$ & 100,00 \\
\hline
\end{tabular}

Tablo 5. 2010-2012 Yılları Ocak-Aralık Döneminde Türkiye’ye Gelen Yabancıların Milliyetlerine Göre Dă̆llımı (Illk 10 Ülke) Kaynak: Kültür ve Turizm Bakanlı̆̆

Yukarıdaki istatistikler incelendiğinde, özellikle 2011-2012 yılı değişim yüzdelerinde bir önceki yıla göre belirgin bir azalma olduğu dikkati çekmektedir. Turizm otoriteleri bu durumu 2012 yılında derinleşen küresel ekonomik kriz ile kapsamı sürekli artan Arap Baharı'nın birleşmesine bağlamaktadırlar. Ancak dünya ile kıyaslandığında ülkemizin turizm verilerinin daha umut verici olduğunu görülmektedir. Turizmi arttırmaya yönelik faaliyetlerin yoğunlaşması, artan turizm çeşitliliği, özellikle son yıllarda uygulanan politikalar sonucunda fiyat kalite dengesindeki avantajlı konum ve yeni destinasyonlar oluşturmak için gerçekleştirilen yatırımlar etkisini göstermektedir.

Diğer tabloda ise ülkemize gelen yabancıların milliyetlerine göre dağılımı verilmiştir. Buna göre en büyük payı ilk defa 5 milyon rakamını geçen Almanya alırken, 3.5 milyonun üzerindeki Rusya ikinci, ortalama 2.5 milyon kişi ile İngiltere'de üçüncü sırayı almıştır.

Türkiye'de 1980'li yıllardan itibaren atılım gösteren turizm sektörünün genel ekonomi üzerinde büyük etkiler yarattığını söylemiştik. Bunlardan en önemlisi, ödemeler dengesine katkıda bulunan döviz girdisidir. Bir diğer önemli faydası da istihdam etkisidir ve bu bağlamda sektör işsizliğin büyük bir sorun olduğu ülkemizde vasıfsız işçilere de istihdam olanağı sağlayarak emek piyasasındaki arz fazlasını bir nebzede olsa azaltabilmektedir. Ayrıca milli gelir üzerinde doğrudan ve dolaylı yarattığı etkiyle hem GSMH'nin hem de vergi gelirlerinin artmasına yardımcı olmaktadır. Diğer sektörlerle ileri ve geri bağlantısı da son olarak değinilmesi gereken 
noktadır. Yani diğer sektörlerden girdi talep etmesi (geri bağlantı etkisi) ve diğer sektörlere mal arz etmesi (ileri bağlantı etkisi) yoluyla ekonomiye olumlu katkı sağlamaktadır (Hepaktan ve Çınar, 2010).

\begin{tabular}{|c|c|c|c|c|c|c|c|c|}
\hline \multicolumn{9}{|c|}{ 2010-2012 YILLARINDA TÜRKİYE’YE GELEN YABANCILARIN MİLLİYETLERİNE GÖRE KARŞILAŞTIRILMASI } \\
\hline \multirow[b]{2}{*}{ MILLIYET } & \multicolumn{3}{|c|}{ YILLAR } & \multicolumn{3}{|c|}{ MILLIYYT PAYI (\%) } & \multicolumn{2}{|c|}{ DEĞİŞİM ORANI(\%) } \\
\hline & 2010 & 2011 & 2012 & 2010 & 2011 & 2012 & $2011 / 2010$ & $2012 / 2011$ \\
\hline ALMANYA & 4385263 & 4826315 & 5028745 & 15,32 & 15,34 & 15,82 & 10,06 & 4,19 \\
\hline AVUSTURYA & 500321 & 528966 & 505560 & 1,75 & 1,68 & 1,59 & 5,73 & $-4,42$ \\
\hline BELÇİKA & 543003 & 585860 & 608071 & 1,90 & 1,86 & 1,91 & 7,89 & 3,79 \\
\hline DANİMARKA & 314446 & 369867 & 391312 & 1,10 & 1,18 & 1,23 & 17,62 & 5,80 \\
\hline FINLANDİYA & 143204 & 186562 & 195083 & 0,50 & 0,59 & 0,61 & 30,28 & 4,57 \\
\hline FRANSA & 928376 & 1140459 & 1032565 & 3,24 & 3,63 & 3,25 & 22,84 & $-9,46$ \\
\hline HOLLANDA & 1073064 & 1222823 & 1273593 & 3,75 & 3,89 & 4,01 & 13,96 & 4,15 \\
\hline İNGÍLTERE & 2673605 & 2582054 & 2456519 & 9,34 & 8,21 & 7,73 & $-3,42$ & $-4,86$ \\
\hline İRLANDA & 111065 & 118620 & 110863 & 0,39 & 0,38 & 0,35 & 6,80 & $-6,54$ \\
\hline İSPANYA & 321325 & 300084 & 278164 & 1,12 & 0,95 & 0,88 & $-6,61$ & $-7,30$ \\
\hline İSVEÇ & 447270 & 571917 & 617811 & 1,56 & 1,82 & 1,94 & 27,87 & 8,02 \\
\hline İSVİÇRE & 271139 & 328825 & 354461 & 0,95 & 1,05 & 1,12 & 21,28 & 7,80 \\
\hline İTALYA & 671060 & 752238 & 714041 & 2,34 & 2,39 & 2,25 & 12,10 & $-5,08$ \\
\hline İZLANDA & 6476 & 6156 & 5797 & 0,02 & 0,02 & 0,02 & $-4,94$ & $-5,83$ \\
\hline LÜKSEMBURG & 11262 & 13286 & 14034 & 0,04 & 0,04 & 0,04 & 17,97 & 5,63 \\
\hline PORTEKİZ & 53373 & 52319 & 46606 & 0,19 & 0,17 & 0,15 & $-1,97$ & $-10,92$ \\
\hline YUNANİSTAN & 670297 & 702017 & 669823 & 2,34 & 2,23 & 2,11 & 4,73 & $-4,59$ \\
\hline ÇEK CUM. & 174426 & 223369 & 223986 & 0,61 & 0,71 & 0,70 & 28,06 & 0,28 \\
\hline POLONYA & 428275 & 486319 & 428440 & 1,50 & 1,55 & 1,35 & 13,55 & $-11,90$ \\
\hline MACARISSTAN & 90944 & 103918 & 94409 & 0,32 & 0,33 & 0,30 & 14,27 & $-9,15$ \\
\hline NORVEÇ & 299405 & 375502 & 406879 & 1,05 & 1,19 & 1,28 & 25,42 & 8,36 \\
\hline SLOVAKYA & 91765 & 122088 & 126974 & 0,32 & 0,39 & 0,40 & 33,04 & 4,00 \\
\hline AVRUPA OECD & 14209364 & 15599564 & 15583736 & 49,63 & 49,59 & 49,03 & 9,78 & $-0,10$ \\
\hline A.B.D. & 642768 & 757143 & 771837 & 2,24 & 2,41 & 2,43 & 17,79 & 1,94 \\
\hline AVUSTRALYA & 131685 & 156009 & 164899 & 0,46 & 0,50 & 0,52 & 18,47 & 5,70 \\
\hline JAPONYA & 195404 & 188312 & 203592 & 0,68 & 0,60 & 0,64 & $-3,63$ & 8,11 \\
\hline KANADA & 152556 & 191903 & 182252 & 0,53 & 0,61 & 0,57 & 25,79 & $-5,03$ \\
\hline YENİ ZELLANDA & 24636 & 26709 & 28278 & 0,09 & 0,08 & 0,09 & 8,41 & 5,87 \\
\hline MEKSİKA & 22908 & 29606 & 31576 & 0,08 & 0,09 & 0,10 & 29,24 & 6,65 \\
\hline G. KORE & 123315 & 149943 & 159084 & 0,43 & 0,48 & 0,50 & 21,59 & 6,10 \\
\hline TOPLAM OECD & 15502636 & 17099189 & 17125254 & 54,14 & 54,36 & 53,88 & 10,30 & 0,15 \\
\hline ESTONYA & 35136 & 34921 & 35459 & 0,12 & 0,11 & 0,11 & $-0,61$ & 1,54 \\
\hline KARADAĞ & 11610 & 13793 & 16559 & 0,04 & 0,04 & 0,05 & 18,80 & 20,05 \\
\hline KOSOVA & 46228 & 56411 & 70156 & 0,16 & 0,18 & 0,22 & 22,03 & 24,37 \\
\hline MALTA & 3361 & 5974 & 6397 & 0,01 & 0,02 & 0,02 & 77,74 & 7,08 \\
\hline LITVANYA & 71992 & 76036 & 69520 & 0,25 & 0,24 & 0,22 & 5,62 & $-8,57$ \\
\hline $\begin{array}{l}\text { G. KIBRIS RUM } \\
\text { YÖN. }\end{array}$ & 15421 & 16749 & 18924 & 0,05 & 0,05 & 0,06 & 8,61 & 12,99 \\
\hline LETONYA & 39102 & 45074 & 45725 & 0,14 & 0,14 & 0,14 & 15,27 & 1,44 \\
\hline BOSNA HERSEK & 47361 & 56522 & 61851 & 0,17 & 0,18 & 0,19 & 19,34 & 9,43 \\
\hline HIRVATİSTAN & 33563 & 41959 & 47144 & 0,12 & 0,13 & 0,15 & 25,02 & 12,36 \\
\hline SLOVENYA & 38597 & 41870 & 39899 & 0,13 & 0,13 & 0,13 & 8,48 & $-4,71$ \\
\hline SIRBİSTAN & 113465 & 137934 & 157568 & 0,40 & 0,44 & 0,50 & 21,57 & 14,23 \\
\hline MAKEDONYA & 115541 & 130648 & 137579 & 0,40 & 0,42 & 0,43 & 13,08 & 5,31 \\
\hline ARNAVUTLUK & 49954 & 53141 & 59565 & 0,17 & 0,17 & 0,19 & 6,38 & 12,09 \\
\hline BULGARİSTAN & 1433970 & 1491561 & 1492073 & 5,01 & 4,74 & 4,69 & 4,02 & 0,03 \\
\hline ROMANYA & 355144 & 390248 & 385055 & 1,24 & 1,24 & 1,21 & 9,88 & $-1,33$ \\
\hline $\begin{array}{l}\text { DIĞER AVRUPA } \\
\text { ÜLKELERI }\end{array}$ & 2407 & 3037 & 2894 & 0,01 & 0,01 & 0,01 & 26,17 & $-4,71$ \\
\hline $\begin{array}{l}\text { TOPLAM } \\
\text { AVRUPA }\end{array}$ & 16622216 & 18195442 & 18230104 & 58,05 & 57,84 & 57,36 & 9,46 & 0,19 \\
\hline AZERBAYCAN & 486381 & 578685 & 593238 & 1,70 & 1,84 & 1,87 & 18,98 & 2,51 \\
\hline $\begin{array}{l}\text { BELARUS (B. } \\
\text { RUSYA) }\end{array}$ & 152421 & 123607 & 138007 & 0,53 & 0,39 & 0,43 & $-18,90$ & 11,65 \\
\hline ERMENISTAN & 69323 & 72393 & 70956 & 0,24 & 0,23 & 0,22 & 4,43 & $-1,98$ \\
\hline GÜRCİSTAN & 1112193 & 1152661 & 1404882 & 3,88 & 3,66 & 4,42 & 3,64 & 21,88 \\
\hline KAZAKİSTAN & 247784 & 315907 & 380046 & 0,87 & 1,00 & 1,20 & 27,49 & 20,30 \\
\hline KIRGIZISTAN & 35665 & 41197 & 42866 & 0,12 & 0,13 & 0,13 & 15,51 & 4,05 \\
\hline MOLDOVA CUM. & 96196 & 101124 & 108032 & 0,34 & 0,32 & 0,34 & 5,12 & 6,83 \\
\hline ÖZBEKİSTAN & 68124 & 85011 & 105976 & 0,24 & 0,27 & 0,33 & 24,79 & 24,66 \\
\hline RUSYA FED. & 3107043 & 3468214 & 3599925 & 10,85 & 11,03 & 11,33 & 11,62 & 3,80 \\
\hline TACIKIISTAN & 17737 & 16822 & 22823 & 0,06 & 0,05 & 0,07 & $-5,16$ & 35,67 \\
\hline TÜRKMENİSTAN & 114390 & 137476 & 135168 & 0,40 & 0,44 & 0,43 & 20,18 & $-1,68$ \\
\hline UKRAYNA & 568227 & 602404 & 634663 & 1,98 & 1,92 & 2,00 & 6,01 & 5,36 \\
\hline BDT & 6075484 & 6695501 & 7236582 & 21,22 & 21,29 & 22,77 & 10,21 & 8,08 \\
\hline CEZAYİR & 67954 & 84844 & 104489 & 0,24 & 0,27 & 0,33 & 24,86 & 23,15 \\
\hline
\end{tabular}




\begin{tabular}{|c|c|c|c|c|c|c|c|c|}
\hline FAS & 57447 & 68645 & 77884 & 0,20 & 0,22 & 0,25 & 19,49 & 13,46 \\
\hline LIBYA & 60917 & 53562 & 213890 & 0,21 & 0,17 & 0,67 & $-12,07$ & 299,33 \\
\hline SUDAN & 6634 & 7458 & 8161 & 0,02 & 0,02 & 0,03 & 12,42 & 9,43 \\
\hline MISIR & 61560 & 79665 & 112025 & 0,22 & 0,25 & 0,35 & 29,41 & 40,62 \\
\hline TUNUS & 57855 & 63176 & 86595 & 0,20 & 0,20 & 0,27 & 9,20 & 37,07 \\
\hline $\begin{array}{l}\text { GÜNEY AFRİKA } \\
\text { CUM. }\end{array}$ & 27177 & 34394 & 40771 & 0,09 & 0,11 & 0,13 & 26,56 & 18,54 \\
\hline $\begin{array}{l}\text { DIĞ.AFRIKA } \\
\text { ÜLKELERI }\end{array}$ & 37756 & 53743 & 69584 & 0,13 & 0,17 & 0,22 & 42,34 & 29,48 \\
\hline TOPLAM AFRIKA & 377300 & 445487 & 713399 & 1,32 & 1,42 & 2,24 & 18,07 & 60,14 \\
\hline B.A.EMIRLIĞİ & 30480 & 35579 & 48071 & 0,11 & 0,11 & 0,15 & 16,73 & 35,11 \\
\hline BAHREYN & 9375 & 9712 & 13342 & 0,03 & 0,03 & 0,04 & 3,59 & 37,38 \\
\hline KATAR & 6043 & 7661 & 13971 & 0,02 & 0,02 & 0,04 & 26,77 & 82,37 \\
\hline KUVEYT & 27281 & 41617 & 65167 & 0,10 & 0,13 & 0,21 & 52,55 & 56,59 \\
\hline IRAK & 280328 & 369033 & 533149 & 0,98 & 1,17 & 1,68 & 31,64 & 44,47 \\
\hline LÜBNAN & 134554 & 137110 & 144491 & 0,47 & 0,44 & 0,45 & 1,90 & 5,38 \\
\hline ÜRDÜN & 96562 & 94914 & 102154 & 0,34 & 0,30 & 0,32 & $-1,71$ & 7,63 \\
\hline S.ARABİSTAN & 84934 & 116711 & 175467 & 0,30 & 0,37 & 0,55 & 37,41 & 50,34 \\
\hline SURIYE & 899494 & 974054 & 730039 & 3,14 & 3,10 & 2,30 & 8,29 & $-25,05$ \\
\hline K.K.T.C. & 191993 & 203272 & 211828 & 0,67 & 0,65 & 0,67 & 5,87 & 4,21 \\
\hline İSRAİL & 109559 & 79140 & 83740 & 0,38 & 0,25 & 0,26 & $-27,76$ & 5,81 \\
\hline YEMEN & 6344 & 8066 & 11826 & 0,02 & 0,03 & 0,04 & 27,14 & 46,62 \\
\hline $\begin{array}{l}\text { DIĞ.BATI ASYA } \\
\text { ÜLKELERI }\end{array}$ & 10093 & 11445 & 14286 & 0,04 & 0,04 & 0,04 & 13,40 & 24,82 \\
\hline TOP. BATI ASYA & 1887040 & 2088314 & 2147531 & 6,59 & 6,64 & 6,76 & 10,67 & 2,84 \\
\hline BANGLADEȘ & 2190 & 6168 & 6652 & 0,01 & 0,02 & 0,02 & 181,64 & 7,85 \\
\hline ÇiN HALK CUM. & 77142 & 96701 & 114582 & 0,27 & 0,31 & 0,36 & 25,35 & 18,49 \\
\hline ENDONEZYA & 24349 & 40282 & 56113 & 0,09 & 0,13 & 0,18 & 65,44 & 39,30 \\
\hline FILIPININLER & 31658 & 51610 & 65272 & 0,11 & 0,16 & 0,21 & 63,02 & 26,47 \\
\hline HINDİSTAN & 63406 & 73731 & 90934 & 0,22 & 0,23 & 0,29 & 16,28 & 23,33 \\
\hline İRAN & 1885097 & 1879304 & 1186343 & 6,58 & 5,97 & 3,73 & \begin{tabular}{|l|}
$-0,31$ \\
\end{tabular} & \begin{tabular}{|l|}
$-36,87$ \\
\end{tabular} \\
\hline MALEZYA & 32458 & 36222 & 41169 & 0,11 & 0,12 & 0,13 & 11,60 & 13,66 \\
\hline PAKİSTAN & 22540 & 26735 & 28394 & 0,08 & 0,08 & 0,09 & 18,61 & 6,21 \\
\hline SINGAPUR & 18994 & 20957 & 22206 & 0,07 & 0,07 & 0,07 & 10,33 & 5,96 \\
\hline TAYLAND & 9282 & 11067 & 12211 & 0,03 & 0,04 & 0,04 & 19,23 & 10,34 \\
\hline $\begin{array}{l}\text { DIĞ.GÜN.ASYA } \\
\text { ÜLK. }\end{array}$ & 48294 & 80838 & 68445 & 0,17 & 0,26 & 0,22 & 67,39 & $-15,33$ \\
\hline TOP.GÜN.ASYA & 2215410 & 2323615 & 1692321 & 7,74 & 7,39 & 5,32 & 4,88 & \begin{tabular}{|l|}
$-27,17$ \\
\end{tabular} \\
\hline TOPLAM ASYA & 4102450 & 4411929 & 3839852 & 14,33 & 14,03 & 12,08 & 7,54 & $-12,97$ \\
\hline $\begin{array}{l}\text { DİĞ. KUZEY } \\
\text { AMERIKA ÜLK. }\end{array}$ & 12403 & 15016 & 11324 & 0,04 & 0,05 & 0,04 & 21,07 & $-24,59$ \\
\hline $\begin{array}{l}\text { DİĞ. ORTA } \\
\text { AMERIKKA ÜLK. }\end{array}$ & 4289 & 7121 & 7654 & 0,01 & 0,02 & 0,02 & 66,03 & 7,48 \\
\hline ARJANTIN & 22255 & 27136 & 28559 & 0,08 & 0,09 & 0,09 & 21,93 & 5,24 \\
\hline BREZILYA & 65246 & 89442 & 88903 & 0,23 & 0,28 & 0,28 & 37,08 & $-0,60$ \\
\hline KOLOMBIYYA & 7129 & 9853 & 12987 & 0,02 & 0,03 & 0,04 & 38,21 & 31,81 \\
\hline Şî́İ & 8183 & 11964 & 12765 & 0,03 & 0,04 & 0,04 & 46,21 & 6,70 \\
\hline VENEZÜELLA & 6769 & 8557 & 9600 & 0,02 & 0,03 & 0,03 & 26,41 & 12,19 \\
\hline $\begin{array}{l}\text { DİĞ.GÜN.AMERİ } \\
\text { KA ÜLK. }\end{array}$ & 9124 & 12126 & 13152 & 0,03 & 0,04 & 0,04 & 32,90 & 8,46 \\
\hline $\begin{array}{l}\text { TOP.GÜN.AMERİ } \\
\text { KA }\end{array}$ & 118706 & 159078 & 165966 & 0,41 & 0,51 & 0,52 & 34,01 & 4,33 \\
\hline $\begin{array}{l}\text { TOPLAM } \\
\text { AMERIKA }\end{array}$ & 135398 & 181215 & 184944 & 0,47 & 0,58 & 0,58 & 33,84 & 2,06 \\
\hline OKYANUSYA & 2876 & 359 & 4694 & 0,01 & 0,00 & 0,01 & $-87,52$ & 1207,52 \\
\hline MILLLIYETSİZ & 23208 & 26518 & \begin{tabular}{|l|}
31739 \\
\end{tabular} & 0,08 & 0,08 & 0,10 & 14,26 & 19,69 \\
\hline $\begin{array}{l}\text { YABANCI } \\
\text { TOPLAM }\end{array}$ & 28632204 & 31456076 & 31782832 & 100,00 & 100,00 & 100,00 & 9,86 & 1,04 \\
\hline
\end{tabular}

Tablo 6. 2010-2012 Yıllarında Türkiye’ye Gelen Yabancıların Milliyetlerine Göre Karşılaştırllması (OcakAralık) Kaynak: Kültür ve Turizm Bakanlı̆̆g (Erişim Tarihi: 23.05.2013)

\section{Türk-Rus Turizm Ekonomisi İlişkileri}

Türk-Rus ilişkilerinin başlangıcı Rusların tarih sahnesine çıktıkları bin yıl öncesine kadar uzanır. Yan yana yaşayan bu iki halk tarih boyunca sık sık savaşmışlardır ancak Avrupa ile kıyaslandığında, ortak yönlerinden dolayı birbirlerine daha yakın hissetmektedirler. Tarihteki en büyük imparatorlukları kuran iki ülkenin bir diğer ortak notası da bu imparatorlukların yakın dönemlerde yıkılması ve yerine yeni devletler kurmuş olmalarıdır. Dolayısıyla yeni kurulan ve benzer kaderleri paylaşan bu iki devlet birbirleriyle yakınlaşma ihtiyacı duymuştur.

Mustafa Kemal'in Lenin'e yazdığı diplomatik ilişkilerin tesisi ve yürütülen bağımsızlık savaşı için yardım talebini içeren 26 Nisan 1920 tarihli mektup ise Türkiye ile Sovyet Rusya arasındaki resmi ilişkilerin başlangıcı 
olarak kabul edilir. Ayrıca Sovyet Rusya, TBMM'yi tanıyan ilk devlet olmuş ve devamında Türk ve Sovyet Hükümetleri arasında 16 Mart 1921 tarihinde Moskova'da Dostluk ve Kardeşlik Anlaşması imzalanmıştır. Böylelikle iki ülke arasındaki diplomatik münasebetlerin yanı sıra ekonomik ve kültürel alanlarda da bir yakınlaşma başlamıştır. İkinci Dünya Savaşı sonrasındaki Soğuk Savaş yıllarında, farklı cephelerde yer alan iki ülke arasındaki yakınlaşma sona ermiş ancak 1991'de SSCB'nin yıkılmasından sonra en büyük mirasçısı Rusya ile ilişkiler tekrar canlanmıştır. 1990' da Bavul Ticareti ile başlayan ilişkiler farklı boyutlarda artarak devam etmiş ve günümüzde liderler tarafından "Stratejik Ortaklık" ifadesinin kullanılmasına kadar gelinmiştir (Orsam, 2010).

Türkiye ile Rusya arasında en fazla gelişme kaydeden ekonomik sektörlerden birisi turizmdir. Rusya resmi verilerine göre 2012'de turistik amaçla yurt dışına çıkan 15 milyon 300 bin Rus vatandaşın yüzde 17'sinin tercihi Türkiye'den yana olmuştur. Bu bağlamda Rusya'da uzun yillardan beri en popüler turizm destinasyonu olan Türkiye'nin bu avantajını 2012 yılında da koruduğunu görmekteyiz. Türkiye'yi bir tatil ülkesi olarak gören Rusların yüzde 75'i yaz turizminin ağırlıklı olduğu Antalya'yı tercih etmektedir.

ABD ve AB ülkelerine dahi vize uygularken, Rusya ile 12 Mayıs 2010'da Ankara'da imzalanan ve 16 Nisan 2011 'de yürürlüğe giren "Vatandaşların Karşılıklı Seyahatlerine İlişsin Usullere Dair Anlaşma” iki ülke arasında vizesiz dönemin başlangıcı olmuştur. Bu anlaşmaya göre; iki ülke vatandaşları 90 gün içinde 30 günü geçmeyen seyahatleri için vize almak zorunda kalmayacaktır. Anlaşmayla beraber Türkiye'ye vize uygulamayan ülke sayısı 58'e, özerk bölgelerle beraber de 64'e çıkmıştır. Devlet başkanları ve birçok yetkili atılan bu stratejik adımın her iki ülke içinde hayırlı olacağını belirtmişlerdir. Gerek turist sayısı gerekse de ticaret hacminin artacağını ve bundan ülke ekonomilerinin büyük oranda etkileneceğini ifade etmişleridir. Nitekim sonraki dönemlerde yaşanan krizlere rağmen özellikle Türkiye açısından elde edilen veriler ümit verici olmuştur.

160 milyonluk büyük bir nüfusa sahip Rusya Federasyonu'ndaki turist potansiyeli Türkiye için yadsınamayacak kadar ciddi büyüklüktedir. TÜIKK ve Kültür Bakanlığı verilerine göre, vize muafiyeti uygulamasının geçerli olmadığı 2010 yılında Rusya'dan ülkemize 3 milyon 107 bin turist gelirken, vizesiz geçişlerin yapıldığı 2012'de bu rakam 492 bin kişilik bir artışla 3 milyon 599 bine çıkmıştır. Rusya açısından bakıldığında ise dünya genelinde ülkeye giriş yapan turist sayısı, 2012'de yüzde 10 artarak 2 milyon 570 bine ulaşmıştır. Aynı yıl Türkiye'den giden turist sayısında ise yüzde 25 ile dünya ortalamasına oranla iki buçuk katlık bir artış olmuş, 101 bin Türk Vatandaşı Rusya'yı ziyaret etmiştir. Turizm Bakanlığı verilerine göre bir turistin ülke ekonomisine katkısının ortalama bin doları bulduğu göze alındığında imzalanan vize serbestliği anlaşmasının, Rusya’ya oranla çok daha fazla turizm potansiyeli olan ülkemiz için ne denli önemli olduğu net bir şekilde ortaya çıkmaktadır. Bu kapsamda 2013 yılı sonunda 4 milyonun üzerinde Rus turistin ülkemize gelmesi beklenmektedir.

Rusların tatil anlayışına değinecek olursak, Rus turistler için Türkiye kelimesinin tatil kavramıyla özdeşleştiğini söylemek mümkündür. Rus Mobaly Turizm Seyahat Acentesi, 2012 yılı içinde tatile getirdikleri 5 bin turist üzerinde yaptığı yüz yüze anket sonucunda Rusların yüzde 85'inin tatil önceliğinin deniz turizmi olduğunu tespit etmiştir. Araştırmaya göre Rus turistler, dünyada tatil yapmada birinci sırada Türkiye, ikinci sırada Mısır, üçüncü sırada Tayland, dördüncü sırada İspanya ve beşinci sırada Yunanistan'1 tercih etmektedirler. $\mathrm{Bu}$ tespitleri doğrulayan Kültür ve Turizm Bakanlığı verilerine göre de Türkiye, tatil tercihinde birinci siraya yüzde 47'lik bir oranla yerleşmiş̧tir. Ayrıca Türkiye, uygun fiyatlı, hizmet ve tesis kalitesine sahip, özgün tarihi ve kültürel değerleri olan ve medeni bir destinasyon olarak algılanmaktadır. Türkiye'de tatil yapanların yüzde 59.4'ü kesinlikle çok memnun kaldıklarını belirtirken, yüzde 5'lik bir kısım ise memnun kalmadığını ifade etmiştir. Otel kalitesi, servis kalitesi, sıcak iklim, doğal güzellikler, eğlence imkanları ve uygun fiyat avantajları, vize kolaylığı ile birleştiğinde çok daha anlamlı hale gelmiş ve 2012 verilerine de artan oranda katkı sağlamıştır. Gelen turistlerin ortalama yüzde 80'inin Haziran-Eylül döneminde geldiğini görmekteyiz. Özellikle kültür, kongre, spor, iş ve sağlık turizmi olanaklarının daha etkin bir şekilde tanıtılmasıyla deniz turizmi ağırlıklı Rus turist profilinin çeşitlendirilmesi mümkün olabilecektir.

\section{Sonuç ve Değerlendirme}

Yıllardan beri süregelen dünya çapındaki krizler ülkelerin ekonomik dengelerini daima değiştirmektedir. Bugün iyi denilen bir ekonominin yarın ne durumda olacağını tahmin etmek çoğu zaman yanıltıcı olabilmektedir. Konjonktürel dalgalanmalardan bir hayli etkilenen özellikle Türkiye gibi gelişmekte olan ülkeler ise kırılgan ve istikrarsız ekonomilere sahiptirler. Gerçekleşen bir krizin bu tarz ülkeleri vurması gelişmiş ülkelere nazaran kuvvetle muhtemeldir.

Gelişmekte olan ülkeler statüsündeki Türkiye için turizm başlıca gelir kaynaklarından biridir. Ülkeye sağladığı döviz girdisi, istihdama etkisi, vatandaşların gelir seviyesine olan katkısı ve alt ve üst yapı yatırımları ile ekonomiye kazandırdığı canlılık en zor ekonomik dönemlerin dahi daha az zararla atlatılmasını sağlamıştır.

Turizmi yalnızca ekonomik getirisi olan bir sektör olarak değil, aynı zamanda farklı kültürler arasında yakınlaşma ve iletişimi arttıran bir faaliyet olarak da düşünmek gerekir. Bu sosyal yönüyle de turizm dünya barışına katkı sunmaktadır. Özellikle son yıllarda Türkiye, turizmin önemini daha çok kavramıştır. Bu bağlamda turizme gerek devlet eliyle, gerekse de özel sektörü teşvik anlamında her türlü yatırım yapılmaktadır. Bu sayede 
ülkenin ihtiyacı olan döviz girdisi önemli oranda sağlanarak ödemeler dengesindeki açıkları kapatma politikası başarıyla uygulanmaktadır.

Turizm gelirlerinin ülke ekonomileri içerisindeki payı her geçen gün artmaktadır. Sahip olduğu doğal ve kültürel zenginliklerden dolayı turizm potansiyeli bir hayli yüksek olan ve bugün dünya ülkeleriyle kıyaslandığında turizm gelirleri bakımından 12'nci sırada yer alan Türkiye, sektörün gelişimine verilen önemin giderek artmasıyla birlikte önümüzdeki yıllarda daha üst sıraları hedeflemektedir. Ülkeye gelen turist potansiyeli açısından ise ilk üç sırada Almanya, Rusya ve İngiltere bulunmaktadır.

Avrasya'nın en büyük ekonomisi olan Rusya, 20 milyar doları aşan ticaret hacmi ile Türkiye'nin en önemli ticari ortaklarından birisidir. Ancak iki ülke arasındaki ekonomik ilişkilere bakıldığında kıyaslanamayacak derecede bir fark olduğu görülmektedir. Bunun nedeni Rusya'ya olan enerji bağımlılı̆̆ıdır ve bu anlamda Rusya ülkeler sıralamasındaki liderliğini günümüzde de sürdürmektedir. Birçok ihtiyacını kendisi karşılayabilecek kapasiteye sahip olan Türkiye'nin, söz konusu enerji kaynakları olduğunda dışa bağımlılığı ön plana çıkmaktadır. Bu kapsamda tüketilen doğalgazın yüzde 50'ye yakını bu ülkeden temin edilmektedir.

Türkiye açısından bakıldığında ise son yıllarda ülkeye gelen turist sayısının artmasına bağlı olarak turizm gelirinin de ekonomiye katkısı artmıştır. 2012 yılında turizm geliri ihracat gelirlerinin yüzde 19.2'sini oluşturmakta, böylelikle de dış ticaret açığının yüzde 34.9'unu kapatmaktadır (Turizm Seyahat Acentaları Birliği). Turizm gelirlerinin 2013 yılında da cari açığın büyük bir bölümünü kapatacağı beklenmektedir.

Son yıllarda karşılıklı ülke çıkarları çerçevesinde Rusya ile olan ikili ilişkiler genişletilmektedir. Gerçekleştirilen vize serbestliği anlaşması da bunlardan en göze çarpanıdır. Bu anlaşma, ABD ve $\mathrm{AB}$ ülkelerine dahi vize uygulayan Rusya'nın Türkiye’ye verdiği önemin bir göstergesidir. Hem ekonomik, hem ticari, hem de sosyo-kültürel alanlardaki işbirliği ve yakınlaşma çabaları her iki ülkeye de kazanç sağlayacaktır. Özellikle Rusya'dan gelen turistlerin bıraktıkları dövizin ülke ekonomisine katkısı göz önüne alındığında, misafirperverliği ve yatırımları sayesinde Türkiye, yaşanan tüm ekonomik krizlere ve bunların yarattığı olumsuzluklara rağmen kazançlı çıkmaya devam edecektir.

\section{Kaynakça}

- DİLBER, İlkay (2007). “Turizm Sektörünün Türkiye Ekonomisi Üzerindeki Etkisinin Girdi-Çıktı Tablosu Yardımıyla Değerlendirilmesi”, Celal Bayar Üniversitesi İktisadi ve İdari Bilimler Fakültesi Yönetim ve Ekonomi Dergisi, Cilt: 14, Say1: 2, s. 205-220.

- HEPAKTAN, C. Erdem, S. ÇINAR (2010). “Turizm Sektörünün Türkiye Ekonomisi Üzerindeki Etkileri”, Celal Bayar Üniversitesi Sosyal Bilimler Dergisi, Cilt: 8, Sayı: 2, s. 135-154.

- Ortadoğu Stratejik Araştırmalar Merkezi (Mayıs 2010). “Komşuluktan Stratejik İşbirliğine: Türk Rus İlişkileri”, Rapor No: 18, The Black Sea International, Rapor No: 3, s. 6-7.

- ÖNAL, Y. Beyazit, M. ÖZMEN, E. KARADENIZ, S. Y. KANDIR (2008). “Türk Turizm Sektöründe Büyüme Göstergelerinin Turizm İşletmelerinin Finansal Performansına Etkisinin İncelenmesi”, Dokuz Eylül Üniversitesi Sosyal Bilimler Enstitüsü Dergisi, Cilt: 10, Sayı: 1, s. 211-237.

- ÖZKÖK, Ferah (2006). "Yoksulluğun Azaltılmasında Turizmin Yeri”, Elektronik Sosyal Bilimler Dergisi, Cilt: 5, Sayı: 15, s. 85-98. http://www.e-sosder.com/

- SARI, Yaşar (2013). “Turizmin Ekonomik Etkileri”, Eskişehir Osmangazi Üniversitesi Turizm ve Otel İşletmeciliği Yüksek Okulu.

- SHOYUNCAP, Olga (2008). "Rusya Türkiye Turizm Ekonomisi İlişkileri”, Yüksek Lisans Tezi, Marmara Üniversitesi Sosyal Bilimler Enstitüsü, İstanbul.

- Türkiye Otelciler, İşletmeciler ve Yatırımcılar Birliği. http://www.turob.com/

- Türkiye Seyahat Acentaları Birliği. http://www.tursab.org.tr/

- Türkiye İstatistik Kurumu. http://www.tuik.gov.tr

- Türkiye Cumhuriyeti Dışişleri Bakanlığı. http://www.mfa.gov.tr/default.tr.mfa

- Türkiye Cumhuriyeti Kültür ve Turizm Bakanlığı. http://www.kultur.gov.tr/

- World Tourism Organization UNWTO. http://www2.unwto.org/ 


\title{
Ülkelerin Turizm İstatistikleri Bakımından Farklı Kümeleme Analizi Metotları ile Sınıflandırılması ve Türkiye'nin Bu Oluşumdaki Yeri
}

\section{Classification of Countries According to their Tourism Statistics via Different Cluster Analysis Methods and the Place of Turkey in this Structure}

\author{
Asst. Prof. Dr. Selay Giray (Marmara University, Turkey)
}

\begin{abstract}
The aim of this study is to classify the countries according to their tourism indicators via different cluster analysis methods and compare the findings. Using classical cluster analysis and fuzzy clustering together will be more appropriate to determine the World tourism structure. In this way the findings can be interpreted more detailed and comparatively. Data obtained from website of Worldbank (3 basic international tourism statistics of 159 countries for the year 2010) and findings are gained using NCSS (statistical software) 2007. According to the findings of fuzzy clustering method, Turkey belogs to a cluster which contains ABD, United Kingdom, China, Austria, France, Germany, Italy, Malaysia, Spain, Hong Kong, Russian Federation, and Ukraine. According to the findings of classical clustering method (k means), Turkey is in the same cluster with same countries except Hong Kong. Also the findings of two techniques are similar about Turkey. Such a result can be expected correspondingly grading the countries about international their tourism data in 2011 . Different clustering methods findings are steady about Euroasian countries too. Except Russian Federation and Ukraine all of the other Euroasian countries are located together in same cluster depending upon two different clustering methods. In conclusion two different clustering methods provide consistent (similar) results about the classification of countries according their internatianol tourism statistics.
\end{abstract}

\section{Giriş}

Turizm, T.C. Kültür ve Turizm Bakanlığı tarafından "Kişilerin ikamet ettiği yer dışındaki bir yere bir yılı aşmamak üzere, boş zaman değerlendirme, iş ve diğer benzeri amaçlarla yaptıkları seyahatler" olarak tanımlanmaktadır. Turizm sektörü ise her ülke için son derece önemli olan çok yönlü bir sektör olup çeşitli yapısal özellikleriyle diğer sektörden farklılık göstermektedir. Sektörün en önemli özelliklerinden biri dünya genelinde çok hızlı gelişmesidir. Turizm sektörü istihdamı arttırıcı bir sektör olup, sektörün ülkeye gelir sağlayıcı etkisi bulunmaktadır. Bunların yanısıra turizm sektörü sosyo-ekonomik ve kültürel gelişmeyi hızlandırmakta, yabancı sermaye girişi ve döviz girdisi sağlamakta, dolayısıyla iktisadi kalkınmada önemli bir unsur olarak nitelendirilmektedir.

Turizm sektörünün her ülke için önemli olduğu belirtilmişti. Sektör, farklı gelişmişlik seviyelerinde olan ülkeler için ayrı ayrı anlam taşımaktadır. Örneğin gelişmiş ülkeler turizm sektörünün gelir etkisinden yararlanmaya çalışmakta iken gelişmekte olan ya da az gelişmiş ülkeler ise bu sektörün döviz kazandırıcı ve yeni istihdam olanakları yaratıcı gücünden faydalanmak istemektedirler. Emek-yoğun hizmet üreten bir sektör olan turizm sektörü işsizlik sorunun çözümünde son derece önemli etkilere sahip bir sektördür. (Yıldız, 2011)

Sektörün diğer sektörlerden yapısal olarak farklılaştı̆̆ı bir diğer nokta da çevre dostu olmasıdır. Turizm sektörü, "bacasız fabrika" ve "açık hava fabrikası" isimlendirmeleriyle sürdürülebilir iktisadi gelişmeye katkı sağlayan son derece önemli bir sektördür. (Karataş ve Babür, 2013) Ayrıca dostluk duygularını geliştirerek dünya barışına katkı sağlayan bir sektör olduğu da genel olarak kabul görmektedir. (Önen, 2008)

Özetle turizm bugün dünya ekonomisi içinde gelir sağlayıcı faktörlerin başında gelmekte, bu sebeple büyük oranda yatırım yapılan ve gelişen bir sektör haline gelmektedir. (Aktaş, 2005) Bütün bunların bir sonucu olarak turizm bütün ülkelerin bahsedilen olumlu sonuçlarından (örneğin ödemeler dengesine olan katkısı ve sebep olduğu ekonomik canlılık) yararlanmak için çaba sarf ettikleri bir faaliyet olup, kalkınma planlarında geniş yere sahiptir. (Çuhadar, 2006)

Uluslararası turizmdeki gelişmeleri takip eden Türkiye'de turizm sektörü 1980'li yılların başından itibaren hızla gelişmeye başlamıştır. Türkiye, uluslar arası turizm pazarındaki payını gitgide arttırmıştır. (Uğuz, 2012) Dünya Turizm Örgütü verilerine göre 2011 yılında Türkiye'ye gelen turist sayısı 30 milyonun üzerinde olup, bu durum Türkiye ekonomisine yaklaşık 23 milyar dolar katkı sağlamıştır. 2011 varış istikametine göre ülkelere gelen turist sayıları açısından Türkiye 2012 yılında dünyada 6.sıradaya, Avrupa'da ise 4. sıraya yükselmiştir. 2011 'de ülkelerin elde ettikleri uluslar arası turizm gelirleri açısından ise Türkiye ilk 10'da yer almamaktadır. Bu konuda ilk sırada ABD yer almaktadır. 2011'de turistlerin gittikleri yerdeki harcamaları açısından Türkiye yine ilk 10 'da yer almamakta olup, bu konuda ilk sırada yer alan ülke Almanya'dır. 
2020 yılında dünya turizm gelirlerinin 2 trilyon dolar civarında olacağı tahmin edilmektedir (Kaynak: Dünya Turizm Örgütü). Yakın gelecek için yapılan bu tahminin sonucunda, her ülke turizm arz potansiyeli oranında pastadan pay alma ya da payını büyütme mücadelesine girişmiştir. Türkiye'de turizm daha da geliştirilebilecek bir yapıdadır. Bu bağlamda öncelikle geniş turizm potansiyeline sahip olan Türkiye'nin turizm sektörünün dünya ülkeleri içindeki yerinin çok değişkenli istatistiksel analizler ile saptanması yararlı olacaktır. Böylece uluslararası turizm verilerine göre Türkiye'nin hangi segmentte hangi ülkelerle birlikte yer aldığı belirlenmiş olacaktır. Bu saptamanın ardından ülke bazında sektöre ilişkin daha da gelişmeye yönelik hedefler daha net ve ayrıntılı bir şekilde koyulabilir.

\section{Literatür Taraması}

Turizm istatistiklerinin çok değişkenli analizi konulu literatür taraması sonucunda ulaşılan bazı temel çalışmalar aşağıda özetlenmiştir:

Uğuz (2012) “Göç ve Turizm: Türkiye-Almanya Örneği” isimli çalışmasında Türkiye ve Almanya arasındaki göç ve turizm hareketliliğinin ampirik kanıtlarını araştırmayı amaçlamıştır. Bu amaçla, Almanya'ya giden göçmen sayısı ile Türkiye'ye gelen turist sayısı arasındaki ilişkiyi, VAR analizi yöntemiyle incelemiştir.

Kılıç vd. (2011), "Bulanık Kümeleme Analizi İle Ülkelerin Turizm İstatistikleri Bakımından Sınıflandırılması" adlı çalışmalarında 2007 yılı verilerini kullanarak 30 ülkeyi 9 değişkene göre standartlaştırılmış ve ham veri kümelerini kullanarak bulanık kümeleme yöntemi uygulamışlardır. Analiz sonucunda ortalama gölge istatistiği, Dunn katsayıları ve ayırma analizi ile 30 ülkenin 3 kümeye ayrıldığını görmüşlerdir.

Cengiz ve Kırkbir (2007), "Yerel Halk Tarafından Algılanan Toplam Turizm Etkisi İle Turizm Desteği Arasındaki İlişkiye Yönelik Yapısal Bir Model Önerisi” isimli çalışmalarında dört turizm etki faktörünün toplam turizm etkisi ve yerel halkın turizme desteği değişkenleri üzerindeki yapısal etkilerini, turizmin gelişimi bağlamında incelemişler, bu amaçla bir model geliştirip yapısal eşitlik modeli metodu ile test etmişlerdir. Çalışmada Bodrum'da ikamet eden 193 kişiye uygulanan anket sonuçları kullanılarak; turizmin ekonomik, sosyal, kültürel ve çevresel boyutlarının turizmin toplam etkisini farklı derecelerde belirlediği ve turizmin toplam etkisinin de yerel halkın turizme destek vermesini şekillendirdiği sonucu bulunmuştur.

Kandır, Özmen ve Önal (2007), "Türk Turizm Sektöründe Büyüme Göstergelerinin Turizm İşletmelerinin Finansal Performansına Etkisinin İncelenmesi” isimli çalışmalarında 1991-2003 yılları için regresyon modelleri yardımıyla turizm gelirlerinin milli gelire oranı ve turizm işletmelerinin finansal performansları arasındaki ilişkiyi incelemişlerdir.

Aktaş (2005), “Türkiye'nin Turizm Gelirini Etkileyen Değişkenler İçin En Uygun Regresyon Denkleminin Belirlenmesi” isimli çalışmasında 1980-2000 zaman periyodundaki yıllık verileri kullanarak çoklu doğrusal regresyon modelleri (ve zaman serisi ekonometrisi yöntemleri) yardımıyla turizm gelirini etkileyen değişkenlerin turist sayısı ve seyahat acentası sayısı olduğunu belirlemiştir.

Karaman (2000), "Balıkesir Yöresine Gelen Fransız Turist Talep Analizi” isimli çalışmasında 1998 yılı Ağustos ayında yapılan bir anket çalışması ile Fransız turistlerin Balıkesir yöresini tercih etme nedenlerini, ziyaret amaçlarını, seyahatlerini, organize biçimlerini, ortalama kalış sürelerini, ortalama harcama tutarlarını, Balıkesir yöresinde tespit ettikleri olumsuz ve olumlu izlenimleri, yöreye tekrar gelip gelmeyecekleri hakkında görüşlerini betimleyici istatistikleri kullanmak suretiyle saptamıştır.

Yürütülen yerli- yabancı literatür taraması sonucunda yapılan çalışmaları kabaca dört grupta toplamanın mümkün olduğu görülmüştür.

1. Tahmin amaçlı ve farklı tekniklerin öngörü başarı performanslarının karşılaştırıldığı çalışmalar (Ör.: "Türkiye Turizm Endüstrisinde Talep Oynaklıklarının Çok Değişkenli GARCH (MGARCH) Modelleri ile Analizi”, "Turizm Talebini Tahminleme Yöntemleri, Trend Analizi, Regresyon Analizi ve Korelasyon Analizi”, "Kuzey Kıbrıs Türk Cumhuriyeti'nde Turizm Sektörünün Yeri ve Ekonomik Büyümeye Olan Etkisi”)

2. Makroekonomik göstergeler arasındaki ilişkilerin zaman serisi ekonometrisi yöntemleri ile araştırıldığ çalışmalar (Ör.: "Türkiye'de Ekonomik Büyüme ve Turizm İlişkisi Üzerine Ekonometrik Analiz", “Türkiye'de Turizm Gelirleri- Ekonomik Büyüme İlişkisi: Nedensellik Analizi [1963-2010]”, “Turizm Gelirlerinin Çeşitli Makro Ekonomik Göstergeler İle İlişkisi: Türkiye Örneği (1992- 2011)”, “Turizm Sektörünün Türkiye'nin Ekonomik Büyümesi Üzerindeki Etkisi: VAR Analizi Yaklaşımı”, “Türkiye'de Turizm ve Ekonomik Büyüme Arasındaki Kısa ve Uzun Dönemli İlişkiler”)

3. Belli bir il veya ilçe için yapılan anket çalışması sonucunda elde edilen verilerin analiz edildiği çalışmalar (Ör.: “ Pamukkale'deki Yöre Halkının Turizmi Desteklemesi İle Turizmin Sosyo-Kültürel Etkileri Arasındaki İlişki”, "Van Halkının Turisti ve Turizmi Algılama Şekli”, "Turizmin Yerel Halk Üzerindeki Etkileri ve Kuşadası İlçesi Uygulaması”) 
4. ̈̈lkeler arası karşılaştırma temelli çalışmalar (Ör.: “Applications of Multivariate Analysis in International Tourism Research: The Marketing Strategy Perspective of NTOs”, "Turistlerin Satın Alma Kararlarındaki Kültürel Farklılıklar Türk- Alman Karşılaştırması”, “Türk Turizm Talebi ve Yunanistan”)

İlk üç grup kapsamında değerlendirilebilecek olan çalışmalara literatürde sıkça rastlanmıştır. Ancak dördüncü grup kapsamındaki çalışmaların nispeten sınırlı olduğu gözlenmiştir.

\section{3 Çalışmanın Amacı ve Kapsamı}

Bu çalışmanın amacı güncel verileri kullanarak dünya ülkelerinin uluslararası turizm açısından kümelenmesini incelemektir. Uygun küme yapısı çeşitli ölçütler ve farklı çok değişkenli analizlerin desteğiyle ortaya konduktan sonra, oluşan kümeler betimleyici istatistikleri yardımıyla tanımlanmış ve Türkiye'nin bu yapı içindeki yeri araştırılmıştır.

Türklerin tarihsel varoluşlarını ortaya koyan bir coğrafya olan Avrasya (Türkler Asya'nın merkezinden Avrasya'nın batı, kuzey, güney bölgelerine doğru yayılma özelliği gösteren uzun bir göç serüvenini bu coğrafyada yaşamışlardır); Avrupa ve Asya kıtalarının ortak adı kavramında kullanılmaktadır. Ancak Avrasya bunun yanısıra sosyal, kültürel, iktisadi, tarihi ve stratejik faktörlerin geri planını oluşturduğu bir biraradalık anlamina gelmektedir.

Oluşan kümelerde Türkiye'nin yeri araştırıldıktan sonra, Türkler için bir anlamda 'Atayurt' demek olan Avrasya bölgesindeki ülkelerin bu kümelerdeki dağılımı ile de ilgilenilmiş, bulgular yorumlanmıştır. (Yazıcı, 2003)

Amaç doğrultusunda kullanılabilecek yöntemlerden bulanık kümeleme analizi ve klasik kümeleme analizi (k Ortalamalar) tekniklerinin ikisinin de kullanılmasının daha yararlı olacağı düşünülmüştür. Böylece iki tekniğin uygulaması sonucunda elde edilen bulgular karşılaştırmalı olarak analiz edilebilecek, yorumlar daha detaylı bir şekilde yapılabilecektir.

Çalışma kapsamında 2010 yılı yatay kesit verileri kullanılmıştır. Veriler Dünya Bankası'nın web sitesinden elde edilmiştir. Dünya Bankası web sitesinde uluslar arası turizm istatistiklerinin üç temel grupta ele alındığı görülmüştür. İlgili göstergeler için kayıp gözlem sayıları hesaplanmış ve her bir değişken grubu için en az kayıp gözlem değerine sahip turizm göstergesi değişkeni analize dahil edilmiştir. Böylece dünya ülkeleri en az veri kaybıyla kümeleme işlemine tabi tutulabilmiştir. Yapılan ayıklamalar sonrasında 159 kayıp gözlemsiz ülke verisi ile çalışılmıştır.

Bunun yanısıra herhangi bir ülkenin turizm verilerinin karşılaştırılabilir olması için ülkenin ekonomisinin de göz önünde bulundurulması gerektiği eleştirisi yapılan literatür taraması aşamasında gözlenmiş ve dikkate alınmıştır. Dolar cinsinden ölçülmüş olan iki uluslararası turizm göstergesi değişkeni (turizm harcamaları ve turizm gelirleri), ülkelerin yine Dolar cinsinden ölçülmüş olan 2010 yılı gayrisafi milli hasılalarına (GSMH) oranlanarak analize dahil edilmiştir. Çalışmada kullanılan üç değişkenin isimleri aşağıda yer almaktadır:

Değişken 1 ( $\mathrm{x}_{1}$ : Expenditures) : Turizm harcamaları / GSMH

Değişken $2\left(\mathrm{x}_{2}\right.$ : Arrivalsnr) : : Gelişs sayısı

Değişken 3 ( $\mathrm{x}_{3}$ : Receipts)

: Turizm gelirleri / GSMH

Turizm Harcaması: Ziyaret edilen ülkede kalınan süre içinde ziyaretçi tarafından veya ziyaretçi adına yapılan tüketim harcamalarıdır. Bir ülkedeki yabancı ziyaretçilerin yapmış oldukları harcamalar o ülke için turizm geliri o ülke vatandaşlarının yurtdışında yapmış oldukları harcamalar ise o ülkenin turizm gideridir. (Önen, 2008)

\section{Metodoloji: Kümeleme Analizi}

Çalışmanın bu kısmında, çalışma kapsamında kullanılan temel metot olan kümeleme analizi kısaca özetlenmiştir.

Çok değişkenli analiz tekniklerinden kümeleme analizinde amaçlanan gözlemlerin (birimlerin) benzerliklerine göre homojen kümelere ayrılmasıdır. Bu amaç doğrultusunda çeşitli uzaklık ölçülerinden yararlanılmakta ve kümeler oluşturulmaktadır. Analiz kapsamındaki her bir birimin yer aldığı küme bellidir. Sosyal bilimler konulu çalışmalarda kesin yorumlar yapmanın çok fazla olanak dahilinde olmadığı söylenebilir. Herhangi bir birimin atandığı küme önemli olmakla birlikte, ilgili birimin bu kümeye hangi olasılıkla atandığını da bilmek daha yararlı olacak, daha sağlıklı yorumlara ulaşmayı sağlayacaktır. Bu sebeple bulguların bulanık kümeleme analizi bulguları ile karşılaştırılarak yorumlanması önem kazanmaktadır.

Klasik kümeleme yöntemleri her bir birim için kesin kararlar alarak bir kümeye atarlarken, bulanık kümeleme analizinde her bir birimin oluşan kümelere ait olma derecesini gösteren ağırlık katsayıları hesaplanmaktadır. Bu katsayıların toplamı 1'e eşittir. Bu yöntemde bir birim için ağırlık katsayılarının toplamı her zaman 1 olmak üzere, bir birimin bir kümede olma olasılığı tüm olası kümeler arasında 0 ile 1 arasında değişmektedir. (Yılancı, 2010) Sonuç olarak birim, ait olma olasılığının en yüksek olduğu kümeye atanmaktadır. Birimlerin ağırlık katsayılarının toplam değeri için üst limit, analizdeki toplam birim sayısına eşit olmaktadır. 
Bulanık kümeleme analizinin en yaygın kullanılan algoritması Kaufman ve Rousseeuw tarafından geliştirilen Fanny algoritmasıdır. Uygulanabilmesi için bütün değişkenlerin ölçek düzeyleri en azından eşit aralıklı ölçek olmalıdır. Algoritmanın amaç fonksiyonu aşağıda yer almaktadır. (Kaufman ve Rousseeuw, 1990)

$$
C=\sum_{v=1}^{K} \frac{\sum_{i, j=1}^{n} u_{i v}^{2} u_{j v}^{2} d(i, j)}{2 \sum_{j=1}^{n} u_{j v}^{2}}
$$

Amaç fonksiyonunun minimizasyonu hedeflenmekte olup, fonksiyonda geçen simgelerin ne anlama geldikleri aşağıda yer almaktadır.

$\mathrm{d}(\mathrm{i}, \mathrm{j})=\mathrm{i}$. ve $\mathrm{j}$. birim arasındaki uzaklık

$\mathrm{K}=$ toplam küme sayısı

$\mathrm{u}_{\mathrm{iv}}=\mathrm{i}$. birimin v kümesine olan bilinmeyen üyeliği $\left(\mathrm{u}_{\mathrm{iv}} \geq 0\right.$ ve $\left.\sum_{v=1}^{K} u_{i v}=1\right)$

$\mathrm{u}_{\mathrm{jv}}=\mathrm{j}$. birimin v kümesine olan bilinmeyen üyeliğ $\mathrm{i}$

$\mathrm{n}=$ Toplam birim sayıs 1

Küme üyelikleri negatif olamaz ve bir birim için kümelere ait olma katsayıları toplamı 1'e eşit çıkmalıdır. Bu kısıtlar aşağıdaki şekilde ifade edilir:

$\mathrm{u}_{\mathrm{iv}} \geq 0$ ve $\sum_{v=1}^{K} u_{i v}=1 ; \mathrm{i}=1, \ldots, \mathrm{n}$ ve $\mathrm{v}=1, \ldots, \mathrm{K}$.

Amaç fonksiyonu bu kısıtlar altında yinelemeli bir algoritma ile minimize edilerek katsayılar matrisine $\left(\mathrm{U}_{\mathrm{nxK}}\right)$ ulaşılır. (Tütmez ve Tercan, 2006) Her birimin tüm kümelerde eşit üyelik katsayısına sahip olması durumunda kümeleme tamamen bulanık olarak isimlendirilir. Kümelemenin ne derece bulanık olduğu hakkında fikir sahibi olabilmek için Dunn'ın Parçalama Katsayısı hesaplanmalıdır.

$$
\mathrm{F}(\mathrm{u})=\sum_{i=1}^{n} \sum_{v=1}^{K} \frac{u_{i v}^{2}}{n}
$$

Görüldüğü gibi bu katsayı üyelik değerlerinin kareler toplamına dayanmakta ve tüm birimlerin tüm kümeler üzerindeki üyelik değerlerini dikkate almaktadır. Dunn'ın Parçalama Katsayısı tamamen bulanık kümeleme durumunda $\left(\mathrm{u}_{\mathrm{iv}}\right.$ değerlerinin $1 / \mathrm{k}$ 'ya eşit olduğu durumda) $1 / \mathrm{k}$ değerini alacak, kümelemenin çok net (katı) olduğu durumda ise (her bir gözlem / birime ait $u_{i v}$ değerlerinin (v-1) tanesinin 0,1 tanesinin 1 olduğu durum: kesin küme durumları) 1'e eşit olacaktır. Dunn'ın Parçalama Katsayısı minimum değeri 0, maksimum değeri 1 olacak şekilde normalleştirilebilir. Böylece katsayı küme sayısından bağımsız hale gelecek şekilde standartlaştırılmış olur. Normalleştirilmiş Dunn Katsayısı Bulanıksızlık İndeksi adını almakta olup, bu indeks değerinin 0 olması tamamen bulanıklığı, 1 olması ise güçlü kümelenmeyi göstermektedir. (Yılanc1, 2010)

$$
F_{k}(U)=\frac{k \cdot F(u)-1}{k-1}
$$

$\mathrm{Bu}$ katsayıya alternatif olarak Kaufman Ayrıştırma Katsayısı'ndan da yararlanılabilmektedir. Kaufman Katsayısı ve Normalleştirilmiş Kaufman Katsayısı formülleri aşağıda yer almaktadır:

$$
\begin{gathered}
D(U)=\frac{1}{n} \sum_{v=1}^{K} \sum_{i=1}^{n}\left(h_{i v}-u_{i v}\right)^{2} \\
D_{c}(U)=\frac{D(U)}{1-\left(\frac{1}{K}\right)}
\end{gathered}
$$

Hesaplanan bu katsayının 0’a yakın olması güçlü kümelenmeyi göstermektedir.

Küme sayısı belirlenirken Bulanıksızlık İndeksi $F_{k}(U)$ değerinin mümkün olduğunca büyük olması istenirken, $D_{c}(U)$ değerinin ise mümkün olduğunca küçük olması istenmektedir. Bu katsayılar literatürde "Küme Geçerlilik İndeksleri” olarak da yer almaktadır. (Alpaslan, 2011) Ayrıca birimlerin ne kadar iyi kümelendiğinin belirlenmesi veya kümelerin kararlılık yapısı için Gölge İstatistiği (SC: Silhoutte Coefficient) kullanılmaktadır. Gölge istatistiği, i. birimin kendi kümesi içindeki diğer birimlerle farklılığını en yakın komşu diğer kümedeki birimlerin farklılı̆̆ 1 ile karşılaştırmaktadır. Hesaplanan istatistik değeri -1 ile +1 arasında olup, +1 'e yakın olması durumunda i. birimin doğru sınıflandırıldı̆̆ı yorumu yapılır. Bu istatistik değerlerinin ortalaması Ortalama Gölge İstatistiği adını almaktadır. Bir veri setindeki kümeleme yapısının 'uygun' olarak nitelendirilebilmesi için bu ortalama değerin 0,50 olması beklenmektedir. (Kılıç ve Özbeyaz, 2010) Ortalama Gölge İstatistiği değeri denenen küme sayılarından hangisinde en yüksek olarak elde ediliyorsa, ilgili küme sayısı analiz için en uygun küme sayısı olacaktır. (Şahin ve Hamarat, 2002) Bulanık kümeleme analizinde küme sayısının belirlenmesinde en çok tercih edilen yöntem, $\mathrm{k}=2,3,4, \ldots$ için analizi gerçekleştirmek, Normalleştirilmiş Dunn Katsayılarını, Normalleştirilmiş Kaufman Katsayılarını ve Ortalama Gölge İstatistiği değerlerini kontrol etmektir. Bunların sonrasında belirlenmiş küme üyelikleri ile diskriminant analizi de uygulanabilir. 


\title{
5 Bulgular
}

Çalışmanın analiz kısmında NCSS 2007 paket programından yararlanılmıştır.

\subsection{Bulanık Kümeleme Analizi Bulguları}

Öncelikle uygun küme sayısı metodoloji kısmında belirtilen ölçütler yardımıyla belirlenmiştir:

\begin{tabular}{lllllll} 
& \multicolumn{3}{c}{ Küme Ortalama } & \multicolumn{2}{c}{ Ortalama } \\
& Saylları Uzaklık Gölge F(U) & Fc(U) & D(U) & Dc(U) & \\
2 & 160612533,37 & 0,671793 & 0,8066 & 0,6131 & 0,0699 & 0,1399 \\
3 & 93972640,02 & 0,710950 & 0,7551 & 0,6327 & 0,0727 & 0,1090 \\
4 & 68131754,32 & 0,547865 & 0,6323 & 0,5097 & 0,1387 & 0,1849 \\
5 & 54217291,78 & 0,534955 & 0,5803 & 0,4754 & 0,1612 & 0,2015
\end{tabular}

Tablo 1. Uygun Küme Sayısının Belirlenmesi

Maksimum $\mathrm{F}_{\mathrm{c}}(\mathrm{U})$ değerini ve minimum $\mathrm{D}_{\mathrm{c}}(\mathrm{U})$ değerini veren küme sayısının 3 olduğu görülmektedir.

Bulanık kümeleme analizi sonucunda elde edilen üyelik değerleri kullanılarak Normal Dağılım ve varyansların homojenliği varsayımları altında uygulanan diskriminant analizi sonucunda doğru sınıflandırma oranının \%92,5 olduğu görülmüştür. Bu oranın yüksekliği de seçilmiş olan küme sayısının uygunluğunun bir göstergesi olarak alınabilir.

Bulanık kümeleme analizi sonucunda oluşan üç kümeye ilişkin betimleyici istatistik değerleri aşağıdaki tabloda yer almaktadır:

$$
\begin{array}{cccc}
\text { Değişken } & \text { Küme 1 } & \text { Küme 2 } & \text { Küme 3 } \\
\mathrm{X}_{1} \text { : Expenditures } & 0,0329 & 0,0071 & 0,0277 \\
\mathrm{X}_{2} \text { : Arrivalsnr } & 603.0008 .611 .000 & 26.875 .000 \\
\mathrm{X}_{3} \text { : Receipts } & 0,0236 & 0,0027 & 0,0149
\end{array}
$$

Tablo 2. Kümelere İlişkin Betimleyici İstatistikler

Sonuçları yorumlamadan önce Silhouette Amount (gölge istatistiği) değerleri incelenmelidir. Bu değerler incelenmiş; hiç birinin negatif olmadığı ve çoğunun 0,5 ’ten büyük olduğu görülmüştür. Bu durumda sonuçların yorumlanmasında herhangi bir sakınca yoktur.

\begin{abstract}
Küme 1:
1 Arnavutluk, 2 Cezayir, 3 Angola, 4 Antigua and Barbuda, 6 Ermenistan, 9 Azerbaycan, 10 Bahama Adaları, 12 Bangladeş, 13 Barbados, 14 Belarus, 16 Belize, 17 Benin, 18 Bermuda, 19 Butan, 20 Bolivya, 21 Bosna Hersek, 22 Botsvana, 25 Burkina Faso, 26 Burundi, 27 Kamboçya, 28 Kamerun, 30 Cape Verde, 31 Orta Afrika Cumhuriyeti, 32 Şile, 34 Kolombiya, 35 Demokratik Kongo Cumhuriyeti 36 Kosta Rika, 37 Fildişi Sahili, 39 Kıbrıs, 42 Dominik, 44 Ekvador, 46 El Salvador, 47 Estonya, 48 Etiyopya, 49 Fiji, 50 Finlandiya, 52 Gambiya, 53 Gürcistan, 55 Gana, 57 Grenada, 58 Guatemala, 59 Guyana, 60 Haiti, 61 Honduras, 64 İzlanda, 67 Irak, 69 İsrail, 71 Jamaika, 74 Kazakistan, 75 Kenya, 77 Kuveyt, 78 Kirgızistan, 79 Lao PDR, 80 Letonya, 81 Lübnan, 82 Lesoto, 83 Litvanya, 84 Lüksemburg, 86 Makedonya, FYR, 87 Madagaskar, 88 Malavi, 90 Maldivler, 91 Mali, 92 Malta, 93 Morityus, 95 Moldova, 96 Moğolistan, 97 Karadağ, 99 Mozambik, 100 Namibya, 101 Nepal, 103 eni Zelanda, 104 Nikaragua, 105 Nijerya, 107 Umman, 108 Pakistan, 109 Panama, 110 Papua Yeni Gine, 111 Paraguay, 112 Peru, 113 Filipinler, 116 Porto Riko, 119 Ruanda, 120 Samoa, 121 Sao Tome ve Principe, 123 Senegal, 124 Sırbistan, 125 Seyşeller, 126 Sierra Leone, 128 Slovakya, 129 Slovenya, 130 Solomon Adaları, 133 Sri Lanka, 134 St. Kitts ve Nevis, 135 St. Lucia, 136 St. Vincent ve Grenadinler, 137 Sudan, 138 Surinam, 139 Swaziland, 143 Tacikistan, 144 Tanzanya, 146 Timor-Leste, 147 Togo, 148 Trinidad ve Tobago, 151 Uganda, 155 Uruguay, 156 Vanuatu, 157 Venezuiela, 159 Yemen

Küme 2:

5 Arjantin, 7 Avustralya, 11 Bahreyn, 15 Belçika, 23 Brezilya, 24 Bulgaristan, 29 Kanada, 38 Hırvatistan, 40 Çek Cumhuriyeti, 41 Danimarka, 43 Dominik Cumhuriyeti, 45 Misır, 56 Yunanistan, 63 Macaristan, 65 Hindistan, 66 Endonezya, 68 İrlanda, 72 Japonya, 73 Ürdün, 76 Kore Cumhuriyeti, 85 Çin Makao, 98 Fas, 102 Hollanda, 106 Norveç, 114 Polonya, 115 Portugal, 117 Romanya, 122 Suudi Arabistan, 127 Singapur, 131 Güney Afrika, 140 İsveç, 141 İsviçre, 142 Suriye, 145 Tayland, 149 Tunus, 158 Vietnam

Küme 3:

8 Avusturya, 33 Çin, 51 Fransa, 54 Almanya, 62 Hong Kong, 70 İtalya, 89 Malezya, 94 Meksika, 118 Rusya, 132 İspanya, 150 Türkiye, 152 Ukrayna, 153 İngiltere, 154 ABD
\end{abstract}

Tablo 3. Bulanık Kümeleme Sonuçlarına Göre Oluşan Kümelerdeki Ülkeler

Birinci küme, gelen turist sayısının diğer kümelere göre en az olduğu kümedir (603.000). Buna karşın turizm gelirinin GSMH'sına oranı en yüksek olan kümedir (\%2). GSMH'sının yaklaşık \%3'ü turizm harcamalarına denk gelmektedir. Bu değer diğer üç kümeye nazaran en yüksek oran değeridir. Özetle turizm harcamaları oranı 
en yüksek, turizm gelirleri oranı da en yüksek ancak gelen turist sayısının en düşük olduğu küme, birinci kümedir. Özetle; bu kümede yer alan 109 ülkeye gelen turist sayısı (diğer kümlerdeki ülkelere kıyasla) az ancak bu az sayıda turistin ülkeye bıraktıkları döviz miktarı yüksektir. $\left(\mathrm{n}_{1}=109\right)$

İkinci kümede ise turizm harcamaları oranı diğer iki kümeye kıyasla en düşüktür (\% 0,7). Benzer şekilde turizm gelirleri oranı da diğer iki kümeye göre daha düşüktür $(\% 0,2)$. Gelen turist sayısı (8.611.000) açısından birinci kümeden daha yüksek, üçüncü kümeden ise daha düşüktür. Yani oluşan kümeler arasında gelen turist sayısının orta olduğu anca turizm gelir ve harcama oranlarının en düşük olduğu küme, ikinci küme olup, 36 ülkeden oluşmaktadır.

Üçüncü küme, gelen turist sayısı açısından en yüksek olan kümedir (26.875.000). Çok fazla sayıda turist ağırlamasına rağmen turizm gelirleri oranı ortadır (\% 1). Turizm harcamaları oranı da, turizm gelirleri oranına benzer şekilde, diğer kümelere kıyasla ortadır (\% 2). Analiz sonucu oluşan bu kümede 14 ülke yer almaktadır.

Avrasya ülkelerinin çoğunun Küme 1'de yer aldığı görülmüştür. Ukrayna ve Rusya'nın ise 3 no.lu kümede yer aldığı saptanmıştır. Türkiye de Rusya ve Ukrayna ile birlikte 3. kümede yer almaktadır.

Üçüncü küme, gelen turist sayısı açısından en yüksek olan küme (ortalama 26.875.000) olup çok fazla sayıda turist ağırlamasına rağmen turizm gelirleri oranı diğer kümelere kıyasla 'orta' (\% 1 civarında) olan kümedir.

Türkiye'nin turizm açısından benzer yapıda olduğu yani aynı kümede yer aldığı 13 ülke ABD, İngiltere (Birleşik Krallık), Almanya, Fransa, İtalya, İspanya, Avusturya, Çin, Hong Kong, Malezya, Meksika, Rusya ve Ukrayna'dır. Türkiye'nin 2012 y1lında uluslar arası turizm istatistikleri 2011 verilerine göre ilk 10 ülkede yer aldığı hatta İngiltere'yi geçip 6. sıraya yükseldiği düşünülürse bu sonucun beklenen bir sonuç olduğu söylenebilir.

Çıktılar incelendiğinde 43 numaralı ülke olan Dominik Cumhuriyeti 'ne ilişkin olasılık değerlerinin 0,4539; 0,4786 ve 0,0675 olduğu görülmüsstür. Dominik Cumhuriyeti'nin tam olarak bir kümeye atanması diğer ülkelere kıyasla zor olmuştur. Ülkenin 1 ve 2 . numaralı kümelerin kesişiminde kaldığı yorumu yapılabilir.

\subsection{Klasik Kümeleme Analizi Bulguları}

Bulanık kümeleme analizi sonucuna paralel şekilde küme sayısını 3 olarak almanın uygun olacağ düşünülmüş ve analiz 3 küme oluşacak şekilde uygulanmıştır. Yine sonuçlar diskriminant analizi ile desteklenmek istenmiş; diskriminant analizi ile belirlenmiş 3 kümeye ilişkin üyelik değerleri kullanılarak gerçekleştirilecek bir analiz sonucunda yüksek bir doğru sınıflandırma elde edilip edilmeyeceği kontrol edilmiştir. Küme üyelik değerleri yardımıyla, normallik ve homojenlik varsayımı altında uygulanan diskriminant analizi sonucunda doğru sınıflandırma oranı \%98,1 olarak elde edilmiştir. Bu oranın oldukça yüksek olduğu görüldükten sonra analizler sonucu elde edilen bulguların yorumlanması aşamasına geçilmiştir.

$$
\begin{array}{ccccc}
\text { Değişken } & \multicolumn{1}{r}{\text { Küme 1 }} & \text { Küme 2 } & \text { Küme 3 } \\
\mathrm{X}_{1} \text { : Expenditures } & 0,0768 & 0,0212 & 0,0196 \\
\mathrm{X}_{2} \text { : Arrivalsnr } & 2.563 .917 & 3.073 .943 & 37.640 .920 \\
\mathrm{X}_{3} \text { : Receipts } & 0,2422 & 0,0415 & 0,0274
\end{array}
$$

Tablo 4. Kümelere İlişkin Betimleyici İstatistikler (k-ortalamalar)

24 ülkeden oluşan birinci küme, gelen turist sayısının diğer kümelere göre en az olduğu kümedir (2.563.917). Buna karşın turizm gelirinin GSMH'sına oranı en yüksek olan kümedir (yaklaşı \%24). GSMH'sının yaklaşık \%7'si turizm harcamalarına denk gelmektedir. Bu değer diğer üç kümeye nazaran en yüksek oran değeridir. Özetle turizm harcamaları oranı en yüksek, turizm gelirleri oranı da en yüksek ancak gelen turist sayısının en düşük olduğu küme, birinci kümedir.

122 ülkeden oluşan ikinci kümede turizm harcamaları oranı diğer iki kümeye kıyasla ortadır (\%2). Benzer şekilde turizm gelirleri oranı da diğer iki kümeye kıyasla ortadır (\%4). Gelen turist sayısı açısından birinci kümeden daha yüksek, üçüncü kümeden ise daha düşüktür (3.073.943). Yani oluşan kümeler arasında gelen turist sayısının, turizm gelir ve harcama oranlarının orta olduğu küme, ikinci kümedir.

13 ülkeden oluşan üçüncü küme ise gelen turist sayısı açısından en yüksek olan kümedir (37.640.920). Çok fazla sayıda turist ağırlamasına rağmen turizm gelirleri oranı en düşüktür (\%2). Turizm harcamaları oranı da, turizm gelirleri oranına benzer şekilde, diğer kümelere kıyasla en düşüktür (\%1).

Kümeleme analizi kapsamındaki değişkenlerin istatistiksel anlamlılı̆g kümeleme analizindeki ANOVA tablosuyla incelenebilir:

$$
\begin{aligned}
& \text { Değişkenler } \quad \mathrm{sd}_{1} \quad \mathrm{sd}_{2} \quad \text { GAKO GIKO F-ORAN } \quad \text { Prob. (Sig.) } \\
& \begin{array}{lllllll}
\text { Expenditures } & 2 & 156 & 3,166805 \mathrm{E}-02 & 2,526112 \mathrm{E}-04 & 125,36 & 0,000000
\end{array} \\
& \begin{array}{llllll}
\text { Receipts } 2 & 156 & 0,4173497 & 9,618066 \mathrm{E}-03 & 43,39 & 0,000000
\end{array}
\end{aligned}
$$

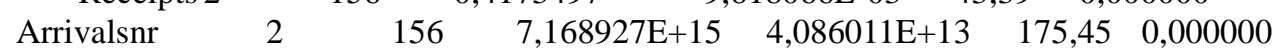

Tablo 5: Kümeleme Analizi'nde Varyans Analizi Tablosu 
Görüldüğü gibi 3 değişken de kümelemede istatistiksel olarak anlamlı bulunmuştur. (prob.<0,05) Kümelerde yer alan ülkeler tablosu aşağıda yer almaktadır.

\begin{tabular}{|l|l|l|}
\hline Küme 1: & Küme 2: & Küme 3: \\
\hline $1,4,10,13,18$, & $2,3,5,6,7,9,11,12,14,15,16,17,19,20,21,22$, & 8 (Avusturya), 33 (Çin), \\
$30,39,62,73$, & $23,24,25,26,27,28,29,31,32,34,35,36,37,38$, & 51 (Fransa), 54 \\
$78,81,82,84$, & $40,41,42,43,44,45,46,47,48,49,50,52,53,55$, & (Almanya), 70 (İtalya), \\
$85,90,92,93$, & $56,57,58,59,60,61,63,64,65,66,67,68,69,71$, & 89 (Malezya), 94 \\
$120,125,127$, & $72,74,75,76,77,79,80,83,86,87,88,91,95,96$, & (Meksika), 118 (Rusya), \\
$130,135,146$, & $97,98,99,100,101,102,103,104,105,106,107$, & 132 (İspanya), 150 \\
156, & $108,109,110,111,112,113,114,115,116,117$, & (Türkiye), 152 \\
& $119,121,122,123,124,126,128,129,131,133$, & (Ukrayna), 153 \\
& $134,136,137,138,139,140,141,142,143,144$, & (Birleşmiş Krallı), 154 \\
& $145,147,148,149,151,155,157,159$ & (ABD), \\
\hline
\end{tabular}

Tablo 6. k Ortalamalar Kümeleme Sonuçlarına Göre Oluşan Kümelerdeki Ülkelerin Numaraları

k ortalamalar kümeleme analizi bulguları incelendiğinde, bulanık kümeleme analizi bulgularına benzer şekilde Avrasya ülkelerinin çoğunun aynı kümede yer aldığ1 görülmüştür (Küme 2). 2. küme profil olarak "oluşan kümeler arasında gelen turist sayısının, turizm gelir ve harcama oranlarının orta olduğu küme" şeklinde tanımlanmıştı.

Yine bulanık kümeleme analizi bulgularına benzer şekilde Avrasya ülkelerinden Ukrayna ve Rusya'nın diğer Avrasya ülkelerinden ayrılarak başka bir kümede yer aldığı (Küme 3) görülmüştür. Türkiye de Rusya ve Ukrayna ile birlikte bu 3. kümede yer almaktadır. 13 ülkeden oluşan üçüncü küme gelen turist sayısı açısından en yüksek olan küme (ortalama 37.640.920) olup çok fazla sayıda turist ağırlamasına rağmen turizm gelirleri oranı diğer kümelerin ortalama oranlarına kıyasla en düşük (\%2) olan küm şeklinde tanımlanmıştı.

Türkiye'nin turizm açısından benzer yapıda olduğu yani aynı kümede yer aldığı 12 ülke ABD, Çin, Fransa, Almanya, İtalya, Malezya, Meksika, Rusya, İspanya, Ukrayna, İngiltere ve Avusturya olarak belirlenmiştir. Klasik kümeleme bulgularının bulanık kümeleme analizi bulgularına paralel olduğu görülmektedir. Türkiye ile aynı kümede yer alan ülkeler aynı çıkmıştır. Sadece bulanık kümeleme analizi sonucunda elde edilen bulgularda Hong Kong'un da bu kümede yer aldığı görülürken, klasik kümeleme analizi sonucunda bu ülke küme değiştirmiş, Türkiye ile aynı kümede yer almamış, 1. kümede yer aldığı görülmüştür.

\section{Sonuç}

Amacı dünya ülkelerinin uluslararası turizm istatistikleri açısından kümelenmesini incelemek ve Türkiye'nin yerini irdelemek olan bu çalışmada, bulanık kümeleme ve klasik kümeleme (k ortalamalar) analizleri uygulamasıyla 159 ülke uluslar arası turizm istatistikleri baz alınarak sınıflara ayrılmıştır. Sınıf (küme) sayısı metodolojide açıklanan çeşitli ölçütler yardımıyla 3 olarak belirlenmiştir. Bu tespit diskriminant analizi ile de desteklenmiştir. Analiz kapsamında kullanılan 3 değiş̧kenin de kümelemede istatistiksel olarak anlamlı olduğu görülmüştür. Oluşan kümelerin betimleyici istatistik değerleri yardımıyla küme profilleri belirlenmiştir.

Elde edilen bulgular incelendiğinde Türkiye'nin her iki metot uygulaması sonucunda da aynı ülkelerle aynı kümede yer aldığı görülmüştür. Benzer şekilde her iki metot uygulaması sonucunda da Avrasya ülkelerinin çoğu aynı kümede yer almıştır. Ve yine her iki teknikte de Rusya ve Ukrayna diğer Avrasya ülkelerinden ayrılarak turizm açısından nispeten daha olumlu olduğu söylenebilen bir kümede yer almışlardır. Türkiye de her iki kümeleme analizi tekniğinde de bu kümede yer almıştır. Bu küme kapsamında dünyanın uluslar arası turizm istatistikleri açısından ilk 10 ülkesinde yer alan çoğu ülke bulunmaktadır.

Bulanık kümeleme analizi sonucunda Türkiye'nin turizm açısından benzer yapıda olduğu yani aynı kümede yer aldığı 12 ülkenin ABD, İngiltere, Almanya, Fransa, İtalya, İspanya, Avusturya, Çin, Malezya, Meksika, Rusya ve Ukrayna olduğu belirlenmiştir. Klasik kümeleme analizi bulgularına göre ise bu kümeye Hong Kong da dahil olmaktadır. Türkiye'nin 2012 yılında uluslar arası turizm istatistikleri 2011 verilerine göre ilk 10 ülkede yer aldığı hatta İngiltere'yi geçip 6. sıraya yükseldiği düşünülürse bu sonucun yapısal olarak beklenen bir sonuç olduğu söylenebilir.

Bunların yanısıra bulanık kümeleme analizi yardımıyla elde edilen küme üyelik değerleri incelenmiş ve iki kümenin kesişiminde kalan bir ülke olduğu (Dominik Cumhuriyeti) tespit edilmiştir.

Sonuç olarak çalışmada birbirlerini tamamlayacak şekilde kullanılan iki farklı kümeleme analizi metodunun tutarlı sonuçlar verdiği görülmüştür. Türkiye, uluslar arası turizm verileri itibarı ile dünya ülkeleri içinde son derece önemli bir konumdadır. Gelen kişi sayısı çok yüksek olmakla birlikte gelen ziyaretçilerin yüksek oranda harcama yapmadıkları dikkat çekmektedir. Önümüzdeki yıllarda alternatif turizm çeşitlerine de daha çok ağırlık verilmesi yoluyla olumlu gelişmeler yaşanabilir. 


\section{Kaynakca}

- Aktaş, 2005. “Türkiye'nin Turizm Gelirini Etkileyen Değişkenler İçin En Uygun Regresyon Denkleminin Belirlenmesi”, Doğuş Üniversitesi Dergisi, 6 (2), 163-174.

- Alpaslan, vd, 2011. "Bulanık Kümelemede En Uygun Küme Sayısının Yapay Sinir Ağları ve Diskriminant Analizi İle Belirlenmesi", 25, http://e-dergi.atauni.edu.tr/index.php/IIBD/article/view/7793

- Chandra and Menezes, 2001. "Applications of Multivariate Analysis in International Tourism Research: The Marketing Strategy Perspective of NTOs", Journal of Economic and Social Research, 3 (1), 77- 98.

- Cengiz ve Kırkbir, 2007. "Yerel Halk Tarafından Algılanan Toplam Turizm Etkisi İle Turizm Desteği Arasındaki İlişkiye Yönelik Yapısal Bir Model Önerisi”, Anadolu Üniversitesi Sosyal Bilimler Dergisi, 1, 19- 37.

- Çuhadar, 2006. Turizm Sektöründe Talep Tahmini İçin Yapay Sinir Ağları Kullanımı ve Diğer Yöntemlerle Karșılaştırmalı Analizi (Antalya İlinin TurizmTalebinde Uygulama), T.C. Süleyman Demirel Üniversitesi Sosyal Bilimler Enstitüsü İşletme Anabilim Dalı, Tez Danışmanı: Prof.Dr. İbrahim Güngör, Yayınlanmamış Doktora Tezi, Isparta. http://eprints.sdu.edu.tr/296/1/TS00460.pdf

- Kandır, vd, 2007. "Türk Turizm Sektöründe Büyüme Göstergelerinin Turizm İşletmelerinin Finansal Performansına Etkisinin İncelenmesi”, Dokuz Eylül Üniversitesi Sosyal Bilimler Enstitüsü Dergisi, 9 (2), 166- 185

- Karaman, 2000. "Balıkesir Yöresine Gelen Fransız Turist Talep Analizi”, Ballkesir Üniversitesi sosyal Bilimler Enstitüsü Dergisi, 3 (4), 298- 312.

- Karataş ve Babür, 2013. “Gelişen Dünyada Turizm Sektörünün Yeri “, KMÜ Sosyal ve Ekonomik Araşırmalar Dergisi, 15 (25), 15-24.

- Kaufman and Rousseeuw, 1990. Finding Groups Data: An Introduction to Cluster Analysis. John Wiley and Sons Inc, New York, http://tr.scribd.com/doc/90234560/Finding-Groups-in-Data-An-Introduction-toCluster-Analysis-Leonard-Kaufman-Wiley-2005-355S

- Kılıç, vd, 2011. "Bulanık Kümeleme Analizi İle Ülkelerin Turizm İstatistikleri Bakımından Sinıflandırılması", İstatistikçiler Dergisi, 4, 31- 38.

- Kılıç ve Özbeyaz, 2010. "Bulanık Kümeleme Analizinin Koyun Yetiştiriciliğinde Kullanımı ve Bir Uygulama", Kocatepe Veteriner Dergisi, 3 (2), 31- 37.

- Uğuz, 2012. "Göç ve Turizm: Türkiye- Almanya Örneği”, Yönetim Bilimleri Dergisi, 10 (9), 1-30.

- Önen, 2008. Dünyada ve Türkiye'de Turizm, Türkiye Kalkınma Bankası A.Ş. Ekonomik ve Sosyal Araştırmalar Müdürlüğ̈̈, Ankara.

- SSahin ve Hamarat, 2002. "G 10, Avrupa Birliği ve OECD Ülkelerinin Sosyo-Ekonomik Benzerliklerinin Fuzzy Kümeleme Analizi İle Belirlenmesi”, http://content.csbs.utah.edu/ ehrbar/erc2002/pdf/P397.pdf

- Tütmez ve Tercan, 2006. s.39-47, http://www.maden.org.tr/resimler/ekler/7e9050c92a851b0_ek.pdf

- Yazıcı, 2003. "Yirmibirinci Yüzyılın Başında Avrasya ve Türkiye'nin Avrasya Vizyonu”, Кати- İŞ (2), 1 12.

- Yılanc1, 2010. "Bulanık Kümeleme Analizi Yardımıyla Türkiye'deki İllerin Sosyoekonomik Açıdan Siniflandirılması",

- http://www.academia.edu/444860/Bulanik_Kumeleme_Analizi_ile_Turkiyedeki_Illerin_Sosyoekonomik_A $\underline{\text { cidan_Siniflandirilmasi }}$

- Yıılız, 2011. "Turizm Sektörünün Gelişimi ve İstihdam Üzerinde Etkisi”, Süleyman Demirel Üniversitesi Vizyoner Dergisi, 3 (5), 54-71.

\section{EK. Bulanık Kümeleme Küme Üyelikleri Matrisi}

$\begin{array}{lrrrr}\text { Satır } & \text { Küme } & \text { Prob in 1 } & \text { Prob in 2 } & \text { Prob in 3 } \\ 1 & 1 & 0,7460 & 0,2109 & 0,0432 \\ 2 & 1 & 0,8053 & 0,1599 & 0,0348 \\ 3 & 1 & 0,9592 & 0,0320 & 0,0088 \\ 4 & 1 & 0,9492 & 0,0397 & 0,0111 \\ 5 & 2 & 0,2807 & 0,6562 & 0,0631 \\ 6 & 1 & 0,9611 & 0,0307 & 0,0082 \\ 7 & 2 & 0,2154 & 0,7277 & 0,0569 \\ 8 & 3 & 0,1024 & 0,1757 & 0,7219 \\ 9 & 1 & 0,9190 & 0,0650 & 0,0160 \\ 10 & 1 & 0,9086 & 0,0736 & 0,0178 \\ 11 & 2 & 0,1699 & 0,6707 & 0,1594 \\ 12 & 1 & 0,9538 & 0,0361 & 0,0100 \\ 13 & 1 & 0,9616 & 0,0302 & 0,0082 \\ 14 & 1 & 0,9383 & 0,0481 & 0,0136\end{array}$




\begin{tabular}{|c|c|c|c|c|}
\hline 15 & 2 & 0,1074 & 0,8533 & 0,0394 \\
\hline 16 & 1 & 0,9501 & 0,0390 & 0,0109 \\
\hline 17 & 1 & 0,9466 & 0,0417 & 0,0117 \\
\hline 18 & 1 & 0,9493 & 0,0396 & 0,0111 \\
\hline 19 & 1 & 0,9278 & 0,0561 & 0,0160 \\
\hline 20 & 1 & 0,9577 & 0,0335 & 0,0088 \\
\hline 21 & 1 & 0,9568 & 0,0338 & 0,0093 \\
\hline 22 & 1 & 0,7930 & 0,1705 & 0,0366 \\
\hline 23 & 2 & 0,3015 & 0,6340 & 0,0645 \\
\hline 24 & 2 & 0,1990 & 0,7461 & 0,0549 \\
\hline 25 & 1 & 0,9522 & 0,0374 & 0,0104 \\
\hline 26 & 1 & 0,9409 & 0,0461 & 0,0130 \\
\hline 27 & 1 & 0,7297 & 0,2250 & 0,0453 \\
\hline 28 & 1 & 0,9618 & 0,0301 & 0,0081 \\
\hline 29 & 2 & 0,1890 & 0,4373 & 0,3737 \\
\hline 30 & 1 & 0,9555 & 0,0349 & 0,0096 \\
\hline 31 & 1 & 0,9297 & 0,0547 & 0,0156 \\
\hline 32 & 1 & 0,6834 & 0,2656 & 0,0510 \\
\hline 33 & 3 & 0,2015 & 0,2433 & 0,5551 \\
\hline 34 & 1 & 0,7517 & 0,2059 & 0,0424 \\
\hline 35 & 1 & 0,9334 & 0,0518 & 0,0148 \\
\hline 36 & 1 & 0,8004 & 0,1641 & 0,0355 \\
\hline 37 & 1 & 0,9513 & 0,0381 & 0,0106 \\
\hline 38 & 2 & 0,0845 & 0,8688 & 0,0467 \\
\hline 39 & 1 & 0,7882 & 0,1745 & 0,0373 \\
\hline 40 & 2 & 0,0722 & 0,8917 & 0,0362 \\
\hline 41 & 2 & 0,0741 & 0,8879 & 0,0380 \\
\hline 42 & 1 & 0,9329 & 0,0522 & 0,0149 \\
\hline 43 & 2 & 0,4539 & 0,4786 & 0,0675 \\
\hline 44 & 1 & 0,9425 & 0,0459 & 0,0116 \\
\hline 45 & 2 & 0,1929 & 0,5441 & 0,2630 \\
\hline 46 & 1 & 0,9325 & 0,0540 & 0,0135 \\
\hline 47 & 1 & 0,7540 & 0,2039 & 0,0421 \\
\hline 48 & 1 & 0,9606 & 0,0310 & 0,0084 \\
\hline 49 & 1 & 0,9618 & 0,0302 & 0,0081 \\
\hline 50 & 1 & 0,5275 & 0,4079 & 0,0645 \\
\hline 51 & 3 & 0,2472 & 0,2822 & 0,4706 \\
\hline 52 & 1 & 0,9348 & 0,0508 & 0,0144 \\
\hline 53 & 1 & 0,8115 & 0,1547 & 0,0338 \\
\hline 54 & 3 & 0,0790 & 0,1201 & 0,8009 \\
\hline 55 & 1 & 0,9514 & 0,0386 & 0,0099 \\
\hline 56 & 2 & 0,1936 & 0,4929 & 0,3135 \\
\hline 57 & 1 & 0,9371 & 0,0490 & 0,0139 \\
\hline 58 & 1 & 0,8362 & 0,1338 & 0,0300 \\
\hline 59 & 1 & 0,9420 & 0,0453 & 0,0128 \\
\hline 60 & 1 & 0,9510 & 0,0383 & 0,0107 \\
\hline 61 & 1 & 0,9552 & 0,0355 & 0,0092 \\
\hline 62 & 3 & 0,1369 & 0,2517 & 0,6114 \\
\hline 63 & 2 & 0,1004 & 0,8397 & 0,0599 \\
\hline 64 & 1 & 0,9610 & 0,0306 & 0,0083 \\
\hline 65 & 2 & 0,2273 & 0,7144 & 0,0583 \\
\hline 66 & 2 & 0,1175 & 0,8412 & 0,0413 \\
\hline 67 & 1 & 0,8891 & 0,0897 & 0,0213 \\
\hline 68 & 2 & 0,1099 & 0,8503 & 0,0398 \\
\hline 69 & 1 & 0,6769 & 0,2714 & 0,0518 \\
\hline 70 & 3 & 0,1653 & 0,2107 & 0,6240 \\
\hline 71 & 1 & 0,8290 & 0,1399 & 0,0312 \\
\hline 72 & 2 & 0,0721 & 0,8919 & 0,0360 \\
\hline 73 & 2 & 0,3873 & 0,5450 & 0,0677 \\
\hline 74 & 1 & 0,5740 & 0,3645 & 0,0615 \\
\hline 75 & 1 & 0,8956 & 0,0843 & 0,0201 \\
\hline 76 & 2 & 0,0754 & 0,8856 & 0,0391 \\
\hline 77 & 1 & 0,9473 & 0,0411 & 0,0115 \\
\hline 78 & 1 & 0,9151 & 0,0682 & 0,0167 \\
\hline 79 & 1 & 0,8672 & 0,1078 & 0,0250 \\
\hline 80 & 1 & 0,9082 & 0,0739 & 0,0179 \\
\hline 81 & 1 & 0,7891 & 0,1737 & 0,0371 \\
\hline 82 & 1 & 0,9588 & 0,0323 & 0,0089 \\
\hline 83 & 1 & 0,8906 & 0,0884 & 0,0210 \\
\hline 84 & 1 & 0,9582 & 0,0331 & 0,0087 \\
\hline 85 & 2 & 0,1695 & 0,6724 & 0,1581 \\
\hline 86 & 1 & 0,9515 & 0,0380 & 0,0106 \\
\hline 87 & 1 & 0,9464 & 0,0419 & 0,0118 \\
\hline 88 & 1 & 0,9597 & 0,0319 & 0,0084 \\
\hline 89 & 3 & 0,0809 & 0,1292 & 0,7899 \\
\hline 90 & 1 & 0,9583 & 0,0331 & 0,0087 \\
\hline 91 & 1 & 0,9437 & 0,0439 & 0,0124 \\
\hline 92 & 1 & 0,9128 & 0,0701 & 0,0171 \\
\hline 93 & 1 & 0,9512 & 0,0388 & 0,0100 \\
\hline 94 & 3 & 0,0883 & 0,1457 & 0,7659 \\
\hline 95 & 1 & 0,9228 & 0,0599 & 0,0172 \\
\hline 96 & 1 & 0,9603 & 0,0312 & 0,0085 \\
\hline
\end{tabular}




\begin{tabular}{|c|c|c|c|c|}
\hline 97 & 1 & 0,9386 & 0,0490 & 0,0124 \\
\hline 98 & 2 & 0,0911 & 0,8568 & 0,0521 \\
\hline 99 & 1 & 0,8601 & 0,1138 & 0,0262 \\
\hline 100 & 1 & 0,9476 & 0,0417 & 0,0107 \\
\hline 101 & 1 & 0,9619 & 0,0300 & 0,0081 \\
\hline 102 & 2 & 0,1459 & 0,7413 & 0,1127 \\
\hline 103 & 1 & 0,7326 & 0,2225 & 0,0449 \\
\hline 104 & 1 & 0,9455 & 0,0434 & 0,0111 \\
\hline 105 & 1 & 0,8838 & 0,0940 & 0,0222 \\
\hline 106 & 2 & 0,3562 & 0,5768 & 0,0670 \\
\hline 107 & 1 & 0,9424 & 0,0460 & 0,0116 \\
\hline 108 & 1 & 0,9529 & 0,0374 & 0,0097 \\
\hline 109 & 1 & 0,9142 & 0,0690 & 0,0168 \\
\hline 110 & 1 & 0,9413 & 0,0458 & 0,0129 \\
\hline 111 & 1 & 0,9605 & 0,0310 & 0,0085 \\
\hline 112 & 1 & 0,7666 & 0,1930 & 0,0403 \\
\hline 113 & 1 & 0,5526 & 0,3844 & 0,0630 \\
\hline 114 & 2 & 0,1788 & 0,6373 & 0,1839 \\
\hline 115 & 2 & 0,1355 & 0,8197 & 0,0448 \\
\hline 116 & 1 & 0,6096 & 0,3319 & 0,0586 \\
\hline 117 & 2 & 0,0954 & 0,8671 & 0,0375 \\
\hline 118 & 3 & 0,0987 & 0,1677 & 0,7336 \\
\hline 119 & 1 & 0,9619 & 0,0301 & 0,0080 \\
\hline 120 & 1 & 0,9386 & 0,0479 & 0,0136 \\
\hline 121 & 1 & 0,9229 & 0,0599 & 0,0172 \\
\hline 122 & 2 & 0,1451 & 0,7436 & 0,1114 \\
\hline 123 & 1 & 0,9533 & 0,0371 & 0,0096 \\
\hline 124 & 1 & 0,9611 & 0,0307 & 0,0082 \\
\hline 125 & 1 & 0,9443 & 0,0434 & 0,0122 \\
\hline 126 & 1 & 0,9275 & 0,0563 & 0,0161 \\
\hline 127 & 2 & 0,0862 & 0,8658 & 0,0480 \\
\hline 128 & 1 & 0,9139 & 0,0692 & 0,0169 \\
\hline 129 & 1 & 0,8373 & 0,1329 & 0,0298 \\
\hline 130 & 1 & 0,9248 & 0,0584 & 0,0167 \\
\hline 131 & 2 & 0,0800 & 0,8844 & 0,0357 \\
\hline 132 & 3 & 0,1933 & 0,2361 & 0,5706 \\
\hline 133 & 1 & 0,9615 & 0,0304 & 0,0081 \\
\hline 134 & 1 & 0,9349 & 0,0507 & 0,0144 \\
\hline 135 & 1 & 0,9540 & 0,0360 & 0,0100 \\
\hline 136 & 1 & 0,9322 & 0,0528 & 0,0150 \\
\hline 137 & 1 & 0,9611 & 0,0306 & 0,0083 \\
\hline 138 & 1 & 0,9472 & 0,0412 & 0,0116 \\
\hline 139 & 1 & 0,9550 & 0,0357 & 0,0093 \\
\hline 140 & 2 & 0,3300 & 0,6041 & 0,0659 \\
\hline 141 & 2 & 0,0721 & 0,8917 & 0,0361 \\
\hline 142 & 2 & 0,0725 & 0,8917 & 0,0357 \\
\hline 143 & 1 & 0,9428 & 0,0446 & 0,0126 \\
\hline 144 & 1 & 0,9595 & 0,0321 & 0,0084 \\
\hline 145 & 2 & 0,1901 & 0,4455 & 0,3645 \\
\hline 146 & 1 & 0,9277 & 0,0562 & 0,0161 \\
\hline 147 & 1 & 0,9469 & 0,0414 & 0,0116 \\
\hline 148 & 1 & 0,9577 & 0,0331 & 0,0091 \\
\hline 149 & 2 & 0,1242 & 0,8332 & 0,0426 \\
\hline 150 & 3 & 0,1036 & 0,1469 & 0,7495 \\
\hline 151 & 1 & 0,9504 & 0,0395 & 0,0101 \\
\hline 152 & 3 & 0,1163 & 0,2049 & 0,6787 \\
\hline 153 & 3 & 0,0840 & 0,1246 & 0,7915 \\
\hline 154 & 3 & 0,2126 & 0,2532 & 0,5341 \\
\hline 155 & 1 & 0,7573 & 0,2011 & 0,0416 \\
\hline 156 & 1 & 0,9355 & 0,0502 & 0,0143 \\
\hline 157 & 1 & 0,9616 & 0,0303 & 0,0082 \\
\hline 158 & 2 & 0,3164 & 0,6184 & 0,0653 \\
\hline 159 & 1 & 0,9444 & 0,0444 & 0,0113 \\
\hline
\end{tabular}




\title{
Endüstri Mirasının Ekonomiye Kazandırılması: Toronto Distilery District Dönüşüm Örneği
}

\section{Benefiting from Industrial Heritage: Toronto Distilery District Urban Transformation Example}

\author{
Assoc. Prof. Dr. Sülün Evinç Torlak (Pamukkale University, Turkey)
}

\begin{abstract}
It is a common fact that the confinement and to become unfunctional of the historical factories due to they have remained behind of technological improvement, not been managed effectively and polluted to the environment. However, their falling into disuse the demolition and the destruction of these buildings cannot be accepted. A lot of factories in Türkiye that have been able to reach today from the industrial background had been demolished for their land value, and a few of them had been re-functioned by transforming. These plants as contributes to the economic development of the countries and bears the stamp of the past, also could be reevaluated and transferred to future generations by preserving their original identities. With the transformation of a historical plant, not only an industrial heritage would be protected but also this act would contribute to the economic development and cultural significance of the urban, and improve the quality of life. On this issue, there are lots of examples in Western countries. In this study, a succesful transformation sample from Canada-Toronto has been handled. In Distillery Region where has a significant role in the establishment, enrichment and physical embodiment of the city of Toronto, the regeneration/transformation process has been achieved thus the region has been redounded to tourism industry. In the study, the development of Distilery and its meaning for the urban is stated, the transformation process and its effect on urban is discussed and at this issue some suggestions are made while determining the deficiencies in Türkiye.
\end{abstract}

\section{Giriş}

Tarihi fabrikaların; teknolojik acıdan geri kalmaları, verimli işletilememeleri, hantal görünümleri ve çevreyi kirletmeleri gibi nedenlerle işlevlerini yitirip, kapatılmaları tüm dünyada karşılaşılan bir durumdur. Ancak, işlevini yitiren bu yapıların bilinçli olarak tahrip edilmesi kabul edilir bir yaklaşım değildir. Ülkemizin, endüstri geçmişinden, günümüze ulaşan tesislerin büyük bir kısmı arsa değeri önde tutularak yıkılmışı̧ı. Bir kısmı da terk edilmiş, harap olmuștur. Çok azı dönüşüm geçirerek yeniden kazanılmıştır. Ülkelerin ekonomik gelişimine katkı sağlayan bu tesisler, geçmişin izleri, yapıların özgün kimliklerini korunarak, yeniden değerlendirilebilir, gelecek kuşaklara aktarılabilir. Eski bir tesisinin, dönüşümü uygulaması ile sadece endüstri mirası korunmayacaktır, Ayni zamanda kentin ekonomik gelişimi, kültürel önemi, yaşam kalitesinin artmasına da katkı sağlanacaktır. Bu konuda Batı ülkelerinde önemli örnekler verilmektedir.

Bu çalışmada, eski tesislerinin dönüşüm uygulaması için öneri geliştirmede yararlı olabilecek, başarılı bir örnek aktarılmaktadır. Toronto- Distilery District dönüşüm uygulaması analiz edilmektedir. Toronto Kentinin kurulması, zenginleşmesi ve fiziki şekillenmesinde önemli rol oynayan, bir dönem çöküntü bölgesi olan Distilery, bir dönüşüm uygulaması ile turizm endüstrisine kazandırılmıştır. Çalışmada kronolojik olarak Distilery'nin gelişimi ve kent için taşılığı anlam verilmiş, yeni uygulama ve bunun kentte etkisi tartışılmış, öneriler geliştirilmiştir. Kompleksin gelişimi ve dönemsel koşullar ile ilgili bilgiler; dönem gazetelerinden, internet sitesinden ve tezlerden yararlanılarak derlenmiştir. Kentte yarattığı etki ile ilgili veriler dönemsel haritalar üzerinden aktarılmıştır. Alan, çeşitli zamanlarda gözlenmiş, rastgele seçilen kişilerin Alan hakkındaki görüşleri alınmış, bu görüşlerden çalışma kapsamında yararlanılmıştır.

\section{Eski Endüstri Tesislerinin Dönüştürülmesi}

\subsection{Endüstri Mirasının Dönüștürülmesi}

Endüstri Bölgelerinin Dönüşümü; 20'nci yy sonu işlevsizleşen sanayi tesisi alanlarının yeniden değerlendirme girişimidir (Yıldırım, 2006:7). Kent için sorunlu hale gelen bu alanları, sağlıklı ve yaşanabilir hale getirmek için dönüşüm projeleri üretilip, uygulanır. Dönüşüm projeleri ile zamanla eskiyen, terkedilen, değer kaybına uğrayan, köhneleşen bu kent alanları, günün sosyo ekonomik, fiziki koşullarına uygun olarak yeniden canlandırılır ve kente kazandırılır (Özden,2000:257). Batı'da amaç, kent ekonomisini canlandırıp, istihdam alanı oluşturmak, yaşam kalitesini arttırmaktır. Türkiye'de endüstri alanları, rant paylaşım aracı olarak görülmektedir. Miras Alanlarının tarihi-kültürel değerinden çok, kentsel toprakların değişim değeri öne çıkmaktadır.

\subsection{Tarihsel Süreç}

1960’li yıllarda Batılı Ülkelerde farklı bir kentleşme süreci başlar. İngiltere başta olmak üzere, Avrupa ve Amerika kentlerinin merkezlerinde yer alan sanayi tesisleri kapanır. Üretim biçimleri değişmiştir, daha geniş 
alanlara gereksinim vardır. Arsa fiyatlarının yükselmesi, trafiğin artması ve güvenliğin azalması vb nedenlerle büyük şirketler sıkıştıkları merkezi alanları terk edip, gelişen ulaşım sistemi sayesinde kent dışına geniş, ucuz alanlara taşarlar (Özdemir-a, 2010:4). Kent içi "sanayisizleşme" sürecine girilir. Bu kaçışa gelir düzeyi iyi olan kesimde eklenir, kentin sıkışık alanlarında banliyölere geçerler. İstihdam kent dışındaki kasabalara kayar. Kent merkezleri; üretim, birikim ve refahın paylaşım merkezi olma canlılığını yitirir. Merkez çevredeki işçi mahalleleri ve yaşam alanları da gözden düşer. Merkezler, dar gelirlilerin yaşam alanlarına dönüşür. Merkezin kayması, kentleri yıpratır, kentlerin gelirleri azalır. Merkezde oturan dar gelirliler, gereksinimlerini karşılayamaz hale gelir. Terk edilen sanayi ve konut alanları sürekli yıpranır. Kent merkezlerinde mekansal sorunların yanı sıra, hırsızlık, çetecilik, uyuşturucu vb sosyal sorunlar da artar. Atıl fabrikaları temizleme ve kent mekânını değerlendirme girişimi başlar. "Buldozer Dönemi"diye atlandırılan bu dönemde dönüşüm projelerinin esası, kentin boşalan, atıl ve çöküntü alanlarının temizlenmesidir.

1970’li yıllarda, kentler genişlemiş büyümüştür. Kurulurken kentlerin çeperinde yer seçen endüstri yapıları, artık kent içinde kalmıştır. Kent içinde ise boş alan kalmamış, arsa değerleri oldukça yükselmiştir. Kentlerin nüfüsları artmış, kent halkının artan ve güncel yaşam koşullarına göre çeşitlenen ihtiyaçlarına yanıt verecek arsa stoku tükenmiştir. Bu durumda kent yönetimleri ve yatırımcılar açısından terk edilen sanayi tesislerinin arsaları çok caziptir. Kentin yaşam kalitesini arttırma, alt yapısını iyileştirme, ekonomik gelişim, girişimciliği ve istihdamı arttrma, mekansal ve sosyal sorunları gidermek üzere temizlenen endüstri bölgelerinin değerlendirilmesi süreci başlar, dönüşüm projeleri uygulanır. "Yaratıcı yıkım" diye atlandırılan yaklaşımın esası, dönüşüm sonrası bölgenin değer kazanmasıdır. Dönüşüm uygulamaları endüstri bölgelerinin temizlenmesi ve civarında yaşayanların kentten uzaklaştırılması "soylulaştırma" şeklinde gelişmiştir. Ancak bu yenileme sürecine tepkiler artar. Refah devleti uygulamalarının etkisi ile 'yumuşak kentsel yenileme' hareketi başlar (AlmanyaKreuzberg örneği). Dönüşümde, fiziksel yapılaşmadan çok sosyal, ekonomik, kültürel yapı önemsenir. (Yiğitcanlar,2001:56). Endüstri alanları yenilenirken; verimliliği arttırmak, yatırımları büyütmek, istihdam yaratmak vb ekonomik amaçlar yanısıra sıkıntıları gidermek, refahı arttırmak, eşitsizliği azaltmak, sosyal adalet sağlamak, suç oranını ve sınıfsal ayrımları azaltılmak gibi sosyal amaçlar da hedeflenir.

1980'li yıllarda ekonominin merkezleri kentlerdir. Yaşanan, Küresel yeniden yapılanmanın odağında kentler yer alır. Teknolojik değişim, üretim sisteminin dünyaya yayılarak parçalanması, finans-hizmet iletişim, ulaşım sektörlerinin parlaması, kentlerde köklü dönüşümlere neden olmuştur. Ekonomik- sosyal yapı, yaşam tarzları farklılaşır, kent mekanı da dönüşür, tüm dünyada belirgin kentsel yenilenme başlar ve dönüşüm, bir süreç olarak kabul edilir. Tüm Avrupa kentlerinde, Amerika'dan esinlenerek büyük iş alışveriş merkezleri, kongre merkezleri, spor tesisleri gibi emlak piyasalarını tetikleyecek, yatırımcı ve turistleri çekmeyi hedefleyen emlak eksenli büyük projeler uygulanır (Özdemir-a, 2010:6). 1981 Avrupa Konseyi, "Kentsel Yenileme İçin Avrupa Kampanyası" başlatır. Kampanya süresince, pek çok Avrupa kentindeki endüstri bölgeleri yenilenir. Yeniden yapılanma üzerine bilimsel çalışmalar başlar. Kentler arasında rekabet artmıştır. Yerel birimler sürekli hiç denenmemiş yaratıcı projeler geliştirir ancak, her projenin taklit edilmesi ile her kent bir birine benzemeye başlar, her kette benzer kent parçaları ortaya çıkar (Özdemir-a, 2010:8). Mekânsal yenileme, kentler arasında rekabette bir avantaj olmaktan çıkar. Tarihi ve kültürel miras ile ekonomik gelişme arasındaki bağın önemi anlaşılır, "koruma" kavramı öne çıkar (Karadağ, 2008). Kentlerin tarihi kimlikleri ve bunun izlerini taşıyan mekanlar önem kazanır.

2000'lerde endüstri mirasını dönüştürme kavramının içeriği ve etkisi genişler, Bugünkü anlamını kazanır. Bu dönemde başta kent insanı olmak üzere, herşey dönüşüm kapsamına girmiştir. Kent insanı; kent mekânı, kent kültürü, kent yaşamı ile birlikte yeniden yapılandırılır. "Bütünleşik Dönüşüm" diye adlandırılan yaklaşımla, ekonomik, toplumsal, çevresel faktörlere dayal, "sürdürülebilir kent"ler gelişimin aracı olarak görülür. Sadece, fiziksel mekân düzenlenmemekte, aynı zamanda halkın katılımı sağlanıp, kentin yeniden canlandırılması ve "kentte kimlik" kazandırmak hedeflenmektedir. Kentsel kimlikler tanımlanırken, kentlerin geçmişi ve bunların mimari izleri, yani kentin varolan kimliğini koruması büyük önem taşır. Kentsel sürdürülebilir en önemli unsurdur, bunu sağlanmak için gelecekle bağları kurulurken, kentlerin geçmişle ilgili bağları da canlandırılmaktadır. Dönüşüm günün koşullarına göre düzenlenirken, tarihi yapılara hassasiyet ön plana çıar.

\subsection{Endüstri Mirası Dönüştürme Yöntemleri}

a) Yenileme: En radikal dönüşüm yaklaşımıdır. Temel anlayış eskiyi tamamen yıkıp, farklı işlev için yeniden inşa etmek, mekanı arsa olarak değerlendirmektir. Rantı değeri, yaşam kalitesi düşmüş, riskli hale gelmiş̧ alanlara yeni imar hakları verilerek, rant ve yaşam kalitesini yükseltilir. Yönetem, Türkiye'de tercih edilmektedir. Arsalar, spekülatif amaçlı el değiş̧irmektedir. Özel girişimci için cazip, karlı bir metottur.

b) Sağlıklaştırma: Yıpranan, işlevlerini yerine getiremeyen, alt yapısı yetersiz, ancak özgün niteliğini kaybetmemiş çevrenin iyileştirilip, tekrar sağlıklı ve değerli hale getirilmesi, yapıların korunup restore edilmesidir. Hizmet sunmak için sağlıklaştırma, gelir için yenileme tercih edilir.

c) Koruma: Tarihi, mimari, kültürel değer taşıyan, işlevlerini yerine getirebilen bölgelerin korunması yaklaşımıdır. Bu yöntemle tarihi ve mimari mirası değerlendirmek üzere; yeni yapılanma koşulları saptanır, 
yapılar güçlendirilir, restarasyon çalışmaları yapılır, alt yapı eksikleri giderilir, açık alanlar düzenlenir, çevre standartları yükseltilir, alana/ bölgeye farklı işlevler verilir.

d) Soylulaştırma: Toplumun geçmiş sosyal, ekonomik koşulları, kültür değerlerini yansıtan fiziksel yapının, günün değişen koşulları altında yok olmasına engel olma, bu yapının çağdaş gelişmelerle bütünleştirilerek yaşatılmasıdır. Soylulaştırma da dönüşüm geçiren alanın kullanıcıları değişir, daha üst gelir düzeyi alana yerleşmektedir. Böylece; alanın kimliği değişir,yeni kullanıcı ile bakım, çevresel nitelik ve yaşam kalitesinin yükseltilir, ancak yöntem sosyal soruları beraber getirmektedir. Yeni kullanıcı eski kullanıcı birlikte bölgede yaşasa da, eski kullanıcılar farklı bölgeye taşınsa da hukuki ve sosyal sorunlar yaşanmaktadır.

İki yollu vardır: 1. Tarihi alanlara, yeni işlev kazandırmak; 2. Tarihi alanda yaşayan kitleyi değiştirip ekonomik yaşanabilirlik sağlamak.

e) Bütünleştirme: Mekânın fiziki, ekonomik, toplumsal, çevresel boyutlarına ek dönüşümün; yasal, kurumsal, örgütlenme, süreçlerini bütünleşik ele alan yaklaşımdır. Çok aktörlü ve sektörlü dönüşüm süreçleri kabul görür. Yöntemde alanın sakinleri bölgede kalır, dönüşüme katkıda bulunur. STK güçlenir, ortaklıklar etkin olur. Yapılaşmaya dokunmadan, bölgeye yeni binaların yapılması yöntemi ile kent kimliği korunurken, mevcut binaların yanına yeni binaların katılımıyla zengin bir çevre oluşturulur.

\section{Toronto - Distilery District Dönüşüm Uygulaması}

\subsection{Alanın Tanıtımı}

Ontario Eyaletinin başkenti Toronto, Kanada'nın en büyük kentidir. Kentin, nüfusu yaklaşık 6 milyondur (wikipedia.org, 2013). Dünya kenti Toronto, Ülkenin ekonomik merkezidir. Kent bir kültür, sanat, eğitim, turizm merkezidir. Kent aynı zamanda ulaşım, haberleşme, bilgi teknolojileri ve tıbbı alanlarında oldukça gelişmiştir. Başta film festivali olmak üzere, dünyanın önde gelen sanat festivallerine ev sahipliği yapar. Güvenli olması, temiz bir çevreye sahip olması, iş bulma olanakları ve üst düzey yaşam standartları ile her yöreden göç alır. 2012'da dünyanın “en yaşanılabilir” dördüncü kenti seçilmiştir. ${ }^{4}$ Kentinin bu özellikleri kazanımında, zenginleşmesinde ve fiziki formunun gelişiminde, Distilery District (Damıtımevi Bölgesi) büyük rol oynamıştır.

Distilery, Toronto Kent Merkezi'nin doğusunda yer alan, olağanüstü mimarisi ile eşsiz bir endüstri yerleşimidir. 1832 yılında kurulan sanayi sitesi, inişli çıkışlı gelişim süreci geçirmiş, yel değirmeni ile başlanan iş, dünyanın en büyük içki üretim merkezine dönüşmüştür. Toronto'nun kuruluşuna ve gelişimine yön vermiştir. Uzun bir dönem, çeşitli şekilde ve ölçekte Kentti hatta Ülkeyi etkilemiştir. Bir dönem çöküntü bölgesi olan Alan, 2003'de yeniden canlandırılarak, Kanada'nın önde gelen turizm merkezlerinden biri haline gelmiştir.

\subsection{Tarihsel Gelişim}

1830 da İrlanda'dan Kanada'ya Göç eden genç Worts, Ontorio Körfezi kenarında eniştesi Gooderham’la birlikte yel değirmeni inşa ederek, öğütme işine başlar. (G\&W) ortaklığı kurulur. (Careless, 1984) Toronto küçük bir yerleşimdir, körfez kıyısı boştur (Goad,1890). İnsanlar kuzeyde çiftliklerde yaşamaktadır. İlk olarak değirmeni kentte bağlayan, zamanla kentin en önemli caddesi olan toprak yol açılır- Değirmen Önü Caddesi. Öğütme süreci sonucu oluşan atıkları değerlendirmek üzere sığır besleme işi başlatılır (Shuttleworth, 1924). Değirmenin etrafı, ahırlar, süt ve et tesisleri ile dolar. Çiftlik çalışanlarının evleri Körfez kenarında yerleşim yeri oluşturur. Değirmen, kentin sınırını belirlemiştir. Kentin Güney sınırı için "Yel Değirmeni Hattı" tabiri kullanılır (Boulton, 1858).

1840’da hasat artışı hat safhadadır, artığı alkole dönüştürüp, satmaya karar verilir. İçki işi tutar, değirmenin önüne içki satış yeri ve pub eklenir. Mekân, Kentin en popular yeri haline gelir. G \& W Kenttin en önde gelen Şirketidir. Şirket, Toronto'ya en fazla katkısı olan kurum ilan eder (Distillery Heritage Website). G \& W viskide başarıdır, Kanada'nın yerel viskisi haline gelir. G\&W, Ülkenin vergi rekortmeni olur (G\&W Heritage Plan Report,1994:4). 1846 İşletmenin önüne İskele yapılır, Liman kentlerine satış başlar. 1850 İngiliz İmparatorluğu'nun en büyük içki üreticisi ve satıcısıdır (G\&W Heritage Plan Report,1994:4). Üretim artınca yeni damıtım evi gerekir. Alkol yanıcı bir malzemedir. Alandaki binalar ahşap yapılmıştır. Dayanıklı yapılar gereklidir. İrlandalı, mimar David Roberts Sr. yeni Damıtım evini kireçtaşından tasarlar. Distilery inşaatı, 1859 başlar, 1861 hizmette açılır (Armstrong,1869). Binaya yapı malzemelerinin taşınabilmesi için Distilery’in önündeki iskele büyütülür. Gemilerle milyonlarca galon içki taşınmaktadır. 1856 Kentte Grand Trunk Demiryolu gelir, uzatma hattı Distilery'den geçer. Muazzam genişleme getirir. Kıta Ülkelerine Montreal, Halifax, New York, Rio, Buenos Aires, Güney Amerika‘ya satış yapılmaktadır.

1870 G \& W dünyanın en büyük içki üreticisidir. Tüm alkol türleri üretilmekte, konserve ve süt tesisleri devam etmektedir. 1886 Kraliçe Victoria madalya ile ödüllendirir (G\&W Heritage Plan Report,1994:5). 1885 alkolü iki yıl bekletme Yasası çıkar (G\&W Heritage Plan Report, 1994:4). Depolama acil mesele haline gelir. Roberts ardı ardına malt ve fiçılama kompleks, saf alkol kompleksi, tank, varil, raf evleri inşa eder. Distilery birçok sokağ 1 olan büyük bir komplekse dönüşmüştür. Binaların karakteri taş Distilery'den farklıdır, Viktorian Tarzı kırmızı tuğladandır. Robert'in ölümünden sonra oğlu Roberts Jr işi devralır. Asıl büyüme onun döneminde yaşanır. Alana inşa edilen son Viktorya Bina (1895) Yangın Pompa Binası olur. Binaların tarzı; fonksiyonel, büyük, pahalı hoş 
tezatları ve uyumu sergiler. İnce detaylı, yeni kırmızı tuğla binalar, yeni üretim süreçlerini, gelişen teknolojiyi ve işlemleri yansıtır. Zamanla, binalar hem fiziksel, hem de fonksiyonel olarak bazı değişikliklere uğrar ancak, mimari bütünlük ve inceliği korunmuştur. Kent İşletmenin etrafında gelişir. Kentin önemli binaları idari ve ticari yapıları, bu bölgede yer seçer. Mimari tarz olarak Site, Kentin diğer binalarını etkilemişi Viktorian Mimari kentte hakim olmuştur.

İki olay şirketin sonunu getirir. Dünya Savaşları (I. 1914-1918 ve II. 1939-1945) ve İçki Yasağı (1916- 1920). I. Dünya Savaşında üretim, patlayıcı bileşenleri aseton ve keton üretimine dönüștürülür. İngiliz Hükümetine üretim yapılır. İşletme ekonomik olarak sarsılmasa da, pazar kaybedilmektedir. Asıl değişim İçki Yasağı ile gelir, üretimi durma noktasına gelir. Şirket bir daha eski konumuna dönemez, tekrar, tekrar satılır. 1930 antifriz üretimi başlar. Tek kullanımlık antifiriz üretilir. Dünyanın en büyük antifiriz üreticisidir. 1934'de Toronto da bardakta içki izne bağlanır, bu İşletme için yeni bir darbedir. Yavaş yavaş, içki üretim kesilir. Rom ve endüstriyel alkoller ana ürün haline alır. 1990'de 158 yll sürekli üretim yapan Distilery'de üretime sona verilir, Alan tamamen kapatılır (Lakey,1990:A2). Alan artık, kent halkı tarafindan tercih edilen bir bölge değildir. Kentin merkezi yer değiştirmiş, önemli yapılar batıya kaymıştır. Mimari tarz farklı anlayışların etkisi altına girmiştir. Distilery, yeni bina eklenmez, olanlar işlev değişimine göre tadil edilir. Tamamen kapanıca, yıkıntı haline gelir. Alan tarihi sit bölgesi olarak tescil edilir.

90'larda Hollywood, Distilery keşfeder. Distilery, Kanada birinci, dünyada Hollywood'dan sonra ikinci büyük film setidir (Goddard, 2002:10). Richard Gere, Meg Ryan, Russell Crowe gibi ikonların rol aldığı, Oskarlı büyük bütçeli yapımlara fon olur. Three Men and a Baby, The Hurricane, X-Men, Dracula, Don't Say a Word, Chicago, Cinderella Man, Alanda çevrilen baş yapıtlardan bazılarıdır (Distillery District, 2006). Film sektörünün mekânı kullanması binaların yıpranmasını bir sure engellemiştir. Kentin sinema sektörü ile birlikte anılmasına neden olmuş, dünyanın önde gelen festivalinin Toronto film festivalli, nüvesi atılmıştır. Sinema sektörü birçok sanatçının kentte gelmesini sağlamıştır. Kentin kültür ve sanat açısından gelişimine ivme kazandırmış, bu kentsel mekân kullanımına yansımıştır (Goddard, 2002:10). Kentte Hollywood yıldızlarının akın etmesi, uzun dönem kentte kalmaları, onların yaşamlarına uygun standartlarda yerleşim yerlerinin ve yaşam alanlarının oluşmasına, lüks-kule evlerin, otellerin yapılmasına neden olmuştur.

\subsection{Distilery District Dönüşüm Uygulaması}

2000'li yıllarda Distilery tekrar unutulur. Victoria Binaları harap olmaktadır. Muhteşem, sanayi sitesinin geleceği hakkında endişeler vardır. Victoria kumaş üretimi yapılması gibi alanın kullanımı ve canlandırılmasına yönelik çeşitli öneriler geliştirilir. Film platosu olarak kullanım, Distilery gündeme getirmiş, pek çok kişi izledikleri filmin mekânlarını görmek arzusu ile Alanı ziyaret etmeye başlar. Yeni sahipleri (Dundee Realty Coorporation) Alanın, sanat ve kültür merkezi olarak değerlendirilmesi kararını alır. Amaç; kentin gurur duyacağı, insanlarda tutku oluşturacak bir yer sağlamak; dinamik, romantik, rahatlatıcı atmosferleri birleştirmektir. Projenin öngörüsü; yaratıcı beyinleri (sanatçı, esnaf, girişimci, işadamı) bir araya, birbirlerine ilham verebilir hale getirmektir. (McClelland, 2005: 20-25).

2003 açılan Distilery için yeni bir dönem başlar. 13 dönümlük bir yerleşimde, 47 bina restore edilir, 10 sokak ve bir meydan yaya alanı olarak düzenlenir. Distilery, kentinin en seçkin mahallelerinden biri, Ontario'nun en canlı turistik alanına dönüşmüştür. Tarihi merkez, bugün Kanada'nın önde gelen sanat, kültür, eğlence hedefi olarak kabul edilir. Hareketli kent çekirdeğinin bir parçası olsa da, farklı karakteri ile kent merkezinin karmaşasından korunmuş; zamanda geriye gidilen, geçmiş yaşam deneyimlerinin yansıtıldığı bir mahalleye olmuştur. Alanda, konut kullanımına yer verilmemiştir. Tiyatrolar, sanat galerileri, dans salonları, modern mobilya ve tasarım atölyeleri, moda tasarımcıları, butikler, mücevher - takı mağazaları, dünya standartlarında hamur işleri, kafeler, ödüllü restoranlar, mikro bira fabrikası vd. Alanda yer almaktadır. Festivallere ve pek çok sanatsal, kültürel etkinliğe ev sahipliği yapmaktadır.

Bütünleşik bir anlayışla ele alınmıştır. Alanın mimari tarzı; eski ve yeni birleşimi, 19. yy malzemeleri, kalas, taş, tuğla ile günümüz malzemeleri, yeşil teknolojilerin karışımıdır. Victorian Mimarisi ve bugünün tasarım anlayışı uyumlaştırılmıştır. Yeni gelişimin, Distilery yakın çevresinin şekillenmesine etkisi hızlı ve büyük olmuştur. Alanın çekim gücünün artması, - günümüz dünya düzeni - maksimum kazanç sağlama dürtüsü ile çevresinde toprak değerinin artmasına, alan içinde ve bölgede rant artışına neden olmuştur. Konut yatırımcıları için eşsiz bir firsat doğurmuştur. Alanın çevredeki çok az kalan araziler üzerinde büyük talep oluşturulmuş, çok uluslu büyük firmalar konut üretimine başlanmıştır. Tarihi Distilery Bölgesinin çevresi yeni inşaatlarla dolmuştur. Distilery yakınlık avantaj olarak kullanmaktadır. Ona, bitişik yeni konut alanları, onun parçası olarak lanse edilmektedir. Kondos sakinlerini ticari ve rekreatif alan gereksinimini Distilery sağlayacaktır.

\section{4 Örneğin Değerlendirilmesi}

G\&W, endüstri mirasının gelecek kuşaklara aktarılması için öneri geliştirmede yararlı olabilecek en güzel örneklerden biridir. G\&W Kentin ekonomik, kültürel ve sosyal gelişimini etkilemiş, kenttin gelişiminde, makro formunun şekillenmesinde belirleyici olmuştur. Değirmen olarak kurulduğu zaman, Toronto tarım kentidir, sanayi sitesine dönüşmüş, dönemin en büyük endüstri yerleşimi olmuştur. $\mathrm{Bu}$ dönemde Toronto, endüstri kenti olarak anılmıştır. Film platosuna dönüşmesi, Toronto’nun bu alanda dünyasının önde gelen kenti olmasını 
sağlamıştır. Bu gün Kent, önemli bir turizm merkezidir. Kentin böyle tanınmasında da Distilery'in büyük payı vardır. Her işlevde dünyanın en iyisi olmayı başarabilmiştir. Etkileyici, pahalı bir yapı tarzı geliştirilmiş, Viktorian Tarzının en önemli örnekleri verilmiş, Dönemin mimari ekolünün önde gelen temsilcisi olmuş, kent ve ülke mimari tarzını etkilemiştir. Koruma altındaki Alan bugün tamamen kültür- sanat ve turizme ayrılmıştır. Çevresinde topraklar üzerinde yarattığı artı değerle, küresel sermayeyi bölgeye çekmiş, kentin şekillenmesinde yeniden rol oynamaya başlamıştır. Çevresi spekülatif baskı altında olsa da, Alanı korumak başarılmıştır. Pek çok örnekte olduğu gibi, işlevini yitirdikten sonra mimari yapı varlığından vazgeçilerek, toprak üzerinden kaba bir rant peşine düşülmemiş, amaç bu ise yapı stoku korunarak da, tarihi bir yerleşmenin kazanç temin edilebilen bir yere dönüşebileceği örneklenmiştir.

\section{$4 \quad$ Türkiye'de Endüstri Mirasının Durum}

Osmanlı'da endüstri girişimi en yoğun, başkent İstanbul ve çevresinde gelişmiştir. 1830-40'larda, son teknolojiyi ithal edilerek, ordu ve sarayın gereksinimlerini karşılamak üzere fabrikalar kurulmuştur (Clark, 1992). 1850’de kent endüstri merkezidir. Fabrikalarının dörtte üçü 1880’lerde kurulmuştur (Pamuk, 1997). 20. yy başı İstanbul'da 256 adet fabrika vardır. Günümüze (2005) sadece 43'ü ulaşabilmiştir. (Ökçün, 1997). Ülkemizin teknoloji tarihinin önemli bileşeni ve kentlerin fiziksel gelişiminde etkin rol alan işletmelerin önemli kısmı, 1980 kadar tam kapasiteyle işletilmiş, bu tarihten sonra işlevini yitirmiş, kapatılmış, çoğu çeşitli nedenlerle yıkılmıştır (Özdemir -b, 2009:73) Pek çok sanayi tesisi 1990 yıllarda, hammadde üretiminin desteklenmemesi, üretimin az çeşitle ve yetersiz düzeyde yapılması, yerli mal kullanımını teşvik eden girişimlerde bulunulmaması vb nedenler, terk edilmiş, ekonomik, fiziksel, sosyal çöküntü bölgesi konumuna gelmiştir. Az sayıda kalan yapı ve tesislerimiz mimari, tarihi ve teknolojik miras olarak koruma altına alınmayı beklemektedir. Çoğunun belgelenmesi dahi yapılmamıştır (Özdemir -b, 2009:77).

Günümüzde, Cumhuriyet Dönemi kamu endüstri yapıları da işlevini ve kullanım yoğunluğunu kaybetmiştir. Özelleştirmelerle tamamen veya parçalanarak satılan tesislerin, satın alınma nedeni, üzerinde yer aldıkları arsalar olmuştur. Zamanla kentlerin içinde kalan bu büyük alanların, arsa değerlerinin artması, tesislerin korunmasını imkansız kılmaktadır. Endüstri yapılarının yıkılmadan, yeni kullanımlar için dönüştürülmesi, yeni yapı inşa etmeye oranla daha ekonomik olsa da, korunmaya değer tesisler, yatırımcılar için çekici özellik taşıyan, kentin rant değeri yüksek alanlarında yer almaktadır (Akitera, 2005). Yeniden işlevlendirmede de rant ön plana çıkmaktadır. Kentsel dönüşüm, başlangıçta büyük maliyet gerektirebilir. (etüdler projler restarasyon çalışmaları) Ancak, Distilery örneğinde olduğu gibi başarılı dönüşümle, bu maliyet geri kazanılmakta, alan içinde ve çevresinde iş olanakları artmakta, ekonomik ve sosyal katkı sağlanmakta.

\section{5 Öneriler}

Öncelikle, Endüstriyel dönemler ve gelişmeler (Sanayi Devriminde olduğu gibi) sadece teknolojik bir devinim değil, aynı zamanda insanların düşünce ve yaşam biçimini değiştiren, sosyal, kültürel ve ekonomik boyutlarıyla çevresel etki yaratan dönüşümlerdir. Bu nedenle endüstri mirasını koruma çalışmalarında, teknik miras sosyal çevreleri ile birlikte ele alınmaktadır. Endüstri sitleri kent ile ilişkilendirilmelidir.

Endüstri mirası sitlerinin yeniden işlevlendirilmesi için, bölge ihtiyacı araştırılmalı. Uygun işlev seçimi, geri dönülebilir değişiklikler, teknik donatının yerinde sunumu, endüstri yapıların mekân ve strüktür niteliklerinin değerlendirilmesi başarılı uygulamalara olanak sağlar.

Tarihi fabrikalar bilinçsiz onarım veya gelişigüzel yeniden işlevlendirme ile de tahrip olmaktadır. Yeniden kullanım projelerinde, yapının sadece cepheleri dikkate alınmakta, içi boş kabul dilmektedir. Oysa asıl amaç bu tesislerin kendilerine özgü niteliklerini korumaktır. Uygulamalar konunun uzmanları tarafından yapılmalı, bilimsel bir yol izlenmelidir. Bu gereklilik üzerine, 1950’lerde endüstri mirasını inceleyen "endüstri arkeolojisi”, mimarlık tarihi, teknoloji tarihi, arkeoloji, koruma boyutlarını birlikte ele alan bir disiplin olarak ortaya çıkmıştır.

Başarılı bir uygulama ve kullanım için, güç birliği şarttır. Bu amaçla halkın, üniversitelerin, yetkili yerel ve merkezi kurumların, ilgili kişi ve kuruluşların ortak çalışması sağlanmalıdır. Diğer yandan kullanıcıların koruma, planlama ve uygulama sürecine katılması, endüstri mirasının geleceğini garanti altına alabilir. Ülke teknoloji tarihinin önemli bir bileşeni olan ve kentlerimizin fiziksel gelişiminde etkin rol alan endüstri mirası gelecek kuşaklara aktarılmalı, endüstri tesisleri için korumaya dayalı dönüşümler ivedilikle yapılmalıdır.

\section{Kaynakça}

- Armstrong, W., 1869. "Gooderham and Worts Windmill," http://www.distillery heritage.com; 2.8. 2012.

- Boulton, W.S., 1858. Plan of Toronto, John Ellis, Toronto.

- Careless, J.M.S., 1984. Toronto to 1918: An Illustrated History, James Lorimer \& Company, Toronto

- Clark, E., 1992. Osmanlı Sanayi Devrimi, Osmanlılar ve Batı Teknolojisi, Yeni Araştırmalar, Yeni Görüşler, İstanbul Üniversitesi, Edebiyat Fakültesi Yayını, İstanbul, 37-52. 
- Distillery District 2006.“Hollywood North,”www.thedistillerydistrict.com; 14.6.2008.

- Distillery Magazine 2004. The Distillery Historic District. Premiere Issue. Markham: Media Diversified Inc.

- Distillery Heritage Website. http:// www.distilleryheritage.com

- Dündar, Ş.G. 2010. Kentsel Gerileme'den Kentsel Rönesans’a Dönüşüm:Newcastle Upon Tyne, İngiltere, Kentsel Dönüşümde Politika, Mevzuat, Uygulama, Nobel Yayınevi, Ankara

- Fisher, K. 1995. Planning for the Built Heritage: The G \& W Redevelopment, Toronto, Ontario. Master Thesis, University of Waterloo.

- Goad, C.E. 1890. “Atlas of the City of Toronto and Vicinity”,http://www.distilleryheritage.com.

- Goddard, P. 2002. "From distillery to film set to art market," Toronto Star, 10 Agustos, p.H10.

- Gooderham \& Worts Heritage Plan Report No. 4, March 1994

- Göksu, F. 2004. “Kent Planlamada Yenilikçi Uygulama Araçları”, http://www.kentselyenileme.org.

- Karadağ, D. 2008. “Kentsel Dönüşümün Tarihi” (www.v3.arkiterara.com-28.02.2012)

• Köktürk, E., 2007. “Türkiye’de Kentsel Dönüşüm ve Almanya Deneyimi”, 11. Türkiye Harita Bilimsel ve Teknik Kurultayı, Ankara

- Lakey, J. 1990. "158-year-old distillery is running out of spirits,” Toronto Star, 25 Agustos, p. A2.

- Lewington, J. 2002. "Historic past, an important future: the new owners of G \&W" Globe and Mail, Ocak

- McClelland, M., 2005. "Learning from the Distillery District," The Canadian Architect, v. 50 (2),pp. 20-25.

- $\quad$ Niksalıoğlu, A. 2007. Kültür Eksenli Kentsel Dönüşüm: İTÜ YL Tezi (www.tez2.yok.gov.tr-11.06.2012)

- Otto, S.A. 1994. "Inventory of Archival Sources,” G\& W Heritage Plan Report No. 4, Toronto.

- Ökçün,G., 1997. Osmanlı Sanayii, 1913, 1915 Yılları Sanayi İstatistiki, Ankara.

- $\quad$ http://www.arkitera.com/haberler/31.10.2005http://www.ERIH.de,2005.

- Ö̈zdemir- a, D., 2010.Kentsel Dönüşüm Olgusunun Süreç İçinde Değişen Anlamları, Kentsel Dönüşümde Politika, Mevzuat, Uygulama, Nobel Yayınevi, Ankara

- Özdemir -b, N., 2009, “Kültür Ekonomisi ve Endüstrileri ile Kültürel Miras Yönetimi İlişkisi”, Millî Folklor, Y11 21, Say1 84, ss:73-86.

- $\quad$ Özden, P.P. 2008. Kentsel Yenileme, İmge Kitapevi Yayınlar1, Ankara

- Pamuk, Ş., 1997. 100 Soruda Osmanl1-Türkiye İktisadi Tarihi 1500-1914, İstanbul.

- $\quad$ Scadding, H, 1966. Toronto of Old, Oxford University Press. Toronto.

- Shuttleworth, E.B. 1924. "The Windmill and its Times:Toronto”, http://www.distilleryheritage.com.

- S Şen B. 2006. "Ekonomik Gelişmenin Kültürel Stratejileri: İstanbul Kent Merkezleri ve Tarihi Kentsel Alanların Yeniden Yapılandırılması”, Planlama Dergisi, Ankara, S: 2006/2

- Şişman A., Kibaroğlu, D. 2009. "Dünyada ve Türkiye'de Kentsel Dönüşüm Uygulamaları", 12. Türkiye Harita Bilimsel ve Teknik Kurultayı, Ankara

- Wikipedia, 2013. “Toronto" http://tr.wikipedia.org.

- Yavuzçehre, P.-Torlak, S.E. 2006. "Kentsel Yaşam Kalitesi ve Belediyeler:Denizli Karşıyaka Mahallesi Örneği”, SDÜ SBE Dergisi, S: 4

- Yildırım, A.E. 2006. "Güncel Bir Kent Sorunu: Kentsel Dönüşüm”, Planlama Dergisi, S: 2006/2 Ankara.

- Yiğitcan, T. 2001. “Kentsel Yenileme Olgusu ve Gelişim Süreci”, Planlama Dergisi, S:2001/4 Ankara. 


\title{
Ülke Kalkınmasında Marmaris Turizm Sektörünün Önemi Ve Rus Turistlerin Marmaris'i Tercih Etme Nedenleri
}

\section{The Importance of Marmaris Tourism Industry on Development and Factors That Influence Russian Tourists in Choosing Marmaris}

\author{
Asst. Prof. Dr. Aziz Bostan (Kyrgyzstan-Turkey Manas University, Kyrgyzstan) \\ Ph.D. Candidate Zehra Türk (Sıtkı Koçman University, Turkey) \\ Ph.D. Candidate Hande Akyurt Kurnaz (Sıtkı Koçman University, Turkey)
}

\begin{abstract}
Turkey thanks to its natural and cultural tourism resources is an international tourism destination characterized by intense mobility. Due to the length and the seasonal availability of sea coast, especially from the Russian tourist market activity experienced in Marmaris. The purpose of this study, to determine the contribution of the tourism sector in the country's economy and Russian tourist profile were examined and investigated the reasons for choosing as a destination of Marmaris. Survey data collection techniques were used in the study of national and international research was supported by literature. In this context, the problem of the study, subject, scope and importance of the material and the methods used are explained and explained and the data obtained were analyzed. The results of this analysis are evaluated.
\end{abstract}

\section{Giriş}

Turizm; bireylerin sürekli ikamet ettikleri ve çalıştıkları yerler dışına seyahat ederek o bölgeye yerleşmeme ve kazanç sağlama amacına yönelik olmamak kaydıyla turizm işletmeleri tarafindan üretilen mal ve hizmetlerden yararlanmaları ve konaklamaları sonucunda ortaya çıkan olayların bütünüdür (Barutçugil, 1998). 2012 yılının verilerine göre; uluslararası turist trafiği \% 4 dolayında büyüyerek 1 milyar 35 milyona yükselmiştir. 2013 yılında da \% 3-4 olarak turizm sektörünün gelişmesi beklenmektedir. Bu bağlamda; turizm sektörü dünya ekonomisinde sürekli gelişen ve büyüyen bir sektör haline geldiğini göstermektedir. Turizm göreceli olarak önemli bir eylem alanı ve turizm ekonomik, sosyal ve fiziksel etkilerinin ortaya çıktığı alandır. Turizmin temel ekonomik faaliyetler arasında yer aldığı ülkeler, bölgeler, şehirler ve turizm destinasyonudur (T.C. Kültür ve Turizm Bakanlığı, 2013a). Bu bağlamda, Türkiye sahip olduğu cazibe merkezleri sayesinde birçok turizm destinasyonuna sahiptir. Bu destinasyonlarından biri de Marmaris'tir. Marmaris'e turist en çok yaz aylarında sonra da sonbahar aylarında gelmektedir. Bunlar en çok hava yolu ve kara yolu ile gelmektedir. Turistlerin büyük çoğunluğu İngiltere, Almanya, Fransa ve Bağımsız Devletler Topluluğu (çoğunlukla Rusya) vatandaşlarından oluşmaktadır (Uzun ve Avcı, 2007).

Turizm, günümüzde döviz girdisini artırıcı ve istihdam sağlayıcı özellikleriyle ulusal ekonomiye katkıda bulunan, uluslararası kültürel ve toplumsal iletişimi sağlayıcı ve bütünleştirici etkisi ile dünya barışının korunmasında büyük payı olan bir sektördür. Türk ekonomisinin de vazgeçilmez temel taşlarından birisi olan turizm, bugünkü dış ticaret açığına, enflasyona ve işsizliğe çare arayan hükümetlerin önemle üzerinde durduğu bir konudur. (Çımat ve Bahar, 2003).

$\mathrm{Bu}$ çalışmada, Marmaris destinasyonunun önemli bir turizm pazarı olan Rus Turizm Pazar Profilinin nitelikleri araştırılmıştır. Özellikle Rus turistlerin Marmaris'i tercih etme nedenlerinin belirlendiği çalışmada, anket veri toplama tekniği kullanılarak araştırma yöntemi tamamlanmıştır. Basit tesadüfi örnekleme seçilip, 3,4 ve 5 yıldızlı konaklama işletmelerinde konaklayan Rus turistler seçilmiştir. Yapılan araştırmada Marmaris'in Rus turizm pazarının gerçekleştirilmesinde çeşitli öneriler sunularak, diğer çalışmalara da örnek olacağ tahmin edilmektedir.

\section{Türkiye Turizm Verileri}

Turizm, uygun tanıtma faaliyetleri ve planlamalar sayesinde ülkelerin turizm gelirlerine ve ülke ekonomilerine olumlu yönde katkı sağlamaktadır. Turizm sektörünü büyütmek ve devamlılığını sağlamak isteyen ülkeler, çeşitli turizm politikaları sayesinde bu katkının devamlılı̆̆ını sağlayacaktır.

Tablo 1 ve 2 incelendiğinde, Türkiye'nin Dünya Turizm gelirleri ve gelen turist sayısı içindeki payının da yükseldiği görülmektedir.

1980 yılında Türkiye'nin dünya turizm gelirleri içindeki payı \% $0.31 \mathrm{iken,} 2011$ y1lında \% 2.23'e yükselmiştir. Yabancı ziyaretçi açısından da dalgalı bir şekilde olmasına rağmen bir artış söz konusudur. Elde edilen sonuçların inişli çıkışlı olmasının sebebi, turizmin diğer sektörlerden ve dünyadaki gelişen olumsuzluklardan 
kolayca etkilenebilmesidir. Türkiye sahip olduğu doğal ve kültürel özelliklerinden dolayı son yıllarda kitlesel turizm hareketlerindeki yaşanan beklenti ve destinasyonların farklılaşması sonucu; farklı turizm ürünleri ortaya çıkmıştır.

\begin{tabular}{|l|l|l|}
\hline Y1llar & Yabanc1 Turist Say1s1 & Turizm Gelirleri (milyar \$) \\
\hline 2005 & 21.124 .886 & 18.2 \\
\hline 2006 & 19.819 .833 & 16.9 \\
\hline 2007 & 23.340 .911 & 18.5 \\
\hline 2008 & 26.336 .677 & 22.0 \\
\hline 2009 & 27.077 .114 & 21.2 \\
\hline 2010 & 28.632 .204 & 20.8 \\
\hline 2011 & 31.456 .076 & 23.0 \\
\hline
\end{tabular}

Tablo 1: Türkiye'de Turizm Gelirleri Ve Turist Sayısındaki Değişmeler Kaynak: T.C. Kültür ve Turizm Bakanlı̆̆l, $2013 b$.

\begin{tabular}{|l|l|l|l|l|c|c|}
\hline & \multicolumn{2}{|l}{ Turizm geliri } & \multicolumn{2}{l|}{ Turizm gideri } \\
\hline Yıllar & Turizm Geliri & $\begin{array}{l}\text { Ziyaretçi } \\
\text { Sayısı }\end{array}$ & $\begin{array}{l}\text { Ortalama } \\
\text { Harcama }\end{array}$ & $\begin{array}{l}\text { Turizm } \\
\text { Gideri }\end{array}$ & $\begin{array}{l}\text { Vatandaş } \\
\text { Sayısı }\end{array}$ & $\begin{array}{l}\text { Ortalama } \\
\text { Harcama }\end{array}$ \\
\hline 2005 & 20322111 & 24124501 & 842 & 3394602 & 4124829 & 823 \\
\hline 2006 & 18593950 & 23148669 & 803 & 3270947 & 4063180 & 805 \\
\hline 2007 & 20942501 & 27214988 & 770 & 4043283 & 4956069 & 816 \\
\hline 2008 & 25415067 & 30979979 & 820 & 4266197 & 4892717 & 872 \\
\hline 2009 & 25064481 & 32006149 & 783 & 5090440 & 5561355 & 915 \\
\hline 2010 & 24930996 & 33027943 & 755 & 5874520 & 6557233 & 896 \\
\hline 2011 & 28115694 & 36151328 & 778 & 5531486 & 6281972 & 881 \\
\hline 2012 & 29351446 & 36776645 & 798 & 4593390 & 5802950 & 792 \\
\hline
\end{tabular}

Tablo 2: Türkiye'nin Turizm Geliri ve Gideri Kaynak: T.C. Kültür ve Turizm Bakanlı̆̆l, 2013 b.

\begin{tabular}{|l|l|l|}
\hline Y1llar & Yabanc1 Ziyaretçi & Turizm Gelirleri \\
\hline 1980 & 0,4 & 0,31 \\
\hline 1990 & 1,1 & 1,22 \\
\hline 2000 & 1,4 & 1,60 \\
\hline 2005 & 2.6 & 2.68 \\
\hline 2006 & 2.3 & 2.30 \\
\hline 2007 & 2.5 & 2.16 \\
\hline 2008 & 2.8 & 2.34 \\
\hline 2009 & 3.0 & 2.49 \\
\hline 2010 & 3.0 & 2.26 \\
\hline 2011 & 3.2 & 2.23 \\
\hline
\end{tabular}

Tablo 3: Türkiye'nin Turizm Gelirleri Ve Yabancı Turist Sayısının Dünya İçindeki Payı (\%) Kaynak: T.C. Kültür ve Turizm Bakanlı̆̆l, 2013 b.

\section{Marmaris'in Turizm Sektöründeki Durumu ve Turizm Ekonomisine Katkısı}

\subsection{Marmaris'in Coğrafi Konumu}

Muğla ilinin güneybatısında bulunan Marmaris, batıdan Reşadiye Yarımadası ve Kerme Körfezi, kuzeyden Ula, doğudan Balan Dağı, Karadağ ve Günlük Tepeleri ile güneyden Akdeniz’le çevrilmiştir. Akdeniz iklimi nedeniyle çok nemli bir havaya sahiptir. Akdeniz ikliminin hakim olduğu ilçede yazlar oldukça sıcak ve kurak, kış ayları ise bol yağışlı geçmektedir. Marmaris Milli Parkı, Marmaris Merkez, İçmeler, Armutalan, Nimara Yarımadası, Yalancıboğaz, Turunç, Kumlubük, Günnücek ve Aksaz geniş bir alanı kapsar. Ayrıca iki özel çevre koruma bölgesi vardır; Gökova Özel Çevre Koruma Bölgesi ve Datça-Bozburun Yarımadası Özel Çevre Koruma Bölgesi'dir. Marmaris Milli Parkı ve özel çevre koruma bölgeleri bitki varlığı açısından Türkiye'nin en zengin bölgelerindendir (MarmarisMarmaris, 2013).

Marmaris Coğrafi konumu nedeniyle Akdeniz ve Ege Denizinin kavuştuğu yerde, önemli bir liman ve sahil kentidir. Bu nedenle ilk çağdan günümüze kadar Ege ve Akdeniz arasında önemli bir geçiş noktası olmuştur. Gerek Marmaris'in gerekse çevresinin kıyı yapısının çok girintili çıkıntılı olması, iyi korunmuş koyları ve limanları bulunması bu bölgenin Asya, Avrupa ve Afrika arasında önemli bir bağlantı noktası olmasını sağlamıştır (MarmarisMarmaris, 2013). 


\subsection{Marmaris'in Turizm Varlıkları}

Marmaris denizi, kumu, ormanı, plajları, meşhur çam balı, Physkos, Loryma, Amos, Hydas gibi antik yerleşimleriyle dikkat çekmektedir. .Marmaris'in turizm varlıkları incelendiğinde hem doğal hem de kültürel özelliklerin bir arada bulunduğunu görmek mümkündür (T.C. Marmaris Belediyesi, 2013):

Marmaris Kalesi: Marmaris'in simgelerinden olan Marmaris Kalesi, yat limanının hemen arkasında yer almaktadır. 1991 yılında restore edilmiş ve Marmaris Müzesi olarak ziyarete açılmıştır. Müzede Hellenistik, Roma ve Bizans dönemlerine ait arkeolojik eserler sergilenmektedir.

Hafsa Sultan Kervansarayı: Osmanlı Dönemi'ne ait yapılardan olan Hafsa Sultan Kervansarayı, 1545 yılında inşa edilmiştir. Kale yolu üzerinde bulunan kervansaray, günümüzde özel mülkiyette olup, turistik ve hediyelik eşya satan dükkânlar olarak kullanılmaktadır.

Halıcı Ahmet Urkay Müzesi: Marmaris'e 10 km uzaklıkta, Muğla yolu üzerinde yer alan Halıcı Ahmet Urkay Müzesi, özel bir müze olup 3 bin m2'lik bir alan üzerine kurulu olan müze etnografya ve arkeoloji olmak üzere iki bölümden oluşmaktadır.

Plajlar: Marmaris'te hem merkezde hem de çevre beldelerde plajlar bulunmaktadır. İçmeler Plajı, Turunç Halk Plajı, Cennet Adası Plajı, Sedir Adası Plajı, Uzunyalı Plajı, Boncuk Koyu Plajı sayılmaktadır.

Koylar: Bördübet, Kumlubük, Abdi Reis Koyu, Ayın Koyu, Kızkumu, Amos Koyu, Marmaris Boncuk Koyu, Turunç, Hisarönü, Selimiye Marmaris’in koylarına örnek olarak verilmektedir.

Antik Kentler: Marmaris'in antik kentleri arasında Physkos, Loryma (Bozukkale), Amos, Cedrae, Hydas, Erine, Castabus (Pazarlık), Saranda (Söğüt), Bybassios, Euthenna (Altınsivrisi) yer almaktadır.

\subsection{Marmaris'in Turizme Katkısı}

Dünyada turizm endüstrisine hala kitle turizmi anlayışı egemen olmakla ve toplam turizm gelirleri içinde büyük paya sahip olmakla birlikte; kültür, macera, otantiklik ve bozulmamış bir çevre arayışı içindeki yüksselen yeni orta sınıfların taleplerine yönelik alternatif turizm anlayışı yaygınlaşmakta ve bu tür turizmden elde edilen gelirler hızla artmaktadır (Purkis, 2009).

\begin{tabular}{|l|l|l|}
\hline Y1llar & Turizm Geliri $(1000 \$)$ & Ziyaretçi Say1sı \\
\hline 2006 & 11.050 .877 & 1.376 .199 \\
\hline 2007 & 11.492 .072 & 1.492 .477 \\
\hline 2008 & 13.589 .597 & 1.657 .268 \\
\hline 2009 & 12.896 .863 & 1.647 .109 \\
\hline 2010 & 13.973 .389 & 1.850 .780 \\
\hline 2011 & 13.955 .725 & 1.793 .795 \\
\hline 2012 & 16.574 .787 & 2.077 .041 \\
\hline
\end{tabular}

Tablo 4: Marmaris Turizm Geliri Kaynak: Marmaris Ticaret Odasl, 2013

\begin{tabular}{|l|l|l|l|l|l|l|}
\hline \multicolumn{4}{|l}{ Turizm İşletme Belgeli Tesislerin Türleri } & \multicolumn{3}{l|}{ Yatırım Belgeli Tesis Türleri } \\
\hline Türü & Tesis S. & Oda S. & Yatak S. & Tesis S. & Oda S. & Yatak S. \\
\hline 5 Yıldızlı T.K. & 2 & 695 & 1.444 & 1 & 367 & 836 \\
\hline 4 Yıldızlı T.K. & 1 & 120 & 240 & 1 & 80 & 160 \\
\hline 5 Yıldız & 13 & 4.212 & 8.995 & 6 & 1355 & 2838 \\
\hline 4 Yıldı & 24 & 3.788 & 7.698 & 5 & 443 & 886 \\
\hline 3 Yıldız & 33 & 2.721 & 5.541 & 5 & 275 & 552 \\
\hline 2 Yıldız & 24 & 1.225 & 2.492 & 3 & 159 & 314 \\
\hline 1 Yıldız & 2 & 81 & 166 & 2 & 48 & 96 \\
\hline Apart & 28 & 1.579 & 3.378 & 3 & 123 & 274 \\
\hline Pansiyon & 2 & 29 & 58 & 1 & 28 & 56 \\
\hline Butik Otel & 1 & 26 & 52 & 1 & 43 & 86 \\
\hline Diğer & 2 & - & - & 4 & 0 & 0 \\
\hline Özel Tesis & 3 & 15 & 30 & 32 & 2921 & 6098 \\
\hline Toplam & 135 & 14.491 & 30.094 & 1 & 367 & 836 \\
\hline
\end{tabular}

Tablo 5: Marmaris'te Turizm Işsletme Ve Yatırım Belgeli Konaklama Tesisleri Ve Yatak Kapasiteleri Kaynak: Muğla İl Kültür ve Turizm Müdürlüğ̈̈, $2013 a$.

Tablo 4'de görüldüğü üzere; ziyaretçi sayısında farklı oranlarda artış görülmektedir. Marmaris sahip olduğu kültürel ve doğal özelliklerden dolayı, uluslararası turizm pazarında belirli bir imaj sahibi olan bir 
destinasyondur. Bu değerlerin daha kaliteli bir şekilde pazarlanarak Marmaris'in bütün turizm çekiciliklerinin belli bir pazar payı alması sağlanmalıdır.

Tablo 5'e göre, Marmaris gelen turist potansiyelini karşılayacak konaklama imkanına sahiptir, Artan konaklama işletmeleri hem turistlerin ihtiyacını karşılamakta hem de sezonluk olarak devam etmesinden dolayı sezon içerisinde istihdamın arttırılmasına yardımcı olmaktadır. Marmaris'te yer alan turizm hareketliliğinin on iki aya yayılmasını sağlayarak işgücü istihdamının sürekliliği sağlanmalıdır.

\begin{tabular}{|l|l|l|}
\hline İlçesi & Marina Sayıs1 & Kapasitesi \\
\hline Bodrum & 7 & 2.441 \\
\hline Marmaris & 6 & 1.567 \\
\hline Fethiye & 7 & 1.378 \\
\hline Köyceğiz & 1 & 63 \\
\hline Daţaa & 1 & 302 \\
\hline Milas & 3 & 165 \\
\hline Toplam & 25 & 5.916 \\
\hline
\end{tabular}

Tablo 6: Bakanlık Belgeli Marinalar (Aralık 2012) Kaynak: Muğla Ill Kültür ve Turizm Müdürlügü̈, $2013 b$.

\begin{tabular}{|l|l|l|}
\hline İlçesi & Marina Sayıs1 & Kapasitesi \\
\hline Marmaris & 2 & 320 \\
\hline Fethiye & 4 & 330 \\
\hline Toplam & 6 & 650 \\
\hline
\end{tabular}

Tablo 7: Belediye Belgeli Marinalar (Aralık 2012) Kaynak: Muğla İl Kültür ve Turizm Müdürlügü, 2013b.

\begin{tabular}{|l|l|l|l|l|}
\hline İlçesi & Plaj & Marina & Yat & Toplam \\
\hline Bodrum & 43 & 3 & 4 & 50 \\
\hline Fethiye & 5 & 2 & 2 & 9 \\
\hline Marmaris & 18 & 2 & & 20 \\
\hline Datça & 6 & - & & 6 \\
\hline Ortaca-Sarıgerme & 3 & - & & 3 \\
\hline Ula-Akyaka & 1 & - & & 1 \\
\hline Toplam & 76 & 7 & 6 & 89 \\
\hline
\end{tabular}

Tablo 8: Mavi Bayrak Ödüllü Plaj Ve Marinalar (Aralık 2012) Kaynak: Muğla İl Kültür ve Turizm Müdürlüğü, $2013 b$.

Tablo 6, 7 ve 8'e göre deniz ve su sporları ile ilgili Marmaris büyük öneme sahiptir. Son yıllarda popüler hale gelen yat ve marina turizmi açısından Marmaris turistik cazibe merkezi haline gelmektedir. Deniz ve yat-marina turizminin sayısal verileri kapsamında Muğla ilçelerinin karşılaştırması yapıldığında; güzel plajları ve kumsallara sahip olan Marmaris ikinci sırada yer almaktadır.

\section{Marmaris'i Tercih Etme Nedenleri}

Marmaris'in turizm arzı potansiyelinin sonucu olarak, uluslararası turizm hareketliliğinin yüksek bir oranda yaşandığı önemli bir destinasyon konumundadır. Marmaris'e turist en çok yaz aylarında sonra da sonbahar aylarında gelmektedir. Bunlar en çok hava yolu ve kara yolu ile gelmektedir. Turistlerin büyük çoğunluğu İngiltere, Hollanda, Almanya, Fransa ve Bağımsız Devletler Topluluğu (çoğunlukla Rusya) vatandaşlarından oluşmaktadır.

\begin{tabular}{|l|l|l|l|l|}
\hline $\begin{array}{l}\text { 2012 YILINA GÖRE İLK } \\
\text { BEŞ ÜLKE }\end{array}$ & $\begin{array}{l}\text { 2010 OCAK } \\
\text { TEMMUZ }\end{array}$ & $\begin{array}{l}\text { 2011 OCAK } \\
\text { TEMMUZ }\end{array}$ & $\begin{array}{l}\text { 2012 OCAK } \\
\text { TEMMUZ }\end{array}$ & $\begin{array}{l}\text { DEĞISŞIM 2012- } \\
2011\end{array}$ \\
\hline İNGILTERE & 916.806 & 800.643 & 718.441 & $-\% 10$ \\
\hline HOLLANDA & 105.432 & 126.038 & 148.695 & $\% 17$ \\
\hline RUSYA FEDERASYONU & 83.227 & 110.047 & 115.249 & $\% 4$ \\
\hline ALMANYA & 87.382 & 85.573 & 95.019 & $\% 11$ \\
\hline FRANSA & 61.804 & 90.502 & 70.811 & $-\% 21$ \\
\hline
\end{tabular}

Tablo 9: Marmaris'e Gelen Turist Sayllarl ve Milliyetlerine Göre Değişimler Kaynak: Getob, 2012.

Uzun ve Avcı'nın 2007 yılında yapmış oldukları araştırmaya göre; yabancı turistlerin Marmaris'e gelişini etkileyen 5 faktör vardır. Bunlar; yaş, gelir düzeyi, eğitim düzeyi, kaldıkları yerin fiyatı ve tarihi -kültürel değerlerdir. Bu bulguların, gelir düzeyi yüksek olan turistlerin daha çok AB üyesi ülkeleri (Fransa, İspanya, İtalya, İngiltere, Yunanistan) tercih ettikleri bilgisi ile örtüştüğü incelenmiştir (Uzun ve Avc1, 2007). 


\section{Araştırma Amacı Yöntemi}

$\mathrm{Bu}$ araştırma; ülke ekonomisinde Marmaris'in turizm kalkınmasındaki yeri ve öneminin belirlenmesi amacıyla yapılmıştır. Ayrıca Rus turistlerin Marmaris’i tercih nedenlerinin belirlenmesi de hedeflenmiştir. Araştırma amacı ve kapsamına uygun olarak ayrıntılı literatür taraması yapılmıştır. Araştırmanın yönteminin temelini oluşturan örnekleme basit tesadüfi örneklem olarak belirlenmiştir. Araştırmanın veri toplama tekniği ankettir. Anket yaklaşık 50 kişiye uygulanarak bir pilot uygulama yapılmıştır. Güvenilirlilik analizi sonucu daha sağlıklı bir ölçüm aracı olması sağlanmıştır. Veriler bilgisayar ortamına aktarılarak SPSS 14.0 programında gerekli analizleri yapılmıştır

\subsection{Anketin Hazırlanması}

Araştırma anketinin hazırlanmasında konu ile ilgili yapılmış ulusal ve uluslararası çalışmaların anket veri toplama örneklerinden yararlanılmıştır. Araştırmanın konusu ile ilgili olan Demirci Orel ve Memmedov 2004 (Demirci Orel ve Memmedov, 2004) yılında yapmış oldukları çalışmanın anketi uyarlanarak veri toplama yöntemi oluşturulmuştur. Araştırma anketinde yer alan 12 adet soru demografik ve seyahat özelliklerini belirlemeye yönelik, 4 adet soru Rus turistlerin konaklama ve bilgi kaynaklarını belirlemeye yönelik ve Marmaris destinasyonunu tercih etme nedenini belirlemeye yönelik 5'li Likert Ölçeği ile derecelendirilmiş soru ile araştırmanın anketi tamamlanmıştır.

\subsection{Verilerin Toplanması}

Araştırmanın kapsamına ve amacına uygun olarak hazırlanan anketlerin güvenirliğini ve geçerliğini belirledikten sonra veri toplama aşamasına geçilmiştir. Verilerin toplanmasında basit tesadüfi belirlenen örnekleme uygun olarak Rus turistlerin Marmaris destinasyonun tercih ettikleri 3, 4 ve 5 yıldızlı otellerde uygulanmış olup, veri toplama işlemi gerçekleştirilmiştir. Toplanan verilerin yüzyüze bir şekilde gerçekleştirilmesinden dolayı herhangi bir değerlendirme dışı bırakılan olmamıştır. Yapılan çalışmanın anketi Rusça'yı ileri derecede bilen rehberler vasıtasıyla toplanmış böylece herhangi bir anlam bozukluğunun olması önlenmiştir. Çalışmanın evreni 2013 yılında Marmaris’i tercih eden Rus turistler oluştururken, örneklemini ise 2013 yılının Mayıs ayında Marmaris'i tercih eden Rus turistler oluşturmaktadır. Bu bağlamda belirlenen örneklem sayısının Tablo 10’da belirtildiği üzere; 381-384 arasında olduğu görülmektedir.

\begin{tabular}{|c|c|c|c|c|c|c|c|c|c|}
\hline \multirow{2}{*}{$\begin{array}{l}\text { Evren } \\
\text { Büyüklüğü }\end{array}$} & \multicolumn{3}{|c|}{$\begin{array}{l}+0.03 \text { örnekleme hatas } 1 \\
\text { (d) }\end{array}$} & \multicolumn{3}{|c|}{$\begin{array}{l}+0.05 \text { örnekleme hatas } 1 \\
\text { (d) }\end{array}$} & \multicolumn{3}{|c|}{$\begin{array}{l}+0.10 \text { örnekleme hatas } 1 \\
\text { (d) }\end{array}$} \\
\hline & $\begin{array}{l}\mathrm{p}=0.5 \\
\mathrm{q}=0.5\end{array}$ & $\begin{array}{l}\mathrm{p}=0.8 \\
\mathrm{q}=0.2\end{array}$ & $\begin{array}{l}\mathrm{p}=0.3 \\
\mathrm{q}=0.7\end{array}$ & $\begin{array}{l}\mathrm{p}=0.5 \\
\mathrm{q}=0.5\end{array}$ & $\begin{array}{l}\mathrm{p}=0.8 \\
\mathrm{q}=0.2\end{array}$ & $\begin{array}{l}\mathrm{p}=0.3 \\
\mathrm{q}=0.7\end{array}$ & $\begin{array}{l}\mathrm{p}=0.5 \\
\mathrm{q}=0.5\end{array}$ & $\begin{array}{l}\mathrm{p}=0.8 \\
\mathrm{q}=0.2\end{array}$ & $\begin{array}{l}\mathrm{p}=0.3 \\
\mathrm{q}=0.7\end{array}$ \\
\hline 100 & 92 & 87 & 90 & 80 & 71 & 77 & 49 & 38 & 45 \\
\hline 500 & 341 & 289 & 321 & 217 & 165 & 196 & 81 & 55 & 70 \\
\hline 750 & 441 & 358 & 409 & 254 & 185 & 226 & 85 & 57 & 73 \\
\hline 1000 & 516 & 406 & 473 & 278 & 198 & 244 & 88 & 58 & 75 \\
\hline 2500 & 748 & 537 & 660 & 333 & 224 & 286 & 93 & 60 & 78 \\
\hline 5000 & 880 & 601 & 760 & 357 & 234 & 303 & 94 & 61 & 79 \\
\hline 10000 & 964 & 639 & 823 & 370 & 240 & 313 & 95 & 61 & 80 \\
\hline 25000 & 1023 & 665 & 865 & 378 & 244 & 319 & 96 & 61 & 80 \\
\hline 50000 & 1045 & 674 & 881 & 381 & 245 & 321 & 96 & 61 & 81 \\
\hline 100000 & 1056 & 678 & 888 & 383 & 245 & 322 & 96 & 61 & 81 \\
\hline 1000000 & 1066 & 682 & 896 & 384 & 246 & 323 & 96 & 61 & 81 \\
\hline 100 milyon & 1067 & 683 & 896 & 384 & 245 & 323 & 96 & 61 & 81 \\
\hline
\end{tabular}

Tablo 10: Örneklem Sayısı Kaynak: Yazıcıoğlu, Y. ve Erdoğan, S. (2004)

Marmaris destinasyonunu ziyaret eden Rus turistlere yönelik olarak yapılan bu çalışma kapsamında verilerin toplanması esnasında bazı sıkıntılar yaşanmıştır. Marmaris’te turizm sezonunun yüksek olduğu bir dönemde olması, turistlerin anketleri zaman kaybı olarak görmesi, otellere gönderilen anketlerin tamamının cevaplanmaması sebebiyle kullanılabilir anket sayısından düşüş yaşanmıştır. Araştırma kapsamında kullanılan anket sayısı 176 olmuştur.

\subsection{Araştırmanın Bulguları ve Değerlendirilmesi}

\begin{tabular}{|c|c|}
\hline $\mathbf{N}$ & Cronbach Alpha \\
\hline 176 &, 903 \\
\hline
\end{tabular}

Tablo 11: Güvenilirlik Analizi Sonucu

Cronbah Alpha; anket ölçeğinin güvenilir olup olmadığının belirlenmesinde önemli bir ölçüttür. Tablo 11 incelendiğinde araştırmanın yüksek derecede güvenilir olduğu belirtilmiştir.

Çalışmanın verilerinden elde edilen demografik bilgiler yüzde ve frekans analizi yapılarak değerlendirilmiştir. 


\begin{tabular}{|c|c|c|c|}
\hline Özellik & Gruplar & $\mathrm{N}$ & $\%$ \\
\hline \multirow{2}{*}{ Cinsiyet } & Kadın & 132 & 75 \\
\hline & Erkek & 44 & 25 \\
\hline \multirow{6}{*}{ Yaş } & 20'den küçük & 20 & 11,4 \\
\hline & 20-29 Yaş Arası & 28 & 15,9 \\
\hline & 30-39 Yaş Arası & 64 & 36,4 \\
\hline & 40-49 Yaş Arası & 28 & 15,9 \\
\hline & 50-59 Yaş Arası & 32 & 18,2 \\
\hline & 60 ve Üzeri & 4 & 2,2 \\
\hline \multirow{3}{*}{ Medeni Durum } & Evli & 92 & 52,3 \\
\hline & Bekar & 76 & 43,2 \\
\hline & Diğer & 8 & 4,5 \\
\hline \multirow{4}{*}{ Eğitim Durumu } & Lise & 20 & 11,4 \\
\hline & Ön lisans & 44 & 25 \\
\hline & Lisans & 72 & 40,9 \\
\hline & Master-Doktora & 40 & 22,7 \\
\hline \multirow{9}{*}{ Meslek } & Kamu Çalışanı & 12 & 6,8 \\
\hline & Özel Sektör & 60 & 36 \\
\hline & Ticaret & 32 & 18,2 \\
\hline & Şirket & 24 & 14 \\
\hline & Ev Hanımı & 28 & 15,9 \\
\hline & Emekli & 12 & 6,8 \\
\hline & Öğrenci & 4 & 2,3 \\
\hline & İşsiz & - & - \\
\hline & Diğger & 4 & 2,3 \\
\hline \multirow{5}{*}{ Aylık Gelir } & -250 \$'dan az & 20 & 11,4 \\
\hline & $250-499 \$$ & 20 & 11,4 \\
\hline & $500-749 \$$ & 36 & 20,5 \\
\hline & $750-999 \$$ & 32 & 18,2 \\
\hline & $1000 \$$ ve üzeri & 68 & 38,5 \\
\hline \multirow{5}{*}{ Seyahate Kiminle Birlikte Çıktınız? } & Yalnız & 36 & 20,5 \\
\hline & Eşimle & 52 & 29,5 \\
\hline & Ailemle & 44 & 25 \\
\hline & Arkadaş Grubu & 32 & 18,2 \\
\hline & Diğer & 12 & 6,8 \\
\hline
\end{tabular}

Tablo 12: Demografik Bilgilerinin Belirlenmesi

Marmaris'i tercih eden Rus turistlerin sosyo- demografik özellikleri incelendiğinde; turistlerin büyük bir oranının kadın, 30-39 yaş arasında, evli, lisans mezunu, özel sektör çalışanı, 1000\$ ve üzeri gelire sahip, evli oranının yüksek olması ile eşiyle birlikte tatil yapmış oldukları incelenmiştir.

\begin{tabular}{|l|l|l|}
\hline Konaklama Şekli & N & $\%$ \\
\hline Yarım Pansiyon & 8 & 4,5 \\
\hline Tam Pansiyon & 8 & 4,5 \\
\hline Herşey Dahil & 160 & 91 \\
\hline
\end{tabular}

Tablo 13: Turistlerin Konaklama Şekilleri

Marmaris'i tercih eden Rus turistlerin konaklama şekilleri incelendiğinde (büyük bir oranın) \%90,9'unun herşey dahil sistemde konaklama biçimini tercih ettiği görülmüştür. Bu durum; Marmaris'inin konaklama sektöründe herşey dahil sisteminin fiyat yönünden daha uygun olduğunun bir göstergesi olabilmektedir.

\begin{tabular}{|l|l|l|}
\hline Tatil Süreleri & N & $\%$ \\
\hline 1 hafta & 40 & 22,7 \\
\hline 10 gün & 44 & 25 \\
\hline 2 hafta & 80 & 45,5 \\
\hline Diğer & 12 & 6,8 \\
\hline
\end{tabular}

Tablo 14: Turistlerin Tatil Süreleri 
Marmaris’i tercih eden Rus turistlerin tatil sürelerine bakıldığında 2 haftalık tatiller şeklinde destinasyonu tercih ettikleri belirlenmiştir.

\begin{tabular}{|l|l|l|}
\hline Ziyaret Siklıkları & N & $\%$ \\
\hline 1. kez & 44 & 25 \\
\hline $2 . \mathrm{kez}$ & 48 & 27,3 \\
\hline 3. kez & 20 & 11,4 \\
\hline 4. kez & 16 & 9 \\
\hline 5. kez ve daha fazla & 48 & 27,3 \\
\hline
\end{tabular}

Tablo 15: Turistlerin Marmaris 'i Ziyaret Siklıklarl

Daha önce Marmaris’i tercih etme sıklığı incelendiğinde ikinci kez gelenler ile beşinci kez ve daha fazla ziyaret sayısına sahip olanların oranlarının eşit olduğu görülmüştür. Bu bağlamda Rus turistlerin Marmaris'e tekrar gelme sıklıkları yüksek olduğu belirlenmiştir.

\begin{tabular}{|l|l|l|}
\hline Bilgi Kaynakları & $\mathrm{N}$ & $\%$ \\
\hline Seyahat Acenteleri & 80 & 45,5 \\
\hline Reklam & 12 & 6,8 \\
\hline İnternet & 48 & 27,3 \\
\hline Deneyimler & 4 & 2,3 \\
\hline Tavsiye & 16 & 9,1 \\
\hline Broşür ve Kataloglar & 8 & 4,5 \\
\hline Diğer & 8 & 4,5 \\
\hline
\end{tabular}

Tablo 16: Turistlerin Marmaris 'i Seçmelerinde Etkili Olan Bilgi Kaynakları

Marmaris'i tercih eden Rus turistler; Marmaris'i tercih etmede kullandıkları bilgi kaynaklarının seyahat acenteleri olduğu görülmüştür. Herşey dahil sistemle gelip belirli paket turlar aracılığı ile tatillerini satın almalarında dolayı, başvurdukları bilgi kaynağı da seyahat acentesi olmuştur.

\begin{tabular}{|c|c|c|c|c|c|c|c|c|c|c|}
\hline \multirow{2}{*}{ İfadeler } & \multicolumn{2}{|c|}{$\begin{array}{l}\text { 1. Hiç } \\
\text { Katılmıyorum }\end{array}$} & \multicolumn{2}{|c|}{$\begin{array}{l}2 . \\
\text { Katılmiyorum }\end{array}$} & \multicolumn{2}{|c|}{ 3. Kararsızım } & \multicolumn{2}{|c|}{ 4. Katıliyorum } & \multicolumn{2}{|c|}{$\begin{array}{l}\text { 5. Tamamen } \\
\text { Katıliyorum }\end{array}$} \\
\hline & $\mathrm{N}$ & $\%$ & $\mathrm{~N}$ & $\%$ & $\mathrm{~N}$ & $\%$ & $\mathrm{~N}$ & $\%$ & $\mathrm{~N}$ & $\%$ \\
\hline Deniz,kum,güneş & 20 & 11,4 & 4 & 2,3 & 8 & 4,5 & 52 & 29,5 & 92 & 52,3 \\
\hline Gece Hayat1 & 24 & 13,6 & 8 & 4,5 & 24 & 13,6 & 52 & 29,5 & 68 & 38,8 \\
\hline Uygun Konaklama İmkanları & 28 & 15,9 & 4 & 2,3 & 16 & 9,1 & 56 & 31,8 & 72 & 40,9 \\
\hline Türk İnsanının Düşünce Yapısı & 20 & 11,4 & 12 & 6,8 & 16 & 9,1 & 56 & 31,8 & 72 & 40,9 \\
\hline Doğal, Tarihi, Kültürel Özellikler & 20 & 11,4 & 4 & 2,3 & 12 & 6,8 & 56 & 31,8 & 84 & 47,7 \\
\hline Misafirperverlik & 16 & 9,1 & 4 & 2,3 & 4 & 2,3 & 60 & 34 & 92 & 52,3 \\
\hline Farklı Turizm Aktiviteleri & 24 & 13,6 & 4 & 2,3 & 20 & 11,4 & 48 & 27,2 & 80 & 45,5 \\
\hline Daha rahat arkadaş ortamı & 16 & 9,1 & 8 & 4,5 & 4 & 2,3 & 44 & 25 & 104 & 59,1 \\
\hline
\end{tabular}

Tablo 17: Turistlerin Marmaris 'i Tercih Etme Nedenleri

Marmaris'i tercih etme nedenleri incelendiğinde; daha rahat arkadaş ortamına Tamamen Katılıyorum oranının \%59,1 olduğu görülmüştür. Bu bağlamda Marmaris sahip olduğu farklı turist profilleri doğrultusunda daha rahat arkadaş ortamının olduğu belirlenmiştir. Daha rahat arkadaş ortamı dışında deniz,kum, güneş tatil anlayışı, misafirperverlik ve Marmaris'in sahip olduğu doğal, tarihi, kültürel özellikler; Rus turistlerin Marmaris'i tercih etme nedenleri arasında yer almıştır.

\begin{tabular}{|l|l|l|}
\hline Önceki Tatil Deneyimleri & N & $\%$ \\
\hline Evet & 140 & 79,5 \\
\hline Hayır & 36 & 20,5 \\
\hline
\end{tabular}

Tablo 18: Önceki Tatil Deneyimleri

Daha önce tatil deneyimleri konusunda; büyük çoğunluğunun tatil yapmış olduğu ve yeterli imkana sahip olduğu belirlenmiştir.

Marmaris sahip olduğu çeşitli özelliklerden dolayı farklı turizm aktivitelerinin yapıldığı önemli bir destinasyondur. $\mathrm{Bu}$ bağlamda, Marmaris'i tercih eden Rus turistler farklı turistik etkinliklere katılmayı düşündükleri belirlenmiştir. Marmaris'in gece hayatının ön planda olmasından dolayı disko turları diğger turistik etkinliklerine göre daha yoğun katılım olmuştur.

Rus turistlerin en fazla harcama yaptığı kalemlerin başında geziler ve alışveriş gelmektedir. Herşey dahil sistemi kullanmalarının bir sonucu olarak yeme-içme maliyeti çok fazla olmamıştır. Ulaşım ve eğlence açısından da çok fazla imkan olması sebebiyle, yüksek düzeyde bir harcama görülmemiştir. 


\begin{tabular}{|l|l|l|}
\hline Turlar & N & $\%$ \\
\hline Disko & 40 & 22,7 \\
\hline Șehir Turu & 36 & 20,5 \\
\hline Diving & 20 & 11,4 \\
\hline Aqualand & 12 & 6,8 \\
\hline Türk Gecesi & 24 & 13,6 \\
\hline Jeep Safari & 12 & 6,8 \\
\hline Yat & 4 & 2,3 \\
\hline Rafting & 4 & 2,3 \\
\hline Diğer & 24 & 13,6 \\
\hline
\end{tabular}

Tablo 19: Turistlerin Tatilleri Boyunca Katılmayı Düşündükleri Turlar

\begin{tabular}{|l|l|l|}
\hline Harcama Kalemleri & $\mathrm{N}$ & $\%$ \\
\hline Yeme içme & 20 & 11,4 \\
\hline Alışveriş & 52 & 29,5 \\
\hline Konaklama & 16 & 9,1 \\
\hline Ulaşım & 4 & 2,3 \\
\hline Geziler & 64 & 36,4 \\
\hline Eğlence & 16 & 9,1 \\
\hline Diğer & 4 & 2,3 \\
\hline
\end{tabular}

Tablo 20: Turistlerin Marmaris 'te En Fazla Harcama Yaptıkları Kalemler

\begin{tabular}{|l|l|l|}
\hline Destinasyon Seçimi & N & $\%$ \\
\hline Antalya & 4 & 2,3 \\
\hline Avustralya & 4 & 2,3 \\
\hline Belli Değil & 40 & 22,6 \\
\hline Bodrum & 4 & 2,3 \\
\hline Bulgaristan & 8 & 4,5 \\
\hline Fransa & 4 & 2,3 \\
\hline Hurvatistan & 4 & 2,3 \\
\hline Marmaris & 88 & 50 \\
\hline Tayland & 4 & 2,3 \\
\hline Türkiye & 8 & 4,5 \\
\hline Ukrayna & 4 & 2,3 \\
\hline Yunanistan & 4 & 2,3 \\
\hline
\end{tabular}

Tablo 21: Turistlerin Bir Sonraki Tatil Yeri Tercihleri

Marmaris'i tatil yeri olarak seçen Rus turistlerin bir sonraki tatil deneyimini gerçekleştirecekleri destinasyon sorulduğunda \%50'lik bir oranda tekrar Marmaris’i tercih edeceklerini belirtmişlerdir. Bu bağlamda Marmaris’e tekrar ziyaret etme niyetlerinin yüksek bir oranda olduğu görülmüştür. Diğer bir sonuca göre Rus turistlerin $\% 22,8$ 'si daha gelecek tatil yeri seçimini belirlemediklerini belirtmişlerdir.

\begin{tabular}{|l|l|l|}
\hline İfade & N & $\%$ \\
\hline Doğa & 12 & 6,8 \\
\hline Cennet & 8 & 4,5 \\
\hline Deniz, kum, güneş & 20 & 11,1 \\
\hline Disko, eğlence & 28 & 15,9 \\
\hline Güzel & 8 & 4,6 \\
\hline Yemek Kültürü & 4 & 2,3 \\
\hline Harika bir tatil & 68 & 38,8 \\
\hline Hiçbir şey & 4 & 2,3 \\
\hline İnci & 8 & 4,5 \\
\hline Lüks & 4 & 2,3 \\
\hline Tutku & 4 & 2,3 \\
\hline Türkiye & 4 & 2,3 \\
\hline Unutulmaz & 4 & 2,3 \\
\hline
\end{tabular}

Tablo 22: Marmaris İsmi Sizin İçin Ne Ifade Etmektedir 
Marmaris'i ziyaret eden Rus turistlere Marmaris isminin ne çağrıştırdığı sorulduğunda; turistlerin çoğunun Marmaris isminin "Harika Bir Tatil”i çağrıştırdığı görülmüştür. Ayrıca disko-eğlence, deniz-kum-güneş ve doğa kelimeleri Marmaris'i en iyi ifade eden tanımlar olarak belirlenmiştir

\section{Sonuç}

Destinasyonlar, turistik çekiciliğe sahip, turistik ürün üreten işletmelerce desteklenmiş, ulaşılabilir turizm bölgeleridir. Turizm bölgeleri ziyaretçilerine, turistik ürün bileşimini bir bütün olarak sunan yerlerdir. Turizm bölgesi ya da destinasyon ifadesi bazen küçük yerel bir bölgeyi ifade ederken bazen de bir coğrafik bölge, bir ülke hatta bir kıta için de kullanılmaktadır (Kılıç, 2011). Ayrıca turizm destinasyonu, ülkeden küçük ve şehirden büyük, belirli bir imaja sahip önemli turistik çekicilikler gibi çeşitli etkinliklere, iyi bir ulaşım ağına, gelişim potansiyeline ve üstyapı turistik tesislerin gelişimi için yeterli coğrafi alana sahip bölgedir (Hosany vd., 2006).

Marmaris sahip olduğu kaynaklar neticesinde doğal ve kültürel özellikleri bir arada taşıyan önemli bir denizkum-güneş destinasyonudur. Genel olarak uluslar arası turizm hareketliliğinde Muğla ili içerisinde oldukça fazla payı olmasına rağmen, gelen turistlerin sosyo demografik nitelikleri bakımından zayıf kaldığı görülmektedir.

Yapılan çalışmanın sonucuna göre; Marmaris'i tercih eden Rus Turistlerin profili belirlenmiştir. Gelen turistlerin çoğunun kadın katılımcılardan oluştuğu, orta yaş grubunda yer aldığı, evli olduğu, özel şirket çalışanı, aylık geliri $1000 \$$ ve daha fazla olan, eşiyle tatile çıkmış olan katılımcılardan oluştuğu belirlenmiştir. Herşey dahil sistem ile gelmiş oldukları, 2 hafta süreliğine tatil yaptıkları, seyahat acenteler vasıtasıyla bilgi topladıkları, Marmaris'i tekrar ziyaret etme sıklıklarının yoğun olduğu incelenmiştir. Ayrıca alışveriş ve geziler için harcama yaptıkları ve en fazla disko turunu tercih ettikleri görülmüştür. Rus turistlere göre Marmaris ismi; harika bir tatil olarak ifade edilmektedir. Bu bağlamda Rus turistler tarafından Marmaris sevilen ve tatil için oldukça uygun görülen destinasyonlar arasındadır. Turistlerin büyük bir çoğunluğunun tekrar Marmaris’i tatil yeri olarak seçeceklerini belirtmişlerdir.

Yeni turizm anlayışına uygun olarak pazarlanan yerler dünyada turizm gelirlerinden giderek daha fazla pay almaya başlarken, Marmaris gibi yeni turizm anlayışlarına ayak uyduramayan bölgeler giderek önemlerini yitirmektedir (Purkis, 2008) Genel olarak Marmaris destinasyonu, Rus Turist Pazar'ında önemli bir yere sahiptir. Ama gelen turist sayısı ve turizm geliri açısından Marmaris olarak daha kaliteli bir altyap1 ve üstyapı hizmetlerinin sunulması, turizm çeşitliliğinde farklılık yaratılması, farklı turizm aktivitelerin tanıtımının yapılarak uluslararası pazarlarda daha farklı ve kaliteli müşteri pazarına ulaşılmalıdır.

\section{Kaynakça}

- Barutçugil, İsmet Sabit, 1998. Turizm İşletmeciliği. İstanbul: Beta Basın Yayın Dağıtım A.Ş.

- Çımat, Ali ve Bahar, Ozan, 2003. "Turizm Sektörünün Türkiye Ekonomisi İçindeki Yeri Ve Önemi Üzerine Bir Değerlendirme”, Akdeniz İI.I.B.F. Dergisi 6, p. 1-18.

- Demirci Orel, Fatma ve Memmedov, İlgar, 2004. "Antalya Bölgesine Gelen Rus Turistlerin Profilini Belirlemeye Yönelik Çalışma”, Aziya İ Afrika Segodnya (Sivodniya) Dergisi, p. -1-15.

- Hosany, Sameer, Ekinci, Yüksel ve Uysal, Muzaffer, 2006. "Destination Image and Destination Personality: An Application of Branding Theories to Tourism Places", Journal of Business Research, 59, p. 638-642.

- K1lıç, Burhan, 2011. "Destinasyon Ziyaretçilerinin Sosyo-Demografik Özelliklerinin Sadakat Eğilimleri Üzerine Etkisi”, Selçuk Üniversitesi Sosyal Bilimler Enstitüsü Dergisi, 26, p. 239-252.

- Purkis, Semra, 2008. “Turizmle Kalkınma ve Kentlerin Kimlik Arayışları: Marmaris Örneği”, Marmaris Ticaret Odasi Ekonomi Yayınları III.

- Purkis, Semra, 2009. "Dünyada Turizm Endüstrisinin Örgütlenmesi ve Marmaris Örneği”, Econ Anadolu 2009: Anadolu International Conference in Economics, June 17-19. Eskişehir.

- Uzun, Emin ve Avc1, Yusuf, 2007. "Yabancı Turistlerin Marmaris’i Tercihine Etki Eden Faktörlerin Araştırılması”, 10, 109.

- Yazıcıŏlu, Yahşi ve Erdoğan, Samiye. 2004. SPSS Uygulamalı Bilimsel Araştırma Yöntemleri. Ankara: Detay Yayıncilık.

- Getob, 2012. Marmaris Turizm Verileri, http://www.getob.org/.

- MarmarisMarmaris, 2013. Marmaris'in Tarihi ve Coğrafi Özellikleri, http://www.marmarismarmaris.com/default.asp?sayfa=3\&id=4.

- Marmaris Ticaret Odas1, 2013. 2011-2012 Turizm Değerlendirmesi, http://www.mto.org.tr/haberler/baysal2011-2012-turizm-degerlendirmesi

- Muğla İl Kültür ve Turizm Müdürlüğü, 2013a. İşletme ve Yatırım Belgeli Tesisler Oda Yatak Kapasitesi, http://www.muglakulturturizm.gov.tr/belge/1-96189/isletme-ve-yatirim-belgeli-tesisler-oda-yatak-kapasites.html. 
- Muğla İl Kültür ve Turizm Müdürlüğü, 2013b. Seyahat Acenteleri, Yat İşletmeleri ve Marinalar, http://www.muglakulturturizm.gov.tr/belge/1-96341/seyahat-acentalari-yat-isletmeleri-ve-marinalar.html.

- T.C. Kültür ve Turizm Bakanlığı, 2013a. Turizm Destinasyonu Nedir?, http://www.kultur.gov.tr/TR,31239/turizm-destinasyonu-nedir.html.

- $\quad$ T.C. Kültür ve Turizm Bakanlığı, 2013b. Turizm Verileri, http://www.kultur.gov.tr/Eklenti/2140,turizmverileripdf.pdf?0.

- T.C. Marmaris Belediyesi, 2013b. Marmaris ve Çevresi, http://www.marmaris.bel.tr/index.asp?s=Icrk\&IcrkID=5 


\title{
Ulusal Otel Zincirinin Büyüme Başarısına İlişsin Bir Değerlendirme: Rixos Otel Zinciri
}

\section{An Assessment on the National Hotel Chain Growth Success: The Case of the Rixos Hotel Group}

\author{
Assoc. Prof. Dr. Ufuk Durna (Akdeniz University, Turkey) \\ Prof. Dr. Mehmet Emin İnal (Akdeniz University, Turkey) \\ Ph.D. Candidate İhsan Kurar (Akdeniz University, Turkey)
}

\begin{abstract}
This study examines the growth phenomenon and strategies of Rixos Hotel Group, which is regarded as one of the local hotel groups. The growth forms of international hotel businesses vary from country to country. The hotel businesses need to get to know the working ways of both local partner and national tourism sector with the fact that legal arrangements and socio-cultural characteristics are very important in terms of growth strategies of hotel businesses in service industry. A Turkish Hotel Group has not been examined so far in the studies which have been already done about multinational hotel businesses. In this context, the growth type, growth strategy, guest relationships, education of employees and innovation applications of Rixos Hotel Group which is regarded one of the local hotel groups, are examined for the first time, which contributes to the importance level of this study in a positive way.
\end{abstract}

\section{Giriş}

Günümüzde artan rekabet koşulları otel işletmelerinin ulusal ve uluslar arası turizm piyasasında doğru stratejilerle geleceklerini planlamalarını zorunlu kılmaktadır. Bu nedenle turizmin gelişmesine yön veren ulaşım olanakları, kişisel gelir artışı, uluslar arası ekonomik ve politik ilişkilerin gelişmesi ve teknolojinin ilerlemesinden dolayı büyük otel işletmelerinin sayısında önemli bir artış görülmektedir. Bu kapsamda büyük otel işletmeleri, çeşitli ülkelerde tesisler kurarak veya yerel markaları satın alarak küreselleşme yoluna gitmektedir. Bu stratejiler, yabancı bir ülke pazarına girişte bir otel zincirinin seçtiği büyüme şeklidir. Bu çalışmada ulusal bir otel grubu olan Rixos Otel Zincirinin büyüme başarısı iki bölümde anlatılmaktadır. Çalışmanın birinci bölümünde grubun büyüme stratejileri anlatılırken, ikinci bölümde ise grubu büyümeye götüren temel yeteneklere yer verilmektedir. Buna göre konaklama sektöründe uluslararasılaşma iki şekilde ortaya çıkmaktadır. Bunlardan biri dikey büyüme, diğeri ise yatay büyüme. Dikey büyüme, girdi üretiminden perakende satışa kadar birbirini izleyen aşamaların aynı firma bünyesinde toplanmasıdır. Yatay büyüme ise bir işletmenin faaliyette bulunduğu iş kolundaki pazar payını artıracak yönde büyümesidir (Öncer, 2012). Rixos Otel Zinciri, sadece konaklama sektöründe hizmet verdiği için yatay bir büyüme izlemektedir.

Bununla birlikte uluslararası otel işletmeleri, farklı stratejilerle büyüme yoluna gidebilmektedir. Örneğin, Inter Continental Hotels Group, Marriott International ve Hilton Hotels Corp. bir den çok büyüme stratejisi izlerken, Wyndham Worldwide ve Choice Hotels International ise sadece franchising vererek büyümektedir. Pegasus Solutions ve VIP Investment Corp., konsorsiyum ile oluşturulmuş en büyük otel gruplarını oluşturmaktadır. Bununla birlikte Four Seasons Hotels and Resorts sadece yönetim anlaşması ile büyüyen bir şirkettir (Met ve Erdem, 2011). Rixos Otel Zinciri ise çoklu bir büyüme stratejisi izlemektedir. Bu nedenle gruba şimdiye kadar tam sahiplik, kiralama, satın alma ve yönetim anlaşmasıyla büyümektedir. Bununla birlikte grubun, lüks otel markalarının bir araya gelerek oluşturduğu bir konsorsiyum olan Global Hotel Alliance (GHA) üyeliği bulunmaktadır. Global Hotel Alliance, dünya genelinde 60 ülkede, 320 lüks otel markası tarafindan oluşturulan bir sadakat programıdır. Bu üyelik gruba ortak pazarlama ve rezervasyon olanakları sağlamaktadır.

Çalışmanın ikinci kısmında büyüme olgusuna, otel işletmeciliğini temel yetenek alanları olarak gören ve küresel bir marka olma yönünde ilerleyen ve her geçen gün zincirine yeni oteller ekleyen Rixos Otel Grubu açısından bakılacaktır. Bu kapsamda gruba ait oteller kent merkezlerinde ve sahil bölgelerinde hizmet sunmaktadır. Kent merkezlerindeki oteller daha çok iş adamlarına hizmet verirken, sahil bölgelerindeki otellerde farklı erklerde müşteriler ağırlanmaktadır. Bilindiği gibi konaklama sektörü işbirliğine dayanmakla birlikte karmaşık da bir yapıya sahiptir. Bu nedenle grubun büyüme stratejileri doğrultusunda sadece konaklama sektörüne yönelik yatırımlar yapılmaktadır. Bu durum grup çalışanlarına önemli avantajlar getirmektedir. Örneğin, turizmde düşük sezon olarak ifade edilen dönemlerde iş görenlerini dünyanın farklı bölgelerindeki otellerine göndererek, düşük sezonda personelin işten çıkarılmaması sektör çalışanları adına önemli bir firsattır. Bununla birlikte Rixos Otel Zinciri mutlaka yerelden personel istihdam etmektedir. Bu nedenle turizmin sürdürülebilirlik ilkesinden yerel refah hedefinin benimsendiği söylenebilir. Bu kapsamda grubu büyümeye götüren temel özellikler arasında yatırım kararları, pazarlama çalışmaları, dış kaynak kullanımına ilişkin 
uygulamaları, kalite standartları, kapasite esnekliği ve personel istihdamına ilişkin politikaları, müşteri ilişkileri uygulamaları, yenilik uygulamaları, iş gören eğitimi ve imaj çalışmalarına yer verilmektedir.

\section{Rixos Otel Grubunun Genel Özellikleri}

Günümüzde artan rekabet koşulları otel işletmelerinin ulusal ve uluslar arası turizm piyasasında doğru stratejilerle geleceklerini planlamalarını zorunlu kılmaktadır. Bu nedenle turizmin gelişmesine yön veren ulaşım olanakları, kişisel gelir artı̧̧ı, uluslar arası ekonomik ve politik ilişkilerin gelişmesi ve teknolojinin ilerlemesinden dolayı büyük otel işletmelerinin sayısında önemli bir artış görülmektedir. Küreselleşme sürecine paralel olarak yaşanan bu artış, son yıllarda çok uluslu otel işletmelerinin etkinliğini arttırmaktadır. Bu nedenle büyük otel işletmelerinin, çeşitli ülkelerde tesisler kurarak veya yerel markaları satın alarak küreselleşme yoluna gittiği görülmektedir. Bu oteller müşterilerine çoğu zaman merkezi bir yönetim ve rezervasyon sistemiyle hizmet sunmaktadırlar. Rixos Otel Grubu 2000 y1lında \% 100 misafir memnuniyeti sağlayarak turizm endüstrisinde lider bir kurum olma amacıyla sektörün başkenti Antalya'da Fettah TAMINCE tarafindan kuruldu. Grubun ana ilkesini yüksek kalitede hizmet sunumu ile misafirlerin ihtiyaçları, duyguları ve hissettikleri tüm faaliyetler oluşturmaktadır. Bu nedenle \%100 müşteri memnuniyeti ve serviste mükemmellik hedefiyle "All Inclusive - All Exclusive" konseptini geliştirilmiştir (http://www.rixos.com/tr/kurumsal/tarih\#sthash.1zASXMa8.dpuf, 2013).

\begin{tabular}{|l|l|l|l|}
\hline Rixos Otel Zincirleri & Açılış Yılı & Oda Sayısı & Yatak Kapasitesi \\
\hline Rixos Labada, Antalya, Türkiye & 2000 & 179 & 448 \\
\hline Rixos Beldibi, Antalya, Türkiye & 2002 & 274 & 685 \\
\hline Rixos Tekirova, Antalya, Türkiye & 2002 & 600 & 2100 \\
\hline Rixos Premium Bodrum, Muğla, Türkiye & 2003 & 769 & 1700 \\
\hline Rixos Premium Belek, Antalya, Türkiye & 2005 & 769 & 1738 \\
\hline Rixos President Astana, Kazakistan & 2005 & 184 & 336 \\
\hline Rixos Konya, Konya, Türkiye & 2005 & 278 & 560 \\
\hline Rixos Prykarpattya, Ukrayna & 2005 & 370 & 691 \\
\hline Rixos Libertas Duprovnik, Hırvatistan & 2007 & 254 & 504 \\
\hline Rixos Sungate, Antalya, Türkiye & 2009 & 1094 & 2300 \\
\hline Rixos Grand Ankara, Ankara, Türkiye & 2009 & 215 & 480 \\
\hline Rixos Almaty, Kazakistan & 2009 & 238 & 460 \\
\hline Rixos Al Nasr Tripoli, Libya & 2010 & 120 & 300 \\
\hline Rixos Lares, Antalya, Türkiye & 2010 & 804 & 2500 \\
\hline Rixos Downtown Antalya, Türkiye & 2011 & 360 & 580 \\
\hline Rixos Taksim İstanbul, İstanbul, Türkiye & 2011 & 200 & 460 \\
\hline Rixos The Palm Dubai, Dubai, UAE & 2012 & 259 & 510 \\
\hline Rixos Bab Al Bahr, UAE & 2012 & 627 & 1850 \\
\hline Rixos Pera, İstanbul, Türkiye & 2012 & 116 & 290 \\
\hline Rixos Bomonty, İstanbul, Türkiye & 2012 & 296 & 490 \\
\hline Rixos Marina West, Bahreyn & 2012 & 254 & 470 \\
\hline Rixos Sharm El Skeikh, Misır & 2012 & 695 & 1950 \\
\hline Rixos Lake Borovoe, Kazakistan & 2013 & 200 & 448 \\
\hline Toplam & 2013 & 9155 & 21850 \\
\hline
\end{tabular}

Tablo 1. Rixos Hotel Kronolojisi

Tablo 1.'de görüldüğü gibi Rixos Otel Grubu, zincirindeki 23 otelle dünyanın 8 ülkesinde misafirlerini ağırlamaktadır. Toplam 9155 oda ve 21850 yatak kapasitesiyle hizmet sunmaktadır. Grubun on üç resort oteli, dokuz şehir oteli ve 2 rezidans otel olmak üzere toplam 23 oteli bulunmaktandır. Rixos Otel Grubu'na ait otellerin 11 tanesi Türkiye'nin farklı bölgelerinde bulunurken, Kazakistan'da 3 tane, Birleşik Arap Emirlikleri (BAE)'nde 2 tane Azerbaycan, Gürcistan, Hırvatistan, Mısır, Ukrayna ve Libya'da birer tane olmak üzere toplam 22 oteli bulunmaktadır. Bununla birlikte gruba yakın zamanda beş yeni otelin katılması beklenmektedir. Bunlar, İsviçre'nin Davos şehrinde, Rusya'da Soçi, BAE Ras San bölgesinde 750-800 odalı bir tesis ve Azerbaycan'da Kuba adı altında bir otel de gruba katılacaktır.

\begin{tabular}{|l|l|}
\hline Y1llar & Çalışan Sayıs1 \\
\hline 2008 & 2,594 \\
\hline 2009 & 4,032 \\
\hline 2010 & 4,666 \\
\hline 2011 & 5,001 \\
\hline 2012 & 5,901 \\
\hline
\end{tabular}

Tablo 2. Çalış̧an Saylsı

Müşterilerine kaliteli hizmet sunmak isteyen işletmelerin oda sayısına uygun personel istihdam etmesi gerekir. Rixos Grubunun uygulamalarında, oda sayısı başına düşen personel sayısının $0,8-1$ arasında değiştiği ve bazı 
otellerde bu oranın 1,5'e kadar yükseldiği görülmektedir. Bu nedenle Rixos Otel Grubunun hizmetini sunan on bine yakın çalışanı bulunmaktadır. Bu çalışanların beş bin kadarı otellerde geriye kalan kısmı da Rixos Villa'da hizmet sunmaktadır. On bin iş gören içinden beş bin çalışan gittiği bölgelere Rixos kültürünü, ürün ve hizmet kalitesi anlayışını taşıdı̆̆ 1 için çok önemli görülmektedir.

Tablo 2.'de görüldüğü gibi 2012 y1lı itibariyle 5,901 kişi Rixos Hotel grupta istihdam edilmektedir. Bu kişilerin kalifiye olması personelin iletişim şekli, özgüveni ve müşteri istekleri karşısında güler yüzlü olarak müşteriye cevap vermesi çok önemli görülmektedir. Önemli olan iş gören bulmak değil, iş görenin işletmeyi temsil edebiliyor olmasıdır. Bu anlamda yılda bir defa insan kaynakları fuarı düzenlenmektedir. Bu fuarda Rixos Grupta çalışmak isteyen ciddi sayıda taleple karşılaşılmaktadır. Bununla birlikte otelin bulunduğu bölgeden çalışanlar mutlaka istihdam edilmektedir. Bu şekilde Rixos Otel Zincri faaliyette bulunduğu bölgenin yerel halkına da istihdam sağlama, malzeme satın alma gibi yöntemlerle hizmet etmeye çalışmaktadır.

Rixos Otel misafirleri ilk deneyimini olumlu veya olumsuz yaşamışsa bunu uygulanan anketlerde yorum ve tavsiye şeklinde paylaşmaktadır. Bu kapsamda Rixos Grubu'nun müşterilerine uyguladığı anketlerin geri dönüş oranının \% 85 olması önemli bir göstergedir. Müşterinin, beklentilerinde veya beklentilerinin üzerinde sunulan hizmetlerden memnun olarak ayrılması Rixos’a yeniden ziyaret eğilimi olarak yansıdığı gibi, pazarlama çalışmalarında da maliyet avantajı sağlamaktadır.

Rixos Grubu'nda konaklayan müşterilerin şikâyetleri müşteri ilişkilerine iki farklı şekilde yansımaktadır. Birincisi müşterilerden konaklama sırasında gelen ve mümkün olduğunca otelde giderilmeye çalışılan şikâyetlerdir ki, grup olarak en iyi yolun bu olduğuna inanılmaktadır. Çünkü müşterinin geri kalan tatilinden memnun olarak ayrılması sağlandığı takdirde grubun sahip olduğu veya müşterinin konakladığı oteli tekrar tercih etme olasılığı artacaktır. İkincisi müşterinin tatilinden sonra merkez ofise gelen şikâyetler. Bu tür şikâyetlerde yorumun doğru yapılması ve problemin çözümüne katkı sağlaması amacıyla ilk olarak otelle görüşülmektedir. İlgili otelden şikâyete yönelik cevap alındıktan sonra müşteriyi Rixos kalitesinde memnun etme çalışmaları yapılır. İlk olarak müşteriden özür dilenir ve problemin şiddetine göre farklı tedbirler alınır. Müşteri memnun edilmeden asla problem kapatma yoluna gidilmez. Bu bakımdan sunulan hizmetler sonrasında müşterilerden gelen geri bildirimler, Rixos için çok önemli görülmektedir. Çünkü bazen müşteri tarafindan şikâyet olarak dile getirilen bir konu, müşteri evine döndükten sonra müşteri tarafından tatlı bir anı olarak da ifade edilebilmektedir.

\subsection{Rixos Otel Grubunun Büyüme Stratejileri}

Uluslararası otel zincirleri, yönetim deneyimi ve bilgisi, marka imajı, ortak pazarlama ve rezervasyon vb. konularda rekabetçi üstünlüklere sahiptirler (Met ve Erdem, 2011). Bu nedenle Rixos Otel Grubu tarafindan her hangi bir ülkeye yatırım kararı alınmadan önce o ülkenin ekonomik, sosyal ve kültürel özellikleri iş geliştirme departmanı tarafından araştırılmaktadır. Araştırmalar karar verilmek üzere yönetim kurulu başkanı ve yönetim kurulu üyelerine sunulmaktadır. Buna göre planlamalar yapılmakta ve yatırımın geri dönüşümü tatminkâr ise yatırım kararı alınmaktadır. Bu kapsamda grubun öncelikli yatırım kararlarını gelişmekte olan pazarlar veya yeni pazarlar oluşturmaktadır. Bu nedenle Rixos Otel Grubu bugüne kadar yeni destinasyonlar açan cesur, girişken, genç ve dinamik bir yapıya sahip grup olarak bilinmektedir. Örneğin, Kazakistan Astana'ya otelcilik Rixos grubu tarafında götürüldüğü için kalite çıtası da Rixos tarafından belirlenmektedir. Çalışmanın bu kısmında Rixos Otel Grubunun büyüme stratejileri üzerinde durulacaktır.

Tam sahiplik, uluslararası işletmelerin ülke riskinin düşük olduğu ve karlı gördüğü sektördeki işletmeleri satın alarak veya ülkede yeni bir işletme kurarak faaliyette bulunmasıdır. Büyüme stratejisi alternatiflerinden "tesis inşa etme" ve "tesis satın alma", şirkete yüksek faaliyet kontrolü sağlamasına karşılık yüzde yüz finansman sorumluluğu ve buna bağlı olarak yüksek yatırım/işletme riski yüklemekte ve yavaş bir büyüme hızı ile kisitlamaktadır (Met ve Erdem, 2011). Rixos Otel Grubunda faaliyet gösteren otellerden Rixos Premium Belek, 769 oda ve 1738 yatak kapasitesiyle öz sermayesinin tamamı ve mülkiyeti gruba ait olmak üzere, 2005 yılında hizmete sunuldu. Bununla birlikte Rixos Tekirova, 2002 yılında satın alma yöntemiyle gruba dâhil edilmiş ve yaklaşık on yıldır Rixos Otel Grubu bünyesinde hizmet sunmaktadır. Bununla birlikte satın alma stratejik bakımdan önemli ve doymuş pazarlara girmenin de etkin bir yolu olduğu için gruba önemli bir avantaj sağlamaktadır (Met, 2005). Bu nedenle 254 odalı ve 504 yatak kapasiteli Rixos Libertas Dubrovnik, satın alınarak 2007 yılında gruba dâhil edilmiştir. Tam sahiplik yöntemiyle büyüme stratejisi her ne kadar yüksek risk içerse de, küresel otel zincirlerinin Türkiye'nin farklı bölgelerinde inşaat halinde olan otel işletmelerini satın alma girişimleri, grubun önceki yıllarda aldığı kararları doğrular niteliktedir.

Kiralama, çok uluslu otel zincirlerinin ülkenin en iyi yerlerindeki bireysel tesisleri elde etmek için kullandığı bir yöntemdir. Genel olarak uzun süreli sözleşmelerin uygulandığı yöntem otelin iç tefrişatı, çevre düzenlemesi ve belirli bir kira bedelini içermektedir (Zhao, 1998). Bundan dolayı kiralama, belirli finansal yükümlülükler ve sabit kira ücreti nedeniyle orta seviyede yatırım ve risklilik özelliği göstermektedir (Met ve Erdem, 2011). Kira usulüyle çalışılan Rixos Lares, 2010 yılında 804 oda ve 2500 yatak kapasitesiyle hizmete sunuldu.

Yönetim sözleşmesi, otelleri sahibi adına yöneten profesyoneller çalıştırmanın ilk formatı kiralamadır. Otel sahipliği ve yönetimin büyük ölçüde ayrıldığı günümüzde her ikisinin de ayrı bir uzmanlık ve deneyim gerektirdiği bilinmektedir. Bununla birlikte otelciliğin yönetimin yoğun olduğu bir sektör olmasından dolay1 
düşük karlılıkların iyileştirilmesinde uzman ve yetenekli yöneticilere ihtiyaç vardır (Tarras, 1991). Buna göre otel sahibi, otel yönetmenin tüm sorumluluğunu yönetim şirketine devretmekte, yönetim şirketi de hizmetine karşılık bir yönetim ücreti almaktadır. Konaklama sektöründe yönetim anlaşmalarına, markalı otel zincirleri ve bağımsız yönetim şirketleri olmak üzere iki farklı şekilde karşılaşılmaktadır (Yu, 1999). 215 oda ve 480 yatak kapasiteli Rixos Grand Ankara, 2009 yılında yönetim sözleşmesiyle gruba katıldı. Bununla birlikte Rixos Şarm El-Şeyh yönetim sözleşmesiyle çalışılan başka bir oteldir.

Otel konsorsiyumu, uluslararası pazara açılmak isteyen birey oteller ya franchise zincirlerine üye olabilirler ya da tümüyle bağımsız kalarak otel konsorsiyumlarına üye olurlar. Bununla birlikte konsorsiyumlar, bir üyelik sistemi olup üye otellere, bağımsızlıklarına müdahale etmeksizin rezervasyon hizmetinin yanı sıra toplu pazarlama ve eğitim desteği hizmeti de sağlayabilirler (Yarcan,1998). Rixos Otel Grubu, Global Hotel Alliance üyesidir. Global Hotel Alliance'ın grubunun bulunmadığı pazarlarda hizmet sunması, bazı avantajlar sağlamaktadır. Örneğin Global Hotel Alliance, ABD, Çin ve Japonya gibi ülkelerde faaliyet gösterirken, Rixos Otel Grubu Rusya, Birleşik Arap Emirlikleri, Kazakistan, Azerbaycan, Gürcistan, Hırvatistan, Misır, Libya ve Ukrayna'da faaliyet göstermektedir. Bu nedenle üyelik gruba ortak pazarlama ve rezervasyon olanakları sağlamaktadır.

\section{Rixos Otel Grubunu Büyümeye Götüren Temel Özellikler}

Rixos dünya da milyonlarca tatil yapan insanın her birine, bir marka değeri olarak ulaşmayı hedeflemektedir. Böyle büyük bir iddianın sorumluluğunun çok yüksek olduğu ifade edilebilir. Bu nedenle Rixos Otel Grubu herkese kapısını açan mutlaka bir gün herkesin Rixos'ların birinde konaklanacağı düşüncesindedir. Bu kapsamda grubu büyümeye götüren temel özellikler arasında yatırım kararları, pazarlama çalışmaları, dış kaynak kullanımına ilişkin uygulamaları, kalite standartları, kapasite esnekliği ve personel istihdamına ilişkin politikaları, müşteri ilişkileri uygulamaları, yenilik uygulamaları, iş gören eğitimi ve imaj çalışmalarına yer verilecektir.

\subsection{Rixos Grubunun Yatırım Kararlarındaki Temel Kriterler}

Küreselleşmenin getirdiği olumlu ortam ve uluslararası piyasalarda artan rekabetten dolayı grup yatırım kararlarını üretim maliyetlerinin düşük olduğu ve alt yap1 hizmetlerinin yoğun olduğu bölgelere doğru yönlendirmektedir. Bununla birlikte, uluslararası alanda faaliyet gösteren yerli bir otel zinciri olmanın getirdiği bazı zorluklarla da karşılaşılmaktadır. Bu nedenle yatırım kararlarını etkileyen birçok değişken söz konusudur. $\mathrm{Bu}$ kapsamda Rixos grubunun ürün ve hizmetlerinin asgari standartlarını yatırım yapılan ülkelerdeki kurallar oluşturmaktadır. Bu durum grup çalışanları tarafından da tam olarak algılanmaktadır. Yatırım yapılan ülkede her ne kadar farklı uygulamalarla karşılaşılsa da grubun vizyonuyla güçlendirdiği temel değerleri, müşterilerin hayal ettiklerinin de ötesinde bir tatil deneyimi yaşayabilmeleri için servis ve ürün kalitesinin yüksek standartlarını korumak, standartlarda sürekli iyileşme ile otel işletmeciliğine daima inovatif fikirleri entegre etmek, Türk kültürü ve geleneklerine özgü Rixos misafirperverliği ve servisini yansıtmaktır.

Günümüzde otel işletmelerine ait yüzme havuzları misafirlerin tatil tercihini önemli ölçüde etkilemektedir. Otelin sahip olduğu havuzların çeşitliliği ve kalitesi, yükse rekabet ortamında, tercih edilmesinde önemli bir etken olarak görüldüğü için Türkiye'de havuz temizliğine çok dikkat edilmektedir. Bu nedenle Rixos Türkiye'nin standartlarını tam olarak sağlamak durumundadır. Bu standartları uygulamanın Rixos'a farklı getiriler olmaktadır. Bu kapsamda, Sağlık Bakanlığı Halk Sağlığı Müdürlüğü tarafından bir yıl süresince yapılan denetim ve analiz sonuçlarına göre havuz hijyeni ve havuz suyu kalitesi bakımından yönetmeliklerde belirtilen kalite standartlarını sağladığı için Rixos Downtown Antalya en temiz havuz ödülüne layık görülmüştür.

Aynı örneğe Kazakistan uygulamalarında bakıldığında havuz suyu hijyeni, temizliği ve gıda güvenliği kontrolleri, Türkiye'deki kadar sıkı olmamakla birlikte oraların da kendine göre standartları bulunmaktadır. Bununla birlikte Rixos olarak yatırım yapılan her ülkenin kriterlerinin yerine getirilmesi temel değerler arasındadır. Bu nedenle ülkelerin kurallarının farklılık göstermesi Rixos Grubu'nun kalite anlayışının dışına çıkartmamaktadır. Çünkü Rixos standartları en iyi şekilde tüm destinasyonlarda uygulama vizyonuyla güçlendirilmiştir.

Grubun yatırım kararlarındaki en önemli faktörlerden birisi de ürün tedarikindeki kolaylıklar oluşturmaktadır. Bilindiği gibi uluslararası malzeme tedariki karmaşık ve uzmanlık gerektirmektedir. Bu nedenle kesintisiz ve güvenilir olarak malzeme akışını sağlamak için birlikte çalışılacak güvenilir tedarikçileri seçmek ve onlarla işbirliği yapmak gerekmektedir. Örneğin, yerelden kaliteli ürün tedariki her zaman mümkün olmadığ1 için yatırım yapılan bölgelerde istenilen kalitede et, peynir ve yoğurt bulmada güçlüklerle karşılaşılmaktadır. Dolayısıyla da sevkiyatın büyük bir kısmı Türkiye'den yapılmaktadır. Bundan dolayı gümrüklerde uzun bekleme süreleri meydana gelmektedir. Bu nedenle de malzeme alımları eldeki stok miktarı gözetecek şekilde yapılmaktadir. 


\subsection{Pazarlama ve İmaj Çalıșmaları}

Müşteri tatminini sağlayan otellerin diğer otellere göre rekabet üstünlüğü sağlayacağı aşikârdır. Bu nedenle, otel işletmelerinde özellikle son zamanlarda görülen kaliteli hizmet ve müşteri odaklı yaklaşımların temeli, otel müşterilerinin beklentilerini karşılamak suretiyle müşteri tatminini arttırmaya dayanmaktadır (Aksu, 2000). Bu kapsamda, üründe marka standardizasyonu ve sürekliliğinin sağlanması Rixos grubunun çok önemli gördüğü yükselen bir değeridir. Grupta ayrıca markanın imajı, gücü, kimliği ve tüketici tarafından konumlandırılmasına da önem verilmektedir. Başka bir ifadeyle Rixos grubuna bağlı oteller, tüketicinin şüphelerini doğru marka konumlandırması sağlayarak gidermeye çalışmaktadır. Marka imajına yönelik olarak yapılan pazarlama çalışmalarıyla sunulan hizmetler birebir örtüştüğünde ise müşterilerin kafasında herhangi bir kuşku ve tedirginliğin kalmadığı görülmektedir. Turizm işletmelerinin potansiyel müşterilerine yönelik çalışmalarında ürün ve hizmet standardizasyonunda ileriye gittiklerini duyurdukları ve bunu da pazarlama çalışmalarıyla desteklediklerine çok sık rastlanmaktadır. Endüstrinin genelinde ise markanın doğru konumlandırması ve marka imajının sürekliliğinin sağlanması rekabette büyük önem taşımaktadır. Bu bakımdan Rixos Grup müşterinin ilk deneyimine çok önem vermektedir. Müşteri ilk deneyimini olumlu veya olumsuz yaşamışsa bunu uygulanan anketlerde yorum ve tavsiye şeklinde paylaşmaktadır. Bu kapsamda Rixos Grubu'nun müşterilerine uyguladığı anketlerin geri dönüşüm oranının \% 85 olması önemli bir göstergedir. Müşterinin, beklentilerinde veya beklentilerinin üzerinde sunulan hizmetlerden memnun olarak ayrılması Rixos'a yeniden ziyaret eğilimi olarak yansıdığı gibi, pazarlama çalışmalarında da maliyet avantajı sağlamaktadır.

Grup öncelikli olarak belirli bir pazara hitap etmekten ziyade müşterilerinin tekrar konaklamasına yönelik çalışmalar geliştirmektedir. Çünkü tatile gelen herkes temiz bir oda, deniz, kum, güneş ve eğlence beklemektedir. $\mathrm{Bu}$ kapsamda yapılan çalışmalar, grubun otellerini tekrar tercih eden müşterilerin oldukça yoğun olduğunu göstermektedir. Çeşitli ülkelerde otelleri olan grubun müşterilerinin, destinasyonlardaki otelleri farklı amaçlarla tercih ettikleri görülmektedir. Örneğin, Rixos Downtown'a tatile gelen bir müşteri bir y1l sonra Almatı'ya iş amaçlı geldiği düşünüldügünde Rixos'u tercih etmesi önemli bir avantaj sağlamaktadır. Bununla birlikte Rixos'un farklı müşterileri city ve resort ayrımında değişik kategorilerde yer almaktadır. Bu nedenle Rixos Grubu'nun sadakat programına geçme planlamaları olmak birlikte grup olarak ürünü sattıktan sonra müşteriye sunulan hizmetin çok daha önemli olduğuna inanılmaktadır. Çünkü tatminkar ve değer verilen müşteri ancak sadık müşteri olabilir.

İmaj, çeşitli kanallar aracılığıyla elde edilen bilgi ve verilerin değerlendirilmesi sonucunda oluşmaktadır. Bu noktada bilgi ve veriler, içinde yaşanılan çevrenin özellikleri ve sahip olunan ön yargılar gibi pek çok kanal aracılığıyla elde edilmektedir (Uzoğlu, 2001). Rixos Otel Zinciri imaj çalışmalarını iki anket grubuyla ölçmektedir. Birinci uygulanan anket hâlihazırda konaklayan müşteriye uygulanan anketlerdir. İkincisi ise müşteriye otelden ayrıldıktan sonra elektronik posta yoluyla uygulanan anketlerdir. Bu anketlerin soruları arasında herhangi bir farklılık bulunmamaktadır. Üzerinden biraz zaman geçtiğinde müşteri olaya çok farklı yaklaştığı için grup için ikinci ankette en az birinci anket kadar önemli görülmektedir. Bu kapsamda elektronik posta yoluyla yapılan anketlerin geri dönüşlerinin $\% 85$ olması çok iyi bir dönüş oranıdır. Bu grubun imajının iyi algılandığını göstermektedir.

\subsection{Dış Kaynak Kullanımı (DKK)}

Dış kaynaklardan yararlanma (DKY) organizasyon dişındaki işletmeler ile ortaklaşa çalışarak maliyetleri düşürme, verimliliği artırma ve müşteri tatminini sağlama amacıyla yapılmaktadır (Gövdere, 2009). Bundan dolayı otel işletmelerinde DKK en fazla ön büro, yiyecek-içecek, house keeping, animasyon, güvenlik, teknik servis ve muhasebe bölümlerinden oluşan hizmetleri kapsamaktadır (Tetik ve Ören, 2007). Konaklama işletmelerinin son yıllarda en çok başvurduğu dış kaynak kullanım şekli çamaşırların dışarıda yıkatılmasıdır. Bu nedenle bütün dünyada olduğu gibi Türkiye'de çamaşır yıkama işletmelerinin sayısı ve oteller tarafindan kullanımı artmaktadır. Türkiye'de 62 otel üzerinde yapılan bir araştırmaya göre tesislerin \% 34'ünün çamaşırhane hizmetlerini dış kaynak kullanımıyla sağladığı görülmektedir (İsfendiyaroğlu, 2001). Bunun en önemli nedeni, çamaşırhane hizmetlerinde maliyetlerin \% 70'inin emek yoğun olmasından ve yeni oteller inşa edilirken çamaşırhane kurmak yerine o bölgedeki çamaşır yıkama tesislerinden yararlanarak bu hizmetleri gerçekleştirmeye çalışmaktan kaynaklanmaktadır (Kesgin, 2005).

Bununla birlikte dışarıdan hizmet satın almaların avantaj ve dezavantajlarının da olduğunu belirtmek gerekir. $\mathrm{Bu}$ şekilde çalışmanın sakıncalarından birisi, anlaşmalı olunan firmanın herhangi bir sıkıntı yaşaması halinde işlerin aksamasının muhtemel olmasıdır. Bunun dışında müşterilerin çamaşırlarının başka otellerin çamaşırlarıyla karışma durumu ve çamaşırların her geldiğinde sayılması başka bir iş yükünü oluşturmaktadır. Aynı şekilde farklı kurumların (örneğin hastaneler ile otellerin) çamaşırlarının yan yana yıkandığı da görülmektedir. Bu nedenle çamaşırhane hizmetleri dışarıdan alınmadığında işler daha kontrollü olmaktadır. Bundan dolayı, Rixos Otel Zincirine bağlı otellerin tamamında kat hizmetleri departmanına bağlı bir çamaşırhane bulunmaktadır. Buralardaki çamaşır makinelerinin ve kazanların bakımına son derece dikkat edilmektedir. Bununla birlikte örgüt kültürü ve marka uyumuna önem verildiği için grubun tüm otellerinde sular arıtmalıdır. Bütün kazanlar aylık ve yıllık olarak kontrolden geçmektedir. Herhangi bir yanma ve sudan bir koku gelmesi söz konusu değildir. Bu şekilde müşteri şikâyetlerinin de önüne geçilmektedir. 
Yiyecek- içecek hizmetleri otellerde konforun bir parçası olmakla birlikte aynı zamanda bir gelir merkezidir. $\mathrm{Bu}$ nedenle yiyecek- içecek hizmetleri otellerin en büyük departmanlarından biri olduğu için personel maliyetlerinin de yarısından fazlasını oluşturmaktadır. Dış kaynaklardan yararlanıldığında bu alanı kontrol etmenin bazı zorluklarıyla karşılaşıılmaktadır. Örneğin, bu alanda dı̧̧ kaynaklardan yararlanıldığında yiyecek ve içecek hizmetlerinin fiyatlama ve promosyon esnekliğinin kaybedilmesine neden olmaktadır. Rixos Otel Zincirinde, yiyecek- içecek hizmetlerinde örgüt kültürüne ve marka uygunluğuna önem verilmektedir. $\mathrm{Bu}$ nedenle, Rixos Grand Ankara ve Rixos Taksim İstanbul'da alakart menüde yiyecek hizmeti sunulmaktadır. Ancak oteller inşa edilirken her şey dahil sistemine göre dizayn edildiği için alakart menüde hizmet sunmak örgüt kültürüne ve marka uygunluğuna göre hareket etmeyi zorlaştırmaktadır. $\mathrm{Bu}$ oteller aynı zamanda grubun yönetim sözleşmesiyle çalışı̆̆ğ işletmeler olduğu için otellerde yeniden bir dizayn ve üretim alanı genişlemesine gidilmemektedir. Bu nedenle personelin yemek hizmeti dış kaynak kullanarak sağlanmaktadır.

Rixos Otel Zincirinin tüm işletmelerinde animasyon faaliyetleri oldukça geniş bir faaliyet alanını kapsamaktadır. Bu hizmetlerin tamamı ücretsiz olarak sunulmaktadır. Eğlence ve animasyon faaliyetleri, otelde konaklayan misafirlerin zamanını eğlenceli bir şekilde geçirmesi için misafirlerin beklentilerine bağlı olarak değişik ilgi odaklarına yönelik hazırlanmaktadır. Bu nedenle animasyon gösterileri haftanın iki günü grubun kendi personeli tarafindan sunulmakla birlikte, haftanın 5 günü dışarıdan dans, müzik, akrobasi, jimnastik, yarışmalar şeklinde bazı özel gösteriler satın alınmaktadır. Bunlar yıllık olarak yapılan sözleşmelerle satın alınan gösterilerdir. Dışarıdan alınan bazı animasyon gösterileri grubun değişik otellerinde gösteri yapmakta, bu da grup oteli olmanın maliyet ve etkinlik çeşitliliği avantajını beraberinde getirmektedir.

Otel işletmelerinin verdiği hizmetler dikkate alındığında, teknik anlamda farklı uzmanlık gerektirdiği görülmektedir. Bu nedenle dış kaynaklardan daha iyi ürün ve hizmet sağlanıyorsa, bu başvurulması gereken bir yöntemdir. Örneğin personel servis hizmeti farklı bir uzmanlık alanı gerektirdiği için grup bu hizmeti dış kaynak kullanarak sağlamaktadır. Çünkü aracın bakımı, onarımı ayrı bir uzmanlık alanı olarak görülmektedir.

\subsection{Rixos Kalite Standartları}

Yoğun rekabetin yaşandığı günümüzde, müşteri memnuniyetinin sağlanması müşteri odaklı yönetim anlayışı ile gerçekleştirilmektedir. Çünkü müşteri memnuniyeti, bir işletmenin ürün ya da hizmetleri kullanması sonucu müşterinin bu ürün ya da hizmetin değeri, niteliği ve özellikleri hakkındaki olumlu ya da olumsuz duygularının tamamını oluşturmaktadır (Altan ve Engin, 2004). Bu nedenle turizm endüstrisinde sunulan hizmetlerin yapısal özelliği olan üretim ve tüketim sürecinin birbirinden ayrılmaması göz önünde bulundurulması gereken en önemli faktördür. Bununla birlikte hizmet işletmelerinde müşterinin sipariş ettiği mal ve hizmetlerin en kısa sürede yerine getirilmesi rakiplere karşı üstünlük sağlanması açısından önemli bir unsur olarak görülmektedir. $\mathrm{Bu}$ durum hizmetlerde bir aksama olması halinde işletmeler açısından bazı riskleri de beraberinde getirmektedir.

Rixos'un kalite anlayışında ise yüksek standartlarını korumak, sahip olduğu standartları sürekli iyileşme ile otel işletmeciliğine inovatif fikirler entegre etmek vardır. Bu kapsamda Rixos 'u tercih eden müşterilerin otelden \%100 memnun ayrılması grubun başlıca değerleri arasında bulunmaktadır. Grup bu amacını tüm işletmelerinde unutulmaz bir konaklama sağlayarak, konuklara özel, Türk kültürü ve geleneklerine özgü Türk misafirperverliği ve servisini yansıtarak gerçekleştirmektedir. Bu nedenle Rixos kalite anlayışını, Türkiye'de ve dünyada güvenilir ve aynı kalitede hizmet veren örgüt kültürüne ve marka uygunluğuna yakışır bir şekilde sürekli olarak fark ve değer yaratan, rakiplerin örnek aldığı, her aşamada bir otelden daha fazlasını vaad eden ve herkesin bir gün yolunun Rixos Otel Zincirin'den birine düşeceği anlayışıyla sürdürmektedir. Bundan dolayı grup, hizmet sektöründe kalitenin kontrol noktasını tüketici olarak algılamaktadır. Bu anlayış gruba farklı erklerde ödüller de getirmektedir. Örneğin, ilk defa 2009 yilında verilmeye başlayan AB Kalite Zirvesi ödülünü Rixos Otel Grubu aldı. Grubun bu ödüle layık görülmesinde koşulsuz müşteri memnuniyeti anlayışı ile verilen hizmet kalitesinin, Avrupa Standartlarının da üzerinde olmasından kaynaklanmaktadır. Bununla birlikte grubun bünyesinde uluslararası alanda faaliyet gösteren birçok otel işletmesinin bulunması ulusal ve uluslararası kalite standartlarına akredite olunmasını gerektirmektedir. Grubun uyguladığı ve akredite olduğu kalite standartları, iç pazarda olduğu gibi dış pazarda da kendine rekabet avantajı sağlamaktadır.

Ulusal ve uluslararası alanda faaliyet gösteren Rixos Grubu'ndaki otellerin akredite olduğu ve uyguladığı kalite standartları, ISO 22000 gıda güvenliği, ISO 14001 çevre güvenliği ve ISO 9001 kalite yönetim sisteminin kurulması esnasında uygulanması gereken şartları tanımlayan ve belgelendirmeyi teşkil eden standartlardır. $\mathrm{Bu}$ kapsamda Rixos Dubrovnik, Rixos Konya ve Rixos Grand Ankara 2011 yılında ISO 22000 gıda güvenliği ödülüne layık görülmüştür.

Grubun bütün otelleri bu sertifikalara sahip olmakla birlikte uygulamada, planlama ve kontrol noktalarına son derece önem verilmektedir. Çünkü üretim ve tüketimin aynı yerde yapıldığı bir endüstride planlamanın önceden tam bir titizlikle yapılması gerekmektedir. Kalite kontrol noktası olan tüketiciye sunulan hizmetlerle ilgili geri bildirimler kalitenin istenilen şartlarda olup olmadığının belirlenmesine yardımcı olur. Bu kapsamda müşterilere uygulanan anketlerle birlikte gelen şikâyetler titiz bir şekilde ele alınmaktadır. 


\subsection{Rixos Kapasite Esnekliği}

Kapasite esnekliği özellikle hizmet sektörü açısından önemli bir sorundur. Talep yetersizlikleri işletmeleri düşük kapasite ile çalışmaya yöneltmektedir. Bundan dolayı otel işletmelerinin büyük bir çoğunluğunun çalışmalarını mevsimsel olarak yürüttükleri görülmektedir. Türk turizm sektörüne mevsimsel olarak bakıldığında, Avrupalı turistler Antalya'da özellikle kış mevsiminde kongre ve toplantı amaçlı bulunurken, yaz döneminde Rus ve Rus dilini konuşan ülkelerden gelen turistlerin konaklamasında bir yoğunluk görülmektedir.

Rixos' da ise mevsimsel bir uygulamadan daha çok gruba ait otellerin farklı konseptlerde tasarlanması bir avantaj olarak görülmektedir. Özellikle Antalya Lara'da hizmet veren Rixos Lares, hem milli takımlardan hem de yurt dışı takımlarından oldukça rağbet görmektedir. Milli takımlar, ulusal futbol kulüpleri ve yurt dış1 takımları tarafından kamp merkezi olarak tercih edilen otelin bünyesinde, üç profesyonel futbol sahası ve profesyonel tartan kortları bulunmaktadır. Türkiye'nin büyük bir futbol kulübü olan Galatasaray’ın tesisde birkaç kez kamp amaçlı konaklaması tercih edilirliğinin yüksek olduğunu göstermektedir. Bununla birlikte Antalya'nın Belek turizm bölgesinde faaliyet gösteren, Rixos Premium Belek'in kendine özgü bir golf sahası olmamasına rağmen otelde golfle ilgili transfer ve golfe ilişkin özelliklerin sergilenmesi farklı zamanlarda tercih edilirliğini arttırmaktadır.

Antalya merkezde faaliyet gösteren Rixos Sungate ve Rixos Downtown oteller, daha çok kongre ve toplantı ağırlıklı tercih edilmektedir. Rixos Sungate otelde, büyük bir kongre merkezi on iki ay boyunca faaliyet göstermektedir. Kongre merkezinin bünyesinde on beş tane toplantı salonunun talebe göre irili ufaklı salonlara dönüştürülebilir özellikte olması rahat bir kullanım sağlamaktadır. Bununla birlikte kongre merkezinin bünyesinde ayrı bir restoranı ve oturma yerlerinin bulunması müşterilere ve işletmeye çok büyük bir rahatlık sağlamaktadır. Otelin bu özelliğiyle toplantı ve tatil amaçlı gelen müşteriler ayrı yerlerde tutulabilmektedir.

Rixos Grubu'nun aynı bölgede birden fazla otelinin olması yüksek talep zamanlarında oteller arasında müşteri transferini mümkün hale getirmektedir. Ayrıcı özel programı olan (şirket toplantıları, kongreler, doğum günü partileri, düğünler gibi) otele personel ve ihtiyaç duyduğu araçlar grubun diğer otelleri tarafindan sağlanmaktadır. Bu da grup oteli olmanın getirdiği en büyük avantajlardan birisidir.

\subsection{Personel Politikası}

Küreselleşme sürecinin ve teknolojik gelişmenin eş zamanlı olarak devreye girmesi, geleneksel rekabet stratejilerinin geçerliliğini azaltmıştır. Günümüzde rekabette üstünlük için verimlilik artışı sağlamak ve yenilik yapmak önemli ölçüde insan kaynaklarına yönelinmesini zorunlu kılmıştır (Aksu, 2000). Bu nedenle otel işletmelerinde hizmet kalitesini arttırmanın en önemli yolu, istihdam edilen personelin memnuniyetinin sağlanmasıdır. Yapılan bilimsel çalışmalara bakıldığında ise ekonomik faktörlere nazaran, psiko-sosyal faktörlerin, işgörenin iş tatmini üzerinde etkisinin daha fazla olduğunu ortaya koymaktadır. Emek-yoğun bir sektör olan turizm sektörüne bağlı konaklama işletmelerinde işgücünün öneminin diğer sektörlere göre daha fazla olduğu görülmektedir. Çünkü hizmeti satın alan müşteri ile hizmet sunan işgörenin iç içe, yüz yüze olduğu bir sektörde, iş tatmini düşük olan işgörenin müşterisine tatmin edici bir düzeyde hizmet sunması ve müşteri tatmini sağlaması mümkün değildir (Akınc1,2002). Başka bir ifadeyle personelini mutlu edemeyen işletmelerin müşterilerini memnun etmesi mümkün değildir.

Çalışan memnuniyeti sağlanan işletmelerin güçlü bir örgüt kültürüne sahip olduğu görülmektedir. Güçlü bir örgüt kültüründe, örgüt üyeleri temel değerleri kabul eder, örgütün amacını bilir ve onun için çalışır. Zayıf örgüt kültüründe ise, ortak bakış açısının yokluğu, yöneticiler ve çalışanlar arasında kopukluklar, diyalog eksikliği, kuşku, düşmanlık hisleri ve gerilime dayalı bir sosyal iklim görülür (Doğan, 1997). Bundan dolayı Rixos Otel Zinciri'nde görev yapan yöneticiler, iş görenlerini sadece ekonomik bir varlık olarak değil aynı zamanda sosyal yönü olan ekonomik beklentilerinin dışında farklı beklentilerini ve ihtiyaçlarını karşılamak için bir örgütte çalıştıklarını göz önünde bulundurarak personele yaklaşırlar. Çünkü çalışanlar, işletmeler için çok önemli sinyallerin alındığı müşteriye küçük dokunma noktalarını (touchpoint) oluşturmaktadır. Bu nedenle, Rixos Otel Zinciri olarak personelin motivasyonu hem ekonomik yönden hem de psiko-sosyal yönden sağlanmaktadır. Bu kapsamda yılda iki kez düzenlenen personel gecelerinde çekilişle maddi değeri yüksek olan hediyeler sunulmaktadır. Örneğin 2012'de düzenlenen personel gecesinde, personelin birine çekilişle 2+1 daire, başka bir personele belli standartlarda araba, birçok personele de çeyrek altın ve farklı Rixos' larda konaklama imkânı verildi. Bununla birlikte yeni evlenen çiftlere balayı ödülü verilmesi veya maddi durumuna bakılarak para desteği sağlama gibi uygulamalar da bulunmaktadır. Bu nedenle grubun, çalışanlarının mutlu olduğu günleri ve üzüntülerini paylaşmak isteyen farklı bir yönü de bulunmaktadır.

Turizm sektörünün hizmet sektörü olması nedeniyle istihdamı olumlu yönde etkilediği bilinmektedir. Buna paralel olarak çalışma hayatıyla ilgili sorunların artması ve çeşitlenmesi de kaçınılmazdır. Otel işletmelerinde aynı çatı altında birden çok hizmet sunulmasından dolayı da istihdam yoğunluğu maliyeti, toplam maliyetler içinde önemli bir payı oluşturmaktadır. Bu nedenle turizm işletmeleri emek yoğun bir endüstride hizmet verdiği için personel sayısının hizmetin kolay, sağlıklı ve kaliteli olmasında önemli bir etkisinin olduğu görülmektedir. Hizmet sektörünün dünyadaki uygulamalarına bakıldığında hemen her sektörde yarı zamanlı (part-time) personel istihdam edilmektedir. Ancak müşterilerine kaliteli hizmet sunmak isteyen işletmelerin oda sayısına uygun 
personel istihdam etmesi gerekir. Rixos Grubunun uygulamalarında, oda sayısı başına düşen personel sayısının 0,8-1 arasında değiştiği ve bazı otellerde bu oranın 1,5'e kadar yükseldiği görülmektedir. Bu şekilde personel istihdamı, hizmeti hem kolay hem de daha sağlıklı kılmaktadır. Bununla birlikte Rixos çalışanlarına belirli davranış kalıpları, kurum kültürü ve çeşitli eğitim faaliyetleriyle sağlanmaya çalışılmaktadır. Çünkü grubun çalışanları her ne kadar Türk olsa da çalışanlar arasında bölge halkından da iş görenler bulunmaktadır. Her zaman otelin bulunduğu bölgeden çalışanlar mutlaka istihdam edilmektedir. Bu şekilde Rixos Grup faaliyette bulunduğu bölgenin yerel halkına da istihdam sağlama, malzeme satın alma gibi yöntemlerle hizmet etmeye çalışmaktadır. Grubun bünyesinde farklı kültürlerden iş görenler bulunduğu için müşteri yürürken ona gülümsemek, selam vermek, herhangi bir şey sorduğunda yakından ilgilenmek, bir problemle karşılaştığında problemi çözmek ya da çözecek kişilerle irtibata geçmek, müşteriye karşı sürekli saygı ve nezaketle davranmak ve konuşmak çalışanlara kazandırılmaya çalışılan temel davranışlardır.

İş tatmini, işgörenin ruhsal sağlığını önemli ölçüde etkilemektedir. Bu nedenle Rixos Gruba bağlı tüm otellerde personelin özlük haklarına son derece önem verilmektedir. Personelin sigortalılığına titizlik gösterilmekte ve sigorta primleri brüt maaş üzerinden yatırılmaktadır. Bununla birlikte personelin işe başlama ve çıkış saatleri parmak izi okuyucularla sağlanmaktadır. Bu şekilde mesai fazlası olan personele, herhangi bir beyanda bulunmasına gerek kalmadan ay sonunda fazla mesai ücreti ödenmektedir. Personelin fazla mesai yapmasına ise bölüm müdürü ve insan kaynakları müdürü birlikte karar vermektedir.

Personelin en önemli motivasyon kaynaklarından biri de onlara ve yaptığı işe değer vermektir. Çalışanlarını dinleyen ve sözlerine önem verildiğini hisseden personelle işletmelerin arasında bir sadakat bağ kurabilmektedir. Bu bakımdan grup, çalışanlarının motivasyon seviyelerini arttırmak amacıyla ayın personeli uygulaması yapmaktadır. Müşteriler ve departman yöneticileri tarafından öne çıkartılan isimlerin görüşüldüğü aylık toplantılarda, farklı departman müdürlerinin de katıldığı oylamayla ayın personeli seçilmektedir. Ayın personeline verilecek hediyelerin niteliği otelin uygulamasına göre farklılık gösterdiği gibi bu konuda oteller özgür bırakılarak herhangi bir kısıtlamaya da gidilmemektedir.

Grubun otelleri arasında personel transferi imkânının olması, personelin iş akdinin askıya alınmasının da önüne geçmektedir. Örneğin, Kazakistan'da Rixos Astana'dan sonra Rixos Almatı'nın açılışı yapıldı. Dolayısıyla Astana'da yetişmiş personel oraya destek amacıyla transfer edilerek, zincire yeni katılan bu otelin Rixos kültürüyle uyum sağlaması hızlandırılmaktadır. Grubun bu yönü hem iş görenler açısından hem de kurum açısından önemli bir avantaj sağlamaktadır. Çünkü herhangi bir kriz durumda personel işten çıkarılmak yerine yoğunluğun yüksek olduğu otele yönlendirilmektedir. Bundan dolayı personelin iş akdinin askıda kalması gibi bir durumla çok fazla karşılaşılmamaktadır. Bununla birlikte iş akdi askıya alınan personel, yoğunluğa göre düğün ve gala gecelerinde, kongre ve toplantı organizasyonlarında istihdam edilmektedir. Bu durum grubun personel ayağını güçlendirmektedir.

Periyodik olarak ülke dışındaki otellerdeki çalışanlarla bir araya gelerek motivasyonlarını arttırmaya yönelik çalışmalar yapılmaktadır. Örneğin Mısır'daki otelin çalışanlarının kendilerini yalnız hissetmesini önlemek için Türkiye'ye toplantıya çağrılararak moral desteği sağlanmaktadır. Çünkü personelin her yerde grup için canla başla mücadele verdiğine inanılmaktadır. Bu nedenle özellikle Türkiye dışındaki otellerde personelle ilgili zaman zaman sıkıntılar olmakla birlikte, merkez ofis olarak otellerle sürekli görüşerek onların yanlarında olunduğunu hissettirerek motivasyonları sağlanmaya çalışılıyor.

Çalışanların eğitimi ve davranışları kadar önemli bir unsur olan görünümlerine son derece dikkat edilmektedir. Çünkü personel dış görünüşüyle otelin yenlikçi kimliği karşılaştırılmaktadır. Rixos Otel Zinciri’nde personelin kıyafeti marka departmanı tarafindan belirlenmektedir. Bu nedenle gruba bağlı otellerin tamamında personelin çalışmaya başladığı andan itibaren ayakkabı, yiyecek-içecek, üniforma ve servis hizmetleri karşılanmaktadır.

\subsection{Personel Eğitimi}

Hizmet işletmelerinin verimli bir şekilde faaliyet göstermesi yapmış veya yapacak olduğu etkin bir iş gören bulma ve seçme sürecine bağlıdır. Bununla birlikte iş görenlerin gelişmesine olanak sağlayarak onların motivasyonuna katkıda bulunmak için ilk olarak personele güven vermek gerekir. Bu nedenle grup personelin yaşam standartlarını geliştirmek için planlı ve sürekli mesleki eğitim politikası uygulamaktadır. Bu nedenle Rixos Otel Zincirindeki işletmelerde iki farklı personel eğitimi yaklaşımı bulunmaktadır. Bu nedenle grubun merkez ofisindeki eğitim departmanı gruptaki tüm otellerden yıllık olarak eğitim programlarının belirlenmesi yönünde çalışma içindedir. Dolayısıyla eğitimlerle ilgili planlar yıllık yapılmaktadır.

Bunlar otelin kendi bünyesinden verdiği eğitimler ve merkez ofis tarafından tüm otellerde verilmesi gereken eğitimlerdir. Bunlar dil eğitimi, iletişim teknikleri, problem çözme teknikleri, müşteri ilişkileri eğitimi ve şikâyet yönetimi eğitimi verilmektedir. Bunların dışında müşteri kontak eğitimi, müşteri dinleme eğitimi, iletişim eğitimleri, doğru iletişim kurma teknikleri, doğru dinleme, doğru cevap verme teknikleri ve acil durumlara müdahale eğitimleri gelmektedir. Bununla birlikte Rixos dil eğitimine çok öenm vermektedir. Grubun uluslararası bir marka olmasından dolayı bünyesinde farklı dillerden ve milletlerden çalışan barındırıyor olması dil eğitimini gerektirmektedir. Aynı dili konuşan insanların birbirleriyle daha iyi anlaşacağı göz önünde bulundurulduğunda personele problem çözme tekniklerinin öncesinde dil bariyerlerini aşmaları yönünde 
eğitimler verilmektedir. Örneğin, Mısır'da çalışan Rixos personeline dil eğitimi verilmektedir. Çünkü Mısır'da bölgede çoğunlukla Arapça konuşulması ve İngilizce imkânlarının çok kısıtlı olması çalışanlara haftada 1-2 gün İngilizce eğitimi vermeyi gerektirmektedir.

Personel eğitimleri kurum içi çalışanlar tarafından verildiği gibi kurum dışından da sağlanmaktadır. Örneğin, otel işletmelerinde oluşabilecek acil durumlarda tesis içerisindeki kişilerin en hızlı ve emniyetli bir şekilde kaçış yolları üzerinden tahliye edilmesi gerekmektedir. Bu nedenle eğitimlerin bazılarının (örneğin, yangın eğitimi) sertifikalı olması gerekmektedir. Bu eğitimlerle işletmedeki tüm çalışanların acil durumlarda üretilen panik çıkış donanımlarını kullanabilmesi hedeflenmektedir. Bundan dolayı bu eğitimler grubun akredite olduğu kurum tarafindan sağlanmaktadır.

Bununla birlikte Türkiye'deki tüm otellerde verilmesi gereken zorunlu bir eğitim olan iş sağlı̆̆1 ve güvenliği eğitimi bütün otellerde verilmektedir. Bunun yanında müşteriye bilgi vererek veya vermeden yapılan yangın eğitimi tatbikatı zorunlu olduğu için bütün çalışanların bu eğitimi alması gerekmektedir. Bununla birlikte kurum çalışanlarının \%20'sinin alması zorunlu olan ilk yardım eğitimi verilmektedir. Rixos Grup çalışanlarına yapılan eğitimlerin tamamı sertifikalandırılması personelin özgeçmişi için önemli görülmektedir. Bununla birlikte departmanın kendi içinde bir eksiği varsa, örneğin ön büroda kullanılan programla ilgili bir eksiklik varsa ilgili eğitimi sadece ön büro personeli almaktadır. Kat hizmetleri departmanında görevli olan ve alanı kimyasallarla ilgili olan çalışanlar anlaşmalı olunan ve kimyasalların satın alındığı firma tarafından ölçeklendirme ve korunma eğitimi verilmektedir.

Rixos Grubu aidiyet duygusuna büyük önem vermektedir. Nitekim üst yönetimde görev yapan personel ortalama en az beş yıllık çalışanlardan oluşmaktadır. Kalifiye personel ağırlıklı olarak üniversite ve turizm meslek lisesi mezunlarından oluşmaktadır. Personelin yoğun sezonların dışındaki dönemlerde işten çıkarılması çok fazla karşılaşılan bir durum değildir. Rixos Otel grubu sürekli büyüdüğü için düşük sezon olarak ifade edilen dönemlerde personelin sezonun yoğun olduğu ülkelere transfer edilmesi grubun işini kolaylaştırmaktadır. Çünkü, Rixos personeli başka bir Rixos'a gittiğinde, gittiği bölgedeki personelle kaynaşarak ona işi öğretiyor.

Değişik ülkelerde faaliyette bulunan Rixos'da pek çok değişik milletten insan çalışmaktadır. Personel arasındaki kültürel farklılıklar bir takım zorlukları da beraberinde getirebilmektedir. Örneğin bazı ülkelerde personel sözlü olarak değil de, yazılı talimatla işini dört dörtlük yapmakta ve iş tanımlarının dişına kesinlikle çıkmamaktadırlar. Örneğin odaları temizleyen personele koridoru ya da merdivenleri temizlememektedir.

\subsection{Rixos Hotel Grubunun Sahip Olduğu Ödüller}

Rixos Grubu farklı erklerde ödüllere layık görülmektedir. Bunlar uluslararası faaliyet gösteren kuruluşlardan ve yerel yönetimlerin takdirleriyle değer bulmuş ödüllerdir. Aynı zamanda Rixos'la ilgili bloklara ve web sitelerine yapılan yorumlarında etkisi olmaktadır. Bununla birlikte günümüzün tatil anlayışı tecrübeyle müspet sonuçlanmaktadır. Bu nedenle müşterilerin memnun olarak ayrılmasının başka getirileri de olmaktadır. Bunların başında ödüller Rixos Grubun en çok değer bulduğu karşılıklardır. Bunlar, bağımsız bir şekilde web 2 olarak ifade edilen sosyal medya sitelerinde yayınlanan, Rixos Otel Zincirine bağlı işletmelerden herhangi birinde konaklayan veya toplantı organizasyonuna katılan müşterilerin yaptığı yorumlar sonucunda gelmektedir. Bu kapsamda şu örnekler verilebilir:

Rixos Downtown, dünyanın en büyük tur operatörü olan TUI tarafindan 'En iyi beş yıldızlı otel' seçildi. Bu ödül Rixos' a TUİ'nin İskandinav ülkeleri kolu TuiNordic'in, 'Blue Awards 2013' ödülleri kapsamında 150 otel işletmesinde 265 bin müşteriye uygulanan anket sonucunda, 2012'de en iyi beş yıldızlı otel kategorisinde verildi.

Holiday Check tarafından verilen 'Quality Selection' ödülü eğlence programının zenginliği, spor aktivitelerinin sürekliliği ve dünyanın ilkleriyle hizmet kalitesinde ayrı bir yerde olan Rixos Sungate’e layık görüldü. Rixos Sungate, Holiday Check tarafindan ödül kriterleri belirlenen ve Hotel Conulting Service tarafından ölçümlenen değerler sonucunda 2011'de “Akdeniz Bölgesi'nin En İyi Entertainment ve Event Oteli” seçildi. Bu seçimde müşterilere sunulan günlük aktivitelerin yoğunluğu, çocuk aktivitelerinin kapsamı ve içeriği gibi kriterler bulunmaktadır.

Rixos Lares hayvanlara yönelik olumlu uygulamalarından dolayı TUI' den 'Hayvan Dostu Ödülü' aldı. Bir benzer ödülde Hayvanlara Etik Muamele İçin Mücadele Edenler-People For the Ethical Treatment of Animals (PETA) adlı hayvan hakları organizasyonundan geldi. Otelin açık yaşam alanında bulunan kuş, kedi, köpek ve caretta caretta'lar için uyguladığı özel bakım hizmetlerinden dolayı bu ödüle layık örüldü. Rixos Lares'in doğal yaşam alanında kedilerin barınmaları için yapılan kedi evleri, hayvanların kontrolsüz çoğalmalarını engellemek amacıyla kısırlaştırma çalışmaları ve hayvanlara düzenli olarak veteriner kontrolleri gibi pek çok faaliyet yapmaktadır. Bu kapsamda kuşların yuvalama alanlarını arttırıldı. Tesis içinde yer alan yüksek ağaçlara kuş yuvaları asılarak kötü hava şartlarından korunmaları sağlandı. Buradaki kuşlar koruma altına alınarak veteriner hekimlere yönlendirilmektedir. Otelin sahilinde yumurta bırakan caretta caretta yuvaları koruma altına alınarak, yuvalarda tespit edilen yumurtaların ve yavruların denize canlı olarak ulaşması sağlanmaktadır

Rixos Libertas otelinin projesi öncelikle bir dönüşüm projesidir. Bu kapsamda değerlerin etkin ve yenilikçi uygulamalarla çevreye kazandırılmış olmasından dolayı Turizm, Seyahat \& Ulaşım Kategorisinde "En İyi Yapı" Ödülüne layık görüldü. 
Bunların dışında grubun otellerine yerel yönetimler tarafindan farklı ödüllere layık görülmektedir. Örneğin denetimler sonucu yapılan değerlendirmeye göre Rixos Downtown Otel 'En İyi Mutfak', 'En Güvenilir Tesis' ve 'En İyi Spa\&Sport' ödülleri verildi.

Türkiye'deki Rixos Grubuna ait otellerin bütün sahilleri Mavi Bayraklıdır. Bilindiği gibi Mavi Bayrak (Blue Flag) ödülü tüm dünyada geçerliği olan temiz sahil, sahil çevresi ve deniz suyuna sahip olan işletmelere verilmektedir. Bu ödüller Rixos Gruba müşteri sağlayan tur operatörlerinin ve devlet tarafından yapılan denetimlerin sonucunda verilmektedir. Rixos Grup için olumlu bir reputasyon olan ödüller, grubunun sunduğu hizmetlerin beğeni topladığını göstermektedir.

\subsection{Yenilik ve CRM Uygulamaları}

Uluslararası otel işletmelerinin yenilik uygulamalarına bakıldığında sahip oldukları inovatif değerleri yeni destinasyonlara taşıdıkları görülmektedir. Bu nedenle grubun uluslararası bir zincir olmasının etkisini yenilik uygulamalarında görmek mümkündür. Bu kapsamda Rixos uygulamalarına bakıldığında bunların başında Müşteri İlişkileri Yönetimine - MIY (Customer Relationship Management-CRM) ilişkin yatırımlar gelmektedir. Müşteri ilişkileri yönetimi; stratejik, analitik, işlevsel ve işbirlikçi olarak örgüt içerisinde uygulanmaktadır. Stratejik müşteri ilişkileri yönetimiyle işletmeler, müşteri amaçlarını tanımlayarak karlılığını belirler. Bu strateji geliştirme ve değer yaratmayla ilgili bir düzeydir (Timur, 2013). Bununla birlikte internet ve yeni haberleşme teknolojilerinin gelişmesiyle, müşteriler artık bilgiye çok çabuk ulaşabilmekte ve sürekli daha iyisini kendilerine daha uygun olanı tercih edebilmektedir. Bu nedenle kurumların müşterileriyle "öğrenmeye dayalı" ilişkiler kurabilmesi için en önemli teknoloji unsurlarını veri tabanlı pazarlama ve e-ticaret oluşturmaktadır (Aktepe vd., 2009). Çalışmanın bu kısmında Rixos Otel Zinciri'nin yenilik uygulamalarına ve müşteri ilişkileri yönetimine ilişkin yaklaşımları incelenecektir.

Yapılan MIY sonuçlarına göre müşterilerin mutfak kültürüne uygun tasarımlar sağlanmaya çalışılmaktadır. Bu kapsamda Rixos'un uyguladığı en önemli strateji, bulunduğu destinasyonları Türk kültüründeki yiyecek ve içeceklerle tanıştırmaktır. Örneğin Kazakistan'ın Türk çayı ve zeytinle tanışması Rixos grubuyla mümkün olmuştur. Rixos'un bu uygulamaları bölge insanın ve zaman zaman orada konaklayan Türk müşterilerinin de beğenisini kazanmaktadır. Bu kapsamda yiyecek-içecek büfelerinin daha çok ilgi uyandırması yönünde ve müşterilerin zevkleriyle uyumlu tasarım çalışmaları yapılmaktadır. Bununla birlikte yiyecek içecek alanında dünya mutfaklarından da ikramlarda bulunulduğu için Michelin yıldızlı aşçılar istihdam edilmektedir. Örneğin, Dubai Rixos' da Türk yemekleri sunulmaktadır. Ancak müşteri büfede dünya yemeklerini de görmek isteyebiliyor. MiY ürün olarak burada otele müşterinin beklentilerinin neler olduğunu önceden bildirerek hizmetleri kolaylaştırmaktadır. Bununla birlikte Rixos Otellerindeki büfelerde minimum 8-10 peynir çeşidi ikram edilmektedir. Müşterilerden bu ürünleri satın alabilecekleri yerlerle ilgili taleplerin gelmesi endüstriyel bir hizmet verilirken bireysele de hitap edildiğini göstermektedir.

Hizmet endüstrideki tüketicilerin beklentileri sürekli değiştiği için markanın tutundurma aşamasında ürün ve hizmet standardı kadar yenilik de önemli görülmektedir. Bu kapsamda markanın çocuklu aile konsepti pazarlama çalışmalarıyla güçlendirilmeye çalışılmaktadır. Örneğin, Rixos Sungate Otel, bir tatil değerlendirme şirketi olan Holiday Check ve Hotel Consulting Service'nin 7 farklı kategori için yaptı̆̆ ölçümlemeleri ve kriterlerine göre tatilcilerin sosyal medyada paylaştı̆̆ yorumları incelenerek 'En İyi Aile Oteli' kategorisinde birinci seçilmesi markanın en yoğun yatırım yaptığı alan olarak görülmektedir. Rixos Sungate Otelde çocuk ve yetişkin plajı olmak üzere iki ayrı plaj bulunmaktadır. Çocuk plajında, çocuk şezlongları, şemsiyeleri, çocuklar için özel güneşlikler, kumdan yapılmış masalar ve oturma yerleri bulunmaktadır. Bununla birlikte çocuklar için özel büfeler hazırlanarak çocukların damak zevkine göre farklı ürün yelpazesi sunulmaktadır.

Otellerin en önemli ek gelir kalemlerinden biri haline gelen SPA'lar en yüksek yatırımları gerektirmektedir. Bununla birlikte bu alandaki yenilikleri de takip etmek gerekmektedir. Bu nedenle Rixos'un kendi özel markas1 olan Rixos Royal Spa merkezlerinde güzellik merkezi, masaj salonu, fitness merkezi, Türk Hamamı, Sauna ve Thalasco Spa hizmetleri verilmektedir. SPA' nın görüntü kalitesine son zamanlarda çok önemli yatırımlar yapılmaktadır. Çünkü müşterilere rahatlık ve huzur sağlayabilmesi için otellerin SPA alanları ve karşılama alanları özellikle iç mimari açısından hassasiyetle üzerinde durulması gereken alanlardır. Örneğin, Rixos Royal Spa merkezlerinde kuru yüzdürme tekniğini içeren dry flotation yatakları yaygın olarak kullanılan bir üründür. Bununla birlikte bu merkezlerdeki görevli terapistler, güzellik uzmanları ve masörler sertifikalı çalışanlardan oluşmaktadır.

Rixos grup olarak otelcilik sektöründe başarının devamının ancak sektördeki yeniliklere önem verilerek gerçekleştirilebileceğine inanılmaktadır. Bu nedenle özellikle şehir otellerinde ev konforu ve ofis teknolojileri bir arada sunulmaktadır. Bu kapsamda MiY'nin gruba katkısı müşterilerin otele giriş yapmadan önce, daha önceki bilgilerden isteklerinin bilinmesi ve bu kişiye özel hizmetleri sunma imkânını vermesidir. Bundan dolayı şehir otellerinde konaklayan iş adamı müşterilere ihtiyaç halinde haberleşme araçları, ofis gereçleri ve sekreterlik hizmetlerinin sunulduğu kullanıma açık büro hizmetleri (business center) verilmektedir. Aynı zamanda bu hizmetler müşterilerin tercihlerine göre oda servisi olarak da sunulmaktadır. 
MIYY anlayışında müşterinin bir kez otele gelmesi yeterli olmaktadır. MiY'in teknolojik yatırım tarafında bu anlamda grubun bütün otelleri birbirine benzemektedir. Örneğin Rixos Astana Kazakistan'da konaklayan müşterilerin giriş-çıkış işlemi arasındaki tüm bilgileri (şikâyetlerde dâhil) internet ortamından sisteme bağlanarak grubun başka bir otelinin görmesi mümkündür. Bu nedenle alerjik rahatsızlığı olanlar (besin veya koku), yastık tipi tercihi (boyunla ilgili problemi olanlarda medikal yastıklar tercih edilmektedir), pike, yorgan tercihi ve özel puro tercihi olanlar gibi çok farklı müşteri istekleri bir veri havuzunda toplanmaktadır. Bu bilgilerden hareketle müşterinin bir sonraki konaklamasında hassasiyet gösterilmektedir. Bununla birlikte boyunla ilgili problemi olan konuklara yastık menüsü sunulmaktadır. Konuklar tercihlerine göre seçtikleri yastık tiplerinde keyifli bir uyku geçirdikleri için yoğun ilgi görmektedir. Yapılan anket çalışmalarında bu hizmetlerin müşterileri memnun ettiği görülmektedir.

Günümüzde birçok aile evcil hayvan beslemektedir. Bu evcil hayvanlar onların hayatlarının bir parçasını oluşturduğu için ayrılmak istememektedirler. Bu nedenle müşterilerin hayvanlarıyla gelebildiği bir otel olan Rixos Premium Belek’te hayvanların kaldığı özel barınaklar bulunmaktadır. Buradaki barınaklar bir veteriner hekim gözetimde sürekli takip edilmektedir.

Turizm sektöründeki aşırı rekabet ve küreselleşme olgusu sektördeki işletmelerin teknolojik gelişmelere paralel olarak yenilikçi ve kaliteli mal ve hizmet sunumunu zorunlu kılmaktadır. Bundan dolayı Rixos Otel Grubu'nun odalarında yenilikçiliğe ve kaliteye çok önem verdiği ifade edilebilir. Bununla birlikte aydınlatma tasarımı, otelin görünümünü güçlendirdiği için mimaride son derece önemli bir rol oynamaktadır. Bu nedenle bir otel binasındaki aydınlatma düzeni görsel konfor koşulları ve güvenliğini sağlamanın yanı sıra, müşterileri yönlendirmek ve mekânlardaki belirli detayları vurgulayarak, değişik işlevlere cevap verebilmek amacıyla tasarlanmalıdır (Şahin, 2006). Bundan dolayı Rixos Otel Zinciri’ndeki oda aydınlatmaları insanın içini karatmayacak şekilde tasarlanmaktadır. Işık tavandan odaya alçıpanın içinden süzüldüğü için doğrudan müşterinin gözüne gelmesi engellenmektedir. Bununla birlikte otellerin iç mimarisinde kişisel kullanımı ön plana çıkarmak için üç çeşit okuma lambası kullanılmaktadır. Lambalardan bir tanesi abajur olarak, bir diğeri etajer, başka bir lambada yatağın yan tarafından ışı sağlayacak özelliktedir. Bununla birlikte lambalarda kullanılan ampullerin 1şık kalitesi insanın gözünü yormayacak şekilde tasarlandığı için istenilen ayara getirilebilir özelliktedir. Bu şekilde odalarda az sarfiyatlı ve 1sı yaymayan aydınlatma gereçleri kullanılarak çevre duyarlılığı ve enerji tasarrufu sağlanmaktadır.

Otel işletmelerinin sunduğu hizmetler, konuğun mutlu ve huzurlu bir tatil geçirmesinde önemli bir yer tutmaktadır. Çünkü rahat ve konforlu yataklarda uyuyan müşteriler, iyi dinlenmiş ve zinde olarak uyanır ve güne başlarlar. Bu nedenle odalarda kişiye özel bulgari marka oda bukletlerin kullanıldığı ve odalardaki yataklar son derece konforlu olduğu Rixos Pera Otel, müşterilerine farklı bir dünyada olmanın hissini vermektedir. Bununla birlikte gün içerisinde havuzda, denizde, otel içi ve otel dışı aktivitelerde yorgun düşen müşteriler için rahatlayabilecekleri yerler olan banyoların tasarımları ve kullanışlı olması konuklar açısından oldukça önemlidir. Bu nedenle otelin suit oda ve villa konseptlerinde küvetler kullanılırken diğer oda tiplerinde duşa kabin mantığ görülmektedir. Duşa kabin odaların konforuna da son derece önem verilmektedir. Buralar müşterinin rahat edeceği genişlikte tasarlanmıştır. Su kalitesi ve su ayarı yapılabilir özellikte olup aynı zamanda duşlarda müzik yayını da yapılmaktadır. Rixos Otel için önemli olan dar alanı estetik bir şekilde tasarlayarak teknolojik ve farklı aksesuarlarla müşterilere hizmet vermektir.

Özellikle yurt dışından gelen müşteriler şampuanlarını çok fazla getirmedikleri bilinmektedir. Rixos'la birlikte var olan Lara marka şampuan müşteriler tarafından çok beğenilmektedir. Kullanan müşteriler, hangi marka şampuan olduğunu sormakta ve temin etme yoluna gitmektedir.

Rixos Grup olarak müşteriler hem hizmet hem de kullanılan ürün olarak memnun edilmeye çalışılmaktadır. Bu nedenle grubun tüm otellerinde sular arıtmalıdır. Bütün kazanlar aylık ve yıllık olarak kontrolden geçmektedir. Herhangi bir yanma ve sudan bir koku gelmesi söz konusu değildir. Çünkü çok ilginç müşteri istekleriyle karşılaşılmaktadır. Örneğin çok titiz bir müşteri İstanbul'da konakladığg 1 sürece normalde müşteri başına odaya iki havlu bırakılırken, o müşteri için her gece için on tane tıraş havlusu bırakılmaktadır.

\section{Sonuç ve Bulgular}

Küreselleşmeyle birlikte uluslararası otel işletmelerinin arasındaki yarış da hızlanmaktadır. Bu pazarlardaki firsatları değerlendirmek için otel işletmelerinin farklı stratejiler izlediği görülmektedir. Rixos Hotel Grubu bu yarış içinde yerli bir otel zinciri olarak konaklama sektöründe farklı stratejilerle yatay bir büyüme izlemektedir. Bu kapsamda farklı destinasyonlarda kiralama, yönetim anlaşması ve konsorsiyum gibi stratejileri takip ettiği görülmektedir. Büyümenin getirmiş olduğu bazı yenilikleri de bünyesine katarak müşterilerinin son derece memnun olarak otelden ayrılmasını sağlamak için oluşturulan MiY biriminde farklı dillerde müşterilerle konuşma yeteneğine sahip personeller istihdam edilmektedir.

MiY uygulamalarıyla birlikte grubun herhangi bir otelinde konaklayan müşterinin istekleri gruba ait başka bir otel tarafindan da görülmektedir. Bu nedenle müşteri rezervasyon yaptırdığı andan itibaren istekleri önceden bilindiği için daha kolay hizmet verilmektedir. 
Otel işletmelerinde hizmet kalitesini arttırmanın en önemli yolu istihdam edilen personelin memnuniyetinin sağlanmasıdır. $\mathrm{Bu}$ nedenle personelin sigorta ve prim gibi özlük hakları brüt ücret üzerinden ödenmesi motivasyonunu arttırmaktadır.

Otel işletmelerinde aynı çatı altında birden çok hizmet sunulmasından dolayı istihdam yoğunluğu maliyeti, toplam maliyetler içindeki önemli bir payı oluşturmaktadır. Buna rağmen, Rixos Otel Grubunun uygulamalarında, oda sayısı başına düşen personel sayısının 0,8-1 arasında değiştiği ve bazı otellerde bu oranın 1,5'e kadar yükseldiği görülmektedir.

Ayrıca Rixos Grup olarak personelin motivasyonuna da son derece önem verilmektedir. Bu kapsamda yılda iki kez düzenlenen personel gecelerinde çekilişle maddi değeri yüksek olan hediyeler sunulmaktadır.

Uluslararası otel işletmelerinin en önemli özelliklerinden biriside gittikleri destinasyonlara sahip oldukları inovatif değerleri taşımasıdır. Bu kapsamda Rixos Otel Grubunun sahip olduğu en önemli inovatif değeri, gittiği destinasyonları Türk kültürü ve yiyecek-içeceğiyle tanıştırmasıdır.

Yerli otel işletmelerinin uluslararasılaşma çabaları sadece şehir otelciliğinde görülürken, Rixos Otel Zinciri, resort otel, şehir oteli ve rezidans otel olmak üç farklı şekilde büyüme eğilimi göstermektedir.

Yerli otel işletmeleri ev sahibi oldukları ülkeye daha çok turist çekme planları yaparken, Rixos Otel Zinciri yeni destinasyonlar açan cesur, girişken, genç ve dinamik bir yapıya sahiptir.

Küresel otel işletmeleri konaklama sektörü pazarına lüks, tam donanımlı hizmet, orta ölçekli hizmet ve ekonomik otellere kadar genişletirken, Rixos Otel Zincirinin lüks ve tam donanımlı hizmet tipiyle büyüme eğilimi göstermesi, dünyanın lider turizm ve konaklama şirketi olma yolundaki başarısını geciktirmektedir.

Rixos Otel Zinciri, yiyecek içecek hizmetinde know-how ya da daha önce başarıya ulaşmış bir konsepti misafirlerin beklentilerini karşılama ve yerel müşterileri etkileme amacıyla dış kaynak kullanım yoluyla gerçekleştirebilir.

Rixos Otel Zinciri, küresel bir restoran zinciriyle ortaklık kurarak iki güçlü markanın karşılıklı olarak kalitelerini ve profillerini geliştirmede katkıda bulunabilir.

Rixos Otel Zincirinde, yiyecek- içecek hizmetlerinde örgüt kültürüne ve marka uygunluğuna önem verilmektedir. $\mathrm{Bu}$ nedenle grup büyüme stratejisine ilişkin çalıştığı işletmelerde (örneğin yönetim sözleşmesi) yeniden bir dizayn ve üretim alanı genişlemesine gitmek yerine, hizmetleri dış kaynak kullanarak sağlamaktadır.

Dışarıdan alınan bazı animasyon gösterileri grubun değişik otellerinde gösteri yapmakta, bu da grup oteli olmanın maliyet ve etkinlik çeşitliliği avantajını beraberinde getirmektedir.

Teknik anlamda uzmanlık gerektiren işler (örneğin, personel servis hizmeti) dış kaynak kullanarak sağlanmaktadır.

Rixos'la birlikte var olan Lara marka şampuan misafir tarafından satın alınabilmesi sağlanmalıdır.

Misafirlere iki otel kullanım imkanı verilmelidir. Konukların aynı gruba ait olan otellere günün istedikleri zamanında giriş-çıkış yapabilmesi ve oradaki hizmetlerden faydalanması sağlanmalıdır. Böylelikle misafir bir ücret ödeyerek iki otelde tatil yapması sağlanabilir.

Misafirlerin otelde tattığı ve çok beğendikleri yiyecekler küçük tatlar halinde otelden ayrılırken hediye olarak vermek misafirlerin otelden memnun ayrılmasına sağlayacaktır.

Özel film gösterimleri ve sinema geceleri düzenlenmelidir. Bu misafirleri büyük bir memnuniyet oluşturacağ gibi otel için de yeni bir gelir kaynağı olacaktır.

Rixos Otel Zinciri’ndeki oda aydınlatmaları insanın içini karatmayacak şekilde tasarlanmaktadır. Otellerin iç mimarisinde üç çeşit okuma lambası kullanılmaktadır. Bunun yerine oda aydınlatmalarında gölge saat olabilir. $\mathrm{Bu}$ sayede konuklar gece uyandıklarında hem saati rahatça görebilir hem de gece lambası olarak kullanabilir.

Yakın gelecekte otel işletmelerinde sıklıkla görüleceği tahmin edilen ve yeni teknoloji ürünlerinden biri olan Glo-Pillow'un odalarda kullanılmasına geçilebilir.

Resepsiyonda m-bot sistemi kullanılarak yabancı konukların klavye kullanarak 17 dil üzerinden anında İngilizceye çeviri yapılabilen bu sistem sayesinde, misafirin resepsiyonist ile çok daha kolay iletişim kurması sağlanabilir.

Rixos Otel Zinciri'nde odalarda engelli konuklara özel yenilik uygulamalarına yer verilmelidir. Örneğin, yatak başlarında veya banyolarda acil çağrı butonları yerleştirerek engellilere kolaylık sağlanabilir.

Rixos Otel Zinciri kendi markası olan Rixos Royal Spa merkezlerinin yanı sıra Avrupa ve Amerika'da sadece çocuklar için açılmış Kids Spalar bulunmaktadır. Çocuklar için yapılacak bu hizmetler Rixos Otel Zinciri’ne rekabet avantajı sağlayabilir.

Rixos çalışanlarına dil eğitimi verilmemektedir. İyi işler yapan işletmeler iyi işler yapan çalışanlar istihdam ederek büyüyebilirler. 
Personelin motivasyonun sürekli olması doğru ve etkili bir ödüllendirme sisteminin kurulabilmesine bağlıdır. $\mathrm{Bu}$ tür ödüle yönelik programlar yeni personelinde ilgisini çekecektir. Böylece işletme içindeki rekabet ortamını arttırabilecektir.

Eski ürünlerin kullanımıyla ilgili kampanyalar yapılırken, yeni ürünlerin tanıtımı da yapılmalıdır.

Rixos Otel Zinciri'nde çalışanlar, mevcut ve potansiyel müşterilerin beklenti ve ihtiyaçları hususunda ortak tavır almak suretiyle kurumsal bir imaja da katkı sağlayacaktır.

Çağrı merkezi kurulmalıdır. Günümüzde çağrı merkezleri, işletmelerin markasıyla buluşma noktası olarak değerlendirilmektedir. Bu bakımdan misafirler, işletmeyle ilgili zihninden geçen düşüncelerin tamamını çağrı merkezlerinin faaliyetleri ve performansları değiştirebilir.

\section{Kaynakça}

- Aksu, A.Akın (2000) Otel İşletmelerinin Başarısını Etkileyen Dış Çevre Faktörleri, Balıkesir Üniversitesi

- $\quad$ Sosyal Bilimler Enstitüsü Dergisi Cilt 3 Sayı:4, s.s. 269-281

- Akıncı,Z.(2002) Turizm Sektöründe İşgören İştatminini Etkileyen Faktörler: Beş Yıldızlı Konaklama İşletmelerinde Bir Uygulama, Akdeniz İ.İ.B.F. Dergisi (4), s.s. 1-25

- Altan, Mikail ve Engin, Orhan (2004) Bir Seyahat İşletmesinde Müşteri Memnuniyetinin Ölçülmesi,"

- $\quad$ Sosyal Bilmler Enstitüsü Dergisi, 11, s.585-598

- $\quad$ Aktepe, Cemalettin, Baş, Mehmet ve Metehan Tolon (2009) Müşteri İlişkileri Yönetimi, Detay Yayıncılık, Ankara

- Coşar, Yeşim (2008) Otel İşletmelerinde rekabet Üstünlüğünü Etkileyen Faktörler:Yöneticiler Üzerine Bir

- Araştırma, Anatolia: Turizm Araştırmaları Dergisi, Cilt 19, Sayı 1

- $\quad$ http://www.anatoliajournal.com/atad/depo/dergiler/Cilt19 Sayi1_Yil2008_1304876885.pdf)

- Doğan, Selen (1997) İnsan Kaynakları Potansiyelini Arttırmada İşletmeleri Etkinliğe Götüren Yol: Örgüt Kültürü, Amme İdaresi Dergisi, Cilt 30, Sayı 4, s.s. 53-74

- Gövdere, Bekir (2009) Türkiye'de Hizmetler Sektöründe Doğrudan Yabancı Yatırımlar, Süleyman Demirel Üniversitesi İktisadi ve İdari Bilimler Fakültesi Dergisi C.14, S.1, ss. 53-68

- İsfendiyaroğlu, H. (2001) Otel İşletmelerinde Çamaşır Yıkama Hizmetlerinin Temizlik İşletmelerine Verilmesi Üzerine Muğla Yöresinde Bir Alan Araştırması, Yüksek Lisans Tezi, Muğla Üniversitesi Sosyal Bilimler Enstitüsü, Muğla

- Kesgin, Muhammed (2005) Otel İşletmelerinde Dış Kaynak Kullanımı: Antalya'da Faaliyette Bulunan 4 ve 5 Yıldızlı Otellerde Bir Araştırma, Akdeniz Üniversitesi, Sosyal Bilimler Enstitüsü,Antalya

- Met, Önder (2005) Çokuluslu Otel Zincirlerinin Büyüme ve Uluslararasılaşma Stratejileri, Akdeniz

- $\quad$ Üniversitesi, İ.İ.B.F. Dergisi (10), ss.111-138

- Met, Önder ve Erdem, Barış (2011) Türk Otel Zincirleri ve Büyüme Stratejileri, Balıkesir Üniversitesi Sosyal Bilimler Enstitüsü Dergisi, ss.333-350

- Tarras, John.M. (1991) A Practical Guide to Hospitality Finance, Van Nostrand Reinhold, New York.

- Timur, Necdet. ve Barış, Gülfidan. (2013) Müşteri İlişkileri Yönetimi, Anadolu Üniversitesi Yayınları No:

- 3001,Anadolu Üniversitesi Web Ofset Tesisleri, Eskişehir

- (http://eogrenme.anadolu.edu.tr/eKitap/PZL208U.pdf)

- Tetik, N. ve ören, E. (2007) Dış Kaynak Kullanımı (Outsourcing): Antalya Yöresindeki Beş Yıldızlı Otellerde Bir Araştırma, Muhasebe ve Finansman Dergisi, Sayı:34, ss. 74-86

- Türksoy, Adnan ve Türksoy, Selcen Seda (2007) Otel İşletmelerinde Diş Kaynaklardan Yararlanma: Çeşme

- İlçesinde Turizm Belgeli Otel İşletmelerinde Dış Kaynaklardan Yararlanma Alanlarına İlişkin Bir

- Araştırma, D.E.Ü.İ.İ.B.F. Dergisi, Cilt:22 Sayı:1 (http://iibf.deu.edu.tr/dergi/2007_1_5.pdf)

- Öncer, Ayla Zehra (2012) İşletmelerin Büyüme Stratejisini Belirlemede Doğrusal Programlama Yaklaşımı

- $\quad$ Marmara Üniversitesi, İ.İ.B. Dergisi, Cilt 33, Say1 2

- (http://dosya.marmara.edu.tr/ikf/iib-dergi/2012-2/19oncer.pdf)

- Şahin, D. (2006) Otel Aydınlatmasında Genel İlkeler ve Otel Yatak Odaları İçin Bir Değerlendirme: Yayımlanmamış Yüksek Lisans Tezi, Yıldız Teknik Üniversitesi, İstanbul

- Uzoğlu, Sevil (2001) Kurumsal Kimlik, Kurumsal Kültür ve Kurumsal İmaj, Kurgu Dergisi, Sayı 18

- Yu, Lawrence ve Chon, Kaye Sung (1999) The International Hospitality Business, Management and

- Operations, The Haworth Hospitality Pres.

- Yarcan, Şükrü (1998). Türkiye'de Turizm ve Uluslararasılaşma, İstanbul: Boğaziçi Üniversitesi Yayınevi.

- Zhao, J.L. (1998) Globalizations, Multinationals and Corporate Strategies, Olsen, M. vd, (Der.), Strategic

- Management in the Hospitality Industry içinde, John Wiley and Sons Inc.

- $\quad$ http://www.rixos.com/tr/kurumsal/tarih\#sthash.1zASXMa8.dpuf, 15.06.2013 


\title{
Stratejik İttifak Olușumundaki Konaklama Sektöründe İşletmeler Arası İlişkileri Düzenleyici Faktörler ve Bir Model Önerisi \\ Inter-Organizational Relations in Hospitality Industry in the form of Strategic Alliance and a Model Suggestion
}

\author{
Ph.D. Candidate Nilüfer Vatansever Toylan (Kırklareli University, Turkey) \\ Prof. Dr. Fatih Semerciöz (Istanbul University, Turkey)
}

\begin{abstract}
In this study, strategic alliances are discussed from the perspective of hospitality industry and inter organizational relation factors that regulate the formation of strategic alliances have been revealed in hospitality industry. In addition, the relations between inter organizational relation factors, knowledge sharing and organizational innovativeness are raised within the scope of the literature and a model is proposed. In this context, with review of literature, relation factors between hospitality businesses that affects knowledge sharing are examined. These factors are specified as inter organizational trust, the intention of learning, shared vision, communication, (partner-specific) absorptive capacity and commitment. Knowledge sharing and innovativeness variables are especially important in terms of competitive advantage in the market for hospitality strategic alliances. Thus, the main problem of the study is to investigate the relationships between all of these variables.
\end{abstract}

\section{Giriş}

Çalışmada öncelikle stratejik ittifak oluşumu içerisindeki konaklama işletmeleri ele alınmıştır. Ardından konaklama işletmelerinde bu ilişkiyi düzenleyen unsurların neler olduğu tek tek ortaya konmuştur. $\mathrm{Bu}$ çalışmanın önemli vurgularından biri bu unsurların örgütler arası bilgi paylaşımını etkilediği yönündedir. $\mathrm{Bu}$ iliş̧i unsurlarının örgütün yenilikçiliğini etkilediği ve bilgi paylaşımı ile örgütsel yenilikçilik arasındaki ilişkiler de araştırılmaktadır. Ayrıca tüm bu değişkenler arasındaki ilişkileri ortaya koyan bir model önerilmektedir.

\section{Stratejik İttifaklar}

Strateji yazınında uzun bir süredir işletmeler bir ürün ya da hizmetin satın alınmasının mı yoksa imal edilmesinin mi daha avantajlı olacağı sorusuna bir yanıt aramaktadırlar. Son yıllarda ise yurt dışı yazında ittifakların bu sorunun cevabı olabilecek şekilde satın almaya, elden çıkarmaya ya da iç gelişmeye nasıl önemli bir alternatif olabileceği yolunda çokça çalışmaya rastlanmaktadır (Gulati ve Larence, 2000).

Drucker (1995) işletmelerin yönetim şekillerinde, ilişkilerin büyümesini sağlayan en büyük değişimin sahiplikten çok ortaklıktan kaynaklandığını vurgulamaktaydı (Drucker, 1995). Koçel'e göre ise bir işletmenin tek başına piyasalara açılıp, global bir çerçeve içinde rekabete girişmesi yerine başka işletmelerle dayanışma içinde olması başarı şansını yükseltebilecektir (Koçel, 2005). Bu nedenle iliş̧i yaratma ve stratejik işbirliği kavramı işletmeler için önemli bir hal almış ve stratejik işbirliklerine iş dünyasının neredeyse her alanında rastlanmaktadır. Günümüzde işletmeler diğer kuruluşlarla ortaklığa giderek, fikirleri, yöntem bilgisi (knowhow)'ni ve yetenekleri tedarik edebileceklerinin farkına varmışlardır (Baloh vd., 2008).

Stratejik ittifaklara özgü karakteristik bir tanımlama, bir değişim ilişkisi kuran ancak ortaklık içermeyen iki ya da daha fazla işletmenin aralarında yapmış oldukları düzenleme şeklinde karşımıza çıkmaktadır (Lowensberg, 2010). Bu tipik ve jenerik tanımlamanın yanı sıra, stratejik ittifakları basit bir şekilde, taraflar için önemli olan ve amaçlarını gerçekleştirmelerine yardım edecek işbirlikleri olarak tanımlayan çalışmalar da mevcuttur (Das ve Teng, 2000a). Bu tanımlamalardaki en önemli ayrımın örgütler arasında her hangi bir hisse sahipliğinin olmaması şeklinde ortaya çıktığı söylenebilir. Zaten Ohmae de ittifak oluşumunun bir ön şartı olarak hisse sahipliği olmaması koşulunu öne sürmektedir (Ohmae, 1989). Hisse, değişken bir ölçek üzerinde örgütsel ilişkilerin derinliğini (yoğunluğunu) ölçmeye yardım eden iyi bir gösterge olarak tanımlanabilir (Loensberg, 2010). Moss Kanter işbirliği düzenlemeleri ya da ittifakları tanımlamada böyle bir ölçek veya düzlem kullanmaktadır. (Yazar bu iki kelimeyi eş anlamlı olarak kullanmaktadır). Bu ölçek zayıf ve uzak ile güçlü ve yakın arasında değişiklik göstererek, ortakların ittifaktan nasıl derinden etkilendiğini gösterir (Kanter, 1994). Newman ve Chaharbaghi, ittifakları benzer bir düzlem üzerinde sınıflandırarak savunmacı mı yoksa saldırgan bir strateji mi izleyip izlemediklerini ortaya koyar (Newman ve Chaharbaghi, 1997). Bunlara ek olarak baz1 yazarlar, metaforlara başvurarak, ittifaktaki ortaklar arasındaki ilişkiyi tıpkı yeni bir evlilikteki ortaklar arasındaki ilişkiye benzeterek kontrollü bir paylaşım şeklinde bir "anlaşma/uyuşma" olarak tanımlar (Ohmae, 1989).

Uzun zamandan beri ittifak tanımlamaları üzerine yapılan çalışmalar, farklı tanımlamalar gelişmesine neden olmuştur. Ancak genelde iki taraf üzerinde yoğunlaşıldığı görülmektedir. Bir tarafta "stratejik ittifak" terimini 
kapsamlı bir tanım olarak benimseyen yazarlar, diğer yandan "stratejik birleşmeler" (Marks ve Mirvis, 2001), “işbirliği sözleşmeleri” (Devlin ve Bleackley, 1997) ya da "işletmeler arası ilişkiler” (Barringer ve Harrison, 2000) gibi terimler kullanarak stratejik ittifak terimini karşılamaya çalışan yazarlar. Sonuç olarak, bu çalışmada stratejik ittifaklar işletmelerin bir ya da birkaç amacı yerine getirmeleri için gerçekleştirilen planlı işbirlikleridir. Yani stratejik ittifakın tasarımında planlı bir amaç vurgusu vardır.

Ayrıca ortaklık anlamında kullanıldığında bir hisse sahipliğini içerir ki, ittifaklar sadece hisse paylaşımını değil, hisse paylaşımı olmaksızın kaynakların da paylaşıldığı bir işbirliği türüdür. Bu işbirliği türünde önemli olan başka bir husus da işletmelerin anlaşma sonrasında hukuki bağımsızlıklarını devam ettirmeleridir. Bu durum stratejik ittifakları, birleşme ve satın almalardan ayıran başlıca özelliktir (Semerciöz ve Çakınberk, 2003).

Böylece stratejik ittifaklar, işletmelerin iş yaşamının hızla değişen koşullarına uyum sağlayabilmeleri, rekabet avantajını elde edebilmeleri ve bunu sürdürebilmeleri için aynı dalda ya da farklı daldaki işletmelerin kaynaklarını bir araya getirmeleri ve bu işbirliğini ihtiyaca göre şekillendirerek, feshetmesi ya da farklı bir boyuta taşıması olarak tanımlanabilir. Ek olarak dikkat edilmesi gereken başka bir husus da işletmelerin anlaşma sonrası bağımsızlıklarının devam ediyor olmasıdır.

Stratejik ittifaklar, ulaştırma sektöründen telekomünikasyona, lojistikten turizme ve tarıma kadar pek çok sektörde (Zhang ve Zhang, 2006), aynı dağıtım kanalını kullanmak, araştırma ve geliştirme birimlerini birleştirmek, ortak girişim oluşturmak, piyasa paylaşımları ve ortak bilgi bankası oluşturmak (Koçel, 2005) gibi daha birçok alanda faaliyetlerini gerçekleştirebilmektedirler.

İşletmeler arası ilişkilerin oluşumunu açıklayan teorilerin kapsamlı bir şekilde ele alındığı çeşitli çalışmalar mevcuttur. $\mathrm{Bu}$ çalışmalar genellikle stratejik ittifakları açıklamak üzere işlem maliyeti ve kaynak temelli yaklaşım teorilerini kullanmaktadırlar. Bu çalışmalardan biri Barringer ve Harrison tarafından yapılarak, bu teorilerin örgütler arası ilişkileri tek başına açıklamaktan çok birlikte ele alındığında bu tür karmaşık ilişkileri açıklamakta etkili olacağı da vurgulanmıştır (Barringer ve Harrison, 2000b). Bunun yanı sıra stratejik ittifakların açıklanmasında içselleştirme ve Pazar şartlarına göre değişen durumlarda bir teorinin diğer teoriye göre daha açıklayıcı olabileceğini söyleyen çalışmalar da mevcuttur (Das ve Teng, 2000b). Bu yaklaşımların dışında Ireland ve diğerlerinin yapmış olduğu çalışmada her ne kadar özellikle işlem maliyeti teorisine, sosyal ağ teorisine ve kaynak temelli görüşe yer verilmiş olsa da, çalışmada evrim teorisi, kurumsal kuram, süreç teorisi, karmaşıklık (kompleksite) yaklaşımı, kaynak temelli görüşün bir uzantısı olarak bilgi temelli görüş, sosyolojik kuramlar, koşul bağımlılık kuramı, vekalet teorisi, dinamik yetenekler yaklaşımı, stratejik davranış görüşü, oyun kuramı ve sosyal değişim teorisi gibi çok çeşitli görüşler de yerini bulmuştur (Ireland vd., 2002). Stratejik ittifaklar ekonomi, pazarlama, yönetim gibi çeşitli alanlarda araştırma konusu yapıldığından ve ayrıca ittifakların sahip olduğu karmaşık yapıdan dolayı konunun çok sayıda teoriyle ve farklı bakış açılarıyla açıklanması olağan kabul edilmektedir.

Bu nedenle bu çalışmada kapsamlı ve açıklayıcı olması açısından Barringer ve Harrison'ın çalışmaları temel alınmış ve teoriler açıklanırken yazarların modeli kullanılmıştır (Barringer ve Harrison, 2000).

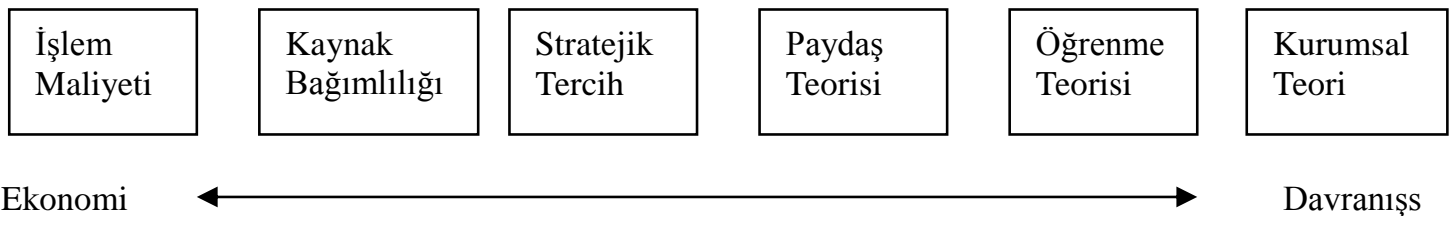

Şekil 1. Barringer ve Harrison, 2000.

İşlem maliyeti teorisi, işlemlerle ilgili maliyetlere vurgu yaparak, piyasa işlemleri görüşünü açıklar. Stratejik işbirlikleri kavramında yöntemler, piyasalar arasındaki işlemleri izleyerek ve yöneterek toplam maliyeti azaltma ile sonuçlanan işlemler için kullanılabilir (Child ve Faulkner, 1998). Sonuçta işletmeler arasında bu türden bir anlaşmanın yapılması da başı ı başına bir maliyet kalemini oluşturmaktadır. $\mathrm{Bu}$ nedenle işletmeler tüm bu maliyetleri azaltmak için doğru ortakla işbirliğine gitme arzusundadırlar. Maliyet azaltmayı vurgulayan işlem maliyeti yaklaşımının aksine, kaynak temelli görüş, değerli kaynaklardan faydalanarak ve onları biriktirerek firmanın değerini maksimize edebileceğini belirtir. Yani işletmeler, tüm kaynaklar arasından en uygun kaynağı bulmaya yönelirler (Balakrishnan ve Koza, 1993). Kaynak temelli yaklaşımın öncülerinden olan Wernerfelt (1984)'e göre bu teori; işletmelerin başarılı olabilmesi için, ihtiyaç duydukları kaynaklara sahip olmaları ve bunları kontrolleri altında tutmaları gerektiği düşüncesi üzerine kurulmuştur (Wernerfelt, 1984). Böyle bir durum işletmelere rekabet avantajı sağlayacak ve fayda yaratacaktır.

Stratejik tercih yaklaşımına göre, bir firmanın stratejik oryantasyonu firmanın içinde bulunduğu pazarın özelliklerinden etkilenir (Luo ve Tan, 1998). Böylelikle işletme pazara uyum sağlayabilmek için bir takım stratejik tercihler geliştirir. Öğrenme teorisi de tıpkı kaynak temelli görüş gibi işletmelerin işbirliği için belirli ortakları neden seçtiğini açıklar (Hitt vd., 2000). Eğer işletme ortaktan yeterince öğrenebiliyor ve bunu içeride uygulayabiliyorsa, ortaklık devam edecek ve belki de uzun süreli bir işbirliği söz konusu olabilecektir. 
Kurumsal kuram ile ilgili yapılan çalışmalarda, stratejik ittifakların doğasında olan teknik faydaların çeşitliliğine ihtiyaç duyulan belirli bir meşruluğu karşıladığı belirtilir. Yani, firma ve ittifak performansının artırılabildiği ve teknik faydaların gerçekleştirilebildiği önemli bir meşruluk olduğu anlamına gelir. Böylece işletmeler, meşruluğu sağlamak ve onu elde etmek için harekete geçerek, bileşenlerden gelen kaynak ve destek gibi stratejik ve teknik faydalara erişebilirler. Bu görüşler ekonomik avantaj ve rekabet avantajı kazanarak örgütler arası bağları oluşturmak için uğraşan işletmelerin çabalarını açıklayan çalışmalar üzerine kurulmuştur (Dacin, vd., 2007). Böylece çalışmanın genelinde bu teorilerin sahip olduğu bakış açısı gözetilmiş ve çalışma bu teoriler çerçevesinde ele alınmıştır.

\subsection{Konaklama Endüstrisinde Stratejik ittifaklar}

Stratejik ittifaklar hem akademisyenler hem de uygulamacılar tarafından özellikle stratejik işbirliğinin alternatif formlarına geçişte tercih edilen biçimlerin başında geldiği kabul edilmiş ve işbirliği ile ilgili konular üzerinde inceleme ve çalışmalar yoğunlaşmıştır (Fyall ve Garrod, 2005). İttifakları sınıflandırırken ittifakın içinde bulunduğu endüstriden büyüklüğüne dek pek çok unsuru göz önünde bulundurmak gerekir. Bu çalışmada ittifakın sektörü belirleyici faktör olarak öne çıkmaktadır.

Chathoth ve Olsen (2003) konaklama sektörü üzerine yapmış oldukları araştırmalarında ittifakları, yönetim sözleşmeleri ve franchise anlaşmaları, tedarikçiler arasındaki ittifaklar, turizm işletmesi ile tedarikçi arasındaki ittifaklar, pazarlama ittifakları, teknoloji ve bilgi transferi ittifakları ve rakip işletmeler arasında yapılan stratejik ittifaklar olarak belirlemiştir (Chathoth ve Olsen, 2003). Bu çalışmada yapılan sınıflamadan hareketle bizim çalışmamızda otel işletmesi odaklı yapılan stratejik ittifak türleri aşağıdaki şekilde gösterilmektedir.

\section{Teknoloji Temelli İttifaklar}

Pazarlama İttifakları

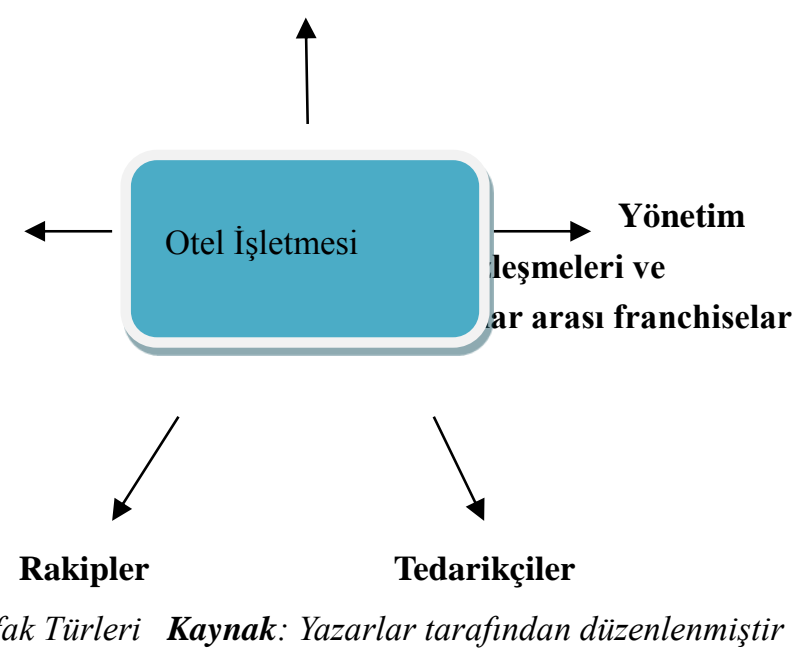

\section{3 Örgütler Arası İlişki Unsurları}

Örgütler arası ilişki unsurları literatürü bu ilişkileri çeşitli açılardan ele almaktadır. Çalışmaların bir kısmı bu unsurların örgütlerin performansı üzerinde etkili olduğunu savunurken, bir kısmı başarı faktörleri olarak belirlemektedir. Bir kısmı ise sadece örgütler arası ilişsileri düzenleyen ve işletmelere rekabet avantajı kazandıran unsurlar olarak ele almaktadır. $\mathrm{Bu}$ çalışmada da örgütler arası ilişkileri düzenleyen söz konusu unsurların işletmeler arası bilgi paylaşımını ve örgütün yenilikçiliğini ne yönde etkilediği ele alınmaktadır. Dolayısıyla literatürdeki diğer çalışmalardan elde edilen ilişki unsurlarının bilgi paylaşımı ve örgütsel yenilikçilik ilişkilerini açıklamak üzere bu çalışmada yer aldığ 1 , bu nedenle de diğerlerinden farklı olduğu göz önünde bulundurulmalıdır.

Bu çalışmalarda başta güven olmak üzere, öğrenme niyeti (Perez- Nordtvedt vd., 2008), paylaşılan vizyon, ilişki gücü, bağlılık, liderlik, iletişim, özümseme kapasitesi’nin önemi vurgulanmıştır (Dyer ve Singh, 1998). Araştırmacılar alıcı işletmeninin öğrenme niyeti ve kaynağın çekiciliğinin bilgi aktarımının etkinliğini etkilediğini göstermişlerdir. Ayrıca, çalışmalar sonunda alıcının öğrenme niyetinin bilgi aktarımının verimliliği üzerinde de etkisi ortaya çıkmıştır (Perez- Nordtvedt vd., 2008). Özümseme kapasitesiyle ilgili olan diğer çalışmalarda da egemen paradigmanın tek yönlü öğrenme odaklı yaklaşımı eksik bulunarak kavramın "sosyoteknik ilişkiler”e dayandığ1, "ilişkisel getiri” sağlayan "yinelemeli bir değiş tokuş süreci” olduğu ve işletmenin özel bir ittifak ortağından gelen değerli bilgiyi tanıma ve sindirme yeteneği olarak tanımlanan "ortağa özgü özümseme kapasitesi”nin önem kazandığı ortaya konmuştur (Dyer ve Singh, 1998).

Yabancı yazında ise bu faktörler bağlılık, koordinasyon, karşılıklı bağımlılık ve güven olarak sıralanmış ve ortaklıktaki önemli faktörler olarak görülmüştür (Mohr ve Spekman, 1994). Stratejik ortaklıklarda başarıyı etkileyen temel faktörler farklı başlıklar altında toplanmaktadır. Bennet, British Airways örneğini incelediği 
çalışmasında; işbirliği stratejisi, ilişki, ortak güven ve anlayış, ortaklık süresince esneklik, kültürel uyumluluk ve karşılıklı çıkarlar başlıklarını başarı kriteri olarak incelemiştir (Bennett, 1997). Rothkegel ve arkadaşları, KOBI'ler ve büyük şirketler arasındaki stratejik işbirliğini inceledikleri çalışmalarında, güven, bağlılık ve kontrolün önemini vurgulamışlardır (Rothkegel, vd., 2006). Pansiri 600 seyahat acentası, tur operatörü ve perakendecisi üzerine yaptığı çalışmasında, bir stratejik ortaklığın sürekliliğin önemli belirleyicisi olan faktörler olarak uyumluluk, yapılabilirlik, bağlılık, kontrol ve güven konularını incelemiştir. Araştırma sonucunda uyumluluk, bağlılık, yetenek ve güvenin ortaklığın performansı ile ilgili tatminde pozitif etkisi olduğu bulunmuştur (Pansiri, 2008). Stratejik ortaklıklar ile ilgili yapılan çalışmalar belirli başlıklar altında gruplandırılabilir. Bir gruplandırmaya göre stratejik ortaklıklar ile ilgili araştırmalar; nasıl ve niçin kuruldukları, kritik başarı faktörleri, başarısızlık nedenleri, ortaklar arasında bilgi, yetenek ve teknoloji transferinin sağlanması ve ortak seçimi şeklinde ayrılabilir (Evans, 2001). Ayrıca Medina-Munoz ve Garcõa-Falcon işletmeler arası ilişkilerde başarıyı etkileyen faktörleri, örgütler arası güven, ilişkiye bağlılık, örgütler arası iletişim, örgütler arası koordinasyon, örgütler arası çatışma, örgütler arası güç ve bağımlılık olarak sıralamıştır (Medina-Munoz ve Garcõa-Falcon, 2000).

$\mathrm{Bu}$ çalışmada yapılan araştırmanın bir yönünün ise söz konusu başlıklardan daha çok işletmeler arasındaki bilgi, yetenek ve teknoloji transferinin sağlanması için gerekli olan örgütler arası ilişki faktörlerinin belirlenmesi alanına girmekte olduğu söylenebilir. Bu durumda çalışmanın öncelikli amaçlarından biri olan örgütler arası ilişki faktörlerinin belirlenmesi için çeşitli çalışmalar incelenmiş ve özellikle örgütler arası bilgi paylaşımını etkileyen faktörler açısından bu unsurlar şu şekilde belirlenmiştir:

- Örgütler arası Güven

- (Ortaktan) Öğrenme Niyeti

- İletişim

- (Ortağın) özümseme kapasitesi

- Paylaşılan vizyon

- Bağlilık

Şimdi kısaca bu unsurların çalışmada nasıl yer aldığı ve bu unsurlarla esas kastedilenin ne olduğu yönünde açıklama getirilmektedir.

Güvenin hem örgüt içerisinde (çalışanlar ve yöneticileri arasında ya da meslektaşların birbirleri arasında gerçekleşen örgütsel bir olgu olarak) hem de örgütler arasında (eknomik hiyerarşi ve etkililik yerine, birliktelik, ortaklaşa ilişkiler, esnek ağlar, ve stratejik ittifaklar sıralanabilir) örgütsel bağlılık, verimlilik, yenilik gibi örgütsel çıktıların arkasındaki en etkili araçlardan biri olduğu söylenebilir (Semerciöz, vd., 2007). Güven konusunu yerli ve yabancı literatürde işletmeler arası ilişkileri düzenleyen, başarı ve performansı arttıran ayrıca bilgi paylaşımını sağlayan en önemli unsur olarak gören çok sayıda çalışma mevcuttur (Lui ve Ngo, 2004; Marshall vd., 2005; Lane vd., 2001; Szulanski, vd., 2004). Bu çalışmalarda güven örgütler arası bilgi paylaşımını etkileyen balıca unsur olarak belirtilmektedir. Ayrıca güven söz konusuysa, izleme ve diğer kontrol mekanizmalarına ihtiyaç azalır (Norman, 2004). Karşılıklı güven ne kadar fazlaysa işletmelerin kendilerini koruma ihtiyaçları da o kadar azalabilmektedir. Ayrıca ifade edilmesi, elde edilmesi ve paylaşılması zor olan böylesine değerli bir varlık olarak bilginin işletmeler arasında aktarımının yapılabilmesi için tarafların bir birbirine güvenmeleri şarttır.

Bir diğer unsur olan öğrenme niyeti ortağın beceri ve yetkinliklerini içselleştirmek için istekli olmak olarak tanımlanır (Perez- Nordtvedt, vd., 2008). Çeşitli çalışmalarda bir stratejik ittifaktaki ortağın sahip olduğu belirli becerileri öğrenme kararlılığı olarak belirtilir. Ayrıca diğer işletmeden öğrenme için bir arzunun var olması şeklinde tanımlanan öğrenme niyeti, bilgi aktarımı için de önemli bir faktör olarak sayılmaktadır (Tsang, 2002; Simonin, 2004). Yani ortakların birbirinden öğrenme niyeti bilgi paylaşımını kolaylaştırabilmektedir.

Bilgi paylaşımı sürecini etkileyen bir diğer unsur iletişim olarak belirlenmiştir. Bilgi paylaşımı işbirliği ortaklarının iletişim kurmasını, problemleri birlikte çözümlemelerini ve örtük bilginin ortaya çıkmasını gerektiren bir ortak öğrenme sürecidir. Bilgi aktarımı iki taraflı, etkileşimli ve tekrarlanan bir süreç olduğundan, değiştirilen ve paylaşılan bilginin miktarı, her bir tarafın kararlılığına ve girdilerine (veri) bağlı olacaktır (Ho, 2008). Bu nedenle iletişim ortaklar arasındaki bilgi paylaşım sürecinde bir nevi araç olarak da görülebilir. Çünkü tüm bu belirtilenler ancak iletişim sayesinde sağlanabilir.

Özümseme kapasitesi geçmiş yıllarda örgütsel araştırmalarda ortaya çıkmış en önemli yapılardan biri olarak görülmektedir. Özümseme kapasitesi işletmenin dış kaynaklardan edindiği bilginin tanımlanması, benimsenmesi ve faydalanılması yeteneğini ifade eder. Bu kapasite diğer firmaların ürün ve süreçlerini sadece taklit etmeyi değil, aynı zamanda temel bilimsel araştırma gibi daha az ticari olarak odaklanmış bilgiden faydalanmayı da içerir. Özümseme kapasitesi yapısının oluşumu işletmenin kaynak temelli görüşün gelişimi ile aynı zamana denk gelir ve bu nedenle bu görüşün ürünü olarak görülmektedir. Böylece özümseme kapasitesi bilgi yönetimi, örgütsel öğrenme, stratejik ittifaklar ve yenilik yönetimi gibi çeşitli alanlarda temel yapı haline gelmiştir (Lane vd., 2002). Bu nedenle özümseme kapasitesi stratejik ittifak ilişkilerinde kullanılmakta ve hem öğrenme hem de yenilik faaliyetlerine katkı sağlayabilmektedir. 
Önceki çalışmalar paylaşılan vizyonun işbirlikçi ilişkileri birçok açıdan kapsadığını belirtmektedir. Paylaşılan vizyon kavramı paylaşılan değerleri, karşılıklı amaçları ve işbirliği ilişkisindeki anlayışı belirtmek için kullanılır. Paylaşılan vizyon konusunda Hakanson örgütsel kültürün dikkate alınması gerektiğini belirterek, örgütsel kültürün üyelerdeki kimlik duygusunun aktarılmasına yardım ettiğini ve örgüte ve hedeflerine bağlılık yaratabildiğini vurgulamaktadır (Hakanson, 1995). Bu nedenle tutarlı bir örgüt kültürü örgütler arasında paylaşılan vizyon yaratmaya yardım eder. Tsai ve Ghoshal'a göre de bir örgütün üyelerinin ortak amaç ve niyetlerinin toplamı paylaşılan vizyonu oluşturur. Paylaşılan vizyon örgütler arasındaki çeşitli kaynak alış verişlerinin gerçekleşmesi için önemli bir şarttır (Tsai ve Ghoshal, 1998). Ortaklar arasındaki paylaşılan vizyon, ortaklar arasındaki inançların ve paylaşılan değerlerin yapısının benzerlik derecesi olarak tanımlanır. Paylaşılan vizyon, ortakların hangi davranışların, amaçların ve politikaların önemli ya da önemsiz, uygun ya da uygun olmayan ve doğru ya da yanlış olduğu konusunda ortak inançlara sahip olmasıdır. Çünkü benzer örgütsel kültürlere sahip işletmelerin ortaklarına daha fazla güvenmeleri de daha mümkün olabilmektedir. Tedarik zinciri içerisindeki işbirliğine yönelik çalışmalarda bu işletmelerin ancak ortakların ortak bir dünya görüşünü paylaşmaları durumunda başarılı olabileceği belirtilmektedir. İşbirliği içerisindeki işletmelerde yaşanan örgütsel uyumsuzluklar, yani ün, iş durağanlığı, stratejik görüşler, kontrol sistemleri ve amaçlar daha az bilgi paylaşımına götürmektedir ( $\mathrm{Li}$ ve Lin, 2006). Bu nedenle stratejik ittifaklar arasındaki bilgi paylaşımını kolaylaştırıcı işletmeler arası ilişki unsurlarından biri olarak görülmektedir.

$B a \breve{g} l ı l ı k$, işletmeler arası ilişkilerde en önemli unsurlardan birisi olarak görülmektedir. Bağlılık, bir işletmenin bir diğer işletme ile olan ilişkilerini sürdürmesinin kendi amaçlarını gerçekleştirmede önemli olduğu konusundaki inancını ifade etmektedir. Bir ilişkide bağlılık yaratıldığında, tarafların daha karlı sonuçlar elde etmek için ilişkinin sürdürülmesine yönelik hareket ettikleri görülmektedir (Morgan ve Hunt, 1994). Diğer taraftan birbirine bağlılık seviyesi yüksek olan taraflar, kısa dönemli avantajlar elde etmek yerine uzun dönemli kazanç elde etmeyi düşüneceklerdir. Bunun sonucunda taraflar arasındaki çatışmalar en az düzeye inecek, yüksek bağlılık seviyesi ise tarafların ortak faaliyetlerden duyduğu memnuniyeti arttıracaktır (Demirbağ ve Mirza, 2000). Birbirine bağlı işletmelerin ilişkilerini uzun dönemde sürdüreceği ve bunun sonucunda işletmelerin sürekli aynı kalitede ürün ve hizmetleri ortaya koyması beklenmektedir. Literatürde yukarıda sözü edilen tüm bu ilişki unsurlarının örgütler arası bilgi paylaşımını etkilediği yönünde çeşitli bulgulara rastlanmaktadir.

\section{4 Örgütler Arası Bilgi Paylaşımı}

İşletmeler günümüzün rekabetçi ortamında kendi kendine yetemediklerinde çeşitli sebeplerle işbirliği yapmak ihtiyacı duyarlar. Böyle durumlarda bilgi ve onun paylaşılması büyük önem taşır. İşletmeler özellikle bilgiye ihtiyaç duymalarından dolayı, bilginin karşılıklı paylaşılması gündeme gelmektedir. Loebecke ve arkadaşları bilgi paylaşımını bilginin yaratılması, aktarılması ve bütünleştirilmesi olarak tanımlamaktadır (Loebecke, vd., 1999).

Strategic Management dergisinin özel bir sayısı ağ/şebeke/network araştırmacılarının, işletmelerin stratejik işbirliği gibi ortaklıklara girerek, onların performanslarını ve yönetilmelerini araştırmak için ağ bakış açısını kullanarak desteklediklerini ortaya koymaktadır (Gulati, vd., 2000). Bu araştırmacılar, firmalar arası ağların, işbirliği içerisindeki işletmelerin birbirlerinin bilgi ve kaynaklarına erişmelerinde, ölçek ve kapsam ekonomilerinin çeşitli avantajlarından yararlanmalarında ve örgütsel öğrenme gibi çeşitli stratejik amaçlara ulaşmalarını sağladığını savunmaktadırlar. Ayrıca bu tür yapılar bir işletmenin eşsiz ve ikame edilemez kaynaklarına erişebilmek için de düşünülebilmektedir (Nahapiet ve Ghoshal, 1998). Son yıllarda gelişen konuyla ilgili araştırmalar işletmeler arasındaki bu yapının bilgi edinimi ve bilginin paylaşılması ile işletmelerin performanslarını arttırdığını varsaymaktadır (Inkpen ve Tsang, 2005). Powell (1990)'a göre işbirliği içerisindeki işletmeler, etkili teknoloji kanalları ve know how aktarımını esnek, çabuk cevap veren ve yenilikçi yapılarıyla firmalar arası ağların avantajlarını sunar (Powell, 1990). Stratejik işbirlikleri stratejik yönetim alanında giderek artan bir öneme sahip olmakla birlikte, bilgi kaynaklarının yönetilmesi ve aktarılmasında da önemli bir rol almaktadırlar. Bilgi yönetimi literatürünün büyük bir kısmı örgüt içerisindeki bilgi edinimi, aktarımı, yaratılması ve bilgi ile değer yaratma gibi konular üzerine odaklanmışken, örgütler arası bilgi yönetimini anlamaya yönelik çok az çalışma mevcuttur (Parise ve Henderson, 2001).

Günümüzün işletmecilik alanında hızla artan bir olgu olan işletmeler arasındaki stratejik ittifaklar bilgi paylaşımı için bir araç olarak kullanılmaktadır (Tan ve Thai, 2012). Ayrıca birçok çalışmada stratejik ittifakların başarısını etkileyen önemli faktörlerden biri olarak sayılmaktadır (Mohr ve Spekman, 1994; Zaman ve Mavondo, 2001). Güçlü işletmeler arası bağlar, sadece asgari düzeyde koordinasyon, bilgi paylaşımı ya da ortakların anlaşmasını gerektiren ortak pazarlama girişimleri ve teknoloji lisanslarından çok, yatırım ve etkileşim açısından daha geniş ve derin bir ilişkiyi gerektiren hisse temelli anlaşmaları, üretim ortak girişimlerini ve ortak AR-GE projelerini içermektedir. Güçlü bağlar iki önemli avantaj sağlar. Güçlü bağları geliştirirken işletmeler birbirleri hakkında bilgi edinirler, birbirlerine daha bağımlı hale gelirler ve ilişkisel güveni geliştirirler. Derin bir karşılıklı anlayışa dayandırılan ilişkilerde, yüksek kaliteli bilgi ve kodlanmamış, örtülü bilgi örgütsel sınırlar arasında daha rahat bir şekilde paylaşılabilmekte ya da aktarılabilmektedir (Baum ve Ingram, 2002). Böylece işletmeler 
stratejik ittifak oluşturup karşılıklı bilgi paylaşımını sağlayarak, bu bilgiden elde edebilecekleri avantajları da elde etmiş olurlar.

Bilgi stratejik ittifaklar için önemli bir çıktı olduğundan, yapılan çalışmalarda bilgi edinimi konusu önem taşımaktadır. Çünkü ittifakın başarısı öğrenme ve bilgi paylaşımı ile ilişkilendirilmektedir, ortaklar öğrenmeye elverişli bir ortam yaratmak için teşvik edilirler. Böyle bir çevrede işletmenin sahip olduğu önemli bilgi ve yetenekler ortağı aydınlatabilir ve bu bilgiyi taklit etmesini ve benimsemesini sağlayabilir. Firmanın özel bilgisini korumak için, işletmeler ortağın öğrenme fırsatlarını kısıtlayarak, bu tür kayıpları ortadan kaldırabilirler. Ancak bu türden davranışlar işletmenin kendi öğrenme firsatlarını azaltabileceği gibi ittifak başarısını da azaltabilir. İşletmeler firmaya has bilginin kaybını ortadan kaldırmak için paylaşılan bilginin hem kalitesini hem de miktarını arttırarak ilişkilerini yapılandırabilir (Norman, 2004). İşletmeler bunun için gerekli ortamı sağlamalıdırlar. Sahip oldukları bilgiyi koruyarak paylaşırlarsa bu hem bilginin değerini kaybetmemesini hem de doğru aktarılıp her iki taraf için de doğru bir şekilde avantaja dönüşmesini sağlayabilir. Bunun için de en uygun araçlardan biri stratejik ittifaklar olarak görülmektedir.

\section{Stratejik İttifaklarda Örgütsel Yenilikçilik}

Drucker'a göre bilginin nasıl yapılacağı tam anlamıyla bilinen işlere uygulanması 'verimlilik', yeni ve farklı amaçlar doğrultusunda uygulanması ise 'yenilik'tir. Bu iki amaca yalnız bilgi sayesinde ulaşılabilir (Koenig ve Srikantaish, 2000). Oslo kılavuzuna göre yenilik, işletme içi uygulamalarda, işyeri organizasyonunda veya dış ilişkilerde yeni veya önemli derecede iyileştirilmiş bir ürün (mal veya hizmet) veya süreç, yeni bir pazarlama yöntemi ya da yeni bir organizasyonel yöntemin gerçekleştirilmesidir (Oslo Klavuzu, 2005). Yeniliğin önemli belirleyicileri olmakla birlikte, stratejik ittifakların, işbirliklerinin, ortak girişimlerin ve çeşitli ortaklıkların yeniliği doğurduğu veya işletmelerin yenilik için bu girişimlerde bulunduğu çeşitli çalışmalarda ele alınmıştır (Tidd vd., 2005).

İşbirliği yaparak elde edilen yenilik göz önüne alındığında, ortaklar arasında yeniliğin maliyetlerini paylaşmak, yeni becerileri ve teknik bilgiyi öğrenmek sinerjiden ve tamamlayıcı kaynaklardan yararlanmak, bilgi aktarımının olumlu etkileri ile mümkün olabilmektedir (Maggioni vd., 2012). Wang ve Fesenmaier'in keşfedici çalışmaları Amerika'da İndiana eyaletindeki Elkhart şehrinde turizm işletmelerinde gerçekleştirilmiş ve mülakat sonucu elde ettikleri bulgularından biri olarak işbirlikçi destinasyon pazarlamasında işletmeleri bu ilişkiye yönlendiren güdüler ortaya konmuştur. Söz konusu güdüler, stratejiyle ilgili güdüler, işlem maliyeti ile ilgili güdüler, öğrenme ile ilgili güdüler, küme rekabeti ve toplumsal sorumluluk olarak sıralanmıştır (Wang ve Fesenmaier, 2007). Birçok çalışma yenilik için stratejik işbirliklerinden söz etmektedir. Diğer bir deyişle stratejik işbirliklerinin çeşitli formlarının yeniliği getirdiğini birçok çalışma ele almaktadır (Kodama, 2007; Wong vd., 2005; Gilsing vd., 2007; Damanpour, 1991; Wolfe, 1994).

Öte yandan düşük teknolojili olarak adlandırılan konaklama endüstrisi gibi endüstrilerde hizmetlerde ve hizmet fonksiyonlarında yapılan yenilikler pratikte yaygın olmakla birlikte yenilik araştırmalarında, yenilik yönetiminde ve yenilik politikalarında fazla önemsenmemektedir. Gerçekte ne yazık ki hizmetlerde özellikle teknolojik olmayan yeniliğe yönelik bir isteksizlik ve üretimde teknolojik yeniliğe doğru köklü bir önyarg1 söz konusudur. Sürekli olarak yeterli veri eksikliği ve ölçüm ve tanımlama problemlerinin var olması, hizmetlerin yeniliğe, verimlilik artışına ve refaha katkısını belirsizleştirir (Hertog vd., 2011). Hizmetlerin yenilik açısından farklı olduğunu söyleyen alternatif bir bakış açısı mevcuttur. Bu görüş hizmetlerde yenilik için, işgücünün becerileri ve tedarikçi ve müşterilerle işbirliği uygulamaları gibi soyut (soft) yeteneklerin devamlı değişimi üzerine vurgu yaparak, daha mekanistik işletme yaklaşımına dayalı iyi tanımlanmış ürünlerin sıçramalı değişimi üzerine kurulu geleneksel "yenilik merdiveni” yaklaşımından daha uygun görülmektedir. Yenilikteki güçlüklerin algılanmasına göre de farklılıklar mevcuttur. Örneğin endüstri işletmeleri, etkili üretim yöntemlerine sahip olmanın ve pazarın ihtiyaç duyduğu ürünün üretilebilme esnekliğine sahip olmanın yanı sıra AR-GE yetkinlikleri ve teknolojik gelişimlere daha fazla önem vermektedirler. Hizmet işletmeleri ise işgücünün profesyonelliğine, becerilerine (özellikle yeniliğe olan uyum konusunda) ve tedarikçileri, müşterileri ve diğer işletmelerle olan işbirliklerine daha fazla önem vermektedirler. Genel olarak bu söylemlerin endüstri işletmelerinin daha çok sert (hard) yönler ve teknoloji kaynakları üzerinde, hizmet işletmelerininse daha çok yumuşak (soft) avantajlar ve tutumlar üzerinde durduğu yargısına ulaştırdığı söylenebilir (Tether, 2005). Bu nedenle hizmet işletmeleriyle ilgili özellikle de turizm sektörüyle ilgili yapılacak yenilikle ilgili akademik ve sektörel çalışmalara ihtiyaç duyulmaktadır. $\mathrm{Bu}$ eksiklik giderildiğinde yeniliğin sadece teknoloji üzerine gerçekleştirilebileceği ve turizm gibi soyut üretim yapan hizmet sektörü üzerindeki yeniliğe dair ön yargı ortadan kalkabilecektir.

Teknoloji işletmeleri dışında kalan işletmeler beklenmedik bir saldırıya maruz kaldıklarında temel yeteneklere daha fazla ihtiyaç duyacaktır. Bunu özellikle konaklama işletmeleri endüstrisinde görmek mümkündür. Oteller "web sayfası girişlerini arttırmak için” geleneksel olmayan temel yeteneklerini kullanarak tur operatörleri ve havayolu acentaları gibi aracılar ile ilişkilerini geliştirerek bunu gerçekleştirebilirler. Yani oteller söz konusu aracılarla ilişki kurmazlarsa web sitelerinin tıklanma olasılığı düşmektedir. Oteller kendi öz yeteneklerinden elde ettiği kazancın bir bölümünü onlara yeni yetenekler kazandıran elektronik iş çevresi ile paylaşmak zorundadırlar 
(Kothandaraman ve Wilson, 2001). Otellerin bu türden yapacakları stratejik ittifak ortaklıkları onlara hem yeni yetenekler kazandırabilecek hem de rekabet avantajı yakalamalarını sağlayabilecektir. Böylece dışarıdan edinilen bilgi yenilikçiliğe de beraberinde getirmektedir.

\section{Model Önerisi}

Çalışma için yapılan teorik araştırma çerçevesinde stratejik ittifak yapmış konaklama işletmelerinin aralarında bu ilişkiyi düzenleyen, kolaylaştıran ve yönlendiren bazı unsurlar elde edilmiştir. Bunlar örgütler arası ilişki unsurları olarak adlandırılmıştır (Li ve Lin, 2006). Bhatti'nin yaptığı doktora tez çalışmasında, firmalar arası kontrol mekanizması olarak ortakların uyum sağlama, cevap verme ve esnek olma gibi bilgi paylaşımının davranışsal yönleri ortaya çıkmıştır. Ortaklığın bu davranışsal yönleri işletmelere hızlı bilgi paylaşımı, yenilikçilik, pazara ulaşma ve karşılıklı gelişim sağlamaktadır (Bhatti, 2011). Li ve Lin çalışmalarında güven, bağlılık ve paylaşılan vizyon gibi örgütler arası ilişki faktörlerinin bilgi paylaşımını etkilediğini ortaya koymaktadırlar (Li ve Lin, 2006). Başka bir çalışmada güven, bağlılık ve öğrenme niyeti gibi unsurların stratejik ittifaklardaki bilgi paylaşımını etkilediği ortaya konmuştur (Wang ve Nicholas 2005). Bu unsurların en belirgin özelliği örgütler arası bilgi paylaşımını etkiliyor olmalarıdır. Yani örgütler arası ilişkileri etkileyen güven, öğrenme niyeti, iletişim, özümseme kapasitesi, paylaşılan vizyon ve bağlılık unsurları örgütler arası bilgi paylaşımını etkilemekte, işletmeler bilgiyi paylaştıkça işletmenin yenilik yeteneği oluşmaktadır. Öte yandan işletmeler arasındaki bilgi paylaşımının yenilikçiliği etkilediğine dair çalışmalar da mevcuttur (Magnini, 2008). Bununla birlikte literatürde örgütler arası ilişkilerin örgütsel yenilikçiliği etkilediğine dair çalışmalara da rastlamak mümkündür (Dewett ve Jones, 2001).

Çalışmada araştırılmak istenen model literatürden edinilen bilgilere dayanarak böyle bir öngörüyle ortaya konmuştur. Bununla birlikte çalışmada örgütler arası ilişki unsurları, bilgi paylaşımı ve örgütsel yenilikçilik değişkenlerinin arasındaki ilişikler ve etki ortaya konmak üzere saha araştırması devam etmektedir. Böylece çalışmada;

- Örgütler arası ilişki faktörleri (güven, öğrenme niyeti, iletişim, özümseme kapasitesi, paylaşılan vizyon ve bağlılık) stratejik ittifak oluşumlarındaki bilgi paylaşımını nasıl etkiler?

- Stratejik ittifak oluşumlarındaki bilgi paylaşımı örgütsel yenilikçiliği nasıl etkiler?

- Örgütler arası ilişki faktörleri (güven, öğrenme niyeti, iletişim, özümseme kapasitesi, paylaşılan vizyon ve bağlılık) stratejik ittifak oluşumlarındaki yenilikçiliği nasıl etkiler?

sorularına yanıt aranmaktadır. Bu nedenle çalışmada üç ana değişken yer almakta ve bu değişkenler arasındaki ilişkiler araştırılmaktadır.

Bu amaç doğrultusunda çalışmada yer alan değişkenler ve değişkenler arasındaki ilişkiler toplu bir şekilde ilişkinin etki yönünü gösterecek şekilde aşağıda verilmiştir.
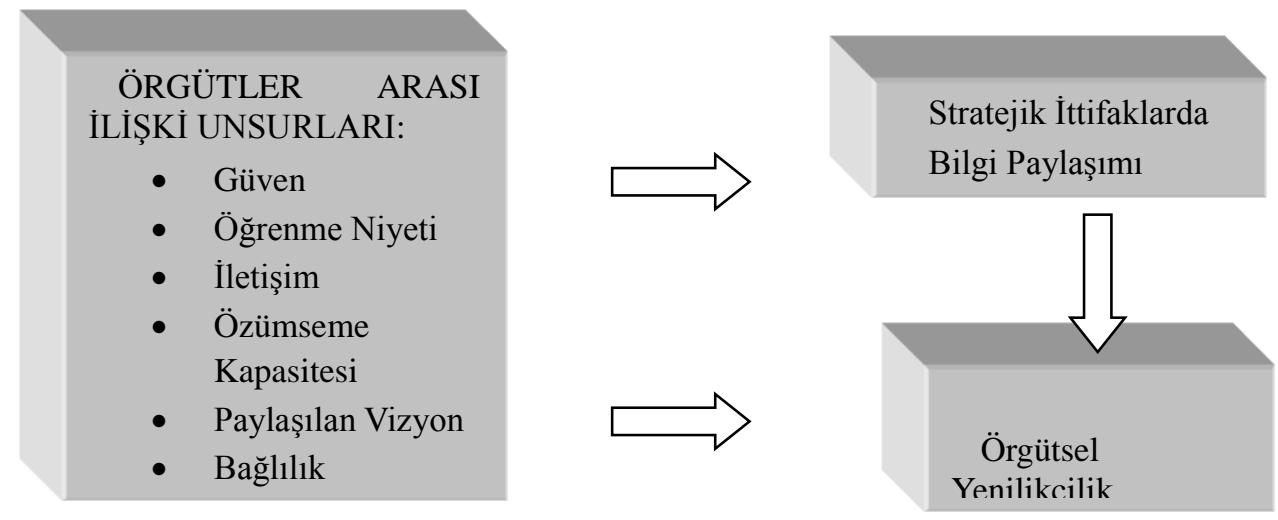

\section{Sonuç}

Çalışmada örgütler arası ilişkileri düzenleyen unsurlar bilgi paylaşımı açısından belirlenmiş ve bu ilişki unsurları kapsamlı bir literatür taraması sonucu, örgütler arası güven, öğrenme niyeti, iletişim, özümseme kapasitesi, paylaşılan vizyon ve bağlılık olarak belirlenmiştir. Bu çalışmada bu unsurların bilgi paylaşımı ve yenilikçilikle ilişkisi ortaya konmuştur. Ayrıca bilgi paylaşımı ve örgütsel yenilikçiliğin de ilişkisi ortaya konmuştur.

Günümüz işletmeleri için bilgi en önemli ve en değerli kaynaklar arasında sayılmaktadır. Bilgiye sahip olan işletmeler rakipleri karşısında her zaman önde olacaklarını bilirler. Çünkü bilgi yeniliği meydana getiren en önemli işletme kaynaklarından biridir. Bu nedenle bilgi yeniliğin hammaddesi olarak görülmektedir. Yenilik ise müşteri beklenti ve memnuniyetini sağlayabilecek, dolayısıyla işletmenin karlılık performansını artırabilecek en 
önemli unsurdur. Bunun farkında olan işletmeler özellikle işletme dışından elde edilecek bilginin işletmeye uyarlanıp, yenilikleri ortaya çıkarabileceğinin de farkındadırlar.

Böylece işletmeler arası bilgi paylaşımının önemi giderek artmaktadır. İşletmeler bilginin saklanarak değil de paylaşıldıkça artacağını bilerek hareket etmeli ve böylelikle hem kendine hem de piyasaya katma değer kazandırmalıdır. İşletmeler var olan bilgilerini diğerleriyle paylaşarak, mevcut bilgilerin yeni şekillerde yorumlanmasını böylece ürün ve hizmetlerde yenilik yapılmasını sağlayabilirler. Ayrıca bilginin örgüt dışındaki ortaklardan elde edilmesi de yine yenilikçiliği ortaya çıkarabilmektedir. Günümüzde örgütler arası ilişkilerin, bilgi paylaşımının ve bunun bir sonucu olarak işletmelerin elde ettiği yenilikçilik yeteneğinin işletmelere sağlayacağı faydalar, bu işletmelerin rekabette avantaj elde etmelerini sağlayabilmektedir.

Sonuç olarak çalışmada, örgütler arası ilişki unsurları, bilgi paylaşımı ve yenilikçilik yeteneği arasındaki ilişkileri ortaya koymayı amaçlayan bir model önerilmektedir. Literatürden edinilen bilgiler sonucunda modelde yer alan değişkenlere ve bu değişkenler arasındaki ilişkilere kısaca yer verilmiştir. Model özellikle konaklama sektöründeki stratejik ittifak oluşturmuş otel işletmelerinin bazı ilişki unsurları sayesinde bilgiyi paylaşarak, yenilikçilik yeteneğini elde edebileceklerini öngörmektedir. Böylece otel işletmelerinin rakiplerine göre pazarda öncelikli duruma geçebilmeleri de mümkün olmaktadır.

\section{Kaynakça}

- Balakrishnan ve Koza, 1993, "Information asymmetry, adverse selection, and joint ventures", Journal of Economic Behavior and Organization, 20, pp. 99-117.

- Baloh, vd., 2008, "Building strategic partnerships for managing innovation outsourcing", Strategic Outsourcing:An International Journal, 1 (2), pp. 100-121.

- Barringer ve Harrison, 2000, "Walking a tightrope: creating value through interorganizational relationships", Journal of Management, 26 (3), pp. 367-403.

- Baum ve Ingram, 2002, "Interorganizational learning and network organization: toward a behavioral theory of the interfirm", in M. Augier and J. G. March (Eds), The Economics of Chioce, Change and Organization: Essays in Memory of Richard M. Cyert, pp. 191-218.

- Bennett, 1997, "Strategic Alliances in the World Airline Industry", Progress in Tourism and Hospitality

- Research, 3, p. 217.

- Bhatti, 2011, Factors Affecting Knowledge Sharing in Strategic Alliances, The role of Knowledge Sharing as Strategic Control Behavior among Multinational Enterprises, PhD Thesis, Hanken School of Economics, Department of Management and Organization, Helsinki, ss. 136-137.

- Chathoth ve Olsen, 2003, "Strategic alliances: A hospitality industry perspective", International Journal of Hospitality Management, 22(4), pp. 419-434.

- Child ve Faulkner, 1998, Strategies of Cooperation: Managing Alliances, Networks, and Joint Ventures, Oxford, New York: Oxford University Press, 1998.

- Dacin, vd., 2007, "The legitimacy of strategic alliances: an institutional perspective", Strategic Management Journal, 28 (2), pp. 169-187.

- Damanpour, 1991, "Organizational Innovation: A meta analysis of effects of determinants and moderators", Academy of Management Journal, 34, p. 555-590.

- Das ve Teng, 2000a, "Instabilities of strategic alliances: an internal tensions perspective", Organization Science, 11 (1), pp. 77-101.

- Das ve Teng, 2000b, “A Resource- Based Theory of Strategic Alliances”, Journal of Management, 26 (1), ss. 31-61.

- Demirbağ ve Mirza, 2000, "Factors affecting international joint venture success: an empirical analysis of foreign local partner relationships and performance in joint ventures in Turkey", International Business Review, 9, pp.1-35.

- Devlin, ve Bleackley, 1997, "Strategic alliances - guidelines for success", in Lloyd, B. (Ed.), Creating Value through Acquisitions, Demergers, Buyouts and Alliances, Pergamon/Elsevier Science.

- Dewett ve Jones, 2001, "The role of information technology in the organization: a rview, model and assessment", Journal of Management, 27, pp. 313-346.

- Drucker, 1995, “The Network Society”, The Wall Street Journal Europe, 30 March, p.8.

- Dyer ve Singh, 1998 "The relational view: Cooperative strategy and sources of interorganizational competitive advantage", The Academy of Management Review, 23 (4), pp. 660-679.

- Evans, 2001, "Collaborative strategy: an analysis of the changing world of international airline alliances", Tourism Management, 22, p. 231.

- Flint, 2006, "Collection innovation, symbolic interaction and customer valuing: Thoughts stemming from a service dominant logic of marketing", Marketing Theory, 6, p. 349-362.

- Fyall ve Garrod, Tourism Marketing: A collaborative Approach, Channel View Publications, Canada, 2005, s.4. 
- Gehani, 2002, “Chester Barnard's executive and the knowledge based firm”, Management Decision, 40, p. 980991.

- Gilsing vd., 2007, "Strategic Alliance Networks and Innovation: A Deterministic and Voluntaristic View Combined”, Technology Analysis \& Strategic Management, 19, pp. 227-249.

- Gulati ve Lawrence, 2000, “Orginizing vertical Networks: A design perspective”, Kellogg Graduate School of Management, working paper.

- Gulati, vd., 2000, "Strategic Networks", Strategic Management Journal, 21, pp. 203-215.

- Hakanson, 1995, "Learning through acquisitions", International Studies of Management and Organization, 25, pp.121-158.

- Hertog, vd., 2011, "Measuring innovation in a 'low-tech' service industry: the case of the Dutch hospitality industry", The Service Industries Journal, 31, pp. 1429-1449.

- Hitt vd., 2000, "Partner selection in merging and developed market contexts: resource-based and organizational learning perspectives", Academy of Management Journal, 43, pp. 449-467.

- Ho, 2008, Knowledge sharing between competing suppliers in the customer's supply chain network, Doctor of Philosophy with a major in management, in the graduate college, The University of Arizona, s.41.

- Inkpen ve Tsang, 2005, "Social Capital, Networks, and Knowledge Transfer," Academy of Management Review, 30 (1), pp. 146-165.

- Ireland, vd., 2002, “Alliance Management As a Source of Competitive Advantage” Jounal of Management, 28, I.3, pp. 413-446.

- Kanter, 1994, “Collaborative advantage: the art of alliances”, Harvard Business Review, 72, 4, pp. 96-108.

- Koçel, 2005, İșletme Yöneticiliği, 10. Bası, Arıkan, İstanbul, s.426

- Kodama, 2007, "Innovation and knowledge creation through leadership-based strategic community: Case study on high-tech company in Japan”, Technovation, 27, pp. 115-132.

- Koenig ve Srikantaish, 2000, The evolution of knowledge management, Medford, NJ: ASIS Monograph series.

- Kothandaraman ve Wilson, 2001, “The Future of Competition Value-Creating Networks”, Industrial Marketing Management, 30, p. 388.

- $\quad \mathrm{Ku}$ ve Fan, 2009, "Knowledge sharing and customer relationship management in the travel service alliances", Total Quality Management, 20, p. 1407.

- Lane, vd., 2001, “Absorptive capacity, learning, and performance in international joint ventures", Strategic Management Journal, 22, s. 1139-1161.

- Lane, vd., 2002, “A thematic analysis and critical assessment of absorptive capacity research", Academy of Management Proceedings, working paper, pp. M1-M6.

- Li ve Lin, 2006, "Accessing information sharing and information quality in supply chain management", Decision Support Systems, 42, p.1647.

- Liao vd., 2007, "Knowledge sharing, absorptive capacity, and innovation capability: an empirical study of Taiwan's knowledge-intensive industries", Journal of Information Science, 33, p.340.

- $\quad$ Loebecke, vd., 1999, "Co-Opetition and Knowledge Transfer". The Database for Advances in Information Systems, 30, pp. 14-25.

- Lowensberg, 2010, “A new view on traditional strategic alliances' formation paradigms", Management Decision, 48 (7), pp. 1090-1102.

- Lui ve Ngo, 2004, "The Role of Trust and Contractual Safeguards on Cooperation in Non-equity Alliances", Journal of Management, 30, pp. 471-486.

- Luo ve Tan, 1998, “A comparison of multinational and domestic firms in an emerging market: A strategic choice perspective”, Journal of International Management, 4 (1), pp. 21-40.

- Maggioni vd., 2012, "Segmenting networking orientation in the hospitality industry: an empirical research on service bundling”, Working Paper n. 5, Università cattolica del Sacro Cuore, Largo A. Gemelli 1, 20123 Milano, Italy, s.9.

- Magnini, 2008, "Practicing effective knowledge sharing in international hotel joint ventures", International Journal of Hospitality Management, 27, pp.249-258.

- Mark ve Mirvis, 2001, "Making mergers and acquitions work: Strategic and psychological preparation", Academy of Management Executive, 15 (2), pp.80.

- Marshall, vd., 2005, "A dynamic model of trust deveopment and knowledge sharing in strategic alliances", Journal of General Management, 31, pp.41-57.

- Medina-Munoz ve Garcõa-Falcon, 2000, "Successful Relationships Between Hotels and Agencies", Annals of Tourism Research, 27, pp. 737-762.

- Mohr ve Spekman, 1994, "Characteristics of partnership success: Partnership attributes, communication behavior, and conflict resolution techniques”, Strategic Management Journal, 15, p. 137. 
- Morgan ve Hunt, 1994, “The commitment-trust theory of relationship marketing”, Journal of Marketing, 58, p. 20-38.

- Nahapiet ve Ghoshal, 1998, "Social Capital, Intellectual Capital and the Organizational Advantage," Academy of Management Review, 23, p. 243.

- Newman ve Chaharbaghi, 1997, "Strategic alliances in fast-moving markets", in Lloyd, B. (Ed.), Creating Value through Acquisitions, Demergers, Buyouts and Alliances, Pergamon/Elsevier Science, Kidlington'dan aktaran Daniel Arturo Lowensberg , "A "new" view on "traditional" strategic alliances' formation paradigms", Management Decision, 48, 7, 2010, pp. 1090-1102.

- Norman, 2004, "Knowledge acquisition, knowledge loss, and satisfaction in high technology alliances", Journal of Business Research, 57, s.611.

- Ohmae, 1989, "The global logic of strategic alliances", Harvard Business Review, March/April, p.p.143154.

- Oslo Klavuzu, 2005, Yenilik verilerinin toplanması ve yorumlanması için ilkeler, 3. Baskı, OECD ve Eurostat ortak yayını.

- Pansiri, 2008, "The effects of characteristics of partners on strategic alliance performance in the SME dominated travel sector", Tourism Management, 29, pp.101-115.

- Parise ve Henderson, 2001, "Knowledge resource Exchange in strategic alliances”, Ibm Systems Journal, 40, pp.908-924.

- $\quad$ Pérez-Nordtvedt, vd., 2008, "Effectiveness and Efficiency of Cross-Border Knowledge Transfer: An Empirical Examination", Journal of Management Studies, 45 (4), pp. 714-744.

- Powell, 1990, "Neither Market nor Hierarchy: Network Forms of Organization", Research in Organizational Behavior, 12, pp. 295-336.

- $\quad$ Rothkegel, vd., 2006, "Strategic Alliances between SMEs and Large Firms: An Exploration of the Dynamic Process", Management Revue, 17, p. 53-55.

- Semerciöz ve Çakınberk, 2003, “Stratejik İttifaklar: Türk İlaç Dağıtım Kanalından bir örnek”, Yönetim Dergisi, 13 (46), s.24.

- Semerciöz, vd., 2007, “Antecedents and consequences of interpersonal trust: An empirical study”, Journal of US-China Public Administration, 7, p.73.

- Simonin, 2004, “An empirical investigation of the process of knowledge transfer in international strategic alliances", Journal of International Business Studies, 35, pp. 407-427.

- Szulanski, vd., 2004, "When and how trustworthiness matters: knowledge transfer and the moderating effect of causal ambiguity", Organization Science, 15, pp. 600-613.

- Tand ve Thai, "Knowledge sharing within strategic alliance Networks and its impact on firm performance in the liner shipping industry", http://www.icms.polyu.edu.hk/ifspa2012/Papers/L06.pdf, erişim: 12.08.2012.

- Tether, 2005, "Do Services Innovate (Differently)? Insights from the European Innobarometer Survey", Industry and Innovation, 12, pp. 153-184.

- $\quad$ Tidd, vd., 2005, Managing Innovation, John Wiley and Sons Ltd., Chichester.

- Tsai ve Ghoshal, 1998, "Social capital and value creation: The role of intrafirm Networks", Academy of

- $\quad$ Management Journal, 41(4), pp. 464-476.

- Tsang, 2002, “Acquiring knowledge by foreign partners from international joint ventures in a transition economy: learning-by-doing and learning myopia”, Strategic Management Journal, 23, p.843.

- Wang, ve Fesenmaier, 2007, "Collaborative destination marketing: A case study of Elkhart county, Indiana", Tourism Management, 28 , p. 868.

- Wang ve Nicholas, 2005, "Knowledge Transfer, Knowledge Replication and Learning in Non-equity Alliances: Operating Contractual JV in China", Management International Review, 45, pp.99-118.

- Wernerfelt, 1984, “A Resource based view of the firm”, Strategic Management Journal, 5, ss.171-180

- Wilson, 2007, "Knowledge, innovation and re-inventing technical assistance for development", Progress in Development Studies, 7, p. 183-199.

- Wolfe, 1994, “Organizational Innovation: Review, Critique and Suggested Research Directions, Journal of Management Studies, p. 405-431.

- Wong, vd., 2005, "Developing relationships in strategic alliances: Commitment to quality and cooperative interdependence”, Industrial Marketing Management, 34, p. 722-731.

- Zaman ve Mavondo, 2001, "Measuring strategic alliance success: A conceptual framework",

- $\quad$ http://www.mendeley.com/research/measuring-alliance-success-role-strategic-fit-manir-zaman-felixmavondo monash-university/

- Zhang ve Zhang, 2006, "Rivalry Between Strategic Alliances", International Journal of Industrial Organization, 24/2, ss. 287-301. 


\title{
Yabancı Turistlerin Güvenlik Algılarının Analizi:Alanya Örneği Analysis of Security Perceptions of Foreign Tourists: The Case of Alanya
}

\author{
Asst. Prof. Dr. Muharrem Aksu (Akdeniz University, Turkey) \\ Asst. Prof. Dr. Ali Rıza Aktaş (Akdeniz University, Turkey) \\ Ph.D. Candidate Onur Oku (Akdeniz University, Turkey) \\ Ph.D. Candidate Faruk Kerem Şentürk (Akdeniz University, Turkey)
}

\begin{abstract}
High risk perception of the tourists affects tourism demand and causes serious declines in the number of tourists to destinations. With this respect, data collected from 500 randomly chosen foreign tourists were analyzed in order to identify their safety perception levels of Alanya town center and in which circumstances and places they have risk perceptions. Factors such as country of origin (nationality), gender, age, travel companion, education level, and duration of stay were tested in order to find out if they have an effect on safety/risk perceptions. Analysis included frequency tables and chi-squared tests. According to the main findings, majority of foreign tourists visiting Alanya find the destination safe (90,6\%). There were significant differences in tourists' perception of risk and safety among issues like traffic and criminal cases such as theft, purse-snatching, sexual harassment, crimes. Additionally, correlation was detected between one of the factors affecting risk perception, -gender and risk types such as -going out at nights, theft and sexual harassment; and foreign tourists' showed different risk perceptions according to their gender.
\end{abstract}

\section{Giriş}

Turizm, güvenlik eksikliğine ve tehlike algılarına son derece duyarlı ve kırılgan bir sektördür. Turizmde suç vakalarının artışı ve güven eksikliği, seyahat ve turizm sektörünü, diğer negatif faktörler kadar tehdit etmektedir. Güvenlik gerek destinasyondaki turistlerin huzurlu bir tatil yapması konusunda gerekse destinasyonun seçiminde önemli bir unsurdur. Emniyet ve güvenliğin, güvenlik yönetiminin ve güvenlik algısının destinasyonları derinden etkilediği de bir gerçektir. Aynı zamanda bir turizm destinasyonun başarı ve başarısızlığı da ziyaretçilere güvenli ve emniyetli bir çevre sağlamaya bağlıdır. Bir turizm bölgesinde siyasi ve ekonomik istikrarsızlıklar, çevre, gıda, sağlık riskleri, terör olayları, turistlere yönelik hırsızlık, kap-kaç, gasp, yaralama ve cinsel taciz gibi olumsuz faktörler nedeniyle hem bölgenin güvenlik imajı zedelenmekte hem de turizm talebinde azalmalar meydana gelmektedir. Diğer yandan bahsedilen olumsuz faktörler ziyatetçilerin risk algılarını güçlendirmekte ve ziyaretçilerde destinasyon hakkında olumsuz algılara neden olmaktadır. Turistler konakladığ 1 ya da konaklayacağı yer ile ilgili olarak kişisel güvenlik açısından herhangi bir risk algılar ya da kendilerini güvensiz hissederlerse bu yerlere ilişkin negatif bir imaj geliştirebilmekte ve tatil planlarında değişiklik yapabilmektedirler. Bir bölgenin güvenliğinin ziyaretçiler tarafından nasıl algılandığının bilinmesi, uygulanacak turizm pazarlama stratejileri konusunda avantaj sağlayacağı gibi turizm güvenliği konusunda da yapıcı/etkili politikaların üretilmesine katkıda bulunacağı şüphesizdir.

\section{Turizm ve Güvenlik İlişsisi}

Turizm endüstrisini güvenlik ve emniyetten bağımsız düşünmek neredeyse mümkün değildir (Tarlow ve Santana, 2002). Turizm sektörü, sosyo-ekonomik, doğal, kültürel ve siyasal olaylara en kısa sürede tepki vermesi nedeniyle oldukça kırılgan bir sektördür. Bu nedenle bir destinasyonun güvenli yer/bölge imajının oluşturulması, ilgili bölgenin tanıtımının en önemli unsurunu oluşturmaktadır.

Turistler, tatil yerlerini belirlerken destinasyonun güvenlik açısından imajını değerlendirerek karar verirler. Dolayısıyla güvenlik ve emniyet konusunda yetkin veya güvenlik riskinin düşük olduğu destinasyonlar, tatilciler açısından tercih edilebilir bölgeler haline gelmektedir. Bu bağlamda turizm güvenliği, seyahat ve turizmin en önemli koşullarından biri (Mansfeld ve Pizam, 2006; Reisinger ve Mavondo, 2005; Ryan, 1993; Sönmez ve Graefe, 1998b), turizm sektörünün gelişiminin de temel koşulu olarak karşımıza çıkmaktadır (George, 2003; Lepp ve Gibson, 2003; Mawby, 2000; Sönmez ve Graefe, 1998b).

Güvenlik ve emniyet, yurt içi ve yurt dışı seyahat edenler için uzun zamandan beri var olan global bir kaygıdır (Smith, 1999). Son yıllarda birçok araştırmacı, turizm destinasyonunda suç ve güvenlik problemlerinin turizm talebine doğrudan ve dolaylı olarak etkisinin olup olmadığını araştırmaya başlamıştır. Araştırmalar suç algısının, turizm talebi üzerinde zararlı bir etkisi olduğunu göstermiştir (Demos, 1992; Barker ve diğerleri, 2003; George, 2003, 2010, 2012). Yapılan çalışmalar, güvenliğin turistin karar alma sürecinde belirleyici bir unsur olduğunu göstermekte ve turizm bölgelerinde güvenli tatilin turistler için azımsanmayacak bir gereklilik olduğu vurgulamaktadir. 


\section{Güvenlik Algısının Turizm ve Turistler Üzerinde Etkisi}

Kriminal aktivitelerden etkilenen turistlerin güvenlik algıları ile turizm arasındaki ilişki ağırlıklı olarak 1990'ların başlarından itibaren incelemeye başlanmıştır. Seyahat riski, endişe ve güvenlik algısı, turistlerin seyahat kararlarını alma esnasında dominant bir faktör olarak ortaya çıkmakta ve turistik tüketicinin seyahate çıkma aşamasında duygusal ya da rasyonel olarak vereceği kararın en etkin elemanı haline gelmektedir. Aynı zamanda algılanan risk ve emniyet, seyahat karar alma sürecini ve destinasyon seçimini de etkilemektedir (George, 2003; Mawby, 2000; Sönmez ve Graefe, 1998b). Güvenlik algısının olumsuz olması ya da kişisel güvenlik endişesi, turistlerin gelecekteki seyahat tercihlerinin de belirleyicisi olmaktadır (Reisinger ve Mavondo, 2005; George, 2003:576-578; Sönmez ve Graefe, 1998a). Seyahatlerinde ya da konaklamalarında kendilerini tehdit altında hisseden turistlerin ilgili destinasyonu tekrar ziyaret etmeleri ve kendilerini tekrar güvende hissetmeleri pek muhtemel değildir (Reisinger ve Mavondo, 2006:17).

Turistlerin güvensizlik ve yüksek risk algıları, bir destinasyonla ilgili ne oranda endişe hissettikleriyle doğrudan ilişkilidir. (Reisinger ve Mavondo, 2006:17). Yukarıda değinildiği gibi, algılanan risk ve güvenlik eksikliği, turistlerin uluslararası seyahat planlarını ve tatil destinasyonu seçimini doğrudan etkilemektedir. Bunun sonucunda da riskli algilanan destinasyonlar, potansiyel olarak gidilebilecek destinasyonlar listesinden çıkartılmaktadır. Kısacası, turistik kararlarda risk algısı, rutin karar almayı bozma potansiyeline sahip güçlü bir etkendir (Sönmez ve Graefe, 1998b:120). Aslında bu karar değişimi, turistler açısından emniyet ve güvenliğin huzurlu bir tatilin ön şartı olduğunu göstermektedir (George, 2003:576).

Diğer yandan insanlar destinasyon seçimini yaparken sadece fiyatına ya da destinasyonun imajına göre seçmezler, aynı zamanda algıladıkları kişisel güvenlik ve emniyete göre de karar vermektedirler (Pizam ve diğerleri, 1997). Gerçekten de güvenlik endişesi ya da risk algısının yüksek olduğu durumlarda, destinasyon seçiminde benzer faydalar sunan iki alternatif arasında -daha ucuz ve daha güvenli- daha güvenli olanın tercih edileceği belirtilmiştir (Sönmez ve Graefe, 1998:120b). Kısacası, turistler tatil destinasyonunda kendini güvensiz ya da tehdit altında hissederse destinasyon hakkında negatif bir izlenim geliştirebilirler. Bu durum, destinasyona zarar verebileceği gibi bölgede turizmin düşmesine neden olabilecektir (George, 2003:577). Yapılan araştırmalarda seyahat amaçları ile risk algıları arasında ters bir ilişki bulunmuştur. Yani, risk algısının yüksek olduğu durumlarda seyahat isteğinin düşük olduğu görülmektedir (Gray ve diğerleri, 2011:65).

\section{Turizmle İlgili Risk Türleri}

Birçok araştırmacı tarafından turizmle ilgili risk türleri oldukça geniş bir yelpazede incelenmektedir. Risk kategorilerini Reisinger ve Mavondo (2005) genişleterek öncelikli olan 13 seyahat riski belirlemiştir. Bunlar; suç, kültürel, sosyal, finansal, sağlık, donanım/ekipman, performans/başarı, fiziksel, siyasi, psikolojik, memnuniyet/tatmin, terörizm ve zamandır. Turistler bu risklerden sadece birini ya da birden fazlasını birlikte algilayabilirler (Reisinger ve Mavondo, 2006:15).

Yapılan birçok araştırmada risk türleri ile turizm ilişkilendirilerek turizm risk kaynaklarının turizme etkisi incelenmiştir. Turizm ve seyahat; doğal felaketler (Faulkner, 2001; Armstrong ve Ritchie, 2007; Mazzocchi ve Montini, 2001; Higgins, 2005; Faulkner ve Vikulov, 2001), kültür ve dil zorlukları (Basala ve Klenosky, 2001), suç (Dimanche ve Lepetic, 1999; Pizam ve Mansfeld, 1996; Brunt ve diğerleri, 2000; Pizam, 1999; Lepp ve Gibson, 2003), sağlık (Richter, 2003; Carter, 1998; Lepp ve Gibson, 2003; Rittichainuwat ve Chakraborty, 2009, Miller ve Ritchie, 2003; McKercher ve Chon, 2004; Cooper, 2005), savaş ve politik istikrarsızlık (Sönmez ve diğerleri, 1999; Gartner ve Shen, 1992; Ioannides ve Apostolopoulos, 1999; Seddighi ve diğerleri, 2000; Lepp ve Gibson, 2003), terörizm (Sönmez, 1998; Aziz, 1995; Sönmez ve Graefe, 1998a, 1998b; Sönmez ve diğerleri, 1999; Richter, 2003; Araña ve León, 2008; Lepp ve Gibson, 2003; Pizam, 2002) gibi bir dizi risk faktörüyle ilişkilendirilmiştir. Turistler, bu risk faktörlerinden herhangi birinin tehdit olduğu algısına sahip olurlarsa seyahat destinasyonu seçimlerini değiştirebilirler ya da seçilen destinasyondan vazgeçebilirler (Kozak ve diğerleri, 2007). Kontrolü zor olan bu faktörler, gerçekleştikleri zaman kalıcı bir etkiye neden olabilmekte (George, 2012:85) ve destinasyon imajına zarar vererek turizmi olumsuz yönde etkileyebilmektedirler (Ukwayi ve diğerleri, 2012:36).

\section{Turistlerde Risk Algısını Etkileyen Faktörler}

Araştırmalar, turistlerin risk algılarını kişilik özellikleri, milliyet, sosyal sınıf, cinsiyet, yaş gibi bir dizi bireysel faktörün etkilediğini göstermektedir (George, 2003, 2012:85). Gerçekten de turistlerin risk algılarını, bireysel bilgi, riski kabul ve riske maruz kalmaya isteklilik (Dowling ve Staelin, 1994), seyahat aşamaları (McIntosh ve diğerleri, 1998), durum, seyahat programları gibi organizasyonel faktörler (Roehl ve Fesenmaier, 1992), motivasyon ve kişilik gibi psikografik faktörler (Lepp ve Gibson, 2003; Carr, 2001; Schweer, 1986; Lepp ve Gibson, 2008; Reisinger ve Mavondo, 2005), cinsiyet (Gibson ve Yiannakis, 2002; Lynch ve Atkins, 1988; Sellick, 2004; Staats ve diğerleri, 2006; Reisinger ve Crotts, 2010), medeni durum (Sellick, 2004), gelir (Sönmez ve Graefe, 1998b; Sellick, 2004), sosyal statü, (Schweer, 1986; Demos, 1992) yaş (Sönmez ve Graefe, 1998b; 
Sellick, 2004; Seddighi ve diğerleri, 2002), gibi sosyo-demografik faktörler, riskin türü ya da riskin tüketici için önemi (Tsaur ve diğerleri, 1997) farklı boyutlarda etkilemektedir. Böylece bireyler aynı riskleri farklı şekillerde algılayabilmektedirler (Kahneman ve Tversky, 1982). Ayrica bireylerin seyahat risk algis1, seyahat bilgi kaynakları (Pizam ve diğerleri, 2004; Kozak ve diğerleri, 2007) geçmiş seyahat deneyimleri (Chen ve Gürsoy, 2001; Lepp ve Gibson, 2003; Floyd ve diğerleri, 2004; Kozak ve diğerleri, 2007) kalış süresi (Barker ve diğerleri, 2003; George, 2003), seyahat tercihleri (Lepp ve Gibson, 2003), destinasyonu ziyaret etme sayıs1 (Demos, 1992), ziyaret amacı gibi (Rittichainuwat ve diğerleri, 2002; George, 2010) çeşitli davranışsal özelliklerden etkilenebilmektedir (George, 2010; Reisinger ve Mavondo, 2006:15-16). Diğer yandan uluslararas1 turizmde turistlerin risk algısı, kültürel, dinsel ve siyasal faktörlere de fazlasıyla bağlı olabileceği belirtilmektedir (Reisinger ve Mavondo, 2006:14). Ayrıca risk algısı milliyete göre değişmekle birlikte (George, 2003, 2010; Seddighi ve diğerleri, 2001; Barker ve diğerleri, 2003; Reisinger ve Mavondo, 2006; Richardson ve Crompton, 1988), farklı milletlerden seyahat edenler aynı riski farklı düzeylerde algılayabilmektedirler (Richardson ve Crompton, 1988).

Risk algısı ve risk önceliği cinsiyet ve yaşa göre farklılık göstermektedir (Carr, 2001). Cinsiyet, farklı risk ve güvenlik algılamalarında önemli bir belirleyicidir (Reisinger ve Mavondo, 2006). Örneğin kadınlar ve daha yaşlı kişilerin kişisel emniyet konusunda daha endişeli oldukları belirtilmektedir. Kadınların seyahat aktivitelerini potansiyel riskle karşılaşmaktan kaçınmak için sınırlandırdıkları (Stanko, 2000), erkeklere göre risk konusunda daha duyarlı oldukları (Gibson ve Jordan, 1998) ve geceleri herhangi bir tehlike söz konusu olduğunda daha yüksek risk algısına sahip oldukları tespit edilmiş̧ir (Carr, 2001). Ayrıca kadınların terörizmle ilgili risk konusunda erkeklerden daha yüksek risk algısına sahip oldukları belirtilmiştir (George, 2010:87) Staats ve diğerleri (2006) ise, cinsiyet farklılıklarının, terör eylemleri sonrasında yapılan gelecek seyahat planlamalarını etkilediğini belirtmişsir.

Yapılan bir araştırmada kişilerin geçmişteki suç deneyimlerinin, milliyetinin ve kalış süresinin güvenlik algılarını etkilediği görülmüştür (George, 2003:582-583). Başka bir araştırma ise daha önce suça maruz kalan kimselerin kendilerini daha az güvende hissettiklerini göstermiştir. Turistlerin daha önceki suç deneyimleri daha güvensiz bir algıya sebep olduğu ve bunun sonucunda da turistler suç korkusuyla destinasyondaki aktivitelerini de sınırlandırdığı tespit edilmiştir. Ayrıca turistlerin hava karardıktan sonra dışarı çıkma konusunda daha dikkatli oldukları da vurgulanmaktadır (Milman ve Bach, 1999:384; Pinhey ve Iverson, 1994:92). Gibson ve Yinannakis (2002)'e göre ise seyahatle ilgili risk algısı yaş ilerledikçe azalmaktadır.

Turistler, suçlular tarafından yanlış yerde yanlış zamanda bulunan kolay hedefler olarak kabul edilmekte ve suç kurbanı olabilmektedirler. Akabinde medyanın ilgisiyle bu destinasyonlarda bulunan ziyaretçilerin ya da potansiyel ziyaretçilerin güvenlik algıları olumsuz olarak etkilenebilmektedir (George, 2003:577). Gerçekten de medyanın turistlerin algılarında önemli bir rol oynayarak (Glenson ve Tepe, 2004; Ukwayi ve diğerleri, 2012:36 Korstanje, 2011) risk alg1 düzeylerini etkilediği bulunmuştur (Gray ve diğerleri, 2011). Keza Mawby’e (2000:101) göre de suç ile ilgili haberler, var olan riski daha da yükseltmektedir.

\section{Metodoloji}

Çalışmanın evreni 2012 yılında Alanya'ya tatile gelen yabancı turistleri kapsamaktadır. Araştırmanın örneklemi ise Alanya kent merkezine gelen yabancı turistlerden rastgele seçilen 500 yabancı turistten oluşmaktadır. Örneklem büyüklüğünün hesaplanmasında kabul edilebilir hata payı 0.05 (\%5) olarak alınmış, $\% 95$ 'lik güven seviyesine göre minimum örneklem büyüklüğü örneklem belirleme çizelgesinden yararlanılarak 384 olarak hesaplanmıştır. Ancak anketlerin yeterli sayıda geri dönmeyebileceği düşünülerek turistlere 550 anket uygulanmış; geri dönen anketlerden eksik/hatalı doldurulanlar çıkarıldıktan sonra 500 anket araştırma için kullanılmıştır.

Araştırmada literatür taraması ve alan araştırması yöntemi kullanılmış. Literatür taramasında ikinci kaynaklardan yararlanılırken alan araştırmasında çalışmanın amacını ortaya koyacak nitelikte bir anket formu kullanılmıştır. Söz konusu anket formu deneklerin demografik özelliklerini ve araştırma alanı ile ilgili güvenlik algılarını belirlemeye yönelik sorulardan oluşmaktadır. Araştırma alanına gelen turistlerin çok farklı dilleri konuşuyor olmasından dolayı anket formları başlıca 3 dilde hazırlanmıştır. Anket, 2012'de sezonun en yoğun olduğu Temmuz-Ağustos aylarında kent merkezindeki bar, restoran, kafe, plaj ve otellerde uygulanmıştır. Anket uygulaması sonucu elde edilen veriler SPSS paket programında analiz edilmiştir. Yapılan analiz iki aşamadan oluşmaktadır. Birinci aşamada deneklerin tüm sorulara verdikleri cevapları frekans çizelgeleri ile gösterilerek, cevapların düzeylere göre dağılımı belirlenmiştir. İkinci aşamada bir faktörün diğer bir faktöre bağlı olup olmadığı veya bir faktör üzerine diğer bir faktörün etkisinin olup olmadığını belirlemek için parametrik olmayan testler içinde en yaygın kullanım alanı olan ki-kare testi yapılmıştır. Ki-kare testinde boş hipotez yani $\mathrm{H}_{0}$ hipotezi sorulara verilen cevaplar arasında "iliş̧ki yoktur" $\left(\mathrm{H}_{0}\right.$ : Değişkenler arasında ilişki yoktur) ve alternatif hipotez yani $H_{A}$ hipotezi ise sorulara verilen cevaplar arasında "ilişski vardır" $\left(H_{A}\right.$ : Değişkenler arasında ilişki vardır) şeklinde oluşturulmuştur. Ki-kare testi yardımıyla aşağıdaki hipotezler test edilmiştir. 
Araştırmada nitel bir değişken olan güvenlik algısı ile yine nitel birer değişken olan cinsiyet, eğitim düzeyi, yaş, gelinen ülke, Alanya'da yerel arkadaşın bulunması, araştırma bölgesinde cinsel taciz, hırsızlık, kapkaç, suç, trafik kazası gibi değişkenler arasında bir ilişki olup olmadığı araştırılmıştır. İlgili analizlerde değişkenlerin nitel değişkenler olması nedeniyle ki-kare bağımsılık testi uygulanmıştır.

\section{Araştırma Bulguları ve Değerlendirmesi}

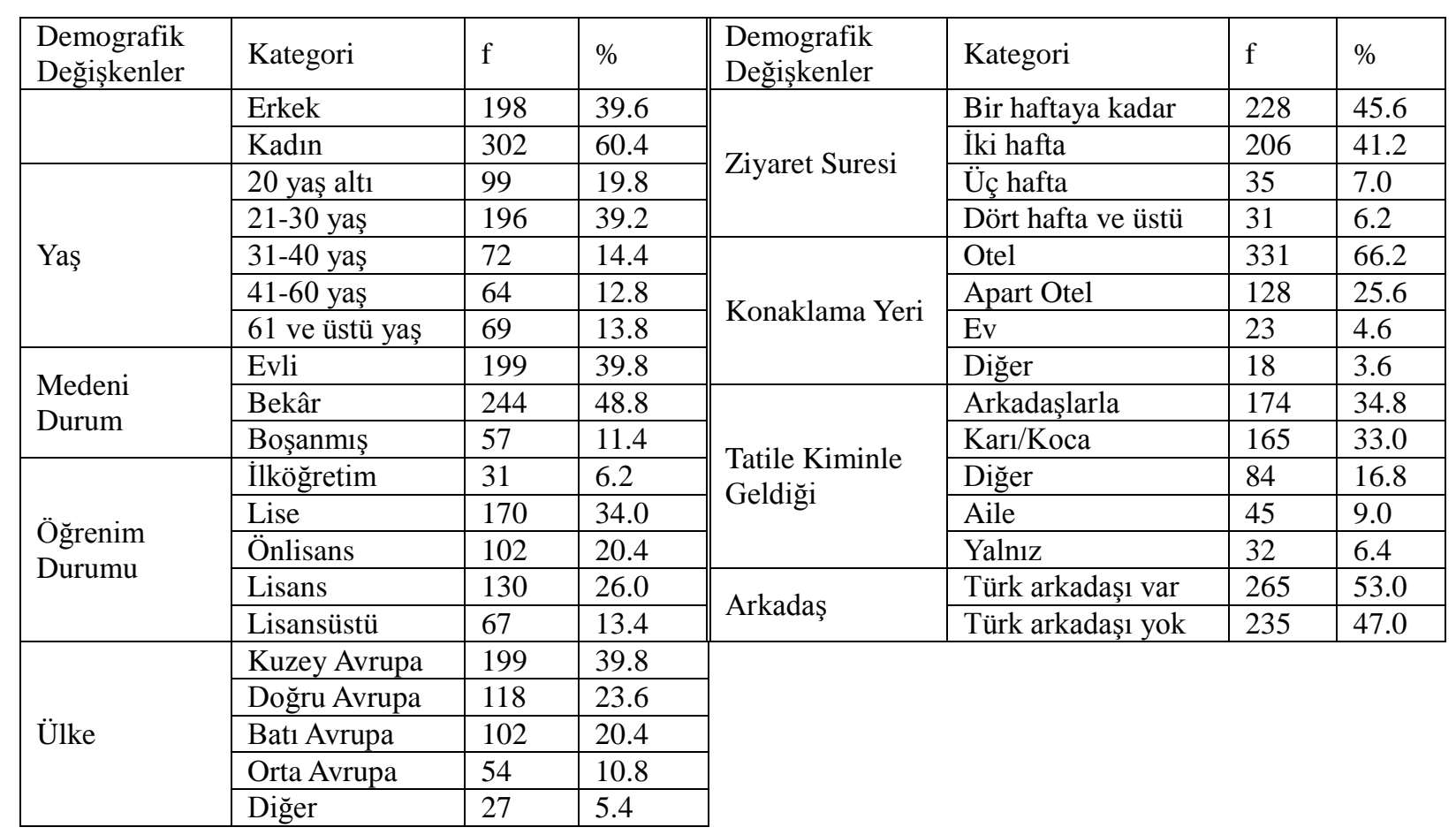

\section{Tablo 1: Demografik değişkenler tablosu}

Araştırmaya katılan turistlerin 198'i erkek (\%39.6) ve 302'sinin ise $(\% 60,4)$ kadın olduğu tespit edilmiştir. Tablo 1'de görüldüğü gibi Alanya'ya gelen turistlerin büyük bir çoğunluğunun 40 ve altı yaş grubundan oluştuğu görülmektedir. Tablo 1'deki verilere göre araştırmaya katılan turistlerin \%48'i bekârdır. Araştırma bölgesine gelen turistlerin büyük bir çoğunluğunun yüksek eğitim seviyesine sahip olduğu görülmekte olup ilköğretim düzeyinde eğitime sahip olanların oranı \%6 düzeyinde kalmıştır. Alanya'ya gelen turistlerin geldikleri ülkelere göre dağılımına bakındığında ise ilk sırada Kuzey Avrupa ülkelerinden gelenler yer almaktadır (\%39.8). Bu ülkeleri sırasıyla Doğu Avrupa ülkeleri (\%23.6), Batı Avrupa ülkeleri (\%20.4) ve Orta Avrupa ülkeleri izlemektedir (\%10.8).

Araştırma kapsamında ankete katılan turistlerin \%45.6'sı bir haftadır Alanya'da bulunduklarını belirtirken \%41.2'si ise iki haftadır Alanya'da olduğunu beyan etmiştir. Alanya'ya gelen turistlerin büyük bir çoğunluğu (\%66.2) otellerde konaklamayı tercih ederken kendi evinde konaklayanların oranı ise \%4.6 olarak tespit edilmiştir. Tablo 1 incelendiğinde araştırma bölgesine gelen turistlerin ağırlıklı olarak eşleriyle veya arkadaşlarıyla tatile geldikleri görülmektedir. Alanya'ya gelen turistlerin yarıdan fazlası bu kentte Türk arkadaşının olduğunu (\%53) belirtmiştir.

Araştırma kapsamında Alanya kent merkezine tatile gelen yabancı turistlerin neredeyse tamamına yakını Alanya'da kendilerini güvende hissettiklerini (\%90.6) ifade ederken güvensiz olduğunu belirtenlerin oranı ise $\% 9.4$ olarak tespit edilmiştir. Güvenli olup olmaması bakımından Alanya’yı kendi yaşadığı kent ile mukayese etmesi istenen turistlerin \%55.8'i kendi kentlerinin daha güvenli olduğunu belirtmiştir. Ankete katılan turistlerin \%75.6's1 güvenlik görevlilerinin (polis, jandarma) hizmetlerinden memnun olduğunu beyan etmişlerdir. Diğer bir ifadeyle turistlerin \%75.6'sı güvenlik hizmetlerini kötü bulmamaktadır. Dolayısıyla bu durum, güvenlik hizmet kalitesinin iyi verilmesinin aynı zamanda Alanya'yı güvenli bulmasında da etkin bir faktör olduğu söylenebilir. İnsanların elbette kendilerini yabancısı oldukları bir ülkeye göre kendi ülkelerinde güvende hissetmeleri doğal bir durum olmakla birlikte Alanya'yı kendi ülkesinden daha güvenli bulanlar ile kendi ülkesiyle fark yok diyenlerin toplam oranının \%44.2 olması, Alanya'nın güvenli bir kent olarak algılandığını gösteren diğer bir veridir.

Araştırma alanındaki turistlerin \%77.6'sının Alanya'ya gelmeden önce Alanya'yı güvenli bir kent olarak gördüklerini, \%22.4'ünün ise güvenli bir kent olarak görmediklerini ifade etmişlerdir. Alanya'ya geldikten sonra güvenlik algılarında olumlu bir değişme olduğunu ifade edenlerin oranı \%34.6, değişmediğini ifade edenlerin oranı \%26.2 iken olumsuz olarak değiştiğini ifade edenlerin oranı ise \%5.8 olduğu tespit edilmiştir. Alanya'ya 
gelmeden önce Alanya'yı güvenli bir kent bulmayanların oranın \%22.4 oranında kalması, Alanya'nın destinasyon imajının genel olarak güvenli bir kent olarak algılandığını göstermektedir. Alanya'ya gelen turistlerden Alanya'ya gelmeden önce güvenli bulan \%77.6'sının (388 kişi) geldikten sonra sadece \%3.4'ünde (13 kişi) olumsuz yönde değişim olmuştur. Buna karşın Alanya’ya gelmeden önce Alanya hakkında güvenlik alg1s1 olumsuz olanlardan (\%22.4) olumlu yönde değişenlerin oranı \%54.5 (61 kişi) olarak tespit edilmiştir. Olumlu yöndeki büyük değişim dikkate alındığında araştırma bölgesinin güvenlik algısının yüksek olduğu söylenilebilir.

\begin{tabular}{|c|c|c|c|c|c|c|c|}
\hline Alg1 Değişkenleri & Kategori & $\mathrm{f}$ & $\%$ & $\begin{array}{l}\text { Alg1 } \\
\text { Değişkenleri }\end{array}$ & Kategori & $\mathrm{f}$ & $\%$ \\
\hline \multirow{2}{*}{$\begin{array}{l}\text { Genel olarak } \\
\text { Alanya'da kendinizi } \\
\text { güvende hissediyor } \\
\text { musunuz? }\end{array}$} & Evet & 453 & 90.6 & \multirow{3}{*}{$\begin{array}{l}\text { Alanya'ya } \\
\text { geldikten sonra } \\
\text { Alanya ile ilgili } \\
\text { güvenlik } \\
\text { algınızda nasıl } \\
\text { bir değişme } \\
\text { oldu? }\end{array}$} & $\begin{array}{l}\text { Olumlu olarak } \\
\text { değişti }\end{array}$ & 173 & 34.6 \\
\hline & Hayır & 47 & 9.4 & & $\begin{array}{l}\text { Olumsuz } \\
\text { olarak değişti }\end{array}$ & 29 & 5.8 \\
\hline \multirow{3}{*}{$\begin{array}{l}\text { Hangi ülkede } \\
\text { (şehirde) kendinizi } \\
\text { daha güvende } \\
\text { hissediyorsunuz? }\end{array}$} & Kendi ülkemde & 279 & 55.8 & & Değişmedi & 298 & 59.6 \\
\hline & Alanya'da & 74 & 14.8 & \multirow{2}{*}{$\begin{array}{l}\text { Başkalarına } \\
\text { Alanya'nın } \\
\text { güvenli bir kent } \\
\text { olduğunu tavsiye } \\
\text { eder misiniz? }\end{array}$} & Tavsiye ederim & 449 & 89.8 \\
\hline & Fark Yok & 147 & 29.4 & & Tavsiye etmem & 51 & 10.2 \\
\hline \multirow{6}{*}{$\begin{array}{l}\text { Alanya'daki güvenlik } \\
\text { görevlilerinin (polis, } \\
\text { jandarma) } \\
\text { hizmetlerinden } \\
\text { memnuniyet dereceniz } \\
\text { nedir? }\end{array}$} & Mükemmel & 69 & 13.8 & \multirow{7}{*}{$\begin{array}{l}\text { Alanya ile ilgili } \\
\text { güvenlik algınızı } \\
\text { hangi kaynaktan } \\
\text { edindiniz? }\end{array}$} & İnternet & 219 & 43.8 \\
\hline & İyi & 204 & 40.8 & & Gazete/Dergi & 84 & 16.8 \\
\hline & Orta & 105 & 21.0 & & TV & 70 & 14.0 \\
\hline & Kötü & 8 & 1.6 & & Tur operatörü & 131 & 26.2 \\
\hline & Çok Kötü & 5 & 1.0 & & Türk arkadaş & 195 & 39.0 \\
\hline & Fikrim Yok & 109 & 21.8 & & Arkadaş & 82 & 16.4 \\
\hline \multirow{4}{*}{$\begin{array}{l}\text { Türk güvenlik } \\
\text { görevlilerine } \\
\text { güveniyor musunuz? }\end{array}$} & Evet & 188 & 37.6 & & Diğer & 56 & 11.4 \\
\hline & Kismen & 135 & 27.0 & \multirow{5}{*}{$\begin{array}{l}\text { Alanya'ya } \\
\text { gelmenizde } \\
\text { etkili olan } \\
\text { faktörler }\end{array}$} & $\begin{array}{l}\text { Güneş/Deniz/ } \\
\text { Doğa }\end{array}$ & 373 & 74.6 \\
\hline & Hayır & 28 & 5.6 & & Tarih/Din & 11 & 2.2 \\
\hline & Fikrim yok & 149 & 29.8 & & Fiyat & 54 & 10.8 \\
\hline \multirow{2}{*}{$\begin{array}{l}\text { Alanya'ya gelmeden } \\
\text { önce Alanya hakkında } \\
\text { güvenlik algınız } \\
\text { nasıldı? }\end{array}$} & $\begin{array}{l}\text { Alanya } \\
\text { güvenlidir }\end{array}$ & 388 & 77.6 & & Güvenlik & 38 & 7.6 \\
\hline & $\begin{array}{l}\text { Alanya güvenli } \\
\text { değildir }\end{array}$ & 112 & 22.4 & & Arkadaşlık & 24 & 4.8 \\
\hline
\end{tabular}

Tablo 2: Algl değişkenleri tablosu

Tablo 2'ye göre araştırmaya katılan turistlerin büyük bir çoğunluğu $(\% 89,8)$ Alanya'yı güvenli bir kent olarak başkalarına tavsiye edeceklerini belirtmektedir. Bu durum özellikle, Alanya’yı ziyaret edenlerin gönüllü birer turizm elçisi olarak potansiyel ziyaretçiler üzerinde Alanya'nın güvenli kent imajının oluşmasını sağlayacaktır. Keza Tablo 3'ten çıkan sonuç da arkadaşlardan alınan bilgilerin (\%95.1) güven algısını yükselttiğini göstermektedir. Araştırmaya katılan turistlerin Alanya ile ilgili güvenlik bilgilerini ağırlıklı olarak internet üzerinden (\%43.8) edinirken bunu sırasıyla Türk arkadaşları (\%39) ve tur operatörleri (\%26.2) takip etmektedir (Tablo 2). Bu veriler daha önce yapılmış olan çeşitli çalışmalardaki bulguları da destekler niteliktedir. Katılımcıların toplamda \%74.6'sının Alanya'nın güvenliği hakkında yazılı ve görsel medyadan bilgi alması medyanın güvenlik algısı oluşturmadaki rolüne işaret etmektedir. Ayrıca Türk arkadaşların güvenlik algısının oluşmasındaki rolü de göz ardı edilmemelidir.

Araştırma kapsamında ankete katılan turistlerin Alanya’yı tercih etmelerinde etkili olan en önemli faktörün güneş-deniz-doğa olduğu görülmektedir. Nitekim güneş-deniz-doğa nedeniyle Alanya'yı tercih edenlerin oranı \%74.6'dır. Bunu sırasıyla Alanya'daki fiyatların uygun olması (\%10.8), Alanya'nın güvenli bir kent olması (\%7.6), arkadaşlık (\%4.8) ve tarihi/dini yerlerin çekiciliği (\%2.2) faktörleri takip etmektedir. Tablo 3 'ten de görüleceği üzere Alanya'nın tercih edilmesinde güvenlik unsuru, üçüncü faktör olarak ortaya çıkmaktadır.

Tablo 3'e göre, araştırma alanına gelen turistlerin demografik değişkenlere göre güven algı düzeyleri düşük düzeyde de olsa farklılık arz etmektedir. Tablo 3 incelendiğinde, erkeklerin kadınlara göre kendini daha fazla güvende hissettiği; 20 yaşın altında olanların 20 yaş üstüne göre kendini daha az güvende hissettiği; eğitim düzeyi arttıkça kendini güvende hissetme oranının yükseldiği; Doğu Avrupa ülkelerinden gelen ziyaretçilerin kendilerini güvende hissetme oranının daha düşük düzeyde olmasına karşın, diğer kategorisinde yer alan Ortadoğu ve Orta Asya'dan gelen ziyaretçilerin kendini daha fazla güvende hissettiği; eşleriyle birlikte tatile gelen turistlerin daha fazla güven algısına sahip olduğu; Alanya'da 1 haftadır bulunanların Alanya'yı güvenli 
bulma düzeyi sonraki haftalarda düşmekteyken 4. hafta ve sonrasında yükseldiği; Türk arkadaşı olanların kendini daha fazla güvende hissettiği; bilgi kaynakları açısından kendi arkadaşlarından bilgi edinenlerin kendilerini daha fazla güvende hissettiği görülmektedir.

\begin{tabular}{|c|c|c|c|c|c|c|c|c|c|c|c|}
\hline \multicolumn{12}{|c|}{ Genel olarak Alanya'da kendinizi güvende hissediyor musunuz? } \\
\hline \multirow{2}{*}{$\begin{array}{l}\text { Demografik } \\
\text { Değişkenler }\end{array}$} & \multirow{2}{*}{ Kategori } & \multicolumn{2}{|l|}{ Evet } & \multicolumn{2}{|c|}{ Hayır } & \multirow{2}{*}{$\begin{array}{l}\text { Demografik } \\
\text { Değişkenler }\end{array}$} & \multirow[t]{2}{*}{ Kategori } & \multicolumn{2}{|l|}{ Evet } & \multicolumn{2}{|c|}{ Hayır } \\
\hline & & $\mathrm{f}$ & $\%$ & $\mathrm{f}$ & $\%$ & & & $\mathrm{f}$ & $\%$ & $\mathrm{f}$ & $\%$ \\
\hline \multirow[t]{2}{*}{ Cinsiyet } & Erkek & 181 & 91.4 & 17 & 8.6 & \multirow{5}{*}{$\begin{array}{l}\text { Tatile kiminle } \\
\text { geldiği }\end{array}$} & Yalnız & 27 & 84.4 & 5 & 15.6 \\
\hline & Kadın & 272 & 90.1 & 30 & 9.9 & & Kar1/koca & 154 & 93.3 & 11 & 6.7 \\
\hline \multirow{5}{*}{ Yaş } & 20 yaş alt1 & 80 & 80.8 & 19 & 19.2 & & Arkadaşlarla & 153 & 87.9 & 21 & 12.1 \\
\hline & $21-30$ & 178 & 90.8 & 18 & 9.2 & & Aile & 39 & 86.7 & 6 & 13.3 \\
\hline & $31-40$ & 71 & 98.6 & 1 & 1.4 & & Diğer & 80 & 95.2 & 4 & 4.8 \\
\hline & $41-60$ & 61 & 95.3 & 3 & 4.7 & \multirow{4}{*}{$\begin{array}{l}\text { Alanya'da } \\
\text { bulunma } \\
\text { süresi }\end{array}$} & 1 hafta & 210 & 92.1 & 18 & 7.9 \\
\hline & $61-+$ & 63 & 91.3 & 6 & 8.7 & & 2 hafta & 183 & 88.8 & 23 & 11.2 \\
\hline \multirow{3}{*}{$\begin{array}{l}\text { Medeni } \\
\text { durum }\end{array}$} & Evli & 188 & 94.5 & 11 & 5.5 & & 3 hafta & 31 & 88.6 & 4 & 11.4 \\
\hline & Bekar & 213 & 87.3 & 21 & 12.7 & & 4 hafta & 29 & 93.5 & 2 & 6.5 \\
\hline & Boşanmış & 52 & 91.2 & 5 & 8.8 & \multirow[t]{2}{*}{ Türk arkadaş } & Var & 244 & 92.1 & 21 & 7.9 \\
\hline \multirow{5}{*}{$\begin{array}{l}\text { Eğitim } \\
\text { durumu }\end{array}$} & İlköğretim & 28 & 90.3 & 3 & 9.7 & & Yok & 209 & 88.9 & 26 & 11.1 \\
\hline & Lise & 155 & 91.2 & 15 & 8.8 & \multirow{8}{*}{ Bilgi kaynağı } & İnternet & 199 & 90.9 & 20 & 9.1 \\
\hline & Önlisans & 89 & 97.3 & 13 & 12.7 & & Gazete & 51 & 91.1 & 5 & 8.9 \\
\hline & Lisans & 118 & 90.8 & 12 & 9.2 & & Dergi & 24 & 85.7 & 4 & 14.3 \\
\hline & Lisansüstü & 63 & 94.0 & 4 & 6.0 & & $\mathrm{TV}$ & 63 & 90.0 & 7 & 10 \\
\hline \multirow{5}{*}{ Ülke } & Batı Avrupa & 94 & 92.2 & 8 & 7.8 & & Tur operatörü & 115 & 87.8 & 16 & 12.2 \\
\hline & Kuzey Avrupa & 181 & 91.0 & 18 & 9 & & Türk arkadaş & 178 & 91.3 & 17 & 8.7 \\
\hline & Orta Avrupa & 49 & 90.7 & 5 & 9.3 & & Arkadaş & 78 & 95.1 & 4 & 4.9 \\
\hline & Doğu Avrupa & 104 & 88.1 & 14 & 11.9 & & Diğer & 51 & 89.5 & 6 & 10.5 \\
\hline & Diğer & 25 & 92.6 & 2 & 7.4 & & & & & & \\
\hline
\end{tabular}

Tablo 3: Demografik değişkenlere göre güvenlik algı düzeylerinin dă̆ılımı

Yukarıdaki veriler (Tablo 3), eğitim düzeyi ile güvenlik algısının doğru orantılı olduğunu göstermektedir. Ayrıca Orta Asya ve Orta Doğu'dan gelen ziyaretçilerin diğer ülkelerden gelenlere göre kendilerini güvende hissetmeleri dil ve din benzerliği gibi faktörlere bağlanabilir. Alanya'ya gelen turistlerin ilk hafta kendilerini güvende hissetme oranı yüksekken sonraki haftalarda düşmesi ve sonrasında ilk haftaya göre biraz daha yükselmesi, turistlerin Alanya'ya yüksek bir güvenlik algısıyla gelmelerine ve Alanya'nın güvenli bir ortam sunmasıyla birlikte güvenlik algılarındaki olumlu değişime bağlanabilir (Bkz. Tablo 5).

\begin{tabular}{|l|l|l|l|l|l|l|}
\hline \multirow{2}{*}{ Değiş̧kenler } & \multicolumn{2}{l|}{ Evet } & \multicolumn{2}{l|}{ Kısmen } & \multicolumn{2}{l|}{ Hayır } \\
\cline { 2 - 7 } & $\mathrm{f}$ & $\%$ & $\mathrm{f}$ & $\%$ & $\mathrm{f}$ & $\%$ \\
\hline Toplu taşıma araçlarında & 252 & 50.4 & 185 & 37.0 & 63 & 12.6 \\
\hline Gece yaya olarak dışarı çıktığınızda & 243 & 48.6 & 178 & 35.6 & 79 & 15.8 \\
\hline Gündüz yaya olarak dışarı çıktığınızda & 400 & 80.0 & 61 & 12.2 & 39 & 7.8 \\
\hline Plajlarda (cinsel taciz ve hırsızlık vb.) & 294 & 58.8 & 120 & 24.0 & 86 & 17.2 \\
\hline Eğlence mekânlarında (bar, disko vb.) & 267 & 53.4 & 157 & 31.4 & 76 & 15.2 \\
\hline Hırsızlık & 229 & 45.8 & 142 & 28.4 & 129 & 25.8 \\
\hline Kap-kaç & 210 & 42.0 & 166 & 33.2 & 124 & 24.8 \\
\hline Cinsel taciz & 243 & 48.6 & 120 & 24.0 & 137 & 27.4 \\
\hline Suç & 273 & 54.6 & 88 & 17.6 & 139 & 27.8 \\
\hline Trafik & 164 & 32.8 & 190 & 38.0 & 146 & 29.2 \\
\hline
\end{tabular}

Tablo 4: Turistlerin Alanya'da çeşitli ortam ve durumlarda kendilerini güvenli hissetme durumlarının dă̆glımı

\begin{tabular}{|l|l|l|l|l|l|}
\hline \multirow{2}{*}{ Değişkenler } & & \multicolumn{2}{l|}{ Kadın } \\
\cline { 2 - 6 } & & $\mathrm{f}$ & $\%$ & $\mathrm{f}$ & $\%$ \\
\hline \multirow{2}{*}{$\begin{array}{l}\text { Alanya'ya gelmeden önce Alanya hakkında } \\
\text { güvenlik algıları }\end{array}$} & Güvenlidir & 159 & 80.3 & 229 & 75.8 \\
\cline { 2 - 6 } & Güvenli değildir & 39 & 19.7 & 73 & 24.2 \\
\hline \multirow{2}{*}{ Alanya'da güvende hissetme durumu } & Güvenlidir & 181 & 91.4 & 17 & 8.6 \\
\cline { 2 - 6 } & Güvenli değildir & 272 & 90.1 & 30 & 9.9 \\
\hline \multirow{2}{*}{$\begin{array}{l}\text { Alanya'ya geldikten sonra Alanya ile ilgili } \\
\text { güvenlik algılarında değişim }\end{array}$} & Olumlu değişti & 59 & 29.8 & 114 & 37.7 \\
\cline { 2 - 6 } & Olumsuz değişti & 14 & 7.1 & 15 & 5.0 \\
\cline { 2 - 6 } & Değişmedi & 125 & 63.1 & 173 & 57.3 \\
\hline
\end{tabular}

Tablo 5: Cinsiyetlere göre güvenlik algı düzeylerinin dă̆llımı 
Alanya'ya gelen turistlerin \%50.4'ü toplu taşıma araçlarında kendilerini güvende hissettiklerini ifade etmiştir. Benzer sonuçlar gece yaya olarak dışarı çıktıklarında da gözlemlenmiştir. Araştırma bölgesine gelen turistlerin büyük bir çoğunluğu plajlarda ve eğlence merkezlerinde kendilerini güvende hissettiklerini belirtmişlerdir. Tablo 4 incelendiğinde turistlerin \%58.8'i plajlarda ve \%53.4'ü ise eğlence mekanlarında kendilerini güvende hissettikleri görülmektedir. Turistler, özellikle trafik konusunda kendilerini güvensiz hissetmekteyken (\%29.2), suç, cinsel taciz, kap-kaç ve hırsızlık durumlarında güvenlik algı düzeyleri düşük ve birbirine yakındır.

Araştırma alanına gelen turistlerin Alanya'ya gelmeden önce Alanya'yı güvenli bulma oranları cinsiyetlere göre incelendiğinde erkeklerin \%80.3'ü Alanya'yı güvenli bulurken kadınların \%75.8’i güvenli bulmaktadır. Alanya'ya geldiklerinde ise hem kadın hem erkeklerde güvenlik algılarında olumlu yönde bir değişim olduğu gözlemlenmektedir. Erkeklerin \%91.4'ü Alanya'yı güvenli bulurken kadınlarda bu oran \%90.1 olarak gerçekleşmiştir. Alanya'ya geldikten sonra Alanya'nın güvenlik algısındaki değişim kadınlarda daha yüksek seyretmektedir. Oysaki kadınların Alanya'ya gelmeden önce, Alanya hakkındaki güvenlik algıları erkeklere göre daha düşüktür. Ankete katılan erkeklerden \%80.3'ü Alanya'yı güvenli bulurken kadınlarda bu oran 75.8'dir.

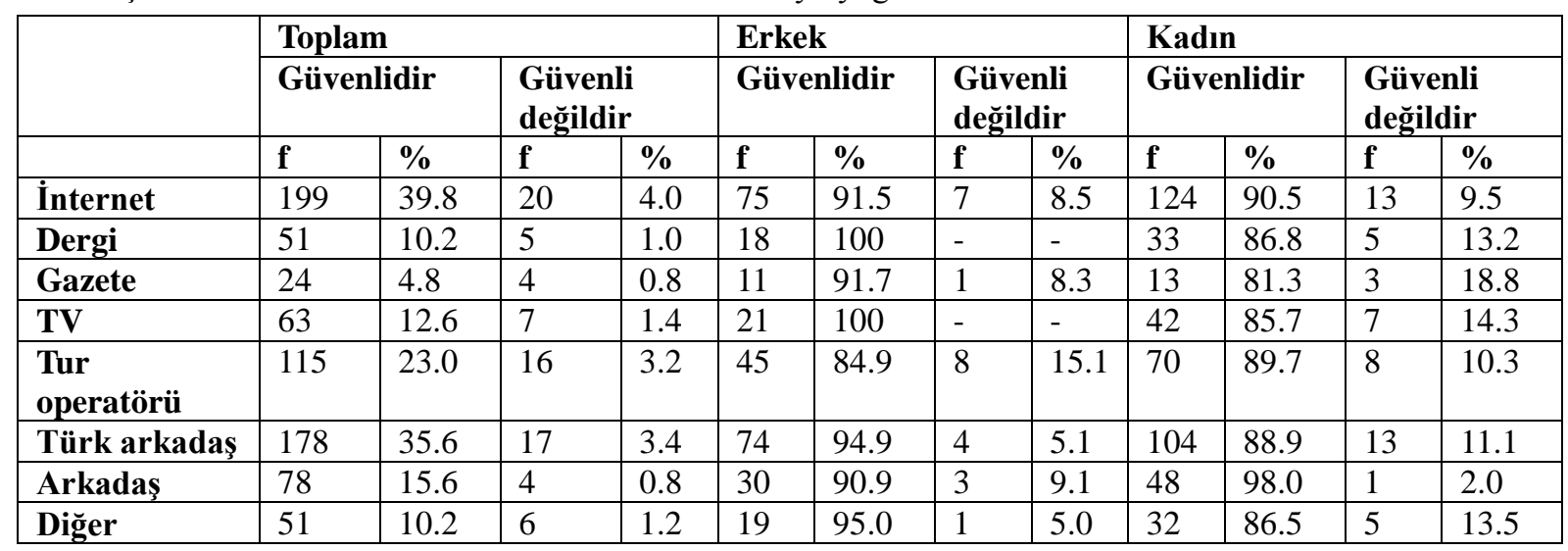

Tablo 6:Turistlerin bilgi kaynaklarına göre Alanya'ya yönelik güvenlik algılarının dă̆llımı

Alanya'ya ile ilgili güvenlik bilgi ediniminde bilgi kaynakları açısından cinsiyetler arası çok farklılık olmamakla birlikte turistlerin en fazla internete (\%39.8) başvurdukları görülmektedir. Turistlerin ikinci sırada Türk arkadaşlarından (\%35.6) üçüncü sırada ise tur operatörlerinden (\%23) bilgi edindikleri görülmektedir. Ayrıca, araştırma bölgesine gelen turistlerin bilgi kaynaklarına göre Alanya’yı güvenli bulmaları bakımından cinsiyetlere göre karşılaştırılması yapıldığında, çok büyük farklılıklar olmamakla birlikte tur operatörleri ve kendi arkadaşlarından bilgi edinen kadınların, erkeklere göre Alanya'yı güvenli bulma oranının daha yüksek olduğu görülmektedir. Buna karşın diğer bilgi kaynaklarıyla kıyaslama yapıldığında Alanya hakkında tur operatörlerinden bilgi edinen erkekler ile gazetelerden bilgi edinen kadınların güvenlik algısının düşük olduğu görülmektedir.

\begin{tabular}{|c|c|c|c|c|c|c|c|c|c|c|c|c|c|c|c|}
\hline & \multicolumn{6}{|c|}{ Erkek } & \multicolumn{6}{|c|}{ Kadın } & \multirow{3}{*}{$\begin{array}{l}\mathbf{S} \\
\mathbf{d}\end{array}$} & \multirow{3}{*}{$\begin{array}{l}\text { Ki- } \\
\text { Kare } \\
\left(\mathbf{X}^{2}\right)\end{array}$} & \multirow{3}{*}{$\mathbf{P}$} \\
\hline & \multicolumn{2}{|c|}{ Evet } & \multicolumn{2}{|c|}{ Kismen } & \multicolumn{2}{|c|}{ Hayır } & \multicolumn{2}{|c|}{ Evet } & \multicolumn{2}{|c|}{ Kismen } & \multicolumn{2}{|c|}{ Hayır } & & & \\
\hline & f & $\%$ & f & $\%$ & f & $\%$ & f & $\%$ & f & $\%$ & f & $\%$ & & & \\
\hline $\begin{array}{l}\text { Toplu taşıma } \\
\text { araçlarında }\end{array}$ & 100 & 50.5 & 74 & 37.4 & 24 & 12.1 & 152 & 50.3 & 111 & 36.8 & 39 & 12.9 & 2 & 0.073 & 0.964 \\
\hline $\begin{array}{l}\text { Gece yaya } \\
\text { olarak dışarı } \\
\text { ç1ktığınızda }\end{array}$ & 110 & 55.6 & 60 & 30.3 & 28 & 14.1 & 133 & 44.0 & 118 & 39.1 & 51 & 16.9 & 2 & 6.418 & $0.040 *$ \\
\hline $\begin{array}{l}\text { Gündüz yaya } \\
\text { olarak dışarı } \\
\text { çıtığınızda }\end{array}$ & 158 & 79.8 & 21 & 10.6 & 19 & 9.6 & 242 & 80.1 & 40 & 13.2 & 20 & 6.6 & 2 & 2.040 & 0.361 \\
\hline Plajlarda & 124 & 62.6 & 38 & 19.2 & 36 & 18.2 & 170 & 56.3 & 82 & 27.2 & 50 & 16.6 & 2 & 4.158 & 0.125 \\
\hline $\begin{array}{l}\text { Eğlence } \\
\text { mekanlarında }\end{array}$ & 111 & 56.1 & 56 & 28.3 & 31 & 15.7 & 156 & 51.7 & 101 & 33.4 & 45 & 14.9 & 2 & 1.494 & 0.474 \\
\hline Hirsızlık & 99 & 50.0 & 42 & 21.2 & 57 & 28.8 & 130 & 43.0 & 100 & 33.1 & 72 & 23.8 & 2 & 8.361 & $0.015^{*}$ \\
\hline Kap-kaç & 87 & 43.9 & 57 & 28.8 & 54 & 27.3 & 123 & 40.7 & 109 & 36.1 & 70 & 23.2 & 2 & 3.024 & 0.220 \\
\hline Cinsel taciz & 117 & 59.1 & 23 & 11.6 & 58 & 29.3 & 126 & 41.7 & 97 & 32.1 & 79 & 26.2 & 2 & 28.80 & $0.000 *$ \\
\hline Suç & 111 & 56.1 & 31 & 15.7 & 56 & 28.3 & 162 & 53.2 & 57 & 18.9 & 83 & 27.5 & 2 & 0.859 & 0.651 \\
\hline Trafik & 66 & 33.3 & 73 & 36.9 & 59 & 29.8 & 98 & 32.5 & 117 & 38.7 & 87 & 28.8 & 2 & 0.179 & 0.914 \\
\hline
\end{tabular}

Tablo 7: Alanya'da Turistlerin cinsiyetleri ile çeşitli ortam ve durumlarda kendilerini güvenli hissetme durumlarının dă̆ılımı 


\section{Hipotezlerin Test Edilmesi}

Turistlerin cinsiyetleri ile toplu taşıma araçlarında, gece ve gündüz yaya olarak dışarı çıktıklarında, plajlarda, eğlence mekânlarında, hırsızlık, kap-kaç, cinsel taciz, suç ve trafik durumunda güvenlik algıları arasında bir ilişki vardır.

Araştırmaya katılan turistlerin kendilerini en fazla güvende hissettikleri durum "gündüz yaya olarak dişarı çıkma" durumu olup bu oran erkeklerde \%79.8 iken kadınlarda \%80.1'dir. En düşük güvende hissettikleri durum ise trafik durumu olup kadın ve erkek turistlerde sirasıyla bu oranlar \%32.5 ve \%33.3 olarak tespit edilmiştir. Tablo 7'deki veriler incelendiğinde araştırma bölgesine gelen erkek turistlerin; toplu taşıma araçlarında, gece yaya olarak dışarı çıkmada, plajlarda, eğlence mekanlarında, hırsızlık, kap-kaç, cinsel taciz, suç ve trafik durumlarında kadın turistlere göre daha yüksek düzeyde kendilerini güvende hissettikleri, kadın turistlerin ise sadece gündüz yaya dışarı çıkmada erkeklere göre kendilerini daha güvende hissettikleri görülmektedir. Ayrıca kadınlarla erkekler arasındaki en büyük farklılık cinsel taciz konusunda ve gece dışarı çıkma konusunda görülmektedir. Dolayısıyla gece yaya olarak dışarı çıkmak, cinsel taciz açısından motive suçlular için uygun ortamı sağlayan bir durum olarak değerlendirildiğinde bu iki faktörün birbirinden bağımsız olmadığı sonucuna varılabilir. $\mathrm{Bu}$ faktörlere bağlı olarak kadınlarda güven algısı erkeklere göre daha düşüktür. Tablo 9 incelendiğinde ise kadınların cinsel tacize maruz kalması sonrasında Alanya hakkında güvenlik algısının erkeklere göre daha düşük oranda (\%45.2) değişmesi, zaten bu konudaki düşük güvenlik algısına bağlanabilir.

Alanya'ya gelen turistlerin cinsiyetleri ile toplu taşıma araçlarında, gece ve gündüz yaya olarak dışarı çıtıklarında, plajlarda, eğlence mekanlarında, hırsızlık, kap-kaç, cinsel taciz, suç ve trafik gibi durumlarda güvenlik algıları arasında bir ilişkinin varlığını araştırmak amacıyla ki-kare testi yapılmıştır. "Gece yaya olarak dışarı çıkma", "hırsızlık" ve "cinsel taciz" durumlarında cinsiyet ile güvenlik algıları arasındaki ilişkiyi belirlemeye yönelik yapılan ki kare testi sonucunda elde edilen ki kare değerleri sırasıly 0.040, 0.015 ve 0,000 olarak hesaplanmıştır. Buna göre $\mathrm{P}<0,05$ olduğundan $\% 5$ anlamlılık düzeyinde $\mathrm{H} 1$ hipotezi kabul edilmişstir. Daha önceki yapılan çalışmalarda, şehirle ilgili geceleri tehlike söz konusu olduğunda, kadınların daha yüksek risk algısına sahip olduğu tespit edilmiştir (Carr, 2001). Gerçekten de Alanya'da özellikle kadınların geceleri yaya olarak dışarı çıktıklarında erkeklere göre kendilerini güvende hissetme oranı (\%44.0) daha düşüktür. Ayrıca toplamda gece dışarı çıkan kadınlarda güvenlik algısı \%44 olmasına rağmen, gece yaya olarak dışarı çıkma konusunda Alanya'ya yalnız gelen kadınların sadece \%27.3'ü kendini güvende hissetmektedir. Kısmen güvende hissedenlerin oranı \%59.1, güvende hissetmeyenlerin oranı ise, \%13.6'dır. Bu veriler, genel olarak Alanya güvenli bir kent olarak algılansa da yalnız gelen kadınların gece dışarı çıkma konusunda güven algılarının yüksek olmadığını göstermektedir.

8.1 Turistlerin cinsel tacize, hırsızlığa, suça, kap-kaça ve trafik kazasına maruz kalmaları durumunda kendini güvende hissetme algıları arasında bir ilișki vardır.

\begin{tabular}{|c|c|c|c|c|c|c|c|c|c|c|c|c|c|}
\hline \multirow{2}{*}{$\begin{array}{l}\text { Yaşanan } \\
\text { olaylar }\end{array}$} & \multicolumn{2}{|c|}{ Erkek } & \multicolumn{2}{|c|}{ Kadın } & \multicolumn{2}{|c|}{ Toplam } & \multicolumn{2}{|c|}{ Güvenli } & \multicolumn{2}{|c|}{ Güvensiz } & \multirow[b]{2}{*}{$\mathrm{sd}$} & \multirow{2}{*}{$\begin{array}{l}\text { Ki-Kare } \\
\left(\mathrm{X}^{2}\right)\end{array}$} & \\
\hline & $\mathrm{f}$ & $\%$ & $\mathrm{f}$ & $\%$ & $\mathrm{f}$ & $\%$ & $\mathrm{f}$ & $\%$ & $\mathrm{f}$ & $\%$ & & & \\
\hline Cinsel taciz & 17 & 28.8 & 42 & 71.2 & 59 & 11.8 & 47 & 79.7 & 12 & 20.3 & 1 & 9.399 & $0.002 *$ \\
\hline Hirsızlık & 17 & 48.6 & 18 & 51.4 & 35 & 7.0 & 27 & 77.1 & 8 & 22.9 & 1 & 8.001 & $0.004 *$ \\
\hline $\begin{array}{l}\text { Suça maruz } \\
\text { kalma }\end{array}$ & 20 & 50.0 & 20 & 50.0 & 40 & 8.0 & 30 & 75.0 & 10 & 25.0 & 1 & 12.424 & $0.000^{*}$ \\
\hline Trafik kazası & 36 & 46.2 & 42 & 53.8 & 78 & 15.6 & 60 & 76.9 & 18 & 23.1 & $\mid 1$ & 20.299 & $0.000^{*}$ \\
\hline Kap kaç & 22 & 47.8 & 24 & 52.2 & 46 & 9.2 & 35 & 76.1 & 11 & 23.9 & |1 & 12.529 & $0.000^{*}$ \\
\hline
\end{tabular}

Tablo 8: Turistlerin cinsel tacize, hırsızlı̆̆a, suça, kap-kaça ve trafik kazasına maruz kalmaları durumunda kendilerini güvende hissetme algılarının dă̆ılımı

Alanya'ya gelen turistlerden cinsel tacize uğradığını belirten 59 kişinin (\%11.8) 47 kişisi (\%79.7) Alanya’yı güvenli bir şehir olarak algılarken 12 kişi (\%21.1) ise Alanya’yı güvenli bir şehir olarak görmemektedir. Hırsızlık olayı ile karşılaşan 35 kişi (\%5.4) tespit edilmiştir. Söz konusu durumla karşılaşan turistlerin büyük çoğunluğu (\%77.1) araştırma bölgesini, bu duruma rağmen hala güvenli buldukları belirtmiş olup güvensiz bulanların oranı sadece \% 22.9 düzeyinde gerçekleşmiştir. Turistlerden herhangi bir suça maruz kalanların oranı $\% 8$, maruz kalmayanların oranı ise \%92 olduğu tespit edilmiştir. Herhangi bir suça maruz kalanların \%75'i Alanya'yı güvenli bir kent olarak bulduklarını beyan etmektedir. Turistlerin araştırma bölgesinde karşılaştıkları sorunlar arasında trafik kazası \%15.6 ile ilk sırada gelmektedir. Trafik kazası geçiren turistlerin \%76.9’u Alanya'yı güvenli bir kent olarak gördüğünü beyan ederken güvensiz bir kent olarak görenlerin oranı ise $\% 23.1$ olarak gerçekleşmiştir. Tablo 8 incelendiğinde araştırmaya katılan turistlerden \%9.2'si Alanya'da tatil süresince kap-kaç olayına maruz kaldıklarını belirtmiştir. Turistlerin kap-kaç olayına maruz kalmasına rağmen büyük bir çoğunluğunun (\%76.1) Alanya'yı hala güvenli bulmaları oldukça dikkat çekicidir. Turistlerin cinsel tacize, hırsızlığa, suça, kap-kaça ve trafik kazasına maruz kalmaları durumu ile güvenlik algıları arasındaki ilişkiyi 
belirlemeye yönelik yapılan ki kare testi sonucunda hesaplanan ki kare değerlerinin hepsi istatistiksel olarak anlamlı bulunmuştur. Buna göre $\mathrm{P}<0,05$ olduğundan $\% 5$ anlamlılık düzeyinde $\mathrm{H} 2$ hipotezi kabul edilmiştir.

8.2 Turistlerin cinsiyetleri ile cinsel tacize, hırsızlı̆̆a, suça, kap-kaça ve trafik kazasına maruz kalmaları sonrasında güvenlik algı değişimleri arasında bir ilişsi vardır.

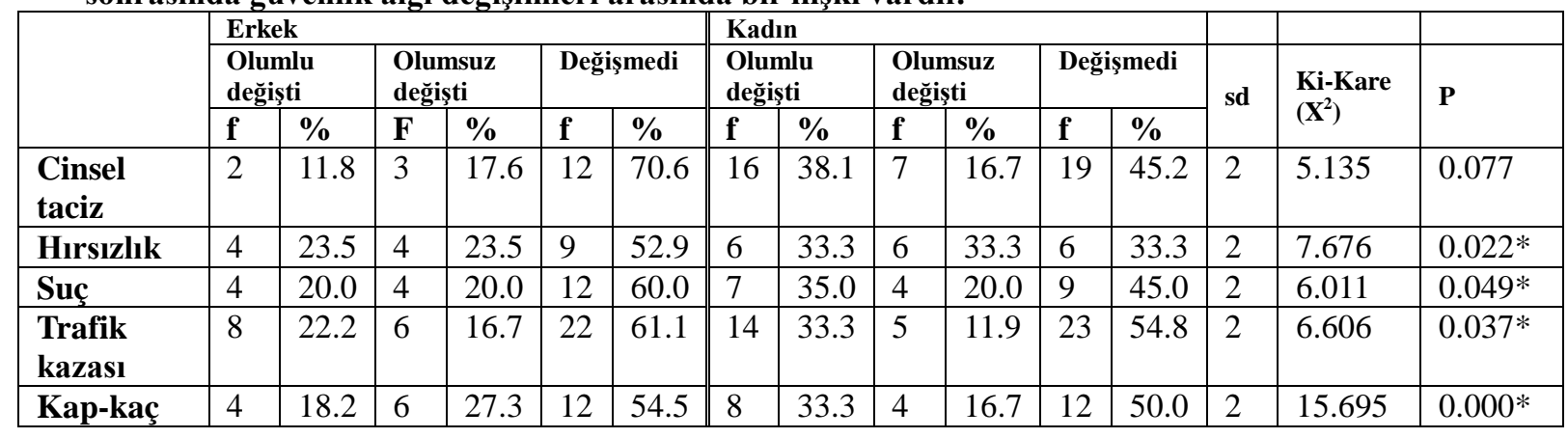

Tablo 9: Turistlerin cinsel tacize, hırsızlı̆̆a, suça, kapkaça maruz kalmaları ve trafik kazası geçirmeleri sonrasında güvenlik algıları arasındaki ilişkinin dağılımı

Araştırma bölgesinde cinsel tacize maruz kalmış erkeklerin \%11.8'inde olumlu yönde değişme olurken kadınlarda bu oran \%38.1 olarak gerçekleşmiştir. Benzer sonuçlar hırsızlık, suç, kapkaç ve trafik kazası konusunda da görülmüş̧ür. Nitekim Tablo 5'deki veriler incelendiğinde erkeklerin Alanya'ya geldikten sonra güvenlik algılarındaki olumlu değişim \%29.8 iken, kadınlarda \%37.7 olarak tespit edilmiştir. Bu verilerden hareketle Alanya'ya gelen kadın turistlerin Alanya hakkındaki güvenlik algı değişimleri erkeklere göre daha yüksek olduğu sonucuna varılabilir.

Turistlerin cinsel tacize, hırsızlığa, suça, kap-kaça ve trafik kazasına maruz kalmaları sonrasında güvenlik algı değişimi ile cinsiyetleri arasındaki ilişkiyi belirlemeye yönelik yapılan ki kare testi sonucunda elde edilen ki kare değerlerinin hepsi istatistiksel olarak anlamlı bulunmuştur. Buna göre $\mathrm{P}<0,05$ olduğundan $\% 5$ anlamlılık düzeyinde $\mathrm{H} 3$ hipotezi kabul edilmiştir.

\section{Sonuç}

Bu çalışmada Alanya'ya gelen yabancı turistlerin Alanya hakkındaki güvenlik algıları araştırılmıştır. Araştırma sonuçları, Alanya'ya gelen turistlerin oldukça yüksek güvenlik algısına sahip olduklarını göstermiştir. Ayrıca cinsel taciz, kapkaç, suç, hırsızlık ve trafik gibi risk türlerine bağlı olarak algı farklılığı olduğu görülmüştür. Her ne kadar turistlerin cinsel tacize, hırsızlığa, herhangi bir kriminal olaya, trafik kazasına, kap-kaç olayına maruz kalmış olmalarına rağmen algılarında önemli bir değişim meydana gelmemiştir. Üstelik güvenlik algılarında da neredeyse yok denecek düzeyde negatif yönde bir değişim olmuştur. Trafik kazaları bir kenara bırakılırsa turistlere yönelik suçların yüksek olmadığı da diğer bir bulgudur. Güvenlik görevlilerine güven düzeyinin ve güvenlik hizmetlerinden memnuniyet oranının yüksek olması aynı zamanda Alanya hakkında güvenlik algısının pozitif yönde etkilemektedir. Alanya'yı ziyarete gelenlerin eğlence mekanlarında ve plajlarda da kendilerini güvende hissettikleri görülmüştür. Bilgi kaynaklarının algı farklılaşmasına etki de bulunduğu diğer veriler arasındadır. Turistlerin kendi arkadaşlarının Alanya hakkındaki düşünceleri de Alanya hakkında güvenlik algısını etkilemektedir. Turistlerin cinsiyetleri ile toplu taşıma araçlarında, gece ve gündüz yaya olarak dışarı çıktıklarında, plajlarda, eğlence mekânlarında, hırsızlık, kap-kaç, cinsel taciz, suç ve trafik olayı durumunda güvenlik algıları arasında bir ilişki bulunduğu gibi, bu tip sorunların yaşanması sonrasında turistlerin cinsiyetleri ile güvenlik algıları arasında farklılıklar tespit edilmiştir. Nihayetinde araştırma bulguları bir bütün olarak değerlendirildiğinde Alanya'nın turistler için güvenli bir kent olmasının yanı sıra huzurlu bir tatil için de gerekli ortamı sağladığı söylenebilir

\section{Kaynakça}

- Araña, J. ve C. León, (2008). "The impact of terrorism on tourism demand”, Annals of Tourism Research 35 (2): pp. 299-315.

- $\quad$ Armstrong, E.K., ve B.W. Ritchie, (2007). "The heart recovery marketing campaign: Destination recovery after a major bushfire in Australia's national capital”, Journal of Travel \& Tourism Marketing, 23 (2/3/4):175-190.

- Aziz, H., 1995. "Understanding attacks on tourists in Egypt", Tourism Management, 16: pp. 91-95.

- $\quad$ Barker, M, S. Page ve D. Meyer, (2003). "Urban Visitor Perceptions of Safety during a Special Event”, Journal of Travel Research, 41: pp. 355-361.

- Basala, L.S. ve D. B. Klenosky, (2001). “Travel style preferences for visiting a novel destination: A conjoint investigation across the novelty familiarity continuum", Journal of Travel Research, 40: 172-182.

- Brunt, P., R. Mawby ve Z. Hambly, (2000). "Tourist victimisation and the fear of crime on holiday". Tourism Management, 21 (4): pp. 417-424. 
- Carr, N., (2001). "An exploratory study of gendered differences in young tourists' perceptions of danger within London”, Tourism Management, 22 (5): 565- 570.

- Carter, S., (1998. "Tourists and traveller's social construction of Africa and Asia as risky locations" Tourism Management, 19: pp. 349 - 358.

- Chen, J. ve D. Gürsoy, (2000). "Cross-cultural comparison of the information sources used by first-time and repeat travellers and its marketing implications", International Journal of Hospitality Management, 19 (2): pp. 191-203.

- Cooper, M., (2005). “Japanese tourism and the SARS epidemic of 2003”, Journal of Travel \& Tourism Marketing, 19 (2/3): pp. 117-131.

- Demos, E., (1992). "Concern for safety: A potential problem in the tourist industry", Journal of Travel and Tourism Marketing, 1(1): pp. 81-88.

- $\quad$ Dimanche, F., ve A. Lepetic, (1999). "New Orleans tourism and crime: A case study", Journal of Travel Research, 38 (August): pp. 19-23.

- Dowling, G. R. ve R. Staelin, (1994). “A model of perceived risk and intended risk-handling activity”, Journal of Consumer Research, 21 (1): pp. 119-135.

- Faulkner, B. ve S. Vikulov, (2001). "Katherine, washed out one day, back on track the next: A post-mortem of a tourism disaster", Tourism Management, 22: pp. 331-344.

- $\quad$ Faulkner, B., (2001). “Towards a framework for tourism disaster management”, Tourism Management, 22: pp. 135-147.

- Floyd, M. F., H. Gibson, L. Pennington-Gray ve B. Thapa, (2004). "The effect of risk perceptions on intentions to travel in the aftermath of September 11, 2001", Journal of Travel and Tourism Marketing, 15 (2): pp. 19-38.

- Gartner, W. ve J. Shen, (1992). "The Impact of Tiananmen Square on China's Tourism Image”, Journal of Travel Research, 30 (4): pp. 47- 52.

- $\quad$ George, R., (2012). "International tourists' perceptions of crime-risk and their future travel intentions during the 2010 FIFA World Cup TM in South Africa”, Crime Prevention and Community Safety, 14 (2): pp. 79-103.

- George, R., (2010). "Visitor perceptions of crime-safety and attitudes towards risk: The case of table mountain national park, Cape Town", Tourism Management, 31 (December): pp. 806 - 815.

- George, R., (2003). “Tourists' perceptions of safety and security while visiting Cape Town”, Tourism Management, 24 (October): pp. 575-585.

- Gibson, H. ve A. Yiannakis, (2002). “Tourist roles: Needs and the adult life course”, Annals of Tourism Research, 2 (2): pp. 358-383.

- $\quad$ Gibson, H. ve F. Jordan, (1998. "Travelling solo: A cross-cultural study of British and American women aged 30-50, (pp. 16-20), Paper presented at the Fourth International Conference of the Leisure Studies Association, (July), Leeds, UK.

- Gray, L. Pennington-, A. Schroeder ve K. Kaplanidou, (2011). "Examining the Influence of Past Travel Experience, General Web Searching Behaviors, and Risk Perceptions on Future Travel Intentions", International Journal of Safety and Security in Tourism/Hospitality, 1, (1): pp. 64-89.

- Higgins, B.A., (2005). "The storm of summer: lessons learned in the aftermath of the hurricanes of '04", Cornell Hotel and Restaurant Administration Quarterly, 46 (1): pp. 40-46.

- $\quad$ Ioannides, D. ve Y. Apostolopoulos, (1999). "Political instability, war and tourism in Cyprus: Effects, management and prospects for recovery", Journal of Travel Research, 38: pp. 51-56.

- Kahneman, D. ve A. Tversky, (1982). "Variants of uncertainty", Cognition, 11 (2): pp. 143-157.

- Korstanje, M.E., (2011). "The fear of traveling: a new perspective for tourism and hospitality", Anatolia - An International Journal of Tourism and Hospitality Research, 22 (2): pp. 222-233.

- Kozak, M., J. Crotts ve R. Law, (2007). "The impact of the perception of risk on international travelers" International Journal of Tourism Research, 9 (2): pp. 233-242.

- Lepp, A. ve H. Gibson, (2008). "Sensation seeking and tourism: Tourist role, perception of risk and destination choice", Tourism Management, 29: pp. 740-750.

- Lepp, A. ve H. Gibson, (2003). "Tourist roles, perceived risk and international tourism”, Annals of Tourism Research 30 (3): pp. 606-624.

- Lynch, G. ve S. Atkins, (1988). "The influence of personal security fears on women's travel patterns", Transportation, 15 (3): pp. 257-277.

- Mansfeld, Y., ve A. Pizam, (2006). "Toward a theory of tourism security", in Y. Mansfeld ve A. Pizam (Eds.), Tourism, security and safety: From theory to practice, (pp.1-28), Burlington, MA: Elsevier, Butterworth-Heinemann.

- $\quad$ Mattila, A., Y. Apostolopoulos, S. Sönmez, L. Yu ve V. Sasidharan, (2001). "The impact of gender and religion on college students' spring break behavior”, Journal of Travel Research, 40 (2): pp. 193-200.

- Mawby, R. I., (2000). “Tourists' perceptions of security: The risk-fear paradox”, Tourism Economics, 6 (2): pp. $109-121$.

- Mazzocchi, M. ve A. Montini, (2001). "Earthquake effects on tourism in central Italy", Annals of Tourism Research, 28: pp. 1031-1046.

- $\quad$ McIntosh, I., V. Swanson, K. Power, F. Raeside ve C. Dempster, (1998). “Anxiety and health problems related to air travel", Journal of Travel Medicine, 5 (4): pp. 198-204.

- McKercher, B. ve K. Chon, (2004). "The over-reaction to SARS and the collapse of Asian tourism", Annals of Tourism Research, 31 (3): pp. 716-719.

- Miller, G.A. ve B.W. Ritchie, (2003). "A farming crisis or a tourism disaster? An analysis of the foot and Mouth disease in the UK", Current Issues in Tourism, 6 (2): pp. 150-171.

- Milman, A. ve S. Bach, (1999). "The impact of security devices on tourists' perceived safety: The central Florida example”, Journal of Hospitality and Tourism Research, 23 (4): pp. 371-386. 
- Pinhey, T. K., ve T. J. Iverson, (1994). "Safety concerns of Japanese visitors to Guam”, Journal of Travel and Tourism Marketing, 3 (2): pp. 87-94.

- Pizam, A. ve Y. Mansfeld, (1996). "Introduction” in: A. Pizam and Y. Mansfeld (eds.) Tourism, Crime and International Security Issues, (pp. 1-7), Chichester, UK: Wiley and Sons.

- Pizam, A., (1999. "A comprehensive approach to classifying acts of crime and violence at tourism destinations", Journal of Travel Research, 38: pp. 5-12.

- $\quad$ Pizam, A., G. H. Jeong, A. Reichel, H. Van Boemmel, J. M. Lusson, L. Steynberg, O. State-Costache, S. Volo, C. Kroesbacher, J. Kucerova, ve N. Montmany, (2004). "The Relationship between Risk-Taking, Sensation-Seeking, and the Tourist Behavior of Young Adults: A Cross-Cultural Study”, Journal of Travel Research, 42 (3): pp. 251-60.

- $\quad$ Pizam, A., P. E. Tarlow ve J. Bloom, (1997). "Making tourists feel safe: Whose responsibility is it?", Journal of Travel Research, 36 (1): pp. 23-28.

- $\quad$ Pizam,A.,(2002).“Editorial: Tourism and terrorism”,International Journal of Hospitality Management,21(4):1-3.

- Reisinger Y. ve F. Mavondo, (2005). "Travel anxiety and intentions to travel internationally: implications of travel risk perception", Journal of Travel Research, 43 (3): pp. 212 - 225.

- Reisinger, Y. ve J. Crotts, (2010). "The Influence of Gender on Travel Risk Perceptions, Safety, and Travel Intentions”, Tourism Analysis, 14: pp. 793-807.

- $\quad$ Reisinger, Y. ve F. Mavondo, (2006). “Cultural Differences in Travel Risk Perception”, Journal of Travel and Tourism Marketing, 20 (1): pp. 13-31.

- Richardson, S. L. ve J. Crompton, (1988). "Vacation patterns of French and English Canadians", Annals of Tourism Research, 15 (3): pp. 430-435.

- Richter, L. K., (2003). "International tourism and its global public health consequences”, Journal of Travel Research, 41 (4): pp. 340-347.

- $\quad$ Rittichainuwat, B. ve G. Chakraborty, (2009). "Perceived travel risks regarding terrorism and disease: The case of Thailand", Tourism Management, 30 (3): pp. 410-418.

- $\quad$ Rittichainuwat, B., H. Qu ve C. Mongkhonvanit, (2002). “A study of the impact of travel satisfaction on the likelihood of travelers to revisit Thailand", Journal of Travel and Tourism Marketing, 12 (2): 19-43.

- $\quad$ Roehl, W., ve D. Fesenmaier, (1992). "Risk perceptions and pleasure travel: An exploratory analysis", Journal of Travel Research, 30 (4): pp. 17-26.

- Ryan, C., (1993). "Crime, violence, terrorism, and tourism: An accident or intrinsic relationship", Tourism Management, 14: pp. 173-183.

- $\quad$ Schweer, J. M., (1986). "Perceived leisure risk: Implications and interventions for therapeutic recreation in clinical settings", Journal of Expanding Horizons in Therapeutic Recreation, 1: pp. 64-66.

- $\quad$ Seddighi, H. R., A. L. Theocharous ve M. W. Nuttall, (2002). "Political Instability and Tourism: An Empirical Study with Special Reference to the Microstate of Cyprus", International Journal of Hospitality \& Tourism Administration, 3 (1): pp. 61-84

- Seddighi, H. R., M. W. Nuttall ve A. L. Theocharous, (2001). "Does cultural background of tourists influence the destination choice? An empirical study with special references to political instability", Tourism Management, 22 (2): pp. 181-191.

- Sellick, M., (2004). "Discovery, connection, nostalgia: key travel motives within the senior market", Journal of Travel \& Tourism Marketing, 17(1): pp. 55-71.

- Smith, G., (1999). “Toward a United States policy on traveler safety and security: 1980-2000”, Journal of Travel Research, 38 (1): pp. 62-65.

- $\quad$ Sönmez, S. F.,(1998). “Tourism, terrorism, and political instability”,Annals of Tourism Research,25(2): 416-456.

- Sönmez, S. ve A. R. Graefe, (1998a). "Determining future travel behavior from past travel experience and perceptions of risk and safety”, Journal of Travel Research, 37 (2): pp. 171-177.

- Sönmez, S. ve A. R. Graefe, (1998b). "Influence of terrorism risk on foreign tourism decisions", Annals of Tourism Research, 25 (1): pp. 112-144.

- Sönmez, S., Y. Apostolopoulos ve P. Tarlow, (1999). "Tourism in crisis: Managing the effects of terrorism” Journal of Travel Research, 38: pp. 13-18.

- $\quad$ Staats, S., P. E. Panek ve D. Cosmar, (2006). "Predicting travel attitudes among university faculty after 9/11", Journal of Psychology, 140 (2): pp. 121-132.

- Stanko, E., (2000). "Victims R Us: The life history of "fear of crime' and the politicization of violence", in; T. Hope ve R. Sparks (Eds.), Crime, risk and insecurity, (pp. 13-30). London: Routledge.

- Tarlow, P. E. ve G. Santana, (2002). "Providing safety for tourists: A study of a selected sample of tourist destinations in the United States and Brazil", Journal of Travel Research, 40 (4): pp. 424-431.

- $\quad$ Tsaur, S. H., G. H. Tzeng ve K. C. Wang, (1997). "Evaluating tourist risks from fuzzy perspectives", Annals of Tourism Research, 24 (4): pp. 796-812. 


\title{
Turizm ile Ekonomik Büyüme Arasındaki İlişki: Akdeniz Ülkeleri Üzerine Bir Panel Veri Analizi \\ Relationship between Tourism and Economic Growth: A Panel Data Analysis on Mediterranean Countries
}

\author{
Asst. Prof. Dr. Ali Rıza Aktaş (Akdeniz University, Turkey) \\ Dr. Fatih Kaplan (Bingöl University, Turkey) \\ Ph.D. Candidate Seyfettin Kocaman (Akdeniz University, Turkey)
}

\begin{abstract}
In this study, unit root tests, co-integration tests and long term co-efficient tests are researched with panel data of GDP and tourism receipts for mediterranean countries between 1995-2011. In the study, as research method tests, first generation root tests (Levin-Lin, Breitung, Im-Pesaran and Shin(IPS), Fisher ADF, Fisher PP and Hadri estimators) and second generation unit root tests (CADF-CIPS estimators) have been used. In order to test cointegration, Pedroni, Kao, Johansen-Fisher and Westerlund co-integration tests have been used, to estimate the long-term coefficients PMGE (Pooled Mean Group Estimation) has been used. As a result of the econometric applications, a cointegration relationship between growth and tourism revenue in the long term with the correlation of .05 has been found.
\end{abstract}

\section{Giriş}

Turizm, boş zamanın ve tasarrufun nasıl kullanılacağına ilişkin ekonomik bir kararla başlayan ve yatırım, tüketim, istihdam, dışsatım ve kamu gelirleri gibi ekonomik yönleri bulunan bir sosyo-ekonomik olaydır. Turizm başlangıçta insanların gezme ve değişik yerler görme merakından doğmuş, özellikle 1950'li yıllardan sonrada hızla gelişerek daha geniş kitlelere ve uzak mesafelere yayılmıştır. Günümüzde parasal ve toplumsal bir olay haline gelen turizmin yarattığı ekonomik ve politik etkiler, ülke ekonomilerinde ve özellikle uluslararası ekonomik ve politik ilişkilerde önemli sonuçlar doğurmaktadır.

Turizm bugün dünya ekonomisi içerisinde gelir sağlayıcı faktörlerin başında yer almakta, büyük oranda yatırım yapılan ve gelişen bir sektör haline gelmektedir. Turizm bir ülkenin ekonomik, sosyal ve kültürel alanlarda kazanım elde etmesini sağlayan en önemli hizmet sektörlerinden biri olarak kabul edilmektedir. Bu nedenle turizm potansiyeli bulunan gelişmiş ve gelişmekte olan ülkeler özellikle uluslararası turizm faaliyetlerine ağırlık vererek, hem ekonomik gelişmelerini hızlandırmak hem de geliri tabana yaymak suretiyle ülkedeki refah düzeyini yükseltmeyi amaçlamaktadırlar. Turizm yönlü büyüme stratejini belirleyen ülkeler, turizm sektörüyle hizmet ihracatı yaparak daha fazla döviz girdisi, istihdam ve dolayısıyla ulusal gelir sağlayabilmektedirler. Milli gelir ve istihdamın artmasıyla vergi tabanının genişlemesi devletin vergi gelirlerinde belirgin bir artışın olmasına neden olacaktır. Artan vergi gelirleri merkezi ve mahalli idarelerce yapılan yatırımları artırarak ülkenin gelişmesine yardımcı olacaktır. Turizm gelirleri milli gelir içinde yer almakta ve ekonomide bir çoğaltan etkisi yaratmakta, ortaya çıkan çarpan etkisi de ekonomi üzerinde olumlu etki yapmakta ve birçok sektörü desteklemektedir.

Turizmi bünyesinde barındıran hizmet sektörü kuşkusuz emek yoğun bir sektördür. Sermayenin yetersiz fakat emeğin yoğun olarak bulunduğu Türkiye gibi gelişmekte olan ülkelerde, turizm sektörünün büyümesi, ülkenin milli gelirinin arttırılmasında bir firsat olarak görülmektedir. Söz konusu emek yoğun ülkeler, turizm sektörünün büyümesi ile hizmet ihracatlarını arttırarak, ülkelerine döviz girdisi sağlayıp, istihdam seviyelerini ve dolayısıyla milli gelirlerini arttırmaktadırlar (Yamak ve diğ., 2012).

Turizm faaliyetleri dünya ekonomisinde giderek artan oranlı bir gelişim göstermektedir. Birçok ülkede turizm, GSMH ile istihdamın önemli bir bölümünü meydana getirmektedir. Buna ilave olarak turizmden elde edilen uluslararası döviz gelirleri ülkelerin mevcut bütçe açıklarını finanse etmeye yardımcı olmaktadır.Turizm gelirinin zengin ülkelerden daha fakir ülkelere, gelişmişlerden gelişmekte ve az gelişmiş ülkelere doğru dağılımına katkı yaparak ülkeler arasında yakınsamaya da neden olmaktadır. Böylece turizm bölgesel gelişmeye de yardımcı olmakta ve bölgesel ekonomik farklılıkların azaltılmasına olanak sağlamaktadır. Dolayısıyla sektöre yapılacak ulusal/uluslararası yatırımlar, kısa sürelerde etkisini göstererek geri kalmış bölgelerin ilerlemesine olumlu yönde etki edebilecektir (Bahar ve Bozkurt, 2010).

Uygarlık seviyelerinin artması, ülkelerin yakınlaşması, hayat standartlarının yükselmesi ve çalışma saatlerinin azalması sayesinde günümüz insanları daha çok seyahat etmeye başlamıştır. Artan bu seyahat eğilimleri sonucu turizm olayı coğrafi olarak daha geniş bir alana yayılmış ve bütün dünya ziyaretçileri tarafından kullanılan bir olgu haline gelmiştir. Geniş ölçekli ve çok boyutlu bir toplumsal olay olan bu harekete, bugün dünya nüfusunun yaklaşık \%12,5'i katılmaktadır (Alaeddinoğlu ve Can, 2007). 
Dünya savaşının hemen ardından 1918-1920 yılları arası modern turizmin başlangıcı olarak kabul edilmektedir. $\mathrm{Bu}$ dönemde turizm, otel, motel, ulaşım araçları ve yolları, plajlar, eğlence ve spor alanları, konaklama tesisleri ve tüm altyapısıyla büyük bir sektör haline gelmiştir. Günümüzde ise, teknolojik ilerlemeler, yaşam standartlarında ortaya çıkan iyileşmeler, küreselleşmenin beraberinde getirdiği seyahat serbestliği, turizm aktivitelerine katılan insan sayısının hızla artmasına neden olmuştur. Bunun doğal bir sonucu olarak da turizm sektörü dünyanın en hızlı gelişen sektörlerinden biri halini almıştır. Öyle ki, dünya turizmi 1980-90 döneminde \%60, 1990-2000 döneminde \%52 artış göstermiştir. 1980 yılında 280 milyon olan turist sayısı 2000 yılında 698 milyona ulaşmıştır. Bu rakam 2007 yılında 903 milyona, 2008 yılında 922 milyona ulaşmış, 2009 yılında 880 milyona gerilemiştir. 2010 yılında turizme katılanların sayısı 940 milyon iken, 2011 yılında turizme katılanların sayısı 983 milyona ulaşmıştır (UNWTO, 2012). Rakamlardan da anlaşılacağı üzere turizm sektörü büyük bir hızla büyümekle birlikte bazı dönemlerde gerek terör sebebiyle gerekse ekonomik konjonktür sebebiyle küçük düşüşler yaşasa da genel olarak büyüme trendini devam ettirmiştir. Bunun bir göstergesi olarak Dünya Turizm Örgütü 2020 yılında 1600 milyon turistin turizm aktivitelerine katılacağını ve bunu ekonomik sonucunun 2 trilyon dolar olacağını tahmin etmektedir. $\mathrm{Bu}$ açıdan bakıldığında yeni gelişmelere sahne olacağı beklenen turizm sektörünün önümüzdeki dönemde de en hızlı büyüyen sektörlerden biri olacağı beklenmektedir.

Dünya genelinde turizm hareketliliklerine bakıldığında, Avrupa destinasyonu uluslararası turizm hareketliliklerinin en yoğun yaşandığ 1 destinasyon konumundadır. Avrupa destinasyonu dünya turizm hareketliliği içerisinde 1990 yılında \%58'lik bir pay alırken 2011 yılında bu oran yıllar itibariye azalarak \%53'e düşmüş olmasına rağmen en yüksek hareketliliğin yaşandığı bölge konumundadır. Tablo 1'de uluslar arası turizm hareketliliklerinin Dünya genelinde bölgeler itibariyle dağılımı gösterilmektedir.

\begin{tabular}{|l|l|l|l|l|l|l|l|}
\hline \multirow{2}{*}{ Bölgeler } & \multicolumn{3}{l}{ Turist Sayıs (Milyon Kişi) } \\
\cline { 2 - 9 } & 1990 & 1995 & 2000 & 2005 & 2009 & 2010 & 2011 \\
\hline Avrupa & 250.80 & 303.50 & 388.80 & 449.20 & 476.80 & 492.90 & 516.60 \\
\hline Asya Pasifik & 58.70 & 86.10 & 113.90 & 152.70 & 179.50 & 204.40 & 215.30 \\
\hline Amerika & 99.30 & 108.50 & 130.80 & 136.50 & 146.90 & 155.80 & 162.00 \\
\hline Orta Doğu & 8.20 & 9.30 & 14.00 & 22.60 & 32.60 & 35.80 & 36.00 \\
\hline Afrika & 9.80 & 11.50 & 14.90 & 19.30 & 25.60 & 28.00 & 29.30 \\
\hline Diğer & 7.80 & 8.60 & 11.20 & 18.40 & 21.60 & 23.00 & 24.00 \\
\hline Toplam (Dünya) & 434.60 & 527.50 & 673.60 & 798.70 & 883.00 & 939.90 & 983.20 \\
\hline Akdeniz Bölgesi & 152.16 & 172.08 & 232.27 & 238.80 & 246.06 & 256.80 & 274.21 \\
\hline $\begin{array}{l}\text { Dünya Turizm Hareketleri } \\
\text { İçinde Akdeniz Bölgesinin } \\
\text { Pay1(\%) }\end{array}$ & 35,01 & 32,62 & 34,48 & 29,90 & 27,87 & 27,32 & 27,89 \\
\hline $\begin{array}{l}\text { Avrupa Destinasyonu İçerisinde } \\
\text { Akdeniz Bölgesinin Payı (\%) }\end{array}$ & 60,67 & 56,70 & 59,74 & 53,16 & 51,61 & 52,10 & 53,08 \\
\hline
\end{tabular}

Tablo 1: Uluslararası Turizm Hareketlerinin Dünya Genelinde Bölgesel Dağılımı Kaynak: UNWTO, Tourism Highlights, 2012.

Avrupa bölgesinde yer alan ve dünya turizminden büyük pay alan ülkelerin de bulunduğu Akdeniz bölgesi içerisinde gerek turizm hareketleri açısından en fazla yoğunlaşma gerekse de turizmden en fazla gelir elde eden ülkeler, Fransa, İspanya, İtalya, Türkiye ve Yunanistan'dır. Tablo 2'de Akdeniz bölgesi içerisinde en fazla turizm yoğunlaşmasının yaşandığı ilk beş ülkeye ilişkin turizm hareketliliklerine ve turizm gelirlerine ilişkin veriler gösterilmektedir.

Akdeniz bölgesi içerisinde turizmden en büyük payı alan kuzeybatı Akdeniz bölgesi (\%66.66) içerisinde, Dünya'da birinci sırada gelen Fransa'nın 2011 verilerine göre 79.50 milyon turist sayısı ile istikrarlı şekilde birinciliğini sürdürdüğü görülmektedir. Dünya turizminde de ikinci sırada yer alan İspanya'nın 2011 yılı turist sayısı ise 56.69 milyondur. Dünya üçüncüsü İtalya ise 2011 yılında 46.11 milyon turisti ağırlamıştır. Kuzeydoğu Akdeniz bölgesi içerisinde iki güçlü rakip, Türkiye ve Yunanistan bulunmaktadır. 2000 yılı itibariyle Türkiye turist sayısında yıllık ortalama \%16,2'lik bir artışla ve 2005 yılında 20,27 milyon turist sayısıyla bu bölgede birinci sırada yer almıştır. 2011 yılı itibari ile Kuzeydoğu Akdeniz bölgesine gelen 55.68 milyon turistin 29.34 milyonunun Türkiye'yi tercih ettiği görülmektedir. Yıllar içindeki turist sayısı artışları incelendiğinde 2005 yılından sonra da artış oranın en yüksek olduğu ülke Türkiye'dir. Kuzeydoğu Akdeniz bölgesinin Akdeniz havzası içindeki turist payı 1990 yılında \%10 iken 2011 yılında bu pay \%20'lere ulaşmıştır.

Akdeniz bölgesi içerisinde yer alan ülkelerden dünya turizm gelirlerinden en büyük payı alan ülkelerin başında gelen ülkelerin başında Fransa ve İspanya gelmektedir. 2011 yılı verilerine göre İspanya dünya turizm gelirlerinden 67.5 milyar dolarlık bir pay alarak Akdeniz bölgesi ülkeleri arasında ilk sırada yer almaktadır. İspanya'yı sırasıyla 65 milyar dolar ile Fransa ve 45 milyar dolar ile İtalya takip ederken 28 milyar dolar turizm geliriyle Türkiye takip etmektedir. Akdeniz bölgesi ülkelerinin turizm gelirlerinde 2000 yılına göre en yüksek artış Türkiye'de gerçekleşmiştir. Nitekim, Türkiye'nin 2000 yılında 7.6 milyar dolar olan Turizm gelirleri geçen 
11 yıllık sürede \%207 oranında artarak 28 milyar dolara ulaşmıştır. Turizm gelirlerinde ikinci en yüksek artış \%106 oranıyla İspanya'da gerçekleşmiş olup bu ülkeleri sırasıyla Fransa (\%69), Yunanistan ve İtalya (\%58) takip etmektedir.

Bu çalışmada, Akdeniz bölgesinde yer alan ve dünya turizm hareketliliği içerinde önemli bir yere sahip olan Fransa, İspanya, İtalya, Türkiye ve Yunanistan'ın turizm gelirlerinin GSMH'leri üzerinde etkisinin olup olmadığ 1995-2011 dönemine ait yıllık panel veriler ile araştırılmaktadır. Bu amaç doğrultusunda, çalışmanın birinci bölümünde söz konusu ülkeler ait sayısal veriler verilmekte, bu ülkelerin dünya ve bölge turizmi içerisindeki yeri ve önemi incelenmektedir. Böylece çalışmada kullanılan örneklemin önemi ortaya konulmaktadır. Uygulamanın yapıldığı çalışmanın ikinci bölümünde, çalışmada kullanılan veriler ve yöntem tanıtılmakta, uygulama sonucunda ulaşılan bulgular sunulmaktadır. Çalışma, genel bir değerlendirmenin yapıldığı sonuç bölümüyle sona ermektedir.

\begin{tabular}{|c|c|c|c|c|c|c|c|c|c|}
\hline \multirow{2}{*}{ Ülkeler } & \multicolumn{4}{|c|}{ Turist Sayısı (Milyon Kişi) } & \multirow{2}{*}{ Ülkeler } & \multicolumn{4}{|c|}{ Turizm Gelirleri (Milyar \$) } \\
\hline & 2000 & 2005 & 2010 & 2011 & & 2000 & 2005 & 2010 & 2011 \\
\hline Fransa & 77.19 & 76 & 77.14 & 79.50 & Fransa & 38.53 & 51.69 & 56.28 & 65.17 \\
\hline İspanya & 47.89 & 55.55 & 52.67 & 56.69 & İspanya & 32.66 & 53.07 & 59.04 & 67.54 \\
\hline İtalya & 41.18 & 36.51 & 43.62 & 46.11 & İtalya & 28.71 & 38.37 & 40.06 & 45.37 \\
\hline Türkiye & 9.58 & 20.27 & 27.00 & 29.34 & Türkiye & 7.64 & 19.72 & 24.78 & 28.06 \\
\hline Yunanistan & 13.09 & 14.27 & 15.00 & 16.42 & Yunanistan & 9.26 & 13.45 & 12.58 & 14.98 \\
\hline $\begin{array}{l}\text { İlk Beş } \\
\text { Toplam }\end{array}$ & 188.93 & 202.6 & 215.43 & 228.06 & Toplam & 116.79 & 176.31 & 192.75 & 221.12 \\
\hline $\begin{array}{l}\text { Akdeniz } \\
\text { Bölgesi } \\
\text { Toplamı }\end{array}$ & 232.27 & 238.80 & 256.80 & 274.21 & & & & & \\
\hline İlk Beş Payı & $81.34 \%$ & $84.84 \%$ & $83.89 \%$ & $83.17 \%$ & & & & & \\
\hline
\end{tabular}

Tablo 2: Akdeniz Bölgesi İçerisinde Yer Alan İlk Beş Ülkenin Turizm Hareketlerinin ve Turizm Gelirlerinin Dağılımı Kaynak: UNWTO, Tourism Highlights, 2012.

\section{Panel Veri Seti ve Birim Kök Testleri}

Çalışmada, 1995-2011 dönemi kapsayan, Fransa, İspanya, İtalya, Türkiye ve Yunanistan'a ait GSMH ile turizm geliri verileri kullanılmıştır. Veriler Dünya Bankası'nın “World Development Indicators “ (WDI) veri tabanından alınmıştır. GSMH ve turizm gelirlerinin logaritmaları alınarak analizleri yapılmıştır.

Panel veri analizlerinde kullanılan değişkenlerin durağan olması gerekmektedir. Durağanlık bir serinin ortalamasının, varyansının ve iki dönem arasındaki ortak varyansının zaman içerisinde sabit kalması durumunu ifade etmektedir (Gujarati, 2009).

\begin{tabular}{|c|c|c|c|c|}
\hline & \multicolumn{2}{|l|}{ GDP } & \multicolumn{2}{|l|}{ TOUR } \\
\hline & Sabitli & Sabitli ve Trendli & Sabitli & Sabitli ve Trendli \\
\hline Levin,Lin\&Chu & $-1.1361^{\mathrm{c}}$ & $-3.57992^{\mathrm{a}}$ & -0.20274 & $-4.84385 a$ \\
\hline Breitung & \begin{tabular}{|l|}
--- \\
\end{tabular} & 0.30683 & $\mid--$ & $-2.49306 a$ \\
\hline Im,Pesaran\&Shin & $1.98576^{\mathrm{c}}$ & $-2.02042^{b}$ & 2.01433 & $-2.78371 a$ \\
\hline Fisher ADF-Chi-square & 5.18050 & $20.1613^{b}$ & 2.64304 & $24.7891 \mathrm{a}$ \\
\hline Fisher ADF-ChoiZ & 1.16451 & $-2.16788^{b}$ & 2.18983 & $-2.77450 a$ \\
\hline Fisher PP-Chi-square & 0.89510 & 2.99661 & 1.95899 & 8.80035 \\
\hline Fisher PP--ChoiZ & 3.31129 & 1.46268 & 3.26465 & -0.11190 \\
\hline Hadri-Ztest & $4.26114^{\mathrm{a}}$ & $4.65992^{\mathrm{a}}$ & $4.97750 \mathrm{a}$ & $2.16765 \mathrm{a}$ \\
\hline Hadri-HeteroZtest & $3.42554^{\mathrm{a}}$ & $3.61827^{\mathrm{a}}$ & $4.84897 \mathrm{a}$ & $2.65228 \mathrm{a}$ \\
\hline \multicolumn{5}{|l|}{ Birinci Farkında } \\
\hline Levin,Lin\&Chu & $-2.36695^{\mathrm{a}}$ & 0.45420 & $-9.43958 \mathrm{a}$ & $-8.76898 \mathrm{a}$ \\
\hline Breitung & --- & $-2.30777^{\mathrm{a}}$ & --- & -0.56717 \\
\hline Im,Pesaran\&Shin & -1.17638 & 0.45016 & $-6.65521 \mathrm{a}$ & $-5.49203 a$ \\
\hline Fisher ADF-Chi-square & 13.3478 & 5.78659 & $55.1898 \mathrm{a}$ & $44.2462 \mathrm{a}$ \\
\hline Fisher ADF-ChoiZ & $-1.58252^{\mathrm{c}}$ & 0.41084 & $-5.74413 a$ & $-4.81065 a$ \\
\hline Fisher PP-Chi-square & 7.14503 & 4.19396 & $36.0061 \mathrm{a}$ & $31.3678 \mathrm{a}$ \\
\hline Fisher PP--ChoiZ & 0.13351 & 1.72696 & -4.08948 & $-3.27292 a$ \\
\hline Hadri-Ztest & 0.21233 & $2.52205^{\mathrm{a}}$ & 0.89544 & $8.01004 \mathrm{a}$ \\
\hline Hadri-HeteroZtest & 0.34345 & $2.55651^{\mathrm{a}}$ & $2.29495 \mathrm{a}$ & $14.8792 \mathrm{a}$ \\
\hline
\end{tabular}

Tablo 3: Birinci Nesil Birim Kök Testleri Sonuçları Not: a, b ve c sırasıyla \% 1, \% 5 ve \% 10 önem düzeylerini göstermektedir. Optimal gecikme uzunluğu için SIC dikkate alınmıştır. 
Uygulamada, panel verilerin durağan olup olmadıklarının tespit edilmesine yönelik olarak geliştirilen I. ve II. nesil panel birim kök testleri kullanılmıştır. I. nesil panel birim kök testleri birimler arasında korelasyonun (yatay kesit bağımlılı̆ıın) olmadığı varsayımına ve/veya temel hipotez $(\mathrm{H} 0=$ yatay kesit bağımlılık yoktur)'ine dayanmaktadır. I. nesil birim kök testleri içerisinde yer alan Levin-Lin\&Chu, Breitung, Im-Pesaran\&Shin, Fisher ADF, Fisher PP ve Hadri testleri sıkça kullanılan testlerdendir (Tatoğlu, 2012).

Yapılan birinci nesil birim kök testleri sonucunda, değişkenlerin bazılarının seviyede bazılarının ise birinci farkta [I(1)] durağan hale geldikleri tespit edilmiştir. Ele alınan değişkenlerin farklı seviyelerde durağan olmaları, yatay kesit bağımlılık probleminin olup olmadığı sorusunu akla getirmiştir. Çünkü birinci nesil birim kök testleri birimler arasında korelasyon olmadığı varsayımı altında yapılmaktadır. Bu nedenle birimler arası korelasyonun varlı̆̆ı/yokluğu, yatay kesit bağımlılı̆̆ araştıran Breush- Pagan (B-P), Pesaran (CDLM), Friedman (FR), Frees (FRS) testleri ile araştırılmıştır (Tatoğlu, 2012, s.215-220). B-P, CDLM, FR ve FRS testleri sonucunda H0 hipotezi reddedilirse, birimler arasında yatay kesit bağımlılı̆̆ın var olduğu kabul edilecektir.

\begin{tabular}{|l|l|l|}
\hline Modeller & İstatistik & Olas1l1k \\
\hline Breush- Pagan (1980) & $101.415^{\mathrm{a}}$ & 0.0000 \\
\hline Friedman (1937) & $33.735^{\mathrm{a}}$ & 0.0000 \\
\hline & & $\begin{array}{l}\text { alpha }=0.10: 0.1521 \\
\text { alpha }=0.05: 0.1996 \\
\text { alpha }=0.01: 0.2928\end{array}$ \\
\hline Frees (1995) & $2.344^{\mathrm{a}}$ & 0.0000 \\
\hline Pesaran (2004) & $3.798^{\mathrm{a}}$ & \\
\hline
\end{tabular}

Tablo 4: Birimlerarası Korelasyon Testi Not: a, b ve c siraslyla \% 1, \% 5 ve \% 10 önem düzeylerini göstermektedir. Optimal gecikme uzunluğu için SIC dikkate alınmıştır.

Tablo 4'te görüldüğü gibi CDLM, FR ,FRS ve BP testleri sonucunda, birimler arasında yatay kesit bağımlılığın olmadığını ileri süren $\mathrm{H} 0$ hipotezi \% 1 önem düzeyinde reddedilmiştir. Bu nedenle çalışmada kullanılan değişkenlere, yatay kesit bağımlılığı dikkate alan ve II. nesil birim kök testleri olarak adlandırılan tahminciler içerisinde yer alan Pesaran'ın CADF-CIPS birim kök testi uygulanmıştır. CADF-CIPS testi, standart ADF birim kök testinin bireysel serilerin birinci farkları ve gecikme seviyelerinin yatay kesit ortalamalarıyla genişletilmişş şeklidir (Pesaran, 2007).

\begin{tabular}{|l|l|l|}
\hline \multirow{2}{*}{ Değişkenler } & \multicolumn{2}{|l|}{ CADF-CIPS Birim Kök Testi } \\
\cline { 2 - 3 } & Sabitli & Sabitli/Trendli \\
\hline GDP & $-2.713^{\mathrm{a}}$ & $-4.421^{\mathrm{a}}$ \\
\hline TOUR & $-2.35^{\mathrm{a}}$ & $-3.185^{\mathrm{a}}$ \\
\hline
\end{tabular}

Tablo 5: Ikinci Nesil Birim Kök Testi Sonuçları Not: a, b ve c sırasıyla \% 1, \% 5 ve \% 10 önem düzeylerini göstermektedir. Optimal gecikme uzunluğu için SIC dikkate alınmıştır:Kritik değerler Pesaran'ın (2007) makalesindeki Tablo C'den temin edilmiştir.

Tablo 5'te görüldüğü gibi CADF Testi sonucunda elde edilen CIPS istatistiklerine göre, çalışmada ele alınan tüm değişkenlerin seviyeleri ile [1(0)] durağan hale geldikleri, yani birim kök içermedikleri tespit edilmiştir.

\subsection{Panel Eş Bütünleşme Testleri}

Çalışmanın bu kısmında GSMH ile turizm gelirleri arasında bir eşbütünleşmenin olup olmadığı sınanmaktadır. $\mathrm{Bu}$ bağlamda, Pedroni, Kao, Johansen-Fisher ve Westerlund eşbütünleşme testleri panel veri setine uygulanacaktır.

Pedroni (1999) "seriler arasında eşbütünleşme yoktur" şeklinde dördü panel ve üçü grup test istatistiği olmak üzere yedi adet panel eşbütünleşme testi önermiştir. Kao (1999), "birimlerde eşbütünleşme vardır" şeklindeki hipotezi sınamak için kalıntı temelli test önermiş̧tir (Baltagi, ve diğ., 2000; Baltagi, 2005). Johansen-Fisher panel eşbütünleşme testi Johansen ve Juselius eş bütünleşme testinin panel verilere uygulanmasıdır. Westerlund (2007), hata düzeltme temelli dört adet panel eşbütünleşme testi önermiş̧tir. Pedroni, Kao ve Johansen-Fisher eş bütünleşme testleri birimler arası korelasyonun olmadığı varsayımında yapılırken, Westerlund eş bütünleşme testi birimler arası korelasyon olması durumunda etkin sonuçlar verebilmektedir. Yapılan Pedroni, Kao, Johansen-Fisher ve Westerlund eşbütünleşme testleri Sonuçları Tablo 6'da yer verilmiş̧tir.

Pedroni eşbütünleşme sonucuna göre panel ADF ve grup ADF test istatistikleri istatistiki olarak anlamlıdır. $\mathrm{Bu}$ testlerin anlamlı çıkması panel verilerinde eşbütünleşmenin var olduğu göstermektedir. Kao eş bütünleşme testi sonucuna göre ise ADF test istatistiği \%1 de anlamlıdır, yani eş bütünleşme vardır. Johansen-Fisher eş bütünleşme testi, en az bir adet eş bütünleşmenin bulunduğunu ifade etmektedir. Westerlund eş bütünleşme testine ise ürettiği dört istatistikten üçünün anlamlı sonuçları vermesi, yine eş bütünleşmenin var olduğu ifade etmektedir.

Pedroni, Kao, Johansen-Fisher ve Westerlund eşbütünleşme testleri sonucunda, GSMH ile turizm gelirlerinin panel verilerinin eşbütünleşik olduğu sonucuna ulaşılmıştır. Modeldeki eşbütünleşme varlığını kabul ettikten sonra, uzun dönem eşbütünleşme katsayısı tespit edilmiştir. 
GSMH'nin bağıml, turizm gelirlerinin bağımsız değişken olduğu modelde uzun dönem etkisinin tahmin edilmesi amacıyla dinamik en küçük kareler yöntemi kullanılacaktır. Modeli tahmin ederken, PMGE (Pooled Mean Group Estimation) veya MGE (Mean Group Estimation) tahmincilerinin tutarlılığını test etmek için Hausman testi uygulanmış (Paseran ve diğ., 2004), PMGE'nin yapılmasına karar verilmiştir. Yapılan PMGE'nin sonuçları Tablo 7' de sunulmuştur.

\begin{tabular}{|c|c|c|c|c|c|c|}
\hline \multicolumn{2}{|l|}{ Pedroni } & \multirow{2}{*}{$\begin{array}{l}\text { Kao } \\
\text { İstatistik } \\
\end{array}$} & \multirow{2}{*}{\multicolumn{2}{|c|}{$\begin{array}{l}\text { Johansen-Fisher } \\
\text { İstatistik }\end{array}$}} & \multirow{2}{*}{\multicolumn{2}{|c|}{\begin{tabular}{|l|} 
Westerlund \\
İstatistik \\
\end{tabular}}} \\
\hline \multirow[b]{2}{*}{ Panel v } & \multirow{2}{*}{$\begin{array}{l}\text { İstatistik } \\
-0.429162 \\
\end{array}$} & & & & & \\
\hline & & \multirow{7}{*}{$\begin{array}{l}\text { ADF } \\
-2.676982^{\mathrm{a}}\end{array}$} & \multirow{4}{*}{ None } & \multirow{2}{*}{$\begin{array}{l}\begin{array}{l}\text { Fisher istatistiği } \\
\text { trace test }\end{array} \\
47.02^{\mathrm{a}}\end{array}$} & & \\
\hline Panel $\rho$ & 1.834006 & & & & Gt & $-8.021^{\mathrm{a}}$ \\
\hline Panel PP & 1.217606 & & & Fisher istatistiği & & \\
\hline Panel ADF & $-1.912046^{b}$ & & & $\begin{array}{l}\text { max-eigen test } \\
38.65^{\mathrm{a}}\end{array}$ & da & -2.253 \\
\hline $\operatorname{Grup} \rho$ & 2.271544 & & \multirow[t]{3}{*}{ At most 1} & $\begin{array}{l}\text { Fisher istatistiği } \\
\text { trace test } \\
19.68^{\mathrm{b}}\end{array}$ & $\mathrm{Pt}$ & -11.034 \\
\hline Grup PP & 1.385223 & & & Fisher istatistiği & & \\
\hline Grup ADF & $-2.717718^{a}$ & & & $\begin{array}{l}\text { max-eigen test } \\
19.68^{\mathrm{b}}\end{array}$ & $\mathrm{Pa}$ & $-9.023^{\mathrm{a}}$ \\
\hline
\end{tabular}

Tablo 6: Eş Bütünleşme Testleri Sonuçları Not: a, b ve c strasıly \% 1, \% 5 ve \% 10 önem düzeylerini göstermektedir.

\begin{tabular}{|c|c|c|c|c|}
\hline & D.GDP & Katsayısı & Std Hatası & Olasılık \\
\hline $\mathrm{ec}$ & TOUR & 1.10121 & 0.081214 & 0.01 \\
\hline \multirow[t]{3}{*}{ SR } & \multirow[t]{2}{*}{$\mathrm{EC}$} & -0.49232 & 0.029125 & 0.00 \\
\hline & & 0.012467 & 0.140826 & 0.13 \\
\hline & $\begin{array}{c}\text { TOUR } \\
\text { D1. } \\
\text { Sabit Terim } \\
\end{array}$ & 1.9340210 & 2.923014 & 0.01 \\
\hline
\end{tabular}

Tablo 7: PMGE Sonuçlarl

Yapılan PMGE tahmincisinin sonucuna göre, hata düzeltme parametresi (-0.50) negatif ve anlamlıdır. İki değişken arasında uzun dönemli bir ilişki mevcuttur. Buna göre, bir dönemde (yani bir yılda) oluşan dengesizliklerin yaklaşık \%50’i, bir sonraki dönemde düzelecek ve uzun dönem dengesine yaklaşması sağlanacaktır. Ayrıca, turizm gelirlerinin uzun dönem parametresi (1.4) anlamlı ve pozitif işaretli, fakat kısa dönem parametresi (0.01) pozitif ve anlamsızdır. Uzun dönemde turizm gelirlerinde meydana gelecek \%1 bir artış, GSMH'i \%1.1 oranında artıracaktır.

\section{Sonuç}

Turizm, cari işlemler hesabındaki uluslararası hizmetler kısmında yer almakta olup ülkeler için önemli bir gelir kalemi niteliğindedir. Turizm bu özelliği sayesinde, milli gelir artışına ve ülkelerin kalkınmasına katkı sağlamaktadır. Önemli bir gelir kaynağı olarak kabul edilen turizm ülkelere sağladığı döviz gelirleri ile ülkelerin dış ve bütçe açıklarının finansmanına yaptığı katkı bakımımdan büyük öneme sahiptir. Turizmin ülke ekonomilere yapmış olduğu bu katkılardan dolayı turizm ile ekonomik büyüme arasındaki ilişki, literatürde son dönemlerde dikkat alınan ve üzerine birçok araştırma yapılan önemli bir konu haline gelmiştir. Bu çalışmanın ana amacı, dünya ve bölge turizm içerisinde önemli yere sahip olan beş büyük Akdeniz ülkesin turizm gelirlerinin GSMH'lerine olan etkilerini araştırmaktır. Çalışmada panel verilerinin eşbütünleşik bulunması sonucunda elde edilen uzun dönem katsayılarına göre, bir yıl içerisinde oluşan dengesizliklerin \%50'sinin, bir sonraki dönemde düzeleceğini ifade etmektedir. Elde edilen bu sonuca göre, mevcut turizm gelirlerinde bir süreklilik olduğunu, her ne kadar da olsa her şey etkilenen turizm sektörünün bir yıl gibi k1sa bir ortaya çıkabilecek olumsuzlukları bir sonraki yıl ortadan kaldırabilecek potansiyele sahip olduğunu göstermektedir. Ayrıca, turizm gelirlerindeki artışın uzun dönemde GSMH'i üzerinde pozitif etki yapması, iktisat teorisi bakımında beklentiler yönündedir. 


\section{Kaynakça}

- Alaeddinoğlu, F. ve A. Can, (2007). “Türk Turizm Sektöründe Tur Operatörleri Ve Seyahat Acenteleri Operatörleri Ve Seyahat Acenteleri”, Ticaret ve Turizm Eğitim Fakültesi Dergisi, 2: ss.50-66.

- Baltagi, Badi H., (2005). Econometric Analysis of Panel Data, 3rd edition, John Wiley\&Sons Ltd., West Sussex, England.

- Baltagi, B.H., H. Bai ve Chihwa Kao, (2000). "Nonstationary Panels, Cointegration in panels: A Survey", Center for Policy Research Working Paper No. 16, http://www.maxwell.syr.edu/uploaded Files/cpr/publications/working_papers/wp16.pdf

- Bahar, O. ve K. Bozkurt, (2010). "Gelişmekte Olan Ülkelerde Turizm-Ekonomik Büyüme İlişkisi: Dinamik Panel Veri Analizi”, Anatolia: Turizm Araştırmaları Dergisi, 21,(2), (Güz), ss.255-265.

- Domar, N. Gujarati, (2009). Temel Ekonometri, (Çev. Ü. Şenesen ve G. G. Şenesen), Ayhan Matbaası, İstanbul.

- Pesaran, M. Hashem, (2007). "A Simple Panel Unit Root Test in the Presence of Cross Section Dependence", Journal of Applied Econometrics, 22, ss.265-312.

- Pesaran, H. M., Shin, Y. ve Smith R., (2004). "Pooled Mean Group Estimation Of Dynamic Heterogenous Panels", ESE Discussion Paper 16: pp.1-26.

- Pesaran, M. H., Y. Shin, ve R. Smith, (1999). "Pooled Mean Group Estimation of Dynamic Heterogeneous Panels", Journal of the American Statistical Association, 94: pp.621-34.

- Pedroni, Peter (1999). "Critical Values for Cointegration Tests in Heterogeneous Panels with Multiple Regressors", Oxford Bulletin of Economics and Statistics, Special Issue, pp. 653-670.

- Tatoğlu, Ferda Yerdelen, (2012). Panel Veri Ekonometrisi Stata Uygulamalı, Beta Yayınları, İstanbul, 2012.

- UNWTO, (2012). “Tourism Highligths", 2012 Edition.

- Westerlund, J., (2007). "Testing For Error Correction in Panel Data", Oxford Bulletin Of Economics and Statistics, 69, (6): pp.709-747.

- Yamak, N., B., Tanrı̈̄ver ve F. Güneysu, (2012). "Turizm - Ekonomik Büyüme İlişkisi: Sektör Bazında Bir İnceleme", Atatürk Üniversitesi İktisadi ve İdari Bilimler Dergisi, 26 (29), ss.205-220.

- Yıldız, Z., (2011). “Turizmin Sektörünün Gelişimi Ve İstihdam Üzerindeki Etkisi”, Süleyman Demirel Üniversitesi Vizyoner Dergisi, 3, (5): ss.54-71. 


\title{
Geçiş Ekonomilerinde Girişimciliğin Ekonomik Büyüme Üzerine Etkileri
}

\section{Effects of Entrepreneurship on Economic Growth in Transition Economies}

\author{
Assoc. Prof. Dr. Mine Gerni (Marmara University, Turkey) \\ Prof. Dr. Murat Nişancı (Erzincan University, Turkey) \\ Asst. Prof. Dr. Ahmet Alkan Çelik (Beykent University, Turkey) \\ Ph.D. Candidate Ziya Çağlar Yurttançıkmaz (Atatürk University, Turkey)
}

\begin{abstract}
The emphasis on entrepreneurship with the importance for economic growth and development is increasing day by day. This situation is particularly feeding the level of development, but also providing to have high level of economic, social, technological and cultural infrastructure in developed countries. In other words, this is particularly the level of sophistication feeding, but also in developed countries, economic, technological, social and cultural infrastructures are also leading to a high level of entrepreneurship. In other words, more entrepreneurial individuals grow in the country which has economic and social conditions in relevant level and this increase the importance of determination on the performance of economic growth. In this study, until the 1990s, private enterprise was almost zero in 1991 to the former socialist countries with the transition process relations of production and consumption was abandoned from planned economy conditions to in the conditions of market economy. In this aspect, the factors affecting economic growth, entrepreneurship and employment variables are the level of savings. After econometric analysis, all independent variables are found significant and the impacts of those variables on economic growth are examined positive. This showed that entrepreneurship took a place as an important factor on growth performance of countries in development such as labour and capital.
\end{abstract}

\section{Giriş}

Küreselleşen bir dünyada işletmelerin yaşamlarını sürdürebilmeleri, hızla değişen teknolojiye ve rekabet koşullarına uyum gösterebilmelerine bağlıdır. Dolayısıyla bu değişime ayak uyduramayanların yaşamlarını sürdürebilme şansı bulunmamaktadır. İşletmenin söz konusu değişime ayak uydurabilmesi ise yönetici ve işletme sahibi konumunda bulunan girişimci ile ilgilidir. İşletmenin başında bulunana girişimcinin başarıya ulaşmak için mücadeleci olması, riskli durumlarla karşı karşıya kaldığında riski-getiri oranını iyi tahlil etmesi ve piyasalardaki belirsizlik durumlarında işletmeyi en iyi şekilde yönlendirmesi büyük önem arz eder. Diğer taraftan Schumpeteryen bakış açısıyla girişimcinin yeni ürünler oluşturma, yeni teknolojiler kullanma ve yeni pazarlara girme konusunda istekli ve yetenekli olmasının yanı sıra kendine güvenmesi onda bulunması gereken temel özelliklerdendir.

Girişimcilik ve ekonomik büyüme arasındaki ilişkide girişimcilik istihdam ve refah artışı oluşturarak ekonomik gelişmeyi hızlandırmaktadır. Burada girişimcilik ekonomide yeniliklerin artması olanak sağlayarak ekonomik büyümeyi, verimliliği ve iş olanaklarını artırmaktadır. Bu çerçevede Romer (1986) ve Lucas (1988) bilginin yayılmasının önemine içsel büyüme modellerinde özellikle vurgu yaparlarken; yayılma etkilerini sağlayan unsur olarak girişimciyi görürler. Audretsch ve Thurik (2004) ile Carree ve Thurik (2005) ise girişimciliğin ekonomik büyümeyi bilgi yayılımı, artan rekabet ve çeşitliliğin artması yoluyla etkilediğini belirtmişlerdir. Girişimciliğin çeşitli ve gelişmiş kanallar aracılığı ile firmalar arası bilgi yayılmasına artırdığı ve bunun da ekonomik büyümeyi olumlu etkilediği belirtilmiştir. Bir kişi veya ekonomik birim tarafından sahip olunan bilginin ticarileştirilerek ekonomik büyümeyi desteklemesi ise ancak girişimci vasıtasıyla olmaktadır. Yeni firmaların kurulması ve girişimciliğin desteklenmesi dışsallıklar oluşturarak bilginin gelişimine katkı sağlar. Ayrıca bilgi dışsallığının da yerel monopoller yerine daha rekabetçi bir çevre oluşturduğu gözlenmiştir. Glaeser vd. (1992) ile Feldman ve Audretsch (1999) da yerel rekabetin yenilikçi çalışmaları ve ekonomik büyümeyi teşvik ettiğine vurgu yapmıştır (Henderson, 2006: 2-6).

Ekonomik gelişmişlik düzeyinin hem sonucu hem de nedeni olan girişimcilik unsuru her şeyin devlet eliyle yürütüldüğü planlı ekonomilerde adeta törpülenmiş vaziyettedir. Çalışmada yaklaşık 3 çeyrek asır sosyalist planlamacılık ile yönetilen ve dolayısıyla girişim unsurunun doğal olarak güdük-bodur bırakıldığı eski demir perde ülkelerinde 1990'ların başında ortaya çıkan geçiş sürecinin atlatılabilirliğinde girişim faktörü en önemli unsur haline gelmiştir. Bu çerçevede eski doğu bloğu ülkelerinde girişim unsurunun yeteri düzeyde oluşup oluşmadığı ve oluştuysa bunun ekonomik büyüme üzerine etkiler yaratıp yaratmadığı araştırmaya değer kabul edilebilir. 


\section{Girişimcilik ve Ekonomik Büyüme İlişskileri}

Girişimciliğin tanımı ilk kez 18. yüzyılın başlarında Fransa'da Richard Cantillon tarafından yapılmıştır. Bu tanıma göre girişimci, henüz belirginleşmemiş bir bedelle satmak üzere üretim girdilerini ve hizmetlerini satın alan ve bunlardan hareketle katma değer yaratarak üretimde bulunan kişidir. Satış fiyatının belirsizliği de girişimcilerin risk üstlenme özelliğini vurgulamaktadır. Jean Baptise Say ise girişimciliği ve girişimcide olması gereken özellikleri geliştirerek onun temel özelliği olan risk üstlenmenin yanı sıra üretim girdilerini örgütleme ve yönetme niteliğine vurgu yapmıştır. Cantillon ve Say’a ilaveten girişimcinin yenilikçi ve dinamik olma özelliği ise Joseph A. Schumpeter tarafından ele alınmıştır. Schumpeter'in çalışmalarında girişimcilik, yenilik yaratma ve teknolojik buluşlar ile açıklanmaya çalışılmış ve yeni ürünler, yeni süreçler ve yeni pazarlar yaratmak için yeni kaynakların oluşturulması gibi konulara ağırlık vermiştir. Schumpeter'in bakış açısında girişimci, toplumda değişimi yaratacak kişi ve kurumlar olarak tanımlanmaktadır (Odabaşı, 2005: 4). Diğer taraftan Wennekers ve Thurik (1999), girişimciyi ekonomideki yeni fırsatların farkına varabilen ve piyasaya yeni fikirler sunan kişiler olarak ele alır iken, Lundström ve Stevenson ise (2005) girişimciyi kendi işlerini yönetmenin, kurmanın ve geliştirmenin farklı safhalarında olan birey olarak tanımlamaktadır. Bu çerçevede girişimcileri de "potansiyel girişimci”, "kendi nam ve hesabına yalnız çalışan girişimci”, "mikro girişimci”, "yaşam-tarzı girişimciliği”", "teknoloji odaklı girişimci”, "yüksek büyüme hızlı girişimci” ve "yenilikçi girişimciler” olarak sinıflandırmaktadirlar (Aslan, 2009: 16-17).

Gelişen şartlara bağlı olarak girişimcilik algısı ve buna bağlı tanımlamaları evrim süreci geçirirken; aynı zamanda tam bir konsensüs ile iktisadi gelişme-büyümenin temelinde girişimciliğin olduğu genel kabul görmektedir. Çünkü artan rekabet ortamında farklılıklar yaratabilmek ancak girişimcilik düzeyine bağlıdır. Bu nedenle girişimde bulunma ve yenilik oluşturma (yeni ürün veya teknoloji geliştirme) ekonomik dinamizmin temellerini oluşturmaktadır. Oluşturulan yenilikler ekonomik büyümeyi ve verimliliği artırarak istihdam üzerinde de olumlu etkiler meydana getirmektedir. Girişimciliğin önemi, özellikle sanayi toplumundan bilgi toplumuna geçiş ile birlikte oldukça fazla artmıştır. Dünya ekonomisinin \%65'ini temsil eden G-7 ülkelerinde (Kanada, Fransa, Almanya, İtalya, Japonya, İngiltere ve Amerika) girişimcilik düzeyi ve yıllık ekonomik büyüme arasında güçlü bir ilişki olduğu yapılan araştırma sonuçlarında somut bir şekilde ortaya konulmuştur (Salvatore, 2005: 63). Bu olguya küresel açıdan bakıldığında, girişimciler tarafından gerçekleştirilen yenilik faaliyetleri ve artan rekabetin bir ülkenin ekonomik büyümesi açısından son derece önem teşkil ettiği bilinmektedir (Keleş vd., 2012: 108; Wennekers ve Thurik, 1999: 42).

Girişimciliğin ekonomideki yeri konusunda ise 1970’lerden itibaren bir değişim meydana gelmiştir. Algıdaki değişime paralel olarak 1970'li yıllardan sonra kendi işine sahip olanların oranlarında bir yükseliş trendi ortaya çıkmıştır (Acs ve Audretsch, 1993; OECD, 1998). Bu değişim başlayana kadar firma ölçeğinin büyüklüğü gerek diğer firmalarla rekabet edebilme açısından, gerekse küresel çapta faaliyet gösterme avantajı nedeniyle önemli bir konuma sahipti. Ancak, 1970’lerden sonra büyük işletmeler, yürüttükleri faaliyetleri büyük çapta ve kendilerinin üretimleri ile sınırlı tutma durumundan vazgeçerek, tedarikçi firmalar ile çalışmaya başlamışlardır. Ortaya çıkan bu durumun yansımaları ise hem çok sayıda küçük girişimcinin kendi firmalarıyla piyasaya girerek gelişmesine hem de büyük firmalara maliyetlerini düşürmesine olanak sağlamıştır. Oluşan yeni düzende büyük firmalar üretilen ürünün ana üreticisi olmakla birlikte, küçük ve orta boy işletmelerden mal ve hizmet tedarik ederek üretimde uzmanlaşmaya gitmişler ve kendi üretim süreçlerinde önemli bir yer tutmayan, ancak üretilmesi gerekli malların üretimini küçük işletmelere vererek kaynak israfını önleme imkanına sahip oldular. Bu çerçevede Carlsson, Amerika'nın en büyük firmalarının küçülmeye başladığını ve 1970'li yıllarda \%20 olan istihdam oranlarının 1996'da \%8.5'e düştügünü vurgulamaktadır. Günümüzde yapılan araştırmalara göre, küçük firmalar büyük firmalara nispetle daha girişimci konumundadırlar (Parker, 2006). Küçük firma olmanın en önemli avantajı ise tüm sektörlerde piyasaya daha fazla ve esnek biçimde giriş-çıkış yapabilmeleri ve daha hızlı büyüme eğilimi gösterebilmeleridir. Dolayısıyla küçük firmaların esnek bir yapıya sahip olmaları ve böylece değişen ekonomik ortama hızlı bir şekilde uyum sağlayabilmeleri, küçük firmaları daha kârlı hale getirmekte ve böylece küçük firmaların kurulmasıyla gerçekleşen girişimcilik değer kazanmaktadır (Aslan, 2009: 20).

Girişimciliğin giderek mikro perspektif kazanması ve esnek yapıya bürünmsinin ülkelerin veya bölgelerin ekonomileri üzerinde büyük etkisi bulunmaktadır. Ekonomik büyüme ve endüstrideki yapısal değişim arasındaki ilişkinin varlığı, Schumpeter'e kadar gitmektedir ve geleneksel Schumpeteryen görüş açısından bakıldığında ekonomik büyüme düzeyi, endüstrinin kıt kaynaklarını en etkili biçimde kullanmasıyla meydana gelmektedir (Carre ve Thurik, 2003: 437-471). Dolayısıyla endüstri yapısındaki değişiklikler aynı zamanda ekonomik büyüme oranlarına etki etmektedir. Endüstri yapısının belirleyicileri ise, teknolojik değişiklikler, küreselleşme, deregülasyon, emek piyasasındaki artışlar ve talepteki çeşitlilikler gibi unsurlardan oluşturmaktadır. Diğer bir ifadeyle endüstri yapısındaki değişikliği sağlayan en önemli unsur küçük firmalardır. Küçük firmaların sayısı arttıkça (yani girişimcilik arttıkça), endüstrinin yapısında da gelişme söz konusu olmaktadır (Aslan, 2009: 21).

Diğer taraftan girişimci ve girişimcilik de içinde bulunduğu çevreden büyük ölçüde etkilenmektedir. Literatürde girişimciliğin altyapısı beş temel kategoride incelenir. Bunlar; (i) insan kaynağı, (ii) finansman, (iii) yasal düzenlemeler, (iv) sosyal, kültürel ve politik altyapı ve (v) girişimciliği teşvik ve desteklerdir. Bu 
çerçevede GEM (2001) raporu insan kaynağının önemi konusunda şu değerlendirmeleri yapmaktadır. 29 ülkede yapılan çalışmalarda 25-34 yaş arası grup girişimciliğin en yüksek olduğu yaş aralığıdır. Toplumun demografik yapısı, istihdam yapısı ve eğitim düzeyi girişimcilik performansı üzerinde etkilidir. Eğitim düzeyinin artması sadece girişimciliği altyapısını desteklemekle kalmaz, aynı zamanda girişimcilerin bilgi ve becerilerini artırarak yeni iş ortaklıkların kurulmasına yardımcı olur (TÜSİAD, 2002). Ayrıca GEM (2001) raporu finansal destek ile girişimcilik düzeyi arasında doğrusal bir ilişki olduğunu göstermektedir. Girişimciler ihtiyaç duydukları finansal desteği ailelerinden, bankalardan, hükümetten veya finansal piyasalardan karşılamaktadırlar. Geleneksel finans kaynaklarının dışında risk sermayesi firmaları, özellikle ABD'deki girişimciler için oldukça büyük miktarlarda finansal kaynak sağlamaktadırlar. Çok sayıda çalışmada ABD'deki hızlı teknoloji ve girişimcilik alanındaki gelişmede risk sermayedarlarının önemini vurgulamaktadır (Çetindamar, 2002).

Girişimcilerin ilgilendikleri yasal konuların başında ise mülkiyet ve tescil, şirket hukuku, vergi ve çalışma hayatını düzenleyen konular gelmektedir. Girişimciler teknolojik devrim oluşturan ve büyük emek ve maddi çaba gerektiren icatlarının veya fikirlerinin mülkiyet haklarını tecil ettirerek koruma sağlamak isterler. Aksi halde kendileri ile rekabet eden rakipleri bu buluşları ve fikri hakları kopyalayarak haksız kazanç sağlayarak kendilerine üstün gelebilirler. GEM (2008) raporu girişimcilik sürecini, girişimcileri farklı kategorilere ayırarak oluşturmaktadır. Bu ayrıma göre girişimcilik süreci; (i) potansiyel girişimciler; yani bir iş kurma niyeti olan ve bunu gerçekleştirebilmek için gerekli bilgi ve yeteneklere sahip olan kişiler; (ii) başlangıç aşamasındaki girişimciler; yani bir işi kurabilmek için gerekli hazırlıkları yapan kişiler; (iii) yeni bir iş sahibi olanlar; yani en çok 3.5 yaşına kadar yeni bir iş yerine sahip olanlar ve (iv) 3.5 yıldan fazla bir süreden beri var olan bir iş yerinin sahibi olan kişilerin oluşturduğu birbirini takip eden dört ana gruba ayrılmaktadır. Girişimcilik düzeyi ise statik ve dinamik olmak üzere çeşitli göstergelere bakılarak ölçülebilmektedir. OECD, GEM ve IMD World Competitiveness Yearbook girişimciliğgin tespiti ve ülkelere ait seriler oluşturulmasında önemli çalışmaları olan kuruluşlardır. Bunların yanı sıra serbest çalışma (self-employment) ya da iş sahipliği (business ownership) oranları (EIM/ENSR, 1997) girişimcilik düzeyini gösteren önemli statik göstergelerdendir. Dolayısıyla ülkedeki küçük ve orta ölçekli işletmelerin (KOBİ) sayısı girişimcilik düzeyini yansıtmaktadır. Bir dinamik gösterge ise kurulma aşamasındaki girişimcilik faaliyetleri (nascent entrepreneurship) ve yeni iş yeri kurmuşlar arasındaki faaliyetlerdir (start-up activity). Ayrıca dinamik gösterge olarak ekonomide meydana gelen firma giriş ve çıkışlar oranlarının toplamı da dinamik bir gösterge olarak ele alınmaktadır (Wennekers ve Thurik, 1999).

\section{Literatür Özeti}

Ekonomik büyümenin sağlanmasında fiziksel sermayenin yanı sıra girişimciliğin önemi 1990'lı yıllarda giderek önem kazanmaya başlamıştır. Büyük firmaların üretim süreçlerini ayrıştırması, giderek artan sayıda küçük ve etkili girişimci firmanın oluşmasına yol açmıştır. OECD (2001) raporlarına göre 1980’lerde ABD, Japonya'ya göre daha fazla girişimcilik oranları sergilemektedir. 1990'lara gelindiğinde ise ABD, Japonya'dan daha yüksek ekonomik performans göstermektedir. Ancak, ABD 1980’lerde bu performansı gösterememektedir. $\mathrm{Bu}$ durum artan girişimcilik düzeyinin gecikmeli bir şekilde de olsa ekonomik büyüme performansını olumlu olarak etkilediğini göstermektedir (Aslan, 2009: 21).

Nickell (1996) ile Nickell vd. (1997) piyasa etkinliğinin bir ölçüsü olarak piyasadaki rakip firma sayısını almışlardır. Buna göre piyasadaki rakip firma sayısının artması yeni bir ürün oluşturma ve piyasaya yeni firmaların girmesini sağlayarak girişimciliği ölçmede etkilidir. 600 İngiliz imalat sanayi firmasından sağlanan 1972-1986 ve 1982-1994 dönemlerini kapsayan verilerle yapılan çalışmada rekabetin artmasının toplam faktör verimliliğini olumlu bir şekilde etkilediği belirtilmiştir. Caree ve Thurik (1998) küçük firmaların piyasa payındaki değişimin endüstri toplam çıktısı üzerindeki payını nasıl değiştirdiğini araştırmışlardır. 13 Avrupa ülkesindeki 14 imalat sanayi endüstrisi için yapmış oldukları çalışma sonuçlarına göre küçük firmaların payının yüksek olduğu endüstrilerde çıktı artışı daha yüksek düzeyli gerçekleşmiştir. Ağca vd. (2008) yaptıkları çalışmada IMD 2003-2006 dönemi verilerini kullanarak 51 ülke için analiz etmişlerdir. Elde edilen sonuçlara göre ülkelerin girişimcilik performansları ile ulusal ekonomi arasında pozitif yönlü bir ilişki olduğu tespit edilmiştir. Holtz-Eakin ve Kao (2003) girişimciliğin ekonomik büyüme üzerindeki etkisini analiz etmişlerdir. Büyüme ölçüsü olarak verimlilikteki değişimi aldıkları çalışmalarında firma kuruluş ve kapanış oranlarındaki değişimlerin pozitif olması durumunda verimliliğin de pozitif olarak etkilendiğini belirtmişlerdir. ABD için girişimciliğin verimlilik artışı üzerinde pozitif bir etkisi olduğu vurgulanmıştır. Acs ve Armington (2006) girişimciliğin ABD’nin ekonomik büyümesi üzerindeki etkisini 1990'lar için incelemişlerdir. Elde edilen sonuçlara göre yükssek girişimcilik aktivitelerinin bulunduğu bölgelerde yükssek ekonomik büyüme oranlarının yakalandığı gözlenmiştir. Audretsch (2007) ise bilginin yayılımı, taşmalar ve ticarileşmesi için girişimciliğin olmazsa olmaz bir olgu olduğunu belirtmiştir. Girişimciliğin bilgi sermayesi ile ekonomik büyüme arasında bir bağlantı noktası olduğunu vurgulayarak ekonomik büyümenin gerçekleşmesi için girişimcilik sermayesi ile yeni firmaların kuruluş ve büyümelerinin desteklenmesi gerektiğini belirtmiştir. Harhoff ve Stahl (1995) ise Almanya'da 11.000 imalat, inşaat, ticaret, finans ve hizmet firmasının verilerini kullanarak yapmış oldukları çalışmada piyasaya giriş sonrasında büyük firmaların ayakta kalma şanslarının daha yüksek olduğunu, ancak firmaların büyüme oranlarında ise küçük firmaların daha yüksek büyüme oranlarına sahip olduğu sonucuna 
ulaşılmıştır. Genel olarak değerlendirildiğinde küçük ve genç işletmelerde büyüme oranlarının daha yüksek olduğu ve özellikle bilgi yoğun endüstrilerdeki küçük ve genç işletmelerde büyüme oranları oldukça yüksek olduğu sonucuna ulaşılmıştır. Küçük ve genç işletmelerin yüksek büyüme performansları ekonominin genel büyüme oranı üzerinde olumlu katkı yapmaktadır.

Acs vd. (2006) 18 ülke için 1981-1998 dönemi verilerini kullanarak girişimcilik ve ekonomik büyüme ilişkisini 2 aşamalı EKK ile araştırmışlardır. Çalışmada girişimcilik göstergesi olarak serbest meslek sahiplerinin oranı kullanılmıştır. Ülkenin bilgi stoku, işgücü, sermaye stoku ve kurumsal faktörlerin de analiz edildiği çalışmada yüksek girişimcilik düzeyine sahip ülkelerin daha iyi ekonomik büyüme performansı gösterdikleri tespit edilmiştir. Camp (2005) ise 1990-2000 dönemi için girişimcilik aktiviteleri ve ABD işgücü piyasalarındaki ekonomik büyümeyi analiz etmiştir. Çalışmada kullanılan girişimcilik endeksi, yeni kurulan firma sayısı ve yeni kurulan firmaların oranlarından oluşmaktadır. Yüksek girişimcilik endeks değerine sahip bölgelerde istihdam, ücret ve verimlilik düzeylerinin de yüksek olduğu sonucuna ulaşılmışır. Audretsch ve Keilbach (2005) Almanya'nın batı bölgelerinden elde ettiği 1989-1992 dönemi girişimcilik sermayesi (yeni kurulan firma sayısı ile ölçülmüş) ile bölge büyüme oranı verilerini kullanarak yapmış olduğu çalışmada yüksek girişimcilik sermayesine sahip olan bölgelerde çıktı düzeylerinin ve işgücü verimliliğin de oldukça yüksek olduğu görülmüştür. Çalışmada ayrıca girişimcilik sermayesi ve ekonomik büyüme ilişkisinin şehir bölgelerinde daha yüksek düzeyli olduğu ve buna karşılık kırsal bölgelerde ise değişkenler arası ilişkinin zayıfladığı tespit edilmiştir.

Autio vd. (2005), Cobb-Douglas üretim fonksiyonunu temel alarak ve GEM 2002 veri seti ile yeni firma kurulumu ve teknolojik gelişmenin büyüme üzerindeki etkisini 37 ülke için yatay kesit veri analizi ile araştırmışlardır. Analiz sonuçlarına göre sadece yüksek büyüme potansiyeli olan girişimcilik alanlarının ekonomik büyüme üzerinde anlamlı bir etkisi olduğu sonucuna ulaşılmış̧ır. Van Stel vd. (2005) Gem monitorun girişimcilik göstergelerinden olan TEA (Toplam Erken Aşama Girişimcilik Faaliyeti) göstergelerini 36 ülke için kullanarak girişimciliğin GSYİH üzerindeki etkisini analiz etmişlerdir. Elde edilen sonuçlara göre girişimcilik düzeyi ekonomik büyüme üzerinde etkilidir. Ancak, bu etki kişi başına GSYIH'ye bağlıdır. TEA endeksi düşük GSYIH düzeyine sahip ülkelerde ekonomik büyümeyi negatif etkilerken, yüksek kişi başına GSYİH düzeyine sahip ülkelerde ekonomik büyümeyi pozitif etkilemektedir. Salgado-Banda (2007), 22 OCECD ülkesinde 19801995 dönemi için girişimcilik ile ekonomik büyüme arasındaki ilişkileri araştırmıştır. Çalışmada bağımlı değişken olarak kişi başına GSYIH, bağımsız değişken olarak ise serbest girişimcilik düzeyi göstergeleri olarak meslek sahipleri (kendi işine sahip olanların oranı) ve patent başvuruları ile başlangıç düzeyi kişi başına GSYIH değeri, ortaokullarda okullaşma oranı, dışa açıklık, kamunun ekonomideki payı ve enflasyon oranı değişkenlerini kullanmıştır. Elde edilen sonuçlara göre patent başvuruları ile ifade edilen verimli girişimcilik ile ekonomik büyüme arasında pozitif yönlü bir ilişki yakalanırken, serbest meslek sahipliği oranı ile gösterilen girişimcilik ve ekonomik büyüme arasında ise negatif yönlü bir ilişki tespit edilmiştir. Özet olarak literatürdeki çalışmalar değerlendirildiğinde, girişimcilik düzeylerinin yüksek olduğu ülke veya bölgelerde ekonomik büyüme oranlarında, verimlilikte ve istihdam oranlarında da yüksek oranlar yakalanmaktadır. Söz konusu durumun istisnası olduğunu gösteren çalışmalar olmakla birlikte girişimciliğin ekonomik büyüme üzerinde anlamlı ve pozitif yönlü bir etkisi olduğu sonucuna ulaşılabilir.

\section{Uygulama Sonuçları}

Orta Asya, Merkezi-Doğu Avrupa ve Kafkasya geçiş ekonomileri ile Türkiye için girişimcilik ve ekonomik büyüme ilişkilerinin araştırılmasına yönelik olarak yapılan bu çalışma her ülke için uygun veri setine ulaşılan yılları kapsamakta olup, bu da 2008-2011 arası dönemi içermektedir. Çalışmada her ülke için GSYIH'nın büyüme oranı (GDP), toplam tasarrufların GSYIH'ye oranı (SAV), 15 yaş üstü çalışan nüfusun toplam nüfusa oranı (EMP) ve girişimcilik göstergesi olarak 15-64 yaş arası çalışan her 1000 kişi başına düşen yeni açılan şirket sayısı (ENT) değişkenleri kullanılmaktadır. Çalışmada öncelikli olarak tanımlayıcı istatistikler ortaya konularak, daha sonra birim kök analizleri ve nedensellik testi uygulamalarına geçilmiştir. GSYİH'nın büyüme oranı bağımlı değişken olarak kabul edilmiş olup, diğer değişkenler bağımsız değişkenlerdir. Çalışmada kullanılan model şu şekilde oluşturulmuştur;

$$
\mathrm{GDP}=\mathrm{b}_{0}+\mathrm{b}_{1} \mathrm{SAV}+\mathrm{b}_{2} \mathrm{EMP}+\mathrm{b}_{3} \mathrm{ENT}
$$

Yukarıdaki model bağlamında uygun veri setine sahip 24 ülkeye (Arnavutluk, Azerbaycan, Beyaz Rusya, Bosna-Hersek, Bulgaristan, Hırvatistan, Çek Cumhuriyeti, Estonya, Gürcistan, Macaristan, Kazakistan, Kirgizistan, Letonya, Litvanya, Makedonya, Moldova, Polonya, Romanya, Rusya, Slovakya, Slovenya, Tacikistan, Türkiye ve Ukrayna)ait değişkenlerin tanımlayıcı istatistikleri Tablo 1'de verilmiştir.

Tanımlayıcı istatistikler incelendiğinde tüm değişkenlerde oldukça büyük farklılıklar olduğu görülmektedir. Jarque ve Bera sınaması için hipotezler; $H_{0}$ : veriler normal dağılım gösterir, $H_{1}$ : veriler normal dağılım göstermez. Herhangi bir serinin normal dağılıp dağılmadığının belirlenmesinde kullanılan Jarque-Bera testi, çarpıklık (Skewness) ve basıklık (Kurtosis ) ölçülerine dayanan bir testtir. Sıfır hipotezi beklenen çarpıklığın 0 değerde ve beklenen basıklık fazlalığının 3 değerde olacağı sıfır hipotezdir; çünkü bir normal dağılım için bu 
değerler gereklidir. Söz konusu duruma göre serilerin normal dağılmadığı görülmektedir. Ayrıca standart hatanın genel olarak yüksek olması da istenmeyen bir durumdur. Standart hata ne kadar küçükse örneklem istatistiği anakütle parametresine o derece yakın, parametre hakkında o kadar duyarlı bir kestirim olacaktır. Standart hata büyüdükçe, bu kestirimin duyarlılığ 1 o derece duyarlı olmaktan çıkacaktır.

Panel veri analizlerinde yatay kesit 24 ülke boyutuna ilaveten 4 yıllık zaman serisi (2008-2011) boyutu söz konusudur. Bu nedenle özellikle zaman boyutunun olduğu verilerde düzmece-sahte regresyon sorunu ortaya çıkabilmektedir. Sahte regresyon sorunu ise yapılan tahminler anlamlı bile olsa, sonuçlarına ihtiyatla bakılmasını gerekli kılmaktadır. Sahte regresyon sorununun önüne geçebilmek amacıyla serilerin durağanlığının-birim kök içerip içermediğinin araştırılmasına gereksinim duyulmaktadır. Bu amaçla Levin-Lin ve Chu (LLC), Fisher ADF ve Fisher PP birinci nesil birim kök testleri olarak adlandırılan tahminciler kullanılarak değişkenlerin birim kök içerip içermediği araştırılmıştır. Çalışmada kullanılan değişkenlere ilişkin birinci nesil birim kök testleri Eviews 6 ekonometri programında hesaplanmış ve bu testlerden elde edilen sonuçları Tablo 2'de verilmiştir.

\begin{tabular}{|l|l|l|l|l|}
\hline & GDP & SAV & EMP & ENT \\
\hline Mean & 2.552 & 20.858 & 51.483 & 2.997 \\
\hline Median & 3.324 & 20.162 & 52.350 & 2.245 \\
\hline Maximum & 21.245 & 52.374 & 67.700 & 11.180 \\
\hline Minimum & -17.954 & 2.003 & 33.500 & 0.270 \\
\hline Std. Dev. & 6.072 & 7.772 & 7.369 & 2.519 \\
\hline Skewness & -0.933 & 1.278 & -0.429 & 1.070 \\
\hline Kurtosis & 5.109 & 6.705 & 3.162 & 3.399 \\
\hline Jarque-Bera & 31.727 & 81.052 & 3.057 & 18.989 \\
\hline Probability & 0.000 & 0.000 & 0.216 & 0.000 \\
\hline
\end{tabular}

Tablo 1: Tanimlayıcı istatistikler

\begin{tabular}{|l|l|l|l|}
\hline Değişkenler & $\begin{array}{l}\text { Levin, Lin \& Chu } \\
\mathrm{t}^{*}\end{array}$ & $\begin{array}{l}\text { ADF - Fisher Chi- } \\
\text { square }\end{array}$ & $\begin{array}{l}\text { PP - Fisher Chi- } \\
\text { square }\end{array}$ \\
\hline GDP (Sabitli) & $-20.80(0.00)$ & $66.69(0.01)$ & $65.71(0.01)$ \\
\hline SAV (Sabitli) & $-10.56(0.00)$ & $16.76(0.03)$ & $22.13(0.00)$ \\
\hline EMP (Sabitli) & $-3.65(0.00)$ & $41.78(0.39)$ & $60.67(0.02)$ \\
\hline ENT (Sabitli) & $15.12(0.00)$ & $16.78(0.03)$ & $24.41(0.00)$ \\
\hline
\end{tabular}

Tablo 2: Birim Kök Testi Sonuçları

\begin{tabular}{|l|l|l|l|l|}
\hline Tüm örneklem & $\begin{array}{l}\text { Test Değeri } \\
(\text { Ki-Kare }(1))\end{array}$ & df & $\begin{array}{l}\text { Olasilık } \\
\text { Değeri }\end{array}$ & Karar \\
\hline F testi & 71.770 & $(26,66)$ & 0.000 & Zaman ya da birim etki var \\
\hline$F_{\mathrm{b}}$ & 17.961 & $(3,89)$ & 0.000 & Birim etki var \\
\hline$F_{\mathrm{z}}$ & 45.919 & $(23,69)$ & 0.003 & Zaman etkisi var \\
\hline LR testi & 27.345 & 3 & 0.000 & Zaman ya da birim etki var \\
\hline $\mathrm{LR}_{\mathrm{b}}$ & 31.170 & 3 & 0.000 & Birim etki var \\
\hline $\mathrm{LR}_{\mathrm{z}}$ & 0.000 & 3 & 1.000 & Zaman etkisi yok \\
\hline
\end{tabular}

Tablo 3: Birim ve/veya Zaman Etkilerinin Varlı̆̆

Değişkenlerin birim kök analizi sonuçları incelendiğinde tüm değişkenlerin seviyede durağan oldukları görülmektedir. Çalışmada kullanılan zaman aralığının kısa olması nedeniyle sadece sabitli birim kök testleri uygulanmıştır. Çalışmada klasik Cobb-Douglas fonksiyonun uygunluğu birim ve zaman etkilerine bakılarak araştırılmıştır. Zaman ve birim etkilerinin var olup olmadığı sabit etkiler modeli için $\mathrm{F}$ testi ve tesadüfi etkiler modeli için ise LR testi uygulanarak araştırılmıştır. Sonuçlar Tablo 3'de sunulmuştur.

Tablodan da görüldüğü üzere, birim ve zaman etkilerinin standart hatalarının sıfira eşit olduğunu söyleyen $H_{0}$ hipotezi reddedilirken; birim ve zaman etkilerin var olduğunu ifade eden $H_{1}$ hipotezi kabul edilmektedir. Dolayısıyla hem sabit etkiler hem de tesadüfi etkiler modelleri için birim etkilerin var olduğu, buna karşılık zaman etkilerinin olmadığı, dolayısıyla tek yönlü modelin tahmin edilmesi gerektiği anlaşılmaktadır. Birim etkisinin sabit mi yoksa tesadüfi olduğunun kararı için Hausman testi sonuçlarına bakıldığında, LR testinde zaman etkisinin olmadığı görülmektedir. Sabit etkili modelinin uygun olduğu görülmektedir.

Çalışmada yapılan Granger nedensellik analizi sonuçlarına göre GDP’nin istihdam düzeyi ve girişimcilik faaliyetleri üzerinde etkili olduğu ve istihdamından girişimcilik üzerinde etkili olduğu görülmüştür. 


\begin{tabular}{|l|l|l|}
\hline $\mathrm{H}_{0}$ Hipotezi & F-İstatistiği & Olas1lık \\
\hline GDP, EMP'nin Granger nedeni değildir. & 3.01847 & 0.059 \\
\hline GDP, ENT'nin Granger nedeni değildir. & 10.7694 & 0.000 \\
\hline EMP, ENT'nin Granger nedeni değildir. & 18.871 & 0.000 \\
\hline
\end{tabular}

Tablo 4: Granger Nedensellik Testi Sonuçlarl

\begin{tabular}{|l|l|l|l|}
\hline Değişkenler & Katsay1 & t-ist. & Prob. \\
\hline SAV & 0.329 & 1.66 & 0.09 \\
\hline EMP & 0.941 & 1.93 & 0.05 \\
\hline ENT & 2.578 & 3.47 & 0.00 \\
\hline Prob(F-statistic) $: 0.025$ & Durbin-Watson stat: 1.896 \\
\hline
\end{tabular}

Tablo 5: EKK Analiz Sonuçlart

Yapılan EKK test sonuçlarına göre geçiş ülkelerinde girişimcilik düzeyi ile ekonomik büyüme arasında pozitif yönlü bir ilişki olduğu sonucuna ulaşılmıştır. Çalışmada zaman etkisinin olmadığı ancak birim etkinin bulunduğu sonucuna ulaşılmıştır. Elde edilen bu göstergelere dayanılarak yapılan EKK testi sonuçlarına göre girişimcilik (\%1 önem düzeyinde), istihdam (\%5 önem düzeyinde) ve tasarruflar (\%10 önem düzeyinde) büyüme üzerinde etkili çıkmıştır. Söz konusu durum mevcut ülkelerdeki ekonomik ve siyasi sistemin bir sonucu olarak düşünülebilir. Söz konusu ülkelerdeki çoğu faaliyetin hala devletin tekelinde olması ve özel sektör yatırımlarına duyulan ihtiyaç böyle bir sonucun çıkmasında etkili olmuştur.

\section{Sonuç}

Girişimciliğin ekonomide yeniliklerin artması olanak sağlayarak ekonomik büyümeyi, verimliliği ve iş olanaklarını artırması başta gelişmekte olan ülkeler olmak üzere tüm ülkeler için önemlidir. Bu açıdan değerlendirildiğinde ekonomik büyümenin sağlanmasında emek ve sermaye birikimi ne kadar önemli ise girişimciliğin de önemi o kadar büyüktür. Çünkü bir ülkede girişimciliği düzeyi ne kadar yüksekse, yeni iş olanakları oluşturulması ve yeni teknik ve fikri gelişimlerin yaşanması daha olasıdır. Bu durum ise ülkelerin ekonomik büyüme performanslarını olumlu bir şekilde etkilemektedir. Yapılan analizlerde 23 geçiş ekonomisi ile Türkiye'de ekonomik büyümenin temel sürükleyici unsurunun emek ve sermayeden de daha fazla önemde, girişimcilik unsurunun olduğu tespiti yapılmıştır. Diğer bir ifadeyle bu ülkelerde girişimcilik düzeyindeki artışların ekonomik büyümeyi olumlu etkiliği görülmüştür. Diğer taraftan yapılan nedensellik sınamalarında girişimcilik unsuru ile ekonomik büyüme arasında çift yönlü nedensellik ilişkisinin varlığ tespit edilmiştir. Bu durum da özellikle piyasa ekonomisi kurallarını kurumsallaştırmaya çalışan geçiş ekonomilerinde girişimciliğin ekonomik gelişmeyi uyardığını ve benzer şekilde ekonomik gelişmişlik düzeyindeki artışların da girişimcilik iklimini iyileştirdiğinin ortaya koymaktadır. Dolayısıyla ekonomik açıdan hala çeşitli sıkıntılar yaşayan ve kamunun ekonomideki ağırlığını azaltmayı hedefleyen geçiş ülkeleri için girişimcilik faaliyetlerinin ve girişimcilerin desteklenmesi istikrarlı ekonomik büyümenin sağlanabilirliği açısından oldukça önemli ve gerekli bir unsur konumundadir.

\section{Kaynakça}

- Acs, Z., and C. Armington (2006), Entrepreneurship, Agglomeration and US Regional Growth, Cambridge, Cambridge University Press.

- Acs, Zoltan, David Audretsch, Pontus Braunerhjelm and Bo Carlsson (2006), "Growth and Entrepreneurship: An Empirical Assessment”, Centre for Economic Policy Research Discussion Paper 5409, January, Available at www.cepr.org/pubs/dps/DP5409.asp

- A Ağca V., S. Dündar ve O. Aydemir (2008), "Some Selected Determinants on Entrepreneurial Performance of Countries: An Empirical Study”, First International Conference on Management and Economics, 28-29 March 2008.

- Aslan, Yasemin (2009), Türkiye'de Büyüme-Odaklı ve Yenilikçi Bir Girişimcilik Politika Çerçevesi Geliştirme ve Politika Açıklarının Belirlenmesi, Süleyman Demirel Üniversitesi Sosyal Bilimler Enstitüsü, Yüksek Lisans Tezi, 2009, Isparta.

- Audretsch, David B. and Max Keilbach (2005), “Entrepreneurship Capital and Regional Growth”, Annals of Regional Science, 35, 457-469.

- Audretsch, David B. (2007), "Entrepreneurship Capital and Economic Growth", Oxford Review of Economic Policy, 23, 63-78.

- $\quad$ Autio, E., Y. P. Ho and P. K. Wong (2005), "Entrepreneurship, Innovation and Economic Growth: Evidence from GEM Data", Small Business Economics, 24, 335-350. http://dx.doi.org/10.1007/s11187-005-2000-1 
- Camp, S. Michael (200), “The Innovation-Entrepreneurship NEXUS: A National Assessment of Entrepreneurship and Regional Economic Growth and Development”, Small Business Research Summary, Small Business Administration, Office of Advocacy No. 256, April.

- Carree, M. and A. Roy Thurik (1998), "Small Firms and Economic Growth In Europe”, Atlantic Economic Journal, 26 (2), 137-146.

- Henderson, J. (2006), “Understanding Rural Entrepreneurs at the County Level: Data Challenges”, Federal Reserve Bank of Kansas City-Omaha Branch, Working Paper, Oct 2006.

- Holtz-Eakin, D. and C. Kao (2003), "Entrepreneurship and Economic Growth: The Proof is in the Productivity", Center for Policy Research, Syracuse University.

- Nickell, Stephen J. (1996), “Competition and Corporate Performance”, Journal of Political Economy, 104 (4), 724-746.

- Nickell, Stephen J., Daphne Nicolitsas and Neil Dryden (1997), “What Makes Firms Perform well?”, European Economic Review, 41, 783-796.

- Salgado-Banda, H. (2007), "Entrepreneurship and Economic Growth: An Empirical Analysis", Journal of Developmental Entrepreneurship, 12 (1), 3-29.

- Van Stel, Andre, Martin Carree and Roy Thurik (2005), "The Effect of Entrepreneurial Activity on National Economic Growth", Small Business Economics, 24, 311-321. 


\title{
Türkiye ve Seçilmiş Bazı Bağımsız Devletler Topluluğu Ülkelerinde Sebze ve Meyve Ürün Grubunda Uluslararası Rekabet Gücü Analizi
}

\section{Competitiveness Analysis of Selected Members of Commonwealth of Independent States and Turkey in Vegetables and Fruit Sector}

\author{
Assoc. Prof. Dr. Fahriye Öztürk (Gazi University, Turkey) \\ Ph.D. Candidate Sitkıcan Saraçoğlu (Gazi University, Turkey) \\ Ph.D. Candidate Işın Kortan (Hacettepe University, Turkey)
}

\begin{abstract}
Our paper aims to quantify levels of competitiveness of the selected Commonwealth of Independent States countries(Belarus, Moldova, Russia and Ukraine) and Turkey in vegetables and fruit sector and sub-sectors during the 1995-2012 period with respect to world market. Because only these CIS countries have prolonged annual data for vegetables and fruit sector in this period, these countries are selected for our paper. Our paper uses export and import data obtained from UNCTAD database and the data set covers the period of 1995 to 2012. To investigate competitiveness of these five countries five indexes are calculated: The Relative Comparative Advantage Index (RCA), The Relative Export Advantage Index (RXA), The Relative Import Penetration Index (RMP), The Relative Trade Advantage Index (RTA) and The Revealed Competitiveness (RC). Our findings indicate that Moldova and Turkey have high comparative advantage in vegetables and fruit sector than Belarus, Russia and Ukraine with respect to the world market. The comparative advantage level of Turkey has decreasing trend during the 1995-2012 period. The import penetration of Moldova has been higher level than Turkey which can be said as her rival.
\end{abstract}

\section{Giriş}

1980 sonrası dönemde uluslararası düzeydeki mal ticareti, mal üretimine oranla çok daha hızlı bir biçimde artmış; liberal iktisat politikaları, uluslararası sermaye akımlarının serbestleştirilmesine yönelik çalışmalar, bilişim teknolojisinde yaşanan gelişmeler ve küreselleşme eğilimi ülkelerin firma ve sektörlerinin küresel piyasada yer almak veya var olan piyasa paylarını artırmak amacıyla rakipleriyle ürün fiyatı ve kalitesi bakımından daha yoğun bir rekabet ortamına yol açmıştır (Kibritçioğlu, 1996). Öte yandan, 1970 sonrası dönem Sovyet Sosyalist Cumhuriyetler Birliği için bir dönüm noktası olmuş, yeni koşullara uyum gösterilememesi, teknoloji ve kaliteden yoksun ürünler, arz ve talep arasındaki dengesizlik ve tarım sektöründe uygulanan hatalı politikalar sonrasında merkezi otorite zayıflamıştır. SSCB’nin dağılması, tüm dünyayı siyasal ve iktisadi anlamda etkileyen bir gelişme olmuş ve bu yeni dönemde SSCB'nin de yerini alacak, eski birliğe oranla daha esnek, ancak etkili yeni bir yapının kurulması için girişimler başlatılmıştır. 8 Aralık 1991'de Beyaz Rusya, Rusya ve Ukrayna, iktisadi işbirliğine dair kapsamlı bir programı içeren Bağımsız Devletler Topluluğu anlaşmasını imzalamış ve 21 Aralık 1991'de Moldova, Ermenistan, Azerbaycan, Kazakistan, Türkmenistan, Özbekistan, Tacikistan ve Kırgızistan ve 1993 yılının Aralık ayında Gürcistan topluluğa katılmıştır. SSCB'nin dağılması sonucu bağımsızlığına kavuşan ülkeler, bağımsız devlet olma özelliklerini kazanma ve merkezi planlı ekonomiden piyasa ekonomisine dönüşüm sürecinin getirdiği sorunlar ve gerçekleştirilen reformlarda yapılan hatalar sonucunda büyük üretim düşüşleri yaşanmış ve 1991-1995 dönemi iktisadi reformların gerçekleştirilmesinden çok iktisadi krizle mücadele yılları olmuştur. 1990'lı yılların ortasında başlayan toparlanma süreci, 1998 Rusya Krizi ve buna eşlik eden petrol fiyatlarındaki düşüş yüzünden sekteye uğramış, döviz kurunun zamanla düşmesi ve petrol fiyatlarında yaşanan artış ile birlikte ise 2000 yılından itibaren söz konusu ülkeler tekrar büyüme sürecine girmiş ve bölge ülkelerinde iktisadi istikrar büyük ölçüde sağlanmıştır. Bağımsız Devletler Topluluğu ve diğer komşu ülkeler arasındaki gıda piyasasının genişlemesi, Bağımsız Devletler Topluluğu'na üye olan ülkelerin üretim ve ihracat konusunda ivme kazanmasını sağlayacak ölçüde geniş topraklara sahip olması, bu ülkelerin kalkınma süreçlerinde tarımı önemli kılmaktadır. Bu çalışmada amaç, Türkiye ve bağımsız Devletler Topluluğuna üye seçilmiş bazı ülkelerin (Beyaz Rusya, Moldova, Rusya, Ukrayna) sebze ve meyve ürün grubunda 1995-2012 yılları arasındaki dönemde uluslararası rekabet gücündeki gelişmenin araştırılmasıdır. Analiz kapsamına alınan ülkelerin seçiminde, ele alınan dönemde tüm yıllar itibariyle verilere ulaşlabilmesi etkili olmuştur. Çalışmada öncelikle rekabet gücüne yönelik tanımlara ve uluslararası rekabet gücü ölçüm yöntemlerine yer verilecektir. Üçüncü bölümde, söz konusu ülkelerin tarım sektöründe uluslararası rekabet gücüne yönelik literatür taraması incelenecektir. Dördüncü bölümde, çalışmaya konu olan Beyaz Rusya, Moldova, Rusya, Türkiye ve Ukrayna'nın SITC Rev.3'e göre 05 Kodlu Meyve Sebzeler ürün grubunda 1995-2012 dönemi diş ticaret dengesine ve çalışmada hesaplanan RCA, RXA, RTA, RMP ve RC endeks değerlerine yer verilmektedir. 


\section{Rekabet Gücü Kavramı ve Uluslararası Rekabet Gücü Ölçüm Yöntemleri}

\subsection{Rekabet Gücü Kavramı}

Rekabet gücü kavramı firma, endüstri ve uluslararası boyutta incelenebilmektedir. Porter (1990), firma düzeyinde rekabet gücünü tanımlarken, firmanın piyasa payı ve verimliliğine ön planda tutarak, faaliyetlerini birincil ve destek faaliyetler biçiminde iki kısma ayırmıştır: Üretim, dağıtım, pazarlama gibi faaliyetleri birincil faaliyetler biçiminde, bu faaliyetlerin sürekliliği için gereken altyapı hizmetleri, teknoloji gibi faaliyetleri destek faaliyetleri biçiminde ifade etmiştir. Porter'a göre, firmaların rekabet gücüne sahip olmaları, teknoloji alanındaki yenilikleri ve farklı girdileri üretim sürecinde kullanmaları yoluyla gerçekleşecektir. Kibritçioğlu'na (1996) göre, bir firmanın rekabet gücüne sahip olması, ürün fiyatı (fiyat ve maliyet rekabet gücü) ve/veya ürün kalitesi, teslimde dakiklik ve satış sonrası hizmet (kalite rekabet gücü) gibi fiyat dışı unsurlar bakımından mevcut dönemde aynı veya daha üstün konumda yer almasıdır. Endüstri boyutunda rekabet gücü, Markusen (1992), bir endüstrinin rakip endüstriler ile karşılaştırıldığında, onlarla eşit veya daha yüksek verimlilik düzeyine ulaşması ve bu düzeyin sürekliliğini sağlayabilme yeteneği veya onlarla eşit ya da daha düşük maliyette üretim yapma ve bu ürünleri satma yeteneği biçiminde tanımlanmaktadır. Landau (1992), bir ülkenin rekabet gücünü, vatandaşlarını daha yüksek ve kaliteli istihdam düzeyine eriştirmek yoluyla, yüksek yaşam standartlarına ve yeterli büyüme oranının sağlanması biçiminde ifade etmektedir. Ülkedeki istihdam düzeyini belirleyen faktörler arasında, ülkede faaliyet gösteren firmaların rekabet güçleri de yer almaktadır. Uluslararası rekabet gücünü, Fagerberg (1988), ödemeler dengesinde sorunlara yol açmadan, iktisadi büyüme ve istihdam artışı gibi bir ülkenin temel iktisat politikası hedeflerini gerçekleştirme yeteneği ve teknoloji, fiyat ve kapasite açısından rekabet üstünlüğüne sahip olması biçiminde ifade etmektedir. Aiginger (1998), bir ülkenin uluslararası rekabet gücünü, ülkenin arzu ettiği mevcut ve gelecek dönemde elde edeceği faktör gelirlerinde ve vatandaşlarınca yeterli görülen iktisadi, çevresel ve sosyal bir makro ekonomik ortamda uluslararası piyasalara yeterli düzeyde ürün ve hizmet satabilme yeteneği, biçiminde ifade etmektedir.

\subsection{Balassa Endeksi}

Balassa, bir ülkenin belirli bir ürün veya sanayi ticareti açısından karşılaştırmalı üstünlüğünü hesaplamak amacıyla, ilgili ürün veya endüstrinin toplam dünya ihracatı içerisindeki payının, ülkenin toplam ihracatı içerisindeki payına oranını ifade eden bir endeks geliştirmiştir. Bu endeks, karşılaştırmalı üstünlüğün kaynaklarını saptamaktan daha çok ülkenin karşılaştırmalı üstünlüğe sahip olup olmadığını saptamaktadır. Balassa'nın geliştirdiği endeks aşağıdaki biçimde ifade edilmektedir (Balassa, 1989):

$$
R C A=\frac{X i j / \sum X i}{X w j / \sum X w}
$$

Yukarıdaki denklemde " $\mathrm{X}_{\mathrm{ij}}$ ", i ülkesinin $\mathrm{j}$ ürünü açısından gerçekleştirdiği ihracatı; " $\mathrm{X}_{\mathrm{i}}$ ”, i ülkesinin gerçekleştirdiği toplam ihracatı; " $X_{\mathrm{wj}}$ " dünya genelinde gerçekleştirilen $\mathrm{j}$ malı ihracatını; " $X_{\mathrm{w}}$ " ise dünya genelinde gerçekleştirilen toplam ihracatı işaret etmektedir. Endeksin değerinin birden büyük olması, analize konu olan ülkenin ilgili malda karşılaştırmalı üstünlüğü sahip olduğuna işaret ederken; endeks değerinin birden küçük olması ise ilgili malda karşılaştırmalı dezavantaj durumuna işaret etmektedir.

\subsection{Vollrath Endeksleri}

Vollrath' a (1991) göre, daha önce oluşturulan endeksler yalnızca ihracatı göz önünde bulundurmakta, ithalatı ise dikkate almamaktadır. Vollrath, 1991 yılındaki çalışmasında ihracat ve ithalat verileri ile net ticaret etkisini içinde barındıran bir endeksi, göreli ticaret avantajı endeksini (RTA), oluşturmuştur. Bu endeks, göreli ihracat avantajı endeksi (RXA) ile göreli ithalat nüfuz endeksi (RMP) arasındaki fark biçiminde ifade edilmektedir.

Göreli ihracat avantajı endeksi (RXA), bir ülkenin belirli bir üründe uluslararası piyasalardaki ihracat payının diğer bütün ürünlerde dünya ihracatındaki payına oranı biçiminde hesaplanmaktadır. Böylece, analize konu olan ürünler ve ülkeler dünya genelindeki toplam ihracat düzeyi hesaplanırken dişarıda tutulmakta dolayısıyla söz konusu ülke ve ürünün iki kez hesaba katılması sorunu ortadan kalkmaktadır (Frohberg ve Hartmann, 1997). Göreli ihracat avantajı endeksi aşağıdaki biçimde gösterilmektedir:

$$
R X A i j=\frac{\sum X i j / \sum_{l, l \neq j} X i l}{\sum_{k, k \neq i} X k j j / \sum_{k, k \neq i} \sum_{l, l \neq j} X k l}
$$

"X" ihracat1, "i” ve "k" ürün kategorilerini, “j” ve "l” ise analize konu olan ülkeleri işaret ederken endeksin 1 'den daha yüksek değer alması analize konu olan ülkenin sözü edilen ürün kategorisinde rekabet avantajı elde ettiğini, 1'den daha düşük değer alması ise rekabet açısından dezavantajlı bir durumun yaşandığını işaret etmektedir.

Göreli İthalat Nüfuz (RMP) endeksinin gösterildiği denklemde “ $M_{i j}$ ”, j ülkesinin i ürünü açısından gerçekleştirdiği ithalatı, " $\mathrm{M}_{\mathrm{il}}$ ", j ülkesi dışarıda tutulduğunda dünya genelinde i ürünü açısından gerçekleştirilen 
ithalatı, " $\mathrm{M}_{\mathrm{kj}}$ ", $\mathrm{j}$ ülkesinin i ürünü dışarıda tutulduğundan geri kalan ürünlerinin ithalatını, " $\mathrm{M}_{\mathrm{kl}}$ ” ise $\mathrm{j}$ ülkesi dışarıda tutulduğunda dünya genelinde i ürünü dışındaki ürünlerin toplam ithalatını işaret etmektedir (Aktan ve Vural, 2004). Endeksin 1'den daha büyük bir değer alması rekabetçi dezavantaj1, 1'den küçük bir değer almas1 ise rekabetçi avantajı işaret etmektedir.

$$
R M P i j=\frac{M i j / \sum_{l, l \neq j} M i l}{\sum_{k, k \neq i} M k j / \sum_{k, k \neq i} \sum_{l, l \neq j} M k l}
$$

Göreli ticaret avantajı endeksi (RTA), aşağıdaki biçimde ifade edilmekte ve endeksin pozitif bir değer alması rekabetçi üstünlüğü, negatif bir değer alması ise rekabetçi dezavantajı işaret etmektedir (Frohberg ve Hartmann,1997):

$$
R T A i j=R X A i j-R M P i j
$$

Göreli Rekabet Üstünlüğü (RC) Endeksi ise aşağıdaki biçimde ifade edilmekte ve endeks değerinin negatif olması rekabet dezavantajını; pozitif olması ise rekabet üstünlügünü işaret etmektedir:

$$
R C=\ln R X A-\ln R M P
$$

\section{Literatür Taraması}

Ülkelerin uluslararası rekabet gücünün ölçülmesi ve karşılaştırılmasına yönelik çok sayıda çalışma yapılmıştır. $\mathrm{Bu}$ çalışmada, yalnızca ele alınan ülke ve ülke grubu itibariyle yapılan bazı çalışmalar ve ulaşılan sonuçlara değinilecektir.

Freinkman vd. (2004) çalışmalarında, 2000 yılı WITS ve COMTRADE verilerinden ve Açıklanmış Karşılaştırmalı Üstünlükler endeksinden yararlanarak Bağımsız Ülkeler Topluluğu'nu oluşturan ülkelerin topluluk içerisinde ve küresel boyutta rekabet gücünü ölçmüşlerdir. Yazarlar, "Meyve ve Sebzeler" ürün ana grubunda küresel piyasada 11.3 endeks değerine sahip olan Moldova'nın rekabet gücüne sahip olduğu, sırasıyla 0.5 ve 0.4 endeks değerleri ile Beyaz Rusya ve Ukrayna'nın rekabet gücüne sahip olmadığı sonucuna ulaşmışlardır.

Ahrend (2006) çalışmasında, 1997-2004 dönemi UN-COMTRADE verilerinden ve Açıklanmış Karşıllaştırmalı Üstünlükler endeksinden yararlanarak Rusya'nın rekabet gücünü ölçmüştür. Kullanılan Açıklanmış Karşılaştırmalı Üstünlükler endeksi, Balassa Endeksinin 100 ile çarpılmış halidir. Ahrend'in çalışmasında ulaşılan bulgulara göre, SITC Rev.3 e göre 05 kodlu "Meyve ve Sebzeler" ürün ana grubundaki endeks değeri, 1997-2004 döneminde ortalama -3.6 düzeyindedir ve Rusya'nın rekabet gücüne sahip olmadığını göstermektedir.

Cooper (2006) çalışmasında, 2000-2004 dönemi UN-COMTRADE verilerinden ve Balassa endeksinden yararlanarak Rusya'nın seçilmiş ülkeler karşısında ve küresel piyasada çeşitli sektörlerdeki rekabet gücünü ölçmüştür. Çalışmanın sonuçlarına göre, SITC 054 kodlu ürün grubundaki RCA değeri 2000 y1lındaki 0.061 düzeyinde 2004 yılında 0.081 düzeyine ulaşmıştır. SITC 056 kodlu ürün grubundaki RCA değeri 2000 yılındaki 0.027 değerinden 2004 yılında 0.037 düzeyine ulaşmıştır. SITC 057 kodlu ürün ana grubundaki endeks değeri 2000 yılındaki 0.058 değerinden 2004 yılında 0.076 değerine ulaşmıştır. SITC 058 kodlu ürün ana grubundaki endeks değeri 2000 yılında 0.142 iken 2004 yılında 0.182 değerine ulaşmıştır. SITC 059 kodlu ürün ana grubundaki endeks değeri 2000 yılında 0.036 iken 2004 yılında 0.122 değerine ulaşmıştır. Elde edilen bu endeks değerleri, Rusya'nın “Meyve ve Sebzeler” ürün ana grubunda rekabet gücüne sahip olmadığını göstermektedir.

Shelburne ve Pidufala (2006), çalışmalarında, 2004 yılı UN-COMTRADE verilerinden ve Balassa Endeksinden yararlanarak Bağımsız Ülkeler Topluluğu'nu oluşturan ülkelerin topluluk içerisinde ve küresel boyutta imalat sanayindeki rekabet gücünü ölçmüşlerdir. Çalışmada SITC Rev.2 'ye göre 05 kodlu "Meyve ve Sebzeler" ürün ana grubunda topluluk içerisinde 36.7, küresel piyasada ise 9.4 endeks değeri ile Moldova'nın bu ana ürün grubunda rekabet gücüne sahip olduğu sonucuna ulaşılmıştır. Moldova'nın küresel piyasada, SITC Rev.3'e göre 056 kodlu ürün grubunda 8.3; 057 ürün grubunda 14.8, 058 ürün grubunda 17.5 ve 059 ürün grubunda 21.7 endeks değerine sahip olduğu bulunmuştur. Elde edilen bu bulgulara göre, Moldova için, topluluk içerisindeki endeks değerleri ise çok daha yüksek düzeyde çıkmıştır.

Karaalp (2011) çalışmasında, 1996-2008 dönemi WTO verilerinden ve içerisinde Balassa Endeksi'nin de bulunduğu çeşitli endekslerden yararlanarak, Türkiye'nin çeşitli sektörlerdeki uluslararası rekabet gücünü ölçmüştür. Türkiye tarım ürünleri sektörünün küresel piyasadaki rekabet düzeyini işaret eden endeks 1996 yılındaki 1.90 değerinden 2008 yılında 1.02 düzeyine; gida sektörünün küresel piyasadaki rekabet düzeyini işaret eden endeks 1996 yılındaki 2.21 değerinden 2008 yılında 1.17 düzeyine gerilemiştir. Bu düşüşe karşın, endeks değerleri sözü edilen sektörlerde Türkiye'nin küresel piyasada rekabet gücüne sahip olduğunu göstermektedir. Moldova'nın tarım ürünleri ve gıda sektörlerinde küresel piyasada sahip olduğu karşılaştırmalı üstünlük 19962008 dönemi boyunca azalış eğilimi izlemiştir. Öte yandan, Moldova tarım ürünleri sektöründe sözü edilen 
dönemde ortalama 5.00 civarında, gıda sektöründe ise ortalama 7.00 civarında endeks değerlerine sahip olduğu ve bu değerlere Türkiye'nin aynı dönemde elde etmiş olduğu endeks değerlerinin oldukça üzerinde seyrettiği gözlenmiştir. Ukrayna'nın tarım ürünleri ve gıda sektöründe küresel piyasada karşılaştırmalı üstünlüğünü işaret eden endeks değeri sözü edilen dönemde çok küçük miktarda da olsa artış kaydetmiştir. Beyaz Rusya'nın, tarım ürünleri ve gıda sektörlerinde küresel piyasada sahip olduğu karşılaştırmalı üstünlük ise 1996-2008 dönemi boyunca azalış eğilimi izlemiştir.

Akgüngör vd. (2002) çalışmalarında, Türkiye İşlenmiş Meyve ve Sebze Sektörünün 1994-1997 döneminde Avrupa Birliği piyasasındaki rekabet gücünü içerisinde RCA endeksinin de bulunduğu çeşitli endekslerden yararlanarak ölçmüştür. Çalışmada, İspanya, Yunanistan ve Portekiz rakip ülkeler olarak belirlenmiş; Türkiye işlenmiş domateste rekabet gücüne sahip olmadığı; işlenmiş üzümde Portekiz ve İspanya'ya karşı, işlenmiş turunçgillerde ise Portekiz ve Yunanistan'a karşı rekabet gücüne sahip olduğu sonucuna ulaşılmıştır .

Özağ vd. (2003) çalışmalarında, Türkiye’nin yaş meyve (turunçgiller, üzüm) ve sebzenin(domates, soğan, patates) de içerisinde olduğu çeşitli tarım ürünlerinde 1995-1999 döneminde Avrupa Birliği piyasasındaki rekabet gücünü içerisinde RCA endeksinin de bulunduğu çeşitli endekslerden yararlanarak ölçmüştür. Sözü edilen dönemde, her iki ürün ana grubunda da Türkiye'nin yüksek rekabet gücüne sahip olduğu sonucuna ulaşılmıştır.

Serin ve Civan (2008) çalışmalarında, Türkiye domates, zeytinyağı ve meyve suyu sektörlerinin 1995-2005 döneminde Avrupa Birliği piyasasındaki rekabet gücünü içerisinde RCA endeksinin de bulunduğu çeşitli endekslerden yararlanarak ölçmüştür. İspanya, İtalya ve Yunanistan rakip ülkeler olarak belirlenmiştir. Zeytinyağı sektöründe, Yunanistan Türkiye'ye karşı belirgin bir karşılaştırmalı üstünlüğe sahipken, Türkiye İtalya karşısında 1999 yılına kadar sahip olduğu karşılaştırmalı üstünlüğü kaybetmiş ve 1999 sonrasında karşılaştırmalı üstünlük sürekli el değiştirmiştir. Domates sektöründe, Türkiye İspanya karşısında 1999 yılına kadar sahip olduğu rekabet gücünü 2000 yılında kaybetmeye başlamıştır. Öte yandan, Yunanistan ve İtalya 1996 yılı dışında sözü edilen sektörde Türkiye’ye karşı karşılaştırmalı üstünlüğe sahiptir. Meyve suyu sektöründe, Türkiye 1998 ve 1999 yılları dışında Yunanistan'a karşı; 2002 ve 2004 yılları dışında İtalya'ya karşı rekabet gücüne sahiptir. İspanya, 2000 yılından itibaren sözü edilen sektörde Türkiye'ye karşı rekabet gücüne sahiptir.

Fidan (2009) çalışmasında, Türkiye turunçgil sektörünün 1990-2003 döneminde AB-15 piyasasındaki rekabet gücünü TÜİK, FAO ve EUROSTAT verilerinde ve RCA, RTA endekslerinden yararlanarak ölçmüştür. Yunanistan, İspanya, İtalya ve Portekiz rakip ülkeler olarak belirlenmiştir. Elde edilen bulgulara göre, Türkiye limon ve greyfurt ürün gruplarında İspanya, İtalya, Yunanistan ve Portekiz’e karşı rekabet gücüne sahiptir.

Utkulu ve Seymen (2004) çalışmalarında, Gümrük Birliği sürecinin Türkiye’nin çeşitli sektörlerdeki rekabet gücü üzerindeki etkisini 1990-2003 dönemi DTM verilerinden ve RCA endeksinin çeşitli versiyonlarından yararlanarak ölçmüştür. Sözü edilen dönem, 1990-1995 ve 1996-2002 biçiminde iki alt dönem ayrılmış, Türkiye'nin 05 kodlu "Meyve ve Sebzeler” ürün grubundaki rekabet gücü Gümrük Birliği sonrasında (19962002) azalmıştır.

\section{Tarım Sektörünün Genel Görünümü}

SSCB’nin dağılması sonucu bağımsızlığına kavuşan ülkeler, tarım alanında büyük ölçekli ve devlete ait arazilerde kolektif üretim, ürün ve girdi ile ilgili kararların ve üretim hedeflerinin merkezi yönetim tarafindan belirlenmesi gibi özellikleri SSCB'den miras olarak almışlardı (Lerman vd., 2004). Bu özelliklerin etkisiyle, 1990’lı yılların ilk yarısında tarımsal üretim keskin bir düşüş yaşamış, 1997 yılı sonrasında yapılan reformlar sonucunda tarımsal üretimin yeniden artmasını sağlamıştır (Lerman, 2008). Bu reformlar, toprak kaynaklarının yeniden yapılandırılması, mülkiyet haklarında ve arazi kullanım kalıplarında değişiklikleri içermekte, bu düzenlemelerle birlikte sosyalist ekonomiden piyasa ekonomisine geçiş hedeflenmiş, Moldova, Gürcistan, Ermenistan devlete ait tarım kuruluşlarından özel arazi sahipliğine hızlı bir biçimde geçmişlerdir (Lerman vd., 2004).

Grafik 1'de seçilmiş ülkelerin 1992 ve 2012 yılları arasındaki dönemde brüt ve net üretim değerleri verilmiştir. Grafik 1'den de izleneceği gibi 1999 yılına kadar gerek brüt gerekse net üretim değerleri düşüş eğilimi, yukarıda da işaret edildiği gibi, tarım sektörüne yönelik gerçekleştirilen reformlar sonucu 1999 yılından itibaren ise artma eğilimi göstermektedir. Ayrıca kişi başına düşen üretim de paralel bir görünüm sergilemektedir.

Grafik 2'de seçilmiş ülkelerin ekilebilir alanları ve tarım alanları verilmiştir. Grafikten de izleneceği gibi ele alınan dönemde tarımsal alanlarda dikkate değer bir değişme olmamıştır.

Grafik 3'de seçilmiş ülkelerde tarıma ilişkin demografik göstergeler yer almaktadır. Grafik'ten de izleneceği gibi ele alınan dönemde gerek kırsal gerekse tarımsal nüfusun mutlak olarak azaldığı dikkat çekmektedir. Böyle bir gelişmenin, zaman içinde ülke ekonomilerinin iktisadi gelişmelerine paralel olarak tarımın ekonomideki göreli öneminin azalması yönündeki beklentilerle tutarlı olduğu söylenebilir. 


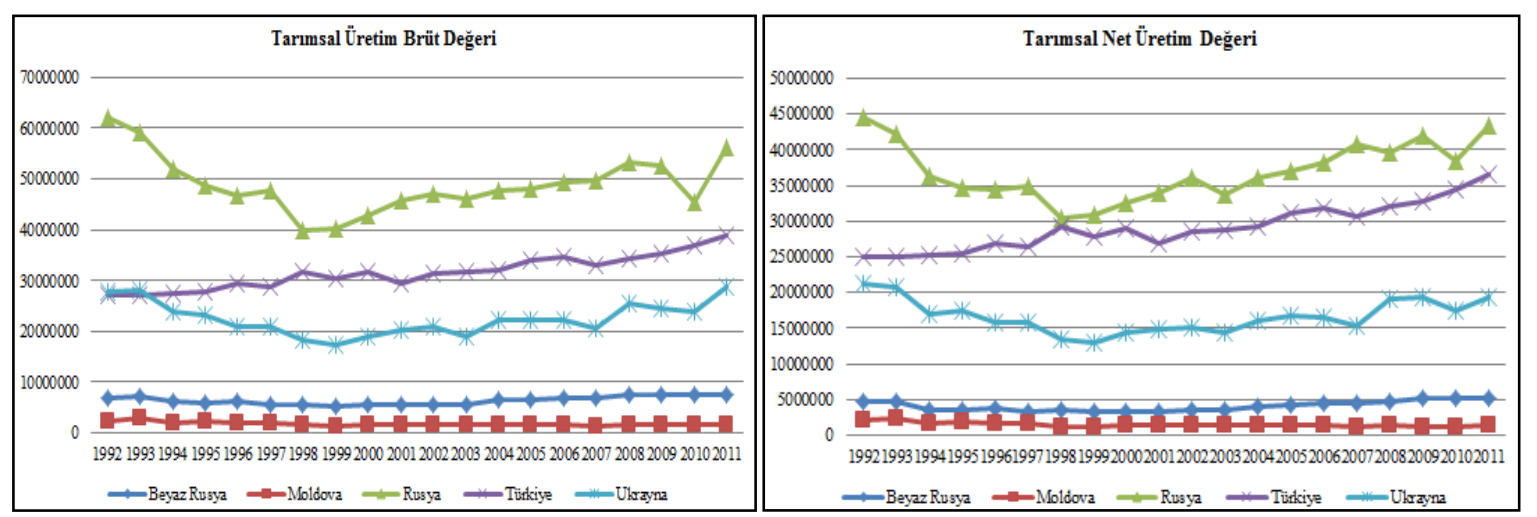

Grafik 1: Seçilmiş Ülkelerde Tarımsal Üretim Brüt ve Net üretim Değerleri (Dolar, 1992-2011) Kaynak: FAOSTAT veritabanı verilerinden yararlanılarak tarafımızdan oluşturulmuştur.

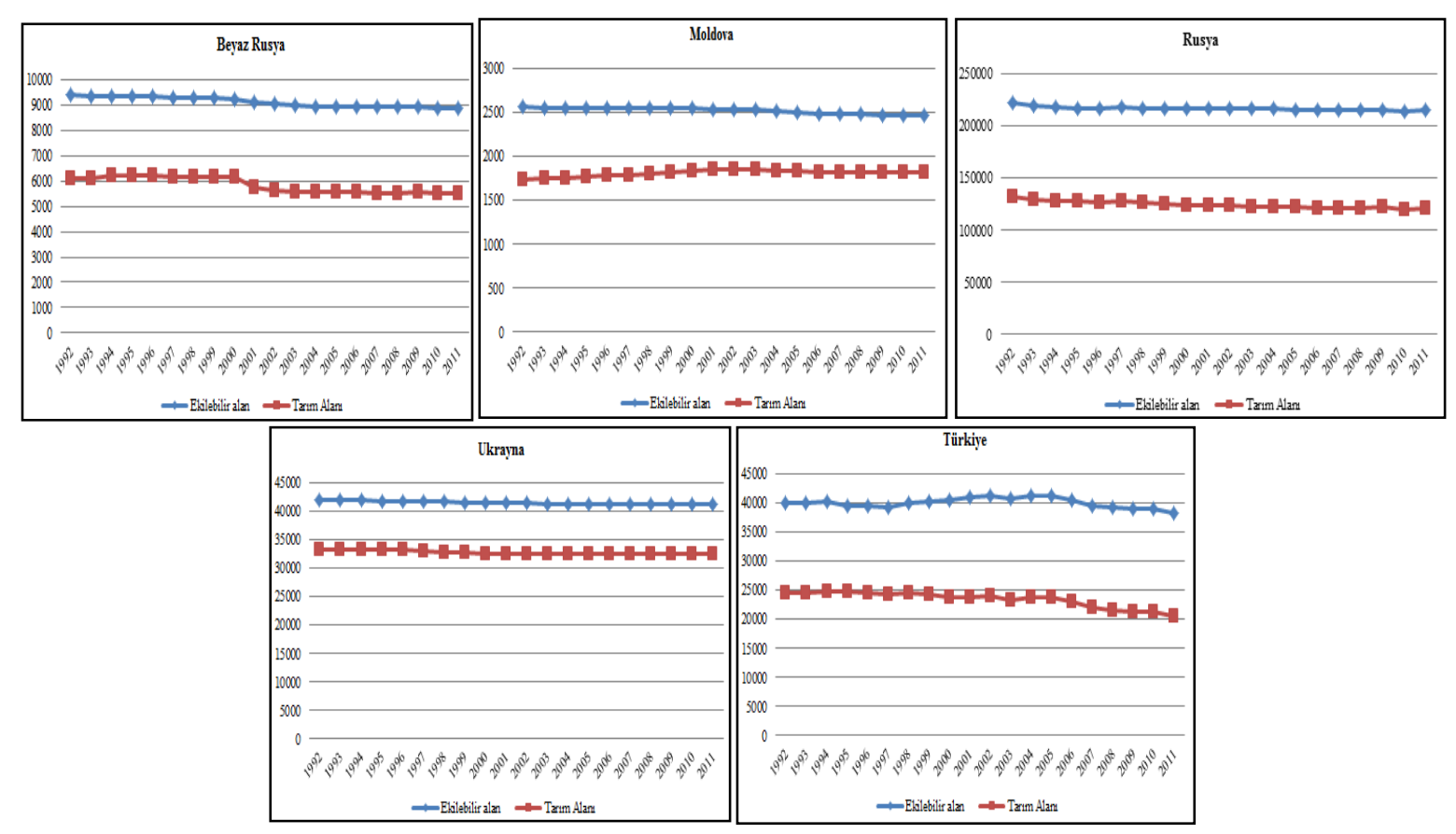

Grafik 2: Seçilmiş Ülkelerde Tarım Alanları (hektar, 1992-2011) Kaynak: FAOSTAT.

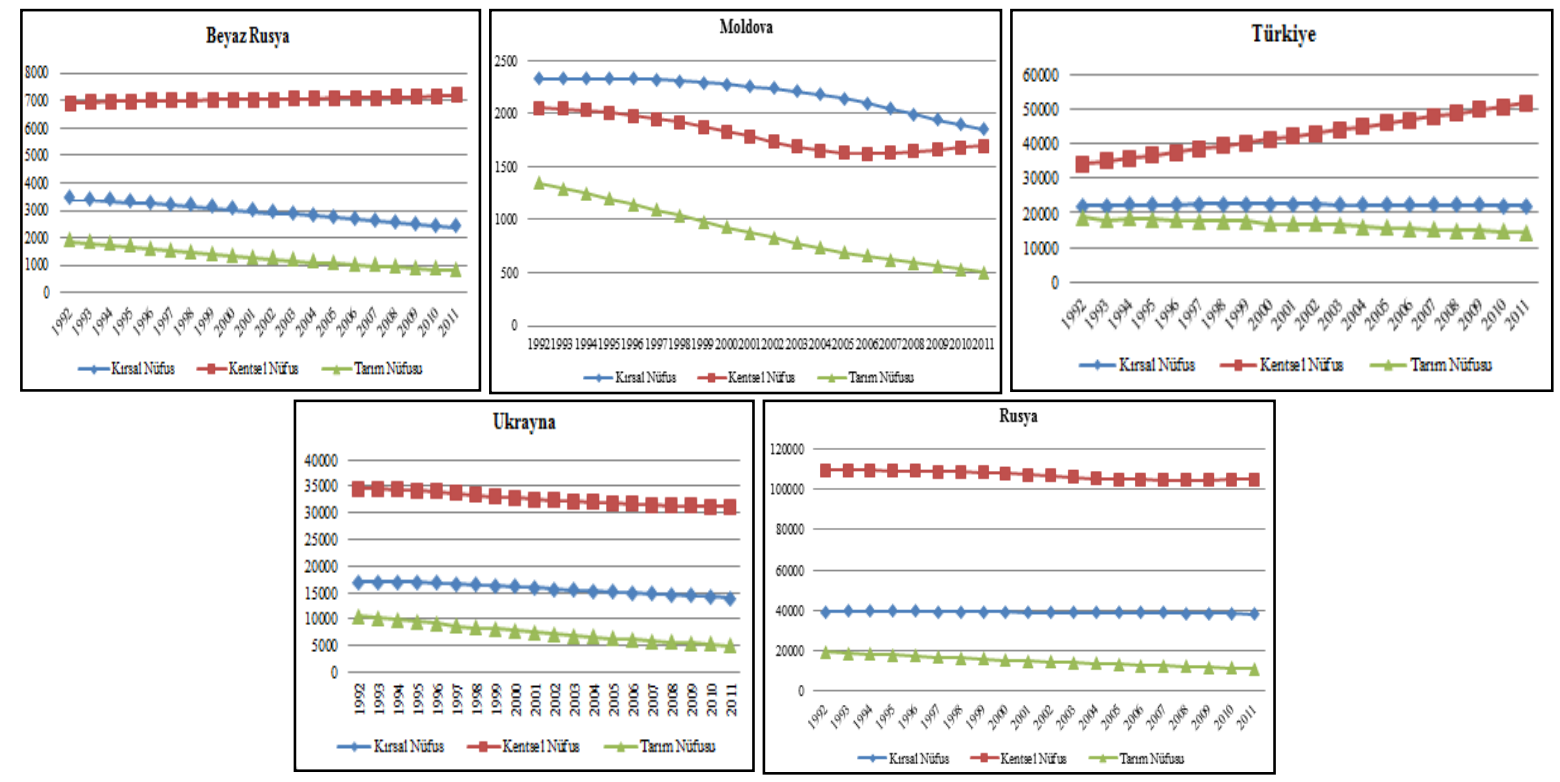

Grafik 3: Seçilmiş Ülkelerde Tarıma ilişkin Demografik Göstergeler(1992-2011) Kaynak: FAOSTAT. 
Grafik 4'de seçilmiş ülkeler itibariyle çalışma kapsamını oluşturan sebze ve meyve grubunda dış ticaret dengeleri verilmiştir. Grafiklerden de izleneceği gibi Türkiye ve Moldova (STIC 054 dişında) hariç diğer ülkeler ağırlıklı olarak net ithalatçı konumundadır.

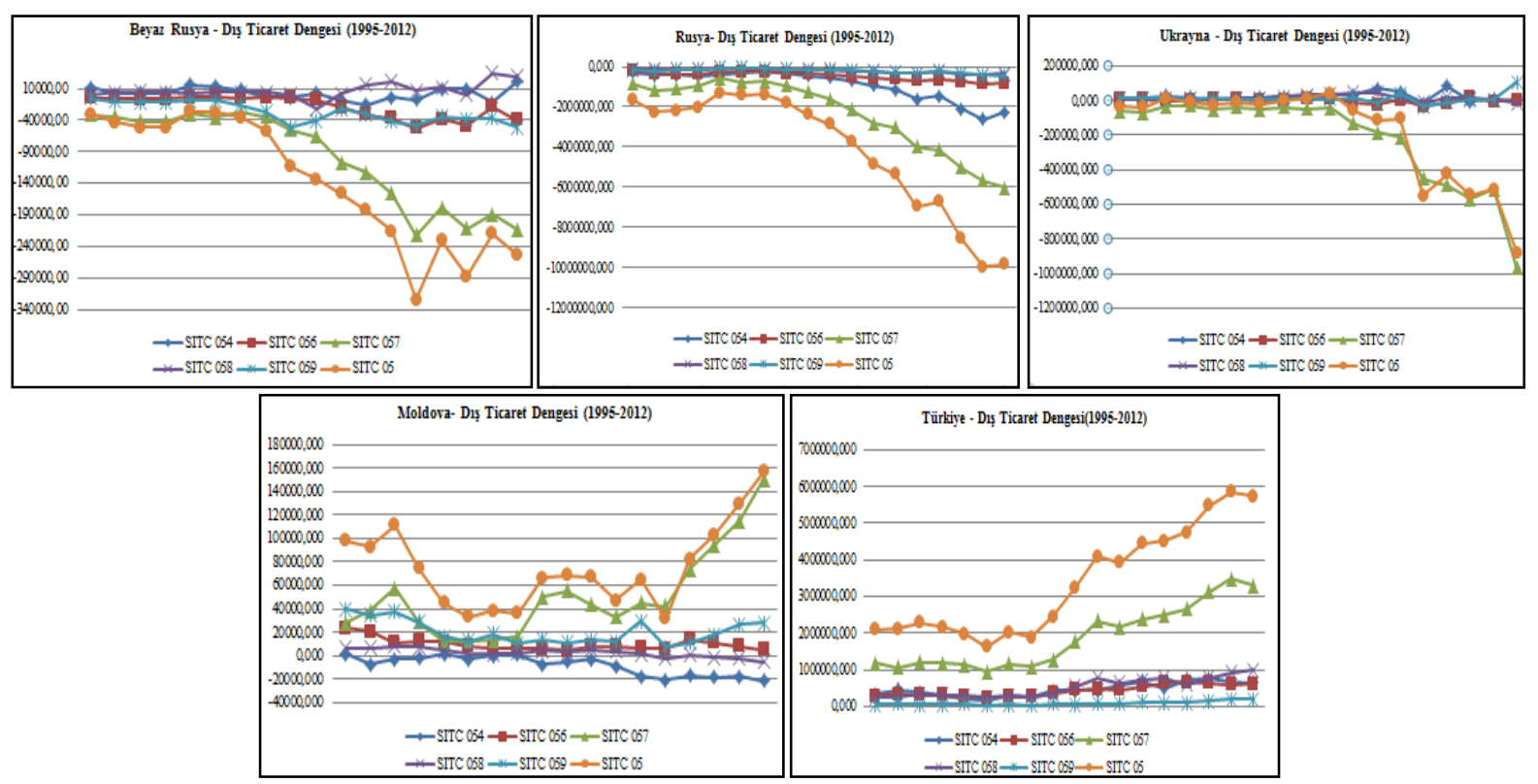

Grafik 4: Seçilmiş Ülkelerde Sebze Meyve Grubunda Dış Ticaret Dengeleri (Dolar, 1995-2012) Kaynak: FAOSTAT veritabanı verilerinden yararlanılarak tarafımızdan oluşturulmuş̧tur.
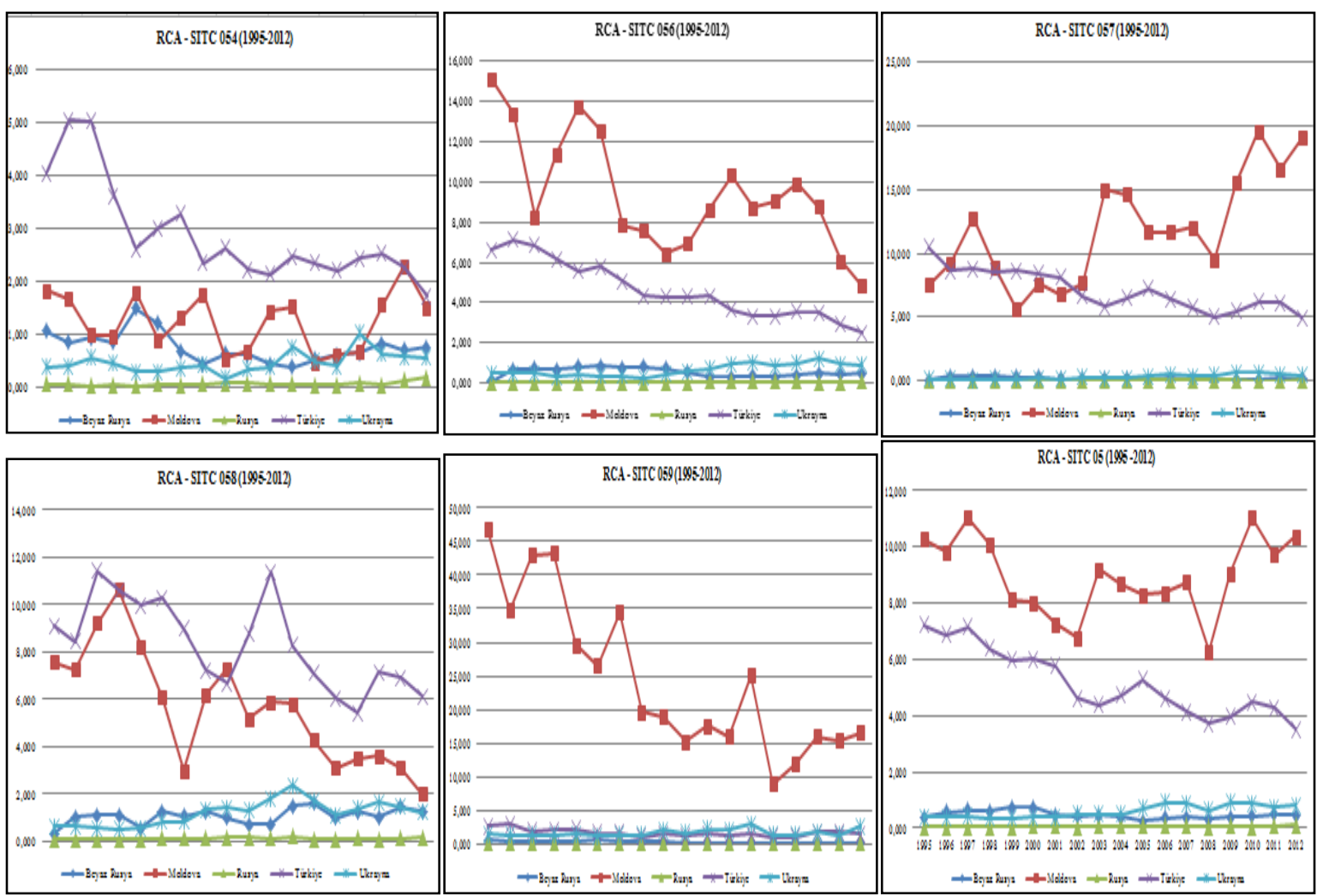

Grafik 5: Seçilmiş Ülkelerde 1995-2012 dönemine ait RCA endeks değerleri Kaynak: UNCTAD veritabanı verilerinden yararlanılarak tarafimızdan oluşturulmuştur.

\section{Seçilmiş Ülkelerde Uluslararası Rekabet Gücü}

\subsection{Yöntem ve Veriler}

Çalışmada yöntem olarak, Bölüm 2.2.'de teorik altyapısına yer verilen RCA, RXA, RMP, RTA ve RC endekslerinden yararlanılmıştır. Çalışmanın veri setinde, UNCTAD veri tabanından 1995-2012 dönemine ait SITC Rev.3 kodlarına göre 05 (Meyve ve Sebzeler) ana ürün grubu ve bu ürün grubuna ait 054(Sebzeler, kuru 
baklagiller vb.), 056(Kurutulmuş sebzeler, sebze unları ve müstahzarları), 057( Taze/kuru meyve ve kabuklu yemişler), 058(Sebze ve meyveden hazırlanmış konserveler), 059(Meyve suları, sebze suları) ürün gruplarına dair ihracat ve ithalat verileri kullanılmıştır.

\subsection{Bulgular}

RCA ve RXA değerlerine göre 059 ürün grubu dışında Türkiye ve Moldova diğer ülkelere oranla daha yüksek rekabet gücüne sahiptir. Türkiye 059 ürün grubunda Moldova'nın oldukça gerisinde kalmıştır. Öte yandan, 05 ana ürün grubuna bakacak olursak, Türkiye'nin dönem başındaki RCA endeks değeri 7,22 düzeyinden 2012 y1lında 3,5 düzeyine gerilemiştir. Türkiye'nin 05 ana ürün grubunda dönem başındaki RXA endeks değeri, 7,92 düzeyinden dönem sonunda 3,61 düzeyine gerilemiştir. Beyaz Rusya, Rusya ve Ukrayna'nın gerek RCA gerekse RXA değerleri dönem boyunca 1'in altında seyretmekte ve bu durumda söz konusu ülkelerin rekabet gücüne sahip olmadığına işaret etmektedir. Grafik 5 ve Grafik 6 incelendiğinde, RCA ve RXA endekslerinin 1995-2012 döneminde birbirine paralel trendlere sahip olduğu görülmektedir.

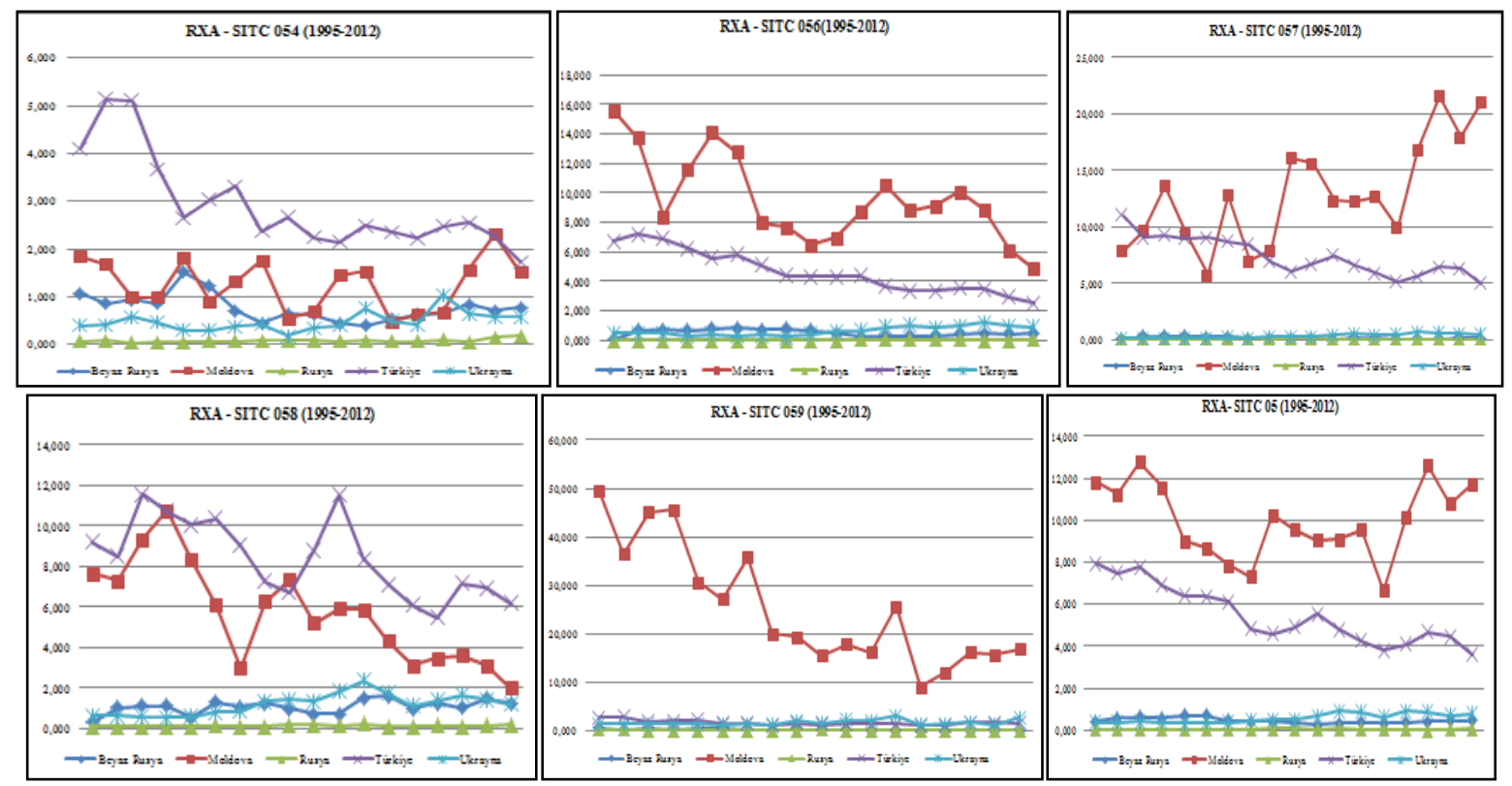

Grafik 6: Seçilmiş Ülkelerde 1995-2012 dönemine ait RXA endeks değerleri Kaynak: UNCTAD veritabanı verilerinden yararlanılarak tarafimızdan oluşturulmuştur.

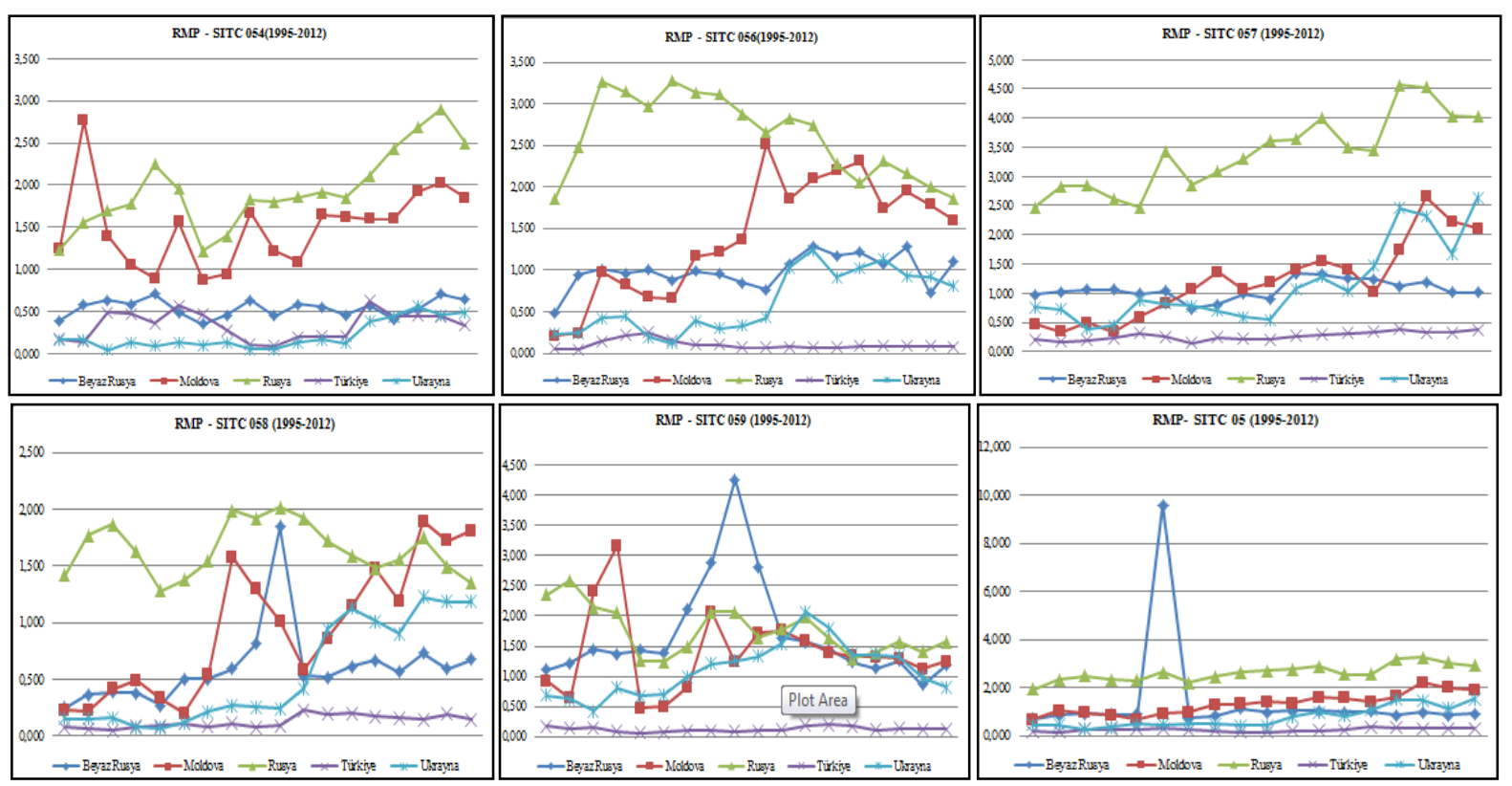

Grafik 7: Seçilmiş Ülkelerde 1995-2012 dönemine ait RMP endeks değerleri Kaynak: UNCTAD veritabanı verilerinden yararlanılarak tarafimızdan oluşturulmuştur. 
Grafik 7 incelendiğinde dönem boyunca Türkiye, gerek alt ürün gruplarında gerekse 05 ana ürün grubunda Türkiye'nin sahip olduğu RMP endeks değerleri 1'in altındadır ve bu durum Türkiye açısından rekabet avantajının olduğunu işaret etmektedir. Moldova'nın, 05 ana ürün grubunda dönem başında sahip olduğu RMP endeks değeri, 7,92 düzeyinden dönem sonunda 3,61 düzeyine gerilemiştir 0,7 düzeyindeyken 1996-2001 döneminde dalgalı bir trend seyretmiş, 2001 sonrasında ise RMP endeksi sürekli olarak 1'in üzerinde değer almıştır. Rusya, 05 ana ürün grubunda1995-2012 döneminde ortalama 2,5 düzeyinde RMP endeks değerine sahiptir.
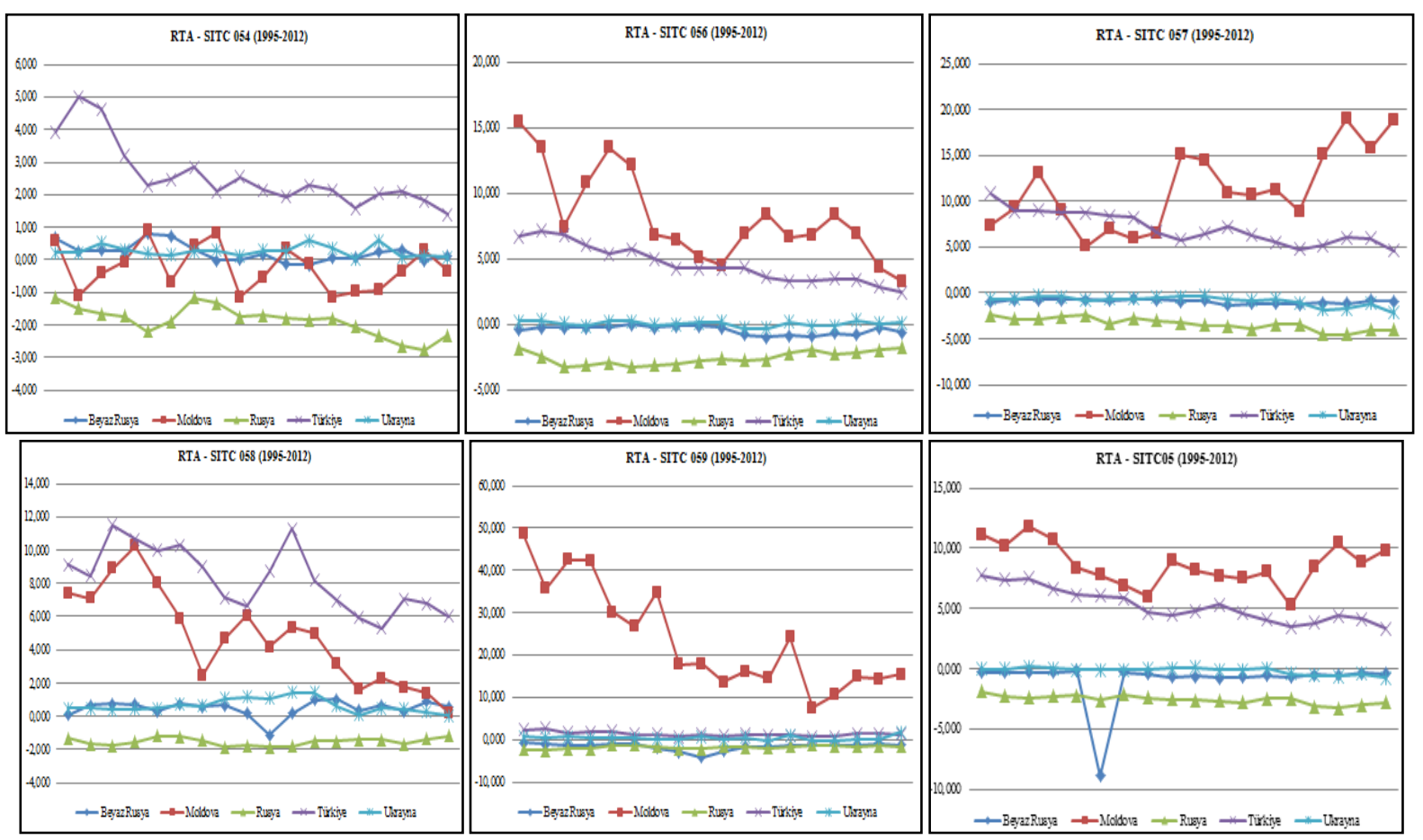

Grafik 8: Seçilmiş Ülkelerde 1995-2012 dönemine ait RTA endeks değerleri Kaynak: UNCTAD veritabanı verilerinden yararlanılarak tarafimızdan oluşturulmuştur.

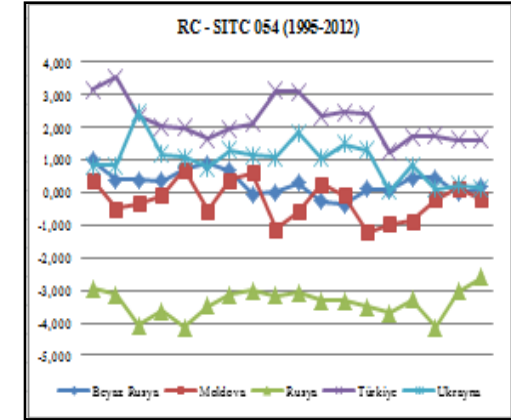

RC-SITC 058 (1968-2012)

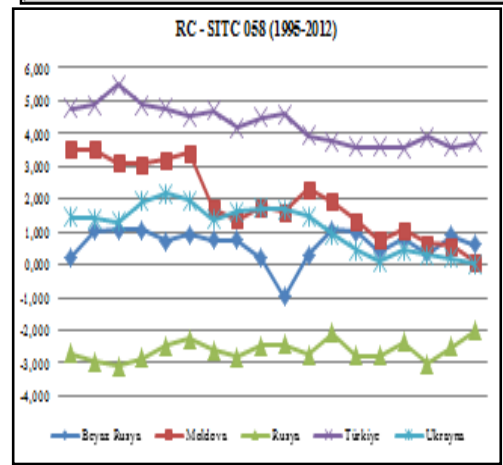

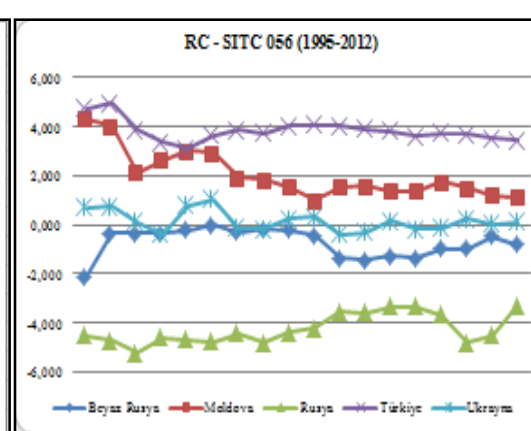

RC-SITC 059 (1988-2012)

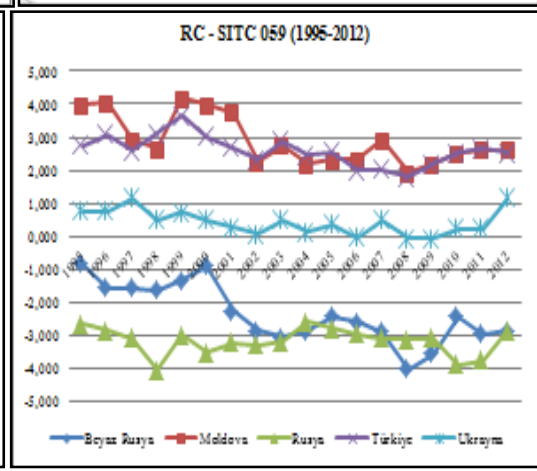

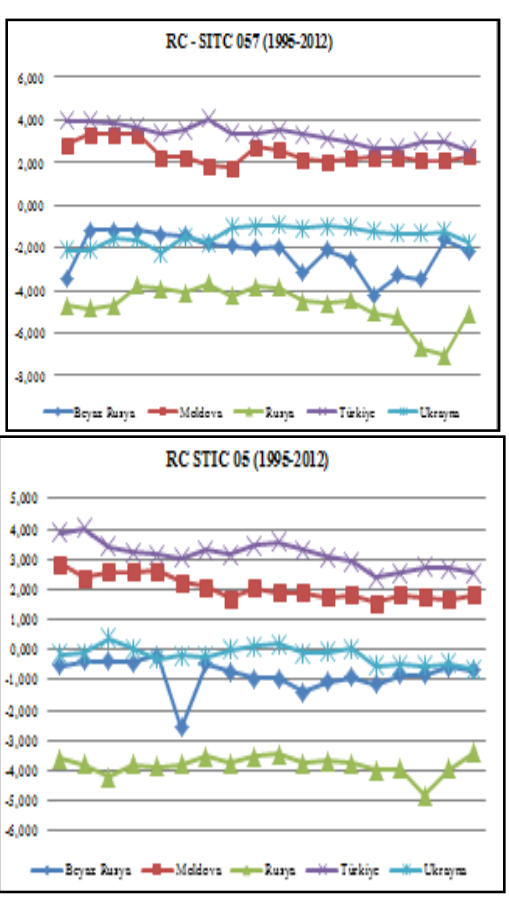

Grafik 9: Seçilmiş Ülkelerde 1995-2012 dönemine ait RC endeks değerleri Kaynak: UNCTAD veritabanı verilerinden yararlanılarak tarafimızdan oluşturulmuştur.

Grafik 8 incelendiğinde Türkiye 059 ürün grubu dışında gerek diğer ürün gruplarında gerekse 05 ana ürün grubunda yüksek RTA değerlerine sahiptir. Moldova 059 ürün grubunda dönem boyunca yüksek RTA değerlerine 
sahiptir. 05 ana ürün grubunda Beyaz Rusya ve Rusya dönem boyunca negatif RTA değerlerinde sahiptir ve bu durum söz konusu ülkelerin rekabet gücüne sahip olmadığını işaret etmektedir. Moldova 059 ürün grubundaki yüksek endeks değerlerinin etkisiyle 05 ana ürün grubunda dönem ortalaması açısından daha yüksek endeks değerlerine sahiptir. Öte yandan 05 ana ürün grubunda Türkiye dönem başında sahip olduğu 7,76 düzeyinden dönem sonunda 3,33 düzeyine gerilemiştir.

Grafik 9 incelendiğinde ise Türkiye dönem boyunca gerek ürün gruplarında gerekse 05 ana ürün grubunda 1 'in üzerinde RC değerlerine sahiptir ve bu durum Türkiye'nin rekabet gücüne sahip olduğuna işaret etmektedir. Moldova 056, 057 ve 059 ürün gruplarında ve 05 aa ürün grubunda 1'in üzerinde RC değerine sahiptir ve bu durum Moldova'nın rekabet gücüne sahip olduğuna işaret etmektedir. Moldova'nın 054 ve 058 ürün gruplarında ise sahip olduğu RC değerleri dalgalı bir seyir izlemektedir. 05 ana ürün grubunda dönem boyunca Rusya ve Beyaz Rusya negatif RC değerlerine sahiptir ve bu durum söz konusu iki ülkenin rekabet gücüne sahip olmadığına işaret etmektedir.

\section{Sonuç}

SSCB'nin dağılması sonucu bağımsızlığına kavuşan ülkeler, bağımsız devlet olma özelliklerini kazanma, merkezi planlı ekonomiden piyasa ekonomisine dönüşüm sürecinin getirdiği sorunlar, tarım alanında büyük ölçekli ve devlete ait arazilerde kolektif üretim ve gerçekleştirilen reformlarda yapılan hatalar sonucunda büyük üretim düşüşleri yaşanmıştır. 1990'lı yılların ilk yarısı iktisadi reformların gerçekleştirilmesinden çok iktisadi krizle mücadele yılları olmuş, bu dönemde tarımsal üretimde keskin bir gerileme yaşanmıştır. 1997 yılı sonrasında yapılan reformlar sonucunda tarımsal üretimin yeniden artması sağlanmış, Bağımsız Devletler Topluluğu ve diğer komşu ülkeler arasındaki gıda piyasasının genişlemesi, üye ülkelerin üretim ve ihracat konusunda ivme kazanmasını sağlayacak ölçüde geniş topraklara sahip olunması, bu ülkelerin kalkınma süreçlerinde tarımın başat rol oynaması sonucunu doğurmuştur. Buradan hareketle, 1990'lı yılların ikinci yarısından 2012 yılına kadar olan süreci kapsayan çalışmamızda, Bağımsız Devletler Topluluğu'ndan seçilen Beyaz Rusya, Moldova, Rusya ve Ukrayna' nın yanı sıra Türkiye eklenerek söz konusu ülkelerin Meyve ve Sebzeler ana ürün grubunda dünya piyasasındaki rekabet düzeyi çeşitli endeksler yardımıyla ölçülmüştür. Elde edilen bulgulara göre, Moldova ve Türkiye diğer ülkelere oranla söz konusu ana ürün grubunda daha yüksek rekabet avantajına sahiptir. RCA ve RXA değerleri incelendiğinde, Türkiye dönem başında daha yüksek rekabet avantajına sahipken, dönem sonunda sahip olduğu rekabet avantajının azaldığ görülmektedir. RMP endeks değerlerine göre, Türkiye daha düşük düzeyde ithalata maruz kalırken, rakibi olarak ifade edebileceğimiz Moldova'nın yüksek RMP değerleri söz konusu ülkenin daha yüksek düzeyde ithalata maruz kaldığına işaret etmektedir.Tüm endeks değerleri birlikte değerlendirildiğinde Ukrayna, Beyaz Rusya ve Rusya'nın rekabet açısından dezavantajılı durumda olduğu görülmektedir.

\section{Kaynakça}

- Ahrend, Rudiger, 2006. "Russian Industrial Restructuring: Trends in Productivity, Competitiveness and Comparative Advantage", Post-Communist Economies, Vol.18, No.3, pp.277-295.

- Aiginger, K., 1998. "A framework for evaluating the dynamic competitiveness of countries", Structural Change and Economic Dynamics, Vol. 9, No. 2, ss.159-188.

- Akgüngör, Sedef, Barbaros R. Funda, and Kumral, Neşe, 2002. "Competitiveness of the Turkish Fruit and Vegetable Processing Industry in the European Union Market", Russian and East European Finance and Trade, vol.38, no.3, May-June 2002, pp.34-53.

- Aktan, Coşkun Can ve Vural, İstiklal Yaşar 2004. Rekabet Gücü ve Rekabet Stratejileri, Rekabet Dizisi:2, Türkiye İşveren Sendikaları Konfederasyonu Yayınları, Ankara.

- Balassa, Bela, 1989. Comparative Advantage, Trade Policy and Economic Development, Harvester Wheatsheaf, New York.

- Cooper, Julian, 2006. “Can Russia Compete in the Global Economy?", Eurasian Geography and Economics, 47, No. 4, pp.407-425.

- Fagerberg, Jan (1988), "International Competitiveness", The Economic Journal, Vol. 98, No. 391 (Jun., 1988), ss. 355-374

- FAOSTAT, 2013, http://faostat.fao.org/site/342/default.aspx

- Fidan, Halil, 2009. "Comparison of Citrus Sector Competitiveness between Turkey and EU-15 Member Countries", HortScience, 44(1): 88-93.

- Freinkman, Lev, Polyakov, Evgeny and Revenco, Carolina, 2004. "Trade Performance and Regional Integration of the CIS Countries", World Bank Working Paper No.38.

- Frohberg, Klaus and Hartmann, Monika,1997. "Comparing Measures of Competitiveness”, Institute of Agricultural Development in Central andEastern Europe DiscussionPaper, No:2. 
- Karaalp, H. Simay, 2011. "Competitiveness of Turkey in Eurasia: A Comparison with CIS countries", China-USA Business Review, Vol.10, No.9, pp.727-744.

- Kibritçioglu,A.,1996, “Uluslararası Rekabet Gücüne Kavramsal Bir Yaklaşım”, Verimlilik Dergisi, Milli Prodüktivite Merkezi Yayınları, Ankara,1996/3

- Landau R., 1992. Technology, Capital, Formation and U. S.Competitiveness, ed. B. G. Hickman. New York: Oxford UniversityPress. içinde R. W. Harrison ve P. L. Kennedy (1997), “A Neo classical Economic and Strategic Management Approach To Evaluating Global Agribusiness Competitiveness"

- $\quad$ Lerman, Z., C. Csaki and G. Gershon Feder (2004). "Evolving Farm Structures and Land Use Patterns in Former Socialist Countries”, Quarterly Journal of International Agriculture 43, No.4: 309-335.

- Lerman, Zvi, 2008. "Agricultural Recovery in the former Soviet Union: an Overview of 15 years of land reform and farm restructruing", Post-Communist Economies, 20:4, 391-412

- Markusen, J. R., 1992, "Productivity, Competitiveness, Trade performance and real Income: The Nexus Among Four Concepts", Minister of Supplyand Services, Canada

- Öză̆, Filiz, Öztürk, Fahriye ve Kaya, Semiha (2003). İktisat Seçme Yazılar içinde ed. Şiir Yılmaz, Hakan Çermikli, Ankara "Türkiye Tarım Sektörünün Avrupa Birliği (AB) Tarım Ürünleri Karşısındaki Uluslararası Rekabet Gücü (URG)” ss.383-408.

- $\quad$ Porter, E. Michael, The Competitive Advantage of Nations, Macmillan Press, London,1990.

- Serin, Vildan and Civan, Abdülkadir, 2008. "Revealed Comparative Advantage and Competitiveness: A Case Study for Turkey towards the EU", Journal of Economic and Social Research, 10(2) 2008, 25-41.

- Shelburne, Robert C. and Pidufala, Oksana, 2006. "Evolving Trade Patterns in the CIS: The Role of Manufacturing”, United Nations Economic Commission for Europe Discussion Paper Series, No. 2006.2.

- UNCTAD, 2013, Trade Structure by parter, product or service-category, http://unctadstat.unctad.org/ReportFolders/reportFolders.aspx

- Utkulu, Utku ve Seymen, Dilek, 2004. “Trade, Competitiveness and Revealed Comparative Advantage: Evidence for Turkey towards the EU", ETSG (European Trade Study Group) Sixth Annual Conference, Nottingham, 9-11 September 2004.

- Vollrath, Thomas L., 1991. “A Theoretical Evaluation of Alternative Trade Intensity Measures of Revealed Comparative Advantage”, Weltwirtschafliches Archiv, 127, 265-279. 


\title{
Tüketim Toplumunun Çevresel Etkileri Environmental Effects of the Consumerist Society
}

\author{
Naile Karakehya (Osmangazi University, Turkey)
}

\begin{abstract}
Consumerist society is a concept which was exist in modern history and raised up with postmodern period. Therefore, it belongs to the period of time corresponding to after modernity of mankind. Some features of the consumerist society like consumption of images and consumption for pleasure, causes serious environmental problems. Because of frantic production and energy consumption in order to meet the demands about consuming and discharging of goods without obsolescence, our planet is becoming less and less livable. Create awareness of this is to be done first to put a stop to dangerous downturn. In order to emerge a social reaction and to provide conscious consumption, it is necessary to create awareness about the damage to the environment of people first. Otherwise it seems to, it will not be a livable world for our future and our children. Here the key issue at this point to keep in mind is, there is no other planet that we can live yet.
\end{abstract}

\section{Giriş}

İçinde bulunduğumuz zaman diliminin modern sürecin devamı mı, yoksa yeni bir süreç mi olduğuna dair tartışmalar hala devam etmekle birlikte, hemen herkesin üzerinde hemfikir olduğu bir husus var ki; o da modern başlangıcın en merkezi zaman dilimi olan 18. yüzyıldan çok farklı bir dünyada yaşamakta olduğumuzdur. Bu farklılık, yaşam tarzımız, imkanlarımız, ihtiyaçlarımız, tatmin noktalarımız ve birbirimizle olan ilişkilerimizin yanında, küreselleşen dünyamızdaki üretim ve tüketim ilişkilerinde de açıkça görülmektedir.

$\mathrm{Bu}$ yeni dönemde kişilerin tüketim davranışları, insanlık tarihinin önceki dönemlerine nazaran fazlasıyla farklılaşmıştır. Hatta bazı toplumlarda sosyal tabakalaşma bile bireylerin tüketim alışkanlıklarıyla şekillenir olmuştur. Dolayısıyla tüketim, içinde yaşadığımız zaman diliminde, toplumsal yaşamın en önemli kavramlarından birisi olmuştur (Baudrillard, 2000).

Bununla birlikte ortaya çıkan yeni tüketim anlayışının bir takım çevresel etkileri de bulunmaktadır. Zevk merkezli olarak tüketen bireyler, eskiden yaşayan insanların tükettiğinden çok daha fazlasını tüketmekte, tüketilen nesneler de çoğu kez atık olarak gezegene bırakılmaktadırlar. Söz konusu tüketim artışının oluşturduğu yoğun mal talebi ise daha fazla üretimi ortaya çıkarmaktadır. Üretim arttıkça, tüketimi sağlamak için kullanılan reklamlar ve diğer pazarlama teknikleri ile tüketim daha büyük boyutlara taşınmaktadır. Dolayısıyla birbirini tetikleyen bir üretim ve tüketim kısırdöngüsü ortaya çıkmaktadır. Ekonomi çevrelerince "ekonomik büyüme" olarak ifade edilen bu çılgın hacim artışının, zannedilenden çok daha fazla çevresel zararları olduğunu ve içinde yaşadığımız gezegenin geleceğine ilişkin karamsar bir tablo oluşturduğunu söylemek yanlış olmayacaktır.

Biz bu çalışmamızda tüketim toplumunun çevresel etkilerini inceleyeceğiz. Bu bağlamda çalışmada öncelikle, tüketimin büyük boyutlara ulaşmasında ve toplumsal refahın artmasında temel kırılma noktasını oluşturan modern sürece ilişkin genel açıklamalar yapılacaktır. Sonrasında ise içinde bulunduğumuz dönemin modern sürecin bir devamı mı; yoksa yeni bir süreç mi olduğu, özellikle tüketim ilişkileri bağlamında irdelenecektir. Daha sonra tüketim toplumu kavramı ele alınacak ve zamane insanının hangi amaçla ve nasıl tükettiği incelenecektir. Son olarak ise bu tüketim alışkanlıklarının çevresel etkileri örneklerle ortaya konularak, gezegenimizin geleceğine ilişkin tehlikeler ifade edilecektir.

Yaşamakta olduğumuz süreci, ekonominin en önemli ayaklarından birisini oluşturan tüketim ve olası çevresel sonuçları bağlamında irdelemenin, özellikle sosyal farkındalık oluşturmak bakımından faydalı olacağını umut etmekteyiz.

\section{Tüketim Toplumunun Ortaya Çıkışındaki Temel Öğe Olarak Modern Dönemin Başlaması}

Modernizm ya da modern süreç, 17. yüzyılda Avrupa'da başlayan ve sonrasında neredeyse tüm dünyayı etkisi altına alan, toplumsal yaşam ve örgütlenme biçimini ifade etmektedir (Giddens, 2011). Modernizmin üç temel ayağı bulunmaktadır. Bir başka deyişle yaşanan toplumsal değişim üç temel alanda kendisini göstermiştir. Birincisi ekonomik alanda sanayileşme yaşanmış, üretim tarzı ve ilişkileri geleneksel yöntemlerden farklılaşmış ve sanayi tarzı üretime geçilmiştir. İkinci olarak sanatta, mimaride ve kültürde bir yenileşme ve farklılaşma başlamıştır. Daha önce yapılmamış tarzda yüksek, büyük ve farklı görünümlü binalar şehirleri kaplamış, daha önce hiç ortaya konulmamış tarzda sanat eserleri ortaya konulmuş, yeni sanat akımları ortaya çıkmış ve toplumsal yaşam kültürü önemli bir değişim göstermiştir. Üçüncü temel değişim ise düşünsel alanda olmuştur. Bu dönemle birlikte akılcılık ön plana çıkmış, bilginin tek kaynağı olarak bilim kabul edilmiş ve aydınlanma gerçekleşmiştir. 
Modern sürecin başlıca özelliklerinden birisi, bilimsel verilerle ortaya konmuş büyük toplumsal projelerin üretilmesidir. Dolayısıyla modern bir sosyal projede, bilimsellik vurgusu ve geniş kitleler için güzel bir gelecek vaadi, ilk göze çarpan öğelerdir. Nitekim modern düşünceye göre, bilim sayesinde insanlık için en iyi olan tespit edilecek, en iyi olana ulaşmak için bilimsel yöntemler geliştirilecek, amaçların gerçekleştirilmesiyle de küresel çapta mutluluk ve refah sağlanacaktır. Dolayısıyla modern düşüncede, akılcı olan ve deneysel bilgiye dayanın faydalı olduğu düşüncesi hakimdir (Horkeimer, 2005).

Ancak modern süreçte aydınlanmanın ve aklın önderliğinin hiç de beklendiği kadar küresel çapta bir refah ve mutluluk getirmediği; birçok büyük sorunu da beraberinde taşıdığı özellikle ikinci dünya savaşından sonra bariz bir şekilde ortaya çıktı. Diğerleri bir tarafa bırakılırsa, modern sürecin beraberinde getirdiği en önemli sorunlardan birisi çevre kirliliği olmuştur. Gerçekten de modern süreç içerisinde, gerek yapılan savaşlar ve kullanılan kimyasal silahlar gerekse de aşırı tüketim ve buna bağlı üretim nedeniyle dünya giderek daha çok kirlenmiş; ekilebilir arazilerin, temiz ırmakların, girilebilir denizlerin sayısı giderek azalmaya başlamıştır. Gerçekten de, aklın ve bilimin kullanılmasıyla geliştirilen ağır silahların kullanıldığı iki dünya savaşı insanlık tarihinde büyük yaralar açtığg gibi, önemli bir çevresel kirlenmeye de neden olmuştur. Bunun yanında teknolojik üretimin çevreye verdiği zararlar, bilimsel gelişmelerin ortaya çıkartabileceği olumsuz sonuçların en açık göstergeleri olmuştur.

Tüketimin toplumsal bir vakıa haline gelişinin temelleri de modern sürecin başlamasıyla atılmıştır. Nitekim sanayi üretimi sayesinde daha çok mal insanların hizmetine sunulmuş ve zaman içerisinde daha çok üretime bağlı olarak bu malların elde edilebilirliği kolaylaşmıştır. Böylelikle daha çok insan daha çok sayıda mala ulaşabilir ve tüketebilir hale gelmiştir. Ancak tüketimin bir kültür haline gelmesi ikinci dünya savaşından sonraki zamanlara tekabül etmektedir.

Bu başlık altında modern sürecin başlamasına, temel unsurlarına ve felsefesine ilişkin bilgiler verilmiştir. Ancak ikinci dünya savaşından sonraki süreçte söz konusu unsurlara ilişkin önemli değişimler olmuştur. Hatta sosyal hayatta yaşanan bu önemli değişim nedeniyle, modern sürecin de ötesine geçen yeni bir döneme girildiğini ileri süren yazarlar da olmuştur (Bkz. Lyotard, 2000). Aşağıda tüketimin bir kültür haline geldiği ikinci dünya savaşı sonrasındaki bu döneme ilişkin tespitler yapılacaktır.

\section{Postmodern Dönem ve Tüketim Toplumunun Yükselişi}

\subsection{Genel Olarak Postmodern Dönem}

Yukarıda da ifade ettiğimiz üzere gerek teknolojik gelişmelerin olumsuz çevresel etkileri gerekse de atom bombası gibi bilimsel icatların insanlığın kötülüğüne kullanımı gibi gelişmeler, modern düşüncede ciddi sarsıntıya neden olmuştur. Bunların yanında, özellikle ikinci dünya savaşından sonra ortaya çıkan başkaca önemli toplumsal değişimleri de gözlemleyen bazı yazarlar, modern dönemin sona erdiği yönünde görüşler ileri sürmeye başlamışlardır. Artık modernliğin de ötesine geçen yeni bir döneme girildiğini savunan bu yazarlardan önemli bir kısmı, bu yeni dönemi postmodern (modern sonrası) dönem olarak adlandırmaktadırlar. Bu teriminin ortaya çıkışında ve yaygınlaşmasında özellikle Lyotard'ın büyük etkisi vardır (Bkz. Lyotard, 2000). Biz de bu genel kullanıma uygun olarak söz konusu süreçten postmodern dönem olarak bahsetmeyi uygun buluyoruz.

Yeni bir döneme girildiğini savunan postmodernistler, bu görüşlerine dayanak olarak, modern dönemin başlarına nazaran içinde bulunduğumuz dönemde ortaya çıkan onlarca değişimi göstermektedirler. Örneğin; bu yeni dönemde, sosyal tabakalaşmanın oluşumunu, modern dönemde olduğu gibi üretim ilişkileri değil; tüketim ilişkileri belirlemektedir. Ayrıca yeni toplumsal düzene simge ve imajlar hakimdir. İnsanlar saçlarının kesimiyle, internetteki profilleriyle, giyimleriyle bir imaj ortaya koymakta ve bu imajlarıyla değerlendirilmektedirler. Yine tüketimde modern dönemin aksine, mal eskitilerek tüketilmemekte, bilakis imajı tükendiği, modası geçtiği için tüketilmiş olmaktadır. Hizmet sektörü ekonomi içerisinde giderek daha büyük bir yer kaplamaya başlamıştır. Ayrıca sanayi üretimi de fordist tarzdan postfordist tarza (esnek üretim tarzına) evrilmiştir. Modern dönemin başlarında olmayan finans ekonomisi giderek ülke ekonomilerinde daha çok rol oynamaktadır. İletişim araçlarının gelişmesi ve küreselleşme ile dünya büyük bir köye dönüşmüş, coğrafi sınırlılıklar önemli ölçüde ortadan kalkmıştır. Ayrıca bilime olan güven sarsılmaya başlanmış; bilim dışı bilgi kaynakları yeniden önem kazanmıştır. Bu gibi nedenlerle söz konusu yazarlar yeni bir toplumsal düzenin ortaya çıtığını ileri sürmektedirler (Şaylan, 2002). Buna karşın modern sürecin hala devam ettiğini, aslında bu sürecin iyi bir süreç olduğunu, ancak bilimin kötüye kullanılması gibi bazı yanlışlıklarının düzeltilmesi gerektiğini savunan yazarlar da bulunmaktadır. Onlara göre modern süreci eleştirmek için illa da postmodern olmaya gerek yoktur. Modern süreç, kendi içerisindeki aksaklıkları giderme gayreti içerisinde yoluna devam etmektedir.

\subsection{Tüketim Toplumunun Yükselişi}

Postmodernistlere göre artık dünyaya kapitalist düzen tam olarak hakim olmuş durumdadır ve bu nedenle gelecek adına umut edecek herhangi bir şey de kalmamıştır. Nitekim kapitalist sistem, özellikle kitle iletişim araçlarıyla örtülü ve sürekli olarak kitlelere kendisinin ideolojik meşruiyetini pompalamakta, bu şekilde de kitlelerin eşitsizliklere dayalı mevcut düzeninin devamına ilişkin rızalarını kazanmakta ve hücrelerimize kadar işlemektedir. Dolayısıyla kapitalist düzen sürekli olarak gündelik yaşamda yeniden üretilmekte ve kitleler için 
kendisini vazgeçilmez kılmaktadır. Ekonomik ilişkiler bağlamında ezilen bir insan bile, her gün iç içe olduğu bu kültürel yeniden üretim nedeniyle, mevcut düzenin en büyük savunucusu konumuna gelebilmektedir (Adorno, 2009).

Üretim artışı ve çeşitliliğine bağlı olarak tüketimin bir haz aracı olması, malın kendisinden çok imajının tüketilir hale gelmesi, esasen ikinci dünya savaşından sonra görülen bir vakıadır. Zaman içerisinde tüketime ilişkin bu toplumsal değişim giderek yaygınlaşmış ve içinde bulunduğumuz zaman dilimine damgasına vurmuş̧ur. Günümüzde, özellikle temel sosyal problemlerini halletmiş batı toplumlarında sosyal statüler ve grupların belirlenmesinde üretimden çok tüketim ilişkilerinin rol oynamaktadır. Bu nedenlerle bazı yazarların içinde bulunduğumuz toplumu, tüketim toplumu olarak isimlendirdikleri görülmektedir (bkz. Baudrillard, 2000).

"Toplumuтиz bir tüketim toplumudur. Ama bütün insanlar dahası bütün canlllar ezelden beri tüketmektedirler. $O$ halde, bir tüketim toplumundan söz ettiğimizde aklimızda o toplumun bütün üyelerinin bir şeyler tükettikleri gibi sıradan bir tespitten öte şeyler vardır ki o da şudur: Nasıl atalarımızın toplumu, kuruluş aşamasındaki modern toplum, endüstriyel çağın toplumu, bir üreticiler toplumu idiyse, aynı derin ve temel anlamda bizim topluтитиzda bir tüketim toplumudur (Bauman, 2006)."

Günümüzde yaygın olan inanış çalışmanın zahmetli, tüketmenin ise zevkli olduğudur. Tüketmek iyidir ve daha fazlası her zaman daha iyidir. Bu inanış önemli ve henüz oldukça yeni bir geçmişe sahiptir. Geçmişte büyük bir insan topluluğu için en çok kaygı uyandıran problem yetersiz üretimdi. Bu kaygı 19. yüzyıldaki hızlı endüstrileşme ile büyük oranda giderildi. Ancak zamanla problemin türü değiş̧ti. ABD'de talebin, ülkenin üretim kapasitesi karşısında yetersiz kalacağı şeklinde yaygın bir korku oluşmaya başladı. Nihayet problem aşırı üretim ve bunun sonucu yetersiz tüketim haline dönüştü. Ekonomistler, iş adamları, dini liderler ve politikacılar tüketimi teşvik etmek için el birliğiyle çalıştı. Faydalılık ve doyumsuzluk gibi bazı yeni kavramların geliştirilmesiyle ve insan davranışının bazı yönlerinin (kabul görme isteği ve sahip olma ile gelen statü gibi) öne çıkartarak tüketimi teşvik ettiler. Hatta tüketime vatanseverlik gibi bir anlam yüklediler. Bu süreçteki en önemli vurgu ise "daha fazlanın her zaman daha iyi olduğu" şeklindeydi (Princen).

Zamanla bu tüketim azmettiriciliği o kadar başarılı oldu ki, artık bireylerin toplum içerisindeki yerinin oluşmasında, hangi marka ayakkabı giydiği, hangi parfümü kullandığı, hangi saati taktığı önemli bir etken haline gelmiştir. Tüm bu tükettiği malların toplam imajı, aynı zamanda bireyin toplum karşısındaki imajını, dolayısıyla grubunu ve sinıfinı belirlemektedir.

$\mathrm{Bu}$ yeni süreçte, bireysel tüketim alışanlıkları da çok ilginç bir şekilde değişmektedir. Artık bireyler ihtiyaçlarını ellerinde olan malın imajına göre belirlemektedirler (Featherstone, 2005). Örneğin bireyin iki çift yeni aldığı ayakkabısı varsa ve bu ayakkabıların imajı tükenmiş ya da bir diğer ifade ile modası geçmişse; bu iki çift yeni ayakkabısı olan bireyde yeni bir ayakkabı (imaj) alma ihtiyacı ortaya çıkmaktadır. Dolayısıyla birey, malın kendisinden çok onun imajını satın almaktadır. Bu bağlamda günümüz toplumlarının önemli bir kısmında tüketim ilişkilerinin tüketeni bireyler iken tüketileninin ise imajlardır.

Bireylerin karşılıklı ilişkilerinde de bu duruma şahit olmak mümkündür. Birey bir başkasıyla aldığı ürün üzerine konuşurken çoğu kez aldığı malın çeşidinden önce markasını (imajını) ifade etmektedir. Artık karşılıklı konuşmalarda "yeni bir ayakkabı aldım." cümlesinden çok "yeni bir adidas aldım." cümlesini duymak daha yüksek bir ihtimaldir.

Bununla birlikte sanayileşmiş ülkelerde inanılmaz bir kullan-at kültürü gelişmiştir. Bireylerle nesneler arasındaki ilişki ve bireylerin nesnelere yükledikleri anlam da bu kültürle birlikte yeniden inşa edilmiştir. Yeni geliştirilmiş modellere sahip olmak uğruna eski Barbie bebeğini parçalayan ve severek elden çıkartan yeni kuşak kız çocuklarıyla, bir çocukluk boyu aynı bez bebeği kullanan ve büyüyünce de saklamaya devam eden büyükanneleri arasındaki farkta bu değişim açıkça görülmektedir (Toffler, 1981). Bolluk içindeki insanlar artık tüm geçmiş zamanlarda olduğu gibi başka insanlar tarafından değil; nesneler tarafından kuşatılmış durumdadır (Baudrillard, 2000).

Ayrıca günümüz insanı gerçek anlamda kullanmak için değil; bilakis haz almak için tüketmektedir. Yukarıdaki örnekte de belirttiğimiz üzere düzinelerce ayakkabısı olan bir kimse, bunlarla haz alma duygusunu tatmin edemeyince yeni bir ayakkabı alma ihtiyacı hissedebilmektedir. Dolayısıyla tüketim toplumunun bireylerinde tüketimi tetikleyen temel güdü; haz ihtiyacının tatminidir. Alış-veriş yapmak artık insanlar için bir hobi, birlikte zaman geçirilecek bir aktivite haline gelmiştir. Günümüz toplumunda üzülünce, keyiflenince ve hatta canı sıkılınca alış-veriş yapan bireyler çok normal karşılanmaktadırlar.

$\mathrm{Bu}$ noktadan hareketle bazı postmodernist yazarlar artık günümüzde üretim ilişkilerinin yerini tüketim ilişkilerin aldığını ileri sürerler. Kanaatimizce bu iddialar dünya popülasyonunun azınlıkta kalan bir kısmını oluşturan varsıl toplumlar için bir ölçüde doğrudur. Bu toplumların sosyal alışkanlıklarını anlamamız bakımından söz konusu tespitler son derece de önemlidir. Ancak dünyanın çoğunluğunu oluşturan toplumlar ve varsıl toplumların alt kesimindeki insanlar için hala imaj pek bir şey ifade etmemektedir. Çünkü insanlar daha temel ihtiyaçlarını bile karşılayamamışken, içlerinde imaj kaygısını da barındırmamaktadırlar. Dünyanın azınlı̆̆na bakarak, bu şekilde küresel bir portre çizmek sakıncalıdır ve asıl önemli hususları gözden 
kaçırmamıza neden olabilir. Bu bağlamda üretim ilişkileri ve sınıf çatışmaları hala dünyada sosyal sınıfların oluşmasındaki en önemli kriterdir kanaatini taşımaktayız.

\section{Günümüzde Tüketimin Çevresel Etkileri}

Sanayi üretimi ile birlikte eskisine nazaran daha çok ve tehlikeli boyutlarda kirlenmeye başlayan gezegenimiz, özellikle ikinci dünya savaşından sonra haz için tüketmeye başlayan kitlelerin ortaya çıkmasıyla daha hızlı ve tehlikeli boyutta kirlenmeye başlamıştır. Nitekim tüketilen mal ve eşyalar çevreye atılmakta ve doğanın bunları kendi içerisinde yok etmesi beklenmektedir. Ancak tüketimin boyutları o derece artmış ve mal yapımında kullanılan malzemeler o denli çeşitlenmiştir ki; doğa atıkları hazmedemez duruma gelmiştir. Gerçekten de karlılığın ön planda olduğu kapitalist sistemde, en ucuza daha dayanaklısını imal etmek için doğayla barışık olmayan malzemelerin kullanımında herhangi bir sakınca görülmeyebilmektedir. Buna direnen işletmeler ise çoğu kez küresel rekabetçi ortamda, kepenk indirmek durumunda kalmaktadırlar.

Nüfus artışı ve teknoloji ile birlikte artış gösteren tüketim, çevresel değişikliklerdeki en önemli nedendir. Ancak günümüze dek araştırmacılar ve politikacılar konuya gereken ilgiyi göstermemiştir (Princen, 1999). Bu konunun önemini ortaya koymak bakımından sadece plastik tüketimini ele almak bile yeterlidir. Plastikler, ucuz, hafif, esnek ve kolay şekil verilebilir olduklarından modern hayatta özel bir yere sahiptirler. Söz konusu özellikleri nedeniyle günümüzde çok çeşitli ürünlerde kullanılmak üzere büyük miktarda üretilirler. Ortaya çıkışının üzerinden henüz bir yüzyıl geçmemişken, 1988'de sadece ABD'de sentetik plastik üretimi yıllık 30 milyon tondan daha fazlaydı. Birçok avantajına karşılık plastiklerin atıldıklarında uzun süre doğada varlığını sürdürmesi, onları çevre açısından önemli bir tehdit haline getirmektedir. Sentetik polimerlerin doğada bozunması için çok uzun bir süre gerekmektedir. Mikro organizmalar onları indirgemek için gerekli enzimlere sahip olmadığından bu atık plastikler, genellikle toprağa gömülerek ortadan kaldırılmaya çalışılmıştır. Ancak gömüldükleri yerde yüzyıllarca varlıklarını sürdüreceklerdir (Derraik, 2002).

$\mathrm{Bu}$ tür olumsuz sonuçlara rağmen, seri üretim o hale gelmiş ve maliyetler o denli ucuzlatılmıştır ki; bazı gelişmiş ülkelerde bir kez giyilen t-shirt veya çorabın yıkanması yerine atılması yoluna gidilebilmektedir. Eskimeyen eşyalar modası geçti diye rahatlıkla gözden çıkartılabilmektedir. Ancak bu tür davranışlarla, bazen inanılmaz bencil olabilen türümüzün, aynı zamanda başka canlıların da yaşadığı ve gelecek nesillerimizin de yaşayacağı bu gezegeni her geçen gün daha yaşanılmaz hale getirdiği açıktır. Maalesef sürdürülebilir kalkınma politikalarıyla gelecek nesillere gelişmiş bir toplum yanında, yaşanabilir bir gezegen bırakma planları da çoğu kez sözde kalmaktadır.

Tüketilen malların çevreye atımı sonucunda meydana gelen çevresel zararların yanında bunların üretim süreci de son derece zararlı sonuçlar doğurmaktadır. Şöyle ki; üretim sürecinde kullanılan enerjiye bağlı olarak doğaya salınan zararlı gazlar nedeniyle atmosferimiz giderek daha çok kirlenmekte, canlıları zararlı 1şınlardan koruyan ozon tabakası gibi koruyucu katmanlar giderek zayıflamaktadır. Bunun yanında büyük hacimde sanayi üretimi yapan ülke sayısındaki artışa bağlı olarak enerjiye olan talep artmakta, bu talebi karşılamaya yönelik olarak da nükleer enerji gibi çevresel riskleri yüksek enerji türlerine doğru bir yönelim olmaktadır. Nitekim tüketim toplumu tüketmek için daha çok yeni telefon, daha çok yeni araba ve daha çok kiyafet beklemektedir.

$\mathrm{Bu}$ tür çevresel zararlarının yanında mevcut sistem de insanları daha çok tüketmeye itmektedir. Değişik pazarlama teknikleri sayesinde, sürekli insanların yeni bir şeylere ihtiyacı olduğu onlara empoze edilmekte, reklam vs. gibi araçlarla sürekli bir şeyler alma arzusu beslenmektedir. Postmodern insan artık ancak tükettiği zaman var olmanın bir anlamı olduğunu düşünmeye başlamıştır. Tüketmeden yaşamak, tüketemiyor olmak bir mutsuzluk nedenidir. Çoğu kimse tüketmeden yaşamanın çok anlamlı olmadığı kanaatini taşımaktadır. Çünkü tüketemeyince haz almamakta, haz almayınca da yaşamdan soğumaktadır.

Özellikle teknolojik ürünler bakımından yeni alınan son teknoloji bir alet bir-iki yıl sonra değersiz, imajı tükenmiş bir elektronik çöpe dönüşebilmektedir. Aslında onunla da ihtiyaçlarını karşılayan birçok insan her gün yeniden üretilen tüketim kültürü nedeniyle "hala 3 megapiksel kameralı telefon mu kullanıorsun?" ya da "şu LCD'nin yerine bir LED veya akıllı TV almadın" gibi toplumsal baskı altında daha çok tüketmeye güdülenmektedirler. Bu tüketme kültürü nedeniyle giderek daha çok tüketilmekte, buna bağlı olarak daha çok talep edilmekte, daha çok üretilmekte ve çevre giderek daha çok kirlenmektedir.

\section{Sonuç}

Modern dönemle birlikte temelleri atılan tüketim toplumu, ikinci dünya savaşı sonrasında postmodern dönem olarak da ifade edilen süreçte giderek daha çok belirginleşmiş ve içinde bulunduğumuz döneme damga vuran bir olgu haline gelmiştir. Bu dönemde sosyal sınıflar bile tüketim alışkanlıklarına göre oluşmaya başlamıştır. Artık tüketim bir yaşam tarzı ve kişilerin kendilerini anlamlandırma biçimi olmuştur. Tüketilen ise nesnelerden çok onların imajlarıdır. Bir malın tüketilmesi ve atılması eskimesine değil; bilakis imajının bitmesine yani modasının geçmesine bağlı hale gelmiştir. Tüketimin temel gayesi ise artık haz ihtiyacını tatminidir. O nedenle alış-veriş arkadaşlarla yapılan ve haz veren sosyal bir faaliyete, can sıkıntısını giderme veya eğlenme aracına dönüşmüştür. 
Ancak bu kadar çok tüketim ve buna bağlı olarak yapılan üretim her geçen gün gezegenimizi daha çok kirletmektedir. Haz alma odaklı olarak sürekli ve giderek daha çok tüketen türümüzün çoğu üyesi ise, maalesef bu durumun tehlikeliliğini tam olarak idrak edebilmiş değildir.

Günümüzde dünyaya hakim olan tam rekabetçi kapitalist sistemde üretim yapılırken ön planda tutulan husus karlılıktır. Bu nedenle üretimin yapıldığı ham maddenin veya ürün tüketildikten sonra ortaya çıkacak atığın ya da üretimde kullanılan enerji araçlarının çevreye ne kadar zarar verebileceğinden çok, ne kadar az maliyetli oldukları göz önünde bulundurulmaktadır.

Ancak görünen odur ki, mevcut durum bu haliyle uzun süre gitmeyecektir. Görece yaşlı dünyamız artık insanlığın çevreye verdiği zararları tolere edemez hale gelmiştir. Dünya dışında yaşayabileceğimiz ve çocuklarımıza bırakabileceğimiz ikinci bir gezegen ise bulunmamaktadır. Bu nedenle artık karlılıktan önce çevresel sonuçların göz önünde tutulduğu bir üretim tarzına geçilmeli, çevreye en az oranda zarar verecek ciddi sürdürülebilir kalkınma politikaları üretilmeli ve bu konularda uluslararası toplum birlikte hareket etmelidir. Nitekim bu husus devletlerin tek başlarına başa çıkabilecekleri bir problem değildir. Çevreyi kirleten devletin yanında ondan binlerce kilometre uzakta bulunan başkaca devletlerin insanları da bu kirlilikten etkilenmektedir. Çevre kirliliği etkileri tüm dünyada görülen küresel bir problemdir. $\mathrm{O}$ nedenle gelecekte de yaşanabilir bir gezegenimizin olması için uluslararası toplumun birlikte hareket etmesi bir zorunluluk olarak karşımıza çıkmaktadır.

\section{Kaynakça}

- Adorno, Theodor, 2009. Kültür Endüstrisi, İletişim Yayınları, İstanbul.

- Bauman, Zygmunt, 2006, Küreselleşme, Ayrıntı Yayınevi, İstanbul.

- Baudrillard, Jean, 2000, Tüketim Toplumu, Ayrıntı Yayınevi, İstanbul.

- Derraik, J.G.B. 2002, The Pollution of The Marine Environment by Plastic Debris: A Review, Marine Pollution Bulletin, 44, 842-852.

- Featherstone, Mike, 2005, Postmodernizm ve Tüketim Kültürü, (Çev. Mehmet Küçük), Ayrıntı Yayınları, İstanbul

- Giddens, Anthony, 2004, Modernliğin Sonuçları, (Çev. Ersin Kuşdil), Ayrıntı Yayınevi, İstanbul.

- Horkheimer, Max, 2005, Akıl Tutulması, Metis Yayınları, (Çev: Orhan Koçak), İstanbul

- Lyotard, J. F., 2000, Postmodern Durum, (Çev: Ahmet Çiğdem), Vadi Yayınları, Ankara

- Princen, Thomas, 1999, “Consumption and Environment: Some Conceptual Issues”, Ecological Economics, 31, 347-363.

- Şaylan, Gencay, 2002, Postmodernizm, İmge Yayınevi, Ankara

- Toffler, Alvin, 1981, Gelecek Korkusu-Şok, (Çev. Selami Sargut), Altın Kitaplar, Yer belirtilmemiş 


\title{
Türkiye’de Kayıtdışı İstihdam Konusu Üzerine Teorik ve Ampirik Bir Çalışma
}

\section{A Study on Informal Employment in Turkey from Theorical and Emprical Perspectives}

\author{
Eren Gül Aydın (Beykent University, Turkey)
}

\begin{abstract}
This paper elaborates both theorical and empirical evolution of the informal employment as an part of the informal economy in Turkey. First of all, economic dualism and migration is emphasized as the main reasons of informal employment and examine other reasons of the informal employment such as social, fiscal and economic.Later of this study, an econometric model is employed by using Multiple Linear Regression Analysis. Informal employment is used as independent variables of industrial production (IPI). The first result of econometrics model, informal employment was seen statistically significiant determinator of IPI. Secondly, some production and employment variables and Gross National Product are used for estimating decisive factor of the informal employment in Turkey between 2005 and 2012. Results show that GDP and all other variables used in regression positively corelated to informal employment except import and export in Turkey.
\end{abstract}

\section{Giriș}

Kayıtdışı istihdam, kayıtdışı ekonominin iş gücü piyasasına yansımasıdır. Kayıt dışı ekonomi, ekonomiyi düzenleyen yasalara ve yönetmeliklere aykırı olarak gerçekleştirilen, belgeye bağlanmamış, kanuni defterlere işlenmemiş tüm ekonomik faaliyetler olarak tanımlanmaktadır (Altuğ, 1999).Kayıt dışı istihdam faaliyeti ise çalışanların ilgili kamu kurum ve kuruluşlarına kayıtlı olmaması ya da eksik bildirilmesi anlamındadır (Bulutay,Taşçı,2002). Kayıtdışı istihdam ile kayıtdışı sektör kavramları çoğu zaman karıştırılmakta veya birbiri yerine kullanılmaktatır.Ancak kayıtdışı sektör ve kayıtlı sektör çalışılan sektörün özelliğine işaret ederken,öte yandan kayıt dışı istihdam faaliyeti bir sosyal güvenlik kuruluşuna kayıtlı olup olmamayı ifade etmektedir (Bulutay ve Taşçı,2002).Yani kişi kayıtdışı sektörde kayıtlı istihdam edilebilir, kayıtlı sektörde de kayıtdışı olarak istihdam edilebilir.Bir başka deyişle kayıt dışı istidamın çalışılan sektörün özelliği ile ilgisi yoktur.

Günümüzde istihdam sosyal ve ekonomik yapının temel sorunlarından biridir. Ülkelerin gelişmişlik düzeyleri, istihdam olanakları ve istihdamın yapısı arasında sıkı bir bağ olduğu bilinmektedir. Gelişmekte olan ülkelerde kayıtdışı istihdam ekonomik yaşamın büyük ve önemli bir parçasıdır. Kayıtdışı istihdam az gelişmiş ve gelişmekte olan ülkelerde gelişmiş ülkelere oranla daha fazla olmakla beraber, gelişmiş ülkeler içinde önemli bir sorun olmaya devam etmektedir. Türkiye'de kayıtdıșı istihdamın \%40'ların üzerinde, istihdam oranının neredeyse yarısına yakın olması kayıtdışı istihdamın Türkiye ekonomisinin gelişmesinin önünde bir engel olarak durduğuna ve çözülmesi gereken öncelikli sorunlardan biri olduğuna işaret etmektedir

Kayıtdışı istihdamın Türkiye gibi gelişmekte olan ülkelerde yüksek olmasının temel ekonomik,sosyal ve mali nedenleri;nüfus artışı, iç göç,vergi sistemindeki aksaklıklar,gelir dağılımındaki adaletsizlikler, işsizlik,enflasyon ve bu ekonomilerin yapısal değişimleridir.

Türkiye'de 1980 sonrası serbest piyasa döneminde ekonomik büyüme ve gelişme hareketiyle birlikte kayıt dişı istihdam,genişleyen iş gücü piyasasıyla önemli oranda büyümeye başlamıştır.Türkiye'de kayıt dışı işgücü piyasasının büyümesinde talep ve arz yönü faktörler eş zamanlı olarak etki etmiştir.İ̧ gücü talebi tarafında, ucuz iş gücü istihdamını gerektiren ve kayıtdışı istihdam oranını arttıran etken, küresel pazarlara entegrasyonu artan Türkiye'nin küresel fiyatlarla rekabet edebilmek için, ticareti yapılan mallarda maliyetleri düşürmek zorunda kalmasıdır.I̦ gücü arzının kayıtdıșı istihdamı artıııı etkisinin nedeni ise özelleştirme ve kamu sektörü istihdamının azalan payı ve kırdan kente göçün artmasının kritik koşullar altında çalışmaya hazır bir iş gücü sağlamış olmasıdır.

Özellikle ekonomik kriz dönemlerinde artış gösterdiğini söyleyebileceğimiz kayıt dıșı istihdam faliyeti olağan dışı ve geçici bir istihdam türü olarak belirli bir zaman diliminde normal karşılanabilir. Ancak Türkiye'ninde içinde bulunduğu gelişmekte olan ülkeler için bu geçici olması beklenen durum yapısal bir sorun haline dönüşmüştür. Kayıt dışı istihdam faaliyetlerinin kayıt altına alınması temel finans kaynağı vergiler olan gelişmekte olan ülkeler için çözülmesi gereken önemli bir sorundur ve bu sorunun çözümü kuşkusuz, nedenlerini ortaya çıkaran sosyal ve ekonomik etkenleri engelleyecek önlemlerin alınmasına bağlıdır.

Bu çalışmada, kayıtdışı istihdama genel bir bakış yapıldıktan sonra, Türkiye'de 2005-2012 yılları arasında kayıtdışı istihdamı etkileyen işsizlik, enflasyon, GSMH, verimlilik, üretim ve istihdam faktörleriyle çoklu regresyon analizi kullanılarak yapılan ekonometrik bir çalışmaya yer verilecektir. 


\section{Kayıtdışı Ekonomi ve Kayıtdışı İstihdama Genel Bir Bakış}

Kayıtdışı ekonomi terimi bir çok farklı şekilde kullanılmıştır.Bunlardan bazıları "düzensiz ekonomi "(Ferman ve Ferman,1973), "gizli ekonomi”(Gutmann,1977), "yeraltı ekonomisi “(Simaon ve Witte,1982), "kara ekonomi" (Dilnot ve Moris,1981), "gölge ekonomi” (Frey vd.,1982), "kayıtdışı ekonomi” (McCrohan ve Smith,1986)'dir (Losby,2002). Kayıtdışı ekonomi sözüyle anlatılmak istenen mevcut faaliyetin gizliliğiyse gizli ekonomi, gölge ekonomi, saklı ekonomi, yer altı ekonomisi; faaliyetin yasa dışılığı belirtilmek isteniyorsa kara ekonomi, gri ekonomi, illegal ekonomi; faaliyetin devletin bilgisi dışında olması irdeleniyorsa gayri resmi ekonomi, enformel ekonomi; son olarak da faaliyetin önemsiz olarak GSMH kayıtlarına alınmaması vurgulanıyorsa da marjinal ekonomi, ikincil ekonomi şeklinde adlandırılır (Azaklı,2009). Kayıtdışı ekonomi ile ilgili ilk çalışma Cagan tarafından yapılmıştır. Cagan 2. Dünya Savaşı sırasında beyan edilmeyen gelirleri parasal araçlar kullanma yoluyla tahmin etmeye çalışmıştır (Cagan,1958).

Kayıtdışı istihdam kavramı ise ilk olarak 1970 yılında ILO’nun düzenlediği Dünya İstihdam Programı (World Employment program) kapsamında ki Kenya Raporunda “enformal sektör” adıyla yer almıştır.Bu raporda işçiler ve ekonomik birimler tarafından gerçekleştirilen tüm ekonomik faaliyetlerin resmi düzenlemeler kapsamında olmadığı,yada resmi düzenlemelerin tüm ekonomik faaliyetleri kayıt alıtna alma konusunda yetersiz olduğu belirtilmiştir.Kayıtdışı faaliyetlerin kayıt altına alınamayışının nedenlerine dair bir ayrımda yapılmıştır; bu faliyetler ya yasa da belirtilmediği için kayıt altına alınamamakda ya da yasada yaptırımı olduğu halde, yasaların uygulamasındaki zorluklar ve yüksek maliyetlerin bu yasaların uygulanmasına engel olması nedeniyle kayıt altına alınamamakta olduğu belirtilmiştir (Bulutay,Taşçı,2002).

1993 yılında düzenelenen Onbeşinci Uluslararası İş Gücü İstatistikleri Konferansında kayıtdışı çalışma satatüsü ücretsiz aile işçileri,serbest meslek çalışanları ve küçük ölçekli işletmeler (belirli bir sayının altında işçi çalıştıran) kayıtdışı ekonominin bir parçası olarak olarak kategorize edilmiştir(Aydn,vd.,2013). Kayıt dışı istihdamın değişik biçimleri bulunmaktadır. Bunlar genel olarak sigortalı çalıştırıldığı halde sosyal güvenlik kuruluşlarına bildirilmeyenler, sigortalı çalıştırıldığı halde sosyal güvenlik kuruluşlarına eksik veya geç bildirilenler, aldıkları ücretten daha az bildirilenler, emekli olup da çalışanlar, yabancı ve çocuk işçilerdir. Buradan hareketle kayıtdışı istihdam kendi adına ve bağımsız ya da bir işverene bağlı çalışanların çalışmalarının veya elde ettikleri ücret ve kazançların, ilgili kamu kurum ve kuruluşlarına hiç bildirilmemesi ya da gün sayısı veya ücret tutarı olarak eksik bildirilmesi olarak ifade edilebilir (Yereli ve Karadeniz, 2004: 180).

Kayıtdışı istihdam genel anlamda istihdam faaliyetlerinin(üretim,hizmet) resmi belgelere dayandırılmaması ve böylece resmi kayıtlara girmemesi,bunun sonucunda vergisel ve zorunlu yasal yükümlülükleri de dahil olmak üzere tüm yükülülüklerin,mali ve sosyal güvenlik kurumlarının denetim alanı dışına çıkarılmasıdır (Güloğlu,2005). Bu tanım ile birlikte kayıtdışı istihdama yönelik tanımların ortak yönü bir sosyal güvenlik kurumuna kayıtlı olmamak ve bunun sonuncunda oluşan vergi ödememe durumu olarak karşımıza çıkmaktadır.

Göç ve kentleşmenin temel nedeni olduğu kayıtdışı istihdamın bir ekonomi için yapısal bir sorun haline dönüşmesinin mali, ekonomik ve sosyal nedenleri vardır (Yılmaz, Öğünç, 2000).

Literatürde kayıtdışı istihdamın nedenlerini anlamaya yönelik bir çok teorik ve ampirik çalışma vardır.Bu çalışmalardan bir kısmı vergi gelirleri ve kayıtdışı istihdamın ilişkisi üzerinedir.Teorik çalışmaların bir çoğu (Rauch,1991 ve Loayza,1996) vergiler ve kayıtdışı istihdam arasında pozitif ilişkiye işaret etmektedir (Elgin,2010).Bu teoriye göre yüksek vergi oranları yüksek kayıtdışı istihdam eğilimine neden olmaktadır.Teorinin aksine bazı ekonometrik çalışmalar (Torgler and Schneider, 2007) vergiler ile kayıtdışı istihdam arasında negatif ilişkiye işaret etmektedir (Elgin,2010).

Saraçoğlu(2007), informal,formal ve tarım sektörü olarak tanımladığı üç sektörlü büyüme modeli ile yaptığı çalışmada,gelir artışıyla birlikte hane halklarının kayıtlı sektördeki malları tercih edeceğini ve bununla birlikte ekonominin büyüyeceğini,ekonomi büyürken artan gelirle beraber kayıt dışı sektördeki malların talebinin azalmasından dolayı kayıtdışılığında zamanla azalacağını savunmuştur.Ayrıca gelir vergisi oranlarının düşürülerek kayıt dışılığın azaltılacağını öne sürmüştür.Ekonomik büyümenin kişi başı gelir üzerinde olumlu etkileri varsa bu durumun geçerliliğinden bahsetmek mümkün olabilir.Ayrıca istihdamı kayıt altına almanın amacı vergi gelirlerini artırmaktır fakat kayıtdışılığın azaltılması amacıyla gelir vergisi oranlarının çok düşük seyretmesi de vergi gelirlerini düşürebilir.Bu nedenle vergi oranları ne kayıtdışılığa teşvik edici düzeyde yüksek olmalı ne de vergi gelirlerini olumsuz etkileyecek kadar düşük olmalıdır.

Göç ve informal istihdam arasında ki bağlantıyı ortaya koyan bir model çalışmasında (Bulutay ve Taşçı,2002) öncelikle Türkiye'de informal istihdamın payının başlıca belirleyicileri olarak, gelir değişkenleri,nüfus değişkenleri ve istihdam değişkenleri tanımlanmıştır.Kurulan ekononometrik modellerde değişkenler öncelikle göçe neden olmakta ve bu göçün sonucunda da kayıtlı veya kayıtdışı istihdam artmaktadır.Bu çalışmanın sonucunda istihdam olanaklarının genişlemesi ve nüfus artışının kayıtdışı istihdamı artırdığı,GSMH daki gelişmenin ise kamu istihdamını ve kayıtlı istihdamı artırabileceği, bu nedenle GSMH'nın kayıtdışı istihdam ile ilşkisinin negatif olduğu öngörüsü göze çarpmakadır. 


\section{Kayıtdışı İsthdamın Nedenleri}

Özellikle az gelişmiş ve gelişmekte olan ülkelerde bir çok insan için kayıtdışı çalışma bir zorunluluk haline gelmiştir.Yüksek enflasyon ve işsizlik sorunuyla karşı karşıya kalan insanlar ya daha az ücretle güvencesiz çalışmak zorunda kalmakta yada çalıştıkları işe ek olarak bir başka iş yapmaktadırlar ve tüm bunlar kayıtdışı istihdamı artırmaktadır.Bundan dolayıda istihdamın kayıt altına alınmasıiçin yapılan çalışmalar ancak nedenlerinin çözüme ulaştırılması ile mümkün olacaktır.(Güloğlu,2005).

\subsection{Sosyal Nedenler}

\section{Ekonomik Düalizm,Göç ve Kayıtdışı İstihdam İlişkisi Üzerine}

Sosyal nedenlerin başında nüfus artışıyla birlikte artan işsizlik,göç ve kentleşme gelmektedir.Kayıtdışı istihdamın sosyal nedenlerinin incelenmesine sanayi devriminden sonra değişen, ikilileşen sosyal ve ekonomik yapının analizi ile başlamakta ve öncelikle emek arzını artıran aynı zamanda emeği işsiz bırakan bir oluşumun temelinde yatan sosyolojik nedenleri görebilmekte fayda var.Bu noktada Sanayi devrimi sürecine gitmek gerekmektedir.Sanayi Devrimi öncesinde genellikle tarımın egemen olduğu ekonomide İngiltere'de başlayan sanayileşme ile birlikte üretimde makineleşme süreci başlamıştır.Makineleşme verimliliği artırmış,emek gücü işsizlikle tanışmıştır.Artan nüfusla birlikte emek arzı fazlalığı kentlere göç etmeye başlamış,düşük ücretlerle,güvencesiz olarak çalışılan bir sektörü oluşturmuşlardır.

Sanayi devrimi yeni bir ekonomik sistem doğurmuş(piyasa sistemi) ve geleneksel olarak üretim,bölüşüm ve dağıtım yapan ülkeler,İngiltere ye göre ekonomik sistemlerini değiştirmek çabasına girmek zorunda kalmışlarıdır.Bu milat niteliğinde ki devrimin geleneksel toplumlarda ekonomik sistemin sosyal yaşamı değişime zorlaması,diğer bir deyişle ekonomik sistemin sosyal yaşama yerleşmesi (Polanyi,1944) gerekliliği yeni piyasa yapısının işleyişi için kuraldı.Bu durum geleneksel toplumlarda kökten bir değişimin başlaması anlamına gelmekteydi.Sanayileşmenin gerisindeki toplumlar yeni ekonomik sisteme ayak uydurmaya çalışmış ve bu sistemin etkileri hem ekonomik hem sosyal anlamda bir dönüşüm süreci yaratmıştır. Ekonominin değişimi ile aynı zamanda toplumların geleneklere bağlı sosyal yaşamları da, kültürleri de değişime uğramıştır.Toplumsallıktan bireyciliğe,ortak mülkiyetten özel mülkiyete ve özgürlüğe doğru bir değişim söz konusuydu,ancak işsizlik sorunu(Köksel,2011) ve üretim araçlarının belirli bir kesim elinde toplanmasıyla toplumsal sınıflar ortaya çıkmış, bir yan kötü ve uzun çalışma şartlarında yaşarken diğer tarafta sürekli zengileşen bir kesim varlığını sürdürmüştür.Dolayısıyla toplumlarda dual(ikili) bir ekonomik yapı oluşmuştur.Düalizm kavram olarak birbirine zit iki farklı olgunun aynı anda bulunması durumudur.Ekonomik alanda bir yanda sanayi/modern sektör diğer yanda geleneksel/tarım sektörünün varlığını sürdürmesi ile artan ikilik az gelişmiş ülkelerde ikili ekonomik yapının yani ekonomik dualizmin oluşmasına neden olmuştur.Bu durum hem az gelişmiş ülkelerde gelir dağılımı eşitsizliğini artırmış hem de ülkeler arası gelir dağılımı eşitsizliğini büyütmüştür.

Bourguignon ve Morrisson (1994), 35 az gelişmiş ülke arasında 1970 yılı kişi başı GSMH,eğitim seviyesi,gini katsayısı,tarım ve sanayi iş gücü verimliliği değişkenlerini kullanarak yaptıkları tahminlerin sonuncunda gelir dağılımı eşitsizliği ile kalkınma arasındaki güçlü bağın temelinde ki en etkili faktörün ekonomik düalizmin genişlemesinin bulunduğunu vurgulamıştır.

Az gelişmiş ve gelişmekte olan ülkelerde hem modern hem geleneksel yaşam tarzı ve üretim tarzı halen bir aradadır. Dolayısıyla geri kalmış ülkelerin ekonomileri de tarımsal/geleneksel ve sanayi/modern olmak üzere halen ikili yapıdadır.Genelde kırsal kesim tarımsal/geleneksel üretime devam ederken büyük kentler sanayi/modern üretimin toplandığı yerler olmaktadır.

Sosyologlar ve antropologlar tarafından 1950 li yıllarda az gelişmiş ülkeler de ki bu ikili yapıya dikkat çekmiş,sonraları ekonomistlerde dualizm ile ilgilenmeye başlamışlardır.

1954 yılında Arthur Lewis ekonomik kalkınma modeli olarak "ikili model”i geliştirmitir.Kırsal kesimdeki sınırsız iş gücü arzının kentlerde ki modern sektör tarafından istihdam edilmesi ve bu yolla az gelişmiş ülkelerde modern sektörün gelişimini öngören bu model için Arthur Lewis analizinin kapitalist sınıfın ortaya çıkışının yarattığı sosyolojik probleme dayandığını söyler(Kirkpatric,Barrientos,2004).İş gücü fazlasının kayıtdışı sektöre kaymasının merkezindeki hem sosyal hem ekonomik bir olgu olan göç hareketlerinin iş gücü piyasalarına yansıması,sanayinin gelişimi için gerekli iş gücü yarattığından olumlu görünebilir ancak öte yandan kayıtdışı istihdam göçün negatif dışallığı olarak karşımza çıkmaktadır.

\section{Çocuk İş Gücü}

Geleneksel aile yapılarında çocukların çalşması,onların hayata hazırlanması,ayrı bir eğitim alması anlamına geldiğinden aileler tarafından desteklenmekteydi.Ne var ki günümüzde çocuk iş gücü yaygınlaşmış önüne geçilmesi gereken bir sorun haline gelmiştir.Özellikle az gelişmiş ve gelişmekte olan ülkeler üretim sürecinde çocuk iş gücünü ucuz iş gücü,maliyet düşürücü bir unsur olarak değerlendirdiğinden çocuk emeği sömürülmektedir.Çocuklar yetişkinler yerine istihdam edilmekte,aynı çalışma saaterinde daha düşük ücretle emekleri sömürülmektedir.Dolayısıyla çocuk istihdamı artık iş gücü piyayasını etkilemektedir. 
Türkiye'de işteki duruma göre; çalışan çocukların \%52,6'sı (470 bin kişi) ücretli veya yevmiyeli, \%46,2'si (413 bin kişi) ise ücretsiz aile işçisidir. Zorunlu eğitim süresinin uzatılması çocukların iş yaşamından geri çekilmelerini sağlayabilecek bir politika olarak uygulanabilir.Öte yandan mesleki eğitimin yaygınlaştırılması staj adı altında çocuk iş gücünün kayıt dışı istihdam edilmesinin önünü açmaktadır.Çocuk işgücü istihdamının önüne geçecek düzenlemeler başta belirttiğimiz gibi zorunlu ve kesintisiz eğitim süresinin uzatılması ve aynı zamanda da yeni yasalarla çocuk iş gücü istihdamının engellenmesidir.

\section{Kadın İș Gücü}

Özellikle istihdam alanında, kadınların erkeklere kıyasla çok daha dezavantajlı bir konumda oldukları, istatistiki sonuçlara bakıldığında da görülmektedir. Ülkemizdeki yasalarda gerçekleştirilen olumlu değişikliklere rağmen kadınların niteliklerinin iş piyasasının gerektirdiği niteliklere uyumlu olmaması ve işgücü piyasasına girişi sağlayacak mekanizmaların yetersizliği nedeniyle kadının işgücüne katılımı hem mutlak olarak hem de erkeklere oranla düşük orandadır.

Kayıt dışı çalışan kadınlar, bütün diğer kayıt dışında çalışanlar gibi sosyal güvenlik hukukunun kendilerine sağlayacağı güvenceden yoksun kalmaktadırlar. Kayıt dışında çalışan kadınların çalışma süreleri uzundur.Ücretleri, özellikle parça başı ücret uygulamasının olduğu tekstil sektöründe düşüktür. Kayıt dışında çalışmalarına bağlı olarak iş kazalarına karşı bir korumaları da bulunmamaktadır.

Türkiye'de kayıt dışı kadın istihdamı giderek artmaktadır.2012 ortalaması \%40.9 olan kayıt dışı kadın istihdamı 2013 Ocak ve Şubat alarında \%41.1 olarak açıklanmıştır.(Tüik,2013).

\section{Kaçak İşçiler}

Uyruğunda bulunmadığı bir ülkede çalışan işçilere yabancı iş̧̧i denir.Türkiye de işsizlik iş gücü piyasası arz ve talebindeki dengesizlik nedeniyle zaten büyük bir sorunken, kaçak işçilerde Türkiye iş gücü piyasasına bir başka sorun eklemektedir(Güloğlu,2005).Kaçak iş̧̧iler girdikleri ülkede iş gücü arzını artıdıkları için ücretleri düşürücü etki yaparlar.Göç veren ülkede ise bunun tam tersi gerçekleşir ve azalan iş gücü arzı nedeniyle ücretler yükselir. Ücretlerde ki yükseliş maliyetleri artıracağıdan göç veren ülkede toplam arz düş̧er, fiyatlar yükselir,tüketim azalır ve ekonomik büyüme olumsuz etkilenir.Kaçak işçilerin engellenmesi yine yasalarla,yeni yaptırımlarla mümkün olabilir.

\subsection{Mali ve Ekonomik Nedenler Vergi sistemi}

Türk vergi sisteminin sürekli yenilenen yasalar ve kararnameler nedeniyle oluşan değişken yapısı, takibini zorlaştırdığından bireyleri vergi ödememeye iten nedenlerden biri olmaktadır.Dolayısıyla vergi ve vergilendirmenin ekonomik ve yasal yanı gibi sosyolojik ve psikolojik yanıda göz önüne bulundurulmalıdır (Altuğ vd.,2010).Bu bağlamda toplumun vergi ahlakı ve ödenen vergilerin nereye harcandığının da bilinmesi,yani hükümet harcamalarındaki şeffaflık da bireylerin kayıtdışı faaliyet gösterme kararlarında önem teşkil etmektedir.Vergi ahlakı bir toplumun kültür seviyesi ile de doğru orantılıdır(Güloğlu,2005). Türkiye'de yüksek gelir vergisi oranları ve vergi adaletsizliği kişileri kayıtdışı faaliyetlere yönlendirmektedir(Saraçoğlu,2008).Sonuç olarak vergi sisteminin anlaşılabilir ve maliye politikalarının şeffaf olması, kayıtdışı faaliyet eğilimini engellemede vergi adaleti kadar önemlidir.

Öte yandan kayıtdışı çalışmayı engellemek amacıyla devletin uyguladığı kimi politikalar kayıtdışılı̆̆ artırabilir.Bu" ters etki" emeklilik yaşının düşürülmesi veya çalışma saatlerinin azaltılması sonucunda ortaya çıkabilir(Yılmaz vd.,2000).Erken emeklilik kişileri sigortasız bir başka işte çalışma firsatı sağlamaktayken öte yandan çalışma saatlerinin düşürülmesi de yine ikinci bir işte kayıtdışı çalışmayı özendirici olabilir.Özetle bu tür politikalar çalışanların çalışma ve boş zaman tercihlerini etkilediğinden uygulamaya koyulmadan önce iyi analiz edilmelidir.

\section{Enflasyon ve Gelir Dağılımı Eşitsizliği}

Türkiye'de kayıtdışı istihdamın genişlemesinin en önemli nedenlerinden biri enflasyondur.Enflasyon nedeniyle gelirlerinde aşınma meydana gelen düşük ve sabit gelirli tüketiciler bu kayıplarını gidermek, enflasyon nedeni ile girdi maliyetlerinde artışlar meydana gelen üreticiler de, maliyetlerini azaltmak amacıyla kayıt dışı istihdama yönelmektedirler. Bu nedenle enflasyon rakamlarının yüksek olduğu ülkelerde kayıt dışı ekonomik faaliyetlerin arttığ gözlemlenmektedir.Ekonomik krizlerin yaşandığı dönemlerde, işsiz kitleler kayıtlı ekonomide bulamadıkları istihdam imkanlarını kayıt dışı ekonomi alanlarında aramaktadırlar. İşletmeler de krizin olumsuz etkilerini azaltmak için üretimlerini kayıt dışı alanlarda yaparak ve kayıt dışı işçi istihdam ederek maliyetlerini azaltmaya çalışmaktadırlar.Öte yandan gelir dağılımında giderek artan eşitsizlik yoksulluğu artırmakta ve yoksul insanlar da düşük ücretle ve güvencesiz de olsa bir işte çalışmaya mecbur kalmaktadırlar.Bu da kayıt dışı istihdamı artırmaktadır.Bu anlamda kayıtdışı istihdamla mücadele aslında bir yanıyla gelir dağılımı eşitsizliği ve yoksullukla mücadele olmalıdır.Çünkü ancak bunlara çözüm üretmekle kayıtdışı istihdamın önüne geçilebilir. 


\section{Türkiye'de Kayıtdışı İstihdam'ın Belirleyici Faktörlerinin Çoklu Regresyon Modeli ile Analizi}

\subsection{Modelin Metodolojisi}

Modeller için seçilen değiş̧kenler kayıtdışı istihdamın gelişimi üzerinde önemli etkilere sahip istihdam,üretim ve işsizlik faktörleridir.Bu faktörler ile kayıtdışı istihdam ilişkisinin incelenmesinde Çoklu Regresyon Analizi kullanılmıştır.

Veri setleri Türkiye İstatistik Kurumu(TÜIK) web sitesi kütüphanesi ve Türkiye Cumhuriyeti Merkez Bankası Elektronik Veri Dağıtım Sisteminden (EVDS) elde edilmiştir. Bu çalışmada farklı değişkenlere ait iki farklı veri seti kullanılmıştır. Kayıtdışı istihdamın belirleyiciliği üzerinde önemli etkiye sahip olduğu düşünülen değişkenlerin tümünün TÜIK tarafından aynı dönemler için yayınlanmamasından dolayı,çeyreklik veriler ve aylık verilerle ayrı regresyonlar yapılmıştırilk veri setinin örneklem aralı̆̆ı 01.2006-12.2012 tarihlerini kapsayan aylık zaman serisinden oluşmaktadır.İkinci veri setinin örneklem aralığı 2005 ilk çeyrek-2012 son çeyrek arasını kapsayan çeyreklik zaman serisinden oluşmaktadır.Ayrıca 2005 öncesi verilerin, TÜIKK tarafından nüfus projeksiyonuna göre güncellenmemesi nedeniyle önceki dönemler ile karşılaştırma yapılamayacağından,yapıldığı taktirde regresyon sonuçlarının yanıltıcı olacağından daha eski tarihli veriler kullanılamamıştır.

Çalışmada verilerin ekonometrik analizinde Eviews 7 istatistik paket programı kullanılmış̧ır.Veriler ve değişkenler kısıtlı olduğu halde modellerin tahmininden sonra Eviews ile görüntülenen tahmin ve gerçek-tahmin uyum grafiklerinde,modeller ile tahmin edilenlerin birbiri ile uyumu gözlenmiştir.

Aylık veri setleri ile yapılan regresyonlarda kayıtdışı istihdam bağımsız değişken olup,sanayi üretim endeksi(SÜE) üzerindeki etkisi tahmin edilmeye çalışılmıştır.SÜE nin aylık verisine ulaşılabildiğinden,GSMH ile birlikte hareket etmesinden ve GSMH nın en önemli göstergesi olmasından dolayı aylık veride GSMH yerine SÜE kullanılmıştır.Çeyreklik verilerle yapılan regresyonlarda ise kayıtdışı istihdam bağımlı değişkendir ve kayıt dışı istidamı etkileyen bazı faktörler tahmin edilmeye çalışılmışıır.

İlk olarak değişkenlere ait zaman serilerinin logaritmaları alınmış ve logaritmik serilere Dickey-Fuller birim kök(durağanlık) testleri yapılmıştır.Logaritmik seriler birim kök içerdiğinden,serileri mevsimsel etkilerden kurtarmak için serilerin birinci farkları alınmış ve seriler tekrar birim kök testinden geçirilmiştir.Birinci farkları alınmış logaritmik serilerin birim kök içermediği tespit edildiğinden yani seriler artık durağan olduğundan regresyonda kullanılmışlardır. Serilerin birim kök içermemesi uzun dönem dengesinin sağlandığı,dengeden sapmaların durağan olduğu anlamına gelmektedir. Durağanlaştırılmış seriler kullanıldığı için de sahte regresyon problemi ortadan kalkmaktadır.Modeller tahmin edildikten sonra otokorelasyon kontrol edilmiş,sıçrama olan dönemler varsa bunlar modele eklenerek model yeniden tahmin edilmiştir.Model tahminini takiben hata terimlerinin normal dağılıma sahip olup olmadığını kontrol etmek için Histogram ve Normallik testi yapılmış ve test sonucunda tüm modellerin hata terimlerinin normal dağıldığ 1 gözlenmiştir.Modellerin değişken varyans sorunu olup olmadığı Heteroskedasticity(değişken varyans) ve F testi yapılarak kontrol edilmiş,test sonuçlarında hiç bir modelde değişken varyans sorununa rastlanmamıştır.Son olarak önemli değişkenlerin hata terimleri içinde olup olmadığını kontrol etmek için Ramsey Reset testi yapılmış tanılama hatası kontrol edilmiştir,modellerde tanılma hatasına rastlanmamıştır.Ayrıca kukla değişken kullanılan modelde(tablo-1-model 4) tahminden sonra 2008 sorası için Chow Kırılma Testi yapılmış, kırılmaya rastlanmamıştır.

Aylık veriler sanayi üretim endeksi(SÜE), kayıtdışı istihdam,Tüketici Fiyat Endeksi(TÜFE) ve dolaylı vergi gelirleridir.Çeyreklik veriler;Gayrı Safi Milli Hasıla(GSMH), kayıtdışı istihdam,toplam istihdam, toplam tarım üretimi ,tekstil üretimi,toplam imalat üretimi, kişi başı imalat üretimi(verimlilik).

\subsection{Bulgular ve Yorumlar}

Model 1, tahmin edildikten sonra $\beta_{2}$ katsayısı istatistiki olarak anlamsız bulunmuş,otokorelasyon kontrolünde de,1.gecikmede de s1çrama görülmüştür.1.gecikme modele eklenerek model-2 tahmin edilmiştir.Model-2 de $\beta_{2}$ katsayısı istatistiki olarak anlamlı hale gelmiş ve $\mathrm{R}^{2}$ den anlaşılacağı üzere modelde iyileşme olmuştur.Ancak 10 ve 12. gecikmelerde sıçramalar görülmüş,bunların olmasının ocak ayı etkisine bağlı olduğu düşünülmüş ve grcikmeler modele eklenerek model 3 tahmin edilmiştir.Otokorelasyon kontrolünde görülen 11.dönemde oluşan sıçrama modele eklenerek ve ayrıca kriz kukla değişkeni ile sanayi üretimi üzerinde 2007 krizinin etkilerinin modele eklenmesi amaçlanarak model 4 tahmin edilmiştir. Heteroskedasticity $\mathrm{ARCH}$ testi yapılmış(F istatistik olasılığ $1=0.44>0.05$ ),modelin değişken varyans sorunu olmadığı saptanmıştır.Modelde kukla değişkenle krizin etkisi yakalanmıştır. 2008 sonrası için Chow krılma testi yapılmış olup kırılma olmadığı bulunmuştur.. Modelin bu çerçevede kırılma testinden geçmesi ile regresyon kabul edilmiştir.Bunda kukla değişkeninin de etkisi söz konusudur.Kukla değişken 0.10 alfa seviyesinde,diğer parametreler ise 0.05 alfa seviyesinde anlamlıdır.Hata terimleri normal dağılıma sahiptir(Jarque-Bera test $=0.25>0.05$ ). Tablodaki katsayıların yorumu örneğin $\beta 1=0.76$ katsayısı için,"kayıtdışı istihdamda \%1 lik bir artış Sanayi Üretim Endeksinde \%0.76 lık bir artış sağlayacaktır "şeklinde yapılır. $\beta_{0}$ katsayıları 4 model içinde istatistiksel olarak anlamsız bulunmuştur ancak regresyon doğrusunun kesene sahip olması bakımından modelden çıkartılmamasına karar verilmiştir. 
Bağımlı Değişken:Sanayi üretim Endeksi (Gayrı Safi Milli Hasıla göstergesi olarak) Aylık Veri Seti- Gözlem sayısı 87

\begin{tabular}{|c|c|c|c|c|}
\hline Regressor & Model(1) & Model(2) & Model(3) & Model(4) \\
\hline $\begin{array}{l}\text { Kayııtdışı istihdam }\left(\mathrm{X}_{1}\right) \\
\text { T değerleri }\end{array}$ & $\begin{array}{l}0.43\left(\beta_{1}\right) \\
(1.92)\end{array}$ & $\begin{array}{l}0.76\left(\beta_{1}\right) \\
(3.98)\end{array}$ & $\begin{array}{l}0.45\left(\beta_{1}\right) \\
(2.70)\end{array}$ & $\begin{array}{l}0.70\left(\beta_{1}\right) \\
(3.74)\end{array}$ \\
\hline $\begin{array}{l}\text { TÜFE }\left(X_{2}\right) \\
\text { T değerleri }\end{array}$ & $\begin{array}{l}0.99\left(ß_{2}\right) \\
(1.03)\end{array}$ & $\begin{array}{l}1.53\left(\beta_{2}\right) \\
(1.93)\end{array}$ & $\begin{array}{l}1.15\left(ß_{2}\right) \\
(1.77)\end{array}$ & $\begin{array}{l}1.69\left(ß_{2}\right) \\
(2.61)\end{array}$ \\
\hline $\begin{array}{l}\text { Dolayli Vergil Gelirleri }\left(\mathrm{X}_{3}\right) \\
\mathrm{T} \text { değerleri }\end{array}$ & $\begin{array}{l}0.13\left(B_{3}\right) \\
(2.17) \\
\end{array}$ & $\begin{array}{l}0.19\left(ß_{3}\right) \\
(3.64) \\
\end{array}$ & $\begin{array}{l}0.16\left(ß_{3}\right) \\
(3.91) \\
\end{array}$ & $\begin{array}{l}0.13\left(\beta_{3}\right) \\
(3.10)\end{array}$ \\
\hline $\begin{array}{l}\text { 1.gecikme }\left(\mathrm{SUE}_{\mathrm{t}-1}\right) \\
\text { T değerleri }\end{array}$ & - & $\begin{array}{l}-0.54\left(\beta_{4}\right) \\
(-5.97)\end{array}$ & $\begin{array}{c}-0.40\left(ß_{4}\right) \\
(-5.13)\end{array}$ & $\begin{array}{l}-0.50\left(\beta_{4}\right) \\
(-6.02)\end{array}$ \\
\hline $\begin{array}{l}\text { 10.gecikme }\left(\mathrm{SUE}_{\mathrm{t}-10}\right) \\
\text { T değerleri }\end{array}$ & $\begin{array}{l}- \\
-\end{array}$ & $\begin{array}{l}- \\
-\end{array}$ & $\begin{array}{c}-0.17\left(\beta_{5}\right) \\
(-2.39)\end{array}$ & $\begin{array}{l}-0.24\left(\beta_{5}\right) \\
(-3.17)\end{array}$ \\
\hline $\begin{array}{l}\text { 11.gecikme }\left(\mathrm{SUE}_{\mathrm{t}-11}\right) \\
\text { T değerleri }\end{array}$ & $\begin{array}{l}- \\
-\end{array}$ & $\begin{array}{l}- \\
-\end{array}$ & - & $\begin{array}{l}-0.23\left(\beta_{6}\right) \\
(-2.33)\end{array}$ \\
\hline $\begin{array}{l}\text { 12.gecikme }\left(\mathrm{SUE}_{\mathrm{t}-12}\right) \\
\mathrm{T} \text { değerleri }\end{array}$ & - & - & $\begin{array}{l}0.49\left(\beta_{6}\right) \\
(6.33)\end{array}$ & $\begin{array}{l}0.35\left(\beta_{7}\right) \\
(3.84)\end{array}$ \\
\hline $\begin{array}{l}\text { Kukla20072009 } \\
\text { T değerleri }\end{array}$ & $\begin{array}{l}- \\
-\end{array}$ & $\begin{array}{l}- \\
-\end{array}$ & $\begin{array}{l}- \\
-\end{array}$ & $\begin{array}{c}-0.02\left(\beta_{8}\right) \\
(-1.89)\end{array}$ \\
\hline $\begin{array}{l}\text { İntercept } \\
\text { T değerleri } \\
\text { SER } \\
\text { R2 } \\
\text { Adj R2 } \\
\text { F stat. }\end{array}$ & $\begin{array}{c}-0.002\left(\beta_{0}\right) \\
(-0.26) \\
0.07 \\
0.12 \\
0.09 \\
3.91\end{array}$ & $\begin{array}{c}-0.005\left(ß_{0}\right) \\
(-0.66) \\
0.060 \\
0.42 \\
0.39 \\
14.09\end{array}$ & $\begin{array}{c}-0.007\left(ß_{0}\right) \\
(-1.08) \\
0.046 \\
0.66 \\
0.63 \\
21.32\end{array}$ & $\begin{array}{c}-0.003\left(\beta_{0}\right) \\
(-0.56) \\
0.044 \\
0.70 \\
0.66 \\
18.66\end{array}$ \\
\hline
\end{tabular}

Tablo 1 Regresyon sonuçlari-1

Bağımlı Değişken:Kayıtdışı İstihdam Çeyreklik Veri Seti

Gözlem sayısı 31

\begin{tabular}{l|ccc|} 
Regressor & Model $(\mathbf{1})$ & Model $(\mathbf{2})$ & Model(3) \\
\hline Gayrı Safi Milli Hasıla $\left(\mathrm{X}_{1}\right)$ & $0.60\left(\beta_{1}\right)$ & $0.36\left(\beta_{1}\right)$ & - \\
T değerleri & $(6.69)$ & $(3.08)$ & - \\
\hline Toplam İstihdam $\left(\mathrm{X}_{2}\right)$ & $0.73\left(\beta_{2}\right)$ & $0.38\left(\beta_{2}\right)$ & $0.51\left(\beta_{1}\right)$ \\
T değerleri & $(4.87)$ & $(2.06)$ & - \\
\hline Tarım İstihdamı $\left(\mathrm{X}_{3}\right)$ & - & $0.30\left(\beta_{3}\right)$ & - \\
T değerleri & & $(3.19)$ & $0.36\left(\beta_{2}\right)$ \\
\hline Toplam Tekstil Üretim $\left(\mathrm{X}_{4}\right)$ & & - & $(2.20)$ \\
T değerleri & & - & $0.27\left(\beta_{3}\right)$ \\
\hline İmalat Üretimi $\left(\mathrm{X}_{5}\right)$ & & $0.21\left(\beta_{4}\right)$ & $(2.04)$ \\
T değerleri & $0.41\left(\beta_{3}\right)$ & $(1.96)$ & - \\
\hline Kişi Baş1 İmalat Üretimi $\left(\mathrm{X}_{6}\right)$ & $(4.41)$ & - & - \\
T değerleri & & - & $-0.07\left(\beta_{4}\right)$ \\
\hline Toplam Tarım Üretimi $\left(\mathrm{X}_{7}\right)$ & & - & $(8.06)$ \\
T değerleri & $-0.026\left(\beta_{0}\right)$ & - & $-0.011\left(\beta_{0}\right)$ \\
\hline İntercept & $(-3.96)$ & $-0.019\left(\beta_{0}\right)$ & $(2.70)$ \\
T değerleri & 0.034 & $(-2.50)$ & 0.031 \\
SER & 0.89 & 0.035 & 0.91 \\
R2 & 0.87 & 0.89 & 0.90 \\
Adj R2 & 0.000 & 0.87 & 0.00 \\
F istatistik (olasılık) & & 0.00 & \\
\hline
\end{tabular}

Tablo 2 Regresyon sonuçlari-2

Regresyon sonucunda kayıtdışı istihdam,TUFE ve dolaylı vergi gelirleri değişskenlerinin GSMH 'nın en önemli göstergesi olan SÜE ile pozitif ilişkiye sahip olduğu tahmin edilmiştir.Diğer bir deyişle bu değişkenlerdeki artış(azalış) GSMH da da bir artış(azalış) olacağı anlamına da gelmektedir.Enflasyon ve kayıtdışı istihdam üretim maliyetlerini düşürücü etkiye sahiptir.Enflasyon reel ücretlerde yarattığı düşüş ve yine kayıtdış1 istihdamın da iş gücü maliyetlerinde yarattığı düşüş karları ve arzı artırmakta ve GSMH da artış meydana getirmektedir.Öte yandan dolaylı vergi gelirleri Türkiye'de genel bütçe gelirlerinin \% 70 ini oluşturmaktadır. Vergi gelirleri yeni yatırımlar için en önemli finansman kaynağı durumundadır ve uzun dönem GSMH büyümesinde bu nedenle olumlu etkiye sahiptir.Ancak dolaylı vergilerdeki artışın kayıtdışı istihdamdaki artışla 
ilikisinide belirtmek gerekir.Kayıtdışı istihdamın artması gelir vergisi üzerinden toplanması gereken direk vergi gelirlerini azalttığından dolaylı vergiler ile bu açık kapatılmaya çalışılmaktadır.Yani dolaylı vergilerdeki yüsek oranlar kayıtdışı faaliyelerdeki artışın bir göstergesi olarak kabul edilebilir.

Modellerde otokorelasyon sorununa rastlanmamıştır.Tüm modeller tahmin edildikten sonra Heterskedasticity testi yapılmış,değişken varyans sorunu olmadığı tespit edilmiştir.Modellerin hata terimleri normal dağılıma sahiptir ve tüm beta katsayıları istatistiki olarak 0.05 alfa seviyesinde anlamlıdır.Toplam istihdam ve tarım istihdamı tüm modellerde kayıtdışı istihdam ile pozitif ilişkide tahmin edilmiştir.Toplam tekstil üretimi,tarım üretimi, imalat üretimi ve kişi başı imalat üretiminden(verimlilik) oluşan üretim değişkenleride yine kayıtdışı istihdamla pozitif ilişkide tahmin edilmiştirToplam ithalat ve ihracat değişkenleride modellerde kullanılmış ancak istatistiki olarak anlamsız olmalarından dolayı modellerden çıkartılmıştır. Tablodaki katsayıların yorumu örneğin $\beta_{1}=0.60$ katsayısı için;"GSMH \%1 lik bir artış kayıtdışı istihdamda \%0.60 lık bir artışa neden olacaktır" şeklinde yapılır.

Tablo 2 de gözlendiği üzere regresyon sonuçlarına göre 2005-2012 dönemleri arasında GSMH tüm modellerde kayıtdışı istihdam ile pozitif ilişkide tahmin edilmiştir. Bulutay ve Taşçı(2002)'nın çalışmalarında GSMH'daki artışın istihdamı kamu sektörüne kanalize eden bir etkiye sahip olduğu, bundan dolayıda kayıtdışı istihdamı azaltacağı sonucuna ulaşılmıştır.Ancak bu çalışmada GSMH'daki artışın kayıtdışı istihdamı artırıcı etkisi tahmin edilmiştir.Bu noktada GSMH daki artışın yanı sıra kayıtdışı istihdam oranının düşmemesinin, Türkiye ekonomisi büyürken öte yandan işsizliğin ve gelir adalesizliğinin de artıyor olmasının bir sonucu olarak karşımıza çıktığı söylenebilir.Ekonomideki büyüme düşük gelirli kesime yansımadığından kayıtdışı istihdamda bir azalış olmamaktadır.Yoksulluk ve işsizlik toplumu kayıtdışı çalışmaya gönüllü hale getirmektedir.Öte yandan güvencesiz işçi çalıştırma yine ucuz iş gücü sağladığından işverenlerin kayıtdışı işçi çalıştırma eğilimi artmaktadır.

Toplam İstihdam, tarım istihdamı ve Kişi Başı İmalat Üretimi (verimlilik) katsayıları yine kayıtdışı istihdam ile bu değişkenlerin birlikte hareket ettiğini göstermektedir.Bulutay ve Taşçı (2002)'ın çalışmalarında ulaştıkları sonuca paralel bir sonuç elde edilmiştir. İstihdam olanaklarındaki genişleme, kırdan kente göçü artırmasından dolayı kayıtdışı istihdamı da yükselten bir etkiye sahiptir (Bulutay,Taşçi,2002). Verimlilik yine kayıdışı istihdam ile doğru orantılı tahmin edilmiştir.Verimlilik teknolojik gelişme ile artabilir ve bu artış aynı zamanda iş gücüne ihtiyacın azalması anlamına gelmektedir.Tarımda veya imalatta verimliliğin artmasıyla birlikte işsizliğin artması ve kırdan kente göçün artması buna bir örnektir. Verimlilik artışılla işsiz kalan vasıfsız iş gücü kayıtdışı istihdama yönelmektedir.Sonuç olarak Türkiye'de 2005-2012 dönemi için istihdam ve üretim değişkenlerindeki artışların kayıtdışı istihdamı artırdığı sonucuna ulaşılmıştır.Bunda kuşkusuz Türkiye'deki iş gücünün yapısının büyük rolü vardır.Eğitimsiz ve donanımsız iş gücünün fazla olduğu ülkemizde kayıtdışı istihdam faaliyetlerinin önüne geçilmesi iş gücü kalitesinin yükseltilmesi buda eğitime yapılacak yatırımlarla da ilgilidir.Kayıtdışı faliyetlerde işgücünün yapısı büyük önem taşımaktadır.

\section{Sonuç}

Önemli bir üretim faktörü olan emeğin konu olduğu kayıtdışı istihdam, ülke ekonomilerine ülkenin üretimine, isihdam ve ücret seviyesine, işçilerin, kadın ve çocuk işçilerin çalışma şartlarına kadar bir çok farklı kanalla, işgücü piyasası dengelerini değiştirmek yoluyla etki etmektedir.

Bireyler özellikle az gelişmiş ve gelişmekte olan ülkelerde yüksek işsizlik enflasyon gibi nedenlerde kayıt dışı olarak çalışmaktadırlar.Kayıt dişı sektörde çalışanlar işsizliğin yoğun olduğu dönemlerde iş imkanı bulabildiklerinden gelir elde edebilirler ve bu onlar içinde işveren içinde olumludur.Ancak ülkemizde olduğu gibi bu durumun yapısal bir soruna dönüşmesi kayıtdışı çalışan kesimin düşük eğitim seviyesi,düşük verimlilik ve düşük ücretler ile çalıştırılmasını da sürekli kılmaktadır.

Kentleşme ve göç kayıtdışı istihdamın temel nedenleri olmakla birlikte mali,ekonomik ve sosyal nedenler de kayıtdışılığın sürekliliğinde etkilidir.Bunlarla birlikte psikoljik,politik ve ahlaki faktörlerde kayıtdışılık ile yakından ilişkilidir.Enflasyon,gelir dağılımı eşitsizliği,ekonomi politikaları ve stratejileri,vergilendirme,vergi denetimi ve yasaları,yaşam memnuniyeti gibi bir çok neden kayıt dışı istihdamın ortaya çıkmasında ve genişlemesinde rol oynamaktadır.

Kayıtdışı istihdam kısa dönemde üretim seviyesini yükseltme,maliyetleri ve işsizliği düşürme gibi ekonomi üzerinde olumlu etkilere sahipse de uzun vade de ekonomik kalkınmaya etkisinin olumsuz olduğunu söylemek mümkündür.Gelişmekte olan ülkeler ucuz işgücünü kısa dönem ekonomik büyüme hedeflerine ulaşabilmek için bir avantaj olarak kullanmaktadırlar ancak bu durum uzun dönem de ekonomik ve sosyal olarak yapısal sorunlar ortaya çıkarmaktadır.Bu nedenle Türkiye gibi gelişmekte olan ülkeler kayıtdışılığı azaltmak ve uzun vade de sağlıklı bir ekonomiye sahip olmak için ekonomi politikalarını gözden geçirmelidir.Bu bağlamda şunu söylemek mümkündür;Türkiye'de çalışanların yarıya yakınının kayıtdışı iş gücüne dahil olduğu göz önüne alındığında, kayıtdışı istihdamın azaltılması için yapılacak ani düzenlemeler işsizliği,enflasyonu ve yoksulluğu artıracak ekonomik büyümeyide olumsuz etkileyecektir.Bu nedenle kayıtdışı istihdamın azaltılması diğer bir deyişle ekonomide ki bu ikili yapının değiştirilmesi için uzun vadeli sosyal ve ekonomik planlar yapılmalıdır.Bu 
planlarda da emek ve sermaye gelirleri arasındaki farkın zamanla azaltılması,yoksulluğun ve işsizliğin önüne geçecek doğru politikalar izlenmesine öncelik verilerek kayıtdışı istihdamı uzun vadede azalması sağlanacaktır.

\section{Kaynakça}

- ALTUĞ, O. (1999). Kayıt Dışı Ekonomi, İstanbul: Türkmen Kitabevi.

- ALTUĞ, E. Figen,Türkiye'de vergi bilinci: İstanbul araştırması./E. Figen altuğ yay.haz.Murat Çak,Murat Şeker,

- Önder Bingöl.-- İstanbul : İSMMMO, 2010

- AYDIN,E., HISARCIKLILAR,M.,KARACAN,İ., Formal versus Informal Labor Market Segmentation in Turkey in the course of Market Liberalization", Journal of Middle Eastern and North African Studies, No. $12,09 / 2013$

- AZAKLI, S. B., Türkiye'de Kayıtdısı İstihdam ve Ekonomik Boyutu,Yuksek Lisans Tezi, Karaman, 2009.

- BULUTAY ,T. ,TAŞÇI, E .(2002), "Informal Sector In The Turkish LaborMarket”,Turkish Economic Asociation, Dicussion papers, Ankara,Turkey

- BOURGUIGNON, F. and MORRISON, C. (1998), "Inequality and development:the role of dualism", Journal of Development Economics, Vol. $57,233-257,1998$.

- CAGAN, P. (1958) "The Demand for CurrencyRelative to Total Money Supply”, National Bureau of Economic Research, 1-37,1958,New York.

- Elgìn, C.(2010), “Vergiler ve Kayıtdışı Ekonomi: Bir Değerlendirme Ve Türkiye Örneği”,,Boğaziçi university, 2010

- GULOĞLU,T.(2005),The Reality of Informal Employment in Turkey, Ithaca, NY: Cornell University, School of Industrial and Labor Relations, International Programs

- KIRKPATRICK, C., and BARRIENTOS, A. (2004), "The Lewis Model After Fifty Years", University of Manchester ,September 2004.

- ÖĞUNÇ, F. and YILMAZ, Gökhan. (2000), "Estimating the Underground Economy in Turkey”, The Central Bank of The Republic of Turkey,2000.

- POLANYİ,K.,(1944),Büyük Dönüşüm.(A.Buğra,çev.),̇letişim Yayınları,9.baskı,2010.

- SARAÇOĞLU,D.Ş. , "The informal sector and tax on employment: A dynamic general equilibrium investigation", Middle East Technical University,2007.

- $\quad$ http://www.tuik.gov.tr/UstMenu.do?metod=temelist,TÜIK,2013. 


\title{
Bankacılık Sektöründe Personel Güçlendirme Uygulamalarının Örgütsel Bağlılığa Etkisi: Trakya Bölgesi Bankalarında Araştırma TheEffects of Empowerment Applications on Organizational Loyality in the Banking Sector: A Study of Trakya Region
}

\author{
Gözde Gürbüz (Trakya University, Turkey) \\ Asst. Prof. Dr. İlknur Kumkale (Trakya University, Turkey) \\ Assoc. Prof. Dr. Adil Oğuzhan (Trakya University, Turkey)
}

\begin{abstract}
It is necessary that several applications should be done by the firms to adaptation to the changing market conditions and taking advantage of loyality. The first-major one of these applications is "empowerment" which is a modern management application. Efforts and labor of employees, who are so important for the firms' developing and growing process, make valuable the firms. As businesses are aware of this, give power, responsibility, authority, and confidence to the employees; and thus they will be empowered. When the employees feel that they are empowered, their loyality will increase to the employer. This is important for the firms in today's hard conditions. In this study, it was investigated how was applied empowerment in the banking sector that there is intensive competition and how the empowerment effect the loyality level on the organization. The study is done via first data acquired from questionnary which were applied to 382 employees in 20 banks in Edirne, Tekirdağ and Kirklareli city-centers, and seconder data is from the literrature. The reliability test, demographical dispersion of employees, interpretation of employee empowerment and organizational commitment's surveys, factor analiysis, variation tests (Kolmogrov-Smirnov Z, Mann-Whitney U, KruskalWallis), regression and correlation analysis was made by SPSS. As a result of the study, it is concluded that, the empowerment applications in the banking sector, increased the loyality of the employee to the organizations.
\end{abstract}

\section{Giriș}

Uluslararası rekabetin artması, küreselleşme, müşteri beklentilerindeki hızlı ve sürekli değişim gibi nedenler işletmelerde insan kaynaklarının önemini artırmış ve bu konudaki çalışmalar da önem kazanmıştır. Çalışanların kendilerini işletmeleriyle özdeşleştirdikleri ve bağlılıklarını artırdıkları ölçüde işletmelerinin performansında artış meydana geldiği görülmüştür.Isşletmelerin verimliliklerinin artmasında güçlü/ güçlendirilmiş personelin önemi konusunda birçok çalışma yapılmaktadır.Personel güçlendirme, işletmelerde bulunan üst yönetimin, astlarına yetki, güç, sorumluluk vererek işin sahibi haline gelmelerini, bir işi yapabilme cesareti kazanmalarını ve kendilerini sürekli geliştirmelerini sağlayan, özgüvenlerini artıran kapsamlı bir süreç olarak tanımlanmaktadır.

Personel güçlendirme uygulamalarına tarihsel olarak bakıldığında, F:W:Taylor'dan günümüze çeşitli aşamalardan geçse ve hala farklı görüşler öne sürülerek tartışılmakta olsa da,personel güçlendirme ile işletmelerin rekabet üstünlüğü elde edebileceği, performanslarını artırabileceği, sürekli değişen ihtiyaçlarınıhızlı bir şekilde karşılayabileceği ifade edilmektedir.

$\mathrm{Bu}$ çalışmadahedeflenen,literatürden elde edilen bilgiler 1şığındaTrakya Bölgesi’nin üç ili olan Edirne, Tekirdağ ve Kırklareli'de banka çalışanlarına yüz yüze anket uygulaması şeklindealan çalışması yaparak Türkiye'deki bankacılık sektöründe uygulanan personel güçlendirmenin, banka çalışanlarının örgüte olan bağlılıklarına etkisi hakkında fikir oluşturmaktır.

\section{Personel Güçlendirme ve Örgütsel Bağlılık Kavramlarına Genel Bakış}

Bu bölümde personel güçlendirme ve örgütsel bağlılık konularında kısaca literatür bilgilerine yer verilecektir.

\subsection{Personel Güçlendirme}

Personel güçlendirme 20. Yüzyılın ortalarında, İnsan İlișkileri kuramcıları tarafından savunulan görüşlerle ortaya çıkmıştır (Emet, 2006). Hawtorne Çalışmaları olarak bilinen ve Elton Mayo önderliğinde yürütülen deneylerde çalışanların yönetime katılımının sağlanmasının maddi ve manevi faydalar sağlayacağı iddia edilmiștir. 1950'lerde Mayo'nun görüşleri esas alınarak Maslow’un başlattığı ve beșeri ilişkiler olarak adlandırılan yaklaşım(Seçgin, 2007), 1960-1970 yılları arasında yöneticilerin, çalışanların önerilerini alan, amaç belirlemede insancıl bir yaklaşım ortaya çıkmış, işgücü devir oranının azaltılmasını amaçlanmıştır (Emet, 2006),. 1970'li yıllarda, başlangıc1 19.yüzyıla uzanan Endüstriyel Demokrasinin popüler bir yaklaşım olarak gündeme gelmesi(Hacımustafaoğlu, 2008) ile çalışanların itaati, hiyerarşik otorite kabulü ve takım çalıșmasıı, yüksek güvene dayalı ilişkiler, göreve içten bağlılık ve çalışanların uzmanlıklarından faydalanmayı içeren yaklaşımlar(Churin, 2006)oluşmuş, 1980'lerde kalite çemberleri, kâr paylaşımı gibi yönetime katılmayı güçlendiren kavramlar ortaya çıkmıştır. 1980 sonrası teknolojik gelişmelerin yaşandığı işletmelerin de buzorlu 
sürece ayak uydurabilmek için esnek bir yapı oluşturmaya özen göstermeleri müşteri kavramına önem vermelerigerektiği anlaşılmıştır(Hacımustafaoğlu,2008). Çalışanı güçlendirme anlayışı yenilik ve esneklik ihtiyacı nedeniyle, 1990'larda örgütlerin yapısına uygun bir kontrolün nasıl geliştirilebileceği sorusu ile karşı karşıya bulunan yöneticilerin, bu sorunu çözmede kullanmaya başladıkları bir anlayış(Özbek, 2008) olmuștur. Çalışanların yönetime katılımının sağlanmasında, işgücü devir hızının düşürülmesinde ve iş tatminin sağlanmasında günümüz iş dünyasında önemli bir yere sahip görünmektedir (Hacımustafaoğlu, 2008). Bowen ve Lawler (1992) personel güçlendirmeyi; "çalışanlara karar verme olanağının tanınması"olarak tanımlarken, Pastor (1996) ise "çalışanların kendi faaliyetlerinde sorumluluk almalarının sağlanması" şeklinde tanımlamıştır. Zemke ve Schaff'a(1989) göre, çalışanların güçlendirilmesinde, müşteriler ile doğrudan iletişimde bulunan çalışanlara özgürlük verilmesinin gerekli olduğu, yaratıcılık ve yenilikleri uygulama konusunda da çalışanların cesaretlendirilmesi gerektiği belirtilmektedir(Karakoç ve Yılmaz,2009). Ripley(1992) ise personel güçlendirmenin, bir kavram, bir felsefe, bir dizi örgütsel davranış ve program olduğuyla ilgili tanımlar yapmıştır(Çavuş, 2006).

Personel güçlendirme ile ilgili tanımlar incelendiğinde, güçlendirmenin temel unsurları çalışanları karar verme aşamasına dâhil etmek, çalışanlara yetki vermek ve çalışanların kendilerini geliştirmesini sağlamak olduğu görülmektedir. Motorola, Marrıot, Wal-Mart, McDonalds, SouthwestAirlines gibi personel güçlendirme anlayışını uygulayan işletmelerin(Doğan, 2006), çalışanlara duydukları güven sonucunda uzun ömürlü işletme haline geldikleri görülmektedir.

\subsubsection{Personel GüçlendirmeYaklaşımları}

Personel güçlendirme konusunda iki temel yaklaşım ortaya çıkmıştır. Birincisi iş yerinde personeli güçlendirici sosyal-yapısal faktörleri göz önünde bulunduran yaklaşım, ikincisi ise personelin psikolojik-motivasyonel yönünü göz önünde bulunduran yaklaşımdır(Çavuş, 2006).

Davranışsal yaklaşım (Yapısal Güçlendirme)teorisi, çalışanların davranışlarını etkileyen koşulları araştıran Kanter tarafindan 1993 yılında geliştirilmiş ve yapısal güçlendirme için dört yapı ortaya konmuștur; Çalışanın kendini geliştirebilmesi için mesleğinin sınırları dışındaki faaliyetlere katılabilmesi, örgütle ilgili tüm bilgiye ulaşabilmesi, karar vermede desteğe sahip olabilmesi, çalışanın istediğinde kaynaklara ulaşabilmesi olaraksıralanabilir(Allanazarov, 2008).

Personel güçlendirmenin psikolojik boyutunda ise, yapılanların işgörenler tarafından nasıl algılandığı konusuna odaklanılmıştır.Spreitzer(1995) güçlendirme algıları(anlam, yetkinlik, özerklik, etki) ile performans arasında pozitif bir ilişki olduğunu ifade etmektedir.

Psikolojik güçlendirmeyi ilk tanımlayanlardan Conger ve Kanungo (1988) güçlendirmeyi, güçsüzlüğü besleyen koşulların belirlenmesi yoluyla, resmi kurumsal uygulamaların ve yeterlilik bilgisi sağlayan gayriresmi tekniklerin ortadan kaldırılması yoluyla çalışanların öz yeterlilik duygusunu arttırma süreci olarak tanımlamışlardır (Vasugi, vd.2011) Öz yeterlilik duygusunun güçlendirilmesi, bireysel güçsüzlüğe neden olan örgütsel faktörler, yönetim tarzı, ödül sistemi gibi faktörlerin indirgenmesi ile mümkündür (Arslantaş, 2007).

\subsubsection{Personel Güçlendirmenin Unsurları}

Bir işletme içerisinde personel güçlendirmeyi uygulayabilmek ve örgüt kültürü içerisine yerleştirebilmek için; katılım, yenilik, bilgiye ulaşılabilirlik ve sorumluluk olmak üzeredört ana koşul vardır(Koç, 2008).

Katılım; güçlendirilmiş personelin yönetime katılımını, yenilik; işlerin yapılmasında karar verme ve yeni fikirler üretme yetki ve cesaretine sahip olmasını, bilgiye ulaşılabilirlik ve bilginin paylaşılması; güçlendirmenin başarılı olabilmesi için bilginin örgüt içinde ve güçlendirilecek personel arasında paylaşılması gerektiğini, sorumluluk ise; yöneticinin güçlendirmeyi uygulayacaksa, yetki ve sorumluluğu dengeli olarak vermesi gerektiğini ifade etmektedir.

\subsubsection{Personel Güçlendirmenin Yararları}

Personel güçlendirme süreci güçlendirilmiş davranışla sona erdiği taktirde, çalışanlar, müşteriler ve işletme açısından yararlı olacaktır. Yararları şu şekilde özetlemek mümkündür:

Çalışanların değişime açık olmasını, kendini geliştirmesini, kendi kendini motive edebilmesini, farklı kademelerdeki çalışanlar arasında canlı, değerli ve anlamlı ilişkilerin oluşmasını sağlamaktadır (Farmer, 2011). Çalışanlar arasındaki bu uyum, çalışanların işlerine daha sıkı sarılmalarına ve işlerini istekle yapmalarına yardımcı olmakta ve çalışanlar kendilerini güvende hissetmektedirler. Güçlenen çalışanlar, iş ve kişiler üzerinde yetki/kontrole sahip olduğunu hissederler ve kurumda kalmak isterler. Personel güçlendirme, işyerinde etkili bir geribildirim sağlamaktadır. İşyerinde uygulanan etkili bir geribildirim sistemi, çalışanların kendi iş alanlarında uzmanlaşmalarına ve performanslarının artmasına yardımcı olabilmektedir. Müşteri ihtiyaçlarına daha hızlı cevap verilebilirler (Schneiervd. 1994). Yöneticiler, güçlendirilmiş çalışanlarına görevlerini devrettiklerinde, idari ve yönetim görevlerine daha az zaman harcayarak, iş planlama ve çalışanları geliştirme gibi önemli işlerini yapabilmeleri için daha çok zamana sahip olurlar (Çavuş, 2006).Bu da performansa olumlu yansımaktadır. 


\section{2 Örgütsel Bağlılık}

Örgütsel bağl1lık, insan kaynakları yönetimi faaliyetlerinin kalbinde yer alan bir kavramdır. Oluşturulan bütün insan kaynakları yönetimi politikalarındaki temel düşünce, olumlu çıktıların sağlanabilmesi için örgütsel bağlılık seviyesinin yükseltilebilmesidir(Bülbül,2007).Bunu gerçekleştiren işletmeler, zor koşullarda daha mücadeleci olurlar, daha emin adımlarla ilerlerler ve rekabette fark yaratıp rekabet üstünlüğü elde edebilirler.

Örgütsel bağlllığı ilk tanımlayanlardan birisi olan Grusky (1966) bağlllığı, "bireyin örgüte olan bağının gücü" olarak tanımlamıştır (İnce ve Gül, 2005). Mowday, Steers ve Porter (1979)'e göre örgütsel bağlllık, örgütün amaç ve değerlerine güçlü bir inanç duyma, örgütün yararına olan her türlü faaliyetlere yönelik olarak çaba sarf etmesi ve son olarak da işgörenin örgütte üyeliğini devam ettirme arzusudur (Yavuz ve Tokmak, 2009;Allen ve Meyer, 1990).

Örgütlerin güçlenerek büyümesi, çalışanların örgüte güçlü duygular beslemesine bağlıdır. Kurumlar, çalışanların kurumuyla ilgili ne düşündüğü ve nasıl hissettiğinin yanı sıra kuruma kendilerini ne şekilde adamaya istekli olacağı ile ilgili yönetimin rolüyle uzun süredir ilgilenmektedir (Roberson ve Strickland, 2010). Yani örgütsel bağlılık çift yönlü bir ilişkiden oluşmaktadır. Çalışanların örgütüne bağlılık hissetmesi için aynı duyarlılığı örgütün de çalışanlarına göstermesi gereklidir(Cengiz, 2001).

\subsection{1 Örgütsel Bağlılık Konusundaki Yaklaşımlar}

Örgütsel bağlılık konusuyla ilgili olarak, çok sayıda farklı yaklaşımlarda bulunulmuştur. Bu yaklaşımları; tutumsal bağlılık, davranışsal bağlılık ve çoklu bağlılık yaklaşımları olmak üzere üç ana grupta toplamak mümkündür.

Bu konuda özellikle Allen ve Meyer'intutumsal bağllık konusundaki çalışmaları öne çıkmış olup,örgütsel bağll1ı̆̆ı, bireyin örgütsel hedeflere ve değerlere inanması, onları kabul etmesi, örgütün bir parçası olmak için çaba göstermesi ve organizasyonun sürekli bir üyesi olma kararını almalarını sağlayan davranış olarak tanımlamışlar(Tak ve Çiftçioğlu, 2009) ve duygusal bağlılık,devam bağlılı̆̆ ve normatif bağlılık olmak üzere üç temel boyutta incelemişlerdir.

\section{Türkiye Trakya Bölgesi'nde Faaliyet Gösteren Bankalarda Personel Güçlendirmenin Örgütsel BağlılıkÜzerindeki Etkilerine Yönelik Araştırma}

\subsection{Yöntem ve Bulgular}

Bu çalışmada, Türkiye'nin Trakya Bölgesinde Edirne, Tekirdağ ve Kırklareli il merkezlerinde faaliyette bulanan bankalarda uygulanan personel güçlendirme uygulamalarının çalışanların örgüte olan bağll1ık(Şekil:1) düzeylerini belirlemek amacıyla bir anket çalışması yapılmıştır. Araştırmada iki ölçekten yararlanılmıştır. Personel güçlendirme ile ilgili ölçek oluşturulurken Cacioppe (1998) ve Hayes (1994) tarafindan geliştirilen ölçeklerden, örgütsel bağll1ık ile ilgili ölçek oluşturulurken ise Allen ve Meyer tarafindan geliştirilen (19911997) ölçeklerden yararlanılmıştır(Şahin,2007). Araştırmanının analizinde betimsel istatistikler yanında ölçeklerin güvenirliliğinin testi,Faktör analizi sonuçları non parametrik testlerden Mann-Whiney U testi ve Kruskal Wallis testinin yanında regresyon korelasyon analizi kullanılmıştır.

\subsubsection{Araştırmaya Katılanların Demografik Özeliklerine Göre Dağılımı}

Üç bölümden oluşan anketin birinci bölümünde; bankada çalışanların cinsiyet, medeni durum, yaş, eğitim seviyesi, toplam kaç yıldır çalışıkları, bulundukları işletmede çalıştıkları yıllar, pozisyonları, gelir düzeyleri, şu an çalıştıkları işyerinde ne sıklıkta eğitim gördükleri ve çalıştıkları bankaların türleri gibi sorulara yer verilmiştir.

Yapılan analiz sonucunda; illere göre dağılım incelendiğinde; en yüksek oran \% 61,5 ile Edirne'ye aittir. İkinci sırada \%22,5 ile Tekirdağ yer almaktadır. Üçüncü sırada ise \%16 ile Kırklareli yer almaktadır.

Bankaların isimleri bilimsel araştırma etiği gereği açıklanmamış olup harflerle ifade edilmiştir. Anket araştırması için gidilen bankaların dağılımına bakıldığında ise, en yüksek oran \%31,9 ile B bankasına aittir. Daha sonra \%16 ile C bankas1, \% 12,8 ile E bankas1, \%11,3 ile A bankas1, \%8,4 ile F bankas1, \%6 ile D bankas1, \%5,2 ile $\mathrm{H}$ ve I bankaları, \%3.1 ile G bankası yer almaktadır. B bankasında oranın yüksek olması ankete katılım gösteren personel sayısının fazla olmasından ve ziyaret edilen üç ilde de uygulanmasından kaynaklandığını belirtmek mümkündür.

Ankete dâhil olan banka çalışanlarının \%50,3'ü bayan iken, \%49,7'lik kısmı erkeklerden oluştuğu, \%55'i evli ve \%45'i ise bekar olduğu görülmektedir. Yaş dağılımı incelendiğinde; \%0.5'inin 18 yaş altı, \%22.3'ünün 18-25 yaş, \%53.4'ünün 26-35 yaş ve \%23.8'inin ise 36 yaş ve üstü yaş grubunda olduğu görülmektedir. Araştırmaya en çok katılan yaş grubunun \%53,4 oranına sahip 26-35 yaş grubu oluşturmaktadır. 36 yaş grubu altındaki çalışanların toplam oranı \%76,2 olduğu görüldüğünden bankalarda çoğunlukla genç ve evli personel istihdam edildiği söylenebilir.

Eğitim düzeylerine bakıldığında; \%14.7'sinin lise ve altı mezunu, \%75.4'ünün lisans mezunu, \%9.9'unun ise lisans üstü mezunu olarak saptanmıştır. Çalışanların toplam kaç yıldır iş hayatında oldukları incelendiğinde; \%5'inin 1 yıldan az süredir çalıştığı, \%37.7'sinin 1-5 yıl arasında çalıştığı, \%33'ünün 6-10 yıl arasında çalıştı̆̆ 
ve \%24.3'ünün ise 11 yıl ve daha uzun süredir çalıştığı belirlenmiştir. Bulundukları bankada çalışma sürelerine ilişkin yapılan analiz sonucunda personelin \%7.1'inin 1 yıldan az, \%44.2'sinin 1-5 yıl, \%31.4'ünün 6-10 y1l ve \%17.3'ünün ise 11 yıl ve daha uzun süredir çalıştıkları ortaya konmuştur. Üç ilde görev yapan banka çalışanlarının oranlarına bakıldığında görev aldıkları işletmelerde genel olarak 1-5 yıl arasında çalıştıklarını beyan etmişlerdir.Personelin bulunduğu pozisyonları belirlemeye yönelik soruların analiz sonuçlarına göre; \%45'i memur, \%36.1'i şef, \%9.7'si müdür yardımcıs1, \%1.6's1 müdür, \%7.6's1 ise güvenlik görevlisi, çayc1 ve temizlik işleriniyapan çalışanlardan oluştuğu görülmekte olup, anketi yanıtlayanların \%45'inin memur, \%47,4‘ünün yönetim kademesindeki kişilerden oluştuğunu söylemek mümkündür.

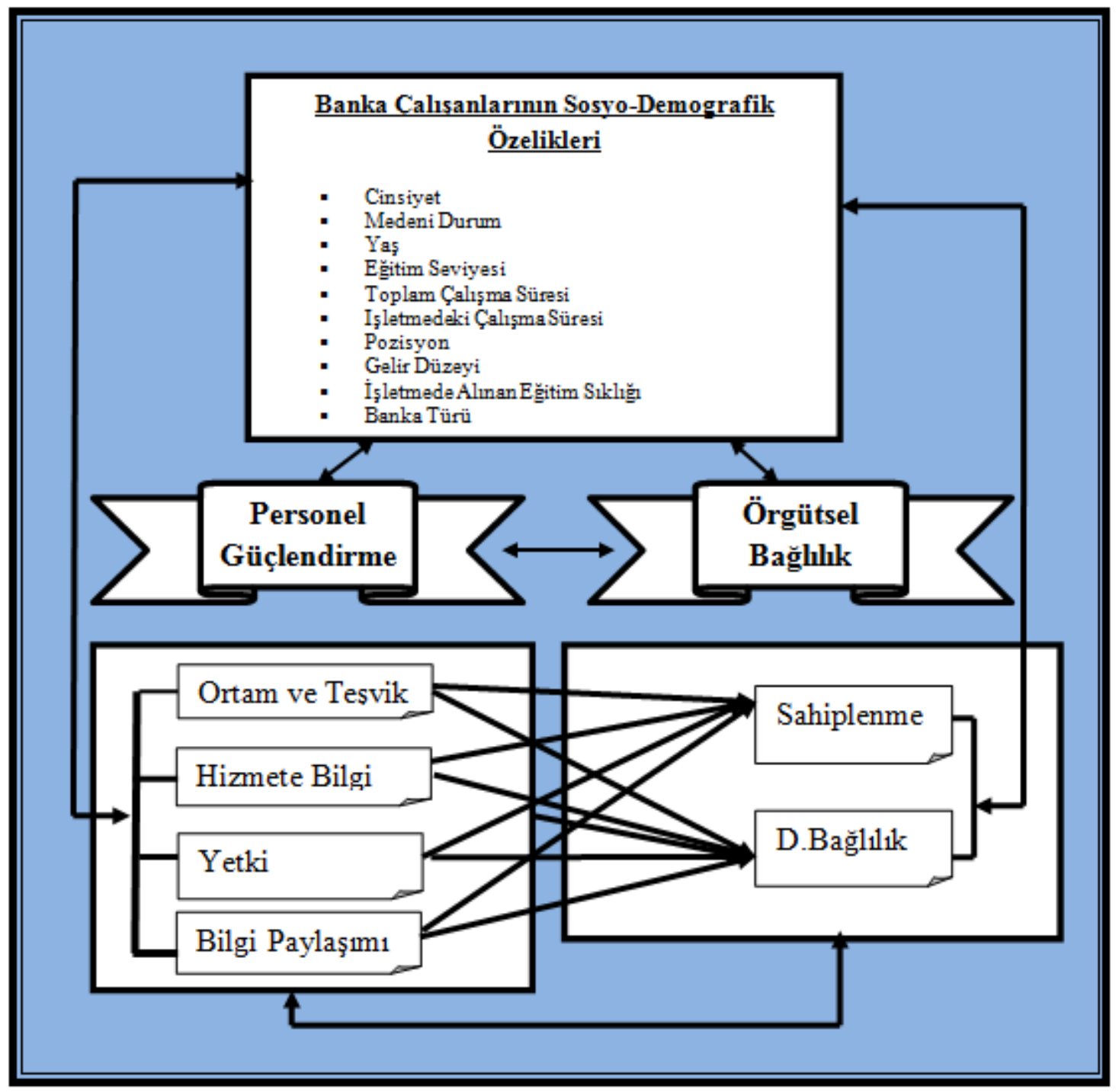

Şekil 1: Araştırma Modeli

Çalışanların işyerlerinden aldıkları aylık toplam gelirlere göre dağılımı göre \%52.9'u 1000-2000, \%35.1'i 2001-3000, \%9.4'ü 3001-4000, \%1'i 4001-5000 ve \%1.6's1 ise 5000'den daha fazla gelir elde etmektedir. Oranlara bakıldığında bankalarda çalışanların çoğunluğunu memurların oluşturmasından dolayı en yüksek oranın 1000-2000 arasında olduğu açıkça görülmektedir.

Bunların yanında ankete katılan banka çalışanlarının bulundukları işyerlerinde ne sıklıkta eğitim gördükleri sorusuna verilen cevaplar incelendiğinde; \%6.3'lük kısmın eğitim görmediği, \%28.8'lik kısmın yılda 1 kez eğitim gördüğ̈̈, \%52.1'lik kısmın yılda birden daha fazla eğitim gördükleri ve \%12.8'lik kısmın ise çalışanların eksik oldukları konularda istedikleri zaman veya sıklıkla eğitim aldıklarını belirterek bu bulgulara ulaşılmıştır. Edirne, Tekirdağ ve Kırklareli'nde bulunan banka personelinin bulundukları işletmelerde ne kadar sıklıkta eğitim aldıklarına dair oranlara bakıldığında en yüksek oranın yılda bir defadan fazla olduğunu belirtmek mümkündür. Aynı zamanda bankalarda çalışan personelin \%93,7'sinin çeşitli eğitimlere tabi tutulduğu görülmektedir.

Edirne, Tekirdağ ve Kırklareli illerinde toplam 5 kamu, 15 özel bankada anket yapılmış olup, \%25'i kamu, \%75'i özel bankadır. Diğer bir yandan çalışanların bulundukları banka türlerine göre dağılım incelendiğinde; \%59.9'unu özel ve \%40.1'ini kamu bankası çalışanları oluşturmaktadır. 


\subsubsection{Faktör Analizi}

Faktör analizi birbiri ile ilişkili çok sayıda değişkeni bir araya getirerek az sayıda kavramsal olarak anlamlı değişkenler (faktörler, boyutlar) bulmayı amaçlayan çok değişkenli bir istatistik yöntemidir. Ayrıca Personel güçlendirme ölçeğin maddelerinin güvenirliği Cronbach alfa katsayısı 0,957 olarak elde edilmiştir. Bu çalışmada Personel güçlendirme ölçeğinin faktör analizinin yapılıp yapılamayacağını ortaya koymak içim K.M.O testi sonucu 0,951 dir. Böylece $p<0,05$ olduğundan faktör analizine uygun olduğu belirlenmiştir.

Yapılan faktör analizinde personel güçlendirme alt boyutlarının dört faktörde ortaya çıktığı gözlemlenmiştir. Buna göre personel güçlendirme alt boyutları; birinci faktörde ortam ve teşvik, ikinci faktörde hizmette bilgi ve güven, üçüncü faktörde yetki ve dördüncü faktörde ise; bilgi paylaşımı olarak belirlenmiştir. Analizin sonucunda ortaya çıkan boyutlardan ortam ve teşvik en fazla paya sahip olan boyuttur. Benzer şekilde Örgütsel bağlılık ölçeğinin maddelerinin güvenirliği Cronbach alfa katsayısı 0,895 olarak elde edilmiştir. Faktör analizinin K.M.O testi sonucu ise 0,921 olarak elde edilmiştir burada $\mathrm{p}<0,05$ olduğundan faktör analizine uygun olduğu belirlenmiştir.

Elde edilen döndürülmüş faktör matrisi, iki faktörden oluşmaktadır. Önemli olarak belirlenen faktörlerden ilki ölçeğe ilişkin toplam varyansın \%41,768'ini, ikincisi \%21,936’sını, açıklamaktadır. İki faktörün açıkladıkları toplam varyans $\% 63,704$ 'tür.

Sahiplenme ve duygusal bağlılık boyutunda yer alan maddelerin ortak varyansı 0,504-0,823 arasında, devam bağlılığı boyutundaki maddelerin ortak varyansı $0,584-0,770$ arasındadır.

Yapılan faktör analizinde örgütsel bağlılık alt boyutları duygusal, devam ve normatif olmak üzere üç boyutta incelenmesi gerekirken banka çalışanlarının normatif bağlılıkla ilgili ifade vermemeleri nedeniyle örgütsel bağlılık alt boyutlarının iki faktörde incelendiği ortaya çıkmıştır. Buna göre örgütsel bağlılık alt boyutları; birinci faktör sahiplenme ve duygusal bağlılık, ikinci faktör ise devam bağlılığı olarak belirlenmiştir. Analizin sonucunda ortaya çıkan boyutlardan sahiplenme ve duygusal bağlılık en fazla paya sahip olan boyuttur.

Sahiplenme ve duygusal bağlılık boyutu; işyerlerinin çalışanlar için özel bir anlam ifade etmesi, çalışanların işyerlerinde ortaya çıkan sorunları kendi sorunları gibi hissetmesi, çalışanların işyerleri ile ilgili gurur duyması, kariyerlerinin geri kalanını bulundukları kurumda devam ettirmekten mutluluk duyulması, işyerinde, kendilerini aileden biri gibi hissetmeleri, işyerlerinin; çalışanların bağımlılığını hak etmesi, çalışanların kariyer gelişimleri açısından işyerlerine karşı kendilerini borçlu hissetmesi, çalışanların bulundukları kurumdan ayrıldıkları takdirde suçluluk duyması, çalışanların işyerinde çalışmaya devam etmelerinin en önemli nedenlerinin sadakatin önemine inanmalarından dolayı işyerinde kalmayı ahlâki zorunluluk olarak görmeleri ifadelerini içermektedir.

Devam bağlılık boyutu ise; çalışanların, işyerlerinde çalışmaya devam etmelerinin nedeni, istek olduğu kadar mecburiyetten de kaynaklanması, iş alternatiflerinin az olması nedeniyle işyerinden ayrılmayı düşünmemeleri, bulundukları kurumda çalışmaya devam etmelerinin nedeni; başka bir işte, şimdiki kazancından daha fazla kazanamayacağının düşünülmesi, eğer çalışanlara başka bir yerden daha iyi bir iş teklifi gelirse işyerinden ayrılma söz konusu olması, çalışanların işyerinden ayrılmaya karar vermesi hâlinde hayatındaki pek çok şeyin olumsuz etkilenmesi ve çalışanların işyerlerine olan katkılarından dolayı başka bir yerde çalışmayı düşünmemeleri ifadelerini içermektedir.

\subsubsection{Personel Güçlendirme Alt Boyutlarının Banka Çalışanlarının Sosyo- Ekonomik Durumlarına Göre Farklılığının Testi}

Banka çalışanlarının cinsiyetlerine, medeni durumlarına, yaşlarına, eğitim seviyelerine, toplam çalışma sürelerine, işletmedeki çalışma sürelerine, pozisyonlarına, gelir düzeylerine, işyerinde aldıkları eğitim sıklığına ve banka türlerine göre personel güçlendirme alt boyutları arasında fark olup olmadığına ilişkin testler ele alınmış, bu amaçla önce personel güçlendirme alt boyutlarına verilen puanların dağılımının normal olup olmadığına bakılarak, parametrik veya parametrik olmayan testler uygulanmıştır.

$\mathrm{Bu}$ nedenle, personel güçlendirme alt boyutlardan olan ortam ve teşvik, hizmette bilgi ve güven, yetki ve bilgi paylaşımı puanlarının dağılımının normalliği Kolmogorov-Smirnov testi ile test edilmiş; sonuç olarak alt boyutlarının puanları normal dağılım göstermediklerinden non parametrik testler uygulanmıştır.

\begin{tabular}{|l|l|l|l|l|}
\hline Personel Güçlendirme & & Cinsiyet & Medeni Durum & Banka Türü \\
\hline Ortam ve teşvik & $\mathrm{Pi}$ & 0,660 & 0,358 & 0,079 \\
\hline Hizmette bilgi ve güven & $\mathrm{Pi}$ & 0,610 & 0,070 & 0,632 \\
\hline Yetki & $\mathrm{Pi}$ & 0,747 & 0,216 & $\mathbf{0 , 0 0 0}$ \\
\hline Bilgi Paylaşımı & $\mathrm{Pi}$ & 0,860 & 0,942 & 0,270 \\
\hline
\end{tabular}

Tablo 1: Personel Güçlendirme Alt Boyutlarının Banka Çalışanlarının Cinsiyetlerine, Medeni Durumlarına ve Çalıştıkları Bankanın Türlerine Göre Mann-Whitney U Testi

Banka çalışanlarının cinsiyetlerine, medeni durumlarına, çalıştıkları bankanın türlerine göre personel güçlendirme alt boyutlarının aldıkları puan düzeyleri arasında bir farkın olup olmadığı Mann-Whitney U testi ile test edilmiş ve bulunan sonuçların anlamlılık düzeyleri verilmiştir. 
Banka çalışanlarının cinsiyetlerine ve medeni durumlarına göre personel güçlendirmenin alt boyutları olan ortam ve teşvik, hizmette bilgi ve güven, yetki ve bilgi paylaşımı boyutlarına yaklaşımlarında farklılık görülmezken, banka çalışanlarının çalıştıkları bankanın türüne göre yaklaşımlarında farklılık görülmektedir. Böylece, banka çalışanları için çalıştıkları bankanın özel veya kamu bankası olmasının onlar için önemli olduğu söylenebilir. Yapılan testler sonucunda kamu bankasında çalışanların personel güçlendirmenin yetkilendirme boyutuna daha olumlu baktıkları görülmüştür. Kamu bankalarında yetki boyutuna daha fazla önem verilmesinin nedeni; kamu bankalarında çalışan ve müşteriyle iletişim hâlinde olan personel sayısının fazla olmasından ve beraberinde getirdiği sorunların da çok olmasından kaynaklanan bir takım problemlere çözüm bulmak, en aza indirgemek, dengelemek ve müşteri memnuniyetini sağlama açısından kaynaklanabilir.

Ayrıca Banka çalışanlarının yaşları, eğitim seviyeleri, toplam çalışma süreleri, işletmedeki çalışma süreleri, pozisyonları, gelir düzeyleri, işyerinde aldıkları eğitim sıklığına göre personel güçlendirme alt boyutları arasında fark olup olmadığını ortaya koymak için Kruskal-Wallis testi aşağıda Tablo 2'de verilmiştir.

\begin{tabular}{|c|c|c|c|c|c|c|c|c|}
\hline $\begin{array}{l}\text { Personel } \\
\text { Güçlendirme }\end{array}$ & & $\stackrel{\pi}{\pi}$ & 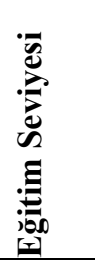 & 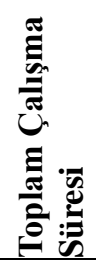 & 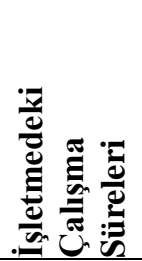 & 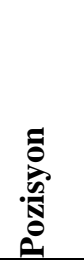 & 胥 & 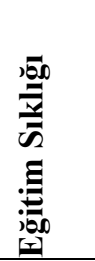 \\
\hline Ortam ve teşvik & $\mathrm{Pi}$ & 0,233 & $\mathbf{0 , 0 3 8}$ & 0,226 & 0,282 & $\mathbf{0 , 0 2}$ & $\mathbf{0 , 0 0 0}$ & 0,064 \\
\hline $\begin{array}{l}\text { Hizmette bilgi ve } \\
\text { güven }\end{array}$ & $\mathrm{Pi}$ & $\mathbf{0 , 0 3 1}$ & 0,418 & $\mathbf{0 , 0 3}$ & 0,143 & 0,02 & 0,002 & 0,861 \\
\hline Yetki & $\mathrm{Pi}$ & 0,310 & $\mathbf{0 , 0 0 3}$ & 0,407 & 0,254 & $\mathbf{0 , 0 2}$ & 0,000 & 0,012 \\
\hline Bilgi Paylaşımı & $\mathrm{Pi}$ & 0,584 & 0,026 & 0,763 & 0,726 & $\mathbf{0 , 0 2}$ & $\mathbf{0 , 0 0 0}$ & 0,044 \\
\hline
\end{tabular}

Tablo 2: Personel Güçlendirme Alt Boyutlarının Banka Çalışanlarının Sosyo-Demografik Yapılarına Göre Farklılı̆̆ının Kruskal Wallis Testi

$\mathrm{P}<0,05$ 'den küçük ise farklılık söz konusudur. Bu temel bilgi dikkate alınarak personel güçlendirmenin birinci alt boyutu olan ortam ve teşvik boyutunda, banka çalışanlarının yaşlarının, toplam ve bulundukları işletmedeki çalışma sürelerinin ve işletmede aldıkları eğitim sıklıklarının banka çalışanları için bu boyuta olan yaklaşımlarını değiştirmediğini yani bir farklılık görülmediğini, ancak banka çalışanlarının eğitim seviyelerine, işletmedeki pozisyonlarına ve gelir düzeylerine göre $\mathrm{p}<0,05$ oluğundan dolayı farklılık görüldüğü söylenebilir. Bu farklılık, eğitim düzeyi lisans üstü (yüksek lisans ve doktora) mezunu olanlardan, bulundukları işletmede müdür konumunda olanlardan, gelir düzeylerinin 4001-5000 gelire sahip olanlardan kaynaklanmaktadır. Yani lisans üstü mezunu olan, müdür olan, gelir düzeyleri 4001-5000 arasında olan banka çalışanları için bulundukları işletmenin çalışma ortamının iyi olması (yöneticilerin çalışanlarına yenilik yapabilmeleri, yaratıcı fikirler üretebilmeleri için gerekli imkânları sunması vb.) ve yöneticilerin onlara destek olması onlar için önem teşkil ettiğini belirtmek mümkündür.

Personel güçlendirmenin diğer alt boyutu olan hizmette bilgi ve güven boyutunda, banka çalışanlarının eğitim seviyelerine, bulundukları işletmedeki çalışma sürelerine ve işletmede aldıkları eğitim sıklıklarına göre $p>0,05$ olduğundan dolayı farklı yargı içinde olmadıkları görülürken, banka çalışanlarının yaşlarına, toplam çalışma sürelerine, işletmedeki pozisyonlarına ve gelir düzeylerine göre $\mathrm{p}<0,05$ olduğundan dolayı farklı yargı içinde oldukları ortaya konulmuştur. Bu farklılığın yaşlara göre 18 yaş altı çalışan yaş grubundan ileri gelirken, toplam çalışma süresinde 11 yıl ve daha üstü olan, işletmedeki pozisyonlarına göre müdür konumunda olanlardan ve gelir düzeyinde ise 5001 ve üstü gelire sahip olanlardan farkın ileri geldiği test sonucunda ortaya çıkmıştır. 18 yaş altı grubunda olan, toplam 11 yıl ve daha uzun süredir çalışan, müdür olan, 5001 ve üstü gelire sahip olan banka çalışanları için, müşteriye verilen hizmette bilgiye sahip olmanın ve çalışanların birbirlerine güven duymalarının önemli olduğu söylenebilir.

Ayrıca personel güçlendirme alt boyutlarından yetki boyutundaki farklılık incelendiğinde, banka çalışanlarının yaşlarına, toplam ve bulundukları işletmedeki çalışma sürelerine göre $\mathrm{p}>0,05$ olduğundan dolayı farklı görüşlere sahip olmadıkları anlaşılmaktadır. Fakat, banka çalışanlarının eğitim seviyelerine, işletmedeki pozisyonlarına, gelir düzeylerine ve işletmede aldıkları eğitim sıklıklarına göre $p<0,05$ olduğundan dolayı farklı görüşlere sahip oldukları görülmektedir. Banka çalışanlarının farklı görüşlere sahip olmaları ise; eğitim düzeylerinin lise ve altı mezunu olan, işletmedeki pozisyonlarının müdür olan, gelir düzeylerinin 4001-5000 arasında gelire sahip olan ve işletmede aldıkları eğitim sıklıklarının ise yılda $1 \mathrm{kez}$ eğitim gören banka çalışanlarından kaynaklanmaktadır. Böylece lise mezunu olan, bulunduğu bankanın müdürü olan, 4001-5000 arasında geliri olan ve işletmede yılda 1 kez eğitim gören banka çalışanları için karar verme yetkisine, sorunları düzeltme yetkisine vb. yetkilere sahip olmak farklı yani olumlu bakmalarına neden olmaktadır.

Personel güçlendirmenin son alt boyutu olan bilgi paylaşımında ise, banka çalışanlarının yaşlarına, toplam ve bulundukları işletmedeki çalışma sürelerine göre $\mathrm{p}>0,05$ olduğundan dolayı birbirine yakın görüşlerin olduğu 
anlaşılmaktadır. Ancak, banka çalışanlarının eğitim seviyelerine, işletmedeki pozisyonlarına, gelir düzeylerine ve işletmede aldıkları eğitim sıklıklarına göre $\mathrm{p}<0,05$ olduğundan dolayı farklı sonuçlar elde edilmiştir.

Elde edilen sonuçlar incelendiğinde, eğitim seviyesi lisansüstü mezunu olanlar, işletmedeki konumu müdür olanlar, gelir düzeyi 4001-5000 gelire sahip olanlar ve işyerinde hiç eğitim almayanlar için, işyerinde veya müşteri ile ilgili herhangi bir sorun ortaya çıktığında, işyerinde meydana gelen değişiklikler hakkında bilgi sahibi olmak istediklerinde vb. durumlarda işyerinde bilgi akışının sağlanması banka çalışanları açısından olumlu algilanmaktadir.

Banka çalışanlarının cinsiyetlerine, medeni durumlarına, çalıştıkları bankanın türlerine göre örgütsel bağlılık alt boyutlarının aldıkları puan düzeyleri arasında bir farkın olup olmadığı Mann-Whitney U testi ile test edilmiş ve bulunan sonuçların anlamlılık düzeyleri Tablo 3'de verilmiştir.

\begin{tabular}{|l|l|l|l|l|}
\hline Örgütsel Bağlılık & & Cinsiyet & Medeni Durum & Banka Türü \\
\hline Sahiplenme ve Duygusal Bağlılık & $\mathrm{Pi}$ & 0,409 & 0,880 & $\mathbf{0 , 0 0}$ \\
\hline Devam Bağlılık & $\mathrm{Pi}$ & 0,642 & 0,078 & $\mathbf{0 , 0 0}$ \\
\hline
\end{tabular}

Tablo 3: Örgütsel Bağlllık Alt Boyutlarının Banka Çalışanlarının Cinsiyetlerine, Medeni Durumlarına ve Çalıştıkları Bankanın Türlerine Göre Whitney U Testi

Banka çalışanlarının cinsiyetlerine ve medeni durumlarına göre örgütsel bağlılığın alt boyutları olan sahiplenme ve duygusal bağlılık ve devam bağlılık boyutlarına yaklaşımlarında farklılık görülmezken, banka çalışanlarının çalıştıkları bankanın türüne göre yaklaşımlarında farklılık görülmektedir. Yani, banka çalışanları için çalıştıkları bankanın özel veya kamu bankası olmasının onların örgüte olan bağlılıklarını etkilemektedir. Buna göre; bazı kamu bankası çalışanları kendilerini örgütün bir parçası olarak ve kendilerine verilen değeri gördükleri kuruma gönüllü olarak bağlandıkları ve istedikleri için kurumda kalmaya devam ederlerken, bazı kamu bankası çalışanları da örgütten ayrılmanın getireceği olumsuz durumlar nedeniyle mecbur kaldığı için örgütte kalmaya devam ederler.

Banka çalışanlarının yaşları, eğitim seviyeleri, toplam çalışma süreleri, işletmedeki çalışma süreleri, pozisyonları, gelir düzeyleri, işyerinde aldıkları eğitim sıklığına göre personel güçlendirme alt boyutları arasında fark olup olmadığını ortaya koymak için Kruskal-Wallis testi aşağıda Tablo 4'de verilmiştir.

\begin{tabular}{|c|c|c|c|c|c|c|c|c|}
\hline Örgütsel Bağlılık & & $\underset{\pi}{\pi}$ & 流䓹 & ⿷匚⿱乛兀 & 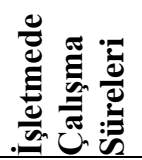 & 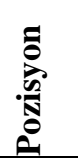 & : 氧 & 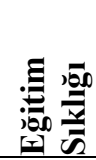 \\
\hline $\begin{array}{l}\text { Sahiplenme ve } \\
\text { Duygusal Bağlılık }\end{array}$ & $\mathrm{Pi}$ & 0,570 & 0,196 & 0,137 & 0,043 & $\mathbf{0 , 0 0}$ & $\mathbf{0 , 0 0}$ & 0,091 \\
\hline Devam Bağlılık & $\mathrm{Pi}$ & 0,450 & 0,019 & 0,701 & 0,511 & $\mathbf{0 , 0 0}$ & $\mathbf{0 , 0 0}$ & 0,006 \\
\hline
\end{tabular}

Tablo 4: Örgütsel Bağlılık Alt Boyutlarının Banka Çalışanlarının Sosyo Demografik Yapılarına Göre Farklılıklarının Kruskal Wallis Testi

Örgütsel bağlılığın alt boyutlarından sahiplenme ve duygusal bağlılık boyutunda, banka çalışanlarının yaşları, eğitim seviyeleri, toplam çalışma süreleri ve işletmede hangi sıklıkta eğitim aldıkları örgüte olan bağlılıklarını etkilemezken yani bir farklılık görülmezken, işletmedeki çalışma sürelerine, pozisyonlarına ve gelir düzeylerine göre $\mathrm{p}<0,05$ olması nedeniyle de farklılık görülmektedir. Bu farklılık, işletmedeki çalışma süreleri 11 yıl ve daha üstü olanlardan, işletmedeki konumu müdür olanlardan ileri gelirken, gelir düzeyinde ise 3001-4000 gelire sahip olanlarda meydana gelmiştir. Yani bulundukları işletmede 11 yıl ve üstü gibi uzun yıllar çalışmış, işletmede müdür olmuş, 3001-4000 gelire sahip olmuş banka çalışanları için, örgüte olan sahiplenme ve duygusal bağlılık boyutlarının yüksek olduğu söylenebilir. Çünkü sahiplenme ve duygusal bağlılık boyutunda, bireyin iş tecrübelerinin, algılamalarının ve kişisel özelliklerinin birleşiminin sonucu olarak örgüte karşı gelişen olumlu tutumlar esas olduğu için uzun yıllar çalışmış, emek harcamış insanların ve bir takım aşamalardan, zorlu süreçlerden geçtikten sonra müdür konuma gelmiş insanların, emeklerinden kolay vazgeçemeyeceği ve Türkiye'nin zorlu koşullarında 3001-4000 gibi yüksek gelire sahip olmuş insanların örgüte olan sahiplenme ve duygusal bağlılıklarının yüksek olması beklenen bir sonuçtur.

Örgütsel bağlılığın diğer önemli boyutu olan devam bağlılık boyutu incelendiğinde ise; banka çalışanlarının yaşlarına, toplam ve bulundukları işletmedeki çalışma sürelerine göre farklı düşüncelere sahip olmadıkları, ancak eğitim seviyelerine, işletmedeki pozisyonlarına, gelir düzeylerine ve işletmede alınan mesleki eğitim sıklıklarına göre ise farklı düşüncelere sahip oldukları Kruskal-Wallis testi yardımıyla ortaya konmuştur. Bu testte meydana gelen farklılıklar, bir çalışanın örgütte çalıştığı süre içerisinde harcadığı emek, zaman ve çaba ile edindiği statü, para gibi kazanımlarını örgütten ayrılmasıyla birlikte, kaybedeceği düşüncesinden yola çıkılarak, çalışanların lisans üstü mezunu olanlarda, şef pozisyonunda bulunanlarda, 4001-5000 gelire sahip olanlarda ve işletmede aldıkları mesleki eğitim sıklıklarına göre ise yılda 1 kez eğitim alanlarda görülmektedir. 


\subsubsection{Personel Güçlendirme İle Örgütsel Bağlılık Arasında Doğrusal Regresyon Modeli}

Araştırmanın bu kısmında, örgütsel bağlılık ve onun alt boyutlarını etkileyen faktörlere ilişkin regresyon modeller aşağıdaki tabloda farklı model denemeleri ele olarak ele alınmıştır.

\begin{tabular}{|c|c|c|c|c|}
\hline & Model 1 & Model 2 & Model 3 & Model 4 \\
\hline & \multicolumn{4}{|l|}{ Bağımlı Değişkenler } \\
\hline Açıklayıcı Değişkenler & $\begin{array}{l}\text { Toplam Örgütsel } \\
\text { Bağlılık }\end{array}$ & $\begin{array}{l}\text { Toplam Örgütsel } \\
\text { Bağlılık }\end{array}$ & Sahiplenme & Devam Bağlılık \\
\hline Sabit & 1,672 & 4,819 & $-4,321$ & 7,358 \\
\hline $\begin{array}{l}\text { Toplam Personel } \\
\text { Güçlendirme }\end{array}$ & $\begin{array}{l}0,798 \\
(25,77)\end{array}$ & - & - & - \\
\hline Ortam ve Teşvik & - & $\begin{array}{l}0,247 \\
(4,725)\end{array}$ & $\begin{array}{l}0,465 \\
(8,712)\end{array}$ & $\begin{array}{l}-0,243 \\
(-3,095)\end{array}$ \\
\hline Yetki & - & $\begin{array}{l}0,446 \\
(8,816)\end{array}$ & $\begin{array}{l}0,241 \\
(4,848)\end{array}$ & $\begin{array}{l}0,550 \\
(7,251)\end{array}$ \\
\hline Bilgi Paylaşımı & - & $\begin{array}{l}0,233 \\
(6,344)\end{array}$ & $\begin{array}{l}0,156 \\
(4,218)\end{array}$ & $\begin{array}{l}0,221 \\
(4,025)\end{array}$ \\
\hline Hizmete Bilgi ve Güven & - & - & $\begin{array}{l}0,073 \\
(1,850)\end{array}$ & - \\
\hline $\mathbf{R}^{2}$ & 0,635 & 0,670 & 0,685 & 0,258 \\
\hline $\mathbf{F}$ & 664,44 & 258,812 & 207,749 & 45,273 \\
\hline
\end{tabular}

Tablo 5: Personel Güçlendirme İle Örgütsel Bağlllık Arasında Doğrusal Regresyon Model Sonuçları *Parantez içindeki değerler tistatistik de ğerleridir.

Belirlenen birinci model, toplam personel güçlendirmenin toplam örgütsel bağlılığa etki düzeyini ölçmek üzere oluşturulmuştur toplam örgütsel bağlılık arasındaki ilişkinin kuvvetli ve pozitif bir ilişki olduğu sonucu ortaya çıkmaktadır. Örgütsel bağlılı̆̆ın $0,635^{\prime}$ 'i personel güçlendirme tarafından belirlenirken kalan $0.365^{\prime} \mathrm{i}$ diğger etmenlerden kaynaklanmaktadır. Ayrıca, personel güçlendirme puanında bir standart sapma artığında örgütsel bağlılık puanının 0.798 standart sapma kadar artacağını da söylemek mümkündür.

Toplam personel güçlendirme ile toplam örgütsel bağlılık arasındaki anlamlılık düzeyine bakıldığında, F değerinin 664,449 ve $\mathrm{p}<0,05$ olması modelin anlamlılığını göstermektedir.

Model 2'de personel güçlendirmenin dört alt boyutundan biri olan faktör 2 (hizmette bilgi ve güven) boyutu istatistiksel açıdan anlamsız bulunduğu için çıkarılmıştır ve personel güçlendirmenin diğer üç alt boyutu; faktör 1 (ortam ve teşvik), faktör 3 (yetki), faktör 4 (bilgi paylaşımı) ile toplam örgütsel bağlılık arasındaki ilişkinin kuvvetli ve pozitif bir ilişki olduğu sonucuna ulaşılmıştır.

Bu modelde, toplam örgütsel bağlılı̆̆ın 0,670’i personel güçlendirmenin üç alt boyutu tarafindan belirlenirken, kalan 0.330 'u ise diğer etmenlerden kaynaklanmaktadır. Ayrıca, personel güçlendirme alt boyutlarının (Faktör 1, Faktör 3, Faktör 4) yargı puanlarındaki bir birimlik artışın toplam örgütsel bağlılık puanının \%82 birim artıracağını da ifade etmek mümkündür. $F$ değerinin 258.812 ve $p<0,05$ olması modelin anlamlı olduğunu göstermektedir.

Ortam ve teşvik, yetki ve bilgi paylaşımı, toplam örgütsel bağlılı̆̆a etkisini gösteren katsayılar örgütsel bağlılığı etkileyen değişkenlerden en önemli değişken yetki faktörü olurken onu sırasıyla ortam ve teşvik ve bilgi paylaşım faktörleri takip etmektedir. Böylece, ortam ve teşvik, yetki ve bilgi paylaşımı boyutlarının banka çalışanlarının toplam örgütsel bağlılığını pozitif yönde etkiledikleri görülmektedir. Banka çalışanlarının çalışma ortamlarından memnun olması, yetkiye sahip olmaları ve işletmede olup bitenlerden haberdar olmaları işlerin yapılmasını hızlandırdığı gibi çalışanların örgüte olan bağlılıklarını da artırmaktadır.

Model 3'de personel güçlendirmenin dört alt boyutu ile örgütsel bağlılığın birinci boyutu olan sahiplenme boyutu arasındaki ilişki incelendiğinde aralarında doğrusal ve pozitif bir ilişki olduğu önem sırasıyla etkileyen değişkenlerin ortam ve teşvik, yetki,bilgi paylaşımı ve hizmette bilgi ve güven olduğu tahmin edilmiştir.

$\mathrm{R}^{2}$ değeri örgütsel bağlılıktaki $0,685^{\prime}$ lik değişimin personel güçlendirme alt boyutları olan tarafindan açıklandığını, geriye kalan 0,315'lik kısmın ise; diğer etmenler tarafından açıklandığını göstermektedir. Personel güçlendirmenin alt boyutları ile örgütsel bağlılığın sahiplenme boyutu arasındaki modelin F değerinin 207.749 $\mathrm{P}<0,05$ olması modelin anlamlı olduğunu söylemek mümkündür.

Model 4'de Personel güçlendirmenin ortam ve teşvik, yetki ve bilgi paylaşımı boyutları ile örgütsel bağlılığın devam bağlılık boyutu arasındaki $\mathrm{F}$ değerinin 45,273 ve $\mathrm{P}<0,05$ olmasından dolayı model anlamlıdır.

Personel güçlendirmenin ortam ve teşvik boyutundaki bir standart sapmalık artış, örgütsel bağlılığın devam bağlılık boyutunu -0,243 standart sapmalık azalmakta ve aralarındaki ilişki negatif çıkmıştır. Devam bağlılık boyutunda, çalışan mecbur kaldığı için örgütte kalmaya devam eder. Bu nedenle, çalışanların bulundukları kurumda çalışma ortamlarının iyi olması ve yöneticiler tarafından destek görmeleri onların duygusal 
bağlılıklarını artırırken devam bağlılıklarını azaltmıştır. Çünkü çalışan mecbur kaldığı için değil istediğgi için örgütte kalmayı sürdürmektedir. Bu nedenle böyle bir olumsuz ilişkinin ortaya çıkması teorik açıdan beklenen bir sonuçtur.

Personel güçlendirmenin yetki boyutundaki bir standart sapmalık artış örgütsel bağlılığın devam bağlılık boyutunu 0,550 standart sapmalık artırırken, personel güçlendirmenin bilgi paylaşımı boyutundaki bir standart sapmalık artış ise örgütsel bağlılığın devam bağlılık boyutunu 0,229 standart sapmalık artırmaktadır. Bu bulgulardan hareketle, personel güçlendirmenin yetki ve bilgi paylaşımı boyutu banka çalışanlarının örgüte olan devam bağlılıklarını olumlu yönde etkilediği görülmektedir. Çalışanlara sadece yetki verilmesi ve bilgilendirme yapılması onlar için bazı durumlarda yeterli olamayabilir. Yani, çalışan kendini işyerinde mutlu ve değerli hissetmiyorsa ellerinde bulunan yetkinin ve bilgiye sahip olmanın onlar için pek bir öneminin kalmadığını ifade etmek yerinde olacaktır.

\section{Sonuç}

Personel güçlendirme, çalışanlara yetki, güç, sorumluluk vererek kararlara katılımını sağlayan, kendilerine güven duyulduğu, fikirlerini özgürce ifade edebildiği, yaratıcılığını geliştirebileceği bir çalışma ortamı sağlayan, eğitimlerin verilmesi ile çalışanların sürekli gelişimini ve değişimine katkıda bulunarak, motive ederek psikolojik yönlerini de besleyen, insanı insan olarak değerli gören bir yaklaşımdır.

Örgütsel bağlılık, çalışanların örgütün amaç ve hedeflerini benimsemesi, bu amaç ve hedefleri büyük bir arzuyla yerine getirmesi, kendilerini örgütün bir parçası olarak görmesidir. Örgütsel bağl1lı̆̆ yüksek olan çalışanlar, örgütte daha uzun süre üyeliklerini devam ettirmek istemekte, örgüt yararına daha fazla yaratıcı ve yenilikçi düşünceler üreterek verimlilik artışına yol açmaktadır. Böylece işletmelerde devamsızlık ve personel devir hızı azalmakta, rekabet avantajı artmakta, ürün veya hizmet kalitesinde önemli artışlar görülmektedir.

Yukarıdaki açıklamalar doğrultusunda, personel güçlendirme ile örgütsel bağlılık kavramlarının birbirini tamamladığ 1 ve işletmelerin hayati önem taşıyan bu iki kavrama önem vermeleri gerektiği vurgulanmaktadır.

Personel güçlendirme ve örgütsel bağlılık ölçeklerine faktör analizi uygulanarak, az sayıda kavramsal olarak anlamlı faktörler bulunmuştur. Personel güçlendirme; ortam ve teşvik, hizmette bilgi ve güven, yetki, bilgi paylaşımı olmak üzere dört boyutta, örgütsel bağlılık ise; sahiplenme ve duygusal bağlılık ve devam bağl1lık boyutu olmak üzere iki boyutta incelenmiştir.

Çalışmaya söz konusu olan Trakya Bölgesindeki üç ilde banka personel güçlendirme ile örgütsel bağlılık ilişkisine yönelik dört model belirlenerek basit doğrusal regresyon analizi de yapılmıştır. Bu modellerden birincisi, toplam personel güçlendirme ile toplam örgütsel bağlılık arasındaki ilişkiyi belirlemek, ikincisi personel güçlendirmenin dört alt boyutundan biri olan faktör 2 (hizmette bilgi ve güven) boyutu istatistiksel açıdan anlamsız bulunduğu için çıkarılmıştır ve personel güçlendirmenin diğer üç alt boyutu; faktör 1 (ortam ve teşvik), faktör 3 (yetki), faktör 4 (bilgi paylaşımı) ile toplam örgütsel bağlılık arasındaki ilişkiyi belirlemek, üçüncüsü personel güçlendirmenin alt boyutları ile örgütsel bağlılığın birinci boyutu olan sahiplenme ve duygusal bağlılık boyutu arasındaki ilişkiyi belirlemek ve dördüncü model ise personel güçlendirmenin üç alt boyutu ile örgütsel bağlılığın ikinci faktörü olan devam bağlılık boyutu arasındaki ilişki düzeyini belirlemektir. Ortaya çıkan sonuçlara bakıldığında ilk üç modelde doğrusal ve pozitif bir ilişki görülürken, dördüncü modelde ilişki düzeyi düşük çıkmıştır. Böyle sonuçların ortaya çıkması teorik açıdan beklenen sonuçlarla örtüşmektedir.

Özet olarak; bankacılık sektöründe uygulanan personel güçlendirmenin ve personel güçlendirme alt boyutlarının(ortam ve teşvik, hizmette bilgi ve güven, yetki, bilgi paylaşımı) çalışanların örgüte olan bağlılıklarını artırdığı sonucuna varılmıştır.

İşletmeler, büyüme politikası olarak kendi bünyesinde çalışan personeli güçlendirmek ve örgüte olan bağlılıklarını artırmak istiyorsa öncelikle güçlendirecekleri personelin istekliliğine ve kapasitesine dikkat etmeleri gerektiği söylenebilir. Çünkü gerçek anlamda güçlendirme, ancak gerçek anlamda çalışanın istekliliğine bağlıdır. İşletmeler, daha sonra bu istekli personeli örgüte kazandırmak ve uzun süre elde tutabilmek için örgüte bağlayıcı faaliyetlerde (çalışanlarını eğitme, ödüllendirme, bilgilendirme, çalışanlarına kariyer imkânları sağlama vb.) bulunmaları gerekir. Böylece, güçlendirilmiş ve örgütüne bağlı hale gelmiş çalışanların bulundukları işletmenin büyümesine ve gelişmesine önemli oranda katkı sağlayacağını belirtmek mümkündür.

\section{Kaynakça}

- Allenve JohnMeyer1990. “ OrganizationalSocializationTactics: A Longitudinal Analysis of Links toNewcomers' Commitmentand Role Orientation”, Academy of Management Journal,”Cilt: 33, Sayı: 4

- Allanazarov, 2008. "Personel Güçlendirme ve Algılanan Kontrolün Örgütsel Bağl1lık Üzerindeki Etkisi: Kültürlerarası Bir Araştırma, Yayımlanmamış Yüksek Lisans Tezi,” Erciyes Üniversitesi Sosyal Bilimler Ens.

- Arslantaş, 2007 “Dönüşümcü Liderliğin Psikolojik Güçlendirme ve Örgütsel Vatandaşlık Davranışı Üzerindeki Etkisi”, Amme İdaresi Dergisi, Cilt:40, Say1:4 http://yayin.todaie.gov.tr/goster.php E.T.15.06.2010.

- Bülbül, 2007.“Örgütsel Bağlılık ve Kamu Kuruşlarına Yönelik Araştırma” Yayımlanmamış Yüksek Lisans Tezi, Kahramanmaraş Sütçü İmam Üniversitesi Sosyal Bilimler Enstitüsü. 
- Cengiz, 2001. “Kişisel Özelliklerin Örgütsel Bağlılık Üzerindeki Etkileri ve Eskişehir'de Sağlık Personeli Üzerine Bir Uygulama” Yayımlanmamış Yüksek Lisans Tezi, Anadolu Üniv.Sosyal Bilimler Ens.

- Churin 2006. “Personel Güçlendirme ve Bireysel Performans İlişkisi Üzerine Bir Araştırma” Yayımlanmamış Yüksek Lisans Tezi, İstanbul Üniversitesi Sosyal Bilimler Enstitüsü

- CCavuş, 2006. “İşletmelerde Personel Güçlendirme Uygulamalarının Örgütsel Yaratıcıllk ve Yenilikçiliğe Etkileri Üzerine İmalat Sanayiinde Bir Uygulama” Yayımlanmamış Doktora Tezi, Selçuk Üniversitesi Sosyal Bilimler Enstitüsü.

- Doğan, 2006. “Büyük Ölçekli İşletmelerde İnsan Kaynakları Yöneticilerinin Güçlendirilmiş Bir İş Çevresi Yaratmaya Ne Kadar İstekli ve Hazır Olduklarının Tespitine İlişkin Bir Araştırma ”, Celal Bayar Üniversitesi İktisadi ve İdari Bilimler Fakültesi Yönetim ve Ekonomi Dergisi, Cilt:13, Sayı:2, http://www2.bayar.edu.tr/yonetimekonomi/dergi/pdf/ C13S22006/SD.pdf E.T.04.03.2011

- Emet 2006."Personel Güçlendirme Algıları İle Örgütsel Kültür Arasındaki İlişkinin Bankacıllk Sektöründe Ampirik Olarak İncelenmesi”,Yayımlanmamış Yüksek Lisans Tezi, Dumlupınar Üniv. Sosyal Bil. Enst.

- Farmer, 2011 "TheEffects ofStaff Empowerment on SupervisoryRelations, BurnoutandJobSatisfaction: A Comparative Case Study of TwoAmericanPrisons", International Journal of Business andSocialScience, Cilt: 2, Say1:13.http://www.ijbssnet.com/journals/Vol._2_No._13_Special_Issue_July_2011/3.pdf E.T.10.01.2012

- Hacımustafaoğlu, 2008. "Personel Güçlendirme Algılamalarının Bireysel Yaratıcıllığa Etkisi ve Otel İşletmelerinde Bir Uygulama" Yayımlanmamış Yüksek Lisans Tezi, İstanbul Üniv. Sosyal Bilimler Enst.

- İnce ve Gül 2005.Yönetimde Yeni Bir Paradigma Örgütsel Bağlılık, Çizgi Kitabevi Yayınları,

- Karakoçve Yılmaz,2009 "Employee Empowerment andDifferentation in Companies: A LiteratureReviewandResearchAgenda”, Enterprise Risk Management, Cilt:1, Say1: 2, ISSN: 19377916http://www.macrothink.org/journal/index.php/erm/article/download/115/48 E.T. 25.12.2011

- Koç, 2008. "Personel Güçlendirme ̇̉le Çalışanların Örgüte Bağlılığı Arasındaki İlişkiye Yönelik Bir Uygulama,” Yayımlanmamış Yüksek Lisans Tezi, Yıldız Teknik Üniversitesi Sosyal Bilimler Enstitüsü,

- Ö̈zbek 2008 “İşgören Güçlendirme ve Örgütsel Bağlllık Arasındaki İlişkinin İşletme İçi Birimler ve Demografik Faktörler Açısından Analizi, Yayımlanmamış Yüksek Lisans Tezi, Gazi Üniv.SosyalBilim.En

- Robersonve Strickland, 2010. "TheRelationshipBetweenCharismaticLeadership, WorkEngagementandOrganizationalCitizenshipCitizenshipBehaviors”, TheJournal of Psychology, Cilt: 144, Sayı: 3 , http://sigittaruna.files.wordpress.com/2011/07/jurnal4-charismaticleadership 2.pdf E.T.18.02.2012

- Schneier, Russell, Beatty ve Llyod, 1994, “The Training and Development Sourcebook”, The Empowerment of Service Workers: What, Why, How andWhen,Derleyen: David E. Bowen ve Edward

- E. LawlerIII Human Resource Development Presss. 415-417. E.T. 10.01.2012

- Seçgin, 2007, "Otel İşletmelerinde Personel Güçlendirme Yönetimi ve Bir Uygulama," Yayımlanmamış Yüksek Lisans Tezi, Gaziosmanpaşa Üniversitesi Sosyal Bilimler Enstitüsü

- Spreitzer1995. "Psychological Empowerment in TheWorkplace:DimensionsMeasurementandValidation" Academy of ManagementJournal, Cilt: 38,Say1: 5, http://webuser.bus.umich.edu/spreitze/Psych Empowerment. pdf E.T.04.01.2011

- Şahin, 2007 "Personel Güçlendirmenin İş Tatmini ve Örgütsel Bağlılık Üzerindeki Etkisi: Dört ve Beş Yıldızlı Otel İşletmelerinde Bir Uygulama” Yayımlanmamış Doktora Tezi, Dokuz Eylül Üniv.Sos Bil. Enst.

- $\quad$ Tak ve Çiftçioğlu,2009. “Algılanan Örgütsel Prestij İle Örgütsel Bağl1lık ve Örgütsel Özdeşleşme Arasındaki İlişkilerin İncelenmesine Yönelik Bir Araştırma”Akdeniz İktisadi ve İdari Bilimler Fakültesi Dergisi,Sayı: 18,

- Vasugi, Kaviatha vePrema, 2011 "AnEmpiricalInvestigation on EmployeeEmpowerment Practices in Indian Software Industries" InterdisciplinaryJournal of ContemporaryResearch in Business, Cilt:2, Sayı:11

- Yavuz ve Tokmak,2009 "İşgörenlerinEtkileşimci Liderlik ve Örgütsel Bağl1lık ile İlgili Tutumlarına Yönelik Bir Araştırma”, Uluslar arası İktisadi ve İdari İncelemeler Dergisi, Cilt: 1, Sayı: 2. 


\title{
Katılım Bankası Müşterilerinde Bankacılık Ürün ve Hizmetlerine Yönelik Memnuniyet: Türkiye Örneği
}

\section{Satisfactions of Islamic Banks' Costumers: The Case of Turkey}

\author{
Asst. Prof. Dr. Bengül Gülümser Kaytancı (Anadolu University, Turkey) \\ Dr. Etem Hakan Ergeç (Osmangazi University, Turkey) \\ Prof. Dr. Metin Toprak (Istanbul University, Turkey)
}

\begin{abstract}
Despite differences in the principles by which they operate between the participation (Islamic) and conventional banks, there is no huge difference between the products and the services provided by these banks. The distinctive features of the participation banks, compliance with the Islamic precepts, are not the only way for these banks to appeal to the customers. For this reason, customer satisfaction is an important element in the banking sector. The major goal of this study is to analyze the level of awareness and satisfaction among the customers of the participation banks. This study which uses the data compiled through the surveys held in Eskişehir with the participation of 500 Islamic bank customers reveals findings that suggest that most of the customers are satisfied with the products and services by the participation banks and that they have high level of awareness on the Islamic banking products.
\end{abstract}

\section{Giriş}

Finansal sistemde faizli bankalar gibi katılım bankaları da benzer fonksiyonları yerine getirmekle birlikte, farklılık düzenleme ve kurallarda kendisini gösterir. Katılım bankaları işlemlerini İslam dini tarafından belirlenen esaslara uygun olarak yürütürler. (Akhtar ve dig., 2011) İslami bankacılık sistemi, Müslüman müşterilerin ihtiyaç ve taleplerini karşılama ihtiyacının bir sonucu olarak oluşturulmuştur. Çünkü geleneksel bankacılık sektörü tamamen faizli sisteme dayanmakta iken İslami kurallara göre faiz almak da vermek de yasaktır. (Khattak ve Rehman, 2010,)

Dünyada 1.8 milyara ulaşan Müslüman nüfusu ve bunun yanında dünyanın birçok yerinde bulunan Müslüman göçmenlerin olması Citibank, HSCB gibi uluslararası bankaların da İslami prensiplerle uyumlu ürün ve hizmetler sunan şubeler ve bölümler açmalarına yol açmıştır. Müslüman nüfusun talepleri doğrultusunda faizsiz işlem yapmaları, bu bankaların kar/zarar ortaklığı prensibine uygun olarak çalışmalarını gerektirmektedir. Diğer bir deyişle katılım bankaları kar /zarar paylaşımı ve kiralama geliri ile ilgili işlemleri gerçekleştirirler. Ayrıca, bu bankalar, alkol, silah üretimi, tütün gibi İslam'ın yasakladığg sektörlere finansman sağlanmamaktadırlar (Saini ve diğ., 2011) Bu temel prensipler çerçevesinde faizsiz finansal kuruluşların geliştirdikleri başlica kredi/fon kullandırma yöntemleri peşin alım taksitle satım olarak tanımlanabilecek olan "murabaha", temel olarak bir yatırım ortaklığı olan "mudaraba", bir kar/zarar paylaşımı olan "muşaraka", geleneksel bankacılıktaki finansal kiralama işlemine karşılık gelen "icara" ve tarafların belirli bir malın anlaşma anında belirlenen ve tamamen ödenen bir fiyattan gelecekteki bir tarihte alım-satımı konusunda anlaştığı yöntem olan "salam” dır.

Faizsiz bankacılık kuruluşları, kredi/fon kullandırma yöntemleri yanında fon toplama yöntemleri açısından da farklılık göstermektedir. Bunlardan bazıları herhangi bir para cinsinden, vade taşımayan ve kar payı gibi herhangi bir getirisi olmayan "özel cari hesaplar"; kâr veya zarara katılma sonucunu veren ve anaparanın aynen geri ödenmesi garanti edilmeyen fonların oluşturduğu "katılma hesapları" ve "faizsiz bono" olarak tanımlanan "sukuk" sertifikaları olarak siralanabilir.(TCMB Finansal İstikrar Raporu, Mayıs 2011)

Dünyadaki ilk İslami bankacılık deneyimi 1963 yılında Mısır'da Mit Ghamr Tasarruf Bankası (Mit Ghamr Saving Bank) tarafından kar ve zarar ortaklığı yatırımı ile başlamıştır. Ancak İslami bankacılık alanında asıl gelişme yeni yatırım teknikleri, stratejileri ve ürün geliştiren ve aynı zamanda dünyadaki ilk İslami banka olarak bilinen Dubai İslam Bankası (Dubai Islamic Bank) 1975 yılında kurulmuştur. (Khan ve Asghar, 2012) Türkiye'de ise bu kurumlar Özel Finans Kurumları adı altında 1985 yılında faaliyetlerine başlamıştır. 2005 yılının sonlarında kabul edilen 5411 sayılı Bankacılık Kanunu ile Özel Finans Kurumlarının adı Katılım Bankaları olarak değiştirilmiştir. Bugün itibariyle Türkiye'de 31'i mevduat bankası ve 13'ü kalkınma ve yatırım bankası olmak üzere toplam 44 adet faizli prensiplere göre çalışan banka ve 4 adet katılım bankası aynı piyasada kendi işlemlerini yan yana yapmaktadırlar. 5411 sayılı kanunun 4. maddesine göre katılım bankaları mevduat kabul edemezken mevduat bankaları da katılım fonu kabul edememektedir.

Son dönemlerde hızla büyüyen İslami bankacılık sektörü, günümüzde 1 trilyon ABD doları varlık büyüklüğü ve 4 trilyon ABD doları küresel potansiyeliyle dikkat çekmektedir. (TCMB Finansal İstikrar Raporu, 2011) Dünyadaki hızlı gelişimine paralel ülkemizde de hızlı bir gelişim performansı gösteren faizsiz bankacılığın gerek bu gelişim ivmesini sağlıklı analiz edebilmek gerekse de bu gelişme sürecini daha iyi bir performansla devam ettirebilmek için, bu banka müşterilerinin memnuniyet düzeylerinin değerlendirilmesi önem arz etmektedir. 
Son dönemlerde sektördeki sıkı rekabet nedeniyle müşteri memnuniyeti, müşteri tutma ve müşteri hizmetlerine odaklanmak herhangi bir bankanın varlığını devam ettirebilmesi için daha da önemli hale gelmiş ve bankacılık işlemlerinde müşteri memnuniyeti anahtar faktör olarak kabul edilmiştir. Çünkü bankasından memnun olan bir müşteri bankayı tekrar tercih edecek ve aynı zamanda başkalarına da memnuniyetini aktaracaktır. Diğer taraftan memnun olmayan müşteri ihtiyaç duyduğu ürün veya hizmeti başkasıyla karşılamaya çalışacak ve bu durumu başkalarına da aktaracaktır. Bu nedenle müşteri memnuniyetinin değerlendirilmesinin önemi giderek artmaktadır. (Akhtar ve dig., 2011) Müşteri memnuniyetini önemli kılan bir başka unsur ise bu bankaların tercih nedenlerini inceleyen çalışmaların ortaya koydukları sonuçlardır. Bu bankalarının tercih edilme nedenini değerlendirme amaçlı birçok çalışmada, Dinin tek tercih nedeni olmadığı tespit edilmiştir. (Haron ve diğ, 1994; Dusuki ve Abdullah, 2007; Erol ve El-Bdour, 1989; Naser ve diğ. 1999, Ergeç ve diğ. 2013).

$\mathrm{Bu}$ çalışmada, katılım bankası müşterililerinin memnuniyetlerini değerlendirme amacıyla, Eskişehir İli genelinde 500 katılım bankası müşterisi ile yüz yüze gerçekleştirilen anket görüşmesinde elde edilen veriler kullanılarak, katılım bankası müşterileri farkındalık, kullanım düzeyi ve memnuniyet düzeyi incelenmistir. Büyükşehir statüsünde olmasının yanında Eskişehir, Türkiye'de faaliyette bulunan tüm katılım bankalarına ait şubelerin bulunması, kentli yüksek nüfus oranı, gelir ve eğitim düzeyi gibi alanlarda önde gelen bir şehir olması gibi nedenlerden dolayı tercih edilmiştir. Ankette müşterilere katılım bankası ürün ve hizmetlerine yönelik farkındalık, kullanım ve memnuniyet alanlarını değerlendirmek için sorular yöneltilmiştir. Bu sorulardan elde edilen cevaplar ile müşterilerin sosyopolitik kimlik, sosyoekonomik statü, genel özellikleri ve çalıştıkları katılım bankasını tercih etmeleri arasında anlamlı ilişki olup olmadığ incelenmiştir.

\section{Literatür}

Müşteri memnuniyeti herhangi bir kuruluşun stratejilerinin temel bileşenlerinden birisidir ve herhangi bir endüstride, müşteri gelirin daimi kaynağıdır. Bankacılık sektöründeki rekabet ve bazı bankaların pazarlama stratejisinin temel bileşeni olarak müşteri memnuniyetinin göz önünde bulundurulması son dönemlerde bankaların müşterilerinin memnuniyeti konusuna odaklanmalarına neden olmuştur. (Khattak ve Rehman, 2010) Bu nedenle, bankacılık sektöründeki rekabetçi ortamda, müşteri memnuniyeti hem mevcut müşterilerin bankayla ilişkilerinin devam etmesi hem de bankaya yeni müşterilerin kazandırılabilmesi açısından önemle üzerinde durulması gereken konulardır. Bu sebeple literatürde yer alan pek çok çalışmada faizsiz banka müşterileri farkındalık, kullanım ve memnuniyet düzeyi açılarından incelenmiştir.

Literatürde yer almış önemli çalışmalardan biri, Metawa ve Almossawi’nin (1998) çalışmasıdır. Bahreyn'deki 300 İslami banka müşterisinin değerlendirildiği bu çalışmada müşterilerin; banka seçim kriterleri, hizmet ve ürünler hakkındaki farkındalıkları ve memnuniyet düzeyleri araştırılmıştır. Çalışmada müşterilerin İslami banka ile çalışmada temel etkenin Din olduğu, çoğu müşterinin İslami banka ürün ve hizmetlerinden memnun olduğu ancak bazı finansman olanaklarının maliyeti ve esnekliği konusunda memnun olmadıkları tespit edilmiştir. Buna göre müşterilerin hizmet sunumunda en memnun oldukları konu banka çalışanları olmuştur. Çoğu müşterinin tasarruf hesabı, cari hesap, ATM gibi temel İslami banka ürün ve hizmetleri hakkında farkındalıklarının yüksek olduğu tespit edilmiştir. Hem var olan müşterilerin kaybedilmemesi hem de yeni müşterilerin çekilmesi ve müşteri ilişkilerinin geliştirilmesi için yazarlar İslami bankaların hizmet kalitesini arttırıcı programlar uygulamaları gerektiğini ve kaliteyi arttırmak için başarılı deneyimleri olan faizli bankaları incelemelerinin yararlı olabileceğini vurgulamışlardır. Bankaların gelecekteki başarıları için yönetim etkinliğine önem vermeleri, bunun için de banka personelinin yönetim etkinliğini geliştirmek için eğitim programlarının iyi bir araç olacağını belirtmişlerdir. (Metawa ve Almossawi, 1998)

Literatürde yer alan önemli bir başka çalışma ise Ürdün'ün değerlendirildiği Naser ve diğerlerinin (1999) çalışmasıdır. Ürdün'de 206 banka müşterisinin, banka seçim kriterleri, hizmet ve ürünler hakkındaki farkındalıkları ve memnuniyet düzeyleri, hem İslami hem de faizli bankalarla çalışma nedenleri araştırılmıştır. Çalışmaya göre müşterilerin İslami banka ile çalışmalarında, din faktörü önemli olsa da, birincil neden bankanın itibarıdır. Müşterilerin çoğu ürün ve hizmetlerden memnun oldukları ve bazı spesifik İslami finansal ürünlerin farkında olmalarına rağmen bunların çoğunu kullanmadıkları tespit edilmiştir. Müşterilerin İslami bankanın sınırlı şube sayısı ve çalışma saatleri nedeniyle memnun olmadıkları ve bu yüzden faizli bankalarla da çalıştıklarını tespit etmişlerdir. Yazarlar İslami bankanın müşterilerini tutabilmesi için müşterilerin ihtiyaçlarını karşılayacak yeniliklere açık olmasını ve İslami bankanın pazarın belirli bir kesimi için 24 saat online bankacılık hizmetlerini sağlamak için internet kullanımını göz önüne alması gerektiğini belirtmişlerdir. Ayrıca müşterilerin spesifik İslami ürünleri kullanmalarını sağlamak için bankanın promosyonları kullanabileceği ve müşterilerin farkında olmadıkları bazı spesifik İslami banka hizmetleri ile ilgili olarak İslami terminoloji hakkında müşterilerin eğitilmesi gerektiğini vurgulamışlardır. (Naser ve diğ., 1999)

Khan ve diğerleri (2007), ise benzer bir çalışmayı Bangladeş’teki 100 İslami banka müşterisini değerlendirerek gerçekleştirmişlerdir. Çalışmada müşterilerin İslami banka ile çalışmada temel etkenin din olduğu, müşterilerin cari hesap ve kar/zarara katılma hesapları gibi temel yatırım araçları için yüksek farkındalıkları varken, bireysel finansman olanakları hakkında düşük farkındalık ve düşük kullanım düzeyine sahip oldukları tespit edilmiştir. 
Yazarlar temel ürünler dışında farkındalık düzeyinin düşük olmasını Arapça konuşulmayan Müslüman ülkelerde bu ürünlerin Arapça terimlerle tanımlanmasının İslami ürün ve hizmetlerin anımsanmasını ve müşterilerin kullandığı bu ürünleri çevrelerine anlatabilmelerini engelleyen bir durum olduğunu ve müşterilere bu tip ürünleri tanıtmak için bazı yöntemler bulunması gereğini belirtmişlerdir. (Khan ve dig., 2007)

Güncel bir başka çalışma ise benzer soruların değerlendirildiği Pakistan için yapılmıştır. 156 müşterinin değerlendirildiği bu çalışmaya göre müşterilerin cari ve vadeli hesaplar gibi genel ürünlerle ilgili farkındalıkları yüksekken, çoğu müşterinin murabaha, icara gibi İslami finans ürünleri hakkında bilgiye sahip olmadıkları tespit edilmiştir. Genel olarak müşterilerin çoğunluğunun banka hizmetlerinden memnun olduğu sonucuna varılmış ve çalışmaya göre banka seçiminde din önemli bir faktör olsa da banka işlemlerinin etkinliği, çalışma saatleri, müşteri bilgilerinin gizliliği gibi faktörlerin de banka seçiminde önem arz ettiği tespit edilmiştir. Yazarlar, müşterilerin İslami terminolojiye hâkim olmamaları nedeniyle İslami bankaların icara, murabaha gibi farklı ürün ve hizmetlerle ilgili bilgilendirme seminerleri düzenlemelerini önermektedirler. Ayrıca, yazarlar müșterilerin çoğunun $(\% 66,7)$ her iki bankacılık sistemini de kullandığını, bunun nedeninin ise İslami bankaların faizli bankaların müşterilerine sundukları kadar etkin ürün sunamamaları olduğunu vurgulamışlardır. Bu yüzden İslami bankaların müşterilerine ürün sağlamaları ve bankacılık ağlarını genişletmelerini önermişlerdir. (Khattak ve Rehman, 2010)

Akhtar ve diğerlerinin (2011), 167 İslami banka müşterisini inceledikleri çalışmaları, Pakistan için yapılmış bir başka güncel çalışmadır. Çalışma; müşterilerin çoğunun, İslami banka terminolojisinin farkında olduğunu, fakat bu ürün ve hizmetleri kullanmıyor olduğunu tespit etmiştir. Hizmet kalitesi ve müşteri memnuniyeti arasında pozitif bir ilişkinin tespit edildiği bu çalışmada, hizmet kalitesinin değerlendirilmesinde ele alınan dört ölçütten ikisi olan "İslami kurallara uyumluluk" ve "müşterilerin ihtiyaçlarını karşılayabilme" ölçütleri ile müşteri memnuniyeti arasında diğer iki ölçüte göre daha güçlü bir ilişki bulunmuştur. Yazarlar, bankaların müşteri sorunlarını daha iyi çözümlemeye dönük hizmetlerini geliştirmeye yardımcı olmak için insan kaynaklarının eğitimine ve gelişimine yatırım yapmalarını önermektedirler. (Akhtar ve dĭg., 2011)

Güney Afrika için Saini ve diğerlerinin (2011) yaptığı çalışmada 250 İslami banka müşterisi incelenmiştir. Çalışmada müşterilerin \%96,6'sının ürünler hakkında bilgi sahibi olduğu, ancak İslami banka ürünlerinin kullanım düzeyinin düşük olduğu tespit edilmiştir. Çalışmaya göre; müşteriler banka seçerken dini sebeplerden ziyade hızlı ve etkili hizmet, düşük masraf, geniş ATM ve şube ağı gibi etkenleri temel olarak dikkate almaktadırlar. Yazarlar, artan rekabet ortamında banka yöneticilerinin müşteri kazanmak ve mevcut müşterileri tutabilmek için müşterilerin ihtiyaçlarını ve beklentilerini karşılayacak ürünlerin geliştirilmesini dikkate almaları gerektiğini vurgulamışlardır. (Saini ve diğ., 2011)

Rehman'nın (2012) çalışması ise literatürde yer alan, gelişmiş ve gelişmekte olan ülkelerin birlikte değerlendirildiği güncel bir çalışmadır. Yazar, müşteri memnuniyeti ve altı bileşen çerçevesinde ele aldığı hizmet kalitesi arasındaki ilişkiyi Pakistan, Birleşik Krallık (İngiltere) ve Birleşik Arap Emirlikleri'ndeki 75'er müşteri için incelemiştir. Araştırma sonucuna göre müşterilerin çoğunun islami bankaların sundukları hizmetlerden memnun oldukları tespit edilmiştir. (Rehman, 2012)

Literatürde yer alan çalışmalar içinde Türkiye'nin değerlendirildiği çalışma Okumuş' un (2005) çalışmasıdır. 161 müşterinin incelendiği bu çalışmada, müşterilerin İslami banka ile çalışmada temel etkenin din olduğu, müşterilerin cari hesap ve kredi kartı gibi ürünler hakkında bilgi sahibi olduğu, ancak spesifik İslami bankacılık terimleri hakkında farkındalıklarının olmadığı ve müşterilerin geniş bir çoğunluğunun ürün ve hizmetlerden memnun olduğu sonucuna ulaşılmıştır. Müşteri memnuniyetinde en yüksek memnuniyet skorunu sırasıyla işlemlerin tamamlanması, personelin yönlendirmesi ve personelin yakın ilgisi takip etmiştir. Yazar, müşterilerin \%55'inin hem İslami hem de faizli banka ile çalışıyor olduğunu tespit etmiş ve bunun nedeni olarak, İslami bankaların geniş şube ağlarının olmaması ve faizli bankaların sunduğu bazı ürün ve hizmetlerin İslami bankalarda olmamasını belirtmiştir. Bu yüzden, İslami bankaların hizmet ve ürün kalitesini faizli bankalarla rekabet edebilecek düzeyde geliştirmeleri gerektiğini ve müşterilerin farkındalığının az olduğu spesifik İslami ürünlerin kullanımı için yönlendirmesinin İslami bankaların büyümesini kolaylaştıracağını belirtmiştir.

\section{3 Örneklem Profili}

Eskişehir ilinin seçildiği bu araştırmanın anket uygulaması için, 500 deneklik bir örnek hacmi tespit edilmiş, daha sonra cinsiyet ve yaş kotaları uygulanmıştır. Yüz yüze anket tekniğinin kullanıldığı bu çalışmada, yarı yapılandırılmış bir form, deneyimli anketörlerce uygulanmıştır. Anketör eğitimi, alan uygulamasından önce gerçekleştirilmiş ve akabinde pilot uygulama yapılmıştır. Daha sonra anket formlarının kalite kontrolü, alan uygulaması esnasında ve sonrasında gerçekleştirilmiştir. Çalışma için kullanılan anket formu, 4'ü açık uçlu olmak üzere toplam 27 sorudan oluşmaktadır. Ankette; cinsiyet, yaş, gelir, eğitim, iş durumu, sosyopolitik kimlik ve sosyo ekonomik statü gibi betimsel kimlik bilgilerine yönelik sorulara yer verilmiştir. Sosyopolitik kimlik kategorisini oluşturma amacıyla, çeşitli düşünce akımları ve dünya görüşleri bir liste halinde sunularak, görüşülen kişilere bu listede yer alan kimliklerden hangilerinin kendisini tanımlamada uygun olduğunu belirtmesi istenmiştir. Yine desteklenen siyasi parti ile namaz kılma ve oruç tutma gibi dini tutumlar da 
sosyopolitik kimliği tespit etme amacıyla ankette sorulan sorular arasında bulunmaktadır. Anket için pilot uygulama 1-5 Mart 2011 tarihleri arasında, anket uygulaması ise 10 Mart 2011-25 Mayıs 2011 tarihleri arasinda, örneklemdeki deneklerle bankada bulundukları sırada veya randevu alınarak ev ve işyerlerinde görüşülmüştür. Elde edilen veriler bir istatistik paket programı yardımıyla analiz edilmiş; analizde bazı değişkenler anket formunda yer aldığı yalın haliyle, bazı değişkenler ise türetilmiş türev değişkenler olarak kullanılmıştır. Örneğin sosyoekonomik statü ve sosyopolitik kimlik değişkenleri başka birkaç değişkenin birlikte değerlendirilmesiyle oluşturulmuştur. Analizlerde betimsel istatistikler ki-kare anlamlılık testi ile sınanmıştır. Bileşik ve kategorik değişkenlerin oluşturulmasında, küme analizi ve faktör analizi yapılmıştır.

Ankete katılan müşterilerin profilini yansıtmak için Tablo 1 düzenlenmiştir. Tablo incelendiğinde, 500 katılım bankası müşterisinin, Türkiye'de ekonomik hayatta aktif rol oynamada erkeklerin baskın görünüme sahip olmasıyla uyumlu olarak, \% 71,4'ünün erkeklerden, \%28,6'sının ise kadın müşterilerden oluştuğu görülmektedir.

Müşterilerin eğitim düzeyleri değerlendirildiğinde \%41'nin eğitim düzeyinin üniversite ve üstü olduğu görülmektedir. Eğitim düzeyi lise olan müssteriler ise $\% 35,4$ 'lük bir pay ile ikinci sırada bulunmaktadır. Görüldüğü gibi banka müşterilerinin eğitim düzeyleri yüksektir. Bu durumun, Eskişehir ilinin Türkiye geneline göre yüksek bir eğitim düzeyine sahip olmasının bir sonucu olduğu düşünülmektedir.

Anketin uygulandığı banka müşterilerinin yaş gruplarına bakıldığında ise 30-40 yaş aralığında olan banka müşterilerinin en yüksek paya sahip olduğu görülmektedir. Banka müsşerilerinin yaş ortalamasının 34,6 olduğu tespit edilmiştir. Banka müşterilerinin iş durumları incelendiğinde, müşterilerin $\% 39,2$ 'si devlette ve ya özel sektörde çalışmakta iken \%21'i kendi işini yapmaktadır. Öğrenci olanların oranı \%12,8'dir. Kendini işsiz olarak tanımlayanların oranı ise \%7,4'dür. Emekli, öğrenci, ev kadını ve işsizler örneklemde anlamlı analizlere imkân verecek düzeyde temsil edilmiştir. Banka müşterilerinin gelir düzeylerine göre dağılımına bakıldığında, \%39,6 oranındaki 2000 TL-3000 TL arasında gelir elde edenlerin gelir grupları arasında en yüksek orana sahip olduğu görülmektedir. Ankete katılan müşterilerin, hanelerine ilişkin aylık gelir düzeyine ilişkin soruya verdikleri yanıtlar ise, en düşük gelir düzeyinin aylık $600 \mathrm{TL}$, en yüksek gelir düzeyinin ise aylık $15000 \mathrm{TL}$ olduğu şeklindedir. Buna göre aylık ortalama gelir düzeyi 2273 TL'dir.

Anket formunda sorulan eğitim düzeyi, yaşam biçimi, gelir düzeyi, meslek grubu, dini ibadet alışkanlıkları ve dünya görüşüne yönelik çeşitli sorular küme analizi, faktör analizi ve diskriminant analizi gibi çeşitli teknikler kullanılarak değerlendirilmiş ve sosyopolitik kimlik ve sosyoekonomik statü değişkenleri geliştirilmiştir. Sosyopolitik kimlik, siyasi parti tercihinden daha kapsamlı ve daha uzun erimli bir değişken olarak tasarlanmış olup, siyasi içerimin yanısıra sosyolojik yapıyı da yansıtmaktadır. Buna göre, Türkiye toplumu MilliyetçiMuhafazakâr, Laik-Modernist ve Sol-Sosyal Demokrat sosyopolitik gruplar olarak sınıflandırılmıştır. Bu gruplar arasında elbette örtüşmeler olmakla birlikte, genelleştirmelere imkân vermesi bakımından Türk toplumunun başlıca üç sosyopolitik grup altında sınıflandırılabileceği kabul edilmiştir. Bu kimlikler çerçevesinde katılım bankaları müşterilerinin sosyal ve politik eğilimleri de tespit edilmiş olmaktadır. Beklenildiği gibi en yüksek oranda olan kesim Milliyetçi-Muhafazakârlardır. Müşterilerin \%77'si bu kimlik grubu içinde yer almıştır. Gelir ve meslek gibi değişkenlerden hareketle oluşturulan sosyoekonomik statüye göre değerlendirdiğimizde ise en yüksek payın \%44,6 ile orta düzey statüye ait olduğu görülmektedir.

\begin{tabular}{|c|c|c|c|c|c|}
\hline & Sayı & $\%$ & & Sayı & $\%$ \\
\hline Cinsiyet & & & İş Durumu & & \\
\hline Erkek & 357 & 71,4 & Devlet-Özel & 196 & 39,2 \\
\hline \multirow[t]{2}{*}{ Kadın } & 143 & 28,6 & İş adamı/Esnaf/Sanaatkar & 106 & 21,2 \\
\hline & & & Öğrenci & 64 & 12,8 \\
\hline Ĕ̆itim & & & Ev Hanımı & 61 & 12,2 \\
\hline Okuryazar & 19 & 3,8 & İşsiz & 37 & 7,4 \\
\hline İlkokul & 38 & 7,6 & Emekli & 35 & 7,0 \\
\hline Ortaokul & 61 & 12,2 & & & \\
\hline Lise & 177 & 35,4 & & & \\
\hline \multirow[t]{2}{*}{ Üniversite ve Üstü } & 205 & 41,0 & Gelir & & \\
\hline & & & $1000 \mathrm{TL} \mathrm{Az}$ & 38 & 7,6 \\
\hline Yaş & & & $1000-1500 \mathrm{TL}$ & 87 & 17,4 \\
\hline 20-30 Yaş Aras 1 & 157 & 31,4 & $1500-2000 \mathrm{TL}$ & 134 & 26,8 \\
\hline 30- 40 Yaş Arası & 205 & 41,0 & 2000-3000 TL & 198 & 39,6 \\
\hline 40 Yaş Üstü & 138 & 27,6 & 3000 TL Üstü & 40 & 8,0 \\
\hline Sosyopolitik Kimlik & & & Sosyoekonomik Statï & & \\
\hline Milliyetçi-Muhafazakâr & 385 & 77,0 & Düşük & 95 & 19,0 \\
\hline Laik-Modernist & 92 & 18,4 & Orta & 223 & 44,6 \\
\hline Sol-Sosyal Demokrat & 23 & 4,6 & Yüksek & 182 & 36,4 \\
\hline
\end{tabular}

Tablo 1: Müşteri Örneklem Profili 


\section{Katılım Bankalarına Bakış: Kullanım, Farkındalık, İmaj ve Memnuniyet Düzeyi}

\subsection{Katılım Bankası Ürün ve Hizmetlerinde Kullanım ve Farkındalık}

Ankette müşterilere, değerlendirmesi istenen bir ürün hakkında fikri olup olmadığı ve bu ürünü kullanıp kullanmadığı sorulmuştur. Bu sorulara verilen cevapların sunulduğu Tablo 2 incelendiğinde, en yüksek farkındalık ve kullanım düzeyine sahip olan katılım bankacılığı ürününün katılma hesabı olduğu görülmektedir. İkinci sırada yer alan bankacılık ürünü ise farkındalıkta cari hesap, kullanımda ise kredi kartları olmuştur. Katılım bankalarının sundukları ürün ve hizmetler konusunda müşterilerinin farkındalık düzeyleri ile bu ürünleri kullanma düzeyleri arasında anlamlı bir farklılık vardır. Buna göre, müşteriler, katılım bankalarının sundukları ürün ve hizmetleri genel olarak ortalama yüzde 54 düzeyinde bilmekte iken, bu ürün ve hizmetleri kullanma oranları ortalama yüzde 27 'dir. Dolayısıyla, ürün ve hizmetleri bilenlerin, bunları kullanma düzeyleri ancak yarısı düzeyindedir. Ticari müşterilere yönelik ürünler olan üretim desteği, leasing, kar zarar (yatırım) ortaklığ ve dış ticaret hizmetlerinin kullanımını dikkate almaz isek, genel olarak bilinme oranı \% 74, kullanım oranı ise ortalama \%45 olmaktadır. Görüldüğü gibi ortalamalar arasındaki fark daha da yükselmiştir.

\begin{tabular}{lll}
\hline \hline & Bilinme Oranı & Kullanılma Oranı \\
\hline Özel cari hesap & 81,6 & 36,4 \\
Katılma hesabı & 93,6 & 79,8 \\
Tüketici kredisi & 66,6 & 30,4 \\
Taşıt kredisi & 49,4 & 11,8 \\
Üretim desteği & 32,8 & 3,8 \\
Leasing (Finansal kiralama) & 23,2 & 2,6 \\
Kar zarar (yatırım) ortaklığı & 39,0 & 9,2 \\
Kredi kartı & 79,8 & 65,0 \\
Diş ticaret hizmetleri & 17,4 & 3,2 \\
\hline \hline
\end{tabular}

Tablo 2: Katılım Bankaları Bankacılık Ürünlerinde Farkındalık ve Kullanım Düzeyi

\section{2 Çalıșılan Katılım Bankasına Yönelik Kanaat}

Müşterilerin genel kanaatini değerlendirmek için, ankete katılan müşterilere öncelikle çalıştıkları katılım bankasına ilişkin genel kanaatlerinin ne olduğu sorusu yöneltilmiştir. Ayrıca müşterilerden, bankalarıni memnuniyet bakımından bazı alanlarda değerlendirmeleri istenmiştir. Müşterilerin cevapları derecelendirilerek, bu memnuniyet alanlarına ilişkin skorlar belirlenmiş, böylelikle skor ortalaması alınarak genel bir memnuniyet düzeyi tespit edilmiştir. Böylelikle, müşterilerin genel beyanları ile memnuniyet alanlarına ilişkin değerlendirmelerinin tutarlı olup olmadığı da kontrol edilebilmiştir. Müşterilerin genel beyanları ile değerlendirme alanlarından elde edilen ortalama memnuniyet düzeyinin uyumlu olduğu görülmüştür. Görüşülen kişilerin yüzde 70,2'si çalıştı̆g katılım bankasıyla ilgili kanaatinin genel olarak olumlu olduğunu belirtirken, olumsuz kanaat belirtenlerin oranı yüzde 5,6'dır. Bu soruya verilen cevapların müşterilerin özelliklerine göre ayrışımı incelendiğinde, müşterilerin gelir düzeyleri, cinsiyetleri ve sosyopolitik kimliklerine göre anlamlı bir farklılık gözlenmemiştir.

Yaş grupları itibariyle genç yaştakilerin olumlu kanaati görece daha düşük düzeyde iken, ileri yaş gruplarındakilerin olumlu kanaatleri daha yüksektir. Eğitim düzeyi yükseldikçe çalışılan bankaya yönelik olumlu kanaatte bir düşüş gözlenmektedir. Meslek grupları itibariyle çalışılan bankaya yönelik kanaat de farklılaşmaktadır. Buna göre, emekliler ve ev kadınları en yüksek düzeyde olumlu kanaat belirtirlerken, işadamı/esnaf/sanatkârlar ile öğrenci kesimi görece daha düşük oranda olumlu kanaat ifade etmektedir. Değişik sosyoekonomik statülerdeki kişiler çalıştıkları bankadan memnuniyet bakımından birbirinden ayrışmaktadır. Buna göre, düşük sosyoekonomik statüdekiler, orta ve yüksek sosyoekonomik statüdekilere göre, çalıştıkları katılım bankası ile ilgili daha yüksek olumlu kanaat belirtmektedir.

\begin{tabular}{lll}
\hline \hline & Sayı & \% \\
\hline Olumlu & 351 & 70,2 \\
Ne olumlu Ne olumsuz & 103 & 20,6 \\
Olumsuz & 28 & 5,6 \\
Fikrim yok & 18 & 3,6 \\
Toplam & 500 & 100,0 \\
\hline \hline
\end{tabular}

Tablo3: Çalışılan Katılım Bankasına Yönelik Kanaat

\subsection{Katılım Bankaları Ürün ve Hizmetlerinden Memnuniyet}

Ankete katılan müşterilerden, çalıştıkları bankalarla ilgili olarak memnuniyet düzeylerini bazı açılardan değerlendirmeleri istenmiştir. Katılım bankası müşterilerinin verdikleri cevaplar kategorize edilmiş ve böylece memnuniyete ilişkin skorlar oluşturulmuştur. $\mathrm{Bu}$ alanların ortalamasından her müşteriye ilişkin genel memnuniyet skoru hesaplanarak, müşterilerin genel memnuniyet düzeyleri değerlendirilmiştir. Genel olarak 
müşteri memnuniyeti yüzde 68 düzeyindeyken, memnun olmayan müşteri oranı yüzde 6 , düşük düzeyde memnuniyet belirtenlerin oranı ise yüzde 26'dır.

\begin{tabular}{lll}
\hline \hline & Sayı & \% \\
\hline Memnun & 339 & 67,8 \\
Çok az memnun & 131 & 26,2 \\
Memnun değil & 28 & 5,6 \\
Toplam & 498 & 99,6 \\
Cevapsız & 2 & 0,4 \\
Toplam & 500 & 100,0 \\
\hline \hline
\end{tabular}

Tablo 4: Katılım Bankalarının Sunduğu Hizmet ve Ürünlerden Memnuniyet Düzeyi (Toplulaştırılmış)

Katılım bankalarının sunduğu ürün ve hizmetlerden genel olarak memnun olma düzeyi, müşterilerin özelliklerine göre değerlendirildiğinde; müşterilerin yaş, gelir düzeyi, sosyoekonomik statüsü ve çalışılan katılım bankası tercihlerine göre memnun olmada, istatistiki olarak anlamlı farklılaşmalar gözlenmiştir. Buna göre, en yüksek memnun olma oranı 30 yaş altı müşteri grubunda gözlemlenirken, en az memnun olma oranına 30-40 yaş arası müşteri grubunda rastlanmıştır. Müşterilerin gelir düzeyi ile memnun olma durumu arasındaki ilişki ayrışımına bakıldığında, çalışılan katılım bankasına ilişkin genel kanaate benzer bir biçimde, gelir düzeyi yükseldikçe memnun olan müşteri yüzdesinin düştüğü görülmektedir. Sosyoekonomik statüye göre değerlendirdiğimizde de benzer eğilimi destekler bir durum görülmektedir. Memnun olan müşterilerin en yüksek yüzdeye sahip olduğu sosyoekonomik statü, düşük sosyoekonomik statü olmuştur. Sosyoekonomik statü yükseldikçe memnun olan müşterilerin oranının düştügü görülmektedir. Memnun olan müşterilerin toplam müşteriler içindeki oranı, tercih edilen bankaya göre istatistiki olarak anlamlı değişim göstermektedir. A ve C katılım bankalarının müşterileri içinde, memnun olanların oranı diğer katılım bankalarına göre daha yüksektir.

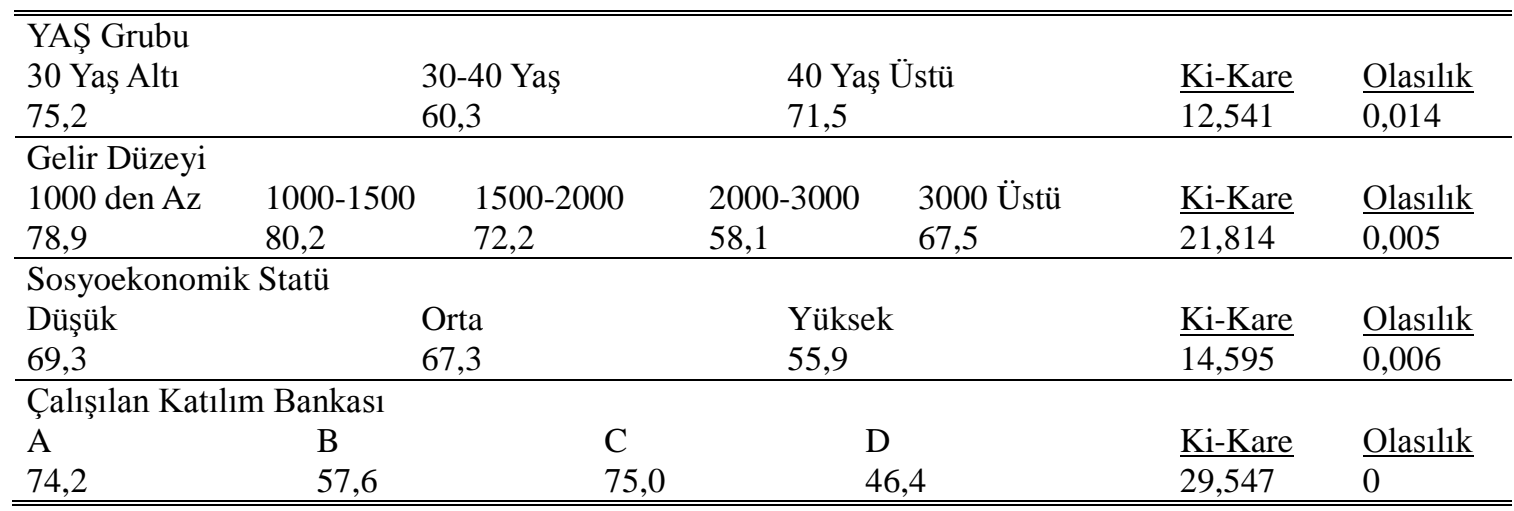

Tablo 5: Ürün ve Hizmetlerden Memnun Olmada Ayrışım (\%) (Toplulaştırılmış)

\begin{tabular}{lll}
\hline \hline & Sayı & Yüzde \\
\hline İşlemlerin tamamlanma hızı ve etkinliği & 414 & 82,8 \\
Personelin yatırıma yönelik tavsiyesi & 365 & 73,0 \\
Şubenin yeri & 343 & 68,6 \\
Şube iç dizaynı & 302 & 60,4 \\
Personelin müşteriye karşı tutumu & 287 & 57,4 \\
Mesai saatlerinin uygunluğu & 240 & 48,0 \\
Müşteri mahremiyetine verilen önem & 236 & 47,2 \\
Yeni ürün ve hizmetler hakkında bilgilendirme ve tanıtım & 196 & 39,2 \\
Kredi koşullarının uygunluğu & 192 & 38,4 \\
Otopark imkânı & 189 & 37,8 \\
Hesaplara yüksek gelir sunması & 180 & 36,0 \\
İnternet bankacılığının kalitesi & 154 & 30,8 \\
\hline \hline
\end{tabular}

Tablo 6: Katılım Bankalarının Sunduğu Hizmet ve Ürünlerden Memnuniyet Düzeyi

Katılım bankası müşterilerinin değerlendirildiği alanlar, ortalama skorlar dikkate alınarak aşağıda verilen tabloda sunulmuştur. Tablo incelendiğinde, katılım bankaları müşterilerinin bankaları ile ilgili olarak en memnun oldukları konunun, banka işlemlerinin tamamlama hız ve etkinliği olduğu görülmektedir. Bunu, personelin yatırım konusundaki danışmanlığı takip ederken, üçüncü ve dördüncü sırada ise şubeye ilişsin fiziki koşullar yer almıştır. Banka müşterilerinin en az memnun oldukları alanlara baktığımızda ise, en düşük skorun, internet 
bankacılığının kalitesine ait olduğu görülmektedir. Bunu, hesaplara yüksek getiri sunulması alanı izlemiştir. Bu listenin alt sıralarında yer alan konular, katılım bankalarının kendilerini geliştirmek için çaba sarf etmesi gereken alanları göstermektedir.

Katılım bankası müşterilerinin, banka ürün ve hizmetlerinden memnuniyet düzeylerini değerlendirmeleri için sunulmuş olan 12 alan; müşterilerin sosyopolitik kimlik, sosyoekonomik statü, betimsel özellik ve çalışılan katılım bankası tercihlerine göre analiz edilmiştir. Böylelikle özeliklerine göre gruplandırılan müşterilerin memnuniyet alanları değerlendirilebilmiştir.

\subsubsection{Yaş Gruplarına Göre Memnuniyet Düzeyinde Farklılaşma}

Banka müşterileri yaş gruplarına göre değerlendirildiğinde, memnuniyet alanlarından 7 tanesinde müşterilerin yaş gruplarına göre anlamlı ayrışım görülmüştür. İstatistiki olarak anlamlı sonuçlara ulaşılan bu değerlendirme alanları; işlemlerin tamamlama hız ve etkinliği, personelin yatırıma yönelik tavsiyesi, şubenin yeri, şube içi tasarım, personelin müşteriye karşı tutumu, müşteri mahremiyetine verilen önem ve mesai saatlerinin uygunluğu alanlarının tümünde 30-40 yaş aralığı müşteriler içinde memnun olma oranı, diğer yaş gruplarına kıyasla daha düşük çıkmıştır.

\begin{tabular}{|c|c|c|c|c|}
\hline 30 Yaş Altı & 30-40 Yaş & 40 Yaş Üstü & Ki-Kare & Olasıl1k \\
\hline \multicolumn{5}{|c|}{ İșlemleri Tamamlama Hızı ve Etkinliği } \\
\hline 84,7 & 80,0 & 84,8 & 11,181 & 0,08 \\
\hline \multicolumn{5}{|c|}{ Personelin Yatırıma Yönelik Tavsiyesi } \\
\hline 77,7 & 68,8 & 73,9 & 10,89 & 0,092 \\
\hline \multicolumn{5}{|c|}{ Şubenin Yeri } \\
\hline 70,7 & 60,0 & 79,0 & 17,051 & 0,009 \\
\hline \multicolumn{5}{|c|}{ Șube İçi Dizayn } \\
\hline 63,1 & 50,2 & 72,5 & 22,732 & 0,001 \\
\hline \multicolumn{5}{|c|}{ Personelin Müșteriye Karșı Tutumu } \\
\hline 63,1 & 47,8 & 65,2 & 13,606 & 0,034 \\
\hline \multicolumn{5}{|c|}{ Müșteri Mahremiyetine Verilen Önem } \\
\hline 47,1 & 40,5 & 57,2 & 14,31 & 0,026 \\
\hline \multicolumn{5}{|c|}{ Mesai Saatlerinin Uygunluğu } \\
\hline 51,0 & 39,5 & 57,2 & 13,237 & 0,039 \\
\hline
\end{tabular}

Tablo 7: Yaş Grubuna Göre Ürün ve Hizmetlerden Memnun Olmada Ayrışım (\%)

Orta yaş grubundaki farklılaşmanın olası nedenini değerlendirmek için banka müşterilerinin yaş ve iş durumu arasındaki ilişki ele alınmıştır. 30 altı yaşta öğrenci ve işsizler, 40 yaş üstünde ise emekliler yüksek bir paya sahip iken, bu grupların 30-40 yaş aralığındaki payları ise düşüktür. Dolayısıyla 30 yaş altı ve 40 yaş üstünde orta yaşa göre daha yüksek bir memnun olma oranının tespit edilmesinin olası nedeninin, ekonomik hayata aktif katılım durumları olduğu düşünülmektedir.

\begin{tabular}{llll}
\hline \hline & 30 yaş altı & $30-40$ yaş & 40 yaş üstü \\
\hline Ücretli Çalışan & 30,30 & 39,80 & 32,30 \\
İşadamı/Esnaf/Sanatkar & 8,50 & 27,90 & 23,30 \\
Emekli & -- & -- & 24,10 \\
Öğrenci & 40,60 & 3,00 & -- \\
Ev kadını & 4,80 & 23,90 & 19,50 \\
İşsiz & 15,80 & 5,50 & 0,80 \\
\hline \hline
\end{tabular}

Tablo 8: İş Durumunun Yaş Aralı̆̆ına Göre Dă̆ılımı

\subsubsection{Sosyopolitik Kimliğe Göre Memnuniyet Düzeyinde Farklılaşma}

Memnuniyete ilişkin değerlendirme alanlarından banka müşterilerinin sosyopolitik kimliğine göre istatistiki olarak anlamlı farklılaşma, ancak iki alanda gözlemlenmiştir. Bunlar internet bankacılığının kalitesi ve yeni ürün ve hizmetler hakkında tanıtım alanları olmuştur. Bu alanlardan memnun olan müşterilerin oranı, milliyetçi muhafazakâr grup için en düşük düzeydedir.

\begin{tabular}{|c|c|c|c|c|}
\hline $\begin{array}{l}\text { Milliyetçi- } \\
\text { Muhafazakar }\end{array}$ & $\begin{array}{l}\text { Laik- } \\
\text { Kemalist }\end{array}$ & $\begin{array}{l}\text { Sol-Sosyal } \\
\text { Demokrat }\end{array}$ & Ki-Kare & Olasılik \\
\hline \multicolumn{5}{|c|}{ İnternet Bankacılığının Kalitesi } \\
\hline 28,8 & 33,7 & 52,2 & 10,813 & 0,094 \\
\hline \multicolumn{5}{|c|}{ Yeni Ürün ve Hizmetler Hakkında Tanıtım } \\
\hline 36,4 & 43,5 & 69,6 & 14,786 & 0,022 \\
\hline
\end{tabular}

Tablo 9: Sosyopolitik Kimliğe Göre Ürün ve Hizmetlerden Memnun Olmada Ayrışım (\%) 


\subsubsection{Eğitim Düzeyine Göre Memnuniyet Düzeyinde Farklılaşma}

Banka müşterileri içinde memnun olma oranının eğitim düzeyine göre anlamlı farklılaşma gösterdiği 7 memnuniyet değerlendirme alanı tespit edilmiştir. Tablo 10'da görünen bu alanlar, işlemlerin tamamlama hız ve etkinliği, şubenin yeri, personelin müşteriye karşı tutumu, hesaplara yüksek getiri sunulması, müşteri mahremiyetine verilen önem, mesai saatlerinin uygunluğu ve yeni ürün ve hizmetler hakkında tanıtım alanları olmuştur. $\mathrm{Bu}$ alanlar içinde, işlemlerin tamamlama hız ve etkinliği, şubenin yeri, personelin müşteriye karşı tutumu alanlarında eğitim düzeyi yükseldikçe, memnun olan banka müşterilerinin oranında artış görülmüştür. Ancak diğer anlamlı ilişki tespit edilmiş olan hesaplara yüksek getiri sunulması, müşteri mahremiyetine verilen önem, mesai saatlerinin uygunluğu ve yeni ürün ve hizmetler hakkında tanıtım alanlarında ise tam tersi bir eğilim görülmektedir.

\begin{tabular}{|c|c|c|c|c|c|}
\hline İlkokul & Ortaokul & Lise & $\begin{array}{l}\text { Üniversite } \\
\text { ve Üstü }\end{array}$ & Ki-Kare & Olasılık \\
\hline \multicolumn{6}{|c|}{ İșlemleri Tamamlama Hızı ve Etkinliği } \\
\hline 84,2 & 77,0 & 78,5 & 87,8 & 31,56 & 0 \\
\hline \multicolumn{6}{|c|}{ Șubenin Yeri } \\
\hline 64,9 & 59,0 & 65,5 & 75,1 & 19,271 & 0,023 \\
\hline \multicolumn{6}{|c|}{ Personelin Müșteriye Karșı Tutumu } \\
\hline 50,9 & 57,4 & 53,7 & 62,4 & 27,683 & 0,001 \\
\hline \multicolumn{6}{|c|}{$\underline{\text { Hesaplara yüksek Getiri Sunmas1 }}$} \\
\hline 45,6 & 47,5 & 37,9 & 28,3 & 17,533 & 0,041 \\
\hline \multicolumn{6}{|c|}{ Müșteri Mahremiyetine Verilen Önem } \\
\hline 57,9 & 45,9 & 51,4 & 41,0 & 18,251 & 0,032 \\
\hline \multicolumn{6}{|c|}{ Mesai Saatlerinin Uygunluğu } \\
\hline 54,4 & 45,9 & 46,3 & 48,3 & 17,362 & 0,043 \\
\hline \multicolumn{6}{|c|}{ Yeni Ürün ve Hizmetler Hakkında Tanıtım } \\
\hline 54,4 & 44,3 & 39,5 & 33,2 & 16,07 & 0,065 \\
\hline
\end{tabular}

Tablo 10: Eğitim Düzeyine Göre Ürün ve Hizmetlerden Memnun Olmada Ayrışım (\%)

\subsection{4 İş Durumuna Göre Memnuniyet Düzeyinde Farklılaşma}

Katılım bankası müşterilerinin iş durumları ile memnuniyet değerlendirilmesinin yapıldığı alanlar bakımından anlamlı ilişki tespit edilmiş alanlar, işlemlerin tamamlama hız ve etkinliği, hesaplara yüksek getiri sunulması, internet bankacılığının kalitesi ve yeni ürün ve hizmetler hakkında tanıtım alanları olmuştur.

İşlemlerin tamamlama hız ve etkinliğinde, memnun olan müşteri oranı tüm iş gruplarında yüksek bir düzeyde çıkmıştır. Ancak bu değerlendirme alanında memnun olan müşteri oranı, nispi olarak iş adamı/esnaf ve sanatkâr iş grubunda en düşük düzeyde çıkmıştır. Bir başka anlamlı ayrışımın gözlemlendiği değerlendirme alanı olan hesaplara yüksek getiri sunulmasından memnun olan müşterilerin dağılımı incelendiğinde ise, en yüksek memnun olma oranı emekli ve ev hanımı gruplarında tespit edilirken, işsiz ve öğrenci grubu bu alanda en düşük memnun olan müşteri oranına sahip olmuştur. Anlamlı ayrışımın gözlendiği bir başka memnuniyet değerlendirme alanı ise internet bankacılığının kalitesi olmuştur. Emekli müşteriler içinde bu alanda memnun olan müşterilerin oranı tüm gruplara göre daha yüksek düzeyde tespit edilirken, bu oranın en düşük kaldığ gruplar ev hanımı ve işsizler olmuştur. Yenilikler hakkında tanıtım konusunda ise diğer gruplara göre emekli ve ev hanımı gruplarında memnun olan müşterilerin oranının daha yüksek olduğu görülmüştür.

\begin{tabular}{|c|c|c|c|c|c|c|c|}
\hline $\begin{array}{l}\text { Ücretli } \\
\text { Çalışan }\end{array}$ & $\begin{array}{l}\text { İşadamı, Esnaf } \\
\text { ve Sanatkâr }\end{array}$ & Emekli & Öğrenci & Ev Hanımı & İşsiz & Ki-Kare & Olasılık \\
\hline \multicolumn{8}{|c|}{ İșlemleri Tamamlama Hızı ve Etkinliği } \\
\hline 86,7 & 73,6 & 85,7 & 79,7 & 86,9 & 83,8 & 26,827 & 0,082 \\
\hline \multicolumn{8}{|c|}{ Hesaplara yüksek Getiri Sunulması } \\
\hline 34,7 & 31,1 & $\overline{54,3}$ & 28,1 & 52,5 & 27,0 & 28,163 & 0,06 \\
\hline \multicolumn{8}{|c|}{ İnternet Bankacılığının Kalitesi } \\
\hline 30,6 & 33,0 & 48,6 & 31,3 & 21,3 & 21,6 & 30,679 & 0,031 \\
\hline \multicolumn{8}{|c|}{ Yeni Ürün ve Hizmetler Hakkında Tanıtım } \\
\hline 38,8 & 39,6 & 57,1 & 40,6 & 44,3 & 13,5 & 37,715 & 0,004 \\
\hline
\end{tabular}

Tablo 11: İ̧ Durumuna Göre Ürün ve Hizmetlerden Memnun Olmada Ayrışım (\%) 


\subsubsection{Sosyoekonomik Statüye Göre Memnuniyet Düzeyinde Farklılaşma}

Sosyoekonomik statü, anlamlı ayrışımın en çok tespit edildiği katılım bankası müşteri özelliklerinden biri olmuştur. 12 değerlendirme alanının 8'inde bu özelliğe göre istatistiki olarak anlamlı ayrışım tespit edilmiştir. Personelin müşteriye karşı tutumu, kredi koşullarının uygunluğu, hesaplara yüksek getiri sunulması, müşteri mahremiyetine verilen önem, mesai saatlerinin uygunluğu alanlarında ve yeni ürün ve hizmetler hakkında tanıtım, katılım bankası müşterilerinin sosyoekonomik statüleri yükseldikçe memnun olan banka müşterilerinin oranın azaldığı görülmektedir. İşlemlerin tamamlama hız ve etkinliği alanında çok zayıf bir farklılaşma görülmekte iken, internet bankacılığı alanında memnun olan banka müşterilerinin oranının sosyoekonomik statü yükseldikçe arttığı görülmektedir.

\begin{tabular}{|c|c|c|c|c|}
\hline Düşük & Orta & Yüksek & Ki-Kare & Olasılik \\
\hline \multicolumn{5}{|c|}{ İșlemleri Tamamlama Hızı ve Etkinliği } \\
\hline 83,2 & 83,9 & 81,3 & 22,328 & 0,001 \\
\hline \multicolumn{5}{|c|}{ Personelin Müșteriye Karșı Tutumu } \\
\hline 60,0 & 61,9 & 50,5 & 17,144 & 0,009 \\
\hline \multicolumn{5}{|c|}{ Kredi Koșullarının Uygunluğu } \\
\hline 42,1 & 39,9 & 34,6 & 14,205 & 0,027 \\
\hline \multicolumn{5}{|c|}{ Hesaplara yüksek Getiri Sunulması } \\
\hline 46,3 & 32,7 & 34,6 & 16,451 & 0,012 \\
\hline \multicolumn{5}{|c|}{ Müșteri Mahremiyetine Verilen Önem } \\
\hline 56,8 & 45,3 & 44,5 & 16,62 & 0,011 \\
\hline \multicolumn{5}{|c|}{ Mesai Saatlerinin Uygunluğu } \\
\hline$\overline{55,8}$ & 48,9 & 42,9 & 13,277 & 0,039 \\
\hline \multicolumn{5}{|c|}{ İnternet Bankacılığının Kalitesi } \\
\hline 31,6 & 27,4 & 34,6 & 11,271 & 0,08 \\
\hline \multicolumn{5}{|c|}{ Yeni Ürün ve Hizmetler Hakkında Tanıtım } \\
\hline 47,4 & 34,1 & 41,2 & 17,919 & 0,006 \\
\hline
\end{tabular}

Tablo 12: Sosyoekonomik Statüye Göre Ürün ve Hizmetlerden Memnun Olmada Ayrışım (\%)

\section{Sonuç ve Öneriler}

Dünyadaki gelişim hızına paralel olarak ülkemizde de hızlı bir gelişim performansı gösteren faizsiz bankacılığın gerek bu gelişim ivmesini sağlıklı analiz edebilmek gerekse de bu gelişme sürecini daha iyi bir performansla devam ettirebilmek için, bu banka müşterilerini değerlendirme odaklı birçok çalışma yapılmaktadır. Bu çalışma da bu amaç doğrultusunda Eskişehir İli genelinde 500 katılım bankası müşterisi ile yüz yüze yapılan anket görüşmesi ile gerçekleştirilmiştir. Ürün ve hizmetlere yönelik memnuniyet, ankete katılan banka müşterilerinin değerlendirildiği alanlardan biri olmuştur. $\mathrm{Bu}$ çalışmada ayrıca banka müşterilerinin sosyopolitik kimlik, sosyo ekonomik statü ve demografik özellikleri açısından memnuniyet düzeylerinde ayrışma olup olmadığı da ele alınmıştır. Eskişehir'deki 500 katılım bankası müşterisinin bu bankaları tercih etme nedenleri içinde ilk sırayı akraba ve arkadaş tavsiyesi alırken, Din 4. sırada yer almıştır. (Ergeç ve diğg, 2013) Bu durum Haron ve Planisek'in (1994) Malezya için yaptıkları çalışmaya benzer sonuçları gündeme getirmektedir. Dinin banka tercihinde tek neden olmaması ve müşteri çekmenin temel yolunun din olmaması bankaların hizmet ve ürün kalitesini arttırmaları gereğini göstermektedir. Bu çalışmada banka tercihinde akraba ve arkadaş tavsiyesinin ilk sırada yer alması, müşterilerin yakın akraba ilişkilerine sahip ve sosyal bağlarının kuvvetli olduğu gerçeğini ortaya koymakta, bu durum da bankaların müşterileriyle iyi ilişkiler kurmasının önemini göstermektedir.

Ankete katılan banka müşterilerinde katılım bankası ürün ve hizmetlerine yönelik genel anlamda yüksek denilebilecek bir farkındalık ve kullanım düzeyi tespit edilmiştir. Ancak ürünler arasında farkındalık ve kullanım düzeyleri farklılık göstermektedir. Katılım bankalarının sunduğu ürünler arasında en yüksek farkındalık ve kullanım düzeyi katılma hesabı için tespit edilmişken, ikinci sıradaki farkındalıkta cari hesap, kullanımda ise kredi kartları yer almıştır. Ayrıca ürün ve hizmetler konusunda müşterilerin farkındalık ve kullanım düzeyleri arasında anlamlı bir farklılık vardır. Banka müşterileri, katılım bankalarının sundukları ürün ve hizmetleri genel olarak ortalama yüzde 54 düzeyinde bilmekte iken, kullanma oranları ortalama yüzde 27'dir. Ticari müşterilere yönelik üretim desteği, leasing, kar/zarar (yatırım) ortaklığı ve dış ticaret hizmetlerinin kullanımı göz önüne alınmaz ise, bu durumda bilinme oranı \%74, kullanım oranı ise ortalama \%45 olmakta, yani ortalamalar arasındaki fark daha da yükselmektedir. Dolayısıyla katılım bankaları, müşterilerinin fikir sahibi oldukları bazı ürünleri kullanmama nedenlerini iyi irdelemelidir.

Ankette müşterilere yöneltilen, bankalarından genel anlamda memnun olup olmadıklarına ilişkin soruya verilen cevaplar göstermektedir ki müşteriler bu konuda yüksek oranda olumlu fikir beyan etmişlerdir. Banka müşterilerinin yüzde 70,2'si kanaatinin genel olarak olumlu olduğunu belirtirken, olumsuz kanaat belirtenlerin 
oranı ancak yüzde 5,6'dır. Cinsiyet, gelir düzeyi ve sosyopolitik kimliğe göre olumlu kanaat belirtmede anlamlı bir ayrışım gözlenmemekte iken, diğer değişkenlere göre bu soruya verilen cevapta anlamlı ayrışımlar tespit edilmiştir.

Genç yaştakilerin olumlu kanaati görece daha düşük, ileri yaş grubundakilerin olumlu kanaatlerinin ise daha yüksek olduğu tespit edilmiştir. Eğitim düzeyi yükseldikçe çalışılan bankaya yönelik olumlu kanaat belirtenlerin oranının düştüğü görülmektedir. Düşük sosyoekonomik statüdekilerde olumlu kanaat belirtme oranının orta ve yüksek sosyoekonomik statüdekilere göre daha yüksek olduğu tespit edilmiştir. Meslek grupları itibariyle dağılım dikkate alındığında ise, emekliler ve ev kadınları en yüksek düzeyde olumlu kanaat belirtirlerken, bu oran işadamı/esnaf/sanatkârlar ile öğrenci kesiminde görece daha düşük gerçekleşmiştir.

Katılım bankalarının müşterilerine sunduğu ürün ve hizmetlerin sunumuna ilişkin 12 memnuniyet alanı hakkında sorular yöneltilmiştir. Sorulara verilen cevaplar derecelendirilerek bu alanlara ilişkin ortalama memnuniyet skorları tespit edilmiştir. Bu alanlar içinde banka işlemlerinin tamamlanma hız ve etkinliği en yüksek memnuniyet ortalamasına sahiptir. İkinci sırada personelin yatırım konusundaki danışmanlığı, üçüncü ve dördüncü sırada ise şubeye ilişkin fiziki koşullar yer almıştır. Memnuniyet derecelendirmesinde listenin en sonunda yer alan alanlara baktığımızda, en düşük skorun, internet bankacılığının kalitesi alanına ait olduğu görülmektedir. Bunu, hesaplara yüksek getiri sunulması alanını izlemiştir. Katılım bankalarının müşteri memnuniyeti için bu listenin alt sıralarında yer alan konulara önem vermeleri gerekmektedir.

Ayrıca bu memnuniyet alanlarına ilişkin her müşteri için ortalama skor hesaplanarak genel anlamda müşteri memnuniyeti de değerlendirilmiş, müşterilerin çalıştıkları katılım bankasına yönelik genel kanaatlerine benzer sonuçlara ulaşılmıştır. Buna göre, hizmetler için genel olarak müşteri memnuniyeti yüzde 68 düzeyindeyken, memnun olmayan müşteri oranı yüzde 6 , düşük düzeyde memnuniyet belirtenlerin oranı ise yüzde 26 'dır. Ürün ve hizmetlerden genel olarak memnun olma düzeyinin müşterilerin özellikleri ile ilişkilendirildiğinde; banka müşterilerinin yaş, gelir düzeyi, sosyoekonomik statü ve çalışılan katılım bankası tercihlerinde memnun olmada anlamlı ayrışım gözlenirken, diğer değişkenler ile benzer bir ilişki tespit edilememiştir. Buna göre, en yüksek memnun olma oranı 30 yaş altı müşteri grubunda gözlemlenirken, en az memnun olma oranına 30-40 yaş altı müşteri grubunda rastlanmıştır. Gelir düzeyi değerlendirildiğinde ise, çalışılan katılım bankasına ilişkin genel kanaate benzer biçimde, gelir düzeyi yükseldikçe memnun olan müşteri yüzdesinin düştügü görülmektedir. Sosyoekonomik statüye göre ayrışıma baktığımızda da benzer eğilimi destekler bir durum görülmektedir. Memnun olan müşterilerin en yüksek yüzdeye sahip olduğu sosyoekonomik statü, düşük sosyoekonomik statü olmuştur. Sosyoekonomik statü yükseldikçe memnun olan müşterilerin oranının düştüğü görülmektedir.

Günümüzde hem birbirleri ile hem de geleneksel faizli bankalar ile rekabet ortamının daha da s1kılaştı ğ dikkate alındığında, bu çalışma ile katılım bankalarının müşteri odaklı değerlendirilmesinde dikkate alınması gereken sonuçlara ulaşılmıştır.

\section{Teşekkür}

Bu çalışma, Eskişehir Osmangazi Üniversitesi Bilimsel Araştırma Projeleri Komisyonu tarafindan 201217001 nolu proje olarak desteklenmiştir.

\section{Kaynakça}

- $\quad$ Akhtar, Hunjra, Akbar, Rehman ve Niazi, 2011, "Relationship Between Customer Satisfaction and Service Quality of Islamic Banks", World Applied Sciences Journal, 13, s. 453-459.

- Bankacilik kanunu, 2013,http://www.bddk.org.tr/websitesi/turkce/Mevzuat/Bankacilik_Kanunu/ 15405411_sayili_kanun_6362_sayili_sermaye_piyasasi_kanunu_ile_degisik_islenmis_hali_9.1.2013.pdf)

- Dusuki, ve Abdullah, 2007, “Why do Malaysian customers patronise Islamic banks?” International Journal of Bank Marketing, 25, s.142-160.

- Ergeç, Arslan ve Toprak, 2013, "Reconciliation or Polarization in Islamic bank preference? Socio-political, Socio-economic and Demographic aspects", International Review of Finance, Yayına gönderildi.

- $\quad$ Erol, ve El-Bdour, 1989, "Attitudes, Behaviour, and Patronage Factors of Bank Customers towards Islamic Banks", International Journal of Bank Marketing, 7, s.31-37.

- Haron, Ahmad ve Planisek, 1994, "Bank patronage factors of Muslim and non-Muslim customers", International Journal of Bank Marketing, 12, s. 32-40.

- Khattak ve Rehman, 2010" "Customer Satisfaction and Awareness of Islamic Banking System in Pakistan”, African Journal of Business Management, 4, s. 662-671.

- Khan ve Asghar, 2012, “Customer awareness and adoption of Islamic Banking in Pakistan”, Interdiciplinary Journal of Contemporary Research in Business, 3, s.359-366.

- Khan, Hassan ve Shahid, 2007, “Banking Behavior of Islamic Bank Customers in Bangladesh”, Journal of Islamic Economics, Banking and Finance, 3, s.159-194. 
- Metawa, Almossawi, 1998, "Banking behavior of Islamic bank customers: perspectives and implications", International Journal of Bank Marketing, 16, s.299-313.

- Naser, Jamal, ve Al-Khatib, 1999, "Islamic banking: a study of customer satisfaction and preferences in Jordan”, International Journal of Bank Marketing, 17, s. 135-151.

- Okumuş, 2005, "Interest -Free Banking in Turkey:A Study of Customer Satisfaction and Bank Selection Criteria”, Journal of Economic Cooperation, 26, s. 51-86.

- Rehman, 2012, "Customer satisfaction and service quality in Islamic banking: A comparative study in Pakistan, United Arab Emirates and United Kingdom", Qualitative Research in Financial Markets, 4, s. 165-175.

- Saini, Bick ve Abdulla, 2011, "Consumer Awereness and Usage of Islamic Banking Products in South Africa”, SAJEMS NS, 3, s. 298-313.

- $\quad$ TCMB Finansal İstikrar Raporu, Mayıs 2011, 12 


\title{
Türk Bankacılığında Rekabet Değerlendirme Yaklaşımları ile Rekabet Dinamiklerinin Ampirik Analizi
}

\section{Emprical Analysis of Competition Dynamics in Turkish Banking via Competition Determination Approaches}

\author{
Asst. Prof. Dr. Utku Altunöz (Sinop University, Turkey)
}

\begin{abstract}
Due to the complex and close interaction of banks with other economic units, any trouble in banking sector might have repercussion on the whole economy which makes the market structure and competition in banking sector as a cynosure. Business world is facing gradually increasing competition. It seems that the existence of firms depends on the power and the advantage of their competitiveness. The purpose of this study is to analyze the competition structure and the market conditions of Turkish banking system. despite the existence of a number of studies about competition in banking sector, there is still a lack of the studies which has been done with Lerner's Index. Due to this fact, Lerner's Indeks is used in this study. Bank level determinants of Lerner Index is analysed using Panel Data Regression Method and was reached to factors effecting competitive behavior in Turkish Banking Sector.
\end{abstract}

\section{Giriş}

Finansal sistem reel kesimin ihtiyaç duyduğu gerekli kaynağı sağlamanın yanı sıra, bu kaynakların etkin bir şekilde ve uygun zamanda yatırımlara aktarılmasını da sağlamaktadır. Finansal sistem, üstlendiği fonksiyonlar itibariyle reel kesimi yakından etkilemektedir. Finansal sistemdeki gelişmeler ve sektörün etkin işlemesi ekonominin bütünü açısından önem arz etmektedir (Kar ve diğ., 2008). Bu görevi önemli ölçüde bankalar yerine getirmektedir. Bankaların etkin çalışabilmelerinin ve kendilerinden beklenen finansal aracılık fonksiyonlarını en iyi şekilde yerine faaliyette bulundukları piyasanın yapısıyla doğrudan ilişskilidir. Bu nedenle bankaların faaliyette bulundukları piyasa yapısının tam rekabetçi olup olmaması, kendilerinden beklenen fonksiyonların etkin bir şekilde yerine getirilmesi açısından önem arz etmektedir. Öte yandan bankacıllk sektörünün diğer piyasalardan farklı olduğu ve bu nedenle de rekabet açısından değerlendirme yapılırken diğer piyasalarla eş tutulamayacağı ileri sürülmektedir. $\mathrm{Bu}$ açıdan bakıldığında sektörde rekabete ilişkin iki farklı görüş ortaya çıkmaktadır. Bir görüşe göre rekabet ile kırılganlık arasında pozitif bir ilişkinin var olduğudur. Bankacılık sektöründeki rekabet, beraberinde kırılganlığı doğuracağı için bu kırılganlığın önce sektörü sonra ise tüm reel kesimi etkileyebileceği yönündedir. Sektörde yaşanabilecek bir yoğunlaşmanın yüksek faiz, ahlaki tehlike ve ters seçim sorununu gündeme getirerek piyasayı ve bütün bir ekonomiyi olumsuz etkileyebileceği yönündedir.

$\mathrm{Bu}$ çalışmanın amacı Rekabet her zaman iyidir önermesinin Bankacılık sektörümüz açısından doğru olup olmadığının sınanmasıdır. Klasik ekonomi teorilerine göre rekabetin artmasının refahı da beraberinde arttırması kabul görmüş bir düşüncedir. Fakat günümüz dünyasında yapılan bilimsel çalışmalarda tersi görüşler de yüksek sesle dile getirilmeye başlanmıştır.

Bir grup bilim adamı banka sektöründeki yoğunlaşmanın kırılganlık ihtimalini azalttığını, çünkü rekabet düzeyinin azaldığını ve buna bağlı olarak kârlılıktaki artışın bankaların risk alma eğilimini düşürdüğünü ileri sürmektedir. Ayrıca aynı bilim adamları, az sayıda büyük bankadan oluşan bir sektörün otoritelerce daha etkin bir şekilde denetleneceğini böylece kriz riskinin daha da düşeceğini savunmaktadır. Karşı görüşteki bilim adamları ise, serbest rekabeti savunurlar ve bu çerçevede yoğunlaşmanın banka sisteminin kırılganlığını arttıracağını ileri sürerler. Onlara göre; eksik rekabet koşullarında faaliyet gösteren dev ölçekli bankalar kredi verme konusunda daha ihtiyatsız olacak, faaliyet zararı riskleri artacaktır. Diğer taraftan, "batmayacak kadar büyük" olduklarından ve elbette bunun farkında olduklarından daha pervasız davranacaklar, gerekirse otoritelerin zararlarını karşılayarak kendilerini ayakta tutacağına güveneceklerdir. Böylece rekabetin azalması, kamu eliyle etkinsizlikler doğuracak ve kırılganlığı arttıracaktır. Yani rekabetle banka kırılganlığı negatif bir ilişki içindedir.

Üçüncü görüş ise, rekabetle banka kırılganlığı arasındaki ilişkinin yönünün ekonomik yapı ve ilişkilere göre farklılaşabileceği, bu anlamda her yerde ve her zaman geçerli yargılara varılamayacağ üzerinedir. Bu görüşü savunan bilim adamları, yaptıkları ampirik araştırmalarda çelişkili sonuçlara ulaşmışlardır. Dolayısıyla, onların diğer iki uç görüşün arasında yer aldıkları söylenebilir.

\section{Bankacılık Sektöründe Rekabet Yaklaşımları}

Genellikle tekelin tersi olarak ifade edilmesine rağmen rekabet, fiyatı ve marjinal maliyeti eşitleyerek kaynakların kullanımında dağılımsal etkinliği temin eden güç olarak ifade bulmuştur(McNulty, 1968). Stigler'in 
(1987) tanımı çerçevesinde "rekabet iki veya daha fazla tarafın, herkesin aynı anda elde etmesi mümkün olmadığı bir şeyi elde etmek için uğraşmasından kaynaklanan yarıştır”. Endüstriyel iktisat (industrial economics) literatüründe, rekabet diğer sektörlerde olduğu gibi bankacılık sektöründe de refahı artırmak için gerekli bir mekanizma olarak kabul edilmektedir (Frexias ve Rochet, 1998).

\subsection{Yapı-Davra nış-Performans Paradigması}

$\mathrm{Bu}$ yaklaşıma göre bir endüstrinin performansı pazarın yapısına bağlı olarak pazardaki alıcı ve satıcıların davranışlarına bağlıdır. Pazar yapısı ise teknoloji, talep gibi temel koşullara bağlıdır. Dolayısıyla yapı, davranış ve performansın tahmin edicisi olarak kullanılır. Pazarın yapısı (tam rekabet, tekel, tekelci rekabet, oligopol gibi) genellikle yoğunlaşma oranları ile tanımlanırken, performans pazar gücü ölçütleri olan getiri (rate of return), fiyat maliyet farkı ile ölçülür. Davranış ise teşebbüslerin ilgili pazar yapısında rekabetçi ya da koordinasyon doğurucu karar almalarını ifade eder. Fiyat, Ar-Ge, reklâm, üretim, teknoloji seçimi, giriş engelleri, yıkıcı fiyat uygulamaları, birleşme gibi kararlar teşebbüslerin davranışlarına örnek olarak sayılabilir. Firmalar arası gizli anlaşma, fiyat ayarlamaları ve normalin üzerinde kâr sağlanması gibi olayları; yapısal faktörler, piyasaya giriş engelleri, ürün farklılaştırması gibi nedenlerle açıklayan bu paradigma refah ekonomisine teorik temel oluşturur.

\section{2 İşbirliği Hipotezi}

Bain'in (1951) "işbirliği hipotezi” (collusion hypothesis) olarak adlandırılan bu görüşe göre, piyasa yoğunlaşması ile karlılık arasında doğrusal, dolayısıyla yoğunlaşma ile piyasa performansı (rekabetçi yapı) arasında ise ters yönlü bir ilişki söz konusudur. Bu hipoteze göre yüksek yoğunlaşma örtülü anlaşmaların maliyetini düşürür ve bunun sonucunda kredilere daha yüksek fiyat uygulanırken, mevduata ödenen faizler düşer, ücretler artar. Rakipler birbirlerinin davranışlarını veri olarak kullanarak kendi stratejilerini oluştururlar. Örneğin, firmaların piyasa fiyatını etkileyemediği ve pasif fiyat alıcıları (price takers) olduğu tam rekabet piyasalarının aksine, oligopol piyasalardaki firmalar tüm piyasa katılımcılarını zarara uğratacak büyük fiyat savaşlarını önlemek için fiyat kırmaktan kaçınırlar. Bu durumda firmalar arasında açık bir iletişim olmasa dahi, tekel fiyatı uygulama konusunda örtülü anlaşma olması durumudur (Kraft, 2006).

\subsection{Etkin Yapı Hipotezi}

Demsetz (1973), etkinlik hipotezinin temellerini attığı çalışmasında, rekabetçi yapının baskısı altında ve etkili giriş engellerinin olmaması durumunda, bir sektörün çıktılarının birkaç firmada yoğunlaşmasının, ürünlerin üretilmesinde ve fiyatlamasındaki üstünlükten veya yalnızca birkaç firmanın faaliyet gösterdiği sektörel yapının üstünlüğünden ileri geldiğini öne sürmektedir.

Etkin yapı hipotezi yoğunlaşma ile kârlılık arasındaki ilişkiyi kabul etmekle birlikte yoğunlaşmanın yalnızca firmalar arasında rastlantısal şekilde meydana gelen anlaşmalardan meydana gelmeyeceğini, bunun rekabetçi ortam vesilesiyle gerçekleşebileceğini vurgulamaktadır. Diğer bir deyişle piyasadaki yoğunlaşma ile karlılık arasında pozitif bir ilişki olmasına karşılık bu ilişki nedensel değildir. Bu da yoğunlaşmanın dışsal bir faktör olduğu anlamına gelir. Piyasa yapısı ise içseldir. Kısaca özetlemek gerekirse Demstez'in etkin yapı hipotezine göre karlılık ile yoğunlaşma arasında gözlemlenen ilişki sahte (spurious) bir ilişki olup esasında yüksek etkinlik, yüksek piyasa payına ve bu da o piyasada yüksek yoğunlaşma oranına neden olmaktadır (Smirlock, 1985).

\subsection{Yarışılabilirlik Teorisi}

Eğer girişler açısından sabit maliyetler batık değilse ve yeni girenler mevcut firmalara kıyasla değişken maliyetlere sahiplerse piyasa "yarışabilir" bir piyasadır ve mevcut satıcılar arasındaki yoğunlaşmadan bağımsız olarak rekabetçi davranacaktır (Baumaol, Panzar ve Willig, 1982). Teoride piyasaya giriş ve çıkış maliyetsiz ve hızlı bir şekilde gerçekleştiği için fiyatı kontrol edecek güçleri olmamaktadır (Martin 1994). Söz konusu teoride, hem firmalar, hem de tüketiciler tam bilgiye sahiptir. Bratland (2004) yarışılabilirlik teorisi altında, çok ürün üreten tekelcilerin bile, potansiyel rakiplerin piyasaya giriş tehditleri nedeniyle fiyatlama davranışlarını kısıtlayabileceğini öne sürmektedir. Yarışılan piyasa " 0 " maliyet marjı ile ilerleme eğiliminde olduklarından, uzun dönemde tam rekabet dengesi ile Pareto optimumu sağlanmış olur.

\subsection{Herfindahl-Hirschman İndeksi (HHI)}

Pazardaki her firmanın piyasa paylarının karelerinin toplamına eşittir. Herhangi bir sektörde HHI değerinin 1000'in altında olması, o sektörün tam rekabet içinde olduğunu gösterir. HHI değerinin 1000 ila 1800 arasında olması, o sektörün "ideal” rekabet ortamında olduğunun göstergesidir. Piyasanın oligopol piyasası olduğu HHI değerinin 1800’ün üzerine çıkmasından anlaşabilir.

Bir pazarda birbirine eşit pazar payına sahip çok sayıda oyuncu olması durumunda HHI sıfıra yakınsayacaktır. Bu tip pazarlara Atomistik Pazar / Atomistik Piyasa denir. Pazarda tek bir firma olması durumunda ise 10.000 (ya da 1) olacaktır.

\subsection{Yoğunlaşma Oranı ( Crm )}

Satış hâsılatına göre, o iktisadi faaliyet sınıfı içindeki N sayıdaki işyeri içinde, faaliyet sınıfı içindeki payı en büyük ' $m$ ' sayıda işyerinin oranıdır. Bu yoğunlaşma ölçütleri arasında en eski ve özellikle ampirik çalışmalarda en yaygın kullanılan $\mathrm{M}$ firma yoğunlaşma oranıdır. 
$\mathrm{CRm}=\mathrm{i}=\mathrm{i}$

Burada,

$\mathrm{Xi}=$ i. firması için $\mathrm{X}$ değişkeninin değeri, $\mathrm{Pi}=$ i. firmasının toplam içindeki oranı veya i. firmasının payı, $\mathrm{X}=$ Tüm sanayi için $\mathrm{X}$ değ gşskenlerinin toplamı, $\mathrm{n}=$ Sanayideki firma sayısı, $\mathrm{CRm}=$ En büyük $\mathrm{M}$ fïmasının toplam piyasa payı içindeki payıdır.

M değeri geleneksel olarak dört, sekiz veya yirmi olarak alınır. Bankacılık sektöründe bu oran, mevduat veya krediler gibi çeşitli büyüklüklerden biri baz alınarak belirlenen aktif toplamlarına göre sıralanan bankalardan ilk M tanesinin temel alınan kriter açısından toplam değerinin, aynı kriter açısından o bankaların yer aldığ endüstride gerçekleşen toplam değere oranlanması ile bulunmaktadır.

Yoğunlaşma oranı ölçütü, araştırmaya konu olacak banka sayısının belirlenmesi hususunda sübjektif bir ölçüt olma özelliği taşımakta olup, aynı zamanda, endüstrideki büyük bankaları dikkate almakta, küçük ve orta büyüklükteki bankaları dikkate almamaktadır. Banka sayısı arttıkça sektördeki yoğunlaşmanın azalması, eşitsizlik endeksi arttıkça ise yoğunlaşmanın artması gerekmektedir. Bu özelliğin matematiksel ifadesi (1.1 ) nolu eşitlikte verilmektedir.

$$
C=f(n, I) f_{n} \leq \text { ve } f_{I} \geq 0
$$

Yukarıdaki eşitlik, sektöre yeni giriş yapan bir bankan〉n yoğunlaşmayı azaltacağı sonucunu doğurmaktadır. Ancak, yeni giriş yapan banka sektörde mevcut bulunanlara göre "yeterince” büyükse yoğunlaşmanın artması mümkündür. Piyasaya yeni giriş yapan bankan`n yarattığı eşitsizlik etkisinin banka sayısındaki artışın yarattığ yoğunlaşma azalışı etkisinden daha fazla olduğu durumlarda sektördeki yoğunlaşma artacaktır.

\subsection{Hannah ve Kay İndeksi}

Herfindahl - Hirschman İndeksi'nin daha genel biçimi olarak ifade edilir. Herfindahl - Hirschman İndeks'deki piyasadaki bütün bankaların piyasa paylarının karesi, güç $\alpha$ 'ya artırılmıştır. Hannah ve Kay indeksi şu şekilde gösterilir:

$$
\mathrm{HK}=\left[\sum_{i=1}^{n} S_{i}^{\alpha}\right]^{1 /(1-\alpha)}
$$

\section{Yapısalcı Olmayan Yaklaşımlar}

Yapısal yaklaşımlar, yoğunlaşmış piyasaların rekabetçi olmadığını çünkü yarışılabilirliğin potansiyel rekabetin derecesine bağlı olduğunu varsayar. Muhtemelen yapısal olmayan yaklaşımların en önemli avantajı, bu seklindeki bir neden sonuç ilişkisini varsaymamasıdır. Yapısal olmayan modellerin bir diğer avantajı, her bir bankanın davranışı kendi piyasa gücü hakkında bir fikir verebildiği için, coğrafi piyasa tanımlamasına gerek olmamasidir (Casu, Girardone, 2006).

\subsection{Lerner İndeksi}

Rekabetin ölçülmesine yönelik ampirik yaklaşımlar genelde problemli olduğundan ölçüm çoğunlukla firma seviyesinde bilgilerin gerekmesi nedeniyle endüstriyel organizasyondaki methodların kullanımı önem kazanmıştır( Guevara, Maudos ve Pe'rez:2005). Akademik alanda, özellikle bankacılık sektöründe rekabetin ölçümüne dair yoğun bir ilgi söz konusu olmuştur. Bu yüzden, geçtiğimiz yıllarda çeşitli araştırmalarda bu konuda rekabet için çeşitli göstergeler ortaya koyularak (Lerner endeksi, Panzar Rosse Testi, Breshanan Testi, Varsayımlı değişken parametre) yeni yöntemler geliştirilmiştir. Lerner'in ortaya koyduğu varsayım, piyasa yapısının nispi marjlar yoluyla açıklanabileceğini, oligopol rekabet modellerinin nispi marj ile piyasanın yapısal ve rekabetçi koşulları arasındaki denge ilişkisini tanımladığını ifade eder.

Lerner İndeksi = (Fiyat - Marjinal Maliyet $)$ / Fiyat'dır. Yani,

Lerner indeksi $=\frac{P-M C}{P}$ olarak formülize edilmektedir.

Lerner indeksinin sıfır değerini alması, tam rekabetçi bankaların varlığını işaret etmektedir. İndeks değeri 1'e yaklaştığında piyasa gücü artmaktadır. Yüksek derecedeki bir piyasa gücüne sahip olan banka, ekonomik faaliyet içinde etkili bir birim olacaktır. Fakat elde edilen yüksek kâr düzeyleri, piyasa gücünün ve kötü ekonomik performansın bir göstergesi olarak karşımıza çıkabilecektir. Bunun tersine rekabetçi durumdaysa, piyasa gücü önemsiz hale gelecektir. bankalar için takdir etme yetkisi ortadan kalkacak ve fiyatlar, maliyetlere doğru düşecektir. Böylece banka piyasada pasif bir birim olacaktır.

\subsection{Panzar-Rosse Modeli}

Literatürde bankacılık sektörü için yapılan piyasa yapısı tahminine yönelik Yeni ampirik endüstrisi iktisadı çalışmalarında genel olarak Panzar ve Rosse (1987) modeli kullanılmaktadır. Oligopolistik, rekabetçi ve monopolistik piyasalar için oluşturulan model çerçevesinde, piyasa yapılarını karşılaştırmak amacıyla bir test istatistiği geliştirmektedir. $\mathrm{Bu}$ test, firma veya banka seviyesinde indirgenmiş form hasılat eşitliğinin özelliklerine dayanmakta olup, belirli koşullarda bankaların rekabetçi davranışlarını ölçümleme işlevi gören $H$ 
test istatistiğini hesaplamaktadır. H testi, hem banka hem de sektör seviyesinde kârların maksimum kıldığı denge üretim miktarı ve banka sayısının belirlendiği genel bankacılık piyasa modelinden elde edilmektedir. Panzar ve Rosse modelinde tahmin edilen indirgenmiş formda gelir denklemi aşağıda verilmiştir.

$$
\operatorname{InR}=j_{0}+\sum_{K=1}^{m} h_{k} \operatorname{In} W_{k_{i}}+j_{1} \operatorname{In} A_{1}+j_{2} \operatorname{In} K_{i} \quad i=1, \ldots, n
$$

Eşitlikte $\mathrm{W}$, girdi fiyat vektörünü, $\mathrm{R}$ firma gelirini, A talep üzerinde etkisi olan değişkenler vektörünü ve $\mathrm{K}$ kapasiteyi temsil eden diğer değişkenler vektörünü ifade etmektedir. Bankacılık sektöründe piyasa yapısının belirlenmesi konusunda yapılan ampirik çalışmalar, Panzar ve Rosse (1987) H istatistiği tahminine yöneliktir. AB bankacılığı üzerine yapılan çalışmaların birçoğu, Türk bankacılık sektörü üzerine yapılan çalışmaların ise tamamı PR H istatistiği tahminine yöneliktir.

\begin{tabular}{|l|l|}
\hline Tahmine Edilen H Değeri & Piyasa Yapısı \\
\hline $\mathrm{H} \leq 0$ & $\begin{array}{l}\text { Tekel Piyasası: Her bir firma kendisine ait talep eğrisi üzerinde bağımsız bir } \\
\text { tekelcifirmas gibi davranmaktadır. (H algılanan talep esnekliğinin azalan bir } \\
\text { fonksiyonudur) }\end{array}$ \\
\hline $0<\mathrm{H}<1$ & $\begin{array}{l}\text { Piyasaya girişlerin serbest olduğu tekelci rekabet hamberlin)modeli. Fazla } \\
\text { kapasite söz konjusudur. (H algılanan talep esnekliğinin artan bir } \\
\text { fonksiyonudur.) }\end{array}$ \\
\hline $\mathrm{H}=1$ & Tam rekabet piyasası. Etkin (tam) kapasite kullanımı söz konusudur. \\
\hline
\end{tabular}

Tablo 1: Panzar ve Rosse H Değerlerine Karşılık Gelen Piyasa Türleri Kaynak: Vesela (1995:59)

Literatürde Panzar ve Rosse (1987) modeli tahminlerinin çoğunda banka gelirlerini temsil etmek üzere modelin bağımlı değişkeni olarak ya net faiz gelirleri, ya da toplam gelir dikkate alınmıştır. Ayrıca söz konusu çalışmalarda bankaların toplam aktifleri, banka gelirini etkilediği düşünülen ve ölçeği yansıtan bağımsız değişken olarak modellerde yer almıştır.

\subsection{Klein Monti Monopol Modeli}

Tam rekabet durumunda tüm bankalar fiyatları veri kabul ederler ve özdeştirler. Rekabetçi dengede, marjinal operasyon maliyeti faiz marjına -hem kredi hem de mevduatta- eşit olmalıdır. Kredi ve mevduat maliyetleri ayrılabiliyorsa çapraz etkiler sıfırdır. Kapsam ekonomileri (economies of scope) çapraz etkiler negatif işaretliyse mevcuttur. Yani, kredi hacmindeki bir artış marjinal mevduat maliyetini azaltıyorsa kapsam ekonomilerinin varlığından bahsedebiliriz. Bu durumda banka kredi ve mevduat fonksiyonlarını tek bir birimde (şube) etkin olarak yerine getirebilir sayılıyor. Literatürde kapsam ekonomilerinin varlığı veya yokluğu, bankacılık sektöründeki rekabetin niteliğini değiştirecek kadar önemli bir konu olarak görülüyor. Ayrıca, sektördeki banka sayısını ve kapsam ekonomilerinden yararlanan "evrensel bankaların" oranını da etkileyecektir. Kapsam ekonomileri, sektördeki yabancı sermaye oranını belirleyebilecek kadar önemli bir etken olabilir (Fındıkçığlu, Çevirim içi, 2012).

Klein Monti Monopol Modeli, tekelci banka modeli bu anlamda tam rekabetin tam tersi bir limit sunmaktadır. her bir bankanın krediler için talep fonksiyonu $L\left(r_{L}\right)$ aşağı yönlü bir eğri ve mevduat için talep fonksiyonu $D\left(r_{D}\right)$ yukarı yönlü bir eğri şeklinde oluşur. Bu fonksiyonların tersi ise $r_{D}(D)$ ve $r_{L}(L)$ şeklindedir. Bankalar kredilerin (L) ve mevduatların (D) miktarlarına karar verebilmektedirler. Bu kararlar da ilgili faiz oranlarını etkilemektedir.

Bankalar için piyasa gücü arttıkça esneklik azalmakta ve Lerner endeksi artmaktadır.

\subsection{Cournot Modeli (Oligopol Varyantı)}

Firmaların üretim miktarlarını belirleme yoluyla rekabet ettikleri Cournot modeli çerçevesinde üretilen ürünün homojen olduğu varsayımı altında yürütülen çalışmanın ortaya çıkardığı çarpıcı sonuçlardan biri, etkinlik yaratmayan yatay birleşmelerin genellikle fiyatı artırdığıdır. Bir diğeri ise, birleşme sonrası fiyat düşüşünün gerçekleşebilmesi için, sabit maliyetlerden ziyade marjinal maliyetlerde düşüşün gerekli olduğudur. Gerekli olan marjinal maliyet tasarrufu miktarı ise tarafların pazar payları ile doğru, talep esnekliği ile ters orantılıdır (Farrell ve Shapiro 1990, 110-122). Tekel yerine oligopol bir piyasa yapısı üzerinden hareket eder. Bir banka diğer rakip bankanın tepkilerini görmesine rağmen görmüyormuş gibi davranır. Esneklikler, banka sayısı ile çarpılır. Bu modelde Klein Monti modelinin birinci dereceden türevi aşağıdaki gibi değişmektedir.

$$
\begin{aligned}
& \frac{r_{L *}-\left(r+c_{l}\right)}{r_{L}}=\frac{1}{N e_{L}\left(r_{L *}\right)} \\
& \frac{r(1-\alpha) C_{D}-r_{D *}}{r_{D *}}=\frac{1}{N e_{d}\left(r_{D *}\right)}
\end{aligned}
$$




\subsection{Bertrant Modeli}

Bertrand türü oligopol modelinde firmalar rakiplerin fiyatlarının veri olarak alınabildiği varsayımı altında karı maksimize edecek fiyatları (miktarları değil) bağımsız olarak belirlemektedirler. Modele yapılan en önemli eleştiri, büyük bankaların diğer küçük bankaların davranışlarına aldırış etmemeleridir.

\subsection{Salop Modeli (Tekelci Rekabet)}

Tam rekabet ve monopol piyasaları arasında yer alan ve gerçek hayatta en sık karşılaşılan piyasa yapılarından bir diğeri ise monopolcü rekabet piyasasıdır. literatürdeki iki uç noktayı temsil eden tam rekabet ve monopolcü yapının birtakım özelliklerini taşır. Tam rekabet piyasasında olduğu gibi monopolcü piyasada da, faaliyet gösteren ekonomik birimlerin sayısı çok fazladır. Ancak bu ekonomik birimler, homojen değil, farklılaştırılmış ürünler arz etmektedirler. Firma sayısının çokluğu nedeniyle, fiyat ya da miktar üzerinde bir anlaşmaya varma olasılığı çok zordur. Monopolcü rekabet piyasa yapısının geçerli olduğu bir bankacılık sisteminde, bankalar, farklılaştırılmış hizmetleri ile rekabet içindedirler. Her bankanın karşı karşıya olduğu talep eğrisi, banka sayısının çokluğu nedeniyle ortaya çıkan ikame kolaylığı nedeniyle çok esnektir. Bankalar, oligopol piyasalarına benzer olarak, reklam ve promosyon gibi rekabet araçlarını kullanarak, hizmet farklılaştırmasına giderler. Monopolcü rekabet bu özellikleri ile özelikle Avrupa'daki bankacılık sistemlerinde, oldukça sık rastlanan bir piyasa yapısıdır. Son yıllarda Avrupa bankacılık sisteminde gözlemlenen ortak eğilim, banka sayılarındaki düşüş ve birleşme oranlarındaki artıştır. Bu durumun rekabeti azaltacağı ve bankacılık hizmet alternatiflerini daraltacağı düşünülmekteydi. Ancak, yüksek yoğunlaşma düşük rekabete yol açar şeklindeki geleneksel görüşün aksine, özellikle Avrupa için yapılan çoğu çalışmada, yoğunlaşma ve rekabet arasında anlamlı bir ilişki bulunamamıştır.

\subsection{Iwata Modeli}

Yeni Ampirik Endüstriyel Organizasyon yaklaşımı temelinde ortaya çıkan yapısal olmayan modellerin öncülüğünü 1974 yılındaki çalışmasıyla Gyoichi Iwata gerçekleştirmiştir. Iwata modeli, oligopolcü bir piyasada, homojen bir ürün arz eden her bir banka için tahmini varyasyon( variation)değerlerinin hesabını mümkün kılar(Koutsomanoli ve Staikouras,2004).

\subsection{Bresnahan ve Lau Modeli}

Bresnahan ve Lau (1989) tarafindan bankacılık sektörüne yönelik geliştirilen ikinci yapısal olmayan model, eş zamanlı denge modelini temel almaktadır. Eş zamanlı arz ve talep fonksiyonlarının yanında, yine eş zamanlı bir fiyat eşitliğinin tahmini ile piyasa gücünün göstergesi geliştirilmektedir(Hempell,2002).

\section{Bankacılık Sektöründe Rekabet Konusunda Yapılan Amprik Çalışmalar}

Bankacılık alanında piyasa gücüne ilişkin yapılan çalışmaları genel hatlarıyla üç farklı gruba ayırmak mümkündür. İlk gruba mikro iktisat ve endüstriyel organizasyon kuramları çerçevesinde yapılan tamamen teorik çalışmaları dâhil etmek olası iken, ikinci grupta daha az kuramsal içeriğe sahip olan "indirgenmiş biçimli modeller" yer almaktadır. Üçüncü grupta ise teoriden ve fiyat, talep ile arz gibi iktisadi parametrelerden bağımsız olarak geliştirilen, piyasa yapısına belirli ölçütler çerçevesinde yaklaşılan betimsel analizler bulunmaktadır.

Panzar-Rosse yönteminin bankacılık sektöründeki ilk uygulamalarından biri olan ve New York'daki bir grup bankanın davranış biçimini inceleyen Shaffer (1982), uzun dönem dengede bankaların ne monopolistik ne de tam rekabetçi davrandığını tespit etmektedir.

Shaffer(1993), 1968-1989 dönemi için Kanada bankacıllk sektöründeki bulguların tam rekabet ile tutarlı olduğunu tespit etmiş ve tekel hipotezini tamamen reddetmiştir. Dolayısıyla, Avrupa'dakine benzer bir konsolidasyonun Kanada bankacılık sektöründe rekabeti fazla etkilemeyeceğini ileri sürmüştür.

Fischer ve Hempell (2008), Alman Bankacılık sektöründe 1993-2001 yılları arasında faaliyet gösteren bankalar için Lerner Endeksini hesaplamışlardır. Hesaplanan Lerner Endeksinden yola çıkılarak, bölgesel piyasa gücünü belirleyen faktörler tespit edilmiştir. Elde edilen bulgulara göre, banka ürünlerinin talebini etkileyen diğer piyasa özellikleri gibi yerel piyasadaki yoğunlaşma düzeyi de piyasa gücü ile ilişkili bulunmuştur. Sonuçların birbirini desteklediği görülmüş ve böylelikle çalışmanın bulgularının doğruluğu kuvvetlendirilmiştir.

Çelik ve Kaplan (2010) ise Türk Bankacılık Sektöründe etkinlik ve rekabet ilişkisini 2002-2007 dönemine ilişkin yatay kesit veriler ile incelemiştir. Çalışmasında etkinlik ile rekabet arasında doğrusal bir ilişki olduğu sonucuna varmış ve etkinliğin arttığı 2005 ve 2006 yıllarında rekabetin de arttığı sonucuna ulaşmıştır.

\section{Türk Bankacılık Sektöründe Rekabet Dinamiklerinin Ampirik Analizi}

Çalışmamızın bu kısmında rekabeti ampirik olarak test eden modellerden Lerner Endeksi'ni kullanarak Türk Bankacılık Sektörü rekabet yapısını analiz edeceğiz. Bankacılık sektörü ve rekabet konusunda yapılan çalışmalar genelde yoğunlaşmanın performans üzerindeki etkilerine odaklanan ve rekabetin ampirik olarak test edilmesine önem veren çalışmalar olmak üzere ikiye ayrılmaktadır. Yeni Ampirik Endüstriyel Organizasyon yaklaşımı çerçevesinde piyasa gücünün ölçülmesinde kullanılan modeller arasında Panzar-Rosse H-istatistigi, Bresnahan Modeli ve Lerner Endeksi sayılabilir. 


\subsection{Türk Bankacılık Sektörü İçin Lerner İndeksinin Hesaplanması ve Veri Seti}

Piyasa yapısının çeşitli unsurlarından meydana gelen monopol derecesini göstermek için kullanılmaktadır. Piyasa gücü göreceli bir kavramdır ve firmaya ya da bir grup firmaya, sattıkları ürünlerin fiyatını, miktarını ve niteliğini belirleme konusunda takdir yetkisi sağlamaktadır. Tam rekabet modelinin aksine firmalar, fiyatı marjinal maliyetin üzerine çıkarabilmektedirler. Dolayısyla piyasa gücünü, fiyatları tam rekabetçi düzeyin üzerine çıkarabilme yeteneğidir şeklinde de tanımlayabiliriz. Lerner indeksi ya da diğer adıyla fiyat-maliyet marjini, piyasa gücünün ölçümünü bize göstermektedir.

Ortalama bir firmanın istediği marjinal getirinin talep fiyatından sapması, piyasa gücünü ifade edecektir. LE, "0" ile "1" arasında bir değer alır. "0", tam rekabet piyasasını, "1" ise tekel durumunu ifade eder. LE'nin "0"'1n altında değer aldığı da görülür ki bunun anlamı, firmaların optimum fiyatlama davranışının dışına çıktığıdır.

Lerner indeksi, bankaların marjinal fiyatını, marjinal maliyetine kıyasla ne kadar arttırabildiğini gösteren bir ölçüttür ve piyasa gücünün hesaplanmasında yaygın olarak kullanılmaktadır. Bu bilgiler 1şı̆̆ında, lerner endeksi sayesinde firma ya da firmalar tam rekabet koşullarında faaliyette bulunmaları halinde elde edecekleri normal kârın üzerinde bir kar elde edebiliyorlarsa tekel gücüne sahiptirler. Bu kâr normal kârdan ne kadar büyükse tekel gücü de o ölçüde büyük demektir. Endüstride tam rekabetten sapılmış olduğunun ve dolayısıyla kârın normal kârın ne kadar üzerinde olduğunun saptanmasında Lerner Endeksine başvurulur. Her firmalar tam rekabet koşullarında faaliyette bulunuyorlarsa fiyat = marjinal maliyet olacağından Lerner endeksi de sıfır olacaktır. Bu da tam rekabet piyasası koşullarında faaliyette bulunan firmaların tekel güçlerinin sıfır olduğunu gösterir. Firma ya da firmalar, tam rekabetten uzaklaştıkça fiyat marjinal maliyetin üzerine çıkarken, Lerner endeksi büyüyecek ve tekel gücü artacaktır. O halde oligopolcü firmalar aralarında anlaşarak arzını kontrol ettikleri malın fiyatını yükselttikleri oranda tekel güçleri artacaktır.

\begin{tabular}{|l|l|l|l|l|l|}
\hline Y1llar & Sektör Ort. & $\begin{array}{l}\text { Kamu } \\
\text { Bankaları }\end{array}$ & $\begin{array}{l}\text { Özel } \\
\text { bankalar }\end{array}$ & $\begin{array}{l}\text { Türkiye'de kurulmuş } \\
\text { Yabanc1 Bankalar }\end{array}$ & $\begin{array}{l}\text { Türkiye'de Şube Açan } \\
\text { Yabancı Bankalar }\end{array}$ \\
\hline 1992 & 0.46 & -0.29 & 0.55 & 0.56 & 0.55 \\
\hline 1993 & 0.55 & 0.33 & 0.46 & 0.71 & 0.66 \\
\hline 1994 & 0.60 & 0.45 & 0.54 & 0.72 & 0.77 \\
\hline 1995 & 0.45 & 0.65 & 0.35 & 0.44 & 0.57 \\
\hline 1996 & 0.17 & 0.32 & 0.36 & -0.99 & 0.33 \\
\hline 1997 & 0.35 & 0.19 & 0.33 & 0.19 & 0.51 \\
\hline 1998 & 0.30 & 0.10 & 0.49 & 0.05 & 0.00 \\
\hline 1999 & 0.35 & 0.21 & 0.47 & 0.39 & 0.05 \\
\hline 2000 & 0.20 & 0.33 & 0.32 & 0.25 & 0.03 \\
\hline 2001 & 0.27 & 0.12 & 0.58 & -0.14 & -0.25 \\
\hline 2002 & 0.23 & 0.07 & 0.17 & 0.55 & 0.33 \\
\hline 2003 & 0.10 & 0.04 & 0.23 & -0.19 & 0.09 \\
\hline 2004 & 0.40 & 0.39 & 0.44 & 0.17 & 0.39 \\
\hline 2005 & 0.16 & 0.25 & 0.36 & 0.02 & -0.34 \\
\hline 2006 & 0.38 & 0.32 & 0.36 & 0.33 & 0.44 \\
\hline 2007 & 0.05 & 0.16 & 0.14 & -0.02 & -0.09 \\
\hline 2008 & 0.40 & 0.33 & 0.42 & 0.33 & 0.44 \\
\hline
\end{tabular}

Tablo 2: Türk Ticari Bankacılık Sektörünün Lerner Endeksi Değerleri

Tablo 2 den izlendiği gibi özellikle 1992-1995 döneminde yabancı bankaların Lerner İndeksileri, yerli bankalara göre oldukça yüksektir. Benzer şekilde özellikle kriz dönemlerinde Piyasa gücünün kullanımı noktasında en etkin bankaların yerli bankalar olduğu da dikkat çekmektedir.

\subsection{Durağanlıkların Test Edilmesi}

Zaman serilerinin durağan olması olarak ifade edilen şey, zaman içinde varyansın ve ortalamanın sabit olması ve gecikmeli iki zaman periyodundaki değişkenlerin ko-varyansının değişkenler arasındaki gecikmeye bağlı olup zamana bağlı olmamasıdır. Çalışmamızda aşağıdaki değişkenlerin durağan olması nedeniyle deterministik bileşenlerinin araştırılmasına gerek duyulmamıştır. Değişkenler arasında sahte ilişkilere neden olunmaması için kullanılan değişkenlerin durağan olması gerekmektedir. Bunun için denklem tahminlerine geçmeden önce değişkenlerin durağan olup olmadıkları Levin, Lin, Chu (2002) birim kök testi ile test edilmektedir.

Levin, Lin, Chu (2002) ise bireysel birim kök testlerinin alternatif hipotezlere karşı sınırlı gücünün olmasını tartışmıştır. Bu, küçük örneklemlerde kendisini daha fazla hissettirmektedir. Levin, Lin, Chu her bir yatay kesit birim için bireysel birim kök testlerine nazaran daha güçlü bir panel birim kök testi önermektedirler. Sıfır hipotezi her bir bireysel zaman serisinin birim kök içerdiği, alternatif hipotez ise her bir zaman serisi durağandır şeklinde kurulmaktadır. Levin, Lin, Chu aşağıdaki gibi bir modeli dikkate alır (Baltagi, 2005). 
Değişkenlerin, deterministik bileşen içerip içermemelerine göre durağanlıkları test edilmiştir. Buna göre aşağıdaki değişkenlerin, deterministik bilesen içermemesi, trend bileşeni içermesi ve kesme bileşeni içermesi durumlarına göre her üç düzeyde de durağan olduğu görülmüştür. Her üç düzeyde de durağan olan değişkenlerin deterministik bileşenlerinin araştırılmasına gerek duyulmamıştır.

\begin{tabular}{|l|l|}
\hline Değişken & Piyasa Gücü (Lerner İndeksi) ile Etkileşimi \\
\hline $\begin{array}{l}\text { Etkinlik Göstergeleri ( Finansal } \\
\text { Rasyolar) }\end{array}$ & $\begin{array}{l}\text { Rasyonun büyük olmasının bankaların } \\
\text { piyasa gücünü azaltacağı kabul edilir. }\end{array}$ \\
\hline Karlılık Göstergeleri & $\begin{array}{l}\text { Rasyonun büyük olmasının bankaların } \\
\text { piyasa gücünü azaltacağı kabul edilir. }\end{array}$ \\
\hline Risk & $\begin{array}{l}\text { Lerner İndeksi ile aralarında negatif ilişki } \\
\text { beklenmektedir }\end{array}$ \\
\hline Uzmanlaşma & $\begin{array}{l}\text { Lerner İndeksi ile aralarında negatif ilişki } \\
\text { beklenmektedir }\end{array}$ \\
\hline Kapitilizasyon & Piyasa gücünü arttırması beklenir \\
\hline Bilanço Yapısı & $\begin{array}{l}\text { Açı pozisyon nedeniyle bankaları kur } \\
\text { riskine maruz bırakacağı için negatif ilişki } \\
\text { beklenir }\end{array}$ \\
\hline Pazar Payı & Piyasa gücünü arttırması beklenir \\
\hline Ölçek & $\begin{array}{l}\text { Büyük ölçeklibankaların maliyet avantajı } \\
\text { sağlayarak piyasa güçlerini arttırması } \\
\text { beklenmektedir }\end{array}$ \\
\hline
\end{tabular}

Tablo 3: Rekabet Yapısını Şekillendiren Aktörler ile Lerner Indeksi Etkileşimi

\begin{tabular}{|l|l|l|l|l|l|l|}
\hline Determ. Bileşen & \multicolumn{2}{l|}{ None } & \multicolumn{2}{l|}{ Kesmeli } & \multicolumn{2}{l|}{ Kesmeli ve Trendli } \\
\hline Değişken & T İstatistiği & Olasılık & t İstatistiği & Olasılık & T istatistiği & Olas1lık \\
\hline Lerner İndeksi & -6.1332 & 0.0000 & -5.9921 & 0.0000 & -5.9999 & 0.0000 \\
\hline ROA & -9.1321 & 0.0000 & -5.3212 & 0.0000 & -8.9878 & 0.0000 \\
\hline ROE & -9.3321 & 0.0000 & -6.1231 & 0.0000 & -10.2102 & 0.0000 \\
\hline Risk & -6.9921 & 0.0000 & $-11,1213$ & 0.0000 & -9.4321 & 0.0000 \\
\hline T.Gel / T. Gid. & -1.9912 & 0.0600 & -3.4212 & 0.0000 & -3.1231 & 0.0000 \\
\hline Tak. Kred. / Krediler & -1.9234 & 0.0000 & -3.4211 & 0.0000 & -3.5213 & 0.0000 \\
\hline NFM & -6.3212 & 0.0000 & -2.9821 & 0.0000 & -6.5423 & 0.0000 \\
\hline Kredi / TA & -11.231 & 0.0000 & -19.3211 & 0.0000 & -8.7752 & 0.0000 \\
\hline Kredi / Mevduat & -58.221 & 0.0000 & -170.3120 & 0.0000 & -201.2319 & 0.0000 \\
\hline Faiz Diş1 Gelir /TA & -8.0012 & 0.0000 & -7.0321 & 0.0000 & -6.4521 & 0.0000 \\
\hline Diğ. Faal. Gid / Top. Faal. Gel. & -3.3212 & 0.0048 & -5.2312 & 0.0000 & -7.8711 & 0.0000 \\
\hline
\end{tabular}

Tablo 4: Levin-Lin ve Chu Durağanlık Testi Sonuçları

Pazar payı ve Öz kaynak/TA değiskenleri hem kesme hem trend içermektedir. Durağan oldukları tespit edilmiştir. LogTA ve Bilanço Yapısı değişkenleri kesme ve trend içerdikleri halde bu düzeyde durağan değildir. $\mathrm{Bu}$ nedenle kesme ve trendden arındırılmış ve durağan hale getirilmiştir. Bilanço Dışı/TA değişkeni ise yalnızca Kesme içermekte olup, bu düzeyde durağandır.

\subsection{Panel Veri Regresyon Modeli İle Analiz}

Panel Veri yöntemi, ülkeler, firmalar, hane halkları, vb. kesit (cross-section) gözlemlerinin belli bir zaman dönemi içinde bir araya getirilmesi olarak tanımlanabilir. Regresyon modeli genel anlamda şu şekilde formülize edilmektedir.

$Y_{i t}=\beta_{1}+\beta_{2} X_{2 i t}+\beta_{3} X_{3 i t}+\cdots+\beta_{n} X_{n i t}+u_{i t}$

Panel veri setinin her bir yatay kesit için eşit uzunlukta zaman serisi içermesi durumu dengeli panel; zaman serisi uzunlukları yatay kesitten yatay kesite değişmesi durumu ise dengesiz panel olarak adlandırılmaktadır (Wooldridge, 2003). Çalışmamızda analizimizde panelin dengeli olması için ilgili dönemde sürekli olarak faaliyet gösteren 27 bankası analize alınmıştır.

\begin{tabular}{|c|c|c|c|}
\hline \multicolumn{4}{|c|}{ Correlated Random Effects: Hausman Test } \\
\hline Test Özeti & Ki Kare İstatistiği & Ki Kare D.f. & Olasılık \\
\hline Cross-Section Random & 39.299 & 13 & 0.000 \\
\hline Period random & 60.121 & 15 & 0.000 \\
\hline
\end{tabular}

Tablo 5: Hausman Model Tanımlama Testi Sonuçları 
Hausman testi sonuçlarına göre, gerek yatay kestiler gerekse zaman serileri için Rassal Etkilerin olasılık değerleri \%5'ten küçük çıkmıştır. Sabit etkiler yöntemine göre yapılan regresyon analizi sonuçları tablo 6 da izlenebilmektedir.

\begin{tabular}{|c|c|c|c|c|}
\hline \multicolumn{5}{|l|}{ MODEL SONUÇLARI } \\
\hline R kare & \multicolumn{4}{|l|}{0.428823} \\
\hline Düzeltilmiş R kare & \multicolumn{4}{|l|}{0.332123} \\
\hline F-İstatistiği & \multicolumn{4}{|l|}{0.461211} \\
\hline Olasılık & \multicolumn{4}{|l|}{0.000000} \\
\hline \multirow{2}{*}{ Durbin Watson } & \multicolumn{4}{|l|}{1.931212} \\
\hline & Katsayı & Standart Sapma & T-İstatistiği & Anlamlilık \\
\hline Kredi / Toplam Aktif* & -0.007701 & 0.003009 & -2.910001 & 0.0032 \\
\hline Kredi/Mevduat* & -0.000040 & 8.121291 & -1.861029 & 0.0564 \\
\hline Faiz Diş1 Gelirler / Toplam Aktif** & -0.031920 & 0.000100 & -1.871231 & 0.4212 \\
\hline Diğer Faal.Gid. / Top. Faal. Gid. & -4.421112 & 0.000000 & 0.3552132 & 0.8921 \\
\hline Top. Gel. / Top. Gid.* & 0.031210 & 0.000122 & 5.0912121 & 0.0001 \\
\hline Takipteki Krediler / Krediler & 5.991921 & 0.000000 & 0.3312121 & 1.0021 \\
\hline Özkaynak Kârlılğ1 & 0.009912 & 0.029022 & 0.0991212 & 0.8616 \\
\hline Aktif Kârlılı̆̆ ${ }^{*}$ & -4.33212 & 0.981212 & -5.761221 & 0.0000 \\
\hline Ölçek & 0.198899 & 0.177771 & -4.442112 & 0.1121 \\
\hline Risk* & -5.441421 & 1.333122 & -5.031231 & 0.0000 \\
\hline Özkaynak / toplam Aktif** & 0.8100875 & 0.453212 & 1.883214 & 0.0321 \\
\hline Pazar Payı & -0.912122 & 2.980090 & 0.870012 & 0.8912 \\
\hline Bilanço Yapısı* & 0.000000 & 0.000000 & 3.121000 & 0.0432 \\
\hline Net Faiz Marj1** & -0.100119 & 0.539812 & -2.091212 & 0.08712 \\
\hline Bilanço Dişı İşlemler / Toplam Aktif & -3.35090 & 2.920129 & -0.912000 & 0.3600 \\
\hline $\mathrm{C}$ & 0.181210 & 0.171200 & 1.1712100 & 0.23198 \\
\hline
\end{tabular}

Tablo 6: Sabit Etkiler Yöntemiyle Panel Veri Regresyon Analizi Sonuçları Not: Bă̆ımlı değişken Lerner Indeksidir. Panel en küçük kareler yöntemi kullanılmıştır. *,\%95 ve **,\%90 güven aralığını ifade etmektedir.

Regresyon analizlerinde, korelasyon katsayıları, Korelasyon katsayısı, regresyon modeli ile bulunan tahmini Y değerlerinin, gerçek değerlere uygunluğunu ölçmede kullanılır. Korelasyon katsayısı -1 ile 1 arasında değişir. Katsayının -1 çıkması, iki değişken arasında ters yönlü tam bir ilişkinin olduğunu, 1 çıkması ise doğru yönlü tam bir ilişkinin olduğunu ifade eder. Katsayının -1'e doğru yaklaşması, değişkenler arasında ters yönlü kuvvetli bir ilişkiyi gösterirken, 1'e yaklaşması değişkenler arasında doğru yönlü kuvvetli bir ilişkiyi ifade eder. Korelasyon katsayısının işareti, regresyon doğru veya eğrisine ait eğim katsayısının işaretidir. bankacılık sektöründe, bankaların aracılık fonksiyonların en önemli göstergelerinden biri Krediler/Toplam Aktifler ve Krediler/Mevduatlar oranlarıdır. Bankalarda aracılık hizmetlerinin etkinliğindeki artış ve rekabet ilişkisi negatif katsayılı ise bu iki göstergenin doğru orantılı olduğunu ifade etmektedir. Çalışmamızda bu iki katsayının negatif değer alması ülkemizde bankalarda aracılık etkinliğinin rekabet ile doğru orantılı olarak arttığını göstermektedir. Analiz sonuçları bu anlayışı desteklemekte ve bankaların mevduatın krediye dönüşüm oranını yüksek tutabilmek için yoğun biçimde rekabet etmek zorunda olduklarını ortaya koymaktadır. Verilen kredi miktarının arttırılması ise, kredi kullananların ekonominin geleceği ile ilgili olumlu beklentilerinin yanı sıra, kredi faizlerinin düşük tutulması ile mümkün olabilir. Analiz sonuçları bu anlayışı desteklemekte ve bankaların mevduatın krediye dönüşüm oranını yüksek tutabilmek için yoğun biçimde rekabet etmek zorunda olduklarını ortaya koymaktadır. Toplam Gelirler/Toplam Giderler Değişkenin pozitif katsayı alması, piyasa gücü ile etkinliğin doğru orantılı olduğu, diğer bir değişle daha etkin bankaların daha fazla piyasa gücü elde edebilecekleri anlamına gelmektedir.

Kârlılık ile ilgili olarak ele alınan iki değişken (ROA ve NFM) piyasa gücü ile negatif ilişkili olarak bulunmuştur. Bankacılık sektörlerinde, diğer tüm sektörlerde olduğu gibi, rekabetin kârlılığı azaltması beklenir. $\mathrm{Bu}$ durumda ulaştığımız sonuç beklediğimiz bir sonuç değildir. Bununla birlikte aracılık fonksiyonlarındaki gelişimle birlikte değerlendirilmesi durumunda lerner indeksi düşük olan bankalarda krediye dönüşüm oranının yüksek olması, kârlılığı yükseltebilecektir. Bankaların toplam aktifleri içerisinde menkul kıymetlerin payının yüksekliği, Türkiye'de banka karlarının yalnızca kredi/mevduat oranına ya da rekabetçi davranışlarına bağlı olmadığını göstermektedir. Bu noktada, Devletin finansman ihtiyacının önemli ölçüde bankalar kanalıyla karşılandığı gerçeği, faiz gelirleri içerisinde menkul kıymetlerden alınan faizlerin büyük bir yer tutmasına, bu vesileyle de kredilere düşük faiz uygulayarak rekabetçi bir davranış sergileyen bankaların dahi yüksek faiz marjları ve yüksek aktif kârlılı̆̆ı elde etmelerine yol açmaktadır. Öz kaynaklar/Toplam Aktifler, Yüksek öz kaynak rasyosuna sahip bankaların, sağlam sermaye yapısına bağlı olarak iflas olasılıklarının, dolayısıyla da finansman maliyetlerinin düşük olduğu kabul edilir. $\mathrm{Bu}$ varsayım altında, daha düşük maliyetler nedeniyle öz kaynak rasyosu ile piyasa gücü arasında pozitif bir ilişki beklenmektedir. Analizden elde edilen sonuçlar, bu beklentiyi doğrulamaktadır. Yabancı para aktifler/toplam aktifler, lerner indeksini arttıran diğer etmendir. 
Dolayısıyla döviz varlıkları yüksek olan bankaların Pazar payında bir yükselme olmuş, bu varlıklar üzerinden beklenen getirinin artmasına bağlı olarak piyasa güçleri yükselmektedir.

Çalışmamızda risk ile Lerner İndeksi arasında anlamlı negatif ilişkidir. Bu sonuç, rekabetin bankalarda risk alımını arttırdığı ve piyasa genelinde istikrarı tehdit ettiği yönündeki Görüşe uyumludur. Rekabetin yoğun yaşandığı piyasalarda bankalar Pazar paylarını genişletmek amacıyla kredi verilecek birimlerin seçiminde daha az seçici davranabilmektedirler.

Faiz Dışı Gelirler/Toplam Aktifler, bankalarda uzmanlaşmanın etkilerini göstermesi bakımından önemli bir değişkendir. Analiz sonuçlarına göre, rekabetçi davranış içerisindeki bankaların faiz dışı gelirlerini arttırdıkları, bu değişken ile lerner indeksi arasındaki negatif katsayı ile anlaşılmaktadır. Yabancı para aktifler/toplam aktifler oranının, bankalarda piyasa gücünü arttıran bir diğer etken olduğu kabul edilmektedir.

Yapı- Davranış-Performans (YDP) hipotezinin geçerliliğini araştırmak amacıyla analize dâhil edilmiş, beklenenin aksine negatif bir katsayı almış, ancak bu sonuç istatistiksel olarak anlamlı bulunmamıştır. Bankaların büyüklüğünü temsil eden bir değişken olan Toplam Aktifler (logaritması), piyasa gücü ile pozitif bir ilişki içerisindedir. Yani banka büyüklüğü arttıkça piyasa gücü de artmaktadır. Analiz sonucu istatistiksel olarak anlamlı değildir.

\section{Değerlendirme Ve Sonuç}

Bu çalışmada amaçlanan Türk bankacılık sektöründe faaliyet gösteren ticari bankaların rekabet dinamiklerini anlayabilmektir. Bu amaçla öncelikle sektördeki rekabet düzeyi banka ölçeğinde belirlenmiş ve her bir bankanın rekabete ilişkin tutumu ortaya konulmuştur. Rekabet düzeyinin göstergesi olarak lerner endeksi kullanılmıştır. Her bir banka için hesaplanabilir oluşu ve banka düzeyinde rekabeti etkileyen değişkenlerin belirlenmesine izin vermesi nedeniyle lerner endeksi tercih edilmiştir.

Bankacılık sektöründe rekabet yapısı çalışmalarında sıkça kullanılmayan ve rekabet konusunda oldukça bir öneme sahip Lerner İndeksi doğrusal regresyon analizi kullanılarak, hesaplanmıştır. Doğrusal regresyon analizi kullanılarak, piyasa yapısı göstergesi olan Lerner Endeksi hesaplanmıştır. Lerner Endeksinin tercih edilmesinin nedeni, diğer piyasa yapısı göstergelerinden farklı olarak bu yöntemin banka düzeyindeki değişkenlerin analizine imkân vermesidir. Başka bir ifadeyle Türk Bankacılık Sektöründe rekabet aracılık fonksiyonunu geliştirmektedir ki bunun da üretim, istihdam, büyüme ve refah artısına katkı sağlayacağı açıktır.

Lerner Endeksinin banka ölçeğindeki belirleyicilerinin tespiti, Panel Veri Analizi ile gerçekleştirilmiştir. Analiz sonucu Türk Bankacilık Sektöründe rekabetçi davranış üzerinde etkili olan faktörlerin, Krediler/Toplam Aktifler, Krediler/Mevduatlar, Faiz Dışı Gelirler/Toplam Aktifler, Toplam Gelirler/Toplam Giderler, Aktif Karlılığı (ROA), Risk, Öz kaynaklar/Toplam Aktifler, Bilanço Yapısı ve Net Faiz Marjı olduğu sonucuna ulaşılmıştır.

\section{Kaynakça}

- Allen ve Gale, 2000. Comparing Financial Systems, Cambridge, MA: MIT Press.

- Bain, 1951. Relation of Profit Rate to Industry Concentration: American Manufacturing, 1936-1940, Quarterly Journal of Economics, 65,293-324.

- Baltagi,1992. Econometric Analaysis of panel Data, 3th edition, Eggers Hall, Syracuse, New York.

- Baumol, 1992. "Horizontal Collusion and Innovation", Economic Journal, 102, 129-137

- Bossone, 2001. "Do Banks Have a Future? A Study on Banking and Finance as we Move into the Third Millennium", Journal Banking and Finance, 25(12), 2239-2276.

- Boyd,Nicolo, ve Smith, 2004. "Crisis in Competitive versus Monopolistic Banking Systems", Jounal of Money, Credit and Banking, 36(3), 487-506.

- Caminal ve Matutes, 2002. "Market Power and Banking Failures", International Journal of Industrial Organisations, 20(9), 1341-1361.

- Casu ve Girardone, 2006. "Bank Competition, Concentration and Efficiency in the Single European Market", Manchester School, University of Manchester, 74(4), 441-468.

- Claessens ve Laeven, 2004. "What Drives Bank Competition? Some International Evidence", Journal of Money, Credit and Banking, 36(3), 563-583.

- Çelik ve Kaplan,2010. " Türk Bankac1lı Sektöründe Etkinlik ve Rekabet: 2002-2007", Sosyo ekonomi,2,728.

- Demsetz, 1973. "Industry Structure, Market Rivalry and Public Policy", Journal of Law and Economics, 16, $1-9$.

- Farell ve Shapirs,1990. "Horizontal Mergers: An Equilibrium Analysis", The American Economic Review, Vol:80, No:1, 107-126. 
- Fındıkçıŏlu, 2012. Fitch ve Durum,(çevirim içi) http://www.dunya.com/fitch-ve-durum150061yy.htm,Erişim:11.12.2012.

- Fischer ve Hempell 2009.Oligopoly and Conduct in Banking-An Ampirical Analysis, www.fep.up.pt/conferences/earie2005/cd_rom/.../IV.L/Fischer.pdf, 2005, erisim: 13.08.2009.

- Freixas ve Rochet, 1998. Microeconomics of Banking, The MIT Press, third edition, Cambridge.

- Greenberg ve Witness 2009. Testing for Competition in the South African Banking Sectorhttp://www.commerce.uct.ac.za/Economics/Seminars/2009/20091106\%20Simbanegavi\%20Measurin g\%20competition\%20in\%20Banking\%20sector.pdf, 1-31 erişim: 04.03.2011

- Guevara, ve Francisco Pe'rez,2005. "Market Power in European Banking Sectors", Journal of Financial Services Research, Vol. 27, No.2, 109-137.

- Günalp ve Özel, 2005. "Rekabet Politikalarının Esasları", Piyasa Dergisi, Yı1.1,Sayı.1, 21-31.

- Hempell, 2002, "Testing for Competition Among German Banks", Discussion Paper, Economic Research Centre of the Deutsche Bundesbank. 4(2),112-113.

- Iwata, 1974. "Measurement of Conjectural Variations in Oligopoly", Econometrica, No: 42,947-966.

- Kar ve Ağır,2008. Finansal Sistem ve Kalkınma, Kalkınma Ekonomisi, Ed: Sami Taban, Muhsin Kar, 2. B., Ekin Yay, Bursa.

- Koutsomanoli, , Anatasia ve Stakouras, 2004. "Competititon and Concentration in the New European Banking Landscape", Cass Business School, City of London, Conferences, 111-132.

- $\quad$ Kraft, E. 2006".How Competitive is Croatia’s Banking System", Croatian National Bank Working Papers, W-14, 121-129.

- Levin, Lin ve Chu, (2002. "Unit root tests in panel data: asymptotic and finitesample properties", Journal of Econometrics, 108, 1-24.

- Mc nulty, 1968. "Economic Theory and Meaning of Competition", The Quarterly Journal of Economics, Cilt 82, Sayı 4639-656.

- Yanık, 2012. Rekabet Hukukunun Hakim Durum ve Hakim Durumun Kötüye Kullanılması Uygulamalarında Piyasa Giriş Engelleri, Ankara, Rekabet Kurumu ,Yayın No:0101, 2003, (Çevrimiçi) http://www.rekabet.gov.tr/pdf/mehmetyanik1.pdf, 12.Kasım 2012.

- Panzar ve Rosse, 1987. "Testing for "Monopoly Equilibrium", Journal of Industrial Economics,443-456.

- Rolnick. ve Weber, 1983. "New Evidence on the free banking Era", American Economic Review, 73, 10801091.

- Shaffer,1982. A Nonstructural Test for Competition in Financial Markets, Federal Reserve Bank of Chicago, Proceedings of a Conference on Bank Structure and Competition, 225-243.

- Shaffer, 1993. "A Test of Competition in Canadian Banking". Journal of Money, Credit and Banking, 25 (1): 49-61.

- Smirlock, 1985. "Evidence on the (Non) Relationship between Concentration and Profitability in Banking", Journal of Money, Credit and Banking, 17(1):69-83.

- $\quad$ Stigler, 1987. Competition, (Editörler: J.Eatwell, M. Miltigate ve P. Newman), The New Palgrave.

- Vadym, 2010. "Testing for Competition in Banking Sector: Evidence from Ukraine, A thesis submitted in partial fulfillment of the requirements for the degree of MA in Economics", Kyiv School of Economics, Ukraine.

- Vesela, 1995. "Testing for Competition in Banking: Behavioral Evidence from Finland", Helsinki: Bank of Finland Studies E:1,12-21.

- Wooldrıdge,2003. Econometric analysis of cross section and panel data, The MIT Press., Cambridge. 


\title{
Sağlık Sektöründe Bilgi Asimetrisinin Hasta Memnuniyetine Etkisi: Yalova Ağız Ve Diş Sağlığı Merkezinde Bir Uygulama Effects of Health Sector Information Asymmetry on Patient Satisfaction: An Appilication on Yalova Oral and Dental Care Centre
}

\author{
Assoc. Prof. Dr. Selami Özcan (Yalova University, Turkey) \\ Kerim Baş (Yalova University, Turkey) \\ Asst. Prof. Dr. H. Yunus Taş (Yalova University, Turkey)
}

\begin{abstract}
Effects of excessive information level difference between providers and receivers of health care services on patients will be presented with this work. Fundamental concepts like health care service, information asymmetry and it's effects will be explained. Information levels of attempts and treatments that were put in practice to the patients, surgical operations and billing will be studied and the outputs of the information level difference between the provider and the receiver will be determined. In this research, it will be revealed if the practical applications and the concepts in the literature overlap each other and developing a new method towards evaluating the information level difference will be attempted. Patients who received a certain number of treatments will be targeted. Survey questions that will be asked to the patients will try to reveal the amount of information on the procedure they have undertaken and the between this level of information and the their satisfaction. SPSS software is used for the analysis of the data. Resolving of the relation between patient satisfaction themeasured percentage of level of information about the procedure the subject have undertaken will be attempted during the evaluation of the survey results. The effects of gender, age and education on level of information-customer satisfaction will also be investigated while determining the patients level of information with this survey.
\end{abstract}

\section{Giriș}

Son on yılda ülkemiz genelinde sağlık hizmetlerinin hızla gelişmesi, vatandaşların bu paralelde gelişen ve artarak devam eden kaliteli, hızlı ve etkin hizmet alma talebiyle birlikte, bilimde, kültürde, ekonomideki olumlu yönde meydana gelen gelişmeler sağlık hizmetlerinde belirli bir standardı yakalama ihtiyacını doğurmuştur. Ancak bu arada sağlık hizmetlerini diğer hizmet sektörlerinden ayıran bir etmen olarak hizmeti alan ile hizmeti veren arsasındaki belirgin bilgi asimetrisi faktörü öne çıkmaktadır. Taraflardan birinin mal ya da hizmet hakkında diğerinden çok daha fazla bilgiye sahip olması diğerini etkileme ve yönlendirme imkânı sunmakta, rekabet koşullarının ve müşteri memnuniyetinin azalmasına sebep olmaktadır. Hasta ile hekim arasındaki bilgi düzeyi arasındaki makasın, hastanın daha fazla bilgilendirilmesi ile azaltılacağı varsayılmaktadır. Tedavi görecek kişinin bilgi düzeyine göre, uygulanan tedaviden sonra bilgi asimetrisinin yukarıda bahsedilen negatif etkilerinin azalacağı düşünülmektedir. Bu araştırmanın konusu bilgi asimetrisinin etkilerinin ortaya konulması olacaktır.

Sağlık hizmeti kavramı koruyucu, tedavi edici ve rehabilite edici her türlü tedavinin yapıldığı hizmet olarak tanımlanır. İnsanlar bu hizmeti almak için belirli bir zaman ve bedel öderler. Kısacası bir piyasa oluşur. Piyasanın kendi dengeleri içinde asimetrik bilgi varlığı piyasa etkinliğinin oluşmasına engel olduğu düşünülmektedir. Hastalar bu belirgin bilgi farklılığından dolayı kendilerine hangi tedavinin ne kadar süreyle ve hangi ücrete yapılacă̆ını bilmez. Bilmediği için hizmeti veren lehine bir durum ortaya çıkar.

Ülkemizde sağlık hizmetlerinde ana geri ödeme kurumu olan ve sağlık hizmetlerinin önemli bir paydaşı olan SGK son yıllarda hastalara uygulanacak olan her türlü tedavinin ücretlendirmesini net bir şekilde yapmıştır. Ayrıca -özellikle özel sağlık kurumlarında- yapılan iş ve işlemlerde ise "paket tedavi” kavramını geliştirerek her bir girişim için standart bir ödeme şekli geliştirmiştir. Burada ki amaç; hastaya ne kadar iş ve işlem yapılırsa yapılsın, tanımlanan "paket tedavi" türü için belirlenmiş olan sabit bir ücretin üzerinde ödeme yapmayacaktır. Böylece hastaya tıbbi anlamda zorunlu olmadıkça kan tahlili, radyolojik görüntüleme, diş dolgusu, protez vb. işlemler yapmak, ekonomik anlamda avantajlı olmaktan çıkarılması hedeflenmiştir. SGK bu uygulamasını ilaç alımında da yapmaktadır. Son olarak SGK hastaları özel sağlık kurumunda gördüğü tedaviye ait faturayı alıp yapılan tedaviyi kontrol etmek imkânına sahip olmuştur. Bu uygulamalar bize sağlık alanında ki belirgin asimetrik bilgi farklılığının olması, suni ya da gerekmediği halde yapılan tedavinin varlığını ortaya koyarken, ona çözüm yolları arandığını gösteriyor. Bu da işin diğer bir boyutudur.

Bilinçlenen hastalar artık her yapılacak olan tedavi ile ilgili olarak bilgilenmek, o bilgilerin doğruluğunu kontrol etmek istemektedir. Kendisine yapılacak olan girişimin ki bu basit bir enjeksiyondan organ nakline kadar herhangi bir işlem olabilir, kendisi için gerekli mi, yan etkileri neler, beklenmeyen sonuçları nedir gibi sorularla 
konuyu anlamaya çalışarak aradaki bilgi uçurumunu kapatmaya çalışmaktadır. Burada bilginin kaynağı gene o hizmeti almayı planladığı satıcısı olduğu için tam güven oluşmadığı gözlemlenebilmektedir. Bu durumda başka bir sağlık hizmeti sunucusuna gidip oradan da bilgiler alınabilmektedir. Bu ikinci başvurulan hizmet sunucusu diğer sağlık kurumu ile aynı tedavi şeklini açıkladığında kafadaki soru işaretleri kalkarken bazen de tersi olup tamamen farklı bir teşhis ve tedavi ortaya çıkabilmektedir. Bu durum hizmeti alacak olan (hastanın) müşterinin kafasındaki güven bunalımını daha da derinleştirecektir. Ortaya çıkacak sonuç sadece rakamsal değil aynı zamanda ve daha da önemlisi tıbben gerekmediği halde yapılmış bir girişim olacaktır. Gerekmediği halde yapılan bir ameliyat, gerekmediği halde çekilen bir röntgen, gerekmediği halde yapılan bir protez hastaya (müşteriye) verilebilecek en büyük zarar olacaktır.

Bilgi asimetrisi kavramı hemen hemen tüm alanlarda mevcuttur. Bankacılık, otomobil tamirciliği, sigortacılık, teknoloji ürünleri ve daha birçok alanda bunu görebiliriz. Ancak kısa bir araştırma ile insanlar bu alanlarda almak istedikleri mal ya da hizmeti detaylı bir şekilde öğrenebilirler. Bu bir otomobil olabilir, bir bilgisayar ya da kasko sigortası... Ancak hiç biri sağlık alanı kadar riskli, sağlık alanı kadar derinlemesine ve çok boyutlu bilgi taşımaz. Bütün bu alanlarda sağlıklı bir piyasa oluşmasına uygun iklim oluşurken sağlık alanında tam anlamıyla bu iklimin oluşması mümkün değildir.

Alıcı ve satıcı arasında her zaman bir güven duygusunun olması gereklidir. Güven arttıkça asimetrik bilgi varlığı önemini yitirmeye başlar. Son zamanlarda ülkemizde hastaların sağlı̆̆a daha kolay ulaşması ve fizik mekânlardaki olumlu gelişmeler olmakta, bu da insanları memnun etmektedir. Ancak esas mesele doğru tedavinin, doğru zamanda ve doğru şekilde yapılması, sık sık görülen ve çok önemli olduğu kabul edilen asimetrik bilgiden kaynaklanan ekonomik amaçlarla, oluşturmak için yapılan işlemler olabildiğince azaltılmasıyla tam memnuniyet tesis olacaktır. Ülke kaynakları boşuna harcanmayacaktır.

\section{Yalova Ağız Diş Sağlığı Merkezinde Bir Uygulama}

Bu araştırmada literatürdeki kavramlarla pratik uygulamaların örtüşüp örtüşmediği ortaya çıkarılmış ve bilgi asimetrisinin ölçümüne yönelik yeni bir yöntem geliştirilmeye çalışılmıştır. Yalova Ağız ve Diş Sağglı̆̆ Merkezine önceden belirlenmiş olan bir tarih aralığında başvuran değişik sosyo-demografik yapıdaki hastalara yöneltilen sorularla hastaların kendisine uygulanan tedaviler hakkındaki bilgi düzeyi ile hasta memnuniyeti arasındaki ilişki ortaya çıkarılmaya çalışılmıştır.

Beşli likert ölçeği kullanılarak SPSS paket programında güvenilirlik analizleri ve ayrıca tutarlılık analizleri yapılmıştır. Anket sonuçları değerlendirilirken deneklerin bilgi düzeyleri, yaşları, cinsiyetleri, eğitim durumları, medeni durumları, sosyal güvenceleri, gelir düzeyleri ve memnuniyetleri ölçülüp \% metodu ile analizler yapılmıştır.

\subsection{Araştırmanın Önemi ve Amacı}

$\mathrm{Bu}$ çalışmayla sağlık hizmetlerinde hizmeti alan ve hizmeti veren taraflar arasındaki aşırı bilgi düzeyi farklılığının hasta memnuniyetine etkisi ortaya konulmaya çalışılmıştır. Burada sağlık hizmeti, bilgi asimetrisi ve etkileri gibi temel kavramlara açıklık getirilmeye çalışılmaktadır. Hastaya uygulanmış olan girişim ve tedavileri, cerrahi operasyonlar ile faturalandırma konularındaki bilgi düzeyleri araştırılıp hizmeti veren ile alan arasındaki bilgi düzeyi farkının neden olduğu çıktılar tespit edilmektedir. Bu araştırmada literatürdeki kavramlarla pratik uygulamaların örtüşüp örtüşmediği ortaya çıkarılarak bilgi asimetrisinin ölçümüne yönelik yeni bir yöntem geliştirilmeye çalışılmıştır.Ankette hastalara yöneltilecek sorular vasıtasıyla kendisine uygulanan işlem hakkında ne kadar bilgiye sahip olduğu ve bu bilgi düzeyi ile memnuniyeti arasındaki ilişki ortaya çıkarılmaya çalışılmaktadır.SPSS paket programı ile güvenilirlik analizleri yapılmaktadır. Anket sonuçları değerlendirilirken deneklerin kendilerine uygulanan tedaviler hakkında \% metodu ile bilgi düzeyleri ölçülüp bu oranlarla hasta memnuniyeti arasındaki ilişki çözümlenmeye çalışılmıştır. Ayrıca bu anketle hastanın bilgi düzeyi tespit edilirken cinsiyet, yaş ve eğitim gibi unsurların da bilgi düzeyi-hasta memnuniyetine etkisi araştırılmıştır.

$\mathrm{Bu}$ çalışma sonucunda elde edilen sonuçlara dayanılarak yapılacak değişiklikler ya da uygulamalarla ağız ve diş sağlığı hizmetlerinde daha yüksek bir hasta (müşteri) memnuniyetinin sağlanması amaçlanmaktadır.

\subsection{Araştırmanın Ana kütlesi ve Örneklemi}

Araştırmanın evreni Yalova Ağız ve Diş Sağlığı Merkezine başvuran toplam hasta sayısıdır. Bu ana kütlenin Yalova Ağız ve Diş Sağlı̆̆ Merkezinde tedavi gören anket tarihindeki karş1lıkları ise araştırmanın örneklemidir.

\subsection{Araştırmanın Sınırlılıkları ve Hipotezi}

$\mathrm{Bu}$ araştırma genel anlamda kamu ağız ve diş sağlığı hizmetlerine yönelik olup Yalova Ağız ve Diş Sağlığı Merkezi ile sınırlandırılmıştır. Yalova Ağız ve Diş Sağlığı Merkezine belirli bir tarih aralığında başvuran 200 hasta üzerinde anket uygulaması yapılmıştır.

Araştırmanın hipotezi ise hastaların yapılacak ya da yapılan tedavi hakkında ne kadar fazla bilgi düzeyine sahipse o kadar fazla memnun kalacağı düşünülmektedir. 


\subsection{Araştırmanın Yöntemi}

$\mathrm{Bu}$ araştırmada Yalova Ağız ve Diş Sağlığı Merkezine önceden belirlenmiş olan bir tarih aralığında, başvuruda bulunan ortalama bir hasta profiline uygun tedavi olmuş olan hastalara bilgi düzeyleri ile memnuniyetleri arasındaki ilişkiyi ortaya çıkaracak şekilde hazırlanmış anket soruları uygulanmıştır. 200 hastaya uygulanan anket daha sonra SPSS paket programı ile değerlendirilmiştir. Anket sonuçları Ayrıca araştırmanın hipotezi ile hangi ölçüde örtüştüğüne bakılıp, çapraz tablolar ve yüzdelik oranlarla sonuç değerlendirmeleri yapılmıştır.

\subsection{Güvenilirlik Analizi}

\begin{tabular}{|l|r|}
\hline Cronbach's Alpha & N \\
\hline 0.724 & 24 \\
\hline
\end{tabular}

Tablo 1. Güvenilirlik Katsayısı

\subsection{Anket Sonuç Bulguları}

Ağız ve Diş Sağlığı Merkezine önceden belirlenmiş olan bir tarih aralığında başvuran 200 hastaya uygulanan ankette, öncelikle sosyo-demografik durumu ortaya çıkarmaya yönelik altı soru yöneltilmiştir.

\begin{tabular}{|c|c|c|c|}
\hline Sorular & Ölçütler & Frekans & Geçerli Yüzde \\
\hline \multirow{2}{*}{ Cinsiyet } & Kadın & 89 & $4 \overline{45,2}$ \\
\hline & Erkek & 107 & 54,3 \\
\hline \multirow{3}{*}{ Yaş } & 18-30 & 75 & 37,5 \\
\hline & $31-50$ & 84 & 42 \\
\hline & 51 ve üstü & 41 & 20 \\
\hline \multirow{3}{*}{ Medeni Durum } & Evli & 121 & 61,7 \\
\hline & Bekâr & 67 & 34,2 \\
\hline & Diğger & 8 & 4,1 \\
\hline \multirow{5}{*}{ Gelir Düzeyi } & Gelirim Yok & 37 & 19 \\
\hline & 1000 Liradan az & 78 & 40 \\
\hline & 1000-2000 Lira aras1 & 62 & 31,8 \\
\hline & 2001-3000 Lira aras1 & 14 & 7,2 \\
\hline & 3001 Lira ve üzeri & 3 & 1,5 \\
\hline \multirow{5}{*}{ Sosyal Güvence } & SSK & 132 & 66,7 \\
\hline & $\mathrm{Bağ} /$ kur & 30 & 15,2 \\
\hline & Emekli Sandı̆̆ 1 & 27 & 13,6 \\
\hline & Yeşilkart & 6 & 3 \\
\hline & Diğer & 3 & 1,5 \\
\hline \multirow{5}{*}{ Eğitim } & Okuryazar & $\overline{66}$ & $\overline{3}$ \\
\hline & İlköğretim & 63 & 31,7 \\
\hline & Lise & 89 & 44,7 \\
\hline & Önlisans & 20 & 10,1 \\
\hline & Lisans & 19 & 9,5 \\
\hline
\end{tabular}

Tablo 2. Sosyo-Demografik Soru Verileri

Merkeze başvuran hastaların yüzde 45,2'si kadın, yüzde 54,3'ü erkek hastalardan oluşmuştur.

Yaşa bağlı başvurularda en fazla başvuru yüzde 42 ile 31-50 yaş arası hastalar oluşturmuş olup, 51 yaş üzeri hasta oranı yüzde 20'de kalmıştır. 18-30 yaş arası hasta oranı yüzde 37,5 olmuştur.

Medeni durumdaki oranlarda evli olanların oranı yüzde 61,7, bekârlar yüzde 34,2 diğerlerinin oranı ise yüzde 4,1 olarak gerçekleşmiştir.

Eğitim düzeyi oranlarında yüzde 44,7 ile en yüksek lise mezunu gelirken, onu yüzde $31,7 \quad$ ile İlköğretim mezunları takip etmiştir. Ardından yüzde 10,1 ile önlisans, yüzde 9,5 ile lisans ve yüzde 1 ile yüksek lisans geldiği görülmüştür.

Sosyal Güvence durumunda da yüzde 66,7 ile en yüksek SSK gelmiştir. Bağ kur yüzde 15,2 ile ikinci sırada yer alırken, Emekli Sandığı mensupları yüzde 13,6, yeşil kart ise yüzde 3 olarak gerçekleşmiştir. Diğer başvuru oranı yüzde 1,5 olmuştur.

Gelir düzeyine yönelik sonuçlarda en yüksek oran yüzde 40 ile bin liradan az geliri olanlar yer almıştır. Ardından yüzde 31,8 ile 1000-2000 lira arası geliri olanlar, yüzde 19'u gelirim yok diyenler, yüzde 7,2'si 2001 3000 lira arası geliri olanlar, yüzde 1,5'i de geliri 3001 liradan fazla olanlar oluşturmuştur. 
Ankette sosyo- demografik sorulardan sonra hastalara on sekiz adet anket sorusu ve bir adet de yorum sorusu yöneltilmiş olup bunlardan yedinci sıradaki soru ile hastanın yapılan tedaviden sonra memnuniyet düzeyi ölçülmeye çalışılmıştır. Yedinci soru ile diğer anket soruları ve sosyo- demografik sorularla yapılan çapraz tablolarda hastanın memnuniyeti ile değişkenler arasındaki bağ ortaya çıkarılmaya çalışılmıştır. Esas amaç olan hastanın bilgi düzeyi ile memnuniyet arasındaki ilişki ortaya konulmaya çalışılmıştır.

Örneğin aşağıdaki tablodan da görüleceği üzere kişinin eğitim durumu ile memnuniyeti arasındaki ilişki pozitif olarak gerçekleşmiştir.

\begin{tabular}{|c|c|c|c|c|c|c|c|}
\hline \multirow{2}{*}{\multicolumn{2}{|c|}{ Eğitim }} & \multicolumn{5}{|c|}{ Yapılan tedavi sonrası memnuniyet } & \multirow[b]{2}{*}{ Total } \\
\hline & & Çok & Yeterince & $\mathrm{Az}$ & Çok az & Hiç & \\
\hline Okur-yazar & $\begin{array}{l}\text { Sayı } \\
\text { yüzde }\end{array}$ & $\begin{array}{l}0 \\
, 0 \% \\
\end{array}$ & $\begin{array}{l}1 \\
20,0 \% \\
\end{array}$ & $\begin{array}{l}4 \\
80,0 \% \\
\end{array}$ & $\begin{array}{l}0 \\
, 0 \% \\
\end{array}$ & $\begin{array}{l}0 \\
, 0 \% \\
\end{array}$ & $\begin{array}{l}5 \\
100,0 \% \\
\end{array}$ \\
\hline İlk Öğretim & $\begin{array}{l}\text { say1 } \\
\text { yüzde }\end{array}$ & $\begin{array}{l}12 \\
25,0 \%\end{array}$ & $\begin{array}{l}18 \\
37,5 \%\end{array}$ & $\begin{array}{l}7 \\
14,6 \%\end{array}$ & $\begin{array}{l}7 \\
14,6 \%\end{array}$ & $\begin{array}{l}4 \\
8,3 \%\end{array}$ & $\begin{array}{l}48 \\
100,0 \%\end{array}$ \\
\hline Lise & $\begin{array}{l}\text { say1 } \\
\text { yüzde }\end{array}$ & $\begin{array}{l}12 \\
20,3 \%\end{array}$ & $\begin{array}{l}32 \\
54,2 \%\end{array}$ & $\begin{array}{l}8 \\
13,6 \%\end{array}$ & $\begin{array}{l}3 \\
5,1 \%\end{array}$ & $\begin{array}{l}4 \\
6,8 \%\end{array}$ & $\begin{array}{l}59 \\
100,0 \%\end{array}$ \\
\hline Ön Lisans & $\begin{array}{l}\text { Sayı } \\
\text { yüzde }\end{array}$ & $\begin{array}{l}1 \\
8,3 \%\end{array}$ & $\begin{array}{l}8 \\
66,7 \%\end{array}$ & $\begin{array}{l}2 \\
16,7 \%\end{array}$ & $\begin{array}{l}0 \\
, 0 \%\end{array}$ & $\begin{array}{l}1 \\
8,3 \%\end{array}$ & $\begin{array}{l}12 \\
100,0 \%\end{array}$ \\
\hline Lisans & & 3 & 8 & 0 & 1 & 0 & 12 \\
\hline
\end{tabular}

Tablo 3. Eğitim İle Memnuniyet Arasındaki İlişki

Memnuniyet ölçütlerinden "çok ve yeterince" düzeylerinin toplamını alarak yapılacak bir değerlendirmede; ilköğretim mezunu bir hastanın toplam memnuniyet oranı yüzde 62,5 iken, önlisans mezunu bir hastanın memnuniyet oranının yüzde 75, lisans mezunu bir hastanın memnuniyeti ise yüzde 91,7 olarak gerçekleştiği görülmektedir. $\mathrm{Bu}$ da eğitim düzeyi ile memnuniyet arasında doğru bir orantının olduğunu göstermektedir. Eğitim düzeyi eşittir bilgi düzeyi olarak değerlendirilirse, bilginin de memnuniyet üzerinde olumlu etki yaptı̆̆ kabul edilebilir.

\begin{tabular}{|c|c|c|c|}
\hline Sorular & Ölçütler & Frekans & Geçerli \% \\
\hline \multirow{4}{*}{ 1.Daha önce kaç kez diş hekimine gittiniz? } & "Hiç & $\overline{14}$ & $\overline{77,0}$ \\
\hline & Bir Kez & 26 & 13,1 \\
\hline & $2-5 \mathrm{Kez}$ & 80 & 40,2 \\
\hline & 5'ten Fazla & 79 & 39,7 \\
\hline \multirow{4}{*}{$\begin{array}{l}\text { 2.Diş hekiminizin size uygulayacağı tedavi } \\
\text { hakkında bir araştırma (internet,dergi, bilen } \\
\text { bir tanıdığınız vb.) yaptınız mı? }\end{array}$} & Evet tamamen & 34 & 17,3 \\
\hline & Kismen yaptım & 51 & 25,9 \\
\hline & Oldukça az yaptım & 20 & 10,2 \\
\hline & Hiç yapmadım & 92 & 46,7 \\
\hline \multirow{5}{*}{$\begin{array}{l}\text { 3.Diş hekiminiz size yapılan tedavi } \\
\text { hakkında önceden bilgi verdi mi? }\end{array}$} & Evet tamamen & 68 & 35,1 \\
\hline & Kismen & 59 & 30,4 \\
\hline & Oldukça az & 9 & 4,6 \\
\hline & Çok az & 21 & 10,8 \\
\hline & Hiç vermedi & 37 & 19,1 \\
\hline \multirow{5}{*}{$\begin{array}{l}\text { 4.Diş hekimi size yapılan tedavi sonrası } \\
\text { yapmanız ve yapmamanız gerekenler } \\
\text { hakkında bilgi verdi mi? }\end{array}$} & Evet tamamen & 97 & $\overline{50,0}$ \\
\hline & Kismen & 50 & 25,8 \\
\hline & Oldukça az & 8 & 4,1 \\
\hline & Çok az & 8 & 4,1 \\
\hline & Hiç vermedi & 31 & 16,0 \\
\hline \multirow{4}{*}{$\begin{array}{l}\text { 5.Diş hekiminin bugün size uyguladığı } \\
\text { tedavinin benzeri (dolgu,protez,kanal } \\
\text { tedavisi vb.) daha önce yapılmış mıydı? }\end{array}$} & İlk kez yapıld1 & 87 & $\overline{446,3}$ \\
\hline & 2-3 kez yapild 1 & 84 & 44,7 \\
\hline & 4-5 kez yapıld 1 & 9 & 4,8 \\
\hline & 6 ve daha fazla yapıld 1 & 7 & 3,7 \\
\hline \multirow{5}{*}{$\begin{array}{l}\text { 6.Diş tedavileri hakkında ne kadar bilgili } \\
\text { olduğunuzu düşünüyorsunuz? }\end{array}$} & Çok & 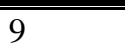 & 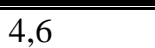 \\
\hline & Yeterince & 62 & 31,8 \\
\hline & $\mathrm{Az}$ & 61 & 31,3 \\
\hline & Çok az & 32 & 16,4 \\
\hline & Hiç bilgim yok & 31 & 15,9 \\
\hline \multirow{2}{*}{$\begin{array}{l}\text { 7.Yapılan tedaviden sonra memnun kaldınız } \\
\text { mı? }\end{array}$} & Çok & 40 & 21,7 \\
\hline & Yeterince & 91 & 49,5 \\
\hline
\end{tabular}




\begin{tabular}{|c|c|c|c|}
\hline & $\begin{array}{l}\mathrm{Az} \\
\text { Çok az } \\
\text { Hiç }\end{array}$ & $\begin{array}{l}28 \\
12 \\
13\end{array}$ & $\begin{array}{l}15,2 \\
6,5 \\
7,1\end{array}$ \\
\hline $\begin{array}{l}\text { 8.Diş hekiminizin size doğru tedaviyi } \\
\text { uyguladığını düşünüyor musunuz? }\end{array}$ & $\begin{array}{l}\text { Evet kesinlikle } \\
\text { Evet } \\
\text { Kismen } \\
\text { Hayır } \\
\text { Kesinlikle hayır } \\
\end{array}$ & $\begin{array}{l}75 \\
65 \\
42 \\
7 \\
5 \\
\end{array}$ & $\begin{array}{l}38,7 \\
33,5 \\
21,6 \\
3,6 \\
2,6 \\
\end{array}$ \\
\hline $\begin{array}{l}\text { 9.Diş hekiminiz size uygulayacağı } \\
\text { tedavinin riskleri hakkında sizi bilgilendirdi } \\
\text { mi? }\end{array}$ & $\begin{array}{l}\text { Evet kesinlikle } \\
\text { Evet } \\
\text { Kismen } \\
\text { Hayır } \\
\text { Kesinlikle hayır }\end{array}$ & $\begin{array}{l}39 \\
54 \\
37 \\
46 \\
11 \\
\end{array}$ & $\begin{array}{l}20,9 \\
28,9 \\
19,8 \\
24,6 \\
5,9 \\
\end{array}$ \\
\hline $\begin{array}{l}\text { 10.Tedavi sonrası ödeyeceğiniz tutar } \\
\text { hakkında önceden bilgilendirildiniz mi? }\end{array}$ & $\begin{array}{l}\text { Evet kesinlikle } \\
\text { Evet } \\
\text { Kismen } \\
\text { Hayır } \\
\text { Kesinlikle hayır }\end{array}$ & $\begin{array}{l}39 \\
52 \\
19 \\
64 \\
13\end{array}$ & $\begin{array}{l}20,9 \\
27,8 \\
10,2 \\
34,2 \\
7,0\end{array}$ \\
\hline $\begin{array}{l}\text { 11.Tedavi yaptırmayı planladığınız diş } \\
\text { hekiminizden başka bir diş hekimine } \\
\text { giderek bilgi alma ihtiyacı duydunuz mu? }\end{array}$ & $\begin{array}{l}\text { Evet kesinlikle } \\
\text { Evet } \\
\text { Kismen } \\
\text { Hayır } \\
\text { Kesinlikle hayır }\end{array}$ & $\begin{array}{l}19 \\
22 \\
13 \\
114 \\
24 \\
\end{array}$ & $\begin{array}{l}9,9 \\
11,5 \\
6,8 \\
59,4 \\
12,5\end{array}$ \\
\hline $\begin{array}{l}\text { 12.Diş hekiminizin yapacağı tedavi ile ilgili } \\
\text { verdiği bilgileri ne kadar anladınız? }\end{array}$ & $\begin{array}{l}\text { Tam olarak } \\
\text { Yeterince } \\
\mathrm{Az} \\
\text { Çok az } \\
\text { Hiç }\end{array}$ & $\begin{array}{l}47 \\
102 \\
14 \\
12 \\
12\end{array}$ & $\begin{array}{l}25,1 \\
54,5 \\
7,5 \\
6,4 \\
6,4\end{array}$ \\
\hline
\end{tabular}

Tablo 4. Anket Sorularına Verilen Cevaplar

Anket sorularında hastanın bilgi düzeyini tespit etmeye yönelik sorularla memnuniyet arasındaki ilişkinin ortaya çıkarılması bakımından çapraz tablolar kullanılmıştır.

\begin{tabular}{|c|c|c|c|c|c|c|c|}
\hline \multirow{2}{*}{\multicolumn{2}{|c|}{$\begin{array}{l}\text { Daha önce kaç kez diş hekimine } \\
\text { gittiniz? }\end{array}$}} & \multicolumn{5}{|c|}{ Tedavi sonrasi memnuniyet } & \multirow[b]{2}{*}{ Total } \\
\hline & & Çok & Yeterince & $\mathrm{Az}$ & Çok az & Hiç & \\
\hline \multirow[t]{2}{*}{ Hiç } & Say1 & 2 & 4 & 3 & 0 & 3 & 12 \\
\hline & Yüzde & $16,7 \%$ & $33,3 \%$ & $25,0 \%$ &, $0 \%$ & $25,0 \%$ & $100,0 \%$ \\
\hline \multirow[t]{2}{*}{ Bir Kez } & Say1 & 8 & 7 & 2 & 3 & 3 & 23 \\
\hline & Yüzde & $34,8 \%$ & $30,4 \%$ & $8,7 \%$ & $13,0 \%$ & $13,0 \%$ & $100,0 \%$ \\
\hline \multirow[t]{2}{*}{$2-5 \mathrm{Kez}$} & Say1 & 18 & 38 & 11 & 5 & 4 & 76 \\
\hline & Yüzde & $23,7 \%$ & $50,0 \%$ & $14,5 \%$ & $6,6 \%$ & $5,3 \%$ & $100,0 \%$ \\
\hline \multirow[t]{2}{*}{5 'ten Fazla } & Sayı & 12 & 42 & 12 & 4 & 3 & 73 \\
\hline & Yüzde & $16,4 \%$ & $57,5 \%$ & $16,4 \%$ & $5,5 \%$ & $4,1 \%$ & $100,0 \%$ \\
\hline
\end{tabular}

Tablo 5. Diş Hekimine Gitme Sayısı İle Memnuniyet Arasındaki İlişki

İlk kez diş hekimine giden bir hastanın diş tedavisi hakkındaki bilgi düzeyi ile birçok kez gitmiş bir hastanın bilgi düzeyinin aynı olamayacağını, çok giden bir hastanın daha fazla bilgiye sahip olduğu düşünülür. $\mathrm{O}$ açıdan bakıldığında Tablo $5^{`}$ te ilk kez giden bir hastanın memnuniyet oranı çok 16.7, yeterince 33.3 gerçekleşmiş olup toplam oran \%50 olmuştur. Bir kez gidende bu toplam oran \%65,2, 2-5 kez giden de \%73,7, beşten fazla giden de ise \% 73.9 olduğu görülmektedir. Bu da bilgi düzeyi arttıkça memnuniyetin de arttığına dair bir gösterge olarak görülebilir.

Hastanın kendisine uygulanacak olan diş tedavisi hakkında önceden bir araştırma yapmış olması kendisine uygulanacak olan tedavi ve sonuçları hakkında az ya da çok bilgi sahibi olacağı düşünülmekte olup sonuç değerlendirmelerine bakıldığında "Evet tamamen araştırma yaptım" diyenlerin memnuniyet oranları çok ve yeterince toplamı olarak\% 84.4 olurken, “ Kısmen Yaptım” diyenlerin memnuniyet oranı \% 83,3 , "Oldukça az yaptım" diyenlerin memnuniyet düzeyleri \% 66,6, "Hiç Yapmadım” diyenlerin memnuniyet oranı ise \%59,1 olarak gerçekleştiği görülmektedir. Burada da bilgi düzeyini kendi çabalarıyla araştırarak yapan müşterilerde de (hastalar) memnuniyet oranıyla bilgili olmak arasındaki doğru orantı görülebilmektedir. 


\begin{tabular}{|c|c|c|c|c|c|c|c|c|}
\hline \multirow{2}{*}{\multicolumn{3}{|c|}{$\begin{array}{l}\text { Diş hekiminizin size uygulayacağ }{ }^{\prime} \text { tedavi } \\
\text { hakkında bir araştırma (internet,dergi, tanıdık } \\
\text { vb.) yaptınız mı? }\end{array}$}} & \multicolumn{5}{|c|}{ Tedavi sonrası memnuniyet } & \multirow[b]{2}{*}{ Total } \\
\hline & & & Çok & Yeterince & $\mathrm{Az}$ & Çok az & Hiç & \\
\hline & \multirow[t]{2}{*}{ Evet tamamen } & Sayı & 9 & 18 & 3 & 2 & 0 & 32 \\
\hline & & Yüzde & $28,1 \%$ & $56,3 \%$ & $9,4 \%$ & $6,3 \%$ &, $0 \%$ & $100,0 \%$ \\
\hline & \multirow[t]{2}{*}{ Kismen yaptım } & Say1 & 11 & 29 & 6 & 0 & 2 & 48 \\
\hline & & Yüzde & $22,9 \%$ & $60,4 \%$ & $12,5 \%$ &, $0 \%$ & $4,2 \%$ & $100,0 \%$ \\
\hline & \multirow[t]{2}{*}{ Oldukça az yaptım } & Sayı & 2 & 10 & 3 & 1 & 2 & 18 \\
\hline & & Yüzde & $11,1 \%$ & $55,6 \%$ & $16,7 \%$ & $5,6 \%$ & $11,1 \%$ & $100,0 \%$ \\
\hline & \multirow[t]{2}{*}{ Hiç yapmadım } & Say1 & 16 & 33 & 16 & 9 & 9 & 83 \\
\hline & & Yüzde & $19,3 \%$ & $39,8 \%$ & $19,3 \%$ & $10,8 \%$ & $10,8 \%$ & $100,0 \%$ \\
\hline \multirow{2}{*}{\multicolumn{2}{|c|}{ Total }} & Say1 & 38 & 90 & 28 & 12 & 13 & 181 \\
\hline & & Yüzde & $21,0 \%$ & $49,7 \%$ & $15,5 \%$ & $6,6 \%$ & $7,2 \%$ & $100,0 \%$ \\
\hline
\end{tabular}

Tablo 6. Tedavi Hakkında Araştırma ile Memnuniyet Arasındaki İlişki

\begin{tabular}{|c|c|c|c|c|c|c|c|}
\hline \multirow{2}{*}{\multicolumn{2}{|c|}{$\begin{array}{l}\text { Diş hekiminiz size yapılan tedavi } \\
\text { hakkında önceden bilgi verdi mi? }\end{array}$}} & \multicolumn{5}{|c|}{ Tedavi sonrası memnuniyet } & \multirow[b]{2}{*}{ Total } \\
\hline & & Çok & Yeterince & $A z$ & Çok az & Hiç & \\
\hline \multirow{2}{*}{$\begin{array}{l}\text { Evet } \\
\text { tamamen }\end{array}$} & Say1 & 25 & 31 & 6 & 2 & 0 & 64 \\
\hline & Yüzde & $39,1 \%$ & $48,4 \%$ & $9,4 \%$ & $3,1 \%$ &, $0 \%$ & $100,0 \%$ \\
\hline \multirow[t]{2}{*}{ Kismen } & Say1 & 6 & 39 & 8 & 1 & 1 & 55 \\
\hline & Yüzde & $10,9 \%$ & $70,9 \%$ & $14,5 \%$ & $1,8 \%$ & $1,8 \%$ & $100,0 \%$ \\
\hline \multirow[t]{2}{*}{ Oldukça az } & Say1 & 1 & 4 & 2 & 1 & 0 & 8 \\
\hline & Yüzde & $12,5 \%$ & $50,0 \%$ & $25,0 \%$ & $12,5 \%$ &, $0 \%$ & $100,0 \%$ \\
\hline \multirow[t]{2}{*}{ Çok az } & Say1 & 3 & 8 & 7 & 1 & 1 & 20 \\
\hline & Yüzde & $15,0 \%$ & $40,0 \%$ & $35,0 \%$ & $5,0 \%$ & $5,0 \%$ & $100,0 \%$ \\
\hline \multirow[t]{2}{*}{ Hiç vermedi } & Say1 & 2 & 9 & 4 & 7 & 11 & 33 \\
\hline & Yüzde & $6,1 \%$ & $27,3 \%$ & $12,1 \%$ & $21,2 \%$ & $33,3 \%$ & $100,0 \%$ \\
\hline \multirow[t]{2}{*}{ Total } & Say1 & 37 & 91 & 27 & 12 & 13 & 180 \\
\hline & Yüzde & $20,6 \%$ & $50,6 \%$ & $15,0 \%$ & $6,7 \%$ & $7,2 \%$ & $100,0 \%$ \\
\hline
\end{tabular}

Tablo 7. Önceden Bilgilendirme ile Memnuniyet Arasındaki İlişki

Tablo 7‘de Hastaya kendisine yapılan tedavi hakkında tedavi öncesi diş hekimi tarafından hangi düzeyde bilgi verildiği sorulmakta olup, alınan cevaplara göre memnuniyet düzeyi ölçülmeye çalışılmıştır. Alınan cevaplar ve memnuniyet oranlarına bakılacak olursa; "Evet tamamen bilgi verildi” diyenlerin \% 39,1oranında çok memnun kaldığ,$\%$ 48,4 oranında da yeterince memnun kaldığı anlaşılmakta olup iki oranın toplamı \% 87,5 olmuştur. "Kısmen Bilgi Verildi" diyenlerin memnuniyet oranı toplamı \%81,8 olurken, "oldukça az bilgi verildi" diyenlerin memnuniyet oranı $\% 72,5$, "Çok az bilgi verildi" diyenlerin memnuniyet oranı \%55, "Hiç bilgi verilmedi" diyenlerin memnuniyet oranı ise \%33,4 olarak gerçekleşmiştir. Bu tabloda da bilgilendirme diş hekimi tarafından yapıllyor ve hasta kendisinin ne kadar fazla bilgilendirildiğini düşünüyorsa o kadar memnunda kalmaktadır. Bilgi düzeyi ve memnuniyet ilişkisi bu tabloda da aynı şekilde tezahür etmektedir.

Tablo 8'de hastalara kendilerine uygulanan tedaviden sonra yapıp yapmaması gerekenler hakkında bilgi verilip verilmediğine göre memnuniyet düzeyi ölçülmeye çalışılmıştır. Zira diş hekimliği uygulamalarında tedavi sonrası başarı hastanın bazı hususlara dikkat etmesiyle mümkün olabilmektedir. Örneğin bir dolgu türünde dolgu yapıldıktan sonra iki saat hiçbir şey yenilmemesi gerekirken eğer bu kurala uyulmazsa dolgu düşecek ve hasta memnuniyetsizliği doğacaktır. "Evet tamamen bilgi verildi" diyen hastaların çok ve yeterince memnun kalma oranları toplamı \% 85,7 iken bu oran "hiç bilgi verilmedi" diyenlerde \% 40,7' ye kadar gerilemektedir. Ayrıca tablonun sağ tarafinda yer alan "çok az" ve "hiç" memnuniyet oranları bilgi verilmemesine bağlı olarak hızla yükselmektedir. Tedavi sonrası yapılacaklar hakkında daha fazla bilgiye sahip olan hastaların memnuniyet oranları belirgin olarak yüksek çıkmıştır.

Diş Hekimi hastaya uygulayacağı tedavinin kapsamlı bir şekilde içeriğini açıklamasına bağlı olarak bilgilendirilmiş olan hastanın memnuniyet düzeyi ölçülmeye çalışılmıştır. "Diş hekimi uygulayacağı tedavinin içeriği hakkında bilgi verdi mi?" sorusuna "kesinlikle verdi ile verdi" cevabını veren hastalarda ki memnuniyet oranı "çok ve yeterince" kıstasları dikkate alarak değerlendirildiğinde \%82,6-87,1 düzeylerindeyken, " hayır ve kesinlikle hayır" cevabı veren hastalarda bu memnuniyet oranı \% 36,6-0 düzeyine inmektedir. O halde kendisine uygulanacak olan tedavinin içeriğini bilen, o konuda bilgi düzeyi daha yüksek olan hastalar daha memnun 
olmaktadır denilebilir.

\begin{tabular}{|c|c|c|c|c|c|c|c|}
\hline \multirow{2}{*}{\multicolumn{2}{|c|}{$\begin{array}{l}\text { Diş hekimi size yapılan } \\
\text { tedavi sonrası yapmanız ve } \\
\text { yapmamanı gerekenler hakkında } \\
\text { bilgi verdi mi? }\end{array}$}} & \multicolumn{5}{|c|}{ Tedavi sonrası memnuniyet } & \multirow[b]{2}{*}{ Total } \\
\hline & & \multirow{2}{*}{$\frac{\text { Çok }}{26}$} & \multirow{2}{*}{$\begin{array}{l}\text { Yeterince } \\
52\end{array}$} & \multirow{2}{*}{$\frac{A z}{8}$} & \multirow{2}{*}{$\frac{\text { Çok az }}{3}$} & \multirow{2}{*}{$\frac{\text { Hiç }}{2}$} & \\
\hline Evet tamamen & Sayı & & & & & & 91 \\
\hline & Yüzde & $28,6 \%$ & $57,1 \%$ & $8,8 \%$ & $3,3 \%$ & $2,2 \%$ & $100,0 \%$ \\
\hline Kismen & Say1 & 7 & 27 & 10 & 3 & 1 & 48 \\
\hline & Yüzde & $14,6 \%$ & $56,3 \%$ & $20,8 \%$ & $6,3 \%$ & $2,1 \%$ & $100,0 \%$ \\
\hline Oldukça az & Say1 & 1 & 2 & 4 & 1 & 0 & 8 \\
\hline & Yüzde & $12,5 \%$ & $25,0 \%$ & $50,0 \%$ & $12,5 \%$ &, $0 \%$ & $100,0 \%$ \\
\hline Çok az & Say1 & 0 & 1 & 3 & 2 & 0 & 6 \\
\hline & Yüzde &, $0 \%$ & $16,7 \%$ & $50,0 \%$ & $33,3 \%$ &, $0 \%$ & $100,0 \%$ \\
\hline Hiç vermedi & Say1 & 5 & 6 & 3 & 3 & 10 & 27 \\
\hline & Yüzde & $18,5 \%$ & $22,2 \%$ & $11,1 \%$ & $11,1 \%$ & $37,0 \%$ & $100,0 \%$ \\
\hline \multirow[t]{2}{*}{ Total } & Say1 & 39 & 88 & 28 & 12 & 13 & 180 \\
\hline & Yüzde & $21,7 \%$ & $48,9 \%$ & $15,6 \%$ & $6,7 \%$ & $7,2 \%$ & $100,0 \%$ \\
\hline
\end{tabular}

Tablo 8. Tedavi Sonrası Bilgilendirme İle Memnuniyet Arasındaki İlişki

\begin{tabular}{|c|c|c|c|c|c|c|c|c|}
\hline \multirow{2}{*}{\multicolumn{3}{|c|}{$\begin{array}{l}\text { Diş hekiminiz uygulayacağ } \\
\text { tedavinin içeriği hakkında bilgi verdi } \\
\text { mi? }\end{array}$}} & \multicolumn{5}{|c|}{ Tedavi sonrası memnuniyet } & \multirow[b]{2}{*}{ Total } \\
\hline & & & Çok & Yeterince & $A z$ & Çok az & Hiç & \\
\hline \multirow{2}{*}{\multicolumn{2}{|c|}{ Evet kesinlikle }} & Say1 & 25 & 13 & 5 & 2 & 1 & 46 \\
\hline & & Yüzde & $54,3 \%$ & $28,3 \%$ & $10,9 \%$ & $4,3 \%$ & $2,2 \%$ & $100,0 \%$ \\
\hline \multirow{2}{*}{\multicolumn{2}{|c|}{ Evet }} & Say1 & 12 & 42 & 7 & 1 & 0 & 62 \\
\hline & & Yüzde & $19,4 \%$ & $67,7 \%$ & $11,3 \%$ & $1,6 \%$ &, $0 \%$ & $100,0 \%$ \\
\hline \multirow{2}{*}{\multicolumn{2}{|c|}{ Kismen }} & Say1 & 1 & 23 & 9 & 2 & 2 & 37 \\
\hline & & Yüzde & $2,7 \%$ & $62,2 \%$ & $24,3 \%$ & $5,4 \%$ & $5,4 \%$ & $100,0 \%$ \\
\hline \multirow{2}{*}{\multicolumn{2}{|c|}{ Hayır }} & Say1 & 1 & 10 & 6 & 5 & 8 & 30 \\
\hline & & Yüzde & $3,3 \%$ & $33,3 \%$ & $20,0 \%$ & $16,7 \%$ & $26,7 \%$ & $100,0 \%$ \\
\hline \multirow{2}{*}{\multicolumn{2}{|c|}{ Kesinlikle hayır }} & Say1 & 0 & 0 & 0 & 2 & 2 & 4 \\
\hline & & Yüzde &, $0 \%$ &, $0 \%$ &, $0 \%$ & $50,0 \%$ & $50,0 \%$ & $100,0 \%$ \\
\hline \multirow{2}{*}{\multicolumn{2}{|c|}{ Total }} & Say1 & 39 & 88 & 27 & 12 & 13 & 179 \\
\hline & & Yüzde & $21,8 \%$ & $49,2 \%$ & $15,1 \%$ & $6,7 \%$ & $7,3 \%$ & $100,0 \%$ \\
\hline
\end{tabular}

Tablo 9. Uygulanacak Tedavinin İçeriği ile İlgili Bilgilendirme Yapılıp Yapılmamasıla Memnuniyet Arasındaki İlişki

\begin{tabular}{|c|c|c|c|c|c|c|c|c|}
\hline \multirow{2}{*}{\multicolumn{3}{|c|}{$\begin{array}{l}\text { Diş hekiminiz size uygulayacağı tedavinin } \\
\text { riskleri hakkında sizi bilgilendirdi mi? }\end{array}$}} & \multicolumn{5}{|c|}{ Tedavi sonrası memnuniyet } & \multirow[b]{2}{*}{ Total } \\
\hline & & & \multirow{2}{*}{\begin{tabular}{|l|l|} 
Çok \\
22 \\
\end{tabular}} & \multirow{2}{*}{$\begin{array}{l}\text { Yeterince } \\
10\end{array}$} & \multirow{2}{*}{$\mathrm{Az}$} & \multirow{2}{*}{ Çok az } & \multirow{2}{*}{$\frac{\mathrm{Hiç}}{1}$} & \\
\hline & Evet kesinlikle & Say1 & & & & & & 38 \\
\hline & & Yüzde & $57,9 \%$ & $26,3 \%$ & $7,9 \%$ & $5,3 \%$ & $2,6 \%$ & $100,0 \%$ \\
\hline & Evet & Say1 & 11 & 35 & 4 & 1 & 1 & 52 \\
\hline & & Yüzde & $21,2 \%$ & $67,3 \%$ & $7,7 \%$ & $1,9 \%$ & $1,9 \%$ & $100,0 \%$ \\
\hline & Kismen & Say1 & 5 & 19 & 8 & 1 & 0 & 33 \\
\hline & & Yüzde & $15,2 \%$ & $57,6 \%$ & $24,2 \%$ & $3,0 \%$ &, $0 \%$ & $100,0 \%$ \\
\hline & Hayır & Say1 & 0 & 21 & 8 & 7 & 7 & 43 \\
\hline & & Yüzde &, $0 \%$ & $48,8 \%$ & $18,6 \%$ & $16,3 \%$ & $16,3 \%$ & $100,0 \%$ \\
\hline & Kesinlikle hayır & Say1 & 1 & 1 & 4 & 1 & 4 & 11 \\
\hline & & Yüzde & $9,1 \%$ & $9,1 \%$ & $36,4 \%$ & $9,1 \%$ & $36,4 \%$ & $100,0 \%$ \\
\hline \multirow{2}{*}{\multicolumn{2}{|c|}{ Total }} & Say1 & 39 & 86 & 27 & 12 & 13 & 177 \\
\hline & & Yüzde & $22,0 \%$ & $48,6 \%$ & $15,3 \%$ & $6,8 \%$ & $7,3 \%$ & $100,0 \%$ \\
\hline
\end{tabular}

Tablo 10. Hastanın Uygulanacak Tedavinin Riskleri Hakkında Bilgilendirilmesiyle Memnuniyet Arasındaki İlişki 
$\mathrm{Bu}$ tablo ile hastanın kendisine uygulanacak olan tedavinin risklerini bilme düzeyi ile memnuniyeti arasındaki bağın çözümlemesi hedeflenmiştir. Diş hekimi tarafından tedavinin riskleri hakkında bilgilendirilme düzeyine bağlı verilen cevaplarda "kesinlikle evet ile evet" olarak cevap verenlerin "çok ve yeterince" toplamı alınarak yapılan değerlendirmede \% 84,2-88,5 düzeyinde bir memnuniyet hâsıl olurken, bu oran "hayır ve kesinlikle hayır" olarak cevap verenlerde $\% 48,8-18,2$ oranlarına düşmüş olduğu görülmektedir. Kısaca burada da bilgi düzeyi ve memnuniyet arasındaki doğru oran kendini göstermektedir.

\begin{tabular}{|c|c|c|c|c|c|c|c|c|}
\hline \multirow{2}{*}{\multicolumn{3}{|c|}{$\begin{array}{l}\text { Tedavi sonrası ödeyeceğiniz tutar hakkında } \\
\text { önceden bilgilendirildiniz mi? }\end{array}$}} & \multicolumn{5}{|c|}{ Tedavi sonrası memnuniyet } & \multirow[b]{2}{*}{ Total } \\
\hline & & & Çok & Yeterince & $\mathrm{Az}$ & Çok az & Hiç & \\
\hline & \multirow[t]{2}{*}{ Evet kesinlikle } & Say1 & 17 & 12 & 3 & 2 & 2 & 36 \\
\hline & & Yüzde & $47,2 \%$ & $33,3 \%$ & $8,3 \%$ & $5,6 \%$ & $5,6 \%$ & $100,0 \%$ \\
\hline & \multirow[t]{2}{*}{ Evet } & Say1 & 7 & 33 & 7 & 3 & 1 & 51 \\
\hline & & Yüzde & $13,7 \%$ & $64,7 \%$ & $13,7 \%$ & $5,9 \%$ & $2,0 \%$ & $100,0 \%$ \\
\hline & \multirow[t]{2}{*}{ Kismen } & Say1 & 3 & 9 & 3 & 2 & 1 & 18 \\
\hline & & Yüzde & $16,7 \%$ & $50,0 \%$ & $16,7 \%$ & $11,1 \%$ & $5,6 \%$ & $100,0 \%$ \\
\hline & \multirow[t]{2}{*}{ Hayır } & Say1 & 10 & 28 & 10 & 5 & 6 & 59 \\
\hline & & Yüzde & $16,9 \%$ & $47,5 \%$ & $16,9 \%$ & $8,5 \%$ & $10,2 \%$ & $100,0 \%$ \\
\hline & \multirow[t]{2}{*}{ Kesinlikle hayır } & Say1 & 2 & 4 & 3 & 0 & 3 & 12 \\
\hline & & Yüzde & $16,7 \%$ & $33,3 \%$ & $25,0 \%$ &, $0 \%$ & $25,0 \%$ & $100,0 \%$ \\
\hline \multirow{2}{*}{\multicolumn{2}{|c|}{ Total }} & Say1 & 39 & 86 & 26 & 12 & 13 & 176 \\
\hline & & Yüzde & $22,2 \%$ & $48,9 \%$ & $14,8 \%$ & $6,8 \%$ & $7,4 \%$ & $100,0 \%$ \\
\hline
\end{tabular}

Tablo 11. Hastanın Tedavi Sonrası Ödeyeceği Tutar Hakkında Önceden Bilgilendirilmesiyle Memnuniyet Arasındaki İlişki

Tablo 16'da hastanın tedavi öncesi ne kadar ücret ödeyeceğine dair bilgilendirilmesi ile memnuniyeti arasındaki ilişki ortaya çıkarılmaya çalışılmıştır. Ücret konusundan bilgilendirildiniz mi sorusuna "evet kesinlikle ve evet" cevabını veren hastaların "çok ve yeterince" düzeylerinde memnun olma oranları toplamı \% 80,5-78,4' iken, "hayır ve kesinlikle hayır" cevabı verenlerdeki memnuniyet oranı \% 64,4-50 olarak gerçekleşmiştir. Yalova Ağız ve Diş Sağlığı Merkezinde sadece protez tedavisinde hastalardan katılım payı alınmakta olup, diğer hiçbir tedavi için ücret talep edilmemektedir. Bu alandaki hastaların verdiği cevap oranlarına bakılarak bu bilgi düzeyindeki artış ta aynı şekilde memnuniyet üzerinde olumlu bir etki yaptığı gözlemlenmiştir.

Tedavi yaptırmayı planladı̆̆ınız diş
$\begin{aligned} & \text { hekiminizden başka bir diş hekimine giderek } \\ & \text { bilgi alma ihtiyacı duydunuz mu? }\end{aligned}$

Tablo 12. Hastanın Tedavisini Yapan Diş Hekiminden Başka Bir Diş Hekimine Giderek Bilgi Alma Ihtiyacı Duymasıyla Memnuniyet Arasındaki İlişki

17 numaralı tablo ile bir hastanın tedavisini yaptırmakta olduğu diş hekiminden yeterince bilgi alamadığg ya da aldığı bilgiden tatmin olmadığından hareketle, kafasındaki soru işaretlerini kaldırmak ve kendisine uygulanacak olan tedaviyle ilgili bilgi donanımını artırmak üzere bir başka diş hekimine gidip bilgi almak istiyorsa bunun hasta memnuniyetine olumsuz etki yapacağı düşünülmektedir. "Evet kesinlikle" şeklinde cevap verenlerin memnuniyet oranı "çok ve yeterince" toplamı alınırsa \%46,4, "evet" diyenlerin memnuniyet oranı \% 71,5, "kısmen" diyenlerin memnuniyet oranı \% 72,7, "hayır" diyenlerin oran1 \% 72,6, "kesinlikle hayır" diyenlerin 
memnuniyet oranı ise \% 81,8 olarak gerçekleşmiştir. Görüldüğü üzere bil açlığı varlığı, ya da yeterince bilgilenme imkânı bulamama durumu memnuniyeti belirgin bir şekilde aşă̆ıya çekmektedir.

\section{Sonuç ve Değerlendirme}

Birinci bölümde etraflı bir şekilde kamu ağız ve diş sağlığı merkezlerinde uygulanmakta olan toplam kalite uygulamalarının değerlendirmesi ve açılımı ele alınmıştı. Dikey ve yatay olarak sıralanan bu toplam kalite yönetimi uygulamaları 2005 yılından günümüze kadar gelişerek ve değişerek şartlara uygun hale gelmektedir. 2002 yılına göre kamu ağız ve diş sağlığı hizmetlerine ulaşım rakamlarında ciddi artışlar olmuş, memnuniyet oranları \% 39,5 ten \% 75,9 kadar çıktığı görülmektedir. Bu oranlar içerisinde diş hekimliği hizmetlerinin de olduğu genel anlamdaki sağlık hizmetlerini içermektedir. Tüm çabalara rağmen son yıllarda bu oranlardaki yükseliş ivmesinin daha önceki yıllara göre yavaşladığı görülmektedir. İște bu noktada bilinen anlamda ki hizmet sektöründe toplam kalite ölçütleri ve memnuniyet ölçümlerinde ele alınmayan ancak önemli bir etken olduğun düşünülen "bilgi düzeyi-memnuniyet" kriterinin de bu değerlendirmelere katılması durumunda daha etkin, daha müşteri odaklı bir anlayışa yaklaşılacağı düşünülmektedir.

Yapılmış olan anket çalışmasının sonucunda deneklerden alınan bilgiler ve değerlendirmeler ışığında hasta memnuniyeti ile bilgi düzeyi arasında olumlu bir bağlantının olduğu anlaşılmaktadır. Hizmet verenler eğer tam anlamıyla bir memnuniyet tesis etmek istiyorsa ki (tüm işletmeler ve kamu hizmet birimlerinin temel hedefi bu olmalıdır) hizmeti almakta olan kişinin tedaviye ilişkin bilgi düzeyinin artırılması yönünde de bir çalışma yapmaları gerekmektedir. Bu çalışma şekli ilkokul düzeyinde milli eğitim bakanlığı aracıllğıyla küçük yaşlarda başlanılacağı gibi hizmeti vermekte olan kurumların kendi bünyelerinde kısa, anlaşılabilir şekilde yapacakları hasta odaklı eğitimlerle de etkili olacaktır. Gelen her hastaya sadece bir tedaviyi yapıp göndermek değil, eğer konuya iliş̧in bilgiler verilirse bir sonraki gelişinde kafasında daha az soru işareti olan bir kişiyi memnun etmek daha kolay olacaktır.

\section{Kaynakça}

- Acuner, Ş.Akın: Müşteri Memnuniyeti ve Ölçümü, MPM Yayınları Nr:655, Ankara, 2003.

- Akerlof, George A. (1970). "The Market for 'Lemons': Quality Uncertainty and the Market Mechanism". Quarterly Journal of Economics, 84 / 3 488-500. http://www.jstor. org/ stable/1879431

- Arrow, K., (1963), "Uncertainty and the Welfare Economics of Medical Care", The American Economic Review, Vol. 53, No.5, pp. 961.

- Aydın, S., SD Dergisi Aralık-Ocak-Şubat 2007-2008

- Bekaroğlu, Ş. (2005). “Toplam Kalite Yönetimi Uygulamalarının ve ISO 9000 Kalite Güvencesine Sahip Olmanın Hastane Performansına Etkileri: İstanbul'daki Özel Hastaneler Üzerine Bir Araştırma”, Akdeniz İ.I.B.F. Dergisi, 18-32)

- Berwick,D.M (2001), Institute for Health Care Improvement, BMJ 312 (7203). n sarp

- Civan, Abdülkadir. Sağllk Sektöründe Devletin Rolü. Fatih Üniversitesi Ekonomi Bölümü

- Coşkun, Ali\&Akın Ahmet (2009) Sağlık İşletmeleri Yönetim Rehberi. Seçkin Yayıncılık

- Donaldson, C. and Gerard,K., 1994. .Economics of Health Care Financing: The Visible Hand. The Macmillan Press Ltd.

- Donabedian, A. (1990),The Seven Pillars of Quality,Archives Pathology

- EFİ,İ (1999), Toplam Kalite Yönetimi ve ISO 9000 Kalite Güvence Sistemi, İstanbul,AlfaYayınları.

- Hayran,O., (2009). Sağlık Hizmetlerinin Yönetimi: Hekimler mi, Profesyonel Yöneticiler mi? (http://www.merih.net/ml/wosmhay21.htm) erişim tarihi, 01 29, 2013.

- Kaya, S., (2005). Sağlık Hizmetlerinde Sürekli Kalite İyileştirme, Ankara.

- Kaul, I., ve CONCEIÇAO, P. (2006). The New Public Finance New York: Oxford University Pres.

- Kitapçı, M., (1999). ISO, Akreditasyon, Toplam Kalite Yönetimi ve Beklentiler, Gazi Kalite Günleri II. Sempozyum Kitabı, Ankara.

- Leebov,W., Scott, Gç, 1994. Service Quality Improvement-The Customer Satisfaction Strategy for Health Care,American Hospital Publishing,Inc.

- Lloyd, P.(1991), Consumerism in the Health Care Setting: An Exploratory Study of Factors Underlying the Selection and Evaluation of Primary Medical Services. Australian Journal of Public Health. Vol. 15, No. 3, s. 194.

- Orhaner, Emine., 2006. “Türkiye’de Sağlık Hizmetleri Finansmanı ve Genel Sağlık Sigortası”, Ticaret ve Turizm Eğitim Fakültesi Dergisi Yıl:2006 Sayı: 1.

- Özevren, M (1997),Toplam Kalite Yönetimi Temel Kavramlar ve Uygulamaları,İstanbul. 
- Maynard, A., Developing the Health Care Market. The Economic Journal. Vol. 101, September 1991, s. 1277-1278.)

- Mutlu, A.\& Işık, A., (2005). Sağlık Ekonomisine Giriş. Ekin Kitabevi, Bursa.Perçin, Selçuk: Hizmet Sektöründe Toplam Kalite Yönetimi, Yüksek Lisans Tezi, Trabzon, 1996.

- $\quad$ Pruitt, S.S., Consumerist Behaviors in Health Care. Unpublished Ph.D. Thesis. Texas Woman's University. 1987, s. 44)

- Sağlık Bakanlığı Sağlık İstatistikleri Yıllığı 2011 Sağlık Hizmetleri Genel Müdürlüğü.

- $\quad$ Sarıkaya, M., C. Ü. İktisadi ve Idari Bilimler Dergisi, Cilt 3, Sayı 2, 2002

- Sayım, F. (2011).Sağlık Piyasası ve Etik. MKM Yayıncılık

- Stamatis, D.H (2000), Total Quality Management in Healthcare, Inwin Proffesional Puplishing.Nsarp

- Şahin, B., Hacettepe Sağlık İdaresi Dergisi cilt: 7, sayı: 2 (2004), "Sağlık Kaynaklarının Kullanımında Değişkenlik Sorunu: Neden Yönetemiyoruz? Nasıl Yönetebiliriz?’

- Tengilimoğlu, D., Akbolat, M., Işık, O., 2009. Sağlık İşletmeleri Yönetimi, Nobel Yayın Dağıtım

- Uyguç, N. (1998). Hizmet Sektöründe Kalite Yönetimi; Stratejik Bir Yaklaşım, Dokuz Eylül Yayınları, İzmir.

- $\quad$ Ünsal, M.E., (2001), Mikro İktisat, 4. Bask1, İmaj Yayıncılık, Ankara.

- Y Yıldırım, H.H., (1999), “Piyasa, Sağlık Bakımı ve Piyasa Başarısızlıkları”, Amme İdaresi Dergisi, Cilt 32, Sayı 1, Mart 1999.

- Yüksel, F., Sadaklığlu, H. (2007). "Sağlık Hizmetlerinde Kalite ve Yerel Yönetimler”, Uluslararası Sağlık ve Hastane Yönetimi Kongresi, 01-03 Haziran 2007 Yakın Doğu Üniversitesi Lefkoşa Kıbrıs. 


\title{
Türkiye ve Rusya Yükseköğretimindeki Araştırma ve Deneysel Geliştirme Faaliyetleri
}

\section{Turkish and Russian Higher Education Research and Experimental Development Activities}

\author{
Dr. Mediha Tezcan (Anadolu University, Turkey)
}

\begin{abstract}
With the developments in Information and Communication Technologies, the competition now seems to be emerging on a global level rather than being on a national level. Communication, knowledge and information flow caused trade, production, consumption and any economic activity to originate the new competition and bond market opportunities on a national and global extent. The most dynamic and affective source of competition is to focus on the production of the new in today's Information Age. Mutual benefits rely mostly upon the technological developments and initiatives. Research and development activities gradually gain importance for the countries. In this paper, the data on research and development between Turkish Republic and Russian Federation is comparison and analyzed.
\end{abstract}

\section{Giriş}

Bilim ve teknoloji alanındaki hızlı değişmeler dünyamızı şekillendirmektedir. Günümüzde; bilim, teknoloji ve teknolojik yenilikte söz sahibi olmak, uluslararası pazarlarda rekabet üstünlüğünü gerçekleştirmektir. Ulusal politikaların ana hedefi; ulusal ve uluslararası pazarlarda rekabet üstünlüğü kazanmaktır. Uluslararası pazarlarda rekabet üstünlüğü kazanmak; pazar payını arttırarak ekonomik gelişmeyi gerçekleştirmek ve geleceğe hükmetmeyi sağlamaktadır.

Uzun dönemde eğitim yatırımlarının artması, insan sermayesi birikimini artırmaktadır. İnsan sermayesi birikiminin yükselmesi; araştırma ve deneysel geliştirme faaliyetlerinde, istihdam edilen araştırmacı birey sayısının artmasına sebep olmaktadır. Bir ülkedeki artan araştırmacı sayısı, araştırma ve deneysel geliştirme faaliyetlerin hızlandırmasına neden olmaktadır. Uzun dönemde araştırma ve deneysel geliştirme faaliyetlerinde istihdam edilen araştırmacı sayısında artış sağlanmasıyla birlikte araştırma ve deneysel geliştirme üretimi yükselmekte ve ekonomik büyümedeki artış ivme kazanmaktadır.

Üniversiteler, araştırma ve deneysel gelişme faaliyetlerinde bulunmakta ve sanayi ile işbirliği; yapmaktadırlar. Üniversite-sanayi işbirliği, bilimsel düşünmenin ve gelişmenin ana üreticisi olan üniversite ile yeni teknolojilerin ve ekonomik gelişmenin temel belirleyicisi olan sanayi sektörün aynı mekânda birlikte araştırma ve deneysel gelişme imkânı veren ekonomik işbirliği ortamlarıdır. Üniversite-sanayi işbirliği, üniversitelerde yapılan bilimsel çalışmaların ticarileştirilerek ekonomide katma değer yaratacak, uluslararası pazarlardaki rekabet gücünün artırılmasına katkı sağlayacak yeni ürün ve üretim yöntemi geliştirilmesi, mevcut üründe ve üretim yönteminde yenilik yapılması amacı ile sanayinin ihtiyaçları doğrultusundaki faaliyetlerdir. Üniversiteler-sanayi işbirliği faaliyetleri ekonomiye doğrudan katkı sağlamaktadır. Üniversite-sanayi işbirliği; ülkelerin, araştırma ve deneysel gelişmelerine büyük destek veren kuruluşlardır.

Eskinin Çarlık Rusya'sı, dünün Sovyetler Birliği ve bugünün Rusya Federasyonu ile ilişkiler, Osmanlı İmparatorluğun'da olduğu gibi Türkiye Cumhuriyeti için de her zaman ön planda yeralmıştır. "Soğuk Savaş Sürecinin" fiilen sona ermesi ile birlikte, ikili ilişkiler, günümüzde işbirliği mekanizmalarına dönüştürülmüştür.

Bu çalışmada; Avrasya'nın iki ülkesi olan Türkiye Cumhuriyeti ve Rusya Federasyonu yükseköğretimlerindeki araştırma ve deneysel gelişme faaliyetleri incelenmiş; birbirlerine olan üstünlükleri açıklanmış ve araştırma ve deneysel gelişme faaliyetlerinde en iyi olan OECD ülkelerin verileri ile de karşılaştırmaları yapılmıştır.

\section{Rusya Fererasyonu}

\subsection{Ekonomisi}

24 Ekim 1917'de Ekim Devrimi ile Rus Çarlığg sona erdi. Yerine Sovyet Sosyalist Cumhuriyetler Birliği (SSCB) kuruldu. Sosyalist ekonomik model ve merkezi hükümet modeli başarısız olması sonucunda 1991 yılında SSCB dağılmıştır. Yeni kurulan Rusya Federasyonu merkezi planlı ekonomik sistemden piyasa ekonomi sistemine geçebilmek için birçok ekonomik reformlar gerçekleştirmiştir (Martinez-Vazquez, ve Boex, 2001; SİSAV, 1995).

Rusya Federasyonu, zengin doğal gaz ve petrol kaynaklarının yanısıra, kömür, alüminyum, bakır, demir, elmas, altın, gümüş maden kaynakları ve ormancılık ürünlerine sahiptir. Rusya Federasyonu dünyanın 2. büyük petrol üreticisi ve dünyadaki kömür rezervlerinin yarısına sahiptir. Zengin doğal kaynaklara sahip olması nedeniyle hammadde ve yarı mamul ihraç eden ve tüketim malı ithal eden bir ülkedir (Benli, 2011; İSO. 2010). 
Petrol ve doğalgaz, Rusya Federasyonuna ekonomik zenginlik elde etmek için karşılaştırılamaz bir üstünlük sağlamaktadır. Rusya Federasyonu ihracatının büyük payını doğal kaynaklar oluşturmaktadır. Bu durum; Rusya Federasyonunda, ekonomik büyümeyi daha çok uluslararası enerji fiyatlarına bağımlı hale getirerek, ekonomik büyümenin sürdürülebilir olmasını olumsuz yönde etkilemektedir (İşcan ve Hatipoğlu, 2011).

Rusya Federasyonunun SSCB döneminden kalan eski ve hantal teknolojiye sahip alt yapısı, üretim sürecinde işgücü verimliliğini olumsuz etkileyerek ülke ekonomisinin performansını düşürmektedir (İşcan ve Hatipoğlu, 2011).

\subsection{Türkiye-Rusya Ekonomik İlişkileri}

Uluslararası Para Fonunun (IMF), 2012 yılında; dünyadaki ülkelerin (nominal fiyatlar ile) gayrisafi milli hasılalarına göre yaptığı gelişmişlik sıralamasını içeren araştırmasında; Rusya Federasyonu dünyanın 8. büyük ekonomisi, Türkiye Cumhuriyeti de dünyanın 17 'ci büyük ekonomisi olarak yeralmışlardır. Iki ülkenin ekonomilerinin büyüklüğünü bu araştırma ortaya koymaktadır (IMF, 2013).

18. Ve 19. Yüzyılın tümü ve 20. Yüzyılın başlarını kapsayan dönemde, iki ülke arasında sayısız savaşlar çıkmıştır (SİSAV, 1995). Türk Halkının Ulusal Kurtuluş Savaşı döneminde Türk-Sovyet dostluğu, unutulmayacak komşuluk ilişkilerine örnek oluşturmaktadır.

Türkiye; eskiden SSCB ile günümüzde de Rusya Federasyonu ile, önemli bir ticaret ortağı konumundadır. 1992 yılında SSCB'nın dağılması ve "Soğuk Savaş" döneminin bitmesinin ardından ticari ve ekonomik faaliyetler artarak devam etmektedir. Türkiye ve Rusya Federasyonu arasındaki stratejik işbirliğinin temelinde, enerji ve ham madde ticareti önemli paya sahiptir. Coğrafî yakınlık Türkiye-Rusya ticari ve ekonomik ilişkilerinin gelişmesine önemli avantajlar sağlamaktadır (İSO, 2010; SİSAV, 1995).

2011 yılı verilerine göre; Türkiye'nin diş ticaretinde, Türkiye'nin ihracat yaptığı ülkeler arasında 5'ınci, Türkiye'nin ithalat yaptığı ülkeler arasında ise Rusya Federasyonu 1'inci sırada yer almaktadır. 2011 yılında Türkiye'nin Rusya Federasyonuna ihracatı 5992 milyon \$ iken, ithalatı 23952 milyon \$'dır. Bu ithalatın 16,832 milyon doları mineral yakıt ve mineral yağlardan oluşmaktadır. Türkiye; enerji ihtiyacının \%70'ini yurt dışından karşılamakta; bu yüzdenin \%65'ini ise, Rusya Federasyonun'dan almaktadır. Türkiye, enerji alanında Rusya Federasyonuna bağımlı hale gelmiştir (Caşın, 2012).

İki ülke arasında turizm, yıllar içinde artmaktadır. 2007 yılında Türkiye’ye gelen Rus turist sayısı; 2.465.336 kişiden 2011 yılında 3.468.214 kişiye yükselmiştir. Türkiye, Rusya Federasyonuna; tekstil, giyim sektörü, tarım ve gida sektörü ile inşaat ve taahhüt hizmetleri gibi alanlarda ihracaat yapmaktadır (Benli, 2011; Caşın, 2012; Duman, ve Samadov, 2003).

Karadeniz Bölgesi, Orta Asya Bölgesi, Orta Doğu Bölgesi ve Kafkasya ötesine geliştirilecek çok taraflı ekonomik işbirliği Türkiye ve Rusya Federasyonu için büyük bir gelecek vaat etmektedir. İki ülke arasında diplomatik, siyasi, ekonomik ve kültürel düzeyde ilişkiler artmaktadır.

\section{Araştırma ve Deneysel Geliştirme}

\subsection{Teknolojik Yenilik}

Bilim; genel anlamda “evrenin yapısını ve davranışlarını gözlem ve deney yardımıyla sistematik bir şekilde inceleyen ve yasalar biçiminde açıklamaya çalışan düzenli "bilgi bütünü” olarak tanımlanabilir (Yörükoğulları, 2013). Teknoloji ise insanın; tabiatı, toplumu kontrol etmek, değiştirmek için, hem kendi hem de toplumsal aklı ve belleği kullanarak elde ettiği sonuçlardır. Teknoloji ya da teknikler bilgisi bir "şeyin" (bu şey bir maddi ürün, bir hizmet hatta bir güzelsanat icrası da olabilir) nasıl üretildiği, nasıl tüketildiği veya nasıl kullandığına dair sistematik, belli bir sistem veya disiplin çerçevesinde sunulmuş bilgiler demetidir (Türkcan, 2011). Teknoloji; bilimsel bilgiden yararlanarak yeni bir ürün geliştirmek, üretmek ve hizmet desteği sağlamak için gerekli bilgi, beceri ve yöntemler bütünüdür (Yörükoğulları, 2013).

Bilimsel bilgi ile teknolojik bilgi arasındaki "organik" bağlar nedeniyle, çok kesin "saf bilim-saf teknoloji" ayrımı yapmak neredeyse imkânsızdır. Bir icadın, bir buluşun, üretime, kullanıma başarıyla uygulanmasına da "yenilik" denir (Türkcan, 2011). Yenilik; yeni fikirlerin uygulamaya konulması ve ticarileştirilmesi sürecidir (Özdaşl1, 2010).

İktisatçılar, her zaman, teknolojik yeniliğin iktisadi bir gelişme için çok önemli olduğuna dikkat çekmişlerdir. Adam Smith; makinelerin gelişmesi ve iş bölüşümünün özel buluşları nassıl teşvik edeceğinden bahsetmiştir. Karl Marx, sermaye mallarında teknolojik yeniliklerin önemini vurgulayarak "burjuvazi, üretim araçlarında sürekli bir devrim yapmadıkça yaşayamaz” fikrini savunur (Freeman ve Soete, 2003). Joseph Schumpeter, 1934 ve 1947 yıllarında yayınladığı eserlerinde, yenilik kavramına yeni bir boyut kazandırmıştır. Schumpeter; bir ekonomik aktivite olarak teknolojik yeniliği çevreleyen süreçleri incelemiş ve teknolojik değişmeyi yönlendiren prensipleri bir piyasa kurgusu ile açıklamaktadır.

Schumpeteryen bakış açısı ile ekonomik büyüme; yenilikçilerin tekelci güçleri temelinde teknolojik olarak ileri ürünleri ortaya çıkardıkları ve yeni ürünlerin eski ürünlerin yerini, yeni tekniklerin, eski tekniklerin yerini ve yeni kurumların eski kurumların yerini aldığı, bir sürekli yaratıcı yıkım sürecidir. 
Ekonomik büyüme; ne sermaye birikimidir ne de mistik bir teknolojik değişme sonucunda üretim fonksiyonundan bir kaymadır; ekonomik büyüme yapısal değişmedir (Yeldan, 2011).

Schumpeter, ekonomik büyümenin yenilikler tarafından; kendisinin "yaratıcı yıkım” olarak adlandırdığı yeni teknolojilerin, eskisinin yerini aldığı dinamik bir süreç yoluyla harekete geçildiğini savunmaktadır (OECD, 2005).

Schumpeter teknolojik değişmeyi yönlendiren prensipleri bir piyasa kurgusu ile açıklamaktadır. Teknolojik yeniliğin piyasada yaptığı değişiklik şu şekilde kurgulanabilir:

Yeni bir malın, yeni bir üretim metodunun sunulması; yeni bir pazarın açılması, yeni bir hammadde kaynă̆ının bulunması ya da piyasada yeni bir pazar örgütlenmesini de kapsar (bir monopolün kırılması ya da oluşması gibi). Müteşebbis; ortaya çıkardığı teknolojik yenilik sayesinde normalin üstünde "süper normal" bir kâr marjı sağlar ve monopol konumuna gelir. Bu yeniliğin zamanla diğer firmalarca da adapte edilmesiyle beraber kâr; normal düzeye iner ve bu durum, başka bir müteşebbis tarafından başka bir teknolojik yenilik yaratılana kadar devam eder. $\mathrm{Bu}$ da ekonomide iş çevrimlerine sebep olmaktadır. Dolayısıyla, girişimcilerin olağanüstü gayretleri ile ortaya çıkan teknolojik yenilik, ekonominin içsel bir unsuru olarak, ekonomik gelişmenin dinamiğini sağlayan en önemli faktör konumuna yerleştirilmiştir (Ansal, 2004).

Dünya'da bilim ve teknoloji çalışmalarıyla bilgi, eski dönemlere göre daha hızlı artmaktadır. Hızlı artan bilgi birikimi, rekabeti büyük ölçüde etkilemektedir. Günümüzde ülkelerin ekonomik gelişmişlik sınıflandırılmaları, bilgi birikimi ve yeni teknoloji üreten ve üretmeyen ülkeler olarak gruplandırılmaktadırlar. Bilim ve teknoloji alanındaki üstünlükler, dünyada gelir dağılımının yeniden dağılımını ve toplumsal refahın yükseltilmesini etkilemektedir.

\subsection{Araştırma ve Deneysel Geliştirme}

Araştırma ve deneysel geliştirme (Ar-Ge), insan, kültür ve toplumun bilgisinden oluşan bilgi dağarcığının arttırılması ve bu dağarcığın yeni uygulamalar tasarlamak üzere kullanılması için sistematik bir temelde yürütülen yaratıcı çalışmalardır (OECD, 2002). Ar-Ge; işletmelerde yeni ürün ve süreçlerin ortaya çıkarılmasına yönelik sistemli ve yenilikçi faaliyetler bütünüdür.

Ar-Ge, ürün, makine-teçhizat ve üretim sisteminde planlı yenilik yapma faaliyetidir. Ar-Ge faaliyetinde bulunan firmaların amacı, verimliliklerini, ürün kalitesini, pazar paylarını ve kârlarını artırmaktır. Ar-Ge faaliyetleri firmalar; bilgi birikimini artırarak, piyasada monopol gücü kazanması ile aşırı kâr elde ederek, hem Ar-Ge; masraflarını karşılarlar, hem de ülke ekonomisine katkı sağlarlar (Demir, Üzümcü ve Duran, 2006).

Paul Romer; bir piyasa optimizasyonu çerçevesinde, büyümenin temel iticisi olarak, teknolojiye ait üç öneride bulundu. Bunlar (Yeldan, 2011):

- Teknolojik yenilik büyümenin nihai kaynağıdır.

- Bir piyasa kurgusu altında teknolojik yenilikler, kâr amaçlayan girişimcilerin bilerek yaptıkları faaliyetlerin sonucudur. Piyasa sinyalleri ve teşvikleri; girişimcileri, sanayi dallarında yenilikçi araştırma ve geliştirme faaliyeti yapmaları ve uygulamaları için yönlendirmede anahtar bir rol oynamaktadirlar.

- Araştırma ve geliştirme teknolojisi, ekonomideki diğer mallardan farklıdır.

Ar-Ge faaliyetlerinde bulunan ülkeler, teknoloji üretme yeteneğini geliştirerek; istikrarlı, güçlü ve verimli bir ekonomik ve toplumsal kalkınmayı sağlarlar. Üretim ve pazarlamada standartlaşmayı, optimal ölçek ekonomisini, yeni mal ve hizmet üretimlerini gerçekleştirmek yolu ile uluslararası ticarette rekabet avantajını artırmak yoluyla verimliliği ve kârlılığı artırırlar (Yanardağ ve Süslü, 2007).

Kalkınma planlarında; bilim, teknoloji ve sanayi politikaları ile eğitim-öğretim ve Ar-Ge politikaları arasında uyum sağlanmalıdır (Kaymakçı, 2006). Bir ülkenin ya da bir firmanın Ar-Ge harcamaları, o ülkenin ve o firmanın teknoloji yeteneğini, büyüme performansını ve uluslararası piyasalardaki rekabet gücünü belirleyen en kritik unsurlardan biridir.

\section{3.Üniversite -Sanayi İşbirliği}

İlk üniversitenin ortaya çıktığı Ortaçağdan, 19. Yüzyıla kadar üniversitenin ana görevi eğitim olmuştur. 19. Yüzyılda üniversiteler eğitim görevlerinin yanında araştırma çalışmaları da yapmaya başlamışlardır (Kiper, 2004).

Üniversite-sanayi işbirliği, üniversitelerin kaynakları ile sanayinin kaynaklarını her iki kuruma ve topluma fayda sağlamak üzere bir yöntem içinde birleştirerek, bilimsel, teknolojik ve ekonomik yönden güçlenmek için yapılan eğitim-öğretim, Ar-Ge ve diğer hizmetler bütünüdür (Demir, Üzümcü ve Duran, 2006).

21. Yüzyılda teknolojik yenilikler çok hızlı gelişmektedir. Bilginin ve yeniliğin rekabet üstünlüğünü sağlamada önem arz ettiği yüzyılımızda; bilginin üretime dönüştürülerek ticarileştirilmesi sonucunda, sanayinin ihtiyacı olan teknik bilginin karşılanması, üniversite ve sanayi işbirliği ile hayata geçirilmektedir. Üniversite- 
sanayi işbirliği; sanayinin ihtiyacı olan teknik bilginin üniversitelerden sağlanması, üniversitelerde üretilen bilginin de ticarileştirilmesini sağlayan kurumlardır.

Üniversite-sanayi işbirliğinin faaliyetlerinin ekonomik etkileri üçe ayırarak incelendiğinde (Andersson, Gråsjö, ve Karsson, 2009; Kiper, 2004):

Üniversite-sanai’ye işbirliğinin üniversiteye olan ekonomik katkıları şu şekilde sıralanabilir;

- Akademisyenlere ve bilimsel araştırmalara uygulama ortamı yaratılması,

- Akademik personel ve öğrencinin etkinlik ve verimliliğinin artırılması v ek gelir sağlanması,

- İnsan sermayesi ve sosyal sermaye oluşumuna katkı sağlanması,

- Görev alan öğrencilerin iş deneyimi kazanmasıyla, mezun olduklarında kolay iş bulma firsatı,

- Üniversitenin, sanayicinin deneyimini öğrenme firsatı bulması,

- Araştırma fonlarının sağlanması,

- Ar-Ge katkısı ile ulusal ekonominin rekabet düzeyinin yükseltilmesi,

- Araştırma sonuçlarının konferans, seminer ve sunumlarla duyurulması ve yayınlanması,

- Fikri mülkiyet haklarının alınması ve prestij elde edilmesi,

- Üniversitelere toplumsal görev ve sorumluluklarını yerine getirme firsatı yaratmasıdır.

Üniversite-sanayi işbirliğinin sanayiye olan ekonomik katkıları şu şekilde sıralanabilir;

- Akademik personelin bilgi birikiminden yararlanma ortamının oluşması,

- Akademik personel ve öğrenciden etkin ve verimli bir şekilde yararlanma firsatı,

- Eğitimli üniversite personeli ile birlikte çalışana firsatı bulan sanayi firma personelinin etkinlik ve verimliliğinin artması,

- Sanayinin sahip olduğu insan sermayesi ve sosyal sermaye birikiminin artması,

- Üniversitelerin sahip olduğu altyapı ve donanımlardan yararlanma firsatı,

- Sanayinin araştırmaları için finansman kolaylığı,

- Yatırımların geri dönüşlerinin yükselmesi,

- Girişimciliğin teșviki,

- Kaynakların etkin kullanımı, kalite ve verimlilik artışı,

- Sanayinin rekabet gücünün artmas1,

- Yeniliğin (inovasyon) artması,

- Sanayinin kârının artması,

- Rekabet gücü ve kârlılığı artan firmanın yeni ticari faaliyetlerini sürdürme firsatı,

- Sanayi Ar-Ge faaliyetleri sonucunda bölgesel ekonomi, ülke ekonomisinin rekabet gücünün artmasına katkı sağlar.

Üniversite-sanayi işbirliğinin devlete olan ekonomik katkıları şu şekilde sıralanabilir;

- Toplumsal yarar,

- Teknolojik yeniliğin teşvik edilmesi,

- Teknolojik tabanlı ekonomik gelişme,

- İnsan sermayesi ve sosyal sermaye stokunun artışı,

- Akademik girişimciliğin teşvik edilmesi ve gelişmesi,

- Üniversitelerin sahip olduğu bilgilerin sanayiye transferlerinin kolaylaştırılması,

- Üniversitelerde oluşturulan yeni bilgi, ya da fikri mülkiyetin sanayi tarafindan satın alınma firsatı,

- Akademik ve sanayi araştırmacılar arasında kişisel ağların oluşması,

- Devletin denetiminin artmasını sağlar.

Üniversite-sanayi işbirliği, yukarıda sıraladığımız yarattığı firsatlar ile Ar-Ge faaliyetlerin artmasını yaygınlaştırır. Yaygınlaşan Ar-Ge faaliyetleri; ulusal ekonomiye katkı sağlayarak, ülke ekonomisinin büyümesi ve uluslararası pazarlarda rekabet etme gücüne erişir. Ar-Ge ile uluslararasında rekabet edebilen ülkelerin refah düzeyleri yükselir. Refah düzeyi yüksek olan ülkelerde demokrası gelişmesiyle toplumsal barış sağlanır.

\section{Türkiye ve Rusya Yükseköğretiminde Ar-Ge Faaliyetleri}

Türkiye Cumhuriyeti ve Rusya Federasyonu yükseköğretiminde araştırma ve deneysel geliştirme (Ar-Ge) faaliyetlerine ait istatistiki veriler aracılığı ile iki ülkenin verilerinin yorumlanması ve karşılaştırılması yapilacaktır.

OECD, 1960 yılından itibarende düzenli olarak üye ülkelerin Ar-Ge verilerini toplamakta ve "Ekonomik Analiz ve İstatistik Merkezi” tarafından yayınlamaktadır. 1990 yılından itibarinde üye olmayan birkaç ülkeye ait 
Ar-Ge verilerini ayrıca da tabloların alt kısmına ekleyerek yayınlamaktadır. Bu çalışmadaki istatistiki veriler, OECD'nin 2013 yılındaki yayınına aittir (OCED, 2013).

Yükseköğretimdeki araştırma ve deneysel geliştirme (Ar-Ge) faaliyetlerinin verileri;

- Cari fiyatlar ve satınalma gücü pariteleri (SAGP) ile, yükseköğrenim araştırma ve deneysel geliştirme (Ar-Ge) harcamaları,

- GSYİH yüzdesi olarak, yükseköğrenim Ar-Ge harcamaları,

- 2005 yılı sabit fiyatları ve SAGP ile, yükseköğrenim Ar-Ge harcamaları,

- Sanayi tarafından finanse edilen yükseköğrenim Ar-Ge harcamalarının yüzdesi,

- Tamgün istihdam edilen yükseköğrenim araştırmacıları,

- Ulusal toplamın bir yüzdesi olarak yükseköğrenim araştırmacıları,

- Tamgün istihdam edilen yükseköğretim toplam Ar-Ge personeli.

Ülkelere ait sayısal veriler yedi başlıkta gruplanarak incelenmiştir.

\subsection{Cari Fiyatlar ve SAGP ile Yükseköğretim Ar-Ge Harcamaları}

2000-2011 yılları arasında her iki ülkedeki cari fiyatlar ve SAGP ile hesaplanan yükseköğretim Ar-Ge harcamalarının düzenli olarak artış içinde olduğu görülmektedir. 2000-2011 yılları arasında Türk yükseköğretiminde Ar-Ge faaliyetlerinin cari fiyatlar ve SAGP olarak değerinin, Rusya'daki faaliyetlerden daha fazla olduğu görülmektedir. İki ülkeye ait sayısal veriler Tablo 1'de yeralmaktadır. 2011 yılında OECD ülkelerinden İngiltere'nin cari fiyatlar ve SAGP ile hesaplanan yükseköğretim Ar-Ge harcamalarının değeri 63 102.01 milyon ABD \$'dır. Her iki ülke, uluslarası rekabette üstünlük sağlamak için İngiltere'nin sahip olduğu değeri aşmalıdırlar (OECD, 64).

\begin{tabular}{|l|l|l|}
\hline Y1llar & Türkiye Cumhuriyeti & Rusya Federasyonu \\
\hline 2000 & 1704.5 & 477.5 \\
\hline 2006 & 2660.5 & 1396.0 \\
\hline 2007 & 3395.9 & 1679.6 \\
\hline 2008 & 3394.0 & 2013.0 \\
\hline 2009 & 4182.0 & 2389.2 \\
\hline 2010 & 4469.1 & 2738.5 \\
\hline 2011 &.. & 3045.8 \\
\hline
\end{tabular}

Tablo 1. Cari fiyatlarla ve SAGP'ri ile yükseköğretim Ar-Ge harcamalarl (Milyon ABD \$). Kaynak: OECD. 2012. Main Science and Technology Indicators.

\subsection{GSYİH Yüzdesi Olarak Yükseköğretim Ar-Ge Harcamaları}

2000-2011 yılları arasında, her iki ülkede GSYİH bir yüzdesi olarak yükseköğretim Ar-Ge harcamalarının düzenli olarak arttığı görülmektedir. 2000-2011 yılları arasında Türkiye’ye ait GSYİH bir yüzdesi olarak yükseköğretim Ar-Ge harcamalarının, Rusya'daki faaliyetlerin yüzde oranından daha fazla olduğu görülmektedir. İki ülkeye ait veriler Tablo 2'de yeralmaktadır. 2011 yılında OECD ülkelerinden Danimarka'nın, GSYİH bir yüzdesi olarak hesaplanan yükseköğretim Ar-Ge harcamalarının değeri \% 0.92'dır. Her iki ülkenin de uluslararası rekabet için sahip oldukları yüzde değerlerin, arzu edilen yüzde değerinin oldukça gerisinde olduğu gözlenmektedir (OECD, 65).

\begin{tabular}{|l|l|l|}
\hline Y1llar & Türkiye Cumhuriyeti & Rusya Federasyonu \\
\hline 2000 & 0.29 & 0.05 \\
\hline 2006 & 0.30 & 0.07 \\
\hline 2007 & 0.35 & 0.07 \\
\hline 2008 & 0.32 & 0.07 \\
\hline 2009 & 0.40 & 0.09 \\
\hline 2010 & 0.39 & 0.10 \\
\hline 2011 &. & 0.10 \\
\hline
\end{tabular}

Tablo: 2. GSYIH yüzdesi olarak yükseköğretim Ar-Ge harcamaları. (\%) Kaynak: OECD. 2012.

\subsection{Yılı Sabit Fiyatları ve SAGP’leri ile Yükseköğretim Ar-Ge Harcamaları}

2000-2011 yılları arasında her iki ülkenin 2005 yılı sabit fiyatları ve SAGP ile yükseköğretim harcamalarının düzenli artış içinde olduğu görülmektedir. 2000-2011 yılları arasında Türkiye'de 2005 yılı sabit fiyatları ve SAGP ile yükseköğretim Ar-Ge harcamalarının, Rusya'daki yükseköğrenim Ar-Ge harcamalarından daha fazla olduğu görülmektedir. İki ülkeye ait veriler Tablo 3'de yer almaktadır. 2011 yılında OECD ülkesi İngiltere'nin 2005 yılı sabit fiyatlar ve satınalma gücü paritesi (SAGP) ile hesaplanan yükseköğretim Ar-Ge harcamalarının 
değeri 55671.0 milyon ABD \$’dır. Her iki ülke, uluslarası rekabet için İngilterenin sahip olduğu üstünlüğe erişmeli ve geçmelidirler (OECD, 66).

\begin{tabular}{|l|l|l|}
\hline Y1llar & Türkiye Cumhuriyeti & Rusya Federasyonu \\
\hline 2000 & 1808.5 & 602.5 \\
\hline 2006 & 2485.3 & 1202.5 \\
\hline 2007 & 3042.4 & 1406.1 \\
\hline 2008 & 2796.2 & 1466.1 \\
\hline 2009 & 3371.9 & 1724.9 \\
\hline 2010 & 3547.1 & 1951.0 \\
\hline 2011 &.. & 2124.7 \\
\hline
\end{tabular}

Tablo 3. 2005 Fiyatlarlyla ve SAGP yüksekögretim Ar-Ge harcamalart. (Milyon ABD \$). Kaynak: OECD. 2012.

\subsection{Sanayi Tarafından Finanse Edilen Yükseköğretim Ar-Ge Harcamalarının Yüzdesi}

2000-2011 yılları arasında; her iki ülkenin, sanayi tarafından finanse edilen Ar-Ge'nin yükseköğretim harcamalarının yüzde miktarlarının, başlangıç yıllarına göre azaldığı görülmektedir. 2000-2011 yılları arasında; Rusya'ya ait sanayi tarafından finanse edilen Ar-Ge'nin, yükseköğretim harcamalarına ait yüzde değerlerinin, Türkiye'deki faaliyetlerin yüzde değerine göre daha fazla olduğu görülmektedir. İki ülkeye ait veriler Tablo 4'de yeralmaktadır. 2011 yılında OECD ülkesi Slovakya Cumhuriyeti'ne ait sanayi tarafından finanse edilen yükseköğretim Ar-Ge harcamaları \%12.5'dir, Rusya'nın sahip olduğu yüzde değeri ile OECD ülkelerinin yüzde değerlerini aşarak üstünlük sağlamıştır (OECD, 67).

\begin{tabular}{|l|l|l|}
\hline Y1llar & Türkiye Cumhuriyeti & Rusya Federasyonu \\
\hline 2000 & 19.4 & 27.3 \\
\hline 2006 & $23.8^{0}$ & 29.3 \\
\hline 2007 & $23.3^{0}$ & 31.0 \\
\hline 2008 & $17.4^{\mathrm{a}}$ & 28.6 \\
\hline 2009 & 16.0 & 22.4 \\
\hline 2010 & 16.2 & 24.5 \\
\hline 2011 &.. & 24.0 \\
\hline
\end{tabular}

Tablo 4. Sanayi tarafindan finanse edilen yükseköğretim Ar-Ge harcamaları yüzdesi. o: Diğer sinıfları içerir. a: Veri kullanılabilir olduğu önceki yıla seri olarak bölünürler. Kaynak: OECD. 2012.

\subsection{Tamgün İstihdam EdilenYükseköğrenimde Araştırmacılar}

2000-2011 yılları arasında her iki ülkedeki yükseköğretimde tamgün (tam zamana eşdeğer) çalışan araştırmacıların sayıları başlangıç yıllarına göre düzenli olarak artmıştır. 2000-2011 yılları arasında Rusya'da tamgün yükseköğretim araştırmacılarının sayısı, Türkiye'deki araştırmacı sayılarına göre bariz bir şekilde fazladır. İki ülkeye ait veriler Tablo 5'de yeralmaktadır. 2011 yılında OECD ülkesi İngiltere'nin tamgün istihdam edilen yükseköğretim Ar-Ge araştırmacı sayısı 163506 kişidir. Her iki ülke, uluslarası rekabet için İngiltere’nin sahip olduğu üstünlüğe erişmeli ve geçmelidirler (OECD, 68).

\begin{tabular}{|l|l|l|}
\hline Y1llar & Türkiye Cumhuriyeti & Rusya Federasyonu \\
\hline 2000 & $16902^{\mathrm{u}}$ & 72264 \\
\hline 2006 & $26713^{\mathrm{u}}$ & 72310 \\
\hline 2007 & $29543^{\mathrm{u}}$ & 76298 \\
\hline 2008 & $29912^{\mathrm{u}}$ & 76797 \\
\hline 2009 & $31037^{\mathrm{u}}$ & 77955 \\
\hline 2010 & $32913^{\mathrm{u}}$ & 84359 \\
\hline 2011 &.. & 89938 \\
\hline
\end{tabular}

Tablo 5. Tamgün istihdam edilen yükseköğrenim araştırmacıları. Dipnot u: Araştırmacılar yerine üniversite mezunları. Kaynak: OECD. 2012.

\subsection{Ulusal Toplamının Bir Yüzdesi Olarak Yükseköğretim Araştırmacıları}

2000-2011 yılları arasında her iki ülkede ulusal toplamın bir yüzdesi olarak yükseköğretim araştırmacıları yüzde değerinin düzenli olarak artığ 1 görülmektedir. 2000-2011 yılları arasında; Türkiye'deki ulusal toplamın bir yüzdesi olarak yükseköğretim araştırmacılarının sayısı, Rusya'daki araştırmacı sayılarına göre bariz bir şekilde fazladır. İki ülkeye ait veriler Tablo 7'de yeralmaktadır. 2011 yılında OECD ülkesi Slovakya Cumhuriyeti'nin 
ulusal toplamın bir yüzdesi olarak yükseköğretim araştırmacıları \% 67.5 dir. Her iki ülke, uluslarası rekabet için Slovakya Cumhuriyeti’nin sahip olduğu üstünlüğe erişmeli ve geçmelidirler (OECD, 69).

\begin{tabular}{|l|l|l|}
\hline Y1llar & Türkiye Cumhuriyeti & Rusya Federasyonu \\
\hline 2000 & $73.2^{\mathrm{u}}$ & 14.3 \\
\hline 2006 & $62.6^{\mathrm{u}}$ & 15.6 \\
\hline 2007 & $59.5^{\mathrm{u}}$ & 16.3 \\
\hline 2008 & $56.6^{\mathrm{u}}$ & 17.0 \\
\hline 2009 & $53.2^{\mathrm{u}}$ & 17.6 \\
\hline 2010 & $51.2^{\mathrm{u}}$ & 19.1 \\
\hline 2011 &.. & 20.1 \\
\hline
\end{tabular}

Tablo 6. Ulusal toplamının bir yüzdesi olarak yükseköğretim araştırmacıları. Dipnot u: Araştırmacılar yerine üniversite mezunlart. Kaynak: OECD. 2012.

\subsection{Tamgün İstihdam Edilen Yükseköğretim Toplam Ar-Ge Personeli}

2000-2011 yılları arasında her iki ülkede tamgün (tam zamana eşdeğer) istihdam edilen yükseköğretim toplam Ar-Ge personel sayısının düzenli olarak arttığı görülmektedir. 2000-2011 y1lları arasında Rusya'da tamgün istihdam edilen yükseköğretim toplam Ar-Ge personel sayısı, Türkiye'deki araştırmacı sayılarına göre bariz bir şekilde fazladır. İki ülkeye ait veriler Tablo 7'de yeralmaktadır. . 2011 yılında OECD ülkesi İngiltere'nin tamgün istihdam edilen yükseköğretim toplam Ar-Ge personeli sayısı 174245 kişidir. Her iki ülkenin de uluslararası rekabette üstünlük sağlayabilmeleri için, İngiltere'nin istihdam ettiği araştırmacı sayılarını geçmeleri gerekmektedirler (OECD, 70).

\begin{tabular}{|l|l|l|}
\hline Y1llar & Türkiye Cumhuriyeti & Rusya Federasyonu \\
\hline 2000 &.. & 99552 \\
\hline 2006 & $26713^{\mathrm{m}}$ & 100990 \\
\hline 2007 & $299543^{\mathrm{m}}$ & 105643 \\
\hline 2008 & $29912^{\mathrm{m}}$ & 106816 \\
\hline 2009 & $31037^{\mathrm{m}}$ & 106443 \\
\hline 2010 & $32913^{\mathrm{m}}$ & 113353 \\
\hline 2011 &.. & 121151 \\
\hline
\end{tabular}

Tablo: 7.Tamgün istihdam edilen yüksekögretim toplam Ar-Ge personeli. Dipnot m: Yetersiz tahmin ya da yetersiz tahmine dayall. Kaynak: OECD. 2012.

Türkiye ve Rusya'daki yükseköğretimdeki AR-GE faaliyetleri incelenip karşılaştırıldığında, her iki ülkenin de üstün olduğu alanlar vardır.

Türkiyenin üstün olduğu alanlar;

- Cari fiyatlar ve SAGP ile, yükseköğrenim Ar-Ge harcamaları,

- GSYİH yüzdesi olarak, yükseköğrenim Ar-Ge harcamaları,

- 2005 yılı sabit fiyatları ve SAGP ile, yükseköğrenim Ar-Ge harcamaları,

- Ulusal toplamın bir yüzdesi olarak yükseköğrenim araştırmacıları.

Rusya'nın üstün olduğu alanlar;

- Sanayi tarafindan finanse edilen yükseköğrenim Ar-Ge harcamalarının yüzdesi,

- Tamgün istihdam edilen yükseköğrenim araştırmacıları,

- Tamgün istihdam edilen yükseköğretim toplam Ar-Ge personeli.

Türkiye ile Rusya yükseköğretimindeki Ar-Ge faaliyetleri karşılaştırıldığında iki ülkenin de birbirlerinden örnek alması ve kendilerini geliştirmeleri gereken alanlar mevcuttur. Her iki ülkenin, üniversite-sanayi işbirliğine faaliyetlerine büyük önem vermeleri ve desteklemeleri gereklidir. Ayrıca, iki ülkenin karşılaştırılan değerlerini gelişmiş ülke seviyelerine yükseltmeleri, uluslararası rekabette söz sahibi olmaları ve ulusal kalkınmaları için zorunludur.

\section{Sonuç}

Ülkelerin kendi toplumlarının refah seviyelerini yükseltme çabaları ve uluslararası ekonomik rekabet, bilim ve teknolojiye önem verilmesine ve ülkelerin yeni keşifler ve buluşlar yapma yönünde amansız bir yarışa girmelerine sebep olmaktadır. Ar-Ge faaliyetlerinde bulunan ülkeler, teknoloji üretme yeteneğini geliştirerek; istikrarlı, güçlü ve verimli bir ekonomik kalkınmayı sağlarlar. Üniversite-sanayi işbirliği, sanayinin ihtiyacı olan teknik bilginin üniversitelerden sağlanması ve üniversitelerde üretilen bilginin de ticarileştirilmesine firsat sağlayan ekonomik faaliyetlerdir. 
Bilgi toplumunda, küresel piyasa ortamında, iletişim ve bilişim teknolojilerinde yaşanan baş döndürücü gelişmelerin yaşandığı bu yüzyılda, firmalar kıyasıya bir ulusal ve uluslararası rekabet ortamındalar. Ar-Ge faaliyetlerinde bulunmayan firmaların uzun süre ekonomik faaliyetlerini sürdürmeleri mümkün olmamaktadır. Aynı şekilde, Ar-Ge faaliyetlerine destek olmayan ulusların, ekonomik büyüme ve uluslararası rekabeti sürdürmelerine imkân yoktur.

Türkiye ile Rusya yükseköğretimindeki Ar-Ge faaliyetleri karşılaştırıldığında her iki ülkenin de birbirlerinden örnek alması ve kendilerini geliştirmeleri gereken alanlar mevcuttur. Her iki ülkenin de uluslararası rekabet için sahip oldukları yüzde değerlerin arzu edilen yüzde değerin oldukça gerisinde olduğu gözlenmektedir Her iki ülkenin de uluslararası rekabette üstünlük sağlamaları ve ülkelerinin ekonomik büyümelerini gerçekleştirmek için işbirliği yapmaları, çıkarları için zorunludur.

\section{Kaynakça}

- Andersson, M., Gråsjö, U., ve Karsson, 2009. The rol of higher education and university R\&D for Industrial R\&D location. İçinde: Atılla V. Universities, knowledge transfer and regional development: Geography, entrepreneurship and policy. Edward Elgar, MA, ABD. p. 90.

- Ansal, H. 2004. Geçmiş ve Gelecekte Ekonomik Gelişmede Teknolojinin Rolü. İçinde. TMMOB. Teknoloji. TMMOB. Ankara. p. 41.

- Benli, A. O, 2011. Rusya Federasyonu. Ülke Raporu. İhracatı Geliştirme Etüd Merkezi, İGEME, Ankara. p. 4, 18, 27.

- Caşın, M.H. 2012. Rusya'nın Orta Asya ve BDT Politikaları Kapsamında Bölgesel güç Dengelerinin Değişimi. İçinde Kılıç, H. ve Toprak, (Eds), (2012). Orta Asya ve Kafkaslarda Siyaset. Anadolu Üniversitesi, Eskişehir. p. 86, 87.

- Demir, O., Üzümcü, A., ve Duran, S. 2006. “İçsel Büyüme İçselleşme Süreçleri: Türkiye Örneği””. D.E.Ü. I.I. B.F. Dergisi. Cilt: 21(1). P. 30.

- Duman, M. ve Samadov. 2003. "Türkiye ile Rusya Federasyonu Arasındaki İktisadi ve Ticari İlişkilerin Yap1sı Üzerinde Bir İnceleme”. Kocaeli Üniversitesi Sosyal Bilimler Enstitüsü Dergisi (6) 2003/2. p.4076.

- $\quad$ Freeman, C. Ve Soete, L. 2003. Yenilik İktisadı. (Çev: E. Türkcan). TÜBİTAK. Ankara. p. 2.

- IMF, 2013. List of Countries by GDP (Nominal). http://en.wikipedia.org/wiki/List of countries by GDP (nominal)

- $\quad$ ISO, 2010. Rusya Ülke Raporu. İstanbul Sanayi Odas1, İstanbul. p. 6, 9, 11, 13.

- İscan, İ.H. ve Hatipoğlu, Y.Z. 2011. Rusya'da Serbest Piyasa Ekonomisine Geçiş ve 2008 Küresel Krizi. İstanbul Üniversitesi İktisat Fakültesi Mecmuasl, 61(1). p. 203, 232.

- Kaymakcı, O. 2006. Bilgi Ekonomisi: "Rekabet, Piyasa ve AR-GE”. İçinde. N. Karg1. (Edi.) Bilgi Ekonomisi. Ekin Kitapevi. Bursa. p. 115.

- Kipper, M. 2004. Teknoloji Transfer Mekanizmaları ve Bu Kapsamda Üniversite-Sanayi İşbirliği. İçinde. TMMOB. Teknoloji. TMMOB. Ankara.p. 84.

- Martinez-Vazquez, J. ve Boex, J. 2001. Russia's Transition to a New Federalism. The World Bank, Washington. p. 6.

- OECD. 2002. Frascati Kılavuzu: Araştırma ve Deneysel Geliştirme Taramaları İçin Önerilen Standart Uygulama. OECD, TÜBITTAK. p. 30.

- OECD. 2005. Oslo Kılavuzu: Yenilik Verilerinin Toplanması ve Yorumlanması için İlkeler. 3. Bask1. OECD. TÜBİTAK. p. 33.

- OECD. 2013. Main Science and Technology Indicators. Volume. 2012, Issues 2, OECD. p. 3, 64, 65, $66,67,68,69,70$.

- Özdaşlı, K. 2010. "İşletmelerde Yenilikçi Örgüt Yapısı Oluşturmak: Çok Unsurlu Bir Model Önerisi”. TSA, 14(1). p.93.

- $\quad$ SİSAV. 1995. Rusya Federasyonundaki Gelişmeler, Etkiler ve Türkiye. Siyasi ve Sosyal Araştırmalar Vakfi, İstanbul. p. IV, 70.

- Türkcan, E. 2011. Teknoloji Tarihi. (Editör: Çalışkan, H.). Anadolu Üniversitesi, Eskişehir. p. 7.

- Yanardă̆, Ö. ve Süslü, B. 2007.’Teknolojik Yeniliklerin Araçları: Türkiye Üzerine Bir İnceleme”. Dokuz Eylül Üniversitesi SBED. 9(4). p. 250.

- Yeldan, E. 2011. İktisadi Büyüme ve Bölüşüm Teorileri. 2. Bask1. Efil Yayınevi. Ankara. p. $221,253$.

- Yörükoğulları, E. 2013. "Tarih Öncesi Çağlarda Bilim ve Teknoloji. İçinde Editör. E. Yörükoğulları ve E. İhsanoğlu. "Bilim ve Teknoloji Tarihi”. Anadolu Üniversitesi, Eskişehir. p. 7, 22. 


\title{
Post - Sovyet Ülkeler Arasında Bölgeselleşme Eğilimleri Regionalism Tendency in Post - Soviet Countries
}

\author{
Prof. Dr. Ekrem Erdem (Erciyes University, Turkey) \\ Dr. Halit Mammadov (Erciyes University, Turkey)
}

\begin{abstract}
We drew attention in our study to two directions of the growing regionalism in the Post - Soviet countries. The regionalism in the Post - Soviet Space has an indecisive character. A group of the country (Ukraine, Moldova, South Caucasus countries) is evaluating the regionalism as a medium of the integration with global markets and liberal world, but the other group (leading through Russia, Belarus and countries of Central Asia) see the regionalism as a factor, which is against the globalism. We made a conceptional analyze in the first part of our study. The second part of our study contents the implementation. The main these of our study "Regionalism processes in the Post - Soviet space" have been researched and analyzed under the title of Commonwealth of Independent States and Eurasian Economic Union. The foundation of the Eurasia Economic Union with the aim of more supporting of the economically integration in the Post - Soviet countries is a very important example of the new regionalism tendencies. There will be analyzed in our studies the phases of the Eurasian Economic Union - Eurasian Economic Community, Custom Union and Common Economic Space in scope of regionalism concept. It will be also explained the strategically aims of the mentioned regional structure.
\end{abstract}

\section{Giriş}

Günümüz sosyal bilimlerinde üzerinde durulan önemli kavramlardan biri bölgeselleşme kavramıdır. Bölgeselleşmenin hayata geçmesi açısından coğrafi yakınlık, istikrarlı ekonomik gelişim, siyasi sistemlerin yakınlığı, sürece verilen toplumsal destek, ortak tehdit ve meydan okumalar gibi faktörler oldukça önem taşımaktadır. Özellikle siyasi ve ekonomik istikrarın sağlanması küreselleşen dünyaya entegre olmayı daha mümkün kılmaktadır.

Bölgeselleşmeyi küreselleşme sürecine karşı geliştiğini öngören argümana göre bölgeselleşme süreci bir tamamlayıc1 unsur değil, tam aksine küreselleşmenin alternatifidir. $\mathrm{Bu}$ argüman bölgeselleşmenin küreselleşmeden daha dinamik gelişen bir süreç olmasına ve sonuçta çok kutuplu bir uluslararası ilişkilerin meydana çıkmasına kuvvetli bir şekilde vurgu yapmaktadır.

$\mathrm{Bu}$ anlamda bölgeselleşme; ortak çıkarları ve kaygıları olan belirli bir bölge ve ülke grublarının ekonomik ve siyasi sistemlerin güçlendiren ve etkin bir gelişimini sağlayan ekonomik ve politik entegrasyon sürecidir. Diğer yandan, bölgeselleşme küreselleşmeyle birlikte oluşturulmaya çalışılan siyasi, ekonomik ve sosyo - kültürel tek tipliliğe karşı da bir tepki niteliği taşımaktadır.

Günümüz uluslararası ilişkilerinde Rusya, Çin gibi ülkeler bölgeselleşmeyi ABD ve Batı hegemonyasına karşı siyasi bir araç olarak görmektedirler. Rusya ve Çin gibi ülkeler çok kutuplu bir dünya düzeninin ortaya çıkmasının bölgeselleşme yoluyla hayata geçeceğini ileri sürmektedirler. Uluslararası sistemde gelişen bölgeselleşme örnekleri ya iktisadi ya da güvenlik amaçlıdır. Bu bağlamda AB, NAFTA, APEC, ASEAN, ŞİÖ gibi bölgesel örgütlerin ve onların temel faaliyet istikametlerinden birini de ekonomi oluşturmaktadır.

Soğuk Savaş'ın sona ermesinden sonra, bölgeselleşme veya bölgesel entegrasyon girişimleri ekonomik geçiş sorunları ile ilgilenmiş ve özellikle Avrupa jeopolitiğinde ekonomik ve güvenlik yapıları ile daha yakın ilişkiler geliştirmiş, istikrarın sağlanmasında önemli bir araç olarak ortaya çıkmıştır.(Celac, 2006)

Günümüzde küreselleşme süreci hız kazanmakla birlikte, bölgeselleşme hareketleri iktisat ve uluslararası ilişkiler disiplinlerinin gündemine dâhil olan konuların başında gelmektedir. $\mathrm{Bu}$ çerçevede dünya ülkelerinin başta iktisadi olmak üzere birçok alanda birbiriyle ortaklık kurma arzusu içerisinde hareket ettiğini müşahede etmek mümkündür.

Bölgeselleşme kavramına baktığımızda, söz konusu kavramın ülkeler için yasal bir çerçeve sunduğu ve ekonomik ilişkilerini geliştirmesine yönelik bir yapılanmayı ifade ettiğini gözlemlemek mümkündür. Bu bağlamda bölgeselleşme muhtelif ülkelerin esasında ekonomik birlikteliğini kapsayan oluşum karakteri taşımaktadır.

Bölgeselleşme ve bölgesel entegrasyonun iktisadi kalkınma üzerindeki etkilerinin boyutuna ilişkin siyaset bilimi ve ekonomi politik arasında tartışma söz konusudur. Ancak son hamlede ekonomik kalkınmanın önemi sürekli olarak dikkat çekmiş ve gündemde olmuştur.(Engel, 2010) Bölgeselleşmenin oluşumu, çeşitli ihtiyaçları veya siyasi, ekonomik veya iktisadi kalkınmayı ihtiva eden stratejik açıdan önemli bir jeopolitik eylemi temsil etmektedir.

Soğuk Savaşın bitimi ile hız kazanan yeni bölgeselleşme dönemi, AB gibi başarılı örneklerden esinlenmiş ve bu aşamada bölgeselleşme hareketlerinde önemli ilerlemeler yaşanmıştır. $\mathrm{Bu}$ dönemde dünyanın muhtelif 
yerlerinde bölgeselleşme arzuları hız kazanmış, ülkeler bölgesel entegrasyonlar yoluyla kendi stratejik hatlarını oluşturmuşlardır.

\section{Post - Sovyet Ülkelerde Bölgeselleşmenin Karakteristiği}

Siyasi ve jeopolitik anlamda parçalanan Post - Sovyet coğrafyasında muhtelif bölgesel yapılanmalar ortaya çıkmıştır. Bu yapılanmaların ilki Baltık ülkeleri dışındaki eski Sovyet ülkelerini kapsayan Bağımsız Devlet Topluluğu (BDT) olmuştur. BDT’nin birçok Post - Sovyet ülkenin dış politika ihtiyaçlarını karşılayamaması yeni bir bölgesel entegrasyonun meydana çıkması için zemin hazırlamıştır. Söz konusu zeminde Azerbaycan, Ukrayna, Gürcistan ve Moldova'nın inisiyatifinde Strasbourg'de 10 Ekim 1997'de GUAM örgütü kurulmuştur. (Papava,2008) 7 Haziran 2001'de, Yalta'da, GUAM'ın ilk zirvesinde örgütün amaç ve ilkeleri belirlenmiştir. GUAM'a katılan ülkeler milli bağımsızlıklarını ve egemenliklerini muhafaza etmek ve Rusya karşısında manevra kabiliyetlerini artırmayı amaçlamışlardır.(Kuzio,2000)

Batı ise Rusya'nın etkisindeki BDT örgütüne karşı GUAM'ı desteklemiştir. Batılı ülkeler özellikle Karadeniz ve Transkafkasya enerji hatlarının güvenliğini teminat altına alınması istikametinde GUAM örgütüne önem vermişlerdir. Bu bağlamda GUAM ilk bakışta ekonomik veya kalkınmaya yönelik bir örgütlenme olarak gözükse de, özellikle Batı açısından söz konusu bölgesel entegrasyonun hedef ve beklentileri güvenlik ve siyasi konular etrafında şekillenmiştir. Böylece, GUAM Batı'ya Kafkasya'daki enerji boru hatları ve ulaşım koridorları üzerinde stratejik bir kontrol sağlama olanağı kazandırmıştır.(Chossudovsky, 2008)

\section{Post - Sovyet Ülkeleri Arasında İlk Bölgeselleşme: Bağımsız Devletler Topluluğu}

Bağımsız Devletler Topluluğu (BDT) (Sodrujestvo Nezavisimih Gosudarstv (SNG) 8 Aralık 1991 yılında Belojevsk'de Rusya, Ukrayna ve Belarus Devlet Başkanları arasında imzalanan anlaşmayla 21 Aralık 1991'de faaliyete başlayan devletlerarası bir örgüttür. 21 Aralık 1991'de Kazakistan'ın Almaty kentinde Gürcistan ve Baltık ülkeleri dışında on bir eski SSCB ülkesi BDT'ye üye olmak için protokol imzalamıştır.(BDT resmi sitesi - 11.05.2013) 1993 yılında kabul edilen BDT tüzüğü (ustav) ekonomik, siyasal, çevresel, insani, kültürel alanlardaki işbirliği konusunda bir dizi kapsamlı hedef amaçlamıştır.( BDT resmi sitesi - 11.05.2013) BDT'nin temel amaçlarından biri de ortak ekonomik alanın yaratılması olmuştur. Diğer önemli nokta ise BDT ülkeleri arasında mevcut olan çatışmaların veya ortaya çıkacak sorunların barışçıl yöntemlerle halledilmesi olmuştur. BDT’nin temel amaçları "BDT üyesi ülkelerin sosyo - ekonomik gelişiminin sağlanması, yaşam standartlarının yükseltilmesi, istikrar ve güvenliğin artırılması" şeklinde ifade edilmektedir.(Konseptsiya Povişenia Prodovolistvennoy Bezopastnosti Gosudarstv - Uçastnikov SNG,2010)

Rusya, BDT'yi gelecekte Post - Sovyet ülkeleri ile ilişkilerini derinleştirecek bir araç olarak değerlendirmiş, özellikle Orta Asya üzerindeki etkisi açısından bu örgüte önem vermiştir. (Purtaş,2008) Bu bağlamda BDT Rusya'nın "Yakın Çevre" (Politika Blijnego Zarubejiya - Near Abroad) olarak adlandırılan Orta Asya ve Kafkasya'ya yönelik politikalarının ilk adımı olarak dikkat çekmektedir. Rusya ilk yıllarda ekonomik ve siyasal anlamda yeteri derecede güçlü olmaması nedeniyle "Yakın Çevre" politikasında söz konusu bölgede yaşayan ve söz konusu coğrafyanın (özellikle Orta Asya) "yumuşak karnı” olan etnik Rusları ve bölgenin ortak dili olan Rusçayı kullanmıştır. (Lepingwell, 1994; Laitin, 1998) Rusya, “Avrasya Ekonomik Topluluğu”na giden yolda BDT'yi ön hazırlık olarak düşünmüştür.

Bu bağlamda BDT Rusya'nın “yakın çevresinde” yeniden güç oluşturması için ekonomik, siyasi ve kültürel araç niteliği taşımaktadır. Küresel güç olması açısından BDT ve eski SSCB coğrafyası Rusya için hiçbir makul alternatifi olmayan bir işbirliği alanı niteliği taşımaktadır. Rusya'nın BDT politikası ekonomik açıdan stratejik bir politikadır ve söz konusu strateji Rus ulusal ekonomisinin geleceğini belirleyecek perspektife sahiptir. (Ekonomiçeskie İnteresi i Zadaçi Rossii v SNG, 2010)

\section{Post Sovyet Coğrafyada Yeni Bölgeselleşme Eğilimi: Avrasya Ekonomik Birliği}

Avrasya Ekonomik Birliği (Evraziyskiy Ekonomiceskiy Soyuz) düşüncesi Rusya’nın önderliğinde eski Sovyet jeopolitiği içinde yer alan devletlerin artan küresel rekabet karşısında bölgesel işbirlikleri ile ayakta kalabilme çabaları sonucu ortaya çıkmıştır. Avrasya Ekonomik Birliği’nin teorik temellerini dört ana hat üzerinde değerlendirmek mümkündür:

1. Atlantikçilik ve onun uzantısı olarak kabul edilen küreselleşmeye karşı koyma, Batı Avrupa'ya ve ABD’ye karşı kültürel, politik ve ekonomik mücadele;

2. Ekonomide devletin güçlü olmasını destekleme; kamu sektörünün muhafaza edilmesi;

3. Rus Ortodoks Kilisesi'nin desteğini arkasına almak ve aynı zamanda diğer geleneksel gruplarla işbirliği;

4. Rusya'nın çekirdek güç olarak yer aldığı, eski SSCB coğrafyasında 'Avrupa Birliği' tarzında bir platformun oluşturulması.(Vasechko, 2007) 


\section{Avrasya Birliği Entegrasyonu Süreci ve Aşamaları:}

1. Serbest Ticaret Bölgeleri

2. Avrasya Ekonomik Topluluğu

3. Gümrük Birliği

4. Tek Ekonomik Saha

5. Avrasya Ekonomik Birliği

6. Avrasya Birliği

1994 yılında Kazakistan Cumhurbaşkanı Nursultan Nazarbayev tarafından söylemselleştirilen Avrasya Birliği düşüncesi 2010 yılında Avrasya Gümrük Birliği'nin (Tamojenniy Soyuz) kurulması ile yeni boyut kazanmıştır. 10 Ekim 2000'de imzalanan Avrasya Ekonomik Topluluğu (AET) anlaşması Gümrük Birliği ve Tek Ekonomik Saha'nın gelişmesi için önayak rolü oynamıştır. Günümüzde Avrasya Ekonomik Topluluğu'na beş ülke dâhildir: Rusya, Belarus, Kazakistan, Kırgızistan ve Tacikistan. 2002 yılından Ukrayna ve Moldova, 2003'den itibaren ise Ermenistan AET’te gözlemci ülke konumundadırlar. Orta Asya ülkelerinden Özbekistan, Topluluğa 2006 y1lında üye olmuş, 2008 yılında ise ayrılmıştır.

AET, Birleşmiş Milletler ve uluslararası hukuk ilkelerine tam uygun olarak kurulmuş ve uluslararası tüzel kişiliğe sahiptir. 2003 yılında, Avrasya Ekonomik Topluluğu'na, BM Genel Kurulunda gözlemci statüsü verilmiştir. (Avrasya Ekonomi Topluluğu resmi sitesi - 15.05.2013) Avrasya Ekonomik Birliği'ne katılan ülkeler (Rusya, Belarus, Kazakistan) Dünya Ticaret Örgütü'nün (DTÖ) belirlemiş olduğu uluslararası norm ve kuralları çerçevesinde hareket edeceklerini belirterek, DTÖ üyeliği konularının önemine vurgu yapmışlardır.

Rusya inisiyatifindeki yeni bölgeselleşme sürecinin temel istikametleri aşağıdaki şekilde karakterize edilmektedir:

- Gümrük Birliği ve Tek Ekonomik Saha'nın tam olarak hayata geçirilmesi;

- Mal, hizmet, sermaye ve emek dolaşımının etkin bir şekilde sağlanması;

- Sanayi, ulaşım, enerji ve tarım politikalarının koordineli şekilde yürütülmesi ve ortak ulus ötesi korporasyonların tesis edilmesi;

- Milli yasaların uyumu ve harmonizasyonu, ekonomi politikalarının koordinasyonu:

- Ekonomi güvenliği, göç sorunlarında işbirliği, sınır ve bölgelerarası işbirliğinin geliştirilmesi.( Avrasya Ekonomik Birliği Komisyonu resmi sitesi - 15.05.2013)

2011 yılından itibaren Avrasya Ekonomik Birliği süreci Rusya Devlet Başkanı Vladimir Putin tarafından ilan edilmiş ve uygulamaya konulmuştur. 2010 yılında Rusya, Kazakistan ve Belarus arasındaki gümrük duvarı kalkmış, 2012 y1lı itibariyle de Tek Ekonomik Saha (Edinoe Ekonomiceskoe Prostranstvo) süreci tamamlanmıştır.

Avrasya Ekonomik Birliği’nin en önemli organı Ekonomik Birlik Komisyonu'dur. Komisyon, 2011 y1lında Rusya, Belarus ve Kazakistan Devlet Başkanlarının kararıyla tesis edilmiştir. Komisyon bu ülkelerin hiçbir kurumuna bağlı olmaksızın faaliyet göstermektedir. Komisyonun temel misyonu Gümrük Birliği ve Tek Ekonomik Saha’nın gelişimine katkı sağlamaktır. (Avrasya Ekonomik Birliği Komisyonu resmi sitesi 15.05.2013)

Günümüzde Avrasya Ekonomik Birliği’ne katılan ülkelerin önemli hedeflerinden biri de ortak para biriminin faaliyete geçirilmesidir. 2004 yılında Belarus Devlet Başkanı Lukaşenko ortak para fikrini ortaya atmıştır. Kazakistan Cumhurbaşkanı Nazarbayev "evraz" veya "Avrasya rublesi” isimli bir para birimini desteklemektedir. Ortak para biriminin 2015 yılından itibaren faaliyete geçmesi öngörülmektedir. Ancak Rusya Devlet Başkanı Putin, Avrasya Birliği sürecinde “AB’nin yaptığı yanlışları göz önünde bulundurduklarını” ve ortak para birimi oluşumu için acele etmeyeceklerini ifade etmiştir. (Kostenko; Novikova, 2012)

\section{Gümrük Birliği}

Gümrük Birliği 6 Ekim 2007'de Tacikistan'ın başkenti Duşanbe'de imzalanan anlaşmayla kurulmuştur. Gümrük Birliğinin yüksek organı katılımcı ülkelerin Devlet ve Hükümet Başkanlarının yer aldığı Devletlerarası Konsey'dir. 2007 yılından itibaren Gümrük Birliği Komisyonu daimi faaliyet gösteren yegâne organdır. Gümrük birliği çerçevesinde ortak gümrük tarifesi ve üçüncü ülkelerle ticaret düzenleyen önlemler alınmıştır. 2009 yılında, Gümrük Birliği Yüksek Organı, Gümrük Birliği Komisyonu ve katılımcı ülkelerin Hükümetleri Ortak Gümrük Tarifesi, Gümrük Kanunu, Gümrük Birliği Divanı Statüsü de dâhil olmak üzere Gümrük Birliği’nin yasal çerçevesini tamamlamak için bir dizi tedbirler almışlardır. (Avrasya Ekonomi Birliği Komisyonu resmi sitesi - 15.05.2013) Bu çerçevede 40’dan fazla uluslararası anlaşma, katılımcı ülkeler tarafından kabul edilmiş ve onaylanmıştır. 
2011 yılında Petersburg'da yapılan Avrasya Ekonomik Topluluğu toplantısında Kırgızistan'ın Gümrük Birliği'ne katılımı deklare edilmiştir. Kırgızistan Cumhurbaşkanı Almazbek Atambayev, 'Kırgızistan'ın Gümrük Birliği'ne katılmak için kararlı olduğunu” bildirmiştir. (Fergana News - 17.05.2013) Rusya Başbakanı Dmitri Medvedev “Kırgızistan'ın Gümrük Birliği ve Tek Ekonomik Saha'ya katılma kararlılığını desteklediklerini ve bu konuda yardım göstermeye hazır olduklarını" beyan etmiştir.(TKS - 11.05.2013) Katılımcı ülkeler ise Gümrük Birliğinin üçüncü ülkelere açık olduğunu defalarca ifade etmişlerdir. Bu çerçevede diğer Post - Sovyet ülkelerinin katılımı özellikle Gümrük Birliğinin geleceği açısında oldukça önem taşımaktadır. Bu bağlamda Ukrayna'nın üyeliği Gümrük Birliği açısından önemli gündem maddesidir.

Ukrayna, nüfusu ve coğrafi konumuyla Gümrük Birliği ve geniş manada Avrasya Ekonomik Birliği'nin gelecek hedefleri açısından kilit ülke konumundadır. Post - Sovyet Ukrayna'nın jeopolitik olarak AB ve Rusya arasında kalması bu ülkenin dış ilişkilerinin gündemini belirlemiştir. Bağımsızlık sonrası Ukrayna, Rusya ve Batı'nın (özellikle AB’nin) rekabet ettiği önemli jeopolitik alan olmuştur. (Snirelman, 2009) Bu nedenle Ukrayna Gümrük Birliği'ne gözlemci statüsünde katılmak istemektedir.

\begin{tabular}{|l|c|c|c|c|c|c|}
\hline \multicolumn{1}{|c|}{ ÜLKELER } & $\begin{array}{c}\text { Sanayi } \\
\text { Üretimi }\end{array}$ & $\begin{array}{c}\text { Tarım } \\
\text { Üretimi }\end{array}$ & $\begin{array}{c}\text { Sabit } \\
\text { Sermaye } \\
\text { Yatırımları }\end{array}$ & $\begin{array}{c}\text { Nakliye } \\
\text { Taşımacılığı } \\
\text { (Boru Hatları } \\
\text { Hariç) }\end{array}$ & $\begin{array}{c}\text { Perakende } \\
\text { Ticaret } \\
\text { Hacmi }\end{array}$ & $\begin{array}{c}\text { Tüketici } \\
\text { Fiyatları } \\
\text { endeksi }\end{array}$ \\
\hline Belarus & 98,9 & 102,5 & 112,5 & 92,5 & 119,1 & 105,4 \\
\hline Kazakistan & 101,9 & 100,4 & 108,5 & 95,8 & 112,5 & 101,9 \\
\hline Rusya & 100,0 & 102,2 & 101,5 & 96,3 & 103,9 & 101,9 \\
\hline $\begin{array}{l}\text { Gümrük Birliği ve } \\
\text { Tek Ekonomik Saha }\end{array}$ & 100,1 & 102,2 & 101,5 & 96,3 & 104,8 & 102,1 \\
\hline
\end{tabular}

Tablo 1. Gümrük Birliği ve Tek Ekonomik Saha Üye Ülkelerinin Esas Sosyo - Ekonomik Göstergeleri Kaynak: Avrasya Ekonomi Komisyonu

\begin{tabular}{|c|c|c|c|}
\hline \multicolumn{4}{|c|}{$\begin{array}{l}\text { GÜMRÜK BİRLİĞİ HAKKINDA RUSYA FEDERASYONU VE } \\
\text { BELARUS CUMHURIYYETİ ARASINDA İMZALANAN ANLAŞMA }\end{array}$} \\
\hline \multicolumn{2}{|c|}{$\begin{array}{l}\text { ANLAŞMAYA KATILAN } \\
\text { ÜLKELER }\end{array}$} & IMZALANDIĞI TARİH & YÜRÜRLÜĞE GİRDİĞİ TARİH \\
\hline \multicolumn{2}{|l|}{$\begin{array}{l}\text { Rusya Federasyonu } \\
\text { Belarus Cumhuriyeti }\end{array}$} & 06.01 .1995 & 30.11 .1995 \\
\hline \multicolumn{4}{|c|}{ GÜMRÜK BİRLİĞİ VE TEK EKONOMİK SAHA ANLAŞMASI } \\
\hline \multicolumn{2}{|c|}{$\begin{array}{l}\text { ANLAŞMAYA KATILAN } \\
\text { ÜLKELER } \\
\end{array}$} & İMZALANDIĞI TARİH & YÜRÜRLÜĞE GİRDİĞİ TARİH \\
\hline \multicolumn{2}{|l|}{ Kazakistan } & 26.02 .1999 & 23.12 .1999 \\
\hline \multicolumn{2}{|l|}{ Belarus } & 26.02 .1999 & 23.12 .1999 \\
\hline \multicolumn{2}{|l|}{ Tacikistan } & 26.02 .1999 & 23.12 .1999 \\
\hline \multicolumn{2}{|l|}{ Kirgizistan } & 26.02 .1999 & 10.04 .2000 \\
\hline \multicolumn{2}{|l|}{ Rusya } & 26.02 .1999 & 02.07 .2001 \\
\hline \multicolumn{4}{|c|}{ AVRASYA EKONOMİK TOPLULUĞUNU KURAN ANLAŞMA } \\
\hline $\begin{array}{l}\text { ANLAŞMAYA KATILAN } \\
\text { ÜLKELER }\end{array}$ & & MZALANDIĞI TARİH & YÜRÜRLÜĞE GİRDİĞİ TARİH \\
\hline $\begin{array}{l}\text { Kazakistan, } \\
\text { Belarus, } \\
\text { Tacikistan, } \\
\text { Kirgizistan, } \\
\text { Rusya }\end{array}$ & $\begin{array}{l}10 . \\
25 . \\
06 .\end{array}$ & $\begin{array}{l}000 \text { (ilk imzalandığ } 1 \text { tarih) } \\
006 \text { (değiştirilme tarihi) } \\
007 \text { (değiştirilme tarihi) }\end{array}$ & $\begin{array}{l}\text { 30.05.2001 (yürürlüğe girdiği tarih) } \\
\text { 28.08.2006 (yürürlüğe girdiği tarih) } \\
21.11 .2008 \text { (yürürlüğe girdiği tarih) }\end{array}$ \\
\hline
\end{tabular}

Tablo 2. Gümrük Birliği Hukuki Altyapısını Oluşturan Temel Uluslararası Anlaşmalar

Diğer bir alternatif süreç ise Ukrayna tarafından ileri sürülen "yarım üyelik" (polovinchatiy) statüsüdür. Bu statü 3+1 şeklinde de formüle edilmektedir. Buna göre Ukrayna Gümrük Birliği'ne aşamalı olarak entegre olmayı hedeflemektedir. Böylece, Ukrayna bugün itibariyle Gümrük Birliği'ne tam katılımı düşünmediğini ortaya koymaktadır. "Yarım üyelik" statüsü Rusya tarafindan makul görülmemektedir. (RİA Novosti 1505.2013) Rusya, Ukrayna’nın Gümrük Birliği'ne tam katılımını istemekte ve oldukça önemsemektedir. Bu çerçevede kısa vadede Ukrayna'nın gözlemci statüde Gümrük Birliği üyesi ülkelerle ekonomik işbirliğine gideceğini gözlemlemek mümkündür. Ukrayna'nın Gümrük Birliği üyeliği ve AB sürecini referanduma götürmesi bile olasıdır.

Ukrayna, 2013 yılının sonuna kadar hem Gümrük Birliği ülkeleri hem de AB ile serbest ticaret anlaşması imzalamayı ümit etmektedir. Ukrayna Dışişleri Bakanı Leonid Kojara Rusya Dışişleri Bakanlığı Diplomasi 
Akademisindeki konuşmasında “Ukrayna'nın hem Gümrük Birliği (Doğu) ve hem de AB (Batı) ile serbest ticaret anlaşması imzalayan tek ülke konumuna sahip olmasından ve bu durumun dünyada tek örnek olma ihtimalinden" bahsetmiştir.(RİA Novosti - 15.05.2013)

\section{Tek Ekonomik Saha}

19 Eylül 2003'de Yalta'da, Rusya, Belarus, Ukrayna ve Kazakistan Devlet Başkanları zirvesinde Tek Ekonomik Saha'nın oluşturulması hakkında anlaşma imzalanmıştır. Rusya, Belarus ve Kazakistan yasama organları anlaşmayı onaylarken, Ukrayna parlamentosu bu Anayasasına ve diş politika önceliklerine ters düşmesi nedeniyle söz konusu anlaşmayı tasdik etmemiştir. (Rusya Ekonomik Gelişim Bakanlığı - 17.05.2013) ) Böylece, Tek Ekonomik Saha üç ülkenin - Rusya, Belarus ve Kazakistan - katıldığı iktisadi bir aşama olmuştur. Tek Ekonomik Sahanın temel amaçları aşağıdaki şekilde sıralanmaktadır:

- Mal, hizmet, sermaye ve emeğin tek pazar altında oluşturulması;

- Üye ülkelerin ekonomik kurumsallaşması ve bu ülkelerde hayat standartlarının yükseltilmesi;

- Vergi, banka, finansal, ticari, gümrük ve tarife politikalarının ortak yürütülmesi;

- Ulaşım, enerji ve iletişim alanlarında ortak bir sistemin geliştirilmesi, ekonomide yüksek teknolojinin uygulanmasında devlet desteğinin sağlanması.(Avrasya Ekonomik Topluluğu - 11.05.2013)

\begin{tabular}{|l|l|l|l|l|l|}
\hline & \multicolumn{1}{|c|}{ İhracat } & \multicolumn{1}{|c|}{ İthalat } & \multicolumn{2}{c|}{ Denge } & \multicolumn{2}{c|}{ 2012 yılının ilk ceyreği (\%) } \\
\cline { 4 - 6 } & & & & \multicolumn{2}{|c|}{} \\
\hline Gümrük Birliği & 140387,2 & 76366,3 & 64020,9 & 93,5 & 105,4 \\
\hline Ayrıca: & & & & 68,2 & 102,7 \\
\hline $\begin{array}{l}\text { Belarus } \\
\text { Cumhuriyeti }\end{array}$ & 5611,3 & 4417,5 & 1193,8 & 110,5 \\
\hline $\begin{array}{l}\text { Kazakistan } \\
\text { Cumhuriyeti }\end{array}$ & 18501,2 & 5919,0 & 12582,2 & 91,1 & 104,0 \\
\hline Rusya & 116274,7 & 66029,8 & 50244,9 & 95,6 & \\
\hline
\end{tabular}

Tablo 3. Gümrük Birliği ve Tek Ekonomik Saha Üyesi Ülkelerin Dış Ticaret Hacmi (2013 yılının ilk çeyreği) Kaynak: Avrasya Ekonomi Komisyonu

16 Ağustos 2006'da Avrasya Ekonomik Topluluğu Devletlerarası Konseyi’nin Devlet Başkanları düzeyinde aldığı kararla Tek Ekonomik Saha'nın yasal çerçevesi için gerekli belgeler geliştirilmeye başlanılmıştır. 2009'da Almati'da yapılan gayri resmi zirvede Rusya, Belarus ve Kazakistan Devlet Başkanları Tek Ekonomik Saha 2010 - 2011 Eylem Planını onaylamışlardır.

Bu çerçevede 2010 yılında Petersburg'da yapılan AET Devletlerarası Konsey toplantısında Tek Ekonomik Saha ile ilgili dört anlaşma imzalanmıştır:

- Rusya Federasyonu, Belarus ve Kazakistan arasındaki teknik düzenlenmelerin ortak ilke ve kuralları;

- Üçüncü ülkelerden yasadışı göçle mücadele için işbirliği;

- Göçmen işçilerin ve aile üyelerinin hukuki statüsü;

- Fiyatlandırma ve tarife politikalarında, elektrik sektöründe doğal tekel hizmetlerine erişim. (Avrasya Ekonomik Topluluğu - 11.05.2013)

\begin{tabular}{|l|c|c|c|}
\hline & ABD Doları (milyon) & $\begin{array}{c}\text { 2012 yılının ilk } \\
\text { çeyreğine göre (\%) }\end{array}$ & İçindeki Payı (\%) \\
\hline Gümrük Birliği & 15006,4 & 90,3 & 100,0 \\
\hline Ayrıca, & & & 1,2 \\
\hline Belarus ve Kazakistan & 175,6 & 86,3 & 35,0 \\
\hline Kazakistan ve Rusya & 5253,5 & 100,5 & 63,8 \\
\hline Rusya ve Belarus & 9577,3 & 85,6 & \\
\hline
\end{tabular}

Tablo 4. Gümrük Birliği ve Tek Ekonomik Saha Üyesi Ülkelerin Karşılıklı Ticaret Hacmi Kaynak: Avrasya Ekonomi Komisyonu

18 Kasım 2011'de Rusya, Belarus ve Kazakistan liderleri Avrasya ekonomik entegrasyon sürecinin bir sonraki aşamaya geçişi hakkında bir Deklarasyon imzalamışlardır. Rusya, Belarus ve Kazakistan Devlet Başkanları "1 Ocak 2015 tarihine kadar Gümrük Birliği ve Tek Ekonomik Saha’nın yasal çerçevesini oluşturan uluslararası anlaşmaları tamamlayarak, söz konusu yasal çerçeve temelinde Avrasya Ekonomik Birliği'ni oluşması için çaba harcayacaklarını" beyan etmişlerdir. (Avrasya Ekonomik Topluluğu - 11.05.2013) Bu süreci tamamlaması için Avrasya Ekonomi Komisyonu görevlendirilmiştir. 
Tek Ekonomik Saha dört temel prensibin hayata geçmesini içermektedir:

- Malların Serbest Dolaşımı

- Hizmetin Serbest Dolaşımı

- Sermayenin Serbest Dolaşımı

- Emeğin Serbest Dolaşımı

Tek Ekonomik Saha ile ilgili yukarıda bahsettiğimiz temel ilke ve kurallar 1 Ocak 2012 tarihi itibariyle yürürlüğe girmiştir. Tek Ekonomik Saha'nın tamamlanmasıyla 2015 yılından itibaren daha ileri entegrasyon aşaması olan Avrasya Ekonomik Birliği sürecinin başlatılması öngörülmektedir.

\section{Stratejik Çıkarımlar}

Soğuk Savaş sonrası ortaya çıkan yeni koşullarda bölgesel örgütlerin temel kaygısını yeni tehditlere ve meydan okumalara karşı hızlı ve etkin bir biçimde cevap verebilecek güvenlik anlayışının geliştirilmesi oluşturmuştur. Günümüz uluslararası koşullarında devletler kendi güvenliklerini tek başına değil, muhtelif bölgesel organizasyonlar aracılığıyla sağlamaktadırlar.

Putin dönemi ile birlikte Avrasya Birliği düşüncesi Rusya için stratejik bir öncelik taşımakta ve tedricen Ş่̇̈Önün önüne geçmektedir. (RİA Novosti - 15.05.2013) Rusya, Putin dönemi ile birlikte değişik bölgeselleşme süreçleri vasıtasıyla çok kutuplu uluslararası ilişkiler sistemini stratejik hedef olarak belirlemektedir. 7 Mayıs 2012'de Rusya Devlet Başkanı Vladimir Putin tarafından imzalanan "Rusya Federasyonu Dış Politikasının Uygulanması İçin Gerekli Önlemler" belgesinde, bölgesel örgütler çok yönlü diplomasi çerçevesinde ele alınmaktadır. (Rusya Devlet Başkanı resmi sitesi - 17.05.2013) Rusya, Şi̇Ö’nün bölgesel rolünü diğer önemli bir yapılanma projesi olan Avrasya Birliği düşüncesiyle desteklemektedir.

Bu bağlamda Avrasya Birliği, ABD ve Çin'in Orta Asya'daki etkinliğini dengelemeye dönük bölge ülkeleri ile Rusya arasında siyasi, ekonomik ve güvenlik alanında entegrasyonu hedeflemektedir. Putin'in iktidara gelişi ile birlikte Rusya, Avrasya bölgesinde bölgesel örgütler yoluyla etkili bir dış politika uygulamaktadır.

Putin'in 2011 yılında ikinci kez iktidara gelişinden sonra Avrasya Birliği projesi Rus dış politikasının temel önceliği haline gelmiştir. Rusya, Avrasya Birliği'nin 2013 yılında öncelikle ekonomik entegrasyon temelinde gelişeceğini hedeflemektedir. Rusya, Avrasya Birliği'nin ekonomik perspektifini serbest ticaret kuralları çerçevesinde değerlendirmektedir. Ekonomik temelli Avrasya Birliği, Avrupa ve dinamik Asya - Pasifik bölgeleri arasında etkin bir "köprü” rolünü oynama potansiyeli taşımaktadır.(İzvestia - 11.05.2013)

Rusça'nın bölgede etkin bir şekilde kullanımı Rusya açısından Avrasya Birliği için önemli bir araç teşkil etmektedir. Rusya Avrasya Birliği düşüncesiyle jeopolitik çıkarlarını gözetlemeyi esas stratejisi olarak benimsemektedir. Avrasya Birliği esas itibariyle ileri aşamada siyasi bir entegrasyon olarak Rusya'nın dış politika önceliğini oluşturmaktadır. Modern Rus dış politikasının ve Avrasyacı ekolün önde gelen fikir adamlarından olan Aleksandr Dugin çok kutuplu bir dünyanın oluşumunun Rusya'nın Avrasya istikametindeki politikasına bağlı olduğunu vurgulamaktadır. Dugin'e göre, Avrasyacılık ve Avrasya Birliği düşüncesi sadece stratejik bir öncelik olduğu kadar, ekonomik, manevi ve siyasi bir anlam da ifade etmektedir. (Dugin'in makaleleri - 17.05.2013)

Bugün ekonomik, askeri ve normatif alanları kapsayan küresel rekabet kavramı, Rus siyasi seçkinleri arasında güçlü bir yankı uyandırmaktadır. Bu düşünce dünya siyasetini sürekli mücadele arenası olarak gören Hobbesian anlayıştan kaynaklanmaktadır. Rusya'nın yeniden süper güç olma iddiası "Yakın Çevresi'ndeki politikaları ve başarılarıyla birebir bağlantılıdır. Bu çerçevede Rusya son dönemde "Yakın Çevresi" ile entegrasyonda hukuki normatif yönlere dikkat çekmektedir. (Dragneva; Wolczuk, 2012)

Bugün Orta Asya'nın Post - Sovyet ülkeleri ortak bir bölgesel kimlik çerçevesinde, Rusya'nın başat güç olacağ1 bir bölgeselleşme projesine katılımı kendi dış politikaları açısından temel öncelik olarak görmektedirler.(Koraboev, 2012) Bu faktör Avrasya Birliği projesinin başarılı olma ihtimalini yükseltmektedir. Rusya ise Avrasya Birliği’ni pragmatik Şanghay İşbirliği Örgütü’nden (ŞiÖ) daha çok önemsemektedir. Sonuç olarak, Avrasya Birliği düşüncesini Rusya’nın Batı merkezli küreselleşme sürecine karşı bölgeselleşme yoluyla tepki koyduğu bir oluşum olarak değerlendirmek mümkündür.

\section{Sonuç}

Bölgeselleşme jeopolitik nedenler ve iç faktörlerin etkisi altında küreselleşme sürecinde yaşananlara paralel olarak gelişim göstermekte ve devletlerin ekonomik yapısını ve bunu müteakiben dış politikalarını da dönüştürme potansiyeli taşımaktadır. Söz konusu dönüşüm hem olumlu, hem de olumsuz istikamette tezahür etmektedir. Örneğin, birçok ülke küresel sisteme entegre olmak için bölgeselleşmeyi bir araç olarak görmekte, bazı ülkeler muhtelif metotlarla (İran, Kuzey Kore ve diğerleri) bölgeselleşmeyi küresel dünyaya karşı bir direniş vasıtası olarak değerlendirmektedir. 
$\mathrm{Bu}$ bağlamda günümüzde bölgeselleşme, iki eğilim istikametinde gelişim göstermektedir. Bunlardan ilki, bölgeselleşmenin, küreselleşmenin tamamlayıcı bir öğesi ve bu sürecin bir parçası olmasıdır. İkinci eğilim ise, bölgeselleşmenin küreselleşmeye alternatif olduğu ve söz konusu iki sürecin zıt anlam taşımasını ihtiva etmektedir.

1991 yılında SSCB'nin dağılmasıyla bağımsızlıklarının kazanan yeni ülkeler ise yeni uluslararası siyasi ve iktisadi koşullara hazırlıksız yakalanan devletlerin başında gelmişlerdir. Yeni bağımsız ülkeler zayıf siyasal sistemleri, dağılmış ekonomik düzenleri, deformasyona uğramış sosyal ve kültürel yapılarıyla ciddi meydan okuma ve tehditlerle karşı karşıya kalmışlardır. Bu ülkeler küreselleşmeyi hem firsat hem de meydan okuma olarak değerlendirmişlerdir.

Post - Sovyet ülkelerin bir kısmı pazar ekonomisi yoluyla dünya iktisadi sistemine eklemlenirken, diğer bir kısım ülke ise ekonomik liberalizayon konusunda acele etmemektedirler. İkinci grup ülkeler bölgesel örgütlenmeler vasıtasıyla ekonomik küreselleşmenin risk ve meydan okumalarını bertaraf etmeyi hedeflemektedirler.

Avrasya Ekonomik Birliği Post - Sovyet coğrafyasını iktisadi anlamda ikiye ayıran bir ekonomik bölgeselleşme sürecidir. Söz konusu bölgesel organizasyon Post - Sovyet ülkelerine alternatif sunsa da ekonomik örgütlenmeden siyasi bir örgütlenmeye geçişi sırasında ciddi jeopolitik sorunlarla karşı karşıya gelebilir.

\section{Kaynakça}

- “28-e Zasedanie Mejgosudarstvennogo Soveta, EvrAzEs( na Urovne Glav Pravitelstv)” 19 Noyabrya 2010 , Moskva, http://www.evrazes.com/mezhgossovet/measure/51 (Erişim Tarihi: 17.05.2013), Ayrıca bkz. "Edinoe Ekonomicheskoe Prostranstvo (EEP). Spravka, RİA Novosti, 1 Ocak 2012, http://ria.ru/spravka/20120101/529308191.html

- “Almazbek Atambayev: Kirgizistan Tverdo Nameren Vstupit v Tamojenniy Soyuz”, 12 Nisan 2013, http://www.fergananews.com/news/20517

- Celac, Sergiu, Manoli, Panagiota, 2006, "Towards a New Model of Comprehensive Regionalism in the Black Sea Area”, Southeast European and Black Sea Studies, Vol. 6, No. 2, s. 193 - 205

- Chossudovsky, Michel, 2008, “The Eurasian Corridor: Pipeline Geopolitics and New Cold War" Global Research, Center for Research on Globalization, www.globalresearch.ca (Erişim Tarihi: 11.05.2013)

- Deklaratsiya o Evraziyskiy Ekonomicheskoy İntegratsii,” Avrasya Ekonomik Birliği Gümrük Birliği resmi sitesi, http://tsouz.ru/MGS/18-11

11/Documents/\%D0\%94\%D0\%B5\%D0\%BA\%D0\%BB\%D0\%B0\%D1\%80\%D0\%B0\%D1\%86\%D0\%B8\% D1\%8F.pdf

- Dragneva, Rilka, Wolczuk, Kataryna, "Russia, The Eurasian Customs Union and the EU: Cooperation, Stagnation or Rivalry?, Chatham House, August 2012

- Ekonomiçeskie İnteresi i Zadaçi Rossii v SNG”, 2010, İnsitut Sovremennogo Razvitiya, Moskova

- Engel, Susan, 2010,“The International Development Institutions and Regionalism: the Case of South-East Asia”, Australian Journal of International Affairs Vol. 64, No. 1, s. 55 - 69

- "Evraziyskiy Ekonomiceskaya Komissiya”, Avrasya Ekonomik Birliği Komisyonu resmi sitesi, http://tsouz.ru/eek/aboutEEK/Pages/default.aspx

- "Evraziyskiy Soyuz - v Razumnih Graniçah", RİA-Novosti, http://ria.ru/analytics/20120614/673087125.html

- “İstoriya Evrazes", http://www.evrazes.com/about/history

- Konseptsiya Povişenia Prodovolistvennoy Bezopastnosti Gosudarstv - Uçastnikov SNG” 2010, Reşenia Soveta Glav Pravitelstva SNG.

- Koraboev, İkboljon, 2010, “Ot Regionalnoy İntegratsyi Tsentralnoy Azii k Evraziyskomu İntegratsyionnomu Prostranstvu? Menyayushaysa Dinamika Postsovetskogo Regionalizma”, Evraziyskaya Ekonomicheskaya Integratsii , No. 3 (8), s. 5 - 30

- Kostenko, Nataliya Novikova, İina, "Vladimir Putin Obyasnil, çem Evraziyskiy Soyuz Perspektivnee ES", Vedomosti Vlasti, 26 Oktyabr 2012, http://www.vedomosti.ru/politics/news/5423271/dazhe_ssha_obgonyaem

- Kuzio, Taras, 2000, "Promoting Geopolitical Pluralism in the CIS: GUAM and Western Foreign Policy", Problems of Post - Communism Vol. 47, No. 3, s. 25 - 35

- Laitin, David, 1998, Identity in Formation: The Russian-Speaking Populations in the Near Abroad, Cornell University Press. 
- Lepingwell, John, 1994, "The Russian Military and Security Policy and "Near Abroad", Global Politics and Strategy, Vol. 36, Issue 3, s. $70-92$.

- "Noviy İntegratsiyonniy Proekt dlya Evrazii - Buduşee, Kotoriy Rojdaetsa Segodnya”, 3 Oktyabr 2011, İzvestiya, http://izvestia.ru/news/502761 (Erişim Tarihi: 11.05.2013).

- “O Tamojennom Soyuze”, http://www.tsouz.ru/ABOUTETS/Pages/default.aspx

- Papava, Vladimer, 2008, “On The Role of The 'Caucasian Tandem' in GUAM”, Central Asia and Caucasus (Special Issue), No. 3 - 4 (51 - 52), s. 47 - 55

- "Podpisan Ukaz o Merah po Realizaçii Vneşnepolitiçeskogo Kursa”, Dokumenti sayta Prezidenta Rossii, 7 May 2012, http://www.kremlin.ru/acts/15256

- Purtaş, Firat, 2008, “Orta Asya’nın Bütünlüğü Sorunsalı ve Orta Asya’da Bölgesel Entegrasyon Girişimleri”, Orta Asya ve Kafkasya'da Güç Politikası, Ed. Turgut Demirtepe, USAK Yayınları: 16 Ankara.

- “Rossiya Podderjit Kirgizistan vo Vstuplenii v Tamojenniy Soyuz”, 25 Nisan 2013, http://www.tks.ru/news/nearby/2013/04/25/0002

- "Shuvalov: Ukraina Ne Mojet Bit Napolavinu v Tamojennom Soyuze”, 29 Mart 2013, RIA Novosti, http://ria.ru/economy/20130329/930027713.html

- $\quad$ Snirelman,Viktor, 2009, "Evrazia ili Evropa? Rol Ukraini v Evraaziyskom i Evrazia v Ukrainskom Diskurse”, Forum Noveysey Vostocnoevropeyskoy İstorii i Kulturi, No.1, 2009, s. 125 - 147

- "Sodrujestvo Nezavisimih Gosudarstv, İstoriçeskaya Spravka”, BDT resmi sitesi http://www.cis.minsk.by (Erişim Tarihi: 11.05.2013)

- “Ukraina Hocet Svobodno Torgovat i s ES, i s Tamojennim Soyuzom, 29 Mart 2013, RİA Novosti, http://ria.ru/economy/20130329/930027713.html

- "Ustav Sodrujestvo Nezavisimih Gosudarstv",

- http://cis.minsk.by/reestr/ru/index.html\#reestr/view/text?doc=187

- Vasechko, Vyecehslav, 2007, "Staroe i Novoe Evraziystva: Kontseptsiya Religii i Politiki”, Vestnik Rostovskogo Gosudarstennogo Eknomiçeskogo Universiteta 'RINX', Vol: 1, s 141 - 146 


\title{
Açık Denizlere Kıyısı Bulunmayan Avrasya Devletlerinin Transit Geçiş Hakkı
}

\section{Transit Passage Rights of Eurasian Countries without Coastal Access to High Seas}

\author{
Asst. Prof. Dr. Abbas Karaağaçlı (Giresun Univesity, Turkey)
}

\begin{abstract}
When the rules of international law, practices and conventions are all studied, it becomes evident that there exist certain rules of international legislation which enable the countries not bordering the high seas to reach the open seas. However, differences in practice arise due to geographical conditions, balance of power and economic development. In order for the countries concerned to reach the open seas and benefit in transit from the territory of the neighboring countries located by the high seas for trade and transportation, it is essential that the two countries should have good relations and that the country bordering the high seas should have good-intention. Because in Eurasian Geography, almost none of the countries in Central Asia and Caucasus do not border the open seas, they are in need of other countries for trade and transport. In this study, the focus is on this issue.
\end{abstract}

\section{Giriş}

Dünya ticaretinin $\% 95$ 'i denizler ve okyanuslar yoluyla gerçekleşmektedir. Yer kürenin 3/4'ü denizler ve okyanuslar kaplamaktadır. Uluslararası ticaretin deniz yoluyla yapılması ve dünya ticaretinin kıtalar arası ulaşımı okyanuslar vasıtasıyla gerçekleşmesinin en önemli nedeni deniz taşımacılığının çok düşük maliyetli olmasından kaynaklanmaktadır. Uluslararası ticaretin deniz taşımacılığıyla gerçekleşmesi açık denizlerde deniz taşımacılığının serbestçe yapılması her zaman kıyısı bulunan ülkelerin ve yine kıyısı bulunmayan devletlerin sorunlar yaşadıkları ve ilgilendikleri bir husus olmuştur. Günümüzde deniz ticaretinin uluslar arası ticaretin gelişmesinde en büyük faktördür. Nitekim Birleşmiş Milletler Ticaret ve Kalkınma Örgütü’ne (UNCTAD) göre: "Açık denizlere kıyısı bulunmayan devletler, gelişmekte olan ülkeler sıralamasında en fakir ülkeler kategorisinde yer almaktadırlar. Karayoluyla açık denizlere ulaşamamaları o ülkeleri dünya pazarlarında inzivaya sürüklemiş ve geliş̧eleri önünde en büyük engeli teşkil etmiştir” (UN. Doc. TD/191, 1976, s.200).

Sovyetler Birliğinin çökmesiyle birlikte Ortaya çıkan yeni durumda Avrasya coğrafyasında yer alan Orta Asya bölgesinde bulunan Kırgızistan, Kazakistan, Tacikistan, Özbekistan, Türkmenistan ve Kafkasya bölgesinde yer alan Ermenistan ve Azerbaycan muhat ülkeler yani açık denizlere kıyısı bulunmayan devletler olarak ortaya çıktılar. Her ne kadar Kazakistan, Türkmenistan ve Azerbaycan Hazar Denizi'ne kıyıdaş olsalar da Hazar Denizi'nin uluslararası denizlerle bağlantısı bulunmaması ve kapalı bir deniz olması sebebiyle söz konusu devletler de muhat (kapalı) devletler konumunda değerlendirilmektedirler.

Orta Asya ve Kafkas devletleri açık denizlerden yararlanma hususunda uluslararası hukuk çerçevesinde bazı haklara sahiptirler. Bağımsızlıklarını kazandıkları 1990'lı yıllardan beri; önceleri dağılan Sovyetler Birliğinin en büyük mirasçısı olan Rusya Federasyonu'nun açık denizlerde bulunan limanlarını kullanırken daha sonraları Avrupa, Amerika ve Asya devletleriyle kurdukları ilişkiler sayesinde dünyaya açılıp açık denizlerin taşımacılık imkânlarından yararlanmayı hedeflemişlerdir. Kazakistan, Azerbaycan ve Türkmenistan zengin doğal kaynaklarını dünya piyasalarına ulaştırmada her türlü firsat ve imkanı değerlendirirken Özbekistan başta pamuk olmak üzere tarımsal ürünlerini dünya piyasalarına ulaştırmakta sorunlar yaşamıştır.

Diğer üç ülke yani Kırgızistan, Tacikistan ve Ermenistan ise uluslararası ticaret açısından çok önemli sanayi veya tarımsal ürün üretemediklerinden dolayı eski Sovyet sisteminin dar ekonomik kalıplarını yıkmakta zorlanmışladır. Her üç ülkenin Rusya Federasyonuyla sıkı ekonomik ilişkilerinin bulunması bu durumun göstergesidir. Elbette Kırgızistan ve Tacikistan'ın Çin Halk Cumhuriyeti ile olan sınır komşuluğu bu iki ülkeye ticari ilişkiler açısından olumlu bir alternatif sunmuştur. Ermenistan ise güneyindeki komşusu İran ile geliştirdiği ekonomik ve ticari münasebetlerle alternatifler yaratmaya çalı̧̧maktadır.

Açık denizlere kıyısı bulunmayan devletlerin hakları konusunda 1958 Cenevre Konvansiyonu ve yine 150 devletin temsilcilerinin 9 yıl çalı̧̧ması sonucunda 1982 yılında ortaya çıkan uluslararası deniz hukuku 3. Birleşmiş Milletler Konvansiyonu'nca ortaya konan çalışmalar çok önem arz etmektedir. Ortaya konan bu konvansiyonlarda açık denizlere kıyısı bulunmayan devletlerin transit hakkı, açık denizlerin tavanından yararlanma, bilimsel ve teknolojik çalışmalara iştirak etmek, açık denizlerde gemi taşımacılığı gibi ekonomik faaliyetler yapmak gibi uygulamaları ön görmektedir.

Orta Asya devletlerinden Kazakistan ve Türkmenistan, Kafkasya'dan ise Azerbaycan zengin ham petrol ve doğalgaz kaynaklarına sahiptirler. Özbekistan ise pamuk ve altın üretiminde söz sahibi olup, Avrasya coğrafyasının önemli ekonomilerinden biri konumundadır. Kazakistan enerji kaynaklarının yanı sıra uranyum, demir çelik ve en önemlisi tahıl üretimiyle coğrafyanın ve hatta dünyanın en önemli üreticilerinden biridir. Diğer 
ülkelere de baktığımızda Avrasya coğrafyasının bu iki bölgesi yer altı ve yer üstü zenginlikleri bakımından büyük önem arz etmelerine rağmen açık denizlere kıyıları bulunmaması bu ülkelerin uluslararası ticaretle entegrasyon sağlamalarında büyük bir dezavantaj ve handikap olarak ortaya çıkmaktadır.

\section{Açık Denizlerde Ulaşım ve Transit Geçişin Önemi}

Sovyetler Birliği döneminde raylı sisteme önem verilmiş, ülkenin dört bir yanı demir ağlarla örülerek kentler, sanayi kuruluşları, limanlar, enerji yatakları ve tarım sahaları birbirlerine bağlanmıştır. O dönemde Orta Asya ve Kafkasya'da ki önemli kentler, sanayi merkezleri Hazar Denizi’nde ki limanlar, petrol ve doğalgaz sahaları birbirlerine bağlanmanın yanı sıra başkent Moskova Saint Petersburg, Karadeniz ve Baltık Denizi'nde ki bütün Limalara bağlanmış durumdaydı. 1990'lar da Sovyetler Birliğinin dağılmasıyla birlikte kurulu bulunan raylı sistem, Sovyetlerin iyi bir ekonomik mirası olarak Orta Asya ve Kafkasya devletlerine intikal etti.

Muazzam bir alt yapıya sahip olan raylı sistemin yanı sıra gelişmiş tren istasyonları, vagon ve lokomotif fabrikaları bağımsızlığını kazanan devletlerde ekonominin hizmetine girerek ham madde ve ürünlerin ulaşımında büyük imkânlar sağladı. Dağlık ve çok engebeli olmaları nedeniyle Tacikistan ve Kırgızistan hariç Kazakistan, Özbekistan, Ermenistan ve Azerbaycan bu imkândan fazlasıyla yararlanmaktadırlar. Tacikistan ve Kırgızistan'ın da önemli ekonomik ve siyasi merkezleri demir ağlarla birbirine bağlanmış durumdadırlar. Hatta Tacikistan'ın hemen hemen en önemli ulaşım ve taşımacılık kanalı demir yolu vasıtasıyla komşu Özbekistan ve Kırgızistan kanalıyla gerçekleşmektedir.

Kara alanlarda sıkışmış devletler ham madde, enerji kaynakları, sanayi ürünleri ve diğer ticari mamullerinin diğer ticari ve tarımsal ürünlerinin ithalat ve ihracatında komşu ülkelerin, kara, demir yolu veya nehirlerinden yararlanmak zorundadırlar. Komşu ülkelerle herhangi bir siyasi kriz veya anlaşmazlık yaşadıklarında bu kanalların kapanması tehlikesiyle karşı karşıya kalınmaktadır. Örneğin karaya sıkışmış Tacikistan enerji ihtiyacını gidermek amacıyla ülkesindeki nehirler üzerine barajlar inşa etmek ve barajların üzerine elektrik santrallerini kurarak enerji ihtiyacını karşılama siyasetini gütmektedir.

Tacikistan'ın Senguvare ve Erguvan Barajlarını inşa etme girişimi barajların yapılacağı nehirlerin suyu azalacağı bahanesiyle pamuk üretiminde söz konusu nehirlerden yararlanan komşu Özbekistan devletini rahatsız etmekte, barajların inşaatı için demir yoluyla İran'da Tacikistan'a sevk edilen inşaat malzemesinin sevkiyatı Özbekistan tarafından sürekli engellenmektedir. Tacikistan'ın açık denizlere kıyısı bulunmamasından dolayı komşu Özbekistan'ın demir yolu ağından yararlanmaya mahkûm bir duruma sokmuştur. Bu durum iki ülke arasında sürekli siyasi krizlere neden olmaktadır. Özellikle farklı alternatifleri bulunmayan devletler bu hususta önemli sıkıntılarla karşı karşıya kalmaktadırlar.

Yine Avrasya coğrafyasının en önemli devletlerinden olan Afganistan'ın açık denizlere kıyısı bulunmamasından dolayı bu ülke açık denizlere ulaşmak için pek çok sorun yaşadığı Pakistan'a muhtaç durumdadır. Afganistan açık denize ulaşmak için 950 kilometrelik demir yolu vasıtasıyla Pakistan'ın Karaçi Limanı'nı ithalat ve ihracat için kullanmaktadır. Yine Nepal ve Bhutan'da açık denizlere ulaşmak için Hindistan'ı kat ederek Hint Okyanusu'na ulaşmak zorundadırlar.

\section{Uluslararası Hukukta Transit Geçiş ve Açık Denizlerde Serbest Geçiş Hakkı}

Uluslararası hukukun en yaygın kaideleri açık denizlerde ki ticaret ve deniz ulaşımıyla ilgili olanlardır. Dünyada ki bütün egemen devletlerin açık denizlerde özgür bir şekilde deniz taşımacılığı, uçuş, petrol boru hattı, kıtalar arası kablolar ve benzer uygulamaları yapmayı gerçekleştirebileceklerini söylemek, günümüz şartlarında doğru bir tespit değildir. Açıç̧ası gelişmiş devletlerin teknolojik imkânları da kullanarak açık denizleri hakimiyet alanları gibi kullanmaları sayesinde açık denizlere kıyısı bulunan devletleri bile kimi zaman sıkıntılarla karşı karşıya getirmekte, kaldı ki açık denizlere kıyısı bulunmayan devletlerin bu haklardan yararlanmaları, kıyısı bulunan devletin rızası ve onayına bağlı bir durumdur. Uluslararası deniz hukuku kurallarına göre kapalı devletlerin açık denizlere ulaşma hakkı söz konusu devletlerin olumsuz coğrafi şartlarından dolayı maruz kaldıkları zararların azaltılması yönünde ön görülen bir hak olarak tecelli etmektedir (Helmut Terkand G. Hafner, 1985, s. 63).

Açık denizlere ulaşma hakkı konusunda ki tezinin savunanları ve karşı çıkanları vardır. Özellikle açık denizlere kıyısı bulunan devletlerin teorilerini savunanlar ülkelerin egemenlik ve hâkimiyet haklarına istinat ederek transit hakkının resmi bir anlaşmayla sağlanması gerektiği tezini ileri sürüyorlar. Bu hususta araştırmaları bulunan Prof. Duvar Zemberger'e göre: "Uluslararası hukuk açık denizlere ulaşmak için hiçbir doğal hak tanımamaktadır. Kapalı devletler uygun bir limandan faydalanmak için komşu devletlerin iyi niyetine bağlıdırlar ve böylece bu hukuku elde etmek için o imkânlardan yararlanmak doğrultusunda anlaşmalar yapılmalıdır" (Robert. K. Redden, 1990, s. 260).

1982 yılında Birleşmiş Milletlerin denizler konvansiyonunun nihai aşamaya geldiği toplantıda kıyıdaş ülkeler kendi toprakları üzerinde gerçekleşen bütün faaliyetleri o cümleden muhat statüsünde ki komşu devletlere tanınan geçiş imtiyazı konusunu kendi ülkeleri açısından bir güvenlik algısı çerçevesinde değerlendirmişlerdir. 
Nitekim bundan önce de 1974 yılında Birleşmiş Milletlerin deniz hukuku konvansiyonunun Karakas'taki 3. Konferansında söz konusu ülkelerin oluşturduğu gurubun düşüncelerini anlatan Kenya devletinin temsilcisi şöyle demiştir: "Hiçbir ülke ikili veya bölgesel anlaşmalar çerçevesi dışında kendi topraklarını transit hakkı için başka bir devlete ihtisas etmek zorunluluğu söz konusu değildir. Bunun dışında ki durumlar gerçekleşir ve transit hakkı kanun olarak konulursa kendi ülkelerinin vatandaşlarının can ve mal güvenliği tehlikeye düşüp, kanun hâkimiyetine helal getirilir (Conf. 62/C. 3/SR. (1974), s. 253).

Kıyıdaş ülkeler transit hakkı karşısında kendilerine karşılık olarak imkânların tanınmasını talep etmektedirler. Onlara göre muhat ülkeler transit hakkı karşılığında kendilerine ticari ve iktisadi haklar sunmalıdırlar. Muhat ülkeler ise transit hakkının doğal bir hakları olduğunu ve serbest geçişin ticaret, ziyaret ve ulaşım için bütün ülkelerin hakkı olduğu tezini savunmaktadırlar. Bu tezi ileri süren Prof. Grosios'a göre: "Başka bir milletin hâkimiyeti altında bulunan topraklar, nehirler ve denizler meşru nedenlerden dolayı buralardan transit geçişe ihtiyaç duyanların kullanımına açık olmalıdır" (Redden, 253).

Uluslararası hukuk örf-adet hukuku kurallarına göre transit geçiş hakkını kullanmanın iki ana şartı söz konusudur.

- Transit geçiş hakkı talebinde bulunan ülke bunun zorunluluk ve gerekliliğini ispat etmelidir.

- Bu hakkın kullanımı sırasında transit geçiş yapılan ülkeye zarar verilmemelidir.

$\mathrm{Bu}$ durumun gerekliliği ispatlansa bile kimi zaman ülkeler arasında ki siyasi krizler transiti imkânsız kılmaktadır. Nitekim 1949-1953 yılları arasında Pakistan topraklarını Afganistan'ın transit geçiş hakkı kullanımı için kapatmıştır. Yine 1970'li yıllarda Hindistan kendi topraklarını Nepal'ın geçiş hakkı için kapatmıştır. Günümüzde ise Ermenistan cumhuriyeti Azerbaycan'la olan sorunlarından dolayı, Azerbaycan'ın kendine bağlı Nahçivan özerk cumhuriyet ile olan transitine kendi topraklarını kullandırmamaktadır. Günümüzde Nahçivan ile ana Azerbaycan toprakları arasında ki geçiş İran toprakları üzerinden gerçekleşmektedir.

Yine dönem dönem ABD'nin insansız savaş uçaklarının Pakistan'ın sivil yerleşim yerlerini hedef alıp, sivil köylüleri katlettiğinde Pakistan hükümeti kamuoyundan gelen tepkiler nedeniyle ABD'ye Afganistan'da ki NATO birliklerine ihtiyaçlarının sevkiyatı için kullanılan transit geçişi kapatmaktadır. Böylece ABD Afganistan'da ki birliklerinin özel ihtiyaçlarını ve özellikle yakıt ihtiyacını karşılamakta zorlanmakta, alternatif olarak Kırgızistan veya Özbekistan'ı kullanmakta, bu sevkiyatta hava yoluyla gerçekleştiğinden dolayı maliyetleri aşırı derecede yükseltmektedir. Genel olarak muhat ülkelerin transit hakkı kullanımlarında 18. yüzyıldan itibaren ekonomik çıkarların söz konusu olduğu görülmektedir. Bununla birlikte: gereklilik ve maslahat serbest transitin 21. yüzyılda en önemli dayanağı olarak öne çıkmaktadır (Martin Glassner, 1970).

Uluslararası deniz hukuku ilk kez Milletler Cemiyeti'nin kuruluş beyannamesinin 23. maddesinin $\mathrm{H}$ bendinde serbest dolaşım ve transit hakkını bütün uluslara tanıyan madde olarak karşımıza çıkmaktadır. Bundan önce Avrupa Devletleri'nin kendi aralarında ikili veya çok taraflı yaptıkları anlaşmalarda bu haklara değinilmiştir. Örneğin 1921 yllında Barcelona'da imzalanan transit hakları, yine 1923 limanlar hakkında ki Cenevre Konvansiyonu, 1921 Paris Konvansiyonu, 1923 Belgrat Konvansiyonu ve 1922 Lozan Anlaşmasın da deniz ve transit haklarına değinilmiştir. 1921 Barselona Konvansiyonu transit hakları konusunda ortaya kesin bir kanı koymaktan uzak durularak, muhat ülkelerin açık denizlerde gemi taşımacılığı haklarına değinmemektedir. 1947 yılında imzalanan Gümrük ve Ticaret Tarifeleri Anlaşması (GATT) da muhat ülkelerin hukuku konusunda sarih bir tanımlama yapmamaktadır.

1947 yılında Küba'nın başkenti Havana'da Dünya Ticaret Örgütü'nü (DTÖ) oluşturmak için toplanan konvansiyon GATT'ın transit haklarından ileriye giderek, ilk kez açık denizlere kıyısı bulunmayan devletlerin haklarını gündeme getirmiştir. 1957 yılında Birleşmiş Milletler Genel Kurulu 11'inci doruk toplantısında deniz hakları konusunda uluslararası bir toplantı düzenlenmesini kararlaştırmıştır. Söz konusu konferans İsviçre'nin Cenevre kentinde toplandı. Toplantı sonucunda yedili Magna Carta (First Conference on the Law of the Sea, ss.78-79) diye adlandırılan haklar ortaya çıtı. Muhat ülkelere tanınan bu haklar;

- Açık denizlere ulaşım hakkı

- Açık denizlerde gemi kullanma hakk1

- Gemilerde bayrak asma hakkı

- Limanların hukuksal konumu

- Serbest transit hakk1

- Transit ülkelerin hakları

- Ticaret, ulaşım ve sigorta konuları

olarak tespit edilmiştir.

Bu çalışmaların ardından 1958 Cenevre Konvansiyonunda 3. maddesinde açık denizlerle ilgili durumlar şöyle tespit edildi;

1. Muhat ülkeler kıyıdaş ülkelerle eşit şartlara sahip olmaları için özgürce açık denizlere ulaşabilmelidirler. Bu doğrultuda açık denizler ile o devletin toprakları arasında bulunan devletlerarasında uluslararası konvansiyonlara göre aşağıdaki imtiyazlar tanınmalıdır: 
- Karşılıklı anlaşmaya göre transit ülkeye serbest geçiş hakkı tanınmalıdır.

- Limanların kullanımında muhat ülke gemilerine eşit muamele yapılmalıdır.

2. Muhat ülkeyle kıyıdaş ülke arasında bulunan 3'üncü devletlerarasında eşitliğe dayanan anlaşmalar yapılarak transit sorunları çözülmelidir.

Görüldüğü gibi bu konferanstan muhat ülkeler nispi bir başarı elde ederek çıkmış ve gelecek toplantılar için konumlarını güçlendirmişlerdir. Ama söz konusu ülkelerin daha işin başında oldukları ve transit haklarını diğer ülkelere kabul ettirmek için çok çaba göstermeleri gerekecektir.

1965 yılında UNCTAD öncülüğünde 23 muhat ülkenin katılımıyla gerçekleşen New York Konvansiyonunda transit hakkı ve sorunları masaya yatırılarak kıyıdaş ülkeler ve 3'üncü ülkelerin konumu ilk kez uluslararası bir toplantının temel esasını oluşturarak dünya gündemine geldi (John. H. Fried, 1965, s. 28-30). Ne var ki 1965 konvansiyonu çok destek görmedi. Ardından çeşitli uluslararası toplantılarda transit hakkı gündeme geldi. 1958 konvansiyonu ve diğerlerinde konu ayrıntılı biçimde değerlendirildi. Transit hakkında karşılıklılık ilkesi sorunları çözmekten uzak bir tez olarak gündemi meşgul etmekteydi. Nitekim 1982 yılında bu madde gündemden çıkartıldı. Hukukçulara göre de:'Bunun için hiçbir hukuki temel dayanak ve gerçekçilik mevcut değildi. Zira fiziki koşullar bakımından da muhat ülkenin transit ülkeye böyle bir karşılık vermesi söz konusu değildir" (Lociuc, C. Caflish, 1978, s. 98).

Açık denizlerde muhat ülkelere tanınan gemi taşımacılığı ve o gemilerde kullanılan bayrak sürekli itilaf konusu olmuştur. 1982 konvansiyonu, 1923 ve 1958 konvansiyonlarından farklıdır. Bu konvansiyonun 131. maddesi açık denizlerde gemi taşımacılığ 1 ve limanların kullanımı konusunda kıyıdaş ülkelerle muhat devletlere eşit haklar tanımaktadır. Bu maddeye göre:” Muhat ülkenin bayrağını taşıyan gemilerle, diğer yabancı gemilere limanlarda eşit muamele yapılmalıdır (United Nations Convention on the Law of the Sea, 1982).

\section{Orta Asya ve Kafkasya Devletlerinin Durumu}

Orta Asya Cumhuriyetleri ve Kafkasya coğrafi olarak uzak ve tarih boyunca genel olarak inzivada yaşamış bölgelerdir. Her ne kadar 8. yüzyıldan itibaren İslamiyet'in bölgeye ulaşması, Çin ve Hindistan ile Avrupa arasında İpek Yolu ve Baharat Yolu'nun gelişmesiyle Orta Asya bölgesi önem kazanmış, ticaretin öne çıkmasıyla gelişme göstermişse de Cengiz Han'ın ortaya çıkmasıyla bu önemini kaybetmiştir. O yıllar da Çin, Hindistan ve İran üzerinden Batı pazarlarına giden ürünler ve karşılıklı olarak Batı'dan gelen mamuller bölgenin ticari ve ekonomik yaşamına canlılık getirmiş, güvenliği sağlanan yollar ve kervansaraylar inşa edilerek, malların transiti kolaylaştırılmıştır.

Sovyetler Birliği döneminde bölge devletlerin komşu devletlerle irtibatı Moskova üzerinden gerçekleştiğinden dolayı söz konusu ülkeler kapalı bir konumdaydılar. 1990'lar da Sovyetler Birliği'nin dağılmasıyla birlikte bu ülkeler farklı aşamalarda serbest piyasa ekonomisine geçip, komşu ve diğer ülkelerle iktisadi, ticari ve siyasi ilişkiler kurarak uluslararası sisteme entegre olmayı hedeflediler. Komşu ülkelerle ilişkilerini geliştirirken egemen bir devlet olarak birbirleriyle de karşılıklı münasebetler kurmaya başladılar. Esasen Sovyetler Birliği'nden tevarüs eden deniz, kara ve demiryolu ulaşım ortaklığg sayesinde ve özellikle demiryolu ağlarının gelişmişlik ve genişliği açısından halen en önemli ulaşım ve taşımacılık unsuru olarak öne çıkmaktadır.

Eskiden Sovyet demiryolu ağının bir parçası olan Orta Asya ve Kafkasya'daki demir yolu idareleri günümüzde hükümetlere bağlı temel bir ulaşım ve ekonomik araç olarak görev ifa etmektedir. Örneğin; Özbekistan demiryolları günümüzde başbakan yardımcısına bağlı devlet idaresinde bir kurum olarak Özbekistan ekonomisinde önemli bir paya sahiptir. Toplam $6600 \mathrm{~km}$ uzunluğunda ki demiryolu ağının 3500 kilometresi genel, diğer kısmı ise yalnızca sanayi taşımacılığında kullanılmaktadır (Uzbekistan, Institute for Political and International Studies (IPIS), 2009, Tahran, ss. 96-97). Bu ülkenin karayolu uzunluğu ise 115000 kilometredir. Kırgızistan'da ise güneydeki Oş ve Celal Abat'ı başkent Bişkek'e ise Özbekistan'ın başkenti Taşkent'e bağlayan bir demiryolu mevcuttur. Ülkenin dağlık olmasından dolayı taşımacılı̆̆ın \%95'i kamyonlarla gerçekleştirilmektedir. Karayollarının uzunluğu $40000 \mathrm{~km}$ civarındadır (Kyrgyztan, Institute for Political and International Studies (IPIS), 2008 Tahran, s. 122).

Türkmenistan'ın en önemli ulaşım ve taşımacılık aracı demiryollarıdır. Bu ülkenin demiryolu uzunluğu 2440 kilometredir. Karayolları ise $19400 \mathrm{~km}$ civarındadır. (Turkmenistan, Institute for Political and International Studies (IPIS), 2009 Tahran, ss. 68-69). Kazakistan ise $2.724 .900 \mathrm{~km}^{2}$ ile Orta Asya ve Kafkasya ülkelerinin toplamından daha da büyük bir ülkedir. Bu ülke gelişmiş, çift şeritli demiryolu ağıyla örülmüş durumdadır. Demiryolu ağ $15.082 \mathrm{~km}$, karayolu ise $93000 \mathrm{~km}$ civarındadır. Kazakistan'da demiryolları sürekli yenilenerek günümüz teknolojik imkânların kullanımıyla ülkenin en önemli ulaşım ve taşımacılık vasıtasıdır (Kazakistan, Institute for Politicaland International Studies (IPIS), 2007 Tahran, s. 136). Tacikistan, Orta Asya'nın en küçük ve dağlık bir ülkesi olarak, $1500 \mathrm{~km}$ civarında demiryolu, $30000 \mathrm{~km}$ civarında ise karayoluna sahiptir. (Tacikistan, Institute for Political and International Studies (IPIS), 2010, Tahran, s. 59). Kafkasya Bölgesi çok dağlı ve engebeli olduğundan dolayı demir yolu ağları Orta Asya gibi gelişmiş değildir. Ermenistan 
Cumhuriyetinde $900 \mathrm{~km}$ civarında demiryolu, $12000 \mathrm{~km}$ civarında da karayolu mevcuttur (Central Asian, 2005 Tahran, s. 216). Azerbaycan'ın ise karayolu ağı 25000 km civarında, demiryolu ağı ise 2120 km civarındadır.

Bağımsızlığını kazanan yeni devletler ekonomik gelişmişlik durumları, gelirleri, sosyal ve siyasal durumlarına göre her sahada olduğu gibi ulaşım yollarının gelişmesine önem verdiler. Örneğin, Özbekistan başkent Taşkent’i doğudaki Andijan, Nemengan ve Fergana illerine bağlayan Hokant'tan geçen yüksek dağlardan dolayı daha önceleri tırların ve otobüslerin geçişine elverişli olmayan Taşkent-Andijan karayolunu önemli bir kaynak harcayarak çift şeritli otobana dönüştürerek Fergana Vadisi'nde üretilen pamuğun başkente taşımasını sağladı. Kazakistan demiryolu ağlarını yenilerken ülkeyi baştanbaşa, doğudan batıya, güneyden kuzeye bağlayan bütün karayolları uluslararası standartlara uygun hale getirdi.

Özellikle eski başkent Almatı'yı, kuzeydeki yeni başkent Astana'ya bağlayan otoban genişliği ve kalitesiyle dikkat çekmektedir. Ayrıca ülkenin en batısını doğudaki Çin sınırında Alataşanko'ya bağlayan demiryolu enerji naklinde büyük önem arz etmektedir (Eastern Europe and the Commonwealth of Independent States, 1994). Kırgızistan kısıtlı imkânlarına rağmen başkent Bişkek'i güneydeki Oş’a bağlayan, yüksek Tanrı Dağları'ndan geçen karayolunu ve tünellerini restore ederek, ülkenin bütünlüğüne önemli katkı sağlayacak karayolunu hizmete sokmuştur.

Üstelik daha önceleri Özbekistan üzerinden gerçekleşen Oş ve Celal Abat kentlerini de Özgen yoluyla birbirlerine bağladı. Türkmenistan Çarju, Merv (Marı) ve başkent Aşkabat'ı birbirlerine ve Hazar kıyısındaki Türkmen başı limanına bağlayan yolları restore ederek ekonomiye kazandırdı. Tacikistan'da ise halen başkent Duşanbe'yi doğuda ki Bedaxşan dağlık özerk cumhuriyeti merkezi Murğab'a bağlayan, yine bu iki merkezi Hocent'e (Lenin Abat) bağlayan karayollarını restore ederek ülkenin birliğine önemli katkı sağlamıştır. Sovyetler Birliği döneminden tevarüs eden gelişmiş demir yolu ağının Avrupa ve Asya'daki demir yolu ağları ile entegrasyonunun önünde önemli bir engel söz konusudur. Zira Sovyetler Birliği muhtemel bir dünya savaş1 sırasında düşman vagonlarının ülkesindeki demir yolu ağını kullanmasını engellemek doğrultusunda demir yolu raylarının uluslararası standarttan $30 \mathrm{~cm}$ civarında geniş tutarak vagonlarını da geniş yapmıştır. Böylece Sovyetler dışından gelen herhangi bir lokomotifin demir yolu raylarını kullanmasını imkânsız hale getirmiştir.

\section{Sonuç Yerine}

Orta Asya ve Kafkas ülkelerinin çok gelişmiş demiryolu ve karayolu şebekelerine sahip olmalarına rağmen ithalat ve ihracatlarını gerçekleştirmek için 2. veya 3. bir ülkeye ihtiyaç duymaktadırlar. Açık denizlere ulaşmak için önlerinde çeşitli alternatifler söz konusudur. Bu seçenekler:

- $\quad$ Rusya Federasyonu üzerinden Karadeniz ve Baltık Denizi alternatifi

- Gürcistan üzerinden Türkiye ve Karadeniz alternatifi

- İran üzerinden Fars Körfezi ve Umman Denizi alternatifi

- Afganistan ve Pakistan üzerinden Hint Okyanusu alternatifi

- Çin Halk Cumhuriyeti üzerinden Çin denizi ve Büyük Okyanus alternatifi

Rusya alternatifine baktığımızda Orta Asya devletlerinin Rusya'nın doğu limanlarına 10.000 km, Doğu Avrupa limanlarına $8.000 \mathrm{~km}$ ve Karadeniz limanlarına $6.000 \mathrm{~km}$ uzaklık mesafesi bulunmasından dolayı çok ağır maliyetin yanı sıra zaman kaybı da söz konusudur. Bu alternatif eskiden kullanılmakta olup, halen dönem dönem kullanılmasına rağmen ekonomik bir alternatif değildir. Üstelik Rusya Federasyonu'nda hâkim olan yoğun bürokratik işlemler, rüşvet ve işlerin ağırdan yürümesi olumsuzluğu artırmaktadır. Kafkas ülkelerinde ise bu alternatif açısından ise mesafenin kısalığı olumlu bir etken iken Kuzey Kafkasya, özellikle Çeçenistan ve Dağıstan'da ki güvenlik ve istikrar sorunu alternatifi çok olumsuz yönde etkilemektedir.

Gürcistan üzerinden Türkiye alternatifi ve buradan Karadeniz yoluyla açık denizlere ulaşmak, Kafkas ülkeleri yani Ermenistan ve Azerbaycan için en ekonomik ve rasyonel alternatif olarak ortada durmaktadır. Nitekim halen Azerbaycan petrolleri Bakü-Tiflis-Ceyhan boru hattı vasıtasıyla dünya pazarlarına ulaşmaktadır. Öte yandan Tanap projesi çerçevesinde Azerbaycan'ın doğalgazını Avrupa'ya ulaştıracak boru hattı da başarılı bir ekonomik proje olarak hayata geçirildiğinde önemli ekonomik katkılar sağlayacaktır.

Kars-Tiflis-Bakü tren demiryolu hattı da Azerbaycan'ı ülkemize bağlayacak, üstelik demiryolu taşımacılığında önemli bir alternatif olarak ortaya çıkacaktır. Ermenistan'la yaşadığımız siyasal sorunlardan dolayı bu ülkeyi çok kısa yoldan Karadeniz'de ki Trabzon'a veya Akdeniz limanlarına bağlayacak alternatifler ortada durmaktadır. Orta Asya devletlerinin Karadeniz ve Akdeniz'e ulaşmaları Hazar Denizi'ni geçme durumuyla ilgilidir. Kazakistan ve Türkmenistan bu alternatifi değerlendirmektedirler.

Orta Asya ve Kafkas ülkelerinin açık denizlere ulaşmalarında bir alternatifte İran üzerinden Fars Körfezi veya Umman Denizi'ne inmektir. İran demiryolu ağları Meşet-Aşkabat güzergahı üzerinden Orta Asya'ya bağlanmış durumundadır. İran'ın Fars Körfezi'nde ki Bender Abbas ve Bender Buşehr gibi limanları demiryolu ve karayoluyla Hazar Denizi'ne bağlanmış durumdadır. Orta Asya ve Kafkas Devletleri bu alternatifi kullanarak açık denizlere ulaşabilirler. Bu alternatif en ekonomik seçenek olmasına rağmen günümüzde İran, başta ABD olmak üzere Batı'yla yaşadığı sorunlardan dolayı Batı'nın hedef tahtasında olup, ambargolara ve yaptırımlara 
matuf kaldığından dolayı bu alternatifin kullanımında sıkıntılar yaşanmaktadır. Öyle ki Türkmenistan sınırda İran'a ham petrol veya doğalgaz teslim edip, güneyde ki limanlarından Türkmenistan adına aynı miktarda doğalgaz veya ham petrol sevkiyatı yapması ABD tarafindan engellenmektedir.

Bir alternatifte Afganistan ve Pakistan üzerinden Hint Okyanusu'na ulaşmaktır. Normal şartlarda bu alternatif ekonomik ve rasyonel bir seçenektir. Bugünkü şartlarda Afganistan'da yaşanan kargaşa, Afganistan-Pakistan sınırında Peştun'ların yaşadığı bölgede Taliban ve El Kaide gibi terör örgütlerin hâkimiyet alanları oluşturmaları önemli bir güvenlik ve istikrar sorunu olarak karşımıza çıkmaktadır. Böylece bu güzergâhın kullanımını zora sokmaktadır.

Çin üzerinden açık denizlere ulaşma alternatifi ise mesafenin uzunluğu ve coğrafi şartlardan dolayı rasyonel bir alternatif değildir. Yalnız son zamanlarda Çin Halk Cumhuriyeti ile Orta Asya devletleri özellikle Tacikistan önemli kara ve demir yolu inşaatı anlaşmaları imzalamaları gelecekte bu seçeneğe geçerlilik kazandıracak gelişmelerdir. Üstelik Orta Asya devletleri ile Çin Halk Cumhuriyetinin Şanghay örgütündeki işbirliği olasılıkları günden güne artarak devam etmektedir.

Avrasya coğrafyasının en önemli bölgelerinden ikisini oluşturan Orta Asya ve Kafkasya'daki muhat ülkeler yani Kazakistan, Kırgızistan, Özbekistan, Türkmenistan, Tacikistan, Azerbaycan ve Ermenistan'ın durumuna baktığımızda açık denizlerde deniz taşımacılığı yapmak gemilerinde bayrak bulundurmak ve diğer ülkelerin limanlarından yararlanmak alternatifleri şimdilik uzak bir alternatif olarak gözükmektedir. Halen bu ülkeler ithalat ve ihracatlarını uluslar arası deniz taşımacılığı yapan dev şirketler vasıtasıyla gerçekleştirmektedirler. Ama gelişen ekonomileri ve büyüyen pazarları mutlaka önümüzdeki dönemlerde bu ihtiyacı hissettirecek ve bu hususta yeni arayışlar bulmaya sevk edecektir. Bu günden bunun alt yapısı yasal mevzuatı ve fizibilitesini yapmak zorundadırlar.

\section{Kaynakça}

- $\quad$ A/Conf. 62/C. 3/SR. (1974), s.253

- Cordesman, Anthony, The Military Balance in the Persian Gulf and Middle East, Center for Defence Studies and Researches, Tahran, 2003.

- Directory of Caspian Region \& Central Asian \& Southern Caucasus Countries, Ebrar Yayınları, 2005, Tahran, s. 216.

- Eastern Europe and the Commonwealth of Independent States, 1994, London, Europa Publications Limited, 1994.

- Ebrahimi-far, Tahereh, The Patterns of Confidence Building Measures in the Persian Gulf, The Institute for POlitical and International Studies, Tahran, 2002.

- $\quad$ First Conference on the Law of the Sea, UN. Offical Records, Vol.VII, ss. 78-79.

- Helmut Tuerkand G. Hafner, "The Land-Lockend Countries and the UN. Convention on the Law of the Sea”, in Essays on the New Law of the Sea, ed by Budislav Vukas, Zagreb, 1985, s. 63.

- John. H. Fried, “The 1965 Convention on Transit Trade of Land-Locked States”, Indian Journal of International Law, Vol. 6, 1966, ss. 28-30.

- Kyrgyztan, Institute for Political and International Studies (IPIS), 2008, Tahran, s. 122.

- Kazakistan, Institute for Politicaland International Studies(IPIS), 2007, Tahran, s. 136.

- Lociuc, C. Caflish, "Land-Lockend States and Their Access to and from Sea”, British Yearbook of Intetrnational Law, Vol. 49, 1978, s. 98.

- Martin Glassner, Access to the Sea For Developing Land-Locked States, the Hague: Martinus Nijhof, 1970.

- Robert. K. Redden, "Land-Locked States”, in Modern Legal Systems Cyclopedia, New York, Williams, Hein Co., Vol. 5A, 1990, s. 260.

- Tacikistan, Institute for Political and International Studies (IPIS), 2010, Tahran, s. 59.

- Turkmenistan, Institute for Political and International Studies (IPIS), 2009, Tahran, s. 68-69.

- UN. Doc. TD/191 (6 Ocak 1976), s. 200.

- United Nations Convention on the Law of the Sea, New York, United Nations, 1983.

- Uzbekistan, Institute for Political and International Studies (IPIS), 2009, Tahran, s. 96-97.

- http://www.azerbaijans.com/content_471_tr.html

- http://www.azerbaijans.com/content_472_tr.html 


\title{
Türkiye'nin Yeni Jeopolitiğinin Çevresi The New Geopolitical Environment of Turkey
}

\author{
Asst. Prof. Dr. Hakkı Çiftçi (Çukurova University, Turkey) \\ Dr. Murat Koç (Gaziosmanpaşa University, Turkey)
}

\begin{abstract}
The World Political Atlas has been reorganized, the direction of this reorganization is determined by shared sovereignty reflexes, and is applied through strategic decisions. Metropolitan and hinterland borders form the backbone of the newly formed world political atlas Various western- (or the US) origin approaches such as "Neo Liberal Colonialism", The Clashes of Civilizations", "The End of History", and Eurasian Sovereignty", introduced as the application components of the framework of sovereignty, attract particular attention as the primary sources of the newly formed political atlas. Within the embracing scope of the concept of globalization, "The new World Order" formed through a new political atmosphere with such concepts and claims as "postmodernism", neo-liberalism", "the end of history", and "the cashes of civilizations" can neither maintain its validity nor is wholly embracing in its attempt to perceive the political future of the world. Instead of establishing a comprehensive reconciliatory platform, all of these concepts and claims reflect enormous controversy due to their characteristics leading to constant arguments and, therefore, result in new conflicts, new political actors, new relations of power, and new searches for sovereignty. New "geopolitical gaps" constitute the focus of sovereignty and power relations of the new process.
\end{abstract}

\section{Giriş}

Dünya Siyasal Atlası yeniden oluşturulmakta, bu oluşumun temel yönelimi, paylaşım egemenlik refleksleriyle belirlenmekte, stratejik belirlemelerle uygulanmaktadır. Bu durum yeni jeopolitik yönelişleri belirlemektedir. Metropol ve hinterland sınırları yeni oluşturulmaya çalışılan dünya siyasal atlasının omurgasını oluşturmaktadır (Hacısalihoğlu, İ.Yaşar, 2005). Batı eksenli (veya ABD) egemenlik şemasının uygulama araçları olarak sunulan "Yeni Liberal Sömürgecilik" (Manisalı, 2005) , "Medeniyetler Çatışması" , "Tarihin Sonu" ve "Avrasya Egemenliği”" gibi yaklaşımlar oluşturulmaya çalışılan yeni siyasal atlasın besleyici kaynakları olarak dikkati çekmektedir. Yeni bir siyasal atmosferle şekillenen "Yeni Dünya Düzeni” küreselleşme kavramının kucaklayıcı yörüngesi içinde, (Giddens, 1996) "postmodernizm", "neoliberalizm”, "tarihin sonu”, "uygarlıklar çatışması" gibi birçok kavram ve savlarla, dünyanın siyasal geleceğini algılamak adına, ya geçerliliklerini koruyamamaktadır ya da bütünüyle kucaklayıcı değildir. Tüm bu kavram ve savlar, geniş bir uzlaşma zemini yaratmak bir yana, sürekli tartışma üreten özellikleriyle derin bir çelişki yumağını yansıtmakta, yeni çekişmeleri, yeni siyasal aktörleri, yeni güç ilişkileri ve yeni egemenlik arayışlarını beraberinde getirmektedir. Yeni "Jeopolitik boşluklar" yeni sürecin egemenlik ve güç ilişkilerinin odağı durumuna gelmektedir (Hacısalihoğlu, 2005a).

Bugünkü dünyada 2000 yılından itibaren bir jeopolitik değişme yaşanmaktadır. Yani tek odaklı güçten çok odaklı güce doğru bir değişme seyri içerisine girilmiştir. ABD'den ayrı olarak, Rusya, Çin, AB bir ölçüde Hindistan, Japonya gibi evrensel değerde güçler oluşmaya başlamıştır (Wolferen, 1992). Onun dışında Türkiye, İran, Endonezya, Brezilya gibi bölgesel güçler teşekkül etmeye başlamıştır (Onay, 2005a). Bu, yeni jeopolitik ortamın iki hali oluşmasına sebep olmuştur. Birincisi, ABD tek gücün egemenliği politikasını sürdürmeye çalışması ve ikincisi diğer güçlerin çok odaklı güç oluşmasına çalışması (Hacısalihoğlu, 2005b). "Tüm bu gelişmelerin çok uzağında olmayan kendisi de son derece dinamik olan bir yapının yine son derece dinamik olan çevrenin içindeki konumunu anlama çabası içerisinde bulunan (Davutoğlu, 2003). Türkiye üç kıtanın birleşme noktası üzerinde bulunmaktadır; doğuyu batıya, batıyı doğuya, kuzeyi güneye, güneyi kuzey açıp kapamaktadır. Üç kıtanın menteşesi durumundadır. Üç kıtaya vurulan kilit ve aynı kilidi açan anahtar değerindedir. BalkanlarOrtadoğu ve Kafkaslar'ın bileşkesi üzerindedir. Dünya adasının iki iç denizine (Akdeniz, Karadeniz) kıyıları bulunmaktadır ve bu iki denizi bağlayan Boğazlara sahiptir. Türkiye Cumhuriyeti çok değerli bir arsa üzerinde kurulmuştur. Kafkaslardan, Karadeniz'e Orta Asya’ya, Balkanlar'dan Akdeniz'e ve Orta Doğu'ya uzanan coğrafi yapı, Soğuk Savaş sonrasının; güçler çekişmesinin ve sınanmasının, Soğuk Savaş kurumları ve davranışlarının meşrulaştırma çabalarının ve küresel-bölgesel güç konumlarının uygulama alanları olarak

\section{Jeopolitiğin Kimliğine Dönük Durum Tespiti}

Jeopolitik politikaya veri hazırlayan, kuramsal tabanı olan birer planlama çalışmasıdır. Jeopolitik, politik düzeyde veri üretmek için coğrafi ve beşeri (ekonomik, sosyal, politik, askeri, kültürel) değerleri kullanır. Jeopolitik, siyasi coğrafyanın beşeri değerlerle aktif hale gelmesidir. Politikanın iki dayanağı olan güç ve hedefi coğrafi açıdan inceler. En başta siyasi coğrafya olmak üzere, coğrafyanın bütün türleri jeopolitik üzerinde söz sahibidir (Brzezınski, 2005). İskender, Anibal, Sezar, Cengiz, Attila gibi kıtalararası uzun seferler yapan liderler 
harekete geçmeden önce hedef ülkelerin ve aradaki coğrafi bölgelerin özelliklerini, hareket istikametlerini tespit ederek yola çıkmışlardır.Coğrafi muhiti politikada kullanma sanatı olan Jeopolitik 20.yy başlarında kavram olarak bu dönemde anlam kazanmaya başlamış ve özellikle iki dünya harbi arasında geliştirilmiştir. Dünya hakimiyeti peşinde koşan veya güçlü kalma uğraşı veren ülkeleri, ortaya attıkları teorilerle etkileyen büyük jeopolitikçiler çoğunlukla bu dönemde yaşamışlardır. Jeopolitiğin Düşünürleri: 19 yy sonları ile 20 yüzyılın başlarında Friedrich Ratzel(1844-1904), Alfred Mahan(1840-1914), Rudolf Kjellen(1864-1922), Nicholas j. Spykman(1893-1943), Karl Hausfer(1869-1946), Halford Mackinder(1861-1947) gibi düşünürler jeopolitiğe doğrudan ya da dolaylı katkıları olmuştur (Aktaran İlhan, 2012).

\begin{tabular}{|c|c|}
\hline Herodot & (M.Ö. 485-425), devlet ile o devletin üzerinde yaşadığı arazinin ilişkilerini incelemişlerdir. \\
\hline Eflatun & (M.Ö. 427-347)devlet ile o devletin üzerinde yaşadığı arazinin ilişkilerini incelemişlerdir. \\
\hline Aristo & $\begin{array}{l}\text { (M.Ö. 384-322),içinde yaşadığı Atina şehrinin özelliklerinden cesaret alarak bir ülkenin } \\
\text { büyüyüp gelişmesi için, muhtemel dış saldırılardan tepeler ve dağlarla korunmuş olması ve } \\
\text { denizaşırı ticaretten azami istifade için iyi bir limana yakın bulunması gerektiğini ileri sürmekte }\end{array}$ \\
\hline Strabo & $\begin{array}{l}\text { (M.Ö.63-M.S.24), devletlerin kültürel ve politik faaliyetleri ile üzerinde yaşadıkları araziler } \\
\text { arasındaki ilişkileri belirtmeye çalışmışır.Bu noktadan hareketle mükemmel coğrafi mevkii, } \\
\text { iklimi ve kaynakları dikkate alındığında, İtalya'nın böyle güçlü bir devlet olabileceğini ileri } \\
\text { sürmüştü }\end{array}$ \\
\hline Jul Sezar & $\begin{array}{l}\text { (M.Ö.100-44), coğrafi unsurların ülke fetihlerine olan etkilerini çok iyi incelediği bilinmektedir } \\
\text { ve yaptığı muharebeleri kazanmasının en önemli sebeplerinden birisinin de coğrafyaya değer } \\
\text { vermesidir denilebilir. "Galya Savaşları" isimli kitabında, coğrafya ile siyaset ve strateji } \\
\text { arasında önemli ilişkiler bulunduğunu öne sürmüştür. }\end{array}$ \\
\hline İbni Haldun & $\begin{array}{l}\text { (1332-1406), coğrafya konusundaki büyük katkısı fiziki coğrafya ile tarihin ilişkisine yönelmiş } \\
\text { olmasıdır. İbni Haldun sayesinde fiziki, sosyal ve ekonomik coğrafya, sosyoloji, ekonomi ve } \\
\text { siyasi tarihle birleşerek “Jeopolitik" adı verilen ve senteze dayanan yeni bir bilim dalı ortaya } \\
\text { çıkmıştır }\end{array}$ \\
\hline $\begin{array}{l}\text { Kardinal } \\
\text { Richelieu }\end{array}$ & (1585-1642), Tabii Sinırlar Tezi \\
\hline Friedrich List & Hayat Sahası Tezi ile, politika ile coğrafyayı birbirine bağlayan anlayışı sergilemiştir. \\
\hline Monteskiyö & $\begin{array}{l}\text { (1689-1775), Monteskiyö, herhangi bir coğrafi alanın iklimine önem vermiş ve bu yerlerde } \\
\text { oturan insanların karakterlerini oturdukları yerin iklimi ile mütalaa etmiştir. }\end{array}$ \\
\hline Emanuel Kant & $\begin{array}{l}\text { (1724-1804),Siyasi coğrafyanın ayrı bir bilim dalı olduğunu ilk olarak ortaya atan “siyasi } \\
\text { coğrafyanın babası” ünvanını bu husustaki görüşleriyle kazanmıştır. Hatta Kant, modern } \\
\text { coğrafyanın kurucusu olarak tanınır. }\end{array}$ \\
\hline Ratzel & $\begin{array}{l}\text { (1844-1904), Çağdaş jeopolitiğin başlangıcı olarak Alman Coğrafyacı ve antropolog Friedrich } \\
\text { Ratzel’e göre siyasi coğrafya mükemmel haritalar yapmakta ve ülkeleri tanımak için yeni } \\
\text { bilgiler getirmekte, havanın, nüfusun, iklimin etkilerini yeterli bir şekilde açılamakta ise de, } \\
\text { siyasi ilimler üzerinde tatmin edici bir duruma ulaşamadığından cansız ve sade kalmaktadır. O } \\
\text { halde coğrafya, siyasi ilimleri de yine kendi sahasında işleyerek ancak Siyasi Coğrafyayı statik } \\
\text { olmaktan kurtaracak ve ona bir hayat ve canlılık kazandıracaktır. Teorisini önce coğrafyanın } \\
\text { politikaya sunduğu iki temel unsura dayandırıyordu. Genişlik, fiziki özellikler, iklim vb. ile } \\
\text { tayin edilmiş "mekan-raum”; mekânın yeryüzündeki vaziyetini tayin eden ve münasebetlerinin } \\
\text { bir kısmını yöneten “konum”. Ratzel, devletin coğrafi ve politik yapıllarını biyolojik } \\
\text { organizmalara benzeten fikirleriyle kendisinden sonra "Hayat Alanı - Rebensraum” adıyla } \\
\text { gelişecek Alman Jeopolitik Ekolü’nün temellerini atmıştır.Ratzel, devletler arasındaki sınırlara } \\
\text { geçici işaretler gözüyle bakıyordu. Sonunda dünya hakimiyeti için muazzam bir mücadeleye } \\
\text { girecek olan bir kaç güçlü devletin ortaya çıkmasına sebep olacak şekilde, küçük politik } \\
\text { bölgeler, daha büyükleri tarafından eritilecektir (Mütercimler,1997) }\end{array}$ \\
\hline $\begin{array}{l}\text { Rudolf } \\
\text { Kjellen }\end{array}$ & $\begin{array}{l}\text { (1864-1922)1916 yılında yazdı̆̆ "Bir Hayat Şekli Olarak Devlet" adlı eserinde, yaşayan bir } \\
\text { organizmaya benzettiği devletin beş aktif unsurunu "Sosyopolitik, Ekonopolitik, Kratopolitik, } \\
\text { Demopolitik ve Geopolitik" olarak adlandırmış ve böylece JEOPOLİTiK terimi doğmuştur. İlk } \\
\text { defa "Jeopolitik" adı altında devleti bir şahısa benzeterek, her ikisinin de organlarını } \\
\text { kıyaslamak suretiyle devletlere davranışlarında, insanlara benzer davranışlar vererek bir doktrin } \\
\text { vazetmiştir. }\end{array}$ \\
\hline $\begin{array}{l}\text { Karl } \\
\text { Hushoffer }\end{array}$ & $\begin{array}{l}\text { Ratzel ve Kjellen'den daha ileri giderek yabancı referanslarla tezini kuvvetlendirme hünerini } \\
\text { gösterdi. Mackinder'in “Kalpgâh"ını biraz daha batıya oynatarak onun fikirlerini Almanlar için } \\
\text { kullandı. }\end{array}$ \\
\hline
\end{tabular}




\begin{tabular}{|c|c|}
\hline $\begin{array}{l}\text { Fransiz Vidal } \\
\text { de Blanche }\end{array}$ & $\begin{array}{l}\text { Alman Jeopolitik Ekolü’nün aksine, olayların sadece müşahade ve sınıflandırılmasında } \\
\text { kalmayarak daima coğrafi olayların izahını aramıştır. Devleti bir canlı organizma değil, } \\
\text { "Kültürel ve Ulusal Bir Varlık” olarak kabul eder. Politikaya insan unsurunun hakim olduğu } \\
\text { görüşündedir, bu nedenle coğrafi determinizme karşıdır. Coğrafi olaylar bir akışkanlığa sahip } \\
\text { olup değişirler. Bu Vidal'in getirdiği önemli bir kavramdır. }\end{array}$ \\
\hline $\begin{array}{l}\text { Sir Halford } \\
\text { Mackinder } \\
\text { (Mackinder, } \\
\text { 1996) }\end{array}$ & $\begin{array}{l}\text { (1861-1947), Mackinder, dünya coğrafyasına politik ve özellikle dünya hakimiyeti açısından } \\
\text { değerlendirme çalışmasına girmiş ve bu çalışmaları ile "Kara Hakimiyet Teorisi”ni } \\
\text { geliştirmiştir. } \\
\text { Mackinder'in coğrafyayı devlet idaresi için bir yardımcı olarak kullanmayı ileri sürmesine } \\
\text { karşılık, Kjellen Coğrafyaya dayalı bir devlet idaresi sistemi formüle etmiştir. Mackinder, } \\
\text { yeryüzünde bir tek büyük kara parçasının olduğunu kabul eder. "Dünya Adası-World Island" } \\
\text { adını verdiği Avrupa-Asya-Afrika kıtalarıdır. Rusya'nın bulunduğu orta bölge "Heartland- } \\
\text { Kalpgah”tır.Mackinder, üç aşamada hudutlarını geliştirdiği Heartland ile meşhur formülünü } \\
\text { ifade eder.“Doğu Avrupa'yı elinde tutan Heartland'e egemen olur, Heartland'i elinde tutan } \\
\text { Dünya Adasına egemen olur, dünyanın bu adasını elinde tutan dünyaya egemen olur."Böyle bir } \\
\text { kara parçasına sahip tek devlet Rusya'dır ve dünya hegemonyasını elde etmesine mani olunmak } \\
\text { isteniyorsa onun açık denizlere çıkmasına müsaade edilmemelidir (Sempa, 2005) }\end{array}$ \\
\hline $\begin{array}{l}\text { Alfred Thayer } \\
\text { Mahan }\end{array}$ & $\begin{array}{l}\text { (1841-1914)1890’da yayımlanan “Deniz Kuvvetlerinin Tarihe Etkisi” adlı eseriyle "Deniz } \\
\text { Hakimiyet Teorisi”nin esaslarını ortaya koymuştur. 19. Yüzyılda endüstri devrimi sonucu bir } \\
\text { yandan yeni keşifler yapılmış, diğer yandan ekonomik ilişkiler büyümüştür. Ham madde arayışı } \\
\text { ve yeni ürünlerin pazarlanması ihtiyacı, deniz yollarının önemini artırmış, gelişen teknoloji ile } \\
\text { mesafeler kısalmıştır. Tarihi ipek yolu önemini kaybederken, Mahan’ın "Denizlere hakim olan } \\
\text { dünyaya hakim olur” tezi tesadüfen ortaya çıkmamıştır. }\end{array}$ \\
\hline $\begin{array}{l}\text { Nicolas } \\
\text { Spykman }\end{array}$ & $\begin{array}{l}\text { (1893-1943), Spykman, 1944'de yayımlanan “Sulhün Coğrafyası” adlı iki önemli eseriyle } \\
\text { jeopolitiği Amerikan milli güvenlik politika ve stratejisinin dayanacağı coğrafi esasları ve } \\
\text { yaptığı dünya coğrafyası değerlendirmesi ile de “Kenar Kuşak Teorisi - Rimland”i ortaya } \\
\text { koymuştur. Spykman bu teori ile aslında Mackinder'in Kara Hakimiyet Teorisine cevap } \\
\text { vermekte ve Sovyetleri Asya’nın merkezi bölgesinde tutacak ve denizlere çıkşını çok büyük } \\
\text { ölçüde engelliyecek politika ve stratejileri ön plana çıkarmaktadır.ABD’nin güvenlik } \\
\text { stratejisinin oluşumunda benimsediği Kenar Kuşak ve Deniz Hakimiyet Teorileri günümüze } \\
\text { kadar aktüelliğini devam ettirmişlerdir. }\end{array}$ \\
\hline $\begin{array}{l}\text { Pascal } \\
\text { Boniface, }\end{array}$ & $\begin{array}{l}\text { Jeopolitik, uluslararası ilişkilerde tarafların genel yaklaşımlarını ortaya koyan, ilgili aktörlerin } \\
\text { satranç hamlelerini analiz etmeye yarayan bir sistem yaklaşımı olarak açıklamaktadır. Boniface } \\
\text { haklı olarak fiziki coğrafyanın, devletlerin politikası üzerinde yakın etkisini jeopolitik olarak } \\
\text { tanımlamak gerektiğini ifade etmektedir. }\end{array}$ \\
\hline Yves Lacoste, & $\begin{array}{l}\text { Günümüzde Jeopolitik teorilerden ziyade "Jeopolitik Problemler" olduğunu ve bu problemlerin } \\
\text { olabildiğince objektif olarak sergilenmesi gerektiğini ve bu maksatla yegane yöntemin } \\
\text { oyunları, gelişmeleri, birbirine zıt argümanlara sahip güçleri ve liderlikleri olduğu gibi ortaya } \\
\text { koymak olduğunu iddia etmektedir. Jeopolitiği ulusal sorunlar ve azınlık sorunları etrafında } \\
\text { odaklayarak da mikro milliyetçiliği körüklemektedir }\end{array}$ \\
\hline Jacque Attali; & $\begin{array}{l}\text { Güç ve güç olabilmenin şartları üzerinde durmakta, 21. yüzyılın jeopolitiğinin iki şeye sık } \\
\text { sıkıya bağlı olacağını ve bunlarında AB ve ABD arasındaki ortaklığın alacağı şekil ile Rusya ve } \\
\text { Çin'in pozisyonları olacağını vurgulamaktadır. }\end{array}$ \\
\hline Foucher & Foucher'e göre bugün jeopolitik, dinamik bir dış politika coğrafyası halini almıştır. \\
\hline Brzezinsk & Brzezinski açıkça; “Avrasya’ya egemen olan dünyaya egemen olur” demektedir. \\
\hline $\begin{array}{l}\text { Samuel } \\
\text { Huntingon }\end{array}$ & $\begin{array}{l}\text { 1993, 21. yüzyıldaki büyük savaşların medeniyetler arasında meydana geleceğini ileri sürerken, } \\
\text { karşıt medeniyetlerin de Katolik Dünyası, Ortodoks Dünyası, İslam Dünyası ve Konfüçyen } \\
\text { devletler olduğunu belirtmektedir. İleri sürdüğü tezin özeti; 19. yüzyılda devletler, 20. yüzyılda } \\
\text { ideolojiler çarpışmıştı, 21. yüzyılda ise kültürler çarpışacaktır (Keskintepe,2003). Huntington } \\
\text { bu tezinde 1960'larda Fransız filozof Raymond Aron ve 1940’lı yıllarda İngiliz Arnold } \\
\text { Toynbee ile Christophe Rufin'in benzer görüşlerinden de destek almaktadır. Huntington'a göre } \\
\text { dünya dini ve etnik blok teşkillerinin ve çatışmalarının eşiğinde olduğu bir çağa giriyordu. } \\
\text { Sınırlar artık ulusal devletleri değil kültür bölgelerini gösterecekti. Geleceğin global politik } \\
\text { çatışmaları uygarlıkları birbirinden ayıran çizgiler üzerinde olacaktı.Rufin bir “Avrupa Kalesi” } \\
\text { eğiliminden bahsederken, Huntington benzer şekilde; her kim batııı bir arada tutmak istiyorsa } \\
\text { ülke içinde batılı kültürü sadece muhafaza etmemeli, aynı zamanda batının sınırlarını da tarif } \\
\text { etmelidir.Uluslararası güç mücadelesinde kültür bilinçli olarak bir araç haline getirilmektedir. }\end{array}$ \\
\hline
\end{tabular}

Jeopolitik yeni ve genç bir bilim dalı sayılabilir. Hatta oluşumu ve gelişimini tamamlayıp temeline oturduğu bile söylenemez(Hacisalihoğlu, 2005b). Guido Fischer'in işaret ettiği coğrafi durum, toprak genişliği, nüfus 
sayısı ve yoğunluğu, organizasyon yeteneği, kültür düzeyi, sınır özellikleri, ve komşu ülkelerin tutumlarından oluşan politik faktörleri, iktisat politikalarının etkinliği, uyum kabiliyeti, yenilikçi zeka gibi psikolojik faktörler, toprak verimi, hammadde kaynaklarının zenginliği, sanayi kapasitesi, teknoloji düzeyi, ticaret hacmi ve finansman imkanları gibi ekonomik faktörleri ele geçirmek maksatlı (Ergin, 2008), nükleer silahların çoğalması, çevrenin bozulması, tekno ekonomik hız gibi olabilecek felaket beklentileri insanlarda gelecek kaygısı oluşturmaktadır (Morin, 2005). Bu kaygıları bertaraf edebilmek için müzakereler, iyi niyet görevi ve uzlaştırıcılık, tek yanlı kararlar, iktisadi baskılar ve savaşa yakın durumlar, tahrik ve tedhiş kampanyaları, sabotajlar ve darbeler, soğuk savaş, sınırlı savaşlar, topyekün savaşlar, değişen dünya ve nükleer silahlar gibi uluslar arası politika aksiyonları çağımızda değişik platform ve zeminlerde kendine yer edinmiştir (Ergin, 2008). Çelişkiler, barışı egemen kılamama, çıkar çatışmaları, sanal düşmanlıklar, yönetme-yönetilme ayrışmasının kökleşmesi gibi hususlar yeni bir düzen arayışını sürdürmekte ve yeni koşulların dinamik ortamından yararlanma yollarıyla egemenlik kutuplarını oluşturmaktadır (Hacısalihoğlu, 2005b). Kuvvetler dengesinin dişında ise, pasifizm, İzolasyonizm, nötralizasyon ve silahsız duruma getirilme, tecavüz savaşlarının kanunsuz aksiyon sayılması, birbiriyle rekabet eden büyük politik ve ideolojik bloklardan birine veya diğerine katılmadığı ve bunlarla askeri bağlaşmayı reddeden nötralizm doktrini gibi doktrinler ise kuvvetler dengesi dışındaki korunma ve savaşsız aksiyon politikaları içerisinde yer almaktadır (Ergin, 2008).Öte yandan bölgesel, global ve fonksiyonel bütünleşme ise ulusal politikalarda belirleyici olmaktadır (Aydın, 2002), Jeopolitik bir düşünce hayatı, politika ve strateji gibi hareket tarzları üretilmesi bağlamında bir çok anlaşmazlığın kaynaştığı bir kavramdır (İlhan,1989). 1967 yılından bu yana savunulduğu gibi, güç merkezlerine göre yapılacak jeopolitik yorum ve değerlendirmeler teorilerin yerini almış, yeni teoriler üretmek gereği kalmamıştır. Evrensel ve bölgesel düzeydeki güç odakları, bunların coğrafi ve jeopolitik kurumları, güçlerin olanakları, niyet ve amaçları belirleyici olmaya devam etmektedir. Jeopolitiğin coğrafi unsurları stratejide "mekân”, beşeri unsurları stratejide "güç" komşuluğudur. Her ikisinde de konuları, düşünceleri akıcı kılan zamandır. Bütün bu unsurların toplu değerlendirmesi coğrafi temele dayanan ulusal gücü belirler. Coğrafyaya dayanmayan, coğrafi değerleri dikkate almayan ulusal güç araştırmaları eksiktir. Ulusal gücün de unsurları olan, jeopolitiğin bu alt birimlerinden her birisi ayrı ayrı stratejik değer taşırlar (Özey,1999).

\section{Türkiye'nin Yer Aldığı Yeni Jeopolitik Ortam}

Türkiye, geniş olduğu kadar, sorunlar, çatışmalar ve istikrarsızlıklar içeren bir coğrafyada yaşamaktadır. Ancak Türkiye, böyle bir bölgede bir barış ve istikrar adası olma özelliğini koruma başarısını göstermiştir. Türkiye, Avrupa'dan Pasifik'e ve Orta Doğu'ya uzanan geniş coğrafyada yer alan ender demokrasilerden biridir.

Büyük ölçüde coğrafi bütünlüğe sahip Anadolu Yarımadası; Balkan Yarımadası, Kafkaslar, İran, Arap Yarımadası ile çevrelenmiştir. Anadolu Yarımadası bu konumu ile bu coğrafyanın kalesi ve Dünya Adasının merkezi görünümündedir. Doğu-Batı ve Güney-Kuzey istikametlerindeki her türlü girişimi bloke eder veya yolunu açar. Türkiye; ABD, Rusya ve $\mathrm{AB}$ gibi güç odaklarının çıkarlarının yol kavşağında, politikalarının güzergahı üzerindedir (Tezkan, 2005). Hatta zaman zaman bu politikaların hedefi veya hareket noktası olabilmektedir. Türkiye coğrafyası, NATO sorumluluk alanı dışında kalan Ortadoğu, Kafkaslar ve Orta Asya bölgelerinde Batı çıkarlarına vaki olabilecek tehditlere, istenmeyen değişimlere müdahale için en yakın ve en uygun bir harekat platformu teşkil eder. Türkiye coğrafyası üzerinde her anlamda ve her alanda zayıf toplumlarını yaşama şansı yoktur. Bir bölge devleti durumunda olan ve evrensel genişlikte etkinlik arayan Türkiye çok duyarlı bir konumdadır (Atalay2000). Türkiye Cumhuriyeti, zor bir coğrafyada yer almaktadır ve uzun vadeli politikalar üretmesi kolay değildir. Çünkü bu politikalar çok yönlü, çok seçenekli ve bağımsız politikalar olmayı gerektirir. Türkiye'nin politika üretiminde yakın çevresi, Avrasya'daki güç odakları ve küresel güç ve aday güçler etkin faktörlerdir. Bu nedenle, Türkiye için seçenekler sunmadan önce, Türkiye'yi çevreleyen coğrafyadaki jeopolitik gelişmeleri ve Avrasya'dan başlayarak ABD, AB Rusya Federasyonu, Balkanlar, Ortadoğu, Kafkasya, Orta Asya ve Çin'in bölgesel ve Avrasya çapındaki muhtemel politikaları ve stratejileri ile Türkiye'ye bakış açılarına özetle yer verilecektir. Brzezinski, aynı eserinde Türkiye'nin önemini aşağıdaki gibi değerlendirmektedir (Brezezinski, 1992). Yeni Jeopolitik Koşullarda Türkiye'nin Konumu ve Seçenekleri Türkiye, üç kıtanın (Asya, Avrupa ve Afrika) teşkil ettiği "Dünya Adası"nın menteşesi durumundadır. Aynı zamanda bu menteşeyi açan ve kapatan bir kilit ve anahtar değerindedir. Bu üç kıtanın iç denizleri olan Akdeniz ve Karadeniz'i birbirine bağlar. Balkanlar, Kafkaslar ve Ortadoğu’yu birleştirir ve ayırır. Bu coğrafi konum dünyada ve bölgede oluşabilecek her türlü güç yapısına göre büyük bir değer taşır. Bu coğrafi konum ve beşeri değerlerle oluşan ülke jeopolitik gücü dünya ve bölge güçleri ile birlikte değerlendirildiği ve yorumlandığı zaman Türkiye'nin Jeopolitik konumu belirlenmiş olur (Serin, 2004)

Türkiye, jeopolitik ve jeostratejik mevkii itibarıyla; dünyanın en önemli petrol rezervlerine sahip Orta Doğu ve Hazar Havzası, önemli deniz ulaştırma yollarının kavşağı durumunda bulunan Akdeniz Havzası, tarihte her zaman önemini sürdürmüş olan Karadeniz Havzası ve Türk Boğazları, SSCB ve Yugoslavya'nın dağılması sonucu yapısal değişikliklere uğrayan Balkanlar, etnik çatışmalar yanında, zengin tabiî kaynaklara sahip Kafkasya ASAM(2003) ve bunun daha ötesinde Orta Asya'nın oluşturduğu coğrafyanın merkezinde etkili bir konumda bulunmaktadır. Üç kıtayı birbirine bağlayan ve çok önemli bir jeostratejik konuma sahip olan Türkiye, 
aynı anda bir Avrupa, Asya, Balkan, Kafkas, Ortadoğu, Akdeniz ve Karadeniz ülkesidir. Kısacası Türkiye bir Avrasya ülkesidir. Anadolu Yarımadası'nın sunduğu zenginlikler ile tarih boyunca jeopolitik bir kavşak niteliği taşımış olan bu topraklarda yaratılan insanî değerlerin en güzel yönlerini benimseyen Türkiye Cumhuriyeti, çeşitli kültürlerin güzel bir sentezini oluşturmaktadır. Demokratik, müreffeh ve istikrarlı bir Türkiye, doğu ile batının değerlerinin bütünleşip, bir arada yaşayabileceğinin çarpıcı kanıtıdır. Türkiye'nin hem doğulu, hem de batılı yönleri, üyesi olduğu uluslar arası örgütlerin çeşitliliği ile de kendini göstermektedir. Türkiye aynı anda NATO, Avrupa Konseyi, Ekonomik İşbirliği ve Kalkınma Örgütü (OECD), Karadeniz Ekonomik İşbirliği (KEI), Ekonomik İşbirliği Teşkilâtı (ECO), D-20 ve İslâm Konferansı Örgütü (İKO) üyesi olan yegâne devlettir (Başoğlu, 1999). Türkiye ayrıca, gelecek yüzyılda Hazar ve Orta Asya doğal kaynaklarının batıya ulaşmasında doğal bir köprü rolü üstlenmektedir. Dünya doğal enerji kaynaklarının \%70'i Türkiye'nin etrafında kümelenmiştir. Hazar petrollerinin batıya taşınmasını öngören ve uluslar arası camiadan büyük destek bulan Bakü-Ceyhan projesi, petrol nakil güzergâhı bakımından en istikrarlı ve güvenli ortamı sunmakta ve çevre korunması bakımından da en az riski taşımaktadır. Soğuk Savaş ertesi şartlar içinde dünyanın en duyarlı bölgelerini oluşturan Balkanlar, Karadeniz ve Akdeniz Havzaları, Kafkasya, Orta Asya ve Orta Doğu coğrafyasındaki gelişmeler, Türkiye'nin bu bölgelerdeki rollerine ve etkinliklerine yenilik ve hareketlilik getirmiştir. Bu coğrafyadaki oluşumlar, dünyanın ve Avrupa'nın geleceğinde belirleyici rol oynayacaktır (Çeçen, 2005). Türkiye bir yandan bu oluşumların yol açtığı sorumluluklarını bütün gücüyle yerine getirmeye, diğer yandan da yeni imkân ve firsatlardan yararlanmaya çalışmaktadır. Böylesine önemli ve geniş bir coğrafyada, Türkiye, etkinliğini ve belirleyici rolünü önümüzdeki yüzyılda da devam ettirme zorunluluğundadır. Balkanlarda, Orta Doğu'da ve Kafkasya'da barış ve istikrar sağlanmadıkça, Avrupa ve Asya'nın tam anlamıyla birbirine kenetlenmesi mümkün değildir (Yıldızoğlu, 2004). Türkiye'nin, Balkanlar, Orta Doğu ve Kafkaslar'daki ihtilâfları söndürme inisiyatiflerine katkısı, bu kenetlenmenin gerçekleşmesine yöneliktir (İlhan, 1999). Jeopolitik firsatlar ve ilişkiler açısından AB, Rusya, Balkanlar, Kafkasya, Orta Asya ve Çin'e kısa bir tur atılırsa; Türkiye'nin AB'ne katılması ile AB coğrafyasının hudutları Asya'ya, Ortadoğu'ya doğru uzanacak; Ortadoğu, Kafkasya güneyi ve Doğu Akdeniz AB'nin hudutlarını teşkil edecektir (Özdağ, 2003).

Öte yandan, Kafkasya açısından yapılacak özet değerlendirmede, Türkiye'nin Kafkasya'dan jeopolitik ve ekonomik yararlar sağlayabilecek durumda olduğu görülmektedir. Türkiye'nin eğilimleri Kafkas ülkeleri üzerinde belirleyici bir etki yapma olanağına da sahiptir. Orta Asya (Türkistan)'da ise, Türkiye'nin hem handikapları ve hem de kuvvetli kozları vardır. Tarihi ve kültürel bağları, Türk özel sektörünün dinamizmi ve eğitim alanındaki girişimler Türkiye’ye özel bir mevki sağlamaktadır. Türkiye, Orta Asya petrol ve doğal gazının önemli bir kısmının dünya piyasalarına ulaştırılmasını üstlenebilirse daha ağırlıklı bir rol oynayabilecektir (Taşağil,2004). Türkiye'nin Çin'e karşı stratejisi 2020 yılları Çin'ine yönelik olmalıdır. Eğer Türkiye Çin'i ihmal ederse bu, Çin'in İran ile işbirliğini daha da güçlendirme sonucunu verir. Çin şimdiden İran'a Ortadoğu'da başlıca müttefiki olarak bakmaktadır. Türkiye Çin’i iyi öğrenmeye çalışmalı, uzun vadeli bir strateji saptayarak çok yönlü ilişkiler içeren "yakın işbirliği”ni tesise gayret etmelidir. Çin’in, bugünkü tek kutuplu küresel sistemi çok odaklı küresel sisteme dönüştürmeye gayret sarf ederken globalleşmeye de ayak uyduracağını ve kendine özgü sistem içinde kendi gelişmesini gerçekleştirmeye gayret edeceğini düşünmek hatalı olmaz (Kuchins, 2005). Ortadoğu ile ilgili firsatlarda ise, Türkiye'nin jeopolitiğinin ve jeostratejisinin şekillenmesinde Ortadoğu'nun payının önemli olduğu bilinmektedir (Hacısalihoğlu, 2005c) Bu gelişmelerin öznesi konumunda olan Türkiye için alternatif olacak firsatlar, ya Soğuk Savaş’tan kalma ABD’ye sadık müttefiklik rolünü, ortaklık kavramının özünü yansıtmayan bugünün "stratejik ortaklık” yakıştırmasıyla yaşamaya devam edecek ya da bölgesinde barış kuşağ1 yaratmayı öncelikli sayan (Şimşek, 2005a), yeni işbirliği ve ilişkiler zemini kurabilen, kalıcı, köklü, dengeleyici ve çok seçenekli ilişkiler üretebilen sözü dinlenen ve sorunlara Türkiye'den ve ulusal çıkarları temelinden ödünsüz bakabilen “aktif bir bölge gücü” olmaya karar verecek (Henze, 1995).

\section{Sonuç ve Öneriler}

Bugün uluslararası ilişkilerin geldiği noktada, "Tek kutupluluk, geçici bir güç boşluğunun doğurduğu durumdur". Waltz ise bu tartışmayı tamamlayıcı bir ifadeyle; "yeni bölgesel güçlerin ortaya çıkmasının zaten çok zayıf olan bu durumu değiştirdiğini” söylemektedir (Waltz, 1993). ABD, iki Almanya'nın birleşmesi, Sovyetler Birliği'nin yıkılması ve Körfez Savaşından sonra bir süre tek kutup olma vasfına sahip olmayı istemiştir. Hatta, belki de bu rolü istemese de yüklenmek zorunda kalmıştır, Ancak, özellikle Almanya, Fransa, Türkiye, Mısır ve İran'ın bölgelerinde ekonomik ve mali bir güç haline gelmeleri, ister istemez ABD'yi bu rolden uzaklaştırmıştır. Dikkat edilirse, Almanya ve Fransa bu süreci AB'yi kullanarak yapmışlardır (Açıkçeşme,2005). Türkiye, Mısır ve İran'ın durumu farklıdır. Bu ülkeler, halkının refahından keserek jeopolitik pozisyonlarını korumuştur ve bölgesel güç olmuşlardır. Yeni uluslararası siyasal sistem, dış politikada olduğu kadar iç politikadaki baskıyı da artırmıştır. Bunun sonucu, iç politikadaki karar verme sürecinde de aktörlerin artması olmuştur (Baldwin, 1995). Bürokratik sınırlamalar, her müzakere sürecini yavaşlatan bir rol oynamaktadır (Fisher, 1997). Büyük güç olmanın getirdiği yükümlülükler, onları bölgesel güçlerden daha fazla güvenliği koruyucu (security manager) olmaya doğru itmektedir (Hopmann, 1995). Ĕger sistemin yapısı, çok merkezli (polycentric) ise, devletlerin 
tehdit algılamaları daha yoğun hissedilir. Hiyerarşik çok merkezli yapıda ise, bir süper gücün tırmanmaya etki yapması veya önlemesi mümkündür (Goldstein ve Pevehouse, 1997).

Öte yandan, dünya, biten Soğuk Savaş'ın ideolojik karşıtlığından yeni çelişkiler üreten ve gerilimi, savaşları tükenmeyen bir atmosfere doğru sürüklenmektedir. Askeri girişimler, silah üretimi, aşırı silahlanma, nükleer, kimyasal ve biyolojik silahlara sahip olma, ileri askeri teknoloji üretimi, yeni askeri örgütlenme çabaları sürmektedir. "Füze kalkanı" projesinden Avrupa ordusu oluşumuna, silahsızlanma anlaşmalarını geçersizleştirme eğilimlerinin belirlenmesinden, kitle imha silahları üretiminin sürmesine, boyutlanan yeni tehdit algılamalarından, küreselleşen teröre dek uzanan geniş yelpaze içinde, biten Soğuk Savaş’ın egemen bir dünya barışına dönüşememesinin yansımalarını görmekteyiz (Onay, 2005b). Türkiye'nin coğrafi konumu, Soğuk Savaş sonrasında ve Avrasya zemininde Avrupa ve Asya uzanımlarıyla temelde iki boyutlu ilişki alt yapısını adeta koşullandırmaktadır. Bu temel iki boyut ayrıca alt seçenekler üreterek, çok boyutlu ilişki düzeneğini Türkiye adına yapılandırmaktadır. Ancak güç şemasında da yansıtıldığı gibi asıl olan sahip olunan coğrafi konumun yönlendiriciliğini benimseyerek, onunla iyi iletişim kurarak, birikimini ve rolünü algılayarak gereğini yapabilmektir. Tüm bu açılımlardan sonra denilebilir ki, dünya siyasal yaşamı adına "tarihin sonu” gelmemiştir. Dünyanın bugününe yansıyan çelişkilerini "Medeniyetler Çatışması” türü tezler açıklayamamaktadır. Assıl çelişki gelişmişlik farklılığını derinleştirmesini önleyememekten kaynaklanmaktadır. Bu tabloyu besleyen ana kaynak ise güç ilişkilerine yansıyan çıkar çatışmasıdır (Tahsin, 2001). Soğuk Savaş sonrasının "jeopolitik boşlukları" yeniden oluşturulmaya çalışılan siyasal atlasın öncelikli paftaları olarak ele alınmaktadır (Hacısalihoğlu, 2005a). Balkanlar'dan sonra Orta Asya ve güncel olarak bugün Orta Doğu (Irak odaklı) yeni çözülmelerin ve düzenlemelerin odağı durumuna gelmektedir. Afganistan (Baleta, 2005) sonrasında Irak'taki odaklanma, oluşturulmaya çalışılan yeni Orta Doğu haritasının temel paftası olarak yansımaktadır (Öztürk, 2005). Bu çerçevede Irak konusundaki ABD 1srarı, Avrasya stratejisinin bir gereği olarak oluşturulmaktadır(Cordier, (2005). Bu çerçevede yer alanlar, ABD açısından bugün de geçerliliğini korumaktadır. Ancak ilaveler de vardır. Örneğin Avrupa (Fransa-Almanya) Rusya yakınlaşması, Rusya'nın ekonomik toparlanması, ABD açısından Avrasya jeopolitiğini boyutlandırmaktadır. ABD’nin Avrupa'ya bakışı farklılaşmıştır. Gerek Avrasya egemenliğine yönelik, gerekse Rusya-Çin Fransa-Almanya dengeleri açısından ABD'nin Avrupa'daki sıklet (ağırlık) merkezi Batıdan daha doğuya doğru kaymaktadır. Polonya, Macaristan, Romanya, Bulgaristan gibi eski Doğu Bloku ülkeleri bu yönelişte önem kazanmaktadır. ABD Baltık’tan-Balkanlar'a, doğu eksenli bir jeopolitik hattan oluşumunu arzulamaktadır. Hem Avrasya'ya yakınlaşmak hem Rusya-Avrupa (Almanya-Fransa) yakınlaşmasını jeopolitik olarak perdelemek, hem de Irak konusunda boyutlanan Fransa-Almanya-ABD ayrışmasının bir uzantısı olarak bu yeni jeopolitik hat ABD’nin Avrupa'ya yönelik güvenilir - güvenilir olmayan müttefik" ayrımına yönelik anlamlar içermektedir (Davutoğlu,2003). AB, ABD bölge açısından bunları düşünürken, Türkiye, kendini tam olarak tanımlayamamakta, stratejik çeşitliliğini oluşturamamakta, $A B$ karşıtlığı veya yandaşlığına sıkıştırılmış, dağınık ve ufuksuz bir çizgi üzerinde seyrini sürdüren bir ülke görünümü vermektedir (Canbolat, 1998). Tüm bunlar yeni Siyasal Atlas'ın oluşum sürecinde, Türkiye'nin yeni bir jeopolitik konum ve ortamla yüz yüze olduğunun resmini çizmektedir. Bu yeni jeopolitik konum ve ortam, Türkiye'nin ulusal duruşunu belirlemesini, “aktif bir bölgesel güç kimliğini”” tartışmasız kılmasını, iç ve diş jeopolitik bütünlüğü oluşturmasını, çok seçenekli, stratejik öngörülerle bezenmiş bir jeopolitik konum elde etmesini koşullandırmaktadır (Arat, 2003). Bu yaklaşım, Türkiye’nin, Doğu Akdeniz, Kıbrıs, AB ve Kuzey Irak gibi güncellik taşıyan ve sıkıntılar üreten konuları karşılayabilme, çözüme kavuşturabilme, gelecek güvencesine bağlayabilmesine olanaklar sunmaktadır (Şimşek, 2005b). Tüm bunlar göstermektedir ki Türkiye, ulusal güvenlik stratejisini yeniden ele almalıdır. Türkiye merkezli bir dünya algılamasıyla tüm gelişmeleri ve yönelişleri derinlemesine irdelemelidir. Jeopolitik konumunun öngördüğü gibi Avrupalı kimliğini, Asyalı kimliğiyle dengelemesi,geleceğin güç ilişkilerini belirleyecek olan Avrasya jeopolitiğinde etkin olabilmenin stratejisini geliştirmesi, kendi tehdit (Yeniçeri) algılamalarının bir gereği olarak ekonomi, kültür, hukuk gibi alanları da içine alan geniş ve etkili yeni bir ulusal güvenlik stratejisi geliştirmesi,yeniden kalkınma heyecanını hissederek, benlikli ve kimlikli bir yükseliş hedeflemesi Türkiye açısından büyük öneme sahiptir (Kabasakal, 1996)

\section{Kaynakça}

- Açıkçeşme, S. 2005. “The Underlying Dynamics of the European Security and Defence Policy” Resarch Assistant,Department of EU studies, Institute of Social Sciences,Ankara University

- Atalay, İ. 2000.“Türkiye Coğrafyası ve Jeopolitiği”, Ege Üniversitesi Basımevi, ISBN:975-94965-5-0, İzmir

- Aydın, S. 2002. “Türkiye’nin Tam Üyeliğinin Avrupa Birliğine ve Türkiye’ye Katkıları”,IKVV Yayınları, No:168, İstanbul Mayıs, 2002, s.7

- Aydın, Mustafa(2000), "New Geopolitics of Central Asia and the Caucassus", SAM papers No.2/2000, Ankara, June 2000

- $\quad$ Arat, F. C. 2003. “Atatürk’ün Strateji Anlayış1”, Anıtkabir dergisi, Y11:3, Sayı:14, Temmuz 2003, Ankara

- ASAM 2003), “Kafkasya’nın Jeopolitik Sorunları”, Avrasya Bir Vakfı, ASAM Yayınları:53/07, Ankara,s.20 
- $\quad$ Baldwin, D. A. 1995. "Security Studies and the End of the Cold War". World Politics. No. 48. 1995, ss.126,127 ve 130

- Baleta, A. 2005., "Eski Jeopolitiğin Yeni Perspektifleri”, http//www.yarindergisi2/ haziran2002, (Erişim Tarihi,09/12/2005)

- Başoğlu,U., Ölmezoğulları N. Ve Parasız İ.1999. “Dünya Ekonomisi”, Ezgi Kitabevi, 1.Baskı, Bursa

- Brezezinski, Zbigniew(2005), “Jeopolitik Boşluk”, http://www.bkd.org.tr/analiz/jeopolitikboşluk.asp, Erişim Tarihi, 09/12/2005

- Canbolat İ.S.1998.“Uluslar üstü Sistem AB: Bir Dönüşümün Analizi”, Alfa Yayınlar, Geliştirilmiş 2.Bask1, İstanbul

- Cordier, De Bruno.2005.“The Southern ex-Soviet republics after one and a half decade of independence:from transition societes to developing countries?, Avrasya etüdleri, 27-28 Sonbahar-kış 2005

- Çeçen, A. 2005. “Avrupa ve Türkiye”, http://www.jeopolitik.org/jeo-4/cecen4, Erişim Tarihi 09/12/2005

- Brezezinski, Z.1992. "Büyük Çöküş”, Türkiye iş Bankası Kültür Yayınları,Genel Yayın no:309, Ankara

- Davutoğlu, A. 2003. "Stratejik Derinlik”, Küre Yayınları 13. Baskı, Stratejik Araştırmalar:1, Haziran, 2003, İstanbul

- Ergin, Feridun, “Uluslararası Politika Stratejileri”, İstanbul Üniversitesi yayınları 2008, İstanbul, s.9

- Fisher, Roger, Andrea Kupfer SCHNEIDER, (1997). Coping with International Conflict. New Jersey: Prentice Hall.1997, s.148

- $\quad$ Giddens, A. 1996. "Beyond Left and Right, The Future of Radical politics, Polity Pres, 1996

- Goldstein, J. S. ve Pevehouse J. C. 1997. "Reciprocity, Bullying and International Cooperation Time Series Analysis of the Bosnia Conflict". American Political Science Review. Vol. 91, No. 31997, s.51).

- Hacısalihoğlu, İ.Y. 2005a."Dünya Siyasal Ortamının Berraklaşanlarla Türkiye’yi Algılamak”, http:www.jeopolitik.org/jeo-3, (Erişim Tarihi:09/12/2005)

- Hacısalihoğlu,İ. Y.2005b. "Jeopolitik Doğarken”, (2005c) "Iraktan Avrasya Jeopolitiğine Yansıyanlar ve Türkiye”, http://www.jeopolitik.org/jeo-4/editörden.asp, (Erișim tarihi:09/12/2005)

- Henze, Paul B.1995. “Türkiye’nin Yeni Jeopolitiği Balkanlardan Batı Çin’e”, Harp Akademileri Basımevi, İstanbul

- Hopmann, 1995, . Terience. (1995). "Two Paradigms of Negotiation: Bargaining and Problem Solving".The Annals 542. ss,36,37

- IIlhan, S. 1989. “Jeopolitik Duyarlılık”, Atatürk, Kültür, Dil ve tarih Yüksek Kurumu Yayınları, VII Dizi s.113,

- IIlhan, S. 1999.“Türkiye’nin Jeopolitik Konumu ve Türk Dünyası”, Atatürk Yüksek kurumu Atatürk kültür Merkezi Başkanlığı”, ISBN:975-16-1164-4, Ankara

- Kabasakal Ö.1996. "Dönüşüm Sosyal ve Stratejik Çözümler”, Seba İlmi Araştırmalar Dizisi 8, Ankara

- Keskintepe,R. 2003. "On the Compatibility of İslam and democracy:The Turkish Experience”,NSF Review,

- Winter 2003, Deputy Director and Directorate General For Policy Planning for the Ministry of Foreign Affairs of Republic of Turkey

- Kuchins, Andrew, “Çin-Rus İttifakının Evrimi”, Çev.İbrahim Kiras, http//www.geocities.com/İbrahimkiras/ cinrus.html,Erişim Tarihi:09/12/2005

- Manisalı,E. 2005. "Batı'da Kapitalizm,Hristiyanlık ve Ulusallık Örtüşmesi”, http://www.jeopolitik.org/ jeo4/jeo-2/manisali-2-1.asp,Erișim tarihi:09/12/2005

- Mackinder, H. J 1996. "The Geographical Pivot of History”,in democratic ideals and reality"

- Morin, E. 2005. “Avrupa Birliği’nin açık bir ahlakı, dinamik bir dini henüz oluşmadı”, İktisat, İşletme ve Finans Dergisi Söyleşi, Y11:20, Sayı 234, s.12, Eylül 2005, Ankara

- Mütercimler, E. 1997. “21.Yüzyıl ve Türkiye Yüksek Strateji”, Erciyas Yayınları,ISBN 975-8029-03-07

- Onay, Y. 2005a.“ Küresel Jeopolitik Durum ve Rusya Değerlendirmesi”, http://www.jeopolitik.org /jeo-2/ Onay2-1, Erişim tarihi:09/12/2005,

- Onay, Y.2005b. "Soğuk Savaş Sonrası Düzenin Getirdiklerinin Türkiye Jeopolitiğine yansıması ve Tehdit Farklılaşması", http://www.jeopolitik.org/jeo-4/onay4-1asp.

- Özdağ Ü, Kalafat Y, Erol,M.S. 2003. “21.Yüzyılda Türk Dünyası Jeopolitiği”, Avrasya Stratejik araştırmalar merkezi yayınları”, Muzaffer Özdağ’a armağan, 3.Cilt, Jeopolitik Strateji terör Dizisi 61, Ankara 
- Özey, R. 1999.“Dünya ve Türkiye Ölçeğinde Siyasi Coğrafya”, Aktif yayınevi, ISBN:975-6755-07-5, İstanbul

- Öztürk, M. O. 2005. “11 Eylül Sonrasında Ortadoğu ve Irak”, http://www.jeopolitik.org/jeo-2/öztürk2-

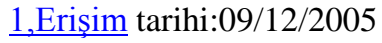

- Sempa,P.(2005)Jeopolitik merkez ve kara hakimiyeti teorisi, http://www.geocities.com/ ibrahimkiras/ jeopol.

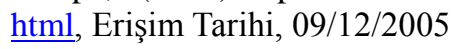

- Serin, Vildan, Aral Berdal, Köse, M.(2004), "The Geopolitical and Economic transition in Eurasia Problems and Prospects", Global Scholary Publication", I-59267-077-6, İstanbul

- Şimşek, H. 2005a. “Türkiye ve Çevresinde Barış Ortamı Koşulları”, http://www.jeopolitik.org/jeo-4/şimșek 4-1.asp/Erişim Tarihi:09/12/2005

- Şimşek,H. 2005b. “Türkiye Kıbrıs ve AB İlişkileri...”, http://www.jeopolitik.org/jeo-2/simsek 2-1.asp

- Tahsin, E. 2001. "Dünya Ekonomisinde Üç Aktör”, İktisat Dergisi, Dünya Ekonomisi Nasıl Yönetiliyor, İFMC Yayınları, Y11:2001, Say1,416, İstanbul

- Taşağil, A. 2004. Türkiye'nin Orta Asya Türk Cumhuriyetleri ile İlişkilerinin Dünü, Bugünü ve yarını”, Stratejik Araştırmalar Dergisi, Genelkurmay Askeri Tarih ve Stratejik Etüt Başkanlığı yayınları, Yıl 2, Şubat 2004, Say1:3

- Tezkan, Y. 2005.“Süper Bir Güç:Rusya ve Türkiye”, http://www.yarindergisi. com/yarindergisi/ haziran 2002, Erişim Tarihi, 09/12/2005

- $\quad$ Waltz, K. N. 1993. "The Emerging Structure of International Politics". International Security. Vol. 18, No. 21993, s.50

- Wolferen K.V. 1992. “Japon Gücünün Sırrı”, Çeviren: İnci Kurmuş, Türkiye iş Bankası Kültür Yayınları”, Genel Yayın No: 308, Ankara

- Yeniçeri, Özcan, “Jeopolitik ve Jeostratejik Konumunun Türkiye’ye Yönelttiği Tehditler”, http //www geocities. com/ İbrahimkiras/ cinrus.html,Erişim Tarihi:09/12/2005

- Yıldızoğlu, E. 2004. “jeopolitiğin Geri Dönüşü”, Stratejik Analiz, Aylık Uluslar arası ilişkiler Dergisi”, Mart 2004, C.4,Say1:47, Ankara 


\title{
Uluslararası Emek Göçü Bağlamında Almanya'ya Türk İşgücü Göçü ve Sosyo-Ekonomik Etkileri \\ Turkish Labor Migration to Germany and its Socio-Economic Impacts in the Context of International Labor Migration
}

\author{
Asst. Prof. Dr. Şenol Yaprak (Kocatepe University, Turkey)
}

\begin{abstract}
Germany being encountered great destruction during the World War 2 has gone through a process of reconstruction and development. However, as it could not be able to find sufficient labor force during this process, Germany has signed subsequent labor migration agreements with Italy, Greece and finally with Turkey in the year of 1961. From this date onwards, a constant labor migration has started in Germany and currently it can be concluded that 3 million Turkish origin people are living in Germany. This study aims to analyze socioeconomically the point that the situation has reached in 50-year period of time. As opposed to the existing aged German population, Turkish people having relatively younger population provides support to necessary labor force. Recently, Turkish people are not only laborers in the context but also with their increasing number they began to become employers in Germany whereby contributing to Germany economy. The number of Turkish entrepreneurs in Germany is estimated to be 70-80 thousand; they operate in diverse sectors and employing approximately 400 thousand laborers. It is estimated that the Turkish businesses are making annual return of 3540 billion Euros in Germany. More and more, a new Turkish generation has been formed there, which embraced Germany as home country and they form plans about future around Germany values. Turkish population living in Germany is crucial in terms of improving the relationships with Germany; therefore importance should be given to this issue and establishment of novel policies by the central authorities in both countries.
\end{abstract}

\section{Giriș}

Küreselleşmenin henüz hayatımızda yer almadığı, bugüne göre oldukça kapalı sayılacak ekonomik sistemlerin hüküm sürdüğ̈̈ yıllarda bile çeșitli nedenlerle uluslararası boyutta bir işgücü hareketliliği yaşanmaya başlamışıı.Özellikle İkinci Dünya savaşı sonrasında ülkelerinin yeniden imarını ve kalkınmasını hedefleyen ülkeler, bunun için gerekli olan işgücünü kendi kaynaklarından sağlayamayınca diğer ülkelerle işgücü göçü anlaşması yapma yoluna gitmişlerdir. Almanya, Avusturya, Hollanda, Belçika, Fransa gibi ülkeler bu amaçla ihtiyaç duydukları emeği diğer ülkelerden sağlamak için anlaşmalar yapmak durumunda kalmışlardır. İşçi ithal eden ülkeler geçmişin acılarını sarmak ve kalkınma yolunda ilerlemek istemişlerdir. Diğer yandan işgücü ihraç eden ülkeler ise, hem işsizliği azaltmak, hem de bu sayede ülkelerine döviz girdisi sağlamak amacı ile bu yola yönelmişlerdir. 1950'li yıllardan itibaren diğer ülkelerden işgücü almaya başlayan Almanya, 1961 yıllnda da Türkiye ile işgücü alımı amacı ile anlaşma yapmıştır. Misafir işçi olarak adlandırılan bu ilk işçi göçü, her iki ülke açısından da geçici bir olay olarak algılanmış ve çalışmalar da ona gore yapılmıştır. Ancak aradan geçen yıllar içerisinde, misafir işçiler kalıcı olmaya başlamışlar ve sayıları da hızla artmıştır. Ellerine aldıkları bir valiz ile para biriktirip, tekrar ülkelerine dönme hayali ile yola çıkan işçilerimizin bu hayalleri boyut değiștirmiș ve ailelerini de yanlarına almaya başlamışlardır. İlk yıllarda binlerle başlayan işgücü hareketi, aradan geçen elli yıllık süreçte hızla artarak, bugün Almanya'daki Türk nüfusu üç milyona yaklaşmıştır. Üstelik artık ilk giden kuşak emekli olmuş, şimdi ikinci, üçüncü dördüncü kuşak orada hayatın her alanında ve her kademede yer almaktadır.

\section{Uluslararası İşçi Göçü Hareketleri ve Nedenleri}

İnsanlar dünyada uzun yıllardır çeşitli nedenlerle yaşadıkları vatanlarını terkederek başka yerlere göç etmektedirler. Bu göçün nedenlerinden biri de emek hareketlerinde yaşanmaktadır. Fakat nedenleri farklı da olsa bütüncül olarak bakıldığında her göçün bir işgücü hareketi olduğu kabul edilebilir. Uluslararası göç hareketlerinin nedenlerini değiş̧ik öçlütlere gore sınıflandırmak mümkündür. Göçün oluş şekline gore yada göç edenlere göre de gruplandırılmaktadır. Genel olarak uluslararası göç çeşitlerini şu şekilde sıralayabiliriz(Çavuşoğlu, 2006):
a) İlkel göç
b) Zorla göç
c) Zorunlu göç
d) Kitle göçü
e) Serbest göç
f) Mülteci göçü 
g) Geçici göç

h) Kalıcı göç

1) İşçi göçü

i) Beyin göçü

İnsanların doğup büyüdükleri, ortak kültürel değerlere sahip oldukları yerleri terkederek, tamamen farklı bir ortamda ve coğrafi alanda yaşamaya yönelmelerine neden olan etkenleri değişik şekilde sınıflandıranlar da bulunmaktadır. Göçe neden olan etkenleri şu şekilde sınıflandırmak da mümkündür (Aksoy, 2012):

a)Ekonomik kaynaklı göç

b)İklim kaynaklı göç

c)Siyasal kaynaklı göç

d)Eğitim kaynaklı göç

e)Beyin göçü

f)Emekli göçü

Aşağıdaki tabloda göçlerin itici ve çekici faktörleri gösterilmektedir. İşçi göçünün de dahil olduğu ekonomik ve demografik göçün itici ve çekici faktörlerine bakıldığında bu etkenlerin Türkiye'den Almanya'ya işçi göçünde de etken olduğu söylenebilir.

\begin{tabular}{|c|c|c|}
\hline & İtici Faktörler & Çekici Faktörler \\
\hline $\begin{array}{l}\text { Ekonomik ve } \\
\text { Demografik }\end{array}$ & $\begin{array}{l}\text {-Yoksulluk } \\
\text {-İşsizlik } \\
\text { •Düşük ücretler } \\
\text { •Yüksek doğum oranı } \\
\text {-Temel eğitim ve sağlık } \\
\text { hizmetlerinden yoksunluk }\end{array}$ & $\begin{array}{l}\text {-Yüksek gelir beklentisi } \\
\text {-Yaşam standardının yükselmesi } \\
\text { potansiyeli } \\
\text {-Kişisel ve mesleki gelişim }\end{array}$ \\
\hline Politik & $\begin{array}{l}\text {-Şiddet, güvensiz ortam } \\
\text {-Zayıf hükümet } \\
\text { •İnsan hakları ihlali }\end{array}$ & $\begin{array}{l}\text {-Güvenlik } \\
\text { •Politik özgürlük }\end{array}$ \\
\hline $\begin{array}{l}\text { Sosyal ve } \\
\text { Kültürel }\end{array}$ & $\begin{array}{l}\text { •Etnik,cinsiyet, dinsel vb. } \\
\text { ayrımc1lılar }\end{array}$ & $\begin{array}{l}\text {-Aile birleşmesi } \\
\text { •Etnik olarak bağlı bulunulan } \\
\text { ülke } \\
\text { •Özgürlük }\end{array}$ \\
\hline
\end{tabular}

Tablo 1: Uluslararası Göçün Belirleyenleri Kaynak: Kara, 2008, s.22

Göç olgusu insanlık tarihi kadar eski olmakla birlikte, tek bir bölgeye yada ülkeye özgü değildir. Göçlerin ortaya çıkmasına neden olan unsurlar her ülkede aynıdır(Koçak ve Terzi, 2012). Göçe neden olan unsurların şiddeti ve kişiler üzerindeki etkisi farklılık gösterse de, genel olarak evrensellik gösterir. Uluslarası işgücü harekeliliği kapitalizmin gelişmesine paralel olarak artmıştır. Ancak bu göçler 1945 ylına kadarki dönemde okyanuslar ötesi bir hareketlilik gösteriken, bu tarihten sonra az gelişmiş ülkelerden, gelişmiş bölgelere doğru bir göç halini almıştır. 1815-1914 arası dönemde 30 milyondan fazla Avrupalı Amerika'ya göç etmiştir. Ayrıca 16. yüzyıldan itibaren çok sayıda Afrikalı da zorla Amerikaya göç ettirilmiştir. 1900'lü yılların başında Almanya ve Fransa'da birer milyondan fazla yabancı olduğu belirtilmektedir. 1945 'ten sonra ise Porto-Riko ve Meksika'dan Amerika'ya, Pakistan, Hindistan ve Jamaika'dan İngiltere'ye, İtalya, Yunanistan ve Portekiz'den de Almanya'ya işçi göçü olmuştur (Sönmez,1980).

Geçmişte bu şekilde bir gelişme gösteren uluslararası işgücü hareketliliği, günümüzde küreselleşme ile birlikte şekil değiştirmiştir. Uluslararası göçün artışının yıllar içerisinde gittikçe artmasının nedeni olarak zenginliğin dünyanın gelişmiş ülkelerinde yoğunlaşırken, fakirliğin ise az gelişmiş ve gelişmekte olan ülkelerde artması ve insanların da daha iyi bir gelecek için ülkeler arasında yer değiştirmektesi gösterilmektedir. 1960 yılında dünyadaki göçmen sayısı 76 milyon iken, bu sayı 40 yılda üç kat artarak 175 milyona yükselmiştir. 2050 yılında ise 400 milyon olacağı tahmin edilmektedir. (Gökbayrak, 2006). Son yıllarda göçün bu hızlı artşında küreselleşme, teknonoloji ve iletişimdeki hızlı değişim ve ülkeler arasında oluşturulan birliktelikler de önemli paya sahiptir.

\section{Türkiye'den Almanya'ya İşçi Göçü}

İkinci Dünya Savaşı sırasında ve sonrasında ortaya çıkan olumsuz tablo nedeni ile ekonomik olarak büyük sıkıntılar yaşayan Almanya, savaş sonrasında yeniden toparlanabilmek amacı ile harekete geçmiştir. Bir yandan yıkılan, harap olan yerleşim yerlerini yeniden imar etmek, diğer yandan da kalkınma ve gelişmeyi hızlandırmak 
amacı ile önemli projelere girişmiştir. Ancak yıllar içerisinde ihtiyaç duyduğu işgücünü kendi ülkesinden karşılayamayınca başka ülkelerden misafir iş̧̧i alımı yoluna gitmek amacı ile çalışmalara başlamıştır.

\subsection{Almanya'daki Türk Nufusu ve Tarihsel Süreç İçerisinde Yaşanan Değiş̧imler}

Batı Avrupa ülkelerinin o yıllardaki tipik özelliği, yavaş artan bir nüfus yapısı ve işgücü yapısına karşın, çok hızlı büyüyen ve hızla gelişen bir ekonomik yapıya sahip olmasıydı. Bu orantısızlık nedeni ile ekonominin ihtiyaç duyduğu işgücünün arzı sorunu nedeni ile mümkün olduğunca emek yoğun yatırımlar yerine sermaye ve teknoloji yoğun yatırımlara yönelmişler, ancak buna rağmen yine de önemli miktarda işgücü ihtiyacı ortaya çıkmıştır. Bu durumda önlerinde iki seçenek vardı; ya yatırımlarını yabancı sermaye transferi yoluyla başka ülkelere yapacaklardı yada yurtdışından yabancı iş̧̧i transfer edeceklerdi. Almanya'nın da içinde olduğu bu ülkeler ikinci seçeneği seçmişler ve yabancı iş̧̧i sağlamak amacı ile işgücü fazlası olan ülkelerle anlaşmalar yapmak amacı ile çalışmalar başlatmışlardır (Yıldırımoğlu, 2005). Savaş sonrasındaki büyük enkazı ortadan kaldırmak amacı ile çalışmalara başlayan Alman İş ve İşçi Bulma Kurumu 1950'li yılların başında dört milyon işgücü ihtiyacı olduğunu hesaplamıştı. Yeniden yapılanma için gereken parayı Amerika'dan sağlayan Almanya, işgücü ihtiyacını sağlamak için de arayışa girmiş ve bu açı̆̆ın ancak başka ülkelerden sağlanacak işçilerle giderilebileceği sonucuna varmıştır (Çelik, 2012). Günün şartlarına göre ekonomik ve teknolojik olarak yeterli kaynağa sahip olduğundan, tek eksiği olan işgücünü de bu şekilde bulmanın kalkınma ve gelişme hamlesi için daha uygun olacağını hesaplamışlardır.

Bu plan doğrultusunda Alman Hükümeti 20 Aralık 1955 tarihinde İtalya ile işgücü göçü anlaşması imzalamış ve 1959 yılında Almanya'ya çalışmak amacı ile giden 25 bin İtalyan işçinin, toplam yabancıların \%31'ini oluşturduğu öçlülmüştü. Bunlar da yetersiz kalınca bu defa 29 Mart 1960'da İspanya, 30 Mart 1960'da da Yunanistan ile işçi temini için anlaşma yapılmıştır. Bu anlaşmalardan sonra Almanya'daki yabancı çalışanların sayısı 122 bine yükselmiştir. Bu iş̧̧ilerin önemli bir kısmı (93 bin) İtalyanlardan oluşmaktaydı ve bu şekilde işe yerleştirilenlerin oranı \%47'ye yükselmişti (Erker, 1967).

Sonraki yıllarda yaşanan büyük işçi göçünden once 1956 yllında Almanya'da bulunan Kiel Üniversitesi Türkiye'de yapılacak Alman yatırımlarını desteklemek amacı ile oralarda çalışacak Türklerin once Alman firmalarında yetiştirilmesini planlamış ve bu amaçla da 12 Türk stajeri aileleri ile birlikte Almanya'ya getirmiştir. Bu amaçla 1957 ylında Türk ve Alman hükümetleri ilk defa bir iş̧̧i göçü anlaşmasını imzalaşmışlardır. Staj programının öngörülenin aksine başarısız olması sonucu, Almanya'ya giden bu ilk işgücü kafilesini oluşturan 12 kişi Türkiye'ye dönmeyerek Almanya'da çalışmaya devam etmişler ve ileride yaşanacak büyük işçi göçünün kapısını aralamışlardır (Kılıçaslan, 2006). O yıllarda belki de hiç Türk vatandaşının bulunmadığı bir ülkede kendilerince bir düzen kuran ve daha sonra bu yolu izleyerek gelecek çok sayıda Türk’e bir yol gösterici olması açısından da bu ilk temsilcilerin varlığı önemli olmuştur.

Bu gelişmelere bağlı olarak Almanya'nın işgücü talebini değerlendiren Türkiye, döviz getirisi elde etmek, işsizliği azaltmak, sonrasında nitelikli işgücüne sahip olmak gibi nedenlerle bu teklife olumlu yaklaşmış ve 31 Ekim 1961 tarihinde Almanya ile işgücü anlaşmasını imzalamıştır (Silkin, 2011). Bu anlaşma sonrasında ilk işçiler de Almanya'ya gitmeye başamış ve ilk yıl bu sayı yedi bine ulaşmışıır.

1961 yılına Almanya'ya giden ilk kafile 1476 kişien oluşuyordu ve bunun 1430'u erkek, 46'sı da kadındı. Başlangıçta kadınların sayısı çok azdı, ancak zamanla bu oran yükseldi ve 1973 yılında kadın oranı $\% 20$ oldu. Aile birleşimi hakkı verilmesi ile birlikte, 1970'li yıllardan itibaren eşlerini de Almanya'ya götürme süreci başlayınca kadın sayısındaki artış hızlanmıştır (Suğanlı, 2003). Başlangıçta belirli bir süre çalışıp geri dönme düşüncesi olduğundan sadece çalışacak olanlar gitmekteydi. Amaç biraz para biriktirip, tekrar Türkiye'ye geri dönmekti. Bu durumu o zaman yapılan araştırmalar da doğrulamaktadır.

1972 yılına Alman Çalışma Kurumu tarafindan Türk işçiler ile yapılan bir anketin sonucuna göre, Almanya'daki Türk iş̧̧ilerin \% 91'inin Türkiye'ye geri dönme düşüncesinde olduğu, sadece \% 9'unun Almanya'ya yerleşmeyi düşündüğü sonucu çıkmıştır. 1974 yılında Marplan adlı bir araştırma kurumunun yaptı̆̆ araştırma sonucuna göre ise Almanya'da kalmak isteyenlerin oranı \%29.1 olarak ölçülmüş, ancak bu orana kalmayı kesin olarak karar verememişler de dahil edildiğinden, kesin olarak kalma düşüncesinde olanların daha düşük düzeyde olduğu anlaşılmaktadır (Demircioğlu, 1983).

Almanya'daki işgücü ihtiyacındaki değişme, yabancılara yönelik politika değişiklikleri, uyum sorunu gibi değişik etkenlere bağlı olarak Almanya'daki Türklerin demografik yapısında da değişimler olmuştur. 1961 yılında işçi ihtiyacının karşılanması için anlaşma yapılmasından sonra işçileri teşvik etmek amacı ile 1964 yılında da iki ülke arasına sosyal güvenlik anlaşması yapılarak, iş̧̧ilerin sağlık, emeklilik, iş kazaları, ölüm, işsizlik sigortası, doğum ve çocuk yardımı gibi konularda yeni haklar tanınmıştır. Ancak Almanya daha sonra 1973 yılında yaşanan petrol krizi ve ortaya çıkan ekonomik kriz nedeni ile yabancı iş̧̧i alımını durdurmuştur. 1980 yılına gelindiğinde ise Türklere vize zorunluluğu getirilmiş, iltica yoluyla gelenlere çalışma izni verilmemiş ve 1983 yılında da geri dönüşü teşvik amacı ile yasal düzenleme yapılmıştır. Bu amaçla 30 Haziran 1984 tarihine kadar Türkiye'ye geri dönecek işçilere 10.500 mark ve çocuk başına da 1.500 mark parasal yardım verileceği, ödedikleri primleri de iki yıl beklemeden geri alacakları yasada kararlaştırılmış, bunun sonucunda da 211.000 Türk, Türkiye’ye geri kesin dönüş yapmıştır (Koçtürk, 2008). 
$\mathrm{Bu}$ gelişmelerden sonra yıllar içerisinde Almanya'daki Türk vatandaşlarının yıllar itibari ile gelişimi aşağıdaki tabloda gösterilmiştir. Göçün ilk yıllarında kadın-erkek oranı kadınlar aleyhine bir durumdaydı ve ilk işçi göçünden oniki yıl sonra da 1973 yılında \% 20’ye yükselmişti. Bugün gelinen noktada Almanya'daki Türk nüfusunun yaklaşık \% 52'si erkeklerden oluşurken, \% 48'i kadınlardan oluşmaktadır. Elli yıllık süreçte nüfus bazında kadın-erkek arasında nisbi bir dengenin oluştuğunu söylemek mümkündür. Alman İstatistik Kurumu'nun verilerinden hazırlanan bu tabloda Alman vatandaşı olan Türk kökenlilerin yer almadığını da dikkate almak gerekmektedir.

\begin{tabular}{|l|l|l|l|}
\hline \multicolumn{1}{|c|}{ Yil } & Toplam & Erkek & Kadın \\
\hline 1975 & 1077097 & 669995 & 407102 \\
\hline 1980 & 1462442 & 876154 & 586288 \\
\hline 1985 & 1401932 & 808468 & 593464 \\
\hline 1990 & 1694649 & 940948 & 753701 \\
\hline 1995 & 2014311 & 1102011 & 912300 \\
\hline 2000 & 1998534 & 1083102 & 915432 \\
\hline 2005 & 1764041 & 937581 & 826460 \\
\hline 2010 & 1629480 & 852633 & 776847 \\
\hline
\end{tabular}

Tablo 2: Almanya'daki Türk Vatandaşlarl (1975-2010) Kaynak: Statistisches Bundesamt, Wiesbaden, 2011

Alman vatandaşlığına geçenleri de dikkate aldığımızda Almanya'daki Türk nüfusunun çok daha fazla olduğu görülecektir. İşçi göçü anlaşmasının yapılığı ilk yıl Alman vatandaşı olan Türk sayısı sadece 13 kişi iken, zamanla bu sayı artarak 2010 yılında 830.736 kişiye yükselmiştir. Burada dikkat çekici olan belirli yıllarda Alman vatandaşlığa geçişin hızla arttığı, ancak özellikle 2000 yılından sonra bu artışın durarak, tersine hızla azaldığ görülmektedir. 1995 'ten 2000 y1lına kadarki beş y1llık süreçte \% 162 artmışken, bu defa yine 2000'den 2005 yılına kadar geçen beş yılda \%153 azalmıştır. 2000 yılına kadar Alman vatandaşlığı Türkler tarafindan çok rağbet görürken, daha sonraki yıllarda bu durum tersine dönmüş ve Alman vatandaşlığına geçenlerin sayısında hızlı bir oransal azalma yaşanmaktadır. Yine de az da olsa her yıl önemli sayıda Türk, Alman vatandaşlığına geçmeye devam etmektedir.

\begin{tabular}{|l|l|}
\hline Yll & Sayı \\
\hline 1961 & 13 \\
\hline 1965 & 39 \\
\hline 1970 & 52 \\
\hline 1975 & 225 \\
\hline 1980 & 399 \\
\hline 1985 & 1310 \\
\hline 1990 & 2034 \\
\hline 1995 & 31578 \\
\hline 2000 & 82861 \\
\hline 2005 & 32661 \\
\hline 2010 & 26192 \\
\hline Genel Toplam & $\mathbf{8 3 0 ~ 7 3 6}$ \\
\hline
\end{tabular}

Tablo 3: Alman Vatandaşlığına Geçen Türkiye Cumhuriyeti Vatandaşlarının Dağılımı (1961-2010) Kaynak: Statistisches Bundesamt, Wiesbaden, 2011

Alman vatandaşlığına geçişte 2000 yılından sonra yaşanan hızlı azalışın temel nedeni Almanya'da yapılan yasal düzenlemelerdir. 2000 yılında yürürlüğe giren Alman Vatandaşlık Yasası ile artık çifte vatandaşlık bütünüyle yasaklanmıştır. Önceden Alman vatandaşlığına geçen ve ayını zamanda da Türk vatandaşlığııı koruyabilen Türkler için Alman vatandaşlığı cazip gelmekteydi. Ancak yeni yasayla birlikte bu durum mümkün olmadığından dolayı Alman vatandaşlığına geçiş te azalmıştır.

2000 yılından itibaren Almanya'da doğmuş olan yabancı kökenli biri, doğumla Alman vatandaşlığını kazanabilmektedir. Ancak bu kişi aynı zamanda bir başka ülkenin de vatandaşı ise reşit olduğunda hangi vatandaşlığı tercih ettiğini görevli makamlara bilirmek zorundadır. Eğer 23 yaşını dolduruncaya kadar tercihini bildirmez ise Alman vatandaşlığını kaybedeceklerdir (madde 29) (Özkan ve Tütüncübaşı, 2008). Daha once böyle bir uygulama ile karşılaşmayan ve böyle bir tercihe zorlanmayan yabancılar için ortaya çıkan bu yeni durumla beraber, Alman vatandaşlığını tercih etmenin önemli bir avantajı olmalıdır ki, insanlar kendi vatandaşlıklarından vazgeçsinler. Almanya'da uygulanan bu yeni sisteme "opsiyon modeli" adı verilmektedir ve bu modelin ortaya çıkardığı sorunlar ülke gündeminde sürekli tartışılmaktadır. Eylül 2013 'te yapılacak genel seçimler öncesi yaşanan önemli tartışma başlıklarından birini de opsiyon modeli uygulaması oluşturmaktadır. Resmi makamlarca 2013 yılında 3.300 gencin bu tercihini bildirmesi gerektiği açıklanmıştır. Bu uygulama devam ederse 2018 yılında bu sayının 40.000 kişiye ulaşacağı öngörülmektedir (Deutsche Welle, 21.02.2013) 
Tablo 4'te Almanya'ya gelen ve ayrılan Türklerin sayıları gösterilmektedir. 2005 yılına kadar gelen vatandaşların sayısı, ayrılanların sayısından daha fazla iken, bu yıldan itibaren ayrılanların sayısı gelenlerin sayısından daha fazla olmaya başlamıştır. Ayrılanların sayısı rakamsal olarak bir artış göstermemiştir, ancak gelenlerin sayısında yıllar itibari ile önemli azalış olduğundan dolayı aradaki fark büyümüştür. Buradan da anlaşıldığı gibi Almanya'dan ayrılanların sayısı artmamakta, aksine azalmaktadır. Yani artık yıllar itibari ile Almanya artık Türkler için kalıcı vatan olmaya başlamıştır. Bunun yanında çeşitli nedenlerle gelenlerin sayısı da azalmaktadır. İş bulma, eğitim, evlilik gibi nedenlerle geçmişte daha fazla insan Almanya'ya gelirken, artık gittikçe azalan sayıda Türk Almanya'ya gelmektedir denebilir.

\begin{tabular}{|l|l|l|}
\hline Y1l & Gelen & Ayr1lan \\
\hline 1998 & 47.858 & 45.142 \\
\hline 1999 & 48.129 & 42.823 \\
\hline 2001 & 40.858 & 26.656 \\
\hline 2002 & 58.128 & 36.750 \\
\hline 2003 & 49.699 & 35.612 \\
\hline 2004 & 42.644 & 38.005 \\
\hline 2005 & 36.019 & 34.466 \\
\hline 2006 & 30.720 & 32.424 \\
\hline 2007 & 27.599 & 29.879 \\
\hline 2008 & 28.741 & 38.889 \\
\hline 2009 & 27.212 & 35.410 \\
\hline 2010 & 27.564 & 31.754 \\
\hline
\end{tabular}

Tablo 4: Almanya 'ya Gelen ve Ayrllan Türk Vatandaşları (1998-2010) Kaynak: Berlin Çalışma Müşavirliği Istatistikleri

Almanya'yı artık kendi vatanı olarak kabul eden yeni nesil göçmen gençler arasında Almanlar ile evlilik olayları da artmaktadır. Almanya'da bulunan 18.2 milyon evli çiftin 1.2 milyonu yabancılarla yapılan evliliği tercih etmişlerdir. Bu yabancı evliliklerin \% 14'ünü de Türklerle yapılan evlilikler oluşturmaktadır. Alman Federal İstatistik Dairesi verilerine göre Alman kadınların yabancı erkeklerle yaptıkları evlilikte ilk sırayı \% 17 ile Türk erkekleri almaktadır. Aynı durumun erkekler içinde geçerli olduğu ve yabancılarla evlenen Alman erkeklerde de \% 11 ile ilk sırayı Türk kadınları almıştır (Sabah Avrupa, 2011).

\subsection{Almanya'daki Türklerin Eğitim Durumu ve İstihdamdaki Yeri}

Almanların Türklere yönelttikleri en büyük eleştirilerden biri eğitime olan ilgisizliktir. Bunu resmi rakamlara da dayandırarak ifade etmektedirler. Federal Göçmen ve Mülteciler Dairesi tarafindan yapılan bir araştırmaya göre "Almanya'da yaşayan Polonyalı göçmenlerin üçte ikisi, Yunan göçmenlerin ise yarısından fazlası ortaokul ve üzerinde eğitim seviyesine sahipken, İtalyanlarda ve eski Yugoslavya ülkelerinin göçmenlerinde bu oran yüzde 44, Türklerde ise yüzde 41 olarak ölçülmüştür. Türk kökenli göçmenler, okuma-yazma oranına göre yapılan değerlendirmede de en arka sırada yer almaktadır. Araştırmaya göre, Almanya'daki Türklerin yüzde yedisi okuma-yazma bilmemektedir.”(DW, 1010,b) . Bu olumsuz görüntünün ve algının değişmesi için Türk çocuklarının daha fazla oranda eğitime yönlendirilmesi gerekmektedir. Diğer göçmenler eğitimin önemini kavradıklarından olayı, Türklere göre daha fazla oranda insan eğitim hayatının içinde yer almaktadır.

Almanya'da üniversitede okuyan çok sayıda Türk kökenli göçmen de bulunmaktadır. Alman İstatistik Kurmu verilerine göre 2009-2010 eğitim öğretim döneminde Almanya'da toplam 24.170 Türk vatanaşı üniversitede okumaktadır. Ancak bu sayıya Alman vatandaşı olan Türkler dahil edilmemiştir. Onları da dikkate aldığımızda sayının 40 bin civarında olabileceği tahmin edilmektedir ve bu üniversite öğrencilerinin \%42 'si de bayanlardan oluşmaktadır. Okul türlerinde ise ilk sırayı dil ve kültürle ilgili bölümler alırken, onu sırasıyla hukuk-ekonomi sosyal bilimler, mühendislik ve matematik-fen alanları izlemektedir (Statistisches Bundesamt, 2011).

Almanya'da işsizleri ve bu işsizler arasında yabancı ülke vatandaşlarının ve Türklerin durumunu görmek için aşağıdaki tabloya bakıldığında 1999 yılında en büyük yabancı grubunu oluşturan Türklerin 176.614'ü işsiz iken on yıl sonra 2009 yılında 157.357'ünün işsiz olduğu görülmektedir.

Almanya'da iş bulma ve eğitimine uygun bir işte çalışma konusunda göçmenlerin Almanlara göre daha dezavantajlı konumda oldukları bilinen bir gerçektir. OECD’nin 2007-2008'de yaptığı bir araştırma sonucuna göre, göçmenlerin Almanlara kıyasla ortalama 5 adet daha fazla iş başvurusu göndermesi gerekmektedir. Yakın zamanda Türkler ile Almanların işe yerleştirilmerindeki farklılığı ortaya koymak amacı ile yapılan bir başka araştırmada, hayali Alman ve Türk isimleri ile 1000 iş başvurusu yapılmış ve Alman şirketlerinin \% 14 oranında daha fazla olarak, isimleri Alman olan iş başvurularını tercih ettikleri ortaya konmuştur. Neden böyle bir tercihte bulundukları sorulduğunda da, Türklerin kalifiye eleman olmadıkları yada müşterilerin rahatsız olduğu gibi cevaplar verilmiştir (DW, 2010c). Ayrımcılığın özellikle işe alınma ve kariyer imkanlarından 
yararlandırma konusunda ortaya çıktığı bilinmektedir. Bu nedenle Türk gençleri Almanlara ve diğer göçmenlere kıyasla daha güçlükle çalışma yaşamında yer alabilmekte ve mücadele etmek durumunda kalmaktadırlar.

\begin{tabular}{|c|c|c|c|c|c|c|}
\hline \multirow{3}{*}{ Köken } & \multicolumn{3}{|c|}{1999} & \multicolumn{3}{|c|}{2009} \\
\hline & \multirow[b]{2}{*}{ Toplam } & \multicolumn{2}{|l|}{ Cinsiyet } & \multirow[b]{2}{*}{ Toplam } & \multicolumn{2}{|l|}{ Cinsiyet } \\
\hline & & Erkek & Kadın & & Erkek & Kadın \\
\hline Toplam & 4.100 .499 & 2.160 .461 & 1.940 .038 & 3.139 .846 & 1.724 .562 & 1.415 .284 \\
\hline Alman & 3.592 .317 & 1.835 .339 & 1.756 .978 & 2.650 .405 & 1.455 .129 & 1.195 .276 \\
\hline Yabancı & 503.341 & 321.564 & 181.777 & 484.931 & 266.783 & 218.148 \\
\hline Yunan & 24.507 & 14.361 & 10.146 & 16.387 & 9.572 & 6.815 \\
\hline İtalyan & 44.187 & 30.532 & 13.655 & 33.406 & 21.114 & 12.291 \\
\hline Hirvat & 14.902 & 8.617 & 6.286 & 10.891 & 5.738 & 5.153 \\
\hline Rus & 18.942 & 8.482 & 10.460 & 21.410 & 9.426 & 11.985 \\
\hline Türk & 176.614 & 114.131 & 62.482 & 157.357 & 93.346 & 64.011 \\
\hline
\end{tabular}

Tablo 5: Almanya'da İşsiz Sayısı, Türkler ve Seçilmi Bazı Yabancılar 1999-2009 Kaynak: Bundesagentur für Arbeit ( Almanya Federal Çalışma Ajannsı) İstatistikleri

Almanya'nın ihtiyaç duyduğu işgücü ihtiyacına göçmenlerinde büyük katkısı bulunmaktadır. Aşağıdaki tabloda Almanya'da sigortalı olarak çalışan Türk vatandaşlarının cinsiyete ve yaşa göre dağılımı gösterilmiştir. Tabloya bakıldığında, rakamlar özellikle genç nüfusta çalışanlar içinde kadın sayısının önemli miktarda olduğunu göstermektedir. Kadınların yaşlarına göre çalışma yaşamındaki oranlarına bakıldığında; 15-20 yaş grubunda çalışan kadın oranı \% 43, 20-25 yaş grubunda \% 40, 25-30 yaş grubunda \% 31, 50-55 yaş grubunda $\%$ 29'dur. Genç yaşlarda çalışanlar içindeki kadın oranı oldukça yüksektir. Toplamda ise çalışanlar içindeki kadın oranı \% 30'dur. Türkiyede toplam istihdamda kadın oranının \% 24 olduğu (TEPAV, 2012) düşünülürse Almanya'da çalışma yaşamında Türk vatandaşı kadınların oranının daha yüksek olduğu anlaşılmaktadır. Türkiye'ye kıyasla Almanya'daki Türkiye kökenli kadınlar, çeşitli etkenlere de bağlı olarak, çalışma yaşamına katılmakta daha istekli durumdadırlar. Bu sonuçta etken olan en önemli nedenlerden biri de yaşadıkları ülkedeki sosyo-kültürel yapıdır.

\begin{tabular}{|l|l|l|l|}
\hline \multirow{2}{*}{ Yaş Grubu } & \multicolumn{3}{|c|}{ Çalışan Sayıs1 } \\
\cline { 2 - 4 } & \multicolumn{1}{|c|}{ Erkek } & \multicolumn{1}{|c|}{ Kadın } & \multicolumn{1}{c|}{ Toplam } \\
\hline $15-20$ yaş aras1 & 9.966 & 7.744 & 17.710 \\
\hline $20-25$ yaş aras1 & 36.208 & 24.924 & 61.132 \\
\hline $25-30$ yaş aras1 & 38.354 & 17.574 & 55.928 \\
\hline $30-35$ yaş aras1 & 57.789 & 19.505 & 77.294 \\
\hline $35-40$ yaş aras1 & 62.955 & 24.193 & 87.148 \\
\hline $40-45$ yaş aras1 & 53.997 & 22.172 & 76.169 \\
\hline $45-50$ yaş aras1 & 53.126 & 18.411 & 71.537 \\
\hline $50-55$ yaş aras1 & 20.494 & 8.765 & 29.259 \\
\hline $55-60$ yaş aras1 & 11.937 & 6.534 & 18.471 \\
\hline $60-65$ yaş aras1 & 5.952 & 2.998 & 8.950 \\
\hline 65 ve yukar1 & 590 & 323 & 913 \\
\hline Toplam & 351.368 & 153.143 & 504.511 \\
\hline
\end{tabular}

Tablo 6: Sigortalı Çalışan Türk Vatandaşlarının Yaşa Göre Dă̆ılımı, 2011 Kaynak: Bundesagentur für Arbeit (Almanya Federal Çalışma Ajannsı) İstatistikleri

\subsection{Almanya'daki İşveren Türkler}

Almanya'da Türk kökenlilerin önemli bir bölümü artık kendi işyerlerini kurmuşlar ve girişimci olarak farklı sektörlerde önemli işler yapmaktadırlar. 1960'larda Türklere yönelik ürün satmak amacıyla açılan ilk Türk işyerlerinin yerini yıllar içerisinde farklı sektörlerde yer alan işletmeler almıştır. Sayıları sürekli artarak büyüyen Türk işletmeleri, Almanya ekonomisine de önemli katkı sağlamaktadır. 1970 yılında Almanya'da çalışan Türklerin ancak 3.300'ü kendi işyerinde girişimcilik faaliyetinde bulunuyordu ve bu oran \%1'den de düşüktü. 1999 ylına gelindiğinde Türk girişimcilerinin sayısı 55.000'e ulaştı ve çalışan Türklerde girişimcilerin oranı da \% 6.7'ye yükseldi (ATGİAD,2011). Bugün gelinen noktada bu sayının çok daha fazla olduğu görülmektedir. Aşağıaki tabloda bu gelişim daha net olarak görülmektedir.

1987 yılında Türk'lerin sahip olduğu işletme sayısı 25.500 iken bu sayı 2008 yılında 72.000'e yükselmiştir. İşletme sayısı ile beraber işletme başına yapılan yatırım tutarları da yükselmiştir. 1987'de işletme başına ortalama yatrım 92 bin Euro iken, 2008'de 115 bin Euroya yükselmiştir. Aynı şekile çalışan sayısı da 87 binden 331.200'e yükselmiştir. Burada dikkat çeken bir diğer nokta da, Türk işletmelerinde çalışan Alman ve diğer 
yabancıların sayısıdır. 1987'de çalışanların \%10'u Türk olmayan kişilerden oluşurken, bu oran 2008'de \%20'ye yükselmiştir. Çalışan sayısı arttıkça, Türk işletmelerinde çalışan yabancı sayısı da artmaktadır. Bu tabloya göre Türk işletmeleri sadece Türk kökenliler için bir istihdam kapısı olmayıp, aynı zamanda Almanlar ve diğer göçmenler için de iyi bir istihdam yeri durumundadır. Bugün gelinen noktada Türk işletmelerinde çalışan her beş kişinden biri, Türk kökenli olmayan çalışanlardır.

\begin{tabular}{|c|c|c|c|c|c|c|c|}
\hline \multirow{2}{*}{\begin{tabular}{|r|} 
Y1l \\
Issletme Sayıs1
\end{tabular}} & & \multicolumn{2}{|c|}{\begin{tabular}{|cc}
$1987 \quad 1992$ & 199 \\
2008888 &
\end{tabular}} & \multirow{2}{*}{$\begin{array}{r}2002 \\
47.000\end{array}$} & \multirow{2}{*}{$\begin{array}{l}2007 \\
56.800 \\
\end{array}$} & 2008 & \multirow[b]{2}{*}{72.000} \\
\hline & & 25.500 & 35.000 & & & 70.300 & \\
\hline $\begin{array}{l}\text { İsletme başına ortal } \\
\text { (Euro) }\end{array}$ & ama yatırım hacmi & 92.000 & 105.000 & 104.000 & 115.000 & 110.000 & 115.000 \\
\hline \multirow{3}{*}{$\begin{array}{l}\text { Almanya'daki } \\
\text { Türk İşletmelerinde } \\
\text { Toplam İstihdam } \\
\text { Sayısı }\end{array}$} & $\begin{array}{l}\text { İstihdam Edilen } \\
\text { Alman ve Diğer } \\
\text { Uyrukluların } \\
\text { Sayısı }\end{array}$ & 8.700 & 15.000 & 28.980 & 43.500 & 67.400 & 66.240 \\
\hline & \begin{tabular}{|l} 
İstihdam \\
Edilen Türk \\
Kökenli Sayısı
\end{tabular} & 78.300 & 110.000 & 178.020 & 246.500 & 269.600 & 264.960 \\
\hline & $\begin{array}{l}\text { Toplam } \\
\text { İstihdam Sayıs1 }\end{array}$ & 87.000 & 125.000 & 207.000 & 290.000 & 337.000 & 331.200 \\
\hline
\end{tabular}

Tablo 7: Almanya'daki Türk Girişimcilerinin Gelişimi (1987-2008) Kaynak: Şen ve Güler, 2009, AB ve Almanya'da Türk Girişimcilerin Ekonomik Gücü Araştırması

Almanya'daki Türk işletmelerinin dağılımı aşağıdaki tabloda gösterilmiştir. Buna göre dışardan bakıldığında, yada eleştiri amacı ile yaklaşıldığında söylenen, "Türkler genelde lokanta-market türü işlerle ilgileniyorlar" söyleminin yanlış olduğu anlaşılmaktadır. Tablodan da anlaşıldığı gibi her sektörde belirli bir oranda Türk firmasının olduğu görülmektedir. Bu sonuçlara göre sadece belirli işleri Türk işletmelerinin işi gibi görmek de yanilticidir.

\begin{tabular}{|l|l|l|}
\hline Faaliyet Alanı & Say1 & Oran $(\%)$ \\
\hline Zanaat, inşaat, imalar sektörü & 11.700 & 17.2 \\
\hline Ticaret & 22.800 & 33.4 \\
\hline Yiyecek-İçecek işletmesi & 18.100 & 26.5 \\
\hline Hizmet & 15.700 & 22.9 \\
\hline Toplam & 68.300 & 100 \\
\hline
\end{tabular}

Tablo 8: Türk İşletmelerinin Sektörel Dă̆ıllımı , 2006 Kaynak:Şen vd. 2008. Almanya ve AB'nde Türk Girişimciler

Yılda ortalama 400 milyar euro ciro yaptığı tahmin edilen Türk girişimcilerin Almanya tarafindan yeterince önemsenmediğini de söylemek mümkündür. Artık bu işletmeler klasik dönerci, yada manav olmanın çok ötesine geçmiştir ve bugün bu cironun ancak \%10'luk kısmı dönercilere yada manavlara aittir. Günümüzde Türkler yüzden fazla değişik alanda faaliyet göstermekte ve 400 bin kişiye istihdam sağlamaktadır (DW, 2010c).

\section{Sonuç}

Türklerin Almanya'ya misafir işçi olarak gittikleri ilk yıl olan 1961 yılının üzerinden elli yıldan fazla zaman geçti. Öncelei binlerle başlayan bu misafirlik, sonraları milyonlarla ifade edilen ev sahipliğine doğru bir dönüşüm yaşadı. Bu süreç içerisinde ilk kuşak emekli oldu, onların çocukları, torunları bugün Almanya'da hayatın her alanında yer almaktadırlar. Başlangıçta geri dönüş düşüncesi egemen olduğu için para biriktiren, tasarruflarını Türkiye'ye aktaran ve yatırımlarını da Türkiye'de yapan göçmen işçiler, Almanya'da kalıcı olmaya başladıktan sonra artık birikimlerini de orada değerlendirme yolunu seçmişlerdir. Siyasetten, ekonomiye, sanattan spora her alanda Türkiye kökenli insanlarımızı görmekteyiz. Misafir işçi olarak başlanılan süreç artık işverenlik, milletvekilliği, bakanlık, siyasi parti başkanlığı, milli sporculuk, yılın işvereni, yılın sanatçısı, yılın başarılı girişimcisi gibi sıfatlarla devam etmektedir.

Bu yaşananların Almanya açısından olduğu kadar Türkiye açısından da aynı derecede önemi bulunmaktadır. Almanya'daki Türk nüfusu ülkemizdeki pek çok şehrin nüfusundan fazladır. Türkiye'nin Avrupa Birliği serüveninde, dış politikasında, ekonomisinde onların destekleri de önemlidir. Bu büyük nüfus, aynı zamanda Türkiye'nin Avrupa'daki görünen yüzü, imajı ve temsilcileri olmuşlardır. Onların yaşadıkları ülkedeki başarıları ve güçleri, aynı zamanda Türkiye'nin başarısı ve gücü olacaktır. Bugün Almanya'da Alman vatandaşı olmuş, dolayısı ile seçme ve seçilme hakkı elde etmiş bir milyona yakın Türkiye kökenli insan bulunmakta, yine yaklaşık aynı sayıda insan Almanya'da yaşamasına ragmen Türkiye'deki seçimlerde seçme ve seçilme hakkına 
sahiptir. Üstelik yapılan son yasal düzenlemelerle birlikte bu vatandaşlar artık oylarını Türkiye'ye gelmeden, Almanya'da kullanabileceklerdir. Bu kadar iç içe bir ilişki yumağı bulunan Almanya'daki Türkler konusunda üretilecek politikalar ve uygulamalar konusunda da iki ülkenin işbirliğine daha fazla ihtiyaç buaunmaktadır.

Almanya'daki Türkler artık Almanya'yı acı vatan olarak görmemekte, kalıcı vatan olarak görmektedir. Kalıcı vatanda da gerek Alman toplumu ile gerekse de diğer göçmen toplumlarla daha güçlü ilişikiler kurabilmenin yolu mutlaka her yönden daha güçlü olmaktan geçer. En önemli güç kaynağı da şüphesiz Türk gençlerinin daha fazla eğitime yönelmeleri, bulundukları ülkenin dilini daha iyi kullanmaları ve bunun yanında da kendi anadillerini de unutmamaları gerekmektedir. Almanya'nın en önemli göçmen grubunu oluşturan Türklerin çağımızın önemli bir stratejik gücü olan lobi faaliyetlerinde de önemi rol oynayabileceklerini de unutmamak gerekir. Son yıllarda sayıları hızla artan Türk girişimciler gerek ciroları ve ürettikleri mal ve hizmetlerle, gerekse de sağladıkları önemli sayıdaki istihdamla Alman ekonomisi için önemli aktörler konumuna gelmişlerdir. Zira bu girşimciler artık klasik manav-dönerci sınıflandırmasını çoktan aşmış ve profesyonel girşimciler olarak ekonomik hayatta yer almaktadırlar. $\mathrm{Bu}$ trend bu şekliyle devam ederse yakın gelecekte işçilikten işverenliğe doğru işleyen süreç daha da hızlanacak ve artık daha fazla oranda göçmen Türk, işçilikten işçi çalıştıran konumuna yükselecektir. Bunun yanında sosyal ve kültürel alanda da Türklerin Almanya'ya katkısının da artarak süreceği söylemek mümkündür.

\section{Kaynakça}

- $\quad$ ATGİAD, 2011. Almanya ve Avrupa'daki Türk Kökenli Girişimciler, Duisburg.

- Berlin Çalışma Müşavirliği, İstatistikler, 2011.Berlin

- Bundesagentur für Arbeit (Alman Çalışma Ajansı) İstatistikleri

- Çavuşoğlu, Halim. 2006.”Uluslararası Göç: Nedenleri, Tipleri, Türleri ve Göçmenler”, Folklor/Edebiyat, Cilt:12, Sayı: 48, 2006/4, Ankara, ss. 83-104

- Çelik, Latif. 2012. “Tarihin Peşinde” Uluslararası Tarih ve Sosyal Araştırmalar Dergisi, Yı1:2012, Sayı:7, Ss.147-164

- Demircioğlu, A.Murat, 1983. "Federal Almanya'dan Kesin Dönüş Yapan İşgücü”, Amme İdaresi Dergisi, C.11-17, Say1: 2, Haziran, ss.96-112

- Deutsche Welle (DW), 2010, Göçmen Türk Gençler Türkiye'de Çalışmak İstiyor, http://www.dw.de/g\%C3\%B6\%C3\%A7men-t\%C3\%BCrk-gen\%C3\%A7ler-t\%C3\%BCrkiyede\%C3\%A7al\%C4\%B1\%C5\%9Fmak-istiyor/a-5242878-1, 12.2.2010

- DW, 2010, Türkler Uyum Konusunda Zorlanıyor, http://www.dw.de/t\%C3\%BCrkler-uyum-konusundazorlan\%C4\%B1yor/a-5479966-1, 18.4.2010

- DW:Girşimci Göçmenlerin sayısı artıyor, http://www.dw.de/giri\%C5\%9Fimcig\%C3\%B6\%C3\%A7menlerin-say\%C4\%B1s\%C4\%B1-art\%C4\%B1yor/a-6059963-1, 01.10.2010

- Gökbayrak, Şenay. 2006. "Uluslararası Göçler ve Kadın Emeği”, Çalışma Ortamı Dergisi, Sayı:86, MayısHaziran

- Kara, Yağmur, 2008. Uluslararası Göç ve İşçi Dövizlerinin Belirleyenleri:Türkiye Örneği, Yayınlanmamış YL Tezi, Muğla Üniversitesi Sosyal Bilimler Üniversitesi.

- Kılıçaslan, Erhan, 2006. Almanya'daki Türklerin Türk-Alman İlişkileri Açısından Önemi ve Türk Nüfusunun Etkinliğinin Arttırılmasına Yönelik Alınabilecek Tedbirler, Atılım Üniversitesi Sosyal Bilimler Enstitüsü, Yayınlanmamış YL Tezi

- Koçak, Yüksel ve Terzi, Elvan, 2012, “Türkiye’de Göç Olgusu, Göç Edenlerin Kentlere Olan Etkileri ve Çözüm Önerileri”, KAÜ, İIBF Dergisi, Cilt: 3, Say1: 3, Yıl: 2012, ss.163-184

- Koçtürk, Milazim. 2008. Almanya’ya Göçün Tarihi, Die Gaste, Sayı:2, Temmuz-Ağustos

- Özkan, Işıl ve Tütüncübaşı, Uğur. 2008. Türk ve Alman Hukukunda Çifte Vatandaşlığa İlişkin Gelişmeler, A.Ü. Hukuk Fakültesi Dergisi, Cilt:57, Sayı:3, ss.599-634

- Silkin, Sema,2011. Üç Kuşağın Çalışma Deneyimleri: Türk Kökenli Kadınların Alman İş Piyasasındaki Fırsat ve Sorunları, Türk Alman İşgücü Anlaşmasının 50.Yılında Almanya Türkleri, Editör:Zehra Gülmüş, Eskişehir. ss.243-258

- Sabah Avrupa Gazetesi, 25.10.2011

- Sönmez, Sinan. 1980 “Neo-klasik Kuramda Uluslararasi İşgücü Hareketliliği”, Ekonomik Yaklaşım, Cilt 1, Sayı 1, ss.41-61

- $\quad$ Statistisches Bundesamt 2011, Statistics. Wiesbaden

- Suğanlı, Mehmet. 2003. Almanya'da Yaşayan ve TC Merkez Bankasında Hesabı Bulunan Türklerin SosyoEkonomik Yapısı ve İşçi Dövizleri, TC Merkez Bankası Yayını, Ankara 2003 
- Şen, Faruk ve Güler, Ahmet, 2009. Avrupa Birliği ve Almanya'da Türk Girişimcilerin Ekonomik Gücü Araştırma Özeti, TAVAK Yayını, Essen.

- Şen, Faruk, Ulusoy, Yunus ve Şentürk, Cem. 2008. “Almanya, ve Avrupa Birliğinde Türk Girişimciler”, Uluslararası Sosyal Araştırmalar Dergisi, Volume:1/2, Winter, 2008. ss.405-418

- $\quad$ TEPAV (2012), İstihdamı İzleme Bülteni, Sayı:4, 12.3.2012

- Yıldırımoğlu, Hakan. 2005. "Uluslararası Emek Göçü”, Kamu İş Dergisi, Cilt:8, Sayı:1

- Zeynep Aksoy, 2012. "Uluslararası Göç ve Kültürlerarası İletişim”, Uluslararası Sosyal Araştırmalar Dergisi, Cilt: 5 Sayı: 20 Kış 2012, ss.292-303

- Erker, Turhan.1967. “Dış Ülkelere İşgücü Akımı ve İş ve İşçi Bulma Kurumu”, Sosyal Siyaset Konferansları Dergisi, Cilt:18, Sayı:1, ss.85-104 


\title{
Rusya’nın Oylama Gücünün Avrasya Ülkeleri Üzerindeki Ekonomi Politiği
Political Economy of Russia's Voting Power on Eurasian Countries

\author{
Asst. Prof. Dr. Ceyhun Haydaroğlu (Bilecik Şeyh Edebali University, Turkey)
}

\begin{abstract}
The relationship between economy and politics shows itself explicitly while governments are determining and implementing national and international economic policies. In democratic societies voting power, which means that economical and political units uses against one another in decision making mechanisms, shapes stability and/or unstability. It can be explained that a government, which is structured by the sovereignty of a single party in a parlament, has a monopoly power. Putin, has an important voting power in both The Council of The Federation and State Duma. The confidence through this voting power, while national economic and political equlibrium is provided, in international context, stable and strong policies are followed. Russia, increases the pressure and makes its economical and political power apperant on the eurasian countries, especially which were under its' authority before. In this context Russia's voting power calculated seperately for all election periods by Normalized Banzhaf Index. According to this, the effect of today's Russia's dominance on the Eurasian countries has been analyzed within the boundaries of political economics dicipline. In consequence of the analysis; it is indicated that, there is a linear relationship between the Russia's voting power and economical stability, and Russia's efficieny on the eurasian countries gradually increases. The most important feature of this study, which makes it differentiated form others, is making political economy of Russia's efficiency on the eurasian countries within the context of political economics literatüre by the voting power perspective, besides cultural, historical and social factors.
\end{abstract}

\section{Giriş}

Politika ile ekonomi, her politik rejimde değişik şekillerde karşı karşıya gelmektedir. Politik yaşam, hem ekonomiden etkilenmekte hem de ekonomiyi etkilemektedir. Bir toplumun politik yapısı, benimsenen politik ideoloji ve yapıya dolaylı ve dolaysız etki yapan bütün faktörler, o ülkenin ekonomi modelini ve işleyişini etkilemektedir. Buna karşın ekonomide geçerli ilkeler, ekonominin yapısı, başarısı ve/veya ortaya çıkardığ sonuçlar da politik modele ve işleyişine yön vermektedir (Onur, 2004:1). Bir ülkenin ekonomik faaliyetlerini etkileyen tek faktör politik konsept olmamasına rağmen, ekonomi alanında yeni bir alt kol olarak ortaya çıkan politik ekonomi, politikanın ekonomik faaliyetleri etkileyip etkilemediği sorusundan kaynaklanan merakların cevaplandırılması için uğraşmaktadır.

Ekonomi bilimi, kıt kaynaklar ile sonsuz istekler arasındaki ilişkiyi temel alarak, insan davranışlarını inceleyen bir bilim olarak tanımlanırsa; politik iktisat, karar vermenin politik yapısını ortaya koyarak, politikanın toplumdaki ekonomik tercihleri nasıl etkileyeceğini incelemektedir. Toplumu oluşturan birimleri ülkeler ve diğer hükümetlerin yanında firmalar, sosyal gruplar ve diğer organizasyonları da içermektedir. Bu nedenle, politik yapının ve aktörlerin kararları piyasa güçleri içinde kıt kaynakların alternatif kullanımları ve fırsat maliyetleri hakkında sinyaller ortaya koymaktadır. Güç ve otoritenin nasıl elde edildiği ve uygulandığını kolektif karar almak için kullanılan mekanizmanın ne olduğu konusu politik ekonominin odak noktasını teşkil etmektedir (Bakırtaş, 2007:10).

Rusya, 2000 yılından itibaren Soğuk Savaş’ın yorgunluğunu üzerinden atarak Putin Dönemi'nde yeni bir reform sürecine girmiştir. Bu bağlamda; Putin Yönetimi, ülke içerisinde federal yapıyı güçlendirerek siyasi otoriteyi yeniden tesis etmiş, ülke dışında $\mathrm{AB}$, Çin ve İran gibi önemli aktörlerle işbirliğini artırmış, enerji kaynaklarını hem ulusal güvenlik hem de ekonomik gelişmeyi sağlayabilecek ustalıkla kullanarak yeniden etkinliğini artırmıştır (Özkan, 2010:110).

Putin'in dış politika yaklaşımı genel olarak; çıkara dayalı işbirliği ve medeni bir rekabetin olduğu çok kutuplu dünya düzeni içerisinde Rusya'nın yeniden bir dünya gücü haline gelmesi, bu konuda Batı'yla işbirliği yapılırken, pragmatik olarak Avrasya kartının da sıkça kullanılması üzerine kurulmuştur (İşyar, 2004:51). Putin'in dış politikada bu kadar güçlü konuma gelmesinin en önemli sebeplerinden biri iç politikada istikrarı yakalaması olmuştur. $\mathrm{Bu}$ çalışma bu istikrarı sağlayan unsurun parlamento temelinde oylama gücü üstünlüğü olduğunu ifade ederek farklı bir anlayış getirmektedir. Bu temelde oylama gücü kavramı, tarihçesi ve oylama gücünün ölçülmesi için sıklıkla kullanılan Banzhaf güç indeksi açıklanmıştır. Ardından Rusya’nın siyasi yapısı ortaya koyularak, parlamento temelli seçimler analiz edilerek oylama güç indeksleri türetilmiştir. Rusya'nın sahip olduğu oylama gücünün Avrasya bölgesi üzerindeki etkinliği tartışılmıştır. Sonuç ve öneriler sunularak çalışma tamamlanmıştır. 


\section{Oylama Gücü Yaklaşımı}

Güç, karar alma sürecinde bir grup veya kişinin diğerleri üzerinde kendi kararının çıkmasına yönelik kullanabileceği artı değerler bütünüdür. Seçim, karar alma sürecinde kişilerin özgür iradeleri doğrultusunda alınacak kararın sonucunu etkileme hakkıdır. İktisatçılara göre oy maksimizasyoncusu davranış sergileyen politikacı, politik bilimcilere göre kişisel güç veya otoritesini maksimize etmeye çalışmaktadır (Bakırtaş, 2007:11). Parlamentoda tek bir partinin hakimiyeti ile oluşturulan hükümetin, bir anlamda tekel gücüne de sahip olduğu ifade edilebilir. Mutlak oylama gücüne sahip bir parti kanunları değiştirme veya yürürlükten kaldırma konusunda tam bir serbestiye sahiptir (Saas, 2001:18).

Politik güç, politik karar alma sürecinin yasal bir sonucu olup muhalefete karşı hükümetin yasama gücü olarak tanımlanabilir. $\mathrm{Bu}$ nedenle politik güç, çoğu kez parlamentoda partiler tarafından elde edilen milletvekili sandalye sayıları olarak algılanabilir. Bununla birlikte, oylama mekanizması içerisinde partinin gücü oylama kurallarına, oluşturulan koalisyonlara ve partiler arasında parlamentoda sandalye dağılımlarına göre şekillenmektedir. Bu unsurların hiçbiri tek başına bir partinin oylama gücünü belirlemez (Bakırtaş ve Koyuncu, 2010:23).

Oylama teorisi ve oylama gücü yaklaşımı, önerilen bir durum için karar verme sürecinde farklı konumdaki üyelerine güç indekslerini kullanarak kararları etkileyebilme konusunda farklı etki düzeylerini sağlayan ve üyelerin oylama süreçlerindeki karar güçlerini analiz eden bir yaklaşımdır.

İlk oylama gücü ölçümleri 1780’lere dayanmakta ve Luther Martin tarafından uygulanmıştır. İlk bilimsel tartışma ise 1946 yılında Lionel Penrose tarafından yapılmış, oylama gücü kavramı tanıtılmış ve oylama birimindeki bir katılımcının sonucu etkileme yeteneğinin ölçüsü olarak tanımlanmıştır. 1954 yılında Lloyd S. Shapley ve Martin Shubik günümüzde en sık kullanılan indekslerden biri olan kendi güç indekslerini tanıtmıştır. Penrose'a benzer bir kavram da 1965 yılında John F. Banzhaf ve 1971 yilında James S. Coleman tarafindan yapılmıştır. Daha sonra çok sayıda güç indeksi de önerilmiştir (Gambarelli ve Stach, 2009).

Birleşmiş Milletler Güvenlik Konseyi'nde alınacak kararlarda üyelerin karar alma sürecindeki oy güçleri, Dünya Bankası gibi uluslararası ekonomi kuruluşlarında üye ülkelerin kararlarda finansal katkıları kadar oy gücüne sahip olması ve AB'nin genişleme sürecinde oylama prosedürlerinin yeniden düzenlenmesi gibi konular günümüzde güncelliğini tekrar kazanan oylama gücü yaklaşımının uygulama kapsamındadır.

Oylama gücü kavramının arkasındaki önemli fikir, seçmenin belli kriterlere göre hesaplanan oy ağırlığının iyi bir güç ölçüsü olmamasıdır. Dolayısıyla, analizde güç kavramı devreye girmektedir. Oylama teorisinin standart terimlerinden olan koalisyon, herhangi bir oyuncular kümesinin oylamada bir durumu oylarken güçlerini birleştirdikleri yapıdır. Bir koalisyon tarafından kontrol edilen toplam oy sayısı koalisyonun ağırlığı olarak adlandırılır. Bazı koalisyonlar kazanmak için yeterli oya sahipken bazıları yeterli oya sahip değildir. Yeterli oya sahip olan koalisyon kazanan koalisyon olarak adlandırılırken yeterli oya sahip olmayan koalisyon kaybeden koalisyon olarak adlandırılır. Tüm oyuncuları içeren koalisyon ise büyük koalisyon olarak adlandırılır. Büyük koalisyon, tüm oyları kontrol ettiğinden her zaman kazanan koalisyondur. Bir oyuncu koalisyondan ayrıldığında o koalisyon kazanan koalisyon durumundan kaybeden koalisyon durumuna dönüyorsa bu oyuncu ilgili koalisyon için kritik oyuncudur. Kazanan koalisyonlar bir ya da daha fazla kritik oyuncuya sahipken nadiren kritik oyuncu içermeyebilir, kaybeden koalisyon ise hiçbir zaman kritik oyuncu içermez. Eğer bir oyuncunun ağırlığı kota değerine eşit ya da büyükse diktatör olarak adlandırılır ve bir oyunda diktatör varsa diğer oyuncuların oyları hiçbirşey ifade etmez ve güce sahip olmazlar. Diktatör olmayan fakat tek başına bir kararın alınmasını engelleyebilen oyuncu ise veto gücüne sahiptir. Oylama gücü analizini yapabilmek için öncelikle ortaya çıkabilecek tüm koalisyonlar analiz edilir, her bir seçmenin belli kriterler göz önüne alınarak çeşitli algoritmalarla ağırlığı bulunur. Daha sonra güç indeksinin hesaplanabilmesi için kararın geçerli olabilmesini sağlayacak lehte verilmesi gerekli minimum oy sayısı olan kota değeri belirlenir ve kota değerine göre kazanan koalisyonlar bulunur. Son olarak, güç indeksleri yardımıyla her bir oyuncuya ait oylama gücü değerleri belirlenir (Tannenbaum, 2004).

Oy ağırlığı ve oylama gücü kavramları birbirinden farklıdır. Bir oyuncunun oylama ağırlığı olması o oyuncunun oylamada gücünün olduğunu göstermez. Bir oyunda oyuncunun oyu sonucu değiştiriyorsa o oyuncunun gücü vardır. Yani oylama gücü, oy ağırlığına orantılı bir kavram değildir (Kirsch et al., 2004). X, Y ve $Z$ gibi üç partinin olduğu bir örnek ile desteklemek gerekirse, 100 sandalyeli parlamentoda $X$ ve $Y$ partileri 49'ar Z partisi ise 2 sandalyeye sahiptir. Basit çoğunluk kuralı geçerli olması halinde herhangi bir partinin hükümeti kurabilmesi için diğer partilerden biri ile koalisyon kurması gerekir. Partilerin tümü koalisyonu kurabilmek için gerekli olan çoğunluğu sağlama bakımından eşit kritik öneme sahiptir. Bu nedenle, üç partinin oylama gücü \%33,3’e eşittir. Görüldüğü gibi büyük partiler için oylama gücü onların oylama ağırlıklarından daha düşükken, küçük partiler için ise oylama gücü oylama ağırlığından daha büyüktür (Reynaud vd. 2007:6).

Oylama gücü analizi ile; bireylerin bir karar üzerinde birbirlerine göre nispi güçlerini hesaplamak, oylama sistemini adil olup olmaması açısından değerlendirmek ve ortalama oy gücünü maksimize etmek, istenen oylama gücü dağılımına ulaşabilmek için ağırlıkları belirlemek ve üyelerin karar alma sürecinde 
etkili olabilmek için oluşturdukları koalisyonların yararlarını anlayabilmek amaçlanmaktadır (Gelman vd., 2002).

Belirli bir karar mekanizmasında oylama gücü analizi, üç faktöre bağlı olarak gerçekleştirilir. Bunlar; partiler arasındaki oyların dağılımı, kullanılan karar kuralları ve partilerin koalisyon oluşturma olasılıklarıdır. Oylama güç indeksleriyle gerçek oylama davranışları değil, çeşitli partilerin potansiyel güçleri belirlenir. Partiler, elde edeceği sonuç için tercihlerini 'evet' veya 'hayır' oyu şeklinde kullanarak açıklar. Bu nedenle partilerin oylama gücünün değeri, tercihlerine, uygulanan kotaya, oluşan koalisyon yapısına ve seçim sistemine bağlıdır. (Raunio ve Wiberg, 1998).

\subsection{Banzhaf güç indeksi}

Sıklıkla kullanılan B.G.İ. kritik oyuncu kuralına dayanmaktadır. N oyunculu bir ağırlıklı oylama sisteminde B.G.İ. hesaplanırken tüm kazanan koalisyonlar ve her bir kazanan koalisyondaki kritik oyuncular belirlenir. Daha sonra tüm oyuncuların kritik olduğu durumların sayısı belirlenir. $\mathrm{Pi}$, i. oyuncu olmak üzere $\mathrm{Pi}^{\text {ee }}$ nin kritik olduğu durumların sayısı belirlenir. Pie nin kritik oyuncu olduğu durumların sayısını tüm oyuncuların kritik olduğu durumların sayısına bölümü ile o oyuncunun B.G.İ. bulunur. Bu işlemler her Pi oyuncusu için yapılırsa B.G.İ. dağılımı bulunur (Tannenbaum, 2004).

Bir karar mekanizmasında, oy dağılımlarına bağlı olarak, her seçmen oluşturulacak koalisyonu etkileyecek mutlak bir güce sahiptir. Bir seçmen oluşturulacak koalisyonun ya kazanan ya da kaybeden tarafinda bulunacaktır. Bir karar mekanizmasında herhangi bir seçmenin belirleyici olma olasılığı, sahip olduğu oy sayısından çok az etkilenmektedir. Oylama gücü, ancak seçim sonucunda sahip olunan oy sayılarının meclis içindeki dağılımlarının ölçülmesiyle hesaplanabilir. Bu ölçüm için sıklıkla Banzhaf indeksi kullanılmaktadır (Felsenthal ve Machover, 1998:8-9).

$\mathrm{N}=\{1,2, \ldots$ i $\ldots, \mathrm{n}\}$ kümesindeki oyuncular göz önüne alındığında, ' $\mathrm{i}$ ' oyuncusu $\mathrm{w}_{\mathrm{i}}$ oylama ağırlığına sahip olmaktadır. $\Omega, \mathrm{N}$ tarafından oluşturulan tüm muhtemel $\mathrm{S}$ koalisyonlar kümesini ifade etmektedir. $\mathrm{S} \in \Omega$ biçimindeki bir kazanan koalisyon, q çoğunluk için gerekli olan sınır değerini gösterdiğinde $\sum_{j \in S} w_{i} \geq q$ ile karakterize edilmektedir. Eğer bir S koalisyonu kazanan koalisyon içerisinde yer alıyorsa, bu koalisyonun ' $v$ ' değeri 1 olarak tanımlanır. Bu durumda S oylamanın sonucunu belirleyebilmektedir. Tüm kaybeden koalisyonlar $\mathrm{v}=0$ değerini almaktadır. Oyuncu 'i' kazanan veya kaybeden koalisyonu etkileyebilmektedir. Oyuncu 'i' kazanan koalisyondan çıktığg zaman koalisyon bozulmakta, kaybeden koalisyon içerisine dahil olduğunda kazanan koalisyon şekline dönüşmektedir. Önemli olan oyuncu 'i’nin kazanan veya kaybeden tarafta yer alması değil, dağılımı etkileyecek bir konuma sahip olup olmamasıdır. Bu açıklamalar 1şığında mutlak Banzhaf indeksi (Absolute Banzhaf Index) ABI, aşağıda eşitlik'de gösterilmektedir (Huber, 2003:337):

$$
\beta_{i}^{*}=\frac{\sum_{S \subset \Omega}[v(S)-v(S /\{i\})]}{2^{n-1}}
$$

$2^{\text {n-1 }}$ ' $\mathrm{i}$ ' oyuncusunun dahil olduğu toplam koalisyonların sayısını temsil etmektedir. Normalize edilmiş Banzhaf indeksi, karar alma mekanizmasında tüm oyuncuların belirleyici olma sayısının 'i' oyuncusunun belirleyici olma sayısına oranı şeklinde ifade edilir. Oyuncu 'i’nin normalize edilmiş Banzhaf indeksi (Non-normalized Banzhaf Index) NBI aşağıda eşitlik’te gösterilmektedir (Huber, 2003:337):

$$
\beta_{i}=\frac{\beta_{i}^{*}}{\sum_{j=1}^{n} \beta_{j}^{*}}=\frac{\sum_{S \subset \Omega}[v(S)-v(S /\{i\})]}{\sum_{j=1}^{n} \sum_{S \subset \Omega}[v(S)-v(S /\{i\})]}
$$

Üç seçmenli ağırlıklandırılmış bir oyunda, A, B ve C seçmenlerinin ağırlıkları sırasıyla 50, 49 ve 1 olmaktadır. Basit oy çokluğu kuralının geçerli olduğu bu oyunda kota 51'dir. Bu karar mekanizmasında oyun [51: 50,49,1] şeklinde ifade edilir. ABI, seçmenlerin belirleyici olma durumlarını belirleyebilmek için tüm olası seçmen kombinasyonları incelenir. ' $n$ ' üyeli bir oyunda her zaman $2^{n}$ kadar dağılım bulunmaktadır. Bu oyunda $2^{3}=8$ farklı kombinasyon vardır. kombinasyonlar sirasıyla: A, B, C, $\underline{\mathbf{A B}}, \underline{\mathbf{A C}}, \mathbf{B C}, \underline{\mathbf{A B C}},(\mathrm{O})$ 'dır. ABI'da 51 olarak belirlenen kotayı aşan kazanan koalisyon dağılımı ortaya konulur. Bunlar: $\underline{\mathbf{A B}}, \underline{\mathbf{A C}}, \underline{\mathbf{A} B C}$ 'dir. Kalın ve altı çizgili seçmenler belirleyici konumda bulunmaktadırlar. Belirleyici seçmenler kazanan koalisyonlardan alınarak koalisyonu kaybeden şekline dönüştürüp dönüştürmediğine bakılarak tespit edilir. Tek tek belirleyici seçmenler tespit edildiğinde bu oyunda kazanan koalisyonlar içinde belirleyici seçmen sayısının beş olduğu görülür. ABI formülünde payda, 'i' seçmenin içinde bulunduğu kazanan veya kaybeden toplam koalisyon sayısını ifade etmektedir. $\mathrm{Bu}$ oyunda $2^{3-1}=4$ olur. Daha sonra her seçmenin belirleyici olma sayısı hesaplanır. ABI, her seçmenin belirleyici olma sayısının her seçmenin içinde bulunduğu toplam koalisyon sayısına bölünmesi şeklinde hesaplandığından seçmen A, B ve C'nin ABI değerleri sırasıyla; 3/4, 1/4 ve 1/4'dür. NBI değeri, seçmenlerin belirleyici olma durumlarının, her seçmenlerin belirleyici olma sayısına oranı şeklinde 
hesaplanmaktadır. Bu oyunda seçmenlerin belirleyici olma durumu beş olduğundan $\mathrm{A}$, B ve $\mathrm{C}$ seçmenlerinin NBI değerleri sırasıyla; $3 / 5,1 / 5$ ve 1/5 şeklinde ölçülmektedir (Louzek, 2004:219).

\subsection{Rusya'nın Oylama Gücü}

1991 yılında Sovyetler Birliğıie nin dağılmasıyla bağımsız bir ülke olarak dünya sahnesine çıkan Rusya Federasyonu, bağımsızlığının ilk yıllarında 75 yıl süren Sovyet yönetiminin ardından yeni bir siyasi sistem oluşturulması sürecinin zorluklarını yaşamıştır. $\mathrm{Bu}$ dönemde, yönetim kademelerinde baş gösteren görüş ayrılıkları 1993 yılında zirveye çıkmış ve aynı yıl Devlet Başkanı Boris Yeltsin askeri kuvvet kullanarak parlamentonun dağıtılmasını ve seçimlere gidilmesini sağlamıştır. Aralık 1993 'teki referandumla kabul edilen yeni anayasa ve seçim sonucunda oluşan ve değişik görüşlerden siyasi partilerin temsil edildiği yeni parlamento, Rus siyasetine istikrar kazandırılması açısından önemli iki adımı temsil etmektedir (Yardımcıoğlu ve Koçarslan, 2012:165).

Devlet Duma'sı ise 4 yılda bir yapılan seçimlerle belirlenmektedir. Duma'nın tarihi 1905 Devrimine kadar uzanmaktadır. 1905'ten sonra kapatılan Duma için, 1917'ye kadar birkaç kez daha yeniden kurulma girişimlerinde bulunulmuştur. 1917'den sonra ilk Duma seçimleri 1993 yılında yapılmıştır.

1993 anayasasına göre Rusya, cumhuriyetle yönetilen, demokratik ve federatif bir hukuk devletidir. Yürütme yetkisi, anayasa tarafından devlet başkanı ve başbakana verilmiştir. Devlet başkanı genel seçimle 4 yıllık bir süre için doğrudan seçilir ve aynı kişi ancak iki kez devlet başkanlığı yapabilirdi. Ancak anayasada yapılan değişiklikle 2012 yllında yapılan seçimle birlikte ilk kez devlet başkanı 6 yıllık bir süre için seçilmiştir (Atasoy, 2008:85).

Dokunulmazlığa sahip olan RF devlet başkanına verilmiş olan bazı yetkiler kendisini yasama organlarının üzerinde bir konuma yerleştirmektedir. Örneğin devlet başkanı, meclisin onayı gerekmeden kanun hükmünde kararnameler çıkartma, belirli şartlar altında Duma" yı dağıtma, Duma"eya yasa taslağı gönderme, gerekli durumlarda kabineyi bütünüyle azletme ve referandum talep etme yetkisine sahiptir. Ayrıca devlet başkanı Duma'nın onayıyla başbakanı atamak ve hükümet toplantılarına başkanlık etmekle sorumludur.

Rusya" 'nın ilk Devlet Başkanı Boris Yeltsin'dir. Yeltsin, 1999 yılının 31 Aralı̆̆ı'na kadar bu görevi iki dönem arka arkaya seçilerek yürüttükten sonra yetkilerini Vladimir Putin'e devretmiştir. 26 Mart 2000 tarihinde gerçekleştirilen devlet başkanlığı seçimlerini ilk turda yüzde 53 oyla kazanan Vladimir Putin, dört yıllık görev süresinin bitiminin ardından 2004 yılının Mart ayında yapılan seçimlerde oyların yüzde 71,31'ni alarak ikinci kez devlet başkanlığına seçilmiştir. Putin, görevdeki ikinci dönemini 2008 yılı başında tamamlayarak başkanlığı, Mart 2008 tarihinde gerçekleştirilen Başkanlık seçimlerini kazanan Dmitriy Medvedev'e devretmiştir. Medvedev yeni görevine 7 Mayıs 2008 tarihi itibariyle başlamıștır. 15 Nisan 2008'de Birleşik Rusya Partisi başına geçen

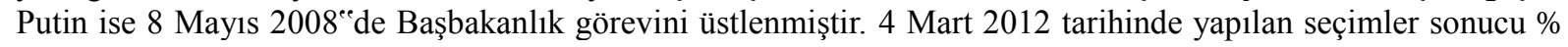
63,6 oyla Rusya Federasyonu'na 3. kez devlet başkanı seçilmiştir (Başbuğ, 2008).

Rusya"da yürütme gücünün diğer bir ayağı da hükümettedir. Rusya hükümeti, başbakan, başbakan yardımcıları ve federal bakanlardan oluşur. Başbakan, görevine devlet başkanı tarafından Devlet Duması'nın onayıyla atanır. Başbakan atandıktan sonra en geç bir hafta içinde federal yürütme organlarının yapısı hakkındaki önerileri ile başbakan yardımcıları ve federal bakanların isimlerini devlet başkanına sunar.

Hükümetin, federal bütçenin belirlenmesi, finans, kredi ve para politikalarının uygulanması, sosyal, yardım, sağlık, kültür, bilim gibi alanlarda uygun devlet politikasının izlenmesi ve ülke savunması ile devlet güvenliğinin sağlanması gibi görevleri vardır. Bu bağlamda, Rusya"da hükümetin, ağıllklı olarak ekonomik yönetim organı olduğu söylenebilir. Rusya"da aynı zamanda Anayasa Mahkemesi, Yargıtay, Danıştay, Sayıştay gibi yargı ve yürütme alanında kurulmuş anayasal devlet kurumları da bulunmaktadır.

Bu kurumlara ek olarak Eylül 2000 tarihinde Devlet Başkanlığı'na bağlı olarak kurulan Devlet Konseyi de danışma organı olarak faaliyet göstermektedir. Genellikle 3 ayda bir toplanan Konsey"de devlet yapılanması, federatif, siyasi, ekonomik ve sosyal konular görüşülmektedir. Federal Meclis ise Rusya'nın parlamentosu, temsil ve yasama organıdır. Federal Meclis"in iki kanadıvardır: Federasyon Konseyi (üst meclis) ve Devlet Dumas1 (alt meclis). Yasama yetkisine sahip olan 628 sandalyeli parlamento (Federal Meclis), 450 sandalyeli alt kanat Devlet Konseyi (Duma) ve 178 sandalyeli Federasyon Konseyi'nden oluşmaktadır.

Federasyon Konseyi'nde Rusya Federasyonu'na dahil olan 89 idari birimden ikişer kişi olmak üzere toplam 178 üye bulunur. Federasyon Konseyi danışma ve temsil özelliği ağır basan bir senato görünümündedir. Ancak son yıllarda öneminin azaldığı bir gerçektir. Devlet Duması ise 4 yılda bir yapılan genel seçimlerle belirlenen 450 milletvekilinden oluşmaktadır. Milletvekilleri belirli bir partiden veya bağımsız olarak seçilebilmektedir.

Federal Konsey ve Devlet Duması'nın görev alanları birbirinden farklıdır. Hatta çalışma yerleri de birbirinden farklı yerdedir. Duma'dan basit çoğunlukla geçen yasaların yürürlüğe girebilmesi için Federal Konsey tarafindan onaylanmaları gerekir. Buna karşın, Duma, üçte iki çoğunluğu yakaladığı takdirde, Federal Konsey'in vetosunu geri çevirebilme yetkisine sahip olduğu gibi, Anayasa değişimleri de önerebilmektedir. Aynı şekilde, Başkan Putin'in vetosunu üçte iki çoğunlukla reddedebilir; önerdiği başbakan adayını da onaylamayabilir; Hatta, Başkan'ın görevine son verilmesini de talep edebilir (Shukurov, 2003). 


\begin{tabular}{|l|l|l|l|l|l|}
\hline & 1995 & 1999 & 2003 & 2007 & 2011 \\
\hline Birleşik Rusya & & 73 & 222 & 315 & 238 \\
\hline Komünist Parti & 157 & 113 & 52 & 57 & 92 \\
\hline Liberal Demokrat Parti & 51 & 17 & 36 & 40 & 56 \\
\hline Adil Rusya & & & 37 & 38 & 64 \\
\hline Azınlık Partileri & 65 & 16 & 35 & & \\
\hline Bağımsızlar & 77 & 114 & 68 & & \\
\hline Anavatan -Tüm Rusya Hareketi & 55 & 68 & & & \\
\hline Sağ Güçler Birliği & & 29 & & & \\
\hline Yabloko & 45 & 20 & & & \\
\hline TOPLAM & 450 & 450 & 450 & 450 & 450 \\
\hline
\end{tabular}

Tablo 1: Rusya Genel Seçim Sonuçlarl

\begin{tabular}{|l|l|l|l|l|l|}
\hline$\%$ & 1995 & 1999 & 2003 & 2007 & 2011 \\
\hline Birleşik Rusya & & 13.33 & 75 & 100 & 100 \\
\hline Komünist Parti & 39.29 & 26.67 & 5 & 0 & 0 \\
\hline Liberal Demokrat Parti & 10.71 & 3.33 & 5 & 0 & 0 \\
\hline Adil Rusya & & & 5 & 0 & 0 \\
\hline Azınlık Partileri & 10.71 & 3.33 & 5 & & \\
\hline Bağımsızlar & 17.86 & 26.67 & 5 & & \\
\hline Anavatan Tüm Rusya Partisi & 10.71 & 13.33 & & & \\
\hline Sağ Güçler Birliği & & 10 & & & \\
\hline Yabloko & 10.71 & 3.33 & & & \\
\hline TOPLAM & 100 & 100 & 100 & 100 & 100 \\
\hline
\end{tabular}

Tablo 2: Rusya Genel Seçim Sonuçlarının NBI Dă̆ılımı

Başkan Putin, Duma'nın üçte ikisini oluşturan Birleşik Rusya Partisi’nin tam desteğine sahip olduğundan Komünist Parti dışında parlamentoda iktidara muhalefet edebilecek veya istenilen yasaların çıkmasını engelleyecek bir siyasi parti veya grup bulunmamaktadır. Dolayısıyla da Putin reformlarına yasama organından bir engelleme çıkması mümkün olmamaktadır. Bu nedenle Rusya'da demokratik hayat ve parlamentonun istikrar içinde çalışması Batı'daki anlamda tam olarak mümkün olamamaktadır. Rusya'da demokrasi geleneği ve siyasi uzlaşının oturması zaman almaktadır (Uslubaş, 2005, s. 120).

\section{Rusya'nın Oylama Gücünün Avrasya Bölgesi Üzerindeki Etkisi}

Vladimir Putin'in bir dönem ara verdikten sonra tekrar Rusya devlet başkanlığı koltuğuna oturmasıyla "Rus İmparatorluk stratejisinin" yeniden vücut bulduğu görüşleri sık sık uluslararası basında yer almış, Başkan Putin, Rusya'nın yaşam sahasının Avrasya coğrafyası üzerinde yer aldığı görüşünde olduğu görülmektedir. Rusya'nın Avrasya politikası çerçevesinde amacı, hem Sovyet bloğu ülkeleri üzerindeki etkisini yeniden tesis etmek, hem de özellikle Akdeniz ve Hazar Havzası'nda varlığına tehdit oluşturabilecek faktörleri bertaraf edebilmektir.

Rusya’nın toparlanma döneminin Vladimir Putin'in 2000 yılında iktidara gelmesiyle başladığg söylenebilir. Nitekim ilk on yıllık süreçteki Yeltsin iktidarı döneminde iç istikrarsızlık derinleşmiş ve ülkede yeniden güvenliğin tesis edilmesinin oldukça zor olduğu algısı yerleşmiştir. Bu nedenle 1990-2000 yıllarını belirsizlik dönemi olarak görmek mümkündür. Putin, Rusya'nın ilk on yılda geçirdiği belirsizlik döneminin ardından iç istikrardaki zafiyetin dış politikayı da etkilediğini görmüştür. Putin, kısa zamanda ilk on yılda oluşmuş oligarşiyi denetimini altına almış, Kuzey Kafkasya bölgesinde Çeçenistan, Dağıstan ve diğer özerk yönetimlerde yerli elitler ile ortak dil oluşturup, güvenliği sağlayabilmiştir. Putin iktidarı, ülke ekonomisini petrol ve gaz ihracatı ile ayağa kaldırmış ancak ülkedeki birçok ekonomik sorunu çözememiştir. Rusya Federasyonu'nda genel Petersburg ve Moskova bölgeleri yani ülkenin batı kısmı gelişmiş durumdadır. Diğer bölgelerin ekonomik durumu daha geridedir.

Yakın gelecekte, Avrasya bölgesinin ekonomik ve siyasi gelişmeyle birlikte rekabet alanı olacağı beklenmektedir. Rusya kendisinin “yumuşak karnı” olarak adlandırdığı Orta Asya'da ve "arka bahçesi” olarak adlandırdığı Kafkasya bölgelerinde ABD, AB, İngiltere, Çin, Hindistan ve Türkiye ile rekabete girmektedir. Bu rekabetin Avrupa bölgesindeki rekabetten ve denge politikasından daha sert bir kıvamda seyredeceğini fark eden Kremlin, Asya'daki rekabet ve denge oyununa hazırlıksız yakalanmaktan edişe etmektedir.

Rusya'nın "arka bahçesi” olarak nitelendirdiği eski Sovyet ülkelerini de içine alan "Avrasya Birliği Projesi” Moskova'nın önderliğinde şekil almaya başlamıştır. Başkan Putin'in yaptığı son açılamaya göre, Avrasya Birliği için taslak anlaşmasının Mayıs 2014 yılına kadar hazır olması beklenmektedir. Bu perspektiften hareketle Rusya'nın yeni dış politika vizyonu değerlendirildiğinde Moskova, global ölçekte istikrarsızlığın arttığı bir dönemde dengeleyici ve barış tedarikçisi misyonuna sahip olmak isteyecektir. Artık Birleşmiş Milletler 
Rusya'nın bakış açısına göre küresel sorunlara çare bulmada son derece "aciz" kalmaktadır. Bunun en somut örneği ise BM'nin Batılı güçlerin bazı ülkelerin uluslararası hukuku çiğneyerek müdahale bulunması karşısında yaptırım uygulayamamasıdır. Rusya'nın yeni dış politika penceresinde ülkeler birbirlerine ekonomik ve siyasal olarak daha bağımlı, dolayısıyla da tek başlarına güvenlik ağı oluşturamayacak kadar yetersiz kalmaktadır.

Rusya, tek kutuplu dünya düzeninin 2008'de ABD'de ve AB'de başlayan ekonomik kriz ve Çin'in yükselişinden sonra devam edemeyeceğini anlamış, Avrupa'da kendi denge politikasını kurarak arka planda güçlenmeyi ve küresel bir güç olarak kabul edilmeyi hedeflemiştir.

Moskova bu nedenle yakın gelecekte oluşabilecek tehditleri önlemek maksadıyla eski etki alanlarında kısa zamanda ekonomik bir birlik kurmayı hedeflemektedir. Rusya böylece AB benzeri bir sistemle merkezi Avrasya bölgesinde yeniden toparlanma politikasını yürürlüğe koymayı amaçlamaktadır. Rusya tasarladığı bu birliği Avrasya Birliği biçiminde tanımlamaktadır. Eski Sovyet ülkelerini kendi çevresinde toparlamayı amaçlayan Moskova, ilk olarak 2012 yılında Kazakistan ve Beyaz Rusya ile gümrük birliği anlaşması imzalamıştır (Kokoshin, 2006:108).

Putin, SSCB’nin dağılmasını "çağın en büyük felaketi” olarak gören ve uluslararası sistemik yapının "çok kutupluluk" çerçevesinde düzenlenmesini arzulayan bir isim olarak ön plana çıkmaktadır. Bu çerçevede, Putin'in, Avro-Atlantik Dünyası'nın sistemsel hâkimiyetine karşı çıkan en önemli aktör olduğu söylenebilir. Ne var ki, Putin oldukça gerçekçi bir liderdir. Ülkesinin ABD ve Çin'in sahip olduğu askeri, siyasal ve ekonomik olanaklar ile AB'nin uhdesinde bulundurduğu "yumuşak güç" unsuruna karşı koyamayacağını bildiğinden, mevcut konjonktürde, kendi ulusal çıkarlarına tamamıyla aykırı bir girişim yaşanmadıkça, ABD, Çin ve $A B$ ile doğrudan bir mücadele içerisine girmemekte ve savunmacı realist bir dış politika anlayışı çerçevesinde hareket etmektedir. Konu Rusya'nın kendi siyasal ve ekonomik kontrolünde olması gerektiğine inandığı Avrasya coğrafyası olduğunda ise, Rusya'nın yaklaşımı farklılaşmakta ve bu ülke, gerektiği an saldırgan realizme kayabilmektedir. 2008 yılında yaşanan Rusya-Gürcistan Savaşı, bu durumun en önemli göstergesidir. Bu durum, Rusya’nın “arka bahçesi” olarak gördüğü eski SSCB topraklarını siyasal kontrolü altında tutmak istemesi ile ilgilidir. Siyasal realizm, Rus milliyetçiliği ve imparatorluk stratejisi ile tarihsel ve sosyo-kültürel unsurların birleşimi doğrultusunda oluşturulmuş Avrasyacılık doktrini ise, Rusya'nın dayandığı en önemli kuramsal boyut olmaktadır. Nitekim bu doktrinin öngördüğü “yakın çevre politikası”, Rusya'nın, eski SSCB topraklarını yeniden kontrolü altına alması gerektiğini belirtmektedir. Vladimir Putin, Rusya’nın yakın çevresi üzerinde sağlayacağı siyasal, askeri ve ekonomik kontrol ile çok kutuplu sistemik yapının önemli bir aktörü haline geleceğine inanmaktadır.

Vladimir Putin'e göre Avrasya Birliği, Rusya-Kazakistan-Belarus arasında kurulmuş olan ve Ocak 2012 itibarıyla ortak ekonomik alana dönüşen gümrük birliğinin, başta diğer Orta Asya ülkeleri olmak üzere, Avrasya coğrafyasında yer alan ve birliğe katılmak isteyen tüm ülkeleri içerecek bir ekonomik entegrasyona dönüşmesidir. Putin, bu işbirliği bağlamında, üye ülkeler arasındaki mali ve ekonomik politikaların koordinasyonunun sağlanabileceğini ve orta vadede ortak para biriminin kullanıma girebileceğini belirtmektedir. Görüleceği üzere, Avrasya Birliği Projesi daha çok bir ekonomik entegrasyon örneği olarak planlanmaktadır. Ne var ki, Rusya'nın bu projeyi ortaya koymaktaki asıl amacı, eski Sovyet coğrafyasını yeniden kendi etkisi altına alabilmek ve böylece diğer küresel ve bölgesel güç odaklarına karşı sistemik gücünü arttırabilmektir. Nitekim Putin'in öngördüğü bu ekonomi eksenli işbirliği girişimi, zaman içerisinde kurumsallaşarak ve gerekli bürokratik yapılanmayı da gerçekleştirerek, geniş çaplı ve stratejik öneme haiz bir siyasal entegrasyon hareketi haline getirilebilir. Rus liderin ortaya attığı Avrasya Birliği Projesi’nin kurumsal manada kendisine örnek alacağı en önemli unsur da, kuşkusuz, AB olacaktır.

Avrasya Birliği Projesi, başarılı olması halinde, bölgedeki siyasal ve ekonomik sorunlardan kaynaklanan istikrarsızlığı ortadan kaldırabilecektir. Ne var ki, bu projenin hayata geçirilmesi, başta ABD ve Çin olmak üzere küresel ve bölgesel aktörlerin kendi politikaları ile uyumlaşmamaktadır. Zira, Avrasya Birliği Projesi’nin odaklandığı Orta Asya-Hazar-Karadeniz Havzası ekseni; sahip olduğu enerji kaynakları, enerji ulaştırma projelerindeki rolü, ekonomik ve ticari potansiyeli ve demografik yapısı ile dünyanın siyasal geleceğine yön verebilecek en önemli coğrafi bölümlenmedir. Avrasya Birliği’nin başarısı ekseninde, Rusya'nın bölge bağlamındaki gücü ve etkinliği artacağı ve ABD, Çin, Hindistan gibi ülkelerin sistemik güç algılarında önemli bir değişim yaşanacağı için, bu projenin diğer küresel/bölgesel aktörler tarafından kabul edilmeyeceği ortadadır. Yeniden başkanlık koltuğuna oturan Putin, hem kendi siyasal geleceğine olumlu katkıda bulunacak hem de Rusya'nın küresel dengelerdeki rolünü güçlendirecek Avrasya Birliği Projesi'ne sıkı sıkıya sarılmış durumdadir.

\section{Sonuç}

Rusya gerçek egemenliği sağlamak için önemli adımlar atmakta; iç güvenliğini sağlamakta, diş borcunu ödemekte, Çin ve Hindistan gibi önde gelen ülkelerle karşılıklı çıkarlara dayalı ilişkiler kurmakta, ülkenin savunma kabiliyetini geliştirmektedir. Ruslara göre gerçek egemenlik ve egemen demokrasinin iki temeli 
bulunmaktadır; ülkenin uluslararası toplum içindeki yerini sağlamlaştıracak şekilde siyasi ve ekonomik kalkınma.

Rusya, Ukrayna'daki Turuncu devrim ile birlikte önce kendi evini düzenlemeye karar verdi. İdeoloji olarak egemen demokrasi batının anladığı biçimde olacak ama gerçek farklı olacaktı. Hukukun üstünlüğü, azınlıkların korunması, özgür basın, politik muhalefet, mülkiyet hakları gibi hususlar batılıların istediği gibi düşünülmüyordu.

Sovyetler Birliği'nin dağılmasından sonra Rusya'nın yeniden Avrasya bölgesinde bir güç olabileceği öngörülmektedir. Ancak Rusya'nın bu kapasiteye sahip olup olmadığı dünya kamuoyunda tartışılmaktadır. Bundan dolayı, Rusya'nın son 20 yıl sürecinde yaşadığı iç ve dış kaynaklı gelişmelerin değerlendirilmesi gerekmektedir.

Rusya'nın oylama gücü literatürde yaygın olarak kullanılan Normalize Edilmiş Banzhaf İndeksi ile her seçim dönemi için ayrı ayrı hesaplanmıştır. Ölçümlenen oylama gücü doğrultusunda günümüz Rusya'sının Avrasya ülkeleri üzerindeki hakimiyetinin etkisi analiz edilmiştir. Analiz yapılırken politik iktisat disiplini içerisinde kalmaya özen gösterilmiştir. Analiz sonucunda Rusya'nın oylama gücünün artışı ile ekonomik istikrarı arasında doğrusal bir ilişki olduğu ve Avrasya ülkeleri üzerindeki etkinliğinin bu ilişki doğrultusunda giderek arttığı sonucuna ulaşılmıştır. Bu çalışmayı diğer çalışmalardan ayıran en önemli özellik; Rusya'nın Avrasya ülkeleri üzerindeki etkinliğinin kültürel, tarihsel, sosyal faktörlerinin yanı sıra politik iktisat literatürü kapsamında oylama gücü perspektifinden bakılarak ekonomi politiğinin yapılmasıdır.

\section{Kaynakça}

- ANDREI Kokoshin, (2006), "Real Sovereignty and Sovereign Democracy, Russia in Global Affairs", Vol.4, October-December, 108.

- $\quad$ ATASOY, Emin, (2008), "Rusya Federasyonu Sınırları İçinde Yer Alan Özerk Cumhuriyetlerin Etnocoğrafya Işığında Değerlendirilmesi ”, Turkish Studies, Cilt:3, Sayı:7, 83-124.

- BAKIRTAŞ, İbrahim, (2007), Ekonomik Analizleri ve Ekonomiye Yansımalarıyla Politik Aktörler, 2. Bask1, Ekin Kitabevi, Bursa.

- $\quad$ BAKIRTAŞ, İbrahim ve Cüneyt, KOYUNCU, (2010), “The Relationship Between Voting Power and Stock Exchange Market: The Case of Turkey", International Research Journal of Finance and Economics, Sayı: 48, ss. 23-32.

- BAŞBUĞ, Fuat, (2008), "Rusya Seçimlerinde Siyasal İletişim Uygulamaları", http://www.siyasaliletisim.org/pdf/rusyasecimlerindesiyasaliletisimuygulamalarifiratbasbug.pdf

- FELSHENTHAL, Dan, S. ve Moshe, MACHOVER, (1998), The Measurement of Voting Power, Edward Elgar Publishing, Cheltenham.

- GAMBARElli, G., Stach, I., (2009), Power Indices in Politics:Some Results and Open Problems, Essays in Honor of Hannu Nurmi, Homo Oeconomicus, 26(3/4): 417-441.

- GELMAN, Andrew, Jonathan, N. KATZ ve Francis, TUERLINCKX, (2002), "The Mathematics and Statistics of Voting Power”, Statistical Science, Say1: 17, No: 4, ss. 420-435.

- $\quad$ HUBER, Gerald, Martin, KOCHER ve Matthias, SUTTER, (2003), “Government Strenght, Power Dispersion in Governments and Budget Deficits in OECD-Countries Voting Power Approach", Public Choice, Sayı: 116, No: 3-4, ss. 333-350.

- IŞYYA, Ömer Göksel (2004), Bölgesel ve Global Güvenlik Çıkarları Bağlamında Sovyet-Rus Dış Politikaları, İstanbul, Alfa Yayınları.

- $\quad$ KIRSCH, W., Machover, M., Słomczyński, W, Życzkowski, K., Preprint 2004, Voting in the EU Council A Scientific Approach, http://www.esi2.us.es/ mbilbao/pdffiles/voting.pdf

- LOUŽEK, Marek, (2004), "Voting Power Indicators in the European Union” Prague Economic Papers, University of Economics, Prague, Say1: 3, ss. 217-236.

- ONUR, Sara, (2004), “Literatürde Ekonomi-Politika İlişkisi”, İş, Güç Endüstri İlişkileri ve İnsan Kaynakları Dergisi, Cilt: 6, Sayı: 1, No: 191.

- ÖZKAN, Gökhan (2010), "Soğuk Savaşsonrası Orta Asya Ve Kafkasya Ekseninde Türkiye-Nato-Rusya İlişkilerive Türk Dışpolitikası'na Yansımaları”, Gazi Üniversitesi İktisadi ve İdari Bilimler Fakültesi Dergisi 12/1, 109-132.

- $\quad$ RAUNIO, Tapio ve Matti, WIBERG, (1998), "Winners and Losers in the Council: Voting Power Consequences of EU Enlargements”, Journal of Common Market Studies, Say1: 36, No: 4, ss. 549-562.

- $\quad$ REYNAUD, Julien, Christian, THIMANN ve Lukasz, GATAREK, (2007), "Proximity and Linkages among Coalition Participants: A New Voting Power Measure Applied to the International Monetary Fund European 
Central Bank", European Central Bank Working Paper Series, No: 819, http://www.ecb.int/pub/pdf/scpwps/ecbwp819.pdf (15.04.2011).

- $\quad$ SAAS, T. R. (2001), "The Anatomy of Political Representation: Direct Democracy, Parliamentary Democracy, and Representative Democracy", The Elgar Companion to Public Choice, William F. SHUGHART ve Laura, RAZZOLINI, (Ed.), Edward Elgar Publishing, USA.

- $\quad$ SHUKUROV, Tarkhan (2003), "Hükümet Sistemlerinin Çeşitli Açılardan Değerlendirilmesi Ve Bu Değerlendirme Işı̆̆ında 1993 Tarihlirusya Federasyonu Anayasasının Getirdiği Hükümet Sistemi”, Yayınlanmamış Yüksek Lisans Tezi.

- TANnENBAUM, P., 2004, Excursions in Modern Mathematics, Fifth Edition, Upper Saddle River, NJ : Pearson Education, 645p.

- USLUBAŞ, F., (2005), “Putin'li Rusya”, Jeopolitik, S.13, s.54-58.

- YARDIMCIOĞLU, M. Ve KOÇARSLAN, H. (2012), “Çok Kutuplu Dünyaya Doğru: Şanghay İşbirliği Örgütü”, KSÜ, İIBF Dergisi, Cilt:2, Sayı:2, 163-174. 


\title{
Türk Hukuk Sisteminde Tahkim Mevzuatı Arbitration Rules in Turkish Legal System
}

\author{
Ahmet Tuncay (Turkish Supreme Court, Turkey)
}

\begin{abstract}
International companies, with the countries having the relations of commerce and investment, would refer to go to arbitrators, which is completely based upon their free will, to remove or minimise the risks in their own legal systems, to provide the disputes resolve fast and effective way, during the resolution of disputes. Also in our country, to provide the improvement of the international commerce and to promote investment of foreign and local corporation, according to the national and international arbitration legal regulations are made and international agreements are signed by taking notice of the international arbitration rules. Under the title of this, Turkish legal system of the arbitration rules will be researched in details.
\end{abstract}

\section{Tahkim Kavramı}

Genel olarak kişiler arasındaki uyuşmazlıkların çözüm yeri mahkemelerdir. Ancak taraflar özel hukuka ilişkin uyuşmazlıklarının, serbest iradeleri ile aralarında yapacakları anlaşma yoluyla mahkemeler dışında tahkim yoluyla çözümünü kararlaştırabilirler.

Bir hak üzerinde uyuşmazlığa düşmüş olan iki tarafin bu uyuşmazlığın çözümlenmesini özel kişi veya kişiler tarafından incelenip karara bağlanması konusunda anlaşma yapmalarına tahkim denir.

Uyuşmazlığın çözümlenmesi işi kendilerine bırakılan bu özel kişi veya kişilere ise hakem denir.

Taraflar uyuşmazlığın çözümü konusunda hakemlerin verecekleri karara önceden razı olurlar, hakemler de uyuşmazlık hakkında mahkemeler gibi yargılama yaparak karar verirler. $\mathrm{Bu}$ nedenle hakemlere hakem mahkemesi de denilmektedir.

\section{Tahkim Türleri}

Tahkim birçok açıdan sınıflandırılabilir.

\section{1 İhtiyari Tahkim-Zorunlu Tahkim}

İhtiyari tahkim tarafların rızaları ile başvurdukları bir tahkim yoludur. Burada taraflar uyuşmazlığın çözümlenmesi için hakeme başvurmak zorunda değildirler. Ancak taraflar aralarında tahkim sözleşmesi yaparak çıkabilecek hukuki uyuşmazlıkların hakem veya hakemler aracılığıyla çözümlenmesini kararlaştırabilirler.

Hukuk Muhakemeleri Kanunu (HMK) ve Milletlerarası Tahkim Kanunu'nda (MTK) yapılan düzenlemeler ihtiyari tahkime yöneliktir.

Zorunlu tahkimde taraflar arasında ortaya çıkabilecek özel hukuk alanındaki uyuşmazlıkların önceden tahkim sözleşmesi yapılmamasına rağmen kanun gereği uyuşmazlığın çözümlenmesi için hakeme başvurmak zorunludur.

Zorunlu tahkime örnek olarak 3533 sayılı Umumi, Mülhak ve Hususi Bütçelerle İdare Edilen Daireler ve Belediyelerle Sermayesinin Tamamı Devlete veya Hususi İdarelere Ait Daire ve Müesseseler Arasındaki İhtilafların Tahkim Yolu ile Halli hakkında Kanun'u verebiliriz.

\section{2 İç Tahkim-Dış Tahkim}

İç tahkim-dış tahkim ayrımında esas alınacak ölçüt toprak ve hukuk sistemi kriteridir.

HMK'da düzenlenen iç tahkimdir. Yabancılık unsuru içeren uluslararası nitelikli sözleşmelerden kaynaklanan uyuşmazlıklarda ise MTK'u uygulanmaktadır.

Dış tahkimden kastedilen aslında milletlerarası tahkimdir. Dış tahkimde tahkim usulünü milletlerarası mevzuat hükümleri belirlemektedir.

Türk hukukunda milletlerarası tahkime yönelik düzenlemeler, Milletlerarası Özel Hukuk ve Usul Hukuku Hakkında Kanun (MÖHUK), Milletler Arası Tahkim Kanunu, 4501 sayılı Kamu Hizmetleri ile ilgili İmtiyaz Şartlaşma ve Sözleşmelerinden Doğan Uyuşmazlıklarda Tahkim Yoluna Başvurulması Halinde Uyulması Gereken İlkelere Dair Kanun'dur.

\subsection{Ad Hoc Tahkim-Kurumsal Tahkim}

Ad Hoc tahkim taraflar arasındaki hukuki uyuşmazlığa konu olayın çözümlenmesi amacıyla tarafların hakemleri, tahkim yerini, tahkim usulünü ve uyuşmazlığa uygulanacak maddi hukuk kurallarını serbestçe kendi iradeleriyle belirledikleri hiçbir örgütün aracılığının söz konusu olmadığı tahkim türüdür. 
Ad Hoc tahkimin ilk düzenlenişi 1961 tarihli Avrupa Milletlerarası Ticari Tahkim Sözleşmesi ile olmuştur. Daha sonra Birleşmiş Milletlerin Milletlerarası Ticaret Hukuku Komisyonu (UNCITRAL) tarafından 15 Aralık 1976 tarihinde hazırlanan modern kurallar Genel Kurulca kabul edilmiştir.

Kurumsal tahkimde daimi bir hakem kuruluşunun idaresi ve onun önceden hazırlanmış kuralları bulunmaktadır. Taraflarca sözleşmede düzenlenmemiş hususlar kurumun kurallarına göre yönetilmektedir.

Bu tahkim kuruluşlarına örnek olarak;

- Milletlerarası Ticaret Odası (International Chamber Of Comberce-ICC)

- $\quad$ Londra Uluslar arası Tahkim Divanı (London Court Of International Arbitration-LCIA)

- Amerikan Tahkim Kurumu (American Arbitration-AAA)

- $\quad$ Tahkim Hakemleri Kurumu (Chartered Institute Of Arbitrators)

gösterilebilir.

\section{Anayasal Düzenleme}

Tahkimle ilgili düzenlemeye Anayasa'nın 125.maddesinde yer verilmiştir.

13.08.1999 tarih 4446 sayılı Kanun'un 2.maddesiyle eklenen hükümle, kamu hizmetleri ile ilgili imtiyaz şartlaşma ve sözleşmelerinde bunlardan doğan uyuşmazlıkların milli ve milletlerarası tahkim yolu ile çözülmesi öngörülmüş, milletlerarası tahkimin söz konusu olabilmesi için yabancılık unsur öğesinin bulunması koşulu aranmıştır.

$\mathrm{Bu}$ düzenleme ile bu tür sözleşmelerden doğacak olan uyuşmazlıkların çözümünün Danıştay’ın görev alanından çıkartılarak uyuşmazlıkların tahkim yoluyla giderilmesine imkan tanınmıştır.

\section{Sayılı Kamu Hizmetleri ile İlgili İmtiyaz Şartlaşma ve Sözleşmelerinden Doğan Uyuşmazlıklarda Tahkim Yoluna Başvurulması Halinde Uyulması Gereken İlkelere Dair Kanun}

4466 sayılı Kanun'la yapılan Anayasa değişikliği doğrultusunda bu değişikliğe paralel olarak bu kanun çıkarılmıştır.

4501 sayılı Kanun 22.01.2000 tarihinde yürürlüğe girmiştir.

Kanunun amacı kamu hizmetleri ile ilgili imtiyaz, şartlaşma ve sözleşmelerinde bunlardan doğan uyuşmazlıkların tahkim yoluyla çözülmesinin öngörülmesi durumunda taraflarca sözleşme yapılırken uyulması gereken ilke ve esasları belirlenebilir.

\section{Milletlerarası Özel Hukuk Usul Hukuku Hakkında Kanun (MÖHUK)}

1982 yılında yürürlüğe giren 2675 sayılı MÖHUK yabancı hakem kararlarının tenfizine ilişkin özel hükümler getirmişti. MÖHUK'nun ilgili maddeleri 1958 tarihli Yabanıı Hakem Kararlarının Tanınması ve Tenfizi Hakkındaki Newyork Sözleşmesi hükümleri kaynak alınarak düzenlenmiştir.

04.12.2007 tarihinde yürürlüğe giren 5718 sayılı MÖHUK'nun 64/1 maddesi ile söz konusu kanun yürürlükten kaldırılmıştır.

Yabancı hakem kararlarının tenfizi anılan kanunun 60-63 maddeleri arasında düzenlenmiştir.

\section{Hukuk Muhakemeleri Kanunu}

1086 sayılı Hukuk Usulü Muhakemeleri Kanunun yürürlükte olduğu dönemde iç tahkim HMUK md. 516-536 arasında düzenlenmiştir. HMUK'nun uygulandığı dönemde milletlerarası tahkim kuralları ile iç tahkime yönelik hükümler arasında önemli farklılıklar vardı. 6100 sayılı Hukuk Muhakemeleri Kanunun düzenlenmesinde UNCITRAL model kanunu esas alınmış Milletlerarası Tahkim Kanunu ile paralellik sağlanarak tahkime ilişkin iki düzenleme arasındaki farklılıkların giderilmesi amaçlanmıştır.

6100 Sayılı HMK 01.10.2011 tarihinde yürürlüğe girmiş olması nedeniyle bu konudaki tahkim ile ilgili düzenlemeler genel olarak açıklanacaktır.

6100 sayılı HMK'unda tahkime ilişkin hükümler 407-444 maddelerde düzenlenmiştir.

6.1 Tahkimin Uygulama Alanı (HMK md. 407)

HMK md. 407'ye göre tahkimin uygulanma alanı bulabilmesi için uyuşmazlığın yabancılık unsuru içermemesi ve tahkim yerinin Türkiye olarak belirlenmesi gerekir.

Bu maddeyle milli tahkim açısından toprak ilkesi kabul edilmiştir. 


\subsection{Tahkime Elverișlilik (HMK md. 408)}

Tahkim sözleşmesi tarafların iradesine tabi olan uyuşmazlıklar için mümkündür. Tarafların dava konusu üzerinde serbestçe tasarruf edemeyecekleri durumlarda örneğin boşanma, medeni hal, soy bağı gibi davalarda tahkim sözleşmesi yapılamaz.

Ayrıca taşınmaz mallar üzerindeki ayni haklara ilişkin uyuşmazlıklar da tahkime elverişli değildir.

\subsection{Tahkim Sözleșmesinin Şekli}

Tahkim sözleşmesinin yazılı şekilde yapılması gerekir. Yazılı şekil ispat şartı olmayıp geçerlilik şartıdır.

Yazılı şekil şartının yerine getirilmiş sayılması için tahkim sözleşmesinin tarafların imzaladığı yazılı bir belgeye veya taraflar arasında teati edilen mektup, telgraf, teleks, faks gibi iletişim aracına veya elektronik ortama geçirilmiş olması ya da dava dilekçesinde yazılı bir tahkim varlığının iddia edilmesine davalının verdiği cevap dilekçesinde itiraz etmemiş olması yeterlidir. Aslı sözleşmenin bir parçası haline getirilmek amacıyla tahkim şartı içeren bir belgeye yollama yapılması halinde de tahkim sözleşmesi yapılmış sayılır.

\subsection{Hakem Sözleşmesi}

Hakem sözleşmesi taraflar ile hakem veya hakemler arasında yapılır. Bu sözleşme tahkim sözleşmesinden farklı olarak özellikle borçlar hukukuna tabi bir sözleşme olup vekalet veya hizmet sözleşmesi niteliğindedir.

Hakem sözleşmesi ile hakemler uyuşmazlığı çözümlemek görevini üstlenirler. Taraflar ise bunun karşılığında hakemlere bir ücret ödemeyi kararlaştırırlar.

\subsection{Hakemlerin Seçimi}

Taraflar hakem seçim usulünü kararlaştırmakta serbesttirler. Taraflar aksini kararlaştırmadıkça ancak gerçek kişiler hakem seçilebilir. Taraflar hakeminin sayısını belirlemekte serbesttirler. Ancak bu sayı tek olmalıdır. Hakemlerin sayısı taraflarca kararlaştırılmamışsa üç hakem seçilir.

Tek hakem seçilecek ise tarafların anlaşamamaları halinde tarafların birinin talebi üzerine hakem mahkemece seçilir.

Üç hakem seçilecek ise taraflardan her biri bir hakem seçer, bu şekilde seçilen iki hakem üçüncü hakemi bizzat belirler. Taraflardan birisi süresinde kendi hakemini seçmezse veya tarafların seçtiği iki hakem süresinde üçüncü hakemi belirleyemezse taraflardan birinin talebi üzerine üçüncü hakem mahkemece seçilir, bu hakem başkan olarak görev yapar.

\section{6 İhtiyati Tedbir ve Delil Tespiti}

HMK'ya yeni eklenen hükümlerden bir tanesidir.

Taraflarca aksi kararlaştırılmadıkça tahkim yargılaması sırasında hakem veya hakem kurulu taraflardan birinin talebi üzerine bir ihtiyati tedbirin alınmasına veya delil tespitine karar verilebilir. (md. 414/1)

Hakemlerin icra organları üzerinde etkisi olamayacağından verilen tedbir kararının icra edilebilirliği yetkisi geçerli bir tahkim sözleşmesinin var olması kaydıyla mahkemeye tanınmıştır.

Mahkemenin verdiği ihtiyati tedbir kararı hakem veya hakem kurulunca değiştirilebilir veya ortadan kaldırabilir.

\subsection{Tahkim Yargılama Usulü}

Taraflar hakemlerin uygulayacağı yargılama usulüne ilişkin kuralları kanunun emredici hükümleri saklı kalmak kaydıyla serbestçe kararlaştırabilirler veya tahkim kurallarına yollama yaparak belirleyebilirler.

Taraflar arasında böyle bir sözleşme yoksa hakem veya hakem kurulu tahkim yargılamasını HMK'nun 407 444'ncü maddeleri hükümlerini gözeterek uygun bulduğu şekilde yürütür.

Hakemler HMK'ya göre tahkikat yapabilecekleri gibi belirleyecekleri başka bir yargılama usulünün de uygulanmasina da karar verilebilirler.

Tahkim yeri taraflarca veya onların seçtiği bir tahkim kurumunca serbestçe kararlaştırılabilir.

HMUK'unda 6 ay olan tahkim süresi HMK'da MTK m 10/B'ye paralel olacak şekilde 1 y1l olarak düzenlenmiştir. Taraflar tahkim süresini uzatabildikleri gibi taraflardan birinin başvurusu üzerine mahkemece de süre uzatılabilir.

HMUK 533. maddesi hükmü yürürlükten kaldırıldığından artık hakem kararlarının temyizi mümkün değildir. Hakem kararına karşı yalnızca tahkim yerindeki mahkemede iptal davası açılabilir. İptal sebepleri HMK'nun 439/3 fikrasında sınırlı olarak sayılmıştır.

Kesinleşmiş hakem kararlarına karşı m. 443 uyarınca yargılamanın iadesi yoluna gidilebilir. Yargılama iadesi sebepleri 443. maddede sınırlı olarak sayılmıştır. 


\section{Milletlerarası Tahkim Kanunu}

Milletlerarası Tahkim Kanunun taslak çalışmaları 1997 yılında Banka ve Ticaret Hukuku Araştırma Enstitüsünce başlatılmış, UNCITRAL model kanunu ve İsviçre Devletler Özel Hukuku Kanunu'nun milletlerarası tahkime ilişkin hükümlerinden esinlenerek hazırlanmıştır. 21.06.2001 tarihinde kabul edilen 4686 sayılı kanun 05.07.2001 tarihinde yürürlüğe girmiştir.

\subsection{Kanunun Amaci ve Uygulama Alanı}

Kanunun amacı milletlerarası tahkime ilişkin usul ve esasları düzenlemektedir. Buna göre milletlerarası tahkim 4686 sayılı MTK'ya, iç tahkim ise 6100 sayılı HMK'ya tabi olacaktır.

Kanunun uygulama alana yabancılık unsuru taşıyan ve tahkim yerinin Türkiye olarak belirlendiği veya bu kanun hükümlerinin taraflar veyahut hakem veya hakem kurulunca seçildiği uyuşmazlıklar girmektedir.

Uyuşmazlığın hangi hallerde yabancılık unsuru taşıdığı kanunun 2. maddesinde sayılmıştır.

"1.Tahkim anlaşmasının taraflarının yerleşim yeri veya olağan oturma yerinin ya da işyerlerinin ayrı devletlerde bulunmast

2.Tarafların yerleşim yeri, olağan oturma yeri veya işyerlerinin;

a)Tahkim anlaşmasında belirtilen veya bu anlaşmaya dayanarak tespit edilen hallerde tahkim yerinden,

b)Asıl sözleşmeden doğan yükümlülüklerin önemli bir bölümünün ifa edileceği yerden veya uyuşmazlık konusunun en çok bağlantılı olduğu yerden,

Başka bir devlette bulunmasi,

3)Tahkim anlaşmasının dayanağını oluşturan asıl sözleșmeye taraf olan șirket ortaklarından en az birinin yabancı sermayeyi teşvik mevzuatına göre yabancı sermaye getirmiş olması veya bu sözleşmenin uygulanabilmesi için yurt dışından sermaye sağlanması amacıyla kredi ve/veya güvence sözleşmeleri yapılmasının gerekli olması

4)Tahkim anlaşmasının dayanağını oluşturan asıl sözleşme veya hukuki ilişkinin, bir ülkeden diğerine sermaye veya mal geçişini gerçekleştirmesi."

Uyuşmazlık yabancılık unsuru taşımasa da tahkim yeri Türkiye olarak belirlenmemiş ise de taraflar uyuşmazlıkların çözümü için MTK'nun uygulanabileceğini kararlaştırabilirler.

\subsection{Kanunun Uygulama Alanı Dışında Kalan Uyuşmazlıklar}

Kanunun 1. maddesi uyarınca;

- $\quad$ Türkiye'de bulunan taşınmaz mallar üzerindeki ayni haklara ilişkin uyuşmazlıklar

- Tarafların iradelerine tabi olmayan uyuşmazlıklar

- Türkiye'nin taraf olduğu milletlerarası anlaşma hükümlerinin saklı tutulması,

\subsection{Tahkim Sözleșmesi}

Tahkim sözleşmesi asıl sözleşmeye konan bir tahkim şartı veya müstakil bir sözleşme şeklinde yapılabilir.

Tahkim sözleşmesinin yazılı olarak yapılması gerekir. Bu bir ispat şartı değil, geçerlilik şartıdır.

Yazılı şekil şartının hangi hallerde yerine getirmiş sayılacağı kanunun 4/2 nci maddesinde belirtilmiştir.

Bu düzenleme 6100 sayılı HMK'daki tahkim sözleşmesine ilişkin hükme paralel bir düzenlemedir.

Hakemlerin seçimin usulü, tahkim süresi , kanun yoluna başvurma, ihtiyati tedbir ve ihtiyati hacze başvurma halleri 6100 sayılı HMK hükümlerine benzer düzenlemeler içermektedir.

\section{Milletlerarası Tahkime İlişkin Sözleşmeler}

\subsection{Newyork Sözleşmesi}

10 Haziran 1958 tarihli Yabancı Hakem Kararlarının Tanınması ve Tenfizi Hakkında New York Konvansiyonu Türkiye'de 1991 yılında onaylanmıştır.

New York konvansiyonu hakem kararlarının verilmesinden sonraki aşama olan hakem kararlarının tanınması ve tenfizine ilişkin bir konvansiyondur.

\subsection{Avrupa (Cenevre) Sözleşmesi}

25 Nisan 1961 tarihli Milletlerarası Ticari Tahkime İlişkin Avrupa - Cenevre Sözleşmesi, Birleşmiş Milletler Avrupa Ekonomik Komisyonu'nun çalışmaları sonucu milletlerarası ticari ilişkilerden doğan ihtilafların tahkim yolu ile çözümünü sağlanmak amacıyla hazırlanmıştır.

Sözleşme akit ülkelerde meydana gelen milletlerarası ticari tahkim prosedürlerini düzenlemek amacıyla çıkarılmıştır.

Sözleşme Türkiye tarafından 08.05.1991 tarih ve 3730 sayılı Kanunla onaylanmıştır. Avrupa Sözleşmesi’nin 1.maddesi tahkimi konu itibariyle Uluslararası ticari ilişkilerle sınırlandırılmıştır. Bu maddeye göre milletlerarası 
ticari ilişkilerden doğan veya doğacak olan uyuşmazlıkların halli için akdolunan ve akdin yapıldığı sırada mutad meskenleri ve muamele merkezleri değişik akit ülkelerinde bulunan tüzel kişiler arasındaki tahkim sözleşmelerinde uygulanır.

Cenevre Konvansiyonunun uygulanabilmesi için biri objektif diğeri subjektif iki şartın gerçekleşmesi gerekir. Sübjektif şart, tahkim anlaşması yapıldığı sırada tarafların mutad meskenlerinin farklı akit devletlerde bulunmasıdır. Dolayısıyla iki tarafin mutad meskenlerinin aynı devlette olması halinde Cenevre Konvansiyonunun uygulanması mümkün değildir. Objektif şart ise, uyuşmazlığın Uluslararası ticari ilişkiden doğmuş olmasına ilişkindir. Ticari olmayan işlerden doğan uyuşmazlıklara Cenevre Konvansiyonu uygulanamaz.

Cenevre Konvansiyonu tahkimin tanıma-tenfizden önceki aşamasını düzenlemektedir.

Taraflar tahkim sözleşmesini esas sözleşmeden ayrı olarak yapabilecekleri gibi esas sözleşmeye bir tahkim şartı da koyarak da yapabilirler. Tahkim sözleşmesinin yazılı olması gerekir. Ancak yazılı şekil şartına esnek bir düzenleme getirilerek tarafların birbirlerine yolladıkları mektup, telgraf veya teleskriptör metni içeriği de kabul edilmiştir.

\subsection{ICSID (Washington) Sözleşmesi (International Center for the Seltlemen Of Investment Disputes)}

Devletler ve Diğer Devletlerin Vatandaşları Arasındaki Yatırım Uyuşmazlıklarının Çözümlenmesi Hakkındaki Konvansiyon 14 Ekim 1966 yılında yürürlüğe girmiş, Türkiye bu sözleşmeyi 27.05.1988 tarih 3460 sayılı yasa ile onaylanmıştır.

ICSID Dünya Bankasının İnsiyatifi ve ön çalışması sonucu kurulmuş Uluslararası hükmü şahsiyete sahip bir kurumdur. Merkezi Washington'dur.

Merkezin amacı sözleşmede yer alan hükümler doğrultusunda taraf devletler ile diğer taraf devletlerin vatandaşları arasında yatırımlardan kaynaklanan uyuşmazlıkların uzlaştırma ve tahkim yolu ile çözümlenmesine çalışmaktır.

\subsection{Enerji Şartı Sözleşmesi (Energy Charter Treaty - ECT)}

Sözleşme 17 Aralık 1994 tarihinde Lizbon'da imzalanmış 16 Nisan 1988 tarihinde yürürlüğe girmiştir.

Türkiye bu anlaşmayı 17 Aralık 1994 tarihinde imzalamış, 4519 sayılı kanunla 6 Şubat 2000 tarihinde onaylanmıştır.

Sözleşmenin 2. maddesinde amaç olarak; Avrupa Enerji şartının amaçları ve prensipleri uyarınca, tamamlayıcılık ve karşılıklı faydalar prensibi baz alınarak, enerji alanında uzun dönemli işbirliğinin teşvik edilmesi için hukuki bir çerçeve tesis etmek olduğu belirtilmiştir.

Enerji şartı Sözleşmesi uyarınca yatırımcı yükümlülüğünü yerine getirmeyen devlete karşı Uluslararası tahkime başvurabilir. Sözleşmeye göre çözülmeyen hukuki uyuşmazlıklarda, akit devletin yükümlülügünü ihlal ettiğini iddia eden yatırımcı uyuşmazlığı;

- Ulusal adli mahkemeye veya idari mahkemeye,

- Önceden kabul edilen diğer bir mahkemeye,

- Sözleşmede düzenlemen tahkime götürebilir.

Her bir taraf uyuşmazlığın Uluslararası tahkime götürülmesine onay vermek zorundadır.

Yatırımcı uyuşmazlığı tahkime götürmeye seçtiği takdirde üç ihtimal bulunmaktadır.

- Washington sözleşmesine uygun olarak ISCID tahkimi,

- UNCITRAL tahkim kurallarına göre oluşturulan tek hakem veya ad hoc hakem mahkemesi,

- Kurumsal tahkim olarak Stockholm Ticaret Odası Tahkim Enstitüsü - SCC

Uluslar arası hakem kararları bağlayıcı ve kesindir.

Her bir taraf devlet bu kararların icra edilmesini sağlamakla yükümlüdür.

\section{5 İki Taraflı Yatırım Anlaşmaları (Bilateral Invenstment Treaties - BIT)}

Yatırımcının vatandaşı olduğu devlet ve yatırımı kabul eden devletin arasında ikili bir anlaşma olmasıdır.

Türkiye'nin taraf olduğu iki veya daha çok taraflı Yatırımların Teşviki Korunması Anlaşmalarının tamamında ev sahibi devlet ile diğer akit tarafa mensup yatırımcılar arasındaki yatırım uyuşmazlıklarının milletlerarası tahkim yolu ile çözümü kabul edilmiştir. Ancak anlaşmalarda adli yargı süreci tamamen kapatılmamış, mahkemelere başvuru genel olarak yatırımcının insiyatifine bırakılmıştır.

Başvurunun yapılacağı Uluslar arası kurumsal tahkim merkezleri olarak;

- $\quad$ ICSID tahkim merkezi

- ICC tahkimi

- UNCITRAL tahkim kuralları uyarınca oluşturulacak hakem mahkemesi belirlenmiştir. 


\section{Sonuç}

Ekonomideki hızlı değişim ve gelişmeler, yeni teknoloji sermaye hareketliliği sayesinde dünyada uluslararası ticaret ve büyük yatırımlar hızla artmıştır.

Yabancı yatırımcı şirketler veya kredi kuruluşları sözleşmelerden doğan uyuşmazlıkların milletlerarası tahkim yoluyla çözümlenmesini talep etmektedir.

Özellikle az gelişmiş ve gelişmekte olan ülkeler milletlerarası tahkim mevzuatına kendi iç hukuklarında yer vermek suretiyle yabancı sermaye girişinin sağlanması, yabancı yatırımcı sayısının artmasını teşvik etmek istemektedirler.

Türkiye de ancak dış finansman ile gerçekleştirilecek büyük alt yapı tesislerinin köprülerin, barajların inşası gibi büyük yatırımların dış sermaye ile sağlanabilmesi için tahkim ile ilgili mevzuatın düzenlenmesi ihtiyacını gözeterek milletlerarası tahkim mevzuatı da dikkate alınarak tahkim kurumunun daha işler hale getirilmesi amacıyla iç ve dış tahkimle ilgili anayasal ve yasal düzenlemelere gitmek ihtiyacını hissetmiştir.

Gelişen ve değişen Uluslararası ticaretin ve dış yatırımların kapsamı, sözleşmelerin uygulanması sırasında ortaya çıkan karmaşık ve değişik hukuki uyuşmazlıklar dikkate alındığında bu hukuki uyuşmazlıkların uzman kişiler tarafından hızlı bir şekilde ve adil olarak çözümlenmesi amacıyla tahkimle ilgili gerek milletlerarası gerekse ülkelerin milli mevzuatlarındaki değişim ve gelişimin de devam edeceği kuşkusuzdur.

\section{Kaynakça}

- Baklacı, A., 2006. İşletme Fakültesi Dergisi Enerji Şartı Antlaşması, İzmir

- Kapsüz, T., 2007. Türkiye'de Milletlerarası Tahkim, Ankara

- Karsl1, 2011. Medeni Muhakeme Hukuku Ders Kitabı, İstanbul

- $\quad$ Kuru, B. ve Arslan, R. Ve Yılmaz, E., 2011. Medeni Usul Hukuk Ders Kitabı, Ankara

- $\quad$ Nomer, E. ve Ekşi, N.ve Öztekin Gelgel, G., 2013. Milletlerarası Tahkim Hukuku, İstanbul, 168s.

- Pekcanıtez, H. ve Atalay, O. ve Özekes, M., 2011. Hukuk Muhakemeleri Hükümlerine Göre Medeni Usul Hukuku, Yetkin Yayınları, Ankara, 775 s.

- Şanlı, C. ve Esen, E. ve Ataman Figenmeşe, İ., 2013. Milletlerarası Özel Hukuk, İstanbul,666 s. 


\title{
Milletlerarası Ticari Tahkim Kuruluşları International Commercial Arbitration Institutes
}

\author{
Uğur Sayın (Turkish Supreme Court, Turkey)
}

\begin{abstract}
Because of exportation and importation of countries, the amount of commerce enlarged, therefore foreign agreements increased. Because of having differnet law systems of the contries the people, working on permanent investment and commerce wishes to have the suitable arbitration that they want.From this point of view, begining from the year 1898, It has been worked on to develop contraptions do international authorized commercial court's duty. Then permanent arbitration council was established, Cenevre Convention, New York Convention was established, and the rules of international arbitration called UNCITRAL was constituted. The countries which are the contracting parties of these agreements, agreed that the implement of rules on their own domestic law systems. In addition, they delegated compulsory execution for these rules. Beside this, to organise the international commercial arbitration, countries and private institues are founded arbitration institues. Today there are hundereds of international commercial arbitration institues, which are called as the same name of their city's, the most favorite and their woking systems are explaned.
\end{abstract}

\section{Giriş}

Yabancılık unsuru taşıyan ticari sözleşmelerden doğan uyuşmazlıkların yargı dışında barışcı yollar ile adil, tarafsız ve hızlı şekilde çözümü uluslararası ticaret için önemlidir. Yatırımcı sağlayacağı kazanç ile birlikte uyuşmazlık halinde yatırımlarının güvence altında olacağını bilmek ister. Finans kurumlarına bu güvenceyi sağlamak ve yatırımları ülkeye yönlendirmek isteyen devletler taraf iradesine dayanan Tahkim Kuruluşlarının oluşumu için Tahkim işleyişine en az müdahalede bulunacak şekilde yasal düzenlemeler yapmışlar, uluslararası anlaşmaları imzalamışlardır. Milletlerarası Ticari Tahkim kuruluşlarından bazıları inceleme konumuzu oluşturmaktadir.

\section{Genel Olarak Milletlerarası Tahkim}

Yabancı finans kurumunun hukuk kuralları ile güvence altına alınması devletlerin de yararınadır. Bu nedenle Uluslararası ticari uyuşmazlıkların yargı dışında çözümlenmesi için hakem (tahkim) usulü konusunda çeşitli düzenlemeler yapılmıştır. Uluslararası anlaşmalar imzalanmıştır. Bu sözleşmelere taraf olan ülkeler tahkim kuruluşları tarafından verilen kararları kendi mahkeme kararları gibi uygulamak, infaz etmek zorundadırlar.Yargı dışı çözüm yolları içeresinde diplomatik yöntemlerde vardır. Ancak her zaman başarılı sonuç vermez.

Uluslararası Tahkim Kurallarının hukuki metin haline getirilmesi,1899 ve 1907 La Haye Barış Konferansında gerçekleşmiştir.1899 yılında aralarında Osmanlı İmparatorluğu'nun da bulunduğu, 26 devlet arasında, 61 maddeden oluşan, 1899 La Haye Sözleşmesi imzalandı. Uluslararası uyuşmazlıkların çözümünde, Sürekli Tahkim Divanı'nın kurulması kararlaştırıldı. 1907 yılındaki Konferans ile kurallar genişletildi.Divan' da hakemlerin listesi ile tahkim kurulunun oluşturulması sistemi vardır. Divan devletlerarasındaki yada devlet ile kişi veya kurumlar arasındaki uyuşmazlıkların çözümünde en eski kuruluştur. Dostça girişim, arabuluculuk, araştırma, soruşturma ve uzlaştırma hizmetleri de sunar.Üç organı vardır.Bunlar, Yönetim konseyi, Uluslararası büro, Hakemler listesidir.

Çarlık Rusya'sı Uluslararası barış ortamının sağlanması için 1898 yılında konferans yapılmasını istedi.Bu çağrı aynı zamanda, Uluslararası ticari uyuşmazlıkların barışçı yollarla çözümü konusunda başlangıç olmuştur.

Rus hükümeti,“ ülkeler arasında silahlı çatışmaların önlenmesi amacıyla, mümkün olan hallerde, dostça girişim, arabuluculuk, ve gönüllü tahkimin kullanılmasının kabulü, bunların kullanım tarzları hakkında anlayış ve tek tip uygulamanın tesisedilmesini öneride bulundu. Bu şekilde tahkim uluslararası uyuşmazlıkların çözümünde alternatif bir yol olarak ortaya çıktı.

Devletlerarasında Ticari Tahkimin gelişmesi, 21 Nisan 1961 tarihli, “ Milletlerarası Ticari Tahkime ilişkin Avrupa Cenevre Konvansiyonu” ile başlamıştır.Bununla Milletlerarası Tahkimin teşkilatlanması ve en iyi şekilde işlemesini sağlamak amaçlanmıştır.

1964 yılında yürürlüğe giren Cenevre Konvansiyonu,10 maddeden oluşmaktadır. (Bunlar, Konvansiyon uygulama alanı, kamu tüzel kişilerinin tahkime tabi olma ehliyeti, yabancıların hakem olarak seçilmesi, hakem heyetinin oluşumu, hakem heyetinin görevsizliği itirazı, tahkim anlaşmasına rağmen mahkemeye müracaat ve bunun sonuçları, uygulanacak hukuk, hakem kararının gerekçeleri hakem kararının iptali ve son hükümleri düzenlemesidir.)

New York Konvansiyonu ise hakem kararlarının sonuçlarını düzenlemiştir.Tanıma ve tenfiz konusunda düzenleme getirilmiştir.Cenevre Konvansiyonunda tanıma ve tenfizden önceki aşama düzenlenmiştir. 
Tahkim anlaşmasını yapan "kişilerin yerleşim yerlerinin ayrı ayrı ülkelerde olması ve sözleşmenin ticari iş olması halinde, tahkim usulü ve hakem kararı Cenevre Konvansiyonu hükümlerine bağlı olacaktır. Uyuş̧mazlığın hakemlerin önüne gelmesinden itibaren kararın verilmesine kadar Konvansiyon hükümleri uygulanır.

Taraflar ayrı bir tahkim sözleşmesi yapabilecekleri gibi, sözleşmelerine tahkim maddesi koyarak hakeme gidileceğini yazılı olarak kararlaştırabilirler.

Cenevre Konvansiyonu'nun (1/2.b md.), taraflar somut olay için seçilmiş hakeme (ad hoc tahkim) gidebilecekleri gibi kurumsal nitelikte oluşturulan daimi tahkim merkezlerine de başvurabilirler.

Milletlerarası Tahkim, "Yabancılık unsurunu taşıyan, ekonomik ve ticari uyuşmazlıkların hakemler vasıtasıyla çözümünü düzenleyen kurallardır. $\mathrm{Bu}$ incelemede, uyuşmazlıkların niteliği dikkate alınarak, Milletlerarası Tahkimde uygulanan kurallar, tahkimi organize edip uygulamayı denetleyen kurumlar yeralacaktır.

Devletlerarası anlaşmalara göre oluşturulan kurallar ile oluşturulan kurumlar nezdinde yürütülen tahkimde, devletlerarası uyuşmazlıklar Devletler Umumi Hukukuna göre çözümlenir.Bunun örneği, B.M bünyesinde bulunun Daimi Hakem Mahkemesi (The Permanent Court of Arbitration) dir.

Konusu ticari ve ekonomik menfaatler olan sözleşmelerden doğan anlaşmazlıklara çözüm bulmak amaciyla kurulmuş tahkim kuruluşları da vardır.Bunlar ICSID (İnternational Center For Settlement Of Investment Disputes) ve WIPO gibi.

Bir kısım tahkimde, doğrudan sektör temsilcileri tarafından oluşturulan, hiçbir uluslararası anlaşmaya dayanmayan kurallara göre oluşturulan tahkim kurumları vardır.Bunlar, ICC (Milletlerarası Tahkim Odası), LCIA (Londra Milletlerarası Tahkim Mahkemesi) örnekleridir.

Milletlerarası Tahkim'in bir kısmı ise Muhtelif ülke devletleri ya da belirli sektör mensupları tarafindan milli hukuk kuralları üzerine kurulan tahkim kuruluşları tarafından yerine getirilir.Çok sayıda tahkim kuruluşları vardır. Bunlara örnek, Avusturya Federal Ekonomi Odası Milletlerarası Tahkim Mahkemesi, Stockholm Tahkim Enstitüsü Hakem Mahkemesi, Rusya Federasyonu Ticaret Odası Milletlerarası Tahkim Mahkemesi sayılabilir.

Milletlerarası tahkimin bir kısmı ise, hiçbir kurumsal tahkim merkezinin denetimine tabi olmaksızın, tarafların aralarında düzenledikleri kurullara ya da atıfta bulundukları kurallara göre yürütülür.

Birinci sırada açıkladığımız, Devletlerarası anlaşmazlıkların çözümünde uygulanan tahkim ile inceleme konumuzu oluşturan, konusu yabancılik unsuru taşıyan, ekonomik ve ticari uyuşmazlıkların çözümünde uygulanan tahkimi ayırmak için, Milletlerarası Ticari tahkim olarak açıklamak daha doğru olacaktır.

\section{Tahkim Türleri}

Tahkim, Ad Hoc Tahkim ve Kurumsal Tahkim olarak iki şekilde incelenebilir.Kurumsal tahkim, bir tahkim kurumunun önceden belirlenmiş kurallarına göre uygulanan onun gözetimindeki tahkimdir.Ad Hoc tahkimde ise, tamamen tarafların iradesine göre oluşturulan tahkim söz konusudur.

\subsection{Ad Hoc Tahkim}

Ad Hoc tahkimde, tarafların kaleme aldığı ya da uygulanmasını istedikleri belirli kurallara göre, tarafların yetkilendirdikleri hakemler tarafından tahkim yerine getirilir.Kurumsal tahkimin bürokratik engelleri gibi sebepler Ad Hoc tahkimin tercih nedeni olmakta, Devletler ve Kamu Kurumları uyuşmazlıklarında Ad Hoc tahkimi tercih etmektedirler.

Ad Hoc tahkimde, yerel tahkim kurallarına tabi olmadan, Milletlerarası kurallara göre tahkimin yürütülebilmesi için BM, Milletlerarası Tahkim Hukuku Komisyonu (UNCiTRAL) tahkim kuralları getirmiştir. Ad Hoc tahkim yolunu seçen taraflar yapacakları bir düzenleme ile UNCITRAL'in 1976 tarihli Tahkim kurallarının uygulanmasını isteyebilirler. Dünyada kabul gören yaygın olarak kullanılan UNCITRAL kuralları ad hoc tahkimde kullanılmak için düzenlenmiştir. Bu tahkim kurallarına göre belirli bir kurum tarafindan izleme, denetim yapılmaz.Sadece tahkim uygulamasına rehberlik edilir.

\subsection{Kurumsal Tahkim}

Ticari Sözleşmelerde taraflar, uyuşmazlık halinde ne yapılması gerektiği hususlarında ayrıntılı düzenleme yapmazlar.Uluslararası sözleşmelerde genellikle uyuşmazlık halinde, Tahkim usullerini tüm ayrıntıları ile düzenleyen, denetleyen, teknik ve idari organizasyona sahip daimi hakem mahkemeleri tercih edilmektedir.Ticaretle uğraşanlar tarafından bu mahkemelerin kuralları ve kararları hareket tarzı bilinmektedir.Bu da ticari hayatta güven sağlayıcıdır.

Bu merkezlerin bazıları, Meslek Odaları ve Birliklerine bağlı olduğu için bu Oda ve Birliklere bağlı olan tacirler arasında farklı etkileri vardır.Bu nedenle tercih edilmektedir.Bugün dünyada tahkim hizmeti veren yüzlerce tahkim Merkezi bulunmaktadır. 


\section{Kurumsal Tahkim Merkezleri}

$\mathrm{Bu}$ tahkim merkezlerinin bir kısmı, özel kişilerce kurulmuş bu kısmı, uluslararası anlaşmalar uyarınca oluşturulan örgütler tarafından bir kısmı, devletler ve bir kısmı da Ticaret Sanayi Odaları, Üniversiteler, Meslek ve Sektör Mensupları tarafindan kurulmuştur.

\subsection{ICSID}

Bu kuruluş Dünya Bankası tarafından "Devletler ile Diğer Devlet Vatandaşları arasındaki Yatırım uyuşmazlıklarının Halline Dair Anlaşma” ile kurulmuş olup, 1966 da yürürlüğe girmiştir.

Dünya Bankasının Washington'daki bürosunda Yatırım uyuşmazlıklarının çözümü için faaliyet gösterir.2011 itibariyle 157 Devlet, bu anlaşmaya taraf olmasına rağmen, Yatırım Sözleşmelerinde ICSID hakemliği çok tercih edilmemektedir. Ancak son yıllarda, yapılan Uluslararası Yatırım Anlaşmalarında, ICSID hakemliği taraflarca kabul edilmektedir. ICSID'E göre 2011 yılı itibariyle bu anlaşmaların sayısı 4673'den

ICSID Konvansiyonu'nun 47. maddesine göre Merkez ihtiyati tedbir karar1 verebilir. ICSID Kararları kendi sistemine göre kesinleştiğinde taraf devletlerin iç hukukuna göre cebri icra kuralları ile doğrudan icra edilebilir.ICSID, İdari Konsey, Sekreterya ve Paneller olmak üzere üç birimden oluşur. Paneller kendi arasında, arabulucular ve hakemler olarak ikiye ayrılmıştır.ICSID bütün dünya ülkelerine açıktır.Dünya Bankasına ve IMF'ye üye olmak gerekmez.

ICSID tahkimi yatırımcı ile ev sahibi ülkenin menfaatleri arasında bir denge kurulacak şekilde düzenlenmiştir. Hakem mahkemesinin tarafların iradesine göre oluşturulması prensibi burada da geçerlidir. Menfaat eşitliği prensibi ile güvensizlik giderilmiş, bir devlete karşı onunla eşit mücadele yapacağı bir ortam sunulmuştur.ICSID arabulucu ya da hakem olarak tahkime katılmaz. Taraflara, hakemlerini serbestce seçme imkanını sağlayan özel nitelikli kişilerden oluşan panellere sahiptir.Konvansiyona üye olma tek başına ihtilafı konvansiyonda çözme yükümlülüğü doğurmaz.Ancak bazı devletler, merkezin yetkisine tabi tutmadıkları ihtilafları bildirmişlerdir.Türkiye'deki taşınmazların mülkiyeti ile ilgili uyuşmazlıklar ICSID’e götürülemez.

ICSID tahkimine gidilebilmesi için taraflardan birisinin devlet, diğerinin ise Konvansiyon'a taraf diğer devlet vatandaşı olması gerekir.Uyuşmazlığın yatırımdan kaynaklanması gerekir. Yatırım, geniş anlamı ile yorumlanmak gerekir. Uzun süreli işler (imtiyaz sözleşmeleri gibi)olmalıdır. Geçici, bir defaya mahsus işler kapsama girmez.

Hakem kurulu, oy çokluğu ile karar verir.Verilen karara karşı taraflar, kararın yorumunu (md.50), yeni maddi vakıaların ortaya çıkması nedeniyle kararın yeniden gözden geçirilmesini (md.51), belirli sebeplerin varlığ halinde kararın hükümsüz kılınmasını (md.52) isteme hakları vardır.

\subsection{WIPO - Dünya Fikri Mülkiyet Örgütü Tahkim Mahkemesi}

1883 tarihli "Sınai Mülkiyetin Korunmasına Dair Paris Konvansiyonu” ile sınai mülkiyet alanında ilk uluslararası düzeyde koruma getirilmiştir.WIPO, 14 Temmuz 1967'de bir anlaşma ile kurulmuş, BM'nin uzman kuruluşlarından birisidir.

WIPO, Fikri Mülkiyete ilişkin eserlerin uluslararası düzeyde korunması için uluslararası anlaşmaların yapılmasında yardımcı olmaktadır.

1994 y1lında, Cenevre'de “Tahkim ve Uzlaştırma Merkezi” kurulmuştur. Bu tahkim ve uzlaştırma merkezinin amacı, Patent, marka, know-how, yazılım lisansı sözleşmeleri gibi sınai ve fikri mülkiyete, internet alan adlarına ilişkin tescil ve ihlallerden çıkan ticari uyuşmazlıklarda tahkim hizmeti sunmaktadır. Özel kuralları vardır.

Taraf iradesi burada da geçerlidir.Tarafların uyuşmazlığın hallini WIPO ya götürmek konusundaki iradelerinin bulunması gerekir.WIPO’ ya gidebilmek için, anlaşmaya taraf devletin vatandaşı olunması gerekmez. WIPO’da 70 ülkeden oluşan 1000 hakem listesi mevcuttur. Taraflar bu listeden hakemlerini seçebilirler. Bu liste dışından da seçim yapmak mümkündür.

WIPO tahkiminde iki ayrı tahkim usulü vardır.Normal tahkim ve hızlandırılmış tahkim.Normal tahkimde hakem tarafından 9 ayda verilecek karar, hızlandırılmış tahkimde 1 hakem tarafından en fazla 3 ayda verilir.Tahkim yerini taraflar serbestçe belirler.Hakem kararları New-York konvansiyonuna göre icra edilir.

\subsection{ICC - Milletlerarası Ticaret Odası Tahkim Mahkemesi}

Milletlerarası Ticaret Odası 1919 yılında uluslararası ticareti geliştirmek amacıyla, dünya özel sektörü tarafından Paris’te kurulmuştur.Özel nitelikte bir kuruluştur.

MTO, uluslararası ticari ve ekonomik uyuşmazlıkları tahkim yolu ile çözümünü organize etmek için 1923 yılında "uluslararası ticaret odası tahkim divanı ismi ile bir mahkeme oluşturdu. Bu tahkim mahkemesi doğrudan ihtilafları çözen daimi bir hakem mahkemesi değildir. MTO tahkim kuralları ile tarafların yada mahkemenin belirlenmesine göre dünyanın neresinde olursa olsun tahkim usulünü organize etmektedir. Hakem heyeti, taraflarca yada verdikleri yetki ile Divan tarafindan oluşturulur.

1.0cak. 2012'de yeniden düzenlenen Tahkim Tüzüğü uygulanmaktadır. Tüzükte, hakem seçimi, müracaat usulü, cevap, karşı dava süreleri, tahkim masrafları, hakem ücretleri, uygulanacak hukukun tespiti, tahkim 
yerinin belirlenmesi, tahkim süresi, karar nisabı, tebliğ, kesinleşme gibi tüm hususlar ayrıntılı olarak düzenlenmiştir.

MTO'de tahkim usulü 5 aşamadan ibarettir.Tahkim talebinin sunulması, hakemleri seçimi, dosyanın sekreterya tarafından hakeme tevdii ve görev belgesi düzenlenmesi, esastan inceleme.Görev belgesinin düzenlenmesinden sonra 6 ay içinde karar tasarısı Divan'a sunulur.Süre uzatılabilir Hakemler davanın esasını tarafların seçtikleri hukuka göre çözerler.Taraflar seçim yapmamışsa, hakemler uygun buldukları hukuka göre çözüm bulurlar.Ihtiyati tedbir kararı verilebilir (md 28).Son aşama, MTO Tahkim Divanının, hakem karar taslağını incelemesi.Karar verme özgürlüklerini etkilemeden, şekil değişikleri yapılması için ve bazı noktalarda hakemlerin dikkatini çekebilir, tavsiyede bulunabilir (md 33).Verilen kararların, şekil ve esas bakımından geçerliliği ve etkinliğini sağlamaya yöneliktir.

Divan tarafından onaylanan ve hakemlerin imzasını taşıyan karar, sekreterya tarafından masrafları alındıktan sonra tebliğ edilir. Taraflar MTO tahkim kurallarını seçmekle, bu karara derhal uyup icra etmeyi temyiz ve itiraz yoluna başvurmaktan feragat etmeyi kabul etmiş sayılırlar (md. 34).

\subsection{SPICAC - Petersburg Uluslararası Ticari Tahkim Mahkemesi}

1997 yılında faaliyete geçmiştir.Petersburg şehrinde ticaret odası tarafından kurulmuş, bağımsız tahkim kuruluşudur.Uncitral kurallarından etkilenerek hazırlanmış Rusya hukuk kurallarına göra tahkim yönetilir.Rus ve yabancılardan oluşan hakem listesi vardır.Taraflar hakem sayısını,uygulanacak dili,uygulanacak hukuku serbestce seçebilirler.Hakem kararlarına itiraz yolu açıktır,sınırlıdır.

\subsection{LCIA - Londra Uluslararası Tahkim Mahkemesi}

İngiliz hukukuna göre, kâr amacı gütmeyen ve ortakları taahhütleri ile sınırlı sorumlu olan bir şirket modelinde kurulmuştur. Uluslararası tahkimlerde ICC'den sonra en çok tercih edilen Uluslararası tahkim kuruluştur.

Bir uyuşmazlıkta, LCIA' nın seçilmesi, zorunlu olarak tahkimin LCIA kurallarına tabi olacağı anlamına gelmez.Taraflar UNCITRAL tahkim kurallarına göre de davanın görüleceğini kararlaştırabilirler.Bu durumda LCIA, hakem seçimi ve tahkim prosedürünün idaresinde rol oynar.Bir başkan, dört başkan yardımcısı ve 25 kurul üyesinden oluşan yönetim kurulu tarafindan idare edilmektedir.

01.01.1998'de revize edilen kurallar, Anglosakson ve Kita Avrupası Tahkim Hukuklarının Sentezi niteliğindedir. LCIA yönetim kurulunun, doğrudan tahkime müdahalesi yoktur.Tahkim hakem tarafindan yürütülür.İngiltere dışındaki faaliyetlerini dünyanın çeşitli bölgelerinde oluşturduğu Konseyleri aracılığı ile gerçekleştirir.Avrupa, Kuzey Amerika-Latin Amerika- Güneydoğu Asya-Afrika konseyleri vardır.

\subsection{ICAC -Rusya Federasyonu Ticaret ve Sanayi Odası Uluslararası Tahkim Mahkemesi}

1932 yılında SSCB Ticaret ve Sanayi Odası Tahkim Mahkemesi olarak kurulmuştur. Bugün uygulanan Tahkim Kuralları, 01.05.1995 tarihinde yürürlüğe giren Rusya Federasyonu Sanayi ve Ticaret Odasınca onaylanan kurallardır. Rusya Federasyonu Ticaret ve Sanayi odasından bağımsızdır, geniş bir hakem listesi vardır. Taraflar bu liste dışından da hakem seçebilirler.

ICAC Başkanı tahkim davasında raportörü belirler, bu raportör hukuki bakımdan tahkime nezaret eder. Merkez Moskova olmasına rağmen, talep ve masraf karşılanması halinde, Moskova dışında da duruşma yapılabilir.

Yargılama süresi, tahkim mahkemesinin oluşumundan itibaren 180 gündür.Mahkeme tarafların seçtiği maddi hukuku uygular.Taraflar hukuk seçimi yapmamışsa, maddi hukuk Rusya Federasyonu Kanunlar ihtilafi kurallarına göre belirlenir. Mahkeme ticari örf adeti de dikkate alır.Taraflar tek hakemde anlaşamazlarsa, mahkeme heyeti üç hakemden oluşur.

\subsection{VIAC - Avusturya Federal Ekonomi Odası Uluslararası Tahkim Merkezi}

Avusturya Federal Ekonomi Odası tarafından Viyana'da kurulmuştur.Tahkim ve uzlaştırma kuralları, 01.07.2006'da yürürlüğe girmiştir.Tahkim prosedürü Viyana'daki Merkez ofiste yürütülür. Viyana dışında da yürütülmesine karar verilebilir.Taraflar hakemlerini serbestçe belirlerler. Liste dışından da hakem belirlenebilir.

\subsection{SCC INSTITUTE - Stockholm Ticaret Odası Tahkim Enstitüsü}

Sovyetler döneminde doğru batı arasındaki Ticaret ve ekonomik sözleşmelerden doğan tahkimlerde kullanılmakta idi. 1977 tarihli anlaşma ile ABD-SSCB Merkezli şirketler arasındaki sözleşmelerden doğan uyuşmazlıkların çözümlenmesinde SCC İnstitute öngörülmüştür. SSCB 'nin dağılmasından sonrada tercih edilmiştir.

Türkiye ile Rusya arasında imzalanan yatırımların teşviki ve korunması anlaşmasında Enstitü Tahkim Mahkemesi olarak kararlaştırılmıştır.

Stockholm ticaret odası tarafindan kurulmuştur.1917'den buyana faaliyetlerini sürdürmektedir. Uluslararası tahkim faaliyeti ile birlikte, hızlandırılmış tahkim, ara buluculuk, sigorta tahkim faaliyetleri de vardır. Odadan bağımsız olarak çalışır. Doğrudan tahkimde görev almaz sadece tahkim prosedürüne nezaret eder.Tahkim kuralları, 2007 yılında yenilenmiştir. 
Taraflar hakem sayısı belirlememişlerse tahkim heyeti üç hakemden oluşur.Tahkim talebinin sunumundan itibaren 6 ay içerisinde karar verilmesi gerekir. Süre uzatılabilir (md 37).Hakem kararı verildiği anda kesin ve bağlayıcıdır.İtiraz yolu yoktur.

\subsection{AAA-Amerika Tahkim Odası}

Merkezi New York'ta bulunan, Uluslararası uyuşmazlık çözüm merkezi ICDR, 1997 yılında kurulmuştur. 01.06.2009'da revize edilen tahkim kuralları AAA geçerlidir.

AAA' nın Uluslararası tahkim kuralları, karışık ve detaylı Amerikan usul Hukuku kurallarından ayrıdır.Diğer tahkim merkezlerinin kurallarına benzer.Kıta Avrupa hukuk kurallarına benzemektedir.Taraflar hakem sayısını belirlememiş ise, kural olarak tek hakem atanır.

\subsection{GAFTA -Hububat ve Yem Ticaret Birliği Tahkim Mahkemesi}

Hububat ve yem ticareti yapan tacirler tarafından Londra'da kurulmuştur. Birlik bünyesinde bir tahkim mahkemesi vardır.Tahkim kuralları,1 Temmuz 2007'de yürürlüğe girmiştir.

Uluslararası hububat, yem ve tohum ticareti yapanlar, Birliğin formüle edilmiş sözleşmesini kullanmaları halinde, uyuşmazlıklar GAFTA tahkim mahkemesince, 125 numaralı kurallara göre karara bağlanır.

Tahkim yeri İngiltere'dir.Taraflarca düzenleme yapılmamışsa, İngiliz tahkim kuralları uygulanır.Kural olarak 3 hakemden oluşur.Taraflar tek hakem belirleyebilirler. Kararlar bağlayıcıdır. Taraflar dilerse, birlik nezdinde 30 gün içerisinde temyiz incelemesine başvurabilirler.Bu durumda karar temyizden sonra bağlayıcı hale gelir.

\subsection{FOSFA- Sıvı ve Hayvansal Yağ ve Tohum Bilirlikleri Federasyonu Tahkim Mahkemesi}

$\mathrm{Bu}$ sektörde faaliyet gösteren tacirler tarafından Londra'da kurulmuştur.Formül sözleşmeleri vardır.Bu sözleşme ile atıf yapılması halinde Birlik nezdinde bulunan Tahkim Mahkemesi yetkilidir.Kararlarına karşı temyiz yolu açıktır.Ücretler harcanan mesaiye göre belirlenir.

\subsection{Refine Şeker Birliği Tahkim Mahkemesi}

$\mathrm{Bu}$ sektörde çalışan tacirler tarafından, 08.01.1891'de kurulmuştur. Merkezi Londra'dır. Formüler sözlemeler ile şeker alım satımını düzenleyen genel şartlar belirlenmiştir.Diğer tahkim kurumlarından farklı olarak tahkim, doğrudan Birlik tarafından yürütülmektedir.Birlik tahkim sistemi, tipik bir mesleki tahkim kurumudur.Kaybeden taraf karar gereğini yirmi sekiz gün içerisinde yerine getirmek zorundadır.

\section{Sonuç}

Finans kuruluşları ve devletlerin imzaladıkları ekonomik ve ticari nitelikteki sözleşmelerin uygulanmasından doğan uyuşmazlıkların çözümü için her devletin içinde değişik nitelikte ulusal ve uluslararası tahkim kurumları oluşturulmuştur. Uluslararası Tahkim Kuruluşlarının büyük bir kısmı doğrudan tahkim işine müdahil olmazlar. Sadece tahkim kurallarını belirleyip, uzman, deneyimli hakem listesi sunarak, tahkim prosedürünü uygularlar. Tahkim kurumunu tercih eden taraflar bu karara uyacaklarını da taahhüt etmiş olurlar. Bu kuruluşlar aynı zamanda milletlerarası ticaret mahkemesi görevi yerine getirirler.

\section{Kaynakça}

- $\quad$ Akıncı Z., 2007 Milletlerarası Tahkim, 798 s.

- $\quad$ Erdoğan, F., 2004.Uluslararası Hukuk ve Tahkim, 420, s.

- $\quad$ Nomer, E. ve Ekşi, N. ve Gelgel Öztekin, G., 2013. Milletlerarası Tahkim Hukuku, 167 s.

- Nomer, E. ve Ekşi, N. ve Gelgel Öztekin, G., 2008, Milletlerarası Tahkime İlişkin Mevzuat ve Anlaşmalar,650.s. 


\title{
Tahkimde Kamu Düzenin Etkisi Effects of Public Policy on Arbitration
}

\author{
Prof. Dr. Mustafa Topaloğlu (Beykent University, Turkey)
}

\begin{abstract}
Public policy is a ambiguous concept. Public policy can be defined as a set of rules which protecting the essential structure of society and its interests. Under New York Convention dated 1958, an arbitration verdict which breaching of public policy in the executing country can't be executed. Same provision valid under Turkish Act Related International Private Law and Procedure Law. An arbitration verdict can't be subject to appeal directly. But, it can be sued for annulment before court of first instance. The public policy is stipulated as a ground of annulment in the Turkish International Arbitration Act. New Turkish Civil Procedure Act accepted same solution about domestic arbitration. In this paper was tried to define the public policy concept and examined point of view of legal rules questioned above.
\end{abstract}

\section{Giriș}

Tahkim, mahkeme dışında alternatif bir ticari uyuşmazlık çözüm metodudur. Tahkim usulünde hakem denilen tahkim heyeti milletlerarası ticari uyuşmazlıkları bağlayıcı şekilde çözmektedirler.

Tahkimde yargısal bir faaliyet söz konusudur. Bu nedenle tahkim, bilirkişilikten, ekspertizlikten ve değerleme uzmanlığından farklıdır.

Milletlerarası ticaret hukukunda tahkim en uygun ve en yaygın bir uyuşmazlık çözüm metodu olarak karşımıza çıkmaktadır.

Tahkim, mahkemelere göre daha hızlı hareket etmektedir. Tahkimde yargılama masrafları ve avukatlık ücretleri devlet yargısına göre daha ucuzdur.

Tahkimde görev alan hakemler milletlerarası ticari uyuşmazlıklar konusunda uzman olduklarından uyuşmazlığın niteliğine uygun ve daha adil karar verebilmektedirler. Aynı zamanda hakemlerin uzmanlığı tahkim yargılamasının mahkemelere göre daha kısa sürmesine de neden olmaktadır.

Hakemler, mahkemeler kadar resmi yaklaşım göstermediklerinden dolayı daha esnek davranabilmektedirler. Hakemler yerine göre kanunlar veya içtihat hukuku yerine hakkaniyete ve ticari hayatın gereklerine özgü karar verebilmektedirler. Mahkemeler kanunların sıkı şekil şartları bağlı olmaları bazen adil olmayan karar verebilmelerine neden olabilmektedir.

Mahkemeler her ne kadar bağımsız da olsalar bulundukları devletin siyasi, sosyal ve ekonomik politikalarından etkilenebilmektedirler. Tahkimde ise hakemler tavır ve davranışları ve verdikleri kararlar ile objektifliklerini ispatlamış kişiler arasından seçilmektedirler.

Buna karşılık tahkimde de hakemlerin özellikle hak ve nefasete göre karar vermeleri halinde adaletsiz ve hakkaniyete aykırı karar verdikleri görülmekte ve tahkim yargılaması sırasında adil yargılama ilkesine aykırı davrandıklarına rastlanmaktadır.

Hakem kararları mahkeme kararlarına göre ilgili ülkede daha yaygın ve kolay bir şekilde icra edilebilmektedir. Yabanıı Hakem kararlarının Tanıma ve Tenfizine ilişkin 1958 tarihli New York Anlaşmasına çok fazla ülke taraftır. New York Anlaşmasına göre taraf ülkelerden birinde verilen hakem kararları diğer bir ülkede de uygulanabilmektedir.

Türk tahkim hukuku uygulamasında ister iç isterse milletlerarası hakem kararı olsun, kamu düzeni kavramı, hakem kararlarının mahkemeler tarafından iptali için anahtar bir kavram olarak kullanılmıştır.

\section{Kamu Düzeni Kavramı}

Kamu düzeni kavramı gerek iç hukukta gerekse milletlerarası hukukta kullanılan bir kavramdır. İç hukuk ve milletlerarası hukukun kamu düzeni yaklaşımı farklı olduğu görülmektedir. Buna rağmen ne iç hukukta ne de milletlerarası hukukta kamu düzeni herhangi bir hukuk metninde yasal olarak tanımlanmış değildir.

Anayasa'da temel hak ve hürriyetlerin kısıtlanmasında, kamu yararı, genel ahlak, genel sağlık gibi ölçülerle kamu düzenin korunması esas alınmış fakat kamu düzenin ne olduğu hususunda herhangi bir belirtme yer almamıştır. Zaman içinde kanun koyucu ve uygulayıcıların siyasi, sosyal, ekonomik ve ahlaki kriterlere atfettiği değere göre kamu düzeninin kapsamı ve içeriği belirlenecektir.

Kamu düzenini iç hukukta Türk toplumunun temel yapısı ve temel çıkarlarını koruyan kuralların bütünü olarak görmek mümkündür. İç hukuktaki bu kurallar herkesin uymakla yükümlü olduğu kamu hukuku veya özel hukuk karakterli olabilir. Bu bağlamda Anayasal temel hak ve özgülüklere aykırılık, Türk Kanunlarının esas 
ilkelerini ihlal ve Türk adap ve ahlak anlayışına karşı gelme hallerinde kamu düzeni mülahazasıyla iç hukukta müdahalede bulunulmaktadır.

Kamu düzeni kavramı ülkeden ülkeye değişiklik gösterir. Aynı zamanda kamu düzeni, sabit bir kavram olmayıp, zaman ve mekana göre de değişen bir özelliğe sahiptir. Kamu düzeni kavramının bu değişken niteliği onu takdire bağlı bir kavram haline getirmektedir. Somut bir olayda kamu düzenine aykırılığın bulunup bulunmadığını hakim takdir yetkisine dayanarak belirleyecektir.

Bireylerin serbest iradelerinin dışında kalan emredici hükümler kamu düzeni amacıyla konulmuştur. Ancak her emredici kural kamu düzeninden sayılmaz. Bununla beraber 6098 sayılı Borçlar Kanununun 27. maddesinde "Kanunun emredici hükümlerine, ahlaka, kamu düzenine, kişilik haklarına aykırı veya konusu imkânsız olan sözleşmeler kesin olarak hükümsüzdür." denilmektedir. BK m.27 hükmünde kamu düzeni kavramı, emredici hükümlerle birlikte irade özgürlügüüün bir sınırı olarak kanunen sayılmıştır. Buna göre gerek emredici hükümlere gerekse kamu düzenine aykırı tahkim sözleşmeleri geçersiz sayılır.

Milletlerarası özel hukukta kamu düzeni kavramı içerik ve işlev bakımından iç hukuktan farklıdır. Milletlerarası kamu düzeni iç hukuka göre daha dar ve sınırlı kapsamdadır. İç hukukta kamu düzeninden sayılan bir husus, milletlerarası özel hukukta kamu düzeninden sayılmayabilir.

Milletlerarası özel hukukta kamu düzenin içeriğini belirlemek çok zordur. Kamu düzeni kavramı zamana ve yere göre değiştiği gibi, ülkeden ülkeye de değişiklik gösterebilir. Kamu düzeni kavramıyla bir ülkedeki temel haklarla ilgili hükümler, anayasasının tüm ilkeleri kamu düzeninden sayılabilir. Her toplumun siyasi, ekonomik, sosyal ve hukuki yapısı o toplumun iç ve dış kamu düzeni anlayışını oluşturmaktadır.

Bütün bu açıklamalardan sonra kamu düzeni kavramını kısaca "toplumun temel yapısını ve çıkarlarını koruyan kuralların bütünü” olarak tanımlamak mümkündür.

\section{Hakem Kararlarının Uygulanmasında Kamu Düzeninin Etkisi}

Hakem kararlarına karşı temyiz yoluna gidilemez. Ancak iptal davası açılması mümkündür. Yabancı mahkeme kararı niteliğindeki kararların da uygulanabilmesi için Türk mahkemelerinde tenfiz davası açılarak tenfiz kararını alınması gerekir. Alınan tenfiz kararı Yargıtay'da temyiz konusu yapılabilir

\subsection{Hakem Kararlarının Tenfizi Davasında Kamu Düzeni}

Türk hukukunda yabancı hakem kararlarının tenfizi, Yabancı Hakem Kararlarının Tanınması ve Tenfizi Hakkında 1958 tarihli New York Anlaşması veya 5718 sayılı Milletlerarası Özel Hukuk ve Usul Hukuku Hakkında Kanun hükümlerine tabiidir.

\section{8 tarihli New York Anlaşması}

New York Anlaşması 1 Ekim 1992 tarihi itibariyle onaylandığı için bu tarihten itibaren Türkiye açısından da uygulama kabiliyeti kazanmıştır. Türkiye'nin koyduğu çekince uyarınca New York Anlaşması taraf olan bir devlette verilen hakem kararının Türkiye'de tanınması ve Tenfizinde uygulama alanı bulabilir.

Türkiye'nin tahkim yeri olduğu hakem kararları ise 4686 sayılı Milletlerarası Tahkim Kanununa tabiidir. Ancak Türkiye'de gerçekleşecek bir tahkim yargılamasının MTK'ya ve 6100 sayılı HMK'ya tabi olmayacağı taraf iradelerinden anlaşılan yabancı unsurlu hakem kararlarına New York Anlaşmasının uygulanması söz konusu olabilir.

New York Anlaşmasının V.maddesinde yabancı hakem kararlarının tenfizi şartları sınırlı şekilde sayılmıştır. Bu şartlardan biri de tenfizi istenen hakem kararının tenfiz devleti hukukunun kamu düzenine aykırı olmamasıdır. Burada dikkate alınması gereken kamu düzeni, iç hukuktaki kamu düzeni değil, milletlerarası unsurlu hukuki ilişkiler bakımından geçerlilik taşıyan kamu düzenidir. Ayrıca, kamu düzenine aykırılığın değerlendirilmesi ise tenfiz devleti olan Türkiye'de tenfize karar verildiği andaki geçerli bulunan anlayışa göre gerçekleştirilecektir.

Yabancı hakem kararlarının tenfizinde kamu düzeni birçok bakımdan değerlendirmeye alınabilir. Bunlardan birincisinde, tenfizi istenen kararın, kumar veya rüşvet alacağı veya ithali veya ihracı yasak bir malın teslimi gibi Türk kanunlarına göre ifası yasak olan edimler içermesi ya da uyuşturucu veya beyaz kadın ticareti gibi genel ahlaka ters düşen sözleşmelerden kaynaklanan edimleri hüküm altına alıyor olması halinde kamu düzenine aykırılık nedeniyle tenfiz talebinin reddedilebilir.

New York Anlaşmasında revizyon sistemi reddedildiğinden tenfiz mahkemesi burada belirtilen şartların dışına çıkarak hakem kararını esastan inceleyemez. Ancak istisnai hallerde kamu düzenine aykırılık iddiasının incelenmesi amacıyla sınırlı olarak hakem kararının içeriğine dahil bazı vakıaların incelenmesi söz konusu olabilir.

New York Anlaşmasının V (2)(b)maddesi anlamında kamu düzenine aykırı sayılabilecek ikinci hal ise, özellikle bazı milletlerarası tahkim merkezlerinde yapılan tahkim yargılaması sırasında hakemlerin bağımsızlığ veya tarafsızlığı ilkelerinin ihlal edilmesidir. Hakemlerin bağımsızlığından kasıt, onların hiçbir makam, merci, organ veya kişiden emir, talimat, tavsiye veya telkin almamaları veya özellikle davanın tarafları ile objektif karar vermeyi engelleyecek ölçüde herhangi bir bağ içinde bulunmamalaradır. Hakimler gibi adil, objektif ve tarafsız 
karar vermeleri gereken hakemlerin bağımsızlığının taraflar için usuli güvence oluşturacağı tartışmadan uzaktır.

Hakemlerin bağımsız olmadıklarına karar verirken sadece şüphe yeterli olmayıp, söz konusu şüphenin kararın muhtevasına yansıması gerekir. Ancak bu şekilde somutlaşmış hakem kararları kamu düzenine aykırı sayılarak tenfizi reddedilebilir. Bazı durumlarda da hakemlerin bağımsız olmadıklarına ilişkin iddialar taraflarla hakem arasındaki rüşvet veya çıkar ilişkileri ispatlanarak açıkça ortaya konabilir.

Üçüncü olarak, bazı usuli hatalar savunma hakkını ihlal ederek kamu düzenini bozabilir. New York Anlaşmasının V (1)(b)maddesi anlamında özellikle taraflardan birinin tahkim usulünden haberdar edilmemiş olması ve bu diğer sebeplerden dolayı savunmamasının alınmamış olması temel hakları ihlal ettiğinden kamu düzenine aykırılık nedeniyle tenfiz engeli oluşturur.

Kamu düzenine aykırı sayılan bir diğer durum da tenfizi istenen hakem kararının kesinleşmiş Türk mahkeme kararına aykırı hükümler içermesidir. Zira, birbirine aykırı hüküm içeren iki ayrı kararın Türkiye'de aynı anda icra edilebiliyor olması, hukuki güvenlik, toplumsal barış ve istikrarı bozacağından, kamu düzeni fikrini ihlal edeceğinde şüphe yoktur.

Son olarak, hakem kararlarının taraflarının anlaşması ile gerekçesiz olarak verilebileceğine ilişkin kuralların işlerlik kazandığı hakem kararları kamu düzeni engeliyle karşılaşır. Anayasanın 141.maddesine göre bütün mahkeme kararları gerekçeli olmak zorundadır. Emredici nitelikte bulunan Anayasa m.141 hükmü hakem kararları için dahi geçerlidir. Diğer taraftan ancak gerekçe taşıyan hakem kararları, tenfiz şartlarına sahip olunup olunmadığı yönünde yapılacak bir incelemeye imkan tanır.

\section{8 sayılı MÖHUK}

New York Sözleşmesi birçok ülke tarafindan onaylanmış olduğu için bu anlaşmaya taraf olmamış devlet kalmamış gibidir. 5718 sayılı MÖHÜK, tenfiz şartları bakımından New York anlaşmasından daha ağır hükümler taşıdığı için tarafların MÖHUK hükümlerini tercih etmeleri pek düşünülemez. Ancak New York Anlaşmasının uygulanamadığı çok sınırlı hallerde yabancı hakem kararların tenfizinde MÖHUK hükümlerinin uygulanması düşünülebilir.

5718 sayılı MÖHUK hükümleri kamu düzeni açısından New York Anlaşması ile benzer hükümler içerdiği için New York Anlaşması için söylenenler burada da geçerlidir.

\subsection{Hakem Kararlarının İptalinde Kamu Düzeni}

Hakem kararlarının iptali tahkimin iç tahkim veya milletlerarası tahkim olmasına göre değişmektedir.

\section{6 sayılı Milletlerarası Tahkim Kanunu}

4686 sayılı MTK, sadece yabancilık unsuru taşıyan ve tahkim yerinin Türkiye olarak belirlendiği veya bu Kanun hükümlerinin taraflar veya hakem kurulu tarafından seçildiği uyuşmazlıklarda uygulama alanı bulmaktadır.

Türk Hukukunda hakem kararlarına karşı asliye hukuk mahkemelerinde iptal davası açma usulünü ilk defa MTK getirmiştir. İptal kararına karşı Yargıtay'da temyiz yoluna başvurmak mümkündür. Esasa girme yasağını öngören MTK'ya göre, mahkemeler ancak iptal sebeplerinin gerçekleşip gerçekleşmediği noktasında hakem kararlarını inceleyebilir.

MTK'ya göre hakem kararının kamu düzenine aykırı olması açık bir iptal sebebi olarak düzenlenmiştir. Bu düzenleme New York Anlaşmasına paraleldir. Her ne kadar tahkim yargılaması Türkiye'de gerçekleşse de yabancılık unsurundan dolayı kamu düzenine aykırılık kavramı belirlenirken milletlerarası kamu düzeni yaklaşımı esas alınmalıdır.

\section{0 sayılı Hukuk Muhakemeleri Kanunu}

Genellikle iç tahkim, hukuk muhakemeleri kanunlarında düzenlenir. Mülga 1086 sayılı Hukuk Usülü Muhakemeleri Kanunu iç tahkime ilişkin hükümler içermekteydi. Mülga HUMK, hakem kararlarına karşı temyiz yoluna başvurma imkanı tanımaktaydı. Kamu düzeni Mülga HUMK'da temyiz sebepleri arasında gösterilmese de, Yargıtay İçtihadı Birleştirme Kararına göre kamu düzenine aykırılık temyiz incelemesi sırasında resen gözetilebilmekteydi. Mülga HUMK döneminde hakem kararlarının kamu düzenine aykırılık nedenine dayalı olarak çok fazla Yargıtay kararı verilmişti.

6100 sayılı yeni HMK ise hakem kararlarına karşı mülga HUMK'dan farklı olarak temyiz yolunu kaldırmış ve MTK'daki düzenlemeye paralel olarak iptal prosedürü öngörmüştür. Buna göre hakem kararından hoşnut olmayan taraf, asliye hukuk mahkemelerinde iptal davası açabilir. Asliye mahkemesinin iptal davasındaki kararına karşı da Yargıtay'da temyiz yolu açıktır.

HMK, mülga HUMK'dan farklı olarak kamu düzenine aykırılığı özel bir iptal sebebi olarak düzenlemiş̧tir. Bu düzenleme New York Anlaşması ve MTK'yla neredeyse aynıdır. Ancak, HMK'da düzenlenen tahkimin iç tahkim olduğu ve bu nedenle kamu düzeni kavramının da Türkiye'ye özgü bir yargılama olduğu dikkate alınarak yorumlanmalı ve değerlendirilmelidir. 


\section{Sonuç}

Son yasal düzenlemelerden sonra Türkiye'de hakem kararlarının kamu düzenine aykırılı̆̆ Anlaşmasına paralel düzenlemeye kavuşmuştur. Ancak HMK, öngörülen kamu düzeni kavramının bir iç tahkim olduğu hususu gözden uzak tutulmamalıdır.

Kamu düzeni kavramı muğlak bir kavram olup tanımlanması zor bir kavramdır. Ancak bu belirsizlik kamu düzenine aykırılık nedeniyle hakem kararlarının içeriğine müdahale imkanı vermez. Tahkim yargılamasını tercih eden taraflar Devlet yargılamasından vazgeçerek hakemlerin hukuk anlayışı ve yaklaşımına razı olmuşlardır. Özellikle milletlerarası tahkimde esasa girme yasağına aykırı yargısal yorum ve uygulamalardan özellikle kaçınılmalıdır.

\section{Kaynakça}

- $\quad$ Akıncı, Z., 2007. Milletlerarası Tahkim, Seçkin Yayınları, Ankara, 798 s.

- Dayınlarlı, K., 2004. HUMK'da Düzenlenen İhtiyari Iç Tahkim, Dayınlarlı Hukuk Yayınları, Ankara, 342 s.

- Goode,R., 2004. Commercial Law, Penguin Books, 1265 s.

- Kalpsüz, T., 2007. Türkiye'de Milletlerarası Tahkim, Ankara, 171 s.

- Nomer, E.,Ekşi, N. ve Öztekin Gelgel, G., 2013. Milletlerarası Tahkim Hukuku, Beta Yayınları, İstanbul, $168 \mathrm{~s}$.

- $\quad$ Pekcanitez, H. ve Atalay, O. ve Özekes, M., 2011. Hukuk Muhakemeleri Hükümlerine Göre Medeni Usul Hukuku, Yetkin Yayınları, Ankara, $775 \mathrm{~s}$.

- Sözer, B., 2001. Legal Environment of Business, Beta Yayınları, İstanbul, 482 s.

- Şanlı, C. ve Esen, E. ve Ataman Figenmeşe, İ., 2013. Milletlerarası Özel Hukuk, İstanbul,666 s.

- Tanrıver, S., 1988. Yabancı Hakem Kararlarının Türkiye'de Tenfizinde Kamu Düzeninin Rolü, Prof. Dr. Ali Bozer'e Armağan, Ankara, s. 567 vd.

- Yılmaz, E., 2012. Hukuk Muhakemeleri Kanunu Şerhi, Yetkin Yayınları, Ankara, 1794 s. 


\title{
Türkiye'de Yabancı Hakem Kararlarının Tanınması ve Tenfizinde Karşılaşılan Sorunlar
}

\section{Problems in Recognition and Enforcement of Foreign Arbitral Awards in Turkey}

\author{
Assoc. Prof. Dr. Adnan Deynekli (Turkish Supreme Court, Turkey)
}

\begin{abstract}
If the arbitral award which requested to recognition and enforcement given in the country is a party to New York Convention dated 1958, primarily the provisions of this Convention shall be applied. The recognition and enforcement of domestic law and regulations duly implemented. Whether judgment fees should be fixed or proportional are discussion. The demand for recognition and enforcement of foreign arbitral tribunal shall not review the basis of the decision of the referee. The necessary conditions for enforcement of foreign arbitral decisions and must be moved. The existence of the arbitration agreement against the enforcement of the arbitration requested by referee assignments, and to be aware of the dispute to arbitration and enforcement required to be favorable verdict must not be contrary to public policy.
\end{abstract}

\section{Giriş}

Yabancı hakem kararlarının Türkiye'de tanınması ve tenfizi konusunda iki düzenleme bulunmaktadır. Bu düzenlemelerden birisi 5718 sayılı Milletlerarası Özel Hukuk ve Usul Hukuku Hakkında Kanunun 60, 61, 62 ve 63. maddelerinde yer alan hükümlerdir. Diğeri ise Türkiye'nin katıldığı Yabancı Hakem Kararlarının Tanınması ve İcrası Hakkındaki 10 Haziran 1958 Tarihli New York Sözleşmesidir.

Ayrıca Türkiye ile bazı ülkeler arasında iki taraflı milletlerarası sözleşmeler de bulunmaktadır.

958 tarihli New York Sözleşmesi'nin 1. maddesine göre sözleşme tanıma ve tenfiz istenen devletten başka devlette verilmiş hakem kararlarını kapsamaktadır. Sözleşmenin 1. maddesinin 3. fikrası uyarınca Türkiye bazı çekincelerle sözleşmeyi onaylamıştır. New York Sözleşmesi Türkiye'nin koyduğu çekinceden dolayı sadece ticari uyuşmazlıklara ve anlaşmaya taraf olan ülkelerden verilen hakem kararlarının tanınması ve tenfizi 1958 tarihli New York Sözleşmesi'ne göre istenebilecektir. Tanınması ve tenfizi istenen yabancı hakem kararının verildiği ülke sözleşmeyi onaylamamışsa yabancı hakem kararın tanınması ve tenfizi 1958 tarihli New York Sözleşmesi’ne göre değil 5718 sayılı MÖHUK hükümlerine göre istenebilecektir.

1958 tarihli New York Sözleşmesi birçok ülke imzaladığı için yabancı hakem kararlarının tanınması ve tenfizinde daha çok 1958 tarihli New York Sözleşmesi hükümleri uygulanacaktır.

\section{Tanınması ve Tenfizi İstenebilecek Yabancı Hakem Kararları}

Bir hakem kararının Türkiye'de tanınması ve tenfizi için bu kararın yabancı hakem kararı olması gerekir.

Hangi hakem kararının yabancı hakem kararı sayılacağı hususunda 2675 ve 5718 sayılı MÖHUK'da hüküm bulunmamaktadır.

Hakem kararının yabancı hakem kararı olup olmadığı konusunda tarafların vatandaşlığı, hakemlerin milliyeti, hakem kararının verildiği yer, hakem kararının otoritesi altında verildiği konu kriterleri kullanılmıştır.

Türk Hukukunda Hukuk Genel Kurulu'nun 7.11.1951 tarihli 126/109 sayılı kararı bu açıdan önemlidir. Hukuk Genel Kurulu bu kararında "bir hakem kararı yabancı bir hakem otoritesi altında verilmiş ise, o kararın yabancı hakem kararı sayılabileceğini" kabul etmiştir.

1958 tarihli New York Sözleşmesi, 1. maddesinde bir hakem kararının yabancı hakem kararı sayılabilmesi için iki kıstas getirmiştir.

Birinci kıstasa göre hakem kararı tenfizi istenen ülkeden başka bir yerde verilmişse bu karar yabancı hakem kararıdır. Görüldüğü gibi bir hakem kararının yabancı hakem kararı sayılması için tenfizi istenen ülkeden başka bir ülkede verilmiş olması yeterli sayılmıştır.

İkinci kıstası göre hakem kararının tanınması ve tenfizi istenen ülkede milli sayılmaması gerekir.

Bir kararın tanınması veya tenfizi talebi ile başvurulan devlet mahkemesi, öncelikle kararın yerli bir hakem kararı mı yoksa yabancı bir hakem kararı mı olduğunu tespit edecektir.

Türk hukuku bakımından yerli hakem kararı Türk usul hukukunun emredici kurallarına uyarak verilmiş olan hakem kararıdır. Yabancı bir devletin usul hukukuna göre verilmiş bir hakem kararı yabancı hakem kararı olarak tanıma ve tenfizi konu edilebilir. 
1 Ekim 2011 tarihinde yürürlüğe giren 6100 sayılı Hukuk Muhakemeleri Kanunu yabancılık unsuru içermeyen ve tahkim yerinin Türkiye olarak belirlendiği uyuşmazlıklar hakkında uygulanacaktır (HMK m. 407).

4686 sayılı Milletlerarası Tahkim Kanunu ise yabancılık unsuru taşıyan ve tahkim yerinin Türkiye olarak belirlendiği veya bu kanun hükümlerinin tarafları ya da hakem veya hakem kurulunca seçildiği uyuşmazlıklar hakkında uygulanır. Türkiye'de cereyan eden yabancı unsurlu tahkimler, hangi usule göre icra edilirse edilsin Türk Milletlerarası Tahkim Kanununa tabi olduklarından hakem kararları Türk hakem kararlarıdır. Tahkim yeri olarak Türkiye öngörülmesine rağmen tahkimin 4686 sayılı kanuna tabi olmayacağı kararlaştırılmışsa hakem kararı yabancılık unsuru içermiyorsa 6100 sayılı HMK hükümlerine tabi olacak, yabancılık unsuru içeriyorsa yabancı hakem kararı sayılacak ve 1958 tarihli New York Sözleşmesi veya 5718 sayılı MÖHUK hükümlerine göre tanıma ve tenfize tabi tutulacaktır.

Tanınması ve tenfizi istenebilecek yabancı hakem kararının ad hoc veya kurumsal tahkim sonunda verilen hakem kararı olmasının tanıma ve tenfiz açısından bir önemi bulunmamaktadır. Kurumsal tahkim merkezleri önceden düzenlenmiş kuralları ve zaman içindeki uygulamaların bilinmesi nedeniyle taraflara güven sağlamaktadır. Tanıma ve tenfizi istenen kararlar göz önüne alındığında kurumsal tahkim hizmeti sağlayan merkezlerin bazılarını sayabiliriz.

Bunlar MTO Tahkim Mahkemesi, Londra Uluslar arası Tahkim Mahkemesi, Rusya Federasyonu Ticaret ve Sanayi Odası Uluslar arası Tahkim Mahkemesi, Avusturya Federal Ekonomi Odası Uluslar arası Tahkim Merkezi, Stockholm Ticaret Odası Tahkim Enstitüsü, Amerika Tahkim Odası, Hububat ve Yem Ticaret Birliği Tahkim Mahkemesi (GAFTA), Suni ve Hayvansal Yağ ve Tohum Birlikleri Federasyonu Tahkim Mahkemesi (FOSFA) ve Rafine Şeker Birliği Tahkim Mahkemesidir.

\section{Yabancı Hakem Kararının Tanınması ve Tenfizi Usulü}

Bu başlık altında görev ve yetkiye ilişkin hususlar ile çeşitli usule ait hususlar tartışılacaktır.

\subsection{Görevli ve Yetkili Mahkeme}

Yabancı hakem kararlarının tanınması ve tenfizinde görevli mahkeme asliye hukuk mahkemesidir (MÖHUK m. 60/2). Görev kamu düzeninden olup (HMK m.1) davanın her aşamasında resen gözetilir (HMK m. 115). Yabancı hakem kararının tanınması ve tenfizi sulh hukuk mahkemesinden istenirse görev dava şartı olması nedeniyle (HMK m. 114) mahkeme resen görevsizlik kararı vermelidir.

Tanınması ve tenfizi istenen yabancı hakem kararı ticari bir uyuşmazlığa dayanıyorsa asliye ticaret mahkemesinde tanıma ve tenfiz talep edilebilir mi?

Şanlı'ya göre ticari uyuşmazlıklarla ilgili olarak verilmiş yabanı hakem kararlarının tenfizi davaları ve bu davaların konusu, "ticari iş" veya "ticari dava" niteliğinde olmadığından, tenfiz davalarında işin esasına girilemeyeceğinden mahkeme burada uzmanlığı gereği ve yargılama yapmayacak, sadece tenfiz şartlarının bulup bulunmadığını tespit edecektir. Bu nedenle uyuşmazlık ticari olsun olmasın yabancı hakem kararlarının tanınması ve tenfizinde görevli mahkeme asliye hukuk mahkemesidir.

Tenfizi istenen yabancı hakem kararına konu sözleşme ve uyuşmazlık Deniz Ticaret Hukukunu veya Fikri ve Sınai Hakları ilgilendiriyorsa görevli mahkemenin Deniz İhtisas Mahkemesi veya Fikri ve Sınai Haklar Mahkemesi olup olmadığ 1 sorunu ortaya çıkabilir.

Yabancı hakem kararlarının tanınması ve tenfizinde yetkili mahkeme, tarafların yazılı olarak kararlaştırdıkları yerdeki mahkemedir. Taraflar arasında böyle bir sözleşme yoksa davalının Türkiye'deki yerleşim yeri, yerleşim yeri yoksa sakin olduğu yer mahkemesi, sakini olduğu yer de yoksa davalının icraya konu teşkil edebilecek mallarının bulunduğu yer mahkemesidir (MÖHUK m. 60/2). Davalının Türkiye'de icraya konu edilebilecek malları yoksa Türk mahkemeleri yabancı hakem kararlarının tanınması ve tenfizi konusunda yetkisiz olacaktır. Ancak yetkinin kesin olmadığı durumlarda mahkeme yetki itirazını resen gözetmez. Davalının cevap süresi içinde yetki ilk itirazında bulunması gerekir.

\subsection{Tanıma ve Tenfiz Başvurusu}

Yabancı hakem kararının tanınmasını ve tenfizini isteyen taraf görevli ve yetkili mahkemeye bir dilekçe ile başvurur. Bu dilekçenin HMK'nın 119. maddesine uygun olarak düzenlenmesi gerekip gerekmediği konusunda tereddüt ortaya çıkabilir. HMK'nun 119. maddesinin a, b, ç, d, ğ h bentlerinde yer alan hususlar tanıma ve tenfiz talebi dilekçesinde bulunması gerekir.

5718 sayılı MÖHUK, dilekçeye bazı belgelerin eklenmesini zorunlu kılmıştır. 1958 tarihli New York Sözleşmesi'nin IV. Maddesinde yabancı hakem kararının tanınmasını ve tenfizi isteyen tarafın sunması gereken belgeleri belirtmiştir.

5718 sayılı MÖHUK'un 61. maddesine göre eklenecek belgeler şunlardır:

i- $\quad$ Tahkim sözleşmesi veya şartının, aslı yahut usulüne göre onanmış örneği

ii- Hakem kararının usulen kesinleşmiş ve icra kabiliyeti kazanmış veya taraflar için bağlayıcılık kazanmış aslı veya usulüne göre onanmış örneği, 
iii- Yukarıda sayılan belgelerin tercüme edilmiş ve usulen onanmış örnekleri

1958 tarihli New York Sözleşmesi'nin IV. Maddesine göre dilekçeye eklenecek belgeler şunlardır:

i- Hakem kararının usulüne göre tasdik edilmiş aslı yahut aslına uygunluğu tasdik edilmiş bir sureti,

ii- Kararın dayandığı tahkim anlaşmasının aslı veya usulü dairesinde tasdik edilmiş sureti.

iii- Hakem kararı veya onun dayandığı tahkim anlaşması tenfizi istenen mahkemenin resmi dilinde yazılmamışsa tercümesi.

\subsection{Başvuruda Alınacak Harc}

Yabancı hakem kararlarının tenfizinde tenfiz isteyen taraftan başvuru harcı ve nisbi harca tabi davalarda nisbi karar ve ilam harcının \%68,31'nü 1/4'ü harç alınır. Uygulamada da harcın bu şekilde alınacağı kabul edilmektedir. Yargıtay bir kararı şöyledir:

"yabancı hakem kararlarının tenfizine ilişkin mahkeme kararından hakem kararının mahiyetine göre (Türk hakem kararları gibi) karar ve ilam harcı alınır. Bu durumda yabancı hakem kararının tenfizini isteyen taraftan başvurma harcı ve nisbi harca tabi davalarda nispi karar ve ilam harcı alınır. Somut olayda nispi harç alınması gerektiği gözetilmeden maktu harç alınması da isabetsizdir.”

Harçla ilgili 1958 Tarihli New York Sözleşmesi’nin III. Maddesi önemli bir düzenlemedir. Hükme göre sözleşme kapsamında hakem kararlarının tanınması ve tenfizi için milli hakem kararlarına nispetle oldukça ağır şartlar yükleyemeyecek ve adli harç alınmayacaktır. 4686 sayılı MTK'nun 15/B maddesine göre hakem kararına karşı açılan iptal davasının reddine ilişkin kararın kesinleşmesinden sonra hakem kararının icra edilebilir olduğuna ilişkin belge istemde bulunan tarafa verilir. Bu belgenin verilmesi harca tabi değildir. Hakem kararının icraya konulması halinde Harçlar Kanununu hükümleri uygulanır. Bu hüküm uyarınca yabancı hakem kararlarının tanınması ve tenfizinde nisbi değil maktu harç alınması gerektiği düşünülebilir.

\subsection{Teminat}

Yabancı hakem kararının tanınması ve tenfizi talebi de dava olduğundan tanıma ve tenfiz hakkında bulunan davacı yabancı ise 5718 sayılı MÖHUK'un 48. maddesine göre, Türkiye'de mutat meskeni bulunmayan Türk vatandaşı ise 6100 sayılı HMK'nun 84. maddesine göre teminat göstermek zorundadır. Davacının mensup olduğu veya ikamet ettiği ülke ile Türkiye arasında teminattan muafiyet konusunda iki veya çok taraflı anlaşma varsa teminat istenmeyecektir.

\subsection{Uygulanacak Yargılama Usul ï}

5718 sayılı MÖHUK'un 61. maddesinin atıf yaptığı 55. maddeye göre tenfiz istemine ilişkin dilekçe duruşma günü ile birlikte karşı tarafa tebliğ edilir. İstem basit yargılama usulü hükümlerine göre incelenerek karara bağlanır. Basit yargılama usulü 1086 sayılı HUMK'un 507-511 maddeleri arasında düzenlenmişken 1 Ekim 2011 tarihinde yürürlüğe giren 6100 sayılı HMK'nun 316-322 maddeleri arasında düzenlenmiştir. Bu yargılama usulünde cevap süresi iki haftadır. Bu süre zarfında mahkemeye başvuran davalıya durum ve koşullarag öre bir defaya mahsus olmak üzere iki haftayı geçmemek üzere ek süre verilebilir (HMK m. 317).

Taraflar dilekçeleri ile birlikte tüm delillerini açıkça ve hangi vakıanın delili olduğunu bildirmek, ellerindeki delilleri dilekçelerine eklemek zorundadır (HMK m. 318).

İddianın genişletilmesi veya değiştirilmesi yasağı dava açılmasıyla, savunmanın genişletilmesi veya değiştirilmesi yasağı cevap dilekçesinin mahkemeye verilmesiyle başlar (HMK m. 319).

Yabancı hakem kararlarının tanınması ve tenfizi talebiyle açılan davalarda ön inceleme ve tahkikat kesin çizgilerle birbirinden ayrılmamıştır (HMK m. 320). Mahkeme ilk duruşmada dava şartları ve ilk itirazlarla hak düşürücü süre ve zamanaşımı hakkında tarafları dinledikten sonra tarafların iddia ve savunmaları çerçevesinde anlaştıkları ve anlaşamadıkları hususları tek tek tespit eder. Uyuşmazlık konularının tespitinden sonra hakem tarafları sulhe teşvik eder. Tarafların sulh olmaları halinde sulhe göre karar verir. Taraflar sulh olmazlarsa anlaşamadıkları hususlar tutanağa yazılır ve tutanağın altı hazır bulunan taraflarca imzalanır (HMK m. 320/2).

Mahkeme tahkikat işlemlerini ön inceleme duruşması hariç iki duruşmada tamamlar. Duruşmalar arasındaki süre bir aydan uzun olamaz. İşin niteliği gereği bir aydan fazla süreli duruşma günü belirleyebilir ve ikiden fazla duruşma yapabilir (HMK m. 320).

Yabancı hakem kararlarının tanınması ve tenfizi talebiyle açılan davalar bir defa takipsiz bırakılabilir. İkinci defa takipsiz bırakılması halinde davanın açılmamış sayılmasına karar verilir (HMK. M. 320/4).

1086 sayılı HUMK'un 176. maddesinde basit yargılama usulüne tabi davaların adli tatilde görülebileceği belirtilmiştir. Bu kanun yerine yürürlüğe giren 6100 sayılı HMK'nun 103. maddesinde adli tatilde görülecek dava ve işler arasında basit yargılama usulüne tabi tutulan dava ve işler sayılmamıştır. HMK'nun 103. maddesinin (h) bendinde kanunlarda ivedi olduğu belirtilen dava ve işlerin adli tatilde görülebileceği hükme bağlanmıştır. Basit yargılama usulüne tabi dava ve işlerin ivedi olup olmadığ hususu yeni bir tartışmayı gündeme getirecektir. Özellikle temyiz sürelerinin adli tatilde işleyip işlemeyeceği konusundaki çıkabilecek tartışmaların önüne geçmek için konuya açıklık getirilmesi uygun olur. 
Basit yargılama usulünde iddianın genişletilmesi veya değiştirilmesi yasağı dava açılmasıyla, savunmanın genişletilmesi veya değiştirilmesi yasağı cevap dilekçenin mahkemeye verilmesiyle başlar (HMK m. 319). Davacı yabancı hakem kararının tenfizini isterken kararda belirtilen yargılama giderini talep etmemişse ve daha sonra yapacağı talep davalının iddianın genişletildiği savunmasıyla karşılaşabilir.

\subsection{Davalının İleri Sürebileceği İtirazlar}

5718 sayılı MÖHUK'un 61. maddesinin 2. fikrasının atıf yaptığ 155 . maddesinin 2. fikrasındaki hüküm yabancı hakem kararlarının tanınması ve tenfizinde de uygulanacaktır. Davalı tenfiz şartlarının bulunmadığını veya yabancı mahkeme ilamının kısmen veya tamamen yerine getirilmiş olduğunu veya yerine getirilmesine engel bir sebep bulunduğunu ileri sürerek tenfiz talebine itiraz edebilir. Bu itirazlar sınırlı olup genişletilemez. Ancak davalı tenfiz isteyen kişinin talepte bulunurken dilekçesine eklemesi gereken belgeleri hiç eklemediğini veya eksiklik bulunduğunu belirterek de itiraz da bulunması mümkündür.

Davalı tahkim yargılamasında ileri sürülen ancak kabul edilmeyen ödeme savunmasını, tenfiz davasında itiraz sebebi olarak ileri süremez. Ancak hakem kararının verilmesinden sonraki ödemeler gözetilir.

\section{7 İncelemenin Kapsamı}

1958 tarihli New York Sözleşmesi'nde ve 5718 sayılı MÖHUK'da mahkemelerin yabancı hakem kararlarının tanınması ve tenfiz davalarında işin esasına göremeyeceği kabul edilmiştir. Yargıtay kararlarında da tenfiz mahkemesinin hakem kararının esasına ilişkin hususlarda inceleme yapamayacağı belirtilmektedir.

"Davalı tek sözleşme olmasına rağmen iki kere tazminata hükmedilmesini savunmanın dikkate alınmadığını gösterdiğini belirterek tenfiz talebinin bu nedenle de reddi gerektiğini savunmuştur. Bu iddia kararın esasına ilişkin olup, hakem kararının doğruluğunu inceleme yapma yasağı (revision au fond) kapsamında bulunduğundan tenfiz mahkemesine bu iddiaları inceleme yetkisi tanınmamıştır."

Tenfiz talebini inceleyen mahkeme tenfiz talebinin reddini gerektiren hususlar yönünden inceleme yapacaktır. MÖHUK'un 62. maddesinde (ç), (d), (e), (f), (g) ve (h) bentlerinde yazılı hususları ispat yükü, hakkında tenfiz istenen tarafa aittir. Aynı maddenin (a), (b) ve (c) bentlerinde yazılı hususlarda ise ispat yükü tenfiz talep eden davacıya ait bulunmaktadır.

1958 tarihli New York Sözleşmesi'ne göre tenfiz şartlarının gerçekleşmediğini ispat yükü, aleyhine tenfiz istenen davalıya aittir. Ancak tenfiz talebini inceleyen mahkeme de hakem kararının tahkime everişli olmayan bir konuda verildiğini veya kamu düzenine aykırı olduğunu tespit ederse tenfiz talebini reddeder (m. V-2).

Davalı hakem tenfizini veya hakemlik prosedürünün kendisine haber verilmediğini belirterek tenfiz talebinin reddini isterse bu durumda menfi vakıanın ispatı mümkün olmadığından ispat yükünün davalıda değil davacıda olduğunu kabul etmek gerekir.

\section{Yabancı Hakem Kararının Tanınması ve Tenfizi İçin Gerekli Koşullar}

\subsection{Tenfizi İstenen Kararın Yabancı Hakem Kararı Olması}

Bir hakem kararının Türkiye'de tanınmasının veya tenfizinin istenebilmesi için bu kararın yabancı hakem kararı olması gerekir.

\subsection{Hakem kararının Kesinleşmesi ve İcra Kabiliyeti Kazanması veya Taraflar İçin Bağlayıcı OIması} (İptal Edilmemiş Olması veya İ́ranın Geri Bırakılmamış Olması)

1958 tarihli New York Sözleşmesi'nde tenfizi istenen yabancı hakem kararının bağlayıcı olması gerektiği kabul edilmiştir (m. V-e). 5718 sayılı MÖHUK'un 60. maddesine göre kesinleşmiş ve icra kabiliyeti kazanmış veya taraflar için bağlayıcı olan yabancı hakem kararları tenfiz edilebilir. 2675 sayılı kanunda yer almayan yabancı hakem kararının bağlayıcı olması 5718 sayılı kanunla getirilmiştir. Bu hükmün amacı yabancı hakem kararlarının tanınmasını ve tenfizini kolaylaştırmaktır. Yargıtay da tenfizi istenen yabancı hakem kararının bağlayıcı olmasını yeterli kabul etmektedir.

"Davacı vekili, taraflar arasında 25.8.1997 tarihinde yapmuk alım satım sözleşmesi akdedildiğini, davalının sözleşmeden doğan edimini yerine getirmediğini, Liverpool Pamuk birliği Hakem Mahkemesine yapılan müracaatın karara bağlandığını ileri sürerek hakem kararının tenfizine karar verilmesini talep ve dava etmiştir.

Davalı vekili 25.8.1997 tarihli sözleşmedeki imzanın müvekkiline ait olmadığını, taraflar arasında geçerli bir tahkim sözleşmesi bulunmadığını, hakemde görülen davada savunma hakkı tanınmadığını, tebligatların usulsüz olduğunu belirterek tenfiz talebinin reddini istemiş̧ir.

Mahkemece, tahkim sözleşmesinin geçerli olduğu, davalının savunma hakkına riayet edildiği, hakem kararının bağlayıcı olduğu, tahkimle çözümlenmesi mümkün bir konuya ilişkin bulunduğu, kamu düzenine aykırı olmadığı gerekçesiyle hakem kararının tenfizine karar verilmiş, hüküm davalı vekili tarafından temyiz edilmiş̧ir.

Dosyadaki yazılara kararın dayandığı delillerle gerektirici sebeplere, delillerin takdirinde bir isabetsizlik bulunmamasına göre, davalı vekilinin yerinde görülmeyen bütün temyiz itirazlarının reddiyle usul ve kanununa 
uygun bulunan hükmün Onanmasına, aşağıda yazılı onama harcının temyiz edenden alınmasına, 21.2.2008 gününde oybirliğiyle karar verildi.”

\subsection{Tahkim Anlaşmasının Yapılmaması}

Taraflar arasında tahkim sözleşmesi yapılmamışsa veya esas sözleşmeye tahkim şartı konulmamış ise tenfiz talebini inceleyen mahkeme tenfiz talebini reddeder (5718 sayılı MÖHUK m. 62).

Türk hukukunda tahkim sözleşmesinin yazılı olarak yapılması geçerlilik şartı olarak kabul edilmiştir (HUMK. m. 517/2; 4686 sayılı MTK m. 4; HMK m. 412/2). 4686 sayll MTK'nun 4. maddesi, HMK'nun 412/2 maddesi ile 1958 tarihli New York Sözleşmesi'nin II/2. maddesinde tahkim sözleşmesinin her iki tarafin imzasını taşıyan bir sözleşme ile yapılabileceği gibi, mektup veya telgraf teatisi yoluyla da yapılabileceği kabul edilmiştir.

Tahkim sözleşmesinin yazılı olması şartının gerçekleşip gerçekleşmediği tarafların anlaşmayı tabi kıldıkları hukuka veya böyle bir anlaşma yoksa hakem kararının verildiği yer kanununa göre tayin edilir (1958 tarihli New York Sözleşmesi m. V/I-a).

Türk hukukuna göre tahkim sözleşmesinin şekli, tarafların bu anlaşmaya uygulanmak üzere seçtikleri hukuka ve böyle bir hukuk seçimi yoksa Türk hukukuna göre belirlenir (4686 sayılı MTK m. 4/3).

Tahkim sözleşmesini imzalayan temsilcinin yetkisizliğinden dolayı tahkim sözleşmesinin geçersizliği şekil kapsamında mı, ehliyet kapsamında mı yoksa esası kapsamında mı değerlendirilecektir?

Temsilcinin tahkim sözleşmesi yapmasına özel yetki verilmiş olması halinde engel bulunmamaktadır (818 sayllı BK m. 388; 6098 sayılı TBK m. 504; 6100 sayılı HMK m. 74).

Temsil yetkisi bulunmayan kişinin imzaladığı tahkim sözleşmesi geçerli değildir. Asıl sözleşmenin geçerli olması veya geçerli kabul edilmesi tahkim sözleşmesini geçerli hale getirmez. Ancak tahkim sözleşmesinin geçersizliğinin ileri sürülmesinin MK'nun 2. maddesine aykırılık teşkil etmesi halinde bu itiraz dinlenmez.

Tahkim sözleşmesini imzalamayan kişi yönünden sözleşme hükümleri uygulanamaz. Tahkim sözleşmesi istisna nitelikte olup sözleşmenin taraflarını bağlar.

Bir sözleşmede yer alan tahkim kurumunun tereddüte yer vermeyecek açıklıkta bulunması gerekir. Bu olayda “bu sözleşme, İngiliz hukukuna tabi olup, uyuşmazlıklar MTO'ya havale edilir” şeklindeki kayıt MTO nezdinde tahkime başvuru nedeni anlaşılır olmadığından MTO tahkim prosedürünün izlenmesini sağlayacak bir tahkim kaydı olarak kabul edilmemiştir.

Yargıtay bir kararında "çıkacak ihtilafların İngiltere'de ki Uluslar arası Tahkim Mahkemesinde çözümleneceğine" ilişkin ibareyi Paris'te bulunan MTO tahkim mahkemesine başvuru için yeterli görmeyerek tahkim mahkemesi olarak kararlaştırılmayan bir hakemin verdiği kararın tenfiz edilemeyeceği kabul etmiştir.

\subsection{Aleyhine Karar Verilen Tarafın Hakem Tayininden veya Tahkim Yargılamasından Haberdar Edilmemesi}

Yabancı hakem kararının aleyhine tanınması veya tenfizi istenen tarafın hakem tayininden haberdar edilmiş olması veya başka bir sebep yüzünden iddia ve müdafaa vasıtalarını ikame etmek imkanından mahrum edilmemiş olması gerekir.

Adil bir yargılama çerçevesinde verilen hakem kararının tanınması ve tenfizi istenebilir.

-Usulüne uygun tebligat yapılmalıdır.

-Hakem seçimi, delillerin sunulması veya savunma hazırlanması için verilen sürelerin yeterli olması gerekir.

\subsection{Uyuşmazlığın Tahkime Elveriş̧i Bulunması}

Tenfizi istenen hakem kararının temyiz devletinin hukukuna göre tahkim yolu ile çözümü mümkün olan bir uyuşmazlıkla ilgili olması gerekir. Taşınmaz mallar üzerindeki ayni haklardan (TMK m. 683, d. 779 vd.) kaynakların uyuşmazlıklar tahkime elverişli değildir (MTK m.1; HMK m. 408).

Ayrıca tarafların iradelerine tabi olmayan işlerden kaynaklanan uyuşmazlıklar da tahkime elverişli değildir. Tenfizi istenen bir kararla ilgili uyuşmazlığın tahkime elverişli olup olmadığının itiraz üzerine mi yoksa resen mi inceleneceği konusunda çeşitli görüşler ileri sürülmüştür.

Tenfizi istenen yabancı hakem kararlarının tahkime elverişli olmaması halinde tenfiz talebini inceleyen mahkeme tenfiz talebini reddedecektir. Uyuşmazlık kısmen tahkime elverişli ise tenfiz istenen kararın tahkime elverişli olan kısmının tenfizine karar verilecektir.

Konu ile ilgili en büyük sorunlardan bir tanesi ise tahkime elverişliliğe hangi hukukun uygulanacağıdır.

1958 tarihli New York sözleşmesinin V/2-a maddesinde bir düzenleme bulunmaktadır. Hükme göre tanıma ve tenfiz isteğini öne sürüldüğü ülkenin kanuna göre uyuşmazlık konusunun tahkime elverişli olmaması halinde tanıma ve tenfiz isteği reddolunabilir. 
İtalyan Temyiz Mahkemesi 1979 tarihli bir kararına bu görüşü kabul etmiştir. İş hukukundan kaynaklanan bir uyuşmazlığın İtalyan hukukuna göre tahkime elverişli olmadığı kabul edilerek tanıma ve tenfiz talebi kabul edilmemiştir.

\subsection{Hakem Kararının Tenfiz Devletinin Kamu Düzenine Aykırı Olması}

Hakemleri bağımsız ve tarafsız olmaması, tahkim anlaşması da taraflardan birine üstünlük tanınması, sözleşme konusunun ahlaka aykırı olması, hakem kararını gerekçesiz olması durumda hakem kararının kamu düzenine aykırı olduğu kabul edilebilir.

1958 tarihli New York Sözleşmesinin V/2-b maddesinde ve 5718 sayılı Kanunun 62/I-b maddesinde kamu düzenine aykırı kararın tenfiz edilemeyeceği hükme bağlanmıştır.

\section{Sonuç}

Yabancı hakem kararlarının verildiği ülkeden başka bir ülkede etki doğurması isteniyorsa bu kararın o ülkede tanınması ve tenfizi gerekir. Yabancı hakem kararlarının tanınması ve tenfizinde ad hoc ve kurumsal hakem kararları arasında bir fark bulunmamaktadır. Yabancı hakem kararlarının tanınması ve tenfizinde sorunlardan biri yabancılık unsurunun tespitidir. 1958 tarihli New York sözleşmesi yabancılık unsuru gözetilerek düzenlenmiştir.

1958 tarihli New York sözleşmesi ve 5718 sayılı MÖHUK yabancı hakem kararlarının tanınması ve tenfizinde paralel düzenlemeler yapmakla birlikte bazı hallerde farklı düzenlemeler de bulunmaktadır.

Yabancı hakem kararının Türkiye'de tenfizini isteyen tarafın nisbi harç mı yoksa maktu harç mı yatıracağı konusunda istikrarlı bir uygulama bulunmamaktadır. Konu ile ilgili düzenleme yapılması veya Harçlar Kanununa konuyu düzenleyen bir hükmü konulmasının uygun olacağı düşünülmektedir.

Yabancı hakem kararının tanınması ve tenfizinde mahkeme hakem kararının esasını inceleyemez. "Revision au fond" yasağı Türk Mahkemelerince kabul edilerek uygulanmaktadır.

Yabancı hakem kararlarının tanınması ve tenfizine engel haller gerekli 1958 tarihli New York Sözleşmesinde gerekse 5718 sayılı Kanunda sayılmıştır. Tahkime elverişlik ve kamu düzeni konusunda uygulamada birlik sağlanmamıştır.

\section{Kaynakça}

- $\quad$ Akıncı, Z., 1994. Milletlerarası Ticari Hakem Kararlarının Tenfizi, Ankara

- Akıncı, Z., 1996. Gerekçesiz Hakem Kararı Türkiye'de Tenfiz Edilebilir mi? (İBD, 1996/1-3, s:7-16).

- Huysal, B., 2010. Milletlerarası Ticari Tahkimde Tahkime Elverişlilik, İstanbul

- Kalpsüz, T., 2010. Türkiye’de Milletlerarası, Tahkim, Ankara

- Kaplan, Y., 2002. Milletlerarası Tahkimde Usule Aykırılık

- $\quad$ Koral, R., 1958. Milletlerarası Hakem Kararlarının İcrası, İstanbul

- $\quad$ Nomer, E.ve Ekşi, N. ve Öztekin-Gelgel, G., 2013. Milletlerarası Tahkim Hukuku, İstanbul, 168 s.

- Özel, S., 2008. Milletlerarası Ticari Tahkimde Kanunlar İhtilafi Meseleleri İstanbul

- Şanlı, C. ve Esen, E. ve Ataman Figenmeşe, İ., 2013. Milletlerarası Özel Hukuk, İstanbul,666 s.

- Şanlı, C., 2005. Uluslararası Ticari Akitlerin Hazırlanması ve Uyuşmazların Çözüm Yolları, İstanbul

- Şit, B., 2005. Kurumsal Tahkim ve Hakem Kararlarının Tanınması ve Tenfizi, Ankara

- Tanrıver, S., 1988. Yabancı Hakem Kararlarının Türkiye'de Tenfizinde Kamu Düzeninin Rolü, Prof. Dr. Ali Bozer'e Armağan, Ankara, s. 567 vd. 


\title{
Ceza Hukukunun Tahkime Etkileri The Effects of the Criminal Law to Arbitration
}

\author{
Assoc. Prof. Dr. Çetin Arslan (Turkish Supreme Court, Turkey)
}

\begin{abstract}
While the arbitration, in essence, is a special law institution, there are various points it intersect with the criminal law. It is quite important to investigate the aforementioned probabilities that criminal law norms may affect the arbitration procedures and/or decisions and the probable consequences of these. In this respect, the feasibility of the use of the Criminal Procedure Law (i.e. criminal conviction, illegal evidence) in the Arbitration Law, the bindingness and the indirect effects of the decisions of the criminal court and the punitive responsibilities of the refrees are all some of the important issues that can be examined under this heading. The subjects mentioned in the paper will be evaluated from the perspective of Turkish Law theory and practice.
\end{abstract}

\section{Giriş}

"Yargı" devlete ait bir fonksiyon olup, “Anayasa (AY)”ya göre Türk milleti adına bağımsız mahkemelerce kullanılır (AY md. 9). Yine Anayasaya göre, hiç kimse kanunen tabi olduğu mahkemeden başka bir merci önüne çıkarılamaz -kanuni hâkim güvencesi- (AY md. 37/1). Bu hükümler göz önüne alındığında herhangi bir neden ve şekilde ortaya çıkan uyuşmazlıkların, kamu görevlisi olan hâkimler tarafından yasalarla belirlenmiş muhakeme prosedürüne göre çözümlenmesi gerekmektedir. Bununla birlikte gerek Anayasamız (md. 59/2, 82/1, 125/1), gerekse başta 12.01.2011 tarih ve 6100 sayılı "Hukuk Muhakemeleri Kanunu (HMK)" (RG, 04.02.2011/ 27836) (md. 74/1, 103/1-g, 116/1-b, 316/1-f, 407- 444) ile 21.06.2001 tarih ve 4686 sayılı "Milletlerarası Tahkim Kanunu (MTK)" (RG, 05.07.2001/24453) olmak üzere çeşitli düzenlemelerde (ör. 4077 sayılı "Tüketicinin Korunması Hakkında Kanun” md. 22 ve 4857 sayılı "İş Kanunu” md. 20) özel hukuka ilişkin uyuşmazlıkların, bazı hallerde tahkim yoluyla halledilebilmesine olanak tanınmıştır. Nitekim "Yargıtay Hukuk Genel Kurulu (HGK)"nun güncel bir kararında bu husus şu şekilde açıklanmaktadır:

“...2709 sayılı 1982 Anayasası'nın 9.maddesinde yargı yetkisinin Türk Milleti adına bağımsız mahkemelerce kullanılacağı öngörülmüştür. Öteki deyişle, kural olarak hak arayan kişiler öncelikle mahkemelere başvuracaktır. $\mathrm{Bu}$ temel kuralın istisnası ise, bazı kanunlarda usul ve amaçları belirtilen özel yargıdır. /Bu özel yargılama usullerinden birisi de tahkim usulüdür./ Tahkimin türlerinden birisi ‘'̇ç Tahkim’dir./ Genellikle tahkimle ilgili hükümler ülkelerin Hukuk Usulü Muhakemeleri Kanunlarında yer almaktadır. Türk hukukunda da, 1086 sayılı Hukuk Usulü Muhakemeleri Kanunu (HUMK)'nun 516-536. maddelerinde ve bazı özel yasalarda iç tahkim usulü düzenlenmiştir./ İç tahkimde kendi içinde 'Mecburi Tahkim' ve 'İhtiyari Tahkim' olmak üzere iki gruba ayrılmaktadır./ Mecburi tahkim; doğrudan doğruya kanundan doğan bir tahkim türüdür. Bu tür tahkimde dava mahkemelerde açılmaz, ihtilaf çözüm için hakemlere götürülür. Mecburi tahkim özel kanunlarla öngörülmüş olup, bu kanunlarda kimin hakem olacağı, hakemin görev ve yetkileri düzenlenmiştir. Mecburi tahkim, HUMK' da yer almamış olup, bu Kanunda sadece 516 ilâ 536. maddeler arasında ihtiyari tahkim hükümlerine yer verilmiştir (Doç.Dr. Kemal Dayınlarlı, HUMK'da Düzenlenen İç Tahkim, Ankara-1977, s.7-11)./ Öteki deyişle; bazı hallerde, taraflar arasında ortaya çıkan özel hukuk alanına ilişkin uyuşmazlıkların, evvelce bu konuda bir tahkim sözleşmesi yapılmamış olmasına rağmen, sıfatları belirtilen kişiler tarafından bakılması zorunlu kılınmıştır ki, buna mecburi ya da kanuni tahkim denilmektedir. / Tahkimin hangi hallerde mecburi olduğu, özel kanun hükümleri ile tayin edilir; mecburi tahkime tabi iş ve davalarda, taraflar Devlet mahkemelerinde yani genel mahkemelerde dava açamazlar; kanunla gösterilen hakemlere başvurmaya, bir başka söyleyişle hakemlerde dava açmaya mecburdurlar..." (HGK, 15.12.2010, 2012/3-213, 2012/200) (UYAPYayınlanmamıştır).

Kanunda, "Tarafların, sözleşme veya sözleşme dışı bir hukuki ilişkiden doğmuş veya doğabilecek uyuşmazlıkların tamamı veya bir kısmının çözümünün hakem veya hakem kuruluna bırakılması hususunda yaptıkları anlaşma..." (HMK md. 412) şeklinde tanımlanan "tahkim"in; taraf iradesinin egemen olduğu bir “Özel Hukuk” kurumu olması karşısında (bkz. HMK md. 408); -ilk bakışta- emredici hukuk kurallarının hâkim olduğu "Ceza Hukuku" ile herhangi bir irtibatının bulunmadığı veya en azından doğrudan bir ilişkisinin olmadığı düşünülebilir. Bununla beraber hukuk düzeninin uyumlu bir bütün olması gerçeği ile ceza hukukunun evrensel hukuk orijinli ilkelerinin bağlayıcılığı olgusu; kimi ceza hukuku kurallarının tahkim sürecine etkilerini kaçınılmaz kılmaktadır. İşte bu tebliğde kanımızca önemli olan, ancak bu güne kadar üzerinde yeterince durulmamış olan bu konuya genel hatlarıyla değinilecektir. 


\section{Tahkime Doğrudan Etkili Hususlar}

\subsection{Hakemin Göreviyle İlgili Bir Suç İşlemesi}

Hakemin Ceza Hukuku Açısından Hukuki Durumu: Tahkim tarafların seçtiği bir hakem veya hakem kurulu tarafından yerine getirilmektedir. Tahkim sürecinde hakemin görev ve sorumluluklarına ilişkin gerek HMK' de gerekse ilgili mevzuatta çeşitli hükümler mevcut ise de, ceza hukukundaki konumunun ne olduğuna ilişkin özel bir düzenleme yoktur. Bu nedenle genel hükümler dikkate alınarak bir değerlendirme yapmak ve sonuca varmak gerekmektedir.

26.09.2004 tarih ve 5237 sayılı Türk Ceza Kanunu (TCK)'un (RG, 12.10.2004/ 25611) 6/1-c ve d. maddesine göre, "c) Kamu görevlisi deyiminden; kamusal faaliyetin yürütülmesine atama veya seçilme yoluyla ya da herhangi bir surette sürekli, süreli veya geçici olarak katılan kişi,/ d) Yargı görevi yapan deyiminden [ise]; yüksek mahkemeler ve adlî, idarî ve askerî mahkemeler üye ve hâkimleri ile Cumhuriyet savcısı ve avukatlar..." anlaşılmaktadır.

Hakem tahkim sürecinde bir tür yargılama işlevi yerine getirmekteyse de, hâkim gibi atama yoluyla görev ifa eden bir devlet görevlisi olmayıp; kural olarak uyuşmazlığın taraflarınca seçilmektedir. Bununla birlikte hakem, tahkim usulüyle uyuşmazlığı çözmekte, kararları yargısal denetime ve cebri icraya konu olmaktadır. Keza hakem, görevini tarafsız ve bağımsız şekilde yerine getirmekle yükümlü olup, aksi halde hâkimlerde olduğu çekinmeleri veya reddi söz konusudur. Bu temel özellikleri itibariyle hakemin yargı görevi yaptı̆̆ı söylenebilirse de; maddede sınırlı olarak sayılan hâkim, savcı veya avukat sıfatını taşımadığından "yargı görevi yapan" kategorisinde düşünülemez. Bununla birlikte yapılan iş kamusal bir faaliyettir ve bu nedenle "hakem", tıpk1 kamusal faaliyetin yürütülmesine atama veya seçilme yoluyla katılan diğer kişiler gibi, TCK açısından kamu görevlisi konumundadır.

Rüşvet: Ancak kamu görevlileri ve belli nitelikteki kişilerin işleyebilmesi nedeniyle "rüşvet suçu" "özgü/mahsus suç" niteliğindedir. Bu nedenle hakemin rüşvet suçunda daha fazla cezayı gerektirecek şekilde cezalandırılması, yaptığı görevin kamusal niteliği ve öneminden kaynaklanmakta ve ayrıca kanun koyucunun yaklaşımını da ortaya koymaktadır. Gerçekten TCK'nin genel hükümlerinde (md.6) hakem açıkça "yargı görevlisi” veya "kamu görevlisi” sayılmasa da, rüşvet suçu bağlamında yargı görevi yapanlarla aynı konumda kabul edilmiştir. Nitekim bu anlayışın bir sonucu olarak hakemin rüşvet alması, bu konuda talepte bulunması veya anlaşmaya varması halinde tıpkı hâkim, savcı, avukat, noter, bilirkişi veya yeminli mali müşavirler gibi, daha fazla cezayı gerektiren nitelikli rüşvet suçundan cezalandırılmaktadır (TCK md. 252/7, 9-e).

Görevi köttïye kullanma, sahtecilik, irtikâp, zimmet vs.: Hakemin tahkim sürecindeki faaliyetleri çerçevesinde görevini kötüye kullanması ihtimalinde mevzuatta açık bir düzenleme bulunmamaktadır. Bununla beraber, biraz önce değindiğimiz üzere, yapılan işin "özel nitelikte bir yargı faaliyeti” olması, hakemin de bu bağlamda kamu görevlisi sayılması karşısında, diğer koşulların bulunması halinde "görevi kötüye kullanma suçu (TCK md. 257)" oluşacaktır. Örneğin herhangi bir nedenle (kayırma, düşmanlık, rüşvet kapsamına girmeyen menfaat temini vb.) taraflı karar verilmesi ihtimalinde durum bu merkezdedir. Keza hakemin tahkimle bağlantılı olarak sahtecilik yapması halinde, fiilin diğer özelliklerine göre, TCK'nin 204-205, 212. maddelerindeki sahtecilik suçları oluşacaktır. Örnekleri çoğaltmak mümkün ise de, [ör. zimmet (TCK md. 247), irtikâp (TCK md. 250)], çalışmanın boyutu itibariyle gerekli değildir.

\subsection{Hakem Haricindeki Kişiler Tarafından Tahkimle Bağlantılı Bir Suç İşlenmesi}

Tahkim hakem tarafindan yürütülen bir süreç olmakla birlikte, gerek tarafların gerekse üçüncü kişilerin katılımı söz konusu olabilir. Dolayısıyla bu kişiler (ör. tanık, bilirkişi, tercüman, vekil vs.) tarafindan da herhangi bir suç işlenebilir. Örneğin taraflardan birisinin tahkime ilişkin bir konuda sahte belge düzenlemesi veya kullanması, yalan tanıklı yapılması veya bilirkişinin sahte rapor düzenlemesi ihtimal dâhilindedir.

\subsection{Ceza Mahkemesi Kararının Etkisi}

Hakemin anılan suçları işlediğinin kesin hükümle sabit olması halinde bu karar tahkim süreci açısından bağlayıcı olur (AY md. 11, 138; TBK md. 74). Keza tahkimin tarafları veya tahkim süreciyle ilgili üçüncü kişilerin tahkimle ilişkili bir suç işlediğinin kesin hükümle sabit olması halinde, bu karar tahkim süreci açısından bağlayıcıdır (AY md. 11, 138; TBK md. 74). Bunun sonucu olarak ise, tahkim sürecinin kesinleşmemiş olması ihtimalinde HMK'nin 439. maddesi gereğince iptal, kesinleşmiş olması ihtimalinde ise HMK'nin 443 gereğince yargılamanın yenilenmesi söz konusu olur.

Hakem, tahkimin tarafları veya ilgilisi hakkında -yukarıda belirtilen suçlar başta olmak üzere- tahkimle ilişkili bir suçtan hakkında hüküm verilmesi (CMK md. 223) halinde bunun tahkime etkisi çeşitli ihtimallere göre değerlendirilmelidir:

1.- Tahkim yargılamasının ilgilisi olan kişi (ör. hakem, bilirkişi, tanık) aynı zamanda ceza mahkemesindeki suçun failidir ve hakkında verilen mahkûmiyet kararı (CMK md. 223/5-6) kesinleşmiştir. Bu durumda kesinleşen mahkûmiyet kararı ceza mahkemesinin sabit gördüğü olay temelinde, tahkim açısından hakemi bağlayıcı niteliktedir (TBK md. 74) (RG, 04.02.2011, 27836). 
2.- Yukarıdaki -(1)- ihtimalde kişi hakkında isnat edilen suçun faili olmaması nedeniyle beraat kararı verilmiş ve karar kesinleşmiştir (CMK md. 223/2-b). Bu durumda kişinin isnat edilen fiili işlemediği ceza mahkemesi kararıyla sabit olmuştur. Bu karar tahkim için bağlayıcıdır (AY md. 11, 138).

3.- Ceza muhakemesi sonucunda yukarıda değinilen mahkûmiyet veya beraat kararı dışında bir karar (ör. kamu davasının düşmesine, reddine veya sanık hakkında ceza verilmesine yer olmadığına) (bkz. CMK md. 223) karar verilmiş olabilir. Bu durumda verilen karar tahkim/hakem açsından bağlayıcı değildir.

\section{Tahkime Dolaylı Etkili Hususlar}

\subsection{Bekletici Sorun Konusu}

Hukuk düzenin bir bütün olması nedeniyle devlet organlarının kararlarının ve özellikle mahkeme kararlarının birbiriyle çelişkili olmaması gereklidir. Bununla birlikte, hukuki iş ve işlemlerin kendine has özellikleri nedeniyle belli bir konularda kısmen farklı hukuki durumlar ortaya çıkabilir.

Bir davada hüküm verilebilmesi, başka bir davaya, idari makamın tespitine yahut dava konusuyla ilgili bir hukuki ilişkinin mevcut olup olmadığına kısmen veya tamamen bağlı ise mahkemece o davanın sonuçlanmasına veya idari makamın kararına kadar yargılama bekletilebilir (HMK md. 165/1).

Tahkim yargılaması sürecinde, tahkimin tarafları veya ilgilileri hakkında bir ceza soruşturması veya kovuşturması söz konusu olabilir. Böyle bir halde, soruşturma ve/veya kovuşturmanın sonucunun tahkimi etkilemesi olasılığı nedeniyle bekletici sorun yapılıp yapılmayacağı hususu gündeme gelmektedir.

Bu bağlamda tahkimle bağlantılı olarak bazı ihtimaller söz konusu olabilir. İlk akla gelen hakem hakkında göreviyle ilgili bir soruşturma veya kovuşturmanın söz konusu olmasi; örneğin görevi kötüye kullanma, rüşvet, sahtecilik vb. bir isnadının bulunulmasıdır. Tahkimin tarafları, tahkim sürecinde görev üstlenen tanık, tercüman vs. hakkında benzer diğer ihtimaldir.

Zikredilen ve benzer hallerin bekletici sorun yapılmasını zorunlu kılan herhangi açık bir hüküm yoktur. Yani hakem söz konusu iddiaların kesin hükümle sonuçlanmasını beklemek zorunluluğunda değildir. Ancak hakem, delillerin yeterliği ve yoğunluğuna göre konuyu bekletici sorun yapabileceği gibi, nispi muhakeme yoluyla kendi de çözüp sonuca ulaşabilir (bkz. HMK md. 214).

Diğer taraftan TBK'nin 74. maddesi göz önüne alındığında; "hakem” zarar verenin kusurunun olup olmadığı, ayırt etme gücünün bulunup bulunmadığı hakkında karar verirken, ceza hukukunun sorumlulukla ilgili hükümleriyle bağlı olmayacağından bu konudaki yargılamayı bekletici sorun yapamaz. Keza ceza hâkiminin kusurun değerlendirilmesine ve zararın belirlenmesine ilişkin kararı da, hukuk hâkimini (ve dolayısıyla hakemi) bağlamadığından, bu konuların da bekletici sorun teşkil etmesi mümkün değildir.

Nihayet kanun koyucu HMK'nin 239/1. maddesinde; yemin eda edildikten sonra, yalan yere yemin nedeniyle açılan ceza davasının, esas dava bakımından bekletici sorun yapılamayacağını düzenlemiştir. $\mathrm{Bu}$ durumda tahkimde yemin edildikten sonra tanık hakkında açılan kamu davası bekletici sorun yapılmayacaktır. Bununla birlikte tanığın bu söz konusu suçtan mahkûm olması halinde yargılamanın yenilenmesi gündeme gelecektir (HMK md. 375, 443).

\subsection{Hukuka Aykırı Delil Sorunu}

Taraflar, hakem veya hakem kurulunun uygulayacağı yargılama usulüne ilişkin kuralları, serbestçe kararlaştırabilecekleri gibi, tahkim kurallarına yollama yaparak da belirleyebilirler. Bu yönde bir sözleşmenin bulunmaması halinde ise, hakem veya hakem kurulu, tahkim yargılamasını, HMK' deki tahkimle ilgili hususları gözeterek uygun bulduğu bir şsekilde yürütür (HMK md. 424). Dolayısıyla tahkimde esas itibariyle tarafların iradesi belirleyici olmaktadır. Bununla birlikte, söz konusu serbesti hukukun genel ilkeleri ve kamu düzenin öngördüğü sınırlamalara tabidir (HMK md. 424, 439/2-, f, g, ğ).

$\mathrm{Bu}$ bağlamda üzerinde durulması gereken konu, hukuka aykırı delil sorunudur. Gerçekten hakemin kararına esas aldığı delil, hukuka uygun olmalıdır. Anayasamızın 03.10.2001 tarih ve 4709 Kanununun 15. maddesiyle değişik 38/6. maddesinde, "Kanuna aykırı olarak elde edilmiş bulgular, delil olarak kabul edilemez." ibaresiyle oldukça kapsayıcı bir şekilde ifade edilen bu husus, - HMK'nin "ispat hakkı" başlıklı 189/2. maddesine göre, "Hukuka aykırı olarak elde edilmiş olan deliller, mahkeme tarafından bir vakıanın ispatında dikkate alınamaz." (ayrıca bkz. AY md. 38/6, CMK md. 216/2) biçiminde formüle edilmiştir. Bu düzenleme her ne kadar doğrudan tahkime ilişkin bir kural değil ise de, uygulanamayacak hükümler kapsamında kalmaması nedeniyle (bkz. HMK md.444) tahkim yargılaması açısından da bağlayıcıdır.

Tahkimde ceza muhakemesiyle bağlantılı olarak hukuka aykırı delil konusunda birkaç husus gündeme gelebilecektir. Bunlardan birincisi, konusu suç teşkil eden delildir. Bu ihtimalde, örneğin işkence, kötü muamele, hırsızlık, konut dokunulmazlığını bozmak, özel hayatın veya iletişim özgürlüğü ihlal etmek yoluyla bir delil elde edilmişse bunun tahkim yargılamasında kullanılması mümkün değildir. İkincisi, ceza mahkemesinde herhangi bir nedenle hukuka aykırı bulunarak itibar edilmeyen (CMK md. 217/2) bir delildir. Hukuk düzenin bir bütün olmas1 ve ceza mahkemesi kararın niteliği gözetildiğinde bu delillere hakem de itibar edemez. Üçüncü ihtimal ise, ceza muhakemesinde sadece belli ağırlıktaki suçların ispatında kullanılabilecek yöntemlerle elde edilen delillerdir. Bu 
kapsamda örneğin iletişim denetlenmesi (CMK md. 135-138), gizli görevli kullanılması (CMK md. 139) ve teknik takip (CMK md. 140) yöntemlerine başvurulmak suretiyle elde edilen deliller (ceza muhakemesinin mahkûmiyetle sonuçlanması hali hariç) tahkimde kullanılmaz. Çünkü iletişimin denetlenmesi, gizli görevli kullanılması ve teknik takip kişinin temel hak ve özgürlüklerinin (özellikle haberleşme özgürlüğü ile özel hayatın gizliliği) (AY md. 20-21) kısıtlanmasına yol açan bir koruma tedbiri olup, ölçülülük ilkesi gözetilmek suretiyle ve ancak kanunla sınırlanabilir (AY md.13, 20, 22). Bu nedenle kanun koyucu tarafindan ancak belli ağırlıktaki suçlar için ve sadece ceza muhakemesi çerçevesinde başvurulabilecek birer koruma tedbiri olan anılan yöntemlere; amacı, konusu ve yöntemi farklı olan özel hukuk alanında (ve bu bağlamda tahkimde) başvurulabileceği düşünülemez.

\section{Sonuç}

Tahkimin klasik bir özel hukuk kurumu olmasına rağmen, ceza hukukuyla zorunlu olarak zaman zaman kesiştiği görülmektedir. Özellikle tarafların, hakemin, süreçte görev alan tanık, bilirkişi, tercüman vs. tahkim sürecinde ve bu süreçteki görevi/konumu nedeniyle bir suç işlemesi durunda bu durum kendini açıkça hissettirmektedir. Zira bu ihtimalde ceza mahkemesi kararı tahkimi doğrudan etkilemektedir. Bunun yanında anılan kişiler hakkında bir ceza davası bulunmamakla birlikte, bu konuda bir iddiada bulunulması durumunda ortaya çıkan bekletici sorun konusudur. Bu halde hakemi doğrudan bağlayıcı bir normun bulunması nedeniyle, konu bekletici sorun yapılabileceği gibi, nispi muhakeme yoluyla da çözülebilecektir. Hakemin bu gibi hallerde dikkatli olması, ciddi delillerin bulunmaması halinde tahkim sürecini uzatmaya yönelik girişimlerden etkilenmemesi gerekir.

Tahkimde ceza hukukuyla bağlantılı olarak hukuka aykırı delil konusu da gündeme gelebilecektir. Bu çerçevede konusu suç teşkil eden veya sadece ceza hukukunda kullanılması gereken ya da ceza mahkemesince hukuka aykırı olduğundan değerlendirmeye alınmayan delillerin tahkimde de değerlendirilmesi mümkün değildir.

Son olarak tahkimi yürüten hakemin ceza hukukunda hukuki durumu açıkça düzenlenmemişse de, gördüğü işin niteliği gereği kamu görevi olması karşısında ve dolayıyla görevi nedeniyle bir suç işlemesi halinde bu statüleri göz önünde tutulacaktır.

\section{Kaynaklar}

- Arslan, Çetin, “Ceza Muhakemesinde İletişimin Denetlenmesi Yoluyla Elde Edilen Delillerin Disiplin Hukukundaki Durumu Üzerine Bir Değerlendirme”, İstanbul Üniversitesi, İstanbul Kültür Üniversitesi, Giessen Üniversitesi ve İstanbul Barosu İşbirliği ile Düzenlenen 4. Yılında Yeni Ceza Adalet Sistemi Özel Hayatın Korunması Uygulamada Yaşanan Sorunlar ve Çözüm Yolları İsimli Uluslararası Konferansta (30.05.09-02.06.09) Yapılan Sunum, İstanbul 2009. [Fasikül Aylık Hukuk Dergisi (CAHAMER), Sa. 3, Seçkin Yayınevi, Ankara 2010’da yayınlanmıştır].

- Egemen, Işı1, "Uluslararası Tahkim Hukukunda Vekilin Özel Yetkisi Olmaksızın Tahkim Anlaşması Akdetmesinin Geçerliliği Sorunu - BK m. 388/III' ün Tahkim Anlaşmalarının Geçerliğiøine Etkisi-”, İstanbul Barosu Dergisi, C. 80, Sa. 5, Y11 2006.

- $\quad$ Erkan, Mustafa, "Tahkim Şartının Ayrılabilirliği Prensibinin Asıl Sözleşmenin Yokluğu Durumunda Değerlendirilmesi” Gazi Üniversitesi Hukuk Fakültesi Dergisi, C. XVII, Y.2013, Sa. 1-2.

- Ghaffari, Amir, "Criminal Offences Committed Through the Arbitration: Duty to Report \& Investigate? Duty to Testify? Liability \& Immunity?", www.arbitration-ch.org,26.05.13 ; Ayrica bkz. "ICC Launches New Task Force on Criminal Law in Arbitration", http:// www. enewsbuilder. net/ uscib_news/ e_article 000348761.cfm?x= b11,0,w, 26.05.13.

- $\quad$ Koral, Rabi, "Yeni ve Eski Hukukumuzda Tahkim (Mukayeseli Etüd)”, İstanbul Üniversitesi Hukuk Fakültesi Dergisi, C. 13, Sa. 1, 1947.

- Mourre, Alexis, “Arbitration and Criminal Law: Reflections on the Duties of the Arbitrator", The Journal of the London Court of International Arbitration, Volume 22, Number 1, London 2006.

- Okuyucu-Ergün, Güneş, “Tahkimde Ceza Hukuku Sorunları”, TBB Dergisi, Sa. 70, Y11 2007.

- Pekçanıtez, Hakan/ Atalay, Oğuz/ Özekes, Muhammet, Hukuk Muhakemeleri Kanunu Hükümlerine

Göre Medeni Usul Hukuku, 12. Baskı, Yetkin Yayınları, Ankara 2011, s. 741, 747-748. 


\title{
Türkiye ve Rusya'da Rekabet Politikası ve Rekabet Hukuku Competition Policy and Competition Law in Turkey and Russia
}

\author{
Asst. Prof. Dr. Hülya Göktepe (Anadolu University, Turkey)
}

\begin{abstract}
Competition law provides the formation and protection of free competition. Modern market economy is the basis of the principle of free competition. Free competition provides an effective utilization of resources, price goes down, saving to reduce costs, find new technologies and their use in production. Desired markets, although a perfect competition market, because of market failures rather than the ideal situation monopolies, cartels can occur. At this stage, competition policies become important because they provide an efficient resource allocation, and constitutes an important element in raising the level of social welfare. Competition law is state intervention tool in order to establish and maintain free competition in the economy. Competition laws is seen as the constitution of the economy. In Russia, first competition authority was created in 1990 and the Law "On Competiton and Ristriction of Monopolistic Activity on Goods Markets" passed in 1991. After the OECD Peer Rewiew Report on Russia's Competition Policy and Law, competition authority was abolished, new Federal Antimonopoly Service (FAS) established in 2004. Also new competition law passed in 2006. In Turkey, competition law passed in 1994, Turkish Competiton Authority was established in 1997. The aim of this study is to analyze competition law rules is implemented in Turkey and Russia. Also Examples of decisions issued by the Turkish competition authority and FAS Russia will be presented.
\end{abstract}

\section{Giriş}

Liberal ekonomik sistemin temeli serbest rekabettir. Serbest rekabet, kaynakların etkin kullanılmasını, fiyatların düşmesini, maliyetleri düşürmek için tasarruf yapılmasını, yeni teknolojilerin bulunmasını ve bunların üretimde kullanılmasını sağlar. Rekabet hukuku serbest rekabetin oluşması ve korunmasını sağlamaktadır. Rekabet kanunları ise, devletin ekonomiye serbest rekabeti kurma ve koruma amaciyla müdahale aracıdır. Rekabet kanunlarında işletmelerin anlaşmalarla, birleşme ve devirlerle veya pazar gücünü kötüye kullanmak suretiyle rekabeti sınırlamaları yasaklanır. Böylece herşeyden önce, kişilerin temel hak ve özgürlüklerinin bir parçası olan firsat eşitliği ve özgürlüğü sağlanmış olur. Sosyal bakımdan tüketicinin korunması yönünde önemli bir gelişme sağlanır (Aslan, 2006).

Rekabet kanunları bir çeşit ekonomi anayasası olarak görülmektedir. Serbest rekabetçi sistemleri benimseyen tüm ekonomilerde, bu sistemi koruyucu nitelikli rekabet kanunlarına gerek duyulmaktadır (Aslan, 2006). Ekonomi hukuku açısından bakıldığında, rekabet kanunlarının ya da ekonomideki ifadesiyle anti tröst kanunlarının amaçlarının, oligopolcü teşebbüslerin kartel oluşturmalarının ya da birleşerek (tröst) monopol gücü elde etmelerinin veya elde etmeye çalışmalarının engellenmesi olduğu belirtilmektedir. Rekabetin ortadan kalkması sonucu ortaya çıkacak sorunların bertaraf edilmesi, ekonomik sistemin bir rekabet kanunu ile desteklenmesi ve bu kanunu uygulayacak etkin bir rekabet otoritesinin tesis edilmesi ile mümkün olabilecektir (Güven, 2009).

Bu çalışmanın amacı Türkiye ve Rusya'daki rekabet hukuku kurallarını incelemek olduğu için çalışmanın 2. bölümünde Rusya rekabet hukuku 3. bölümünde Türkiye rekabet hukuku kuralları incelenmektedir. Ayrıca çalışmanın içerisinde Türk Rekabet Kurulunun ve Rus Rekabet Otoritesinin (FAS) kararlarından örneklere yer verilmektedir.

\section{Rusya Federasyonu Rekabet Politikası ve Rekabet Hukuku}

Rusya Federasyonu 11 saat dilimini kapsayan dünyadaki en büyük ülkedir. Sovyetler Birliğinin çökmesini takiben 1988 yılında Rusya Federasyonu ilk Sovyet Cumhuriyeti olmuş ve bağımsızlığını açıklamıştır. Bu durum Moskova tarafından 1991 yılında tanınmıştır. Bağımsızlığın kazanılmasından sonra Rusya ekonomisinde bir çöküş yaşanmıştır. Develüasyon olmuş, borç ödemede yetersizlik ve banka iflasları ortaya çıkmıştır. Yapılan reformlar ile Rusya'nın ticarette rekabet edebilirliği artmış ve gayrisafi milli hasılada artış görülmüştür. 20022003 yıllarında büyüme kuvvetlenmiştir. Amerika Birleşik Devletleri ve Avrupa Birliğinin katkılarıyla Rusya'nın pazar ekonomisine geçişi sağlanmıştır.

\subsection{Rusya Rekabet Hukuku Tarihi}

Rusya'da önce rekabet otoritesi kurulmuş sonra rekabet kanunu kabul edilmiştir. İlk Rusya Rekabet Otoritesi 1990 yılında kurulmuştur, adı Yeni Ekonomik Yapıyı ve Tekel Karşıtı Politikayı Destekleme Bakanlığıdır (Devlet Komitesi) (kısaca MAP olarak anılmaktadır). İlk rekabet kanunu ise 1991 yılında çıkarılmıştır. Adı "Ürün Pazarlarında Tekelci Faaliyetlerin Kısıtlanması ve Rekabet Üzerine Kanun” 'dur. 1993 Anayasasında ve diğer temel yasalarda da örneğin 1994 Medeni Kanununda rekabete destek veren ifadelere yer verilmiştir. 
2003 yılında OECD, Rusya'nın rekabet hukuku ve politikasındaki on yıllık deneyimini detaylı olarak değerlendirmeye almıştır. Değerlendirme raporu sonuçlarına göre rekabetin yasal olarak düzenlenmesi ve kanunlardaki rekabeti destekleyen kuvvetli açıklamalara rağmen iç pazarlarda rekabetin yaratılması ve korunması Rusya'nın öncelikli politikası değildi. Rekabet otoritesinin geniş sorumlulukları vardı. Otorite pazarlardan, kamu çıkarının ve zayıf tarafların korunmasından sorumlu olduğu kadar tüketicinin korunmasından, reklam düzenlemelerinden, emtia alım satımının gözetiminden, küçük işletmelerin korunmasından da sorumluydu. Oysa bu alanların her biri farklı prosedür ve işlemler gerektirmekte ve kurumun etkinliğini azaltmaktaydı. Ayrıca 1991 yılında çıkarılan Rekabet Kanunu çoğu rekabet ihlallerinde nispeten hafif yaptırımlar içermekteydi, ya çok azdı yada caydırıcı etkisi yoktu. Bireyleri cezalandırmak ya da doğrudan para cezası uygulamak yerine iptal, durdurma gibi yaptırımlar tercih edilmekteydi. Kanun ceza yaptırımları içermesine rağmen bunlar hiç uygulanmıyordu. Bu durum problemlere sebep olmakta ve rekabet hukuku ile ilgili adalet endişelerini arttırmaktaydı. Yeni kuralların konulmasında da isteksizlik yaratmaktaydı. Sonuç olarak geniş sorumluluklar ve uygulanabilir yaptırımların yokluğu rekabet hukuku uygulamalarını önemli ölçüde sınırlamaktaydı. Rekabet Otoritesinin soruşturma gücü ile ilgili de eksiklikler vardı, prosedür çok ağırdı, soruşturmalarda tanıklık etmek için zorlayamıyordu.

OECD’nin değerlendirme raporundan sonra Rusya Hükümeti yürütme organlarının temel olarak yeniden yapılanmasını sağlamıştır, bunlara yeni rekabet otoritesinin oluşturulması da dahildir. 2004 yılında Rusya Federasyonu Başkanının “Federal Yürütme Organlarının Sistemi ve Yapısı Hakkındaki Kararnamesi” ile Yeni Ekonomik Yapıyı ve Tekel Karşıtı Politikayı Destekleme Bakanlığı feshedilmiştir. Bunun yerine Federal Tekel Karşıtı Kurum (Federal Antimonopoly Service-FAS) kurulmuştur. Feshedilen Bakanlığın görevleri bu kuruma devredilmiştir, fakat küçük işletmelerin desteklenmesi ve tüketici haklarının korunması görevleri bunun dışında tutulmuştur. Yeni rekabet kanunu çalışmaları da başlatılmıştır.

2006 yılında yeni rekabet kanunu kabul edilmiştir.

\subsection{Rusya Rekabet Kanunu Sistemi ve Uygulanması}

16 Haziran 2006 tarihli ve 135-FZ numaralı Rekabetin Korunması Hakkında Federal Kanun (k1saca Rekabet Kanunu), 2006 yılında yürürlüğe girmiştir. Bu kanun ile birlikte daha önce yürürlükte olan 22 Mart 1991 tarih ve 948-1 numaralı Ürün Pazarlarında Tekelci Faaliyetlerin Yasaklanması ve Rekabet Üzerine Kanun, 23 Haziran 1999 tarih ve 117-FZ numaralı Finansal Hizmet Pazarında Rekabetin Korunması Üzerine Kanun yürürlükten kaldırılmıştır. Böylece daha önce genel kanun ve finansal hizmetler sektöründe uygulanan kanun olmak üzere rekabet ile ilgili iki kanun, tek bir rekabet kanunu haline getirilmiştir. 2006 tarihli Rekabet Kanununda 2011 yılında değişiklik yapılmıştır.

Kanunun konusu ve amaçları; rekabeti korumak için yasal ve organizasyonel temeli oluşturmak, tekelci faaliyetlerin ve haksız rekabetin kısıtlanması ve önlenmesi, federal yönetici otoriteler, kamu otoriteleri, yerel otoriteler, Rusya Merkez Bankası tarafindan rekabeti önleyen, kısıtlayan, ortadan kaldıran faaliyetlerin kısıtlanması ve önlenmesidir. Rekabet kanunu ekonomideki bütün sektörlerde uygulanmaktadır, sektör ayrımı yoktur.

Rekabet Kanunu, Rusya tüzel kişileri, yabancı tüzel kişiler, organizasyonlar, federal yönetici otoriteler, yerel otoriteler, diğer organizasyonlar, gerçek kişiler, bireysel teşebbüslerin dahil olduğu haksız rekabet ve tekelci faaliyetlerin kısıtlanması ve önlenmesi de dahil rekabetin korunması ile bağlantılı ilişkilere uygulanmaktadır. Federal kanunun maddeleri, Rus ve yabancı kişiler ya da Rusya federasyonu dışındaki kuruluşlar arasındaki Rusya federasyonundaki rekabeti etkileyen anlaşmalara da uygulanır.

Rekabet kanunu Rus ve yabancı şirketler arasında yapılan bütün anlaşmalara ve faaliyetlere uygulanır. Rusya dışında yapılsa bile eğer bu anlaşma Rusya Federasyonu sınırları içinde rekabeti etkiliyorsa bu anlaşmaya da uygulanır. Rus rekabet otoritesi bu anlaşmaları değerlendirmek ve Rusya içindeki rekabet üzerinde bir etkisi olup olmadığına karar vermekle yükümlüdür.

Rekabet Kanununun 14. maddesinde haksız rekabete değinilmektedir. Kanuna göre haksız rekabet, ekononik teşebbüslerin işletme faaliyetlerini yerine getirirken Rusya federasyonu yasalarına, iş geleneklerine, saygınlık, akılcılık ve eşitliğe aykırı olarak, rakiplerinin ekonomik olarak zarar görmesine ve iş itibarlarının zarar görmesine sebep olup bundan fayda sağlamayı amaçlamasıdır. Haksız rekabete izin verilmemekte ve haksız rekabet halleri şöyle sıralanmaktadır:1. Ekonomik zarara sebep olan ya da iş itibarının zarar görmesine sebep olan yanlış, hatalı, çarpıtılmış bilginin yayılması, 2. Malın niteliği, niceliği, tüketim özellikleri, üretim yeri, yöntemi, doğası ile ilgili ya da üretici ile ilgili olarak yanlış beyanda bulunulması, 3. Rakibinin sattığı ve ürettiği ürünler ile kendi sattığı ve ürettiği ürünlerin yanlış karşılaştırılması, 4. Bir malın dolaşıma girişi, satışı, değişimi sırasında fikri mülkiyetle ilgili yasadışı kullanımı, 5. Kanunlarla korunan sırların yasa dışı olarak elde edilmesi, kullanılması, bilginin açıklanması.

Rekabet Kanununun 19.maddesinde bazı faaliyetlerin yerine getirilmesinde devlet kurumlarına öncelik verileceği düzenlenmiştir. Bu maddenin başlığı devlet ve belediye tercihleri olarak geçmektedir. Buna göre Rusya sınırları içindeki yetkili otorileteler, federal yönetici otoriteler, yerel otoriteler ya da diğer acentalar veya kuruluşların yasal faaliyetleri temelinde, devlet ve belediye tercihleri yapılabilir. Bu tercihlerin özellikle şu 
amaçlar için yapılabileceği belirtilmektedir: kuzey ve kuzeye yakın bölgelerde yaşayan nüfusun yaşamsal faaliyetlerini güvence altına almak, eğitim ve bilimin ilermesini sağlamak, araştırma projelerini yapmak, çevreyi korumak, kültürel mirası korumak (tarihsel anıtları ve kültürü), kullanmak, yaygınlaştırmak, sanat ve kültürü geliştirmek, kültürel değerleri korumak, spor ve fiziksel kültürü geliştirmek, ulusal savunma ve güvenliği temin etmek, tarımsal ürünleri üretmek, sosyal güvenlik hizmetlerini sağlamak, iş güvenliğini sağlamak, vatandaşın sağlı̆̆ını korumak, küçük ve orta ölçekli işletmeleri desteklemek. Belirtilen bu amaçlar dışında devlet ve belediye tercihleri yasaklanmıştır.

Rekabet Kanununa göre, rekabetin kısıtlanması işaretleri şunlardır: ürün piyasasında ekonomik teşebbüslerin sayısının azalması, pazardaki genel koşullarda ortaya çıkan değişikliklerle bağlantılı olmayan artan ve azalan fiyatlar, ürün pazarında bağımsız davranabilecek, aynı grubun üyesi olmayan ekonomik teşebbüslerin reddedilmesi, ekononik teşebbüsler arasında yapılan anlaşma ile ürün pazarında ürünün dolaşımının genel koşullarının tanımlanması ya da diğer kişi tarafından zorlayıcı koşulların ileri sürülmesi, ekonomik teşebbüsler tarafindan ürün pazarında koordinasyon faaliyetlerinde bulunulması, birkaç ekonomik teşebbüsün birlikte ürün dolaşımının genel koşullarını etkilenmesi

Tekelci faaliyet, tekel karşııtı düzenlemeler tarafından yasaklanan anlaşmalar ve uyumlu eylemler ya da tekelci faaliyet olarak tanımlanan diğer faaliyetler ile hakim durumda olan grubun veya ekonomik teşebbüsün bunu kötüye kullanması olarak tanımlanmaktadır.

Rekabet Kanununun uygulanmasından Rus Rekabet Otoritesi (Federal Antimonopoly Service-FAS) sorumludur. FAS'ın başlıca görevleri şunlardır: 1) tekel karşıtı yasaların gözetilmesi ile ilgili olarak ekonomik teşebbüsler, gerçek kişiler, federal yönetici otoriteler, kamu otoriteleri, yerel otoriteler, diğer kuruluşlar, kamu bütçe dışı fonlar üzerinde devlet kontrolünü sağlamak; 2) tekel karşıtı yasaların ihlallerini durdurmak, ihlallerin durdurulması için önlemler almak, bu ihlalleri incelemeye almak; 3) tekelci faaliyetleri, haksız rekabeti, diğer ihlalleri önlemek 4) toprak, maden kaynakları, su ve diğer doğal kaynaklar ile ilgili ekonomik yoğunlaşmalar üzerinde devlet kontrolünü uygulamak.

FAS ve onun bölgesel ofisleri rekabet kanununun ihlali durumunda Rekabet Kanununu ve İdare Kanunundaki (30 Aralık 2001 tarih ve 195-FZ numaralı Rusya Federasyonu İdari Suçlar Kanunu ) kartel yasaklamalarılla ilgili maddeleri uygulamaktadır. Ihlal aynı zamanda suç olarak kabul ediliyorsa bu durumda araştırma İçişleri Bakanlığı (Ministry of Internal Affairs, kısaca MIA) tarafindan, Ceza Kanunu (13 Haziran 1996 tarih ve 63-FZ numaralı Rusya Federasyonu Ceza Kanunu) ve Ceza Usulü Kanunu'na (18 Aralık 2001 tarih ve 174-FZ numaralı Ceza usulü kanunu) göre yapılmaktadır. Buna göre FAS'ın sadece idari soruşturma gücü vardır, ceza soruşturma gücü ise MIA'ya verilmiştir. Genellikle Rekabet Kanunu ihlali FAS tarafindan tespit edilir ve kartel dosyası kapatılır. Otorite dosya belgelerini ceza sürecinin başlatılması için MIA'ya gönderir. MIA sadece ciddi ve karmaşık dolandırıcılıklarla ilgili kartel durumlarında ceza soruşturması yapar. Bunu yaparken FAS ile işbirliği yapabilir. MIA, ceza işlemlerini Ceza Usulü Kanunu ve Kolluk İşlemleri Kanununa göre yürütür. FAS soruşturmayı kendi insiyatifi ile açar. Soruş̧urma için diğer devlet ve belediye otoriteleri, bireyler, tüzel kişiler, kitlesel medya kaynaklarından alınan bilgiler ve FAS'ın kendi soruşturma sonuçları ya da kartel kanıtlarının tespiti sonuçları esas olarak alınır. FAS soruşturma açıp açmayı düşünür ve FAS tarafından rekabet ihlali bilgisinin alınmasını takip eden bir ay içinde soruşturma açılır. Eğer ilave bilgiye ihtiyaç varsa su süre üç aya uzayabilir. Soruşturma ile ilgili temel kurallar Rekabet kanunu 24 ve 26 maddeleri arasında bulunmaktadır. Olağandışı durumlarda, FAS tarafından yapılan soruşturmaya savcılık kurumları da dahil olmaktadır.

Her bir rekabet ihlalinin incelenmesi için FAS bir komisyon kurar. Komisyon FAS yetkililerinden oluşur. Otoritenin başkanı, yapısal birim başkanı ya da başkan yardımcısı komisyonun başkanı olabilir. Komisyon üye sayısı en az üç olmalıdır. Bankacılık hizmetleri pazarında kredi kuruluşlarının rekabet ihlallerinin incelenmesinde Rusya Merkez Bankasından temsilciler de komisyona katılır ve temsilciler üyelerin yarısını oluşturur. Komisyon tarafindan düzenlenen duruşma sırasında, teşebbüs ve ilgili tarafların yazılı ve sözlü açıklamalar göndermek hakkı vardır. Komisyon davanın başlamasından itibaren üç ay içinde üyelerin basit çoğunluğu ile nihai kararını verir, bu dönem altı aya kadar uzatılabilir. Komisyon uyarı verir, iptal eder, kararlar verir ve tespitler yapar. Komisyon kararına karşı üç ay içinde tahkim (ticari) mahkemesinde temyiz davası açılabilmektedir.

Rekabet Kanunu 41.maddeye göre zamanaşımı süresi rekabet kanunu ile ilgili davalarda rekabetin ihlalinin belirlenmesi tarihinden itibaren üç yıldır. Ceza kanununa göre sure suçun işlendiği tarihten itibaren on yıldır.

FAS kartel oluşturma ya da kartele katılıma para cezası uygulayabilir. Bu para cezasının miktarı ihlalin olduğu pazarda malın satışından şirketin elde ettiği gelir payına bağlıdır. Gelirin belli bir oranı para cezası olarak belirlenir. Oran, duruma göre yüzde 10'dan yüzde 50'ye değişir, fakat para cezasının miktarı 100.000 rubleden az olamaz. FAS kimya, ilaç, cenaze hizmetleri, enerji ürünleri, gıda ürünleri, hava taşımacıllğı ve sigorta pazarının da dahil olduğu finansal hizmetler pazarlarında rekabet konusunda çok özen göstermektedir.

Şirket yetkilileri de hem idari hem cezai sorumluluğa sahiptir. Kartel oluşturma veya kartele katılma durumunda 20.000 den 50.000 rubleye kadar idari para cezası ya da üç yıla kadar yetkisizleştirme cezası verilebilmektedir. Aynı suç için ceza sorumluluğunun sonucu ya 1 milyon rubleye kadar para cezası ya da beş 
yıla kadar hapis cezası, birden üç yıla kadar yetkisizleştirme cezasıdır. Bazı nitelikli suçlar daha ağır cezai sorumluluk ile cezalandırılabilir. Yetkisizleştirme demek bu kişilerin bir tüzel kişinin yöneticisi, yönetim kurulu üyesi olmasının, yönetim ile ilgili işletme faaliyetlerini yapmasının yasaklanmasıdır.

\subsection{Hakim Durum ve Hakim Durumun Kötüye Kullanılması}

Rekabet Kanunu once hakim durumu ayrıntılı bir şekilde tanımlamış ondan sonra hakim durumun kötüye kullanılması hallerine örnekler vermiştir. Rekabet Kanununa göre hakim durum, bir veya birkaç ekonomik teşebbüsün belirli emtia pazarında, emtia pazarındaki genel koşulları etkileyebilecek kararı alabilmesi ya da diğer ekonomik teşebbüsleri bu pazarın dışına itebilmesi ya da diğer ekonomik kuruluşların bu pazara erişimini engelleyebilmesi durumu olarak tanımlanmaktadır. Finansal kuruluşlar hariç pazar payı yüzde elliyi aşan teşebbüsler hakim durumda kabul edilmektedir. Yeni rakipler pazara giremiyorsa ve rakiplerin payları ile karşılaştırıldığında teşebbüsün payı önemliyse pazar payı yüzde ellinin altında olsa bile bu teşebbüslerde hakim durumda kabul edilmektedir. Ekonomik teşebbüsün (finansal kuruluşlar hariç) pazar payı yüzde otuzbeşi aşmıyorsa hakim durumda olmadığg kabul edilmektedir.

Rekabet Kanunu belli ürünlerin pazarında pazar payı yüzde 35 den az olan teşebbüsleri de bazı durumlarda hakim durumda kabul etmektedir. Bu durumlar şöyle sıralanmaktadır: 1.Ekonomik teşebbüs mal fiyatlarını belirliyorsa ve malın dolaşımını etkileyen kararlar alıyorsa, 2. Yeni rakiplerin ilgili pazara girişini özellikle ekonomik, teknolojik, idari ve diğer kısıtlamalarla zorlaştırıyorsa, 3. Ekonomik teşebbüs tarafından satılan veya satın alınan mallar tüketimde başka mallarla ikame edilemiyorsa (buna endüstriyel amaçlarla kullanımda dahil), yani malın talep esnekliği yoksa, 4. Malların değişen fiyatı talepte uygun bir azalmaya sebep oluyorsa.

Birden fazla ekonomik teşebbüs de belli koşulların oluşması durumunda birlikte hakim durumda kabul edilebilir. Bu koşullar şunlardır: a.en fazla üç ekonomik teşebbüsün toplam payının yüzde elliyi aşması, bunların herbirinin paylarının pazardaki diğer ekonomik teşebbüslerin paylarını aşması, en fazla beş ekonomik teşebbüsün toplam payının yüzde yetmişi aşması, bunların herbirinin paylarının diğer ekonomik teşebbüslerin paylarını aşması, ( bu madde yukarıda bahsedilen ekonomik teşebbüslerin en az birinin payı yüzde sekizden daha azsa uygulanmaz) b. en az bir yıl, bu ekonomik teşebbüslerin paylarının büyüklüğünün aynı kalması yada pazara yeni rakipler girsede önemsiz değişiklikler olması, c. ekonomik teşebbüs tarafından satılan ya da satın alınan emtianın, tüketim sürecinde başka bir emtia ile ikame edilememesi (buna üretim amacı için tüketimde dahildir).

Ekonomik teşebbüs mahkemeye gidilmeden once hakim durumda olmadığını kanıtlama hakkına sahiptir. Doğal tekele konu olan ekonomik teşebbüsün durumu hakim durum olarak tanımlanır.

Finansal kuruluşların (kredi kuruluşları hariç) hakim durumda olduğunu tespit eden koşullar Rusya hükümeti tarafından Federal kanundaki kısıtlamalar göz önüne alınarak tanımlanır. Kredi kuruluşlarının hakim durumda olduğunu tespit eden koşullar ise Rusya Merkez Bankası ile Rusya hükümeti tarafından belirlenir. Işletme ortaklıkları durumunda, pazar payları sadece Rusya'da yüzde onu aşmıyorsa ya da diğer mallarla birlikte emtia pazarında payları yüzde yirmiyi aşmıyorsa hakim durumda olmadıkları kabul edilir.

Kanunun 6. Maddesi tekelci yüksek fiyatlamayı düzenlemektedir. Tekelci yüksek fiyatlama hakim durumdaki teşebbüs tarafından yapılmaktadır. Eğer fiyat, malın üretim, dağıtım maliyetleri ve kar toplamını aşıyorsa ya da pazarda rekabetçi koşullara oluşan fiyatı aşıyorsa tekelci yüksek fiyatlamadan söz edilir. Fiyatta artışla birlikte şu koşulların ortaya çıkması da aranmaktadır: a) üretim ve dağıtım için gerekli masraflar aynı kalıyorsa ya da değişiklik fiyat değişikliği ile uyuşmuyorsa b) satıcı ve alıcılar değişmiyorsa ve değişiklik önemli değilse c) pazarda malın dolaşımı koşulları devlet düzenlemeleri, vergi ve tarife düzenlemeleri dahil aynı kalıyorsa ya da değişiklikler fiyat değişimi ile orantısızsa.

Kanunun 7.maddesi tekelci düşük fiyatlamayı düzenlemektedir. Tekelci düşük fiyatlama hakim durumdaki ekonomik teşebbüs tarafından belirlenen fiyatın malın üretim ve dağıtım maliyetleri ve kar toplamının altında kalmasıdır ya da pazarda rekabetçi koşullara göre oluşan fiyatın altında kalmasıdır. Önceden belirlenen fiyattaki azalma ile birlikte aşağıdaki koşullar oluşuyorsa tekelci düşük fiyatlamadan söz edilir. Bu koşullar: a) üretim ve dağıtım için gerekli olan masraflar aynı kalıyorsa ya da değişiklik fiyat değişikliği ile uyuşmuyorsa, b) satıcı ve alıcılar değişmiyorsa ya da değişiklik önemsizse, c) malın dolaşımı koşulları aynı kalıyorsa ya da değişiklik fiyat değişikliği ile aynı oranda değilse.

Rekabet Kanununa göre hakim durumda olan bir teşebbüsün, rekabeti önleyen, sınırlayan, ortadan kaldıran faaliyetleri yasaklanmıştır. Bu faaliyetlere örnek olarak şunlar sayılmıştır: 1) Tekelci yüksek ya da tekelci düşük fiyatlama yapılması ve buna devam edilmesi; 2) Malların dolaşımdan çekilmesi böylece malın fiyatında artış olmasına sebep olunması; 3) Sözleşmenin konusuyla bağlantılı olmayan sözleşme koşullarının zorla uygulanması; 4) Ekonomik ya da teknolojik olarak haksız bir şekilde malın üretiminin azaltılması veya kesilmesi. Eğer malın talebi varsa yada sipariş veriliyorsa ve karlı bir ürün olma olasılığı varsa. Aynı zamanda bu azaltma ve kesme doğrudan kanunlara göre ve yetkili otoritelere göre sağlanmıyorsa; 5) Haksız olarak alıcı (müşteri) ile sözleşme yapmanın reddedilmesi; 6) Haksız olarak aynı mallar için farklı fiyatlar (tarifeler) uygulanması; 7) Finansal kuruluşlar tarafından haksız bir şekilde finansal hizmetlerin yüksek ya da düşük fiyatla belirlenmesi; 8) Ayrımcı koşullar yaratılması; 9) Diğer ekonomik teşebbüslerin pazara girişlerine engel olunması 
ya da pazardan ayrılmasının sağlanması; 10) Yasal düzenlemelere göre oluşturulan fiyat prosedürünün ihlali; 11) Elektrik enerjisi toptan ve perakende pazarında fiyatlar üzerinde manipülasyon yapılması

Hakim Durumun Kötüye Kullanılması Ile Ilgili Karar Örnekleri

Telekomünikasyon pazarı: FAS Rusya ve Kazakistan Rekabet Otoritesi, OJSC MTS, OJSC VympelCom, OJSC MegaFon ( Rusya Federasyanu) ve "GSM Kazakhstan" Ltd, "Kar-Tel" Ltd, "Mobile Telecom-Service" Ltd (Kazakistan Cumhuriyeti) isimli mobil operatorlerle ilgili, tekelci yüksek fiyat uygulamalarına yönelik ortak bir soruşturma yaptılar. Üç büyükler olarak adlandırılan Rus şirketleri rekabet ihlali yaptıklarını kabul ettiler ve bu şirketlere 38 milyon ruble (1,2 milyon US Doları) para cezası verildi. FAS Rusya üç büyük operatörün tekelci yüksek fiyat tespit ettiğini ve hesaplamalardaki değișikleri abonelerine haber vermeksizin haksız sözleşme şartları uyguladıklarını belirledi. Üstelik operatörler Rusyaya gelen konuklara verilen hizmetlerde aşırı kar kazanmayı temin etmeye yönelik karşılıklı anlaşmalarla tekelci yüksek fiyatlar uyguluyorlardı. Soruşturmanın sonucunda şirketler Bağımsız devletler topluluğunu oluşturan ülkelerde sunulan hizmetler için önemli ölçüde fiyatlarını azalttılar. Ayrıca Rus ve Kazakistan operatörleri Bağımsız Devletler Topluluğu ülkelerindeki operatörlere tarifelerin azaltılması teklifi gönderdiler ve bu teklif yüzde 70 kabul edildi. Ayrımcı olmayan koşulların kabul edilmesini reddeden operatörler hakkında Bağımsız Devletler Topluluğunu oluşturan ülkelerdeki rekabet otoritelerine bilgi gönderidli.

Havaalanı hizmetleri pazarı: 2010 yılında FAS Rusya bazı Rus şehirlerindeki birkaç havaalanına karşı hakim durumun kötüye kullanılması ile ilgili olarak soruşturma başlattı. Toplam olarak 10 milyon ruble (333000 US Doları) para cezası uygulandı. Ihlal, jet yakıt hizmeti veren havaalanları ve ekonomik teşebbüslerin hava taşıyıcılarının bu havaalanlarında kendi yakıtlarını depolamasına karşı çıkmasıydı. FAS Rusya, OJSC"AeroflotRussian airlines"şirketinin iddiaları ile bu soruşturmayı başlattı. Şirket ilgili havaalanları ve ekonomik teşebbüslerin havaalanlarında önerilenden daha düşük maliyetle elde edilebilecek olan kendi jet yakitlarını sağlamalarına izin verilmesini istedi, fakat havaalanları bunu reddetti. İlgili havaalanları ve ekonomik teşebbüsler yerel jet yakıt pazarında hakim durumda olduğundan onların faaliyetlerinin jet yakıt pazarında rekabetin sınırlanmasına sebep olduğuna karar verildi. Yargısal işlemler FAS Rusya kararını destekledi böylece havaalanlarında jet yakıt hizmetlerinin girişinin temin edilmesi ile ilgili başarılı bir uygulama yapılmış oldu.

Gübre üretimi Pazarı: Şirkete karşı soruşturma FAS Rusya tarafından OJSC "Voskresenski NIYiF" şirketinin başvurusu ile 2008 yılında başladı. İddia OJSC "Voskresenskie fertilizers"şirketinin haksız olarak fosforik asit satmadığı ve ekonomik çıkarları ihlal ettiği idi. Şirkete fosforik asit pazarında hakim durumunu kötüye kullandığı için yaklaşık 1,5 milyon ruble (50000 US Doları) para cezası verildi. Eylül 2010'da üst Tahkim Mahkemesi FAS'ın kararını onayladı ve şirkete idari sorumluluk getirdi.

\subsection{Teşebbüsler Arası Rekabeti Kısıtlayıcı Anlaşmalar ve Uyumlu Eylemler}

Rakip teşebbüsler arasında anlaşmalar kartel olarak kabul edilmekte ve bu anlaşmalar yasaklanmaktadır. Rekabeti sınırlama amacı olan bu anlaşmalardan örnekler de verilmiştir. Bunlar: fiyatı (tarifeyi), indirimleri, ek fiyatları belirleme anlaşmaları; rekabete açık ihale sırasında fiyatların artırılması, azaltılması, muhafaza edilmesi anlaşmaları; pazarın, mal ve hizmetlerin satış ve alıs hacminin bölünmesi ya da satıcıların veya alıcıların sıralanması anlaşmaları;malların üretiminin azaltılması veya sona erdirilmesi anlaşmaları; belli satıcı veya alıcılar ile sözleşme yapmanın reddedilmesi anlaşmaları.

Teşebbüsler arasında malların fiyatlarının belirlenmesine sebep olan, rakibin malını satmamasına zorlayan dikey anlaşmalar yasaktır. Eğer teşebbüslerin pazar payı yüzde yirmiyi aşmıyorsa dikey anlaşmalara izin verilmektedir (finansal kuruluşlar arasındaki dikey anlaşmalar hariç)

Teşebbüsler arası uyumlu eylemlerde yasaklanmıştır. Eğer bu uyumlu eylemler; fiyatların indirimlerin, ek ücretlerin belirlenmesini sağlıyorsa, ihalede fiyatın artmasını azalmasını, devamını sağlıyorsa, pazarları, mal ve hizmetlerin satış ve alış hacmini bölüyorsa, malların üretimini azaltıyorsa ve sona erdiryorsa, belli satıcılar ve alıcılarla sözleşme yapmayı reddediyorsa yasaktır. Elektrik enerjisinin toptan ve perakende pazarında, ticari altyapı organizasyonlarında, teknolojik altyatırım organizasyonlarında, iletişim organizasyonlarında teşebbüsler arası uyumlu eylemler yasaklanmıştır.

Rekabeti kısıtlayan anlaşmalar, uyumlu eylemler ve işlemlere bazı durumlarda muafiyet verilebilir. Eğer bu anlaşmalar, uyumlu eylemler ve işlemler, malın iyileştirilmesini, malın satışının ya da teknik, ekonomik ilerlemesinin teşvik edilmesini, dünya pazarında Rusya'nın rekabet kapasitesinin arttırılmasını sağlıyorsa, teşebbüslere göre tüketiciler bundan daha fazla fayda sağlıyorsa, bunlar yasaklama kapsamı dışında tutulmaktadir.

Kanunun 15. Maddesine göre; federal yönetici otoriteler, kamu otoriteleri, yerel otoriteler ve diğer kamu kurumlarının rekabet ihlalleri de yasaktır. Madde 16 'ya göre de bu otoritelerin rekabeti kısıtlayıcı anlaşmaları ve uyumlu eylemleri yasaklanmıştır.

Rekabeti Kısıtlayıcı Anlaşmalarla ilgili Karar Örnekleri

Kömür Santrali Pazarı: Aralık 2010'da FAS Rusya, OJSC "SUEK", OJSC "Russian coal" and CJSC "Stroyservice" şirketlerinin rekabeti ihlal ettiklerine karar verdi. Şirketler kömür santrali pazarında pazarı bölen 
ve fiyat belirlemeyi amaçlayan bu yüzden rekabeti kısıtlayan anlaşma yapmışlardı. Kömür santrali pazarındaki bu anlaşma nedeniyle Rusya İçişleri Bakanlığı'da OJSC "SUEK” ve kartel anlaşmasının diğer taraflarının yetkilileri ile ilgili Ceza Kanununun 178.maddesine göre ceza davası başlattı. OJSC "SUEK", OJSC "Russian coal" and CJSC "Stroyservice" şirketleri tarafından bu anlaşma nedeniyle elde edilen kar 100 milyon rubleyi aşıyordu. Kartelle ilgili kanıtlar ilk defa FAS Rusya ve İçişleri Bakanlığı (polis) tarafından birlikte toplandı. FAS Rusya'nın soruşturmadan elde ettiği sonuçlar ceza davası için İçişleri Bakanlığına gönderildi.

Kimya Endüstrisi: Aralık 2010'da FAS Rusya, OJSC “Uralkali”, OJSC “Silvinit” and "Mineral Trading” Ltd şirketlerinin rekabeti ihlal eden anlaşma yaptıklarını kabul etti. Şirketler arasındaki anlaşma rekabet kanunu tarafından yasaklanan dikey anlaşmaydı. $\mathrm{Bu}$ anlaşma potasyum klorür üzerinde tekrar satış fiyatının belirlenmesine sebep olan bir anlaşmaydı. FAS Rusya'nın bu şirketlerle ilgili kararı pazarın devamlılığı, rekabetin geliştirmesi ve sonuç olarak ulusal gıda güvenliğinin sağlanmasını amaçliyordu. Nisan 2010 tarihinde FAS bu şirketlere yaklaşık 264 milyon ruble (8,8 milyon US Doları) para cezası uyguladı. Ağustos 2010 tarihinde Tahkim Mahkemesi bu kararı onayladı.

\subsection{Ekonomik Yoğunlaşmalar (Birleşme ve Devralmalar)}

Ekonomik yoğunlaşmalar üzerinde devlet kontrolü Kanunun 7. Bölümünde yer almaktadır. Kanunun 26 (1). Maddesi devlet kontrolüne tabi işlemleri düzenlemektedir. Bu bölüme göre, Rus finansal kurumlarının, maddi ve maddi olmayan varlıkları Rusya Federasyonunda yer alan ticari ve ticari olmayan Rus kuruluşlarının ve Rusyaya mal satan yabancı kişi ve kuruluşların birleşme ve devralma işlemleri, işlemin yapıldığı yıl bir milyar ruble'nin üzerinde ise devlet kontrolüne tabidir. Şu işlemler sadece tekel karşıtı (rekabet otoritesinin) kurumun izniyle yapılabilir: 1. en son bilançoya göre toplam varlıklarının değeri yedi milyar rubleyi aşan ya da birleşmeden önceki takvim yılında malların satışından elde edilen toplam gelirleri on milyar rubleyi aşan ticari kuruluşların birleşmesi (finansal kuruluşlar hariç), 2. en son bilançoya göre varlıklarının toplam değeri 7 milyar Ruble'yi aşan ya da katılmadan önceki takvim yılında satıştan elde edilen toplam gelirleri on milyar rubleyi aşan bir veya birkaç ticari kuruluşun diğer ticari kuruluşlara katılması (finansal kuruluşlar hariç) 3. son bilançayo göre varlıklarının toplam değeri Rusya hükümeti tarafından belirlenen miktarı aşan finansal kuruluşların birleşmesi ya da bir veya birkaç finansal kuruluşa katılması (finansal kuruluşların birleşme veya konsolidasyonu durumunda, bu miktar Rusya Federasyonu Merkez Bankası ile koordineli olarak Rusya Federasyonu Hükümeti tarafindan belirlenir)

\section{Birleşme ve devralmalarla ilgili karar örnekleri}

Birleşme ve devralmanın rekabet kanununa aykırı olmadığına dair menfi tespit verilmesi: 2010 yılında FAS Rusya süt ve süt ürünleri pazarında satış, üretim ve satın alma üzerine birbiriyle bağlantılı üç işlemi onayladı. Üç işlem süt ve süt ürünleri üretimi ve satışının birleşmesini amaçlıyordu. DANONE'nin de dahil olduğu grup, UNIMILK'e ait olan diğer grup ile ortak girişim kurmak üzere bir karar vermişlerdi. FAS Rusya belli koşullarla DANON-UNIMILK ortak girişimine izin verdi. Bu koşullar süt ve süt ürünlerinin satışı, üretimi ve satın alınmasında rekabetin devamlılılığının sağlanmasını amaçlıyordu. FAS'a göre UNIMILK grup bazı bölgelerde özellikle süt satın alınan pazarlarda yüksek pazar potansiyeline sahipti. DANONE şirketi aynı zamanda süt ve süt ürünleri pazarında UNIMILK şirketinin dışındaki bölgelerde faaliyet gösteriyordu. Pazar araştırma verilerine göre, Pazar bölümlemesi temelinde işlem, bazı Pazar bölümleri ile ilgili olarak süt ve süt ürünlerinin satışı, üretimi ve satın alınmasında belli bölgelerde hakim durumun yaratılmasına sebep olabilirdi. FAS Rusya şu şartla izin verdi. Danone-Unimilk ortak girişimi, süt ve süt ürünlerinin alış fiyatları, satış fiyatları ve bazı diğer koşulların yerine getirildiği ile ilgili olarak FAS Rusya'yı üç ayda bir bilgilendirmelidir.

Birleşmenin reddedilmesi: 2010 yılında FAS Rusya tarafından, OJSC "Ural mining and smelting"şirketinin LLC "Shatravan Holdings Limited"şirketine ait payların yüzde 100'ünü devralması ile ilgili bildirimi reddedilmiştir. Verilerin incelenmesi üzerine FAS Rusya bu işlemin tamamlanması ile OJSC'nin pazar payının bakır ve bronz pazarında yüzde 35'den daha büyük olacağı, nikel pazarında ise yüzde 50'den daha büyük olacağına karar vermiştir. Böylece FAS bu bildirimi reddeden bir karar vermiştir. Pazar payının yüzde 35 olması FAS Rusyanın birleşmeye izin vermemesi için asıl sebep değildir bildirilen işlem ile rekabet üzerinde olumsuz bir etki olacağı belirtilmiştir.

\section{Türk Rekabet Hukuku}

1970’li yıllardan itibaren Türkiye'de rekabet hukuku ile ilgili çalışmalar yapılmasına karşın, “4054 sayılı Rekabetin Korunması Hakkında Kanun (RKHK)”, 07.12.1994 tarihinde kabul edilerek yürürlüğe girmiştir. Türkiye'de bir rekabet kanununun çıkarılması ve uygulanması öncelikle anayasal bir zorunluluk olarak ortaya çıkmaktadır. Kanunun hazırlanmasında etkili olan bir diğer unsur da, uluslararası anlaşmaların Türkiye'ye yüklediği yükümlülüklerdir. Türkiye ve AET arasındaki 12 Eylül 1963 tarihli Ortaklık Anlaşması'nın (Ankara Anlaşması) 16 ncı maddesi, Roma Antlaşması'nın rekabet, vergi ve mevzuatın uyumlaştırılması ile ilgili hükümlerinde anılan ilkelerin, ortaklık ilişkisinde uygulanmasını öngörmüştür. Nitekim Türk Rekabet Kanunu büyük ölçüde Roma Antlaşması'nın 81 ve 82 nci maddelerini kaynak almıştır. Ayrıca AB ile Türkiye arasındaki Ortaklık Anlaşması çerçevesinde oluşturulan Ortaklık Konseyi’nin 6 Mart 1995 tarih ve 1/95 sayılı kararı ile bir 
Gümrük Birliği kurulmuştur. Türkiye ile $\mathrm{AB}$ arasında Gümrük Birliği kuran bu karar 01.06.1996 tarihinde yürürlüğe girmiştir. $\mathrm{Bu}$ karara göre $\mathrm{AB}$ ile Türkiye arasanda oluşturulacak gümrük birliğinin önemli araçlarından birisi de tarafların rekabet politikası ve rekabet hukuklarının birbirine uyumlaştırılmasıdır. Başka bir deyişle Türkiye'nin AB rekabet politikalarını ve rekabet hukukunu benimsemesidir. Gümrük birliği kararı ile Türkiye sadece bir rekabet kanunu çıkarmayı taahhüt etmekle kalmamış, yasa, ikincil mevzuat ve içtihat ve ilkeler bakımından da $\mathrm{AB}$ hukukuna uygun davranacağını da taahhüt etmiştir.

RKHK'nun uygulanmasını gözetecek makam Türk Rekabet Kurumu'dur ve 1997 yılında kurulmuștur. Kurum Kanun'un kendisine verdiği görevleri yaparken ve Kanunun uygulanmasını gözetirken "mal ve hizmet piyasalarının serbest ve sağlıklı bir rekabet ortamı içinde teşekkülünün ve gelişmesinin teminini" amaçlayacaktır. Rekabet Kurumu kamu tüzelkişiliğine, idari ve mali özerkliğe sahip bir kurumdur. Kurum görevini yaparken hiçbir organ, makam, merci veya kişiden emir ve talimat almaz. Tamamen kendi araştırma sonuçlarıyla ulaştı̆ı kanaate göre karar verir. Rekabet Kurumunun merkezi Ankara'dadır. Kurum gerek görürse başka yerlerde de şube yada irtibat bürosu kurabilecektir. Rekabet Kurumu, Rekabet Kurulu, Başkanlık ve Hizmet birimlerinden oluşur. Rekabet Kurumunun ana organı Rekabet Kurulu'dur. RKHK'nun uygulanması görevi esas olarak ve genel bir hükümle Rekabet Kurumu'na verildiğinden RKHK'da aksi belirtilmediği sürece bu görevleri Rekabet Kurulu yürütecektir. Rekabet Kurulu yedi üyeden oluşmaktadır.

\subsection{RKHK'nun Sistemi ve Uygulanması}

RKHK'un amacı, mal ve hizmet piyasalarındaki rekabeti engelleyici, bozucu veya kısıtlayıcı anlaşma, karar ve uygulamaları ve piyasaya hakim olan teşebbüslerin bu hakimiyetlerini kötüye kullanmalarını önlemek, bunun için gerekli düzenleme ve denetlemeleri yaparak rekabetin korunmasını sağlamaktır.

Türkiye Cumhuriyeti sınırları içinde mal ve hizmet piyasalarında faaliyet gösteren ya da bu piyasaları etkileyen her türlü teşebbüsün aralarında yaptığı rekabeti engelleyici, bozucu ve kısıtlayıcı anlaşma, uygulama ve kararlar ile piyasaya hakim olan teşebbüslerin bu hakimiyetlerini kötüye kullanmaları ve rekabeti önemli ölçüde azaltacak birleşme ve devralma niteliğindeki her türlü hukuki işlem ve davranışlar, rekabetin korunmasına yönelik tedbir, tespit, düzenleme ve denetlemeye ilişkin işlemler Kanun kapsamında yer almaktadır. Serbest rekabeti etkileyebilecek olan hükümet tasarrufları, devlet yardımları ve ayrı bir kanunla düzenlenmiş olan ithalatta damping bu Kanun'un konusu dışındadır. Danping ve devlet yardımlarına ilişkin konular Kanun'da ayrıca düzenlenmediğinden bu konuların denetimi RKHK'nun kapsamı dışında kalmaktadır.

Özel teşebbüsler olduğu kadar kamu teşebbüsleri de kanun kapsamında kabul edilmiştir. Madde gerekçesinde rekabet kurallarının ekonomik faaliyette bulunan her teşebbüse uygulanması gerektiği, teşebbüslerin kamu kurumlarına veya özel kişilere ait olmasının bir önemi olmadığı, her ne kadar rekabet hukukunda da kamu yararı ve kamu düzeninin korunması amaçları ön plana çıkıyorsa da genel ekonomik menfaatlere hizmet etmekle görevlendirilmiş teşebbüslerin bu görevlerini yerine getirmelerinin rekabet kurallarıyla çatışmaması gerektiği ifade edilmiştir. Buna göre kamu teşebbüsleri ile özel teşebbüsler arasında bir ayırım yapılmamış temel kriter olarak "ekonomik faaliyette bulunma" esas alınmıştır.

Özelleştirme yoluyla yapılacak devralmaların denetlenmesi de RKHK kapsamı içerisinde yer almaktadır. Kartellerin denetimi de RKHK'nun kapsamı içerisinde yer almaktadır. Rekabet Kurumu "Kartellerin Ortaya Çıkarılması Amacıyla Aktif İşbirliği Yapılmasına Dair Yönetmelik” yayınlamıştır. Rekabet Kurulu, RKHK'un devlet ihalelerine de uygulanacağına karar vermiştir.

RKHK teşebbüslere (işletmelere) uygulanmaktadır. RKHK'nun 3. maddesinde “Teşebbüs; piyasada mal veya hizmet üreten, pazarlayan, satan gerçek ve tüzel kişilerle bağımsız karar verebilen ve ekonomik bakımdan bir bütün teşkil eden birimler" olarak tanımlanmıştır. Teşebbüs birlikleri ise, teşebbüslerin belirli amaçlara ulaşmak için oluşturduğu tüzelkişiliği haiz ya da tüzel kişiliği olmayan her türlü birliklerdir.

Sektörel açıdan bütün mal ve hizmet sektörleri Kanun kapsamına girmektedir. RKHK'da sektör bazında herhangi bir ayırım yapılmamıştır.

RKHK'nun kapsamı, rekabetin Türkiye sinırları içinde kurulması ve korunmasıdır. Ancak, Kanun sadece Türkiye'de yerleşmiş işletmelere değil, başka ülkelerde yerleşmiş olmakla birlikte Türkiye'de bulunan mal ve hizmet piyasalarını etkileyen işletmelere de uygulanır. RKHK'nun 2.maddesine göre, "Türkiye Cumhuriyeti sınırları içinde mal ve hizmet piyasalarında faaliyet gösteren ya da bu piyasaları etkileyen her türlü uygulama" bu kanun kapsamındadir.

Türkiye'de haksız rekabete ilişkin düzenlemeler Türk Ticaret Kanununda (TTK) yer almaktadır. Hangi hallerin haksız rekabet sayılacağı da TTK'da belirtilmektedir. Haksız rekabete ilişkin ihtilaflar Rekabet Kurumu dahil olmaksızın özel davalarla çözümlenmektedir. Tüketicilere zarar veren aldatıcı uygulamalar ise 1995 yılında kabul edilen Tüketicinin Korunması Hakkında Kanun çerçevesinde düzenlenmiştir. İlgili Kanuna göre aldatıc1 reklam faaliyetleri konusunda kuralları uygulama yetkisine sahip bir Reklam Kurulu oluşturulmuştur. Gümrük ve Ticaret Bakanlığı bünyesindeki Tüketicinin Korunması ve Piyasa Gözetimi Genel Müdürlüğü de Kanunun diğer hükümlerini uygulama yetkisine sahiptir. 


\subsection{RKHK'da Yasaklanan Faaliyetler}

RKHK kapsamında yasaklanan faaliyetleri üç ana başlık altında toplamak mümkündür. Bunlar; 1.Türkiye Cumhuriyeti sınırları içinde mal ve hizmet piyasalarında faaliyet gösteren ya da bu piyasaları etkileyen her türlü teşebbüsün aralarında yaptığı rekabeti engelleyici, bozucu ve kısıtlayıcı anlaşma, uygulama ve kararlar (RKHK m.4), 2. Piyasada hâkim durumda olan teşebbüslerin bu güçlerini kötüye kullanması (RKHK m.6), 3. Hâkim durum yaratmaya veya var olan bir hâkim durumu güçlendirmeye yönelik ve bunun sonucu olarak rekabeti önemli ölçüde azaltacak birleşme ve devralma niteliğindeki her türlü hukuki işlem ve davranışlardır(RKHK m.7).

\section{Rekabeti Sınırlayıcı Anlaşma, Uyumlu Eylem ve Kararlar}

Rekabet hukukunda, teşebbüsler arası anlaşmalar, teşebbüs birliği kararları ve uyumlu eylemler yoluyla gerçekleştirilen rekabet ihlalleri hukuka aykırı ve yasak kapsamında kabul edilmiştir. Teşebbüslerin aralarında yapacakları gizli veya açık anlaşmalarla veya uyumlu davranışlarla rekabeti sınırlamaları mümkündür. Teşebbüsler aralarında oluşturacakları birliklerin kararlarıyla da bu sonucu doğurabilirler. Birden fazla teşebbüs birlikte davranarak rekabeti sınırlamaktadır. Teşebbüsler arası anlaşmalar yatay ve dikey anlaşmalar olarak iki kategoride incelenir. Yatay anlaşmalar, üretimden tüketime kadar uzanan zincirin aynı seviyesindeki işletmeler arasında (rakipler) yapılan anlaşmalara denir. Dikey anlaşmalar ise farklı seviyelerdeki işletmeler arası yapılan anlaşmalardır.

RKHK'nun 4.maddesinde üç husus yasaklanmaktadır. Bunlar rekabeti sınırlayıcı olan teşebbüsler arası anlaşmalar, teşebbüsler arası uyumlu davranışlar ve teşebbüs birlikleri kararlarıdır. Teşebbüsler arası anlaşma, uyumlu eylem ve teşebbüs birliği kararlarının yasaklanabilmesi için ya amaçlarının ya da doğurdukları ekonomik etkilerin rekabeti sınırlayıcı olması gerekmektedir. Bir anlaşma henüz uygulanmamış ve dolayısıyla rekabeti henüz sınırlamamış bile olsa hükümlerinden rekabeti sınırlayıcı amaçlı olduğu anlaşılıyorsa, uygulamadaki etkilerini görmek için beklemeye gerek yoktur. Doğrudan doğruya daha uygulamadan önce yasaklanır. Rekabeti sınırlayıcı etkisi çok küçük olan anlaşma, karar ve uyumlu eylemler kanunun kapsamı dışındadır. Bir anlaşmanın hükümleri rekabeti sınırlayıcı amaçlı olmasa bile, uygulandığı zaman fiilen rekabeti sınırlayıcı etkiler doğuruyorsa bu anlaşmayı yapan işletmelerin amaçlarının ne olduğuna bakılmaz. Bu anlaşma da yasaklanır.

Teşebbüsler arasındaki anlaşmalar, teşebbüs birliği kararları ve uyumlu eylemler yoluyla gerçekleştirilen rekabet ihlallerinin en sık rastlananları RKHK'nun 4.maddesinde örnek olarak sayılmıştır. Bunlar; fiyatların ve diğer ticari koşulların tespiti, pazar paylaşma, üretimin sınırlanması, girişlerin engellenmesi, ayrımcılık, ek yükümlülük koymak gibi hallerdir.

Rekabeti sınırlayıcı nitelik taşıyan anlaşma ve uyumlu eylemler, belirli koşulları taşımaları halinde yasaklama dışında bırakılmaktadır. Muafiyet. bireysel muafiyet ve grup muafiyeti olmak üzere ikiye ayrılır. Grup muafiyeti, muafiyet şartlarının gerçekleşmesi halinde Rekabet Kurulunun belirli konulardaki anlaşma türlerine çıkartacağ tebliğler ile grup olarak muafiyet tanımasıdır. Bireysel muafiyet ise grup muafiyeti tebliği kapsamı dışında kalan durumlarda muafiyet şartlarının gerçekleşmesi halinde Kurul tarafindan verilen muafiyettir. RKHK'nun 5.maddesine göre muafiyetin verilebilmesi için aranan şartlar şunlardır: Malların üretim veya dağıtımı ile hizmetlerin sunulmasında yeni gelişme ve iyileşmelerin ya da ekonomik veya teknik gelişmenin sağlanması; tüketicinin bundan yarar sağlaması; ilgili piyasanın önemli bir bölümünde rekabetin ortadan kalkmaması; rekabetin belirtilen amaçların elde edilmesi için zorunlu olanlardan fazla sınırlanmaması. Muafiyet verilebilmesi için bu dört şartın bir arada bulunması gerekmektedir, sadece birisinin bulunmaması halinde muafiyet talebi kabul edilmez. Muafiyetin en önemli sonucu ilgililerin yasal belirlilik ve güvenlik içinde olmasıdır. Muafiyet verilen bir anlaşma hakkında para cezası uygulanmaz. Muafiyet devam ettiği sürece bu anlaşmaya dayanarak yapılan her türlü hukuki işlem geçerlidir. Muafiyet kararı çeşitli şartlara ve yükümlülüklere bağlı olarak verilmiş olabilir. Taraflar bu şart ve yükümlülüklere uymak zorundadırlar. Aksi halde muafiyet kararı geri alınır.

\section{Rekabet Kurulu Kararlarından Örnekler}

Çimento Karteli: Çimento üreticileri Ege, Marmara, İç Anadolu ve Akdeniz bölgelerinde yapacakları satışları kendi aralarında tespit ederek pazarları paylaşmışlardır. Bu bölgeler dışında kalan yerlerde de hangi fabrikanın ne kadar satış yapacağını veya söz konusu yerleşim biriminde yapılacak satışlardan kimin ne kadar pay alacağını ve tüm bölge düzeyindeki fiyatları birlikte belirlemişlerdi. Bunlara ek olarak "klinker fazlalığı" olarak nitelenen ürün, yapılan anlaşmalar yoluyla zorunlu olarak ihracata tabi tutulmuştur. Ayrıca yapılan incelemelerde, fabrikaların bulunduğu merkezlerde fiyat ve diğer satış koşullarının rekabetçi yapıdan çok uzak bir şekilde tespit edildiği ve teşebbüslerin iç pazardaki karlılığı korumaya yönelik bir ihracat karteli oluşturduğu belirlenmiştir. Soruşturma sonucunda hem teşebbüslerin Kanun'u ihlal edici davranışlarına son verilmiş, hem de teşebbüsler idari para cezasına çarptırılmıştır.

LPG Pazarında Rakiplerin Piyasa Dışına Çıkarılması ve Yıkıcı Fiyat Uygulaması: LPG dolumu ve dağıtımı alanında faaliyet gösteren 3 büyük gruba bağlı teşebbüsler aralarında anlaşarak Adıyaman'da 1997 yılı içinde 12 kg.'lık LPG tüpünün fiyatını yarı yarıya indirmişlerdir. İlk bakışta tüketici lehine olarak gözüken bu davranış, yerel bir rakip teşebbüsün şikayeti üzerine Rekabet Kurumu tarafindan incelemeye alınmıştır. Yapılan soruşturma neticesinde fiyatların toplu halde ve anlaşma yoluyla maliyetinin de altına indirilmesinin arkasında 
şikayetçi yerel teşebbüsün piyasa dışına çıkarılması amacı olduğu anlaşılmıştır. Rekabet Kurumunun müdahalesiyle yerel rakibi aleyhine "yıkıcı fiyat" uygulamak olarak adlandırılan bu davranış engellenerek tüketicinin ileride rekabetten arındırılmış bir ortamda daha yüksek fiyatlarla karşılaşma ihtimalinin de önüne geçilmiştir.

\section{Hâkim Durumun Kötüye Kullanılması}

RKHK'nun 6. maddesi teşebbüslerin faaliyet gösterdikleri mal ya da hizmet piyasalarında oluşturdukları hakim durumu kötüye kullanmalarını yasaklamaktadır. Bu maddeye göre, "Bir veya birden fazla teşebbüsün ülkenin bütününde ya da bir bölümünde bir mal veya hizmet piyasasındaki hakim durumunu tek başına yahut başkaları ile yapacağı anlaşmalar ya da birlikte davranışlar ile kötüye kullanması hukuka aykırı ve yasaktır”.

Bir teşebbüsün faaliyet gösterdiği piyasada hakim durumda bulunması sahip olduğu yüksek pazar payından kaynaklanacağı gibi, üretim kapasitesinden, ürettiği malın kalitesinden, kullandığı markanın yüksek çekici gücünden de kaynaklanabilir. Rekabet hukuku tarafindan yasaklanan, herhangi bir teşebbüsün belli bir pazarda hakim durumda bulunması değil, bu konumunu kötüye kullanmasıdır. Birden fazla teşebbüsün birlikte hakim durumda bulunmaları halinde, bu konumlarını ortaklaşa kötüye kullanmaları da hukuka aykırı kabul edilecektir (Poroy ve Yasaman, 2001).

RKHK'nun 3.maddesinde hakim durumu tanımlanmıştır. Buna göre hakim durum "Belirli bir piyasadaki bir veya birden fazla teşebbüsün, rakipleri ve müşterilerden bağımsız hareket ederek fiyat, arz, üretim ve dağıtım miktarı gibi ekonomik parametreleri belirleyebilme gücünü” ifade etmektedir. RKHK, hakim durumun kötüye kullanılmasına örnek oluşturacak bazı halleri saymıştır. RKHK'nun 6.maddesine göre bu haller; girişleri engellemek ve rakipleri zor durumda bırakmak, eşit durumdaki alıcılar arasında ayrımcılık yapmak, bir mal veya hizmetin satımında alıcılara ek yükümlülük koymak, bir pazardaki hakim durumun başka bir pazarda kötüye kullanılması, tüketicinin zararına olarak üretimin, pazarlamanın ya da teknik gelişmenin kısıtlanması gibi hallerdir.

\section{Rekabet Kurulu Kararlarından Örnekler}

Belko Kararı: Ankara ilinde kömür satışı konusunda yasal tekel olan Büyükşehir Belediyesi'nin firması Belko'nun kömürü komşu illerdeki benzer pazarlara nazaran \%60-70 daha yüksek fiyattan satması üzerine Rekabet Kurulu tarafindan soruşturma açılarak bu firmaya para cezası verilmiştir. Buna ilave olarak, Rekabet Kurulu'nun görüşü doğrultusunda Belko'nun Ankara ilindeki kömür satışında sahip olduğu tekel hakk1 kaldırılmıştır. Bu karar tüketicinin yararına olarak Ankara ilinde yüksek kömür fiyatlarının düşmesine sebep olmuştur.

Biryay Kararı: Gazete ve dergi dağıtım pazarında birlikte hakim durumda olan BBD, BİRYAY ve YAYSAT'ın, bayilerini diğer dağıtım şirketlerince dağıtılan gazete ve dergileri satmamaları konusunda zorlamaları hakim durumun kötüye kullanılması olarak değerlendirilmiş ve adı geçen teşebbüslere para cezası verilmiştir. Bu karar ile Türkiye'de, belediyelere ait olan gazete ve dergi satış büfelerine her dağıtım şirketince sağlanan yayınları satma zorunluluğu getirilmiş ve böylece, tüketicilerin son satış noktalarında istediği gazete ve dergileri bulabilmesinin önü açılmıştır.

\section{Birleşme veya Devralmalar}

Pazarda faaliyet gösteren teşebbüslerin birleşme ya da devralma işlemleri ile güçlerini birleştirmeleri, ürünlerin daha ucuza sunulması, yeni ürünlerin geliştirilmesi ya da kalitenin arttırılması gibi çeşitli faydaları beraberinde getirebilir. Bununla birlikte, bu tür işlemler hakim durum yaratmak ya da hakim durumu güçlendirmek suretiyle pazardaki rekabeti de azaltabilirler. Tüketiciler bakımından fiyatları arttıran, çeşitliliği azaltan ve innovasyonu zayıflatan bu tür birleşme/devralma işlemleri RKHK'nun 7. maddesi çerçevesinde yasaktır. 7. maddeye göre; "Bir ya da birden fazla teşebbüsün hakim durum yaratmaya veya hakim durumlarını daha da güçlendirmeye yönelik olarak, ülkenin bütünü yahut bir kısmında herhangi bir mal veya hizmet piyasasındaki rekabetin önemli ölçüde azaltılması sonucunu doğuracak şekilde birleşmeleri veya herhangi bir teşebbüsün ya da kişinin diğer bir teşebbüsün mal varlığını yahut ortaklık paylarının tümünü veya bir kısmını ya da kendisine yönetimde hak sahibi olma yetkisi veren araçları, miras yoluyla iktisap durumu hariç olmak üzere, devralması hukuka aykırı ve yasaktır".

Küçük işletmelerin birleşmelerinde ilk anda rakip sayısı azaldığından rekabetin de azalacağı düşünülebilirse de büyük işletmelere karşı küçük işletmelerin birleşmeleri rekabeti arttıracaktır. Küçük işletmeler böylece ölçek ekonomilerine yaklaşacaklar, araştırma ve geliştirme için daha büyük fonlar ayırabilecekler, üretim, dağıtım, personel gibi konularda iyileşme sağlayacaklardır. Bu nedenle her türlü birleşmenin hukuka aykırı sayılması ve RKHK sistemine göre izne tabi olması gerekmemektedir. Müdahale ancak rekabetin bozulması tehlikesinin varlığı halinde söz konusu olacaktır. Küçük işletmelerin birleşmesi rekabet için olumlu bir uygulama olarak görülürken, büyük ya da pazara hakim işletmelerin birleşmesi sakınca doğurabilecek niteliktedir.

Bir birleşme ve devralmanın hukuken geçerlik kazanabilmesi için Rekabet Kurulu'na bildirilerek izin alınması gerekmektedir. Rekabet Kurulu rekabeti bozucu bulduğu işlemleri geçersiz kılabilir. Eğer işletmeler fiilen birleşmişlerse bunların ayrılmalarına da karar verebilir. RKHK'nun 7. maddesi çerçevesinde birleşme ve 
devralma sayılan haller, hukuki geçerlilik kazanabilmesi için Rekabet Kurulu'ndan izin alınması gereken birleşme veya devralmalar ile bunların Rekabet Kurulu'na bildirilmesi usul ve esasları Rekabet Kurulu'ndan Izin Alınması Gereken Birleşme ve Devralmalar Hakkında Tebliğ (Tebliğ No : 2010/4) kapsamında düzenlenmiştir. $\mathrm{Bu}$ Tebliğ çerçevesinde ciro eşikleri öngörülmüştür. İlgili pazardaki toplam ciroları belirtilen eşiklerin üzerinde olan teşebbüslerin gerçekleştirdikleri birleşme ve devralmalar hakkında izin almak üzere kuruma başvurulması gereklidir. Ancak, ortak girişimler hariç olmak üzere, belirtilen eşikler aşılsa dahi, herhangi bir etkilenen pazarın bulunmadığı işlemler için Kuruldan izin alınması gerekmez.

\section{Rekabet Kurulu Kararlarından Örnekler}

Trakmak Traktör ve New Holland NV Arasındaki Devir İşlemine Koşullu İzin: İngiltere'de kurulu New Holland N.V. unvanlı teşebbüsün, Koç grubuna ait Trakmak Traktör ve Ziraat Makinaları Ticaret A.Ş. hisselerinin \%37.5'ini devralmasına ilişkin işlem 1998 yılında Rekabet Kurulu'nca nihai incelemeye alınmıştır. Yapılan incelemede, Koç grubu ile New Holland arasında kurulan bu ortaklığın temel olarak traktör ve biçerdöver piyasalarını etkileyeceği belirlenmiştir. Rekabet Kurulu, söz konusu işlemin, traktör piyasasında bir sakınca yaratmayacağına karar verirken; biçerdöver piyasasının arz seviyesinde hakim durumu güçlendirici; dağıtım seviyesinde ise hakim durum yaratıcı etkisine dikkat çekmiştir. Bu nedenle Kurulca biçerdöver piyasasına yönelik olarak New Holland'a Trakmak Traktör ile aynı koşulları yerine getiren diğer teşebbüslere de talep etmeleri halinde eşit davranarak distribütörlük tesis etmeleri zorunluluğu getirilmiş, devralma işlemine bu koşulun yerine getirilmesi kaydıyla izin verilmiştir.

Ortak Girişime (Joint Venture) İzin: Emaye bobin teli üreten dört teşebbüs tarafindan kurulan ortak girişime Kurulca izin verilmiştir. Kurulan bu ortak girişim pazarda lider konuma geçecek bir pazar payı büyüklüğüne ulaşmaktadır. Pazardaki yoğunlaşmanın artmasına karşılık, Kurul özellikle emaye bobin teli üretiminde uluslar arası rekabet bakımından ölçek büyüklüğünün önemi üzerinde durmuş; sektördeki yurt içi ve yurt dışı rekabet koşullarını, ithalat ve pazara giriş imkanlarını, alıcıların gücünü ve pazardaki rakip teşebbüslerin mevcut ve potansiyel rekabet güçlerini de dikkate alarak işleme izin vermiştir.

\section{Sonuç (Türk Rekabet Hukuku İle Rus Rekabet Hukukunun Karşılaştırılmasıı)}

Türkiye'de haksız rekabete ilişkin düzenlemeler Türk Ticaret Kanununda (TTK) yer almaktadır. Hangi hallerin haksız rekabet sayılacağı da TTK'da belirtilmektedir. Haksız rekabete ilişkin ihtilaflar Rekabet Kurumu dahil olmaksızın özel davalarla çözümlenmektedir. Tüketicilere zarar veren aldatıcı uygulamalar ise 1995 yılında kabul edilen Tüketicinin Korunması Hakkında Kanun (TKHK) çerçevesinde düzenlenmiştir. Rusya'da ise haksız rekabet ile ilgili düzenlemeler rekabet kanununun 14.maddesinde yer almaktadır. Haksız rekabet tanımlandıktan sonra haksız rekabet sayılan haller sıralanmıştır. Haksız rekabetin tespiti, önlenmesi ve ortadan kaldırılması Rus Rekabet Otoritesinin yetkisine görmektedir ve görevleri arasında sayılmaktadır.

Türkiye'de serbest rekabeti etkileyebilecek olan hükümet tasarrufları, devlet yardımları ve ithalatta damping RKHK'da düzenlenmemiştir. Devlet tekeli ile ilgili düzenlemeler yoktur. Özel teşebbüsler olduğu kadar kamu teşebbüsleri de kanun kapsamında kabul edilmiştir. Kamu teşebbüsleri ile özel teşebbüsler arasında bir ayırım yapılmamış temel kriter olarak "ekonomik faaliyette bulunma" esas alınmıştır. Genel ekonomik menfaat için hizmet etmekle görevlendirilmiş olan işletmelere de aynı rekabet kuralları uygulanır. Sektörel açıdan bütün mal ve hizmet sektörleri Kanun kapsamına girmektedir. RKHK'da sektör bazında herhangi bir ayırım yapılmamıştır. Rusya'da ise özel teşebbüsler ve kamu teşebbüslerinin rekabet ihlalleri ayrı olarak düzenlenmiştir. Devlet tekeline ilişkin düzenlemeler bulunmaktadır. Rus Rekabet Kanununda da sektör ayrımı yoktur, bütün sektörlerde uygulanmaktadır.

Rus Rekabet Kanununda hakim durum ayrıntılı bir şekilde tanımlanmıştır. Ayrıca tekelci yüksek fiyatlama ve tekelci düşük fiyatlamaya yer verilmiştir. Hakim durumun kötüye kullanılması halleri hem Türk hem Rus rekabet kanununda sıralanmıştır.

Rekabeti sınırlayan anlaşmalar uyumlu eylemler iki ülkenin rekabet kanununda da yasaklanmıştır. Ayrıca muafiyete yer verilerek şartları açıklanmıştır. Ayrıca bazı konularda Türk Rekabet Kurumu tarafından Grup Muafiyet Tebliğleri çıkarılmıştır. Rus Rekabet Kanununda grup muafiyetinden bahsedilmemektedir. Rus Rekabet Kanununda kamu teşebbüslerinin rekabeti sınırlayan anlaşmaları ayrı olarak düzenlenmiştir.

Türk Rekabet Kanununda birleşme ve devralmalar olarak düzenlenen konu Rusya Rekabet Kanununda ekonomik yoğunlaşmalar olarak geçmektedir. Birleşme ve devralmalar RKHK'nun 7.maddesinde düzenlenmiştir ve bu maddenin uygulanması için Rekabet Kurumu tarafından bir Tebliğ yayınlanmıştır. Rekabet Kurulundan İzin Alınması Gereken Birleşme ve Devralmalar İle İlgili Tebliğ 7 Ekim 2010 tarihinde yenilenmiştir. Rus Rekabet Kanunu, Devlet kontrolüne tabi birleşme ve devralmalar ile ilgili ayrıntılı hükümlere sahiptir. Türkiye’de Tebliğ ile düzenlenen konu Rusya'da Rekabet Kanununun içerisinde yer almaktadır.

Türkiye'de rekabet ihlali durumunda Rekabet Kanunu uygulanmaktadır. Kanunun uygulanmasından Rekabet Kurumu sorumlu olduğu için ön araştırma ve soruşturma Rekabet Kurumu tarafindan yerine getirilmektedir. Yaptırımların uygulanmasından da Rekabet Kurumu sorumludur. Rusya'da ise rekabet ihlali durumunda Rekabet 
Kanununun yanı sıra İdari Suçlar Kanunu ve Ceza Kanunu da uygulanmaktadır. Rekabet ihlali varsa Rus Rekabet Otoritesi (FAS), Rekabet Kanunu ve İdari Suçlar Kanununa göre soruşturma yürütür ve para cezası verir. Eğer ihlal suç kapsamında ise soruşturma İçişleri Bakanlığı tarafından Ceza Kanununa göre yapılmaktadır.

Rekabet ihlali soruşturmalarında Türkiye'de rekabet kurulu nihai kararı verecek organdır ve 7 kişiden oluşmaktadır. Rusya'da ise her soruşturma için en 3 kişilik bir komisyon kurulur. Bankacılık sektörü ile ilgili ihlallerde Rusya Merkez Bankasından temsilciler de komisyona katılır.

Her iki ülkede de rekabet kurumunun verdiği kararlar temyiz edilebilir. Temyiz davası Türkiye'de Danıştay’da, Rusya'da ise bir tahkim (ticaret) mahkemesinde açılabilir.

\section{Kaynakça}

- $\quad$ Aslan, İ.Y. (2006), Rekabet Hukuku Dersleri, Ekin Kitabevi, Bursa.

- Güven, P. (2009), Rekabet Hukuku, Yetkin Yayınları, Ankara.

- Poroy, R. ve Yasaman H. (2001), Ticari İşletme Hukuku, Beta Yayınları, İstanbul.

- Türkiye'de Rekabet Hukuku ve Politikası, OECD Yayınları, 2005.

- Türk Rekabet Kurumu, http://www.rekabet.gov.tr

- OECD Peer Review Report on Russia's Competition Law and Policy, Document CCNM/GF/COMP/WD (2004) 2, www.oecd.org/.../competition/prosecutionandlawenforcement/32005515.pdf

- Federal Antimonopoly Service of Russian Federation, http://en.fas.gov.ru/

- Dmitriy Yanin, Russian Federation, http://competitionregimes.com/pdf/Book/Asia_Pacific/28RussianFederation.pdf

- $\quad$ Russia - Global Competition Review, Yaroslav Kulik, http://globalcompetitionreview.com/reviews/47/sections/164/chapters/1846/russia/ 


\title{
İnsan Ticaretinin Ekonomik ve Hukuki Boyutları Economic and Legal Aspects of Trafficking in Human Beings
}

\author{
Asst. Prof. Dr. Filiz Tepecik (Anadolu University, Turkey)
}

\begin{abstract}
In the next decade, trafficking in human beings is expected to be the largest part of the illegal markets such as drug and arms trafficking. Trafficking in human beings can be done in many different purposes which includes the sexual exploitation, the practices similar to slavery or servitude. The problem is becoming visible both for the Eurasian countries and for Turkey. Despite being an inhuman trade, all parties of the trafficking in human beings are rational economic agents and they are acting according to the rules of supply and demand. Therefore in this paper, this economic structure that nourish the illegal market is primarily be discussed. It is focused on the push and pull factors to this market members and this is tried to shown in a quantitative dimension of the market. Secondly, in order to combat trafficking in human beings, legal and social measures are being taken. These regulations generally aim to find and punish perpetrators, and /or protect victims of trafficking. But these regulations always cause a change of the benefits and the costs of the parties involved in trafficking in human beings. Thus the economic perspective are convenient to analyze these results. Finally, with this paper it is aimed to produce a common ground for people who want to work in this academic field.
\end{abstract}

\section{Giriș}

Insan ticareti kavramı, 19.yy’nın “beyaz köle ticareti” kavranmının izlerini taşımaktadır. 19.yy’da beyaz köle ticareti kavramı, Avrupalı ya da Amerikalı beyaz kadınların ticari seks piyasasında çalıştırılmak üzere transferini ve ticaretini ifade etmek için kullanılıyordu. Genellikle çalışan işçi sınıfından kadınları hedef alan bu ticaret, Josephine Butler (1828-1906) gibi kölelik karşıtı ve fahişeler için refah artırıcı tedbirleri savunan feministlerin düzenledikleri kampanyalarla 1910'da Mann Yasası (The White-Slave Traffic Act - Beyaz Kadın Ticareti Yasası) ile engellenmeye çalışılmıştır (Mann Yasası, 2013). Mann Yasası'nın ilk hali "herhangi bir ahlaksız amaç için beyaz kölelerin ve kadınların eyaletler arasında ulaşımını yasaklıyordu ve Avrupa ve Amerikalı çoğunluğu işçi sınıfından kadınları koruma altına alırken aynı zamanda göç ve mekânsal hareketliliğine bir sınırlılık getiriyordu (Doezema, 2002). Benzer şekilde 1911'de Hollanda'da genelevler yasaklanmıştı, 1919'da Rusya'da eski Çarlık rejiminin isteksiz kurbanları olan kadınların yeniden eğitilerek farklı mesleklere yönlendirilmelerinden bahsediliyordu (Prostitution, 2013).

1980'lerde yeniden küçüklerin fuhuş sektöründe yer alması, seks turizmi ve hatta AİDS'in yayılması ile insan ticareti ilgi çekmeye başlamıştır. 1996'da Birleşmiş Milletler, fuhuşu tanımlayarak insan ticaretini ile bağlantılı olarak "kadına yönelik şiddet” konusunda dünya çapında bir araştırma yapmak üzere Özel Raportör atamıştır. Bunu 2000 tarihli insan kaçakçılığı bağlantılı uluslararası organize suçlara ilişkin Sınıraşan Örgütlü Suçlara Karşı Birleşmiş Milletler Sözleşmesi takip etti. Sözleşme, uluslararası sınırlar arasında kişi, silah ve uyuşturucunun taşınmasını sınırlandırıyordu.

İnsan ticareti, "kuvvet kullanarak veya kuvvet kullanma tehdidi ile veya diğer bir biçimde zorlama, kaçırma, hile, aldatma, nüfuzu kötüye kullanma kişinin çaresizliğinden yararlanma veya başkası üzerinde denetim yetkisi olan kişilerin rızasını kazanmak için o kişiye veya başkalarına kazanç veya çıkar sağlama yoluyla kişilerin istismar amaçlı temini, bir yerden bir yere taşınması, devredilmesi, barındırılması veya teslim alınması anlamına gelmektedir. Bu tanım Birleşmiş Milletler çerçevesinde 12-13 Aralık 2000 tarihlerinde Palermo'da düzenlenen konferansta kabul edilen "Sınıraşan Örgütlü Suçlara Karşı Birleşmiş Milletler Sözleşmesine Ek İnsan Ticaretinin, Özellikle Kadın ve Çocuk Ticaretinin Önlenmesine, Durdurulmasına ve Cezalandırılmasına İlişkin Protokol'ün 3 maddesinden gelmektedir (Palermo protokolü, 2003)

Madde istismar terimini son derece detaylı ifade etmiştir. Maddeye göre istismar, asgari olarak, başkalarının fuhuşunun istismar edilmesini veya cinsel istismarın başka biçimlerini, zorla çalıştırmayı veya hizmet ettirmeyi, esareti veya esaret benzeri uygulamaları, kulluğu veya organların alınmasını içerecektir ( $3 / \mathrm{a})$. Bu nedenle insan ticareti, bireylerin cinsel sömürü, zorla çalıştırılma ve/veya organları için ticaretini içermektedir ve bu haliyle de insan ticareti modern kölelik olarak isimlendirilmektedir. Bu çalışmada da temelde bu üç başlık altında insan ticaretinin nedenleri ve boyutları üzerinde durulacaktır. Hukuki düzenlemelerin bu kara ticaretinin gelişimini üzerindeki etkisi tartışılacaktır.

\section{2 İnsan Ticareti}

İnsan ticareti bireylerin tedarik edilmelerini, kaçırılmalarını, bir yerden başka bir yere götürülmeleri, sevk edilmeleri veya barındırılmaları içerdiği için, farklı kavramlarla ifade edildiği görülmektedir. Örneğin "yasadışı göç”, “düzensiz göç”, “yabancıların kaçakçılı̆̆ı”, "sığınmacı hareketi” gibi kavramlar, biraz farklılıklarla aynı bireyleri sınıflandırmakta kullanılıyor olabilir. Bu nedenle Palermo protokolü, insan ticareti ile diğer insan 
hareketlerini ayırıcı bir tanım getirmek zorundadır. Tablo 1'de insan ticareti, cebri (zorla) çalışma koşulları ve insan kaçakçılığı arasındaki fark ve uluslararası düzenleme belgeleri yer almaktadır.

\begin{tabular}{|c|c|c|}
\hline Kullanılan Terim & Tanım & Belge \\
\hline İnsan Ticareti & $\begin{array}{l}\text { “İnsan ticareti”, kuvvet kullanarak veya } \\
\text { kuvvet kullanma tehdidi ile veya diğer bir } \\
\text { biçimde zorlama, kaçırma, hile, aldatma, } \\
\text { nüfuzu kötüye kullanma kişinin } \\
\text { çaresizliğinden yararlanma veya başkası } \\
\text { üzerinde denetim yetkisi olan kişilerin rızasını } \\
\text { kazanmak için o kişiye veya başkalarına } \\
\text { kazanç veya çıkar sağlama yoluyla kişilerin } \\
\text { istismar amaçlı temini, bir yerden bir yere } \\
\text { taşınması, devredilmesi, barındırılması veya } \\
\text { teslim alınması anlamına gelir. İstismar terimi, } \\
\text { asgari olarak, başkalarının fuhuşunun istismar } \\
\text { edilmesini veya cinsel istismarn başka } \\
\text { biçimlerini, zorla çalıştırmayı veya hizmet } \\
\text { ettirmeyi, esareti veya esaret benzeri } \\
\text { uygulamaları, kulluğu veya organların } \\
\text { alınmasını içerecektir. }\end{array}$ & $\begin{array}{l}\text { Sınıraşan Örgütlü Suçlara Karşı } \\
\text { Birleşmiş Milletler Sözleşmeşine } \\
\text { Ek İnsan Ticaretinin, Özellikle } \\
\text { Kadın ve Çocuk Ticaretinin } \\
\text { Önlenmesine, Durdurulmasına ve } \\
\text { Cezalandırılmasına İlişkin } \\
\text { Protokol, } 2000 \\
\text { (Palermo protokolü) }\end{array}$ \\
\hline $\begin{array}{l}\text { Sömürü, zorla veya } \\
\text { zorunlulukla çalıştırma }\end{array}$ & $\begin{array}{l}\text { Cezalandırma tehdidi altında, söz konusu } \\
\text { kişinin rızası olmaksızın iş ve hizmet } \\
\text { gördürme }\end{array}$ & $\begin{array}{l}\text { Cebri veya Mecburi Çalıştırmaya } \\
\text { İlişkin Sözleşme, } 1930\end{array}$ \\
\hline İnsan Kaçakçılığ & $\begin{array}{l}\text { Vatandaşı olmadığı bir ülkeye, bir kişinin } \\
\text { mali veya maddi çıkar elde etmek amacıyla } \\
\text { illegal girişi }\end{array}$ & $\begin{array}{l}\text { Sınıraşan Örgütlü Suçlara Karş1 } \\
\text { Birleşmiş Milletler Sözleşmesi, } \\
2000 \text {. }\end{array}$ \\
\hline
\end{tabular}

Tablo 1: İnsan Hareketliliği Kavramları ve Uluslararası Düzenlemeler Kaynak: ICPC, 2012: 27.

Tablodan görüklebileceği gibi, insan ticaretinde de, baskı ve/veya daha iyi iş ve kazanç vaadi ile evlerinden, ülkelerinden göçen bireyler söz konusudur. Fakat bununla birlikte göçen bireyler, ulaştıkları ülkelerde serbest olmamaktadırlar, Genellikle getiren birey ya da kuruluşa borç ya da benzeri başka bir esaret zinciri ile bağlılıkları sürmektedir. Cebri çalıştırma denilebilecek bu durum, insan kaçakçıllı̆ında ticari seks piyasasından ağır bedensel iş̧̧ilik gerektiren inşaat ya da tarla iş̧̧iliğine, askerliğe kadar uzanabilmektedir. Göçmen kaçakçılığı ise, bireylerin gönüllü olarak, yasal girişin ya da çıkışın mümkün olmadığı bir ülkeden diğerine gidebilmek için birini kiralamasını içermektedir. Hedef ülkeye ulaşıldıktan sonra genellikle, kaçak birey ne yapacağı konusunda özgürdür.

Diğer bir bakış açısı ile insan kaçakçılığı göçmenlik yasaları ihlali nedeniyle devlete karşı bir suçtur. Oysa insan ticareti, baskı ve sömürü yoluyla kurbanın haklarını ihlal ettiği için kişiye karşı bir suçtur (ICMPD, 2013). Bu iki tanımın dolaylı sonucu olarak, göç söz konusu olduğunda, suç denetiminin odağı, bir ülkeye yasadışı giriş̧ veya konaklama olmaktadır ve yasayı ihlal eden göçmenin kendisidir. Bu odak, insan hakları ihlallerini ve sömürüyü içine alamadığı için, insan ticareti sözkonusu olduğunda doğru suçluyu bulma konusunda yetersiz kalabilmektedir. Hatta çoğunlukla geri planda kalan organize bir örgüt aynı işi yapmaya devam edebilmektedir. Hükümetler (yönetimler) öncelikle işverenleri ve sömürücüleri hedef alsa bile, suçun mağdurlarının işbirlikçi olarak değerlendirilme riski vardır (UNODC, 2008: 90).

İnsan kaçakçılığının kurbanları, göçmeye ikna edildikleri için sınırlardan hukuka uygun olarak ya da olmayarak geçtiklerinde göçmen olduklarını düşünmektedirler. Götürenler için yoğun beden faaliyeti gerektiren işlerde ya da daha kötüsü ahlak dışı işlerde çalışmaya zorlandıklarında, bulundukları durumun hukuki adıda değişmektedir. Tablo 2'de Belser'in Dünya Çalışma Örgütü (ILO) için hazırladığı insani hareketliğin boyutlarına ilişkin bir tahmin görülmektedir. Tabloyu yorumlamadan önce suç istatistiklerinin niteliklerinden bahsetmek anlamlı olabilir. Diğer istatistiklerden farklı olarak suç istatistikleri büyük bir karanlık alan taşılar. Örneğin işlenmekle birlikte bazı suçlar açığa çıkmaya bilir, açık hale gelenler ihbar edilmeyebilir. Bu nedenle istatistiklerin gösterdiği resmi suçluluk ile gerçek suçluluk arasında büyük farklar vardır. Bu karanlık alan, illegal mal ve hizmet alanlarında daha büyüktür. Diğer bir ifade ile bu makalede kullanılacak olan veriler büyük bir karanlık alanın açıya çıkmış kısmı olarak değerlendirilmelidir. Tablo 2'de 2005 yılı için cebri ve mecburi çalıştırmanın diğer sömürü çeşitlerine baskın olduğu görülmektedir ve sayılar bu tür uygulamaların en yaygın şekilde Asya ve Pasifik'de olduğunu düşündürmektedir. Tablodan sanayileşmiş ekonomilerde ve geçiş ekonomilerinde cinsel sömürünün; diğerlerinde ise, cebri çalıştırılmanın baskın olduğu da düşünülebilir. 


\begin{tabular}{|c|c|c|c|c|c|c|c|c|}
\hline & $\begin{array}{l}\text { Zorla } \\
\text { Ticari } \\
\text { Cinsel } \\
\text { Sömürüi } \\
\text { (kişi) }\end{array}$ & $\%$ & $\begin{array}{l}\text { Zorla } \\
\text { Ekonomik } \\
\text { Sömürü } \\
\text { (kişi) }\end{array}$ & $\%$ & $\begin{array}{l}\text { Karışık } \\
\text { veya } \\
\text { Belirsiz } \\
\text { (kişi) }\end{array}$ & $\%$ & $\begin{array}{l}\text { Toplam } \\
\text { (kişi) }\end{array}$ & $\%$ \\
\hline $\begin{array}{l}\text { Sanayileşmiş } \\
\text { ekonomiler }\end{array}$ & 200000 & 14,4 & 84000 & 1,1 & 58000 & 9,5 & 342000 & 3,5 \\
\hline$\%$ & 58,5 & & 24,6 & & 17,0 & & & \\
\hline Geçiş ekonomileri & 98000 & 7,1 & 10000 & $\mathbf{0 , 1}$ & 103000 & 16,9 & 211000 & 2,2 \\
\hline$\%$ & 46,4 & & & & 48,8 & & & \\
\hline Asya \& Pasifik & 902000 & 64,9 & 5964000 & 76,3 & 434000 & 71,0 & $\begin{array}{l}7300 \\
000\end{array}$ & 74,4 \\
\hline$\%$ & 12,4 & & 81,7 & & & & & \\
\hline $\begin{array}{l}\text { Latin Amerika \& } \\
\text { Karaibler }\end{array}$ & 115000 & 8,3 & 994000 & 12,7 & 3000 & 0,5 & 1112000 & 11,3 \\
\hline$\%$ & 10,3 & & 89,4 & & & & & \\
\hline Sahra altı Afrikası & 50000 & 3,6 & 531000 & 6,8 & 13000 & 2,1 & 594000 & 6,1 \\
\hline$\%$ & 8,4 & & 89,4 & & & & & \\
\hline $\begin{array}{l}\text { Orta Doğu ve Kuzey } \\
\text { Afrika }\end{array}$ & 25000 & 1,8 & 229000 & 2,9 & - & & 254000 & 2,6 \\
\hline$\%$ & 9,8 & & 90,2 & & & & & \\
\hline Dünya & $\begin{array}{l}1390 \\
000\end{array}$ & 100 & 7812000 & 100 & 611000 & 100 & $\begin{array}{l}9813 \\
000\end{array}$ & 100 \\
\hline$\%$ & 14,2 & & 79,6 & & 6,2 & & 100,0 & \\
\hline
\end{tabular}

Tablo 2: Dünya'daki Insan Ticaretinin Boyutları Kaynak: Belser, deCock, Mehran (2000)

\section{3 İnsani Sömürünün Yüzleri}

İnsani sömürü, hukuki açıdan birkaç farklı şekil alabilmektedir. Cebri çalıştırma amacıyla, cinsel sömürü amacıyla, organ ticareti amacıyla insan ticareti yapıldığı görülmektedir:

Cebri Çalışma İçin İnsan Ticareti: Uluslarası Çalışma örgütüne göre kölelik, adam kaçırma, kamu hizmetlerine zorla katılım, tarım sektöründe zorla çalıştırılma, alıkonarak çalıştırma, asker tarafından zorla çalıştırılma, asker olarak çalıştırılma gibi formlarndan bahsetmiş olmasına rağmen, cebri çalıştırılma "ter işleri" denilen yoğun bedensel aktivite gerektiren herhangi bir alanda olabiliyor. Geçmişte daha çok tarım sektöründe iken, günümüzde yaşlıların bakımı, ev bakımı gibi iç kulluk kabul edilebilecek işlerde, inşaat sektörü gibi ağır işçilikte kadın, erkek veya çocuklar zorla, uzun saatler ve ücretsiz çalıştırılabilmektedir. Kurbanlar, genellikle sahte seyahat belgeleri ile seyahat ederler ve onlara bu belgeleride sağlayan organize bir ağ tarafindan, daha sonra borç sözleşmeleri ile bağlanacakları, cinsel köleliğe, sahte evliliklere zorlanacakları hedef ülkeye taşınırlar. Aşağıda Avrupa İnsan Hakları Mahkemesi'ne yansıyan olaylardan bir örnek görülmektedir. Tablo 2'de ve Şekil 1 'de insan ticaretinin büyük bir kısmının cebri çalışmadan oluştuğu görülmektedir.

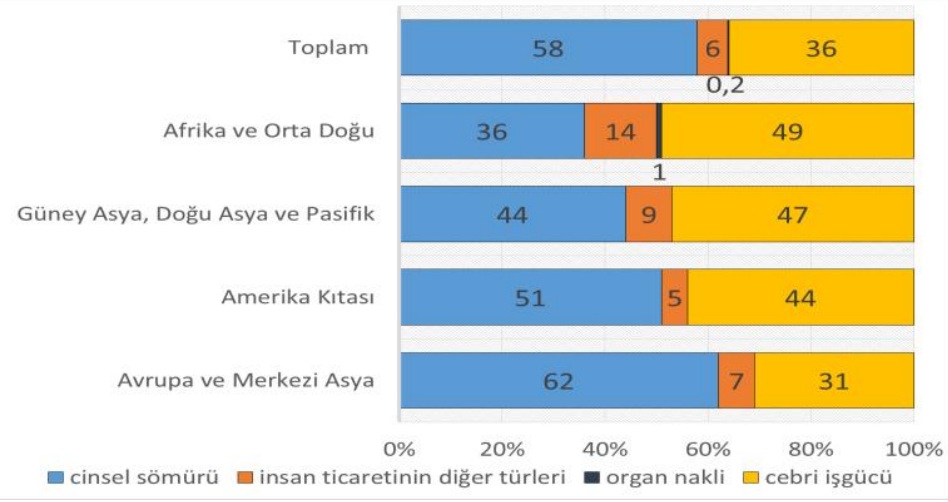

Şekil 1: Sömürü Biçimlerine Göre Tesbit Edilen Kurban Sayılarının Oranı (\%, 2007-2010) Kaynak: UNODC, 2012: 35 .

C.N. - Birleşik Krallık Davası (no. 4239/08): Uganda vatandaşı başvuran, Uganda'da cinsel tacizden kaçarak sahte pasaportla Birleşik Krallık’a geldiğini iddia etmektedir. Ülkeye giriş yaptıktan sonra belgeleri elinden alınmış ve Parkinson hastası bir yaşlının bakımında çalıştırılmıştır. Hem gece hem gündüz çalışmaya zorlandığı halde kendisine hiçbir ücret ödenmemiştir. Sürekli tecrit halinde tutulmuş, şiddet ve sınırdış1 
edilmekle tehdit edilmiştir. O sırada yürürlükte bulunan kanunlarda kullaştırma ve zorla çalıştırma suçları yer almadığı için İngiliz mahkemelerinden koruma talebinde bulunamadığından bahisle, Birleşik Krallık'ın özellikle 4. Maddeyi ihlal ettiğinden şikayetçidir. (Avrupa İnsan Hakları Mahkemesi, Bilgi Notu- Zorla çalıştırma ve insan ticareti, Eylül 2012)

Cinsel Sömürü Amacıyla Kadın Ticaret: İnsan ticaretin bu yaygın formu dünyanın bütün bölgelerini etkilemektedir. İnsanlar kendi ülkelerinden ikna edilerek ya da zorla bir başka bölgeye, ülkeye göçmeye ikna edilerek fuhuş sektörünün herhangi bir alanında kendi rızası olmadan ve çoğunlukla ücret almaksınız çalıştırılmaktadır. Diğer bir ifade ile ticari seks piyasasında çalışma cebri çalışmanın bir sektörde yoğunlaşmış şeklidir. Cebri çalışmada yoğun olarak erkekler çalıştırılmasına rağmen ticari seks piyasası daha çok kadınları ve yetişkin kadınları içermektedir (Şekil 2). Ticari seks sektörü, randevu evleri, gece kulüpleri ve teknolojinin gelişmesi ile internet aracılığı ile yapılan her türlü pornografik yayın aracılığı ile gelişmektedir. Bu sektör temel metası olarak kadını kullanmaktadır.

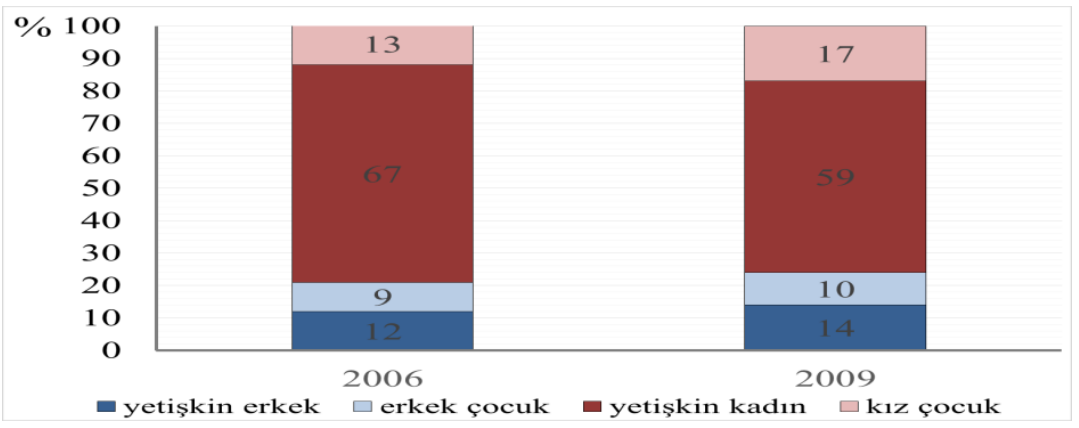

Şekil 2: İnsan Ticaretinden Etkilenen Bireylerin Oranları Kaynak: UNODC, 2012: 26-27.

Turizmde çocukların ticari cinsel sömürü: Cinsel sömürü amacıyla insan ticaretin daha da kötüsü küçüklerin (18 yaşından küçükler) ticaretinde ortaya çıkmaktadır. Uluslarası sözleşme kendi rızası ile bile olsa küçüklerin ticaretini illegal kabul etmiştir (Palermo protokulu, 3/c). Bununla birlikte farklı ülkelerde cinsel ilişki ve evlilik yaşı ile ilişkili farklı hukuki düzenlemeler vardır. Bu nednele 18 yaşından küçükler cinsel ilişki için ehil sayıldıkları ülkeler olabilir. Cinsel ilişki için kimin küçük sayıldığına ilişkin bu farklılıklar, küreselleşmenin de etkisiyle, küçüklerle cinsel ilişkiye girmek isteyenler için ekonomik bir pazar yaratmaktadır. Örneğin 18 yaşından küçüklerin cinsel istismarının hukuki olarak yasaklanmadığı veya kovuşturulmadığı ülkelere, ucuz hava yolculukları ile gidilen turistik gezileri düzenlenmektedir. Şekil 3'de küreselleşme ile artan çocuk pornografisi de dikkat çekmektedir.

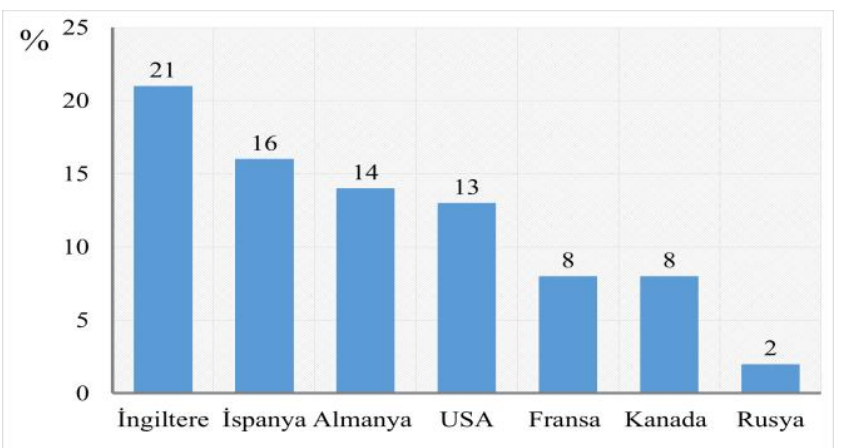

Şekil 3: Çocuk Prografisi Paylarl (2009) Kaynak: UNODC, 2010: 13

Organ ticareti: Organlarını (sadece böbreklerin de değil, kalp, karaciğer, doku) kullanmak amacıyla insanların ticareti, hızla büyüyen bir suç alanıdır. Birçok gelişmiş ülkede, yaşlanan nüfus ve diyabetin artışı ile tetiklenen organ nakli ihtiyacı, tıp alanındaki nakil için gereken koşullarının azaltılması ile, suç örgütleri için paha biçilmez bir alan haline gelmesine neden olmaktadır. Suç örgütleri, çaresiz hastalar ile bazen gönüllü bezen gönülsüz potansiyel donörler arasında bağlantı kurarak para kazanmaktadırlar. Nakil işlemleri genellikle tıbbi takip koşullarından uzak, kötü koşullarda yapıldığı için, gönüllü olsa bile dönerlerin sağlıkları, hatta hayatları risk altında kalmaktadır. Fakat bu endüstri sadece organlarla sınırlı değil. Taşıyıcı annelikten, kan ve doku nakline, hatta tıp fakültelerinin ihtiyacı olan vücut ve iskeletlerin teminine oldukça geniş bir yelpazeyi içeriyor. $\mathrm{Bu}$ alanda Hindistan adı ençok geçen ülke olarak dikkat çekmektedir. Örneğin, Hindistan 1985'de insan kalıntılarının ihracatını yasaklayıncaya kadar bu alandaki en büyük tedarik kaynağı idi (Scott, 2007).

Yasaklama tedarik piyasasının çökmesine neden olduktan sonra, Batılı ülkeler Çin ve Doğu Avrupa'ya döndü. Bununla birlikte Batı Bengal karaborsa satıcıları, eski usul yöntemlerle, mezar soygunları ile tedarik ediyor olabilirler (Scott, 2007). Burada dikkat edilmesi gereken nokta, insanların yasal bağışçılarda olabilecekleridir. 
Dğer bir ifade ile insan bedeninin parçalarının nakillerinin insan ticaretine konu olabilmesi için, nakil olan bireylerin rızasının olmaması gerekmektedir. Örneğin Tablo 3'de, eğer yasal mirasçılarının bilgisi dışında insan bedeninin parçalarını temin ediyorlarsa, mezar soyguncuları, morglar ya da cenaze evleri yasal olmayan yerler arasında düşünülebilir. Bunun dışında örneğin kan çiftliği, kaçarılmış bireyleri zorla bir yerde tutarak belirli aralıklarla kan satışı yapmak için onlardan zorla kan alan bir ticaret fikridir. Çin'de idam mahkumlarının bedenlerinden yararlanıldığı benzer şekilde çıkan haberler arasındadır.

\begin{tabular}{|c|c|c|}
\hline İnsan Bedeninin Parçaları & Fiyat1 & Temin Noktaları \\
\hline İskelet & $2993-5500$ dolar & Mezar soygunculuğu; yasal bağışlar. \\
\hline Kan & $\begin{array}{l}\text { Hindistan: Yarım litresi } 25 \\
\text { dolar } \\
\text { ABD: yarım litresi } 337 \text { dolar }\end{array}$ & $\begin{array}{l}\text { Kan bağışlayanlar; Hindistan'da kan } \\
\text { çiftliği }\end{array}$ \\
\hline Saç & 308 dolar & Dolaysız satışlar; Hint tapınakları \\
\hline Kornea & 24400 dolar & Morglar; hayatını kaybedenlerden \\
\hline Kalp & $\begin{array}{l}\text { Yasal:997 700; yasa dışı: } 119 \\
000\end{array}$ & Çinli mahkûmlar; \\
\hline Karaciğer & 557100 dolar - 157000 dolar & İdam mahkûmları; Filipinlerde satış \\
\hline Böbrek & $\begin{array}{l}\text { Hindistan: } 15 \text { 000 dolar; Çin: } \\
62000 \text { dolar; ABD: } 262900 \\
\text { dolar }\end{array}$ & $\begin{array}{l}\text { Hayatını kaybedenlerden, yasal bağışçılar; } \\
\text { idam mahkûmları, organlarını satanlar }\end{array}$ \\
\hline $\begin{array}{l}\text { Rahim (taşıyıcı annelik } \\
\text { olarak) }\end{array}$ & $\begin{array}{l}\text { Hindistan. } 20000 \text { dolar }-30 \\
000 \text { dolar }\end{array}$ & Bazı ülkelerde yasal \\
\hline Kemik & 5465 dolar & $\begin{array}{l}\text { Cenaze evleri, morglar, ölümlerinden } \\
\text { sonrasını planlayan yasal bağışçlar }\end{array}$ \\
\hline
\end{tabular}

Tablo 3: Organ Borsası Kaynak: Koçak, 2011.

\section{4 İnsan Ticaretinin Belirleyenleri}

Insan ticareti, diğer ticaret alanları gibi fayda maliyet analizi yapılan bir alandır. Diğer bir ifade ile insanları sömürü aracı olarak alan satan insan tacirleri, sadece piyasa koşulları kâr için uygun olursa, seks sömürüsü ya da organ sömürüsü için insan satacaktır. Kanıtlar, insan tacirlerinin organize suç şirketlerine dahil olduklarını ve kâr amacı güden işadamları gibi hareket ettiklerini göstermektedir (Jakobsson ve Kotsadam, 2011: 88).

Tablo 3'de organ piyasasının fiyat koşullarının kâr için uygun olduğu görülmektedir. Ekonomik ya da seks sömürü için piyasa koşulları ülkeden ülkeye değişmektedir. Örneğin ticari seks endüstrisi içn, piyasa kimi ülkeler de tamamen yasaklanmış kimi ülkelerde tamamen serbest bırakılmış kimi ülkelerde kısmen düzenlenmiştir. Örneğin Almanya'da 2002'den beri fahişelik düzenli vergiye konu bir iş kabul edilmektedir. Düzenlemeden günümüze Avrupa'nın en büyük fuhuş piyasalarından biri olarak ayrıca dikkat çekmektedir (Cho, Dreher ve Neumayer, 2013: 75). İsveç 1999'da ticari seksin bütün türlerini yasaklamıştır. Danimarka ise, bireysel ve kendi hesabına çalışanlar tarafından yapılan fuhuşa izin vermektedir. Fakat genelev ya da herhangi bir seviyede işverenin bulunduğu örgütlü bir fuhuş illegal kabul edilmektedir. Ya da çok bilinen Hollanda, Amsterdam'da belli bir bölgede, işverenlerinde bulunduğu cinsel ticarete belgeli olarak izin vermektedir. Yasaklamaların olduğu ülkelerde fuhuşa katılan taraflar, özellikle arz edenler cezalandırılır; düzenlemenin yapıldığı ülkelerde ise, fuhuşun piyasasının nasıl sunulacağı düzenlenmektedir; legalleştirme durumunda ise, satın alıcılar için cezalar düşünülmüştür (Jakobsson ve Kotsadam, 2011: 90-91).

Farklı şekillerde düzenlenmiş bu piyasa yapıları, insan ticareti ile ilişkisi açısından çok tatışılmaktadır. Örneğin Agnatise (2004) fuhuşu yasaklamanın insan ticaretini ile mücadele de kanun gücünün ellerini bağladığını düşünmektedir (Cho, Dreher ve Neumayer, 2013: 88). Hughes (2000: 651) kanıtların seks endüstrisinin legalleşmesinin bu sektörünün ihtiyacı olan kadınların talebini karşılamak için ticaretin artmasına neden olduğunu gösterdiğini düşünmektedir. Farley (2009: 313) benzer şekilde fuhuşun legalleştiği yerlerde, bu bölgelere yönelik ticaret artışı olduğunu iddia etmektedir. Aksine Cho, Dreher ve Neumayer (2013: 67) fuhuşun legalleşmesinin seks çalışanları için çalışma ve güvenlik şartlarını geliştirdiğini, piyasa fiyatını düşürmesi nedeniyle de kadın ticaretini azaltıcı etkisi olduğunu düşünmektedirler. Bununla birlikte yaptıkları ampirik çalışmada, legal fuhuş deneyimine sahip olan ülkelerde, ölçek ekonomisinin çalışması nedeniyle daha büyük ticaretle yüzyüze kaldıklarını düşünmüşlerdir (Cho, Dreher ve Neumayer, 2013: 76).

Ayrıca hukuki düzenleme piyasanın fiyat yapısını değiştirmektedir. Bir mal ve hizmet için olası piyasanın yasaklanması, arz maliyetlerini arttırıcı unsur olarak yansımaktadır. Diğer bir ifade ile fiyat artmakta ve tüketilebilir miktar düşmektedir. Bununla birlikte karaborsa kartellerinin kurulmasına, sunulan hizmetin kalitesinin düşmesine, hatta şiddet kullanımının artmasına ya da resmi görevlilere verilen rüşvet nedeniyle yozlaşmanın artmasınada neden olabilir. 
Ekonomi içinde ayrıca arz ve talep taraflarını harekete geçiren yapıda önemlidir. Bir insan tacirinin yasaklanmış ya da belli düzenlemelerle legalleşmiş bir piyasada devam etmesini sağlayan piyasanın potansiyel karlılı̆̆ıdır. Kâr hasıla ve maliyet arasındaki ilişkiye bağlı olduğu için, hasıla fiyata ve satış miktarına, onlarda piyasanın talep yapısına diğer bir ifade ile hedef ülkedeki kişi başına gelire bağlı olarak düşünülebilir.

İnsan ticaretinin maliyetleri arasında, menşe ülkedeki bireyin hedef ülkeye ulaştırılması için gerekenler, örneğin sahte pasaport belgeleri, sınırı aşmak için gereken düzenlemeler, ya da hedef ülkedeki sahte firmalar vb. bulunabilir. Bu nedenle kaçakçıllk genellikle organize suç örgütleri ile yakın ilişkilili kabul edilmektedir.

Sosyologlar ve ceza konusunda araştırmalar, bireyleri çeken ve iten bazı faktörlerin, işgücü piyasasında bireyi, insan ticareti ve sömürü için uygun ve savunmasız yaptığını düşünmektedirler (Tablo 4). Örneğin özellikle kadınlar için uygun ve yeterli ücret içeren işlerin azlığı, bulundukları ülkede politik yapının bozulmuş olması, onları kendi ülkesinden uzaklaşmaya hazır hale getirmektedir; ülkelerinden itmektedir. Küreselleşme, ekonomik ve politik istikrarsızlık, hastalıklar, ailelerin parçalanması, savaş gibi pek çok neden yüzünden Dünyanın her tarafinda savunmasız insanlar var (Wheaton vd, 124) ve pek çok neden yüzünden insan ticareti için uygun adaylar haline geliyorlar. Bu ülke içinde ya da ülkeler arasında, tacirler tarafinda ulaşılan savunmasız insan sayısının artmasına neden olmaktadır. Bireylerin gitmek istedikleri ülkedeki daha iyi yaşam koşulları, daha iyi işler de onlar için çekici faktörler olarak işlemektedir.

\begin{tabular}{|l|l|l|}
\hline Iten Faktörler & Çeken Faktörler & \\
\hline Istihadam yetersizlĭgi, & Ekonomik eşitsizlik (evsahibi ülke zengin olarak görülüyor); & Joudo Larsen, \\
Eğitimsizlik, & Daha iyi yaşam kalitesi; & Lindley, and \\
Çevresel bozulma, & Girmek için firsat (göç konusunda yolsuzluk ya da yasal & Putt (2009). \\
Doğal afetler & boşlukları); & \\
Zulüm, savaş, & Gözenekli sınırları; & \\
Huzursuzluk, & Yasadı̧ı̈ göç için cezaların caydırıcı olmaması. & \\
Politik istikrarsızlık. & & \\
\hline & & Othman \\
\hline Cinsiyet, & Yerel ekonomi & $(2006)$ \\
Yaş, & Kültür, & \\
Eğitim, & Politik istikrar & \\
Çocuksayısı, & Küreselleşme, & \\
Sosyal statü, & Bilgi & \\
Hanehalkı & & \\
kombinasyonu, & & \\
Aile refahı & & \\
\hline
\end{tabular}

Tablo 4: Bireylerin Karar Vermesinde Etkenler

Bütün bu faktörlerle birlikte, maliyetlere katkı yapan, liberal fuhuş düzenlemeleri de düşünmek gerekmektedir. SSCB dağılmadan önce, ekonomik huzursuzlukların olduğu Afrika, Latin Amerika insanları için kaçılan yerler haline gelmiş̧ir. Gitmek için seçilen ülkeler ise, insan kaçakçılarının, gerek sınırlardan geçerken sorun yaşamadığı, gerek daha sonraki sömürü için uygun ortamın bulunduğu ülkeler arasından seçilmektedir. Bu günümüz dünyasında geçiş ekonomileri için Türkiye, Rusya ve çeşitli Avrupa ülkeleri gibi görülmektedir. Tablo 5 'de seçilmiş ülkeler için insan ticaretinin yolları görülmektedir.

Tabloya göre Rusya ana transit yolu olarak dikkat çekmektedir. Dağılan SSCB'nin eski üye devletlerinin insanlarının önce Rusya'ya, oradan da satın almak ve kullanmak için yeterince parası olan Batı Avrupa'ya ya da ABD'ye aktığı görülmektedir. Türkiye'nin de Rusya gibi ana arter olmamakla birlikte, bu ticarette benzer bir tarnsit rol üstlenmiş görülmektedir. Hem Rusya hem de Türkiye için, insan tacirliğinin yöntemlerini kolaylaştıııı bazı özellikler taşıdıkları söylenebilir.

\section{Sonuç}

Güvenlik açıkları daha iyi bir yaşam ya da baskı veya yoksulluk kaçmak ihtiyacı için arzuyu içermektedir. Gelişmekte olan pek çok ülkelerin insanlarının ihtiyaçlarını karşılamaktaki yavaşlıkları, sıradan insanların yaşamlarını savunmasız hale getirmektedir. Bu durumu düzeltmek ya da daha doğru bir ifade ile düzenleyebilmek, insan ticaretinin çok yönlü yapısını anlamaktan geçmektedir. 


\begin{tabular}{|c|c|c|}
\hline \multirow[b]{3}{*}{ 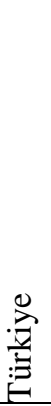 } & Menşe: orta & $\begin{array}{l}\text { Rapor edilen istikametler } \\
\text { Orta: ingiltere } \\
\text { Düșük: Avusturya, Almanya, Yunanistan, Israil, Italya, Suudi Arabistan }\end{array}$ \\
\hline & Transit: yüksek & $\begin{array}{l}\text { Azerbaycan ve Bağımsız DevletlerTopluluğu diğer devletlerinden Avrupa'ya. } \\
\text { Moldova, Romanya, Rusya, Ukrayna'dangenelolarakİsrail'eve Batı Asya’ya. }\end{array}$ \\
\hline & $\begin{array}{l}\text { Hedef: Çok } \\
\text { Yüksek }\end{array}$ & $\begin{array}{l}\text { Türkiye için rapor edilen kökenler: } \\
\text { Yüksek: Bulgaristan, Gürcistan, Moldova, Romanya, Rusya, Ukrayna. } \\
\text { Orta: Azerbaycan, Beyaz Rusya, Çek Cumhuriyeti, Kazakistan, Kırgızistan. } \\
\text { Düşük: Arnavutluk, Ermenistan, Hırvatistan, Macaristan, Hindistan, İran, Irak, Ürdün, } \\
\text { Letonya, Litvanya, Filipinler, Tacikistan, Özbekistan }\end{array}$ \\
\hline \multirow{3}{*}{ 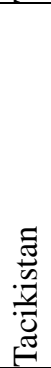 } & Menşe: orta & $\begin{array}{l}\text { Rapor edilen istikametler } \\
\text { Orta: Kanada, Almanya, İsrail, ABD, belirtilmemişBatıAvrupa. } \\
\text { Düşük: Arnavutluk, Belçika, Kıbrı, Fransa, Yunanistan, Macaristan, İran, İtalya, } \\
\text { Japonya, Kazakistan, Kırgızistan, Hollanda, Pakistan, Polonya, Portekiz, Kore } \\
\text { Cumhuriyeti, Rusya, Suudi Arabistan, İsviçre, Türkiye, Ukrayna, Birleşik Arap } \\
\text { Emirlikleri, İngiltere, Özbekistan, genel olarak Batı Asya, Yemen. }\end{array}$ \\
\hline & Transit: N.R. & NR \\
\hline & $\begin{array}{l}\text { Hedef : Çok } \\
\text { düşük }\end{array}$ & Çok Düşük: Kazakistan, Ukrayna, Özbekistan. \\
\hline \multirow[b]{3}{*}{$\stackrel{\pi}{\stackrel{\pi}{2}}$} & $\begin{array}{l}\text { Menşe: } \\
\text { ÇokYüksek }\end{array}$ & $\begin{array}{l}\text { Ülke dışına rapor edilen istikametler: } \\
\text { Yüksek: Belçika, Bulgaristan, Finlandiya, Almanya, Yunanistan, İsrail, İtalya, Japonya, } \\
\text { Hollanda, Polonya, İspanya, İsviçre, İngiltere, Türkiye, ABD. } \\
\text { Orta: Arnavutluk, Avusturya, Bosna Hersek, Kanada, Çin, ÇekCumhuriyeti, } \\
\text { Danimarka, Mısır, Fransa, Kosova- (Sırbistan ve Karadağ), Makao ÇinSAR, Norveç, } \\
\text { Güney Afrika, Tayland, Makedonya. } \\
\text { Düşük: Avustralya, Bahreyn, Kosta Rika, Kıbrıs, Estonya, HongKong ÇinSAR, } \\
\text { Letonya, Lübnan, Litvanya, Malezya, Meksika, Pakistan, Filipinler, Portekiz, Katar, } \\
\text { Kore Cumhuriyeti, Romanya, Suudi Arabistan, Sırbistan ve Karadağ, Slovenya, } \\
\text { SriLanka, Suriye Arap Cumhuriyeti, İsveç, Ukrayna, Birleşik Arap Emirlikleri. }\end{array}$ \\
\hline & Transit: Orta & $\begin{array}{l}\text { Insan ticareti mağdurları için AnaTransit: } \\
\text { Orta Asya ve Moldova'dan İsrail'e ve bazı Batı Avrupa ülkelerine. }\end{array}$ \\
\hline & Hedef: Orta & $\begin{array}{l}\text { Orta: Ukrayna. } \\
\text { Düşük: Ermenistan, Azerbaycan, Beyaz Rusya, Brezilya, Çin, Kazakistan, Kırgızistan, } \\
\text { belirtilmemiş Orta Asya, Tacikistan, Zambiya. }\end{array}$ \\
\hline \multirow{3}{*}{ 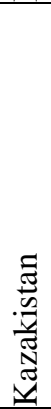 } & $\begin{array}{l}\text { Menşei: } \\
\text { Yüksek }\end{array}$ & $\begin{array}{l}\text { Ülke dışına rapor edilen istikametler: } \\
\text { Yüksek: Yunanistan. } \\
\text { Orta: Bosna Hersek, Kanada, Fransa, Almanya, İsrail, İtalya, KoreCumhuriyeti, } \\
\text { Türkiye, Birleşik Arap Emirlikleri, ABD. } \\
\text { Düşük: Arnavutluk, Belçika, Çin, Kıbrıs, Japonya, Kosova (Sırbistan ve Karadağ), } \\
\text { Malezya, Hollanda, Pakistan, Portekiz, Rusya, İsviçre, Tacikistan, İngiltere. }\end{array}$ \\
\hline & Transit:Orta & $\begin{array}{l}\text { Kırgızistan'dan Birleşik Arap Emirlikleri’ne; Batı Asya'dan, Batı Avrupa'ya ve } \\
\text { Rusya’ya }\end{array}$ \\
\hline & Hedef: Orta & $\begin{array}{l}\text { Orta: Kırgızistan. } \\
\text { Düşük: Tacikistan, Özbekistan. }\end{array}$ \\
\hline \multirow{3}{*}{ 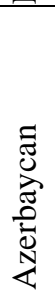 } & Menşei: Orta & $\begin{array}{l}\text { Ülke dışına rapor edilen istikametler: } \\
\text { Orta: Kanada, Almanya, Türkiye, Birleşik Arap Emirlikleri, ABD. } \\
\text { Düşük: Bosna Hersek, Kıbrıs, Mısır, Fransa, Yunanistan, İran, İsrail, İtalya, Japonya, } \\
\text { Lübnan, Hollanda, Norveç, Pakistan, Polonya, Rusya, İspanya, İsveç, İsviçre, } \\
\text { Makedonya, İngiltere, Özbekistan. }\end{array}$ \\
\hline & Transit:Düşük & Moldova, Rusya, Ukrayna ve BDT'dan genel olarak Türkiye’ye ve BatıAsya'ya \\
\hline & Hedef: NR & NR \\
\hline \multirow{3}{*}{ 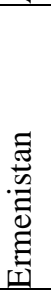 } & $\begin{array}{l}\text { Menşei: } \\
\text { Yüksek }\end{array}$ & $\begin{array}{l}\text { Ülke dışına rapor edilen istikametler: } \\
\text { Orta: Kanada, Almanya, İsrail, ABD, belirtilmemişBatıAvrupa. } \\
\text { Düşük: Bosna Hersek, Mısır, Fransa, Yunanistan, İtalya, Japonya, Lübnan, Hollanda, } \\
\text { Polonya, Rusya, İsviçre, Makedonya, Türkiye, Birleşik Arap Emirlikleri, İngiltere, } \\
\text { genel olarak Batı Asya. }\end{array}$ \\
\hline & Transit:NR & NR \\
\hline & Hedef: NR & NR \\
\hline
\end{tabular}




\begin{tabular}{|c|c|c|}
\hline \multirow{3}{*}{ : } & Menşe: Yüksek & $\begin{array}{l}\text { Ülke dışına rapor edilen istikametler: } \\
\text { Yüksek: Yunanistan, Türkiye, belirtilmemiş BatıAvrupa. } \\
\text { Orta: Kanada, Kıbrıs, Fransa, Almanya, İsrail, İtalya, İngiltere, ABD. } \\
\text { Düşük: Belçika, Bosna Hersek, Bulgaristan, Danimarka, Mısır, Japonya, Lübnan, } \\
\text { Lüksemburg, Hollanda, Norveç, Polonya, Portekiz, Kore Cumhuriyeti, İspanya, } \\
\text { İsviçre, Makedonya, Ukrayna, Birleşik Arap Emirlikleri, Batı Asya. }\end{array}$ \\
\hline & Transit:Orta & $\begin{array}{l}\text { Rusya'dan ve Ukrayna'dan Türkiye'ye. } \\
\text { Yunanistan'a ve İsrail'e kaçırılan kurbanları için. } \\
\text { Azerbaycan dışında çıkarılan insan ticareti mağdurları için. }\end{array}$ \\
\hline & $\begin{array}{l}\text { Hedef: } \\
\text { Çokdüşük }\end{array}$ & Düşük: Ukrayna. \\
\hline \multirow{3}{*}{ 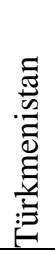 } & Menşei: Orta & $\begin{array}{l}\text { Ülke dışına rapor edilen istikametler: } \\
\text { Orta: Kanada, Almanya, ABD, belirtilmemişBatıAvrupa. } \\
\text { Düşük: Fransa, İsrail, İtalya, Japonya, Hollanda, İsviçre, Birleşik Arap Emirlikleri, } \\
\text { Birleşik Krallık. }\end{array}$ \\
\hline & Transit:NR & NR \\
\hline & Hedef: NR & NR \\
\hline \multirow[t]{3}{*}{ 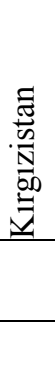 } & Menşei: Orta & $\begin{array}{l}\text { Ülke dışına rapor edilen istikametler: } \\
\text { Orta: Kanada, Almanya, İtalya, Kazakistan, Türkiye, Birleşik Arap Emirlikleri, ABD. } \\
\text { Düşük: Arnavutluk, Belçika, Çin, Kıbrıs, Danimarka, Estonya, genel olarak Avrupa } \\
\text { Birliği, Fransa, Yunanistan, HongKong ÇinSAR, Hindistan, İran, İsrail, Japonya, } \\
\text { Lüksemburg, Malezya, Hollanda, Polonya, Portekiz, Katar, KoreCumhuriyeti, Rusya, } \\
\text { İsveç, İsviçre, İngiltere. }\end{array}$ \\
\hline & $\begin{array}{l}\text { Transit: Çok } \\
\text { düşük }\end{array}$ & Bağımsız DevletlerTopluluğu ülkelerinin dışına \\
\hline & Hedef: Düşük & Düşük: Tacikistan \\
\hline
\end{tabular}

Tablo 5: İnsan Ticareti Yolları Kaynak: UNODC, 2012.

\section{Kaynakça}

- Agnatise, E. 2004. Traffiking for prostitution in Italy: Possible Effects of Goverment Proposals for legalization of Brothels, Violance Against Woman, 10 (10), 1126-1115.

- Belser, Patrick, 2005. Forced Labour and Human Trafficking: Estimating the Profits, ILOWorking Paper no: 42, ILO, Geneva.

- Carney, Scott, 2007. "Inside India's Underground Trade in Human Remains”, Wired Magazine, Issue: 15/12, http://www.wired.com/medtech/health/magazine/15-12/ff_bones

- Cho, Seo-Young, Dreher, Axel and Neumayer, Eric, 2013. "Does Legalized Prostitution Increase Human Trafficking?", World Development, 41, 67-82.

- Doezema, Jo. 2002. "TheIdeology of Trafficking”, Consultative Meeting of the Center for Ethics and Value Inquiry (CEVI) for "Human Trafficking, ”www.nswp.org/pdf/DOEZEMA-IDEOLOGY.PDF, Erişim: 01.06.2013.

- Eurostat, 2013. Trafficking in Human Beings, Luxembourg: Publications Office of the European Union.

- Farley, M. 2009: "Theory versus reality: Commentary on four articles about trafficking for prostitution", Women's Studies International Forum, 32, 311-315

- Hughes, D., 2000: “The Natasha Trade: the Transnational Shadow Market of Trafficking in Woman, Journal of International Affair, 53 (2), 1-18

- Joudo Larsen, J., Jade Lindley ve Judy Putt, 2009. Trafficking in Persons Monitoring Report ,

- ICMPD (International Centre for Migration Policy Development). Difference between Smuggling and Trafficking, http: //www.anti-trafficking.net/differencebetweensmugglingand.html, Erişim: 28.05.2013

- ICPC (International Centre for the Prevention of Crime), 2012. International Reporton Crime Prevention and Community Safety. Montreal: ICPC.

- Jakobsson, Niklas ve Andreas Kotsadam, 2013. "The law and economics of international sex slavery: prostitution law sand trafficking for sexual exploitation", European Journal of Law and Economics, 35 (1), 87-107.

- Koçak, S., “Organ karaborsasında olup bitenlerin içyüzü”, 3 mart 2011, Aktüel, http://www.sabah.com.tr/fotohaber/yasam/organ_karaborsasinda_olan_bitenlerin_icyuzu/29664

- Mann Yasası (The White - Slave Traffic Act - Beyaz Kadın Ticareti Yasası), http://www.law.cornell.edu/topn/white-slave_traffic_act, Erişim: 01.05.2013.

- Othman, Z., 2006. "Trafficking in woman from the Former Soviet Union for the Purposes of Sexual Exploitation”, Trafficking and Global Sex Industry, New York 
- Prostitution internet sayfas1, http: //prostitution.procon.org/view.resource.php?resourceID=000117), Erişim, 03.05.2013

- Palermo Protokolü, Sınıraşan Örgütlü Suçlara Karşı Birleşmiş Milletler Sözleşmesine Ek İnsan Ticaretinin, Özellikle Kadın ve Çocuk Ticaretinin Önlenmesine, Durdurulmasına ve Cezalandırılmasına İlişkin Protokol, 2003.Sınıraşan Örgütlü Suçlara Karşı Birleşmiş Milletler Sözleşmesine Ek İnsan Ticaretinin, Özellikle Kadın ve Çocuk Ticaretinin Önlenmesine, Durdurulmasına ve Cezalandırılmasına İlişkin Protokolün Onaylanmasının Uygun Bulunduğuna Dair Kanun, Kanun no: 4804, http://www.tbmm.gov.tr/kanunlar/k4804.html

- UNODC(United Nations Office on Drugs and Crime), 2012. Global Report on Trafficking in Persons 2012 , United Nations Publication.

- UNODC(United Nations Office on Drugs and Crime), 2010. The Globalization of Crime- A Transnational Organized Crime Threat Assessment.

- UNODC (United Nations Office on Drugs and Crime), 2008. An Introduction to Human Trafficking: Vulnerability, Impactand Action, United Nations, NewYork, USA.

- Wheaton, Elizabeth, Edward Schouer, Thomas Galli, 2010. "Economics of Human Trafficking, International Migration”, Special Issue: Special Issue on Human Trafficking, 48 (4), 114-141. 


\title{
Çevrenin Ceza Hukuku Yoluyla Korunması Kapsamında Çevrenin Kirletilmesi Suçları
}

\section{Protection of the Environment through Criminal Law and Crimes of Pollution}

\author{
Asst. Prof. Dr. Nazmiye Özenbaş (Anadolu University, Turkey)
}

\begin{abstract}
Environmental problems due to economic growth and development policies in the last century ignorant to humanitarian values has become a risky issue for the future of humanity. Since 70's it become a debatable problem in the international arena and due to the search of solutions for the environmental problems, right to environment has stated as a part of fundamental human rights and protected with law. Recently with the emphasis to the preventive functions of criminal law actions against the right of living in a healthy and balanced environment has started to be described as crime and are becoming subject to penalty in the criminal codes. With this study we will analyze crimes of polluting the environment.
\end{abstract}

\section{Giriş}

Geçtiğimiz yüzyılda kapitalizm ile birlikte teknoloji ve sanayileșmenin hızla gelişmesi, bazı gelişmiș ülkelerin çevreye ilişkin değerleri gözardı eden ekonomik büyüme ve kalkınma politikaları ve küreselleşme olgusu, hızla artan nüfus, buna bağlı olarak artan üretim ve tüketim faaliyeti, kaynakların bilinçsizce ve acımasızca kullanılması çevrede de acımasız tahribatlar yaratmışıtır. Bu sorunlar öylesine ciddi boyutlara ulaşmıştır ki insanoğlunun sahip olduğu hakların en temeli olan "hayat hakkını" tehdit eder hale gelmiştir (Kaboğlu, 1996, s.9).

Zamanla, bu durum karşısında ülkelerin yapılan uluslararası toplantılar ile kalkınma ile doğal kaynaklar dengesinin korunması gerektiği ve çevreyi dışlamayan sürdürülebilir bir kalkınmanın mümkün olduğu anlayışını benimsediklerini görmekteyiz. Çevre gerek uluslararası, gerekse anayasalarda yer alan hükümlerle ulusal düzeyde tanınmış bir hak konumuna gelmiştir.

Çevre sorunlarının devletleri karşı karşıya getirecek ölçüde büyümesi, gelişmiş-gelişmemiş ülkeler çatışması, gelişmiş ülkelerin gelişmemiş ülkelerin doğal kaynaklarını sömürmesi ve bu ülkeleri sanayi ve nükleer artıklarını bıraktıkları çöplük olarak görmeleri gibi uluslararası çevre ihlalleri, devletlerin sağlıklı ve düzenli bir çevrede yaşama hakkının öznesi olarak ortaya çıkmalarına neden olmuştur (Özdek, 1993, s. 111-112)

Geldiğimiz noktada ise özel hukuka ve idare hukukuna ilişkin yaptırımların çevrenin korunmasında gerektiği ölçüde etkili olamaması üzerine, çevreyi ciddi biçimde tehlikeye sokan ve ona zarar veren, bu yolla insan sağlığını ve hayatını tehdit eden fiillerin suç olarak ceza kanunlarında düzenlenmesi ve ciddi cezai müeyyidelere bağlanması gerektiği düşüncesi hâkim olmaya başlamıştır (Şen, 1994, s. 77-78).

Türkiye'nin de taraf olduğu Avrupa Birliği Konseyi'nin 27 Ocak 2003 tarih ve 2003/80/JHA sayılı Çevrenin Ceza Hukuku Yoluyla Korunması Hakkındaki Yönerge, Avrupa Birliği üyesi devletlere çeşitli çevre suçlarını ceza kanunlarında düzenleme ve bunlar için özgürlüğü bağlayıcı cezalar ve tüzel kişilere özgü yaptırımlar öngörme yükümlülügü getirmektedir (Erman, 2004, s. 187). Bu kapsamda korunan hukuksal yarar açısından çevreye ayrı bir değer atfedilmiş ve 2005 yllında yürürlüğe giren 5237 sayılı Türk Ceza Kanunu'nda önceki (765 sayılı) TCK'da olmayan yeni suç tipleri olarak çevreye karşı suçlar düzenlenmiştir.

\section{2 Çevre Hakkı}

\section{1 Çevre Hakkının Tarihsel Gelişim Süreci}

1970'li yıllarda ekonomik büyümeyi tek amaç olarak belirleyen anlayış sonucu ortaya çıkan çevre sorunlarının insanlık bakımından çok ciddi problemleri beraberinde getireceği ve bu konuda önlem alınması ve ülkelerin bu kapsamda ortak bir mücadele yürütmesi gerekliliği hususu üzerinde durulmaya başlanmıştır. Bu kapsamda ilk kez Haziran 1972'de Birleşmiş Milletler tarafından Stockholm'de Çevre ve Kalkınma Konferansı düzenlenmiş̧tir. Konferans sonunda yayınlanan ve Türkiye'nin de taraf olduğu Stockholm Bildirgesi’ne göre; "İnsan, kendisine onurlu ve iyi bir yaşam sürmeye olanak veren nitelikli bir çevrede, özgürlük, eşitlik ve tatmin edici yaşam koşulları temel hakkına sahiptir...”. Böylece çevre hakkı bir insan hakkı olarak ilk kez uluslararası bir belgede tanınmıştır (Şen, 1994, s. 34; Keleş ve Ertan, 2002, s. 98).

28 Ekim 1982 tarihinde Birleşmiş Milletler Genel Kurulu'nda kabul edilen Dünya Doğa Şartı, çevre hakkının uygulamaya geçirilmesi konusunda devletlerin yükümlülüklerini ve bireylerin katkılarını belirleyerek daha somut ilkeler öngörmüştür (Kaboğlu, 1996, s. 18; Keleş ve Ertan, 2002, s. 99, 214). 
Birleşmiş Milletler öncülüğünde Haziran 1992'de Rio de Janerio'da toplanan Çevre ve Gelişme Konferansı sonunda yayınlanan Rio Bildirgesi'nin 1. maddesinde “insanlar sürekli ve dengeli kalkınmanın merkezindedir. Doğa ile uyum içerisinde sağlıklı ve verimli yaşama hakları vardır” ifadesine yer çevre hakkı vurgulanmıştır (Kuzu, 1997, s. 92-93). Bu konferans sonunda Türkiye tarafından da imzalanan "Biyolojik Çeşitlilik Sözleşmesi”, yeryüzündeki bitki ve hayvan türleri ile doğal kaynakların korunmasını öngörmektedir. "İklim Değişikliği Çerçeve Sözleşmesi” ise; küresel ısınma ile atmosferde sera etkisi yaratan gaz emisyonlarının azaltılmasını öngörmektedir. Söz konusu sözleşmeye Türkiye 2004 yılında taraf olmuştur (Ceylan, 2008, s. 7).

İklim Değişikliği Çerçeve Sözleşmesi'ne bağlı olarak Aralık 1997'de Japonya'nın Kyoto kentinde gerçekleştirilen III. Taraflar Konferansı sonunda kabul edilen Kyoto Protokolü ile özellikle gelişmiş ülkelere seragazı azaltımı konusunda yükümlülükler getirilmiştir. Türkiye ise İklim Değişikliği Çerçeve Sözleşmesi’ne başlangıçta taraf olmadığı için Kyoto Protokolü’ne de taraf olmamıştır(Ceylan, 2008, s. 7).

Birleşmiş Milletler Avrupa Ekonomik Komisyonu (UNECE) tarafından Haziran 1998'de hazırlanarak imzaya açılan, herkesin çevreyle ilgili bilgilere serbestçe ulaşma, çevreyle ilgili konularda karar alma surecine katılma ve yargı yoluna başvurma haklarını güvence altına alan ve bu amaca ulaşmak için taraf devletlere somut yükümlülükler yükleyen Çevresel Konularda Bilgiye Erişim, Karar Sürecine Halkın Katılımı ve Yargıya Başvuru Sözleşmesi’ne (http//www.unece.org/env/pp/documents/cep43e.pdf) ise Türkiye henüz taraf olmamıştır.

Avrupa Konseyi bünyesinde ise gerek 1950'de kabul edilen İnsan Hakları ve Temel Özgürlükleri Koruma Sözleşmesi'nde (Avrupa İnsan Hakları Sözleşmesi) ve Ek protokollerde, gerek 1961'de kabul edilen Avrupa Sosyal Şartı'nda sağlıklı ve düzenli bir çevrede yaşama hakkı, özgün bir insan hakkı olarak tanınmamıştır (Kaboğlu, 1996, s. 137). Ancak Avrupa İnsan Hakları Mahkemesi (AİHM) içtihatlarında çevre hakki, Sözleşme'nin yaşam hakkı (m. 2), özel yaşam ve aile yaşamına saygı (m. 8), aşağılayıcı muamele yasağı (m. 3), mülkiyet hakkı (1 no.lu Ek Protokol, m.1) gibi diğer haklar aracılığıyla dolaylı olarak korunmaktadır (Keleş ve Ertan, 2002, s. 94-95).

\section{2 Çevre Hakkının Kime Ait Olduğu Sorunu}

En genel anlamıyla insan hakları, devlet tarafından güvence altına alınsın ya da alınmasın, insanlığın ulaştığı her gelişme aşamasında, bütün insanların hiçbir ayrım gözetmeksizin sadece insan oluşlarından dolayı insan onurunun gereği olarak, insanın kendine özgü doğasını gerçekleştirmek ve onurlu bir yaşam sürdürmek için sahip oldukları tüm hakları ifade etmektedir (Gemalmaz, 1997, s. 326-349).

Çevre hakkı ise üçüncü kuşak insan haklarındandır. 20. yüzyılın son çeyreğinde ortaya çıkan üçüncü kuşak haklar, tüm insanlığın yan yana geldiği takdirde çözebileceği, yoksa tek tek insanların ya da ülkelerin üstesinden gelemeyeceği sorunlardan kaynaklanan ve konularını evrensel değerlerin oluşturduğu haklardır.

Çevre hakkı, en genel anlamıyla çevrenin korunması ve geliştirilmesidir (Ceyhan, 2008, s. 22). Diğer bir ifadeyle bu hakkın konusu, insan ve diğer canlıların yaşamını sürdürdüğü ve kısa ya da uzun dönemde etkileşim içinde bulunduğu yaşam çevresidir (Keleş ve Ertan, 2002, s. 82).

Sağlıklı ve düzenli bir çevrede yaşama hakkının en başta ve en acık yararlanıcıları bireylerdir. Tüm bireylerin sağlıklı ve düzenli bir çevrede yaşama hakkının yararlanıcısı (alacaklısı) olmasının somut anlamı, sağlıklı ve düzenli bir çevrede yaşama hakkının ihlali halinde, çevreye olumsuz bir müdahalede bulunulduğunda veya hakkın gerçekleştirilmesi için olumlu bir müdahaleye gerek duyulduğunda, herkesin, tüm bireylerin tek tek haklarını hakkın yükümlüsüne (muhatabına) karşı ileri sürebilmeleridir (Özdek, 1993, s. 107).

Hukuksal metinlerde yer alan "herkes, sağlıklı ve dengeli bir çevrede yaşama hakkına sahiptir" ifadesindeki "herkes" ibaresi, sadece tek tek bireyleri değil, birey topluluklarını ve tüzel kişiliği olan kamusal ve özel kuruluşları da kapsar (Keleş ve Ertan, 2002, s. 84-85). Bu durum çevre ile ilgili karar alma süreçlerine halkın katılımını sağlıklı ve düzenli bir çevrede yaşama hakkının etkin bir şekilde kullanılmasını hayata geçirilmesini sağlamak bakımından önemlidir.

Bugünkü kuşakların sağlıklı ve dengeli bir cevrede yaşamlarını sürdürebilmeleri için tanınan sağlıklı ve düzenli bir çevrede yaşama hakkı, aynı zamanda gelecek kuşakların da çıkarlarını gözetmektedir. Bugünkü kuşakların, gelecek kuşaklara bugünkünden aşağı olmayan bir biyolojik çeşitlilik ve zenginliği güvence altına alan nitelikli toprağı iletme ödevi vardır (Kaboğlu, 1991, s. 123).

Çevre sorunlarının devletleri karşı karşıya getirecek ölçüde büyümesi, gelişmiş-gelişmemiş ülkeler çatışması, gelişmiş ülkelerin gelişmemiş ülkelerin doğal kaynaklarını sömürmesi ve bu ülkeleri sanayi ve nükleer artıklarını bıraktıkları çöplük olarak görmeleri gibi uluslararası çevre ihlalleri, devletlerin sağlıklı ve düzenli bir çevrede yaşama hakkının öznesi olarak ortaya çıkmalarına neden olmuştur (Özdek, 1993, s. 111-112).

Bireyler, topluluklar ve devlet sağlıklı ve düzenli bir çevrede yaşama hakkının alacaklısı olduğu kadar borçlusudur da. Yalnız gelecek kuşaklar, hakkın gerçekleştirilmesinden sorumlu tutulamazlar. Ancak en önemli ve öncelikli muhatap devlettir. Devlet, gerek ulusal gerek uluslararası alanda çevrenin koruyuculuğu ve iyileştirilmesi ödevlerini üstlenir; sağlıklı ve düzenli bir çevrede yaşama hakkının gerçekleştirilmesini gözetir (Özdek, 1993, s. 113). 


\section{Türk Hukukunda Sağlıklı Ve Düzenli Bir Çevrede Yaşama Hakkı}

Türk hukukunda sağlıklı ve düzenli bir çevrede yaşama hakkı ilk kez, 1982 Anayasası'nın 3. bölümünde düzenlenen Sosyal ve Ekonomik Haklar ve Ödevler başlığı altındaki 56. maddesiyle anayasal bir hak olma niteliğini kazanmıştır. Söz konusu maddeye göre:

"Herkes, sağlıklı ve dengeli bir çevrede yaşama hakkına sahiptir.

Çevreyi geliştirmek, çevre sağlığını korumak ve çevre kirlenmesini önlemek Devletin ve vatandaşların ödevidir.

Devlet, bu görevini kamu ve özel kesimlerdeki sağlık ve sosyal kurumlarından yararlanarak, onları denetleyerek yerine getirir."

Çevre ile ilgili bu hükmün amacı, insan haysiyetine uygun bir hayatın sağlanabilmesidir (Şen, 1194, s. 49).

Sağlıklı ve düzenli bir çevrede yaşama hakkının 1982 Anayasası ile tanınmasından sonra çıkarılan 9.8.1983 tarih ve 2872 sayılı Çevre Kanunu çıkarılmıştır. Bu kanun, kirleten öder ilkesi, çevre zararlarının tazmininde kusursuz sorumluluk kuralı, çevresel etki değerlendirmesi gibi kavramların Türk Çevre Hukukuna kazandırılmasını sağlayan kanun olmuştur. Kanunun amacı bütün canlıların ortak varlığı olan çevrenin, sürdürülebilir çevre ve sürdürülebilir kalkınma ilkeleri doğrultusunda korunmasını sağlamaktır.

Çevre kanunu dışında çevreyi korumaya yönelik pek çok yasal düzenleme yapılmıştır. Kültürel çevre ile ilgili 2863 sayılı Kültür ve Tabiat Varlıklarını Koruma Kanunu, 2873 sayılı Milli Parklar Kanunu, 2960 sayılı Boğaziçi Kanunu, 2634 sayılı Turizmi Teşvik Kanunu, 3621 sayılı Kıyı Kanunu, 3194 sayılı İmar Kanunu, 618 sayılı Limanlar Kanunu, 167 sayılı Yeraltı Suları Kanunu, 3167 sayılı Kara Avcılığı Kanunu, 6831 sayılı Orman Kanunu, 1380 sayılı Su Ürünleri Kanunu gibi birçok kanun, çevreyle ilgili doğrudan ya da dolaylı hükümler içermektedir.

Bunun dışında çevrenin korunması ve geliştirilmesine yönelik pek çok da yönetmelik çıkarılmış durumdadır (Çevresel Etki Değerlendirmesi Yönetmeliği, Atık Yağların Kontrolü Yönetmeliği, Tarımsal Kaynaklı Nitrat Kirliliğine Karşı Suların Korunması Yönetmeliği gibi).

Tüm bu düzenlemeler çerçevesinde, çevreye karşı gerçekleştirilen ihlaller karşısında hukuki ve idari nitelikte yaptırımlar uygulanması söz konusu olmaktadır. Bunun dışında ceza kanunlarında da çevreye yönelik fiillerin suç olarak düzenlenip cezai yaptırımlarla karşılanması da mümkündür. Bu hususu daha ayrıntılı olarak özellikle Türk Ceza Hukuku kapsamında aşağıda inceleyeceğiz.

\section{Türk Ceza Kanunu’nda Çevrenin Korunması}

\subsection{Genel Olarak}

Önceleri sadece idari, siyasi ve ekonomik bazı müdahalelerin çevreyi korumada yeterli olabileceği savunulmuş ise de, bu gün artık çevreye yönelik ihlallerin sadece belli kişilere karşı değil kamuya ve topluma karşı işlenmiş suçları oluşturabileceği ve bu suçlarda gerçek mağdurun toplum olduğu (Toprak, 1988-1989, s. 100) ceza hukukunun bu alanda da etkili olması gerektiği ve ceza hukukunun müdahalesinden vazgeçilemeyeceği genellikle kabul edilmektedir (Toroslu, 1981, s. 153; Turgut, 2001, s. 613 vd).

Ülkemizde 765 sayılı Türk Ceza Kanunu döneminde derli toplu çevre ceza normlarına yer verilmemiş; ancak çevreyi kirletme ve bozma fiillerinin halkın sağlığını tehlikeye düşürmesi haline ilişkin 369 (yangın çıkarmak), 394 (halkın içeceği suları zehirleyerek veya bozarak umumun sıhhatini tehlikeye düşürmek), 526 (yetkili makamların emir ve talimatlarına aykırı davranmak) gibi münferit hükümler bulunmakta idi.

Avrupa Birliği Konseyi'nin 27 Ocak 2003 tarihli ve 2003/80/JHA sayılı “Çevrenin Ceza Hukuku Yoluyla Korunması Hakkında Yönerge”nin yürürlüğe girmesinden sonra pek çok üye devlet, bunu iç hukukuna geçirmiş veya iç hukukunda bulunan çevre suçları hükümlerini Yönerge ile uyumlu hale getirmiştir.

Türk Ceza Hukuku'na çevrenin korunmasına ilişkin suç tipleri, 2004 yılında hazırlanan 5237 sayılı TCK ile ilk kez açıkça ceza hukukumuza girmiştir. Kanun'un Topluma Karşı Suçlar başlıklı 3. kısmında ayrı bir bölüm halinde Çevreye Karşı Suçlar düzenlenmiştir. Bu suçlar, "çevrenin kasten kirletilmesi” (m. 181), "çevrenin taksirle kirletilmesi" (m. 182), "gürültüye neden olma" (m. 183), “imar kirliliğine neden olma" (m. 184) suçlarıdır. Ayrıca Kanun'un 1. maddesinde "kamu sağlığı ve çevre”nin korunması, kanunun amaçları arasında sayılmıştır.

Çevre suçlarında ihlaller genelde üç aşamada gerçekleşmektedir. Birinci aşamada çevre üzerinde herhangi bir tehlike veya zarar yaratan eylemin varlığı aranmamakta, sadece ihlali oluşturan davranışın varlığı yeterli görülmektedir (Turgut, 2001, s. 638). Bu aşamada "daha ziyade bazı engel suçlar yaratan veya objektif hedefi bakımından doğanın bütünlüğüne zarar vermeye elverişli davranışları yasaklayan” ceza normları söz konusudur (Toroslu, 1981, s. 154). Çevreyi kirletici nitelikte veya çevre için tehlike yaratan maddelerin üretilmesi, ticari amaçla bulundurulması veya ülkeye sokulmasının yasaklandığı ceza normları örnek olarak verilebilir. Bu tip 
fiillerin yasaklanmasındaki amaç, çevre ve insan üzerinde henüz bir zarar gelmeden önüne geçmektir (Şen, 1994, s. 154).

İkinci aşamada, yine çevreyi kirletme tehlikesini önleme amacını güden tedbirlere aykırılık fiilleri yer almaktadır. Bu anlamda "belirli bir sanayi faaliyetini icra edebilmek, sanayi artıklarını atabilmek ve tesislerin durumunu tespit edebilmek için belli bir yetkilendirme veya izne sahip olma yükümlülügünü ihlal eden davranışları yahut bu faaliyetlerin icrası ile ilgili olarak kanun veya idari makamlar tarafindan konan tedbir kurallarının ihlalini cezalandıran normlar" gündeme gelmektedir (Toroslu, 1981, s. 154). Böylece soyut ya da potansiyel bir tehlike önlenmek istenmektedir. İlgili kanunlarla belirlenen teknik usullere aykırı olarak kirletme (m. 181, f. 1), atık veya artıkları izinsiz olarak ülkeye sokma (m. 181, f. 2), ilgili kanunlarla belirlenen yükümlülüklere aykırı olarak gürültüye neden olma (m. 183), yapı ruhsatı almadan veya ruhsata aykırı olarak bina yapma (m. 184) suçları birinci ve ikinci aşamaya ilişkin suçlara örnek olarak verilebilir.

Üçüncü aşama ise, bizatihi çevreyi kirletici faaliyetin gerçekleştirilmesidir. Öncelikle kirletici maddelerin atılması veya salınması ile buna bağlı olarak zararlı sonucun ortaya çıkması halinde devreye giren suç tipleri bu kapsamdadır (Toroslu, 1981, s. 155). Ne var ki bu aşamada çoğu zaman zararın ortaya çıkmış olması, çevrenin kirletilmiş veya bozulmuş olması nedeniyle artık ceza normunun önleyici rolünün gerçekleşme olanağı kalmamış olmaktadir.

Çevreye karşı suçlar ile korunan hukuki yarar hava, toprak, su, bitki örtüsü, hayvan türleri gibi doğaya ilişkin ekolojik menfaatler ile yaşam ve sağlık gibi insanı esas alan hukuksal menfaatlerdir (Ünver ve Nuhoğlu, 1999, s. 40).

\section{2 Çevrenin Kasten ve Taksirle Kirletilmesi Suçları (TCK m. 181 ve 182) Genel Olarak}

5237 sayılı TCK'nın 181. maddesinde çevrenin kasten kirletilmesi, 182. maddesinde ise çevrenin taksirle kirletilmesi düzenlenmiştir. Madde metinleri şu şekilde kaleme alınmıştır:

\section{"Çevrenin kasten kirletilmesi}

Madde 181- (1) İlgili kanunlarla belirlenen teknik usullere aykırı olarak ve çevreye zarar verecek şekilde, atık veya artıkları toprağa, suya veya havaya kasten veren kişi, altı aydan iki yıla kadar hapis cezası ile cezalandırılır.

(2) Atık veya artıkları izinsiz olarak ülkeye sokan kişi, bir yıldan üç yıla kadar hapis cezası ile cezalandırılır.

(3) Atık veya artıkların toprakta, suda veya havada kalıcı özellik göstermesi halinde, yukarıdaki fıkralara göre verilecek ceza iki katı kadar artırılır.

(4) Bir ve ikinci fikralarda tanımlanan fiillerin, insan veya hayvanlar açısından tedavisi zor hastalıkların ortaya çıkmasına, üreme yeteneğinin körelmesine, hayvanların veya bitkilerin doğal özelliklerini değiştirmeye neden olabilecek niteliklere sahip olan atık veya artıklarla ilgili olarak işlenmesi halinde, beş yıldan az olmamak üzere hapis cezasına ve bin güne kadar adlî para cezasına hükmolunur.

(5) Bu maddenin iki, üç ve dördüncü fikrasındaki fiillerden dolayı tüzel kişiler hakkında bunlara özgü güvenlik tedbirlerine hükmolunur.

\section{Çevrenin taksirle kirletilmesi}

Madde 182- (1) Çevreye zarar verecek şekilde, atık veya artıkların toprağa, suya veya havaya verilmesine taksirle neden olan kişi, adlî para cezası ile cezalandırılır. Bu atık veya artıkların, toprakta, suda veya havada kalıcı etki bırakması halinde, iki aydan bir yıla kadar hapis cezasına hükmolunur.

(2) İnsan veya hayvanlar açısından tedavisi zor hastalıkların ortaya çıkmasına, üreme yeteneğinin körelmesine, hayvanların veya bitkilerin doğal özelliklerini değiştirmeye neden olabilecek niteliklere sahip olan atık veya artıkların toprağa, suya veya havaya taksirle verilmesine neden olan kişi, bir yıldan beş yıla kadar hapis cezası ile cezalandirılır".

Çevre kirliliği gündelik hayat içinde bireylerin mutat faaliyetleri sebebiyle olabileceği gibi, gerçek veya tüzel kişilerin ticari ve sınaî üretim faaliyetleri sonucu da ortaya çıkabilir.

Çevre üzerinde çok büyük olumsuz etkiler yaratmayan ve daha çok gerçek kişilerin evsel ve bireysel atık ve artıklar ile gerçekleştirdikleri kirletme fiilleri, genellikle 5326 sayılı Kabahatler Kanunu ve 2872 sayılı Çevre Kanunu kapsamında idari yaptırım gerektiren fiiller olmaktadır.

Kabahatler Kanunu'nun “çevreyi kirletme” başlıklı 41. maddesinde, evsel ve bireysel atık ve artıkların toplanmasına veya depolanmasına özgü yerler dışına atılması, hayvan kesimine tahsis edilen yerler dışında hayvan kesilmesi veya kesilen hayvan atıklarının sokağa veya kamuya ait sair alanlara bırakılması, inşaat atık ve artıklarının bunların toplanmasına ve depolanmasına özgü yerler dışına atılması, kullanılamaz hale gelen veya ihtiyaç fazlası ev eşyasının bunların toplanmasına ilişkin olarak belirlenen günün dışında sokağa veya kamuya ait sair bir yere bırakılması, kullanılamaz hale gelen motorlu kara veya deniz nakil araçları ya da bunların mütemmim cüzlerinin sokağa veya kamuya ait herhangi bir yere bırakılması fiilleri kabahat olarak tanımlanmış ve bu fiiller karşılığında idari para cezası öngörülmüştür. Ancak bireysel kirletme fiilleri de somut olayın 
şartlarına göre suç teşkil edebilir. Ya da fiil, bazen hem suç hem de kabahat oluşturabilir. Bu durumda Kabahatler Kanunu m. 15 f. 3 hükmü uyarınca sadece suçtan dolayı yaptırım uygulanır. Ancak, suçtan dolayı yaptırım uygulanamayan hallerde, kabahat dolayısıyla yaptırım uygulanabilir.

Çevre üzerinde asıl önemli olumsuz etkiler yaratan ve çevre unsurlarını çoğu zaman uzun vadede telafisi güç, hatta imkânsız zararlara uğratan, insan ve diğer canlı yaşamını tehdit eden kirletme fiilleri ise, ticari ve sınai faaliyetler sebebiyle ortaya çıkmaktadır. Ceza hukukunun ilgi alanı içinde bulunan fiiller daha çok bu tarz fiillerdir.

\section{Suçla Korunan Hukuki Değer}

Çevrenin kasten ve taksirle kirletilmesi suçları ile korunan hukuki değer, sağlıklı ve dengeli bir cevrede yaşama hakkıdır (Anayasa m. 56). Çevrenin kirletilmesi fiillerinin suç olarak tanımlanması ile Devlet, Anayasa'nın 56/2. maddesinde kendisine yüklenen "çevreyi geliştirmek, çevre sağlı̆̆ını korumak ve çevre kirlenmesini önlemek” görevini yerine getirmiş olur. Böylece çevre kirliliğinin önlenmesi ile sağlıklı ve düzenli bir çevrede yaşama hakkının güvence altına alınması da sağlanmıştır (Parlar ve Hatipoğlu, 2010, s. 294).

\section{Suçun Maddi Konusu}

Çevrenin kasten ve taksirle kirletilmesi suçlarında, suçun konusu atık ve artıklarla kirletilen çevreyi oluşturan toprak, su ve havadır. Yani kirletme eyleminin üzerinde gerçekleştiği toprak, su ve hava gibi alıcı ortamlardır. Sucun işlenmesi ile bu çevre unsurları saldırıya uğramaktadır. Alıcı ortamlar olan toprak, su ve hava, aynı zamanda kendilerine bağlı canlı hayatının devam ettiği ortamlar olduğundan, bu ortamlarda yaşayan insanlar ile hayvanlar, bitkiler ve diğer mikroorganizmalar da sucun konusuna dahil edilmelidir (Kayan, 2008, s. 130-131).

\section{Fail ve Mağdur}

Kanun koyucu TCK 181 ve 182. maddelerde tarif edilen çevrenin atık ve artıklarla kirletilmesi suçlarında fail bakımından belli bir sıfat veya nitelik aramamaktadır. Bu suçların faili herkes olabilir.

Ceza sorumluluğunun şahsiliği kuralı gereği, tüzel kişilerin suç faili olması mümkün değildir (Özen, 2003, s. 65) ve tüzel kişiler hakkında ceza yaptırımı uygulanamaz. Ancak tüzel kişiler hakkında suç dolaysıyla kanunda öngörülen güvenlik tedbiri niteliğindeki yaptırımlar, kanunda özel olarak belirtilen hallerde uygulanabilir. Çevrenin kirletilmesi eylemlerinin bir özel hukuk tüzel kişisinin faaliyeti çerçevesinde ve tüzel kişinin yararına işlenmesi halinde, tüzel kişi hakkında TCK'nın 60. maddesinde öngörülen güvenlik tedbirleri uygulanacak; faaliyet izninin iptaline ve suçun işlenmesi ile elde edilen ekonomik kazancın müsaderesine karar verilecektir.

TCK sistematiğinde “Topluma Karşı Suçlar” kısmında düzenlenen çevre suçlarının mağduru belirli bir kişi değildir. Bu suçlarda toplumu oluşturan herkesin yanı sıra, belirli bir kişi veya kişiler de suçun işlenmesiyle haksızlığa uğramış, mağdur edilmiş olabilir (Kayan 2007, s. 40).

\section{Suçun Maddi Unsuru}

Çevrenin kasten kirletilmesini düzenleyen TCK m. 181 f. 1'deki suç tipinde fiil, "ilgili kanunlarla belirlenen teknik usullere aykırı olarak ve çevreye zarar verecek şekilde, atık veya artıkları toprağa, suya veya havaya kasten çevreye zarar verecek şekilde verilmesi”dir.

TCK m. 182 f. 1'deki suç tipinde fiil, “çevreye zarar verecek şekilde, atık ve artıkların toprak, su veya havaya taksirle verilmesi"dir.

181. maddenin 2. fikrasındaki fiil ise, “atık ve artıkların izinsiz olarak ülkeye sokulması"ndan ibarettir.

$\mathrm{Bu}$ suç tipleri, yapılması yasaklanan veya yapılmaması istenen bir hareketin yapılması şeklinde olduğundan icrai suçlardır. Ancak sadece irai hareketlerle işlenmeleri söz konusu olmayıp, ihmal suretiyle icrai nitelikte de gerçekleştirilebilirler.

Maddede sözü edilen atık ve artığın ne olduğu TCK'nın herhangi bir maddesinde tanımlanmamıştır. Ancak Çevre Kanunu'nun "Tanımlar" başlıklı 2. maddesine göre, "atık; herhangi bir faaliyet sonucunda oluşan, çevreye atılan veya bırakılan her türlü maddeyi” ifade eder. Çevre Kanunu'nda artık tanımlanmamıştır. Ancak genellikle bir sanayi faaliyeti sonunda yararlanılması mümkün olmayan ve çevreye bırakılan maddelere artık denir (Parlar ve Hatipoğlu, 2010, s. 298).

Suçun oluşabilmesi için atık ve artıkların alıcı ortamlara verilmesi kanunlarla belirlenen teknik usullere aykırı olarak yapılmalıdır. Eğer atık veya artıklar kanunlarla belirlenen teknik usullere uygun olarak doğal ortama bırakılırsa, suçun oluştuğundan söz edilemez. Ancak ne Çevre Kanunu'nda ne de diğer ilgili kanunlarda atık ve artık maddelerin güvenli bir şekilde çevreye zarar vermeden doğal ortama verilmesi, bertaraf edilmesi ve imhasına ilişkin teknik usuller doğrudan düzenlenmiş değildir. Yaşadığımız çağda çevre ve insan hayatı bakımından tehlike yaratan atık ve artıkların sayısı ve çeşidi kadar teknolojik gelişmelerle bunların nasıl bertaraf edileceği zaman içinde sürekli değişmektedir ve bu yüzden atık ve artıkların imhası ve bertarafına ilişkin teknik usullerin kanunlarla belirlenmesi çok güç, hatta imkânsızdır (Kayan, 2008, s. 142; Yaşamış, 2005, s. 140). Çünkü çevre sorunlarının doğası gereği teknik usuller son derece ayrıntılıdır ve günün koşullarına göre sürekli yenilenmek ve değişmek zorundadır. Bu nedenle tüm dünyada yönetmelik ve standart gibi ikincil mevzuat 
metinleriyle düzenlenirler (Endüstri Tesislerinden Kaynaklanan Hava Kirliliğinin Kontrolü Yönetmeliği (22.07.2006, RG 26236), Bitkisel Atık Yağların Kontrolü Yönetmeliği (19.04.2005, RG 25791) gibi).

Atık ve artıkların teknik usullere aykırı olarak doğal ortama verilmesi fiilin cezalandırılabilmesi için yeterli değildir. Fiilin "çevreye zarar verecek şekilde" olması da gereklidir. Bundan kasıt, fiilin çevresel varlıkları (toprak, su, hava) zarar tehlikesi ile karşı karşıya bırakmış olmasıdır. Kirliliğin çevreye zarar verecek boyutta olması yeterli olup, bu zararın gerçekleşmesi şart değildir (Parlar ve Hatipoğlu, 2010, s. 298). Bu nedenle m. 181 f. 1 ile m. 182 f. 1'de tanımlanan suç tipleri, netice unsuru bakımından somut tehlike suçlarıdır.

Öğretide 181. maddenin metninde açıkça "ilgili kanunlarla belirlenen teknik usuller" ibaresi kullanılarak suçun tanımının yapıldığı, dolayısıyla Çevre Kanunu'na istinaden çıkartılan yönetmeliklerde düzenlenen teknik usullere aykırılığın suçun oluşumu için yeterli olmadığı, teknik usullere ilişin düzenlemenin mutlaka kanunla yapılması gerektiği yönünde görüşler de bulunmaktadır (Ünver, 2005, s. 53).

TCK m. 181, f. 2'de düzenlenen suç tipinde ise fiil, atık ve artıkların izinsiz olarak ülkeye sokulmasıdır. Gelişmiş ülkelerde endüstriyel faaliyet sonucu ortaya çıkan pek çok tehlikeli atık ve artıklar, zehirli kimyasal madde ve atıklar farklı şekillerde gelişmemiş veya çevre duyarlılığı olmayan ya da mevzuat engeli olmayan ülkelere dış ticaret adı altında ihraç edilmekte ve çoğu zaman bu ülkelerde çevre sorunlarına, felaketlerine yol açılmaktadır. Bu anlamda ülkemizde son yıllarda gelişen çevre bilincinin etkisiyle kanun koyucu bu tarz tehlikeli madde, atık ve artıkların ticaretini, ihraç ve ithal edilmesini, taşınmasını ve ülkeden transit geçişini belli koşullar ve izinlere bağlamakta veya yasaklamaktadır. Örneğin tehlikeli kimyasallar ve atıkların ticaretiyle ilgili Çevre Kanunu'nun 13. maddesi, tehlikeli atıkların ithalatını yasaklamıştır. 14.03.2005 tarih ve 25755 sayılı Resmi Gazete'de yayınlanan Tehlikeli Atıkların Kontrolü Yönetmeliği'nin 41. maddesine göre de atıkların, serbest bölgeler dahil Türkiye Cumhuriyeti Gümrük Bölgesine girişi yasaktır. Ancak, sektör itibari ile ekonomik değere haiz atıklar ise izinle ithal edilebilir.

TCK m. 181 f. 2 ile atık ve artıkların izinsiz olarak ülkeye sokulması fiili bir soyut tehlike suçu olarak tanımlanmaktadır. Buna göre atık ve artıkların izinsiz olarak ülkeye sokulması ile çevre açısından tehlike gerçekleşmiş kabul edilmekte ve suç oluşmaktadır. Bu hükümle atık ve artıkların sınır aşan tehlike boyutu gözetilerek, özellikle gelişmiş ülkelerden gelişmemiş ülkelere taşınmasına sıkça rastlanan bu maddelerin ülkemize sokulması önlenmeye çalışılmıştır (Parlar ve Hatipoğlu, 2010, s. 300).

\section{Suçun Manevi Unsuru}

TCK m. 181 f. 1.de yer alan atık ve artıkların ilgili kanunlarla belirlenen teknik usullere aykırı olarak ve çevreye zarar verecek şekilde, toprak, su veya havaya verilmesi suçu, kasten işlenen bir suçtur. Buna göre fail, atık ve artıkları alıcı ortamlar olan toprak, su veya havaya verme fiilini bilerek ve isteyerek icra etmeli, ayrıca fiilinin bu konuyla ilgili kanunlarda belirlenen teknik usullere aykırı olduğunu ve çevreye zarar verecek nitelikte olduğunu bilmelidir. Bu suç doğrudan kastla işlenebileceği gibi olası kastla da işlenebilir. TCK m. 181 f. 2 .de düzenlenen atık ve atıkların izinsiz olarak ülkeye sokulması suçu da, doğrudan veya olası kastla işlenebilir.

Çevrenin atık ve artıklarla kirletilmesi suçunun taksirli hali m. 182'de ayrıca düzenlenmiştir. Buna göre kendisinden beklenen dikkat ve özen yükümlülüğüne aykırı hareketi neticesinde çevrenin kirlenmesine yol açan fail, taksirli hareketi nedeniyle sorumlu olacaktır.

\section{Suçun Nitelikli Halleri}

TCK m. 181 f. 3 ve f. 4.de atık veya artıklarla çevrenin kirletilmesi ile atık veya artıkların izinsiz ülkeye sokulması suçlarının nitelikli halleri düzenlenmiştir.

Üçüncü fikraya göre, bu suçların konusunu oluşturan atık veya artıkların toprakta, suda veya havada kalıcı özellik göstermesi halinde failin cezası iki katı kadar artırılacaktır. Kalıcı özellik göstermekten maksat, kirletmenin uzun süre devam etmesidir (Parlar ve Hatipoğlu, 2010, s. 301).

Maddenin dördüncü fıkrasında ise, suç konusu atık ve artıkların insan veya hayvanlar açısından tedavisi zor hastalıkların ortaya çıkmasına, üreme yeteneğinin körelmesine, hayvanların veya bitkilerin doğal özelliklerini değiştirmeye neden olabilecek niteliklere sahip olması halinde cezanın ağırlaşacağı ifade edilmiştir. Bu ağırlaştırıcı neden bakımından önemli olan, atık ve artıkların niteliklerinin anılan zararlı neticeyi meydana getirmeye elverişli olmasıdır. Yani bu tür bir zararlı netice ortaya çıkmamış olsa dahi, atığın böyle bir neticeyi doğurmaya elverişli olduğunun tespiti halinde cezanın artırılması gerekecektir.

\section{Suçun Özel Görünüş Biçimleri}

TCK'nın 181. maddesinde öngörülen çevrenin kasten kirletilmesi suçu bakımından teşebbüs mümkün iken, 182. maddesinde öngörülen suçun taksirli bir suç olması sebebiyle ve kanunda teşebbüsün sadece kasıtlı suçlarda mümkün olabileceğini ifade etmesi dolayısıyla bu suça teşebbüs mümkün değildir.

Aynı şekilde çevrenin kasten kirletilmesi suçuna iştirak mümkün iken çevrenin taksirle kirletilmesi suçuna iştirak mümkün değildir.

Kanunda çevreyi kirletme suçları bakımından özel içtima kuralları öngörülmemiş olduğundan suçların içtimaı konusundaki genel hükümler uygulanacaktır. 


\section{Yer Bakımından Uygulama Alanı}

Türk Ceza Kanunu'nun 13. maddesinin 1. fikrasının (d) bendi ile çevrenin kasten kirletilmesi suçunun yabancı bir ülkede işlenmesi halinde failin Türk vatandaşı veya yabancı olmasına bakılmaksızın Türkiye'de Türk kanunlarına göre yargılanacağı hüküm altına alınmıştır. Böylece uluslararası ceza hukuku güvencesi getirilmiş ve Türkiye'nin egemenlik alanı dışında işlenmiş çevreyi kasten kirletme eylemleri bakımından da 181. maddenin uygulanması sağlanmış olmaktadır. Ancak suç nedeniyle Türkiye'de yargılama yapılması Adalet Bakanı'nın talebine bağlı olup, ayrıca fail hakkında yabancı ülkede mahkûmiyet veya beraat kararı verilmemiş olmalıdır.

\section{Sonuç}

Sanayileşme ve hızlı nüfus artışı ile birlikte, çevresel faktörleri gözardı eden büyüme ve kalkınma politikaları sonucu oluşan çevre kirliliği, bugün insanların hayat ve sağlık haklarını tehdit eder boyutlara ulaşmıştır. Bu durumun farkına varılmaya başlanması ile önce uluslararası boyutta çalışmalar yapılmış daha sonra da anayasalarda sağlıklı ve düzenli ir çevrede yaşama, bir insan hakkı olarak düzenlenmeye başlanmıştır.

Çevreye zarar verici nitelikteki eylemler, önceleri özel hukuk yaptırımları ve idari yaptırımlar ile karşılanırken, çevreyi ciddi biçimde tehlikeye sokan ve insan sağlığına zarar verici nitelikteki bazı fiillerin sadece bu yaptırımlar ile karşılanmasının yetersiz bulunması üzerine, sağlıklı ve düzenli bir çevrede yaşama hakkını garanti altına almak amacıyla ceza kanunlarında çevreye karşı suçlar düzenlenmiştir.

Türk Ceza Kanunu'nda düzenlenen çevreye karşı suçlar arasında Çevrenin Kasten Kirletilmesi (TCK m. 181) ve Çevrenin Taksirle Kirletilmesi (TCK m. 182) suçları da yer almaktadır.

"Çevrenin kasten kirletilmesi” suçunda (TCK m.181), “çevrenin kasten kirletilmesi” ve "atık ve artıkların izinsiz olarak ülkeye sokulması" olmak üzere iki farklı suç tipine yer verilmiştir. Maddenin ilk fikrasında düzenlenen "çevrenin kasten kirletilmesi" suçunun oluşabilmesi için atık veya artıkların ilgili kanunlarla belirlenen teknik usullere aykırı olarak toprağa, suya veya havaya verilmesi, ayrıca fiilin çevreye zarar verecek şekilde işlenmesi gerekmektedir. Bu noktada belirtmek gerekir ki suçun bağlı hareketli bir suç olarak düzenlenmiş olması hukuksal korumayı zayıflatmaktadır. Suçun serbest hareketli bir suç olarak düzenlenmesi, örneğin atık ve artıkların hukuka aykırı olarak işlenmesi, depolanması, nakledilmesi, imha edilmesi gibi çevre kirliliğine neden olabilecek farklı fiillerin de suç kapsamına dahil edilmesini sağlayabilirdi.

Suçun somut tehlike suçu olarak düzenlenmesi de nedensellik bağının ispatında güçlük yaratmaktadır. Daha güçlü bir hukuksal koruma bakımından suçun, soyut tehlike suçu olarak düzenlenebileceği öğretide savunulmaktadir.

Çevrenin kirletilmesi suçları TCK'nın 13. maddesinin 1.fikrası ile düzenlenmiş bulunan evrensellik ilkesi kapsamında takip edilebilecek suçlardandır. Bu durum çevrenin kirletilmesi fiillerinin sadece bir ülkenin zararına işlenen fiiller olmadığı gerçeğine de uygun olarak, bu suçların uluslararası alanda takibini mümkün kılması bakımından oldukça önemli bir koruma sağlamaktadır.

\section{Kaynakça}

- Ceyhan, 2008. 5237 Sayılı Türk Ceza Kanunu'nda Çevre Hakkının Korunması (Çevreye Karşı

Suçlar). Yayınlanmamış Yüksek Lisans Tezi, İstanbul Üniversitesi Sosyal Bilimler Enstitüsü Kamu Hukuku Anabilim Dalı, İstanbul.

- Erman, 2004. “TCK Tasarısında Çevre Suçları”, Hukuki Perspektifler Dergisi, Sonbahar 2004, S. 2, s. 187 vd.

- Gemalmaz, 1997. Ulusalüstü İnsan Hakları Hukukunun Genel Teorisine Giriş. Beta, İstanbul.

- Kaboğlu, 1991. “Çevre Hukuk Dernekleri Dünya Toplantısı Limoges Bildirgesi 16 Kasım 1990”, Argumentum, Mart 1991, C. 1, S. 8, s. 123 vd.

- Kaboğlu, 1996. Çevre Hakkı. İmge Kitabevi, İstanbul.

- Kayan, 2007. Çevre Hakkı Ve Türk Ceza Kanununda Çevreye Karşı Suçlar. Yayınlanmamış Yüksek Lisans Tezi, Sakarya Üniversitesi Sosyal Bilimler Enstitüsü, Kamu Yönetimi Anabilim Dalı, Sakarya.

- Kayan, 2008. "Çevrenin Atık ve Artıklarla Kirletilmesi Sucu”, Ceza Hukuku Dergisi, S. 6, s. 117 vd.

- Keleş ve Ertan, 2002. Çevre Hukukuna Giriş. İmge Kitabevi, Ankara.

- Kuzu, 1997. Sağlıklı ve Dengeli Bir Çevrede Yaşama Hakkı, Fakülteler Matbaası, İstanbul.

- Özdek, 1993. İnsan Hakkı Olarak Çevre Hakkı, Todage, Ankara.

- OÖzen, 2003. “Türk Ceza Kanunu Tasarısının Tüzel Kişilerin Ceza Sorumluluğuna İlişkin Hükümlerine Bir Bakış", $A \ddot{U} H F D$, C. 52, S. 1, s. 63 vd.

- Parlar ve Hatipoğlu, 2010. Cezai Ve Hukuki Sorumluluk Boyutlarıyla Çevre Hukuku, Adalet yayınevi, Ankara. 
- Şen, 1994. Çevre Ceza Hukuku (Ceza Hukuku Açısından Sağlıklı ve Düzenli Bir Cevrede Yaşama Hakkı). Kazancı Hukuk Yayınları, İstanbul.

- Toprak, 1988-1989. “Çevre Hakkı ve Yerel Yönetimler”, İnsan Haklarl Yıllığı, 1988-89, C. 10- 11, s. 91 vd.

- Toroslu, 1981. “Doğal Çevrenin Kirletilmesi ve Ceza Hukuku”, Prof.Dr. Akif Erginay'a 65. Yaş Armağanı, AÜHF Yayını, Ankara, s. 149 vd.

- $\quad$ Turgut, 2001. Çevre Hukuku, Yenilenmiş 2. Bası, Savaş Yayınevi, Ankara.

- Ünver ve Nuhoğlu, 1999. Federal Almanya Çevre Ceza Hukuku, Beta, İstanbul.

- Yaşamış, 2005. "Çevre Ceza Hukuku'nda Son Gelişmeler: Yeni Türk Ceza Kanunu ve Kabahatler Kanunu”, TBB Dergisi, S. 58, s. 137 vd. 


\title{
Türkiye'de Giderek Artan Hukuka Aykırı Bir Ekonomik Faaliyet Olarak Kredi Kartı Kullanılması Suretiyle Tefecilik Usury by Using Credit Card as an Increasing Unlawful Economic Activity in Turkey
}

\author{
Assoc. Prof. Dr. Hakan Karakehya (Anadolu University, Turkey)
}

\begin{abstract}
Usury is regulated in article 241 of the Turkish Penal Code as a crime in the field of the economy, industry and trade. The state aims with the regulation to protect continuation of the economic order in the country. Usury by using credit card is one of the most common committing methods of the usury crime in Turkey. Due to this crime, there are many people in the economic difficulties and too much tax losing for the state, recent years in Turkey. Nevertheless usury by the credit card is getting increase with each passing day, because of the easiness, profitability, being risk-free of the action. Increasing controls and reduction to more reasonable levels of the prescribed interest for the credit card debts will be effective in the fight against the crime.
\end{abstract}

\section{Giriş}

İnsanların borç alabilecekleri kişi veya kurumlara duydukları ihtiyaç çok eski tarihler de bile varlığını hissettirmiştir. Öyle ki, Eski Mısır'da, Sümerlerde ve Babil İmparatorluğunda borç alıp verme işlemleriyle uğraşan kişiler ticari hayatın ayrılmaz parçası haline gelmişlerdi. İnsanların dokunulmazlıkları olan mabetlerde kendilerini daha güvende hissetmeleri ve din adamlarının da toplumda itimat edilir kimseler olarak görülmelerine bağlı olarak, bu tür borç işlemleriyle ilk olarak din adamları uğraşmıştır. Hatta tapınaklarda yapılacak bazı vadesi gelen borcun tahsil usulleri, alınacak faiz oranları, gibi hususlar Hammurabi kanunlarında ayrıntılı olarak düzenlenmişlerdir (Tarlan, 1987).

Dolayısıyla borç alınacak kişi ve kurumlara duyulan ihtiyacın ticari hayatın başladığı zamanlardan beri varlığını hissettirdiğini söylemek yanlış olmayacaktır. Bu nedenle günümüzde de ticari hayatın temel bir gereksinimi olan bu tür faaliyetlere izin verilsin veya verilmesin, ekonomik hayatın içinde borç verme ve alma faaliyetinin önüne geçmek pek mümkün görünmemektedir. Ancak günümüzde ekonomik faaliyetlerin alanı o kadar çeşitlenmiş ve bu tür faaliyetler toplumsal düzeni o kadar etkiler hale gelmiştir ki; birçok devlet ortaya çıkabilecek kontrolsüz toplumsal hareketlenmelerin önüne geçme gerekçesiyle borç alınıp-verilmesi faaliyetlerini denetim altında tutma eğilimindedir (Özgenç, 2010). Hatta sadece borç alınıp verilmesi değil; toplum içerisinde parasal hareketliliği etkileyen ve ekonomi alanında önemli yansımaları bulunan diğer birçok ekonomik faaliyet de devlet tarafindan kontrol altına alınmaya çalışılmakta, devlet denetimi dışında hareket eden kişiler de değişik cezai yaptırımlara muhatap kılınmaktadırlar. Türk hukuk sistemi bakımından Bankalar Kanunu m.151'de düzenlenen izinsiz bankacılık faaliyetinde bulunma ve Türk Ceza Kanunu (TCK) m.241'de düzenlenen tefecilik suçları, bu durumu yansıtan en önemli düzenlemelerdir. Bu düzenlemelerle devlet mevduat toplama, borç verme gibi bir takım eylemlerin, sadece kendi izin verdiği ve dolayısıyla denetleyebildiği kişi ve kuruluşlar eliyle yapılmasına imkan sağlamaktadır. Gerekli koşulları gerçekleştirmeksizin bu tür işlemlerde bulunanlar ise söz konusu suç tiplerinde öngörülen cezai müeyyidelere muhatap olma durumuyla karşı karşıya kalmaktadır.

Biz bu çalışmamızda kazanç elde etmek amacıyla başkasına borç para vermek şeklinde gerçekleştirilen tefecilik suçunun yeni bir işleniş şekli olan kredi kartı tefeciliğini inceleme konusu yapacağız. Bu bağlamda tefecilik suçunun unsurları ve kredi kartı tefeciliğinde bu unsurların ne şekilde meydana geldiği, suçun cezası, suçun kredi kartı kullanılmak suretiyle işlenmesinin boyutları ve son dönemde kredi kartı tefeciliğinde görülen artışın nedenleri çalışmada ele alınacak başlıca konular olacaktır. Çalışma sırasında Yargıtay içtihatlarından faydalanmak suretiyle uygulamadaki durumu tespit etmek ve normatif düzenleme 1şı̆̆ında kendi görüşlerimizi neden-sonuç ilişkisi içerisinde açıklamak ise temel çalışma yöntemimizi oluşturacaktır.

\section{Tefecilik Suçuna İlişkin Genel Bilgiler, Suçunun Hukuki Konusu ve Sosyal Bir Vakıa Olarak Kredi Kartı Tefeciliği}

Tefecilik suçu yürürlükte bulunan 5237 sayılı Türk Ceza Kanununun 241. maddesinde düzenleme altına alınmıştır. Söz konusu hükme göre; "Kazanç elde etmek amacıyla başkasına ödünç para veren kişi, iki yıldan beş yıla kadar hapis ve beş bin güne kadar adlî para cezası ile cezalandırılır." Madde gerekçesinde ise suç tipinin ihdasına ilişkin şu açıklamalar yapılmıştır: "Madde metninde tefecilik fiili suç olarak tanımlanmıştır. Faiz veya başka bir namla da olsa kazanç elde etmek amacıyla başkasına ödünç para verilmesi, tefecilik suçunu oluşturur. Tefecilik suçu, iktisadi hayatımızda, "senet kırdırma” denen usulle de işlenebilir. Örneğin henüz vadesi gelmemiş bir bononun vadesinden önce başkasına verilerek karşıllğgında bono üzerinde yazılı meblă̆dan daha az bir paranın alınması durumunda tefecilik suçu oluşur. Çünkü bu durumda bononun el değişstirmesi, 
kişiler arasında doğmuş olan bir alacak borç ilişkisine dayanmamaktadır. Iffade yerinde ise, bu durumlarda, birer ödeme aracı olan bononun veya çekin kendisi satılmakta ve satın alınmaktadır. İzlenen suç politikası gereğince, kazanç elde etmek amacıyla başkasına ödünç para veren kişi cezalandırllmaktadır. Buna karşılık, ödünç para alan kişi cezalandırllmamaktadır."

Suçun hukuki konusu; suçla ihlal edilen hukuki varlık veya menfaattir. Suçun ihlal ediciliği kaynağını hukuki konudan alır. Her suçta nasıl bir fail varsa, bir de hukuki konu vardır (Toroslu, 2005). Yukarıda da açıkladığımız üzere devletler ortaya çıkabilecek olumsuz toplumsal sonuçlarını engellemek amacıyla ödünç para verme işlemlerini kontrol altında tutma eğilimindedirler. Nitekim kamusal bir kontrol mekanizması olmaksızın faiz karşılığı para alınıp verilmesi, sonuçta birçok kişinin ekonomik olarak zora düşmesi sonucunu ortaya çıkartabilecektir (Parlar, 2011). Toplumda bu şekilde zora düşen kişilerin sayısının artmasıyla birlikte ise gerek ekonomik gerekse toplumsal dalgalanmalar ortaya çıkabilecektir. Bu bağlamda devlet kazanç sağlamak amacıyla bu tür faaliyetlerde bulunacak kişi veya kuruluşları kontrol eder ve bunların ödünç para verme işlemlerinde uygulayacakları faiz oranı için sınırlar belirler. Bu bağlamda tefecilik suçunun hukuki konusunu ekonomi alanındaki kamusal düzen oluşturur (Özgenç, 2010). Nitekim suç tipini düzenleyen 241. madde, TCK'nın ikinci kitabının, üçüncü kısmının, dokuzuncu bölümündedir. Bu bölümün başlığı ise Ekonomi, Sanayi ve Ticarete Illişkin Suçlardır.

Kredi kartı tefeciliği ise son dönemde tefecilik suçunun en yaygın işlenme yöntemlerinden birisini oluşturmaktadır. Son dönemde tefecilik suçunun bu yöntemle işlenmesinin boyutlarını göstermesi bakımından şu alıntıyı paylaşmayı uygun buluyoruz: "Türkiye ekonomisine, yolsuzluk suçları kadar büyük oranda zarar veren tefecilik suçu boyut değiştirdi. Kredi kartı ile pos tefeciliği yaygınlaşmaya başladı. Pos tefeciliği yapan kişilerin, ticari faaliyet adı altında kamufle olabilmeleri ve illegal faaliyetlerini legal gösterebilmelerindeki kolaylı, bu suçun artışında etkili oluyor. Son iki yıl içerisinde tefecilere yönelik toplam bin 165 operasyonda 3 bin 37 şüpheli şahıs yakalandı. Emniyet Genel Müdürlüğ̈̈ Kaçakçılık ve Organize Suçlarla Mücadele (KOM) Daire Başkanlığı'nın 2010 yılı raporunda, tefeciliğe ilişkin dikkat çekici bilgiler yer alıyor. Son dönemlerde bankalara borcunu ödeyemeyerek kara listeye girmiş olan insanlar, tefecilere giderek yüksek faizlerle borç para aldıkları, ancak sonucunda sahip oldukları tüm mal varlıklarını kaybettikleri ve tefecilik mağduru çok sayıda şahsın ise intihar girişiminde bulundukları ortaya çıktı. Her geçen gün tefecilik yaparak kolay yoldan para kazanacağını düşünen kişiler ile tefecilerin ă̆ına düşen vatandaşların sayısının artması, vergisiz olarak kolay para kazanma hırsını artırdı. Bu durum ise işlerini kanunlara uygun olarak yapan kişileri olumsuz etkiliyor (Sabah Gazetesi (27.04.2012)."

Gerçekten de daha önceden tefecilik suçu işlenirken ödünç para verilen kişiden bir senet vs. alınır ve bu şekilde tefeci kimse ileride alacağı parayı teminat altına almaya çalışırdı. Senedin tahsil edilememesi durumunda ise bazen çek-senet mafyası denilen örgütsel yapılar olaya müdahil olur ve cebir-tehdit kullanmak suretiyle parayı tahsil ederlerdi. Oysa günümüzde uygulanan kredi kartı tefeciliğinde, tefeci bakımından parayı tahsil edememe gibi bir risk bulunmamaktadır.

\section{$3 \quad$ Kredi Kartı Tefeciliği Bağlamında Tefecilik Suçunun Unsurları}

\subsection{Genel Olarak}

Bir fiilin suç teşkil edebilmesi için tipiklik, hukuka aykırılık ve kusurluluk unsurlarının gerçekleşmiş olması gerekir. Bu bağlamda aşağıda "kredi kartı tefeciliği”nin işleniş biçimi de göz önünde bulundurulmak suretiyle, tefecilik suçunun unsurları inceleme konusu yapılacaktır.

\subsection{Tipiklik}

Tipiklik, failin gerçekleştirdiği fiilin kanunda yer alan suç tanımı ile örtüşmesini ifade etmektedir. Bu bağlamda gerçekleştirilen fiil suç tanımına uymuyorsa; ortada ihlal edilmiş bir norm ve dolayısıyla suç da olmayacaktır. Tipiklik; "maddi ve manevi tipiklik", "tipik maddi unsur ve tipik manevi unsur" ya da "maddi unsurlar ve manevi unsur" terimleri kullanılmak suretiyle ikiye ayrılabilir. Biz maddi ve manevi unsurların tipiklik içerisinde yer aldığını vurgulaması bakımından "tipik maddi unsur ve tipik manevi unsur" (der objektive Tatbestand- der subjektive Tatbestand) şeklindeki kullanıma bağlı kalmayı uygun buluyoruz (Aynı yönde bkz. Stratenwerth, 2000). Suçun tipik maddi unsurunun içerisine suç tanımının içerdiği suçun maddi konusu, fail, mă̆dur ve fiil girmektedir. Suçun tipik manevi unsuru ise fiil ile fail arasındaki psişik bağı ifade etmektedir.

\section{Tipik Maddi Unsur:}

Suçun Maddi Konusu: Maddi konu suçun üzerinde gerçekleştirildiği eşya veya kişi olarak ifade edilebilir. Ancak bu, failin fiziki faaliyetinin somut olarak üzerinde gerçekleştiği her kişi ya da eşya değil; sadece suçu düzenleyen normdaki tanımda söz konusu olan kişi veya eşyadır (Toroslu, 2005). Tefecilik suçunun maddi konusunu, kazanç amacıyla ödünç verilen para oluşturur. Kanunda bu husus açıkça belirtildiğinden, kanunilik ilkesi gereği başkaca şeylerin verilmesi bu suça vücut vermez. Bu bağlamda örneğin altın veya gümüşün kazanç elde etmek maksadıyla başkasına ödünç verilmesi tefecilik olmaz (Parlar, 2011). Buna karşın paranın Türk lirası veya başka bir para birimi olmasının önemi bulunmamaktadır. Dolar veya euro gibi yabancı paraların faiz karşılığında verilmesi de tefecilik suçunu oluşturacaktır. 
Kredi kartı tefeciliğinde ise bu maddi konu, kart çekildikten sonra mağdura verilen para olarak karşımıza çıkmaktadır.

Fail: Fail, kanunda tanımlanan suç tipini ihlal eden davranışı gerçekleştiren kişidir. Fail, fiilin aktif süjesi olarak ifade edilebilir (Toroslu, 2005). Bu suçun faili herkes olabilir. Bu bağlamda failin kamu görevlisi, kadın veya erkek olmak gibi herhangi bir özel vasıf taşımasına gerek yoktur (Parlar, 2005). Tefeciliğin kredi kartı vasıtasıyla işlenmesinde de özellik arzeden bir durum bulunmamaktadır.

Mağdur: Mağdur suçla korunan hukuki menfaat veya varlığın sahibidir. Mağdur suçun pasif süjesi olarak da ifade edilebilir (Toroslu, 2005). Tefecilik suçunun mağduru ise hem bu tür fiillerin yaygınlaşmasına bağglı olarak ekonomik düzeninin devamlllı̆̆ tehlikeye düşecek olan toplum hem de kazanç elde etmek amaciyla kendisine para verilen kimsedir (Meran, 2012). Kredi kartı tefeciliğinde ise mağdur, kredi kartıyla belirli bir para meblağı çekildikten sonra, kendisine karttan çekilen bu meblağın daha azı verilen kişi olarak karşımıza çıkmaktadır.

Fiil: Kanuni tanıma göre tefecilik suçunu oluşturan fiil, başkasına kazanç amacıyla ödünç para vermektir. Bu tanıma ilk bakışta fiil bakımından ödünç para verme ve kazanç sağlama amacı olmak üzere iki belirleyici özelliğin olduğu göze çarpmaktadır. Ödünç verilecek şeyin para olmasının, bu suçun oluşması bakımından zorunlu olduğunu, yukarıda maddi konuya ilişkin açıklamalarımızda belirtmiş̧ik. Bunun dışında kazancın da mutlaka maddi bir kazanç olması gerekir (Özgenç, 2010). Yardım etme duygusunun tatmini, sevap kazanmak, iyilik zinciri oluşturmak gibi manevi kazançlar bu suçun oluşmasına vücut vermez.

Bununla birlikte kazanç için verilenin para olması zorunluyken, maddi kazancın muhakkak para olması gerekli değildir. Ödünç parayı, ödünç verilen miktardan daha fazla değere sahip bir mülkün kendisine vermesi karşılığında veren kişi de bu suçu işlemiş olacaktır (Parlar, 2010). Tefeciliğin kredi kartı vasıtasıyla işlenmesinde halinde ise hem ödünç verilen meblağ hem de kredi kartı borcu olarak bankaya ödenen meblağ, para olarak karşımıza çıkmaktadır.

Tefecilik suçu ödünç paranın borç alana verilmesiyle tamamlanmış olmaktadır. Suçun tamamlanması için ödünç paranın karş̧lığının elde edilmiş olması şart değildir. Bunun elde edilip edilmemesinin suçun gerçekleşmesi bakımından bir etkisi yoktur (Uğur, 2007). Kredi kartı tefeciliğinde de aynı şekilde tefecilik suçunun tamamlanması paranın borç para alan kişiye verilmesiyle gerçekleşir. Bu konuda sadece anlaşmaya varılmış olması, suçun oluşumuna etki etmez.

Ancak 5237 s. TCK'daki açık düzenlemeye rağmen, tefecilik suçunun oluşumuna ilişkin Yargıtay uygulaması, uzunca bir süre kanuni düzenlemeden farklı gelişti. Nitekim 5237 sayılı TCK'nın 2005 yılında yürürlüğe girmesinden önce, Yargıtay uygulamasında tefecilik suçunun oluşması bakımından, birden fazla kişiye kazanç elde etmek için borç para verilmesi, bu faaliyetin sürekli ve sistemli olarak gerçekleştirilmesi gibi koşullar aranıyordu. Yargıtay tefecilik suçunun oluşması bakımından bu koşulları aramaya, $5237 \mathrm{~s}$. TCK döneminde de devam etti (Örnek olarak bkz. Yargitay 7. CD. 07.10.2009, 5900/10180). Ancak daha sonra yerinde olarak uygulamasını değiştirerek, kanunda tanımlanan fiilin bir kere gerçekleştirilmesi halinde de tefecilik suçunun oluşacağını kabul etmiştir (Örnek olarak bkz. Yargıtay 4. CD 14.03.2012, E.2011/20476, K.2012/5992)

Kredi kartı tefeciliği genelde şu şekillerde işlenmektedir: "Kredi kartı borcu ya da nakit paraya ihtiyacı olan kişi, pos tefeciye gidiyor. Pos tefeci ile örneğin 8 bin liralık borcu veya nakit para ihtiyacı için pazarlık yapıyor. 12 taksitte ödenmek üzere 10 bin liraya anlaşıyor. Pos tefeci 8 bin lirayı bankaya ödeyip, kredi kartı borcunu kapatıyor veya 8 bin lira nakit parayı o kişiye ödüyor. Aynı kredi kartından 10 bin liralık çekimi 12 ay taksitlendiriyor. Karşlığında 'mal satılmış gibi' belge veriliyor. Vatandaş da 10 bin lira borcunu taksitler halinde ödüyor. Olay kredi kartı faizinden daha düşük olduğu için vatandaşa cazip geliyor. Uzaktan baktığınızda olay mal satışı olarak gözüküyor. Aslında yapılan iş yüzde 25 komisyonla tefecilik oluyor... (Kızılot, 2012)"

Pos makinesinden komisyon olarak ifade edilen faiz ile birlikte toplam miktarı çeken tefeci, artık alacağı parayı da tahsil etmiş olmaktadır. Nitekim bu şekilde para alan kimse tefeciye değil; kredi kartını aldığı bankaya borçlu hale gelmektedir. Bu nedenle tefeciden para alan mağdur, ileride kredi kartı taksitlerini ödeyemezse, hukuki ihtilaf tefeci ile mağdur arasında değil; bilakis mağdur ile banka arasında ortaya çıkacaktır.

\section{Tipik Manevi Unsur}

Tefecilik suçu kasten işlenebilen bir suçtur. Ancak burada genel kast da yeterli değildir. Suç tipinde tefeciliğin oluşabilmesi için failin para kazanma amacıyla hareket etmesi aranmıştır. Dolayısıyla bu suçun manevi unsuru kazanç elde etme amacından oluşan özel kasttır (Meran, 2012). Fail bu özel kasta sahip olmaksızın söz konusu suçtan cezai sorumluluğu oluşmaz.

\subsection{Hukuka Aykırılık}

Ceza normu ile yasaklanmış tipik davranışların gerçekleştirilmesi hukuka aykırılı̆̆ın karinesini oluşturur. Ancak bazı hallerde hukuk düzeni, tipiklikte formüle edilmiş olan yasağı hukuka uygunluk nedenleri denilen müsaade edici durumların mevcudiyeti halinde kaldırır. Böylece herhangi bir fiilin hukuka aykırı olduğu konusundaki kesin hüküm, ancak herhangi bir hukuka uygunluk nedeninin somut olayda bulunmaması halinde verilebilir (Hakeri, 2007). İlgili kanunlarda öngörülen izinlerin alınması suretiyle, kazanç amaçlı ödünç para verilmesi hukuka uygun olacağından, hukuka aykırılık unsurunun eksikliğinden dolayı tefecilik suçu oluşmaz. 
Örneğin bankalar gibi özel kanunla kendilerine verilmiş izne dayalı olarak, kazanç elde etme amacıyla ödünç para veren kurumların eylemleri tefecilik suçunu oluşturmayacaktır. Bu bağlamda bu suç bakımından en sık rastlanan hukuka uygunluk sebebi kanun hükmünü icradır.

\subsection{Kusurluluk}

Kusurluluk failin fiilinin kınanabilirliğine ilişkin atfedilen değer yargısını ifade etmektedir (Koca-Üzülmez, 2008). Tefecilik suçunda kusurluluk bakımından özellik arzeden bir durum bulunmamaktadır. Dolayısıyla örneğin cebir-tehdit altında bu tür fiilleri işleyen kimseler bakımından kusurun bulunmaması nedeniyle cezai sorumluluk oluşmayacaktır.

\section{Suçun Özel Beliriş Biçimleri}

\subsection{Teşebbüs}

Teşebbüs kişinin işlemeyi kastettiği bir suçu elverişli hareketlerle doğrudan doğruya icraya başlayıp da elinde olmayan nedenlerle tamamlayamamasıdır (Hakeri, 2007). Tefecilik suçuna teşebbüs kanaatimizce mümkündür. Konuyu kredi kartı tefeciliği bağlamında ele alırsak, örneğin kazanç amacıyla verdiği parayı kişiye teslim ederken yakalanan kimse tefeciliğe teşebbüsten sorumlu olacaktır. Nitekim suçu işlemeye yönelik olarak doğrudan icra hareketlerine başlamış; ancak fiilini elinde olmayan nedenlerle tamamlayamamıştır.

\section{2. İștirak}

Suça iştirak, tek bir kişi tarafindan işlenebilen bir suçun, birden fazla kişinin bir araya gelmesiyle işlenmesi halinde söz konusu olur (Toroslu, 2005). Tefecilik suçu, tek bir kişi tarafindan işlenebilen bir suç olması nedeniyle iştirake müsaittir (Meran 2012). Örneğin ortak çalışan iki kişiden birisi müşteri bulup diğeri pos cihazını kullanmak suretiyle kişileri borçlandırıyorsa müşterek fail olarak cezai sorumluluğa sahip olacaklardır. Benzer şekilde pos cihazına sahip bir işletmeci hiç aklında yokken, arkadaşının bu tür faaliyetlerde bulunması konusundaki telkinleriyle tefecilik yaparsa, arkadaşı azmettiren olarak kendisi ise fail olarak suçtan sorumlu olacaklardır. Kredi kartı tefeciliğini yapanların yanında genelde müşteriyle bankaya gidip kart borcunu sıfırlayan yardımcıları da vardır. Bu kişiler de tefecilik fiiline yardım eden olarak cezai sorumluluğa sahiptirler.

\section{3. İçtima}

Kanunda tanımlanan suça ilişkin fiillerin bir defa gerçekleştirilmesi tefecilik suçunun meydana gelmesi bakımından yeterlidir. Dolayısıyla işlenen her bir fiil, fail bakımından kural olarak kanunda belirlenen cezanın ayrı ayrı uygulanmasını gerektirir. Kredi kartı tefeciliği üzerinden örneklerimize devam edersek, on farklı kişiye, kredi kartı vasıtasıyla kazanç elde etmek için para veren kimse, on kez tefecilik suçunu işlemiş olacaktır ve fiiller nedeniyle ayrı ayrı cezalandırılacaktır. Bununla birlikte fiilin zincirleme suç şeklinde de işlenmesi mümkündür. Örneğin bir kişiye kredi kartı vasıtasıyla kazanç elde etmek için para vermeye karar veren fail, bu tek suç işleme kararı kapsamında farklı zamanlarda bu kişiye karşı kredi kartı vasıtasıyla tefecilik suçunu işlese, zincirleme suç hükümlerinin uygulanması gerekecektir (TCK m.43). Bu bağlamda tek suç işleme kararı kapsamında işlenen fiiller için faile tek bir suçun cezası verilecek, daha sonra ceza, kanunda belirtilen oranlar dahilinde arttırılarak belirlenecektir.

Bankalar Kanununun 151. maddesinde düzenlenen, izinsiz bankacıllk faaliyetinde bulunma suçu kapsamındaki hareketlerden birisi olarak tefecilik sayılabilecek fiillerin işlenmesi söz konusu olabilir. Nitekim izinsiz bankacılık faaliyetinde bulunan gerçek veya tüzel kişilerde kazanç amacıyla ödünç para verme işlemleri gerçekleştirilebilirler. Bu durumda tefecilik eylemleri izinsiz bankacılık faaliyetini oluşturan eylemlerden birisi olduğu için failin sadece izinsiz bankacılık faaliyetinde bulunma suçundan cezalandırılması gerekir (Karakehya, 2008).

\section{Cezai Müeyyide ve Takibat}

Fiil karşıllı̆ında iki yıldan beş yıla kadar hapis ve beş bin güne kadar adli para cezası şeklinde cezai yaptırım öngörülmüştür. Dolayısıyla faile hem adli para cezası hem de hapis cezası uygulanacaktır. Adli para cezası bakımından alt sınır gösterilmediği için TCK'nın 52. maddesi gereğince beş gün adli para cezası şeklinde belirlenen alt sınır geçerlidir (Meran 2012).

Mahkeme hapis cezası ve adli para cezasını belirlerken öncelikle bu sınırlar arasında TCK'nın 61 . maddesindeki ilkeleri göz önünde bulundurarak temel cezayı belirleyecek ve yine aynı maddede belirlenen düzenlemeler 1şığında arttırma ve indirimlerle sonuç cezaya ulaşacaktır. Sonuç olarak belirlenen gün adli para cezası bakımından ise kişinin ekonomik durumu göz önünde bulundurularak her bir gün için yirmi ile yüz lira arasında bir miktar takdir edilecek, daha sonra bu miktar gün sayısı ile çarpılarak somut para cezasına ulaşılacaktır.

Bununla birlikte suçta kullanılan anapara ve suç kaynaklı olarak ortaya çıkan faiz miktarı da TCK'nın 54 . maddesi gereğince müsadere edilecektir (Özgenç 2010). 
Suç re'sen takip edilen bir suç olduğu için mağdurun şikayetçi olmasına veya herhangi bir merciin iznine gerek olmaksızın takibat yapılacaktır. Dolayısıyla böyle bir suçun işlendiği şüphesi ile karşılaşan soruşturma organları re'sen harekete geçecek (CMK m.160/1), yeterli delile ulaşılması durumunda yargılamaya başlanacak (CMK m.170/2) ve sonuçta mahkeme fiile ilişkin vicdani kanaate ulaşırsa mahkumiyet hükmünü kuracaktır (CMK $\mathrm{m} .223 / 5)$.

\section{Kredi Kartı Tefeciliğinde Son Dönemde Görülen Artışın Nedenleri}

Pos tefecilik fiilinde görülen artışın en önemli nedenlerinden birisi bu tür faaliyetlerin oldukça kazançlı olmasıdır. Ciddi anlamda bu işten günde binlerce liralık kazanç sağlayan işletmeler olduğu görülmektedir. Hukuka aykırı bile olsa bu kadar kazançlı bir işin taliplisi de oldukça fazla olmaktadır.

Ayrıca kredi kartı vasıtasıyla tefecilik yapan kişi, faizle para verdiği kişinin kredi kartını, taksitli satış şeklinde pos cihazından geçirdiği anda alacağını tahsil etmiş olduğundan, çek-senet mafyası tarzı yapılanmalara da bu tür tefecilik faaliyetlerinde artık iş düşmemektedir. Bu bağlamda daha önceden bu tür alacakların tahsili bazen cebir ve tehdit kullanımı gerektiren işler olarak görüldüğünden, tefecilik yapanlar daha çok ya çek-senet mafyası tarzı yapılanma içerisinde olan kişiler veya bu tür yapılarla yakın ilişkisi bulunanlar arasından çıkıyordu. Ancak "pos tefecilikte" artık alacağın tahsili sorunu ortadan kalktığı için, bu faaliyet, maddi kayıp açısından risksiz bir iş olarak görülmektedir. Kazancın bu kadar fazla, kayıp riskinin de son derece az olduğu bu işi yapma taliplileri de ister istemez çoğalmakta; bu da söz konusu yöntemle işlenen tefecilik suçlarında ciddi bir artışa neden olmaktadır.

Bununla birlikte bu yolla tefecilik işlemenin son derece kolay oluşu da kişileri tefecilik yapmak konusunda cezbetmektedir. Nitekim fiil, pos cihazı kullanma imkanına sahip herkes tarafindan, kartı makineden geçirmek suretiyle rahatlıkla işlenebilecek bir fiildir. Bu basitlik de bu fiile girişenlerin artmasındaki bir diğer önemli nedendir.

Tefecilerin aldığı faizin genelde kredi kartı faizinden daha düşük oranlara tekabül etmesi de, tefecilerden kredi kartı vasıtasıyla para talebinde bulunan kredi kartı borçlularının sayısını arttırmıştır. Bu talebe bağlı olarak oluşan arz da tefeciliğin kredi kartı vasıtasıyla işlenmesinde artışa neden olmaktadır.

\section{Sonuç}

Tefecilik TCK'nın 241. maddesinde ekonomi, sanayi ve ticarete karşı suçlar arasında düzenlenmiştir. kanunkoyucunun bu suçun ihdası ile korumaya çalıştğ̆ hukuki menfaat ekonomik düzenin korunması ve devamlılı̆̆ının sağlanmasıdır. Bu suç tipinin kredi kartı vasıtasıyla işlenmesinin boyutları, Türkiye'de son zamanlarda tehlikeli boyutlara ulaşmaya başlamıştır. Fiilin pos cihazına sahip herkes tarafından kolaylıkla işlenebilir olması, kredi kartı çekildikten sonra paranın tahsili bakımından risksiz oluşu gibi nedenlerle, bu tür fiilleri işleyenlerin sayısı giderek daha çok artmaktadır. Büfe, kuyumcu gibi birçok işyerinin bu fiillerin gerçekleştirildiği mekanlar haline geldiği görülmektedir. Hukuka aykırı bir eylem olması nedeniyle devlet denetimi dışında yapılan bu tür işlemler neticesinde, gerek borç para alan şahısların borç batağına düşmeleri gibi bir takım zararlı sonuçlar ortaya çıkabilmekte gerekse de devletin ciddi bir vergi kaybı söz konusu olmaktadır. Yapılacak denetimlerin arttırılması ve kredi kartı faizlerinin daha makul seviyelere çekilmesi ise bu suçla mücadele adına öncelikle alınması gereken önlemlerdir.

\section{Kaynakça}

- Hakeri, Hakan, 2007, Ceza Hukuku Genel Hükümler, Seçkin Yayınevi, Ankara

- Karakehya, Hakan, 2008, “İzinsiz Bankacılık Faaliyetinde Bulunma Suçu,” İstanbul Üniversitesi Hukuk Fakültesi Dergisi, 2008/1.

- Kızılot, Şükrü, 2012, "Pos Tefeci Avı Başladı,” Hürriyet Gazetesi, (26.11.2012) http://www.hurriyet.com.tr/yazarlar/22012688.asp

- Koca, Mahmut ve Üzülmez, İlhan, 2008, Ceza Hukuku Genel Hükümler, Seçkin Yayınevi, Ankara.

- Meran, Necati, 2012, Tefecilik, Ekonomi, Sanayi ve Ticarete İlişkin Suçlar, Seçkin Yayınevi, Ankara

- Özgenç, İzzet, 2010, “Tefecilik Suçu” Gazi Üniversitesi Hukuk Fakültesi Dergisi, C.XIV, 2010/1.

- Parlar, Ali, 2011, Türk Ceza Hukukunda Tefecilik ve İhale Sürecinde İşlenen Suçlar, Bilge Yayınları, Ankara.

- Sabah Gazetesi (27.04.2011), http://www.sabah.com.tr/Ekonomi/2011/04/27/kart-tefeciligi-engellenemiyor

- Stratenwerth, Günter, 2000, Strafrecht Algemeiner Teil I, Carl Heymanns Verlag, Köln.

- Tarlan, Selim, 1987, Tarihte Bankacılık, Maliye ve Gümrük Bakanlığı Araştırma, Planlama ve Koordinasyon Kurulu Yayını, Ankara 
- Toroslu, Nevzat, 2005, Ceza Hukuku Genel Kısım, Savaş Yayınları, Ankara.

- Uğur, Hüsamettin, 2007, “Tefecilik Suçunun Pozitif Dayanakları ve Uygulama İlkeleri,” Terazi Hukuk Dergisi, 2007/Nisan sayıs1. 


\title{
Türkiye'de Giderek Artan Hukuka Aykırı Bir Ekonomik Faaliyet Olarak Kredi Kartı Kullanılması Suretiyle Tefecilik Usury by Using Credit Card as an Increasing Unlawful Economic Activity in Turkey
}

\author{
Assoc. Prof. Dr. Hakan Karakehya (Anadolu University, Turkey)
}

\begin{abstract}
Usury is regulated in article 241 of the Turkish Penal Code as a crime in the field of the economy, industry and trade. The state aims with the regulation to protect continuation of the economic order in the country. Usury by using credit card is one of the most common committing methods of the usury crime in Turkey. Due to this crime, there are many people in the economic difficulties and too much tax losing for the state, recent years in Turkey. Nevertheless usury by the credit card is getting increase with each passing day, because of the easiness, profitability, being risk-free of the action. Increasing controls and reduction to more reasonable levels of the prescribed interest for the credit card debts will be effective in the fight against the crime.
\end{abstract}

\section{Giriş}

İnsanların borç alabilecekleri kişi veya kurumlara duydukları ihtiyaç çok eski tarihler de bile varlığını hissettirmiştir. Öyle ki, Eski Mısır'da, Sümerlerde ve Babil İmparatorluğunda borç alıp verme işlemleriyle uğraşan kişiler ticari hayatın ayrılmaz parçası haline gelmişlerdi. İnsanların dokunulmazlıkları olan mabetlerde kendilerini daha güvende hissetmeleri ve din adamlarının da toplumda itimat edilir kimseler olarak görülmelerine bağlı olarak, bu tür borç işlemleriyle ilk olarak din adamları uğraşmıştır. Hatta tapınaklarda yapılacak bazı vadesi gelen borcun tahsil usulleri, alınacak faiz oranları, gibi hususlar Hammurabi kanunlarında ayrıntılı olarak düzenlenmişlerdir (Tarlan, 1987).

Dolayısıyla borç alınacak kişi ve kurumlara duyulan ihtiyacın ticari hayatın başladığı zamanlardan beri varlığını hissettirdiğini söylemek yanlış olmayacaktır. Bu nedenle günümüzde de ticari hayatın temel bir gereksinimi olan bu tür faaliyetlere izin verilsin veya verilmesin, ekonomik hayatın içinde borç verme ve alma faaliyetinin önüne geçmek pek mümkün görünmemektedir. Ancak günümüzde ekonomik faaliyetlerin alanı o kadar çeşitlenmiş ve bu tür faaliyetler toplumsal düzeni o kadar etkiler hale gelmiştir ki; birçok devlet ortaya çıkabilecek kontrolsüz toplumsal hareketlenmelerin önüne geçme gerekçesiyle borç alınıp-verilmesi faaliyetlerini denetim altında tutma eğilimindedir (Özgenç, 2010). Hatta sadece borç alınıp verilmesi değil; toplum içerisinde parasal hareketliliği etkileyen ve ekonomi alanında önemli yansımaları bulunan diğer birçok ekonomik faaliyet de devlet tarafindan kontrol altına alınmaya çalışılmakta, devlet denetimi dışında hareket eden kişiler de değişik cezai yaptırımlara muhatap kılınmaktadırlar. Türk hukuk sistemi bakımından Bankalar Kanunu m.151'de düzenlenen izinsiz bankacılık faaliyetinde bulunma ve Türk Ceza Kanunu (TCK) m.241'de düzenlenen tefecilik suçları, bu durumu yansıtan en önemli düzenlemelerdir. Bu düzenlemelerle devlet mevduat toplama, borç verme gibi bir takım eylemlerin, sadece kendi izin verdiği ve dolayısıyla denetleyebildiği kişi ve kuruluşlar eliyle yapılmasına imkan sağlamaktadır. Gerekli koşulları gerçekleştirmeksizin bu tür işlemlerde bulunanlar ise söz konusu suç tiplerinde öngörülen cezai müeyyidelere muhatap olma durumuyla karşı karşıya kalmaktadır.

Biz bu çalışmamızda kazanç elde etmek amacıyla başkasına borç para vermek şeklinde gerçekleştirilen tefecilik suçunun yeni bir işleniş şekli olan kredi kartı tefeciliğini inceleme konusu yapacağız. Bu bağlamda tefecilik suçunun unsurları ve kredi kartı tefeciliğinde bu unsurların ne şekilde meydana geldiği, suçun cezası, suçun kredi kartı kullanılmak suretiyle işlenmesinin boyutları ve son dönemde kredi kartı tefeciliğinde görülen artışın nedenleri çalışmada ele alınacak başlıca konular olacaktır. Çalışma sırasında Yargıtay içtihatlarından faydalanmak suretiyle uygulamadaki durumu tespit etmek ve normatif düzenleme 1şı̆̆ında kendi görüşlerimizi neden-sonuç ilişkisi içerisinde açıklamak ise temel çalışma yöntemimizi oluşturacaktır.

\section{Tefecilik Suçuna İlişkin Genel Bilgiler, Suçunun Hukuki Konusu ve Sosyal Bir Vakıa Olarak Kredi Kartı Tefeciliği}

Tefecilik suçu yürürlükte bulunan 5237 sayılı Türk Ceza Kanununun 241. maddesinde düzenleme altına alınmıştır. Söz konusu hükme göre; "Kazanç elde etmek amacılla başkasına ödünç para veren kişi, iki yıldan beş yıla kadar hapis ve beş bin güne kadar adlî para cezası ile cezalandırllır." Madde gerekçesinde ise suç tipinin ihdasına ilişkin şu açıklamalar yapılmıştır: "Madde metninde tefecilik fiili suç olarak tanımlanmıştır. Faiz veya başka bir namla da olsa kazanç elde etmek amacıyla başkasına ödünç para verilmesi, tefecilik suçunu oluşturur. Tefecilik suçu, iktisadi hayatımızda, "senet kırdırma" denen usulle de işlenebilir. Örneğin henüz vadesi gelmemiş bir bononun vadesinden önce başkasına verilerek karşıllğ̆ında bono üzerinde yazılı meblă̆dan 
daha az bir paranın alınması durumunda tefecilik suçu oluşur. Çünkü bu durumda bononun el değiştirmesi, kişiler arasında doğmuş olan bir alacak borç ilişkisine dayanmamaktadır. Ifade yerinde ise, bu durumlarda, birer ödeme aracı olan bononun veya çekin kendisi satılmakta ve satın alınmaktadır. İzlenen suç politikası gereğince, kazanç elde etmek amacıyla başkasına ödünç para veren kişi cezalandırılmaktadır. Buna karşılık, ödünç para alan kişi cezalandırılmamaktadır.”

Suçun hukuki konusu; suçla ihlal edilen hukuki varlık veya menfaattir. Suçun ihlal ediciliği kaynağını hukuki konudan alır. Her suçta nasıl bir fail varsa, bir de hukuki konu vardır (Toroslu, 2005). Yukarıda da açıkladığımız üzere devletler ortaya çıkabilecek olumsuz toplumsal sonuçlarını engellemek amacıyla ödünç para verme işlemlerini kontrol altında tutma eğilimindedirler. Nitekim kamusal bir kontrol mekanizması olmaksızın faiz karşılığı para alınıp verilmesi, sonuçta birçok kişinin ekonomik olarak zora düşmesi sonucunu ortaya çıkartabilecektir (Parlar, 2011). Toplumda bu şekilde zora düşen kişilerin sayısının artmasıyla birlikte ise gerek ekonomik gerekse toplumsal dalgalanmalar ortaya çıkabilecektir. Bu bağlamda devlet kazanç sağlamak amacıyla bu tür faaliyetlerde bulunacak kişi veya kuruluşları kontrol eder ve bunların ödünç para verme işlemlerinde uygulayacakları faiz oranı için sınırlar belirler. Bu bağlamda tefecilik suçunun hukuki konusunu ekonomi alanındaki kamusal düzen oluşturur (Özgenç, 2010). Nitekim suç tipini düzenleyen 241. madde, TCK'nın ikinci kitabının, üçüncü kısmının, dokuzuncu bölümündedir. Bu bölümün başlığı ise Ekonomi, Sanayi ve Ticarete Ilişkin Suçlardır.

Kredi kartı tefeciliği ise son dönemde tefecilik suçunun en yaygın işlenme yöntemlerinden birisini oluşturmaktadır. Son dönemde tefecilik suçunun bu yöntemle işlenmesinin boyutlarını göstermesi bakımından şu alıntıyı paylaşmayı uygun buluyoruz: "Türkiye ekonomisine, yolsuzluk suçları kadar büyük oranda zarar veren tefecilik suçu boyut değiştirdi. Kredi kartı ile pos tefeciliği yaygınlaşmaya başladı. Pos tefeciliği yapan kişilerin, ticari faaliyet adı altında kamufle olabilmeleri ve illegal faaliyetlerini legal gösterebilmelerindeki kolaylı, bu suçun artışında etkili oluyor. Son iki yıl içerisinde tefecilere yönelik toplam bin 165 operasyonda 3 bin 37 şüpheli şahıs yakalandı. Emniyet Genel Müdürlüğü Kaçakçılık ve Organize Suçlarla Mücadele (KOM) Daire Başkanlığı'nın 2010 yılı raporunda, tefeciliğe ilişkin dikkat çekici bilgiler yer alıyor. Son dönemlerde bankalara borcunu ödeyemeyerek kara listeye girmiş olan insanlar, tefecilere giderek yüksek faizlerle borç para aldıkları, ancak sonucunda sahip oldukları tüm mal varlıklarını kaybettikleri ve tefecilik mağduru çok sayıda şahsın ise intihar girişiminde bulundukları ortaya çıktı. Her geçen gün tefecilik yaparak kolay yoldan para kazanacağını düşünen kişiler ile tefecilerin ă̆ına düşen vatandaşların sayısının artması, vergisiz olarak kolay para kazanma hırsını artırdı. Bu durum ise işlerini kanunlara uygun olarak yapan kişileri olumsuz etkiliyor (Sabah Gazetesi (27.04.2012)."

Gerçekten de daha önceden tefecilik suçu işlenirken ödünç para verilen kişiden bir senet vs. alınır ve bu şekilde tefeci kimse ileride alacağı parayı teminat altına almaya çalışırdı. Senedin tahsil edilememesi durumunda ise bazen çek-senet mafyası denilen örgütsel yapılar olaya müdahil olur ve cebir-tehdit kullanmak suretiyle parayı tahsil ederlerdi. Oysa günümüzde uygulanan kredi kartı tefeciliğinde, tefeci bakımından parayı tahsil edememe gibi bir risk bulunmamaktadır.

\section{Kredi Kartı Tefeciliği Bağlamında Tefecilik Suçunun Unsurları}

\subsection{Genel Olarak}

Bir fiilin suç teşkil edebilmesi için tipiklik, hukuka aykırılık ve kusurluluk unsurlarının gerçekleşmiş olması gerekir. Bu bağlamda aşağıda "kredi kartı tefeciliği”nin işleniş biçimi de göz önünde bulundurulmak suretiyle, tefecilik suçunun unsurları inceleme konusu yapılacaktır.

\subsection{Tipiklik}

Tipiklik, failin gerçekleştirdiği fiilin kanunda yer alan suç tanımı ile örtüşmesini ifade etmektedir. Bu bağlamda gerçekleştirilen fiil suç tanımına uymuyorsa; ortada ihlal edilmiş bir norm ve dolayısıyla suç da olmayacaktır. Tipiklik; "maddi ve manevi tipiklik", "tipik maddi unsur ve tipik manevi unsur" ya da "maddi unsurlar ve manevi unsur" terimleri kullanılmak suretiyle ikiye ayrılabilir. Biz maddi ve manevi unsurların tipiklik içerisinde yer aldığını vurgulaması bakımından "tipik maddi unsur ve tipik manevi unsur" (der objektive Tatbestand-der subjektive Tatbestand) şeklindeki kullanıma bağlı kalmayı uygun buluyoruz (Aynı yönde bkz. Stratenwerth, 2000). Suçun tipik maddi unsurunun içerisine suç tanımının içerdiği suçun maddi konusu, fail, măgdur ve fiil girmektedir. Suçun tipik manevi unsuru ise fiil ile fail arasındaki psişik bağı ifade etmektedir.

\section{Tipik Maddi Unsur:}

Suçun Maddi Konusu: Maddi konu suçun üzerinde gerçekleştirildiği eşya veya kişi olarak ifade edilebilir. Ancak bu, failin fiziki faaliyetinin somut olarak üzerinde gerçekleştiği her kişi ya da eşya değil; sadece suçu düzenleyen normdaki tanımda söz konusu olan kişi veya eşyadır (Toroslu, 2005). Tefecilik suçunun maddi konusunu, kazanç amacıyla ödünç verilen para oluşturur. Kanunda bu husus açıkça belirtildiğinden, kanunilik ilkesi gereği başkaca şeylerin verilmesi bu suça vücut vermez. Bu bağlamda örneğin altın veya gümüşün kazanç elde etmek maksadıyla başkasına ödünç verilmesi tefecilik olmaz (Parlar, 2011). Buna karşın paranın Türk lirası 
veya başka bir para birimi olmasının önemi bulunmamaktadır. Dolar veya euro gibi yabancı paraların faiz karşılığında verilmesi de tefecilik suçunu oluşturacaktır.

Kredi kartı tefeciliğinde ise bu maddi konu, kart çekildikten sonra mağdura verilen para olarak karşımıza çıkmaktadır.

Fail: Fail, kanunda tanımlanan suç tipini ihlal eden davranıșı gerçekleștiren kişidir. Fail, fiilin aktif süjesi olarak ifade edilebilir (Toroslu, 2005). Bu suçun faili herkes olabilir. Bu bağlamda failin kamu görevlisi, kadın veya erkek olmak gibi herhangi bir özel vasıf taşımasına gerek yoktur (Parlar, 2005). Tefeciliğin kredi kartı vasıtasıyla işlenmesinde de özellik arzeden bir durum bulunmamaktadır.

Mağdur: Mağdur suçla korunan hukuki menfaat veya varlı̆̆ın sahibidir. Mağdur suçun pasif süjesi olarak da ifade edilebilir (Toroslu, 2005). Tefecilik suçunun mağduru ise hem bu tür fiillerin yaygınlaşmasına bağlı olarak ekonomik düzeninin devamlılı̆ı tehlikeye düşecek olan toplum hem de kazanç elde etmek amacıyla kendisine para verilen kimsedir (Meran, 2012). Kredi kartı tefeciliğinde ise mağdur, kredi kartıyla belirli bir para meblağı çekildikten sonra, kendisine karttan çekilen bu meblağın daha azı verilen kişi olarak karşımıza çıkmaktadır.

Fiil: Kanuni tanıma göre tefecilik suçunu oluşturan fiil, başkasına kazanç amacıyla ödünç para vermektir. Bu tanıma ilk bakışta fiil bakımından ödünç para verme ve kazanç sağlama amacı olmak üzere iki belirleyici özelliğin olduğu göze çarpmaktadır. Ödünç verilecek şeyin para olmasının, bu suçun oluşması bakımından zorunlu olduğunu, yukarıda maddi konuya ilişkin açıklamalarımızda belirtmiştik. Bunun dışında kazancın da mutlaka maddi bir kazanç olması gerekir (Özgenç, 2010). Yardım etme duygusunun tatmini, sevap kazanmak, iyilik zinciri oluşturmak gibi manevi kazançlar bu suçun oluşmasına vücut vermez.

Bununla birlikte kazanç için verilenin para olması zorunluyken, maddi kazancın muhakkak para olması gerekli değildir. Ödünç parayı, ödünç verilen miktardan daha fazla değere sahip bir mülkün kendisine vermesi karşıllı̆ında veren kişi de bu suçu işlemiş olacaktır (Parlar, 2010). Tefeciliğin kredi kartı vasıtasıyla işlenmesinde halinde ise hem ödünç verilen meblağ hem de kredi kartı borcu olarak bankaya ödenen meblağ, para olarak karşımıza çıkmaktadır.

Tefecilik suçu ödünç paranın borç alana verilmesiyle tamamlanmış olmaktadır. Suçun tamamlanması için ödünç paranın karşıllı̆̆ıın elde edilmiş olması şart değildir. Bunun elde edilip edilmemesinin suçun gerçekleşmesi bakımından bir etkisi yoktur (Uğur, 2007). Kredi kartı tefeciliğinde de aynı şekilde tefecilik suçunun tamamlanması paranın borç para alan kişiye verilmesiyle gerçekleşir. Bu konuda sadece anlaşmaya varılmış olması, suçun oluşumuna etki etmez.

Ancak 5237 s. TCK'daki açık düzenlemeye rağmen, tefecilik suçunun oluşumuna ilişkin Yargıtay uygulaması, uzunca bir süre kanuni düzenlemeden farklı gelişti. Nitekim 5237 sayılı TCK'nın 2005 yılında yürürlüğe girmesinden önce, Yargıtay uygulamasında tefecilik suçunun oluşması bakımından, birden fazla kişiye kazanç elde etmek için borç para verilmesi, bu faaliyetin sürekli ve sistemli olarak gerçekleştirilmesi gibi koşullar aranıyordu. Yargıtay tefecilik suçunun oluşması bakımından bu koşulları aramaya, $5237 \mathrm{~s}$. TCK döneminde de devam etti (Örnek olarak bkz. Yargitay 7. CD. 07.10.2009, 5900/10180). Ancak daha sonra yerinde olarak uygulamasını değiştirerek, kanunda tanımlanan fiilin bir kere gerçekleştirilmesi halinde de tefecilik suçunun oluşacağını kabul etmiştir (Örnek olarak bkz. Yargıtay 4. CD 14.03.2012, E.2011/20476, K.2012/5992)

Kredi kartı tefeciliği genelde şu şekillerde işlenmektedir: "Kredi kartı borcu ya da nakit paraya ihtiyacı olan kişi, pos tefeciye gidiyor. Pos tefeci ile örneğin 8 bin liralık borcu veya nakit para ihtiyacı için pazarlık yapıyor. 12 taksitte ödenmek üzere 10 bin liraya anlaşıyor. Pos tefeci 8 bin lirayı bankaya ödeyip, kredi kartı borcunu kapatıyor veya 8 bin lira nakit parayı o kişiye ödüyor. Aynı kredi kartından 10 bin liralık çekimi 12 ay taksitlendiriyor. Karşıllı̆ında 'mal satılıış gibi' belge veriliyor. Vatandaş da 10 bin lira borcunu taksitler halinde ödüyor. Olay kredi kartı faizinden daha düşük olduğu için vatandaşa cazip geliyor. Uzaktan baktığınızda olay mal satışı olarak gözüküyor. Aslında yapıllan iş yüzde 25 komisyonla tefecilik oluyor... (Kızılot, 2012)"

Pos makinesinden komisyon olarak ifade edilen faiz ile birlikte toplam miktarı çeken tefeci, artık alacağı parayı da tahsil etmiş olmaktadır. Nitekim bu şekilde para alan kimse tefeciye değil; kredi kartını aldı̆̆ı bankaya borçlu hale gelmektedir. $\mathrm{Bu}$ nedenle tefeciden para alan mağdur, ileride kredi kartı taksitlerini ödeyemezse, hukuki ihtilaf tefeci ile mağdur arasında değil; bilakis mağdur ile banka arasında ortaya çıkacaktır.

\section{Tipik Manevi Unsur}

Tefecilik suçu kasten işlenebilen bir suçtur. Ancak burada genel kast da yeterli değildir. Suç tipinde tefeciliğin oluşabilmesi için failin para kazanma amacıyla hareket etmesi aranmıştır. Dolayısıyla bu suçun manevi unsuru kazanç elde etme amacından oluşan özel kasttır (Meran, 2012). Fail bu özel kasta sahip olmaksızın söz konusu suçtan cezai sorumluluğu oluşmaz.

\subsection{Hukuka Aykırılık}

Ceza normu ile yasaklanmış tipik davranışların gerçekleştirilmesi hukuka aykırılığın karinesini oluşturur. Ancak bazı hallerde hukuk düzeni, tipiklikte formüle edilmiş olan yasağı hukuka uygunluk nedenleri denilen müsaade edici durumların mevcudiyeti halinde kaldırır. Böylece herhangi bir fiilin hukuka aykırı olduğu konusundaki kesin hüküm, ancak herhangi bir hukuka uygunluk nedeninin somut olayda bulunmaması halinde 
verilebilir (Hakeri, 2007). İlgili kanunlarda öngörülen izinlerin alınması suretiyle, kazanç amaçlı ödünç para verilmesi hukuka uygun olacağından, hukuka aykırılık unsurunun eksikliğinden dolayı tefecilik suçu oluşmaz. Örneğin bankalar gibi özel kanunla kendilerine verilmiş izne dayalı olarak, kazanç elde etme amacıyla ödünç para veren kurumların eylemleri tefecilik suçunu oluşturmayacaktır. Bu bağlamda bu suç bakımından en sık rastlanan hukuka uygunluk sebebi kanun hükmünü icradır.

\subsection{Kusurluluk}

Kusurluluk failin fiilinin kınanabilirliğine ilişkin atfedilen değer yargısını ifade etmektedir (Koca-Üzülmez, 2008). Tefecilik suçunda kusurluluk bakımından özellik arzeden bir durum bulunmamaktadır. Dolayısıyla örneğin cebir-tehdit altında bu tür fiilleri işleyen kimseler bakımından kusurun bulunmaması nedeniyle cezai sorumluluk oluşmayacaktır.

\section{Suçun Özel Beliriş Biçimleri}

\subsection{Teşebbüs}

Teşebbüs kişinin işlemeyi kastettiği bir suçu elverişli hareketlerle doğrudan doğruya icraya başlayıp da elinde olmayan nedenlerle tamamlayamamasıdır (Hakeri, 2007). Tefecilik suçuna teşebbüs kanaatimizce mümkündür. Konuyu kredi kartı tefeciliği bağlamında ele alırsak, örneğin kazanç amacıyla verdiği parayı kişiye teslim ederken yakalanan kimse tefeciliğe teşebbüsten sorumlu olacaktır. Nitekim suçu işlemeye yönelik olarak doğrudan icra hareketlerine başlamış; ancak fiilini elinde olmayan nedenlerle tamamlayamamıştır.

\section{2 İştirak}

Suça iştirak, tek bir kiși tarafından işlenebilen bir suçun, birden fazla kişinin bir araya gelmesiyle işlenmesi halinde söz konusu olur (Toroslu, 2005). Tefecilik suçu, tek bir kişi tarafindan işlenebilen bir suç olması nedeniyle iştirake müsaittir (Meran 2012). Örneğin ortak çalışan iki kişiden birisi müşteri bulup diğeri pos cihazını kullanmak suretiyle kişileri borçlandırıyorsa müşterek fail olarak cezai sorumluluğa sahip olacaklardır. Benzer şekilde pos cihazına sahip bir işletmeci hiç aklında yokken, arkadaşının bu tür faaliyetlerde bulunması konusundaki telkinleriyle tefecilik yaparsa, arkadaşı azmettiren olarak kendisi ise fail olarak suçtan sorumlu olacaklardır. Kredi kartı tefeciliğini yapanların yanında genelde müşteriyle bankaya gidip kart borcunu sıfırlayan yardımcıları da vardır. Bu kişiler de tefecilik fiiline yardım eden olarak cezai sorumluluğa sahiptirler.

\section{3 İçtima}

Kanunda tanımlanan suça ilişkin fiillerin bir defa gerçekleştirilmesi tefecilik suçunun meydana gelmesi bakımından yeterlidir. Dolayısıyla işlenen her bir fiil, fail bakımından kural olarak kanunda belirlenen cezanın ayrı ayrı uygulanmasını gerektirir. Kredi kartı tefeciliği üzerinden örneklerimize devam edersek, on farklı kişiye, kredi kartı vasıtasıyla kazanç elde etmek için para veren kimse, on kez tefecilik suçunu işlemiş olacaktır ve fiiller nedeniyle ayrı ayrı cezalandırılacaktır. Bununla birlikte fiilin zincirleme suç şeklinde de işlenmesi mümkündür. Örneğin bir kişiye kredi kartı vasıtasıyla kazanç elde etmek için para vermeye karar veren fail, bu tek suç işleme kararı kapsamında farklı zamanlarda bu kişiye karşı kredi kartı vasıtasıyla tefecilik suçunu işlese, zincirleme suç hükümlerinin uygulanması gerekecektir (TCK m.43). Bu bağlamda tek suç işleme kararı kapsamında işlenen fiiller için faile tek bir suçun cezası verilecek, daha sonra ceza, kanunda belirtilen oranlar dahilinde arttırılarak belirlenecektir.

Bankalar Kanununun 151. maddesinde düzenlenen, izinsiz bankacılık faaliyetinde bulunma suçu kapsamındaki hareketlerden birisi olarak tefecilik sayılabilecek fiillerin işlenmesi söz konusu olabilir. Nitekim izinsiz bankacılık faaliyetinde bulunan gerçek veya tüzel kişilerde kazanç amacıyla ödünç para verme işlemleri gerçekleştirilebilirler. Bu durumda tefecilik eylemleri izinsiz bankacılık faaliyetini oluşturan eylemlerden birisi olduğu için failin sadece izinsiz bankacılık faaliyetinde bulunma suçundan cezalandırılması gerekir (Karakehya, 2008).

\section{Cezai Müeyyide ve Takibat}

Fiil karşılığında iki yıldan beş yıla kadar hapis ve beş bin güne kadar adli para cezası şeklinde cezai yaptırım öngörülmüştür. Dolayısıyla faile hem adli para cezası hem de hapis cezası uygulanacaktır. Adli para cezası bakımından alt sınır gösterilmediği için TCK’nın 52. maddesi gereğince beş gün adli para cezası şeklinde belirlenen alt sınır geçerlidir (Meran 2012).

Mahkeme hapis cezası ve adli para cezasını belirlerken öncelikle bu sinırlar arasında TCK'nın 61. maddesindeki ilkeleri göz önünde bulundurarak temel cezayı belirleyecek ve yine aynı maddede belirlenen düzenlemeler ışığında arttırma ve indirimlerle sonuç cezaya ulaşacaktır. Sonuç olarak belirlenen gün adli para cezası bakımından ise kişinin ekonomik durumu göz önünde bulundurularak her bir gün için yirmi ile yüz lira arasında bir miktar takdir edilecek, daha sonra bu miktar gün sayısı ile çarpılarak somut para cezasına ulaşılacaktır.

Bununla birlikte suçta kullanılan anapara ve suç kaynaklı olarak ortaya çıkan faiz miktarı da TCK'nın 54 . maddesi gereğince müsadere edilecektir (Özgenç 2010). 
Suç re'sen takip edilen bir suç olduğu için mağdurun şikayetçi olmasına veya herhangi bir merciin iznine gerek olmaksızın takibat yapılacaktır. Dolayısıyla böyle bir suçun işlendiği şüphesi ile karşılaşan soruşturma organları re'sen harekete geçecek (CMK m.160/1), yeterli delile ulaşılması durumunda yargılamaya başlanacak (CMK m.170/2) ve sonuçta mahkeme fiile ilişkin vicdani kanaate ulaşırsa mahkumiyet hükmünü kuracaktır (CMK $\mathrm{m} .223 / 5)$.

\section{Kredi Kartı Tefeciliğinde Son Dönemde Görülen Artışın Nedenleri}

Pos tefecilik fiilinde görülen artışın en önemli nedenlerinden birisi bu tür faaliyetlerin oldukça kazançlı olmasıdır. Ciddi anlamda bu işten günde binlerce liralık kazanç sağlayan işletmeler olduğu görülmektedir. Hukuka aykırı bile olsa bu kadar kazançlı bir işin taliplisi de oldukça fazla olmaktadır.

Ayrıca kredi kartı vasıtasıyla tefecilik yapan kişi, faizle para verdiği kişinin kredi kartını, taksitli satış şeklinde pos cihazından geçirdiği anda alacağını tahsil etmiş olduğundan, çek-senet mafyası tarzı yapılanmalara da bu tür tefecilik faaliyetlerinde artık iş düşmemektedir. Bu bağlamda daha önceden bu tür alacakların tahsili bazen cebir ve tehdit kullanımı gerektiren işler olarak görüldüğünden, tefecilik yapanlar daha çok ya çek-senet mafyası tarzı yapılanma içerisinde olan kişiler veya bu tür yapılarla yakın ilişkisi bulunanlar arasından çıkıyordu. Ancak "pos tefecilikte" artık alacağın tahsili sorunu ortadan kalktığı için, bu faaliyet, maddi kayıp açısından risksiz bir iş olarak görülmektedir. Kazancın bu kadar fazla, kayıp riskinin de son derece az olduğu bu işi yapma taliplileri de ister istemez çoğalmakta; bu da söz konusu yöntemle işlenen tefecilik suçlarında ciddi bir artışa neden olmaktadır.

Bununla birlikte bu yolla tefecilik işlemenin son derece kolay oluşu da kişileri tefecilik yapmak konusunda cezbetmektedir. Nitekim fiil, pos cihazı kullanma imkanına sahip herkes tarafindan, kartı makineden geçirmek suretiyle rahatlıkla işlenebilecek bir fiildir. Bu basitlik de bu fiile girişenlerin artmasındaki bir diğer önemli nedendir.

Tefecilerin aldığı faizin genelde kredi kartı faizinden daha düşük oranlara tekabül etmesi de, tefecilerden kredi kartı vasıtasıyla para talebinde bulunan kredi kartı borçlularının sayısını arttırmıştır. Bu talebe bağlı olarak oluşan arz da tefeciliğin kredi kartı vasıtasıyla işlenmesinde artışa neden olmaktadır.

\section{Sonuç}

Tefecilik TCK'nın 241. maddesinde ekonomi, sanayi ve ticarete karşı suçlar arasında düzenlenmiştir. kanunkoyucunun bu suçun ihdası ile korumaya çalıştı̆̆ hukuki menfaat ekonomik düzenin korunması ve devamlılı̆̆ının sağlanmasıdır. Bu suç tipinin kredi kartı vasıtasıyla işlenmesinin boyutları, Türkiye'de son zamanlarda tehlikeli boyutlara ulaşmaya başlamıştır. Fiilin pos cihazına sahip herkes tarafından kolaylıkla işlenebilir olması, kredi kartı çekildikten sonra paranın tahsili bakımından risksiz oluşu gibi nedenlerle, bu tür fiilleri işleyenlerin sayısı giderek daha çok artmaktadır. Büfe, kuyumcu gibi birçok işyerinin bu fiillerin gerçekleştirildiği mekanlar haline geldiği görülmektedir. Hukuka aykırı bir eylem olması nedeniyle devlet denetimi dışında yapılan bu tür işlemler neticesinde, gerek borç para alan şahısların borç batağına düşmeleri gibi bir takım zararlı sonuçlar ortaya çıkabilmekte gerekse de devletin ciddi bir vergi kaybı söz konusu olmaktadır. Yapılacak denetimlerin arttırılması ve kredi kartı faizlerinin daha makul seviyelere çekilmesi ise bu suçla mücadele adına öncelikle alınması gereken önlemlerdir.

\section{Kaynakça}

- Hakeri, Hakan, 2007, Ceza Hukuku Genel Hükümler, Seçkin Yayınevi, Ankara

- Karakehya, Hakan, 2008, "İzinsiz Bankacılık Faaliyetinde Bulunma Suçu,” İstanbul Üniversitesi Hukuk Fakültesi Dergisi, 2008/1.

- Kııılot, Şükrü, 2012, "Pos Tefeci Avı Başlad1,” Hürriyet Gazetesi, (26.11.2012) http://www.hurriyet.com.tr/yazarlar/22012688.asp

- $\quad$ Koca, Mahmut ve Üzülmez, İlhan, 2008, Ceza Hukuku Genel Hükümler, Seçkin Yayınevi, Ankara.

- Meran, Necati, 2012, Tefecilik, Ekonomi, Sanayi ve Ticarete İlişkin Suçlar, Seçkin Yayınevi, Ankara

- Özgenç, İzzet, 2010, “Tefecilik Suçu” Gazi Üniversitesi Hukuk Fakültesi Dergisi, C.XIV, 2010/1.

- Parlar, Ali, 2011, Türk Ceza Hukukunda Tefecilik ve İhale Sürecinde İşlenen Suçlar, Bilge Yayınları, Ankara.

- Sabah Gazetesi (27.04.2011), http://www.sabah.com.tr/Ekonomi/2011/04/27/kart-tefeciligi-engellenemiyor

- $\quad$ Stratenwerth, Günter, 2000, Strafrecht Algemeiner Teil I, Carl Heymanns Verlag, Köln.

- Tarlan, Selim, 1987, Tarihte Bankacılık, Maliye ve Gümrük Bakanlığg Araştırma, Planlama ve Koordinasyon Kurulu Yayını, Ankara

- Toroslu, Nevzat, 2005, Ceza Hukuku Genel Kısım, Savaş Yayınları, Ankara.

- Uğur, Hüsamettin, 2007, “Tefecilik Suçunun Pozitif Dayanakları ve Uygulama İlkeleri,” Terazi Hukuk Dergisi, 2007/Nisan sayıs1. 


\title{
Grev İşçinin Temel Hakkıdır, Engellenemez Strike is a Fundamental Right for Workers
}

\author{
Prof. Dr. Faruk Andaç (Çağ University, Turkey)
}

\begin{abstract}
Strike is a temporary action for a mass refusal of employees to work in order to ensure that their demands are met. It is called "Strike" in English (which means to break, to burn, to attack) because the first strike events occurred in England as which involved breaking the machines using brake blocks. Workers used to show their reactions towards their employer as by breaking the machines. The same phenomenon existed also in France. Workers in France used to leave their working places all together and go to the Greve area next to River Seine and seek solution to their problems in the cafes. This is how the concept of going on strike, Aller à la Grève (in French), was adopted by Turkish. Strike is a right for workers. It is to leave a workplace unanimously. It is not considered a reason for annulment of employment contract. It is legal and aims to ameliorate the working conditions. Workers should possess the same conditions as their employer in order to determine working conditions by their own free will. Although the employer seems to possess a stronger position as he/she owns the workplace, the workers may possess the same rights as their employers by becoming members of a trade union. When the workers and the employer are unable to reach an agreement on the working conditions, all the workers leave their workplace and go on strike. They partially or completely hamper the activities of the employer. During the strike the workers do not receive their salaries.
\end{abstract}

\section{Giriş}

Grev, sendikacılık hareketlerinin başladığı 19. yüzyılın ilk günlerinden bu yana sürekli uygulanan işçilerin barışçıl bir hak arama yoludur. Bugün dünya devletlerinin büyük bir kısmında yasal bir hak haline getirilmiştir. Çalışanların temel hakkıdır. Grev, bir baskı unsuru olarak işçiler için çok önemli bir mücadele aracıdır. Grev, aynı zamanda siyasi bir baskı unsuru olarak toplum için de önemlidir (Güzel,1980:40). Grev genellikle yaşam düzeyini geliştirmek için işçilerin, gerek işverenler ve gerekse ülke yöneticileri üzerinde baskı kurmak amacıyla toplu halde işbirliği yaparak dayanışmayı sağlamalarına imkan vermektedir.

\section{Grev Kavramı}

Kavram olarak grev, İngilizce "Strike" dir. İngilizcede Strike, aynı zamanda vurmak, çarpmak, saldırmak, hücum etmek, yakmak, çakmak, bulmak, çalmak, etkilemek, etki bırakmak, basmak gibi anlamlarda da kullanılmaktadır. Bunun bu tür anlamlara gelmesinin başlıca nedeni, sanayi devriminin başlamasıyla İngiltere'de XIX. Yüzyılın başlarında emeğin yerini sermayenin (makinenin) almasıyla büyük bir işsizlik ve sefalet başlamış, kapitalist ekonomik sistemin gereği ekonomiye devlet müdahalesi olmamış ve emeği ile çok zor şartlarda çalışmak zorunda kalanlar öfkelerini makinelerden alarak makine kırıcılığı yapmışlardır. Hatta bu kırıcılık hareketlerini sabo ayakkabıları (bir çeşit tahtadan ayakkabı) ile yaptıklarından bu tür hareketlere halen sabotaj denilmektedir. Bu işlemler aslında makinelere karşı değil, kendilerine insanca davranmayan işverenlerine ve ekonomik sisteme isyan etmek idi(Güzel,1980:9-10). Zaten zamanla zorunlu olarak çalışma şartlarında önlemler alınmaya başladıkça bu tür eylemler azalmıştır. Özellikle İngiltere'de 1799 yılında çıkarılan her türlü örgütlenmeyi yasaklayan "Birleşme Yasası (Combination Act)", 1824 yılında yürürlükten kaldırıldıktan sonra sendikal faaliyetler artmaya başlayınca yasal olmayan grevlerde beraberinde artmaya başlamıştır. Fakat bu grevler uzun zaman baskı altında tutulmuştur. Bu nedenle bu grevlere vurmak, kırmak, etkilemek anlamlarına gelen "Strike" denilmektedir. İngiltere'de 1944 yılına kadar grevin yasal bir dayanağı olmamıştır. Ancak uygulanmasını engelleyen bir yasal düzenleme de bulunmamakta idi. 1944 yılında çıkarılan bir özel yasa ile grev tanımlanmış ancak bu yasa da kısa süre sonra yürürlükten kaldırılmıştır. Bugün için grevler halen yargının takdirine bırakılmaktadır(Reisoğlu, 1975:285).

“Grev” sözcüğü Türkçeye Fransızcadan girmiştir. Grev, Fransa'da Paris’te Seine nehri kıyısında kahvelerinde işsiz işçilerin iş bekledikleri veya işvereniyle anlaşamayıp toplu olarak işyerinden ayrılıp gelip oturdukları bir meydanın adıdır. Fransa'da 1789 yılından itibaren gelişen Liberalizm Devrimi ve İngiltere'de 1750 lerden sonra gelişen Sanayi (Makine) Devrimi, Avrupa'da daha önce ev ve el sanatları ile geçimini sağlayan kimselerin işsiz kalmalarına ve kırsal alanlardan sanayi merkezlerine yığılmalarına neden olmuştur. Sanayi merkezlerinde işsiz ve sefalet içerisinde yaşarken işyerlerinde her türlü şartlarla çalışmayı kabul etmek zorunda kalmışlardır. Bu durum Fransa da da kendini göstermiştir. Fransa'da işçiler, çok ağır şartlar altında çalışırken 1864 yılına kadar grev suç (délit de coalition) sayılmakta idi. 1864 yılında çıkarılan bir yasa ile grev suç olmaktan çıkarıldı ancak ceza olarak iş sözleşmesinin feshi şeklinde nitelendirildi. 1946 yılında Fransız Anayasa'sında yapılan değişiklik ile grev bir hak olarak tanındı ve 1950 tarihli yasa ile de grev nedeniyle iş sözleşmesinin feshedilemeyeceği yasallaştırıldı (J.Rivero-J.Savatier,1970:204)(Sur,1987:3). 
Fransa'da 1864 yılından önceleri grev yasağının olduğu dönemlerde iş̧̧iler işyerlerinde işverenle iş mücadelesine girdikleri zaman, kumsal boş alan anlamına gelen Grev Meydanına gelerek sorunlarına birlikte çözüm aramaya çalışırlardı. Bu nedenle birlikte iş yerini terk edip Grev Meydanına gitmek, "Greve Gitmek" (Aller à la Grève) kavramı olarak Türkçeye girmiştir.

\section{Grev Tanımı}

Grev, amacina ve uygulama şekillerine göre veya geniş ve dar anlamlarına göre çeşitli şekillerde tanımlanmaktadır. Genellikle "Grev iş̧̧ilerin, isteklerinin yerine getirilmesini sağlamak amacıyla toplu bir kararla çalışmayı reddedip, geçici olarak işyerini terk etmeleridir” (Sinay,1966:133) (Esener,1978:587) (Talas,1976:456) şeklinde tanımlanmaktadır.

Bu tanıma göre grev, işçilerin işverenlere isteklerini kabul ettirmek amacıyla yapılmaktadır. İşçiler aralarında kararlaş̧ırarak topluca hareket etmektedirler. İşyerinde çalışmayı birlikte reddetmektedirler. İşyerini topluca iş sözleşmesini feshetmeden işi terk etmektedirler.

İşçiler isteklerini işverene kabul ettirmek için işyerinde topluca üretimi yavaşlatmak veya durdurmak şeklinde işverene karşı tehditte bulunmaktadırlar. Bu tehdidi yaparken kendileri de ücretlerinden fedakarlık etmektedirler. Ücretlerinden vazgeçmektedirler, ücret alamamaktadırlar.

\section{Grevin Özellikleri}

\subsection{Grev, İş̧iler İçin Bir Haktır}

Grev, her emeği ile çalışanlar için değil, sadece İşçi olarak çalışanların başvurması gereken bir eylemdir(Sur,1987:30ve dv.). Çünkü emeği ile çalışan bazı kimseler, örneğin Kamu Çalışanları, daha önceden belirlenmiş olan çalışma şartlarını peşin olarak kabul ederek çalışmaya başlamışlardır. Bu tür çalışanlar, hem çalışma şartlarını önceden bilmektedirler ve hem de iş güvencesine sahiptirler. İşleri süreklidir. İşçiler gibi her an için işsiz kalma ihtimalleri bulunmamaktadır. Kamu Çalışanının, işyerindeki ferdi uyuşmazlıklarını yargı vasıtası ile çözümlemesi gerekir(Esener, 1978:48). Çünkü Kamu Çalışanlarının çalışma şartları yasayla statik olarak önceden belirlenmiş olup, çalışan bu şartları önceden bilmekte ve kabul etmektedir. Diğer taraftan kamu hizmeti gören çalışanların, kendi çıkarlarını sağlamak uğruna, grev esnasında kamu hizmetlerini aksatmaları, toplumun doğal haklarından olan kamu hizmetlerinden yararlanma hakkını engellemektedirler. Buna hakları yoktur. Toplum, başkasının çıkarları uğruna kendisini huzursuz eden olayları hoş karşılamaz. Bu nedenlerle Kamu Çalışanlarının grev haklarından söz etmek kamu yararı ile bağdaşmamaktadır. Özellikle sağlık, eğitim, doğal afet, güvenlik gibi konularda grev düşünülmemelidir.

İşçi ise, iş sözleşmesi ile çalışmaktadır (Esener,1978:47)(Andaç,2008:35). Sözleşmeler, Roma Hukukundan bu yana gelen gelenekle kişilerin özgür iradelerine dayanılarak yapılmaktadır(Çağıl,1971:349). İşs sözleşmesi de tarafların özgür iradeleri ile yapılan ve iki tarafa borç yükleyen sözleşmedir. İş sözleşmesi, hem iki tarafa borç yüklemekte ve hem de işçinin her an işsiz kalmasını kolaylaştırmaktadır. Çünkü iş sözleşmesi, diğer sözleşmeler gibi tarafların özgür iradeleri ile kabul edildikleri gibi yine özgür iradeleri ile sona erdirilebilmektedir. $\mathrm{Bu}$ nedenle işçi iş güvencesine sahip değildir. İşçi, işini kaybetmemek ve çalışma şartlarını da kendi isteklerine uygun duruma getirebilmek için grev yapmak zorundadır.

\subsection{Grev, Toplu Olarak İşyerini Terk Etmektir}

İşçi, her zaman ekonomik güce sahip olan işveren karşısında, iş sözleşmesi yaparken özgür iradesi ile isteklerini sözleşmeye yansıtamamaktadır. Çünkü işveren işyerinin mülkiyet hakkına sahiptir. İşveren, mülkiyet hakkına dayanarak işletmesinin üzerinde kullanma, yararlanma ve tam tasarruf etme yetkisine sahiptir. İşveren, işletmesinin devamlılı̆ııı sağlamak amacıyla çalışma şartlarını tek taraflı belirleme ve kararları tek başına alma imkanına sahiptir ve zorundadır. Bu nedenlerle işletmelerde işverenler bağımsız olarak kendi kararlarını kendileri verebilmekte ve çalışma şartlarını haklı olarak kendileri belirlemek istemektedirler. Böyle olunca bir işçinin, özgür iradesi ile tek başına işverenle iş sözleşmesi yapması her zaman mümkün değildir. Bu nedenle çalışan diğer iş̧̧ilerle birleşerek müşterek olarak, işverenin karşısına daha güçlü çıkmak zorunda kalmaktadır. Bunun için İş̧̧inin çalışma şartları, işverenle ikinci bir defa daha sendika aracıllğıyla pazarlık edilerek toplu iş sözleşmesi ile belirlenmektedir. Yani işçinin çalışma şartları, bireysel iş sözleşmesinin yanında ayrıca işverenle sendika aracıllğı ile pazarlık edilerek ikinci bir daha belirlenmektedir. İşçiler, toplu işs sözleşmesi esnasında isteklerini kabul ettiremezler ise, o zaman işverene baskı yapabilmek için işini aksatmak amacıyla topluca işyerini terk edip greve gitmektedirler.

\subsection{Grev, İş Sözleşmesinin Feshine Neden Değildir}

Daha önceleri özellikle Fransa'da 1864-1946 yılları arasında iş sözleşmesinin feshedileceği şeklinde düşünülmekte idi(Camerlynck/Lyon-Caen,1975:592). Halbuki grev, iş̧̧inin doğal temel hakkı olup işverene karş1 çalışma şartlarının düzenlenmesinde etkili olmaya çalışmasıdır. İş sözleşmesini feshetmek amacında değildir. Başka bir art niyeti yoktur. Doğal hakkı olan çalışma şartlarının kendi isteğine uygun olarak da düzenlenmesini istemektedir. Tek taraflı işveren isteğine uygun çalışma şartlarının düzenlenmesi, zaten özgür irade ile sözleşme 
yapılmasının mantığına da uygun değildir. Bu nedenle ulusal yasalarla grev esnasında iş sözleşmesinin feshedilemeyeceği güvenceye alınmaktadır.

\subsection{Grev, Çalışma Şartlarının Düzenlenmesi Amacını Taşır}

Grevin amacı, işverenle çalışma şartlarını belirlerken işçinin de kendi isteklerine uygun şartların sözleşmede yer almasını sağlamaktır. Bunu yaparken işvereni etkileyebilmek için toplu halde hareket etmek gerekir. Bunun dışında bir iş̧̧inin tek başına grev yapması ne işvereni etkiler ve ne de işçiye yarar sağlar. Üstelik ücret kesintisine veya iş sözleşmesinin feshine firsat vermiş olur. Bu nedenle toplu hareket etmek gerekir. Amaç, işvereni iş̧̧inin isteklerine razı etmektir.

İşçiler tarafından, bir başka işyerlerinde çalışan işçilere destek verebilmek için yapılan "Dayanışma Grevi", siyasi otoriteyi baskı altına alarak iş̧̧i isteklerine uygun yasaların oluşturulmasını ve uygulanmasını istemek amacıyla yapılan "Siyasi Grevler", tüm iş̧̧ileri ilgilendiren haklı isteklerini kabul ettirmek ve kamu oyunu etkilemek amacıyla yapılan "Genel Grevler", diğer taraftan yapılan "Boykotlar", "Öğrenci Gösterileri”, bazı toplum örgütlerinin yaptığ1 "Gösteriler" hem yasalarla desteklenmemektedir ve hem de grev özelliklerini taşımamaktadırlar.

\subsection{Grev, Yasal Dayanağa Sahiptir}

Grev nitelikli bir eylemin mutlaka yasal dayanağı olmalıdır. Yasal dayanağı olmayan bir eylem, hem toplum tarafindan benimsenmez ve hem de amacına çoğu zaman ulaşamaz. Bu nedenle grev, yasal kurallar kapsamında etkili olur. Grevi etkili kılabilmek için ulusal yasalarla desteklenmelidir.

Grevle ilgili bazı uluslar arası kuruluşların kabul etmiş olduğu sözleşmeler de bulunmaktadır. Örneğin Avrupa Konseyi tarafından 1961 yılında Torino'da imzalanıp, 1965 yilında yürürlüğe giren ve 1996 yllında Strasbourg'da (Gözden Geçirilmiş) Avrupa Sosyal Şartı'nın II. Bölümünün 6/4. Maddesine ile Grev için uluslar arası yasal dayanak getirilmiştir. Şöyle ki, "Menfaat uyuşmazlı̆̆ durumunda çalışanların ve işverenlerin, daha önce yapılan toplu sözleşmelerden doğabilecek yükümlülüklere bağlı olmak koşuluyla grev hakk dahil, toplu eylem hakkını tanır." şeklindedir. Avrupa Konseyi üye devletlerin birçoğu bu 6/4. Madde hükümlerini onaylamıştır. Türkiye'de 2007 yılında onaylamıştır (RG;T:9.4.2007-S:26488). Ancak yine aynı sözleşmenin IV. Bölümünün G/1. Maddesine göre; “...demokratik bir toplumda başkalarının hak ve özgürlüklerinin korunması ya da kamu yararının, ulusal güvenliğin, halkın sağlığının ya da ahlakın korunması için ve ancak yasayla sinırlamaya ve kisitlamaya tabi tutulabilir. "şeklinde greve bir sınırlama getirilmiştir(Sur,1987:1dipnot).

1919'da Versailles Barış Anlaşması uyarınca kurulmuş ve 1946 yılında BM'in (Birleşmiş Milletler) uzmanlık kuruluşu olarak, sosyal adalet ilkeleri, evrensel insan ve çalışma haklarının korunması amacıyla kurulmuş olan ILO (International Labour Organisation), çalışma standartlarını sözleşmeler ve tavsiyeler yoluyla oluşturmaktadır. Ancak, grev konusunda ILO'nun Grev Hakkı ile ilgili Sözleşmesi veya Tavsiye Kararı bulunmamaktadır. Halbuki ILO (Uluslararası Çalışma Teşkilatı) "Grev Hakkının” temel bir sendikal hak olduğunu savunmaktadır. Fakat bu hakkın kullanılması ile ilgili bir yasal belgesi bulunmamaktadır. ILO için bu bir eksikliktir. Grev konusu, ILO'da yapılan hazırlık çalışmalarında bir çok kere gündeme gelmiş, ancak nedense Konferans Gündemine alınamamıştır.

1948 yllında Birleşmiş Milletler Genel Kurulunda kabul edilmiş olan “İnsan Hakları Evrensel Bildirisi”nin 23/4. Maddesinde ise "Herkesin, çıkarlarının korunması için sendikalar kurmaya ve bunlara katılmaya hakkı vardır.” denilmekte, fakat grev hakkından söz edilmemektedir. Bu da BM için bir eksikliktir.

Türk Anayasa ve İş Hukukunda grev konusunda 1961 yılından bu yana çeşitli şekillerde düzenlemeler yapılmış olup, günümüzde 1982 Anayasa'sının 54. Maddesinde ve 18.10.2012 tarihli ve 6356 sayılı Sendikalar ve Toplu İş Sözleşmesi Kanunu'nun (RG;T:7.11.2012-S:28460) XI. Bölümünde 58. Maddeden itibaren düzenlemeler bulunmaktadır.

\section{Sonuç}

İşçiler, işverenle çalışma şartları konusunda özgür iradeleri ile başa baş yaptıkları iş sözleşmelerinde, işveren karşısında pazarlık gücü her zaman zayıf kaldığından sendikalaşarak hep birlikte sendika vasıtasıyla işverenle ikinci bir sözleşme yapmaktadırlar. Ancak bu ikinci defa yapılan sözleşme görüşmeleri esnasında taraflar anlaşamadıkları takdirde işçiler greve giderek, işvereni isteklerine razı edebilmek amacıyla, toplu olarak işyerini terk etmek suretiyle işverenin faaliyetini ya kısmen veya tamamen durdurmaktadırlar. Bu davranış, işçilerin temel hakkıdır. Bunu engellemek, işçinin özgür iradesiyle çalışma şartlarını belirlemelerine engel olmaktır. İşçinin özgür iradesini kısıtlamak, demokratik düşüncenin kabul edemeyeceği bir davranıştır. Bu ancak demokrasi dışı ülkelerde uygulanan bir yöntemdir. Saygılarımla. 


\section{Kaynakça}

- $\quad$ ANDAÇ,F.: “İş Hukuku”, Adalet Yayınevi, Ank.2008.

- CAMERLYNCK,G.H.-LYON-CAEN,G.: “Droit du Travail”, Précis Dalloz, 7.éd. Paris 1975.

- ÇAĞIL,O.M.: "Hukuka ve Hukuk İlmine Giriş”, İst.Ü. Hukuk Fak. Yayını no:338, 4.Bası, İst.1971.

- $\quad$ ESENER,T.: “İş Hukuku”, Ank.Ü. Hukuk Fakültesi Yayınları no:432, 3.Bası, Ank.1978.

- GÜZEL,M.Ş.: “Grev”, Bilimsel Yayıncılık, Ank.1980.

- REİSOĞLU,S.: “Toplu İş Sözleşmesi Grev ve Lokavt Kanunu Şerhi”, Ank.Ü.Hukuk Fak. Yayını no:359, 2. Bask1, Ank.1975.

- RIVERO,J.-SAVATIER,J.: "Droit du Travail”, 5.éd. P.U.F. Thémıs, Paris 1970.

- SINAY,H.: "La Grève”, Précis Dalloz, t. VI, Paris 1966.

- SUR,M.: “Grev Kavramı”, D.E.Ü. Yayınları, İzmir 1987.

- TALAS,C.: “Sosyal Ekonomi”, S Yayını, 4. Bask1, Ank.1976. 


\title{
Kyoto Protokolü Esneklik Mekanizması: Emisyon Ticareti Flexible Mechanisms of the Kyoto Protocol: Emissions Trading
}

\author{
Prof. Dr. Müslüme Narin (Gazi University, Turkey)
}

Özet

The growth of the world economy, rapid population growth and urbanization increased the demand for energy. Nowadays, a large part of the growing demand for energy provided by fossil fuels, carbon dioxide and greenhouse gas emissions resulting from the burning of these fuels leading to climate change and global warming. Reduction of greenhouse gas emissions in 1994 to the United Nations Framework Convention on Climate Change, the Kyoto Protocol entered into force in 2005. The Kyoto Protocol, emission volume of the three market-based flexibility mechanisms have to be considered. One of these mechanisms is emissions trading. This study will focus on emissions trading systems and carbon markets. All over the world in recent years, based on the spot and futures contracts are traded on the carbon. In this direction of the world's carbon stocks and its activities will be discussed. Also in 2008, in the aftermath of the global crisis and European Debt Crisis its effects on carbon markets will be investigated.

\section{Giriş}

Dünya ekonomisindeki büyüme ve nüfus artışı, enerjiye olan talebi hızla artırmaktadır. Günümüzde artan enerji talebinin yaklaşık \%70’i fosil yakıtlardan karşılanmaktadır. Fosil yakıtların yakılması sonucu karbondioksit gazı açığa çıkmakta, bu da 1sının uzaya çıkışını yavaşlatarak sera gazının oluşumuna neden olmaktadır. Sera gazı emisyonu, iklim değişikliğine, hava kirliliğine yol açarak, bitki ve hayvan türlerini yok etmektedir. $\mathrm{Bu}$ olası sonuçların yarattığı endişe, enerji ile ilgili bilimsel çalışmaları hızlandırmıştır. Bu doğrultuda bir yandan hızla yeni ve yenilenebilir enerji kaynaklarına yönelik çalışmalar yoğunlaşmış, öte yandan fosil yakıtların neden olduğu sera gazlarının yol açtığı iklim değişikliğine çözüm aramak üzere Birleşmiş Milletler İklim Değişikliği Çerçeve Sözleşmesi (BMİDÇS) ve Kyoto Protokolü gibi uluslararası girişimlerde bulunulmuştur.

Çalışmanın amacı, fosil yakıtların yol açtığı sera gazı emisyonları ve bu emisyonların azaltılması amacıyla oluşturulan BMIDÇS ve Kyoto Protokolü'nü incelemektir. Bu doğrultuda öncelikle dünyada ve Türkiye'de enerji tüketimi ve sera gazı emisyonları ele alınacak, daha sonra BMIDÇS ve Kyoto Protokolü'ne yer verilecektir. Ardından emisyon ticareti sistemleri ve karbon borsaları, son olarak da karbon piyasalarının büyüklüğü üzerinde durulacaktır.

\section{Dünyada Enerji Tüketimi ve Karbondioksit Emisyonları}

Dünya ekonomisi, 1980'li yıllardan itibaren ortalama \%3 civarında büyüme gösterirken, 2008 küresel krizden sonra büyüme hızı yavaşlamış 2011 yılında büyüme hızı \%2,7düzeyinde gerçekleşmiştir. Ayrıca gelişmiş ülkelerin büyüme hızları yavaşlarken hatta düşerken, gelişmekte olan Çin, Hindistan, Türkiye gibi ülkelerin 2008 küresel krizine rağmen büyüme hıları artmaya devam etmiştir ( UNCTAD, 2012: 422, 424, 426).

1990 yılında 5 milyar civarında olan dünya nüfusunun 2011 yılında yaklaşık 7 milyara ulaştı̆̆ı, şehir nüfusunun payının ise 1990 yılına göre oldukça arttığı görülmektedir. Dünya genelinde 1990 yılında \%42,9 olan şehir nüfusunun payı 2011 yılında \%51,3'e çıkmıştır. Bu pay, özellikle gelişmekte olan ülkelerde çok daha hızlı artmıştır (UNCTAD, 2012: 454, 462, 463, 465, 468).

\begin{tabular}{|l|l|l|l|}
\hline & 1973 & 2005 & 2010 \\
\hline Petrol & 50,6 & 39,5 & 36,1 \\
\hline Kömür & 34,9 & 40,5 & 43,1 \\
\hline Doğal Gaz & 14,4 & 19,7 & 20,4 \\
\hline Diğer & 0,1 & 0,3 & 0,4 \\
\hline Toplam (\%) & 100,0 & 100,0 & 100,0 \\
\hline Toplam Milyon Ton $\mathrm{CO}_{2}$ & 15.637 & 27.136 & 30.326 \\
\hline
\end{tabular}

Tablo 1. CO2 Emisyonlarının Enerji Kaynaklarına Göre Payları (\%) Kaynak: IEA, $2012 a: 44$.

Özellikle yükselen piyasa ekonomilerinin hızlı büyümesi, dünya nüfusunun ve şehirleşme oranlarının artışına bağlı olarak enerji tüketimi de hızlı artmıştır. 1973 yılında 4.672 Mtoe olan enerji tüketimi 2010 yılında yaklaşık iki katına çıkarak 8.677 Mtoe'ye çıkmıştır. Bu verilere göre, 1973-2010 döneminde dünya birincil enerji talebi yıllık ortalama \%1,7 civarında artmıştır. Artan birincil enerji talebi içerisinde en büyük payı petrol oluşturmakta, 
onu doğal gaz ve kömür izlemektedir (IEA, 2012a:.28). Yine aynı dönemde enerji tüketiminin payı OECD ve Avrupa ülkelerinde düşmüş, ancak diğer bölgelerde artmıştır (IEA, 2012: 30).

Petrol, kömür ve doğal gazdan oluşan fosil yakıtların yakılması sonucu oluşan karbondioksit $\left(\mathrm{CO}_{2}\right)$ emisyonları ve bu emisyonların enerji kaynaklarına ve bölgelere göre payları Tablo 1'de verilmiştir. 1973 yılında dünya $\mathrm{CO}_{2}$ emisyonlarının yarısından fazlası petrolden kaynaklanırken, bu pay 2005 ve 2010 yıllarında azalmıştır. Ancak kömür ve doğal gazın payları artmıştır. Öte yandan CO2 emisyonlarına ağırlıklı olarak OECD ülkelerinin neden olduğu, bu ülkeleri tek başına Çin'in izlediği Tablo 2'de görülmektedir.

\begin{tabular}{|l|l|l|}
\hline & 1973 & 2010 \\
\hline OECD & 66,1 & 41,0 \\
\hline Afrika & 1,8 & 3,1 \\
\hline OECD diş1 Amerika & 2,6 & 3,5 \\
\hline Asya (Çin Hariç) & 3,0 & 11,1 \\
\hline Çin & 5,9 & 24,1 \\
\hline OECD Dışı Avrupa ve Avrasya & 16,2 & 8,6 \\
\hline Orta Doğu & 0,8 & 5,1 \\
\hline Tankerler & 3,6 & 3,6 \\
\hline
\end{tabular}

Tablo 2. CO2 Emisyonlarının Bölgelere Göre Payları (\%) Kaynak: IEA, 2012a: 45.

Enerji talebi ve enerji kaynakları bileşiminde kısa vadeli değişiklikler, büyük ölçüde ekonomik koşullar, enerji fiyatları ve iklim koşullarına bağlıdır. Ancak uzun vadeli trendler, enerji ve iklim değişikliğine ilişkin hükümet politikalarına ilişkin varsayımlarına göre değişen World Energy Outlook (WEO)nun üç farklı senaryosuna göre oluşturulmaktadır. Bu senaryolar arasında da büyük farklılıklar bulunmaktadır. Bu senaryolar içinde Yeni Politikalar Senaryosu ana senaryo olarak dikkate alınmaktadır. Bu senaryonun hükümetlerin en son politikalarına göre uygulandığı varsayılmaktadır (IEA, 2011: 1). Bununla birlikte enerji trendleri bazı temel senaryolar karşısında devam etmektedir. Bunlar; artan gelir ve nüfus enerji talebini artırmakta, enerji piyasa dinamikleri giderek gelişmekte olan ekonomiler tarafından belirlenmekte, fosil yakıtlar dünya enerji talebinin büyük bölümünü karşılamakta ve dünyanın enerji yoksullarına enerjinin sağlaması zor bir hedef olarak kalmaktadır (Tablo 3).

Bu temel trendlerden birincisi, dünya enerji ihtiyacının artıyor olmasıdır. Yeni politikalar ve programlarla enerji tasarrufu teşvik edilse dahi, küresel ekonomideki gelişme ve nüfus artış1 enerji talebini artıracaktır. Dünya birincil enerji talebi Yeni Politikalar Senaryosuna göre (uzun dönemde ortalama dünya sıcaklığının 3,5 derece artacağı öngörüsüne paralel olarak) 2010-2035 döneminde \%35 artacağ1, yıllık ortalama artışın ise yıllık ortalama \%1,2 olacağı öngörülmüştür. Mevcut Politikalar Senaryosuna göre enerji talebi \% 46,7, yıllık ortalama ise $\% 1,5$ oranında, 450 Senaryosuna göre ise $\% 16,2$, yıllık ortalama $\% 0,6$ oranında artacağı öngörülmektedir (IEA, 2012b:.50).

\begin{tabular}{|l|l|l|l|l|l|l|l|l|}
\hline & & \multicolumn{3}{|l|}{ Yeni Politikalar } & \multicolumn{2}{l|}{ Mevcut Politikalar } & \multicolumn{2}{l|}{ 450 Senaryosu } \\
\hline Yıllar & 2000 & 2010 & 2020 & 2035 & 2020 & 2035 & 2020 & 2035 \\
\hline Kömür & 2.378 & 3.474 & 4.082 & 4.218 & 4.417 & 5.523 & 3.569 & 2.337 \\
\hline Petrol & 3.659 & 4.113 & 4.457 & 4.656 & 4.542 & 5.053 & 4.282 & 3.682 \\
\hline Doğal Gaz & 2.073 & 2.740 & 3.266 & 4.106 & 3.341 & 4.380 & 3.078 & 3.293 \\
\hline Nükleer & 676 & 719 & 898 & 1.138 & 886 & 1.019 & 939 & 1.556 \\
\hline Hidro & 226 & 295 & 388 & 488 & 377 & 460 & 401 & 539 \\
\hline Biyoenerji & 1.027 & 1.277 & 1.532 & 1.881 & 1.504 & 1.741 & 1.568 & 2.235 \\
\hline Diğer Yenilenebilir & 60 & 112 & 299 & 710 & 265 & 501 & 340 & 1.151 \\
\hline Toplam & 10.097 & 12.730 & 14.922 & 17.197 & 15.332 & 18.676 & 14.176 & 14.793 \\
\hline Fosil yakıtların pay1 (\%) & 80 & 81 & 79 & 75 & 80 & 80 & 77 & 63 \\
\hline OECD diş1 pay (\%) & 45 & 55 & 60 & 65 & 61 & 66 & 60 & 63 \\
\hline CO2 Emisyon (Gt) & 23,7 & 30,2 & 34,6 & 37,0 & 36,3 & 44,1 & 31,4 & 22,1 \\
\hline
\end{tabular}

Tablo 3. Farklı Senaryolara Göre Dünya Birincil Enerji Talebi ve Enerjiyle İligili CO2 Emisyonlarl (Mtoe) Kaynak: IEA, 2012b:.51.

İkinci temel trend, enerji piyasaları dinamiklerinin yükselen ekonomiler tarafindan belirlenecek olmasıdır. Küresel birincil enerji talebinde OECD dişı ülkelerin payı 1973 yılında \%36 iken, 2000 yılında \%45, 2010 y1lında \%55 olmuş, her bir senaryoya göre de gelecekte artmaya devam edecektir. Bu durum, OECD diş1 yükselen piyasa ekonomilerinde nüfus, ekonomik faaliyetler, şehirleşme ve sanayi üretiminde hızlı artışı göstermektedir.

Üçüncü trend, petrol, kömür ve doğal gazdan oluşan fosil yatıklara yönelik dünya enerji ihtiyacının artmaya devam etmesidir. 2010 yılında dünya enerji talebi içerisinde \%81 olan fosil yakıtların payı, tüm senaryolarda 
temel enerji kaynakları olarak kalmaya devam edecektir. 2035 yılında bu pay, Mevcut Politikalar senaryosuna göre \%80, 450 senaryosuna göre $\% 63$ oranında gerçekleşecektir.

Dördüncü trend, dünyanın en yoksullarına evrensel enerjinin sağlanması konusunda başarısız kalınmıştır. En son tahminlere göre dünya nüfusunun \%20'sini oluşturan yaklaşı 1.3 milyar kişinin elektriğe erişiminin olmadığı, 2.6 milyar kişinin de yemek pişirmek için geleneksel biyokütle enerjisi kullandığı tespit edilmiştir. Bu kişilerin \%95'inden daha fazlasının Sahra-altı Afrika ya da gelişmekte olan Asya ülkelerinde olduğu görülmektedir.

Üç senaryoyu önemli ölçüde değiștiren durum ise karbondioksit emisyonlarının seyridir. Tahminlere göre enerji ile ilgili CO2 emisyonları 2011 yılında 31.2 Gt'ye ulaşmış olup, küresel sera gazı emisyonları içerisinde yaklaşık \%62 ile en büyük paya sahiptir (IEA, 2012b: 246). Farklı senaryolara göre enerji ile ilgili CO2 emisyonları Şekil 1'de görülmektedir. Yeni Politika Senaryosuna göre 2035 yılına kadar emisyonlar artmaya devam edecek, küresel isınma uzun dönemde ortalama 3,6 derece artacaktır. Yeni politikalar olmazsa küresel 1sınma Mevcut Politikalar Senaryosuna göre 5,3 derece, 450 Senaryosunda ise 2 derece artacağ öngörülmektedir.

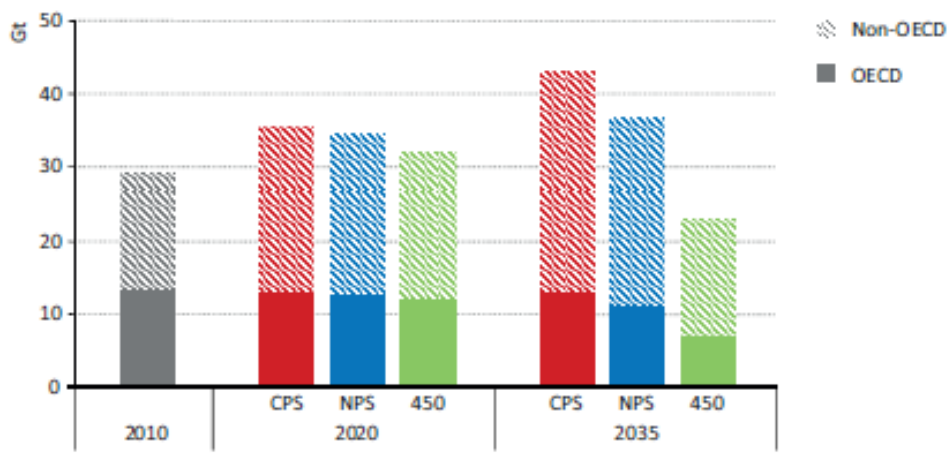

Note: NPS $=$ New Policies Scenario; CPS $=$ Current Policies Scenario; $450=450$ Scenario

Şekil 1. Farklı Senaryolara Göre Enerji ile ilgili CO2 Emisyonları Kaynak: IEA, World Energy Outlook 2012.

OECD ve OECD dışı ülkelerin farklı senaryolara göre enerjiyle ilgili CO2 emisyonları Şekil 2'de görülmektedir.

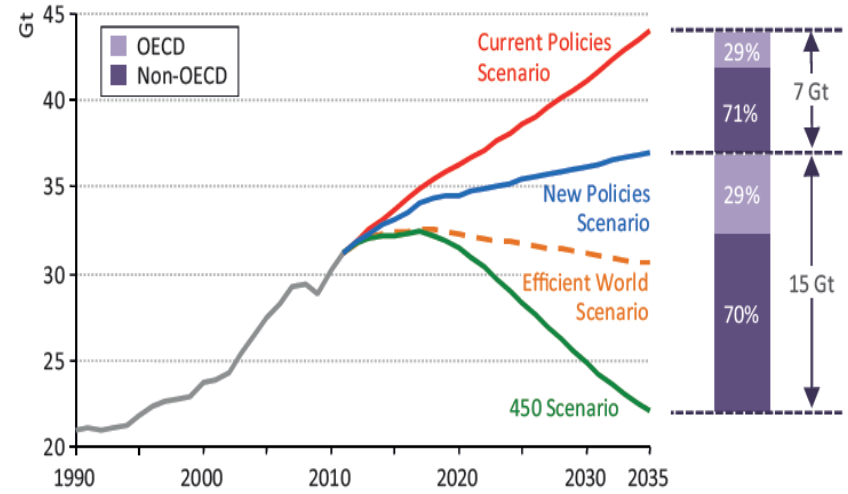

Şekil 2. Farklı Senaryolara Göre OECD ve OECD Ülkelerinin Enerji ile ilgili CO2 Emisyonları Kaynak: IEA, World Energy Outlook 2012, s. 246.

Ayrıca Atmosferdeki $\mathrm{CO}_{2}$ emisyonunun ulaşması hedeflenen 450 ppm (part per million: milyonda bir) düzeyine ilişkin geliştirilen 450 Senaryosuna göre, toplam emisyonlar 2020 yılında 31,4 civarına çıkacaktır. Ancak daha sonraki yıllarda CO2 emisyonları; sanayide, binalarda ve taşımacılıkta fosil yakıt kullanımında verimlilik sağlama, nükleer ve yenilenebilir enerji kaynaklarının payını artırma, elektrik üretiminde ve sanayide $\mathrm{CO}_{2}$ emisyonları yer altında depolama teknolojisinin (CCS) kullanımıyla azaltılabilecek ve 2035 yılında $22,1 \mathrm{Gt}$ olması hedeflenmektedir (IEA, 2012b: 253).

\section{Küresel Isınma ve İklim Değişikliği}

Küresel ısınma, dünya çapında genel sıcaklığın artması olarak tanımlanmakta ve atmosferdeki sera gazlarının yoğunluğunun değişmesiyle meydana gelmektedir. Küresel ısınmaya neden olan sera gazları içerisinde en büyük 
paya karbondioksit sahiptir. 2010 yılında enerjiye bağlı payı karbondioksit, toplam sera gazlarının yaklaşık $\%$ 62'ni oluşturmaktadır (IEA, 2012b: 246).

Küresel düzeydeki sıcaklık artışının en büyük etkisi ise iklim sistemi üzerinde meydana gelmektedir. Küresel 1sınmaya bağlı olarak ortaya çıkan iklim değişikliği de, atmosfer içinde doğal olarak bulunan ve sera gazları olarak adlandırılan bazı gazların yoğunluklarının değişmesine, buna bağlı olarak da yerkürenin aşırı olarak 1sınmaya başlaması ve birtakım ekolojik dengesizliklerin ortaya çıkmasına yol açmaktadır.

Fosil yakıtların yanmasıyla oluşan karbondioksit (CO2) ile arazi kullanımı ve tarım faaliyetleri sonucu açığa çıkan metan (CH4), nitröz oksit (N2O) ve uzun ömürlü sanayi gazlarının atmosferde belli bir konsantrasyonun üzerinde olması sera etkisini artırmaktadır. $\mathrm{CO} 2$, sera etkisini yükselten ana gazdır. Sanayi devriminin gerçekleştiği 1850'li yıllardan günümüze CO2 birikiminin yaklaşık 280 ppm'den 380 ppm'e, CH4 birikiminin 715 ppb'den 2.000 ppb'ye ve N2O birikiminin de 270 ppb'den 320 ppb'ye yükseldiği görülmektedir. Artan sera etkisi dünya ortalama sıcaklığını yükseltmekte ve küresel iklim sistemini bozmaktadır (Arı, 2010:8).

Birleşmiş Milletler İklim Değişikliği Çerçeve Sözleşmesi (BMIDÇS)'nde iklim değişikliği, "karşılaştırılabilir zaman dilimlerinde gözlenen doğal iklim değişikliklerine ek olarak, doğrudan veya dolaylı olarak küresel atmosferin bileşimini bozan insan faaliyetleri sonucunda iklimde oluşan bir değişikliktir" şeklinde tanımlanmaktadır (EIEE, 2013). Sera gazlarının yol açtığı iklim değişikliğine çözüm bulmak üzere BMİDÇS ve Kyoto Protokolü gibi uluslararası girişimlere gidilmiştir.

Birleşmiş Milletler İklim Değişikliği Çerçeve Sözleşmesi. Son yıllarda toplumun ilgisini çekmeye başlayan artan sera etkisi ve küresel ısınma, yüz yılı aşkın bir süredir bilinmekte ve incelenmektedir. Atmosferdeki $\mathrm{CO}_{2}$ emisyonunun artmasına bağlı olarak iklimin değişebileceği görüşü, ilk kez 1896 yılında Nobel Ödüllü İsveçli S. Arrhenius tarafından ortaya atılmıştır (Türkeş, 2006). Bu konuda 1970'li yıllara kadar bilimsel çalışmalar devam etmiş, ancak ilk kez 1979 yılında Dünya Meteroloji Örgütü (WMO) öncülüğünde iklim konferansı düzenlenmiştir. İklim değişimine ilişkin gerçekleştirilen uluslararası iklim rejimi süreci Tablo 4'ta özetlenmiştir.

21 Mart 1994 tarihinde yürürlüğe giren BMIDÇS, sürdürülebilir kalkınmanın kurumsal çerçevesini oluşturan en önemli yapıtaşları arasında yer almaktadır. Bu sözleşmede iklim değişikliğinin ve zararlarının insanlığın ortak kaygısı olduğu, insan etkinliklerinin atmosferdeki sera gazları yoğunluğunu artırdı̆̆ı ve bunun atmosferde sıcaklık artışıyla sonuçlanarak insanlığa zarar verdiği, küresel sera gazı emisyonunda en büyük payın gelişmiş ülkelerden kaynaklandığı ve iklim değişikliğinin küresel boyutu nedeniyle uluslararası boyutta işbirliğine gidilmesi gerektiği belirtilmektedir (Arıkan, 2006: 5).

$\mathrm{Bu}$ sözleşmenin ekindeki listede ülkeler gruba ayrılmış ve sorumlulukları belirlenmiştir. Ek-1 listesinde OECD ülkeleri, $\mathrm{AB}$ ve pazar ekonomisine geçiş sürecinde bulunan ülkelerden oluşan 36 ülke yer almaktadır. Bu listede bulunan ülkeler, emisyon azaltımından sorumlu tutulmuştur. Türkiye, özel koşullar tanınarak bu listeye dâhil edilmiştir. Ek-2 listesinde Türkiye hariç OECD ülkeleri, AB-15'den oluşan 25 ülke yer almaktadır. Bu listedeki ülkeler, teknoloji transferi ve mali destek sağlamaktan sorumlu tutulmuştur. Ek-1 dişı ülkeler listesinde ise iki listede yer almayan Çin, Hindistan, Pakistan, Meksika, Brezilya gibi ülkeler yer almakta ve bu ülkelerin yükümlülükleri bulunmamaktadır.

2001 yılında Marakeş’te gerçekleştirilen 7. Taraflar Konferansı'nın (COP7) Türkiye'nin konumu değiştirilmiştir. Sözleşmenin Ek-1 listesinde yer alan diğer ülkelerden farklı bir konumda olan Türkiye'nin özel koşullarının tanınarak, adının Ek-1 listesine alınarak Ek-2 listesinden silinmesi yönünde karar alınmıştır (UNFCCC, 2013). Bu sözleşmeye Türkiye 24 Mayıs 2004 tarihinde resmen taraf olmuştur.

Kyoto Protokolü. Kyoto Protokolü, küresel ısınma ve iklim değişikliği konusunda mücadele vermek amacıyla BMİDÇS içinde imzalanmıştır. 1997 yılında Japonya'nın Kyoto şehrinde imzaya açılan ve 2005 y1lında Rusya'nın anlaşmayı onaylaması üzerine yürürlüğe giren Protokol'e günümüzde 191 ülke ve Avrupa Birliği taraf olmuştur (UNFCCC, 2013). Bu Protokol, BMIDÇS'nin sera gazı emisyonlarının azaltılmasına yönelik hukuki açıdan bağlayıcı bir belgesidir. Bu protokolü, Türkiye 26 Ağustos 2009 tarihinde özel şartlı Ek-1 üyesi olarak imzalamıştır.

Kyoto protokolü, ülkelerin ortak ancak farklı sorumlulukları, ulusal ve bölgesel kalkınma öncelikleri, amaçları ve özel koşulları dikkate alınarak, öncelikli olarak gelişmiş (sanayileşmiş) ülkelerin sera gazı emisyonlarını azaltmaları yönünde yükümlülükler getirmektedir. BMIDÇS Ek-1 listesinde yer alan gelişmiş ülkeler, Kyoto Protokolü Ek-B listesinde belirlenen sayısallaştırılmış emisyon sınırlamalarına uymayı taahhüt etmiştir. Bu ülkelerin toplam sera gazı emisyonlarını ilk yükümlülük dönemi olan 2008-2012 döneminde, temel olarak alınan 1990 yılı düzeyinin en az \%5 altına indirmesini taahhüt etme zorunluluğu getirilmiştir. Ayrıca Ek-1 taraflarından her biri 2005 yılına kadar bu protokoldeki yükümlülüklerini yerine getirmede gösterilebilir bir ilerleme kaydetmiş olacaktır. Bağlayıcı hedefleri olan ülkeler, dünya karbon salınımının \%45'ini temsil etmektedir (UNFCCC, 2013).

7-8 Aralık 2012 tarihinde Katar'ın başkenti Doha'da gerçekleşen BMIDÇS 18. Taraflar Konferansı (COP18) ve Kyoto Protokolü'nün (KP) 8. Taraflar Buluşması (COP/MOP8) görüşmelerinde, uluslararası iklim değişikliği rejimini düzenleyen mevcut tek resmi mekanizma olan Kyoto Protokolü'nün devamı konusunda karar alınmıştır. Bu doğrultuda, Kyoto Protokolü'nün ikinci yükümlülük dönemi 1 Ocak 2013 tarihinde başlayacak 31 Aralık 
2020 yılına kadar devam edecektir. Japonya, Kanada, Rusya ve Yeni Zelanda ikinci yükümlülük döneminde yer almayacağını belirtirken, Avrupa Birliği'ne üye 27 ülke, gelişmiş ülkelerden Avustralya, İsviçre, 2020 yılına yönelik emisyon azaltım hedeflerini ortaya koymuşlardır. Türkiye ise birinci yükümlülük dönemine benzer şeklide, henüz bir salım azaltım yükümlülüğü belirtmemiştir (UNFCCC, 2013).

\begin{tabular}{|c|c|c|}
\hline Y1l & Atılan Adım & Önemi \\
\hline 1979 & $\begin{array}{l}\text { Dünya Meteoroloji Örgütü (WMO) Birinci İklim } \\
\text { Konferans1 }\end{array}$ & $\begin{array}{l}\text { Fosil yakıtlara bağımlılığın sonucu CO2 gazının } \\
\text { tehlikeli olacağı açıklandı. }\end{array}$ \\
\hline \multirow[t]{2}{*}{1988} & $\begin{array}{l}\text { WMO Hükümetler Arası İklim Değişikliği Paneli } \\
\text { (IPCC) Kuruluşu }\end{array}$ & $\begin{array}{l}\text { İklim değişikliği alanında uluslararası bilimsel bir } \\
\text { komite kuruldu. }\end{array}$ \\
\hline & BM Küresele İklimin Korunması Kararı & Konu ilk defa BM gündemine geldi. \\
\hline 1990 & $\begin{array}{l}\text { Dünya Meteoroloji Örgütü (WMO) İkinci İklim } \\
\text { Konferansı (Cenevre) }\end{array}$ & $\begin{array}{l}\text { 1992-Rio'da bir çerçeve sözleşmesinin gereği için } \\
\text { Bakanlar Deklarasyonu onaylandı }\end{array}$ \\
\hline 1991 & Birinci Değerlendirme Raporu & \\
\hline \multirow[t]{2}{*}{1992} & BMİDÇS imzaya açıldı & $\begin{array}{l}\text { Sera gazı emisyonlarının iklim sistemi üzerindeki } \\
\text { etkisini önlemeyi amaçlayan uluslararası bir } \\
\text { anlaşma imzalandı. }\end{array}$ \\
\hline & $\begin{array}{l}\text { Birleşmiş Milletler Çevre ve Kalkınma } \\
\text { Konferans1 (Rio) }\end{array}$ & $\begin{array}{l}\text { Rio sözleşmeleri ile çevre ve kalkınma birlikte ele } \\
\text { alındı. }\end{array}$ \\
\hline 1994 & $\begin{array}{l}\text { Birleşmiş Milletler İklim Değişikliği Çerçeve } \\
\text { Sözleşmesi yürürlüğe girdi. }\end{array}$ & BMİDÇS uygulanmaya başlandı \\
\hline 1995 & İkinci Değerlendirme Raporu & \\
\hline 1997 & Kyoto Protokolü (3. Taraflar Konferans1, COP3) & $\begin{array}{l}\text { BMİÇS'nin Ek-1 ülkelerine zamana bağlı (2008- } \\
\text { 2012) sayısal emisyon azaltım hedefi verildi. }\end{array}$ \\
\hline 2001 & $\begin{array}{l}\text { Marakeş Uzlaşmaları (7. Taraflar Konferansı, } \\
\text { COP7) }\end{array}$ & KP esneklik mekanizmalarının işleyişi belirlendi \\
\hline 2005 & Kyoto Protokolü yürürlüğe girmiştir. & $\begin{array}{l}\text { Rusya'nın KP'ye taraf olmasıyla, KP yürürlüğe } \\
\text { girdi ve taraf ülkelerin KP sorumlukları başladı. }\end{array}$ \\
\hline 2007 & $\begin{array}{l}\text { Bali Eylem Planı (13. Taraflar Konferansı, } \\
\text { COP13) }\end{array}$ & $\begin{array}{l}2012 \text { yılı sonrasına yönelik iklim değişikliği } \\
\text { müzakerelerinin yol haritası çizildi }\end{array}$ \\
\hline 2009 & $\begin{array}{l}\text { Kopenhag Mutabakatı (15. Taraftlar Konferans1, } \\
\text { COP15 ve MOP5) }\end{array}$ & $\begin{array}{l}2012 \text { yılı sonrası için yeni iklim rejimine yönelik } \\
\text { bir anlaşma müzakereye açıldı. }\end{array}$ \\
\hline 2010 & $\begin{array}{l}\text { Cancun Mutabakat1, Meksika(16. Taraflar } \\
\text { Konferans1, COP16) }\end{array}$ & $\begin{array}{l}2020 \text { yılında kurulması hedeflenen "Yeşil Fon"un } \\
\text { resmiyet kazandı. }\end{array}$ \\
\hline 2011 & $\begin{array}{l}\text { Durban, Güney Afrika (17. Taraflar Konferansı, } \\
\text { COP17) }\end{array}$ & $\begin{array}{l}2012 \text { yılı sonunda ilk yükümlülük dönemi bitecek } \\
\text { olan Kyoto Protokolü sonrasında uluslararası iklim } \\
\text { değişikliği rejimini şekillendirmek üzere ülkeler bir } \\
\text { kararlar paketi üstünde anlaşmaya varıldı. }\end{array}$ \\
\hline 2012 & Doha, Katar (18. Taraflar Konferans1, COP18) & $\begin{array}{l}\text { Kyoto Protokolü'nün devamı konusunda karar } \\
\text { alındı. Kyoto Protokolü'nün } 2012 \text { yılında } \\
\text { tamamlanan birinci yükümlülük döneminin } \\
\text { ardından ikinci yükümlülük dönemi, } 1 \text { Ocak } 2013 \\
\text { tarihinde başlayacak } 31 \text { Aralık } 2020 \text { yılına kadar } \\
\text { devam edeceği kararına varıldı. }\end{array}$ \\
\hline
\end{tabular}

Tablo 4. Uluslararası İklim Değişikliği Müzakerelerinin Süreci

\section{Kyoto Protokolü Esneklik Mekanizmaları}

İklim değişikliğine yol açan insan etkinliklerinden kaynaklanan sera gazı emisyonlarının en az maliyetle indirilmesi temel hedef olmuştur. Ancak sera gazı emisyonlarının birim azaltım maliyeti de ülkelere göre farklılık göstermektedir. Kyoto Protokolünde tanınan esneklik mekanizmaları sayesinde Ek-1 ülkeleri, düşük maliyetten yararlanabilecektir. Protokolde tanımlanan esneklik mekanizmaları, Ek-1 ülkelerinin yükümlülüklerini yerine getirmelerine yardımcı olacak teknik ve ekonomik araçlar olup üç başlıkta toplanmıştır. Bunlar; emisyon ticareti (karbon piyasası), temiz kalkınma mekanizması ve ortak yürütme mekanizmasıdır. Bu mekanizmalar aşağıda sıralanmıştır (UNFCCC, 2013).

Temiz Kalkınma Mekanizması (Clean Development Mechanism-CDM): Kyoto Protokolünün 12. maddesiyle düzenlenen bu mekanizma, Ek-1 dışı ülkelerin sürdürülebilir kalkınma ilkesi doğrultusunda Ek-1 ülkelerinin sera gazı azaltımına katkı sağlamalarını amaçlamaktadır. Ek-1 listesinde yer alan tarafların emisyon azatlım taahhüdünü gerçekleştirmek için Ek-1 dışı ülkelerde yapacakları projeler sonucu "Sertifikalandırılmış Emisyon Azaltım Kredisi” (Certified Emissions Reduction Credits-CER) elde edeceklerdir. 
2012 yılı itibariyle 78 ülkede CDM projelerinin olduğu ve CDM'de toplam 4.601 kayıtlı projenin bulunduğu, 2012 Eylül ayına kadar yaklaşık 3.275 projeden 1 milyardan fazla sertifikalandırılmış emisyon azaltım birimi (CER) kazanıldığı bildirilmektedir (UNFCCC, 2012: 7).

Ortak Yürütme Mekanizması (Joint Implementation-JI): Kyoto Protokolünün 6. Maddesi ile düzenlenen bu mekanizma, Ek-I listesinde yer alan tarafların emisyonların azaltılmasına veya yutaklar yoluyla sera gazlarının giderilmesine yönelik etkinlikler yürütmesine olanak sağlamaktadır. Bu mekanizma yoluyla gerçekleştirilen projeler sayesinde emisyonlarda kaydedilen azalma miktarı "Emisyon Azaltma Birimi" (Emission Reduction Unit-ERU) olarak adlandırılan bir birimle hesaplanmaktadır. Bu projeden yararlanan taraflar ERU kazanmakta ve kazanılan bu birimler toplam hesaptan düşülmektedir.

Emisyon Ticareti (Emission Trading-ET): Kyoto Protokolünün 17. maddesiyle düzenlenmiş olan mekanizma, Ek-1 ülkeleri arasında emisyon ticaretine izin vermektedir. Dolayısıyla Ek-1 listesinde yer alan ülkelerden biri, Ek-B'de belirlenmiş emisyon azatlım miktarının bir bölümünün ticaretini yapabilecektir. Satılan emisyonlar, satan ülkenin belirlenmiş azaltım biriminden (Assigned Amount Units-AAU) düşürülüp satın alan ülkenin belirlenmiş azaltım birimine eklenmektedir. Emisyon ticareti aynı zamanda ülkelerin emisyonlarını kendi salım yükümlülüklerinin altına düşürme açısından da iyi bir teşvik sağlamaktadır.

$\mathrm{Bu}$ protokol kapsamında karbon dinamikleri ikiye ayrılmaktadır. Bunlardan birincisi Cap and Trade (ETS) piyasalarıdır. Bu piyasada talep tarafı, faaliyet alanı nedeniyle sera gazı salınımı yapan bir şirket, kendi sera gazı limitini aşmak durumunda kaldığında bir başka salınım yapan şirketten salınım hakkı alarak limitini genişletebilmekte ve limit aşımına rağmen üretimine devam etmektedir. Arz tarafı ise bir şirket salınım kotasını aşmaz ise aşmadığı miktarı karbon piyasasında satabilmekte veya bir sonraki yıla saklayabilmektedir. İkincisi ise proje temelli piyasalardır. Bu piyasada, salınım yapan bir şirket dünyanın farklı bölgelerinde ve ülkelerinde yapmış olduğu yatırımlar ile elde edeceği kredilerle kotasını genişletebilmekte veya bu kredileri piyasada satabilmektedir.

\section{Karbon Piyasaları}

Karbon piyasası, karbondioksit başta olmak üzere küresel iklim değişikliğine neden olan sera gazlarının önlenmesi ya da azaltılmasına dönük, tanımlanmış kurlar ve standartlar dahilinde elde edilen karbon kredilerinin, diğer bir deyişle karbon sertifikalarının alınıp satıldığı piyasayı ifade etmektedir. Karbon piyasası, piyasa kuralları doğrultusunda çalışmak koşulu ile emisyonları azaltmada önemli bir araç olarak görülmektedir. Bu piyasa, emisyonları azaltmak için belirlenen limitten fazla salım yapanları cezalandırırken, daha az salanlar ise ödüllendirerek mevcut kaynakların en düşük maliyetle kullanılmasını sağlamaktadır. Ayrıca karbon piyasası, fiyatlandırdığı kirletme birimlerini mülkiyet hakkına dönüştürerek karbonun tüm dünyada ticaretinin yapılmasını mümkün kılmaktadır. Böylece işletmelerin daha az sera gazı emisyonunu teşvik ederek temiz teknolojiyi kullanmaya yönlendirmektedir.

\begin{tabular}{|c|c|c|c|c|c|c|}
\hline \multicolumn{7}{|c|}{ Emisyon Ticareti Mekanizmaları } \\
\hline \multirow{6}{*}{$\begin{array}{l}\text { Kyoto } \\
\text { Protokolü } \\
\text { Kapsamındaki } \\
\text { Zorunlu } \\
\text { Mekanizmalar }\end{array}$} & \multicolumn{2}{|c|}{ Mekanizma } & $\begin{array}{l}\text { İlgili KP } \\
\text { Maddesi }\end{array}$ & $\begin{array}{l}\text { Proje } \\
\text { Bazli }\end{array}$ & $\begin{array}{l}\text { Ürün } \\
\text { Sertifikas1 }\end{array}$ & $\begin{array}{l}\text { Uygulandığ } \\
\text { Ülkeler }\end{array}$ \\
\hline & \multicolumn{2}{|c|}{ Temiz Kalkınma Mekanizması (CDM) } & 12. Madde & $\mathrm{X}$ & CER & $\begin{array}{l}\text { Ek-B alıc1 } \\
\text { Ek-1 dış1 } \\
\text { ülkeler satıc1 }\end{array}$ \\
\hline & \multicolumn{2}{|c|}{ Ortak Uygulama (JI) } & 6. Madde & $\mathrm{X}$ & ERU & Ek-B ülkeleri \\
\hline & \multirow{3}{*}{ ETS } & $\begin{array}{l}\text { Uluslararas1 Emisyon Ticareti } \\
\text { Sistemi (IETS) }\end{array}$ & 17. Madde & & AAU & Ek-B ülkeleri \\
\hline & & AB-ETS & 17. Madde & & EUA & Avrupa Birliği \\
\hline & & Karbon Fiyat Mekanizması & 17. Madde & & $\mathrm{CU}$ & Avustralya \\
\hline \multirow{4}{*}{$\begin{array}{l}\text { Ülke ve Eyalet } \\
\text { Mekanizmaları }\end{array}$} & \multicolumn{2}{|c|}{$\begin{array}{l}\text { Avustralya karbon denkleştirme } \\
\text { programı }\end{array}$} & & $\mathrm{X}$ & AACU & Avustralya \\
\hline & \multicolumn{2}{|c|}{ Küresel Isınma Cözümleri Kanunu } & & & CCA & Kaliforniya \\
\hline & \multicolumn{2}{|c|}{$\begin{array}{l}\text { Hindistan İklim Değişikliği Ulusal } \\
\text { Eylem Planı (NAPCC) }\end{array}$} & & & REC & Hindistan \\
\hline & \multicolumn{2}{|c|}{ Bölgesel Sera Gazı Oluşumu } & & & RGGI & ABD \\
\hline $\begin{array}{l}\text { Gönülllü } \\
\text { Mekanizmalar }\end{array}$ & \multicolumn{2}{|c|}{ Tezgahüstü Gönüllü Karbon Piyasaları } & & $\mathrm{X}$ & VER & Muhtelif \\
\hline
\end{tabular}

Tablo 5. Emisyon Ticareti Mekanizmaları Kaynak: Mazıbaş, 2013:7.

Karbon piyasaları, zorunlu (Kyoto Protokolü esneklik mekanizmaları) ve gönüllü olmak üzere iki kategoride incelenmektedir. Zorunlu karbon piyasaları, Kyoto Protokolünde tanımlanan esneklik mekanizmaları ile ülkelerin düşük maliyetle emisyon azaltımı yapabilmesine olanak tanımaktadır. Gönüllü Karbon Piyasaları, 
bireylerin, kurum ve kuruluşların, firmaların, sivil toplum örgütlerinin faaliyetleri sonucu oluşan sera gazı emisyonlarının gönüllü olarak azaltımını dengeleyebilmesini kolaylaştırmak amacıyla oluşturulan bir piyasadır.

Ekonomideki dalgalanmalar karşısında $\mathrm{AB}$ iklim politikası ve küresel karbon piyasalarının temelini oluşturan AB Emisyon Ticaret Sistemindeki karbon fiyatları 2011 yılı sonuna doğru düşmeye başlamıştır. Fiyatlar düşmesine karşın, işlem hacmi hızla yükseldiği için küresel karbon piyasasının değeri 2011 yılında artmıştır. Piyasanın toplam değeri \%11 oranında büyüyerek 176 milyar dolara çıkmış, işlem hacmi de 10,3 milyar ton CO2e'ye ulaşmıştır. Tablo 6'da 2005-2011 döneminde küresel karbon piyasasının piyasa değeri görülmektedir.

\begin{tabular}{|l|l|l|l|l|l|l|}
\hline & $\begin{array}{l}\text { EU ETS } \\
\text { Tahsisler }\end{array}$ & $\begin{array}{l}\text { Diğer } \\
\text { Tahsisler }\end{array}$ & $\begin{array}{l}\text { Birincil } \\
\text { CDM }\end{array}$ & $\begin{array}{l}\text { İkincil } \\
\text { CDM }\end{array}$ & $\begin{array}{l}\text { Diğer } \\
\text { Offsets }\end{array}$ & Toplam \\
\hline 2005 & 7,9 & 0,1 & 2,6 & 0,2 & 0,3 & 11,0 \\
\hline 2006 & 24,4 & 0,3 & 5,8 & 0,4 & 0,3 & 31,2 \\
\hline 2007 & 49,1 & 0,3 & 7,4 & 5,5 & 0,8 & 63,0 \\
\hline 2008 & 100,5 & 0,1 & 6,5 & 26,3 & 0,8 & 135,1 \\
\hline 2009 & 118,5 & 4,3 & 2,7 & 17,5 & 0,7 & 143,7 \\
\hline 2010 & 133,6 & 1,3 & 3,6 & 20,4 & 1,2 & 159,2 \\
\hline 2011 & 147,8 & 0,1 & 3,9 & 22,3 & 0,9 & 176,0 \\
\hline
\end{tabular}

Tablo 6. Karbon Piyasasl: Piyasa Değerleri (Milyar Dolar) Kaynak: World Bank, 2012.

2005-2011 döneminde karbon varlık işlemlerinin değeri Şekil 3'te görülmektedir.

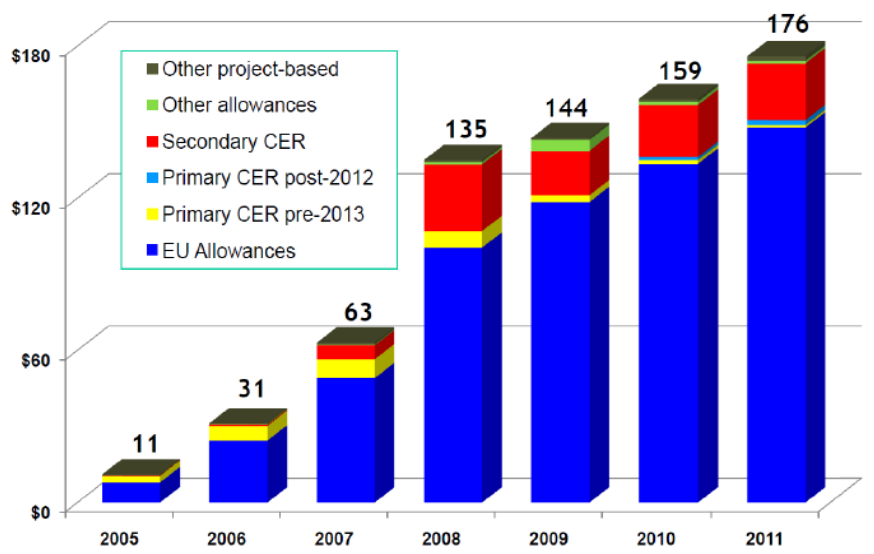

Şekil 3. Karbon Varlık İslemlerinin Değeri (Milyar Dolar) Kaynak: CDC Climat Research, 2013: 29.

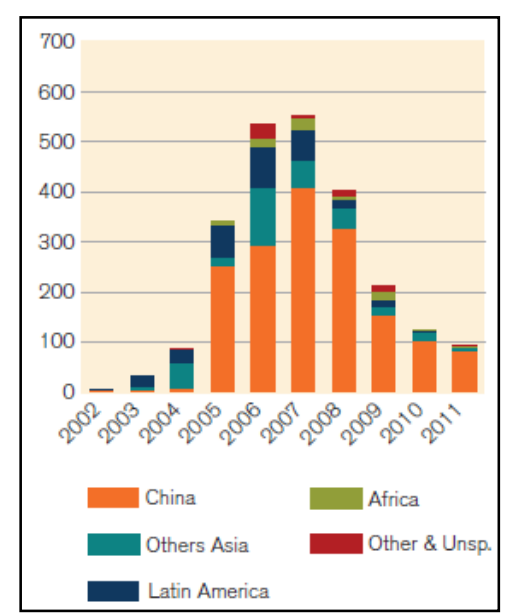

Şekil 4. Ülke Bazında Satıcılar Tarafindan Gerçekleştirilen İşlem Hacmi (MTCO2e) Kaynak: World Bank.

$\mathrm{Bu}$ verilerden de görüldüğü gibi, zorunlu piyasaların piyasa değeri ve işlem hacmi gönüllü piyasalarınkinden oldukça fazladır. Özellikle 2008-2009 döneminde ortaya çıkan finansal krizin etkileri karbon piyasalarına da yansımıştır. Ayrıca 2011 yılı da sermaye piyasaları açısından çalkantılı bir yıl olmuştur. Arap Baharı'nın başlaması, Fukushima felaketinin ardından Japonya ve Almanya'da nükleer santrallerin kapatılması, ABD'nin kredi notunun düşürülmesi ile karbonu da kapsayan enerji ile ilgili malların piyasasında dalgalanma artmıştır. Aynı şekilde Yunanistan borç krizi ve bu krizin AB ekonomisine de yayılması yaşanan güven sorununu daha da artırmıştır. 


\subsection{Zorunlu Piyasalar (Proje Bazlı)}

Temiz Kalkınma Mekanizması (CDM), proje temelli uygulamalar arasında en çok kullanılan yöntemdir. Onaylı salınım azaltmaları (CER) birimine dayalı ürün sertifikaları alınıp satılmaktadır. 2002-2011 döneminde ülke bazında satıcılar tarafından gerçekleştirilen işlem hacmi Şekil 4'te görülmektedir.

Ortak Uygulama (JI), emisyon azaltım birimi (ERU) olup, \%60'^ Rusya ve Ukrayna'da uygulanmıştır. En çok yatırımı ise Fransa yapmıştır. Ülke bazında devam eden ortak uygulama projesi sayısı Şekil 5 'te görülmektedir. Ortak Uygulama (JI) ve CDM kapsamındaki CER ve ERU'lar organize ikincil piyasalarda işlem görmektedir. Y1llı CER ve ERU işlem hacmi Şekil 6'da verilmiştir.

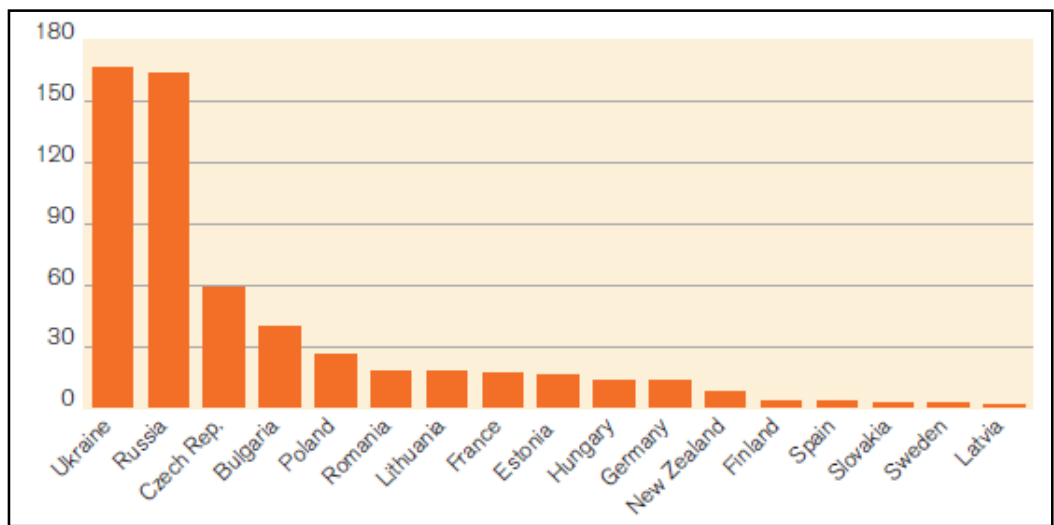

Şekil 5. Ülke Bazında Devam Eden Ortak Uygulama Projesi Saylları Kaynak: World Bank, 2012: 59.

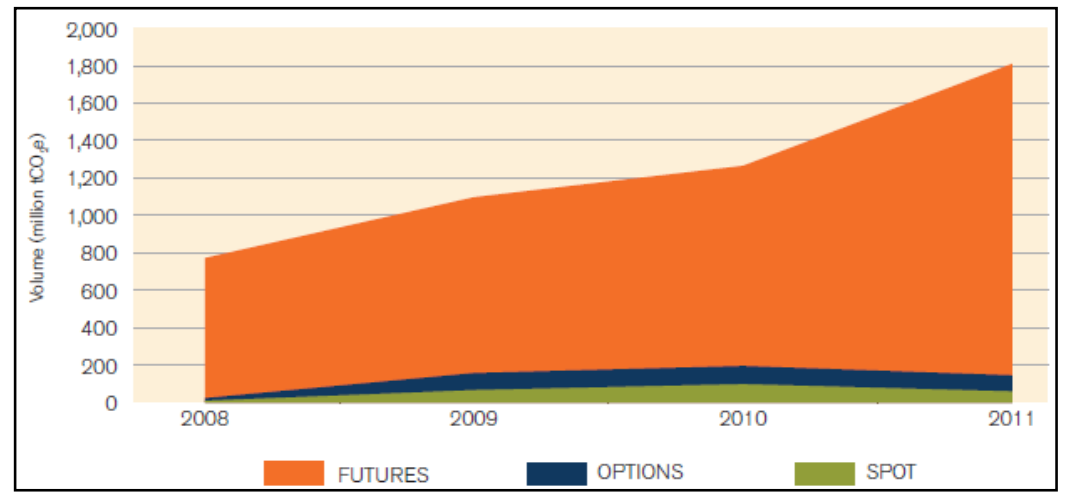

Şekil 6. Ylllık CER ve ERU İşlem Hacmi (Milyon tCO2e) Kaynak: World Bank, 2012: 38.

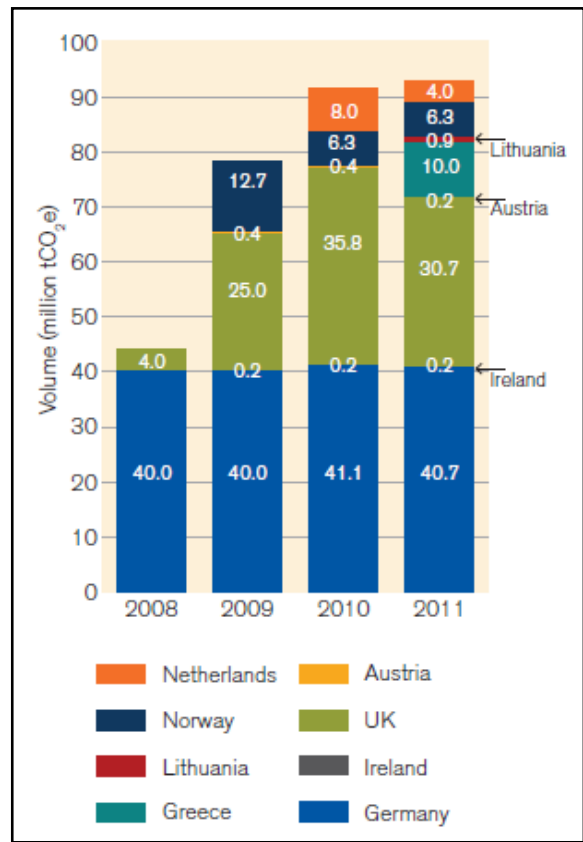

Şekil 7. AB Üye Ülkelerin EUA Yıllık İşlem Hacmi Kaynak: World Bank, 2012: 32. 


\subsection{Zorunlu Piyasalar (Piyasa Bazlı)}

Emisyon Ticaret Sistemi (ETS): Kyoto Protokolü'nün 17. maddesinde tanımlanmıştır. Emisyon izinlerini aşan şirketler alıcı, emisyon izinlerinin altında kalanlar ise satıcı konumundadır. Ticareti "Assigned Amount Unit (AAU)" üzerinden EK-I ülkeleri arasında yapılabilmektedir. 2010 yılında 19 milyon ton CO2 salınımına denk gelen AAU ticareti yapılmış, 265 milyon dolarlık işlem oluşmuştur (Mazıbaş, 2013: 12).

AB - ETS ve EUA Piyasası, dünyada en çok işlem gören karbon ürünüdür. EUA işlem hacmi 2011 'de \%11 artarak 147,8 milyar dolara ulaşmıştır. Birincil piyasada ihraç edilen EUA'ların piyasa değeri, toplam piyasanın \%1'lik kısmını oluşturmaktadır. 2008-2011 döneminde AB üye ülkeler tarafından satılan birincil EUA'ların yıllık işlem hacmi Şekil 8'de görülmektedir. EUA piyasasındaki işlemleri \%88'i vadeli, \%10'u opsiyon, \%2'si ise spot piyasalarda gerçekleşmiştir. Gerçekleştirilen işlemlerin \%49'u borsalarda, \%39'u borsa dişında ( over the counter, OTC), \%12'si iki taraflı anlaşmalarla sağlanmıştır (Şekil 7).

Karbon Fiyat Mekanizması: Bu mekanizmada Carbon Unit (CU) kullanılarak işlem yapılmaktadır. Bu mekanizma, Avustralya'nın yıllık karbon salınımını 2000 yılındaki salınım seviyesini 2020 yılına kadar \%5, 2050 yılına kadar \%80 azaltmak amacıyla kurulmuştur. CPM'in Avustralya emisyon salınımının \%60'ının sahibi olan 500 işyerini kapsaması beklenmektedir. Fiyatlama üç döneme ayrılmaktadır: Sabit fiyat dönemi 1 Temmuz 2012 olup 23 Avustralya Doları olarak belirlenmiştir. Esnek fiyat dönemi 1 Temmuz 2015 olup, Taban: 15 / Tavan: 25 Avustralya Dolarıdır. Serbest fiyat dönemi ise 1 Temmuz 2018'dir.

\section{3 Ülke ve Eyalet Piyasaları}

Avustralya Karbon Denkleştirme Programı ve ACCU Piyasası: CPM kapsamına girmeyen ve Kyoto'da tanımlanmayan projeler Avustralya hükümetince desteklenecektir. Çöplüklerden metan salınımının yasaklanması, gübre kullanımı, anız yakılmasının önlenmesi, ağaçlandırma ve teraslama için 250 milyon Avustralya Doları ayrılmıştır (Mazıbaş, 2013: 16).

Kaliforniya Küresel Isınma Çözümleri Kanunu ve CCA Piyasası: 2006 yılında çıkan bu kanun, eyaleti sera gazı salınımını 2020 yılında, 1990 seviyelerine geri çekme konusunda yükümlü kılmıştır. Kaliforniya üst sınır ticareti (cap-and-trade) düzenlemeleri 2011 yılının Ekim ayında yapılmaya başlanmıştır. Eylül 2011'de ICE ve Green Exchange'de işlem görmeye başlamıştır. 2013-2020 döneminde WCI yıllık piyasa dengesi Şekil 8'de görülmektedir.

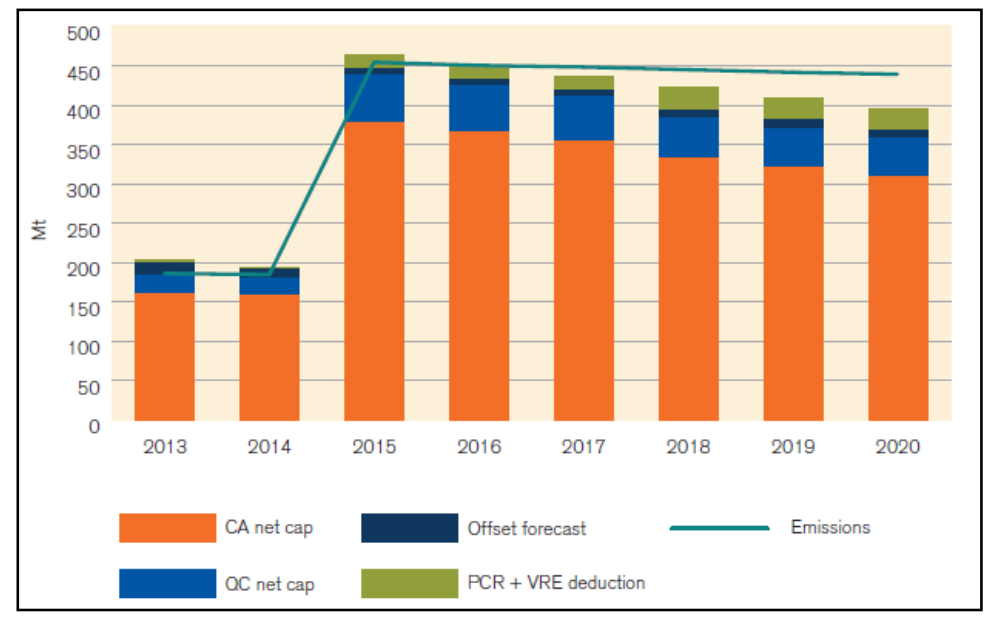

Şekil 8. 2013-2020 döneminde WCI Ylllık Piyasa Dengesi Kaynak: World Bank, 2012: 88.

Bölgesel Sera Gazları İnisiyatifi ve RGGI Piyasası: ABD’nin 10 eyaletinde enerji üreticilerine karbon salınımını azaltmaları konusunda yaptırımlar getirilmiştir. Yaratılan 925 milyon dolarlık gelirin \% 048 'i enerji verimliliği programlarına, \%20'si eyalet genel bütçelerine, \%7'si yenilenebilir enerji üretimi kaynaklarına, \%11 değişik çevresel faaliyetlere aktarılmıştır. CCX kurulmuş, ancak daha sonra ICE'ye satılarak kapatılmıştır. ICE'de RGGI işlemleri devam etmektedir. 2010 ve 2011 yıllarında ortaya çıkan arz fazlalığı nedeniyle taban fiyat 1,89 dolara düşmüştür. Ayrıca 2009 yılında borsa üzerinde yapılan işlem hacmi \%85 iken 2011'de \%6 düzeyine inmiştir (Şekil 9).

\subsection{Gönüllü Karbon Piyasaları}

Gönüllü karbon piyasaları, devletlerin belirlediği politikalar ve hedeflerden bağımsız olarak gönüllülük esasında gerçekleştirilmektedir. Gönüllü projelerin emisyon azaltım kredileri (VER) Kyoto Protokolü kapsamında kurulan uygunluk piyasalarında kullanılamamaktadır. Karbon nötr olmak isteyen organizasyonlar, karbon ayak izlerini hesaplayarak bu emisyonlarını azaltmak ve dengelemek üzere, gönüllü bir standart çerçevesinde sağlanmış emisyon azaltımları sonucu oluşturulan karbon sertifikalarını satın alırlar. 2010-2011 
yılları arasında VER piyasasında işlem hacmi $69 \mathrm{MtCO} 2 \mathrm{e}$ den $87 \mathrm{MtCO} 2 \mathrm{e}$ 'ye çıkmış, işlem değeri de 414 milyon ABD Doları'ndan 569 milyon ABD Doları'na ulaşmıştır (World Bank, 2012: 115).

Dünyadaki başlıca karbon piyasalarında işlem gören ürünlerin işlem hacimleri Tablo 7'de görülmektedir.

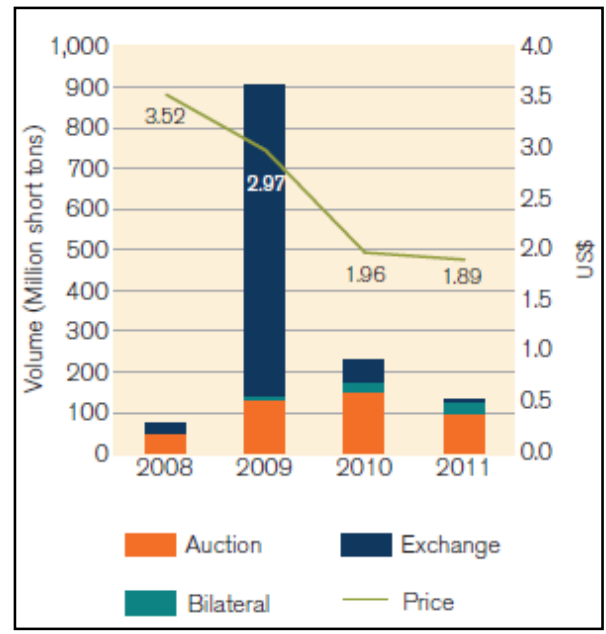

Şekil 9. RGGI Hacim ve Fiyatları Kaynak: World Bank, 2012: 80.

\begin{tabular}{|c|c|c|c|c|}
\hline & \multicolumn{2}{|l|}{2010} & \multicolumn{2}{|l|}{2011} \\
\hline & Hacim $(\mathrm{MtCO} 2 \mathrm{e})$ & Değer (ABD Doları) & $\begin{array}{l}\text { Hacim } \\
\text { (MtCO2e) }\end{array}$ & Değer (ABD Doları) \\
\hline \multicolumn{5}{|c|}{ Allowances market (Tahsisler piyasası) } \\
\hline EUA & 6,789 & 133,598 & 7,853 & 147,848 \\
\hline AAU & 62 & 626 & 47 & 318 \\
\hline RMU & - & - & 4 & 12 \\
\hline NZU & 7 & 101 & 27 & 351 \\
\hline RGGI & 210 & 458 & 120 & 249 \\
\hline $\mathrm{CCA}$ & - & - & 4 & 63 \\
\hline Diğerleri & 94 & 151 & 26 & 40 \\
\hline Alt Toplam & 7,162 & 134,935 & 8,081 & 148,881 \\
\hline \multicolumn{5}{|c|}{ Spot ve İkincil Piyasa } \\
\hline SCER & 1,260 & 20,453 & 1,734 & 22,333 \\
\hline sERU & 6 & 94 & 76 & 780 \\
\hline Diğerleri & 10 & 90 & 12 & 137 \\
\hline Alt Toplam & 1.275 & 20,637 & 1,822 & 23,250 \\
\hline \multicolumn{5}{|c|}{ Forward (birincil) proje bazlı işlemler } \\
\hline pCER pre-2013 & 124 & 1,458 & 91 & 990 \\
\hline pCER post-2012 & 100 & 1,217 & 173 & 1,990 \\
\hline pERU & 41 & 530 & 28 & 339 \\
\hline Voluntary market & 69 & 414 & 87 & 569 \\
\hline Alt toplam & 334 & 3,620 & 378 & 3,889 \\
\hline TOPLAM & 8,772 & 159,191 & 10,281 & 176,020 \\
\hline
\end{tabular}

Tablo 7. Karbon Piyasalarında Işslem Gören Ürünler ve Işlem Hacimleri Kaynak: World Bank, 2012: 10.

\section{Sonuç}

Çevre sorunlarının başında gelen küresel ısınma, atmosferdeki sera gazı emisyonlarının artmasıyla ortaya çıkmaktadır. Bu emisyonların azaltımı için BMİDÇS ve Kyoto Protokolü gibi çözümler önerilmiştir. BMIDÇS ile başlayan bu süreç taraflar toplantıları ile halen devam etmektedir. Kyoto Protokolü bir çevre koruma anlaşması olmakla birlikte, ticari ve ekonomik ilişkilerin sürdürülmesi yönünde şekillenmiş bir anlaşma olma özelliği taşımaktadır.

Kyoto Protokolü'nün ortak uygulama (JI), temiz kalkınma mekanizması (CDM) ve emisyon ticaretinden oluşan esneklik mekanizmaları bulunmaktadır. Söz konusu mekanizmalar, endüstrileşmiş ülkelerin protokol ile belirlenen hedeflerine ulaşmaları için kullanabilecekleri yöntemlerdir. Ortak uygulama yöntemi ile Ek-1 ülkeleri arasında gerçekleşir. Sera gazı emisyonunun azaltılmasını amaçlayan projelere yatırım yapan ülke, emisyon azaltma birimi (ERU) kazanmaktadır. Kazanılan ERU, ülkenin Kyoto hedefine ulaşmasında hesaba katılacaktır. 
Temiz kalkınma mekanizması ise Ek-1 ülkelerinin, Ek-1 olmayan ve protokole taraf ülkelerden birinde yapacağ emisyon azaltıcı projeleri sertifikalandırılmış emisyon azaltımı karşılığı (CER) desteklemesidir. Emisyon ticaret sisteminde ise taahhüt edilen emisyon miktarından daha fazla azaltım yapan ülke, bu azaltımı başka ülkeye satabilmektedir. Emisyon indirimleri olan (ERU ve CER), dünyada birçok karbon borsasında işlem görmektedir. $\mathrm{Bu}$ ürünler pazarlarda spot veya vadeli işlem ile satılabilmektedir.

2005 yılından itibaren karbon piyasaları çok hızlı büyümüş, 2011 yılı itibariyle değeri 176 milyar dolara yükselmiştir. Yaşanan küresel kriz ve Avrupa borç krizi nedeniyle karbon piyasalarında fiyatlar düşmüş, ancak işlem hacmi artmaya devam etmiştir.

Sonuç olarak sürdürülebilir kalkınmanın bir parçası olarak değerlendirilen karbon piyasaları finansal piyasaların derinleşmesine önemli katkılar sağlaması beklenmektedir.

\section{Kaynakça}

- Akkaya, G. Cenk ve Uzar, Ceren, 2012. "Karbona Dayalı Finansal Gelecek sözleşmeleri ve Fiyat Gelişimi Üzerine Bir İnceleme", Dumlupınar Üniversitesi, Sosyal Bilimler Dergisi, DPUJSS NUMBER 32, VOL. I, APRIL 2012, http://sbe.dpu.edu.tr/dergi/32/cilt1/67-80.pdf, (25.05.2013).

- Ar1, İzzet (2010), İklim Değişikliği ile Mücadelede Emisyon Ticareti ve Türkiye Uygulaması, DPT Uzmanlık Tezleri, Ankara, 2010, http://www.kalkinma.gov.tr/DocObjects/View/9840/tez-iari.pdf, (15.05.2013).

- Arıkan, Y., 2006. “Birleşmiş Milletler İklim Değişikliği Çerçeve Sözleşmesi ve Kyoto Protokolü”, Bölgesel Çevre Merkezi, REC Türkiye, Nisan 2006, Ankara, http://iklim.cob.gov.tr/iklim/Files/REC_unfccc.pdf, (15.05.2013).

- Asia Carbon Global, 2013. Carbon Trading, http://www.asiacarbon.com/Carbon_Trading.html, (25.05.2013).

- Carbon Market Data, 2013. http://www.carbonmarketdata.com/cmd/publications/world_ets_brochure.pdf, (25.05.2013).

- CCFE, 2013. Chicago Climate Futures Exchange, http://www.ccfe.com/, (25.05.2013).

- CCX, 2013. Chicago Climate Exchange, https://www.theice.com/ccx.jhtml, (25.05.2013).

- CDC Climat Research, 2013. Carbon markets from Kyoto to Doha, Current mechanisms and the stakes of international climate negotiations, January 2013, http://www.cdcclimat.com/IMG//pdf/13-01-

11_kit_pedagogique_finance_carbone_va.pdf, (35.05.2013).

- Climate Change Economics, 2013. European Climate Exchange, http://climatechangeecon.org/index.php?option=com_mtree\&task=viewlink\&link_id=1837\&Itemid=20, (22.05.2013).

- Climex, 2013. Carbon Credits Energy Contracting, http://www.climex.com/default.aspx, (22.05.2013).

- EA, 2013). Termination of Bluenext European carbon market, http://www.enercee.net/energy-policyeu/global-strategies/detail/artikel/termination-of-bluenext-european-carbonmarket.html?pager\%5Bpage\%5D=2\&cHash=ff6ab82947bbebb9472abf959fcf7f0d, (25.05.2013).

- EEX, 2013. The European Energy Exchange (EEX), http://www.eex.com/en/EEX, (22.05.2013).

- $\quad$ EİE, 2013. "İklim Değişikliği Nedir?", TC. Enerji ve Tabi kaynaklar Bakanlığı, Yenilenebilir Enerji Genel Müdürlüğü, http://www.eie.gov.tr/iklim_deg/i_deg_nedir.aspx, (10.05.2013).

- Ellerman, A. Denny ve Joskow, Paul L., 2008. The European Union's Emission Trading System in Perspective, http://www.c2es.org/docUploads/EU-ETS-In-Perspective-Report.pdf

- Envex, 2013. Products and services for the environmental market, http://www.envex.com.au/, 825.05.2013).

- EXA, 2013. Energy Exchange Austria, http://www.exaa.at/en, (22.05.2013).

- Graus, Wina ve Voogt, Monique, 2007. Small Installitions with in the EU Emissions Trading Scheme, Report under the Project "Review of EU Emissions Trading Scheme", http://ec.europa.eu/clima/policies/ets/docs/finalrep_small_installations_en.pdf

- IEA, 2007. Key World Energy Statistics, 2007, http://www.iea.org/textbase/nppdf/free/2007/Key_Stats_2007.pdf, (15.07.208).

- $\quad$ IEA, 2011. World Energy Outlook 2011, http://www.worldenergyoutlook.org/media/weowebsite/2011/es_turkish.pdf, (20.05.2013).

- $\quad$ IEA, 2012a. Key World Energy Statistics, 2012, http://www.iea.org/publications/freepublications/publication/kwes.pdf, (20.05.2013). 
- $\quad$ IEA, 2012b. World Energy Outlook 2012, http://www.iea.org/publications/freepublications/publication/English.pdf, (21.05.2013).

- İklim Platformu, 2012. Doha İklim Müzakereleri Nasıl Tamamlandı?, 11 Aralık 2012, http://www.iklimplatformu.org/haberler/216-doha-iklim-muzakereleri-sona-erdi, (21.05.2013).

- Kıvılcım, İlge, 2012. BM İklim Değişikliği Konferansı-Doha: Taraflar, Öncelikler ve Gerçekler, İktisadi Kalkınma Vakfi, IKV Değerlendirme Notu, Aralık 2012, http://www.ikv.org.tr/images/upload/data/files/doha_yazisi.pdf, (21.05.2013).

- Mazıbaş, Murat, 2013. Karbon Piyasaları, ODTÜ Petrol Araştırma Merkezi ve Enerji Bakanlığı, "Karbon Piyasası ve Karbondioksitin Yer Altında Depolanmasında Dünyadaki Gelişmeler ve Türkiye", 29 Mayıs 2013, ODTÜ Kültür Merkezi, http://co2depolama.labkar.org.tr/images/29May/MuratMazibas.pdf, (30.05.2013).

- NAO, 2004. National Audit Office, The UK Emissions Trading Scheme, A New Way to Combat Climate Change, http://www.nao.org.uk/wp-content/uploads/2004/04/0304517.pdf, (25.05.2013).

- Nordpool, 2013. http://www.nordpoolspot.com/About-us/

- POLPX, 2013. Emission Allowances Market - (CO2 Spot), http://www.polpx.pl/en/40/emission-allowancesmarket-co2-spot, (22.05.2013).

- $\quad$ Sandor, Richard L., 2010. Chicago Climate Exchange, Inc, http://www.asianfinancialforum.com/aff2010/pdf/tp_RichardSandor.pdf, (25.05.2013).

- TMX, 2013. Montreal Exchange, Canadian Derivatives Exchange, Historical Highlights, http://www.mx.ca/qui_histo_en.php, (25.05.2013).

- $\quad$ TÜİK, 2013. Seragazı Emisyon Envanteri, 1990-2011, 12 Nisan 2013 tarih ve 13482 sayılı haber bülteni, http://www.tuik.gov.tr/PreHaberBultenleri.do?id=13482, (20.05.2013).

- Türkeş, , 2006. İklim Değişikliği Çerçeve Sözleşmesi ve Kyoto Protokolü Tarihçe, Yükümlülükler, Kurumlar ve İşleyiş, Bölgesel Çevre Merkezi REC Türkiye, Eğitimler, http://www.rec.org.tr/?module=training\&item=training_info\&training_info_id=40, (15.05.2013).

- UNCTAD, 2012. Handbook of Statistics 2012, http://unctad.org/en/PublicationsLibrary/tdstat37_en.pdf, (20.05.2013).

- UNFCCC, 2012. Executive Board Annual Report 2012, Clean Development Mechanism, http://unfccc.int/resource/docs/publications/pub_cdm_eb_annual_report_2012.pdf, (15.05.2013).

- UNFCCC, 2013. United Nations Framework Convention on Climate Change, http://unfccc.int/2860.php, 2013, (15.05.2013).

- World Bank, 2012. State and Trends of the Carbon Market 2012, http://siteresources.worldbank.org/INTCARBONFINANCE/Resources/State_and_Trends_2012_Web_Opti mized_19035_Cvr\&Txt_LR.pdf, (26.05.2013). 


\title{
Türkiye’de Sürdürülebilir Çevre Politikaları: İklim Değişikliği Örneği
}

\section{Sustainable Environmental Policy in Turkey: Climate Change Case}

\author{
Asst. Prof. Dr. Abdulmenaf Turan (Yüzüncü Y1l University, Turkey) \\ Assoc. Prof. Dr. Mahmut Güler (Trakya University, Turkey)
}

\begin{abstract}
Environmental problems have become the main agenda of all countries in the world since 1970's. Various reports have been written, international meetings have been held and various contracts, agreements and action plans were accepted according to these decisions. Each of these arrangements has reflected to policies of countries. The most important issue of international meetings is that environmental values and natural resources should be used rationally and without extravagancy, should be protected and sustained considering the policy of using rights and benefits of current and future generations. In this sense, the concept of "sustainable development" which aims at enabling economic growth and is defined as an environmentalist view in included in the report called Our Common Future which is prepared by Bruntland in 1987 and presented to United Nations Commission of Environment and Development. Later on, this principle was accepted as the main principle of meeting in RIO Summit of 1992. Turkey which is one of the developing countries did not remain out of this process and determined environmental policies in accordance with decisions in global level. Turkey participated in both meetings mentioned above; carried out preparation studies according to these principles and adapted these principles to legal regulations and policies about environmental and economic development. In this study, first of all historical development of sustainable development concept in global sense will be explained and then it will be evaluated how this principle influences environmental policies in Turkey in analytical way together with examples of practice.
\end{abstract}

\section{Giriş}

1970’li yıllardan bu yana çevre sorunları dünyanın bütün ülkelerinin ana gündem konularından biri haline gelmeye başlamıştır. Bu konuda çok sayıda raporlar yazılmış, uluslararası toplantılar gerçekleştirilmiş, bu toplantılarda alınan kararlar doğrultusunda çeşitli sözleşmeler, anlaşmalar ve eylem planları kabul edilmiştir. Bu düzenlemelerin her biri ülkelerin uygulamış oldukları politikalara yansımıştır. Bütün bu düzenlemelerin nedeni çevre sorunlarının küresel niteliğe sahip olmalarından kaynaklanmaktadır. Doğal varlıklar üzerinde gelecek kuşakların da söz hakkı sahibi olduğu düşüncesi küresel çevre politikalarının en önemli yanlarından birisidir. Bu bağlamda ekonomik gelişmenin sağlanmasını amaçlayan ve çevreci görüş olarak tanımlanan "sürdürülebilir gelişme” 1987 yılında Bruntland tarafından hazırlanan ve Birleşmiş Milletler Çevre ve Kalkınma Komisyonuna sunulmuş olan Ortak Geleceğimiz isimli raporda yer almıştır. Daha sonra 1992 yılındaki RIO Zirvesi'nde bu ilke toplantının ana ilkesi olarak kabul edilmiştir. BM'nin bu tarihten sonraki bütün toplantılarında da bu ilke ana gündem konusu olmuştur. Gerek 2002 yılındaki Johannesburg Zirvesi gerekse 2012 yılındaki RIO+20 Zirvesi sürdürülebilir gelişmenin sağlanması konusundaki ilkelerin belirginleştiği toplantılar olmuştur. Küresel bir sorun olarak nitelendirilen çevre sorunlarına yönelik politikalar, sorunun doğasından kaynaklanan özelliklerinden dolayı küresel düzeydeki politikaların ülkelerin iç politikalarına dönüşmesini zorunlu kılmıştır. Bundan dolayı herhangi bir ülkenin çevre politikalarını incelerken küresel aktörlerin bu konudaki politika ve eylemlerini esas almak bir zorunluluktur. Sürdürülebilir gelişme kavramı da söz konusu politika ve eylemler sonucunda ortaya çıkmış olan ve yalnızca çevre politikaları alanında değil birçok alanda esas alınan bir ilke haline gelmiștir.

Gelişmekte olan ülkelerden biri olan Türkiye de bu sürecin dışında kalmamış ve küresel düzeyde alınan kararlar doğrultusunda çevre politikalarını belirlemiştir. Çevre politikalarını belirleme konusunda uluslararası düzeyde alınan en önemli kararlardan biri de sürdürülebilir gelişme ilkesinin hayata geçirilmesi olmuştur. Yukarıda adı geçen her iki toplantıya da katılan Türkiye hem bu ilkelere yönelik hazırlık çalışmaları yapmış hem de çevre ve ekonomik gelişmeye ilişkin yasal düzenleme ve politikalarına bu ilkeleri uyarlamıştır. Bu çalışmada ilk olarak sürdürülebilir gelişme kavramının tarihsel gelişimi anlatılacak ardından da bu ilkenin Türkiye'deki çevre politikalarını iklim değişikliği örneğinde nasıl etkilediği analitik bir biçimde değerlendirilecektir. İklim değişikliğine ilişkin sorunlar ile sürdürülebilir gelişme ilkesinin aynı yazı kapsamında ele alınması her iki olgunun da neredeyse eş zamanlı olarak uluslar arası kamuoyunun gündemine gelmesinden dolayıdır. İklim değişikliği aynı zamanda ekonomik kalkınma ile çevre arasındaki çatışmalı sürecin bir tezahürüdür. Çalışmamızın temel varsayımı şudur: İklim değişikliği diğer adıyla küresel 1sınma sorunu ancak kuşaklar arası adaleti önceleyen ve sürdürülebilir gelişme ilkesinin uygulanmasıyla mümkün olabilir. Ancak kavrama yüklenen toplumsal, ekonomik ve çevresel sürdürülebilirliğin gerçek anlamıyla tahrif edilmeksizin kullanılması koşuluyla. 


\section{Küresel Çevre Politikalarının İnşasında Sürdürülebilir Gelişme İlkesi}

Sürdürülebilir gelişme kavramının tarihsel ve kuramsal gelişiminden önce değinilmesi gereken önemli kavramlardan biri çevre politikası kavramıdır. Çevre politikası, çevre konularında devletin etkinlikleri için oluşturulan kurumsal yap1 ve yöntemler biçiminde dar; toplumun çevreyle olan ilişsisini düzenlemek için belirlenen amaçlar, hedefler, ilkeler ve tercihler ile çevre korunması ve geliştirilmesine dönük olarak alınan önlemler bütünü biçiminde de geniş anlamlı olarak tanımlanmaktadır (Keleş vd., 2012). Bu yönüyle geniş anlamda çevre politikasının insan ve doğa arasındaki ilişkileri düzenleme amacı taşıdığı belirtilebilir. Ancak bunun bir politika haline gelmesi için gerekli olan toplumsal iradenin sağlanmasında devlet en önemli aktördür. Küreselleşme süreci ile birlikte devletin yanısıra uluslararası devlet örgütleri, sivil toplum örgütleri ve ulusaşırı şirketlerin de birer önemli aktör haline gelmiş olduğu görülmektedir. Dolayısıyla hem çevre sorunlarının doğasından kaynaklanan ulusaşırı olma hem de küreselleşme sürecinin de etkisiyle çevre politikalarının oluşturulması ve uygulanması çok aktörlü bir yapının karşılıklı işbirliği ve müzakeresi ile olanaklı hale gelmektedir. Bu politikaların başarıya ulaşması ise belirlenmiş olan ilkelerin uygulanabilir olmasına bağlıdır. Bu ilkeler arasında uygulama olanağı bulan ve kabul gören ve belki de en yaygın olan ilkelerden biri sürdürülebilir gelişmedir. Böylece sürdürülebilir gelişme kavramı uluslararası çevre politikalarının ekonomik araçlarından birine dönüşmüştür (Kaplan, 1999). Kavramın büyüme, kalkınma, eşitlik ve çevreciliğin en acil ve ihtilaflı sorunları arasında bir uzlaşmayı temsil ettiği belirtilmektedir (Hayırsever Topçu, 2008). Ancak bu kavramın tartışılmadığı anlamına da gelmemelidir (tartışmalar için bkz. Kaplan, 1999; Bozlağan, 2004; Hayırsever Topçu, 2008).

Sürdürülebilir gelişme kavramı aslında çevre sorunlarının küresel düzeyde bir sorun olarak kabul edilmesinden sonra ortaya atılmış ise de aslında “ilk kez Federal Almanya'nın Baden bölgesinde 18. yüzyıl sonu ve 19. yüzyıl başında Karaormanların yok edilmesini önlemek amacıyla çıkarılan yasalarda kullanılmış; toplumsal gelişme kavramına da uyarlanan sürdürülebilir gelişme kavramı asıl anlamını 1987 yılında yayınlanan Bruntland Raporu'yla kazanmıştır (Hill, 1993 'ten aktaran Kaplan, 1999). Bozlağan (2005), kavramın tarihsel kökenlerinin Ortaçağ'a hatta Antik Yunan dönemine dek götürülmüş olduğunu (Campbell, 1996) ve (O’Riordon, 1998)'e atıfla belirtmekte, ancak kavramın Antik Yunan dönemine dayandırılmasının nesnel olmadığını, Doğu kültüründe de benzer temalar bulunduğunu, kavramın birçok geleneksel kültürden beslendiğini ifade etmektedir. Raporda kısaca tanımlanmakla birlikte kavramın, ekolojik, sosyal ve ekonomik yaşamın tüm alanlarını içine alacak şekilde geniş kapsamlı olduğu ve kavramın bütüncül bir düşünce ve yaşama biçimini öngördüğü söylenmektedir (Bozlağan, 2004). Dünya yoksullarının temel gereksinmelerini karşılama ve bugünkü ve gelecekteki gereksinmeleri karşılayabilme yeteneğine teknolojinin ve toplumsal örgütlenmenin getirdiği sınırlamaları kavramlarına dayanan sürdürülebilir gelişme "bugünün gereksinmelerini gelecek kuşakların kendi gereksinmelerini karşılama olanaklarını onların ellerinden almadan karşılamak” olarak tanımlanmaktadır (Keleş vd., 2012).

1992 yılında Rio'da düzenlenen BM Çevre ve Kalkınma Konferansı'nda ortaya çıkan belgelerden biri olan Rio Bildirgesi'nde yer alan 27 ilke arasında sürdürülebilir gelişme kavramı önemli bir yer tutmuştur. Kalkınma hakkının bugünkü ve gelecek kuşakların kalkınma ve çevre gereksinmeleri arasındaki dengenin kurulaması yoluyla gerçekleştirilmesi, çevrenin korunmasının bağımsız olarak ele alınmaması, kalkınma süreciyle bütünleştirilmesi, tüm dünyada sürdürülebilir gelişmeyi gerçekleştirecek ekonomik büyümenin sağlanması için devletlerin uluslararası ekonomik sistemi harekete geçirmekle sorumlu kılınması doğrudan sürdürülebilir gelişme kavramına ilişkin atıflardır. Öte yandan Konferans'tan sonra bu ilkeleri hayata geçirmek üzere Sürdürülebilir Kalkınma Komisyonu kurulmuştur. Yine Konferans'ın sonucunda ortaya çıkan Gündem 21'in ilkeleri arasında sürdürülebilir gelişme kavramı oldukça önemli bir yer tutmaktadır (Bkz. Keleş vd., 2012). Gündem 21 kavramın yalnızca ekonomik değil diğer açılardan da kullanımına katkıda bulunmuştur. Örneğin, demografik hareketler ve sürdürülebilirlik, sürdürülebilir insan yerleşimlerinin geliştirilmesi, sürdürülebilir dağ yönetimi, sürdürülebilir tarım ve kırsal kalkınma, sürdürülebilir gelişmede kadınlar için küresel eylem, sürdürülebilir gelişmede bilim, sürdürülebilir gelişme için veri ve bilgi alışverişi vs. 2002 yılındaki Johannesburg Zirvesi'nde ise hem sürdürülebilir gelişmenin boyutları ortaya konmak istenmiş hem de yoksulluğun ortadan kaldırılmasının, üretim ve tüketim kalıplarının değiştirilmesinin ve ekonomik-toplumsal kalkınma amaçlarıyla kullanılmasının sürdürülebilir gelişmenin temel koşulları olduğuna dikkat çekilmiş ve devlet ve hükümet başkanlarının sürdürülebilir gelişmeyi ortaklaşa sağlamak ve korumak konusundaki kararlı tutumları sergilenmek istenmiştir (Keleş vd., 2012).

2012 yılında yine BM öncülüğünde düzenlenen RİO+20 Zirvesi "BM Sürdürülebilir Kalkınma Konferansı" olarak adlandırılmıştır. İlginin oldukça yoğun olduğu Konferans’ta sürdürülebilir gelişme ve yoksulluğun azaltılması çerçevesinde yeşil ekonomi ve sürdürülebilir gelişmenin kurumsal çerçevesi tartışılmıştır (Sürdürülebilir Kalkınma, 2012). Zirve'de 283 maddelik “İstediğimiz Gelecek” isimli sonuç bildirgesi kabul edilmiştir. Bildirge'de sürdürülebilirlik kavramının neredeyse bütün alanlara uyarlanmış olduğunu söyleyebiliriz.

Yalnızca Birleşmiş Milletler değil OECD ve Avrupa Birliği gibi örgütlenmelerin de ilkeleri arasında sürdürülebilir gelişme kavramı önemli bir yer edinmiştir. Görüldüğü üzere sürdürülebilir gelişme kavramı 
dinamik bir kavram olarak sürekli yenilenmiş ve içeriği bakımından zenginleştirilmiştir. Böylece kavram, "çevre ve kalkınma hareketlerinin başlıca söylemi” haline gelmiştir (Bozlağan, 2005).

\section{3 İklim Değişikliğinin Küresel Bir Çevre Sorununa Dönüşmesi}

İklim değişikliği 1970'li yıllarda sorun olarak gündeme gelmiş olmakla birlikte uluslararası bir sorun olarak kamuoyunun dikkatini daha erken bir zamanlarda çekmiştir. Fakat iklim değişimine neden olan gazların azaltımı konusunda ortaya konan önerilerin değişik ulusal çıkarları etkilemesi sonucunda birlik oluşturulamamaktadır. Değişimin olması için, iklim değişikliği yapılacak anlaşmanın içeriği her bir ülkenin kendi özel durumuna uygun olabilecek yapıda olmalıdır. Bu bağlamda 1970'li yıllarda başlayan uluslararası görüşmelerden sorunun çözümüne yönelik tatmin edici bir sonuç alınamamıştır.

Küresel çevre sorunları ve iklim değişimine neden olan atmosferde sera etkisi yapan gazlar gelişmiş ve azgelişmiş ülkeleri karşı karşıya getirmiştir. Gelişmiş ülkeler azgelişmiş ülkeleri; nüfus artış1, yoksulluk, yenilenebilir ve yenilemez kaynakların tahrip edilmesi, yağmalanması gibi sorunların nedeni olarak görmekte ve bunun da iklim değişikliğine neden olan faktörler olduğunu ileri sürmektedirler. Buna karşılık az gelişmiş ülkeler; geniş anlamda çevre sorunlarının kendilerinin az gelişmişliklerinden değil, sanayileşmiş ülkelerin çevreye verdikleri zarardan kaynaklandığını ileri sürmüşlerdir. Bu iki farklı dünyanın çevre konusundaki görüşleri kuzey-güney çekişmesi olarak adlandırılmaktadır. Kuzey’in bakış açısına göre çözümü etkin doğum kontrolü politikası, azgelişmiş ülkelerin dış borçlarından kurtulmaları ve çevre teknolojisinin bu ülkelere transferidir. Güneyin çevre sorunlarının çözümü ise, kendi azgelişmişliklerinin ve Kuzey ülkelerinin savurganca üretim ve tüketim alışkanlıklarının bir sonucudur. Azgelişmiş ülkeler mutlak olarak ekonomik ve toplumsal gelişmeyi gerçekleştirmek istemekte ve Kuzey’in “bedava teknoloji” transferi yapmasını ve dış borçlarını silmelerini beklemektir (Güler ve Dural, 2007).

\subsection{Stockholm Konferansı 1972}

Stockholm Konferansı "Birleşmiş Milletler Çevre ve Kalkınma Programı (UNEP) tarafından oluşturulmuştur. Bu konferansta konu ilk kez uluslararası boyutta tartışılmıştır. Geri kalmış ülkeler kirlilikte paylarının olmadığını dolayısıyla her hangi bir sorumluluk yüklenmeyeceklerini belirtmişlerdir. Buna karşın gelişmiş ülkeler "yoksulluğun ortaya çıkardığı kirlilik" kavramını ortaya atıp, gelişmemiş ülkelerin yoksulluğunun kirliliğin ana unsuru olduğunu iddia etmişlerdir.

Stockholm'den sonra Antarktika'da ozon tabakasının hasar görmesinin farkına varılması ve bunun fotoğrafla kanıtlanmasının ardından basın ve kamuoyunun, sorunun uluslararası alana taşıması girişimleri de hızlandırmıştır. Bağlayıcı bir protokol hazırlamak için Nisan 1987'de Cenevre'de gerçekleştirilen toplantıda, 1990'dan başlayarak CFC tüketiminin 1986 düzeyinde dondurulması, 1992'ye kadar \% 20 azaltılması üzerine uzlaşma sağlanmıştır. Eylül 1987'de Montreal'de bağlayıcı hükümleri olan bir protokol üzerinde uzlaşılan bir başka konu olmuştur.

\section{2 İklim Değişikliği Çerçeve Sözleşmesi (Rio 1992)}

Rio toplantısı Avrupa, Kuzey Amerika ve Japonya'nın meydana getirdiği Kuzey ile Afrika, Latin Amerika ve bazı Asya ülkelerinin oluşturduğu Güney konferans boyunca çekişmelerini sürdürmüştür. Toplantının amaçları arasında, küresel ısınma ve sera etkisi yapan gaz emisyonlarının kısıtlanması, ülkelerin sera etkisi yaratan gaz emisyonlarını sınırlaması ve Güney ülkelerine bu yönde maddi yardımı içermiştir. Tartışmalı geçen bu toplantıda somut olarak Avrupa Topluluğu, karbon emisyon düzeylerini 2000 yılına kadar 1990 düzeyinde tutmayı önermiştir. Birçok delege bu sözleşmenin daha işlevsel olabilmesi için, sözleşmeye sera etkisine neden olan diğer gazların emisyonlarını azaltacak maddelerin konmasını önermiştir. Ama dünyanın en çok karbondioksit üreten ülkesi olan ABD, bunun endüstriyel üretimini düşüreceği ve işsizliği arttıracağı gerekçesiyle uzun süre direnmiştir (Güler ve Dural, 2007). İnsan kaynaklı sera gazı salımlarını 2000 yılına kadar 1990 düzeylerine çekme, mali kaynak, teknoloji transferi vb temel konulardaki ana yükümlülük ise, Ek I (OECD ve eski sosyalist Doğu Avrupa ülkeleri) ve Ek II (OECD ülkeleri) taraflarına bırakılmıştır.

\section{3 Üçüncü Taraflar Konferansı (Kyoto 1997)}

Konferans öncesi Küçük Ada Devletleri Birliği (AOSIS); Ek I Taraflarının CO2 salımlarını 2005 yılına kadar 1990 yılı düzeyine göre \% 20 azaltmalarını” hedefleyen protokol önerisi olmuştur. Buna karş1lık AB, karbondioksit (CO2) ve öteki sera gazı salımlarını 2010 yılına kadar 1990 yılı düzeyinin \% 15 altına indirmek olarak açıklamıştır. Bu azaltmanın \% 7.5’i 2005 yılına kadar gerçekleştirilmesi öngörülmüştür. AB'nin önerisi birçok ülke tarafından desteklenmesine karşın başta ABD, Japonya, Kanada gibi bazı gelişmiş ülkeler tarafından olumlu karşılanmamıştır. Kyoto'da OECD’nin 24 zengin ülkesi ve eski Sovyetler Birliği'nin Avrupa ülkeleri 2010 yılına kadar sera etkisi yaratan gaz emisyonlarını keseceklerini belirtmişlerdir. Fakat indirim için orman alanlarını geliştireceklerini belirtmişlerdir. Protokol, AB, ABD ve Japonya’ya 1990 yılı emisyon seviyelerine göre \% 8, \% 7 ve \% 6 azaltma yükümlülüğü getirmiştir. Fakat ABD daha Kyoto'da dönemin Başkan Yardımcısı Al Gore'un ağzından ABD’nin niceliksel olarak belirlenmiş olan salım azaltma yükümlülüğü \% 7'yi kabul etmeyeceğini açıklamıştır. Sonuç olarak Kyoto Protokol'üne göre, taraf ülkeler insan kaynaklı karbondiokside 
eşdeğer sera gazı salımlarını 2008-2012 yılı arasında 1990 yılı düzeyinin en az \% 5 altına indirilmesi yükümlülügü getirmiştir. $\mathrm{AB}$, hem birlik olarak hem de tek tek üye ülkeler açısından \% 8'lik bir azaltma yükümlülüğünü almıştır. Bazı taraflar, bu yükümlülük döneminde sera gazı salımlarını arttırma ayrıcalığı alırken (örneğin Avusturalya \% 8, İzlanda \% 10 ve Norveç \% 1 düzeyinde arttırabilecektir), Yeni Zelanda, Rusya Federasyonu ve Ukrayna sera gazı salımlarını 1990 yılı düzeyinde tutabilecektir (Güler ve Dural, 2007).

\begin{tabular}{|l|l|}
\hline EK-I Ülkeleri & Ek-II Ülkeleri \\
\hline AB, Belçika, İngiltere, İtalya, Norveç, & AB, Belçika, İngiltere, İtalya, Norveç, İsveç, \\
Almanya, Danimarka, İrlanda, İzlanda, & Almanya, Danimarka, İrlanda, İzlanda, Portekiz, \\
Portekiz, ABD, Finlandiya, İspanya, & ABD, Finlandiya, İspanya, Japonya, Yeni \\
Japonya, Yeni Zelanda, Avustralya, Fransa, & Zelanda, Avustralya, Fransa, Lüksemburg, \\
İsveç, Lüksemburg, Yunanistan, Avusturya, & Yunanistan, Avusturya, Hollanda, İsviçre, \\
Hollanda, İsviçre, Kanada, Türkiye. & Kanada. \\
Pazar Ekonomisine Geçiş Sürecinde Olan & \\
Ülkeler (PEGSÜ): & \\
Rusya Federasyonu, Çek Cumhuriyeti, & \\
Hirvatistan, Beyaz Rusya, Litvanya, Slovenya, & \\
Ukrayna, Polonya, Romanya, Letonya, Slovakya, & \\
Bulgaristan, Estonya, Macaristan. & \\
\hline
\end{tabular}

Tablo 1: BM İklim Değişikliği Çerçeve Sözleşmesi Ekleri

Dördüncü Taraflar Konferansı Kasım 1998 Buenos Aires’te, Beşinci Taraflar Konferansı 1999 yılında Bonn’da gerçekleştirilmiştir. Altıncı Taraflar Konferansı Kasım 2000 ve Temmuz 2001'de olmak üzere iki kez yapılmıştır Altıncı TK'nın ilki Lahey'de yapılmış ve konferans ABD ile AB arasında görüş ayrılıklarının keskinleşmesine tanık olmuştur. 2001 yılında yapılan Konferans ilkinin devamı niteliğinde sayılmış ve Bonn'da yapılmıştır. Bu konferansta Kyoto Protokolü'nün yeniden canlandırılması amaç edinilmiştir. Bu da Protokol hükümlerinden ödün verilmesiyle mümkün olmuştur. Ödün, dünya salım miktarının \% 55'ni karşılayan ülkeleri kazanmak için verilmiştir. Bonn'da yapılan Taraflar Konferansı'ndan sonra sırasıyla; 2001 yılında 7. TK Fas'ın Marakeş kentinde, 8. TK 2002 yılında yeni Delhi-Hindistan, 9. TK 2003 y1lında Milano-İtalya, 10. TK., 2004 y1lında Buenos Aires-Arjantin, 11. TK 2005 yılında Montreal-Kanada, 12. TK 2006 y1lında Nairobi-Kenya, 13. TK. 2007 yılında Bali-Endonezya, 14. TK. Poznan-Polonya, 15. TK. 2009 yılında Kopenhag- Danimarka, 16. TK. 2010 yılında Meksika, 17. TK. 2012 yılında Güney Afrika Cumhuriyetinde gerçekleştirilmiştir.

\begin{tabular}{|l|l|l|}
\hline Sözleşme Listeleri & Ülkeler & Sorumluluklar \\
\hline Ek-1 & $\begin{array}{l}\text { OECD + AB + PEGSÜ }(*) \\
(41 \text { ülke) } \\
\text { Türkiye (Özel şartları tanınarak) }\end{array}$ & Emisyon Azaltımı \\
\hline Ek-2 & $\begin{array}{l}\text { OECD + AB-15 } \\
(24 \text { ülke) } \\
\text { Türkiye (hariç) }\end{array}$ & $\begin{array}{l}\text { Teknoloji Transferi ve Mali Destek } \\
\text { Sağlamak }\end{array}$ \\
\hline Ek-1 Dışı & $\begin{array}{l}\text { Diğer Ülkeler (Çin, Hindistan, } \\
\text { Pakistan, Meksika, Brezilya, ...) }\end{array}$ & Yükümlülükleri yok... \\
& & \\
\hline
\end{tabular}

Tablo 2: Ülkelerin Hangi Eklerde Olduğu ve Sorumluluklart (*)Pazar Ekonomisine Geçiş Sürecindeki Ülkeler

Sonrasında, 2009 yılında ülkemiz Kyoto Protokolüne resmen taraf olmuş, ancak, Kyoto Protokolü'nün ilk uygulama döneminin bittiği 2012 tarihine kadar sayısal bir emisyon azaltım ve sınırlama hedefi almamıştır. Uluslararası iklim müzakereleri her yıl gerçekleştirilen taraflar konferansı (Conference of Parties) ismindeki çoklu oturumlu toplantılar yoluyla yürütülmekte olup, toplantı kararları toplantının gerçekleştirildiği yerin ismiyle anılmaktadır. Türkiye'nin Kyoto Protokolüne taraf olduğu 2009 yılından sonra alınan karar metinleri sırasıyla aşağıda sunulmuştur.

\subsection{Kopenhag Mutabakatı (COP-15, 2009)}

Kopenhag Mutabakatı'nda aşağıda sayılan kararlar alınmıştır:

- Artan ortalama küresel sıcaklığın $2^{\circ} \mathrm{C}$ nin altında tutulması,

- EK-I ülkelerinin sera gazı emisyonu 2020 hedeflerini; EK-I dışı ülkelerin ise, ulusal programlarına uygun azaltım faaliyetlerini (NAMAs) Sekretarya'ya iletmesi,

- Afrika, Az Gelişmiş Ülkeler ve Küçük Ada Devletlerinin uyum faaliyetlerinin finansmanına öncelik verilmesi,

- Gelişmekte olan ülkelerin uyum ve azaltım faaliyetlerinin finansmanı için 2010-2012 periyodunda 30 milyar ABD dolarlık, 2012-2020 arasında yıllık 100 milyar ABD dolar kaynak sağlaması, 
- "Kopenhag Yeşil Çevre Fonu”nun oluşturulması,

- 2015 yılında bu mutabakatın uygulanmasına yönelik değerlendirme yapılması.

3.5 Cancun Anlaşması (COP-16, 2010)

Cancun Anlaşmasında 26/CP.7 kararına atıf yapılarak, ilk defa Türkiye'nin diğer EK-I ülkelerinden farklı koşullarda olduğu tüm ülkeler nezdinde tanınmıştır. Anlaşma ile aşağıdaki hususlar karar altına alınmıştır.

- Küresel sıcaklık artışının $2^{\circ} \mathrm{C}$ derece ile sınırlandırılması,

- Ek I ülkelerinin (Gelişmiş ülkeler) ekonomileri genelinde sayısal azaltım hedefleri almaları ve düşük karbonlu büyüme planları ve stratejileri yapmaları,

- Ek I dışı (Gelişmekte olan ülkeler) ülkelerin destek talep edilen NAMA'lar ve sağlanan destekler için kayıt sistemi kurması, ulusal programlarına uygun azaltım faaliyetleri gerçekleştirmeleri ve düşük karbonlu büyüme planları ve stratejilerini teşvik etmeleri,

- Yeşil İklim Fonu adı altında bir fon kurularak; gelişmekte olan ülkelere kısa dönemde (2012 yılına kadar) 30 milyar dolar, uzun dönemde ise (2020 yılından sonra her yıl) 100 milyar dolar finansman yardımı yapılması,

- İklim değişikliğine uyum konusunda 'Cancun Uyum Çerçevesi' kurulması,

- “Teknoloji İcra Komitesi ve İklim Teknoloji Merkezi ve Ağı” kurulması.

3.6 Durban İklim Konferansı (COP-17, 2011)

Konferans sonucunda; 2012 yılı sonunda ilk yükümlülük dönemi bitecek olan Kyoto Protokolü sonrasında uluslararası iklim değişikliği rejimini şekillendirmek üzere ülkeler bir kararlar paketi üstünde anlaşmaya varmıştır. Kararlar Paketi ile tüm ülke taraflarını kapsayan yasal bir anlaşmanın sağlanmasına yönelik "Durban Güçlendirilmiş Eylem Platformu Geçici Çalışma Grubu" oluşturulmuştur. 2020 yllında yürürlüğe girecek yeni anlaşmaya ilişkin çalışmaların 2015 yılı sonuna kadar tamamlanması hedeflenmiştir. Alınan kararlar şunlardır (Iklim.cob,2013):

- Kyoto Protokolünün II. Yükümlülük Döneminin 1 Ocak 2013 tarihinde başlamasına ve yükümlülük döneminin müzakere sürecinde alınacak karar çerçevesinde 5 ila 8 yıl uzatılmasına karar verilmiştir.

- Kanada Kyoto Protokolünden çekileceğini, Rusya ve Japonya Protokolün II. dönemi için taahhüt almayacaklarını açıklamışlardır.

- Gelişmiş ve gelişmekte olan ülkelerin sera gazı emisyon azaltım raporlamaları için çerçeve oluşturulmuştur.

- 2020 yılında yıllık büyüklüğünün 100 milyar ABD dolarına ulaşması hedeflenen Yeşil İklim Fonu işler hale getirilmiştir.

- Teknoloji mekanizmasının 2012 yılından itibaren işler hale getirecek İklim Teknoloji Merkezi ve Ağı'nın yapısı belirlenmiştir.

- Sözleşme altında her ülkenin kendi ulusal koşullarına uygun şekilde katılabileceği, küresel emisyon azaltımlarını maliyet etkin şekilde gerçekleştirmek ve desteklemek amacıyla yeni bir mekanizma tanımlanmıştır.

- İklim değişikliğine uyum konusunda küresel koordinasyonu sağlayacak Uyum Komitesi kurulmuştur

\section{Türkiye'de Çevre Politikalarına İlişkin Yasal Düzenlemelerde Sürdürülebilir Gelişme İlkesi}

Çevre politikalarının gelişimine geçmeden önce bu konudaki iki temel düzenlemeye değinmek uygun olacaktır. İlki 1982 Anayasası diğeri de 2872 sayılı Çevre Kanunu'dur. 1982 Anayasası'nın 56. maddesinde yer alan "Herkes sağlıklı ve dengeli bir çevrede yaşama hakkına sahiptir. Çevreyi geliştirmek, çevre sağlığını korumak ve çevre kirlenmesini önlemek, devletin ve vatandaşların ödevidir." hükmü ile çevreyi dolaylı olarak ele alan hükümleri çevreye bakış açısına ilişkin değişikliğin de yansımasıdır. Kuşkusuz 1982 Anayasası'nın çevreye ilişkin düzenlemesi yalnızca bu hüküm değildir. Anayasa'da çevreye ilişkin çok sayıda düzenleme mevcuttur. 1982 Anayasası'nın yürürlüğe girmesinden sonra çıkarılmış olan 2872 sayılı Çevre Kanunu da bu konuda atılan ve sürdürülebilir gelişmeye yer veren bir temel düzenlemedir. 2872 sayılı Kanununda (5491 say1lı Kanunla yapılan değişiklik sonucunda) sürdürülebilir kalkınma ve sürdürülebilir çevre kavramları kullanılmıştır (Keleş, 2013).

Keleş'in de (2013) belirttiği üzere çevre ile ilgili ilk yasal düzenlemeler bütün dünyada olduğu gibi ülkemizde de insan ve çevre sağlığının düzenlenmesine ilişkin olanlardır. Bu bakımdan ilk yasal düzenleme 1930 yılında çıkarılan 1593 sayılı Umumi Hıfzısıhha Kanunu'dur. Yine 1930 yılında çıkarılan ve 2005 yılına dek yürürlükte kalan 1580 sayılı Belediye Kanunu'nda da çevre konusunun aynı bağlamda ele alındığı ve kent ve kasabaların sağlık koşullarının iyileștirilmesi konusunda belediyelerin görevli kılındıkları belirtilebilir. 1961 Anayasası'nda da çevre konusu sağlık hakkı başlığı altında "Devlet, herkesin, beden ve ruh sağlığı içinde yaşamasını sağlamakla ödevlidir" şeklinde ele alınmıştır.

1973-1977 yıllarını kapsayan III. Beş Yıllık Kalkınma Planı'nda ise çevre bölümü ilke kez ayrı bir başlık olarak ele alınmış ve kalkınmaya zarar verebilecek çevre politikalarının uygulanmayacağı belirtilmiştir (Keleş vd., 2012). Bu yönüyle sözkonusu planın çevre konusunda negatif bir yaklaşım içerdiği belirtilmektedir (Keleş, 
2013). Bu negatif yaklaşımın nedeninin 1972 yılındaki Stockholm Konferansı'nda azgelişmiş ülkelerin tezleriyle uyumluluk gösterdiği söylenebilir (Mengi ve Algan, 2003). Bu yaklaşım 1979-1983 dönemi için hazırlanan IV. Beş Yıllık Kalkınma Planı'nda terk edilmiş ve çevrenin, sanayileşme, tarımda modernleşme ve kentlileşme sürecinde önemli bir öğe ve etken olarak dikkate alınması gerektiği; çevre sorunlarının ortaya çıkmadan önce önlenmelerine öncelik verilmesi gerektiği; kirliliğin yoğun olduğu yerlere yönelik projelere öncelik verilmesi gerektiği ve bu süreçte kararların yerel yönetimlere bırakılması ve sivil toplum örgütlerine vurgu bu planın çevreye ilişkin ilkeleri olarak özetlenebilir (Keleş vd., 2012). Bu yönüyle planda önleyici politikalar esas alınmış, 1978 yılında Başbakanlık Çevre Müsteşarlığı kurulmuş ve aynı plan döneminde 2872 sayılı Çevre Kanunu yürürlüğe girmiştir (Mengi ve Algan, 2003). Yine aynı Plan döneminde 1984 yılında Çevre Müsteşarlığ Çevre Genel Müdürlüğü’ne dönüştürülmüştür (Keleş, 2013).

V. Beş Yıllık Kalkınma Planında (1985-1989) ise sürdürülebilir gelişme kavramı kaynakların gelecek kuşakların da yararlanabilmesi için en iyi biçimde korunması ve geliştirilmesi şeklinde yer almıştır (Keleş vd., 2012). Bu planda Ortak Geleceğimiz Raporu'nun etkilerinin olduğu söylenmektedir (Mengi ve Algan, 2003). Bu Plan döneminde 1989 yılında Çevre Genel Müdürlüğü yeniden Çevre Müsteşarlığı’’na dönüştürülmüştür (Keleş, 2013).

VI. Beş Yıllık Kalkınma Planı'nda (1990-1194), sürdürülebilir gelişme kavramına doğrudan yer verilmemiş olmakla birlikte söz konusu ilkeyi esas alan bir yaklaşım benimsenmiş ve küresel çevre politikalarının etkileri doğrudan varlık bulmuştur (Keleş vd., 2012; Mengi ve Algan, 2003). Bu Plan döneminin belki de en önemli özelliği 1991 yılında Çevre Bakanlığı'nın kurulmuş olmasıdır.

VII. Beş Yıllık Kalkınma Planı’nda (1996-2000) ise sürdürülebilir gelişme kavramı temel strateji haline getirilmiştir. $\mathrm{Bu}$ plan döneminde hazırlanmış olan ve sürdürülebilir gelişme kavramını merkeze alan Ulusal Çevre Stratejisi Eylem Planı (UÇEP) çevre konusundaki uluslararası sorumlulukların belirlendiği bir belgedir. UÇEP, ilgili tüm kurum ve kuruluşların yanı sıra sivil toplum örgütleri, özel sektör temsilcileri ve bilimsel kuruluşlardan çok sayıda temsilcinin katılımıyla hazırlanmış olan bir belge niteliği taşımakta ve sürdürülebilir nitelikte bir ekonomik, toplumsal ve kültürel gelişme sağlanması hedeflenmiştir. UÇEP'in sürdürülebilir gelişme konusundaki politikaları eyleme dönüştürecek öncelikleri belirleyen, Türkiye'nin sürdürülebilir gelişme konusunda küresel ve bölgesel düzeydeki uluslararası sorumluluklarını yerine getirebileceği bir belge niteliğine sahip olduğu belirtilmektedir. Ancak UÇEP'in yasal bir nitelik taşımaması Türkiye'deki resmi politikalarında sürdürülebilir gelişme ilkesinin öncelikli hedefleri arasında yer almadığı şeklinde yorumlanmaktadır (Mengi ve Algan, 2003).Yine aynı dönemde gündeme gelen ve 1996 yılında başlatılan Ulusal Gündem 21 Projesi'nin de sürdürülebilir gelişme konusunda atılmış olan önemli bir adım olduğu ancak bunun da UÇEP gibi yeterince uygulama alanı bulamadığı belirtilmektedir (Mengi ve Algan, 2003).

VIII. Beş Yıllık Kalkınma Planı'nda (2001-2005) sürdürülebilir gelişme konusunda yeterince bir başarı elde edilemediği belirtilmektedir (Keleş vd., 2012). Bu Plan döneminde çevre yönetimi konusunda önemli bir değişiklik gerçekleştirilmiş ve 1991 yılında kurulan Çevre Bakanlığı Çevre ve Orman Bakanlığı haline getirilmiştir (Keleş, 2013).

Son plan olan IX. Kalkınma Planı'nda (2007-2013) sürdürülebilir gelişme konusunda ikircikli ve kararsız bir tutum benimsendiği ve kavramın Plan'ın tümünde yalnızca bir kez kullanıldığı, ancak sürdürülebilirlik kavramının sık sık ama "sürüp gitme, kesintiye uğramama" anlamında kullanıldı̆̆ 1 belirtilmektedir (Keleş vd., 2012). Bu Plan döneminde de “12 Haziran 2011 genel seçimlerinden önce Meclis’ten aldığı kanun hükmünde kararname çıkarma yetkisini bakanlık sistemini değiştirmek yönünde kullanan hükümet, seçimlerden önce, kent ve çevre politikalarını yönlendirme konusunda yetkili olmak üzere Çevre, Orman ve Şehircilik Bakanlı̆̆g'nın kurulmasına ilişkin kanun hükmünde kararname çıkarmışsa da seçimlerden sonra yeni bir kararname ile bu alanda iki farklı bakanlık kurulmuştur: Çevre ve Şehircilik Bakanlığı ile Orman ve Su İşleri Bakanlığıı" (Turan, 2011).

\section{Sürdürülebilir Gelişme İlkesi Bağlamında Türkiye’de İklim Değişikliği Politikaları}

Günümüzde Türkiye'nin birçok alanda çevre sorunlarına ilişkin politikalar geliştirdiği söylenebilir. Genel olarak ifade etmek gerekirse çevre politikalarında ekonomik kalkınma ile çatışmalı bir politik sürecin yaşandığı belirtilebilir.

Türkiye, Rio’da düzenlenen Birleşmiş Milletler İklim Değişikliği Çerçeve Sözleşmesi ve Kyoto Protokolü’nde belirtilen gelişmiş ülkeler grubunda gösterilmesine itiraz etmiştir. Türkiye'nin temel itirazı Kyoto'da Türkiye'nin gelişmiş ülkeler grubundan çıkartılmasına yönelik olmuştur. Fakat Türkiye'nin bu itirazı ABD ve AB tarafından kabul edilmemiştir. Kanada, Avustralya ve bazı OECD üyesi ülkeleri, Türkiye'nin sözleşmenin eklerinden çıkma isteğini anlayışla karşıladıklarını açıklamışlar, ancak Türkiye’nin gönüllü yükümlülük almasını istemişlerdir (Sümer, 1997). Türkiye hem OECD ve eski Doğu Blok'u ülkelerinin bulunduğu Ek I ve yalnızca OECD ve AB ülkelerinin bulunduğu Ek II'de bulunmaktaydı. Dolayısıyla ABD, Japonya ve AB ülkeleri gibi aynı salım indirimine gitmek zorunda kalmıştır. Üstelik iki listede birden yer aldığından pazar ekonomisine geçiş sürecinde bulunana eski Doğu Blok’u ülkelerinin yararlandığı haklardan yararlanamayacağı gibi, gelişmekte olan ülkelerin Sözleşme uyarınca yerine getirmekle yükümlü oldukları akçal kaynak ve teknoloji karşılanmasına da katkıda 
bulunma yükümlülüğü altına alınmıştır (Duru, 2000). 1998 Taraflar Konferansında ve yardımcı organlar toplantılarında da istemini tekrarlamış, fakat başta $\mathrm{ABD}$ ve $\mathrm{AB}$ olmak üzere diğer gelişmiş ülkeler karş1 çıkmıştır. Türkiye'nin isteği 2000 Lahey ve 2001 Bonn Konferanslarında da yanıt bulamamıştır.

AB adaylık süreci içinde Türkiye'nin Kophenag kriterlerine uyum sağlamak üzere bir Ulusal Program hazırlaması öngörülmüştür. Bunun üzerine Türkiye Katılım Ortaklığı Belgesi ve Çevre Yönetmeliğini 2001 başlarında onaylamasının ardından, Türkiye, AB müktesebatının üstlenilmesine ilişkin 26 Mart 2001 tarihinde Ulusal Programını Komisyona iletmiştir. Ulusal Programın giriş bölümünde Birleşmiş Milletler İklim Değişikliği Çerçeve Sözleşmesi sürecine katılmak üzere çalışmaların sürdürüldüğü ve sera gazı salım envanterlerinin çıkarılacağı belirtilmektedir.

Avrupa Birliği, 2002 tarihinde Johannesburg'da gerçekleşen Sürdürülebilir Kalkınma Dünya Zirvesi’nden önce üyelerinin Kyoto Protokolü'nün onay sürecini tamamlamalarını istemiştir. Temmuz 2001 tarihinde Bonn ve Kasım 2001 tarihli Marakeş anlaşmalarıyla özellikle Kyoto Protokolünün düzeneklerinin uygulama kurallarının belli olması üzerine, üye devletler onay işlemlerine başlamışlardır. AB, Mayıs 2002 tarihinde 15 üye devletin onay işlemlerini tamamlaması sonucunda, Kyoto Protokolünü onayladığını açıklamıştır. Bu çerçevede Türkiye Birleşmiş Milletler İklim Değişikliği Çerçeve Sözleşmesini 16 Eylül 2003 tarihinde TBMM'de 4990 sayılı Kanun ile onaylamış ve 24 Mayıs 2004 tarihi itibarıyla sözleşmeye taraf olmuştur. Türkiye iklim değişikliği konusunda sürdürülen bilimsel ve teknik çalışmaların yanı sıra ulusal çalışmaların daha etkin bir şekilde yürütülmesi, eşgüdüm sağlanması, strateji belirlenmesi ve kararların bir uzlaşmaya dayanarak alınması amacıyla 2001 yılında Başbakanlık Genelgesi ile İklim Değişikliği Koordinasyon Kurulu (IDKK), BM/IDÇS'ne taraf olmamızdan doğan sorumluluklarını göz önüne alarak 2004 yılında yeni bir Başbakanlık Genelgesi ile tekrar düzenlemiştir. Yeni İklim Değişikliği Koordinasyon Kurulu kapsamında, Türkiye'nin Sözleşme Sekretaryasına vermekle yükümlü olduğu Ulusal Bildirimin içeriği dikkate alınarak sekiz adet çalışma grubu oluşturulmuştur. Türkiye AB'ye adaylık süreci ve 2001 tarihinde Marekeş’te gerçekleştirilen 7. Taraflar Konferansı'nda alınan “Türkiye'nin isminin Ek II'den silinmesi ve özgün koşulları dikkate alınarak, diğer Ek I ülkelerinden farklı bir konumda Ek I'de yer alacağı şeklinde özetlenen 26/CP.7 numaralı karar, Türkiye'nin Sözleşmeye taraf olma sürecini belirleyen en önemli gelişme olmuştur (Güler ve Dural, 2007).

Türkiye 5386 Sayılı Birleşmiş Milletler İklim Değişikliği Çerçeve Sözleşmesine Yönelik Kyoto Protokolüne Katılmamızın Uygun Bulunduğuna Dair Kanun’un 5 Şubat 2009'da Türkiye Büyük Millet Meclisi'nce kabulü ve 13 Mayıs 2009 tarih ve 2009/14979 Sayılı Bakanlar Kurulu Kararı'nın ardından, katılım aracının Birleşmiş Milletlere sunulmasıyla 26 Ağustos 2009 tarihinde Kyoto Protokolü'ne taraf olmuştur. Protokol kabul edildiğinde BMIDÇS tarafı olmayan Türkiye, EK-I taraflarının sayısallaştırılmış salım sınırlama veya azaltım yükümlülüklerinin tanımlandığı Protokol EK-B listesine dâhil edilmemiştir. Dolayısıyla, Protokol'ün 2008-2012 yıllarını kapsayan birinci yükümlülük döneminde Türkiye'nin herhangi bir sayısallaştırılmış salım sınırlama veya azaltım yükümlülüğü bulunmamaktadır.

Birleşmiş Milletler İklim Değişikliği Çerçeve Sözleşmesi 17. Taraflar Konferansı (COP 17) ile Kyoto Protokolü 7. Taraflar Toplantısı (CMP 7) sonunda 2012 yılından sonra geçerli olacak iklim değişikliği rejiminin belirlenmesine ilişkin bir yol haritası üzerinde anlaşmaya varılmış olmasını Türkiye memnuniyetle karşılamıştır. Durban Taraflar Konferansında ayrıca, özel konumu Marakeş (2001) ve Cancun (2010) Taraflar Konferanslarında tanınmış olan Türkiye'ye, salım azaltımı, iklim değişikliğine uyum, teknoloji geliştirilmesi ve transferi, kapasite oluşturma ve finansman alanlarında sağlanacak desteğin modalitelerinin belirlenmesine ilişkin görüşmelerin sürdürülmesi karara bağlanmıştır. Türkiye iklim değişikliğiyle mücadelede 'ortak fakat farklılaştırılmış sorumluluklar' ve 'her ülkenin kendi imkan ve kabiliyetlerine göre değerlendirilmesi' ilkeleri çerçevesinde, adil, kapsamlı, kurallara dayalı ve hukuken bağlayıcı bir uluslararası düzenlemeye gidilmesini savunmuştur (ÇEVKO, 2013).

Durban'da Taraflar Konferansı ayrıca; Türkiye'nin Sözleşmenin Ek-1 listesindeki ülkelerin konumundan farklı bir konumda olduğunun tanındığı 26/CP.7 ve 1/CP.16 sayılı kararları hatırlatarak, "Taraflar Konferansınca Özgün koşulları tanınan Taraflara, Sözleşmenin uygulanmasına yardımcı olmak için azaltım, uyum, teknoloji geliştirme ve transferi, kapasite geliştirme ve finansman konularında destek sağlanmasına yönelik usulleri tartışmaya devam etmek konusunda anlaşmaya varır.” kararı almıştır.

Kopenhag İklim Zirvesi müzakerelerindeki çalışmaların sonucunda oluşturulan içerik daha sonraki yıllardaki Taraflar Konferanslarına taşınmış ve 2010 yılında kabul edilen Cancun Anlaşması ve Aralık 2011 yılında Güney Afrika'nın Durban kentinde yapılan Konferansta kabul edilen kararlar paketi içerisinde bazı kısımları karara bağlanabilmiştir (İklim Cob, 2013).

\section{Sonuç Yerine: Sürdürülebilir Gelişme Çevre ile Kalkınma Arasındaki Çatışmanın Çözümü İçin Bir Araç Olabilir mi?}

Bu soruya yanıt vermek için öncelikle Kalkınma Bakanlığı tarafından hazırlanan Rio'dan Rio’ya: Türkiye'de Sürdürülebilir Kalkınmanın Mevcut Durumu (2012) isimli taslak rapora değinmek uygun olacaktır. Rapor'da, yoksulluğun giderilmesi, sürdürülebilir üretim ve tüketim ve sürdürülebilir doğal kaynak yönetimi sürdürülebilir 
kalkınma için atılması gereken somut konular olarak belirlenmiştir. Bu konular RİO+20'ye hazırlık için belirlenmiş olan öncelikli konularadır. Rapor'da VI. Beş Yıllık Kalkınma Planı'ndan itibaren sürdürülebilir gelişme ilkesine yer verildiği, VII. Beş Yıllık Kalkınma Planı döneminde 1992 Rio Zirvesi ve sonrasındaki gelişmelerin etkili olduğu, Gündem 21, BM Çölleşme ile Mücadele Sözleşmesi, BM İklim Değişikliği Çerçeve Sözleşmesi, BM Biyolojik Çeşitlilik Sözleşmesi gibi zirve çıktılarının Türkiye'nin sürdürülebilir politikalarını etkileyen belgeler olarak nitelendirilmiştir. Türkiye'nin AB'ye üyelik sürecinin de bu politikaları etkileyen önemli bir etmen olduğunun da altı çizilmiştir. Özellikle Gündem 21 ve onunla bağlantılı olana Türkiye Yerel Gündem 21 Programı'nın 2001 yılında en iyi uygulama örneği seçilmesine atıf yapılarak bu bağlamda 5393 sayılı Belediye Kanunu ile kent konseylerinin kuruluşuna yasal zemin hazırlandığı belirtilmiştir. Yine 2004 yılında Ulusal Sürdürülebilir Kalkınma Komisyonu'nun kurulması, 2004-2006 yılları için hazırlanmış olan Ön Ulusal Kalkınma Planı'nın, 2007-2023 yılları için hazırlanmış olan AB Entegre Çevre Uyum Stratejisi ile birlikte yapısal, yönlendirici değişim programlarının (eğitim, sağlık ve sosyal güvenlik) ve yasal değişikliklerin sürdürülebilir kalkınma anlayışına uygun olduğu vurgulanmıştır. Rapor'da dikkat çeken konulardan birisi de iklim değişikliğinin sürdürülebilir kalkınma için en büyük tehdit olarak ifade edilmesidir. Öte yandan iklim değişikliğinin doğal afetlerin oluşturduğu risk düzeyini de etkilediği, bu bakımdan sürdürülebilir kalkınmanın sağlanması açısından iklim değişikliğinin gelecekte ele alınması gereken en önemli konulardan biri olarak saptanmıştır. Çünkü iklim değişikliğinin afet risklerinin mekânsal dağılımını ve sıklığını etkilediği gibi diğer bir çok sosyoekonomik ve çevresel değişken üzerinde de etkili olduğu belirtilmektedir. Bu bağlamda önemli bir sorun alanı olarak görülen iklim değişikliği için 2007 yllında Türkiye'nin İklim Değiş̧ikliği Birinci Bildirimi, Ulusal İklim Değişikliği Eylem Planı ve Taslak İklim Değişikliğine Uyum Stratejisi'ni hazırlamış olduğu vurgulanmakta ve söz konusu düzenlemelerde iklim değişikliği sorununun üstesinden gelinmeye çalışıldığı ifade edilmektedir. Rapor'un genel olarak sürdürülebilir gelişme ilkesinin ekonomik, sosyal ve çevresel boyutları esas alınarak hazırlanmış olduğunu belirtebiliriz. Sorunların tespiti konusundaki güçlü yönüne rağmen çevresel sürdürülebilirlik ilkesinin hayata geçirilmesi konusunda ise daha az etkili bir tutumun sergilenmiş olduğunu en azından çevreye bir yaşam alanından çok doğal kaynak olarak bakıldığını belirtmek yanlış olmayacaktır.

Sonuç olarak Türkiye'de, çevre yönetimine ilişkin sorunlar, doğal varlıklar üzerinde baskılar, çevre hakkının kullanımına ilişkin sorunlar ve çevre sorunlarını algılama sorunları gibi sorunların bulunduğunu ve bu sorunların da gelişmekte olan bir ülkenin kalkınma refleksinden kaynaklandığını belirtebiliriz. Sürdürülebilir gelişme ilkesinin çevre ile kalkınma arasındaki çatışmanın çözümü için bir araç olabilmesi için Türkiye'nin kalkınma sorununu aşması gerektiği ise yaygın bir kanıdır.

\section{Kaynakça}

- Bozlağan, Recep, 2004, “Sürdürülebilir Gelişme Kavramı Üzerine Yapılan Tartışmalara Bir Bakış”, Atatürk Üniversitesi İktisadi ve İdari Bilimler Dergisi, 18 (3-4), ss. 1-19.

- Bozlağan, Recep, 2005. "Sürdürülebilir Gelişme Düşüncesinin Tarihsel Arka Planı", Sosyal Siyaset Konferansları Dergisi, İstanbul Üniversitesi, İktisat Fakültesi Yayını, 50. Kitap, İstanbul, ss. 1011-1028.

- ÇEVKO, 2013. http://www.cevko.org.tr/cevko/Ic-Sayfa/Cevko/Haberler/Bm-iklim-Degisikligi-cerceveSozlesmesi.aspx.

- Duru, Bülent, 2002. “Viyana'dan Kyoto’ya İklim Değişikliği Serüveni”, Mülkiye Dergisi, C. XXV, S.230, Eylül-Ekim.

- Güler, Mahmut ve Dural, Baran, 2007. "Climate Change Protection and Its Effect" Journal of Environmental Protection and Ecology, Vol:8, No:2, 2007, pp:410-417.

- Hayırsever Topçu, Ferhunde, 2008. Küreselleşme ve Uluslararası Çevre Politikaları: Yönetimden 'Yönetişim'e Geçiş Sorunu, Turhan Kitabevi, Ankara.

- İklim Cob, 2013. http://iklim.cob.gov.tr/iklim/Files/yay\%C4\%B1nlar/makale-Doha.pdf.

- Kaplan, Ayşegül, 1999. Küresel Çevre Sorunları ve Politikaları, Mülkiyeliler Birliği Vakfı Yayınları, Ankara.

- Keleş, Ruşen, 2013. 100 Soruda Çevre, Çevre Sorunları ve Çevre Politikası, Yakın Kitabevi, İzmir.

- Keleş, Ruşen, Can Hamamcı ve Aykut Çoban, 2012. Çevre Politikası, İmge Kitabevi, Ankara.

- Mengi, Ayşegül ve Nesrin Algan, 2003. Küreselleşme ve Yerelleşme Çağında Bölgesel Sürdürülebilir Gelişme, Siyasal Kitabevi, Ankara.

- Sümer, U. 1997. III'rd COP Meeting Report of UNFCCC. Ankara.

- Sürdürülebilir Kalkınma, 2012. http://www.surdurulebilirkalkinma.gov.tr/Rio+20.portal.

- Turan, Menaf, 2011. "Yerel Yönetimlerin İmar ve Planlama Yetkileri”, Beşinci Ulusal Yerel Yönetimler Sетровуити, 21-23 Kasım 2011, Ankara Üniversitesi Siyasal Bilgiler Fakültesi, Ankara.

- Wikipedia, 2013. http://tr.wikipedia.org/wiki/. 


\title{
Küresel İklim Değişikliği Sorununa Çözüm İçin Nasıl Bir Sürdürülebilir Kalkınma Anlayışına İ́tiyacımız Var? What Kind of Sustainable Development do we need for the Solution of Global Climate Change Problems?
}

\author{
Dr. Ayşen Satır (Ministry of Environment and Forestry, Turkey) \\ Asst. Prof. Dr. Hakan Reyhan (Hitit University, Turkey)
}

\begin{abstract}
The base issue is for sustainable development is removed on discrepancies of arising from ecological, economic and cultural concepts. Sustainability is procurable with balance on this three factor. Setting up this balance is presented to change of life style and economic manner especially development countries. Sustainability manner is not only in countries, but also providing for base on ethics and climate justice based upon rationalism in abroad. For this reason, sustainable development approach have need to review is to remedy of solutions from the point of global climate change/ global warming as known prime environment problems.
\end{abstract}

\section{Giriș}

İklim değişimi, etkileri bakımından şu anda dünyada en önemli çevresel, sosyal ve ekonomik tehdidi oluşturmaktadır. İktisadi kalkınma ile insanların refah ve mutluluğunun artırılması hedeflenirken küresel ısınma ve küresel iklim değişikliği ortaya çıkardığı sosyo-ekonomik maliyetlerle bu refah öngörüsünü tehdit etmektedir. Sürdürülebilir kalkınma politikaları ile küresel kaynakların kullanılması sonucu ortaya çıkan net fayda azamileştirilerek ekonomik verimliliğin sağlanması mümkündür. Ancak bu "kaynak kullanımı”nın ne ölçüde olması durumunda ekolojik döngü ve çevresel sürdürülebilirlik sağlanabilir, özel olarak da küresel 1sınma engellenebilir? İşte temel tartışma sorusu budur. $\mathrm{Bu}$ soruya verilen her cevap birçok farklı sürdürülebilir kalkınma yaklaşımını ve modelini gündeme getirmiştir. Küresel iklim değişikliği sorununa klasik sürdürülebilir kalkınma yaklaşımı ile çözüm bulunabileceği yönündeki değerlendirmelerin genellikle soruna ancak yüzeysel bir çözüm getireceğini düşündürmektedir. Sorunun temelden çözümünün ise daha radikal bir çevreci yaklaşımla mümkün olabileceği düşüncesi, "kalkınma" kavramının kapsamı, içeriği, getirdikleri üzerindeki tartışmaları yoğunlaştırmaktadır.

Bu süreçte küresel iklim değişikliği/ küresel 1sınma sorununun ortaya çıkardı̆̆ı sosyo-ekonomik maliyet sadece klasik sürdürülebilir kalkınma yaklaşımı ile değil, "çevresel adalet”, iklim adaleti gibi yeni politik ekoloji kavramlarıyla birlikte politik gündeme taşınmaya başlamıştır. Yani artık anlaşılmaktadır ki, mevcut sürdürülebilir kalkınma perspektifi doğanın/ekolojik sisteminin aldığı yaraları tedavi etmeye yetmemektedir. Temelden çözümcü ve bütüncül stratejilerin geliştirilmesi gerekmektedir. Bu bildiride, küresel iklim değişikliği ve sürdürülebilir kalkınma yaklaşımı arasındaki bağlantı bu yeni eğilim çerçevesinde ele alınacaktır.

\section{2 Çevre Sorunlarına Sürdürülebilir Kalkınmacı Yaklaşım}

Birleşmiş Milletler Çevre Konferansı, ekoloji ve kalkınma arasındaki dengeyi ön plana çıkaran "eko kalkınma" politikası çerçevesinde sürdürülebilir kalkınmanın iki temel öğesi olan "insan merkezlilik" ve "gelecek nesillerin kaynaklarının korunması" konularını gündeme getirmiştir. Ancak sürdürülebilir kalkınmanın küresel çapta aktif bir politika hâline dönüşmesi 20 yıllık bir gecikme ile, 1992 Rio Zirve'sinden sonra mümkün olabilmiş̧tir. (Dulupçu, 2010) Dünyadaki “sürdürülemez" kalkınmanın önündeki engellerin başında yoksulluk, nüfus artış1 ve etkin olmayan kaynak kullanımı ve zengin ülkelerdeki israfa kaçan tüketim gelmektedir. Yeşil alanların azalması, besin gereksinimini karşılayan arazinin giderek küçülmesi, hava kirliliğinin artışı, ozon tabakasının delinmesi, iklim değişikliği ve ekolojik dengenin bozulması gibi sorunlar, uluslararası ortaklaşa önlem almayı kaçınılmaz hale getirmiştir. (Öğütçü, 2004) Bu süreçte gerçekleşen "tüketim toplumu” eleştirisi ekolojik krizin ağırlıklı olarak sanayileşmiş ülkelerin eseri olduğu ve bu yüzden öncelikle bedel ödemesi gereken ülkelerin bu ülkeler olması gerektiği şeklinde tezahür eden, "sürdürülebilir kalkınmaya yönelik üçüncü dünyacı eleştirel tutumu" kuvvetlendirmiştir. $\mathrm{Bu}$ yaklaşıma göre; sürdürülebilir kalkınma politikalarının üçüncü dünyanın yoksul ülkelerinin kalkınma sorununun çözümünü engelleyici boyutta olmaması; dünyasal eşitsizliğin ve yoksulluğun ortadan kaldırılması durumunda bu politikaların dünyada geçerli olabileceği vurgulanmıştır. Özellikle, Üçüncü Dünya'nın etkin sözcülerinden Hindistan Başbakanı İndira Gandhi’nin 1972'deki Stockholm Çevre Konferansı'nda sarf ettiği şu sözler bu eleştirel tutumu çarpıcı bir şekilde özetlemektedir: "Yoksulluk ve karşılanmayan insan gereksinimleri, en önemli kirlenme biçimleri değil midir? Köylerimizde ve gecekondularımızda yaşayan kitlelere, yaşamlarının kaynağında mikroplar içerisinde bulunurken havayı, denizleri ve akarsuları temiz tutmanın zorunluluğunu nasıl anlatabiliriz? Çevreyi, yoksulluk koşulları içerisinde iyileştirmek imkânsızdır” (Keleş-Çoban-Hamamcı, 2009) 
Çevre sorunları ve sürdürülebilir kalkınmacı yaklaşım "Sürdürülebilir kalkınmanın çevre sorunlarıyla ilgili dört temel konusu üzerinde yoğunlaşmaktadır: (i) ne ölçüde çevresel koruma gereklidir ve ekonomik kalkınma gibi diğer amaçlarla kıyaslandığında öncelik neye göre verilmelidir? (ii) çevresel eşitlik ve adaletin anlamı; (iii) çevresel amaçları formüle etme, uygulama ve meşrulaştırmada daha kapsayıcı ve katılımcı politika-oluşturma süreçlerinin rolü; (1v) daha çevre dostu bir ekonomik sisteme yönelmek için gereken siyasal eylemler ve kurumsal yapılanmalar nasıl olmalıdır? üzerinedir. (Jacobs, 2003) Bu yüzden en güçlü ekolojik ortamda farklı doğal sermaye varlıklarının özellikle yenilenemez kaynaklar açısından yenilenebilenlerin ikamesi, piyasa değerlemesine dayanan sürdürülebilir kalkınma, doğal-sermaye açısından yapılan yaklaşımların yetersizliğini gözler önüne sermektedir. (Burkett, 2008) Herhangi bir piyasa-temelli ikame işlemi, parasal fiyatlarla kayıt altına alınamayan fakat önemsenmesi gereken ekolojik kullanım değerlerini hesaba katmayı zorunlu kılmaktadır.

Yoksullukla savaşım, doğal kaynaklardan yararlanma adâleti, nüfus denetimi ve çevre dostu teknolojilerin geliştirilmesi sürdürülebilir kalkınma ile doğrudan ilişkilidir (UNCED, 2013). Çevre sorunları; az gelişmiş ülkelerde; yoksulluk, açlık, nüfus artışı, dengesiz toprak dağılımı, doğal kaynakların tüketimi; gelişmiş ülkelerde ise endüstriyel kirlenme, katı atıklardaki artış, sınırsız tüketim olarak görülmektedir (Merchant, 1992). Söz konusu sorunların açıklanması gelişmiş ülkelerde yaşananların sanayileşme ve kalkınma sonrasında yaşanan sorunlar olduğunu, azgelişmiş ülkelerde yaşanan sorunların ise belirli bir gelişme süreci gerektirdiğini göstermiştir. $\mathrm{Bu}$ durum, iktisadî büyüme olgusunda kalkınma ve doğal kaynakların tüketilmesi arasındaki ilişkinin tartışılmasını gündeme getirmektedir. Bir yandan hızlı iktisadi büyümeden kaynaklanan, diğer bir yandan ise yoksulluktan kaynaklanan sorunlar vardır. Yoksulluğu önleme ve iktisadi büyüme stratejileri mevcut sürdürülebilir kalkınma yaklaşımları içerisinde şimdiye kadar yer edinebilmiştir. Ancak, bu çerçevede ele alınan klasik sürdürülebilir kalkınma politikalarının küresel 1sınma/küresel iklim değişikliği sorunu gittikçe derinleşirken yeniden değerlendirilmesi gerekliliği de tartışılmaktadır.

\section{Sürdürülebilir Kalkınma ve İ́klim Değişikliği İlişkisi}

Sürdürülebilir Kalkınma (SK) kavramının ardında basit ama önemli bir fikir bulunmaktadır: "Günümüzde ve gelecekteki kuşaklar da dâhil olmak üzere herkes için çok daha yüksek bir yaşam kalitesine erişmek felsefesi”. Kavram, ilk olarak 1987 Brundtland Raporu'nda "bugünün ihtiyaçlarının, gelecek kuşakların kendi ihtiyaçlarını karşılama kabiliyetlerinden ödün vermeden karşılanması" olarak tanımlanmış, 1997 yılında Amsterdam Antlaşmasıyla Avrupa Birliği’nin (AB) temel hedefi haline gelmiştir. Ancak ilk planlı Strateji 2001 Gothenburg Avrupa Konseyi'ne kadar geliştirilememiştir. 2001 Gothenburg Avrupa Konseyinde, AB Ülkeleri, "Daha İyi Bir Dünya İçin Sürdürülebilir Bir Avrupa ve Sürdürülebilir Kalkınma için ise Avrupa Stratejisi", hedefiyle SK Avrupa Birliği temelinde aşılması güç fakat gerekli bir sorunsal olduğunu ifade etmişlerdir. Gothenburg Stratejisi ismiyle tanınan bu strateji, 2010 yılına kadar olan dönem için hedefler belirlemiştir. Strateji SK konusunda kilit sayılabilecek öncelikli alanlar; İklim Değişikliği ve Temiz Enerji, Sürdürülebilir Ulaşım, Sürdürülebilir Tüketim ve Üretim, Doğal Kaynakların Korunması, Halk Sağlığı ve Sosyal Refah, Nüfus ve Göç ile Küresel Yoksulluk temalarıdır. (European Commission, 26/7/2013) Sürdürülebilirlik için, başta toplumsal, ekonomik ve siyasal alanlarda olmak üzere, insan yaşamının her alanında yeni düzenlemeler yapılmalıdır. Modern Toplumda Sürdürülebilirlik Arayışları Sanayileşme ve İklim Değişikliği sonuçları bakımından (Kılıç, 2006) neden olmaktadır.

2007 yılında ortaya konulan Sürdürülebilir Kalkınma Stratejisi üzerine ilerleme raporunda, küresel 1sınma ve enerjinin de dâhil olduğu öncelikli alanlarda, bu konuda ilerlemenin somut bir eyleme dönüşmediği de ifade edilmektedir (AB-Türkiye Görünüm, 2000). Son 20 yılda dünyada yaşanan gelişmeler ve değişimler bu gündemin daha da güçlendirilmesi ve desteklenmesine olan ihtiyacı artırmıştır (Kalkınma Bakanlığı, 2012). Gerçekte Sürdürülebilir kalkınmanın küresel ısınma ile ilintili olduğu gerçeği ortadadır. Çünkü; küresel ısınma nedeniyle küresel kaynakların birçoğu yok olmakta bir kısmı ise istenilen etkinlikte kullanılamayarak ekonomik verimliliği engellenmektedir. İklim Değişikliği'nin doğrudan ve parasal olarak ölçülebilen zararları UNEP tarafından Johannesburg Zirvesinde yayınlanmıştır. Zirve sonrasındaki değerlendirme raporunda 20. Yüzyıl'daki iklimsel afetlerin yılda \%10 hıla şiddetlenip sıklaştı̆̆ tazminatlarının 1 trilyon \$ düzeyine eriştiği ve 2002 zararının 150 milyar \$ olduğu ifade edilmektedir. İklim değişikliği ile ilgili gerekli önlemler alınmadığı takdirde, küresel ısınmanın dünya ekonomisine 2100 yılına kadar birikimli maliyetinin 2 katrilyon \$ civarında olacağı öngörülmektedir. Bu büyüklük dünya üretiminde yıllık \% 6-8 oranında bir küçülmeye işaret etmektedir. Ortalama 4 derecelik bir 1sı artışının yiyecek sektöründe 9,9 milyar $€$, akaryakıt sektöründe 5,9 milyar $€$ ve bankacılık sektöründe 8,9 milyar $€$ sermayeyi riske atacağ tahmin edilmektedir. Ayrıca küresel 1sınmanın çeşitli etkileriyle doğrudan insan sağlığı üzerinde de tehdit oluşturduğu ve artan sayıda ölümlere neden olduğu da ortaya konulmaktadır. (United Nations Environment Programme, 2002) Bütün bu göstergeler çerçevesinde küresel iklim değişikliğinin getirdiği sosyoekonomik maliyetler göz önünde bulundurulduğunda; "sürdürülebilir kalkınma" stratejilerinin, yeni çevre sorunlar dikkate alınarak, "iklim adaleti”, "çevresel adalet" vs. gibi kavramlarla -küresel bir düzlem içerisinde- yeniden değerlendirilmesi gerektiği ortadır. 
Çevresel adalet fikri, içinde bulunduğumuz çağda etkileri gündelik yaşamda daha fazla belirginleşmeye başlayan ve artık dünya ekonomisinin istikrarı açısından da küresel bir tehdit olarak algılanmakta olan ekolojik krizin nedenleri üzerine odaklanarak bu çerçevede adaletli bir çözüm oluşturulması gerekliliği üzerinden başlayan bir tartışma sürecinde şekillenmiştir. Şöyle ki; daha önce de yer yer belirtildiği gibi, ekolojik krizin oluşmasında en büyük pay sahibi olan sanayileşmiş ülkelerin çözüm sürecinde de en fazla yükümlülüğü üzerlerine almaları gerekliliği, bu fikrin temel argümanı olmuştur. Az gelişmiş ülkelerin kısa sürede çözmek zorunda oldukları kalkınma sorunlarının dünya ekosistemine yeni baskılar oluşturmaması için az gelişmiş ülkelerin ekonomik sorunlarının çözümü konusunda gelişmiş ülkelerin önemli ölçüde yükümlülükler üstlenmesi gerekliliği bu fikir çerçevesinde tartışılmaktadır. Bu açıdan çevresel adalet fikri, sürdürülebilir kalkınma kavramının içeriğinde "sosyal adalet”'in daha hissedilir olmasını salık vermektedir (Dobson, 2003).

İklim adaleti kavramını da çevresel adalet fikrinin küresel iklim değişikliği süreci içerisindeki daha özel biçimi olarak değerlendirmek gerekir. Son zamanlarda küresel iklim değişikliğinin yarattığı sonuçlara karşı yeni bir toplumsal hareket olarak da beliren iklim adaleti hareketinin temel varsayımı iklim değişikliğinde en büyük paya sahip olan zengin/sanayileşmiş Kuzey ülkelerinin, az gelişmiş/gelişmekte olan Güney ülkelerine "ekolojik borç" yükümlülüklerinin olduğudur (Roberts-Parks, 2007). Bu çerçevede Kuzey’den Güney’e olan iklim borçlarının tazminatı ve bu bağlamda bir maddi transferin sağlanması; öncelikle Kuzey ülkelerinin ve Güney ülkelerinin seçkin sınıflarının aşırı tüketimleri açısından bir sınırlandırmaların getirilmesi iklim adaleti hareketinin temel argümanlarını oluşturmaktadır (Benlisoy, 2009). Bunların gerçekleşmesi durumunda sürdürülebilir kalkınma politikalarının dünya ekonomisi ve ekosistem açısından daha işlevsel olabileceği düşünülebilir. Ancak mevcut sürüdürlebilir kalkınma anlayışının ortaya çıkardığı sonuçlar bu açıdan bir eksikliğin olduğunu gözler önüne sermektedir.

\section{4 İklim Adaleti Çerçevesinde Sürdürülebilir Kalkınma}

Bir yandan sanâyileşme, nüfus artışı ve "daha çok tüketim" eğilimi, diğer yandan doğal kaynakların, enerjinin gelecek nesillerin ihtiyacını karşılayabilecek şekilde dengeli kullanılması ihtiyacı "çevre" ve "kalkınma" konularını zaman zaman birbirlerinin alternatifi durumuna getirmiştir. Bu karşılıklı bağımlılık, kalkınmanın bütün unsurlarının çevresel faktörlerle ilişsisini incelemeyi de gerektirmiştir. Bu yüzden, dünya üzerindeki canlı yaşamı için büyük önem taşıyan konulardan biri olan iklim değişikliğinin; sürdürülebilir kalkınma çerçevesinde ele alınarak irdelenmesi gerekmektedir. Çünkü, zengin ülkelerde mevcut zenginlik büyük toplumsal sorunlara yol açmaktadır. Ekonomik büyüme ile refah değerleri ancak belirli bir seviyeye kadar ilişkilidir. Bu seviyenin üzerine çıkıldığında, aradaki bağlantı görece daha sorunlu bir hal almaktadır. Bu yüzden dünya üzerindeki, aşırı kalkınmanın yol açtığı sorunlara işaret etmek, iklim değişikliğinin kontrol edilmesi açısından değerlendirildiğinde; iklim değişikliğinin küresel iklim adaleti gibi yeni argümanların çevre politikalarına yansıtılması gerekliliğini ortaya koymaktadır.

İklim değişikliğinin yol açtığı sosyoekonomik maliyetlerin giderilmesi doğrultusunda ortaya atılan klasik sürüdürülebilir kalkınmacı stratejilerin mevcut küresel ekonomik adaletsizliği daha da derinleştirdiği görülmektedir. Bu durum iki farklı şekilde kendisini göstermektedir: (1) Sürdürülebilir kalkınma çerçevesinde geliştirilen bütün ülkeleri bağlayıcı ilkelerin kalkınma açığını kapatmak üzere hızlı büyüme arayışı içerisindeki az gelişmiş ülkelerin ekonomilerinin gelişmiş ülke ekonomilere yetişmesinin mümkün olmaması, (2) Gelişmiş ülkelerin kendi karbon açıklarını daraltmak üzere özellikle "kirli üretim” yatırımlarını az gelişmiş ülkelere kaydırarak ciddi bir "karbon ihracı" veya "kirlilik ihracı" oluşturmalarıdır.

Böyle bir sürdürülebilir kalkınma perspektifinde, az gelişmiş ülkelerin kalkınma yarışında geri kalmaları durumunun devam etmesine üstelik ekolojik sistemlerinin de tahrip edilmesine yol açacağı görülmekte ve böylesine bir "adaletsizlik tablosu” içerisinde küresel düzlemde gerçekleşen "çevre adaleti” ve "iklim adaleti” gibi sorgulayıcı-eleştirel hareketlerin doğması kaçınılmaz olmaktadır.

$\mathrm{Bu}$ süreçte "adalet" kavramı genişlemiş "iklim adaleti”, "çevresel adalet" ve "atmosferik adalet" gibi kavramlar etrafında kümelenen yeni siyasal sistem, yeni demokrasi önerileri gündeme gelmeye başlamıştır. Yeni demokrasi ve yeni siyasal sistem tartışmalarının son çeyrek asırdır iyice yoğunlaşmasında elbette küresel iklim değişiminin yarattığı ekolojik krizin ve bu krizin artık güncel toplumsal ve siyasal yaşamda hissedilir bir etkiye ulaşmasının payı büyüktür. (Wanderheiden, 2008) Örneğin çevre sorunu veya daha özel olarak küresel iklim değişikliği denilen sorunun ekonomi politik bir temele dayandığı, ancak iklim ile ilgili en cesur ekonomik yaklaşımların bile -sürekli büyümekten ve kâr maksimizasyonundan vazgeçmediği için- yeryüzünü korumaktan uzak olduğu ifade edilmiştir. (Foster-Clark-York, 30) Yine bu çerçevede küresel iklim değişikliğinin yol açtığ sorunların kapitalizm dairesinde çözülemeyeceği, çünkü zaten sorunun kaynağının üretimi ve tüketimi sürekli artırmaya dayalı bir sistem olan kapitalizm olduğu vurgulanmıştır. (Çoban, 2010) Buna rağmen küresel iklim değişikliğinin yol açtığı sorunları gidermek üzere şimdiye kadar ortaya konan çözüm çerçevesini genellikle klasik sürdürülebilir kalkınma anlayışı belirlemiş, ancak yine de özellikle üçüncü dünya ülkeleri ve bazı küresel toplumsal hareketler, küresel çevre politikalarına "iklim adaleti” ilkeleri doğrultusunda müdahil olmaya çalışmışlardır. 


\section{Küresel İklim Değişikliği Sorununa Farklı Çözüm Arayışları}

Küresel iklim değişikliğiyle ilgili çözüme yönelik ilk uluslararası girişim 2007 yılında Kyoto Protokolü’nün yürürlüğe girmesiyle gerçekleşti. Dünya ülkelerine, özellikle de sorunun asıl kaynağını teşkil ettiği düşünülen sanayileşmiş ülkelere kürsel ısınmaya neden olan sera gazlarının salınımının azaltılması yükümlügüün getiren bu antlaşma-özellikle ABD, Çin gibi- sanayi devlerinin muhalefetiyle karşılaştı̆̆ i ç̧in tam anlamıyla yürürlüğe girememiş, bu yüzden Kyoto Protokolü'nün devamı niteliğinde 2007 yılında Bali'de 2009 sonunda yeni bir uluslar arası iklim anlaşması imzalamak için gerekli adımları oluşturmak üzere "Bali Yol Haritası ve Eylem Planı" hazırlanmıştır. (The Worldwatch Institute, 2009) Daha sonra 2009 yılı Aralık ayında Kopenhag İklim Zirvesi yapılmıştır. Özellikle Çin'in uluslararası denetim mekanizmasına itirazları ve sanayileşmiş ülkelerle sanayileşmekte ülkeler çelişkisinden -iklim adaleti talepleriyle gerçekleşen toplumsal hareketlerle birliktekaynaklanan bazı sıkıntıların yansıdığı zirvenin sonunda kürsel sıcaklık artışının 2 dereceyi aşmasını sağlayacak çalışmalar yapmayı ve gelişmekte olan ülkelere mali yardımlarda bulunmayı içeren "Kopenhag Mutabakatı" imzalanmıştır. Bu mutabakatta yapılacaklar iki başlık altında toplandı: Birincisi, gelişmiş ülkelerin tamamının kendi ülkelerinden kaynaklanan karbon salınımını sınırlandırmaları yönünde -her ne kadar uluslararası yaptırımı olan bir yükümlülük henüz bağıtlanmamış olsa da- bir irade beyan etmeleri; ikincisi de gelişmekte olan ülkelerin küresel ısınmayı önleyici uygulamalara uyum sağlamak üzere sanayi kapasitelerinin adaptasyonunu sağlamak üzere bu ülkelere 2020 yılına kadar uygulamak üzere 100 milyar dolarlık mali yardım programının başlatılmasıdır. Kongre ilk defa bütün ülkelerin küresel iklim değişimine karşı önleyici politikalara katılma iradesi göstermesi bakımından olumlu bulunsa da yine de bu sorunun en büyük kaynağı olarak gösterilen özellikle ABD, Çin gibi sanayileşmiş ülkelerin gevşek tutumu ve bağlayıcılık gücünün zayıf olması açısından eleştirilmiştir. (CnnTürk, 2009). Sonuçta Kopenhag Mutabakatıyla somut bir bağlayıcı metin ortaya çıkmamış mutabakat geleceğe yönelik öngörülerle sınırlı kalmıştır.

2010 Aralık ayında Meksika’nın Cancun kentinde gerçekleşen İklim Zirvesi’nde bu öngörülerin sağlam somut bir plana dönüşmesi hedeflenmekteydi, ancak yine karbon salınım oranlarının düşürülmesiyle ilgili uzun vadeli öngörüler ve temenniler dışında kayda değer somut bir sonuç alınamadı. İklim değişiminin önlenmesi konusunda çok daha radikal, doğrudan doğruya kapitalist sisteme yönelik eleştiriler getiren ülkelerden biri olan Bolivya dışında bütün dünya ülkelerinin sonuç metnini imzaladığı bu zirvede alınan "en geç 2020 yılına kadar "Yeşil İklim Fonu" kurulması ve yoksul ülkelerin desteklenmesi için taraf ülkelerin 100 milyar dolar aktarması" kararı en somut görünen karar olarak algılandı. (http://tr.wikinews.org, 2010) Bu karar, 2012 yılında ilk dönemi bitmiş olan Kyoto protokolü sonrasında küresel iklim rejimini belirlemek üzere toplanan Aralık 2011 Durban İklim Kongresi'nde -öncelikle bu fonu oluşturmak üzere bir organizasyon oluşturmak üzere- uygulamaya geçirilmiştir. (Çevre ve Şehircilik Bakanlığı, 2013) Bu kararlarla birlikte klasik sürdürülebilir kalkınma politikalarının yenilenmesi sinyallerinin verildiğini düşünmek mümkün olmakla birlikte yeterli olmadığı düşünülmektedir. Mevcut politikaların yetersizliğini gösteren sayısal değerler daha dikkatlice incelendiğinde soruna daha somut bir çözüm çerçevesi oluşturabilmek mümkün olabilecektir.

\section{Niceliksel Değerlendirme}

İklim değişikliği ve çevre sorunun değerlendirilmesi ancak değerlendirme sistemleri içerisinde niceliksel olarak ifade edilebilmektedir. Bu nedenle sürdürülebilir kalkınma aslında bir değişim sürecidir. (Keleş ve Hamamc1,1998:158) Mevcut durumun tespiti ve izlenmesi konusunda yapılan ölçüm sistemlerinin başında sürdürülebilir kalkınma endeksleri, ekolojik ayak izi, Çevresel Performans İndeksi (ÇPE), Çevresel Sürdürülebilirlik Endeksi (ÇSE), Gerçek İlerleme Göstergesi gibi ölçümler yer almaktadır. 2008 yılı verilerine göre kişi başına düşen küresel yenilenebilir biyolojik kapasite ortalama olarak 2.1 küresel hektar olarak hesaplanmakta iken insanoğlunun küresel ortalama ekolojik ayakizi bu kapasitenin \%30 üzerindedir. Küresel ayakizinin yarıdan fazlasını karbondioksit emisyonları yaratmış, Fosil yakıt kullanımından salınan karbondioksit artarken ekosistemlerin karbondioksiti özümseme kapasitesi düşmektedir. Enerjiye bağlı olmayan küresel ayakizi ise henüz kapasitesinin \%70'ini kullanmaktadır. Teknolojik gelişmeler her hektardan sağlanan ürünü artırıyor olsa da, geriye kalan \%30 rezerv giderek azalmaktadır. (Nükhet Barlas, 2013) Columbia ve Yale üniversiteleri ile Avrupa Komisyonu ve Dünya Ekonomik Formu'nun ortak çalışması ile geliştirilen Çevresel Performans Endeksi (ÇPE) Binyıl Kalkınma Hedefleri raporunda çevresel hedefleri desteklemek ve ülkelerin çevre ile ilgili performansını karşılaştırmak için geliştirilmiştir. ÇPE, 2010 yılı için herbiri farklı ağırlıklara sahip olan 25 adet gösterge 3 seviye için hesaplanmıştır. (Bkz.Tablo 1).

Hesaplanan endekslere göre 2012 yılı için ÇPE Endeksi en yüksek olan ülke 76,69 değeri ile İsviçre olmuştur. İsviçre'yi Litvanya takip etmektedir. Türkiye 44,8 puanla 109. Sırada yer almaktadır.

Bu karşılaştırma 2010 yılı Çevresel Performans Endeksi ile karşılaştırıldığında 93,5 puan ile İzlanda birinci sırada iken Türkiye 60 puan ile 77. Sırada yer almaktadır. Listenin sonunda Angola, Moritanya, Orta Afrika Cumhuriyeti, Sierra Leone ve Tayvan bulunmaktadır. 2010 ve 2012 yılları için hesaplanan Çevresel Performans Endeksi değerleri, ülke sıralamaları ve Çevresel Performans Endeksi puanlamaları yer almaktadır.(Bkz.Tablo 2, Tablo 3). 


\begin{tabular}{|c|c|c|}
\hline $\begin{array}{l}\text { Amaçlar ve Ağırlıkları (ÇPE'nin } \\
\% \text { ’si) }\end{array}$ & $\begin{array}{l}\text { Politika Kategori ve Ağırlıkları } \\
\text { (ÇPE’nin \%'si) }\end{array}$ & Göstergeler ve Ağırlıkları \\
\hline \multirow[t]{6}{*}{ Çevre Sağlığ1 } & \multirow{2}{*}{$\begin{array}{l}\text { Hastalıkların Çevresel Yükü } \\
25\end{array}$} & Hastalıkların Çevresel Yükü: 25 \\
\hline & & İçme Suyuna Erişim : 6.25 \\
\hline & Su (İnsan Üzerine etkileri) & Kanalizasyon Hizmetlerine \\
\hline & \multirow{3}{*}{$\begin{array}{l}\text { Hava Kirliliği (İnsan Üzerine } \\
\text { etkileri }\end{array}$} & Erişim 6.25 \\
\hline & & Binaiçi Hava Kirliliği: 6.25 \\
\hline & & Dışi ortam Hava Kirliliği: 6.25 \\
\hline \multirow[t]{20}{*}{ Ekosistem Canlılığı 50} & \multirow{4}{*}{$\begin{array}{l}\text { Hava Kirliliğinin Doğa Üzerine } \\
\text { Etkileri }\end{array}$} & Sülfürdioksit emisyonları: 2.1 \\
\hline & & Azot oksit emisyonları \\
\hline & & $\begin{array}{l}\text { Metan dişı uçucu organic } \\
\text { bileşik emisyonları: } \quad 0.7\end{array}$ \\
\hline & & Ekosistem ozon seviyesi : 0.7 \\
\hline & \multirow[t]{3}{*}{ Suyun Doğa Üzerine Etkileri } & Su kalitesi endeksi: 0.7 \\
\hline & & Su stresi indeksi: 2.1 \\
\hline & & Su kıtlığ1 endeksi: 1.05 \\
\hline & \multirow[t]{2}{*}{ Biyolojik Çeşitlilik Habitat } & Biyom koruması: 1.05 \\
\hline & & Kritik habitat koruması: 2.1 \\
\hline & \multirow[t]{2}{*}{ Ormanc1lık } & Deniz koruma alanları : 1.05 \\
\hline & & Yetişen stok değişimi: 1.05 \\
\hline & \multirow[t]{3}{*}{ Balıkçılık } & Orman örtüsü değişimi : 2.1 \\
\hline & & Deniz tropic endeksi $: 2.1$ \\
\hline & & Tarama yoğunluğu : \\
\hline & \multirow[t]{3}{*}{ Tarım } & Tarımsal su yoğunluğu 2.1 \\
\hline & & Tarımsal sübvasyonlar 2.1 \\
\hline & & Pestisit düzenlemesi \\
\hline & \multirow[t]{3}{*}{ İklim değişikliği } & $\begin{array}{ll}\begin{array}{l}\text { Kişi başına sera gazı } \\
\text { emisyonları }\end{array} & 12.5 \\
\end{array}$ \\
\hline & & $\begin{array}{lr}\text { Elektrik üretimi başına } \mathrm{CO}_{2} \\
\text { emisyonları }\end{array}$ \\
\hline & & $\begin{array}{l}\text { Endüstriyel karbon yoğunluğu } \\
6.25\end{array}$ \\
\hline
\end{tabular}

Tablo 1 : Çevresel Performans Endeksi Çerçevesi (2010) Kaynak: World Economic Forum, Ylkmaz (2011:65)

2010 ve 2012 yılları arasında ülkelerin ÇPE karşılaştırıldığında Ülkelerin Performans değerlerinin değiştiği hatta gittikçe bu değerin giderek düştüğü gözlenmektedir. Bu sonuç ise kaynakların yeterince etkin kullanılmadığı hatta küresel boyutta çevresel tahribatın şiddetlendiği, iklim değişiminin küresel boyutta değiştiğini de niceliksel olarak ifade etmektedir.

Çevresel Sürdürülebilirlik Endeksi ise (ÇSE) çevresel sürdürülebilirliğin izlenmesine yönelik geliştirilen, geçmişteki ve mevcut durumdaki çevre kirliliği düzeyleri, çevre yönetim faaliyetleri, küresel değerlerin korunmasına yönelik katkılar ve toplumun çevresel performansın artırılma kapasitesi gibi konuları içermektedir. Toblo 2 de belirtildiği gibi ÇSE, gösterge ve değişkenler ile ifade edilerek toplamda 76 veri setinin kullanıldı̆̆ 21 gösterge çerçevesinde küresel çapta sorumluluk, çevresel sorunlarla mücadelede kurumsal ve toplumsal kapasite, insanların çevreye yönelik baskılardan zarar görebilirliğinin azaltılması gibi konular dikkate alınarak hesaplanmıştır. (Yıkmaz, 2011:72-73) Sonuçta çevresel adalet kavramını güçlendiren bu niceliksel değerler göstermektedir ki az gelişmiş ülkelerin kısa sürede çözmek zorunda oldukları kalkınma sorunlarının dünya ekosistemine yeni baskılar oluşturmaması için az gelişmiş ülkelerin ekonomik sorunlarının çözümü konusunda gelişmiş ülkelerin önemli ölçüde yükümlülükler üstlenmesi gerekmektedir.

Diğer bir değerlendirme sistemleri içerisinde yer alan Ekolojik ayakizi ise; tabiatın taşıma kapasitesini ölçmek için geliştirilmiş olan bir yöntemdir ve sonuçları bir ülkenin sürdürülebilir kalkınma derecesinin göstergesi olarak kullanılmaktadır. WWF (World Wild Fund)'a göre ekolojik ayak izi 1961 ile 2007 y1lları arasında iki katına çıkmış, 2007 yılında insanlığın toplam ayakizi 18 milyar küresel hektar, yani kişi başına 2,7 hektar olarak hesaplanmıştır. Dünyanın biyolojik kapasitesi ise yanlızca 11,9 milyar hektardır, yani kişi başına 1,8 hektardır. Bu yüzden bu şekilde devam edilirse 2030 yılında 2; 2050 yılında ise 2,8 gezene daha ihtiyacımız olacağı düşünülmektedir. (Günsoy, 2006) Dünyada ekolojik ayakizi en yüksek ülkeler Birleşik Arap Emirlikleri, Katar, Danimarka, Belçika, Amerika Birleşik Devletleri, Estonya, Kanada, Kuveyt ve İrlanda'dır. Yapılan hesaplamalar ile bir ABD vatandaşının ekolojik ayakizinin 43 Afrikalı’ya eşit düzeyde olduğunu göstermektedir. 
2007 yılı verilerine göre Türkiye'de kişi başına düşen biyokapasite 1,32 hektar iken, ekolojik ayakizi değeri 2,7 hektar olarak hesaplanmıştır. (Günsoy, 2006) 1961-2007 yılları arasında Türkiye’nin ekolojik ayakizinin gelişimi görülmektedir. (Bkz, Şekil 1).

\begin{tabular}{|c|c|c|}
\hline Ülke & $\begin{array}{l}\text { ÇPE (Çevresel Performans } \\
\text { Indeksi) } 2010\end{array}$ & $\begin{array}{l}\text { ÇPE } 2010 \\
\text { Siralamas1 }\end{array}$ \\
\hline İzlanda & 93.5 & 1 \\
\hline İsviçre & 89.1 & 2 \\
\hline Kosta Rika & 86.4 & 3 \\
\hline İsveç & 86.0 & 4 \\
\hline Norveç & 81.1 & 5 \\
\hline Mauritius & 80.6 & 6 \\
\hline Fransa & 78.2 & 7 \\
\hline Avustralya & 78.1 & 8 \\
\hline Küba & 78.1 & 9 \\
\hline Kolombiya & 76.8 & 10 \\
\hline Malta & 76.3 & 11 \\
\hline Finlandiya & 74.7 & 12 \\
\hline Slovakya & 74.5 & 13 \\
\hline Birleşik Krallık & 74.2 & 14 \\
\hline Yeni Zelanda & 73.4 & 15 \\
\hline Şili & 73.3 & 16 \\
\hline Almanya & 73.2 & 17 \\
\hline İtalya & 73.1 & 18 \\
\hline Portekiz & 73.0 & 19 \\
\hline Japonya & 72.5 & 20 \\
\hline Haiti & 39.5 & 155 \\
\hline Mali & 39.4 & \\
\hline Türkmenistan & 38.4 & 157 \\
\hline Nijer & 37.6 & 158 \\
\hline Togo & 36.4 & 159 \\
\hline Angola & 36.3 & 160 \\
\hline Moritanya & 33.7 & 161 \\
\hline Orta Afrika Cumhuriyeti & 33.3 & 158 \\
\hline Tayvan & - & - \\
\hline Ortalamalar & 58.4 & 163 \\
\hline
\end{tabular}

Tablo 2 : Seçilmiş Ülkelerin ÇPE Sıralaması (2010) Kaynak : World Economic Forum (2011: 173-176)

\begin{tabular}{|l|l|}
\hline Ülkeler & ÇPE 2012 \\
\hline İsviçre & 76.69 \\
\hline Norveç & 69.92 \\
\hline Luxemburg & 69.92 \\
\hline Kosta Rica & 69.92 \\
\hline Fransa & 69.0 \\
\hline Avusturya & 68.92 \\
\hline İtalya & 68.9 \\
\hline Birleşik Krallık & 68.82 \\
\hline İsveç & 68.8 \\
\hline Mekadonya & 46.96 \\
\hline Kırgizistan & 46.33 \\
\hline Sirbistan & 46.14 \\
\hline Türkiye & 44.8 \\
\hline Azerbeycan & 43.11 \\
\hline Suriye & 42.75 \\
\hline İran & 42.73 \\
\hline Çin & 42.24 \\
\hline Irak & 42.16 \\
\hline Pakistan & 39.56 \\
\hline
\end{tabular}

Tablo 3 : Seçilmiş Olan Ülkelerin Çevresel Performans Indeksi (2012) Kaynak: Yale 


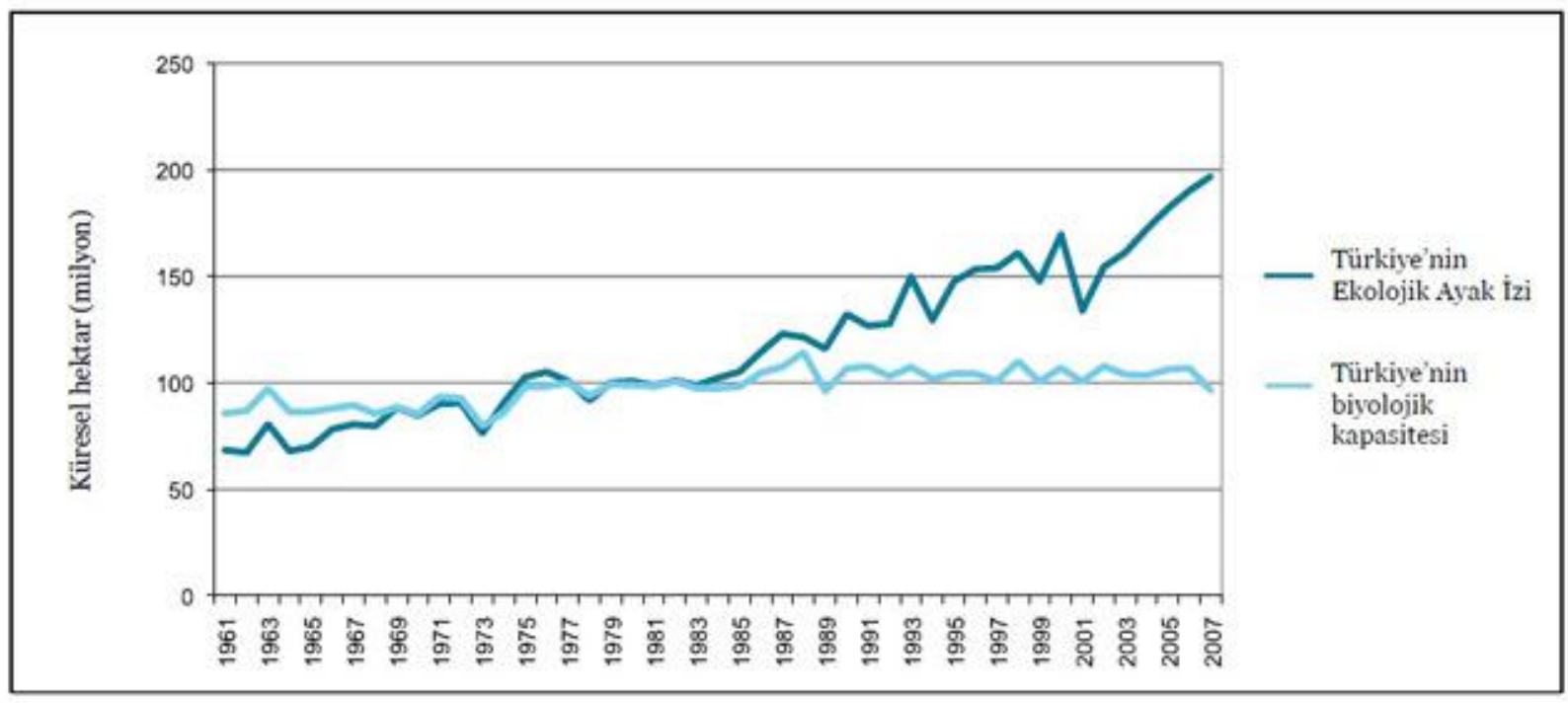

Şekil : 1 Türkiye’nin Ekolojik Ayak İzi (1961-2007) Kaynak: Çevko, 20/7/2013

Görüldüğü gibi 1980 li yıllardan itibaren ekolojik ayakizi ile biyolojik kapasite arasındaki fark sürekli açılmaktadır. Gelişmiş ülkelerin ekolojik ayakizi ise ortalama 8-10 hektar düzeyindedir. Bu durum ülkelerin tüketim düzeylerinin yüksek olmasına ve dünya kaynaklarını aşırı derecede baskı altında tuttuklarını göstermektedir. (Günsoy, 2006) Türkiye'nin ekonomik, sosyal ve sera gazlarına ilişkin göstergeleri gerek ekonomik kalkınmışlık düzeyi gerekse sera gazı emisyonları açısından BMIDÇSS Ek-1'de yer alan gelişmiş ülklerle benzer durumda olmadığını da göstermektedir.

\section{Sonuç}

İklim değişikliği, insanların her türlü faaliyeti üzerinde ciddi değişiklikler meydana getirme potansiyeline sahiptir. Dünyanın hemen her bölgesinde doğal kaynaklar ve geçim kaynakları üzerinde önemli değişikler meydana gelebilmekte, küresel ısınma birçok sosyo-ekonomik sorunu da beraberinde getirmektedir. Ekolojik krizin küresel boyutlarının kalkınma ve sürdürülebilirlik kapsamında algılanması ve köklü çözüm önerilerinin geliştirilmesi için, sorunun yeni bir sürdürülebilir kalkınma yaklaşımıyla azgelişmiş ülkeler açısından yeniden değerlendirilmesi gerekmektedir.

Bu durumda, sadece çevresel sürdürülebilirliği değil, bütünüyle dünya ekonomisinin geleceğini de tehdit eden küresel iklim değişikliğini önleyici radikal tedbirler almak, bu doğrultuda küresel çevre politikaları oluşturmak gerekmektedir. $\mathrm{Bu}$ amaçla; genel olarak yaşam kalitesi, küresel ihtiyaçlar doğrultusunda önceliklerin belirlenmesi; yoksullar için -önceki büyüme süreçlerinin olumsuz örneklerinden de dersler çıkararak-ekolojik sistemi tahrip etmeden kalkınmanın ve büyümenin yolunun açılması; zenginler için ise yeşil perspektifli, aşırı/sorumsuz üretim ve tüketim sarmalından çıkaran yeni bir sürdürülebilir kalkınma fikrinin geliştirilmesi artık kaçınılmaz hale gelmiştir.

$\mathrm{Bu}$ çerçevede küresel iklim değişikliğine/küresel 1sınmaya karşı tüm dünya toplumlarının ortak hedefler altında birleşmesi amacıyla ülkelerarası imzalanacak protokoller çerçevesinde yeni politikalar belirlenmelidir. Yeni sürdürülebilir kalkınma yaklaşımı içerisinde ayrıca, sadece küresel aktörlerin ve devletlerin "yeni politika" oluşturma çabalarının ötesinde; toplumların bilinçlenmesine; üretim ve tüketim kültürlerinin değişmesine; yenilenebilir enerji, temiz yakıtlar, suyun tasarruflu kullanımı ve çevre dostu ürünler kullanımı gibi bireysel adımlara da ihtiyaç duyulmaktadır.

Bireyler olarak, en başta tüketim alışkanlıklarını değiştirmek, enerji ve kaynak tüketimini azaltmak gerekmektedir. Eko etiket, yeşil sertifika gibi araçlar ürünlerdeki örünmeyen ayakizini anlamaya yardımcı olacaktır. Bu konuda yapılacak her adım küresel düzeyde iklim değişimini önlemeye katkı sağlayacaktır.

Son yıllarda, ekonomik krizin de etkisiyle gelişmiş ülkelerde görülen küçük düşüşlere ragmen, hızla kalabalıklaşıp endüstriyelleşen dünyamızda toplam enerji talebi de giderek artmaktadır. Mevcut üretim biçiminin bu şekli ile, gelişmiş ülkelerinde yer aldığı çevresel performansları ve sürdürülebilirlikleri de dikkate alındığunda yetersiz kaldığını göstermiş, enerji gereksinimimizin çok büyük bir kısmını sağlayan fosil yakıtlardan çıkan sera gazlarının iklimi değiş̧iriyor olması, önümüze yeni kısıtlar getirmektedir. Temiz enerji teknolojilerinde olumlu gelişmeler sağlanmasına ragmen bunların fosil yakıtların sağladığı enerjiyi sağlaması mümkün gözükmemektedir.

Küresel iklim değişikliği ile mücadele kapsamında alınması gereken önlemler, çevresel adalet çerçevesinde ele alındığında sürdürülebilir kalkınma kavramı daha da işlevsel ve çözüme yönelik hale gelecektir. Zira iklim 
değişikliği ile mücadele önlemlerinin uygulanması ile 2030 yılına kadar hava kirliliğinin azaltılmasına önemli katkı sağlayacağı düşünülmekte, hava kirletici emisyonlarını kontrol altında tutmanın toplam maliyetinin 10 milyar Avro'ya düş̧eceği öngörülmektedir.

\section{Kaynakça}

- Avrupa Komisyonu Türkiye Delegasyonu, AB Türkiye Görünüm, Sürdürülebilir Kalkınma, Sayı:12, 2000, s.2-3.

- Barlas, Nükhet, 2013. “Küresel Krizlerden Sürdürülebilir Topluma Çağımızın Çevre Sorunları”, Boğaziçi Üniversitesi Yayınları, 1. Baskı, s.185-190, İstanbul.

- Batie,Simon, 1989. "Sustainable Devolepment; Challenges to the Profession of Agricultiral Economics," American Journal of Agricultural Economics, Vol. 71, s.1086.

- Benlisoy, Stefo, 2009. “Çözüm İklim Adaleti Hareketi”, www.ekolojistler.org, (19.12.2009).

- Burkett, Paul, 2008. "Marksizm ve Ekolojik İktisat, Kızıl ve Yeşil Bir Ekonomi Politiğe Doğru”, Çeviren: Ertan Günçiner, Yordam Kitabevi, s. 146, İstanbul.

- Çoban, Aykut . "Aykut Çoban ile Çevresel ve Siyasal Adalet Üzerine Bir Söyleşi”, www.350gram.blogspot.com, (14.01.2010) .

- Çevko,http://www.cevko.org.tr/tr/cevko/Ic-Sayfa/Cevko/Haberler/Türkiyenin-Ekolojik-BilançosuCikarildi.aspx (22.06.2013).

- Dobson, Andrew, 2003. Introduction, Fairness and Futurity/Essays on Environmental Sustainability and Social Justice, (Ed.Andrew Dobson), Oxford Press, s-3-4.

- Dulupçu, Ali, 2010. "Sürdürülebilir Kalkınma Politikasına Yönelik Gelişmeler",Başbakanlık Dış Ticaret Müsteşarlığı, http://sosyalbilimler.sdu.edu.tr/PDF/yil2_sayi4_08.pdf, (22.10.2012)

- Foster, John ; Clark, Brett ; York, Richard, 2008. "Ekoloji: Karar Anı Bir Giriş", Monthly Review, Sayı, 19, s.31.

- Giddens, Anthony, 2013. "İklim Değişikliği Siyaseti”, Çeviren: Erhan Baltacı, Ankara, Phoenix Yayınevi, s.94.

- Günsoy, Bülent, 2006. "Piyasa Dostu Sürdürülebilir Kalkınma Politikaları: Eleștirel Bir Yaklaşım”, Mevzuat Dergisi, Say1:101.

- http: // ec.europa.eu/sustainable/history/index_en.htm, 11.4.2013.

- http://iklim.cob.gov.tr/iklim/Files/yay\%C4\%B1nlar/makale-Doha.pdf, (10.05.2013)

- http://www.unep.org/Documents.Multilingual/Default.asp?ArticleID=3140\&DocumentID=266, (05.06.2010)

- $\quad$ http://tr.wikinews.org, (12.12.2010).

- http://epi.yale.edu/epi2012/rankings

- Jacobs, Micheal, 2003. "Sustainable Development as a Contested Concept Fairness and Futurity", Andrew Dobson, Oxford : Oxford :University Press.

http://www.oxfordscholarship.com/view/10.1093/0198294891.001.0001/acprof-9780198294894-chapter-2, (22.07.2013)

- Kalkınma Bakanlığı, 2012. “Türkiye'nin Sürdürülebilir Kalkınma Raporu: Geleceği Sahiplenmek, En İyi Uygulama Örnekleri”, s.1, ISBN: 978-605-466701-7, Ankara.

- Keleş, Ruşen ; Hamamcı, Can; Çoban, Aykut, 2009. Çevre Politikaları, İmge Kitabevi, s.59-62, Ankara,

- Keleş, Ruşen, 2013. 100 Soruda Çevre, Çevre Sorunları ve Çevre Politikası, Yakın Kitabevi Yayınları, s.109-110.

- K1lıç, Selim, 2006. "Yeni Toplumsal Arayışlar Sürecinde Sürdürülebilir Kalkınma”, Gazi Üniversitesi İktisadi ve İdari Bilimler Fakültesi Dergisi 8/2 s.88, Ankara.

- Merchant, C, 1992. "Radical Ecology", Routledge, s.212.

- New Scientist, 2002. "African Droughts Triggered By Western Pollution", http://www.newscientist.com/article/dn2393-african-droughts-triggered-by-western-pollution.html, $(05.06 .2010)$

- Öğütçü, Mehmet, 2004. “Küreselleşmede Nereye Gidiyoruz”, Finans Dünyası, sayı: 170,s.14

- Pamukçu, K, 2006. "Küresel Isınmaya Karşı Küresel İşbirliği Uluslararası İliş̧iler”, Cilt 3, Sayı 10, s.173-207. 
- Roberts, Timmons; Parks, Bradley, 2007. A Climate of Injustice: Global Inequality/North-South Politics and Climate Policy, The MIT Press, s.21,London

- Science Daily, 2007. "Death Rates Will Rise Because of Global Warming”, Researchers Warn, http://www.sciencedaily.com/releases/2007/07/070702145431.htm 04.06.2010.

- The Earth Summit, United Nations Conference on Environment and Development (UNCED), Rio de Janeiro, p. 3-4, http://www.un.org/geninfo/bp/enviro.html , (03.03.2013)

- The Worldwatch Institute, 2009. Dünyanın Durumu 2009 Raporu: Isınmakta Olan Bir Dünyaya Bakış, İş Kültür Yayınları, s. 339, İstanbul.

- United Nations Environment Programme, 2002. "Financial Sector", Governments and Business Must Act on Climate Change or Face the Consequences,

- $\quad$ www.cnnturk.com, (19.12.2010).

- Wanderheiden, Steve, 2008. Abstract, Atmospheric Justice/A Political Theory of Climate Change, Oxford University Press, New York.

- Y1kmaz, Rıza Fikret, 2011 , Sürdürülebilir Kalkınmanın Ölçülmesi ve Türkiye için Yöntem Geliştirilmesi, Devlet Planlama Teşkilatı, Sosyal Sektörler ve Koordinasyon Genel Müdürlüğü, Ankara.

- Yazıcı, Miraç, 2007. "İklim Değişikliğinin Türkiye İhracatına Etkileri”, Ankara Üniversitesi, Siyasal Bilgiler Fakültesi, 28.07.2013 


\title{
Karadeniz Havzasında Sınıraşan Çevresel Zararlar ve Bölgesel Sorumluluk Rejimi
}

\section{Transboundary Environmental Damages in the Black Sea Basin and Regional Liability Regime}

\author{
Ph.D. Candidate Arda Özkan (Giresun University, Turkey)
}

\begin{abstract}
The Black Sea is a significant basin where transboundary environmental damage activities take place. The environmental problems in the Black Sea are not only on the agenda of six Black Sea littorals, but also the states in the wider Black Sea basin. The large scales of strategic, economical and political problems in the region require entrepreneurship and co operations of the other states on the same platform. This study has two main environmental security dimensions: One of them is identifying the damages and opponents; the other one is the security problem in transboundary environment and the responsibilities of the Black Sea states. In this regard, this study aims to initiate a conversation in precautions against transboundary environmental damages considering the current security risks.
\end{abstract}

\section{Giriş}

Çevre sorunları son yılların en çok tartışılan konularından ve günümüze kadar insanlığın karşılaştığı en büyük sorunlardan birisidir. Özellikle son elli yılda boyutları giderek büyüyen ve bütün insanlığı tehdit eder hale gelen çevre sorunlarının çözümüne yönelik gerekli çabalar sarf edilse de, tatmin edici adımların atıldığı pek ileri sürülemez. Geçtiğimiz yıllarda sorunun çözümü konusunda uluslararası düzeyde bazı somut adımlar atılmış ve ülkeler bazında ciddi girişimlerde bulunulmuş olmasına rağmen, bunlar sağlıklı bir çevrede yaşamak ve bu çevreyi gelecek kuşaklara devretmek için yeterli değildir (Ökmen, 2003). Aslında çevre sorunlarının nedenlerinin karmaşıklı̆̆ ve sınır tanımama özelliği, küresel çevre politikalarının aktörleri olan ulusal devletler, uluslararası ve ulusüstü örgütlerin yoğun bir biçimde işbirliğini gerektirmektedir (Kaplan, 1999).

Çevre sorunlarına neden olan çevresel zararlar, genel olarak insan faaliyetlerine bağlı ekosistem zararlarını veya insan varlığı için değer taşıyan yapıların ya da doğal kaynakların tükenmesi tehlikesini ifade etmektedir. Sınıraşan nitelikteki çevresel zararlar ise, bir ülkedeki tüm çevresel yıkımların o ülkeyle sınırlı kalmayıp başka ülke topraklarını veya uluslararası alanları olumsuz etkilemesi olarak tanımlanabilir. Nükleer kirlilik, deniz petrol taşımacılığı, tehlikeli madde taşımacılığı veya diğer çevresel kirlilikler sınıraşan çevresel zararlara verilebilecek örneklerdir. Ekonomik, sosyal, kültürel, siyasal ve yönetsel açıdan sınıraşan zararların öne çıkan en temel özelliği küresel düzeyde ortak projelerle ve ülkeler arası işbirliğiyle çözümlenebilecek bir nitelik taşımasıdır.

Sınıraşan nitelikteki çevre sorunları; ulusal, bölgesel ve küresel konseptlere sahiptir. Karadeniz havzası da, çevre sorunlarının küresel, bölgesel ve ulusal nitelikleri olduğunu gözler önüne seren önemli bir örneği oluşturmaktadır. Karadeniz bugün, hem nedenler hem de sonuçlar bağlamında, altı kıyıdaş ülkenin çok ötesinde boyutlara ulaşmış bir çevre felaketi ile karşı karşıyadır. Bölgenin jeo-stratejik, jeo-ekonomik ve jeo-politik önemi, çevre sorunları alanında önemli çıktıları da beraberinde getirmekte ve bu bağlamda yapılması artık zorunluluk haline gelmiş bir takım girişimleri ve işbirliği çabalarını gerekli kılmaktadır. Bu çevresel sorunlar öncelikle ve özellikle kıyıdaş altı ülkenin bölgesel nitelikte ortak sorunudur. Fakat, Karadeniz'in kirliliği sorunu, kıyıdaş ülkelerin olduğu kadar bütün havza ülkelerinin sorunudur ve hızla uluslararası bir nitelik kazanmaktadır (Ökmen, 2011).

Karadeniz havzasında çevresel sorunlara yönelik atılacak en önemli adım, bölgesel işbirliği ve küresel düzeyde bir ortak çalışma anlayışı ve bunun uygulamaya konulmasıdır. Ancak bu anlayış ve çabalar hayata geçirildiği oranda ortak geleceğimizden umutlu olabiliriz (Ökmen, 2000). Atılacak adımların, havzada bulunan ülkeler, uluslararası ve bölgesel oluşumlar tarafindan gerçekleştirilmesi gerekmektedir. Özellikle hem kıyıdaş ülkelerde, hem de kıyısı bulunmayan ülkelerde çevre ile ilgili faaliyetlerde bulunan sivil toplum örgütlerinin gerek ulusal, gerek bölgesel ve gerekse küresel düzeydeki çabaları, konumuz açısından çok önemi haiz bir durumu gözler önüne sermektedir.

\section{Sinıraşan Çevresel Zararlar}

Çevresel güvenliği tehdit eden bir öğe olarak çevresel zararlar, genel olarak insan faaliyetlerine bağlı ekosistem zararlarını veya insan varlığı için değer taşıyan yapıların ya da doğal kaynakların tükenmesi tehlikesini ifade etmektedir (Schacter, 2001). Daha genel bir kavram olan çevresel zararların aksine sınıraşan zararlar, bir devletin diğer devlete karşı doğrudan sorumlu olacağı, dar kapsamlı bir kavramdır (Jain, 2008). 
Genel bir tanımla sınıraşan zararlar, bir ülke sınırları içinde meydana gelen diğer bir ifadeyle herhangi bir devletin yol açtığı zararın başka ülke ya da alanları etkilemesini ifade etmektedir. Bir zararın sınıraşan bir nitelik kazanması için dört unsurun bir arada bulunması gerekmektedir (Xanqin, 2003). Bu unsurlar; zararın insan kaynaklı olması, insan faaliyeti sonucu ortaya çıkan zararın fiziksel bir nitelik taşıması, söz konusu fiziksel etkilerin ulusal sınırları aşması, zararın önemli ya da büyük çapta olması olarak sıralanabilir.

Sınıraşan ciddi zarar riski taşıyan faaliyetler ya belirli bir ülke toprağında ya da o devletin yetkisi altında bulunan herhangi bir alanda gerçekleştirilebileceği gibi hiçbir devletin yetki ve egemenliğinin bulunmadığı uluslararası alanlarda da gerçekleştirilebilmektedir (Sürmelioğlu, 2010). Sinıraşan zararlara neden olan faaliyetlerin yol açtığı zararların bir kısmı birden ve genellikle öngörülmeyen bir şekilde ortaya çıkabilmektedir. Nükleer faaliyetler, petrolün deniz yoluyla taşınması, uzay faaliyetleri ve diğer bazı tehlikeli maddelerin üretimi gibi oldukça tehlikeli sonuçlara yol açan faaliyetler bir kaza sonucu ya da bir sürecin sonunda aniden ortaya çıkabilmektedir. Kimi faaliyetlerin yol açtı̆̆ı zararlar ise aniden değil sürekli artış göstermeye bağlı olarak kümülatif etkileri içine almaktadır. Atıkların nehir ya da denize boşaltılması gibi tekrarlanan faaliyetler, sanayi bacalarından çıkan dumanların salımı gibi aralıksız devam eden bir süreçten kaynaklanan çevresel zararlar söz konusu duruma örnek oluşturmaktadır. Daha çok kirlilik zararı olarak ortaya çıkan bu tür faaliyetlerin sebep olduğu olumsuz etkiler klasik çevre kirliliği (hava, toprak ve su kirliliği) şeklinde kendini göstermektedir (Xanqin, 2003).

Sınıraşan zararlara neden olabilen en tehlikeli kaynak nükleer kirlenmedir. Nükleer zarara sebep olabilecek faaliyetler, özellikle açık denizlerde yapılan nükleer denemeler, nükleer santraller, nükleer gemiler ve nükleer maddelerin taşınması sırasındaki sızıntılar ve kazalar ile atılan radyoaktif atıklardır. Nükleer faaliyetler ilk olarak devletlerin askeri güçlerini artırmak amacıyla gerçekleştirilmiştir. Bu faaliyetler insan kontrolü dışında ve geri dönüşümü olmayacak feci sonuçlar doğurabilmektedir. Nükleer gelişmelerin ilk yıllarında bu tür faaliyetlerin yol açtığı zararlar daha çok askeri nükleer silah denemelerinden ve nükleer tesislerden kaynaklanmıştır. Günümüzde ise bu tür eylemler yalnızca askeri amaçlı değil, enerji üretimi gibi barışçıl amaçlarla da kullanılmaktadır. Nükleer enerjinin barışçıl amaçlarla kullanımı da bu yüzden birtakım yıkıcı sonuçlar doğurabilmektedir (Pazarcı, 2005; Görmez, 2007).

Sınıraşan zararlara neden olabilecek önemli kaynaklardan bir diğeri deniz petrol taşımacılığıdır. Günümüzde teknolojik gelişmelere bağlı deniz ve denizcilik, yük ve yolcu taşımacılığı öncelikli olmak üzere, gemi inşa sanayi, liman hizmetleri, deniz turizmi, canlı ve cansız doğal kaynakların üretimi gibi yönleriyle başlı başına bir endüstri alanı olduğu kadar ticaret ve hizmet dalını oluşturmakta; aynı zamanda dünya ticaretinin de \% 80'ni deniz yoluyla gerçekleştirilmektedir (Devlet Planlama Teşkilatı, 2007). Petrol ise yaygın kullanımı ve sınırlı sayıda devletin bu rezerve sahip olmasından dolayı önemli bir ihracat kaynă̆ıdır. Petrolün önemli ihracat yollarından birisini de deniz yolu taşımacılığı oluşturmaktadır. Deniz taşımacılığı önceki senelere göre önemli oranda arttığı için deniz trafiğindeki ve uluslararası deniz ulaşımındaki tıkanıklığı gidermek amacıyla petrol taşıyan gemilerin tonajları artırılmıştır. Fakat bu durum petrol sızıntılarını da ciddi boyutlara ulaştırmıştır. Denizde özellikle petrol taşımacılığı sırasında meydana gelen çeşitli kazalar sonucu hem kıyı devletlerinin doğal çevre hayatı, hem de açık denizler gibi uluslararası alanlar olumsuz etkilenmektedir (Xanqin, 2003).

Çevre kirliliği ya da hava, su ve toprak kirliliği gibi kronik kirlilikler de sınıraşan nitelik gösteren tehditlerdendir. Çevre kirliliği zararlı etkilerin birikimi sonucunda ortaya çıkmaktadır. Bu gibi kirliliğe sebep olan faaliyetlerin yol açtığı zararlar da oldukça ciddi boyutlara ulaşabilmektedir. Hava kirliliği, havada yabancı maddelerin bulunması ya da havanın bileşim maddelerinde önemli bir değişikliğin meydana gelmesini ifade etmektedir. Söz konusu kirlenme insan faaliyetleri sonucu meydana gelerek insan sağlığını ve canlıların yaşamını tehlikeye sokmakta, çevresel dengeyi bozan bir nitelik taşımaktadır (Pazarcı, 2005). Su kirliliği, suyun içerisine su kaynaklarının kullanılmasını bozan veya zarar verme derecesinde kalitesini düşüren organik, inorganik, radyoaktif veya biyolojik herhangi bir maddenin karışmasını ifade etmektedir. Ekonomik kalkınma amacıyla suların kullanımı ve paylaşımı sonucu ortaya çıkan su kirliliği devletlerin karşı karşıya kaldığı ciddi küresel sorunlar oluşturmakta; suların yönetim ve paylaşımı, ilgili devletler arasında uyuşmazlık sebebi olmaya devam etmektedir. Toprak kirliliğinin ise temel kaynağı, evsel atıklar ve sanayi atıkları, tarımda verimliliği artırmak için kullanılan ilaçlama, gübreleme gibi kimyasallar, erozyon ile iklim değişikliğine bağlı ortaya çıkan olumsuz nitelikteki faaliyetlerdir (Görmez, 2007). Toprak kirliliğinin sınıraşan nitelik kazanması özellikle bir devletin başka ülke sınırına yakın bir alanda gerçekleştirdiği faaliyetler sonucunda ortaya çıkmaktadır. Kimyasal atıklar gibi zararlı maddelerin ya da nükleer santral gibi son derece büyük risk taşıyan tesislerin başka ülke sınırına yakın bir alanda kurulması söz konusu sınır ülkelerinde kaygılara sebep olmaktadır (Xanqin, 2003).

Sınıraşan nitelik gösteren son zararlı tehdit ise tehlikeli diğer maddelerdir. Kimyasal madde sızıntısı, toksik atıklar ile çevre için tehdit oluşturan kimi tüketim ürünleri de çevre ve insan hayatına tehlike oluşturmaktadır. Bu tür faaliyetler, insan sağlı̆̆ı ve diğer canlı yaşamını olumsuz etkilemekte ve büyük miktarda zarara sebebiyet vermektedir (Cane, 2001). 


\section{Karadeniz Havzasında Sınıraşan Çevre Sorunları}

Karadeniz'in çevre sorunları çok boyutlu ve karmaşık bir görünüm arz etmektedir. Karadeniz'in yapısal özelliklerinin de etkisiyle çeşitli kaynaklardan gelen kirlilik dışında ve bu kirliliğin de etkisiyle oluşan birçok sorun, üstesinden gelinmesi son derece güç bir boyut kazanmıştır. Karadeniz çevre sorunları, birbirleri ile etkileşim ve sebep sonuç ilişkisi ve karmaşası içinde, Karadeniz'in ekolojik sistemini, biyo-çeşitliliğini, sudaki yaşam olanaklarını, balıkçılık ve turizm gibi sektörleri olumsuz bir şekilde etkilemeye devam etmektedir. Bu çevresel sorunlar kıyıdaş devletlerde sosyal ve ekonomik yapı üzerinde onarılması giderek güçleşen sorunlara yol açmaktadır (Güneş, 2001).

Karadeniz'de gerek deniz, gerekse kara kökenli kirlenme sorunları mevcut olmakla beraber çevre sorunlarını daha vahim hale getiren, akarsular ve diğer kara kökenli boşaltımlar sonucu oluşan kirliliktir (Sorensen, 1995). İki tabakalı yapısı, alt tabakanın yaşam destek unsurlarından tamamen yoksun oluşu ve yarı-kapalı konumu nedeniyle mevcut su miktarının tümüyle değişebilmesi için iki bin yıl gibi bir zaman dilimine ihtiyaç duyulması gibi faktörler (Balkaş, 1990), Karadeniz’i özellikle kara kökenli kirlenmelerde kaydedilen çarpıcı artış karşısında son derece savunmasız bırakmaktadır (Bakan ve Büyükgüngör, 2000). Arıtma işleminden geçirilmeden, doğrudan doğruya veya akarsular vasıtasıyla denize boşaltılan kanalizasyon, tarımsal faaliyetlere bağlı olarak oluşan atıklar, endüstriyel faaliyetler sonucu oluşan kirlilik ile hepsinden daha da tehlikeli olan nükleer kirlenmeler, kara kökenli kirlenmenin çeşitli biçimleri olarak karşımıza çıkmaktadır (Gençkaya, 1993).

Karadeniz'de meydana gelen petrol kirlenmesinin ise bir kısmı kara kökenli olup, nehirler yoluyla taşınmakta veya kıyılardan doğrudan doğruya denize atılmaktadır. Diğer bir kısım petrol kirliliği ise gemilerin normal operasyonları sırasında veya kazalar sonucu meydana gelmektedir. Karadeniz'deki kirliliğin \%75'ini oluşturan kara kökenli kirlenmeler içinde petrol kirliği, önemli bir yer tutmaktadır. Yılda 100.000 tona ulaşan kirlilik miktarı, dünyada bugüne kadar meydana gelen en büyük tanker facialarında oluşan kirlilikten daha yüksek bir rakamı ifade etmektedir (BSTDA, 1997). Bu veriler petrol taşımacılığından kaynaklanan kirlenmeyi kapsamadığ için, Karadeniz'deki petrol kirliliğini tam olarak yansıtmamakla beraber, sorunun ciddiyetini ortaya koyması nedeniyle son derece önemlidir (Güneş, 2001).

Karadeniz'de çevre sorunları, hem denizde hem de kıyılarda olmak üzere bu denize kıyısı bulunan ülkelerden kaynaklandığı gibi uluslararası niteliklerde de ortaya çıkabilmektedir Karadeniz havzasında yaklaşı 160 milyon insanın ürettiği büyük miktarlarda fosfor, inorganik azot, petrol, cıva ve DDT için dev bir çöplük olmuştur. Burada dikkati çeken önemli bir nokta, Karadeniz'de çeşitli niteliklerde ortaya çıkan kirlenmede kıyısı bulunan 6 ülke kadar özellikle Avrupa kaynaklı bölgesel ve uluslararası etkenlerin de oldukça önemli bir yere sahip olması gerçeğidir. Konu denize kıyısı bulunan ülkeleri aşmış, bölgesel ve uluslararası bir sorun haline gelmiştir. Orta Avrupa'dan doğan ve Karadeniz'e dökülen Tuna nehri, Orta ve Doğu Avrupa endüstrisinin aşırı kiriyle Karadeniz'e erişmekte ve gerek bitki, gerekse canlı çeşidi açısından zengin bir güzelliğe sahip olan Tuna Deltası'nı tehdit etmektedir (Ökmen, 2011).

Karadeniz'in özellikle enerji kaynaklarının taşınması noktasındaki merkezi konumu, bölgedeki çevre sorunlarının uluslararası niteliğini daha da öne çıkarmaktadır. Biraz önce de bahsettiğimiz gibi, Karadeniz’i, organik ve sınai atıkların kısmen kıyı ama özellikle nehirler yoluyla yarattı̆g kirlenme ile tankerle petrol taşımacılığından kaynaklanan kirlilik olmak üzere, başlıca iki önemli kirlilik kaynağı tehdit etmektedir. Özellikle Rusya ve Türkiye'den nehirlerle taşınan endüstriyel ve evsel atıklar, özellikle bölgede önemli çevresel sorunlara sebep olmaktadır. Ayrıca, deniz ortamına bırakılan ağır metal konsantrasyonları, denizdeki doğal ortam ve midye vb. canlılar aracılığgyla da insanlar için önemli bir tehdit oluşturmaktadır (Çevik, vd. 2008).

Karadeniz'in jeo-stratejik ve jeo-ekonomik konumu da bu bölgedeki çevre sorunlarının uluslararası boyutunu öne çıkaran önemli bir etkendir. Bu bağlamda kirlenmenin boyutları hızla artmaktadır. Karadeniz ve Azak Denizi'nin, özellikle toprak kaynaklarından ileri gelen kirlenme sonucunda felaket boyutlarında bir ekolojik zarara maruz kaldığını gösteren bilimsel kanıtların sayısı hızla artmaktadır. Bu ekolojik zarar, ötrofikasyona ve patojenik mikroplar ve toksik kimyasal maddeler ile kirlenmeye yol açmıştır. Sonuç olarak, kıyı ülkeleri hemen hemen tamamen tükenmeye yüz tutan değerli su ürünleri kaynaklarından ve çok büyük bir rekreasyon ve turizm potansiyelinden mahrum kalmaktadır (Goyet, 1995).

\section{4 Çevresel Sorumluluk Rejimi}

Günümüzde, çevre sorunlarının boyutlarının giderek artması ve sınıraşan bir tehdit durumuna gelmesi sonucu, çevre alanında uluslararası işbirliği önem kazanmaya başlamıştır. Karadeniz Bölgesi’nde yaşayan insanlar için de bu, güncel bir konudur. Karadeniz ve korunmasına ilişkin ortak sorunlar bölge insanlarını birbirine bağlamaktadır. Özellikle petrol ve petrol ürünleri başta olmak üzere, Karadeniz'in değişik yükleri taşımada yoğun bir şekilde kullanılması, gelişigüzel balık avlanması, atık ve kanalizasyon suları, Karadeniz'in ekolojisine olumsuz etkide bulunan unsurlardan sadece birkaçıdır. Gerek altı Karadeniz ülkesinin her birinin özel koşullarından ve gerekse çevre sorunlarının, özellikle sınır tanımaz niteliğiyle uluslararası bir aktör haline gelmesi başta olmak üzere, kendine özgü nitelikleri, konuyla ilgili teorik ve pratik bazı sorunları 
güçlendirmektedir. Karadeniz'in, dünya okyanuslarından izole olmuş kapalı bir deniz olması da konuyla ilgili bir sınırlılık olarak, bölgedeki çevre sorunlarını olumsuz olarak etkilemektedir (Doussis, 2006).

Karadeniz'de gerek var olan kirliliğin ortadan kaldırılması, gerekse bu bağlamda ortaya çıkabilecek sorunların önlenmesine yönelik bu faaliyetler bölge yönetimlerinin ve toplumlarının işbirliğini zorunlu kılmaktadır. Bu çerçevede bölgesel ve uluslararası düzeyde ortaya konan ekonomik, sosyal ve hukuki işbirliği çabaları oldukça önemlidir. Bu çabalar, bölge ülkelerinin merkezi ve yerel yönetimlerinden üniversitelere, bölgesel ve uluslararası örgütlerden gönüllü kuruluşlara kadar geniş bir yelpazeyi kapsamaktadır (Ökmen, 2011). BM, AB, OECD ve Avrupa Konseyi gibi kuruluşlar gerek çevre alanındaki faaliyetlerini yoğunlaştırarak, gerekse üye ülkelerini bu faaliyetlere katılmaya teşvik ederek, çevre konusunda küresel bir sistem oluşturma yolunda çalışmalarını sürdürmektedir (Arslan ve Ökmen, 2006).

Çok zengin bir ekosisteme sahip olan Karadeniz'in hem karadan hem de denizden ciddi bir kirlilik tehdidiyle karşı karşıya olması ve bu kirlilikle mücadelenin ancak bölgesel düzeyde sağlanacak işbirliği ile mümkün olabileceğinin anlaşılması üzerine, 1992 yılında Karadeniz’e kıyısı olan 6 ülke Türkiye, Rusya, Romanya, Bulgaristan, Ukrayna ve Gürcistan bir araya gelerek “Karadeniz'in Kirlenmeye Karşı Korunması Sözleşmesi”ni (Bükreş Sözleşmesi) imzalamış ve bu sözleşme daha sonraki yıllarda değişik protokollerle zenginleştirilmiştir. Karadeniz'in çevre sorunlarına ilişkin olarak taraf ülkelerin alması gereken önlemlere esas teşkil eden bu sözleşme ve bağlı protokolleri, Karadeniz kirliliğine karşı çevre hareketlerine ivme kazandıran 1993 tarihli "Odessa Deklarasyonu" ve Karadeniz ekosisteminin rehabilite edilmesi, korunması, kaynakların sürdürülebilir şekilde kullanılması ve geliştirilmesi amacıyla hazırlanan politika ve eylemleri içeren 1996 tarihli "Karadeniz'in Korunması ve İyileştirilmesi Stratejik Eylem Planı” izlemiştir. Bu eylem planı 2009 yılında güncellenerek, kirlilikle mücadelede öncelikler ve eylemler tekrar düzenlenmiştir (Durusu, 2010).

Bilindiği üzere, 1992 yılında Karadeniz’e kıyısı bulunan devletler, Karadeniz'de kirliliğin önlenmesine ilişkin olarak Bükreş’te bir konferans düzenlemişlerdir. Karadeniz'e kıyısı bulunan devletlerin yanında, devlet düzeyinde Ermenistan, Yunanistan, Moldova ve Yugoslavya'nın; uluslararası örgüt düzeyinde ise Tuna Komisyonu, Birleşmiş Milletler Çevre Programı, Uluslararası Denizcilik Örgütü, Uluslararası Meteoroloji Örgütü Birleşmiş Milletler Kalkınma Programı ve Dünya Sağlık Örgütü gibi kuruluşların gözlemci statüsü ile katıldıkları Konferans’ta, Bükreş Sözleşmesi dışında, Sözleşme’ye ek olarak, “Karadeniz Deniz Çevresinin Kara Kökenli Kaynaklardan Kirlenmeye Karşı Korunmasına Dair Protokol”, "Karadeniz Deniz Çevresinin Petrol ve Diğer Zararlı Maddelerle Kirlenmesine Karşı Acil Durumlarda Yapılacak İş Birliğine Dair Protokol”, "Karadeniz Deniz Çevresinin Boşaltmalar Nedeniyle Kirlenmesinin Önlenmesine Dair Protokol” başlıklı üç ayrı protokol kabul edilmiştir (BSEP, 1993).

Karadeniz ülkelerinin Karadeniz kaynaklarının korunması ve kullanılmasına yönelik genel politikaları ise, Odessa Deklarasyonu'nda ifadesini bulmuştur. Bu belge, 7 Nisan 1993 tarihinde, Odessa kentinde Bulgaristan, Gürcistan, Rusya, Romanya, Türkiye ve Ukrayna çevre bakanları tarafından imzalanmıştır. Bu deklarasyon Karadeniz'in çevresinin korunması amacıyla toplumun bütün kesimlerinin çabalarını birleştirmeye yönelik eylemleri zamanlamalarıyla birlikte gerekçeli olarak düzenlemektedir. Aslında bu deklarasyon, Bükreş Sözleşmesi'nde ifade edilen fikirleri geliştirmekte ve daha somut hale getirmektedir. Özellikle bu konu temelinde GEF (Global Environmental Facility - Küresel Çevre Fonu)'in himayesinde 1993-1996 yılları için sözleşme koşullarını yerine getirmede Karadeniz ülkeleri hükümetlerine yardıma yönelik olarak Karadeniz'in Durumunun Yönetimi ve Korunması Programı'nın (Karadeniz Çevre Programı) temeli atılmıştır. Aslında bu program, Bükreş Sözleşmesi'nin hükümlerinin yerine getirilmesi için etkin bir mekanizma oluşturma konusunda kurumsal bir temel olmuştur (Kuznyetsov, vd., 2000).

\section{Sonuç: Havza Ülkelerine Çözüm Önerileri}

İlk bakışta ulusal düzeyde görülen çevre sorunları, yaşanan çevresel kirliliğin uzun vadeli olumsuz etkileri nedeniyle sınıraşan bir nitelik göstererek önce bölgesel, sonrasında da küresel sorunlara neden olabilmektedir. Sınıraşan zararlara neden olan faaliyetlerin yol açtığı zararların bir kısmı, örneğin nükleer faaliyetler, petrolün deniz yoluyla taşınması, uzay faaliyetleri ve diğer bazı tehlikeli maddelerin üretimi gibi oldukça tehlikeli sonuçlara yol açan faaliyetler bir kaza sonucu ya da bir sürecin sonunda aniden ve genellikle öngörülmeyen bir şekilde ortaya çıkabilmektedir. Daha çok kirlilik zararı olarak ortaya çıkan faaliyetlerin sebep olduğu olumsuz etkiler hava, toprak ve su kirliliği şeklinde kendini göstermektedir. Kimi faaliyetlerin yol açtığı zararlar ise aniden değil sürekli artış göstermeye bağlı olarak ortaya çıkmaktadır. Atıkların nehir ya da denize boşaltılması gibi tekrarlanan faaliyetler, sanayi bacalarından çıkan dumanların salımı gibi aralıksız devam eden bir süreçten kaynaklanan çevresel zararlar bu duruma örnek oluşturmaktadır. Öte yandan, Karadeniz için genel olarak kara kökenli ve gemi kaynaklı olarak sınıflandırılabilecek temel kirlilik kaynaklarının çok geniş bir havzayı ilgilendirmesi ve oluşan kirliliğin birçok ülkenin ortak sorumluluğunda bulunması konusu da, Karadeniz'deki sınıraşan nitelikteki kirlilikle mücadelede bölgesel işbirliğinin önemini artırmaktadır.

Karadeniz havzasında günümüz gereksinimlerine göre oluşturulan çeşitli mekanizmalar ve yaptırımlar, ancak Bükreş Sözleşmesi’yle kurulan hukuksal çerçeve içerisinde yaşama geçirilebilecektir. 1992 yılında imzalanan 
Bükreş Sözleşmesi ile Karadeniz'in kirliliğe karşı korunması amaçlanmış ise de, bu sözleşmeye taraf ülkelerce etkin bir şekilde uygulamaya konulduğu ve Karadeniz'e yönelik kirlilik tehdidi ile etkin bir şekilde mücadele edildiği ileri sürülebilecek bir durum ortada bulunmamaktadır. Bu nedenle, başta Türkiye olmak üzere bölge ülkeleri için çok önemli bir yaşam kaynağı olan ve sayısız olanaklar sunan Karadeniz'in çevre güvenliğinin korunması ve kaynaklarının sürdürülebilir kullanımı konusunda son yıllarda artan bir hassasiyetin oluştuğu gözlenmektedir (Durusu, 2010). Fakat, alınacak önlemlerin Karadeniz'in deniz çevresini korumakta etkili olabilmesi, zaman içinde yitirilen canlı kaynaklarının ve ekosistemin geri kazanılmasına yardımcı olabilmesi tüm Karadeniz ülkelerinin ortak çabasını gerektirmektedir (Sav, 1992). Bu işbirliği içinde, bölge ülkelerinde ve genel olarak çevre konularında faaliyet gösteren gönüllü kuruluşların ayrı bir yeri vardır. Karadeniz'de çevresel kirliliğin önlenmesi konusunda, sivil toplum kuruluşlarının sesi henüz cılız olmakla birlikte, resmi kurumlar ve girişimler yanında ağırlıkları giderek artmaktadır. Kıyıdaş ülkelerin ekonomik ve sosyal kalkınmalarıyla uyum içinde bir çevresel politikanın bölgede hayata geçirilebilmesinde, sivil toplum kuruluşlarına büyük sorumluluklar düşmektedir. Özellikle, sürdürülebilir kalkınma kavramı odaklı politikalar çerçevesinde bunun yapılabilirliği, bu program sayesinde daha da güçlenmiştir (Moomaw, 2006).

Karadeniz havzasında çevresel sorunlara yönelik oluşturulan temel yaklaşımı anlayabilmek için, Karadeniz bölgesinin çevresel yönden sağlıklı kalkınmasını temin etmek amacıyla hukuksal, siyasal ve ekonomik düzeylerde yaptırım araçlarını hazır bulundurmaya yönelik faaliyetleri öngören Karadeniz Çevre Programı'na bakmak gerekmektedir. Karadeniz Çevre Programı, kamunun duyarlılaştırılması ve harekete geçirilmesi, etki yönlendirmeli faaliyetler ve yerel, ulusal çıkarlara önem verilmesi bağlamında hükümet dışı örgütlerin etkin yapısını tanımakta ve Karadeniz'in ekosisteminin bozulması hakkında etkili araştırmalarda bulunan ilgili örgütlerin programlarının hayata geçirilmesine katılımı teşvik etmeyi hedeflemektedir (Ökmen, 2011). Karadeniz'e kıyısı olan Türkiye, Rusya, Ukrayna, Romanya, Bulgaristan ve Gürcistan'ın bir araya gelerek kabul ettikleri ve hukuksal alt yapısını sırasıyla 1992 Bükreş Sözleşmesi, 1993 Odessa Bildirgesi ile 1996 Karadeniz Stratejik Eylem Planı’nın oluşturduğu Karadeniz Çevre Programı ile bölge devletleri, Karadeniz çevre sorunlarına ilişkin ortak önlemler alma çabası içine girmişlerdir (Güneş, 2001). Bu bağlamda, Bükreş Sözleşmesi'ne taraf olan ülkelere ve ayrıca Karadeniz havzasında yer alan ülkelerin hükümetlerine çevre sorunlarına dair işbirliğini gerektiren birtakım tavsiyelerde bulunmak yerinde olacaktır.

Öncelikle, Bükreş Sözleşmesi’ne ve ek protokollere taraf olan devletler ile Sözleşme’ye taraf olmayan Karadeniz havzasında bulunan diğer devletler, iç hukuksal ve kurumsal çerçevelerini düzenlemelidir. Bunun gerçekleşebilmesi için, taraf olunan bölgesel ve diğer uluslararası anlaşmalardaki hükümlerin yerine getirilmesi için güvenilir mekanizmalar geliştirilmeli; ulusal ve bölgesel düzeyde, özellikle de Karadeniz ile ilgili geliştirilen politika ve çevresel nitelikteki düşüncelerin güçlendirilmesi için gerekli adımlar atılmalı; Sözleşme'nin yürütülmesi ve uyuşmazlıkların gözden geçirilmesi için bir mekanizma kurulmalı; Karadeniz'deki mevcut kaynakların sürdürülebilir olmayan aşırı kullanımını önlemek için yapılacak faaliyetler teşvik edilmelidir.

İkinci aşamada, Karadeniz ekosisteminin korunmasını ve sürdürülebilir yönetimini sağlamak için kaynakların ulaşılabilirliğini artırmalı ve olanakları güçlendirmek amacıyla Bükreş Sözleşmesi’ni geliştirmeye yönelik teşvikler ve gerçek mekanizmalar yaratmalı; Sözleşme'nin güncellenmesi için harekete geçmeli ve bu sayede Avrupa Birliği’nin ve diğer bölgesel ekonomik işbirliği organizasyonlarının katılımını sağlamalı; sivil toplumun Avrupa Komşu Ülkeler Politikası'na ve Karadeniz Sinerji İşbirliği İnisiyatiflerine katılımı güvence altına alınmalıdır.

Son olarak, geniş Karadeniz havzasında bulunan tüm devletler, bu bölgelerde yaşayan halkın bilinçlenmesi için çaba göstermelidir. Havza içinde bulunan tüm devletler, çevreye ilişkin konularda bilgiye doğru bir şekilde ulaşılmasına ve adaletin hakim olmasına olanak sağlayacak ortamlar hazırlamalı; sivil toplumun ve Karadeniz bölgesindeki paydaşların, karar alma süreçlerine etkin olarak katılmalarını sağlamalı; sivil toplumun gelişmesini sağlamak için özel çaba harcamalı; bunun için Sivil Toplum Kuruluşları'na ulusal düzeyde destek olmalıdır.

\section{Kaynakça}

- $\quad$ Arslan, N. ve Ökmen, M., 2006. “The Economical and International Dimensions of the Environmental Problems, Environmental Problems in the Black Sea Region and the Role of the Voluntary Organizations, Building and Environment, 41 (8), pp. 1040-149.

- Bakan, G. ve Büyükgüngör, H., 2000. “The Black Sea”, Marine Pollution Bulletin, 41 (1-6), pp. 24-43.

- Balkaş, T. İ., 1990. "Mediterranean and the Black Sea Pollution”, State of Art, Mediterranean in the Nineties, TÇSV Yayını, Ankara.

- BSEP (Black Sea Environmental Programme), 1993. "Analysis and Evaluation of the Project, RegionalEnvironmental Management and Protection of the Black Sea”, PCU (Programme Coordination Unit), İstanbul.

- BSTDA (Black Sea Transboundary Diagnostic Analysis), 1997. “Global Environmental Programme, Programme Coordination Unit, United Nations Publications”, İstanbul. 
- Bükreş Sözleşmesi, http://www.milliparklar.gov.tr/DKMP/Files/Mevzuat/hukuk/sozlesme/bukres (Erişim Tarihi: 20 Nisan 2013).

- Bucharest Convention, http://www.blacksea-commission.org/_convention-fulltext.asp (Erişim Tarihi: 20 Nisan 2013).

- Cane, P., 2001. “Are Environmental Harms Special?”, Journal of Environmental Law, 13 (1), pp. 3-20.

- Çevik, U., vd. 2008. "Assessment of Metal Element concentrations in Mussel in Eastern Black Sea, Turkey", Journal of Hazardous Materials, 160, pp. 396-401.

- Devlet Planlama Teşkilatı, 2007. “Dokuzuncu Kalkınma Planı (2007-2013): Denizyolu Ulaşımı, Özel İhtisas Komisyonu Raporu”, 2725, ÖİK, 678, Ankara.

- Doussis, E., 2006. "Environmental Protection of the Black Sea: A Legal Perspective", Southeast European and Black Sea Studies, 6 (3), pp. 355-369.

- Durusu, B., 2010. “Karadeniz'in Kirliliğe Karşı Korunmasında Uluslararası İşbirliği ve Ortak Denetim Projesi”, Saylştay Dergisi, 77, ss. 171-178.

- Environmental Programmes in the Black Sea, http://www.blackseaweb.net/general/enviprog.htm (Erişim Tarihi: 30 Nisan 2013).

- Gençkaya, Ö.F., 1993. "The Black Sea Economic Cooperation Project: A Regional Challenge to European Integration”, International Social Science Journal, 138, pp. 549-557.

- Goyet, S., 1995. "Karadeniz'in Korunması: Bölgesel ve Kurumsal Bir Yaklaşım”, Karadeniz Çevre Konferansı, Türkiye Çevre Vakfı Yayını, ss. 25-29.

- Görmez, K., 2007. Çevre Sorunları, Nobel Yayın Dağıtım, Ankara.

- Güneş, Ş., 2001. “Karadeniz'de Çevresel İşbirliği: 1992 Bükreş Sözleşmesi”, ODTÜ Gelişme Dergisi, 28 (34), ss. 311-337.

- Jain, T., 2008. "Transboundary Harm: An Environmental Principle in International Context”, The Icfai University Journal of Environmental Law, 7 (4), pp. 9-22.

- Kaplan, A., 1999. Küresel Çevre Sorunları ve Politikaları, Mülkiyeliler Birliği Vakfı Yayınları, Ankara.

- Kuznyetsov, V., vd., 2000. “Karadeniz'in Deniz Ortamının Korunması Alanında Uluslararası Faaliyet”, Avrasya Çevre Konferansı, Türkiye Çevre Vakfı Yayınları, Ankara, ss. 93-99.

- Moomaw, W., 2006. "Enrivonmental Sustainability and Collaboration in South Eastern Europe", Southeast European and Black Sea Studies, 6 (3), pp. 307-313.

- Ö̈kmen, M., 2000. “Çevre Sorunlarının Sistemler Üstü Niteliği ve Orta Asya”, Bilig, 14, ss. 17-30.

- Ökmen, M., 2003. Kent, Çevre ve Globalleşme Alfa Yayınları, İstanbul.

- Ö̈kmen, M., 2011. “Karadeniz'de Çevre Sorunları ve İşbirliğine Yönelik Yerel, Bölgesel Perspektifler”, Bilig, 56, ss. 165-194.

- Pazarcı, H., 2005. Uluslararası Hukuk, Gözden Geçirilmiş 3. Baskı, Turhan Kitabevi, Ankara.

- Sav, Ö. N., 1992. “Karadeniz’de Deniz Çevresinin Korunması İçin Alınan Önlemler”, Ankara Üniversitesi, SBF Dergisi, 47 (1-2), Ankara, ss. 115-137.

- Schacter, O., 2001. “The Emergence of International Environmental Law”, Journal of International Affairs, 44 (2), pp. 457-493.

- $\quad$ Sorensen, J., 1995. "A Comparative Analysis and Critical Assessment of the Regimes to Manage the Black Sea and Mediterranean Sea”, Proceedings of MEDCOAST, 95, pp. 697-718.

- Sürmelioğlu, D., 2010. Uluslararası Çevre Hukukunda Sınıraşan Zararlar, Karadeniz Teknik Üniversitesi, Sosyal Bilimler Enstitüsü, Trabzon.

- $\quad$ Toffler, A., 1996. Üçüncü Dalga, Altın Kitaplar Yayınları, İstanbul.

- Xanqin, X., 2003. Transboundary Damage in International Law, Cambridge University, UK. 


\title{
Ekolojik Çevreye Duyarlı İşletmecilik Yaklaşımı: Unilever Örneği Ecological Environment Friendly Business Approach: The Example of Unilever
}

\author{
Çetin Kalburan (Pamukkale University, Turkey) \\ Assoc. Prof. Dr. Selçuk Burak Haşıloğlu (Pamukkale University, Turkey)
}

\begin{abstract}
Environmental awareness has increased as a result of disruption of the ecological balance. As consumers' concerns about the natural environment have been increasing with each passing day, consumers act environmentally-friendly in developed societies. In fact, environmental awareness is not only for consumers, but also it is important for companies. Because the companies are required to meet consumers' needs and expectations. Many companies are implementing environmental awareness within the framework of green marketing practices. They also try to be superior to their competitors. In today's world, companies must be sensitive to the ecological environment in order to be able to survive and compete.
\end{abstract}

\section{Giris}

Tüm birey ve kurumların içinde yaşadığı çevreye karşı sorumlulukları bulunmaktadır. Örneğin, bir işletmenin kendi çalışanlarına, pay sahiplerine, ortaklarına olduğu kadar dış çevreye karşı da sorumlulukları vardır. Aktan (2008: 103), çalışanlara, hissedarlara ve yöneticilere karşı sorumluluğu organizasyon içi sorumluluk; diğer altı sorumluluk türünü ise organizasyon dışı sorumluluk olarak tanımlamıştır. Bu doğrultuda işletmelerin başlıca sorumlulukları dokuz tanedir: (1) Çalışanlara karşı sorumluluk, (2) Hissedarlara yönelik sorumluluk, (3) Yöneticilere karşı sorumluluk, (4) Müşterilere (tüketicilere) yönelik sorumluluk, (5) Rakiplere yönelik sorumluluk, (6) Doğaya ve çevreye karşı sorumluluk, (7) Tedarikçilere karşı sorumluluk, (8) Devlete karş1 sorumluluk, (9) Topluma karşı sorumluluk. Diğer yandan, Uydacı (2011: 129) işletmelerin genişletilmiş sosyal sorumluluklarının bir alt sistemi olarak pazarlamada sosyal sorumluluğun altını çizmiş ve bu sosyal sorumlulukların istenirse sürdürülebilir gelişmeyle uyumlaştırılabildiğini belirtmiştir.

Pazarlamanın sosyal sorumluluğu ve sürdürülebilir gelişme tüketicinin arzu, istek, ihtiyaçlarıyla ve ürünlerin çevre koruma prensiplerine uygunluğu ile ilgilenir. Bunların yanında sosyal pazarlama ve toplumsal pazarlama uygulamalarının birçoğunda çevreye duyarlı işletmecilik yaklaşımları yer almaktadır.

Kotler'e göre sosyal pazarlama, bireyin, grubun ya da tüm toplumun yararına olan ve hedef kitleyi etkileyen pazarlama uygulamalarıdır. Yani sosyal pazarlama konuları genellikle toplumu ilgilendirmektedir. Çevre kirliliğinin önlenmesi, yaban hayatının korunması, sigara ve alkol kullanımının önlenmesi, aile planlamasının yapılması, bulaşıcı hastalıklardan korunma, göğüs kanserinin erken teşhisi ve tedavisi, alkollü araba kullanmayı önleme, trafikte aşırı hızı önleme, aşı kampanyaları, anne sütüyle besleme ve bunun gibi toplumdaki bireylerin yaşam kalitesini yükseltecek ve refahını sağlayacak konularda davranış değişikliği meydana getirmek sosyal pazarlamanın amaçları arasında yer alır (Eser ve Özdoğan, 2006: 4).

Kotler ve Lee'nin belirttiğine göre, toplumsal pazarlama ise, pazarlama faaliyetleri esnasında sosyal ve etik konuların pazarlamacılar tarafından dikkate alınmasını gerektirmektedir. Bu noktada bazen çatışan, işletme karı, tüketici tatmini ve toplum refahı kavramları arasında denge kurulmalıdır (Korkmaz vd., 2009: 40).

Yeşil pazarlama, toplumsal pazarlamadan doğmuştur. Toplumsal pazarlama, müşterileri sadece memnun etmekle kalmayıp toplumun ilgilerini de göz önüne almayı amaçlayan bir pazarlama yaklaşımıdır. Çevreye duyarlı işletmecilik yaklaşımları da bunlardan biridir. Kotler'e göre toplumsal pazarlamada işletmeler tüketicinin arzu, ihtiyaç ve çıkarlarını rakiplerinden daha etkin bir şekilde tatmin ederken bunu tüketicinin ve toplumun refahını muhafaza edecek veya daha da arttıracak şekilde yerine getirecektir. Toplumsal pazarlama kavramı pazarlayıcılardan, pazarlama faaliyetlerinde sosyal ve ahlaki düşünceler üzerinde durmalarını da ister. Çok defa, işletmeler, birbirleri ile çatışmalı olan kar, müşteri arzularının tatmin edilmesi ve halkın çıkarları ölçütlerini birbirleriyle birleştirip bir denge sağlanacak tarzda hareket etmelidirler (Emgin ve Türk, 2004).

Sosyal pazarlama ve toplumsal pazarlama birbirinden farklı kavramlar olsa da her ikisinin temelinde yatan düşünce sosyal sorumluluk ve etik'tir. Sosyal pazarlama, pazarlama temelli bir yöntem iken toplumsal pazarlama, pazarlama anlayışında gelinen son noktadır; çevreye duyarlılık gibi sosyal sorumluluklar her ikisini besleyen kaynak olarak görülmelidir (Velioğlu ve Çoknaz, 2010: 474).

\section{2 Çevre Kirliliği}

Genel anlamıyla çevre; canlıların içinde yaşadığı, hayati bağlarla bağlı oldukları, çeşitli şekillerde etkiledikleri ve etkilendikleri bir ortam olarak tanımlanabilir (Yıldız vd., 2008: 14). Diğer bir tanımla çevre; insan, diğer 
canlılar, doğal yapı ve bu yapı üzerine insanlar tarafindan eklenen unsurlardan oluşan ve bu unsurların sürekli olarak birbirleriyle karşl1ıklı etkileşim halinde olduğu sosyal ve fiziki bir sistemdir (Uydacı, 2011: 25).

Çevre kirliliğinin genel tanımı; "insanların etkinlikleri sonunda, ekolojik dengenin bozularak, bazı maddelerin dünyanın bazı katmanlarında/kompartımanlarda birikmesi ve o katmanın doğal kompozisyonunun bozulmasıdır" şeklinde yapılabilir. Çevre kirliliğinin insan merkezli tanımı ise; "insanın yaşadığı ortamda bazı maddelerin miktarının artması ve bu artışın insan yaşamını olumsuz yönde etkilemesidir" şeklinde yapılabilir (Akdur, 2005: 14-15).

Yirmi birinci yüzyılın başlangıcında insanların yeryüzü tarihinde daha önce rastlanmamış büyüklükte çevre sorunlarıyla karşı karşıya olduklarını söylemek yanlış olmayacaktır. Dünya üzerinde yaşamın sürekliliğini sağlayan hava, su ve toprak gibi doğal kaynaklar ürkütücü boyutlarda kirlenmekte veya tükenmektedir. Nüfus hızlı biçimde artmakta ve besin temini için gerekli tarım arazileri, ekolojik dengenin sigortası olan ormanlar ve ana biyolojik sistemler hızla kaybolmaktadır. Gelecek kuşakları tehdit eden zehirli gaz ve atıklar tüm dünyada artmaktadır. İklim değişikliğini doğuran nedenler, ozon tabakasını delecek ve birçok kara parçasını sular altında bırakacak seviyeye getirmiştir. Öncelikle yaşanan tüm bu sorunların yalnızca "teknik" bir sorun olmadığı; bundan öte, daha büyük çaplı "toplumsal" sorunların bir boyutu olduğunu söylemek gereklidir (Karaca, 2008: 20).

Drucker'a göre, globalleşme, ekolojiye uluslar-aşırı bir boyut kazandırmaktadır: "Çevre de artık para gibi, bilgi gibi, ulusal sınırlar tanımamaktadır. Çevreyle ilgili çok önemli ihtiyaçlar -sözgelimi atmosferin ve dünya ormanlarının korunması- ulusal düzeydeki önlemler ve ulusal yasalarla karşılanamaz, karşı tarafta bir rakibin bulunduğu meseleler gibi ele alınamazlar. Bu meseleler için, uluslar aşırı düzeyde uygulanacak uluslar-aşırı politikalar gerekmektedir" (Düren, 2000; 160).

\subsection{Hava kirliliği}

Hava kirlenmesi, havanın doğal ve beşeri faaliyetler sonucu, atmosfere karışan katı, sıvı ve gaz halinde bulunabilecek kirleticilerin etkisiyle, doğal özelliğini kaybederek, insan ve diğer canlılar ile cansız varlıkları olumsuz yönde etkileyebilecek duruma gelmesi olarak tanımlanabilir (Yıldız vd., 2008: 107).

Hava genel alıcı ortamlardan birisidir. Birçok insan eylemi sırasında havaya çeşitli kirleticiler salınmaktadır. Salınan bu kirleticilerin miktarı havanın kendi kendini temizleme kapasitesini aşarsa bunlar havada birikerek hava kirliliği oluşur. Hava kirliliği, insan sağlı̆̆ına, hayvan ve bitkilere, eşya ve tarihi değerlere zarar verir. İlk ciddi yerel hava kirliliği olgusu 1909 Glasgow'da yaşanmış ve tanımlanmıştır. Daha sonra Aralık 1930 Belçika'nın Meuse Vadisi'nde, Ekim 1948 Pennsylvania Donova bölgesinde yoğun hava kirlilikleri yaşanmıştır. Aralık 1952 'de 4000 kişinin ölümü ile sonuçlanan Londra hava kirliliği, tarihte yaşanan en büyük yerel hava kirliliklerinden biridir (Akdur, 2005: 16-17).

\subsection{Su kaynaklarının kirliliği}

Su kirliliği, su ortamlarının, çeşitli yollardan karışan bazı maddelerle ilk özelliklerinin ve kalitesinin değişerek insan ve diğer canlıların yaşamını olumsuz yönde etkileyebilecek biçimde bozulmasıdır. Özellikle sanayi atıklarının ve evsel atıkların doğrudan veya dolaylı olarak akarsu, göl ve denizlere boşaltılması, kıyılardaki çarpık kentleşme, tarımda kullanılan mücadele ilaçları ile aşırı gübre kullanılması, deniz taşımacılığı ve deniz kazaları suların kirlenmesine neden olan faaliyetlerdir (Y1ldı vd., 2008: 124).

Kazalar dışında su kirlenmesine neden olan faaliyetleri de üç başlık altında da toplamak mümkündür (Uydacı, 2011: 42):

- Tarımsal faaliyetlerin neden olduğu kirlilik

- Sanayi faaliyetlerinin neden olduğu kirlilik

- Yerleşim alanlarından kaynaklanan kirlilik

\subsection{Toprak kirliliği}

Çevre sorunlarının hemen hepsi, doğal kaynakların yanlış ve bilinçsizce kullanılması sonucu ekolojik dengenin bozulmasıyla ortaya çıkmaktadır. Toprak kirliliği de toprağa karışan zararlı katı, sıvı ve gaz atıklar ve insanların yanlış kullanımı sonucu toprağın doğal özelliğinin değişmesiyle görülür. Toprak kirliliğini doğal ve yapay etmenlerle toprağın fiziksel, kimyasal ve biyolojik özelliklerinin bozulması olarak tanımlamak mümkündür (Yıldız vd., 2008: 139).

Yirminci yüzyılın başından itibaren modern tarıma geçilmesi ve sanayileşmenin hızlanması ile birlikte, toprak kirliliği de bir çevre sorunu olarak ortaya çıkmaya başlamıştır. Daha önceki yüzyıllarda kullanılan güç ve enerji kaynaklarının yetersiz olması, nüfusun azlığı, endüstrinin henüz gelişmemiş olması sebebiyle, diğer çevre faktörlerinde olduğu gibi toprakta da herhangi bir kirlenme söz konusu değildi. Özellikle yirminci yüzyılın ortalarına doğru hızlı nüfus artışı ile birlikte, tarım ve diğer alanlardaki sanayi ve teknolojinin hızla gelişmesine paralel olarak, toprak kirliliği de artmaya başlamıştır (Kurgun vd., 2008: 28). 


\subsection{Gürültü kirliliği}

Gelişigüzel bir yapısı olan ve istenmeyen seslere gürültü, bu seslerin ortamda bulunması olayına da gürültü kirliliği denir. Başka bir tanıma göre ise; ortamda belirli bir şiddetten daha fazla ses bulunması olayına gürültü kirliliği denir. Gürültü kirliliği insan sağlığını ve başarısını önemli oranda olumsuz etkiler. Yaşam kalitesini düşürür. Günümüzde tüm yerleşim birimleri az ya da çok gürültü kirliliğinin etkisi altındadır (Akdur, 2005: 18).

Gürültü doğrudan bir çevresel değerin bozulması sonucunda ortaya çıkmamakta, ancak diğer çevresel değerleri etkileyen sağlık bozucu bir durum olmaktadır (Keleş ve Hamamcı, 2005: 110). Ayrıca Yücel vd.'ne göre, gürültü insanlar üzerinde fiziksel (işitme bozukluğu), fizyolojik (solunum ve kalp atışlarının hızlanması, kan basıncının artışı gibi vücut aktivitelerinde değişmeler), psikolojik (öfkelenme, sıkılma gibi davranış bozuklukları), performans etkileri (konsantrasyon bozukluğu, iş veriminde düşme vb. rahatsızlıklara) ve hatta ciddi beyin tahribatına neden olmaktadır (Üstünay, 2008: 16).

\subsection{Radyoaktif kirlenme}

Radyoaktif kirlenme hava, su ve toprak gibi alıcı ortamlara radyoaktif maddelerin karışması ile meydana gelir. Radyoaktivitenin doğal kaynağı, yeryüzündeki ve deniz dibindeki kayalar ile atmosfere gelen güneş 1şınlarıdır. Diğer radyoaktivite kaynakları ise nükleer silah fabrikaları, nükleer silahlar, bunların denenmeleri ve kullanılmaları ile nükleer enerji santralleri ve atıklarıdır (Yıldız vd., 2008: 143-144).

Teknolojideki çok hızlı gelişmeler sonucu üretilen çeşitli elektronik cihazların (TV, radyo, bilgisayar, röntgen ve tomografi gibi tıbbi cihazlar) yaygınlaşması ile meydana gelen radyasyonun elektromanyetik kirliliğe yol açtığı anlaşılmıştır. Radyoaktif kirleticiler özellikle insan, hayvan ve bitki sağlı̆̆ına olumsuz etkiler yaparak, çevreyi ve ekolojik dengeyi bozmaktadır (Kurgun vd., 2008: 37-38).

\section{3 İşletmelerin Ekolojik Çevresi}

İşletmeler, en genel anlamda, çevreyle çok yönlü alışveriş halinde olan girdi-çıktı süreçlerinden meydana gelmektedir. İşletme ve ekolojik çevre, bu süreci beslemek için, sürecin her aşamasında karşılıklı etkileşime girmektedirler. İşletmecilik faaliyetleri, ekolojik çevre ile etkileşimlerinde genellikle yerel, bölgesel ve global olmak üzere, kademeli olarak yayılan zararlara, başka bir ifadeyle, kirlenmelere neden olmaktadır (Düren, 2000; 192-193).

Ekonomik bir birim olan işletmeler, bir takım sosyal, siyasal ve kültürel faaliyetlerin etkisi altındadır. Bir başka deyişle, faaliyet gösterdikleri çevre ile karşılıklı etkileşim içerisindedir. İşletmeler mal ve hizmet üreten bir kurum olarak işlevlerini yerine getirerek bunun karşılığında kazanç elde ederken aynı zamanda toplumun ekonomik, sosyal ve kültürel ihtiyaçlarına da cevap vermek ve sosyal sorunların çözülmesine yardım etmek gibi geniş bir fonksiyon üstlenmektedir (Yücel ve Ekmekçiler, 2008: 327).

İşletmeleri ve tüketicileri etkileyen dış çevre faktörlerinin en önemlilerinden biri ise dünyanın doğal dengesi ve ekolojiyi oluşturan unsurlardır. Belirli bir dönem, gerek bireylerin bilinçlenme süreci gerekse toplumsal ve ülkesel sorunlar nedeniyle fazla ön planda olamayan ekoloji ve doğal dengenin önemi, son yıllarda daha çok konuşulur hale gelmiştir. İşletmeler üretim stratejilerinde ve ürün tasarımlarında bu konuya dikkat etmekte, tüketiciler ise ürün tercihlerinde ürünlerin çevreye zarar verip vermediklerini incelemektedirler. Üretici ve tüketici arasındaki bu etkileşimin sonucunda çevre bilinci ve doğal dengeyi koruma anlayışı her iki taraf açısından daha belirgin bir şekilde oluşmaya başlamıştır (Çabuk ve Nakıboğlu, 2003: 40).

Anlaşılacağı üzere çevreye duyarlı yaklaşımlar, işletmeler için, günümüz toplumu açısından son derece önemlidir. Bu bağlamda birçok işletme faaliyet ve stratejilerine bu yaklaşımı da dahil etmiştir. Böylece; doğayı koruyan ürünler geliştirmek, yeniden kullanıma sunulabilen ve geri dönüşümlü paketleme, daha iyi kirlenme kontrolü ve daha iyi enerji etkinliği sağlayacak operasyonlar bunlara birer örnektir. Çünkü çevreci pazarlamanın (yeşil pazarlama), bütün çevre yönetiminin bir parçası olarak farkına varılması önemlidir (Keleş, 2007: 22).

\section{4 Çevreye Duyarlı İşletmecilikte Yeşil Pazarlama}

Doğal kaynakların saklı olduğu yer olarak çevre; ekonomik gelişmeyi etkileyen ve canlıların hayati ihtiyaçlarını karşılayan bir üretim alanı ve yaşamı doğrudan etkileyen bir estetik unsurudur. Çevrenin sunduğu olanaklar, ekonomik faaliyet sürecinde üretim ve birey tarafından doğrudan tüketim için kullanılmaktadır. Üretim süreci doğada ham madde olarak bulunan kaynakları, mal ve hizmete dönüştürerek kullanıma sunmaktadır. Ekonominin çevre sorunlarına dahil edilmesi kirlenmenin vazgeçilmez bir sonucudur. Üretim mutlaka kirletmektedir ve kirlenmeyi tümüyle ortadan kaldırmak da mümkün değildir (Yıldız vd., 2008: 259260).

Çevreye duyarlı işletmeciliğin pazarlama uygulaması olan yeşil pazarlama, tüketici davranışlarının çevreye daha duyarlı hale gelmesiyle ortaya çıkmıştır. Bu da pazarlama düşüncesinin çağın ihtiyaçlarına adapte edilmesi sürecinin devamı olarak görülebilir (Karna, 2003: 10). 
Yeşil pazarlama toplumun ihtiyaçlarını ve isteklerini tatmin etmeye istekli değişimlerin meydana getirilmesi ve kolayca uygulanması amacıyla doğal çevreye en az seviyede zarar vermek suretiyle oluşturulmuş faaliyetler topluluğudur (Uydac1, 2011: 130).

Yeşil pazarlama, işletmelerin pazarlama stratejilerini, politikalarını ve programlarını doğal çevreyi koruyacak ve geliştirecek biçimde belirlemesi ve bu yönde uygulaması olarak tanımlanabilir. Çevre bilincinin gelişmesi, tüketicilerin çevresel duyarlılığını arttırmıştır. Bu bağlamda çevre dostu ürünlerin tüketiciler tarafından daha fazla tercih edildiği işletmelerce fark edilmiş ve onlar da ürünlerini çevre dostluğu ile uyumlu hale getirmeye başlamıştır. Bu akıma "yeşil pazarlama” denmektedir (İslamoğlu, 2011: 36).

Yeşil pazarlama tanımı değişikliklere ve zaman içindeki oluşumlara uyumlu olmak zorundadır. Dinamik ve global olmalı, çevrede oluşan değişimlere rahatlıkla uyum sağlayabilmelidir. Yeşil tanımı bugünün çevresinde değişik şekillerde algılanabilir. Bugünün yeşil olguları seneler sonra varlığını yitirebilir. Örnek olarak, klorofloro-karbonlarda olduğu gibi ilk icat edildiğinde bu madde mükemmel olarak nitelendirilmekte, ancak bugünkü teknolojik bilgi ışığında maalesef dünyaya zarar veren tehlikeli bir madde olarak kabul görmektedir (Uydac1, 2011: 127-128).

Peattie yeşil pazarlamayı karlı ve sürdürülebilir şekilde müşterilerin ve toplumun ihtiyaçlarını belirlemek, öngörmek ve tatmin etmeye yönelik sorumlu bütünsel bir yönetim süreci olarak tanımlamaktadır. Ayrıntılı olarak çevresel pazarlamanın temel özellikleri şu başlıklar altında özetlenebilir (Karna, 2003: 11):

- İşletmelerin ve toplumların sosyal, teknolojik, ekonomik ve fiziksel bakış açılarında dengeli bir yaklaşım, bu da işletmelerin bir adım öne çıkmalarına olanak sağlar;

- K1sa vadeli sürdürülemez niceliksel büyüme yerine uzun vadeli niteliksel gelişmeyi amaçlar;

- Önceki indirgemeci, parçalı iş teori ve pratiğini bütüncül bir yaklaşımla tersine çevirmeyi hedefler;

- Tüketicilerin varsayımsal olarak rasyonel ekonomik birimler olarak görülmesi yerine tüketicileri gerçek birer insan olarak görür;

- Tüketicilerin yüzeysel arzuları yerine gerçek ihtiyaçlarını karşılamayı vurgular;

- Tüketicilerin ve toplumun çoklu ve bazen birbiriyle çelişen istek ve ihtiyaçlara sahip olduğunu kabul eder;

- Şirket ve tüm faaliyetleri tüketilen ürünün bir parçası olarak görülür;

- Mevcut ekonominin büyük ölçekli olma ile uzun mesafe özelliklerinin sürdürülebilir olmadığını ve gelecekte küçük ve yerel ekonominin daha güzel olacağını kabul eder;

- Şirketlerin piyasa dışı çıktılarını bünyesinde barındıran eko-performans kavramını; kullanım sırasında ve sonrasında ürün performansını; tedarik zincirinin herhangi bir aşamasındaki ürünün yaratılması ve pazarlanmasına katkıda bulunan şirketlerin çevresel etkilerini benimser;

- Tekno-ekonomik katma değerin yanında sosyo-çevresel değerlerin de üzerinde durur.

Yeşillenme iç veya dış baskıların bir sonucu olarak oluşabilir. Dış baskılar şunlardır (Polonsky ve Rosenberger, 2001: 22):

Tüketici talebinin karşılanması: McDonald's polistiren kapaklı ambalajını tüketicilerin polistiren üretiminde kullanılan kloro-floro-karbon hakkındaki endişelerinden dolayı, çok çevreci bir karar olmasa da parafin kaplı kağıt ile değiştirmiştir.

Bir rakibin yeşillenme eylemlerine karşılık verme: Starkist firması orkinos balıkçılı̆̆ sırasında yunuslara verilen zarara karşı "dolphin free” kampanyasını açıkladığında rakiplerinin hepsi aynı şeyi yapmak zorunda kalmışlar ya da pazar paylarını kaybetmişlerdir.

Girdileri değiştirmeye yönelik kanal/tedarikçi istekleri: ISO 14000 uyumlu firmalar tedarikçilerinin çevresel performanslarını değerlendirme ihtiyacı duyarlar. Uygun standartları karşılamaları konusunda tedarikçilere baskı yaparlar.

Yeşil faaliyetlerin gerçekleşmesindeki iç baskılara verilebilecek bazı örnekler şunlardır:

Maliyet: Yeşillenme, daha fazla kaynak verimliliğine, daha az girdi kullanımı ile daha az atığın ortaya çıkması ve üretim sonucu daha az kirlilik meydana gelmesi ile finansal tasarrufa neden olabilir. Dow firması bir tesisinde atıkların aynı tesisin başka bir kısmında yeniden kullanılması amacıyla 250.000 dolarlık bir yatırım yapmış ve yıllık 2.4 milyon dolarlık bir tasarruf sağlamıştır.

Felsefe: Firmalar çevresel hedeflerini diğer kurumsal hedeflerle aynı derecede önemli gördüğünde yeşil konular firmanın stratejilerinde hayata geçecek ve daha sonra taktiksel faaliyetlerine entegre edilecektir. Besin takviyesi ve sağlık ürünleri firması Blackmores’ın kurucusu Maurice Blackmore daha 1967 yılında çevre sorunlarını firmanın faaliyetlerinin temel odağı haline getirmiştir.

Yeşil pazarlama uygulayan işletmeler genellikle şu tip girişimlerde bulunmaktadır (Oyewole, 2001: 240):

- Geri dönüştürülebilir, yeniden kullanılabilir, 1şıkta parçalanabilen ve/veya doğada çözünebilir ambalaj ve hammadde kullanmak,

- Kirletici olmayan üretim süreci,

- Aerosol içermeyen hammadde, 
- Pestisit içermeyen tarım,

- Gida korunmasında kimyasal olmayan yöntemlerin uygulanmasi,

- Daha az hammadde kullanarak daha az hacimli ambalaj ortaya çıkarma,

- Suni olmayan doğal gübre kullanmak vb.

Ayrıca, Oyewole'ya (2001: 240) göre işletmeler yeşil pazarlamanın teknik yönü üzerinde daha fazla odaklanmaktadır. Ancak yeşil pazarlamanın etik yönü de aynı derecede önem taşımaktadır. Yeşil pazarlama, çevre ile birlikte çevre içerisinde bulunan insanları da göz ardı etmemelidir. Diğer bir deyişle çevresel adaletle ilgili olmalıdır.

\section{Unilever Örneği}

Unilever, Hollandalı margarin üreticisi Margarine Unie ile İngiliz sabun üreticisi Lever Brothers'ın 1930 yılında birleşmesiyle oluşmuştur. Firma gıda ve dondurma, ev bakımı ve kişisel bakım ürünleri olmak üzere onlarca marka ile günümüzde dünyanın 190 ülkesinde tüketiciye ulaşmaktadır (http://www.unilever.com.tr/ aboutus/intro ductiontounilever/).

Unilever'in sürdürülebilirlik faaliyetlerinin ilk adımı, 2005'te Unilever markalarının dünya üzerindeki sosyal, ekonomik ve çevresel etkilerinin ölçümlenmesine olanak tanıyan 'Marka İzi' yaklaşımıyla atılmıştır (http://www.lipton.com.tr/surdurulebilirlik_vizyonu.asp). Unilever, Kasım 2010'da 10 yıllı bir süreci kapsayacak olan “Unilever Sürdürülebilir Yaşam Planı"'nı kamuoyuna duyurmuştur. Plan, değer zincirinin tamamında geçerli olma üzerine vurgu yapmaktadır ve içeriğinde planı destekleyen yaklaşı 60 hedef bulunmaktadır (http://www.unilever.com.tr/sustainable-living/uslp/). Unilever sürdürülebilir yaşam planı üç ana başlık altında toplanmaktadır:

1. Sağlık ve esenliği arttırmak,

2. Yaşam koşullarını iyileştirmek,

3. Çevresel etkiyi azaltmak.

Çevresel etkiyi azaltmaya dair alt başlıklar ise şunlardır:

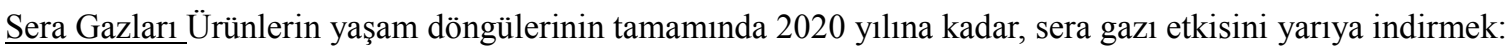

- Çamaşır yıkamadan kaynaklanan sera gazı salımlarını azaltmak,

- Üretim sürecimizdeki sera gazı emisyonlarını azaltmak,

- Nakliyeden kaynaklanan sera gazı salımını azaltmak,

- Soğutmadan kaynaklanan sera gazı salımlarını azaltmak,

- Cilt temizleme ve saç yıkama ürünlerindeki sera gazı emisyonlarını azaltmak.

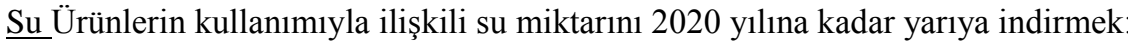

- Tarımda su kullanımını azaltmak,

- Üretim sürecindeki su kullanımını azaltmak,

- Çamaşır yıkama sürecindeki su kullanımını azaltmak,

- Cilt temizleme ve saç yıkamadan kaynaklanan su kullanımını azaltmak.

Atık Ürünlerin imhasıyla ilişkili atık miktarını 2020'ye kadar yarıya indirmek:

- Ambalajları azaltmak,

- Ambalajları yeniden kullanmak,

- Ambalajları geri dönüştürmek,

- Üretim atıklarınıazaltmak.

Bu hedefler dışında planın "yaşam koşullarını iyileştirmek” başlığg altında çevre ile yakından ilişkisi olan, 2020’ye kadar, tarımsal hammaddelerin \%100’ünü sürdürülebilir şekilde tedarik etme ve ofis atıklarının azaltılması hedefleri bulunmaktadır.

Unilever firması konulan hedeflere ulaşılmasında katedilen yolu göstermek amacıyla "Sürdürülebilir Yaşam Planı İlerleme Raporu" raporu yayınlamaktadır. Yukarıda ana başlıkları belirtilen hedeflere ilişkin rapor Tablo 1 'de gösterilmektedir (Kavoğlu, 2012: 23).

\section{Sonuç}

Sonuç olarak, değişen toplumsal evrede tüketicilerin ihtiyaç ve beklentileri de değişmiştir. Elli y1l öncesine kadar sadece ürün odaklı hareket eden tüketiciler, bugün daha fazlasını arzulamaktadırlar. Diğer yandan da rekabet o kadar yoğun seyir etmektedir ki, işletmeler rakiplerinden bir adım önde olmak için büyük çabalar harcamaktadır. Bu aşamada çevreye duyarlılık faktörünün rolü büyüktür. Günümüz tüketicileri ekolojik çevreye 
çok daha fazla duyarlıdırlar ve bu duyarlıktan daha fazlasını işletmelerden beklemektedirler. Diğer yandan işletmeler çevreye duyarlılık uygulamalarını yeşil pazarlama çerçevesinde hayata geçirerek bu sayede rakiplerinden üstün olmaya çalışmaktadır. Yeşil pazarlama, işletmelerin doğal çevreye mümkün olduğunca az zarar vermek, hatta katkıda bulunmak suretiyle tüketici tatminini sağlama sürecidir. Günümüzde işletmeler hem ayakta durabilmek, hem de rekabette üstün olabilmek amacıyla ekolojik çevreye duyarlı faaliyetler göstermek zorundadır. Hatta bu faaliyetlerine çevre dostu ürün ve üretim sistemlerini de dahil etmelidirler.

\begin{tabular}{|c|c|c|c|}
\hline Konu & Yüklenici Marka & $\begin{array}{l}\text { Proje } \\
\text { Hedefi }\end{array}$ & 2011 Gerçekleşme \\
\hline & \multicolumn{3}{|l|}{ Sera Gazları } \\
\hline $\begin{array}{l}\text { Sivı deterjanları daha konsantre, toz } \\
\text { deterjanları daha kompakt hale } \\
\text { getirmek. }\end{array}$ & Çamaşır Deterjanları & $\% 100$ & $\% 8$ (14 ülke) \\
\hline $\begin{array}{l}\text { Fabrikaların CO2 salımlarını } \\
\text { azaltmak. }\end{array}$ & Tüm Fabrikalar & $\% 63$ & $\% 20$ \\
\hline $\begin{array}{l}\text { Yenilenebilir enerji kullanımını } \\
\text { arttırmak. }\end{array}$ & Tüm Fabrikalar & $\% 40$ & $\% 20$ \\
\hline $\begin{array}{l}\text { Lojistikten kaynaklı CO2 salımlarını } \\
\text { azaltmak. }\end{array}$ & Tüm İşletmeler & $\% 40$ & $\% 8$ \\
\hline \multirow{2}{*}{$\begin{array}{l}\text { İklime dost soğutuculu (hidrokarbon) } \\
\text { dondurma dolapları kullanımını } \\
\text { arttırmak. }\end{array}$} & Dondurmalar & 850 bin & $470 \mathrm{bin}$ \\
\hline & Su Kullanımı & & \\
\hline Tarımda su kullanımını azaltmak & Gıda Ürünleri & Belirsiz & Belirsiz \\
\hline $\begin{array}{l}\text { Daha az suyla temizlik sağlayan } \\
\text { ürünler sunmak. }\end{array}$ & One Rinse & 50 milyon & 12,5 milyon \\
\hline Cilt temizleme ve saç yıkama & Cilt Temizleme ve Saç & 400 & Belirsiz \\
\hline $\begin{array}{l}\text { ürünleri kullanımında davranış } \\
\text { değişikliği sağlamak. }\end{array}$ & Yıkama Ürünleri & milyon & \\
\hline \multirow{2}{*}{$\begin{array}{l}\text { Üretim sürecindeki su kullanımını } \\
\text { azaltmak }\end{array}$} & Tüm Fabrikalar & $\% 78$ & $\% 17$ \\
\hline & Atık ve Ambalajlama & & \\
\hline Ambalajların ağırlığını azaltmak & Tüm Ürünler & $\% 33$ & $\% 4$ \\
\hline Ambalajları yeniden kullanmak & $\begin{array}{l}\text { Ev ve Kişisel Bakım } \\
\text { Ürünleri }\end{array}$ & Belirsiz & Belirsiz \\
\hline Ambalajları geri dönüştürmek & Tüm Ürünler & $\% 15$ & $\% 3,4$ \\
\hline $\begin{array}{l}\text { Üretimden kaynaklanan atıkları } \\
\text { azaltmak }\end{array}$ & Tüm Fabrikalar & $\% 80$ & $\% 40$ \\
\hline $\begin{array}{l}\text { Tek kullanımlık esnek ambalaj } \\
\text { atıklarını azaltmak }\end{array}$ & Tüm Fabrikalar & Belirsiz & Belirsiz \\
\hline Pvc'yi ortadan kaldırmak & Tüm Ürünler & $\% 100$ & $\% 95$ \\
\hline
\end{tabular}

Tablo 1. Unilever sürdürülebilir yaşam planı, çevresel etkiyi azaltma verileri (Kavoğlu, 2012: 23)

\section{Teşekkür}

Yazarlar, Pamukkale Üniversitesi Bilimsel Araştırma Projeleri (BAP) birimine, bu çalışmaya vermiş oldukları destekten dolayı teşekkür ederler.

\section{Kaynakça}

- Akdur, R. (2005). Avrupa Birliği ve Türkiye'de çevre koruma politikaları "Türkiye'nin Avrupa Birliğine uyumu”. ATAUM Araştırma Dizisi No:23, Ankara Üniversitesi Basımevi, Ankara.

- Aktan, C. C. (2008). "Meslek Ahlakı ve Sosyal Sorumluluk”, İş Ahlakı Dergisi, 1(1): 99-121.

- Çabuk, S. ve Nakıboğlu, M. A. B. (2003 ). "Çevreci Pazarlama ve Tüketicilerin Çevreci Tutumlarının Satın Alma Davranışlarına Etkileri ile ilgili Bir Uygulama”, Çukurova Üniversitesi Sosyal Bilimler Enstitü Dergisi, 12(12), 39-54.

- Düren, A. Z. (2000). 2000’li Yıllarda Yönetim: Sürekli Değişim ve Belirsizlik Ortamında Gelişen Yönetsel Yaklaşımlar, Alfa Basım Yayım Dağıtım, İstanbul. 
- $\quad$ Emgin, Ö. ve Türk, Z. (2004). "Yeşil Pazarlama”, Mevzuat Dergisi, 7(78).

- Eser, Z. ve Özdoğan, B. (2006). Sosyal Pazarlama: Toplumun Refahı ve Kaliteli Yaşamı için, Siyasal Kitabevi, Ankara.

- İslamoğlu, A. H. (2011). Pazarlama Yönetimi, Beta Yayıncılık, İstanbul.

- Karaca, C. (2008). "Çevre, İnsan ve Etik Çerçevesinde Çevre Sorunlarına ve Çözümlerine Yönelik Yaklaşımlar”, Çukurova Üniversitesi İktisadi ve İdari Bilimler Fakültesi Dergisi, 12(1), 19-33.

- Karna, J. (2003). Environmental Marketing Strategy and Its Implementation in Forest Industries, (Basılmamış Doktora Tezi), Univesirty of Helsinki Department of Forest Economics, Helsinki.

- Kavoğlu, S. (2012). "İtibar Yönetimi Açısından Yeşil Pazarlama: Örnek Olay İncelemesi”, Tarih Kültür ve Sanat Araştırmaları Dergisi, 1(4), 13-31.

- Keleş, C. (2007). Yeşil Pazarlama Tüketicilerin Yeşil Ürünleri Tüketme Davranışları ve Yeşil Ürünlerin Tüketiminde Kültürün Etkisi ile ilgili Bir Uygulama, (Basılmamış Yüksek Lisans Tezi), Çukurova Üniversitesi, Sosyal Bilimler Enstitüsü, Adana.

- Keleş, R. ve Hamamcı, C. (2005). Çevre Politikası, İmge Kitabevi, Ankara.

- Korkmaz, S., Eser, Z., Öztürk, S. A. ve Işın, F.B. (2009). Pazarlama: Kavramlar, İlkeler, Kararlar, Siyasal Kitabevi, Ankara.

- Kurgun, E., Tarkay, N. ve Aydın, N. (2008). Çevre El Kitabı, T.C. Çevre ve Orman Bakanlığı, Ankara.

- Oyewole, P. (2001). "Social costs of environmental justice associated with the practice of green marketing", Journal of Business Ethics, 29(3), 239-251.

- Polonsky, M. J. ve Rosenberger, P. J. (2001). "Reevaluating Green Marketing: A Strategic Approach", Business Horizons, September-October, 21-30.

- Üstünay, M. (2008). İşletmelerin Sosyal Sorumlulukları Çerçevesinde Yeşil Pazarlama Uygulamaları ve Kimya Sektörüne Yönelik Bir İnceleme, (Basılmamış Yüksek Lisans Tezi), Trakya Üniversitesi, Sosyal Bilimler Enstitüsü, Edirne.

- Uydacı, M. (2011). Yeşil Pazarlama, Türkmen Kitabevi, İstanbul.

- Velioğlu, N. M. ve Çoknaz, D. (2010). Sosyal pazarlama. İ. Varinli ve K. Çatı (editörler). Güncel Pazarlama Yaklaşımlarından Seçmeler, Detay Yayıncılık, Ankara.

- Yıldız, K., Sipahioğlu, Ş., Yılmaz, M. (2008). Çevre Bilimi ve Eğitimi. Gündüz Eğitim ve Yayıncılık, Ankara.

- Yücel, M. ve Ekmekçiler, Ü. S. (2008). "Çevre Dostu Ürün Kavramına Bütünsel Yaklaşım: Temiz Üretim Sistemi, Eko Etiket, Yeşil Pazarlama”, Elektronik Sosyal Bilimler Dergisi, 7(26), 320-333.

- $\quad$ http://www.lipton.com.tr/surdurulebilirlik_vizyonu.asp (09.03.2013 tarihinde alınmıştır.)

- http://www.unilever.com.tr/aboutus/introductiontounilever/ (16.04.2013 tarihinde alınmıştır.)

- $\quad$ http://www.unilever.com.tr/sustainable-living/uslp/ (09.04.2013 tarihinde alınmıştır.) 


\title{
Avrasya Doğal Gaz Boru Hattı Projeleri Özelinde Kafkasya Üzerine Bir Değerlendirme
}

\section{An Evaluation of Caucasian Countries with respect to Eurasian Natural Gas Pipeline Projects}

\author{
Ph.D. Candidate Nuri Gökhan Toprak (Kırklareli University, Turkey)
}

\begin{abstract}
Breaking down the natural gas export monopoly of Russia against to the European countries is one the very challenging issues of European authorities in the past thirty years. Despite the introduction of the Norwegian and Algerian gas to the European market in recent years, European countries are still in search of the alternative gas exporter countries to meet their increasing gas consumption. When the expectations of European countries were combined with the relative stabilization of political structure in both South Eastern European and Caucasian countries, the alternative Eurasian natural gas pipeline projects came to the European agenda gradually. In this study, it will be analyzed that both the economic and political situation of Azerbaijan, Georgia and Armenia in terms of their participation to the ongoing Eurasian natural gas projects that plans to deliver natural gas resources of the Caspian Basin to Europe. Within this context, after the brief introduction to explain what those Eurasian natural gas projects are, it will be given information, analyzed and discussed that the current positions of the Caucasian countries against these projects. It is important that the evaluation of the Eurasian Natural Gas Pipeline Projects in the case of the Caucasian countries makes the final step more reliable which will strengthen the economic integration and regional cooperation of Caucasian countries.
\end{abstract}

\section{Giriş}

Avrupa ülkelerine Rusya'nın kurmuş olduğu 13 doğal gaz boru hattına alternatif bir boru hattı üzerinden doğal gaz arz etme planı olarak ortaya çıkan Avrasya Doğal Gaz Boru Hattı Projeleri, faaliyete geçebilmek için ilk etapta yaklaşık 8 milyar metreküp doğal gaza ihtiyaç duymaktadır. Uzun vadede ise 40 milyar metreküp kaynağa ihtiyaç duyacak bu projelerde resmi olarak yer alan hiçbir ülkenin bu miktarda doğal gaz kaynağına sahip olmaması, bu ülkelerin ilgisini geniş çapta doğal gaz ihraç edebilecek diğer bölgelerden biri olan Kafkasya'ya kaydırmıştır. AB'nin Kafkasya ülkelerine çeşitli seviyelerde gerçekleştirdiği resmi ziyaretlerle devam eden Avrasya Doğal Gaz Boru Hattı Projelerine iştirakçi ülke bulma girişimleri, daha çok bu bölgelerle ilişkileri daha eski, köklü ve en önemlisi de genellikle olumlu olan Türkiye tarafından gerçekleştirilmektedir.

Çalışmamıza Avrasya Doğal Gaz Boru Hattı Projeleri'nin ilk etabında 'projenin doğal gaz kaynăğ' olabilme potansiyeline sahip bir ülke olan Azerbaycan'ın enerji görünümünü ve bu projelerin bir parçası olma ihtimali üzerinden başlayacağız. Azerbaycan ve Türkiye arasında doğrudan bir sınır ilişkisinin olmaması, her iki ülkeye sınırı olan üçüncü bir ülke üzerinden transit geçiş yapılmasını zorunlu kılmaktadır. Bu bağlamda 2005 yılında Bakü-Ceyhan Petrol ve 2007 yılında Bakü-Erzurum Doğal Gaz Boru Hatlarında transit ülke olarak projelere dâhil olan Gürcistan, incelenecek ikinci ülke olacaktır.

Çalışmada son olarak, Ağustos 2008'de Rusya ve Gürcistan arasında yaşanan savaşın, Gürcistan'ın gelecekteki muhtemel bir enerji boru projesinde 'güvenli transit geçiş ülkesi' olarak yer alma ihtimali üzerindeki etkilerini incelenecek; bu noktadan hareketle de bölgedeki diğer ülke Ermenistan'ın, Azerbaycan ve daha doğusundaki doğal gaz kaynağı geniş ülkelere ulaşmada alternatif bir transit geçiş ülkesi olma ihtimali üzerinde durulacaktır.

\section{Avrasya Doğal Gaz Boru Hattı Projeleri Hakkında}

\subsection{Nabucco Doğal Gaz Boru Hattı Projesi}

Türkiye-Bulgaristan-Romanya-Macaristan-Avusturya Doğal Gaz Boru Hattı olarak da bilinen Nabucco Doğal Gaz Enerji Boru Hattı Projesi “...ilk etapta güzergâh üzerindeki ülkelerin gaz ihtiyacının karşılanması, takip eden yıllarda ise Avusturya'nın Avrupa'da önemli bir doğal gaz dağıtım noktası olma özelliğinden de faydalanılarak diğer ülkelerin gaz taleplerindeki gelişmelere göre Batı Avrupa'ya ulaşılması amaçlanmaktadır" (BOTAŞ, 2011). İki buçuk milyon ton çeliğin kullanılmasıyla inşa edilecek boru hattının, yaklaşık 3900 kilometre uzunluğunda olması planlanmıştır (Nabucco Gas Pipeline International GmbH, 2011a). Kullanım ömrü 50 yıl olarak öngörülen projenin Haziran 2011'deki yeniden değerlendirme sürecine göre yaklaşık 7,9 milyar avroya mal olması beklenmektedir (Nabucco Gas Pipeline International GmbH, 2011b).

Nabucco Doğal Gaz Enerji Boru Hattı Projesi'ne (Nabucco) ilişskin ilk çalışmalar, Şubat 2002'de BOTAŞ'ın girişimi ve Bulgargaz (Bulgaristan), MOL (Macaristan), TRANSGAZ (Romanya) ve OMV Gas \& Power GmbH (Avusturya-Şimdiki OMV Gas) şirketleri ile yaptığı görüşmeler sonucunda oluşturulan çalışma grubu ile başlatılmıştır. 22 Aralık 2003’te Nabucco Projesi'ne iştirak eden beş ortak ve AB Komisyonu arasında, projenin 
teknik ve iktisadi fizibilitesinin finansmanının yarısının 'hibe kredi' şeklinde AB Komisyonu tarafından karşılanmasına ilişkin, 'Trans-European Transport Network (TEN) Fonu Hibe Anlaşması' imzalanmıştır.

2004 yılında teknik ve iktisadi fizibilite çalışmaları tamamlanması sonucunda 24 Haziran 2004 tarihinde Nabucco müşterekleri arasında 'Nabucco Company Study Pipeline GmbH' kurulmasını öngören Ortaklık Anlaşması imzalanmıştır. Proje geliştirme sürecinde gelinen aşama göz önünde bulundurularak projenin finansmanını sağlayıp yatırımlarını gerçekleştirmesi amacı ile daha sonra Nabucco Company Study Pipeline GmbH, 28 Haziran 2005'te, 'Uluslararası Nabucco Doğal Gaz Anonim Şirketi'ne (NIC)' dönüştürülmüsşür. Bu dönüşümle birlikte her bir transit ülkede Ulusal Nabucco Şirketleri’nin (NNC) kurulmasına da karar verilmiştir. Hâlihazırda Romanya, Macaristan, Avusturya ve Bulgaristan'da NNC kurulumları tamamlanmış olup, Türkiye NNC kurulumlarına dair girişimlerini sürdürmektedir.

'Majör Yeni Şirket Ortağı' adayları içerisinde öncelikli olarak tespit edilen şirketlerin projeye eşit oranda (yaklaşı 16,6\%) katılım için görüşmeler 2007 yılı boyunca sürdürülmüş, bu görüşmelerin nihayetinde 05 Şubat 2008 tarihinde Alman RWE Midstream GmbH Şirketi resmi olarak Nabucco Projesi'nin altıncı ortağı olmuştur (Komarek, 2008).

Nabucco'nun teknik çerçevesinin belirginleştirilmesinden sonra, proje kapsamında doğal gaz sevkiyatının başlatılabilmesi için gerekli olan hukuki ve siyasi çerçeve, 'Nabucco Doğal Gaz Boru Hattı Projesi Hükümetlerarası Anlaşması'nın Ankara'da AB Komisyonu Başkanı José Manuel Barroso ile Türkiye, Romanya, Avusturya, Macaristan ve Bulgaristan Başbakanları tarafindan 13 Temmuz 2009 tarihinde imzalamasıyla çizilmiştir (T.C. Başbakanlık Basın-Yayın ve Enformasyon Genel Müdürlüğü, 2011).

\subsection{Trans Anadolu Doğal Gaz Boru Hattı Projesi}

Azerbaycan, Nabucco ve Trans Hazar projeleri ile Avrasya Doğal Gaz Boru Hattı Projelerinde stratejik bir öneme sahip olduğunu göstermiştir. Ancak her iki proje de, nedenlerini Azerbaycan'ın Enerji Görünümü başlığ1 altında daha detaylı değineceğimiz sebeplerden ötürü, yabancı yatırımcıların altyapı ve know-how desteğine ihtiyaç duymaktadır. Rusya, Avrupalı veya Amerikan yatırımcıların bu desteği sağlamadan önce her iki projeyi de devre dışı bırakacak hamleler gerçekleştirmek için Azerbaycan doğal gazına ön ödemeli teklifler götürmüş̧ür (Hurriyer Daily News, 2010). Bu durum karşısında Azerbaycan 14 Kasım 2008'de, çokuluslu bir enerji zirvesini Bulgaristan, Estonya, Yunanistan, Gürcistan, Macaristan, İtalya, Letonya, Lituanya, Polonya, Romanya, Türkiye, Ukrayna, İsviçre, $\mathrm{ABD}$ ve $\mathrm{AB}$ Komisyonu'nun temsilcileri ile birlikte Bakü’de gerçekleştirmiştir. Zirvede sonuç olarak, Azerbaycan gazını Avrupa'ya çok yönlü taşımayı destekleyen altyapı çalışmalarına; Hazar Havzası'nın petrol ve doğal gaz kaynaklarının çeşitlendirilmesine destek verilmesine; enerji üreticileri, müş̧eriler ve transit ülkeler için daha mücadeleci bir ortamın yaratılmasına; Avrupa'nın enerji güvenliği için başta Interconnector Turkey-Greece-Italy (ITGI), Nabucco ve Azerbaycan-Gürcistan ve Türkiye üzerinden geçecek diğer olası doğal gaz projelerinin desteklenmesine karar verilmiştir (Baku Energy Summit Declaration, 2008). Türkmenistan ve Kazakistan zirveye katılmış olsalar da, sonuç bildirgesinde yatırımcı ülkelerin öngördüğü desteklere dair ayrıntılara yer vermemiş olmalarını neden göstererek, ortak bildiriye imza atmamışlardır (Socor, 2008), (United Press International, 2008).

Bakü Zirvesi’nden kısa bir süre sonra 29 Kasım 2008'de Azerbaycan Cumhurbaşkanı İlham Aliyev ve Türkiye Cumhurbaşkanı Abdullah Gül Türkmenistan'a yapmış oldukları ziyarette Bakü Zirvesi sonuçları doğrultusunda niyetlerini belirtmişlerdir. Görüşmeler sonunda resmi bir antlaşma imzalanmamış olsa da Türkmenistan Cumhurbaşkanı Berdimuhammedov Asya ve Avrupa arasında bir köprü vazifesi gören Hazar Havzası'nın önemine dikkat çekmiş ve doğal gaz üretimi ve ulaşımında çeşitlendirmeye gidilmesine sıcak bakabileceğini belirtmiştir (Upstream, 2008). Nitekim 25 Ekim 2011 tarihinde Azerbaycan'ın Şahdeniz II Bölgesi’nin doğal gazının Türkiye'ye ve Türkiye'den de AB'ye ulaştırılmasını öngören Hükümetlerarası anlaşma İzmir'de; Trans Anadolu Doğal Gaz Boru Hattı'nın yapımına ilişkin mutabakat zaptı ise 26 Aralık 2011 tarihinde Ankara'da imzalanmıştır. Söz konusu anlaşmanın Şahdeniz II Projesi kapsamında üretilecek gazın hem Türkiye'de kullanılması hem de bir kısmının Avrupa'ya aktarılmasını öngördüğünü anımsatan Türkiye Enerji ve Tabii Kaynaklar Bakanı Taner Yıldız, mutabakat zaptı ile hükümetler arası anlaşmayı daha somut hale getirdiklerini belirtmiş̧ir (Anadolu Ajansı, 2011). 26 Aralık 2011 tarihinde imzalanan mutabakat zaptında, 'Trans Anadolu ismi verilen söz konusu münhasır boru hattına yönelik çalışmaların ivedilikle başlanılması ve iki ülke tarafından tayin edilen şirketlerin ortak bir konsorsiyum tesis etmeleri' konusunda mutabakat sağlanmış olduğu; bu çerçevede, söz konusu şirket birlikteliği içerisinde SOCAR, BOTAŞ ve TPAO'nun ilk ortaklar olarak yer alacağı; süreç içerisinde diğer uluslararası petrol ve doğal gaz şirketlerinin de şirket birlikteliğine dahil olabileceği belirtilmiştir (Socar Türkiye, 2012).

\subsection{Türkiye-Yunanistan-İtalya Doğal Gaz Boru Hattı Projesi}

Yaklaşık 2 milyar avroya mal olması beklenen Türkiye-Yunanistan-İtalya Doğal Gaz Boru Hattı Projesi'yle (ITGI), Azerbaycan'ın Şahdeniz II bölgesinden gelecek doğal gazın Türkiye, Yunanistan ve İtalya üzerinden Avrupa'ya dağıtılması planlanmaktadır. Yunanistan'ın DEPA ve İtalya'nın Edison şirketlerinin ortak girişimleriyle başlatılan ITGI projesinin Türkiye ve Yunanistan'ı bağlayan 296 kilometrelik ilk kısmı, BOTAŞ ve DEPA arasında Mart 2002'de imzalanan anlaşma gereği, Eylül 2007'de tamamlanmıştır. 
Hattın Yunanistan'dan İtalya'ya uzanan bölümü, Nisan 2005'te DEPA ve Edison arasında imzalanan mutabakat zaptı ile belirlenmiştir. Haziran 2010'da DEPA, Edison ve BOTAŞ arasında imzalanan mutabakat zapt1 ile projeye son şekli verilirken, Ocak 2011'de Avrupa Komisyonu Başkanı Jose Manuel Barroso ve Azerbaycan Cumhurbaşkanı İlham Aliyev arasında imzalanan anlaşma ile proje kaynak ülke sorununu çözme yolunda önemli bir adım atmıştır.

ITGI kapsamında Avrupa’ya ulaştırılması gereken 10 milyar metreküp doğal gazın mevcut şartlarda Şahdeniz II tarafından karşılanabilecek olması, projenin gerçekleşmesi için umut vericidir. Bunun ötesinde DEPA yöneticisi Harry Sachinis, Azerbaycan'a yapılacak bir yardımla Şahdeniz II'den yaklaşık 24 milyar metreküp doğal gaz temin edilebileceğini belirtmiştir (Pipelines International, 2011).

\subsection{Trans Adriyatik Doğal Gaz Boru Hattı Projesi}

870 kilometrelik uzunluğu ile ITGI'den daha kısa bir rotayı takip eden Trans Adriyatik Doğal Gaz Boru Hattı Projesi (TAP) de yaklaşık 10 milyar metreküp doğal gaz kaynağına ihtiyaç duymaktadır (Margheri, 2011). 2003 yılında ilk hali İsviçre merkezli enerji şirketi EGL Grup (şimdiki adı Axpo) tarafindan hazırlanan projeye Şubat 2008'de Norveç merkezli Statoil dahil olmuş, daha sonrasında ise projenin Haziran 2008'de Yunanistan ve Arnavutluk üzerinden İtalya'yı kapsamasına karar verilmiştir. Mart 2009'da İtalya ve Arnavutluk hükümetleri TAP için ortaklık anlaşması yaptıktan sonra Ocak 2010'da TAP, Yunanistan, Arnavutluk ve İtalya'da ofissler kurmuştur. 07 Temmuz 2010'da da Almanya merkezli E ON Ruhrgas projeye iştirak etmiştir (Pipeline \& Gas Journal, 2010).

Şubat 2012 itibariyle kaynak ülke arayışlarına resmiyet kazandıran TAP, Şahdeniz Konsorsiyumu ile görüşmelere başlamış; konsorsiyum ortakları BP, SOCAR ve Total enerji şirketleri TAP projesinde \%50 pay sahibi olma konusunda proje yöneticileri ile anlaşmıştır. 22 Kasım 2012'de TAP, konsorsiyum ile birlikte, Trans Anadolu Doğal Gaz Boru Hattı ortakları ile mutabakat zaptı imzalayarak, iki taraf arasında işbirliği çerçevesinin kurulmasını sağlamıştır (TAP AG, 2013a). Projeye eklemlenecek İyonya Adriyatik Boru Hattı ile TAP'ın Bosna Hersek, Hırvatistan ve Karadağ'1 da kapsayacak şekilde düzenlenmesi sonucu 12 Haziran 2013 tarihinde bu ülkelerinkine ek olarak Yunanistan, Arnavutluk ve İtalya dışişleri bakanları bir araya gelerek projeye desteklerini açıklamışlardır (TAP AG, 2013b).

\section{Avrasya Doğal Gaz Boru Hattı Projeleri Çerçevesinde Kafkas Ülkelerinin Durumu}

\subsection{Azerbaycan’ın Enerji Görünümü}

Bağımsızlığını kazandığı 1991 yılına dek Azerbaycan'da başta Azerbaycan Devlet Petrol Şirketi (SOCAR) olmak üzere, bütün enerji şirketlerinin kamu iktisadi teşebbüsü formunda olması, dolayısıyla serbest piyasa şartlarının gerekliliklerini tam anlamıyla yerine getirebilecek kapasitede veya anlayışta olmaması, zengin petrol yataklarının kapasitesinin altında işletilmesine ve Sovyetlerden kalma enerji boru altyapı ağına bağımlılığı zorunlu kılmıştır (EIA, 2012).

Dört büyük petrol sahasıyla önümüzdeki yirmi yıl boyunca enerji sektörünün petrol ayağını güvenlik altına almış olan Azerbaycan'da doğal gaz için ise daha bulanık bir görünüm mevcuttur. Azerbaycan'daki mazisi petrol kadar eski olmayan, dolayısıyla iktisadi girdi olarak daha az bir paya sahip olan, doğal gazın üretimi için gerekli olan alt yapı çalışmaları yıllar içerisinde oldukça düşük bir oranda gerçekleştirilmiştir (Parini, 2012). Sovyet Dönemi'nde dünyanın en büyük doğal gaz rezervine sahip Rusya'ya ile doğrudan doğal gaz enerji boru hatlarına sahip olmak ve doğal gazın petrole göre iletim ve depolama maliyetlerinin oldukça yüksek olması, Azerbaycan'ın doğal gaz konusunda bu geri kalmışlığının ardında yatan temel sebep olmakla beraber, durum 2007 yılına kadar da değişmemiştir.

Bugün Azerbaycan, Rusya ve İran'ı devre dışı bırakarak Hazar Havzası'nın zengin enerji kaynaklarını ihraç etmek suretiyle alternatif bir doğal gaz iletim projesine dâhil olacaksa, ülke enerji alanına yapacağı altyap1 yatırımını arttırmanın yanında uluslararası sermayenin yardımlarına da ihtiyaç duyacağı kesindir. Azerbaycan geçmiş yıllarda petrol sektörüne yıllık bütçesinin yaklaşık \%25'lik kısmını (üç milyar dolar Amerikan dolarına yakın) ayırmıştır (Holuj, 2009). Bu oran, başkent Bakü dışında iktisadi bir çeşitliliği ya da kalkınma hareketi gözlemlenmeyen ve toplam nüfusunun yarıya yakını fakirlik sınırında olan Azerbaycan için oldukça önemli bir miktarı oluşturmaktadır. Ancak bu yatırım miktarı Azerbaycan'ın petrol sektörünün serbest piyasada mücadele gücünü arttırmaya yetmemektedir. Bu yüzden Azerbaycan kurmuş olduğu Devlet Petrol Fonu üzerinden 2001 yılında International Monetary Fund (IMF) fonlarına başvuru yapmıştır (IMF Public Information Office, 2002). 2001'den itibaren IMF'de alınan fon yardımı ile sektörün kalkınması için kullanılan miktar 2009 yılında yıllık 18 milyar dolara ulaşarak Azerbaycan'ın genel bütçesinin yarısına yaklaşmıştır. Bu durumda Azerbaycan'ın bütçesinin başat girdisi olan petrol sektörüne bile yatırım yapmakta zorlandığı sonucunu çıkarabiliriz.

Azerbaycan petrol üretimi için gerekli olan finansman desteğini IMF'de alırken, AB ve ABD gibi ülkeye başta doğal gaz olmak üzere uzun vadeli yatırım yapmak isteyen yatırımcılar bu isteklerini gerçekleştirememektedirler. $\mathrm{Bu}$ duruma, Azerbaycan'daki çeşitli iç faktörlerin yanında; Karabağ sorunu, Türkiye-Ermenistan, RusyaGürcistan arasındaki sorunlar, Kuzey Kafkasya'da yaşanan çeşitli etnik ayrılıkçı hareketler ve İran'ın nükleer programı yüzünden uluslararası sistemden dışlanması gibi dış faktörler neden olmaktadır. Ezcümle, 
Azerbaycan'ın enerji sektöründeki sorunları sadece enerji alt yapısında modernleşme ve bunu karşılayacak olan iktisadi yeterliliklerin eksikliğinin ötesinde bir husustur.

\subsection{Azerbaycan ve Avrasya Doğal Gaz Boru Hattı Projeleri}

Bakü Tiflis Erzurum Doğal Gaz Boru Hattı (BTE) için gerekli olan doğal gaz, 2007 yılında Azerbaycan'ın başat doğal gaz sahası olan Şahdeniz'den pompalanmaya başlanmıştır. Bölgede Gazprom'a ait tekeli yıkmada ilk adım olarak görülen bu proje kapsamında yılda 8,8 milyar metreküp gaz Türkiye'ye gönderilmektedir. BTE'den önce Azerbaycan, Bakü-Astara ve Gazi-Magomed-Mozdok Doğal Gaz Boru Hatları ile sadece Rusya ve İran'a gaz iletimi yapmaktaydı. BTE ise Azerbaycan'a, Gürcistan üzerinden Türkiye'ye gaz iletimini sağlamıştır.

Azerbaycan'ın hâlihazırda doğal gaz rezervi 0,9 trilyon metreküp olarak hesaplanmıştır (British Petroleum, 2013). On beşincisi Bakü'de gerçekleştirilen Uluslararası Hazar Petrol ve Gaz Konferansı'na katılan SOCAR'ın Birinci Başkan Yardımcısı Khoshbakht Yusifzade'nin yaptığı açıklamaya göre de bu rezervin yıllık 27,4 milyar metreküpü üretilebilmektedir (The Economic Times, 2008). Yapılan hesaplamalara göre ise mevcut şartlar altında Azerbaycan'ın rezervi elli yıl daha bu kapasitede bir üretim yapabilecekken, sadece BTE kapsamında yıllık yirmi milyar metreküp üretim yapılabilecektir. Şahdeniz rezervlerine ek olarak bulunan Azeri-ÇıralıGüneşli (ACG Deepwater) sahasındaki doğal gaz rezervi, Azerbaycan'ın bir gaz üreticisi olarak rezerv kapasitesini arttırmıştır. Bu rezervler doğrultusunda gerçekleştirilecek yeni projelerle genel doğal gaz üretiminin mevcudun iki misline çıkartılarak Rus gazına ve Sovyet dönemi boru hatlarına bağımlılığın azalacağı öngörülmektedir (Pitt, 2006). Azerbaycan Rusya'ya olan bu bağımlılığını azaltma yolunda ilerlemek isterken mevcut gaz rezervlerinin üretimine ve dahası geniş kapsamlı olarak ihracata geçebilmesi için dört milyar dolarlık Trans Kafkasya projesi gibi birçok proje için finansmana ihtiyaç duymaktadır. \%10'u SOCAR'a ait olan Şahdeniz üretim paylaşım antlaşmasının (PSA) \%90'ının altı uluslararası petrol şirketi tarafindan üstlenmesi (British Petroleum, 1996) de Azerbaycan'ın gerektiğinde bu ihtiyacının dış yatırımla desteklenebildiğini gösteren iyi bir örnektir.

Azerbaycan'ı gaz üretim seviyesinin belirli bir konuma getirmesini ve daha da ileriye taşımasında motive eden en büyük unsur, kendi kapasitesine ek olarak doğusunda bulunan ülkelerde toplam 7,1 trilyon metreküp doğal gaz rezervinin bulunmasıdır. Doğusunda 'kara ile kuşatılmış' bu ülkelerle enerji ithalatında Rus tekeline bağımlı olmaktan rahatsız olan batısındaki gelişmiş ülkeleri birbirine kavuşturabilecek güzergâh üzerinde olması bu motivasyonunu temel dinamikleridir. Öte yandan, Azerbaycan'ın da kara ile kuşatılmış olması ve mevcut uluslararası siyasi şartları nedeniyle doğal gazını sıvılaştırarak ihraç etmek zorunda kalması, doğal gazın taşıma maliyetini yükseltmektedir. Rusya veya İran üzerinden geçecek bir boru hattının doğal gaz taşıma maliyetini iyice düşürecek olmasına karşın gaz ithal edecek Avrupa ülkelerinin bu iki ülke üzerinden geçecek projelere sıcak bakmaması nedeniyle bu olumsuz durum devam edecek gibi görünmektedir. Öte yandan Rusya, Gazprom'un Ukraynalı ortakları ile kurmuş olduğu RosUkrEnergo şirketi vasıtasıyla Türkmenistan, Kazakistan ve Özbekistan ile imzalamış olduğu ikili anlaşmalar yoluyla Güney Koridor ve Kuzey Akım projelerinde Azerbaycan'ı Ukrayna veya Karadeniz üzerinden devre dışı bırakma yolunda adımlar atmaya başlamıştır (Jeffers, 2011). İktisadi şartlardan ziyade siyasi durum göz önüne alınarak yapılan bu hamleler Azerbaycan'ın ancak doğu batı ekseninde yapılabilecek bir enerji hattının inşasında yer bulabilmesine imkân sağlamaktadır.

Finansal ve siyasal engellerin yanında Hazar'ın statüsü sorunu olarak da bilinen hukuki sorun da Azerbaycan'ın Güney Koridoru yolunda önünde duran bir engeldir. Uluslararası hukuka göre Hazar'ın bir deniz olarak kabul edilmesi durumunda Hazara kıyısı bulunan her ülkeye on iki deniz mili karasuyu hakkı tanınacaktır. Bu durumda Hazar'ın ortasında yaklaşık iki yüz deniz mili kadar da bir münhasır iktisadi bölge oluşacaktır. Öte yandan Hazar'ın bir göl olarak kabul edilmesi durumunda, Hazar'dan elde edilecek gelirlerden projeye dâhil olsun olmasın her sahildar ülke proje gelirlerinden pay alma hakkına sahip olacaktır. Azerbaycan, Rusya ve Kazakistan Hazar'ın statüsü konusunda karşılıklı anlaşmalar yapmışken, Trans Hazar Hattı için Azerbaycan'ın Türkmenistan'la da benzer bir anlaşma yapması da zorunlu gözükmektedir.

\section{Gürcistan}

\subsection{Gürcistan'ın Enerji Görünümü}

2011 yılı itibariyle 1 milyar 700 milyon metreküp doğal gaz ithal eden Gürcistan, bu ihtiyacını 70'e yakın gaz dağıtım şirketi ile Azerbaycan ve Rusya'dan temin etmektedir. Ülkenin toplam 6013 kilometre uzunluğa sahip doğal gaz boru hattı sisteminin \%19'u 30 yıldan eskiyken, \%76's1 10 ila 30 yıldan önce, $\% 5$ 'i ise 10 ylldan az bir zaman önce inşa edilmiştir (Chikhladze, 2010). Mevcut şartlarda Gürcistan bu boru hatlarının maksimum kapasitesinin ancak \%21'ini kullanabilmektedir. Öte yandan Hazar petrolünün Bakü-Novorossisk ve Bakü-Supsa Petrol Boru Hatları ile Karadeniz limanlardan uluslararası müşterilere ulaştırılması, İstanbul ve Çanakkale Boğazlarında oldukça tehlikeli ve yoğun trafiğe neden olmaktadır. 2005 yılında tamamlanan $1768 \mathrm{~km}$ uzunluğundaki BTC petrol boru hattı ve 692 kilometre uzunluğundaki BTE doğal gaz boru hattı, AzerbaycanGürcistan ve Türkiye'nin iktisadi ve siyasi işbirliğinin birer meyvesi olarak hem bu trafiğgi azaltma yolunda hem de Gürcistan'ın mevcut doğal gaz altyapısının geliştirilmesinde atılan önemli bir adım olmuştur. Bu meyveden 
Gürcistan'ın payına düşen ise yıllık 62,5 milyon Amerikan dolarlık bir gelire ek olarak işsizlik oranlarında yaklaşık \%30'luk düşüş gösterebilir (Papava, 2005).

BTC ve BTE'nin gerçekleştirilmiş olması Kafkas ülkelerinden sonra Merkezi Asya ülkeleriyle de gerçekleştirilecek işbirliklerinin zemini hazırlanmıştır. Nitekim 16 Haziran 2006'da Azerbaycan Cumhurbaşkanı İlham Aliyev ve Kazakistan Cumhurbaşkanı Nursultan Nazarbayev'in imzaladıkları Trans-Hazar Petrol Ulaşım Sistemi Mutabakat Zaptı, Kaşagan ve Tengiz sahalarındaki petrolün tankerlerle Hazar Denizi'ni geçerek Azerbaycan'ın Sangaçhal Terminali'ne, Sangaçhal'den de BTC'yle bütünleşerek uluslararası piyasalara ulaştırılmasını öngörmüştür (Today.Az, 2006) (Azernews, 2011).

\subsection{Savaşı'nın Gürcistan'ın 'Transit ve Alternatif Enerji Boru Hattı Ülkesi’ İmajına Etkisi}

2008 yılına gelindiğinde Gürcistan, enerji alanında BTC ve BTE projelerinde yer alarak önemli bir stratejik konum kazanmış durumdaydı. Yıllık 7,23 milyar metreküplük gaz sevkiyatı ile dünya çapında gerçekleştirilen gaz sevkiyatının sadece \%1,23'lük kısmını (British Petroleum, 2009) oluşturmasına rağmen BTE, bölgede ABD'nin rakip olarak gördüğü, İran ve Rusya'yı devre dışı bırakarak Avrupa'ya gaz sevkiyatının gerçekleştirilmesiyle, Gürcistan'a stratejik bir konum kazandıran temel etmenlerden biriydi. Gürcistan'ın sahip olduğu bu stratejik avantaj aynı zamanda Gürcistan'ın kırılgan siyasi yapısını, doğal gaz projelerinde devre dışı bırakılan ülkelerin hedefi haline getirmiştir. Ağustos 2008'de İran'a nazaran Gürcistan üzerindeki etkisi daha yoğun olan ve bölgedeki batı yanlısı eğilimleri daha ciddi bir tehlike olarak gören Rusya'nın, Gürcistan'ın Güney Osetya ve Abhazya'da yaşanan etnik çatışmalara müdahil olmasını, bu bağlamda yorumlayan çalışmalar mevcuttur (Nichol, 2009), (Skarbo \& Petre, 2008), (BBC News, 2008).

Ağustos 2008'te gerçekleşen savaşın Gürcistan'ın 'Kafkaslardaki güvenli transit enerji koridoru' görüntüsü üzerine doğrudan ve dolaylı bazı etkileri olmuştur. Her ne kadar Rusya'nın enerji boru hatlarını doğrudan işgal ederek çalışmalarını kontrol altına aldığı gözlemlenmese de teknik nedenlerle Bakü-Supsa hattı karşısında dezavantajlı durumda olan Bakü-Novorossiisk hattının savaş boyunca tam kapasiteyle çalışması veya BTC'nin kesintiye uğraması, savaşın bu imajın bozulmasına neden olan doğrudan etkileri olarak sayılabilir. Öte yandan Gürcistan'ın bölgedeki güvenilir ve alternatif transit koridor imajını sarsan bu savaşın, Gürcistan'ın enerji boru hatları üzerine inşa ettiği uzun vadeli iktisadi ve siyasi kalkınma projesini derinden sarstığ gerçeğine ek olarak, dış yatırımların güvenilir bir ortam bulacaklarına dair inançlarının sarsılması Gürcistan'a dolaylı olarak da büyük zarar vermiştir. Öyle ki savaş sırasında gerçekleşen kesintiler Gürcistan'ın projedeki gelirlerinde ciddi bir azalmaya neden olmamış olsa da, yatırımcılar nazarında oluşan güvensizlik imajı nedeniyle, Gürcistan'ın zararının bir milyar doları aştığı düşünülmektedir (Bilefsky, 2008).

\subsection{Savaşı Sonrası Gürcistan ve Avrasya Doğal Gaz Boru Hattı Projeleri}

2008 Savaşı, AB'nin Türkmenistan'ın zengin doğal gaz yataklarına Nabucco ile Gürcistan üzerinden ulaşma yolunda atmış olduğu önemli adımlar sırasında gerçekleşmiştir. Gürcistan'ın projeye katılma yönündeki istekliliği savaş sonrası dönemde de sürmüş, Ocak 2009'da Gürcistan Cumhurbaşkanı Saakaşvili eski Başbakan Lado Gurgenidze'yi Nabucco başta olmak üzere uluslararası enerji projelerinde temsilci olarak atamıştır (Press Office of the President of Georgia, 2009). 2008 yılında yaşanan savaş Gürcistan'a dışarıdan yatırım çekme konusunda dezavantaj sağlarken, savaş süresince Rusya’nın Gürcistan'a karşı göstermiş olduğu tutum, Nord Stream ve Güney Akım Doğal Gaz Boru Hattı Projeleri vasıtasıyla Rusya ile olan işbirliği devam eden AB ülkelerinin ve Rusya ile İran'ı devre dışı bırakacak tüm projelere destek verebilecek ABD'nin alternatif arayışlarını hızlandırmıştır. Bu bağlamda Kasım 2008'de Bakü'de aralarında Türkiye'nin de bulunduğu ülkelerin katılımıyla gerçekleşen enerji zirvesinde Moskova'nın tekelci politikası ve enerji sektöründe yaratmış olduğu baskı eleştirilirken, Gürcistan'ın bu konudaki önemine yer verilmiştir. Öte yandan 2009'un başında ise ABD ve Gürcistan arasında stratejik ortaklık anlaşmasıyla, Avrasya enerji güvenliğinin özellikle Güney Koridoru ile desteklenmesini de kapsayan 'ortak çıkarlar' konusunda mutabakata varılmıştır (Bureau of European and Eurasian Affairs, 2009).

ABD başta olmak üzere Batılı yatırımcılar Gürcistan'da yaşanan savaş ortamından olumsuz etkilenmiş olsalar da Gürcistan'ın Hazar ve Orta Asya'nın enerji kaynaklarına ulaşmada önemli bir transit konumda bulunuyor olması nedeniyle Gürcistan'ın desteklenmesine devam etme kararı almışlardır. Rus tarafında ise Dışişleri Bakanı Sergey Lavrov Nabucco için "iktisadi açıdan mantıklı görünmeyen açıkça araçsal bir proje" ifadesini kullanmıştır (Lavrov, 2008). Bu noktada görülmektedir ki Gürcistan Savaşı'nın nedenlerinden biri de, bir tarafında $\mathrm{ABD}$ ve $\mathrm{AB}$ 'nin desteklediği ve Türkiye ile Azerbaycan'ın bizzat parçası olduğu enerji boru hattı projeleri, diğer tarafta aynı coğrafyayı stratejik bir arka bahçe olarak gören Rusya'nın bulunduğu, uluslararası çekişmedir (Socor, 2004). Gürcistan'ın, Rusya'nın bu hedefine gerek siyasi gerekse enerji yoluyla iktisadi olarak muhalefeti, Ağustos 2008'deki gibi bir müdahalenin gerçekleşmesinde şüphesiz önemli bir rol oynamıştır.

\subsection{Ermenistan'ın Enerji Görünümü}

2011 yılındaki 2 milyar 77 milyon metreküplük doğal gaz tüketiminin bir milyar üç yüz milyonuna yakınını Rusya'dan, kalan yaklaşık dört yüz milyon metreküp doğal gazı da İran'dan ithal eden Ermenistan, doğal gaz üretimi yapamayan 'net enerji ithalatçısı' statüsündeki ülkelerden biridir (British Petroleum, 2013). Mevcut enerji altyapısının tamamına yakını Ermeni-Rus ortak girişimi ArmRusGasprom şirketine bağlı olan ülke, başta 
elektrik enerjisi ithal ettiği İran ve/veya tarihi-siyasi uyuşmazlıklar nedeniyle ilişkilerinin gergin olduğu Türkiye vasitasıla 'transit enerji koridoru' ülkesi olmak istemektedir (Central Intelligence Agency, 2012). Bu bağlamda 1992'de İran ile doğal gaz boru hattı inşası için anlaşan Ermenistan, iki yüz milyon dolara yakın maliyeti olan projeyi ancak 2007 yilında faaliyete geçirebilmiştir. Yüz kırk bir kilometre uzunluğundaki projeyle İran'dan ithal ettiği yıllık dört yüz milyon metreküp doğal gazın tamamını ithal eden Ermenistan'ın, projenin son fazında yalnız İran üzerinden iki buçuk milyar metreküp doğal gaz ithal edebilecek seviyeye gelmesi planlanmaktadır (BBC News, 2007).

Avrasya Doğal Gaz Boru Hattı Projeleri gelecekte ister İran'ın ister Hazar Havzası'nın enerji kaynaklarını kullansın, Ermenistan transit enerji koridoru olarak bu projelerde oldukça stratejik bir konumda olacaktır. $\mathrm{Bu}$ bağlamda projelere dâhil olması kuvvetle ihtimal olan Azerbaycan'ın yine projenin esas unsurlarından biri olan Türkiye ile bağlantısını Gürcistan veya Ermenistan üzerinden kurabilecektir. Çalışmamızın bu kısmında Ermenistan'ın Avrasya Doğal Gaz Boru Hattı Projeleri bağlamında nereye oturduğunu göstermeye çalışacağız.

\subsection{Ermenistan ve Avrasya Doğal Gaz Boru Hattı Projeleri}

Ağustos 2008'deki Gürcistan-Rusya Savaşı, Hazar Havzası ve Kafkasya'nın enerji kaynaklarının Türkiye üzerinden AB'ye ulaştırılmasını öngören Avrasya Doğal Gaz Boru Hattı Projelerinin olası güzergâhında bazı değişiklikleri gündeme getirmiştir (Engdahl, 2009). Gündeme gelen bu değişikliklerden biri, gerek Azerbaycan'ın öz kaynaklarını gerekse başta Türkmenistan olmak üzere Hazar Havzası kaynaklarını Anadolu'ya taşıması beklenen Nabucco Projesi'nin boru hattı güzergâhına, Ermenistan'ın dahil edilmesi fikrinin ortaya çıkmasıdır.

Ermenistan'ın Nabucco ile Avrasya Doğal Gaz Boru Hattı Projelerine dahil edileceğini öngören fikirlerin temel dayanak noktaları iki başlık altında toplanabilir. Bunlardan ilki Ermenistan'ın geniş doğal gaz rezervlerine sahip İran'la arasında inşa etmiş olduğu doğal gaz boru hattıdır. Bu hattın yıllık iki buçuk milyar metreküp doğal gaz sevkiyatına izin veren kapasitesinin arttırılmasıyla, projelerin ilk fazda ihtiyaç duyacağı doğal gazın iletilebileceği bu fikrin esasını oluşturmaktadır. Ancak bu fikrin pratiğe dönüşmesinin önünde duran iki temel engel bulunmaktadır. Bu engellerden ilki Ermenistan enerji altyapısının tümünün Rus-Ermeni ortak girişimi ArmRusGasprom vasıtasıyla Rusya'nın kontrolünde olmasıdır (Akkan, 2009). Yüzde sekseni Ruslara ait bir firmanın altyapısının $\mathrm{AB}$ tarafindan finanse edilerek yenilenmesi siyasi nedenlerle pek de mümkün görünmemektedir. Öte yandan hattın İran ayağı da yatırıma muhtaçtır. Bu engelin aşılamamasının ardında yatan sebep ise, dünyanın en geniş ikinci doğal gaz rezervine sahip olmasına rağmen, İran'ın kendi doğal gaz altyapısını yenileyememesidir. AB ve ABD haricinde başka bir ülkeden İran'ın doğal gaz iletim altyapısının yenilemesi yönünde gelebilecek olası bir dış yardım da İran Anayasası gereğince engellenmektedir. İranErmenistan Doğal Gaz Boru Hattı'nın Avrasya Doğal Gaz Boru Hattı Projelerine eklemlenmesini zorlaştıran diğer bir engel ise AB ve ABD'nin İran'a karşı uygulamış oldukları izolasyon politikasıdır. Bu ülkenin nükleer programının neden olduğu izolasyon, hattın projelere eklenmesini kati surette engellemektedir.

Ermenistan'ın Nabucco ile Avrasya Doğal Gaz Boru Hattı Projelerine dahil olacağını öngören fikirlerden ikincisinin temelinde, Ermenistan ve Türkiye arasında 10 Ekim 2009 tarihinde 'Türkiye Cumhuriyeti ile Ermenistan Cumhuriyeti Arasında Diplomatik İlişkilerin Kurulmasına Dair Protokol'ün imzalanması yatmaktadır. Bu fikre göre, Rusya'nın Avrasya enerji kaynaklarını doğruda veya dolaylı olarak hükmettiği mevcut durumu değiştirmek isteyen ABD, Türkiye ve Ermenistan ilişkilerinin geliştirilmesinde her iki ülkeyi de desteklemektedir. ABD'nin desteği ile diplomatik ilişkileri kuran Türkiye ve Ermenistan, Nabucco'nun gerçekleştirilmesi yolunda sınır kapılarını karşılıklı olarak açabilecek ve Dağlık Karabağ sorununda Ermenistan, Minsk Grubu üyesi Türkiye ile fikir alışverişi yapabilecektir. 2009'da imzalanan anlaşmayla siyasi ilişkiler gibi enerji ilişkilerinin de güçlendirileceği öngörülmüş olsa da Ermenistan-Türkiye yakınlaşmasına Azerbaycan'ın göstermiş olduğu olumsuz tepkinin yoğunluğu, tarafların emellerini gerçekleştirmesini engellemiştir (Cihan Haber Ajansı, 2009). Azerbaycan'ın Türkiye-Ermenistan ilişkileri konusundaki tavrını daha önceden net ve sert bir şekilde ortaya koyuşu ve protokolün imzalanması üzerine çok hızlı bir şekilde Rusya ile doğal gaz anlaşması yapması, Nabucco Projesi özelinde Avrasya Doğal Gaz Boru Hattı Projeleri’nin nasıl hassas bir zeminde olduğunu ve dengeleri göz ardı eden bir adımla nasıl altüst olabileceğini gösteren bir örnek olarak karşımıza çıkmıştır.

\section{Sonuç ve Değerlendirme}

Çalışmamızın son kısmında, enerji görünümlerini incelediğimiz Kafkas ülkelerini Avrasya Doğal Gaz Boru Hattı Projeleri kapsamında tek tek değerlendirmeye çalışarak, bu ülkelerin projelere iştirak edecek ülkelerle olan işbirliği ihtimalleri üzerinde duracağız. Bu bağlamda değerlendireceğimiz ilk ülke Azerbaycan olacaktır.

Azerbaycan'ın Dağlık Karabağ ve Hazar'ın statüsü gibi yaşamış olduğu uluslararası sorunlar, Rusya'yı devre dışı bırakacak olası bir boru hattı projesinin önünde duran diğer büyük engellerdir. Azerbaycan'ın bu sorunların çözümünde Azerbaycan tezlerine daha mesafeli davranan Rusya'yı ikna etmek yerine AB ve ABD'den siyasi destek alabilmek adına enerji işbirliğini bir alternatif olarak düşünmesi beklenebilir. Bu noktada Azerbaycan'ın Avrasya Doğal Gaz Boru Hattı Projeleri arasında yer alan Nabucco veya benzeri bir başka proje çatısı altında, 
batısındaki ülkeler ile işbirliği kurması, siyasi açıdan, olası görünmektedir. Ancak iktisadi açıdan Azerbaycan'ın Rusya'yı tercih etme olasılığı aralarında Türkiye'nin de bu bulunduğu bu ülkeler ile gerçekleştirilecek bir işbirliğinden daha mümkün görünmektedir.

Değerlendirme kısmında ele alacağımızı ikinci ülke olan Gürcistan'ın Azerbaycan ile birlikte Rusya'nın stratejik olarak oldukça önem atfettiği Güney Kafkasya'da, batı ile bütünleşme konusunda oldukça istekli davranıyor olması, bu ülkeyi Rusya'nın açık bir hedefi haline getirmektedir. Türkiye, gerek ABD'nin gerekse AB'nin siyasi ve iktisadi desteğiyle birlikte, Gürcistan'ın alternatif bir enerji transit ülkesi olarak uluslararası enerji boru hattı projeleriyle bütünleşmesi için en somut adım atan ülkedir. Bu yüzden birbirleriyle doğrudan bir çekişme içerisinde bulunmayan Türkiye ve Rusya'nın özellikle enerji boru hatları üzerinden bu coğrafyada da gelecekte bir çekişme içerisinde olacağını söyleyebiliriz.

Dağlık coğrafyaya sahip olmak, doğal gaz rezervlerine sahip olmamak, transit koridor olabilmek için gerekli altyapıya olmamak, Azerbaycan ve Türkiye ile derin siyasi çatışmalara sahip olmak, AB ve ABD tarafından uluslararası alandan izole edilmeye çalışılan İran ile enerji münasebetine sahip olmak gibi oldukça fazla sorunu barındıran Ermenistan'ın Avrasya Doğal Gaz Boru Hattı Projelerine dâhil olması ise, mevcut dinamikler çerçevesinde, kanımızca imkânsız görünmektedir.

\section{Kaynakça}

- Akkan, F. (2009, Eylül 08). “Rus Gazetesi: Ermenistan'ı Nabucco Hattına İtiyorlar”, Zaman Gazetesi.

- Anadolu Ajansı. (2011, Aralık 27). "Türk-Azeri Enerji İşbirliği”. Dünya Gazetesi, s. 13.

- Azernews. (2011, Ocak 25). Kazakhstan Seeks to Resume BTC Oil Experts. http://www.azernews.az/en/oil_and_gas/29002-

- Baku Energy Summit Declaration. (2008, November 14). http://www.president.pl/ download/gfx/prezydent/en/defaultaktualnosci/13/161/1/baku-energy-summit-declaration-eng.pdf

- $\quad$ BBC News. (2007, March 19). "Iran, Armenia Open Gas Pipeline”. http://news.bbc.co.uk/2/hi/europe/6466869.stm

- BBC News. (2008, August 12). "BP Shuts Down Georgia Pipelines". http://news.bbc.co.uk/2/hi/business/7556215.stm

- Bilefsky, D. (2008, September 27). "War Left Georgia Economy Bruised But not Broken”. The New York Times.

- $\quad$ BOTAŞ. (2011, Ağustos 01). Nabucco DGBH Projesi. http://www.botas.gov.tr/icerik/tur/projeler/yurtdisi.asp\#05

- British Petroleum. (1996, June 04). Agreement on the Exploration, Development and Production Sharing for the Shah Deniz Prospective Area in the Azerbaijan Sector of the Caspian Sea. http://www.bp.com/liveassets/bp_internet/bp_caspian/bp_caspian_en/STAGING/local_assets/downloads_pd fs/s/SD-PSA.pdf

- $\quad$ British Petroleum. (2009, June). BP Statistical Review of World Energy June 2009.

http://www.bp.com/liveassets/bp_internet/globalbp/globalbp_uk_english/reports_and_publications/statistical _energy_review_2008/STAGING/local_assets/2009_downloads/statistical_review_of_world_energy_full_re port_2009.pdf

- British Petroleum. (2013). BP Statistical Review of World Energy June 2013. London: British Petroleum. http://www.bp.com/content/dam/bp/pdf/statistical-review/statistical_review_of_world_energy_2013.pdf

- Bureau of European and Eurasian Affairs. (2009, January 09). United States-Georgia Charter on Strategic Partnership. http://www.state.gov/p/eur/rls/or/121029.htm

- Central Intelligence Agency. (2012, Nisan 10). The Wolrd Fact Book. https://www.cia.gov/library/publications/the-world-factbook/geos/am. html

- Chikhladze, N. (2010). Gas Sector in Georgia (Current Situation and Sector Regulation). National Association of Regulatory Utility Comissioners, (s. 7). http://www.naruc.org/international/Documents/ prezentacia\%20nana_en\%20(gas\%20sector).pdf

- Cihan Haber Ajansı. (2009, Eylül 17). “AB: Ermenistan Nabucco'da Yer Almayacak”, Türkiye Gazetesi, s. 7.

- Cornell, S. E., Popjanevski, J., \& Nilsson, N. (2008). "Russia's War in Georgia: Causes and Implications for Georgia and the World". Central Asia-Caucasus Institute\& Silk Road Studies Program, pp. 16-18.

- EIA. (2012, January 09). Azerbaijan Analysis http://www.eia.gov/countries/cab.cfm?fips=AJ

- Engdahl, W. F. (2009, July 17). US Strategy of Total Energy Control Over the European Union and Eurasia. http://www.globalresearch.ca/index.php?context=va\&aid=14412

- Holuj, B. (2009, Spring). Azerbaijan at a Crossroads: Unlocking the Caspian Natural Gas Wealth. Michigan Journal of Public Affairs, 6, p. 5.

- Hurriyer Daily News. (2010, September 02). Russian President in Azerbaijan to Secure Border, Energy Deals. http://www.hurriyetdailynews.com/default.aspx?pageid=438\&n=russian-president-in-azerbaijan-tosecure-border-energy-deals-2010-09-02 
- IMF Public Information Office. (2002). IMF Concludes 2001 Article IV Consultation with the Azerbaijan Republic. http://www.imf.org/external/np/sec/pn/2002/pn0224.htm

- Jeffers, I. (2011). Economic Developments in Contemporary Russia, Routledge, New York.

- Komarek, E. (2008, February 05). Nabucco Confirms RMW is Pipeline Partner- Update 2, http://www.reuters.com/article/2008/02/05/nabucco-rwe-idus10518499320080205

- Lavrov, S. (2008, Марта 31). Министр Иностранных Дел России Сергей Лавров: "Мы Стараемся Деидеологизировать Наши Действия. (Izvestia, Röportaj Yapan)

- Margheri, M. (2011, May 20). ITGI and IGB Opening the Southern Corridor. CERI Sciences-Po Seminar, http://www.sciencespo.fr/enerpol/wp-content/uploads/2011/05/Marco-Margheri.pdf

- $\quad$ Nabucco Gas Pipeline International GmbH. (2011a, Temmuz 31). 2011 Üçüncü Çeyrek Durum Raporu: Nabucco-Avrupa ve Türkiye'nin Ortak Projesi, http://portal.nabucco-pipeline.com/portal/ page/portal/tr/press/downloads/tr\%20status\%20presentation\%20june\%202011.pdf

- Nabucco Gas Pipeline International GmbH. (2011b, Ağustos 01). Genel Bakış, http://www.nabuccopipeline.com/portal/page/portal/tr/pipeline/overview

- Nichol, J. (2009, March 03). "Russia-Georgia Conflict in August 2008: Context and Implications for US Interests", Congressional Research Service, R134618, p. 13.

- Papava, V. (2005). "The Baku-Tbilisi-Ceyhan Pipeline: Implications for Georgia", The Baku-TblisiCeyhan Pipeline: Oil Window to the West, ed. F. S. Starr, \& S. E. Cornell, Central Asia-Caucasus Institute and Silk Road Studies Program, Uppsala, p. 87. .

- Parini, S. (2012). Central Asian and Caspian Gas Production and the Constraints on Export. The Institute for Energy Studies, University of Oxford Press.

- Pipeline \& Gas Journal. (2010, July). "E.ON Ruhuras Becomes Shareholder in Trans Adriatic Pipeline", Pipeline \& Gas Journal, 237(7). http://www.pipelineandgasjournal.com/eon-ruhrgas-becomes-shareholdertrans-adriatic-pipeline

- Pipelines International. (2011, October 5). Proposal Submitted for ITGI System, http://pipelinesinternational.com/news/proposal_submitted_for_itgi_system/064050/\#

- $\quad$ Pitt, A. (2006, September 14). "Shah Deniz Taps Primed", Upstream, http://www.upstreamonline.com/live/article119108.ece

- Press Office of the President of Georgia. (2009, Ocak 30). The President of Georgia Mikheil Saakashvili Presented the New Prime Minister to the Georgian Government, http://www.president.gov.ge/en/pressoffice/news?2290

- Skarbo, S., \& Petre, J. (2008, August 10). “The Pipeline War: Russian Bear Goes for West's Jugular”, The Daily Mail.

- Socar Türkiye. (2012, Ocak 03). “Türkiye ve Azerbaycan Tarihi bir Projeye Daha İmza Koydu”, Socar Türkiye, s. 93.

- Socor, V. (2004). "The Frozen Conflicts: A Challenge to Euro-Atlantic Interests”, Karadeniz Bölgesi için Yeni Avro-Atlantik Stratejisi Raporu, http://www.jamestown.org/fileadmin/vlads_corner/policypapers/konstron.doc

- Socor, V. (2008, December 1). “Azerbaijan Quietly Lending Impetus to Nabucco Project”, Eurasia Daily Monitor, 5, 228, http://www.jamestown.org/single/?no_cache= 1\&tx_ttnews\%5btt_news\%5d=34195

- T.C. Başbakanlık Basın-Yayın ve Enformasyon Genel Müdürlüğü. (2011, Ağustos 03). “13 Temmuz 2009”, Ayın Tarihi, Madde 7, http://www.byegm.gov.tr/ayin-tarihi.aspx

- $\quad$ TAP AG. (2013a, March 13). TAP Continues to Receive Strong Political Support in South Eastern Europe, http://www.trans-adriatic-pipeline.com/news/news/detail-view/article/408/

- $\quad$ TAP AG. (2013b, March 07). TAP and TANAP Enjoy Close Cooperation, Following Signing of MoU in November 2012, http://www.trans-adriatic-pipeline.com/news/news/detail-view/article/384/

- The Economic Times. (2008, June 04). “Azerbaijan to Nearly Double Gas Production by 2015”, The Economic Times, http://articles.economictimes.indiatimes.com/2008-06-04/news/28469959_1_gasproduction-oil-production-oil-and-gas

- Today.Az. (2006, June 16). Kazakh Leaders Signed Agreement on Kazakh Oil's Delivery via BTC, http://www.today.az/news/business/27333.html

- United Press International. (2008, November 25). Azerbaijan to Host Turkmeistan's Gas, http://www.upi.com/business_news/energy-resources/2008/11/25/azerbaijan-to-host-turkmenistans-gas/upi$60861227648317 /$

- Upstream. (2008, November 28). Caspian Pair Look at Export Options, http://www.upstreamonline.com/live/article167078.ece 


\title{
Trans-Anadolu Doğal Gaz Boru Hattı Projesi'nden Ekonomik ve Stratejik Beklentiler
}

\section{Economic and Strategic Expectations of Trans-Anatolian Natural Gas Pipeline Project}

\author{
Assoc. Prof. Dr. Osman Nuri Aras (Fatih University, Turkey) \\ Ph.D. Candidate Elchin Suleymanov (Qafqaz University, Azerbaijan) \\ Assoc. Prof. Dr. Fakhri Hasanov (Qafqaz University, Azerbaijan)
}

\begin{abstract}
The Republic of Azerbaijan is one of the oil and gas rich countries of the former Soviet Union. After the second stage of the Shah Deniz gas field, natural gas extraction and exportation became one of the key elements of Azerbaijan's oil and gas strategy. Diversification of the oil and gas transportation has a great importance in Azerbaijan's energy security policy and in this regard, TANAP is an important project after Baku-Tbilisi-Ceyhan oil pipeline. TANAP is a proposed natural gas pipeline project to transport Azerbaijani natural gas through Turkey to Europe in two directions. The project was firstly announced on 17 November 2011 at the Third Black Sea Energy and Economic Forum in Istanbul. It was launched in 2014 and will be expected to finish in 2018. TANAP will cost seven billion USD and will have the capacity of 23 billion cubic meters by 2023 and 31 billion cubic meters by 2026. This paper analyzes expected strategic and economic outcomes of TANAP.
\end{abstract}

\section{Giriş}

Bağımsızlık sonrası Azerbaycan'ın uluslararası şirketlerle petrol ve doğal gaz anlaşmaları yapması ve bu çerçevede ortak faaliyetler gerçekleştirmesi, ülkeye gelişmiş modern teknolojilerin getirilmesine, enerji sektörü altyapısının yeniden kurulmasına imkan sağlamıştır. Sovyetler Birliği döneminde Azerbaycan'ın doğal gaz sektörü petrol sektörünün bir hayli gerisinde kalmıştır(Suleymanov,Zeynalov,2009).Üretimine başlandığı tarihten itibaren Azerbaycan'da en fazla doğal gaz üretimi 17 milyar m³ ile 1981 y1lında gerçekleştirilmiştir.1980'lerde doğal gaz üretimi yıllık olarak 14 milyar $\mathrm{m}^{3}$ 'e çıkmıştır. Ancak 1990'dan itibaren üretim önemli düzeyde gerileme kaydederek geçen yüzyılın 60’lı yıllarındaki düzeyine inmiştir. 2007 yılına kadar üretilen doğal gaz ülke içi talebin sadece \%40’nnı karşılayabilmekteydi (Aras,2008;159). Üretimin ülke içi talebi karşılayacak seviyede olmaması nedeniyle Azerbaycan doğal gaz ithal edilmekteydi. Doğal gaz üretiminin 5-6 milyar metreküpe kadar gerilemesi sonucu, Azerbaycan Sovyetler döneminde Ermenistan ve Gürcistan'a doğal gaz ihraç ederken, 1990'dan itibaren Türkmenistan ve İran'dan doğal gaz ithal etmek mecburiyetinde kalmıştır (Aslanlı , 2004). Ancak bu ülkelerden doğal gaz ithalatını 1995'de durdurmuştur. 2000 yılında ise Rusya'dan ithal etmek üzere anlaşma yapmıştır. Rusya'dan doğal gaz ithali, 2006 yılı sonlarına kadar devam etmiştir.Azerbaycan'ın doğal gaza olan talebinin ülke içi üretim tarafından karşılanması, ancak 2007 yılında "Şah Deniz" yatağından doğal gaz elde etmeye başlanmasıyla mümkün olabilmiştir(Aras, Suleymanov, 2010).Azerbaycan'da 2007 yılında doğal gaz üretimi bir önceki yıla göre yaklaşı \%81 artışla 11 milyar metreküp olarak gerçekleşmiştir. 2008 yılındaki üretim artışı ile yıllık üretim hacmi yaklaşık 15 milyar metreküpe yükselmiştir. Yapılan hesaplamalara göre, 2015 yılına kadar Şah Deniz yatağından yılda yaklaşık 30 milyar metreküp doğal gaz elde edilecektir. 2007 yılından itibaren Bakü-Tiflis-Erzurum Doğal Gaz Boru Hattı ile doğal gaz ihracına başlanmıştır.(Sucayev,2003:36-37) “Azeri-Çırak-Güneşli(AÇG)" yataklarında petrol üretimine ve ihracına başlanmasının yanı sıra "Şah Deniz" yatağında da doğal gaz üretimine ve ihracına tam olarak başlanmasının ardından Azerbaycan, petrolün yanı sıra doğal gaz üretimiyle de yüksek düzeyde bir ekonomik kalkınma, yeniden yapılanma ve dünya ekonomisine entegre olma imkânına kavuşmuştur. Aynı zamanda Azerbaycan, Türkiye ve Avrupa ülkelerine doğal gaz ihracında, Rusya, Kuzey Afrika ve diğer doğal gaz üreticilerine rakip olmuştur.

Dünyada enerji ihtiyaçlarının karşılanmasında önemi her gün biraz daha artan doğal gaz, bütün enerji tahmin senaryolarında, özellikle elektrik üretiminde kendisine genişleyen bir yer sağlamaktadır. 2020 yılına kadar, elektrik enerjisi üretimi için kullanılan doğal gaz miktarının, toplam doğal gaz tüketiminin \%33'üne ulaşması beklenmektedir. (Suleymanov,Aras , 2012)Doğal gaz, santrallerde ekonomik olarak türbinlerin etkinliğini sağlamasının yanı sıra alternatifler arasında zararlı dışsallı̆̆ın (çevre kirliliği v.b.) daha düşük olması nedeniyle de tercih edilmektedir.(Sucayev,2003) Doğal gaz yakıldığında, kömür ve petrole göre daha az sülfür dioksit, karbon dioksit ve atık açığa çıkmaktadır. Dünya doğal gaz rezervleri son yirmi-yirmi beş yılda \%100'ün üzerinde bir artış göstermiştir. Söz konusu rezerv artışları Eski Sovyet Cumhuriyetleri'nde, Ortadoğu, Güney ve Orta Amerika ile Asya Pasifik bölgelerindeki ülkelerde görülmüştür. Antarktika dışında tüm kıtalarda doğal gaz üretilmektedir. Dünyada doğal gaz kaynaklarının bölgesel dağılımına bakıldığında rezervlerin petrole göre daha geniş bir alana yayıldığı görülmektedir. Ortadoğu, petrol rezervlerinin \%65'ine sahip olduğu halde doğal gaz rezervlerinin 
\%35'ine sahip bulunmaktadır (Suleymanov,Aras ,2012). Sınırlı petrol rezervlerine sahip bazı bölgeler doğal gaz kaynaklarının daha büyük bir kısmına sahiptirler.

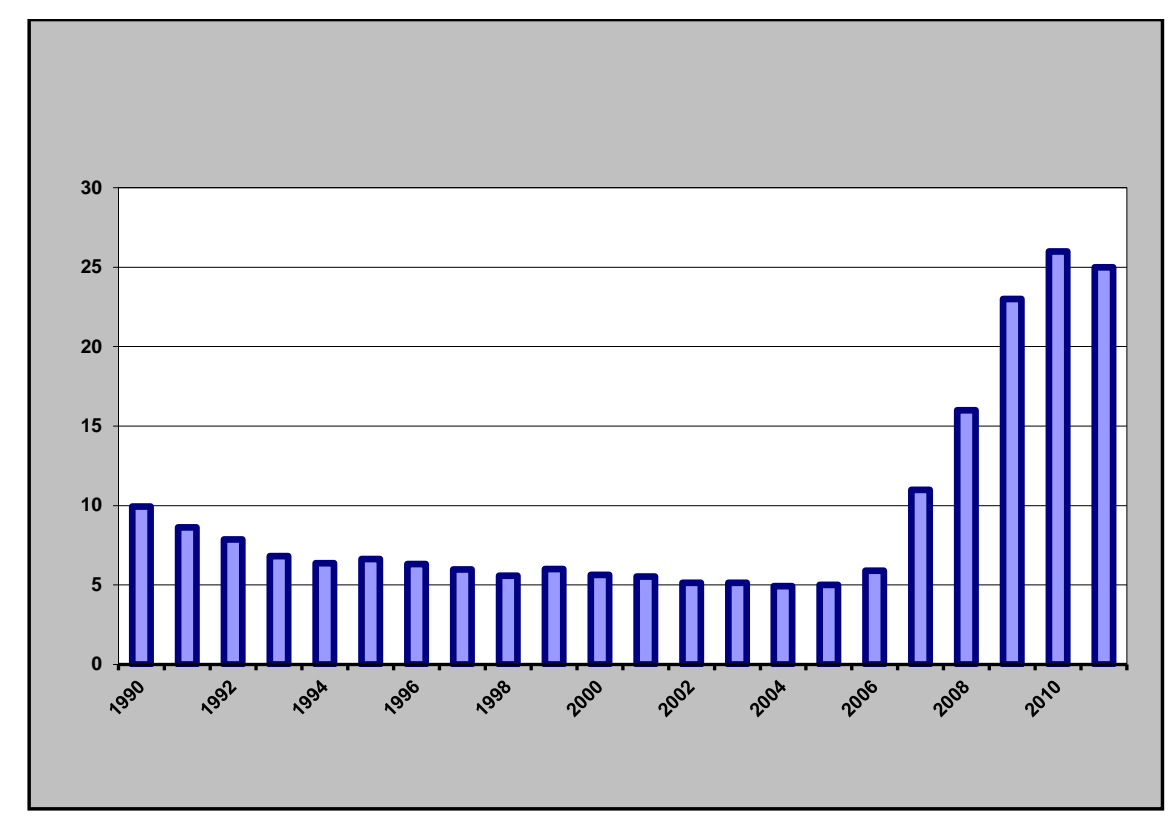

Grafik-1: Azerbaycanda Doğal Gaz Üretimi (milyarmetreküp)

\begin{tabular}{|l|l|l|l|l|}
\hline Bölge & $\begin{array}{l}\text { BP } \\
(2011 \text { sonu } \\
\text { itibariyle) }\end{array}$ & $\begin{array}{l}\text { CEDIGAZ } \\
\text { (Ocak-2011 } \\
\text { itibariyle) }\end{array}$ & $\begin{array}{l}\text { Oil \& Gas } \\
\text { Journal } \\
\text { 2011 (Ocak- }\end{array}$ & $\begin{array}{l}\text { World Oibariyle) }^{3} \text { (2011 } \\
\text { sonu itibariyle) }\end{array}$ \\
\hline Kuzey Amerika & 274.879 & 274.909 & 276.888 & 278.042 \\
\hline Merkezi ve Güney Amerika & 247.786 & 245.439 & 240.745 & 246.866 \\
\hline Avrupa & 200.541 & 234.421 & 180.301 & 182.761 \\
\hline Avrasya & $2,058.347$ & $2,020.866$ & $2,014.800$ & $2,040.742$ \\
\hline Orta Doğu & $2,546.048$ & $2,578.560$ & $2,566.038$ & $2,531.563$ \\
\hline Afrika & 507.826 & 508.819 & 484.433 & 490.882 \\
\hline Asya & 523.746 & 517.612 & 419.487 & 455.698 \\
\hline Dünya Toplamı & $6,359.172$ & $6,380.625$ & $6,182.692$ & $6,226.555$ \\
\hline
\end{tabular}

Tablo-1: Dünya Doğal Gaz Rezervi (Tcf) Kaynak: Energy Information Administration.

Bu bakımdan doğal gaz dünya enerji sahnesine, önemli bir yakıt olarak yeni girmiş sayılabilir. 1938'de kömür birincil enerji tüketiminin yaklaşık 3/4'ünü ve petrol \%21'ini oluştururken doğal gazın payı sadece \%5.6 idi. 1950 'de bu oran \%9.7'ye çıkmıştır. 1960'lı yıllarda doğal gaz tüketiminin coğrafi bölgeler itibariyle belirgin bir dağılımı meydana gelmiştir. 1965 'de toplam enerji tüketimindeki payı \%16'ya yükselmiştir. Bu oran 1970'de \%17, 1980'de \%19.1, 1990'da \%22.2, 1996 'da \%23.3 olarak gerçekleşmiştir. Günümüzde ise bu oran \%25 düzeydedir.Bir yandan dünya doğal gaz tüketimi hızla artış göstermekte, diğer yandan ise doğal gaz tüketiminin dünya enerji kaynakları tüketimi içerisindeki payı yükselmektedir. 1980 yılında 53 Tcf (1 kübik feet $=28,32 \mathrm{~cm}^{3}$; $1 \mathrm{~m}^{3}=35,3$ kübik feet), 1990 y1lında 73 trilyon kübik feet (Tcf) olan dünya doğal gaz tüketimi, 2000 y1lında 85 Tcf $\left(2,4\right.$ trilyon $\left.\mathrm{m}^{3}\right)$ seviyesine yükselmiştir. 2020 yılına kadar doğal gaz tüketiminin 167 Tcf'ye $\left(4,72\right.$ trilyon $\left.\mathrm{m}^{3}\right)$ ulaşması beklenmektedir. Yirmi birinci yüzyılın ilk çeyreğinde Rusya ve Orta Asya ülkeleri ile Ortadoğu bölgesi doğal gazda en önemli arz merkezleri olacaktır. Orta Asya ve Afrika kaynakları artan oranda uluslararası piyasalara çıkarak artan talebi karşılayacaktır. Türkiye ise Orta Asya doğal gazının Avrupa piyasalarına ulaşmasında köprü görevini görecektirBakü-Tiflis-Ceyhan Petrol Boru Hattı ile Bakü-Tiflis-Erzurum Doğalgaz Boru Hattı'nın ardından Azerbaycan'ın Hazar Denizi'nde yerleşen yataklarından üretilen enerji kaynaklarının Türkiye ve Batı piyasalarına nakli amacıyla Türkiye ve Azerbaycan arasında 27 Haziran 2012 tarihinde İstanbul'da yapılan Hükümetlerarası anlaşma ile gerçekleştirilmesine karar verilen üçüncü boru hattı projesi Trans Anadolu Doğalgaz Boru Hattı Projesi (TANAP) olmuştur. TANAP, yaklaşık 1,2 trilyon metreküp doğalgaz potansiyeline sahip olan ve Azerbaycan'ın Hazar Denizi’nde yerleşen Şahdeniz yatağının ikinci aşamasından elde edilecek olan doğalgazın Türkiye ve Avrupa'ya ihracını hedeflemektedir. Kimi ülkeler isteyerek kimi ülkeler istemeyerek, kimi ülkeler içten kimi ülkeler kerhen, kimi ülkeler sesliolarak kimi ülkeler "sükût 
ikrardandır” düşüncesiyle sessiz kalarak TANAP’a “evet” demişlerdir. TANAP’a denen bu “evet”ler, tedarikçi, talep edici, taşıyıcı ve bölge yerleşen ya da yerleşmeyen ama enerji kaynaklarının nakline ilgi duyan ülkeler bakımından hem yeni hem de önemli ekonomik ve stratejik sonuçlar ortaya çıkarmıştır.

$\mathrm{Bu}$ çalışmada, önce taraflarca Trans Anadolu olarak adlandırılan projenin inşası amacıyla Azerbaycan ve Türkiye arasında hükümetlerarası yapılan anlaşmaya kadar geçen süreç, projenin özellikleri ve aşamaları hakkında genel bilgiler verilecek, daha sonra çeşitli ülkelere bakan yönüyle söz konusu projenin ekonomik ve stratejik sonuçları analiz edilecektir.

\section{TANAP'a Giden Süreç}

Petrol stratejisinin başarıyla hayata geçirilmesinin ardından Azerbaycan, gaz ihracat politikası ile ilgili stratejik amaçlar belirlemeye başlamıştır. Azerbaycan, hâlihazırda uluslararası piyasalara (Türkiye, Rusya, Gürcistan) gaz ihraç eden, bölge genelindeki tek ülkedir. Bu nedenle de AB tarafından, Güney Gaz Koridoru'nun "sağlayıcı ve iştirakçi”si olarak görülmektedir.Bu strateji doğrultusunda, Azerbaycan, uzun vadede AB için önemli ve stratejik bir doğal gaz ihracatçısı ülke olmayı hedefliyor. Şah Deniz Sahası (SD) alanından Avrupalı son kullanıcılara, değer zincirinin her halkasında yer edinmeyi amaçlıyor.Proje Destek Anlaşması (PDA) üzerine gelişen SD II, 2036 yılına kadar geçerli olup, projenin ömrü bugünden itibaren 24 yıldır O zamana kadar SOCAR'ın (Azerbaycan Devlet Petrol Şirketi) sözleşme koşullarını veya hisse değerlerini mümkün olmayacaktır. Ancak bugün, hızla gelişen maddi gücü ve projedeki stratejik konumu ile değer zincirinde daha fazla hisse satın alması mümkündür. $\mathrm{Bu}$ durum, pay sahibi olduğu piyasaya gaz ulaştırarak altyapıyı kontrol etmesi adına SOCAR'a imkân sağlar.Bu aşamada Azerbaycan, net hammadde ihracatçısı olarak Türk-Avrupa sınırında sadece satıcı rolüyle yetinmek istemiyor. Gaz stratejik bir üründür ve bu ürün akıllıca kullanıldığı zaman SOCAR ile Azerbaycan önemli bir jeostratejik ve finansal konuma erişebilir. Gelecekteki muhtemel bağlantıları yönetmek gün geçtikçe daha da önemli hal almaktadır. Bu durum SOCAR'1 gelecek 20 yılki gaz firmaları ve Avrupa'nın temel yapısına bağlanmaktan; bu sayede de ekonomik ve politik manipülasyona maruz kalmaktan korumaktadır(Rzayeva,2012). Güney Kafkasya Boru Hattı (SCP) projesinin büyümesiyle, Azerbaycan potansiyel gaz hacmini kaynağından son kullanıcıya kadar kontrol ederek çıkarlarını korumuş olacaktır. Ancak bu düzenleme gaz ihracını yaygınlaştırma hedefinde olan bir ülkeyi tatmin etmeyecektir. Azerbaycan, gaz kaynakları olan bi SOCAR'ın böyle bir adım atmasının iki sebebi vardır. İlki, ölçeklenebilir altyapının 2017'den sonra SD gazını taşıyabilmesi ve 2025'ten sonra yeni keşiflerden çıkan gazla birlikte Azerbaycan gaz üretiminin her yıl 50 milyar metreküpe çıkması hedefidir(Rzayeva,2012).Bu tasarıların gerçekleşmesi halinde, oldukça yüksek hacimde gaz nakliSOCAR'ın Türk topraklarında, değerler zincirinin alt sıralarındaki çıkarlarını ileride muhafaza edebilmesi için yukarıda bahsedilen stratejinin geliştirilmesi ciddi bir gereklilik halini almıştır. 17 Kasım 2011'de Trans Anadolu Boru Hattı'nın ilanıyla gelen çözüm, Güney Gaz Koridoru'nda kaçınılmaz bir oyun değiştirici olmuştur. Beklenildiği üzere, Azerbaycan ve Gürcistan topraklarındaki yer değişimin ardından boru hattı, SCP'nin geliştirilmesi yoluyla Türk topraklarındaki Doğu Nabucco'yu değiştirecektir.Trans Anadolu Boru Hattı (TANAP) ilk olarak Ekim 2011'de TürkiyeAzerbaycan transitmüzakereleri esnasında "aniden gündeme gelmiş" ve 25 Ekim 2011 tarihinde IGA'daki (Hükümetlerarası Anlaşma) "ilave bir madde" ile güvence altına alınmıştır. Sonrasında 24 Aralık 2011'de TANAP için Mutabakat Zaptı (MOU) ve 26 Haziran 2012'de özel IGA imzalanmışt Her iki tarafın da kabul ettiği üzere, TANAP aracılığıyla Türk piyasasına 6 milyar metreküp gaz ihraç edilmesi şartının metne eklenmesi SOCAR açısından önemliydi. 6 milyar metreküp gaz olmaksızın TANAP'ın hayata geçirilmesi mümkün değildir. Çünkü 56 inç ve 31 milyar metreküp kapasiteli boru hattı, yalnızca 10 milyar metreküplük bir başlangıç hacmi ile ekonomik açıdan uygun olmayacaktır. Bu sebeple Türk Meclisi tarafından onaylanmış olan 25 Ekim 2011 tarihli IGA'nın "transit" başlıklı kısmı ve aynı tarihte imzalanan BOTAŞ-SOCAR Transit Gaz Anlaşması (GTA) gayri resmi manada TANAP projesi için "uygulanamaz" hükmündedir. Azerbaycan ve Türk hükümetlerince TANAP ciddi manada desteklenmektedir. Ayrıca TANAP İngiltere, ABD, AB ve hatta Trans Adriyatik Boru Hattı (TAP) ile Nabucco konsorsiyumları tarafından da desteklenmektedir. BP ise farklı yaklaşımlardan ötürü hem TANAP hem de BOTAŞ şebekesini desteklemektedir.TANAP'a karar verilmesi ve inşassına başlanmasına ilişkin süreçte dikkat çeken dört aşama bulunmaktadır. Aşağıda bu dört aşama ayrı ayrı ele alınacaktır

\section{1 Ön Anlaşma}

Hazar Denizi'nin Azerbaycan sektöründe yer alan Şahdeniz yatağından ikinci aşama olarak elde edilecek olan doğalgazın hem Türkiye tarafından satın alınması hem de Avrupa piyasalarına Türkiye üzerinden transit olarak naklini öngören Hükümetlerarası Anlaşma, Azerbaycan ve Türkiye arasında 25 Ekim 2011 tarihinde İzmir'de imzaland1.

İzmir-Aliağa'da Azerbaycan Devlet Petrol Şirketi SOCAR ile TURCAS Enerji AŞ tarafindan yapılacak olan Star Rafinerisi'nin temel atma töreninin ardından Türkiye Cumhuriyeti Başbakanı Erdoğan ve Azerbaycan Cumhuriyeti Cumhurbaşkanı Aliyev'in de katılımıyla gerçekleştirilen toplantının ardından imzalanan bu anlaşmada, Azerbaycan doğalgazının Avrupa'ya transit taşınmasında iki farklı alternatif dikkate alınmıştır. Söz 
konusu alternatiflerden biri Türkiye'nin ulusal doğalgaz iletim sistemi, diğer alternatif ise münhasır bir boru hattının inşa edilmesi olmuştur. Hükümetlerarası anlaşma TANAP'a giden yolun temellerini atmıştır.

\subsection{Projenin Kamuoyuna İlk Duyurusu}

Trans Anadolu Doğalgaz Boru Hattı bir proje olarak ilk defa 17 Kasım 2011 tarihinde İstanbul'da düzenlenen Üçüncü Karadeniz Enerji ve Ekonomi Forumu'nda Azerbaycan Devlet Petrol Şirketi SOCAR (State Oil Company of Azerbaijan Republic) tarafından kamuoyuna açıklanmıştır. SOCAR Başkanı tarafından yapılan açıklamada, Azerbaycan'ın zengin doğalgaz potansiyelinin uzun vadede Türkiye ve Avrupa piyasalarına arz edilmek üzere, Türkiye'nin doğu sınırından başlayıp batı sınırına kadar uzanan Trans Anadolu Boru Hattı Projesi'ne ilişkin çalışmaların başladığını ifade etmiştir.

\subsection{Mutabakat Zaptı}

Yapılan ön anlaşmadan yaklaşık iki ay sonra Türkiye Cumhuriyeti Enerji ve Tabii Kaynaklar Bakanlığı ile Azerbaycan Sanayi ve Enerji Bakanlığı arasında, "Trans Anadolu Doğalgaz Boru Hattı” yapımına ilişkin mutabakat zaptı, 26 Aralık 2011 tarihinde Ankara'da imzalandı.

İmzalanan mutabakat zaptı ile Trans Anadolu ismi verilen söz konusu münhasır boru hattına yönelik çalışmaların ivedilikle başlatılması ve iki ülke tarafından tayin edilen şirketlerin ortak bir konsorsiyum tesis etmeleri konusunda mutabakat sağlandı.

Münhasır boru hattının inşasına ilişkin teşkil edilecek olan konsorsiyum içerisinde Azerbaycan Devlet Petrol Şirketi SOCAR ve Türkiye'den Boru Hatları ile Petrol Taşıma Anonim Şirketi BOTAŞ ile Türkiye Petrolleri Anonim Ortaklığı TPAO'nun ilk ortaklar olarak yer alması kararlaştıılmıştır. Mutabakat zaptında süreç içerisinde diğer uluslararası petrol ve doğalgaz şirketlerinin de konsorsiyuma dahil olabilecekleri dikkate alınmıştır.

Böylece imzalanan mutabakat zaptı ile 26 Ekim 2011 tarihli anlaşma daha somut hale getirilmiş oldu.

\subsection{Nihai Anlaşma}

Azerbaycan'ın Şahdeniz-2 doğalgazının Türkiye ve Avrupa'ya ihracına münhasır yeni bir hattın Trans Anadolu adı altında inşası amacıyla Türkiye ve Azerbaycan arasında tarihi işbirliğine yönelik olarak 27 Haziran 2012 tarihinde İstanbul'da yapılan üç anlaşma ile adım atılmıştır. Söz konusu anlaşmalar projeye ilişkin hükümetlerarası anlaşma, ev sahibi ülke anlaşması ve boru hattına ilişkin mutabakat zaptından oluşmaktadır.

TANAP Hükümetlerarası Anlaşma:Sahip olduğu rezerv miktarı bakımından dünyanın önemli doğalgaz yataklarından olan Şahdeniz-2'den elde edilecek doğalgazı Türkiye üzerinden Avrupa'ya ulaştıracak olan TANAP'a iliş̧in hükümetlerarası nihai anlaşma ise 27 Haziran 2012 tarihinde İstanbul'da imzalandı.

Ev Sahibi Ülke Anlaşması:Türkiye Cumhuriyeti Hükümeti ile Trans Anadolu Doğalgaz Boru Hattı Şirketi arasında,hem Türkiye'nin hem de Avrupa'nın doğalgaz ihtiyacının karşılanması bakımından önemli bir katkıda bulunacak olanTrans Anadolu Doğalgaz Boru Hattı sistemine ilişkin ev sahibi ülke anlaşması Enerji ve Tabii Kaynaklar Bakanı Taner Yıldız ile SOCAR Başkanı Rövnag Abdullayev tarafından imzalandı.

Hatta Ilişskin Mutabakat Zaptı:Azerbaycan'ın Şahdeniz-2 doğalgaz yatağından elde edilecek olan doğalgazı Türkiye'nin yanı sıra Türkiye üzerinden Avrupa'ya ulaştıracak olan Trans Anadolu Doğalgaz Boru Hattına ilişkin mutabakat zaptı da SOCAR Başkanı Rövnag Abdullayev ile BOTAŞ Genel Müdür Vekili Mehmet Konuk tarafından imzalandı. Anlaşma iki ülke enerji bakanlarının tanıklığında imzalandı.

\section{Projenin Genel Özellikleri}

TANAP boru hattı, Azerbaycan doğalgazının Gürcistan'dan geçerek Türkiye üzerinden satılmasını ve naklini öngörmektedir. Giriş noktası Türkiye sınırı Türkgözü girişi olan hattın Türkiye içi çıkış noktaları Eskişehir ve Trakya bölgesi olacaktır. Hattın Türkiye'den Avrupa'ya çıkış noktaları ise Yunanistan ve/veya Bulgaristan sınırları olacaktır. Yani hattın Avrupa'ya çıkışına ilişkin güzergâhı henüz tam olarak kararlaştııılmamış olmakla birlikte bir kolunun Yunanistan'a diğer kolunun ise Bulgaristan'a ulaşması düşünülmektedir.

Trans Anadolu Doğalgaz Boru Hattı Projesi’nin yatırım maliyetinin yaklaşık 7 milyar dolar olacağı tahmin edilmektedir. Yıllık kapasitesinin 31 milyar metreküpe kadar çıkması planlanan projenin ilk aşamasının altı yıl içinde tamamlanması hedeflenmektedir.

TANAP için oluş̧urulan konsorsiyumda Azerbaycan'dan Azerbaycan devlet petrol şirketi SOCAR ile Türkiye'den BOTAŞ ve TPAO ilk ortaklar olarak yer almaktadır. TANAP Konsorsiyumunda Türkiye adına BOTAŞ ve TPAO $\% 20$ paya, Azerbaycan adına SOCAR ise $\% 80$ paya sahiptir.

Projenin dört aşamada gerçekleştirilmesi öngörülmüştür:

Hattın Faaliyete Geçiş Aşaması: Proje için öngörülen dört aşamanın ilki 2018'de ilk doğalgaz akışıyla gerçekleşecektir. İlk aşamada Şahdeniz doğalgazının Gürcistan'dan geçerek Türkiye'ye satılması öngörülmektedir. Yani boru hattının faaliyete geçeceği ilk aşama olan 2018'de Türkiye yılda 6 milyar metreküp doğal gaz satın alacaktır. 
Hattın Kapasitesinde Birinci Artış Aşaması: İkinci aşama olarak 2020'de hattın kapasitesinin yıllık 16 milyar metreküpe ulaşması hedeflenmektedir. Bu aşamada Şahdeniz-2 Konsorsiyumu'nun üreteceği 16 milyar metreküplük doğalgazın, 6 milyar metreküplük kısmı Türkiye’ye satılacak, 10 milyar metreküplük kısmı ise Avrupa'ya ihraç edilecektir.

Hattın Kapasitesinde İkinci Artış Aşaması: Üçüncü aşamada ise 2023 yılında hattın kapasitesinin yıllık 23 milyar metreküp ile ulaşması hedeflenmektedir.

Nihai Aşama: Nihayet dördüncü aşamada 2026 yılında hattın kapasitesinin yıllık 31 milyar metreküpe kadar ulaşması hedeflenmektedir.

Sonraki aşamalarda doğalgaz kaynak ve ihtiyaç değişimine bağlı olarak, TANAP projesi kapsamında doğalgazın yıllık ihracının 50 milyar metreküpe kadar ulaşması hedeflenmektedir.

\section{TANAP'in Ekonomik Sonuçları}

Şahdeniz-2 doğalgazının Avrupa piyasalarına nakline ilişkin dört farklı alternatif proje gündeme getirilmişti. Bu projeler "Büyük Nabucco", "Trans-Adriyatik", İTGİ (Türkiye-Yunanistan-İtalya) ve SEEP (Güney Doğu Avrupa) projeleriydi. Avrupa Birliği ve ABD tarafından destek verilen proje ise Büyük Nabucco Projesiydi. Bu projenin finansmanına ilişkin yaşanan sorunların, belirsizliklerin yanı sıra stratejik açıdan yapacağı etkilerden dolayı bazı ülkelerin karşı çıkması, bazı ülkelerinde taraf olup-olmama noktasında görüş beyan etmeme durumu söz konusuydu. Hatta kaynak sağlayıcı ülkelerin başında yer alan Azerbaycan'ın da görüşü ekonomik ve stratejik nedenlerle belirsizlik taşımaktaydı. TANAP'a ilişkin Türkiye ve Azerbaycan arasında yapılan nihai anlaşmanın ardından Nabucco Konsorsiyumu Büyük Nabucco'yu Nabucco Batı Projesi olarak revize etmek zorunda kaldı. Revizyon sonucu 3440 kilometre olarak öngörülen Büyük Nabucco'nun Türkiye kısmının TANAP'a dönüşmesiyle, Nabucco Batı Projesi kısalmış oldu. Nabucco Batı Doğalgaz Boru Hattı’nın öngörülen uzunluğu ise 1300 kilometredir. Nabucco Konsorsiyumu'nun TANAP'a olumlu bakışı ve Avrupa piyasalarına Şahdeniz-2 doğalgazının ihracı amacıyla TANAP'a ek olarak teklif ettiği Nabucco Batı Projesi de Azerbaycan tarafından kabul edilmiş oldu.

Azerbaycan bakımından ise ülkenin sahip olduğu doğalgaz kaynaklarının yeni piyasalara ihracında büyük ekonomik kazanımları beraberinde getirmektedir.TANAP'taki hissenin \%80'inin Azerbaycan'a ait olduğu son duruma göre Azerbaycan doğalgazını Türkiye arazisinden kendisi taşımış gibi olacaktır. Zira Azerbaycan doğalgazın Avrupa piyasalarına naklinden elde edilecek geliri de kedisi elde etmek istiyordu. Böylece Azerbaycan'ın uzun yıllar Büyük Nabucco'ya olumlu bakmamasının önündeki ekonomik engellerden biri de aradan kalkmış oldu. Yani Azerbaycan Şahdeniz-2 doğalgazının Avrupa piyasalarına hem satışından hem de naklinden gelir elde edecektir.

Bu projenin gerçekleştirilmesine ilişkin çalışmalar Türkiye'de yeni istihdam imkânlarının oluşması bakımdan önem taşımaktadır. Azerbaycan ve Türkiye işbirliği ile Petkim'de de büyük bir rafineri projesinin temeli atılmıştır. İki büyük proje dikkate alındığındaSOCAR olarak Türkiye'ye Azerbaycan'ın yapacağı yatırım miktarı 17 milyar dolara ulaşacaktır. Böylece Türkiye sanayisine yatırım yapan en büyük ülke Azerbaycan, en büyük şirket de SOCAR olacaktır. Bakü-Tiflis-Ceyhan ve Bakü-Tiflis-Erzurum Boru Hatları'nın ardından, TANAP ve Petkim'de rafineri projesine ilişkin Türkiye ile yaptı̆̆ı anlaşmalarla Azerbaycan, Türkiye'nin bölgede hem enerji koridoru olma hem de enerji üssü olmasına önemli ekonomik ve stratejik katkıda bulunmuş olmaktadır.

Ekonomik olarak çeşitli açılardan önem taşıyan bu projenin gerçekleşmesidurumunda, bu hattan gelecek doğalgazın bir kısmı (6-10 milyar metreküp) Türkiye pazarında kalacak, önemli bir kısmı (10-25 milyar metreküp) ise Avrupa ülkelerine satılacaktır. Türkiye içi çıkış noktaları dikkate alındığında, Trans Anadolu Hattı Türkiye Ulusal İletim Hattının batı girişini besleyerek, batı bölgesi arz güvenliğini kuvvetlendirecek bir hat olacağı da görülmektedir.

\section{TANAP'ın Stratejik Sonuçları}

Büyük Nabucco Projesinin, TANAP ve Nabucco Batı olarak iki kısma ayrılmasının ekonomik nedenlerinin dışından stratejik bazı sonuçları da söz konusudur. TANAP başta Türkiye ve Azerbaycan olmak üzere bölge ülkeleri ve Avrupa ülkeleri bakımından çok büyük stratejik öneme sahiptir.

Uygun fiyat ve tanımlanmış doğalgaz kapasitesi dikkate alındığında kaynak ve güzergâh çeşitlendirmesi dolayısıyla enerji arz güvenliğine katkıda bulunması bakımından Türkiye ve Avrupa Birliği ülkeleri için TANAP büyük önem taşımaktadır.

Büyük Nabucco'ya Avrupa Birliği ve ABD’nin destek verirken, Rusya ise hep karşı çıkmıştır. Bu ise hattın temel tedarikçisi Azerbaycan için yönetilmesi zor bir süreci karşısına çıkarmıştı. Adeta iki ateş arasında kalan Azerbaycan'ın Türkiye ile işbirliğine giderek TANAP'ı gündeme getirmesi ve bu projeye ilişkin anlaşmaların imzalanması hem Batı'nın, hem de Türkiye arazisinde Batı'nın stratejik üstünlüğe sahip olmasını istemeyen Rusya'nın Azerbaycan üzerindeki baskısını elimine edici olmuştur. Zira Büyük Nabucco yerine Nabucco Batı'ya “evet” demekle Avrupa'nın taleplerini bir bakıma karşılamış olan Azerbaycan'ın, TANAP çerçevesinde Türkiye 
arazisinden doğalgazın nakline Nabucco Konsorsiyumu'nu dahil etmeyerek boru hattını daha çok kendi elinde tutacak olmasıyla da Rusya'yı bir nebze teskin etmiştir. Ancak ne Avrupa Birliği Şahdeniz doğalgazının kendi piyasalarına ihracı konusunda Türkiye arazisinde söz sahibi olabilmiştir, ne de Rusya Şahdeniz doğalgazının Avrupa piyasalarına nakline Türkiye üzerinden engel olabilmiştir. Dolayısıyla Büyük Nabucco'nun TANAP ve Nabucco Batı olarak iki projeye dönüşmesi hem Avrupa Birliği ve ABD'nin hem de Rusya'nın hedeflerine tam olarak ulaşmasına imkân vermemiştir. Aksine projelerin hayatiyet kazanması durumunda Türkiye ve Azerbaycan söz konusu ihraçta daha üstün konuma gelmiş olacaktır. Trans Anadolu Boru Hattı gelecekte Türkmen gazının Türkiye ve Avrupa'ya nakline yönelik alternatif bir hat olma özelliğini de potansiyel olarak taşımaktadır. Dolayısıyla stratejik açıdan düşünüldüğünde zamanla Hazar Havzası doğal gazının, hatta Orta Doğu ülkelerinde üretilecek olan doğalgazın da batı piyasalarına ihracında Türkiye ile birlikte Azerbaycan'ın da söz sahibi olması gibi bir durum da ortaya çıkacaktır.

Nabucco Batı Boru Hattı ile Güney Doğu Avrupa ülkelerinin hemen hemen tümünün doğalgaz ihtiyacının karşılanması hedeflenmektedir. Şahdeniz yatağındaki doğal gaz potansiyeli 1,2 trilyon metreküp olan Azerbaycan'ın sahip olduğu diğer kaynaklardaki doğalgaz potansiyeli ise yaklaşık 2,6 milyon metreküptür.Şahdeniz yatağının yanı sıramevcut ve muhtemel diğer doğalgaz yataklarının potansiyeli de dikkate alındığında Azerbaycan'ın 2020-2025 arasında doğal gaz üretiminin 50 milyar metreküpe ulaşacağı tahmin edilmektedir. Bu tahminler Nabucco Batı vasıtasıyla Avrupa piyasalarına daha fazla miktarda doğalgazın ihracı için Azerbaycan’ı önemli bir doğalgaz tedarikçisi konumuna getirmektedir.

Aslında yukarıda Azerbaycan'ın Şahdeniz-2 doğalgazının hem ekonomik hem de stratejik açıdan kendi ülkesinin menfaatleri istikametinde naklini netice verecek şekilde doğalgaz nakil hattının Büyü Nabucco yerine TANAP olarak gerçekleşmesinde etkin olduğugibi bir sonuca varılmıştır. Böyle bir sonuç, Şahdeniz-2 doğalgazının ihracına münhasır boru hattı konusunda temel belirleyici ülkenin Azerbaycan olduğu gibi bir algıyı da oluşturmakta veya böyle bir algıya da dayanmaktadır. Şayet bölge enerji kaynaklarının üretim ve uluslararası piyasalara naklinde en etken olan gücün Rusya olduğu kabul edildiğinde ise süreç ve sürecin ekonomik ve stratejik sonuçları farklı olmaktadır: Hazar Havzası ve Orta Asya enerji kaynaklarının üretimini ve daha çok uluslararası piyasalara naklini kendi ülke topraklarından geçecek boru hatları ile kontrol etmeyi stratejik hedefleri arasında ön sıraya yerleştiren Rusya, söz konusu stratejik hedefleri doğrultusunda karşı olduğu Büyük Nabucco projesinin gerçekleşmemesi için büyük çaba harcamış ve bölgede aktif bir politika izlemiştir. Rusya'nın izlediği Büyük Nabucco karşıtı politika doğrultusunda bölgede doğalgaz tedarikçisi konumundaki Azerbaycan, Kazakistan ve Türkmenistan ile yapmış olduğu anlaşmalar Büyük Nabucco’ya tedarik konusunda endişeleri artırmıştır. (Gültekin,2012) Yapılan anlaşmaların da verdiği güçle Rusya daha sonra, Ukrayna'yı devre dış1 bırakacak şekilde Karadeniz altından geçerek Bulgaristan, Macaristan, Sırbistan ve Slovakya üzerinden Batı Avrupa’ya doğal gaz taşımak üzere Güney Akım adlı Doğalgaz Boru Hattı Projesi’ni inşa etmek üzere harekete geçmiştir. Güney Akım Hattı'nın 900 kilometrelik kısmı Türkiye'nin Karadeniz'deki münhasır ekonomik bölgesinden geçmektedir. Güney Akım'ın Türkiye'nin Karadeniz'deki münhasır ekonomik bölgesinden geçmesi için Türkiye ile anlaşan Rusya, Şahdeniz-2 doğalgazının sadece Azerbaycan ve Türkiye ortaklığı ile Türkiye'nin batı sınırına kadar ulaştırılmasına da kerhen de olsa "evet" demiş, ya da ses çıkarmayarak onay vermiştir. Böyle bir yorum, Azerbaycan’ın gündeme geldiği günden itibaren Büyük Nabucco’ya ilişkin kanaatinin hep belirsizlik taşımasının arakasındaki nedenin, Rusya'nın Büyük Nabucco'ya karşı olduğu sonucunu doğurmaktadır. (Gültekin,2012) Azerbaycan'ın ekonomik menfaatleriyle örtüşecek şekilde TANAP'ın inşasına yönelik Azerbaycan ve Türkiye arasında nihai anlaşmaların atılmasının ise, Rusya'nın Güney Akım konusunda Türkiye ile anlaşmasından sonraya denk gelmesi, süreçte en etkin gücün Rusya olduğu kanaatini ve sonucunu desteklemektedir.Rusya tarafından Nabucco ve TANAP'1 Güney Akım için rakip olarak görülmediği açıklaması yapılmıştır. Şahdeniz-2 doğalgazının Türkiye üzerinden ihracına engel olamayacağını anlayan Rusya, bir yandan Güney Akım için Türkiye'yi ikna etmiş, bir yandan da Şahdeniz gazının Türkiye topraklarından nakline ilişskin boru hattı konusunda Büyük Nabucco’ya göre “ehveni şer” olan ve Rusya'nın stratejik hedefleri doğrultusunda Şahdeniz doğalgazının ihracı konusunda Nabucco Konsorsiyumu'nun Türkiye arazisinde söz sahibi olmasını önleyen, dolayısıyla Büyük Nabucco Hattı'nın yaklaşık \%70'ini devre dışı bırakanTANAP'a engel olmayacak şekilde Azerbaycan'a inisiyatif kullanma alanı bırakmıştır.

Projenin sadece Türkiye ve Azerbaycan'ın finans ve teknik imkânlarıyla yürütülecek olması, projeyi TürkiyeAzerbaycan özelinde gerçekleştirilecek bir proje konumuna getirmiştir. TANAP,Türkiye ve Azerbaycan'ın enerji nakli konusunda Avrupa pazarına birlikte çıkması anlamına da gelmektedir.

TANAP önceki Bakü-Tiflis-Ceyhan ve Bakü-Tiflis-Erzurum boru hatlarına ilave olarak Hazar Havzası enerji kaynaklarının Batı piyasasına ulaştırılmasında Türkiye'nin önemli bir alternatif enerji koridoru olduğuna ilişkin konumunu güçlendirmiştir.

Türkiye'nin Büyük Nabucco'da 1srar etmeyerek Trans Anadolu'ya “evet” demesinin, Türkiye'ye bakan yönüyle çeşitli stratejik sonuçları vardır. Bunlardan biri ve en önemlisi; Büyük Nabucco'nun gerçekleşmesinde gösterdiği aktif politika ile Türkiye, Avrupa Birliği’nin enerji arz çeşitliliği ve güvenliğine önemli katkıda bulunduğunu ve bu hususta üzerine düşeni fazlasıyla yapmaya çalıştığını ortaya koyarak, Avrupa Birliği ülkelerinin de Türkiye'nin AB'ye kabulünde olumlu katkıda bulunacak şekilde üzerine düşeni yapmalarını, 
böylece AB'ye üyelik konusunda önemli bir mesafe almayı hedefliyordu. TANAP'a "evet" demesiyle Türkiye Büyük Nabucco'ya da "hayır” demiş oldu. Dolayısıyla AB'ye kabul konusunda bir etki unsurundan vazgeçmiş gibi oldu. Aslında yaşanan süreçten anlaşıldığı kadarıyla Türkiye, AB’ye üyeliğini sağlayacak bir etki unsurundan vazgeçmekten daha çok $A B$ 'ye üyelikte 1srardan vazgeçmiştir. En azından, yaşanan son ekonomik krizin AB'deki devam eden olumsuz etkileri, Türkiye'yi AB'ye üye olmada eskisi kadar istekli olmamaya yöneltmiş, dolayısıyla Büyük Nabucco yerine TANAP’tan yana tavır almaya yöneltmiştir. Büyük Nabucco yerine TANAP'a “evet” diyen Türkiye, Azerbaycan'ın yanı sıra ve daha çok Rusya ile işbirliğine daha fazla önem verme yolunu da seçmiş oldu. Zira bir yandan Türkiye Rusya'nın Güney Akım projesine "evet” derken, diğer yandan da Rusya Azerbaycan'ın Türkiye ile işbirliği içerisinde TANAP'ı inşasına kerhen de olsa "evet" demiş oldu.

\section{TANAP'in NABUCCO'ya Etkisi}

TANAP'ın inşasına ilişkin hükümetlerarası anlaşma, orijinal ya da Büyük Nabucco olarak adlandırılan projenin tamamen rafa kaldırılıp-kaldırılmadığı hususunda önem taşımaktadır.TANAP ile ilgili anlaşmanın imzalanması Nabucco için bir engel teşkil etmemekle birlikte, Büyük Nabucco Projesi yerini Nabucco Batı ve TANAP'a bırakmış olmaktadır.

Avusturya'nın OMV, Almanya'nın RWE, Macaristan'ın MOL, Türkiye'nin BOTAŞ, Bulgaristan'ın Bulgarian Energy Holding (BEH) ve Romanya'nın Transgaz şirketlerinin desteklediği Nabucco Batı Projesi'ne ilişkin teklif 16 Mayıs tarihinde Şahdeniz-2 Konsorsiyumu'na sunuldu. Şahdeniz-2 Konsorsiyumu 28 Haziran 2012'de yaptığı açıklamayla Azerbaycan'ın Şahdeniz-2 yatağından Avrupa’ya doğalgaz aktarımı için Nabucco Batı Projesi'ni uygun gördüğünü açıkladı. Türkiye, BOTAŞ vasıtasıyla Nabucco Batı Projesi'nin ortaklarından birisidir.

1300 kilometre uzunluğundaki Nabucco Batı Doğalgaz Boru Hattı, Türkiye-Bulgaristan sınırı yakınlarından başlayarak, geçiş ülkelerindeki istasyonlar aracılığıyla Bulgaristan, Romanya ve Macaristan üzerinden Avusturya'ya doğalgaz taşıyacaktır.

Büyük Nabucco projesinde yaşanan finansman sorununun Nabucco Batı projesinde yaşanmaması beklenmektedir. Nabucco Konsorsiyumu'nun Azerbaycan doğalgazının Avrupa'ya taşınması için Büyük Nabucco Projesi'nin kısaltılmış ya da küçültülmüş versiyonu olan Nabucco Batı'ya desteği sürmektedir. Nabucco Konsorsiyumu Avrupa Yatırım Bankası (EIB), Avrupa Kalkınma Bankası (EBRD) ve Uluslar arası Finans Kurumu (IFC) ile bir ön anlaşma yapmış bulunmaktadır.

Nabucco Batı ve TANAP'ın birbiriyle bağlı bir tedarik hattı oluşturacaktır. Birbirini tamamlayıcı olmaları yönüyle iki hat birlikte düşünüldüğünde, Avrupa'nın enerji arz çeşitliliği ve güvenliği açısından büyük bir önem taşımaktadırlar.

Nabucco Batı Boru Hattı ile artmakta olan doğalgaz talebini karşılamak amaciyla uzun vadede 23 milyar metreküp doğalgazın Avrupa ülkelerine nakli hedeflenmektedir. Konsorsiyum tedarik ve ihtiyaca bağlı olarak kapasite artımını da dikkate almaktadır.

Nabucco Batı'nın ihraç kapasitesi bakımından hedeflenene ulaşması için Azerbaycan'ın yanı sıra Orta Asya ve Ortadoğu doğalgaz kaynaklarının da tedarik zincirine eklenmesi gerekmektedir. Bu doğrultuda Kuzey Irak'ta keşfedilmeyi bekleyen doğalgaz yataklarının, hatta Türkmen doğalgazının Türkiye üzerinden Avrupa'ya ulaştırılmasına ilişkin adımların atılması gerekmektedir.

Kuzey Irak’ta doğal gazın keşfedilmesi durumunda, bu doğal gazın Türkiye üzerinden Avrupa'ya transferi için elbette yeni bir boru hattına da ihtiyaç duyulacaktır.

\section{Sonuç}

Kısaca Hazar Havzası, Orta Asya ve Orta Doğu enerji kaynaklarının dünya piyasalarına ihracı ve ihracına münhasır boru hatlarının, ülkelerin ekonomik ve stratejik menfaatlerini maksimize edecek mahiyette rekabete ve mücadeleye konu olması, TANAP ile yeni bir boyut kazanırken, söz konusu rekabet ve mücadele bundan sonra da ülkelerin vizyon ve stratejilerine bağlı olarak devam edecektir.Özellikle Hazar enerji resurslarının farklı güzergahlarla taşınması ülke ekonomisinin bir ülkeden bağımlı olması problemini azaltmaktadır. TANAP konsorsiyumunun şirket olarak Hollanda merkezli işlerini ise Türkiye'de kuracağı şube üzerinden gerçekleştirecektir. Bilerek ya da bilmeyerek, Güney Akım AG firması da yeniden Hollanda'ya taşınacaktır. Rusya ve Gazprom agresif bir şekilde büyük Güney Koridor Projesi'nin bir parçası olan Batı Nabucco Projesi'yle hemen hemen aynı piyasa ve istikamete sahip Güney Akım Projesi'nin gerçekleşmesi için uğraşmaktadır. Güney Koridor'la rekabet içerisinde olan Güney Akım konsorsiyumu, Orta ve Güney Doğu Avrupa piyasasında irtibat halinde olduğu ülkelerle Transit Gaz, IGA ve alım satım anlaşmaları imzalamak için acele etmektedir. Güney Akım ve bazı Orta Avrupa ülkeleri arasında anlaşmalar söz konusudur. Bu ülkeler ya Güney Akım'la birlikte Rusya'ya bağımlılıklarını artırmak istememekte, ya da anlaşmaları olsa bile fizibilite çalışmaları aracılığıyla başlangıç tarihini ertelemekte ve Başlangıç Aşaması Mühendislik Dizaynı (FEED) 
sayesinde yeşil ışık yakmak için Rusya'dan ciddi teşvik primleri almaktadırlar. Bulgaristan Nisan ayından Aralık 2012'ye kadar Gazprom'dan \%11 gaz indirimi elde etmiştir. Açıkça görülüyor ki bunun karşıllğında Rusya, Bulgaristan'dan Başlangıç Aşaması Mühendislik Dizaynı için onay alacaktır.Sırbistan 5 milyar metreküp gaz için 10 yıllığına Gazprom'la bir alım satım anlaşması imzalamıştır. Sonuç olarak Avrupa piyasası gayri resmi biçimde Gazprom ve SD konsorsiyumu arasında bölünmüş durumdadır: Orta Avrupa Gazprom'a ait, Batı Balkanlar ve İtalya ise SD konsorsiyum öncülüğünde BP ve SOCAR'a aittir.Türkiye açısından, hızla büyüyen gaz talebini karşılamak için 6 milyar metreküplük SD II gazı net biçimde yeterli olmayacaktır. Türkiye bu durumdan endişe etmekte ve İran'la Rusya'dan sağlanan gaz teminini çeşitlendirmeyi amaçlamaktadır. Kuzey Irak bu durumda Türk gaz piyasası için anahtar rolü görmektedir. Her ne kadar Irak gazı TANAP'la Türkiye'ye yahut ileri de Batı istikametlere ulaştırılmayacak olsa da, Türkiye şu anda bütünüyle Kuzey Irak gaz sahasına ilişkin gelişmelere odaklanmış durumdadır ve Türk enerji firmaları bu alanlarda devasa yatırımlar yapmaktadirlar.

\section{Kaynakça}

- $\quad$ ARAS Osman Nuri, Azerbaycanın Hazar Ekonomisi ve Stratejisi, Derin Yayınları, İstanbul, 2008.

- $\quad$ ARAS Osman Nuri, Elçin Süleymanov, Azerbaycan Ekonomisi, Şark-Garb Matbaası, Bakü, 2010.

- $\quad$ ASLANLI Araz, "Bakü-Tiflis-Ceyhan: Petrolün Ötesinde Önem Taşıyan Hat”, TUSAM Ulusal Güvenlik Stratejileri Araştırma Merkezi, 05.10.2004, http://www.tusam.net/makaleler.asp?id=48\&sayfa=53. (25.12.2007). ss.36-37

- Azerbaycan Devlet Statistik Kurumu Verileri 2012, Azerbaycan Regemlerle 2012, http://www.azstat.org(25.02.2013).

- Dr. Burcu Gültekin Azerbaycan-Türkiye İlişkilerinde Bir Adım: Trans Anadolu Boru Hattı (TANAP) Hazar Raporu Ekim-Aralık 2012 Hazar Stratejık Araştırmalar Enstitusu Yayını No 1.

- $\quad$ GELB Bernard A., Caspian Oil and Gas: Production and Prospects, CRS Report for Congress, 8 September 2006.

- Gulmira Rzayeva TANAP - Hazar Gazını Avrupa’ya Taşıyan Atılım Projesi Hazar Raporu Ekim-Aralık 2012 Hazar Stratejık Araştırmalar Enstitusu Yayını No 1.

- SUCAYEV Fikret, “Azerbaycanda Qaz Hasilatı ve Ona Olan Telebatın Ödenilmesinin Başlıca İstiqametleri”, Azerbaycan Müsteqillikden Sonra Beynelhalq Konfrasın Materiallarl, Bakl, 3-4 Mart 2003,

- Suleymanov, Elchin and Aras, Osman Nuri, The Importance of Azerbaijan's Energy Revenues in Its Exports Volume and the Effects on the National Economy (October 12, 2012). International Conference on Eurasian Economies 11-13 October 2012 - Almaty, KAZAKHSTAN, səhifə/səhifə aralığg: 225-232, Okt 2012. Available at SSRN: http://ssrn.com/abstract=2167935 or http://dx.doi.org/10.2139/ssrn.2167935

- Suleymanov, Elchin and Zeynalov, Ayaz, Azerbaycan Ekonomisinin Bagimsizlik Sonrasi Makroekonomik Gostericilerinin Ekonomik Istikrar Acisindan Genel Degerlendirilmesi (The General Assessment of Macroeconomic Indicators of Azerbaijan Economy after Independence from the Economic Stability Point of View) (October 28, 2009). Journal of Qafquaz University, 2009. Available at SSRN: http://ssrn.com/abstract $=2167943$ 


\title{
Avrupa Birliği ve Enerji Arzı Güvenliği Açısından Trans Anadolu Doğalgaz Boru Hattı \\ Security of Energy Supply for European Union and Trans Anatolian Natural Gas Pipeline Project
}

\author{
Dr. Nuran Belet (Gazi University, Turkey)
}

\begin{abstract}
The fact that global economies are growing rapidly, unequal geographical distribution of energy resources and the fact that no renewable energy resource can compete with oil and natural gas at least in the near future strengthens the energy subject. In this regard, energy demands of the developed countries and the world intensifies on the energy resources of Eurasia Region, especially Caspian Region. The main factor of the energy demand isn't the supply of energy for the least possible cost but the transfer of the needed energy via secure gas pipes so that the national economies can continue producing. Russia is the most important supplier of natural gas for European countries. Eurasian regian and the Caspian Basin countries have become strategic actors in the energy market because of their rich natural gas reserves. Russia's cutting off natural gas to Europe across Ukraine upon the crisis with this country has caused a deep concern. European Union wishes to support security projects for supply synchronically of different countries into which Ukraine and Belarus -those it uses as transit for gas transfer- aren't included because of political and economical reasons to meet its energy demand. In this respect, Turkey plays a key role in supplying energy from this region to minimize the risks of energy supply security. Turkey is located in the center of a geopolitical region which produces oil and natural gas. But it can't make use of its potential. Turkey has to create opportunities to play an active role in various energy projects and pipeline routes. This is an analysis of TANAP project's impacts on European Union's energy supply security, Azerbaijan, Turkey and other countries of the region.
\end{abstract}

\section{Giriş}

Dünya ekonomilerinin hızlı büyüme hamlesi içinde olmaları, enerji kaynaklarının eşitsiz coğrafi dağılımları ve hiç bir yenilenebilir enerji kaynağının ticarî ölçekte petrol ve doğalgazla en azından önümüzdeki 60 ve belki de 100 yıl içinde gerçek anlamda rekabet edemeyeceği gerçeği, enerji konusunun gelecekteki önemini daha da pekiştirmektedir. Ekonomik büyüme ve kalkınmanın en önemli kaynaklarından biri kabul edilen enerji ve enerji sektörü; toplumsal yaşam ve ekonomik gelişme üzerindeki doğrudan ve dolaylı etkisi sebebiyle bütün ülkelerin gündeminde önemli bir yer tutmaktadır.

Teknolojik gelişmelerin küresel ölçekte yarattığı değişmeler, enerji ihtiyacını çeşitlendirerek ekonomik rekabet yanında petrol ve doğal gaz rezervlerini yoğun olarak coğrafyasında tutan ülkelere, stratejik ülkeler tanımı getirmiştir. Başta Hazar Bölgesi olmak üzere zengin doğalgaz ve petrol kaynaklarına sahip ülkeler, bunları dünya pazarlarına güvenli ve ekonomik şekilde arz edebilmek amacıyla çeşitli petrol ve doğalgaz boru hattı projeleri geliştirmektedirler. SSCB'nin dağılmasını takiben, elindeki sınırlı rezervler nedeniyle gelişmiş dünya ülkelerinin, özellikle Avrupa'nın, enerji ihtiyacının karşılanması genelde Avrasya bölgesi, özelde de Hazar Bölgesindeki enerji kaynakları üzerinde yoğunlaşmıştır. Bu süreçte öne çıkan unsur, her ne pahasına olursa olsun ucuza kaynak temin etmek değil, ulusal ekonomilerin herhangi bir kesinti yaşanmaksızın üretime devam edebilmeleri için ihtiyaç duyulan enerjinin, güvenli taşıma sistemleri ve güzergâhları yoluyla ülkeye ulaştrrılmasıdır. Bu anlamda, enerji arz güvenliği meselesi, 21. yüzyıla damga vuracak en önemli politika değişkeni olacaktır. Haritalar ve sınırlar, yeni enerji güzergâhlarına göre değişecektir.

Bu kapsamda, son 20 yılda en fazla dikkat çeken ülke Türkiye'dir. Türkiye, jeopolitik konumuyla ve transit geçiş ülkesi olarak Hazar Bölgesi petrol ve doğalgaz kaynaklarının Avrupa'ya ulaş̧ırılmasında kilit önemdedir. Türkiye, bu yeni enerji jeopolitiğinin tam ortasında yer almasına rağmen, bulunduğu coğrafyanın kendisine sunduğu "enerji yıldızı" olabilme potansiyelinden henüz yeterli düzeyde yararlanamamaktadır. Böyle bir konuma sahip olan Türkiye'nin petrol ve doğalgaz fakiri olması, bölgenin jeopolitik konumu nedeniyle yaşadığı çatışmalar pek çok sorunu da beraberinde getirmektedir. Türkiye'nin içinde bulunduğu enerji bölgesinin özellikleri, Türkiye'yi değiş̧ik "enerji projelerinde" ve aktif rol alabileceği "firsatlara" yönelmesini, enerji stratejileri ortaya koymasını gerekli kılmaktadır. Bu çalışmada bahsedilen enerji stratejilerinden birisi olarak görülen; Azerbaycan doğalgazını Avrupa'ya taşıyacak TANAP- Trans Anadolu Doğalgaz Boru Hattı Projesi 'nin hayata geçirilmesi ve bunun Avrupa Birliği enerji arz güvenliği olmak üzere, Azerbaycan, Türkiye ve bölgedeki diğer aktör ülkeler açısından etkileri ele alınmaktadır. 


\section{Enerji Piyasasına Genel Bakış}

\subsection{Dünya Enerji Dengesi ve Avrasya Bölgesi}

Dünya ekonomilerinde, 1973-74 yıllarında OPEC üyesi ülkeler tarafından ham petrol fiyatlarının tek yanlı olarak büyük oranda arttırılması ve bunun uzun dönemli olumsuz ekonomik ve sosyal etkileri nedeniyle enerji ve enerjiye ulaşımın sosyo ekonomik boyutu ve önemi net olarak kavranmıştır. Uluslararası Enerji Ajansı(IEA) ile enerji sistemleri arasında başlatılan büyük dönüşüm özellikle, sanayileşmiş ülkelerin geçmişteki büyük krizlere yakalanma olasılığını düşürmektedir. Bu ülkeler, geçmişte gördükleri yüksek petrol fiyatları nedeniyle yaşadıkları sıkıntıları bertaraf etmek için, alternatif enerji kaynaklarına yönelme çabaları yanında, AR-GE harcamalarını başta enerji sakıngan teknolojilere yönelme ve enerji verimliğini artırmak olmak üzere petrol tüketimlerini azaltıcı politikalar uygulamaktadırlar(Bahgat, 2011).

Enerji piyasalarını dolayısıyla enerji dengesini koruyan ülkeler yükselen piyasa ekonomileridir. Bu ülkeler içinde Asya da özellikle Çin 2035 e kadar \%60 lık talep artışı ile enerji kullanımındaki payını en çok arttıran ülke olacaktır. Petrol krizlerini takip eden dönemde, sektörel bazda, petrol kullanımında en büyük pay ve artış ulaştırma sektöründe yaşanmıştır. Rakamlarla ifade edersek, 1973-1999 döneminde, ulaştırma sektörünün dünya toplam petrol tüketimindeki payı \% 42'den \% 58'e sıçramıştır (IEA, 2005).

Günümüzde, ulaştırma sektörünün dünya genel enerji tüketimindeki payının \% 20 olduğu, bunun da 3/4'ünün karayolu taşımacılığına gittiği ve karayollarında seyahat eden taşıtların temel yakıt olarak hâlâ petrol kullanıldı̆̆ı görülmektedir. Hidrojen, elektrik ya da metanol/ etanol gibi enerji kaynaklarının ulaştırma araçlarında petrolü ikame edecek ekonomik bir alternatif yakıt bulunamadığı veya bu alternatiflere dayalı yakıt hücreleri benzeri bir teknolojik devrim yaşanmadığı sürece, bu yüzyılın en azından ilk yarısında petrolün öneminin azalacağını ileri sürmek mümkün değildir (IEA, 2011). Yakın gelecekte nispi olarak önemi azalacak olmakla birlikte, petrol, büyük otomotiv ve inşaat şirketlerinin hatta ilgili yan sanayilerin öneminde, Asya ve özellikle Çin'in katlanarak artan enerji açlığ 1 devam ettiği sürece siyah altın, dünya enerji dengesinin en önemli bileşenlerinden biri olmaya devam edecektir. Dünyanın 'petrol açlı̆̆g', yeni bir kaynağın, Hazar Petrolleri'nin dünya pazarlarına sunulmasının arkasında yer alan en önemli unsurlardan biridir.

\subsection{Hazar Bölgesi ve Enerji Dengesi}

Hazar Denizi'ne kıyısı olan Azerbaycan, Kazakistan, Türkmenistan, Rusya ve İran ile Bölge hinterlandında yer alan Özbekistan; Hazar Bölgesi'ndeki temel enerji üreticileridir. Ancak, dünyanın önde gelen ham petrol ve doğalgaz üreticilerinden Rusya Federasyonu ve İran'ın, Hazar kıyısında önemli sayılabilecek bir petrol rezervi bulunmamaktadır. Avrasya bölgesi ve özelliklede Hazar kıyısında yaşanan pek çok sorun, Batı Sibirya petrol üretimi giderek pahalılaşan Rusya ile dünya iktisadi sisteminden kopmuş durumda olan İran'ın, Hazar'1 "kurtarıcı" olarak görmelerinden kaynaklanmaktadır (Pala ve Engür, 1998;25). Hazar Bölgesi tanımının, sadece Azerbaycan, Kazakistan, Türkmenistan ve Özbekistan'dan, ya da diğer adiyla “Hazar Dörtlüsü”nden oluştuğunu belirtmekte yarar görüyoruz. Kazakistan tarafından Rusya'ya "sus payı" olarak verilen Kuzeybatı Hazar'daki iki saha da Kazakistan bünyesinde değerlendiriliyor (Pala, 2008; 150).

Hazar Bölgesi diye tanımlanan bölge Orta Doğu'ya nazaran uzun yıllar Sovyet egemenliğinde kalmış olmasından ötürü çok daha bakir olduğu düşünülen ve gelecekte yaşanması beklenen fosil yakıt kaynakları kıtlıklarına karşı dünya petrol ihtiyacını giderebilecek en önemli alternatiflerden birini teşkil etmektedir. Bu alan üzerinde küresel bir enerji mücadelesinin yanında, bölgesel bir rekabetinde olması doğal ve kaçınılmazdır. Bölgenin petrol tarihinden günümüze kadar olan mücadelede siyasi, iktisadi, sosyal ve hukuki yönlerin bütünün etkisi bulunmaktadır. Hazar Havzası'nda petrolün varlığı 8. yüzyıldan beri bilinmekte olup, bu havzadaki en zengin yataklardan birine sahip olan Azerbaycan -Bakü'de 15.yüzyıldan bu yana petrol çıkarılmaktadır. Önceleri sadece gaz lambalarında kullanılmak için sı̆̆ kuyulardan elde edilen petrol, Bölge'de 1825'de 120 olan kuyu sayısı, 1840'larda 133'e, 1860'lı yıllara gelindiğinde ise 2272'ye ulaşmıştır. 1872'de yapılan gerekli yasal düzenlemelerin sonrasında, 19. yüzyılın başından itibaren ticari önem kazanmaya başlamış ve kısa süre içinde dünyanın önde gelen petrol üretim merkezlerinden biri haline gelmiştir. Marco Polo, 'Seyahatler'adlı kitabında, 1271-1273 tarihlerinde ziyaret ettiği Kuzey İran'1 anlatırken, 'netf'in (Petrol), Bakü'de, o zamanın koşullarına göre ticari bir ölçekte işletilmekte olduğundan bahseder ve Bakü'deki bu ticaretin büyüklüğünden ne kadar etkilenmiş olduğunu kayda geçer. 1889 yılında, Nobel Kardeşler bölgede ilk boru hattını da inşa etmişlerdir. Yaklaşık $70 \mathrm{~km}$ uzunluğundaki bu hattın yapılma amacı, Bakü-Batum demiryolunun dik yamaçlı dağlık bölgeden geçen kısmında lokomotiflerin 5-6 tanker vagonundan fazlasını çekememesi sebebiyle demiryolunun bu bölümünü 'by-pass' etmekti. Böylece, Nobel kardeşlerden Alfred Nobel'in icadı olan dinamit de, boru hattının geçeceği kayalık bölgede güzergah açmak amacı ile ilk defa burada kullanılmış oldu (Pala, 2008;148).

Sovyet Dönemi’nde, rejim nedeniyle bölge dünya pazarında bir rekabet unsuru olamamış, Sovyetler Birliği'nin dağılması sonrasında ise, Hazar'a kıyısı olan Hazar Dörtlüsüne, İran dahil 5 ülkenin enerji pastasından ne nispette pay alacağı meselesi; Hazar Denizinin hukuksal statüsü sorununu da beraberinde getirmiştir. Bu sebeple, Hazar nüfuz mücadelesinin en sert geçtiği bölgelerin başında gelmektedir. Bölgede sürdürülen güç mücadelesi, sadece enerji yataklarından alınacak payları değil, bu havzada üretilecek enerjiyi dünya pazarlarına taşımanın hangi güzergâhlar vasıtasıyla yapılacağını da içermektedir (Yücel, 2008;158). 
Sovyetler Birliğgi'nin dağılmasıyla birlikte, ideolojik rekabet yerini ekonomik rekabete bırakmış, çevresinde yeni bağımsız ülkelerin yer aldığı, petrol ve doğalgaz rezervlerinin önemli bir kısmını barındıran Hazar Havzası, bölgesel ve küresel güçlerin dikkatini çekmiştir. Kafkasya'nın , jeopolitik açıdan büyük önem taşıma nedenleri şu şekilde sıralanabilir; 1. Jeostratejik anlamda Orta Asya'ya giriş kapısıdır. 2. Orta Asya bakımından bölge, Batı pazarına açılan direkt bir geçittir. 3. Orta Asya ile bir bütün olarak ele alındığında bölge önemli miktarda petrol ve doğalgaz potansiyellerine sahiptir. 4. Rusya Federasyonu açısından, Akdeniz ve Basra'ya uzanan jeopolitik bağlantı hattıdır.

Önemli petrol ve doğalgaz rezervlerinin bulunduğu Hazar bölgesindeki devletler enerji piyasası açısından küresel ölçekte önem kazanmaya, stratejik aktörler haline gelmeye başlamışlardır. Ancak, enerjinin paylaşım savaşını veren petrol şirketleri, bulundukları devletlerin dış politikalarında çok etkili oldukları gibi, dünya siyasetine de ekonomisine de az veya çok yön verebilmektedirler. Bu anlamda 21. yüzyılda da şiddetle sürdürülen enerji rekabeti, son yıllarda Hazar bölgesinde giderek artan derecede hissedilmiştir. 21. yüzyılın mücadelesi Avrasya satranç tahtasında oynanacaktır. Bu mücadelenin merkezinde, her zaman olduğu gibi, enerji kaynaklarının öncelikli rolü yer alacaktır. Coğrafi anlamdaki merkezlerden birisi de Hazar Bölgesi olacaktır (Brzezinski, 1998; 72).

Tablo 1. de yer alan Hazar bölgesi doğalgaz rezervlerine göre; önemli bir güç olmasına karşın, bölgedeki petrol ve doğalgaz rezervlerinin büyük kısmı henüz geliştirilememiş ve önemli bir kısmında rezerv tespiti dahi halen yapılmamıştır(Yücel, 2008;165).Bu haliyle Hazar havzasında yer alan dört ülkenin ispatlanmış doğalgaz rezervlerindeki toplamı dünya toplamının nerdeyse \%8'ine denk gelmektedir. Bölgeyi yeni boru hatlarının yatırımları açısından cazip kılan unsur ise, bölgedeki mevcut hatların artık ekonomik ve fiziki ömürlerini tamamlamış olmalarıdır. Hazar bölgesindeki petrol ve Doğalgaz boru hatlarının büyük bölümü Sovyetler Birliği döneminde inşa edilmiş olduğundan, çoğu Rusya içlerine dağıtım yapmak amacıyla planlanmıştır. Hatların ihracat amaçlı kullanımı uygun olmayıp, büyük bölümünde de bakımsızlıktan kaynaklanan sorunlar bulunmaktadır.

\begin{tabular}{|l|l|l|l|}
\hline ÜLKELER & $\begin{array}{c}\text { İspatlanmış } \\
\text { Rezervler }\end{array}$ & $\begin{array}{c}\text { Dünya Toplam } \\
\text { Rezervlerindeki Payı (\%) }\end{array}$ & $\begin{array}{c}\text { Dünya Toplam } \\
\text { Üretimindeki Payı (\%) }\end{array}$ \\
\hline Azerbaycan & 1 & 0.5 & 0.5 \\
\hline Kazakistan & 1.3 & 0.7 & 0.6 \\
\hline Türkmenistan & 17.5 & 9.3 & 17.6 \\
\hline Özbekistan & 1.1 & 0.6 & 1.7 \\
\hline
\end{tabular}

Tablo1. Hazar Bölgesinin İspatlanmış Doğalgaz Rezervleri, Üretim ve Dünya Toplamı içindeki payl, (\%), 2013, Kaynak: BP Statistical Review of World Energy June 2013, s.20, 24, trilyon metre küp.

Hazar bölgesinde eski rezervlere ek olarak, zengin yeni hidrokarbon rezervlerinin keşfedilmesi, 21. Yüzyıl'da, bu yeni rezervler, bölgenin ikinci bir Orta Doğu/Basra Körfezi olabileceği düşüncesinin ortaya çıkmasına yol açmıştır. Bulunan enerji rezervlerinin dünyada üçüncü sırada yer alacak potansiyele sahip olduğu belirtilmektedir (Borombaeva, 2002; 14).

Dünya ekonomisi-fosil yakıt evliliği Katolik bir evlilik olup (Pala, 2003;5), Avrupa ve Asya pazarlarının artan ihtiyaçlarını karşılamak üzere, yeni yüzyılın gözdesi Hazar Bölgesi'dir.Bu bölgede yer alan ham petrol ve doğalgaz rezervlerinin hızla geliştirilmesinin Batı açısından önemi daha da artacaktır. Bunun temel nedeni , petrolün, 2020'ye kadar, özellikle kara ve hava taşımacılı̆̆ karşılanmasında artan oranda kullanılacağını göstermektedir.Yapılan projeksiyonlara göre, önümüzdeki 20 yıl içinde, dünya petrol tüketiminde gerçekleşecek yaklaşık 2 milyar tonluk (15 milyar varil) ilave artışın \% 59'u 'ulaştırma' sektöründen kaynaklanacaktır (IEA, 2001).

Yakın bir gelecekte, petrol potansiyeli açısından Azerbaycan ve Kazakistan’ın, doğalgaz deposu olarak daha çok Türkmenistan ve Özbekistan'ın öne çıkacağını söylemek mümkündür. Yaklaşık 2 Trilyon $\mathrm{m}^{3}$ 'lük rezerv tespit edilen Şah Deniz keşfi ile birlikte, sadece petrol değil bir doğalgaz ülkesi olacağının da sinyallerini veren Azerbaycan'1, bu son gruba da dahil etmek yanlış olmayacaktır ( IEA, 2011).

\subsection{Doğalgaz Rezervleri ve Jeopolitik Etkileri}

Önümüzdeki yirmi yılda doğalgaz tüketiminde meydana gelecek artışın kilit sektörü ise 'elektrik' olacaktır. Günümüz global gaz tüketiminde \% 35 ile en büyük pay 'elektrik sektörüne' aittir. Özellikle Kombine Çevrimli doğalgaz Türbinleri’nin ısıl verimliliğinde beklenen sürekli iyileştirmeler ve çevre dostu bir yakıt olması nedeniyle 2020'ye kadar, yeni elektrik santrallerinde daha çok doğalgazın tercih edileceği görülmektedir. Bunun sonucu olarak; santrallerden kaynaklanacak doğalgaz talebinin \% 4'lük bir yıllık ortalama artış hızıyla büyüyeceği tahmin edilmektedir. Dolayısıyla, doğalgaz rezervlerini ve bulundukları ülkeler de jeopolitik konumları açısından etkileneceklerdir.

Tablo 2'de, özellikle gelişmiş ülkelerin petrol krizleri sonrasında uyguladıkları sanayileşme, enerji ve teknoloji politikalarının enerji tüketimi ve gelecek projeksiyonlarını göstermektedir.Buna göre,1973'de \% 53 ile dünya birincil enerji tüketiminde en üst düzeye ulaşan petrol payının, 2005 sonu itibarıyla \% 36.4'e gerilediğini 
göstermektedir. Fosil yakıtlar arasındaki ikamede kömür ve doğalgaz paylarının önemli ölçüde artarak, global enerji tüketiminden yaklaşık aynı oranda pay aldıkları gözleniyor. Fosil yakıt dışı enerji kaynakları arasında ise en büyük katkının nükleer enerji tarafından yapıldığı görülmektedir. Bu süreçte değişmeyen tek şey fosil yakıt bağımlılığıdır: 1973'de global enerji tüketiminin yaklaşık \% 87'sini sağlayan fosil yakıtların payı, 2005'de yani 32 yıl sonra bile, hala \% 88'ler düzeyindedir. Aynı tablodan, fosil yakıtların 2020 dünya enerji tüketiminin de en az \% 92'sini karşılamasının beklendiği görülmektedir. Önümüzdeki 20 yıl dünya ülkelerinin ne fosil yakıt ne de kömür tüketiminden kolayca vazgeçemeyeceklerini söylemek mümkündür. Üstelik, diğer fosil yakıtların "düşme" eğilimine girip, giderek daha pahalı hale gelecekleri 2050'lerden sonra, tıpkı petrol krizlerinin ardından yaşanan gelişmeler gibi yine kömürün "dengeleyici kaynak" olarak stratejik önemini arttırması beklenebilir. (IEA, 2012)

\begin{tabular}{lllll}
\hline & $\mathbf{1 9 7 3}$ & $\mathbf{2 0 0 5}$ & $\mathbf{2 0 1 3}$ & $\mathbf{2 0 2 0}^{\mathbf{2}}$ \\
\hline Petrol & 53 & 36.4 & 33 & 38 \\
Kömür & 18 & 27.8 & 29 & 29 \\
Doğalgaz & 16 & 23.4 & 24 & 25 \\
Fosil Yakitlar & 87 & 87.6 & 91 & 92 \\
Nükleer & 1 & 5.9 & 4.6 & 4 \\
Hidroenerji & 2 & 6.3 & 6.6 & 3 \\
Diğer Yenilenebilirler* & 10 & 0.2 & 1.9 & 1 \\
\hline
\end{tabular}

Tablo 2. Dünya Birincil Enerji Tüketiminde Yakıt Payları1, 1973-2020 (\%) * Hidrolik hariç, güneş, rüzgar, gelgit, jeotermal, geleneksel ve modern biyolojik yakıtlar. Kaynak: BP Statistical Review of World Energy June 2013 s. 40, (1) trilyon metre küp.(2) Projeksiyon rakamı (IEA, 2012:6-9).

Petrolün yanı sıra doğalgazın da kolay ve daha düşük maliyetlerde çıkarılması ve taşınması ve petrole kıyasla çevreye daha duyarlı bir enerji kaynağı olması, onun kullanımını giderek daha yaygın hale getirmektedir. Ayrıca, Birim kitle başına düşen ısı enerjisi bakımından doğalgazın petrole yakın olması da piyasa değerini artırmaktadır. Boru hattı sistemlerinin mevcut olduğu ya da kurulabileceği yerlerde, yeni elektrik santralleri gibi pek çok uygulamada yakıt seçeneği olarak daha çok doğalgazın tercih edileceği anlaşılmaktadır(IEA, 2012). Bir anlamda doğalgaz, bugün bir duraklama dönemi geçiren nükleer enerjinin tekrar büyük oranda devreye girene kadar, yani 2050'ler sonrasına kadar, özellikle çevresel açıdan bir 'geçiş yakıtı' görevi üstlenecektir. Doğalgaza, '21. yüzyılın yakıtı' denilmesinin asıl nedeni budur (Pala, 2003;8). Petrol tarihinde her zaman önemli bir rol üstlenmiş olmasına rağmen, Hazar'da büyük ölçekli hidrokarbon üretimi ve dünya pazarlarına taşınması konusu, Sovyetlerin dağılması ve yeni bağımsız devletlerin kendi ayakları üzerinde durmaya çalıştıkları yakın döneme rastlamıştır. Yakın gelecekte 2015 den itibaren yaklaşık 50 yıl sürecek doğalgazın altın çağına geçileceği öngörülmektedir. (IEA, 2012;6-9).

Küresel enerji politikaları ve boru hattı projelerinin hayata geçirilebilmesi uzun dönemli işbirliği ve anlaşmaların imzalanması ile mümkün olabilmektedir. Ancak enerji rezervlerinin durumu ve bölgelerindeki jeopolitik gelişmeler bu anlaşma ve işbirliklerinin çalıştırılmasında ve uzun solukluluğunda bazı sıkıntıları da beraberinde getirebilmektedir.ABD’nin Exxon önderliğinde geliştirilen ShaleGas (Kaya Gazı) teknolojisi sayesinde ABD'nin doğalgaz bağımlılı̆̆ı değişecek ve kaya gazına dayalı LNG pazarına ihracatçı olarak gireceği, Asya pazarlarına gaz satacağı ve Ruslara rakip olacağı ileri sürülmektedir (The Economist, 2010;6769).ABD gazı Asya'ya giderse Avrupa’yı Türkiye üzerinden geçen boru hatları besleyecek, yani ABD burada yer almak yerine, sonuçta Hazar ve Orta Doğu gazının Avrupa'ya sokarak Rusya’yı tüm piyasalarda sıkıştırmış olacaktır.

\section{Enerji Güvenliği ve Boru Hatları}

\subsection{Enerji Arz Güvenliği Sorunları ve Mevcut Boru Hatları}

Ulusal kaynakları yetersiz ülkeler, gereksindikleri enerjiyi zamanında, kesintisiz ve en güvenli şekilde sağlamak için sürekli yeni arayış içindedirler.11 Eylül sonrasında dünya ekonomilerinin en önemli meselelerden biri “enerji arz güvenliğinin sağlanması”olmuştur. Özellikle enerji ithalatına bağımlılığı artan gelişmiş Batı ekonomileri için Orta Doğu bölgesinin jeopolitik sorunları ve siyasi kaynaklı enerji arz kesintileri karşısındaki tek dengeleyici rezerv alanı Hazar bölgesi görülmektedir. Ayrıca,AB'nin önümüzdeki 15-20 yıl içinde fiziki ve ekonomik ömrünü tamamlayacağı hesap edilen Kuzey Denizi rezervlerine uzun zamandır aramakta olduğu ikame kaynakları, kısa vadede Rusya'da, orta ve uzun vadede ise Orta Asya ve Hazar Bölgesi'nde bulmuştur.

SSCB'nin dağılmasından sonra, bölgenin hızlı değişimlere uğraması, dağılan yapı içindeki ülkelerin yeni rolleri, Batı enerji diplomasisi, ilk önce Hazar'ın enerji kaynaklarını garanti altına alacak üretim-paylaşım anlaşmalarının tamamlanması üzerinde yoğunlaşmıştır. Bu bölgedeki temel üreticilerle 30 yıllık uzun erimli işbirliği imkanları imza altına alınmasıyla ,Batı'nın 15-20 yıllık bir plan dahilinde tedrici olarak Kuzey Denizi kaynakları yerine geçireceği alternatif enerji arz kaynaklarına, Hazar rezervlerine yönelmiştir. 2020 yılında 
doğalgaz ihtiyacının \% 70'ini ithalat ile karşılayacak olan, günümüzde toplam doğalgaz tüketiminin \% 26'sından fazlasını Rusya Federasyonundan sağlayan AB çıkarları açısından, Rus petrol ithalatı da önemli olmakla birlikte, esasen Rus doğalgazı stratejik bir parametredir

Rusya'nın Ukrayna ile yaşadığı kriz neticesinde, Ukrayna üzerinden Avrupa'ya sağladığı doğalgazda kesintiye gitmesi ciddi kaygıya neden olmuştur. Avrupa ülkelerinin en önemli doğalgaz tedarikçisi Rusya'dır. Rusya'nın doğalgazda kesintiye gitmesi enerji güvenliği ve gaz tedarikçilerinin çeşitlendirilmesi konusu bir kez daha gündeme getirmiştir. Orta Asya Avrupa açısından en önemli alternatif doğalgaz tedarikçisi konumundadır. Bu bağlamda güvenlik risklerinin minimize edilerek Orta Asya'dan Avrupa'ya petrol ve doğalgaz ihracatının gerçekleştirilebilmesi noktasında Türkiye önemli bir rol oynamaktadır (Erdağ, 2013;869). Söz konusu petrol ve doğalgazın alternatif olarak (İran, Irak) taşınması ekonomik açıdan ciddi yük oluşturacak, hem de güvenlik açısından bazı riskleri de beraberinde getireceğinden (Ayhan, 2009;156), Avrupa diğer ülkelerden geçirebileceği ve çeşitlendirebileceği boru hatlarına yönelmiştir.

\subsection{Mevcut Boru Hatları}

Avrupa'yı, Rusya başta olmak üzere doğalgaz rezervlerine sahip ülkelere bağlayan boru hatlarının yanı sıra Avrupa ülkeleri arasında da son derece gelişmiş bir boru hattı ağı bulunmaktadır. Fakat bu ağın etkin bir biçimde çalışabilmesi için gaz rezervlerine sahip ülkelerden tedarikin güvence altına alınması gerekiyor. 2013 başı itibarıyla dünyada 1033.4 milyar metreküplük doğalgaz ticaretinin 705 milyar metreküpü boru hatlarıyla, kalan 327.9 milyar metreküpü ise LNG ile yapılmış. Dolayısıyla ticaretin yaklaşık \%75'i boru hatları ile kalan \% 25 ise LNG ile yapılmaktadır (BP, 2013; 28).

Bölge devletlerinin sahip oldukları enerjinin dünya pazarlarına ulaştırılabilmesi için, son yıllarda, çeşitli boru hatları gündeme gelmiştir. Bunlardan bir kısmının inşaatına başlanmış olup, bir kısmı ise halen proje aşamasındadır. Bunlardan bazıları şunlardır; (1) Bakü-Tiflis-Ceyhan Ham Petrol Boru Hattı Projesi. (2) BaküTiflis-Erzurum Doğalgaz Boru Hattı Projesi. (3) Türkmenistan-Türkiye-Avrupa (Hazar Geçişli) Projesi. (4) Türkiye-Yunanistan Doğalgaz Boru Hattı Projesi. (5) Mavi Akım Doğalgaz Boru Hattı Projesi. (6) Aktau (Kazakistan petrollerinin Bakü-Ceyhan'a aktarılması) Projesi. (7) Orta Asya Doğalgaz Boru Hattı (Centgaz) Projesi (Türkmenistan-Afganistan-Pakistan). (8) Türkmenistan-İran-Türkiye Doğalgaz Boru Hatt1. (9) SamsunCeyhan Ham Petrol Boru Hattı . (10) Türkmenistan-Çin Doğalgaz Boru Hattı. (11) Kazakistan-Rusya (AtrauSamara) Ham Petrol Boru Hatt1 Projesi ( Uluatam, 2010;62).

$\mathrm{AB}$ arz güvenliğinin sağlanması bakımından bugüne kadar temel olarak aşağıdaki boru hattı projelerini kullanılmıştır: 1)Yamal-Avrupa I, 2)Ukrayna Boru Hatları, 3) Brotherhood,4) Soyuz, 5) NorthernLights (Urengoi-Pomary- Uzhgorod/Trans-Siberya), 6) Mavi Akım (Blue Stream), 7) Bakü-Tiflis-Erzurum (BTE) Doğalgaz Boru Hattı(South CaucasusPipeline), 8)Yeşil Akım (GreenStream), 9)Langeled

Avrupa Birliği, enerji açığını kapatmak ve arz kaynaklarını çeşitlendirmek için birçok büyük çaplı projeyi eşzamanlı olarak desteklemektedir. Bu nedenle Avrupa'ya gaz sevk ederken, siyasi ve iktisadi nedenlerle ihtilaflar yaşadığı Ukrayna ve Beyaz Rusya'nın dâhil edilmediği, farklı ülkelerden geçen güvenli güzergâhların yer aldığı projeleri desteklemektedir. Bunlardan bazıları yapım bazıları ise planlama aşamasında olan boru hatları güzergahlarıdır. Yapılması düşünülen yeni boru hattı projeleri:1)Yamal-Avrupa II, Beyaz Akım (White Stream), 3)Nabucco,4) Kuzey Akım (NordStream),5)Güney Akım (South Stream). Ayrıca, Rus rezervlerinin yanı sıra Türkmen, Kazak ve Azerbaycan gazının da Avrupaya taşınması için , Türkiyenin de dahil olduğu boru hattı projeleri de geliştirilmektedir. Bunlar ise, 1)Türkiye-Yunanistan-İtalya Doğalgaz Boru Hattı (Poseidon), 2)Mavi Akım II (Blue Stream), 3)Trans-Adriyatik Boru Hattı (TAP), 4) TANAP-Trans Anadolu Doğalgaz Boru Hattı.

Avrupa'nın ihtiyaç duyduğu petrol ve doğalgazın Orta Asya'dan taşınması konusunda Türkiye önemli adımlar atmaya başlamıştır. Bakü-Tiflis-Ceyhan petrol boru hattı projesi ile Akdeniz'de önemli bir enerji köprüsü konumuna gelen Türkiye (İpek, 2006), Nabucco projesinin imzalanması ile birlikte Avrupa'ya gaz tedarikinde güvenli bir enerji koridoru oluşturmuştur. Türkiye doğalgaz boru hattı projeleri ile stratejik hamlelerle Rusya gibi büyük oyuncuların arasında yer alamaya çalışarak, gelecek zamanlarda “ aktörler” arasında yer almayı amaçlamaktadır. Gerek Bakü-Tiflis-Ceyhan ve gerek Samsun-Ceyhan petrol boru hatları, gerekse TürkiyeYunanistan-İtalya ve Nabucco doğalgaz boru hattı projeleriyle Orta Asya'daki kaynakların Batı'ya aktarılmasını sağlayacak ülke konumundaki Türkiye, Avrupa Birliği'nin (AB) geleceğe dair enerji planlarında da önemli bir yer tutmaya başladı. Doğalgaz ithalatında büyük ölçüde Rusya’ya bağımlı hale gelen AB, hem bu tekeli kırmak hem de kaynak çeşitliliği yaratmak için en önemli koridor ülkelerden biri olarak Türkiye'yi seçmiş bulunuyor. Türkiye'nin lokasyon itibariyle AB'yi, zengin Orta Asya ve Ortadoğu enerji kaynakları ile buluşturabilecek tek ülke olduğundan; zengin Hazar ve Ortadoğu kaynaklarının Türkiye'nin imza attığı BTC, Şah Deniz, Nabucco ve Türkiye-Yunanistan-İtalya gibi stratejik öneme sahip projelerle Avrupa'ya gitmesi söz konusu olacaktır. Bu projelerin devamı niteliğinde son olarak, Türkiye ile Azerbaycan arasında Şah deniz bölgesindeki doğalgazın Türkiye ve Avrupa'ya ulaştırılması maksadıyla Anadolu Geçişli Doğalgaz Boru Hattı Projesi (TANAP) 2011 yılında imza altına alınmıştır. 


\section{Avrupa Birliği Doğalgaz Talebi ve Trans Anadolu Doğalgaz Boru Hattı -TANAP}

Avrupa Komisyonu 7 Eylül 2011 tarihli COM(2011)539 “The EU Energy_Policy: Engaging_with_Partners Beyond Our_Borders" belgesiyle,AB dışındaki ülkelerle enerji alanında kurulacak ilişkilerin temellerini ortaya koymuş ve buna ilişkin öncelikler:1. Enerji iç pazarının harici dünyaya ilişkin yapısının inşa edilmesi, 2.Emniyetli, sürdürülebilir ve rekabetçi enerji piyasasına yönelik işbirliğinin güçlendirilmesi, 3.Gelişmekte olan ülkeler için sürdürülebilir enerjiye erişim imkanlarının geliştirilmesi ve 4.AB politikalarının $\mathrm{AB}$ dışındaki ülkelerde daha iyi tanıtımı (Özen, 2012;59) olarak belirlenmiştir.Mevcut boru hatlarının yanı sıra geliştirilen orta ve büyük ölçekli projeler, Avrupa doğalgaz piyasasının ne denli rekabetçi bir yapıya sahip olduğunu net bir biçimde ortaya koymaktadır. Avrupa Birliği'nin hemen hemen tüm politika belgelerinde de belirtildiği gibi, Birliğin birinci önceliği, enerji arz güvenliği ve çeşitliliğini sağlamak. Bu bağlamda AB'nin Doğu'daki komşu ülkeleri stratejik bir öneme sahiptir.

Boru hattı teknolojisindeki iyileştirmeler ve sıvılaştırılmış doğalgaz kullanımındaki artış, doğalgazı yerel nitelikli bir meta olmaktan çıkarmış, uluslararası ticaretin parçası haline getirmiştir. Doğalgaz, 21. yüzyılın en önemli yakıtı olmaya adaydır. Uluslararası Enerji Ajansı,IEA, doğalgazın, dünya birincil enerji tüketiminden alınan pay itibarıyla 2020 yılında kömürü geçerek, petrolün hemen ardından ikinci sıraya yerleşeceğini öngörmektedir. Dünya birincil enerji tüketiminde \% 21'lik pay alan doğalgaz, 2020'de global enerji tüketiminin \% 24'ünden sorumlu olacaktır. Temel olarak elektrik üretimindeki artan ağırlığı nedeniyle bu yüzyılın en azından ilk yarısı boyunca en stratejik yakıt haline gelecek doğalgaz, enerji portföyünde kömür ve nükleer enerjinin boşalttığı alanı dolduracaktır (IEA, 2005;80-6).

Dünya petrol üretiminin zirveye (peak) ulaşacağı 2015-2033 zaman aralığı, dünya enerji ihtiyacının karşılanması, enerji kaynaklı global $\mathrm{CO}_{2}$ emisyonlarının azaltılması ve emisyon ticareti ile Kyoto Protokolü'ne işlerlik kazandırılması sürecinde doğalgazın çok daha aktif rol üstleneceği tarihi bir dönemeç olacaktır. Dolayısıyla, Rusya'nın tekeli Gazprom'u kullanarak dünya doğalgaz sahnesinde ve dış politika alanında daha bugünden yakaladığı manivela kabiliyetini, gazın hayati öneme sahip olacağı geleceğe taşıma firsatı bulacaktır. (Pala, 2003). Doğalgazın gücü, sadece ihracat geliri sağlanmasından ibaret değildir. Fosil yakıtlar arasında en az karbon emisyonuna yol açan doğalgazın anavatanı konumundaki Rusya, önümüzdeki 25 yıl boyunca, fosil yakıt tüketiminden vazgeçemeyen ABD, Japonya ve diğer Batılı ülkelerin en önemli emisyon ticaret ortağı da olacak; böylece daha şimdiden 50 milyar \$’a ulaşması beklenen bu piyasanın kritik bir oyuncusu haline gelerek ülke ekonomisine ilave döviz girdisi sağlayacaktır.

Dünya genelinde de, doğalgazın toplam enerji tüketimindeki payının artması gözlemlenmektedir. Bu sonuç, büyük doğalgaz kaynaklarına sahip ülkelerin, özellikle Rusya'nın, dünya enerji ekonomisinde rolünün giderek yükselmesine sebep olmaktadır. Rusya'nın, Avrasya'nın zengin doğalgaz kaynaklarını kendi tekeline almak isteği, son yıllarda, Kazakistan, Türkmenistan ve Özbekistan gibi zengin doğalgaz kaynaklarına sahip ülkelerle yoğun temaslar içerisine girmesi, bu isteği doğrultusunda ne denli kararlı olduğunu göstermektedir (Ener ve Ahmedov, 2008;6).

Avrupa Birliği 'nin enerji politikasında, petrol ve doğalgaz çok önemli bir yer tutmakla birlikte, topluluğun enerji ihtiyacının büyük bir bölümünü halen petrol karşılamaktadır. Bu oranın gelecekte de önemli ölçüde azalmayacağ 1 ve petrolün birincil enerji kaynağı konumunu sürdüreceği tahmin edilmektedir. Ancak, doğalgaz ise ikinci sıradadır. Bu durumu AB açısından daha da önemli kılan, bu iki kaynak için birliğin dışa bağımlı olmasıdır. AB' nin en önemli enerji sağlayıcıları İngiltere, Danimarka, Norveç, Orta Doğu ülkeleri, Rusya ve Kuzey Afrika ülkeleridir. 2006 sonu verilerine göre AB' nin toplam petrol iç tüketiminin 727 milyon ton olmasına karsın, AB' nin ithalatı 588 milyon ton olup, iç tüketimin \% 80’ ni karşılamaktadır (Eurostat, Statistical Books Energy, 2007). Bunun dışında, birincil enerji kaynakları içerisinde petrol \% 44' lük payla ilk sıradadır. Doğalgaz tüketimi ise \% 26'lik bir oranla ikinci sırada bulunmaktadır. Avrupa' nın birincil enerji tüketiminde doğalgazın payı ise, giderek artmaktadır. Doğalgaz payı, 2010 yılında \%24'larda olup, 2030 yılında 30,1\%'e yükseleceği öngörülmektedir (IEA, 2012).

Rusya’yı Kıta Avrupası'na bağlayan dev boru hatları bulunmasına rağmen Rusya enerji kozunu sık sık doğalgaz tedarik ettiği ülkelere yönelik yumuşak güç olarak kullanmaktadır. Ukrayna ve Rusya arasında 20052006'da, 2007-2008'de ve son olarak 2008-2009'da patlak veren enerji krizleri yüzünden Ukrayna'nın yanı sıra, birçok AB ülkesi günlerce gazsız bırakmıştır. Son olarak Haziran 2010'da Belarus'la yaşanan kriz Avrupa'nın enerji konusunda Rusya'ya aşırı derecede bağımlı olmasının doğurabileceği sakıncalı durumu bir kez daha ortaya koymaktadır. Sonuç olarak, Avrupa Birliği arz çeşitliliğini ve güvenliğini sağlamak için son yıllarda Trans-Avrupa Enerji Ağı çerçevesinde birçok strateji ve proje geliştirmekte ve desteklemektedir.

Rusya artan gaz ihtiyacının karşılanmasında en güvenilir kaynak olarak durmakla birlikte, bu ülkeye gaz ithalatı bağlamında aşırı bağımlılık oluşmaması ve alternatif tedarik kaynaklarının devreye konulması stratejisi, Orta Doğu ve Hazar Bölgesi ülkelerindeki zengin doğalgaz kaynaklarının batıya transfer edilmesi ,AB acısından kaçınılmaz bir hedef olarak ortaya çıkmaktadır. Türkiye'nin içinde bulunduğu coğrafyadan ve enerji bölgesine yakınlığı nedeniyle sahip olduğu Jeostratejik avantajı nasıl kullanacağı hep gündem konusu olmuştur. 
Başta Azerbaycan olmak üzere, bağımsızlıklarını kazanan bu yeni devletler sahip olduğu doğal kaynaklar nedeniyle uluslararası alanda önemli bir cazibe merkezi haline gelmişlerdir. 2000'li yıllardan itibaren Türkiye'nin bölgede küresel politikalar uygulamak isteyen, tarihsel olarak bölgede bulunmasıyla bölgede söz sahibi olma politika tercihinin arkasından, Bakü-Tiflis-Ceyhan petrol boru hattı projesi (BTC) bölgedeki dengeleri değiştirmiş ve bölgenin enerji politikalarında Türkiye'nin ağırlık kazanmasını sağlamıştır (Erdağ, 2013).Azerbaycan ve Türkiye'nin Avrasya bölge ekonomisindeki rolü onların coğrafi ve jeopolitik konumlarına bağlı olmalarının dışında ayrıca Azerbaycan'ın zengin petrol ve doğalgaz kaynaklarına sahip olmasıyla da ilişkilidir(Ener ve Ahmedov, 2008;1).

\subsection{Trans Anadolu Doğalgaz Boru Hattı- TANAP Projesi -}

AB'ye Türkiye üzerinden gaz sevkiyatı acısından en uygun coğrafik yerleşimde yer alan ve zengin doğalgaz kaynaklarının bulunduğu bu üç ülke (İran, Irak ve Türkmenistan) ile ilgili belirsizlik ortamının sona ermesi ve bu ülkelerin Türkiye ile birlikte AB'ye gaz ihracını sağlayacak üretim ve taşınmasında gerekli alt yapılarına sahip olmaları yakın gelecekte mümkün görülmemektedir. Dünyadaki en büyük gaz ithalatçısı konumundaki AB'ye doğalgazın Hazar bölgesi ve Ortadoğu ülkelerindeki bu zengin üretim alanlarından boru hatlarıyla iletiminde en elverişli güzergahların Türkiye üzerinden geçişin öngörülmektedir.Dolayısıyla, uluslararası enerji arenasında doğalgaz sektöründe Türkiye'nin rolü daha da öne çıkmaktadır.

Trans Anadolu Doğalgaz Boru Hattı -TANAP-, Azeri gazının yıllık 10 BCM miktarının 2017 yılından itibaren Türkiye üzerinden Avrupa'ya transit edilmesi yönünde, 26 Aralık 2011'de mutabakat zaptı imzalanan, 26 Haziran 2012'de de Hükümetler arası imzaların atıldığı en yeni son proje olmaktadır. Türkiye'nin TANAP projesinin tamamlanması ile birlikte güvenli enerji koridoru rolünün daha da güçleneceği söylenebilir (Erdağ, 2013:869)TANAP Projesi, Türkiye ve Azerbaycan'ın bugüne kadar başarı ile yürüttükleri projelerin enerji alanındaki en önemli temsilcilerinden biridir. Tarihten gelen kardeşlik bağlarını bugünün koşullarında "Bir Millet İki Devlet" misyonunla perçinleyerek sürdüren iki ülke için de büyük öneme sahip TANAP Projesi, dünya enerji piyasalarında da ses getirecek dev bir projedir (http://www.tanap.com/tanap-nedir.2013).

Avrupa'nın ve Türkiye'nin doğalgaz ihtiyacını karşılamayı bunun yanı sıra bölgede gaz çeşitliliğinin sağlanmasını hedefleyen TANAP projesi, enerji alanında Bakü-Tiflis-Ceyhan Petrol Boru Hattı ve Bakü-TiflisErzurum Doğalgaz Boru Hattı Projeleri ile ivme kazanan stratejik iş birliklerini daha da kapsamlı hale gelmiştir. TANAP, Türkiye ve Avrupa'nın doğalgaz arzına, Azerbaycan Şah Deniz-2 sahası ve ilave kaynaklardan doğalgaz tedarikiyle büyük katkı sağlayacaktır.Giriş noktası Azerbaycan, Türkiye sınırı Türkgöz girişi olan 56 inçlik hattın, Avrupa'ya çıkış noktaları Yunanistan ve Bulgaristan sınırları, Türkiye içi çıkış noktaları ise Eskişehir ve Trakya bölgesi olacaktır. TANAP Projesi için öngörülen 4 aşamanın ilki 2018'de ilk gaz akışılla gerçekleşecek. 2020'de y1llık 16 milyar metre küp olacak kapasitenin, 2023'te 23 milyar metre küp, 2026'da ise 31 milyar metre küp seviyesine kadar ulaşması hedeflenmektedir.

Hazar doğalgazını Avrupa pazarlarına taşıma fikrini yeniden gündeme taşıyan Türkiye ve Azerbaycan, Trans Anadolu Doğalgaz Boru Hattı projesini (TANAP) hayata geçirmek için düğmeye basarken, söz konusu proje, Rus doğalgazına olan bağımlılığını azaltma açısından Avrupa'nın önemli bir tercihidir. Avrupa'nın doğalgaz kaynaklarını çeşitlendirme ihtiyacını en uygun şekilde karşılamasının yanında, Türkiye'nin bir geçiş ülkesi olarak sahip olduğu rolü güçlendirmesi bakımından da son derece önemli bulunmaktadır. Ayrıca, proje Rusya'nın etrafından dolaşan bir güney enerji koridoru kurma fikrinin ardındaki "stratejik gerekçeleri canlı tutmaktadır. Bunun yanında, Azerbaycan için yeni ihracat fırsatları ve sabit gelir imkanı sunmanın yanı sıra, dış ilişkilerde arzu edilen çeşitliliği de sağlayacaktır. Rusya halen Türkiye'nin bir numaralı doğalgaz tedarikçisi konumunda. Türkiye, Rus doğalgaz tekeli Gazprom'un en büyük ikinci pazarı. Ancak artık Türkiye de doğalgaz pazarına sağlam bir adım attığından, Rusya, Güney Akımı boru hattına alternatif olarak getirilen projeleri, Avrupa pazarındaki egemenliğine yönelik bir tehdit olarak görebilir.

\section{Sonuç}

Avrupa Birliği’nin tüm politika belgelerinde de belirtildiği gibi, birliğin birinci önceliği enerji arz güvenliği ve çeşitliliğini sağlamaktır. Bu bağlamda AB'nin Doğu'daki komsu ülkeleri stratejik bir öneme sahiptir. Rusya, Avrupa'nın en büyük petrol ve doğalgaz tedarikçisi olup gelecekte de bu konumunu sürdürecektir. En güvenilir ilave enerji tedarikçileri olan Orta Asya, Karadeniz ve Hazar Denizi bölgelerinin potansiyeli henüz tam olarak keşfedilmemiştir.

Günümüzde, Türkiye'nin enerji terminali olma vizyonu; en kritik enerji kaynakları olarak değerlendirebileceğimiz petrol ve doğalgaz kaynaklarının en zengin olarak Türkiye'nin yakın coğrafyasında yer almasıyla yakın ilişkilidir. Dünyadaki en_büyük gaz ithalatçısı konumundaki AB'ye doğalgazın Hazar bölgesi ve Ortadoğu ülkelerindeki üretim alanlarından boru hatlarıyla iletiminde en elverişli güzergahların Türkiye üzerinden geçişi öngören güzergahlar olduğu dikkate alındığında,uluslararası enerji arenasında Türkiye'nin rolünün önem taşıdığı alan olarak doğalgaz sektörü öne çıkmaktadır.

Hazar geçişli bir boru hattının inşasının önünü_açacak şekilde bu denizin hukuki statüsünün_belirlenmesinde, kıyısı olan ülkelerce uzlaşma sağlanmasına yönelik çabalar AB tarafından_devam ettirilmekle birlikte, böyle bir 
bağlantının gerçekleşmesinde çıkarı olmayıp tersine olumsuz_etkilenmesi daha muhtemel olan İran ve_Rusya'nın böyle bir konsensüse varması da zor_görünmektedir. Azerbaycan ve Türkmenistan_arasında bir ikili mutabakat sağlanarak, iki ülkenin_Hazar Denizi’ndeki üretim sahalarının birbirine_bağlanması üzerinde durulan bir seçenek konumundadır.

Avrasya ve Hazar bölgesinde gerek Türkiye'nin gaz arzı ihtiyacının karşılanması,gerekse AB'ye gaz sevkiyatı açısından belirsizliği devam etmektedir. Türkmen tarafının konuya yaklaşımı ise kendi sınırları ötesinde aktif bir durumda yer almamak şeklinde olmuş, hatta son derece önemli bir konu olan Hazar Denizi’nin kıyı ülkelerce kullanımına dair statütüsünün belirlenmesinde pasif bir tutum takınmıştır. İran'ın doğalgaz rezervleri açısından Rusya'dan sonra en zengin ülke olması; bu ülkede yabancı sermaye yatırımları açısından teşvik_edici bir atmosfer olmaması, ABD ile ilişkilerde gerginlikler sonucu ülkeye uygulanan yaptırımlar gibi olumsuz unsurlara rağmen, İran ile doğalgaz alanında işbirliği çabalarının Türkiye dahil birçok ülke ve enerji şirketleri tarafından

sürdürülmesine yol açmaktadır._Irak gazı, Avrupa için en ekonomik alternatiflerden biridir ve ne yazık ki Brüksel'in bu konuda Türkiye'yi de kapsayan hiç bir ciddi girişimi bulunmuyor. Oysa, Irak, yılda 11-12 milyar metreküp gazı hiç bir tüketim ve işleme imkanı bulunmadığı için kuyu başında yakıyor. Kuyu başında yakılan gazın, ITGI yani Türkiye üzerinden Yunanistan ve İtalya'ya uzanacak boru hattını ya da Arnavutluk üzerinden İtalya'ya uzanacak TAP boru hattını tümüyle doldurmaya yetecek düzeydedir.İran gazının önünü kapayan ABD, önümüzdeki 5 yıllık süreçte politik ve ticari koşulların elvermesi durumunda, Rus gaz jeopolitiği açısından kara delik konumundaki Irak’’ sahneye sürebilir. Rusya, Irak gazının fiyatına doğrudan ya da dolaylı olarak müdahale edemeyecektir. Irak gazı, Azerbaycan dışındaki Hazar kaynaklarının önünü kesebilecek konuma gelebilir_(Pala, 2010;88-93)._Nabucco ve diğer projelerin hayata geçip geçmeyeceğini, AB-Rusya ilişkilerinin seyri ve AB'nin yeniden nükleer enerjiye dönüp dönmeyeceği hususları belirleyecektir. AB içinde son 3 yıldır kapalı kapılar ardında yeni bir nükleer planlama yapıldığı artık bir sır değil. Önümüzdeki 5 yıl içinde ekonomik krizin etkisiyle dibe vuran $\mathrm{AB}$ doğalgaz talebinin ciddi oranda artmayacağını, hatta ciddi al ya da öde sorunları yaşanacağını ve ABD menşeli kaya gazı (shalegas) keşfinin doğalgaz arzında "bolluk" yaratacağını da düşünmemiz gerekmektedir.

Türkiye, Avrupa'ya ulasan temel enerji transit güzergâhlarının merkezinde, özel bir konuma sahiptir. Küresel petrol ve doğalgaz rezervlerinin yaklaşık \% 70’i Türkiye’ye komşu bölgelerde toplanmaktadır. Enerji arz güvenliğini artırmak için Türkiye'nin coğrafi pozisyonunun tam olarak kullanılması hem Türkiye'nin, hem_de AB'nin çıkarınadır.Mühendislik ve boru hattı projeleri özünde bir optimizasyon meselesidir. Küresel ekonomik krizin global kredi havuzundaki finansal kaynaklarını sınırlandırdığı düşünülecek olursa, Avrupa hedefli boru hatlarının da acilen optimize edilmesi, belki tümüyle ya da kısmi olarak birleştirilmesi bu olmuyorsa bazılarından vazgeçilmesi hususları bilimsel açıdan değerlendirilebilir. Proje optimizasyonunu takiben, sınırlı gaz ihracat imkanı, kapasite ve zamanlama dikkate alınarak alternatif gibi gösterilen boru hatları önceliklendirilebilir. Bu sayede hangi projenin, hangi gaz kaynă̆ına dayalı olarak ve hangi yılda devreye alınacağı gerçekçi biçimde ortaya konulabilir. Müşterisi hazır ve daha küçük miktarları garantileyen proje ile başlanır ve böylece Doğu'daki kaynakların önü beklenenden çok daha önce açılabilir. Ardından diğer projeler ve diğer kaynaklar senkronize biçimde devreye alınabilir. Kuşkusuz, bu kritik konuda sadece şirketlere değil, hükümetlere de büyük rol düşecektir.

Sınırlı miktardaki Azeri gazı ve yüksek maliyeti nedeniyle geleceği şimdilik meçhul gözüken Nabucco ise ancak ve ancak Irak gazı ile ciddi bir ivme kazanabilir. Aksi halde, AB'nin meşhur 20-20-20 hedefine (2020'de enerji üretiminin \%20'sini yenilenebilir enerji kaynaklarından sağlamak, karbon emisyonlarını \%20 azaltmak); Nabucco'nun zamanlamasını kapsayan, mesela "Nabucco beyond 2020” (Nabucco 2020'den Sonra), başlıklı yeni bir "20" hanesi daha eklemesi, "bir avuç Azeri gazı için” kıyasıya rekabet eden ülkeler ve şirketlerin bekası bakımından çok yerinde bir hareket olacaktır.

Haziran 2013, çok önemli bir dönüm noktasıdır. Azeri gazının TANAP ve TANAP sonrasında hangi proje ile taşınacağına karar verilecektir. Nabucco ile yarışan ve pek çok uzmana göre, en iyi proje olan TAP, Türkiye'nin Balkanlardaki gücünü arttırmak açısından da çok kritiktir. Türkiye TAP projesine ortak olma şansını şimdilik askıya almıştır. Mesele, sadece transit ülke olup, 20 dolara bu gazın ülkemiz üzerinden geçişine izin vermek değildir. Oyunda aktif rol üstlenerek hem üretimde hem taşıma da ama mutlaka gaz ticaretinde pay almadan Türkiye'nin bu süreci karlı kapatması mümkün değildir. Ancak Azerbaycan her açıdan avantajlı çıkacak ve AB arz güvenliğinde Rus gazı ile gaza gaz rekabet yaratarak AB tüketicilerini Rusya tekelinden kurtaracaktır. Beklentiler, Türkiye bu satranç oyununu iyi okuması ve enerji oyununun dikey entegre yapısını dikkate alarak, ve üye olarak girme konusunda kapısında sıkıntılar yaşadığı AB'ye, önemli bir gaz oyuncusu olarak dahil olmasıdır. Bunu Azerilerle yapılması iki arasındaki bağların ülke ekonomileriyle de çok uzun dönemli ve daha sağlam olarak pekiştirilmesidir. 


\section{Kaynakça}

- Ayhan, Veysel, 2009. “Avrupa’nın Enerji Arz Güvenliğinde Türkiye: Petrol, Doğal Gaz ve Entegrasyon”, Uluslararası İliş̧kiler, 5:20, s.155-178.

- Aydın, Nermin, Zahide, 2012. "Hazar Enerji Kaynakları ve Siyaset”, KSÜ Sosyal Bilimler Dergisi, Cilt 9, Say1 2, s.207-224.

- Bahgat, Gawdat, 2011. Energy Security: An Interdisciplinary Approach, West Sussex, John Wiley\&Sons.

- Brzezinski, Zbigniew Kazimierz, 1998. Büyük Satranç Tahtası, İstanbul, Sabah Kitapları

- BP, 2013.Statistical Review of World Energy, London, June .

- CERA,1998. "New Bridges to Turkey’s Hydrocarbon Future”, Private Report, Cambridge Energy Research Associates, April.

- Borombaeva, Elvina, 2002. "21. Yüzyılda Türkiye Üzerinden Dünya Pazarlarına Ulaştırılacak Hazar Petrol Boru Hatları Seçenekleri ve Türkiye”, Yayınlanmamış Yüksek Lisans Tezi, Ankara Üniversitesi, SBE, Ankara,

- Erdağ, Ramazan, 2013. “Anadolu Geçişli Doğal Gaz Poru Hattı Projesi (TANAP)'nn Küresel Enerli Politikalarına Etkisi Üzerine Bir Değerlendirme, The Journal of Academic Social Science Studies ,International Journal of Social Science, Volume 6 Issue 3, p. 867-877, March .

- Ener, Meliha ve Ahmedov, Orhan, 2008, “Türkiye -Azerbaycan Doğalgaz Boru Hattı Projelerinin Ülke Ekonomileri ve Avrupa Birliği Açısından Önemi”, 2. Ulusal iktisat Kongresi /20-22 Şubat 2008/ DEÜ I.I.B.F İktisat Bölümü / İzmir-Türkiye.

- EIA, 2007. System for the Analysis of Global Energy Markets. www.eia.doe.gov/oiaf/aeo,2013

- M.M. Foss, 2011. The Outlook For US.Gas Prices 2020, Henry Hup at $3 \$$ or $10 \$$. The Oxford Institute For Energy Studies.

- Pala, Cenk, 2007. 20.Yüzyılın Şeytan Üçgeni:ABD-Petrol-Dolar, Yasak Elma Enerji Kitapları Dizisi, Ankara.

- Pala, Cenk, 2003. Doğu-Batı enerji Koridoru'nun İlk Basamağı Gerçekleşiyor: Bakü-Tiflis-Ceyhan Ham Petrol Boru Hattı Projesi", I.Ü. Iktisat Fakültesi Mezunları Cemiyeti (IFMC), Ikktisat Dergisi, "Savaşın Gölgesinde Orta Doğu", Sayı: 433-434, s. 85-93, Ocak-Şubat,

- Pala, Cenk, 2003a.“21. Yüzyıl Dünya Enerji Dengesinde Petrol ve Doğal Gazın Yeri ve Önemi: Hazar Boru Hatlarının Kesişme Noktasında Türkiye”, Avrasya Dosyası, Cilt 9, Sayı 1, Bahar, Ankara: 5-37.

- Pala, Cenk, 2008, "Hazar Petrol ve Doğalgazının Uluslararası Piyasalara Taşınması ve Bir Örnek Olarak Bakü-Tiflis-Ceyhan Ham Petrol Boru Hattı Projesi’nin Önemi”, (Der.), Gülten Kazgan, Türkiye-Rusya Arasında İhtilaflı Konular ve Çözümleri, İstanbul, İstanbul BilgiÜniversitesi Yayınları.

- Pala, Cenk, 2010. "Nabucco” Özelinde Türkiye Üzerinden Geçecek Doğal Gaz Boru Hatlarının Geleceğine Dair Bir Not: Quo vadis?, Dış Ticarette Durum Dergisi Enerji Özel Sayı, Türkiye Dış Ticaret Derneği, 2010, Sayı:70, s.88-93,TURKTRADE, Aralık, 2010.

- Pala, Cenk, ve.Engür, Ergün, 1998.“Kafkasya Petrolleri: 21. Yüzyılın Eşiğinde Hazar Havzası ve Türkiye”, Işsletme ve Finans, Say1 152, s.21-39.Kasım, Ankara.

- İpek,Pınar, 2006. "The Aftermath of Baku-Tbilisi-Ceyhan Pipeline: Challenges Ahead for Turkey", Perceptions, Bahar, ss.1-17.

- E. Özen, 2012. Türkiye Doğalgaz Piyasasi:Beklentiler, Gelişmeler 2012, Deloitte.

- Uluatam, Ela,2010. “Avrupa Doğalgaz Piyasasında Yeni Dengeler”, Ekonomik Forum,TOBB, Ağustos, s.6267.

- Ulçenko, Natalya,2001.“Rusya ve Türkiye'nin Güvenliğinde Enerji İhracat ve İthalatının Rolü”, Avrasya Dosyast- Rusya Özel, Cilt 6, Sayı 4, Kış s.:147-8.

- IEA, 1998a.World Energy Outlook-1998 Edition, OECD/IEA Pub., Paris.

- IEA,1998b.Caspian Oil and Gas-The Supply Potential of Central Asia and Transcaucasia, OECD/IEA Pub., Paris.

- IEA, ,2001. Assessing Today's Supplies toFuel Tomorrow's Growth, World Energy Outlook,

- IEA, 2005. International Energy Agency, Key World Energy Statistics, OECD/IEA. Paris,

- IEA, 2011. Are We Entering AGoldAge of Gas?, World Energy Outlook, Special Report, $\quad$ Paris, OECD/IEA Pub.

- IEA, ,2012. World Energy Outlook, Paris, OECD/IEA Pub. 
- The Economist, 1998.“A Caspian Gamble”, A Survey of Central Asia, Feb. 7.

- The Economist, 2010. “An Unconventional Glut”, March 13.

- Yüce,Çağrı, Kürşat, 2008. “Hazar Enerji Kaynaklarının Türk Cumhuriyetler İçin Önemi”, Stratejik AraştırmalarDergisi/Journal of Strategic Studies 1(1),2008, 158-183, http://www.beykent.edu.tr/docs/7.doc?phpMyAdmin=26b1ab37aa748d52c4747d623bec741b,

- $\quad$ Eurostat, Statistical Books Energy, 2007

- http://epp.eurostat.ec.europa.eu/portal/page/portal/eurostat/home/, 2013

- http://www.tanap.com/tanap-nedir 


\title{
Geçiş Sürecindeki Orta Asya Cumhuriyetlerinde Enerji Tüketimi ve Büyüme İlişkisi
}

\section{The Relationship between Energy Consumption and Growth in the Transition Economies of Central Asian Republics}

\author{
Asst. Prof. Dr. Abdullah Özdemir (Adnan Menderes University, Turkey) \\ Asst. Prof. Dr. Mehmet Mercan (Hakkari University, Turkey) \\ Mr. Erkan Dendeş (Adnan Menderes University, Turkey)
}

\begin{abstract}
The transition period from the socialist system to the capitalist system is used to describe economies in transition. With the dissolution of the Soviet Union in the 1990s, with Central and Eastern European Countries, the Countries in Central Asia have entered into this process. Central Asian Countries haven't entered into this process providently a lot in transitional stage. At the end of secession process from the Soviet Union, these countries had only limited industrial plants and natural resources. However, reserves of energy resources that these countries have in their economic growth have been a pusher factor. No doubt, increasing energy consumption has a significant effect in the development of the countries. The main purpose of this study is to test the existence of growth relation and energy consumptions in Central Asian Countries that live the transition period accordingly. This study investigates relationship between economic growth and energy consumption for Central Asian Countries over the period 1990-2010 by using panel data analysis. As a conclusion it is reached that there is a significant correlation between energy consumption and economic growth for these countries.
\end{abstract}

\section{Giriș}

Enerji, ekonomik ve sosyal kalkınmanın en önemli girdilerinden birisini teşkil etmektedir. Sürdürülebilir kalkınmanın sağlanması ve yaşam standartlarının yükseltilmesinde önemli bir rol oynayan enerjinin dünyanın geleceğinde konumu her geçen gün artmaktadır. Ancak önemli enerji kaynaklarını oluşturan petrol, doğalgaz, kömür gibi fosil yakıtların hızla tükenmekte oluşu ve alternatif enerji kaynaklarının da yetersiz oluşu, bu kaynakların önemini her geçen gün arttırmaktadır. Günümüzde tüm dünyada özellikle ekonomisi hızla büyüyen ülkelerde fosil yakıt tüketimi hızla artmaktadır. Enerjiye olan talebin giderek artmasıyla birlikte 19. yüzyıldan itibaren enerji kaynaklarına sahip olmak, üretimini gerçekleştirmek ve iletim hatlarına sahip olmak büyük ülkelerin temel amaçları arasında yer almıştır. Artan enerji ihtiyacı karşısında, Orta Asya Ülkelerinin enerji rezervleri bakımından zengin olmaları bu sürecin onların lehine olması anlamına gelmektedir.

$\mathrm{Bu}$ çalışmanın ana amacı bu doğrultuda geçiş sürecini yaşayan Orta Asya ülkelerindeki enerji tüketimleri ile büyüme ilişkisinin varlığını test etmeye yöneliktir. Bu doğrultuda önce geçiş ekonomisi kavramı ve geçiş sürecinde Orta Asya Ülkeleri üzerinde durulacak, daha sonra dünya enerji kaynakları ile Orta Asya Ülkelerinin enerji kaynakları potansiyeli hakkında bilgi verilecektir. Çalışmanın devamında panel veri analizi ile Orta Asya Ülkelerinde tüketim büyüme ilişkisi ortaya konulmaya çalışılacaktır.

\section{Geçiş Ekonomileri}

Geçiş sonucunda ekonomik yapı ile üretici ve tüketici davranışlarında temel bir takım değişimler meydana gelmiştir (Yavuz, 2005). Bu değişimin temelini ekonomik faaliyetlerin, fiyatların ve piyasa işlemlerinin serbestleştirilmesi, kaynakların yeniden dağıtılarak etkin kullanılmasının sağlanması, piyasa ağırlıklı araçların geliştirilerek makro ekonomik istikrarın tekrar sağlanması, ekonomik verimlilik sağlanabilmesi için özelleştirmeler ve sıkı bütçe uygulamalarının yapılması oluşturmaktadır. Ayrıca mülkiyet hakları, sağlam ve işleyen hukuki sistem ile şeffaf pazar oluşturulması çalışmalarını da kapsamaktadır (Akar, 2007).

\subsection{Geçiş Ekonomileri Tanımı, Kapsamı ve Özellikleri}

İktisat Literatürüne 80'li yılların sonunda giren geçiş ekonomileri terimi, merkezi planlamayı terk ederek, piyasa ekonomisi sistemini kurmaya çalışan eski sosyalist ülkeleri ifade etmek için kullanılır (Tandırcıoğlu, 2002). Geçiş ekonomisi ile ifade edilen; bir ülkenin var olan mevcut üretim tarzının rakipleri ile rekabet edememesi neticesinde kısmen veya tamamen çökerek kurumsal yapısını değiştirmeye zorlamasıdır. Başka bir ifade ile Sosyalist veya karma ekonomik yapıdan piyasa ekonomisine geçiş sürecidir (Yavuz, 2005). Özellikle 1980'li yıllardan sonra hızla değişen dünyada oluşan yeni küresel eğilimler ve yeni küresel değerler devletin görevlerini ve ekonomik rollerini de hızla değiştirmiştir. Bunun sonucunda da birçok ülkede korumacı devlet anlayışı yıkılmış ve bunun yerini piyasa ekonomisini benimsemiş dışa açık ve rekabetçi devlet anlayışı almıştır (Uçkaç, 2011) 
Geçiş ekonomileri kapsamında 12 Merkezi ve Doğu Avrupa Ülkeleri, 15 eski Sovyetler Birliği Cumhuriyetleri ile Moğolistan, Çin ve Vietnam değerlendirilmektedir. Bu ülkeler gruplandırılacak olursa 1. grupta Bağımsız Devletler Topluluğu (BDT) ile eski Sovyetler Birliği Cumhuriyetleri, 2. grupta Merkezi ve Doğu Avrupa Ülkeleri (Baltık Cumhuriyetleri Dahil) ve 3 grupta ise Çin ve Vietnam yer almaktadır (Altay, 2002). Bu ülkeler arasında bir takım temel farklılıklar bulunmaktadır. Bu temel farklılıklar ekonomik altyapı, politik sistem, coğrafik konum, kurumsal başarı, demokratik kültür ve doğal kaynaklardan kaynaklanmaktadır (Ağcakaya, 2009). Bu farklıklara rağmen geçiş ekonomilerinin başlangıçta şu ortak özellikleri bulunduğu söylenebilir: Emek verimliliği OECD ülkelerinin 1/3'üdür, ücret oranının verimlilik ve beşeri sermaye yatırımıyla ilişkisi yoktur, sanayi sektöründeki ücret farklıkları diğer sektörlere göre daha düşüktür, ücretsiz eğitimin kırsal kesim veya fakirlik açısından soysal ilerlemeye katkısı yoktur, hükümetler genelde işsizliği kabul etmemişler veya etseler bile işsizlik araştırmalarını ele alan politikaları göz ardı etmiş̧lerdir (Akar, 2007).

Geçiş ekonomileri, merkezi planlı ekonomiden piyasa ekonomisine geçiş sürecinde "Big Bang" (Büyük Patlama) ve gradualism (aşamalı) adı verilen iki farklı yaklaşım belirlemiştir. Şok terapi olarak da ifade edilen birinci yaklaşım (Büyük Patlama) Uluslararası Para Fonu (I.M.F.) ve Dünya Bankası tarafından geliştirilmiş olup ekonominin yeniden yapılandırılması için uygulanacak bütün makro ve mikro politikaların hızlı bir biçimde uygulanması gerektiğini ifade etmektedir. İkinci aşama ise merkezi planlı ekonomiden planlı ekonomiye geçiş süreci ve bu süreç içerisinde yapılması gereken reformları aşamalı olarak gerçekleştirilmesi esasına dayanır (Çatalbaş-Yıldırım, 2008).

Şok terapi politikaları, ekonomik koşulları aşırı derecede tahrip olmuş ve reform sürecinin başında radikal ekonomik reformlara taraftar bir politik iklimin hakim olduğu ülkelerce benimsenmiştir. İstikrarlı politik ve makro ekonomik koşulları sağlayan ülkelerde ise aşamalı politikalar uygulanmıştır (Güler, 2012). Bu iki yaklaşımdan birincisini seçen çoğu ülkeler zamanla yaşanan olumsuzluklar nedeniyle birinci yaklaşımı terk ederek ikinci yaklaşımı tercih etmişlerdir (Çatalbaş-Yıldırım, 2008).

Ancak geçen sürede edinilen tecrübeler reformların başarısını etkileyen birçok faktörün olduğunu göstermiştir. Özellikle eski sistemin genel özellikleri, uygulanan reformların başarısı üzerinde hala önemli etkilere sahiptir. Bu özellikler; Komünist partinin siyasi tekeli, sanayi sektöründe bulunan tekelci yapı, ürünlerin kalitesiz oluşu ve tüketim mallarında kıtlık sorunu, bastırılmış enflasyon, mali dengesizlikler ve gevşek bütçe politikası, sanayi sektöründe işsizliği teşvik edici sosyal güvenlik tedbirleri olarak sayılabilir. (Acartürk ve Arslaner, 2004).

Reformların başarılı olması şüphesiz bu unsurların ne ölçüde giderildiği ile ilgilidir. Başka bir değişle, bu unsurların sırasıyla piyasa ekonomisi ortamını yaratacak boyuta çekilmesi gerekmektedir.

Bunun için; Siyasette bulunan tekelci yapının demokratik rekabetçi bir düzene, iktisadi tekelci yapının kırılarak rekabetçi firma düzenine, malların kıtlı̆̆ının giderilmesinde serbest fiyat düzenine, mali dengesizlikleri azaltan mali disiplin ortamına, enflasyonla mücadele için sıkı para politikası uygulamasına, çalışmayı caydırıcı uygulamaların ortadan kaldırılarak çalışmayı teşvik eden bir yapıya kavuşturulmaları gerekmektedir.

Ancak bunlar yerine getirildiğinde ekonomide merkezi karar alma mekanizması yerine, özgürce ekonomik kararların alındığı liberal bir ekonomik sistemden söz etmek mümkün olabilir (Uçkaç, 2011)

\subsection{Geçiş Sürecinde Orta Asya Cumhuriyetleri}

Sovyet Sosyalist Cumhuriyetler Birliği'nin dağılmasından sonra ulusal bağımsızlıklarını ilan eden Kazakistan, Kırgızistan, Tacikistan, Türkmenistan, Özbekistan ve Azerbaycan aynı zamanda piyasa ekonomisine geçerek de ekonomik bağımsızlıklarını ilan etmişlerdir. Piyasa sisteminin temel unsuru olan fiyatların serbestçe oluştuğu ve kaynak dağılımını üstlendiği bu sisteme uyum süreci adı geçen ülkeler bazında çok sancılı geçmiştir. Bu ülkeler serbest piyasa ekonomisinin gerektirdiği kurumsal ve hukuki yapıyı oluşturmak için, dış kaynaklardan da yardım alarak, geçiş programları uygulamışlardır (Altınbaş vd., 2008).

Bölgenin ekonomik gelişimini etkileyen ve geçiş sürecinin sancılı olmasına neden olan pek çok faktör mevcuttur. Bu faktörler arasında ekonomik, politik ve coğrafi özellikler sayılabilir. Petrol, doğalgaz, altın ve diğer metalleri içeren önemli doğal kaynaklara sahip oluşu, geniş bir coğrafi alana kapsaması ve sosyalist ekonomik modelin izleri bu özellikler arasında sayılabilir (Çelik, 2007).

Geçiş sürecinin en çarpıcı özelliği ise sürecin başlamasından hemen birçok ülkede gözlemlenen ekonomik duraklamadır. Bu duraklama dönemi üretimde çok büyük miktarlara varan azalmalar ve işsizlikte büyük oranlı artışlarla kendini göstermiştir. Geçişi takiben ekonomik faaliyetlerde yaşanan büyük daralma, uzun yıllar kapitalist ve sosyalist sistemler üzerine araştırmalarda bulunmuş olan Macar asıllı iktisatçı Janos Kornai tarafindan "Geçişsel Resesyon" (Transitional Recession) ya da "Geçiş Resesyonu" (Transition Recession) olarak adlandırılmış ve bu kavram, geçiş ekonomileri literatüründe de büyük ölçüde kabul görmüştür (Güler, 2012).

Tablo 1'den de görüldüğ̈̈ üzere ekonomik durgunluğun en uzun yaşandığı Orta Asya Cumhuriyeti ülkesi 9 yıl ile Türkmenistan olmuştur. Türkmenistan'ı 8 yıl ile Tacikistan ve 7 yıl ile Kazakistan ve Azerbaycan takip etmiştir.

Geçişin yaşandığı ilk yıllarda büyüme oranları bütün Orta Asya Cumhuriyetleri'nde eksi olarak gerçekleşmiş ve bu eksi büyüme 1995 yılında da devam etmiştir. Ekonomik büyümenin eksi çıkmasının en büyük 
nedenlerinden birisi şüphesiz yaşanan ekonomik durgunluktur. 2000 Y1lında ise \% 11,1 ile en fazla büyüme oranına sahip ülke Azerbaycan olurken onu \% 9,8 ile Kazakistan ve \% 8,3 ile Tacikistan takip etmiştir. 2008 yılında büyüme 2005 yılına oranla Kazakistan'da ve Azerbaycan'da azalma gözlemlenirken diğer ülkelerde ise 2005 yılına göre artış gözlemlemiştir. 2011 yılında en fazla büyüme oranına sahip ülke \% 14,7 ile Türkmenistan olmuştur. Türkmenistan'ı sırasıyla \% 8,3 ile Özbekistan ve \% 7,5 ile Kazakistan takip etmektedir.

\begin{tabular}{|l|l|l|l|}
\hline Ülkeler & Resesyon Başlangıç & Resesyon Bitiş & Resesyon Süresi \\
\hline Kazakistan & 1989 & 1995 & 7 Yil \\
\hline Kırgızistan & 1991 & 1995 & 5 Yil \\
\hline Tacikistan & 1989 & 1996 & 8 Yil \\
\hline Türkmenistan & 1989 & 1997 & 9 Yil \\
\hline Özbekistan & 1991 & 1995 & 5 Y1l \\
\hline Azerbaycan & 1989 & 1995 & 7 Y1l \\
\hline
\end{tabular}

Tablo 1: Ülkelere Göre Geçiş Resesyonu Döneminin Uzunluğu. Kaynak: Güler, 2012.

\begin{tabular}{|l|l|l|l|l|l|l|l|l|}
\hline Ülkeler & 1991 & 1995 & 2000 & 2005 & 2008 & 2009 & 2010 & 2011 \\
\hline Kazakistan & -11 & $\ddot{U} 8,2$ & 9,8 & 9,7 & 3,3 & 1,2 & 7,3 & 7,5 \\
\hline Kirgizistan & $-7 \mathrm{i} 9$ & $-5,4$ & 5,4 & $-0,2$ & 8,4 & 2,9 & $-0,5$ & 6,0 \\
\hline Tacikistan & $-7,1$ & $-12,4$ & 8,3 & 10,5 & 21,2 & 3,9 & 6,5 & 7,4 \\
\hline Türkmenistan & $-4,6$ & $-7,2$ & 5,5 & 13,0 & 14,7 & 6,1 & 9,2 & 14,7 \\
\hline Özbekistan & $-0,5$ & $-0,9$ & 3,8 & 7,0 & 9,0 & 8,1 & 8,5 & 8,3 \\
\hline Azerbaycan & $-0,7$ & $-11,8$ & 11,1 & 26,4 & 10.8 & 9,3 & 5,0 & 1,0 \\
\hline
\end{tabular}

Tablo 2: GSYİ Büyüme Oranlarl (\%). Kaynak: World Bank, 2013.

\begin{tabular}{|l|l|l|l|l|l|l|l|l|}
\hline Ülkeler & 1991 & 1995 & 2000 & 2005 & 2008 & 2009 & 2010 & 2011 \\
\hline Kazakistan & 91 & 176,3 & 13,2 & 7,6 & 17,2 & 7,3 & 7,1 & 8,3 \\
\hline Kirgizistan & 85 & 43,5 & 18,7 & 5,2 & 24,5 & 6,9 & 8,0 & 16,5 \\
\hline Tacikistan & 111,6 & 609 & 32,9 & 7,3 & 20,5 & 6,4 & 6,4 & 12,4 \\
\hline Türkmenistan & 102,5 & 1005,3 & 8,3 & 10,7 & 14,5 & $-2,7$ & 4,5 & 5,8 \\
\hline Özbekistan & 82,2 & 304,6 & 25,0 & 10,0 & 12,7 & 14,1 & 9,4 & 12,8 \\
\hline Azerbaycan & --- & 411,8 & 1,8 & 9,7 & 20,8 & 1,4 & 5,7 & 7,9 \\
\hline
\end{tabular}

Tablo 3: Tüketici Fiyatları ile Yıllık Enflasyon (\%). Kaynak: World Bank, 2013.

Geçişin yaşandığı ilk yıllarda enflasyon oranlarının yüksek olduğu görülmektedir. Orta Asya Cumhuriyetlerinde enflasyon 2000 yılından sonra kontrol altına alınabilmiştir. 2011 yılında en yüksek enflasyonun yaşandığı Orta Asya ülkesi \% 16,5 ile Kırgızistan olmuştur. Kırgızistan'ı sırasıyla \% 12,8 ile Özbekistan ile \% 12,4 ile Tacikistan takip etmiştir. Enflasyonun en düşük olduğu ülke \% 5,8 ile Türkmenistan'dır.

\begin{tabular}{|l|l|l|l|l|l|l|l|l|}
\hline Ülkeler & 1991 & 1995 & 2000 & 2005 & 2008 & 2009 & 2010 & 2011 \\
\hline Kazakistan & 24,9 & 20,4 & 18,3 & 57,1 & 133,4 & 115,3 & 148,0 & 188,0 \\
\hline Kırgizistan & 2,6 & 1,7 & 1,4 & 2,5 & 5,1 & 4,7 & 4,8 & 6,2 \\
\hline Tacikistan & 2,5 & 1,2 & 0,9 & 2,3 & 5,2 & 5,0 & 5,6 & 6,5 \\
\hline Türkmenistan & 3,2 & 2,5 & 2,9 & 8,1 & 19,3 & 20,2 & 22,5 & 28,1 \\
\hline Özbekistan & 13,8 & 13,4 & 13,8 & 14,3 & 27,9 & 32,8 & 39,3 & 45,4 \\
\hline Azerbaycan & 8,8 & 3,1 & 5,8 & 13,2 & 48,9 & 44,3 & 52,9 & 63,4 \\
\hline
\end{tabular}

Tablo 4: Gayri Safi Yurtiçi Hasıla (Milyar Dolar). Kaynak: World Bank, 2013.

\begin{tabular}{|l|l|l|l|l|l|l|l|l|}
\hline Ülkeler & 1991 & 1995 & 2000 & 2005 & 2008 & 2009 & 2010 & 2011 \\
\hline Kazakistan & 1512 & 1288 & 1229 & 3771 & 8514 & 7165 & 9070 & 11357 \\
\hline Kirgizistan & 576 & 364 & 280 & 476 & 966 & 871 & 880 & 1124 \\
\hline Tacikistan & 468 & 213 & 139 & 358 & 771 & 734 & 820 & 935 \\
\hline Türkmenistan & 848 & 593 & 645 & 1707 & 3918 & 4059 & 4393 & 5497 \\
\hline Özbekistan & 65 & 586 & 558 & 547 & 1023 & 1182 & 1377 & 1546 \\
\hline Azerbaycan & 1209 & 397 & 655 & 1578 & 5575 & 4950 & 5843 & 6912 \\
\hline
\end{tabular}

Tablo 5: Kişi Başı Gayri Safi Yurtiçi Hasıla (Dolar). Kaynak: World Bank, 2013.

Tablo 4'de Gayri Safi Yurtiçi Hasıla incelendiğinde 1991 yılında 24,9 Milyar \$ ile Kazakistan ilk sırada yer alırken onu sırasıyla 13,8 Milyar \$ ile Özbekistan ve 8,8 Milyar \$ ile Azerbaycan izlemektedir. 2011 yılı itibariyle ilk üç sıra içerisinde yine aynı ülkeler yer almıştır. Tablo 4'de dikkati çeken bir diğer nokta Kırgızistan 
ve Tacikistan'ın diğer dört ülkeye nazaran Gayri Safi Yurtiçi Hasılasının oldukça düşük olmasıdır. Bunun nedeni bu iki ülkede doğalgaz ve petrol kaynaklarının çok az olmasıdır.

Tablo 5'de kişi başı gayri safi yurtiçi hasılalar verilmiştir. 1991 yılında en yüksek kişi başı geliri elde eden ülke 1512 Dolar ile Kazakistan'da elde edilmiştir. Kazakistan'ı sırasıly 1209 Dolar ile Azerbaycan, 848 Dolar ile Türkmenistan ve 576 Dolar ile Kırgızistan takip etmektedir. 2008 yılında yaşanan ekonomik kriz şüphesiz birçok ülkenin ekonomik yapısını etkilemiştir. Nitekim Türkmenistan ve Özbekistan hariç Kazakistan, Kırgızistan, Tacikistan ve Azerbaycan'da 2008 y1lında göre 2009 y1lında kişi başı gelirde azalmalar meydana gelmiştir. 2011 yılında en fazla kişi başı gelir 11357 Dolar ile Kazakistan'da elde edilmiş̧ir.

\section{Orta Asya Cumhuriyetlerinde Enerji}

Kazakistan, Türkmenistan, Özbekistan ve Azerbaycan enerji kaynakları bakımından hidrokarbon rezervleri (ham petrol, petrol ürünleri, doğalgaz, LNG ve kömür), Tacikistan ve Kırgızistan ise hidroelektrik potansiyeli açısından önemli ülkeler arasında yer almaktadır (Kuzu, 2012). Tablo 10'da Orta Asya ülkelerinin kanıtlanmış doğalgaz ve petrol rezervleri verilmiştir.

Tablo 6'da 2010 yllı itibariyle enerji üretiminde kaynakların payı incelendiğinde Kazakistan'da en fazla üretilen enerji kaynağı \% 80,7 ile kömür, Kırgızistan'da \% 91 ile Hidroelektrik, Tacikistan'da \% 96,6 ile hidroelektrik, Türkmenistan'da \% 100 ile doğalgaz, Özbekistan'da \% 73,4 ile doğalgaz ve Azerbaycan'da ise \% 81,4 ile doğalgaz olduğu görülmektedir.

Tablo 7 de Orta Asya Cumhuriyetlerinin enerji üretimleri verilmiştir. 2010 yılı itibariyle en fazla enerji üretimi 5,82 katrilyon btu ile Kazakistan olurken onu sirasiyla 2,87 katrilyon btu ile Azerbaycan ve 2,51 katrilyon btu ile Özbekistan takip etmektedir.

Tablo 8'e göre en fazla enerji tüketimi olan Orta Asya ülkesi 2,26 trilyon btu ile Kazakistan olurken onu sırasıyla 2,00 trilyon btu ile Özbekistan ve 0,92 trilyon btu ile Türkmenistan'ın takip ettiği görülmektedir.

\begin{tabular}{|l|l|l|l|l|l|l|}
\hline $\begin{array}{l}\text { Enerji } \\
\text { Kaynakları }\end{array}$ & Kazakistan & Kırgızistan & Tacikistan & Türkmenistan & Özbekistan & Azerbaycan \\
\hline Petrol & 0,8 & 0,0 & 0,0 & 0,0 & 1,5 & 0,2 \\
\hline Kömür & 80,7 & 2,3 & 0,0 & 0,0 & 4,1 & 0,0 \\
\hline Doğalgaz & 8,9 & 6,7 & 3,4 & 100,0 & 73,4 & 81,4 \\
\hline $\begin{array}{l}\text { Hidrolik } \\
\text { Enerji }\end{array}$ & 9,6 & 91,0 & 96,6 & 0,0 & 21,0 & 18,4 \\
\hline TOPLAM & 100,0 & 100,0 & 100,0 & 100,0 & 100,0 & 100,0 \\
\hline
\end{tabular}

Tablo 6: Orta Asya Cumhuriyetlerinin Enerji Üretiminde Kaynakların Payl (2010 Yllı \%). Kaynak: World Bank, 2013.

\begin{tabular}{|l|l|l|l|l|l|l|}
\hline Ülkeler & 1995 & 2000 & 2005 & 2008 & 2009 & 2010 \\
\hline Kazakistan & 2,33 & 3,38 & 4,86 & 5,55 & 5,57 & 5,82 \\
\hline Kırgizistan & 0,13 & 0,15 & 0,15 & 0,12 & 0,11 & 0,11 \\
\hline Tacikistan & 0,15 & 0,14 & 0,17 & 0,17 & 0,16 & 0,16 \\
\hline Türkmenistan & 1,36 & 2,05 & 2,66 & 2,91 & 1,77 & 2,04 \\
\hline Özbekistan & 2,14 & 2,41 & 2,50 & 2,79 & 2,55 & 2,51 \\
\hline Azerbaycan & 0,65 & 0,84 & 1,18 & 2,52 & 2,79 & 2,87 \\
\hline Dünya & 361,70 & 397,10 & 456,38 & 488,33 & 487,32 & 508,87 \\
\hline
\end{tabular}

Tablo 7: Orta Asya Cumhuriyetleri Enerji Üretimi (Katrilyon Btu). Kaynak: EIA, 2013.

\begin{tabular}{|l|l|l|l|l|l|l|}
\hline & 1995 & 2000 & 2005 & 2008 & 2009 & 2010 \\
\hline Kazakistan & 1,90 & 1,83 & 2,23 & 2,37 & 2,14 & 2,26 \\
\hline Kurgizistan & 0,19 & 0,24 & 0,21 & 0,18 & 0,21 & 0,20 \\
\hline Tacikistan & 0,21 & 0,24 & 0,28 & 0,26 & 0,19 & 0,19 \\
\hline Türkmenistan & 0,30 & 0,40 & 0,83 & 0,93 & 0,89 & 0,92 \\
\hline Özbekistan & 1,87 & 1,95 & 2,16 & 2,35 & 2,00 & 2,00 \\
\hline Azerbaycan & 0,73 & 0,52 & 0,66 & 0,72 & 0,57 & 0,56 \\
\hline Dünya & 362,95 & 400,07 & 459,29 & 490,69 & 487,58 & 510,55 \\
\hline
\end{tabular}

Tablo 8: Orta Asya Cumhuriyetleri Enerji Tüketimi (Katrilyon Btu). Kaynak: EIA, 2013. 


\section{Ampirik Analiz}

\subsection{Veri Seti ve Model}

Bu çalışmada, altı Orta Asya Ülkesi’ne ait, 1990-2010 dönemi, yıllık GSYIH (GDP-kişi başı GDP, 2000 sabit fiyatlart) ve enerji tüketimi (EUSE-kişi başı enerji tüketimi, kg petrol eşdeğeri) verileri kullanılmıştır. Veriler, dünya Bankası web sayfasından temin edilmiştir (World Bank, 2013) Seriler logaritmik olarak analize dahil edilmiştir.

Çalışmamızın ekonometrik modeli:

$$
G D P_{t}=\propto_{0}+\propto_{1} E U S E_{t}+u_{t}
$$

biçimindedir. Analiz için Stata 11 ve EViews 7.1 ekonometrik analiz programlarından yararlanılmış olup, model seçimi ve doğrulama testleri (değişen varyans ve otokorelasyon) için kodlar kullanılmıştır.

\subsection{Yöntem}

Farklı ülkelere ait verileri bir arada inceleyebilmek için, panel veri analizi yöntemi kullanılmıştır. Panel veri analizi (Baltagi, 2001; Gujarati, 1999):

$$
Y_{i t}=\propto+X_{i t}^{\prime} \beta+u_{i t}
$$

modelinde yer alan hata teriminin $\left(u_{i t}\right)$ bireysel ve zaman etkileri yönünden bileşenlerine ayrıştılmasına dayanmaktadır. Modelde $i$ ülkeleri, $t$ de zamanı göstermektedir. Hata terimi ayrıştıııldı̆̆ında:

$$
u_{i t}=\mu_{i}+\lambda_{t}+\vartheta_{i t}
$$

elde edilir. Elde edilen bu son eşitliğe, hata bileşenleri modeli (error component model) denir. Burada $\mu_{i}$; bireysel etkieri, $\lambda_{t}$ ise zaman etkilerini gösterir. $\mu_{i}, \lambda_{t}$ ve $\vartheta_{i t} \sim I I D\left(0, \sigma^{2}\right)$ (Independent Identically Distributed) yani hata terimlerinin ortalamasının sıfır, varyansının sabit olduğu ve normal dağıldığı (beyaz gürültü sürecine sahip olduğu) varsayılmaktadır.

Panel veri analizinde; önce serilerin durağanlıkları panel birim kök testleriyle incelenmektedir. Sonra bireysel ve zaman etkilerinin türü belirlenmelidir. Açıklayıcı değişkenler arasında, açıklanan değişkenle yakın ilişki içinde olduğu düşünülen ve dolayısıyla içselliğinden şüphelenilen değişken olduğunda, içsellik sınaması yapılmalıdır. Sonrasında model tahmin edilip, modelde değişen varyans ve ardışık içsel bağımlılık (otokorelasyon) sorunlarının varlığı test edilmelidir.

\subsection{Seçilmiş Literatür}

Enerji tüketimi ile büyüme arasındaki ilişkinin test edildiği çalışmalardan ilki Kraft ve Kraft (1978)'ın ABD için 1947-1974 dönemini kapsayan çalışmalarıdır. Makalede Sims Nedensellik testi uygulanmış ve büyümenin enerji tüketimini etkilediği sonucuna ulaşılmıştır.

Yu and Choi (1985) çalışmalarını Güney Kore ve Filipinler üzerine yapmışlardır. Çalışmalarında Granger nedensellik testi yapmışlar ve büyümenin enerji tüketimini etkilediği sonucuna ulaşmışlardır.

Glasure ve Lee (1987) Güney Kore ve Singapur için 1961-1990 dönemini kapsayan çalışmalarında Hata Düzeltme Modeli ve Ko-entegrasyon analizi yapmışlar ve analizde enerji tüketimi ile büyüme arasında çift yönlü bir ilişkinin olduğu sonucuna ulaşmışlardır.

Masih ve Masih (1998) çalışmalarında Güney Kore ve Singapur için Hata Düzeltme Modeli ve Koentegrasyon analizi yapmışlar ve analizde enerji tüketiminin büyümeyi etkilediği sonucuna ulaşmışlardır.

Hondroyiannis vd. (2002) çalışmalarını Yunanistan ekonomisi üzerine ve 1960-1996 dönemi için uygulamışlardır. Çalışmalarında Hata Düzeltme Modelini uygulamışlar ve analizde enerji tüketimi ile büyüme arasında çift yönlü bir ilişkinin olduğu sonucuna ulaşmışlardır.

Fatai vd. (2004) çalışmalarında Endonezya, Hindistan, Tayland, Filipinler ve Güney Koreyi Toda Yamamoto Nedensellik testini uygulamışlardır. Çalışma sonucunda Endonezya ve Hindistan'da enerji tüketiminin büyümeyi etkilediği, diğer ülkelerde ise enerji tüketimi ile büyüme arasında çift yönlü bir ilişkinin olduğu sonucuna ulaşmışlardır.

Zou ve Chau (2006) Çin ekonomisi için 1953-2002 dönemini kapsayan çalışmalarında koentegrasyon testi uygulamışlar, petrol tüketimi ile ekonomik büyümenin aynı yönde hareket ettiği sonucuna ulaşmışlardır.

Belke vd. (2010) 25 OECD ülkesi için 1981-2007 dönemini kapsayan çalışmalarında koentegrasyon testi uygulamışlar, uzun dönem enerji tüketimi ve reel GSMH arasında çift yönlü bir ilişkinin var olduğu sonucuna ulaşmışlardır.

Shaari vd. (2012) Malezya için 1980-2010 dönemini kapsayan çalışmalarında koentegrasyon testi uygulamışlar, uzun dönemde enerji tüketimi ile büyüme arasında bir ilişkinin olduğu sonucuna ulaşmışlardır. Granger Nedensellik testi sonuçlarına göre ise, büyümenin enerji tüketimi üzerinde bir etkisi olduğu sonucunu elde etmişlerdir. 


\subsection{Panel Birim Kök Analizi}

Verinin hem zaman hem de yatay kesit boyutuna ilişkin bilgiyi dikkate alan panel birim kök sınamalarının, sadece zaman boyutuyla ilgili bilgiyi göz önüne alan zaman serisi birim kök sınamalarından, istatistiksel anlamda güçlü olduğu kabul edilmektedir (Im, Pesaran ve Shin,1997; Maddala ve Wu, 1999; Taylor ve Sarno, 1998; Levin, Lin ve Chu, 2002; Hadri, 2000; Pesaran, 2006; Beyaert ve Camacho, 2008). Çünkü yatay kesit boyutunun analize eklenmesiyle, verideki değişkenlik artmaktadır.

Panel birim kök sınamasında karşılaşılan ilk sorun, paneli oluşturan yatay kesitlerin birbirinden bağımsız olup olmadıklarıdır. Panel birim kök testleri bu noktada; birinci kuşak ve ikinci kuşak testler olmak üzere ikiye ayrılmaktadır. Birinci kuşak testler de homojen ve heterojen modeller olmak üzere ikiye ayrılmaktadır. Levin, Lin ve Chu (2002), Breitung (2000) ve Hadri (2000) homojen model varsayımına dayanırken; Im, Pesaran ve Shin (2003), Maddala ve Wu (1999), Choi (2001) heterojen model varsayımına dayanmaktadır. Başlıca ikinci kuşak birim kök testleri ise MADF (Taylor ve Sarno, 1998), SURADF (Breuer et all., 2002), Bai ve Ng (2004) ve CADF'dir (Pesaran, 2006).

Bu çalışmada, analize dâhil edilen ülkeler homojen olmadığı için, Im, Pesaran ve Shin (2003) (IPS) testi kullanılacaktır. Ayrıca test sonuçlarını karşılaştırmak amacıyla Levin, Lin ve Chu (2002) (LLC) testi de yapilacaktır. IPS testi:

$$
\Delta Y_{i t}=\propto_{i} Y_{i t-1}+\sum_{j=1}^{P_{j}} \beta_{i j} \Delta Y_{i t-j}+X_{i t}^{\prime} \delta+\varepsilon_{i t}
$$

modeline dayanmaktadır. Burada $\propto_{i}$; hata düzeltme terimi olup, $\left|\propto_{i}\right|<1$ olduğunda, serinin trend durağan , $\left|\propto_{i}\right| \geq 1$ olduğunda ise birim köke sahip, yani durağan olmadığı anlaşılmaktadır. IPS testi, $\propto_{i}{ }^{\prime}$ lerin yatay kesit birimleri için farklılaşmasına, yani heterojen panel yapısına izin vermektedir. Testin hipotezleri:

$\mathrm{H}_{0}: \propto_{i}=1$ bütün yatay kesit birimleri için. Yani seri durağan değildir.

$\mathrm{H}_{1}: \propto_{i}<1$ en az bir yatay kesit birimi için. Yani seri durağandır.

Test sonucunda elde edilen olasıllk değeri 0.05 'ten küçük olduğunda, $\mathrm{H}_{0}$ reddedilmekte ve serilerin durağan olduğuna karar verilmektedir. IPS panel birim kök testi sonuçları, Tablo 9'da yer almaktadır.

\begin{tabular}{|l|l|l|l|l|}
\hline \multirow{2}{*}{ Değişken } & \multicolumn{2}{|l|}{ LLC } & \multicolumn{2}{l|}{ IPS } \\
\hline & Test İst. & Prob. & Test İst. & Prob. \\
\hline$G D P$ & -0.88 & 0.18 & -0.12 & 0.44 \\
\hline$E U S E$ & -7.22 & 0.00 & -5.22 & 0.00 \\
\hline$\Delta G D P$ & -3.91 & 0.00 & -2.56 & 0.00 \\
\hline$\Delta E U S E$ & -2.66 & 0.00 & -3.60 & 0.00 \\
\hline
\end{tabular}

Tablo 9: IPS ve LLC Panel Birim Kök Testi Sonuçları

Not: Panel birim kök sınamasında Schwarz kriteri kullanılmış olup, gecikme uzunluğu 3 alınmıştır.

Tablo 9'daki sonuçlar incelendiğinde, GDP serisinin birinci farkta durağan hale geldiği, LUSE serisinin ise düzeyde durağan olduğu görülmektedir. Yani, incelenen dönemde, makroekonomik değişkenlerden GDP'nin durağan olmadığı ve bu değişkenler üzerine gelen şokların etkisinin, zaman içinde kaybolmadığı görülmüştür.

\subsection{Breush- Pagan Lagrange Multiplier (LM) Testi}

Analizin bu aşamasında, bireysel etkilerin ve zaman etkisinin türünün (rassal veya sabit olduğunun) belirlenmesi amacıyla, LM testi yapılmıştır. Seçilen ülkeler belirli bir ekonomik grubun üyesi olmadığı için, bireysel ve zaman etkilerinin rassal olabileceği varsayılmıştır. Etkilerin gerçekten rassal olup olmadıklarına, LM testi ile karar verilebilmektedir (Baltagi. 2001:15).

$\mathrm{LM}$ testi, $\mathrm{LM}_{1}$ ve $\mathrm{LM}_{2}$ şeklinde ikiye ayrılmaktadır. $\mathrm{LM}=\mathrm{LM}_{1}+\mathrm{LM}_{2}$ 'dir. $\mathrm{LM}_{1}$; bireysel etkilerin rassallığını, $\mathrm{LM}_{2}$ de zaman etkilerinin rassallığını test etmektedir.

$\mathrm{LM}_{1}$ testinde; $\mathrm{H}_{0}: \sigma_{\mu}^{2}=0$ (Bireysel etkiler yoktur) hipotezi, $\mathrm{LM}_{1}$ istatistiği ile test edilmektedir. $\mathrm{LM}_{1}$ istatistiği, aşağıdaki formülle hesaplanmaktadır.

$$
L M_{1}=\frac{N . T}{2 .(T-1)}\left[\frac{\sum_{i=1}^{N}\left(\sum_{t=1}^{T} \widehat{u}_{i t}\right)^{2}}{\sum_{i=1}^{N} \sum_{t=1}^{T} \widehat{u}_{i t}{ }^{2}}-1\right]^{2}
$$

Burada $\mu$; (4) nolu denklemdeki bireysel etkileri, $N$; yatay kesit (ülke) sayısını, $T$; zaman boyutunu, $\hat{u}$; (3) nolu denklemdeki hata terimlerinin tahminini ifade etmektedir. Bu test sonucunda elde edilen olasılık değeri, 0.01 'ten küçük olduğunda, $\mathrm{H}_{0}$ reddedilmekte ve bireysel etkilerin rassal olduğuna karar verilmektedir. 
$\mathrm{LM}_{2}$ testinde; $\mathrm{H}_{0}: \sigma_{\lambda}^{2}=0$ (Zaman etkileri yoktur) hipotezi, $\mathrm{LM}_{2}$ istatistiği ile test edilmektedir. $\mathrm{LM}_{2}$ istatistiği, aşağıdaki formülle hesaplanmaktadır.

$$
L M_{2}=\frac{N \cdot T}{2 \cdot(N-1)}\left[\frac{\sum_{t=1}^{T}\left(\sum_{n=1}^{T N} \widehat{u}_{i t}\right)^{2}}{\sum_{i=1}^{N} \sum_{t=1}^{T} \hat{u}_{i t}{ }^{2}}-1\right]^{2}
$$

Burada $\mu$; (4) nolu denklemdeki bireysel etkileri, $N$; yatay kesit (ülke) sayısını, $T$; zaman boyutunu, $\hat{u}$; (3) nolu denklemdeki hata terimlerinin tahminini ifade etmektedir. Bu test sonucunda elde edilen olasılık değeri, 0.01 'ten küçük olduğunda, $\mathrm{H}_{0}$ reddedilir ve zaman etkilerinin rassal olduğuna karar verilmektedir.

$\mathrm{LM}=\mathrm{LM}_{1}+\mathrm{LM}_{2}$ testinde;

$\mathrm{H}_{0}: \sigma_{\mu}^{2}=\sigma_{\lambda}^{2}=0$ (Bireysel etkiler ve zaman etkileri yoktur)

$\mathrm{H}_{1}: \sigma_{\mu}^{2} \neq 0$ veya $\sigma_{\lambda}^{2} \neq 0$ ya da her ikisi de $\neq 0$ (Etkilerden en az biri ya da ikisi de rassaldır).

Elde edilen olasılık değeri, 0.01 'ten küçük olduğunda, $\mathrm{H}_{0}$ reddedilmekte ve etkilerin her ikisinin de rassal olduğuna karar verilmektedir. Bu durumda iki yönlü rassal etki modeli ile tahmin yapılmaktadır. Tablo 10 LM testlerinin sonuçları yer almaktadır.

\begin{tabular}{|l|l|l|}
\hline Test & Olasılık Değeri & Karar \\
\hline $\mathrm{LM}_{1}$ & 0.00 & Bireysel Etkiler Rassaldır. \\
\hline $\mathrm{LM}_{2}$ & 1.00 & Zaman Etkileri Rassal Değildir. \\
\hline LM & 0.01 & Bireysel Etkiler ve Zaman Etkileri Rassaldır. \\
\hline
\end{tabular}

Tablo 10: LM Testleri

Tablo 10'daki sonuçlara genel olarak bakıldığında, bireysel etkilerin rassal, zaman etkilerinin ise rassal olmadığı görülmektedir. Fakat LM testinde ise bireysel ve zaman etkilerinin rassal olduğu belirlenmiş, bu sonuçtan hareketle tahmin, iki yönlü rassal etki modeli ile yapılmıştır.

\subsection{Hausman İçsellik Testi}

Çalışmanın bu aşamasında, bireysel etkilerle açıklayıcı değişkenler arasında ilişki (içsellik problemi) olup olmadı̆̆ 1 , Hausman yöntemi ile test edilmiştir. Testin hipotezleri:

$$
\begin{aligned}
& \mathrm{H}_{0}: \operatorname{Cov}\left(\mu_{i}, x_{i t}\right)=0 \text { İçsellik problemi yoktur. } \\
& \mathrm{H}_{1}: \operatorname{Cov}\left(\mu_{i}, x_{i t}\right) \neq 0 \text { İçsellik problemi vardır. }
\end{aligned}
$$

Burada $\mu_{i}$; (4) nolu denklemdeki bireysel etkileri, $X_{i t}$ ise (3) denklemdeki açıklayıcı değişkenleri göstermektedir. Analiz sonucunda elde edilen $\chi^{2}$ (Chi2=Kikare)'nin olasılık değeri 0.01 'ten küçük olduğunda, $\mathrm{H}_{0}$ reddedilmekte ve modelde içsellik probleminin olduğuna karar verilmektedir. İçsellik problemi olduğunda, sabit etkiler modeli kullanılır (Greene, 2003). $\mathrm{H}_{0}$ kabul edildiğinde ise rassal etkiler modeli kullanılmaktadır. Bu tahmin; etkin, sapmasız ve tutarlıdır. Hausman testi, LM testinin bir alternatifi değildir. Ancak, LM testi ile verilen kararın bir sağlaması işlevini de görmektedir.

Hausman testi yapılmış ve Chi2 $=5.16$ ve Chi2 olasılık değeri=0.023 bulunmuş olup, bu değer 0.01 'ten büyük olduğu için, H0 hipotezi kabul edilmiş, modelde içsellik sorunun olmadığına karar verilmiştir. Bu durumda, analizin rassal etkiler modeliyle yapılması gerekmektedir ve bu sonuç da LM testi sonuçlarını desteklemektedir.

\section{7 İki Yönlü Rassal Etkiler Model Tahmini}

\begin{tabular}{|c|c|c|c|c|}
\hline Değişken & Katsayı & Std. Hata & t-İstatistiği & Olasılık Değeri \\
\hline GDP(-1) & 0.5018 & 0.0771 & 6.5036 & 0.000 \\
\hline EUSE & 0.2249 & 0.0716 & 3.1401 & 0.002 \\
\hline Sabit Terim & 0.0067 & 0.0042 & 1.5911 & 0.114 \\
\hline \multicolumn{5}{|l|}{ Tanısal Testler } \\
\hline R-kare: & 0.40 & \multicolumn{3}{|c|}{ Bağımlı değişken ortalaması $\quad 0.003$} \\
\hline Ağırlılandırılmış R-kare: & 0.38 & \multicolumn{3}{|c|}{ Bağımlı değişken hatası $\quad 0.038$} \\
\hline DW & 1.96 & \multicolumn{3}{|c|}{ Denklemin Standart Hatası $\quad 0.030$} \\
\hline $\mathrm{F}_{\text {ist }}$ & $37.03(0.00)$ & \multicolumn{2}{|c|}{ Hata Kareleri Toplamı } & 0.100 \\
\hline \multicolumn{5}{|c|}{ Lagrange Multiplier (LM) Değişen Varyans Testi: prob:0.470 } \\
\hline \multicolumn{5}{|c|}{ Karar: (Ho ret), değişen varyans sorunu yoktur. } \\
\hline \multicolumn{5}{|c|}{ Otokorelasyon Testi: $\quad$ prob:0.217 } \\
\hline
\end{tabular}

Panel veri analizi, iki yönlü rassal etki modeli ile tahmin edilmiş ve elde edilen sonuçlar Tablo 11 'de sunulmuştur.

Tablo 11: Tahmin Sonuçlarl 
Rassal etki modellerinde, ağırlıklandırılmış istatistik değerleri kullanılmaktadır (Baltagi 2001: 21). Tablo 11'deki ağırlıklandırılmış test istatistiklerine bakıldığında, modelin istatistikî olarak güvenilir olduğu görülmektedir. Modelde otokorelasyon sorunu tespit edilmiş, bağımlı değişkenin gecikmeli değeri modele ilave edilerek bu sorun giderilmiştir. Modelde değişen varyans ve otokorelasyon sorunu olmadığı görüldüğü için, tahmin sonuçları güvenilirdir ve yorumlanabilir.

\section{Sonuç}

Sovyetler Birliğinin dağılması sonucu bağımsızlıklarını kazanan Orta Asya Ülkeleri hem ekonomi hem de iletişim bakımından daha açık hale gelmişlerdir. Orta Asya ülkelerinin zengin enerji kaynakları rezervlerine sahip olması ve gerçekleştirdiği üretimin tüketimden daha fazla olması bölge ekonomisi ve gelişimi üzerinde büyük etki yaratmaktadır. Özellikle bağımsızlıklarını kazanmalarından sonra Orta Asya Ülkelerinin hızlı ekonomik büyüme sağlayabilmeleri için sahip oldukları enerji kaynakları rezervleri büyük bir rol oynamaktadır.

Orta Asya Ülkelerinde enerji tüketiminin ekonomik büyüme üzerindeki etkisi beklentilerimize paralel olarak pozitiftir ve istatistikî olarak anlamlıdır. Enerji tüketimindeki \%1'lik artış ekonomik büyümeyi \%0.22 oranında arttırmaktadır. Milli gelir beklentilerinin gelir üzerindeki etkisi arttırıcı yönde ve anlamlı düzeydedir.

Öte yandan Orta Asya ülkelerinin enerji üretimi ve dağıtımında ortak strateji izlemeleri, ortak çıkarların sağlanarak sosyal refahın arttırılması ve dünya enerji piyasasında söz sahibi olmaları sosyal, siyasal ve ekonomik açıdan son derece yararlı sonuçlar doğuracaktır. Ayrıca enerji dışında diğer sektörlerin ekonomik kalkınmada itici rol oynayabilmelerine yönelik çalışmaların biran önce yapılması ve desteklenmesi gerekmektedir.

\section{Kaynakça}

- $\quad$ Acartürk, Ertuğrul - Hakan Arslaner; “Geçiş Ülkelerinde Devletin Ekonomik Rolü Yabancı Sermaye Ve Özelleştirme: Kırgızistan Örneği”, http://www.Econturk.Org/Turkiye2004.Html. (Erişim: 07.05.2013).

- Ağcakaya, Serpil, 2009. Geçiş Ekonomilerinden Orta Asya Türk Cumhuriyetleri’nde Bütçe Yönetimi Ve Mali Disiplin Sorunu, Akademik Bakış, Sayı 16, Nisan-2009, Uluslararası Hakemli Sosyal Bilimler EDergisi.

- $\quad$ Akar, Pınar Gümüş, 2007. Geçiş Ekonomileri Merkezi Ve Doğu Avrupa Ülkeleri Analizi (1989-2006): Çek Cumhuriyeti, Polonya, Macaristan Ve Bulgaristan Örnekleri, Gaziantep Üniversitesi Sosyal Bilimler Enstitüsü İktisat Ana Bilim Dalı Yüksek Lisans Tezi, Eylül-2007, Gaziantep.

- Altay, Asuman, 2002. Geçiş Ekonomilerinde Devletin Ekonomik Rolleri, Rolleri Ve Kobi’lerin Durumu, İstanbul Üniversitesi Maliye Araştırma Merkezi Konferansları, 41. Seri, İstanbul, 2002, ss. 59-87.

- Altıntaş, Mustafa, Güvercin, Deniz, Uğurlu, Erginbay, 2008. Geçiş Ekonomilerinde Doğrudan Yabancı Sermaye Yatırımları Ve Ekonomik Büyüme İlişkisi, Ekonomik Yaklaşım, Cilt 19, Özel Sayı, 2008, ss. 17-32.

- Bai J.and Ng S., 2004. “A Panic Attack on Unit Roots and Cointegration”, Econometrica, vol. 72, pp. $1127-$ 1178.

- $\quad$ Baltagi B. H., 2001. Econometric Analysis of Panel Data, (2d ed). New York: John Wiley \& Sons.

- Belke, Ansgar Bekle; Dreger, Christian; Frauke De Haana, 2010. Energy Consumption And Economic Growth - New Insights into the Co-integration Relationship, Ruhr Economic Papers, Department of Economics Universität sstr. Bochum, Germany.

- Beyaert A. and Camacho M., 2008. "TAR Panel Unit Root Tests And Real Convergence: An Application to the EU Enlargement Process", Review of Development Economics, Vol: 12(3), pp. 668-681.

- BP, 2011. Statistical World Review of Energy, UK.

- Breitung J., 2000. “The Local Power of Some Unit Root Tests for Panel Data. in B. Baltagi (ed.), Nonstationary Panels, Panel Cointegration, and Dynamic Panels ”, Advances in Econometrics, Vol: 15: Amsterdam: Jai, pp. 161-178.

- Breuer B., Mcnown R. and Wallace M., 2002. "Series-Specific Unit Root Test With Panel Data", Oxford Bulletin of Economics and Statistics, vol. 64, pp. 527-546.

- Choi I., 2001. "Unit Roots Tests For Panel Data”, Journal of International Money and Finance, vol. 20, pp. 229-272.

- Çatalbaş, Nazım ve Yıldırım Zubeyr, 2008. Geçiş Ekonomilerinde Bütçe Açıklarının Nedenleri: Polonya Ve Kırgızistan Örneği. Sosyo Ekonomi, Ocak-Haziran-2008-I, ss. 134-156.

- Çelik, Neslihan, 2007. SSCB Sonrası Orta Asya Türk Cumhuriyet'lerinde Endüstriyel Performans Ve İnovasyon Politikaları, Marmara Üniversitesi İktisadi Ve İdari Bilimler Fakültesi Dergisi, Cilt 23, Sayı 2, ss. 117-132. 
- Energy Information Administration (EIA), 2013. International Energy Statistics, http://www.eia.gov/cfapps/ipdbproject/iedindex3.cfm (Erişim: 07.05.2013).

- $\quad$ Fatai, K., L. Oxley, and F. G. Scrimgeour, 2004. Modeling The Causal Relationship Between Energy Consumption and GDP in New Zealand, Australia, India, Indonesia, The Philippines and Thailand. Mathematics and Computers in Simulation, Vol: 64(3-4), pp. 431-445.

- Glasure, Y. and A. Lee, 1998. Cointegration, Error-Correction and The Relationship Between GDP and Energy: The Case of South Korea and Singapore. Resource and Energy Economics, Vol: 20(1), pp. 17-25.

- Greene, W. H., 2003. Econometric Analysis, (5th Ed). Upper Saddle River, N.J., Prentice- Hall.

- Gujarati, D. N., 1999. Basic Econometrics, Mc Graw Hill, (3rd Ed.), Literatür Yayıncılık, İstanbul.

- Güler, Esra, 2012. Sosyalizmden Kapitalizme Geçiş Sürecinde Rusya: Nasıl Bir Kapitalizm?, Business And Economics Research Journal, Cilt 3, Say1 3, ss. 93-120.

- Hadri, K., 2000. "Testing for Stationarity in Heterogenous Panels". Econometrics Journal, vol. 3, pp. 148161.

- Hondroyiannis, G., S. Lolos, and G. Papapetrou, 2002. Energy Consumption And Economic Growth: Assessing The Evidence from Greece. Energy Economics, Vol: 24, pp. 319-336.

- Im K., Pesaran H. and Shin Y., 1997. “Testing For Unit Roots in Heterogenous Panels”, Mimeo, Department of Applied Economics, University of Cambridge.

- Im K., Pesaran H. and Shin Y., 2003. “Testing For Unit Roots İn Heterogenous Panels”. Journal of Econometrics, vol. 115, pp. 53-74.

- Kraft, J. and A. Kraft, 1978. “On the Relationship Between Energy and GNP”, Journal of Energy and Development, Vol. 3, pp. 401-403.

- Kuzu, Serdar; "Dünya Enerji Piyasasında Orta Asya Cumhuriyetlerinin Konumu”, http://www.eecon.info/papers/480.pdf (Erişim: 07.05.2013).

- $\quad$ Levin A. Lin C. and Chu J., 2002. "Unit Roots Tests in Panel Data: Asymptotic and Finite Sample Properties", Journal of Econometrics, Vol. 108, pp. 1-24.

- Maddala G.S and Wu S., 1999. "A Comparative Study of Unit Root Tests with Panel Data and a New Simple Test", Oxford Bulletin of Economics and Statistics, vol. 61, pp. 631-652.

- Masih, A. M. M. and R. Masih, 1998. A Multivariate Cointegrated Modelling Approach İn Testing Temporal Causality Between Energy Consumption, Real Income and Prices with an a Application to Two Asian LDCs. Applied Economics Vol: 30(10), pp. 1287-1298.

- Pesaran, H., 2006. “A Simple Panel Unit Root Test in the Presence of Cross Section Dependence”, Cambridge University, Working Paper, No:0346.

- Shaari, Mohd Shahidan; Hussain, Nor Ermawati; Mohammad Shariff Ismail, 2013. Relationship Between Energy Consumption and Economic Growth: Empirical Evidence for Malaysia, Business Systems Review, ISSN: 2280-3866, Volume: 2, Issue: 1.

- Tandırcıoğlu, Haluk, 2002. Geçiş Ekonomilerinde Özelleştirme, Dokuz Eylül Üniversitesi Sosyal Bilimler Enstitüsü Dergisi, Cilt 4, Sayı 3, İzmir, ss. 198-226.

- Taylor M. and Sarno L., 1998. "The Behaviour of Real Exchange Rates During the Post-Bretton Woods Period”, Journal of International Economics. Vol. 46, pp. 281-312.

- Taylor, J. B., 2009. "The Financial Crisis and The Policy Responses: An Emprical Analysis of What Went Wrong”, NBER Working Paper 14631, January, http://www.nber.org

- Uçkaç, Bekir Cihan, 2011. Geçiş Ekonomilerinde Özelleştirme Uygulamaları: Kırgızistan Örneği, Kırgızistan-Türkiye Manas Üniversitesi Sosyal Bilimler Enstitüsü Maliye Anabilim Dalı, Doktora Tezi, Bişkek.

- World Bank, 2013. Energy Statistics, http://data.worldbank.org/indicator/EG.ELC.HYRO.ZS (24.05.2013).

- Yavuz, Hasan Bilgehan, 2005. Geçiş Ekonomileri, Gelişmekte Olan Ülkeler Ve Türkiye, Çukurova Üniversitesi Sosyal Bilimler Enstitüsü İktisat Ana Bilim Dalı Yüksek Lisans Tezi, Ekim-2005, Adana.

- Yu, E. and J. Choi, 1985. The Causal Relationship Between Energy and GNP: An International Comparison. Journal of Energy and Development vol.10, pp. 249-272.

- Zou, Gaolu and K. W. Chau, 2006. "Short and Long-Run Effects Between Oil Consumption and Economic Growth in China”, Energy Policy, Vol: 34, pp. 3644-3655. 


\title{
Elektrikli ve Elektronik Atıkların Geri Dönüşümünde Tüketici Davranışları: İstanbul Örneği
}

\section{Consumer Behavior in the Recycling of Electrical and Electronic Waste: The Case of Istanbul}

\author{
Ph.D. Candidate Aslı Okay Toprak (Kırklareli University, Turkey) \\ Asst. Prof. Dr. Elif Haykır Hobikoğlu (Istanbul University, Turkey) \\ Ph.D. Candidate Taha Eğri (Istanbul University, Turkey) \\ Prof. Dr. Zekai Özdemir (Istanbul University, Turkey)
}

\begin{abstract}
An inevitable consequence of the technological advances has increased electrical and electronic equipment consumption at a dizzying manner in the world. Especially advances in personal computer and telephone technology within the impact of the rapid changes in this sector reached enormous figures launched an e-waste production. Therefore, e-waste has become one of the major environmental problems of modern world. Besides the environmental problems they cause e-waste, along with the precious metals they contain they have an economic potential. No doubt the realization of e-waste recycling with the right methods point out both economic and environmental social benefit. However, at this point, both the manufacturers' and end-users' sensitivity loom large. This study was conducted on the basis of end users' awareness of e-waste with a survey conducted on the basis Istanbul.
\end{abstract}

\section{Giriş}

Elektrikli ve elektronik araçların üretimi günümüzün en hızla büyüyen endüstrilerden biri olduğundan, yaşanan süreç, e-atık oranlarındaki artışı da beraberinde getirmiştir (Babu, Parande, \& Basha, 2007). Elektronik endüstrisi, modern yaşam tarzımızı sürdürebilmemiz için zaruri hale gelen ürünleri üretirken henüz sürdürülebilirliği tam olarak tespit edilmemiş bir üretim alanını da temsil etmektedir (Hester \& Harrison, 2009). Nitekim elektrikli ve elektronik araçlar, sürekli gelişme süreci içinde olmaları ve her yeni nesil üründe maliyetlerin düşmesi ile karakterize edilmektedirler (Hester \& Harrison, 2009). Bu nitelikleri ile gün geçtikçe artan bir kitlesel tüketim eğiliminin merkezi haline gelen elektronik araçların kullanım sürelerinin kısalması, eatıkları sanayileşmiş dünyanın en hızlı büyüyen atık kollarından biri haline getirmiştir (Puckett, ve diğerleri, 2002). Özellikle cep telefonları gibi moda trendi yüksek ürünlerinin tasarımsal ömürlerinin kullanım ömürlerine göre çok kısa olması ve eskisi ile yenisi arasındaki değişim süresinin kısalığı bu yüksek tüketim hacmini tetiklemektedir (Hester \& Harrison, 2009). Ancak bilgi teknolojilerinin göz kamaştırıcı yükselişinin derinliklerinde karanlık bir taraf da bulunmaktadır (Puckett, ve diğerleri, 2002). Yükselen e-atık dağı istenilen düzeyde geri dönüştürülemediğinden dünya genelinde hem önemli bir kaynak israfina yol açmış hem de dikkat çekici bir çevre sorununa dönüşmüş durumdadır. Bu bağlamda özellikle gelişmiş ülkelerde e-atık geri dönüşümünün kontrollü bir hale gelmesi için çalışmalar yürütülmektedir. Avrupa komisyonu "Waste Electrical and Electronic Equipment(WEEE) (Atık Elektrik Elektronik Cihazları)" yönergesi ile e-atıkların geri dönüşümünü zorunlu hale getirirken, "Restriction of the Use of certain Hazardous Substances (RoHS) (Bazı zararlı maddelerin kullanımının sınırlandırılması) yönergesi ile de elektrikli ve elektronik cihazların üretim sürecinde belirli maddelerin kullanımını kısıtlamıştır. Türkiye'de de bu yönergelere uyumlu yasal düzenlemeler gerçekleştirilmektedir (Yazıcı \& Deveci, 2009). Ancak yönergelerin fiili uygulamalarda da yerini bulması için belirli değişkenlerin etkisinin olması gerekmektedir. Widmer e-atık geri dönüşüm sistemlerini karşılaştırırken yapısal anlamda, merkezi ve yerel yönetimlerin işbirliği ve etkinliği, e-atık geri dönüşümü için gerekli alt yapı ve teknik yeterlilik, sanayileşme düzeyi ve sosyal ve kültürel yapıda geri dönüşüm kültürünün yaygınlığı ve çevre bilincini ele almaktadır (Widmer, Oswald-Krapf, Sinha-Khetriwal, Schellmann, \& Böni, 2005). Türkiye açısından bu değerlendirme ele alındığında tüketicilerin e-atık geri dönüşümü ile ilgili bilgi ve bilinç düzeylerinin sınırlı olmadı ve e-atık geri dönüşümünü gerçekleştirebilecek tesislerin sınırlılığı önemle üzerinde durulması gereken konulardır. Türkiye'deki son kullanıcıların e-atıkların geri dönüşüm sürecinin önemi hakkındaki bilgilendirilmesi şu aşamada mevcut potansiyelin değerlendirilmesinde önemli bir fark yaratacaktır.

\section{E-Atık Tanımı ve Türleri}

E-Atıklar, buzdolabı ve klima gibi büyük ev aletlerinden, kişisel bilgisayar ve telefonlara kadar uzanan geniş bir elektronik araç çeşitliliğine sahiptir (Puckett, ve diğerleri, 2002). Bu nedenle, WEEE Direktifi, hane halkının kullandığı tüm elektrikli ve elektronik cihazlarından büyük çaptaki belediye atıklarına kadar geniş bir atık çeşitliliğine sahiptir. Direktifte elektrikli ve elektronik cihazlar 10 ana kategoride sınıflandırılmaktadır (Press, 2003). 
- Büyük Ev Eşyaları (Buzdolabı, çamaşır makinesi, bulaşık makinesi vb.)

- Küçük Ev Aletleri (Elektrik Süpürgesi, Tost makinesi vb.)

- Bilişim ve Telekomünikasyon Ekipmanları (Bilgisayarlar, Telefonlar vb.)

- Tüketici Ekipmanları (Video Kameralar, Müzik Enstrümanları vb.)

- Aydinlatma Ekipmanları

- Elektrikli ve Elektronik Aletler ( Büyük Sanayi Aletleri hariç olmak üzere matkaplar, testereler vb.)

- Eğlence ve Spor Aletleri ile Oyuncaklar

- Tibbi Cihazlar

- İzleme ve Kontrol Aletleri ( Termostatlar, Isı Ayarlayıcılar vb.)

- Otomatlar

E-atıklar, hem kimyasal hem de fiziksel olarak belediye ya da sanayi atıklarından farklı niteliklere sahiptirler. E-atıklar, çeşitli değerli madenlerin yanında insan sağlı̆̆ını tehdit eden bileşenleri de içerdiklerinden geri dönüştürmeleri sürecinde çok daha ileri düzeyde ayrıştırma teknikleri kullanılması gerekmektedir (Robinson, 2009).

\section{E-Atıkların Çevresel Etkileri}

E-Atıkların geri kazanımı sadece bir insan sağlığı ve çevre problemi değil aynı zamanda içeriklerinde barındırdıkları değerli madenler açısından da kaynak israfının önlenmesinde ve ülke kaynaklarının verimli kullanılmasında önemli bir etkendir. Örneğin ortalama 100 gram ağırlığındaki bir cep telefonu ortalama 25 gram değerli maden içermektedir ve bu oranın büyük bir kısmı bakırdan oluşmaktadır dolayısıyla küçük boyutuna rağmen sadece Mobil telefonlarının içerdiği değerli madenler toplamda önemli bir ekonomik kaynağa işaret etmektedir (Press, 2003).

Dünya genelindeki e-atık oluşumuna en fazla katkısı olan ürünlerin ağırlıklı olarak bilgisayarlar ve mobil telefonla olduğu yönünde ortak bir görüş birliği mevcuttur. Herhangi bir ürünün e-atık oluşumuna katkısını hesaplanırken[E=kg/yıl] ele alınan değişkenler; ürünün ağırlığı,[M(kg)], kullanımdaki ürün sayısı[N] ve ortalama kullanım ömrü[L=yıl] şeklinde sıralanmaktadır. $\mathrm{E}=\mathrm{MN} / \mathrm{L}$ şeklinde formülize edilen denklemden yola çıkarak ortalama kullanım ömrü 3 yıl olan bilgisayarın e-atık oluşumuna katkısı ile ortalama kullanım ömrü 10 ile 12 yıl arasında değişen buzdolabının e-atık oluşumuna katkısının farklı düzeyde olduğunu söyleyebiliriz (Robinson, 2009).

Dünya genelinde senede meydana gelen 20-25 milyon ton elektronik atıkların en fazla oluştuğu yerler; teknolojik ürün kullanımının ve kişi başına düşen gelirin yüksekliğinin bir sonucu olarak Avrupa ülkeleri ve ABD'dir (Robinson, 2009). Her yıl ortalama 5-7 milyon ton elektronik atığın oluştuğu ABD'de, oluşan bu atıkların \%10’u geri kazanım işlemine tabi tutulmakta ve \%30'u depolanmaktadır. Avrupa'daki elektronik atık oluşumunun ise her yıl \% 3-5 oranında arttığı gözlenmektedir (W.J.Rankin, 2011). Dünyanın önemli e-atık üretim kaynaklarından biri olan Avrupa ülkelerinde her yıl oluşan 8,7 milyon ton e-atığın 6,6 milyon tonu geri dönüşüme tabi tutulmaktadır. Geri dönüşüm işlemine uğrayan bu e-atıkların \%10 bilgisayar ekipmanı, \%14’ü ise televizyondur (Çiftlik, ve diğerleri, 2009).

E-atık oluşumundaki bu hızlı artış ve geri dönüşüm oranlarındaki düşük düzey, son yıllarda gelişmeye başlayan çevresel duyarlılık ve sorumluluk anlayışının etkisiyle e-atık önemli bir gündem konusu haline gelmiştir (Hester \& Harrison, 2009). Avrupa Birliğinde Elektrikli ve Elektronik cihazların üretiminde tehlikeli maddelerin kullanımını kısıtlayan (2002/95/EC) ve bu tür cihazların toplanması ve geri dönüşümünü teşvik eden (2002/96/EC) mevzuatı 2003 şubat ayından beri yürürlüktedir. Mevzuat tüketiciler için ücretsiz olarak e-atık geri toplama programlarının oluşturmasına imkân sağlamaktadır. Bu programların amacı elektrikli ve elektronik cihazların geri dönüşümünü yaygınlaştırmak ve e-atık geri dönüşüm faaliyetlerine daha geniş toplumsal katılımı sağlamaktadır. Ayrıca WEEE mevzuatı, civa, artı altı değerlikli krom, polibromürlü bifeniller ve polibromine difenil eterler gibi ağır metallerin yerini daha güvenli alternatiflerin almasını da amaçlamaktadır (European Commision, 2013).

Gelişmiş ülkelerdeki mevzuat ve yönetmelikler e-atık geri dönüşümünü kontrol alma çabasının somut bir göstergesidir ancak dünya genelinde artan e-atıkların geri dönüşümünde bazı ülkelerde çocuk işçiler çalıştırılmakta ve bu çocuk işçiler, elektronik cihazların demonte işlemlerinde ve e-atıklardaki değerli madenlerin ayrıştırılmasında sırasında zehirli kimyasallara maruz kalmaktadırlar (Miller \& Spooman, 2012). Birleşmiş Milletlerin verilerine göre e-atıkların \%70'nin yolculuğu Çin'de sonlanmaktadır (Miller \& Spooman, 2012). Çin'in küçük bir liman kenti olan Guiyu'da e-atık geri dönüşümünde çalışanlar genellikle maske ve eldiven kullanmadan havalandırma olmayan odalarda zehirli kimyasallara maruz kalarak çalışmaktadırlar (Miller \& Spooman, 2012). Televizyon tüplerinin çekiçlerle parçalanarak kurşun tozunun açığa çıkarılması ve havaya karışması, bilgisayar kablolarının yakılarak bakır açığa çıkarılması, bilgisayara ana kartalarının değerli maden 
elde etmek için asit kullanılarak eritilmesi insan ve çevre sağlığı için çok büyük bir tehdit meydana getirmektedir (Miller \& Spooman, 2012). Guiyu'daki ilkel e-atık geri dönüşüm metotları;

Dioksin ve ağır metal emisyonları,

Mavi, sarı ve kırmızı tonerlerin yol açtığı zehirlilik,

Hava, su ve toprağa karışan hidrokarbon külleri,

Ağır metal ve hidrokarbon emisyonları,

Nehirlere karışan ağır metallerin ve hidrokarbonların neden olduğu balık türlerinin ve bitki örtüsünün yok olmas1,

Yer altı sularında kurşun kirliliği gibi sorunlarla karşı karşıya kalmalarına neden olmuştur (Puckett, ve diğerleri, 2002).

AB dışına yasadışı e-atık ticareti ve mevcut uygulamadaki aksaklıklar neticesinde Avrupa Komisyonu giderek artan e-atık geri dönüşüm problemini çözmek adına 2008 yılında direktifi revize etmiştir. Bu yeni düzenleme elektrikli ve elektronik cihaz üretimi yüksek olan üye ülkelerin sorumlu oldukları geri dönüşüm oranlarının yükseltilmesi aracılığı ile her ülkenin ürettiği e-atık oranında geri dönüşüm yapmasını sağlamak şeklinde değerlendirilebilir (Puckett, ve diğerleri, 2002). Daha sonraki süreçte 2012 yılı ocak ve şubat aylarında gerçekleştirilen Avrupa Parlamentosu toplantılarında "Elektrikli ve Elektronik Ekipman Atıklarına Dair Direktif" ve “Atık Yönetimi Direktifinin Uygulanması Bağlamında Alınan AP Kararı" ile üye ülkelerde bazı yeni hedefler belirlenmiştir. Bu çerçevede hedefler aşağıdaki gibi sıralanmaktadır (AB İMMİ, 2013).

Üye ülkelerde 2016 yılında, önceki 3 yıl içerisinde kilo bazında oluşacak e-atıkların \%45'nin ve 2019 yılında ise $\% 65$ 'nin toplanması hedeflenmektedir.

10 ülke için 2016 yılındaki hedef \%40 oranında geri dönüşüm iken, 2021 y1lı için nihai hedef \%80 olarak hedeflenmiştir.

Üye ülkelerdeki üreticiler diğer ülkelere elektrikli ve elektronik ürün sattıklarında ilgili üye ülkede direktiflerden sorumlu tutacakları yetkili temsilciyi yazılı olarak atamak zorundadırlar.

Avrupa Atık Yönetim Ajansının kurulum çalışmalarına başlanmıştır.

\section{E-Atıkların Ekonomik Etkileri}

E-Atıkların geri kazanımı genel olarak birincil kaynakların tüketim hızını azaltması, katı atık miktarının azaltılması, metal dışı malzemenin kazanılması, demir, demir dışı ve değerli madenlerin kazanılması gibi önemli avantajların yaratılmasında faydalı olmaktadır. İkincil kaynak elde edişi olarak ifade edilen e-atık geri dönüşüm işleminden metal elde edilmesi sırasında harcana enerji cevherden metal elde edilmesinde kullanılan enerji miktarından düşük olması nedeniyle önemli bir enerji tasarrufu sağlamaktadır. Dolayısıyla e-atıklardan metal geri kazanımı hem enerji tasarrufu hem de ulusal kaynakların etkin kullanımına katkıda bulunmaktadır (Yazıcı \& Deveci, 2009). Ayrıca çeşitli metotların uygulanması amacıyla ileri tekniklerle donatılmış yüksek teknolojik alt yapıya sahip tesisler, nitelikli işgücü için yaratılmış önemli bir istihdam kaynağı olacaktır. Bu anlamda bu tür tesislerin çoğalması hem enerji tasarrufu, hem kaynak verimliliği hem de istihdam yaratma niteliği ile ekonomide genişletici bir etki yaratacaktır. Tablo 2'de birincil kaynaklara kıyasla geri kazanımın sağladığı enerji tasarrufu oranları verilmektedir.

\begin{tabular}{|l|l|}
\hline Metal/Malzeme & Enerji Tasarrufu \\
\hline Alüminyum & 95 \\
\hline Bakır & 85 \\
\hline Demir ve Çelik & 74 \\
\hline Kurşun & 65 \\
\hline Çinko & 60 \\
\hline Kağıt & 64 \\
\hline Plastik & $>80$ \\
\hline
\end{tabular}

Tablo 1. Birincil Kaynaklara Kıyasla Geri Kazanımın Sağladı̆̆̆ Enerji Tasarrufu Kaynak: Ersin Yener Yazıcı, Hacı Deveci, “E-Atıklardan Metallerin Geri Kazanımı”, Madencilik, Cilt.48, Sayı: 3, 2009, s.5.

E-Atıkların geri kazanımında fiziksel yöntemler, Hidrometalurjik yöntemler, Biyometalurjik Yöntemler ve Pirometalurjik yöntemler kullanılmaktadır. E-Atıkların geri kazanımında kullanılacak metot seçiminde yapısal anlamda karmaşı olan elektrikli ve elektronik aletlerin fiziksel ve kimyasal yapısının analizi yapılacak işlemin verimliliği açısından vazgeçilemez bir koşuldur. Tablo 3'de kullanılan metotların avantaj ve dezavantajları verilmektedir (Yazıcı \& Deveci, 2009). 


\begin{tabular}{|c|c|c|}
\hline & Avantajlar & Dezavantajlar \\
\hline Fiziksel Yöntemler & $\begin{array}{l}\text { Tüm e-atıklarda kullanılabilecek basit } \\
\text { prosedürler mevcut. }\end{array}$ & Değerli metal kaybı yüksek. \\
\hline Hidrometalurjik Yöntemler & $\begin{array}{l}\text { Metal kazanma verimi yüksek, esnek, küçük } \\
\text { ölçekte uygulanabilir ve Zaralı gaz çıkışı } \\
\text { yok. }\end{array}$ & $\begin{array}{l}\text { Ön hazırlık işlemi } \\
\text { gerektiriyor. Atık çözeltinin } \\
\text { arıtılması gerekiyor. }\end{array}$ \\
\hline Biyometalurjik Yöntemler & $\begin{array}{l}\text { Çevresel etkisi düşük. Küçük ölçekli } \\
\text { firmaların uygulayabileceği nitelikte. }\end{array}$ & Liç süresi uzun \\
\hline Pirometalurjik Yöntemler & Çoğu e-atık türü için uygun & $\begin{array}{l}\text { Pahalı ve enerji yoğun bir } \\
\text { işlem. }\end{array}$ \\
\hline
\end{tabular}

Tablo 2. E-Atıkların Geri Kazanımında Kullanılabilecek Metotların Karşılaştırılması (Yazıcı \& Deveci, 2009)

E-Atık geri dönüşüm metot seçiminde toplama ve transfer, parçalama ve sınıflandırma, geri kazanım süreci, yakma işlemi ve arazi giderleri ele alınan ve değerlendirilen maliyet kalemleridir. Ancak birçok bilim adamına göre en kötü geri dönüşüm faaliyetinin en verimli madencilik çalışmasında daha iyi sonuç verdiğini iddia etmektedir. Dünya genelinde bakır, altın, alüminyum, plastik ve çelik gibi maddelere olan ihtiyaç her geçen gün arttığından, bu gereksinimi sadece madencilik faaliyetlerinden sağlamak hem finansal açıdan hem de çevre açısından mümkün görünmemektedir (Çiftlik, ve diğerleri, 2009).

\section{Türkiye’de E-Atık Geri Dönüşüm Uygulamaları ve Yasal Düzenlemeler}

Türkiye'de elektrikli ve elektronik atıklara yönelik ilk çalışma 2004 yılında Marta Projesi adıyla Hollanda hükümeti ile gerçekleştirilmii ardından da WEEE ve RoHS Direktiflerinin uygulanmasına dair UK Department for Business Enterprise and Regulary Reform(BERR) kurumu ile bilgi paylaşımında bulunulmuştur. Şu an halen AEEE ve RoHS Direktifleri ile ilgili çalışmalar devam etmektedir (E-Atık, 2012). 22 Mayıs 2012 tarihli Resmi Gazete 'de yayınlanan ve Mayıs 2013 itibariyle işlevsel olarak yürürlüğe giren Atık Elektrikli ve Elektronik Atıkların Kontrolü Yönetmeliği(AEEE), Türkiye'de e-atıkların geri dönüşümü için insan ve çevre sağlığını gözeten yeni bir sürecin başlangıcını ifade etmektedir. 2002/96/EC-WEEE Direktifine paralel olarak hazırlanan yönetmelik; belediyeleri, Elektrikli ve Elektronik araç üreticilerine, dağıtıcılarına ve tüketicilerine çeşitli sorumluluklar yüklemektedir. Bu süreçte kurulacak olan Bakanlığa rapor sunmakla görevlendirilmiş olan Koordinasyon Merkezlerinin toplanan, geri dönüştürülen ve ihraç edilen e-atık miktarı ve oranı hakkındaki faaliyetleri T.C. Çevre ve Şehircilik Bakanlığı tarafından netleştirildiğinde atık geri dönüşüm sektörünün önemli bir gelişme göstermesi beklenmektedir. T.C. Çevre ve Şehircilik Bakanlığı verilerine göre; Türkiye'de yılda 539 bin ton e-atık oluşmakta ve söz konusu atıkların sadece 20 bin tonu doğru ve sağlıklı yöntemlerle geri dönüştürülmektedir. Bakanlığın açıklamalarında ayrıca en fazla çöpe atılan ürünlerin televizyon ve CRT monitörler olması ve en çok e-atık üreten şehirler sıralamasında İstanbul, Kocaeli ve Ankara yer alması dikkat çekici noktalardır. Türkiye'de ayrıca 2011 yılı sonu itibariyle lisanslı E-atık işleme tesis sayısı 21 olarak açıklanmıştır (Çevre Koruma ve Ambalaj Atıkları Değerlendirme Vakfı, 2013). Türkiye' de e-atıkların toplanması ve çevre ve insan sağlığını dikkate alarak geri dönüştürülmesiyle ilgili son yıllarda önemli adımlar atılmaktadır. Ancak bu sürecin işlemesi ve sürdürebilirliği e-atık üretici ve tüketicilerin çevre bilinci ile doğrudan ilişkilidir ve ancak bu bilinç geliştikçe verimli sonuçlara ulaşmak mümkün olabilecektir.

\section{Araştırmanın Amacı ve Metodolojisi}

\subsection{Araştırmanın Amacı}

$\mathrm{Bu}$ araştırmanın amacı; İstanbul'da artan e-atık kapasitesinin ekonomiye geri kazanımı ile ilgili bölge potansiyelini ve bölge halkının bu konudaki tutum, davranış, bilgi düzeyini tespit etmektir. Araştırma sonuçları, e-atık geri kazanımı ile ilgili verimli ve uygulanabilir faaliyetlerin gerçekleştirilmesinde, yatırım kararları alınmasında ve bu amaca yönelik politikaların oluşturulmasında yönlendirici olacaktır.

\subsection{Araștırmanın Yöntemi}

Bu araştırmada, kantitatif araştırma yöntemi ve bu yöntemin yüz yüze anket tekniği uygulanmıştır. Görüşülen bireylerin \%78.3' ü ile sokakta, \%16.7'si ile evde, \%11.0'i ile işyerinde yapılmıştır.

\subsection{Araștırmanın Örneklemi}

Basit tesadüfi örneklem türüne göre İstanbul genelinde toplam 1092 kişi ile görüşülmüştür. 


\section{Araştırma Bulgularının Değerlendirilmesi}

\subsection{Hanehalkının Demografik Özellikleri}

Araştırma katılanların \%26.4 'sı 25-34, \%21,5'i 34-44, \%17.7'si 18-24, \%17,5'i 55 yaş üstü ve \%16.9'u 45-54 yaş aralığındadır. Katılımcıların \%50,2' si kadın, \%49,8'si erkektir. Katılımcıların \%4'ü okur-yazar değil, \%4.8'i okur yazar, \%29.2'si ilkokul mezunu, \%20.3'ü ortaokul ya da ilköğretim mezunu, \%27.5'i lise mezunu ve \%14.2'si üniversite mezunudur. Katılımcıları iş durumu ise sırasıyla \%35.2 ev hanımı, \%12.5 eğitimli işçi, \%12.1 emekli, \%10.1 eğitimsiz işçi, \%9 esnaf, \%8.2 öğrenci, \%4.8 geliri düşük serbest meslek, \%3.6 işsiz, \%2.8 memur ve \%1.7 ise geliri yüksek meslek grubuna mensuptur. Katılımcıların gelir grubu dağılımı \%19.7 alt gelir, $\% 2.6$ üst gelir ve \%77.7 orta gelir grubu şeklindedir.

\subsection{Hanehalkının E-Atık Geri Dönüşümü İle İlgili Bilinç Düzeyi}

İstanbul genelinde yapılan görüşmelerde; bireylerden elektronik atıklar ve çevre bilinci ile ilgili toplam 14 ifadeyi 5 puan üzerinden değerlendirmeleri istenmiştir.

\begin{tabular}{|c|c|c|c|c|c|c|c|c|}
\hline & & 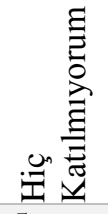 & 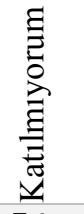 & 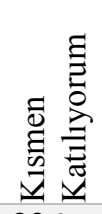 & 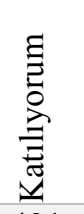 & 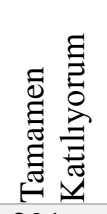 & $\frac{\Xi}{\frac{\pi}{2}}$ & 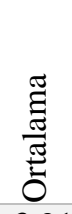 \\
\hline \multirow{2}{*}{$\begin{array}{l}\text { Yaşadığım şehirde merkezi bir geri } \\
\text { dönüşüm tesisi kurulursa atıkları } \\
\text { oraya bırakırım }\end{array}$} & Frekans & 5 & 76 & 226 & 491 & 291 & 1089 & \multirow[t]{2}{*}{3,91} \\
\hline & Yüzde & 0,5 & 7,0 & 20,8 & 45,1 & 26,6 & 100 & \\
\hline \multirow{2}{*}{$\begin{array}{l}\text { Yaşadığım mahallede geri dönüşüm } \\
\text { konteynırları olursa atıkları oralara } \\
\text { bırakabilirim }\end{array}$} & Frekans & 9 & 46 & 312 & 477 & 244 & 1088 & \multirow[t]{2}{*}{3,83} \\
\hline & Yüzde & 0,8 & 4,2 & 28,7 & 43,9 & 22,4 & 100 & \\
\hline \multirow{2}{*}{$\begin{array}{l}\text { E-atıklar zararlı olduğu için normal } \\
\text { çöpe atılmamalıdır. }\end{array}$} & Frekans & 35 & 116 & 251 & 520 & 167 & 1089 & \multirow[t]{2}{*}{3,61} \\
\hline & Yüzde & 3,2 & 10,7 & 23,0 & 47,8 & 15,3 & 100 & \\
\hline \multirow{2}{*}{$\begin{array}{l}\text { E-atıklar içerisinde değerli } \\
\text { madenler bulunmaktadır. }\end{array}$} & Frekans & 15 & 101 & 426 & 500 & 44 & 1089 & \multirow[t]{2}{*}{3,42} \\
\hline & Yüzde & 1,4 & 9,3 & 39,2 & 46,0 & 4,1 & 100 & \\
\hline \multirow{2}{*}{$\begin{array}{l}\text { E-atıklar elle parçalanarak } \\
\text { ayrıştırılabilirler }\end{array}$} & Frekans & 137 & 341 & 330 & 272 & 10 & 1090 & \multirow[t]{2}{*}{2,70} \\
\hline & Yüzde & 12,6 & 31,2 & 30,3 & 25,0 & 0,9 & 100 & \\
\hline \multirow{2}{*}{$\begin{array}{l}\text { Geri dönüşüm çalışmaları } \\
\text { için ek vergi veririm }\end{array}$} & Frekans & 172 & 502 & 248 & 118 & 49 & 1089 & \multirow[t]{2}{*}{2,42} \\
\hline & Yüzde & 15,8 & 46,1 & 22,8 & 10,8 & 4,5 & 100 & \\
\hline \multirow{2}{*}{$\begin{array}{l}\text { Çevreyi koruma ve geliştirme } \\
\text { için fazladan vergi öderim }\end{array}$} & Frekans & 133 & 534 & 281 & 135 & 6 & 1089 & \multirow[t]{2}{*}{2,40} \\
\hline & Yüzde & 12,2 & 49,0 & 25,8 & 12,4 & 0,6 & 100 & \\
\hline
\end{tabular}

Tablo-3 Ifadelere ne derece katıldı̆̆ı̆ızı «1.Hiç katılmıyorum- 5.Kesinlikle katıllyorum» belirtir misiniz?

Anket katılımcılarının elektronik ve çevre bilincini ölçmek amacıyla puanlamalarının istedikleri ifadelerin ilki "Yaşadı̆̆ım şehirde merkezi bir geri dönüşüm tesisi kurulursa atıkları oraya bırakırım" şeklindedir. İfadeye katılıyorum diyenler $\mathbf{\% 4 5 , 1}$ ile en yüksek orana sahiptir. Tüm katılımcılar arasında bu ifadenin puan ortalaması 3,91 düzeyindedir ve genel olarak katılımcılar ifadeyi "katılıyorum" şeklinde değerlendirmiştir. Dolayısıyla bu ifadeye yaklaşımları ile katılımcıların çevreci ve bilinçli bir eğilim içinde olduklarını söyleyebiliriz.

“Yaşadı̆̆ım mahallede geri dönüşüm konteynırları olursa atıkları oralara bırakabilirim” ifadesine katılıyorum diyenlerin oranı \% 43,9'dur. Tüm katılımcılar arasında bu ifadenin puan ortalaması 3,83 düzeyindedir ve genel olarak katılımcılar ifadeyi "katılıyorum" şeklinde değerlendirmiştir. Dolayısıyla bu ifadeye yaklaşımları ile katılımcıların çevreci ve bilinçli bir eğilim içinde olduklarını söyleyebiliriz.

"E-atıklar zararlı olduğu için normal çöpe atılmamalıdır" ifadesine katılımcılar \%47,8 düzeyinde katılmışlardır. Tüm katılımcılar arasında bu ifadenin puan ortalaması 3,61 düzeyindedir ve genel olarak katılımcılar ifadeyi "katılıyorum" şeklinde değerlendirmiştir. Dolayısıyla bu ifadeye yaklaşımları ile katılımcıların çevreci ve bilinçli bir eğilim içinde olduklarını söyleyebiliriz.

"E-atıklar içerisinde değerli madenler bulunmaktadır" ifadesine katılıyorum diyenlerin oranı \% 46'dır. Tüm katılımcılar arasında bu ifadenin puan ortalaması 3,42 düzeyindedir ve genel olarak katılımcılar ifadeyi "katılıyorum" şeklinde değerlendirmiştir. Dolayısıyla bu ifadeye yaklaşımları ile katılımcıların çevreci ve bilinçli bir eğilim içinde olduklarını söyleyebiliriz.

"E-atıklar elle parçalanarak ayrıştırılabilirler" ifadesinde katılımcılar \%31,2'si "katılmıyorum” görüşünü tercih ederken, katılımcıların \% 30,3'ü “kısmen katıllyorum” görüşünü tercih etmişlerdir. Tüm katılımcılar arasında bu ifadenin puan ortalaması $\mathbf{2 , 7 0}$ düzeyindedir ve genel olarak katılımcılar ifadeye "kısmen 
katılıyorum" şeklinde değerlendirmiştir. Dolayısıyla bu ifadeye yaklaşımları ile Katılımcıların bu ifadeye yaklaşımlarının çevreci ve bilinçli bir eğilim içinde olmadıklarını söyleyebiliriz.

“Geri dönüşüm çalışmaları için ek vergi veririm” ifadesine "katılmıyorum” diyenlerin oranı \% 46,1'dir. Tüm katılımcılar arasında bu ifadenin puan ortalaması 2,42 düzeyindedir ve Katılımcıların bu ifadeye yaklaşımlarının çevreci ve bilinçli bir eğilim içinde olmadıklarını söyleyebiliriz.

"Çevreyi koruma ve geliştirme için fazladan vergi öderim" ifadesinde en fazla tercih edilen \% 49 oranıla "katılmıyorum" seçeneği olmuştur. Tüm katılımcılar arasında bu ifadenin puan ortalaması 2,40 düzeyindedir. Katılımcıların bu ifadeye yaklaşımlarının çevreci ve bilinçli bir eğilim içinde olmadıklarını söyleyebiliriz.

\begin{tabular}{|c|c|c|c|c|c|c|c|c|}
\hline & & 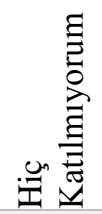 & 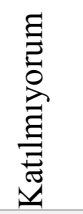 & 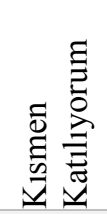 & 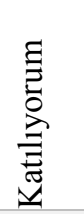 & 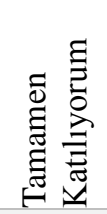 & $\frac{\tilde{J}}{2}$ & $\frac{\widetilde{Z}}{\tilde{\Xi}}$ \\
\hline \multirow{2}{*}{$\begin{array}{l}\text { Geri dönüşüm için } \\
\text { atıkların evillanılacak } \\
\text { beklerim }\end{array}$} & Frekans & 4 & 36 & 229 & 532 & 289 & 1090 & \multirow[t]{2}{*}{3,98} \\
\hline & Yüzde & 0,4 & 3,3 & 21,0 & 48,8 & 26,5 & 100 & \\
\hline \multirow{2}{*}{$\begin{array}{l}\text { Geri dönüşüm için ekstra masraf } \\
\text { ödemek istemem }\end{array}$} & Frekans & 15 & 54 & 266 & 531 & 223 & 1089 & \multirow[t]{2}{*}{3,82} \\
\hline & Yüzde & 1,4 & 5,0 & 24,4 & 48,7 & 20,5 & 100 & \\
\hline \multirow{2}{*}{$\begin{array}{l}\text { Yeni çıkan ürün kullanmak benim } \\
\text { için önemlidir }\end{array}$} & Frekans & 28 & 90 & 322 & 507 & 143 & 1090 & \multirow[t]{2}{*}{3,59} \\
\hline & Yüzde & 2,6 & 8,3 & 29,5 & 46,5 & 13,1 & 100 & \\
\hline \multirow{2}{*}{$\begin{array}{l}\text { Geri dönüşüm için mahallemden } \\
\text { dışarı çıkamam }\end{array}$} & Frekans & 17 & 177 & 390 & 363 & 142 & 1089 & \multirow[t]{2}{*}{3,40} \\
\hline & Yüzde & 1,6 & 16,3 & 35,8 & 33,3 & 13,0 & 100 & \\
\hline \multirow{2}{*}{$\begin{array}{l}\text { İstihdam ve ekonominin gelişmesi } \\
\text { benim için çevreden önce gelir }\end{array}$} & Frekans & 115 & 315 & 294 & 330 & 36 & 1090 & \multirow[t]{2}{*}{2,87} \\
\hline & Yüzde & 10,6 & 28,9 & 27,0 & 30,2 & 3,3 & 100 & \\
\hline \multirow{2}{*}{$\begin{array}{l}\text { Teknolojik ürünlerin fiyatı benim } \\
\text { için çevre dostu olmasından daha } \\
\text { önemlidir }\end{array}$} & Frekans & 101 & 307 & 425 & 245 & 11 & 1089 & \multirow[t]{2}{*}{2,78} \\
\hline & Yüzde & 9,3 & 28,2 & 39,0 & 22,5 & 1,0 & 100 & \\
\hline \multirow[t]{2}{*}{ E-atıklar sağlığa zararlı değildirler } & Frekans & 214 & 492 & 240 & 141 & 1 & 1088 & \multirow[t]{2}{*}{2,29} \\
\hline & Yüzde & 19,7 & 45,1 & 22,1 & 13,0 & 0,1 & 100 & \\
\hline
\end{tabular}

Tablo.4 Ifadelere ne derece katıldı̆̆ınızı «1.Hiç katılmıyorum- 5.Kesinlikle katıllyorum» belirtir misiniz?

Ankete katılanların "Geri dönüşüm için kullanılacak atıkların evimden alınmasını beklerim" ifadesine kat1lyyorum diyenlerin oranı $\mathbf{\% 4 8 , 8}$, tamamen katıliyorum diyenlerin ise $\mathbf{\% 2 6 , 5}$ 'dur. Cevapların puan ortalamas 1 3,98 olduğundan genel görüşün "katıllyorum" şeklinde olduğunu ifade edebiliriz. Katılımcıların bu ifadeye yaklaşımlarının çevreci olmayan ve bilinçsiz bir eğilim içinde olduklarını söyleyebiliriz.

Ankete katılanların "Geri dönüşüm için ekstra masraf ödemek istemem" ifadesine katılyorum diyenlerin oranı $\mathbf{\% 4 8 , 7}$, tamamen katılıyorum diyenlerin ise \%20,5'dir. Cevapların puan ortalaması 3,82 olduğundan genel görüşün "katılıyorum" şeklinde olduğunu ifade edebiliriz. Katılımcıların bu ifadeye yaklaşımlarının çevreci olmayan ve bilinçsiz bir eğilim içinde olduklarını söyleyebiliriz.

Ankete katılanların "Yeni çıkan ürün kullanmak benim için önemlidir" ifadesine katılıyorum diyenlerin oranı \% 46,5, tamamen katılıyorum diyenlerin ise \%13,1'dir. Cevapların puan ortalaması 3,59 olduğundan genel görüşün "katılıyorum" şeklinde olduğunu ifade edebiliriz. Katılımcıların bu ifadeye yaklaşımlarının çevreci olmayan ve bilinçsiz bir eğilim içinde olduklarını söyleyebiliriz.

Ankete katılanların "Geri dönüşüm için mahallemden dışarı çıkmam” ifadesine kısmen katılıyorum diyenlerin oranı \% 35,8, katılıyorum diyenlerin ise $\mathbf{3 3 , 3}$ 'dür. Cevapların puan ortalaması $\mathbf{3 , 4 0}$ olduğundan genel görüşün "katılıyorum" şeklinde olduğunu ifade edebiliriz. Katılımcıların bu ifadeye yaklaşımlarının çevreci olmayan ve bilinçsiz bir eğilim içinde olduklarını söyleyebiliriz.

Ankete katılanların "İstihdam ve ekonominin gelişmesi benim için çevreden önce gelir" ifadesine katıl1yorum ve tamamen kat1liyorum diyenlerin toplamı \%33,5, katılmıyorum diyenler ise \%28,9'dur. Cevapların puan ortalaması 2,87 olduğundan genel görüşün "klsmen katılıyorum" şeklinde olduğunu ifade edebiliriz. Katılımcıların bu ifadeye yaklaşımlarının çevreci olmayan ve bilinçsiz bir eğilim içinde olduklarını söyleyebiliriz.

Ankete katılanların "Teknolojik ürünlerin fiyatı benim için çevre dostu olmasından daha önemlidir" ifadesine kısmen katılıyorum diyenlerin oranı \%39 iken Katılmıyorum ve hiç katılmıyorum diyenlerin toplam oranı \%37,5'dir. Cevapların puan ortalaması 2,78 olduğundan genel görüşün “kısmen katılıyorum” şeklinde olduğunu 
ifade edebiliriz. Katılımcıların bu ifadeye yaklaşımlarının çevreci olmayan ve bilinçsiz bir eğilim içinde olduklarını söyleyebiliriz.

Ankete katılanların "E-atıklar să̆ğğa zararlı dĕgildirler" ifadesine katılmıyorum şeklinde yanıtlayanların oranı \% 45,1 iken kısmen katılıyorum şeklinde yanıtlayanların oranı \% 22,1'dir. Cevapların puan ortalaması 2,29 olduğundan genel görüşün "katılmıyorum" şeklinde olduğunu ifade edebiliriz. Katılımcıların bu ifadeye yaklaşımlarının çevreci olmayan ve bilinçsiz bir eğilim içinde olduklarını söyleyemeyiz.

Çevreci ve bilinçli olmayı sorgulayan ifadelerden elde edilen ortalama puan yaş, cinsiyet, eğitim durumu ve gelir gruplarına göre incelenmiştir. Cinsiyete göre ortalama puanların farklılık gösterme durumu t testi ile incelenmiştir. Cinsiyete göre bireylerin çevreci ve bilinçli olmaları bakımından farklılık göstermedikleri görülmektedir. Yaş gruplarına ve eğitim durumuna göre yapılan inceleme ise varyans analizi ile yapılmıştır. Yaş ve eğitim duruma göre elektronik atıklar konusunda bilinç düzeyi ve çevrecilik bilinci farklılık göstermemektedir. İstanbul genelinde elektronik atıklar konusundaki bilinç düzeyi ve çevrecilik anlayış1 ortalama bir düzeydedir, 5 puan üzerinden 3,18 olarak hesaplanmıştır. Gelir gruplarına göre yapılan incelemede ise gelir arttıkça çevreciliğin da arttığı görülmektedir.

İstanbul'da bireyin demografik özellikleri çevre bilinci üzerinde etkili faktörler değildir. Gelir düzeyinin çevre bilinci konusunda etkili bir faktör olduğu tespit edilmiştir. Gelir arttıkça çevre bilinci de artmaktadır.

Çevreci ve bilinçli olmayı sorgulayan ifadelerden elde edilen ortalama puan yaş, cinsiyet, eğitim durumu ve gelir gruplarına göre incelenmiştir. Cinsiyete göre ortalama puanların farklılık gösterme durumu t testi ile incelenmiştir. Cinsiyete göre bireylerin çevreci ve bilinçli olmaları bakımından farklılık göstermedikleri görülmektedir. Yaş gruplarına ve eğitim durumuna göre yapılan inceleme ise varyans analizi ile yapılmıştır. Yaş ve eğitim duruma göre elektronik atıklar konusunda bilinç düzeyi ve çevrecilik bilinci farklılık göstermemektedir. İstanbul genelinde elektronik atıklar konusundaki bilinç düzeyi ve çevrecilik anlayışı ortalama bir düzeydedir, 5 puan üzerinden 3,18 olarak hesaplanmıştır. Gelir gruplarına göre yapılan incelemede ise gelir arttıkça çevreciliğin da arttı̆̆ görülmektedir.

İstanbul'da bireyin demografik özellikleri çevre bilinci üzerinde etkili faktörler değildir. Gelir düzeyinin çevre bilinci konusunda etkili bir faktör olduğu tespit edilmiştir. Gelir arttıkça çevre bilinci artmaktadır.

\begin{tabular}{|c|c|c|}
\hline & Frekans & Yüzde \\
\hline Geri dönüşüme ayrılır & 158 & 50,3 \\
\hline Hurdaciya veya eskiciye verilir & 46 & 14,6 \\
\hline Çöpe atılır & 27 & 8,6 \\
\hline $\begin{array}{l}\text { Atık ürünlerin toplanabileceği toplama alanları oluşturulup buralarda } \\
\text { toplanabilir }\end{array}$ & 24 & 7,6 \\
\hline Aldığımız yere iade edilebilir & 16 & 5,1 \\
\hline Depolarda saklanır & 10 & 3,2 \\
\hline Belediyeye verilir & 10 & 3,2 \\
\hline Eşyalar yenilenir & 10 & 3,2 \\
\hline İkinci el kabul eden yerlere satılır & 5 & 1,6 \\
\hline Atık tesisi varsa oraya verilir & 4 & 1,3 \\
\hline İhtiyacı olan birine verilir & 2 & 0,6 \\
\hline \multirow[t]{2}{*}{ Satıp paraya çevrilebilir } & 2 & 0,6 \\
\hline & 314 & 100 \\
\hline
\end{tabular}

Tablo.5 Elektronik eşyaların kullanım ömrü dolduğunda neler yapılması gerektiğini belirtir misiniz?

Anket katılımcılarına yöneltilen "Elektronik eşyaların kullanım ömrü dolduğunda ne yapılması gerektiğini biliyor musunuz” sorusuna \%29 oranında biliyorum ve \%71 oranında da bilmiyorum şeklinde yanıt alınmıştır. Biliyorum yanıtını veren 314 katılımcıya "Elektronik eşyaların kullanım ömrü dolduğunda neler yapılması gerektiğini belirtir misiniz?" sorusunu yöneltildiğinde ise \%50,3 gibi yüksek bir oranda "geri dönüşüme ayrılır" yanıtı alınmıştır. Diğer yanıtlar sırasıyla \%14,6 oranında "Hurdacıya veya eskiciye verilir", \%8,6 oranında "çöpe atılır", \% 7,6 oranında "Atık ürünlerin toplanabileceği toplama alanları oluşturulup buralarda toplanabilir”, \% $\%, 1$ oranında aldığımız yere iade edilebilir şeklinde sıralanmaktadır. Depolarda saklanır, belediyeye verilir ve eşyalar yenilenir cevaplarının her üçünün de oranı \%3,2 iken, ikinci el kabul eden yerlere satılır yanıtının oranı 1,6'dır. Atık tesisi varsa oraya verilir yanıtının oranı \%1,3, ihtiyacı olan birine verilir ve satıp paraya çevrilebilir yanıtlarını veren her iki grupta da oran \%0,6 dır. Genel olarak yanıtları incelediğimizde bilgi sahibi olduğunu ifade eden katılımcıların önemli kabul edilebilecek bir kesiminin e-atıkların bir atık türü olarak geri dönüşüme ayrılması gerektiği konusunda bilgi sahibi olduğu sonucuna ulaşabiliriz. 


\begin{tabular}{|l|l|l|l|}
\hline Baz:1092 Kişi & Frekans & $\begin{array}{l}\text { Cevapların } \\
\text { Yüzdesi }\end{array}$ & $\begin{array}{l}\text { Deneklerin } \\
\text { Yüzdesi* }\end{array}$ \\
\hline Eskiciye veririm & & 588,8 & 53,8 \\
\hline Çöpe atarım & 195 & 16,9 & 17,9 \\
\hline İhtiyacı olan birine veririm & 157 & 13,6 & 14,4 \\
\hline İkinci el dükkanlarına satarım & 120 & 10,4 & 11,0 \\
\hline Geri dönüşüm kutusuna bırakırım & 56 & 4,8 & 5,1 \\
\hline Evde saklarım & 8 & 0,7 & 0,7 \\
\hline Cevap yok & 33 & 2,9 & 3,0 \\
\hline & 1157 & 100,0 & 106,0 \\
\hline *Birden çok cevap alınmıștır. & & & \\
\hline
\end{tabular}

Tablo.6 Elektronik cihazlarınızı değiştirdiğinizde eski cihazlarınızı nasıl dĕ̆erlendirirsiniz?

Anket katılımcılarının \%50,8'i elektronik cihazlarını değiştirdiklerinde eski cihazlarını eskiciye vererek değerlendirdiklerini ifade etmişleridir. Katılımcıların \%16,9'u eski cihazlarını çöpe attığını, \%13,6'sı ise ihtiyacı olan birine verdiğini belirtmiştir. Eski cihazlarını ikinci el dükkânlarına satmayı düşünenlerin oranı \%10,4 iken eski elektronik cihazlarını geri dönüşüm kutusuna bırakırım diyenler \% 4,8 gibi bir orana sahiptir.

\section{Sonuç}

Çevre ve insan sağlığı için oluşturduğu tehdit ve yol açtığı kaynak israfı ulusal ve uluslararası düzeyde etkin bir e-atık geri dönüşüm politikasının gerekliliği konusunu önemli bir gündem konusu haline getirmiştir. Nitekim konunun merkezi ve yerel yönetimler ile sivil kuruluşlar nezdinde yoğun olarak dile getirilmesi de bu durumun en somut göstergelerinden biridir. Ancak söz konusu politikaların uygulanması, yürürlülükteki yönetmeliklerin gündelik hayatta karşılığını bulması büyük oranda kişilerin konuya atfettikleri önem ve ilgi ile doğrudan alakalıdır. E-atık konusunda üreticiler kadar son tüketicilere de önemli sorumluluklar düşmektedir. İstanbul halkının e-atık konusundaki çevre bilinç düzeyi ve davranışlarına yönelik yaptığımız anket sonuçlarında hanehalkında merkezi bir geri dönüşüm tesisine atıklarını koyma eğiliminin yanında geri dönüşüm için kullanılacak atıkların evinden alınmasını tercih edenler de olmuştur. Zararlı içerikleri nedeniyle diğer evsel atıklarla birlikte çöpe atılmaması gerektiği konusunda da bilinçli olan katılımcıların yanında e-atıkların elle parçalanabileceğini düşünen katılımcılar da mevcuttur. Sonuçlarda en dikkat çekici nokta katılımcıların çevreyi koruma ve geliştirme adına ek vergi ödemek gibi ekstra ödemelere razı olmamalarıdır. Genel itibari ile İstanbul özelinde e-atık geri dönüşümün önemi ve yaratacağı toplumsal fayda konusunda toplumun daha fazla bilgi aktarımına ihtiyaç duyduğu görülmektedir. Nitekim demografik özellikler çevre bilincinde etkili değilken eğitim düzeyinin bilinçli bir çevre yaklaşımı ile doğrudan ilişkili olduğunu görmekteyiz.

\section{Kaynakça}

- AB İMMİB. (2013, 05 17). http://ab.immib.org.tr adresinden alındı

- $\quad$ Babu, B. R., Parande, A. K., \& Basha, C. A. (2007). "Electrical and Electronic Waste: A Global Environmental Problem", Waste Management \& Research, 4(25), pp. 307-318.

- Çevre Koruma ve Ambalaj Atıkları Değerlendirme Vakfi. (2013, 05 17). http://www.cevko.org.tr/cevko/IcSayfa/Cevko/Haberler/AEEE.aspx

- Çiftlik, S., Handırı, İ., Beyhan, M., Akçil, A. U., Ilgar, M., \& Gönüllü, M. T. (2009). "Elektrikli ve Elektronik Atıkların (E-Atık) Yönetimi, Ekonomsi ve Metal Geri Kazanım Potansiyeli Bakımından Değerlendirilmesi", Türkiye'de Katı Atık Yönetimi Sempozyumu (s. 1-8). İstanbul: Yıldız Teknik Üniversitesi.

- $\quad$ E-Atık. (2012, 06 06). http://www.e-atik.com

- European Commision, (2013, Mayıs 07). European Commission. Recast of the WEEE Directive: http://ec.europa.eu/environment/waste/weee/index_en.htm

- Hester, R. E., \& Harrison, R. M. (2009). Electronic Waste Management: Design, Analysis and Application. The Royal Society of Chemistry.

- Hester, R., \& Harrison, R. (2009). Electronic Waste Management, RSC Publishing, Cambridge.

- Miller, G. T., \& Spooman, S. E. (2012). Living in the Environment. Volando Cossio.

- $\quad$ Press, B. (2003). Statistics on Waste Eectrical and Electronic Equipment, Ekspressen Tryk and Kopycenter, Kopenhag.

- $\quad$ Puckett, J., Byster, L., Westervelt, S., Gutierrez, R., Davis, S., Hussain, A., \& Dutta, M. (2002). Exporting Harm:The High-Tech Trashing of Asia. (Ed. J. Puckett, \& T. Smith) 
- $\quad$ Robinson, B. H. (2009). "E-waste: An assessment of global production and environmental impacts", Science of the Total Environment(408), 183-191.

- W.J.Rankin. (2011). Minerals, Metals and Sustainability Meeting Future Material Needs, Csiro Publishing, Oxford.

- Widmer, R., Oswald-Krapf, H., Sinha-Khetriwal, D., Schellmann, M., \& Böni, H. (2005). "Global Perspectives on E-waste", Environment Impact Assessment Review(25), 436-458.

- Yazıcı, E. Y., \& Deveci, H. (2009). "E-atıklardan metallerin geri kazanımı", Madencilik, 48(3), 4. 


\title{
Doğu Akdeniz Enerji Kaynaklarının Güney Kıbrıs Rum Yönetimi Ekonomisine Etkileri
}

\section{The Effect of Eastern Mediterranean Energy Reserves on Economy of Greek Cypriot Administration of Southern Cyprus}

\author{
Prof. Dr. Halil İbrahim Ülker (At1lım University, Turkey) \\ Asst. Prof. Dr. Poyraz Gürson (Atılım University, Turkey) \\ Mustafa Kemal Topcu (Fibonasi Yönetim Danışmanlık, Turkey) \\ Asst. Prof. Dr. Turan Erman Erkan (Atılım University, Turkey)
}

\begin{abstract}
Eastern Mediterranean harbors nearly one-sixth or global trade volume. However, challenge in the region is not only related to control over trade route, it is also concerned with sovereignty over energy and events taking place in the Middle East and the North Africa. Situation amid the convergence point among and between Asia, Africa, and Europe, directly control over the Suez Canal and Aegean Sea, and opening point of energy reserves of Middle East and Caucasus to the world empower its strategic position. To this end, geostrategic significance of Cyprus, as a flowing platform and situated in the main heart of Eastern Mediterranean, has been improved with the discovery of hydrocarbon reserves in the region. It was declared that the volume of the reserves is anticipated between 140 and 226 billion $\mathrm{m}^{3}$. In case Greek Cypriot Administration of Southern Cyprus announced its bailout, financial burden of oil and gas reserves as the last resort could not be taken over by itself. In this sense, Greek Cypriot Administration of Southern Cyprus should be cautious in the use of reserves that are the insurance of public future welfare to exploit them to recover its downturn economy.
\end{abstract}

\section{Giriș}

Doğu Akdeniz tarihin her çağında önemini korumuş, zenginlik ve refahın kaynağında yer almıştır (Tarakçı, 2012). Coğrafyasına bakıldığında Süveyş Kanalı, Türk Boğazları ve Ege Denizini içerisinde barındıran Orta Doğunun nabzını tutan bir konuma sahiptir. Orta Doğu petrol rezervlerinin yaklaşık üçte ikisine, doğal gaz kaynaklarının da yüzde kırkına ev sahipliği yapmaktadır (Yıldız ve Yaşar, 2012). Bu nedenle ticaret yolu olma özelliğinin yanında enerji koridoru görevi de bulunmaktadır. Doğu ile Batı arasındaki en kısa deniz yolu olan Süveyş Kanalı’nın barındırması enerji koridoru vasfını güçlendirmektedir. Diğer taraftan Doğu Akdeniz'de ticaret hacmi günlük yaklaşık 3000-4000 gemi kadardır (Yıldız, 2011). Bu haliyle Doğu Akdeniz dünya ticaretinin yaklaşık altıda birine ev sahipliği yapmaktadır. Doğu Akdeniz'deki mücadele yalnızca ticaret yolunun kontrolü ve enerji hakimiyetine dayanan bir mücadele olmamış aynı zamanda Orta Doğu ve Kuzey Afrika'daki gelişmelerle de ilintili olmuştur. Asya, Afrika ve Avrupa kıtalarının birleşme noktasında yer alması, Ege Denizi ile Süveyş Kanalı'nı doğrudan kontrol etmesi ve Orta Doğu ile Kafkasların enerji kaynaklarının dış dünyaya aç1lış noktası olması stratejik konumunu güçlendirmektedir. Yoğun ticaret trafiği önemini sürekli korumasını sağlamıştır. Aynı zamanda deniz aşırı operasyonlar için ideal bir ileri üs olma özelliği küresel güçlerin bölge üzerinde kendilerini yakın hissettirmeleri açısından mükemmel bir imkan sunmuştur. Özellikle Orta Doğu'daki kriz bölgelerine müdahale için bir sıçrama noktası niteliğindedir (Kuloğlu, 2012).

\section{Kıbrıs Adası ve Küresel Bağlamda Önemi}

Doğu Akdeniz'deki mücadele yalnızca ticaret yolunun kontrolü ve enerji hâkimiyetine dayanan bir mücadele olmamış aynı zamanda Orta Doğu ve Kuzey Afrika'daki gelişmelerle de ilintili olmuştur. Asya, Afrika ve Avrupa kıtalarının birleşme noktasında yer alması, Ege Denizi ile Süveyş Kanalı'nı doğrudan kontrol etmesi ve Orta Doğu ile Kafkasların enerji kaynaklarının dış dünyaya açılış noktası olması stratejik konumunu güçlendirmektedir. Yoğun ticaret trafiği önemini sürekli korumasını sağlamıştır. Aynı zamanda deniz aşırı operasyonlar için ideal bir ileri üs olma özelliği küresel güçlerin bölge üzerinde kendilerini yakın hissettirmeleri açısından mükemmel bir imkan sunmuştur. Özellikle Orta Doğu'daki kriz bölgelerine müdahale için bir sıçrama noktası niteliğindedir (Kuloğlu, 2012). Nitekim İngilizlerin egemenlik bölgelerinden vazgeçmemeleri, BM'nin Lübnan'da devam eden operasyonları için lojistik maksatlı stratejik liman olarak Kıbrıs'1 kullanması da bu görüşü desteklemektedir. Öte yandan küresel hedefleri olan hiçbir güç Kıbrıs Adasını göz ardı edememektedir (Yılmaz, 2013). Bu anlamda, AB açısından öncelikli konu enerji arz güvenliğini oluşturmaktadır. Avrupa Birliğinin toplam enerji tüketimi içerisinde doğalgaz \%24'lük bir yer işgal ederken, Rusya Federasyonun enerji ithalatındaki payı yaklaşık \%60'dır (Economist, 2008). Rusya Federasyonuna olan bağımlılığın azaltılması ve arzın çeşitlendirilmesi açısından Doğu Akdeniz olası bir koridor olarak önem taşımaktadır. İsrail'in kendi bölgesinde tespit ettiği rezervler ile GKRY'nin sözde MEB'de bulunan rezervlerin bu amaca hizmet edeceği değerlendirilmektedir. Özellikle bu kaynakların Avrupa üzerinden pazarlanmasının hem güvenliğe hem de 
ekonomiye katkısı olacağı aşikârdır. Bu durum Türkiye'nin hem stratejik konumuna, hem bölgesel güç olma hedefine, hem enerji güvenliğinde söz sahipliğine hem de Doğu-Batı arasında enerji düğümü olma pozisyonuna tehdit oluşturmaktadır. Çünkü Kıbrıs hem Mersin Limanını hem de mevcut ve planlı tüm petrol nakil hatlarının buluştuğu İskenderun Limanını kontrol altında bulundurmaktadır.Kıbrıs Adasının Türkiye açısından stratejik önemi; Yunanistan'a karşı sigorta görevi üstlenmesi, Anadolu'nun güvenliğinin sağlanması, Doğu Akdeniz deniz ticaretinde söz sahibi olma, ulaşım ve nakil hatlarının kontrolünden kaynaklanmaktadır (Tarakçı, 2012). Yakın zamanlarda Doğu Akdeniz Türkiye açısından bir sorun bölgesi olarak görülmek yerine ekonomik firsatlar alanı olarak kabul edilmeye başlanmıştır. Böylelikle Doğu Akdeniz'de ekonomik ve diplomatik varlığını daha da ileri götürmüştür. ABD açısından ise bölgenin önemi asıl adı "Genişletilmiş Orta Doğu ve Kuzey Afrika Bölgesi ile Müşterek Bir Gelecek ve İlerleme için Ortaklık Projesi” olan BOP merkez bölgesi olmasından kaynaklanmaktadır (Yıldız, 2012). Bilindiği kadarıyla proje stratejik enerji kaynaklarının ve ulaşım hatlarının denetim altına tutulmasına yönelik geliştirilmiştir (Günal, 2004:159). Ayrıca ABD'nin Orta Doğu'daki sorunlara askeri güçle müdahale yöntemi Kıbrıs'ın önemini daha da artırmaktadır.

\section{GKRY Enerji Kaynakları}

Doğu Akdeniz’in kalbinde yer alan ve yüzen bir uçak gemisi niteliğindeki Kıbrıs adasının bölgede keşfedilen hidrokarbon kaynakları ile birlikte jeostratejik önemi bir kat daha artmıştır. GKRY'nin AB üyeliği ve Türkiyeİsrail arasındaki ilişkilerin bozulması GKRY'nin deniz yetki alanlarının belirlenmesine yönelik faaliyetlerinde ayrı bir üstünlük sağlamıştır. GKRY Münhasır Ekonomik Bölgenin (MEB) sınırlarını tek taraflı olarak 2004 yılında ilan etmiş ve aynı yıl Mısır'la, 2007 yılında da Lübnan ile MEB sınırlandırma anlaşmalarını imzalamıştır. Benzer şekilde 2010 yılı Aralık ayında ise İsrail ile anlaşma imzalanmış ve aynı zamanda petrol ve doğal gaz aranması konusunda işbirliği konusunda da anlaşılmıştır. GKRY tarafından 2007 yılında Kıbrıs'ın güneyinde sözde MEB'inde 70 bin km2 bir alanda 13 adet petrol arama ruhsat sahası ilan edilmişstir (Erdurmaz, 2012). GKRY'nin Afrodit olarak isimlendirdiği sahada 2011 yılında petrol arama çalışmaları başlatılmış ve 140 ila 226 milyar $\mathrm{m}^{3}$ seviyesinde olduğu tahmin edilen doğal gaz rezervi bulunduğu ilan edilmiştir. 12.Parsel olarak da ifade edilen bu saha İsrail'in Leviathan Sahası ile komşudur. Ayrıca 100 trilyon ABD doları değerindeki zengin yataklarda petrol rezervleri bulunduğu ileri sürülmektedir (Dinç, 2012).

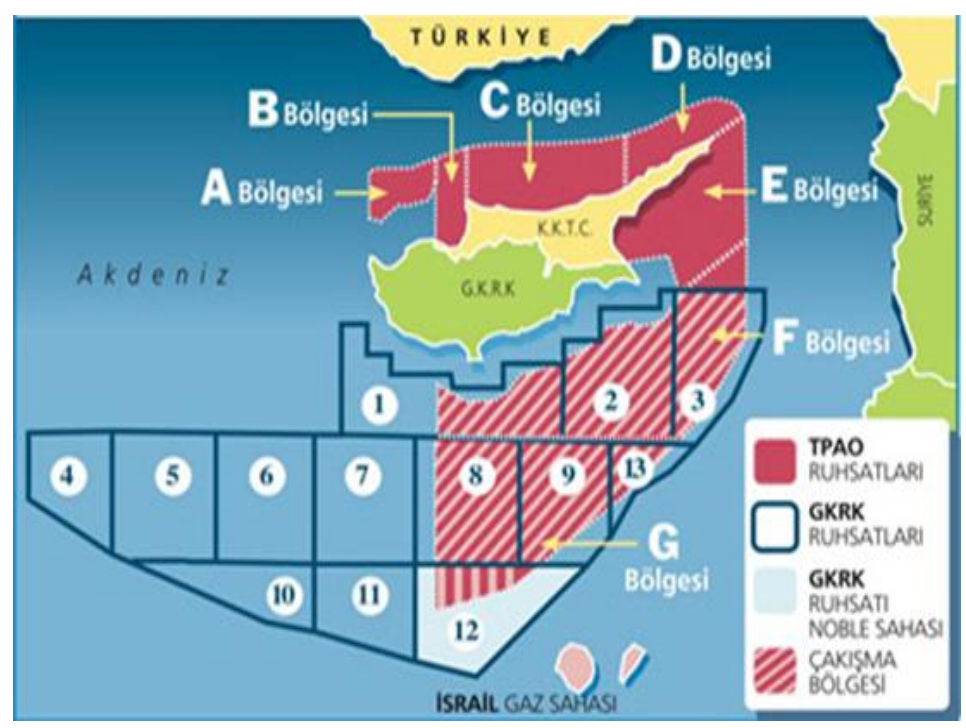

Şekil 1 Arama Bölgeleri

GKRY Lideri sözde MEB'inden elde edilecek refahtan Ada haklarının eşit bir şekilde yararlanacağını belirtmiştir (Lüle, 2012). Türkiye 1960 anlaşmasına aykırı bulduğu GKRY'nin sözde MEB sınırlandırmaları ve doğal kaynak arama çalışmalarının Ada'da kalıcı bir çözüme kavuşmadan yapılmaması gerektiğini belirtmektedir. GKRY'nin soruna bölgesel nitelik kazandırmak ve uluslararası platforma taşıyarak kamuoyu oluşturmak temelindeki politikaları GKRY'nin 2004 yılında AB üyeliğine Ada'nın tek temsilcisi olarak kabul edilmesiyle meşrulaşmıştır. Benzer şekilde Doğu Akdeniz'de doğal gaz ve petrol rezervlerinin bulunması ve bu imkanın yarattığı işbirliği fırsatları GKRY ile İsrail'i de birbirine yakınlaştırmıştır. GKRY ile İsrail arasında imzalanan doğal kaynakları arama işbirliği anlaşmasıyla da bölgesel ittifak oluşumlarının yolu açılmıştır. İsrail'in Türkiye ile olan ilişkilerinin bozulması da bu sürece katkıda bulunmuştur. İsrail Tamar ve Leviathan havzalarında 2010 yılında doğal gaz tespit etmiştir. Tamar sahasındaki gaz rezervleri İsrail'in 40 yıllık ihtiyacına cevap vereceği bilinmektedir (Kariotis, 2011:48). Leviathan sahasındaki rezervlerin ise Tamar sahasındakinin iki katı olduğu tahmin edilmektedir (Kariotis, 2011:48). Bu sahalardan çıkarılacak gazın GKRY'ye taşınması ve burada LNG haline getirilerek ihraç edilmesi konusu hala gündemdedir. 


\section{Enerji Kaynakları ve GKRY Ekonomisi}

GKRY'nin enerji kaynaklarının üzerinde 1srarla durmasının ana nedenleri arasında yaşanan ekonomik istikrarsızlık ön plana çıkmaktadır. GKRY'nin doğal müttefiki olan Yunanistan'ın ve bağlı olarak AB'nin yaşadığı ekonomik kriz GKRY'yi çok derinden etkilemiştir. Yunanistan'daki krizin ABD kaynaklı küresel krizden kaynaklanmadığı bilinmektedir (Kouretas ve Vlmais, 2010). Yunanistan krizinin temel nedenleri arasında, ekonomik gerilemeden ve reel GSYH'de beklenenden daha büyük bir düşüşten kaynaklanan "ekonomik döngü" etkisi, gelir toplama mekanizmalarının gevşekliğinden ve harcamaların yüksekliğinden kaynaklanan "seçim veya politik döngü" etkisi ve vergileri toplama, harcamaları kontrol etme ve verileri kaydetmeye ilişkin yaygın yapısal yetersizliklerden ve eksikliklerden kaynaklanan "yapısal" etki yer almaktadır (akt. Köse ve Karabacak, 2011: 295). Yine de küresel krizden etkilenen özel sektörün borçlarının devlet tarafindan üstlenilmesi de kamu borç stokunun artmasına neden olmuştur (Kouretas ve Vlmais, 2010:391). Bunlarla birlikte sosyal güvenlik reformu gibi yapısal reformların yapılmaması, ulusal rekabet gücünün kaybı ve finansal kaynaklara kolay erişim de krizin derinleşmesinde etken olmuştur (Akram ve ark., 2011:123). 2010 yıl1 Mayıs ayı içerisinde IMF destekli 110 milyar avro değerinde üç yıl sürecek bir kurtarma paketi onaylanmıştır.

GKRY ise 07 Aralık 2012 tarihinde resmen iflasını açıklamıştır. Vasiliko Elektrik Santralinde 11 Temmuz 2012 tarihindeki patlama sonucu meydana gelen ağır hasar iflas öncesinde GKRY ekonomisini daha da derinden sarsmıştır. AB'den kurtarma yardım paketi almak zorunda kalan GKRY yeni silah alımlarını da durdurmuştur.

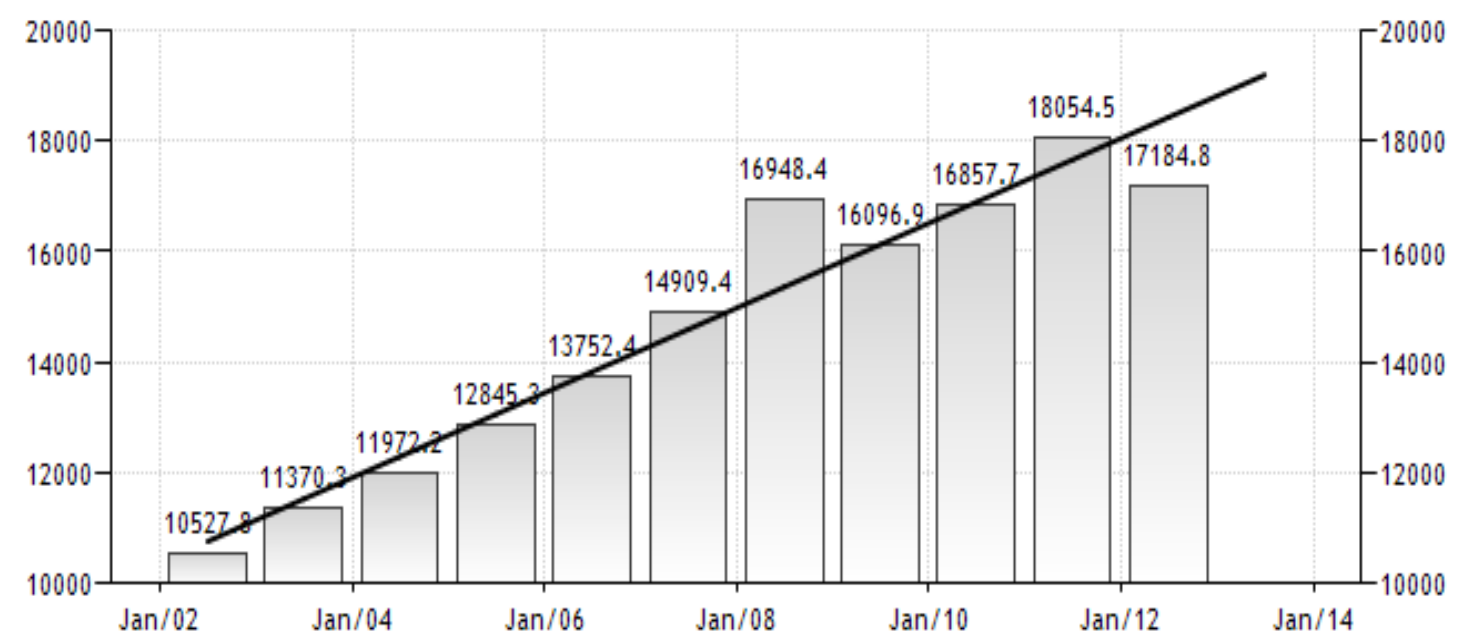

Şekil 2 GKRY GSMH Kaynak: GKRY İstatistik Dairesi

GKRY ekonomisi açık bir ekonomi olmasına karşın oldukça dar kapsama sahiptir. GKRY'nin yıllık GSMH'si 24 milyar, kamu kesimi harcamaları ise 11 milyar ABD dolarını bulmaktadır (Hargreaves, 2013). Petrol ve petrol ürünlerinin tamamını ithal etmektedir. Tekstil, kimyasal, elektronik, makine ve otomotiv ürünlerinin \%80'den fazlası yurtdışından gelmektedir. Ekonominin yaklaşık \%45'i nerdeyse tamamını uluslararası sermayenin oluşturduğu bankacılık kesimi oluşturmaktadır. Kısa zamanda bankacılık kesimindeki sermayenin de \%90’1 kaybolmuş vaziyettedir (Smith, 2013). Uluslararası piyasada ülkenin kredibilitesini yitirmesiyle birlikte, GKRY'nin önünde fazla seçenek de bulunmamaktadır. Bu kapsamda turizm sektörü önde bulunsa da avroyla birlikte ücretlerdeki yükselişs sektörü sekteye uğratmaktadır. Diğer bir sektör de Orta Doğu'ya iş yapan şirketlere lojistik ve destek hizmeti sağlanmasıdır. Sözde MEB'inin bir kısmında bulunan doğal gaz rezervi hidrokarbon seçeneğidir (Stambolis, 2013). Elektrik krizi yaşadığı dönemde KKTC'den elektrik almak durumunda kalan GKRY, halk ve kilisenin tepkisini almıştır. Bu nedenle Doğu Akdeniz'de petrol ve doğal gaz aranması "ulusal onur" haline de getirilmiştir (Kutlay, 2012). GKRY açısından petrol ve doğal gaz rezervleri hem bir enerji kaynağı olarak kullanılabilecek hem de ekonomik bir kaynak olacaktır. GKRY'nin ana düşüncesi, yurtiçi Pazar payı çok az olduğundan ihracata yönelik politika şekillendirmektir (Karbuz, 2012:22). Ancak, GKRY'nin içinde bulunduğu istikrarsızlık petrol arama faaliyetlerinin getireceği mali yükü yüklenemeyeceğini göstermektedir. Ancak mevcut finansal durumda GKRY'nin bir an önce eyleme geçmesini gerektirmektedir. Rus enerji devi Gazprom yardım etme karşılığında doğal gazlarının devrine ilişkin bazı teklifler sunduğu da bilinmektedir (Hargreaves, 2013). Projeksiyonlara bakılacak olursa, 2020 yılı itibarıyla, GKRY doğal gaz rezervleri sayesinde ekonomisine yıllık 3 milyar ABD doları doğrudan kazandıran ve 1 milyar ABD dolarlık vergi kazancı yaratan bir konuma kavuşması içten bile değildir (Hargreaves, 2013). Diğer bir beyan ise 25 yıllık dönemde GKRY'nin doğal gaz rezervlerinden kazancının, Avrupa doğal gaz fiyatlarının mevcut seyrini koruyacağı varsayılarak, yaklaşık 50 milyar ABD doları olacağı yönündedir (Stambolis, 2013). GKRY'nin bu projeksiyonları kullanmak suretiyle gaz rezervlerini teminat göstererek kaynak yaratma arayışı bulunduğu tahmin edilmektedir (Stambolis, 2013). GKRY refahının geleceği konumundaki rezervleri kullanırken azami dikkati göstermek durumundadır. 
Doğru yapılandırmak şartıyla doğal gaz-para değişimi GKRY için en makul çözüm gibi durmaktadır. Ancak Venezuela ve Meksika gibi ülkelerin yaşadıkları da birer örnek olarak karşımıza çıkmaktadır. Bu ülkeler öz kaynaklarını ve aldıkları dış yardımları rezervleri bulma yolunda israf ettikleri için ellerini güçlü tutamamıştır (Hargreaves, 2013).

\section{Sonuç}

Doğu Akdeniz'de Türkiye hem siyasi açıdan hem de ekonomik açıdan belirgin üstünlüğü son dönemdeki istikrarlı uygulamaları ile pekiştirmiştir. Elektrik krizi yaşadığı dönemde KKTC'den elektrik almak durumunda kalan GKRY halk ve kilisenin tepkisini almıştır. Bu nedenle Doğu Akdeniz'de petrol ve doğal gaz aranması "ulusal onur" haline de getirilmiştir (Kutlay, 2012). Bu durum GKRY'nin KKTC'ye bağımlı hale getirebilmenin mümkün olduğunu göstermiştir. Türkiye de bu bağlamda boru hatları ile Ada'ya su taşınması, hidroelektrik santrallerin inşası ve petrol boru hattının inşası gibi projelerle KKTC'yi ekonomik olarak güçlendirmeye çalışmaktadır. GKRY'nin içinde bulunduğu istikrarsızlık petrol arama faaliyetlerinin getireceği mali yükü yüklenemeyeceğini de göstermektedir. İsrail'in Leviathan ve Tamar sahalarında elde edeceği gazı GKRY'den ihracına yönelik proje alternatifleri açısından İsrail için maliyeti en düşük ve en karlı yatırım aracı olarak görünmektedir. Alternatifleri Türkiye üzerinden taşımak, Arap gaz boru hattını kullanmak ve Yunanistan üzerinden nakli gerçekleştirmektir. Ne var ki, GKRY'nin hem siyasi istikrarsızlığı hem ekonomik darboğazı İsrail açısından projenin hayata geçirilmesini zorlaştırmaktadır. Ayrıca boru hattının güvenliğinin sağlanması da İsrail için diğer bir zorlaştırıcı etkendir. GKRY ise elindeki mevcut rezervleri doğru kullanarak ekonomik darboğazdan bir çıkış yolu bulabilir gibi görünmektedir. Ancak kendi ekonomisi ne rezervleri çıkarmaya, ne işlemeye ne de transfer etmeye yetecek güçtedir. Yunanistan'ın da ekonomik kriz içerisinde olması GKRY'nin müracaat edeceği ilk kapıyı kapatmaktadır. Ancak Rusya Federasyonu enerji kaynaklarını bir etki aracı kullanma politikası kapsamında GKRY'nin enerji kaynaklarını çıkarma, işleme ve dağıtma işlerini üstlenebilir pozisyondadır. Bu sebeple GKRY'nin alacağı teklifler karşısında dikkatli olması gerekmektedir. Günün kurtarılması karşısında halkın gelecekteki refahından ödün verilmesi söz konusu olabilir.

\section{Kaynakça}

- Akram, Muhammad, Sajjad, Humna, Fatima, Tooba, Mukhtar, Sidra ve Alam, Hassan Mobeen , 2011. "Contagious Effects of Greece Crisis on Euro-Zone States," International Journal of Business and Social Science, Vol. 2 No. 12, ss.120-129.

- Dinç, Engin, 2012. “Doğu Akdeniz'de Petrol Savası Kızışıyor,” www.ozgundurus.com.

- Economist, 2008. The War in Georgia Puts Energy Security Back on Europe's Agenda, 21 August 2008.

- $\quad$ Erdurmaz, Serdar, 2012. 'Doğu Akdeniz'de GKRY'nin Münhasır Ekonomik Bölge İlanı, Petrol Aramaları ve Türkiye," www.turksam.org.

- GKRY İstatistik Dairesi, 2013, www.tradingeconomics.com.

- Günal, Altuğ, 2004. “Büyük Ortadoğu Projesi ve Türkiye,” Ege Akademik Bakış, ss.156-164.

- Hargreaves, Steve, 2013. "Cyprus is sitting on a natural gas gold mine," http://money.cnn.com/2013/03/21/news/economy/cyprus-natural-gas/index.html.

- Karbuz, Sohbet, 2012. "Doğu Akdeniz Son Gelişmeler”, Enerjide Hedef, Türkiye Petrolleri, Yı1 4, Sayı 6, ss.18-23.

- Kariotis, Theodore C., 2011. "Hydrocarbons and the Law of the Sea in the Eastern Mediterrenian: Implications for Cyprus, Greece, and Turkey," Mediterrenian Quarterly, Cilt 22, Nu.2.

- Köşe, Yaşar ve Karabacak, Hakan, 2011. "Yunanistan Ekonomik Krizi: Nedenleri, Etkileri ve Alınan Tedbirlere İlişkin Bir Değerlendirme,” Maliye Dergisi, Sayı 160, ss.289-306.

- Kouretas, Georgios P. ve Vlamis, Prodromos, 2010. The Greek Crisis: Causes and Implications," Panoeconomicus, 4, ss.391-404.

- Kuloğlu, Armağan, 2012. "KKTC’nin Stratejik Önemi ve Türk Cumhuriyetleri ile Dayanışma," www.beykent.edu.tr.

- Kutlay, Mustafa, 2012. “Doğu Akdeniz’de Sertleşen Rekabet: Güney Kıbrıs Rum Kesimi-Türkiye Gerginliğinin Analizi,” www.usak.org.tr.

- Lüle, Zeynel, 2012. “Müstakbel Rum liderden Kıbrıs’ta çözümün şifreleri,” http://www.hurriyet.com.tr/planet/21355818.asp.

- Smith, Yves, 2013. "Destruction of Cyprus Economy Proceeding Ahead of Schedule," http://www.nakedcapitalism.com/2013/03/destruction-of-cyprus-economy-proceeding-ahead-ofschedule.html. 
- Stambolis, Costis, 2013. "Can hydrocarbon reserves save the Cyprus economy?," http://www.financialmirror.com/blog-details.php?nid=1060

- Tarakçı, Nejat, 2012. "Yeni Basra Körfezi: Doğu Akdeniz,” www.tasam.org.tr.

- Yıldız, Dursun, 2011. “Doğu Akdeniz'de Enerji Politik’e Karşı Supolitik,” www.topraksuenerji.org.

- Y1ld1z, Dursun, 2012. “Doğu akdeniz Neden Önemli?”, www.topraksuenerji.org.

- Yildız, Dursun ve Yaşar, Doğan, 2012. Doğu Akdeniz’de Küresel Satranç, İstanbul: Truva Yayınları.

- Y1lmaz, Sait, 2013. "Büyük Güçler ve Kıbrıs” www.beykent.edu.tr. 


\title{
Только Правильная Политика Вернет Доверие Only the Correct Policy will Return Trust
}

\author{
Prof. Dr. Turar Koychuev (National Academy of Sciences, Kyrgyzstan) \\ Prof. Dr. Merim Koichueva (Kyrgyz-Russian Slavic University, Kyrgyzstan)
}

\begin{abstract}
The given paper analyzes and assesses the socio-economic development of the Kyrgyz Republic in period of 22 years. The objects of attention were the problems of market economy, social problems such as poverty, unemployment, internal and external labor migration, issues of active economic policy and its unconditional implementation. The results, obtained from the critical analysis, allow giving recommendations to include in the policy renovation and development components and achieve stable and sustainable growth in economy to ensure an increase in its scale and efficiency.
\end{abstract}

Прошло почти 22 года, как страна стала суверенной республикой. Стали обвинять во всех грехах, недостатках развития советскую систему. Конечно, авторитарная система изживала себя, но при ней достигнуты были и успехи, и в ней присутствовали определенные привлекательные и положительные черты общественного развития. Исторический объективный анализ пройденного пути еще предстоит обществоведами.

Прослеживая и оценивая состояние, динамику развития стран СНГ, приходится констатировать, что эйфоричное отношение к декларируемой политической демократии, исходя из опыта других стран и еще не осознанной на собственном опыте и не совсем понятой обществом, слепая вера в рыночную экономику и безграмотная ее реализация, не познав ее научные основы, привели к тому, что и в общественно-политическом, государственно-правовом и социально-экономическом устройстве серьезные «недоделки», сдерживающие развитие и искажающие ценности. Скажем, в Кыргызстане до сих пор не достигнута политическая стабильность. Экономика в ряду отсталых экономик мира. Уровень жизни населения низкий. Безработица. Резкий разрыв в доходах социальных слоев, если их сгруппировать по размерам доходов. Отсюда, социальной солидарностью в обществе не «пахнет». Подозрительность и агрессия. Расцветает коррупция. Неподкупная, ради народа работающая власть не проглядывается. Нравственная и моральная распущенность. Криминал. Исчезают патриотизм, чувство родины. Тает доверие общества к власти. Трудоспособная часть населения из года в год покидает страну, уменьшая трудовой потенциал страны. Кто же будет строить будущее страны? Не будем голословными, обратимся к фактам и еще раз к фактам.

Валовой внутренний продукт, по данным Нацстаткома КР («Социально-экономическое положение Кыргызской Республики» (январь-декабрь) 2012), в 2012 году оказался ниже и составил 99,1\% объема 2011 года. ВВП в 2011 году по сравнению с 2010 годом возрастал на 6,0\%, и, вдруг, в 2012 году последовал провал. Это следствие структурного дисбаланса, когда судьба экономики страны зависима от ограниченного круга производств. Это мягко говоря, а если жестко - от работы одного производства - по разработке золоторудного месторождения «Кумтор». В ВВП республики доля «Кумтора» в 2012 году составила 6,6\%. Без «Кумтора» ВВП возрос на 5,0\%, т.е. уменьшение общего объема ВВП на 0,9\% связано с уменьшением объема производства на «Кумторе». Без учета «Кумтора» объем промышленной продукции возрос на 6,1\%, а с «Кумтором» понизился до 79,8\% уровня 2011 года. «Кумтор» значительно сократил объем производства. Тем не менее, доля «Кумтора» в объеме промышленной продукции республики составила 37,8\%. Неустойчивая работа «Кумтора» ощутимо сказывается на экономике и бюджетной устойчивости страны. Это ненормально, когда одно предприятие делает погоду и свидетельствует об ущербности структуры экономики.

Неустойчивая динамика экономического развития Кыргызстана, когда прирост потом прерывается спадом, связана не только негативами в развитии экономики, но и политической нестабильной ситуацией в стране. Практически политические события и дворцовые перевороты не дают экономике нормально развиваться, и она практически оказывается в состоянии паралича. Бедность не уменьшается, уровень жизни невысокий.

По данным Всемирного Банка из 131 страны, по которым составлен доход о мировом развитии, 35 стран в 2008 г. относились к странам с низкими доходами, валовой национальный доход которых в расчете на душу населения был равен 975 долларам и ниже. Кыргызстан - в числе 26 самых отсталых стран.

Бедность в Кыргызстане прочно заняла свое место в социальной характеристике страны. Трудно предположить, каков реальный уровень бедности населения, а по официальным статистическим данным он составлял: в 2007 г. - 35,0\%; в 2008 г. - 31,7\%; в 2009 г. - 31,7\%; в 2010 г. - 33,7\%; в 2011 г. - 36,8\% 
(«Уровень жизни населения Кыргызской Республики. 2007-2011 гг., 2012). И эти уровни достаточно высокие. Более того, что видно из приведенных данных, проглядывается тенденция повышения уровня бедности. В 2011 г. из 5,6 миллионного населения 2,1 млн. человек находились ниже черты бедности. Опасная ситуация. Возможны социальные конфликты.

Рассмотрим подробнее в разрезе городских и сельских местностей, высокогорных, среднегорных и равнинных районов, по территории страны. В 2011 г. уровень бедности составил: городского населения $30,7 \%$; сельского населения - 40,4\%; в высокогорных районах - 38,8\%; среднегорных районах - 38,3\%; в равнинных - 36,3\%; в Баткенской области - 35,6\%; в Джалал-Абадской области - 45,3\%; Иссык-Кульской области - 29,5\%; в Нарынской области - 49,9\%; Ошской области - 44,7\%; Таласской области - 50,2\%; Чуйской области - 28,6\%; в г. Бишкек - 18,4\%.

Как показывают данные, заметны различия между городом и деревней, особенно они существенны в разрезе регионов. А «поясные» данные говорят о том, что, на какой бы высоте не жило население, уровень бедности примерно одинаков. Практически вся страна горная, равнины незначительны, в окружении гор и полностью находятся под природно-климатическим воздействием гор.

Уровень бедности существенно различается в домашних хозяйствах в зависимости от количества детей. Так, в 2011 году, по данным выборочного обследования, из всех домашних хозяйств 1 ребенка имели $25,4 \%$ домашних хозяйств, 18,0\% из них считались бедными; 2 детей имевших 35,1\% домашних хозяйств, 37,8 - бедные; 3 детей имели 24,6\% домашних хозяйств, 56,3\% - бедные; 4 детей имели 10,9\% домашних хозяйств, 64,7\% - бедные; 5 и более детей имели 3,9\% домашних хозяйств, 88,2\% - бедные.

Сокращение и ликвидация бедности - наиболее острая социальная проблема. Масштабное проявление бедности связано с экономическим кризисом, негативным структурным развалом - потерей промышленности, потерей рабочих мест и безработицей, безответственностью властей в решении проблем бедности и безработицы и отсутствием глубоко продуманной и принятой стратегии и реализуемой политики.

По данным интегрированного обследования бюджетов домашних хозяйств и рабочей силы в 2011 г., численность экономически активного населения в возрасте 15 лет и старше насчитывала 2,5 млн. человек, из них 2,3 млн. занятых, 212,4 тыс. безработных, или уровень экономической активности составил 64,9\% против 64,0\% в 2003 г., т.е. практически сильного сдвига нет. Уровень занятости населения несколько больше возрос: если в 2003 г. он был равен 57,7\%, то в 2011 г. составил 54,3\%. Считается, что уровень достаточно положительный.

Тем не менее, экономически неактивное население в 2011 г. составило 1,3 млн. человек, что составляет $54,0 \%$ активного населения. Из экономически активного населения 212,4 тыс. человек - безработные. В сфере занятых - 2,3 млн. человек. Численность населения в 2011 г. составляла 5,5 млн. человек. Значит, на 1 занятого приходилось 2,4 неработающих, включая всех незанятых: экономически неактивных, безработных, пожилых, детей и т.д.

Бедность и безработица обусловили в массовых масштабах трудовую миграцию ресурсов труда в другие страны: и ближнего, и дальнего зарубежья.

По данным Нацстаткома безработных насчитывается в 200 с лишним тыс. человек. Это официально зарегистрированные. В действительности их гораздо больше. К сожалению, налаженного учета нет. Конечно, к числу безработных не отнесли трудовых мигрантов, выбывших из страны. Но они, ведь, выбыли по причине того, что не нашли у себя на родине рабочие места.

Не секрет, что значительную часть мигрантов составляют именно трудовые мигранты (до 500 тыс. человек и более). Они выезжают за пределы страны на свой страх и риск. Среди них есть люди как с профессией и квалификацией, так и без профессии, квалификации и опыта работы. Не все люди с квалификацией находят на новом месте соответствующую профессию и опыт работы, а те, которые без профессии, идут на самые низкоквалификационные, непрестижные работы. Нужда заставляет.

Нередко в республике, как бы «с удовлетворением», отмечают, что трудовые мигранты прислали семьям столько-то (называется сумма до 1-2 миллиардов) долларов в год, и вносят свой «вклад» в благополучие населения. Но почему-то умалчивается, какой ценой в большинстве случаев достаются эти доллары: через унижения, слезы, невыносимые условия труда и быта.

Трудовая миграция наносит вред и семейным отношениям. Дети остаются без присмотра и опеки матерей, либо отцов, которые убывают. Случаются частые семейные разлады. Разрушаются семьи.

Трудовая миграция и экономике наносит вред. Отток профессионалов высоких квалификаций и с опытом тормозит восстановлению и возрождению привлекательных и приоритетных производств, появлению новых современных отраслей. Отток ресурсов трудов вообще понижает возможности обеспечения развития и роста масштабов производства ресурсами труда. Вводит дисбаланс.

В социальном плане трудовые мигранты за рубежом практически бесправны. Они не защищены правовыми законами. У них не такая уж «сладкая жизнь». 
В настоящее время экономика республики в таком трудном положении и ожидать, что в ближайшее время она будет способна более или менее обеспечить собственные ресурсы труда рабочими местами не приходится. Возможно, еще длительное время трудовая миграция из Кыргызстана будет вынужденным объективным процессом. Но она не должна оставаться «собственной попыткой» мигрантов на свой страх и риск.

Если государство считает себя государством и представляет себя таковым, уважает собственных граждан и действительно их судьба является объектом внимания, государство должно не только фиксировать, а инициативу мигрирования населения взять «в свои руки», чтобы она носила экономически, социально и в правовом плане благоприятный характер. Государство должно договариваться с соответствующими государствами об условиях труда, быта, социальных и правовых поддержках, чтобы уважались и призывались свободы и права человека. Мигранты вносят свой вклад в экономическое развитие страны - пребывания. И они по праву должны пользоваться всеми условиями жизнеобеспечения так же, как граждане страны - пребывания. Всемирная декларация прав и свобод человека имеет приоритетное значение перед национальными утвержденными документами.

Внешняя миграция действительно положительно сыграет свою экономическую и социальную роль для Кыргызстана, если мигранты найдут достойную сферу приложения своего труда, приобретут знания, высокую квалификацию, опыт, высокую нравственность и культуру, гуманность человеческих отношений, культуру быта, затем привнесут эти качества в Кыргызстан. Государство должно учитывать и эти моменты.

Для того, чтобы трудовые мигранты чувствовали себя в странах пребывания общественно «комфортно», может быть целесообразно ставить вопросы о двойном гражданстве тех, кто хочет этого. Ведь факт, что многие из трудовых мигрантов затем не возвращаются на родину, предпочитая оставаться там, где садаптировались. Так, нужно признать права человека на выбор гражданства.

Серьезную озабоченность вызывает внутренняя миграция. Регионы страны по своему социальноэкономическому развитию отличаются друг от друга. Есть развитые регионы, есть отсталые, как и в любой стране в большинстве случаев. В Кыргызстане относительно экономически развитым является Чуйская долина, на которой «расположены» столица Кыргызской Республики Бишкек и Чуйская область. В экономически и социально трудные годы суверенного Кыргызстана в г. Бишкек и Чуйскую область хлынул поток мигрантов из других, экономически менее развитых регионов. Оставляют свою «малую родину» молодежь и взрослые трудоспособного возраста. Кому же поднять экономику отсталых регионов и окраин? Оголяются территории. Это угроза не только экономике, но и национальной безопасности. Поток мигрантов осложняет развитие и г. Бишкек и Чуйской области. Они не могут всех обеспечить рабочими местами и жильем. Возникают сложности, которые прибавляются к «собственным» проблемам.

Чтобы у себя на родине повысить уровень жизни населения и обеспечить рабочими местами ресурсы труда в большей мере, главное - добиться стабильной и устойчиво положительной динамики экономики; обеспечить увеличение ее масштаба и эффективности. А это требует решительного изменения идеологии развития - уповать не на ресурсные возможности (природные и трудовые), а «перевести» ориентацию на инновационные решения и осуществить индустриально-инновационную структурную перестройку экономики. Без такой структурной перестройки невозможно перейти на высокотехнический, наукоемкий, технологически современный путь развития. Продуманно нужно возродить машиностроение, тщательно, с учетом научно-технических достижений, народнохозяйственной структуры экономики для выбора приоритетных, предпочтительных производств машиностроения, которые создадут индустриальную основу инновационной экономики.

Изменение идеологии экономики и ориентация на инновационный путь развития предъявляют высокие требования к качеству ресурсов труда: обученности, квалификации, профессии, опыту. В этом плане предстоит большая работа. За двадцать с лишним лет суверенности мы не улучшили, а ухудшили качество ресурсов труда, начиная от управленцев и инженерно-технических кадров до промышленных и строительных рабочих, сельскохозяйственных работников и представляющих их различные услуги. Предприниматели недостаточно квалифицированные и образованные, еще не сформировались на национальном уровне как дееспособный класс.

Резюме. Безусловно, главной основой «закрепления» кадров у себя в республике, - что важно для повышения уровня жизни народа, сохранения и укрепления государственности, обеспечения социальной солидарности в обществе, политической стабильности в стране, - является оздоровление экономики, достижение ее роста и устойчивости. Дееспособная и волевая власть, адекватно отражающая состояние и направления развития - избранную модель, ориентация идеологии развития на формирование образованного и культурного общества и знаниеемкой экономики, жесткая борьба с коррупцией и ликвидация еe как массового общественно негативного явления, повышение духовности и нравственности в обществе, возрождение и пробуждение активного патриотизма, умение и способность развивать внешние связи и занять свое достойное место в мировом сообществе, - вот те обобщенно 
основные факторы достижения прогресса в развитии, что порождает доверие народа к политике и реальным действиям власти.

\section{Литература}

- Нацстатком КР «Социально-экономическое положение Кыргызской Республики» (январьдекабрь) 2012. - Б., 2013. С. 79.

- Здесь и далее по данным Годовой публикации Нацстаткома КР «Уровень жизни населения Кыргызской Республики. 2007-2011 гг.». - Б., 2012. сс. 19, 22, 26. 


\title{
Рыночный фундаментализм и провал экономических реформ в постсоветском пространстве
}

\section{The Failure of Market Reforms in post-Soviet Space}

\author{
Prof. Dr. Khodjamakhmad Umarov (Institute of Economics, Tajikistan)
}

\begin{abstract}
The article is devoted to the false conceptions of economic reforms in the post-Soviet space, which in the aggregate are characterized as market fundamentalism. It revealed the true intentions of the international financial and economic organizations for which market reforms in the former Soviet Union acted as a tool for a complete change in the geopolitical and geo-economic patterns of the planet. Their goal was to transform the post-Soviet space in the mineral-raw-material appendage of the developed capitalist countries. The author considers necessary radical reorientation of economic reform toward a consistent solution of social problems.
\end{abstract}

В постсоветском пространстве через 20 лет после распада плановой системы сформирована рыночная экономическая система. Становление последней происходила путем проведения рыночных реформ. В разных отраслях реформы проводились по-разному. За некоторыми исключениями сценарии проведения таких реформ разрабатывались на Западе, главным образом в США. Сама рыночная экономика которая сложилась в этих странах представляет из себя конгломерат англо-саксонского типа капитализма добавленными всякого рода рецептами феодального и полуфеодального образца управления и хозяйствования. Теоретические исследования показали что по своему содержанию эти реформы выражали интересы определенных геополитических сил.

Нетрудно ныне убедиться в том, что политическая составляющая экономических реформ преобладала по сравнению с социально-экономическими. Главная цель реформ заключалась в ликвидации социализма как общественной системы, уничтожение СССР и раздел России на многочисленные, слабосвязанные друг с другом государства. Один из ярых антисоветчиков и идеологов разрушения социализма как системы Збигнев Бжезинский в первые годы после развала социализма грозил самым недвусмысленным образом : «Мы уничтожили СССР, уничтожим и Россию...Россия - это вообще лишняя страна...Эта побежденная держава. Она проиграла титаническую борьбу. И говорить «Это была не Россия, а Советский Союз» - значит бежать от реальности. Эта была Россия названная Советским Союзом. Она бросила вызов США. Она была побеждена. Сейчас не надо подпитывать иллюзий о великодержавности России. Нужно отбить охоту к такому образу мыслей...Россия будет раздробленной и под опекой» (Комсомольская правда зарубежом. 3-9 апреля, 2013 года).

В результате реформы не только была уничтожена плановая система. Оказался уничтоженным огромный производственный потенциал. Потери намного превысили те потери, которые были понесены Советским Союзом в годы Великой Отечественной Войны. Такую экономическую катастрофу ХХ век до того не испытывал.

В отличии от политологов типа Бжезинского среди идеологов - экономистов, прикомандированных из Запада никто не хочет брать ответственность за катастрофические результаты этих реформ.

Во главе реформ стояли международные финансово-экономические организации. Их полномочные представители - советники преимущественно разделяли неоклассические идеи, а точнее идеи монетаристской школы экономической науки. В качестве консультанта в России был направлен известный представитель названной школы профессор Джеффри Сакс. В других постсоветских странах всю работу по реформированию экономики так же консультировали представители монетаристской школы, которые разделяли мнение о всесилии «невидимой руки», о необходимости полного задействования рыночных методов регулирования экономики.

Еще до начала реформ, начиная со второй половины 80-ых годов, различные центры Запада приступили к подготовке лидеров реформ из числа ученых экономистов молодого поколения - выходцев из всех советских республик. Тогдашнее руководство Советского Союза благосклонно относилось к такому мероприятию.

После распада Советского Союза были приняты срочные практические меры для немедленного и необратимого разрушения плановой экономики и административно-командных методов управления. Госпланы бывших союзных республик были трансформированы в министерств экономики, которыми руководили молодые люди, специально подготовленные в роли терминаторов социалистической экономики. Ученые-экономисты, которые были сторонниками рыночных методов регулирования были приглашены в качестве организаторов рыночных реформ. Большинство из этих ученых не обладали 
достаточными и глубокими знаниями не только о методах проведения реформ, но и о возможных социально-экономических последствиях таких преобразований.

Различные международные финансово-экономические организации контролировали различные направления реформ, речь идет о таких организациях как Всемирный Банк, Международный Валютный Фонд, Европейский Банк Реконструкции и Развития, Азиатский Банк Развития, а также ПРООН. В процессе реформ был подключен и USAID. В своих действиях они полностью придерживались неолиберальными позициями.

Эти организации не скрывали свои намерения полностью и окончательно отделиться не только с плановой экономикой, но и с государственным регулированием экономики. Была поставлена цель в очень короткие исторические сроки либериализовать внутренний рынок, внешние экономические отношения и регулирование экономики. Под последним они понимали представление полной свободы рыночным силам.

По их замыслу экономический рост должен основываться, главным образом, на частную инициативу, поскольку она способствовала бы использованию сравнительных преимуществ в экономике. Неолиберальные реформаторы, как зарубежные, так и отечественные требовали существенного сокращения присутствия государства в экономике, для того чтобы не допустить дефицита государственного бюджета. Они очень хорошо знали что радикальные трансформационные сдвиги с неизбежностью приведут к резкому сокращению государственных доходов.

Дерегулирование экономии ими рассматривалось как условие для обеспечение гибкости, которая требуется для рыночной реструктуризации и повышения роли рыночных сил в упорядочении хозяйственной активности фирм и компании. Реформаторы постоянно подчеркивали, что либерализация внешней торговли, в особенности импорта призвана создать атмосферу высокой конкурентности во внутреннем рынке и повысить конкурентоспособность отечественных хозяйственных субъектов. Предоставление неограниченной свободы иностранному капиталу в экономике переходных обществ объяснялось необходимостью увеличения доступа последних к зарубежным финансовым ресурсам, привлечение новейших технологий, установление прочных связей с транснациональными корпорациями и мировым рынком, внедрение в постсоветских странах практики современного менеджмента и т.д. (Chandrasekhar C.P., Ghosh Jayati (2011), p.p. 19-31)

Последующие события показали что все эти рекомендации претворившись в реальности способствовали глубокому трансформационному спаду по всему постсоветскому пространству. К тому же они открывали путь для широкого участия криминальных групп в распределении и перераспределении собственности. Ведь здравый смысл говорит, что в течении весьма сжатого времени не представляется возможным формирование прослойки эффективных собственников. Только мафиозными методами можно было передать отдельным лицам громадные производственные мощности, которые в условиях нормальной рыночной экономики можно было бы создать в течении 50 - 100 лет по мере накопления финансовых ресурсов.

Идеологами реформ полностью исключалось идея одновременного осуществления рыночных реформ и положительных темпов экономического роста. Посредством финансовых нажимов правительством постсоветских стран не позволяли использовать другие модели трансформации плановой экономики в рыночной, включая китайскую модель градуалистского типа. В средствах массовой информации была организована наступательная пропаганда метода «шоковой терапии».

Последствие рыночных реформ оказались крайне разрушительными, а социальные результаты этих реформ - катастрофическими, в результате чего все постсоветские страны стали получателями гуманитарной помощи Запада. Идеологи реформ постоянно твердили, что трансформационный спад является неизбежным. Опыт Китая, Вьетнама и Беларусь показывает, что трансформационного спада можно было избежать.

Неолиберальные реформы и жесткие требования международных финансово-экономических организаций относительно быстрого внедрения рыночных методов регулирования привели к полному разрыву хозяйственных связей, из-за которых пострадали самые передовые отрасли экономики постсоветских стран - машиностроения, металлообработка, электротехническая, автомобильная, авиационная промышленность, судостроение, станкостроение и т.д. По всему постсоветскому пространству в начале 90-х годов прокатился процесс деиндустриализации. В течении короткого времени отрасли с высоким уровнем добавленной стоимости, и прежде всего, отрасли обрабатывающие промышленности почти полностью приостановили свою деятельность. В результате во всех этих странах сложился высокий уровень безработицы, которая охватывала основную часть квалифицированных работников и специалистов. Реформаторы оказались не в состоянии создать эффективно действующие рынок труда и рынок капиталов для того, чтобы предотвратить самый глубокий в истории спад экономики. 
Из-за неумело осуществленных реформ пострадали крупнейшие предприятия в промышленности, в сельском хозяйстве, в строительстве и транспорте. Идеологами реформ распространялись мифы о ненужности крупных предприятий, которые были построены при социализме, хотя они прекрасно знали, что производственное лицо развитых капиталистических стран определяются именно крупными предприятиями.

Рыночные реформы были полностью лишены человеческого лица. Практически профсоюзы как защитники интересов трудящихся масс были ликвидированы. Если обратить внимание на социальное составляющее реформ, то можно прийти к выводу об отсутствии тезисов об ориентации рыночных реформ на улучшение жизненных условий людей. Практически была ликвидирована система социальной защиты населения, которая была создана при социализме. Массовая безработица сопровождалась обнищанием широких слоев населения, распространением явлении голода и недоедания, резким повышением уровня бедности, быстрым увеличением масштабов внешней трудовой миграции населения, ростом сердечно-сосудистых и психических заболеваний, возрастанием разводов и разрушением домохозяйств.

После распада социализма повсеместное распространение получили коррупция, рейдерство, воровство в крупных масштабах. Всемирный Банк и МВФ очень хорошо знают о существовании коррупции на самом высоком уровне, но делают вид, что в экономике все обстоит нормально. Теневая экономика процветает и расширяет свои горизонты. В некоторых странах масштабы формальной экономики превышают масштабы неформальной экономики. Главными виновниками сложившейся ситуации являются идеологи «шоковой терапии». Они знали, что высокие скорости рыночных реформ с неизбежностью приведут к криминализации экономики, к быстрой концентрации богатства в руках небольшого количества лиц, к обязательному формированию олигархических групп. Нередки случаи неформальных союзов между олигархами и высшими руководителями отдельных стран. Такие союзы наносят огромный ущерб государственным интересам, служат причиной многих отрицательных явлений включая бедность и нищету. Например, в Таджикистане от выплаты налогов освобождена компания IRS, которая является собственностью лиц из высоких эшелонов власти. То же самое относится и к «Кont group», которая является совместным владением одного из бюрократов высшего ранга и иностранного партнера - известного махинатора и манипулятора. В результате рыночных реформ произошло полное изменение в структуре экономики. Если в советское время преобладали отрасли с высоким уровнем добавленной стоимости, то в настоящее время более половины ВВП приходится на сырьевые отрасли. В некоторых странах удельный вес сырьевых отраслей доходит до 80-85 \%. В экономической литературе преимущественно сырьевая структура экономики называется колониальной структурой.

Иностранные инвесторы ориентированы на вложение средств в добывающие и сырьевые отрасли экономики, а также на сферу услуг. Основная часть прямых иностранных инвестиций направляется в нефтегазовую отрасль, металлургии, химические и горнорудные промышленности. Исключение составляют автомобильная промышленность, для которой в России и в других постсоветских странах имеется широкая база продаж. В другие отрасли обрабатывающей промышленности практически уничтожены.

Преобладание такой структуры в экономики постсоветских стран выступает в качестве главного фактора несбалансированности между экспортом и импортом. В Таджикистане объемы импорта в 2012 году превысили объем экспорта более чем в 3,5 раза. Благоприятная среда для такого дисбаланса была создана либерализацией и торговлей. Она привела к прекращению деятельности обрабатывающих отраслей, продукция которых подвергается незначительным колебанием цен на мировом рынке. Что касается продукции сельского хозяйства и сырьепроизводящих отраслей промышленности, то на международных рынках они подвергаются существенным колебаниям цен. К тому же диспаритет в ценах между сырьевыми и готовыми товарами из года в год увеличивается. Можно согласится с известным американским экономистом Рави Батра в том, что «постоянный торговый дефицит негативно влияет на собственную промышленность, а также на реальную заработную плату.., более свободная торговля выгодна экспортирующим отраслям промышленности и наносит вред тем, которые конкурируют с импортом» (Рави Батра. (2006), стр.380). Такие страны как Киргизстан, Молдавия и Таджикистан вряд ли в ближайшие годы в состоянии справиться с хроническим отрицательным сальдо торгового баланса. Хронически и растущий дефицит внешней торговли давно привел бы и их финансовому дефолту, если не огромные суммы внешних трудовых мигрантов.

С дефицитом внешней торговли тесно связан феномен сокращения объемов государственного бюджета. Растущее отрицательное сальдо торгового баланса приводит к деиндустриализации, а следовательно, к сужению доходной базы государственного бюджета. По этой причине почти во всех переходных обществах в течении продолжительного времени государственные бюджеты оставались дефицитными, хотя в ряде из них были существенным образом сокращены социальные затраты, чтобы через профицит показать видимость благополучия бюджета. 
Заметно сократились государственные затрата на развитие образования, здравоохранения, культуры. Из-за этого растет малограмотность молодого поколения, расширяется деградация образовательной системы, культуры и социальной защиты населения.

Горе-реформаторы чувствуя провал реформ предпринимают попытки для приукрашивания ситуации с экономикой. Официально провозглашаемые темпы экономического роста не соответствуют действительности во многих постсоветских странах. Между этими темпами нормой валовых накоплений никакого соответствия нет. Некоторые лидеры в постсоветских странах преподносят высокие темпы, которые на самом деле являются фальсифицированными для восстановления эффективности своей деятельности, насаждении своего культа и увековечивании своего имени.

По заданию специальных служб Запада организаторы реформ одновременно ведут работу по стимулированию анти российских настроений. Предпринимаются попытки оторвать от России остальные постсоветские страны. Тот же самый Бжезинский еще в 1988 году сумел дать прогнозы будущего России: «Длительные, но так и не ведущие к определенным результатам беспорядки...Дальнейшие уступки и необдуманные перемены...Реформа в экономике, вероятно, лишат советских рабочих главных благ, а именно гарантии занятости и стабильной зарплаты...Усиление среди народов СССР национальных и религиозных конфликтов или сепаратистских устремлений»( Комсомольская правда зарубежом. 3-9 апреля, 2013 года). Оказывается эксперт по коммунизму смотрел в воду.

Таким образом в процессе осуществления рыночных реформ их идеологи и организаторы на целенаправленной основе подготовили и реализовали схему по поддержанию постоянной зависимости постсоветского пространства от мировых геополитических центров. В данном случае, речь идет о международных и региональных финансово-экономических организациях и правительстве США. Судьба приготовила странам постсоветского пространства роль сырьевых придатков развитых стран запада. Однако в этих странах в настоящее время развертывается процесс переосмысления экономических реформ, которые вытекали не просто из неолиберальных концепций, а стали проявлением позиции рыночных фундаменталистов. Нет необходимости давать оценку попыток реформаторов, которые по сути являлись терминаторами переходных экономик. Осуществить эксперимент неограниченной либерализации всей совокупности экономических связей в рассматриваемых странах. При этом они ссылались на огромный исторический багаж классической и неоклассической школы.

Нередко, реформаторы - рыночные фундаменталисты ссылаются на теории «невидимой руки рынка» Адама Смита и сравнительных преимуществ Давида Рикардо. Однако, они не хотят говорить об эпохе интенсивной колонизации Азии, Африки и Америки, и об интересах, которые выражали основоположники классической политической экономии. Учения А. Смита и Д. Рикардо были ярким выражением интереса в метрополе (в данном случае Англии) в отношении недавно захваченных колоний. Они оба были теоретиками поднимающие голову промышленной буржуазии в Британии последние четверти XVII и первой четверти XIX в.в. Идея свободной торговли, которое они выдвигали в условиях огромной технологической разницы между метрополей и колониями способствовал разгрому местных промыслов в колониях и превратили их в исключительных производителях и экспортерах сырья для быстроразвивающейся промышленности Британии. Свобода торговли существовала для метрополей, которая проводила индустриализацию за счет ресурсов колонии. Последние же ввиду технологической и финансово-экономической неконкурентоспособности оказались не в состоянии воспользоваться плодами либерализации торговли (Patnaik, Utsa (2007). p.p. 17-24).

За последние 200 лет социально-экономическая природа либерализации торговли не изменилась, хотя колониальные режимы в настоящее время нигде не существуют. Современные неоклассические теории претерпели риторические изменения, стали более тонкими, более приспособленными к современным изменениям. Они находятся на службе современного колониализма, которая умело модернизировала старые концепции рыночного фундаментализма современным реальностям. Свое концентрированное выражение они нашли в документе под названием «Вашингтонский Консенсус», под которым стоят подписи представителей правительства США, Всемирного Банка и МВФ. ВБ и МВФ будучи самыми влиятельными финансово-экономическими организациями в мире и стали неисправимыми проповедниками и проводниками идеи свободной торговли. Однако их деятельность основывалась на полное отсутствие экономической логики. Известный норвежский экономист Эрик С. Райнерт справедливо заметил, что «слишком поспешное введение свободной торговли убивала промышленность, при этом погибали все виды экономической деятельности, которые имели возрастающую отдачу. Массовая безработица, падение реальной заработной платы и все большее недоедание - все это шло рука об руку со слепой верой в то, что именовалось «свободная торговля» и «силы рынка». На деле они сводились к управляемой свободной торговлей, которая приносила людям только бедность и страдания» (Райнерт Эрик С.(2011), стр. 210.).

Современный финансово-экономический кризис показал несостоятельность неоклассических концепций развития мировой экономики, включая осуществление рыночных реформ в постсоветском 
пространстве. Как те, так и другие направлены против жизненно важных интересов человечества. Ныне мировая политическая ситуация втягивается в новый цикл. Имеют место первые признаки поворота к социально-ориентированной рыночной экономике. Отсюда выводы о демократизации международных и экономических отношений, о формировании нового мирового экономического порядка, одинаково выгодного всему мировому сообществу.

\section{Литература}

- $\quad$ Райнерт Эрик С. Как богатые страны стали богатыми и почему бедные страны остаются бедными. Издательский дом ГУ-ВШЭ. М;2011.

- Chandrasekhar C.P., Ghosh Jayati: The market That Failed. Neoliberal Economic Reforms in INDIA «Left Word Books», Delhi, 2011

- Bhaduri Amit. Essays in the Reconstruction of Political Economy, Aacar Books, Delhi; 2010.

- Jain Neeraj. Globalisation or Recolonisation. Alika Joshi, 2007

- Patnaik Utsa. The Republic of Hunger and other Essays. Glorious Printers. New Delhi 2007.

- Умаров Х. Кризис в Таджикистане. «Ирфон», Душанбе,2010

- Комсомольская правда зарубежом 3-9 апреля 2013 г. 


\title{
«Структурная лестница» устойчивого экономического роста (на примере Республики Молдова) \\ Structural Ladder of Sustainable Economic Growth: Republic of Moldova Example
}

\author{
Prof. Dr. Tatiana Pyshkina (Academy of Economic Studies of Moldova, Moldova)
}

\begin{abstract}
Using the experience of our prior research, and adapting that experience to the existing conditions in Moldova, this paper links sustainable economic growth with the structure of the economy. We present our Concept of New Structural Development (CNSD), where we outline possibility and mechanism of the transition of the Moldovan economy to the economy oriented on innovations that could deliver the new quality of growth that accompanies sustainable development as oppose to growth without development as it has been the case for the last 20 years. We also present a fragment of the CNSD decision tree in this paper. This Concept is universal for many countries from the point of view of the methodology of choice of structural priorities under the conditions of globalization, and practical recommendations for its application (taking into consideration and adapting for national differences), which makes it suitable for many developing countries.
\end{abstract}

\section{1 Введение}

Одним из основных процессов, воздействующих на все страны в системе единой мировой экономики, является процесс глобализации. Глобализация усиливает неравномерность экономического развития и конкуренцию между государствами. В мировой экономической системе остаются на одном полюсе развитые страны, выступающие в роли «глобализаторов», в то время как на другом концентрируются страны «глобализуемые». Не просматривается тенденции к их сближению и сокращению разрывов в доходах. Более того, наблюдается прямо противоположная тенденция к усилению дифференциации в доходах богатых и бедных стран.

В то же время, в условиях глобализации усиливаются процессы растущей интеграции национальных экономик в движении к единому мировому рынку. Мировой порядок очерчивается вокруг крупных силовых полюсов. На нашем континенте таким полюсом является Европейский Союз (ЕС) с его возрастающей политической и экономической значимостью. Европейская интеграция оказывает определяющее влияние на экономическое, политическое и социальное развитие Республики Молдова. Для Молдовы интеграция в ЕС рассматривается в качестве ключевой цели, для реализации которой необходимо добиться реальных успехов в социально-экономическом развитии и создании конкурентоспособной экономики с тем, чтобы впоследствии стать равноправным членом Европейского Союза.

Для реализации поставленных задач необходимо, изменить структурные приоритеты экономики.Почему именно структурные приоритеты мы считаем одним из ключевых элементов воздействия на экономику?

Структура экономики - это «фундамент» развития любой экономической системы. Устойчивость и качество этого «фундамента», а, следовательно, устойчивость и качество экономического развития, определяются структурными приоритетами, то есть, стратегическими предпочтениями в распределении ключевых факторов экономического роста: капитала, труда, технологий в те или иные сферы деятельности. Структура экономики влияет на объем валового внутреннего продукта, а, следовательно, на уровень жизни населения; определяет возможности выхода на внешние рынки, конкурентоспособность и качество экономического роста той или иной страны: Между структурными приоритетами и экономическим ростом существует функциональная взаимосвязь. В одних случаях (например, в развитых странах) структурные приоритеты меняются вследствие экономического роста. В других случаях (пример Молдовы и многих развивающихся стран) без смены структурных приоритетов невозможен устойчивый экономический рост (может иметь место рост без развития). Почему в контексте глобализации необходимо исследовать структурные приоритеты экономики? Глобализацию мы рассматриваем как расширяющийся «поток», определяющий направленность движения (экономического развития) любой страны в рамках единой закрытой планетарной экономики. Чтобы устойчиво развиваться, каждая страна должна двигаться по «течению», то есть, в русле мировой структурной динамики. Направленность этого движения задается структурными приоритетами. Поэтому мы рассматриваем структурные приоритеты как элемент национальных стратегий, определяющий траекторию, перспективы и качество экономического роста любой страны. Для того чтобы изменить качество роста, необходимо, на наш взгляд, изменить структурные приоритеты экономики. 


\section{2 Эффективна ли молдавская экономика?}

«Если россияне перестанут пить молдавское вино, экономика Молдовы рухнет». Это утверждение можно было бы считать шуткой, если бы оно ни было так близко к правде, являясь емкой констатацией сложившейся отраслевой структуры молдавской экономики. Сегодня Молдова - самая бедная европейская страна. Валовой внутренний продукт равен 7,166 млрд. долларов США (2011). Это примерно 2,047 доллара на душу населения в год. По индексу развития человеческого потенциала страна на 111 месте из 187 стран (2011г.); по индексу глобальной конкурентоспособности - на 93 из 142 стран (2011-2012гг.) (World Bank, 2012). Молдова, как и другие бывшие социалистические страны, пережила трансформационный кризис, последствия которого оказались самым глубоким по сравнению с другими странами с переходной экономикой. До настоящего времени не удалось достичь уровня производства предкризисного 1990 года. Представленный ниже график иллюстрирует данный вывод.

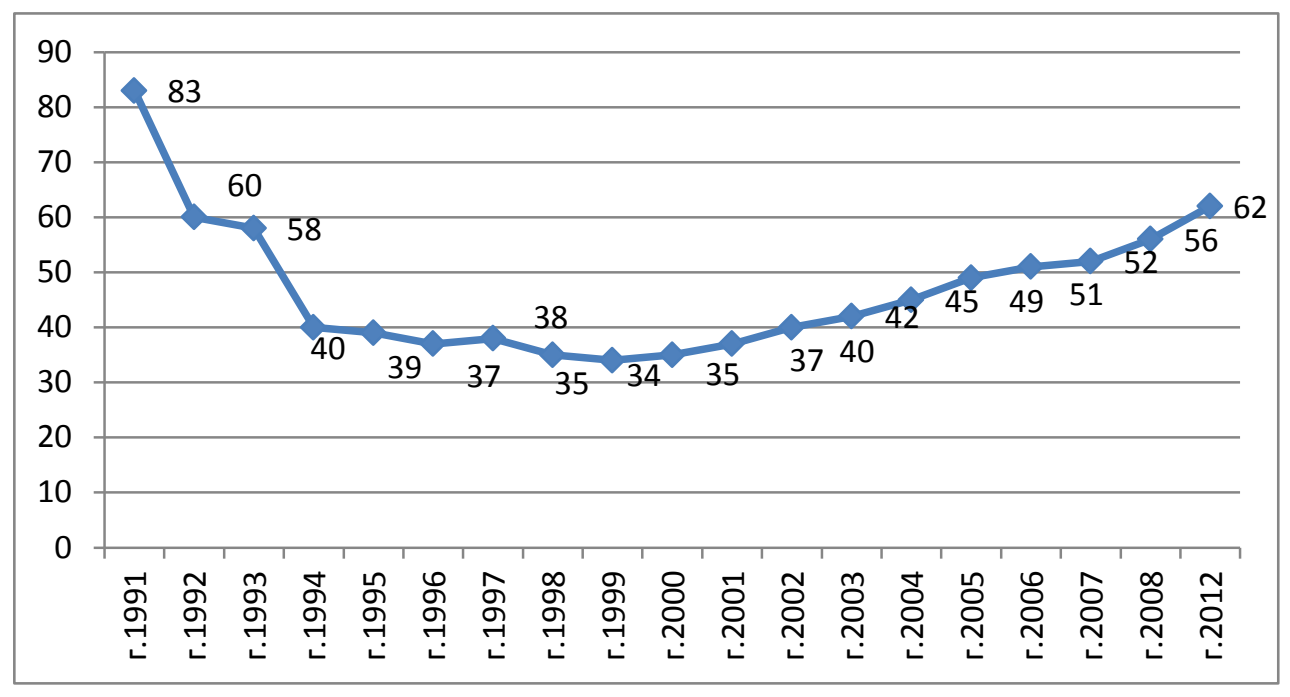

Pис.1. Динамика объема реального ВВП Республики Молдова за период 1991-2012zг., в проиентах $(1990=100 \%)$

По расчетам экспертов выйти на уровень 1990года Молдове удастся только к 2020 году. Производительность труда в молдавской экономике в 5,6 раза ниже, чем в Венгрии и Словакии, в 3,2 раза ниже, чем в Румынии, на 45\% ниже, чем в Украине

Структурные трансформации, которые происходили в стране на протяжении ряда лет, по выражению Дж.Стиглица, позволяют извлечь уроки о том. как не надо проводить рыночные преобразования, хотя в марте 1995г. журнал «The Economist» описал Молдову «как модель правильных реформ»...совершенную лабораторию реформ (UNDP, 2005)

Одной из причин этих неудач явилась ошибочная концепция структурного развития, рекомендованная Молдове на начальном этапе постсоциалистического реформирования, следствием исполнения которой стали негативные деформации отраслевой структуры экономики и снижение экономического потенциала страны. В течение всех лет реформирования в экономике происходили серьёзные количественные и качественные изменения, принявшие форму долговременных тенденций, среди которых разрушение наукоемких отраслей промышленности (электроники, приборостроения), тяжелой индустрии (тракторостроения и ряда других) и интенсивного сельского хозяйства. Страна оказалась “отброшенной” с инвестиционной стадии развития на стадию, движимую факторами производства, на которой она находится по сей день.

Наиболее разрушительным последствием деиндустриализации страны стало снижение потенциального уровня валового внутреннего продукта, и ослабление способности экономики к устойчивому экономическому росту.

Подобное явление в мировой практике считается макроэкономическим нонсенсом, и потому его можно назвать одним из парадоксов молдавской экономики.

С середины 90-х годов Молдова стала страной, чьи граждане активно представлены на рынках труда Европы и России. Количественная оценка масштабов процесса массовой трудовой миграции за рубеж потрясает: более 25 \% населения страны покинули ее пределы в поисках работы. Процесс массового 
«исхода» трудоспособного населения с национального рынка труда продолжается и сопровождается "утечкой мозгов" из страны и деградацией ее научного потенциала. Это стало одной из самых серьезных негативных долговременных тенденций, характерных для процессов социально-экономического развития Молдовы.

Модель функционирования молдавской экономики сводится к следующей схеме: граждане получают деньги из-за рубежа. Тут же используют их для приобретения товаров и оплаты услуг. При этом более 60 процентов стоимости потребительской корзины составляет импорт.

При незначительном объеме внутреннего производства резко повышается степень зависимости от импорта и внешних кредитов. Объем внешней торговли составляет 110\% ВВП. Доля импорта - 80\% к ВВП, что значительно превышает допустимый мировой практикой уровень. Основные статьи импорта: минеральные продукты; машины и оборудование; химическая продукция; текстиль. Структура экспорта, как известно, отражает структуру производства: продаем то, что производим. Основными статьями молдавского экспорта являются вино, табачные изделия; продукция растениеводства; текстиль. Около одной пятой всего объема экспорта составляет экспорт вина. При этом около 95\% всего винного экспорта предназначено для рынков СНГ. Одним из наиболее конкурентоспособных видов экспорта остается рабочая сила.

В структуре экспорта преобладает продукция с низкой добавленной стоимостью, в структуре импорта продукция с высокой добавленной стоимостью. Это означает, что при сложившейся структуре производства, сальдо торгового баланса страны не может в принципе быть положительным. Динамика внешней торговли представлена на рисунке №2.

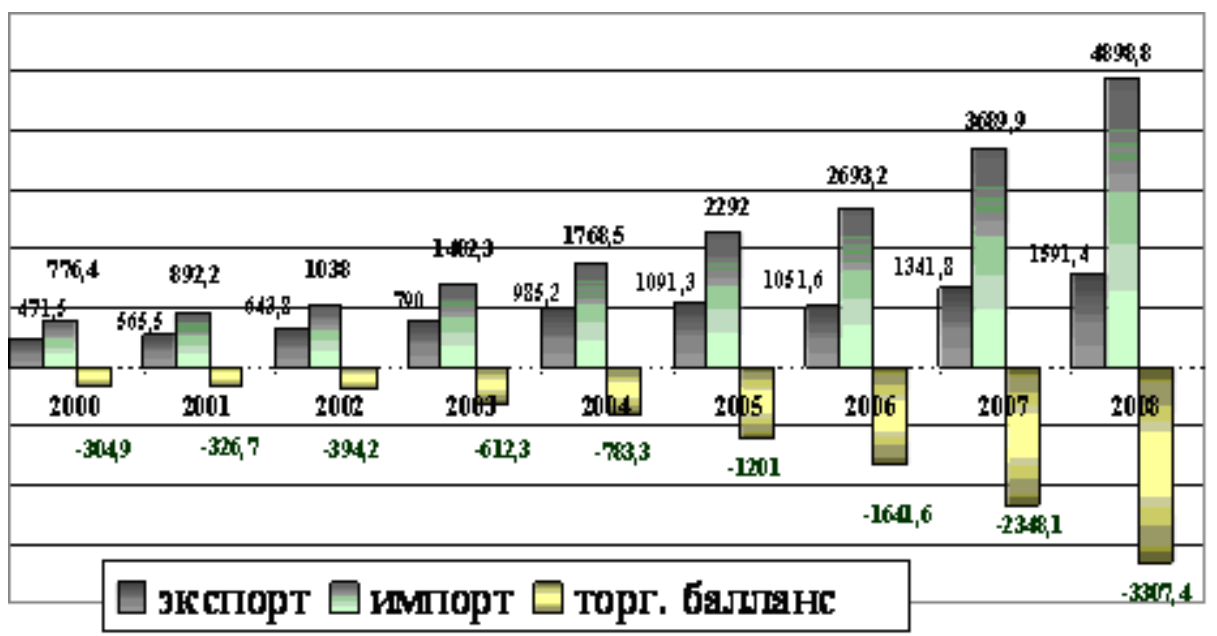

Pис.2. Динамика внешнеторгового оборота Республики Молдова, в млн. долларов США

Молдова ни разу, начиная с 1993г., не имела положительное сальдо текущего счета платежного баланса, без которого невозможно обслуживание внешнего долга.

Основой экономического роста молдавской экономики, который начался в 2001 году и составлял в среднем около 5-7\% в год, стали три фактора: денежные переводы мигрантов, работающих за границей, рост внешних заимствований; рост налогов на импорт. Приток средств от мигрантов привел к росту потребления, которое стало главным фактором подъема. В последние годы потребление домашних хозяйств устойчиво превышает валовой внутренний продукт за счет отрицательного чистого экспорта и низкого уровня накопления. Безусловно, это бесперспективный путь экономического развития, который не соответствует долгосрочным целям достижения устойчивого экономического роста.

Факторы, которые привели к экономическому росту в Молдове, не могут существовать сколь угодно долго. Речь идет, прежде всего, о денежных переводах, поступающих в страну от молдавских граждан, работающих за рубежом, а также о факторе сравнительного преимущества, которое Молдова имеет благодаря дешевой рабочей силе. Интенсивный отток рабочей силы с национального рынка труда объясняется ее дешевизной внутри страны: 1,5 евро в час(!) Низкий уровень оплаты труда не может рассматриваться как долгосрочный фактор экономического роста

Экономический рост в Молдове является ростом без развития. Он не вызван какими-либо кардинальными переменами в национальной экономике, напротив, происходит на фоне снижения величины ключевых факторов экономического роста - труда, капитала, технологий. Их снижение не компенсируется эффективными технологическими сдвигами. Поэтому можно предположить, что 
экономический рост носит адаптационный восстановительный характер и, кроме того, является скорее номинальным, чем реальным .

Экономический рост в Молдове нестабилен. Экономика страны весьма чувствительна к действию внешних факторов, от которых она сильно зависит. Одной из причин этого является моноструктурность производства и, следовательно, экспорта. Неблагоприятные изменения внешних условий создают шоковые ситуации в экономике страны, которые негативно сказываются на качестве и стабильности экономического роста.

Например, российское эмбарго на импорт молдавской алкогольной продукции стало серьезным внешним шоком для национальной экономики, вызвавшим снижение реальных объемов производства в ряде ключевых отраслей промышленности, таких как пищевая, производство технологического и лабораторного оборудования, производство сопутствующих материалов для производства вина, картонной и стеклотары, материалов для бутилирования. В результате появились признаки промышленной стагнации в стране. Еще одним серьезным шоком стал ценовой шок, связанный с повышением цен на природный газ, импортируемый из России, также оказавший дестабилизирующее воздействие на национальную экономику.

Структура экономики, сложившаяся в Молдове за период перехода к рынку, фактически обрекает страну на роль хронического должника и пожизненного европейского аутсайдера с однобокой неэффективной экономикой, чрезвычайно низкой степенью использования человеческого и интеллектуального потенциала, поставщика дешевой рабочей силы на мировой рынок труда. На примере Молдовы подтверждается тот факт, что, хотя в условиях рыночной экономики живет почти все человечество, во всех странах экономика работает по-разному, в зависимости от национальных особенностей, структурных факторов и эффективности управления. Уместно привести фразу, которая достаточно образно характеризует многоликость рынка: "We're not talking about pulling somebody out of the sea...We're talking about something stronger than that, actually, something even more elemental. The market. Which can also be ruthless, and also be destructive". Пример Молдовы наглядное тому подтверждение.

Таким образом, на вопрос: «Эффективна ли молдавская экономика?», - нельзя ответить положительно. Способность к реальному экономическому росту ограничена сокращением ключевых факторов экономического роста - труда и капитала, снижением эффективности их использования, неэффективной структурой производства и внешней торговли, не эффективным управлением. В результате в Молдове до сих пор происходит так называемый экономический рост без развития.

\section{3 Сможет ли Молдова стать Силиконовой долиной Европы?}

Положение Молдовы в мировой экономике несколько специфично. С одной стороны, это сегодня самая бедная страна в Европе, однако бедность эта своеобразна. На фоне шикарных особняков, современных автомобилей, роскошных гостиниц и ресторанов, столица Молдовы не производит впечатления столицы бедного отсталого государства. Этот факт неоднократно отмечается и иностранцами, посещающими страну. Высокий уровень бедности характерен для сельской местности, где проживает свыше 40 процентов населения .

При низком уровне жизни основной массы населения, уровень общего и профессионального образования рабочей силы в Молдове более высокий, чем в странах с аналогичным уровнем экономического развития. Кроме того, в отсталой в целом экономике, в некоторых ее секторах, созданы серьезные заделы для производства более высокого уровня, чем уровень экономики в целом. Это, прежде всего, касается некоторых инфраструктурных отраслей. Так, в последнее время в Молдове интенсивно развивается сектор информационных услуг, связанный с высокими технологиями, который стал относительно новой статьей молдавского экспорта. Однако, пока доля высоких технологий в экспорте Молдовы незначительна.

Помимо этого, в стране имеются научные разработки в области лазерной технологии и биотехнологии. То есть, еще сохраняются реальные возможности для возрождения на новой технологической основе комплекса наукоемких отраслей (электроника, полупроводники, нелинейная оптика), который был достаточно эффективным в советское время и определял индустриально-аграрный статус Молдовы ( в отличие от сегодняшнего аграрно-индустриального).

Молдова могла бы стать Силиконовой долиной Европы, переориентировав структурные приоритеты на инновационную экономику.

\section{1 Возможно ?}

Возникает вопрос: «Возможно ли в развивающихся странах, в том числе и в Молдове, ориентировать

структурные приоритеты на инновационную экономику? На наш взгляд, возможно. Почему? Обоснуем данное утверждение некоторыми выводами, сделанными на основе проведенного нами исследования 
динамики, тенденций и влияния мировых структурных приоритетов на экономическое развитие общества в условиях глобализации как нового феномена. (PîşсhinaТ.(Пышкина),2009).

I. Экономическое развитие общества логично представить как последовательное восхождение по ступеням «структурной лестницы»: от экономики, основанной на факторах, к экономике, основанной на знаниях, или, используя элементы теорий стадий роста М.Портера, от факторной стадии, к стадиям, движимым инвестициями, затем, инновациями, и, наконец, богатством. Этот процесс сопровождается, как правило, отраслевыми структурными трансформациями и изменением отраслевых структурных приоритетов в определенной последовательности - от добычи и переработки сырья, к производству материалоемких и трудоемких товаров, за которыми следуют капиталоемкие, затем техноемкие и наукоемкие и, наконец, исследования и разработки.

2. Эта своеобразная модель движения вверх (к новому качеству развития) по ступеням «структурной лестницы» - от экономики, основанной на факторах, к экономике, основанной на знаниях - отражает, эталонную траекторию (или вектор) мирового структурного развития.

3. Переход в развитии общества на новую ступень «структурной лестницы», фиксируется своеобразным индикатором, роль которого выполняют отраслевые структурные приоритеты мировой экономики. Они же являются и индикаторами глобализации как нового феномена, поскольку непосредственно влияют не только на количественные (объемы мирового производства, мировой торговли), но и на качественные показатели экономического развития, а также и на возможности стран мира к интеграции.

4. Для характеристики феномена глобализации мы предлагаем использовать метафору расширяющегося «потока», определяющего направленность экономического развития любой страны в рамках единой планетарной экономики.

Мы полагаем далее, что каждая страна, особенно развивающаяся и попадающая в категорию «глобализуемых», чтобы выжить в этом «потоке», должна двигаться по «течению», то есть, в русле мировой структурной динамики, соблюдая вектор (направление) мирового структурного развития.

5. Мы считаем также, что в условиях глобализации вектор мирового структурного развития отражает переход мировой экономической системы к инновационно-ориентированной экономике.

6. Переход к инновационно-ориентированной экономике предполагает для каждой отдельной страны коррекцию ее отраслевых структурных приоритетов в соответствии с вектором мирового структурного развития.

Особенно важна такая коррекция для развивающихся стран, так как структурная динамика развитых стран совпадает с мировой структурной динамикой.

7. Мы полагаем, что в условиях глобализации для развивающихся стран становится возможным одновременное прохождение нескольких ступеней «структурной лестницы».

8."Почему возможно?” Ответ зависит от нескольких причин. Одна из них связана с тем, что условиях глобализации, с учетом ее взаимосвязей с интеграцией, локализацией и регионализацией у многих развивающихся стран, в том числе и у Молдовы, появляются потенциальные «точки роста» сразу по нескольким ступеням «структурной лестницы», которые, при условии использования механизмов инновационного развития, могут повысить конкурентоспособность национальных экономик и изменить качество экономического роста. Так, например, деятельность на национальных рынках транснациональных кампаний распространяет мировые условия конкурентоспособности в национальные экономики, на какой бы ступени структурного развития они не находились.

Однако, необходимо иметь в виду, что на настоящем этапе предпосылки для перехода ряда развивающихся стран, в том числе и Молдовы, на инновационную стадию, и тем более на стадию, движимую богатством, недостаточны. Поэтому, на краткосрочном временном интервале речь может идти только о «встраивании» отдельных элементов инновационной экономики в определенные ступени «структурной лестницы».

\section{2 Как?}

Ответ на вопрос "Как реально осуществить процесс одновременного прохождения нескольких ступеней «структурной лестницы»?” зависит от конкретной страны, ее национальной специфики. Для Молдовы, например, возможно достаточно быстро организовать конкурентоспособное производство материалоемких товаров: стройматериалов, химических продуктов, простых металлоизделий, сравнительно простого оборудования, в том числе и для малого бизнеса, а также трудоемких товаров. Молдова, по опыту таких стран как Шри-Ланка, Индонезия, Филиппины могла бы добиться повышения конкурентоспособности в тех отраслях, в которых новые индустриальные страны утратили преимущества из-за роста цены такого фактора, как рабочая сила. Этими отраслями могли бы стать текстильная, швейная, обувная. Реальным для Молдовы является форсированное развитие сферы услуг: страхование, мобильная связь, программное обеспечение, финансовые услуги и др. 
Одновременно возможна организация производства техноемких изделий, таких, например, как контрольные и измерительные приборы.

Для производства наукоемких изделий могут использоваться собственные научные заделы, организованы сборочные производства относительно менее сложных и рыночно востребованных видов наукоемкой продукции (например, бытовой электроники). В республике имеются научные разработки в области лазерной технологии и биотехнологии, которые должны также найти промышленную реализацию. Производство всех этих групп товаров должно быть ориентировано не только на внутренний рынок, но и на экспорт.В этих сферах необходима активная политика стимулирования отечественного производителя с учетом так называемого "infant industry argument"и опыта быстро развивавшихся стран (Пышкина,Т,2010). По отдельным позициям возможна активизация научных исследований, совместно с западными учеными, в направлении создания новых инновационных технологий.

Таким образом, исходя из вышеизложенного, мы полагаем, что в условиях глобализации для развивающихся стран приемлема модель структурного развития с одновременным прохождением основных ступеней «структурной лестницы» на основе «встраивания» отдельных инновационных (или квазиинновационных) элементов в определенные ее «ступени».

\section{3 История имеет значение}

Вторая причина, делающая возможным одновременное прохождение нескольких ступеней «структурной лестницы» связана с “механизм генетической памяти”.Дело в том, что путь от факторной стадии к стадии, движимой инвестициями, а затем и инновациями (Пышкина,Т,2006), некоторыми развивающимися странами уже был однажды пройден. Например, Молдова к 1990г. прошла определенные ступени «структурной лестницы» и вплотную подошла к тадии, движимой инновациями

Дело в том, что в Молдове вплоть до 90-х годов интенсивно развивался машиностроительный комплекс отраслей, а также наукоемкие отрасли промышленности, что и определяло индустриально-аграрной статус экономики страны. Однако, после затяжного циклического спада (1991-2000гг.), страна оказалась отброшенной на более низкую, факторную стадию, что проявилось в снижении потенциального уровня выпуска, негативных деформациях отраслевой структуры экономики, связанных с еe деиндустриализацией, и в смене статуса страны с индустриально-аграрной на аграрно-индустриальную. Статистические данные подтверждают этот вывод. Так, например, по индексу человеческого развития, в 1990 г. Молдова находилась на 64 месте среди 174 стран, включаемых в рейтинг-лист ООН. В 1990г. индекс человеческого развития был максимальным для Молдовы и составлял 0,736 .В 2011г. страна в мировой классификации перешла на 111 место

Тем не менее, “механизм генетической памяти”, касающийся движения от факторной стадии к инвестиционной, а затем и к инновационной, остался. Сохранились и определенные сравнительные конкурентные преимущества для развития этих отраслей (которые постепенно исчезают), например, квалифицированная и дешевая рабочая сила, а также некоторые элементы материальной индустриальной базы. В настоящее время необходимы определенные усилия для возрождения машиностроительного кластера отраслей на новой технологической основе (инновационной или квазиинновационной). Пример Молдовы не уникален. Он характерен для многих постсоциалистических стран.

Таким образом, исходя из вышеизложенного, мы полагаем, что в условиях глобализации для развивающихся стран приемлема модель структурного развития с одновременным прохождением основных ступеней «структурной лестницы» на основе «встраивания» отдельных инновационных (или квазиинновационных) элементов в определенные ее «ступени». Двигаясь таким образом по структурной лестнице, Республика Молдова может и стать Силиконовой долиной Европы ,придав экономическому росту новое качество - устойчивость и реальное развитие.

\section{4 Методология успеха}

Методологической основой алгоритма структурного развития с одновременным прохождением основных ступеней «структурной лестницы» на основе «встраивания» отдельных инновационных (или квазиинновационных) элементов в определенные ее «ступени» являются следующие принципы.

1. Структурная диверсификация через квазииновации. Как показывают исследования, проведенные зарубежными экономистами, механизмы, определяющие экономическое развитие, не обязательно основываются на принципе сравнительного преимущества. Напротив, оказывается, что чем ниже уровень экономического развития страны, тем более широкий спектр видов деятельности необходимо развивать стране, вместо того, чтобы ограничиваться единственным, пусть и достаточно успешным.

На основе анализа моделей отраслевой концентрации и диверсификации по ряду стран, (Imbs, Jean and Wacziarg, Romain, 2003) была установлена одна из казалось бы парадоксальных, с точки зрения 
принципа сравнительного преимущества, закономерностей мировой структурной динамики. Суть ее в следующем: высокие показатели отраслевой специализации характерны только для стран с высоким уровнем дохода (Rodrik, D.,2004, 95 ). Из этого утверждения можно сделать вывод о том, что для развивающихся стран, особенно с низким уровнем дохода, необходима структурная диверсификация производства. При этом, чем ниже уровень экономического развития страны, тем сильнее должна быть степень диверсификации. Этот вывод крайне важен для многих развивающихся стран, включая Молдову. От способности той или иной страны к диверсификации видов деятельности во многом зависят возможности выхода на внешние рынки и национальная конкурентоспособность.

Отметим, что процесс диверсификации не является естественным, внутренне присущим любой экономической системе. Структура экономики любой страны отличается высокой степенью инерционности, поскольку связана с распределением факторов производства и технологиями, а создание новых производств и отраслей требует как перераспределения факторов, так и освоения новых инновационных или, чаще всего, квазиинновационных технологий (особенно для развивающихся стран и стран с низким уровнем экономического развития). Поэтому процесс диверсификации отраслевой структуры предполагает определенные усилия и предпосылки, которые, на наш взгляд, должны создаваться через механизмы государственного воздействия на экономику.

Один из наиболее эффективных способов диверсификации отраслевой структуры, принятых в мировой практике, заключается в адаптации к местным условиям уже апробированных и известных за рубежом технологий. Таким образом, в той или иной стране становится возможным организовать производство так называемых «квазиинновационных» товаров и услуг. Под «квазиинновационными» товарами в данном контексте понимается производство в данной стране уже известного и распространенного на мировых рынках продукта с более низкими издержками. Процесс «запуска» такого продукта начинается, как правило, с адаптации иностранной технологии к местным условиям. Для диверсификации, проводимой на основе квазиинноваций, необходимы, на как минимум, две предпосылки:

-национальные производители должны быть способны адаптировать к местным условиям уже апробированные и известные за рубежом технологии; -производство новых для данной страны «квазиинновационных» товаров должно быть прибыльным .С точки зрения первого условия, в ряде развивающихся стран, включая Молдову, вопрос упирается, с одной стороны, в неадекватную научную базу, а с другой - в недостаток «инноваторов», которыми могли бы стать, прежде всего, транснациональные корпорации и венчурные фонды. Именно эти структуры способны наиболее эффективно реализовать взаимосвязи глобализации и локализации, корректируя при этом структурный вектор национального развития в соответствии с мировой структурной динамикой. Имитация технологий, разработанных в развитых странах, исторически является одним из важнейших факторов, позволяющих развивающимся странам ориентироваться на мировые достижения научно-технического прогресса. Как показывает мировой опыт, квазииновации стали важным фактором экономического роста во многих странах, например, в Японии, Бразилии, Мексике, Индии, Колумбии, Бангладеш, Пакистане, Чили, Израиле и др.В мире известно немало примеров, когда из эксперимента одного предпринимателя, запускающего квазииновациоонный продукт, возникала целая отрасль, например, швейная промышленность в Бангладеш, промышленное разведение лосося в Чили или цветов в Колумбии.

Условием диверсификации отраслевой структуры является способность и желание национальных производителей адаптировать к местным условиям уже апробированные и известные за рубежом технологии (квазиинновации). Это невозможно без государственной поддержки. Поэтому необходимо соблюдение второго принципа.

2. Координация усилий бизнеса и государства. Имитационные механизмы, касающиеся производства квазииновационных товаров, могут обеспечить более низкие издержки и, следовательно, прибыльность квазииновационного бизнеса, в тех случаях, когда успешно решаются проблемы координации действий государства и бизнес-сектора.

При этом, в мировой практике принято, что издержки по осуществлению квазииновационной деятельности берет на себя частный предприниматель, в то время как издержки по созданию необходимой инфраструктуры должно взять на себя государство. Недостаток инноваторов в странах с низким уровнем дохода часто связан и с неразвитостью инфраструктурного блока отраслей. В полной мере это относится и к Молдове. Для того, чтобы новые виды деятельности стали прибыльными, необходимы одновременные разнонаправленные инвестиции бизнес-сектора и государства. Считается, что зарождающаяся отрасль требует государственной поддержки в первую очередь, в части развития соответствующей инфраструктуры. Идея координации усилий бизнеса и государства лежит в основе теории кластеров и касается, в первую очередь, развития таких отраслей, как туризм, фармацевтика и биотехнологии. Основной причиной проблем координации считается трудность сопоставления инвестиций с производственными решениями различных предпринимателей. В некоторых случаях, когда производство в определенной отрасли хорошо организовано и отлажено, а доходы от необходимых 
инвестиций могут быть локализованы, координация может быть достигнута бизнес - сектором самостоятельно, без особого вмешательства государства. Но чаще, когда новое производство или новая отрасль только начинают развиваться, и необходимо наладить инфраструктуру, участие правительства необходимо.

3. Стимулирование «новых» областей деятельности. В поддержке нуждаются не столько отдельные отрасли, сколько конкретные технологии, в которых присутствует положительная экономия от масштаба и которые не способны развиваться без поддержки извне. Поэтому нужны протекционистские меры, которые должны быть направлены не на отрасль или сектор рынка, а на конкретный вид деятельности (новая технология, особый способ обучения, новый товар или услуга), в котором существует проблема координации.

В соответствие с данным принципом, стимулирующие программы нужны для активизации процессов зарождения новых потенциально конкурентоспособных сегментов отраслей, но не для всего малого и среднего бизнеса. Только такие структурные трансформации способны продуцировать экономический рост и расширить производственный потенциал страны .

4. Целевая компенсация провалов рынка. Суть его заключается в необходимости государственных межотраслевых программ, которые охватывали бы сразу несколько отраслей и напрямую компенсировали бы недоработки рынка. Так, например, в государственной поддержке и специальных программах и субсидиях нуждается инфраструктурная сеть, например, строительство и обустройство дорог, или, например, разработка и реализация современных учебных проектов, а также проектов, направленных на развитие и адаптацию иностранных технологий к местным условиям .

5. Получение мультипликативных позитивных эффектов (информационных, технологических или других) от субсидируемых новых видов деятельности для стимулирования инвестиционной активности во взаимодополняющих отраслях.

6. Динамичность означает, что структурную политику нельзя рассматривать как единовременный акт. Это процесс, требующий постоянной коррекции и обновления целей, приоритетов и инструментов воздействия на экономику. Не существует неизменного трафарета или модели. Со временем меняются приоритеты и целевые установки, однако сам процесс структурных преобразований - это перманентный эволюционный процесс, который отражает мировую структурную динамику.

7. Взаимосвязи глобализации, и регионализации. Для Молдовы учет этих взаимосвязей исключительно важен. Являясь европейской страной, Молдова зависит от развития европейского открытого регионализма, который открывает простор для глобализации в связи с созданием единого экономического пространства в рамках Европейского Союза. Тенденция сближения Молдовы с Западом под влиянием глобальных процессов является, безусловно, перспективной. В тоже время, геополитическое положение Молдовы и близость стран СНГ также должны использоваться для дальнейшего развития и укрепления страны. С другой стороны, закрытый регионализм неизбежен, поскольку неизбежна защита региональных интересов, реализуемая через поиск компромисса между глобальными и региональными интересами и критериями.

Это означает, что цели и результаты структурного реформирования зависят от возможностей и ограничений, определяемых национальными особенностями страны, уровнем ее экономического развития, а также, действиями ее правительства. Национальные государства должны научиться жить в режиме международной конкурентоспособности, не теряя при этом своей уникальности.

8 Взаимосвязи глобализации и локализации. В экономической литературе существует точка зрения на локализацию, как на наиболее перспективную экономическую стратегию глобализации на современном этапе. Более того, применяется и такой термин как «глокализация», означающий глобальную локализацию. Некоторые авторы, однако, полагают, что одним из основных противоречий, присущих процессам глобализации, является парадокс «глобализация-локализация». Дж. Найсбитт в книге «Глобальный парадокс» делает следующий вывод: «Чем выше уровень глобализации экономики, тем большую силу имеют её мельчайшие частицы». В качестве примеров локализации, можно привести деятельность на национальных рынках транснациональных корпораций, эффективно работающих с потребителями, в какой бы стране они ни находились, с учетом адаптации к местным условиям и особенностям. Локализация отражает структурный вектор мирового развития, и призвана реализовать в национальных экономиках мировые условия конкурентоспособности. Стратегия для отдельно взятой страны состоит в том, чтобы найти свое место в условиях глобализации и использовать ее преимущества для получения определенных выгод. 


\section{5 Алгоритм перехода к инновационно - ориентированной экономике}

Основываясь на результатах проведенного исследования (îșchinaT,2010) , с учетом изложенных выше принципов, нами разработана Концепция структурного развития (КНСР), с алгоритмом перехода Республики Молдова к инновационно - ориентированной экономике, продуцирующей новое качество экономического роста - рост с развитием. Фрагмент «дерева целей» Концепции представлен на рис.4.

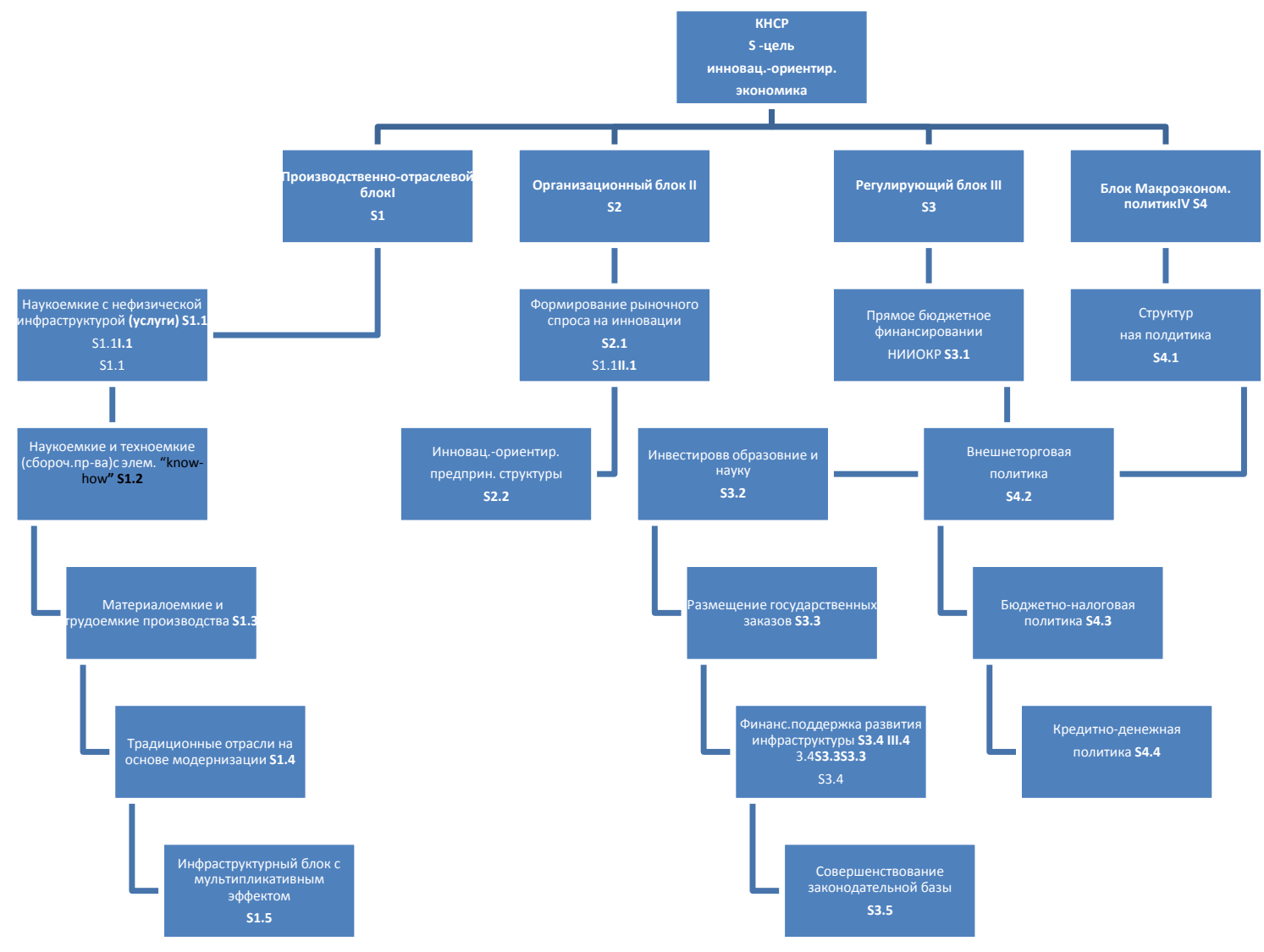

Рис.4 Фрагмент «дерева иелей» КНСР

\section{Литература}

- Imbs, Jean and Wacziarg, Romain. (2003) ‘American Economic Review’ 2003

- Porter, Michael. (1990). The Competitive Advantage of Nations. Porter M The Free Press, N. Y., 1990

- Пышкина, Т.В. (2006). 'Структурные приоритеты экономики в условиях глобализации (методология, принципы, опыт)', Монография, Кишинев, ASEM, 2006, с.121-137

- PîşchinaT. (2009). Стратегия развития Республики Молдова на перспективу În: Analele Academiei de Studii Economice din Moldova. Chişinău, 2009 , ed. VII, p.192-198

- PîşchinaT. (2010). Экономический рост, конкурентоспособность и проблемы структурной перестройки экономики. În: Analele Academiei de Studii Economice din Moldova. Chişinău, 2010

- Rodrik, D. (2004). 'Industrial Policy for the Twenty-First Century', Kennedy School of Government, Harvard University, 2004

- World Bank, 2012. Official Website: http://worldbanc.org

- UNDP, 2005. Economic Trends, Moldova 


\title{
Государственный и частный сектор в системе здравоохранения Кыргызстана и перспектива их сотрудничества
}

\section{The Public and Private Health Sectors in Kyrgyzstan and Prospects for their Cooperation}

\author{
Assoc. Prof. Dr. Damira Japarova (Kyrgyzstan-Turkey Manas University, Kyrgyzstan)
}

\begin{abstract}
The public sector does not provide funding for the program of state guarantees. Private sector where high levels of profitability and higher prices. The purpose of public-private partnerships in health care - the preservation and improvement of the health status of the population. In Kyrgyzstan, the investment in health infrastructure of the state are planned. The private investor can build a building and provide meals for patients as required by the hospital. Require opening a public-private laboratories for urgent tests at each hospital and clinic. To finance the public-private partnership in the health sector can be used in co-financing, guarantee the payment rate for OMS services.
\end{abstract}

Государственный сектор не обеспечивает финансирование Программы государственных гарантий. Частный сектор там, где высокая рентабельность и уровень цен выше. Цель государственно-частного партнерства в здравоохранении - сохранение и улучшение состояния здоровья населения. В Кыргызстане инвестиции в инфраструктуру здравоохранения со стороны государства не планируются. Частный инвестор может построить здание и обеспечивать питание больных стационара согласно требованиям. Необходимо открытие государственно-частных экспресс-лабораторий для срочных анализов при каждой больнице и поликлинике. Для финансирования государственно-частного партнерства в сфере здравоохранения в могут использоваться софинансирование, гарантия выплаты тарифа ОМС за услуги.

Ключевые слова:

Программы государственных гарантий, частный сектор в здравоохранении, государственно-частное партнерство, софинансирование, покупка услуг.

\section{1 Государственный сектор в здравоохранении}

В Кыргызской Республике Система здравоохранения включает в себя государственный и частный сектор. Государственный сектор в современных условиях здравоохранения не обеспечивает полностью финансирование Программы государственных гарантий и обеспечения граждан бесплатной медицинской помощью. Система обязательного медицинского страхования в условиях Кыргызстана не выполняет функций страхования. Она превратилась в финансовую организацию по передаче денежных средств лечебно-профилактическим учреждениям за диагностику и лечение больных.

Средства бюджета и дополнительные средства, поступающие от сооплаты пациентов, не позволяют лечебно-профилактическим организациям предоставлять качественные медицинские услуги в полном объеме.

\begin{tabular}{|l|l|l|l|l|l|}
\hline \multirow{2}{*}{} & \multicolumn{2}{|l|}{ Сумма, млн сомов } & \multirow{2}{*}{$\begin{array}{l}\text { Рост в } \\
\text { Всего, }\end{array}$} & \multicolumn{2}{|l|}{ Удельный вес } \\
\cline { 5 - 7 } & 2006 & 2012 & 2006 & 2012 \\
\hline в том числе средства: & 2421,2 & 9753,8 & 290 & $100 \%$ & $100 \%$ \\
\hline -республиканского бюджета & & & & & \\
\hline -местного бюджета & 1454,4 & 6741,0 & 363 & 60,1 & 69,1 \\
\hline -обязательного медстрахования & 312,0 & 916,4 & 194 & 12,9 & 9,4 \\
\hline -сооплаты & 393,2 & 1529,8 & 289 & 16,2 & 15,7 \\
\hline Специальные средства & 188,0 & 350,1 & 86 & 7,8 & 3,6 \\
\hline
\end{tabular}

Таблица 1. Исполнение консолидированного бюджета за 2006-2012год (Данные МЗ/а)

Как видно из таблицы, доля государственного бюджета продолжает оставаться превалирующим, и из года в год увеличивается. С начала реализации программы «Манас таалими», (2006г.) т.е. второго этапа реформы, общие расходы на здравоохранение увеличились на 3 млд сомов, т. е. на 24,6 \%, государственные расходы выросли на $30 \%$. Следует учесть, что при этом уровень инфляции, за указанный период составил, 50\%. (Концепция здравоохранения,2012/a) 
Однако государственное финансирование здравоохранения остается недостаточным. Так, не хватает средств для закупки в необходимом количестве лекарственных средств, на модернизацию оборудования, техническое обслуживание и укрепление инфраструктуры, а также повышение профессионального уровня персонала. Дефицит денежных средств, необходимых для реализации Программы государственных гарантий в 2012 году составил 1,5 млрд. сомов. Следует отметить, что 82, 5\% из средств «Единого плательщика», в 2012 году были использованы на выплату заработной платы. (Динара Сагинбаева, 2012)

Сокращение финансирования гарантированных государством услуг, в государственных медицинских учреждениях, привело к снижению объемов бесплатной медицинской помощи. Государство декларирует о бесплатных услугах, а пациент, попадая в больницу, должен покупать лекарства, платить за лечение. В условиях высокого уровня бедности, активно развивается тенденция введения платы за услуги населением. Следует отметить, что совмещение в государственных медицинских учреждениях оказания бесплатной медицинской помощи и предпринимательской деятельности, т.е. оказания платных услуг, не позволяет осуществлять эффективный контроль целевого использования бюджетных средств и средств обязательного медицинского страхования.

Во первых, платные медицинские услуги оказались вне сферы управляющего воздействия государства, (прейскуранты есть, но они устарели, объем услуг не предусмотрен). Во-вторых, платные услуги осуществлются на базе государственных медицинских учреждений, т.е. появилась тенденция использования государственного сектора для оказания платных услуг. В этой связи имеют место необоснованные госпитализации в государственной больнице, в так называемых платных палатах. Появилась проблема неээффективного использования ресурсов здравоохранения и дополнительные расходы коммунальных услуг. Все это противоречит оптимизации стационарной помощи.

\section{2 Частный сектор в здравоохранении}

В Кыргызстане альтернативой государственному здравоохранению, в настоящее время уже сформировался частный сектор здравоохранения, который берет на себя существенный объем специализированной медицинской помощи населению. Вложены значительные инвестиции в отрасль оказывающую населению медицинскую помощь с применением современных высоких технологий и дорогостоящего импортного оборудования. И в последние годы негосударственный сектор здравоохранения получил интенсивное развитие.

По данным Министерства здравоохранения Кыргызской Республики, в 2011 году зарегистрировано более 700 частнопрактикующих врачей.(Данные M3,20126) Оказание медицинских услуг частными медицинскими центрами сосредоточено в крупных городах республики - Бишкек, Ош, Джалал-Абад, Каракол и др. В сельских районах услуги на основе частной практики, не получили широкого развития.

Следуя законам рынка, частный сектор осваивает в первую очередь свободные ниши, где возможна высокая рентабельность и быстрая окупаемость вложенных средств. Основной сегмент, освоенный частными практикующими врачами в республике - это диагностика. В основном, частные медицинские центры предоставляют ультразвуковые, лабораторные, стоматологические и другие услуги. Так, 90 \% обследования на компьютерном томографе и более $50 \%$ магнитно-резонансных томограф исследований в Кыргызстане проводятся частными медицинскими центрами.

Таким образом, частный сектор восполняет пробел, имеющийся в государственном секторе, по предоставлению высокотехнологичных диагностических процедур. Государственные медицинские учреждения часто пользуются услугами медицинских центров, направляя пациентов для прохождения диагностических исследований. И это становится нормой.

И частная компания, мотивированная на результат, по-настоящему обладает эффективным управлением. Частный сектор в здравоохранении снижает нагрузку на государственный сектор, что позволяет провести реструктуризацию государственных организаций здравоохранения, повысить эффективное использование ресурсов. Однако развитие частного сектора невозможно без развития государственного, вместе с тем в современных условиях потенциал частного сектора в Кыргызстане недостаточно востребован государством.

Уровень цен в частных медицинских центрах и кабинетах выше, чем за аналогичные платные услуги в государственных организациях здравоохранения. Так, стоимость компьютерно-томографического исследования в частном медицинском центре в Бишкеке, выше в 2,5-3 раза, а магнитно-резонансного томографа - в 2-2,5 раза. (Концепция здравоохранения, 2012/b). И, несмотря на разницу в ценах, частные медицинские центры пользуются большим спросом среди населения. Это обусловлено хорошим обслуживанием и благоприятными условиями пребывания пациентов, наличием в полном объеме изделий медицинского назначения и применением современных технологий. Основную роль в сложившейся разнице цен играют несколько факторов: уровень оплаты за инфраструктуру, амортизация оборудования, более высокий уровень заработной платы. 
Среди отрицательных черт прямых иностранных инвестиций в систему здравоохранения, можно выделить внутреннюю «утечку мозгов», т.е. отток высококвалифицированных специалистов в частные медицинские центры, где заработная плата и условия работы, существенно, лучше, чем в государственных учреждения. В частных медицинских центрах сосредоточиваются высокоспециализированные технологии и медицинские кадры, что привлекает как население, так и самих медицинских работников. Медицинские работники мигрируют из государственного сектора в частный сектор, из больниц в фармацевтические компании. В результате, сектор общественного здравоохранения, потребность в котором особенно велика у пожилого и отягощенного различными заболеваниями населения, страдает от недоукомплектованности медицинскими кадрами и оборудованием, в нем существуют длинные очереди на госпитализацию и прием специалистов.

Вследствие этого в результате нехватки персонала в государственных лечебных учреждениях, люди вынуждены длительное время ожидать нужные операции, и визиты к нужным для обследования специалистам. Для решения данной проблемы интересным представляется опыт Турции. Врачи, оказывающие медицинскую помощь в учреждениях государственной формы собственности, получают зарплату на основании общегосударственной тарифной сетки. Сверх этого им начисляются дополнительные выплаты из оборотных средств.( Çetin. A, 2007)

Оборотные средства или возобновляемые фонды формируются путем сбора средств в государственных учреждениях. Государственные медицинские учреждения устанавливают финансовые связи с государственными и частными организациями, а также с отдельными гражданами, от которых получают плату за оказанные медицинские услуги. Полученные таким образом доходы распределяются между работниками медицинского учреждения. Вторая часть заработной платы абсолютно независима от государственного участия. Иногда этот дополнительный доход может намного превышает размер основной заработной платы.

Следует отметить, что наблюдается тенденция роста тарифов на медицинские услуги. При низком уровне доходов большинства населения, происходит снижение объемов бесплатной медицинской помощи и расширение системы оплаты медицинских услуг. Таким образом, происходит постепенное формирование двухступенчатой системы здравоохранения, где складывается сектор более качественных платных услуг для состоятельных людей, и низкокачественных бесплатных услуг для тех, кто не может платить.

При предоставлении медицинских услуг, государственный и частный секторы должны конкурировать между собой не только по вопросам качества оказания медицинской помощи, но и стоимости услуг. В этих условиях важно, чтобы конкуренция в сфере оказания медицинских слуг не ухудшала доступ населения к медицинским услугам, не приводила к разложению государственного сектора в здравоохранении.

\section{3 Формы взаимоотношений бюджетных и частных медицинских учреждений}

В условиях, когда частные медицинские учреждения получили достаточно широкое распространение, неизбежно возникают различные формы взаимоотношений бюджетных и частных медицинских учреждений. Недостаток денежных средств в государственных бюджетных учреждениях, для обеспечения отрасли, требуют привлечения частных источников финансирования. Одним из путей решения этих проблем стала разработка и использование особой институциональной системы по привлечению частного сектора к строительству и эксплуатации объектов здравоохранения, которая на Западе получила название Public-Private Partnership (PPP) или Государственно-частное партнерство.

Государственно-частное партнерство между государством и бизнесом осуществляется в целях реализации национальных и международных общественно-значимых проектов. Для их осуществления государство использует частный сектор. Государственно-частное партнерство это соглашение о планировании совместной деятельности между государственными и частными секторами о совместном финансировании проектов, эксплуатации и техническом обслуживании объектов. Целью государственночастного партнерства в здравоохранении является сохранение и улучшение состояния здоровья населения путем создания эффективной, доступной системы предоставления медицинских услуг организациями здравоохранения, независимо от форм собственности.

Государственно-частное партнерство в здравоохранении можно определить как юридически закрепленную на определенный срок, форму взаимодействия между государством и частным сектором в отношении объектов здравоохранения, а также соответствующих медицинских услуг. Обязательным условием государственно-частного партнерства, является софинансирование государством и частными компаниями и разделение рисков между всеми участниками проекта. Иногда проект может финансироваться на 100\% частным сектором. Таким образом, в государственно-частном партнерстве происходит объединение ресурсов и потенциалов двух хозяйствующих субъектов, существенное 
расширение пространства для свободного движения капитала, проникновение частного сектора в те сферы, которые ранее были для него недоступны.

Передача частным компаниям разработки, строительства, финансирования и обслуживания новых зданий медицинских учреждений, позволит здравоохранительным учреждениям сконцентрироваться на выполнении своей основной функции - предоставлении медицинских услуг.

Государственно-частное партнерство оформляется специальным договором (соглашением, контрактом) между государством и участниками со стороны частного сектора и осуществляется в течение определенного, закрепленного в договоре срока. По завершении проекта партнерство может быть продолжено на основе нового договора.

Государственно-частное партнерство позволяет государству передавать объекты во владение и пользование частному сектору сохраненяя при этом право государственной собственности. Это позволит переложить функции строительства, эксплуатации объектов здравоохранения на частный сектор, что значительно сократит расходы государства и увеличит налогооблагаемую базу. В случае нарушения частной компанией условий контракта, государство можно прерывать действие контракта в и возвращать объект в государственное управление.

Участие бизнеса в проектах государственно-частного партнерства позволяет частной компании получать в долговременное владение и пользование государственными активами здравоохранения, причем часто на льготных условиях. Вкладывая инвестиции в объекты государственной и муниципальной собственности, предприниматель имеет достаточные гарантии прибыльности, поскольку государство как его партнер несет определенные риски по обеспечению минимального уровня рентабельности. При решении наиболее социально значимых проблем здравоохранения государство доплачивает из бюджета частному оператору, при улучшении им качества медицинского обслуживания. (пример: Программы по борьбы с туберкулезом.)

Инициатива создания смешанных частно-государственных структур была выдвинута Всемирной организацией здравоохранения в 1995 году. Целью была разработка эффективных механизмов привлечения государственных и частных поставщиков медицинской помощи для лечения туберкулеза и борьбы с ним в соответствии Международными стандартами лечения.

Экономический эффект для общества состоит в том, что вследствие объединения активов двух секторов государственно-частное партнерство обеспечивает оптимальное разделение обязанностей и лучшее использование активов. Создаются условия и предпосылки для эффективного функционирования объектов здравоохранения, находящихся в государственной и муниципальной собственности. Благодаря совершентсвованию стандартов, повышается качество медицинских услуг, усилится ответственность и улучшится контроль использования ресурсов, используемых в рамках контракта.

Наиболее активно процесс привлечения бизнеса в здравоохранение на партнерской основе, наблюдается в Великобритании и Австралии. В Великобритании государственно-частное партнерство развивается в двух направлениях: строительство и реконструкция основных фондов в отрасли и предоставление медицинских услуг. По официальным данным еще в 2003 году свыше 600 объектов общественной собственности, в том числе - 34 больницы находились в условиях государственно-частного партнерства. В государственно-частных проектах этой страны, на здравоохранение приходится $12 \%$ всех инвестиций. (PFI: meeting the investment challenge. 2003). В настоящее время в Великобритании в рамках государственно-частного партнерства 130 больниц финансируется частным сектором, что обеспечивает высокое качество медицинских услуг. (Материалы конференции 2012 г.Красноярск. ).

Далее, медицинские услуги, предоставленние частными компаниями на объектах государственной и муниципальной собственности в соответствии с долгосрочными контрактами, оплачиваются частному сектору постепенно, в течение всего срока контракта (как правило, 30 лет). Платежи производятся каждый год, но только при соответствии оказанной частной услуги принятым в стране стандартам обслуживания в данной области. При этом государство остается ответственным за предоставление населению основных услуг.

Правительство Санкт-Петербурга совместно с Комитетом по здравоохранению города стали одними из первых в области создания государственно-частного партнерства для здравоохранения в Российской Федерации. На основе государственно-частного партнерства развивается несколько сетей гемодиализных центров в регионах РФ. Государство предоставляет помещения для диализного центра на безвозмездной основе и освобождает от уплаты налогов на прибыль и НДС. Эта сфера здравоохранения особо привлекательна для частных инвесторов, что объясняется относительной простотой организации таких центров и их сервисным уклоном, по сравнению с больницами. Как правило частный сервис всегда был лучше государственного.

Следующий важный проект государственно-частного партнерства в системе здравоохранения это сотрудничество клиник «Медси», с правительством Москвы. В 2012г. в обмен на 25\% акций объединенной компании, правительство Москвы передало «Медси» 5 поликлиник, 3 стационара и 3 
санатория. К участию в партнерстве был приглашен американский инвестиционный фонд ApaxPartners, специализирующийся на медицинских активах, и РФПИ, которые совместными усилиями вложат порядка 6 млрд. долл. в развитие сети. Доли участников распределятся следующим образом: половину получит АФК «Система», четверть - правительство Москвы, по одной восьмой - ApaxPartners и РФПИ.

В Кыргызстане в последнее время наметилась тенденция по привлечению частного сектора в систему оказания медицинских услуг населению. Сотрудничество государственной и частной структуры пока осуществляется эпизодически и носит стихийный характер. Так, государственные медучреждения направляют пациентов в частные центры для лабораторных, ультразвуковых исследований и в центры компьютерной томографии. В проекте предстоит создание централизованной аккредитованной лаборатории для медучреждений Бишкека, оснащенной современным оборудованием для обработки клинических анализов. Кроме того, предлагается открыть экспресс-лаборатории для срочных анализов при каждой больнице и поликлинике.

Закон о Государственно-частном партнерстве, принятый в январе 2012 года открывает возможности для привлечения частного финансирования инфраструктурных проектов. Для Кыргызстана, с низкой эффективностью государственного сектора в здравоохранении, эффект государственно-частного партнерства будет значительно более высоким. Необходимо развивать партнерские отношения частных медицинских организаций здравоохранения и Фонда обязательного медицинского страхования при Правительстве Кыргызской Республики. Это может осуществляться путем оплаты медицинских услуг со стороны государства в форме «государственного заказа», по обеспечению граждан медико-санитарной помощью в рамках Программы государственных гарантий.

Инвестиции в инфраструктуру со стороны государственного сектора не планируются. И в этой связи разработан проект организация питания в Кыргызском научно-исследовательском институте курортологии и восстановительного лечения.

Цель проекта заключается в организации централизованного диетического питания для всех пациентов, а также для сотрудников Института. Планируется, что частный инвестор построит здание современной столовой, которая будет оснащена современным оборудованием, будет удобной для пациентов и сотрудников, и будет обеспечивать сбалансированное питание согласно диетологическим и санитарным требованиям. (Меморандум проекта. Бишкек, 2012)

В данном проекте как государственным партнером собственник института, выступает Министерство Здравоохранения. Частный партнер будет отобран в результате открытого местного тендера. Государственный партнер будет закупать услугу у частного партнера: трехразовое питание для пациентов, согласно требованием по энергетической и диетической ценности рациона питания.

Проект рассчитан на 10 лет с последующей передачей здания и оборудования в функциональном состояниигосударству. Частный партнер разрабатывает проект строительства и согласовывает его с государственным партнером. После окончания срока договора, т.е. по истечению 10 лет, частный партнер обязуется передать государственному партнеру здание в отремонтированном состоянии, с оборудованием в рабочем состоянии. При успешной работе государственный партнер может продлить договор на оказание услуг питания.

Итак, при выборе проектов государственно-частного партнерства необходимо разработать те проекты, для которых частный сектор может принести наибольшую пользу по сравнению с традиционным подходом к реализации проектов государством (например, новые технологии, новые методы строительства, передовые методы работы, эффективность управления, сокращение затрат). В здравоохранении это касается организации таких услуг, как питание пациентов, прачечные и стерилизационные услуги, лабораторные услуги. Если частный инвестор принимает на себя капитальные затраты и обслуживание объекта на протяжении всего его дальнейшего существования, он мотивирован оптимизировать совокупные затраты на проект. Поэтому учет затрат на протяжении всех этапов реализации проекта, что является одним из основных условий государственно-частного партнерства.

Важно отметить, что в рамках государственно-частного партнерства, страховые компании, как правило, должны работать совместно с государственным сектором, поскольку они являются основным источником выручки для больниц. При планировании проекта необходимо на основе несколько вариантов, точно сформулировать потребности и ожидаемые выгоды, определить соотношение затрат и выгод.

Источниками финансирования проектов государственно-частного партнерства в Кыргызстане, могут быть строительные и страховые компании, банки, международные финансовые институты, государство и муниципальные органы власти. Также для финансирования партнерства в сфере здравоохранения могут быть использованы такие платежные механизмы, как софинансирование строительства, гарантия выплаты по тарифам обязательного медицинского страхования частным медицинским центрам за оказанные услуги.

Выводы: 
В Кыргызстане государственный сектор не обеспечивает финансирование Программы государственных гарантий, что привело к снижению объемов бесплатной медицинской помощи.

Произошел отток специалистов в частные медцентры и для решения проблемы предлагается опыт Турции, где врачи получают зарплату на основании тарифной сетки. Сверх этого им начисляются дополнительные выплаты из оборотных средств.

Государственно-частное партнерство в здравоохранении - это софинансирование и разделение рисков, в отношении объектов здравоохранения и медицинских услуг.

Объединение активов двух секторов обеспечивает оптимальное использование активов.

В Кыргызстане инвестиции в инфраструктуру здравоохранения со стороны государства не планируются, поэтому частный инвестор может построить здание современной столовой и обеспечивать питание согласно диетологическим и санитарным требованиям.

Предлагается партнерство путем оплаты медицинских услуг со стороны государства в форме «государственного заказа», по обеспечению граждан медико-санитарной помощью в рамках Программы государственных гарантий.

Необходимо открыть государственно-частные экспресс-лаборатории для срочных анализов при каждой больнице и поликлинике.

Для финансирования ГЧП в сфере здравоохранения в могут использоваться такие платежные механизмы, как софинансирование строительства, гарантия выплаты тарифа медицинского страхования за услуги частным медицинским центрам.

\section{Литература}

- Данные министерства здравоохранения К.Р. за 2006-2012 годы

- Концепция совершенствования системы здравоохранения с учетом развития частной медицины и межсекторных договорных отношений. www.gov. kg/wp-Бишкек(АКИpress) / content/uploads/2012/10/Приложение-на-русс.doc

- Динара Сагинбаева Министр здравоохранения Кыргызстана www.akipress.org/zdorovie/news:13937

- Çetin, A.C., Sağlam H, 2007. Performansa Dayalı Döner Sermaye Prim Sistemi Uygulamasının Hizmet Sunumuna, Sağlık Çalışanlarına ve Hasta Memnuniyeti Üzerine Etkileri: Isparta Sağlık Ocaklarında Bir Araştırma, Süleyman Demirel Üniversitesi, Sosyal Bilimler Enstitüsü Dergisi, Y11: 3, Say1: 5, 56-78, Isparta.

- $\quad$ http://www.regnum.ru

- PFI: meeting the investment challenge. 2003: www.hm-treasury.gov.uk

- Современные проблемы Россйской экономики. Материаль 9 научно- практической конферениии 2012 г.Красноярск.

- $\quad$ http://www.sistema.ru/

- http://www.knews.kg/society/19921/

- Организация питания в Кыргызском научно-исследовательском институте курортологии и восстановительного лечения. Информационный меморандум проекта. Министерство здравоохранения Кыргызской Республики Бишкек, 2012 


\title{
Налоговая нагрузка как критерий реформы в налоговой системе Кыргызской Республики
}

\section{The Tax Burden as a Criterion for the Reform in Tax System of the Kyrgyz Republic}

\author{
Assoc. Prof. Dr. Khicheza Fynchina (Kyrgyz-Russian Slavic University, Kyrgyzstan)
}

\begin{abstract}
The most revealing criterion of effectiveness of tax reforms is the level of the tax burden. Optimal way to estimate sectoral tax burden is to use tax burden coefficient for a newly created value. Other indicators of tax burden differ because of over detailing which doesn't allow making right accentuation in analytical conclusion. This idea is supported by Chick:"in complicated system, the results gained by detailed investigation of particular aspects can't be generalized over the whole issue of the research..." (Chick,1864). Based on this, the analysis of structure and the level of tax burden in different branches of economics of the Kyrgyz Republic for the period of 2005 through 2011 was conducted. It was found that main tax burden carries the industry with big inequality. The main tax burden in Kyrgyzstan falls on mineral resource industry (coefficient of tax burden an average of $30)$, while in manufacturing industry it is one of the lowest indexes $(0,68)$ and in health care $(0,63)$. The structure of tax burden has changed in relation to the introduction of sales tax. In addition there is a big portion in tax burden among almost all sectors of economics and VAT (for domestic products). The ways to reform the tax system are: the harmonization of indirect taxes (for example through the cancellation of the sales tax while increasing the rate of VAT), review of tax exemptions, conditions and methods of supply, the list of taxable supplies, as well as the principles for determining excise goods.
\end{abstract}

\section{1 Введение}

Известная фраза французского философа XVIII в. Шарля Луи Монтескье: «Ничто не должно столь точно регулироваться мудростью и разумом, как соотношение между той частью, которую забирают у подданных, и той, которую им оставляют» лучше всего предостерегает от несправедливости в сфере налогообложения. Она может вызвать серьёзные негативные социально-экономические последствия. Основополагающий принцип налогообложения должен быть положен при определении основных направлений налоговой политики любого государства.

Кыргызская Республика на пороге вступления в Таможенный Союз. Налоговая система в Кыргызской Республике среди стран СНГ в настоящее время отличается либеральностью. Например, ставки подоходного налога и налога на прибыль установлены в размере 10 процентов, налог на добавленную стоимость - 12 процентов. Кроме того, по последнему налогу имеются освобождения на многие поставки, в частности, это касается реализации и аренды земельных участков, жилых помещений; реализации сельскохозяйственной продукции, лекарственных средств; реализации услуг благотворительных организаций; транспортных пассажирских перевозок, импорта определённого перечня товаров, таких, как детское питание, тех же лекарственных средств, научного оборудования геологических экспедиций, некоторых товарных позиций основных фондов. Относительно узок перечень товаров, облагаемых акцизами. Здесь отсутствуют такие стандартные подакцизные товары, как ювелирные изделия, изделия из меха и др.

Налоговая система Кыргызской Республики постоянно совершенствуется. Последняя реформа осуществлена в 2009 году, итоги которой, если крупно обозначить, заключаются в снижении ставки НДС с 20 процентов до 12, введении налога на недвижимое имущество юридических и физических лиц, отмене налога за пользование автомобильными дорогами и отчислений в фонд предупреждения и ликвидации последствий чрезвычайных ситуаций. Остальные изменения в целом касались совершенствования системы администрирования и систематизации нормативно-правового регулирования в сфере налогообложения.

\section{2 Отраслевая налоговая нагрузка и структура ВВП}

Государственная налоговая служба при Правительстве Кыргызской Республики в целях определения эффективности совершенствования налоговой системы сравнивает темпы роста ВВП и налоговых доходов в отраслевом разрезе. Например, определялись отклонения темпов роста ВВП и налоговых поступлений в 2012 г. по сравнению с предшествующим годом по следующим направлениям: промышленность - горнодобывающая промышленность, обрабатывающая промышленность, включая энергетику - строительство и другие отрасли. 


\begin{tabular}{|l|l|l|l|l|}
\hline & $\begin{array}{l}\text { Горнодобывающая } \\
\text { промышленность }\end{array}$ & $\begin{array}{l}\text { Обрабатывающая } \\
\text { промышленность, } \\
\text { включая энергетику }\end{array}$ & Строительство Другие отрасли & - \\
\hline ВВП & $-19,1$ & $-8,1$ & $-12,6$ & $-4,0$ \\
\hline Налоговые поступления & $-15,8$ & $-22,9$ & $-9,2$ \\
\hline
\end{tabular}

Таблица 1. Изменение в темпах роста ВВП и налоговых поступлений по отдельным отраслям экономики Кыргызской Республики в 2012 г. по сравнению с 2011 г.

Соответственно, делается вывод о снижении налоговой нагрузки на горнодобывающую отрасль и её повышении на обрабатывающую промышленность, включая энергетику, строительство и другие отрасли.

Однако самым показательным для органов налоговой службы КР является всё же налоговая нагрузка субъекта экономики, в качестве которой принимается уплачиваемая сумма налога. При этом используется самый простой метод - метод прямого подсчёта. Он не требует специальных исследований и большой информации. Основан на определении суммы налога, исходя из изменений в налоговой системе по условному предприятию, являющимся типичным, на которого распространяется действие основных налогов. Расчёты делаются и по определённым организациям разных видов деятельности, например, торговли, финансовой организации, предприятия промышленности и других с конкретными цифровыми данными. Расчёты соответственно показывают несомненное снижение налогового бремени: соотношение налоговой нагрузки, рассчитанной по новым и ранее действовавшим условиям налогообложения, колеблются на уровне 60-70 процентов.

Как видно, компетентные органы ограничиваются простейшими расчётами для оценки динамики налоговой нагрузки на макроуровне.

Автором изучены и обобщены мнения разных исследователей по поводу критериев определения налоговой нагрузки (Фынчина, 2008a), а также произведены оценки налогового бремени по отраслям экономики в Кыргызской Республики (Фынчина, 2007 и 2008б). Результаты исследований не имеют однозначной оценки и требуют дальнейших исследований в этой области с тем, чтобы при определении фискальной политики максимально обеспечить реализацию принципа равномерности налогообложения.

Эффективность налоговых реформ можно определить по нескольким критериям. Исходя из цели, которую ставит Правительство Кыргызской Республики - сделать более привлекательным инвестиционный климат в стране - наиболее показательным представляется уровень налогового бремени. В мировой практике с целью расчёта этого показателя сопоставляют налоговые доходы с объёмом ВВП.

Существуют разные точки зрения по поводу оценки такой налоговой нагрузки. Первая - чем ниже доля налоговых доходов в ВВП, тем привлекательнее налоговый климат страны (Шаталов, 2011). Есть мнение, что, «чем выше доля налогов в ВВП, тем больше его объём перераспределяется через систему налогообложения и тем эффективнее налоговая система» (Сайфиева, 2012), при этом оговаривается необходимость проведения комплексного анализа системы налогообложения в разрезе основных видов экономической деятельности и отраслей промышленности, включающий анализ структуры ВВП по видам первичных доходов, их налоговому потенциалу, оценку коэффициента отраслевой налоговой нагрузки и отраслевой структуры налоговых доходов.

Определение автором налоговой нагрузки предприятий разных отраслей экономики Кыргызской Республики по двухпараметрической модели А.В. Игнатова позволило установить зависимость налоговой нагрузки от двух показателей: трудоёмкости и материалоёмкости. Данные построенной матрицы показывали высокий уровень налоговой нагрузки по тем сферам экономики, где большой удельный вес занимает фонд оплаты труда (и соответственно, меньший - материальные затраты), и низкую налоговую нагрузку на предприятиях с маленькой долей фонда оплаты труда и большой долей материальных затрат. Разброс показателей по этим субъектам чрезвычайно большой: от 4,3-8,7 сом. на каждые 112 сом. выручки-брутто до 26,7 сом. (FynchinaKh.,2008в).

Сайфиевой С.Н. предлагается для оценки налогового бремени по отраслям промышленности использовать следующие индикаторы (Сайфиева, 2010а и 2010б. С. 39):

1. Коэффициент налоговой нагрузки $(\mathrm{HH})$ на вновь созданную стоимость - отношение отраслевой налоговой нагрузки к валовой добавленной стоимости (ВДС), позволяет определить влияние налогового бремени на отраслевую продуктивность.

2. Коэффициент НН на прибыль в ВДС - отношение отраслевой НН к величине прибыли в ВДС, позволяет определить соотношение налогового бремени и собственных финансовых источников предприятия, включающих амортизацию и прибыль. 
3. Коэффициент НН на чистую прибыль, рассчитанную как разницу между валовой прибылью и потреблением основного капитала, включая скрытую заработную плату. Этот показатель позволяет определить соотношение налогового бремени и чистой прибыли в ВДС каждой отрасли.

В своих расчётах налоговой нагрузки в отраслевом разрезе (Сайфиева, 2012), автор не берет во внимание страховые взносы и налоги, уплачиваемые во внешнеэкономической деятельности, оговаривая затруднённость получения официальной статистической информации последних (добавим, и не только в отношении них, но и по страховым отчислениям, администрируемым социальным ведомством). В других расчётах налоговой нагрузки в разрезе основных видов экономической деятельности и отраслей промышленности (Сайфиева, 2010а и 2010б), названными промежуточными, учтены отчисления на социальные нужды посредством распределения их пропорционально структуре заработной платы наёмных работников за каждый год анализируемого периода.

На наш взгляд, предлагаемая методика в целом отличается излишней детализацией, нагромождением цифр, что не позволяет сделать правильные акценты на аналитических выкладках. Здесь уместны слова В. Чик (американский экономист, последователь теории Кейнса. Основные труды: «Теория монетарной политики» (1977), «Макроэкономика после Кейнса» (1983) и др.), что «в сложной системе результаты, полученные путём детального изучения определённых её аспектов, не могут распространяться на весь предмет исследования... Чем сложнее система, тем меньше мы знаем о всех происходящих в ней процессах. Ни действия агентов внутри системы, ни изучение её извне не могут основываться на полной информации. Совершенное знание недостижимо» (цит. по: Ш. Доу, 2006. С. 63).

Экономический смысл предлагаемых индикаторов эффективности отраслевого совокупного налогообложения, по мнению Сафиевой, заключается в измерении величины ВДС и валовой прибыли в ВДС, перераспределяемых с помощью налогообложения. Представляется, что в основе предлагаемых индикаторов лежит международный подход сопоставления величины налоговых сумм и социальных взносов во внебюджетные социальные фонды к регистрируемому статистикой ВВП (в отраслевом разрезе - валовая добавленная стоимость), а также - на микроуровне - соотношение уплаченных налогов также к добавленной стоимости или чистой прибыли (подробно см. Фынчина, 2008а). И оценка их также нужно делать, следуя международным критериям, отмеченным, как указывалось выше, д.э.н. С.Д. Шаталовым.

Исходя из вышеизложенного, рассчитаны показатели налогового бремени в отраслевом разрезе, по которым можно оценить эффективность развития налоговой системы в Кыргызской Республике.

Произведём оценку налоговой нагрузки по отраслям экономики по общепринятой методике, сравнив налоговый потенциал соответствующей отрасли с отраслевой структурой ВВП. Полученный результат коэффициент налоговой нагрузки - показывает превышение налоговой нагрузки по отрасли над средней по всем секторам экономики (Сайфиева, 2012. С. 123).

Как видно из табл. 2, выявляется картина, которая разрушает сложившееся представление и не позволяет объяснить явные факты. Основное налоговое бремя несёт промышленность (налоговое бремя стабильно превышает вклад в ВДС отрасли в среднем в 2 раза). Рассматривая промышленность в разрезе, выявляется, что не все её секторы находятся в равном положении. Так, основную налоговую нагрузку в Кыргызстане несёт горнодобывающая отрасль - в 2011 г. коэффициент налоговой нагрузки составил 36,62, в то время как в обрабатывающей промышленности, включающей и переработку сельскохозяйственной продукции, и текстильную и швейную промышленность, и производство древесины и деревянных изделий и др. (разделы 15-37), он один из самых низких $(0,68)$ наряду со здравоохранением $(0,63)$. Для сравнения: в Российской Федерации отрасль по добыче полезных ископаемых также несёт самое большое налоговое бремя, равное 1,931, а обрабатывающая - «только» 1,077 (Сайфиева, 2012. С. 124).

Далее по коэффициенту налоговой нагрузки после горнодобывающей промышленности по убывающей располагаются секторы финансовых услуг $(2,17)$, государственного управления $(1,76)$, транспорт и связь $(1,58)$. Наименьшую налоговую нагрузку имеет сельскохозяйственный сектор экономики, определённый государством, как приоритетный, где налоговая нагрузка в анализируемый период несколько выросла и составила от 0,3 до 1 процента.

Следует отметить, что сравнение показателей до и после налоговой реформы 2009 г. не будет в полной мере объективным вследствие, в первую очередь, того, что действие налога на недвижимое имущество, введённое взамен двух оборотных налогов, было приостановлено. Негативное воздействие оказано на экономику страны ипродолжающимся мировым финансовым кризисом, но в большей степени, возможно, повлияли внутриполитические события в 2010 г., в результате которых требовалось предоставления пострадавшим налоговых послаблений или времени на восстановление экономической деятельности, и то, и другое вызвало сокращение налоговой базы и, соответственно, налоговых отчислений. Сравнение показателей 2008 г. и 2011 г. представляется более характерным. 


\begin{tabular}{|c|c|c|c|c|c|c|c|c|c|c|c|c|}
\hline \multirow{2}{*}{$\begin{array}{l}\text { Отрасль } \\
\text { экономики }\end{array}$} & \multicolumn{3}{|c|}{2005} & \multicolumn{3}{|c|}{2006} & \multicolumn{3}{|c|}{2007} & \multicolumn{3}{|c|}{2008} \\
\hline & ВДС & $\mathrm{HH}$ & KHH & ВДС & $\mathrm{HH}$ & KHH & ВДС & $\mathrm{HH}$ & $\mathrm{KHH}$ & ВДС & $\mathrm{HH}$ & $\mathrm{KHH}$ \\
\hline $\begin{array}{l}\text { Сельское хозяйство, } \\
\text { охота и лесное хозяйство }\end{array}$ & 28,5 & 0,3 & 0,01 & 28,7 & 0,4 & 0,02 & 26,9 & 1,0 & $\begin{array}{l}0,03 \\
7\end{array}$ & 25,8 & 0,8 & 0,03 \\
\hline Промышленность & 17,3 & 45,9 & 2,65 & 14,8 & 41,6 & 2,81 & 13,1 & 30,1 & 2,30 & 14,0 & 27,7 & 1,98 \\
\hline $\begin{array}{l}\text { Горнодобывающая } \\
\text { промышленность }\end{array}$ & 0,5 & 17,2 & 34,4 & 0,4 & 14,4 & 36,0 & 0,5 & 8,9 & 17,8 & 0,5 & 11,1 & 22,2 \\
\hline $\begin{array}{l}\text { Обрабатывающая } \\
\text { промышленность }\end{array}$ & 12,9 & 24,1 & 1,99 & 11,0 & 22,0 & 2,00 & 9,9 & 16,4 & 1,66 & 11,3 & 12,9 & 1,14 \\
\hline $\begin{array}{l}\text { Производство и } \\
\text { распределение } \\
\text { электроэнергии, газа и } \\
\text { воды }\end{array}$ & 3,9 & 4,6 & 1,18 & 3,4 & 5,2 & 1,52 & 2,7 & 4,8 & 1,78 & 2,2 & 3,7 & 1,68 \\
\hline Строительство & 2,7 & 4,1 & 1,18 & 2,7 & 4,0 & 1,48 & 3,6 & 5,1 & 1,42 & 3,1 & 5,3 & 1,71 \\
\hline $\begin{array}{l}\text { Торговля; ремонт } \\
\text { автомобилей, бытовых } \\
\text { изделий и предметов } \\
\text { личного пользования }\end{array}$ & 17,8 & 8,5 & 0,48 & 18,4 & 10,6 & 0,58 & 17,9 & 14,8 & 0,83 & 18,6 & 15,6 & 0,84 \\
\hline Гостиницы и рестораны* & 1,4 & $\ldots$ & & 1,4 & $\ldots$ & & 1,2 & 1,5 & 1,25 & 1,3 & 1,0 & 0,77 \\
\hline Транспорт и связь & 6,6 & 21,8 & 3,30 & 6,1 & 22,4 & 3,67 & 7,4 & 22,3 & 3,00 & 8,4 & 16,6 & 1,98 \\
\hline $\begin{array}{l}\text { Финансовая } \\
\text { деятельность }\end{array}$ & 2,2 & 4,2 & 1,90 & 2,6 & 3,7 & 1,42 & 3,4 & 4,3 & 1,26 & 6,1 & 6,2 & 1,00 \\
\hline $\begin{array}{l}\text { Государственное } \\
\text { управление }\end{array}$ & 4,6 & 7,7 & 1,67 & 4,4 & 10,4 & 2,36 & 4,3 & 11,4 & 2,65 & 4,2 & 16,6 & 3,90 \\
\hline Образование $* *$ & 3,8 & 3,1 & 0,82 & 4,0 & 3,2 & 0,8 & 4,5 & 2,7 & 0,60 & 4,4 & 2,4 & 0,55 \\
\hline $\begin{array}{l}\text { Здравоохранение и } \\
\text { предоставление } \\
\text { социальных услуг }\end{array}$ & 2,0 & 1,7 & 0,85 & 2,3 & 1,7 & 0,74 & 2,1 & 1,6 & 0,76 & 1,9 & 1,6 & 0,84 \\
\hline $\begin{array}{l}\text { Предоставление } \\
\text { коммунальных, } \\
\text { социальных } \\
\text { и персональных услуг }\end{array}$ & 1,2 & 2,2 & 1,83 & 1,3 & 2,3 & 1,77 & 1,6 & 1,5 & 0,94 & 1,6 & 1,3 & 0,81 \\
\hline
\end{tabular}

\begin{tabular}{|c|c|c|c|c|c|c|c|c|c|c|c|}
\hline \multirow[t]{2}{*}{ Отрасль экономики } & \multicolumn{3}{|l|}{2009} & \multicolumn{3}{|c|}{2010} & \multicolumn{3}{|l|}{2011} & \multicolumn{2}{|c|}{$\begin{array}{l}\text { Изменение } \\
\text { КНН } 2011 \text { г. } \\
\text { по } \\
\text { сравнению с } \\
2008 \text { г. }\end{array}$} \\
\hline & ВДС & $\mathrm{HH}$ & KHH & ВДС & $\mathrm{HH}$ & KHH & ВДС & $\mathrm{HH}$ & KHH & ВДС & $\mathrm{HH}$ \\
\hline $\begin{array}{l}\text { Сельское хозяйство, охота } \\
\text { и лесное хозяйство }\end{array}$ & 18,8 & 1,0 & 0,06 & 17,5 & 0,57 & 0,03 & 16,6 & 0,5 & 0,03 & $-9,2$ & $-0,3$ \\
\hline Промышленность & 16,9 & 32,4 & 1,92 & 20,7 & 37,3 & 1,80 & 22,5 & 44,7 & 1,99 & 8,5 & 17,0 \\
\hline $\begin{array}{l}\text { Горнодобывающая } \\
\text { промышленность }\end{array}$ & 0,5 & 8,8 & 17,52 & 0,6 & 26,2 & 43,67 & 0,8 & 29,3 & 36,62 & 0,3 & 18,2 \\
\hline $\begin{array}{l}\text { Обрабатывающая } \\
\text { промышленность }\end{array}$ & 14,2 & 17,0 & 1,2 & 17 & 7,9 & 0,46 & 18,3 & 12,5 & 0,68 & 7 & $-0,4$ \\
\hline $\begin{array}{l}\text { Производство и } \\
\text { распределение } \\
\text { электроэнергии, газа и воды }\end{array}$ & 2,2 & 6,6 & 3,0 & 3,1 & 3,2 & 1,05 & 3,4 & 2,9 & 0,85 & 1,2 & $-0,8$ \\
\hline Строительство & 6,7 & 6,1 & 0,91 & 5,5 & 6,1 & 1,11 & 4,9 & 4,5 & 0,91 & 1,2 & $-0,8$ \\
\hline $\begin{array}{l}\text { Торговля; ремонт } \\
\text { автомобилей, бытовых } \\
\text { изделий и предметов личного } \\
\text { пользования }\end{array}$ & 16,8 & 15,5 & 0,92 & 16 & 11,9 & 0,74 & 15,2 & 13,0 & 0,86 & $-3,4$ & $-2,6$ \\
\hline Гостиницы и рестораны & 1,3 & 0,8 & 0,62 & 1,3 & 0,6 & 0,46 & 1,5 & 0,6 & 0,41 & 0,2 & $-0,4$ \\
\hline Транспорт и связь & 8,8 & 18,7 & 2,12 & 8,6 & 13,8 & 1,61 & 8,1 & 12,8 & 1,58 & $-0,3$ & $-3,8$ \\
\hline Финансовая деятельность & 4 & 6,6 & 1,65 & 3,9 & 6,2 & 1,6 & 3,5 & 7,6 & 2,17 & $-2,6$ & 1,4 \\
\hline
\end{tabular}




\begin{tabular}{l|l|l|l|l|l|l|l|l|l|l|l|l|}
\hline Государственное управление & 5,3 & 16,1 & 3,04 & 5,6 & 13,5 & 2,4 & 5,1 & 9,0 & 1,76 & 0,9 & $-7,6$ \\
\hline Образование & 4,4 & 2,8 & 0,64 & 4,4 & 2,5 & 0,58 & 5,3 & 3,2 & 0,6 & 0,9 & 0,8 \\
\hline $\begin{array}{l}\text { Здравоохранение и } \\
\text { предоставление } \\
\text { социальных услуг }\end{array}$ & 2,6 & 2,0 & 0,75 & 2,6 & 1,7 & 0,67 & 3 & 1,9 & 0,63 & 1,1 & 0,3 \\
\hline $\begin{array}{l}\text { Предоставление } \\
\text { коммунальных, социальных } \\
\text { и персональных услуг }\end{array}$ & 2,1 & 1,2 & 0,57 & 2,2 & 1,3 & 0,55 & 1,9 & 2,3 & 1,21 & 0,3 & 1,0 \\
* В отчётности эта позиция за данный период отдельно не выделена, а включена в сектор «Торговля; ремонт автомобилей, бытовых \\
$\begin{array}{l}\text { изделий и предметов личного пользования». } \\
\text { ** Структура налоговой нагрузки по отраслям «Образование» и «Здравоохранение» определена пропорционально структуре } 2007 \text { г. }\end{array}$
\end{tabular}

Таблица 2. Расчёт коэффициента налогового бремени по секторам экономики Кыргызской Республики за период 2005-2011 г2. Источник: рассчитано автором по Статсборнику Национальные счета Кыргызской Республики 2005-2011 г2.

Если смотреть из этих позиций, то налоговая нагрузка в горнодобывающей промышленности после реформирования выросла на 18,2 процента, доля же валовой добавленной стоимости выросла только на 0,3 процента.

Политика поддержки приоритетов экономического развития привела к снижению налогового гнёта по предприятиям обрабатывающей промышленности: доля валовой добавленной стоимости выросла на 7 процентов, а налоговая нагрузка снизилась на 0,4 процента.

В сфере производства и распределения электроэнергии, газа и воды также рост доли валовой добавленной стоимости на 1,2 процента сопровождалось снижением налоговой нагрузки на 0,8 процента. Снижение налоговой нагрузки отмечается и по сектору государственных услуг, где доля валовой добавленной стоимости выросла на 0,9 процента, а налоговая нагрузка снизилась на 7,6 процента. В сфере финансовой деятельности произошло усиление налоговой нагрузки. Так, если доля финансовых, страховых и пр. услуг в валовой добавленной стоимости экономики Кыргызской Республики сократилась на 2,6 процента, то повышение налоговой нагрузки составило 1,4 процента. Снижение налоговой нагрузки отмечается и по предприятиям питания, гостиницам (0,4 процента), строительным организациям (0,8 процента).

Доля ВДС по сельскому хозяйству в структуре ВВП к 2008 г. сократилась по сравнению с 2005 г. на 2,7 процента, в то время как доля налоговой нагрузки повысилась на 0,5 процента, превышение коэффициента налоговой нагрузки составило 0,02. Сравнение показателей по данной отрасли экономики 2008 г. (до реформирования налоговой системы) по сравнению с 2009 г. (после реформы в сфере налогообложения) показывает относительно значительное снижение доли ВДС - на 7 п.п., и некоторый рост налоговой нагрузки - на 0,2 п.п.

Таким образом, выявлено относительно большое несоответствие структуры валовой добавленной стоимости по отраслям экономики структуре налоговых доходов (если в РФ коэффициент налоговой нагрузки составляет в среднем от 0,6 до 2 процентов, не считая сельское хозяйство, то в КР - от 0,6 до 40). Вряд ли это объясняется только особенностями действующей модели налогообложения или спецификой национальной экономики.

\section{3 Структура налоговых доходов основных отраслей экономики}

При анализе налоговой нагрузки представляется важным оценить влияние каждого из налогов, формирующих её. Понятно, что перечень налогов в разных сферах неодинаков. Принцип дисперсности в налогообложении несколько снижает налоговое бремя предприятий отдельных отраслей экономики.

Следует учесть, что при анализе уровня и структуры налоговой нагрузки в расчётах отражены практически все налоги, в том числе и подоходный налог. В настоящих расчётах не включены налог на добавленную стоимость и акцизный налог на импортируемую продукцию, которые, как указывалось выше, администрируются Государственной таможенной службой Кыргызской Республики. В то же время, есть мнение, что следует исключить из расчёта налоговой нагрузки такие платежи, как налог на добавленную стоимость, подоходный налог с физических лиц, отчисления во внебюджетные социальные фонды. Аргументом здесь служит характеристика этих налогов как транзитных, нейтральных для предприятия, перелагаемых, как правило, на конечных потребителей. Но нейтральных для предприятия налогов просто не существует: они реально уплачиваются за счёт текущих денежных поступлений.

Рассмотрим изменение структуры налоговой нагрузки по угольной и нефтегазовой промышленности в результате налоговой реформы 2009 г. (см. табл. 3). 


\begin{tabular}{|c|c|c|c|c|c|c|c|c|}
\hline \multirow{3}{*}{ Вид налога } & \multicolumn{4}{|c|}{ Угольная и нефтегазовая отрасль } & \multicolumn{4}{|c|}{ Цветная металлургия } \\
\hline & \multicolumn{2}{|c|}{2008} & \multicolumn{2}{|l|}{2011} & \multicolumn{2}{|l|}{2008} & \multicolumn{2}{|l|}{2011} \\
\hline & $\begin{array}{l}\text { сумма, } \\
\text { млн. } \\
\text { сом. }\end{array}$ & $\begin{array}{l}\text { процент } \\
\text { от } \\
\text { общей } \\
\text { суммы }\end{array}$ & $\begin{array}{l}\text { сумма, } \\
\text { млн. } \\
\text { сом. }\end{array}$ & $\begin{array}{l}\text { процент } \\
\text { от } \\
\text { общей } \\
\text { суммы }\end{array}$ & $\begin{array}{l}\text { сумма, } \\
\text { млн. } \\
\text { сом. }\end{array}$ & $\begin{array}{l}\text { процент } \\
\text { от } \\
\text { общей } \\
\text { суммы }\end{array}$ & $\begin{array}{l}\text { сумма, } \\
\text { млн. } \\
\text { сом. }\end{array}$ & $\begin{array}{l}\text { процент } \\
\text { от } \\
\text { общей } \\
\text { суммы }\end{array}$ \\
\hline Подоходный налог & 35,6 & 15,1 & 60,2 & 10,0 & 158,8 & 14,2 & 314,4 & 4,6 \\
\hline Налог на прибыль & 44,6 & 18,9 & 74,1 & 12,3 & 27,5 & 2,5 & 93 & 1,4 \\
\hline $\begin{array}{l}\text { НДС на внутреннюю } \\
\text { продукцию }\end{array}$ & 129,1 & 54,7 & 219,8 & 36,4 & 5,9 & 0,5 & 23 & 0,3 \\
\hline Налог с продаж & - & - & 118,6 & 19,7 & - & - & 51,9 & 0,8 \\
\hline Земельный налог & 5,4 & 2,3 & 8,6 & 1,4 & 31,9 & 2,9 & 9,5 & 0,1 \\
\hline Акцизный налог & 0,06 & 0,03 & 0,7 & 0,1 & - & - & - & - \\
\hline $\begin{array}{l}\text { Налог на доходы } \\
\text { лиц-нерезидентов }\end{array}$ & 5,6 & 2,4 & 68,6 & 11,4 & 66,8 & 6 & 18,9 & 0,3 \\
\hline $\begin{array}{l}\text { Налог за пользование } \\
\text { недрами }\end{array}$ & 15,9 & 6,7 & 53 & 8,8 & 774,9 & 69,3 & 226 & 3,3 \\
\hline Налоги от Кумтор & - & - & - & - & 53,1 & 4,7 & 6066,4 & 89,2 \\
\hline \multirow{3}{*}{ Вид налога } & \multicolumn{4}{|c|}{$\begin{array}{l}\text { Пищевая промышленность, } \\
\text { кроме алкогольной и табачной }\end{array}$} & \multicolumn{4}{|c|}{ Лёгкая промышленность } \\
\hline & \multicolumn{2}{|c|}{2008} & \multicolumn{2}{|l|}{2011} & \multicolumn{2}{|l|}{2008} & \multicolumn{2}{|l|}{2011} \\
\hline & $\begin{array}{l}\text { сумма, } \\
\text { млн. сом. }\end{array}$ & $\begin{array}{l}\text { процент } \\
\text { от } \\
\text { общей } \\
\text { суммы } \\
\end{array}$ & $\begin{array}{l}\text { сумма, } \\
\text { млн. сом. }\end{array}$ & $\begin{array}{l}\text { процент } \\
\text { от } \\
\text { общей } \\
\text { суммы } \\
\end{array}$ & $\begin{array}{l}\text { сумма, } \\
\text { млн. сом. }\end{array}$ & $\begin{array}{l}\text { процент } \\
\text { от } \\
\text { общей } \\
\text { суммы } \\
\end{array}$ & $\begin{array}{l}\text { сумма, } \\
\text { млн. сом. }\end{array}$ & $\begin{array}{l}\text { процент } \\
\text { от } \\
\text { общей } \\
\text { суммы }\end{array}$ \\
\hline Подоходный налог & 29,1 & 31,7 & 58,0 & 16,3 & 11,6 & 33,4 & 14,4 & 13,4 \\
\hline Налог на прибыль & 43,1 & 46,9 & 58,6 & 16,5 & 9,5 & 27,4 & 9 & 8,4 \\
\hline $\begin{array}{l}\text { НДС на внутреннюю } \\
\text { продукцию }\end{array}$ & 11,3 & 12,3 & 87,4 & 24,6 & 11,5 & 33,1 & 6,9 & 6,4 \\
\hline Налог с продаж & - & - & 147,1 & 41,4 & - & - & 76 & 70,8 \\
\hline Земельный налог & 8,2 & 8,9 & 3,8 & 1,1 & 2,1 & 6,1 & 1,1 & 1 \\
\hline \multirow[b]{3}{*}{ Вид налога } & \multicolumn{4}{|c|}{ Производство строительных материалов } & \multicolumn{4}{|c|}{ Прочие отрасли промышленности } \\
\hline & \multicolumn{2}{|c|}{2008} & \multicolumn{2}{|c|}{2011} & \multicolumn{2}{|c|}{2008} & \multicolumn{2}{|l|}{2011} \\
\hline & $\begin{array}{l}\text { сумма, } \\
\text { млн. сом. }\end{array}$ & $\begin{array}{l}\text { процент } \\
\text { от } \\
\text { общей } \\
\text { суммы }\end{array}$ & $\begin{array}{l}\text { сумма, } \\
\text { млн. сом. }\end{array}$ & $\begin{array}{l}\text { процент } \\
\text { от } \\
\text { общей } \\
\text { суммы }\end{array}$ & $\begin{array}{l}\text { сумма, } \\
\text { млн. сом. }\end{array}$ & $\begin{array}{l}\text { процент } \\
\text { от } \\
\text { общей } \\
\text { суммы }\end{array}$ & $\begin{array}{l}\text { сумма, } \\
\text { млн. сом. }\end{array}$ & $\begin{array}{l}\text { процент } \\
\text { от } \\
\text { общей } \\
\text { суммы }\end{array}$ \\
\hline Подоходный налог & 73,7 & 57,6 & 64,9 & 16,2 & 200,8 & 52,7 & 213,8 & 19,2 \\
\hline Налог на прибыль & 195,1 & 152,5 & 45,9 & 11,5 & 77,8 & 20,4 & 112,2 & 10,1 \\
\hline $\begin{array}{l}\text { НДС на внутреннюю } \\
\text { продукцию }\end{array}$ & $-166,7$ & $-130,3$ & 50,2 & 12,5 & 9,6 & 2,5 & 419 & 37,7 \\
\hline Налог с продаж & - & - & 142,9 & 35,7 & - & - & 245,6 & 22,1 \\
\hline Земельный налог & 10,5 & 8,2 & 9 & 2,2 & 39,5 & 10,4 & 39,4 & 3,5 \\
\hline Акцизный налог & - & - & - & - & 3,3 & 0,9 & 4,8 & 0,4 \\
\hline $\begin{array}{l}\text { Налог на доходы } \\
\text { лиц-нерезидентов }\end{array}$ & - & - & 28,6 & 7,1 & 27,8 & 7,3 & 28,6 & 2,6 \\
\hline $\begin{array}{l}\text { Налог за пользование } \\
\text { недрами }\end{array}$ & 15,4 & 12 & 59,3 & 14,8 & 22,2 & 5,8 & 47,7 & 4,3 \\
\hline \multirow[b]{3}{*}{ Вид налога } & Электроэю & гетика & & & Строитель & & & \\
\hline & 2008 & & 2011 & & 2008 & & 2011 & \\
\hline & $\begin{array}{l}\text { сумма, } \\
\text { млн. сом. }\end{array}$ & $\begin{array}{l}\text { процент } \\
\text { от } \\
\text { общей } \\
\text { суммы }\end{array}$ & $\begin{array}{l}\text { сумма, } \\
\text { млн. сом. }\end{array}$ & $\begin{array}{l}\text { процент } \\
\text { от } \\
\text { общей } \\
\text { суммы } \\
\end{array}$ & $\begin{array}{l}\text { сумма, } \\
\text { млн. сом. }\end{array}$ & $\begin{array}{l}\text { процент } \\
\text { от } \\
\text { общей } \\
\text { суммы }\end{array}$ & $\begin{array}{l}\text { сумма, } \\
\text { млн. сом. }\end{array}$ & $\begin{array}{l}\text { процент } \\
\text { от } \\
\text { общей } \\
\text { суммы } \\
\end{array}$ \\
\hline Подоходный налог & 127,1 & 29,1 & 190,6 & 26,3 & 127,1 & 22,6 & 536,4 & 47,7 \\
\hline Налог на прибыль & 66,6 & 15,2 & 68,8 & 9,5 & 72,8 & 5,5 & 126,9 & 11,3 \\
\hline $\begin{array}{l}\text { НДС на внутреннюю } \\
\text { продукцию }\end{array}$ & 232,5 & 53,1 & 412,6 & 57 & - & - & - & - \\
\hline Налог с продаж & - & - & 43,4 & 6 & - & - & 308,8 & 27,5 \\
\hline Земельный налог & 11,3 & 2,6 & 9,1 & 1,3 & 16,1 & 2,9 & 13,2 & 1,2 \\
\hline & Торговля & гедприятия & итания & & Финансо & услуги & & \\
\hline & 2008 & & 2011 & & 2008 & & 2011 & \\
\hline Вид налога & $\begin{array}{l}\text { сумма, } \\
\text { млн. сом. }\end{array}$ & $\begin{array}{l}\text { процент } \\
\text { от } \\
\text { общей } \\
\text { суммы }\end{array}$ & $\begin{array}{l}\text { сумма, } \\
\text { млн. сом. }\end{array}$ & $\begin{array}{l}\text { процент } \\
\text { от } \\
\text { общей } \\
\text { суммы } \\
\end{array}$ & $\begin{array}{l}\text { сумма, } \\
\text { млн. сом. }\end{array}$ & $\begin{array}{l}\text { процент } \\
\text { от } \\
\text { общей } \\
\text { суммы }\end{array}$ & $\begin{array}{l}\text { сумма, } \\
\text { млн. сом. }\end{array}$ & $\begin{array}{l}\text { процент } \\
\text { от } \\
\text { общей } \\
\text { суммы } \\
\end{array}$ \\
\hline Подоходный налог & 132,1 & 9,0 & 286,1 & 8,6 & 201,3 & 29,5 & 551,7 & 28,8 \\
\hline Налог на прибыль & 380,4 & 25,8 & 445,5 & 13,3 & 214,6 & 31,5 & 396,3 & 20,7 \\
\hline $\begin{array}{l}\text { НДС на внутреннюю } \\
\text { продукцию }\end{array}$ & 886,7 & 60,2 & 1143,6 & 34,2 & 27,8 & 4,1 & 275 & 14,3 \\
\hline
\end{tabular}




\begin{tabular}{|l|l|l|l|l|l|l|l|}
\hline Налог с продаж & - & - & 1391,2 & 41,6 & - & - & 440 \\
\hline Земельный налог & 74,6 & 5,1 & 76,6 & 2,3 & 4,5 & 0,7 & 14,9 \\
\hline Акцизный налог & - & - & - & - & - & - & 0,8 \\
\hline $\begin{array}{l}\text { Налог на доходы } \\
\text { лиц-нерезидентов }\end{array}$ & - & - & - & - & 233,7 & 34,3 & - \\
\hline
\end{tabular}

Таблица 3. Структура налоговых доходов в основных отраслях экономикиКыргызской Республики в 2008 и 2011 г2. Источник: рассчитано по данным ГНС при Правительстве Кыргызской Республики

Структура налоговой нагрузки изменилась после реформирования, прежде всего, в связи с введением налога с продаж, составивший относительно большой удельный вес - 19,7 процентов. Но, как и в 2008 г., основную долю в налоговой нагрузке этой отрасли экономики составляет НДС на внутреннюю продукцию (36,4 процента). Почти в 5 раз увеличилась доля налога на доходы нерезидентов.

Следует отметить, что специфику цветной металлургии Кыргызской Республики определяют ЗАО «Кумтор Голд Компани» (КГК) и ЗАО «Кумтор Оперейтинг Компани» (КОК), налоговая нагрузка которых составляет около 90 процентов всех налоговых доходов цветной металлургии Кыргызской Республики. Деятельность данной организации в экономике Кыргызской Республики имеет большое значение. По предварительным данным Национального статистического комитета КР доля «Кумтора» в ВВП страны в 2011 году составила 11,7 процента; доля «Кумтора» в общем объеме промышленного производства - 26,1 процента; доля золота в общем объеме экспорта в 2011 году составила 51,1 процента. Поэтому налогообложение с Кумтор осуществляется по особому контракту - налог на валовой доход от Кумтор налог на основе отдельного соглашения. Соглашение по налогу на валовой доход отКумторпредусматривает перечисление 17 процентов (при подписании соглашения в 2009 г. ставка составляла 13 процентов) от валового дохода деятельности ЗАО КГК и ЗАО КОК от продажи золота и серебра без зачетов. Эти платежи не подпадают под действие НК КР. В соответствии с бюджетной классификацией КР определены как налоги, не распределяемые по категориям.

Все остальные платежи - таможенные сборы, налог с продаж, НДС, акцизный и подоходный налог с работающих, а также лицензионные платежи и отчисления в Социальный фонд - эти организации платят в соответствии с действующим налоговым законодательством Кыргызской Республики. Помимо этого, они производят уплату одного процента от валового дохода в Фонд развития Иссык-Кульской области.

По данным СМИ государственная комиссия по «Кумтору» в одном из своих заключений сделала выводы, что если бы «Кумтор» работал с 2009 года на основе общего налогообложения, то за три последних года бюджет Кыргызстана получил бы на 100 млн. долларов меньше. Между тем определение особых условий налогообложения инициировано самим «Кумтор». Представляется, что особый статус налогообложения имеет политическую подоплёку. Возможно, это имеет и экономические основания, что требует проведения более глубокого и всестороннего анализа, чем было до сих пор. Однако общий анализ можно провести по статистическим показателям. Так, сравнение доли чистой прибыли, как составного элемента ВДС, по горнодобывающей промыщленности и сфере торговли и ремонту автомобилей, бытовых изделий и предметов личного пользования находится в соотношении: в 2008 г. 4,1 и 91 процент, в 2011 г. 41,5 (рост за счёт снижения долей прочих налогов и потребления основного капитала) и 91,1 процент (авторские расчёты по данным СНС КР). Таким образом, можно заключить, что эти вопросы налогообложения являются проблемными и требуют скорейшего разрешения.

Налоговая нагрузка на предприятия пищевой промышленности, кроме алкогольной и табачной, как видно из таблицы, усилилась вследствие введения налога с продаж, доля которого составила более 40 процентов, в два раза увеличилась доля налога на добавленную стоимость. Такие изменения повлекли за собой снижение налога на прибыль и подоходного налога. В 2 раза повысилась доля НДС на производимую продукцию, что связано с ростом налогооблагаемой базы, как с изменением условий налогообложения, так и в связи с ростом объёма продажи. Значительное снижение доли земельного налога объясняется пересмотром в сторону уменьшения зональных корректировочных коэффициентов, учитывающих месторасположение субъекта экономики в населённом пункте.

Структура налоговых доходов по лёгкой промышленности, являющейся флагманом кыргызской экономики, по определению экспертов-экономистов, не внушает оптимизма. Определим вклад этой отрасли промышленности в налоговых поступлениях, администрируемых ГНС КР. До введения новой редакции Налогового кодекса он составлял 33,4 процента, после - 10,7 процента, в 2011 г. - 11,1.

А к 2011 г. возрос не намного - 13,4 процента. Структура налогообложения в лёгкой промышленности более чем на 70 процентов сложилась из вновь введённого налога с продаж. Вызывает вопрос отсутствие корреляции между этим налогом и НДС, налоговая нагрузка по которому сократилась в 1,7 раза, а доля в общей сумме налоговых платежей - более чем в 5 раз.

В производстве строительных материалов изменение структуры налоговых платежей вызвано также налогом с продаж. Но и тем, что в 2008 г. имело место большая переплата по НДС, зачтённая в последующий год. 
В электроэнергетике изменения в структуре налоговых взносов коснулись только налога на прибыль, доля которого несколько сократилась за счёт увеличения платежей по НДС и налога с продаж.

Строительство - тот сектор экономики, который в Кыргызской Республике, на наш взгляд, обладает большим налоговым потенциалом. Некоторое усиление налогового администрирования, предусмотренного новой редакцией Налогового кодекса, позволило, по нашему мнению, повысить удельные веса налога на прибыль и подоходного налога более чем в 2 раза, при этом значительную долю в структуре налоговых платежей составил вновь введённый налог с продаж.

Для торговли и предприятий питания основными налоговыми платежами являются косвенные налоги: если в 2008 г. более 60 процентов всех платежей составлял только один налог - НДС, то после реформирования налоговой системы два налога - НДС и налог с продаж - составили уже почти 76 процентов, причём на долю налога с продаж приходится большая доля в размере 41,6 процентов.

Структура налоговых отчислений сектора финансовых услуг сформирована в основном из прямых налогов: налогов на доходы и прибыль (95,3 процента в 2008 г.) - основную долю занимал налог на доходы нерезидентов $(34,3$ процента), затем налог на прибыль $(31,5)$ и подоходный налог $(29,5)$. После внесения изменений в налоговую систему налоговое бремя в финансовом секторе распределяется более равномерно, однако превалирование доли прямых налогов в структуре налоговых изъятий осталось $(37,3: 62,8)$.

\section{4 Выводы}

Развитие экономики Кыргызской Республики сопровождается постоянным совершенствованием и системы налогообложения, которое требует проведения анализа эффективности предполагаемых фискальных мер. Исходя из этого проведены расчёты показателей структуры и уровня налогового бремени в отраслевом разрезе, по которым можно оценить эффективность развития налоговой системы в Кыргызской Республике.

В результате проведён анализ большого цифрового массива, отражающего налоговую нагрузку по разным отраслям экономики, и выявлено:

1. Основное налоговое бремя несёт промышленность, внутри которой обнаружена большая неравномерность: высокую налоговую нагрузку в Кыргызстане несёт горнодобывающая отрасль, по которой в анализируемый период коэффициент налоговой нагрузки составил в среднем 30 , в то время как в обрабатывающей промышленности он один из самых низких $(0,68)$ наряду со здравоохранением $(0,63)$.

2. Далее по коэффициенту налоговой нагрузки располагаются секторы финансовых услуг $(2,17)$, государственного управления $(1,76)$, транспорт и связь $(1,58)$. Наименьшую налоговую нагрузку имеет сельскохозяйственный сектор экономики, где налоговая нагрузка в анализируемый период составил от 0,3 до 1 процента.

3. Налоговая нагрузка в горнодобывающей промышленности после реформирования выросла на 18,2 процента, доля же валовой добавленной стоимости выросла только на 0,3 процента.

4. Снизилась налоговая нагрузка после реформирования налоговой системы КР в 2009 г. по предприятиям обрабатывающей промышленности: доля валовой добавленной стоимости выросла на 7 процентов, а налоговая нагрузка снизилась на 0,4 процента.

5. Снижение налоговой нагрузки отмечается и по предприятиям питания, гостиницам $(0,4$ процента), строительным организациям (0,8 процента), где традиционно преобладает малое предпринимательство.

6. Структура налоговой нагрузки изменилась после реформирования, прежде всего, в связи с введением налога с продаж. Высока доля в налоговой нагрузке практически всех отраслей экономики также и НДС (на внутреннюю продукцию). Доли налога на прибыль и подоходного налога меняются значительно по отдельным секторам экономики, изменения по ним вызваны не переменами в схеме налогообложения, а исключительно усилением налогового администрирования, предусмотренного новой редакцией Налогового кодекса.

7. При определении путей дальнейшего реформирования следует исходить из выявленного неравномерного распределения налоговой нагрузки, перераспределения её на сферу торговли и услуг, на предприятия обрабатывающей промышленности, кроме предприятий по переработке сельскохозяйственной продукции.

8. Развитие налогообложения должно сопровождаться ростом налогового потенциала соответствующих отраслей экономики, что не может быть обеспечено без сбалансированности налоговой нагрузки и отраслевой структуры ВДС.

9. Реформирование налоговой системы может идти по пути гармонизации соотношения прямых и косвенных налогов (например, через аннулирование нового оборотного налога - налога с продаж с одновременным повышением ставки НДС), введения прогрессивного налогообложения по прямым 
налогам (предусматривающего элемент сверхдоходности и расслоение общества), пересмотра налоговых преференций, условий и методов их предоставления, перечня облагаемых и освобождённых поставок, а также принципов определения подакцизных товаров.

10. Конкретизация путей совершенствования налогообложения и поиск повышения эффективности фискальной политики в Кыргызской Республике требует проведения дополнительного анализа структуры ВДС и ВВП по видам доходов.

\section{Литература}

- $\quad$ Фынчина Х.А. «Методологические приёмы к содержанию и методике определения налогового бремени», Вестник КЭУ. 2008а. №3. С. 186-192.

- Fynchina Kh. «Tax Burden of Economic Sectors in Kyrgyz Republic», Sosio ekonomi: yil: 4 sayi: 8|2008б2 KDV Dahil Fiyati: 5 YTL. S. 179-187.

- Фынчина Х.А. «Количественная оценка уровня налогового бремени в экономике Кыргызской Республики», Вестник КазЭУ. 2007, №4. С. 287-291.

- Шаталов С.Д. «Развитие российской налоговой системы», Финансы. 2011, №2. С. 4.

- Сайфиева С.Н. «Российская система налогообложения: взгляд изнутри», Вопросы экономики.2012, №2. С. 117.

- Сайфиева С.Н. «Методика расчёта и эффективность отраслевой налоговой нагрузки в 2000-2008 гг., Финансы. 2010а, №12. С. 40-46.

- Сайфиева С.Н. «Налоговая нагрузка на ключевые секторы российской экономики в 2000-2008 гг.»Финансы. 2010б, №8. С. 37.

- Ш. Доу, «Математика в экономической теории: исторический и методологический анализ», Вопросы экономики.2006, №7. С. 63.

- Статистические сборники: Система национальных счетов Кыргызской Республики 2005-2011 гг.

- Данные Государственной налоговой службы при Правительстве Кыргызской Республики. 


\title{
О влиянии интеграционных процессов на агарный рынок Казахстана
}

\section{The effect of integration processes on agricultural market of Kazakhstan}

\author{
Prof. Dr. Gani Kaliev (Academy of Agricultural Sciences, Kazakhstan) \\ Ph.D. Candidate Nikitina Galina (Kazakh Scientific Research Institute, \\ Kazakhstan)
}

\begin{abstract}
In the article the authors describe the process of interstate integrat on and show the changes it causes in the agro-food market in Kazakhstan. It is noted that current situation of national food market is unstable, the market is out of balance, that causes price increase in all phases of product movement. The authors also examine the changes of the external trade flows, which clearly defined the growth of imports from the Customs Union countries, which effect is increasing by many kinds of raw materials and food products. The demand is not provided by the domestic commodity producers, in particular on industrial products, as well as existing high wholesale and retail prices in the domestic market, promote the increase its attractiveness and growth of imports. Russian Federation is the main trading partner. The role of Belarus is seen on meat-milk and sugar markets. But the trade balance with both countries on major goods is negative. The surplus is preserved only on grain, vegetables and fruits. As a result, relative balance of supply and demand on food market in Kazakhstan is largely supported by the import of food products, and first of all, industrial products. Current changes are mainly formed under the influence of internal factors, however, and the integration processes affect the status of national market.
\end{abstract}

\section{1 Введение}

Для Казахстана построение интеграционных объединений имеет особое значение, поскольку его участие в международной экономической интеграции является условием обеспечения высокого экономического роста, вхождения его в мировое сообщество в качестве полноправного члена. Республика Казахстан является одним из первых лидеров и активным последовательным организатором интеграционных процессов на постсоветском пространстве. Согласно ранее звучащим заявлениям казахстанских политиков, ни одна из стран нынешнего мира не может существовать обособлено, а потому интеграционные процессы являются жизненно необходимыми. Вместе с тем, власти Казахстана вполне осознают поджидающие нас на интеграционном пути риски. Поэтому во избежание негативных моментов и необходимы четко продуманные и наперед просчитанные ходы.

Особую важность исследованиям процессов интеграции придает тот факт, что в центре внимания оказываются такие существенные проблемы как обеспечение устойчивости развития важнейшей отрасли экономики интегрирующийся стран - аграрной. Выявление положительных процессов, с точки зрения их способности решить данные проблемы, так и отрицательных - усиливающих зависимость от импортных поступлений. Интенсивная интеграция в рамках Единого экономического пространства является наиболее перспективной тенденцией в современный период. Президент Республики Казахстан Н.А. Назарбаев в своем очередном ежегодном послании народу отметил: «Таможенный союз - очень прагматичный проект, решающий экономические задачи наших стран. Единое экономическое пространство (ЕЭП) открывает огромный рынок сбыта для казахстанского бизнеса» (Назарбаев Н.А., 2011).

Поскольку процесс интеграции в межгосударственные объединения изменяет конкурентную среду на товарных рынках и в первую очередь на продовольственном, то дифференциация стран по природным и экономическим условиям производства продовольствия, а также по величине и структуре потребительского спроса на него диктует различные требования к аграрному сектору производства, оказывая при этом различное влияние его развитие.

\section{2 Основы формирования Единого экономического пространства}

ЕЭП формируется постепенно и поэтапно с учетом основных принципов и правил ВТО, что означает постепенное повышение уровня интеграции, через синхронизацию осуществляемых сторонами преобразований в экономике, совместных мер по проведению согласованной экономической политики, гармонизацию и унификацию законодательства в сфере экономики, торговли и по другим направлениям, 
с учетом общепризнанных норм и принципов международного права, а также опыта и законодательства Европейского союза.

Ввиду множественности различий в уровнях экономического и социального развития, а также в степени единообразия действующего в государствах национального законодательства, формирование Единого экономического пространства происходит в соответствии с заявленными принципами разноуровневой и разноскоростной интеграции, что означает свободу определения государством направления развития интеграции и интеграционных мероприятий, в которых оно будет принимать участие, а также объем такого участия (Соглашение о формировании ЕЭП, 2006).

Основа перехода государств к Единому экономическому пространству условно заложена в едином перечне международных соглашений, устанавливающих основные единые принципы и нормы регулирования интегрируемых сфер экономической жизни. Унификация нормативно-правовой базы, отвечающей национальным интересам каждого государства-участника ЕЭП, является обязательным условием эффективного формирования и развития этого межгосударственного объединения. Поскольку противоречия между странами-участниками могут возникнуть из-за различной направленности политических и экономических интересов суверенных государств. Особое место занимают модельные акты, которые разрабатываются в целях создания единого правового пространства, сближения законодательных решений его государств-участников по наиболее важным, принципиальным вопросам, требующим унификации правового регулирования, устранения противоречий и расхождений.

Использование понятия «согласованная политика» демонстрирует сложность и неготовность в настоящий момент осуществить переход к единой налоговой, денежно-кредитной и валютно-финансовой политике, что совершенно определенно дает нам право говорить о наличии определенных этапов более глубокой интеграции уже на стадии формирования Единого экономического пространства. Поэтому принятые соглашения, касающиеся сферы экономической политики, предусматривают поэтапное введение в действие их положений. Временной период становления межгосударственной экономической организации вроде ЕЭП, по мнению экспертов, исчисляется от 6 до 10 лет (Шибутов М., 2012). В итоге получается, что окончательное формирование ЕЭП произойдет только к 2020 году. Поскольку для развития всей нормативной базы по ЕЭП должны быть еще разработаны почти 70 новых соглашений.

В настоящее время проявляется двойственный характер влияния ЕЭП на аграрный сектор Казахстана. С одной стороны, расширяется поле конкуренции и конкурентная среда, что даст импульс отечественным предприятиям для повышения конкурентоспособности, и, в конечном счете, расширения рынка сбыта своей продукции. С другой стороны, единый экономический режим функционирования производства приведет к усилению присутствия на национальном рынке российской и белоруской продукции, то есть создаст угрозу для поддержания продовольственной безопасности.

Для нашей республики актуальное значение имеет диверсификация и создание совместных производств - это дополнительные рабочие места, технологии, инвестиции. ЕЭП развило и углубило тенденцию на сближение экономик. Начался переток капиталов, а с ними и рабочей силы.

ЕЭП формируется с учетом основных принципов и правил ВТО, что означает постепенное повышение уровня интеграции, через синхронизацию осуществляемых сторонами преобразований в экономике, совместных мер по проведению согласованной экономической политики, гармонизацию и унификацию законодательства в сфере экономики, торговли и по другим направлениям, с учетом общепризнанных норм и принципов международного права, а также опыта и законодательства Европейского союза.

\section{3 Оценка состояния аграрного сектора и рынков Казахстана}

Социально-экономическое положение казахстанского аграрного сектора при осуществлении широкой государственной поддержки проявляет темпы роста. Объем валовой продукции сельского хозяйства за последние 10 лет вырос в 4,2 раза (в 2011 г. по сравнению с 2001 г.). При этом значительное влияние оказало повышение цен (в 2,8 раза), поэтому индекс физического объема валовой продукции за это время составил только 1,4 раза, что опережает рост численности населения республики.

Посевная площадь сельскохозяйственных культур увеличилась на $31 \%$. Основу ее занимают зерновые культуры - 77\%, и в первую очередь пшеница (65\%). Следует отметить, что в 2010-2012 гг. посевы зерновых несколько сократилась (на 6\%) за счет пшеницы, ячменя, овса.

Валовой сбор зерновых культур в 2011 г. достиг 26,9 млн, но в 2012 г. отмечалась сильная засуха и производство продукции растениеводства было низким - зерна 12,9 млн тонн. Тем не менее, с учетом переходящих запасов зерна, которые на 01.01.12 г. составили 20,7 млн, в том числе продовольственного зерна - 17,4 млн тонн, данные объемы позволили обеспечить внутренние потребности страны и экспортный потенциал порядка 7,8 млн. тонн (в основном реализовывалась продукция предыдущего года). В русле диверсификации производства в последние годы значительно расширяется производство 
масличных культур - в 5,5 раза, что повысило самообеспеченность республики растительным маслом (Сельское, лесное и рыбное хозяйство в Республике Казахстан, 2012).

Темпы роста производства продукции растениеводства достаточно высоки. Однако ясно видна и значительная колеблемость урожаев в зависимости от погодных условий, что снижает устойчивость предложения продукции на рынок. Вместе с тем в структуре посевов все еще не достаточно зернофуражных и крупяных культур, сахарной свеклы, сокращаются площади и производство кормовых культур, снижается производство и фруктов.

Более устойчиво предложение животноводческой продукции, которое обеспечивается в основном ростом поголовья - за последние десять лет в 1,6 раза. Наибольшие темпы отмечаются в овцеводстве и птицеводстве. Следует отметить, что проведенное МСХ РК в 2011-2012 гг. переучет поголовья отдельных видов скота, показал, что их численность в хозяйствах населения преувеличена. В итоге поголовье КРС сократилось на 7,7\%, свиней- 10,4\%. Это привело к замедлению темпов предложения продукции животноводства на рынок.

Несмотря на все проблемы, производство большинства видов сельскохозяйственной продукции в расчете на душу населения в Казахстане наращивается (таблица 1).

Как видим, уровни среднедушевого производства в Казахстане превышают аналогичный показатель Беларуси и России по продовольственному зерну (даже в условиях жесткой засухи). Российский уровень превышен по овощам, мясу, молоку, но значительно ниже по большинству продуктов белорусских показателей. Производя в 2 раза больше зерна, чем в РБ, наша республика производит, практически в 1,5 раза меньше продукции животноводства в расчете на душу населения. Это позволяет говорить о возможном наращивании присутствия белорусской продукции на нашем рынке.

\begin{tabular}{|l|l|l|l|l|l|l|}
\hline \multirow{2}{*}{ Продукция } & \multicolumn{2}{l|}{ Казахстан } & \multicolumn{2}{l|}{ Справочно (2011 г.) } \\
\cline { 2 - 6 } & 2000 г. & 2005 г. & 2011 г. & 2012 г. & Беларусь & Россия \\
\hline Зерно & 777 & 910 & 1638 & 775 & 886 & 657 \\
в т.ч. продовольственное & 634 & 843 & 1410 & 624 & 343 & 489 \\
Картофель & 114 & 116 & 188 & 188 & 812 & 228 \\
Овощи & 104 & 142 & 177 & 180 & 211 & 103 \\
Сахарная свекла & 18 & 20 & 12 & 9 & 475 & 290 \\
Мясо & 43 & 51 & 57 & 56 & 87 & 43 \\
Молоко & 251 & 314 & 315 & 289 & 690 & 222 \\
Яйцо (шт.) & 114 & 166 & 225 & 219 & 380 & 287 \\
\hline
\end{tabular}

Таблица 1 - Производство сельскохозяйственной продукичи в Казахстане, кг на душу населения

\section{(рассчитано по данным Казахстан и страны СНГ, 2013)}

По продукции пищевой промышленности сохраняются недостаточные объемы переработки сельскохозяйственного сырья - перерабатывается мяса - 26\%, молока - 35\%, пшеницы - 39\%, овощей $2 \%$. Поэтому мощности перерабатывающих предприятий используются не рационально, сложился низкий коэффициент их использования (мукомольные заводы - 41,4\%, крупяные заводы - 30,8, молочные и мясные предприятия - 29-49\%). Это приводит к недостаточной выработке продовольствия, уровень которого значительно ниже, чем в других странах Таможенного союза. Явное преимущество имеется по производству муки и макаронных изделий.

В итоге процесс интеграции в межгосударственные объединения изменяет конкурентную среду на товарных рынках и влияет на развитие продовольственного рынка (таблица 2).

\begin{tabular}{|l|l|}
\hline $\begin{array}{l}\text { Позитивные факторы } \\
\text { возможности) }\end{array}$ & $\begin{array}{l}\text { Негативные факторы } \\
\text { (ограничители) }\end{array}$ \\
\hline $\begin{array}{l}\text { Рост численности населения } \\
\text { республики }\end{array}$ & $\begin{array}{l}\text { Потребление продовольствия ниже научно обоснованных } \\
\text { норм }\end{array}$ \\
\hline $\begin{array}{l}\text { Рост номинальных денежных } \\
\text { доходов населения }\end{array}$ & $\begin{array}{l}\text { Энергетическая и пищевая ценность потребляемого набора } \\
\text { продуктов ниже нормативного уровня }\end{array}$ \\
\hline $\begin{array}{l}\text { Увеличение покупательной } \\
\text { способности населения }\end{array}$ & $\begin{array}{l}\text { Рост цен на факторы производства и дефицит } \\
\text { инвестиционных ресурсов в сфере производства } \\
\text { продовольствия }\end{array}$ \\
\hline $\begin{array}{l}\text { Увеличение потребления основных } \\
\text { продуктов питания }\end{array}$ & $\begin{array}{l}\text { Индекс цен на продовольствие промышленной выработки } \\
\text { по-прежнему опережает рост цен на } \\
\text { сельскохозяйственную продукцию }\end{array}$ \\
\hline $\begin{array}{l}\text { Высокая емкость рынка, расширение } \\
\text { спроса, в том числе } \\
\text { производственного характера }\end{array}$ & $\begin{array}{l}\text { Высокий удельный вес мелкотоварного и } \\
\text { низкоэффективного сектора хозяйствования, низкий } \\
\text { уровень товарности сельскохозяйственной продукции, }\end{array}$ \\
\hline
\end{tabular}




\begin{tabular}{|l|l|}
\hline & (исключая зерно) \\
\hline $\begin{array}{l}\text { Рост цен на мировых рынках } \\
\text { повышает конкурентоспособность } \\
\text { отечественной продукции }\end{array}$ & $\begin{array}{l}\text { Низкий уровень загрузки перерабатывающих предприятий } \\
\text { и узкий ассортимент выпускаемой продукции }\end{array}$ \\
\hline $\begin{array}{l}\text { Отсутствие ограничений по размерам } \\
\text { сельхозугодий, что дает }\end{array}$ & $\begin{array}{l}\text { Недостаточная конкурентоспособность отечественного } \\
\text { продовольствия }\end{array}$ \\
\cline { 2 - 2 } роста спроса на продовольствие & $\begin{array}{l}\text { Недопустимо высокий объем импорта мяса птицы, мясо- } \\
\text { молочных продуктов, сахара, растительного масла, } \\
\text { фруктов, овощей и продуктов их переработки }\end{array}$ \\
\hline
\end{tabular}

Таблица 2 - Позитивные и негативные факторы развития агропродовольственного рынка Казахстана

Таким образом, усиливается влияние внешних факторов на обеспечение продовольственной безопасности Казахстана и продовольствие становиться основной в международных отношениях. В конечном счете, состояние продовольственной безопасности определяется сочетанием, взаимным влиянием внутренних и внешних факторов. И если в целом продовольственная безопасность в 2012 г. была обеспечена на 67\% (Показатели государственной программы по индустриально-инновационному развитию, 2012), то степень самообеспеченности по различным продуктам существенно меняется.

\section{4 Основные торговые взаимоотношения со странами ЕЭП}

Сложившиеся на продовольственном рынке Казахстана относительное равновесие спроса и предложения во многом поддерживается импортом продуктов питания. Сальдо торгового баланса складывается отрицательное - 2 млрд. долл. При этом значительными темпами наращивается импорт продовольствия из стран ЕЭП (рисунок 1).

В целом в структуре импорта преобладает продукция глубокой переработки, отмечается чрезмерное давление на национальный рынок импорта белого сахара, при этом отечественное производство продолжает сокращаться - с 384 тыс. до 271 тыс. т за последние три года (Экспорт и импорт Республики Казахстан в разрезе товар-страна, 2009, 2010, 2011, 2012).

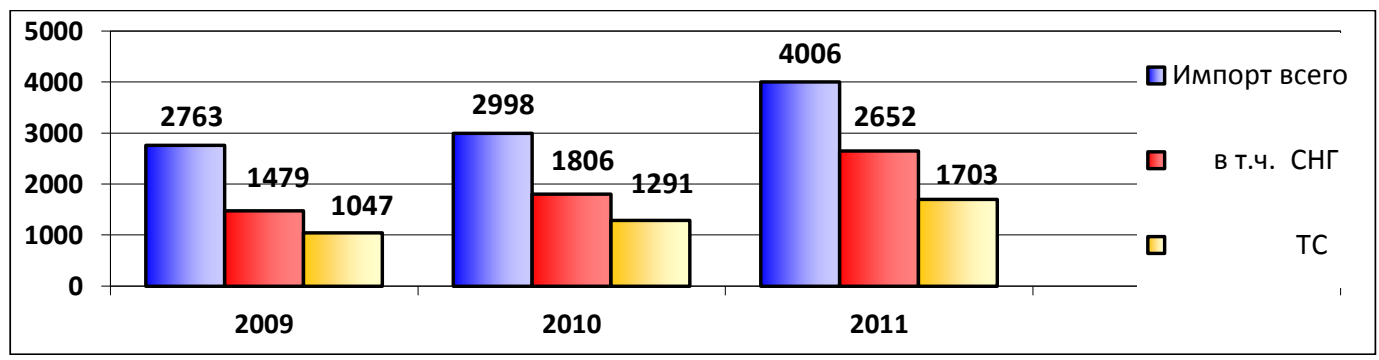

Рисунок 1 - Импорт продовольствия и сельскохозяйственного сырья в Казахстан, млн. долл.

Растет импорт растительного масла, и в первую очередь, подсолнечного, не смотря на принимаемые меры по развитию производства масличных культур и их переработки. Тем не менее, спрос на эту продукцию превышает отечественное предложение. Ввоз растительного масла в страну обусловлен рядом причин. Во-первых, недостаточной самообеспеченностью товаром внутреннего рынка из-за недостаточно эффективного использования отечественного сырья, и в частности, семян хлопка, сафлора.

Особое значение на нашем рынке имеет консервированная импортная продукция (овощные, фруктовые, мясные консервы), импорт которых за 2009-2012 гг. значительно вырос.

Более высокий удельный вес занимает импорт молочной продукции . В его ассортименте превалирует молоко и сливки сгущенные и не сгущенные, а также сыры, сливочное масло и молочные жиры. Импорт сухого молока, сгущенных и не сгущенных молочных продуктов растет высокими темпами. При этом следует отметить, что импорт из стран Таможенного союза сливочного масла сократился, что связано с падением спроса на эту продукцию в республике. Кроме того, значителен ввоз пахты, йогурта, кефира и прочей продукции.

Основным торговым партнером является Российская Федерация. Роль Беларуси проявляется на мясомолочном и сахарном рынках. Но при этом сальдо торговли с обеими странами складывается отрицательное. Положительное сальдо сохраняется только по зерну, овощам и фруктам (рисунок 2). 


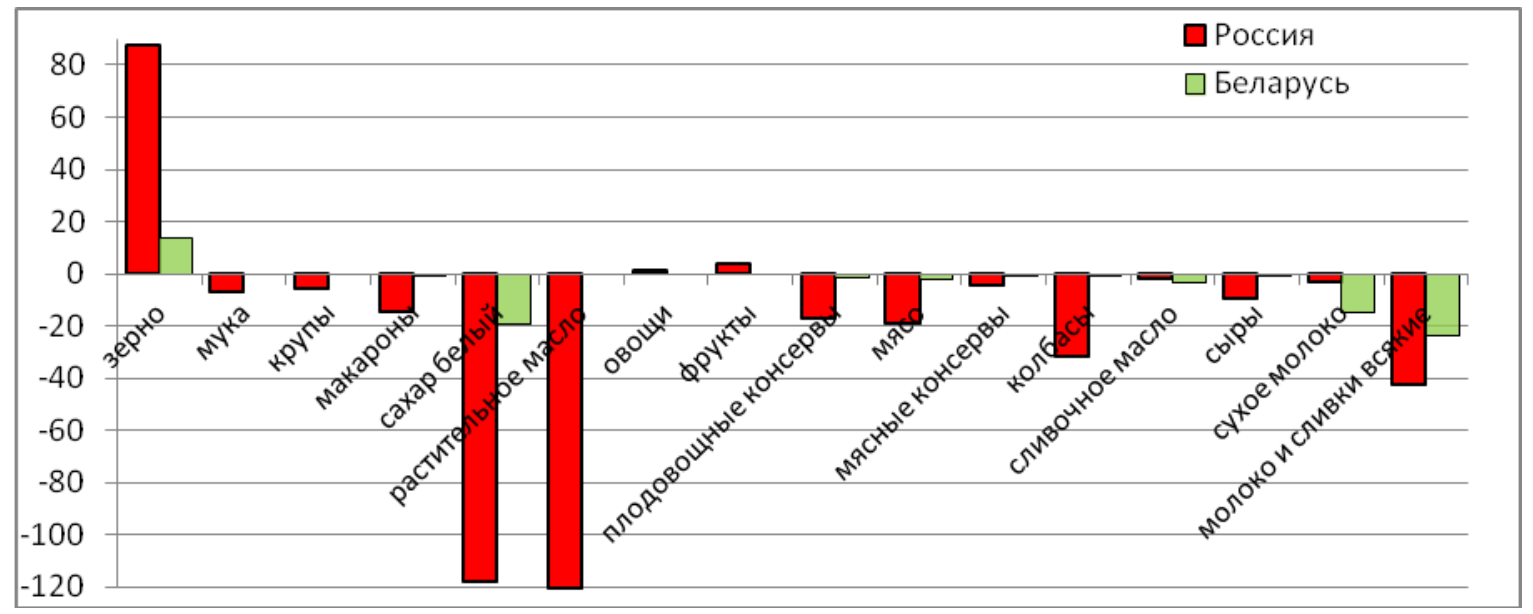

Рисунок 2 - Сальдо торговли агропромышленной продукичей с Россией и Беларусью (2011 г.), тысс. тонн

\section{5 Оценка факторов влияния интеграционных процессов на развитие агропродовольственного рынка Казахстана}

На рынке мяса птицы согласно общемировой тенденции, а также вследствие более низких цен, происходит изменение потребительских предпочтений, в сторону увеличения потребления белого мяса птицы. За период 2010-2012 гг. потребление мяса птицы на душу населения возросло на 35\%, достигнув величины 16 кг, тогда как потребительский спрос на красное мясо понизился на 7\%. В 2012 г. розничная цена 1 кг мяса птицы на рынках республики была ниже говядины на 52\%, свинины - 37,8, баранины $50 \%$.

Важным фактором, влияющим на устойчивость спроса на мясо птицы, является конкурентоспособность отечественного товара, которая в последние годы по отношению к импортируемому из стран ТС товару, повышается. Так, если в 2009 г. индекс конкурентоспособности составлял 0,62, то в 2012 г. уже 1,03. Это следствие снижения стоимости отечественного товара на 20\%, при одновременном увеличении стоимости импортируемого товара (на 28,5\%). То есть, на внутреннем рынке по стоимости казахстанский товар становится конкурентным российскому, белорусскому.

Однако ориентация на импортную продукцию из стран ЕЭП вызывает снижение прибыли отечественного товаропроизводителя и его мотивации к ведению расширенного воспроизводства, и, следовательно, к насыщению рынка конкурентоспособным по цене и качеству товаром.

Не обеспеченный отечественным товаропроизводителем высокий спрос на мясо птицы, а также сложившиеся более высокие оптовые и розничные цены на внутреннем рынке, способствуют усилению его привлекательности и росту импорта. Резюмируя вышесказанное можно отметить, что на рынке мяса птицы сложилась ситуация, во многом зависящая от импорта (таблица 3).

\begin{tabular}{|c|c|c|}
\hline \multirow[t]{2}{*}{ Характеристика } & \multicolumn{2}{|l|}{ Внешние факторы } \\
\hline & позитивные & негативные \\
\hline $\begin{array}{l}\text { Рост спроса, } \\
\text { сопровождающийся } \\
\text { низкой насыщенностью } \\
\text { отечественным товаром } \\
\text { (на } 54 \% \text { ), ростом } \\
\text { импорта, в том числе и } \\
\text { из стран ТС и } \\
\text { повышением оптовых и } \\
\text { розничных цен }\end{array}$ & $\begin{array}{l}\text { физическое насыщение рынка } \\
\text { продукцией, позволяющее } \\
\text { удовлетворить спрос, согласно } \\
\text { изменению потребительских } \\
\text { предпочтений; } \\
\text { более высокое качество товара, } \\
\text { поставляемого из стран ТС; } \\
\text { рост конкуренции и } \\
\text { привлекательности продукта, } \\
\text { вызвавшие повышение } \\
\text { конкурентоспособности } \\
\text { отечественного товара }\end{array}$ & $\begin{array}{l}\text { чрезмерное давление на } \\
\text { отечественного } \\
\text { товаропроизводителя, имеющего } \\
\text { высокую локальную концентрацию } \\
\text { производства при неразвитой } \\
\text { логистической связи, сдерживает } \\
\text { развитие отечественного } \\
\text { производства; } \\
\text { более высокое качество продукции } \\
\text { из стран ТС, вызывает } \\
\text { переориентацию спроса, снижает } \\
\text { емкость рынка для отечественной } \\
\text { продукции и доходность } \\
\text { производства }\end{array}$ \\
\hline
\end{tabular}

Таблица 3-Характеристика самообеспеченности мясом птищы и влияние внешних факторов на ее состояние 
Факторы, определившие высокую импортную зависимость рынка колбасных изделий в основном характеризуются, низкой насыщенностью отечественным товаром, ростом розничных цен и стабилизацией потребительского спроса. То есть имеют внутреннее происхождение, связанные с сосредоточением производства мяса преимущественно в мелкотоварных хозяйствах населения, не создающих товарных партий качественного сырья для промышленной переработки, не применяющих передовые технологии содержания скота. В итоге за период 2009-2011 гг. цены на говядину повысились на $23,2 \%$, на конину на $21 \%$, на свинину снизились на 7,3\%, а на колбасы вареные на $33,5 \%$, на варенокопченые на $58,4 \%$.

Это при низкой платежеспособности основной части населения республики сдерживает спрос на отечественную продукцию и диктует необходимость сокращения производства, которое снизилось на $10 \%$.

Ввоз же более дешевых колбас из России - ниже отпускной цены отечественных предприятийпроизводителей на $62,6 \%$, позволил ее товаропроизводителям занять лидирующее место на национальном рынке - доля ее товара в емкости внутреннего рынка достигла 45,4\%. Ее конкурентные ценовые преимущества обусловлены производством колбас с преимущественным использованием более дешевого мороженого импортного сырья.

Спрос на сливочное масло снижается. Поскольку высокая закупочная цена коровьего молока (за последние три года она повысилась на 47,9\%) сдерживает выработку животного масла и провоцирует производство спредов, то есть масла на основе растительных жиров. Цены на эту продукцию не отражают качественные характеристики товара, поскольку сложившаяся потребительская цена в размере 1240 тенге за 1 кг не отвечает по качеству натуральному сливочному маслу.

Кроме внутренних факторов на ситуацию на рынке оказывают влияние и внешние факторы. Более низкая цена импортируемого из стран ТС товара позволяет завоевывать значительную долю национального рынка. В 2011 году ее величина составляла 4328,5 долл. за тонну, что ниже отпускной цены отечественного товаропроизводителя на $17,8 \%$, в том числе из России на $32,7 \%$. Весомая доля продукции из стран Таможенного союза занимает в емкости рынка 23,1\%, в том числе товара из Беларуси $15 \%$, а из России $8,3 \%$.

При этом явно выражены конкурентные преимущества белорусского сливочного масла. Из России же преимущественно импортируются спреды, по цене 3483,2 долл. за тонну. Так как отпускная цена российских предприятий-производителей сливочного масла составляет 6585 долл. за тонну или выше стоимости экспортируемого в Казахстан товара в 1,9 раза.

Следовательно, самообеспеченность спроса на сливочное масло низка (66\%) и находится под высоким влиянием внешних факторов (таблица 4).

\begin{tabular}{|c|c|c|}
\hline \multirow{2}{*}{ Характеристика } & \multicolumn{2}{|l|}{ Внешние факторы } \\
\hline & позитивные & негативные \\
\hline \multicolumn{3}{|l|}{ Сливочное масло } \\
\hline $\begin{array}{l}\text { При снижении спроса, } \\
\text { отмечается } \\
\text { сокращение } \\
\text { отечественного и } \\
\text { импортного } \\
\text { предложения, } \\
\text { замещение натуральной } \\
\text { продукции спредами и } \\
\text { рост розничных цен }\end{array}$ & $\begin{array}{l}\text { более высокая ценовая } \\
\text { конкурентоспособность товара } \\
\text { импортируемого из стран } \\
\text { Таможенного союза, позволяет } \\
\text { сдерживать падение спроса; } \\
\text { усиление конкурентной } \\
\text { борьбы, создающей импульс } \\
\text { для совершенствования } \\
\text { отечественного производства }\end{array}$ & $\begin{array}{l}\text { поставка спредов как сливочного } \\
\text { масла; } \\
\text { высокие цены на не натуральную } \\
\text { продукцию не соответствующие } \\
\text { его качеству; } \\
\text { несовершенство системы } \\
\text { ценообразования на импортную } \\
\text { продукцию, что не позволяет } \\
\text { малообеспеченным слоям } \\
\text { населения удовлетворить спрос } \\
\text { хотя бы на не натуральную } \\
\text { продукцию }\end{array}$ \\
\hline \multicolumn{3}{|l|}{ Сыры } \\
\hline $\begin{array}{l}\text { Увеличение } \\
\text { самообеспеченности, } \\
\text { вызванное } \\
\text { стабилизацией спроса } \\
\text { на основе роста цен, а } \\
\text { также отечественного } \\
\text { предложения } \\
\text { продукции }\end{array}$ & $\begin{array}{l}\text { поставки более } \\
\text { конкурентоспособного } \\
\text { импортного товара, } \\
\text { позволяющего обеспечить } \\
\text { физическую насыщенность } \\
\text { рынка; } \\
\text { высокие потребительские } \\
\text { качества импортного сыра, } \\
\text { приводят к переориентации } \\
\text { спроса }\end{array}$ & $\begin{array}{l}\text { ввоз сырного продукта из России, } \\
\text { изготовленного с использованием } \\
\text { растительного масла; } \\
\text { несовершенство системы } \\
\text { ценообразования, не } \\
\text { соответствующей принципу цена : } \\
\text { качество }\end{array}$ \\
\hline
\end{tabular}


Таблица 4 - Характеристика самообеспеченности молочной продукцией и влияние внешних факторов на ее состояние

Стабилизация спроса отмечается на различные сыры, при этом ситуация с самообеспеченностью растет, так как увеличивается отечественное предложение (отмечается рост производства невыдержанных и плавленых сыров) при стабилизации импорта из стран Таможенного союза. При этом цены на продукцию повышаются, что и является основным фактором снижения спроса - так цена предприятий-производителей сыра повысилась на 25,5\%, оптовая цена увеличилась на 25,9\%, а розничная поднялась на $22,4 \%$, что вызвано недостаточным предложением товарных партий сыропригодного молока и ростом издержек.

В итоге сыры, импортируемые из стран ТС, дешевле отпускной цены отечественных товаропроизводителей на $36,1 \%$. Однако средняя отпускная цена сычужного сыра выработанного на российских предприятиях достигает 6156 долл. за тонну или выше стоимости поступающего на казахстанский рынок продукта на 38,5\%. Такое не соответствие связано с более низкой закупочной ценой молока в отдельных регионах России, а также осуществлением ввоза сырного продукта, изготовляемого с добавлением растительного масла. В итоге доля ТС в емкости внутреннего рынка достигла 20,3\%, что указывает на высокие конкурентные преимущества данного товара, выраженные в более высоком качестве, а по стоимости их товар дешевле отечественного.

В настоящее время Россия претендент на занятие существенной ниши на казахстанском рынке сыров. Однако развитие конкурентной борьбы - важный фактор, влияющий на ситуацию рынка и дающий импульс развитию отечественного производства.

Низкий уровень обеспечения спроса внутренним производством сложился по плодоовощной консервированной продукции. Серьезным фактором, влияющим на изменение ситуации в отечественном овощеводстве, является ценообразование на внутреннем потребительском рынке, на что в свою очередь существенное влияние оказывает организация логистики и импортные поставки - так среднегодовые темпы прироста средней цены реализации снизилась на капусту с 24,0 до 13,6\%, на помидоры с 31,2 до $16,7 \%$, на морковь с 39,2 до 10,8\%, а отечественное производство свежих овощей увеличилось на $17,1 \%$. В итоге спрос на рынке овощей и продукции их переработки имеет тенденцию роста.

При этом следует отметить, что свежих овощей из Таможенного союза поступает не много (22 тыс. т), но эти страны играют значительную роль на рынке консервированных овощей, импорт которых за последние три года вырос в 1,3 раза. Основным поставщиком является Россия. Значительные объемы импорта консервированной продукции являются следствием состояния отечественной промышленности, которая на фоне низкой товарности и высокой сезонности производства сырья, отсутствия необходимых для переработки сортов находится на низком уровне, вырабатывая всего по 0,5 кг на жителя республики в год.

Отсутствие надежных каналов реализации овощей приводит к экономически необоснованным ценам на сырье и значительно удорожает готовую продукцию, снижая ее конкурентоспособность. Функционирование консервных предприятий осложняется и не отрегулированностью экономических отношений между отраслями. В результате в межсезонный период спрос удовлетворяется за счет импорта. Только продукция ТС занимает в емкости национального рынка более $16 \%$.

Подобное можно отнести и к фруктовым консервам, джемам, варенью, производство которых в республике чрезвычайно низкое - 0,04 кг. Имеющийся спрос населения зависит от импорта этой продукции. Из стран Таможенного союза поступает значительное количество фруктовых консервов, занимающих в емкости казахстанского рынка 53\% (таблица 5).

\begin{tabular}{|l|l|l|}
\hline \multirow{2}{*}{ Характеристика } & Внешние факторы \\
\cline { 2 - 3 } & позитивные & негативные \\
\hline Дефицит отечественного & оптимальное & высокая ценовая \\
обозводства, не & соотношение цены и & конкурентоспособность и \\
спрос населения на & качества импортного & значительные объемы импорта \\
консервированные овощи и & товара, формирует & консервированной продукции, \\
фрукты, что вызывает рост & вовышение спроса & особенно фруктовой, является \\
цен & & одним из условий сдерживания \\
& & развития отечественного \\
& & производства; \\
& & при высоких качественных \\
& & характеристиках импорта \\
& &
\end{tabular}


Таблица 5 - Характеристика самообеспеченности плодоовощчной консервной продукцией и влияние внешних факторов на ее состояние

Одной из причин низкого развития выработки фруктовых консервов, является отсутствие положительных тенденций в развитии садоводства и чрезвычайно низкая самообеспеченность фруктами - за последние три года наблюдаем значительное снижение доли отечественной продукции в насыщении внутреннего рынка, которая в 2011 г. составила всего 37,0\%.

При этом отмечаем усиление интеграционных связей Казахстана со странами ТС. В 2011 г. на национальный рынок из стран Таможенного союза поступило 18,1 тыс. тонн фруктов, против 1,5 тыс. тонн в 2009 г. Вся продукция завозится из России.

Тем не менее, значительной роли эти связи, так же как и на рынке свежих овощей не играют, поскольку основная масса импортных фруктов поступает из Центрально азиатских стран и Китая.

Однако учитывая состояние садоводства в Казахстане, можно предположить, что импорт его продукции будет наращиваться, в том числе и отдельных видов - из Таможенного союза.

Серьезная ситуация складывается по обеспеченности республики сахаром. Весомое влияние на изменение соответствия спроса и отечественного предложения, в сторону значительного увеличения зависимости внутреннего рынка оказал высокий рост цен на мировом рынке на сахар-сырец. В 2011 году по отношению к 2009 году цена за 1т импортируемого в республику тростникового сахара-сырца повысилась на $56 \%$, что вызвало резкий рост цены отечественных производителей белого сахара (на $60,1 \%)$.

Кроме того, выросли объемы поступления более конкурентоспособного сахара-песка из России и Беларуси. Коэффициент соотношения цены белого сахара отечественного товаропроизводителя к российскому товару составил 1,39 и белорусскому 1,31. Доля импорта белого сахара из России в потреблении достигла $31,5 \%$, а из Беларуси только 4,3\%, то есть их влияние на рынок принимает чрезвычайный характер (таблица 6).

\begin{tabular}{|c|c|c|}
\hline \multirow[t]{2}{*}{ Характеристика } & \multicolumn{2}{|l|}{ Внешние факторы } \\
\hline & позитивные & негативные \\
\hline \multicolumn{3}{|l|}{ Белый сахар } \\
\hline $\begin{array}{l}\text { Значительные } \\
\text { диспропорции } \\
\text { спроса и } \\
\text { предложения } \\
\text { отечественного } \\
\text { товара }\end{array}$ & $\begin{array}{l}\text { высокие объемы импорта } \\
\text { белого сахара из стран ТС, } \\
\text { обеспечили физическое } \\
\text { насыщение рынка; } \\
\text { низкие цены на импортный } \\
\text { белый сахар, позволили } \\
\text { сохранить экономическую } \\
\text { доступность товара }\end{array}$ & $\begin{array}{l}\text { рост цен на мировом рынке на } \\
\text { сахар-сырец, снижает } \\
\text { эффективность и } \\
\text { конкурентоспособность } \\
\text { отечественного сахара; } \\
\text { высокие объемы импорта } \\
\text { готового сахара, оказывают } \\
\text { понижающее действие на } \\
\text { отечественное производство }\end{array}$ \\
\hline \multicolumn{3}{|l|}{ Подсолнечное масло } \\
\hline $\begin{array}{l}\text { Высокий спрос на } \\
\text { подсолнечное масло } \\
\text { не в полной мере } \\
\text { удовлетворяется } \\
\text { отечественным } \\
\text { предложением, что } \\
\text { вызывает рост цен } \\
\text { на рынке }\end{array}$ & $\begin{array}{l}\text { высокая } \\
\text { конкурентоспособность } \\
\text { российского товара создает } \\
\text { импульс развитию } \\
\text { отечественного производства; } \\
\text { поставки дешевого импорта, } \\
\text { занимающие в емкости рынка } \\
\text { более } 38 \%, \text { сдерживают рост } \\
\text { цен отечественных } \\
\text { производителей, сохраняя } \\
\text { экономическую доступность } \\
\text { товара }\end{array}$ & $\begin{array}{l}\text { значительные объемы импорта } \\
\text { дешевого подсолнечного масла } \\
\text { не позволяют в полной мере } \\
\text { задействовать имеющиеся } \\
\text { мощности масложировой } \\
\text { промышленности }\end{array}$ \\
\hline
\end{tabular}

Таблиия 6 - Характеристика самообеспеченности сахаром бельм и подсолнечным маслом и влияние внешних факторов на ее состояние

В основе этого лежит высокий уровень эффективности сахара-песка вырабатываемого из свекловичного сырья, поскольку стоимость свекловичного сырья приобретенного перерабатывающими предприятиями составила 480,2 долл. за тонну, что значительно ниже (на 28,3\%) стоимости тростникового сахара-сырца, закупаемого казахстанскими заводами. В итоге полная себестоимость российского сахара-песка выработанного из свекловичного сырья в 2010 г. составила 737,2 долл. за 
тонну, что позволило экспортировать в Казахстан белый сахар по стоимости 799,6 долл. за тонну, обеспечив российским товаропроизводителям средний уровень рентабельности в размере $3,5 \%$.

В результате развития конкуренции, позиции казахстанских производителей снизились, поскольку наращивание ввоза белого сахара из РФ с 0,6 до 118 тыс. т, оказало снижающие влияние на цены, которые стали понижаться до 158 тенге за кг или на 77\% к уровню 2010 г. В итоге производство сахарапеска в республике сократилось на 23,9\%.

Определяющее влияние на устойчивость конъюнктуры национального рынка оказывают предложение семян масличных культур и цены, поскольку именно низкая урожайность подсолнечника в республике является основой высокой себестоимости и стоимости масличного сырья, вызывая тем самым повышение цены отечественного производителя подсолнечного масла. Например, за период 2009-2011 гг. при снижении урожайности подсолнечника на 19,3\% и росте затрат на возделывание 1 га посевов на 14,8\%, себестоимость 1 ц семян подсолнечника в сельхозформированиях увеличилась на 42,3\%, а цена их реализации возросла на 43,8\%. Цена выработанного не рафинированного подсолнечного масла на предприятиях республики повысилась на 41,0\%.

Отмечается и значительный разрыв между розничной ценой товара и оптовой, последняя в 1,6 раза выше.

Значительное влияние на удовлетворение спроса на подсолнечное масло оказывает рост поставок из России, объемы которых за последние три года выросли в 1,4 раза. При этом следует отметить, что российская продукция дешевле отечественной на 50,8\%, что и формирует на нее спрос.

\section{6 Заключение}

Таким образом, формирование Единого экономического пространства стран-участниц Таможенного союза оказывает двойственное влияние на агропродовольственный рынок Казахстана. И суммируя, все выше сказанное, следует отметить, что усиливающееся присутствие импорта на рынке молочной продукции, мяса птицы, колбасных изделий, сахара, плодоовощных консервов, подсолнечного масла приводит к отрицательному влиянию на развитие внутреннего производства и состояние продовольственной безопасности. Поскольку:

- проявилась невозможность защиты внутреннего рынка страны от конкуренции со стороны российских, белорусских товаров. Казахстан до последнего времени сдерживал импорт, прежде всего российских товаров на казахский рынок. В ЕЭП это делать невозможно;

- усиливающиеся влияние импортной продукции, решая проблему насыщения рынка, способствует стагнации отечественного производства. Значительные проблемы создаются в секторе обрабатывающей промышленности. Главная из них - низкая конкурентоспособность большинства ее отраслей и предприятий, устаревшее оборудование, не позволяющее производить продукцию в соответствии с международными стандартами;

- приход импортного продовольствия на внутренний рынок может ослабить позиции отечественных сельскохозяйственных производителей, а затем ускорить рост цен на продовольствие, что неблагоприятно скажется на доходах жителей и ухудшит ситуацию с экономической доступностью продовольствия;

- значительная доля импортируемой продукции по ценам ниже тех, которые обеспечивают прибыльность отечественных предприятий, приведет к сокращению производства, росту безработицы, уменьшению платежеспособного спроса населения;

- возможное выравнивание и рост цен на продовольствие в ЕЭП (хотя и при некотором сохранении их зональности) при низком платежеспособном спросе, сложившимся в республике и пределе ценовой нагрузки, приведет к его снижению, расширению малообеспеченных групп населения.

С другой стороны, импорт продукции, и в первую очередь, промышленной выработки, позволяет:

во-первых, повысить обеспечить физическую насыщенность дефицитных рынков, в первую очередь, продовольствием промышленной выработки;

во-вторых, стимулируется спрос на продовольствие, который отстает от научно обоснованных нормативов, за счет поставки более дешевой продукции;

в-третьих, формируется конкурентная среда, создающая импульсы для повышения конкурентоспособности отечественной продукции.

Следовательно, необходим поиск равновесия между положительными и деструктивными факторами влияния межгосударственной интеграции. В противном случае возможна потеря продовольственной независимости, и впоследствии вытеснить импорт с национального рынка будет практически невозможно. 


\section{Литература}

- Послание Президента Республики Казахстан Н.А. Назарбаева народу Казахстана, 2011, http:// www. akorda.kz

- $\quad$ Соглашение о формировании Единого экономического пространства, 2003 (включая изменения от 2006) - М. - 5 c.

- Шибутов М.,2012. Жизнь ЕЭП, или медленно и печально, http://www .vlast.kz

- Сельское, лесное и рыбное хозяйство в Республике Казахстан, 2012 //Статистический сборник / Агентство РК по статистике, 248 с.

- К Казахстан и страны СНГ. Ежеквартальный журнал /Агентство Республики Казахстан по статистике. - Астана, 2013. -1, 92 с.

- Показатели государственной программы по форсированному индустриально-инновационному развитию Республики Казахстан на 2010- 2014 годы //Статистический бюллетень / Агентство РК по статистике, $180 \mathrm{c}$.

- Экспорт и импорт Республики Казахстан в разрезе "товар-страна" со странами Таможенного союза, 2009, 2010, 2011, 2012, http:// www. stat.kz 


\title{
Значение географических факторов для положения государств их политики и экономики The Effect of Geographical Factors on State Policies and Economy
}

\author{
Asst. Prof. Dr. Saadat Demirci (Çankırı Karatekin University, Turkey)
}

\begin{abstract}
This study emphasizes environmental, especially spatial and geographical factors and determining and conditioning effects of economical and political behaviors of states. Natural values, location and geography determine policies and economic welfare of states. Various geographic characteristics and climates determine potential power of states. States, that have natural wealth and using will of this wealth, create economical and then political power. The main goal of this study is to analyze the concept of location and relation between power and its components.
\end{abstract}

\section{1 Введение}

Положение страны не смотря на множество спорных вопросов многими исследователями расматривается как важный фактор его перспективного развития. Анализы международной политики и теории международных отношений во многом потверждают влиятельные значения пространствана развитие государства. Оно сущуственно влияет на развитие всех её подсистем: экономики, политики и демографии. Экономико-географическая составляющая определяет её политическое положение, так как каждая страна испытывает потребность в не только природных ресурсах но и вчеловеческих. Так в исторические времена многие империалистические государства для удовлетворения трудовых ресурсов использовали колониальные системы. Таким образом можно построить цепочку факторов нужных для образования и развития государства. Наиболее важный из них это географический фактор, под ним подразумевается географическое местоположение, климат и оссобенности местной культуры которая устанавливает оссобенности институциональных систем. Главным образом управленческих институтов и оссобенности режимов управления. Внешняя среда через свои составные части влияет на обьект и на государство, которое в свою очередь влияет на собственное окружение. Здесь уместно упомянуть слова Наполеона который определял географию как судьбу, а также слова гениального геополитика Спикмана: “ география является базовым фактором для определения международных отношений, ибо он остается самым неизменным. Министры могут сменится, диктаторы умереть тогда как горы остаются на месте”.

\section{1 Влияние местоположения на внешную политику государства.}

Местоположение стран имеет большое значение как для внутренней так и внешней политики государств. Зависимость внешней политики от географических особенностей стран можно обьяснить просто.Так страна которая разделяет водные ресурсы вынуждена налаживать хорошие добрососедские отношения с государствами с которыми разделяет береговые зоны. Придерживать ровные дипломатические отношения, чтобы не иметь вопросов по поводу использования вод и её ресурсов.Географическое положение стран определяет также политику безопасности стран. Страны не защищённые отвнезапных нападений морями или неприступыми горамиболее уязвимы чем те страны которые ими окружены. Соответственно политика добрососедских отношений важна как главная составляющая внешней политики.Этокасается и экономики: выгодные природные ресурсы, климат и местоположение определяют экономическое развитие стран, следовательно его политическую мощь и место в мировой политике. Но эта взаимосвязь не всегда успешна, поскольку не всегда богатые запасы природных ископаемых делают их успешнее чем страны не обладающие этими ресурсами. Если проанализировать страны которые не имеют выхода к морю не смотря на богатые природные резервы по экономическим данным относятся к категории беднейших стран, а их правовой статус оценивается как близкий к распаду. Примером этих стран может выступить Афганистан, страны Африки, Сомали, Ливан, Хаити, Йемен, Ирак. Специалисты на этом этапе разделяют данные страны по типу развитости как несостоятельные, страны которые идут к несостоятельности ( failingstates), страны рискующие стать несостоятельными, слабые государства, государства изгои (roguestates), распавшие государства(Taşdemir,2013)

Специалисты по странам выдвигают теоретическое различие между распавшими и несостоятельными государствами. Распавшие государства это крайняя форма несостоявшего государства, этот тип государственной формы имеют весьма выгодное значение для экономически состоявшихся стран которые используют эти страны как выгодный рынок для продажи оружия, нередко наркоторговли и во многих случаях дешёвой трудовой силы. Это формулировка нужна была для выяснения положения стран которые 
имея природные ресурсы не имеют условий для их выгодного использования. Для полного сравнительного анализа стоит расмотреть и те страны которые не имеют богатых залежей выгодных полезных ископаемых но не смотря на это сумели организовать имеющиеся в странах ресурсы и обрести стойкую развитую экономику. Таким примером может послужить Норвегия которая в 496 раз богаче Бурунди, где на душу населения приходится 84.290 долларов(Kemal, 2012).Норвегия страна которая после разрыва со Швецией в 1905 году обрела независимость и наравне с Финляндией и Исландией считалась самой бедной страной Европы. Сегодня они стоят на ступенях самых ведущих экономических держав. Многие присчитывают быстрый темп развития экономики Норвегии к богатым ресурсам нефти и газа. Но этот аргумент нельзя отнести к Финляндии и Исландии . Исландия не имеет ничего кроме рыбной продукции а Финляндия лесной промышленности. Что касается Норвегии, то она всегда имела богатые залежи нефти и газа но вышла на мировой рынок лишь тогда когда смогла достигнуть высоких технологических стандартов и роста квалифицированной рабочей силы. Отсюда следует вывод: первичным фактором высокого экономического преобразования Норвегии является квалифицированная рабочая сила, а природные ресурсы вторичным (Sevinçer, 2009).

Опираясь на этот пример можно вывести следующее заключение; выгодные природные ресурсы конечно же являются важным факторомэкономического роста но не единственным и первостепенным, так как без организации квалифицированной рабочей силы и высоких технологий трудно добится эффективных результатов. Видимым пример тому может послужить Ирак который опередив Иран занимает третье место по резервам нефти.По последним данным в Ираке найдены новые залежи нефти которые привели к росту резервов на 25\% составив 143 мильярдов и 100 миллионов барелей (www.ydh.com.tr, 2010). Ситуация в Ираке достаточно дает понять второстепенность как выгодных ресурсов так и местоположения.

\section{2 Значение человеческих факторов в развитии экономики и политики стран.}

Профессор Кембриджского университета Сир Партха Дасхупта провёл эмперическое исследование для ООН относительно баланса доходов населения . По мнению профессора Дасхупта национальное богатство складывается из совокупности человеческого капитала, всего того что опосредственно человеческим трудом и природных богатств. Надо заметить что финансовые ресурсы не считаются национальным богатством. Специалисты ООН просчитали величину всех этих совокупностей. Сложив в общую сумму национальный доход и разделив его на число населения опредилили сумму дохода на душу населения. Конечно без усилий можно предположить что самой богатой страной была обьявлена Америка национальное богатство которой на 2008 год была определена как 118 триллион долларов. Это превышает сумму национального дохода в 10 раз. В списке расчётов дохода на душу населения Япония стоит на первом месте. В Японии доход на душу населения составляет 420.000 долларов. Америка с 400.000 долларов на душу населения стоит на втором месте.В Саудовской Аравии на которую приходится 16\% мировых резервов нефти доход на душу населения составляет 105000 долларов. Казалось бы здесь есть какая то ошибка. Всё дело в том, что по мнению профессора Дасгупта человеческий капитал является самым главным источником государства. Это заключение можно потвердить примером Японии которая почти не имеет природных ресурсов и Нигерии которая является одним из самых больших производителей нефти. Природные ресурсы беспорно являются важным элементом национального дохода но не самым главным. Пробелы в отсуствии природных ресурсов, страны обладающие высокой технологией, капиталом и квалифицированной рабочей силой заполняют переработкой сырья извне. Основными факторами которые делают значительными природные ресурсы это потенциал и рост человеческих ресурсов а также развитие технологии. Рост населения способствует расширению рынков а рост технологии эффективному использованию природных ресурсов.

\section{3 Значение институциальных структур для роста экономики и стабилизации государства.}

Другой турецко-американский исследовательизучающий взаимодействие человеческих и природных ресурсов и влияние на них социальных и политических факторов Дарон Ажемоглу обращает внимание на важность институциональных структур. Влияние политики как внешней так и внутренней на экономику страны беспорно высока. Ажемоглу здесь подчёркивает оссобую важность устойчивых и ориентированных на нужды населения системы государства основанной на равноправном и демократичном правлении. Ажемоглу считает принуждение и негаранатированность защиты прав является тем самым злом который ведёт к упадку государства. Приводя примеры стран которые долгие годы оказались под колониальным управлением можно заметить следующее, страны колонизаторы используя ресурсы этих стран богатели а колониальные страны даже обретя независимость долгие годыне могли поднять уровень как экономической так и политической системы. Это оправдывается тем, что став независимыми в этих странах всё ещё продолжали действовать жёсткие правила олигархии, где 
правовая система защищала теперь уже интересы пришедших на смену новых местных элит. Сомали и Южный Судан не смотря на то что имеют международно признанное правительство практически не имеют власти . Эти страны веками даже после обретения независимости управлялись не центральной властью с международным правопорядком а клановой системой основанной на диктатуре правителя. Здесь уместно вставить цитату профессора Дарона Ажемоглу : “ Без централизованного порядка не бывает правопорядка, без правопорядка не бывает настоящей экономики, а без настоящей экономики страна обречена на развал (Аджемоглу, Джеймс 2012).

\section{4 Значение правовых институтов для развития экономики и государства.}

Другой пример Колумбии где правопорядки не имеют места ни в одной из систем государства где часть страны находится под контролем левацких партизанских ополченцев. Революционные вооруженные силы Колумбии - Армия народа (FARC), Народно-освободительная армия (EPL), Армия национального освобождения (ELN). Отсуствие государства остро сказывается на цикле жизни стран, где присуствует дефицит здравохранения и институтциализированных прав собственности. Все эти факторы приводят к постепенному упадку государства. Следующий пример Узбекистана страна где хлопок является одним из важных продуктов экспорта государства. С наступлением сентября когда настаёт время сбора урожая школьные скамьи пустеют так как все школьники проводят время на поле собирая урожай который потом будет выгодно продан для того чтобы местная элита получила из этого хорошую прибыль. Страна до сих пор не может выбится из общей нищеты а правовые институты не имеют стойких правовых ценностей которые должнывыступать в защиту прав местного населения. Сегодня доход на душу населения в Узбекистане лишь немногим выше того низкого уровня, который установился на момент развала СССР. После справки всех этих стран можно вывести основной тезис который жирным шрифтом подчёркивает Американско-Турецкий профессор Ажемоглу. Страны системы которых разрушены отсуствием правовых норм и корумпированностью местных властей никогда не поднимутся на ноги. Обьяснение тому очень простое, политический курс правящих элит сама способствует блокировке возможности долговременного экономического прогресса. И делают они это не по ошибке или незнанию а вполне осознанно, поскольку реализуют свои жизненно важные интересы(Аджемоглу, Джеймс, 2012). Отсюда следует основной вывод того что уровень экономического роста стран нельзя искать на стыке лищь экономических, природных или географических факторов. Этот стык приходит на точку соприкосновения политики и права а также уровня культурной системы. Если ещё проще в стране может быть изобилие ресурсов, но без правильной организации структуры правления государств и правовых институтов а также поддержки квалифицированных человеческих ресурсов плюс техники страна не сможет обрести экономической мощи и поднять уровень национального благосостояния (Типатов,2013). Получается что ни географические факторы ни климатические условия и резервы выгодных запасов не могут способствовать самостоятельно росту уровня экономики страны и национального блогосостояния. Иначе сегодня не было бы большого различия в экономике и уровня жизни между Южной и Северной Кореей. Обе эти страны находятся на одном континете с общей географией и климатическими условиями, в одной существует жёсткий контроль, а права отсуствуют. В Северной Корее запрещено частное владение собственностью, все вынуждены работать на государство. Здесь присуствует ещё один пример неэфективности принуждения он уничтожает стимул и приводит к кризису экономики. Главенствующие экономическиеинституты которых учённые экономисты называют “присваювающими” являются главнойсилой разрушающей экономику и препятствующийросту иноваций, при этом сами эти “присваивающие институты” наживаются на разных видах присвоения - будь то добыча полезных ископаемых, эксплуатация принудительного труда или взимание монопольной ренты (Аджемоглу, Джеймс 2012).

\section{5 Заключение}

Внешние факторы имеют немаловажную роль в развитии экономики и страны в целом. Быстрому росту национальных доходов способствуют природные ресурсы и выгодные климатические условия создающие благоприятную среду для разработки и производства. Но одних этих факторов не достаточно для экономического роста и стабильности страны. государство может обладать богатыми ресурсами и стоять в списке экономически неразвитых стран не смотря на благоприятные условия и географическое местоположение. За этим критическим разбором стоит основной тезис того, что географические, природные и культурные условия не стоят за процветанием или наоборот крахом страны. Есть масса примеров некогда бедных стран которые сегодня являются ведущими экономическими державами. Замечания по поводу культурного различия тоже не отражают истинных фактов. Уже был приведён пример Южной и Северной Кореи среди которых нет видимых культурных различий. Но есть различия институциональных систем. В одной системе поддерживается частная собственность, в другой она практически запрещена. Отсуствие права на собтвенность приводит к экономическому развалу. Экономический кризис приводит к низкому уровню жизни и росту корупции, которая является самым 
важным барьером к росту и развитию страны. Страны построенные на эксплуатации теряют свою значимость, терпят крах . Преобразования возможны только тогда когда их начинают требовать, в основном со стороны тех кого не допускали к власти. Не трудно догаться что эти институты не проявляют оссобых рвений к переманам и потому возникают столкновения и войны подобные “ арабской весне “.

\section{Литература}

- Аджемоглу,Дарон, РобинсонДжеймс, (2012), “Несовместимые с жизньюгосударства”, www.itogi$\underline{\text { 2012.ru }}$

- Аджемоглу,Дарон, РобинсонДжеймс, (2012) “Странынесовместимые с жизнью”, www.esquire.com/Acemoglu/Robinson

- Kemal, İsmail,(2012), “Ülkeler niçin başarısız olur?”, www.kıbrısgazetesi.com

- Sevinçer, Vedat,(2009), "Bir Ülke Petrolle Nasıl Zengin Olmaz?: Norveç, Petrol ve Eğitimli, İnsan Gücü Faktörü”, www.bilgesam.com

- Типатов, Николай,(2013), “ Почемуоднинациибедные, а другиебогатые?”, www.subscribe.ru

- Taşdemir Fatma, (2013), "Başarısız Devletler, İç Savaş ve Terörizm”, www.ankarastrateji.org/yazar/doc/basarısız-devletler-1c-savas-ve-terrorım

- Yakın Doğu Haberler, (2013), “Irak, Petrolde İran'1 Geçti”, www.ydh.com.tr 


\title{
Водный вопрос Центральной Азии и борьба за региональное лидерство
}

\section{Water Cooperation in Central Asia and Competition for Regional Dominance}

\author{
Ph.D. Candidate Dina Kurkova (National Research University, HSE, Russia)
}

\begin{abstract}
This article examines the water related problem in the context of contemporary security relation in Central Asia. The competition for regional dominance has developed in Central Asia for the last decade. The waterrelated problems are likely to increase tensions in the region, even to begin the wars over water. In this article the author explains why water-related problems in Central Asia can't be solved in medium-term perspective. Global hegemon, the USA, regional hegemons, Russia and China, and regional hegemon challengers, Uzbekistan and Kazakhstan, use fresh water as a weapon to pressure each other. Given the fact that the interaction between these states concerns question not just of water cooperation but also of balance of political, military and economic dominance, the author assumes that the water-related problem in Central Asia can be understood as one tool in hegemonic completion.
\end{abstract}

\section{1 Введение}

Риски, с которым сталкивается сегодня постсоветская Центральная Азия, приводят к тому, что конфликтогенный уровень в регионе достаточно высок. В первую очередь риски центральноазиатского региона принято связывать с угрозами терроризма, экстремизма, в том числе религиозного, и с борьбой за энергетические ресурсы. Однако в последние годы все чаще среди потенциальных угроз называют и проблему обеспеченности водными ресурсами. Для территории с жарким и сухим климатом вопрос обеспечения населения пресной водой всегда был актуальным, особенно в условиях орошаемого земледелия. Но только в начале XXI века споры за доступ к пресной воде стали грозить перетечь в вооруженные конфликты. Истоки этой проблемы уходят в 1930-40-е годы, когда советская власть инициировала создание в регионе электроэнергетической отрасли на базе горных рек. Именно в тот момент были созданы предпосылки для сегодняшнего острого противоречия между интересами низинных, но более развитых в экономическом отношении стран и интересами стран, контролирующих высокогорные районы, где берут свое начало реки, питающие весь регион.

Необходимость поиска компромисса в пользовании трансграничными бассейнами крупных рек не раз вставала перед самыми разными странами. Вопросы регулирования водопользования рассмотрены международным правом, многочисленные международные организации занимаются выработкой возможных вариантов взаимовыгодного решения или, по крайней мере, консенсуса. Такие проекты неоднократно создавались и для Центральной Азии, но не нашли своего воплощения. Уникальность ситуации состоит в том, что страны Центральной Азии уже имеют опыт совместного водопользования в рамках заданной системы. Речь идет о советской эпохе, когда поставки углеводородов и жесткий контроль над режимом водопользования создавали условия для соблюдения относительного баланса интересов. Безусловно, данная система не могла продолжить свое существование после распада СССР и перехода к рыночному хозяйству. Однако она не просто не была модифицирована под новые политические и экономические условия. В настоящий момент можно наблюдать своеобразное отрицание странами региона любой предлагаемой системности в попытке урегулирования водного вопроса. При декларируемой в политической риторике первостепенной важности решения проблемы пользования водными ресурсами вектор принимаемых усилий направлен не на кооперацию, а на индивидуализацию. Очевидно, что, руководствуясь лишь стремлением учесть только собственные национальные интересы, вопросы трансграничного характера решить невозможно. В случае, если бы не существовало предыдущего, советского, опыта взаимодействия стран по этому вопросу, можно было бы предположить, что компромисс действительно не может быть найден, а интересы стран региона строго полярны. В существующей же ситуации объяснением такого рода тактики может служить гипотеза о том, что существуют некие иные интересы, которые препятствуют взаимодействию стран по водному вопросу, а водный вопрос является лишь инструментом в реализации этих интересов, а не собственно приоритетом деятельности. На наш взгляд основной целью в стратегическом взаимодействии центральноазиатских стран является завоевание регионального лидерства, а водноэнергетическая проблема рассматривается как рычаг в этой борьбе.

Соответственно, водный вопрос в ЦАР можно рассматривать как состоящий их двух компонентов экономико-экологического (ухудшение положения с водными ресурсами в регионе невозможно отрицать) 
и политического. Экономико-экологическая компонента определяет силу действия этого рычага в политической борьбе. Чем острее встает водный вопрос, тем эффективнее становится рычаг воздействия. Следовательно, заинтересованность в решении водноэнергетической проблемы в политическом истеблишменте крайне низкая. Водный ресурс исключительно выгодный аргумент в политическом дискурсе, т.к. пресная вода жизненно важна, не имеет альтернативы, не несет на себе стереотипа сырья для торговли и спекуляции. Политическая компонента в водном вопросе выражается в стремлении использовать «водный рычаг» в борьбе за региональное лидерство и тем самым реализовать имеющиеся преимушества. Соответственно, решив вопрос, какая из компонент доминирует, можно будет судить о возможных путях решения водноэнерегетической проблемы в ЦАР и вообще о возможности ее решения.

\section{2 Экономико-экологическая составляющая водноэнергетической проблемы ЦАР}

Основной характеристикой водного потенциала Центральной Азии является его неравномерное распределение. При усредненной оценке на регион в целом обеспеченность водными ресурсами можно определить как выше среднего. Однако неравномерность распределения и специфика использования имеющейся пресной воды приводят к фактической ее нехватке. Водный потенциал Центральной Азии обеспечивается в основном стоком двух самых крупных рек региона - Сырдарьи и Амударьи. Особенностью водостока этих рек является тот факт, что $3 / 4$ их водостока формируются в высокогорных районах Киргизии (в случае Сырдарьи) и Таджикистана (в случае Амударьи), а в нижнем течении в основном расходуются на орошение сельскохозяйственных земель. Также основные запасы пресной воды Центральной Азии сосредоточены в ледниках (60\% из которых контролирует Таджикистан). Кроме того, в регионе имеются крупные озера естественного происхождения (Сарыкамыс, Соленое, Сарез и др.), а также сеть искусственных водохранилищ, каналов, гидроузлов, построенных большей часть в советскую эпоху для обеспечения ирригации и выработки электроэнергии. Таким образом, в ЦА можно четко выделить две группы стран: страны-доноры (Таджикистан и Киргизия - 2 и 3 место по СНГ после РФ по обеспеченности водой), контролирующие истоки основных рек и горные ледники, и страны-акцепторы, получающие пресную воду из рек, берущих начало в соседних странах (Узбекистан, Туркменистан, Казахстан). При этом в экономическом отношении страны-потребители являются экономическими лидерами региона. Именно на них приходится основное потребление пресной воды (более половины потребления пресной воды в регионе приходится на Узбекистан). Кроме того, имеет место столкновение двух традиционных типов хозяйствования: равнинного земледелия и скотоводства, в том числе и высокогорного. Узбекистан и Туркменистан с развитым аграрным сектором, ориентированным на выращивание промышленных культур, вынуждены получать воду от стран, где более $80 \%$ территории занимают горные массивы, развито преимущественно скотоводство, а аграрный сектор представляет собой мелкие домохозяйства.

Нехватка пресной воды как для хозяйственных, так и для бытовых нужд населения региона становится все более существенной проблемой в последние десятилетия. Отчасти эта проблема стала следствием введенной советским правительством системы хозяйствования в регионе. Среднеазиатские республики позиционировались как территория для выращивания хлопчатника, необходимого промышленного сырья. Это стимулировало развитие ирригационных систем в регионе, в том числе достаточно передовых для своего времени. Были построены сети каналов (Каракумский, Кызылкумский, Большой Ферганский, Южноферганский, Чуйский и др.), благодаря которым удалось существенно расширить посевные площади региона. Так, если в начале XX в. посевные площади составляли около 2,5 млн. га, то к концу $\mathrm{XX}$ в. они превысили 8 млн га. Водопользование в ту эпоху регулировалось центром и ориентировалось на экономическую целесообразность в хлопководстве. Преимущество в пользовании водными ресурсами имели республики, выращивающие хлопчатник. Киргизия и Таджикистан использовали не более четверти собственных водных запасов, а нехватка энергии в зимние периоды компенсировалась поставками углеводородов из соседних республик. Несмотря на то, что кризисные явления в центральноазиатском водопользовании принято связывать прежде всего с постсоветской эпохой, тупик в развитии подобной системы хозяйствования наметился еще в советское время. Расход воды достиг 90\% от всей пресной воды региона, поэтому возможности для расширения орошаемых земель существенно снизились. Ирригационная система, модернизированная на уровне гидроузлов и каналов, оканчивалась традиционными арыками с грунтовыми стенами. Около трети воды уходило в почву, засаливая грунты, что еще больше снижало плодородность. Неконтролируемое использование удобрений и пестицидов также способствовало засаливанию и образованию целых озер сточных с полей вод, загрязненных химикатами. Итогом такого подхода стала экологическая катастрофа Аральского моря, когда недостаток стока Амударьи привел к потере более 60\% площади моря. Экологические проблемы, доставшиеся центральноазиатским государствам в наследство от советской эпохи, требуют значительных материальных вложений, которые вряд ли будут сделаны в среднесрочной перспективе, учитывая общий невысокий уровень экономического развития региона. Односторонние же усилия не дают нужного эффекта, а зачастую обнуляются действиями соседних стран. Так, приложенные Казахстаном усилия по 
оводнению северной части Арала могут быть сведены на нет решением Туркменистана о строительстве водохранилищ в Каракумах.

Помимо экологических проблем на водный вопрос в Центральной Азии имеет огромное влияние, нарастающее демографическое давление в регионе. Особенностью ЦАР является наличие огромных территорий малопригодных для проживания. Это прежде всего горные массивы, пустыни и полупустыни. В результате средняя плотность населения в стране не полностью отражает существующую остроту ситуации. Ярким примером является Узбекистан. Несмотря на большую площадь республики, все население сконцентрировано преимущественно в плодородных долинах рек, где находятся как сельскохозяйственные земли, так и крупные города. Это приводит к тому, что в некоторых районах страны, таких как Каракалпакия, откуда наблюдается стремительный отток населения в связи с опустыниванием и пересыханием Аральского моря, плотность населения составляет всего $6-8$ человек на 1 кв. км. Тогда как в таких областях, как Ферганская и Андижанская, плотность населения превышает 400 человек на 1 кв. км. В среднем по стране плотность населения составляет 62,9 человек на кв. км. Аналогичная ситуация характерна для Таджикистана, 80\% территории которого занимают горные массивы. Основная масса населения сосредоточена в Гиссарской и Вахшской долинах, где средняя плотность населения превышает 200 человек на 1 кв. км., в то время как на Памирском нагорье она меньше 0,5 человека на кв. км. Менее остро демографическое давление ощущается в Киргизии, но и там основная масса населения сосредоточена в долинах, например в Чуйской, где находится Бишкек, там плотность населения превышает 100 человек на 1 кв. км, при средней по стране в 27,9 человек на 1 кв. км. В результате самые густонаселенные районы наиболее чувствительны к нехватке воды, т.к. именно там сосредоточены сельскохозяйственные угодья. При этом в постсоветский период экономики центральноазиатских стран пережили серьезный регресс к аграрно-индустриальному, а в некоторых регионах и к аграрному типу хозяйствования. Население ранее занятое в промышленности или сфере обслуживания в ходе деиндустриализации было вынуждено вернуться к традиционному земледелию. Высокое демографическое давление служит катализатором социальных конфликтов. Общее стремление власти «предъявить счет» за нехватку воды или отсутствие электричества соседнему государству приводит к тому, что социальное напряжение выражается в межэтнических столкновениях. Миграция является тем клапаном, который помогает частично снять демографическое давление. Но, учитывая, что водный вопрос так и не находит своего решения, водный дефицит будет и дальше стимулировать миграцию молодого населения из региона, т.к. сельское хозяйство не сможет обеспечить необходимый уровень жизни, а сокращение посевов промышленных культур неминуемо скажется на производстве.

Безусловно, экологическое и демографическое давление вносят весомый вклад в экономикоэкологическую составляющую водного вопроса. Тем не менее основной конфликтный потенциал находится на стыке водного и энергетического вопросов. Единая региональная энергосистема, созданная в советское время, существует до сих пор. Однако принцип цикличности, положенный в её действие, нарушен, что неминуемо приводит к конфликтам. Система была построена на сезонных циклах, при которых ГЭС Киргизии и Таджикистана в теплое время года поставляли электроэнергию в соседние республики, а зимой весь регион получал энергию от ТЭС, расположенных в равнинных республиках, а в Киргизию и Таджикистан поставлялись углеводороды для обогрева. С разрушением единой экономики система циклов не была адаптирована к рыночным условиям и функционированию между независимыми государствами. Сложная экономическая ситуация в стране не всегда позволяла зимой Киргизии и Таджикистану закупать углеводороды в достаточном количестве, особенно в условиях, когда соседние страны (в том числе Узбекистан) сезонно поднимали цены на газ. За неимением собственных источников углеводородов основная нагрузка в холодное время года в этих странах ложится на электроэнергию. В этой связи периодически зимой происходят сбросы воды из высокогорных водохранилищ, что приводит зимой к затоплениям посевных площадей в странах ниже по течению, а летом - к засухам. В результате интересы стран, находящихся выше по течению пришли в противоречие с интересами стран, находящимися ниже по течению. Первые стремятся получить максимальную выгоду от производства и продажи излишков электроэнергии. Вторые требуют соблюдения необходимого режима водостока, чтобы обеспечить ирригацию сельскохозяйственных территорий. В результате сложившуюся ситуацию можно описать как игру с нулевым результатом. Гидроэнергетическая система Киргизии и Таджикистана работает на обеспечение нужд сельского хозяйства соседних стран, что блокирует возможности для наращивания мощностей и экспорта электроэнергии в соседние страны. Страны в нижнем течении Амударьи и Сырдарьи оказались в водной зависимости от своих соседей и, несмотря на свое экономическое превосходство, могут рассчитывать только на добрую волю соседей, периодически оказываясь перед угрозой наводнения или засухи.

Экспортный потенциал и Таджикистана, и Киргизии крайне ограничен. В этой связи их стремление к коммерциализации водной отрасли понятно, т.к. это может дать стабильный приток в бюджет иностранной валюты. Страны-доноры используют на свои нужды только 20\% водных ресурсов, остальные $80 \%$ безвозмездно потребляются соседними странами. Все республики в нижнем течении рек 
негативно воспринимают практику превращения воды в товар, т.к. считают воду всеобщим и жизненно важным достоянием, торговля которым невозможна. Такой подход действительно правомерен, однако в случае Центральной Азии страны низовий рек получают воду через сеть гидротехнических сооружений, находящихся на территории соседних стран, но предназначенных для нужд стран-акцепторов. В результате финансовое бремя поддержания работоспособности системы полностью ложится на плечи стран-доноров. При этом любые попытки стран-доноров модернизировать гидротехнические сооружения на своей территории под свои нужды, т.е. для увеличения производства электроэнергии, воспринимаются странами-акцепторами крайне негативно, т.к. это может привести к изменению режима водообеспечения.

Таким образом, можно заключить, что экономико-экологическая составляющая водной проблемы обладает большим конфликтогенным потенциалом. На самых разных уровнях от угрозы экологической катастрофы до межэтнических столкновений пресная вода в Центральной Азии может стать поводом для конфликта. При этом очевидно, что ни одна из указанных выше проблем не является тупиковой. Часть их них может быть решена путем материальных вливаний (модернизация арычной системы и системы ЖКХ, строительство новых гидротехнических сооружений, экологические мероприятия, препятствующие загрязнению и засаливанию почв и пр.). Другие лежат в плоскости социальных проблем и могут быть решены только в ходе развития экономики и общества. Ключевая же проблема конкуренции гидроэнергетики и сельского хозяйства не является уникальной в мировой истории. Проекты по решению такого рода задач предполагают обычно либо оплату за полученную летом воду (как это и делалось, по сути, в СССР), либо строительство собственных водохранилищ на территории нижних по течению стран (в случае ЦА это низкоэффективный вариант, т.к. большое поверхностное испарение приводит к большой потере воды, тем не менее подобные водохранилища строятся во всех трех низинных странах ЦАР), либо строительство каскадов ГЭС и водохранилищ, где верхние уровни будут использованы для выработки электроэнергии, а нижние для аккумуляции воды в сезон (что требует кооперации и высокого уровня доверия, которого пока невозможно достичь). Однако ни один из возможных вариантов в Центральной Азии не реализуется. Несмотря на явную тенденцию к усугублению ситуации, очевидно желание республик сохранить статус-кво. Отчасти это может быть объяснено трудной экономической ситуацией, в которой оказались центральноазиатские государства после обретения независимости. Водный вопрос в такой ситуации не рассматривается как приоритетный для принятия конкретных мер и поисков решений. В условиях присутствия террористической и экстремистской угроз экологические проблемы, даже непосредственно связанные с таким жизненно важным ресурсом как пресная вода, отодвигаются на второй план. А столкновение интересов гидроэнергетики и аграрного сектора рассматривается в качестве столкновения национальных интересов, выводя этот вопрос из плоскости экономики в политический дискурс. Именно этот переход к политической составляющей делает невозможным решение водного вопроса с помощью проектов, основанных на принципах экономической целесообразности и сотрудничества. Гидроэнергетическая система Центральной Азии изначально создавалась как единая. Более того, до сих пор она продолжает работать как единая для всего региона, хотя все стороны высказывают недовольство результатами ее работы. Безусловно, получение республиками независимости и переход к рыночным отношениями сделали необходим реформирование принципов организации этой системы. Однако уже в течение более, чем 20 лет этого не происходит, а по мере усугубления проблемы правительства всё больше уводят её в область политики.

\section{3 Политическая составляющая в водноэнергетическом вопросе в Центральной Азии}

Важнейшей составляющей международных и политических процессов в Центральной Азии на сегодняшний день является борьба за региональное лидерство. В теории международных отношений существует несколько подходов к теории глобального лидерства (hegemony), в соответствии с которым выстраивается глобальная иерархия соотношения сил. Большинство из теорий были выработаны после окончания «холодной войны» и определяли США как глобального гегемона. В связи с тем, что концепция иерархии изначально разрабатывалась в парадигме политического реализма и неореализма, то фактор силы (power) был ключевым для определения места в иерархии. Стоящий на вершине иерархии гегемон исполнял роль мерила силы, соответственно, остальные места в иерархии распределялись относительно его влияния. Концепция регионального лидерства (regional hegemony) была разработана гораздо позже. В данной работе мы будем исходить из концепции многоуровневой иерархии (multi-level hegemony), основываясь на идеях Д. Лемке о мультииерархичной модели (Lemke, 2002) и теории региональных комплексов безопасности Б. Бузана (Buzan and Waever, 2003). Согласно Д. Лемке, глобальная иерархия состоит из параллельных и соподчиненных субиерархий регионального и субрегионального масштаба. Они устроены согласно логике глобальной иерархии, и во главе каждого региона или субрегиона стоит региональный или субрегиональный лидер. Глобальные и региональные лидеры могут вмешиваться в дела нижестоящих иерархий, если существующее положение дел расходится с направлением их развития. В остальных случаях субрегиональные и региональные вопросы решаются собственными лидерами без 
вмешательства лидеров, вышестоящих в иерархии силы. (Lemke, 2002) Согласно, Б. Бузану существуют сверхдержавы и великие державы, которые взаимодействуют на глобальном уровне, в то же время существуют региональные державы, чье влияние на локальном уровне может быть чрезвычайно высокими, однако они не включены и не будут включены в круг мировых лидеров. Однако Б. Бузан применяет свою теорию исключительно к вопросам безопасности, не рассматривая экономическое влияние или т.н. «мягкую силу». (Buzan and Waever, 2003) И глобальная, и региональные иерархии периодически переживают трансформации, лидерство в них оспаривается новыми державами, претендующими на первенство (challengers). Соответственно, борьба за лидерство - это тот процесс, в ходе которого определяется структура новой иерархии, причем данный процесс свойственен иерархиям всех уровней. Однако мы предполагаем, что лидеры вышестоящих иерархий могут вмешиваться в борьбу за лидерство в нижестоящих иерархиях.

В данной работе под субрегионом мы будем подразумевать Центральную Азию, под регионом постсоветское пространство. В субрегиональном масштабе в Центральной Азии в последнее десятилетие имеет место процесс формирования иерархии. Находившиеся сначала под контролем Российской империи, а затем в составе СССР республики обрели независимость в 1990-е гг., и центральноазиатский субрегион выделился на постсоветском пространстве. Первое десятилетие определило векторы развития каждой из республик. Этот период был временем государственного строительства, в процессе которого для некоторых стран Центральной Азии остро стоял вопрос простого выживания. В этот период было задано то направление экономического и общественно-политического развития, которое мы можем наблюдать сейчас. Иерархии в чистом виде на тот момент в субрегионе сформировано не было.

К началу 2000-х годов в Центральной Азии национальные государства в Центральной Азии полностью оформились и начались процессы формирования субрегиональной иерархии. Двумя основными конкурентами являются Казахстан и Узбекистан. Помимо лидерских амбиций, подкрепленных историческими и мифологическими основаниями, эти два государства демонстрируют самые высокие темпы экономического развития в субрегионе. Кроме того, явно авторитарный вектор внутренней политики в этих республиках определяет и внешнеполитические лидерские амбиции. При этом, Узбекистан обладает крайне выгодным геополитическим положением, находясь в самом сердце Центральной Азии и контролируя древние культурные центры. Кроме того, Узбекистан располагает самыми мощными в Центральной Азии военными силами. Это позволяет ему вести независимый от РФ политический курс, избегать в вступления в инициируемые ей интеграционные объединения, в то время как остальные страны Центральной Азии продолжают видеть в России гаранта безопасности, а следовательно вынуждены действовать с учетом ее интересов. Выход Узбекистана из ОДКБ особенно ярко продемонстрировал эту тенденцию. Отсутствие общей границы с Китаем позволяет Узбекистану занимать достаточно гибкую позицию в отношениях с ним и ограничивать его экономическую экспансию в регионе. Дополнительным фактором в стремлении к субрегиональному лидерству Узбекистана является его готовность взаимодействовать напрямую с глобальным лидером - США. Вывод войск из Афганистана в 2014 г. заставляют США искать партнера в Центральной Азии. Именно Узбекистан с его относительно независимой от РФ политикой рассматривается как основной партнер. Казахстан, демонстрируя гораздо более высокие темпы развития, обладая большей территорией и населением, а также большими ресурсами углеводородов, оказался в гораздо более сложной ситуации для выражения своих лидерских амбиций в субрегионе. Тесные связи с соседними Россией и Китаем, необходимые для успешного экономического развития, особенно в энергетическом секторе, связывают Казахстан в наращивании собственного веса в субрегионе, особенно в отношении наращивания военной силы. Таджикистан в силу тяжелой политической и экономической ситуации долгое время не мог претендовать на участие в борьбе за лидерство. Однако с относительным урегулированием ситуации в стране, а также после изменения курса президента Э. Рахмона в сторону более авторитарного, Таджикистан пытается принять участие в борьбе за место в иерархии. Безусловно, он не претендует на место гегемона, его тактика заключается скорее в ослаблении позиции соперников с помощью всех возможных рычагов. Киргизия до середины 2000-х действовала в теоритическом ключе, активно разрабатывая историкомифологические основания для своего лидерства в субрегионе. Затянувшийся политический кризис и экономическая стагнация полностью лишили Киргизию шансов на повышение своих позиций в иерархии. Она остается аутсайдером региона, и её слабость используют ьроее сильные региональные игроки, Россия и Китай. Особенное положение занимает Туркменистан. Имея достаточно крепкую экономику, основанную на экспорте газа, Туркменистан занимает обособленную позицию и ориентирован на внешние силы, а не на поиск своего места в субрегиональной иерархии.

В результате на субрегиональной арене происходит соперничество трех сил, две из которых (Казахстан и Узбекистан) претендуют на позицию субрегионального лидера, а третья (Таджикистан), не имеющая достаточного потенциала, но обладающая некоторыми рычагами влияния на соперников (в том числе водный вопрос), активно принимает участие в гонке. 
Одновременно с субрегиональными акторами в установлении субрегиональной иерархии происходит борьба между региональными лидерами (Россия и Китай) и глобальным лидером (США), пытающимся утвердиться как субрегиональный лидер в Центральной Азии. Влияние регионального лидера, России, в Центральной Азии было традиционно высоким. Хотя сама Россия столкнулась с серьезными трудностями в переходный период после распада СССР, она всегда сохраняла свое присутствие в Центральной Азии в основном в сфере энергетики и в вопросах безопасности. До настоящего времени сотрудничество именно в этих направлениях остается приоритетным. Кроме того, центральноазиатский регион продолжает сохранять для России статус «зоны политических интересов». Политические элиты центральноазиатских стран сменились еще не полностью относительно советского периода, что во многом сближает их с РФ. Россия же реализует свои амбиции регионального лидера, выступая с интеграционными инициативами, целевой аудиторией которых оказываются прежде всего центральноазиатские страны. Китай осуществляет экономическую экспансию в регион и, несмотря на обширные инвестиции (в том числе в энергетическую отрасль), его интересы не входят в прямое противоречие с интересами РФ, которая претендует на политическое влияние. В рамках ШОС Россия и Китай ведут согласованную политику безопасности. Такое комплементарное совпадение позиций РФ и Китая позволяет им вести относительно согласованную политику против попыток глобального лидера США утвердить свое влияние в Центральной Азии. После распада СССР США планомерно пытается усилить свое присутствие в регионе, используя как экономические методы, так и распространяя свое военное присутствие, что противоречит интересам и РФ, и Китая. Борьба с терроризмом и ввод войск в Афганистан позволяли США в начале 2000-х открыть свои военные базы в Узбекистане и Киргизии. В связи с выводом войск из Афганистана в 2014 году США в настоящий момент работают над созданием надежной площадки для установления контроля над центральноазиатским регионом, включая Афганистан. Об этом свидетельствуют и новые стратегии США, такие как «Новый шелковый путь», и усиление инвестиционных потоков в экономики центральноазиатских стран. Каспийские углеводороды являются объектом пристального внимания со стороны США. Казахстан контролирует большую часть углеводородных запасов Каспия на суше в ЦА и все больше открывает рынок добычи этих ресурсов для Китая.

Таким образом, помимо борьбы между субрегиональными претендентами на лидерство в иерархии, в которой принимает участие и региональный лидер РФ, в Центральной Азии развернулась борьба за место в региональной иерархии между глобальным лидером США и региональными лидерами РФ и Китаем. При этом Китай пока занимает сдержанную позицию, действуя преимущественно экономическими методами, а в вопросах безопасности проводя политику, не противоречащую позициям РФ.

В условиях этой борьбы все стороны используют прямо или опосредовано «водный рычаг» для укрепления своих позиций. Связка воды и энергетики расширяет круг заинтересованных сторон и одновременно усиливает эффективность рычага. Активнее прочих проблему водных ресурсов использует Узбекистан, т.к. он является страной-реципиентом, что ставит его в позицию жертвы и служит оправданием агрессивным высказываниям. При этом поддержка со стороны США делает позицию Узбекистана все более сильной и независимой от России. Ослабление собственного влияния на Ташкент и усиление присутствия США в регионе РФ воспринимает достаточно болезненно, что заставляет ее оказывать давление на Узбекистан через лояльных России соседей. В случае с лояльными Киргизией и Таджикистаном самое эффективное воздействие может быть оказано именно через водный вопрос. Одним из примеров использования водного вопроса в условиях борьбы за региональное лидерство можно было наблюдать осенью 2012 года. В конце августа 2012 года помощник по Южной и Центральной Азии Роберт Блейк посетил Узбекистан, где презентовал новую стратегию США «Новый Шелковый путь», которая является реакцией на интеграционные инициативы России в Центральной Азии. Согласно этой стратегии, должны быть усилены связи между Центральной и Южной Азией, в том числе за счет строительства транспортной инфраструктуры и обеспечения транзита энергетических ресурсов. Такой проект, очевидно, входит в конфликт и с российскими инициативами, и с китайскими попытками включить Центральную Азию в зону своего влияния. В ходе визита были заключены договора на 2,8 млдр. долларов прямых инвестиций в экономику Узбекистана, также заключены договоренности о закупках в Узбекистане для американской группировки в Афганистане, кроме того заключен параллельный договор с Южной Кореей о прямых инвестициях в экономику Узбекистана. В неофициальных кругах появилась информация о возможных договоренностях о закупке узбекского урана американцами. Надо отметить, что свой визит в Центральную Азию Р. Блейк начал с Казахстана, однако в итоге презентация стратегии и заключения договоров происходили именно в Узбекистане. Кроме того, Узбекистан получает гарантии о модернизации собственных военных сил за счет техники, которую после вывода войск американская сторона передаст Узбекистану. Уже в начале сентября 2012 г. И. Каримов в ходе своего визита в Казахстан заявляет, что водный вопрос достиг такой остроты, что может быть решен с помощью военных действий. (Inosmi.ru, 2012) Указав, что строительство новых ГЭС коснется не только узбеков, но и казахов, И. Каримов тем не менее не получил поддержки казахского руководства. Менее, чем через две недели, в сентябре 2012 года, президент России В. Путин в Киргизии В. Путин заявляет о 
том, что будет поддерживать стремление Киргизии вступить в Таможенный союз и одновременно заключает соглашение о строительстве сразу 2 крупных гидротехнических сооружений в Киргизии Камбар-Атинской ГЭС-1 и Верхне-Нарынского каскада ГЭС, что напрямую затрагивает интересы Узбекистана, т.к. уменьшится сток Нарына, а следовательно, водоснабжение Ферганской долины. (Newsru.com, 2012) Вторым пунктом российского-киргизского диалога было обсуждение российской военной базы рядом с Бишкеком. Уже в октябре 2012 г. В. Путин посещает Таджикистан. Там он заключает договор о продлении российского военного присутствия в Центральной Азии в виде 201 российской военной базы, обещая поддержать таджикские инициативы по строительству средних и малых ГЭС, не упоминая финансирование самого амбициозного таджикского проекта, Рогунской ГЭС. Также В. Путин приглашает Таджикистан присоединиться к Таможенному союзу. (Vedomosti, 2012) Параллельно Китай активизирует свои проекты по строительству ЛЭП «Датка - Кемин», который позволит Китаю получать электричество от каскада Нарынских ГЭС напрямую из Киргизии без транзита через узбекскую территорию. (Kabar.kg, 2012) В результате в ответ на шаги узбекского руководства по сближению в США все соперничающие игроки региона оказали на него давление с использованием двух основных рычагов - усиления военного присутствия и ужесточения позиций по водному вопросу. Уже в декабре 2012 г. И. Каримов заявил, что Узбекистан заинтересован в добрососедских отношениях и военного конфликта в Центральной Азии инициировано не будет. (Rosbalt, 2012) Очевидно, что все участники борьба за регионально лидерство продолжат движение к выбранным стратегическим ориентирам, а водный вопрос наряду с военным присутствием будет использован как инструмент в борьбе.

\section{4 Заключение}

Водноэнергетическая проблема Центральной Азии имеет две составляющие: экономико-экологическую и политическую. Перспективы решения водноэнерегетической проблемы напрямую зависят от того, какова будет доля политической составляющей. Экономико-экологическая составляющая, безусловно, задает остроту проблемы, но с помощью создания совместных консорциумов и определения режима взаимовыгодного пользования водными ресурсами может быть решена. На сегодняшний день основным препятствием к урегулированию водного вопроса в Центральной Азии является отсутствие политической воли к его урегулированию. Это связано с тем, что водный вопрос используется как рычаг влияния на соперников в ходе борьбы за региональное лидерство. Причем этим рычагом пользуются как местные, субрегиональные, игроки, так и игроки более высокого уровня, что продемонстрировано на кейсе о противостоянии блока Узбекистан - США и Россия - Китай - Киргизия - Таджикистан осени 2012 г. Более того, обострение водноэнергетического вопроса в данных условиях является выгодным для всех участников политической борьбы, т.к. это повышает эффективность рычага влияния. Соответственно, ожидать в среднесрочной перспективе урегулирования водноэнергетического вопроса в Центральной Азии не приходится. До тех пор, пока в регионе не сформируется относительно твердая иерархия сил, водный вопрос будет необходим для осуществления давления на соперников. Осень 2012 г. показала, что он с успехом потенциально может быть использован как повод для развязывания краткосрочной войны в регионе. Усиление Узбекистана после вывода американских войск из Афганистана может стимулировать желание этой страны утвердиться на лидерских позициях в регионе с помощью начала военных действий, например, в Ферганской долине с Киргизией. Наращивание российского военного присутствия будет сдерживающим фактором для такого развития событий. Однако во многом среднесрочная перспектива будет определяться и теми силами, которые сменят у власти президента И. Каримова.

\section{Литература}

- Lemke, 2002, Regions of War and Peace, Cambridge Studies in International Relations

- Buzan, Weaver, 2004, Regions and Powers, Cambridge Studies in International Relations

- Inosmi.ru, 13.09.2012 http://www.inosmi.ru/sngbaltia/20120913/199096072.html

- Newsru.com, 20.09.2012 http://newsru.ru/world/20sep2012/kyrgyzbase.html

- Ведомости, 05.10.2012 http://www.vedomosti.ru/politics/news/4700171/putin_obmenyal_bazu_v tadzhikistane na_smyagchen ie

- Kabar.kg, 24.08.2012 http://www.kabar.kg/rus/economics/full/39169

- Posbalt.ru, 10.12.2012 http://www.rosbalt.ru/exussr/2012/12/10/1069524.html 


\title{
Открытая экономика и экономическая интеграция в рамках Евразии
}

\section{Open Economy and Economic Integration within the Framework of Eurasia}

\author{
Prof. Dr. Omurbek Karatalov (Kyrgyz-Russian Slavic University, Kyrgyzstan)
}

\begin{abstract}
The Kyrgyz Republic economy openness is studied within the framework of the Eurasia. Insufficient level of the financial and economic standing of Kyrgyzstan is clarified. Reasons for Governmental regulating use in the area of monetary, tax and budget policy in USA have been set up. Conditions of the development of industrial countries economy are under consideration. The necessity of financialisation of all capital of country is defined. Kyrgyzstan public budget's permanent deficiency formation reasons are studied. A necessity of integration economic relations development within the framework of Eurasia is offered. A necessity of sustainable economic relations establishment as well as finding solution for external debt between Kyrgyzstan and Russia have been justified. It is recommended to strengthen effective fight against a scale corruption, «shadow» economy and criminalization of economy and finances. The increase of efficiency and responsibility of top managers of the public administration level have been offered. The necessity of the independent mastering of own gold-mining fields is justified. The need to attract the foreign direct investments to the area of mining and processing industry have been offered. Within the framework of acceleration of economic integration. Needs for the development of exploring and processing of hydrocarbons as well as building of large economic entities especially the hydroelectric power stations, namely Kambar-Ata-1 Hydro-Power Plants have been suggested. By this it is also suggested to Russia to develop this as strategic partner of Kyrgyzstan. Creation of integral customs system and energy cooperation suggested. It should be supported by establishment of unique equivalent among Eurasia states. By this it is to be possible to find acceptable solutions in finance and economy and to form a united economic cooperation considering a sovereignty of each state. It is necessary to develop the identical financial reporting of point-of-sale and payment balances, balance of international investments, compliable national republics and on the whole on Eurasia. To walk away from the calculation and actual use of dollar of the USA in finance and economic operations. Based on econometric prognosis of gross internal product and the public budget of Kyrgyzstan is made calculating on the per to 2025 year.
\end{abstract}

В ходе развития человеческого общества, возникали все новые проблемы и для своевременного их разрешения государственная власть, пыталась принимать соответствующие меры. Однако отдельные проблемы, финансово-экономического характера оставались решенными не до конца. И правители государства всегда были вынуждены обращаться к экономической науке, такая необходимость особенно остро ощущалась в периоды затяжных мировых кризисов.

Основным стержневым вопросом, для государства, и для предпринимателей, в условиях глобализации мировой экономики, это углубленное освоение рыночных отношений и преодоление кризиса. Научнообоснованные, практические рекомендации и предложения, направленные на улучшение социальноэкономического развития страны - это современные требования открытой экономики для всех игроков рынка, ради достижения поставленных целей.

Необходимость применения данных методик возникла ещё раньше в период первого мирового (1930 г.) и глобального экономического кризиса (2008 г.). Кризис 2008 г. обвалил макроэкономические показатели не только государств Евразии, но и СНГ, находящихся в условиях переходного периода, но и промышленно развитых стран мира. Для выхода из кризиса важная роль принадлежать государству. Например, «Роль государства США чрезвычайна, велика...во внешнеэкономических связях и др. Но главным, несомненно, представляется макроэкономическая регулирующая роль государства как... через отработанные многолетней практикой механизмы косвенного регулирования экономическими процессами - денежно-кредитную...налоговое и бюджетное регулирование...является налоговая политика...». Следовательно, «...регулирование стало органической частью рыночного хозяйственного механизма США. Развитие американского капитализма свидетельствует о чередовании периодов усиления рыночного конкурентного механизма с периодами государственного регулирования экономики» (Экономика США, 2003а).

Если в США в условиях рыночных отношений осуществляется активное государственное регулирование денежно-кредитной и налогово-бюджетной политики, под оком Международных финансовых институтов, последние, не замечая этого процесса, они одновременно активно пересекают стран переходной экономики, которые не нарушали принципы рыночной экономики. Индустриально- 
промышленные развитые страны под прикрытием различных специализированных международных институтов с поддержки США, Великобритании, и отдельных стран Евразии обеспечивали развитие экономики своей страны.

Изменение уровня мировой экономики, прежде всего, связано с ростом индексов, формируемых международными рыночными институтами: показателями фондовых рынков мира, повышением цен на энергетические ресурсы, которые положительно воздействуют на состояние экономики индустриальнопромышленных стран мира и на этой основе обеспечивают необходимое вложение капитала - индекса развитие человеческого потенциала (далее ИРЧП). Одновременно это положение отрицательно повлияло на финансово-экономическое состояние не только на отдельные страны с очень высоким уровнем развития человеческого потенциала, но и в значительной степени на уровень развивающихся стран и стран с переходной экономикой. Эксперты ООН отследили и рассчитали ИРЧП большинства стран мира на основе показателя ВВП на душу населения по странам мира с учетом уровня развития человеческого потенциала. По их определению ИРЧП является составным показателем, оценивающим уровень средних достижений стран по трем основным направлениям в области развития человеческого потенциала. Разумеется, это - долголетие на основе здорового образа жизни, определяемое с точки зрения продолжительности жизни, знания, измеряемые уровнем грамотности взрослого населения и совокупным валовым коэффициентом поступивших в начальные, средние и высшие учебные заведения; достойный уровень жизни, оцениваемый ВВП на душу населения при паритете покупательной способности долларов США (Copyright, 2010).

Для этого аналитики данной организации в 2003-2010 гг. отобрали почти 170 стран мира по уровню ИРЧП и сформулировали их в четыре группы: к первой группе отнесены страны с очень высоким уровнем; ко второй группе - страны с высоким уровнем; к третьей группе - страны со средним уровнем развития человеческого потенциала, и к четвертой группе - страны с низким уровнем развития человеческого потенциала. В странах первой группы, особенно с очень высоким уровнем развития индустриально-промышленных стран, в основном ежегодно (кроме 2010 г.) обеспечивался устойчивый экономический рост. В то же время в указанном году по сравнению с 2008 г. (кроме США), по этой же группе заметно снизился уровень ВВП на душу населения. Несмотря на это данный показатель этой группы по сравнению с остальными группами оказались заметно выше.

Экономические показатели стран данной группы имеют также положительные изменения по показателям-индексам: экспортно-импортные отношения, отсутствие или незначительная степень коррупции и «теневой» экономики. Необходимое обеспечение этих соотношений способствует укреплению экономики и, соответственно, уменьшается или сокращается до минимума нищета и бедность населения. Таким образом, улучшение условий развития человеческого потенциала в первой группе стран обеспечивалось за счет повышения экономических показателей и улучшения жизненного уровня данной группы стран, но с одновременным ослаблением и ухудшением экономических показателей соответственно в остальных трех группах стран мира.

Большинства страны, входящие во вторую группу с высоким уровнем ИРЧП, за год показали неплохой рост экономических показателей, даже по сравнению с первой группой. Однако объемы ВВП на душу населения оставались значительно ниже по сравнению со странами первой группы. Как известно, что в четвертую группу вошли страны с низким уровнем развития человеческого потенциала. Здесь финансово-экономический рост оказался самым низким по сравнению с остальными группами (первой, второй, третьей) стран мира. Следует заметить, что из всех бывших 15 союзных республик в состав первой группы вошла только (Эстония), во второй - (9 республики: Литва, Латвия, Беларусь, Россия, Казахстан, Азербайджан, Украина, Грузия, Армения) и в третьей - (5 республики: Туркменистан, Молдова, Узбекистан, Кыргызстан, Таджикистан).

Итак, улучшение финансово-экономических показателей любой страны в мире может положительно повлиять на повышение уровня жизни через потребление энергии, обеспечивая сокращение уровня нищеты и бедности населения, и на этой основе произойдет увеличение человеческого развитие в обществе. Основные мировые показатели-индикаторы формируются международными финансовоэкономическими институтами, другими рыночными структурами и в основном они могут повлиять непосредственно или опосредованно на уровень социально-экономического развития любой страны мира. В частности, через повышения показателей-индикаторов фондовых рынков мира, уровня цен на энергетические ресурсы, которые положительно воздействуют на состояние экономики индустриальнопромышленных стран мира. И на этой основе обеспечиваются необходимое вложение капитала в развитие человеческого потенциала. Одновременно, к сожалению, отрицательно повлияло на финансовоэкономическое состояние развивающихся стран и стран с переходной экономики.

Наблюдая за происшедшими событиями необходимо отметить, что любое добро или зло происходили от общества самого, или государства или индивидуума, с помощью человека или с использованием его ума, таланта и профессионального качества. Это происходило по заказу со стороны, либо по отрицательному замыслу самого человека, с применением новейшего вооружения, направленного на 
массовое уничтожение всего живого существа. Заранее выработанные сценарии, придуманные спецподразделениями отдельных государств под прикрытием обеспечения национальной безопасности и улучшения обороноспособности, внедрялись в слаборазвитые страны, особенно где имеются значительные топливно-энергетические ресурсы, для их использования или ослабления их экономику, а впоследствии и возможно полного уничтожении, какого либо намека на развитие.

Почти все страны мира имеют министерства обороны (в названиях министерств этого профиля отсутствуют нападающее, т.е. агрессивное направление), так от кого защищаться, от «марсиан»? Если все министерства являются оборонительными и укрепляющими обороноспособность своего государства и обеспечение безопасности страны. «Безопасность - это состояние и тенденции развития защищенности жизненно важных интересов общества, государства и человеческой личности, а также всех их структур от внутренних и внешних угроз» (Вечканов Г.С., 2007а).

Поэтому появились вопросы укрепления уровня обороноспособности каждого государства, и при необходимости для защиты дальнейшего развития демократических принципов управления страной и от распространения религиозного экстремизма, идет усиленная защита отечества. Прорабатываются оперативные планы для ликвидации очагов терроризма/оппозиционеров, правительственных войск, в тех странах, где имеются запасы энергетических ресурсов. Для решения вопросов религии или сохранения мира, создаются новые коалиции, союзы в регионах под координацией сочувствующих или заинтересованных стран. В конечном итоге все эти проблемы подаются в рамках решения проблем для сохранения суверенитета страны, которые участвуют в локальном конфликте, впоследствии в очагах противостоянии почти всё разрушаются, уничтожаются движимые и недвижимые имущества, погибают значительное количество боевиков и правительственных войск, а также мирное население: старики и дети. На этой трагедии отдельные субъекты военно-промышленного комплекса делают деньги. И в финале, после истечения 3-5 лет, начинается процесс восстановления, на, что израсходуются колоссальные средства. Всё это, в конечном счете, делается в рамках улучшения уровня финансовоэкономической безопасности и сохранения суверенитета страны.

Подобные «операции» влекут за собой изменение биосферы; нарушение экологического равновесия, учащения возникновения стихийных бедствий: землетрясений, наводнений, изменения климата, массовые эпидемии. Данные факторы отрицательно влияют на состояние здоровья и уровень воспроизводства населения, трудоспособность и продолжительности жизни, а также усиливают процесс роста бедных слоев населения, нищеты и соответственно количество бедных стран мира.

Государство обязано уважать и обеспечивать достойной жизнью в родной стране каждого гражданина находящегося в пределах его юрисдикции, вне зависимости половой, расовой, религиозных, политических или иных убеждений.

Развитие финансово-экономического состояния государства, прежде всего, связано с развитием экономической науки и обеспечением национальной безопасности. Эту закономерность можно проследить на примере Кыргызской Республики (далее КР), образованной в 1990 г. после распада Советского Союза. В условиях суверенитета и освоения рыночной экономики Кыргызстан испытывал и испытывает трудности развития капиталистической системы, вопросов экономики и финансов, обеспечения национальной безопасности, сохранения суверенитета страны и расширения демократических принципов управления обществом.

В Кыргызстане не только среди стран Евразии, но и в странах СНГ низкий уровень показателя ВВП на душу населения, наличие коррупции и «развитие теневой экономики», недостаточный рост основных социально-экономических индикаторов уровня жизни населения, низкий уровень пенсионного и социального обеспечения населения, и другие показатели, негативно отражаются на уровне социальноэкономического развития республики. Всё это свидетельствует о недостаточной эффективности и ответственности работы органов государственного управления, регионов, местного самоуправления, правоохранительных органов и судебной власти.

Для улучшения экономических и финансовых показателей и человеческого потенциала необходимо провести изучение, анализ и оценку основных аспектов финансово-экономического состояния страны. Для сохранения и укрепления государственности и общественного строя А. Смит поставил две задачи: «во-первых, обеспечить народу обильный доход или средства существования, а точнее, обеспечить ему возможность добывать себе их; во-вторых, доставлять государству или обществу доход, достаточный для общественных потребностей. Она (политическая экономия) ставит себе целью обогащение, как народа, так и государя» (Смит А., 2009а). Одновременно А. Смит считал, что необходимо организовать защиту и охрану страны и подчеркнул, что «государь со всеми своими судебными чиновниками и офицерами, вся армия и флот представляют собою непроизводительных работников. Они являются слугами общества, и содержаться на часть годового продукта труда остального населения» (Смит А., 2009b).

А. Смит считал, что для обеспечения значительного дохода как для государства, так для общества основным источником является постоянное развитие торговли. Одновременно он указывал на 
необходимость введения ограничения на ввоз из-за границы таких продуктов, которые могут быть произведены внутри страны и низкими издержками в расчете на единицу товара. И рекомендовал эти проблемы решить путем регулирования экспортно-импортных отношений (Смит А., 2009с). Указанные составные задачи данного направления впоследствии определяли экономическую и национальную безопасность, которая со времени появления новых государств и до настоящего времени в условиях развития рыночных отношений и глобализации мировой экономики сохраняет свою особую актуальность.

А. Маршал подчеркнул, что возможность прогресса «...в большой мере зависит от фактов и заключений, входящих в компетенцию экономической науки, и именно это составляет главное и высшее предназначение экономических исследований» (Маршалл А., 2008а). В то же время, учитывая причины отставания в развитии экономической науки, он указал, что «...в действительности число ученыхэкономистов было всегда невелико по сравнению со сложностью проблем, которые этой науке надлежало решать, и в результате она все еще пребывает почти в младенческом состоянии». Глубже изучив развитие экономической науки и изменения общественных процессов, он указывает, что «...из тех способов производства, распределения и потребления, которыми занимается современная экономическая наука, возникли лишь в самое последнее время». Развивая экономические мысли он делает акцент, что необходимо осуществлять свободное предпринимательство и сохранить безопасности (подчеркнуто О.К.) «...во всех аспектах - политических и социальных - стоит отстаивать любой ценой, за исключением потери безопасности». Далее он подчеркнул, что «...экономисты рассматривали свободное предпринимательство, по существу, не как абсолютное благо, а как меньшее зло с действовавшими в те времена порядками». Он понимал, что все эти действия впоследствии могут способствовать росту накоплению денег и улучшить покупательную способность, которые «...составляют главный стержень, вокруг которого концентрирует свое внимание экономическая наука, объясняется это не тем, что деньги или материальное богатство рассматриваются как главная цель человеческой деятельности или даже как основной предмет исследования экономиста». И он видел, что каждое возрастание богатства, увеличение численности интеллекта, создает условие высокоразвитой организации производства, что способствует производительности капитала и труда (Маршалл А.,b), и это эффективно достигается в отраслях промышленности.

В то же время Дж.М. Кейнс считал, что для преодоления кризиса необходимо обеспечить государственное регулирование, стимулирование производства, снижение процентных ставок. В труде «Мировой денежный рынок и кризис» и в рамках «Трактата о деньгах» он высказал целый ряд идей, отражающих его понимание методов борьбы с кризисом, в частности, он указал на необходимость снижения процентных ставок инвестиций путем государственного вмешательства (Кейнс Дж. М., 2008).

Поэтому без обеспечения соответствующего финансово-экономического уровня невозможно своевременное решение стоящих перед государством задач, как на национальном, так и на международном уровне. И всё это, в конечном счете, направлено на улучшение человеческого общества. Естественно государственная стратегия финансово-экономической безопасности, являясь неотъемлемой частью национальной безопасности любого государства, заключается в обеспечении защиты населения через повышение уровня и качества жизни, эффективное решение открытых внутренних экономических и социальных задач, а также дозированное влияние на мировые процессы с учетом национальных интересов страны, в рамках экономики Евразии. В этой связи наделение государства функциями национальной безопасности является стержневым вопросом. И он непосредственно взаимосвязан и взаимозависим от уровня финансово-экономической безопасности страны. В условиях развития рыночных отношений обоснована взаимосвязь между отраслями экономики и финансовым сектором республики. Поэтому необходимы финансиализации всего капитала, соответственно показатели экономической безопасности в целом по стране в обобщенном виде должны отражаться в показателях финансово - экономической безопасности. Поэтому финансиализация и финансовые механизмы, и инструменты являются основными методами увеличения финансовых ресурсов. «Именно для индустриально-промышленных стран мира финансовые рычаги позволяют государству быстро реагировать на изменения экономического развития. США, как и другие развитые страны, обладают значительной государственной собственностью на финансовые ресурсы (Экономика США, 167b).

Для этого была подписана и утверждена с кыргызской стороной поэтапная программа геологического изучения недр на двух перспективных нефтегазоносных площадях - Кугартская и Участок Восточный Майлису IV. На Кугартской площади будет выполнена сейсморазведка 2D в объеме 450 пог. км и разведочные работы - 523 кв. км. На Участке Восточный Майлису IV запланирована сейсморазведка 2D в объеме 50 пог. км и разведочные работы - 44 кв. км.

Вместе с тем, вышеуказанные тенденции цепного индекса КР, связаны недостаточным ростом финансово-экономических показателей на микро - и макро-уровнях, а также значительные объемы внешних и внутренних долгов. Кроме того, имели место неустойчивости уровня социально- 
экономического развития и в отдельные годы общественно-политической ситуации в республике (2005 г. и 2010 г.).

Следовательно, структура национального богатства состоит в основном, из природного и человеческого потенциала, экономических, научно-технических достижений и финансовых ресурсов. Всё эти важные ресурсы, факторы и условия концентрируются в макроэкономических показателях, прежде всего, ВВП и госбюджета страны. Действительно, «показатель ВВП представляет собой ключевой параметр системы национальных счетов США, используемый для измерения и оценки тенденций развития американской экономики в долгосрочном плане. Динамике ВВП отражает колебания и перепады состояния национальной экономики, служит основой для выработки экономической политики страны, своеобразным «компасом» ее фискальной и монетарной составляющих» (Экономика США, 2003c).

В Кыргызстане открытость экономики зашкаливает за 100\% (в 2011 г.). В 2000-2011 гг. ВВП вырос в 4,2 раз, в то же время оказание услуг потребителям в структуре ВВП подрос в 5,8 раз, а производство товаров возросло всего лишь 3 раза (Нацстаткомитет КР, 2012). Здесь доминирующим фактором в формировании ВВП оказался оказание услуг и ежегодно возрастало производство товаров и услуг, а также чистые налоги на продукты. В то же время в структуре ВВП по сравнению производством услуг заметно отставало доля производство товаров: с 61\% в 2000 г. до 43,6\% в 2011 г. За этот период возросла доля услуг - соответственно с 32,1\% до 44,9\%. Одновременно произошло увеличение суммы чистых налогов на продукты с 6,9\% до 11,5\%. Причем, темпы прироста производство услуг, начиная с 2009 г. заметными темпами опережали прироста производство товаров. Если такая тенденция будет сохранена и дальше то, забегая вперед можно сказать, что и неизбежны проблемы, как и в предыдущие годы появления отрицательного сальдо торгового и платёжного баланса. Впоследствии снижение поступления твердой валюты от внешнеторговой деятельности, уменьшения доходов госбюджета и вследствие появления его дефицита. И такая цепная реакция ослабевает уровня финансово-экономического состояния КР.

Теперь нам необходимо рассмотреть динамику изменения структуры ВВП в КР. Для чего приводим доли и структуры ВВП по основным отраслям экономики. «Уверенно» сдают свои позиции сельское хозяйство и промышленность - до недавнего времени считающиеся флагманами экономики. Причины общеизвестны: «как следует, реформировались и приватизировались по коррупционной схеме», а также потери внешних вертикально-интеграционных экономических связей со странами дальнего и ближнего зарубежья. Повиляли также результаты уровня эффективность и ответственность руководителей органов государственного управления и других республиканских структур при принятии и применении нормативно-правовых актов, налогово-бюджетного и денежно-кредитного механизмов, создание централизованных фондов и отмывание собственных и заемных финансовых средств Кыргызстана.

Были определены «приемлемые условия (тарифы на лицензии) по проведению геологоразведочных работ и добычи природных ископаемых (в основном в пользу иностранных инвесторов), особенно в горнодобывающей и обрабатывающей промышленности. В частности, по освоению золоторудных месторождений и вывоза, и продажи, не только готового золотого слитка, но и полученных других попутных драгметаллов, и даже в добычи и обработке основной руды. Кроме того, в организации внешней торговли, были установлены приемлемые условия экспортно-импортных поставок, и в этом процессе лоббировали некоторые руководители государственного управления. Впоследствии эти действия отрицательно оказались и на формирование ВВП КР, в том числе на отдельные - ключевые отрасли реального сектора экономики, в частности: сельское хозяйство и промышленность и эти отрасли в структуре ВВП республики в 2000-2010 гг. соответственно снизились с 34,1 до 18,0\% и с 25 до 20,7\%.

Одновременно следует подчеркнуть, что объем ВВП КР, в том числе уровень промышленности в определенной степени поддерживается результатом работы Кумтор Оперейтинг Компании (далее КОК). Хотя, от этой компании финансово-экономическое состояние республики всё еще прямого эффекта полностью не получает, кроме налоговых, социальных и одноразовых гуманитарных пожертвований жителям КР. В настоящее время (в 2010-2011 гг.) отдельные эксперты считают, что от КОК увеличились поступление налогов от валового дохода по разработке золоторудного месторождения. По данным НСК КР объем указанного налога в 2010 и2011 гг. возрос с 4,4 млрд. сомов до 6,1 млрд. сомов, или соответственно 2,0 и 2,2\% к ВВП КР. Однако, удельный вес показанных налогов к налоговым доходам Кыргызстана составляет соответственно всего лишь 11 и 11,4\%. [(Справочное: Национальная валюта сом введена Жогорку Кенешем - (Парламентом) КР от 10 мая 1993 г. Тогда 3,98 сома = за \$1)].

Тем более в соответствии со статьей 16 «Запреты и ограничения экспорта и/или импорта исходя из национальных интересов» Закона КР (1997г.) «О государственном регулировании внешнеторговой деятельности в Кыргызской Республике», исходя из национальных интересов, могут быть, установлены запреты и ограничения экспорта и/или импорта товара, работ, услуг, для предотвращения исчерпания невосполнимых природных ресурсов, чтобы обеспечивать национальной безопасности КР (подчеркнуто автором - О.К.). Необходимо обеспечить самостоятельное освоение собственных золоторудных месторождений. Национальное золото - это постоянный источник - инвестиции. 
В КР одновременно произошли положительные сдвиги по увеличению доли в структуре ВВП, в частности, в строительстве, торговли, оказание услуги, чистые налоги на продукты и др. Эти тенденции могли бы еще улучшаться, если темпы прироста производительности труда, были бы значительно выше, чем темпы прироста его оплаты сектора экономики и соответственно в целом по стране.

В динамике производство ВВП в целом по стране на душу населения в 2005-2008 гг. (если не считать 2000г.) имеет тенденции роста. Однако, начиная с 2009 г. производительность труда по стране не достаточно выросла. Хотя, за сопоставимый период производство ВВП на душу населения выросло в 3,9 раза. В то же время за изучаемый период среднемесячная номинальная зарплата 1-го работника по КР в основном имеет тенденции роста. Пик прироста заработной платы по сравнению с производительностью труда отмечен в 2005, 2008 и 2011 гг. (соответственно в 2; 1,1 и 1,3 раза), а в остальные годы, начиная с 2008 г. она имела тенденции роста и в целом по стране за изучаемый период увеличилась в 7,8 раза.

Доля промышленной продукции в структуре ВВП в 2000 г. составляла 25\% и занимала второе место после сельского хозяйства, а в 2011 г. она снизилась до 20,7\%, или на 4,3 процентных пункта. Хотя в данной отрасли также имеются неиспользованные возможности. Заметное изменение произошло в объемах продукции в обрабатывающей промышленности и в отрасли производства и распределения электроэнергии, газа и воды. Недостаточная эффективность производства сектора экономики, прежде всего, было связано с тем, что за изучаемый период в структуре ВВП произошло заметное уменьшение объема и удельного веса товаров, нестабильность вложенных инвестиций. Впоследствии произошло снижение уровня ввода в действие основных фондов, влияние уровня инфляции, некоторый рост уровня внешней миграции, не снижения доли чистого экспорта, а также наличие безработных в республике.

Поэтому нам необходимо в динамике изучить тенденции изменения цепного индекса основных финансово-экономических показателей реального сектора экономики (табл.). За сопоставимый период замечается неустойчивая тенденция роста цепного индекса по вложенным инвестициям в основной капитал и по привлечению ПИИ. В большинстве случаев, наоборот наблюдается снижения уровня этих показателей, особенно, по инвестициям в основной капитал. Вместе с тем ожидается увеличение инвестиции в основной капитал и по привлечению ПИИ со стороны стратегического партнера Кыргызстана - Российской Федерацией намечается крупное вливание для развития отраслей промышленности.

Поэтому Gazprom International, единый оператор зарубежных проектов «Газпрома» России в области поиска, разведки и разработки месторождений углеводородов, завершил оформление лицензионных приложений для продолжения геологоразведочных работ на территории Кыргызстана. Для этого была подписана и утверждена с кыргызской стороной поэтапная программа геологического изучения недр на двух перспективных нефтегазоносных площадях - Кугартская и Участок Восточный Майлису IV. На Кугартской площади будет выполнена сейсморазведка 2D в объеме 450 пог. км и разведочные работы 523 кв. км. На Участке Восточный Майлису IV запланирована сейсморазведка 2D в объеме 50 пог. км и разведочные работы - 44 кв. км.

\begin{tabular}{|l|l|l|l|l|l|l|}
\hline Показатель & 2000 г. & 2005 г. & 2008 г. & 2009 г. & 2010 г. & 2011 г. \\
\hline Инвестиции в основной капитал & 137,3 & 97,1 & 105,7 & 130,8 & 90,8 & 93,4 \\
\hline $\begin{array}{l}\text { Прямые иностранные инвестиции, млн. долл. США } \\
\text { (без оттока) }\end{array}$ & 82,5 & 119,8 & 198,3 & 76,3 & 100,8 & 77,3 \\
\hline Кредитные вложения в экономику & 96,1 & 129,0 & 128,3 & 116,5 & 106,4 & 115,8 \\
\hline Ввод в действие основных фондов & 277,4 & 82,9 & 119,9 & 105,7 & 83,9 & 101,8 \\
\hline Валовой выпуск сельского хозяйства & 103,9 & 95,8 & 100,8 & 107,0 & 97,4 & 102,3 \\
\hline Продукция промышленности & 106,0 & 87,9 & 114,9 & 93,6 & 109,8 & 111,9 \\
\hline Среднегодовая численность занятые в экономике & 100,2 & 102,9 & 101,5 & 101,5 & 101,2 & 101,5 \\
\hline $\begin{array}{l}\text { Среднемесячная реальная заработная плата одного } \\
\text { работника }\end{array}$ & 98,5 & 111,8 & 108,8 & 107,3 & 108,0 & 111,1 \\
\hline Общий объем оборота торговли & 107,8 & 113,5 & 109,6 & 100,1 & 94,4 & 106,7 \\
\hline Объем услуг & 104,4 & 112,6 & 113,1 & 104,5 & 92,6 & 109,2 \\
\hline Внешняя миграция & 156,7 & 119,4 & 81,6 & 80,9 & 163,2 & 83,9 \\
\hline Экспорт товаров & 111,2 & 93,5 & 140,4 & 90,6 & 105,0 & 127,9 \\
\hline Импорт товаров & 92,4 & 117,2 & 146,0 & 74,7 & 106,0 & 132,2 \\
\hline ВВП & 134,3 & 115,9 & 108,4 & 102,9 & 99,5 & 105,7 \\
\hline То же, на душу населения & 133,0 & 109,2 & 131,7 & 105,9 & 108,2 & 122,6 \\
\hline Доходы госбюджета & 128,2 & 111,5 & 129,4 & 119,5 & 104,1 & 134,1 \\
\hline Расходы госбюджета & 125,6 & 106,9 & 125,3 & 130,2 & 117,4 & 132,7 \\
\hline
\end{tabular}

Таблица 1. Уровень цеепного индекса основных финансово-экономических показателей КР (к предыдущему году сопоставимых ијенах),(\%), в 
Вместе с тем, вышеуказанные тенденции цепного индекса КР, связаны недостаточным ростом финансово-экономических показателей на микро - и макро-уровнях, а также значительные объемы внешних и внутренних долгов. Кроме того, имели место неустойчивости уровня социальноэкономического развития и в отдельные годы общественно-политической ситуации в республике (2005 г. и 2010 г.).

В условиях переходного периода и интенсивного освоения золоторудных месторождений, следовало бы модернизировать формирование отечественной финансовой системы основанной на создание собственных источников инвестиции за счет средств госбюджета, с учетом эффективного использования полезных ископаемых, в рамках продвижения золотого стандарта в экономике и финансов республики.

Вместе с тем вышеуказанные тенденции впоследствии отрицательно воздействовали валового объема продукции сельского хозяйства и выпуска продукции промышленности. Хотя стабилизировалась среднегодовая численность работников, занятых в экономике и имеет тенденции роста среднемесячной реальной заработной платы одного работника. Хотя в отдельные годы обладает тенденции роста внешней миграции, связанные недостаточным развитием отраслей экономики, особенно в сельских районах страны. Численность, безработных за изучаемый период составила свыше 60,0 тыс. чел.

В динамике (кроме 2010 г.) замечается некоторый рост общего объема оборота внешней торговли и объема услуг, которые в основном были связаны опережающим ростом импорта товаров, над его экспортом. Хотя экспорт товаров (кроме 2005 г. и 2009 г.) также имеет тенденции роста. Однако в целом показатель чистого экспорта был почти всегда отрицательным знаком, что способствовал, вывоза капитала за границу и соответственно, и снизил объемы валовой добавленной стоимости. Впоследствии недостаточно вырос объем ВВП и доходы госбюджета. К сожалению, расходы бюджета имели тенденции роста по сравнению доходной части госбюджета, и в 2009-2011 гг. образовался, значительная сумма дефицита госбюджета, и за счет увеличение неоправданного роста расходов, особенно на содержание госаппарата КР.

Основным источником доходов госбюджета являются: налоговые (почти 70\%) и неналоговые доходы (свыше 20\%), а также полученные официальные трансферты (более 10\%), которые имеют тенденции роста. Если в 2000 г. каждый 8 сом произведенной продукции или оказанной услуги облагался налогом, то начиная с 2005 г. по 2011 г. этот показатель снизился с 6 до 5 сом. Впоследствии вырос налоговая задолженность, наблюдалось увеличение объемов скрытой и не наблюдаемой экономики и ухудшались многие финансово-экономические показатели страны.

Необходимо заметить, что за сопоставимый период из-за ослабления уровня экспортного потенциала в КР коэффициент покрытия импорта экспортом снизился с 91 до 53. Это свидетельствует об увеличении отрицательного сальдо торгового баланса с 49 млн. долл. США до 2015 млн. долл., или в свыше 40 раз. В 2007-2011 гг. внешнеторговый оборот Кыргызстана со странами ближнего и дальнего зарубежья вырос с 3551,2 млн. долл. до 6240,1 млн. долл. США, или в 1,8 раз. В том числе со странами СНГ соответственно с 2091,3 млн. долл. до 2934,6 млн. долл. США, или возрос в 1,4 раз. Из них Российская Федерация с 547 млн. долл. до 1714,0 млн. долл. США, или в 3,1 раз. По внешнеторговому обороту между Кыргызстаном и Россией обеспечен рекордный уровень по сравнению со странами ближнего и дальнего зарубежья, в том числе партнерами по СНГ. Причем удельный вес между двумя республиками в структуре СНГ сохранился почти одном и том же уровне 58,0 и 58,4\%. Хотя внешняя торговля дала значительную выгоду для России, которая возросла с 744,2 млн. долл. в 2007 г. до1145,2 млн. долл. США в 2011 г., или за 5 лет выгода в пользу России составила 4082,1 млн. долл. США. А это в условиях рыночных отношений почти равносильно строительству двух Камбаратинских ГЭС для Кыргызстана.

Учитывая традиционные связи между Кыргызстаном (Президент А. Атамбаев) и Россией (Президент В. Путин) в рамках эффективного углубления экономической интеграции стран Евразии и СНГ в строительстве крупных экономико-образующих объектов, в том числе гидроэлектростанций, особенно в строительстве Камбар-Атинская ГЭС-1, которая явиться крупнейшим объектом, с ежегодной потенциальной выработкой электрической энергии порядка 5,1 млрд. кВт.-ч. Уполномоченными организациями сторон по реализации соглашения между правительством КР и правительством РФ о строительстве и эксплуатации указанной ГЭС-1 являются: от кыргызской стороны - ОАО «Электрические станции»; от российской стороны - ОАО «ИНТЕР РАО ЕЭС». ПроекТ реализуется ЗАО «Камбаратинская гидроэлектростанция-1» со следующим распределением долей в уставном капитале: ОАО «Электрические станции» - 50\%; ОАО «ИНТЕР РАО ЕЭС» - 50\%.

Принят Федеральный закон «О ратификации Соглашения между правительством Российской Федерации и правительством Кыргызской Республики о строительстве и эксплуатации ВерхнеНарынского каскада гидроэлектростанций». Федеральный закон принят Государственной Думой и одобрен Советом Федерации в апреле 2013 г. Соглашением предусматривается реализация проекта строительства и эксплуатации 4-х ГЭС Верхненарынского каскада на территории Кыргызстана (Акбулунская ГЭС, Нарынская ГЭС-1, Нарынская ГЭС-2 и Нарынская ГЭС-3). Для реализации 
указанного проекта уполномоченные организации сторон учреждают совместное предприятие с паритетным распределением долей в уставном капитале. Вклад российской уполномоченной организации в уставный капитал ЗАО «Верхне-Нарынские ГЭС» составит 50\% от стоимости реализации проекта. Кыргызская сторона в качестве вклада своей уполномоченной организации, в уставный капитал названного ЗАО вносит право пользования земельными участками, отведенными под строительство Верхненарынского каскада ГЭС, и другие активы, в том числе нематериальные, в размере 50\% от стоимости реализации проекта.

На период окупаемости проекта за российской стороной закреплено стратегическое и оперативное управление проектом за счет преобладания ее представителей в совете директоров и правлении совместного предприятия. При этом кыргызская сторона передает в доверительное управление российской стороне $25 \%$ своих акций $3 \mathrm{AO} \mathrm{«Верхне-Нарынские} \mathrm{ГЭС».} \mathrm{Соглашением} \mathrm{предусматривается}$ реализация проекта строительства и эксплуатации на территории КР Камбар-Атинской ГЭС-1 и воздушных линий, обеспечивающих экспорт электрической энергии, вырабатываемой указанной ГЭС, в энергосистемы сопредельных государств. Проект реализуется существующим совместным предприятием — ЗАО «Камбаратинская ГЭС-1».

Следует подчеркнуть, что по итогам 2009-2012 гг. отмечались отрицательные тенденции, влияющие на формирование ВВП и госбюджета КР. Такое нежелательное изменение связано, с тем, что в динамике прослеживалось недостаточное поступление налоговых доходов к ВВП и опережающие расходы госбюджета, над его доходами. Кроме того, произошло заметное снижение коэффициента покрытия импорта экспортом, и впоследствии образован значительный объем дефицита госбюджета, допущено несвоевременное обслуживания графика ГВД. Тем более объемы государственных внешних заимствований в 2000-2011 гг. вырос свыше 2 раз и на душу населения он увеличился с 285 до 509 долл. США. Впоследствии международные инвестиционные позиции КР были ослаблены. За указанный период иностранные активы увеличились в 6,5 раза, одновременно объем внешних финансовых обязательств повысился в 2,8 раз. В итоге чистая международная инвестиционная позиция Кыргызстана сформировалась отрицательная, и её уровень возросла с -1658,8 млн. долл. США до -2772,0 млн. долл. США, или, в 1,5 раза.

Выше отмеченные диспропорции впоследствии ухудшали показателей платежного баланса, особенно счета текущих операций. Кроме того, они были связаны, прежде всего, недостаточным ростом производства конкурентоспособных и экспорта - ориентированных товаров КР. За изучаемый период производство товаров, хотя увеличилось почти 3 раз. К сожалению, их доля в структуре ВВП, снизилась с 61,0\% в 2000 г. до 43,6\% в 2011 г. За это время, хотя ВВП вырос в 4,2 раз. Одновременно денежная масса возросла почти в 10 раза, и она в отношение к ВВП увеличилась с 12\% до 29\%. В структуре денежной массы, деньги вне банков в основном имеют тенденцию ежегодного роста и они увеличились в 11,5 раза. Впоследствии скорость обращения М2Х снизилась с 8,9 до 3,8, или на 57,3\%, что свидетельствует о снижения уровня мобильности экономики и потребность в деньгах возрастает и для других целей. В этом процессе не исключается участие также коррупционной схемы и «теневой» экономики республики. И естественно, они замедляют скорость оборота денег, и снижаются функции денег, как средства обращения. Вследствие отмечается постоянный рост степени коэффициента монетизации ВВП по денежному агрегату М2, хотя этот процесс отслеживается и со стороны МВФ. Такая тенденция в определенной степени связана с ростом общей суммы импортируемых товаров, розничного товарооборота, уровня инфляции, роста внешних заимствований, а также недоверия отдельных категорий граждан к АКБ.

Хотя, имеет тенденции к снижению средневзвешенная годовая ставка по депозитам АКБ, как в национальной, так и иностранной валюте. Одновременно так же в динамике снижается средневзвешенная ставка по кредитам в национальной и иностранной валюте АКБ. В то же время отклонения ставки по кредитам АКБ по сравнению с депозитами, замечается снижения. Однако данная разница, по сравнению средневзвешенной годовой ставкой по депозитам АКБ, как в национальной, так и иностранной валюте начали расти соответственно с 2,1 до 9,8 раза и с 7,4 до 22,9 раза.

Впоследствии начиная с 2009 г. замечался увеличение процесса дефицита госбюджета (почти 3 млрд. сом, или 1,5\% к ВВП КР). В 2010, 2011 и 2012 гг. были допущены суммы дефицита госбюджета соответственно: 10,8, 13,5 и 23,1 млрд. сом, или почти 5\% к ВВП КР. Согласно проекту закона «О внесении изменений в закон КР «О республиканском бюджете КР на 2012 год и прогнозе на 2013-2014 гг.», уточненный дефицит республиканского бюджета на 2012 г. составил 21, 7 млрд. сомов, что составил 7,1\% к ВВП КР. Для покрытия дефицита бюджета образованного в 2012 г., из всех предусмотренных источников финансирования намеченной Правительством КР (далее ПКР) более эффективным вариантом является обозначенное выделение (в четвертом квартале 2012 г.) стратегическим партнером Правительством Российской Федерации безвозмездного гранта в размере $\$ 25$ млн. долл. США (или 1,2 млрд. сомов.) для поддержания бюджетной устойчивости Кыргызстана. 
Президентом России подписан Федеральный закон «О ратификации Соглашения между Правительством РФ и Правительством КР об урегулировании задолженности КР перед РФ по ранее предоставленным кредитам». В межправительственном соглашении, которое было подписано в сентябре прошлого года, пересматриваются условия погашения и обслуживания двух долговых обязательств Кыргызстана, общий объем которых составляет 488,9 млн. долл. США (сентябрь 2012 г.). Как уточняет российское агентство РИА «Новости», одна задолженность составляет 188,9 млн. долл. — она, согласно документу, будет списана единовременно в полном объеме в момент вступления в силу соглашения. При этом начисление и выплата процентов на имеющийся остаток долга производиться не будут. Вторая задолженность, в размере 300 млн. долл., будет списываться равными долями в течение 10 лет, начиная с марта 2016 г. Оговаривается, что остаток долга уплачивается кыргызской стороной до марта 2016 г., после чего проценты на остаток не начисляются и не выплачиваются.

Справедливости ради следует подчеркнуть, что при значительном дефиците госбюджета КР в течение многих лет и из-за недостаточного поступления налоговых доходов и незначительного роста объема производство товаров в структуре ВВП страны, опережающего роста импорта товаров по сравнению с ростом экспорта, большие средства были направлены на содержание органов государственного управления. Этот процесс заметно увеличивается, начиная с 1997 г. и по настоящее время. Если в 1995 г. расходы на финансирование государственных услуг общего назначения, оборону, общественный порядок и безопасность составили 19,6\% годового бюджета, то в 2007 г. они возросли до 25,1\%, или на 5,5 процентных пункта. За этот период в условиях развития рыночных отношений расходы социальнокультурной сферы снизились. Расходы бюджета только по двум указанным направлениям составляют свыше 80\%. Финансирование секторов экономики в структуре бюджета повысилось. На финансирование производства товаров расходы были мизерными, т.е. средства были распределены по остаточному принципу.

Итак, улучшение финансово-экономическое состояние республики обеспечивается увеличением производства товаров, наращиванием экспортного потенциала, применением эффективного механизма и инструментов финансово-кредитной системы, самое главное искоренением коррупции, контрабанды и других экономических преступлений. Это способствует своевременному погашению внешнего долга, повышению доверия населения к ПКР, а также улучшению уровня экономических показателей страны.

Поэтому необходимо обеспечить динамичный рост основных отраслей реального сектора экономики и важных макроэкономических показателей. При обеспечении этих условий можно улучшить степень показателей, характеризующие состояние экономики и финансов республики и на этой основе можно ослабить влияние глобального финансово-экономического кризиса в КР. Финансово-экономические и правовые механизмы должны инициировать и стимулировать возрождение ключевых отраслей экономики.

Для этого необходимо привести обобщающие основные факторы и условия, обеспечивающие развитие национальной экономики Кыргызстана (рис.). Основными источниками для поддержания национальной экономики является оптимальный уровень инвестиции в основной капитал. Причем в структуре основного капитала должны быть правильное сочетание между объемами внешней и собственной инвестиции в рамках соблюдения национальных интересов республики. Такое сочетание, прежде всего, обеспечивается за счет роста отечественных источников, особенно наращиванием добывающей и обрабатывающей промышленности, в том числе освоением национальных золоторудных месторождений и увеличением запаса собственного золото.

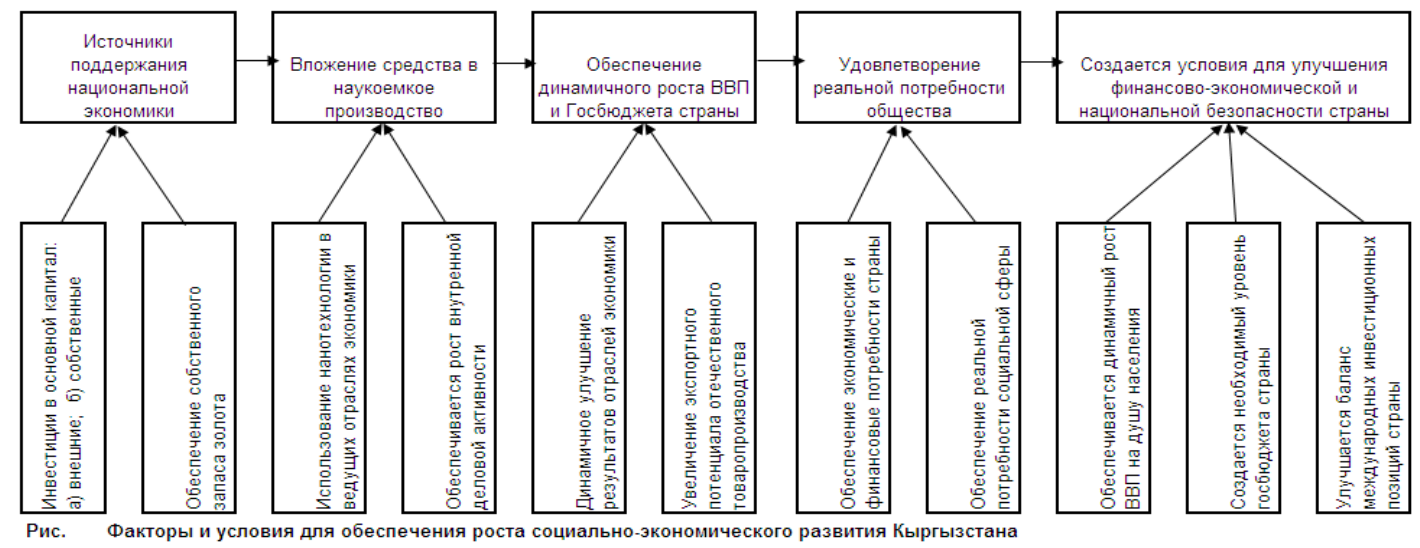

Рисунок 1. Факторы и условия для обеспечения роста социально-экономического развития Кьргызстана. 
В условиях открытость экономики и дальнейщего развития интеграционных процессов в рамках укрепление экономики государств Евразии, следует поэтапно и на основе приблежения относительного уровня финансово-экономического состояние будущих членов таможенного союза необходимо ускорять расширение границы данного союза, и с учетом сохранения суверенитета государств создать единое таможенное, энергетическое и, далее, на основе применение единой эквивалентной денежной единицы для свободного обращения среди государств нового общества и их объединять как добровольное объединение стран ( далее ДОС) в условиях продвижения международной интеграции по финансовоэкономическим вопросам, и на этой основе затем сформировать единое экономическое пространство (далее ЕЭП) в рамках развития экономики Евразии, и при сохранении функций национальных валют каждого суверенного государства. Поэтапное осуществление этих направлений приближает процесс разработки идентичной финансовой отчетности торгового и платежного балансов, баланса международных инвестиций национальными банками и национальными статистическими комитетами каждой республики Евразии. И отходить от расчетного и фактического использования доллара США в Международных финансово-экономических операциях.

В конечном итоге обеспечивается динамичный рост ВВП на душу населения, создается необходимый уровень госбюджета страны и улучшается баланс международных инвестиционных позиций страны. И создается условия для улучшения финансово-экономической и национальной безопасности каждой страны Евразии, в том числе КР.

В целом макроэкономическая стабильность на 2013-2017 гг. должна отражаться в обеспечении следующих параметров: среднегодовой рост ВВП не ниже 7-9\%; уровень инфляции не более 5-7\%; уровень дефицита госбюджета к ВВП не более 2-4\%; государственный долг к ВВП не выше 35-40\%. На основе эконометрики определено, как в отдаленной перспективе предвидится, что предусмотренные узловые макроэкономические показатели в основном будут обеспечены в 2017-2019 гг. В 2017 г. по сравнению с 2011 г. ожидается увеличение ВВП на душу населения республики как минимум свыше в 1,5 раз. Одновременно предвидится рост госбюджета на душу населения республики минимум в 2,1 раза. И на этой основе ожидается улучшение уровня социально-экономического развития, особенно социальной сферы КР.

\section{Заключение}

В обобщенном виде теоретические и практические аспекты открытой экономики и экономической интеграции Кыргызстана, прежде всего, зависит в рамках формирования экономики Евразии на основе обеспечения следующих важных направлений:

наличия природно-сырьевого, достаточного экономического, эффективного и конкурентоспособного инновационного потенциала и уровня разработки и применения нанотехнологии в рамках собственных финансовых ресурсов, обеспеченных национальным золотым эквивалентом государств Евразии;

обеспечение реального темпа прироста ключевых секторов экономики, освоения и полная переработка сырьевых ресурсов, уровня развития конкурентоспособного эффективного индустриальнопромышленного производства: сельского хозяйства, динамики развития отраслей, обеспечивающих энергетическую, промышленную, продовольственную и экологическую безопасность в рамках ускорения Международной экономической интеграции. И на этой основе создание единое таможенное, энергетическое новое общество, и, применение единой эквивалентной денежной единицы для свободного обращения среди государств Евразии и их объединять как ДОС по финансово-экономическим вопросам и далее сформировать ЕЭП, при сохранении суверенитета каждого государства;

осуществление этих направлений приближает процесс разработки идентичной финансовой отчетности торгового и платежного баланса, баланса международных инвестиций, составляемые национальными банками и национальными статистическими комитетами каждой республики и в целом по Евразии с применением единой эквивалентной денежной единицы. И отходить от расчетного и фактического использования доллара США в Международных финансово-экономических операциях.

внешнеэкономической и внешнеторговой деятельности, которые в определенной степени положительно обеспечивают необходимого уровня торгового и платежного баланса и способствуют привлечению ПИИ для создания крупных бюджете - образующих и конкурентоспособных, особенно для начала в создании совместных экспорта - ориентированных национальных хозяйствующих субъектов;

активности эффективной борьбы масштабной коррупцией, «теневой» экономикой и криминализацией экономики и финансов; повышение эффективности и ответственности работы руководителей государственного управления в обеспечении намеченных параметров социально-экономического развития страны;

улучшения качественного уровня жизни населения, повышения степени человеческого потенциала главный барометр безопасности; 
эффективности развития основных отраслей экономики обеспечивается в рамках одновременного формирования их инфраструктуры - основы динамичного обеспечения роста макроэкономических показателей, из них особенно собственных финансовых ресурсов и улучшения социальной сферы, определяющего социально-экономического развития, сохранения целостность и суверенитета республики;

в отдаленной перспективе предвидится, что предусмотренные узловые макроэкономические показатели в основном будут обеспечены в 2017-2019 гг. В 2017 г. по сравнению с 2011 г. ожидается увеличение ВВП на душу населения республики как минимум свыше в 1,5 раз. Одновременно ожидается рост госбюджета на душу населения республики минимум в 2,1 раза, что обеспечить укрепления национальной экономики страны.

Итак, высокоэффективная работа ключевых отраслей экономики и его инфраструктуры являются основой развития трансформирующейся экономики, финансов и на этой основе обеспечивается динамичный рост валового национального дохода страны, что способствуют ускорению преодоления финансово-экономического кризиса и улучшению жизненного уровня населения республики.

\section{Литература}

- Экономика США (2003), / Под ред. В.Б. Супяна.- СПб.: Питер, - С. 157, 159a; 167b; 94c.

- Copyright (2010), - 1 UN Plaza, New York, NY 10017, USA. Palgrave Macmillan, St Martinis Press LLC, 175 Fifth Avenue, New York, NY 10010. Издательство «Весь Мир», 20-е, Москва, - С. 143-146 и 206 210.

- $\quad$ Вечканов Г.С. (2007) - Экономическая безопасность: - СПб.: Питер. - С. 26.

- Смит А. (2009) - Исследования о природе и причинах богатства народов: Пер. с англ. В.С. Афанасева. - Москва, Эксмо, - С. 419a, 339b, 440-443c,

- Маршалл А. (2008) - Основы экономической науки / А. Маршалл; [предисл. Дж. М. Кейнса; пер. с англ. В.И. Бомкина, В.Т. Рысина, Р.И. Столпера ]. - Москва, Эксмо, - С. 59a; 61b; 61, 62, 65, 67, 75, $325 \mathrm{c}$.

- Кейнс Дж. М. (2008) - Общая теория занятости, процента и денег. Избранное / Дж. М. Кейнс; вступ. статья Н.А. Макашевой. - Москва, Эксмо,- С. 895-898.

- Нацстаткомитет КР. (2012). В тексте статьи аналитические данные подсчитаны автором за соответствующие годы из указанного источника.- Бишкек. 


\section{Author Index}

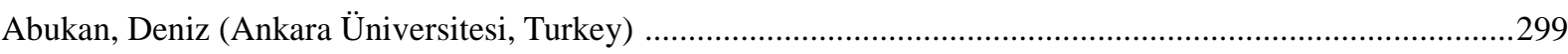

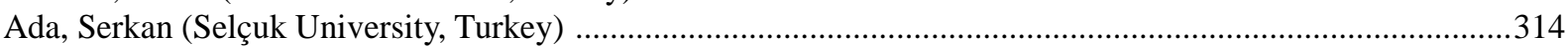

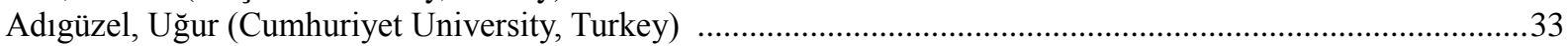

Ağayev, Seymur (Recep Tayyip Erdoğan University, Turkey) …………………………………….................372

Ağır, Hüseyin (Sütçü İmam University, Turkey) ……………….................................................................133

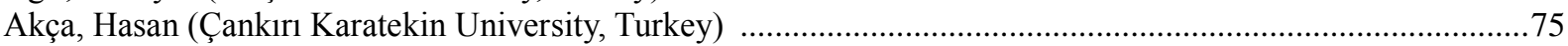

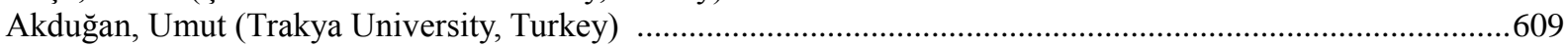

Akmaz, Hakan Kasım (Çankırı Karatekin University, Turkey) ........................................................................323

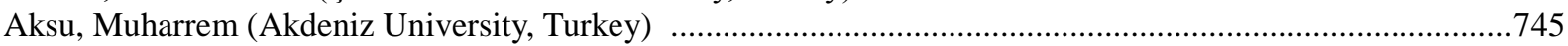

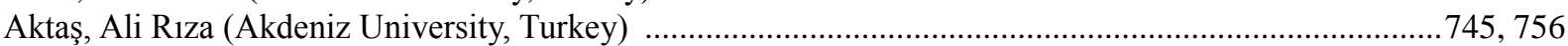

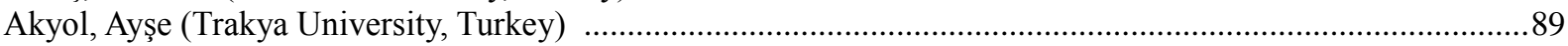

Akyurt Kurnaz, Hande (Sitkı Koçman University, Turkey) ..............................................................................712

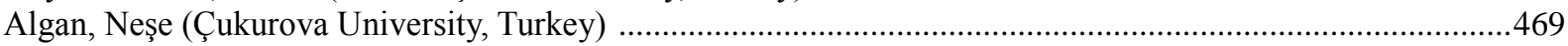

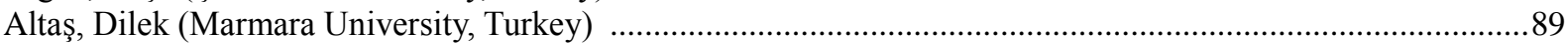

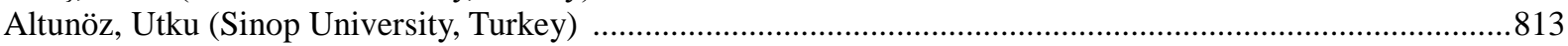

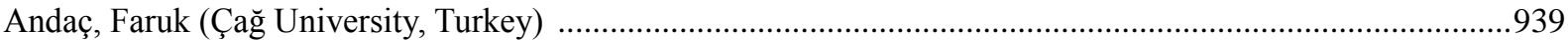

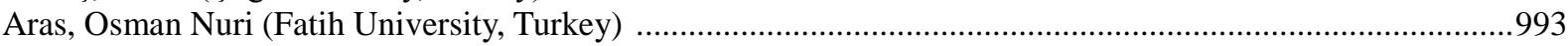

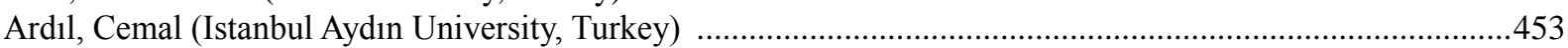

Arpal, Ziya (Kyrgyzstan-Turkey Manas University, Kyrgyzstan) ................................................................549

Arslan, Çetin (Turkish Supreme Court, Turkey) …………………………………………………...............901

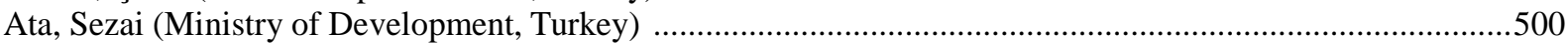

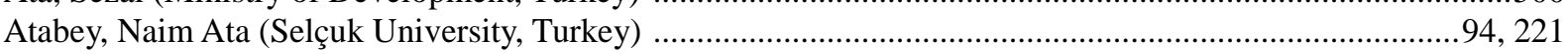

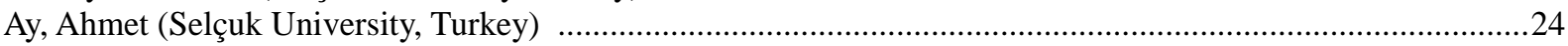

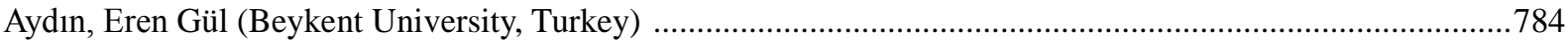

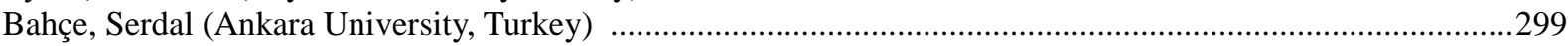

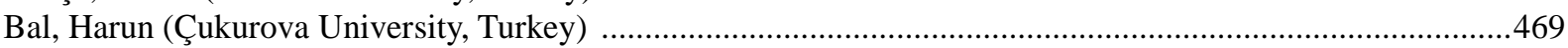

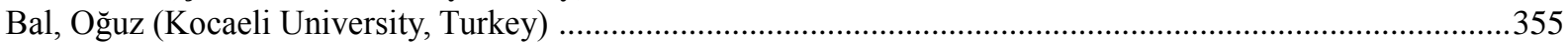

Balcılar, Mehmet (Eastern Mediterranean University, Cyprus) .................................................................109, 469

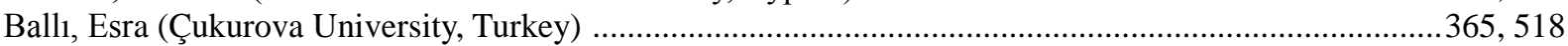

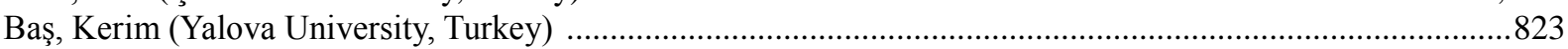

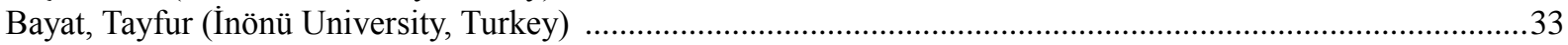

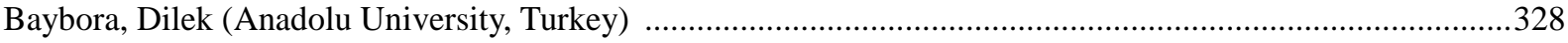

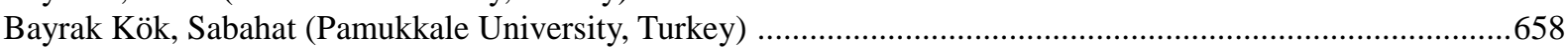

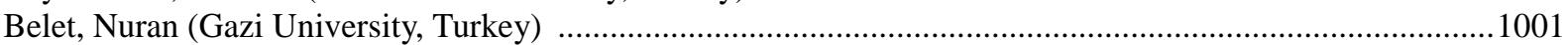

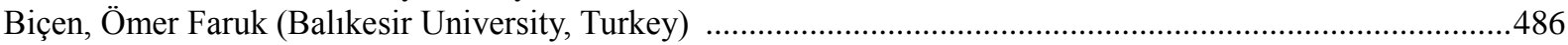

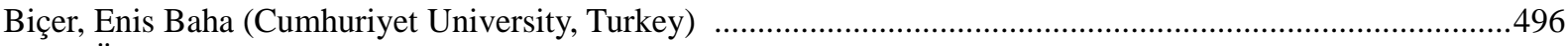

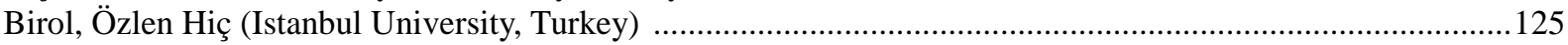

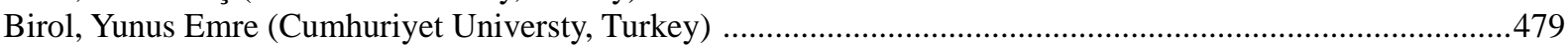

Bostan, Aziz (Kyrgyzstan-Turkey Manas University, Kyrgyzstan) .................................................................712

Bozdağ, Emre Güneşer (Gazi University, Turkey) …………….......................................................................41

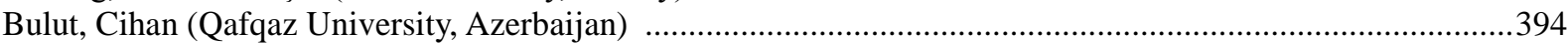

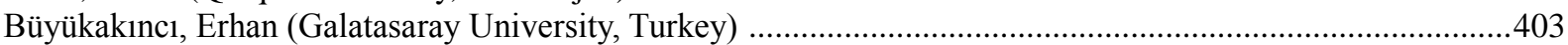

Çadırcı, Bülent Diclehan (Erzincan University, Turkey) ……………..........................................................565

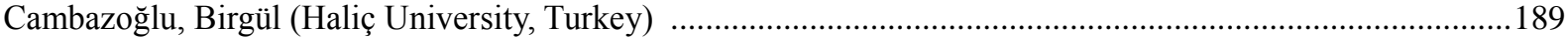

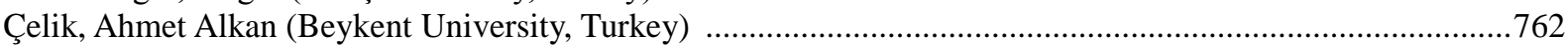

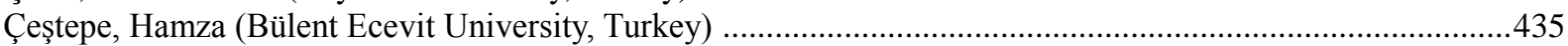

Çetin, Ahmet (Çankırı Karatekin University, Turkey) ……………………………………..............................323

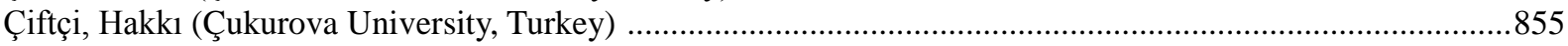

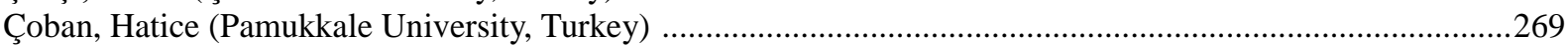

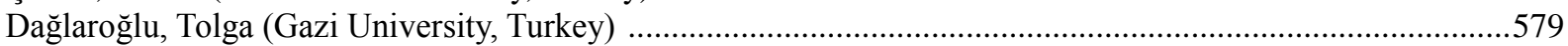

Dağlı Ekmekçi, Yeter Aytül (Pamukkale University, Turkey) ………………………………………………....636

Dedeoğlu, Dinçer (Bahçeşehir University, Turkey) ………...................................................................................

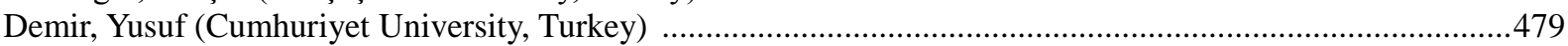

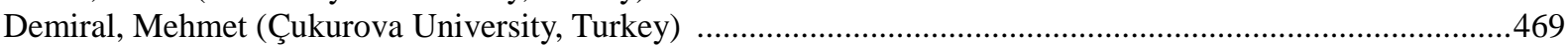

Demirci, Saadat (Çankırı Karatekin University, Turkey) ………………………………….............................. 1077

Demirel, Baki (Gaziosmanpaşa University, Turkey) .......................................................................................579

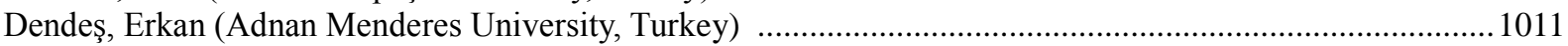

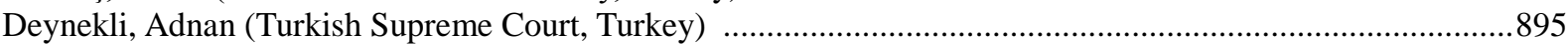

Doker, Aslı Cansın (Erzincan University, Turkey) …………….....................................................................172 
Dökmen, Gökhan (Bülent Ecevit University, Turkey)

Doman, Malgorzata (Poznan University of Economics, Poland) ..............................................................152

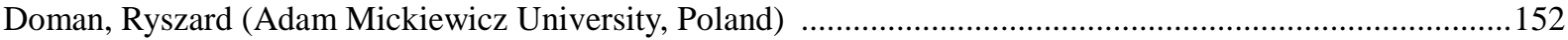

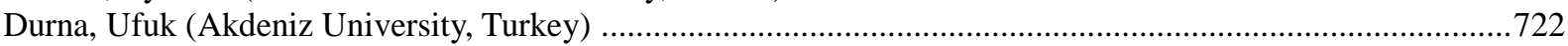

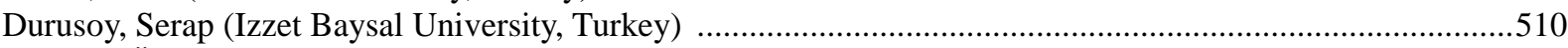

Durusoy Öztepe, Nagihan (Pamukkale Universty, Turkey) ...................................................................308

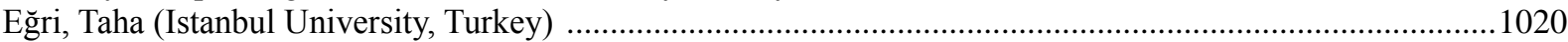

Emsen, Ömer Selçuk (Atatürk University, Turkey) ...........................................................................412

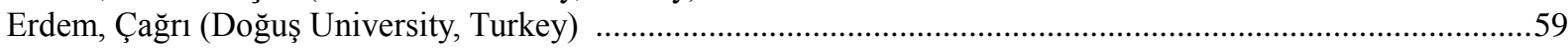

Erdem, Ekrem (Erciyes University, Turkey) …......................................................................79, 841

Ergeç, Etem Hakan (Osmangazi University , Turkey) ….......................................................................802

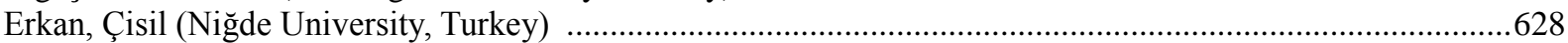

Erkan, Turan Erman (Atılım University, Turkey) ....................................................................574, 1029

Erol, Yücel (Gaziosmanpaşa University, Turkey) ...................................................................................496

Fernandez-Grela, Manuel (University of Santiago de Compostela, Spain) …..............................................227

Firat, Emine (Aksaray University, Turkey) ............................................................................599, 628

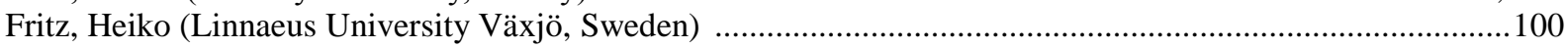

Fynchina, Khicheza (Kyrgyz-Russian Slavic University, Kyrgyzstan) ....................................................1058

Galina, Nikitina (Kazakh Scientific Research Institute, Kazakhstan) .......................................................1067

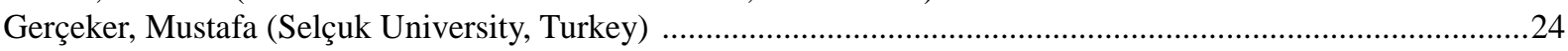

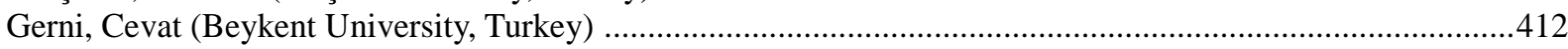

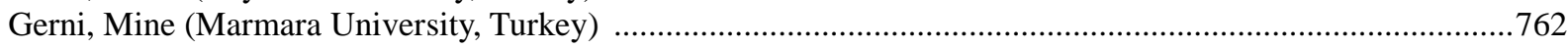

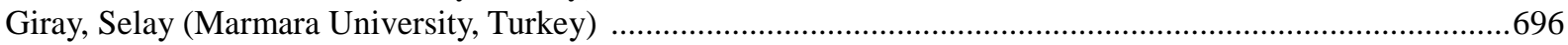

Gökçek Karaca, Nuray (Anadolu University, Turkey) ..........................................................................428

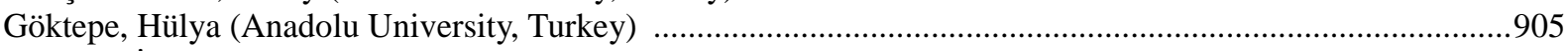

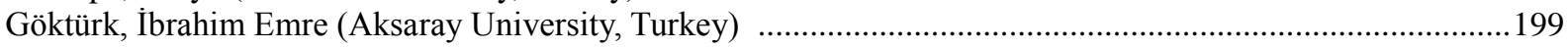

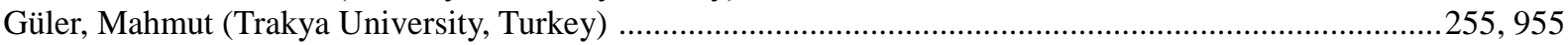

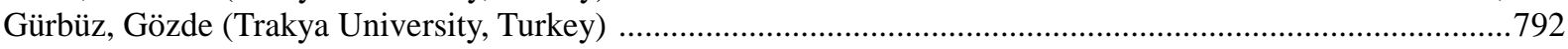

Güreşçi Pehlivan, Gülçin (Dokuz Eylül University, Turkey) ...................................................................518

Gürson, Poyraz (Atılım University, Turkey) .........................................................................574, 1029

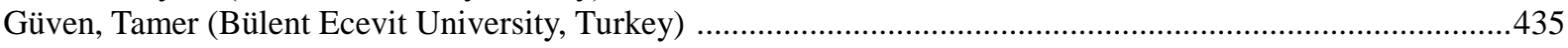

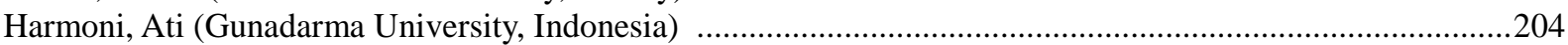

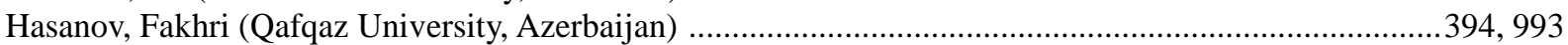

Haşıloğlu, Selçuk Burak (Pamukkale University, Turkey) ....................................................................978

Haydaroğlu, Ceyhun (Bilecik Şeyh Edebali University, Turkey) ...........................................................8. 872

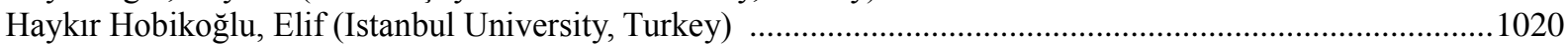

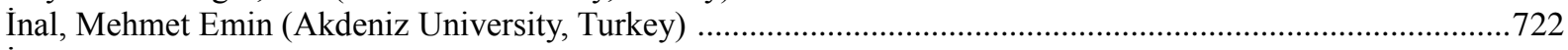

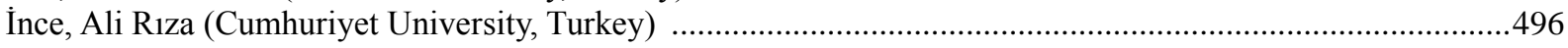

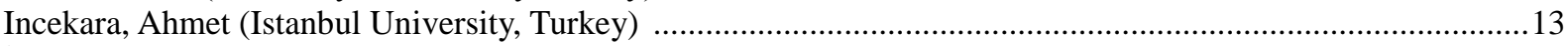

İrmiş, Ayşe (Pamukkale University, Turkey) ............................................................................269, 636

Japarova, Damira (Kyrgyzstan-Turkey Manas University, Kyrgyzstan) ................................................... 1052

Kalburan, Çetin (Pamukkale University, Turkey) ..........................................................................978

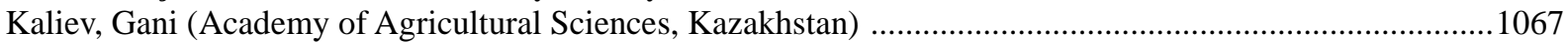

Kamalova, Anara (Academy of Public Administration, Kyrgyzstan) ...........................................................5

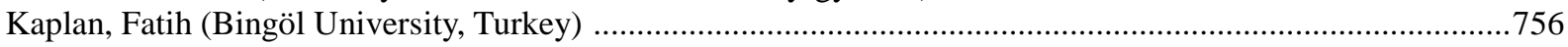

Kaptanoğlu, Aysegül (Trakya University, Turkey) ...........................................................................24

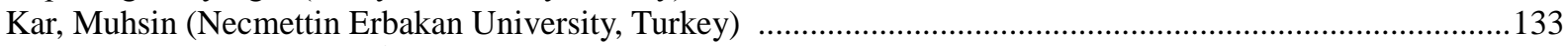

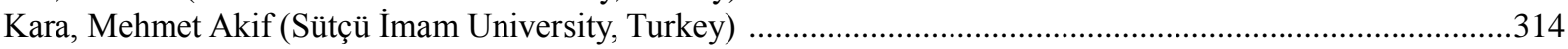

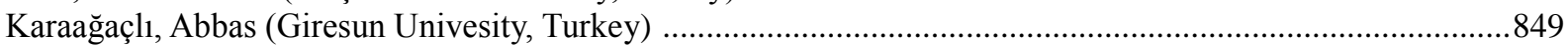

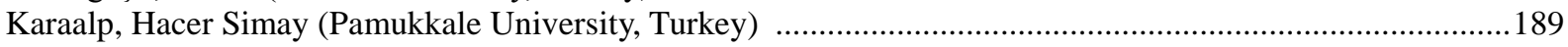

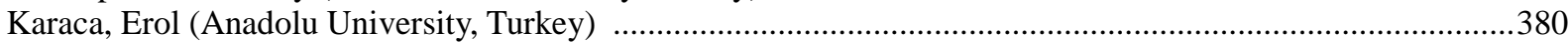

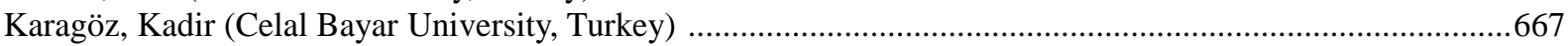

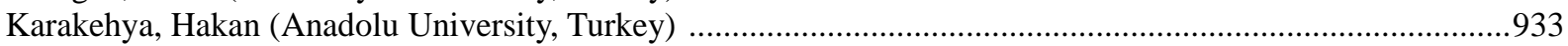

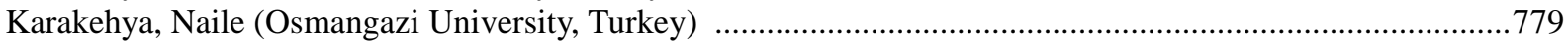

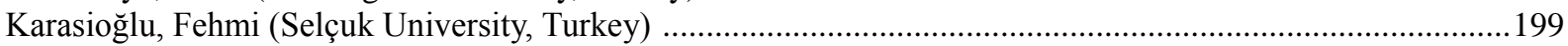

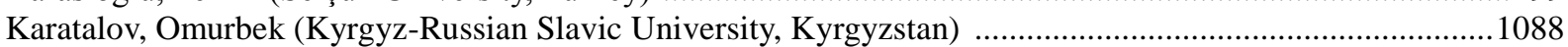

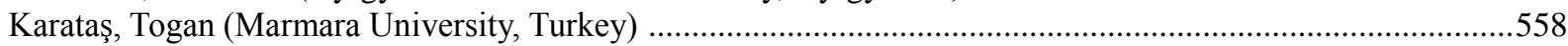

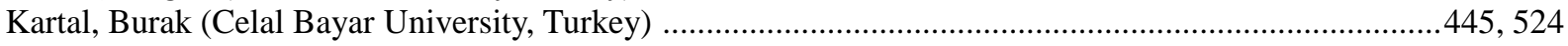

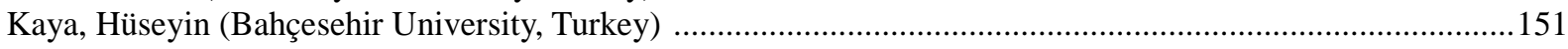

Kayani, Farrukh (COMSATS Institute of Information Technology, Pakistan) ...............................................238

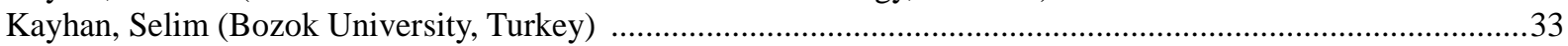




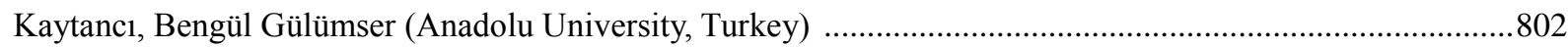

K1lınç Savrul, Burcu (Canakkale Onsekiz Mart University, Turkey) ……….......................................................50

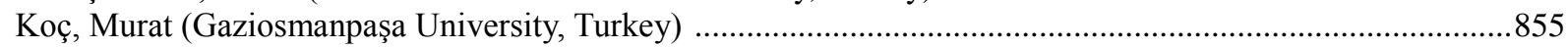

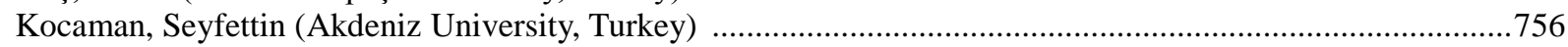

Koichueva, Merim (Kyrgyz-Russian Slavic University, Kyrgyzstan) ..........................................................1034

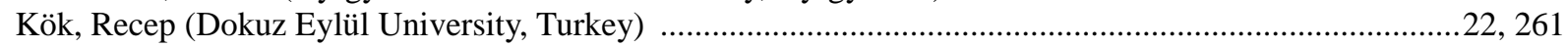

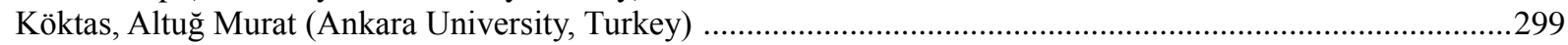

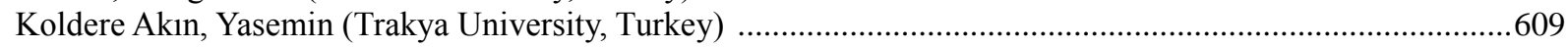

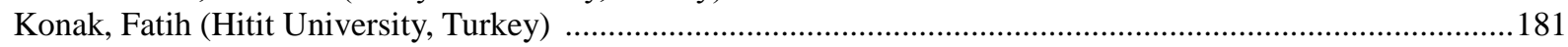

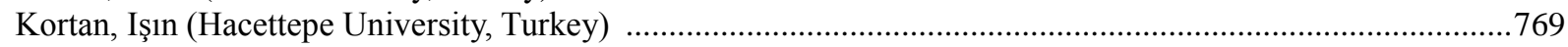

Koychuev, Turar (National Academy of Sciences, Kyrgyzstan) …….......................................................2, 1034

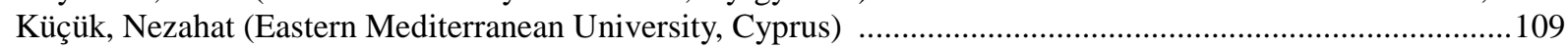

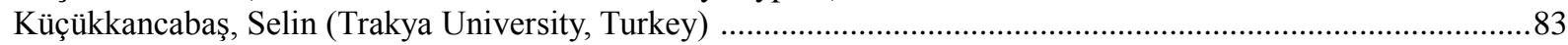

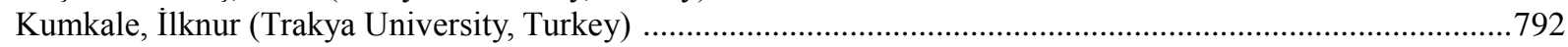

Kupsuralieva , Elmira (Kyrgyzstan-Turkey Manas University, Kyrgyzstan) ......................................................389

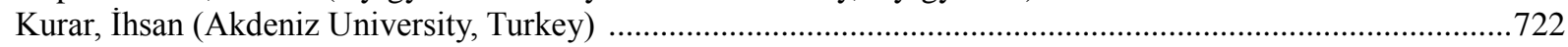

Kurkova, Dina (National Research University, HSE, Russia) ........................................................................ 1081

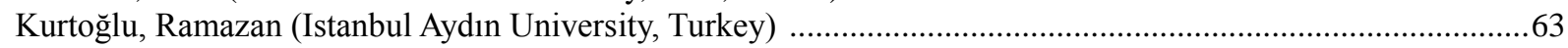

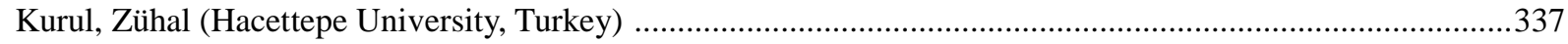

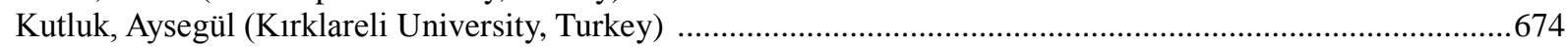

Kutlutürk, Murat Mustafa (Çankırı Karatekin University, Turkey) ………………............................................323

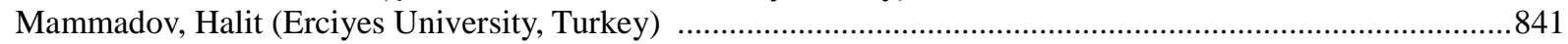

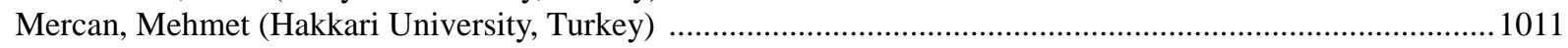

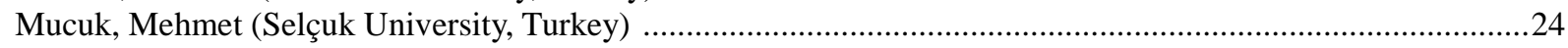

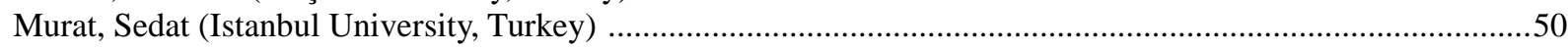

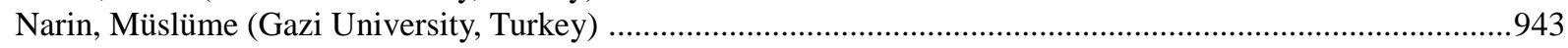

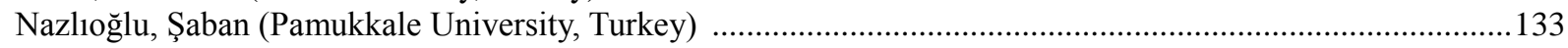

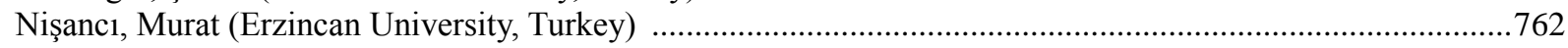

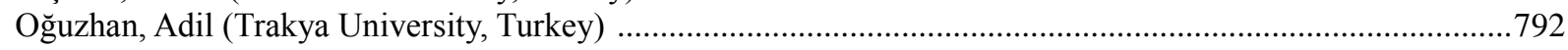

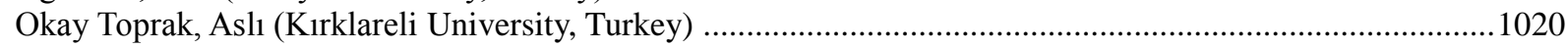

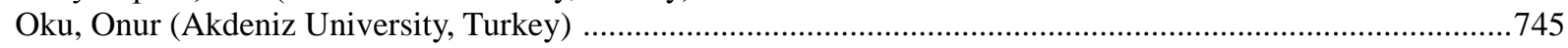

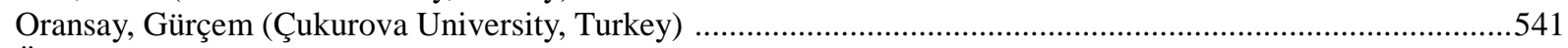

Özcan, Selami (Yalova University, Turkey) …………………........................................................289, 823

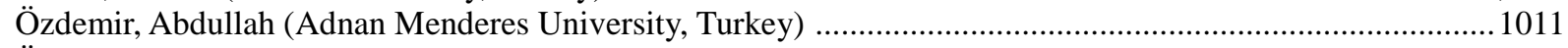

Özdemir, Dilek (Atatürk University, Turkey) …………………………………………................................412

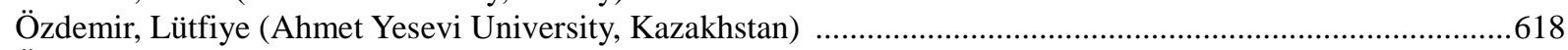

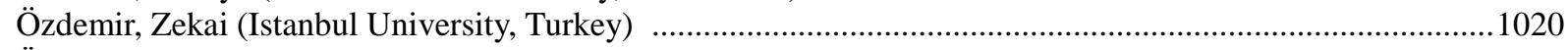

Özenbaş, Nazmiye (Anadolu University, Turkey) ………………………………………...........................925

Özer, Ali (Erzincan University, Turkey) ……………………………………………...................172, 565

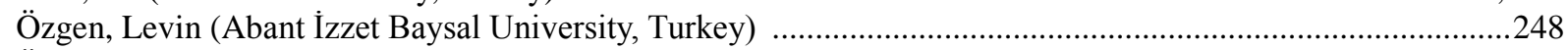

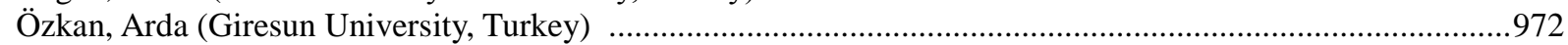

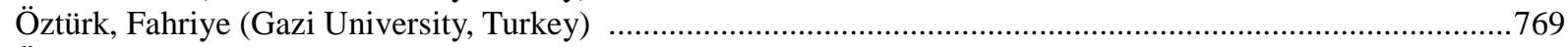

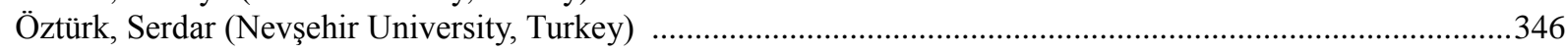

Pirimbaev, Jusup (Kyrgyzstan-Turkey Manas University, Kyrgyzstan) ................................................................

Pyshkina, Tatiana (Academy of Economic Studies of Moldova (ASEM), Moldova) ........................................1043

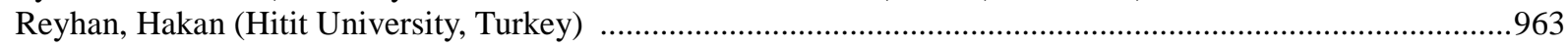

Rüstemoğlu, Hasan (Eastern Mediterranean University, Cyprus) ....................................................................211

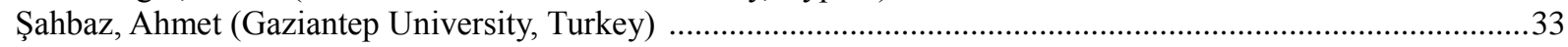

Şahin, Levent (Çankırı Karatekin University, Turkey) …………………………………................................

Samambayeva, Aizhan (Universidade de Santiago de Compostela, Spain) ......................................................227

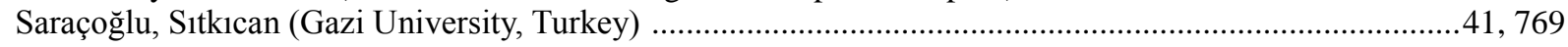

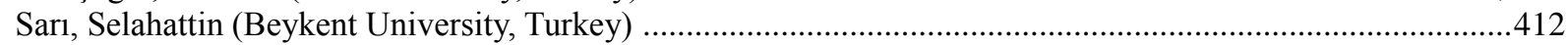

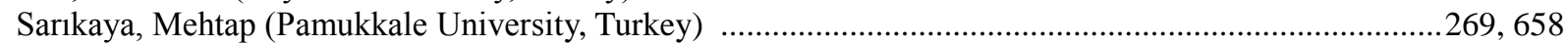

Satır, Ayşen (Ministry of Environment and Forestry, Turkey) ………………………….................................963

Savrul, Mesut (Çanakkale Onsekiz Mart University, Turkey) ……………………………...............................13

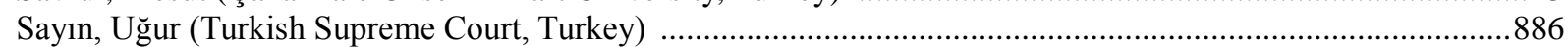

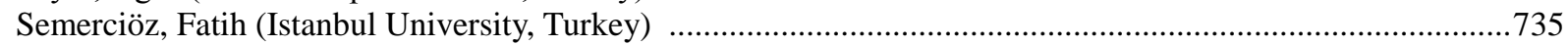

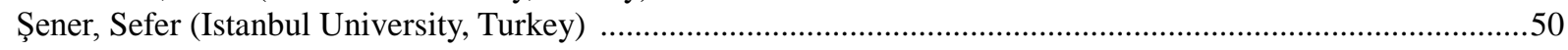

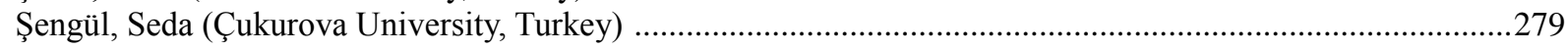

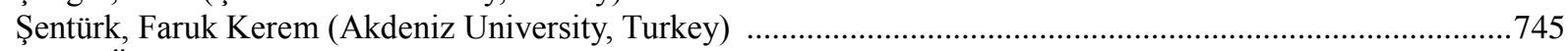

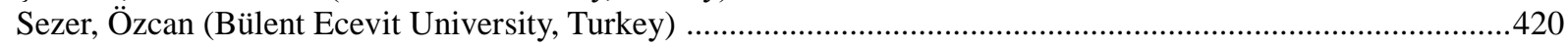


Sezer, Pınar (Hacettepe University, Turkey)

Sigeze, Çiler (Çukurova University, Turkey)

Şimşek, Halil (Istanbul Aydın University, Turkey)

Sofyalığlu, Çiğdem (Celal Bayar University, Turkey) ......................................................................524

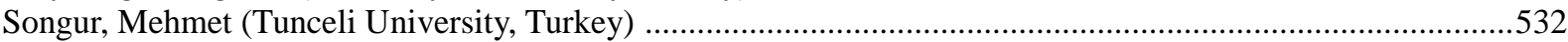

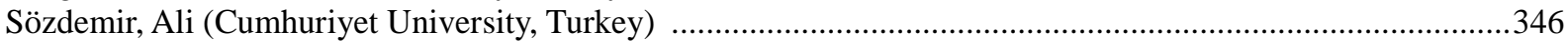

Suhendra, Euphrasia Susy (Gunadarma University, Indonesia) ................................................................144

Suleymanov, Elchin (Qafqaz University, Azerbaijan) ..................................................................394, 993

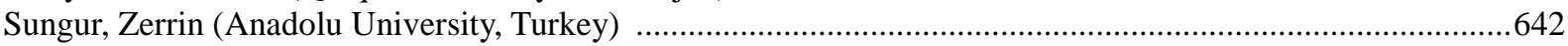

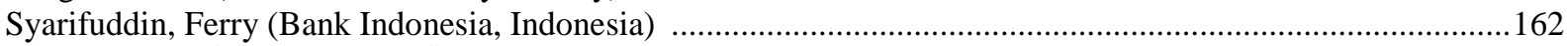

Tamer, Gülay (İstanbul Aydın Üniversitesi, Turkey) ...........................................................................650

Taş, H. Yunus (Yalova University, Turkey) ................................................................................289, 823

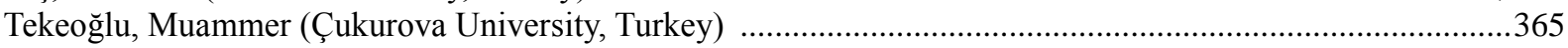

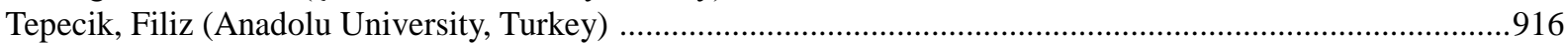

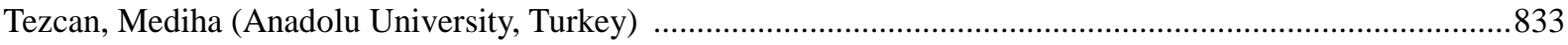

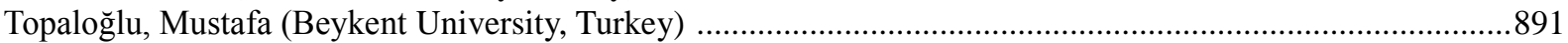

Topcu, Mustafa Kemal (Fibonasi Yönetim Danışmanlık, Turkey) ...................................................574, 1029

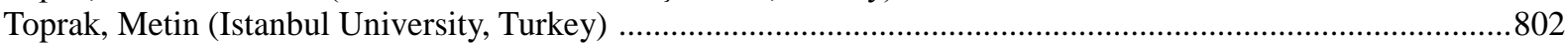

Toprak, Nuri Gökhan (Kirklareli University, Turkey) .........................................................................985

Toren, Evrim (Eastern Mediterranean University, Cyprus) ...................................................................... 116

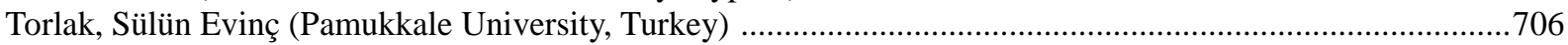

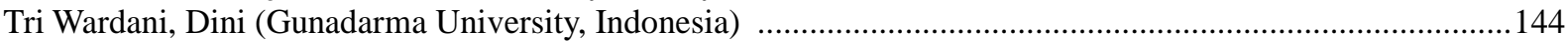

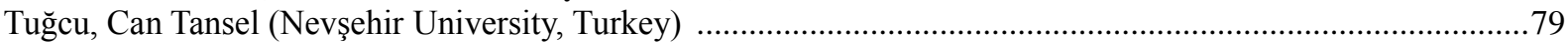

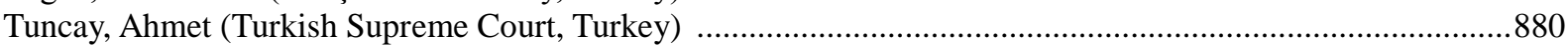

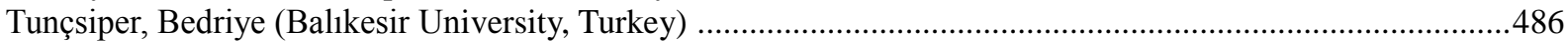

Turan, Abdulmenaf (Yüzüncü Y1l University, Turkey) .............................................................255, 955

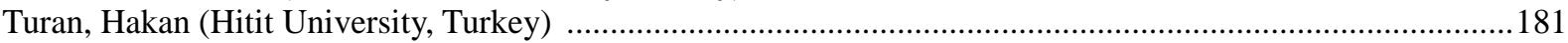

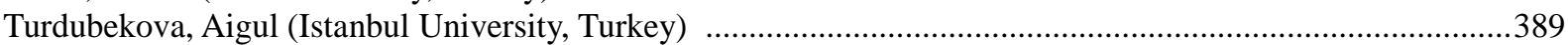

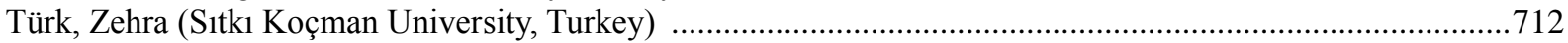

Türkmen, Adem (Erzincan University, Turkey) .....................................................................172, 565

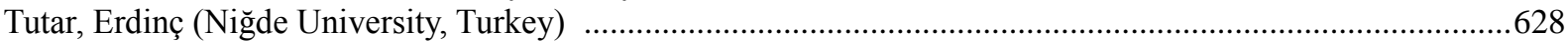

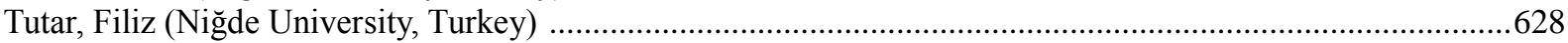

Ŭgural, Sevin (Eastern Mediterranean University, Cyprus) ..................................................................211

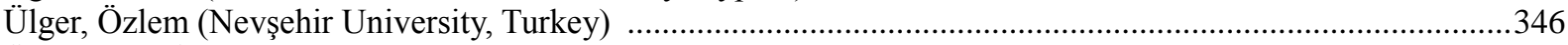

Ülker, Halil İbrahim (Atılım University, Turkey) ....................................................................574, 1029

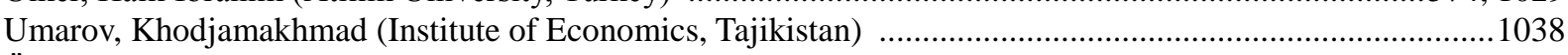

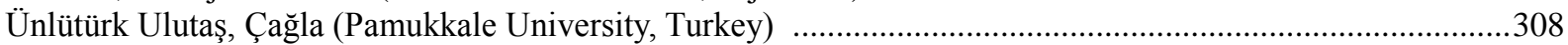

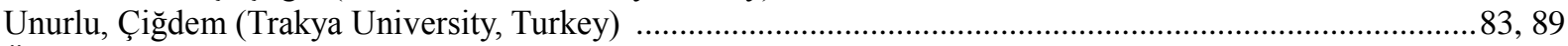

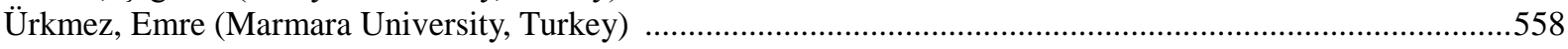

Usta, Emine Ebru (Ministry of Family and Social Policies, Turkey) ........................................................461

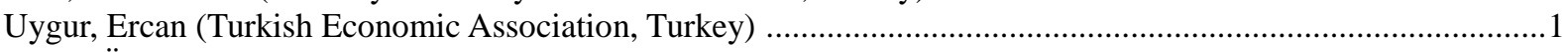

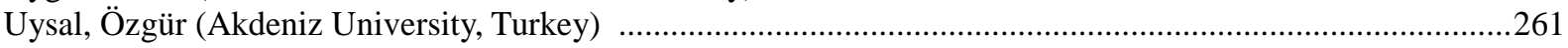

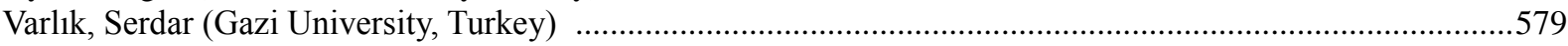

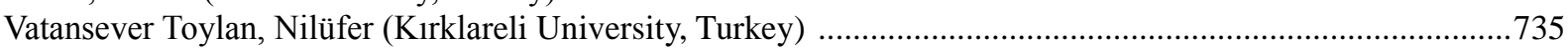

Vergos, Konstantinos (University of Portsmouth, United Kingdom) ........................................................189

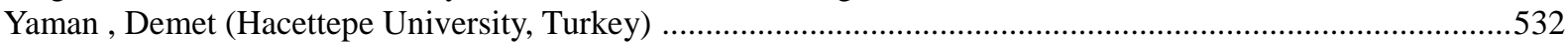

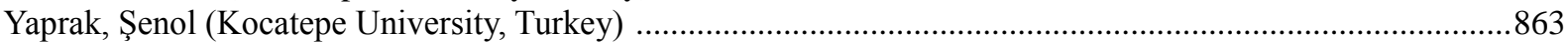

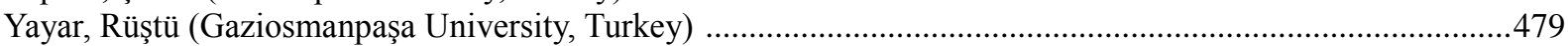

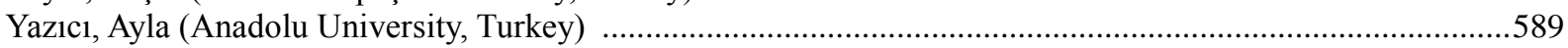

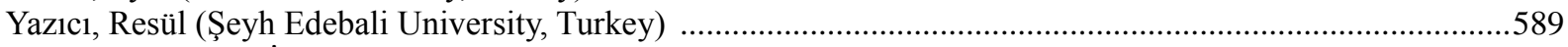

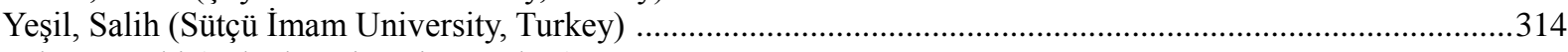

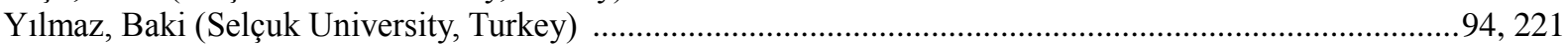

Yılmaz, Fatma Özlem (Selçuk University, Turkey) ...........................................................................94, 221

Yurtseven, Çağlar (Bahçeşehir University, Turkey) ...............................................................................23

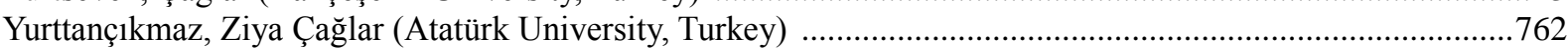

